W 


\section{Cornell University Library}

The original of this book is in the Cornell University Library.

There are no known copyright restrictions in the United States on the use of the text. 


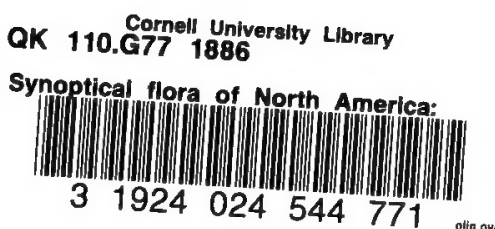



SYNOPTICAL

FLORA OF NORTH AMERICA. 



\section{SYNOPTICAL}

\section{FLORA OF NORTH AMERICA:}

\section{THE GAMOPETALA,}

BEING

A Second Edition of Vol. I. Part II., and Vol. II. Part I., collected.

\section{Br ASA GRAY, LL.D.,}

F.M. R S. \& L.S. Lond., R.I. A. Dubl, Phil. Soc. Cambr., Roy. Soc. Upsala, Stockholm, Göttingen, Edinb. ; Roy. Acad. Sci. Munich, \&c.; Corresp. Imp. Acad. Sci. St. Petersburg,

Roy. Acad. Berlin, and Acad. Scí. Instit. France.

FISHER PROFESSOR OF NATURAL HISTORY (BOTANY) IN HARVARD UNIVERSITY.

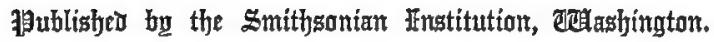

NEW YORK:

IVISON, BLAKEMAN, TAYLOR, AND COMPANY.

LONDON : WM. WESLEY, 28 ESSEX ST., STRAND, AND TRÜBNER \& CO.

LEI PS I C : O SW A L D WEIGEL.

J ANTART, 1886.

$59)$ 
A. 20606

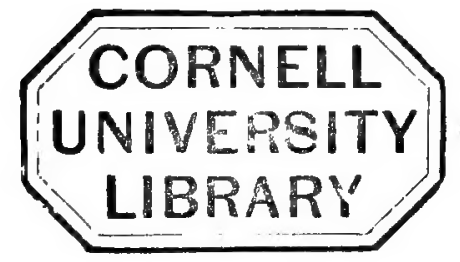

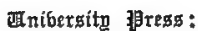

JoHN WILsoN AND SoN, CAMBRIDGE. 


\section{N O T I C E.}

EXPERIENCE having shown that some years must elapse before this work can be completed, and a new impression of the part first published (in 1878) being called for, it is expedient now to issue the two parts, which together comprise all the Gamopetalous Dicotyledons, in the form of a single ro'"me, under the auspices of the Smithsonian Institution.

Both parts have been corrected, as far as could well be done upon the electrotype plates; a supplement of eleven pages is added to the very recently published Volume I. Part II., and its full index has been made anew. The tabular enumeration of the contained genera and species has been transferred to the end of the Gamopetalæ. To Volume II. Part I., a supplement of seventy pages is added, and a few pages have been recast; a tabular enumeration of all the gamopetalous genera and species is appended, and a complete index of genera, species, synonyms, \&c., - making an extension from 402 to about 500 pages.

\section{Herbariom of Harvard UNIVERsity,}

January 1, 1886. 



\section{SY NOPTICAL}

\section{FLORA OF NORTH AMERICA.}

\section{Division II. GAMOPETALOUS DICOTYLEDONOUS PLANTS.}

Perranth consisting of both calyx and corolla, the latter more or less gamopetalous. (Exceptions: A part of Ericacece, Plumbaginacece, Styracacece, and Oleacece have unconnected petals; some Oleacece, \&c., are apetalous.)

\section{General Key to the Orders.}

* Ovary inferior or mainly so: stamens borne by the corolla, alternate with its lobes, and

\section{- Unconnected: leaves opposite or whorled.}

69. CAPRIFOLIACE 2 . Stamens as many as corolla-lobes (one fewer in Linnoea, doubled by division in Adoxa). Seeds albuminous. Leaves opposite : stipules none, or rare as appendages to base of petiole.

70. RUBIACE出. Stamens as many as corolla-lobes, mostly four or five. Ovary with two or more cells or placentæ. Seeds albuminous. Leaves all simple and entire, with stipules between or within the petioles or bases, or whorled without stipules, the additional leaves probably representing them.

71. VALERIANACE.E. Stamens fewer than corolla-lobes, one to four. Ovary with one cell containing a suspended ovule which becomes an exalbuminous seed, and commonly two empty cells or vestiges of them. No stipules.

72. DIPSACACE㭱. Stamens as many as or fewer than corolla-lobes, two or four. Ovary simple and one-celled, with a single suspended ovule, becoming an albuminous seed. Flowers capitate. Corolla-lobes imbricated in the bud.

$$
\text { + + Stamens with anthers connate into a tube. }
$$

73. COMPOSIT压. Syngenesious stamens as many as their corolla-lobes, five, sometimes four. Ovary one-celled, with a solitary erect ovule, becoming an exalbuminous seed in an akene. Lobes of the corolla valvate in the bud. Flowers in involucrate heads. No stipules. 
* * Ovary either inferior or superior, two-several-celled: stamens free from the corolla or nearly so, inserted with it, as many or twice as many as its lobes or petals, when of same number alternate with them: no stipules. (Orders from these onward are in Vol. II. Part I.)

+ Juice milky except in the first order: corolla-lobes valvate or induplicate in the bud.

74. GOODENIACE无. Corolla irregular, epigynous. Stamens or at least filaments distinct. Stigma indusiate. Juice not milky.

75. LOBELIACE \&. Corolla irregular, epigynous or perigynons. Stamens five, monadelphous or syngenesious, or both. Stigma not indusiate. Cells of ovary or placentæ two. Seeds numerous. Juice usually more or less milky and acrid. Inflorescence centripetal.

76. CAMPANULACEAE. Corolla regular, epigynous. Stamens five, mostly distinct. Stigmas two to five, introrse, at the summit of the style, which below bears pollencollecting hairs. Cells of ovary and capsule two to five, many-seeded. Juice milky and bland. (Exception: Sphenoclea.)

+ Juice not milky nor acrid: corolla-lobes or petals imbricate or sometimes convolute in the bud.

77. ERICACE 疋. Flowers mostly regular, symmetrical, and tetra-pentamerous throughout: corolla sometimes moderately irregular, epigynous or hypogynons. Stamens distinct, as many and oftener twice as many as petals or corolla-lobes. Cells of the ovary (with few exceptions) as many or even twice as many as the divisions of the calyx or corolla. Style and mostly stigma undivided.

* * * Ovary superior, many-celled : stamens five to eight, as many as the lobes of the hypogynous corolla, and borne in the throat of its long tube.

78. LENNOACE正. Root-parasites.

* * * Ovary superior: stamens (or antheriferous stamens) of the same number as the proper corolla-lobes or petals and opposite them: flowers regular.

+ Ovary one-celled, with solitary ovule or free placenta rising from its base: seeds small.

80. PlumbaginaCEE. Stamens and styles or lobes of the style five, except in Plumbago, the former hypogynous or borne on the very base of the almost or completely distinct unguiculate petals. Ovary uniovulate, in fruit becoming an akene or utricle. Herbs or somewhat shrubby.

81. PRIMULACE $\approx$. Stamens four or five, rarely six to eight, borne on the corolla (or in Glaux, which is apetalous, on the calyx alternate with its petaloid lobes) : staminodia only in Samolus. Ovules several or numerous, sessile on the central placenta. Fruit capsular. Herbs.

82. MYRSINACEæ⿸ Shrubs or trees, with dry or drupaceous fruit and solitary or very few seeds, usually immersed in the plincenta : otherwise as Primulacece. 
+ + Ovary few-several-celled, with solitary opules in the cells, usually only one maturing into a large bony-coated seed in a fleshy pericarp.

83. SAPOTACE正. Shrubs or trees, mostly with milky juice and alternate simple leaves. Flowers small, hermaphrodite, tetra-heptamerous. Calyx and corolla much imbricated in the bud; the latter often bearing accessory lobes or appendages within, sometimes petaloid staminodia also.

***** Ovary inferior or superior, few-several-celled: cells of the fruit one-seeded: stamens at least twice as many as the petals or lobes of the corolla, sometimes indefinitely numerous and borne on or united with their base or tube: flowers regular: shrubs or trees, with simple alternate leaves, sometimes a resinous but no milky juice.

84. EBENACE正. Flowers diœcious or polygamous; the male ones polyandrous. Ovary superior and corolla hypogynous. Styles as mauy or half as many as the cells of the ovary, distinct or partly united. Fruit fleshy, containing solitary or few large seeds with bony testa and cartilaginous albumen.

85. STYRACACE正. Flowers hermaphrodite, nearly pentapetalous and a numerous cluster of stamens adnate to base of each petal, or more gamopetalous and the fewer stamens monadelphous in a single series. Style and stigma entire. Corolla epigynous, in Styrax perigynous. Fruit dry or nearly so, one-four-seeded, when dehiscent the seed bony: albumen fleshy.

****** Ovary or gynœcium superior, dicarpellary, or in some monocarpellary, very rarely tri-pentacarpellary, sometimes appearing to be tetracarpellary by the division of the two ovaries: stamens borne on the corolla (in apetalous Oleacer, \&c., on the receptacle), alternate with its divisions or lobes, of the same number or fewer.

- Corolla not scarious and veinless,

* Regular with stamens fewer than its lobes or petals, or no corolla: style one : seeds solitary or very few.

86. OLEACEE. Trees or shrubs, with opposite (rarely alternate) leaves : no stipules, 'no milky juice. Stamens usually two, alternate with the carpels; these two-ovuled, or sometimes four-ovuled : seed mostly solitary, albuminous. Forestiera and part of Fraxinus apetalous and even acblamydeous.

+ + Corolla regular and stamens as many as its divisions, five or four.

$=$ Ovaries two (follicular in fruit); their stigmas and sometimes styles permanently united into one: plants with milky juice: flowers hermaphrodite: leaves simple, entire.

87. APOCYNACE E. Stamens distinct, or the anthers merely connivent or lightly cohering: pollen ordinary. Style single.

88. ASCLEPIADACEE. Stamens monadelphous and anthers permaneritly attached to a large stigmatic body : pollen combined into waxy pollinia or sometimes granulose masses. Carpels united only by the common stigmatic mass. - 
$==$ Ovaries two, with styles slightly united below or distinct. Vide 94 .

$===$ Ovary one, compound, with two or three (very rarely four or five) cells or placentre : stamens distinct (or anthers at most lightly connate).

a. Leaves opposite, simple, and mostly entire, with stipules or stipular line connecting their bases: no milky juice.

89. LOGANIACE无. Ovary dicarpellary, two-celled : style single, but stigmas occasionally four, usually only one. Seeds numerous : embryo rather small, in copious albumen.

\section{b. Leaves with no trace of stipules: milky juice only in Convolvulaceæ.}

90. GENTIANACE㭱. Leaves opposite, sessile, simple and entire, except in Menyanthea. Ovary dicarpellary, one-celled, many-ovuled: placentæ or ovules parietal. Stigmas mostly two, introrse. Fruit capsular, septicidal, i. e. dehiscent through the placentæ or alternate with the stigmas. Seeds with minute embryo in fleshy albumen. Herbage smooth.

79. DIAPENSIACE 2 . Leaves alternate and simple, smooth. Ovary tricarpellary, three-celled, as also the loculicidal many-seeded capsule, which has a persistent columella. Stamens five, either borne in sinuses of the corolla or monadelphous : in some a series of petaloid staminodia alternate with the true stamens. Anthers inflexed on apex of the filament, or transversely debiscent. Calyx and corolla imbricated in the bud. Style one : stigma three-lobed. Embryo small in fleshy albumen. Depressed or scapose and acaulescent perennials.

91. POLEMONIACE 2 . Leaves opposite or alternate, from entire to compound. Ovary tri-(very rarely di-)carpellary, with as many cells, becoming a loculicidal capsule, with solitary to numerous seeds borne on a thick placental axis. Stamens five, distinct, borne on the tube or throat of the corolla; the latter convolute in the bud, the calyx imbricated. Style three-cleft or three-lobed at the summit: stigmas introrse. Seeds with comparatively large straight embryo in rather sparing albumen.

92. HYDROPHYLLACE无. Leaves mostly alternate, disposed to be lobed or divided. Inflorescence disposed to be scorpioid in the manner of the next order. Corolla five-lobed, imbricated or sometimes convolute in the bud. Stamens five, distinct. Ovary undivided, dicarpellary, and style (with one exception) two-parted or twolobed : stigmas terminal. Capsule one-celled with two parietal or introflexed placentæ, each bearing two or more peridulous (or when very numerous horizontal) seeds, or sometimes two-celled by the junction of the placentr in the axis. Seeds with reticulated or pitted or roughened testa : a small or slender straight embryo in solid albumen.

93. BORRAGINACEA. Leaves alternate, mostly entire, and with whole herbage apt to be rough, hirsute, or hispid. Inflorescence cymose, commonly in the scorpioid mode, the mostly uniparous or biparous cymes evolute into unilateral and often ebracteate false spikes or racemes. Corolla five-lobed, sometimes four-lobed, imbricate or convolute or sometimes plicate in the bud. Ovary dicarpellary, but usually seeming tetramerous, being of four (i. e. two biparted) lobes around the base of the style, maturing into as many separate or separable nutlets; or ovary not lobed, two-fourcelled, in fruit drupaceous or dry, containing or splitting into as many nutlets. Solitary seed with a mostly straight embryo and little or no albumen : radicle superior or centripetal. 
94. CONVOLVULACE无. Leaves alternate and petioled. Stems usually twining or trailing, but some erect, many with milky juice. Flowers borne by axillary peduncles or cymose-glomerute. Calyx of imbricated sepals. Corolla with four-five-lobed or commonly entire margin, plicate and the plaits convolute in the bud, sometimes induplicate-valvate or imbricated. Ovary two-celled or sometimes three-celled, with a pair of erect anatropous ovules in each cell, becoming comparatively large seeds (these sometimes separated by spurious septa of the capsular fruit), with smooth or hairy testa. Eubryo incurved, with ample foliaceous plaited and crumpled cotyledons (in Cuscuta embryo long and spiral without cotyledons) surrounded by little or no albumen : radicle inferior. Dichondra has two distinct ovaries.

95. SOLANACE无. Leaves alternate, sometimes unequally geminate. Inflorescence various, but no truly axillary flowers. Corolla in some a little irregular, its lobes or border induplicate-plicate or rarely imbricate in the bud. Ovary normally two-celled (occasionally three-five-celled) and undivided, with many-oruled placentæ in the axis : style undivided : stigma entire or bilamellar. Seeds numerous, with incurred or coiled or rarely almost straight embryo in copious fleshy albumen : cotyledons seldom much broader than the radicle.

+ + + Corolla irregular, more or less bilabiately so ( $(2)$; its lobes variously imbricate or convolute, or sometimes almost regular: stamens fewer than corolla-lobes, four and didynamous, or only two: style undivided: stigma entire or two-lobed or bilamellar; the lobes anterior and posterior: ovary in all dicarpellary; the cells or carpels anterior and posterior.

$$
=\text { Pluriovulate or multiovulate. }
$$

96. SCROPHULARIACE无. Ovary and capsule completely two-celled : placentæ occupying the middle of the partition. Seeds comparatively small or minute, mostly indefinitely numerous, sometimes few. Embryo small, straight or slightly curved, in copious fleshy albumen : cotyledons hardly broader than the radicle.

97. OROBANCHACE疋. Ovary one-celled with two or four (doubled) parietal manyovuled placentæ. Seeds very many in fleshy albumen, with minute embryo, having no obvious distinction of parts. Root-parasites, destitute of green herbage.

98. LENTIBULARIACE正. Ovary one-celled, with a free central multiorulate placenta : globular capsule mostly bursting irregularly. Seeds destitute of albumen, filled by a solid oblong embryo. Bilabiate corolla personate and calcarate. Stamens two: anthers confluently one-celled. Aquatic or paludose plants, with scapes or scapiform peduncles, sometimes almost leafless.

99. BIGNONIACE正. Ovary and capsule two-celled by the extension of a partition beyond the two parietal placentæ, or in some genera simply one-celled. Seeds numerous, large, commonly winged, transverse, filled by the horizontal embryo: cotyledons brosd and foliaceous, plane, emarginate at base and summit, the basal notch including the short radicle: no albumen. Trees or shrubs, many climbing, large-flowered : leaves commonly opposite.

100. PEDALIACE正. Ovary one-celled, with two parietal intruded placentre, which are broadly bilamellar or united in centre, or two-four-celled by spurious septa from the walls. Fruit capsular or drupaceons, few-many-seeded. Seeds wingless, with thick and close testa, filled by the large straight embryo: cotyledons thickish. Herbs, with mainly opposite simple leaves : juice mucilaginous. 
101. ACANTHACE正. Ovary two-celled, with placentæ in the axis, bearing a definite number of ovules (two to eight or ten in each cell), becoming a loculicidal capsule. Seeds wingless, destitute of albumen (or a thin layer in Elytraria), either globular on a papilliform funicle, or flat on a retinaculum. Fmbryo with broad and flat cotyledons.

$==$ Cells of the ovary uniovulate or biovulate.

102. SELAGINACE无. Ovary two-celled : ovule suspended. Embryo in fleshy albu. men : radicle inferior. Leaves alternate.

103. VERBENACE 2 . Ovary two-four-celled, in fruit di-tetrapyrenous, not lobed, in Phryma one-celled and becoming an akene. Ovule erect from the base of each cell or half-cell. Seed with little or no albumen : radicle inferior.

104. LABIAT \&. Ovary deeply four-lobed around the style, the lobes becoming dry seed-like nutlets in the bottom of a gamosepalous calyx. Ovule erect. Seed with little or no albumen : radicle inferior. Commonly aromatic herbs or undershrubs.

++ Corolla scarious and nerveless : flowers tetramerous, regular.

105. PLANTAGINACEE. Calyx imbricated. Corolla-Iobes imbricated in the bud. Stamens four or fewer. Style entire. Ovary and capsule one-two-celled : cells sometimes again divided by a false septum. Seeds mostly amphitropous and peltate, with straight embryo in firm fleshy albumen. Chiefly acaulescent herbs, with onemany-flowered commonly spike-bearing scapes, arising from axils of the leaves. 


\section{Order LXIX. CAPRIFOLIACE $Æ$.}

Shrubby, or a few perennial herbaceous plants, with opposite leaves normally destitute of stipules, and regular or (in the corolla) irregular hermaphrodite flowers; calys-tube adnate to the 2-5-celled or by suppression 1-celled ovary; stamens as many as lobes of the corolla (in Linnaa one fewer, in Adoxa doubled) and alternate with them, inserted on its tube or base; embryo small in the axis of fleshy albumen. Corolla-lobes generally imbricated in the bud. Ovules anatropous, when solitary suspeaded and resupinate; the rhaphe dorsal. Seed-coat adherent to the albumen. Flowers commonly 5-merous.

Tribe I. SAMBUCEE. Corolla regular, short, rotate or open-campanulate, 5-lobed. Style short or hardly any : stigmas 3 to 5 . Ovules solitary in the (1 to 5) cells. Fruit baccate-drupaceous; the seed-like nutlets 1 to 5 . Inflorescence terminal and cymose.

* Herb, with stamens doubled and flowers in a capitate cluster. Anomalous in the order.

1. ADOXA. Calyx with hemispherical tube adnate to above the middle of the ovary; limb about 3-toothed. Corolla rotate, 4-6-cleft. Stamens a pair below each sinus of the corolla, each with a peltate one-celled anther, and the short subulate filaments approximate or united at base (one stamen divided into two). Ovary 3-5-celled: style short, 3-5-parted. Ovule suspended from the summit of each cell. Fruit greenish, maturing 2 to 5 cartilaginous nutlets. Cauline leaves a single pair; radical ones and scales of the rootstock alternate!

* * Frutescent to arborescent: inflorescence compound-cymose: flowers articulated with their pedicels : stamens as many as corolla-lobes: anthers 2-celled: calyx 5-toothed.

2. SAMBUCUS. Leaves pinnately compound. Corolla rotate or nearly so. Ovary 3-5celled, forming small baccate drupes with as many cartilaginous nutlets. Embryo nearly the length of the albumen.

3. VIBURNUM. Leaves simple, sometimes lobed. Corolla rotate or open-campanulate. Ovary 1-celled and 1-ovaled, becoming a drupe with a single more or less flattened nutlet or stone. Embryo minute. Cymes in some species radiate.

TRIBE II. LONICERE无. Corolla elongated or at least campanulate, commonly more or less irregular. Style elongated : stigma mostly capitate. Fruit various. Stipules or stipular appendages seldom seen.

* Herbs, with axillary sessile flowers and drupaceous fruit.

4. TRIOSTEUM. Calyx-lobes 5. Corolla tubular-campanulate, somewhat unequally 5lobed; tube gibbous at base. Stamens 5. Ovary 3- (sometimes 4-5-) celled, with a single suspended ovale in each cell: style slender: stigma 3-lobed. Fruit a fleshy drupe, crowned with the persistent calyx-lobes : putamen bony, costate, at length separable into 3 (rarely 4 or 5 , or by abortion 2) thick one-seeded nutlets.

* * Fruticulose creeping herb, with long-pedunculate geminate flowers and dry one-seeded fruit, but a 3-celled ovary.

5. LINN AA. Calyx with limb 5-parted into subulate-lanceolate lobes, constricted above the globular tube, decidoous from the fruit. Corolla campanulate-funnelform, not gibbous, almost equally 5-lobed. Stamens 4, two long and two shorter, included. Ovary 3-celled; two of the cells containing several abortive ovules; one with a solitary suspended ovule, forming the single seed in the dry and indehiscent coriaceous 3-celled small fruit. Style exserted: stigma capitate.

* * * Shrubs, with scaly winter-buds, erect or climbing : fruit 2-many-seeded : style slender: stigma capitate, often 2-lobed.

6. SYMPHORICARPOS. Calyx with a globular tube and 4-5-toothed persistent limb. Corolla regular, not gibbous, from short-campanulate to salverform, 4-5-lobed. Stamens as 
many as the lobes of the corolla, inserted on its throat. Ovary 4-celled; two cells containing a few sterile ovules: alternate cells containing a single suspended ovule. Fruit a globose berry-like drupe, containing 2 small and seed-like bony smooth nutlets, each filled by $a$ seed; sterile cells soon obliterated.

7. LONICERA. Calyx with ovoid or globular tube and a short 5-toothed or truncate limb. Corolla from campanulate to tubular, more or less gibbous at base; the limb irregular and commonly bilabiate $\left(\begin{array}{l}4 \\ 1\end{array}\right)$, sometimes almost regular. Stamens 5, inserted on the tube of the corolla. Ovary 2-3-celled, with several pendulous ovules in each cell, becoming a fewseveral-seeded berry.

8. DIERVILLA. Calyx with slender elongated tube, and 5 narrow persistent or tardily deciduous lobes. Corolla funnelform (or in large-flowered Japanese species more campanulate), inconspicuously gibbous at base; a globular epigynous gland within occupying the gibbosity; limb somewhat nnequally or regularly 5-lobed. Stamens 5, inserted on the tube or throat of the corolla: anthers linear. Ovary 2-celled. Fruit a narrow capsule, with attenuate or rostrate summit, septicidally 2-valved, many-seeded.

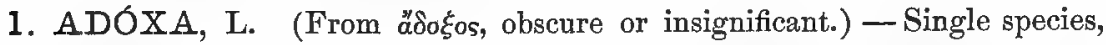
an insignificant small herb, of obscure affinity, now referred to the present order.

A. Moschatéllina, L. (Moscratel.) Glabrous and smooth: stem and once to thrice ternately compound radical leaves a span high from a small fleshy-scaly rootstock: cauline pair of leaves 3-parted or of 3 obovate and 3-cleft or parted leaflets : flowers small, greenishwhite or yellowish, 4 or 5 in a slender-pedunculate glomerule: corolla of the terminal one 4-5-cleft, of the others 5-6-cleft: drupe merely succulent: odor of plant musky. - Lam. Ill. t. 320 ; Gærtn. Fruct. t. 112 ; Schk. Handb. t. 109 ; Torr. \& Gray, Fl. i. 649. - Subalpine, under rocks, Arctic America to N. Iowa, Wisconsin, and the Rocky Mountains to Colorado. (Eu., N. Asia, \&c.)

2. SAMBÚCUS, Tourn. Elder. (Classical Latin name, said by some to come from $\sigma \alpha \mu \beta v v^{\prime}$, a stringed musical instrument.) - Suffrutescent to arborescent (in both Old and New World) ; with large pith to the vigorous shoots, imparipinnate leaves, serrate leaflets, small flowers (usually white and odorous) in broad cymes, and red or black berry-like fruits. Stems with warty bark. Stipule-like appendages hardly any in our species; but stipels not rare. Flowers occasionally polygamous, produced in summer.

* Compound cymes thyrsoid-paniculate; the axis continued and sending off 3 or 4 pairs of lateral primary branches, these mostly trifid and again bifid or trifid: pith of year-old shoots deep yellow-brown: no obvious stipule-like nor stipel-like appendages to the leaves : early flowering and fruiting.

S. racemósa, L. Stems 2 to 12 feet high, sometimes forming arborescent trunks : branches spreading: leaves from pubescent to nearly glabrous: leaflets 5 to 7 , ovate-oblong to ovatelanceolate, acuminate, thickly and sharply serrate: thyrsiform cyme ovate or oblong: flowers dull white, drying brownish: fruit scarlet (has been seen white), oily : nutlets minutely punctate-rugulose.-Spec. i. 270; Jacq. Ic. Rar. i. t. 59 ; Hook. Fl. i. 279; Gray, Bot. Calif. i. 278. S. pubens, Michx. Fl. i. 181 ; DC. Prodr. iv. 323 ; Torr. \& Gray, Fl. ii. 13 ; Meehan, Nat. Flowers, ser. 2, ii. t. 21, flowers wrongly colored. S. pubescens, Pers. Syn. i. 328 ; Pursh, Fl. i. 204. - Rocky banks and open woods, Nova Scotia to the mountains of Georgia, in cool districts, west to Brit. Columbia and Alaska, and the Sierra Nevada, California. (Eu., N. Asia.)

Var. arboréscens, TorR. \& GRAT, 1. c. A form with leaflets closely serrate with strong Ianceolate teeth. - Washington Terr. to Sitka.

Var. laciniáta, KocH, with leaflets divided into 3 to 5 linear-lanceolate 2-3-cleft or laciniate segments, occurs on south shore of L. Superior, Austin.

S. melanocárpa, Gray. Glabrous, or young leaves slightly pubescent: leaflets 5 to 7 , rarely 9: cyme convex, as broad as high: flowers white: fruit black, without bloom: otherwise much like preceding.-Proc. Am. Acad. xix. 76. - Ravines of the Rocky Mountains of Montana (Watson) to those of E. Oregon (Cusick), south to the Wahsatch (Watson), 
New Mexico (Fendler), and the Sierra Nevada, California (Brewer, Bolander) : a plant with foliage not unlike that of $S$. Canadensis.

* * Compound cymes depressed, 5-rayed ; four external rays once to thrice 5-rayed, but the rays unequal, the two outer ones stronger, or in ultimate divisions reduced to these; central rays smaller and at length reduced to 3-flowered cymelets or to single flowers: pith of year-old shoots bright white: "berries" sweet, never red: nutlets punctate-rugulose.

S. Canadénsis, L. Suffrutescent or woody stems rarely persisting to third or fourth year, 5 to 10 feet high, glabrous, except some fine pubescence on midrib and veins of leaves beneath : leaflets ( 5 to 11 ) mostly 7 , ovate-oval to oblong-lanceolate, acuminate, the lower not rarely bifid or with a lateral lobe: stipels not uncommon, narrowly linear, and tipped with a callous gland : fruit dark-purple, becoming black, with very little bloom. - Spec. i. 269 ; Michx. Fl.i. 281 ; Torr. \& Gray, Fl. ii. 13. S. nigra, Marsh. Arbust. 141. S. humilis, Raf. Ann. Nat. 13. S. glauca, Gray, Pl. Wright. ii. 66 (not Nutt.), narrow-leaved form; Bot. Mex. Bound. 71. - Moist grounds, New Brunswick to the Saskatchewan, south to Florida, Texas, west to the mountains of Colorado, Utah, and Arizona; fl. neur midsummer. Nearly related to S. nigra of Eu.

Var. laciniáta. Leaflets or most of them once or twice ternately parted into lanceolate divisions. - Indian River, Florida, Palmer. A still more dissected form, in waste places, Egg Harbor, Mrs. Treat, may be S. nigra, var. laciniata, of the Old World.

S. glaúca, Nutr. Arborescent, 6 to 18 feet high; the larger forming trunks of 6 to 12 inches in diameter, glabrous throughout: leaflets 5 to 9 , thickish, ovate to narrowly oblong; lower ones rarely 3-parted: stipels rare and small, subulate or oblong: fruit blackish, but strongly whitened with a glaucous mealy bloom, larger than in S. Canadensis. - Nutt. in Torr. \& Gray, Fl. ii. 13; Wats. Bot. King Exp. 134; Gray, Bot. Calif. i. 278, in part. Oregon and throughout California, common near the coast, eastward to Idaho and Nevada.

S. Mexicána, Prest. Arborescent, with trunks sometimes 6 inches in diameter : leaves and young shoots pubescent (sometimes slightly so, sometimes cinereous or tomentulosecanescent) : leaflets, \&c., nearly as preceding: fruit (as far as seen) destitute of bloom. Presl. in DC. Prodr. iv. 323 ; Gray, Pl. Wright. ii. 66, \& Bot. Mex. Bound. 71 . S. glauca, Benth. Pl. Hartw. 313 ; Gray, Bot. Calif. 1. c. in part. S. velutina, Durand in Pacif. R. Rep. r. 8. - California, from Plumas Co. southward to mountains of Arizona, and New Mexico on the Mexican border. Glabrate forms too near S. Canadensis. (Mex.)

3. VIBUtRNUM, L. (Classical Latin name of the Wayfaring-Tree, $V$. Lantana, of Europe.) - Shrubs or small trees (of various parts of the world); with tough and flexible branches, simple and not rarely stipulate or pseurlo-stipulate leaves, and terminal depressed cymes of mostly white flowers, produced in spring or early summer. - Viburnum and Opulus, Tourn.

V. Tinus, L. (Tinus, Tourn., Erst.), the LAURestrxus, cultivated from Europe, with putamen not flattened and ruminated albumen, is left out of view in our character of the genus, as also the outlying forms with campanulate or more tubular corolla, upon which Girsted (in. Vidensk. Meddel. 1860) has founded genera, with more or less reason. The albumen in the N. American species is even, or obscurely ruminated in the first species.

$\S 1$. Cyme radiant; marginal flowers neutral, with greatly enlarged flat corollas as in Hydrangea: drupes coral-red turning dark crimson or purple, not acid : putamen sulcate: leaves pinnately straight-veined, scurfy: winter-buds naked.

V. lantanoídes, Michx. (HоввLebesir.) Low and straggling, with thickish branches, sometimes 10 feet high, scurfy-pubescent on the shoots and inforescence: leares ample (when full grown 6 inches long), conspicuously petioled, rounded-ovate, abruptly acuminate, finely doubly serrate, membranaceous, minutely stellular-pubescent and glabrate above, rusty-scurfy beneath on the 10 or 12 pairs of prominent veins, and when young also on the very numerous transverse connecting veinlets: stipules small and subulate, or obsolete: fruit ovoid, flattish; the stone moderately flattened, 3-sulcate on one face, broadly and deeply sulcate on the other, and the groove divided by a strong median ridge, the edges also 
slightly sulcate : seed reniform in cross section and somewhat lobed; the albumen not ruminated. - Fl. i. 179; Torr. \& Gray, Fl. i. 18; Audubon, Birds Amer. i. t. 148. V. alnifolium, Marsh. Arbust. 162. V. Lantana, var. grandiflorum, Ait. Kew. i. 372. V. grandifolium, Smith in Rees Cycl. - Moist woods, New Brunswick and Canada to N. Carolina in the higher mountains; fl. spring. (Japan?)

$\S 2$. Cyme radiant, or not so: drupes light red, acid, edible, globose: putamen very flat, orbicular, even (not sulcate nor intruded or costate): leaves palmately veined: winter-buds scaly. - Opulus, Tourn.

V. Opulus, L. (High Cranberry, Cranberry-Tree.) Nearly glabrous, occasionally pubescent, 4 to 10 feet high: leaves dilated, three-lobed, roundish or broadly cuneate at 3 -ribbed or pedately 5-ribbed base; the lobes acuminate, incisely dentate or in upper leaves entire: slender petioles bearing 2 or more glands at or near summit, and usually setaceous stipules near base: cymes rather ample, terminating several-leaved branches, radiant. Spec. i. 268 ; Ait. Kew. i. 373 (var. Americanum) ; Michx. Fl. i. 180 (vars.); Torr. \& Gray, 1. c. V. trilobum, Marsh. Arbust. 162. V. opuloides, Muhl. Cat. V. Oxycoccus \& V. edule, Pursh, Fl. i. 203. - Swamps and along streams, New Brunswick to Saskatchewan, Brit. Columbia and Oregon, and in Atlantic States south to Pennsylvania. Variable in foliage; no constant difference from the European, which is cultivated, in a form with most flowers neutral, as Sxowball and Guelder Rose. (Eu., N. Asia.)

V. pauciflórum, Pycaie. Glabrous or with pubescence, 2 to 5 feet high, straggling: leaves of roundish or broadly oval outline, unequally dentate, many of them either obsoletely or distinctly 3-lobed (the lobes not longer than broad), about 5-nerved at base, loosely veiny : cymes small, terminating short and merely 2-leaved lateral branches, involucrate with slender subulate caducous bracts, destitute of neutral radiant flowers: stamens very short: fruit nearly of preceding. - Pylaie, Herb.; Torr. \& Gray, Fl. ii. 17; Herder, Pl. Radd. iii. t. 1, f. 3. V. acerifolium, Bong. Veg. Sitka, 144. - Cold moist woods, Newfoundland and Labrador, mountains of New England to Saskatchewan, west to Alaska and Washington Terr, southward in the Rocky Mountains to Colorado.

$\S 3$. Cyme never radiant: drupes blue, or dark-purple or black at maturity.

* Leaves palmately 3-5-ribbed or nerred from the base, slender-petiolate: stipules subulate-setaceous: pubescence simple, no scurf: primary rays of pedunculate cyme 5 to 7 : filaments equalling the corolla.

+ Pacific species: drupe oblong-oval, nearly half-inch long, bluish-black.

V. ellípticum, Ноок. Stems 2 to 5 feet high: winter-buds scaly: leaves from orbicularoval to elliptical-oblong, rounded at both ends, dentate above the middle, not lobed, at length rather coriaceous, 3-5-nerved from the base, the nerves ascending or parallel : corollas 4 or 5 lines in diameter: stone of fruit deeply and broadly sulcate on both faces; the furrow of one face divided by a median ridge. - Hook. Fl. i. 280; Gray, Bot. Calif. i. 278. - Woods of W. Washington Terr. and Oregon (first coll. by Douglas), to Mendocino and to Placer Co., California, Kellogg, Mrs. Ames.

+ + Atlantic species: drupe globular, quarter-inch long, bluish-purple or black when ripe: cyme mostly with a caducous involucre of 5 or 6 small and subulate or linear thin bracts.

V. acerifólium, L. (ARrow-wood, DockMAckis.) Soft-pubescent, or glabrate with age, 3 to 6 feet high, with slender branches: winter-buds imperfectly scaly: leaves membranaceous, rounded-ovate, 3-ribbed from the rounded or subcordate base, and with 3 short and acute or acuminate divergent lobes (or some uppermost uцdivided), usually dentate to near the base (larger 4 or 5 inches long): cymes rather small and open : corolla 2 or 3 lines in diameter: stone of drupe lenticular, hardly sulcate on either side. - Spec. i. 268 ; Vent. Hort. Cels. t. 72 ; Michx. Fl. i. 180; Wats. Dendr. Brit. ii. t. 118 (poor); Hook. Fl. i. 280 (partly); Torr. \& Gray, 1. c. 17; Emerson, Trees of Mass. ii. t. 19. - Rocky and cool woods, New Brunswick to Michigan, Indiana, and N. Carolina.

V. densiflórum, Chapr. Lower, 2 to 4 feet high: leaves smaller (inch or two long), with mostly shorter lobes or sometimes none: cyme denser: involucrate bracts more conspicuous and less caducous: stone of the drupe undulately somewhat 2-sulcate on one face and 3-sulcate on the other. - Fl. ed. 2, Suppl. 624. - Wooded hills, W. Florida, Chapman. Also, Taylor Co., Georgia, Neisler, a glabrate form. Too near V. acerifolium. 
* Lesres pinnately and conspicuously veiny with straight reins (impressed-plicate above, prominent beneath and the lowest pair basal), thimnish, coarsely dentate: stipules subulate-setaceous: cynes peilunculate, about 7-rayed: stone of the drupe more or less sulc atc. Alirow-wood.

+ Stone and seed flat, slightly plano-convex: leaves all short-petioled or subsessile.

V. pubéscens, Pr rsix. Sleuder, $\underline{\text { to }} 5$ feet high : leaves oblong-or more broadly ovate, acute or acnminate, acutely dentate-serrate ( $1 \frac{1}{2}$ to 3 inches long, on petioles 2 to 4 lines long, or upper hardly any), soft-tomentulose with simple downy hairs beneath, but varying to slightly pubescent (and in one form almost glabrous with upper face lucidulous): peduncle generally shorter than the cyme: drupe oral, + lines long, blackisli-purple, flattened when young; stone lightly 2-sulcate on the faces, margins narrowly incurved, no intrusion on ventral face. - Fl. i. 202 (excl. habitat, aud syn. Michx.); Torr. Fl. i. 320; DC. Prodr. iv. 326; Hook. Fl. i. 280 ; Torr. \& Gray, Fl. ii. 16; Gray, Man. ed. 5, 206; GErst. 1. c. t. 7 , fig. 21, 22. I. dentatum, rar. pubescens, Ait. INew. 1. 372? T. dentatum, var. semitomentosum, Michx. Fl. i. 179, in small part (spec. from L. Champlain). V. villosum, Raf. in Med. Rep. 1 sos, \& Desr. Jour. Bot. i. 22s, not Swartz. T. Rafinesfuiumum, Rœm. \& Sichult. Sirst. v. 630. - Rocky ground, Lower Canada to Saskatchewan, west to Illinois, south to Stone Mountain, Georgia. (Not, as Pursh would have it, in the lower parts of Carolina.)

+ + Stone deeply sulcate-intruded rentrally: transverse section of seed about three-fourths annular, with flattish back: leaves rather slender-petioled.

V. dentátum, L. shrub 5 to 15 feet high, with ascending branches, glabrons or nearly so, no stellular pubescence: leaves from orbicular- to oblong-ovate, with rounded or subcordate bise, acutely many-dentate ( 2 or 3 iuches long); primary veius 8 to 10 pairs (some of them once or twice forked), often a tuft of hairs in their axil : peduncle generally longer than the cyme: drupe ovoid, three lines long, terete, bright blue, darker at maturity. Śpec. i. 268 ; Jacq. Hort. Vind, i. t. 36 ; Torr. 1. c.; Wats. Dendr. Brit. t. 25 ; Torr. \& Gray, 1. c., excl. var.; Gray, Man. 1. c. $V$. dentatum, var. luridum, Ait. INew. l. c. - Wet ground, chiefly in swamps, New Brunswick to Michigan, and south to the mountains of Georgia. Seems to pass into following, but the extremes widely different.

V. mólle, Mrchx. Young shoots, petioles, cymes, \&c. beset with stellular pubescence: leares orbicular or broadly oval to ovate, more crenately dentate, soft-pubescent at least beneath (larger 4 inches long); veins of the preceding or fewer: petioles shorter: drupe 4 lines long, more pointed by the style: calyx-teeth more conspicuous. - Fl. i. 180, but foliage only seen; Gray, Man. ed. $3 \&$ ed. 5, 206. V. dentatum, var. semitomentosum, Michx. 1. c. in large part; Ell. Sk. i. 365. V. dentatum, rar. ? scabrellum, Torr. \& Gray, Fl. ii. 16. V. scrbrellum, Chapm. Fl. i. 72. - Coast of New England (Martha's Vineyard, Bessey) to Texas : flowers at the north in summer, later than $V$. dentatum.

* * Leares lightly or loosely pinnately veined, of firmer or somewbat coriaceous texture, petioled, mostly glabrous: stipales or stipule-like appendages none: mature drupes black or with a blue bloom, mealy and saccharine; the stone and seed flat or lenticular, plane: winterbuds of few and firm scales: petioles and rays of the cyme mostly lepidote with some minute rusty scales or scurf.

+ Crmes peduncled, about 5-rayed: drupes globose-ovoid, 3 lines long: stone orbicular, flattenedlenticular: shrubs 5 to 8 or 12 feet bigh, in swamps.

V. cassinoídes, L. (WIтHE-RoD.) Shoots scurfy-punctate: leares thickish and opaque or dall, orate to oblong, mostly with ol,tuse acumination, obscurely veiny ( 1 to 3 inches long), with margins irregularly crenulate-denticulate or sometimes entire: peduncle shorter than the cyme. - Spec. ed. 2, if. 384 (pl. Kalm), excl. syn., at least of Mill. \& Pluk.; Torr. Fl. i. 318 ; DC. 1. c. V. squamatum, Willd. Enum. i. 327 ; Wats. Dendr. Brit. t. 24. V. pyrifolium, Pursh, Fl. j. 201, not Poir. V. nudum, Hook. Fl. i. 279; Emerson, Trees of Mass. ed. 2, 411 , t. 18. V. nudum, var. cassinoides, Torr. \& Gray, Fl. ii. 14; Gray, Man. 1. c. - Swamps, Newfoundland to Saskatchewan, New England to New Jersey and Pennsylvania: flowers earlier than the next.

V. núdum, L. Obscurely scurfy-punctate: leaves more veiny, oblong or oval, sometimes narrower, entire or obsoletely denticulate, lucid above (commonly 2 to 4 inches long): peduncle usually equalling the cyme. - Spec. i. 268 (pl. Clayt.); Mill. Ic. t. 274 ; Willd. Spec. i. 1487 ; Michx. Fl. i. 178; Sims, Bot. Mag. t. 2281 ; Torr. \& Gray, l. c., var. Claytoni. - Swamps, New Jersey or S. New York to Florida and Louisiana: fl. summer, or southward in spring. 
Var. angustifólium, Torr. \& GRA r, 1. c. Leaves linear-oblong or oblong-lanceolate. -V. nitidum, Ait. Kew. i. 371, ex. char. - N. Carolina to Louisiana.

Var. grandifólium. Larger leaves 8 inches long, 4 wide. - E. Florida, Mrs. Treat.

Var. serótinum, Ravenel, in Chapm. Fl. Suppl. 624. A strict or more simplestemmed form, with foliage of the type, and smaller blossoms, produced in November!On the Altamaha River, near Darien, Georgia, Ravenel.

+ + Compound cymes sessile, of 3 to 5 cymiferous rays, subtended by the upper leaves,

4- Many-flowered: trees or arborescent, 10 to 30 feet high: winter-buds minutely rusty-scurfy or downy, ovoid and acuminate: leaves ovate or oval, lueid, closely and acutely serrate, abruptly rather long-petioled: drupes comparatively large, oval, 5 to 7 lines long, when ripe sweetish and black or bluish from the bloom, with very flat stone. - BLack HAW, SHEEP-BERRY, Swete Viburnum.

V. Lentágo, L. Often arboreous: leaves ovate, acuminate (larger 3 or 4 inches long), thickly beset with very sharp serratures : petioles mostly undnlate-margined : larger winterbuds long-pointed, grayish. - Spec. i. 268; Michx. 1. c.; Wats. Dendr. Brit. t. 21 ; Hook. 1. c.; Torr. \& Gray, 1. c. 15. - Woods and banks of streauns, Canada to Saskatchewan, Missouri, and mountains of Georgia; fl. spring.

V. prunifólium, L. Seldom arboreous : leaves from roundish to ovate or oval with little or no acumination and finer serratures (larger ones 2 or 3 inches long) : petioles naked, or on strong shoots narrowly margined, these and the less pointed winter-buds often rufouspubescent. - Spec. i. 268 (Mespilus prunifolia, \&c., Pluk. Alm. t. 4, f. 2); Michx. 1. c.; Duham. Arb. ii. t. 38 (Wats. Dendr. Brit. t. 23?) ; Torr. \& Gray, l. c. V. pyrifolium, Poir. Dict. viii. 653; Wats. Dendr. Brit. t. 22.-Dry or moist ground, New York (and Upper Canada?) to Michigan, Illinois, and south to Florida, Texas, and Kansas: flowering early.

++ Cymes (3-4-rayed) and the lucid coriaceous commonly entire leaves small.

V. obovátum, WALT. Shrub 2 to 8 feet high: leaves from obovate to cuneate-spatulate or oblanceolate, obtuse or retuse, with some obsolete teeth or none (half-inch to thrice that length), narrowed at base into very short petiole: flowering cymes little surpassing the leaves: drupes oval, 5 lines long, black; stone thickish-lenticular, the faces obscurely sulcate. - Walt. Car. 116 ; Pursh, Fl. i. 201 ; Ell. Sk. i. 366 ; Lodd. Bot. Cab. t 1476 ; DC. Prodr. iv. 326. V. cassinoides (Mill. Ic. t. 83?); Willd. Spec. i. 1491; Michx. Fl. i. 179, not L. V. levigatum, Ait. Kew. i. 371 ; Pursh, 1. c. ; DC. l. c. - Wooded banks of streams and swamps, Virginia to Florida in the low country.

4. Triósteum, L. Feverwort, Horse-Gentian. (Name shortened by Linnæus from Triosteospermum, Dill., meaning three bony seeds or stones to the fruit.) - Coarse perennial herbs (of Atlantic N. America, one Japanese and one IIimalayan); with simple stems, ample entire or sinuate leaves more or less connate at base, and pinnately veiny; the dull-colored sessile flowers in their axils, either single or 2 to 4 in a cluster, produced in early summer, followed by orange-colored and reddish drupes. In our species the foliaceous linear calyx-lobes are as long as the corolla (about half-inch), and longer than the fruit. - Lam. Ill. t. 150 ; Gærtn. Fruct. t. 26. Triosteospermum, Dill. Elth. 394 , t. 293.

T. perfoliátum, L. Minutely soft-pubescent, or stem sometimes hirsute, stout, 2 to 4 feet high : leaves ovate to oblong, acuminate, narrowed below either to merely connate or more broadened and connate-perfoliate base: corolla dull brownish-purple : nutlets of the drupe 3.ribbed on the back. - Spec. i. 176 ; Schk. Handb. t. 41 ; Bigel. Med. Bot. i. 90, t. 19 ; Bart. Veg. Mat. Med. t. 4 ; Sweet, Brit. Fl. Gard. ser. 2, t. 45 ; Torr. \& Gray, Fl. ii. 12. T. majus, Michx. Fl. i. 107. - Alluvial or rich soil, Canada and New England to Illinois and Alabama. - Also called Tinker's-Weed, Wild Coffee, \&c.

T. angustifólium, L. 1. c. Smaller: stem hirsute or hispid: leaves oblong-lanceolate or narrower, tapering above the more or less connate bases: corolla yellowish. - Torr. \& Gray, 1. c. T. minus, Michx. l. c. Periclymenum herbaceum, \&c., Pluk. Alm. t. 104, f. 2. - Shady grounds, Virginia to Alabama, Missouri, and Illinois. 
5. LINN ÆA, Gronov. Twin-rówer. (Dedicated to Linnœus.) - Gronov, in L. Gen. ed. i. 188. - Single species; fl. carly summer.

L. boreális, Groxov. Trailing and creeping evergreen, with filiform branches, somewhat pubescent: leaves obovate and rotund, half-inch to inch long, crenately few-toothed, somewhat rugose-veiny, tapering into a short petiole: peduncles filiform, terminating ascending short leafy branches, bearing at summit a pair of small bracts, and from axil of cach a filiform one-flowered pedicel, occasionally the axis prolonged and bearing another pair of flowers; pedicels similarly - 2-bracteolate at summit, and a pair of larger ovate glandularhairy inner bractlets subtending the orary, soon connivent over it or enclosing and eren adnate to the akene-like fruit: flowers nodding: corolla purplish rose-color, rarely alnnost white, sweet-scented, half-inch or less long. - L. Fl. Lapp. t. 12, f. 4, \& Spec. ii. 631; Wahl. Fl. Lapp. 1; l, t. 9, f. 3; Fl. Dan. t. 3 ; Schk. Handb. t. 176; Lam. Ll. t. 536; Torr. \& Gray, Fl. ii. 3. - Cool woods and bogs, New England to New Jersey and mountains of Maryland, north to Xerffundland and the Arctic Circle, westward in the Rucky Mountains to Colorado and Ltah, the Sierra Nerada in Plumas Co., California, and northwest to Alaskan Islands; in Oregon, \&c. Var. Long IFLorA, Torr. in Wilkes S. Pacif. E. Ex. xvii. 327 , with longer and more funnelform corolla. (N. Eu., N. Asia, \&..)

\section{SYMPHORICÁRPOS, Dill. Snowberry, Ixdian Currant,} ( $\Sigma$ $\nu \phi о \rho \epsilon ́ \omega$, to bear together, карлós, fruit, the berry-like fruits mostly clustered or crowded.) - Low and branching shrubs (N. American and Mexican), erect or diffuse, not climbing; with small and entire (occasionally undulate or lobed, very rarely serrate) and short-petioled leaves, scaly leaf-buds, and z-bracteolate small flowers, usually crowded in axillary or terminal spikes or clusters, rarely solitary, produced in summer; the corolla white or pinkish. - Dill., Elth. 371, t. 278; Juss. Gren. 211 ; DC. Prodr. iv. 338; Benth. \& Ilook. Gen. ii. 4; Gray, Jour. Linn. Soc. xiv. 9. Symphoria, Pers. Syn. i. 214. long.

$\S 1$. Short-flowered: corolla urceolate- or open-campanulate, only 2 or 3 lines

* Style hearded: fruit red: flowers all in dense and short axillary elusters: corolla 2 lines long, glandular within at base.

S. vulgáris, Michx. (Coral-Berry, Ixdiax Currant.) Soft-pubescent or glabrate: branches slender, often virgate, flowering from most of the axils: leaves oval, seldom over inch long, exceeding the ( 1 to 4 ) glomerate or at length spiciform dense flower-clusters in their axils: corolla sparingly bearded inside : fruits very small, dark red. - Fl. i. 106; DC. Prodr. iv. 339 ; Torr. \& Gray, Fl. ii. 4 ; Gray in Jour. Linn. Soc. l. c. I0. Symphoricarpos, Dill, 1. c. S. parififora, Desf. Cat., \&c. Lonicera Symphoricarpos, L. Spec. i. 175. Symphoria conglomerata, Pers. 1. c. S' glomerata, Pursh, Fl. i. 162. - Banks of streams and among rocks, W. New York and Penn. to llinois, Nebraska, and Texas.

Var. spicátus (S. spicatus, Engelm. in Pl. Lindh. ii. 215) is a form with fructiferous spikes more elongated, sometimes equalling the leares. - Texas, Lindhermer.

* * Style glabrous: fruit white, in terminal and upper axillary clusters, or solitary in some axils.

S. occidentális, Hook. (WoLf-BERRY.) Robust, glabrous, or slightly pubescent: leaves oval or oblong, thickish (larger 2 inches long) : axillary flower-clusters not rarely pedunculate, sometimes becoming spicate and inch long: corolla 3 lines high, 5 -cleft to beyond the middle, within densely villous-hirsute with long beard-like hairs: stamens and style more or less exserted. - Fl. i. 285; Torr. \& Gray in Fl. ii. 4 Gray in Jour. Linn. Soc. 1. c. Symphoria occidentalis, R. Br. in Richards. App. Frankl. Jour. - Rocky ground, Michigan to the mountains of Colorado, Montana (and Oregon?), north to lat. $64^{\circ}$.

S. racemósus, Mrchx. (Svow-Berrx.) More slender and glabrous: leaves round-oval to oblong (smaller than in the preceding): axillary clusters mostly few-flowered, or lowest one-flowered: corolla 2 lines high, 5-lobed above the middle, moderately villous-bearded within, narrowed at base : stamens and style not exserted. - Fl. i. 107; Hook. 1. c.; 'Torr. \& Gray, 1. c.; Gray, 1. c. Symphoria racemosa, Pers. 1. «; Pursh, Fl, i. 169; R. Br. Bot. 
Mag. t. 2211 ; Lodd. Bot. Cab. t. 230 ; Bart. FI. Am. Sept. i. t. 19. S. elongata and S. heterophylla, Presl, ex DC. - Rocky banks, Canada and N. New England to Penn., Saskatchewan, and west to Brit. Columbia and W. California, even to San Diego Co.

Var. pauciflórus, Robisss. Low, more spreading: leaves commonly only inch long: flowers solitary in the axils of upper ones, few and loosely spicate in the terminal cluster. - Gray, Man. \& in Jour. Linn. Soc. 1. c. - Mountains of Vermont and Penn., Niagara Falls to Wisconsin and nortliward, in Rocky Mountains south to Colorado, west to Oregon.

S. móllis, Nutr. Low, diffuse or decumbent, soft-pubescent, even velvety-tomentose, sometimes glabrate: leaves orbicular or broadly oval (half to full inch long) : flowers solitary or in short clusters: corolla open-campanulate and with broad base (little over line high), 5-lobed above the middle, barely pubescent within: stamens and style included. - Torr. \& Gray, Fl. 1. c.; Gray, 1. c. \& Bot. Calif. i. 279. S. ciliatus, Nutt. in Torr. \& Gray, 1. c., a glabrate form, from the char. - Wooded hills, California, both in the Coast Ranges and the Sierra Nevada, first coll by Coulter and Nuttall.

Var. acútus. Not improbably a distinct species, but materials incomplete: leaves very soft-tomentulose, oblong-lanceolate to oblong, acute at both ends or acuminate, sometimes irregularly and acutely dentate. - S. mollss? Torr. in Wilkes Pacif. E. Ex. xvii. 328. Washington Terr. east of the Cascade Mountains, Pickering \& Brackenridge, with the narrower and entire leares. Lassen's Peak, N. I. California, Mrs. Austin, with broader leaves, commonly having 3 or 4 unequal serratures on each margin.

§ 2. Longer-flowered: corolla from oblong-campanulate to salverform, 5-lobed only at summit: fruit (in the Mexican S. microphyllus flesh color, ex Bot. Mag. t. 4975) in ours white: flowers mostly axillary: leaves small.

* Style glabrous: corolla with broad and short lobes slightly or merely spreading.

S. rotundifólius, Grax. Tomentulose to glabrate: leaves from orbicular to oblongelliptical, thickish (half to three-fourths inch long) : corolla elongated-campanulate, 3 or 4 lines long; its tube pubescent within below the stamens, twice or thrice the length of the lobes: nutlets of the drupe oval, equally broad and obtuse at both ends. - P1. Wright. ii. 66, Jour. Linn. Soc. 1. c., \& Bot. Calif. i. 279. S. montanus, Wats. Bot. King Exp. 132, partly. - Mountains of New Mexico and adjacent Texas to those of Utah, N. W. Nevada, adjacent California, and north to Mt. Paddo, Washington Terr., Suksdorf: first coll. by Wright and Bigelow.

S. oreóphilus, GRAY. Glabrous or sometimes with soft pubescence: leaves oblong to broadly oval, thinner: corolla more tubular or funnelform, 5 or 6 (rarely only 4) lines long; its tube almost glabrous within, 4 or 5 times the length of the lobes: nutlets of the drupe oblong, flattened, attenuate and pointed at base. - Jour. Linn. Soc. 1. c. 12, \& Bot. Calif. 1. c. S. montanus, Gray in Am. Jour. Sei. xxxiv. 249, not HBK. - Mountains of Colorado, Utah, and Arizona, to the Sierra Nevada, California, and E. Oregon; first coll. by Parry.

* Style bearded: corolla with oblong widely spreading lobes.

S. longiflórus, Grax, 1. c. Glabrous or rarely minutely pubescent, glaucescent : leaves spatulate-oblong varying to oval, thickish, small (quarter to half inch long): corolla white, salverform, slender; the tube 4 to 6 and lobes one and a half lines long, very glabrous within : anthers linear, subsessile, half included in the throat: nutlets of the fruit oblong. Mountains of S. Nevada and Utah, Miss Searls, Parry, Ward, Palmer, \&c. Apparently also S. W. Texas, Havard.

7. LONICERA, L. Honeysuckle, Woodbine. (Adam Lonitzer, Latinized Lonicerus, a German herbalist.) - Shrubs of the northern hemisphere, some erect, others twining; with normally entire leaves, occasionally on some shoots sinuate-pinnatifid; the flowers variously disposed, produced in spring or early summer.

§1. XrLósteon, DC. Flowers in pairs (rarely threes) from the axils of the leaves, the common peduncle bibracteate at summit, the ovaries of the two either 
distinct or connate: ours (the genuine species of the section) all erect and branching shrubs, with rather short corollas; the calyx-limb minute or obsolete. - Xylosteon, Tourn., Juss. Xylosteum, Adans., Michx., \&c.

* Bracts at the sumnit of the peduncle small or narrow, often minute, sometimes obsolete or caducous: bractlets to the two flowers minute or none.

+ Leaves glaucescent or pale both sides, oblong-elliptical, very short-petioled, reticulate-venulose beneath: corolla ochroleucous, sometimes purplish-tinged, 4 to 6 lines long.

L. cærúlea, L. A foot or two high, from villous-pubescent to glabrous or nearly so: leaves little over inch long, very obtuse: peduncles shorter than the flowers, usually very short: corolla moderately gibbous at base, not strongly bilabiate (sometimes glabrous, sometimes hairy): bracts subulate or linear, commonly larger than the ovaries; these completely united, forming a globular 2-eyed (black and with the bloom blue) sweet-tasted berry. - Spec. i. 174 ; Pall. Fl. Ross. t. 37 ; Sims, Bot. Mag. $t$ 1965; Jacq. Fl. Austr. v. Suppl. t. 17 ; Hook. Fl. i. 283; Torr. \& Gray, Fl. ii. 9; Herder, Pl. Radd. iii. 15, t. 3. L. villosa (Mubl. Cat.) \& L. velutina, DC. Prodr. iv. 337, excl. syn. in part. Xylosteum villosum, Michx. Fl. i. 106 (the very villous or hirsute form, $L$. carulea, var. villosa, Torr. \& Gray, 1. c.) ; Bigel. Fl. Bost. ed. 2, 88; Richards. App. Frankl. Jour. X. Solonis, Eaton, Man. Bot. 518. - Moist ground, Newfoundland and Labrador, south to the cooler parts of New England, Wisconsin, sc., north to the Arctic Circle, west to Alaska, and sonth in the higher nountains to the Sierra Nevada, California. The American and E. Asian forms somewhat different from the European. (Eu., N. Asia.)

L. oblongifólia, Hook. A yard or more high, minutely puberulent to glabrous, glaucescent: leaves 1 to 3 inches long: peduncles filiform, commonly inch long: corolla with conspicuous gibbosity at base, deeply bilabiate, the narrow lower lip separate far below the middle: bracts minute or caducous: ovaries either distinct, or united at base, or completely connate (even on the same plant): berries red or changing to crimson, mawkish. -Fl. i. 284, t. 100 ; Torr. \& Gray, 1. c. L. villosa, DC. 1. c. in part. Xylosteum oblongifolium, Goldie in Edinb. Phil. Jour, vi. 323. - Bogs, Canada and N. New England and New Iork to Michigan.

++ Leares bright green, thinnish, ovate or oblong: peduncles slender: berries red: shrubs with slender spreading or straggling branches.

+ Corolla dark dull purple, strongly bilabiate: calyx-teeth subulate: bracts subulate, caducous.

I. conjugiális, Kenlogg. Leaves pubescent when young, ovate or oval, often acuminate, short-petioled ( 1 to 21 inches long): peduncles at least thrice the length of the flowers: corolla 4 or 5 lines long, gibbous-campanulate, with upper lip crenately 4-lobed; throat with lower part of filaments and style very hirsute: ovaries two-thirds or wholly connate. - Proc. Calif. Acad. ii. 67, fig. 15; Wats. Bot. King Exp. 133. L. Breweri, Gray, Proc. Am. Acad. vi. 537, vii. 349. - Woods of the Sierra Nevada, California and adjacent Nevada, at 6,000-10,000 feet, first coll. by Veatch. Also mountains of Washington Terr., Howell, Suksdorf.

+ ++ Cornlla honey-yellow or ochroleucous, rarely a slight tinge of purple, oblong-funnelform, two-thirds to three-fourths inch long, with 5 short almost equal lobes; the tube with a small but prominent saccate gibbosity at base, merely pilose-pubescent within: calyx-limb barely crenate-lobed or truncate: divergent ovaries and mostly the berries quite distinct, subtended by very small subulate bracts, and each with minute rounded bractlets.

L. Utahénsis, WATs. Leaves oval or elliptical-oblong, ronnded at both ends, very shortpetioled, glabrous or nearly so from the first, or soon glabrate, not ciliate, reticulate-venulose at maturity (inch or two long): peduncle seldom over half-inch long. - Bot. King Exp. 133. - Mountains of Utah, Watson, Parry, Siler. Montana, and Cascades from Oregon to Brit. Columbia.

L. ciliáta, Mchl. (Fux-Honeysuckne) Leaves ovate to oval-oblong, acutish or somewhat acuminate, loosely pilose-pubescent when young, especially the margins, 2 inches long at maturity, more distinctly petioled : full-grown peduncles two-thirds to nearly inch long: berries distinct, light red, watery. - Cat. 22; DC. Prodr. iv. 235; Hook. Fl. l. c. ; Torr. \& Gray, 1. c. L. Canadensis, Rœm. \& Schult. Syst. v. 260. Xylosteum Tartaricum, Michx. 
Fl. i. 106. X. ciliatum, Pursh, FI. i. 161, excl. var., which is Symphoricarpos racemosus according to Nutt. Vaccinium album, L. Spec. i. 350, specimen of Kalm. - Rocky moist woods, New Brunswick to the Saskatchewan, and New England to Penn. and Michigan. Flowering in spring, when the leaves are developing.

L. TARTARICA, L., of the Old World, with rose-colored flowers, is commonly planted as an ornamental shrub, and is becoming spontaneous in Canada.

* * Bracts at the summit of the peduncle oblong to ovate or cordate and foliaceous: bractlets conspicuous and accrescent.

L. involucráta, BANks. Pubescent, sometimes glabrate, 2 to 10 feet high : leaves from ovate to oblong-lanceolate, from acutish to acuminate, 2 to 5 inches long, petioled : peduncles an inch or two long, sometimes 3-flowered : corolla yellowish, viscid-pubescent, half-inch or more long, tubular-funnelform, with 5 short hardly unequal lobes: bractlets 4 or united into 2, viscid-pubescent, at first short, obovate or obcordate, in fruit enlarging and enclosing or surrounding the two globose dark-purple or black berries. - Spreng. Syst. i. 759 ; DC. Prodr. 1. c. 336 ; Lindl. Bot. Reg. t. 1179 ; Torr. \& Gray, 1. c. ; Gray, Bot. Calif. i. 280. L. Ledebourii, Esch. Mem. Acad. Petrop. (1826) x. 284 ; DC. 1. c. L. Mociniana, DC. 1. c., probably from California, not Mexicu. L. intermedia, Kellogg, Proc. Calif. Acad. ii. 154, fig. 47. Xylosteum involucratum, Richards. App. Frankl. Journ. 6. - Wooded grounds, from Gaspé Co., Lower Canada (Allen), and S. shore of Lake Superior northward, west to Alaska, southward in the Rocky Mountains to Colorado and Utah, and nearly throughout California.

§ 2. Caprifólidm, DC. Flowers sessile in variously disposed terminal or axillary clusters, commonly quasi-verticillate-capitate : corolla more or less elongated: berries orange or red at maturity : stems climbing (twining) : upper leaves usually combined into a connate-perfoliate disk. - Caprifolium, Juss.

* Limb of corolla almost regular or slightly bilabiate, very much shorter than the elongated tube: stamens and style little exserted: flowers nearly scentless. - Periclymenum, Tourn. Thumpet-Huneysuckiles.

L. sempérvirens, L. Evergreen only southward, glabrous: leaves oblong, glaucous or glancescent beneath, uppermost one or two pairs broadly connate : flowers in 2 to 5 more or less separated whorls of 6 : the spike pedunculate: corolla scarlet-red varying to crimson and yellow inside, or sometimes wholly yellow; the narrow tube inch or more long; lobes sometimes almost equal, sometimes short-bilabiate, merely spreading, seldom over 2 lines long. - Spec. i. 173 (Herm. Hort. Lugd. 484, t. 483); Ait. Kew, i. 230; Walt. Car. 131 ; Sims, Bot. Mag. t. 1781, \& 1753 ; Bot. Reg. t. 556; Torr. \& Gray, Fl. ii. 5 ; Meehan, Nat. Flowers, ser. 2, i. t. 45. L. Virginiana \& L. Caroliniana, Marsh. Arbust. 80. Taprifolium sempervirens, Michx. Fl. 105; Pursh, Fl. i. 160; Ell. Sk. i. 271. - Low grounds, Connecticut and Indiana to Florida and Texas. Commonly cultivated. (There are indications of a nearly related species in Lower California.)

L. ciliósa, Pour. Leaves ovate or oval, glaucous beneath, usually ciliate, otherwise glabrous; uppermost one or two pairs connate into an oval or orbicular disk: whorls of flowers single and terminal, or rarely 2 or 3, and occasionally from the axils of the penultimate pair of leaves, either sessile or short-peduncled: corolla glabrous or sparingly pilose-pubescent, yellow to crimson-scarlet, with thicker tube than the preceding, more ventricose-gibbous below; limb slightly bilabiate; lower lobe 3 or 4 lines long. - Dict. v. 612; DC. Prodr. iv. 333; Torr. \& Gray, 1. c. Caprifolium riliosum, Pursh, Fl. i. 160. C. occidentale, Lindl. Bot. Reg. t. 1457. Lonicera occidentalis, Hook. Fl. i. 282. - Rocky Mountains in Montana to the coast of Brit. Columbia, the mountains of California and of Arizona. From mountains near Chico, California, comes a form which, by nearly naked margin of leaves and three-whorled pedunculate spike, makes transition to $L$. sempervirens.

* Limb of cornlla ringent; the sprealing or recurved lips comparatively large, and stamens and style conspicuously exserted. - Caprifolium, Tourn. True Honersuckues.

- Tube of corolla elongated (fully inch long), wholly glabrous inside, as are stamens and style: flowers very fragrant: Atlantic species resembling the cultivated Italian or Sweet Honeysuckle of Middle and S. Europe, L. Cuprifolium, L. 
L. gráta, Art. Glabrous : leaves obovate or oblong and the upper one or two pairs connate, paler or somewhat glaucous beneath: flowers in terminal capitate cluster and from the axils of the connate-perfoliate leaves : corolla reddish or purple outside ; the limb white within, fading to tawny yellow; lips over half-inch long; tube not gibbous : berries orangered.-Kew. i. 231 ; Willd. Spec. i. 984 ; DC. Prodr. iv. 332 ; Darlingt. Fl. Cest. ed. 2, 159; Torr. \& Gray, Fl. ii. 5. Caprifolium gratum, Pursh, Fl. i. 161. - Moist and rocky woodlands, N. New Jersey to Pennsylvania and mountains of Carulina according to Pursh, to "W. Louisiana, Hale," in Torr. \& Gray, Fl. But it may be doubted if really different from $L$. Caprifolium of Europe, and if truly indigenous to this country.

++ Tube of corolla less than inch long, but larger than the limb; the throat or tube below hairy within: Atlantic species.

+ Corolla bright orange-vellow; tube not gibbous, fully half-inch or more long: filaments and style glabrous: "Howers fragrant," produced early.

L. fláva, Srms. Somewhat glancous, wholly glabrous: leaves broadly oval, 2 or 3 upper pairs connate into a disk : flowers in a terminal capitate cluster : corolla glabrous ; the slender tube at upper part within or prolonged adnate base of filanents hirsute-pubescent. Bot. Mag. t. 1318 ; Lodd. Bot. Cat. t. 338; DC. Prodr. iv. 332. Caprifolium Fraseri, Pursh, Fl. i. 160, excl. N. Y. habitat. C. flavum, Ell. Sk. i. 271. - "Exposed rocky summit of Paris Mountain in S. Carolina," in Laurens Co., Fraser. This very ornamental plant was first noticed in Drayton's View of South Carolina, published in 1802, p. 64, as growing on Paris Mountain, Greeuville; afterwards it was collected by Fraser. Ell. 1. c. Upper Georgia, Boykin, \&c. It has not been found elsewhere; but it is still sparingly in cultivation.

++ + Corolla shorter, more or less hirsute within the throat; tube usually somewhat gibbous.

$=$ Rather freely twining and high-climbing, little or not at all glaucous, pubescent: leaves deep green above.

L. hirsúta, EAtor. Leaves oral, conspicuuusly veiny and venulose both sides (3 or 4. inches long), soft-pubescent (as also usually the branchlets) and pale beneath; upper one or two pairs connate, lower short-petioled: corolla orange-yellow fading to dull purplish or brownish, more or less viscid-pubescent outside; tube half-inch long, little exceeding the limb; throat and lower part of filaments hirsute. - Eaton, Man. Bot. ed. 2, 307 (1818); Torr. Fl. i. 342 ; Hook. Bot. Mag. t. 3103, \& Fl. i. 282 ; Torr. \& Gray, Fl. ii. 6 . L. villosa Muhl. Cat. 22, not DC. L. Douglasii, Hook. 1. c., being Caprifolium Douglasii, Lindl. Trans. Hort. Soc. vii. 244; DC. 1. c.; Loudon, Encl. Trees \& Shrubs, 530, fig. 972. L. pariflora, var.? Torr. \& Gray, Fl. ii. 7, mainly. L. pubescens, Sweet, Hort. Brit. 194; DC. Prodr. if. 332 ; Loudon, Encl. Trees \& Shrubs, 529 (under L. flaca). L. Goldii, Spreng. Syst. i. 758. Caprifolium pubescens, Goldie in Edinb. Phil. Jour. vi. 323; Hook. Exot. F1. t. 27. - Rocky banks, \&c., Northern New England and Canada to Penn., Michigan, and north shore of Lake Superior to the Saskatchewan.

$==$ Feebly twining or merely sarmentose or bushy, 2 to 6 feet high, conspicuously glaucous.

L. Sullivántii, Gray. At length much whitened with the glancous bloom, 3 to 6 feet high, glabrous: leaves oval and obovate-oblong, thickish, 2 to 4 inches long, all those of flowering stems sessile, and most of them connate, the uppermost into an orbicular disk: corolla pale yellow, glabrous outside; tube half-inch or less long, little longer than the limb: filaments nearly glabrous. - Proc. Am Acad. xix. 76. - L. u. sp.? Sulliv. Cat. Il. Columb. 57. L. flava, var. Torr. \& Gray, Fl. ii. 6 ; Gray, Man., mainly. - Central Ohio to Illinois, Wisconsin, and Lake Winnipeg - also Tennessee and apparently in mountains of N. Carolina.

L. glaúca, HrLl. Glabrous, or sometimes lower face of leaves tomentulose-puberulent, 3 to 5 feet high, generally bushy: leaves oblong, often undulate (glaucous, but less whitened than in the preceding, 2 or at most 3 inches long), 2 to 4 upper pairs connate: corolla quite glabrous outside, greenish yellow or tinged or varying to purple, short; the tube only 3 or 4 lines long, rather broad, nearly equalled by the limb, withiu and also style and base of filaments hirsute. - Hort. Kew. (1769) 446, t. 18; Gray, Proc. Am. Acad. xix. 77. L. dioica, L. Syst. Veg. 215 ; Ait. Kew. i. 230 ; Bot. Reg, t. 138, but not diœcious. L. media, Murr. in Comm. Gcett. 1776, 28, t. 3, L. parviflora, Lam. Dict. i. 728 (1783); Torr. Fl. i. 243 ; DC. 
1. c. ; Hook. l. c.; Torr. \& Gray, 1. c. excl, var.; Gray, Man., and a part of var. Douglasii. Caprifolium glaucum, Mœnch, Meth. 502. C. bracteosum, Michx. F1. i. 105, C. parviflorum, Pursh, Fl. i. 161. C. dioicum, Rom. \& Schult. Syst. v. 260. - Rocky grounds, Hudson's Bay? and to Saskatchewan, Canada, New England, Penn., and mountains of Carolina?

I. albiflóra, Torr. \& Grax. Wholly glabrous, or with minute soft pubescence, bushy, also disposed to twine, 4 to 8 feet high : leaves oval, inch long, or little longer, glaucescent both sides, usually only uppermost pair connate into a disk and subtending the simple sessile glomerule: corolla white or yellowish-white, glabrous; the tube 3 to 5 lines long, hardly at all gibbous: style and filaments nearly naked. - Fl. ii. 6; Gray, Pl. Lindh. ii. 213. L. dumosa, Gray, Pl. Wright. ii. 66, Bot. Mex. Bound. 71, the minutely pubescent form. - Rocky prairies aud banks, W. Arkansas and Texas to New Mexico and Arizona, first coll. by Berlandier, Leavenworth, Lindheimer, \&c. (Adj. Mex., Palmer.)

+++ Tube of corolla only quarter-inch long, equalled by the limb, gibbous, more or less hairy within: Pacitic species.

L. hispídula, Dougx. Bushy and sarmentose, often feebly twining: leaves small (inch or so in length, or the largest $2 \frac{1}{2}$ inches), oval, or from orbicular to oblong, rounded at both ends, or lower and short-petioled ones sometimes subcordate, uppermost connate or occasionally distinct: spikes slender, commonly paniculate, of few or several whorls of flowers : corolla from pink to yellowish, barely half-inch long: filaments and especially style more or less pubescent at base. - Dougl. in Lindl. Bot. Reg. t. 1761 (the latter figured and published the species as Caprifolium hispidulum); Gray, Proc. Am. Acad. viii. 627, \& Bot. Calif. i. 280. L. microphylla, Hook. Fl. i. 283. - Polymorphous species, of which the typical form (var. Douglasii, Gray, 1. c.) is hirsute or pubescent with spreading hairs, disposed to climb : lower leaves mostly short-petioled and inclined to subcordate, not rarely a foliaceous stipulelike appendage between the petioles on each side : inflorescence and pink corollas glabrous. - Wooded region of Brit. Columbia to Oregon, first coll. by Douglas.

Var. vacíllans, Gray, l. c. Stem and leaves either glabrous or pubescent, with or without hirsute hairs: inflorescence and corollas pubescent or glandular, varying to glabrous : otherwise like the Oregon type. - L. Californica, Torr. \& Gray, Fl. ii. 7 ; Benth. Pl. Hartw. L. ciliosa, Hook. \& Arn. Bot. Beech. 143, 349, not Poir. L. pilosa, Kellogg, Proc. Calif. Acad. i. 62. - From Oregon to Monterey, California.

Var. subspicáta, Grar, 1. c. Bushy, more or less pubescent or glandular-pubescent above, at least the pale pink or yellowish flowers: leaves small (half-inch to inch long), even uppermost commonly distinct: stipule-like appendages rare. - L. subspicata, Hook. \& Arn. Bot. Beech. 349 ; Torr. \& Gray, 1. c. ; Torx. Bot. Mex. Bound. 71, t. 29. - Common in California, from Monterey to San Diego.

Var. interrúpta, GRAY, 1. c. Like the preceding, or sometimes larger-leaved and more sarmentose, but glabrous or minutely puberulent, more glaucous: spikes commonly elongated, of numerous capitellate whorls: corolla perfectly glabrous, pinkish or yellowish, less hairy inside. - L. interrupta, Benth. Pl. Hartw. 313. - Common in California : also Santa Catalina Mountains, Arizona, Pringle, Lemmon.

8. Diervilla, Tourn. Bush Honeysuakle. (Dr. Dierville took the original species from Canada to Tournefort in the year 1708.) - Low shrubs (of Atlantic N. America, Japan, and China); with scaly buds, simply serrate membranaceous leaves, and flowers in terminal or upper axillary naked cymes, produced in early summer. - The E. Asian species, Weigela, Thunb. (of which D. Japonica is common in cultivation), have ampliate and mostly rose-colored corollas, herbaceous calyx-lobes deciduous from the beak of the fruit, and reticulate-winged seeds. Ours have small and narrow-funnelform corollas, of honeyyellow color, thin-walled capsule, and close coat to the seed, the surface minutely reticulated; herbage nearly glabrous. - Torr. \& Gray, Fl. ii. 10.

D. trífida, Мєгсн. Branchlets nearly terete; leaves ovate-oblong, acuminate, distinctly petioled: axillary peduncles more commonly 3-flowered : limb of the corolla nearly equalling the tube, sometimes irregular, three of the lobes more united, the middle one deeper 
yellow and villous on the face: capsule oblong, with a slender neck or beak, crowned with slender-subulate calyx-lobes. - Meth. 492; 'Torr. \& Gray, l. c. excl. var. D. Acadiensis fruticosa, \&c., Tourn. Act. Acad. Par. 1706, t. 7, f. 1; L. Hort. Cliff. 63, t. 7 ; Dullam. Arb. ed. 1. D. Toumefortii, Michx. Fl. i. 107. D. humilis, Pers. Syn. i. 214. D. Canadensis, Willd. Enum. 222; DC. Prodr. iv. 330; Hook. Fl. i. 281. D. lutea, Pursh, Fl. i. 162. Lonicera Diervilla, L. Mat. Med. 62, \& Spec. i. 175. - Rocky and shady ground, Newfoundland and Hudson's Bay to Saskatchewan, south to Kentucky and Maryland, and in the mountains to N. Carolina.

D. sessilifólia, Buckler. Branchlets quadrangular: leaves ovate-lanceolate, gradually acuminate, closely sessile, of firmer texture, more acutely serrulate : cymes several-flowered; corolla-lobes nearly equal, shorter than the tube, one of them obscurely pilose : capsule shortoblong, short-necked, and crowned with short lanceolate-subulate calyx-lobes. - Am. Jour. Sci. xlv. 174; Chapm. Fl. 170; Fl. Serres, viii. 292. - Rocky woods and banks, mountains of Carolina and Tennessee, first coll. by C'urtis.

\section{Order LXX. RUBIACEA.}

Herbaceous or woody plants; with opposite entire and stipulate leaves, varying to verticillate, or in the Stellate the leaves in whorls without stipules (unless accessory leaves be counted as such); mostly hermaphrodite regular flowers, either 5-merous or 4-merous; calyx-tube adnate to the ovary; and stamens as many as and alternate with the lobes of the corolla, inserted on its tube or throat. Style single, sometimes with 2 or more lobes or stigmas. Fruit various: seeds in our genera albuminous.

Of this vast and largely tropical order 26 of the 140 recognized genera come within our limits, but more than half of them only in subtropical Florida. They rank under 14 of the 25 recognized tribes, - too large a scaffolding for a fragmentary structure. So they are here disposed under three series; of which the third is only a special modification in foliage of the second.

\section{Series I. Cinchonace.e. Ovules numerous in each cell.}

* Fruit capsular : seeds numerous, flat, winged all round.

1. EXOSTEMA. Calyx with clavate tube, 5-toothed. Corolla salverform, with long and narrow tube and 5-parted limb; lobes long-linear, inbricated in the bud. Stamens inserted near the base of the corolla-tube: filaments and style filiform, exserted: anthers slenderlinear, fixed by the base. Capsule 2-celled, septicidal. Seeds downwardly imbricated on the placentæ.

2. PINCKNEYA. Calyx with clavate tube; limb of 5 subulate-lanceolate lobes, or in the outer flowers of the cyme one (or rarely two) of them an ample petaloid and petiolate leaf, all deciduous. Corolla salverform with somewhat enlarging throat, and 5 oblong recurvedspreading lobes, valrate or nearly so in the bud. Stamens inserted low down on the corolla: filaments filiform : anthers oblong, fixed by the middle, slightly exserted. Style exserted: stigma barely 2-lobed. Capsule didymous-globular, 2-celled, loculicidal, and valves at length 2-parted. Seeds horizontal, with small nucleus, broad and thin lunate-orbicular wing, and comparatively large embryo : cotyletons broad.

3. BOUVARDIA. Flowers heterogone-dimorphous. Calyx with turbinate or campanulate tube, and 4 subulate persistent lobes. Corolla tubular or salverform, the 4 short lobes valvate in the bud. Stamens inserted on the throat or on the tube below it: anthers subsessile, oblong or linear. Style filiform and more or less exserted in long-styled flowers, much shorter in the other sort: stigmas 2, obtuse. Ovary 2-celled. Capsule didymous-globose, coriaceous, loculicidal. Seeds peltate, somewhat meniscoidal, imbricated on the globular placentæ. 
* * Fruit capsular or at least dry, 2-celled: seeds several or numerous in each cell, wingless: calyx-tube short; lobes persistent: corolla valvate in the bud : almost all herbs, with leaves no more than opposite: stipules not setose, or in one species setulose.

+ Summit or sometimes even three fourths of the capsule free from the calyx at maturity: flowers in most and probably in all heterogone-dimorphous: seeds peltate: albumen corneous.

4. HOUSTONIA. Flowers 4-merous. Calyx-lobes mostly distant. Corolla salverform to funnelform, with 4-parted limb. Stamens (according to the form) inserted either in the throat or lower down on the tube: anthers oblong or linear, fixed by near the middle. Style reciprocally long or shorter: stigmas 2, linear or oblong. Capsule usually somewhat didymous-globular, or emarginate at the free summit, there loculicidal, occasionally afterwards partially septicidal. Seeds few or moderately numerous in each cell, on usually ascending placentæ, acetabuliform, meniscoidal, or sometimes barely concave on the hilar face, not angulate; testa scrobiculate or reticulate.

+ + Summit of capsule not extended beyond the adnate calyx-tube: flowers not heterogone-dimorphous, small: seeds numerous, angulate or globular, smooth or nearly so: albumen fleshy.

5. OLDENLANDIA. Flowers 4-merous. Corolla from rotate to short-salverform, 4-lobed. Stamens short: anthers oval. Capsule hemispherical, oval, or turbinate, loculicidal across the summit.

6. PENTODON. Flowers 5-merous. Calyx-tube turbinate or obpyramidal : limb of 5 deltoid-subulate teeth, in fruit distant. Corolla short-funnelform, 5-lobed. Stamens 5, short: anthers short-oblong. Capsule obconical, obscurely didymous, loculicidal across the truncate summit. Seeds very numerous, minute, reticulated. Stipules or some of them 2-4subulate.

* * Fruit baccate or at least fleshy and indehiscent, many-seeded (rarely few-seeded),

$$
\text { + Five-celled: shrubby. }
$$

7. HAMELIA. Calyx 5-toothed, persistent. Corolla tubular, 5-lobed, imbricated in the bud. Stamens inserted low on the tube: filaments short: anthers linear. Style filiform: stigma fusiform, sulcate. Berry ovoid. Seerls very numerous in the cells, minute, angulate or flattened. Inflorescence scorpioid-cymose.

++ Ovary and fruit 2-celled, sometimes imperfectly so by the placentæ not meeting in the axis: shrubs.

8. CATESB ÆA. Flowers 4-merous. Calyx-lobes subulate, persistent. Corolla funnelform; lobes short, ovate or deltoid, valvate in the bud. Stamens inserted low down on the tube: anthers linear. Ovary 2-celled: style filiform: stigma undivided. Berry coriaceous, globular. Seeds flattened.

9. RANDIA. Flowers 5-merous, rarely 4-7-merous. Corolla salverform or somewhat funnelform; the lobes convolute in the bud. Stamens inserted on the throat of the corolla: filaments short or none: anthers linear, acute or acuminate. Ovary completely 2-celled: style stout: stigma clavate or fusiform, entire or 2-lobed. Berry globose or ovoid. Seeds mostly imbedded in the pulpy placentr, sometimes very few: testa thin, adherent to the corneous albumen.

10. GENIPA. Flowers 5-merous. Calyx-tube more or less produced beyond the summit of the ovary, the border truncate or sometimes bearing small teeth. Corolla salverform; the lobes convolute in the bud. Anthers linear, nearly sessile. Ovary one-celled, with two projecting parietal placentæ which almost meet in the centre. Berry large, becoming 2celled by the junction or coalescence of the ample pulpy many-seeded placentæ in the centre. Seeds large, flat : albumen cartilaginous.

Series II. Cofreacem. Ovules solitary in the cells of the ovary: leaves with obvious stipules, opposite or only casually in threes or fours.

* Shrubs: flowers compacted in pedunculate heads with a globose receptacle.

11. CEPHALANTHUS. Flowers 4-merous, crowded in a long-perlunculate head, but distinct, dry in fruit. Calyx oblong, soon obpyramidal: limb obtusely 4-lobed. Corolla 
tubular-funnelform, with 4 short lobes imbricated in the bud, one lobe outside. Stamens included: filaments short, inserted in the throat: anthers 2-mucronate at base. Style longexserted: stigma clavate-capitate. Ovary 2-celled, a solitary anatropous ovule penduious from near the summit of each cell. Fruits akene-like, obpyramidal by mutual pressure, 1-2seeded.

12. MORINDA. Flowers usually 5-merous, compacted and the oraries or fruits confluent in a short-peduncled fleshy head. (alyx urceolate or hemispherical, with truncate or obscurely dentate limb. Corolla salverform or somewhat funnelform, mostly short; lobes valvate in the bud. Stamens short, inserted in the throat. Sitle bearing 2 slender stigmas. Ovary 4-celled, or rather 2-celled and the cells 2-locellate; an ascending urule in each cell. Fruits drupaceous, maturing 2 to 4 bony seed-like nutlets, all confluent into a succulent syncarp.

* Shrubs: flowers distinct, in cymes or panicles : fruit drupaceous, + With 4 to 10 cells, at least in the ovary.

13. GUETTARDA. Flowers 4-9-merous (sometimes polygamo-diœcious). Calyx with ovoid or globular tube, continued above the uvary into a cupulate or campanulate limb; the border truncate, commonly irregularly denticulate or dentate. Corolla salverform, with elongated tube, and rounded or oblong lobes imbricated in the bud. Stamens inserted on the tube or throat of the corolla, iucluded : filaments short or none: anthers linear. Style filiform: stigma subcapitate or minntely 2-lobed. Ovary 4-9-celled : an anatropous ovule suspended from the summit of each cell on a thickened funiculus. Drupe globular, with thin flesh, and a bony or ligneous 4-9-celled and lobed putamen; the cells and contained seed narrow. Embryo cylindrical : albumen little or none.

14. ERITHALIS. Flowers 5-merous, varying to 6-10-merous. Calyx with obovate or globular tube and a truncate or denticulate short limb or border. Corolla rotate, parted into 5 or more oblong-linear divisions, valvate, or at tips slightly imbricated in the bud. Stamens inserted on the base of the corolla: filaments hairy at base: anthers linear-oblong. Style thickish : stigma of 5 or more minute lobes. Ovary 5-10-cellel, with solitary pendulous ovules. Drupe small, globose, 5-10-sulcate, containing as many bony seed-like nutlets. Embryo small in copious albumen.

+ - With 2 (rarely by variation 3 ) cells to the ovary : ovules anatropous.

15. CHIOCOCCA. Flowers 5-merous, in axillary panicles or racemes. Calyx with ovoid or turbinate tube and 5-toothed limb. Corolla funuelform, 5-cleft; the lobes valvate or at apex obscurely imbricated in the bud. Stamens inserted on the very base of the corolla: filaments monadelphous at base, somewhat hairy : anthers linear. Nityle filiform: stigma clavate. Ovules suspended. Drape globular, small, containing two coriaceous seed-like nutlets.

16. PSYCHOTRIA. Flowers (small) 5-merous, sometimes 4-merous, in terminal naked cymes. Calyx short. Corolla from campanulate to short-tubular or funnelform, not gibbous; lobes valrate in the bud. Stamens short, inserted in the throat of the corolla, clistinct. Stigma 2-cleft. Ovule erect from the base of each cell. Drupe globular, small, containing 2 flattened and commonly costate or cristate nutlets. Leaves mostly dilated and membranaceous. Flowers in some heterogone-dimorphous.

17. STRUMPFIA. Flowers (very small) 5-merous, in axillary thyrsiform cymes. Calyx short, 5-toothed. Corolla short, 5-parted; lobes oblong-lanceolate, liglitly imbricated in the bud. Stamens inserted on the very base of the corolla: filaments very short, monadelphous: anthers oblong, with adnate introrse cells, connate by their broad coriaceous connectives into an ovoid tube. Style hirsute: stigmas 2, obtuse. Ovule erect from the base of each cell. Drupe small, with a 2-celled 2-seeded (or by abortion single-seeded) putamen. Leaves linear, rigid, Rosemary-like.

* * Suffruticose and procumbent plants: flowers axillary and sessile: fruit drupaceous, 2-celled: seeds peltate.

18. ERNODEA. Flowers 4-6-merous. Calyx-tube ovoid; lobes elongated, subulate-lanceolate, persistent. Corolla salverform; lobes valvate in the bud, linear, at length revolute. Stamens inserted on the throat of the corolla, much exserted: filaments filiform: anthers linear-oblong. Orary 2-celled, with a peltate amphitropous ovule borne at the middle of the 
cells. Style filiform, exserted: stigmas 2, obtuse. Drupe obovate, thin-fleshy, containing 2 cartilaginous planomconvex nutlets. Seed plano-convex. Embryo straight in fleshy albumen : cotyledons cordate, foliaceous : radicle inferior. Leaves fleshy-coriaceous, sessile.

**** Low herbs, with entire and naked interpetiolar stipules : ovules erect, anatropous : style filiform: stigmas filiform or linear.

19. MITCHELIA. Flowers (3-6-) generally 4-merous, heterogone-dimorphous, geminate at the summit of a peduncle and the ovaries of the two connate. Calyx-teeth persistent. Corolla between salverform and funnelform; lobes valvate in the bud, upper face densely villous-bearded within. Stamens inserted in the throat of corolla, with oblong anthers, on short filaments when the filiform style is exserted, on long exserted filaments when the style and stigmas are included. Style-branches 4, hirsute-stigmatose down the inner side. Fruit a globular baccate syncarp, containing 8 compressed roundish cartilaginous nutlets (4 to each flower). Albumen cartilaginous : embryo minute. Prostrate and creeping evergreen.

20. KELLOGGIA. Flowers (3-5-) generally 4-merous, singly slender-pedunculate. Calyx with obovate tube and minute persistent teeth. Corolla between funnelform and salverform; lobes naked, valvate in the bud. Stamens inserted in the throat of the corolla, more or less exserted : filaments flattened: anthers oblong-linear, fixed above the base. Style filiform, exserted : stigmas 2, linear-clavate, papillose-pubescent. Ovary 2-celled: ovules erect from the base, anatropous. Fruit small, dry and coriaceous, beset with uncinate bristles, separating at maturity into 2 closed carpels, which are conformed and adherent to the seed, somewhat reniform in cross section. Embryo comparatively large, in fleshy albumen : cotyledons elliptical, as long as the radicle.

***** Low herbs, with short-vaginate stipules setiferous or sometimes only 4-6-cuspidate: ovary 2-4-celled: solitary ovules borne on the septum and amphitropous: fruit dry: seed sulcate or excavated on the ventral face: embryo in corneous or firm-fleshy albumen; the radicle inferior: flowers small, sessile in terminal and axillary glomerules : corolla funnelform or salverform; lobes valvate in the bud.

+ Fruit circumscissile, upper part with persistent calyx-limb falling off, exposing the seeds.

21. MITRACARPUS. Flowers commonly 4-merous, capitate-glomerate. Calyx-lobes persistent, unequal, the alternate pair mostly shorter or minute and stipule-like. Stamens inserted on the throat of the corolla. Short style-branches or stigmas 2. Fruit didymous, membranaceous, 2-celled, a pyxidium, the upper half separating from the lower by transverse circular dehiscence. Seed cruciately 4-lobed on the ventral side.

+ + Fruit septicidal into its 2 to 4 component carpels : calyx-limb gamophyllous at base and circumscissile-deciduous as a whole at or before dehiscence: stamens borne on the throat of the corolla.

22. RICHARDIA. Flowers (4-8-) commonly 5-6-merous and 2-4-carpellary. Calyx-lobes ovate-lanceolate or narrower. Corolla funnelform. Stigmas 2 to 4 , linear or spatulate. Carpels separating from apex to base, coriaceous, roughish, closed or nearly so; no persistent axis.

23. CRUSEA. Flowers (3-5-) usually 4-merous and 2- (sometimes 3-4) carpellary. Calyxlobes subulate to triangular-lanceolate, sometimes very unequal or intermediate ones reduced to small teeth. Corolla salverform to narrow funnelform. Stigmas 2 to 4 , linear to spatulate-oval. Fruit 2-4-lobed, separating from a persistent axis into obovoid or globular chartaceous carpels, which either open at the commissure or sometimes remain closed.

+++ Fruit septicidal at summit or throughout, its 2 or rarely 3 carpels or valves bearing persistent and quite or nearly distinct calyx-teeth.

24. SPERMACOCE. Calyx-teeth, lobes of the short corolla, and stamens 4, or two of the former sometimes abortive. Fruit small, from membranaceous to thin-crustaceons, one or both the carpels opening ventrally to discharge the seed : no persistent carpophore, or sometimes a thin dissepiment remaining.

25. DIODIA. Calyx-lobes ( 1 to 6 ) usually 2 or 4, distinct, distant. Corolla funnelform or nearly salverform, with mostly 4 -lobed limb, and stamens as many, inserted in its throat. Style filiform, entire or 2-cleft: stigmas 2. Fruit somewhat fleshy-drupaceous or crustaceocoriaceous, tardily separating through the dissepiment into 2 closed carpels: no carpophore. 
Series III. Stellates. Ovules (peltate and) solitary in the cells of the ovary: embryo incurved, in corneons albumen: leaves verticillate without stipules, unless the supernumerary leaves be foliaceous stipules, which may in some cases be nearly demonstrated.

26. GALIUM. Flowers 4-merous (rarely 3-merous), 2-carpellary, sometimes diœcious. Calyx-tube globular; limb obsolete, a mere ring or obscure border. Corolla rotate; lobes valvate, and commonly acuminate or mucronate apex inflexed in the bud. Stamens with short filaments and anthers. Style 2-cleft or styles 2: stigmas capitellate. Ovary 2-celled, 2-lobed; a single amphitropous ovule borne on the middle of the dissepiment in each cell. Fruit didymous, dry, fleshy-coriaceous, or occasionally baccate, articulated on the pedicel, tardily separating into two closed carpels, or only one maturing. Seed deeply hollowed on the face: seed-coat adnate to the albumen within, and often also to the pericarp.

1. EXOSTÉMA, Rich. (Not Exostemma, to which later authors have changed the name, which is from $\tilde{E} \xi \omega$, on the outside, and $\sigma \tau \hat{\eta} \mu \alpha$, stamen, i. c. stamens exserted.) - Tropical American shrubs or trees, one reaching Florida. Rich. in Humb. \& Bonpl. Pl. Equin. i. 131, t. 38. Exostemma, DC. Prodr. iv. 358 ; A. Rich. Rub. 200 ; Benth. \& Hook. Gen. ii. 42. Cinchona § Exostema, Pers. Srn. i. 195 (1805), where the name first appears.

E. Caribǽum, Rєæ. \& Schurt. Shrub 6 to 12 feet high, glabrous: leares oblong-ovate to lanceolate, coriaceous: stipules subulate, small : flowers on short and simple axillary peduncles, fragrant: calvx-teeth very short: corolla white or tinged with rose; tube inch lọng and lobes hardly shorter: seeds narrowly winged. - Srst. v. 18; Torr. \& Gray, Fl. ii. 36. Cinchona Caribrea, Jacq. Amer. t. 179; Lamb. Cinch. t. 4. C. Jamaicensis, Wright, in Phil. Trans. Ixrii. t. 10; Andr. Bot. Rep. t. 481. - Keys of Florida. (W. Ind., Mex.)

\section{PINCKN'́tya, Michx. Georgia Bark. (Charles Cotesworth Pincl-} ney.) - Single species.

P. púbens, Michx. Tall shrub or small tree, pubescent: leaves ample, oblong-oval to ovate, acute at both ends, petioled: stipules subulate, caducous: cymes terminal and from upper axils, pedunculate: petaloid calyx-lobe resembling the leaves in form, pink-colored, 2 inches or more long: corolla inch long, cinereous-pubescent, purplish: capsule half-inch in diameter. -Fl. i. 103, t. 13; Miehx. f. Sylv. t. 49; Bart. Fl. Am. Sept. t. 7 ; Audnbon, Birds, t. 165; Torr. \& Gray, Fl, ii. 37. P. pubescens, Gærtn. Fruct. iii. 80, t. 194. Pinluncu pubescens, Pers. Srn. i. 197. Cinchona Caroliniana, Poir. Dict. vi. 40. - Marshy banks of streams in pine barrens of the low country, S. Carolina to Florida; fl. early summer.

3. BOUVÅRDIA, Salisb. (Dr. Charles Bouvard.) - Low shrubs or perennial herbs (from Texas to Central America, some cultivated for ornament); with mostly sessile and not rarely verticillate leaves, subulate interposed stipules, and handsome tubular flowers in terminal cymes. - Parad. Lond. t. 88 ; HBK. Nov. Gen. \& Spec. iii. t. 288; Benth. \& Hook. Gen. ii. 36. - Leaves in our snecies mostly verticillate and corolla not glabrous, its short lobes ascending or barely spreading. Flowers heterogone-dimorphous in the manner of Houstonia.

B. ováta, Grar. Herbaceous, glabrous, obscurely scabrous: leaves mostly in fours, shortpetioled, ovate, one or two inches long, costately 5-veined on each side of the midrib : corolla probably purple or reddish, inch long, minutely puberulent. - Pl. Wright. ii. 67. - S. Arizona, between San Pedro and Santa Cruz, Wright.

B. triphýlla, SALIsB. Suffruticose or more shrubby, scabro-puberulent, 2 to 5 feet high: leaves in threes or fours (or on branchlets in pairs), from oblong-ovate to broadly lanceolate, usually hispidulous-scabrous, at least the margins, 3-4-veined each side of the midrib : corolla scarlet, about inch long, outside furfuraceous-pubescent. - Parad. Lond. 1. c. (broad-leaved var, but not with villous-closed throat in any form); Ker, Bot. Reg. t. 107; Sims, Bot. 
Mag. t. 1854 ; Lindl. Bot. Reg. xxvi. t. 37. B. Jacquini, HBK. 1. c. 385 ; DC. Prodr. iv. 365; Gray, Pl. Wright. ii. 67. B. quaternifolia, DC. 1. c. ? B. coccinea, Link, Enum. i. 139. B. ternifolia, Schlecht, in Linn. xxvi. 98. B. splendens, Graham in Bot. Mag. t. 3781. Ixora ternifolia, Cav. Ic. iv. t. 305. I. Americana, Jacq. Hort. Schœnb. iii. t. 257. Houstonia coccinea, Andr. Bot. Rep. t. 106. - Rocky ground, S. Arizona, \&c., Wright, Thurber, Rothrock, Pringle, Lemmon. (Mex.)

Var. angustifólia. Cinereous-puberulent or hirtelious: leaves smaller (8 to 18 lines long), subsessile, less veiny, from oblong-lanceolate to almost linear. - B. hirtella \& $B$. angustifolia, HBK. 1. c. 384. B. hirtella, Gray, Pl. Wright. i. 80, ii. 67. - S. W. Texas to Arizona, Wright, \&c. (Mex.)

4. HOUSTÓNIA, Gronov. (Named by Gronovius, as says Linnæus, in memory of $D r . W m$. Houston, who died in Jamaica in 1733.) - Low herbs, or one or two suffruticulose (Atlantic-American and Mexican), with heterogonedimorphous flowers; the corolla blue or purple to white, upper face of lobes sometimes puberulous. - L. Hort. Cliff. 35, \& Gen. ed. 1 (1737); Juss. Gen. 197; Gray, Proc. Am. Acad. iv. 313, \& Man. ed. 5, 212 ; Benth. \& Hook. Gen. ii. 60. Hedyotis in part (Wight \& Arn.), Torr. \& Gray, Fl. ii. 36. (Macrohoustonia, Gray, Proc. Am. Acad. iv. 314, is a peculiar group of Mexican species, between this genus and Bouvardia.)

$\S 1$. Eunoustóxis. Low herbs, comparatively small-flowered: leaves not rigid: capsule more or less didymous or emarginate, sometimes septicidal as well as loculicidal across the broad summit.

* Delicate species, inch to span high: corolla salverform: anthers or stigmas included or only parti.lly emerging from the throat: peduncles single, elongated and erect in fruit: seeds rather few acetabuliform with a deep hilar cavity: stipules a transverse membrane uniting the petioles, mostly entire or truucate and naked.

+ Perennial by delicate filiform creeping rootstocks or creeping stems: peduncles filiform, inch or two long: seeds subglobose with orifice of the deep hilar cavity circular.

H. cærúlea, L. (Bluets of the Canadians, Innocence.) Perennial by slender rootstocks, forming small tufts, erect, a span or more high, glabrous, and with lower leaves hispidulous : these spatulate to obovate and short-petioled; upper small and nearly sessile: corolla violetblue to lilac, varying to white, with yellowish eye; tube (2 or 3 lines long) rouch exceeding calyx-lobes, longer than or equalled by those of corolla: capsule obcordate-depressed, half free. - Spec. i. 105 (Moris. Hist. sect. 15, t. 4, f. 1 ; Pluk. Alm. \& Mant. t. 97, f. 9); Sims, Bot. Mag. t. 370; Barton, Fl. Am. Sept. t. 34, f. 1. H. pusilla, Gmel. Syst. i. 236 ? H. Linncei, var. elatior, Michx. Fl. i. 85. H. serpyllifolia, Grahan, Bot. Mag, t. 2822, from habitat and figure, but corolla-tube too short. Hedyotis cerulea, Hook. Fl. i. 286; Torr. \& Gray, Fl. ii. 38. H. gentianoides, Endl. Iconogr. t. 89. Oldenlandia corulea, Gray, Man. ed. 2, 174. - Low and grassy grounds, Canada to Michigan and the upper country of Georgia and Alalıama; fl. early spring.

H. serpyllifólia, Mrcsx. Perennial by prostrate extensively creeping and rooting filiform stems, and some subterranean ones, glabrous or slightly and minutely hispidulous below : leaves orbicular to ovate or ovate-spatrlate ( 2 to 4 lines long) and abruptly petioled, or upper ones on flowering stems oblong and vearly sessile: corolla deep riolet-blue, rather larger than in H. carulea.-Fl. i. 85; Pursh, Fl. i. 106. H. tenella, Pursh, 1. c. Hedyotis serpyllifolia, Torr. \& Gray, Fl. ii. 39. Oldenlandia serpyllifolia, Gray, Man. ed. 2; Chapm. FI. 180:- Along streamlets and on mountain-tops in the Alleghanies, from Virginia to Tenn, and S. Carolina; flowering through early summer.

+ + Winter-annuals, branching from the simple root, glabrous or obscurely scabrous: peduncles a quarter-inch to at length sometimes an inch long: capsule somewhat didymous, less than balf free: mature seeds generally as of the preceding.

H. pátens, ELl. An inch to at length a span high, with ascending branches and erect peduncles: leaves spatulate to ovate: corolla much smaller than that of $H$. carulea; the tube twice the length of the calyx-lobes and more or less longer than its lobes, violet-blue or pur. 
'plish without yellowish eye.-Sk. i. 191 ; Gray, Proc. Am. Acad, iv. 314. II. Linncei, var. minor, Michx. Fl. i. 85. Hedyotis minima, Torr, \& Gray, F'l. I. c. in part, \& II. carulea, var. minor. - Dry or sandy soil, s. Virginia to Texas in the low country, also Illinois? and Tennessee; fl. early spring.

Var. pusilla. An inch or so high, more diffuse in age: leaves narrowly spatulate (half a line or a line wide); ulper ones nearly linear: sects smoother, with more open and oval hilar cavity, and sometimes an elevated lime witlin, as described in P'roc. Im. Acad. 1. c., a character not found in the larger and brouler leaved form. l'erhaps from the char. this is the true H. patens, Ell. But we have it only from Louisiana (Hale, Drummond) and Texas, Drummond and others: there passing into the other form.

H. mínima, Beck. More diffuse, commonly scalurons: leaves spatulate to ovate: flowers usually larger : calyx-lobes more foliaceous, oblong-lanceolate, sometimes 2 lines long, very much longer than the ovary, eqnalling the tube of the purple or violet corolla; lobes of the latter 2 or 3 lines long: primary peduncles sometimes declined in fruit? - Amer. Jour. Sci. x. 262; Gray, l. c. IIedyotis ininima, Torr. \& Gray, 1. c., in part ouly. - Dry hills, Missouri and Arlkansas to Texas, first coll. by $L$. C. Beck about St. Louis ; fl. early spring.

* Sl.nder leafy-stemmed annul, with lateral horizontal peduncles, and very small flowers: corolla short-salverform: seeds crateriform, witl a medial hilar ridge.

H. subviscósa, GrıY. \ span or two high, minutely visciclulous-pubescent, with rather simple spreading branches: leaves narrowly linear, half-inch long: peduncle in first fork and from all following nodes, rather shorter than leaves, horizontally refracted in fruit: calyx and capsule a line high : corolla about same length, white : capsule dirlymous, only the summit free: seeds 10 in each cell. - Proc. Am. Acarl. ir. 314. Oldenlandia subriscosa, Wright in Grar, Pl. Mright. ii. 68. - S. Texas, Berlandier, Wright.

* * Depressed or low-tufted species: corolla salverform or in one species funnelform: filaments as well as anthers or summit of style reciprocally exserted quite out of the throat: fructiferous peduncles all short and recurvel.

+ Annual, with small funnelform corolla: seeds open-crateriform: scarious stipules setuloseciliate!

H. humifúsa, GrAx. Much branched from the root, repeatedly dichotomous, forming a depressed tuft, puberulent and viscid : leaves linear-lanceolate, thickish (half-inch or more long), mucronate: flowers in all the forks, crowded with the leaves at the ends of branchlets : calyx 4-parted into long setaceous-subulate spreading lobes: corolla pale purple or nearly white, open-funnelform, 3 lines long, hardly twice the length of the caly $x$; the oblong lobes puberulous inside: capsule a line in diameter, globose-didymous, three-fourths free, only the base girt ly the short accrete calyx-tube. - Proc. Am. Acad. iv. 314 (not of Hemsl. Biol. Bot. which is H. Wrightii). Hedyotis (Houstonia) humifusa, Gray, Pl. Lindh. ii. 216. - Sandy or gravelly plains and hills, Texas, Wright, Lindheimer, Reverchon, \&c. : fl. spring.

+ + Perennials, prostrate, with naked stipules and elongated salverform corolla, flowering conspicuously in early spring; later growth producing through the summer inconspicuous cleistogamous flowers, with short (yet mostly well-formed but unopening) corollas.

H. rotundifólia, Mrchx. Perennial by slender rootstocks or shoots, more or less creeping, glabrous or with some hispidulons pubescence: leaves somewhat orbicular, slightly petioled, not longer than the internodes: peduncles 2 to 4 lines long or in cleistogamous flowers very short: developed corollas bright white, with filiform tube (3 or 4 lines long) longer than the oblong lobes: capsule more than half free, somewhat didymous: seeds comparatively large (half-line in diameter), rough-scrobiculate, acetabuliform. - Fl. i. 85; Pursh, 1. c.; Ell. 1. c. Hedyotis rotundifolia, Torr. \& Gray, Fl. ii. 38. Oldenlandia rotundifolia, Chapm. Fl. 180, the later "apetalous fruiting" flowers noted. - Low sandy ground, $\therefore$ Car. to Florida and Louisiana.

H. rúbra, $C_{A v}$. Suffrutescent and multicipital from a deep root, forming a depressed tuft of 2 to 4 inches bigh, glabrous or ninutely puberulent, densely leafy: leaves narrowly linear, an inch or more long, or earlier ones rather lanceolate and shorter: corolla "red" or rather purple, sometimes lilac or varying to white; tube half-inch to nearly inch long, slender; oblong acute lobes 2 or 3 lines long: capsule 2 lines wide, less high, didymous, fully three-fourths free: seeds open-crateriform. - Ic. v. t. 474; Benth. Pl. Hartw. 15. IIedyotis (Houstonia) rubra, Gray, Pl. Fendl. 61. Oldenlandia (Houstonia) rubra, Gray, P1. Wright. ii. 68. - Stony or grarelly hills, New Mexico and Arizona. (Mex.) 
+++ Lignescent-rooted perennial, with small and short corolla and naked stipules.

H. Wríghtii, Gray. Mazy-stemmed from a deep root, a span or less high, erect or spreading, glabrous or very obscurely pruinose: branches quadrangular: leaves thickish, linear or lowest rather lanceolate (half-inch to inch long): flowers in terminal glomerate leafy cymes: corolla purplish or nearly white, between salverform and funnelform, 2 to hardly 4 lines long, with narrow oblong lobes: capsules on very short recurved peduncles, globose-didymous, about three-fourths free: cells 5-8-seeded: seeds crateriform, with a small hilar rirge. - Proc. Am. Acad. xvii. 202. H. humifusa, Gray, Pl. Wright. i. 82, \& Oldenlandia humifusa, P1. Wright. ii. 68, chiefly, not Pl. Lindh. - Hills, S. W. Texas and New Mexico to S. W. Arizona, first coll. by Wright. (Adj. Mex., Parry \& Palmer.)

* * * Erect perennials : corolla funnelform or in one species almost salverform, small: stamens and summit of style reciprocally exserted quite out of the throat : fructiferous peduncles erect: capsule fron a third to nearly half free: seeds oval or roundish, barely concave on ventral face and with more or less of a medial hilar ridge: stipules entire, scarious, between and connecting the bases of the sessile cauline leaves: fl. mostly in summer.

H. purpúrea, L. Forming small tufts or offsets by filiform rootstocks, a span to a foot high, hirsutulous-pubescent to glabrous: radical leaves ovate or oblong, short-petioled: flowers corymbosely cymose : corolla funnelform, light purple or lilac, varying to nearly white: capsule globular and obseurely didymous, upper half free. - Spec. i. 105; Pursh, Fl. i. 107 ; Gray, Man. ed. 5, 212. H. rarians, Michx. F1. i. 86. H. pubescens, Raf. Med. Rep. \& Desv. Jour. Bot. i. 230, if of the genus. Oldenlandia purpurea, Gray, Man. ed, 2, 173. Hedyotis lanceoluta, Poir. Suppl. iii. 14. H. umbellata, Walt. Car. 85? Anotis lanceolata, DC. Prodr. iv. 433. - Canada to Texas. - Truly polymorphous, of which the typical form "leaves ovatelanceolate," L., or latifolia, is comparatively large, often a foot high and pubescent: leaves ovate to ovate-lanceolate, inch or two long, the larger with rounded closely sessile base: calyx-lobes subulate, sometimes slightly sometimes conspicuously surpassing the emarginate stummit of the capsule. $-H$. purpurea, Torr. \& Gray, Fl. ii. 40. This form from Maryland to Arkansas, and southward to Alabama, especially in and near the mountaius.

Var. cilioláta, Gray, Man. 1. c. A span high: leaves only half-inch long, thickish; canline oblong-spatulate; radical oval or oblong, in rosulate tufts, hirsute-ciliate : calyx-lobes a little longer than the capsule. - H. ciliolata, Torr. in Spreng. Syst. Cur. Post. 40, \& Fl. i. 173. H. longifolia, Hook. Bot. Mag. t. 3099, not Gærtn. Hedyotis ciliolata, Torr. \& Gray, Fl. ii. 40 (excl. syn. H. serpyllifolin, Graham). - Chiefly northward, on rocky banks along the Great Lales and their tributaries, Canada to Michigan and south to Kentucky, passing into the next.

Var. longifólia, Grat, l. c. A span or two high, mostly glabrous, thinner-leaved: leaves oblong-lanceolate to linear ( 6 to 20 lines long) ; radical oval or oblong, less rosulate, not ciliate: calyx-lobes little surpassing the capsule. - $H$. longifolia, Gærtn. Fruct. i. 226 , t. 49, f. 8; Willd. Spec. i. 583. Hedyotis longifolia, Hook. Fl. i. 286; Torr. \& Gray, l. c. $H$. angustifolia, Pursh, Fl. i. 106, partly. - Rocky or gravelly ground, Canada to Saskatchewan, Missouri, and Georgia.

Var. tenuifólia. Slender, lax, diffuse, 6 to 12 inches high, with loose inflorescence, almost filiform branches and peduncles: cauline leaves all linear, hardly over a line wide: otherwise as preceding, - II. tenuifolia, Nutt. Gen. i. 95. Hedyotis longifolia, var. tenuifolia, Torr. \& Gray, 1. c. - S. E. Ohio, and through the mountains, Virginia to N. Carolina and Tennessee.

Var. calycósa. Near a foot high: leaves broadly lanceolate, thickish : calyx-lobes elongated (2 to 4 lines long), much surpassing the capsule. - Hedyotis calycosa, Shuttlew. in distrib. Pl. Rugel. - Mountains of Alabama (Rugel) to Arkansas (Nuttall), and Illinois (E. IIall); also coll. by Drummond.

H. angustifólia, Mıсnx. Rather rigid, becoming many-stemmed from a perpendicular root, glabrous: leaves narrowly linear or lowest somewhat spatulate, on the stems commonly fascicled in the axils: flowers corymbosely or paniculately cymose, short-pedicelled or subsessile: corolla nearly salverform, 2 or 3 lines long, mostly white, upper face of the lobes commonly villous-pubescent: capsule with turbinate or acutish base, only the summit free, and barely equalled by the short calyx-teeth, first opening across the tip, at length septicidal: seeds obscurely concave on the hilar face. (Transition to Oldenlandia.) - Fl. i. 85 ; Gray, 1. c. H. fiuticosa \& H. rupestris, Raf. Hedyotis stenophylla, Torr. \& Gray, 1. c. Olden- 
landia angustifolia, Gray, I1. Wright. ii. 68, \& Man. ed. 2. - Barrens, Mlinois to Kansas, and Tennessee to Florida and Texas.

Var. filifólia. Diffuse, disposed to be lignescent at base : cauline leaves mostly filiform: flowers and capsules smaller, more pedunculate. - Oldenlanlia anqustifolia, Chapm. F1. 181. - Rucky pine barrens near the coast, Florida. In Texils passing into the ordinary form.

Var. rigidiúscula. A span to a foot high, stouter: leaves mostly rigid, from linear to lanceolate : flowers disposed to be glomerate and sessile, but some pedunculate. $-\mathrm{S}$. and Ii. Texas, Palmer, Hatard, \&c. Coast of E. Florida, Ruget. (Mex.)

§ 2. Ereicótis. Fruticose or fruticulose: leaves setaceous or accrose-linear, rigid, fascicled : flowers (purplish) and seeds nearly as in the last preceding subdivision. - Gray, Proc. Am. Acad. xvii. 203.

H. fasciculáta, GRAr, 1. c. A span to a foot or more high, decidedly shrubby, with rigid and tortuous spreading branches, glabrous or hirtello-puberulent: stipules very short: leaves subulate-linear, thickish, 2 to 4 lines long, much fascicled : flowers cymulose, shortpedicelled: corolla 2 or 3 lines long, between salverform and funnelform, the tube sometirnes hardly or sometimes twice longer than the lobes: capsule barely a line long, about one-third free: seeds 4 or 5 in each cell, elongated-oblong, barely concave on the ventral face. - Includes some of Hedyotis stenophyllu or Oldenlandin angustifolia, var. parviflora of Gray, Pl. Wright. i. \& ii. - S. W. borders of Texas and adjacent New Mexico, Bigelow, Wright, G. R. Vasey. (Adj. Mex., Palmer.)

H. acerósa, Grat, l. c. A span or two high, fruticulose, tufted, with slender asconding branches, minutely hispidulous-pubescent or glabrate, very leafy throughout: stijules short, commonly with a median cusp: leaves acicular-setaceous, 3 to 5 lines long: 'alyx-lobes similarly setaceous : flowers sessile : corolla purplish, salverform with slightly dilated throat; its slender tube 3 or 4 lines long, much exceeding the ovate lobes: capsule globular, over a line long, about a quarter part free, much overtopped by the acicular calyx-lobes; cells 12-20-seeded: seeds roundish, with small ventral excavation. - IIcdıotis (Lreicotis) acerosa, Gray, Pl. Wright. i. 81. Oldenlandia acerosa, Gray, Pl. Wright. ii. 67. Mallostoma acerosa, Hemsl. Biol. Centr.-Am. Bot. ii. 31. - High plains and hills, S. W. Texas, and adjacent New Mexico, Wright, \&c. (Adj. Mex., first coll. by Gregg.)

5. OLdENLÁNdiA, Plum. (Dr. H. B. Oldenland.) - Mostly subtropical and humble herbs, with inconspicuous white or whitish flowers. - Nov. Gen. 42, t. 36, \& Pl. Am. ed. Burm. t. 212, f. 1; L. Gen. ed. 1, 362 ; Benth. d Hook. Gen. ii. 58.

* Corolla salverform, surpassing the calyx : flowers cymose : calyx-lobes distant in fruit.

O. Greénei, Gray. Erect annual, paniculately branched, a span or more high, glabrous: leaves spatulate-linear or broadly linear with narrowed base (the larger ones inch long): flowers sessile in the forks and along the lax branches of the pedunculate cyme: calyx-tceth triangular-subulate, about the length of the turbinate tube : corolla less than 2 lines long, with tube longer than its own lobes and those of the calyx: capsule quadrangular-hemispherical, or at first somewhat turbinate: seeds moderately angled. - Proc. Am. Acad. xix. 77. - Pinos Altos Mountains, New Mexico, Greene. Huachuca Mountains, S. Arizona, Lemmon

* * Corolla rotate, shorter than the calyx-lobes, inconspicuous: capsule rounded at base: stjpules mostly bimucronate or bicuspidate: calyx-teeth approximate at base: diffuse low herbs; fl. summer.

O. Bóscii, Chapm. A span or so high from a perennial root, diffusely spreading, slender, glabrous: leaves linear with attenuate base, inch or less long, obscurely one-nerved: flowers few or solitary and nearly sessile at the axils: calyx-teeth broadly subulate, rather shorter than the capsule.-Fl. 181. Bedyotis Bosci. DC. 1. c. 420; Torr. \& Gray, Fl. ii. 41. - Low or wet ground, S. Carolina to Arkansas and Texas.

O. glomeráta, Michx. A span to a foot high from an anuual root, erect or soon diffuse, freely branching, somewhat hirsutulous-pubescent: leaves from ovate to oblong, thinnish, 
half-inch long, contracted at base as if petioled : flowers in terminal or lateral sessile glomerules, rarely solitary : calyx-Iobes ovate or oblong, foliaceous, longer than the subglobose or hemispherical hirsute capsule. - Fl. i. 83; Pursh, Fl. i. 102. O. uniflora, L. Spec. i. 119 name passed by as incorrect. Hedyotis auricularia, Walt. Car. 85, not L. H. glomerata, Ell. Sk. i. 187 ; DC. 1. c.; Torr. \& Gray, 1. c. H. glomerata \& H. Virginica, Spreng. Syst. i. 412. - Low grounds near the coast, Long Island, New York, to Florida and Texas. (Cuba.)

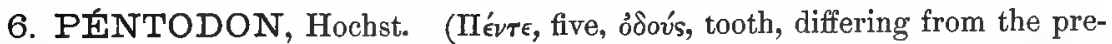
ceding genus in 5-merous flowers, therefore five calyx-teeth.) - Tender and weak somewhat succulent annuals, glabrous; with 4-angular branching and diffusely spreading stems, ovate or oblong short-petiolate leaves, 2-3-flowered terminal peduncles, occupying the forks of the stem or becoming lateral, or by suppression of leaves bearing several quasi-racemose flowers: corolla white. - Flora, 1844, 522 ; Benth. \& Hook. Gen. ii. 59. Hedyotis § Pentotis, Torr. \& Gray, Fl. ii. 42. - Consists of an African species ( $P$. decumbens, Hochst. 1. c., Oldenlandia pentandra, DC.) and the following, which differs from the character of that plant in the points mentioned below.

P. Hálei. Leaves rather obtuse: peduncles shorter than the leaves, or hardly any: pedicels only twice the length of the forvering of fruiting calyx, soon clavate-thickened: corolla only a line long, not hirsute within. - Hedyotis Halei, Torr. \& Gray, 1. c. Oldenlandia Halei, Chapm. Fl: 181. - Low swampy grounds, W. Lonisiana, Hale. Florida, Rugel, Garber, Curtiss. (Cuba.)

7. HAḾfLIA, Jacq. (H. L. DuHamel du Monceau.) Tropical American shrubs: with petiolate sometimes verticillate leaves, interpetiolar lanceolatesubulate stipules, and red or yellow flowers in naked and scorpioid terminal cymes. - Stirp. Amer. 71. t. 50. Duhamelia, Pers. Syn. i. 203.

H. pátens, JACQ. 1. c. Shrub 8 or 10 feet high, cinereous-pubescent on all young parts : leaves more commonly in threes, oval-oblong, acuminate: cyme 3-5-rayed, with flowers almost sessile along its branches: corolla crimson, puberulent, almost cylindrical, over halfinch long: fruits black, small. - Desc. Fl. Ant. t. 107. H. coccinea, Swartz, Prodr. 46. Keys and shores of E. Florida. (W. Ind. to Brazil.)

8. CATESB A, Gronov. (Mark Catesby, author of Nat. Hist. of Carolina, Florida, etc., and of Hortus Brit.-Amer., etc.) -W. Indian spinose shrubs; one has reached the shores of Florida. - L. Gen. ed. 1, 356.

C. parviflóra, Swartz. Shrub 4 to 6 feet high, with rigid very leafy branches, glabrous, spinose from the axils: leaves mostly fascicled at the nodes, coriaceous, shorter than the spines (quarter to half inch long), roundish, lucid: flowers very small for the genus, solitary and sessile : corolla only half-inch long, white : berry small, white. - Prodr. 30, \& Fl. i. 236; Vahl, Ecl. i. 12, t. 10 ; Griseb. Fl. W. Ind. 317; Chapm. Fl. ed. 2, Suppl. 625. - Bahia Honda Key, S. Florida, Curtiss. (W. Ind.)

9. RÅNDIA, Houst. ex L. (Dedicated by Houston, in a letter to Linnæus, to John Rand, an English apothecary.) - As now received, an ample genus of tropical shrubs or trees, largely Asiatic and African, but the original species American, often spinose, and with sessile flowers in the axils or terminating short branchlets. - L. Hort. Cliff. 485, \& Gen. ed. 1, 376; Benth. \& Hook. Gen. ii. 88.

R. aculeáta, L. Shrub 4 to 8 feet high, glabrous, with rigid spreading branches: axillary spines simple, sometimes few, not rarely wanting: leaves obovate to elliptical, at length coriaceous, from 2 inches down to half-inch long, many fascicled in the axils or on short spurs: calyx-teeth short and small : corolla white, 3 or 4 lines long: berries less than half 
inch long, subglobose, blue or black, not many-seeded. - P. Browne, Jam. t. 8, f. 1 ; Griceb, Fl. W. Ind. 318; Chapm. Fl. 179. R. aculeata \& $R$. mitis, L. Spec. ii. 1192, the latter nearly a spineless form. $R$. latifolia, Lam. Dict. iii. 24, \& Ill. t. 156. Gardenia Randia, Swartz, Fl. Ind. Occ. i. 526; Sims, Bot. Mag. t. 1841. - Coast and Keys of S. Florida. (IT. Ind., \&c.)

R. Xalapensis, Mart.\& Gal., occurs not very far beyond the Mexican border.

10. GÉNIPA, Plum. (Altered from an aboriginal name.) - Shrubs or small trees of Tropical America; with ample coriaceous and mostly lucid leaves, deciduous interpetiolar stipules, no spines, but rather large white or whitish flowers which are more or less pedunculate in a terminal cyme, and a large firm-rinded berry. - Plum. Cat. 20. \& Pl. Amer. ed. Burm. 127, t. 136; Tourn. Inst. 658 , t. 436, 437 ; Griseb. Fl. W. Ind. 316.

G. clusiæefólia, Griseb. 1. c. Glabrous:,plant blackening in drying : leaves obovate, very obtuse or retuse, mucroulate, slightly petioled, 2 to 5 inches long, nearly straight-veined, fleshr-coriaceous, lucid: truncate calyx-limb bearing 5 distant and slender subulate teeth: corolla inch long, fleshy, glabrous within and without; tube longer than the oblong-lanceolate lobes: acute tips of anthers exserted: stigmas 2, subulate : fruit 2 or 3 inches long, ovoid. Gardenia clusicefolia, Jacq. Coll. App. 37, t. 4; DC. Prodr. iv. 381. Randia? clusiafolia, Chapm. Fl. 179. Seven-years Apple, Catesb. Car. i. 59, t. 59. - Keys and shores of S. Florida, first coll. by Blodgett. (Bahamas, Cuba.)

GaRdenia Florida, L., cult. as CAPE Jessamine, belonging to the genus most allied to Genipa, is planted out freely in the Southern Atlantic States.

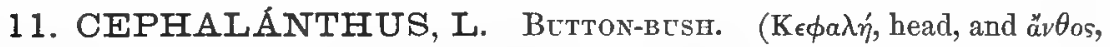
flower, the blossoms densely aggregated in a round head.) - Two or three American and as many Asiatic or African species.

C. occidentális, L. Shrub 3 to 15 feet high, glabrous or pubescent : stipules one on each side between the petioles, triangular, sphacelate, at length deciduous : leaves ovate to lanceolate: flowers white: setiform bractlets between the flowers glandular-capitate: calyx not glandalar, a little hairy around the base.-Spec. i. 95; Lam. Ill. t. 59; Michx. F1. i. 87 ; Schk. Handb. t. 21 ; Bart. Fl. Am. Sept. iii. t. 91 ; Torr. \& Gray, Fl. ii. 31 ; Gray, Bot. Calif. i. 282. - Swamps and along streams, Canada to Florida and Texas, Arizona, and California; fl. summer. Var. brachypodus, DC, of Texas, and rar. C'alifornicus, Benth. PI. Hartw., are mere forms, with leaves short-petioled and often in threes. Var. salicifolius (C. salicifolius, Humb. \& Bonpl. P1. Equin. t. 98) is an unusually narrow-leaved Mexican form. (Mex., Cuba.)

12. MORINDA, Vaill. (Name contracted from Morus Indicus, the syncarp resembling a mulberry.) - Tropical shrubs or small trees, mostly glabrous; with oval to lanceolate leaves, their bases or petioles united by small scarious stipules, terminal or axillary peduncles, and white flowers. - Roioc, Plum. Nov. Gen. 11, t. 26.

M. Roíoc, L. Low shrub, or sometimes climbing by twining: leaves oblong-lanceolate: stipules subulate-pointed: peduncles solitary, bearing single or sometimes geminate small heads. - Spec. i. 176 ; Jacq. Hort. Vind. t. 16; Desc. Fl. Ant. t. 129. - Coast and Keys of S. Florida. (W Ind.)

13. GUETTÁRDA, L. (Dr. J. E. Guettard.) - Tropical and subtropical shrubs, chiefly American, and one widely diffused littoral species : leaves ovate to oblong, petioled, with prominent primary veins beneath: flowers in axillary pedunculate cymes; the corollas sericeous-canescent outside. - L. Gen. ed. 5, 428; Vent. Choix, t. 1; DC. Prodr. iv. 455, excl. §4. Mathiola, Plum. Gen. 16 ; L. Gen. ed. 1, 49. 
G. scábra, LAM. Arborescent: leaves obovate to oblong (4 or 5 inches long), mucronate, coriaceous, at length rugose, hispidulous-papillose and scabrous above, soft-pubescent beneath; primary veins ( 9 to 11 pairs) very prominent beneath and veinlets between well reticulated: peduncles elongated: corolla often inch long; tube retrorsely silky-villous; lobes 5 , rarely 6 or 7 : drupe quarter-inch in diameter, 4-6-celled. - Ill. t. 154, f. 3 ; Vent. Choix, t. 1; DC. 1. c. 456 ; Griseb. Fl. W. Ind. 332 . G. ambigua, Chapm. Fl. 178, not DC. Mathiola scabra, L. Spec, ii. 1192. - S. Florida, Chapman, Garber. (W. Ind.)

G. ellíptica, Swartz. Arborescent: leaves from broadly oval to elliptical-oblong (inch or two long), thinnish, pilose-pubescent, often glabrate, at least above; primary veins 4 to 6 pairs; transverse veinlets not prominent: peduncles and small cymes shorter than the leaves. flowers usually 4-merous: corolla quarter-inch long, externally canescent: drupe size of a pea, 4-8-celled, 4-2-seeded.-Prodr. 59, \& Fl. Ind. Ucc. i. 635 ; DC. 1. c. 457 ; Torr. \& Gray, Fl. ii. 35; Griseb. 1. c. G. Blodgettii, Shuttlew. distrib. coll. Rugel; Chapm. Fl. 178. - S. Florida, first coll. by Blodgett. (W. Ind., Mex.)

14. ERITHALIS, P. Browne. (Ancient Greek name of some plant, from ๕̌pl, very much, and $\theta a \lambda \lambda$ ós, green shoot. Pliny applied it to some green Sedum, and $P$. Browne to this lucid green shrub.) - West Indian littoral shrubs or low trees, very smooth and resiniferous: the following is the principal species.

F. fruticósa, L. Leaves mostly obovate, about 2 inches long, coriaceous : cymes pedunculate, many-flowered: border of the calyx repand-truncate: corolla white, quarter-inch long; lobes widely spreading: drupes not over 2 lines in diameter, purple. - Spec. ed. 2, ii. 251 ; DC. Prodr. iv. 465 ; Desc. Fl. Ant. t. 242 ; Torr. \& Gray, Fl. ii. 35 ; Griseb. Fl. W. Ind. 336. E. fruticulosn, \&c., P. Browne, Jam. 165, t. 17, f. 3. E. odorifera, Jacq. Stirp. Amer. 72, t. 173, f. 23. - Shores and Keys of S. Florida. (All W. Ind.)

15. CHIOCÓCCA, P. Browne. SNowberry. (Xı́́v, snow, кóккоs, berry.) - Tropical American shrubs, commonly sarmentose or twining, glabrous; with coriaceous shining leaves on short petioles, and small yellowish-white flowers in axillary racemes or panicles; the small berry-like drupes at maturity white. P. Browne, Jam. 164; Jacq. Stirp. Amer. 68; L. Gen. ed. 6, 92. - Some species are obviously heterogone-dimorphous!

C. racemósa, L. Usually twining and climbing: leaves from ovate or oval to lanceolateoblong, shining, about equalled by the racemiform panicles : corolla short-funnelform, at most 4 lines long: anthers included : mature drupe quarter-inch in diameter and globose; only the immature flattened and when dried didymous. - Spec. ed. 2, i. 246 ; Audr. Bot. Rep.t. 284 ; Hook. Exot. Fl. t. 93; DC. Prodr. iv. 482 ; Torr. \& Gray, Fl. ii. 32. Lonicera albr, L. Spec. ed. 1, 175. - Var. parrifolia (C. parvifolia, Griseb. Fl. W. Ind. 337) is a smaller-leaved and low form, mostly with simple and shorter racemes. - Coast and Keys of Florida. (W. Ind. to S. Am.)

16. PSYCHOTRIA, L. (Name changed by Linnæus from the original Psychotrophum of P. Browne, which was formed of $\psi v \chi \gamma^{\prime}$, soul, and $\tau \rho \circ \phi \dot{\eta}$, nourishment: seeds used as a substitute for coffee.) - A large genus of shrubs, of most tropical regions, commonly with membranaceous leaves, and small flowers in naked terminal cymes; in some heterogone-dimorphous. - Psychotrophum \& Myrstiphyllum, P. Browne.

P. undáta, JACQ. Shrub 8 to. 18 feet high, with woody spreading branches, glabrous or with some ferruginous pubescence: stipules rather large, broad, blunt, united and sheathing, sphacelate-scarious, caducous (the sheath usually splitting down one side): leaves from oval to elliptical lanceolate, acuminate at both ends ; primary veins transverse or little ascending: cyme sessile, of about 3 primary rays and secondary divisions : corolla white or whitish, villous in the throat, with lobes shorter than tube: drupes red, ellipsoidal when dry (subrotund, Jacquin), the nutlets striate-costate on the back. - Hort. Schoenb. iii. 5, t. 260; DC. Prodr. 
iv. 513 ; Griseb. Fl. W. Ind. $342 . \quad P$. nervosa, Swartz, Fl. Ind. Occ. i. 403. P. lanceolata, Nutt. in Am. Jour. Sci. v. 290, ferruginous-pubescent form, in fruit, and glabrous form also mentioned; DC. l. c. 513. P. chimamhoides, \& P. oligotricha, DC. 1. c. 514, glabrous or nearly glabrous forms. P. ru/tescens, HBK. ? Griseb. l. c., the ferruginous-pubescent forn. - Woods of E. and S. Florida along the coast, first coll. by Wichux and Ware. (W. Ind., Mex.?)

P. tenuifólia, Swartz. Shrub 1 to + feet high, with more simple and erect partly herbaceous flowering branches, glabrous or commonly with a very minute pruinose puberulence, no ferruginous hairiness: stipules distinct, ovate, often acute, sometines setaceonsly-acuminate, caducous : leaves oblong-lanceolate or broader ( 3 to 6 inches long), acuminate at both ends : cyme either short-peduncled or sessile, compactly many-flowered: flowers nearly of the preceding : drupes not seen in the Florida plant, according to Swartz "oblong," (ellipsoidal, Grisebach,) in Cuban specimens globose. -Fl. Ind. Occ. i. 402 (ex char.); Griseb. 1. c. 341. $P$. lanceolata, in distrib. coll. Rugel, in part, \& coll. Curtiss; also Chapm. FI. l. c. in part; Griseb. Cat. Cub. 135, not Nutt. (Near P. pubescens, Swartz, but has different stipules.) - Rich roods, s. Florida; Tampa and Manatee River, Leavenworth, Rugel, Indian River, Curtiss. (IV. Ind.)

17. STRÚMPFIA, Jacq. (C.C. Strumpf, who edited the fourth edition of Linn. Genera Plantarum.) - Stirp. Amer. 218; Lam. Ill. t. 731 ; A. Rich. Mem. Rub. t. 9 ; Benth. \& Hook. Gen. ii. 117. — Single species.

S. marítima, JAcQ. Low shrub, much branched, erect, exceedingly leafy : branches where the leaves have fallen annulate-ronghened by the squarrose remains of the stipules, which closely approximate: leaves more commonly in threes, firm-coriaceous and rigid, linear, with strongly revolute margins, glabrous or puberulent, at length shining, inch or less long, mostly exceeding the flower-clusters: corolla white: fruit white. - Desc. Fl. Ant. t. 208; DC. Prodr. iv. 470; Chapm. Fl. 178 ; Griseb. l. c. 336 . Tournefortia, \&c., Plum. Amer. ed. Burm. t. 251, f. 1. - Rocks on the sea-shore, Keys of Florida. (W. Ind.)

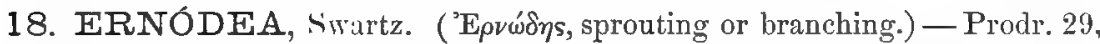
\& Fl. Ind. Occ. 1. 223, t. 4. Knoxia, P. Browne, Jam. 140. Thymelea, Sloane, Hist. Jam. t. 169. — Single species.

E. littorális, Swartz, l. c. Procumbent, suffruticose, glabrous: leaves fleshy-coriaceous, lanceolate, acute, inch or less long, crowded on the branchlets, obscurely nervose-veineà : stipules short-vaginate, produced between the leaf-bases into cuspidate points : corolla yellowish, half-inch or less long: drupe yellow, pisiform, crowned by the conspicuous calyxIobes. - A. Rich. Mem. Rub. t. 5, f. 2 ; Torr. \& Gray, Fl. ii. 30; Griseb. Fl. W. Ind. 347. Shores of S. Florida. (W. Ind.)

19. MitChÉlLA, L. Partridge-Berry. - (Dr. John Mitchell of Virginia, earliest $\mathrm{N}$. American botanical author, founder of several new genera in 1741.) - Gen. ed. 5, 49; Lam. Ill. t. 63. Chamadaphne, Mitch. - Of a single species, for that of Japan seems not different.

M. répens, L Small creeping evergreen, glabrous or nearly so: leaves deep green, ovate or subcordate, half-inch to near an inch in length, slender-petioled : stipules triangular-subulate, minute: peduncle short, terminal: corollas white or tinged with rose outside; tube halfinch long, surpassing the oblong lobes; two-eyed "berry" rather dry and tasteless, bright red, sometimes white. - Spec. i. 111 (Lonicera, \&c., Gronov.; Syringa baccffera, \&c., Pluk. Amalth. t. 444, Catesb. Car. t. 20) ; Lodd. Bot. Cab. t. 979 ; Bart. Fl. Am. Sept. t 95, f. 1 ; Torr. \& Gray, Fl. ii. 34; Gray, Struct. Bot. ed. 6, fig. 467-469. M. undulata, Sieb. \& Zucc.; Miquel, Prolus. Jap. 275. - Woods, especially under Coniferæ, Nova Scotia and Canada to Florida and Texas. (Mex., Japan.)

20. KELLÓGGIA, Torr. (Dr. Albert Kellogg, of California.) - Wilkes, S. Pacif. Ex. Exped. xvii. 332 (1874), t. 6 (1862); Benth. \& Hook. Gen. ii. 137; 
Gray, Proc. Am. Acad. vi. 539, \& Bot. Calif. i. 282. - Single species : most allied to Galopina of S. Africa.

K. galioídes, Torr. 1. c. Slender and glabrous or puberulent perennial, a span to a foot high, with foliage of a Houstonia (leaves only opposite, lanceolate, sessile, with small and entire or 2-dentate interposed stipules), fruit and paniculate inflorescence of a Galium, and corolla (of Asperula) white or pinkish, 2 or 3 lines long, the lobes equalling or shorter than the tube. - Mountain woods, mostly under coniferous trees, Sierra Nevada, California (first coll. by Brewer and Torrey), sonth to mountains of Arizona, east to Utah, and north to Washington Terr. and N. W. Wyoming.

21. MITRACÁRPUS, Zuccarini. (Mírpa, a girdle or head-band, evidently taken in the sense of mitre, and карлós, fruit.) - Low annuals or perennials (American and one or two African); with the habit of Spermacoce, and with small white flowers. - Zucc. in Rom. \& Schult. Syst. Mant. iii. 210, name given only in the accusative case, "Mitracarpum," in index rightly under the nominative "Mitracarpus." Mistaken for a nominative, we have the ungrammatical Mitracarpum, by Cham. \& Schlecht., followed by A. Rich., DC., Endl., Benth. \& Hook., and wrongly corrected by Benth. Bot. Sulph. and Gray, Pl. Wright., into Mitracarpium. (Vide Proc. Am. Acad. xix. 77.) Staurospermum, Thonning in Schum. Pl. Guin. 73, is of same date (1827).

M. breviflórus, Grar. Annual, a span or two high, nearly glabrous and smooth, bearing 2 or 3 axillary verticillastrate-capitate clusters and a terminal one : leaves lanceolate, about inch long: stipules with few setiform appendages: two larger calyx-lobes lanceolate-subulate, Ionger than tube, equalling or surpassing the small (barely line long) glabrous white corolla; intermediate ones small and dentiform, hyaline.-Pl. Wright. ii. 68; Rothr. in Wheeler Rep. vi. 137. - Ravines and hillsides, S. Arizona, Wright, Thurber, Rothrock, \&c. (Adj. Mex., Berlandier, \&c.)

M. Lineáris, Benth. Bot. Sulph., of Lower California,'also coll. by Xantus, has narrow leaves, and tube of corolla at least twice the length of the calyx.

22. RICHÁRDIA, Houst., L. (Dr. H. Richardson of London, father of Richard Richardson, the correspondent of Gronovius, \&c. See Smith's Corr. Linnæus and other Naturalists, ii. 173.) - Hispid or hirsute perennials or annuals, natives of Tropical America; with broadish subsessile leaves, setiferous stipules, and whitish flowers; these mostly in a terminal capitate cluster, involucrate by the one or two uppermost pairs of leaves. - Gen. Pl. ed. 1, 100; Gærtn. Fruct. t. 25 ; Ruiz \& Pav. Fl. Per. \& Chil. t. 279; Hiern in Fl. Trop. Afr. iii. 242. Richardsonia, Kunth in Mem. Mus. Par. iv. 430, \& HBK. Nov. Gen. \& Spec. iii. 350 , t. 279 : but it appears that this, which correctly indicates the naturalist to whom the genus was dedicated, cannot be allowed to supersede the original name, faulty as it is in this respect.

R. SCÁBRA, L. Loosely branching, and spreading: leaves ovate to lanceolate-oblong (inch or two in length), roughish: stipules with rather few setiform appendages: glomerules of flowers and fruit depressed : corolla 2 or 3 lines long. - Spec. i. 330. R. pilosa, Ruiz \& Pav. 1. c.; HBK. 1. c. Richardsonia scabra, St. Hil. Pl. Us. Bras. 8, t. 8; DC. Prodr. iv. 567 ; Chapm. F1. ed. 2, Suppl. 624. - Low or santly grounds, abundantly naturalized in the low country, S. Carolina to Texas, called Mexican Clover in Alabama, and relished by cattle; the root in S. America used as an emetic and as a substitute for Ipecac. Sparingly occurs as a ballast-weed at Northern ports. (Nat. from Mex. \& S. Am.)

23. CRÚSEA, Cham. (Prof.'Wm. Cruse, of Konigsberg, who wrote on Rubiacece.) - Perennials or annuals (of Mexico and adjacent districts), with habit 
of Diodia, the rose-colored or white corollas elongated in the typical species : stamens and style usually exserted. - Linnæa, v. 165; DC. Prodr. iv. 566 ; Hook. \& Arn. Bot. Beech. t. 99 ; Benth. \& Hook. Gen. ii. 144 (calyx wrongly said to persist on the fruit); Gray, Proc. Am. Acad. xix. 77, - where the genus is extended.

* Corolla rose-purple, with slender almost filiform tube: erect annual.

C. Wrightii, Grar. Sparsely hirsute, about a foot ligh, with long internodes: leares oblong-lanceolate, nervose-veiny, upper attenuate-acute; uppermost four or more involucrato around the solitary capitate glomerule: calyx-lobes 4, attenuate-subulate and almost equal, nearly equalling the corolla-tube, or two of them sometimes very short, hispid-ciliate towarl the base : corolla salverform, 2 lines long: stigmas 2, short-linear: ovary and immature fruit didymous. - Pl. Wright. ii. 68. - Plains and mountains of S. Arizona, Wright, Lemmon. Habit of C. rubra, but far smaller-flowered.

* * Corolla white or whitish, small (about 2 lines long): stamens and style little exserted: stigmas short: low and diffuse annuals or perennials.

C. subuláta, GraY. Glabrous and smooth throughout: stems ascending from an annual root, a span or two high, somewhat paniculately branched: branches flowering from most of the axils : leaves narrowly linear becoming subulate (inch or less long): clusters rather fer-flowered : corolla almost salverform: calyx-lobes 2 or 3 lanceolate and foliaceous, one or two much smaller and partly scarious or reduced to stipule-like teeth : gynœecium 2-merous : fruit cuneate-obovate, slightly didymous, obscurely puberulent: carpels coriaceous, at mar turity separating from a narrow linear and bifid persistent carpophore (not unlike that of some Umbelliferæ) and opening on the ventral face. - Proc. Am. Acad.xix. 78, not that of Hemsl. Biol. Centr.-Am., which is a slip of pen or type for C. sulalata, Hook. \& Arn. Spermacoce subulata, Pav. ex DC. (Borreria subulata, DC. P'rodr. iv. 543); Hemsl. 1. c. 60. S. Arizona, Wright (from seeds which were raised in Botanic Garden, Cambridge, in 1852), Lemmon. (Mex.)

C. allocócca, Grar, 1. c. Hirsute or hispidulous to almost glabrous, diffusely branched from a perennial root, low and much spreading or depressed, flowering from summit and uppermost axils: leaves from linear to oblong-lanceolate (half-inch to barely inch long): corolla funnelform, 3-4-lobed: calyx-lobes 3 to 5, commonly 4 and equal, lanceolate, longer than the ovary and fruit: gynœcium 3-4-merous: stigmas short and broad: fruit obovatoglobose, sometimes glabrous and smooth, sometimes partially or wholly hispidulous, 3-4coccous, more commonly 3-coccous; the carpels flattened on the ventral face, separating from a weak scarious carpophore, either closed or torn open ventrally. - Diodia tricocca, 'Torr. \& Gray, Fl. ii. 30. D. tetracocca, Hemsl. Biol. Centr.-Am. Bot. ii. 56, t. 40, f. 10-15. Spermacoce? tetracocca, Martens \& Gal. Bull. Acad. Brux. xi. 132, fide Herasl. - Prairies of Texas, first coll. by Berlandier, Drummond, \&c. (Mex.)

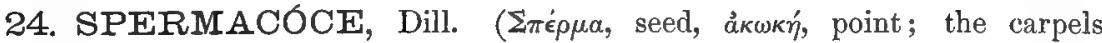
pointed or crowned with one or more calyx-teeth.) - Low herbs, with small and white sometimes bluish or purplish flowers, and small fruits in sessile glomerules at the nodes; chiefly tropical, the greater number American. - Dill. Elth. ii. 370 , t. 227 ; L. Gen. ed. 1, 25 ; Benth. \& Hook. Gen. ii. 145. Spermacoce \& Borreria, Meyer, Prim. Fl. Esseq. 79 ; Cham. \& Schlecht. in Linn. iii. 310, 355 ; DC. Prodr. iv. 540, 552. F1. summer : corolla in our species short and white.

S. involvcráta, Pursh, Fl. i. 105, appears to have been founded on Crusea rubra, Cham. \& Schlecht. (notwithstanding the "flowers white"), and without much doubt was wrongly attributed to this country.

* Leaves from oval to oblong-lanceolate, contracted into a narrow base or short and margined petiole, obliquely more or less pinnate-veined, in ours smooth and glabrous or a little scabrous: fruit splitting into the two carpels, one broadly open on the ventral face and discharging its seed, the other closed (at least at first) by the membranaceous or coriaceous dissepiment. Spermacoce, G. F. W. Meyer, l. c.; DC. 
+ Corolla very villous in the throat, very short: root apparently perennial.

S. glábra, Micrix. Spreading or decumbent, smooth and glabrous : stems a foot or so long: leaves oblong-lanceolate and oblong (inch or two long), not prominently veined: corolla more campanulate than funnelform, little surpassing the large calyx-teeth (only a line and a half long): subsessile anthers and style included: fruit somewhat turbinate, smooth (nearly 2 lines long), crowned by the 4 conspicuous at length triangular-lanceolate spreading calyxteeth, their bases slightly united. - F1. i. 82; Pursh, Fl. i. 105 (excl. the remark that corolla is longer than in the next); Torr. \& Gray, Fl. ii. 27. Diodia glabra, Pers. Syn. i. 124. Probably Spermacoce verticillis tenuioribus, Dill. Elth. l. c., therefore S. tenuior, L. Spec. except as to syn. Pluk. - River-banks, S. Ohio to Florida, Arkansas, and Texas.

++ Corolla glabrous or merely pubescent in the throat: root annual.

S. tenúior, L. partly, LA.r. Ascending or spreading: leaves oval-oblong to oblong-lanceolate, more or less seabrous, with 4 or 5 pairs of more prominent veins: corolla funnelform, twice or thrice the length of the calyx, and with more or less exserted stamens and style, yet in some plants nearly as short as in the preceding species, and with stamens and style included (probably dimorphous): fruit didymous-obovate, commonly pubescent or puberulent (only a line or so long), coriaceo-crustaceous, crowned with the four short deltoid or triangular-lanceolate distinct calyx-teeth. - L. Spec. i. 102, as to Pluk. Alm. t. 136, f. 4, perhaps also of Dill. Elth. 1. c.; Pursh, Fl. 1. c.; Lam. Inl. i. 273, t. 62, f. 1; Schk. Handb. t. 32 ; A. Rich. Mem. Rub. t. 4, no. 2, excl. fig. c?; Griseb. Fl. W. Ind. 349. S. Chapmanii, Torr. \& Gray, Fl. ii. 27, form with the more conspicuous corolla, \&c. - River-banks, Florida and Louisiana; rare. (W. Ind. to Brazil.)

S. Portoricénsis, Balbis. Annual or perhaps perennial, diffusely spreading, wholly smooth and glabrous: leaves smaller than in the preceding (half-inch to inch long), drying blackish, with inconspicuous venation: glomerules mostly small and few-flowered: corolla only half-line long, short-campanulate, glabrous inside: subsessile anthers and style included: fruit globular (a line or less long), rery smooth or rarely obscurely puberulent, thinnish, crowned with small narrowly subulate calyx-teeth, their bases distant: seed strongly scrobiculate-punctate.-DC. Prorr. iv. 552; Polak in Linn. xli. 373. S. tenuior, Torr. \& Gray, Fl. ii. 27, \& of distrib. Rugel, Curtiss, \&c. S. tenuior, var. Portoricensis, Griseb. - Keys and near shores of Southern Florida, Blodgett, Rugel, Garber, Curtiss. (W. Ind., \&c.)

* * Leaves in our species narrow and sessile : fruit septicidal through the thin dissepiment and both carpels ventrally dehiscent. - Species of Borreria, Meyer, 1. c.; DC. 1. c. Bigelovia, Spreng. Syst.

S. parviflóra. Annual, glabrous or a little hirtellous-pubescent: stems slender, spreading or erect, a span to a foot high: leaves from narrowly lanceolate to spatulate-oblong (inch or less long), obscurely veined: glomerules in many of the axils, globose: corolla salverform, about a line long: stamens and style included: fruit half a line long, didymous-globular, thinnish, surmounted by the four attenuate-subulate and longer nearly equal calyx-teeth, two on each carpel: seed scrobiculate. - Borreria parviftora, Meyer, Fl. Esseq. 83, t. 1, f. 1-3; DC. 1. c. B. micrantha, Torr. \& Gray, Fl, ii. 28. B. Domingensis, Griseb. Cat. Cub. 141. Hardly Spermacoce hirta, Swartz, referred here by Griseb. - Waste grounds, S. Florida, Leavenworth, Garber, Curtiss. (W. Ind., Mex., S. Am.)

S. podocéphala. Suffrutescent perennial, a span to a foot high in tufts, glabrous and smooth or sometimes obscurely hirtello-puberulent: stipnlar bristles few: leaves numerous, about the length of the internodes and usually axillary-fascicled, narrowly linear (inch or less long), seldom over a line wide, veinless, not rarely with revolute margins, 2 to 6 uppermost raised on a longer peduncle-like internode and involucrating the solitary terminal globose glomerule: corolla short-funnelform, a line or little more in length : fruit obovate and didymous, each carpel surmounted by a rather shorter subulate or obtuse calyx-tooth; intermediate teeth rudimentary or wanting: seed minutely scrobiculate. - Borreria podocephala, DC. Prodr. iv. 542 ; Chapm. Fl. 175 (var. pumila); Griseb. Fl. W. Ind. 350, the W. Indian specimens attenuate and with less fascicled leaves. Spermacoce pygmoea, Wright in Sauv. Fl. Cubana, 72. - S. Florida, Blodgett, \&c. S. Texas, Berlandier, Palmer. (Mex., W. Ind.)

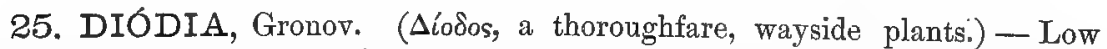
herbs (nearly all American), usually decumbent; with white or bluish flowers 
either solitary or few and sessile in the axils of the leaves, produced all summer; stipules long-setiferous. - L. Hort. Cliff. App. 493, \& Gen. ed. 2, 291 (barl character, genus there attributed to Gronorius); Jacq. Ic. Rar. t. 29; Lam. Ill. i. 276, t. 63 ; Torr. \& Gray, Fl. ii. 28, excl. spec. 3. Diodia § Eudiodia, DC.

$\S 1$. Strcle 2-cleft and stigmas filiform, and anthers nearly linear; both exserted: fruit somervhat drupaceous-fleshy before maturity.

D. Virginiána, L. Diffusely spreading or procumbent from a perennial root, from nearly glabrous to hirsute: leaves from oblong to lanceolate, inch or two long, bright green, with 4 or 5 pairs of oblique veins: stipular bristles strong and flat, not very mauy, commonly sparingly hirsute: corolla about half-inch long, with slender tube: fruit 3 or 4 lines long, from glabrous to hirsute, crowned with 2 (or sometimes 3 or 4 ) lankcolate conspicuous calyxteeth : carpels suberuge-crustaceous, with a thin epicarp, 3-costate on the back. - Spec. i. 104, \& Mant. ii. 330 ; Torr. \& Gray, Fl. ii. 29, with vars, D. Tirginica, Jacq. Ic. Rar. 1. c.; Lam. l. c.; Michx. Fl. i. 81 ; Pursh, Fl. i. 105; DC. Prodr. iv. 562. D. tetragona, Walt. Car. 87. D. hersuta, Pursh, Fl. i. 106. Spermacoce Virginiana, A. Rich. Mem. Rub. t. 4, no. 3, fruit only. - Low grounds, along streams, S. New Jersey to Florida, Texis, and Arkansas.

§2. Style entire: stigma capitate-2-lobed, and with the short anthers shorter than the purplish corolla-lobes: fruit wholly dry and thin-crustaceous.

D. téres, $\Pi_{\text {ALT. }}$. Diffusely spreading or ascending from an annual but sometimes lignescent root, rigid, from puberulent to hirsute: branches terete, rather quadrangular above: leaves from linear to lanceolate, commonly inch long, rather rigid, scabrous: bristles of the truncate stipules numerous, long and slender, usually equalling the flowers and surpassing the fruit: corolla only 3 lines long: fruit obovate-turbinate, commonly hispidulons, only 2 lines high, crowned with the mostly 4 shorter and equal or unequal deltoid-lanceolate or at length ovate calrx-lobes, of ten 3 ou une carpel and one on the other. - Car. 87; DC. Prodr. iv. 562; Torr. \& Gray, 1. c. Diodia, Gronor. in Clayt. Fl. Virg. ed. 1, 71 , ed. 2, 17, at least in part, fide herb. Spermacoce diodina, Hichx. Fl. i. 82; Pursh, Fl.i. 105. - S. Santly soil, New Jersey and Penn., towarl the coast, to Florida, Texas, and in Mississippi Valley to Wr. Illinois. (Adj. Mex., W. Ind., for it probably includes $L$. prostrata, Swartz.)

Var. angustáta. Slender: stem often simple, all the upper part quadrangular: leaves narrowly linear-lanceolate or linear: fruit hispidulous to puberulent, varying to quite smooth, and to smooth and glabrous herbage. - D. teres, var.? Gray, Pl. Wright. ii. 69. S. Arizona, Thurber, Wright, Lemmon, the latter specimens a remarkably smooth form.

26. GÁliUM, L. Bedstraw, Cleavers. (Gallium, as written by the old herbalists, and even by Tournefort; supposed to come from yáda, milk, which some species were used to curdle, in place of rennet.) - Very large genus, indigenous to all temperate regions: leaves sessile: flowers small, in summer.Gen. ed. 5, 46. Galium \& Aparine, L. Gen. ed. 1-3. Gullium, Aparine, \& Cruciata, Tourn. G'alium \& Relbunium, Benth. \& Hook. Gen. ii. 149.

Rúbia (R. tinctoria, L., of the Old World, is the cultivated MADDER) has 5-merous flowers and baccate fruit, the latter a character of several species of Galium.

Aspértea odorÁta, L., the WondrcF of Europe, sweet-scented in drying, has been oceasionally found around German settlements.

\section{$\S 1$. Species locally naturalized in the Atlantic States: fruit dry at maturity.}

G. vérux, L. Perennial : stems smooth, erect: leaves 8 or sometimes 6 in the whorls, linear, roughish, soon deflexed: flowers very numerous, paniculate, yellow, rarely cream-color: fruit usually smooth. - Dry fields, E. Massachusetts. (Nat. from Eu.) ,

G. MoldUGo, L. Perennial, smooth throughout: stems erect or diffuse, 2 or 3 feet long: leaves 8 or on branchlets 6 in the whorls, oblanceolate to nearly linear: flowers very numerous in ample almost leafless panicles: fruit smooth. — Roadsides and fields, New York and Penn. (Nat. from Eu.) 
G. Axglicum, Huds. Annual, slender, diffuse, seldom a foot high, glabrous: leaves 5 to 7 in the whorls, oblanceolate to nearly linear (quarter-inch long), minutely spinulose-scabrous on margins and angles of stem: flowers rather few, cymulose on leafy branches, greenishwhite, very small: fruit glabrous, but more or less tuberculate-granulate. - G. Parisiense, L. var. Anglicum, Hook. \& Arn. Brit. Fl. \&c. - Roadsides in dry soil, Bedford Co., Virginia, A. II. Curtiss. (Nat. from Eu.)

G. Tricórne, Wrtr. Annual, resembling G. Aparine, rather stout, with simple branches, spreading or procumbent: leaves 6 or 8 in the whorls, oblanceolate, cuspidate-mucronate (inch or less long), retrorsely prickly-hispid on margins, as also on angles of stem: flowers usually only 3 in the umbelliform cymules, dull white: fruits comparatively large, tuberculate-granulate, not hairy, hanging on recurved stout pedicels (likened to the three balls of a pawnbroker's shop). - Rare in waste or cult. fields eastward. (Nat. from Eu.)

\section{§ 2. Indigenous species : fruit dry.}

* Annuals: fruit more or less uncinately hispidulous or hirsute, in one species sometimes naked: flowers hermaphrodite: corolla white or whitish.

$$
\text { + Coarse, reclining: leaves } 6 \text { to } 8 \text { in the whorls. }
$$

G. Aparíne, L. (Chesters, Goose-Grass.) Stems 1 to 4 feet long, retrorsely aculeolatehispid on the angles, as also on the margins and midrib of the oblanceolate or almost linear cuspidate-acuminate leaves: peduncles rather long, I to 3 in upper axils or terminal, bearing either solitary or 2 or 3 pedicellate flowers: fruit not pendulous, rather large, granulatetuberculate and the tubercles tipped with bristles. - Reichenb. Ic. F1. Germ. t. I597. - Shaded grounds, Canada to Texas, and Aleutian Islands to California ; eastward mainly as an introduced plant, or appearing so. (Eu., Asia.)

Var. Vaillántii, Kocr. Smaller, more slender: leaves seldom inch long: flowers usually more numerous : fruit smaller (carpels when dry only a line or so in diameter), hirsute or hispidulous. - Fl. Germ. ed. 1, 330. G. Aparine, var. minor, Hook. Fl. i. 290. G. Vaillantii, DC. Fl. Fr. iv. 203. - Texas to California, Montana, and Brit. Columbia ; certainly indigenous: perhaps so in Canada, \&c. (Eu.)

+ - Small and low, more erect: leares mostly 4 in the whorls.

t+ Flowers on solitary naked peduncles.

G. bifólium, WAtson. Smooth and glabrous, a span or two high, sparingly branched slender: leaves oblanceolate to nearly linear, four in the whorls (larger half-inch long), the alternate ones smaller, or uppermost nearly reduced to a single pair: fructiferous peduncles about the length of the leaves, horizontal, and the minutely hispidulous fruit decurved on the naked tip. - Bot. King Exp. 134, t. 14. - Mountains of Utah, Nevada, and S. Montana, Watson. W. Colorado, Brandegee, and Sierra Nevada, California.

G. Texénse, Gray. Hispidulous-hirsute or upper part of stem glabrous, weak and slender, a foot or less high : leaves broadly oval, equal, in fours, thin, one-nerved (only 3 or 4 lines long), the sides and margins equally beset with straight bristly hairs: peduncles terminal and 1-flowered; the primordial ones naked and filiform, 4 to 10 lines long; single axils proliferous into a similar shoot which bears an unequally 4-leaved small whorl and a short peduncle or pedicel: bristles of the fruit much shorter than the carpels, barely uncinulate. Proc. Am. Acad. xix. 80. G. Californicum, var. Texanum, Torr. \& Gray, Fl. ii. 20. G. uncinulatum, Gray, Pl. Lindh. ii. 215? probably not DC., nor G. obstipum, Schlecht., which are perhaps perennial and have a different inflorescence, but are nearly allied. - Hills and riverbanks, Texas, Drummond (immature), Lindheimer, Wright, Hall, Reverchon.

+ ++ Flowers and fruit solitary and sessile between a pair of bracteal leaves which resemble the cauline ones: stem and leaves hispidulous, or sometimes nearly glabrous.

G. virgátum, Nuтt. A span or two high, simple or with simple and strict branches from the base: leaves oblong-linear or oblong, thickish, 2 or 3 lines long; most of the axils floriferous: peduncles exceedingly short, reflexed in fruit, not proliferous: carpels copiously uncinate-hispid, shorter than the arrect bracteal leaves, which often appear as if belonging to the whorl itself. - Torr. \& Gray, Fl. ii. 20; Gray, P1. Lindh. ii. 215. G. Texanum, Scheele in Linn. xxi. 597, badly described. - Naked prairies of Arkansas, W. Louisiana, and Texas, first coll. by Nuttall.

Var. leiocárpum, Torr. \& Gray, 1. c. Fruit quite smooth and glabrous: herbage commonly almost so. - With the ordinary form. 
G. proliferum, Grar, More branching, less hispidulous or glabrate, weaker: leaves thinner, oval or oblong, alternate ones rather smaller: flowers solitary terminating a pedunculiform axillary brauch of twice or thrice the length of the whorled leaves, and the fruit barely surpassed by its pair of bracts, or one or even two more by prolification from the bracts: fruit of the preceding. - Pl. Wright, ii. 67. G. virgatum, var, diffusum, Gray, P1. Wright. i. 80. - Stony hills, along the Rio Grande between Texas and New Mexico, Wright, \&c. Hills near Tucson, Arizona, Pringle. Perhaps S. Utah, M. E. Jones, specimen insufficient. (Adj. Mex., Palmer.)

* * Perennials, wholly herbacenus: slender roots of several species containing red coloring-matter (madder): flowers hermaphrodite (at least not diœcious): bristles on the fruit short and uncinate or none.

+ Leaves in fours throughout or rarely even fewer, comparatively large, either broad or inch or more long, none cuspidate-pointed,

* Broad, one-nerved, with usıally an obscure pair of lateral veins at base: flowers yellowish white to brown-ptrplish: fruit hispid.

G. pilósum, AIt. Commonly hirsutulous-pubescent: stems ascending, two feet long, paniculately branched above: leaves oval, callous-mucronulate, puncticulate (the largest hardly inch long): cymules few-flowered: flowers all short-pedicelled. - Ait. Kew. i. 145; Pursh, Fl. i. 104; Torr. \& Gray, Fl. ii. 24. G. Bermuderise, L. Spec. i. 105, as to syn. Pluk., from which also the specific name, but with the incongruous char. "foliis linearibus"; and the plant seems unknown from Bermuda. G. purpureum, Walt. Car. 87, not L. G. puncticulosum, var. pilosum, DC. Prodr. iv. 601,- Open woods in dry soil, S. New England to Indiana, Arkansas, Texas, and Florida. (G. obovatum, HBK., of S. America, is near to this.)

Var. puncticulósum, Torr. \& Grar, l. c. Almost glabrous: leaves varying to elliptical-oblong, hispidulous-ciliate. - G. Bermudense, L. 1. c. as to syn. Gronov. G. puncticu losum, Michx. Fl. i. 80; DC. 1. c. G. Bermudıanum, Pursh, Fl. i. 104. G. punctatum, Pers. Syn. i. 128. - Virginia to Texas.

$+\div$ Leaves broad, distinctly 3-nerved, pointless or merely callous-mucronate: flowers never bright white.

= Fruit hispid: cymes rather few-flowered, with divisions or peduncles in fruit divaricate or diverging: corolla from dull cream-color or greenish to browa-purplish: stems comparatively simple and low.

G. Kamtscháticum, Steller. A span to a foot high: stems weak, mainly glabrous: leaves orbicular to oblong-ovate, thin (half-inch to inch or so long), slightly pilose or hirsutulous, at least the nerves and margins : flowers few or several in the pedunculate cymules, all distinctly and rather slenderly pedicellate: corolla glabrous, yellowish white, not turning dark, its lobes merely acute. - Steller in Rom. \& Schult. Syst. iii. Mant. 186; Gray, Proc. Am. Acad. xix. 80. G. obovatum, Ledeb. Fl. Ross. ii. 412; Schmidt, Fl. Sachal. 263 ; Maxim. Mel. Biol. ix. \&c., not of HBK., which is S. Amer. and has pinnately veiny leaves. $G$. Littellii, Oakes in Hovey Mag. vii. 177 (1841); Gray, Proc. Am. Acad. viii. 388. G. circcaans, var. montanum, Torr. \& Gray, Fl. ii. 24. - Mountains of Gaspé, Lower Canada (Dr. Allen), higher mountains of New England (Littell, Tuckerman, Oakes, \&c.); also those of Oregon and Washington Terr. (Hail, Howell, Henderson, Suksdorf, chiefly forms with oblong-ovate and acutish leares), to Unalaska, Eschscholtz. (Adj. E. Asia, the Sachalin plant exactly that of N. New England and Canada.)

G. circáezans, Mrchx. About a foot high, hirsutulons-pubescent or glabrate: leaves oval or oblong-ovate, obtuse (largest inch and a half long): flowers short-pedicelled or subsessile in the fork and along the simple branches of the cyme: fruit at length deflexed: corolla greenish, hirsutulous outside, the lobes acute or acuminate.-Fl. i. 80: DC. 1. c.; Torr. \& Gray, 1. c. excl. vars. G. brachiatum, Muhl. Cat., not Pursh. G. boreale? Walt. Car. 257. G. circaoides, Rcem. \& Schult. Syst. iii. 256. - Dry woods, Canada to Florida, N. W. Arkansas, and Texas. Leaves sweet-tasted, wherefore called Wild Liquorice.

G. lanceolátum, Torr. A foot or two high, simple-stemmed, nearly glabrons: leaves (except lowest) broadly lanceolate, verging to ovate-lanceolate, acute or acutish (2 inches long): corolla glabrous, larger and the lobes more acuminate than in preceding, yellowish turning dull purple: Inflorescence similar: fruit less hispid.-Fl. N. \& Midd. States, 168; Hook. Fl. i. 280; Gray, Man. G. Torreyi, Bigel. Fl. Bost. ed. 2, 56. G. circazans, var. 
lanceolatum, Torr. Cat. PI. N. Y. 23; Torr. \& Gray, Fl. ii. 24.-Dry woods, New England to Upper Michigan and Canada.

$=$ Fruit very smooth and glabrous, rather fleshy: corolla dark brown-purple; lobes acuminate.

G. latifólium, Мrснх. A foot or more high, somewhat glabrous: leaves oblong- to ovatelanceolate (mostly 2 inches long), hispidulous-ciliate, lineate-puncticulate, almost petiolate: cymes effusely paniculate, many-flowered; flowers on filiform pedicels, which are erect even in fruit.-F1. i. 79; DC. Prodr. iv. 599; Torr. \& Gray, Fl. ii. 25, excl. var. - Open woods in the Alleghany Mountains, Penn. (Porter) to Carolina and Tennessee, first coll. by Michaux.

++++ Leaves narrow, with lateral nerves obscure or none: otherwise like G. latifolium.

G. Arkansánum, Grar. Less than foot high: stem and branches glabrous, slender: leaves from lanceolate to linear (at most inch long, 1 to 3 lines wide), hispidulous-ciliate on the margins and midrib beneath : effuse cymes, flowers, \&c. of the last preceding: fruiting pedicels minutely upwardly scabrous. - Proc. Am. Acad. xix. 80. G. latifolium, var., Torr. \& Gray, 1. c. - Arkansas, near the Hot Springs, Engelmann, Dr. Foreman.

+++ Leaves narrow, distinctly 3-nerved, blunt: flowers bright white, copious.

G. boreále, L. Erect, a foot or two high, mustly smooth and glabrous, very leafy: leaves from linear to broadly lanceolate, often with fascicles of smaller ones in the axils: flowers in numerous close cymules collected in a terminal and ample thyrsiform panicle; the uppermost leaves being reduced to pairs of small oblong or oval bracts : fruit small, hispidulous, or at first canescent and soon glabrous and smooth. - Spec. i. 108; Fl. Dan. t. 1024; Pursh, Fl. i. 104 ; Hook. Fl. i. 289 ; Torr. \& Gray, l. c. G. septentrionale, Røin. \& Schult. Syst. iii. 253; DC. Prodr. iv. 601. G. strictum, Torr. Cat. P1. N. Y. 23. G. rubioides of Am. authors, form with smooth fruit and broadish leaves. (True G. rubioides, L., N. Asia to Kamtschatka, has evident reticulate venation between the ribs of the broader leaves, and enlarged vesicular as well as smooth fruit.) - Rocky banks of streams, Canada to Penn., New Mexico, ('alifornia, and north to Arctic regions, in various forms. (Eu., N. Asia.)

+ + Leaves in fours, fires, or sixes, small, one-nerved, pointless: plants low, slender and weak, and slender-rooted: flowers very small, white: fruit smooth and glabrous.

G. Brandegéi, Gray. Loosely cespitose-depressed, with the aspect of Callitriche or Elatine, smooth and nearly glabrous: branchès or stems a span or less long: leaves in fours, obovate to spatulate-oblong, slightly succulent, 1 to 3 lines long, one or two of the whorl usually smaller than the others; midrib indistinct: peduncles solitary in upper axils or geminate and terminal, one-flowered, little longer than the leaves. - Proc. Am. Acad. xii. 58. - New Mexico, in valley of the upper part of the Rio Grande at Los Pinos, 9,000 feet, spreading on moist ground, Brandegee.

G. trifidum, L. Weakly erect, branching, 5 to 20 inches high, smooth and glabrous, except the retrorsely scabrous angles of the stem and usually more hispidulous and sparse roughness of the midrib beneath and margins of the leaves: these in sixes, fives, or not rarely fours, linear or oblanceolate, or lanceolate-oblong, obtuse, 4 to 7 lines long; the midrib evident: peduncles slender, scattered, 1-several-flowered; flowers often 3-merous (whence the specific name), as commonly 4-merous. - Spec. i. 105; Fl. Dan. t. 48; DC. Prodr. iv. 597 ; Torr. \& Gray, Fl. ii. 22. G. tinctorium, L. 1. c. 106; DC. l. c., larger form with leaves in sixes and flowers 4-merous. G. Claytoni, Michx. Fl. i. 78; Hook. Fl. i. 288. - Sphagnous bogs and wet ground, Newfoundland and Labrador to Aleutian Islands, and south to Texas, Arizona, and California. (Eu., N. Asia, Japan.)

Var. pusíllum, GraY, Man., among the many forms of the species, is the smallest, a span or two high: leaves only in fours, 3 or 4 lines long, narrow, in age often reflexed: peduncles 1-flowered. - In cold bogs, a Northern form, and in the Rocky Mountains and Sierra Nevada to Colorado and California.

Var. latifólium, Torr. The larger and broadest-leaved form: leaves 6 or 7 lines long, often 2 lines wide: cymules few-several-flowered. - Fl: N. \& Midd. States, 165; Gray, Man. G. obtusum, Bigel. Fl. Bost. ed. 2, 65. - Canada to Texas and mountains of California.

G. concínnum, ToRr. \& Grax. Diffuse and erect, freely branching, about a foot high, smooth and glabrous, except the roughened angles of the stem and margins of the leaves: these all in sixes, oblanceolate-linear, mucronulate, veinless, rather lucid and firm (drying bright green), the midrib prominent beneath: flowers numerous in loose and open cymes on 
filiform peduncles or branchlets, and on filiform but rather short pedicels: corollas bright white. - Fl. ii. 23; Gray, Man. 1. c. Perhaps G. parviflorum, Raf. in Med. Rep. v. 360, \& Desv. Jour. Bot. i. 227? - Dry hills, Penmsylvania and Virginia to Michigan, Illivois, Iientucky, and Arkansas, first coll. by Short.

+++ Leaves in sixes, sometimes fives or on the branchlets fours, cuspidately mucronate or acuminate.

+ Fruit smooth and glabrous: plant rough and adhesive by retrorse prickles: flowers bright white.

G. aspréllum, Mrchx. Glabrous, paniculately branched, erect and 2 feet high, or when supported by bushes 3 to 5 feet high, very floriferous: leaves lanceolate, about half-inch long, in sixes or on the branchlets fives or fours; their margins, midrib beneath, and prominent angles of the stem armed with strong retrorse prickles rather than bristles : cymes many-flowered: fruits small, like those of G. trifidum.-Fl. i. 78 ; DC. I'rodr. iv. 598; Torr. \& Gray, Fl. ii. 23. G. Pennsylranicum, Muhl. Cat.; Willd. ex Roem. \& Schult. Syst. Mant. iii. 183. G. spinulosum, Raf. Prec. Decouv. 1814, 40. G. micranthum, Pursh, Fl. i. 103 ? by the char., except as to fruit. - Alluvial ground, especially low and shaded banlss of streams, Canada, New England to Michigan and mountains of Carolina. (E. Asia?)

+ +- Fruit from scabrous or papillose to uncinately hispid: angles of the stem and midrib beneath minutely retrorse-hispidulous or scabrons or nearly naked in the same species: margins of leaves either antrorsely or retrorsely hispidulous-ciliolate, or naked in the same species, or even on different parts of same leaf.

G. aspérrimum, Grar. Stems erect or diffusely ascending, but weak, a foot or two high, probably from a perennial root: leaves lanceolate (about half-inch to inch long): cymes twice or thrice dichotomous, with filiform peduncles and pedicels: corolla white or turning purplish : ovary merely puberulent or scabrous: fruit granulate-scabrous, and sometimes minutely hispidulous. - Pl. Fendl. 60, \& Bot. Calif. i. 284; Watson, Bot. King Exp. 134; Rothrock in Wheeler Rep. vi. 138. - Shady places in mountains, New Mexico (first coll. by Fendler) and Arizona to Nevada, California, and E. Oregon; mostly var. asperulum, Gray, Bot. Calif. 1. ¿. ; but the hispid or hispidulous roughness very variable.

G. triflórum, MicHx. Diffusely procumbent, smoothish: herbage sweet-scented (as of Asperula odorata) in drying: stems a foot to a yard long: leaves elliptical-lanceolate to narrowly oblong (inch or two long): cymes once or twice 3-rayed: pedicels soon divaricate: corolla yellowish white to greenish, its lobes hardly surpassing the bristles of the ovary: fruit uncinate-hispid.-Fl. i. 80 ; Willd. Hort. Berol. t. 66 ; Pursh, Fl. i. 104 ; Hook. 1. c. ; Torr. \& Gray, l. c. G. cuspidatum, Muhl. Cat.; Ell. Sk. i. 197; DC. 1. c. G. brachiatum, Pursh, l. c. 103. G. suaveolens, Wahl. Fl. Lapp. 48. G. Pennsyluanicum, Barton, Comp. Fl. Philad. 83. - Open and dry or moist woods, Canada to Alabama, Colorado, Rocky Mountains, W. California, and north to Alaskan Islands. (N. Eu., Japan.)

* * * Perennials with suffrutescent or suffruticose base: leares 4 in the whorls; their margins, midrib, and angles of stem destitute of retrorse hispidness or roughness: fruit hirsute with long and straight (not at all uncinate-tipped) bristles: Western species of arid districts. $-\S T$ richogalium, Gray.

+ Flowers hermaphrodite or monœcious-polygamous, paniculate and short-pedicelled, small: corolla only a line in diameter, brown-purple: stems numerous in tufts from the woody base, a foot or less high, slender, much branched: leaves narrow, 2 to 4 lines long, one-nerved, pointless.

G. Rothróckii, GRaY. Glabrous, erect: leaves narrowly linear, rigid : bristles not very copious, not longer than the body of the fruit.- Proc. Am. Acad. xvii. 203. - S. Arizona, Wright (mixed with the following species), Rothrock, Lemmon. (Lower Calif., Orcutt.)

G. Wríghtii, Grar. Hirsute-pubescent throughout, diffuse: leaves linear to narrowly oblong, hardly at all rigid: bristles of fruit as long as its diameter. - Pl. Wright. i. 80, ii. 67. - Crevices of rocks in ravines, W. Texas to S. Arizona, Wright, Lemmon.

++ Flowers diœcious: corolla greenish white or yellowish.

+ Leaves narrowly linear, with midrib little prominent and no lateral nerves or veins: stems elongated.

G. angustifólium, Nuтr. Becoming shrubby at base, 1 to 4 feet high, with rigid virgate branches, smooth and glabrous or minutely pruinose-puberulent: leaves barely mucronulate 
(half-inch to inch long or on branches shorter, half-line to line wide): cymes small, in narrow panicles, the fertile more or less condensed: corolla a line or two in diameter, dull white; bristles of the fruit about the length of the body. - Gray, Bot. Calif. i. 285. G. trichocarpum, Nutt. (not DC.) \& G. angustifolium, Nutt. in Torr. \& Gray, Fl. ii. 82. California, common from Santa Barbara to San Diego, Tejon, and apparently to the Mohave.

++ Leaves narrowly-lanceolate to ovate, with midrib prominent beneath and continnous with stem-angles, sometimes a pair of lateral nerves: stems low or diffuse.

G. Matthéwsii, Grar. Glabrous and smooth, paniculately much branched, woody at base: leaves rigid, oblong- to ovate-lanceolate, veinless, with stont midrib, 2 or 3 lines long, some of the upper cuspidate-acute: flowers (of fertile plant) naked-paniculate: corolla barely a line in diameter: bristles of immature fruit rigid, not longer than the body. - Proc. Am. $\Lambda$ cad. xix. 80. Arid district, Inyo Co., E. California, Dr. Matthews. Probably same from borders of S. W. Colorado and New Mexico, with rather longer and narrower leaves, Brandegee.

G. stellátum, KellogG. Diffuse and bushy from woody base, a foot or two high, much branched, hispidulous-puberulent, sometimes nearly glabrous: leaves rigid, ovate-lanceolate (and 4 or 5 lines long) to narrow-lanceolate and small on flowering branches, acuminatecuspidate, destitute of lateral nerves and veins; margins either naked or hispidulous-ciliate: flowers paniculate and crowded : corolla white, little over a line in diameter : bristles of the fruit soft and flaccid at maturity, longer than the body. - Proc. Calif. Acad. ii. 97, fig. 26. G. acutissimum, Gray, Proc. Am. Acad. vii. 350, male plant. - Rocky cañons and dry hills, S. Utah and Arizona, first coll. by Newberry. (Islands off Lower California.)

G. multiflórum, KellogG. A span to a foot high from a barely suffrutescent base, in tufts, glabrous, pruinose-puberulent or sometimes pubescent: leaves from broadly ovate to ovate-lanceolate, mucronate-apiculate, or minutely and abruptly acuminate, thickish, 4 to 7 lines long, a pair and sometimes two pairs of indistinct or obvious lateral nerves from the base; uppermost leaves on flowering shoots usually only opposite: flowers short-pedicelled, thyrsoid-crowded in upper axils, or the fertile often solitary and sparse : corolla yellowish, a line or two in diameter : fruit when well formed densely clothed with hirsute bristles considerably longer than the body. - Proc. Calif. Acad. 1. c., fig. 27. (Very poor name, the flowers not abundant for the genus and scattered.) G. Bloomeri \& G.hypotrichium, Gray, Proc. Am. Acad. vi. 538, the latter founded on imperfect specimens with polygamous flowers and undeveloped fruit. G. Bloomeri \& G. multiflorum, Watson, Bot. King Exp. 135; Gray, Bot. Calif. i. 285. E. California to Utah, on the mountains of the drier districts, first coll. by Bloomer, Veatch, \&c. Specimens east of the Sierra Nevada and vicinity mostly of the subjoined var.

Var. Watsóni. Mostly glabrous and smooth: leaves thinner, oblong-lanceolate (commonly about half-inch long and 2 lines wide), with lateral nerves either distinct or obsolete. - G. multiflorum, Watson, 1. c. in great part.-Cañons and gulches, N. Arizona to $\mathrm{E}$. Oregon and adjacent Idaho.

Var. hirsútum, G. Bloomeri, var. hirsutum, Gray, Bot. Calif. 1. c., is an ambiguous form, with broad but thinnish leaves and whole herbage hirsute-pubescent. - Sierra Valley, California, Lemmon.

$\S 3$. Indigenous species, perennials : fruit baccate (leaves 4 in the whorls, onenerved). - Relbunium, Endl.

* Pacific species, with ovate to oblong-linear (not rigid acerose) leaves: flowers of most and perhaps of all subdicecious or polygamous, yellowish, purplish, or white; sterile flowers in small loose cymes; fertile somewhat solitary and scattered.

+ Berry so far as known purple or black, small.

G. púbens, Grax. Wholly herbaceous, somewhat cinereous with a fine and partly soft partly scabrous pubescence: stems much branched, diffuse, a foot or two long: leaves from roundish-oval to oblong, thickish, mostly pointless (largest half-inch long); margins at most hispidulous-scabrons: forming fruit glabrous and smooth; mature fruit not seen, probably fleshy. - Proc. Am. Acad. vii. 350 ; Bot. Calif. i. 284, with var. scabridum, growing in more exposed situations. - California, in and near Yosemite Valley, first coll. by Torrey and Bolander. 
G. Califórnicum, Ноок. \& ARN. Wholly herbaceons, from slender creeping rootstocks, often in low tufts, a span or two high, or diffuse, with slender stems a foot long, hispid or hirsute, rarely glabrate in age: leaves thinnish, ovate or oval, apiculate-acuminate (quarterinch to half-inch long), margins and midrib lispid-ciliate; fruit glabrous, on recurved pedicels. - Hook. \& Arn. Bot. Beech. 349 ; Torr. \& Gray, 1. c. 20 (excl. var. Texanum); Gray, Bot. Calif. i. 283. - Shady ground, common in the western part of California, especially in the coast ranges.

G. Nuttállii, Gray. Tall and much branched from suffrutescent base, often supported by and as if climbing over bushes, or procumbent, mostly glabrous, except minntely aculeolatehispidulous angles of stem and margins of leaves, these sometimes naked: leaves small, oval to linear-oblong, mucronate, mucronulate, or obtuse : fruit smooth and glabrous. - Pl. Wright, i. 80, \& Bot. Calif. i. 283. G. suffruticositm, Nutt. in Torr. \& Gray, Fl. ii. 21, not Hook. \& Arn. - California toward the coast, from San Diego to Humboldt Co.

$$
++ \text { Berry white (blackening in drying), very smooth, juicy. }
$$

G. Bolánderi, GraY. Herbaceous from a woody root, diffuse, a foot or two high, glabrous, sometimes pubescent: angles of the stem not at all or harlly scabrous: leaves oblong-linear or lanceolate, rather acute, about half-inch long, thickish, with margins and midrib either smooth and naked or sparsely hispidulous; those of branchlets not rarely opposite: corolla dull purplish. - Proc. Am. Acad. vii. 350, xix. 80, \& Bot. Calif. i. 284, male plant. G. margaricoccum, Gray, Proc. Am. Acad. xiii. 371, in fruit. - Dry ground, western side of Sierra Nevada, California, from the Yosemite northward, and apparently to Humboldt Co.; first coll. by Bolander, and the fruit by Gray and Hooker.

* * New Mexican, with linear leaves, diœcious: fruit unknown.

G. Féndleri, Grar. A span or two high from a tufted frutescent base, cinereous-puberulent and barely scabrous, slender: "leaves hardly if at all rigid except the very small and squamaceous ones which are imbricated on the bases of the annual shoots; those above linear, abont 4 lines long, less than line wide, rather acute, with midrib somewhat conspictous beneath: flowers somewhat paniculate, short-pedicelled: corolla yellowish. - Pl. Fendl. 60.Exposed mountain-sides, near Santa Fé, New Mexico, Fendler, male plant; and a female which is glabrous (also the ovary), or below barely pruinose-puberulent, perhaps not of the species. Santa Rita Mountains, Arizona, Pringle, male only.

* * Texano-Californian, herbaceous, with very narrow and rigid small leaves, and very small white corollas.

G. Andréwsii, Gray. Depressed-cespitose and with slender creeping rootstocks, glabrous or nearly so; the matted tufts a span or less high: leaves very crowded, acerose-subulate, usually shining, either naked or sparsely spinulose-ciliate, 2 to 4 lines long: flowers dioecious; male slender-pedicelled in few-flowered terminal cymes; female solitary, sultended by a whorl of leaves which are longer than the fructiferous at length deflexed pedicel: berry dark-colored, smooth. - Proc. Am. Acad. vi. 538, \& Bot. Calif. I. c. 286. - Dry hills, on the coast of California from Lake Co. to San Diego, and in the interior to Tejon, first coll. by Dr. Andrews. Also Oregon, Howell.

G. microphyllum, Grax. Diffusely spreading or ascending, smooth and glabrous, but not shining; branches a span to a foot long: leaves shorter than the internodes and narrowly linear (or small, broader, and crowded at the base of stems), usually mucronate, with narrow midrib prominent beneath and callous naked margins, mostly 2 to 4 (rarely 5 or 6 ) lines long: flowers apparently all hermaphrodite, solitary on a very short or on a longer and pedunclelike axillary branchlet and sessile in its whorl of involucriform leaves, or this proliferous and bearing a second whorl and flower: ovary and young fruit scabro-puberulous or at length granulose, at maturity fleshy-baccate. - Pl. Wright. i. 80, ii. 66. Relbunium microphyllum, Hemsl. Biol. Centr.-Am. Bot. ii. 63. - Rocky ravines, \&c., S. W. Texas to S. Arizona, first coll. by Wright. (Adj. Mex., where there is a pubescent variety, Relbunium polyplocum, Hemsl. 1. c.)

* * * Atlantic North American, herbaceons, with oval to linear leaves, and usually solitary hermaphrodite flowers: corolla white: berry purple, in our species naked-pedicellate beyond the ultimate involucriform whorl, mostly pendulous at maturity. - Relbunium, Benth. \& Hook.

G. uniflórum, МrсHx. Smooth and glabrous : stems assurgent from filiform rootstocks, slender, rather simple: leaves linear (about inch long and a line wide), with somewhat 
scabrous margins: flowers solitary or in pairs from the pedunculiform axillary branchlet; the pedicels in fruit longer than or equalling the involucrate whorl, when in pairs one of the two commonly involucellate or unibracteate; ovary and berry glabrous. $-F l$. i. 79 ; Ell. Sk. i. 95; Torr. \& Gray, Fl. ii. 21. - Woods in rich soil, S. Carolina to Florida and Texas.

G. hispídulum, Micux. 1. c. Hirsute-pubescent, hispidulous, scabrous, or sometimes almost smooth and glabrous, a foot or two high, diffusely branched and spreading: leaves oblong or oval, mucronate, a quarter to half an inch long : branchlets only floriferous: pedicels solitary or commonly 2 or 3 from the small involucral whorl, all naked, or one of them minutely bracteolate : ovary scabrous-puberulent: berry glabrate.-Ell. 1. c.; Torr. \& Gray, 1. c. G. hispidum, Pursh, Fl. i. 104. Rubia peregrina, Walt., not L. R. Brownei, Michx. 1. c., excl. syn. Browne. R. Walteri, DC. Prodr. iv, 590. - Dry or sandy soil, S. New Jersey to Florida, along the coast.

\section{ORDER LXXI. VALERIANACEA.}

Herbs (rarely suffruticose); with opposite leaves, no stipules, hermaphrodite or sometimes polygamo-diøcious flowers in cymose inflorescence, a 5-merous somewhat irregular epigynous corolla, bearing fewer (1 to 3, rarely 4) stamens on its tube, an ovary invested by the calyx-tube, and of one to three cells, but only one ovuliferous, a solitary suspended seed with a straight embryo and no albumen. Limb of calyx none, or of lobes or teeth, or evolved on the fruit into a kind of pappus. Corolla either obscurely or manifestly irregular (bilabiately, $\frac{2}{3}$ ); lobes imbricated in the bud. Filaments and style filiform: stigma undivided and truncate, or minutely 3-cleft. Ovule anatropous. Fruit dry and indehiscent, a kind of akene.

1. VA.tERIANA. Calyx-limb of 5 to 15 setiform lobes, which are inrolled and inconspictous until fruiting, when they are evolute and form a kind of plumose pappus. Corolla from campanulate-funnelform to salverform, the tube or body often gibbous or slightly saccate anteriorly. Stamens 3. Ovary I-celled, and with mere vestiges of two lateral cells, ripening into a flattened akene, which is mostly 1 -nerved on one face, 3-neryed on the other, and with a more or less evident nerve at each margin, which marks the position of a suppressed empty cell. - Perennials (with hardly an exception), the roots with a peculiar scent.

2. VALERIANELLA. Calyx-limb not pappose, in all ours more or less obsolete. Corolla from short-funnelform to salverform, with or without gibbosity, or sometimes a sac or spur at base; limb 5-parted, from nearly regular to obscurely or plainly bilabiate, or 4-parted with the posterior lobe notched or 2-cleft. Stamens 3, very rarely 2. Fruit various, the two abortive cells sometimes obsolete and nerviform at the lateral angles, commonly enlarged, sometimes converted into wings. Annuals, with entire or sparingly dentate or incised leaves; cauline sessile.

1. VALERIÁNA, Tourn. (Old herbalist's name, from valeo, to be strong, from use in medicine.) - Herbs '(chiefly of northern temperate zone); with roots of peculiar scent, various leaves, and white or rose-colored flowers, in terminal cymes, produced in early summer. - L. Gen. 8, in part; DC. Prodr. iv. 632; IIœck in Engler, Bot. Jahrb. iii. 2.

Phylláctis obovata, Nutt. Gen. i. 21, is omitted, having been described from a plant of the Upper Missouri, not yet in flower, perhaps an undeveloped $V$. edulis.

* Erect from a large fusiform perpendicular stock branching below into deep and thickened roots: leaves thickish, nervosely veined, not serrate.

V. édulis, NtтT. Glabrous or glabrate; the nascent herbage often tomentulose-puberulent, sometimes remaining so on the leaf-margins, a foot or at length 3 feet or more high: radical leaves oblanceolate to spatulate, tapering into a margined petiole, entire or some sparingly 
laciniate-pinnatifid ; cauline rarely none, commonly 1 to 3 pairs, sessile, and pinnately parted into 3 to 7 linear or lanceolate divisions, or terminal one spatulate; flowers polygamo-diocious, yellowish white, sessile in the cymules, which form an elongated thyrsiform naked panicle : fruit ovate, puberulent or glabrous. - Nutt. in Torr. \& Gray, Fl, ii. 48 ; Gray, P1. Fendl. 61, \& Man. Bot. I'. ciliata, Torr. \& Gray, 1. c. Patrinia ceratophylla, Hook. Fl. i. 290. P. longifolia, Macnab in Edinb. Phil. Jour. xix, - Wet plains and prairies, Ohio and W. Canada to Brit. Columbia, and south in the mountains of Colorado and Nevada to New Mexico and Arizona. Root a staple food of the Root-diggers and other Indians.

* * Erect from creeping or ascending (but not vertical) jootstocks, which emit slender roots, glabrous or with a little sparse pubescence: leaves thimnish, loosely veiny, often with some simple and some divided and margins either entire or dentate on same plant; the radical ones on slender naked petioles: bracts of the cyme slenderly linear-subulate, mostly longer than the (usually quite glabrous) fruit: flowers hermaphrodite, but in the first species more or less dimorphous: corolla white to light rose-color.

+ Tube of corolla from shorter than the throat and limb to less than twice their length: no sarmentose radical branches.

V. sylvática, Barкs. Stems from 8 to 30 inches high: radical leaves mostly simple and ovate to oblong, occasionally some 3-5-foliolate; cauline more or less petioled, 3-11-foliolate or parted, the divisions entire or rarely few-toothed: fruiting cymes open, at length thyrsoidpaniculate: corolla 3 lines or in more fertile form only 2 lines long; the tube short: stigma nearly entire. - Richards. App. Frankl. Journ. ed. 2, 2; Hook. Fl. i. 291 ; Beck, Bot. 164 ; Torr. \& Gray, Fl. ii. 47 (with var. uliginosa, a somewhat pubescent form); Gray, Man. \& Bot. Calif. i. 287. V. dioica, Pursh, Fl. ii. 727. V. dioica, var. sylnatica, Gray in Proc. Acad. Philad. 1863, 63; Watson, Bot. King Exp. 136. - Wet ground, Newfoundland and Hudson's Bay country, south to S. New York, west to Brit. Columbia, and southward in the mountains to New Mexico and Arizona. In S. Utah it occurs with puberulent fruit, as collected by Palmer.

V. Sitchénsis, Bosg. More robust, from thicker and branching ascending rootstocks: leaves larger; canline short-petioled, only 3-5-foliolate; the divisions orbicular to oblongovate, or in the upper leaves ovate-lanceolate, not rarely dentate or repand (larger 2 or even 3 inches long): cymes contracted: corolla funnelform, 4 lines long (but also a shorter form): stigma entire. - Veg. Sitch. 145; Ledeb. Fl. Ross. ii. 438. V. pauciflora, Hook. Fl. i. 292, t. 101, not Michx. V. capitata, var. Hookeri, Torr. \& Gray, Fl. ii. 48. - Moist woods, Sitcha, British Columbia, and through Washington Territory to S. Idaho and the northern Rocky Monntains.

V. capitáta, PacL. Stem rather slender from a creeping rootstock, 6 to 20 inches high, with long internodes; cauline all sessile (or lowest very short-petioled), only 2 or 3 pairs, all undivided and entire or few-toothed or some of them 3-parted, mainly ovate or oblong, an inch or two long: cyme capituliform or in fruit open-glomerate: corolla, \&c. as of the preceding, 3 or 4 lines long: stigma 3-lobed.- "Link Jahrb. i. 3, 66," ex Rcom. \& Schult. Syst. Mant. i. 257 ; DC. Prodr. iv. 637; Hook. 1. c.; Torr. \& Gray, 1. c. (excl. var.) ; Ledeb. Ic. Pl. Ross. t. 346, \& FI. Ross. ii. 435; Trautv. Imag. t. 39. - Alaskan coast and Islands, north to Aretic region, first coll. by Pallas. (Adj. Asia to N. Eu.)

++ Tube of corolla slender, much longer than the throat and limb.

V. Arizónica, Grax. A span or two high from tufted creeping rootstocks, glabrous, no sarmentose branches: leaves somewhat succulent; radical ovate (inch long), mostly entire and simple, some with one or two pairs of minute lobes on upper part of the rather long and margined petiole; cauline 2 pairs, subsessile, 3-5-parted, lobes oblong to lanceolate: cyme glomerate: corolla half-inch long, tubular, with gradually expanding throat: stigma minutely 3-cleft. - Proc. Am. Acad. xix. 81. - Arizona, in the mountains near Prescott, Palmer. Santa Catalina Mountains, Lemmon. Fruit not seen.

V. pauciflóra, Michx. Stem 1 to 3 feet high from a slender creeping rootstock, erect, and with basal sarmentose branches or runners: leaves thin; radical and lowest cauline cordate and long-petioled, crenate or entire, not rarely with one and sometimes two pairs of small roundish lateral leaflets; upper cauline pinnate, with 3 larger leaflets ovate, one or two lower pairs smaller and more remote, lowest near base of petiole: cyme corymbiform and somewhat glomerate, commonly many-flowered (notwithstanding specific name): tube of 
corolla almost filiform, half-inch and more long, several times longer than the throat and limb. - Fl. i. 18; Nutt. Gen. i. 20; Torr. \& Gray, 1. c. - Alluvial river-banks, Pennsylvania to Illinois, Missouri, and Tennessee; first coll. by Michaux.

* * Sarmentose-climbing or diffuse, with fibrous roots, glabrous: flowers very numerous in diffuse and compound paniculate cymes: bracts very small: corolla minute, seldom over a line long.

V. sorbifólia, HBK. A diffuse form of the Mexican species: stem weak, 2 or 3 feet long, springing from an annually produced small oblong tuber: leaves pinnate (except sometimes the radical), 5-13-foliolate; leaflets from rounded-ovate to oblong-lanceolate, coarsely serrate, or even laciniate: cymes loosely flowered in an elongated and naked (often foot long) terminal panicle. - Nov. Gen. \& Spec. iii. 332. - Cañon in the Huachuca Mountains, S. Arizòna, Lemmon, in a form with only 5 to 7 unusually large and broad leaflets, some almost 2 inches long, from rounded-ovate to oblong. (Mex.)

V. scándens, L. Root unknown : stem sarmentose and feebly twining, branching: leaves long-petioled; cauline 3-foliolate, with leaflets from deltoid- to oblong-ovate, acuminate, entire or repand, rarely with a few teeth, or lowest leaves simple and cordate: panicles effuse, axillary and terminal, elongated, the ultimate branches with the sessile flowers spicately disposed. - Spec. ed. 2, i. 47; Willd. Spec. i. 180 ; DC. I. c.; Torr. \& Gray, Fl. ii. 47. - Thickets in S. Florida, climbing several feet high. (W. Ind. to Brazil.)

2. V.ALERIANÉlLa, Tourn. Corn Salad. (Diminutive of Valeriana.) - Annuals, commonly winter-annuals (of the northern temperate zone), mostly low or slender and erect, ours glabrous or nearly so, except the fruit: leaves similar in all the species, from obovate to oblong and spatulate, entire or upper ones occasionally incised or toothed, radical rosulate, cauline sessile or even somewhat connate at base: flowers variously glomerate-cymose, the corolla from white to rose-color or rarely bluish. As in some species of Valeriana, so in some of these, the hermaphrodite flowers in different individuals are dimorphous as to size of corolla and exsertion of stamens and style, yet not as in heterogone dimorphism. - Vaill., Haller, \&c.; Gray, Proc. Am. Acad. xix. 81. Valerianella \& Fedia, Monch, Meth. 486, 493. Fedia, Gærtn. Fruct. ii. 36, t. 86; Woods in Trans. Linn. Soc. xviii. 23, t. 21 ; Torr. \& Gray, Fl. ii. 50. Valerianella, Dufresnia, Betckea, \& Fedia, DC. Prodr. Valerianella, Plectritis, \& Fedia, Benth. \& Hook. Gen. ii. 155, 156.

$\S 1$. VALerianélla proper. Corolla with nearly regular 5-parted limb, funnelform or more open throat with or without a small saccate gibbosity at its base anteriorly, and a short proper tube: stamens 3 : fruit with the two empty cells manifest, or often enlarged and closed, sometimes at length confluent into one and rarely bursting: calyx-limb in American species none, or a mere tooth or oblique border: stem dichotomous above; the branches or pedunculiform branchlets terminated by corymbosely disposed glomerate cymes or cymules of small flowers. - Valerianella, Mœnch ; Dufresne, Hist. Valer. 56; Krok, Monogr. Valer. in Svenska Vetensk. Acad. Handl. v. no. 1, 1864; Benth. \& Hook. Gen. ii. 156, excl. § Siphonella.

* Introduced species : corolla bluish : a gibbous corky mass at the back of the fertile cell of the fruit.

V. olitóRIA, Poll. Fruit flattish and obliquely roundish-rhomboidal : empty.cells as large as fertile one and its corky back, contiguous, the thin partition between them at length breaking up.-Hist. Pl. Palat. i. 30; Monch, 1. c.; Dufresne, Valer. 56, t. 3, f. 8; Krok, 1. c. 88, t. 4, f. 40 . V. ccerulea (\& rhombicarpa), Aikin in Eat. Man. Bot. Valeriana locusta, olitoria, L. Spec. i. 33. Fedia olitoria, Vahl, Enum. i. 19; Woods, 1. c. 430, t. 24, f. 1; Torr. \& Gray, Fl. ii. 51 ; Porter in Am. Nat. vi. 386, fig. 102. - Old fields near dwellings, New York to Penn. and Louisiana; not common. (Nat. from Eu.) 
* * Indigenous species: corolla white: no corky mass behind fertile cell of the fruit.

- Fertile cell decidedly larger and broader than the two empty ones, and cross section of the fruit. more or less triangular, the empty cells occupying the obtuser angle : tube of the corolla slender, commonly as long as the throat and limb.

V. chenopodifólia, DC. Stem a foot or two high, with long internodes and few forks: leaves comparatively large ( 1 to 3 inches long): glomerate small cymes few and slenderpeduncled: bracts broadly lanceolate, narrowly scarious margined when dry : fruit glabrous or minutely pubescent, 2 lines long, ovate-triangular, the cross section triquetrous or more or less rounded at the sterile angle, two empty cells about as deep but not as broad as the fertile, sometimes confluent into one when old. - Prodr. iv. 629; Gray, Proc. Am. Acad. xix. 82, founded on Fedia chenopodifolia, Pursh, Fl. ii. 727, from specimen in herb. Sherard. $V$. triquetra, Hochst. \& Steud. ex Shuttlew. in Flora, 1837, 211, t. 3 ; Krok, 1. c. 54, t. 2, f. 13. Fedia radiata, Torr. Fl. i. 35, not Michx. F. Fagopyrum, Torr. \& Gray, Fl. ii. 51 ; Gray, Struct. Bot. ed. 5, fig. 881-884; Torr. Fl. N. Y. i. t. 46; Porter, 1. c. fig. 103 : name from likeness of fruit to buckwheat. Valerianella Fagopyrum, Walp. Repert. ii. 527.- Moist grounds, W. New Iork to Wisconsin, Kentucky, and Virginia.

V. amarélla, Krok. A span or two high, amply corymbosely branched above, bearing numerous and more open cymes: bracts lanceolate-linear, small: fruits very small (about half a line long), trigonous-ovate, densely white-hirsute, with rather obtuse lateral angles and that of the empty cells rounded, these decidedly shorter as well as much smaller than the fertile, almost filiform or sometimes almost obliterated. - Monogr. 1. c. 55, t. 2, f. 14 ; Gray, 1. c. Fedia amarella, Tindheimer, ex Engelm. in Pl. Lindh. ii. 217. Spec, name from a peculiar bitterness of the herbage. - Low grounds, Texas, Lindheimer, ITright, IIall, Reverchon, \&c. Gibbosity at base of corolla-throat sometimes very prominent and saccate, almost spur-like.

+ + Fertile cell fully as broad as the two introrse and parallel contiguous and more or less inflated empty ones, occupying the whole back of the fruit, apex projecting in a short obtuse tooth of a line long, the cross section quadrate, a conspicnous groove down the anterior face: stem a foot or two bigh, twice or thrice forked and spreading, the pedunculiform branchlets bearing one to three glomerate cymes: fruit in same species either pubescent or glabrous.

V. radiáta, Dufr. Fruit ovate-tetragonal, downy-pubescent or sometimes glabrous on one or all sides; fertile cell oblong-ovate, flattish ; sterile cells as thick as or thicker than the fertile, a broad shallow groove between them. - Hist. Valer. 57 ; Krok, l. c. 64, t. 2, f. 22, not DC, who seems to have had $V$. olitoria. Valeriana locusta, radiata, L. 1. c. (the plant of Clayton); Walt. Car. 166. V. radiata, Willd. Spec. i. 184. Fedia radiata, Michx. F1. 1. 118 ; Ell. Sk. i. 42 ; Torr. \& Gray, Fl. ii. 52 ; Porter, 1. c. fig. 164. - Low grounds, Penn. to Michigan, Florida, and Texas. Var. leiocurpa is a smooth-fruited form of it.

V. stenocárpa, Кroк. Fruit tetragonal-oblong, commonly glabrous, sometimes pubescent; fertile cell oblong, obscurely narrowed upward, flattish and straight, thicker than the linear-oblong approximate sterile cells, and the groove between the latter narrow. Monogr. Valer. 1. c. t. 2, f. 1. Fedia stenocarpa, Engelm. Pl. Lindh. ii. 216. - Texas, Berlandier (part of no. 334), Lindheimer, Hall.

+++ Fertile cell much narrower or smaller than the ampliate empty ones, one-nerved on the back, the fruit of orbicular or round-ovate circumscription, glabrous or with slight sparse pubescence.

V. Woodsiána, WALP. Habit of $V$. radiata and $V$. chenopodifolia. Fruit a line or more long; fertile cell oblong-ovate or ovate-lanceolate, tipped by a small soft and blunt tooth; empty cells introrse, either contiguous or somewhat diverging, inflated, with an oblong depression in the middle, sometimes an open concavity. - Walp. Repert. ii. 527; Krok, l. c. 66, t. 3, f. 23 ; Gray, 1. c. 82. Fedia Woodsiana, Torr. \& Gray, 1. c. 52. F. radiata, var., Porter, 1. c. fig. 105. - Moist grounds, New York and Penn. to Texas.

Var. umbilicáta, Grax, 1. c. Empty cells ampliate and in age confluent, vesicular by incurvation of circular margin, forming a deep and rounded or obscurely cruciform umbilication. -V. umbilicata, Krok, 1. c. 67, t. 3, f. 25. Fedia umbilicata, Sulliv. in Am. Jour. Sci. xlii., \& Gray, Man. ed. 1, 183. F, radiata, var. umbilicata, Porter, 1. c. 387, fig. 108.New York \& Penn. to Ohio and southward, first coll. by Sullivant.

Var. patellária, GRAX, 1. c. Empty cells divergent and obcompressed-dilated, so that the sterile face becomes open-concave, emarginate at top and bottom, and the whole 
fruit meniscoidal or saucer-shaped, the expanded and flattened sterile cells forming a kind of wing, or at length this incurved at base, or also at summit, and so nearly passing into var. umbilicata. - V. patellaria, Krok, 1. c. 67, t. 3, f. 24. Fedia patellaria, Sulliv. 1. c. V. radiata, Shuttlew. in Flora, 1837, 209, t. 3. Fedia radiata, var. patellaria, Porter, 1. c. 387, fig. 106. - Ohio (Sullivant), Pennsylvania, \&c.

§ 2. Siphonélta, Krok. Corolla salverform; the slender tube double or quadruple the length of the obscurely bilabiate-irregular limb, commonly bearing a minute boss or incipient spur near middle or base, sometimes with none; lobes oblong, the two posterior slightly more united and averse from the three anterior: stamens 3 : fruit with divergent empty cells much larger than the fertile: habit and inflorescence of the preceding: bracts ciliate with gland-tipped denticulations. - Gray, 1. c. 82. Fedia § Siphonella, Torr. \& Gray, Fl. ii. 50. (Species referred to Plectritis by Nutt. in herb.)

V. longiflóra, WALP. Leaves ligulate-oblong and lower ones spatulate : cymes glomerate, many-flowered, corymbosely disposed: tube of corolla nearly filiform, 4 or 5 lines long, not rarely with a small boss at base, purplish or pink, 3 or 4 times the length of the lobes: fruit nearly orbicular in outline, somewhat meniscoidal; the semioval empty cells coriaceous with membranous face, parallel-contiguous and separated by a narrow partition, but widely diverging, each larger than the oblong obtusely short-tipped fertile one. - Repert. ii. 527; Krok, Monogr. 1. c. 97, t. 4, f. 46. Fedia longiflora, Torr. \& Gray, 1. c. - Low rocky grounds, N. W. Arkansas, Nuttall, Engelmann, Harvey.

V. Nuttállii, WALP. 1. c. Tube of the white or cream-colored corolla only about twice the length of the limb, bearing a little boss near the middle: fertile cell with a narrow soft projecting tip. - Krok, l. c. Fedia Nuttallii, Torr. \& Gray, l. c. - Plains of Arkansas, Nuttall, Engelmann. Handsome in cultivation, a span or two high, very floriferous.

§3. Plectrítis, Lindl. Corolla with either manifestly or very obscurely bilabiate limb; proper tube shorter than the broadly or narrowly funnelform throat, which bears a descending spur at its base, this in one species obsolete or wanting : fruit one-celled, its body triangular or nearly so, one angle dorsal, the lateral angles bearing wings (these in place of the two empty cells, and appareutly formed by their early separation and evolution from the middle of the ventral face), or in one species wingless: calyx-limb none: plants all nearly alike in herbage and thyrsoid-glomerate inflorescence; the cymules condensed into a capituliform or interrupted spiciform glomerule terminating stem or branches, and commonly one to three others verticillastrate at the nodes or axils below: flowers rose-color or white: all Pacific-American. - Bot. Reg. t. 1094; Gray, Proc. Am. Acad. xix. 83. Plectritis \& Betckea, DC. 1. c. Plectritis, Benth. \& Hook.

* Fruit somewhat meniscoidal, only obtusely angled dorsally: cotyledons incumbent, i. e. parallel to the ventral face and expanded wings.

V. macrócera, GrAY. Flowers small, commonly in 2 to 4 somewhat distant and spicately disposed verticillastrate clusters : corolla narrow, white or pinkish, only a line or two long, with spur sometimes as long as the throat or body, sometimes only half its length; limb somewhat equally spreading and hardly at all bilabiate, or equally 4-lobed and posterior lobe emarginate-bifid : fruit commonly glabrous or puberulent, obtuse or even lightly lin. eate-sulcate on the dorsal angle, the broad wing of orbicular circumscription, sometimes spreading or very open, so that the ventral face is saucer-shaped, sometimes incurved so that it is acetabuliform. - Proc. Am. Acad. xix. 83. Plectritis congesta, var. minor, Hook. Fl. i. 291. P. macrocera, Torr. \& Gray, Fl. ii. 50 ; Gray, Bot. Calif. i. 287, excl. syn. Fisch. \& Meyer. - Dry ground, Washington Terr. to S. California, Nevada, and Arizona. Varies much in length and thickness of the spur, also in that of the tubular part of the corolla below the spur, which is sometimes slender and stipe-like, sometimes short. 
* Fruit strongly carinate-angled dorsally: cotyledons accumbent (transrerse) to the ventral face. + Wings conspicuous, more or less introrse, in the last species small.

V. congésta, LINDL. Commonly rather stout: flowers in a capituliform or oblong simple or interrupted thyrsus, or sparingly verticillastrate below : corolla rose or flesh-colored, 3 or 4 lines long or in some individuals smaller, with obviously bilabiate limb, and spur half or less the length of the very gihbous throat: fruit broadly winged, and with prominent but rather obtuse keel, from glabrous to puberulent or sometimes thickly short-villous either on fertile cell or ou wings also. - Bot. Reg. t. 1094 ; Gray, 1. c. Plectritis congesta, DC. Prodr. iv. $631^{\circ}$; Hook. 1. c. ; Torr. \& Gray, 1. c.; Gray, Bot. Calif. i. 287. P. brachystemon, Fisch. \& Mejer, Ind. Sem. Petrop. 1835, Suppl. 47 (22), a form with smaller flowers (the state with included stamens and style) and villous-pubescent fruit, according to specimen from St. Petersb. garden; but the char. of flowers, four times smaller than in $P$. congesta and white, would be that of $I$. mucrocera. - Low and moist ground, Brit. Columbia to W. California.

V. anómala, GRır. Either slender or rather stout, freely branching : corolla only a line long, white or flesh-colored, wholly destitute of spur, at most a small mammæform gibbosity near the base of the short and broadly funnelform throat; limb small, obscurely bilabiate (usually 4-lobed and posterior lobe emarginate or 2-cleft) : fruit comparatively large (mostly a line and a half long), acutely angled with sharp edge on the back, with broad wings usually inflexed at base and expanding above, but some fruits wingless. - Proc. Am. Acad. xix. 83. - Wet grounds on and near the Columbia River; Multnomah Co., Oregon, Howell, and Klickitat Co., Washington Terr., Suksdorf.

V. aphanóptera, GRAr, I. c. Slender, with aspect and inflorescence of the next: corolla only a line long, white, with obvionsly bilabiate limb and short basal spur: fruit puberulent or glabrate, trigonous; dorsal angle salient but rather obtuse; lateral angles with distinct but narrow incurved wings. - Springy ground on hillsides, along the Columbia River, Washington Terr., Suksdorf. Columbia Plains, Nuttall, under unpublished name of Plectritis capitata, appears to be the same; specimen insufficient.

+ Wings wholly wanting to the triquetrous fruit, the lateral angles of which resemble the dorsal.-Betckiea, DC.

V. samolifólia, Gray, l. c. A span to a foot high: verticillastrate clusters 2 to 4, small: bracts slender-subulate (not pinnately parted as Hœck states, but uppermost sometines palmately 3-parted) : corolla a line or so in length, obscurely bilabiate, with short conical-saceate spur: akene-like fruit of the shape of buckwheat, glabrous or a little pubescent, in Chilian plants hardly, in ours rather over, a line long. - Betckea samolifolia, DC.l. c. 642 . B. major, Fisch. \& Meyer, l. c. (5) 30. Plectritis samolifolia \& P. major, Hoeck in Engler, Jahrb. iii. 3 r. - Low grounds on the Columbia River, Washington Terr., Oregon (Suksdorf), and coast of California, coll. by the Russian botanists. (Chili, smaller form.)

\section{ORDER LXXII. DIPSACACEE.}

Herbs (all of the Old World); with opposite or verticillate leaves, no stipules, capitate and involucrate inflorescence; the flowers subtended by bracts, and each with a more or less obvious involucel, hermaphrodite; calyx-tube adnate to the one-celled simple ovary; corolla epigynous; stamens inserted on its tube alternate with its lobes, of equal number or fewer, wholly unconnected; style filiform and stigma simple; ovule solitary and suspended, anatropous; seed with a straight embryo in fleshy albumen. Corolla irregular or nearly regular; the lobes imbricated in the bud. Fruit an akene, more or less adnate to the involucel which embraces it.

Scabiósa atropurpúrea, L., Sweet Scabiots of the gardens, is familiar; and one or two of the following genus have become spontaneous.

1. DIPSACUS, Tourn. Teased. (Greek and Latin name of Teasel, said to come from $\delta \iota \psi^{\prime}$ s, thirsty.) - Flowers in a terminal head or short spike, in which, 
however, the anthesis is not simply centripetal; the subtending bracts and those of the conspicuous polyphyllous and unequal involucre spinescent. Involucel calyx-like, prismatic, truncate and crenulate at the border, enclosing the whole ovary and fruit, at length adnate to its thin walls. Calyx-limb cup-like, 4-toothed or lobed. Corolla tubular-funnelform, 4-lobed, nearly regular. Stamens 4. Stigma lateral. Coarse and rough or prickly biennials, with cauline leaves mostly connate and cup-like at base.

D. sycrístris, Mind. Prickly, 3 to 5 feet high: leaves lanceolate-oblong: involucre longer than the head: flowers flesh-colored: bracts of the receptacle tipped with a long and straight flexible awn. - Roadsides of the Eastern States: fl. summer. (Nat. from Eu.)

D. FUllóndm, L. (Fuller's Teasel.) Probably an ancient derivative of the preceding: involucre usually shorter than the cylindraceous head, at length reflexed: bracts of the receptacle rigid-spinescent, the tips recurved or hooked; whence useful for raising a nap on woollen cloth. - Escaped from cult. in some places, apparently established in S. California. (Nat. from $\mathrm{Eu}$. )

\section{ORDER LXXIII. COMPOSIT A.}

Flowers in an involucrate head on a simple receptacle, 5-merous or sometimes 4-merous; with lobes of the epigynous corolla valvate in the bud; stamens as many as corolla-lobes and alternate with them, inserted on the tube; anthers connate into a tube-(syngenesious); style in all fertile flowers 2-cleft or lobed at summit and bearing introrse-marginal stigmas; ovary one-celled, a single anatropous ovule erect from the base, becoming an exalbuminous seed with a straight embryo, the inferior radicle shorter and narrower than the cotyledons; the fruit an akene. Tube of calyx wholly adnate to the ovary; its limb none, or obsolete, or developed into a cup or teeth, scales, awns, or capillary bristles. Corolla with nerves running to the sinuses, then forking and bordering the lobes, rarely as many intermediate nerves. Anthers commonly with sterile tip or appendage; the cells introrse, discharging the pollen within the tube; this forced out by the lengthening of the style, which in hermaphrodite and male flowers is commonly hairytipped or appendaged. Pollen-grains globose, echinulate, sometimes smooth, in Cichoriacer 12-sided. Leaves various: no true stipules. Development of the flowers in the head centripetal ; of the heads, when clustered or associated, more or less centrifugal, i. e. heads disposed to be cymose. Juice watery, in some resinous, in the last tribe milky.

Heads homogamous when all its fowers are alike in sex; heterogamous when unlike (generally marginal flowers female or neutral, and central hermaphrodite or by abortion male); androgynous when of male and female flowers; monocious or dicecious when the flowers of separate sexes are in different heads either on same or different plants ; radiate when there are enlarged ligulate flowers in the margin; wholly ligulate when all the flowers have ligulate corollas; discoid when there are no enlarged marginal corollas. When these exist they are sometimes collectively called the ray: the other flowers collectively occupy the disk. The head (compound flower of the early botanists), in Latin capitulum, is also named anthodium. Its involucre (periclinium of authors) is formed of separate or sometimes connate reduced leaves, i. e. bracts (squamce or scales of De Candolle, \&c.) : the innermost of these bracts subtend the outermost or lowest flowers. The axis within or above these is the receptacle (clinanthium of some), which 
varies from plane to conical, or oblong, or even cylindrical or subulate. When the receptacle bears flowers only, it is naked, although the surface may be alveolate, foveolate, or merely areolate, according as the insertion of the ovaries or akenes is surrounded or circumscribed by honeycomb-like or lesser elevations; or, when these project into bristles, slender teeth, or shreds, it is fimbrillate: it is paleaceous when the disk-flowers are subtended by bracts; these usually chaff-like, therefore called palex, chaff, or simply bracts of the receptacle. In place of calyx-limb there is more commonly a circle of epigynous bristles, hairs, or awns, the pappus, a name extended to the calyx-limb of whatever form or texture: its parts are bristles, awns, palex, teeth, \&c., according to shape and texture. Corollas either all tubular (usually enlarging above the insertion of the stamens into the throat, and 4-5-lobed at summit, mostly regular); or the marginal ones strap-shaped, i. e. ligulate, the elongated limb (ligule) being explanate, and 3-5-toothed at the apex. Such are always female or neutral, or, when all the flowers of the head have ligulate corollas, then hermaphrodite. Anthers with basal auricles either rounded or acnte, or sometimes produced into tails (caudate). Branches of the style in female flowers and in some hermaphrodite ones margined with stigma, i. e. stigmatic lines, quite to the tip; in most hermaphrodite flowers these lines shorter, occupying the lower portion, or ending at the appendage or hairy tip. - An immense order, comprising a tenth part of known phrnogamous plants, an eighth of those of North America.

\section{KEY TO THE TRIBES.}

Ser. I. Tubuliflones. Corollas tubular and regular in all the hermaphrodite flowers.

Heads homogamous and discoid : flowers all hermaphrodite and never yellow : anthers not caudate at base.

Style-branches elongated filiform-subulate, hispidulous thronghout; stigmatic lines only near the base: leaves alternate. . . . . . I. VERNONIACE\&E.

Style-branches elongated, more or less clavate-thickened upward and obtuse, minutely papillose-puberulent, stigmatic only below the middle. II. EUPATORIACE $\mathbb{E}$.

Heads homogamous or heterogamous, discoid or radiate : flowers not rarely yellow: style-branches of hermaphrodite flowers with stigmatic lines mostly prominulous and extending either to the naked summit or to a more or less distinct pubescent or hispidulous tip or appendage.

Anthers not caudate at base : style-branches in hermaphrodite flowers flattened and with a distinct (but sometimes very short) terminal appendage : disk-corollas generally yellow : rays of same or different color. . . . . . III. ASTEROIDE无.

Anthers caudate: style-branches of hermaphrodite flowers slender, destitute of any terninal appendage, the stigmatic lines extending quite to (or vanishing near) the naked obtuse or truncate summit: leaves alternate: heads in our genera discoid except in Inula. . . . . . . . . . . . . . . IV. INULOIDEÆ.

Anthers not caudate : style-branches with truncate or variously appendiculate pubescent or hispid tips: involucre not scarious : receptacle paleaceons, i. e. with chaffy bracts subtending at least the outer disk-flowers: pappus various or none, never of fine capillary bristles. . . . . . . . . . . . V. HELIA NTHOIDEÆ.

Anthers not caudate : receptacle naked : pappus from paleacenus to setiform or none: herbage often punctate with resinous or pellucid dots or glands: otherwise nearly as preceding. . . . . . . . . . . . . VI. HELENIOIDEE. 
Anthers not candate: receptacle naked or sometimes paleaceous: involucre of dry and scarious bracts : style-branches mostly truncate : pappus coroniform, or of short paleæ or squamellæ, or none. . . . . . . . . . . VII. ANTHEMIDEE.

Anthers not cauclate : receptacle naked : involucre little or not at all imbricated, not scarious. Pappus of numerous soft-capillary bristles. VIII. SENECIONIDE正.

Anthers conspicuonsly caudate, and with elongated mostly connate cartilaginous appendages at tip : stylé-branches short or united, destitute of appendage, stigmatic quite to the obtuse summit, smooth and naked, but sometimes a pubescent or hispidulons ring or node below : involucre much imbricated: receptacle densely setose or fimbrillate, or favose : akenes thick and hard : pappus usually plurisetose. Heads never truly radiate. . . . . . . . . . . . IX. CYNAROIDEA.

Also Gochnatiea of X. MUTISIACEZ.

Ser. II. Labiatiflores. Corollas of all or only of the hermaphrodite flowers bilabiate.

Receptacle naked: anthers conspicuonsly caudate: style-branches short, smooth, not appendaged. . . . . . . . . . . . . X. MUTISIACE尔.

Ser. III. Liguliflorde. Corollas all ligulate and flowers hermaphrodite.

Receptacle naked or paleaceous : anthers not candate : style-branches filiform, naked, atigmatic only toward the base. Herbage with milky juice. XI. CICHORIACEÆ.

TRIBE I. VERNONIACE正. Heads homogamous, discoid, with flowers all hermaphrodite and corollas tubular, regular or nearly so, except Stokesia. Involucre imbricated. Anthers without tails at base. Style-branches slender, filiform or attenuate-subulate, acute, hispidulous or hispid; stigmatic lines only near the base. Leaves usually alternate. Flowers never yellow.

* Anomalous genus, with enlarged and palmately quasi-ligulate outer corollas.

1. STOKESIA. Heads many-flowered. Involucre broad; its bracts in several series; outermost wholly foliaceous and spreading; inner with foliaceous pectinately spinulose-ciliate spreading appendage to an appressed coriaceous base. Receptacle fleshy, flat, naked. Central corollas tubular and deeply 5-lobed, slightly more cleft posteriorly, otherwise regular; outer successively more and more palmately ligulate and radiant, the marginal ones larger and wholly so, the narrowly cuneate-oblong ligule longer than the tube and (regularly or irregularly) 5-cleft. Akenes short, thick, 3-4-angled, slightly contracted at the callous base and apex. Pappus of 4 or 5 aristiform smooth and white paleæ, caducous. Flowers blue.

* * Normal genera, with tubular 5-lobed corollas.

2. ELEPHANTOPUS. Heads 2-5-flowered, condensed into glomerules. Involucre narrow, compressed; the imbricated bracts dry and somewhat chaffy, alternately plane and conduplicate; the four outermost shorter. Receptacle small, naked. Corolla commonly. a little irregular, being slightly deeper cleft on the inner side; the deeply 5-lobed limb therefore somewhat palmate. Akenes 10-striate, the apex truncate. Pappus of rigid bristles or awns, mostly with paleaceous base, persistent.

3. VERNONIA. Heads not glomerate, several-many-flowered, rarely one-flowered. Involucre of dry or partly herbaceous much imbricated bracts. Receptacle plane, naked. Corolla regularly 5-cleft into narrow lobes. Akenes mostly 10-costate, with truncate apex and a cartilaginous callous base. Pappus double, at least in all our species; the inner of rigid capillary hirtello-scabrous bristles, outer a series of small squamellæ or short and stout bristles, both more or less persistent.

TRIBe II. EUPATORIACE E. Heads homogamous, discoid, with flowers hermaphrodite and corolla tubular and regular. Receptacle in a few genera paleaceous, in most naked. Anthers without tails at base. Style-branches elongated, more or less clavate 
or thickened upward, minutely papillose or puberulous, or glabrous; the stigmatic lines only near the base and inconspicuous. Leaves either opposite or alternate. Flowers never yellow, at most ochrolencous.

* Akenes 5-angled, destitute of intervening ribs : corolla-lobes or teeth usually short.

- Pappus various, but never wholly capillary, sometimes obsolete or wanting.

+- Involucre 5-flowered (sometimes 3-4-flowered), cylindrical, of 5 or 6 mostly equal rather rigid bracts : receptacle small, naked : corolla narrow.

4. STEVIA. Akenes linear, slender, sometimes compressed. Pappus coroniform-paleaceous or aristiform, or composed both of awns (one or more) and short scales.

* + Involucre many-flowered, lax, of 12 to 18 herbaceous or submembranaceous equal and nerveless bracts : receptacle naked : corolla abruptly much dilated above the narrow tube, rose-purple or flesh-color.

5. SCLEROLEPIS. Receptacle conical. Style-branches elongated, filiform-clarate. Akenes with an inane stipitiform base. Pappus conspicuous, of 5 broad and very obtuse or truncate cartilaginous nerveless seales. Leares verticillate.

6. TRICHOCORONIS. Receptacle convex. Style-branches comparatively short, linear, flat or flattish-filiform, not enlarged upward. Akenes not contracted above the basal callus. Pappus minute or small, multisetulose-coroniform. Leaves opposite or alternate.

+* +t Involuere many-flowered, campanulate or hemispherical, of 2 or more series of striate-nerved bracts, more or less imbricated: receptacle flat or convex : corolla rather narrow: akenes not stipitate-attenuate, but with a strong basilar callus.

7. AGERATUM. Involucre of mostly narrow bracts in 2 or 3 series, not conspicuously unequal. Receptacle either naked or paleaceous. Pappus simple, paleaceous, and the palex either muticous or aristate, or coroniform; the crown sometimes almost obsolete.

8. HOFMEISTERIA. Involucre more imbricated; outer bracts successively shorter. Receptacle naked. Pappus of 2 to 12 slender or capillary bristles equalling the narrow corolla, and as many or fewer alternating or exterior short and thin palese.

++ Pappus wholly of capillary and mostly uniserial bristles;

* These merely scabrous, indefinitely numerous : receptacle naked.

9. MIKANIA. Involucre 4-flowered, composed of 4 or sometimes 8 similar and equal thin bracts, with or without a loose and somewhat herbaceous subtending one. Receptacle small. Stems (at least in ours) twining.

10. EUPATORIUM. Involucre few-many-flowered, of more than 4 bracts. Neither twining nor climbing.

++ +* These long-plumose, rather few: receptacle naked.

11. CARMINATIA. Involucre several-flowered, cylindraceous, of several lanceolate-linear 3-5-striate thin imbricated bracts, the exterior shorter. Receptacle small, flat, naked. Corollas slender, 5-toothed. Style-branches filiform, acutish. Akenes slendler, narrowish at the apex. Pappus of 10 to 18 bristles, which are slightly coherent at base in a single series, plumose with long arachnoid hairs, deciduous together.

* * Akenes 10-costate or striate.

- Bracts of the involucre not herbaceous, striate-nerved, conspicuously so when dry, reguIarly imbricated; the outer ones successively shorter: receptacle naked : corollas slender, 5-toothed at summit; the teeth mostly glandular externally: pappus a single series of plumose or scabrous capillary bristles : hearls few-many-flowered.

12. KUHNIA. Pappus conspicuously plumose. Bracts of the involucre narrow, in few series. Leaves nearly all alternate.

13. BRICKELLIA. Pappus from barbellate or subplumose to merely scabrous. Leaves opposite or alternate.

+ + Bracts of the involucre somewhat herbaceous or partly colored, inconspicuously when at all striate or nerved, even when dry,

+ Well imbricated, the outer successively shorter: leaves punctate, entire: flowers rosecolor, or abnormally and rarely white. 


\section{- Pappus paleaceous-aristiform : leaves opposite.}

14. CARPHOCH ZTE. Heads 4-6-flowered. Involucre cylindrical; the bracts acuminate, rather few. Receptacle small, naked. Corolla narrow and long, hypocrateriform; limb 5-parted into slender linear-lanceolate lobes. Akenes slender, barely puberulent. Pappus of long linear-subulate erose-denticulate scarious palex, the thickened costa continued into a barbellulate scabrous awn; and with 1 to 5 small nearly nerveless muticous paleæ.

$==$ Pappus of numerous capillary or stouter bristles, from plumose to barbellulate-scabrous : anther-tips emarginate or retuse: leaves alternate.

15. LIATRIS. Heads 4-many-flowered. Involucre spirally imbricate. Receptacle naked. Corolla narrow, with gradually dilated throat and elongated-lanceolate or linear spreading lobes. Akenes slender or tapering from apex to base, pubescent. Pappus about a single series of firm and mostly equal bristles, from plumose to barbellate. Herbs, with heads in a terminal reversed spike or raceme, sometimes becoming paniculate.

16. GARBERIA. Heads about 5-flowered. Involucre imbricate in 5 nearly vertical ranks (3 or 4 in each rank) of somewhat herbaceous acute bracts. Receptacle small, naked. Corollas with slender tube, abruptly cyathiform-ampliate throat, and lanceolate spreading lobes. Akenes, \&c. of Liatris. Pappus copious, in two or more series of slender barbellatescabrous bristles, the outer smaller and shorter. Broad-leaved shrub, with heads corymbosely cymose.

17. CARPHEPHORUS. Heads many-flowered. Involucre campanulate; the imbricated bracts all appressed. Receptacle chaffy; the chaff subtending the outer flowers, and mostly shorter than they, thin, deciduous with the fruit. Corolla-lobes ovate or short-lanceolate. Akenes of Liatris. Pappus of one or more series of barbellate or plumose bristles. Herbs, with heads corymbosely cymose.

++ ++ Little-imbricated involucre of bracts nearly all equal in length: receptacle plane, naked : corolla narrow, with short-ovate or oblong lobes: leaves broad, obscurely or not at all punctate: perennial herbs, fibrous-rooted from a small caudex.

18. TRILISA. Heads 5-10-flowered. Pappus of rather rigid minutely barbellate bristles, nearly in a single series. Leaves entire; cauline sessile. Cymules paniculate or somewhat cymose.

TRIBE III. ASTEROIDEÆ. Heads either heterogamous and radiate, the ligulate rayflowers feminine or rarely neutral, or homogamons with the flowers all hermaphrodite and tubular, or rarely the female flowers with filiform corolla and no ligule, or in Baccharis diøcions and the female corollas all filiform. Receptacle seldom paleaceous. Corolla of the hermaphrodite flowers regularly 5-lobed, rarely 4-lobed (obscurely palmate in Lessingia). Anthers obtuse and entire or barely emarginate at base. Stylebranches of hermaphrodite flowers flattened, conspicuously margined by the stigmatic lines, and extended into a hispid or papillose (sometimes very short) appendage. Pappus various, or sometimes none. Leaves mostly alternate, Disk-flowers usually yellow. - Tribe of nearly 100 genera, the largest being Aster and Solidago. 'The characters of the subtribes fajl in a few instances, either through absence of the rays, or as to their color.

Subtribe I. Hомоснвомед. Disk wholly of hermaphrodite flowers, of the same color as the ray when that is present, mestly yellow : these corollas tubular with more or less ampliate throat and 4-ö-lobed limb. Receptacle not chaffy, flat or merely convex. Involucre closely imbricated, mostly in several series. (Flowers white in most species of Lessingia: rays often white in Pentachceta and in one Solidago.)

* Pappus none, or coroniform or paleaceous, or squamellate, or somewhat setose only in infertile disk-flowers: heads radiate: involucral bracts coriaceous or chartaceous, sometimes with herbaceous or greenish tips, the outer successively shorter. (See also Pentachata. The four following genera are very close.)

19. GYMNOSPERMA. Heads several-flowered. Involucle ovoid or oblong; its bracts obtuse, concave. Receptacle small. Ligules very small, not surpassing the disk-corollas. Akenes oblong, slightly compressed, 4-5-costate, glabrous, destitute of pappus. Heads very small and numerous, in glomerate terminal cymes. 
20. XANTHOCEPHALUM. Heads many-flowered, pluriradiate. Involucre broadly campanulate or hemispherical. Receptacle flat or convex. Ligules usually elongated, numerous. Akenes truncate and naked at summit, or edged with a ring bearing a minute coroniform or squamellate pappus, or none. Heads larger, solitary at the end of the branchlets or in open cymes.

21. GUTIERREZIA. Heads few-many-flowered. Involucre oblong-clavate or turbinate to campanulate. Receptacle from plane to conical, commonly alveolate or fimbrillate. Style-appendages mostly slender. Ligules 1 to 8 . Akenes short, obovate or oblong, terete or 5-angled. Pappus pluripaleaceous, but the palex often reduced to a crown or minute, in the ray commonly smaller and sometimes wanting. Heads small, paniculate or cymoseclustered. Disk-tlowers, or some of the central ones, occasionally infertile.

22. AMPHIACHYRIS. Heads few-many-flowered; the ray-flowers only fertile; those of the disk hermaphrodite or subhermaphrodite but infertile. Involucré, \&c. of Gutierrezia. Style-appendages lanceolate; the stigmatic lines below them indistiuct or obsolete. Fertile akenes pubescent. Pappus of the ray-flowers obsolete or coroniform, or of a few setiform squamellæ; of the disk setiform-paleaceous, viz. of 5 to 20 aristiform paleæ or weak bristles more or less dilated and united at base, nearly equalling the corolla.

33. BRACHYCH $₫$ TA. Heads, \&e. as in Solidago. Pappus both in the ray and disk of bristles abbreviated to squamellæ.

* * Pappus panciaristate, i. e. of few (less than 10) elongated awns or rigid bristles, sometimes cadncous or wanting : heads radiate or in same genus rayless, solitary at the end of the branches.

23. GRINDELIA. Involucre many-flowered, hemispherical or at first globose; its bracts numerous and narrow, imbricated in many series, firm and rigid, with more or less herbaceous tips. Style-appendages lanceolate or linear. Akenes short and thick, compressed or turgid, or the outer triangular, truncate, glabrous. Pappus of 2 to 8 caducous nearly smooth awus or corneous bristles.

24. PENTACH ÆTA. Involucre many-several-flowered, hemispherical or campanulate, of thin and scarious-margined appressed bracts, destitute of herbaceous tips, commonly tipped with a delicate mucro. Style-appendages filiform-subulate, hispid. Akenes oblong to fusiform-obovate, somewhat compressed and villous. Pappus of mostly 5 (rarely 3 to 6 or even 12) slender and persistent scabrous bristles with somewhat enlarged base, sometimes relluced to this base, or even this obsolete. Receptacle short-alveolate. Rays either yellow, or white or pink !

* * Pappus multisetose in either the disk or ray, but not in both, and akenes of disk and ray unlike.

25. BRADBURIA. Involucre campanulate, of rather broad and thin scariously margined and mucronate-acuminate appressed bracts. Ray-flowers about 12, fertile; the style very short. Disk-flowers about the same number, infertile; their style-branches destitute of stigmatic lines, filiform, barbellate-hispid. Akenes of the ray sparsely villous, trigonal-turbinate with a strong rib at each angle; the pappus of numerous unequal rigid capillary bristles, little Ionger than the akene: those of the disk abortive, with pappus of very few (usually 2) bristles which are somewhat chaffy-dilated at base.

26. HETEROTHECA. Involucre hemispherical or broadly campanulate, of narrow rather rigid bracts. Receptacle alveolate. Ray-and disk-flowers numerous, both fertile. Stylebranches of the hermaphrodite flowers tipped with a lanceolate or sometimes (in the same species?) ovate-triangular appendage. Akenes of the ray thickish, often triangular, with no pappus or an obsolete crown, rarely a bristle or two; of the disk compressed, sericeoushirsute, and with a double pappus; the inner of copious and long capillary scabrous bristles, outer of numerous short and stout bristles or setiform squamellæ.

* * * Pappus multisetose and double, both in disk and (when present) in the ray; the inner capillary; outer very short and setulose or squamellate.

27. CHRYSOPSIS. Heads many-flowered, with rays numerous, or rarely wanting. Involucre campanulate or hemispherical, of narrow regularly imbricated bracts. Styleappendages from linear-filiform to slender-subulate. A kenes compressed, but often turgid, from obovate to linear-fusiform. Principal pappus of numerous capillary scabrous bristles; 
this surrounded at base by a series of minute short bristles or squamellæ; these sometimes inconspicuous or obsolete. (One or two species of Erigeron with ochroleucous and even yellow rays may be sought here.)

***** Pappus multipaleolate or aristate rather than capillary-setose: involucre subglobose or bemispherical, of very broad bracts, all or inner ones scarious-margined; receptacle alveolate-fimbrillate; the fimbrillæ little shorter than the akenes.

28. ACAMPTOPAPPUS. Heads 12-36-flowered, discoid or radiate: flowers all fertile. Bracts of the involucre chartaceo-coriaceous, round-oval or broadly oblong and concave, bordered by an erose-fimbriate thin-scarious margin, closely imbricated in about 3 series. Disk-corollas funnelform. Style-branches tipped with a thickish subulate appendage. $\Lambda$ kenes globular-turbinate, very densely long-villous and at length tomentose, 5-nerved under the wool. Pappus hardly longer than the akene, equalling the corolla, of 15 to 18 flattened and rigid paleaceous awns, the tips of which are mostly a little dilated, and of as many shorter unequal setiform awns or bristles, persistent.

29. XANTHISMA. Heads many-flowered, radiate; the flowers all fertile. Bracts of the involucre closely imbricated and appressed, mainly orate or obovate, with short coriaceous base and herbaceous upper portion, more or less scarious-margined; some smaller inner ones. Disk-corollas narrowly funnelform. Style-branches tipped with a filiform-subulate appendage. Akenes turbinate, 4-5-costate-angled, and with intermediate less conspicuous ribs, sericeous-pubescent. Pappus paleaceous-aristate, persistent, composed of 10 or 12 rigid bristles which are minntely scabrous above, gradually paleaceous-dilated towards the base, and longer than the disk-corolla, as many more one-half shorter, and usually 5 still smaller and shorter external ones.

* **** * Pappus capillary-multisetose and mostly alike in all the flowers, simple, consisting of numerous capillary scabrous bristles in one or more series : receptacle more or less alveolate and the alveoli often dentate.

+ Disk-corollas 5-toothed or 5-lobed, the lobes from ovate to oblong or narrower: flowers yellow, with rare exceptions : style-appendages from ovate-lanceolate to filiform.

27. CHRYSOPSIS. Species with outer pappus obscure or wanting would be sought here.

30. APLOPAPPUS. Heads usually many-flowered, radiate, rarely discoid, or with infertile rays. Disk-corollas narrow, 5-toothed. Involucre usually (but not always) broad; the bracts with or without herbaceous tips. Akenes from turbinate to linear.

31. BIGELOVIA. Heads 3-30-flowered, destitute of rays, small. Involucre narrow; the bracts chartaceous or coriaceous, mostly destitute of foliaceous or herbaceous tips. Akenes narrow, terete or angled, hardly compressed, mostly at least 5-nerved. Pappus of somewhat equal bristles. Inflorescence not racemiform.

32. SOLIDAGO. Heads few- or several-, rarely many-flowered, mostly radiate, small, commonly in racemiform or spiciform clusters, sometimes fastigiate-cymose or in a thyrsus. Involucre narrow; its bracts mostly not herbaceous-tipped. A kenes terete or angulate, 5-12nerved or costate. Pappus of equal elongated bristles. Leaves not corclate.

33. BRACHYCH ÆTA. Heads (very small) and flowers of Solidago. Pappus of mere rudimentary bristles, shorter than the akene. Lower and radical leaves cordate.

++ Disk-corollas with limb 5-parted into long and narrow lobes, in the same genus either yellow, white, or violet-purple : no true rays: style-tips comose-bearded.

34. LESSINGIA. Heads homogamons, 5-25-flowered : flowers all perfect. Corollas with slender tube divided into long and narrow lobes; the marginal ones sometimes larger and with a deeper cleft on the inner side, somewhat imitating a palmate ligule. Involucre campanulate or turbinate : its bracts well imbricated and appressed, mostly with herbaceous tips. Receptacle flat, alveolate. Anthers included, tipped with a slender-subulate appendage. Stylebranches tipped with a very short and obtuse or truncate densely hispid appendage, which usually bears either a setiform cusp among the tufted bristles, or a more conspicuous subulate prolongation. Akenes turbinate or cuneiform, silky-villous, 2-5-nerved. Pappus of numerous or fewer unequal rigid and scabrous and sometimes awn-like bristles.

Subtribe II. Heterochromet. Disk of hermaphrodite and mostly fertile flowers; their corolla yellow, or rarely cream-color, sometimes changing to purple; the ray not 
yellow, wanting only in certain species (much reduced and inconspicuous in a section of Erigeron and one of Aster). Reeeptacle naked (not paleaceous), with an occasional exception.

* Pappus of both disk and ray none or coroniform.

+ Involucre broad, many-flowered : rays numerous, fertile, conspicuous.

35. BELLIS. Bracts of the involucre nearly equal in length, herbaceous or somewhat membranaceous. Receptacle conical or hemispherical. Style-brauches tipped with a short triangular appendage. Akenes obovate and compressed, nerveless except at the margins. Pappus none.

36. APHANOSTEPHUS. Bracts of the involucre imbricated in few series, broadly lanceolate, somewhat herbaceous with scarious apex and margins, the outer shorter. Receptacle conical or hemispherical. Style-branches with a rery short and obtuse appendage. Akenes prismatic or terete, truncate : the broad apex bordered with a short coroniform and either dentate or entire and minutely setulose-ciliate pappns. Base of corolla-tube often skirrous-thickened in age.

37. GREENELLA. Bracts of the involucre imbricated in a few series, the outer shorter, all oblong, coriaceo-chartaceous, with scarious margins and an herbaceous dorsal tip. Receptacle flat, barely convex. Style-branches with a linear rather obtuse appendage, which is four times the length of the quadrate stigmatiferous portion and much exserted. Akenes short, somewhat turbinate, obscurely 8-nerved, hispidulous. Pappus a hyaline-scarious crown cleft into numerous setulæ or denticulations.

$$
+ \text { - Involucre narrower and flowers less numerous. }
$$

38. KEERLIA. Involucre narrowly campanulate or turbinate; its bracts imbricated in few series, of unequal length, oblong, smooth, thin-membranaceous with scarions margins, mostly setaceously mucronate. Receptacle small and flat. Rays 5 to 15, with oblong ligule on a slender tube. Style-appendlages either short and obtuse or long and slender. Akenes obovate and compressel or subclavate, 2-3-nerved, and with very small epigynous disk; those of the disk-flowers mostly sterile. Pappus minute and coroniform or evanescent from the mature akenes.

* * Pappus of solitary or few setiform awns or bristles and of a few palea or a crown: rays conspicuous, fertile: akenes without wings or callous margius: receptacle flat or nearly so.

39. CHÆTOPAPPA. Involucre several-many-flowered, campanulate or narrower; its bracts oblong or lanceolate, thin-herbaceous, with scarious margins and tip, imbricated in two or more ranks, the outer shorter. Rays 5 to 20 ; the ligule oblong, raised on a slender tube. Disk-flowers often sterile: their style-appendages short. Akenes either fusiform or compressed, 2-5-nerved. Pappus of five or fewer thin and nerveless short palex, alternating with as many or fewer mostly long and setiform scabrous awns, or the latter sometimes wanting.

40. MONOPTILON. Involucre many-flowered, broad; its numerous bracts equal and almost in a single series, narrowly linear, somewhat herbaceous. Rays numerous; the ligule obovate or oblong and with a rather long tube: this and the tube of the disk-corolla sparsely villous. Style-appendages triangular and obtuse. Akenes oblong-obovate, compressed, onenerved at each margin, or the outermost also on one face. Pappus both in disk and ray a short and cupuliform barely denticulate crown, and a single setiform awn which is barbellate or plumose toward the apex.

* * Pappus short-setrulose or squamellate and mostly biaristate, i. e. a ring of very short bristles or setiform squamellæ and a pair of naked upward-tapering awns, one over each edge of the broad and flat winged or callous-margined akene: involucre many-flowered, hemispherical or broader; the bracts somewhat herbaceous and thin-margined: receptacle strongly convex or low conical : rays conspicuous, fertile; their akenes occasionally 3-winged.

41. DICHATOPHORA. Involucre somewhat uniserial; the lanceolate bracts of equal length. Style-appendages of the disk-flowers triangular-lanceolate. Akenes surrounded by an almost orbicular firm wing, its edge and the body of the akene glochidiate-hispid. Pappus of two divergent awns p bout half the length of the akene, and of several minute 
squamellx, which are shorter than and concealed by the bristly hairs of the akene. Low annual.

42. BOLTONIA. Involucre imbricated, appressed; the outer bracts shorter. Style-appendages short-lanceolate. Akenes obovate, very flat, with callous or winged margin, glabrous or minutely and sparsely hispidulous. Pappus of several short-setulose squamellæ, and usually of 2 (rarely 3 or 4 ) elongated rigid awus. Leafy-stemmed perennials.

* ** * Pappos a single series of long awns (or only 2 or 3 ) or of coarse and rigid bristles, or in the (fertile and conspicuous) ray reduced to squamellæ or palex: receptacle flat.

43. TOWNSENDIA. Iuvolucre broad, many-flowered, imbricated; the bracts lanceolate, with scarious margins and tips, outer usually shorter and inner more membranaceous. Receptacle broad, merely areolate. Style-appendages lanceolate. Akenes obovate or oblong, much compressed, and with thickish or mostly callous margins, those of the ray sometimes triangular. Awns or bristles of the pappus from hispidulo-scabrous to barbellulate.

***** Pappus of numerous capillary bristles, at least in the disk, with or without a short setulose or squamellate outer series: receptacle flat or barely convex : akenes mostly compressed.

+ Style-appendages of disk-flowers comose-bearded: anthers tipped with slender-subulate appendages, as in Lessingia: rays neutral.

44. CORETHROGYNE. Involucre broad, imbricated; its bracts with herbaceous or green tips. Receptacle foveolate, rarely with a few chaffy bracts toward the margin. Styleappendages short-lanceolate, dorsally beset with long hispid hairs forming a bearded tuft. Akenes of the ray abortive and with reduced scanty pappus or none; those of the disk narrow, silky-villous or pubescent, few-nerved; their pappus of rather rigid and unequal capillary bristles.

+ + Style-appendages merely hispidulous or puberulous, not comose.

+- Pappus none or a mere vestige in the ray-flowers : these often sterile but styliferous.

45. PSILACTIS. Involucre hemispherical; its bracts imbricated in 2 or 3 series, and with herbaceous tips, or the outer herbaceous. Rays in a single series, sometimes short. Akenes pubescent, narrow; those of the ray sometimes with an obscure ring in place of pappus; those of the disk bearing a single series of soft capillary bristles. Leafy-stemmed annuals.

++ Pappus present and mostly similar in ray and disk: flowers (with rare exceptions) all fertile. Genera of difficult limitation.

46. EREMIASTRUM. Involucre broad, many-flowered, of numerous lax́ and linear bracts, all as long as the disk and nearly in a single series, herbaceous, with hyaline-scarious and erose-fimbriate margins, their back setose-hispid. Receptacle broad and flat. Rays numerous in a single series; ligules broad, their base and tube villous-barbate. Style-appendages lanceolate. Akenes obovate-oblong, compressed, 2-nerved. Pappus of rather few very unequal and somewhat rigid bristles; the stronger ones considerably shorter than the disk-corolla and only 8 to 12 ; the smallest and outermost setulose and scarcely longer than the hirsute pubescence of the akene, sometimes coalescent irregularly at base; intermediate ones of various length and more numerous. Depressed winter-annual.

47. SERICOCARPUS. Involucre several-flowered, narrow, of closely imbricated and appressed whitish and coriaceous or cartilaginous bracts, with green-herbaceous abrupt and looser or spreading tips. Receptacle small, foveolate. Corollas both of ray and disk white or cream-color; the rays seldom over 5 or 6 , rather broad; disk-corollas (8 to 20) with 5-cleft limb. Style-appendages lanceolate-subulate. Akenes narrow, little compressed, 2-nerved; sericeous-pubescent. Pappus of numerous unequal scabrous bristles. Leafy-stemmed perennials.

48. ASTER. Involucre from hemispherical to campanulate, sometimes oblong or turbinate, imbricated in several or few series of unequal bracts, mostly in part herbaceous. Rays numerous, not very narrow. Style-appendages from slender-subulate to ovate-acute, commonly lanceolate. Akenes mostly compressed, 10-4-2-nerved, and the pappus mostly simple and copious, rarely distinctly double. Leafy-stemmed herbs, the greater part perennials.

49. ERIGERON. Differs from Aster in the more naked-pedunculate heads, simpler inrolucre of narrow and erect equal bracts, which are never coriaceous, nor foliaceous or with distinct herbaceous tips, narrower and usually very numerous rays often occupying more 
than one series, very short and roundish or obtuse style-appendages, small akenes for the greater part 2-nerved, and more scanty or fragile pappus, in unany with a conspicuous short outer series.

Subtribe III. ConYzese. Characters of the preceding subtribe; but corolla of the numerous female Howers reduced to a filiform or short and narrow tube, wholly destitute of ligule.

50. CONYZA. Heads small, many-flowered. Bracts of the campanulate involucre narrow, inappendiculate, in I to 3 series. Female flowers much more numerous than the hermaphrodite; their filiform or slender tubular corolla shorter than the disk and style, truncate or 2-4-toothed at the apex. Akenes small, compressed. I'appus a single series of soft capillary bristles, sometimes an added outer series of short bristles or squamellx.

Subtribe IV. Baccharidere. Heads discoid and unisexual. Corolla of the fertile flowers filiform. Pappus of capillary bristles.

51. BACCHARIS. Heads completely dicecious, many-flowered. Involucre regularly imbricated, of squamaceous bracts. Receptacle mostly flat and naked, rarely chaffy. Flowers of the male heads with tubular-funnelform 5-cleft corrlla, and style-branches as of Aster or Solidago, but the stigmatic portion obsolete and ovary abortive; the female with corolla reduced to a slender truncate or minutely toothed tube, shorter than the filiform style. Akenes 5-10-costate. Pappus of the male flowers of a series of seabrous and often tortuous and more or less clavellate bristles; of the fertile flowers of usually more numerous and fine bristles, and often elongated in fruit. Shrubby or some herbaceous.

Tribe IV. Indoloides. Heads heterogamous and either radiate or discoid; the female flowers being either ligulate or filiform (rarely open-tubular), or sometimes homogamous and tubuliflorous. Anthers sagittate, and the base of the lobes produced into more or less of a tail (caudate) or other appendage. Style-branches of the hermaphrodite flowers filiform or flattish, not appendaged; the stiymatic lines running to or vanishing near the roundish or truncate tip, which is at most papillose or somewhat penicillate: style of staminate-sterile flowers commonly entire. Pappus usually capillary or none. Leaves mostly alternate and heads homochromous; the involucre commonly dry or scarious, rarely foliaceous. See also Senecionidece, subtribe Tussilaginece. (No North American species has conspicuous rays, except a naturalized Inula.)

Subtribe I. Pudcheinese. Heads discoid, heterogamous and mostly androgynous. Involucre more or less dry, but hardly scarious. Receptacle not paleaceous. Female flowers with filiform corolla. Adjacent anther-tails or acuminate bases connate, at least in our genera.

52. PLUCHEA. Heads many-flowered, largely of female flowers, a few hermaphrodite but usually sterile ones in the centre. Involucre imbricated, of coriaceous to submembranaceous bracts ; the outer broad, all but the innermost persistent. Receptacle flat, naked and glabrous. Corolla of the female flowers reduced to a slender truncate or 2-3-toothed tube, shorter than the style; of the hermaphrodite-sterile ones regularly 5-cleft, the style either entire or 2-cleft at apex. Akenes small, 4-5-angled or sulcate. Pappus a series of capillary and soft or rigid bristles. Heads cymosely clustered or scattered.

53. PTERocatlon. Heads and flowers as in Pluchea, but involucre of fewer and linear or subulate bracts: these deciduous with the matured flowers, leaving a few short basal ones which are more persistent, mainly by their implexed wool. Receptacle small, naked, sometimes pilose. Heads glomerate and the glomerules spicate. Perennial herbs.

Subtribe II. Filagines. Heads heterogamous, mostly androgynous, discoid. Involucre of few scarious or firmer bracts. Receptacle chaffy; a chaff (palea) or involucral bract enclosing or subtending each female flower or akene. Corolla of the female flowers a filiform tube, shorter than the style; of the few hermaphrodite commonly sterile flowers regularly $4-5$-toothed; their anthers sometimes only acutely sagittate or auriculate at base, and the short style-branches or undivided style not 
truncate. Akenes (with one or two exceptions) smonth and even, small and seedlike, the very thin pericarp destitute of nerves or other markings, conformed to the seed and sometimes connate with the simple seed-coat, or evanescent. Low and floccose-woolly annuals. (Characterized to the exclusion of three outlying Indo-African genera.)

* Akenes gibbous, so that the corolla- and style-bearing true apex is introrsely lateral, enclosed in the compressed and cucullate mostly indurating bracts or chaff.

54. MICROPUS. Heads several- but hardly many-flowered; female flowers in one or two series on a small and rarely somewhat elevated receptacle, each enclosed (all but the style) in a conduplicate cucullate herbaceous lanate bract or chaff, only the tip of which is scariousappendiculate; the few hermaphrodite-sterile ones in the centre mostly naked. Involucre outsicle of the flower-bearing bracts scanty and scarious. Ovary and akene obovate, laterally compressed, destitute of pappus, remaining enclosed in the usually indurating laterally compressed fructiferous bracts, which sooner or later fall away. Pappus of the sterile flowers none, or rarely a few caducous bristles.

* Akenes (straight or slightly curved) with the minute epigynous disk at the summit.

+ Female flowers all bracteate and all destitute of pappus;

* The fructiferous bracts enclosing the akenes and deciduous with them, tipped with a hyaline appendage.

55. STYLOCLINE. Heads oroid; the boat-shaped fructiferous bracts borne on a slender column or receptacle, their erect hyaline tips usually conspicuous, the involute or saccateconduplicate body or base embracing the obovate or oblong more or less compressed akene : those subtending the 4 or 5 central hermaphrodite-sterile fiowers barely concave or plane. Pappus of the latter flowers a very few caducous bristles or none.

56. PSILOCARPHUS. Heads globose; the numerous fructiferous bracts heaped on the globular or oval receptacle, cucullate-saccate and utricular, half-obovate or half-obcordate in outline, very rounded at top, herbaceo-membranaceous, the apex introrse, and the ovate or oblong hyaline appendage inflexed or porrect, or sometimes erect. Akene loose in the comparatively ample ntricular bract, oblong or narrower, straight, slightly compressed. No bracts and no pappus to the few hermaphrodite-sterile flowers. Leaves mainly opposite!

++ Fructiferous bracts open and merely subtending the (usually numerous) akenes.

57. EVAX. Akenes from obcompressed to terete, sometimes minutely papillose or puberulent. Bracts of the female flowers from scarions to firm-chartaceous, not hyaline-appeadaged. Hermaphrodite flowers sometimes fertile, destitute of pappus. Receptacle from barely convex to subulate.

++ Female flowers more or less of two kinds: the upper ones surrounding the bermaphrodites and like them with a capillary pappus; the others destitute of pappus.

58. FILAGO. Receptacle from subulate to obconical or hemispherical; its naked summit or centre bearing several or somewhat numerous commonly fertile flowers, which are all provided with a pappus of rather copious capillary bristles; the few central ones hermaphrodite, the others female; the cluster subtended by open scarious bracts; the sides or base of the receptacle bearing several or numerous female flowers, each subtended or its calvous akene loosely enclosed by a concave or boat-shaped bract. Akenes terete or obscurely compressed, sometimes roughish-papillose.

Sulstribe III. Graphadief (Veræ). Heads discoid, heterogamous and androgynous or diœciously homogamous; the hermapbrodite or staminate flowers when in the same head much fewer than the female; the latter with filiform-tubular corolla shorter than the style; the former with style or style-branches mostly truncate ; all usually with capillary pappus. No bracts or chaff on the receptacle : bracts of the involucre numerous, more or less scarious, or with scarious and often colored or petaloid summits. Anther-tails slender. Ours floccose-woolly herbs, with alternate leaves.

59. ANTENNARIA. Heads dicecious, many-flowered. Involucre pluriserially imbricated. Receptacle convex or flattish. Male flowers with mostly undivided style and a rather scanty pappus of clavellate or apically barbellulate or crisped bristles. Female flowers with oblong 
or narrower and terete or flattish akenes, and a copious fine-capillary pappus, the solt and naked bristles of which are commonly united at base, so as to fall in a ring. Low perennials.

60. ANAPHALIS. Heads diocious, but usually with a few hermaphrodite-sterile flowers in the centre of the female heads. Pappus of male flowers of bristles little if at all thicker at the apex; of the female flowers not united at base but falling separately. Otherwise as in the preceding; the female plant differing from the following only in the sterility of the few central flowers.

61. GNAPHALIUM. Heads heterogamous, fertile throughout, of few or many series of female surrounding a smaller number of liermaphrodite flowers. Involucre pluriserially imbricated; the scarious and commonly partly woolly bracts with or without colored papery tips or appendages. Style of hermaphrodite flowers 2-cleft. Pappus of numerous merely scabrous capillary bristles, in a single series.

Subtribe IV. EuInules. Heads heterogamous, with the female ligulate and radiate, and the disk-flowers all hermaphrodite and fertile (or the former sometimes wanting). Receptacle naked. Style-branches of the latter linear, rounded at the apex. Akenes mostly coriaceuns. Old-world genera, one naturalized.

62. INULA. Heads many-flowered; the rays numerous. Involucre imbricated, hemispherical or campanulate; outer bracts herbaceous. Receptacle flat or nearly so. Akenes more or less 4-5-costate. Pappus of capillary scabrous bristles. Flowers yellow.

Subtribe V. Adenocadlese. Heads heterogamous, discoid; both female and hermaphrodite (sterile or fertile) flowers with tubular more or less ampliate 4-5-toothed or lobed corollas. Involucre not scarious. Receptacle naked. Akenes elongated, striate or nerved : pappus none. Leaves alternate, partly floccose-woolly. (Here also Carpesium, L.)

63. ADENOCAULON. Heads several-many-flowered; the marginal flowers female; the more numerous central ones hermaphrodite-sterile. Involucre of few thin-herbaceous bracts. Receptacle flat, naked. Corollas all somewhat alike; of the sterile flowers broadly funnelform and deeply 4-5-cleft; of the fertile ones less arapliate, either regularly 4-lobed or (in the Chilian species) bilabiate, the outer lip 3-lobed; the style of the former undivided, somewhat clavate; of the latter with short and broad stigmatic branches. Anthers sagittate, and the auricles minutely but evidently caudate, connate. Akenes obovoid-oblong or clavate, very obtuse, lightly $4-5$-nerved, much exceeding the involucre, the upper part beset with stout stipitate (nail-shaped) glands : ovary of the sterile flowers inane. Leaves floccose-woolly underneath.

Tribe V. Helianthoidea. Heads heterogamous and the female flowers ligulate and radiate, or rarely with corolla wanting, and in the latter case some are monœcious ; or sometimes homogamous by the absence of the ligulate ray-flowers; those of the disk all with regularly 4-5-toothed tubular corolla. Receptacle paleaceous, i. e. with bracts (palect, chaff) subtending either all the disk-flowers or the marginal ones only, except in the first subtribe and the peculiar uniflorons or 2-4-locular heads of the third. Anthers at most sagittate, not caudate at base. Style-branches of hermaphrodite or sterile flowers (or the undivided style in some of the latter) truncate or continued into a hairy (from conical to subulate) appendage. Pappus various or none, never of truly capillary bristles. Leaves more commonly opposite, at least the lower ones. - A varied tribe of more than 100 genera.

Subtribe I. Milueries. Ray-flowers solitary or few and fertile: disk-flowers hermaphrorite-sterile. Receptacle naked. Pappus none. (Artificial group.)

64. PLUMMERA. Heads of 2 to 5 ray and 6 or 7 disk-flowers. Involucre obpyramidal, double; the outer composed of mostly 4 ovate-oblong obtuse carinate bracts, which arc united to or above the middle into a coriaceous or cartilaginous cupule; the inner of as many barely equal cuneate-obovate plane alternating bracts, their rounded summit firmscarious. Receptacle flat, naked. Female flowers with a dilated-cuneate 3-lobed ligule on a 
short tube. Hermaphrodite-sterile, with usually a stipitiform abortive ovary, tubular-funnelform 5-toothed corolla, its short proper tube thickened, and a truncate-bicapitellate style. Akene of the fertile flowers obovate, turgid, free, thinnish, nearly nerveless, the upper part villous with long soft hairs, wholly destitute of pappus; the epigynous areola small and slightly depressed. Flowers yellow.

156. BLENNOSPERIMA. Heads many-flowered. Involucre simple, broad. Akenes pyriform. Perhaps belongs here rather than to the Helenioidece, where it has no near relatives: perhaps it should stand next to Crocidium, no. 186.

Subtribe II. MELAMPODIE无. Ray-flowers ligulate (sometimes obscurely so) and fertile, the ligule mostly deciduous: disk-flowers hermaphrodite-sterile. Akenes usually with coriaceous or thicker pericarp, the style nostly entire. Receptacle paleaceous throughout, Parthenice excepted. (Artificial group.)

* Involucre of the several-flowered heads cylindrical or fusiform, of membranaceous or thinnish and striate-nerved oblong bracts, not enclosing or embracing the few narrow and somewhat obcompressed akenes; those of the small and flat receptacle scarious. (Allied to the Coreopsidee.)

65. DICRANOCARPUS. Involucre of 3 or 4 narrow bracts (and rarely 1 or 2 short and subtending herbaceous ones), at length loose, deciduous in age. Ray-flowers 3 or 4 ; the ligule very small, shorter than the style, 2-3-lobed, and with hardly any tube. Disk-flowers 3 or 4 : corolla with rotately-spreading limb parted into 5 ovate lobes, rather longer than the narrow tube: style tipped with an entire conical appendage: ovary inane. Akenes dimorphous, one or two elongated to fully twice or thrice the length of the involucre, from subulate to oblong-linear, nearly smooth, puberulent, long persistent on the receptacle, tipped with two diverging or divaricate and stout persistent naked rigid awns or horns; the others shorter, comparatively thicker, often tuberculate-rugose, the truncate apex bearing a pair of very short divaricate horns or hardly any.

66. GUARDIOLA. Involucre of 3 concave and herbaceo-membranaceous bracts completely enclosing 3 or 4 narrower white-scarious ones; and there are narrower similar palea subtending the sterile flowers. Tube of the corolla both of ray and disk long and filiform; in the 1 to 5 fertile flowers equalling the oblong ligule; in the 5 to 20 sterile flowers commonly several times longer than the abruptly dilated deeply 5-cleft limb (its lobes linear). Filaments very villous! Style of the disk-flowers mostly 2-cleft at apex, its branches linear or subulate, hispid to the base : ovary inane. Akenes oblong, slightly obcompressed, smooth, the rounded apex wholly destitute of pappus; the base suberose-fleshy, sometimes as a boss upon one side.

* * Involucre of the many-flowered heads broad; the inner bracts concave, embracing and half enclosing the thick and turgid obovoid akenes: pappus none.

67. POLYMNIA. Heads hernispherical or broader. Involucre of about 5 loose exterior bracts, and as many or more numerous smaller and thinner interior ones, subtending as many fertile flowers: sterile flowers subtended by mostly scarious chaffy bracts of the flat receptacle. Ray-flowers with a short hairy tube bearing either a short or a long ligule, or none at all. Corolla of the disk-flowers thin, ampliate ahove, and with ovate lobes. Sterile style commonly 2-cleft or 2-pointed at the hairy apex. Akenes very thick, short, smooth, marginless.

* * Involucre double, strongly dimorphous; exterior of 4 or 5 herbaceous or foliaceous plane bracts; interior of a single series of small bracts, which completely and permanently enclose the obovate or oblong more or less compressed smooth and glabrous akenes with a pericarp-like accessory covering, at length deciduous together : pappus none.

68. MELAMPODIUM. Fructiferous and transformed involucral bracts commonly indurated, naked or unarmed. Receptacle convex or conical. Akenes more or less obovate and incurved.

69. ACANTHOSPERMUM. Fructiferous involucral bracts armed with hooked prickles or spines, forming a kind of bur. Otherwise as Melampodium. Ligules minute, concave or cucullate.

* * * Involucre broad, of plane or barely concave bracts; innermost subtending ob. compressed (mostly much flattened) akenes, but not enclosing nor embracing them. 
+ Ray-flowers, or rather their ovaries and akenes, in more than one series, and with elongated exserted deciduous ligules; the akenes falling free, or with only the subtencling bract. (Schizomeria of Mexico is of this section, but with fewer ray-flowers.)

70. SILPHIUM. Heads large, many-flowered. Involucre of thickish more or less foliaceous imbricated bracts; the innermost (next to the akenes) small and chaffy. Receptacle comparatively small, the central part bearing the sterile flowers somewhat turbinate in age; its chaffy bracts linear, flat, or involute around the pedicilliform abortive ovaries. Corollas of the ray with a long and spreading ligule on a very short tube; of the disk cylindricaltubular, the teeth very short and thickish. Sterile strle entire, much elongated in anthesis, hispidulous. Akenes very flat and broad, imbricated in 2 or 3 series, completely free from the subtending bract and from those of adjacent male flowers, surrounded by a winged margin which is produced more or less beyond the summit on each side into a callous tooth or auricle; pappus none or sometimes a pair of short rigid awns or teeth, with which the wing is confluently united.

+ - Ray-flowers and akenes in a single series; the latter with 2 or 3 bracts of sterile flowers (palex of the receptacle) attached to their base on the inner side, which they take with them, and commonly also the subtending involucral bract, when they fall.

+ Heads conspicuously radiate; the ligules plane and exserted, subsessile, yellow, oblong or oval : receptacle flat : its bracts or chaff, or at least the outer, of rather firm texture and more or less involving their sterile flowers or inane ovaries.

71. BERLANDIERA. Heads broad, with 5 to 12 radiate fertile and many hermaphroditesterile flowers. Involucre hemispherical or broader; its bracts in about three series; outermost smaller and more foliaceous; the succeeding larger and usually dilated-obovate; innermost thinner, becoming membranaceous or chartaceous and reticulated in age. Diskcorollas, style, \&c. as in Silphium. Akene very flat or slightly meniscoidal, obovate, wingless, not toothed or notched at summit, carinately nnicostate down the inner face, with evanescent or obsolete pappus (sometimes two minute and caducous bristly teeth or awns), at the back more or less coherent with the base of the subtending plane involucral bract, at length falling away with it, the rentral face partly covered by the spatulate bracts of the 2 or 3 attached sterile flowers. Alternate-leaved perennials.

72. CHRYSOGONUM. Heads of mostly 5 radiate fertile and rather numerous sterile flowers. Involucre campanulate, double; outer of 5 loose and obovate or spatulate foliaceous bracts which surpass the disk; inner of as many small oval firm-membranaceous erect bracts, each subtending a fertile flower. Chaffy bracts of the receptacle thin, linear, the outer broader and partly enclosing as many sterile flowers. Ligules oblong : disk-corollins cylindraceous, with 5 small spreading teeth. Akene obovate or oval, flat or slightly meniscoidal, with acute but wingless margins, one-nerved on the convex back, carinately 1-2costate on inner face, crowned with a truncate or crenately emarginate semi-cupulate pappus, i. e. the crown wanting on the inner side; the involucral bract with which it falls little larger than its back, and closely applied to but not cohering with it: adjacent sterile bracts less persistent with the akene than in the following genus. Low and opposite-leaved perennial.

73. LINDHEIMERA. Heads of 4 or 5 radiate fertile and rather numerous sterile flowers. Involucre double; outer of 4 or 5 loose and foliaceous narrow lanceolate bracts; inner of as many larger ovate-oblong herbaceous bracts, becoming chartaceo-membranaceous, subtending the fertile flowers. Receptacle small; its inner bracts chaffy, narrowly linear and nearly plane; the outer more herbaceous, spatulate, and enclosing the filiform abortive ovary, which forms a long pedicel to the subtended sterile flower. Ligules oval or oblong, almost entire: disk-corollas funnelform. Akere obovate, flat, slightly meniscoidal, unicostate on the middle of each face (dorsally not adnate to the much larger subtending bract), surronnded by a cartilaginous entire wing, which is confluent at apex with two triangularsubulate rigid teeth or horns; a similar but smaller and naked tooth projecting from the summit of the ventral costa. Erect annual, with sessile leaves, the upper opposite.

74. ENGELMANNIA. Heads of 8 to 10 conspicuously radiate and of many sterile flowers. Involucre hemispherical, somewhat double; the outer of about io rather linear mainly foliaceous bracts in two series, $i$. e. the outermost smaller and wholly loose and foliaceous, the succeeding similar but with ovate-dilated and appressed coriaceous base; inner of firm- 
coriaceous oval or obovate concave bracts with short and abrupt foliaceous tips, subtending the fertile flowers. Bracts of the receptacle all firm-coriaceous and persistent, linear or lanceolate, partly enclosing the sterile flowers or their pedicel-like inane ovary. Ligules oblong, almost entire: disk-corollas narrowly funnelform, 5-lubed. Sterile style somewhat clavate, very hispid. Akenes filling nearly the whole deeply concave face of the subtending bract (not adnate to it), and covered by the 2 or 3 rigid internally attached chaffy bracts of sterile flowers, obovate, wingless, both faces carinately unicostate: indurated bases of the bract, the chaff, and the akene firmly and inseparably united, tardily falling away from the receptacle. Pappus a conspicuous and persistent firm-scarious and hispid crown, more or less cleft into 3 or 4 irregular Jobes or into a pair of lanceolate scales; that of the abortive ovaries somewhat similar but rudimentary, nearly as in Silphium. Alternate-leaved perennial.

+ + Heads small, mostly hemispherical, nearly or quite discoid; the corolla of the 5 to 8 female flowers with the ligule very short, often broader than long, or obsolete: receptacle conical or convex: flowers whitish : corollas of the sterile ones tubular-funnelform, and the style glabrous except the more or less dilated and truncate pubescent summit, their ovary obsolete: akenes more turgid dorsally : involucre of rather few ovate or orbicular appressed bracts, in about two series: leaves alternate.

75. PARTHENIUM. Fertile flowers 5, with obcordate or 2-lobed almost sessile concave ligule barely surpassing the disk, or a truncate emarginate cup. Bracts of the involucre chartaceous or partly herbaceous, and the inner more scarious : those of the usually conical receptacle cuneate, tomentose at summit, partly enclosing the sterile flowers. Akenes oval or obovate, commonly pubescent, surrounded by a filiform callous margin, which is firmly coherent at base with the bases of the bracts of the contiguous pair of sterile flowers and of the subtending bract, at length tearing away from the akene; the summit bearing the marcescent corolla, and a pappus' of two chaffy awns or scales, or sometimes hardly any.

76. PARTHENICE. Fertile flowers 6 to 8 , with corolla hardly equalling the disk, not longer than the style, an obliquely cleft tube, with ligule obsolete or reduced to 2 or 3 small teeth; sterile flowers 40 or 50, with funnelform corolla. Involucre of 5 somewhat herbaceous oval exterior bracts, and of 6 or 8 somewhat larger orbicular-obovate and more scarious interior ones, these subtending the fertile flowers. Receptacle convex, with linearoblong or spatnlate chaffy bracts subtending the outer series of sterile flowers, but mostly minute or wanting to the inner flowers. Akenes oblong-obovate, glabrous, wingless, but acute-margined, with an incurved apiculation terminated by a small sphacelate obtnse tip, inserted by a rery small base, falling away at maturity with the involucral and two receptacular bracts, but these readily separating. Pappus none; and conolla deciduous.

Subtribe III. Ambrosies. Fertile flowers apetalous, or with corolla reduced to a tube or ring around the base of the 2-parted style: disk-flowers staminate, with funnelform or obconical 4-5-lobed corolla, anthers slightly united and their short terminal appendage inflexed, the abortive style hairy only at the somewhat enlarged and depressed summit, the ovary a mere rudiment. Pappus none (or a vestige in Oxytenia and Dicoria). Heads small; the flowers whitish or greenish.

* Head androgynous (rarely all male in Dicoria), having few (or rarely solitary) female flowers at the margin ; the more numerous male flowers all or most of them subtended by slender and commonly spatulate chaffy bracts: anther-tips short and obtuse, rarely pointed : involucre open : akenes usually large for the size of the head, free. - Ivec, DC.

+ Akenes turgid, mostly obovate or pyriform, marginless: dilated summit of the sterile style hispidulous or radiately penicillate.

77. IVA. Female flower's 1 to 5, with or without the tube or cup representing a corolla. Akenes more or less obcompressed, glabrous, puberulent, or glandular; the terminal areola small.

78. OXYTENIA. Female flowers about 5, wholly destitute of corolla; their style with 2 oval or oblong and very obtuse stigmatic lobes. Involucre of about 5 coriaceo-herbaceous dilated-ovate and rather rigidly acuminate bracts. Receptacle convex, small; the 10 to 20 sterile flowers subtended by slender chaffy bracts with cuneate-dilated tips, or these wanting to the central ones. Akenes (immature) obovate and turgid, very villous, nearly pyriform 
(sometimes with a single diaphanous and minute squamella to represent pappus !), with large terminal areola bearing around the base of the style a fleshy annular disk. Lower part of the disk-flowers and their chaff beset with some villous hairs, like the very long and soft ones which thickly clothe the akenes.

$$
+ \text { - Akenes flattened, obcompressed, wing-margined. }
$$

79. DICORIA. Female flowers one or two, wholly destitute of corolla; male flowers 6 to 12 , with mere rudiments of ovary and style. Involucre of 5 oval or oblong herbaceous bracts; and within one or two larger and broad thin-scarious bracts, subtending the fertile flowers; or these wanting in male heads. Receptacle small, flat, with a few narrow and hyaline chaffy bracts among the flowers. Filaments almost free from the obconical corolla, monadelphous up to the lightly connected anthers! the tube dilated and 5-toothed at summit. Akenes much surpassing the outer involucre, oblong, anteriorly flat, convex or somewhat angled dorsally, abruptly bordered by a thin-scarious pectinate-dentate wing or edge. Pappus rudimentary, of several small and setiform squamella.

* Heads unisexual, moncecious; the fertile with solitary or 2 to 4 completely or nearly apetalous female flowers in a closed nutlet-like or bur-like involucre, only the stylebranches ever exserted; the sterile of numerous male flowers in an open involucre, the heads in a raceme or spike of centripetal evolution: akenes turgid-obovoid or ovoid, wholly destitute of pappus: flowers greenish or yellowish: male corollas obconical. Ambrosiece, DC.

+ Involucre of the sterile heads gamophyllous; the receptacle low, and abortive style witl dilated apex radiately penicillate or fimbriate.

80. HYMENOCLEA. Involucre of the male flowers saucer-shaped and 4-6-lobed, rarely more cleft: bracts of the receptacle subtending the outer flowers obovate or spatulate; inner filiform or none: filaments distinct: anther-tips blunt. Involucre to the solitary fertile flower ovoid or fusiform, beaked at apex, the lower part furnished with 9 to 12 dilated and silvery-scarious persistent transverse wings.

81. AMBROSIA. Involucre of the male flowers from depressed-hemispherical to turbinate, 5-12-lobed or truncate, herbaceous. Receptacle flat or flattish, usually with some filiform chaff among the outer flowers. Anther-tips (at first inflexed, at length erect) setiferousacuminate. Involucre to the solitary fertile flower nucumentaceous, apiculate or beaked at the apex, and usually armed with 4 to 8 tubercles or short spines in a single series below the beak. Sterile heads spicate or racemose above the fewer fertile ones.

82. FRANSERTA. Heads of male flowers as Ambrosia, or sometimes intermixed with the female. Fertile involucre 1-4-flowered, 1-4-celled, is single pistil to each cell, 1-4. rostrate, more or less bur-like, being armed over the surface with several or numerous prickles or spines (the spiny free tips of component bracts) in more than one series. Leaves mostly alternate.

++ Involucre of the sterile heads polyphyllous, and the receptacle cylindraceous.

83. XANTHIUM. Involucre of the globular sterile heads one or two series of small narrow bracts : receptacle distinctly paleaceous, a cuneate or linear-spatulate chaffy bract partly enclosing each male flower: filaments monadelphous: anthers distinct but conrivent; the inflexed apical appendage mucronate: sterile style unappendaged. Fertile heads a closed and ovoid bur-like 2-celled and 2-flowered involucre, 1-2-beaked at the apex, the surface clothed with uncinate-tipperl prickles: each flower a single pistil, maturing a thick ovoid akene, the two permanently enclosed in the indurated prickly involucre. Leaves alternate.

Subtribe IV. ZrNnIEse. Ray-flowers ligulate and fertile; the ligule with rery short tube or none, persistent on the akene and becoming papery in texture! (but at length falling or decaying away in Heliopsis loevis) : disk-flowers hermaphrodite and in our genera fertile, numerous, subtended or embraced by chaffy bracts; the corolla cylindraceous. Leaves opposite and heads singly terminating the stem or branches.

* Leaves all or mostly entire: akenes of the disk compressed, all or some of them (either of disk or ray) toothed or awned from the summit of the angles or edges.

84. ZINNIA. Involucre campanulate or cylindraceous; its closely appressed-imbricated bracts dry and firm, broad, with rounded summit often margुined. Receptacle becoming 
conical or cylindraceous; the chaffy bracts conduplicate around the disk-flowers. Lobes of the disk-corolla mostly velvety-villous. Style-branches of disk-flowers with either truncate or subulate tips. Akenes wingless or nearly so; of the ray obcompressed-triquetrous, of the disk much compressed. Pappus when present of erect awas or chaffy teeth. Leaves mostly sessile and rays showy.

85. SANVITALIA. Involucre short and broad, of dry or partly herbaceous bracts. Receptacle from flat to subulate-conical, at least in fruit; its chaffy bracts concave or partly conduplicate. Ligules (entire or 2-toothed at apex) often short and small. Disk-corollas with glabrous lobes. Style-branches of disk-flowers truncate or capitellate at tip. Akenes either all or the exterior thick-walled; of the ray commonly 3 -sided, and the angles produced into as many thick and rigid divergent awns or horns; those of the disk often heterogeneous, from compressed-quadrangular to flat, some usually wing-margined, the pappus of one or two slender awns or teeth or none. Leaves commonly petioled.

* *eaves commonly serrate, slender-petioled : akenes not compressed.

86. HELIOPSIS. Involucre short, of nearly equal oblong or lanceolate bracts, the outer herbaceous. Receptacle from high-convex to conical; the pointless chaffy bracts partly embracing the disk-flowers. Ligules large, oblong or narrower: disk-corollas glabrous. Style-branches tipped with a very short conical hirsute appendage. Akenes short aid thick, obtusely 4-angular, or in the ray somewhat triangular, with broad truncate summit, wholly destitute of pappus, or sometimes with the annular'border 1-4-dentate.

99. BALSAMORRHIZA § KaLLIACTIS also has persistent ligules!

Subtribe V. Verbesines. Ray-flowers ligulate and either fertile or neutral, or not rarely wanting, the ligule not becoming papery and persistent on the fruit (with one exception), but sometimes marcescent: disk-flowers hermaphrodite and fertile (or some of the inner often failing to produce fruit), subtended and sometimes enwrapped by the bracts of the receptacle. Anthers often blackish. Akenes various but those of the disk never olcompressed: pappus cupulate or coroniform, or of teeth or awns from the 2 to 4 principal angles, or of some squarneliæ, or of a few stout (but not capillary) bristles, or none. Leaves either opposite or alternate.

* Involucre 4- rarely 5-lobed and foliaceous, valvate and saliently 4-5-angled in the bud: akenes short and thick: pappus when present pluripaleaceous in the manner of Helenioidece.

87. TETRAGONOTHECA. Heads many-flowered; ray-flowers few or several, fertile. I'rincipal involucre membranaceo-foliaceous, spreading in anthesis; the 4 or 5 broadly ovate bracts connate at base; within are 6 to 15 small chaffy bracts subtending ray-flowers, and similar to the thin-membranaceous and nervose lanceolate chaffy bracts of the at length conical receptacle. Ligules with short tube or almost nearly sessile, 5-8-nerved : disk-corollas with elongated cylindraceous throat, 5-lobed. Style-branches of the disk-flowers hispid above, and tipped with a rather long acute or acnminate appendage. Akenes more or less 4-sided, with a broad flat summit, destitute of pappus, or with a crown of numerous chaffy squamella. Leaves opposite.

* Involucre of several or numerous distinct bracts.

+ Bracts of the receptacle permanently investing the akenes as an indurated accessory covering.

88. SCLEROCARPUS. Heads many-flowered; the ray-flowers several, neutral. Involucre of rather few more or less herbaceous bracts, the outer loose and spreading. Receptacle convex or conical; its at length coriaceous or cartilaginous bracts closely investing the akenes and falling away with them by an articulation. Disk-corollas 4-5-cleft: style-branches mostly with subulate appendages. Akenes smooth, oblong or obovoid: pappus a short crown or ring, or none. Brauching herbs.

+ + Bracts of the receptacle mostly reduced to awn-8haped chaff or bristles subtending the naked akenes.

89. ECLIPTA. Heads many-flowered : ray-flowers numerous, small and short, fertile. Involncre broad, of one or two series of herbaceous bracts. Receptacle nearly fat. Diskcorollas 4-toothed, rarely 5-toothed; their style-branches with short obtuse or triangular tips. 
Akenes thick, in the ray mostly 3-sided and in the disk compressed, more or less margined, without pappus, or sometimes with 2 to 4 teeth or short awns. Leaves opposite aud heads small.

+++ Bracts of the many-flowered receptacle concave or complicate, loosely cmbracing or subtending the disk-akenes, mostly persistent.

* Rays uniformly none, the flowers all hermaphrodite and fertile: involucre dry or partly so: akenes not flat nor margined: pappus of slender awns or none.

90. MELANTHERA. Involucre hemispherical; the disk in fruit globular, and squarrose with the mostly pointed rather rigid striate concave bracts of the convex or low-conical receptacle; bracts of the involucre ovate to lanceolate, thickish, nerveless, in 2 or 3 series, somewhat equal in length. Corolla 5-lobed, with campanulate-oblong ampliate throat. Style-branches tipped with a subulate hispid appendage. Akenes thick and short, compressed-quadrangular, somewhat obpyramidal, with broad truncate summit: pappus of 2 or more slender caducous awns. Leaves opposite, petioled.

91. VARILLA. Involucre short, of rather few and small linear-lanceolate appressed-imbricate and mostly few-striate bracts, similar to those of the at length higl-conical or oblong receptacle. Corolla with narrow cylindraceous throat, 5-toothed. Style-branches with short and obtuse or minutely apiculate conical tips. Akenes narrow, linear oblong, terete, rather thin-walled, smooth, evenly 8-15-nerved: pappus setulose or none. Shrubby or suffruticose.

92. ISOCARPHA. Involucre, receptacle, and dry bracts nearly of the preceding genus. Corolla similar but small. Style-branches with subulate tips. $\Lambda$ kenes $4-5$-angled, small, little compressed, destitute of pappus. Herbaceous.

93. SPILANTHES. Some (exotic) species have no ray-flowers, and akenes not flat, with pappus also wanting: these resemble Isocarpha.

+ Rays present, but in several genera occasionally wanting: involucre commonly herbaceous or foliaceous, or partly so.

- Receptacle high, from conical to columnar or subulate, at least in fruit. (Here Gymnolomix, as to two species, would be sought.)

a. Rays fertile, or not rarely wanting: style-branches of the disk-flowers truncate and sometimes penicillate at tip : akenes small : leaves opposite.

93. SPILANTHES. Involucre of a few somewhat herbaceous loosely appressed bracts. Bracts of the receptacle soft and chaffy, shorter than the flowers, more or less conduplicate and embracing the akenes, at length falling with them. Disk-corollas 4-5-toothed. Akenes of the ray triquetrous or obcompressed; those of the disk either moderately or much compressed and with acute or nerve-like margins, sometimes ciliate-fimbriate. P'appus a setiform awn from one or more of the angles, or none.

b. Rays sterile (imperfectly styliferous in Echinacea, otherwise completely neutral), soon drooping, sometimes marcescent, the ligule with very short tube or none: style-branches tipped with an acute or obtuse hispid appendage: leaves mostly alternate.

94. ECHINACEA. Involucre imbricated in 2 or 3 or more series and squarrose; its bracts lanceolate. Disk at first only convex, becoming ovoid and the receptacle acutely conical. Chaffy bracts of the latter firm and completely persistent, livear-lanccolate, carinate-concave, acuminate into a rigid and spinescent cusp, surpassing the disk-flowers. Ligules elongated and pendent in age, rose-colored or rose-purple, marcescent, usually imperfectly styliferous. Disk-corollas cylindraceous, with 5 erect teeth and almost no proper tube (a ring upon which the stamens are inserted). Akenes suberose-cartilaginous, acutely quadrangular, somewhat obpyramidal, with a thick coroniform pappus more or less extended into triangular teeth at the angles; the basal areola central.

95. RUDBECKIA. Involucre looser, spreading, more foliaceous. Disk from hemispherical or globose to columnar, and receptacle from acutely conical to cylindrical and subulate; its chaffy bracts not spinescent, but sometimes soft-pointed. Ligules yellow or partly (rarely wholly) brown-purple. Disk-corollas with a short but usually a manifest proper tube. Akenes 4-angled, prismatic, in some species quadrangular-compressed, or in one nearly terete. Pappus a coriaceous or firm-scarious and often 4-toothed crown, sometimes deep and cupuliform, sometimes obsolete, or none. 
96. LEPACHYS. Akenes short and broad, compressed, acutely margined or sometimes winged at one or both edges, somewhat laterally or obliquely inserted on the slendersubulate receptacle: pappus a chaffy or aristiform tooth over one or both edges, or none, the crown minutely squamellate and evanescent or none. Chaffy bracts of the receptacle conduplicate or deeply navicular, with thickened and truncate or somewhat hooded summit, embracing and hardly surpassing the akenes, at length deciduous with them. Corollas of the disk with hardly any proper tube. Ligules, involucre, \&c., of Rudbeckia.

$==$ Receptacle from flat to convex, or in certain species conical: akenes not winged nor very flat, when flattened not margined or sharp-edged.

a. Rays fertile: style-branches of the disk-flowers hispid for all or much of their length: receptacle flat or merely convex: ray akenes commonly triquetrous or obcompressed: pappus persistent or none.

97. WEDELIA. Akenes thick and turgid, cuneate-oblong or pyriform, with roundish summit; those of the disk obtusely if at all quadrangular, or flattened only at the inane base: pappus a paleaceous commonly lobed and at length indurated cup. Involucre rather simple and foliaceous. Leaves opposite: stem herbaceous.

98. BORRICHIA. Akenes equably and acutely quadrangular, or in the ray triangular: pappus a somewhat toothed cup or crown. Involucre imbricated; outer bracts sometimes foliaceous. Bracts of the receptacle concare, rigid. Leaves opposite : 'stem woody.

99. BALSAMORRHIZA. Akenes destitute of pappus, oblong; of the disk quadrangular and often with intermediate nerves (these and the angles usually salient). Ligules with a distinct tube. Involucre broad; the outer bracts foliaceous, sometimes enlarged. Bracts of the receptacle linear-lanceolate. Style-appendages filiform or slender-subulate. Tuberousrooted low herbs.

100. WYETHIA. Akenes prismatic, large, 4-angled, or in the ray 3-angled and in the disk often flattened, also with intermediate salient nerves: pappus a lacerate chaffy or coriaceous crown, or cut into nearly distinct squamellæ, commonly produced at one or more of the angles into chaffy rigid awns or teeth. Involucre campanulate or broader, more or less imbricated; outer bracts often foliaceous. Bracts of the receptacle lanceolate or linear, partly embracing the akenes. Style-appendages slender-subulate or filiform, very hispid. Thick-rooted and large-headed herbs, with alternate leaves.

b. Rays sterile, rarely wanting: akenes quadrangular-compressed or more turgid, or flatter, but none margined or winged; those of the ray inane or sterile: chaffy bracts of the convex or conical receptacle either strongly concave or conduplicate and embracing the akenes: leaves either opposite or alternate.

101. GYMNOLOMIA. Pappus none or a minute denticulate ring; the truncate apex of the short akenes commonly at length covered by the base of the corolla, the tube of which is usually pubescent.

102. VIGUIERA. Pappus of two chaffy awns or paleæ, one to each principal angle of the akene, or occasionally one or two more, and of two or more intermediate shorter communly truncate paleæ or squamellæ on each side, either persistent or deciduous. Akenes commonly pubescent. Peduncles slender.

103. TITHONIA. Pappus of Viguiera or more persistent: habit of the annual species of Helianthus: involucre somewhat peculiar, of about two series of bracts, with appressed and rigid usually striate base and loose foliaceous tip. Peduncles clavate and fistular under the head.

104. HELIANTHUS. Pappus promptly deciduous, of two scarious and pointed or somewhat awned palex, mostly no intermediate squamellæ or palex, except sometimes as detached or partly united portions of the principal paleæ. Akenes usually glabrons or glabrate. Proper tube of disk-corollas'short, and the throat cylindrical and elongated.

$===$ Receptacle flat, convex, or sometimes becoming conical: akenes (of the ray or margin often triquetrous) of the disk either flat-compressed and margined or thin-edged, or if turgid some of them winged: pappus not caducous.

a. Truly shrubby, rayless, alternate-leaved: akenes wingless.

105. FLOURENSIA. Rays none in the Mexican (several and neutral in the Chilian) species. Involucre of 2 or 3 series of oblong or lanceolate bracts, at least the outer herbar 
ceous or foliaceous. Receptacle flat; its chaffy bracts scarious-membranaceous, conduplicate around the akenes and tardily deciduous with them. Proper tube of the corolla fully half the length of the oblong-campanulate throat. Appendages of the style-branches from oblong to dilated-spatulate, obtuse. Akenes compressed, narrowly oblong-cuneate, callousmargined, very villous, bearing a nearly persistent pappus of a subulate somewhat chaffy awn from each angle of the truncate summit, and commonly some intermediate smaller ones or squamellæ.

b. Herbaceous, or sometimes shrubby: leaves never decurrent on the stem: rays neutral, rarely wanting : mature akenes all wingless or nearly so, emarginate or truncate at summit, the margins either villous-ciliate or naked.

106. ENCELIA. Pappus none, or an awn or its rudiment answering to each margin of the wingless akene: no intermediate squamello.

107. HELIANTHELLA. Pappus of delicate squamellæ between the two chaffy teeth or awns which surmount the two acute margins of the akene (and sometimes the lateral angles when there are any), or these obsolete in age, but not caducous. Ovary often wingmargined, but mature akene not so.

c. Herbaceous, or rarely suffruticose: rays fertile or sometimes neutral in Verbesina, or occasionally wanting: akenes or some of them developing winged margins, or sometimes all wingless, none villous-ciliate: style-appendages acute.

108. ZEXMENIA. Involucre campanulate or hemispherical, imbricated; the bracts colnmonly broad, erect, and dry, or the outermost sometimes loose and foliaceous or with spreading herbaceous tips. Rays fertile. Receptacle flat or convex. Akenes of the ray or outermost of the disk triquetrous; of the disk more or less compressed, sometimes flat, truncate at summit, variably and narrowly winged or acutely margined, awned from one or more of the margins or angles, the awns either connected by dilated bases or with intermediate and separate or confluent persistent squamellæ. Leaves opposite, rarely alternate.

109. VERBESINA. Involucre campanulate or hemispherical and more or less imbricated, rarely more spreading, from somewhat herbaceous to foliaceous. Rays fertile, or styliferous but infertile, or sometimes neutral, sometimes none. Receptacle from convex to conical: disk from convex to ovoid, not squarrose in fruit. Akenes usually winged and flat or much compressed, 2-awned, or in the ray triquetrous and I-3-awned, with no intermediate squamellæ, and even the awns sometimes obsolete or wanting. Leaves opposite or alternate, apt to be decurrent as wings on the stem.

110. ACTINOMERIS. Involucre simple, of few and small herbaceous and loose bracts, deflexed under the globular fruiting disk, which is globose even in anthesis, and echinatesquarrose in fruit by the spreading of the akenes in all directions on the small and soon globular receptacle. Ray's neutral, few and irregular or none. Akenes flat, obovate, winged or wingless in the same head. Pappus of 2 slender-subulate naked awns, at length divergent, sometimes with 2 or 3 intermediate awns or awn-like squamellæ.

Subtribe VI. COREOPSIDEE. Akenes obcompressed or sometimes terete, and the subtending chaffy bracts flat or hardly concave: otherwise as in Verbesinece. Heads many-flowered. Leaves mostly opposite, Style-tips of the disk-flowers produced into a cusp or cone, or sometimes capitellate-truncate.

* Involucre single: habit of the preceding group.

111. SYNEDRELLA. Heads with few or several fertile ray-flowers and more numerous disk-flowers; the latter with slender tube to the corolla. Involucre ovoid or oblong, of rather few bracts; the outer larger than the inner, erect, mostly foliaceous. Bracts of the receptacle scarious-membranaceous. Style-appendages of the disk-flowers slender. Akenes or some of them wing-margined, and the wings commonly lacerate or undulate, in the ray often triquetrous, the angles or wings surmounted each by a rigid naked awn. Annuals.

* Involucre double, rarely indistinctly so: receptacle flat or merely convex; the thin chaffy bracts of the receptacle mostly deciduous with the akenes. Base of style not rarely bulbous-dilated.

+ Rays always neutral (rarely wanting): akenes never rostrate-attenuate nor with retrorsely barbed awns: no ring at the junction of tube and throat of disk-corolla. 
112. COREOPSIS. Involucre of two distinct series of bracts, all commonly united at the very base; outer foliaceous, narrower, and usually spreading; inner erect or incurved after anthesis, more membranaceous, each series commonly 8 in number. Rays about 8 , wanting in one or two species. Disk-corollas with slender tube and funnelform or campanulate 5-lobed or 5-toothed limb. Akenes flat, or becoming meniscoidal, orbicular to linear-oblong, winged or wingless, truncate or emarginate at summit, bearing 2 , rarely 3 or 4 naked (or upwardly hispid) awns, or naked scales, or teeth, or sometimes wholly destitute of pappus.

+ + Rays fertile or neutral, or wanting: awns of the pappus when present retrorsely barbed or hispid.

+ Bracts of the involucre distinct, or united only at the common base.

113. BIDENS. Akenes neither winged nor beaked, 2-5-awned; the awns retrorsely hispid or aculeolate, mostly persistent. Rays neutral (in one Mexican species styliferous), yellow or white, sometimes wanting : no ring to the disk-corollas.

114. COSMOS. Akenes slender and beaked: rays purple or rose color, in one species orange-yellow: otherwise as Bidens; the awns apt to be deciduous.

115. HETEROSPERMUM. Akenes dimorphous; the onter with winged or callous margin, mostly cymbiform; inner narrower, attenuate upward, marginless; these and sometimes the outer with 2 retrorsely barbed awns. Rays fertile: no ring to the disk-corollas. Heads rather few-flowered.

116. LEPTOSYNE. Akenes oval or oblong, truncate or emarginate, some of them usually wing-margined or bordered. Rays pistillate and often fertile, occasionally neutral. Disk-corollas with slender tube girt at summit or near it by a bearded or naked ring, a dilated throat, and 5-lobed limb.

$$
+ \text { - Bracts of the inner involucre united into a cup. }
$$

117. THELESPERMA. Involucre of Coreopsis; but the bracts of the inner connate to or above the middle, fleshy below, their free summits more membranaceous and scariousmargined; outer of shorter and narrow somewhat foliaceous spreading bracts, connate at base with the inner. Chaffy bracts of the flat receptacle wholly white-scarious, with a 2-nerved midrib, otherwise nerveless, decidnous with the akenes. Rays about 8, neutral, cuneate-obovate, or in some species wanting. Disk-corollas with long and slender tube, abrupt campanulate or cylindrical throat, and linear to ovate spreading lobes. Anthers wholly exserted. Style-appendages tipped with a cusp or cone. Akenes slightly obcompressed or terete, narrowly oblong to linear, marginless, beakless, attached by a broad callus, at least the outer ones tuberculate, papillose, or rugose; the abrupt summit crowner with a pair of persistent and stout awns or xather scales, the margins of which are retrorsely hispid-ciliate, or sometimes pappus obsolete or wanting. Leaves opposite.

Subtribe VII. GaLINSOgers. Pappus pluripalenceous, and akenes commonly turbinate and 5-angled: otherwise nearly as Verbesinece. Receptacle chaffy throughout: otherwise as Helenioidece. Ours all herbs, and leaves except in Galinsoga alternate and entire.

* Bracts (chaff) of the receptacle concreted, coriaceous or cartilaginous, persistent, forming deep alveoli, resembling honeycomb, in which the akenes are enclosed : rays neutral.

118. BALDWINIA. Heads many-flowered, conspicuonsly radiate. Involucre imbricated, shorter than the convex disk; its bracts small, coriaceous and partly herbaceous. Diskcorollas with a short soon indurated tube, above cylindraceous, 5-toothed; the teeth glandular-puberulent. Style-appendages truncate and penicillate, with a subulate tip. Akenes turbinate, silky-villous: pappus of 7 to 12 nerveless thin-scarious palex.

* * Bracts of receptacle distinct, linear or filiform, rigid : rays none : paleæ of the pappus thin-scarious, nerveless.

119. MARSHALLIA. Heads many-Howered, homogamons. Involucre one or two series of narrow and equal herbaceous bracts. Receptacle at length conical. Corollas with a filiform tube and the limb 5-parted into linear lobes. Style-branches truncate at apex. Akenes turbinate, 5-costate: paleie of the pappus 5 or 6, ovate or lanceolate deltoid, acute or acuminate, nearly eutire and naked. 
* * Bracts of the receptacle distinet, chaffy-membranaceous or scarious, mostly deciduous with the fruit: rays fertile, 2-3-lobed: palea of the pappus firmer, with a thickish axis and fimbriate or barbellate margins, or sometimes wanting.

120. GALINSOGA. Heads small, with 4 or 5 short rays and rather numerous diskflowers. Involucre broadly campanulate or hemispherical, of ovate and thin nearly equal bracts in two series. Receptacle conical. Disk-corollas short, 5-toothed: style-tips acute. Akenes turbinate, 4-5-angled. Pappus of several thickish oblong or obovate paler, with fimbriate-barbellate or almost plumose margins or summit, or wanting. Leaves opposite, serrate.

121. BLEPHARIPAPPUS. Heads with 3 to 6 exserted fertile rays, and 7 to 12 diskflowers; the central of these commonly infertile. Bracts of the involucre linear-lanceolate, erect, nearly equal, in one or two series. Receptacle convex; the chaff thin or scarious and narrow. Rays 3-cleft : disk-corollas 5-cleft. Style of fertile disk-flowers filiform, 2-cleft at apex ouly, and the short branches merely truncate; of the central and infertile ones entire. Akenes turbinate, silky-villous. Pappus of rather numerous narrow linear or aristiform paleæ, with thickish axis, and hyaline margins which are mostly lacerate-fimbriate so as to appear pectinate-plumose, sometimes abortive or wanting.

Subtribe VIII. MadIEe. Ray-flowers ligulate and fertile (rarely wanting), each subtended by a bract of the mostly uniserial involucre which partly or completely encloses its akene: disk-Howers hermaphrodite, but some or all of then sterile (sometimes all fertile); their style-branches subulate and hispid. Bracts of the receptacle always present between ray-and disk-flowers, generally none to the central ones. Pappus none (or a mere rudiment or crown) to the ray-akenes, paleaceous or aristiform or else none to the disk-flowers. Pacific-American herbs, conmonly glandularviscid and heavy-scented : such in California called Tarweeds.

* Akenes laterally compressed, those of the ray particularly so, and enclosed in conduplicate-infolded laterally-compressed involucral bracts.

122. MADIA. Heads many-several-flowered. Involucre ovoid or oblong, few-many-angled by the salient narrow or carinate backs of the involucral bracts. Receptacle flat or convex, bearing a single series of bracts enclosing the disk-flowers as a kind of imer involucre, either separate or connate into a cup. Ray-flowers 1 to 20, with cuneate or ollong 3-lobed ligules; their akenes more or less oblique and with flat sides: disk-flowers with or without a pappus, either sterile or fertile.

* Akenes of the ray from obovate or triangular with broad rouncled back to clavateoblong, more commonly obcompressed, never laterally compressed with narrow back,

- Arcuate-incurved and obcompressed, completely invested by the whole of the conformed at length coriaceous involucral bracts.

123. HEMIZONELLA. Heads few-flowered; the ray-flowers only 4 or 5 ; disk-flowers solitary or rarely 2 to 4 ; both fertile and destitute of pappus. Involucre as in Madia $\$$ Marpcecarpus, but the 4 or 5 arcuate infolded bracts broad on the back and rather olicompressed; those of the receptacle 3 to 5 and connate into a cup. Ligules minute. Akenes glabrous or sparsely pilose, obovate or somewhat fusiform; of the disk straight but oblique. Leaves mostly opposite.

++ Ray akenes thick and short, turgid, partly enclosed by the lower part of the involucral bract.

124. HEMIZONIA. Heads many- or sometimes few-flowered : bracts of the involucre rounded on the back. Ray-akenes more or less oblique; those of the disk abortive or infertile, or in the later sections some or even most of them fertile, with or without pappus. Leaves mainly alternate.

+++ Ray akenes mostly obcompressed, never laterally compressed, wholly enclosed in an obcompressed basal portion of the subtending involucral bracts, the dilated margins of which are abruptly infolded.

125. ACHYRACH ANA. Heads many-flowered: ray-flowers 6 to 10, with 3-cleft ligule much shorter than its filiform tube, little surpassing the disk: disk-corollas slender, 5- 
toother. Involucre oblong-campanulate, of lanceolate thin-herbaceous bracts, deciduous at maturity: bracts of the nearly flat receptacle similar but thinner, only between the disk and ray, distinct. Akenes all clavate, with attenuate base, symmetrical, 10-costate, the ribs or the alternate ones tuberculate-scabrous at maturity; those of the ray slightly obcompressed, rounded at apex and with slightly protuberant areola, not rarely an abortive pappus in the form of a minute denticulate crown; those of the disk chiefly fertile, the truncate apex bearing a large pappus of 10 elongated-oblong obtuse silvery-scarious palex, the 5 inner as long as the corolla and akene, the alternate outer ones shorter.

126. LAGOPHYLLA. Heads several-flowered: ray-flowers about 5, with 3-parted or deeply 3-cleft ligules : disk-flowers sterile, with 5-lobed corollas. Bracts of the involucre thin-herbaceous, deciduous with the enclosed akene: bracts of the small receptacle 5 to 12 between the ray and disk. Akenes of the disk slender, abortive, destitute of pappus or with some caducous bristles; of the ray obcompressed, oblong-obovate, smooth and glabrous, nearly straight, the areola not protuberant, rarely a saucer-shaped cup in place of pappus.

127. LAYIA. Heads many-flowered, broad: ray-flowers 8 to 20, with 3-lobed or toothed ligules: disk-flowers fertile, or the central sometimes infertile; their corollas cylindraceousfunnelform and 5-lobed. Bracts of the involucre flattened on the back below, with abruptly dilated thin margins infolded so as to enclose the ray-akene. Receptacle broad and flat, bearing a series of thin chaffy bracts between the ray- and disk-flowers, sometimes additional more scarious ones among the flowers. Akenes of the ray obcompressed, obovate-oblong or narrower, almost always smooth and glabrous, destitute of pappus (or rarely a crown or vestige), the terminal areola somewhat protuberant and disciform; those of the disk similar or more linear-cuneate, mostly pubescent, bearing a pappus of 5 to 20 bristles, awns, or paleæ, or rarely none.

TRIBE VI. HELENIOIDEæ. Heads heterogamous and the ligulate ray-flowers mostly fertile, or homogamous; the disk-flowers hermaphrodite and fertile, rarely some infertile, with regular 4-5-toothed tubular corolla, Receptacle naked, i. e. destitute of bracts (palece), but rarely fimbrillate. Bracts of the involucre herbaceous or membranaceous, not scarious. Style-branches of hermaphrodite flowers with either truncate or appendiculate tips. Pappus paleaceous or aristiform, or sornetimes plurisetose, but the bristles when capillary always more or less rigid. - A peculiarly American tribe, differing from the preceding in the total absence of receptacular bracts; some genera with setose pappus making transition to the Senecionidece; others, with short pappus or none, to the Anthemidea.

Subtribe I. JAтмтEж. Involucre of broad bracts imbricated in two or more series. Ligules not persistent. Akenes 5-angled or terete and several-nerved. Many-flowered heads in ours radiate, and the ray-flowers fertile. No oil-glands.

* Receptacle setose-fimbrillate, convex: pappus plurisetose.

128. CLAPPIA. Involucre hemispherical, of rather few oval and very obtuse somewhat striate coriaceous bracts, imbricated in 2 or 3 series. Rays 12 to 15 , linear, 3-denticulate at apex. Disk-corollas with slender tube and campanulate 5-cleft limb. Style-branches conical-tipped. Akenes equalled by the very slender fimbrille of the receptacle, oblongturbinate, texete, 8-10-nerved, hirtellous on the nerves. Pappus of 20 to 25 rigid and somewhat paleolate hispidulous-scabrous distinct bristles, broader toward the base, longer than the akene. Fruticulose, with alternate fleshy leaves.

* Receptacle naked: pappus in ours none.

129. JAUMEA. Involucre campauulate, its bracts fleshy or membranaceous, the outer shorter. Corollas glabrous. Receptacle in ours conical. Style-branches papillose or hairy, truncate or short-conical at tip. Akenes 10-nerved: pappus in exotic species of narrow and pointed or awned strongly l-nerved palex, in ours none.

130. VENEGASIA. Involucre very broad, of 2 or 3 series of roundish membranaceous erect bracts, some innermost narrower and scarious, and a series of outer and loose narrower herbaceous ones. Receptacle flat. Rays numerous, elongated, entire or 3-toothed at the narrow apex: tube of corollas glandular-bearded, especially at base. Style-branches very obtuse. Akenes many-nerved, destitute of pappus. 
Subtribe II. RIDDELLIEx. Involucre of narrow equal erect bracts. Ligules persistent and becoming papery on the usually striate-nerved akenes. Herbage more or less white-woolly : no oil-glands.

\section{* Pappus paleaceous : rays very broad, few.}

131. RIDDELLIA. Heads with 3 or 4 ray-and 5 to 12 disk-flowers, all fertile. Involncre cylindraceous-campanulate, of 4 to 10 linear-oblong coriaceous woolly bracts, and a few smaller scarious ones within, sometimes an alditional narrow outer one. Receptacle small, fat. Ligules as broad as long, abruptly contracted at base into a short tube, truncate and 2-3-lobed, 5-7-nerved, the nerves uniting in pairs within the lobes. Disk-corollas elongatedcylindraceous, with very short proper tube, and short externally glandular-bearded teeth. Style-branches truncate-capitate. Akenes narrow, terrete, obseurely striate or angled. Pappus of 4 to 6 hyaline nerveless and pointless palex.

\section{* Pappus none: rays several or numerous : disk-flowers numerous.}

132. BAILEYA. Involucre hemispherical, of numerous thin-herbaceous linear bracts in 2 or 3 series, very woolly on the back. Receptacle flat or barely convex. Ray-flowers 5 to 50 ; the ligules from round-oval to oblong-cuneate, 3-toothed at apex, 7-nerved, tapering into a narrow but not tubular base, becoming scarious-papery but thin, persistent on the truncate summit of the akene. Disk-flowers fertile; their corollas tubular-funnelform above the short proper tube, 5-toothed; the teeth glandular-bearded. Style-branclies short, with truncate-capitate tips. Akenes oblong-linear or clavate, somewhat angled, pluricostate or striate; the truncate apex obscurely toothed by extension of the ribs, or in the ray callousthickened.

133. WHITNEYA. Involucre campanulate, of 9 or 12 oblong or broadly lanceolate equal thin-herbaceous bracts, nearly in a single series, in fruit somewhat cymbiform-carinate near the base, not villous. Receptacle narrow-conical, villous. Ray-flowers 7 to 9 ; ligule elongated-oblong, minutely 3-toothed at apex, 10-16-nerved (the nerves also prominent on the short tube), becoming thin-papery, persistent. Disk-flowers numerous, infertile, the tabular-funnelform obtusely 5 -toothed corollas persistent on the sterile akenes: style-branches linear, pubescent externally, with rather obtuse tips. Ray-akenes only maturing, oblong, slightly obcompressed, obtuse at both ends, lightly nerved.

Subtribe III. Peritrlese. Involucre of equal and narrow erect bracts, in only one or two series. Ray-flowers female or none ; the ligule deciduous: disk-corollas narrow, 4-toothed. Akenes flat, with only marginal callous nerves, usually much ciliate. Style-branches and their appendages slender. Receptacle flat or convex. Plants not floccose-tomentose, and with no oil-glands. (Hulsea, 154, might be sought here. Eatonella, 137, and Crockeria, $137^{\mathrm{a}}$, also have flat and ciliate akenes with strong marginal nerves.)

134. LAPHAMIA. Head several- to many-flowered. Bracts of the hemispherical involucre distinct, more or less overlapping. Style-tips setaceous-subulate, hirsute. Margin of akenes naked or not much ciliate. P'appus none, or of one or two, or sometimes about 20 bristles. Suffruticulose perennials, or herbaceous from a thick woody base, mostly yellowflowered.

135. PERITYLE. Head many-flowered. Involucre of preceding, or the bracts more carinate-concave and partly embracing outer akenes. Style-branches with either short (acute or obtuse) or slender hirsute tips. Akenes at maturity cartilaginous-margined, usually strongly ciliate. Pappus a squamellate or cupulate crown, and commonly a slender awn from one or both angles. Mostly annuals, white- or yellow-flowered.

136. PERICOME. Head many-flowered, homogamous. Involucre a strictly single series of numerous narrow bracts, which are lightly connate by their edges into a campanulate cup. Disk-corollas slender, with viscous-glandular tube nearly the length of the cylindrical throat, from which the anthers are much exserted. Style-tips filiform, rather obtuse. Akenes strongly villous-ciliate. Pappus a squamellate lacerate-ciliate crown, and sometimes a pair of short awns, one from each angle of the akene. Perenuial, yellow-flowered, with long-acuminate leaves. 
Subtribe IV. HeLenies. (Baeriece \& Euheleniece, Benth. \& Hook., excl. gen.) Involucre hardly at all imbricated; its bracts when broad nearly equal or in a single series. Ligules not persistent. Disk-flowers numerous except in Schkuhria, with 5 or rarely 4 teeth or lobes. Akenes few-nerved or angled, or more numerously striateangled only when turbinate or pyriform. No oil-glands. (Raillardella, 190, might be sought here.)

* Anomalous: akenes (as in Peritylece) flat-compressed, with no lateral nerves, the callous or nerved margins densely ciliate-fringed : rays fertile or none: disk-corolla with dilated limb: style-tips truncate-capitate, with or without a slight cusp.

137. EATONELLA. Involucre of 5 to 8 oval or oblong obtuse and distinct bracts. Recep)tacle hardly convex. Disk-corollas short. Akenes callous-margined, ciliate with dense very long villosity, outermost obcompressed. Aspect of Ériophyllum.

137a. CROCKERIA. Involucre and other characters of Lasthenia § Hologymne. Akenes obovate-oval, very densely fringed with clavate glandular hairs. - See Supplement.

* * Baeria type : receptacle conical, mostly high-conical and acute, beset after the akenes have fallen by projecting points (as if pedicels, on which they were inserted): bracts of the involucre herbaceous, in one or rarely two series and commonly browd, sometimes cupulate-connate: female flowers ligulate, or sometimes wanting: akenes narrow and from oblong (or in one Monolopia somewhat obovate) to linear, usually tapering to the base, few-nerved and angled or nerveless, not callous-margined: herbage not impressedpunctate nor resinous-atomiferous.

+ Involucre (almost always) gamophyllous and simple, hemispherical or campamulate: disk-corollas with rather slender tube and dilated throat or limb: anther-tips ovate or oblong: style-tips capitate-truncate or obtuse.

143. ERIOPHYLLUM. A kenes slender, and usually with a paleaceous pappus.

138. MONOLOPIA. Head conspicuously radiate, with broad ligules: inner disk-flowers often infertile. Receptacle high-conical. Involucre broad, of one or rarely two series of bracts, which are normally connate by their edges into a several-toothed or lobed hemispherical cup, but sometimes distinct even to the base. Lobes of disk-corollas somewhat bearded. Akenes obovate or obovate-oblong, quadrangular-compressed or the outer obcompressedtriangular, sometimes acute-margined, with small terminal areola, and no pappus. Floccosetomentose and alternate-leaved annuals.

139. LASTHENIA. Iread radiate, or discoid by diminution of the ligules: disk-flowers all fertile. Involucre a single series of bracts connate by their edges into a 5-15-toothed glabrous green cup. Disk-corollas 4-5-lobed. Akenes linear or narrowly oblong, compressed, slightly 2-3-nerved or nerveless, nearly marginless, scabro-puberulent or glabrous. I'appus of 5 to 10 firm and subulate-tipped palex, or none. Glabrous and smooth annuals, with opposite entire sessile leaves.

++ Involucre of few or several distinct and thinnish herbaceous bracts in a single series, loose, open at maturity of fruit, not rarely deciduous: disk-corollas with slender tube which equals or exceeds in length the campanulate or cyathiform 5-lobed (rarely 4-lobed) limb : leaves all opposite, sometimes connate at their sessile bases.

140. BURRIELIA. Head few-flowered, discoid, the 1 to 3 female flowers with ligule wanting or shorter than the style. Involucre cylindraceous, of 3 or 4 narrowly oblong plane bracts. Receptacle slender-subulate. Style-tips short-ovate, rather obtuse. Akenes slender, fusiform-linear, flattish. Pappus of 2 to 4 long attenuate-subulate paleæ.

141. BAERIA. Head mostiy many-flowered, radiate: rays 5 to 15 , conspicuous. Bracts of the campanulate or hemispherical involucre as many, ovate or oblong, plane or becoming somewhat carinate at middle, at least below. Receptacle subulate to high-conical. Styletips from truncate-capitate, with or without a central apiculation, to ovate and sometimes with a cuspidate appendage. Akenes clavate-linear to linear-cuneate. Pappus a few palex or paleaceous awns, or both, often wanting.

* * Bahia type: receptacle fat or convex (rarely obtusely conical) : akenes from linear to obpyramidal, rarely 5-angled, occasionally with intermediate nerves: flowers (with few exceptions) all fertile. 
+ Involucre many-flowered, from hemispherical to cylindraceous ; the bracts strictly erect, not membrauaceous, persistent, from oblong to oval, more or less carinate-concave in fruit and partly receiving the subtended akene: herbage mostly floccose-woolly, not impressedpunctate nor resinous-atomiferous: leaves alteruate or opposite.

142. SYNTRICHOPAPPUS. Involucre narrow, of about 5 equal and oblong carinateconcave thinnish-herbaceous bracts, which are partly wrapped around the ray-akenes. Receptacle flat. Ray-flowers about 5, with oval ligules 3-lobed or toothed at summit. Disk-corollas with very short proper tube, and elongated funnelform or cylindraceous throat, the stamens therefore inserted near the base; lobes 5, ovate-oblong. Anther-tips slender, long-lanceolate or linear. Style-tips elongated-lanceolate, acute, flattened, of the Asteroid type. Akenes linear-turbinate, 5-costate or angled, hairy. Pappus of numerous barbellulate white bristles in a single series, rather shorter than the disk-corollas, paleaceously and somewhat unequally united into a ring at base, deciduous, or in the second species wanting. Low and branching annuals, short-peduncled.

143. ERIOPHYLLUM. Involucre from hemispherical-campanulate to oblong, commonly equalling the disk, of one or sometimes two series of oblong or narrower firm-herbaceous or coriaceous permanently erect bracts, either distinct or sometimes partially united in to a cup, at least in fruit concave or concave-carinate at centre, into which concavity the subtended akenes are partially received. Receptacle from convex or rarely conical to plane. Rayflowers usually with broad ligules, very rarely none. Disk-corollas with distinct and sometimes slender proper tube. Style-tips truncate, ohtuse, or obscurely capitellate-conical. Akenes narrow, from clavate-linear to cuneate-oblong, mostly 4-angled. Pappus of nerveless and mostly pointless (rarely awned or setiform) palex. Floccose-tomentose or ravely glabrate herbs, rarely suffruticose.

++ Involucre many- (at least 12-20-) flowered; the bracts wholly herbaceous, not colored nor scarious-tipped, broad or broadish, plane or merely concave, equal and in a single or hardly double series, not embracing akenes: receptacle small; corolla-lobes or teeth short: herbage destitute of impressed punctures and resinous atoms, not floccose-lanate.

144. BAHIA. Involucre hemispherical or obovate and lax or open in fruit; the plane bracts distinct to and commonly narrower at the base. Receptacle small, mostly flat. Female flowers with exserted ligules, or rarely none. Style-tips truncate or obtuse. Akenes narrow, quadrangular. Pappus (rarely wanting) of several scarious palex, with callousthickened opaque base, which is sometimes extended into a strong midnerve (costa).

145. AMBLYOPAPPUS. Characters of Bahia; but involucre of only 5 to 6 broadly obovate bracts, their centre in age more or less carinate-concave; small receptacle conical; head discoid; corollas all short-tubular, and in the few female flowers minately 2-3-toothed, shorter than the style, in the hermaphrodite flowers 5 -toothed, the teeth soon connivent. Akenes elongated-obpyramidal, pubescent. Pappus of 8 to 12 oblong obtuse rather firm paleæ, with merely thickened base and no costa, nearly equalling the corollas.

+++ Involucre 3-9-flowered; its bracts few, equal, broad and with roundish more or less scarious-petaloid summit, concave-carinate: corollas only 5 -toothed: herbage minutely impressed-punctate and resinous-atomiferous.

146. SCHKUHRIA. Heads effusely paniculate. Involucre clavate-turbinate or obpyramidal, of 4 or 5 erect bracts and sometimes an accessory bractlet at base. Receptacle very small. Female flowers only one or two, with a short or sometimes obsolete ligule not exceeding the hermaphrodite flowers, or altogether wanting. Akenes obpyramidal-tetragonal, the faces not rarely 2-3-striate. Pappus of 8 scarious palex, the larger often equalling the short corolla, either nerveless with callous-thickened base, or with a prominent costa. Leaves or their divisions filiform.

++++ Igvolucre many- (rarely 12-15-) flowered; its bracts mostly appressed, with scarious-membranaceous and usually colored tips and sometimes margins: disk-corollas deeply 5-cleft : anthers partly or wholly exserted : leaves alternate, not impressed-punctate except in Hymenopappus: receptacle small and flat: heads except in two species homogamous: flowers seldom yellow, but sometimes so.

147. HYMENOTHRIX. Involucre turbinate-campanulate, or in age more open, about 30 -flowered, shorter than the disk; its principal bracts 7 to 10 , obovate or lanceolate-oblong, 
thin, half or more scarious-petaloid, plane; commonly one or more accessory outer bracts. Ray-flowers 6 to 10 and with oblong exserted ligule 3-cleft at the apex, or none. Diskcorollas with narrow tube and lobes, one or two of the sinuses a little deeper than the others. Style-branches flattish, with subcapitate tips, with or without a central cusp. Akenes 4-5angled, tapering from broad summit to attenuate base. Pappus about the length of the akene, of 12 to 20 narrow lanceolate hyaline palex, traversed by a strong costa which is excurrent into a scabrous awn.

148. HYMENOPAPPUS. Involucre broadly campanulate; its bracts 6 to 12, equal, obovate to broadly oblong, thin, the rounded summit and usually the margins scarious-colored or petaloid. Ray-flowers none. Disk-flowers numerous, all alike. Corolla with narrow tube, abruptly dilated throat, and ovate reflexed or widely spreading lobes. Style-branches with short and thick conical appendages. Akenes obpyramidal, 4-5-angled, with attenuate base, the faces 1-3-nerved; the nerves at maturity sometimes as prominent as the angles, except in one species. Pappus of 10 to 20 thin-scarious and mostly hyaline obtuse palea, with or without a costa or central opacity, sometimes very short and small or quite obsolete.

149. FLORESTINA. Involucre turbinate-campanulate, 15-25-flowered; its bracts 6 to 8 in a single series, equal, obovate-spatulate, thin-herbaceous, with scarions-colored (whitish or purplish) rounded tips. Ray-flowers none. Disk-flowers with corolla widely dilated above the short narrow tube, deeply 5-cleft into oblong spreading lobes. Style-branches terminated by a rather long attenuate-subulate hispid appendage. Akenes narrowly obpyramidal, 4-5angled, pubescent. Pappus of 6 to 8 obovate pointless paleæ, hyaline-scarious from a callous thickened narrow base or axis.

150. POLYPTERIS. Involucre from broadly campanulate to turbinate; its bracts from spatulate to linear-lanceolate, commouly in two series and equal, rarely with some accessory shorter ones, the tips or (in the original species) a larger portion membranaceous and colored or petaloid. Rays in one species distinctly evolute into a palmate ligule and fertile; in the others wanting. Corolla of the disk-flowers with filiform tube abruptly dilated into a 5-parted limb, the long lobes lorate-linear. Stamens wholly exserted. Style-branches filiform, wholly hispidulous, acutish or barely obtuse. Akenes from linear and downwardly attenuate to clavate-obpyramical, 4-sided, only minutely pubescent. Pappus of 6 to 12 equal palea, with a strong percurrent costa, otherwise hyaline-scarious, rarely abortive or wanting; in the outermost flowers usually shorter.

+++++ Involucre many- (or 12-30-) flowered; its bracts linear (rarely broader), erect, equal and similar in a single or hardly in two series, herbaceous to the tip, inclined to embrace subtended akenes: receptacle flat, mostly small: akenes sleuder, linear-tetragonal or more compressed, merely pubescent: head discoid (rarely an inconspicuous ligule) : corollas with short lobes or teeth and long throat: leaves alternate.

$$
\text { + Leaves simple, entire: flowers never yellow. }
$$

151. PALAFOXIA. Heads homogamous and flowers all alike, except in the pappus. Involucre oblong or campanulate. Corolla with tube and narrow lobes shorter than the cylindraceous throat. Style-branches elongated, filiform and obtuse or obscurely thickened toward the summit, puberulent for the whole length (altogether of the Eupatoriaceous type, but the stigmatic lines traceable nearly to the apex). Pappus of 4 to 8 usually unequal paleæ, with strong costa.

152. RIGIOPAPPUS. Heads heterogamous, inconspicuously radiate. Involucre turbinate-campanulate, of numerous narrowly linear rather rigid herbaceous bracts, which are somewhat involute at maturity. Ray-flowers 5 to 15 ; the corolla with slender tube, and oblong entire or 2-toothed ligule, not surpassing the disk. Disk-flowers more numerous; corolla small, with short proper tube, elongated narrow throat, and 3 to 5 short erect teeth. Anthers included. Style-branches with short and linear glabrous stigmatic portion, and a larger slender-subulate hispidulous appendage. Pappus nearly similar in disk and ray, of 3 to 5 rigid and wholly opaque paleaceous naked awns (smooth, flat, gradually tapering from base to apex), rarely obsolete.

$$
++ \text { Leaves mostly cleft or compound: flowers in some species yellow. }
$$

153. CHANACTIS. Heads homogamous and tubuliflorous; but the marginal flowers commonly with ampliate limb to the corolla. Involucre campanulate or hemispherical. 
Receptacle flat, naked, in one species bearing a few setiform bracts or fimbrillæamong the flowers. Corollas with short tube, long and narrow throat, and short teeth, or in the marginal flowers of some species with larger lobes or even imperfect palmate ligules, forming a kind of ray. Anthers usually partly exserted. Style-branches pubescent nearly throughout, slender, filiform or with attenuate-subulate tips. Pappus of hyaline nerveless palea (or rarely with the vestige of a costa), in one species wanting.

++++++ Involucre many-flowered, hemispherical; its bracts in 2 or 3 series, thin-herbaceous, rather loose, sometimes unequal, from linear to oblong, plane: receptacle flat, corneous-scrobiculate: disk-corollas with long and narrow throat and 5 short lobes or teeth: style-branches with short and thickened obtuse tips: akenes linear-clavate or cuneate-oblong, villous: pappus of 4 or 5 wholly hyaline paleæ; these erose or lacerate at summit, or dissected into capillary bristles : leaves mostly alternate, woolly or glabrate.

154. HULSEA. Bracts of the involucre linear or lanceolate. Ray-flowers numerous (10 to 60) and ligulate, but sometimes short and inconspicuous. Disk-corollas with proper tube slender or narrow, but shorter than the cylindraceous throat. Akenes linear-cuneate, compressed or somewhat tetragonal, soft-villous, especially the margins. Pappus of mostly 4 truncate paleæ, from erose or lacerate at summit to nearly entire.

155. TRICHOPTILIUM. Bracts of the involucre abont 20, equal; those of the outer series ovate-lanceolate; those of the inner narrowly spatulate or lanceolate and membranaceons. Ray-flowers none. Disk-flowers 30 to 40 ; the corollas with very short tube, cylindraceous-funnelform throat, and 5 short ovate lobes, those of the marginal flowers slightly enlarged after the manner of Chcenactis, but regular, the nerves deeply intramarginal. Anther-tips oblong-lanceolate. Style-branches linear, glabrous and with stigmatic lines continned up to the obtuse tip. Akenes oblong-turbinate, 5-nerved or angled, hirsute-villous. Pappus of 5 ovate or oblong hyaline nerveless paleæ, which are resolved above into numerous slender bristles, the middle ones rather shorter than the corolla.

* * * Receptacle flattish or convex, many-flowered: ray-flowers female and fertile; those of the disk sterile: involucral bracts few in a single series, broad and plane, membranaceous: akenes pyriform.

156. BLENNOSPERMA. Involucre hemispherical or depressed; its bracts 5 to 12, equal, oblong, plane, herbaceous or partly membranaceous, the tips sometimes colored, the bases somewhat nnited. Ray-flowers 5 to 12 : some of them in our species not rarely apetalous, the others with ligule oblong or elliptical, entire, sessile on the ovary, being destitute of tube: style-branches flat, linear or oblong. Disk-flowers numerous ( 20 or more): corollas with narrow tube, abruptly expanded into a broadly campanulate 4-5-lobed limb: anthers oval: style undivided, with capitate or disk-shaped apex: ovary abortive, a mere rudiment. Akenes (of the ray) obscurely 8-10-ribbed, with small areola, wholly destitute of pappus; the surface powdered with papillæ which develop mucilage when wet.

***** Receptacle from convex to oblong: involucre many-flowered, various, of more than one series of bracts, or irregular: akenes short, obpyramidal or turbinate, sometimes more oblong, 5-10-costate or angled, mostly silky-villous or hirsute: disk-flowers all fertile; the corolla 4-5-toothed: leaves alternate, in many minutely impressed-punctate or resinons-atomiferous.

+ Receptacle naked, i. e. clestitute of awn-like fimbrillæ among the flowers: style-branches of the disk-flowers dilated-truncate and somewhat penicillate at tip. + Involucre erect, at least not spreading or refiexed.

148. HYMENOPAPPUS, with turbinate or obpyramidal costate akenes, might be sought here.

64. PLUMMERA is like Actinella $\S$ Hymenoxys, without pappus, and disk-flowers sterile.

157. ACTINELLA. Heads radiate (except in S. American species). Involucre campanulate or hemispherical, or sometimes broader; its bracts in two or more series, somewhat herbaceous or coriaceous, often rigid; outer sometimes united. Receptacle from conical to convex. Rays fertile. Pappus of 5 to 12 thin and mostly hyaline palex, with more or less manifest costa or none; these sometimes truncate, more commonly acuminate or aristate at tip. Mostly low herbs, and bitter-aromatic. 
+ + Involucre spreading or soon reflexed, herbaceous, usually with some inconspicuous short scarious interior bracts: akenes turbinate, 8-10-costate: heads mostly radiate: receptacle more or less elevated.

158. HELENIUM. Bracts of the involucre subulate or linear. Rays fertile or sterile, rarely none. Disk-corollas commonly with short or almost obsolete proper tube (the stamens inserted close to the base), and 4-5-toothed limb; the teeth obtuse, glandular-pubescent. Pappus of usually 5 or 6 thin scarious palex. Leaves commonly impressed-punctate, mostly decurrent.

159. AMBLYOLEPIS. Principal bracts of the involucre foliaceous, lanceolate; an inner hyaline-scarious series resembling the conspicuous blunt nerveless palex of the pappus. Rays fertile, ample. Disk-corollas glabrous throughout, and with a distinct tube as long as the ampliate throat, 5-cleft; the lobes lanceolate, attenuate-acute. Akenes broadly turbinate and with 10 thick ribs. Leaves neither punctate nor decurrent.

+ + Receptacle (from convex to globular) beset with setiform or subulate or rarely small dentiform fimbrillæ among the flowers.

160. GAILLARDIA. Involucre broad; the bracts in 2 or 3 series, all but the short inner series largely foliaceous or herbaceous and lax. Ray-flowers neutral, rarely styliferous and fertile, sometimes none: ligules 3-toothed or 3-cleft. Disk-corollas with short narrow tube, enlarged cylindraceous throat, and 5 ovate-triangular to subulate teeth or short lobes, which are beset with jointed hairs. Style-branches with penicillate tuft at summit of the stigmatic portion, thence produced into a filiform or shorter appendage. Akenes turbinate, 5-costate, covered with long villous hairs which sometimes rise only from the base of the akene. Pappus conspicuous, longer than the akene, of 5 to 10 hyaline-scarious palex, with a costa mostly excurrent into an awn, which about equals disk-corollas.

Subtribe V. Fuaveriem. Involucre of the swall hearls composed of a few equal connivent bracts in a single series, sometimes one or two small additional ones at base. Ligules small (little or not at all surpassing rlisk-flowers), not persistent. Akenes terete, oblong or linear, 8-10-striate-costate. Style-branches truncate. Leaves opposite. No oil-glands, nor resinous atoms.

161. SARTWELLIA. Heads with about 5 ligulate female and rather numerous hermaphrodite tubular flowers. Bracts of the involucre 5, oval or obiong, somewhat fleshy, in fruit somewhat carinate-concave and subtending ray-akenes. Receptacle convex. Iigules mostly entire, obovate or roundish. Disk-corollas narrow, 4-5-toothed. Pappus a deep paleaceous cupule with minutely fimbriolate edge (dloubtless composed of 4 or 5 truncate paleæ which are completely connate), or of 4 or 5 narrowly oblong fimbriolate-truncate nerveless palex alternating with as many setiform awns, all united only at the base.

162. FLAVERIA. Heads one-several-flowered; the flowers all fertile, homogamous and tulular, or one female and short-ligulate. Disk-corollas 5-toothed. Involucre of 2 to 5 mustly carinate-concave bracts. Pappus none.

Subtribe VI. TAGETINeAE. Involucre a series of equal bracts, either distinct or united into a cup or tube, dotted or striped with oil-glands, not rarely subtended or calyculate by some loose accessory bracts, several-many-flowered. Rays when present fertile; ligules not persistent. Akenes mostly narrow and striate. Pappus various. - Mostly glabrous and smooth herbs or undershrubs, strong-scented, the herbage like the involucre commonly dotted with some oil-glands.

* True Tagetinez. Style-branches of hermaphrodite flowers more or less elongated, appendiculate or truncate.

+ Pappus simple, of copious capillary scabrous bristles: akenes linear: receptacle small, naked and smooth: bracts of the involucre distinct

163. POROPHYLLUM. Ray-flowers none. Disk-flowers numerous or several. Involucre of 5 to 10 bracts. Style-branches tipped with long filiform-subulate hispid appendages.
Akenes slender. 
164. CHRYSACTINIA. Ray-flowers conspicuous, with linear ligules. Disk-flowers numerous; their corolla narrow and 5-toothed, and style-branches tipped with short obtuse or conical appendages. Involucre of 10 or more short bracts. Akenes short-linear, not attenuate upward. Flowers all yellow.

++ Pappus of distinct bristles and distinct palew : bracts of the many-flowered involucre distinct.

165. NICOLLETIA. Involnere oblong or cylindraceous, of 8 to 12 thinnish bracts, nearly naked at base. Receptacle quite uaked. Disk-corollas narrow-tubular, 5-toothed. Stylebranches tipped with long filiform-subulate appendages. $\Lambda$ kenes filiform-linear, with tapering base. Pappus double; outer of indefinitely numerous capillary bristles like those of Porophyllum; inner of 5 lanceolate long hyaline palex, with costa excurrent into a scabrous awn.

+++ Pappus either wholly paleaceous, or some or all of the palea bearing or largely resolved into awns or capillary bristles: bracts of the involucre gamophyllous or sometimes distinct: receptacle variously fimbrillate, alveolate--lentate, or more strictly naked.

166. DYSODIA. Pappus multisetose-polyadelphous, i. e. all or most of the 10 or more paleæ resolved, except a basal portion, into several (9 or more) or indefinitely numerous capillary but rather stiff bristles. Involucre hemispherical or campanulate, usually calyculate with a series of loose accessory bracts, the proper liracts generally gamophyllous at base, rarely quite separate, rarely united to near the summit. Style-appendages sometimes slender, sometimes an abrupt apiculation or short obtuse cone.

167. HYMENATHERUM. Pappus of sereral or numerous palea, either 1-5 aristate or pointed, or partly resolved into as many bristles, or some or all of them entire and even truncate (rarely even concreted). Involucre campanulate, cupulately gamophyllous high up, with or without some loose accessory bracts. Style-branches truncate or very obtuse, sometimes tipped with a minute apiculation. Akenes mostly terete, and striate.

168. TAGETES. Palex of the pappus 3 to 6 , firm, commonly unequal, entire, not setiferous, but one or more of them frequently subulate-pointed or aristiform. Involucre naked at base, gamophyllous nearly thronghout into an oblong or more elongated cup or tube. Akenes compressed or angulate, hardly striate. Herbs.

* Pectider. Style of hermaphrodite flowers slender, hispidulous, termiuated by two very short obtuse and inappendiculate stigmatic branches.

169. PECTIS. Heads radiate, several-many-flowered. Involucre naked at base, or nearly so, cylindrical or campanulate, of few or several equal carinate bracts in a single series. Receptacle small, naked. Disk-corollas 5-lobed, one or two sinuses often deeper, thus becoming bilabiate. Akenes linear, terete or angled. Pappus of few or numerous bristles or awns, sometimes paleaceous-dilated at base, or of palex, or reduced to paleaceous-coroniform, rarely obsolete. Opposite-leaved herbs.

TRIBe VII. ANTHEMIDEE. Heads homogamous with flowers all tubular and hermaphrodite, or more commonly heterogamons, with the female flowers ligulate and radiate, or sometimes with corolla reduced to a tube or obsolete. Receptacle either naked or with some chaffy bracts. Bracts of the involucre imbricated, wholly or partly dry and scarions or scale-like, not foliaceons, seldom herbaceons. Anthers without tails at base. Style-branches of the hermaphrodite flowers truncate, and sometimes with obscure conical tips. Akenes usually small and short, with no pappus or a paleaceous crown, or a circle of squamellæ. - Strong-scenterl or bitter-aromatic herbs or undershrubs, the greater part of the Old World; with alternate leaves: distinguished from the preceding tribe by the scarions imbricated involucre; from the Asteroidece, by the truncate style-tips, \&c. The first genus would go with Helenioidere, except for the paleæ of the receptacle.

* Receptacle paleaceous, i. e. with chaffy bracts subtending some or all the disk-flowers: heads radiate, or the rays wanting in certain species.

- Anomalous, with involucre (of comparatively few and broad thin bracts) and aspect of Hymenopappus. 
170. LEUCAMPYX. Involucre broadly hemispherical; its bracts broadly oval, equal,' in 2 or 3 series of 4 or 5 each, membranaceous, their margins white-scarious. Receptacle somewhat convex, with oblong-lanceolate wholly scarious bracts subtending disk-flowers and partly folded round the akenes. Ray-flowers 8 or 10, fertile ; ligule cuneate-obovate, ample, on a slender glandular tube, somewhat persistent on the akene. Disk-flowers numerous: corolla with narrow tube, ampliate-campanulate throat, and 5 spreading lobes: style-branches linear, with an obscure obtuse tip slightly produced beyond the stigmatic portion. Akenes large for the tribe, obovate-trigonoụs, with narrowed base and rounded summit, lightly 5-nerved, glabrous, slightly incurved. Pappus an obscure sq́uamellate crown, soon obsolete.

+ + Involucre of comparatively small imbricated bracts, the outer successively shorter: receptacle convex to oblong: style-branches truncate-penicillate.

171. ANTHEMIS. Involucre hemispherical, many-flowered. Chaffy bracts of receptacle sometimes hyaline, sometimes aristiform. Akenes terete or 4-10-angled or ribbed, not flattened, glabrous; the truncate summit naked, or with a very short coroniform or auriculate pappus. Heads comparatively large.

172. ACHILLEA. Involucre campanulate or obovate. Chaffy bracts of the receptacle membranaceous, like the innermost bracts of the involucre. Rays few or several, short and broad. Akenes oblong or obovate, obcompressed, callous-margined, glabrous, destitute of pappus.

* * Receptacle naked, i. $\bullet$ destitute of bracts or chaff among the flowers.

- Heads comparatively large, radiate, or rarely discoid and homogamous by the absence of ligulate female flowers, pedunculate, solitary at the summit of the branches, or sometimes corymbosely cymose, never racemosely paniculate: akenes glabrous: tube of diskcorolla either terete or ancipital.

173. MATRICARIA. Receptacle conical or ovoid, or rarely lower when young. Akenes 3-5-ribbed or nerved on the face or sides, rounded on the back.

174. CHRYSANTHEMUM. Receptacle from flat to hemispherical. Akenes (at least of the disk) 5-10-ribbed or nerved all round; of the ray in certain species triquetrous.

+ + Heads sessile, discoid, heterogamous: female flowers most numerous, apetalous; their akenes pointed or armed with indurated persistent style.

175. SOLIVA. Heads many-flowered, largely of female fowers : a few hermaphrodite but mostly sterile ones in the centre ; these with a short and thick 2-6-toothed corolla and usually undivided style. Involncre of 5 to 12 nearly equal bracts in not more than 2 series. Receptacle flat. Akenes obcompressed, with rigid wings or callous margins, which are commonly spinulose-pointed at summit, and the apex armed by the spiniform persistent style. Pappus none.

+++ Heads slender-peduncled, discoid, heterogamous : female flowers apetalous : style deciduous.

176. COTULA. Heads many-flowered: female flowers in one or two rows: disk-flowers with 4-toothed corolla, fertile or infertile. Bracts of the involucre greenish, in about 2 ranks. Akenes raised on pedicels at maturity (these remaining on the flat or convex receptacle), obcompressed, commonly thick-margined or narrowly winged, in our species destitute of pappus or nearly so.

++++ Heads discoid, heterogamous, and the few or uniserial female flowers with a tubular 2-3-toothed or lobed corolla (in one species imperfectly radiate), or sometimes homogamous, the female flowers wanting and the hermaphrodite rather few: style deciduous: akenes truncate or obtuse : receptacle quite naked or sometimes hirsute: involucre imbricated in few or several ranks.

177. TANACETUM. Heads corymbosely cymose or glomerate, rarely solitary, manyflowered: female flowers with tubular 3-5-toothed corolla, either equal or oblique or imperfectly ligulate. Akenes 5-ribbed or 3-5-angular, with broad truncate summit, bearing a coroniform pappus or none. Anther-tips broad and mostly obtuse.

178. ARTEMISIA. Heads paniculately disposed, few-many-flowered, small, wholly discoid, heterogamous, the female flowers with small. and slender tubular corolla, and the her- 
maphrodite either sterile or fertile; or homogamous, with the flowers all hermaphrodite and fertile. Anther-tips slender and pointed. Akenes obovate or oblong, mostly with small epigynous disk or summit, and no pappus.

TRIBE VIII. SENECIONIDEA. Heads heterogamous or homogamous. Involucre mostly one or two series of equal (and not scarious) bracts, sometimes unequal or even imbricated, with or without loose and short accessory ones at base. Receptacle naked. Anthers without tails at base, but not rarely sagittate. Style-branches of hermaphrodite flowers most commonly truncate or obtuse, tipped with short appendages or none. Pappus of numerous capillary bristles, sometimes caducous. Leaves usually alternate. (Copious capillary pappus, comparatively simple involucre, short or conical if any style-tips, tailless anthers, and naked receptacle, are the marks of this tribe, no account being here taken of the tropical American subtribe Liabea.)

* Style-branches of hermaphrodite fertile flowers roundish-obtuse, or at least not truncate, and wholly without appendage or hispidity at summit, simulating Inuloidea or Eupatoriacece: pappus-bristles merely denticulate : receptacle naked, flat. - Subtribe Tussilagineo, Benth. \& Hook.

- Heads submonocious or subdicecious; the hermaphrodite flowers (with rather deeply 5-cleft corolla) essentially sterile : akenes narrow, 5-10-costate, with elongating soft and white pappus : involucre a series of soft herbaceous bracts, with few or no loose accessory ones at base. - True Tussilaginea.

179. TUSSILAGO. Head solitary, yellow-flowered, monocious: female flowers in several series in the ray, slenderly ligulate: numerous subhermaphrodite flowers in the centre, with undivided style and sterile ovary.

180. PETASITES. Heads racemosely or corymbosely disposed, white- or purplish-flowered, subdiœcious: heads in the truly fertile plant wholly or chiefly of female flowers, with slender-tubular and irregularly 2-5-toothed or distinctly ligulate corolla; in the substerile with few of these in the margin, and numerous hermaphrodite-infertile flowers, like those of Tussilago, but their style commonly with 2-cleft or 2-toothed apex.

+- + Hearls homogamons, discoid, of wholly hermaplirodite and fertile flowers: stylebranches very minutely granular-puberulent.

+- Corollas yellow, rather deeply 5-cleft, the lobes lanceolate: anthers much exserted and with lanceolate tips: akenes linear, glabrous: involucre hardly herbaceous, simple, of carinately one-nerved narrow bracts, and with few and small or no accessory bracts.

181. CACALIOPSIS. Heads very miny-flowered. Involucre broadly campanulate, of 14 to 30 lanceolate-linear mostly acuminate bracts. Corolla with the cylindraceous throat rather longer than the slender tube. Anthers entire at base. Style puberulent for some distance below the slightly flattish branches. Akenes 10-striate. Pappus rery copious, soft and white, equalling the corolla. Leaves palmately lobed, petioled.

182. LUINA. Heads about 10-flowered. Involucre oblong-campannlate, of 8 to 10 linear bracts. Corolla of the preceding, or the throat more ampliate. Anthers sagittate at base. Style glabrous, its flattened and linear branches obscurely papillose on the back, truncately obtuse. Akenes (immature) obscurely 10-striate. Pappus of the preceding, but less copious. Leaves entire, veiny, sessile.

+ + Corollas yellowish, obtusely 5-toothed: anthers little exserted, with oval obtuse tips: involucre mostly foliaceous!

183. PEUCEPHYLLUM. Heads 12-25-flowered. Involucre campanulate, of numerous subulate-linear or almost filiform nerveless bracts which resemble the leaves, in about 2 series, some of the outer looser and similar to the uppermost leaves. Corolla with very short proper tube and long cylindrical throat; the 5 teeth short, ovate, obtuse, erect, obscurely puberulent. Anthers minutely sagittate at base. Style-branches linear, flattish or semiterete, obscurely papillose-puberulent, the very obtuse tip wholly destitute of appendage. Akenes turbinate-oblong, obscurely 10-striate, very hirsute. Pappus shorter than the corolla, of very numerous and unequal rather sordid and roughish capillary bristles. Leaves short-filiform, crowded. 
* Style-branches of hermaphrodite flowers either truncate or capitellate at tip, which is either naked or penicillate or birsute, and not rarely bearing a short conical or flattened appendage. - Subtribe Eusenecionece, Benth. \& Hook.

+ Involucre lax (not erect-connivent), commonly of much orerlapping or unequal bracts, 10-many-flowered.

+ Herbs, with alternate well-developed leaves and many-flowered heads.

184. PSATHYROTES. Heads homogamous; the flowers all hermaphrodite and fertile. Involucre of somewhat numerous bracts in two series, at least the outer more or less herbaceous. Receptacle flat. Corolles with extremely short proper tube (the filaments therefore inserted near the base), elongated cylindrical throat, and $\mathbf{5}$ very short obtuse teeth. Style-branches flattish, very obtuse or truncate, and with obscure appendage if any. Akenes terete, more or less turbinate, obscurely striate, villous or hirsute. Pappus copious, shorter than the corolla, of very unequal rather rigid obscurely denticulate bristles, at least in age fuscous or ferrugineous.

185. BARTLETTIA. Heads heterogamous, radiate: flowers all fertile. Involucre broadly campanulate, of 12 to 14 oblong-lanceolate bracts in 2 or 3 series, rather lax; the inner and larger membranaceous, 2 or 3 outermost short and more herbaceous. Receptacle convex, tuberculate. Corollas with long and slender pubescent tube; of the ray with narrowly oblong exserted ligule; of the disk with dilated-funnelform throat longer than the 5 ovate lobes. Anthers with ovate obtuse tips. Style-branches rather short, linear, flat, truncate, minutely hairy at the broad summit, and usually with a central setula. Akenes (at maturity) compressed, cuneate-oblong, with a strong salient nerve to each margin and usually on the middle of one face, these densely long-hirsute, the faces glabrate. Pappus equalling the disk-corolla; its numerous somewhat unequal bristles in a single series, rather rigid, barbellulate, fuscous.

186. CROCIDIUM. Heads heterogamous, radiate: flowers all fertile. Involucre hemispherical or more open, of 9 to 12 nearly equal and similar oblong-ovate or oblong-lanceolate thin-herbaceous bracts; no external calyculate ones. Receptacle conical. Ray-flowers about 12, with oval or oblong rather ample ligules: disk-corollas with slender tube rather longer than the campanulate throat; lobes 5, spreading. Anthers with deltoid-ovate acute tips. Style-branches short and broad, terminated by large deltoid appendages. Akenes fusiformoblong, obscurely 3-5-costate, beset with hyaline oblong papilla, which, detaching when wetted, throw out a pair of spiral threads, in the manner of Senecio, \&c. Pappus a single series of equal white barbellate bristles, which are very deciduous, in the ray commonly wanting.

$$
++ \text { Herb, with opposite leaves and many-flowered heads. }
$$

187. HAPLOESTHES. Heads heterogamous, many- (at least 20-) flowered, radiate: flowers all fertile. Involucre short-campanulate, of 4 or 5 nearly equal and similar rather fleshy orbicular or broadly oval bracts, the outer strongly overlapping the inner. Receptacle flat. Corollas with somewhat slender tube: ligules of the rather few and short ray-flowers oval: disk-corollas narrowish, deeply 5-toothed. Anther-tips lanceolate. Style-branches of Senecio. Akenes linear, terete, striate-costate, glabrous. Pappus a single series of rather rigid and scabrous whitish bristles, about equalling the disk-corolla.

++ Shrub, with alternate leaves reduced to scales, and 10-18-flowered heads with imbricated involucre.

188. LEPIDOSPARTUM. Heads homogamous. Involucre oblong-campanulate; its bracts scarious-chartaceous, regularly imbricated in 3 or 4 series, oblong, obtuse; the outer successively shorter; outermost ovate, passing into similar scaly bracts on the pedicel. Receptacle naked. Corolla with elongated tube, and lanceolate-linear spreading lobes, which much exceed the open campanulate throat. Anthers wholly exserted, slenderly and almost caudately sagittate at base, the tips lanceolate. Style-branches flattish, ending in short acutish pubescent tips. Akenes oblong, terete, obscurely 8-10-nerved, with large epigynous disk. Pappus very copious, of soft and whitish minutely scabrous capillary bristles.

+ + Involucre of 4 to 6 firm and concave close and strongly overlapping bracts, 4-9flowered: shrubs, with alternate leaves.

189. TETRADYMIA. Heads homogamous. Involncre cylindrical to oblong, naked, i. e. no accessory bracis. Receptacle flat, small. Corollas with elongated tube, and lanceolate 
or linear spreading lubes longer than the short-campanulate throat. Antluers wholly exserted, acutely and even caudately sagittate at base; the tips triangular-lanceolate. Style-branches flattish, the truncate and miuntely penicillate tips terminated by a very short and low obtuse cone. Akenes terete, short, obscurely 5-nerved, from extremely longvillous to glabrate or even glabrous. Pappus of fine and soft minutely scabrous capillary long bristles, white or whitish.

+++ Involucre of numerous or several connivent-erect herbaceous equal bracts (with or without short accessory ones at base), many-flowered, or in some species of Cacalia of few bracts and few-flowered: ours herbs, the flowers all fertile : heads either homogamous or heterogamous with ligulate ravs.

+ Pappus of comparatively few and unusually stout plumose bristles. (Transition to Helenioidex.)

190. RAILLARDELLA. Heads 15-many-flowered (fewer-flowered only in depauperate plants), homogamous or heterogamous. Involucre cylindraceous or campanulate, a single series of linear equal bracts, their edges lightly connate below the middle, or not manifestly overlapping. Receptacle flat. Ray-flowers (when present) with irregular and cuneate deeply 3-4-cleft fertile ligules. Disk-corollas with rather short proper tube, elongated and narrow-funnelform throat, and 5 orate obtuse nakel teeth. Style-appendages flattish, hispidulous, tapering into lanceolate or cuspidate tips. Akenes linear, somewhat terete, obscurely several-nerved, pubescent. Pappus of 12 to 25 equal aristiform but soft and plumose bristles, nearly equalling the disk corollas

++ Pappus a single series of numerous rather rigid capillary bristles, from scabrous to barbellate: leaves chiefly opposite.

191. ARNICA. Heads many-flowered, conspicuously radiate, or the rays rarely wanting. Involucre campanulate, not calyculate-bracteolate at base, of several thiu-herbaceous oblonglanceolate to linear equal bracts in a single or sumewlrat double series. Receptacle flat, sometimes fimbrillate or villous. Corollas of the disk-flowers with a commonly elongated hirsute tabe, a funnelform or cylindraceous throat, 5-lobed at summit. Style-branches flattish, at least above, there hirsute, with obtuse or acute tips. Akenes linear, more or less 5-10-costate or angled.

+++ Pappus of soft-capillary and merely scabrous very numerous bristles: stylebranches narrow, truncate or capitellate and often bearing a bearded ring at tip, which sometimes is produced into a short central cusp or obscure cone : leaves in our geuera all alternate.

192. SENECIO. Heads heterogamous and radiate, or by the absence of ray homogamous and discoid, usually many-flowered. Corollas yellow, those of the disk 5-toothed, occasionally 5-lobed.

193. CACALIA. Heads homogamous, the flowers all hermaphrodite, few or numerous. Corollas white, rarely flesh-colored, with 5-cleft or 5-parted limb, the lobes usually with a midnerve.

194. ERECHTITES. Heads heterogamous and discoid, many-flowered : numerous outer flowers female; central ones hermaphrodite. Corollas all slender-tubular; those of the female flowers filiform and with usually slightly dilated and 2-4-toothed summit; of the hermaphrodite flowers with long filiform tube and short cyathiform 4-5-lobed limb. Receptacle flat, naked. Bristles of the pappus very soft and fine, elongated. Flowers whitish or yellowish.

Tribe IX. CYNAROIDE无。 Heads homogamous and tubiflorous, the flowers all hermaphrodite and with equally or sometimes rather unequally 5-cleft corollas, the lobes long and narrow; or sometimes radiatiform (falsely radiate) and heterogamous by enlargement of Jimb of corollas of marginal flowers, which are conimonly neutral. Involucre much imbricated. Receptacle mostly flat or convex, often fimbrillate or densely setose. Anthers with tails at base, and commonly with elongated and connate cartilaginous apical appendages, their tips distinct. Style-branches destitute of appendage, short, sometimes distinct or partly so, more commonly united up to the simply obtuse tips, not hirsute or hispid, but sometimes an hispidulous or pubescent 
ring or node below. Akenes thickish and hard. Pappus setose or rarely paleaceous. Leaves alternate, the teeth or margins often prickly. (Nearly all the indigenous American representatives are Thistles.)

Crtptostemima caliendolacea, of S. Africa, of the tribe Arctotidece (lying between this tribe and Anthemidece, and to which belongs Gazania of the gardens), is a ballast-weed at some ports in California, which it has reached via Australia.

Subtribe I. CaRduINes. Akenes attached by their very base, mostly very glabrous : flowers all perfect (one Thistle diøecious), in ours numerous or in the first genus rather few in the head.

* Filaments distinct.

+ Leaves never prickly: style-branches partly distinct, slender : akenes oblong: filaments glabrous.

195. SAUSSUREA. Involucre obovoid to oblong; bracts appressed, muticous. Receptacle with setiform chaff among the flowers, or rarely naked. Pappus of numerous plumose bristles, more or less connate in an indurated ring at base, so falling from the akene in connection; with commonly some onter and smaller bristles, either less plumose or naked, which are separately deciduous.

196. ARCTIUM. Involucre globular; bracts slender-subulate or aristiform and spreading above the broader appressed base, hooked at tip. Receptacle densely setose. Pappus of numerous short and rigid or chaffy bristles, separately deciduous.

++ Leaves more or less prickly: style-branches concreted to or near the tip into a filiform or rarely short-cylindrical body; a pubescent ring below this either manifest or quite obsolete. akenes obovate or oblong, compressed or somerhat turgid: pappus simple; its numerous bristles connate into a ring at base and falling from the akene in connection : filaments bearded or papillose-pubescent, rarely glabrous : involucre of numerous much imbricated and often prickly-tipped bracts, manj-flowered.

197. CARDUUS. Bristles of the pappus naked, or at most barbellulate, not plumose: otherwise like Cnicus.

198. CNICUS. Bristles of the pappus long-and soft-plumose, or only their tips naked, or those of some marginal flowers occasionally almost naked to the base. Receptacle densely villous-setose.

199. ONOPORDON. Receptacle fleshy, alveclate, not setose: pappus not plumose: otherwise like Cnicus.

Cynara, Artichoke, Cardoon, is sparingly cultivated, but not naturalized.

* Filaments monadelphous below, glabrous: otherwise as preceding subdivision.

200. SILYBUM. Involucre depressed-globose, of rather large and rigid bracts in a few series; their upper portion herbaceous, spinose along the margins, and tapering into a rigid prickle, widely spreading. Receptacle and flowers nearly as in common Thistles. Bristles of the pappus numerous in more than one series, flattish, barbeliulate-ciliolate or scabrous.

Subtribe II. Centadrines. Akenes obliquely attached by one side of the base or more laterally.

201. CENTAUREA. Involucre ovoid or globose, many-flowered, mostly firm or rigid; bracts appressed and variously appendaged. Receptacle densely setose. Flowers sometimes all hermaphrodite and with corollas equally or obliquely 5-cleft into narrow lobes; more commonly the marginal ones neutral or sterile, and their corollas sometimes enlarged and widely spreading, forming a kind of false ray. Style-branches either concreted or partly separate. Akenes obovoid or oblong, turgid or compressed, usually smooth and glabrous, with a large epigynous disk, commonly surrounded by an elevated entire or denticulate margin. Pappus various, setose or partly paleaceous, occasionally obsolete or wanting.

Tribe X. MUtisiace无. (Ser. Labiatiflore, DC.) Heads in one sulbtribe homogamous, the hermaphrodite flowers all with regularly 5-cleft corollas; otherwise either homogamous or heterogamons and corollas. bilahiate in the hermaphrodite 
flowers, sometimes simply ligulate in female ray-flowers. Anthers with long tails at base. Receptacle naked. Style-branches of hermaphrodite flowers not appendaged, usually short or very short, and like those of Cynaroidece (but no node below) or of Inuloidece. Leaves alternate. (Mostly South American, a few in other parts of the world : our five genera belong to three subtribes.)

Subtribe I. GochNatiezs. Heads homogamous ; the corollas almost or quite regularly and deeply 5-cleft into linear lobes: style-branches usually rounded at tip. Ours shrubs. (Transition to Cynaroidece and Inuloidea.)

202. HECASTOCLEIS. Heads one-flowered, in a fascicle, surrounded by an involucriform cluster of leaves. Involucre cylindraceous, of several narrowly lanceolate rather rigid and cuspidate-acuminate bracts, appressed-imbricated. Flower hermaphrodite. Corolla rather chartaceous, narrow, equally cleft to the middle; the linear lobes wirlely spreading, not revolute. Anthers wholly exserted, subcoriaceous, bearing naked tails; the linear terminal appendages lightly connate, as long as the polliniferous portion. Style glabrous and even, not cleft, but terminated by an emarginate-2-lobed stigma. Akene (immature) cylindraceous, glabrons. Pappus coroniform, laciniate-dentate, corneous.

203. GOCHNATIA. Heads few-many-flowered, fasciculately paniculate or cymose. Involucre campanulate or oblong, of dry or coriaceous rogularly imbricated bracts. Receptacle flat, naked. Corolla-lobes mostly revolute. Style-branches sometimes very short, sometimes fully twice longer than broad, flat, roundish-obtuse or nearly truncate at summit. Akenes oblong, silky-villous. Pappus of copious rather rigid capillary scabrous or barbellulate bristles, nearly equalling the corolla.

Subtribe II. Gerberex, \& III. Nassauvieze. Heads heteroganıus or homogamoin: corollas either all bilabiate $\left(\frac{2}{3}\right)$, or marginal ones simply ligulate.

* Heads heterogamous and radiate: ray-flowers female and simply ligulate.

204. CHAPTALIA. Heads many-flowered: female flowers in two or more series and fertile; hermaphrodite flowers in the disk, all or some of them sterile. Involucre campanulate or turbinate, of narrow appressed-imbricated bracts, outer successively shorter. Corolla of the marginal flowers simply ligulate and 3-toothed at the end, or entire; those of an inner series more filiform, the ligule reduced to less than the length of the style; those of the hermaphrodite flowers more or less bilæbiate, outer lip 3-toothed, inner 2-lobed or parted. Style in hermaphrodite flowers obtusely 2-lobed at apex, or when sterile entire. Akenes oblong or fusiform, 5-nerved, attenuate or rostrate at apex, bearing a copious pappus of very soft and fine capillary bristles. Scapigerous and monocepbalous herbs.

* * Heads homogamous, of hermaphrodite and fertile flowers, all of them with bilabiate (g) corollas, the lower lip larger in marginal flowers, not rarely more elongated and radiatiform: style-branches comparatively long, mostly dilated or flattened above and truncate, rarely somewhat penicillate.

205. PEREZIA. Involncre few-many-flowered, imbricated in few to several series; bracts dry, chartaceous or coriaceous. Receptacle fiat, naked, rarely pilose or fimbrillate. Akenes commonly papillose-puberulent, elongated-oblong, terete or obscurely angled, sometimes narrowed at apex, not rostrate. Pappus of copious capillary scabrous bristles, either rather rigid or soft. Flowers neprer yellow.

206. TRIXIS. Involucre several-many-flowered; proper bracts 8 to 12, equal in a single series, or in two unequal series, little if at all imbricated, usually subtended by a few foliaceous loose accessory ones or by bracteiform leaves. Receptacle in genuine śpecies pilose. Akenes more slender, with a tapering or rostrate summit. Pappus soft. Flowers yellow.

Tribe XI. CICHORIACEE. (Ser. Liguliflore, DC.) Heads homogamous and ligulate; the flowers all hermaphrodite and with ligulate corolla; ligule 5-toothed at the truncate apex. Anthers sagittate-auriculate at base, not caudate: pollen-grains dodecahedral. Style-branches filiform, minutely papillose, not appendaged, but stigmatic lines evident only toward base. Receptacle almost always plane. Herbs (except a few insular genera), mostly with milky and hitter juice : leaves alternate. (Natural 
and well-definable subtribes being still a desideratum, artificial sections based primarily on the pappus are here employed.)

Series I. Pappus none : receptacle naked.

* Akenes truncate at base and apex, short, smooth : leaves all radical : involucre of nearly nerveless bracts, nearly unchanged in fruit, rather many-flowered.

207. PHALACROSERIS. Involucre of 12 to 16 equal and nearly herbaceous lanceolate bracts, naked or loosely unibracteate at base. Akenes short-oblong, slightly incurved, obscurely quadrangular: pericarp thin-coriaceons. Scape naked, monocephalous: flowers yellow.

208. ATRICHOSERIS. Involncre of 12 or more equal lanceolate bracts, and calyculate with a few minute ones. Akenes oblong, with corky pericarp, more or less 8-10-costate, the alternate ribs thicker. Scape bracteate and polycephalous : flowers white and purplish.

211. KRIGIA, \& 219. MICROSERIS, very rarely want the pappus, or nearly so.

* * $\Lambda$ kenes with rounded or somewhat contracted apex and small areola, narrow at base: involucre of several one-nerved equal bracts, unchanged or concave-convex in fruit, 8-20flowered: corollas yellow.

209. LAMPSANA. Involucre narrow, minutely calyeulate-bracteate at base; the true bracts carinate, at least in fruit, then erect. Akenes narrowly obovate-oblong and somewhat obcompressed, minutely nervose-striate, smooth. Leafy-stemmed and branching Old World annuals.

210. APOGON. Involucre not calyculate, of usually 8 oblong-lanceolate herbaceous bracts, in fruit becoming rather ovate by broadening of the base, concave and the tips conniving. Akenes terete, obovoid, merely rounded at summit, 10-costate, obscurely scabrons-lineolate transversely, rarely an obsolete vestige of pappus. Low annuals, becoming caulescent.

Series II. Pappus paleaceous or partly so, or aristiform, or plumose.

* Involucre simple and naked, i. e. of equal bracts and no short calyculate ones at base: akenes truncate : pappus of paleæ and (usually) of bristles: receptacle naked.

211. KRIGIA. Heads several-many-flowered. Bracts of the involucre thin-herbaceous. Akenes short-columnar or turbinate, pluricostate, terete or somewhat angular, with broad truncate summit. Pappus double; outer of pointless thin pales; inner of delicate naked bristles, these rarely wanting in one species. Flowers yellow.

* * Involucre either calyculate or imbricated, i. e. principal bracts equal and some short ones at base, or of less unequal bracts in two or more series, simple only in Tragopogon.

+ Akenes usually short, with truncate summit (sometimes a little narrowed beneath it, not rostrate) : receptacle not chaffy : flowers never yellow: caulescent, with small or reduced leaves on the rigid stems or branches: flowers matutinal.

212. CICHORIUM. Heads several-many-flowered. Involucre double; its bracts herbaceous with coriaceous and indurating base, those of the inner series partly enclosing the subtended akenes, the 4 or 5 outer more spreading and herbaceous. Akenes somewhat angled; the broad summit bordered with a crown-like pappus of numerous short and blunt palex, in 2 or more series. Flowers normally blue.

213. STEPHANOMERIA. Heads 5-12-flowered, rarely 3-20-flowered. Involucre cylindraceous or oblong, of several appressed and equal plane membranaceous bracts and some short calyculate ones, not rarely with 2 or 3 of intermediate length, thus becoming imbricate. Akenes 5-angled or ribbed, sometimes with intermediate ribs. Pappus a series, of plumose bristles, or rarely chaffy awns, not rarely naked toward the bases, which sometimes are lightly connate in phalanges. Flowers pink or rose color.

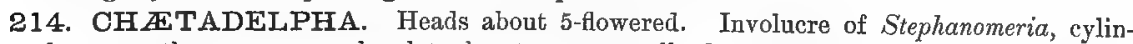
draceous, the accessory calyculate bracts very small, the membranaceous proper ones 5 . Akenes short-linear, 5-angled, very smooth. Pappus of 5 rigid upwardly tapering awns, which bear on each side toward the base 3 to 5 rather shorter and slender rigid bristles. Flowers rose-color.

+ + Akenes long-rostrate, base more or less excavated at insertion: receptacle naked: heads rather-many-flowered : pappus a series of long-plumose bristles or awns. 
215. RAFINESQUIA. Involucre conical or cylindraceous, of 7 to 15 linear acuminate equal bracts, somewhat fleshy-thickened at base, and some loose calyculate ones. Akenes terete, somewhat fusiform, obscurely few-ribbed, attenuate into a slender beak, not callousthickened at the insertion. Pappus (white) of 10 to 15 slender bristles, softly long-plumose from base to near the tip. Leafy-stemmed and branching anuuals : flowers white or tiuged with rose-color.

216. TRAGOPOGON. Involucre campanulate or oblong, of several lanceolate and upwardly attenuate equal herbaceous bracts; no calyculate ones. Akenes somewhat fusiform, 5-10-costate, more or less excavated at insertion, tapering into a long beak, except perhaps the outermost. Pappus a series of numerous stout bristles, somewhat connate at base into a ring, long-plumose to near the apex, the plumes arachnoid and more or less interlacing. simple-stemmed or branching biennials or perennials, with gramineous leaves, and large solitary heads of yellow or purple flowers.

+++ Akenes either truncate or inner ones rostrate : receptacle paleaceous : soft slender chaff amoug the flowers: head rather many-flowered: involucre sparingly inbricated: flowers yellow.

217. ANISOCOMA. Involucre cylindraceous, of thin and very obtuse appressed bracts, somewhat herbaceous in centre and with broad white-scarious margins; innermost linearoblong, 2 or 3 intermediate ones oblong; outer ones short-oval and orbicular. Chaffy bracts of receptacle long, linear-filiform or setiform. Akenes terete, linear-turbinate, 10-nerved, pubescent, short-attenuate at base, the truncate summit crowned with a narrow entire cuplike border or ring, within which is inserted the bright white pappus, of 10 or 12 rather rigid long bristles, in two series; the 5 longer ones (equalling the involucre) long-plumose above the middle; the others much shorter, less plumose, sometimes naked. Scapes monocephalous.

218. HYPOCHCERIS. Inrolncre campanulate, of somewhat herbaceous marginless bracts. Chaffy bracts of the receptacle narrow and scarious. Akenes glalorous or scabrous, 10-ribbed, oblong or fusiform, tapering upward, at least the inner ones, into a beak. I'appus a series of fine plumose bristles, with or without some naked aud shorter outer ones. Leaves chiefly radical and scapes bracteolate, often branching.

++++ Akenes either truncate at summit or upwardly attenuate, yet with no distinct or prolonged beak : receptacle not chaffy : pappus of awned or pointed scarious palese or of awus or bristles with paleaceous base, or plumose: flowers yellow, open in murning and dull weather.

219. MICROSERIS. Heads several-many-flowered, on naked simple scapes or peduncles. Corollas mostly with a hairy tube. Akenes 8-10-costate, with a basal callosity which is hollowed at the insertion. Pappus simple; its bristles or awns naked, in one or two species plumose (and then white) or barbellate.

220. LEONTODON. Heads many-flowered, on simple or branching scaly-bracteolate scapes. Involucral bracts narrow. Akenes minutely striate or rugulose, fusiform and tapering to the narrow summit, sometimes by more or less of a beak. Pappus one or two series of plumose (sordid) bristles, which are more or less lanceolate-widened at base, persistent.

220. PICRIS. Heads many-flowered, terminating leafy stems. Outer bracts of involucre loose or sprearling. Akenes terete, 5-10-costate; the ribs rugose. Pappus one or two series of slender plumose bristles, not paleaceous at base.

Series III. Pappus of capillary bristles, scabrous, rarely barbellulate, never plumose nor paleaceous-dilated.

* Receptacle paleaceous, i. e. bearing narrow chaffy bracts among the flowers: corollas rose-color or rose-tinged.

221. PINAROPAPPUS. Involucre many-flowered, campanulate; its bracts imbricated and outer successively shorter, thinnish, the tips sphacelate. Chaff of the receptacle attenuatelinear, deciduous with the akenes. Akenes glabrous, slender, terete, 10-15-costate, tapering from the callous base into a short slender beak. Pappus sordid, of copious soft-capillary bristles, one or two outer series shorter, rather persistent. 
* Receptacle bearing some capillary bristles among the flowers: pappus all or the greater part deciduous in connection: akenes not flattened.

222. CAL YCOSERIS. Involucre many-flowered, oblong-campanulate, of numerous exect linear-lanceolate scarious-margined bracts in a single series, and of a short and loose calyculate outer series. Delicate capillary bristles of the receptacle, one to each flower, as long as the akenes and deciduous with them. Akenes fusiform or oblong, 5-costate, attenuate into a short beak, which terminates in a shallow and denticulate scarious pappus-like crown, surrounding the base of a copious and white soft-capillary pappus; its bristles equal, deciduous all together.

223. MALACOTHRIX. The species with bristle-bearing receptacle belong here. Akenes short-columnar, truncate at both ends.

230. TROXIMON. One species sometimes bears chaffy bracts among the flowers: akenes short-rostrate.

* * Receptacle naked.

+ Akenes not flattened: pappus promptly deciduous, mainly altogether, soft and white.

223. MALACOTHRIX. Involucre many-flowered, either imbricated or only calyculate. Receptacle sometimes with or sometimes without delicate capillary bristles interposed among the flowers. Akenes short, oblong or columnar, glabrous, terete and striately 5-15-costate, or 4-5-angled by the prominence of stronger ribs, slightly or not at all narrowed either way, with broad truncate apex having an entire or denticulate border or sharp edge. Pappus a series of soft and scabrous or near the base barbellulate bristles, which are deciduous more or less in connection, and commonly 1 to 8 outer and stronger ones which are more persist-

ent and smoother.

228. CREPIS. One or two species incline to have most of the pappus-bristles fall in connection, also a few less deciduous.

224. GLYPTOPLEURA. Involucre 8-18-flowered, cylindraceous, of 7 to 12 nearly' membranaceous linear-lanceolate equal hardly scarious-margined bracts, which are partly connate below, and some loose foliaceous ones or subtending leaves at base. Akenes narrowly oblong, often somewhat incurved, slightly tapering downward, with 5 thick obtuse ribs or angles, and the intervals conspicuously cancellate-sculptured, so as to form single rows of pits, at summit a short thick and 5-ribbed hollow beak exserted from a cupulate shoulder, and slightly dilated to bear the pappus: this bright white, of very numerous and fine hardly scabrous capillary bristles, in more than one series, caducous, outermost falling separately, inner mostly in connection at base.

+ + Akenes not flattened: pappus persistent, or bristles tardily falling quite separately, never in connection (except, perhaps, by the breaking of the summit of an attenuate beak).

+ Beak to the akenes none or a mere attenuation.

$=$ Heads solitary, terminating simple bractless scapes : flowers yellow.

225. APARGIDIUM. Involucre rather many-flowered, cylindraceous-campanulate ; bracts somewhat herbaceous, lanceolate, acuminate, one-nerved, rather few in 2 or 3 series, or outer and broader ones more calyculate. Akenes linear-oblong, columnar, glabrous and smooth, truncate, not tapering at either end. Pappus sordid or brownish, of rather copious minutely barbellulate and rather fragile capillary bristles, with some outer and smaller ones merely scabrous. Perennial.

230. TROXIMON. Involucre many-flowered. Akenes tapering, 10-costate, beakless in original species.

$==$ Heads seldom solitary, borne by leafy stems or more or less bracteate scapes.

a. Flowers yellow (in an adventive species red-orange), or in one species white.

226. HIERACIUM. Involucre several-many-flowered, of narrow equal bracts and some short calyculate ones, or sometimes imbricate, having those of intermediate length, not thickened at base nor with thickened midribs. Akenes oblong or columnar, smooth and glabrous, mostly 10-ribbed or striate, either terete or 4-5-angular, slightly contracted at very base, commonly of same thickness to the truncate top, but in several species tapering to a narrower summit. Pappus of rather rigid scabrous fragile bristles, sordescent or fuscous, rarely 
white and soft, then passing into Crepis. Perennials, commonly with hispid or hirsute, or often glandular pubescence.

227. CREPIS. Involucre few-many-flowered, somewhat imbricated, or more commonly a series of equal bracts and some short calyculate ones, sometimes thickened at base after anthesis. Akenes from columnar to fusiform, 10-20-costate. Pappus of copious white and usually soft capillary bristles. Annuals or perennials.

b. Flowers from whitish or cream-color to violet or rose-red: involucre narrow, unchanged in age, a series of equal erect bracts, and a few short calyculate ones at base: styles usually long and slender: akenes columnar or linear, or even fusiform, mostly truncate at summit.

228. PRENANTHES. Heads 5-30-flowered, mostly nodding before or during anthesis. Akenes terete or 4-5-angled, commonly striate, sometimes striately pluricostate, with truncate summit. Pappus of copious rather rigid capillary bristles, in the section Nabalus from whitish to ferruginous. Leafy-stemmed perennials, with paniculate or racemiform-thyrsoidly disposed heads: leaves dilated.

229. LYGODESMIA. Heads 3-12-flowered, erect. Akenes terete, obscurely few-striate or angled, commonly linear or slender-fusiform, in the larger species concave at insertion. Pappus of copious and usually unequal capillary bristles, either soft or rigidulous, from sordid-whitish to white. Stems mostly rush-like and striate, in one species spinescent, and leaves narrow-linear or reduced to scales. Flowers rose-colored.

+ + Beak to the akenes distibct and slender, except in one or two species of Troximon : heads erect before and during anthesis: iuvolucre unchanged in age: akenes oblong or obovate to linear.

230. TROXIMON. Heads many-flowered, solitary, terminating simple naked scapes. Involucre campanulate or oblong, more or less imbricated. Akenes 10-costate or 10-nerved, smooth, not muricate nor sculptured, with or without a small callus at insertion; the beak various, or in two species wanting. Pappus white or whitish. Flowers yellow, orange, or rarely purple.

231. TARAXACUM. Heads many-flowered, solitary, terminating simple and fistulons naked scapes. Involucre campanulate or oblong, a single series of nearly equal narrow bracts, a little connate at base, and several or numerous calyculate bracts at the base. Style-branches slender and nearly filiform, as in most genera. Akenes oblong-obovate to fusiform, 4-5-costate or angled, and usually with some intervening nerves, muricate or spinulose, at least near the summit, which is abruptly contracted into it filiform beak. Pappas soft and capillary, dull white, no woolly ring at its base. Flowers yellow.

232. PYRRHOPAPPUS. Heads and involucre nearly of Taraxacum, terminating scapose or leafy stems or branches. Style-branches short, oblong, very obtuse. Akenes oblong or linear-fusiform, about 5-costate or sulcate, muriculate-rugulose or hirsutulous-scabrous, tapering abruptly into a long filiform beak. Pappus copious, soft and capillary, fulvous or rufous, its base usually surrounded by a soft-villous ring. Flowers yellow.

233. CHONDRILLA. Heads several-flowered, sessile or short-peduncled on slender branches. Involucre cylindrical, of several linear equal bracts, and some short calyculate ones. Akenes 4-5-angled and with intervening nerves or ribs, muricate toward the summit, which is abruptly produced into a filiform beak. Pappus fine and soft, bright white. Flowers yellow.

+++ Akenes flattened: pappus of copious fine and soft capillary bristles: leafystemmed plants, with more or less paniculate heads.

234. IACTUCA. Involucre cylindraceous, or in fruit somewhat conoidal, several-manyflowered, either calyculately or more regularly imbricated. Akenes obcompressed, and with a beak or narrowed summit, which is more or less expanded at apex into a pappiferous disk. Pappus of bright white or rarely sordid bristles, falling separately.

235. SONCHUS. Involucre campanulate or broader, in age usually broadened and fleshythickened at base, and becoming conical. Akenes obcompressed, destitute of beals or neck or dilated pappiferous disk. Pappus of very soft and fine flaccid bristles, which fall more or less in connection, and commonly one or more stronger ones, which fall separately. 


\section{Tribe I. VERNONIACEA, p. 50.}

1. STOKESIA, L'Her. (Jonathan Stokes, a British botanist, coadjutor of Withering: some say Dr. Wm. Stokes of Dublin.) - A most peculiar genus, of a single species, of local habitat; a perennial, flowering in early summer; the large and showy head of flowers having considerable resemblance to that of a China Aster. - Benth. \& Hook. Gen. ii. 234.

S. oyánea, L'Her. A foot high: stem stout, at first floccose-lanate; the few branches terminated by solitary heads : leaves glabrous, bright green, puncticulate, thickish; radical and lower canline entire, oblong-lanceolate, tapering into a margined petiole; upper becoming ovate.lanceolate, partly clasping, and bearing toward their base some spimulosearistiform teeth; some subtending the head and passing into the bracts of the involucre: head, with the radiant marginal corollas (of an inch long), 3 inches in diameter: flowers bright purplish-blue. - L’Her. Sert. Angl. 27 ; Ait. Kew. ed. 2, iv. 491 ; Torr. \& Gray, Fl. ii. 60 ; Hook. Bot. Mag. t. 4966 ; Meehan, Nat. Flowers, ii. t. 13. Carthamus lavis, Hill, Hort. Kew. 57, t. 5. Cartesia centauroides, Cass. Bull. Philom. 1816. Centaurea Americana, Hook. Comp. Bot. Mag. i. 48, by mistake. - Moist ground, in the low country, from southwestern part of S. Carolina to E. Louisiana: rare.

2. ELEPHÁNTOPUS, Vaill., L. (Greek for Elephant's foot, which is a translation of a Malabarian name of the original species.) - Perennial herbs, of warm regions, extending northward almost through the Atlantic U. S. ; with undivided pinnately-veined leaves and usually bluish-purple flowers. — Benth. \& IIook. Gen. ii. 237. Elephantopus, Elephantosis, \& Distreptus (Cass.), Less., DC. Our species all belong to the typical section of the genus; with stem dichotomously branching; heads capitately glomerate at the summit of pedunculiform branches, the compound glomerule involucrate by two or three cordate and closely sessile bracteiform leaves; and simple pappus of about 5 awns or rigid bristles, with chaffy-dilated base: fl. late summer. Of the nearly related species (with glabrous corolla) $E$. scaber belongs to the extra-American and $E$. mollis to the American tropics. Schultz Bip., in Linnæa, xx. 514, too hastily combined all the American species. .

* Stem leafy: upper cauline leaves very similar to the basal.

E. Caroliniánus, WILLD. Rather softly hirsute or pubescent, sometimes 3 feet high: leaves thin, oval-obovate or ovate, crenate or repand-dentate, not rugose, nor prominently veined (the larger 4 to 8 inches long and 2 to 4 wide); uppermost oblong: chaffy base of awns of the pappus decidedly longer than the diameter of the akene, lanceolate-subulate and very gradually attennate into the awn. - Spec. iii. 2390 (excl. syn.); Nutt. Gen. ii. 187; Ell. Sk. ii. 480; Torr. \& Gray, Fl. ii. 60. E. scaber, Walt. Car. 217, \&c, not L. - Dry soil in open woods, Pennsylvania to Illinois, Kansas, 'Texas, and Florida.

* * Stem usually naked and scapiform: its few leaves small and bract-like; principal leares radical and flat on the ground.

E. tomentósu.s, L. Somewhat canescently hirsute and villous; leaves silky-villous beneath (rather than tomentose), varying from obovate or rarely oval to narrowly-spatulate; veins of the lower surface prominent: scapiform stem a foot or two high: involucre of the large glomerules rigid: pappus-scales about the length of the breadth of the akene, triangularsubulate, attenuate into the bristle. - Spec. ii. 814, \& ed. 2, excl. syn. Browne; Torr. \& Gray,

- Fl. l.c. E. Carolinianus, var. simplex, Nutt. Gen. ii. 187. E. nudicaulis, Ell. Sk. ii. 481. E. elatus, Bertol. Misc, xi. 21, t. 5. - Virginia and Kentucky to Florida and Louisiana.

E. nudátus, Gray. Minutely strigose-pubescent: leaves membranaceous, green, at most somewhat hirsute beneath, from spatulate-obovate to oblanceolate, not prominently veined: glomerules smaller: pappus-scales very short, broadly deltoid, abruptly terminated by the 
bristle. - Proc. Am. Acad. x7. 47. (Echinophorce affinis Mariana, etc., Pluk. Mant. 66, t. 388, fig. 6?) E. scaber, Michx. Fl. in part; Torr. \& Gray, Fl. l. c., not L. E. nudicaulis, Ell. in herb. Hook, not of Sk. l. c. - Low and sandy woodlauds, Delaware (Canby) to Georgia, W. Louisiana, and Arkansas (Harvey).

3. VERNÓNIA, Schreb Iron-weed. (Wm. Vernon, an early collector in Virginia, \&c.) - Perennial herbs (or some in the tropics shrubs); with alternate and pinnately-veined leaves, and usually purple or rose-colored flowers, occasionally varying. to white. - Gen. 541; DC. Prodr. v. 15; Torr. \& Gray, Fl. ii. 57 ; Benth. \& Hook., Gen. ii. 227. - A huge genus, of nearly 400 species, the greater part S. American, some S. African and S. Asian; the N. American species all of the section Lepidaploa, Benth. \& Iook. l. c. (Lepidaploa, \&c., Cass.), having somewhat spherical heads in terminal cymes or terminating corymbiform branches. Ours all many-flowered; the (fuscous or even ferruginous) pappus persistent or nearly so, and double; akenes commonly sprinkled or beset with resinous atoms between the salient ribs; foliarse often puncticulate. Fl. late summer and autumn. The species are extremely difficult: there are spontaneous hybrids between such very different species as $V$. Arkansana and V. Baldwinii, V. fasciculata and V. Baldwinii, and even between V. Baldwinii and V. Lindheimeri!

* Stems leafy throughout: short outer pappus conspicuous, and squamellate rather than setose.

+ Heads large, sometimes an inch high, 50-i0-flowered.

V. Arkansána, DC. Tall (8 or 10 feet), rather glabrous: leaves all linear-lanceolate (4 to 12 inches long and lines wide), attenuate-acuminate, runcinately denticulate: lieads all on simple and somewhat clavate peduncles, nearly hemisplerical: involucre green, very squarrose ; its bracts all equalling the clisk, and with long filiform tips (those of the upper reddish), the onter and loose ones filiform nearly or quite to the base: akenes minutely hispid on the ribs. - Prodr. vii. 264 ; Nutt. in Trans. Am. Phil. Soc. n. ser. vii. 283; Torr. \& Gray, Fl. ii. 59; Torr. in Sitgreaves Exped. t. 2. - Plains and alluvial banks of streams, Missouri and Kansas to E. Texas.

+ + Heads smaller, half-inch high or less, 15-40-flowered, rarely only 10-flowered.

+ Leares slightly or not at all scabrous, and without revolute margins, most of them acutely denticulate or serrate with rigid or somewhat spinulose teeth, varying from linear-lanceolate to oblong-ovate, acuminate or very acute, pinnately veined: stems leafy up to the inflorescence; cymes mostly compound. (Species not clearly limited.)

- Akenes under a lens more or less hispidulous on the ribs.

V. Noveboracénsis, Willd. Somewhat glabrous or pubescent, 3 to 6 feet high : leaves from elongated- to oblong-lanceolate ( 3 to 9 inches long): heads in an open cyme, 20-40flowered: involucre commonly brownish or dark purplish; the wate and ovate-lanceolate bracts (or at least the upper ones) abruptly acuminate into a slender cusp or slender tortuous awn, usually some of the lower wholly aristiform and loose. - Spec. iii. 1632 ; DC. Prodr. จ. 63; Torr. \& Gray, F1. ii. 57. Serratula Noreboracensis (founded on Herm. Parad. Bot., \& Dill. Elth. 355, t. 263) and $S$. praalta (in herb. and of Dill. Elth. t. 264, bracts more aristate than the figare shows), L. Spec. ii. 818. V. prreulta, Less. in Linn. iv. 264; Hook. Fl, i. 304. V. tomentosa, Ell. Sk. ii. 288 (C'hrysocoma tomentosa, Walt. Car. 196), a form with tomentulose pubescence. Varies with pale or sometimes white instead of pink-purple corollas, the involucre then greenish. - Low grounds, coast of New England to Georgia, west to Wisconsin and Missouri, but mostly an eastern species.

Var. latifólia. Lower, 2 to 5 feet high: leaves oblong-ovate or broadly lanceolate, pale or glaucescent beneath, the larger more coarsely serrate: heads fewer: involucre varying from hemispherical (of fewer bracts) to somewhat turbinate, and its bracts merely acute, acuminate, mucronate, or some with a short filiform cusp. - Serratula glauca, L. 1. c., founded on Dill. Elth. 354, t. 262 ; the specimen has many aristate-tipped bracts. Vernonia glauca (and nearly V. proalta), Willd. Spec. iii. 1633. V. ovclifolia, Torr. \& Gray, 1. c.; Chapm. 
Fl. 187, extreme form, mostly with muticous involucral bracts. - In shady places, Penn. and Ohio to Florida.

V. Baldwínii, Torr. Tomentulose, 2 to 5 feet high : leaves oblong- or ovate-lanceolate : involucre (a quarter-inch high) when young globose, hoary-tomentose, greenish, squarrose by the spreading or recurved acute or acuminate tips of its bracts. - Ann. Lyc. N. Y. ii. 211 ; Torr. \& Gray, 1. c. V. sphceroidea, Nutt. in Trans. Am. Phil. Soc. 1. c. - Prairies and barren hills, E. Missouri to Texas; flowering early, in July and August. Passes into the next.

V. altíssima, Nuтr. Nearly glabrous, or sometimes cinereous-pubescent, 5 to 10 feet high: leaves thinnish, veiny, obscurely if at all puncticulate, lanceolate or lanceolate-oblong: cyme usually loose or open: involucre of wholly appressed obtuse or merely mucronate-acute bracts : ribs of the akenes minutely or sparsely hispidulous. - Gen. ii. 134; Ell. Sk. ii. 289; Less. in Linu. vi. 639, partly. V. procalta, Michx. 1. c., partly; DC. 1. c., partly. V. fasciculata, var., Torr. \& Gray, Fl. ii. 59 ; Chapm. Fl. 188. Chrysocoma gigantea, Walt. 1. c. Varies much, especially in the size of the heads: the form parviflora, with involucre only 2 or 3 lines high and rather pauciseriate, being Nuttall's original. - Low or wet grounds, W. Penn. to Illinois, Louisiana and Florida.

Var. grandiflóra. Less tall : heads larger : involucre mostly 4 lines high; the bracts 35 to 40 and in more numerous ranks. - Nutt. in Herb. Acad. Philad. - Low prairies and along streams, Illinois and Kentucky to Texas.

$==$ Akenes smooth and glabrous on the ribs, or nearly so: bracts of the involucre all closely appressed and inappendiculate, coriaceo-chartaceous.

V. fasciculáta, Mrcix. Glabrous, or the cyme puberulent, 2 to 5 feet high: leaves thickish, when dry puncticulate, from linear (and with obscure veins or veinlets) to oblonglanceolate (and more evidently veined), conspicuously spinulosc-denticulate: heads numerous and crowded on the branches of the compound cyme: involucre ( 3 or 4 lines high) 20-30flowered; its bracts all obtuse, or some of the uppermost abruptly mucronate-acute. Fl. ii. 94; Torr. \& Gray, l. c., excl. vars. V. corymbosa, Schweinitz, in Keating, Narr. Long Exped. Mississ., the form with broad and short leaves. V. altissima, DC. l. c. partly, \& excl. syn. Dill., \&c. - Low grounds, prairies and river-bottouns, Ohio and Kentucky to Dakota and south to Texas.

+ Leaves perfectly glabrous and smooth, veinless, commonly entire, narrowly linear, plane: heads narrow, few-flowered.

V. Lettermáni, Ergerm. Habit of the preceding, 2 to 4 feet high, fastigiately and. cymosely much branched at summit: leaves 3 or 4 inches long, only a line wide, the margins not revolute: heads numerous, pedunculate, clavate-cylindraceous, 10-14-flowered, half-inch long: bracts of the involucre all appressed and inappendiculate, but acute or acuminate; outermost ovate-subulate, innermost narrowly lanceolate and purple: ribs of the glandular akenes obscurely scabrous. - Proc. Am. Acad. xvi. 78.- Arkansas, on Cooper's Creek, Bigelow. Gravelly banks and sand-bars of the Washita, Letterman.

V. Jamésii, Torr. \& Grıy. Glabrous or nearly so, a foot or two high: leaves linearlanceolate or linear, like those of narrowest forms of $V$. fasciculata, but smaller and less or obsoletely denticulate; veins and veinlets obscure: heads few or numerous in a loose and open corymbiform cyme, all pedunculate: involucre (4 or 5 lines high) 15-25-flowered, from hemispherical-campanulate to turbinate-oblong; its bracts all or mostly obtuse, or (in the larger form of involucre) acute or acuminate. - Fl. 1. c.; Gray, P1. Wright. i. 82. V. altissima, var. marginata, Torr. Ann. Lyc. N. Y. ii. 210. - Plains of Nebraska and Arkansas to W. Texas and E. New Mexico, first coll. by $D r$. James.

+4 Leaves with upper face scabrous and margins often revolute, then entire, not canescent.

V. angustifólia, Micmx. Stem a foot to a yard high, slender, from roughish-hirsute to nearly glabrous: leaves from narrowly linear or approaching filiform to lanceolate, the hroader ones sparsely denticulate and also veiny: cyme loose, simple or componnd, sometimes paniculate, sometimes umbelliform, mostly naked: heads 15-25-flowered : involucre abont 3 lines high, commonly somewhat turbinate; its bracts or most of them mucronate, sometimes cuspidate-acuminate: akenes minutely hirsute, at least on the ribs, - Fl. ii. 94 ; Ell. Sk. ii. 87; Torr. \& Gray, 1. c. V. fasciculata, DC. 1. c., not Michx. Chrysocoma graminifolia, Walt. Car. 196. Liatris umbellata, Bertol. Misc. v. t. 4. - Dry pine barrens, N. Carolina to Florida, Arkansas, and Texas. 
Var. scabérrima. Leaves mostly short and sparsely denticulate or toothed, from linear to oblong-lanceolate, scabrous to rough-hispidulous above: bracts of the involucre or some of them produced into long and loose or spreading subulate or filiform tips. - Torr. \& Gray, 1. c. V. scaberrima, Nutt. Gen. ii. 134; Ell. 1. c. - South Carolina to Florida.

Var. Texána. Stem virgate, rather tall : lower leaves large, lanceolate (3 to 6 inches long); upper ones small, linear or subulate: cyme naked : bracts of the involucre all pointless or merely mucronate. - Torr. \& Gray, 1. c., character, without name. - l'ine woods, Arkansas, Louisiana, and Texas.

Var. ptumila, Chapm. Glabrous and hardly at all scabrous, even the leaves; these small, mostly linear and entire: stem slender, a span to 18 inches high : cyme of few heads: bracts of the involucre pointless. - Bot. Gazette, iii. 5. - Wet pine barrens, S. E. Florida, Blodgett, Garber.

+++ Leaves with revolute entire margins, not scabrous, veinless, lanose beneath.

V. Lindheímeri, Gray \& Exgelm. About a foot high, excessively leafy up to the corymbiform cyme, lanose-canescent, even to the obtuse and pointless bracts of the involucre: leaves narrowly linear ( $1 \frac{1}{2}$ to 3 inches long, a line or two wide), glabrate and green above; heads all pedunculate: akenes glabrous : pappus purple.-Proc. Am. Acad. i. 46, \& Pl. Lindh. ii. 217. - Rocky hills and plains, W. Texas, Lindheimer, Hright, \&c. Berlandier collected an apparent hybrid between this most distinct species and $V$. Baldwini.

* * Outer pappus inconspicuous and rather setose than squamellate: cauline leaves few and snall.

V. oligophýlla, Mrcux. Minutely scabrous-pubescent: stem about 2 feet high, slender, bearing a few heads in a very loose naked cyme: radical leaves ample (4 to 8 inches long) in a rosulate tuft, oblong; cauline lanceolate, few and small, the uppermost reduced to subulate bracts; all veiny and denticulate: heads 15-30-flowered: bracts of the involucre subulate (mostly from a broad base), loose: bristles of the pappus slender: akenes hirtellous on the ribs.-FI. ji. 94 ; DC. Prodr. v. 62 ; Torr. \& Gray, Fl. ii. 57. Serratula Curolinensis, Dill. Elth. t. 261. Chrysocoma acaulis, Walt. Car. 196. - Low pine barrens, N. Carolina to Florida, near the coast. - Varies with foliage soft cinereous-pubescent: S. Carolina, $J$. Donnell Smith.

\section{TRIBE II. EUPATORIACEÆ, p. 50.}

4. STEVIA, Cav. (Dr. Pedro Esteve.) - Herbs, rarely suffrutescent plants ; with mostly opposite and triplinerved leaves, small and narrow heads usually corymbosely crowded in terminal naked cymes or fascicles, and flowers white or rose-purple: pappus variable; the awns when present barbellate-scalorous. A large Mexican genus (a few species reaching our borders), also well developed on the eastern side of South America in corresponding latitudes. - Cav. Ic. iv. 32, t. 354-356; Schultz Bip. in Linn. xxv. 268.

* Branches and heads paniculate, loose: root annual.

S. micrántha, L.1. Puberulent and somewhat viscid: stem slender, a foot or two high, bearing short flowering branches almost from the base: leaves thin, ovate with sulucuneate or rarely subcordate base, serrate (inch long), petioled : heads pedicellate in the loose clusters, 3 and 4 lines long: pappus of 3 awns with short paleaceous-clilated base, or in one or two flowers occasionally awnless. - Elench. Hort. Madrid, 1815, \& Nov. Gen. \& Spec. 27. S. macella, Gray, Pl. Wright. ii. 70. - Shady cliffs, New Mexico, Wright. Southern Arizona, Lemmon, by which is generally meant Mr.J.G. and Mrs. Sara Plummer Lemmon, associates in exploration. (Mex.)

* Heads loosely cymose-paniculate and pedunculate: root perennial.

S. amábilis, Leммом. Stem slender and virgate, or with long virgate branches, about 2 feet high: leaves all alternate, linear with narrowed base, or the lowest oblanceolate, entire, thinnish: involucre slender, glandular-viscid: flowers purple: pappus of 5 long awns and with extremely short (broader than long) intermediate palea. - Gray, Proc. Am. Acad. xix. 1. - Plains near Cave Cañon, S. Arizona, Lemmon. 
* * Heads subsessile and fasciculate; the fascicles corymbosely cymose: root perennial.

- Herbaceous, leafy up to the derise fastigiate clusters of heads: leaves subsessile, serrate.

S. serráta, Cav. Pubescent or somewhat hirsute: leaves often alternate, crowded, from spatulate-linear to oljlong-spatulate, irregularly and sometimes coarsely serrate or some entire, loosely veiny, strongly punctate : flowers white or pale rose: pappus 1-5-aristate or in some flowers reduced to a crown of short obtuse paleæ. - Ic. iv. t. 355 ; DC. Prodr. v. 118. S. ivofolia, Willd. Mag. Naturf. Berl. 1807, 137, \& Enum. 855. S. canescens, HBK. Nov. Gen. \& Spec. iv. 143; Benth. Pl. Hartw. 19; Gray, Pl. Wright. ii. 71. S. virgata, HBK. 1. ․ S. punctata, Schultz Bip. in Linn. xxv, 286. Ageratum punctatum, Jacq. Hort. Schœnbr. iii. t. 300. (Variable species.) - New Mexico and Arizona, Wright and later collectors. (Mex., Venezuela.)

S. Plúmmeræ, Gray. Puberulent and almost glabrous: leaves nearly all opposite, less crowded, oblong-lanceolate or broader, acute, incisely serrate, bright green, very conspicuously nervose-veiny and reticulated, hardly punctate ( 2 inches long): flowers rose-color: pappus of 4 broad and truncate fimbriate-denticulate paleæ. - Proc. Am. Acad. xvii. 204. S. Arizona, Rucker Valley of the Chiricahua Mountains, Mrs. Lemmon, born Plummer.

Var. álba. Flowers white : leaves less serrate and not so strongly veiny. - S. Arizona, in Ramsey's Cañon, Lemmon.

$$
++ \text { Shrubby: leares subsessile, mostly entire and opposite. }
$$

S. Lemmóni, Grax. Fruticose, puberulent throughout, leafy up to the dense clusters of very numerous heads: leaves linear-oblong, obtuse, thinnish, obscurely triplinerved: involucre somewhat viscid-pubescent: flowers apparently white: pappus a cupulate and nearly entire or merely lacerate crown. - Proc. Am. Acad. 1. c. - S. Arizona, cañons in the Santa Catalina Mountains, Lemmon, Pringle.

S. salicifólia, CAv. Frutescent, low, nearly glabrous : leaves coriaceous, linear or linearlanceolate, occasionally serrate, commonly glutinous-lucid: heads in small and more open fascicles: flowers white: pappus 1-3-aristate, or sometimes of obtuse paleæ. - Ic. 1. c. t. 354 ; Schultz Bip. 1. c. 290 ; Gray, Bot. Mex. Bound. 73. S. angustifolia, HBK. I. c. (awnless pappus). - S. border of Texas, Parry, a low and very narrow-leaved form. (Mex.)

5. SCLERÓLEPIS, Cass. ( $\Sigma_{\kappa} \lambda \eta \rho o ́ s$, hard, and $\lambda \epsilon \pi i ́ s$, scale, from the cartilaginous paler. of the pappus.) -Genus of a single species, peculiar to the Atlantic coast. Fl. summer.

S. Verticilláta, CAss. Subaquatic perennial, nearly glabrous, stoloniferous from the base: stems slender, usually simple, above the water bearing many whorls of narrowly linear onenerved entire sessile leaves (half-inch to an inch long), and terminated by a solitary pedunculate small head (rarely branching at top and 3-4-cephalous): flowers rose-purple. Diet. xxv. 365 ; DC. Prodr. v. 114 ; 'Torr. \& Gray, Fil. ii. 65. Ethulia unifora, Walt. Car. 195. Spargonophorus verticillatus, Michx. Fl. ii. 95, t. 42. - Low pine-luarren ponds and streams, in shallow water, New Jersey to Florida. Leares 4 to 6 in the whorls.

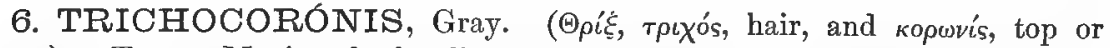
apex.) - Texano-Mexican herbs, fiblous-rooted, aquatic or paludose; with stems creeping at base or spreading, branching, leafy, pubescent with somewhat viscid and weak multicellular hairs: leaves of soft texture, opposite or the upper alternate, sessile and partly clasping, glabrate: heads slender-peduncled, terminating the branches: flowers flesh-color or rose-purple. - Pl. Fendl. 65; Benth. \& Hook. Gen. ii. 240.

T. Wríghtii, Gray, l. c. Stems assurgent from an annual root, paniculately-branched above: leaves undivided, sparingly serrate, half-inch or more long; the lower opposite and oblong; upper alternate and cordate-lanceolate: heads diffusely panicled, only two lines high and wide: involucral bracts about 18, oblong-lanceolate: receptacle convex : tube of the corolla shorter than the expanded throat and limb: style-branches narrow: pappus a minute but evident crown of more or less concreted setuliform squamellæ, or some of them aristellate. - Ageratum? (Micrageratum) Wrightii, Torr. \& Gray, Proc. Am. Acad. i. 46. 
Margacola prrvula, Buckl. in Proc. Acad. Philad. 1861, 1862. - Wet ground in prairies, Texas, Wright, Buckley, \&c. (Mex., Palmer.)

T. rivuláris, GrAx, l. c. Stems floating, in shallow water rooting, and flowering branches emersed and ascending : leaves succulent, mostly opposite, an inch or two in length, cuneateobovate, sparingly incised or palmately 3-lobed, contracted iuto a narrow connate-clasping auriculate base: heads fewer or solitary on simple peluncles, 3 or 4 lines in diameter: involucral bracts about 12 , oval, obtuse: receptacle highly convex : tube of corolla slender, equalling the hemispherical throat and limb : style-branches flat and linear, acutish : pappus a minute aud evanescent or obscure setulose crown. - In springs and streamlets, S. W. Texas, Wright, \&c. (Adjacent Mex., Gregg, \&e.)

7. AGERATUM, L. (Ancient Greek and Latin name of some aromatic

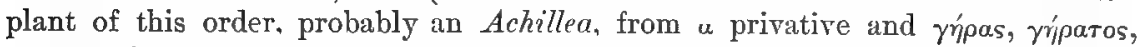
not waxing old, transferred by Linnæus to an American genus.) - Chiefly tropical, herbaceous, aud with opposite petiolate leaves; heads small in terminal corymbiform cymes or rarely paniculate; flowers blue, purple, or white, in summer. - Benth. \& Hook. Gen. ii. 241, excl. syn. Oxylobus. Ageratum \& Coelestina, Cass., DC. ; to which should be added Alomia, HBK., differing only in the want of pappus.

$\S 1$. Euageratum. Pappus of distinct aristate or sometimes muticous paleæ: receptacle naked.

A. Conyzoínes, L. Annual, pubescent: leaves ovate or deltoid-subcordate, crenately serrate: pappus of 5 to 7 lanceolate rigid scales, mostly tapering into a scabrous awn which nearly equals the blue or white corolla. - Schk. Handb. t. 238; Hook. Exot. F1. t. 15. A. Mexicanum, Sims, Bot. Mag. t. 2524, \&c., a more pubescent form, common in ornamental cultivation. Sparingly naturalized near towns in the S. Atlantic States. (Nat. from Trop. Amer., \&c.)

§ 2. CGefestína. Pappus coroniform or cupulate (by the union of the palese into an entire or toothed cup or border), sometimes obsolete. - Coelestina, Cass., DC., \&c. (In our species the receptacle is naked, duration of root uncertain. and flowers usually blue or violet.)

A. corymbósum, Zuccagni. Scabrous-puberulent, erect: leaves short-petioled, ovate to oblong-lanceolate, irregularly few-several-toothed: floriferous branches naked above: corolla-tube glanduliferous : pappus prominently cupulate, more or less dentate. - Zuccagni ex Balb. in Hort. Taur. 1806 ; Pers. Syu. ii. 402. A. calestinum, Sims, Bot. Mag. t. 1730 ; Lodd. Bot. Cab. t. 623. C'olestina ageratoides, IIBK. Nov. Gen. \& Spec. iv. 151; Gray, Pl. Wright. ii. 70. C. ccerulece, Cass. Dict. vi. suppl. 8, t. 93. C. corymbosa, DC. Prodr. v, 108. - New Mexico, Wright, \&c. (Mex.)

A. littorále, GRAY. Glabrous, decumbent or assurgent: leaves rather succulent, long-petioled, ovate with cuneate base, serrate : corolla glabrous: pappus an extremely short crown, with or without several minute narrow teeth, or reduced to a mere ring. - Proc. Am. Acad. xvi. 78. - Colestina maritimu, Torr. \& Gray, Fl. ii. 64; not Ageratım maritimum, IIBK., which is a true Ageratum with diminutive pappus. - Key West, S. Florida, Bennett, Blodgett, Palmer, Garber.

8. HOFMEIST'́tRIA, Walp. (W. Hofmeister, a vegetable histologist.) - Low suffrutescent plants; with heads terminating slender peduncles, small incised leaves either opposite or alternate on long petioles, and whitish flowers; the style-branches clavate. - Two species, the original one (H. fasciculata, Walp. Rep. vi. 106 ; Helogyne, Benth. Bot. Sulph. 20, t. 14), of Lower California, with 2-3-awned pappus.

H. pluriséta, GRAY. Slightly puberulent and viscidulous, much branched : leaves with small (2 to 5 lines long) deltoid to oblong blade very much shorter than the petiole: heads about 
20-flowered, 4 or 5 lines long: bracts of involucre with pointed somewhat spreading tips: akenes rather short: pappus of 10 or 12 bristles and about as many small and narrow acute squamella. - Pacif. R. Rep. vi. 96, t. 9, \& Bot. Calif. i. 299. - Cañons, San Bernardino desert, Southeast California to Arizona and S. Utah, Bigelow, Parry, Newberry, \&oc.

9. MIKÁNIA, Willd. (Prof. J. G. Mikan, of Prague, or his son and successor, J. C. Mikan, who collected in Brazil.) - Twining perennials, or many erect and shrubby in tropical America, where most of the numerous species occur; with opposite leaves and small variously clustered heads. Our species, confined to the Atlantic States, have slender-petioled angulate-cordate leaves, corymbosely cymose heads of pale flesh-colored and more or less fragrant flowers, produced in summer and autumn; the throat of the corolla abruptly dilated from the narrow tube, and broadly campanulate. - Willd. Spec. iii. 1472 ; Benth. \& Hook. Gen. ii. 246.

M. scándens, WILLD. Glabrous or puberulent: herbaceous stems high-twining: leaves somewhat hastately or deltoidly corclate, acuminate, irregularly and obtusely angulatedentate or repand, rarely almost entire : heads crowded, about 3 lines long: involucral bracts lanceolate, acuminate or slender-apiculate: corolla-lobes ovate, much shorter than the very wide throat: "akenes a line long, resinous-atomiferous. - Torr. \& Gray, Fl. ii. 91 ; Baker in Fl. Bras. vi. 248 , in part. Eupatorium scandens, L. ; Jacq. Ic. Rar. t. 169 ; Michx. Fl. ii. 97. - Moist ground along streams, New England and W. Canada to Florida and Texas. (Mex. and W. Ind. to S. Brazil, mostly in peculiar forms, if not species.)

Var. pubéscens, Torr \& Grar, 1. c. From slightly to densely puberulent. - $M$. pubescens, Muhl. Cat. 71; Nutt. Gen. ii. 136. M. menispermea, DC. Prodr. v. 200. - Southern Atlantic States to Texas.

M. cordifólia, WiLLD. Puberulent or pubescent, frutescent at base: branchlets often striate-angulate: leaves broadly cordate and angulate: inflorescence more compound: heads 4 or 5 lines long: involucral bracts oblong-linear, obtuse or muticous : corolla-lobes oblonglanceolate, fully as long as the campanulate throat: akenes $1 \frac{1}{2}$ to 2 lines long, glabrous. Cacalia cordifolia, L. f. Suppl. 351, \& herb. Mutis, fide Baker, 1. c. 253. M. cordifolia (and according to Baker also $M$. rubiginosa), Smith. $M$. suareolens, HBK. Nov. Gen. \& Spec. iv. 135. $M$. gonoclada, DC. 1. c. 199. M. convolvulacea, DC. 1. c. - W. Louisiana, Hale. (Mex., W. Ind., Brazil.)

10. EUPATÓRIUM, Tourn. Tḥorougmwort, \&c. (Mithridates Eupator, king of Pontus.) - Perennial herbs, a few annuals, and some shrubby in the warmer regions; with commonly opposite leaves, mostly resinous-atomiferous and bitter; the small heads corymbosely cymose, or sometimes paniculate, rarely solitary. Fl. late summer and autumn. A vast genus as received in DC. Prodr. v. 141 , and more extended by Benth. \& Hook. Gen. ii. 24j; chiefly American. The sections are too confluent for good subgenera.

$\S 1$. Osmia, Benth. Involucre cylindrical or cylindraceous; the bracts squamaceous, coriaceous or firm-chartaceous, striate, pluriseriate, closely imbricated, the exterior successively shorter, obtuse: receptacle of the flowers flat or rarely convex: heads mostly clustered in corymbiform cymes: branching shrubs, or rarely herbs with suffrutescent base, tropical or subtropical: leaves all opposite. -Osmia, Schultz Bip. § Cylindrocephala, DC.

* Involucral bracts abruptly appendiculate with short foliaceous or partly colored squarrose tips: heads pedunculate. - \$ Phyllacrocephala, Gray, Pl. W right. i. 88.

E. sagittátum, Grax, 1. c. Probably suffruticose, puberulent: leaves (inch long) slenderpetioled, sagittate or hastate, otherwise entire, acute or acuminate : heads nearly half-inch long, in threes terminating divergent branchlets: involucre 30-40-flowered, its bracts firm. 
coriaceous, hardly striate, prominently appendaged by deltoid spreading foliaceous tips: flowers probably purplish. - "California," Coulter, no. 294. But the same as 253 of Upper Sonora in the Mexican collection, doubtless the real habitat. Yet may reach into Arizona. (Adj. Mex., Coulter, Gregg, Palmer.)

E. ivæfólium, L. Herbaceous or merely suffrutescent, somewhat hirsute or pubescent, strictly erect, 2 to 5 feet high : leaves lanceolate or the upper ones linear, hardly petioled, 3-nerved, sparsely and often coarsely serrate at the middle, mostly obtuse, roughish, an inch or two long: heads small ( 3 or 4 lines long), 10-20-flowered, in small and loose cymes: bracts of the cylindraceous involucre oblong, striate, with the very short somewhat truncate tips purple or greenish and slightly squarrose-spreading: flowers light purplish-blue or reddish. - Amoen. Acad. v. 405, \& Spec. ed. 2, I174; Torr. \& Gray, Fl. ii. 81 ; Griseb. Fl. W. Ind. 359 ; Baker in Fl. Bras. I. c. 290 . (E. obscurum, DC., \& E. concinnum, Hook. \& Arn., ex Baker.) E. calocephalum, Nutt. in Trans. Am. Phil. Soc. n. ser. vii. 286. Liatris oppositifolia, Nutt. in Am. Jour. Sci. v. 299. - Old fields, \&c., Lower Mississippi, Louisiana, and Texas; the var. Ludovicianum, Torr. \& Gray, 1. c., a form with less serrate leaves and less squarrose involucre, the tips of the upper scales mostly petaloid and purple. (W. Ind. \& Mex. to S. Brazil.)

$$
\text { * Inrolucral bracts wholly inappendiculate and appressed. }
$$

E. heteroclínium, Griseb. Herbaceous, with somewhat ligneous base, 2 or 3 feet high, rather strong-scented, pubescent: branches ascending: leaves rather short-petioled, ovatelanceolate with cuneate or truncate base to deltoid, obtusely serrate, 3-nerved, about an inch long: heads scattered, 5 or 6 lines long, 20-25-flowered, short-peduncled : involucre cylindraceous, glabrous, smooth and somewhat shining, pale; the bracts very obtuse, about 7-striate, more than usually deciduous: receptacle of the purple or bluish flowers convex. Fl. Brit. W. Ind. 358. Conoclinium rigidum, Chapm. in Bot. Gazette, iii. 6, not DC. - Keys of S. Florida, Blodgett, Chapman, Curtiss. (Jamaica.)

E. conyzoídes, VAFL. Shrubby, with herbaceous divergent flowering branches, 4 to 10 feet high, from villous-pubescent to glabrate : leares slender-petioled, ovate-lanceolatc, varying to ovate, acuminate, mostly cuneate at base, sparsely and acutely serrate or sometimes entire, 3-nerved or triplinerved (larger 3 to 5 and smaller 1 or 2 inches long) : heads numerous in the corymbiform open cymes, a third to half-inch long, 12-30-flowered: involucre cylindraceous or cylindrical, glabrous; the bracts 3-5-striate, rounded and somewhat greenish at the tip: receptacle of the pale blne or white flowers flat. - Symb. iii. 96; Schrank, Hort. Monac. t. 85 ; Baker, I. c. E. odoratum, L., in part. - Along the Rio Grande on the Mexican border of Texas, Berlandier, Schott, Bigelow, \&c. Mouths of the Mississippi, Trecul. E. Sabeanum, Buckley in Proc. Acad. Philad. 1861, 456. The form with stouter heads and firmer greenish-tipped involucral bracts, common in Mexico, \&c. (E. floribundum, HBK., $E$. divergens, Less., E. Maximiliani, Schrader, $E$. conyzoides folio molli et incano, etc., Pluk. t. 177, fig. 3), not the W. Indian form with more slender and pallid fewer-flowered involucre, and innermost bracts often acute, which approaches E. odoratum. (Trop. Amer.)

$\S 2$. Eupatoridu proper. Involucre various; the bracts from thin-membranaceous or scarious to herbaceous, nerveless or few-nerved, mostly lax, either imbricated or equal and nearly uniseriate: receptacle flat, not hairy.

* Involucre cylindrical and imbricate in the manner of $\S 1$, but thin-membranaceous and somewhat scarious when dry, faintly 3-striate: heads very numerous, corymbiform-cymose, mosily 5-10-flowered: leaves verticillate: stem herbaceous: herbage nearly destitute of resinous globules. - $\S$ Verticillata, DC.

E. purpureum, L. (Jok-Pre WEed, Trumper WeEd.) From pubescent to nearly glabrous : stems simple, 3 to 9 feet high, usually lineolate-punctate, often fistular : leaves commonly 3-6-nate, from oval-ovate to oblong-lanceolate, acuminate, coarsely serrate, reticulateveiny, the base narrowed into a short petiole : cymes polycephalous, compound-corymbose and numerous : involucre ( 3 or 4 lines long) whitish and flesh-colored : flowers dull flesh-color or purple, rarely almost white. - Spec. ii. 838 (Corn. Canad. t. 72 ; Herm. Parad. t. 158; Moris. Hist. vii. t. 18) ; Torr. \& Gray, Fl. ii. 81. E. trifolatum, L. 1. c., pl. Gronov. Virg. E. maculatum, L. Amcen. iv. 288, \& Spec. ed. 2, 1174 ; Bart. Fl. Am. Sept. t. 102. E. verti- 
latum, Muhl. in Willd. Spec. iii. 760. E. ternifolium, Ell. Sk. ii. 306 ; DC. Prodr. v. 151. Low or wet ground, New Brunswick to Saskatchewan, Florida, and westward in wooded stricts to New Mexico, Utah, and Brit. Columbia. Varies greatly, yet manifestly one ecies. The typical form very tall, growing in shady places, with smooth stem (usually rple above the nodes), large and thin leaves and loose inflorescence, its branches slenderduncled. A narrow-leaved and attenuated form (var. angustifolium, Torr. \& Gray, 1. c.) is falcatum, Michx. Fl. ii. 99, and E. lovigatum, Torr. Cat. Pl. N. Y. The best marked of e variations are the following.

Var. maculátum, DARL. Common in open ground, 3 or 4 feet high, often roughishbescent : stem commonly purple, striate or sulcate ; leaves somewhat rugose, 3-5-nate: inrescence more compact and depressed. - Fl. Cest. 453 ; Torr. \& Gray, 1. c. E. maculatum, 1. c. E. fusco-rubrum, Walt. Car. 199? E. punctatum, Willd. Enum. ii. 853. E. dubium, ir. Suppl. ii. 606. - The most widely distributed form.

Var. amóenum. Leaves opposite or at most 3-4-nate, ovate or oblong, smoothish : sm slender, 2 feet high : heads fewer and only 3-5-flowered.-E. amønum, Pursh, Fl. ii. 4. - An attenuate or depauperate form, growing in rather dry woods, mountains of Viraia to New York.

* Involucre imbricated, rather lax; the bracts of at least three or seldom only two lengths, the outer successively shorter. - \$ Subimbricata, DC.

- Heads as many as 20-flowered, large (about half-inch long): bracts of the involucre of 4 or 5 lengths, striate-nervose in the way of Brickellia: perennial herbs, of a Mexican type.

+ Leaves entire, tomentose beneath.

Bigelóvii, Gray. Cinereous-pubescent, paniculately branched: leaves all opposite, ate-lanceolate with a rounded or obscurely cordate base, acute, entire, short-petioled, berulent above, soft-tomentose beneath, 3-5-ribbed at base: inflorescence somewhat pa:ulate: peduncles 3-5-cephalous: involucre turbinate, tomentulose, regularly imbricated; ter bracts ovate-lanceolate, acute, coriaceous, the innermost linear: flowers purplish: enes nearly glabrous. - Bot. Mex. Bound. 75. - Arizona, on the Gila, Bigelow.

+* Leaves acutely serrate, narrowed at the pinnately veined base, very short-petioled.

3rúneri. Minutely puberulent, apparently only a foot or two high: leaves opposite, ate-oblong, acute, loosely veiny ( 2 or 3 inches long) : paniculate rather slender peduncles aring 3 or more sessile or short-peduncled heads : involucre camapanulate, of comparatively $\checkmark$ obscurely striate obtuse bracts; the outer oval, puberulent; inner ones scarious and ibrous, flesh-color (as probably are the flowers) : akenes glabrous. - Damp ground, in the cky Mountains at Fort Collins, N. Colorado, Dr. Bruner.

t-t t-t Leaves coarsely and often obtusely dentate, 3-5-ribbed at the cordate or sometimes truncate dilated base, slender-potioled, thin, bright greeen, acute or acuninate: flowers white or whitish: bracts of the campanulate involucre conspicuously striate-nerved: akenes minutely pubescent, not rarely 6-nerved, or with one or two of the nerves double!

'éndleri, Gray. A foot or two high, leafy, obscurely puberulent: leaves opposite or - upper alternate, deitoid-subcordate, tapering gradually to an acute or acuminate point: ads comparatively small and numerous, paniculate, all peduncled: bracts of the involucre obtuse, the outer oblong. - Proc. Am. Acad xvii. 205. Brickellia Fendleri, Gray, Pl. ndl. 63, \& Pl. Wright. ii. 73. (Some secondary or double ribs on many of the akenes unect this with Brickellia.) - Mountains of New Mexico and Arizona, Fendler, Wright, eene, Lemmon, Rusby.

'árryi, GRAY. Hirsutely pubescent (the spreading hairs of the stem somewhat glandular d viscid), loosely branched: leaves (so far as knowa) alternate, broadly ovate and rather sply cordate, crenately dentate: heads rather few and large in an open naked panicle, nder-pedunculate: bracts of the involucre thin, oblong-lanceolate, acuminate, the innerst produced into a setiform tip. - Bot. Mex. Bound. 75. - Sierra de Carmel, S. border of xas, on the Mexican side of the Rio Grande, Parry. (Mex.)

+ Heads 3-9-flowered, small (only 2 or 3 lines long), paniculate: leares (at least the lower) pinnately dissected, many of them alternate: involucral bracts 6 to 10 , narrow, acute or abruptly pointed, narrowly scarious-margined, nerveless: flowers white or whitish: herbs very leafy', much branched, with habit of Conyza and Artemisia. 
t- Very numerous heads in corymbosely paniculate cymules, 5-9-flowered.

F. pinnatífidum, Elc. Pubescent, 3 or 4 feet high . cauline leaves mainly opposite, sometimes 4-nate; lower 2-3-pinnately parted and incised into oblong or lanceolate divisions and lobes; npper once or twice parted into linear lobes: involucral bracts obtuse with a mucronate cusp. - Sk. ii. 295 ; DC. Prodr. v. 176 (not of 149 , which is the earlier E. bruniifolium, Hook. \& Arn., \& E. pinnatifissum, Buek.); Torr. \& Gray, 1. c. 83. - Low grounds, near the coast, N. Carolina to Florida.

+- +- Very numerous heads racemosely and thyrsoidly paniculate, 8-6-flowered: autumnal.

E. coronopifólium, W ILLD. l'uberulent and sometimes pubescent, somewhat glutinous and balsamic-aromatic, 3 or 4 feet high: lower leaves more commonly opposite, twice 3-7parted into linear entire or sparingly incised lobes; upper less compound, uppermost often entire, from broadly to narrowly linear: heads from over 2 to 3 lines long, in close spiciform panicles which are usually collected in an oblong thyrsus. - Spec. iii. 1750; DC. 1. c. 176 ; Torr. \& Gray, 1. c. 83. E. compositifolium, Walt. Car. 199. E. racemosum, Bertol. Misc. จ. 26, t. 1, from specimen with upper cauline and rameal leaves all entire. - Chrysocoma coronopifolia, Michx. Fl. ii. 102. - Sandy or dry soil, N. Carolina to Florida and Texas. Narrow-leaved forms too nearly approach the next.

E. fœniculáceum, WiLld. l.c. (Dog-Fennet.) Herbage fennel-scented when bruised, and slightly acrid: stem villous below with many-jointed slightly viscid hairs, 4 to 10 feet high, extremely leafy: leaves mostly glabrous, nearly all alternate, more compound than of the preceding and the lobes very narrowly linear or filiform: heads 2 lines long, loosely racemose-paniculate at the ends of the upper branches. - E. foniculoides, Walt. 1. c. E. leptophyllum, DC. 1. c. Artemisia procerior, etc., Dill. Elth. i. 38, t. 37. A. capillifolia, Lam. Dict. i. 267. Mikania artemisioides, Cass. Dict. Sci. Nat. liv. 130. Traganthes, Wallr. Sched. Crit. i. 456, ex Cass. 1. c. - Moist pine barrens and low fields, common from N. Carolina to Florida. The varieties, glabrum and lateriflorum, Torr. \& Gray, Fl., have no permanence. $\boldsymbol{E}$. leptophyllum, DC., is only the more slender form. (W. Ind.)

+++ Heads 3-15-flowered, 3 to 5 lines long: leaves undivided: flowers white (rarely purplish): involucre of rather few (8 to 12 or rarely 15 ) bracts.

* Thyrsoid-paniculate, suffruticose: involucral bracts 3-nerved.

E. solidaginifólium, GRAY. A foot or two high, with simple branches, glabrate or minutely pubescent: leaves opposite, very short-petioled, oblong- or narrowly ovate-lanceolate from a rounded base, acute, entire or obscurely dentate, 3-nerved at or near the base, 10 to 18 lines long: thyrsus small (2 or 3 inches long), leafy at base, oblong or interrupted: heads few and crowded in each short-pedunculate cymule, 3-5-flowered: involucral bracts about 8 , almost in two ranks, linear-lanceolate, acute: akenes pubescent. - Pl. Wright. i. 87, \& ii. 74. - Dry hills between the Limpio and the Rio Grande in W. Texas, and near Santa Cruz, Arizona, Wright, Pringle, \&c.

+ + + Corymbosely cymose or fastigiate inflorescence: herbaceous perennials, mostly copiously resinous-atomiferous, some species becoming balsamic-glutinous: involucral bracts nerveless or nearly so.

- Leaves conspicuously petioled from a mostly truncate or abrupt base, strongly serrate: cymes broad: involucre cinereous-pubescent.

E. mikanioídes, Снарм. 'Tomentose-pubescent when young, soon glabrate: stems simple, a foot or two high from a creeping base: leaves opposite, deltoid-ovate or the uppermost oblong, obtuse, thickish and rather fleshy, glandular-punctaite, obtusely dentate (an inch or two long): heads 5-flowered: involucral bracts linear, rather obtuse. $-\mathrm{Fl}$. 195. E. crassifolium, Shuttleworth in distrib. coll. Rugel. - Low and sandy ground, coast of Florida, Chapman, Rugel, \&c.

E. serótinum, Mrcux. Puberulent : stems 5 to 7 feet high, corymbosely branched above: leaves oblong- or ovate-lanceolate, acute or acuminate, thinnish, acutely serrate (3 to 6 inches long), many of the upper alternate, some of these cuneate at base: heads 7-15-flowered, very numerous: involucral bracts (10 or 12) linear-oblong, very obtuse. - Fl. ii. 100; Torr. \& Gray, Fl. ii. 89. E. ambiguum, Hook. Comp. Bot. Mag. i. 96, as to 'Covington' plant, is either this species or a (hybrid ?) form between it and E. semiserratum, DC., the E. parviflorum, Ell. - Low grounds, Maryland to Iowa, Florida, and Texas ; Sept. to Nov. (Adj. Mex.) 
$==$ Leaves from linear to oblong, sessile or some short-petioled from a narrowed base, chiefly opposite: heads mostly 5-flowered, occasionally 6-7-flowered.

a. Involucral bracts with conspicuous white-scarious acute tips; the inner equalling the flowers.

E. álbum, L. Pubescent with jointed spreading hairs: stem 2 feet high: leaves oblonglanceolate or narrowly oblong, commonly obtuse, coarsely serrate, veiny, sessile (2 to 4 inches long): cymes fastigiate: involucre (4 or 5 lines long) mostly bright white and glabrous throughout, well imbricated; its bracts slender-mucronate, the outer sometimes pubescent and dark-dotted with resinous globules. - Mant. 111; Walt. Car. 199. E. glandulosum, Michx. Fl. ii. 98. E. stigmatosum, Bertol. Misc. v. 15, t. 5. - Sandy fields and pine barrens, Long Island, N. Y., and Penn. to Florida and Louisiana.

Var. subvenósum. More minutely roughish-pubescent: leaves smaller, only an inch or two long, mostly acute, with smaller and more appressed serratures, less veiny and more manifestly 3-nerved at base, where the upper cauline are not narrower : involucral bracts not so white. - Long Island (E: S. Miller) and New Jersey. Burke Co., N. Carolina?

E. leucólepis, Torr. \& Gray. Puberulent : stem slender, about 2 feet high : leaves lanceolate or linear, minutely and sparingly appressed-serrate, thickish, obscurely 3-nerved at base, closely sessile ( 1 to 3 inches long) : involucre ( 3 lines long) canescently pubescent; the narrowed tips of the bracts white-scarious. - Fl. ii. 84. E. linearifolium, Miclix., Pursh, \&c., partly. E. hyssopifolium, Ell. Sk. ii. 296; Hook. Comp. Bot. Mag. i. 96. E. glaucescens, var. leucolepis, DC. 1. c. 177. - Moist pine barrens, New Jersey to Florida and Louisiana, in the low country.

b. Involucral bracts obscurely if at all scarious, mostly obtuse, at length shorter than the flowers.

E. hyssopifólium, L. Merely puberulent: stems about 2 feet high, very leafy, commonly with fascicles in the axils, simple, corymbosely branched at summit: leaves occasionally verticillate, linear, obtuse, entire or sparingly dentate, narrowed at base, 是 to 2 inches long, the broader forms with lateral nerves: cymes crowded: involucre (3 lines long) canescently pubescent and glandular; bracts rather few, the inner with somewhat scarious margins and tips, obtuse, sometimes apiculate.-Spec. ii. 836 (Dill. fig. \& Pluk.); Torr. \& Gray, F1. ii. 84. E. linearifolium, Walt. Car. 199; Michx.1. c. (partly); Willd. 1. c. E. linearifolium \& hyssopifolium (chiefly), DC. 1. c.-Dry and sterile soil, Mass. to Florida and Texas, along and toward the const. Varies greatly in the foliage, the extreme forms being, on one hand, that with very narrowly linear and much fascicled leaves; on the other, the

Var. laciniátum. Leaves lanceolate and linear-lanceolate, irregularly and coarsely dentate, even laciniate. - Penn. and Kentucky to Carolina and Louisiana.

Var. tortifólium. Leaves oblanceolate or sṕatulate-linear, mostly short, all entire, inclined to be vertical by a twist at base, many of them alternate. $-E$. tortifolium, Chapm. in Bot. Gazette, iii. 5. E. cuneifolium, A. H. Curtiss, distrib. 1194.- Sandy pine barrens, S. Carolina, Georgia, and Florida. The lower leaves resemble the uppermost of $E$. cuneifolium, but are all entire, often reflexed as well as vertical.

E. cuneifólium, WILLD. Habit, involucre, and pubescence of the preceding: leaves short (half to a full inch long), oblanceolate to cuneate-spatulate, obtuse, glancescent, few-toothed toward the extremity, or the upper entire, uppermost very small and oblong-linear. - Spec. iii. 1753, excl. syn. (not DC.) ; Torr. \& Gray, 1. c. 85; Chapm. 1. c. E. linearifolium, Michx. 1. c., in part. E. glaucescens, Ell. 1. c. 297 ; DC. 1. c., excl. var. E. hyssopifolium, DC. 1. c., in part. E. cassinifolium, Bertol. Misc. v. 17, t. 6. - Dry ground, South Carolina, Georgia, Alabama, and Florida.

F. semiserrátum, DC. Tomentulose-pubescent: stems 2 or 3 feet high, much branched above: leaves oblong-lanceolate, mostly acute or acuminate (commonly 2 or even 3 inches long), serrate with numerous unequal teeth from above or below the middle to the apex, triplinerved, rather veiny, narrowed at base, the lower into a short nostly distinct petiole: cymes numerous : heads small : involucre ( 2 lines long) canescently pubescent, of few bracts; the longer linear-oblong, very obtuse, the others much shorter. $-E$. semiserratum \& $E$. cuneifolium, DC. Prodr. v. 177. E. parviflorum, Ell. Sk. ii. 299; Torr. \& Gray, 1. c., not Swartz. E. ambiguum, Hook. Comp. Bot. Mag. i. 96 (1835), in part only, the Jacksonville plant, but heads not "8-10-flowered." - Virginia to Florida, Arkansas, and Texas. In dry and open ground, plants with smaller and firmer leaves pass into

Var. lancifólium. Glabrate: leaves lanceolate and verging to linear, 5 to 2 lines 
wide, rather rigid, 3-nerved from near the base. - E. parviflorum, var. lancifolium, Torr. \& Gray, 1. c. - W. Louisiana and Texas, Drummond, Leavenworth, Hale.

E. altíssimum, L. Pubescent: stems 4 to 7 feet high, branched at summit, very leafy: leaves lanceolate, tapering gradually to both ends, acuminate, acutely serrate above the middle, 2 to 4 inches long, with 3 conspicuous parallel nerves (giving the aspect of a triplinerved Solidago); uppermost entire: cymes numerous and irregular: heals fully 3 lines long: involucre canescently pubescent; its bracts oblong and very obtuse. - Jacq. Hort. Vind. t. 164; Michx. Fl. ii. 97; Torr. \& Gray, I. c. Kuhnia glutinosa, DC. Prodr. v. 127, not Ell. - Dry ground, Penn. to Iowa, N. Carolina, and Texas.

$===$ Leaves sessile or very short-petioled with a broad base, normally opposite, occasionally 3-nate: involucre pubescent.

a. Heads mostly 5-flowered, in one species 6-8-flowered: herbage roughish-pubescent: inner bracts of involucre acutish or acute, or sometimes acuminate at the thin tip.

E. teucrifólium, WILLD. Stem 2 or 3 and even 8 feet high, not very leafy: leaves oblong, coarsely and irregularly serrate, rarely somewliat incised, slightly petioled (2 to 4 inches long); the upper small and few-toothed, sometimes hastately 1-2-toothed near the broad sessile base, or lanceolate and entire, usually alternate, as are the branches of the corymbiform general inflorescence: cymes rather small and dense. - Spec. iii. 1753, \& Hort. Berol. t. 32 ; Torr. \& Gray, 1. c. E. pilosum, Walt. Car. 199? E. verbenafolium, Michx. Fl. ii. 98. E. lanceolatum, Muhl. in Willd. I. c. E. pubescens, Bigel. Fl. Bost. ed. 2, 296, not Muhl. - Moist and shady ground, Mass. to Florida and Louisiana.

E. rotundifólium, L. Stern a foot to a yard high, strict, corymbosely branched at summit: leaves in the typical form round-ovate, obtuse or abruptly acute, sessile or nearly so from a truncate or obscarely cordate base, regularly and closely crenate-dentate, veiny (larger 2 inches long): cymes corymbosely fastigiate, dense. - Spec. ii. 837 (PIuk. Alm. 141, t. 88, fig. 4); Torr. \& Gray, l. c. E. Marrubium, Walt. Car. 199 ? - Dry and sterile soil, especially in pine barrens, Canada ! and New Jersey to Florida and Texas.

Var. scábridum. A form with smaller (an inch or two long) and more scabrous or cinereous leaves, the upper and sometimes all with cuneate base; affecting drier and more sterile soil. - E, scabridum, Ell. Sk. ii. 298; Chapm. FI. 196. - Lower part of S. Carolina to Florida and Texas.

Var. ovátum, Tork. Commonly taller and larger: leaves ovate (often 2 or 3 inches long), acute, hardly truncate at base, more strongly serrate, sometimes laciuiately so, either roughish-pubescent or smoother and glabrate: heads sometimes but not generally 7-8-flowered. - Torr. in DC. Prodr. v. 178. E. pubescens, Muhl. in Willd. Spec. iii. 1155; Willd. Enum. ii. 852 ; Torr. \& Gray, 1. c. . E. obovatum, Raf. in Med. Rep. hex. 2, v. 359 ? E. ovatum, Bigel. Fl. Bost. ed. 2, 296. - Massachusetts to S. Carolina, near the coast.

b. Heads 5-flowered: herbage glabrous: narrow involucre more imbricated; its bracts obtuse.

E. sessilifólium, L. Corymbosely branched above, 2 to 6 feet high: leaves oblong- or ovate-lanceolate, tapering from near the rounded or truncate closely sessile base into a narrow acumination, finely serrate, pinnately veiny ( 3 to 6 inches long): cymules small and crowded, few-headed, numerous in effusely compound cymes. - Spec. ii. 837; Torr. \& Gray, 1. c. E. truncatum, Ell. Sk. ii. 298, not Willd. - Dry and wooded ground, Mass, to lllinois, Virginia, and along the mountains to Alabama.

c. Heads 10-15-flowered (or by confluence sometimes many-flowered), much crowded: leaves perfo-

liate or connate-clasping, divaricate, narrow and elongated, one-ribbed: stems 2 to 4 feet high.

E. perfoliátum, L. (Thoroughwort, Boneseт.) Sten villous-pubescent, fastigiately branched above, stout: leaves lanceolate, connate-perfoliate, tapering gradually to an acuminate apex, finely and closely crenate-serrate, rugose, soft-pubescent, or almost tomentose beneath, 4 to 8 inches long: heads small ( 3 lines long) but very numerous, in dense compound-corymbose cymes, mostly 10-flowered: bracts of the involucre linear-lanceolate, with slightly scarious acutish tips. - Spec. ii. 838 (Pluk. Alm. 140, t. 87, fig. 6); Bart. Veg. Med. Mat. t. 37 ; Bigel. Med. Bot. i. 38, t. 2 ; Raf. Med. Bot. t. 36 ; Torr. \& Gray, 1. c. 88. - Wet ground, New Brunswick to Dakota, south to Florida and Louisiana. Varies with purple flowers (Penn. Porter), and with leaves in threes (Virginia, Curtiss, \&c.); also into

Var. truncátum, with the upper or even all of the leaves disjoined and truncate at 
base; some of them alternate.-E. truncatum, Muhl. in Willd. Spec. iii. 1751. E. salvioefolium, Sims, Bot. Mag. t. 2110. - With the normal form.

Var. cuneátum, ENGELM. (E. cuneatum, Engelm. in Torr. \& Gray, 1. c.), with smaller leaves narrowed as well as disjoined at base, and fewer-flowered heais, has the appearance of being a hybrid between $E$. serniserratum and $E$. perfoliatum. - Eastern Arkansas and Missouri, Engelmann. Also Louisiana, Hale, a form between this state and the preceding.

E. resinósum, Torr. Puberulent, glutinous with resinous atoms: stem slender, 2 or 3 feet high, fastigiate-corymbose at summit: leaves linear-lanceolate ( 4 to 6 inches long, 4 to 6 lines wide), half-clasping or slightly connate, finely serrate, glabrate above, canescent beneath ; cymules numerous in compound cymes: bracts of the 10-15-flowered involucre narrowly oblong, obtuse. - DC. Prodr. v. 176; Torr. \& Gray, Fl. ii. 88. - Wet pine barrens, New Jersey, where it was first collected by Bartram.

++++ Heads 24-30-flowered, hardly over 2 lines long: bracts of the involucre of three

lengths, obtuse, thin, conspicuously few-nerved: habit of the following section.

E. pycnocéphalum, Liss. Pubescent or nearly glabrous : stems slender, erect or spreading from a perennial root, a foot or two high: leaves membranaceous, deltoid-ovate or subcordate, acute or acuminate, coarsely serrate or dentate, slender-petioled: cymes small and compact, solitary or corymbosely clustered at the end of naked branches : heads very shortpedicelled: involucre campanulate; the bracts mostly glabrous, oblong and oblong-linear, very obtuse; innermost equalling the white flowers. - Less, in Linn. vi. 404. E. Schiedeanum, Schrad. Ind. Sem. Hort. Gœett. 1832, 3; DC. Prodr. v. 159. E. muitinerie, Benth. Pl. Hartw. 76. E. Sonorce, Gray, Pl. Wright. ii. 76. - Rocky ravines, S. Arizona and along the Mexican borders of Texas; a form with small and deeply dentate leaves, and comparatively few and small heads. E. Schiedeanum, var. grosse-dentatum, Gray, Bot. Mex. Bound. 76. (Mex., \&c.)

* * * Involucre (campanulate or oblong) of bracts all of the same length or nearly so, in one or two series, or with only a few accessory and shorter ones at base: leaves mainly opposite, petioled. $-\$$ Eximbricata, DC.

+ Shrubby, freely branched: flowers white, sometimes purplish-tinged.

E. Wríghtii, GraY. A foot or two high, puberulent: branches very leafy: leaves small (half-inch long), ovate, obtuse, entire or obscurely few-toothed, thickish, scabrous, abruptly contracted into a short margined petiole : heads ( 3 or 4 lines long), about 12-flowered, rather few in a somewhat leafy terminal cyme: involucre half the length of the flowers, of about 10 oblong-lanceolate acute or obtusish greenish obscurely 3-nerved and equal bracts in a double series, sometimes one or two small accessory ones. - Pl. Wright. i. 87, ii. 73. Guadalnpe Mountains, western borders of Texas, Wright.

E. villósum, Swartz. Shrub 4 to 6 feet high, rusty-pubescent: leaves ovate or somewhat deltoid, rather obtuse, sparingly serrate or some entire, tomentulose beneath ( 1 to 3 inches long), on short slender petioles: heads small (2 or 3 lines long), 8-15-flowered, numerous and crowded in corymbiform cymes: involucre half the length of the fully developed flowers, of 8 to 10 oblong-lanceolate obtuse and nerveless equal bracts. - DC. Prodr. v. 172 ; Chapm. Fl. 196. E. Cubense, DC. l. c.?- S. Florida, Blodgett, Garber, Curtiss, \&c. (W. Ind.)

E. ageratifólium, DC. Shrub 3 to 7 feet high, with slender and spreading mostly herbaceous branches, green and nearly glabrous: leaves deltoid-ovate, obtusish or obtusely acuminate, coarsely and rather obtusely dentate (2 or 3 inches long), slender-petioled: heads (5 lines long), pedicelled, numerous in corymbiform cymes, 10-30-flowered : involucral bracts 8 to 12, narrowly lanceolate or linear, acutish, greenish, nerveless above, somewhat 2-ribbed at base. - Prodr. v. 173; Torr. \& Gray, Fl. ii. 90 (var. Texense, which does not differ); Gray, Pl. Lindh. ii. 219; Griseb. Fl. W. Ind. 360. E. Berlandieri, DC. 1. c. 167. E. Lindheimerianum, Scheele in Linn. xxi. 599. Bulbostylis deltoides, Buckley in Proc. Acad. Philad. 1861, 456. - Rocky shaded hills and ravines, Texas, Lindheimer, Wright, \&c. ; fl. Nov, to May. (W. Ind., Mex.)

++ Herbaceous perennials, or the first species barely lignescent at base.

+ Corolla wholly glabrous even in the bud.

E. occidentále, Hook. Minutely puberulent, glabrate: stems 8 to 20 inches high, strict, simple or with few ascending branches: leaves ovate with truncate base, rarely subcordate 
or roundish, obtuse or acute, sparingly dentate, sometimes merely repand or entire, an inch or two long, rather short-petioled : cymes small and rather compact, somewhat paniculate: heads ( 4 or 5 lines long) 15-25-flowered: involncre hardly longer than the mature akenes; its bracts about 15 in two series, nearly equal, lanceolate, rather firm, nearly nerveless: corolla white or flesh-color. - Fl. i. 305 ; Torr. \& Gray, Fl. ii. 91. E. Oregrnum, Nutt. Trans. Am. Phil. Soc. vii. 286. - Crevices of rocks, Washington Territory and Oregon east of the Cascade Mountains, N. Nevada, and through the Sierra Nevada of California.

Var. Arizónicum. Larger (2 feet high), more branching and floribund: leaves sometimes $2 \frac{1}{2}$ inches long. $-E$. ageratifolium, var.? herbaceum, Gray, P1. Wright. ii. 74. E. Berlandieri, Gray, Bot. Mex. Bound. 76, not DC. - Mountains of Arizona and New Mexico : also California, Bridges. The opposite extreme from the plant of Oregon, which has small and thinnish leaves, but not unlike plants from the Sierra Nevada.

E. incarnátum, WALT. More or less pubescent: stems 2 or 3 feet long, slender and weak, loosely or diffusely branched: leaves thin, deltoid, or ovate-lanceolate with broad truncate or cordate base, tapering to a mostly acuminate apex, coarsely crenate or serrate (an inch or two long), veiny, slender-petioled: cy'mes small and lax: heads (2 or 3 lines long) about 20-flowered: involucre nearly equalling the pale purple or sometimes white corolla; its bracts unequal, narrow, thin and 2-nerved when dry, the inner linear, a few external ones mouch shorter. - Car. 200; Ell. Sk. ii. 306; DC. Prodr. v. 175; Torr. \& Gray, 1. c. - N. Carolina to Florida, Louisiana, and Texas. (Adj. Mex.)

\footnotetext{
++ Lobes of the pure white corolla more or less bearded outside in the bud, sometimes very sparsely and minutely so, or the beard fugacious: heads 15-30- or sometimes 8-14-flowered, cymose.

$=$ Involucre 2 or 3 lines long, rather narrow; the linear bracts nearly equal, green externally and nerveless when fresh, but more or less 2-nerved when dried: cymes corymbiform and naked, usually ample.
}

E. ageratoídes, L.f. Nearly glabrous, sometimes pubescent: stems 1 to 3 feet high, branching above: leaves bright green, membranaceous, long-petioled, ovate, with truncate or subcordate or broadly cuneate base, acuminate, coarsely and rather sharply dentateserrate, conspicuously veiny, 3 to 5 inches long: cymes ample, corymbose-cymose. - Suppl. 355; DC. Prodr. v. 175; Torr. \& Gray, Fl. ii. 89. E. urticœfolium, Reich. Syst. iii. 719 ; Michx. Fl. ii. 100, not L. f. E. altissimum, L. Syst. Veg. 614. E. odoratum? Walt. Car. 200? E. Fraseri, Poir. Suppl. ii. 600 (Lam. Ill.t. 672, fig. 4). Ageratum altissimum, L. Spec. ii. 839 (Corn. Canad. t. 21 ; Moris. Syst. sect. 7, t. 18, f. 11).-Moist woodlands and rich soil, Canada to Minnesota, Arkansas, Georgia, and Louisiana. A state with viscid-villous stem and petioles, Bedford Co., Virginia, C'urtiss.

Var. angustátum. Smaller, slender: leaves from ovate-lanceolate to broadly lanceolate, much acuminate, coarsely serrate with only 3 to 6 teeth on each margin, commonly cuneate at base : cymes looser : heads only 8-12-fowered. - W. Louisiana, Hale. Texas, Wright, Lindheimer.

F. aromáticum, L. Herbage not aromatíc, minutely puberulent: stems more simple, a foot or two high: leaves dull green, thicker, mostly short-petioled, ovate, often subcordate, acutish or obtuse, crenate-serrate, $1 \frac{1}{2}$ to 3 inches long: cymes simpler. - Spec. ii. 839 , fide herb. \& syn. Pluk. \& Gronov.; DC. 1. c. ; Torr. \& Gray, 1. c. E. cordatum, Walt. Car. 199 ? E. ceanothifolium, Muhl. in Willd. Spec. iii. 1755 ; Ell. Sk. ii. 303; DC. 1. c. - Dry woods and pine barrens, mostly in sterile soil, coast of Massachusetts to Florida. Passes on the one hand almost into the preceding; on the other, into

Var. melissoídes. Slender, roughish-puberulent, strict, somewhat paniculately cymose at summit: heads 5-12-flowered: leaves subcordate-ovate or oblong, $\frac{8}{4}$ to 2 inches long, obtuse, crenulate-dentate or with few coarser teeth, very short-petioled or even subsessile, somewhat scabrous, most of them much shorter than the internodes. $-E$. melissoides, Willd. 1, c. E. cordiforme, Poir. Suppl. ii. 600. E. cordatum, DC. 1. c., \& var. Fraseri. Sterile soil, Penn.? to Florida and Louisiana.

Var. incísum. An insufficiently known plant, with the straggling habit and glabrous involucre of $E$. incarnatum; probably a form either of this or the preceding species: leaves slender-petioled, thickish, coarsely or laciniately dentate, broadly cuneate at base, considerably like those of $E$. colestinum, var. salinum, Griseb. . "flowers very fragrant." $-E$. suaveolens, Chapm. Bot. Gazette, iii. 5, not of HBK. - Manatee, \&c., S. Florida, Chapman. 
$==$ Involucre less than 2 lines long; the bracts broader, green externally, 2-3-nerved when dry: inflorescence somewhat paniculate and leafy.

E. paupérculum, GRAx. A foot or two high, nearly glabrous: leaves ovate-lanceolate (mostly inch long), roundish at base, obtusely serrate, on rather short slender petioles: heads 25 -flowered, small (2 lines high), few in the numerous small cymes, which are paniculately disposed, terminating short leafy branches: bracts of the involucre 10 or 12, oblonglanceolate, puberulous, little over half the length of the white flowers: corolla-lobes slightly hirsute outside or becoming naked : pappus soft and white. - Proc. Am. Acad. xvii. 205. Santa Rita Mountains, S. Arizona, along brooks and on dripping rocks, Pringle.

$===$ Heads comparatively large and few in the cymes, 25-35-flowered: involucre 3 or 4 lines high, rather broad.

E. Rothróckii. Glabrous (or peduncles somewhat pubescent) : stems a foot or two high, simple or brachiately branched above: leaves bright green, ovate or deltoid-ovate, usually acuminate, coarsely and sharply serrate, sometimes irregularly or doubly serrate, and the teeth tipped with a callous gland (the larger 2 inches long, with petiole half-inch or less, smaller in depauperate plants nearly sessile): bracts of the involucre 15 to 17 , equal and similar, linear-lanceolate, mostly acute, glabrous, when dry pale and somewhat scarious and conspicuously 2-3-nerved, nearly equalling the white and soft barbellulate-scabrous pappus : corolla-lobes rather strongly bearded externally. - Mountains of S. Arizona : on Mount Graham, Rothrock (740,74I); Chiricahua Mountains, Lemmon. Heads larger and fewer than in the Mexican $E$. grandidentatum, DC.; the involucre not imbricated as in $E$. Fendleri.

§3. ConoclínIUm, Benth. Receptacle of the flowers conical or hemispherical : otherwise as in the Eximbricata subsection of the preceding: habit of Ageratum § Colestina: flowers blue or violet (sometimes white), sweet-scented: bristles of the pappus rather scanty in a single series: leaves opposite : perennial herbs. Conoclinium, DC. Prodr. v. 135.

E. cœlestínum, L. (Mist-rLower.) Somewhat pubescent: stems erect, branched at summit: leaves deltoid-ovate or subcordate, obtuse or acutish, obtusely serrate, rarely with some coarser salient teeth, slender-petioled: cymes rather compact: receptacle obtusely conical. - Spec. ii. 838 (Dill. Elth. t. 114; Pluk. Mant. t. 394); Michx. Fl. ii. 100. Colestina carulea, Spreng. Syst. iii. 446, not Cass. Conoclinium calestinum, DC. 1. c. ; Torr. \& Gray, Fl. ii. 92. - Moist shady ground, New Jersey to Florida and Texas, and west to Arkansas and Illinois. Conoclinium dichotomum, Chapm. in Bot. Gazette, iii. 5, appears to be a lax and more branched form, of Florida and Texas, found only on the coast, approaching the var. salinum, Griseb. Cat. Cub. 146. (Cuba.)

Đ. betónicum, HemsL. From tomentose-villıus to glabrate : stems lax, loosely branching : branches naked and pedunculiform at summit, bearing some small corymbose or paniculate cymes : leaves oblong, mostly obtuse, in the original form with cordate base, crenate, petioled : receptacle low-conical. - Biol. Centr.-Am. Bot. ii. 93. Conoclinium betonicum, DC. Prodr. v. 135; Gray, Bot. Mex. Bound. 76. - Southern border of Texas on the Rio Grande, Schott, a glabrate form. (Adjacent Mex.)

Var. subíntegrum. Leaves sometimes truncate, commonly obtuse or cuneate at base, obscurely crenate, denticulate, repand or entire, from villous or cinereous-tomentulose to nearly glabrous. - C'onoclinium betonicum, var. integrifolium, Gray, PI. Wright. i. 88 . Eupatorium Hartwegi, Benth. Pl. Hartw. 19 ? - Southern border of Texas, Wright, Bigelow, \&c. (Mex.)

E. Gréggii. Minutely puberulent: stems erect, a foot or two high, bearing one or few small and dense cymes at the naked pedunculiform summit: leaves nearly sessile, palmately 3-5-cleft or parted; the divisions laciniate-pinnatifid into narrow lobes : receptacle low-conical. - Conoclinium dissectum, Gray, Pl. Wright. i. 88; Bot. Mex. Bound. 76. Eupatorium dissectum, Gray, Proc. Am. Acad. xviii. 100 (name only), not Benth. Bot. Sulph. 113, with which Hemsley has confounded it. - Low ground, S. Texas to Arizona near the Mexican border, Wright, \&c. (Adjacent Mex., first coll. by Gregg.)

E. LÚteuM, Raf. in Med. Rep. N. Y., is doubtless a false species. E. CRAssifólidm and E. vIOLACEUM, Raf. FI. Ludov, are fictitious, as are all the species of that work. 
11. CARMINÁtiA, Moçino. (Prof. B. Carminati, of Pavia, wrote on the materia medica.) - Single species, an annual; with opposite or partly alternate broad and long-petioled thin leaves, and racemiform-paniculate heads of whitish flowers. - DC. Prodr. vii. 267 ; Deless. Ic. Sel. iv. 98.

C. tenuifíra, DC. 1. c. Sparsely pubescent or hirsute: stems a foot to a yard high, terminating in a leafless virgate panicle: leaves broadly deltoid-ovate, as wide as long, repanddentate, veiny, often shorter than the petiole: heads half-inch long: soft pappus bright white. - Gray, Pl. Wright. ii. 71. - New Mexico and Arizona, Wright, \&c. (Mex., first coll. by Moçino.)

12. KUUHNIA, L. (Dr. Adam Kuhn, of Philadelphia, took the original species to Linnæus.) - Perennials of Atlantic U. S. and Mexico; with chiefly alternate leaves (more or less sprinkled with resinous atoms, as in allied genera), usually. with scattered or corymbosely cymose heads, these of 10 to 30 whitish or at length purple flowers, produced in late summer or autumn: pappus mostly tawny. - Spec. ed. 2, ii. 1662 (excl. syn. Pluk.), \& Gen. ed. 6, 95 (the anthers wrongly described, from imperfect or monstrous blossoms). Critonia, Gærtn., not Browne. Kuhnia § Strigia, DC. Prodr. v. 126.

K. Schaffreri, Gray, Proc. Am. Acad xvii. 207, of Mexico, is a peculiar species, with scapiform monocephalous peduncles and tuberous roots. The rest of the genus is the following.

K. eupatorioídes, L. Stems wholly herbaceous, 2 or 3 feet high: leaves from oblong(or even ovate-) lanceolate to linear, irregularly few-toothed or upper ones entire, the lower narrowed at base and sometimes short-petioled: pubescence minute or soft and cinereous, or hardly any: heads more or less cymose-clustered. - L. f. Dec. ii. 21, t. 11; Torr. \& Gray, Fl. ii. 78. $K$. eupatorioides \& $K$. Critonia, Willd. Spec. iii. 17ร3. $K$. dasypia, glutinosa, elliptica, tuberosa, fulva (media, glabra), \& pubescens, Raf. Citionia Kuhnia, Grertn. Fruct. ii. 411, t. 174, f. 7; Michx. T1. ii. 101.-Dry ground, New Jersey and Penn. to Montana, and south to Texas. Very variable; the extreme forms are

Var. corymbulósa, Torr. \& GraY, 1. c. A foot or two high, stouter, somewhat cinereous-pubescent or tomentulose: leaves rather rigid and sessile, from oblong to lanceolate, coarsely veiny: heads rather crowded. $-K$. glutinosa, Ell. Sk. ii. 292, not DC. $K$. suaveolens, Fresen. Ind. Sem. Francf. 1838. K. Maximiliani, Sinning in Neuwied. Trav. K. macrantha, Buckley in Proc. Acad. Philad. 1861, 456. - Prairies and plains, Illinois to Dakota and Nebraska, and south to Alabama and Texas.

Var. grácilis, Torr. \& GRAT, 1. c. Leaves from lanceolate to very narrowly linear, few-toothed or all but lower entire, mintely puberulent or nearly glabrous : general inflorescence more open and paniculate. $-K$. paniculata, Cass. Dict. xxiv. 516; DC. 1. c. K.Critonia, Ell. l. c. - Carolina to Florida, Alabama, \&c. Seems to pass into the following.

K. rosmarinifólia, VExT. Perhaps more lignescent at base, a foot or two high: leaves all entire, linear or linear-lanceolate, mostly with revolute margins, and the upper almost filiform, from a quarter of a line to 2 lines wide, somewhat scabrous: heads more scattered or paniculate: plume of the bristles of the pappus perhaps a little shorter. - Hort. Cels. t. 91 (poor figure of a broadish-leaved form, with too much imbricated involucre) : DC. 1. c. (excl. syn. Ort. ?), but surely from Mexico, not "Cuba." $K$. frutescens, Hornem. Hort. Hafn. ii. 791. K. leptophylla, Scheele in Linn. xxi. 598. K. eupatorioides, var. gracillima, Gray, Pl. Lindh. ii. 218, a very slender-leaved form, which connects with the slenderest of the preceding. - Rocky open ground, Texas to Arizona. (Mex.)

13. BRICKELLIA, Ell. (Dr. John Brickell of Georgia, correspondent of Muhlenberg and Elliott.) - Herbs or undershrubs ; with opposite or alternate veiny leaves, and variously disposed heads of white, ochroleucous, or rarely fleshcolored flowers, in late summer. A genus of about 40 species, of the warmer parts of the U. S. and Mexico. A single annual species ( $B$. diffusa, which may 
reach Florida) is widely tropical American, and there is an anomalous species in Brazil. - Sk. ii. 290 ; Benth. Bot.' Sulph. 22 ; Gray, Pl. Wright. i. 84, \& Proc. Am. Acad. xvii. 206; Benth. \& Hook. Gen. ii. 247. Coleosanthus, Cass. Dict. x. 36. Rosalesia, Llave \& Lex.? Clavigera \& Bulbostylis, DC. Prodr. v. 127, 138.

B. mLstÁtA, Benth., is a well-marked species of Lower California, described in Bot. Sulph. 21. In that work the genus was first extended to its proper limits, but made to rest on the bulbous base of the style (which is of little account) instead of the 10-costate akene.

* Heads 35-50 flowered, large or middle-sized: pappus-bristles merely scabrous or densely serrulate.

- Herbage white-tomentose: leaves rounded, pointless.

B. incána, Gray. A foot or two high, loosely branched from a suffrutescent base; dense and fine tomentum somewhat deciduous: leaves alternate, sessile, subcordate-rotund or ovate, entire (less than inch long) : heads solitary terminating the branchlets, inch high, pedunculate : involucre broadly campanulate, pluriserial; its bracts firm-chartaceous; short outer ones ovate, inmost lanceolate-linear: akenes (5 lines long) cinereous-pubescent. - Proc. Am. Acad. vii. 350, \& Bot. Calif. i. 300. - S. E. California along the Mohave River, Cooper, Parry, Parish.

++ Puberulent to almost glabrous: leaves sessile or subsessile, all alteruate, not cordate, * Rigid-corjaceous, spinulose-pointed and toothed: fruticulose.

B. atractyloídes, Gray. A foot or less high, woody except the new shoots, much branched : leaves ovate, acuminate, bright green, minutely scabrous-atomiferous, 3-nerved and reticulate-veined (an inch or less long): branchlets terminating in a solitary (balf-inch long) and slender-pedunculate hearl: involucre campanulate; its bracts firm-chartaceous; outer ovate, acuminate, little shorter than the linear-lanceolate innermost.-Proc. Am. Acad. viii. 290. - Rocky ravines, S. Ltah (Palmer, Parry) to S. E. California.

+- Leaves not coriaceous, pointless, seldom an inch long, sometimes viscidulous: stems herbaceous from a lignescent base or stock, a span to a foot or so high, leafy to the top: heads mostly singly terminating corymbose leafy branches.

$=$ Heads three fourths of an inch long, involucrately surrounded or subtended by small uppermost leaves.

B. Greénei, GraY. Very viścid; leaves ovate, obtuse, minutely more or less serrate, and the lower short-petioled; upper oblong and often entire, uppermost forming accessory loose bracts to the involucre: proper involucral bracts lanceolate and linear, acuminate, glabrous: akenes not glandular, glabrous, or at the upper part hirtellous with a few scattered short bristles on the ribs. - Proc. Am. Acad. xii. 58. - N. E. California, on Scott River, Greene.

$==$ Heads two-thirds or over half inch long, naked at base, commonly somewhat peduncled: leaves entire, larely with a tooth or two, obscurely 3-nerved, puberulent and minutely somewhat grandular-granulose or atomiferous, graveolent, becoming slightly viscidulous.

B. oblongifólia, Nutr. Leaves oblung or some upper ones lanceolate, obtuse or mucronate: involucral bracts all acute or mucronate-pointed ; outer and short ones oblong-lanceolate; inner narrowly linear: akenes sprinkled with minute sessile and stipitate glands, toward summit often a few bristles. - Trans. Am. Phil. Soc. 1. c. 288; Torr. in Wilkes Pacif. Exp. xvi. t. 9; Eaton, Bot. King Exp. 137. - In gravelly or dry soil, E. Oregon to Brit. Columbia, first coll. by Nuttall.

Var. abbreviáta, Gray. Dwarf: leaves selđom half-inch long: involucral bracts less acute : akenes minutely and sparsely glandular on the ribs, otherwise glabrous. - Eaton, 1. c., t. 15, f. 7-10. - W. Humboldt Mountains, Nevada, Watson.

B. linifólia, $\mathrm{E}_{\mathrm{A} \text { ToN }}$ Rather more pubescent: leaves oblong-lanceolate to almost linear: involucre of the preceding, or bracts nore attenuate-acute: akenes minutely hispid on the ribs, not glandular. - Bot. King Exp. 137, t. 15, f. 1-6. - Sandy banks of streams, \&c., Sierra Nevada, California, to Utah and borders of Arizona ; first coll. by Watson.

B. Mohavénsis. Low, more cịnereous-pubescent, brachiately branched: leaves narrowly oblong: bracts of the involucre obtuse, rather broadly linear, outermost oblong: akenes cinereous-hispidulous: pappus-bristles approaching barbellulate. - Rocky washes in the Mohave Desert, S. E. California, Parish. 
+++ Barely pubescent or glabrate perennial herbs, not viscid: leaves slender-petioled, at least all the lower ones opposite, deltoid-ovate or cordate, serrate, mostly acuminate or attenualeacute, thinnish: heads half to two-thirds inch long: involucre subtended by some loose linearsubulate accessory bracts. Typical species.

B. cordifólia, ExL. 1. c. Minutely soft-pubescent; stem branching, 3 feet high: leaves deltoid-cordate or the upper deltoidly ovate-lanceolate, crenate-serrate: heads rather few, loosely corymbosely cymose, 40-50-flowered : involucral bracts somewhat coriaceous, linear, mostly obtuse: pappus rufous or tawny. - Torr. \& Gray, Fl. ii. 80. Eupatorium Brickellia, DC. Prodr. F. 182. - Wooded hills, W. Georgia and adjacent parts of Alabama and Florida: rare, first coll. by $\mathrm{Dr}$. Brickell.

B. grandiflóra, Nutт. Puberulent or almost glabrous: stem 2 or 3 feet high, paniculately branched; the numerous heads paniculate-cymose and drooping: leaves broadly or narrowly deltoid-cordate, or the upper deltoid-lanceolate, coarsely dentate-serrate and with an entire gradually acuminate apex (the larger 4 inches long): involucre about 40 -flowered; its bracts papery and scarious-margined when dried; the short outer ones orate; inner oblong-linear, obtuse or acutish, or some exterior ones with loose subulate acumination: pappus white, inclined to deciduous. - Trans. Am. Phil. Soc. u. ser. vii. 287; Torr. \& Gray, 1. c. Eupatorium? grandiflorum, Hook. F1. ii. 26. - Hills along streams of the Rocky Mountains and the Sierra Nevada, from Montana to the borders of Oregon, and south to New Mexico and Arizona. Name of the species not appropriate.

Var. petioláris, Gray. Heads and leaves commonly smaller; the latter inclined to hastate-deltoid, and equalled or even surpassed by the slencler petiole! - l'roc. An. Acad. xvii. 207.- Mountains of Arizona, Lemmon, and the borders of New Mexico, Rusly. Passes into the following and into the typical form.

Var. minor, Gray (Proc. Acad. Philad. 1863,67), is a smaller form, with leaves only an inch or two long, heads proportionally small, involucre 30-35.flowered. - Clear Creek, Colorado, to California in the Sierra Nevada above Lake 'Tahoe, and mountains of Arizona.

B. simplex, Grar. Resembles the preceding: stem a foot or two high, slentler, simple, bearing a single terminal or 3 or 4 racemose slender-pedunculate comparatively large heads, or producing numerous simple floriferous branches: involucre about 30-flowered, of less imbricated and acute bracts, most of them linear, the outer series very short, as are the few loose subtending ones: leaves 10 to 20 lines long, from deltoid-cordate to deltoid-oblong, mostly oltuse. - I'l. Wright. ii. 73. - Shaded hills, Arizona, IIright, Thurber, Lemmon.

* * Heads 9-25-flowered (or in the penultimate species 3-5-flowered), not over half an inch long: pappus-bristles scabrous or not manifestly barbellate, except in the penultimate subdivision.

- Leaves slender-petioled, all opposite, deltoid-cordate or triangular-hastate, small: heads pedunculate, in naked cymes terminating the stem or branches: bracts of the involucre thin, smooth and glabrons: shrublyy.

B. Coúlteri, Grar. A foot to a yard high, with numerous spreading slender branches, only the flowering ones herbaceous, minutely puberulent to glabrous: leaves from sparingly laciniate-dentate to nearly entire, acute or acuminate (larger ones an inch long, smaller less than half-inch): heads rather few in the naked and very open cymes, slender-peduncled, half-inch high: involucre about 12-flowered; its bracts linear-lanceolate, subulately acuminate or acute: akenes pubescent. - Pl. Wright. i. 86. - Common in Arizona, in cañons, first coll. by Coulter. (Adj. Mex., Gregg, Palmer, \&c.)

++ Leaves distinctly petioled, all or mostly alternate: stems shrubby at base: inflorescence thyrsiform,

+ Naked when well developed; the heads distinctly peduncled or in pedunculate small corymbiform cymes, forming an ample nearly leafless open paniculate thyrsus.

B. floribunda, Gray. Glabrate or barely puberulent below, but the branches with the inflorescence and outer involucral bracts glandular-pubescent and viscid: stem 4 feet high, woody only at base, much branched : leares slender-petioled, deltoid-ovate or the lower subcordate, irregularly dentate (2 and 3 inches long); veins loosely reticulated : heads (5 lines long) 15-22-flowered: bracts of the involucre broadly linear and obtuse, with some oblongovate acutish short ones, and often 2 or 3 loose and herbaceous ones subtending the head. Pl. Wright. ii. 73. B. Wrightii, Rothrock in Wheeler Rep. vi. 140, not Gray, l. c. - Ravines and river banks, S. Arizona, Wright, Palmer, Rothrock, Lemmon, Pringle. 
++ Foliose, i. e. the heads sessile or short-peduncled, terminating short leafy branchlets or in axillary clusters, forming a spiciform, paniculate, or interrupted leafy thyrsus.

= Involucre naked at base, all the bracts dry and chartaceous, glabrous and smooth, the outermost very short and appressed, wholly destitute of green tips.

a. Leaves mainly with truncate or subcordate base, crenate or dentate, but not laciniate: involucral bracts all obtuse, or innermost linear ones abruptly acute; short outermost oval and ovate: heads 10-20-flowered, 4 or 5 lines high.

B. Rúsbyi. Tall, copiousiy branched, largely herbaceous, amply floriferous, with the habit of $B$. floribunda, except that the inflorescence is thyrsoid-paniculate, minutely puberulent: leaves (2 to 4 inches long) from deltoid-ovate to ovate-lanceolate, with truncate or some with more or less cuneate base, gradually tapering to an acute or acuminate apex, unequally dentate to or above the middle. - Mountains of New Mexico, Greene, Rusby, $G$. $R$. Vasey, aud of S. Arizona, Lemmon.

B. Wríghtii, Grax. Usually much branched from a woody base, 2 to 4 feet high, puberulent, sometimes a little scabrous : leaves broadly deltoid-ovate, or rounded-cordate and obtuse, or at most acute (but not prolonged upward), more. or less crenate-dentate (larger cauline an inch and a half long, smaller only half-inch): heads glomerate-paniculate, the clusters shorter than or little surpassing the subtending leaves : involucre often purple. - Pl. Wright. ii. 72. B. Califorrica, var., Gray, PI. Fendl. 64. - W. border's of Texas to Colorado and Arizona, where it is not clearly distinguishable from $B$. Californica.

Var. ténera. A form with thin dilated-ovate leaves, fewer heads, and pale involucre, evidently growing in shade. - B. tenera, Gray, Pl. Wright. ii. 72. - Mountain ravines, S. Arizona, Wright, Lemmon.

Var. renifórmis. Leaves also thin, broader than long, some of them quite reniform, coarsely crenate, mostly surpassing the glomerules of heads. $-B$. reniformis, Gray, Pl. Wright. i. 86; an older name than $B$. Wrightii, but inappropriate for the species, of which this is an extreme form. - Mountain valley near the western border of Texas, Wright.

B. Califórnica, Grax. Moderately and virgately branched, 2 or 3 feet high, minutely puberulent: leaves ovate, obtuse, rarely subcordate, somewhat crenate-dentate, commonly an inch or less long, mostly surpassed by the small clusters of heads, these rather spicately glomerate, forming an interrupted strict thyrsus, - Pl. Fendl. 64, P1. Wright. i. 85, \& Bot. Calif. i. 300. Bulbostylis Cavanillesii, DC. Prodr. v. 38, as to Calif. plant. B. Californica, Torr. \& Gray, Fl. ii. 79. - California, from Mendocino Co. southward to adjacent parts of Nevada and Arizona, and Utah?

$b$. Leaves cuneate at base, tapering into the petiole, very numerous, incised or deeply toothed, seldom an inch long, the upper about equalling the glomerate heads in their axils: involucre narrow, 4 or 5 lines long; bracts mostly obtuse, the outer oblong, innermost linear: much branched and shrubby, 2 to 5 feet high.

B. baccharídea, GrAx. Leaves coriaceous, resinous-atomiferous and very glutinous, rhombic-orate or oblong, and with 2 to 5 strong teeth to each margin, much reticulated: heads 15-18-flowered. - Pl. Wright. i. 87. - Mountains of S. W. Texas, east of El Paso, Wright. San Francisco Mountains, N. E. Arizona, Greene.

B. laciniáta, Grar. Leaves thiu, puberulent and somewhat scabrous, orate-cuneate and oblong, laciniate-toothed or lobed, obscurely veiny: heads 9-12-flowered. - Pl. Wright. i. 87. B. dentata, Schultz Bip. Bot. Herald, 301, excl. syn. DC. - S. W. Texas, east of El Paso, Wright. S. Arizona, Thurber. (Mex., first coll. by Berlandier.)

$==$ Involucre of firmer bracts, the outer with greenish and somewhat spreading tips, outermost loose and berbaceous and passing' into the small leares of the branchlets.

B. microphýlla, Gray. Glandular-puberulent or pubescent and viscid, a foot or two high from a partly woody base, paniculately much branched; the short leafy branchlets terminated by 1 to 3 heads: leaves subcordate or ovate to oblong, when old somewhat scabrous, obtuse or apiculate, sparingly denticulate or nearly entire, the larger half-inch long, those of flowering branchlets a line or two long; heads nearly half-inch long, about 15-flowered. Pl. Wright. i. 85; Bot. Calif. i. 300. Bulbostylis microphylla, Nutt. Trans. Am. Phil. Soc. u. ser. vii. 287 ; Torr. \& Gray, Fl. ii. 79. - Dry interior of Oregon and California in the eastern part of the Sierra Nevada to Idaho, the mountains of Utah, and S. W. Colorado. Var. scabra, Gray, Proc. Am. Acad. xi. 74, is a small-leaved scabrous form. 
+++ Leares sessile, subsessile, or the lower short-petioled: heads not pendulous.

+ Leaves mainly opposite, reiny: heads mostly pedunculate: bristles of the pappus merely scabrous or barbellulate-serrulate under a lens: last two species with much imbricated involucre.

= Stems lignescent at base, slender.

B. oligánthes, Gray. Cinereous-puberulent, a foot or two high : leaves coriaceous, from oblong to linear, obtuse, obtusely and often obscurely serrate, an inch or two long, canescent and the veins very prominently reticulated beneath: peduncles mostly elongated, axillary and terminal, 1-3-cephalous, racemosely or somewhat corymbosely disposed : heads half-inch long, 10-12-flowered: bracts of the involucre mostly acute or acuminate; the short outermost ovate, innermost linear. - Pl. Wright. i. 84, \& ii. 71. Eupatorium oliganthes, Less. in Liun. iv. 137. Bulbostylis oliganthes, DC. Prodr. v. 139. - S. Arizona, Wright, Thurber, Lemmon, mostly a narrow-leaved form. (Mex.)

B. párvula, Grax. Minutely scabro-puberulent, low: leaves deltoid-ovate, coarsely fewtoothed, green both sides, barely half-inch long; the upper oblong, sparse and much smaller: peduncles few and slender, monocephalous, corymbosely disposed at the summit of the stems: head 5 lines long, about 12-flowered: bracts of the involucre few-ranked; innermost linear, rather obtuse ; outer broaler and mucronate-acute. - Pl. Wright. i. 87. - Mountains of S. W. Texas near the pass of the Rio Limpio, Ir'right.

$$
==\text { Stems herbaceous to the base: leares reticulate-reiny. }
$$

B. Wislizéni, Grax. Glandular-hirsute, 2 or 3 feet high : cauline leaves lanceolate-oblong with a subcordate closely sessile base, acute, acutely and numerously serrate, thin, loosely veiuy, $1 \frac{1}{2}$ to 3 inches long; those of the branches mainly obtuse at base : peduncles axillary and simple and as long as the leaves, or exceeding them on axillary branches, filiform: heads 5 or 6 lines long, 12-20-flowered: bracts of the involucre all lanceolate and gradually acuminate, or the innermost linear. - Pl. Fendl. 64; Pl. Wright. i.84, \& ii. 71. — S. Arizona, on mountain-sides, Wright. (Heads rather smaller and fewer-flowered than in the original of adjacent Mex.)

Var. lanceoláta. Loosely paniculate-branched and floribund, the numerous heads smaller: leaves broadly lanceolate, the cauline half-inch wide, those of the branches small, or the upper minute. - San Francisco Mountains, S. E. Arizona, Greene.

B. betonicæélia, Grax. More minutely glandular-hirsute: stems 1 to 3 feet high, virgate: leaves subeordate-oblong, olstuse, crenate or obtusely dentate, rugosely veiny; the lower mostly with short but distinct petioles: inflorescence virgate-racemiform: peduncles mostly shorter and the 12-flowered heads rather smaller: otherwise nearly as the preceding. -Pl. Wright. ii. 72. - Hills, New Mexico and Arizona, Wright, Thurber, Greene, \&c.

B. Lemmóni, Gray. Cinereous-puberulent, not glandular, slender, a foot or two high: leaves lanceolate, all acute at base and as if with short margined petiole, remotely or obscurely serrate, lightly triplinerved (inch or two long): heads (5 or 6 lines long) numerous in a rather loose narrow leafy thyrsus, on slender short peduncles, 10-12-flowered : bracts of the involucre nearly all acute; the rather few and short outer ones ovate- to oblong-lanceolate, inner linear: akenes canescent.-Proc. Am. Acad. xvii. 206.-Chiricahua Mountains, S. Arizona, Lemmon.

B. Prínglei, Grar, 1. c. Cinereous-puberulent and the foliage scabrous : stem strict, rather stout, 2 feet high: leaves oblong-lanceolate, acute, mostly obtuse at base, on very short but distinct petioles, somewhat serrate, nearly coriaceous, 3-nerved from just above the base, conspicuously and beneath saliently reticulated : heads (half-inch long) in a loose and narrow leafy thyrsus, 20-24-flowered: involucre glabrous, rather longer than the scaly-bracteatc peduncles; their rounded bracts passing above into the ovate and obtuse or barely mucronulate outer bracts of the involucre, the innermost of which are lanceolate and acute: akenes canescent. - Rocky cañons, S. Arizona, Pringle, Lemnion.

B. cylindrácea, Grax \& Exgelm. Cinereous-pubescent, somewhat scabrous: stem commonly stout and strict, 2 to 4 feet high: leaves oblong-ovate to ovate-lanceolate, mostly obtuse at both ends, obtusely serrate, thickish, 3-nerved or triplinerved from near the subsessile base (about 2 inches long) : heads ( 6 to 8 lines long) numerous in a virgate racemiform thyrsus, short-peduncled, sometimes almost sessile, 10-flowered: involucre cylindrical, closely imbricated; the broadly ovate outer bracts in several ranks, mucronate, multistriate, mostly villous when young; inner broadjy linear, obtuse or mucronulate: akenes pubescent, - 
Proc. Am. Acad. i. 46, Pl. Lindh. ii. 218, Pl. Wright. 1. c.-Hillsides and thickets, Texas, Berlandier, Wright, Lindheiner, \&c. Varies into

Var. láza, GrAY. Paniculately branched, and the branches bearing numerous smaller (5 or 6 lines long) loosely disposed and sometimes slender-peduncled heads, having fewer bracts to the involucre: leaves of the branches either subsessile or abruptly petioied. - Proc. Am. Acad. xrii. 207. - S. W. Texas, Palmer.

++ ++ Leaves alternate, veiny: stems herbaceous from a perennial root: pappus barbellate.

B. Riddéllii, GraY. Minutely cinereous or puberulent, glabrate : stem strict and stont, 2 to 4 feet higl, simple or fastigiately branched above, exceedingly leafy to the summit: leaves oblong-lanceolate, rather acute, sparingly denticulate, occasionally more dentate, often entire, thickish, obscurely veiny, 8 to 18 lines long: heads subsessile, numerous, crowded in a leafy spiciform thyrsus, 15-20-flowered, 4 or 5 lines long: involucre campanulate, somewhat pubescent; the bracts few-striate, obtuse or mucronate; the outer ovate, inner oblonglanceolate: pappus barbellulate under a lens. - Pl. Wright. i, 83. Clavigera dentata, DC. Prodr. v. 128, but the character does not well agree, and the specific name is inappropriate. C. Riddellii, Torr. \& Gray, Fl. ii. 77. - River banks, middle and southern parts of Texas, Berlandier, Riddell, Wright, Lindheimer, \&c.

B. brachyphýlla, Grar. Minutely puberulent: stems a foot or two high from a lignescent caudex, slender, simple, and bearing a few racemosely paniculate slender-pedunculate heads, or paniculately branched and polycephalous: leaves oblong-lanceolate, entire or sparingly serrate, half-inch or the larger an inch long: heads 5 lines long, 9-12-flowered: involucral bracts few, acute, short outermost ovate or oblong, inner linear: pappus-bristles almost plumose under a lens. - Pl. Wright. i. 84. Clavigera brachyphyllu, Gray, Pl. Fendl. 63. - Rocks and ravines, western border of Texas, New Mexico, and Arizona, Fendler, Bigelow, Greene, Lemmon, \&c.

++++ Leares mostly nervose and narrow, entire, the lower opposite: stems paniculately much branched: heads very numerous, thyrsoid-paniculate: akenes usually glabrous: pappus inerely scabrous: plants nearly glabrous. (B. spinulosa, Gray, of Mexico, is of this group.)

B. squamulósa, Gray. Suffrutescent at base, 2 or 3 feet high: stems or shoots of the first year bearing narrowly linear (2 or 3 inches long, less than 2 lines wide) obscurely 3-nerved deciduous leaves; flowering shoots the next year bearing only minute squamiform obtuse leares of a line or less in length, and closely imbricated on short branchlets and thence passing into the bracts of the involucre: heads 10-12-flowered, turbinate, about 5 lines long: involucral bracts pluriseriate, thickish, obscurely nerved, green with whitish margins, externally somewhat canescent; the short outer ones ovate or oblong and obtuse, inner narrow and acutish. - Proc. Am. Acad. xv. 30. - New Mexico near Santa Rita del Cobre, Greene. S. Arizona, near Fort Huachuca, Lemmon. (San Luis Potosi, Mex.)

B. longifólia, Wa tson. Suffruticose: flowering branches leafy: leaves lanceolate-linear (I to 3 inches long, 2 or 3 lines wide), 3-nerved; npper gradually diminished in the openpaniculate leafy thyrsus : heads subsessile in small clusters, $3-5$-flowered, only 3 lines long: bracts of the involucre about 10 , of 2 or 3 lengths, conspicuously striate, obtuse. - Am. Nat. vii. 301 ; Rothr. in Wheeler Rep. vi. 139, t. 5. - S. Utah and S. Nevada, Wheeler, Mrs. Thompson, Palmer.

B. multiflóra, KKellogr. Suffruticose: cauline leaves ovate-lanceolate and with divergent lateral nerves, an inch or two long; those in the crowded panicle from lanceolate to linear, small, and with olscure lateral nerves: heads 3-5-flowered: akenes sparsely hairy: otherwise much resembling B. longifolia. - Kellogg in Proc. Calif. Acad. vii. 49 ; Greene, Bull. Calif. Acad. i. 8. - On rocks, in a cañon of King's River, southern part of the Sierra Nevada, California, Kellogg.

++++ Leaves all alternate, spatulate, veinless: stems shrubby: heads sparse or solitary.

B. Prutéscens, GraY. Rigid undershrub with divaricate branches, cinerons-pubescent: leaves spatulate or obovate, entire, 3 to 5 lines long, including the attenuate petiole-like base: heads (half-inch long) terminating the branchlets, about 20-flowered : involucral bracts rather obtuse; outer ones somewhat greenish-tipped: akenes hispidulons-scabrous : bristles of the pappus very minutely but densely serrulate. - Proc. Am. Acad. xvii. 207. - Southern bor ders of California, Sutton Hayes, Palmer, G. R. Vasey, Parish. 


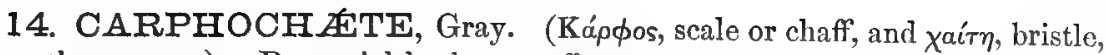
from the pappus.) - Perennial herbs or suffrutescent plants (of New and Northern Mexico), glabrous or nearly so ; with opposite and entire sessile thickish 1-3nerved but nearly veinless leaves, and solitary or somewhat clustered heads, terminating leafy or pedunculiform branches: the flowers (about an inch long) much exceeding the involucre: this and the corolla rose-colored: nearly of Liatris habit, and pappus somewhat of Stevia. - Pl. Fendl. 65; Pl. Wright. i. 89 , ii. 71 .

C. Bigelóvii, Gray, 1. c. A span to a foot high, wooty at lase, fasciculately branched: lower leaves spatulate-oblong, inch long, and fascicles of smaller ones in the axils, upper oblong or linear : heads sessile or very short-peduncled, mostly terminating very leafy somewhat paniculate short branchlets : aristiform palex of the lappus 11 to 14 , and a few very small exterior squamellæ. - N. New Mexico, Bigelow, W'right, Greene. Arizona, Pringle. S. W. Texas, Girard. The one or two other species are more herbaceous, sleuder, and with loose pedunculate heads.

15. LIÁtris, Schreb. Blazivg Star, Button Snakeroot. (Name of unknown derivation.) - Perennial Atlantic N. American herbs; with simple virgate very leafy stems from a tuberous or mostly globose and corm-like stock, bearing reversely racemose or spicate heads of handsome rose-purple flowers (rarely also white), in late summer and autumn; the leaves all alternate, narrow, entire, rigid or with cartilaginous margins, mostly glabrous or glabrate. - Gen. 542 (where Gærtner's name is mentioned; but Grertuer takes up the genus, like Schreber, from the Anonymos, Walt., under the name Suprago, confusing it with Vernonia, and in a volume two years later than Sehreher's); Torr. \& Gray, IN. ii. 67 (excl. § $2 \& 3$ ); Benth. \& Hook. Gen. ii. 248.

* Pappus very plumose : heads 4-5-flowered: inner involucral bracts with prolonged petaloid tips. - Calostelma, Don.

L. élegans, Willd. Partly pubescent, 2 to 3 feet high: linear upper leaves commonly soon reflexed: spike or raceme virgate, dense, 3 to 20 inches long : heads either sessile or on bracteolate pedicels, about half-inch long: bracts of the involucre few-ranked, the inner dilated at tip into an oblong or lanceolate mucronate-acuminate rose-red spreading appendage, which surpasses the flowers and pappus. - Spec. iii. 1065; Michx. Fl. ii. 91 ; Ker, Bot. Reg. t. 267; DC. Prodr. v. 129 ; Torr. \& Gray, I. c. Stchelina elegans, Walt. Car. 202. Serratula speciosa, Ait. Kew. iii. 138. Eupatorium speciosum, Vent. Cels. t. 79. Lialris radians, Bertol. Misc. v. 9, t. 1. - Dry pine barrens, Virginia? to Florida and Texas.

* Pappus rery plumose: heads 16-60-flowered, cylindracenus with turbinate base: bracts of involucre much imbricated, with herbaceous tips if any: lobes of the corrolla pilose inside: leaves all linear and rigid, bardly punctate; the lower elongated and graminiform.

L. squarrósa, Wuldo. Pubescent or partly glabrous: stem stout, 6 to 20 inches high: heads few (even solitary), or sometimes numerous in a leafy spike or raceme, rarely somewhat paniculate, the larger an inch or more long: bracts of the involucre all herbaceous and acuminate, or with foliaceous or herbaceous (or innermost slightly colorell) lanceolate rigid and somewhat pungent tips; these usually squarrose-spreading and prolonged.Torr. \& Gray, 1. c., incl. rars, floribunda \& contpacta. Cirsium tuberosum, etc., Dill. Elth. t. 71, fig. 82. Serratula squarrosa, L. Spec. ii. 818. Pteronia Caroliniana, Walt. Car. 292. - Dry gravelly or sandy soil, Upper Canada to Florida, Nebraska, and Texas. Passes into

Var. intermédia, DC. Heads narrow: bracts of the involucre erect or little spreading, less prolonged. - Prodr. v. 129 ; Torr. \& Gray, 1. c., with var. compacta. L. intermedia, Lindl. Bot. Reg. t. 948. - Upper Canada to Nebraska, Louisiana, and Texas.

L. cylindrácea, Mıснx. Mostly glabrous, a foot high: heads few or several, 16-20flowered, an inch or less long: bracts of the involucre all appressed, barely herbaceous, rounded and abruptly mucronate at tip, the outermost very short. - Fl. ii. 93 ; Ell. Sk. 
ii. 275; Torr. \& Gray, 1. c., not Pursh. L. graminifolia, Willd. Spec. iii. 1636, excl. syn. Walt. \& hab.; Muhl. Cat. 73. L. stricta, Macnab in Edinb. Phil. Jour. xix. 60. L. flexuosa, D. Thomas, in Am. Jour. Sci. xxvii. 338 ? - Dry prairies and open woodlands, Upper Canada and Michigan to Minnesota and Missouri.

* * Pappus distinctly plumose to the naked eye: heads 3-6-flowered : bracts of the involucre acuminate or mucronate, coriaceo-herbaceous, not appendaged: corolla-lobes naked: leaves all narrowly linear or the upper acerose.

L. punctáta, Hоok. Stems a span to 30 inches high from a thick and branching or sometimes globular stock, stout: leaves as well as bracts commonly punctate, rigid: head 4-6flowered, oblong or cylindraceous, thickish, from half to three-fourths inch long, mostly numerous and crowded in a dense (below leafy) spike: bracts of the involucre oblong, abruptly or sometimes more gradually cuspidate-acuminate, often lanuginous-ciliate : pappus almost as plumose as in the preceding. - Fl. i. 306, t. 55; Torr. \& Gray, l. c. L. cylindrica, Torr. Ann. Lyc. N. Y. ii. 210. L. resinosa, DC. Prodr. v. 129 (pl. Arkans.), not Nutt. Dry prairies and plains, Saskatchewan and Minnesota west to Montana and Colorado, south to Texas and New Mexico. (Mex.)

L. acidóta, ENGELM. \& GRAY. Stem a foot or two high from a globose or at length elongated tuber: leaves very slender: heads 3-5-flowered, three-fourths to half an inch long, numerous in a slender and strict naked spike: bracts of the involucre rather few, thinnish, mostly glabrous, ovate- and oblong-lanceolate, gradually or abruptly acuminate or cuspidatemucronate: pappus short-plumose.-Pl. Lindh. i. 10; Gray, Pl. Wright. i. 83. L. mucronata, Torr. \& Gray, Fl. ii. 70, not DC. - Prairies of Texas, Drummond, Wright, Lindheimer, \&c. Var. vernalis, Engelm. \& Gray, l. c., is a depauperate vernal form.

Var. mucronáta. Heads and flowers smaller; involucral bracts abruptly mucronate-pointed. - L. mucronata, Engelm. \& Gray, Pl. Lindh. i. 10. - Texas, Lindheimer.

L. Boýkini, Torr. \& Gray. Glabrous: stem very slender, a foot or two high: leaves punctate; lower narrowly linear, upper acerose : heads rather numerous in a strict naked spike, 3-4-flowered, hardly half-inch long: bracts of the involucre only about 8, thin, lanceolate, acuminate, the inner somewhat scarious at margins and tip: pappus short-plumose. - Fl. ii. 70. - Near Columbus, Georgia, Boykin. Not since found.

* * * Pappus from barbellulate to minutely short-plumose under a lens, not to the naked eye.

+ Heads subglobose or hemispherical, 15-40-flowered : involucral bracts mostly spatulate, many-

ranked, somewhat spreading : corolla-lobes comparatively short.

L. scariósa, Willo. Pubescent or glabrate: stem stout, 1 to 5 feet high : leaves spatulateor oblong-lanceolate and tapering into a petiole (4 to 6 inches long, half-inch to inch and a half wide); upper narrowly lanceolate; uppermost small, linear, sessile: heads racemose or spicate, few or numerous ( 3 to 50 ), mostly $25-40$-flowered and about an inch high and wide: involucral bracts broadest and rounded at'summit, there either herbaceous or scarious edged and tinged with purple (rarely white-scarious): pappus-bristles minutely barbellate. Willd. Spec. iii. 1635; Sims, Bot. Mag. t. 1709 ; Ker, Bot. Reg. t. 590; Lindl. Bot. Reg. t. 1654; Meehan, Nat. Flowers, ser. 2, ii. t. 29. L. aspera \& sphceroidea, Michx. Fl. ii. 92. L. scariosa \& L. sphceroidea, DC. 1. c. L. sphoroidea, Brit. Fl. Gard. t. 87. L. borealis, Nutt. in Paxt. Mag. v. t. 27. L. squarrosa, Sweet, Brit. Fl. Gard. t. 44? Serratula scariosa, L. Spec. ii. 818. - Dry and usually sandy ground, Upper Canada and New England to the Saskatchewan, west to the Rocky Mountains, south to Florida and Texas. Varies greatly; in the involucre, which is either herbaceous or with the tips largely scarious and colored; in the size of the heads, \&c., passing into the extreme microcephalous form (which except for the transitions would be regarded as a distinct species), viz. :-

Var. squarrulósa. Comparatively small and slender: heads merely half or twothirds inch long, 14-20-flowered: involucral scales narrower, innermost sometimes linear or lanceolate and acutish. - L. squarrulosa, Michx. 1. c. L. heterophylla, R. Br. in Ait. Kew. ed. 2, iv. 503; Pursh, Fl. ii. 508; Nutt. Gen. ii. 131.-Open woods, N. Carolina to Texas. The heads of ordinary $L$. scariosa, when abnormally numerous and paniculate, are sometimes reduced to the smallest size.

++ Heads oblong, 5-flowered: involucre squarrose by the spreading colored tips of the bracts.

L. pycnostáchya, Micrix. Hirsute, or below glabrous: stem stout, 3 to 5 feet high: leaves crowded throughout; the lower lanceolate and the upper very narrowly linear: spike 
dense, cylindrical ( 5 to 18 inches long) : heads ( 4 to 6 lines long) all sessile: bracts of the involucre 14 to 16 , oblong or the inner narrower; the more or less scarious squarrose tips purple or purplish, usually acute: pappus copious, minutely barbellate - Fl. ii. 91 ; Pursh, Fl. ii. 507 (excl. syn. Dill. \& Walt. ?); Torr. \& Gray, l. e. L. brachystachya, Nutt. in Jour. Acad. Philad. vii. 72, a glabrous form. - Prairies, Illinois and Iowa to Arkansas and Texas. Apparently this hybridizes with $L$. spicata: at least specimens occur which are intermediate between the two species.

+++ Heads from short-oblong to cylindraceous: bracts of the involucre all appressed, + Obtuse and mostly rounded at the pointless apex.

= Leaves narrowly linear, or the lowermost larger and broader; upper ones gradually reduced to linear-subulate bracts.

L. spicáta, WiLLd. Glabrous, or with some sparse hirsute pubescence : stem stout or tall, usually 2 to 5 feet high, very leafy : heads 8-13- (sometimes 5-7-) flowered, half-inch long, almost erect, closely sessile and numerous in a dense spike of a span to a foot or more in length: involucre obtuse or rounded at base; its bracts obscurely if at all glandular-punctate, but not rarely glutinous; the tips of the iuner usually with narrow colored scarious margin. - Sims, Bot. Mag. t. 1411 ; Torr. \& Gray, I. c. 73 ; Torr. Fl. N. Y. 35, t. 47. Cirsiun tuberosum, \&c., Dill. Elth. t. 72, fig. 83. Serratula spricata, L. Spec. ii. 819 (excl. syn. Gronov.); Andr. Bot. Rep. t. 401. S. compta, Dryander in herb. Banks, cited by Pursh under the next. Liatris macrostachya, Michx. Fl. ii. 91 ; Pursh, 1. c. L. resinosa, Nutt. Gen. ii. 131, a small form with 5-flowered heads. L. sessiliflora, Bertol. Misc. v. 10, t. 2 (but our specimen from coll. Alabama, Gates, has hirsute foliage), a form with slender and looser spike. - Moist or rich soil, Mass. and New York to Wisconsin and Arkansas, and south through the upper country to Florida and Louisiana.

Var. montána. Low and stout, 10 to 20 inches high: leaves broader, lower ones half to two-thirds inch wide, obtuse: spike proportionally short and heads large. $-L$. macrostachya, Michx. 1. c., in part. L. pumila, Loddiges. L. spicata, Sweet, Brit. Fl. Gard. t. 49. L. pilosa, in part, Torr. \& Gray, Fl. ii. 74. - Rocky mountain-tops in Virginia and N. Carolina, where it abounds.

L. graminifólia, Pcrsh. More slender than the preceding, mostly only 2 or 3 feet high : leaves usually ciliate toward the base with scattered hispid hairs, rigid, often sparse : heads more sparsely spicate or scattered, not rarely becoming racemose or paniculate, mostly halfinch long: involucre acutish at base; its bracts firmer, oval and oblong, glandular-punctate on the herbaceous back, the rounded (or sometimes slightly herbaceous-apiculate) tip hardly at all scarious-edged. - (Willd. Spec. iii. 1636, only as to name \& syn. of Anonymos graminifolia, Walt., which is also uncertain.) Pursh, Fl. ii. 308 (excl. portions of char, taken from Willd.) ; Nutt. Gen. ii. 131 ; Ell. Sk. ii. 274 ; DC. Prodr. v. 130, chiefly ; Torr. \& Gray, Fl. ii. 72. L. pilosa, var. gracilis, Nutt. Gen. ii. 131. L. virgata, Nutt. Jour. Acad. Philad. vii. 72, \& Trans. Am. Phil. Soc. n. ser. vii. 284, a form running into compound-paniculate inflorescence, with small heads. Serratula fuliis linearibus, Gronov. Virg. ed. 1, 92 ; cited by Linnæus under S. spicata. - Dry or moist ground, Virginia to Florida.

Var. dúbia, GRAY. Spike strict and virgate, with many approximate rather large heads, or occasionally racemiform, or abnormally paniculate: bracts of the involucre narrower and thinner, sometimes obscurely scarious-margined. - Man. 224 (Torr. \& Gray, l. c.). L. pilosa, Willd. (Serratula pilosa, Ait. Kew. ed. 1, iii.'138?, apparently a state with unusually narrow infolucral scales, and like Lodd. Cab. t. 356, the only character being " $S$. folits linearibus pilosis, floribus axillaribus longe pedunculatis"); Pursh, 1. c. ; Ell. 1. c. ; Lindl. Bot. Reg. t. 595. L. pilosa, var. lavicaulis, \& L. spicata, var. racemosa, DC. 1. c. L. dubia, Bart. Mat. Med. ii. 222, t. 49. L. propinqua, Hook. Bot. Mag. t. 3829. - Sandy pine barrens, New Jersey to Florida and Alabama, near the coast, in wet or dry soil.

L. grácilis, Pursh. Cinereous-pubescent or glabrate: stem slender, 1 to 3 feet high: leaves rather short, mostly spreading; lower usually oblong-linear or oblanceolate, upper small and narrow: heads small ( 4 or 5 lines long), 3-5- or rarely 6- 7 -flowered, numerous in a virgate raceme, on spreading or horizontal slender pedicels, or rarely spicate, often loosely compound-paniculate: bracts of the involucre lax, rather few (7-10), thinnish, commonly glandvlar-puberulent, not scarious at tip. - Fl. ii. 508; Torr. \& Gray, 1. c. L. pauciflosculosa, Nutt. in Joux. Acad. Philad. 1. c. 71. L. lanceolata, Bertol. Misc. v, 11, t. 3. - Dry pine barrens, Georgia, Alabama and Florida. 


\section{$==$ Leaves all very slender: heads 4 or 5 lines long.}

L. tenuifólia, Nutr. Glabrous or with a few bristles below : stem strict and slender, 2 to 4 feet high: leaves rigid, attenuate-linear and when dry with revolute margins; radical and lower cauline very numerous and erowded, a foot or less long, a line or two wide; upper cauline short, becoming acerose or filiform and reduced to setaceous bracts: heads about 5 -flowered and 4 lines long, very numerous in a strict virgate raceme (of a foot or two in length), which occasionally develops into a panicle: involucre of about 10 oblong bracts, not punctate, the inner more or less scarious and purplish : pappus strongly barbellate. Gen. ii. 131 ; EII, Sk. ii. 275 ; Torr. \& Gray, 1. c. L. lcevigata, Nutt. Trans. Am. Phil. Soc. 1. c. 285, a large form with coarser radical leaves. - Dry pine barrens, N. Carolina to Florida.

+++ Involucral bracts or most of them acuminate or mucronate-tipped, $=$ Hirsute with short many-jointed hairs.

L. Gárberi, Grax. A foot or two high, hirsute with many-jointed spreading hairs, or the linear and rigid strongly punctate leaves glabrate: upper leaves very short, linear-subulate, erect: heads 6-7-flowered, 5 or 6 lines long, crowded in a dense spike: involucre campannlate; its bracts (about 10) greenish and very glandular-punctate, villous-hirsute, in age glabrate; outer ones ovate, inner oblong, all obtuse and conspicuonsly mucronate-pointed : pappus minutely barbellate. - Proc. Am. Acad. xv. 48. - Tampa, Florida, Garber.

$==$ Involucre glabrous or nearly so, narrow, indistinctly glandular-punctate, 3-5-flowered (bracts variable): pappus more distiuctly barbellate toward the base.

L. Chapmánii, Torr. \& Grar. Tomentulose-puberulent, glabrate: stem a foot or two high, strict and rigid: leaves short, linear, or the lower oblong-linear and obtuse ( 1 to 3 inches long) and the upper small asd narrow: heads numerous, mostly 3-flowered, erect in a strict and dense virgate spike: involucre cylindrical; its bracts thinnish, lanceolate or the short outer ones oblong, mostly acute and mucronate or short-acuminate, sometimes pointless: flowers large for the size of the head, two thirds of an inch long: pappus half-inch long. - Fl. ii. 502 ; Chapm. Fl. 191. - Dry sandy ridges, Middle Florida, first coll. by Chapman.

L. pauciflóra, Pursh. Glabrous or minutely puberulent: stem slender, often weak and declining : leaves rigid, linear, mostly narrow: heads numerous in a virgate often secund spiciform raceme (of 6 to 24 inches in length), when secund on short spreading or recurving pedicels: involucre cylindraceous; its bracts thinnish, oblong, or the short outermost oval and the inner lanceolate, mostly mucronate-acute or acuminate: flowers 5 or 6 and pappus 4 or 5 lines long. - Fl. ii. 510; Chapm. 1. c. I. secunda, Ell. Sk. ii. 278 ; Torr. \& Gray, Fl. ii. 71. - Sandy pine woods, S. Carolina to Florida.

16. GARBÉRIA, Gray. (The late Dr. A. P. Garber, the re-discoverer.) Proc. Acad. Philad. Nov. 1879, 379, \& Proc. Am. Acad. xvi. 79. Liatris $\S$ Leptoclinium, Nutt. in Trans. Am. Phil. Soc. n. ser. vii. 285 ; Torr. \& Gray, Fl. ii. 76. Leptoclinium, Gray, Proc. Am. Acad. xv. 48, not Benth. \& Hook.

G. fruticósa, Grar, l. c. Shrub 4 to 6 feet high, branching, leafy: branchlets and involucre puberulent: leaves with base of a short petiole articulated with the stem, vertical by a twist, glalsous, pale and of the same hue both sides, nearly veinless, obovate, retuse (barely inch long): lheads (half-inch long) numerous in fastigiate naked terminal cymes: involucre much shorter than the pappus. - Liatris fruticosa, Nutt. in Am. Jour. Sei. v. 299. Leptoclinium fruticosum, Gray, l. c. - S. Florida, Ware, Garber. Found by the latter on dry sandridges of the western coast, at Tampa Bay. Lower leaves opposite according to Nuttall.

17. CARPHÉfHORUS, Cass. (Kápфos, chaff, and фopós, bearing.) Perennials, with no bulbiform stack or tuber; the rose-purple or white flowers in cymosely disposed heads; all N. American, late-flowering. - Bull. Philom. 1816, \& Dict. vii. 148 ; DC. Prodr. v. 132 (one species); Torr. \& Gray, Fl. ii. 65.

$\S 1$. Pappus of copious and unequal minutely barbellate bristles, occupying more than one series: flowers purple: stem simple, leafy: even the lowest leaves alternate, cauline ones sessile : Atlantic-States species, herbs. 
* Leaves all acerose, erect or appressed.

C. Pseudo-Liátris, Cass. 1. c. Cinereous-pubescent, glabrate below, glaucescent: stems a foot or two high, very strict: leaves with base half-clasping the stem, rigid, somewhat carinate; lowest 8 or 10 inches long, a line or less broad; cauline gradually reduced to subulate appressed bracts: heads few or numerous in a small compact terminal cyme: involucral bracts ovate-lanceolate, acuminate, densely pubescent. - Torr. \& Gray, 1. c.; Bertol. Misc. v. 14. Liatris squamosa, Nutt. Jonr. Acad. Philad. vii. 73; IIook. Comp. Bot. Mag. i. 95. - Grassy pine barrens, Alabana, Middle Florida, and Mississippi to Louisiana.

* Leares plane, thickish; radical ones spatulate, tapering into a margined petiole; cauline oblong, short, closely sessile: bracts of the involucre pluriserial.

C. tomentósus, Torr. \& Grir, 1. c. About 2 feet high, tomentulose, or below hirsute and glabrate: heads numerous in the cyme (over lalf-inch long): bracts of the involucre canescently hirsute and viscid, mostly acute. - Liatris tomentosa, Michx. Fl. ii. 73. L. Walteri, Ell. Sk. ii. 285, excl. syn. Walt. - Low pine barrens, N. Carolina to Florida.

C. corymbósus, Torr. \& Gr.ıY, l. c. Stouter and taller, minutely hirsute or pubescent: cauline leaves broadly oblong: heads numerous in the compound cyme: involucre glabrous ; the bracts all very obtuse or truncate, inner ones scarious-margined and erose at apex. Liatris corymbosa, Nutt. Gen. ii. 132, excl. syn. L.tomentosa, E11. 1. e, not Miclix. - Margin of swamps in pine barrens, $\mathbf{N}$. Carolina to Florida.

C. bellidifólius, Torr. \& Grax, 1. c. About ^ foot high, rather slender, often branched below the middle, almost glabrous: cauline leaves narrowly oblong or oblanceolatc: heads fewer and scattered, more pedunculate : involucre of looser bracts; the lower rather spreading, innermost thin and linear, all very obtuse. - Liafris bellidifulia, Michx. 1. c. ; Nutt. l. c. Anonymos uniflcrus, Talt. Car. 198? - Sandy woods and pine barrens, from Wilmington, N. Carolina, to Georgia.

\$2. Kumniomes, Gray. Pappus a single series of about 15 plumose bristles: flowers white or ochroleucous: bracts of the involucre fewer, in about 3 ranks: stems much branched, shrubby at base, few-leaved: lower leaves opposite: Pacific species. [See Supplement, Bebbria, p. 453.]

C. júnceus, Bentr. Minutely hispid or glabrate, or above somewhat canescent, 2 or 3 feet high: branches slender and rigid, junciform; the branchlets often leatless, terminated by solitary or 2 or 3 hemispherical heads (of half-inch length) : leaves linear, sometimes sparivgly lobed, upper ones filiform or reduced to subulate bracts, or early deciduous: bracts of the involucre obtuse or acutish; outer ones canescently hirsute and ovate or oblong; inner ones thin and narrower. - Bot. Sulph. 21 ; Gray, Proc. Am. Acad, viii. 632, \& Bot. C'alif. 301. Sandy banks of streams, southern borders of California to Arizona, where the involucral bracts are narrower. (S. Calif., first coll. by Hinds.)

C. atriplicifólics, Gray, Proc. Am. Acad. v. 159, from Cape San Lucas, S. California, Xantus, is possibly a form of the last, with oblong laciniate-toothed or somewhat hastate leaves," on distinct petioles, and rather oblong heads : specimens insufficient.

18. TRfLISA, Cass. (The name is most obviously an anagram of Liatris.) - Atlantic U.S. perennials ; with simple and erect rather tall leafy stems, terminating in a thyrsus or panicle of cymules of small heads: leaves entire, oval to lanceolate; cauline partly clasping, radical much larger and tapering at base into a margined petiole. Flowers rose-purple, autumnal. Involucre of few oval or oblong somewhat herbaceous equal bracts, usually with 2 or 3 small and loose exterior ones. - Bull. Philom., 1818, \& Dict. iv. 310; Benth. \& Ilook. Gel. ii. 248. Liatris § Trilisa, DC., excl. spec.; Torr. \& Gray, Fl. ii. 76.

T. odoratíssima, Cass. l. c. (Vanilla-Plant, Houndstongue.) Glabrous: stem 2 or 3 feet high: leaves thickish, pale, often glaucous, obscurely-veined, vanilla-scented in drying; radical and lower cauline 4 to 10 inches long, oval or oblong, upper ones becoming very small: heads (3 ог 4 lines long) rather numerous in open cymules, and these cymosely paniculate: akenes glandular. - Anonymos odoratissimus, Walt. Car. 198. Liatris odoratissima, 
Willd. Spec. iii. 1637; Michx. Fl. ii. 93 ; Andr. Bot. Rep. t. 633 ; Don in Brit. Fl. Gard. ser. 2, t. 184 ; Torr, \& Gray, Fl. ii. 76. Eupatorium glastifolium, Bertol. Misc. v. 16, t. 4. Low pine barrens, near the coast, Virginia? to Florida and Louisiana.

T. paniculáta, CAss. l. c. Viscid-pubescent or the foliage glabrate, a foot or two high: leaves smaller, green; radical lanceolate-spatulate; small cauline ones oblong-lanceolate: cymules short-peduncled, crowded in a narrow panicle or thyrsus: akenes minutely pubescent. - Anonymos paniculatus, Walt. 1. c. Liatris paniculata, Michx. Fl. ii. 93; Willd. Spec. iii. 1637; Torr. \& Gray, Fl. ii. 76. - Damp pine barrens, Virginia to Florida, near the coast.

\section{Tribe III. ASTEROIDE $\approx$, p. 52.}

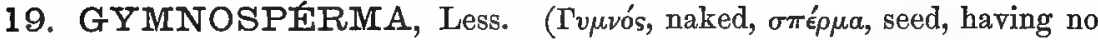
pappus.) - Perennial herbaceous or suffrutescent plants, erect, glabrous, mostly glutinous; with alternate entire narrow leaves, and small heads of yellow flowers in fastigiately corymbose glomerate cymes. Involucre about 2 lines long: ligules very small and short. - Syn. 194; DC. Prodr. v. 312, excl. \$ 2. - Founded on Selloa glutinosa, Spreng., said to come from S. Brazil, with infertile disk-flowers, to which DeCandolle added three Mexican species; but these are all reducible to one, viz. : -

G. corymbósum, DC. Woody at base, 2 or 3 feet high: leaves from oblong-lanceolate to linear; lower ones distinctly 3-nerved : flowers of the ray 5 to 9 , of the disk mostly fewer, all fertile.-Torr. \& Gray, Fl. ii. 192; Gray, Pl. Wright. ii. 94. G. corymbosum, multiflorum, \& scoparium, DC. 1. c. - Rocky soil, S. Texas; fl. autumn. (Mex.)

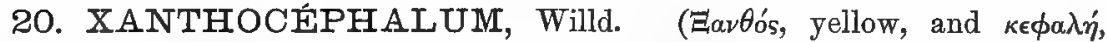
head.) - Herbaceous or suffruticose plants (chiefly Mexican); with alternate entire or lobed leaves, and yellow flowers in scattered or loosely cymose heads; the smaller-flowered species approaching the following genus. - Willd. in Gesel. Nat. Fr. Berl. 1807, 140; Benth. \& Hook. Gen. ii. 249. Xanthocoma, HBK. Nov. Gen. \& Spec. iv. 310, t. 412; DC. Prodr. v. 311.

X. sericocarpum, Gray, Proc. Am. Acad. xv. 31, from San Luis Potosi, Mexico, has car nescent akenes: in all other species they are glabrous or only sparsely pubescent. Our species are annuals.

X. Wríghtii, GruY. Very glabrous, not glutinous: stems slender, a foot or two high, corymbosely paniculate at summit: leaves linear, entire : heads rather numerous, terminating pedunculiform branchlets: involucre barely 3 lines high and wide; the bracts broad, obtuse, or apiculate with a short green tip : rays 12, oblong: style-appendages linear-lanceolate, acute : akenes all surmounted by an entire or obscurely denticulate coroniform border, without proper pappus. - Proc. Am. Acad. viii. 632. Gutierrezia Wrightii, Gray, PI. Wright, ii. 78. -S. Arizona and New Mexico, Wright, Thurber, Bigelow, Greene.

X. gymnospermoídes, Bextr. \& Hook. 1. c. Glutinous when young, occasionally with some deciduous tomentum: stem stout, 2 to 4 feet high: leaves oblong-lanceolate with a tapering base, sometimes sparingly denticulate; the lowest often broader, petioled, occasionally incised and even pinnatifid : heads corymbosely cymose, crowded : involucre hemispherical, 4 lines high, very many-flowered; the bracts narrow and with acute green tips, not very unequal : flowers deep golden-yellow : rays 30 to 50 , only 2 lines long : style-appendages ovate: pappus in the ray none; in outer disk-flowers setulose-coroniform; in central and less fertile flowers of several unequal awns and mostly coroniform-concreted at base. Rothrock in Wheeler Rep. vi. 140; Hemsl. Biol. Centr.-Am. Bot. ii. 111 . Grutierrezia ? gymnospermoides, Gray, P1. Wright. 1. c.; Hook. Bot. Mag. t. 5155. - Banks of streams, Arizona, first coll. by Wright. (Mex., Parry \& Palmer, which has been wrongly referred to the largerflowered very serrate-leaved $X$. Benthamianum, Hemsl.) 
21. GUTIERREZIA, Lag. (Named for some member of the noble Spanish family, Gutierrez.) - Herbs or suffrutescent plants (N. \& S. American), glabrous, often glutinous; with narrowly linear and entire alternate leaves, and small heads of yellow flowers, either solitary terminating the branchlets, or in dense cymes in the manner of Gymnosperma, from which it is distinguished mainly by the pappus. - Nov. Gen. \& Spec. 30 ; Hook. \& Arn. Comp. Bot. Mag. ii. 51; Torr. \& Gray, Fl. ii. 193. Brachyris, Nutt. Gen. ii. 103. Brachyachyris, Spreng. Syst. iii. 574. Brachyris (excl. spec. and § 2), Hemiachyris, \& Odontocarpha, DC. Prodr. v. 312, 71.

G. LINEARIFólis, Lag., the original species (of which no specimen named by Lagasca is extant), on account of the oblong involucre with bracts loose at apex, enclosing only about 8 or 10 flowers, may with the highest probability be referred to a Chilian species, the Brachyris paniculata, DC. Prodr. v. 313; and this, although not traceable at Madrid, was collected by Née, and has been communicated to herb. DC. and herb. Boissier, to the latter by Pavon.

$\S 1$. Pappus of ray and disk similar, or in the former shorter: ligules mostly short: involucral bracts in N. American species all appressed. - Brachyris, Nutt.

* Suffruticose, and the woody base much branched: heads fastigiately or paniculately cymose: receptacle plane or small: palex of the pappus conspicuous, from narrowly oblong to linearsubulate.

G. Euthámiæ, TorR. \& Grat. Bushy, from glabrous to hirtellous-puberulent, 6 to 18 inches high, with mostly strict and fastigiately polycephalous branches: leaves narrowly linear, verging to filiform: heads mostly clavate-oblong, few-several-flowered, not over 2 lines long, sume short-pednnculate, others 3 to 5 in a glomerule (in the manner of Solidago $\S$ Euthamia): flowers of disk and ray not numerous (commonly 3 or 4 each, or the latter 5 or 6, sometimes only one or two each): akenes sericeous-pubescent. - Solidago Sarothro, Pursh, Fl. ii. 540. Brachyris Euthamice, Nutt. Gen. ii. 163; Hook. Fl. ii. 23. B. Euthamios $\&$ B. dizaricata, Nutt.Trans. Am. Phil. Soc. vii. 313, the latter an open form. Brachyachyris Euthamia, Spreng. Syst. iii. 574. Gutierrezia Euthanice \& G. divaricata, Torr. \& Gray, Fl. ii. 193. - Arid plains and rocky hills, Saskatchewan to Montana, south to New Mexico, Arizona, and borders of California. (Adj. Mex., where there is also a form with rather broadly linear leaves, coll. Berlandier; Thurber.)

Var. microcéphala. Heads smaller, narrower, few-flowered, commonly oblongcylindraceous and the involucre of fewer and narrower bracts : flowers of disk and ray mostly reduced to one or two each: leaves either narrowly linear or nearly filiform: pappus, as in the species, varying from short-oblong and obtuse (as in Berlandier's Saltillo specimens) to linear-lanceolate, and even attenuate-acute (as in Parry \& Palmer's) : certainly passes into G. Euthamia. - G. microcephala, Gray, Pl. Fendl. 74, Pl. Wright., \&c. G. microphylla, Durand \& Hilgard, Pl. Heerm. 40. Brachyris microcephala, DC. Prodr. v. 313. - S. Texas and New Mexico to S. California. (Adj. Mex., first coll. by Berlandier.)

G. Califórnica, Torr. \& Grar, 1. c. More loosely branched: heads seldom glomeratefascicled, obovate-turbinate, 2 or 3 lines long: involucral bracts (except small outermost) broad, ohlong to obovate: rays 8 to 10, short: disk-flowers 6 to 12 : akenes more villous. Brachyris Californica, DC. 1. c. Gutierrezia linearifolia (with some of $G$. Euthamio), Gray, Bot. Calif. i. 302, not Lag. - Hills, California near the coast, from San Francisco Bay southward (first coll. by Douglas) : also San Bernardino Mountains (Parish), and Mesas of Arizona, Palmer, Lemmon, Pringle.

* Annual herbs, loosely much branched: heads singly terminating the branchlets and paniculate: involucre hemispherical or obscurely obovate, about 2 lines in diameter, many-flowered: rays 9 to 15 ; disk-flowers 20 to 30 : receptacle more or less elevated and hirsute-fimbrillate: akenes very short, obovate or turbinate, 10-costate; the ribs very silky-villous.

G. sphærocéphala, Grar. Low: receptacle of the flowers obtusely conical or hemispherical: pappus of 5 or 6 ovate short coroniform-concreted palea, barely half the length of the akene. - Pl. Fendl. 73, P1. Wright. ii. 79.-S. W. Arkansas, E. New Mexico, and S. W. Texas, Fendler, Wright, \&c. 
G. eriocárpa, Grat. Low or taller (a foot or two high) : receptacle obtusely high-conical : pappus of 12 or more linear-lanceolate or subulate and mostly distinct paleæ, about half the length of the akene. - Pl. Wright. i. 94. - Plains and prairies, S. and W. Texas, Wright, Havard. (Mex.)

G. Berlandif́ri, Gray, Proc. Am. Acad. xv. 31, is an allied species of the northern part of Mexico, with a pappus of numerous minute paleæ, which do not surpass the silky hairs of the akene.

$\S 2$. Pappus wanting in the ray-flowers: ligules comparatively long: habit of the preceding subsection. - Hemiachyris, DC.

G. Texána, Torr. \& Gray. Annual, effusely much branched, 2 or 3 feet high: branches slender, bearing the very numerous pedunculate heads in open compound panicles: involucre turbinate-campanulate, a line or two long: rays 8 to 10 (3 or 4 lines long); disk-flowers as many: akenes minutely pubescent; those of the disk with a minute pappus of ovate or subulate palex, of length less than the breadth of the akene.-Fl. ii. 194. Hemiachyris Texana, DC. Prodr. v. 314. Brachyris microcephala, Hook. Ic. t. 147, not DC. - Sterile plains, W. Arkansas to Texas. (Adjacent Mex.)

22. AMPHIÁCHYRIS, Nutt. (Brachyris § Amphiachyris, DC.) ('A $\mu \phi i$, about, or on both sides, and äxvoov, chaff.) - As here constituted, the genus consists of two rather low and fastigiately or diffusely much-branched and erect glabrous plants, with entire leaves; the first with the habit of Gutierrezia, the second sufficiently different to form a subgenus (Amphipappus, Torr. \& Gray) : fl. yellow in late summer and autumn.

A. dracunculoídes, Nutr. Annual, rather low, effusely corymbiform, the slender branches and branchlets terminating in single pedunculate heads : leaves narrowly linear or the uppermost filiform: involucre hemispherical or short-campanulate; the bracts 10 or 12 , firm-coriaceous and whitish with abrupt green tips, mostly ovate or oval : rays 5 to 10 , oval or oblong, nearly as long as the involucre; disk-flowers 10 to 20 , wholly sterile, the ovary quite abortive; their pappus of 5 to 8 scarious almost aristiform smooth paleæ, cupulately united at base and slightly dilated upward : akenes (of the ray) with a minute or obscure. coroniform pappus. - Trans. Am. Phil. Soc. vii. 313; Torr. \& Gray, Fl, ii. 192. Brachyris dracunculoides, DC. P1. Rar. Genev. vii. 1, t. 1, \& Prodr. v. 313. Brachyris ramosissima, Hook. Ic. t. 142 ; DC. Prodr. vii. 278. Gutierrezia Lindheimeriana, Scheele in Linn. xxii. 351. - Plains, Kansas to Texas.

A. Fremóntii, Gray. Shrubby, a foot or two high, with rigid tortuous branches · leaves short (half or quarter-inch long), obovate or spatulate, commonly narrowed at base into a margined petiole: heads mostly sessile and glomerate in small corymbosely disposed cymes : involucre campanulate or oblong, 2 lines long; the bracts 7 to 9 , thin, mostly destitute of green tips: rays 1 or 2 , short: disk-flowers 3 to 6 , with infertile glabrous ovary, and a pappus of about 20 flattish denticulate-hispid tortuous bristles, some of them branching or irregularly paleaceous-concreted at base: ray-akenes with a pappus of fewer and short bristles or squamellæ, more united at base. - Proc. Am. Acad. viii. 633, \& Bot. Calif. i. 302. Amphipappus Fremontii, Torr. \& Gray in Jour. Bost. Soc. Nat. Hist. v. 4; Torr. Pl. Frem. 17, t. 9. - Arid deserts on the Mohave, S. E. California, Fremont, to S. W. Utah, Palmer.

23. GRINDELIA, Willd. (Prof. Hieronymus Grindel, of Riga and Dorpat.) - Herbs, or some species shrubby, of coarse habit (American, mostly of the U. S. west of the Mississippi) ; with sessile or partly clasping and usually serrate rigid leaves, and rather large heads of yellow flowers terminating the branches; the narrow rays usually numerous, occasionally wanting; central diskflowers not rarely infertile. HIerbage often balsamic-viscid, the heads especially so before and during anthesis (whence called Gum-PLANT in California): fl. all 
summer. - Gesel. Nat. Fr. Berl. Mag. 1807, 259 ; Dunal, Mem. Mus. Par. v. 48; DC. Prodr. v. 314 ; Benth. \& Hook. Gen. ii. 250. Demetria, Lag. Donia, R. Br. Aurelia, Cass.

G. cononopifólıa, Lehm., of Mexico, is Xanthocephalum centauroides, Willd, the original of that genus.

G. ANGOSTIFólis, DC. in Dunal, founded on a drawing only, is not identified; probably of some other genus.

G. $\operatorname{costAt}$, Gray, Proc. Am. Acal. xvii. 208, is a northern Mexican species, allied to $G$. squarrosa and $G$. subdecurrens, with lunate-gibbous 10-ribbed akenes. It may reach the U. S. borders.

* Stem or branches (at least above) and sometimes the leaves pubescent: rays very numerous: awns of the pappus 2 or 3 , sometimes solitary: plants a foot to a yard high.

+ Atlantic and Mexican species: root in U.S. annual or biennial, perhaps more enduring in Mexico: akenes with no terminal border or teeth.

G. inuloídes, WiLLD. 1. c. Pubescence minute or short: leaves from oblong to lanceolate or almost ovate, serrate down to the partly clasping or broad base with close-set and often gland-tipped salient teeth : involucre glabrous (half-inch or more in diameter), at length squarrose: akenes short and turgid (the length barely double the breadth), with roundedtruncate summit and small areola, smooth or becoming corky-rugose transversely. - I Dunal, 1. c. 50, t. 5 ; Bot. Reg. t. 248 ; DC. Prodr. v. 315 ; Hook. Bot. Mag. t. 3737 ; Torr. \& Gray, 1. c., excl. var. B. G. pubescens, Nutt. Jour. Acad. Philad. vii. 74. Inula serrata, Pers. Syn. ii. 451. Demetriu spathulata, Lag. Elench. Madr. 1814, 20. - Plains of Arkansas and Texas; common. (Mex.)

Var. microcéphala, Grıx. Smaller, more branching: heads only half as large: akenes more commonly rugose-tlickened but sometimes smooth: involucral bracts usualiy shorter and closer: the extreme forms seeming very distinct from the type, but connected by intermediate states. - Bot. Mex. Bound. 81, G. microcephala, DC. Prodr. v. 315. S. Texas, first coll. by Berlandier. (Mex.)

+ +- Pacific species: root perennial but sometimes flowering the first year: akenes truncate and with a prominulous irregularly undulate or obscurely 3-5-toothed border around the terminal areola: pappus-awns stouter and more corncous, flattish: involucre in the same species either naked or surrounded by spreading foliaceous bracts passing into leaves.

G. hirsútula, Hook. \& ARs. A foot or two high, simple or sparingly branched, villoushirsute, or glabrate, sometimes even tomentose when young: leaves rather rigid and commonly serrate with rigid salient teeth, in the typical plant oblong, or lower ones spatulate and obtuse (cauline inch or two long and about hall-inch wide), upper with partly clasping but not widened base, varying however to lanceolate and acute : heads solitary or few : involucre half-inch in diameter; its proper bracts with or without subulate-attenuate squarrose tips, and with or without the surrounding loose foliaceous bracts, which may surpass the disk. - Bot. Beech. 147, 351 ; DC. Prodr. vii. 278; Torr. \& Gray, 1. c.; Gray, Bot. Calif. i. 103. G. rubricuulis, IC. Prodr. v. 316. - Hills and open grounds, California from Mouterey northward, where it seems to pass into or is not well discriminated from the following; first coll. by Douglas.

G. integrifólia, DC. A foot to a yard high, the taller plants corymbosely branching at summit and bearing several or numerous heads: pubescence soft-villous, sometimes sparse or vanishing: leaves of soft texture, commonly entire, occasionally serrate; cauline lanceolate, 3 or 4 inches long, mostly tapering from a broad base to an acute or acuminate apex ; radical spatulate and obtuse: bracts of the involucre with mostly elongated setaceous-subulate points to the bracts. - Prodr. v. 315; Torr. \& Gray, 1. c. G. stricta, DC. Prodr. vii. 278. $G$. virgata, Nutt. Trans. Am. Phil. Soc. vii. 314, slender form. Donia imuloides, var., Hook. F1. ii. 25. - Moist or shady ground, Oregon to British Columbia, chiefly toward the coast. Varies greatly in open ground having leaves of firmer texture, the lower sometimes coarsely serrate, even the upper barely acute: on the shores of British Columbia occurs a low form, glabrate and thickish-leaved, which perhaps too nearly approaches $G$. cuneifolia.

* Whole herbage glabrous: stems equably leafy, a foot or two high: root mostly shortwlived perennial, but sometimes annual in the same species: leaves firm or rigid. 
+ Akenes squarely truncate and even at the summit, not bordered nor toothed: pappus-awns only 2 or 3 .

G. Arizónica, Grax. Rather low and slender : cauline leaves oblong-linear or narrowly oblong, obtuse, mostly spinulose-denticulate or dentate: heads small (half-inch high): bracts of the involucre short and rather broad, the acnte or subulate-acuminate tips not prolonged nor spreading. - Proc. Am. Acad. xvii. 208. G. microcephala, Rothr. in Wheeler Rep. vi. 141, not DC. - Mesas of Arizona and New Mexico, Wright, Rothrock, Brandegee. (Adj. Mex.)

G. squarrósa, Dunal. Commonly only a foot or two high and branched from the base: leaves rigid; cauline from spatulate- to linear-oblong and with either broadish or narrowed half-clasping base, acutely and often spinulosely serrate or denticulate; sometimes radical and even cauline laciniate-pinnatifid: involucre strongly squarrose with the spreading and recurving short-filiform tips of the bracts: outer akenes commonly (but not always) corkythickened and with broad truncate summit, those toward the centre narrower and thinnerwalled and with smaller areola. - DC. Prodr. v. 315; Torr. \& Gray, 1. c. Donia squarrosa, Pursh, Fl. ii. 559 ; Sims, Bot. Mag. t. 1706 ; Nutt. Gen. ii. 163. Aurelia amplexicuulis, Cass. Dict. xxxvii. 468. Grindelia subdecurrens, DC. 1. c. G. arguta, Gray, P1. Wright. ii. 81, not Schrader. - Plains and prairies, Minnesota and Saskatchewan to Montana and south to Missouri and Texas, west to Nevada, Arizona, and borders of California. (Mex.) - Heads small or middle-sized : involucre half to two-thirds inch in diameter, very glutinous. Varies much : the following are the most marked forms.

Var. núda, Gray. Rays wanting.-G. squarrosa, Gray, PI. Fendl. 77. G. nuda, Wood in Bot. Gazette, iii. 50. - With the usual radiate form in New Mexico, Colorado, and recently about St. Louis, Missouri.

Var. grandiflóra, Gray. Heads larger and with very numerous rays (of an inch in length): stem 2 to 4 feet high, strict and simple below: upper leaves from ovate to oblong, broader or not narrowed at base, more numerously and equally serrate either with obtuse or spinulose teeth. - Pl. Wright. i. 98. G. grandiflora, Hook. Bot. Mag. t. 4628. G. Texana, Scheele in Linn. xxi. 60. - Texas, in two forms; one by Berlundier, Wright, \&c., with heads no larger than is common in $G$. squarrosa, and the leaves elliptical or oval and obtuse, closely beset with obtuse callous teeth; the other collected by Lindlieimer, Reverchon, \&c., with spinulose or almost aristate teeth.

G. Oregána. Stem rather stout and tall, branched above: leaves thickish, not rigid, sparsely denticulate or entire, mostly obtuse, oblong-spatulate or lingulate, or the upper lanceolate (the larger cauline 4 inches long and an inch wide): heads large (rays an inch long): bracts of the involucre with erect or spreading slender linear-subulate tips : akenes minutely striate. $-G$. virgata, in part, Nutt. Trans. Am. Phì. Soc. vii. 314. G, integrifulia, in part, Nutt. 1. c.; Torx. \& Gray, 1. c., not DC. Lonia glutinosa, Hook. Fl. ii. 25, not R. Br.Oregon to Idaho, in dry soil.

++ Akenes all or some outer ones 1-2-dentate or auriculate-bordered at the summit, except perhaps in G. glutinosa.

+- Atlantic species: pappus-awns mostly 2.

G. lanceoláta, Nutr. Stem 2 feet high, slender : leaves lanceolate or linear, acute, spinulose-dentate or denticulate (lower sometimes laciniate): heads as in $G$, squarrosa but the subulate-attenuate elongated tips of the involncral bracts straight and erect or the lower spreading : summit of the alkene produced from each or the outer margin into a short tooth. - Jour. Acad. Philad. vii. 73; Torr. \& Gray, Fl. ii. 248. - Prairies and barrens, Texas, Louisiana, Arkansas, and Tennessee. (Barrens near Nashville, Gattinger, where it is probably indigenous.)

++ Pacific species.

G. cuneifólia, NסTT. Suffrutescent, stout, 3 or 4 feet high, mostly maritime, much branched: leaves thick, from cuneate-spatulate to linear-oblong, almost all with narrowed base, denticvlate-serrate or entire: involucre half-inch or more high, little glutinous, the tips of the bracts either scarcely or decidedly squarrose: pappus-awns 5 to 8. - Trans. Am. Phil. Soc. 1. c. 315 ; Torr. \& Gray, 1: c.; Greene in Bot. Gazette, viii. 256. G. robusta, var. angustifulia, Gray, Bot. Calif. i. 304, chiefly.- Salt marshes and shores, California, from Santa Barbara Bay northward; flowering in October. Woody base of stem becoming an inch or two thick. 
G. glutinósa, Dunal. Herbaceous nearly or quite to the base ("fruticose," Cav.), a foot or two high : leaves rather large, obovate or spatulate, mostly rounded at summit and with partly clasping (broad or narrowish) base, more or less serrate : heads large: involucre half to three-fourths inch high, its bracts close, acute or acuminate, with no prolonged squarrose tips : akenes obscurely if at all bordered at summit: pappus-awns 5 to 8, stout and flattened, sparingly ciliolate-scabrous or nearly smooth. - Mem. Mus. 1. c. 49; DC. Prodr. v. 314; Gray, 1. c. 303. Aster glutinosus, Cav. Ic. ii. 53, t. 168. Doronicum glutinosum, Willd. Spec. iii. 2115. Inula glutinosa, Pers. Syn. ii. 452. Donia glutinosa, R. Br. in Ait. Kew, ed. 2, v. 82. Denetria glutinosa, Lag. Nov. Gen. \& Spec. 30. Aurelia decurrens, Cass. Dict. xxxvii. 468. (The pappus-awns in old-time cultivated specimens sparsely hirtello-ciliolate indeed, but not as figured by (avanilles; in Californian specimens varying from obscurely so to smooth.) Grindelia latifolia, Kellogg, Proc. Calif. Acad. v. 36. - Shore of California, from Humboldt Co. (Bolander) and San Francisco Bay to Santa Barbara Islands, whence a very large-leaved and robust form was deseribed by hellogg. Fl. summer. ("Mexico," Cavanilles. "P'eru," Bentham in Gen. Original habitat seemingly quite unknown, but doubtless it came from the Pacific shores.)

G. robústa, Nurx. Herbaceous to the base, rigid, branching, usually glutinous in the manner of $G$. squarrosa, which it resembles in the attenuate-acuminate and squarrose spreading or recurved tips to the involucral bracts: leaves more rigid and larger, oblong, varying to lanceolate, rigidly spinulose-serrate or denticulate, or uppermost entire: heads usually halfinch high : akenes (at least outer ones) obliquely anriculate or broadly unidentate at summit: pappus-awns 2 or 3, rarely more. - Trans. Am. Phil. Soc. 1. c. 314 ; Torr. \& Gray, 1. c. ; Gray, Bot. Calif. l. c., excl. vars. latifolia \& angustifolia in part, incl. var. rigida. G. squarrosa, Hook. \& Arn. Bot. Beech. 147, not Dunal. - The common GCM-PLAxt of California, common throughout the western part of the State, on dry hills, \&c. : fl. summer.

G. nána, Nттт. Rather low and slender, 6 to 30 inches high, the larger plants corymbosely and freely branched above: leaves thinnish, lanceolate and linear, or the lower spatulate, entire or spinulose serrate: heads small (a quarter to a third of an inch high): bracts of the involucre with slender and squarrose soon revolute tips, in the manner of $G$. squarrosa (which this species represents northwestward): rajs 16 to 30: akenes narrow, excisely truncate or bidentate at summit: pappus-awns mostly 2. - Trans. Am. Phil. Soc. 1. c. 314. G. humilis, Torr. \& Gray, Fl. ii. 248, not Hook. \& Aru. G. Pacifica, Marcus E. Jones in Bull. Torrey Club, ix. 31, in a habitat much out of range; namely, at Santa Cruz, California. - Washington Terr. and east to X. W. Wyoming, south to Shasta, California. Some Oregon specimens have heads as large as those of $G$. squarrosa, but the akenes are different.

Var. discoídea, a rayless state of the species. $-G$. discoidea, Nutt. l. c. 315, not Hook. \& Arn. - Oregon and Washington Terr., Nuttull, \&c.

* * Anomalous and obscure species, wholly glabrous: cauline leaves all very small and narrow, almost filiform.

G. húmilis, Hook. \& ARs. Not glutinous, apparently perennial: stem simple, slender, 7 inches high, 2-cephalous at summit: radical leaves linear, 2 inohes long, 2 lines wide at the obtuse obscurely denticulate apex, thence gradually tapering to base; cauline nearly all small and bract-like, all but lowest half-inch long, not over one third of a line wide, attenuate-acute: involucre half-inch high; bracts lanceolate, acute, largely green, erect, the outer successively shorter: rays rather long: bristles of the pappus apparently 3 or 4, slender. - Bot. Beech. 147. - Single specimen known, "California, Beechey," therefore probably from Monterey. Very unlike any other.

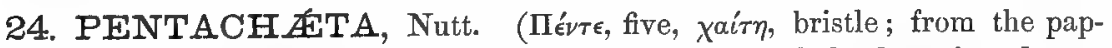
pus of the original species.) - Californian annuals, low and slender, often depauperate, glabrous and smooth or with some pubescence; with filiform-linear and entire alternate leaves, heads terminating the pedunculiform summit of the stem and loose branches, with either homochromous or heterochromous flowers, pro- . duced in spring. - Trans. Am. Phil. Soc. n. ser. vii. 336; Gray, Proc. Am. Acad. viii. 633, \& Bot. Calif. i. 305. Pentachata \& Aphantochata, Torr. \& Gray; Benth. \& Hook. Gen. ii. 251. (See p. 445.) 
$\S 1$. Flowers of both ray and disk golden yellow : involucre of comparatively numerous and regularly imbricated bracts.

P. aúrea, Nutr. 1. c. At length diffusely branched, 3 to 12 inches high: heads mostly large for the size of the plant and many-flowered, but greatly varying: rays 7 to 40 (2 to 5 lines long): bracts of the involucre broadly lanceolate, mostly setaceous-acuminate, with green centre and broad scarious margins : akenes villous-pubescent: pappus-bristles 5, sometimes 6 to 8, as long as disk-corollas. - Gray, Bot. Mex. Bound. 81, Bot. Calif. 1. c. - Open and dry ground, in the southernmost counties of California; first coll. by Nuttall.

$\S 2$. Flowers of the ray white or purple-tinged, sometimes wanting or else few and wanting the ligule: disk-corollas yellow or yellowish, or changing to purple in age: bracts of involucre somewhat equal and fewer, mostly obtuse and narrowly scarious-margined.

P. exílis, Grax, l. e. A span or so high, with simple or from the base simply branched monocephalous erect stems: heads in the larger form (here taken as the type) manyflowered, with hemispherical or broadly campanulate involucre (3 lines high), and 8 to 14 oblong rays, these 2 lines long: akenes oblong-turbinate, villous: pappus-bristles 5, shorter than disk-corollas, in some plants abortive or obsolete. - Bot. Calif. 1. c.; Greene in Bot. Gazette, viii. 256. - Dry hills, middle part of California, from Santa Clara Co. northward.

Var. aphantochǽta, Gra r, l. c. More or less depauperate, 2 to 4 inches high: heads narrower, from rather few- to 25-flowered, discoid, mostly having 3 to 5 female flowers with corolla destitnte of ligule, sometimes these wanting: pappus reduced to 3 or 5 short cusps or obsolete. - P. aphantochosta, Greene in Bot. Gazette, 1. c. Aphantochaeta exilis, Gray, Pacif. R. Rep. iv. 99, t. 11, a delicate and few-flowered form. - Dry ground, from the Salinas Valley to El Dorado Co., first coll. by Bigelow. Var. discoidea, Gray, l. c., is partly a small form of this without female flowers, and partly the following, into which it may pass.

P. alsinoídes, Greene. A span high, at length diffusely and several times branched from the base, with pedunculated discoid heads in the forks: involucre only 2 lines long, of only 5 to 7 bracts, "3-5-" or 6-7-flowered : flowers apparently all hermaphrodite: pappus-bristles 3 or 4 , fully equalling the corolla and as long as the obovate-clavate pubescent alienes, rarely obsolete in some flowers. - Bull. Torrey Club, ix. 109, \& Bot. Gazette, 1. c. - Hills or dry ground around San Francisco Bay to El Dorado Co., first coll. by $\mathbf{K}$ ellogg and Bolunder.

P. GRAcilis, Benth. in Hook. Ic. t. 1101, from Mexico, is Oxypappus, Benth.

25. BRADBÚRIA, Torr. \& Gray. (In memory of John Bradbury, who collected plants on the Missouri which were published in Pursh's Flora.) - Fl. ii. 250 ; Benth. \& Hook. Gen. ii. 251. - Single species.

B. hirtélla, Torr. \& Gray, 1. c. Annual, branched from the base, a foot or so high, hispid: slender branches terminated by single rather small heads of yellow flowers: radical and lower cauline leaves narrowly spatulate; those of the flowering branches small, spatulatelinear to nearly filiform, mucronate-pointed: rays 3 or 4 lines long.-Dry ground, Texas, Drummond, Wright, Lindheiner, \&c.

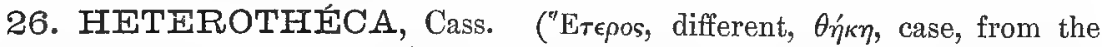
unlike akenes of ray and disk.) - N. American and Mexican herbs (probably only three species, two of them very variable), with the aspect of Chrysopsis, hirsute or scabrous: flowers yellow: pappus reddish or ferruginous: lower leaves at base of petiole commonly with a foliaceous stipuliform dilatation, upper partly clasping. Peduncles and involucre more or less glandular. A bristle or two of pappus rarely found on ray-akenes. - Bull. Philom. 1817, \& Dict. xxi. 130; DC. Prodr. v. 316; Torr. \& Gray, Fl. ii. 251.

H. Lamárckii, Cass. 1. c. Biennial or sometimes annual, 1 to 3 feet high, somewhat heavy-scented, branching, usually bearing numerous corymbiform-paniculate rather small heads: radical leaves oval or oblong, slender-petioled; cauline oblong; the upper mostly 
with subcordate-clasping base: involucre 3 to 5 lines high: rays abont 20; their akenes mostly glabrons and obscurely crowned: outer pappus of the disk-fowers conspicuous. H. Lamarckii \& H. scalru (also apparently H. Chrysopsidis \& H. leptoglossa), DC. ]. (., 317. H. scabra (var. ('alycium \& var. nuda, which are confluent), Torr. \& Griv, Fl. ii. 251. H. latifolia, Buckley in Proc. Acad. Philad. 1861, 459. Inula subaxillaris, Lam. Dict. iii. 259, fide Cass. I. scabra, Pursh, Fl. ii. 531. Chrysopsis scabra, Nutt. Gen. ii. 151 ; Ell. Sk. ii. 339 ; Bertol. Misc. vii. t. 4. - Sandy or barren dry soil, coast of Carolina to Texas, Arkansas, S. Arizona, and perlaps within the borders of California. (Mex. In original specimens of $H$. Chrysopsidis, DC., and others from Saltillo, \& ${ }^{\circ}$, a setose pappus to the rayflowers only abnormally occurs. H. leptoglossa, DC., has the crown of the ray-akenes with a sharp and sometimes nndulate edge. In Parry \& Palmer's no. 373 the crown is more salient and setulose-denticulate!)

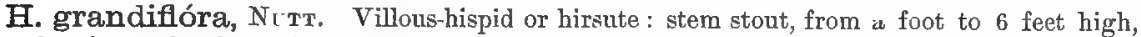
bearing rather large (sometimes rather small) heads : cauline lcaves not clasping, or hardly so, and clasping base of petioles of the lowest occasionally wanting: involucre 4 or 5 lines high: rays about 30 ; their akenes minutely pubescent or glabrate: outer pappus of the disk-flowers less conspicuous: style-appendages shorter, mostly obtuse. - Traus. Am. Phil. Soc. vii. 315 ; Torr. \& Gray, 1. c. Diplopappus scaber, Hook. F1. ii. 22. IJelerotheca florilundu, Benth. Bot. Sulph. 24. $T$. floribunda (excl. pl. Coulter, which helongs to the preceding and is probably from Arizona) \& II. grandiflora, Gray, Bot. Calif. i. 308. - California from Santa Barbara southward and east to the borders of Nevada. - Heads always smaller than those of $H$. inuloides, sometimes no larger than of the preceding species.

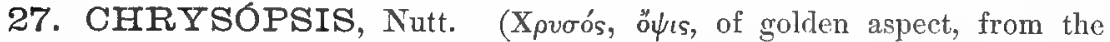
color of the blossom.) - Herbs (N. American, extending into Mexico), mostly perennials; with silky. lanate, hirsute or hispid pubescence, or rarely glabrous, entire or sometimes fer-toothed leaves, the cauline sessile, and middle-sized heads of yellow flowers terminating the stem and branches; in late summer and autunn: pappus commonly fuscous or ferruginous. - Gen. ii. 150, under luulu; DC. Prodr. v. 326 ; Torr. \& Gray, Fl. ii. 252.

\section{$\S 1$. Ecchrysopsis. II ads radiate: outer short pappus mostly manifest.}

* Leaves narrow, elongated and nervose, gramineous or rather Luzula-like: whole herbage sericeous-lanate, or in age glabrate: root perennial: akenes compressed-fusiform: outer pappus squamellate-setulose. - Pityopsis, Nutt. Trans. Am. Phil. ,rrc. n. ser, vii. 317.

C. graminifólia, Nстт. Stem a foot or two high, slender, generally leafy, stoloniferous underground: leaves 3-5-nerved or striate, silvery-kericeous, at least when young, lanceolate to linear; radical a span to a foot long; cauline successively shorter and becoming linearsubulate, erect: heads few or several and paniculate: involucre (half-inch or less high) somewhat turbinate; its regularly imbricated bracts many-ranked, glabrate, sometimes granulose-glandulitr on the back: peluneles when glabrate often hirtellous-glandular.Torr. \& Gray, Fl. ii. 252; Bertol. Misc. Bot. vii. t. 3. C. graminifolia \& C. argentea, Nutt. Gen. ii. 151 ; Ell sk. ii. 234 ; DC. Prodr. v. 326. C. oligantha, Chapm. Fl. 216, an earlyflowering form with few leaves and heads. Inula graminifolin, Michx. Fl. ii. 122. I. argentca, Pers. Syn. ii. 452. Erigeron nerrosum, Willd. Spec. iii, 1953. E. glandulosum, Poir. Dict. viii. 487. Diplonappus graminifolius, Less. in Linn. v. 310. D. sericeus, Hook. Comp. Bot. Mag i. 97. Pityopsis (Sericophyllum) graminifolia \& urgentea, Nutt. Trans. Am. Phil. Soc. 1. c. - Dry pine barrens or sandy ground, Maryland to Florida and Texas; fl. autumn. A characteristie but rariable species: leaves from i to 9 lines wide, and heads when numerous smaller than when few. (Mex. Probably Hectorea rillosissima, DC.)

Var. áspera (C. aspera, Shuttlew. in distrib. coll. Rugel), a glabrate rigid and polycephalous state, near St. Marks, Florida (probably on the very coast), the stem and leaves sparsely tylandular-hispidulous!

C. pinifólia, ELJ. A foot high, slender (the flowering branches almost filiform); verg early glabrate, appearing glabrous, smooth throughout: lowest leaves narrowly linear and 2-3-nerved (at most a line and a half wide, 2 to 6 inches long); cauline filiform: heads solitary terminating the branches, or corymbose pedunculate, nearly as large as the average in 
C. graminifolia : akenes the same. - Sk. ii. 335. Pityopsis pinifolia, Nutt. 1. c. - Georgia, on sand-hills between the Flint and Chattahoochee, Jackson (Ell.), Baldwin.

C. falcáta, ELL. Low, seldom a foot high, branched from the base, very leafy to the top, loosely lanate, at length glabrate, not glandular: leaves from narrowly to oblongllinear, obscurely few-nerved, rigid ( 1 to 3 inches long); the cauline spreading and sometimes falcate-recurving: heads mostly numerous and cymose, small: involucre campanulate (3 or 4 lines long). - Sk. ii. 336 (note); DC. 1. c.; Torr. Fl. N. Y. i. t. 56. Inula falcata, Pursh, Fl. ii. 532. Pityopsis falcata, Nutt. Trans. Am. Phil. Soc. 1. c. - Barren land along the coast, Cape Cod to New Jersey.

* * Leaves not nervose or gramineous: involucre hemispherical: akenes turbinate-oborate and turgid-flattish (or in the last species more oblong), 3-5-nerved: outer pappus squarnellate or setulose.

+ Pubescence arachnoid-lanate or cottony-villous and flocculent, deciduous, leaving a glabrous or minutely scabrous and glandular surface, sometimes glabrate from the first except on rosulate tufts of radical leaves: Atlantic species.

+ Heads comparatively small, seldom half-inch high, commonly cymose: arachnoid hairs sparse or wanting: stems very leafy : root no more than biennial.

C. scabrélla, Torr. \& GRAY. Glandular-scabrous even to the rather obtuse bracts of the involucre, destitute of cobwebby hairs: stem rather stout: leaves oblong-lanceolate or spatulate: outer pappus setiform.-Fl. ii. 255. - Pine woods, Tampa, Florida, Leavenworth, Garber. Too near the broad-leaved form of the next.

C. trichophýlla, Nutr. Villous when young with very long and soft usually scattered hairs which mostly have a stouter base : stem slender, I to 3 feet high: leaves oblong-spatulate or oblanceolate and obtuse, or upper linear: bracts of the involucre smooth, acute: outer pappus squamellate-setulose. - Gen. ii. 150; Torr. \& Gray, 1. c. Diplopappus trichophyllus, Hook. Comp. Bot. Mag. i. 97. - Dry ground, N. Carolina to Florida and Lonisiana, in the low country, chiefly on and near the coast. Broad-leaved form approaches C. Mariana: narrower comes too near the next.

C. hyssopifólia, Nuтt. Glabrate and smooth, but the rosulate linear-spatulate or sometimes broadly spatulate (barely inch long) radical leaves floccose-woolly when young: stem slender, virgate, 2 or 3 feet high, very leafy with spatulate-linear to almost filiform (inch or so long) glabrous leaves : heads often numerous and cymose: otherwise as the preceding. Jour. Acad. Philad. vii. 67. C. trichophylla, var. hyssopifolia, Torr. \& Gray, Fl. ii. 254, excl. syn. Hook. - Sand-hills and dry pine barrens of Florida, on the coast.

t+ +t Heads larger: wool floccose: akenes often with 2 to 4 salient and glandular-thickened nerves or ribs: outer pappus more squamellate: leaves occasionally with a few serratures or denticulations, oblong, or the lower spatulate or obovate and uppenost lanceolate.

C. Mariána, Nutr. A foot or two high from a perennial root, loosely silky-villous with arachnoid hairs, glabrate in age: leaves thinnish, green: heads several in a corymbiform cluster: involucre glabrous but granulate-glandular.-Gen. 1. c. (under Inula); Torr. \& Gray, 1. c.; Bertol. Misc. vii. t. 2. Inula Mariana, L. Spec. ed. 2, ii. 1240. Aster Carolimianus pilosus, etc., Mill. Ic. t. 57. Diplopappus Marianus, Hook. 1. Ł.-Pine barreus and sandy soil, coast of New York to Florida and Louisiana.

C. gossypina, Nuтr. 1. c. A foot or two high from a biennial root, densely lanate, the wool becoming tomentose-floccose: leaves all obtuse, mostly short and spatulate or oblong: heads terminating pedunculiform branches or loosely corymbose: involucre very woolly, or becoming glabrate or even glandular. - Torr. \& Gray, l. c.; Bertol. Misc. vii. t. 1. Inula gossypina, Michx. Fl. ii. 122. I. glandulosa, Lam. Dict. iii. 259? Erigeron pilosum, Walt. Car. 206. Chrysopsis dentata, Ell. Sk. ii. 337, a form with lower leaves few-toothed. C. decumbens, Chapm. Fl. 217, a coast form with glandular peduncles and involncre. - Sandy pine barrens, N. Carolina to Florida and Alabama, in the low country.

+ + Pubescence from hispid to silky-villous, persistent: root perennial. Includes a multitude of forms, seemingly not distinguishable into species.

C. villósa, Nutr. 1. c. A foot or two high : leaves from oblong to lanceolate, rarely fewtoothed, usually cinereous or canescently strigose or hirsute and sparsely hispid along the margins and midrib, an inch or two long: heads mostly terminating leafy branches sometimes rather clustered, naked at base or foliose-bracteate: involucre campanulate, 4 or 5 
lines high; its bracts commonly strigulose-canescent, sometimes almost smooth, acute: akenes oblong-obovate, villous : outer pappus setulose-squamellate. - A mellus villosus, P'urslı, Fl. ii. 564. Diplopappus villosus \& D. hispielus, Hook. Fl. ii. 22. Chrysopsis villosa, hispida, foliosa, mollis, \& sessiliflora, Nutt. Trans. Am. Phil. Soc. 1. c.; Torr. \& Gray, 1. c.; also C. canescens, Torr. \& Gray, C. echioides, Benth. Bot. Sulph. 25 \& Pl. Hartw. 316 . - Prairies, plains, and other open grounds, from Illinois and W. Alabama north to saskatchewan, south to Arizona, and west to British Columbia and the coast of California; in various forms. The typical eastern and northern plant is rather large, with cinereous and roughish but not canescent pubescence. Westward, extending to the southern part of California, it usually becomes more canescent and villous as well as hirsute and hispid; the size and fulness of the heads greatly varying. The more marked but quite unlimited forms are the following :-

Var. híspida, GRAx. Small and low, with hirsute and hispid pubescence, not canescent : heads particularly small : involucre not cunescent, sometimes glabrous. - Proc. Acad. Philad. 1863, 65. Diplopappus hispidus, Hook. Fl. ii. 22. Chrysopsis hispida, DC. Prodr. vii. 279 ; Nutt. 1. c. - Saskatchewan to Idaho, south to W. Texas, Nevada, and Arizona. And forms between this and the next in California.

Var. víscida. Low: leaves small, oblong to spatulate, green, sparingly if at all hispid, not rough, but viscid-hirtellous or with viscid points, and the involucre commonly viscidulous. - Utah and Arizona, in the mountains, Jones, Greene, Pringle, Lemmon.

Var. discoídea. Heads destitute of rays: involucre somewhat canescent: otherwise nearly as var. hispida. - Cañons, W. Montana, Wutson.

Var. stenophýlla, Grar. Low and rough-hispid, rigid: leaves spatulate-linear, only a line or two wide: heads small. - Pl. Lindh. ii. 223. - Crevices of rocks, W. Texas, Lindheimer, and S. W. Arkansas, Bigelow.

Var. canéscens. Wholly canescent with short and appressed sericeous pubescence, and with some spreading hispid bristles along the stem and margins of the narrow mostly oblanceolate leaves: heads small : involucre also canescent: outer pappus less distinct. ... Aplopappus? (Leucopsis) canescens, DC. Prodr. v. 349. Chrysopsis cantscens, Torr. \& Gray, Fl. ii. 256. - Texas, Berlandier, Drumniond, Wright, Lindheimer, \&c. Stems a foot, sometimes " 2 to 5 feet," high; very leafy and branching.

Var. foliósa, Fitox. Canescent with appressed sericeous puljescence, mostly soft and destitute of hispid bristles; but stem often hirsute or villous: leaves short, oblong or elliptical: heads small, rather numerous and clustered. - Bot. King Exp. 164. C C foliosa \& C. mollis, Nutt. 1. c. C. foliosa, Gray, P1. Wright. i. 99, \& ii. 81, a smilll-leaved aud somewhat hispid form, between this and var. hispida. - Rocky Mountains of Iroming to Utah and Arizona.

Var. Rútteri, Rотнвоск. Most like the preceding, equally sericeous-canescent with usually longer soft hairs: heads of double the size, fully half-inch high and wide, solitary or few in a cluster, foliose-bracteate: rays 30 to 40 , half-inch long. - Wheeler Rep. vi. 142. C. foliosa, var. sericeo-villosissima, \&c., Gray, Pl. Wright. ii. 81. - S. Arizona, Wright, Rothrock, Lemmon. - Seemingly the most distinct form of all; but connected with the eastern type by one with slightly canescent leaves, Colorado, Greene.

Var. sessiliflóra. From hirsute and hispid or greenish to villous-canescent: leaves oblong or spatulate: heads mostly large, solitary and foliose-bracteate at base: outer pappus more conspicuous and squamellate. - C. (Phyllotheca) sessiliflora, Nutt. Trans. Am. Phil. Soc. 1. c. 317 ; Gray, Bot. Calif. i. 309, partly, especially var. Bolınderi. C. Liolunderi, Gray, Proc. Am. Acad. vi. 543, which is a well-developed form. - California, near the coast, from Mendocino Co, to San Diego and Arizona. Disk-corollas in the bud tipped with some scattered very slender hairs.

Var. echioides. A branching form, with rather numerous and naked heads of small size, and usually small leaves, commonly canescently hispid, sometimes greener : passes into var. foliosa, var. hispida, \&c. $-C$. echioides, Benth. Bot. Sulph. 25 (from Bodegas, a form nearer the foregoing) \& Pl. Hartw. 316, form with small and scattered heads. C. sessiliflora, var. echioides, Gray, Bot. Calif. i. 309. - California, common from the Sacramento southward to Arizona.

* * Leaves not nervose, somewhat veiny: involucre hemispherical: akenes turgid-obovate and flattish, indistinctly 10-ierved, minutely pubescent: outer pappus paleolate and conspicuous; inner not very copious: root annual. 
C. pilósa, Nuтr. A foot or two high, branching: branchlets terminated by solitary middlesized heads : pubescence soft-hirsute or villous, also a minute glandulosity : leaves oblonglanceolate, occasionally denticulate or toothed; the lower sometimes incised: bracts of the involncre acumiṇate, glandular-viscid : rays almost half-inch long. - Jour. Acad. Philad. vii. 66, \& Trans. Am. Phil. Soc. 1. c. (\$ Phyllopappus); Torr. \& Gray, 1. c., \$ Achyrca.Open pine and oak woods, N. W. Arkansas, W. Louisiana, and Texas, first coll. by Nuttall.

§2. Aмmódia, Gray. Rays none : outer pappus slender-setulose, inconspicuous or obscure: somewhat viscid and pubescent perennials, with bracts of the involucre thinner and more scarious. - Proc. Am. Acad. vi. 543. Ammodia, Nutt. Trans. Am. Phil. Soc. n. ser. vii. 321.

C. Oregána, Grax. A foot or two high, paniculately branched: leaves oblong or lanceolate, sometimes hirsute or almost hispid; midrib conspicuous: involucre nearly equalling the flowers; its bracts pluriseriate: corollas slender: akenes oblong.-Proc. Am. Acad. 1. c. \& Bot. Calif. i. 309. Ammodia Oregana, Nutt. 1. c.; Torr. Bot. Wilkes Exped. t. 9, A. Brickellia Cumingii, Klatt, in Abh. Nat. Gesells. Halle, xv. 5. - Sandy or gravelly banks of streams, Oregon and W. California.

Var. scabérrima. Leaves (of branches) small, these and the branches very hispid scabrous. - Dry creek, Tulare Co., California, Congdon.

C. Bréweri, Gray, l. c. A foot or more high, more slender, less pubescent or almost glabrous: leaves shorter, ovate-lanceolate or lanceolate, 3-nerved at base (an inch or two long): heads naked-pedunculate : involucre shorter; its bracts fewer-ranked and somewhat broader: corollas funnelform: akenes obovate. - California, in the Sierra Nevada, from 4,500 to 11,000 feet, in open woods, first coll. by Brewer.

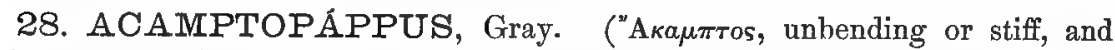
$\pi a ́ \pi \pi$ os, pappus.) - Low shrubs, of the Arizona-Nevadan desert region, a foot to a yard high, glabrous or obscurely puberulous, not glandular nor resinous : leaves small, entire, sessile, nearly veinless except midrib, lower spatulate, upper linearoblong to linear: heads terminating pedunculiform branchlets, yellow-flowered. - Proc. Am. Acad. viii. 634, xvii. 208.

A. sphærocéphalus, GraY, l. ঊ. Branches striate, corymbosely polycephalous : heads discoid, homogamous, depressed-globular, 4 or 5 lines liigh: bracts of involucre whitish, outer ones commonly with a pale greenish spot.-Aplopappus (Acamptopappus) sphcerocephalus, Gray, PI. Fendl. 76 ; Torr. in Pacif. R. Rep. vii. t. 6. - Arizona and S. Utah to the Mohave desert in California, first coll. by Coulter.

A. Shockléyi, Gray. Branchlets simpler, monocephalous: head hemispherical, radiate: rays 10 to 12, elongated, linear-oblong, bright yellow: outer bracts of involucre more conspicuously green on the back. - Proc. Am. Acad. xvii. 208. - Mountains of S. W. Nevada, at Candelaria, Esmeralda Co., W. S. Shockley.

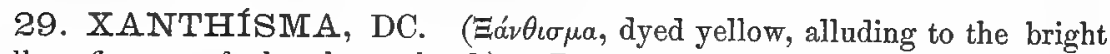
yellow flowers of the showy head.) - Prodr. v. 94; Benth. \& Hook. Gen. ii. 253. Centauridium, Torr. \& Gray, Fl. ii. 246. - Single species, near to Aplopappus, showy in cultivation.

X. Texánum, DC. 1. c. Nearly glabrous, biennial or annual, 1 to 4 feet high, with virgate branches terminated mostly by solitary large heads: leaves from narrowly oblong to lancenlate; radical and lower cauline not rarely laciniate-pinnatifid and even bipinnately parted; canline sessile, sparsely serrate or denticulate, or the upper entire; outer bracts of the involucre commonly narrowed below the green body or appendage; this whitish-margined, and sometimes with rounded barely mucronate summit, oftener either gradually or abruptly acuminate and cuspidate: rays about 20 , an inch or less long, the ligule borne on a very short tube, and the style short. - Gray, Pl. Wright. i. 98 (var. Berlandieri, with rounded obtuse involucral bracts, and var. Drummondii, with pointed ones); Torr. Bot. Marcy Rep. 
t. 10. Centauridium Drummondii, Torr. \& Gray, F1. ii. 246; Gray, Pl. Lindh. ii. 223. Macharanthera grandiftora, Buckley in Proc. Acad. Philad. 1861, 456. - Open woods, Texas, Berlandier, Drummond, Lindheimer, \&c.; fl. all summer.

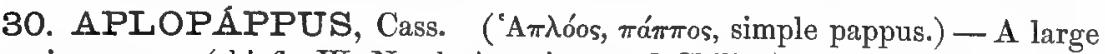
American genus (chiefly W. North American and Chilian) the analogue of Aster in the heterochromous division and equally polymorphous; mostly herbaceous perennials, some suffruticose or even shrubby, a few annual: the flowers all jellow, produced in summer and autumn. - Dict. 1vi. 168. Haplopappus \& Ericameria, Benth. \& Hook. Gen. ii. 253, 255. - Note that one or two species occasionally and certain species uniformly want the ray-flowers, obliterating the distinction between this genus and the following !

§ 1. Prionópsis, Gray. Heads very large and broad: involucre depressedhemispherical, of lanceolate acuminate bracts, the outer mostly foliaceous and spreading: rays very numerous: disk-corollas narrow, merely 5-toothed: styleappendages short and rather obtuse: akenes very glabrous; those of the ray short, turgid-elliptical; of the disk oblong or narrower, and the central ones inane: pappus of very rigid and unequal bristles and comparatively little aumerous; the innermost and larger ones somewhat flattened toward the base and their margins scabrous-ciliolate; the outermost very small and short: root annual or biennial. - Pl. Wright. i. 98. Prionopsis, Nutt. Trans. Am. Phil. Soc. n. ser. vii. 329. - (Connects with Xrnthisma and has the foliage of Grindelia.)

A. ciliátus, DC. Very glabrous: stem 2 to 5 feet high, bearing few or several somewhat cymose-clustered heads (with the disk an inch in diameter), equally leafy to the top: leaves oval or the lower obovate (1 to 3 inches long), very obtuse, veiny, evenly and somewliat pectinately dentate with bristle-pointed teeth: pappus of the fertile akenes disposed to be deciduous in a ring. - Prodr. v. 346; Gray, Pl. Wright. i. 98. Donia ciliata, Nutt. Jour. Acad. Philad. ii. 118; Hook. Exot. Fl. i. t. 45. Prionopsis ciliata, Nutt. 1. c.; Torr. \& Gray, Fl. ii. 245. - Hillsides and river-banks, Missouri and Kansas to Texas.

§ 2. Aplopappus proper. Ileads large or middle-sized, or sometimes small, commonly broad and with involucre of firm well-imbricated or rigid bracts: rays numerous, several, or rarely wanting: disk-corollas narrow, merely 5-toothed: style-appendages from ovate to linear-subulate: pappus commonly fuscous or rufous, and more or less rigid. (Habit and special characters various, but the groups too confluent and indefinite for first-class sections.)

* Heads rayless: bracts of the involucre rigid, appressed-imbricate with the outer successirely shorter, all with abrupt and more or less spreading herbaceous tips: style-appendages ovate- or oblong-lanceolate: pappus rather rigicl: leaves coriaceous, mostly obloug and spinulose-dentate. - Aplopappus $\S$ Aplodiscus, Torr. \& Gray, Fl. ii. 242, excl. the first species, which is $\S$ Apludiscus, DC. § Hapludiscus \& Eriocarpce, Benth. \& Hook. 1. c. - (One of the transitions to Bigelovia $\S$ Aplodiscus.)

A. squarrósus, Hooк. \& Arx. Suffruticose, 2 or 3 feet high, somewhat pubescent, glandular and glutinous : leaves thickly dentate (about inch lovg): heads numerous and spicately thyrsoid at the end of the branches, half-inch long: involucre elongated-turbinate; its bracts imbricated in many ranks, the lower usually imbricated on the peduncle, their tips mostly squarrose and glandular: akenes fusiform, glabrous, or sparsely pubescent. - Bot. Beech. 146; Torr. \& Gray, Fl. ii. 242. Pyrrocoma grindelioides, DC. Prodr. v. 350. Homopappus squarrosus, Nutt. Trans. Am. Phil. Soc. 1. c. 332. - Dry hills on the caast of California, from Monterey to San Diego; first coll. by Douglas. Also on the foot-hills of the San Bernardino Mountains, Parish, \&c.

A. Nuttállii, Tork. \& Gray, 1. c. Herbaceous from a ligneous stock, a span to a foot high : leaves from spatulate-oblong to almost lanceolate, rather sparsely pectinately dentate: 
heads few terminating the branches, one-third inch high: involucre hemispherical; the bracts fewer-ranked and with slightly spreading greenish tips: akenes short, sericeouscanescent. - Eviocarpum grindelioides, Nutt. Trans. Am. Phil. Soc. 1. c. 321. - Rocky Mountains and adjacent plains, north to Idaho and Saskatchewan, south to New Mexico anil Arizona; first coll. by Nuttall.

* * Heads radiate, with rays not rarely neutral or sterile, or in one species commonly discoidal by the diminution of the ligules: involucre well imbricated, of firm texture, the bracts either coriaceous with herbaceous tips or coriaceo-foliaceous: akenes (with two exceptions) glabrous and narrow: pappus capillary but rigid: style-appendages long and slender, acute or acutish: perennials, rigid-leaved. - § Pyrrocoma, Gray, Pl. Wright. i. 98. Pyrrocoma \& Homopappus, in part, Nutt. Trans. Am. Phil. Soc. vii. 330, 333.

+ Shrubby: rays conspicuous but sterile: appendage of the slender style-branches of the length and breadth of the stigmatic portion: akenes very glabrous, narrow, compressed, 4-nerved.

A. Berbéridis. Suffruticose, a foot or two high : flowering branches somewhat virgate, when young tomentose-pubescent, equably leafy, bearing numerous and racemose or sometimes solitary heads : leaves oval, very obtuse, spinulosely and evenly multidentate, halfclasping by an abrupt somewhat adnate base (half to full inch long), coriaceous, with conspicuous midrib but obscure veins: involucre broadly turbinate; its bracts numerous, in snccessively shorter ranks, broadly linear or outermost oblong, smooth, all with very obtuse and short rather appressed green tips: rays numerous, a quarter to nearly half an inch long, seldom styliferous: pappus merely sordid. - All Saints Bay, Lower California, so near that it may be expected within the U. S. border, Parry, Miss $F$ ish.

+ + Herbaceous: style-appendages from subulate-filiform to narrowly subulate, much longer than the stigmatic portion.

+ Heads large and discoid, the sterile rays being hardly apparent or very small for the size of the head (when styliferous the style-branches sometimes tipped with a hispid appendage!): akenes completely glabrous and smooth, slender but flattish, 4-costate or nerved, often finely striate: rigid leares commonly spatulate or" lanceolate, on the same plant either entire or sparsely spinulose-toothed.-- Pyrrocoma, Hook.

A. carthamoídes, GrAy. Commonly a foot high, rather stout and leafy, scabro-puberulent when young, becoming smooth, bearing a solitary terminal large head and sometimes one or two in axils: leaves from spatulate to oblong or lanceolate: involucre hemispherical, half to three-fourths inch high, often leafy-subtended at base; its proper bracts coriaceonsrigid, from oblong to broadly lanceolate or innermost linear, more or less scarious-margined, most of them tipped with an abrupt muero or cusp, the outer commonly loose and becoming leaf-like, either entire or spinulose-denticulate: rays almost always present and rather numerous; but their ligules inconspicuous, being short, involute, and concealed in the at length rufous or fulvous pappus. - Proc. Acad. Philad. 1863, 65. Pyrrocoma carthamoides, Hook. Fl. i. 306, t. 107; Torr. \& Gray, Fl. ii. 243. - Dry plains and hills, Oregon, Washington Terr, and Idaho; first coll. by Douglas. Polymorphous species: the extremes are

Var. máximus. Robust, leafy, sometimes 2 feet high: radical leaves obovate or oval, 3 to 7 inches long; cauline oblong, with partly clasping base : heads ample, in fruit an inch high and broad : involucre of very numerous and broad or broadish bracts : rays sometimes more evolute, but small. - Pyrrocoma radiata, Nutt. Trans. Am. Phil. Soc. vii. 333; Torr. \& Gray, 1. c. - Of the same district, first coll. by Nuttall.

Var. Cusickii. Smaller: stems only a span or two high, ascending, few-leaved: leaves mostly spatulate-lanceolate: head three-fourths to nearly inch high in fruit, but narrow and much fewer-flowered: bracts of the involucre correspondingly fewer, lanceolate, mostly acute or acuminate. - Union Co., Oregon, flowering earlier (in June), Cusick. Perhaps a distinct species, but appears to pass into the smaller forms of the type.

+ Heads middle-sized to small, evidently radiate; the exserted rays often infertile but styliferous: plants comparatively slender and more capituliferous.

$=$ Pubescence either cottony-tomentose and deciduous or none: leaves firm-coriaceons or rigid; cauline and mostly the radical lanceolate, the former disposed to be sparse or small at the upper part of stem: akenes or ovaries not rarely with some villous pubescence. - Homopappus, Nutt., excl. H. uniflorus.

A. racemósus, TorR. Stems usually virgate and simple, rigid, a foot or two high, leafy: leaves lanceolate or radical, sometimes oblong-spatulate ( 4 to 6 inches long, tapering into a 
petiole), entire-or denticulate or on same plant spinulose-serrate: heads several or rather numerous, racemosely or spicately disposed along naked upper part of the stem or (either singly or 2 or 3 together) iu axils of upper leaves: involucre (half-inch or less high) from hemispherical to turbinate-campanulate; its bracts rigid, well-imbricated, and with short abrupt mostly mucronate-pointed or apiculate green tips, these either erect or somewhat squarrose: rays (8 to 20) 2 or 3 lines long. - Torr. in Sitgreaves Rep. 162, as to syn., \&c., probably not as to the specimen. Homopappus racenosus, Nutt. Trans. Phil. Soc. 1. c. 332. Pyrrocomn racemosa, Torr. \& Gray, Fl. ii. 244. The type is a form with virgate stem, bearing 3 to 9 racemosely or spicately disposed and approximate or remote heads, of the larger size, with involucre half or two-thirds inch broad as well as high, and akenes (or at least ovaries) more or less beset with villous hairs. A. lanceolntus, var. strictus, Gray, Proc. Am. Acad. viii. 389, is a form with more villous akenes. - Plains of Oregon, Nuttall, Hall, \&c. . also Northern, California, Greene, where it varies with many and correspondingly smaller heads, these glomerate in numerous axils, and the campanulate involucre disposed to be squarrose. Also it evidently passes into

Var. glomeréllus. Heads narrower and smaller, disposed to be fascicled in twos or threes in the axils of small upper. Ieaves, or at summit of stem or short peduncles: involucre often turbinate: akenes glabrate or sometimes glabrous: herbage somewhat more disposed to be balsamic-viscid. - Homopappus glomeratus, paniculatus, \& argutus, Nutt. 1. c. 331. Pyrrocoma glomerata, paniculata, \& arguta (the latter a stouter and more leafy state), Torr. \& Gray, 1. c. Aplopappus paniculatus, Gray, Bot. Calif. i. 311. - Plains of the Columbia, E. Oregon, Nuttall, Nevius, Cusick, \&c. N. W. Nevada, Anderson, Lemmon.

Var. virgátus. Slender and smaller, with strict virgate stems and narrow leaves: heads as in the type, but only half the size, few, or in depauperate plants solitary. $-A$. paniculatus, var. virgatus, Gray, Bot. Calif. i. 312. - Eastern part of the Sierra Nevada, Califoruia, Bolander, Lemmon, \&c. Passes into

Var. stenocéphalus. This is to var. glomerellus what var. virgatus is to the type: it has scattered heads; these narrow, comparatively few-flowered; the bracts of the oblongturbinate involucre rigid and more pointed. - A. paniculatus, var. stenocephalus, Gray, Bot. Calif. l. c. - With preceding var., Lemmon.

A. apargioídes, Grar. Low, with numerous ascending or diffuse few-leaved or sometimes scapiform stems from a thick caudex, a span to a foot high, bearing solitary or few pedunculate heads: leaves lanceolate or the radical broader, from denticulate to laciniatedentate or even pinnatifid : involucre hemispherical (a third to half an inch high); its bracts lanceolate to narrowly oblong, mostly obtuse, imbricated in few rather loose ranks, outer sometimes equalling the inner' : rays 20 or more, oblong, comparatively large, commonly fertile : pappus softer. - Proc. Am. Acad. vii. 354, \& Bot. Calif. i. 311. - Eastern parts of the Sierra Nevada, California and adjacent Nevada, from Sierra Co. to San Beruardino Mountains; first coll. by Bolander.

$==$ Pabescence not tomentose nor floccose, but rather villous and persistent: leaves thinnish, oblong, more regularly and closely spinulose-serrate, numerous and approximate on the stem or branches up to the heads or nearly: rays fertile.

A. hirtus. A foot or less high, hirsutely pubescent and villous, even to the involucre, or at base lanuginous: stems rather simple, ascending, bearing few or scattered pedunculate heads: leaves membranaceous, pectinately serrate with long and salient slender-subulate teeth; cauline an inch or two long, radical sometimes 4 inches long and with margined petioles : involucre hemispherical, half-inch or more high; its bracts rather loose, linear, acuminate or acute, all about equalling the disk, the outer mainly foliaceous: rays 20 or more, conspicuous: akenes rather short, sericeous-puluescent: pappus soft, whitish.-Baker Co., Oregon, Cusick. Washington Terr., Brandegee. Might be arranged in a following subdivision, with $A$. uniflorus, but has the habit of the next.

A. Whitnéyi, Gray, About a foot high, somewhat minutely villous-pubescent, or foliage glabrous, branching, bearing rather numerous fasciculate-panicied and mostly sessile heads : leaves inch or less long, spinulose-dentate, those subtending the lower heads hardly smaller than the main cauline ones: involucre narrow, oblong-turbinate (about half-inch long), glabrous; its bracts lanceolate, acute, appressed, subcoriaceous, with short and sometimes indistinct green tips, well imbricated, outer successively shorter: rays 5 to 8 , with oblong and small ligules, little surpassing the 10 to 20 disk-flowers: akenes oblong-linear, glabrous, 
striate : pappus rigidulous, rufous. - Proc. Am. Acad. vii. 354, \& Bot. Calif. i. 312. - Sierra Nevada, California, at 8,500 to 9,000 feet, in open woods, Sonora Pass, Bolander, and on bleak summits in Siskiyon Co., Greene, Pringle. Involucre rather of the Errcameria section.

* * Heads conspicuously radiate, large and showy: rays fertile, very numerous, half-inch to inch long: involncre well imbricated, of numerous oblong to lanceolate firm bracts: akenes (and ovaries) wholly glabrous, flat and rather broad: pappus pale: style-appendages broadish, oblong to lanceolate, shorter or not longer than the stigmatic portion: wholly herbaceous perennials, smooth and glabruus, except some soft-villous pubescence or tomentum when young: leaves coriaceous, entire.

+ Stems equably and very leafy up to the sessile or subsessile heads.

A. Fremónti, Gray. A foot or less high, from slender lignescent rootstocks, simple or fastigiately branched above: leaves lanceolate ( 2 to 4 inches long, 3 to 8 lines wide), obscurely 3-5-nerved; lower narrowed and upper partly clasping at base: involucre (inch or less high) broadly campanulate; its bracts broadly lanceolate, conspicuously and often cuspidately acuminate; rays half-inch long' style-appendages ovate-oblong, obtuse: akenes obovate; striate-nerved, almost as long as the rigid pappus. - Proc. Acad. Philad. 1863, 65; Porter \& Coulter, F1. Colorad, 67. Pyrrocoma foliosa, Gray in Jour. Bost. Soc. Nat. Hist. v. 109. - Plains and rocky hills, Colorado, common on the Arkansas from Pueblo upward; first coll. by Fremont.

Var. Wárdi. Dwarf: fascicled stems only a span high: leaves proportionally small, linear-lanceolate, destitute of lateral nerves: heads one-half smaller, 2 or 3 in a terminal glomerule: akenes double the length of the scanty pappus. - Wyoming (probably in southwestern part), L. F. Ward.

++ Stems simple, solitary or sereral from a thick caudex, above with decreasing or sparse leaves and solitary or few naked and usually pedunculate heads, at base a tuft of ample lanceoIate- or spatulate-oblong radical leaves (in the manner of the preceding and succeeding subdivisions): involucre hemispherical or broader: rays 30 to 50 .

A. cróceus, Gray. Stem stout and erect, commonly a foot or two high, and with radical leaves a foot or less long (including the petiole). cauline leaves ovate-oblong to lanceolate, partly clasping (upper an inch or two long) : head mostly solitary: involucre a full inch in diameter; its bracts ovate to spatulate-oblong, rery obtuse, lax, inner with scarious exosedenticulate margins: rays saffron-yellow, sometimes inch long: akenes narrowly oblong, nearly the length of the pappus. - Proc. Acad. Philad. 1.c. - Rocky Mountains of Colorado, especially in Middle Park, first coll. by Parry. A dwarf form in N. Arizona, Rusby.

A. integrifólius, T. C. Porter. Stems several from the caudex, ascending, a foot or less high: radical leaves 3 to 8 inches (including short petiole or tapering base); cauline lanceolate, or small uppermost linear: heads solitary or 2 or 3 in axils, smaller than in foregoing : involucral bracts narrowly oblong to linear-lanceolate, some loose outer ones usually equalling: the disk and more foliaceous: rays bright yellow, half-inch long: immature akenes oblong. - Gray, Proc. Am. Acad xvi. 79.-Mountain meadows, Wyoming and Montana, Burke (in herb. Hook.), J. M. Coulter, Watson, Canby. Verges to the larger-flowered form of the next species.

* * * Heads conspicuously radiate, smaller: rays fertile, half to barely quarter inch long: akenes turbinate or oblong, silky-pubescent or villous: style-appendages from ovate to subulate, shorter or rarely longer than the stigmatic portion. (ILere $A$. Whitneyi might be sought.)

- Perenujal herbs, with mostly simple stems and a 1 uft of radical leaves from a thickened somewhat fusiform caudex: leaves coriaceous and when dry rigid, entire or spinulose-serrate, the cauline diminished upward: heads solitary or rather few, pedunculate: involucre hemispherical or broader, of firm and herbaceous-tipped or foliaceous bracts : rays 20 to 50: pappus pale or merely sordid, rather soft and fine: herbage more or less flocculent-tomentose when young, glabrate in age and smooth. - §Arnicellct, Torr. \& Gray, partly of Benth. \& Hook.

A. uniflórus, Torr. \& Grar. Stems a span to barely a foot high, ascending or erect, sometimes 5 6-leaved, sometimes rather scapiform or upper leaves reduced and bract-like, bearing a solitary head, rarely one or two from lower axils: leaves lanceolate or sometimes broader; radical 2 or 3 inches long and usually petioled : involucre commonly half-inch high and the linear or oblong-linear bracts all of same length, rather loose, outer all foliaceous: rays in larger heads 40 or 50. - A. uniflorus \& $A$. inuloides, Torr. \& Gray, Fl. ii. 241. Donin uniflora, Hook. Fl. ii. 25, t. 124. Homopappus inuloides, Nutt. Trans. Am. Phil. Soc. I. c. 333, 
a woolly form. - Plains of the Saskatchewan to Montana, and along the mountains to Utah and Colorado; first coll. by Drummond. Varies much in size, especially of the head; in the larger forms much broader than high, and very many-flowered.

A. lanceolátus, ToRr. \& GRA , l. c. Habit of the preceding : stems generally more leafy and bearing 3 to 15 heads; these when few subcorymbose, when more numerous racemosely or paniculately disposed : involucre in the type fully half-inch high; its bracts rather closely imbricated in 3 or 4 unequal series, lanceolate, acutish, with short green tips and whitish coriaceous base; outer successively shorter, occasionally some of them longer and more herbaceous. Such forms, when heads are very few or solitary, effect is transition to the foregoing species. - Eaton, Bot. King Exp. I60. Donia lanceolata, Hook. l. c. Homopappus (Actenaphoria) multuforus, Nutt. 1. c.-Plains of Saskatchewan to the borders of Brit. Columbia, Idaho, and N. Nevada; first coll. by Drummond. The more robust form, with few and large heads, usually corymoosely disposed, and rays 30 or 40 in number and halfinch long, passes freely into

Var. Vaséyi, PARry in Eaton, l. c., with heals a third or quite half smaller, disposed to be racemose, and involucre closer. - Saskatchewan to Wyoming, Utah, and Colorado.

Var. tenuicaúlis (A. tenucaulis, Eaton, l. c.), is an extreme very slender and marked variety. sometimes a foot high and bearing several racemose heails, sometimes more depauperate and only a span high: heads only 3 or 4 lines ligh : rays correspondingly reduced : involucre close, with short green tips. - Alkaline meadows, Nevada and Utah, first coll. by Watson. Apparently a form with laciniate leaves, in alkaline soil, E. Oregon, Cusick.

+ + Perennial herbs from a lignescent multicipital caudex or suffruticose base, with slender and branchung stems, leafy up to the small heads: leaves all narrow and quite entire: involucre turbinate or obovate (4 or 5 lnes high); its bracts well imhricated, appressed, chartaceo-coriaceous, with short and abrupt acnte green tips, or these wanting in some: rays 7 to 10 , with oblong ligules: disk-flowers not numerous: style-appendages ovate to narrow-lanceolate (thus distingusshed from the Ericameria section, to which there is an approach).

A. multicaúlis, Grar. Very dwarf, tufted, tomentulose, but early glabrate and smooth: stems 1 to 3 inches high from a ligneons caudex, simple or forked, bearing 3 or 4 leaves and few heads : leaves narrowly linear, or the lowest obscurely spatulate (about inch long) : bracts of the involucre large and rather few (9 to 11), from ovate to oblong-lanceolate, cuspidateacuminate, marked with a green spot below the slender cusp, or the outermost with a larger foliaceous tip: rays few : style-appendages ovate-triangular, half the length of the stigmatic portion: pappus scanty, somewhat fulvous. - Am. Nat. viii. 213. Slenolus mullncaulis, Nutt. Trans. Am. Phil. Soc. 1. c. 335; Torr. \& Gray, Fl. ii. 238. - On rocks, Rocky Mountaius of N. W. Wyoming, Nuttall, Geyer, Parry.

A. Hállii, Grax. A foot or two high, paniculately branched from a suffrutescent or even more woody base, glabrous, very leafy: leaves lanceolate or linear, short (larger over inch long, 3 lines wide and spatulate-lanceolate), rather rigid, mostly scabrous (at least the margins); midrib prominent beneath and commonly some lateral veins: heads paniculate, terminating short branchlets or sometimes rather congestel : involncral bracts broadishlinear, imbricated in sereral ranks, the outer successively shorter, the short tips merely mucronate-acute : rays about 10 : style-appendages lanceolate, rather obtuse, about the length of stigmatic portion: pappus barely sordid.-Proc. Am. Acad. viii. 389, first described from mere branchlets, and these not well developed. - Base of the Cascade Mountains, Oregon and Washington Terr., Hall, Howell, Suksdorf, Pringle.

+++ Annual or perennial herbs, branching, leafy: leares not rigid, spinulosely dentate or pinnatifid, the teeth and tips commoniy bristle-tipped: heads middle-sized or small: involucre hemispherical, of well-imbricated narrow bracts, the outer successively shorter: rays conspicuous, mostly numerous: pappus rather rigid, its bristles very unequal in size and strength. (Analogue of Macharanthera in Aster.) - $\$$ Blepharodon, DC., excl. spec.

+ Akenes short-turbinate, not compressed, obscurely 5-10-nerved under the canescent villosity: style-appendages short and broad, ovate or deltoid: rays 18 to 25 , deep golden yellow: leaves not deeply cleft.

A. atureus, Gray. Perennial? and branched from the base, at first lightly lanuginous, minutely scabrous-glandular, a span or two high: leaves all narrowly lincar, sparingly pinnatifid-dentate, at least toward the base (an inch or less long): heads 4 lines high: bracts of the involucre linear-oblong, mostly obtuse and muticous; the outer ones with short deltoid- 
ovate green tips, the longer innermost nearly scarious: stronger bristles of the pappus only 10 or 12. - Pl. Fendl. 76. - Low prairies, near Houston, Texas, Wright. Not since collected.

A. rubiginósus, Torr. \& Gray. Annual, 1 to 3 feet high, viscid-glandular and pubescent or puberulent: leaves lanceolate or narrowly oblong, incisely pinnatifid or dentate with salient narrow teeth: heads somewhat cymosely paniculate, 5 or 6 lines high, usually nakedpedunculate: bracts of the involucre linear-subulate and with slender spreading green tips : stronger bristles of the fulvous or at length rufous pappus more numerous. - Fl. ii. 240. Low grounds from S. Texas to plains of Colorado up to the base of the Rocky Mountains; first coll. by Drummond.

Var. phyllocéphalus. A lower form, spreading, leafy up to the heads, which singly terminate the branches, and are accordingly larger or broader, leafy-involucrate and therefore sessile, or at least some of outermost bracts loose and foliaceous, inner less imbricated. - A. phyllocephalus, DC. Prodr. v. 347 ; Gray, Bot. Mex. Bound. 80. Without much doubt a state of $A$. rubiginosus (in which case a misleading name for the species); but may hold distinct. - Sea-beaches, S. Texas, also S. Florida. (Adj. Mex. Berlandier.)

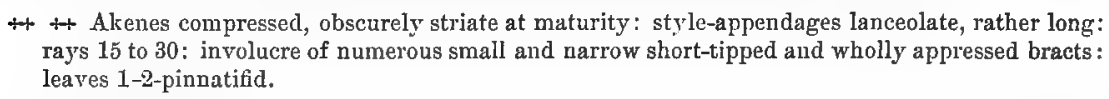

A. grácilis, GRAY. Annual or becoming lignescent at base and more enduring, canescently pubescent, occasionally glabrate and glandular-scabrous: stems a span to a foot high, much branched : leaves linear or the lowest spatulate, pinnatifid, or the upper few-toothed or entire, tipped or also sparsely fringed with long and slender bristles: heads 4 or 5 lines high: bracts of the involucre mostly setaceous-tipped: pappus rigid; its larger bristles manifestly dilated below. - Pl. Fendl. 76, \& Bot. Calif. i. 613. Dieteria (Sideranthus) gracilis, Nutt. PI. Gamb. 177. - Plains, W. Texas to S. Utah, Arizona, and the southern border of California; first coll. by Gambel.

A. spinulósus, IC. Perennial, canescently puberulent or tomentulose, or glabrate : stems a span to a foot high, commonly spreading, cymosely branched at summit: leaves broader in outline than the preceding, pinmately and the lower often bipinnately parted into rather numerous lobes; lobes and teeth mucronate-setigerous: heads and involucre of the preceding: pappus more capillary and soft. - Prodr. v. 347 ; Torr. \& Gray, Fl. ii. 240. Amellus? spinulosus, Pursh, Fl. ii. 564. Starkea? pinnata, Nutt. Gen. ii. 169. Diplopappus pinnatifidus, Hook. Fl. ii. 22. Dieteria spinulosa, Nutt. Trans. Am. Phil. Soc. 1. c. $301 .-$ Plains from Saskatchewan to Texas, and west to Dakota, Colorado, and Arizona. Varies in Texas to mearly glabrous throughout, also sometimes with divisions of the leaves nearly filiform. (Mex.)

A. ARgnÁrius, Benth. Bot. Sulph., from Cape Lucas, Lower California, may have heterochromous heads, and be an Aster.

§3. IsopÁPPos, Benth. Heads small and narrow, loosely paniculate: involucre of subulate-lanceolate bracts, destitute of distinct green tips, appressed and imbricated in few ranks, the outer shorter: rays 5 to 15 : disk-flowers 10 to 25 ; their corolla slightly ampliate upward, 5-toothed: style-appendages linearsubulate, much longer than the stigmatic portion: akenes narrow, sericeouscanescent: pappus ferruginous, of rather scanty fine and soft bristles: annuals, or sometimes more enduring, narrow-leaved. - Isopappus, Torr. \& Gray.

A. divaricátus, Grax. A foot or two high, with somewhat the aspect of Chrysopsis graminifolia, more slender and effusely paniculate, scabrous-pubescent or glandular, sometimes glabrate: leaves rigid, linear-lanceolate or lower spatulate-lanceolate, mucronate-acute or cuspidate, entire or beset with a few spinulose teeth, more or less setose-ciliate toward the base; the upper small and subulate and in the diffuse naked usually polycephalous panicle minute: heads 3 or 4 lines high : peduncles sometimes filiform, sometimes short: involucral bracts subulate-attenuate. - Proc. Am. Acad. xviii. 102. 1sopappus divaricatus, Torr. \& Gray, F1. ii. 239. Chrysopsis (Inula) divaricata, Nutt. Gen. ii. 152. C. Lamarckii, Nutt. in Trans. Am. Phil. Soc. 1. c. 315. Beterotheca Lamarckii, DC. Prodr. v. 317, as to 
char. \& syn. Nutt. \& Ell., excl. syn. Cass., Lam., \& Pluk. Alm. - Dry and sandy ground, Georgia and Florida to Arkansas and Texas; flowering late. A rigid and rough-hispidulous form with less open inflorescence (Lindheimer, 254, Lrummond, 157) is Aplopappus Hookerianus, Gray, Pl. Lindh. i. 40.

A. Hookeriánus. Low, loosely branched from the base, barely hirsute, not glandular: leaves not rigid, entire; upper linear or attenuate-lanceolate, sparingly hispidly ciliate; lower spatulate, short, naked: involucral bracts subulate-lanceolate, with less attenuate points. - Isopappus Hookerianus, Torr. \& Gray, Fl. ii. 239. - Gonzales, Texas, Diummond (184 of coll. 3 ); not since found : perhaps an unusual state of $A$. divaricatus.

§ 4. Stexótus, Gray. Heads middle-sized, mostly broad: bracts of the involucre from ovate to lanceolate or even linear, not rigid, all of equal or moderately unequal length: rays several or numerous: disk-corollas somewhat ampliate upward and deeply 5-toothed: style-appendages varions: pappus soft and white or whitish: perennials (herbaceous or fruticulose), of the Rocky Mountains and westward, with leaves all entire. - Proc. Am. Acad. vii. 353. Stenotus, Nutt. Trans. Am. Phil. Soc. 1. c. 334.

* Solidaginiform herb: heads corymbiform-cymose or glomerate at the summit of a leafy stem: incolucre campanulate: rays 12 to 20 , small and narrow: akenes short and glabrous or nearly so.

A. Párryi, Gray. Green and almost glabrous, puberulent and somewhat viscid above: stems 6 to 18 incles high from slender rootstocks : leaves oblong-obovate and spatulate, or the upper oblong-lanceolate, thinnish, loosely veiny (2 to 4 inches long): heals nearly halfinch high, rather numerous (in a dwarf form reduced to a glomerule of 2 or 3 ): involucral bracts oblong, obtuse, pale and chartaceous or the outer partly herbaceous, in about three moderately unequal ranks: flowers pale-yellow: style-appenclages lanceolate, rather longer than the stigmatic portion. - Am. Jour. Sci. ser. 2, xxxiii. 10; Eaton, Bot. King Exp. 162. - Rocky Mountains, from those of Colorado to the Wahsatch, in open woods, 6,000 to 10,000 feet; first coll. by Parry. Has somewhat the aspect and character of a large corymbose Solidigo. - Var. minor is a reduced subalpine form (Wahsatch Mountains, Utah, at 12,000 feet, 11 . E. Jones), with leaves only an inch or two long, and 2 or 3 narrower heads.

* * Typical species, herbaceous or suffruticulose and dwarf : heads solitary, terminating simple stems or branches: rays conspicuous.

- Wholly herbaceous, chiefly alpine, disposed to be cespitose or multicipital, a span or less in height: leares soft, not persistent: involucre hemispherical: rays 15 to 20 : style-appendages oblong to subulate, shorter or not longer than the stigmatic portion.

* Green, not woolly, mostly equably leafy up to the (half-inch) head.

A. pygmǽus, GRAY. Less than a span high, soft-pubescent or glabrate, not viscid nor glandular : leaves from linear-spatulate to spatulate-oblong: involucral bracts oblong, outer ones foliaceous and loose, very obtuse, equalling the thinner innermost : akenes pubescent. Am. Jour. Sci. ser. 2, xxxiii. 239. Stenotus pygmaus, Torr. \& Gray, Fl. ii. 237. - Rocky Mountains, Colorado, strictly alpine; first coll. by James.

A. Lyálli, Gray. Rather taller, larger-leaved, viscid-puberulent: leaves obovate-spatulate to oblanceolate: involucre glandular; its bracts lanceolate, acute, sometimes 2 or 3 outermost oblong and more foliaceous: akenes and ovaries glabrous or nearly so. - Proc. Acad. Iliilad. 1863, 64. - Alpine region of Colorado Rocky Mountains, first coll. by James. Also in northern Rocky and Cascade Mountains, Montana to Oregon and Brit. Columbia; first coll. by Lyall.

+ Woolly or tomentose, at least the inrolucre, above less leafy, or head pedunculate.

A. lanuginósus, GraY. Fully a span high from creeping rootstocks, floccose-tomentose; leaves soft, narrowly spatulate or upper linear (inch or two long); the sparse uppermost almust filiform : involucre half-inch high; its bracts lanceolate, acute or acuminate, thin, nearly equal, in two series, outer barely greenish: style-appendages elongated-subulate: akenes sericeouscanescent. - Wilkes Ex. Exped. xvii. 347. - Mountains of Washington Terr.; first coll. by Pickering and Brackenridge, recently by Nevius, Howell, Brandegee; and Montana, Watson. 
A. Brandegéi. A span high from a tufted caudex, cinereous-pubescent or puberulent, and the involucre lanuginous-tomentose: radical leaves obovate or spatulate or roundish (halfinch long), contracted into a slender petiole; cauline few and sparse, small (quarter-inch long), oblong or lanceolate: head one-third inch high and broad : bracts of involucre loose, lanceolate, nearly equal: young akenes hirsute-pubescent: pappus rather scanty: styleappendages triangular-subulate. - Mountains of Washington Terr., in the Yalkima district, Brandegee. - Aspect of an alpine Erigeron; but rays deep yellow and style-appendages acute.

+ + Depressed-cespitose from a multicipital lignescent caudex, glabrous or puberulent-scabrous: leaves rigid and persistent, crowded on the crowns of the caudex or on short shoots, and a few on the lower part of the scapiform flowering stems: rays 6 to 15, rather broad: styleappendages subulate: akenes canescently villous. - Stenotus, Nutt.

A. acaúlis, Grax. Leaves from spatulate (and inch or less long) to oblanceolate or linear (and 2 or 3 inches long), mucronate, more or less 3-nerved and the broader ones veiny, commonly scabrous: scapiform flowering stems an inch to a span high, mostly monocephalous: bracts of the involucre from ovate to ovate-lanceolate, mucronately acute or acuminate, destitute of greenish tips; the outer a little shorter than the inner. - Proc. Am. Acad. vii. 353; Eaton, Bot. King Exp. 161. Chrysopsis acaulis, Nutt. in Jour. Acad. Philad. vii. 33, t. 3. Stenotus acaulis, Nutt. in Trans. Am. Phil. Soc. 1. c. 334; Torr. \& Gray, 1. c. - Dry rocks on the mountains (at 6,000 to 8,000 feet, and extending to the alpine region), from Saskatchewan and N. Wyoming to E. Oregon, and south to Utah and the Sierra Nevada, California. Passes into

Var. glabrátus, EATon, 1.c. Glabrous and smooth or almost so: flowering stems disposed to be leafy above and to branch, so bearing 2 or 3 heads. - Chrysopsis coespitosa, Nutt. in Jour. Acad. Philad. 1. e. Stenotus ceespitosus, Nutt. in Trans. Am. Phil. Soc. 1. c.; Torr. \& Gray, 1. c. - Wyoming to Nevada and N. Arizona.

A. armerioídes, GRAY. Smooth and glabrous: flowering stems naked above (for 1 to 3 inches), sometimes nearly scapiform: bracts of the campanulate involucre broadly oval, rounded-obtuse or retuse, muticous, of about three lengths; the outermost much shorter, most of them greenish at apex. - Stenotus armerioides, Nutt. 1. c.; Torr. \& Gray, 1. c. Rocks on mountains, from Wyoming to New Mexieo and S. Utah; first coll. by Nuttall. Too near the preceding.

A. stenophýllus, Gray. More suffruticulose, hirtellous-scabrous: leaves very narrow, linear-spatulate to filiform-linear (commonly inch or less long and half a line wide), onenerved: scapiform peduncles inch or two long: involucral bracts linear, glandular-puberulent, equal, in one or two series. - Wilkes Ex. Exped. xvii. 347. - Mountains and stony hills, W. Idaho and Washington Terr. to northeastern borders of California, Pickering and Brackenridge, Burke, Nevius, Howell, Lemmon.

* * Anomalous species, shrubby, a transition to the following section, of which it has the foliage and habit, but with broad rather large heads and little-imbricated involucre.

A. linearifólius, DC. Undershrub, a foot to a yard or more high, fastigiately much branched, with herbage often resinous-dotted and balsamic-viscid : branches thickly leafy: leaves all narrowly linear (an inch or less long, a line or less wide), sometimes almost filiform, many in axillary fascicles : heads solitary terminating the corymbiform branchlets, on peduncles bearing one or two setaceous-subulate bracts : involucre fully half-inch high; its bracts thin, lanceolate, acute or acuminate, somewhat scarious-margined (at least when dry), in about 2 series of nearly equal length: rays about 12, oblong or broadly lanceolate, in largest heads nearly three-fourths inch long, in smaller only half that length: style-appendages from ovate- to lanceolate-subulate: akenes densely silvery-villous : pappus white, rather deciduous. - Prodr. v. 347; Gray, Bot. Calif. i. 311. Stenotus linearifolius, Torr. \& Gray, F]. ii. 238. - Dry hills, coast ranges of California from San Francisco Bay southward; and mountains of San Bernardino Co. to S. Utah and adjacent Arizona. Southward it bears more numerous and smaller heads than at the north.

§5. ERICAmÉRIa, Gray. Heads small or barely middle-sized, paniculately or corymbosely disposed: involucre oblong or campanulate, of well-imbricated bracts ; these all chartaceous or thinner, appressed, and wholly destitute of herbaceous 
tips, or some outer looser ones foliaceous or foliaceous-tipped: rays few, sometimes only one (which alone definitely separates the group from Bigelovia, and even this fails in one or two species !) : disk-corollis commonly somewhat ampliate upward and rather deeply 5-toothed: style-ippendages (with some exceptions) filiform or slender-subulate : akenes slender: pappus fine and soft: all W. North American shrubby or fruticulose plants, very leafy, mostly with Heath-like foliage, glabrous or almost so, except in one species, disposed to be resinous-dotted and balsamic-viscid. - Pl. Wright. ii. 80. Ericameria, Nutt. Trans. Am. Phil. Soc. 1. c. ; Benth. \& Hook. Gen. ii. 2 כ̌

* Anomalous for its broad although small leaves, also in the frequent absence of the scanty rays: involucral bracts (as of the next following group) all close and unappendaged, the outer successively shorter.

A. cuneátus, Grar. Shrub a foot or so high, intricately branched and spreading, balsamic-glutinous : leares thick, cuneate or rarely obovate, retuse, sumetimes apiculate, entire but inclined to be undulate, usually resinous-punctate, 2 to 4 lines long, larger ones petioled : heads corymbosely fasciculate, 5 or 6 lines long: involucre turbinate; bracts lanceolate or nearly linear, rather obtuse: rays 2 or 3, or solitary and small, or as commonly wanting: style-appendages slender-subulate, not longer than the stigmatic portion: akenes pubescent. - Proc. Am. Acad. viii. 635, \& Bot. Calif. i. 312. Bigelovia spathulata, Gray, Proc. Am. Acad. xi. 74 , \& Bot. Calif. i. 613, also B. rupestris, Greene in Bot. Gazette, vi. 184, the rayless state! - Cañons and cliffs in the Sierra Nevada, California, from Placer Co. and the Yosemite to the Mexican border below San Diego, and in Arizona; first coll. by Bolander and southward by Palmer, \&c.

* * Typical species: leaves from filiform to very narrowly linear, thick : proper bracts of the involucre obtuse or barely acute and close: shrubs a foot to a yard or more high.

- Heads only 3 or 4 lines high, in close cymose clusters terminating fastigiate branchlets: bracts of the involucre in only 2 or 3 series, no loose outer ones: leaves half-inch or less long: akenes villous: style-appendages shorter than the linear stigmatic portion, not attenuate.

A. laricifólius, Grax. About a foot bigh: leaves linear-acerose, rigid, mucronate, conspicuously resinous-punctate and becoming viscid, crowded but seldom axillary-fascicled; larger ones narrowed downward and flatter: involucral bracts subulate-linear, acute: rays 3 to 6 , with rather conspicuous oblong ligules: disk-flowers 10 or 12 : style-appendages linear, rather obtuse. - Pl. Wright. ii. 80, \& Pacif. R. Rep. iv. 99 ; Rothrock in Wheeler Rep. vi. I44. - Western borders of Texas to mountains of Arizona, first coll. by Wright, Bigelow, \&c.

A. monáctis, Gray. A foot to a yard or more high, hardly becoming viscid: leaves not punctate, mostly obtuse or pointless, more disposed to have axillary fascicles, otherwise not unlike those of the foregoing: involucral bracts only 8 or 10, oblong or linear-oblong, obtuse, thin-chartaceous: ray-flower solitary with an elongated-oblong ligule, wanting to some heads : disk-flowers 5 or 6: style-appendages oblong-ovate, acute. - Proc. Am. A cad.xix. 2. - S. E. California, on the San Bernardino Mountains and Mohave Desert, Palmer, Parish, Pringle.

+ + Heads 4 or 5 lines high, paniculate: involucral bracts imbricated in several ranks: styleappendages filiform-subulate: leaves all filiform or nearly terete, excessively numerous and axillary-fascicled.

+ Involucre narrow, 7-20-flowered; its bracts all erect, more of less obtuse, somewhat tomentulose-ciliolate when young; outer successively shorter, becoming greenish and passing into the rery short leaves of the ultimate branchlets: cauline leaves short: shrubs 2 to 5 feet high, bearing very numerous heads : young parts disposed to be cinereous-pruinose or puberulent.

A. ericoídes, Hook. \& Ars. Fastigiately much branched : cauline leaves only half-inch and those of the dense fascicles 2 or 3 lines long: rays 3 to 5, short: akenes glabrous. Bot. Beech. 146 ; DC. Prodr. v. 346 ; Gray, Bot. Calif. i. 313. Diplopappus ericoides, Less. in Linn. vi. 117. Ericameria microphylla, Nutt. Trans. Am. Phil. Soc. 1. c.; Torr. \& Graף, 1. c. - California along the coast, especially on sand-hills near the sea; first coll. by Chamisso.

A. Pálmeri, Gray. Paniculately much branched: cauline leaves often inch long: lower bracts of involucre more greenish-tipped : rays 3 or 4 and disk-flowers 5 to 15 : akenes pubes- 
cent. - Proc. Am. Acad. xi. 74, \& Bot. Calif. i. 613. - S. California, on hills, Los Angeles to the Mexican border (Palmer, Nevin, Lyon, and mountains of San Bernardino Co. to the desert on the Colorado River, Parry, Lemmon, Parish, Pringle. Heads of the plant in the interior districts very numerous in ample and rather naked panicles, at Los Angeles sparse and racemosely disposed along the elongated and intricate branches.

+ + Involucre larger, campanulate, 15-30-flowered, subtended by several loose onter bracts having elongated-subulate herbaceous tips: leaves longer.

A. pinifólius, Gray. Shrub 2 to 5 feet high, rather stout, with rigid erect branches: cauline leaves from very narrowly linear to filiform, an incl or more long, mucronate; those of the fascicles and branchlets much shorter: heads not very numerous in a contracted panicle, or scattered: proper bracts of the involucre broadly lanceolate and with a greenish keel or midrib; loose outer ones normally subulate, shorter than the innermost, and passing into the small leaves of the flower-bearing branchlet, or in a vernal state (with solitary larger heads) developed into an involucriform rosette of acerose-filiform leaves: rays commonly 6 to 10, short: akenes almost glabrous. - Proc. Am. Acad. viii. 636, \& Bot. Calif. i. 312, there described from the abnormal vernal state, in which the large and many-flowered head, terminating a very leafy branch, seems to consist of two or three confluent ones. In autumn the normal paniculate and naked heads are developed. $-\mathrm{S}$. California, from Los Angeles Co. to the foot-hills of the San Bernardino, Bolander, Parry, Nevin, Parish, \&c.

* * Leaves from narrowly linear to lanceolate-spatulate, not rigid nor punctate, mostly plane, seldom with axillary fascicles: low and suffruticose, not at all or very slightly balsamic or viscidulous: at least the outer involucral bracts acute or acutely herbaceous-tipped: akenes pubescent to glabrate.

$$
\text { - Glabrous throughout: leaves narrow. }
$$

A. Bloómeri, Gray. A foot or two high, with erect and rigid usually virgate branches, sometimes lower, very leafy: leaves from narrowly spatulate-linear to filiform-linear, an inch or two long: heads showy, half to three-fourths inch high, in dwarf plants solitary terminating fastigiate branches, commonly several and racenosely clustered, or more numerous and thyrsoid-paniculate: involucre oblong; its inner bracts oblong-lanceolate or linear, chartaceous with thin-scarious and erose-ciliate margins, some obtuse, some acute or tipped with a soft cusp, most of the outer bearing a filiform foliaceous tip: rays 2 to 4, rarely solitary, oblong, deep yellow, half-inch or less long: disk-flowers 8 to 20 : their style-appendages long and much exserted, setaceous-subulate: akenes 3 or 4 lines long, sparsely pubescent. - Proc. Am. Acad. vi. 541, vii. 354, viii. 356, \& Bot. Calif. i. 313, with var. angustatus, the narrowerleaved form, passing freely into the broader, and to this belongs $A$. resinosus, Gray in Wilkes Ex. Exp. xvii. 346, t. 10. Ericameria erecta, Klatt in Abh. Naturf. Gesel. Halle, xv. 6, from the char. \& habitat. - California and adjacent Nevada, along the Sierra Nevada from Kern Co. northward to Washington Terr. ; first coll. by Pickering and Brackenridge, next by Bloomer and Anderson.

A. nánus, Ea ton. A span to a foot high, in depressed tufts, fastigiately branched, disposed to be balsamic-glutinous: leaves from narrowly linear to narrowly spatulate (the largest less than inch long): heads solitary or fastigiate-clustered at summit of branchlets, 3 or 4 lines high, narrow: bracts of the involucre lanceolate, acute or acuminate, pale, wholly destitute of green tip or midrib, except one or two looser and subulate outermost: flowers all pale or ochroleucous, or even "white" : rays small, 3 to 6 or in some heads wanting; disk-flowers 8 to 12, with deeply 5-cleft corolla: style setaceous-subulate and hispid : akenes either pubescent or glabrous. - Bot. King Exp. 159. A. resinosus, Gray, Bot. Calif. 313. Ericameria nana \& E. resinosa; Nutt. Trans. Am. Phil. Soc. 1. c. 319 ; Torr. \& Gray, Fl. ii. 236.Rocky hills and cliffs, eastern borders of Washington Terr. and Oregon, adjacent Idaho, and W. Nerada; first coll. by Nuttall. Flowers said by Cusick and Brandegee to be white; by $N$ uttall, in his $E$. resinosa, ochroleucous; by Suksdorf, white to pale yellow.

Var. cervínus. Leaves broader; lower ones from oblanceolate to obovate-spatulate: heads more scattered. $-A$. cervinus, Watson, Am. Nat. vii. 30; Rothrock in Wheeler Rep. vi. 142, t. 6. - Cañons, S. W. Utah and adjacent Arizona, Wheeler, Palmer.

+ Minutely viscidulous-pubescent.

A. Watsóni, Grat. A span or two high, like the broader-leaved variety of the foregoing, but coarser and manifestly pubescent: leaves from lanceolate with narrowed base to obovatespatulate, thinnish: heads half-inch or less high, loosely fastigiate-clustered: involucral 
bracts linear-lanceolate, attenuate-acute, usually one or two outer ones loose and foliaceous, these sometimes equalling the head and resembling uppermost leaves of the branchlets : rays 4 to 8 , about 3 lines long: disk-flowers hardly more numerous : young akenes pubescent. Proc. Am. Acad. xvi. 79. Part of A. suffuticosus, Eaton, 1. c., which, indeed, it approaches, but is nearer the preceding. - Mountains of Nevada, Watson, Palmer, and of E. Utah, M.E. Jones.

§6. Macroníma, Gray. Heads middle-sized or rather large, solitary or few, terminating leafy branches: involucre campanulate, of lanceolate or linear bracts in few ranks and of somewhat equal length; innermost thin-chartaceous or partly scarious; outer with conspicuous foliaceous tips, or loose and foliaceous, passing into leaves: rays few and conspicuous, or in the typical species wanting: styleappendages long and attenuate-filiform, much exserted: akenes slender, compressed, few-nerved, soft-pubescent: pappus soft and slender: low and manystemmed from a suffrutescent base, not resinous-punctate: stems or branches leafy to the summit, but no axillary fascicles: leaves soft, spatulate-oblong to broadly linear, sessile, entire, but margins sometimes undulate. - Proc. Am. Acad. vi. 542, xvi. 79. Macronema, Nutt. Trans. Am. Phil. Soc. 1. c. 322.

* Connecting with preceding group; the involucre being somewhat imbricated.

A. Greénei, Gray. Abont a foot high, branching from a decidedly shrubby base, not viscidulous, or above very obscurely viscid-puberulent: the typical form otherwise quite glabrous: leaves spatulate-oblong or somewhat lanceolate (half-inch to barely inch long, 2 or 3 lines wide), obtuse or mucronate: heads solitary or few and crowded, half-inch high: bracts of the involncre in about 3 series, lanceolate to linear, all but the innermost with conspicuous and spreading mostly elongated-subulate foliacevus tips: rays 2 to 7,3 or 4 lines long: disk-flowers 10 to 16. - Proc. Am. Acad. xvi 80. - Mountaing of N. California, about the heads of the Sacramento, Greene, Pringle. Also monntains of Oregon and Washington Terr., Cusick. Passes freely into

Var. móllis, Grar, 1. c. From cinereous-puberulent to canescent-tomentose, even to the more foliaceous involucre. - A. mollis, Gray, Proc. Am. Acad. xvi. 80, -N. California (the intermediate form), Pringle. Mountaius of Oregon and Washington Territory, Cusick, Brandegee, \&c.

* Low, a span or two high, viscidly glandular-puberulent: heads commonly solitary, terminating the leafy simple stema or branches: involucre simpler and loose outer bracts more foliaceous, often enlarged: species probably confluent.

A. suffruticósus, Gray. Destitute of tomentum: stems glandular-pubescent or puberulent: heads two-thirds to three-fourths inch high: rays 2 to 5 and somewhat exserted, or none: disk-flowers 10 to 30.-Proc. Am. Acad. vi. 542, \& Bot. Calif. i. 313. Narronema suffraticosa, Nutt. 1.c. - Alpine or subalpine region of the Sierra Nevada, California, from Mariposa Co. and Humboldt Mountains, Nevada, northward to Oregun and N. Wyoming ; first coll. by Nuttall.

A. Macronéma, GrAY, l. c. Stems stouter, whitened by a dense and close tomentum: head commonly larger (inch long) : rays always wanting. - Macroneme discoidea, Nutt. l. c. - Rocky Mountains in Coloradoand Wyoming, and higher mountains in Nevada and eastern border of California; first coll. by Nuttall.

31. BIGELÓVIA, DC. (Dr. Jacob Bigelow, author of Florula Bostoniensis, Medical Botany of U.S., \&c.) - The original a perennial herb, most related to Solidago; as now extended a large genus (N. American, mainly western, with an anomalous Andean representative), mostly of suffrutescent or more shrubby plants, the genuine species with few-flowered heads of marked habit and character, while others are only artificially and not definitely distinguished from Aplopappus, especially from $§$ Ericameria, by the total want of ray-flowers. Yet some genuine Aplopappi are rayless. - DC. Mem. Comp. t. 5, \& Prodr. v. 329 
(excl. § 3) ; Gray, Proc. Am. Acad. viii. 638 ; Benth. \& Hook. Gen. ii. 1232. Chrysothamnus, Nutt. Trans. Am. Phil. Soc. ser. 2, vii. 323 ; Benth. \& Hook. Gen. ii. 255. Linosyris, Torr. \& Gray, FI. ii. 232, not Cass., which Old-World genus differs in that its heads when perchance heterogamous are heterochromous. The various types in the genus are connected by gradations, so that the sections are not very distinct.

§ 1. Chrysothamnópsis, Gray, 1. c. Heads comparatively large but narrow, at least half-inch long, 5-20-flowered: bracts of the involucre comparatively large, chartaceous and acuminate, and some outer ones prolonged into a slender herbaceous tip or appendage; when numerous the vertical ranks become more or less apparent: corollas 5-toothed or barely 5-lobed at summit: low and suffrutescent, with linear entire leaves, not punctate nor viscid or resinous, except that the first species is slightly so.

* Genuine: style-appendages setaceous-subulate or filiform, conspicuously exserted out of the corolla: akenes slender, sericeous-pubescent: anther-tips oblong-lanceolate: involucre cylindraceous, shorter than the developed (5 to 15$)$ flowers and pappus: stems or branches whitened (at least when young) by a close pannose tomentun: heads thyrsoidly paniculate or glomerate. Connects on one hand with Aplopappus $\S$ Macronema, on the other with $\S$ Chrysothamnus. $B$. ceruminosa, of the latter, approaches this group.

+ Bracts of the involucre comparatively few, not showing obvious vertical ranks.

B. Bolánderi, GRAY, 1. c. Leaves oblanceolate-linear or narrower, green and glabrate, somewhat viscidulous (about inch long), very obscurely 3-nerved : heads few and clustered, sometimes three-fourths inch long, 5-11-flowered: bracts of the involucre only about 10, thinchartaceous, lanceolate, with a soft acuminate apex, or one or two outermost herbaceoustipped : alveoli of the receptacle paleaceous-dentate. - B. Bolanderi \& B. Howardii in part (sp. Boland.), Gray, Bot. Calif. i. 315, 316. Linosyris Bolanderi, Gray, Proc. Am. Acad. vii. 354. - Mono Pass in the Siexra Nevada, California, at 10,000 feet, Bolander.

B. Párryi, Gray, I. c. Not viscidulous : stems rather strict, leafy to the summit: leaves linear ( 2 or 3 inches long, 2 lines or less wide), obscurely 3-nerved, glabrous; upper ones hardly diminished in size and overtopping all the heads of the strict and narrow thyrsiformvirgate panicle: heads little over half-inch long, 10-15-flowered: bracts of the involucre about 12, lanceolate and gradually acuminate, rather prominently 1-nerved, thin-chartaceous, a few exterior tapering into a prolonged subulate-linear herbaceous appendage: alveoli of receptacle short and nearly entire. - Linosyris Parryi, Gray in Proc. Acad. Philad. 1863, 66. - Parks of the Colorado Rocky Mountains, Parry, Hall \& Harbour, \&c.

+ - Bracts of the involucre more numerous and disposed to fall into 4 or 5 rertical ranks, in the manner of $\$$ Chrysothamnus.

B. Nevadénsis. Rigid, more branching, cinereous-puberulent or tomentulose when young: leaves coriaceous, oblanceolate to linear, mucronate (the mucro generally recurving), obscurely or not at all 3-nerved, at most inch long: heads few and glomerate at the naked summit of the branches, often three-fourths inch long, 5-flowered: bracts of cylindrical involucre more imbricated and numerous (15 to 18), rigid-chartaceous, pubescent or somewhat hirsute-ciliate, all with prolonged sleader acumination, outer broadly lanceolate or oblong and with prolonged slender-subulate tip or appendage recurving and rigid. B. Howardi, var. Nevadensis, Gray, Proc. Am. Acad. viii. 641, \& Bot. Calif. i. 316. Linosyris Howardi, var. Nevadensis, Gray, 1. c. vi. 541. - Eastern and arid portion of the Sierra Nevada, \&c., on the borders of California and Nevada, Bloomer, Anderson, Brewer, Watson, \&c. Is the analogue of Aplopappus Bloomeri.

B. Howárdi, Gray. Lower, more tufted, canescently tomentulose when young: leaves narrowly linear, rigid (an inch or two long, barely a line wide), obscurely l-nerved; upper mostly overtopping the glomerate (about half-inch Iong) narrow heads: involucre 5-flowered, glabrous; its bracts thinnish, lanceolate, apiculate-acuminate, or some loose outer ones with prolonged subulate-filiform appendage. - Proc. Am. Acad. viii, 641, excl. var. Linosyris Bowardi, Parry, in Gray, Proc. Am. Acad. vi. 541, excl. var. - Parks of the Rocky Moun- 
tains in Colorado to the borders of New Mexico and Utah; first coll. by Parry. Forms approach $B$. graceolens.

* * Style-appendages short-subulate, these and the deltoid-ovate obtuse anther-tips hardly exserted: akenes linear-oblong, glabrous: involucre campanulate-cylindraceous, equalling the 15 to 20 flowers: herbage glabrous throughout.

B. Engelmánni, Grar. A span or two high, in tufts from a suffrutescent subterranean branching caudex or rootstock: stems simple, very leafy up to the cymose-glomerate heads: leaves all narrowly linear (inch or two long, only a line wide), rigid: heads (few or rather numerous in the cluster) barely half-inch long: bracts of the involucre firm-chartaceous, oblong or innermost lanceolate, regularly imbricated and appressed, outer similar but short, all abruptly mucronate or short-cuspidate, slightly greenish below the tip. - Proc. Am. Acad. xi. 75. - Plains of Colorado at Hugo Station, Engelmann, Parry, Patterson.

§ 2. Chrisothámés, Grą, 1. c. Heacls narrow or small, 5-flowered (in B. Douglasii sometimes 6-7-flowered), mostly numerous and crowded: involucre (anomalous first species excepted) of dry and chartaceous more or less carinate bracts imbricated so as to form 5 conspicuous vertical ranks (less manifestly so when the bracts are less numerous): corollas narrow: style-appendages with exserted subulate- or setaceous-filiform appendages : akenes slender : fruticose or suffruticose and branching, with entire narrow leaves. - Bigelovia, § 2, DC. 1. c. Chrysothamnus, Nutt. Trans. Am. Phil. Soc. 1. c.

* Transition to preceding section: involucral bracts comparatively large, not carinate nor obviously 5-stichuus, some outer ones foliaceous-acuminate or appendaged: anther-tips very short and obtuse: corollas said to be even "white."

B. álbida, M. E. Joxes. Shrubby, a foot or two high, more or less resinous-riscid, fastigiately branched, very leafy: leaves all filiform, mucronate, not obviously punctate: heads fastigiate-glomerate at the summit of the branchlets, 5 or 6 lines long: involucre oblongturbinate or cylindraceous; its bracts rather few and coriaceo-chartaceous, lanceolate; outer with rather rigid subulate-acuminate and recurved or spreading foliaceous tip or appendage; inner wholly chartaceous and pointless: corollas probably ochroleucous; lobes of the deeply cleft limb linear-lanceolate: akenes pubescent. - Gray, Proc. Am. Acad. xvii. 209. - Arid districts, east of the Sierra Nevada: Owens Valley, California, coll. 1875, Kellogg. Wells Station, W. Nevada, Marcus $E$. Jones, who states that the flowers are white.

* * Genuine species, with thinner more chartaceous and carinate involucral bracts, none foliaceous-tipped: anther-tips lanceolate or narrowly oblong.

+ Akenes and ovaries glabrous, 4-6-angled and with broad epirgnous disk: pappus rigidulous: corollas 5-tnothed or short-lobed: bracts of the involucre acute or acuminate, numerous and strictly 5-stichous, 5 or 6 in each rertical rank: herbage not punctate, slightly or not at all balsamic-resinous: heads half to three-fourths inch long, somewhat fastigiately glomerate.

B. depréssa, Gra Ý, 1. c. Obscurely scabro-puberulent and pale, a span or two high from a decumbent woody base: branches leafy up to the glomerule or fasciculate cyme of few heads : leaves short (about half-inch or less long), lanceolate or lowest rather spatulate, rigid, mucronate-acute, with carinate midrib and no veins: heads half-inch long: involucral bracts lanceolate, gradually acuminate into an almost setaceous tip. - Chrysothamnus deprrssus, Nutt. Pl. Gamb. 171. Linosyris depressa, Torr. in Sitgreaves Rep. 161. - 1'lains of S. Colorado to adjacent New Mexico and S. Ltah; first coll, by Giambel.

B. pulchélla, Gray, l. c. Glabrous and green, shrubby, 2 or 3 feet high, fastigiately much branched, very leafy up to fastigiate-cymose heads: leaves narrowly linear, plaue (inch or less long), rather obtuse, with ciliolate-scabrous margins and midrib not prominent: heads two-thirds to three-fourths inch long: involucral bracts rigid-chartaceous and lower ones obscurely herbaceous on the back, much carinate, acute and cuspidate-mucronate - Linosyris pulchella, Gray, P1. Wright. i. 96; Torr. in Sitgreaves, 1. c. t. 4. - W. borders of Texas to adjacent New Mexico and Colorado; first coll. by Wright.

B. Bigelóvii, Grax, 1. c. Canescent with fine close tomentum when young, glabrate, shrubby, a foot to a yard high, fastigiately much branched, rigid : branches less leafy, bearing a few fastigiate-clustered heads (these half to two-thirds inch high): leaves nearly fili- 
form: involucral bracts lanceolate, acute, thinnish, all pale: receptacle sometimes bearing a prominent chaffy cusp. - Linosyris Bigelovii, Gray, Pacif. Ex. Exp. iv. 98, t. 12. - N. New Mexico and adjacent Colorado; first coll. by Bigelow.

++ Akenes (smaller) canescently pubescent or villous (B. leiosperma excepted!): herbage commonly graveolent, and in most species becoming more or less resinous-pruinose or balsamicviscid.

+ Leafless or sparsely leaved, shrubby, with rush-like or broom-like branches, 2 feet or more high: leaves when present filiform, not punctate: heads fasciculate-clustered: involucre somewhat clavate, 4 or 5 lines long, very glabrous; the bracts wholly thin-chartaceous and pale, very strictly pentastichous and about 5 in each vertical rank, all muticous; the inner ones linear, outer successively and regularly shorter, outermost minute: akenes slender, appressedvillons.

B. júncea, Greeve. Strict, fastigiately very much branched: branches slender and junciform, mostly leafless, greenish and minutely canescent, apparently not becoming viscid: bracts of the involucre acutish, at least the innermost: corolla-lobes short-lanceolate, in the bud externally beset with delicate long hairs. - Bot. Gazette, vi. 184. - E. Arizona, on calcareous bluffs of the Gila, near the New Mexican boundary, Greene.

B. Mohavénsis, Gri:ene. Stouter, with fewer and looser sometimes flexuous rigid branches, canescent with a fine pannose tomentum, or in age glabrate and becoming viscidulous : sparse leaves often present, an inch or less long: bracts of the involucre obtuse: corolla-lobes narrowly lanceolate, wholly glabrous. - Bull. Torr. Club, ined̃. B. juncea, Gray in distrib. Pringle, not Greene. - On the Mohave Desert, Greene, Parry, Pringle. Host-plant of Pholisma, according to Pringle.

++ Leaves numerous, fillform or nearly so, not obviously punctate: heads shorter: involucral bracts 3 or 4 in each vertical rank, some or most of them with small setaceous or subulate spreading or recurving tips: lobes of 5-cleft limb of corolla linear or linear-lanceolate: stems fastigiately branched.

B. ceruminósa, Gray. Shrubby, a foot or two high, glabrate, balsamic-viscidulous or pruinose-resinous: leaves rather scattered on the slender branches, spreading or recurving: heads cymose-fascicled, about 5 lines long, narrow: bracts of the viscidly lucid involucre narrowly lanceolate, abruptly produced into a spreading setiform tip or short awn, or the much shorter outermost muticous. - Proc. Am. Acac. viii. 648, \& Bot. Calif. i. 316. Linosyris ceruminosa, Durand \& Hilgard, Pl. Heerm., \& Pacif. R. Rep. v. 9, t. 6. - S. California in Tejon Pass, Ir. Heermann. Not since seen.

B. Greénei, Gr.ly. Suffruticose, about a foot high, green and glabrous, more or less balsamic-viscid : leaves very numerous on the branches, filiform-acerose, but flat and margins minutely ciliolate-scabrous: heads numerous and fastigiate-cymose, 3 or 4 lines high : bracts of the subclavate involucre fewer and firmer-chartaceous, oblong, abruptly subulate-tipped or short outermost mucronate, only about 3 in each vertical rank, these ranks comparatively indistinct: anthers and stigmas less exserted. - Proc. Am. Acad. xi. 75. - Colorado ; on the Huerfano Plains, Greene. Near Twin Lakes in the Colorado Mountains, and Cottonwood Caĩon, Utah, $M . E$. Jones.

+ Leaves numerous, all involnte-filiform, resinous-punctate and glabrous, as are the branchlets, but at length balsamic-viscid or pruinose-waxy: no tomentum: heads open-paniculate, 4 or 5 lines high: bracts of the cylindraceous involucre less numerous, only 3 or 4 in each vertical rank, from oblong to linear, obtuse and pointless, little carinate: corolla with shurt oblong lobes or teeth: pappus soft: low-shrubby, fastigiately or paniculately much branched, very leafy: leaves an inch or less long.

B. teretifólia, GraY. Branches rigid, fastigiate: involucral bracts narrowly oblong to broadly linear, rather firm-chartaceous, in about 4 vertical ranks, all but innermost tipped with a greenish and glandular subapical spot. - Proc. Am. Acad. viii. 644, \& Bot. Calif. i. 316. Linosyris teretifolia, Durand \& Hilgard, Pl. Heerm., \& Pacif. R. Rep. v. 9, t. 7. - Arid hills, S. E. California, bordering the Mohave Desert; first coll. by Dr. Heermann. Perhaps also in Arizona.

B. paniculáta, GRAY, 1.c. Less woody, more paniculate: involucral bracts broader, thinner, about 3 in each vertical rank, pale and wholly naked. - Linosyris viscidifora, var. paniculata, Gray, Bot. Mex. Bound. 80. - Desert wastes, San Bernardino Co. to S. Utah? First coll. by Schott, later by Parry, Parizh, Palmer. 
+++++ Leares numerous, from filiform-linear or involute-filiform (but mostly plane or only canaliculate) to broadly linear or lanceolate, not resinous-punctate but sometimes riscidulous: heads fastigiate-cymose or somewhat thyrsoid: bracts of the involucre obtuse or somewhat acute and muticous (in one ambiguous form even pointed!): slender style-appendages well exserted, especially in the first species.

= At least the branches when young, and commonly in age, whitened by a close pannose tomentum: subutate-filiform style-appendages longer than the stigmatic portion: pappus soft.

B. gravéolens, Grar. A foot to a yard or more high, bearing numerous crowded heads : these half or two-thirds inch bigh: leaves mostly flocculent-tomentose when young, often glabrate in age, not rigid; the larger spatulate-linear, or linear-lanceolate (2 inches long and fully 2 lines wide, obscurely if at all 3-nerved); the narrowest almost filiform, at least when dry, and margins involute: involucre thin-chartaceous when dry: corolla-lobes or teeth short, from lanceolate to nearly ovate: akenes linear: pappus soft. - Proc. Arn. Acad. viii. 644. - The typical form of this polymorphous species has the bracts of sometimes viscidulous involucre narrowly oblong to linear-lanceolate, rather obtuse to acutish or even quite acute: short corolla-lobes commonly oblong-lanceolate, varying to nearly ovate and shorter, the tube naked or nearly so. - Chrysocoma dracunculoides, Pursh, Fl. ii. 517, not Lam. C. graveolens, Nutt. Gen. ii. 136. Bigelovia dracunculoides, DC. Prodr. v. 329. Chrysothamnus dracunculoides \& $C$. speciosus, Nutt. Trans. Am. Phil. Soc. 1. c. Linosyris graveolens, Torr. \& Gray, Fl. ii. 234. - Sterile and especially alkaline soil, I)akota to British Columbia, and south to S. California and New Mexico. Heads sometimes cymose, sometimes thyrsoidglomerate. Forms of the latter occur with firmer involucral bracts, some of them even acuminate, as if connected with $B$. Howardi.

Var. glabráta, Grar, 1. c. Includes forms of the above with the usually narrow leaves early glabrate or perhaps glabrous from the first, sometimes balsamic, sometimes not. - Inclades Linosyris viscidiflora, Hook. Lond. Jour. Bot. vi. 243, in part, no. 102, Geyer, from the northern Rocky Mountains, and Bigelovia Douglasii, var. stenophylla, Gray, Bot. Calif. i. 614, from the southern borders of California, Palmer. Not rare in Colorado, where even the branches sometimes early lose their liglit tomentum.

Var. albicaúlis, Grax, l.e. Branches for the most part permanently and very densely white-tomentose and leaves floccose-tomentose: involucre either tomentulose or gla brate; its bracts commonly acutish : corolla-lobes more or less lanceolate and the tube villous- or arachnoid-pubescent. - Chrysocoma nauscosa, Pursh, 1. c., Nutt. Gen. 1. c., therefore Biyelovia Missouriensis, DC. 1. c., but chiefly found west of the Rocky Mountains. Chrysothannus speciosus, var. albicaulis, Nutt. Trans. Am. Phil. Soc. 1. c. Linosyris albicaulis, Torr. \& Gray, Fl. ii. 234. - Rocky Mountains of Wyoming to Brit. Columbia, and the eastern side of the Sierra Nevada to San Bernardino Co., California.

Var. latisquámea, GRAY, 1. c. Rather stout, white-tomentose or partly glabrate: heads numerous in the corymbiform cymes: bracts of the glabrous involucre raostly elliptical-oblong, very obtuse: lobes or teeth of the corolla short, somewhat lanceolate, the tube glabrous. - S. E. Colorado to adjacent New Mexico, and S. Utab, Fendler (no. 341), Bigelow, Dr. Henry Ward.

Var. hololeúca, GRAY, 1. c. Slender, white-tomentose even to the heads; these rather small, numerous in corymbiform cymes terminating sparsely-leaved branches: leaves very narrowly linear, inch long, and uppermost short and bract-like : involucral bracts small, linear-oblong, very obtuse: corolla merely 5-toothed, its tube bearing cobwebby hairs: akenes (as in the species) villous-pubescent. - Owens Valley in the southeastern part of the Sierra Nevada, California, Dh. Horn.

B. leiospérma. A foot or two high, with rigid slender branches, bearing small glomerate cymes, white-tomentose, or in age somewhat glabrate: leaves sparse, and uppermost very small, involute-filiform: involucre glabrous; its bracts small, oblong, or innermost linearoblong, very obtuse : corolla glabrous and with 5 short ovate teeth : ovary and akenes completely glabrous ! - St. George, Southern Utah, Palmer, coll. 1875. Candelaria, S. W. Nevada, W. H. Shockley.

$=$ Green, no tomentum, either smooth and glabrons or scabro-puberulous: style-branches less exserted, thicker, shorter than the stigmatic portion: pappus rigidalous: akenes shorter.

B. Douglásiii, GrAY, 1. c. From 6 inches to 6 feet high, fastigiately branched, sometimes resinous-viscid, often slightly or not at all so leaves from very narrowly linear or almost 
filiform (but plane or canaliculate) to lanceolate-oblong, mostly 3-nerred: heads few or numerous and fastigiate-cymose, 3 or 4 lines high : bracts of the involucre comparatively few, only 2 to 4 in each vertical rank (these ranks therefore less conspicuous), from broadly to linear-oblong or lanceolate, obtuse (rarely acute), firm-chartaceous, not rarely some of the outer with firmer and indistinctly greenish apex: corollas rather deeply cleft into oblongIanceolate lobes. - (Crinitaria viscidiflora, Hook. Fl. ii. 24, apparently, in part: this founded on two specimens, both with heads undeveloped, one puberulent, one glabrous, to be referred either to this species or to Aplopappus, Ericameria, nanus.) Chrysothamnus viscidiflorus \& C. pumilus, Nutt. Trans. Am. Phil. Soc. 1. c. Bigelovia viscidiflora, DC. Prodr. vii, 279. Linosyris viscidiflora, Torr. \& Gray, 1. c. Brickellia linearifolia, Klatt, Abh. Nat. Gesells. Halle, xv. 5. - Plains and mountains, in sterile soil, Dakota to Washington Terr. and border of Brit. Columbia, dry eastern border of California, and south to Arizona and New Mexico; in various forms. Taking the forms with linear and lanceolate smooth leaves as the type, the marked variations are

Var. púmila (Chrysothamnus pumilus, Nutt. 1. c., with his var. euthamioides), a dwarf northern and mountain state, a span or two high, glabrous or minutely puberulent and disposed to be viscidulous; the simple branches bearing very few heads in a close cluster: outer involucral bracts either somewhat greenish-tipped or passing into bract-like leaves. N. Montana to Washington Terr. and mountains of Utah.

Var. serruláta, Gray, 1. c. Taller: leaves linear or narrowly lanceolate, serrulateciliolate, sometimes scabrous and rigid. - Linosyris serrulata, Torr. in Stansbury Rep. 389; Eaton, Bot. King Exp. 157. - Common through the whole dry interior region.

Var. tortifólia, Gray, 1. c. Leaves twisted: otherwise like the preceding. - Plains of Colorado to the Sierra Nevada, California. Here Linosyris lanceolata, Hook. Lond. Jour. Bot. vi. 243.

Var. stenophýlla, Gray, l. c. Leaves slender, at most a line wide by an inch or two long, or narrower and varying to filiform, smooth: flowers sometimes only $4 .-\mathrm{N}$. W. Nevada to S. E. California, Utah, and New Mexico.

Var. latifólia, Grar, l. c. Stouter and taller, smooth and glabrous, or puberulent: leaves lanceolate to narrowly oblong (the broadest even half-inch wide by thrice that length), often obtuse, 3-5-nerved : flowers sometimes 6 or 7 in the head. - Linosyris viscidiflora, var. latifolia, Eaton, Bot. King Exp. 1. c. - S. Idaho, Nevada, and Utah.

Var. lanceoláta. Low, but bearing compact cymes of numerous (5-7-flowered) heads: leaves short, lanceolate or broadly linear, scabro-puberulent. - Chrysothamnus lanceolatus, Nutt. Trans. Am. Phil. Soc. 1. c. Linosyris lanceolata, Torr. \& Gray, Fl. ii. 233. Bigelovia lanceolata, \& B. Douglasii, var. puberula, in part, Gray, 1. c. 639, 644. (Linosyris viscidiflora, var. puberula, Eaton, 1. c., is mainly a scarcely puberulent narrow-leaved form of the type.) - Head-waters of the Platte, Wyoming and Montana, \&c. Passes into var. serrulata and var. tortifolia.

+++ Akenes glabrous, as also the ovaries, nearly terete: bracts of involucre rounded-obtuse, not prominently pentastichous: anthers and style-tips little exserted: suffrutescent, green and glabrous, not punctate.

B. Vaséyi, Gray. A span or two high, somewhat balsamic-viscid but wholly glabrous, leafy up to the fastigiate-cymose cluster of heads: leaves linear or spatulate-linear, obtuse, plane (at most inch long), with obscure midrib: involncre cylindraceous, 3 or 4 lines long; its bracts narrowly oblong, firm-chartaceous, and all but innermost with a thickened greenish spot at the very obtuse apex: Iobes of the corolla short-linear: style-appendages narrowly subulate, rather obtuse, half the length of the stigmatic portion: pappus fine and soft, rather short. - Proc. Am. Acad. xii. 58. - Coloraclo Rocky Mountains, in Middle Park and Gunnison Valley, Vasey, Parry. Utah, Ward. - Transition to Solidago and to § Aplodiscus.

§ 3. Edbigelóvia, Gray, l. c. Heads as of preceding section, very narrow, 3-4-flowered: alveoli of the receptacle prolonged into subulate teeth or at the centre into a chaff-like cusp : limb of corolla enlarging and 5-cleft : style-appendages ovate-subulate, shorter than the stigmatic portion: akenes short, somewhat turbinate: pappus rigidulous: wholly herbaceous perennial, with entire narrow leaves: habit of Solidago § Euthamia. 
B. nudáta, DC. Glabrous : stems slender, a foot or two high from a small caudex, strict and simple up to the compound-fastigiate and corymbose cyme of numerous heads: leaves not punctate nor obviously viseid, spatulate to nearly filiform, uppermost small and bractlike: heads barely 3 lines high, subclavate: bracts of the involucre about 3 in each rather indistinct vertical rank, oblong-linear, obtuse and firm-chartaceous, or at least outermost with short greenish tips. Leaves in the original of the species spatulate-linear, or uppermost narrower, lowest and radical commonly broader (sometimes half-inch wide) and roundedobtuse. - Prodr. v. 329, \& Mem. Comp. t. $5 \quad$ B. nudata, var. spathule folia, Torr. \& Gray, F1. ii. 232. Chrysocoma nudata, Michx. Fl. ii. 101 ; Nutt. Gen. ii. 137. - Low pine barrens, New Jersey to Florida and Louisiana; fl. autumn.

Var. virgáta, Torr. \& GraY, 1. c. Cauline leaves linear-filiform, or lowest and the radical linear-spatulate. - B. virgata, DC. 1. c. Chrysocoma virgata, Nutt. 1. c. - New Jersey to Texas. Passes into the broader-leaved form.

§ 4. Euthamiópsis. Heads (small) 7-25-flowered: bracts of the involucre wholly chartaceous, or in some obscurely greenish at tip, hardly carinate, obtuse or nearly so and muticous, appressed-imbricated in 3 or 4 series, but vertical ranks inconspicuous: style-appendages hardly exserted out of the 5-lobed limb of the corolla, subulate-oblong to short-filiform, shorter or not longer than the stigmatic portion: akenes mostly short and turbinate, sericeous-pubescent: shrubby, becoming more or less balsamic-viscid, and with entire punctate leaves: corollas of outermost flowers sometimes deformed.— $§$ Aplodiscus, Euthamioidea, mainly, Gray, Proc. Am. Acad. viii. 639.

* Stems simple below and fastigiately branched above, 3 to 12 feet high, bearing numerous heads in close and ainple corymbiform cymes: leaves plane: involucral bracts small, lanceolate, wholly chartaceous and pale, or midnerve obscurely greenish.

B. Paríshii, Grefexe. Leaves thickish, lanceolate or oblong-linear (inch or two long, quarter to nearly half an inch wide), mucronate, strongly punctate; heads 10-12-flowercd, fully 3 lines long). - Bull. Torr. Club, ix. 62. - Mountains near San Bernardino, S. E. California, Parish, \&c. Stems sometimes 2 or 3 inches in diameter.

B. arboréscens, Grax. Leaves narrowly linear, very numerous (1 to 3 inches long, a line wide), moderately punctate: heads 20-25-flowered, barely 3 lines long: outer flowers often deformed. - Proc. Am. Acad. viii. 640. Linosyris arboresceris, Gray, Bot. Mex. Bound. 79. - Dry ground, common in the Coast Ranges of California, sparing]y in the Sierra Nevada: first coll. by Fitch and Kellogg.

* * Branched from the 'base: heads paniculate or more scattered: leaves filiform, thickish : bracts of involucre larger and rather few, oblong, obtuse.

B. Coóperi, Gray. Apparently low, with leaves half-inch or less long, balsamic-viscid: heads few in a cluster at the end of the branchlets, 6-8-flowered : bracts of involucre narrowly oblong, chartaceous, pale to the apex: style-appendages ovate-subulate. - Proc. Am. Acad. viii. 640, \& Bot. Calif. i. 315. - S. E. California, on eastern slope of Providence Mountains, Cooper. Not again found: only branchlets known.

B. brachylepis, Gray. Shrub 4 to 6 feet high: leaves inch or half-inch long, balsamicviscid, conspicuously resinous-punctate: heads loosely paniculate or solitary terminating paniculate branchlets, 8-12-flowered, 4 or 5 lines high: bracts of the campanulate involucre oblong, more or less carinate by a glandular thickened midnerve ; innermost not surpassing the linear-oblong akenes, outermost passing into small commonly imbricated scales on the peduncle: style-appendages subulate-filiform. - Bot. Calif. i. 614. - S. California, along the southern borders of San Diego Co., near the Mexican frontier, Palner, Cleveland, Nevin. (Adj. Lower Calif.)

B. DIFFúsa, Gray, Proc. Am. Acad. viii. 640 (Linosyris Sonoriensis, Gray, 1. c. 291, Ericameria diffusa, Benth. Bot. Sulph. 23, Solidago diffusa, Gray, Proc. Am. Acad. v. 159), of Lower California (Hinds, Xantus) and Sonora (Palmer), is a species of this group, with filiform leaves obscurely punctate, and involucral bracts of firmer texture, the tips greenish, verging therefore to the next section. 
§ 5. Aplodíscus, Gray, 1. c. Heads several-many-flowered: bracts of the involucre either coriaceous or firm-chartaceous, and usually somewhat herbaceous or thickened at the obtuse or barely acute apex, all strictly appressed and well imbricated, but the vertical ranks inconspicuous: style-appendages subulatelanceolate or broader, shorter than the stigmatic portion : akenes short, sericeouspubescent: herbaceous or suffruticose, commonly more or less balsamic-viscid: leaves not punctate, sometimes dentate or pinnatifid. - Aplopappus $\S$ Aplodiscus, DC. Prodr. v. 350, excl. A. ramulosus, which is a Baccharis.

* Herbaceous down to suffrutescent base: leaves linear: bracts of the involucre thin-coriaceous or almost chartaceous, and with obscure if any greenish tips.

B. pluriflóra, Gray, 1. c. Leaves narrowly linear, entire: heads 15-18-flowered, 4 lines high: involucre somewhat turbinate, very smooth; its thinnish bracts lanceolate, acute: otherwise like the next, of which it is perhaps a mere form, but is insufficiently known. Chrysocoma graveolens, Torr. Ann. Lyc. N. Y. ii. 211, not Nutt. Linosyris pluriflora, Torr. \& Gray, Fl. ii. 233. - Colorado? probably on the Arkansas or South Fork of the Platte, James in Long's expedition.

B. Wrightii, Grax, 1. c. Commonly glabrous or nearly so : stems rather strict and slender, a foot or two high from the lignescent base : leaves thickish, narrowly linear, entire, sometimes lower ones sparingly laciniate-dentate, margins either smooth or sparingly hirtelloscabrous: heads (4 or 5 lines high) 7-15-flowered, usually numerous and crowded in a corymbiform cyme: bracts of the involucre oval-oblong to broadly lanceolate, obtuse; the back at or near the apex usually greenish, but no definite tip. - Linosyris Wrightii \& $L$. heterophylla, Gray, Pl. Wright. i. 95, ii. 80. - Banks of streams and in saline soil, W. Texas to S. Colorado and Arizona ; first coll. by Wright.

Var. hirtélla. Leaves cinereons-hirtellous or hirsute-pubescent and ronghish, but often glabrate in age or only ciliolate: stems sometimes pubescent. - Linosyris hirtella, Gray, Pl. Wright. i. 95. - Same range ; first coll. by Wright.

* * Suffrutescent: leares linear-filiform and pinnately parted: involucrë nearly of the preceding.

B. coronopifólia, Grar, I. c. Glabrous : stems freely branching, slender, a foot or two high, leafy : divisions of the leaves 3 to 9 , often half-inch long, not thicker than the filiform rhachis, setulose-mucronate: heads somewhat thyrsoid-glomerate (4 or 5 lines long), 10-12flowered. - (Excl. pl. Arizona, Palmer.) Linosyris coronopifolia, Gray, Pl. Wright. i. 96. S. Texas along the Rio Grande, Wright, Bigelow, Havard, Palmer.

* * * Suffruticose: bracts of involucre more coriaceous and more definitely greenish-tipped.

* Leaves all entire (or rarely a tooth or two), linear or spatulate-linear: branches partly herbaceous : glabrous.

B. Drummóndii, Gray, 1. c. About a foot high, with many slender erect or ascending branches or stems from a woody base: leaves all narrowly linear, with tapering base (inch or two long, seldom over a line wide) : heads 5 or 6 lines high, rather numerous in a corymbiform cyme, 18-30-flowered: involucre campanulate; its bracts linear-oblong, with obtuse or obtusish and short green or greenish tips: pappus rather soft. - Linosyris Drummondii, Torr. \& Gray, Fl. ii. 233. - Coast of Texas, and Lower Rio Grande ; first coll. by Berlandier, Lrummond, Trecul. E. Arizona, Rusby. (Adj. Mex., Palmer.)

B. acradénia, Greeve. A foot or so high, very many slender stems or branches forming broad tufts from a woody base: leaves spatulate-linear (half-inch to inch long), entire or rarely some small teeth: heads glomerate-cymose, 4 lines high, 10-20-flowered: involucre campanulate, of more rigid oblong bracts, the back at the obtuse apex bearing a protuberant rounded resiniferous gland: pappus rigid, of very unequal bristles. - Bull. Torr. Club, x. 126. - Mohave Desert, S. E. California, Greene, Parry, Jared, \&c. S. Utah, Palmer. Transitions apparently occur between this and the next.

+ - Leaves serrate, dentate, or pinnatifid, occasionally entire : shrubby, 2 to 4 feet high.

B. venéta, Gray. Glabrous, or the herbage when young loosely pubescent, or almost tomentose : leaves short (half-inch or lower twice or thrice this length), spatulate or oblanceolate, or sometimes cuneate-oblong, sparsely or irregularly spinulose-dentate or serrate, or 
denticulate with spinulose teeth, sometimes incised, some upper or fascicled ones varying toward linear and entire : heads more or less glomerate at the end of the branchlets, 15-35flowered, 4 or 5 lines high: bracts of the turbinate or campanulate involucre with obtuse or sometimes acutish or mucronate-acute green tips (these occasionally bearing an indistinct resinous gland) : pappus of rather rigid and very mequal bristles. $-B$. veneta \& $B$. Menziesii, Gray, Prac. Am. Acad. viii. 638, \& Bot. Calif. i. 315. Baccharis veneta, HBK. Nov. Gen. \& Spec. iv. 68. Linosyris Mexicana, Schlecht. Hort. Halens. 7, t. 4. Aplopappus discoideus, DC. Prodr. v. 350. A. Menziesii, Torr. \& Gray, Fl. ii. 242. Pyrrocoma Menziesii, Hook. \& Arn. Bot. Beech. 351. Isocoma vernonioides, Nutt. Trans. Am. Phil. Soc. vii. 320. (B. tridentata, Greene, Bull. 'Torr. Club, l. c., Linosyris dentata, Kellogg, Proc. Calif. Acad. ii. 16, is apparently a form of this, from Cedros Island off Lower California.) - Southern part of California (first coll. by Menzies) to borders of Arizona. (Mex.)

B. Hartwégi, Grar. Cinereous-puberulent or glabrate, a foot or two high: leaves from linear to narrowly oblong, pinnatifid; the lobes 5 to 11 , oblong-linear, short (only a line or two long): heads smaller than in the preceding, into which it may pass. - Hemsl. Biol. Centr.-Am. Bot. ii. 115. - S. Arizona, Palmer (taken for B. coronopifolia in Proc. Am. Acad. viii. 639), Lemmon. (Mex.)

32. SOLIDÁGO', L. GOLDEN-RoD. (Solidus and ago, to make solid or draw together, in allusion to reputed vulnerary properties.) - Perennial herbs (one species somewhat shrubby); with mostly strict stems, entire or serrate alternate leaves, the cauline sessile or nearly so, the radical tapering into margined petioles (never cordate); the small heads thyrsoid-glomerate, or sometimes corymbosely cymose, or more commonly in racemiform secund clusters; the flowers yellow, or in one species whitish in the disk and white in the ray; rarely the rays wanting. - Gen. ed. 1, 253 (name from Vaill.); Torr. \& Gray, Fl. ii. 195. - A large genus, of nearly 100 species, mostly Atlantic N. American, but with several Pacific species, a few Mexican or S. American, one or two European and N. Asiatic: fl. late summer and autumn. - For notes on the species in the older herbaria, and a synopsis, see Proc. Am. Acad. xvii. 177-199.

S. Lateriflóra, L. Spec. ii. 879, is Aster diffusus, Ait.

S. Noveboracénsis, L. I. c., is probably Aster Tartaricus, and not North American.

Species founded on garden plants and not identified with, or obviously referable to, North American originals, are the following : -

S. A MBíg UA, Ait. Kew. iii. 217, cult. 1759 by Miller, of unknown source, appears to have been some European form of $S$. Virgaurea, although later plants cultivated under this name may be derivatives of $S$. latifolia, $\mathrm{L}$.

S. Elliptica, Ait. Glabrous and smooth up to the flowering branches, 2 or 3 feet high, equably leafy: leaves of rather firm texture, oval or oblong, acuminate at both ends, the larger 3 or 6 inches long, $1 \frac{1}{2}$ or 2 wide, more or less serrate with fine acnte teeth, somewhat veiny: thyrsus somewhat leafy; the heads ( 3 lines long) racemose-paniculate on erect branches, little or not at all secund: bracts of the involucre oblong-lanceolate, acutish or obtuse: rays 7 to 9 : akenes villous-pubescent. - Kew. iii. 214; DC. Prodr. v. 334 ; Gray, Proc. Am. Acad. xvii. 181. S. plantaginea, Desf. Cat. ed. 3, 402. - Cultivated from early times in European gardens, not identified as indigenous. The typical form is here taken to be that of the Banksian herbarium, cult. hort. Kew. 1778. A second original specimen, to which the syn. Mill. Dict. belongs, is

Var. AxılLiflórA, Gray, 1. c. Leaves of somewhat firmer texture, from oval to broadly lanceolate: heads rather larger, in short or somewhat elongated and racemiform erect or spreading clusters, which are mostly axillary and shorter than the leaves. - S. latifolia, L., as to Pluk. Alm. 389, t. 235, f. 4. S. latissimifalia, Mill. Dict. ed. 7. S. lateriflora, Willd. Spec. iii. 2057, \&c., not L. nor Ait. S. fragrans, Willd. Enum. Suppl. 331, a narrower-leaved form. S. verrucosa, Schrad. Hort. Gœett. 12, t. 6? S. Clelice, DC. Prodr. v. 331, \& perhaps S. dubia, Scop. Del. Insub. ii. 19, t. 10. - Cultivated from ante-Linnæan times in European collections, not identifed in N. America, but doubtless of American origin. 
S. ReCURvAtA, Willd., and S. Lf́vidA, Willd. (Enum. $889 \& 491$ ), described from cultivated plants, are referred to under S. ccesia, L., p. 145.

S. LITHosPermifólis, Willd. Enum. 891, referred to under S. sempervirens, L., was probably derived from that, under cultivation becoming pubescent and duller green. But without the transitions as seen in S. integrifolia, Desf., this would seem improbable.

S. Corymbósa, Poir. Suppl. v. 461 (not Ell.), is only the European S. Firgaurea, L.

S. GRANDifLórA, Desf. Cat. ed. 3,403, of unknown source, is evidently a tall cultivated state of the Italian S. littoralis, Sari.

S. FUsc $\AA_{\mathrm{TA}}$, Desf. 1. c. 402. Glabrous and very smooth (the inflorescence barely puberulent) : stem 3 or 4 feet high, with numerous ascending purplish branches, very leafy: leaves oblonglanceolate, acute at both ends or acuminate, entire, or the lower ( 3 or 4 inches long) with a few minute and obscure teeth, of somewhat firm texture, and minutely reticulated inconspicuous venation, a pair or two of primary veins more evident: heads hardly 3 lines long, numerous in a narrow or virgate thyrsus, not secund: bracts of the involucre rather broad (outer oblong) and obtuse: rays 6 to 8, short: young akenes puberulent.-Of nnknown source; cult. in Paris Garden from 1828. Habit somewhat of S. puberula.

Of species founded on indigenous specimens there remains wholly obscure only the following :-

S. PAUCIFlóra, Raf. in Med. Rep. (hex. 2), v. 359. "Stem simple, smooth: leaves oblonglanceolate, acute, entire: flowers 1 to 5, terminal. - Gloucester Co., New Jersey, and Kent Co., Delaware," Rafinesque. Not to be identified.

§1. VIRGAÚREA, DC. (Virga-aurea, Tourn.) Receptacle of the head alveolate: rays commonly fewer or not more numerous than disk-flowers: herbs.

* Involucre squarrose, the bracts having herbaceous recurving or spreading tips (yet occasionally erect in all the species): general inflorescence tbyrsiform or reversed racemiform-paniculate, not unilateral: leaves pinnately veined, from ovate to lanceolate; the lower ones commonly petioled, and acutely more or less serrate; the upper often entire. (Chrysastrum, Torr. \& Gray.) Squarrosa.

+ Rays none: ovaries hirsute: bristles of the pappus unequal, all with clavellate tips.

S. discoídea, Torr. \& Grax. Pubescent or hirsute, somewhat cinereous: stem branching above: lower leaves ovate, coarsely serrate, on slender and margined petioles, 3 inches long: upper small, often entire, oval or oblong: heads ( 3 or 4 lines long) rather scattered in the racemiform thyrsus, 10-20-flowered: disk-corollas deeply 5-cleft : pappus often tinged with purple. - Fl. ii. 195. Aster? discoideus, Ell. Sk. ii. 358. - Dry soil, Georgia to Florida and Louisiana; first coll. by Elliott.

+ + Rays present and conspicuous, rather numerous: bristles of the pappus not evidently elavellate-thickened: akenes glabrous or nearly so.

S. squarrósa, Muнl. Green, pubescent or glabrate: stem stout and simple, $\mathbf{2}$ to $\mathbf{5}$ feet high: lower leaves ovate or oblong, 6 to 10 inches long: heads ( 5 or 6 lines long) numerous and crowded at least on the lower branches of the (foot or two long) leafy thyrsus: green squarrose tips of the involucral bracts short and broad, obtuse or abruptly acute. - Cat. 79; Nutt. Gen. ii. 161 ; Torr. \& Gray, 1. c. S. confertiflora, Nutt. in Jour. Acad. Philad. vii. 102 ; Hook. Fl. ii. 4, not DC. - Rocky soil, New Brunswick and Canada to Ohio and upper part of Virginia.

S. petioláris, Ait. Puberulent or pubescent with fine short hairs, somewhat pale or cinereous : stem slender, a foot to a yard high: Ieaves comparatively small, elliptical-oblong to broadly lanceolate, scabrous-ciliate; the lower 2 inches or so in length, serrate with a few coarse teeth toward the apex, narrowed at base, obscurely or sometimes distinctly and abruptly short-petioled, mostly glabrous or glabrate above, minutely hairy at least along the veins beneath; upper smaller, sessile, entire: heads ( 3 to 5 lines long) loosely or sometimes more compactly disposed in a narrow or irregular thyrsus: involucral bracts narrow and acute; the outer green or with green tips, and more or less squarrose; inner ones appressed. - Ait. Kew. iii. 216; Smith in Rees Cycl.; Torr. \& Gray, Fl. ii. 203, not Muhl., Ell., or Less. S. erecta, Nutt. Gen. ii. 161. S. elata? Ell. Sk. ii. 389. S. squarrosa, Nutt. in Jour. Acad. Philad. vii. 102, not Nutt. Gen., nor Muhl. S. petiolaris, var. squarmilosa, Torr. \& Gray, 1. c. - Dry 
soil, especially in pine barrens, N. Carolina to Florida, Kansas, and Texas. The specific name quite inappropriate; and the squarrose tips of the bracts are sometimes obsolete, thus invalidating the rather marked character of this group.

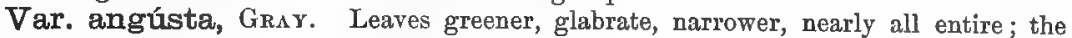
lower sometimes 3 or 4 inches long and half-inch or less wide, tapering into a margined petiole. - Proc. Am. Acad. xvii. 189. S. angusta, Torr. \& Gray, Fl. ii. 204. - W. Louisiana, Hale, and Fredericksburg, Texas, Thurber.

* * Involucre of inappendiculate and wholly appressed bracts in this and all the following divisions: heads small (at most 3 lines long), disposed more or less in axillary glomerate or short-racemiform clusters along the leafy stem, or not rarely with some or most of the clusters in an almost naked thyrsus: leaves unicostate, pimately veiny. - Guomenulifore, Torr. \& Gray.

+ Akeues canescently hirsute-pubescent: leaves normally thin and membranaceous, very sharply serrate, acuminate, bright green, usually surpassing the short clusters in their axils, except where these become confluent into a thyr'sus at the summit.

+ Stem and branches terete, often glaucous.

S. cǽsia, L. Slender, commonly branching and glabrous or nearly so up to the peduncles, smooth, a foot or two high: leaves lanceolate or the lower from ovate- to oblong-lanceolate, sessile, serrate with erect or ascending teeth, the venation not prominent: hearls small, fewflowered: bracts of the involucre all obtuse. - Spec. ji. 879 (founded on I)ill. Eith. 414, t. 307, \& Virga-aurea LLarilandica, etc., Ray); Ait. Kew. iii. 217; Torr. \& Gray, Fl. ii. 199. S. flexicaulis, L. 1. c., as to herb., excl. char. \& syn. - Shaded banks, or in wooded grounds, Canada to N. W. Arkansas, Georgia, and Texas.

Var. axilláris, Gray, Proc. Am. Acad. 1. c. (S. axillaris, Pursh, Fl. ii. 542), is a common form in shade, with elongated-lanceolate thin leaves, all much exceeding the short clusters of rather few heads. - Chiefly northern, in woods.

Var. paniculáta, Grar, 1. c. Paniculately branched above, smaller-leared, floribund; the clusters of heads becoming racemose-paniculate toward the end of the branches: stems often purple and branchlets occasionally pubescent. $-S$. gracilis, Poir. Dict. viii. 4i6; DC. Prodr. v. 336. S. Schraderi, DC. 1. c.? (alonormal form), \& of the Gardens. S. arguta, Spreng. Syst, not Ait. S. argentea, Hornem. ex Spreng.-A form of drier and open grounds, commoner in S. States, and of European cultivation, where it is much altered, and appears to pass into

S. Reccrvat , Willd. Enum. 889 (not Mill. Dict.). Tall, more paniculate, and the heads in racemosely crowded clusters on spreading (but hardly recurved) or ascending flowering branches, few if any in the axils of cauline leaves; usually some pubescence. - European gardens. May be a hybrid between S. casia and $S$. ulmifolia or S. rugosa.

S. Lfrrda, Willd. 1. c. 491. Stonter, purple-stemmed, with thyrsiform-paniculate inflorescence of more crowded heads ; apparently a cultivated modification of S. casia, var. paniculata, with a large-flowered indigenous form of which (from Monticello, Georgia, Porler) it is congruons. It is S. flabellata, Schrader ex Spreng. ( $S$. arguta, Spreng.), and S. flabelliformis, Weudl. in DC. Prodr. v. 336.

++ Stem and branches angled, manifestly so in dried specimens, green, not glaucous.

S. latifólia, L. Stem much angled, often flexuous, glabrous, 1 to 3 feet high: leaves ample and normally thin, broadly ovate or the upper ovate-lanceolate, conspicuously acuminate, abruptly and acuminately contracted at base into as it were a winged petiole of usually about the length of the axillary clusters, mostly pilose-pubescent beneath, thickly and coarsely serrate with salient subulate teeth: rays 3 or 4 : disk-flowers 6 or 7 : akenes very hirsute. Spec. ii. 879 (ex herb. \& habitat, excl. syn. Pluk.); Torr.\& Gray, Fl. ii. 198. S. fiexicaulis, L. 1. c. ex syn. \& char. (not of herb.); Ait. Kew. iii. 217 ; DC. Prodr. v. 335. S. flexicaulis, var. latifolia, Willd. Spec. iii. 2064. S. macrophylla, Bigel. Fl. Bost. ed. 2, 305, not Pursh. Moist woods and shaded banks, Nova Scotia to Minnesota, south to Missouri and along the mountains to Tennessee and Georgia. In grounds exposed to the sun, the clusters of heads are often extended and spiciform, or the whole inflorescence becomes a terminal thyrsus.

S. lancifólia, Torr. \& Gray. Nearly glabrous: stem strict and stout, 3 or 4 feet high, sulcate-angled : leaves elongated-lanceolate or the lower broader, sessile by a gradually narrowed entire base, above sharply serrate with the teeth ascending, 4 to 8 inches long: heads 
larger than in the preceding ( 3 lines long), usually more spicately clustered and with more numerous flowers (rays about 8 ): involucre of more imbricated and broader very obtuse narrowly oblong bracts, externally granular-puberulent when young: akenes canescently hirsute. - Chapm. Fl. 209. S. ambiyua, var. ? lancifolia, Torr. \& Gray, Fl. ii. 200. - Damp woods of the higher Alleghanies in N. Carolina and Tennessee; first coll. by Curtis.

S. Curtísii, TorR. \& GRAY. Glabrous or somewhat pubescent: stem commonly branching, slender, moderately angled, 2 feet high: leaves from oblong to elongated-lanceolate, with gradually attenuate entire base, subsessile, serrate with ascending subulate teeth, 3 to 5 inches long: heads in looser clusters, smaller and fewer-flowered (rays 4 to 7 ) : bracts of the involucre much fewer, linear, obtuse.-Fl. ii. 200 (excl. var.); Chapm. 1. c. S. flexicaulis, in part, in herb. Michx. - Open woods, mountains of Virginia to Georgia, at low or moderate elevations; first coll. by Michaux, next by Curtis.

Var. púbens, GRAY, 1. c. From sparsely to somewhat densely pubescent: leaves from ovate with tapering base to lanceolate. - S. pubens, M. A. Curtis in Torr. \& Gray, Fl. ii. 198; Chapm. 1. c. - Common in the mountains of Carolina, Tennessee, and Georgia; first coll. by Curtis.

$\leftarrow+$ Akenes glabrous: inforescence less axillary-clustered, more virgately thyrsoid.

S. montícola, Torr. \& Grar. Nearly glabrous : stem slender, a foot or two high : leares from oblong-orate to oblong-lanceolate, thinnish, acuminate or acute at both ends, 1 to 4 inches long; the lower rather sparingly serrate with acute teeth: heads small: involucral bracts linear, acutish: rays 5 or 6, yellow. - Chapm. Fl. 209. S. Curtisii, var. ? monticola, Torr. \& Gray, Fl. ii. 200. - Alleghany Mountains, from Maryland to Georgia and Alabama; first coll. by Curtis.

S. bícolor, L. Puberulent, commonly cinereous: stem often hirsute below, strict, a foot to a yard (rarely a span) high: leaves oblong or the lower obovate and ovate, short, mostly obtuse; lower slightly or obtusely serrate : clusters crowded in a simple or compound often elongated thyrsus : involucral bracts linear-oblong, very obtuse : rays from 5 to 14 , small, white, and the disk-corollas also white or yellowish. - Mant. 114; Ait. Kew. iii. 216; Torr. \& Gray, Fl. ii. 197. S. alba, Mill. Dict. Virga-aurea flore albo, etc., Pluk. Alm. t. 114, fig. 8. S. viminea, Bosc in herb. Poiret, therefore S. erecta, DC. Prodr. v. 340. Aster bicolor, Nees, Ast. 283.-Dry ground, Nova Scotia to Virginia and the upper part of Georgia.

Var. cóncolor, Torr. \& GRAY, 1. c. Flowers both of ray and disk yellow (or some rays yellow, others white) : foliage sometimes greener, sometimes lanate-hirsute. - S. hispida, Muhl. in Willd. Spec. iii. 2063. S. hirsuta, Nutt. in Jour. Acarl. Philad. vii. 103, \& Trans. Am. Phil. Soc. n. ser. vii. 327. - New Brunswick and Maine to Lake Superior, Missouri, and Tennessee.

Var. Ianáta, GrAY, 1. c. Low, villous-lanate: heads simply spicately crowded at the summit of the stem or branches. - S. lanata, Hook. Fl. ii. 4. - Plains of the Saskatchewan toward the Rocky Mountains, Drummond.

* * Heads nostly large for the genus (in some 6 and seldom less than 4 lines long, smaller in forms of $S$. humilis, \&c.), many-flowered, collected in thyrsoidal inflorescence which is not at all secund nor strictly racemiform (but in two species approaches corymbiform): rays 6 to 14: leaves veiny from a simple midrib, in most species bright green: stems commonly low or not tall. (From the inflorescence a few other species, such as $S$. speciosa, might be sought here.) - Thy rSiflore.

+ Southwestern species, fully 2 feet high: leaves very numerous up to or into the inflorescence, uniform in size and shape, short (inch or two long), closely sessile, of rather firm texture, entire, rough-margined, somewhat scabrous: pubescence minute and somewhat cinereous: heads 4 lines long: bracts of the involucre narrow, obtusish, or in some acute.

S. Bigelóvii, Gray. Cinereous-puberulent: leaves oval and oblong, mostly obtuse at both ends and hispidulous on the margin: thyrsus simple or compound, rather dense or at length open: involucre broadly campanulate, puberulent: akenes minutely pubescent or glabrate. - Proc. Am. Acad. xvi. 80, xvii. 190. S. petiolaris, Gray in Bot. Mex. Bound. 79, not Ait. - Mountains of New Mexico and Arizona, Bigelow, Wright, Parry, Greene, Lemmon. (Adj. Mex.)

Var. Wrightii, Gray, l. c. Leaves sometimes narrower: thyrsus simple and short, of comparatively few heads, or corymbiform almost in the manner of the Corymbosce. - 
S. petiolaris, var., Gray, PL. Wright. i. 94. S. Californica, var., Rothrock in Wheeler Rep. vi. 145. - S. W. Texas and New Mexico to Arizona; same collectors.

S. Lindheimeriána, Scheece. Obscurely puberulent and glabrate, strict, more rigid, especially the broadly lanceolate or oblong more acute and greener leaves: heads densely glomerate in an oblong spiciform thyrsus : involucre oblong-campanulate, its bracts more unequal : akenes glabrous. - Linn. xxi. 599. S. speciosa, var. rigidiuscula, Gray, Pl. Lindh. ii. 222, not Torr. \& Gray. - Texas, on rocky bluffs and in exsiccated beds of streams, Lindheimer, Reverchon.

+ - Southern Alleghanian species: leaves thinner, mostly ample, bright green, tapering to both ends, some of them acutely serrate: pubescence loose and somewhat hirsute.

S. Buckléyi, Torr. \& Grar. Stem 2 or 3 feet high, glabrous below : leaves ovate-oblong to oblong-lanceolate (the larger 3 to 6 inches long): thyrsus loose and elongated, nearly naked : heads 4 or 5 lines long, mostly pedunculate: bracts of the involucre narrowly oblong with rounded-obtuse green tips: akenes glabrous. - Fl. ii. 198. - Lincoln Co., N. Carolina, Curtis. Middle Alabama, Buckley. Jasper Co., Georgia, Porter.

S. glomeráta, Micix. Mostly glabrous up to the inflorescence: stem stout, 1 to 3 feet high, leafy to the top: leaves ample, from oblong-ovate to lanceolate-oblong, acuminate (the lower 5 to 12 inches long): heads 5 or 6 lines long, in a leafy interrupted thyrsus, or often in remote axillary clusters, all or most of them much shorter than the subtending leaves: involucral bracts oblong, obtuse : akenes glabrate. - Fl. ii. 117 ; Torr. \& Gray, Fl. ii. 209. Moist wooded sides of the high mountains of Carolina and Tenn., especially Grandfather and Roan. The well-developed inflorescence hardly ever glomerate, therefore the name of this most marked species is misleading.

S. spithamǽa, M. A. Curtis. Stems a span to a foot high, roughish-pubescent, leafy to the top: leaves glabrate; lower obovate-spatulate; upper oblong (an inch or two in length), acute: heads (barely 4 lines long) somewhat corymbosely glomerate at the summit, also (in cult.) in low axillary clusters : involucral bracts acute or acutish : rays short, hardly surpassing the disk: akenes pubescent. — Gray in Am. Jour. Sci. xlii. 42; Torr. \& Gray, Fl. ii. 208. - Rocky summits of the higher mountains in N. Carolina, especially on Grandfather and Roan; first coll. by Curtis.

+++ Boreal and montane, of difficult and uncertain limitation: rays usually numerous.

$$
+ \text { Bracts of the involucre acute. }
$$

S. macrophýlla, Pursr. Glabrous or a little pubescent: stem stout, 8 inches to 3 or even 4 feet high, leafy to or near the summit: leaves thin, ovate or the upper ovate-lanceolate, acuminate, acutely serrate; the lower ( 3 or 4 inches long) rounded at base or abruptly contracted into a long winged petiole: heads ( 5 or 6 lines long) mostly pedunculate, few or loose in the clusters, which in smaller specimens form a simple oblong or racemiform thyrsus, and in the larger occupy the axils of many of the cauline leaves: bracts of the involucre narrowly lanceolate-linear, thin and when dry somewhat scarious : rays rather long and narrow: akenes glabrous or rarely a little pubescent at summit. - Fl. ii. 542; Gray in Proc. Am. Acad. xvii. 187, 191. S. thyrsoidea, E. Meyer, Pl. Labrad. (1830), 63; Torr. \& Gray, Fl. ii. 207. S. leiocarpa, DC. Prodr. v. 339. S. Virgaurea, Bigel. Fl. Bost, ed. 2, 306, excl. var. S. multiradiala, Nutt. Trans. Am. Phil. Soc. 1. ser. vij. 328, not Ait. - Mountain woods of N. New England, extending upward to the limit of trees, north to L. Superior, Hudson's Bay, and Labrador. (Approaches S. Virgaurea, var. leiocarpa, of E. Asia.)

S. multiradiáta, Aır. Villons-pubescent above or glabrate, a span to a foot or so high : leaves of rather firm texture and fine venation, minutely and sparingly serrate above, sometimes entire; cauline spatulate to lanceolate, all tapering gradually to sessile base, or the radical into a slender margined petiole: heads (mostly 4 lines long) generally few and glomerate in $a$ single terminal roundish or oblong compact often corymbiform cluster, occasionally with one or two looser axillary clusters or branches: bracts of the involucre narrowly lanceolate, thinnish or thin-edged : rays numerous and narrow: akenes pubescent. Ait. Kew. iii. 218; Pursh, Fl. ii. 542; Hook. Fl. ii. 5. S. compacta, Turcz. in Bull. Mosq. 1840, 73, ex char. S. Virgaurea, var. arctica, DC. Prodr. v. 239. S. Virgaurea, var. multiradiata, Torr. \& Gray, Fl. ii. 207. - Labrador and Hudson's Bay to Behring Strait and Unalaska. The original high northern form very near to forms of S. Virgaurea. Bracts of the involucre attenuate. On the northern Rocky Mountains passes into 
Var. scopulórum, GRAx, 1. c. More glabrous, 3 to 18 inches high, commonly strict: heads when numerous in a more open or compound cluster, mostly smaller: bracts of the involucre closer, shorter, and merely acute. $-S$. corymbosa, Nutt. 1. c. (S. heterophylla in herb.). - Along the higher Rocky Mountains to New Mexico, Utah, \&c., the Cascade Mountains, and rare (in a dwarf state) along the Sierra Nevada.

Var. Neo-Mexicana. Two feet high, with numerous heads more loosely disposed in approximate axillary as well as terminal clusters, composing a narrow elongated thyrsus, somewhat like that of $S$. macrophylla. - High summits of the Mogollon Mountains, N. Mexico, Rusby. A doubtful plant.

S. Virgaúrea, L. Of this Old World and polymorphous or confused species, the var. alpestris (of which S. macrophylla is the American representative) reaches the Asiatic side of Behring Strait, and seems to pass into S. multiradicta. The var. Cambrica is represented by

Var. alpína, Biges. Dwarf, 2 to 8 inches high, obscurely pubescent or glabrons: leaves few, thickish, spatulate or obovate, mostly obtuse; cauline sessile, the uppermost lanceolate, lowest and radical narrowed into a margined petiole: heads (4 lines long) 3 to 7 in a terminal cluster, or also subsolitary in uppermost axils: involucre broad; its bracts rather broadly lanceolate, barely acute: akenes pubescent. - Fl. Bost. ed. 2, 307; Torr. \& Gray, 1. c. - Alpine summits of the mountains of N. New York, New England, and Lower Canada, on Anticosti, and Hudson's Bay? Seems nearly to pass into S. humilis, and like that to be somewhat viscid.

++ Bracts of the involucre obtuse.

S. húmilis, Pursh. Glabrous, disposed to be glutinous, bright green : stems strict, a span to a foot high, leafy: leaves of firm texture and fine venation, smooth; cauline all sessile; upper lanceolate to nearly linear, entire; lower and radical becoming spatulate with long

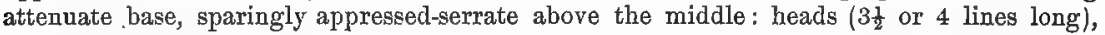
rather crowded in a narrow racemiform paniculate simple or sparingly branched thyrsus (which is leafy below and naked above) : bracts of the involucre oblong-linear: akenes pubescent. - Fl. ii. 543 (the Newfoundland plant, in herb. Banks, where Solander indicated the species); Hook. Fl. ii. 5; Torr. \& Gray, Fl. ii. 206, not of Desf. \& DC. S. stricla, Hook. l. c, partly. S. Virgaurea, var. humilis, Gray, Man. 241. - Rocky ground, Newfoundland to Saskatchewan and Rocky Mountains, Northern New England, and at two remarkable southern stations in the Atlantic States (viz. on the Susquehanna, York Co., Penn., Porter, and Great Falls of the Potomac, Robbins, Vasey): in the Rocky Mountains south to New Mexico and Utah, perhaps also Sierra Nevada in California, there too like S. multiradiata, var. scopulorum. The typical plant is narrow-leaved, with slender but rigid stems and virgate inflorescence : it often becomes larger, broad-leaved, and with ample compound thyrsus; and on mountains occurs a dwarfer broad-leaved form, passing to

Var. nána. A western alpine form, analogous to S. Virgaurea, var. alpina, 2 to 5 inches high, with spatulate to obovate leaves, and few heads in a close glomerule, or more numerous in a spiciform thyrsus. - S. Virgaurea, var. humilis, Gray, Proc. Am. Acad. viii. 389. S. Virguurea, var. alpina, Rothrock in Wheeler Rep. vi. 145. - High Rocky Mountains, Colorado (first coll. by Parry), and the Cascades of Oregon and Washington 'Ierr., Hall, Howell, Suksdorf.

Var. Gillmáni, Gray, Proc. Am. Acad. xvii. 191. Làge, 2 feet high, rigid, in cultivation with compound ample panicle, and laciniate-dentate leaves. - Sand-hills of the Lake sbores, N. Michigan, Gillman, W. Boott.

S. confertiflóra, DC. A foot or two high, strict, rigid, sometimes strikingly glutinous or resiniferous: leaves nearly of the preceding: heads smaller and numerous, fewer-flowered, crowded in a virgate or pyramidal compound thyrsus. - Prodr. v. 339; Fisch. \& Meyer, Ind. Sem. Petrop. (1840), vii. 57. S. glutinosa, Nutt. Trans. Am. Phil. Soc. 1. c. 328. - Coast of Brit. Columbia to Oregon, first collected by Hanke, with inflorescence incompletely evolute. Shoalwater Bay, Cooper. Sauvie's Island, Howell. Near Portland, Pringle, in a form too near $S$. humilis.

$$
++++ \text { Californian coast species: rays inconspicuous, shorter than the disk. }
$$

S. spathuláta, DC. Glabrous, glutinous : stem a foot high, few-leaved, terminated by a single spiciform thyrsus, the upper clusters of which are monocephalous, the lower 2-5-cephalous, and ahout equalled by the small subtending leaves: lower and radical leaves spatulate, 
rounded at apex, these sharply serrate, below long-attenuate into a margined petiole: heads 4 lines long: involucral bracts oblong and broadly linear: akenes silky-pubescent. - Prodr. v. 339 ; Gray, Proc. Am. Acad. xvii. 191. S. petiolaris, Less. in Linn. vi. 502; Ilook. \& Arn. Bot. Beech. 145, in part." S. spiciformis, Torr. \& Gray, Fl. ii. 202. Homopappus? spathulatus, Nutt. Trans. Am. Phil. Soc. vii. 332. - Monterey, California, first coll. by Houle, Chamisso, Coulter. Not "Mexico" where, however, is the somewhat related S. simplex, HBK., recently rediscovered by Schaffner.

* * * Heads small or middle-sized (2, 3, or rarely 4 lines long), not in a terminal corymbiform cyme, but in paniculate or racemiform elusters, which when well developed are collected in a terminal and more or less naked compound paricle or set of panicles (a few species tend to have axillary clusters, or the panicle leafy below); when the clusters are racemiform and spreading they are apt to be secund: stems generally simple or branching only at summit. - (Erecto in part and Unilaterales, DC.) Paxiculate.

+ Confined to the sea-coast or the vicinity of brackish water, very smooth and glabrous, and with firm and thickish or eren somewhat flesly bright-green foliage; but occasionally varying with some minute pubescence in and toward the inflorescence, \&c. (S. lithospermifolia is manifestly pubescent, but that species is not known as an indigenous plant): leaves obscurely pumeticulate, entire, or some lower ones a little serrate, with a prominent midrib, but incouspicuous veins and reinlets in a fine reticulation; the lower leaves sometimes with one or two pairs of low-lateral or basal ribs or reins: inflorescence thyrsoidal, but the cluster's sometimes racemiform and even secund. - Maritime.

+ Flowering rather early, commonly stout and midale-sized or tall: general inflorescence paniculate or hardly strict, leafy at the base: upper leaves not notably unlike the lower ones; and not appressed.

S. confínis, GrdY. Apparently pale green: leaves lanceolate and rather short (cauline 2 to 3 inches long), or the radical obovate: heads small (2 lines long), crowded in a dense oblong panicle, not secund, on glabrous pedicels : rays small, not surpassing the disk-flowers: akenes canescently pubescent.-Proc. Am. Acad. xvii. 191. S. sempervirens, Gray, Bot. Calif. i. 319, as to pl. coll. Palmer. - S. California; in San Diego Co., Palmer, Cleveland, Vasey. San Bernardino Co., at hot springs on the lower mountains, Parish.

S. sempérvirens, L. Bright green, leafy to the top, 2 to 8 feet high: leaves lanceolate or varying to linear and mostly acute or the lower obtuse, lowest often oblong and spatulate, of firm or rather fleshy texture: heads commonly large ( 4 or 5 lines long, or in slender forms only 3 lines long) and showy, numerous in short racemiform or corymbulose and somewhat secund clusters collected in an open thyrsus, or when fewer loosely paniculate: flowers golden yellow; rays 7 to 10, mostly large. - Spec. ii. 878; Ait. Kew. iii. 214; DC. Prodr. v. 335; Torr. \& Gray, Fl. ii. 211. S. Mexicana, L. 1. c. 879, \& authors. S. carnosa \& Noveboracensis, Mill. Dict. S. lavigata, Ait. Kew. 1. «. 215; Nutt. Gen. ii. 159. S. limonifolia, Pers. Syn. ii. 249. S. Azorica, Hochst. in Seubert, Fl. Azor. 31. - Along and near the sea-coast and tidal streams, New Brunswick and Canada to Florida, in wet or dry soil. Also San Francisco Bay, \&c., on the Pacific. Inflorescence occasionally pubescent, and when away from salt water not rarely the upper part of the stem also, and leaves duller, so approaching the following cultivated variety. (Mex., Bermuda, Azores.)

Var. vimínea, Grar, Proc. 1. c. 192. Cultivated form, with duller-green leaves, which have lost the somewhat fleshy-coriaceous texture: upper part of stem and the inflorescence appressed-puberulent: racemiform clusters hardly developed, but the heads more scattered in a leafy panicle. - S. integerrima, Mill. Dict. S. viminea, Ait. Kew. 1. c. 215 ; Willd. Spec. iii. 2064. S. integrifolia, Desf. Cat. 1804, 103, \& ed. 3, 402; DC. Prodr. 1. c., excl. syn. Nutt. S. carinata, Schrad. in DC. 1. c. 337. - Common in European Botanic Gardens; passes into

S. Lithospermifólia, Willd. Enum. 891, and S. elata, Pursh (Solander, mss.), Fl. ii. 543). Taller, robust, larger-leaved, even the leaves somewhat puberulent. Unknown as indigenous, obviously S. sempervirens, var. viminea, more altered; but so unlike the species that it demands separate mention.

it ++ Late-flowering, wholly glabrots, virgate; the upper portion of the stem beset with small appressed leaves: heads (commonly 3 lines long) in a strict and narrow naked panicle.

S. strícta, Art. Stem simple, slender, very strict, 3 to 8 feet high: leaves all entire or the lowest cauline and radical rarely a little serrate; these oblong or spatulate and very obtuse; cauline very numerous, approximate, small and becoming bract-like, appressed, from oblong 
or spatulate to linear-lanceolate, obtuse but mucronate-apiculate: heads conmonly in a simple and very narrow virgate panicle of a span or two in length, but not rarely fastigiate compound: rays 5 to 7.- Ait. Kew. iii. 216 (as to the true original, cult., with inflorescence branched); Pursh, Fl. ii. 540; Gray, Proc. Am. Acad. xvii. 182, 192, not of subsequent authors. S. virgata, Michx. Fl. ii. 117 ; Ell. Sk. ii. 384 ; Torr. \& Gray, Fl. ii. 201. S. linoides, Solander, in herb. Banks, not Boott \& A. Gray. S. genistoides, Bertol. Misc. Bot. vii. 37. - Low and sandy pine barrens. New Jersey to Florida and Louisiana. (Cuba.)

Var. angustifólia, GRAY, 1. c. Leaves narrower and the lower longer, all entire; radical mostly lanceolate or narrowly spatulate ( 4 to 7 inches long, 4 to 9 lines wide); cauline lanceolate gradually reduced to subulate-linear : clusters of the strict panicle often more racemiform and secund. - S. angustifotia, Ell. Sk. ii. 3.88; Torr. \& Gray, ii. 212. Forms in brackish soil not clearly distinguished from the most slender and narrow-leaved $S$. sempervirens. - Carolina to Florida and Texas, along the coast,

S. flavóvirens, Chapm. Stem 2 to 6 feet high : radical and lower cauline leaves oblongovate or oblong, obtusely serrate, ample (4 to 6 inches long besides the winged petiole); upper oblong (gradually reduced to half or quarter inch), all obtuse and yellowish green: inflorescence and heads of the preceding, but the short racemiform clusters at length more sprearling and secund: rays few, mostly 3.-Fl. 211. - Florida, in brackish marshes at Apalachicola, Chapman. Robust and largest-leaved specimens of $S$. stricta seem to pass into this.

++ Not maritime, nor alpine, nor canescently pubescent, and leaves not triple-ribbed. Yet in some a pair of stronger primary veins in the larger lower leaves gives nearly the character of the Triplinervice, and the Pacific species, S. lepida and S. elongata, referred to the latter, would rather be sought here. - Unicostatee.

+ Slender, wholly glabrous and smooth, with narrow obscurely veined leaves, rayless!

S. gracíllima, Torr. \& Gray. Stem simple or with long and very slender branches, 2 or 3 feet high: leaves thickish; radical and lower cauline spatulate-lanceolate with long tapering base, 3 or 4 inches long, obscurely serrulate; upper mostly linear and becoming small, entire: heads comparatively large, 3 lines long, more or less secund in a long and slender and virgate racemiform or sometimes paniculate inflorescence (its apex often recurving): involucre broad; its bracts oblong, very obtuse, thickish, mostly greenish at the tip : flowers 9 to 12, one sometimes imperfectly ligulate: akenes pubescent. - Fl. ii. 215; Chapm. Fl. 212. - Dry pine barrens, Middle Florida, Chapman, \&c.

++ +- Rather small-leaved, minutely puberulent, but with no other pubescence: leaves not at all triple-ribbed, the small upper ones only obscurely venulose: heads (small) in a narrow thyrsoid panicle, never secund.

S. pubérula, NuTT. Smooth, the soft puberulence nearly imperceptible to the naked eye: stem rather slender, 2 feet or more high, very leafy, strict: leaves obovate and oblong, or the lower ( 1 to 3 inches long) spatulate, these more or less serrate; upper entire, from oblong to lanceolate: heads crowded on the short branches of the thyrsus; involucral bracts subulate-lanceolate: rays small, about 10: akenes glabrous. - Gen. 162 ; Torr. \& Gray, Fl. ii. 202. S. pubescens, Ell. Sk. ii. 381. - Sandy ground, New Brunswick (glabrate and ambiguous form) and New England (chiefly along the coast, vccasionally on the mountains) to Florida and Mississippi. Southward the characteristic minute puberulence is more manifest in

Var. pulverulénta, CHAPM. Almost cinereous-puberulent; the upper cauline leaves shorter and broader, gradually diminished to half or quarter inch in length. - Fl, 210. S. pulverulenta, Nutt. 1. c. 161; Eil. 1. c.; Torr. \& Gray, Fl. 1. c. S. obovata, Bertol. Misc. Bot. vii. 36. - Lower Georgia, Alabama, Florida.

++++ Obscurely-yeined and mainly entire-leaved species; the cauline leaves closely sessile or partly clasping by a broad base, with midrib prominent beneath, but veins and veinlets usually very inconspicuous: heads (about 2 lines long) crowded in slender spreading or recurving racemiform and secund clusters, which are all collected in a mostly short and broad naked terminal panicle: involucre of narrow and rather obtuse few-ranked bracts: rays 3 to 5 or rarely more: disk-flowers hardly more numerous.

$=$ Leaves all entire and glabrous, smooth, except the margins, usually more or less pellucidpunctate.

S. odóra, AIt. Stem simpile, 2 or 3 feet high, rather slender, often reclining, glabrous, or above minutely pubescent in lines: leaves commonly anise-scented when bruised, narrowly 
or linear-lanceolate, acute, spreading ( $1 \frac{1}{2}$ to 4 inches long, half-inch or much less in width): rays rather small. (A form, var. inodora, Gray, Man., gruwing with the ordinary plant, is scentless.) - Ait. Kew. iii. 214 (Pluk. Alm.t. 116,f. 6, \& 236, f. 1); Pursh, Fl. ii. 539; Bigel. Med. Bot. i. 188, t. 20; Torr. \& Gray, Fl. ii. 219. S. retrorsa, Michx. Fl. ii. 117. S. puncticulata, DC. Prodr. v. 332. - Dry or sandy soil, Canada to Florida and T'exas, chiefly near the coast, but as far interior as Kentucky. (Mex.)

S. Chapmáni, Gray. Rather stouter and more rigid: stem roughish-puberulent above: leares oblong or elliptical, obtuse or even rounded at the apex, about an inch long; those next the broad expanding thyrsus very small, often roundish. - Proc. Am. Acad. xvi. 80, xvii. 193. S. odora, Chapm. Fl. 213, in part.-Pine barrens of Florida, Chapman, Garber, Curtiss, distributed as S. tortifolia. Between S. odora and S. pilosa.

$==$ Lower leaves more or less serrulate and all scabrous or pubescent, not punctate, more evidently veiny than the preceding, spreading: stem very leafy: rays small, hardly surpassing the disk-flowers.

S. tortifólia, ELL. Stem slender, 2 or 3 feet high, scabrous-puberulent: leaves all linear (an inch or two long, $1 \frac{1}{2}$ to 3 lines wide), acutish, commonly twisted, especially in age, hirtello-puberulent or glabrate, the lower with a few sharp denticulations: heads small, fewflowered. - Sk. ii. 377; Hook. Comp. Bot. Mag. i. 97; Torr. \& Gray, Fl. ii. 220. S. odora, Michx. Fl. ii. 118, not Ait. S. retrorsa, Pursh, Fl. ii. 539 ; Nutt. Gen. ii. 159, not Michx. Dry sandy soil, coast of Virginia to Florida and Texas.

S. pilósa, WALT. Stem stouter, 3 to 7 feet high, hirsute with short spreading hairs: leaves lanceolate-oblong ( 2 or 3 inches long), or the upper elliptical or oblong (8 to 18 lines long), these mostly obtuse, the midrib beneath and margins scabrons- or hirsute-ciliate; the lower with some acute small teeth: rays several or few and trifid, very small. - Car. 207 (not Mill. Dict.) ; Torr. \& Gray, Fl. ii. 219. S. fistulosa, Mill. Dict. S. altissıma, Michx. 1. c., ex berb. S. pyramidata, Parsh, Fl. ii. 537; Nutt. Gen. ii. 118. S. villosa, Ell. Sk. ii. 372 ; DC. Prodr. v. 333. - Moist ground, New Jersey (pine barrens) to Florida and Louisiana, in the low country: flowering late.

++++ Leaves not small for the size of the plant, not prominently veiny, of firm texture, entire or little serrate, glabrous and smooth, but sometimes with ciliolate-scabrous margins: beads (middle-sized) crowded in thyrsoid inflorescence, not secund.

= Pacific species: rays rather numerous ( 8 to 15) and small: akenes pubescent.

S. Tolmieána. Low, a foot or less high, leafy up to the short and rather broad inflorescence of spiciform somewhat corymbosely disposed clusters : leaves thickish and veins very inconspicuous, linear or lanceolate ( 2 or 3 inclies long), entire, rarely with some minute serratures, the margins usually scabrous-ciliolate: heads about 3 lines high: involucral bracts lanceolate, acutish, thin. (Has been taken for a form of S. Missouriensis, var. montana.) Idaho, Washington Territory and Oregon; first coll. by Tolmie, then by Spalding and later collectors.

S. Guiradónis, Gray. Slender, 2 feet high, bearing rather few heads in a simple virgate thyrsus: leaves all quite entire, thickish, bright green, attenuately cuspidate-acuminate; radical and lower cauline linear-lanceolate ( 2 to 4 lines wide, about 4 inches long); upper more attenuate: bracts of the involucre small, lanceolate or linear, acutish. - Proc. Am. Acad. vi. 543, \& Bot. Calif., in part. - California, along brooks, base of San Carlos Peak, Fresno Co., Guirado, an assistant of Prof. Brewer.

S. spectábilis, Gray. A foot or two high: heads numerous and crowded in a narrow or compound and broader thyrsus : leaves paler, sometimes thinner; cauline lanceolate, or the small uppermost becoming linear, acute; lower and radical spatulate-lanceolate or oblong, acutish or obtuse, often an inch wide and obscurely triple-ribbed; radical rarely with a few serratures; involucral bracts lanceolate or broader, mostly obtuse. - Proc. Am. Acad. xvii. 193. - S. Guiradonis, var. spectabilis, Eaton, Bot. King Exp. 154. S. Guiradonis, in part, Gray, Bot. Calif. i. 319 ; Rothrock in Wheeler Rep., \&c. - From the western slopes of the Sierra Nevada, California, to the interior mountains of Nevada, Bloomer, Watson, \&c.

$==$ Atlantic species: akenes glabrous or sometimes slightly and sparsely pubescent: rays conspicuous, 5 or 6.

S. vliginósa, NuTr. Stem 2 or 3 feet high, strict: leaves lanceolate and oblong-lanceolate, mostly acute or acuminate, acutely and sparsely serrulate or else entire; radical and lower 
cauline 4 to 8 inches long, tapering gradually into a margined petiole; some ascending primary veins obvious: thyrsus narrowly oblong or virgate, dense, the short clusters appressed: heads 3 lines long: bracts of the involucre narrowly oblong or nearly linear. Jour. Acad. Philad. vii. 101, mainly; Gray, Proc. Am. Acad. xvii. 193. S. stricta, Hook. Fl. ii. 4, in part; Torr. \& Gray, Fl. ii. 204, not Ait. - Bogs and wet ground, Newfoundland and Canada to L. Superior, south to New England and the monntains of Pennsylvania.

S. speciósa, Nutr. Commonly 3 to 6 feet high and robust: leaves thickish and generally ample, oval, ovate, or oblong, entire or little serrate, rather abruptly narrowed into a sessile base, or the larger into a winged petiole (these often 4 to 6 inches long and 2 or 3 wide); uppermost small and lanceolate or oblong; primary veins spreading and ohscure, seldom more obvious than the finely reticulated veinlets: thyrsus narrow, composed of numerous short or rarely elongated spiciform clusters, rigid, rather showy : heads 3 or 4 lines long: bracts of the well-imbricated involucre of firm texture, narrowly oblong, very obtuse, and with a greenish midnerve.-Gen. ii. 160 (excl. syn. Pers.); Torx. \& Gray, Fl. ii. 205. S. sempervirens, Michx. FI. ii. 119, in part. S. petiolaris, Muhl. Cat. 79, not Ait. - Margin of woodlands, in moist or rather fertile soil, Canada and E. New England to N. Carolina and west to Arkansas.

Var. angustáta, Torr. \& Grax, 1. c. Stem 2 or 3 feet high : leaves smaller; the lower spatulate-oblong or oblanceolate, 2 to 4 inches long, seldom an inch wide, sometimes entire; upper an inch or two long: thyrsus commonly more simple and virgate, sometimes racemosely compound. $-S$. erecta? Fll. Sk. ii. 385 ; DC. Prodr. v. 340 ? - Sandy open ground or prairies, New Jersey to Minnesota and south to Florida and Texas.

Var. rigidiúscula, Tork. \& GRAr, 1. c. A form of the var. angustata, growing in dry open places, with more rigid and rougher-edged small leaves. - Minnesota to Nebraska and Texas.

++++++ Leaves veiny, at least the lower serrate (except sometimes in $S . j u n c e a)$ : heads racemosely paniculate; the racemiform clusters when well developed secund and commonly scorpioid-recurving, sometimes not so in the earlier species. Atlantic species.

= Leaves (the lower ample, those of the branches small) shagreen-scabrous on the upper face: involucral bracts broadish : heads many-flowered, rather large.

S. pátula, Murl. Stem strongly angular and striate, rather stout, 2 to 4 feet high, with rigid elongated branches: leaves pale green, loosely venose and venulose, sharply and rather finely serrate, smooth and glabrous (as is the stem), except the upper face which is strikingly scabrous when rubbed from point to base (being thickly set with minute sharp callosities antrorsely directed); cauline oval or oblong, 4 to 8 inches long besides the abruptly narrowed base or winged petiole of the lowest; the uppermost and those of the fiowering branches sometimes equalling the at length spreading clusters of the narrow or virgate thyrsus : heads 3 or even 4 lines long: bracts of involucre linear-oblong, very obtuse : rays 6 or 7 , small, light yellow : disk-flowers 8 to 12 : akenes minutely pubescent. - W,illd. Spec. iii. 2059; Torr. \& Gray, Fl. ii. 213. S. asperata, Pursh, Fl. ii. 538, as to herb. Lamb. "S. angulata, Muhl.," ex Spreng. in herb. Willd.; Schrad. in DC. Prodr. v. 331. S. Frankii, Hochst. \& Steud. in distrib. Frank. - Wet soil, Canada to Wisconsin, south to Georgia, Missouri, and Texas. Flowering rather early.

Var. stríctula, Tork. \& Grax, 1. c. Narrower leaved, and with simpler and strict inflorescence. - S. salicina, Ell. Sk. ii. 389 , ex char. S. scabra, Hook. Comp. Bot. Mag. i. 97. - Commoner southward to Louisiana and Florida. $=$ Leaves not scabrous, both faces minutely cinereous puberulent: heads small, many-flowered,

S. vérna, M. A. Curtis. Stem 2 or 3 feet high, cinereous-pubescent, bearing a loose naked panicle: leaves thinnish; radical and lower cauline oval or ovate, mizutely serrate (2 to 4 inches long), abruptly contracted into a margined petiole, the primary veins (2 or 3 pairs) rather conspicuous; upper cauline small and sparse, oblong, entire: heads barely 3 lines long: bracts of the involncre rather narrow and thin : rays 10 or 12 : akenes pubescent. - Torr. \& Gray, Fl. ii. 205. - Open and sandy pine woods, near Wilmington, North Carolina, Curtis, T. F. Wood, \&c. Flowering in May!

$===$ Leaves commonly thin and membranaceous, loosely veiny (if firmer the veinlets of the lower face conspicuously reticulated), small or not large: heads small (about 2 lines long): bracts of the involucre rather few and narrow, obtuse: akenes pubescent. 


\section{a. Rays from none to 3 : leaves clasping!}

S. amplexicaúlis, Torr. \& Grar. Minutely soft-pubescent or glabrate: stem slender, 1 to 3 feet high, with spreading branches: leaves ovate, acute or acuminate, acutely serrate, rather scabrous above and soft-pubescent beneath; the upper slightly narrowed above the dilated auriculate-clasping base; lower cauline with longer contracted portion; lowest and radical wing-petioled below the truncate or subcordate base of the lamina (this about 2 inches long) : racemiform clusters of the thyrsus slender, secund, often simple: pappus shorter than the disk-corolla. - Fl. ii. 218 (not Martens, which is S. Riddellii); Chapm. Fl. 213. - Open dry woods, Florida to Louisiana, Leavenworth, Chapman, Rugel, distributed by Shuttleworth as $S$. auriculata. Makes the nearest approach to Brachychata.

b. Rays 4 to 6 or rarely more, small, and disk-flowers little more numerous: leaves sessile by a narrow base, pinnately veiny: pubescence of spreading hairs, or hardly anf.

S. rugósa, MrLl. Stem hirsute or pubescent with spreading hairs, low or moderately tall ( 1 to 6 feet high), mostly slender, very leafy to the top: leaves thin and soft, or in dry open ground becoming thicker and firmer, from oval-ovate to oblong-lanceolate ( 1 to 4 inches long), mostly acute or acuminate, sometimes obtuse, usually hirsute on the veins and veinlets beneath; these conspicuous and often rugose-reticulated, sometimes scabrous above: inflorescence when well developed recurved-spreading, but sometimes erect: bracts of the involucre linear. - Dict. ed. 8; Willd. Spec. iii. 2058; Ait. Kew. ed. 2, v. 66 ; Gray, Proc. Am. Acad. xrii. 194. Virga-aurea sp., Dill. Elth. 406-411, t. 304, 305, 308, appended in L. Spec. 878 to $S$. altissima, but not referred to it. S. altissima \& S. aspera, Ait. Kew. iii. 212 ; Willd. 1. c. S. scabra, Muhl. in Willd. 1. c. S. villosa, Pursh, Fl. ii, 537. S, humilis, Desf. Cat. ed. 3, 402; DC. 1. c., a low form, cornmonly with the racemiform clusters erect, or hardly spreading and secund. S. asperula, Desf. Cat. 1.c. 403? S. hirta, Willd. Enum. 891. S. rigidula, Bosc, in hort. Paris? S. asperata, Soland. mss., and so of Pursh as to herb. Banks. S. altissina, Torr. \& Gray, Fl. ii. 216 (incl. altissima, pilosa, recurvata, Virginiana, Mill. Dict.), not L. - Moist or dry ground, Newfoundland and Labrador to Texas; very common eastward in the Atlantic States. Polymorphous, not readily sorted into definable varieties; in shade thin-leaved; in open and dry soil has small and broader, firmer, more scabrous, and rugose-reticulated leaves. S. rigosu, Mill., is the best of the old names to take up.

S. ulmifólia, Mrenc. Résembles the thinner-leaved and least pubescent forms of the preceding (into which it appears to pass), but with stem smooth and glabrous, except perhaps the summit: leaves bright green, nearly smooth and glabrous, or pulescent, membranaceous, acute or acuminate at both ends, usually coarsely serrate, the larger veins conspicuous but veinlets inconspicuous: thyrsus more naked: bracts of the involnere of firmer texture and more obtuse. - Willd. Spec. iii. 2060; Darlingt. Fl. Cest. 457; Torr. \& Gray, Fl. ii. 217. S. lattriflora, Ait. Kew. iii. 211, not L. - Moist woodlands and copses, Maine to Iowa, Arkansas, and Texas. . S. mulliflora, Desf. (in Poir. Suppl. v. 462) Cat. l. c. 402, DC. Prodr. v. 336, appears to be a state of this, altered by cultivation.

Var. microphylla. A reduced and rather rigid form; with lower leaves 2 inches long; upper reduced to half an inch, obtuse, obscurely serrate. - Texas, Lindheimer, Wright.

$====$ Leaves usually of firm texture and inconspicuons reticulation, occasionally thin and membranaceous or more veiny, not scabrous above, commonly glabrous as also the stems: bracts of the involucre from broadly linear to narrowly oblong, obtuse.

u. Stem equably and very leafy up to or into the pyramidal compound thyrsus: leaves comparatively short and broad, even the lower not much narrowed downward, the secondary veins often manifest.

S. Fllióttii, Torr. \& Grar. Smooth and glabrous throughout, or the thyrsus somewhat pubescent: stem tall, rigid : leaves from ovate-oblong to oblong-lanceolate, apiculate-acuminate or acute, minutely and sparsely serrate with appressed teeth, scabrous on the margin, mostly closely sessile by a broadish base (1 to 4 inches long): heads ( 3 lines long) crowded on the secund and spreading or sometimes ascending and straight racemiform or spiciform branches of the pyramidal panicle: bracts of the involucre rather broadly linear: rays 8 to 12, short: akenes pubescent. - Fl. ii. 218, and S. elliptica of the same, as to the plant of New York. S. elliptica? Ell. Sk. ii. 376. S. elongata, Hort. Par. 1832. - Moist ground near the coast, Massachusetts to New York and through the low country south to Georgia. 
b. Less leafy, or leaves toward the naked panicle small compared with the lower, which are contracted or tapering into a conspicuous narrowed base or winged petiole: veins inconspicuous: panicle commonly narrow, or its branches short: plants wholly smooth and glabrous, except the somewhat ciliolate-scabrous margins to the leaves, in drier ground sometimes obscurely scabrous.

S. neglécta, Torr. \& GRAY. Stem strict and simple, 2 to 4 feet high : leaves bright green, lanceolate or the larger oblong-lanceolate, acute, mostly serrate or serrulate; radical ones ample (often a foot or more long, including the elongated petiole) : panicle generally thyrsoid and narrow, of short and crowded more or less secund clusters, or in larger plants more compound with spreading racemiform branches: heads at most 3 lines long: involucral bracts oblong-linear: rays 3 to 7 and disk-flowers 5 to 7 : akenes from sparsely puberulent to glabrous. - Fl. ii. 213; Gray, Man. ed. 2, 204. - In swamps, especially in sphagnous bogs, or on their borders, Lower Canada to Maryland, west to Illinois and Wisconsin. Forms with almost entire leaves and strict panicle too nearly approach $S$. uliginosa, Nutt., while some with large and serrate leaves are more like $S$. arguta. The most slender is

Var. linoídes. Stem simple, commonly 2 feet high, slender : radical leaves 4 to 8 inches long, a third to half inch wide; upper cauline very small and erect : panicle of rather few and approximate racemiform secund clusters : heads rather smaller: rays only 2 or 3. - S. uliginosa, Nutt. in Jour. Acad. Philad. vii. 101, in part, but not of his own herb. nor descr. S. linoides, Torr. \& Gray, F1. ii. 216, not of Soland. in herb. Banks, which is S. stricta, Ait. Bigelovic ? uniligulata, DC. Prodr. v. 329. Chrysoma uniligulata, Nutt. Trans. Am. Phil. Soc. vii. 325. - Sphagnous swamps, Massachusetts to New Jersey.

S. Terræ-Nóvæ, Torr. \& Gray. Still obscure species, probably a form of S. neglecta, somewhat dwarfed and with a corymbosely paniculate thyrsus: involucral bracts rather thinner and narrower. - Fl. ii. 206. - Sphagnous bogs, Newfoundland, Pylaie, Miss Brenton.

c. Stems not strict, disposed to branch below the inflorescence: racemiform clusters of the inflorescence often leafy-bracteate, rather rigid, sparse and ascending, or forming a loose elongated thyrsus: leaves more veiny and serrate; cauline commonly abruptly contracted into a petiole-like or narrow base: rays not numerous, sometimes wanting: bracts of the involucre rather firm, obtuse, mostly greenish toward the tip.

S. Boóttii, Hook. Sometimes minutely scabrous-pubescent, or below birsute with jointed hairs, often quite glabrous: stem slender, 2 to 5 feet high: leaves rather finely serrate with ascending teeth; radical and lower cauline from ovate to oblong-lanceolate, acuminate (the larger 3 to 5 inches long, besides the petiole-like base); upper small, oblong to narrowly lanceolate, often entire: heads ( 2 and 3 lines long) rather loosely racemose: bracts of the campanulate involucre oblong-linear: rays 2 to 4 or xarely 5 , sometimes solitary or none: akenes pubescent. - Comp. Bot. Mag. i. 97 ; Torr. \& Gray, El. ii. 215. S. juncea, DC. Prodr. v. 334, not Ait. - Dry wooded ground, Virginia to Florida, Louisiana, and Texas. The larger forms northward nearly approach the next species. Southward the smaller ones pass into

Var. brachyphýlla, Gray. More slender; the flowering branches even filiform: larger leaves an inch or two long, all from ovate to oblong, seldom acuminate, commonly obtuse, upper reduced to half or quarter inch, sessile by a broad base: heads sparse, 4-7flowered: rays none or an imperfect one.-Proc. Am. Acad. xvii. 195. S. brachyphylla, Chapm. in Torr. \& Gray, Fl. ii. 215, \& Fl. 213. - Dry woodlands, Georgia and Florida, Chapman, \&c.

Var. Ludoviciána, Grar, 1. c. Perhaps a distinct species, stouter, tall, rather largeleaved: lower leaves and lower part of the stem sometimes roughish-hirsute or hispidulous with many-jointed hairs, or glabrous: heads larger, even 4 lines long! $-S$. Boottii, var. $\epsilon$, partly, Torr. \& Gray, 1. c.-W. Louisiana, Hale.

S. arguta, Art. Glabrous, sometimes slightly pilose-pubescent: stem 2 to 4 feet high: leaves thinnish (in shade membranaceous), usually ample; the lower and larger 5 to 9 inches long, ovate or oval, acuminate, very strongly and sharply (or even doubly) serrate with salient teeth; upper reduced to obloug-lanceolate, only the small ones of the branches entire: heads somewhat crowded on the branches of the irregular panicle, fully 3 lines long: involucral bracts oblong-linear: rays 5 to 7, rather large: disk-flowers 10 to 12 : akenes glabrous or sometimes slightly pubescent. - Ait. Kew. iii. 213; Pursh, Fl.ii. 538; Muhl. Cat.; Darlingt. Fl. Cest. 458; DC. Prodr. v. 333 ; Gray, Proc. Am. Acad. xvii. 180, 195; not Torr. \& Gray, 
who followed a wrong determination. S. verrucosa, Schrad. Hort. Gott. 12, t. 6? S. Mullenbergii, Torr. \& Gray, Fl. ii. 214. - Moist woodlands, New England and Canada to Ohio, through Pennsylvania to the mountains of Virginia.

Var. Caroliniána. Leaves of firmer texture, simply serrate as in S. Boottii, but larger: heads thicker, with 4 or 5 short rays and 10 to 14 disk-flowers; involucral bracts firmer, oblong: akenes pubescent. - Mountains of N. Carolina and of adjacent S. Carolina and Georgia, G. R. Tasey, J. Donnell Smith. Perhaps distinct both from this and the preceding species.

d. Stems not strict, simple or corymbosely branched at summit: inflorescence an open spreading panicle, usually as broad as high, composed of recurving naked and minutely subulate-bracteate secund-racemiform clusters of crowded small beads, the rhachis and pedicels slender: rays numerous and small.

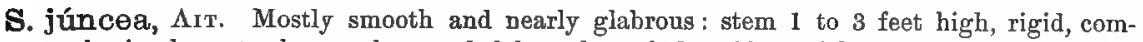
monly simple up to the mostly crowded branches of the wide panicle: leaves of rather firm texture; radical oval to oblong-spatulate, tapering into a winged petiole, usually large and sharply serrate; cauline from narrowly oblong to lanceolate (larger 3 or 4 inches long), not rarely almost entire or sparsely serrulate, the small upper not much narrowed at base : paniculate racemes slender: heads seldom over 2 lines long: bracts of the involucre small and pale : rays 7 to 12, hardly surpassing and little fewer than the disk-flowers: akenes glabrous or slightly pubescent. - Kew. iii. 213; Pursh, 1. c.; Hook. Fl. ii. 3 ; Gray, Proc. 1. c. S. ciliaris, Muhl. in Tilld. Spec. iii. 2056; Darlingt. 1. c.; DC. 1. c. 331 (excl. syn. S. glabra). S. arguta, Torr. \& Gray, Fl. ii. 214, not Ait., \&c., as was wrongly supposed. - Common in dry or rocky ground, Hudson's Bay and Saskatchewan to Wisconsin, and through the Northern States to the upper country of Carolina and Tennessee. - The original type by Solander is a small form from Hudson's Bay. The specific name alludes to the inflorescence, remotely resembling that of some species of Juncus. S. ciliaris is a common broad leaved form, the larger leaves a little ciliate. - Var. scabrella (S. arguta, var. scalrella, Torr. \& Gray, 1. c.) is a form with rigid and roughish leaves, growing in arid suil. Wisconsin and Illinois to Kentucky; in which district the leaves become more or less triple-ribbed and rigid, and seemingly pass into $S$. Missouriensis.

+++ Not maritime: leaves more or less triple-ribbed, or with a pair of lateral veins continued by inosculation parallel to the midrib, yet these sometimes obscure or evanescent. Tripline rvice.

* Smooth and glabrous, at least as to the stem and bright green leaves (the latter sometimes a little pilose-pubescent in $S$. serotina), not cinereous or canescent: inflorescence when well developed of naked and secund commonly recurving racemiform clusters, collected in a terminal compound panicle: akenes more or less pubescent.

= Leaves of firm texture, rather rigid, lancenlate, acute or acuminate, the slender lateral ribs not rarely evanescent in the upper leaves: bracts of the involucre rather firm; the short outermost ovate or oval and the inner oblong-linear, all obtuse. A form of the first species connects with the last preceding.

a. Rays rather small: stems leafy to the summit: leares commonly with scabrous margins, the larger mostly with some scattered teeth or denticulations.

S. Missouriénsis, Nutr. Low or middle-sized, smooth : leaves thickish, mostly tapering to both ends, and the serratures when present sharp and rigid, somewhat nervose; lower spatulate-lanceolate (larger 4 to 6 inches long); upper mostly linear and entire, acute; sometimes all entire: racemiform clusters approximated in a short and broad panicle (like those of S. juncea, but usually shorter), recurving in age: rays 6 to 13, small. - Jour. Acad. Philad. vii. 32, \& Trans. Am. Phil. Soc. vii. 327 (excl. hab. N. Carol.) ; Torr. \& Gray, Fl. ii. 322. S. serotina, Hook. Comp. Bot. Mag. i. 97, not Ait. S. glaberrima, Martens in Bull. Acad. Brux. viii. (1841), 68, - Dry prairies, Indiana and Tennessee to Texas, and westward to the Rocky Mountains; in the more eastward stations passing into or else lyybridizing with $S$. juncea.

Var, montána, GRA . Dwarf, 6 to 15 inches high: leaves entire or with few small serratures; cauline obscurely triplinerved, an inch or two long: panicle small and compact (at most 2 or 3 inches long); its clusters short, crowded, seldom recurved or much secund. Proc. Am. Acad. xvii. 195. S. Missouriensis, Nutt. Jour. Acad. Plilad. 1. c., as to the original from "upper branches of the Missouri, Wyeth." - Dakota to the Saskatchewan and west to Idaho. 
Var. extrária, GRAY, 1. c. A foot or two high, robust:. leaves broader (the largest sometimes an inch wide), sparingly serrate or entire : heads rather larger : rays more conspicuous. - Dry ground, in the mountains, Colorado to S. Arizona, Parry, Hall \& Harbour, Greene, Pringle, Lemmon, \&c.

S. Gattíngeri, Chapm. ined. Slender, mostly strict and barely 2 feet high: branches and inflorescence perfectly smooth and glabrous: leaves ciliolate; lowest cauline and radical lanceolate-spatulate, appressed-serrulate, obviously triplinerved; upper cauline mainly entire and without lateral ribs, oblong-lanceolate and an inch or so long, and the upper reduced to half or quarter inch, but near the inflorescence very small and bract-like : racemiform clusters of small heads open and spreading, not recurving, disposed to form a corymbiform very naked panicle: involucral bracts oblong, very obtuse, yellowish in the dried plant: flowers 15 to 20 in the head: akenes appressed-puberulent or the Iower part glabrous. - S. Missouriensis, var. pumila, Chapm. Fl. Suppl. 627. - Rocky barrens and cedar glades, Rutherford Co., Tennessee, Gattinger. Between the preceding and the following.

S. Shórtii, Torr. \& Gray. Slender, 2 to 4 feet high : upper part of stem and flowering branches scabrous with minute appressed puberulence : leaves bright green, oblong-lanceolate, rather short (longer only 2 or 3 inches long, toward the inflorescence moderately reduced), acute, mostly with a few small serratures: panicle oblong or pyramidal; its racemiform clusters commonly slender and soon recurving: heads narrow, 10-14-flowered: involucral bracts narrowly oblong: akenes pubescent. - FI. ii. 222. - Rocks, at the Falls of the Ohio, near Lonisville, Rafinesgue, Short. N. W. Arkansas, F. L. Harrey.

b. Leaves with entire and smooth margins: rays larger.

S. Marshálli, Rothr. Tall (only the upper part of stem known), slender : leayes linearlanceolate, acute; the lateral ribs mostly obscure : panicle naked, of loose recurving racemes; the rhachis and slender pedicels setaceously bracteate: heads 3 lines long, rather broad: bracts of the involucre broadish, of firm texture, mostly greenish on the back : rays about 8 , and clisk-flowers more numerous: akenes pubescent. - Rothrock in Wheeler Rep. vi. 146. - Mountains of S. Arizona, near the Chiricahua Agency, Lieut. Marshall.

$==$ Leaves thinner, sometimes membranaceous: bracts of the involucre chiefly linear, obtuse:

branches and upper part of the stem not rarely scabrous-puberulent or minutely hairy.

S. Leavenwórthii, Torr. \& Grar. Stem strict, slender, rigid, 2 to 4 feet high, scabropuberulent even to below the middle: leaves mostly linear ( 3 or 4 inches long and as many lines wide), very sharply and finely serrate, both ribs and veins inconspicuous: heads 3 lines long, in an ample open panicle : involucral bracts thin, linear, obtuse : rays 10 or 12 , small. - Fl. ii. 223; Chapm. Fl. 214. - Damp soil, Florida to S. Carolina, near the coast, Leavenworth, Chapman.

S. rupéstris, RAF. Stem lax, 2 or 3 feet high, smooth nearly to the small paricle : leaves membranaceous, linear-lanceolate, sparsely and sharply serrulate or denticulate, or the upper entire (1 to 3 inches long): heads very small (barely 2 lines long): rays 4 to 6 , small. Ann. Nat. 14; Torr. \& Gray, FI. ii. 225. - Rocky banks of streams, along the Ohio River, Kentucky, Indiana, and Western Virginia. Probably only an extreme glabrous form of S. Canadensis.

S. serótina, Art. Stem stout, 2 to 7 feet high, very smooth and glabrous up to or near the ample panicle, sometimes glancous : Ieaves commonly ample, lanceolate or broader ( 3 to 6 inches long), sharply and saliently. serrate, in the typical plant glabrous both sicles: heads crowded, rather large and full (3 lines long) : rays 7 to 14 , moderately large and conspicuous : bracts of the involucre broadly linear or linear-oblong. - Kew. iii. 211; Gray, Proc. Am. Acad. xvii. 179, 196. S. gigantea, Willd. Spec. iii. 2056, and subsequent authors. S. glabra, Desf. Cat. ed, 3, 402 ; DC. Prodr. v. 331. S. fragrans, Hort. Par., not Willd. S. Pitcheri, Nutt. Jour. Acad. Philad. vii. 101, \& Trans. Am. Phil. Soc. 1. c. 326, forms with broad and comparatively short leaves and rather smaller heads. S. elongata, var., Torr. \& Gray, l. c., in part. - Moist or rich soil, Newfoundland to Brit. Columbia, Oregon, and south to Texas. Passes insensibly into

Var. gigantéa, GRAY, 1.c. Commonly tall, 5 to 8 feet high : leaves with the Tateral ribs more prominent beneath, and these more or less pilose-pubescent or hispidulous, sometimes the veins or even the whole under surface pubescent. - S. gigantea, Ait. 1. c. S. serotina, Willd.; Torr. \& Gray, etc. - Chiefly in the Atlantic States, from Canada to 
Texas. From Willdenow to the latest authors this has passed as the true S. serotina, and that for this.

+ + Minutely pubescent or glabrate, not cinereous nor scabrous, thinnish-leaved, and the lateral ribs commonly obscure: panicle mostly erect and thrrsiform, often compact, and the heads little if at all secund: involucre of small and thin narrow bracts : rays 12 to 18 , small. (Related to the preceding and following, also to $S$. rugosa.)

S. lépida, DC. A foot or two high : leaves from oblong to broadly lanceolate, acute, 3 or 4 inches long, very sharply and mostly coarsely serrate, sometimes for most of their length, sometimes only above the middle, in some the teeth almost none: thyrsus very short and compact, an inch or two long, little surpassing the upper leaves, not at all secund: heads fully 3 lines long: bracts of the involucre subulate-linear, attenuate-acute. - Prodr. v. 339. S. gigantea, Hook. Fl. ii. 2, in part. - Alaska, coast and islands, Hrenke, Kellogq, \&c., and Brit. Columbia.

S. elongáta, NuTt. Like the preceding, or taller, sometimes a yard high: leaves commonly narrower: thyrsus more developed and compound, 3 to 8 inches long, its branches occasionally spreading: bracts of the involucre linear, acutish or obtuse. - Trans. Am. Phil. Soc. 1.c.; Torr. \& Gray, Fl. 223, mainly. S. stricta, Less. in Linn. vi. 502. S. elata, Hook. Fl. ii. 5, not Solander. - Along streams, Brit. Columbia to California, and east to Montana, Slave Lake, \&c. Seemingly passes on the northwest coast into S. lepida, and eastward into S. Canadensis.

+- ++ Pubescent (at least the stem), either hirsutely or canescently, or hispidulous-scabrous: branches of the panicle when well developed secund.

$=$ Leaves tapering gradually to an acute or acuminate point, generally thin or thinnish: panicle open, of naked and secund mostly recurving racemiform clusters: bracts of the involucre narrow and thin: rays small and short.

S. Canadénsis, L. Stem 2 to 6 feet high, from scabrous- or cinereous-puberulent to hirsute : leares mostly lanceolate, puberulent, pubescent, or nearly glabrous, sharply serrate or the upper entire, veiny, and with lateral ribs prolonged parallel to the midrib: heads small, ordinarily only 2 lines long: bracts of the involucre small and pale, narrowly linear, acutish or obtuse: rays 9 to $\mathbf{1 6}$, more numerous than the disk-flowers. - Spec. ii. 878 (excl. syn. Pluk.); Ait. Kew. iii. 210; Torr. \& Gray, Fl. ii. 221. S. altissima, L. 1. c., that is Virgaaurea altissima, etc. Martyn, "Cent." (Hist. Pl.) 14, t. 14; not of most subsequent authors, who have followed the conjectural references to Dill. Elth. S. reflexa, Ait. 1. c. 211 ; Willd. Spec. iii. 2056. S. nutans, Desf. Cat. ed. 3, 402. S. longifolia, Sichrader, in DC. Prodr. v. 330. - Moist or dry and shady ground, New Brunswick to Brit. Columbia (and north to Slave Lake), south to Florida and mountains of Arizona: flowering rather early. - The more marked forms varying from the ordinary are the following.

Var. prócera, ToRr. \& Grax, 1. c. Leaves less serrate or the upper entire, at least the lower face and upper portion of the stem cinereous-pubescent or tomentulose with very short and fine pubescence: inflorescence less open or the branches ascending in less developed or cultivated plants: heads sometimes larger. $-S$. mocera, Ait. 1. c.; Willd. 1. c. S. eminens, Bischoff, hort. Heidelb. - Opén ground, Canada and Saskatchewan to Idaho and Texas, the northwestern forms commonly dwarf.

Var. scábra, Torr. \& GRAY, 1. c. Like the foregoing, but the short pubescence rough or hispidulous: leaves shorter, oblong-lanceolate to oblong-ovate, more entire, more veiny (approaching rough-leaved forms of $S$. rugosa): heads sometimes 3 lines long. S. scabra, Muhl. Fl. Lancast. ined., not Willd., which is $S$. rugosa. - Drier and sumnier places, Penn. to Florida and Texas. (S. scabrida, DC. Prodr. v. 331, of Mexico, appears to be a form of this.)

Var. canéscens, Grar. Stem and both faces of the narrow and commonly entire leaves canescent with soft and fine pubescence: bracts of the involucre broader and more obtuse.-Proc. Am. Acad. xvii. 197.-S. W. Texas, Berlandier, Lindheimer, Bigelow, and S. New Mexico, Thurber.

Var. Arizónica, Grax, 1. c. Minutely cinereous-pubescent or puberulent, hardly scabrous: stems low: heads mostly 3 lines long: thin bracts of the involucre commonly acutish. - S. mallis, Rothr. in Wheeler Rep. vi. 146. - Mountains of S. Utah, Ward, and of New Mexico \& Arizona, Bigelow, Rothrock. (Heads, \&c., nearly of S. velutina, DC., a Mexican species, which approaches this and the preceding ambiguous forms of $S$. Canadensis.) 
$=$ Leares obtuse or abruptly apiculate, or acutish, of firm or coriaceous texture, upper ones entire: pubescence all close, cinereous or canescent, or scabro-hispidulous; lateral ribs commonly incomplete, often obscure or wanting: panicle mostly compact, naked : bracts of the involucre broadish and obtuse, of firm texture: rays fewer and larger, golden yellow. The species are confluent.

u. Cinereous to canescent with fine and soft or at length minutely scabrous pubescence: leaves firm but seldom very rigid.

S. Califórnica, Nutr. Stem rather stout, either low or tall, canescently puberulent or pubescent: leaves oblong or the upper oblong-lanceolate and the lower gbovate, obtuse or apiculate, entire or the lower with some small teeth, canescently puberulent or beneath more pubescent: thyrsus virgate, 4 to 12 inches long, dense; the racemiform clusters erect or barely spreading in age, when elongated mostly secund, and even with the apex at length recurved: heads 3 or 4 lines long: bracts of the involucre lanceolate-oblong or oblong-linear, mostly obtuse, externally somewhat puberulent: rays 7 to 12 , fewer than the disk-flowers: akenes minutely pubescent. - Trans. Am. Phil. Soc. 1. c.; Torr. \& Gray, Fl. ii. 203; Gray, Bot. Calif. i. 319. S. puberula, Cham. \& Schlecht. in Linn. vi. 502, not Nutt. S. petiolaris, Hook. \& Arn. Bot. Beech. 145, partly. S. velutina, DC., var. " panicula contracta," DC. Prodr. v. 332, Hrenke, whose "Real del Monte" is Monterey, California. - Dry ground, California to the borders of Nevada and Mexico.

Var. Nevadénsis, Gray. Thyrsus and its clusters more secund: heads rather smaller: involucre mostly glabrous. - Bot. Calif. 1. c. - Sierra Nevada, California, and Nevada from Plumas Co. to Owens Valley, \&c. Transition to S. nemoralis.

S. nemorális, AIт. Mostly low, with the fine and uniform close pubescence êither soft or (in age and in dried specimens) minutely scabrous: leaves from spatulate-obovate to oblanceolate or somewhat linear; upper entire and small (half-inch or more long); radical and lower cauline sparingly serrate: thyrsus and its compact racemiform clusters secund, commonly recurved-spreading: heads 2 or 3 lines long: bracts of the involucre oblong-linear or narrower, obtuse, smooth and glabrous: flowers (appearing rather early) deep yellow: rays 5 to 9 , usually more numerous than the disk-flowers : akenes closely pubescent. - Kew. iii. 213 ; Pursh, Fl. ii. 537; DC. Prodr. v. 333 ; Torr. \& Gray, Fl. ii. 220. S. hispida, Muhl. in Willd. Spec. iii. 2063 ; Pursh, Fl. ii. 541. S. conferta, Poir. Dict. viii. 459. S. cinerascens, Schwein. in Ell. Sk. ii. 375. S. decemflora, DC. Prodr. v. 322. S. puberula, DC. 1. c. 333 , not Nutt. - Dry hills or sterile soil, throughout Canada and Saskatchewan to Florida and Texas, and west to Arizona, Utah, and Nevada; in the eastern region soft-cinereous; beyond the Mississippi often greener and more scabrous; or in Utah and New Mexico greenish and hardly scabrous. In the Rocky Mountains and northward mostly occur low and more canescent forms. (Adj. Mex.)

Var. incána, Gray, Proc. 1. c. Dwarf, a spań to a foot high: leaves oval or oblong, rigid, more or less canescent, sometimes rather strongly serrate, sometimes mostly entire: racemiform clusters erect or the lower somewhat spreading, collected in a dense oblung or conical thyrsus. $-S$. mollis, Bartl. Ind. Sem. Hort. Gœett. 1836, 5; DC. Prodr. v. 279 ; in cult. specimens the involucral bracts are narrowish and somewhat acute, as also in one form of S. incana, Torr. \& Gray, Fl. ii. 221 (excl. var.), while in a similar one, collected with it by Nicollet, they are linear-oblong and obtuse. - Plains of Minnesota and Dakota (Nicollet, \&c.) to the Rocky Mountains of Montana and Colorado. (Adj. Mex.)

S. nána, Nutr. A span to a foot high, canescent with minute dense puberulence, not scabrous in age: leaves mostly obovate or spatulate and entire, small: heads (3 lines long) broad, few or tather numerous in an oblong or corymbiform panicle, not at all secund: bracts of the involucre oval or oblong, very obtuse : otherwise nearly as $S$. nemoralis. - Nutt. Trans. Am. Phil. Soc. 1. c. 327 (in herb. "S. pumila"); Torr. \& Gray, 1. c. - Rocky Mountains and high plains, Wyoming to N. Arizona and N. E. Nevada; first coll. by Nuttall.

b. Hispidulous-scabrous, rigid, green!

S. rádula, Nutr. Stem a foot or two high, scabro-puberulent: leaves rigidly coriaceous, short; loosely reticulate-veined, occasionally with well-developed lateral ribs, obtuse, sparsely serrate or entire, from oval or obovate to oblong-spatulate (lowest 2 or 3 inches long, uppermost an inch or less, or rounded ones on the branches reduced to half or quarter inch), very hispidulous-scabrous at least on the veins, the midrib and margins often hispid: branches of the thyrsus secund and when well developed recurved-spreading: heads 2 and at most 3 
lines long: bracts of the involucre rather rigid, glabrous, oval to linear-oblong : rays 3 to 6 , rather fewer than disk-flowers: akenes minutely pubescent.-Jour. Acad. Plilad. vii. 327 ; Torr. \& Gray, Fl. ii. 220. S. rotundifolia, DC. Prodr. v. 332, \& S. scaberrima, Torr. \& Gray, l. c., broad-leaved form. S. decemflora, Gray, Pl. Lindh. ii. 223, not DC,-Dry hills and prairies, S. W. Illinois to Arkansas, W. Louisiana, and Texas; first coll. by Berlandier and Nuttall.

c. Scabro-puberulent, somewhat cinereous, small-leaved: the lateral ribs obsolete.

S. sparsiflóra, Grar. Founded on incomplete specimens (branclies), of doubtful affinity, scabrous rather than puberulent, leafy into the narrow and strict branches of the panicle: leaves all small (the larger hardly an inch long), lanceolate-linear, rather acute at both ends, rigid, entire, with lateral ribs and veins almost obsolete: heads somewhat scattered or few in the short imperfectly racemiform and somewhat secuud clusters, 3 lines long: bracts of the involucre rather small, oblong-linear, barely obtuse: rays 6 to 10 , little surpassing the disk. - Proc. Am. Acad. xii. 58; Rothr. in Wheeler Rep. vi. 146. - S. Arizona, near Camp Lowell, Rothrock. Llano Estacado, N. W. Texas on the borders of New Mexico, Bigelow. To which must be added

Var. subcinérea, GraY. Quite cinereously puberulent, the leaves scabro-puberulent : heads more crowded and secund in the virgate panicles: rays more conspicuous. - Proc. Am. Acad. xvii. 197. - Rucker Valley, S. Arizona, Lemmon. Base of stem and lower leaves nnknown: the affinity decidedly with $S$. nemoralis. Also a form between this and $S$. Canadensis, var. canescens, with larger heads, \&c., coll. New Mexico in the Mogollon Mountains, 1881, Rusby.

$===$ Leares thinnish, puberulent but green, broad, acute, divergently triplinerred and veiny: branches of the loose panicle racemiform, secund, leafy: bracts of the involucre narrowly oblong, obtuse, outer with greenish tips: rays few.

S. Drummóndii, Torr. \& GRAY. Soft-puberulent: stem 3 feet high, freely branched: leaves ovate or broadly oval, nearly or quite glabrous above; cauline copiously serrate, commonly acnte at both ends, almost petioled (lower 3 or 4 inches long and 2 or more broad); those of the flowering branches numerous even through the inflorescence, from 2 . inches down to a quarter-inch long, obtuse, sparingly denticulate or entire: rays 4 or 5, often 3-lobed, rather large. - F1. ii. 217. S. ulmifolia, Hook. Comp. Bot. Mag. i. 97. - S. W. Ilinois and Missouri to Louisiana, flowering late; first coll. by Lrummond. Allied in some respects to $S$. rugosa and $S$. amplexicaulis.

* * * * Heads in a compact and corymbifnrm thyrsus or cyme: radical leaves mostly long-petioled and with prominent midrib: akenes except in the first species wholly glabrous. Соктмвоs .

+ Leaves, even the radical, not triplinerved, flat; cauline sessile, very numerous: involucre of oblong-linear to oval faintly striate bracts: akenes very glabrous.

S. rigida, L. Somewhat cinereous with a short and dense, either soft or (in age) rather scabrous pubescence: stem stout, $\mathbf{2}$ to 5 feet high (rarely more dwarf) : leaves rigid, obscurely serrate or entire; radical and lowest cauline oval or oblong, rounded at both ends or acute at base, 3 to 7 inches long; upper cauline ovate-oblong, gradually smaller upward, with slightly clasping or decurrent base: clusters dense: heads about 5 lines long, campanulate, many- (over 30-) flowered: involucral bracts broad: rays 7 to 10 , rather large: akenes turgid, 12-15-nerved. - Spec. ii. 880; Ait. Kew. iii. 216; Michx. Fl. ii. 118; E11. Sk. ii. 390 ; Torr. \& Gray, Fl. ii. 208. S. grandiflora, Raf. in Med. Rep. hex. 2, v. 359, \& Desv. Jour. Bot. i. 226. - Dry and gravelly or sandy soil, Canada to the Saskatchewan, south to the upper part of Georgia, southwest to Texas and W. Colorado. Varies with smaller heads, looser inflorescence, and greener more scabrous leaves, in Texas, \&c.

S. corymbósa, ELI. Stem and leaves (except their margins) quite smooth and glabrous, green: heads ( 3 to 5 lines long) in lonser inflorescence: akenes short, turgid, 10-nerved: otherwise as in the preceding, of which it may be a glabrous variety. - Sk. ii. 378; Torr. \& Gray, l. c. ; not of Poir. Suppl. v. 461, which is a form of S. Virgaurea. - Upper and middle Georgia and Alabama; first coll. by Mr. Jaclson; apparently also in Texas.

S. Ohioénsis, Riddelc. Glabrous and smooth throughout: stem slender, 2 or 3 feet high: radical and lower cauline leaves lanceolate or elongated-oblong, 5 to 9 inches long, half-inch to an inch or more wide, attenuate at base, almost entire; upper lanceolate, sessile by a 
narrowed base: cyme fastigiate: heads pedicellate, small (3 lines long), narrow, 16-24flowered: bracts of the involucre narrower: rays 6 to 9 , small: akenes slightly 5-nerved. Synop. 57; Torr. \& Gray, 1. c. - Low prairies or meadows, W. New York to Ohio and Indiana; first coll. by Riddell.

$$
++ \text { Leaves somewhat conduplicate; lower slightly triplinerved. }
$$

S. Riddéllii, Frank. Glabrous and smooth, or the inflorescence puberulent: stem a foot or two high, very leafy: leaves elongated-lanceolate, entire; radical 8 to 12 inches long, attenuate at both ends; cauline rather long, exect at the base which nearly sheathes the stem, partly conduplicate above, and the upper part falcately arcuate: heads densely cymose, 3 or 4 lines long, 20-30-flowered : rays 7 to 9 , small and narrow: akenes faintly 5-nerved.Riddell, Synops. 1. c.; Torr. \& Gray, Fl. ii. 210. S. amplexicaulis, Martens in Bull. Acad. Brux. viii. (1841) 68, - Wet prairies, Ohio (first coll. by Riddell) to Iowa and Missouri. (Also Fort Monroe, Virginia, Vasey and Chickering, these adventive?)

S. Houghtóni, Torr. \& Gray. Stem slender, 10 to 20 inches high: leaves indistinctly nerved, rather rigid, scattered ( 3 or 4 inches long, 2 to 4 lines wide): heads rather few in a corymbiform cyme, 20-30-flowered: rays 7 to 10, rather large: bracts of the involucre oblong-linear: akenes 4-5-nerved. - Gray, Man. ed. 1, 211, ed. 5, 242. - Swamps, north shore of L. Michigan, Houghton. Genessee Co., New York, Paine. Flowering early.

+++ Leaves flat, smooth, and glabrous, linear or linear-lanceolate, entire, more or less triplinerved or 3-nerved, or nervose: heads only 3 or 4 lines long.

S. nítida, Torr. \& GraY. Stem 2 or 3 feet high, very smooth except the summit and inflorescencé, which are minutely hirsute: leaves coriaceous and rigid, evidently nervose, punctate (the larger 4 to 6 inches long, 3 to 5 lines wide): heads numerous in the corymbiform cyme, about 14-flowered : rays 2 or 3, large: bracts of the involucre narrowly oblong: akenes 10-nerved. - Fl. ii. 210. - Dry pine woods and barrens, W. Louisiana and Texas; first coll. by Lrummond and Leavenzorth.

S. púmilla, Torr. \& GRAY. Dwarf, a span or more high, many-stemmed from a woody branching and cespitose caudex, glabrous throughout, punctate, somewhat resinous : leaves rigid, 3-nerved, acute; radical 2 or 3 inches long: cyme glomerate-fastigiate: heads narrowly oblong, 5-8-flowered : rays 1 to 3 , short: involucral bracts rigid, somewhat carinate, and with small green (sometimes mucronulate) tips: mature akenes flattish and unusually broad, rather longer than the rigid pappus: akenes 5-nerved. - Fl. ii. 210. Chrysoma pumilu, Nutt. in Trans. Am. Phil. Soc. vii. 325. - Rocky dry places, N. W. Texas to S. W. Utah, Nevada, and Idaho, mostly in the mountains; first coll. by Nuttall.

§ 2. Euthimia, Nutt. Receptacle of the flowers fimbrillate or the alveoli pilose: rays very small, almost always more numerous than the disk-flowers and never surpassing them in height: heads glomerately and fasciculately cymose, small : leaves very numerous, all linear, entire, 1-5-nerved, somewhat punctate, sessile: akenes villous-pubescent, short and turbinate: filiform rootstocks extensively creeping. - Euthamia, Cass. Dict. xxxvii. 471 ; Nutt. 'Trans. Am. Phil. Soc., 1. c.

$$
\text { * Taller and paniculately branched Pacific species. }
$$

S. occidentális, Nutr. Sterns 2 to 6 feet high; the branches terminated by small clusters of mostly pedicellate heads: leaves usually 3-nerved, glabrous and smooth even on the midrib, and margins obscurely scalurous : bracts of the involucre rather narrow : rays 16 to 20 : disk-flowers 8 to 14. - Torr. \& Gray, Fl. ii. 226; Eaton in Bot. King Exp. 156. S. lanceolata, Cham. \& Schlecht. in Linn. vi. 502; Hook. Fl. ii. 6, partly. Euthamia occidentalis, Nutt. in Trans. Am. Phil. Soc. «. ser. vii. 326. Aplopappus bacchuroides, Benth. Bot. Sulph. 24. - Moist ground, British Columbia to S. California, extending eastward to New Mexico, Colorado, and Montana. - Long rootstocks tuberous-thickened at the extremity.

* * Comparatively low, a foot or at most a yard high, cymosely much branched above and flattopped: heads mostly glomerate-sessile: Atlantic species.

S. lanceoláta, L. Leaves lanceolate-linear, distinctly 3-nerved and the larger with an additional outer pair of more delicate nerves, minutely scabrous-pubescent on the nerves 
beneath: outer bracts of the involucre ovate or oblong, and the inner linear: rays 15 to 20 : disk-flowers 8 to 12. - Mant. 114; Ait. Kew. iii. 214; Torr. \& Gray, Fl. ii. 226. \$. graminifolia, Ell. Sk. ii. 391. Chrysocoma graminifolia, I. Spec. ii. 841. Euthamia graminifolia, Nutt. Gen. ii. 162 (subgen.), \& Trans. Am. Phil. Soc. 1. c. - Low ground, Canada to Georgia, and northwest to Montana.

S. tenuifólia, Pursu. Lower (a foot or two high), slender, more resinous-atomiferous and glutinous, but glabrous: leaves all narrowly linear, one-nerved or with a pair of indistinct lateral nerves: heals smaller: rays 6 to 12 : disk-flowers 5 or 6 . - Fl. ii. 540; Ell. Sk. ii. 392 ; Torr. \& Gray, 1. c. S. lanceolata, var. minor, Michx. Fl. ii. 116. Erigeron Carolinianum, L. Spec., being Iirgaurea Carol., \&c., Dill. Elth. 412, t. 306, f. 394. Euthamia tenuifolia, Nutt. I. c. - Sandy or gravelly and moist or dry ground, coast of New England to Florida and Texas.

S. leptocéphala, Torr. \& Grar. A foot or two high, with more simple branches, wholly smooth and glabrous except the margin of the leaves; these with prominent midrib, very obscure lateral nerves, and no apparent veins: bracts of the involucre and the liead narrower: rays 8 or 10 : disk-flowers 3 or 4 . - Fl. ii. 226. - Low ground, W. Louisiana and Texas; first coll. by Leavenworth and Drummond. Also, in a narrow-leaved form, N. W. Arkansas, F. L. Hurvey.

§ 3. Chrysóma, Torr. \& Gray. Suffruticose : leaves fleshy-coriaceous, peculiarly areolate-venulose in the dried state: otherwise as § Virgaurea. C Chrysoma, Nutt., in part.

S. pauciflosculósa, Micrx. A foot or two high, much branched from the shrubby base, glabrous, somewhat viscid : leaves from spatulate-oblanceolate to linear, very ointuse, entire, an inch or two long and with a contracted petiole-like base, one-nerved or obscurely 3-nerved, not venose, but minutely and uniformly venulose, the impressed veinlets forming microscopic quadrate or roundish meshes over both surfaces: tliyrsus somewhat corymbosely pauiculate; the clusters only obscurely secund: heads 3 or 4 lines long: rays 1 to 3 , rather large : diskflowers 3 to 5, deep yellow: akenes pubescent: pappus brownish. - Fl. ii. 116; Torr. \& Gray, Fl. ii. 224. Chrysoma solidaginoides, Nutt. in Jour. Acad. Philad. vii. 67, \& Trans. Am. Phil. Soc. vii. 325. - Dry hills and sand-banks on the sea-shore, S. Carolina to Florida and Alabama; flowering late. (Bahamas.)

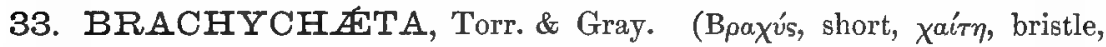
from the very abbreviated setose pappus, which, with the cordate leaves, somewhat artificially distinguishes the genus from Solidago.) - Single species, flowering in late summer and autumn. - Fl. ii. 194.

B. cordáta, Torr. \& GraY, 1. c. Soft-pulescent: stems 2 or 3 feet ligh from a perennial root: leaves membranaceous, veiny, mostly acutely serrate; ralical rather large, roundcordate, on long and nearly wingless petioles; cauline ovate, the lower on winged petioles: heads 2 or 3 lines long, narrow, solitary or fascicled in the racemiform and secund clusters or narrow thyrsus: bracts of the involucre with greenish tips, inner ones linear-oblong: flowers golden yellow, those of the disk and short ray each 4 or 5 : pappus shorter than the akene and shorter than the proper tube of the corolla. - Solidago spliacelata, Raf. Ann. Nat. (1820), 14. S. cordnta, Short, Cat. Pl. Kentucky, Suppl. Brachyris ovatifolia, DC. I'rodr. v. 313. - Open woods, \&c., W. North Carolina and E. Kentucky to the upper part of Georgia ; apparently first coll. by Rafinesque.

34. LESSINGIA, Cham. (Dedicated to the eminent German author, G. E. Lessing, and to his grand-nephews, Karl Lessing the painter, and Christian Fr. Lessing, author of Syn. Gen. Compositarum.) - Californian annuals or biennials, flocculent-woolly when young; with alternate leaves and rather small heads of flowers, either of the xanthic or cyanic series; the pappus becoming fuscous or rufous. Nerves of the corolla-lobes deeply intramarginal, the restivation indu- 
plicate up to the nerve. - Linnæa, iv. 203; Gray in Benth. Pl. Hartw. 315, Proc. Am. Acad. vii. 351, viii. 364, \& Bot. Calif. i. 306. - Flowering spring and summer.

* Flowers yellow, sometimes purplish in age; some of the marginal ones with conspicuously larger and more or less irregular and radiatiform cololla: bracts of the involucre with herbaceous tips: akenes narrow, compressed, 2-3-nerved: style-branches truncate-obtuse, bearing a brush-like tuft of bristles, in which a ninute or obscure setiform tip is partly or wholly hidden : heads about 3 lines high, terninating spreading slender branchlets.

L. Germanórum, Crram. L. c. Low and diffusely spreading from the base, or procumbent, arachnoid-lanate with appressed white tomentum, glabrate with age; filiform flowering branches sparsely leafy or naked: lower leaves spatulate and usually pinnatifid or incised, with long tapering entire base; those of the branches becoming linear and entire, all narrowed at base: involucre hemispherical; its bracts with loose and foliaceous tips or the outer foliaceous, all glandless. - Torr. in Wilkes Exped. xvii. 326, t. 7 (style bad); Gray in P1. Hartw. 1. c., \& Bot. Calif. 307, only in part. - Open dry ground, near San Francisco and in adjacent parts of California; first coll. by Chamisso. Corollas said by Chamisso to be "croceous."

L. glandulífera, Grar. Diffusely much branched from an erect stem, more rigid, above glabrous or early glabrate: leaves more commonly entire, sometimes spinulose-dentate; those of the branches small and very numerous ( 3 to 1 lines long), or minute and almost covering flowering branchlets, ovate-lanceolate or oblong, thick and rigid, commonly beset along the margins with yellowish tack-shaped glands : involucre campanulate to turbinate; its bracts more appressed, the outer successively shorter, and some or all of them glanduliferous. - Proc. Am. Acad, xvii. 207. L. Germanorum in part, \& L. ramulosa, var, tenuis, Gray, Bot. Calif. 1. c., in part. - Arid grounds, from Monterey to San Diego, San Bernardino, \&c.; common. The glands are like those of Calycadenia on a smaller scale, sometimes copious and strongly marked, sometimes few and inconspicuous.

* * Flowers purple or white; the corollas all alike and regular or nearly so: bracts of the involucre with appressed or erect tips: akenes less or hardly at all compressed, 4-5-nerved.

+ Stems slender and loosely branching, erect, a span to a foot or two high: white wool deciduous in age: leaves oblong to lanceolate or the lower spatulate, entire or sparingly dentate, the small upper with partly clasping or adnate base: involucral bracts mostly herbaceous-tipped.

L. ramulósa, Gray, l. c. Somewhat granulose- or hirtellous-glandular on the glabrate branches and upper leaves, occasionally with some minute tack-shaped glands: stem usually stout at base: heads ( 3 or 4 lines long) terminating diffuse slender branchlets: involucre campanulate or somewhat turbinate, 10-20-flowered : corollas short (purple) : style-append- . ages with minute setiform tip. - On dry hills, not rare through the northwestern part of California to Bay of San Francisco; first coll. by Pickering and Brackenridge.

Var. ténuis, Grar. A slender and ambiguous form, not thickened at base of stem, low and diffuse, analogous to the depauperate states of the next species. - Bot. Calif. i. 307, as to pl. of Rothrock in Wheeler Rep. vi. 364. - Southeastern California, at head of Peru Creek, Rothrock.

L. leptóclada, Gray. Glabrous after denudation of the floccose wool: stem slender (the taller forms 2 feet or more high, the most depauperate only 3 or 4 inches), and with long virgate or filiform branches bearing solitary or few heads: upper leaves commonly with Eagittiform-adnate base: involucre turbinate, from 20-flowered down (in depauperate plants) to 5-flowered; its bracts in numerous ranks : corolla conspicuously exserted: style-appendages with a conspicuous subulate tip. - Proc. Am. Acarl. vii. 351, \& Bot. Calif. 1. c. - Dry ground, common through the western and central parts of California, in very diverse forms; sometimes with numerous heads spicately crowded along the summit of the branches, and too nearly approaching the next.

L. virgáta, GrAY. More densely woolly: stem and virgate branches more rigid: upper leaves appressed, concave, carinately one-nerved: heads spicately sessile, each in the axil of a leaf of nearly the same length: involucre cylindrical, woolly, 5-7-flowered: style-branches with a conspicuous subulate tip. - Pl. Hartw. 1. c.; Bot. Calif. 1. c.-On the Sacramento, probably in the northern part of the State, Pickering and Brackenridge, Newberry. 
++ Depressed or dwarf, flowering from the ground: inner bracts of involucre cartilaginousaristate!

L. nána, Grar, l. c. Usually stemless, a very woolly and pellet-like tuft from a slender root, an inch or two high, a cluster of sessile (half-inch long) heads, each surrounded by a rosulate cluster of spatulate or lanceolate leaves : involucre 10-12-flowered; its outer bracts linearlanceolate, mucronate-acute or cuspidate, little herbaceous; inner ones pearly white, scariouschartaceous, tapering into a rigid subulate acumination or awn which equals the flowers and very rufous pappus: akenes short and turgid : tip to the tufted style-appendages wanting. Torr. in Wilkes Exped. xvii. 338, t. 7, poor. - Dry ground, foot-hills of the Sierra Nevada, from Siskiyou Co. to Kein Co., Pickering, Fitch, Muir, C'unby, Rothrock.

Var. cauléscens. Leaves larger; radical ones much surpassing the sessile heads in their axils: also several developed stems, of an inch to 4 inches high, sparsely leaved, and bearing either solitary or 3 or 4 spicately disposed hearls. $-S$. California, at Tehachipi Pass, Parry.

35. BELLIS, Tourn. DAIsy. (Latin name, from bellus, pretty.) - Low herbs, of the northern hemisphere; the typical species peremial and stemless: radical leares obovate: rays white, rose-colored, or purple. The akenes in the two perennial Mexican species, viz. B. xanthocomoides (Brachycome, Less.) and B. Mexicana, Grily, Pl. Wright. i. 93 (coll. Wright and Bourgeau), as also in our annual species, are less flat, and marginal nerves slender or less thickened, than in the Old World species. - Benth. \& Hook. Gen. ii. 265.

B. PERExyis, L., the common European DaIsy, is escaping from cultivation and beginning to be spontaneous in a few places.

B. integrifólia, Mrсн. Annual, sparsely pilose-pubescent, diffusely branched and leafy, a span to a foot high: leaves spatulate-obovate and the upper narrower, entire: peduncles terminating the branches: bracts of the involucre ovate-lanceolate, acuminate, scarious-margined : rays half-inch or less in length, usually pale violet.-Fl. ii, 131; Hook. Bot. Mag. t. 3455 ; Torr. \& Gray, Fl. ii. 189. Eclipta integrifolia, Spreng. Syst. iii. 602. Astranthium integrifolium, Nutt. Trans. Am. Phil. Soc. ser. 2, vii. 312.-Low grounds, Kentucky to Arkansas and Texas; $f$. spring and summer.

36. APHANÓSTEPHUS, DC. ('Aфav'ฑs, vanishing or inconspicuous, and $\sigma \tau^{\prime} \dot{\phi} o s$, crown ; from the pappus.) - Texano-Mexican annuals or biennials, sometimes perhaps of longer duration, pubescent, leafy-stemmed and branching; with rather showy heads, resembling those of Daisy, on solitary peduncles terminating the branches, and nodding before anthesis : leaves from entire to pinnately lobed: rays from white to violet-purple: akenes almost or quite glabrous. F1. summer. - Gray, Pl. Wright. i. 93 ; Benth. \& Hook. Gen. ii. 262; Gray, Proc. Am. Acad. xvi. 80. Aphanostephus, Keerlia (excl. one species, which is a Xanthocephalum), \& Leucopsidium, DC. Prodr. v. 309, 310, vi. 43.

* Pappus a very short crown with a ciliate-fringed edge, which commonly is obsolete in age: base of the corolla-tube seldom thickened.

A. Arizónicus, Gray. Erect, a foot high, minutely soft-pubescent, not cinereous: upper leaves linear and entire; lower linear-spatulate, 3-5-lobed or laciniate: hearls small, on at length clavate-thickened peduncles: akenes narrow, terete, evenly striate with about 10 narrow ribs. - Proc. Am. Acad. xvi. 81. A.ramosissimus, Rothrock in Wheeler Rep. vi. 147. - Arizona, on the Gila River, Rothrock.

A. ramosíssimus, DC. Erect or at length diffuse, slender, a foot or less high, hispidulous-pubescent: upper leaves linear or lanceolate, entire or few-toothed; lower laciniatepinnatifid or incised: heads on slender peduncles: rays 3 to 5 lines long: akenes almost terete and even, the ribs or nerves few and mostly obscure, except on some outermost. Prodr.v. 310; Gray, Pl. Wright. I. c.; Torr. in Marcy Rep. t. 9. A. Riddellii, Torr. \& Gray, Fl. ii. 189. A. pilosus, Buckley in Proc. Acad. Philad,, a remarkably hispid form. Egletes 
ramosissima, Gray, Pl. Fendl. 71, \& Pl. Lindh. ii. 220. - Rocky。 and sandy prairies, Texas. (Adjacent Mex.)

A. húmilis, Grar, l.c. Low and diffuse, soft-pubescent and cinereous: leaves rarely entire, often pinnatifid: heads on slender peduncles: rays 3 or 4 lines long: akenes shorter and more distinctly costate-angulate. - Leucopsidium humile, Benth. Pl. Hartw. 18. Egletes humilis, Gray, Pl. Fendl. 71. - Southern and western borders of Texas, Wright, Palmer (but his plant, no. 494, doubtful), Reverchon. (Mex.)

A. ramósus, Gray, Proc. Am. Acad. xvi. 90 (Keerlia ramosa, DC.), Mexico, Keerl, is imperfectly known.

* * Pappus more conspicuous and dentate or laciniate: base of the corolla-tube in age prominently thickened and indurated, long persistent on the strongly angulate-costate akene.

A. Arkansánus, Gray, l. c. Diffuse, a foot high, cinereous-pubescent: leaves from oblong-spatulate to broadly lanceolate; lower often toothed or sinulate-lobed : heads larger: rays commonly half-inch long: outer akenes usually suberose-angled or ribbed: pappus mostly obtusely 4-5-lobed or pluridentate. - Leucopsidium Arkansanum, DC. Prodr. vi. 43. Keerlia skirrobasis, DC. Prodr. v. 310; Deless. Tc. iv. t. 18; Hook. Ic. t. 240. Egletes Arkansana, Nutt. Trans. Am. Phil. Soc. vii. 394 ; Torr. \& Gray, Fl. ii. 4l1. - Plains of Arkansas, Kansas, and Texas ; first coll. by Berlandier.

Var. Hállii, GRAX, 1. c. Somewhat smaller : leaves varying from entire to pinnately parted: crown of the pappus more conspicuous, deeply cleft into 4 or 5 unequal subulateacuminate lobes! - Texas, E. Hall (no. 303, 304), Palmer.

37. GREENELLA, Gray. (Rev. Edward Lee Greene, the discoverer.) - Slender and low winter annuals; the typical species (analogous to Gutierrezia) diffuse and conspicuously radiate; an ambiguous species rayless, and perhaps not truly congeneric. - Proc. Am. Acad. xvi. 81.

G. Arizónica, GraY, l. c. Smooth and glabrous, diffusely branched from the base: leaves small (inch or less long), entire, veinless, sessile, alternate; raclical ones lanceolate or obscurely spatulate, hispidulous-ciliolate; cauline narrowly linear and gradually reduced to subulate : heads solitary at summit of divergent filiform branchlets: involucre 2 or 3 lines high and wide; bracts with a conspicuous subapical green spot: rays 10 to 16 , oblong or obovate, white: mature akenes densely white-villous, the lhairs tipped with a capitellate gland: borler of the pappus-crown multisetulose-dissected. - Mesas of Arizona, Greene (1877), Lemmon, Pringle. The rout obviously not perennial.

G. discoídea, Gr.y. Stems or branches numerous from a probably monocarpic but lignescent root, strict, very leafy : leaves all narrowly linear, acute; the lower (over an inch long) with obscurely ciliolate-scalrous margins: helds somewhat corymbose: involucre barely 2 lines high; the bracts more scarious and with indistinct green spot: rays none: ovaries glabrous: pappus pluridenticulate. - Proc. Am. Acad. xix. 2.-S. Arizona, in Tanner's Cañon, Lemmon.

38. KEFRIIA, Gray. (F. W. Keerl, a German traveller in Mexico.) Diffusely and slenderly branched Texan herbs, leafy-stemmed; with small paniculate heads on almost capillary peduncles, white or purple rays, and oblong entire sessile leaves; the style-appendages in one species much elongated (in the manner of the preceding genus), and this has only sterile ovaries in the disk. - Pl. Lindh. ii. 220, \& Pl. Wright. i. 92, not DC., whose genus of this name was founded on two species of Aphanostephus and a Xanthocephalum, to which was added a synonyme belonging to a Bellis.

K. bellidifólia, Gray \& ExGeLm. Annual, pubescent, effusely branched from near the base, a span or two high; when young with the habit of Bellis integrifolia: lower leaves obovate or spatulate; uppermost somewhat linear: involucre only 2 lines long: rays 4 to 15 , blue: style-appendages in the disk-flowers short and very obtuse: akenes obovate-clavate and moderately compressed. - Proc. Am. Acad. i. 47; P1. Lindh. 1. c.; Pl. Wright, 1. c. Fertile soil, Texas, Lindheimer, Wright. 
K. effúsa, Gray. Perénnial, often 2 feet high, with simple stem branching above into an effuse ample panicle : leaves (an inch or less long) hispid as well as the stem, rigid and scabrous, oblong, mostly with a broad sessile base: heads very numerous: involucre more turbinate: rays 4 to 7 , white: disk-flowers somewhat more numerous, apparently always sterile, and with elongated linear-lanceolate style-appendages: fertile akenes obovate, flat, callons-nerved at the margins (or with one margin 2-nerved). - Pl. Lindh. ii. 221; Pl. Wright. i. 93. - Hillsides, central parts of Texas, Berlandier, Lindheimer.

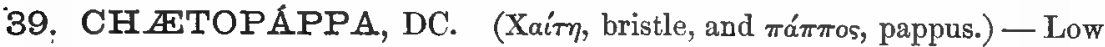
and small Texano-Mexican winter annuals, diffusely branched; the branches terminated by small heads : rays white or purple: leaves entire, the lower spatulate, upper gradually becoming linear or reduced to subulate bracts. Fl. spring and early summer. - Chatanthera, Nutt. Jour. Acad. Philad. vii. 111. Chatophora, Nutt. in DC. Chrotopappa \& Distasis, DC. Prodr. v. 301, 279; Benth. \& Hook. Gen. ii. 268. Diplostelma, Gray, Pl. Fendl. 72.

C. asteroídes, DC. 1. c. Slender, 2 to 10 inches high, pubescent: involucre (2 lines long) rather narrow, of 12 to 14 bracts: rays 5 to 12 : disk-flowers 8 to 12 : style-appendages very obtuse: akenes slender, little compressed, obscurely few-nerved, pubescent, all the central ones sterile and often awnless: paleæ of the pappus very thin and hyaline, narrowly oblong, not rarely lacerate or cleft. - Torr. \& Gray, Fl. ii. 187. Chotanthera asteroides, Nutt. 1. c. Dry ground, Texas to Arkansas and the borders of Missouri. (Adjacent Mex.)

Var. imbérbis, GrAY. Awns of the pappus wanting in all the flowers: the palex rather broader and sometimes coroniform-concreted. - Proc. Am. Acad. xvi. 82. - E. Texas, Wright.

C. Párryi, Gray. More rigid, 9 inches or more high: leaves subcoriaceous, hispidulous and glabrate: involucre (3 lines long) turbinate: rays 6 or 7 : style-appendages short and very obtuse: akenes quite glabrous; the fertile ones fusiform and somewhat compressed, 4-nerved, with a pappus of 4 or 5 firmer and cuneiform-quadrate palea which are laciniately fimbriate at the truncate apex, and of few or sometimes solitary more delicate awns, these occasionally little longer than the palex, sometimes wanting; disk-akenes mostly inane and awnless. - Proc. Am. Acad. xvi. 82. Listasis modesta, var., Gray, Bot. Mex. Bound. 78. Mt. Carmel, on the Rio Grande, between Texas and Mexico, Parry.

C. modésta, Grat, l. c. Less slender and pubescence more hirsute than in $C$. asteroides: involucre broadly campanulate; its bracts obtuser and more numerous: rays 9 to 20 : diskflowers 40 to 60 , all but the central fertile; their style-appendages narrower and acutish: akenes oblong or linear, much compressed, pubescent when young, with merely marginal nerves or occasionally a facial one, only the central ones sterile: pappus of 5 oblong erosetruncate at length subcoriaceous paleæ, alternating with as many rather rigid awns.-Distasis modesta, DC. Prodr. v. 279. Diplostelma bellioides, Gray, Pl. Fendl. 73.-Dry ground, Texas, Berlandier, Wright, \&c. (Adjacent Mex.)

Dístasis? heterophýlla, Hemsl. Biol. Centr.-Am. Bot. ii. 119, of Mexico, is hardly of this genus, probably not of the tribe.

40. MONÓPTILON, Torr. \& Gray. (Móvos, single, $\pi \tau i$ גov, feather, alluding to the solitary plumose bristle of the pappus.) - Jour. Bost. Nat. Hist. Soc. v. 106, t. 13 ; Benth. \& Hook. Gen. ii. 307; Gray, Bot. Calif. i. 306. - Single species.

M. bellidifórme, ToRr. \& GRAY, 1. c. A small but pretty annual, much branched from the very base, depressed, villous-hirsute: heads terminating the numerous leafy branchlets, halfinch in diameter, inclusive of the white or violet-purple rays: leaves small, spatulate or linear-spatulate, the uppermost involucrate around the head. - Arid or desert plains, S. E. California to S. W. Utah, Fremont, Parry, Palmer, Parish.

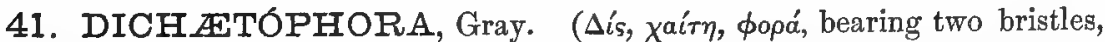
i. e. pappus-awns.) - Pl. Fendl. 73. - Single species; in Benth. \& Hook. Gen. 
ii. 209, referred (along with a species of Perityle and an Achotogeron) to a section of Boltonia.

D. campéstris, GrAY. A small and Daisy-like winter annual, at first acaulescent with a scapiform peduncle ( $\mathbf{l}$ to 3 inches high ), at length with leafy branches terminated by 2 slender monocephalous peduncle: leaves spatulate, entire, somewhat hirsute: head 2 or 3 lines high, the ovate disk soon surpassing the involucre: rays 16 to 20 , apparently white or rosecolor. - Pl. Fendl. 73, perhaps excl. syn. Brachycome? xanthocomoides, Torr. \& Gray, F]. ii. 190, the specimen of which is too young for determination. - Southern borders of Texas, Berlandier (no. 1465, specimen too young), Havard, in fruit. (Adj. Mex., Gregg, Palmer.)

42. BOLTONIA, L'Her. (James Bolton, an English botanical author.) - Perennial and leafy-stemmed herbs (wholly of the United States), Aster-like, glabrous, glaucescent, mostly tall; with striate-angled stems, entire sessile leaves commonly becoming vertical by a twist at base, rarely decurrent; and with rather showy heads; the numerous rays white, purplish, or violet; fl. autumn. - Sert. Angl. 27 (with figures cited which were never published); DC. Prodr. v. 301 ; Benth. \& Hook. Gen. ii. 289, excl. § Asteromcea, Blume, which passes into Calimeris, and also $\S 3$, which is a mixture. Wings of the akene broadish and thin, narrow and thickish, or obsolete in the same species, or even in the same head.

* Stems (2 to 7 feet high) paniculately much branched and slender: heads small; the disk only about 2 lines high and wide.

B. diffúsa, Ell. Lower leaves lanceolate; upper linear, those of the loose and almost filiform flowering branches or branchlets becoming linear-subulate and minute: rays mostly white, barely 2 lines long: involucre as in the next, but the bracts more numerous and unefual. - Sk. ii. 400 ; Hook. Comp. Bot. Mag. i. 97 ; DC. 1. c. \& Torr. \& Gray, 1. c., excl, syn. Bot. Mag. - Low grounds, South Carolina to Texas and along the Mississippi region north to Illinois.

* * Stems (2 to 8 feet high) simple and more cymose-paniculate at summit: leaves broadly lanceolate or the uppermost linear-lanceolate heads short-peduncled, larger; the disk in fruit a third to half an inch in diameter: rays 4 to 6 lines long.

B. asteroídes, L'Her. Bracts of the involucre lanceolate, acute, mostly greenish : rays from white to purplish or pale violet-color: setulose squamellæ of the pappus mostly nnmerous and conspicuous: the two awns sometimes wanting or obsolete, more commonly present and little shorter than the akene. - Matricaria asteroides, L. Mant. i16. M. glastifulıa, Hill, Hort. Kew. 19, t. 3. Chrysanthemum Carolinianum, Walt. Car. 204. Boltonia glastifoiıa \& B. asteroides, L'Her. l. c.; Michx. Fl. ii. 132; Willd. Spec. iii. 2162 ; Sims, Bot. Mag. t. 2381 \& 2554 ; DC. 1. c. - Moist or wet ground along streams, Pennsylvania to Illinois and Florida. The awnless form ( $B$. asteroides) is not constant to this character, but is commonly smaller, and with fewer and smaller heads.

Var. decúrrens, Engelm in herb. A large form (in cultivation 7 or 8 feet high). with leaves alate-decurrent on the stem and even the branches; the wings sometimes ending below in a free and subulate point: pappus-awns slender. - Missouri, Egygert.

B. Iatisquáma, Gray. Heads rather larger and more showy rays blue-violet: bracts of the involucre oblong to ovate, obtuse or mucronate-apiculate : awns of the pappus uniformly present and conspicuous, the setulose squamellæ small. - Am. Jour. Sci. ser 2, xxxiii. 238. - Kansas and W. Missouri, near the mouth of the Kansas River, Parry. Now not rare in cultivation, the handsomest species.

Var. occidentális. Heads rather smaller: rays white. - River-bottoms of Union Co., Eastern Oregon, Cusick.

43. TOWNSENDIA, Hook. (David Townsend, botanical associate of Dr. Darlington of Penn.) - Depressed or low many-stemmed herbs (of the Rocky Mountains); with from linear to spatulate entire leaves, and comparatively large heads, resembling those of Aster; the numerous rays from violet or rose- 
purple to white; fl. from early spring to summer. Akene commonly beset with bristly "duplex" hairs, having a forked or glochidiate-capitellate apex. Involucral bracts mostly ciliate. - Fl. ii. 16, t. 119 ; Torr. \& Gray, Fl. ii. 185 ; Gray, Proc. Am. Acad. xvi. 82. For structure of the achenial hairs, see Macloskie in Proc. Am. Nat. xvii. 31, xviii. 1102.

* Bracts of the involucre conspicuously attenuate-acumingate: bead large; the involucre half-inch or more high, and rays half-inch long: fl. summer.

+ Caulescent biennials or annuals, somewhat hirsute-pubescent, but the foliage at length glabrate: involucre uaked; its bracts from lanceolate to ovate-lanceolate: rays showy, bright blue or violet. (Pappus of the first species anomalous!)

T. exímia, Gray. Stems erect, simple or sparingly branching, 6 to 14 inches high: leaves spatulate or the upper lanceolate: head sparingly leafy-bracted or naked at base: involucral bracts ovate-lanceolate and somewhat rigidly cuspidate-acuminate, whitish-scarious with green centre: akenes broadly obovate, almost cartilaginous, glabrate (sprinkled with a few short and obscure glochidiate-tipped hairs) : pappus wholly persistent, of 2 subulate at length corneous stout awns which are rather shorter than the akene (sometimes wanting in the ray), and a circle of rigid squamella which are mostly coroniform-concreted at base and rigid in age. - Pl. Fendl. 70 ; Pacif. R. R. Exp. iv. 98 ; Proc. Am. Acad. 1. c. 83. - Mountain sides, New Mexico and adjacent part of Colorado, Fendler, Bigelow, \&c.

T. grandiflóra, Nutr. Stems spreading from the base, sometimes divergently branched above, a span or two high: upper lenves often linear, 2 or more uppermost subteuding the head : involucre nearly of the preceding: akenes narrowly obovate, sprinkled with glochidiate-capitellate hairs : pappus in the ray reduced to a crown of short squamella, in the manner of the genus, and of the disk plurisetose and longer than the akene. - Trans. Am. PJill. Soc. ц. ser. vii. 306; Torr. \& Gray, 1. c. - Plains and hills, Wyoming and W. Nebraska to the borders of New Mexico; first coll. by James and Nuttall.

T. Párryi, Eaton. Stems erect, simple, stout, naked and pedunculiform above, 2 to 6 inches high (the taller forms sometimes branching) : leaves mostly spatulate : bracts of the very broad involuce lanceolate, thinner, with softer and less attenuate tips, or the outer barely acuminate: akenes narrowly obovate, canescently pubescent, the hairs acute and simple or many of them 1-2-dentate at tip: pappus of the ray plurisetose like that of the disk, or somewhat more scanty, rays "blue" or violet. - Am. Naturalist, viii. 212 ; Gray, Proc. Am. Acad. xvi. l. c. - Wyoming, Montana, and E. Idaho, Hayden, Parry, \&c.

Var. alpína, GraT, 1. c. A dwarf and alpine form, more pubescent and cinereous: leaves very small, at most half-inch long: flowering stem about the same leugth or hardiy any involveral bracts less pointed: "rays pink." - Wyoming on the high divide between Stinking Water and the Yellowstone (confounded with T. spathulata), Parry.

$\leftarrow+$ Depressed-stemless and monocephalous perennial.

T. condensáta, PArry. Very lanuginous with long and soft arachnoid hairs, the spatulate obovate leaves (with blade 2 or 3 lines long and tapering into a very much longer petiole) rosulate-crowded around the large and broad sessile head, the whole forming a glolular or hemispherical woolly tuft, an inch and a half high and surmounting a slender stoloniform caudex: bracts of the involucre linear and soft, with a weak attenuate apex, all nearly equal in length: rays 100 or more, narrow: disk-flowers also very numerous pappus of ray and disk similarly and slenderly plurisetose and long. - Am. Nat. viii. 213 (description by Eaton). - Wyoming, on a high alpine peak of the Owl Creek range, July, J. D. Futnam.

* * Bracts of the involncre not prominently if all acuminate: heads mostly smaller or narrower: pappus of the disk and often of the ray plurisetose.

+ Hairs on the akene mostly copious and slender, some simple, others bifid or bi- (rarely tri.) dentate at the apex, the teeth or lobes ascending or merely spreading and usually acute: heads middle-sized, more or less naked-pedunculate: the pink oj rarely white rays and the involucre each from a third to bareiy half an inch long: bracts of the latter few-ranked: annuals or biennials. (The most western species in range.)

+ Pappus of the ray like that of the disk, but somewhat shorter.

T. flórifer, Grax. A span or more high, cinereous-hirsute: stems rather slender from an annual root, leafy. leaves linear or the lowest lanceolate-spatulate, acute, mostly apiculate- 
acuminate: involucral bracts linear-lanceolate, little unequal. - Proc. Am. Acad. xvi. 84. T. strigosa, Grav, in Wilkes Exped. xvii. 344, not Nutt. Erigeron florifer, Hook. Fl. ii. 20. Aplopappus florifer, Hook. \& Arn. Bot. Beech. 351. Stenotus florifer, Torr. \& Gray, Fl. ii. 238. - Sandy banks of the Columbia River and its tributaries, east of the Cascades, Montana to Washington Terr. and Oregon; first coll. by Dauglas.

T. scapígera, EAToN. Low (2 to 4 inches high), hirsutely pubescent : heads on scapiform 1-2-leaved stems: radical leaves spatulate (often broad and short, with a long narrowed base or petiole): involucral bracts rather broadly lanceolate. - Bot. King Exp. 145, t. 17. Aplopappus florifer, var., Hook. \& Arn. Bot. Beech. 351 ? - Rocky ridges in the mountains, Nevada and Modoc Co., N. E. California, Watson, Lemmon, Mrs. Austin. Flowering early: a winter annual or biennial.

Var. cauléscens, Laton, 1. c. A summer form, more slender and sparingly leafystemmed, with rather smaller heads. - Nevada, in Monitor Valley, Watson.

Var. ambígua, Grar, 1. c. More leafy-stemmed from a slender root, fully a span high: rays white: pappus of the ray sometimes little more than half the length of that of the disk. - Rabbit Valley, Ltah, at 7,000 feet, Ward.

+ + Pappus of the ray setose-squamellate, shorter than the breadth of the akene-

T. Watsóni, Grax, 1. c. Somewhat cinereous with a close short pubescence : stems 4 to 7 inches high from a slender root, spreading, nearly all branching above and sparsely leafy, therefore bearing numerous short-pedunculate heads: leaves narrowly spatulate and oblanceolate : involucral bracts oblong-lanceolate : hairs of the akene rather shorter and obtuse or at length 2-3-dentate at tip. - T. strigosa, Eaton, Bot. King Exp. 145, not Nutt. - Great Salt Lake, Utah, on the shore of Stanbury Island, June, Watson.

+ + Hairs on the akene, or most of them, glochidiate-capitellate, i. e. obtusely bidentate at apex, and the apparently somewhat glandular lobes recurved or revolute, thus appearing to be minutely depressed-capitate under a lens.

* Head large, three-fourths to a full inch long (without the rays): plants green and glabrate, depressed-acanlescent from a peremial root, with habit of $T$. sericea : leaves large, much surpassing the head, minutely sericeous-pubescent when voung, in age with only some ciliate or other hairs toward the attenuate petiole-like base, plane and coriaceous: involucre well imbricated.

T. Wilcoxiána, Woon. Leaves linear-spatulate, elongated (1 to 3 inches long including the petiole-like base): head mostly solitary, sometimes an inch long, short-peduncled or subsessile: bracts of the involucre lanceolate or the inner linear, barely acutish : ray and disk-pappus of similar slender and elongated bristles, - Bull. Torr. Club, vi. 163, \& Bot. Gazette, iii. 50. - Colorado, in the San Luis Mountains, E. K. Smith. Indian Territory, Dr. Wilcox. Patagonia Mumntains, A rizona, Lemmon.

T. Rothróckii, Gray. Leaves more broadly spatulate and shorter (inch or less long), rosulate around the solitary head which is closely sessile at the surface of the ground, or at length with one or two additional heads and tufts from the same crown: involucre shorter and broader; its bracts oblong, mostly obtuse : ray-pappus of squamellate bristles not longer than the breadth of the akene, or with one or two more elongated. - Rothrock, in Wheeler Rep. vi. 148, t. 7 ; Proc. Am. Acad. xvi. 85. - Mountains of South Park, Colorado, in the alpine district, at 13,500 feet, Rothrock, J.D. Allen.

+ Heads from three fourths down to one third of an inch long, sessile, or rarely on a very short naked peduncle: plants sericeous- or strigulose-pubescent, depressed-acaulescent or lowcaulescent: involucre well imbricated: ray-pappus mostly plurisetose.

T. serícea, Hook. Depressed-acaulescent perennial, with closely sessile solitary or few heads on the crown next the ground, surrounded and surpassed or equalled by the linear or linear-spatulate leaves, at length multicipital and pulvinate-tufted, an inch or two high: head an inch or less long: involucral bracts narrowly lanceolate, mostly acute: rays white or purplish-tinged: pappus of the ray pluirisetose like that of the disk (forma papposa, Gray, Pl. Fendlit), or of fewer but similar bristles, or (in the northern part of its range) with most of the bristles short and aristiform, and even reduced to squamellæ little longer than the width of the akene. - Fl. ii. 16, t. 119; Torr. \& Gray, Fl. ii. 185; Gray, Pl. Fendl. 69 ; Meehan, Nat. Flowers, ser. 2, i. t. 47 ; Gray, Proc. 1. c. 85. Aster? exscapus, Richards. Appx. Frankl. Journ. 32. - On dry hills, plains, or mountains, Saskatchewan to Rocky Mountains in lat. $54^{\circ}$, thence south to New Mexico and Arizona; fl. April and May. - Varies from 
large-headed, comparatively broad-leaved, and glabrate forms (which may almost pass into the two preceding species), to a narrowly leaved and more sericeous form with head barely two-thirds inch long, as in the original northern specimeus (both grow together in ('olorallo, "the latter flowering two weeks later"), or sometimes even yet more reduced, so that the heads are barely half-inch long.

Var. leptótes, Gray, is an ambiguous form from Middle Park, Colorado (Parry), with heads less than half-inch long, and all but the primary ones somervhat distinctly pedunculate: leaves narrowly linear with attenuate base. Perhaps a distinct species.

T. Arizónica, Grar. Depressed subcaulescent and multicipital, or branching from a perennial root, forming a lax pulvinate tuft of 2 or 3 inches high, minutely sericeous-canescent: leaves spatulate, short (about half-inch long), seldom surpassing the barely sessile and mostly foliose-fulcrate hemispherical heads (these merely half-inch high) : bracts of the involucre lanceolate, mostly obtuse : pappus of ray and disk alike and of equal length, rather rigid, about the length of the akene (2 or 3 lines long). - Proc. Am. Acad. xvi. 85. - Arizona, adjacent Utah (Palmer), and N. W. New Mexico, Coues \& Palmer, MI. E. Jones, Matthews.

T. incána, Nстт. Depressed-caulescent or subcaulescent from a winter annual or perennial root, an inch to a span high, branching, strigulose-cinereous or canescent: leaves frum narrowly spatulate to almost linear; uppermost fulcrate around the sessile (about half-inch) heads and seldom surpassing them: involucral bracts more sericeous and ciliate and less obtuse than in the foregoing: pappus of the ray from a third to half the length of that of . the disk. - Trans. Am. Phil. Soc. 1. c. T. Fremontii, Torr. \& Gray, in Jour. Bost. Nat. Hist. Soc. v. 108, where the heads are wrongly said to be larger than those of $T$. sericea. Mountains of Wyoming to S. Utah and the borders of S. Nevada; first coll. by Nuttall.

+++ Heads about one-third inch long, sessile among the rosulate lerves: herbage softlanate: pappus deciduous in a ring! - Urophorus, Nutt.

T: spathuláta, NLTT. Depressed and multicipital from a slender perennial root, forming a tuft an inch or so high: leaves crowded, spatulate, densely villous-lanate; the upper about equalling the heads: bracts of the involucre oblong-lanceolate, acute: rays rather short, pinkish: pappus of ray and disk similar and of the same length, of slender bristles. Trans. Am. Phil. Soc. 1. c. - Rocky Mountains in Wyoming; on the Black Hills of the Platte, Nittall, and Wind-River Mountains, Parry.

+++ Heads small, only a quarter-inch high (exclusive of the rays), mostly short-pedunculate, hemispherical: involucre of few-ranked broadly lanceolate and barely acute bracts: caulescent and branching (at least in age) and summer-flowering: pappus of the (sometimes infertile but feminine) ray shorter, commonly setose-squamellate.

$$
=\text { Green and glabrate, perennial. }
$$

T. glabélla, GrAy. An inch or two high from a slender rootstock, nearly simple, sparsely pilose-pubescent when young: leaves thickish, soon glabrous, spatulate (an inch or less long, including the usually slender petiole); the uppermost usually surpassed by the slender and naked (sometimes inch-long) peduncle: involucre glabrous: pappus of the ray in one specimen plurisetose and nearly half the length of that of the disk, in another reduced to short squamellæ. - Proc. Am. Acad xvi. 86. - Pagosa, S. W. Colorado, Neuberry.

$==$ Cinereous with fine and close somewhat strigulose pubescence, flowering from near the ground at first, but becoming taller ( 4 to 10 inches ligh) and loosely branching: pappus of rayakenes always reduced to a crown of short squamella, with rarely one or two short bristles. (Species hardly distinct.) - $\$$ Nanodia, Nutt.

T. Féndleri, Gray. Root slender, but apparently perennial leaves linear: bracts of the involucre unequal, in about 3 ranks, acutc. - Pl. Fendl. 70, \& Proc. Am. Acad. 1. c. Gravelly hills, New Mexico and S. Colorado, fl. May to Sept.; first coll. by Fendler.

T. strigósa, Nctr. Winter annual, with slender root, flowering when only half-inch high, often attaining a span in height: early leaves spatulate; later ones linear: heads rather smaller: bracts of the involucre broader, acutish, in about 2 ranks, the outer shorter. Trans. Am. Phil. Soc. 1. c.; Gray, PI. Fendl. 1. c. - Gravelly hills and plains, Wyoming to New Mexico and Arizona; first coll. by Nuttall.

T. MexicAna, Gray, Pl. Fendl. 70 (from about Saltillo, \&c., Mexico, Gregg, Parry, Palmer, and from farther south, Galeotti), differs slightly from the last in having the two ranks of involucral bracts of equal length and all very obtuse. 
44. CORETHRÓGYNE, DC. (Kó $\rho \theta \rho o v, ~ \gamma v v '$, besom-style, from the brush-like tuft of bristles on the style-appendages.) - Rather low and Aster-like Californian perennials, whitened, at least when young, with cottony tomentum; the stem or branches terminated by solitary somewhat large and showy heads: rays violet-blue or purple: disk yellow, often changing to purplish: pappus tawny or ferruginous: peduncles, with the bracts, \&c., usually glandular under the wool : leaves sessile, entire, or merely serrate. Fl. summer. - Prodr.v. 215; Nutt. in Trans. Am. Phil. Soc. vii. 290 ; Torr. \& Gray, Fl. ii. 97 ; Gray, Bot. Mex. Bound. 76, Proc. Am. Acad. vii. 351, \& Bot. Calif. i. 320.

* Heads pretty large and broad, disposed to be solitary, terminating a simple stem or simple branches : involucre hemispherical, half-inch or more in diameter; its bracts little unequal and outer ones largely herbaceous: style-appendages strongly comose.

C. obováta, Benтr. Stems decumbent from spreading rootstocks, a foot or two long: leaves obovate or spatulate, obtuse, sparsely serrate or dentate above; those of the ascending branches small, from oblong to linear-lanceolate: rays violet, varying to white suffused with pink. - Bot. SuIpl. 22. C. spathulata, Gray, Proc. Am. Acad. vii. 317, \& Bot. Calif. l. Ł. Coast of California, from Bodegas (where it was first coll. by Hinds) to Humboldt Co., Bolander, Kellogg, \&c.

C. Califórnica, DC. Stems erect or ascending: leaves linear and entire, or the lowest lanceolate-spatulate and few-toothed: sometimes a few bracts on the receptacle, like the innermost of the involucre, subtending outer flowers: rays violet or purple. - l'rodr. v. 215; Gray, Bot. Calif. i. 321. C. Californica \& C. incana (the common state, with no bracts on the receptacle), Nutt. 1. c.; Torr. \& Gray, 1. c. - California, along and near the coast, Monterey to San Diego ; first coll. by Douglas.

* * Heads smaller, solitary and terminating the branches, or often more numerous and loosely paniculate: involucre campinulate or broadly turbinate, much imbricated; the bracts mainly appressed, outer ones successively shorter; all with short green tips: style-appendages scantily comose.

C. filaginifólia, NUTт. Stems slender, erect or ascending, a foot or two high, commonly bearing few or (when depauperate) even solitary heads : leaves oblanceolate-spatulate and few-toothed or entire; upper often linear or reduced and bract-like on the branchlets; the white tomentum usually persistent, or when deciduous the branchlets and involucre little if at all glandular: rays violet. - Trans. Am. Phil. Soc. vii. 290; Gray, Bot. Mex. Bound. 76, \& Bot. Calif. 1. c. Aster? filaginifolius \& A. tomentellus, Hook. \& Arn. Bot. Beech. 146. Diplopappus leucophyllus, Lindl. in DC. v. 278. Aplopappus (Pyrochaetn) H(enkei, DC. 1. c. 349. Corethrogyne filaginifolia \& C. tomentella, Torr. \& Gray, Fl. ii. 99. - Common through the western and southern parts of California from Monterey southward; flowering at almost all seasons, varying greatly. The following are the more extreme forms.

Var. virgáta, GraY. Slender, becoming glabrate and greener in age, often bearing numerous heads in a very open panicle: involucre and naked branchlets disposed to be glandular-viscidulous. - Bot. Calif. 1. c. C. virgata, Benth. Bot. Sulph. 23. - Common from Monterey southward ; first coll. by Hinds and by Fremont.

Var. rígida. A stouter and rigid form, either very white-tomentose or in age glabrate, then viscidulous-glandular: leaves from spatulate-lanceolate to oval or obovate: heads commonly numerous and paniculate. - C. incana, var. rigida, \&c., Benth. Pl. Hartw. 316. C. tomentella, Durand, Pacif. R. Rep. r. App. 8. C. filaginifolia, var. tomentella, Gray, Bot. Calif. 1. c., in part. - Dry and open ground, Monterey to San Bernardino ro.

C. Detónsa, Greene in Bull. Torr. Club, x. 41 (Bull. Calif. Acad. i. 223), appears to be Diplostephium (Aplostephium) canum, Gray, Proc. Am. Acad. ii. 75, of Lower California, and not of this genus.

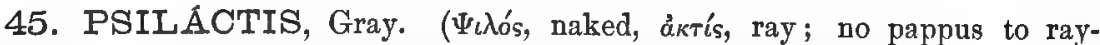
flowers.) - Texano-Mexican annuals, minutely pubescent, or glandular, or glabrate; with slender and loosely paniculate-branching stems, pinnatifid or incised lower leaves tapering into a petiole, and narrow often entire upper ones; the 
heads small, terminating the branches, with violet or purplish or white rays; these usually infertile: fl. summer. - Pl. Fendl. 71; Benth. \& Hook. Gen. ii. 269 .

P. Coúlteri, Gray, 1. c. Branched from near the base, glabrous or obscurely hispidulouspuberulent, or the rigid spreading flowering branchlets, granulose-glandular : leaves all short, rigid, mostly incisely dentate, those of the branchlets minute: involucral bracts oblong or broadly lanceolate: rays conspicuous (quarter-inch long) and rather broad: pappus copious. - S. Arizona, Palmer, Lemmon, Pringle, \&c. Mohave Desert, California, Parish, Conlter, \&c. (Adj. Mex.)

P. asteroídes, GRAY, l. c. Scabro-puberulent, a foot to a yard high from a plainly annual root: lower leares spatulate or oblong, sometimes laciniate-pinnatifid, sometimes barely dentate; upper mostly linear and entire: involucral bracts lanceolate or linear : ravs smaller and narrower: pappus less copious. - S. W. Texas to Arizona, Wright, \&c. (Adj. Mex.)

P. Brevilisgrláta, Schultz Bip., of Mexico, the remaining species, resembles P.asteroides, but is more slender, with narrower leaves, smaller heads, and small rays which hardly surpass the pappus.

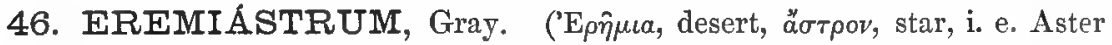
of the desert.) - Pl. Thurb. in Mem. Acad. v. 320 ; Benth. \& Hook. Gen. ii. 270; Torr. in Pacif. R. Rep. v. 361, t. 6. - Single species.

E. bellioídes, Gray, l. c. Small winter annual, diffusely branched from the rery base and depressed, hirsutely hispid throughout: leaves linear-spatulate, entire (half-inch long); those at the summit of the flowering branches loosely rosulate-involucrate around the solitary heads, and passing into involucral bracts: rays oblong-linear, white, acutely 2-3-dentate at the apex, 4 lines long: disk yellow. - On the desert near the Rio Colorado, borders of California and Arizona; fl. January and February, Thurber, Newberry, Schott, Palmer, W. G. Wright, \&c., and borders of S. Utah, Parry. - Seldom, if ever, are the bristles of the pappus combined in clusters so as to form laciniate paleæ.

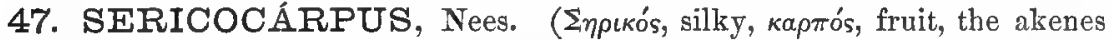
sericeous-pilose.) - Perennial herbs, of low or moderate stature (all N. American); with alternate commonly entire and sessile leaves, and small heads usually fascicled in a terminal compact cyme; both disk and ray white or whitish, or the latter changing in age to purplish: fl. midsummer. - Nees, Ast. 148 ; DC. Prodr. v. 261 ; Torr. \& Gray, Fl. ii. 101 ; Benth. \& Hook. Gen. ii. 270.

* Pappus ferruginous: leaves sparingly serrate, comparatively thin and veiny, and the radical ones large.

S. conyzoídes, Nees, l. c. A foot or two high, and slightly pubescent or glabrate: radical and lower cauline leaves spatulate ( 2 to 5 inches long, tapering into a margined petiole), obtuse; upper ones oblong-lanceolate: involucre turbinate, 18-20-flowered: rays rather short and broad. - Conyza asteroides, L. Spec. ii. 861. Aster Marylandicus (Pluk. Mant.), Michx. Fl. ii. 108. A. conyzoides, Willd. Spec. iii. 2043. - Dry woodlands, common from Maine to Ohio and south to Florida.

* * Pappus white: leaves entire, firmer, smaller, obscurely veined, disposed to be vertical, mostly - obtuse: green tips of involucral bracts short, seldom squarrose: stems more leafy.

- Atlantic species: akenes short, canescent-sericeous.

S. solidagíneus, NeEs, 1. c. Green, almost glabrous: stems strict and slender, 2 feet high, acutely striate-angled: leaves from linear to spatulate-lanceolate, an inch or two long. heads mostly glomerate and sessile, narrow, rather few-flowered: involucral bracts oblong, very smooth and rigid : rays at length elongated. - Conyza linifolia, L., 1. c. Aster Amerlcanus albus, \&c., Pluk. Alm. t. 79, fig. 2. A. solidagineus, Michx. 1. c. A. solidaginordes, Willd. I. c. Galatella obtusifolia, Lehm. Ind. Sem. Hamb. 1837. - Moist woodlands, Canada to Tenvessee, Alabama, and Louisiana. 
S. tortifólius, NeEs, 1. c. Cinereous-puberulent and somewhat scabrous : stems not angled, a foot or two high: leaves conspicuously vertical by a twist, obovate or spatulate, short: heads more corymbosely cymose and most of them pedicellate, somewhat turbinate: involucral bracts more numerous and narrower, the innermost linear, puberulent : rays small. Conyza bifoliata, Walt. Car. 204. Aster tortifolius, Michx. 1. c.; Ell. Sk. ii. 341. A. scalrosus, Bertol. Misc. Bot. vii. t. 5. A. (Leucocoma) Collinsii, Nutt. Jour. Acad. Philad. vii. 82, a form with leaves sparingly crenate-serrate (S. tortifolius, var. Collinsii, Torr. \& Gray, Fl. ii. 102). - Dry pine woods and barrens, Virginia near the coast to Florida and Louisiana, flowering later than the others.

+ + Pacïfic species: akenes more slender, less canescent.

S. rígidus, LINDL. Green, from scabrous-pubescent to nearly glabrous : stems a foot or two high, somewhat striate-angled: leaves oblong-lanceolate (an inch or two long), acute or obtuse, hardly rigid : heads crowded, either short-pedicelled or glomerate, somewhat turbinate, about 15-flowered: involucral bracts rather narrow and one-nerved: rays small and short, but sometimes surpassing the disk. - Hook. Fl. ii. 14, \& DC. l. c.; Gray, Bot. Calif. i. 320. S. Oreconensis, Nutt. Trans, Am. Phil. Soc. n. ser. vii. 302, a form with larger rays and rather large leaves. - Woods, Washington Terr. to the Sierra Nevada, California.

48. ÁsterR, Tourn. Starwort, Aster. ('A name for these and similar radiate-flowered and Daisy-like plants.) - Herbs, mainly of the northern hemisphere, and especially of North America, the larger part perennial : fl. late summer and autumn. The yellow disk-flowers in several species change to purple or rose-color. - L. Gen. ed. 1, 254; DC. Prodr. v. 261; Torr. \& Gray, Fl. ii. 103 ; Benth. \& Hook. Gen. ii. 271, at least as to American species; Gray, Proc. Am. Acad. xvi. 97, \& xvii. 164.

The line between Aster and Erigeron is arbitrary. Aster is far the most difficult of our genera, both for the settlement of the names of the species and for their limitation, in respect to which little satisfaction has been attained as the result of prolonged and repeated studjes. For full reasons why the following Linnæan species subside, see Proc. Am. Acad. xvii. supra cit.

A. orvarićátus, L. Founded, as to the specimen in the herbarium, upon the upper part of a plant of A. corymbosus, Ait., wanting the cordate serrate leaves; as to the plants of Plukenet and Gronovius, upon $A$. infirmus, Michx.

A. Rigidus, L. Founded wholly upon Clayton's plant as described in Fl. Virg.; is a mere synonym of $A$. linariffolius, L.

A. Linifólics, L., and A. HYssopifólios, L. Mant., belong to Galatella, and are not American. The plant of Gronov. Fl. Virg., referred to, is $A$. tenuifolius, L.

A. ÁNuUs, L., is well known as Erigeron annuus.

A. VÉRxus, L., is Erigeron nudicaulis, Michx.

A. mutABILIs, L. Not to be found in the Linnæan herbarium. In the first ed. of the Spec. Pl. was compared with an "A. serotinus," which was nęither published nor preserved in the herbarium, has as a synonym a plant figured by Plukenet which is not preserved in his herbarium: finally, in ed. 2, the character was reconstructed in a manner incompatible with the original one, and before the Plukenetian synonym "Herm. Hort. Lugd. t. 67" was introduced, which, on the authority of the herbaria of Royen and of Sherard, is A. lavis, L., and the comparison was changed to one with A. Tradescanti, L. A. mutabilis of later authors belongs to oldernamed species.

A. Míser, L. Founded wholly upon a much exaggerated figure in Dillenius, with fictitious character, drawn from the plate. See A. vimineus, var. foliolosus.

A. cluiftus, Walt. Car. 209, is not at all identified.

Series I. Perennials, with multicipital rootstocks or caudex, usually multiplying by creeping subterranean shoots.

§ 1. Amellástrum. Bracts of the broad involucre 2-3-serial, of slightly unequal length; outer foliaceous or herbaceous-tipped: akenes broad, obovate, 
compressed, mostly flat' and with callous marginal nerves only: pappus simple, or with an indistinct short outer series. - Gray, Proc. Am. Acad. xvi. 97. Consists of $A$. Amellus and the following, of less marked character.

A. alpinus, L. A span or more high, with simple erect stems from a thickish caudex, bearing a single large head, cinereous-pubescent: leaves entire, somewhat 3-nerved, spatulate; upper small and linear: involucral bracts loosely erect, oblong-linear, herbaceous, all nearly equalling the disk: rays violet: akenes hirsute: usually a manifest short outer pappus. Spec. ii. 872; Jacq. Fl. Austr. t. 88; Bot. Mag. t. 199 ; Hook. Fl. ii. 6. - Arctic shores, Pelly. Alpine region of northern Rocky Mountains, down to about lat. $49^{\circ}$, Drummond, Burke, Bourgeau, Macoun. The American plant mostly with fewer and shorter rays. (Ev., N. Asia.)

§ 2. Megal Sstrcy. Head very large (an inch in diameter exclusive of the large and numerous rays, pedunculate and solitary, terminating rigid branches) : bracts of the hemispherical involucre imbricated in 2 or 3 unequal series, somewhat herbaceous, gradually attenuate-acuminate: akenes oblong, compressed, 2-4-nerved: pappus-bristles unusually coarse and rigid, rather scanty. - Gray, Pl. Wright. ii. 75. (Related to subsection Xylorrhiza and to Townsendia.)

A. Wríghtii, Gray, 1. ¿. Viscous-pubescent, a foot or more high : leaves oblong-spatulate, setiferous-mucronate, entire, or with one or two setiferous teeth, an inch and a half long including the margined petiole, thickish, obscurely reined: bracts of the involucre ovatelanceolate or the inner narrower, rather lax, viscid, slightly scarious-margined, the caudateacuminate tips surpassing the disk: rays purple, narrowly obloug, 30 to 40 ( 8 or 9 lines long): akenes (young) loosely pubescent: pappus white, of unequal strongly denticulate bristles, the larger almost aristiform. - Townsendia (Mryulustrum) Wrightii, Gray, Bot. Mex. Bound. 78. - Rocks and stony hills on the Rio Grande, S. W. Texas, from the mouth of the great cañon, Wright, Bigelow.

A. tortifólius, Gray. Tomentose-pubescent, at length glabrate, 2 feet high: leaves from oblong to narrowly lanceolate, rigid, spinulosely dentate and acuminate, sometimes incisely pinnatifid, veiny: involncral bracts narrower and more numerous, lanceolate-subulate, rigid, the longest barely equalling the disk : rass pale purple or violet, often an inch long: akenes sericeous-canescent: pappus at length ferruginous, deciduous in a ring. - Proc. Am. Acad. vii. 35.3, \& Bot. Calif. i. 323, not Michx. Aplopappus tortifolius, Torr. \& Gray, Jour. Bost. Soc. Nat. Hist. v. 109. - Mountains bordering the Mohave Desert, S. E. California to S. Utah, fremont, Newberry, C'ooper, \&c.

§3. Hereástrcy. Heads mostly smaller: pappus (simple) unusually coarse and rigid, the stronger bristles somewhat clavellate at tip: bracts of the involucre partly or the outer wholly foliaceous and linear-lanceolate, rigid, imbricated in several series, but the outermost little shorter than the inner: receptacle alveolate or fimbrillate: style-appendages filiform-subulate: akenes narrow and mostly slender, little compressed, 8-10-nerved, nearly glabrous: leaves all linear and entire or with some spinulose teeth, rigid, one-nerved and with obscure lateral nerves: rays numerous and elongated: pappus ferruginous or tawny. - Gray, Proc. Am. Acad. xvi. 97. Heleastrum, DC. Prodr. v. 263.

* Leaves as if gramineous, and bearing some spinuliform serratures or denticulations, mostly cuspidate at tip, smooth and glabrous: stems simple from a tuberiform rootstock, strict and slender, rigid, 2 feet high, pilose below, or the base of the leaves ciliate with some long and jointed hairs: flowering in summer.

A. eryngiifólius, Tonr. \& Gray. Stems hearing solitary or 2 or 3 large heads : leavcs mostly lanceolate-linear ( 2 or 3 lines wide, the larger 4 inches long, upper ones gradually reduced to erect bracts) : involncre hemispherical, very many-flowered; its bracts linearlanceolate, attenuate into an almost setiform cusp : rays an inch long, pale blue or white.- 
Fl. ii. 502 ; Chapm. Fl. 199. Prionopsis? Chapmanii, Torr. \& Gray, 1. c. 245.-Low pine barrens on the coast, Florida, Chapman, Rugel, Mohr.

A. spinulósus, Снарм. Stem bearing few or several spicately disposed smaller heads : leaves narrowly linear, attenuate (half to 2 lines wide); the lower and radical 6 to 12 inches long, upper gradnally reduced to setaceous-subulate appressed bracts; the margins merely spinulose-denticulate or mostly entire: involucre campanulate, its bracts mostly subulate from a broad base: rays half-inch long, pale violet. - Fl. 199. - Damp pine barrens, W. Florida near the coast, Chapman.

* * Leaves all entire, thickish: pubescence if any short and scabrous: flowering in autumn.

A. paludósus, Art. Stems sometimes branching, a foot high, bearing few or several often racemosely or spicately disposed heads (of half-inch height): leaves from broadly to narrowly linear (1 to 4 lines wide, 2 to 4 inches long): involucre nearly hemispherical; its bracts more unequal, the outer lanceolate-subulate and lax, inner linear-spatulate with herbaceous merely acute tips: rays rather short, deep violet. - Hort. Kew. iii. 201 ; Ell. Sk. ii. 343 ; Torr. \& Gray, Fl. ii. 109 ; Chapm. l. c. A. grandiflorus, Nutt. Gen. ii. 156, not L. Tripolium paludosum, Nees, Ast. 155. Heleastrum paludosum, DC. Prodr. v. 264.-Wet pine barrens in the low country, N. Carolina to Texas, Arkansas, and Missouri.

§ 4. Hesper Astrum. Heads with neutral rays: bracts of the campanulate involucre well imbricated and unequal, the outer with short herbaceous spreading tips * style-appendages slender-subulate: akenes narrow, hardly at all compressed, 5-nerved and with intermediate striæ: pappus simple and soft. - Gray, Bot. Calif. i. 323, \& Proc. Am. Acad. xvi. 97. (Resembling on the one hand \$ Machceranthera, and Corethrogyne on the other.)

A. Shasténsis, Grat, l. c. A span or two high, in small tufts from a perennial root, paniculately branched, sleuder, canescently puberulent: leaves eutire, an inch or less long: lower spatulate; uppermost linear and reduced to subulate bracts: heads rather numerous, scattered: involucre (nearly half-inch high) somewhat viscid-glandular; its bracts lanceolate or linear, mostly with acute and spreading green tips: rays 12 to 20, violet, 3 to 5 lines long, occasionally (var. eradiatus) wanting. - Macharanthera (Hesperastrum) Shastensis, Gray, Proc. Am. Acad. vi. 539. - California: on Mount Shasta, above and below the limit of trees, first coll. by Brewer, and on Lassen's Peak, Mrs. Austin. The rayless state on Scott Moun. tains at 9,000 feet, Greene.

§ 5. Biótia. Heads (small or middle-sized) corymbosely cymose: bracts of the campanulate well-imbricated involucre subcoriaceous and wholly appressed, obtuse and merely greenish or thickish but not spreading at the tip (transition to $\$$ Orthomeris, but passing into the succeeding subsection): outer successively shorter: rays not numerous (6 to 18 ), white or purplish-tinged: style-appendages subulate-lanceolate: akenes 3-several-ribbed or nerved, hardly or moderately compressed, mostly linear: pappus slightly rigid, simple: radical and lower cauline leaves cordate, on long naked petioles, ample, conspicuously serrate and acuminate: fl. midsummer and early autumn. (Other Asters with cordate petiolate leaves are only the Heterophylli.) - Torr. \& Gray, Fl. ii. 104. Biotia, DC. Prodr. v. 264.

A. corymbósus, AIt. Stem slender, 2 feet high, sometimes flexmous, terete: leaves membranaceous, much longer than wide, gradually or very prominently acuminate and acuminately serxate: involucre only one-fourth inch high, little sûrpassing the rather broadly compressed fusiform akenes: rays 6 to 9, white. - Kew, iii. 207; Willd. Spec. iii. 2036; Torr. \& Gray, 1. c. A. divaricatus, L. Spec. ii. 873, as to herb., excl. syn. Gronor. \& Pluk. (which relate to $A$. infirmus), and cordate leaves not described; name to subside, $A$. cordifolius, Michx. Fl. ii. 114, in part. Eurybıa corymbosa, Cass. Dict. xxxvii. 487; Nees, Ast. 143 ; Lin 1 . Bot. Reg. t. 1532. Biotia corymbosa, DC. 1. c. 265. - Woodlands, Canada to upper part of Georgia. 
A. macrophyllus, L. Stem stout, somewhat striate-angled, 2 or 3 feet high: leaves thickish, serrate with proportionally smaller and broader less salient teeth, abruptly acuminate ; radical and lowest usually broadly ovate- or even reniform-cordate ( 4 to 10 inches loug) ; upper ovate to oblong, often wing-petioled, and uppermost sometimes sessile by a broad base: involucre commonly 5 lines bigh, often viscid-puberulent, in fruit nuch surpassing the fusiform-linear obscurely compressed akenes: rays 10 to 15 , white or tinged with bluish purple. - Spec. ed. 2, ii. 1232; Willd. 1. c.; Torr. \& Gray, 1. c. Eurybia macrophylla \& E. Jussiei, Cass. Dict. l. c. E. macrophylla (larger-leaved and more scabrous form), glomerata, \& Schreberi (thinner-leaved form in shade and drier soil), Nees, Ast. 140. Biotia Schreberi, latifolia (A. latifolius, Desf. Cat., form approaching A. corymbosus), glomerata, \& macrophylla, DC. l. c. - Woodlands, commonly in damp or rich soil, from Canada and Manitoba to the mountains of Georgia. Vrable species; of which forms with smaller heads and thinner leaves appear to pass into A. corymbosus. A robust form, with large heads, more glandular inrolucre and peduncles, upper leaves ovate and sessile, lower and petioled cauline leaves all rounded at base, and most of the radical ones little cordate ( $A$. macrophyllus of Willd. herb. chiefly, the rays perhaps violet), comes near the next following.

§6. Aster proper. Heads various: bracts of the involucre (or at least the outer ones) with green herbaceous tips or appendages, or wholly or partly foliaceous, imbricated or pluriserial, their margins not scarious : akenes from obovateoblong to linear, 3-several-nerved: pappus rather fine and soft, or in the first subsection more coarse and rigid, simple, i. e. with no exterior setulose series. $\S$ Aster proper, with part of Oritrophium \& Calliastrum, Torr. \& Gray, Fl. Probable hybrids abound.

* 1. Involucre well imbricated; the bracts appressed and coriaceous, with short and abrupt mostly obtuse herbaceous or foliaceous spreading tips (the ontermost sometimes loose and more foliaceous): akenes narrow, 5-10-nerved, from minutely pubescent to glabrous: pappus mostly more rigid than in any of the following: rays showy, blue or violet: leaves of firm texture, more or less scabrous (the last species excepted), none of them cordate or clasping ( $\$$ Calliastrum, Tort \& Gray, Fl. ii. 106, excl. spec.).- SPECTABILEs.

- Radical and lowest canline leaves ovate or ovate-oblong, some with rounded base, or even subcordate: heads half-inch high: involucre nearly hemispherical; the green tips of the involucral bracts very short and either indistinct and erect or abruptly spreading: stems a foot or two high. Transition to Biotia, possibly hybrids of the preceding species with true Asters, being local and rare, but if so the other parent not at all determinable.

A. mirábilis, ToRr \& GraY. Scabrous-pubescent, bearing few or several somewhat paniculate heads: leaves all ovate or oval, finely and acutely serrate, hispidulous-scabrous above; upper small and roundish, lower abruptly contracted into margined petioles (true radical not seen): involucre nearly smooth and glabrous, neither glandular nor viscid; its bracts with roundish-obtuse abrupt and very short squarrose-spreading tips: rays about 20, half-inch long, violet: pappus ferruginous. -F1. ii. 165. - Near Columbia, S. Carulina, Gibbes, Sept., 1835 , not since collected.

A. Hervéyi, Grax. Slightly scabrous, the corymbose branches and short peduncles glandular-paberulent: leaves minutely or obscurely serrate; radical and lowest cauline ovate on slender naked petioles; upper lanceolate: heads loosely corynubiform-cymose: involucral bracts all erect and with less distinct close tips, pulverulent-glandular ; the short outer oblonglinear: rays 15 to 24 , narrow, half-inch long, lilac or violet. - Man. erl. 5, 230. Eurybia commixta, Nees, Ast. 143. Biotia commixta, DC. Prodr v. 265 (excl, syn. ?), is a robust cultivated form of this, which has long been in the gardens, of unknown origin. - Borders of oak woods, E. Mass. and Rhode Island, near the coast, Hervey, Sargent, \&c. Grows in company with $A$. macrophyllis and $A$. spectabilis, evidently most related to the former, both in foliage and involucre: fl. Aug., Sept.

+ - Radical leaves all tapering at base into winged or margined petioles.

+ Involucre squarrose by the spreading or recurving herbaceous tips of the bracts: akenes slender, slightly pubescent: leaves obscurely veined, slightly scabrous : rootstocks slender and creeping: stems low, bearing few or several (rarely solitary) short-peduncled and showy heads. Atlantic U. S. species. 
A. spectábilis, Aıт. A foot or more high, bearing several somewhat paniculate or cymose heads: leaves oblong-lanceolate or the lower spatulate- or oval-oblong, obscurely serrate or the upper entire: involucre hemispherical, half-inch high; the bracts glaudular-pubexulent and somewhat viscid, upper half of most of them herbaceous and recurved-spreading: rays numerous, three-fourths inch long or more, bright violet. - Kew. iii. 209 ; Nutt. Gen. ii. 157; Nees, Ast. 42 ; Lindl. Bot." Reg. t. 1527 ; Torr. Fl. N. Y. i. 336, t. 51. A. elegans, Willd. Spec. iii. 2042 (ex. char, and mainly herb.); Wenderoth in Act. Soc. Nat. Marb. ii. 17. $A$. speciosus, Hornem. Hort. Hafn. ii. 816, fide DC. - Sandy soil, Massachusetts to Delaware, near the coast, and perhaps farther southward, where it is replaced by the next.

A. surculósus, Micix. A foot or less high from long filiform rootstocks, bearing solitary or few pedunculate heads, which are generally smaller than those of $A$. spectabilis, but not dissimilar: leaves entire or nearly so, rigid, lanceolate or the upper linear and the radical oblong-lanceolate: involucre sometimes puberulent, but hardly glandular. - Fl. i. 112; Nutt. Gen. ii. 157 ; Ell. Sk. ii. 354, ex char.; Nees, Ast. 40; Torr. \& Gray, Fl. ii. 109. - Moist rocky and gravelly ground, or sometimes in sand, coast of New Jersey to Georgia, and on the Blue Ridge in North and South Carolina, where it was first collected by Michaux, and where it abounds.

A. grácilis, Nutr. About a foot high, slender, from slender and occasionally tuberousthickened rootstocks, smoothish, not glaudular nor viscid, bearing few or several cymosely disposed small heads: leaves oblong-lanceolate, entire or nearly so, small (an inch or two long, 2 to 6 lines wide): involucre turbinate, a quarter or third of an inch long, glabrous, coriaceons and whitish, with very short deltoid or ovate green tips, only about 30-flowered: rays 9 to 12, a quarter to half an inch long: akenes rather short. - Gen. ii. 158; Torr. \& Gray, 1. c. - Piue barrens, New Jersey to N. Carolina, also E. Kentucky and Tennessee, according to Nuttall. The larger forms closely related to $A$. spectabilis, with which it is associated : the more slender ones nearly approach Sericocarpus.

+ Involucre hardly if at all squarrose; the tips of the bracts less definite and less spreading: stems very leafy: leaves pinnately veiny and reticulated, acutely serrate, more or less scabrous: hearts middle-sized, corymbosely cymose or rarely solitary: style-appendages rather short and thick: Northern and Western species.

A. rádula, Aıт. Nearly glabrous or with some scattered hairs: stem slender and strict, a foot or two high, bearing few or solitary mostly slender-pedunculate heads: leaves veiny, oblong-lanceolate or narrower, acuminate, somewhat hispidulous-scabrous, thinnish (inclined to be rugulose in drying, about 2 inches long, 3 to 9 lines wide), each margin with 3 to 7 serratures toward the middle; upper cauline sometimes oblong-ovate with subcordate sessile base: involucre nearly hemispherical, 3 or 4 lines high; its bracts in few series, obtuse, ciliolate: the outermost oblong, inner narrower, shorter than the disk: rays half-inch long, pale violet: akenes glabrous, striate-nerved. - Kew. iii. 210; DC. Prodr. 1. c. 230; Torr. \& Gray, Fl. ii. 106 ; Torr. Fl. N. Y. i. t. 50. A. nudiflorus, Nutt. Gen. ii. 157, a broaderleaved and most luxuriant southern form. Was cultivated in 1839 in the Berlin Garden as Brotia commita, var. stricta. - Swamps, Delaware to $\mathbf{E}$. Massachusetts, west to the mountains of Pennsylvania (Pocono), thence north to Nova Scotia and Newfoundland. Passes into

Var. stríctus. Reduced boreal form, a span to a foot high, with either oblong or narrowly lanceolate barely serrulate leaves, and solitary or rarely 2 or 3 heads. -4 . biflorus, Michx. Fl. ii. 111 ; Torr. \& Gray, 1. c. A. strictus, Pursh, Fl. ii. 556. - Higher mountains of New England to Labrador.

A. Sibíricus, L. A span to a foot high, often fastigiately branched from the base, somewhat cinereous-pubescent or puberulent, or the foliage scabrous : heads solitary, terminating the stem or corymbiform branches: leaves oblong-spatulate to broadly lanceolate, acutely more or less serrate (an inch or more, or in largest form even 3 inches long): involucre broally campanulate, 3 lines high, shorter than the disk; its bracts narrowly lanceolate, with mostly acute and loose herbaceous tips: rays 3 or 4 lines long, violet: akenes pilose-pubescent. - Spec. ii. 872 (Gmel. Fl. Sibir. ii. t. 80. f. 2), larger than American form; Herder in Radde, Reis. iii, 11, A. montanus, Richards. App. Frankl. Jour. 32; Torx. \& Gray, F1. ii. 107. A. Richardsoni, Spreng. Syst. iii. 528; Hook. Fl. ii. 7. A. Espenbergensis, Nees, Ast. 36. A. Prescottii, Lind! in DC. Prodr. v. 231. - Arctic coast and Alaskan Islands to Rocky Mountains in Wyoming and Montana. (N. F. Asia to Arctic Eu.) 
Var. gigantéus, A. Richardsonï, var. giganteus, Hook. l. c., and $A$. montanus, var. giganteus, Torr. \& Gray, 1. c., is a stout and large form, of the Arctic regions, nearly answering to the original $A$. Sibiricus, L., of Siberia.

A. radulinus, Grar. Between the preceding and the following, 10 to 20 inches high: leaves from oval-obovate to broadly lanceolate ( 2 to 4 inches long), serrate with numerous sharp teeth, scabrous: heads numerous, corymbosely cymoso: involncre broadly turbinate, 3 or 4 lines high; its bracts regularly imbricated and outer successively shorter, cinereouspubescent or glabrate, not glandular nor viscid, from broadly lanceolate or oblong to linear, abruptly acutish or obtuse: rays 3 to 5 lines long, pale violet, sometimes whitish : akenes minutely pubescent. - Proc. Am. Acad. viii. 388, \& Bot. Calif. i. 323. A. radulu, Less. in Linn. vi. 125, not Ait. - Dry ground, California, from Monterey northward, and in the Sierra Nerada to Oregon and Washington Terr.

A. conspícuus, Lrvol. Scabrous : stem 2 feet high, stout, rigid, bearing several or numerous corymbosely cymose heads : leaves rigid, ovate, oblong, or the lower obovate, acute, ample (commonly 4 to 6 inches long and $1 \frac{1}{2}$ to 4 inches broad), acutely serrate, rigid, reticulate venulose as well as veiny : involucre broadly campanulate, about equalling the disk, 5 to 6 lines high; its bracts in several series, minutely glandular-puberulent or viscidulous, lanceolate, acute, the greenish tips little spreading: rays half-inch long, violet: akenes minutely pubescent. - Hook. Fl. ii. 7, \& DC. Prodr. v. 230; Torr. \& Gray, Fl. ii. 107. Saskatchewan to British Columbia, and south to the Yellowstone in the Rocky Mountains; first coll. by Drummond.

$+\ldots$ Involucre very squarrose by the foliaceous widely spreading tips of the bracts, smooth and glabrous, as is also the foliage: heads large and paniculate: Alleghanian.

A. Curtísii, Torr. \& GraY. Almost wholly glabrous and smooth : stems 2 or 3 feet high, rather slender, the larger loosely paniculately branched; branches bearing scattered large heads : radical and lower leaves ( 3 or 4 inches long) ovate-lanceolate, acuminate, sparingly serrate, gradually or abruptly contracted into winged petioles; upper ones lanceolate and sessile, becoming entire : involucre hemispherical, equalling the disk, half-inch high; the much imbricated coriaceous bracts very conspicnously appendaged with foliaceous ovate or short-lanceolate tips, or the outer more than half foliaceous: rays rather broad, half-inch long or more, deep violet-blue : akenes compressed, broader upward and with narrowed apex, glabrous. - Fl. ii. 110. - Margin of woodlands, in dry soil, through the Alleghanies in N. Carolina and adjacent borders of Tennessee: very showy.

* 2. Involucre and usually branchlets viscidly or pruinose-glandular, therefore more or less graveolent, either well imbricated or loose: rays showy, violet to purple: akenes mostly severalnerred and narrow : pubescence not sericeous: leaves all entire or lower with few and rare teeth, except in the last species; cauline all sessile or partly clasping: true perennials, mostly multiplying by subterranean rootstocks or other shoots. (Glandular involucre also in species of \$ Machoranthera, some of which are short-lived perennials.) - GLa ndulosi.

+ Bracts of involucre rather well imbricated, commonly with more or less rigid appressed base and foliaceous or herbaceous tips: rays not extrentely numerous, from 15 to 40 .

* Stem simple: leaves and heads proportionally large: Rocky Mountain alpine or subalpine species.

A. integrifólius, Nuтr. Stem mostly a foot or more high, stout, sparsely leafy, villouspubescent but glabrate, bearing few or several racemosely or thyrsoidly disposed heads: leaves of firm texture, oblong or spatulate (the larger 4 to 7 inches long) or the smaller upper ones lanceolate, sometimes obsoletely repand-serrulate, apiculate, traversed by a strong midrib, venulose-reticulated, glabrate, half-clasping; lowest tapering into a long stout wingmargined petiole with clasping base: heads fully half-inch high, hemispherical : involucre and branchlets viscid-glandular; its bracts few-ranked, linear, ascending, not squarrose; the outer sometimes short and rather close, commonly larger and more foliaceous, nearly equalling the inner; these equalling the disk: rays 15 to 25 , bluish-purple, half-inch long: akenes compressed-fusiform, 5-nerved, and sometimes with intermediate nerves, sparsely pubescent: pappus decidedly rigid, - Trans. Am. Phil. Soc. n. ser. vii. 291 ; Torr. \& Gray, Fl. ii. 111; Gray, Bot. Calif. i. 324. - Open and moist subalpine woods or meadows, Montana to the Cascade Mountains in Oregon, south to Colorado, and along the Sierra Nevada, California, in the Yosemite, \&c.; first coll. by Nuttall. 
A. Kíngii, Eaton. A span or less high, cespitose : leaves mainly radical, spatulate, entire, or with few sharp teeth, mucronate, thinnish, glabrous or nearly so (1 to 3 inches long): flowering stems pubescent and above glandular, bearing solitary or 3 to 5 middle-sized heads: involucre somewhat campanulate, 4 or 5 lines high, merely puberulent-glandular, hardly at all viscid; the bracts linear-lanceolate with attenuate and squarrose-spreading green tips: rays less than 30, barely half-inch long, white: akenes narrow, pubescent. - Bot. King Exp. 141, t. 16. - Utah, in the Wahsatch Mountains at 7,000 to 11,000 feet, Watson, Parry, M. E. Jones.

++ +- Stems branching: leaves comparatively small: species neither alpine nor subalpine.

$=$ Involucre of the small and scattered or somewhat racemosely disposed heads not squarrose; the green tips of the bracts more or less erect: slender and low species, a span to a foot or less high, of the Rocky Mountain and interior western region.

A. campéstris, Nutr. Pruinose-puberulent and viscidulous, somewhat heavy-scented : leaves linear (about an inch long, a line or two wide) or lower narrowly lingulate-spatulate (radical “serrulate," Nuttall), mostly glabrate, some obscurely 3-nerved : involucre 3 or 4 lines high, hemispherical, of rather few-ranked and little unequal linear acute bracts, pruinose-glandular: rays 3 or 4 lines long, light violet or purple. - Trans. Am. Phil. Soc. (n. ser.) vii. 293. - Low grounds and plains, interior of Washington Terr. and Idaho to Montana (first and sparingly coll. by Nuttall and Spalding, recently by Watson, Suksdorf, Forwood, \&c.), E. Oregon (Cusick) to N. California (Greene).

Var. Bloómeri. More rigid (in drier more exposed situations) : stem and leaves hirsutulous: involucral bracts sometimes more unequal. - A. Bloomeri, Gray, Proc. Am. Acad. vi. 539, \& Bot. Calif. 323. - High slopes, \&c., W. Nevada, Bloomer, Lemmon, in specimens of the latter, from Carson, passing into A. campestris.

A. Féndleri, Grar. Rigid, a span to a foot high, sparsely hispidulous: the linear onenerved firm leaves hispid-ciliate, otherwise usually smooth and glabrous : involucre somewhat campanulate ( 3 lines high); outer bracts shorter, linear-oblong, obtuse, pruinose-glandular, inner acute or apiculate: rays violet, 4 lines long. - Pl. Fendl. 66. A. Nuttallii, var. Fendleri, Gray, Pacif. R. Rep. iv. 97. - Plains and sand-hills, from W. Kansas to S. Colorado and N. New Mexico ; first coll. by Fendler.

$==$ Involucre of the large heads very squarrose-foliaceous: leaves proportionally very small, rigid, recurved or reflexed.

A. grandiflórus, L. About 2 feet high, with long and slender spreading rigid branches, hispid with short spreading bristles, not viscid: leaves oblong-linear or obscurely spatulate, rough-hispidulous; cauline rarely 2 inches long; of the branches half to less than quarter inch long; uppermost passing into bracts of the (half-inch high) many-ranked obscurely granulose-viscid involucre; the green tips oblong-linear or shorter, or the inner linear: rays three-fourths inch long, deep violet, large and numerous, rather broad : akenes little compressed, canescent, 7-10-costate. - Spec. ii. 877 (Martyn, Hist. Pl. Rar. t. 191 ; Dill. Elth. t. 36, fig. 4I) ; Mill. Ic. t. 282 ; Bot. Reg. t. 273 ; Hoffm. Phyt. Blatt. 65, t. A, f. 1. A. asperrimus, Nutt. Trans. Plil. Soc. vii. 293. - Dry and gravelly soil, Virginia to Georgia in the middle country.

$===$ Involucre of middle-sized ( $a$ third to half inch) heads well imbricated; the unequal

bracts with loose squarrose-spreading tips: leaves not rigid, spreading.

A. Novæ-Ángliæ, L. Stem stont and strict, 2 to 8 feet high, very leafy to the top, coarsely hirsute or hispid with many-jointed hairs, also with glandular pubescence: leaves lanceolate or broadly linear, pubescent ( 2 to 5 inches long), entire, slightly if at all narrowed below, half-clasping by a strongly auriculate-cordate base: heads crowded: rays 50 to 60 or more, fully half-inch long, purple. - Spec. ii. 875 (Hort. Cliff. 408; Herm. Par. Bot. t. 98); Bot. Reg. t. 183 ; Torr. \& Gray, Fl. ii. 144. A. amplexicaulis, Lam. Dict. i. 304, excl. syn. Tourn. A. spurius, Willd. iii. 2032, a low and branching form with scattered heads. A. concinnus, Colla, Hort. Rip. App. iii. t. 12, not Willd. - Low grounds, Canada and Saskatchewan to S. Carolina and Colorado. A peculiar and handsome species.

Var. róseus, DC. Rays rose-colored.-(Bot. Reg. l. c. fig. d.) A. roseus, Desf. Cat. ed. 3, 401, not Stev. - With the ordinary form occasionally, permanent in cultivation.

A. oblongifólius, Nurrs. About 2 feet high : stem hirsute-pubescent, very leafy, corymbosely branched: leaves from narrowly oblong to broadly linear (larger cauline 2 inches 
long, 3 or 4 lines wide), somewhat hispidulous-puberulent; those of flowering branchlets not rarely glandular: involucre campanulate, aromatic-scented, the linear bracts granuloseglandular and viscidulous : rays 25-30, bright violet, 5 or 6 lines long: akenes cinereouspubescent. - Gen. ii. 156, \& Trans. Am. Phil. Soc. 1. c. 294; Torr. \& Gray, Fl. ii. 143. A. biennis, Torr. Ann. Lyc. N. Y. ii. 122, not Nutt. A. multiceps, Lindl. in DC. Prodr. v. 237 , from St. Louis, not "Louisiana." - Rocky banks and bluffs, Penn. and Virginia, from the Alleghanies westward to Wisconsin, Kansas, and Texas.

Var. rigídulus. - Low, more fastigiate, with more rigid and hispidulous scabrous leaves. - A. Kumleini, Fries, in distrib. Mus. Ups. no. 5. - In drier and more exposed places, Illinois and Wisconsin, to Texas and Colorado.

+ + Bracts of the involucre loose and more or less herbaceous (or somewhat colored) almost from the base, linear-attenuate, all equalling the disk: heads hemispherical, numerous and usually thyrsoidly or cymosely congested at the summit of the simple very leafy stem: rays numerous and narrow: style-appendages lanceolate: akenes hirsute.

A. modéstus, Lindu. Merely pubescent or glabrate: stem more slender, 2 feet high: leaves thinnish, lanceolate or broader (2 to 4 inches long), sparingly and acutely serrate or denticulate, very acute, mostly narrowed to a sessile or partly clasping but not auriculate base : heads fewer and smaller than in the preceding: bracts of the involucre and rays less numerous; these "pale blue." - Hook. Fl. ii. 8, \& DC. 1. c. 231 ; Torr. \& Gray, 1. c. A. Sayanus, Nutt. Trans. Am. Phil. Soc. 1. c. 294. A. Unalaschkensis? var. major, Hook. Fl. ii. 7. A. mutatus, Torr. \& Gray, Fl. ii. 142. - Moist woods, Oregon to Brit. Columbia on the Pacific, and east to Saskatchewan and Pembina (Hacom).

* 3. Involucre imbricated, hemispherical, not glandular nor viscid, squarrose with ovate or lanceolate foliaceous tips to the bracts: pubescence wholly sof't and cinereous: cauline leaves all with sagittate-auriculate clasping base, both sides of the same hue, entire: base of stem said to be somewhat woody! - SAGITTIFERI.

A. Caroliniánus, WALT. Minutely and softly cinereous-pubescent, not glandular nor viscid: stem diffusely branched, often reclining, 4 to 10 feet long, with straggling slender branches: leaves oblong-lanceolate, an inch or two long, contracted above the sagittately auriculate insertion: heads terminating small-leaved branchlets : bracts of the involucre well imbricated; the outer shorter and somewhat spatulate, with ovate-lanceolate green tips or more foliaceous; inner linear: rays 5 or 6 lines long, narrow, pale purple or rose-color: akenes narrow, glabrous, 10-nerved. - Car. 208; Michx. Fl. ii. 211; Ell. Sk. ii. 353; Chapm. Fl. 205. A. scandens, Jacq. f. Ecl. t. 125. - Marshes and river-banks near the coast, S. Carolina to Florida.

* 4. Involucre imbricated; the bracts with coriaceous base and foliaceous or herbaceous loose tips: pubescence soft-sericeous and sometimes silvery: leaves of the same hue both sides, all entire, disposed to become vertical by a twist near the sessile base: heads middle-sized or smaller: rays violet: akenes narrow, 8-10-nerved. - SERICEO-COXCOLORES.

- Heads terminating open branches, middle-sized (about half-inch high): involucre loose and foliaceous, of comparatively large bracts; the outermost passing into leaves of the branchlets: leares mucronate: akenes glabrous.

A. seríceus, VExT. A foot or two high, paniculately branching : leaves silvery-white with soft silky pubescence, oblong (an inch or less long), or the lowest oblanceolate (3 inches Iong): involucre oblong; foliaceous tips of the bracts from ovate to lanceolate, sericeouscanescent: rays 18 to 25 , fully half-inch long, rather broad, deep violet. - Hort. Cels. t. 33 ; Pursh, Fl. ii. 348; Torr. \& Gray, 1. c. 112. A. argenteus, Michx. Fl. ii. 111.-Prairies and dry banks, Minnesota and Illinois to Tennessee and Texas.

Var. montánus. Less silvery, merely canescent : leaves commonly narrower : upper leaves and bracts of the shorter involucre sometimes glabrate and villose-ciliate; approaching the next species. - A. montanus, Nutt. Gen. ii. 155. - In the mountainous district from Buncombe Co., N. Carolina, to N. W. Georgia.

A. phyllólepis, Torr. \& Gray. More slender and with long simple branches, merely canescent: leaves small; lower cauline inch or more long, oblong; the branches elliptical to oblong-lanceolate, half to quarter inch long; uppermost and the large ovate or ovate-lanceolate foliaceous portion of the involucral bracts cuspidate-acuminate, glabrate, conspicuously hirsute-ciliate: rays less than half-inch long. - Fl. ii. 113. A. sericeus, var. microphyllus, 
DC. Prodr. v. 233. A. ciliatus, Nutt. Trans. Am. Phil. Soc. vii. 295, not Walt. - Prairies, W. Louisiana and Texas ; first coll. by Drummond.

+ + Heads smaller, usually numerous and racemosely disposed on virgate simple stems: involucre closer and of small bracts : akenes sillky-villous.

A. cóncolor, L. Stems slender, 2 feet high, sometimes from a tuberous-thickened rootstock, very leafy: leaves small, canescent with minute pubescence, rarely glabrate, from oblong to short-linear; the lower on fertile stems only inch long, above gradually reduced in the inflorescence to small bracts: heads rather narrow (4 lines high): bracts of the involucre lanceolate, erect, sericeous-canescent; the tips short and narrow, or sometimes more prolonged: rays 10 to 15,3 or 4 lines long, violet-purple. - Spec. ed. 2, ii. 1228 ; Walt. Car. 209; Torr. \& Gray, FI. ii. 113; Bertol. Misc. Bot. vi. t. 5. - Sandy or gravelly soil, mostly in pine barrens, toward the coast, Rhode Island to Florida and Louisiana.

* 5. Involucre turbinate, pluriserial, not glandular; the appressed coriaceous whitish bracts with definite and short (mostly ovate) and slightly squarrose green tips, outer successively shorter: heads rather small, but large in proportion to the minute (line on two long) crowded and uniform cauline leaves; radical leaves rosulate, subsessile, abruptly larger and very unlike the cauline, sometimes an inch long: herbage scabrous: rays violet, 3 or 4 lines long: akenes short, pubescent: flowering late in autumn. - BRACHYPrYLLI.

A. squarrósus, WALT. Stems rigid, slender, paniculately much branched, a foot or two high, bearing scattered heads: branches throughout uniformly squarrose with the minute recurved-spreading rigid leaves; these mostly ovate-subulate and a line long; lowest on sterile shoots 2 or 3 lines long, lanceolate-subulate, mucronate-cuspidate: bracts of the obovate-turbinate involucre with very obtuse or roundish green tips. - Car. 209; Michx. Fl. ii. 112 ; Ell. Sk. ii. 530; Torr. \& Gray, Fl. ii. 114.-Dry pine barrens, N. Carolina to Florida.

A. adnátus, Nutr. More hispidulous-scabrous and virgately branched: leaves almost imbricated on the stem and branches, lanceolate-oblong, with clasping base, appressed and by the midrib adnate to the stem for most of their length, only the lowest larger and free: heads rather smaller and involucral bracts acutish. - Jour. Acad. Philad. vii. 82; Hook. Comp. Bot. Mag. i. 97 ; Torr. \& Gray, 1. ¿. A. microphyllus, Torr. ex Lindl. in DC. Prodr. v. 244 ; Bertol. Misc. Bot. vi. t. 5. - Pine barrens of Alabama and W. Florida.

* 6. Involucre ovoid with turbinate base or campanulate, appressed-imbricated, pluriserial; the bracts narrow, corjaceous, minutely granulose or scabrous, but not glandular, acute, with indistinctly marked green tips, the outer successively shorter: whole herbage scabrous-pubescent: cauline leaves all with sessile and completely cordate-clasping base, the basal lobes generally meeting or overlapping arourd the stem; radical not cordate; all entire: heads showy: akenes many-striate, sericeous-pubescent, narrow. - PATENTEs.

A. pátens, Aтт. Stems 2 or 3 feet high, with long and slender rigid divergent branches, mostly bearing single heads: leaves from oblong to broadly lanceolate, rather rigid, scabrous, rarely with obscure serratures, roughly hispidulous-ciliolate; the cauline an inch or two long, sometimes narrowed above the broad auriculate clasping base; those of the branchlets gradually reduced to small subulate bracts : heads half-inch or less high : rays a third to half an inch long, about 24, deep violet. - Ait. Kew. iii. 201 ; Pursh, Fl. ii. 551 ; Torr. \& Gray, Fl.' ii. 114. A. undulatus, Ell. Sk. ii. 36I, not L. A. amplexicaulis, Michx. Fl. ii. 114; Bigel. Fl. Bost. ed. 2, 312, not Lam. A. patentissimus, Lindl. in DC. Prodr. v. 232, a rigid and longbranched form. - Dry open grounds, Massachusetts to Florida, west to Michigan, Arkansas, and Texas.

Var. grácilis, Ноок. A foot or two high, more slenter : heads and oblong to oval leaves smaller and more 'scabrous. - Comp. Bot. Mag. i. 97. - Alabama to Texas, \&c., a common Southwestern form.

Var. phlogifólius, Nees. The other extreme: leaves larger (cauline 3 or 4 inches long, an inch or more wide, softer and membranaceous), hardly scabrous, sometimes contracted above an auriculate-dilated base: heads paniculate on shorter branches: involucral bracts in fewer ranks, almost glabrous. - Ast. 49; Torr. \& Gray, 1. c. A. phlogifolius, Muhl. in Willd. iii. 2034 ; Nutt. Gen. ii. 156. A. alatus, Aikin in Eaton \& Wright, Man. 146 ? A. auritus, Lindl. in DC. 1. c., cultivated form, with thinner and lax involucre. - In woods or shady moist ground, New York to North Carolina and Tennessee. A part of $A$. undulatus, L., may belong here. 
* 7. Heads small, or in one species middle-sized, paniculate: lower cauline and radical leaves cordate and petioled: no glandular or viscid pubescence: akenes compressed, short, 3-5-nerved: rays violet, purplish, or sometimes almost white: bracts of the involucre with short and appressed green tips, except in the first. - HETERopIryLI.

+ Anomalous species, with middle-sized heads, many rays, and squarrose foliaceous involucre!

A. anómalus, Evgelur. Pubescent and somewhat scabrous, a foot to a yard high, paniculately or virgately branched above, bearing numerous loosely disposed heads : leaves veiny, thinnish, entire, mostly oblong- to lanceolate-ovate with narrow and often deep cordate base, those of branchlets reduced and lanceolate to subulate: heads half-inch high: inrolucre pluriserially imbricated, hirsutulous-pubescent, of attenuate-linear bracts; their foliaceous upper half recurved or widely spreading: rays bright violet, about 40 , quarter to half an inch long: akenes glabrons. - Torr. \& Gray, Fl. ii. 503. - Limestone cliffs, Illinois, Missouri, and Arkansas ; first coll. by Engelmann.

++ True Heterophylli, with smaller heads, 10 to 20 rays, and a close involucre of appressed or erect bracts. Occasional specimens with only the radical leaves cordate.

i- Leaves all entire or nearly so (lower sometimes with a few teeth), of rather firm texture, all much longer than wide, none clasping: heads sbowy: rays violet, 5 or even 6 lines long, 15 to 20 in number: involucie 3 or + lines high; its bracts all appressed and with mostly definite short green tips, outer successively shorter.

A. Shórtii, Hook. Stem 2 to 4 feet high, rather slender, leafy to the summit, bearing racemose-paniculate heads: leaves minutely soft-pubescent, mostly glabrate and smooth above, thin-veiny, nearly all petioled; radical and principal cauline ovate-lanceolate with distinctly cordate base and on slender naked petioles, tapering-acute ( 3 to 5 inches long), only on ultinate short branchlets or peduncles reduced to nimute subulate bracts : involucre sometimes puberulent; its bracts narrow, less rigid and less definitely green-tipped than in the next: rays light violet. - Fl. ii. 9; Torr. \& Gray, Fl. ii. 118. - Border of thickets and shaded banks, Ohio to Georgia in the upper country, west to Kentucky and Illinois ; first coll. by Short.

A. azúreus, Linde. Stem 2 to 4 feet high, paniculately or racemosely compound at summit : branches slender and rigid: leaves hirtello-scabrous both sides; radical and lowest cauline ovate-lanceolate with subcordate base, on slender petioles ( 3 to 6 inches long); cauline oblong or lanceolate with winged petiole or attenuate base, verging to linear, and on the branchlets reduced to numerous small and slender-subulate rigid bracts: involucre glabrous and smooth; green tips of the bracts ovate or deltoid : rays deep violet-blue. - Hook. Comp. Bot. Mag. i. 98, \& DC. Prodr. v. 244 (incompletely described for want of lower leaves); Torr \& Gray, Fl. ii. 118. A. Oolentangiensis, Riddell, Synops. 55. - Prairies and border of woods, W. New York and Ohio to Minnesota, and southwest to Arkansas and Texas, wiere there are forms with hardly a cordate leaf!

+ Leaves some entire, but lower almost always somewhat serrate, rather firm in texture, longer than broad; the base, or that of wing-margined petiole of lower cauline, cordate-clasping: greenish tips of the less rigid involucral bracts short and rather obtuse.

A. undulátus, L. Pale or dull with a minute somewhat cinereous and sometimes scabrous pubescence: branches rather rigid, racemosely or paniculately bearing several or rather numerous racemosely disposed heads: leaves at most inconspicuously or obtusely serrate; upper mainly entire, lanceolate or oblong with partly clasping base, above diminished to subulate bracts; middle ones ovate or ovate-lanceolate, abruptly contracted below and with dilated cordate-clasping base, sometimes panduriform, below subcordate on nargined petioles; lowest cauline and radical cordate on slender naked petioles: heads 4 lines high: rays bright violet or sometimes paler. - Spec. ii. 875 (Hort. Cliff. \& Herm. Parad.t. 96, whence the name, \& Moris. Hist. 120) ; Ait. Kew. iii. 206 ; Hoffm. Phyt. Blatt. 77, t. C, f. 1 ; Torr. \& Gray, 1. c. ; Sprague, Wild Flowers, t. 4. A. diversifolius, DC. Prodr. v. 234. A. paniculatus, Nutt. Gen. ii. 56, not Ait., nor Lam. A. sagiltifolius, Ell. Sk. ii. 362, not Willd. - Dry ground, margin of woods, \&c., Canada to Florida, Kentucky, and Arkansas. Southward in the low and middle country the common form is

Var. diversifólius. More rigid, scabrous or scabro-puberulent, and with longer virgate flowering branches, which are beset with minute subulate or lanceolate (or below oblong) leaves, only the lower cauline having a narrowed base or winged petiole. $-A$. diversifolius, Michx. Fl. ii. 113. A. scaber, Ell. Sk. ii. 262. A. asperulus, Torr. \& Gray, Fl. 
ii. 120, not Wall. A. Buldwinii, Torr. \& Gray, Fl. ii. 127, from specimens with rameal leaves only. - Dry ground, S. Carolina to Florida and Louisiana. (Named as distinct new species in herb. Poiret and herb. Banks.)

+ + Leaves nearly all sharply serrate, thinner, none cordate-clasping either by base of upper sessile ones or by appendage at base of petiole.

- Involucral bracts obtuse or obtusish with conspicuously marked and definite very short green tips : heads small and numerous.

A. cordifólius, L. Green, slightly pubescent to nearly glabrous, paniculately much branched above into thyrsoidal inflorescence of very many small heads : leaves membranaceous, acutely serrate, cordate-ovate on nearly naked petioles, or uppermost lanceolate and sessile, acuminate: heads 2 or 3 lines high: rays only 10 to 12, pale violet or whitish. Spec. ii. 875, mainly (Hort. Cliff., \& syn. Cornuti \& Morison); Ait. 1. c. 207 ; Lindl. Bot. Reg. t. 1597 (unusual form); Pursh, Fl. ii. 552; Torr. \& Gray, Fl. ii. 120; Gray, Proc. Am. Acad. xvii. 165. A. paniculatus \& A. heterophyllus, Willd. Spec. iii. 2035. A. paniculatus, heterophyllus, \& cordifolius, Nees, Ast., chiefly. - Common in woodlands, New Brunswick to the mountains of Georgia, west to Wisconsin and Missouri. A singular abnormal state, collected by Moser on the Pocono in Pennsylvania, has some of the lower cauline leaves lanceolate and laciniate; others oblong-ovate, simply serrate, barely subcordate-contracted into a winged petiole: perhaps a hybrid with $A$. diffusus.

$==$ Involucral bracts acute or acutish, with the green tips more indefinite.

w. Heads rather larger than in the last preceding ( 3 or 4 lines high), numerous, thyrsoid-paniculate on the rather rigid branches: stems rather stout, 2 to 6 feet high: leaves mostly gradually acuminate.

A. Drummóndii, Lindu. Pale with a fine and mostly soft cinereous pubescence : leaves from cordate to cordate-lanceolate and mostly on margined petioles, or the small uppermost lanceolate and sessile by a narrow base, obtusely or acutely serrate (the large 4 inches, smaller about an inch long), sometimes scabrous above: bracts of the involucre acute or acutish: rays violet-blue or paler, 3 to 5 lines long. - Hook. Comp. Bot. Mag. i. 97, \& DC. 1. c. 234; Torr. \& Gray, 1. c. - Open grounds and border of woods, Illinois and Minnesota to Texas. Forms pass into the next.

A. sagittifólius, WILLD. Green, from glabrous to sparsely pilose-pubescent: stem strict, 2 or 3 feet high: leaves oblong- and ovate-lanceolate, acutely more or less serrate; radical and lowest cauline narrowly cordate, on naked petioles; upper subcordate or truncate at base and contracted into a winged petiole ( 3 to 5 inches long); uppermost linear-lanceolate and sessile : heads densely thyrsoid-paniculate: bracts of the involucre subulate-linear and mostly attenuate, the tips rather loose: rays purplish, pale violet, or bluish, sometimes nearly white. - Spec. iii. 2035 ; Nees, Ast. 56; Hook. Fl. ii. 9 ; Torr. \& Gray, Fl. ii. 121. A. cordifolius, Willd. 1. c., as to spec. from Muhl. A. paniculatus, Muhl. Cat.; Darlingt. Fl. Cest. 464. A. hirtellus \& A. urophyllus, Lindl. in DC. Prodr. v. 233, from "St. Louis, Drummond," not "Louisiana." - Open grounds, Canada and W. New York to Dakota, Missouri, and Florida.

b. Heads larger (4 or 5 lines high) and comparatively few in a loose thyrsus or panicle terminating the simple stem: only lowest leaves cordate or subcordate: involucral bracts looser and less imbricated.

A. Lindleyánus, Torr. \& Grar. Green, sparsely pilose or nearly glabrous : stem 10 to 20 inches high, rather stout, the smaller plants bearing few heads : radical and lowest cauline leaves ovate, moderately or some obscurely cordate, on winged or margined petioles; upper ovate- to oblong-lanceolate; uppermost sessile and acuminate at both ends : bracts of the involucre linear-attenuate; the outer little shorter: rays pale violet, 3 to 5 lines long. - Fl. ii. 122. A. paniculatus, Ait. Kew. iii. 207; Hook. Fl ii. 8 (chiefly), not Lam. A. prcecox, Lindl. in Hook. II. ii. 9, not Willd - Labrador to Upper Canada, Lake Superior, Saskatchewan, and the borders of British Columbia. The original of the species was raised by Gordon from Labrador seeds, and has more extended inflorescence of smaller heads than is common in the wild plant.

Var. ciliolátus (A. ciliolatus, Lindl. in Hook. Fl. \& DC. Prodr. 1. c. 235), is a dwarf arctic form, a span to 8 inches high, bearing few (not cordate) leaves and only 2 to 7 heads; from Slave Lake, Richardson. 
* 8. Heads and inflorescence various: no cordate petioled leaves; radical leaves all acute or attenuate at base : not glandular nor viscid, nor silky-canescent: akenes compressed, few-nerved. - HoMorhy LLI, Nees.

+ Whole plant very smooth and glabrous (sometimes lispidulous roughness on leaf-margins or a little pubescence on branchlets or peduncles): involucie of middle-sized or rather large heads pluriserial, from turbinate to campanulate, of rather firm closely imbricated appressed bracts with short green tips, outer successively shorter: leaves of firm texture, entire, or sometimes with a few teeth: rays of the showy heads violet or blue, rarely pale. - Lares.

++ Typical species, usually pale and glaucescent or glaucous; with involucral bracts whitish-coriaceous below and abruptly green-tipped (most conspicuous in dried specimens): akenes 4-5ribbed: leaves on flowering branchlets commonly much reduced to rigid subulate bracts.

A. turbinéllus, Lindu. Slender, 3 feet high, diffusely paniculate above: leaves light green, not rigid, from oblong to narrowly lanceolate, and all with narrow base (2 or 3 inches long), scabrous-ciliolate: heads (half-inch or more high) terminating divergent and minutely bracteolate slender branchlets : involucre elongated-turbinate or subclavate; its many-ranked bracts with very short and obtuse green tips: rays a third to half inch long, bright blueviolet : akenes minutely pubescent. - Comp. Bot. Mag. i. 98, \& DC. Prodr. v. 244 ; Torr. \& Gray, Fl. ii. 117. - Hillsides and plains, Hlinois and Missouri to W. Arkansas and Louisiana. Handsome species, flowering late.

A. virgátus, ELL. Slender, strict and simple, with few or several racemose heacls, or with virgate branches terminated with single heads; these and the flowers nearly as of $A$. loeris: cauline leaves lanceolate or linear, of firm texture, little if at all dilated at base; lower ones usually long and narrow; those of the branchlets subulate-acute and rigid. - Sk. ii. 353; Torr. \& Gray, Fl. ii. 116; Chapm. Fl. 201. A. vimineus, Willd. Spec. iii. 2046? (ficle herb., but a peculiar and imperfect specimen), not Lam. nor Nees. A. purpuratus, Nees, Ast. 118 , \& A. miser, Lam. Dict. i. 308. A. attenuatus, Lindl. in Comp. Bot. Mag. i. 97. A. gracilentus, Torr. \& Gray, l. « 166. - Upper S. Virginia to Louisiana and Texas. Form with narrow and linear leaves (lower 3 or 4 inches long by 2 or 3 lines wide) seems very distinct: broaderleaved forms pass into the next.

A. lǽvis, L. Stouter, 2 to 4 feet high, rigid: leaves from ovate or oblong to lanceolate (4 or 5 inches long, decreasing upward); radical and lowest cauline contracted below into a winged petiole; upper all with auriculate or subcordate partly clasping base: heads sparsely thyrsoid-paniculate, on short and rigid branchlets : involucre campanulate or obscurely turbinate; the whitish coriaceons bracts bearing abrupt rhomboid or deltoid short green tips: rays 20 or 30 , broadish, sky-blue verging to violet: akenes glabrous or nearly so. - Spec. ii. 876 ; Ait. Kew. iii. 206 ; Nees, Ast. 128, partly; Torr. \& Gray, Fl. ii. 116 (the var. $\beta$ is the typical plant); Gray, Proc. Am. Acad. xvii. 166. A. rubricaulis, Lam. Dict. i. 305 ; Nees, Ast. 131. A. amplexicaulis, Muhl. in Willd. Spec. iii. 2046; Nees, 1. c., not of others. A. Pennsylvanicus, Poir. Suppl. i. 498. A. cyaneus, Hoffm. Phyt. Blatt. 71, t. B, f. 1 ; Nees, l. c. ; Lind1. Bot. Reg. t. 1495. A. glaucescens \& A. politus, Nees, Synops. 23. A. laerigatus, Hook. Bot. Mag. t. 2995, not Lam. nor Willd. - Borders of woodland, in dry or barely moist ground, Canada to Louisiana and west to the Rocky Mountains from Saskatchewan to New Mexico. A form from Fort Edward, N. Y. ( Vanderberg), bore white rays changing to rose.

Var. Géyeri. A foot or two high: involucre broader and less imbricated; its bracts of thinner texture, mostly attenuate-acute, the green tip less definite. - Valleys of the Northern Rocky Mountains to Idaho, south to Wyoming, \&c.

+ ++ Ambiguous species, green, at least not glaucous: involucre greener and somewhat looser.

A. versícolor, WILLD. Leafy up to the more corymbosely disposed inflorescence: leaves thinner than in preceding, bright green, oblong-lanceolate, obscurely if at all auriculate and not bruadened at insertion, lower with some sharp serratures : involucre short-canpanulate: rays "changing from white to deep violet," or commonly pale or bright violet from the first. - Spec. iii. 2045 \& Enum. ii. 885 ; Nees, Ast. 128. A. lcevigatus, Willd. 1. c. 2046 (in part); Nees, 1. c. 129, not Lam. A. laris of the same authors, Lindl. Bot. Reg. t. 1500. A. mutabilis, Willd. 1. c. 2045 ; Nees, 1. c. 125 . A. confertus, Nees, Ast. 146, white-fl. state.Common in European gardens, doubtless from Atlantic N. America; but decisive indigenous specimens hardly known.

A. concínnus, WiLld. Stem and paniculate branches slender, 1 to 3 feet high (above often showing traces of pubescence in lines): leaves pale green, lauceolate, mostly some- 
what serrate or serrulate; upper ones an inch or two long; lowest and radical spatulatelanceolate and tapering into a winged petiole: heads much smaller than in preceding, numerous : rays 4 or 5 lines long, violet. - Enum. ii. 884 ; Nees, Ast. 121 (excl. $\beta$ ?); Lindl. Bot. Reg. t. 1619. A. elegans, Hort. Par. 1814, not Willd. - North America, received by Willdenow from Muhlenberg. An indigenous specimen from Pennsylvania, Minn, in herb. Cosson. This and perhaps that of N. Carolina, Schweinitz in herb. Ell. (now lost), and Arkansas, Harvey, seem to be the only indigenous ones seen.

+ + Involucre of the small or barely middle-sized and paniculately or racemosely disposed heads ( 3 or 4 lines high) pluriserially imbricated; its bracts rather rigid, narrow, with subulate or acute green nearly erect tips: rays white, sometimes turning purplish or violaceous: leares mostly narrow and entire, narrowed at base : akenes minutely pubescent. - Ericoidei.

* Heads disposed to be corymbosely or open-paniculate on erect branches: involucre nearly hemispherical: rays numerous, bright white, disposed to turn rose-purplish, 4 lines long.

A. Pórteri, Gray. A foot or less high, glabrous and smooth (except hirsute ciliation of lowest leaves), either simple or branching above, bearing several or numerous thyrsoidly or corymbosely disposed lieads: leaves linear or lower spatulate-linear ( 2 to 4 inches long, 1 to 3 lines wide), radical spatulate: heads broad: involucral bracts linear-subulate; outer little shorter than inner. - Proc. Am. Acad. xvi, 99. A. ericoides, var.? Proc. Acad. Philad. 1863, 64. A. ericoides, var. strictus, Porter \& Coult. Fl. Colorad. 56. - Common in the Colorado Rocky Mountains at middle elevations, Fremont, Parry, Hall \& Harbour, \&c.

A. polyphýllus, WILLD. Mostly tall (4 or 5 feet high), with virgate branches, glabrous: cauline leaves narrowly lanceolate or linear ( 4 or 5 inches long, quarter to half inch wide); those of flowering branchlets small and subulate-linear: heads paniculate (4 lines high): involucral bracts lanceolate-subulate, outer successively shorter. - Enum. 888; Spreng. Syst. iii. 536. A. Americanus Belviderefolius, \&c., Pluk. Alm. t. 78, f. 5? A. tenuifolius, Nees, Ast. 119, in part; Torr. \& Gray, Fl. ii. 132, in part. - N. Vermont to Wisconsin, south to Penn. and N. Carolina. Showy in cultivation, flowering much earlier than A. ericoides.

+ Heads disposed to be racemose along spreading branches or branchlets: rays 15-25, and smaller, bright white, rarely purplish-tinged.

A. ericoídes, L. Glabrous or nearly so in the typical form (but with hirsute varieties), rather rigid, a foot to a yard high, with lateral branches spreading or ascending and commonly unilaterally capituliferous : radical leaves oblanceolate and spatulate, often sparingly serrate; cauline narrowly lanceolate or linear and narrowed at both ends, entire; those of the branches and branchlets gradually diminished to setaceous-subulate: heads usually 3 lines high: tips of the involucral bracts somewhat abruptly subulate-acute or acuminate from a rigid or coriaceous base: akenes little compressed, scarcely nerved. - Spec. ii. 875 (specimen in herb. an attenuate cultivated form, not of syn. Dill. \& Gronov., which are of A. multiflorus); Ait. Kew. iii. 202 ; Spreng. Syst. iii. 531 ; Torr. \& Gray, Fl. ii. 123 ; Grav, Proc. Am. Acad. xvi. 165, not of Lam. nor Michx. A.tenuifolius, Willd. Spec. iii. 2026 (excl. syn.); Nutt. Gen. ii. 155; Nees, Ast. 119, partly. A. dumosus, Hoffm. Phyt. Blatt. t. A, f. 2. A. ericoides \& A. glabellus, Nees, Ast. 107. A. pauciflorus, Martens, Bull. Acad. Brux. viii. (1841), 67. - Dry and open ground, Canada to Florida and the Mississippi.

Var. Reevésii (A. Reevesii of the gardens) is the most rigid form, comparatively stont, glabrons except that the leaves are often hispidulous-ciliate toward the base; the heads and rays as large and the latter about as numerous as in $A$. polyphyllus. It is A. virgatus. A. H. Curtiss, distrib. no. 1279, from dry river-banks near Nashville, Tenn.

Var. villósus, Torr. \& Gray, l. c. Stem (generally low) with branches and not rarely the leaves villous-hirsute or hispid-hirsute. - A. villosus, Michx. Fl. ii. 113. A. pilosus, Willd. Spec. iii. 2055; Nees, Ast. 109. - Ohio to Iowa and Missouri, south to W. North Carolina. The var. platyphyllus, Torr. \& Gray, 1. c., is a very hirsute state of this, with leaves broader, some even an inch wide and sparingly serrate.

Var. pusíllus. Slender, a span to a foot high, glabrous : canline leaves mostly slender-subulate or filiform: heads small (2 lines high), narrow, few-flowered : involucre turbinate; its bracts less rigid : rays 2 lines long. - Serpentine barrens, Lancaster, Penn., Porter. A singular form, probably dwarfed by sterility of soil.

Var. Prínglei. A slender and strict glabrous form, seldom over a foot high, simple or with few erect branches, rather small heads, and shorter tips to the involucre, mentioned 
in Proc. Am. Acad. xvi. 99. - Rocky islands and shores, northern part of Lake Champlain, Pringle, E. Brainard.

+++ Involucre of the numerous small and racemosely disposed heads with squarrose or at least spreading herbaceous tips to the well-imbricated unequal bracts, these tips obtuse or merely mueronate-apiculate: cauline leaves small, all linear and entire, not at all or scarcely narrowed at the abrupt closely sessile or partly' clasping base: akenes canescent-hirsute: herbage with somewhat cinereous or hirtellous pubescence. - Multiflori.

+ Rays amethystine-violet or purple: leaves not rigid.

A. amethystinus, Nutr. Cinereously puberulent or the stems hirsutulous, 2 to 5 feet high, paniculately much branched: heads 3 lines high: tips of involucral bracts merely spreading, acutish, not ciliate: rays rather numerous, 3 lines long. - Trans. Am. Phil. Soc. (n. ser.) vii. 294 ; Torr. \& Gray, Fl. ii. 144; Gray, Man. ed. 5, 234. - Rather low grounds, E. Massachusetts to Illinois and Iowa. This has been cult. in European gardens under the names of $A$. pilosus and Bostoniensis. It has much the habit of $A$. oblongifolius, but is destitute of viscidity and aroma.

$$
++ \text { Rays white, rarely bluish or purple-tinged. }
$$

A. multiflórus, AIT. Low (a foot or two high), bushy-branched, cinereous or green : leaves rigid, scabrous- or hispidulous-ciliate; uppermost of the branchlets passing into involucral bracts; these mostly with obtuse tips: heads in the ordinary forms little over 2 (at most 3) lines long, and with only 10 to 15 or 20 rays. - Kew. iii. 203; Willd. Spec. iii. 2027; Torr. \& Gray, Fl. ii. 124, with var. stricticaulis, a slender strict form of the North. A.ericoides, dumosus, Dill. Elth. t. 36. A. ericoides, L. spec. as to syn. Dill.; Michx. Fl. ii. 113 ; Schk. Handb. t. 245, \& (var. multiflorus) Pers. Syn. ii. 443. A. ciliatus, Muhl. in Willd. Spec. iii. 2027. A. scoparius, DC. Prodr. v. 242, a rather strict slender-leaved Texan form. A. hebecladus, DC. I. c., a very small-leaved hirtellous Texano-Arizonian form. - Dry or sterile ground, Canada to Georgia and Texas, conmon throughout Atlantic States, southwest to Arizona, northwest to Saskatchewan and Brit. Columbia. (Mex.) The most wide-spread species.

A. commutátus. A foot or so high, with divergent branches: heads more scattered and twice or even thrice the size of those of $A$. multiflorus ( 3 or 4 lines high and broad) : rays 20 to 30 : otherwise nearly as the preceding. - A. multiflorus, var. commutatus, Torr. \& Gray, 1. c., excl. syn. A. biennis, Torr. Ann. Lyc. N. Y., at least mainly. A. ramulosus, var. incanopilosus, LindI. in DC. Prodr. 1. c. \& Hook. Fl. ii. 12. - Plains and river-banks, Dakota and Saskatchewan, to Utah and E. Oregon. Seems to pass into the preceding on one hand, and into $A$. adscendens on the other.

A. falcátus, Lixdu. Much like a strict and simple-stemmed A. multiflorus, perhaps a high northern form of it: leaves all narrowly linear, glabrate or sparingly and minutely (and the stem more obviously) pubescent with soft somewhat appressed hairs: involucre broader, glabrous ; its bracts thinner and looser; outer herbaceous to near the base and as long as the attenuate innermost. - Torr. \& Gray, Fl. ii. 126. A. falcatus \& A. ramulosus (as to the type), Eindl. in DC. Prodr. v. 241, 243, \& Hook. Fl. ii. 12. - Subaretic America, from Cumberland House to Fort Franklin, near the Arctic Circle and Arctic coast, Richardson.

++++ Involucre of the small (2 or 3 lines high) and numerous heads nearly of the Heterophylli, pituriserial; the bracts not coriaceous, regularly and closely imbricated (outer successively shorter), smooth and glabrous, mostly whitish below and with definite short green tips, these not spreading: stems usually slender and not rery tall; the branches divergent or divaricate (except in $A$. racemosus), and racemosely branched or racemosely capituliferous: leaves from lanceolate to subulate, not cinereous nor more than minutely scabrous, commonly spreading: all Atlantic species. - Divergentes.

- Heads more scattered and singly terminating the racemose or compound-paniculate minutely foliose slender branches.

A. dumósus, L. Mostly quite glabrous and smooth, 1 to 3 feet high: leaves all entire and obtuse, commonly reflexed or widely spreading; the cauline linear ( 1 to 3 inches long and as many lines wide), of rather firm texture; those of branches and branchlets gradually smaller and shorter; ultimate ones reduced to minute bracts: involucre campanulate or short-turbinate ( 2 or 3 lines long), well imbricated and with very definite and broadish oval or oblong green tips to the obtuse or sometimes barely acutish bracts : rays from violet to nearly white, 2 lines long, - Spec. ii. 873 (with syn. mainly); Ait. Kew. iii. 202 ; Torr. \& Gray, Fl. 
ii. 128. A. sparsiflorus, Michx. Fl. ii. 112; Willd. Enum. 880 (with unusually large lower leaves); Nutt. Gen. ii. 155. A. fragilis, Lindl. Bot. Reg. t. 1537, \& herb. - Border of moist or dry woods, New England and W. Canada to Florida and Texas. Runs into various forms, such as

Var. coridifólius, Tonr. \& Gray, l. c. A more rigid and effuse Southern form, with rather coriaceous leaves, especially the very small ones of the elongated branches and branchlets; involucral bracts also more rigid. - A coridifolius, Michx. Fl. ii. 112 ; Willd. Spec. iii. 2028 ; Nees, Ast. 104 ; Lindl. Bot. Reg. t. 1487. A. foliolosus, Ell. Sk. ii. 345, not Ait. A. foliolosus, var. coridifolius, Nutt. Gen. ii. 155. A. multiflorus, Bertol. Misc. v. t. 5, fig. 3. - Pine barrens, S. Carolina to Florida and Louisiana.

Var. subulæfólius, ToRR. \& GRAY, l. c. Rather rigid form, with ascending flowering branches, on which the somewhat large heads are often subracemosely paniculate and bearing erect or little spreading subulate-linear or linear-oblong very small leaves. - Open woods and pine barrens, Carolina to Texas; also N. W. Arkansas. The var. subracemosus, Torr. \& Gray, l. c., was made up of specimens, some fairly referable to the present form, others to $A$, vimineus, var. foliolosus, or of intermediate forms.

++ Heads racemosely unilateral, usually numerous or crowded along the flowering branches; the branchlets or minutely leafy pedincles shorter or little longer than the involucre: diskflowers apt to turn purple:

A. racemósus, ELI. Minutely scabrous-pubescent along the numerous slender erect or ascending branches, probably rather tall (base of stem unknown): leaves rigid; linear, small, acute, entire: heads small (little over 2 lines high), somewhat spicately or more loosely racemose: involucre hemispherical and of narrower and acuter bracts than in the following: rays only a line or two long, purplish. - Sk. ii. 348; Torr. \& Gray, Fl. ii. 127.S. Carolina to Florida and Louisiana, in the low country or along the coast. Perhaps also Texas, but specimens (of Lindheimer) insufficient. Species insufficiently understood.

A. vimíneus, Lam. Nearly glabrous: stem 2 to 5 feet high, slender, simple, with numerous usually horizontal foliolose flowering branches, bearing numerous usually crowded heads : leaves linear or narrowly lanceolate, entire, or the lower with few serratures (the longer cauline 3 to 4 or 5 inches long, 2 to 4 lines wide): heads 2 or 3 lines high: bracts of involucre linear, usually acutish : rays commonly pure white (not rarely changing to purplish, even on a part of the plant), about 2 lines long. - Dict. i. 306 (1783, form with somewhat lanceolate cauline leaves); Gray, Proc. Am. Acad. xvii. 169. A. Tradescanti, L., as to one specimen in herb. Cliff., of very doubtful authority, also of hort. Par. in early days, of Nees, DC., Torr. \& Gray, Fl. ii. 129, with var. fragilis; not of herb. L. (hort. Ups.), nor A. Tradescanti, Morison. A. secundiflorus, Desf. Hort. Par. 1815, \& A. diffusus, DC. Prodr. v. 242, partly. A. multiflorus, Nutt. Gen. ii. 155, excl. syn. A. tenuifolius, Ell. Sk. ii, 347, not L. A. fragilis, Nees, Ast. 101, in part, not Willd. - Moist ground, Canada to Florida and west to Arkansas, most common northward; flowering rather early.

Var. foliolósus. Leaves linear, entire: branches ascending, bearing sparse or more paniculate heads: consists of forms intermediate between $A$. vimineus and $A$. dumosus, but with smaller heads than is usual in the latter, and thinner as well as narrower involucral bracts. - A. foliolosus, Ait. Kew, iii. 202. A ericoides, Meliloti agraria umbone, Dill. Elth. 39 , t. 35, a coarsely exaggerated figure: from which figure solely the char. \& descr. of $A$. miser, L. Spec. ii. 877 , were made, neither these nor the figure answering at all well to the dried specimen in herb. Sherard; which is said to have been raised from New England seeds. $A$. dumosus, var. subracemosus, Torr. \& Gray, Fl. ii. 128. - New England to Illinois.

A. diffúsus, AIt. Either pubescent or almost glabrous, a foot to- 4 or 5 feet high; the larger plants widely and divergently branched: leaves thinnish, mostly broadly Ianceolate or wider, with much narrowed base, acute or acuminate; lower cauline generally 3 to 5 inches long, sparingly and acutely serrate; those of the flowering branches becoming small and entire, some of them surpassing the crowded or sometimes more scattered heads, which are usually disposed along the length of the flowering branches, either singly or in clusters; radical leaves ovate and slender-petioled: involucre campanulate; its bracts linear, obtuse or sometimes acutish, and with a definite short green tip : rays small, white, or sometimes tinged with purplish or violet, - Ait. Kew. iii. 205 ; Nees, Ast. 1. c., \&c. A. divergens, Ait. 1. c.; Nees, 1. c. A. pendulus, Ait. 1. c. 204 (a form with narrowish and less serrate leaves, verging to or connecting with the preceding species); Nees, Ast. 100. A. Tradescanti, 
Michx. Fl. ii. 115, not of L., \&c. A. miser, Nutt. Gen. ii. 158 (a cinereous-pubescent variety or state, of sun-burnt situations, short-leaved and glomerate-clustered, partly the var. glomerellus, Torr. \& Gray, under this name); Torr. \& Gray, Fl. ii. 129; not L. (pl. Dill.), nor Ait. A. parviflorus, Darlingt. Fl. Cest. 446, not Nees. Solidago lateriflora, L. Spec. ii. 879.Dry or barely moist ground, Canada to Texas and west to Missouri. $\boldsymbol{A}$. diffisus is, on the whole, the best of three names of same date.

Var. horizontális. A robust, very bushy-branched and exceedingly floriferous cultivated form; the leaves thickish, those of the widely spreading flowering branches small and short, entire: white rays more conspicnous. $-A$. horizontalis, Desf. Cat. ed. 3, 402. A. recurvatus, Willd. Spec. iii. 2047. - A plant of the gardens, not exactly matched by indigenous specimens, but evidently of this species.

Var. thyrsoídeus. From slightly to distinctly cinereous-pubescent: leaves from ovate-oblong to lanceolate : flowering branches ascending, rather rigicl, either short or somewhat elongated: heads thyrsoid-paniculate or spicate-glomerate, less secund. - Part of $A$. miser, var. glomerellus, Torr. \& Gray, 1. c. - New York to Illinois and Upper Canada. Western forms connect with the next species.

Var. hirsuticaúlis (A. hirsuticaulis, Lindl. in DC. Prodr. v. 242, and A. miser, var. hirsuticaulis, Torr. \& Gray, Fl. 1. c.), founded only on specimens from Albany, N. Y., Beck, in herb. Torr. \& Lindl, is a singular form, probably growing in much shade, with long and narrow leaves, as of $A$. vimineus, the midrib of these beneath and the stem very hirsute. Other forms in Torr. \& Gray, Fl, are ambiguous between this and A. vimineus.

Var. bifrons. A luxuriant form, growing in shady and moist grounds, with large and thin elongated-lanceolate leares, and spreading branches with loosely disposed and mostly larger heads: a transition to the following section and to A. paniculatus, Lam. - A. bifrons, Lindl. in DC. Prodr. v. 243. - Shady banks of Kentucky River (Short) to Illinois.

+++++ Involucre various, in some imbricated and with short close tips, as in the last preceding section, in others more loose and herbaceous : heads when numerous either thyrsoidor open-panjculate on erect or ascending branches. -Vulgares.

++ Cauline leaves sessile, but neither with cordate or auriculate base (except in forms of $A$. NoviBelgii and $A$. foliaceus), nor with abrupt winged-petiole-like lower portion.

= Atlantic United States species, with branching stems or several or many heads when well developed, none alpine or subalpine: herbage disposed to be glabrous, but branches often pubescent in lines.

a. Involucre of the small or middle-sized heads close and erect; its bracts narrow. imbricated in successive lengths, the small green tips not dilated nor spreading. Species seemingly confluent in a series.

A. Tradescánti, L., partly. Stem slender, 2 to 4 feet high, with numerous erect or ascending branches and branchlets: leaves lanceolate or linear, slightly serrate or entire, thinnish: small heads numerous, corymbosely or somewhat racemosely paniculate, only two or thre $\theta$ lines high: bracts of the involucre linear, acutish, partly green at tip and down the back: rays white, or sometimes tinged with lilac, only about 2 lines long. - Spec. ii. 876 (as to Hort. Cliff. in part, if herb. Cliff. is of any authority, and as to syn. A. Virginianus parvis floribus Tradescanti, Moris. Hist. iii. 121, whence the name); Ait. Kew. iii. 204 (var. fl. albis); Gray, Proc. Am. Acad. xvii. 166 ; not of L. Hort. Ups. \& herb., only in small part of Torr. \& Gray, Fl. A. miser, Ait. Kew. iii. 205, not L. A. fragilis, Willd. Spec. iii. 2051 ; not A. Tradescanti fragitis, Torr. \& Gray. A. leucanthemus, Desf. Cat. 102 ; Poir. Suppl. i. 500. A. artemisiceflorus, Poir. 1. c., ex char. A. parviflorus, Nees, Ast. 99, a rather strict form. A. tenuifolius, var., in part, Torr. \& Gray, 1. c. 132, not of others. - Open grounds, Canada to Virginia, Illinois, and Saskatchewan. Cult. from earliest days in European gardens. Some forms, both cult. and wild, show affinity to $A$.dumosus, vimineus, and diffusus; others differ from the next following species only in the smaller heads and flowers.

A. paniculátus, LAM. Stem 2 to 8 feet high, freely and paniculately branched: leaves from elongated oblong to narrowly lanceolate, mostly attenuate-acuminate, sharply serrate or denticulate, or upper entire, thin : heads about a third of an inch high, in loose and open mostly leafy panicles : bracts of the involucre narrowly linear, with tapering acute or acuminate green tips (or outermost wholly green on back): rays 3 or 4 lines long, white rarying to purplish or pale violet (in drying often turning blue). - Lam. Dict. i. 306 (1783, the char. not good for the involucre, but it is the 4 . serotinus procerior, \&c., Tourn, cited by Lam.); 
not Ait. 1789, nor of Willd. A. Tradescanti, L. Spec. ii. 876, as to herb. ("H. U.") \& Hort. Ups. 262, not Hort. Cliff. \& syn. Morison (whence the name Tradescanti); Ait. Kew. 1. 204, as to var. floribus caruleis. A. junceus, Ait. I. c., as to pl. H. Kew. 1777 only. A. dracunculoides, Willd. Spec. iii. 2050, a form nearest to the preceding species, not Lam. A. recurvatus, Willd. Herb. fol. 1, but hardly of Spec. iii. 2047. A. lanceolatus, Willd. 1. c., \& $A$ : bellidiflorus, Willd. Enum., are.cultivated forms. A. Lamarckianus, Nees, Ast. 100, at least as to syn. Lam. A. temuifolius (Nees in part), and A. simplex, Torr. \& Gray, 1. c., mainly, and $A$. carneus, Nees, Syn. 27 \& Ast. 96, by the char., belong to this rather than to the next species, as do some indigenous (but not original) specimens named by Nees. A. salicifolius, Scholler, Fl. Barb. Suppl. (1785), 328, - to which belong A. salignus, Willd. Spec. iii. 240, A. simplex, Willd. Enum. 887, and probably A. strictus, Poir. Suppl. 498,-represents a form of this same species, either very early naturalized in Hungary and Germany, or possibly indigenous. A. laxus, Willd. Enum. 886, seems to be a similar form. - Low or moist ground, New Brunswick to Saskatchewan, E. Montana, and Louisiana, abundant in the Northern States, and polymorphous. A small and slender form, in Northern sphagnous bogs, with linear leaves, resembles $A$. longifolius in habit and foliage.

A. salicifólius, (LAm.?) AIт. Resembles the preceding, equally branching: leaves commonly less elongated, less serrate or entire, of firmer texture, apt to be scabrous, and the fine reticulation of the veinlets manifest: involucre roore imbricated; its bracts firmer, linear, with shorter and more definite green tips, these acute or obtusish: heads (as large as in preceding or broader) disposed to be thyrsoid or racemose-glomerate on the ascending branches: rays purplish to violet, rarely white.-Lam. Dict. 1. c.? (no Lamarckian specimens seen); Ait. Kew. iii. 203; Muhl. Cat.; Darlingt. Fl. Cest. 467. A. proaltus, Poir. Suppl. i. 493, merely a change of Aiton's name, not Nees. A. eminens, Willd. Enum. 886, is either this or the preceding. A. rigidulus, Desf. Cat. (1815), 122. A. obliquus, Nees, Ast. 76, cult. form. A. onustus? and perhaps A. carneus, Nees, Ast. 122, 96, on cult. forms, but char. and some specimens of latter are of the preceding species. A. stenophyllus, Lindl. in DC. Prodr. v. 242, narrow-leaved form. A. carneus, in part, \& A. Greenei, Torr. \& Gray, Fl. ii. 134. - Low grounds, Canada and New England to Saskatchewan, E. Montana, and Texas : most abundant in the Mississippi valley. The original of Ait. Kew., in the Banksian herbarium, is of flowering branches only, with small leaves.

Var. subásper. A rigid and commonly scabrous form, with thyrsoid-contracted and foliose inflorescence: broad heads commonly foliose-bracteate: bracts of involucre broader and firmer, often obtuse: rays violet. - A. subasper, LindI. in Comp. Bot. Mag. i. 97, \& DC. Prodr. v. 257. A. carneus, var. subasper, Torr. \& Gray, l. c. - Illinois to Texas.

Var. caruléscens. A strict and rigid form, with the rather large heads in a more naked inflorescence, and leaves all entire: involucral bracts with narrower acute or acutish tips. - A. ccerulescens, DC. Prodr. v. 235. - Rocky banks, E. to W. Texas, Berlandier, Lindheimer, \&c.

b. Involucre of the small or barely middle-sized heads looser and less imbricated; but its bracts erect or hardly at all spreading, narrow and linear, with acute and not at all dilated green tips, or outermost wholly herbaceous, these little shorter or equalling the inner: leaves linear or lanceolate, not rigid, not dilated at base, sparingly denticulate or entire.

A. júnceus, AIt. Slender, a foot to a yard high, the smaller plants simple-stemmed and with few heads, smooth and nearly glabrous: leaves linear or nearly so ( 3 to 5 inches long, 2 to 4 lines wide), entire, or lower with rare denticulations : involucre 3 lines high; its bracts all small, narrowly linear and erect, thinnish, manifestly imbricated in 2 or 3 series, and the outer more or less shorter (thus connecting with $A$. paniculatus of the preceding subdivision) : rays light violet-purple, 4 or 5 lines long. - Hort. Kew. iii. 204, the indigenous specimen Halifax, Halbgren. A. salicifolius, Richards. App. Frankl. Journ. ed. 1, 478, ed. 2, 20, not Ait. A. laxifolius, Lindl. in Hook. Fl. ii. 10, mainly; hardly of Nees, Ast., who had a cult. plant of Leyden Garden, and in herb. Lindl. so named a plant of A. paniculatus? $A$. laxifolius, var. borealis, \& var. latiflorus, Torr. \& Gray, Fl. ii. 138. A. astivus, Gray, Man. mainly. A. borealis, Provancher, Fl. Canad. i. 308. - Wet meadows and cold bogs, Nova. Scotia to Ohio, Michigan, Wisconsin, and north to Hudson's Bay, Saskatchewan, and Rocky Mountains, \&c. Appears to pass into the next.

A. longifólius, Lam. A foot to a yard high, glabrous or pubescent, leafy : leaves elongated-lanceolate to linear-lanceolate, entire or sparingly serrulate, 3 to 7 inches long; taper- 
ing to both onds : involucre 4 or 5 lines high, little or not at all imbricated; its bracts all of nearly equal length, some looser outermost not rarely quite herbaceous: rays 3 or 4 lines long, violet or purplish, rarely almost white. - Dict. $i .306$, chiefly (and partly $A$. paniculatus, Lam.), fide herb. Par. A. cestivus, Ait. Kew. iii. 203; Willd. Spec. iii. 2030; Nees, Ast. 74 ; a shorter-leaved cultivated form. A.eminens, Nees, Ast. 87, in part, perbaps also A. laxifolius, Nees, certainly Hook. Fl., in part. A. salicifolius, Willd.? herb. (not Ait.), therefore? seemingly $A$. hiemalis, Nees, Ast. 77, said to blossom late. A. floribundus, Willd. fide spec. cult. herb. Par. 1814, hardly of Spec. Pl. A. virgineus, Nees, Astt 88. A. squarrulosus, Nees, Ast. 86 ? - Low grounds or along streams, Labrador to Montana, Slave Lake, south to Canada and N. New England. Like other boreal species, flowers early when cultivated in lower latitudes.

Var. villicaulis. A small and low form, with simple stem (a foot or less high) and midrib of narrow leaves beneath densely white-villous: heads few or solitary: rays deep violet. - Northern Maine, at Fort Kent, Miss Furbish.

c. Involucre of the middle-sized heads of firmer and more herbaceous or foliaceous-tipped and linear to spatulate bracts, imbricated in few to several series, of more or less unequal length, their summits from slightly to squarrose-spreading: leaves of rather firm texture: rays violet: comparatively late-flowering.

A. Novi-Bélgii, L. Rather low, rarely tall, glabrous and smooth, or pubescent in lines on the branches: leaves from oblong to linear-lanceolate, entire or sparsely or obscurely serrate; upper with sessile base partly clasping and not rarely somewhat auriculate: heads mostly 4 or 5 lines high and bright blue-violet rays of equal length. - The commonest laterflowered blue Aster of the Atlantic border, in low or wet grounds, truly polymorphous, both in wild forms and in those of long European cultivation, many of which are not identified with indigenous originals. - Spec. ii. 877 (truly founded on the $A$. Novce-Belgive, etc., Herm. Hort. Lugd. 67, t. 69, raised from seed collected about the year 1680 in the vicinity of New York, whence the name, and probably represented by the plant of Hort. ('liff. 408, not by indigenous specimen in herb. Linn. from Kalm, which is A. puniceus, L., nor by plant in herb. from Upsal garden); Nees, Ast. 79; Gray, Proc. Am. Acad. xvii. 167. A. serotinus, Mill. Dict., probably. A. floribundus, Willd. Spec. iii. 2048. Assume as most normal, if not the original Leyden type, the common form away from influence of salt water, and with leaves not thickish; these from narrowly to oblong-lanceolate, their upper surface not rarely scabrous, and linear involucral bracts with narrow and acute spreading or recurving upper portion. Common in wet grounds, New Brunswick and Canada to Georgia, chiefly eastward, but extending to Ohio and Illinois. A. eminens, var. virgineus, Lindl. Bot. Reg. t. 1656, appears to be a nearly white-rayed form. A. laxus, Torr. \& Gray, Fl. ii. 134, a very narrow-leaved form, and $A$. prcealtus (Nees.?), Torr. \& Gray, 1. c., one with broader leaves. A. longifolius, Gray, Man. ed. 5, 233 ; Sprague, Wild Flowers, 49, t. 10.

Var. Iævigátus. Smooth and glabrous throughout or nearly so: leaves mostly oblong-lanceolate, little if at all thickened; upper cauline disposed to be half-clasping by an abrupt or obscurely auriculate base: involucrai bracts in few ranks, rather short, all not far from same length, loosely erect, and with comparatively short acutish herbaceous tips; thus resembling $A$. versicolor except that the involucral bracts are much less imbricated and little unequal. - A. lovigatus, Lam. Dict. i. 306 ; Poir. Suppl. i. 498, not Willd. \&c. A. mutabilis, Ait. Kew. iii. 205 (cult. hort. Collinson \& Kew, 1777, \& herb. Jacq.) ; not L. by char., syn. Pluk., nor syn. Herm. A. serotinus \& Novi-Belgii, in part, Willd. Spec. iii. 2048; Nees, Syn. Ast. 24. A. brumalis (also A. onustus, partly, \& A. eminens, var. lovigatus), Nees, Ast. 88, \&c. A. argutus, Nees, Ast. 69, file spec. Schultz Bip., hort. Bonn.; but char. does not accord. Newfoundland to New England: hardly any wild specimens exactly answering to the plant cultivated and even naturalized in Europe ; but many that connect with the following, viz. :-

Var. litóreus. Stems rigid, low, or sometimes.3 or 4 feet high and then paniculately much branched, very leafy: leaves thickish and firm, very smooth (rarely upper face somewhat scabrous), oblong to lanceolate, upper partly clasping and sometimes auriculate : bracts of the involucre loosely imbricated in several ranks, onter commonly spatulate, all but innermost with broadish or obtuse herbaceous and mostly thickish tips. $-A$. Novi-Belgii, L, as to Hort. Cliff., at least herb. Cliff. A. tardiflorus, Willd. Spec. iii. 2049, and of most later authors, not L. A. adulterinus, Willd. Enum. 884; Lindl. Bot. Reg. t. 1571. Symphyotrichium unctuosum, Nees, Ast. 135. . The synonyms all from cultivated plants, less showy than 
the wild ; and a dwarf form, very floriferous, with small leaves and small heads, is $A$. coespitosus of the gardens (as cited by Lindley under $A$. adulterinus), probably the parent also of A. Novi-Belgii, var. minimus, of the gardens, with rose-purple rays. - Saline marshes and shores, Canada and New England to Georgia : evidently passes into the thinner-leaved form taken as the type, wherever it recedes from the influence of brackish water. The old cultivated forms evidently much altered in the European gardens.

Var. elódes. Slender, a foot or two high and simple, sometimes taller and with ampler panicle: leaves thickish, long aud narrowly linear ( 2 to 5 inches long, 2 or 3 lines wide), entire; those of flowering branches or open panicle sunall and bract-like : involucre of rather well-imbricated narrow bracts, with short and mostly spreading acutish tips. $-A$. elodes, Torr. \& Gray, Fl. ii. 136, chiefly. A. longifolius, Gray, Man. 233, in part, not Lam. Swamps near the coast, New Jersey to Virginia. Would seem to be a most distinct species; but passes by gradations.into forms of the type of the species, with narrow-lanceolate denticulate leaves of thinner texture; and the broad-leaved var. of Torr. \& Gray, 1. c., into the preceding variety.

Var. thyrsiflórus. Very leafy, smooth : cauline leaves narrowly lanceolate or nearly linear ( 2 to 4 inches long, 2 to 4 lines wide below the middle), attenuate-acuminate, commonly serrulate, of rather firm texture: heads numerous in a narrow thyrsoid panicle, or somewhat racemosely paniculate on elongated branches, rather large: involucre of the narrow bracts with attenuate and spreading or squarrose-recurving tips, as in the typical form. - A. thyrsiflorus, Hoffm. Phyt. Blatt. i. 83, t. D, f. 1 (yet figure and description answer rather to a broader-leaved form, either of the type or of the var. lovigatus); Poir. Suppl. i. 502 ; Nees, Ast. 65; DC. Prodr. v. 235, with var. squarrosus, Lindl. in DC. (A. eminens, Lindl. Bot. Reg. t. 1614, with abnormally foliose involucre.) A. spectabilis, Willd. Spec. iii. 2048, as to descr. (not char.) \& herb., not Ait. - Said to come from Virginia : cullivated plants not matched by indigenous specimeus.

$==$ Pacific or Rocky Mountain species.

a. Involucre of the middle-sized or small heads conspicuously and regularly pluriserially imbricated; outer bracts successively shorter; all loosely erect or little spreading, and with obtuse or obtusish mostly short and broadish herbaceous tips (occasionally in early or less developed heads some outer bracts foliaceous): leaves entire, or lower sometimes slightly serrate.

1. Heads mostly half-inch high, hemispherical, loosely paniculate: leaves comparatively large, none broadened at the insertion.

A. Chamissónis, GraY. Rather tall (2 to 4 feet high), with loosely spreading branches and branchlets, pubescent with spreading hairs or glabrate: leaves bright green, broadly lanceolate (larger canline 3 to 6 inches long and an inch or less broad, those of flowering branchlets small) : bracts of the broad involucre all but inner with obtuse and oval or apparently spatulate obtuse green tips (coarser and looser than in the next) : rays bright violet, 4 to 6 lines long. - Torr. in Wilkes Exped. xvii. 341; Bot. Calif. i. 324. A. radula, Less. in Linn. vi. 125, fide Nees. A. Chilensis, Nees, Ast. 133; Torr. \& Gray, Fl. ii. 112, but not at all Chilian. A. spectabilis, Hook. \& Arn. Bot. Beech. 146, not Ait. A. Neesii, Schultz Bip. in Flora, 1856, 354, name merely suggested. - Moist thickets and along streams, California toward the coast, for nearly the whole length of the State, apparently reaching Oregon; first coll. by Hcenke and Chamisso.

2. Heads smaller, 3 to 5 lines high.

A. Menziésii, Linde. A foot or two high, strict, from cinereous-pubescent throughout to almost glabrous, bearing mostly numerous or thyrsoidly racemose-paniculate and rather small heads on rigid erect branchlets or peduncles: leaves lanceolate or the lower spatulateoblong ( 2 or 3 inches long), on the branches small and linear or reduced to linear-subulate, so that the well-developed panicle is comparatively naked: involucre seldom over 3 lines high, short-turbinate, of linear slightly spatulate bracts in several rather closely imbricated ranks, nearly all obtuse : rays violet or purple, 3 lines long. - Hook. Fl. ii. 12, \& DC. Prodr. v. 243; Torr. \& Gray, Fl. ii. 113 (described from the original, starved and arid, cinereouscanescent specimens, collected by Menzies in California, not "Oregon"); Torr. in Wilkes Exped. xvii. t. 8 (a similar form, collected on the Sacramento); Gray, Bot. Calif. i. 324. A. Durandii, Nutt. ex Durand in Pacif. R. Rep. v. 8. Has been sometimes taken for A. falcatus. - Dry or moist ground, throughout California to W. Nevada. There are connecting forms between this and the preceding, aud others verging to the following. 
A. adscéndens, Linde. A span to a foot or two high, rather rigid, from nearly glabrous to strigulose-hirsutulous: stems ascending or erect from creeping rootstocks, commonly branching, bearing few or rather numerous loosely paniculate or subcorymbose heacls (these 4 or 5 lines high): leaves of firm and thickish texture (veins obscure), linear to spatulatelanceolate, entire, with margins commonly hispidulous-ciliate or scabrous: bracts of the hemispherical involucre oblong-linear or obscurely spatulate, moderately unequal and in comparatively few ranks; the green tips looser, either glalrous, pulerulent, or ciliolate ; inner often mucronulate: rays 3 or 4 lines long, violet or purple. - DC. Prodr, v. 231, \& Hook. Fl. ii. 8; Torr. \& Gray, Fl. ii. 111. A. denudatus, var. ciliatifolius, Nutt. Trans. Am. Phil. Soc. vii. 293. A. falcatus, Eaton in Bot. King Exp. 140, mainly. A. multiflorus, var. commutatus, Gray, Pl. Wright. ii. 76, a large form. - Plains and moist banks, Saskatchewan and Montana, to Colorado, New Mexico, N. Arizona, and W. Nevada, ascending the mountains to 10,000 feet ; first coll. in Brit. America by Drummond.

Var. denudátus, Torr. \& Grax, l. c. A low or slender form, smoother, less leafy, or rameal leaves much reduced in size, and smaller heads and rays. - A. derudatus ( $A$. ramulosus, in part, as to specimens), Nutt. 1. c. 292. A. Nuttallii, Torr. \& Gray, 1. c. 126 ; Eaton in Bot. King Exp., l. c. - Plains of Utah to S. Idaho; first coll. by Nuttall.

Var. Yosemitánus. Greener, less rigid, with comparatively large heads and looser involucre. - Sierra Nevada, from Summit to the Yosemite Valley.

A. Hállii, Gray. Stem strict, a foot or two high, leafy to the top, bearing numerous short racemosely disposed and ascending flowering branches; these minutely pubescent: leaves ( 1 or 2 inches long, barely 2 lines wide) entire, scabrous-ciliolate, otherwise smooth and glabrous, neither dilated nor contracted at base: heads small ( 3 lines high) and numerous, somewhat racemosely paniculate and crowded : involucre campanulate, glabrous; the bracts subspatulate-linear with oval or oblong green tips rather close and erect: rays 2 or 3 lines long, white or whitish. - Proc. Am. Acad, viii. 388, name only. - Dry ground, Oregon, E. Hall (distrib. no. 243), Lobb (289), Henderson. Perhaps this is A. bracteolatus, Nutt. Trans. Am. Phil. Soc. vii. 293, no specimens of which seem to have been preserved, and which is compared with $\boldsymbol{A}$. campestris, but is said to have a smooth involucre.

b. Involucre of the middle-sized heads more or less imbricated but looser; the bracts all narrow (linear or approaching subulate), thinnish, from moderately to hardly unequal, loosely erect, all acute or acutish, with not at all dilated tips, nor are the outermost normally enlargecl-foliaceous : leaves mostly entire.

1. Low, or only a foot or two high, chiefly of the mountains and high northward, mostly glabrous or a little pubescent.

A. Andínus, Nutr. Dwarf, with decumbent stems 2 or 3 inches long from filiform creeping rootstocks, bearing a solitary comparatively large head: leaves only half-inch long; radical and lower canline spatulıte; cauline ( 2 or 3 ) linear-lanceolate: involucre hemispherical, 4 lines high; its linear acutish bracts of almost equal length, nearly glabrous : rays violet, 4 lines long ( 35 to 40) : style-tips short-lanceolate, acute. -Trans. Am. Phil. Soc. vii. 290; Torr. \& Gray, Fl. ii. 154. - Rocky Mountains at Thornberg's Ridge, Wyoming, lat. $42^{\circ}$, near perpetual snow, Nuttall. Not since found: perhaps a high alpine state of $A$. Fremonti.

A. spathulátus, LINDL. Low, a span or two high, with ascending stems sparingly branched above and bearing 3 to 5 corymbosely disposed pedunculate rather large (half-inch high) heads: leaves ( $1 \frac{1}{2}$ to 3 inches long) linear-spatulate or upper linear-lanceolate with halfclasping base, and radical broader : involucre hemispherical; its linear bracts acutish, nearly equal : rays rather short, 3 lines long. - DC. Prodr. v. 231, \& Hook. Fl. ii. 8; Torr. \& Gray, 1. c. - Subarctic America, between Bear Lake and Fort Franklin, on the Mackenzie River, Richardson. A pproaches the next; but not matched.

A. Fremónti. A span to a foot (rarely 2 feet) high, glabrous or some minute soft pubescence along the upper part of the slender erect stem: leaves thinner and with margins either quite naked and smooth or obscurely ciliolate-scabrous; radical and lowest cauline oblong or oblanceolate, or somewhat obovate (inch or two long), and tapering into a slender margined petiole; cauline from oblong-lanceolate to linear, commonly half-clasping at base; heads solitary in the smaller specimens, several in the larger, one third to half an inch high (and the numerous violet rays 4 lines long), somewhat naked-peduncled: bracts of the involucre narrowly linear, obtuse or acutish, or the inner acute, some of the outer shorter, all 
loose and similar. - A. adscendens, var. Fremonti, Torr. \& Gray, Fl. ii. 503. A. adscendens? partly, Gray, Bot. Calif. i. 324. A. laxifolius, in part, Hook. Lond. Jour. Bot. vi. 160.Rocky Mountains, from Montana to Colorado and Utah, in wet ground below the alpine region, west to the Cascade Mountains, lat. $49^{\circ}$, and along the Sierra Nevada, California.

Var. Paríshii. A dubious form (connecting with the next species?), with more imbricated and acute involucral bracts, their margins ciliolate. - Bear Valley in the San Bernardino Mountains, S. E. California, Parish.

A. occidentális, Nutr. A span to a foot or more high, smooth and glabrous (except some minute pubescence below the head), slender; smaller plants simple, bearing solitary or fow heads; larger with slender branches and several or more numerous corymbose or paniculate heads (these 4 or 5 lines high): leaves mainly livear and narrow; cauline 1 to 3 inches long and only a line or two wide, rarely lanceolate and larger, occasionally (in Nuttall's specimens) bearing one or two salient lateral teeth or lobes; radical sometimes lanceolate-spatulate with long tapering base: involucre of narrowly or subulate-linear acutish or acute thinnish loose bracts, obviously imbricated, of 2 or 3 lengths: rays light violet, about 4 lines long. - Torr. \& Gray, Fl. ii. 16ะ (Tripolium occidentale, Nutt. Trans. Am. Phil. Soc. vii. 296), a small and weak alpine form, apparently of a species which at lower elevations becomes taller, rather freely branched, and in Oregon passes into a diffusely much branched and paniculate polycephalous form. - Moist grounds and along streams, Idaho to Washington Terr., and along the Sierra Nevada, California, to Kern Co. (A. astivus, Rothrock in Wheeler Rep.) ; first coll. in Oregon by Douglas.

Var. scabriúsculus. More strict, rather rigid, probably in drier soil with more exposure to aridity: stem and leaves scabrous-puberulent- $-A$. cestivus, Eaton in Bot. King Exp. 141. - Mountains of N. E. Nevada and Utah, Watson, Wood.

Var. intermédius. Ambiguous between $A$. occidentalis and a glabrous variety of A. Menziesil or of $A$, adscendens, a foot or two high, rather rigid, somewhat sparingly leafy, with paniculate flowering branches short outer bracts of the involucre often quite obtuse, but narrower than in the two last-mentioned species: radical and sometimes cauline leaves lanceolate. - Wet meadows, Falcon Valley, \&c., Washington Terr., Suksdorf, Howell, Brandegee, and N. California, Pringle.

2. Tall ( 3 to 8 feet high) and branching, leafy to the top, paniculately polycephalous: Southwestern.

A. hespérius. Resembles $A$. paniculatus and $A$. salicrfolius of the East, equally variable, from nearly glabrous and smooth to scabrous-pubescent. leaves lanceolate, entire or the larger with a few denticulations ( 2 to 5 inches long, 3 to 8 lines wide): heads rather crowded, 4 or 5 lines high : involucre of narrowly linear or more attenuate acute or gradually acuminate erect bracts, either unequal and imbricated, or with some loose and slender herbaceous exterior ones which equal the inner: rays either white or violet, 3 or 4 lines long. - Damp soil and along streams, S. Colorado and New Mexico to Arizona and S. California. Has been variously taken for $A$. longifolius, Novi.Belgii, astivus, \&c., and coll. by Wright, Greene, Rothrock, Cleveland, Parish, Lemmon, \&c.

c. Involucre loose and foliaceous-bracteate. at least some of the outer bracts herbaceous or foliaceous to the base or nearly so, equalling the inner, and more or less enlarged, either ascending or squarrose-spreading: the involucre of primary or early heads is more foliaceous; but, when the heads are more numerous, the enlarged outer bracts are not rarely wanting.

1. Heads small.

A. Oregánus, Notr. Nearly glabrous: stem rather slender, 2 feet high, paniculately branched at summit, or bearing several to many paniculate heads; these about 3 lines high: leaves linear-lanceolate, entire ( 2 to 4 lines wide): outer and herbaceous involucral bracts lanceolate, acute, not longer than the thin and narrow inner ones (in some heads few or none) : rays about 2 lines long, white or purplish - Torr. \& Gray, Fl. ii. 163, viz. Tripolium Oreganum, Nutt. Trans. Am. Phil. Soc. vii. 296, on small and hardly developed specimens. A. simplex and perhaps A. carneus, Eaton in Bot. King Exp. 1. c. "A. laxrfolius, in part, Hook. Lond Jour. Bot. vi. 240, not Nees, - Wet banks of streams and hoggy meadows, Idaho and N. Nevada to Oregon and Washington Terr. : probably also N. California.

2. Heads middle-sized or large: rays violet or purple. (Species confluent.)

A. Douglásii, LrNdu. Smooth, glabrous or nearly so: stems 2 or 3 feet high, with erect or ascending branches, bearing several or numerous paniculate heads; these 5 or 6 lines 
high: cauline leaves (either thinnish or rather firm) lanceolate ( 2 to 6 inches long, 3 to 8 lines broad in the middle), tapering to both ends, inserted by a narrow base, commonly serrate along the middle by acute and appressed or erect teeth: bracts of the involucre linear and acute, loosely imbricated and the small green tips commonly spreading; outer foliaceous ones few and not dilated, often wanting: rays 5 or 6 lines long. - DC. Prodr. v. 239 (not of herb. DC.), \& Hook. Fl. ii. 11 ; Torr. \& Gray, Fl. ii. 138. A. subspicatus, Nees, Ast. 74, from Cape Mulgrare, Alaska, is duubtless a form of this or of the next, and the name might apply to some specimens of either with contracted inflorescence. - Moist ground, commonly in shade, Northern Brit. Columbia to Oregon and N. Califoruia.

A. foliáceus, Lixpl. Smooth and glabrous, or upper part of stem tomentulose or pubescent: leaves from broadly lanceolate to oblong and the lower spatulate, entire or nearly so; upper cauline very commonly with partly clasping and sometimes even subcordate-auriculate base: heads half-inch high, when few or solitary fully as broad, when more numerous less ample: involucre mostly with conspicuous loose foliaceous lanceolate or broadly linear outer bracts, which equal the imner, or sometimes more imbricated and squarrose: rays violet or purple, in the larger heads nearly half-inch long,-DC. Prodr. v, 228. Here made to include very various forms. The originals, from Unalaska and Sitka, are rather low, simple, or simple-stemmed with short monocephalous branches, leafy about the heads: fartler south it becomes more branching, 2 or 3 feet high; generally differing from the preceding species in the ampler and broader as well as entire leaves, disposed to be half-clasping at base, and the leafy-bracted or much greener involucre. A. Douglasii, Eaton, Bot. King Exp. 141, \& Gray, Bot. Calif. i. 324, mainly. - Wet ground, Alaska, Brit. Columbia, and along the mountains to eastern part of California and Nevadn. Eastward it passes into

Var. fróndeus. Stem simple or with sparing erect flowering branches, sparsely leaved: leaves comparatively ample, 4 or 5 inches long; lower tapering into winged petioles, upper often with clasping base: heads solitary or few, naked-pedunculate, broad: involucral bracts linear-lanceolate, loose and not imbricated, all equalling the disk, occasionally the outermost broader and leaf-iike. - 4. adscendens, var. Parryi, Eaton, Bot. King Exp. 139. Subalpine on the Cascade and Rucky Mountains, from the borders of Brit. Columbia to those of Colorado and the Wahsatch in Utah.

Var. aprícus. Like a dwarf state of the preceding variety, grown in exposed places, somewhat rigid, thicker-leaved : stems ascending from tufted rootstocks, a span or two high, bearing solitary or 2 to 3 broad heads: involucral bracts all alike, somewhat spatulate-linear, obtuse or acutish : rays "deep blue-violet and reddish-purple intermixed." - High mountains of Colorado, at Lnion Pass, Rothrock, and near Gray's Peak, at 11,000-12,000 feet, in open and very dry places, Patterson. On Mount Paddo, Washington Terr., Suksdorf, Howell, the Jatter in a taller form, and looking toward A. spathulatus.

Var. Párryi. Includes some ambiguous forms, seemingly between the preceding variety and $A$. Fremonti, with stems a spau to a foot high, with smooth and thickish rather large leaves, mostly naked heads; the iuvolucre sometimes foliaceous-bracteate in the manner of the present species, sometimes wholly of the narrow and closer bracts of $A$. Fremonti. With that species this has been referred to $A$. adscendens. - Rocky Mountains of Colorado, subalpine, Parry (417), Hall \& Marbour (253), Vasey (251), \&c., and S. Wyoming, H. Engelmann.

Var. Burkei. A foot or two high, rather stont, simple or branched above, leafy to the top: leaves thickish, very smooth, ample; upper cauline mostly oblong, and with broadly half-clasping usually auriculate insertion: heads solitary or several, very broad: involucre of oblong or spatulate and obtuse loosely imbricated bracts, the outer commonly shorter, or outermost sometimes more foliaceous and equalling the disk. - Rocky Mountains, Burke in herb. Hook. Simcoe Hills, Washington Terr., Howell. Wahsateh Mountains at Alta, Utah, M. E. Jones. Mogollon Mountains, New Mexico, and Arizona, Rusby.

Var. Cánbyi. Like the preceding form in foliage, apparently tall and stout (base of stem and lower leaves wanting), leafy throughout the thyrsoid panicle of numerous subgessile heads: these comparatively small: upper leaves (only ones seen) rather broadly oblong and with broad half-clasping base obscurely auriculate: bracts of the involucre imbricated, with small and erect lanceolate green tips, only in some heads a few of the outermost loose and foliaceous, but seldom equalling the disk. - On White River in Western Colorado, Vasey, 1868, distributed under the name of A. Canbyi, Vasey; perhaps a distinct species. 
Var. Fatóni. Rather tall (2 or 3 feet high), branching, bearing numerous and smaller paniculate or glomerate heads, and comparatively narrow lanceolate leaves: involucre loosely imbricated; outer and sometimes inner bracts foliaceous, either erect or squarrose-spreading: transitional between $A$. foliaceus and $A$. Oreganus, and some specimens approaching $A$. Chamissonis. - A. Douglasii mainly, Eaton, Bot. King Exp. 141. - Open ground or woods and along streams, Brit. Columbia to California along the borders of Nevada, and northeastward to Montana.

A. ámplus, Lindu. Glabrate : stem over 2 feet high, strict, robust, remotely leafy : leaves thinnish, acutely and saliently serrate or serrulate, or some entire, oblong or oral-lanceolate; cauline $2 \frac{1}{2}$ to 5 inches long, mostly with narrowed partly clasping base; radical larger (over inch and a half wide), tapering into very long wing-margined petioles: heads several on rather naked peduncles: bracts of the involucre lanceolate and linear, of about two series, loose, of equal length, all rather shorter than the developed disk. - Hook. Fl. ii. 10, \& DC. 1. c. 236 ; Torr. \& Gray, Fl. ii. 137. - Northern Rocky Mountains, Drummond. Not since collected, seen only in herb. Hook, perhaps rather of the followiug group.

++ ++ Cauline leaves either conspicuously contracted at base, some as it were into a winged petiole, or with auriculite-clasping insertion, or with both: involucre lax.

$=$ Narrowed base of leaves not cordate- or auriclate-clasping at insertion.

A. Ellióttii, Torr. \& GraY. Glabrous, or the stout (2 or 3 feet high) stem minutely pubescent, very leafy to the corymbosely paniculate inflorescence: leaves thickish, oblong-lanceolate, serrate with small and appressed rather obtuse teeth, tapering below into the narrowed and as if wing-petioled base; upper 4 to 6 inches and lowest a foot or less long, including the channelled winged petiole : heads numerous, nearly half-inch high : bracts of involucre all of nearly equal length, loose, very narrowly subulate-linear, their green tips mostly spreading: rays narrow, "bright purple," 5 lines long. - Fl. ii. 140; Chapm. Fl. 204. A. puniceus, Ell. Sk. ii. 355, by the detailed descr. and specimen, excl. char. from Willd. - Swamps in the low country near the coast, S. Carolina to Florida.

A. pátulus, Lam. Glabrous or somewhat pubescent, either low or 2 to 4 feet high, with loose flowering branches: leaves ovate- or oblong-lanceolate, sharply serrate in the middle, acuminate at both ends, the lower into wing-margined petiole or attenuate base, even the upper with obscure if any auriculate insertion: heads loosely paniculate, about 4 lines high : bracts of involucre linear, erect or nearly so, loosely imbricated, the outer more or less shorter: rays light violet or purple, varying to white. - Dict. i. 308 ; DC. Prodr. v. 234. A. Tradescanti, Hoffm. Phyt. Blatt. 86 , t. D, f. 2, not L. A. pallens \& probably A. proecox, Willd. Enum. Suppl. 58. A. Cornuti (Wendl. ex Nees, where published, and why Cornuti?) \& A. acuminatus, Nees, Ast. 58 \& 60. A. abbreviatus, Nees, Syn. Ast. 16. - Canada and New Brunswick to E. New England, chiefly known in cultivation: introduced into the Paris garden in the days of Tournefort and Vaillant. There is a low form in the gardens, early flowering, having weak and often decumbent stems, as Lamarck characterized his species. The taller plants flower later.

$==$ Base of most cauline leaves auriculate- or cordate-clasping at insertion : involucral bracts loose, disposed to be equal in length' and the outer foliaceous.

$$
\text { u. Atlantic species, chiefly Northern. }
$$

A. tardiflórus, L. A foot or two high, glabrous or stem somewhat pubescent (not hispid), bearing corymbosely disposed heads : leaves lanceolate or oblong-lanceolate, gradually acuminate, mostly with contracted or tapering base and with auriculate or obliquely semiauriculate insertion: heads about 5 lines high : rays pale violet. - Spec. ed.2, ii. 1231 (founded on plant cult. in hort. Upsal., low, with weak stems, which grew for 18 years before it flowered, and then late, whence the name: represented in the herb. by two specimens of the non-flowering, with the semi-amplexicaul spatulate-lanceolate leaves well marked, and one flower-bearing), not of later authors and gardens. A. vimineus, Nees, Ast. 68, in part, not Lam. nor Willd. - Along streams, Lower Canada and New Brunswick to Labrador. Nearly related to $A$. patulus on the one hand, to the succeeding and to $A$. puniceus, var. loevicaulis, on the other. Ordinarily not a late-flowered species.

A. prenanthoídes, Muhl. A foot or two high, nearly glabrous, or the slender stem pulescent in lines, bearing loosely corymbiform cymose heads: leaves thin and elongated 
( 4 to 8 inches long), oblong- or ovate-lanceolate, saliently serrate in the middle, attenuateacuminate, and lower half or third narrowed as if into a broadly winged petiole, which is more or less (in most cases conspicuously) dilated into an auriculate-clasping base; upper surface minutely scabrous, lower smooth: heads (mostly 4 lines high) on short rather rigid and divergent peduncles: rays not very numerous, about 5 lines long, pale violet or in shade whitish: bracts of involucre narrow and outer more or less spreading - Willd. Spec. iii. 2046 ; Nees, Ast. 61 ; Darlingt. Fl. Cest. 465 ; Torr. \& Gray, Fl. ii. 142. - Moist ground especially along streams, W. New England to Penn. and Wisconsin, and throughout Canada. The var. scaber, Torr. \& Gray, 1. c. (New York \& Penn. in few specimens, with stem almost hispid in the upper part, or else tall and branching), is probably a hybrid with $A$. puniceus.

A. puníceus, L. Stem commonly 3 to 7 feet high, loosely branching above, rather stout, often red or purple (whence the name), hispid with spreading bristles which are taperpointed from a thickened rigid base (but sometimes these are few and sparse): leaves not rigid ( 3 to 6 inches long), oblong-lanceolate, acuminate, from coarsely and irregularly serrate to sparingly denticulate or sometimes entire, not at all or slightly narrowed toward the subcordate-semiamplexicaul base, commonly scabrous above and often hispid along the midrib beneath : heads ( 4 to 6 lines high) subsessile, either sparsely paniculate or thyrsoid-crowded: involucre of loose and thin soft and narrowly linear merely herbaceous bracts, with or without some larger and more foliaceous accessory ones : rays half-inch long, violet, varying to purple or occasionally white. - Spec. ii. 875 (Hort. Cliff., Herm. Lugd. t. 651, \&c.); Ait. Kew. iii. 208; Michx. Fl. ii. 115 ; Lindl. Bot. Reg. t. 1636 (var. demissus), Torr. \& Gray, Fl. ii. 140. A. hispidus \& A. amcenus, Lam. Dict. i. 306. A. blandus, Lodd. Bot. Cab. t. 959. Swamps and low thickets, Nova Scotia and Canada, west to Dakota, and common in the Atlantic States as far south as N. Carolina and the upper part of Georgia. A common species in cool districts, generally well marked, but running into some peculiar varieties, which may mostly be grouped under the following.

Var. lævicaúlis. Usually lower, a foot to a yard high : stem mostly green, smooth and naked below, above with mere traces of the characteristic hispicl or hirsute pubescence : leaves serrate. - A. blandus, Pursh, Fl. ii. 555 (Solander in herb. Banks), appears to be this, but may be $A$. tardiflorus. A. firmus, Nees, Ast. 66, a low form, certainly of puniceus, with few-flowered branches. A puniceus, var. frmus, Torr. \& Gray, 1. c. A. confertus, Hort. Par. 1835-1869 (but not of Nees, Ast. 126), a form with numerous thyrsoidcrowded heads. A. vimineus, Nees, Ast. 68 (form with longer and nearly glabrous branches), not of Willd., nor of Lam. - New England, Canada, \&c.

Var. lucídulus. A foot to a yard high, very leafy : stems glabrous, or with vestiges or even conspicuous traces of hispidulous pubescence: leaves lanceolate, entire or sparingly denticulate, somewhat lucid, wholly glabrous, but upper surface more or less scabrous: heads commonly numerous and thyrsoid-paniculate: involucral bracts less loose and less attennate. - A. lucidus, Wenderoth, Ind. Sem. Marb., ex DC. Prodr. v. 247. A. puniceus, var. vimineus, Torr. \& Gray, 1. c., chiefly. - Low ground, New England to Illinois, Wisconsin, and northward.

\section{b. Rocky Mountain and Western species.}

A. Cusíckii, Grar. Soft-pubescent throughout, or sometimes approaching to glabrous: stems a foot or so high, simple or corymbosely branched, leafy to summit: leaves thin, nearly entire, oblong-lanceolate or oblong; upper ones moderately contracted above the deeply cordate-clasping base; lower with more elongated narrow lower portion or winged petiole with dilated but smaller auriculate-clasping insertion: heads large (over balf-inch high) and broad, terminating stem or leafy short branches: involucre very foliaceous or foliose-subtended and loose; the larger and broader-lanceolate outer bracts fully equalling the inner : rays numerous, narrowly linear, nearly half-inch long, pale violet : akenes glabrous. - Proc. Am. Acad. xvi. 99. - Along subalpine streams, in mountains of E. Oregon, Cusick. Mountain meadows of W. Idaho, Watson. The latter seemingly connects with

Var. Lyálli. Villous with soft pubescence : stem over 2 feet high, rather stout: radical leaves not seen; cauline mostly narrowed below and with more or less auriculate halfclasping base, but even lower and larger ( 5 inches long and inch broad) not petiolarcontracted: heads terminating simple leafy branches: rays long for the size of the head ( 8 or 9 lines). - Between the Kootenay and Pend Oreille, Washington Terr., Aug., 1861, Lyall. Perhaps a distinct species and more allied to A. amplus, seen only in herb. Kew. 
§ 7. ERIGERASTRUM. Involucre of Erigeron, i. e. broad, of very many and narrow acute or attenuate bracts, all of the same length, herbaceous, with no distinction of body and tip: rays numerous and narrow: pappus simple: heads solitary, or rarely two, large, terminating the simple stem: this leafy to the top, in which and in the acute style-tips the section differs from Erigeron, to which it makes transition: arctic and subarctic species.

A. peregrínus, Porst. Tomentose-pubescent and glabrate, a span to 20 inches high from a thickish creeping rootstock: leaves oblong-lanceolate or upper ovate-lanceolate, these closely sessile by partly clasping base (inch or two long), either entire or sharply denticulateserrate: head half-inch high and broader: bracts of the involucre attenuate, tomentosepubescent or villous, not at all viscid or glandular: rays half-inch long, violet-purple. F1. ii. 556 ; Torr. \& Gray, Fl. ii. 155 ; Herder in Pl. Radd. ii. 10, in part. A. Unalaschensis, Less, in Linn. vi. 122? A. Tilesii, Wikstr. in Act. Holm. 1822, 13? A. salsuginosus, Hook. Fl. ii. 7, in part. A. consanguineus, Ledeb. Fl. Ross, ii. 473? - Alaskan Islands to Arctic coast; first coll. by $N$ elson. (Arct. E. Asia.) Has been confused with $A$, salsuginosus, Richards., now removed to Erigeron, which is naked.stemmed, above, its involucre viscidulous-glandular and not villons.

A. pygmæéus, LINDL. Villons-pubeseent and below glabrate, a span or less high and loosely cespitose: stems assurgent from a slender rootstock or creeping base: leaves lingulate-lanceolate to linear, entire, obtuse, nearly veinless (mostly an inch long): head about 4 lines high, solitary: bracts of the involucre spreading, linear, acute or obtuse, flaccid, densely or sparsely villous: rays 30 or more, apparently violet. - Hook. Fl. ii. 6 , \& DC. Prodr. v. 228,; Torr. \& Gray, Fl. ii. 154. - Arctic sea-coast, Richardson, Rae, \&c. Seemingly connects with Erigeron grandiflorus; but has subulate and very acute style-tips.

§ 8. Deellingríria. Pappus manifestly double; outer setulose, i. e. of numerous rigid and short bristles or squamellæ in a distinct series, inner of long capillary bristles, some of which are usually clavellate-thickened at the tip: involucre of $\S$ Orthomeris, i. e. bracts destitute of herbaceous tips and thin-coriaceous, - shorter than the disk: rays not numerous (8 to 13), always white: disk-corollas barely yellowish: akenes mostly obovate, several-nerved : heads corymbosely cymose (rarely solitary) at summit of stem or sparing branches, not large: leaves mostly entire, not rigid, veiny: pappus becoming tawny. - Gray, Proc. Am. Acad. xvi.98. Diplostephium, Cass. Dict. xxxvii. 486, not HBK. Dollingeria, Nees, Ast. 176, excl. spec. Diplostephium, § 1, DC. Prodr. v. 272, excl. spec. Diplopappus § Triplopappus, Torr. \& Gray, Fl. ii. 182. (The most distinct subgenus, even worthy of generic rank, except for some transitions. A. obovatus, Meyer, Rhinactina, Less., has similar pappus, but is otherwise as Xylorrhiza.)

* Leaves acute or acuminate, all entire, generally green and almnst glabrous, with loose veins and beneath a minute reticulation of veinlets (visible only under a lens): bracts of the short involucre mostly obtuse: akenes turgid-obovate at maturity, glabrate or glabrous: pappus rather rigid, at least some of the longer bristles clavellate: disk-corollas deeply 5-lobed.

A. umbellátus, Mrtc. Stem 2 to 7 feet high, generally tall and corymbose at summit, very leafy, bearing numerous rather crowded cymosely disposed heads : leaves lanceolate to oblong-lanceolate (3 to 6 inches long), acuminate and with tapering base: involucre hardly longer than the akenes; its bracts lanceolate-linear, rather obtuse: style-appendages deltoid-ovate, acutish: stronger pappus-bristles delicately clavellate. - Dict. ed. 7, no. 2; Ait. Kew. iii. 199 ; Hoffm. Phyt. Blatt. 74, t. B, f. 2. A. amygdalinus, Lam. Dict. i. 305; Michx. Fl. 109; Lindl. Bot. Reg. t. 1517. Chrysopsis amygdalina, Nutt. Gen. ii. 153. Diplostephium umbellatum \& $D$. amygdalinum, Cass. 1. c.; DC. 1. c. 272; Diplopappus umbellatus, and D. amygdalinus, partly, Torr. \& Gray, l. c. 183. - Low grounds, Newfoundland, S. Labrador, and Saskatchewan to Arkansas and Georgia; the typical form commoner northward: low forms with broader and more scabrous leaves common southward. 
Var. púbens. Lower face of the oblong-lanceolate leaves tomentulose-pubescent, alsu usually the flowering branchlets. - Saskatchewan to Upper Michigan.

Var. latifólius. Stems 2 to 5 feet high: leaves from ovate-lauceolate to ovate, comparatively short, less narrowed or sometimes even rounded at base, - A. humilis, Willd. Spec. iii. 2038, as to char. and indigenous specimen in herb., from Muhl., not Hort. Berol. t. 67. A. amygdalinus, Bertol. Misc. vi. t. 5, f. 1. Dellingeria amygdalina, Nees, Ast. 179, chiefly, excl. syn. D. comifolia, Lindl. in Hook. Comp. Bot. Mag. i. 98 . Diplopappus amygdalinus, Torr. \& Gray, l. c. - Low pine barrens, \&c., Penn. and New Jersey to Florida and Texas. Extreme forms seem very different from $A$. umbellatus, having leaves even 2 inches vide by 3 in length. In specimen from Georgia, J. Donnell Smith, style-appendages (abnormally?) rounded-obtuse.

A. infírmus, Michx. Stem slender, often flexuous, a foot to a yard high, less leafy, simple or with diverging flowering branches, bearing several or few (or even solitary) pedunculate heads: leaves obovate to ovate or oblong (rarely lanceolate, lower small and scattered), with attennate base and hispidulous-ciliolate margin and midrib, more copious primary and some loosely reticulated secondary veins : involncre more imbricated, of thicker and broader obtuse bracts: style-appendages linear-subulate: pappus more rigid; bristles of the longer pappus nearly all clarellate, rather scanty. - Fl. ii. 109. A. divaricutus, L. Spec., as to syn. Gronov. \& Plok. Alm. t. 79, not of herb., nor char. A. cornifolius, Mubl. in Willd. Spec. iii. 2039. A. humilis, Willd. Hort. Berol. t. 67 (not herb. nor Spec. 1. c.); Pursh, Fl, ii. 548; Ell. Sk. ii. 366. Chrysopsis humilis, Nutt. Gen. ii. 153, at least partly. Doellingeria cornifolia, Nees, Ast. 181. Diplostephium cornifolium, DC. 1. c. Diplopappus cornifolius, Torr. \& Gray, Fl. ii. 182. - Open woodlands, Massachusetts and Penn. to Upper Georgia, Tennessee, and Louisiana?

* Leares obtuse, occasionally toothed, both veins at d veinlets conspicuously reticulated beneath: akenes oblong, pubescent: pappus softer and finer, inner bristles not clarellate: diskcorollas with short lobes.

A. reticulátus, Pursh. Canescently puberulent: stems strict, I to 3 feet high, simple or fastigiately branched at summit, bearing few or numerons slender-pedunculate heads : leaves oval or oblong, or lowest obovate (larger 3 inches long and 2 wide) : iuvolucral bracts lanceolate: rays 10 to 13 , rather long and narrow. - Fl. ii. 548. Chrysopsis obovata, Nutt. Gen. ii. 152. Aster obovatus \& $A$. dichotomus (the latter a slender and paniculately branching state), Ell. Sk. ii. 368, 366. Diplosteplium boreale, Spreng. Syst. iii. 544. D. obovatum \& D. dichotomum, DC. 1. c. Dollingeria obovata, Nees, Ast. 182. Liplopappus obovatus, Torr. \& Gray, Fl. ii. 184. - Low pine barrens, S. Carolina to Florida.

§ 9. IÁnthe. Pappus less distinctly double; outer setulose (in one species obscure), inner not clavellate: otherwise as in $\S$ Orthomeris: involucre about equalling the disk, of narrow and appressed well-imbricated bracts : rays 10 to 18, violet: akenes narrow, villous : low and tufted plants, with rigid stems, which are thickly beset with the small linear or lanceolate entire and rigid one-nerved and veinless leaves. - Gray, Proc. Am. Acad. xvi. 98. Diplostephium $§$ Amelloidea, Nees, Ast. 199. Diplopappus § Amelloidei, DC. Prodr. v. 277, partly. Diplopappus § Ianthe, Torr. \& Gray, Fl. ii. 181.

* Head rather large (balf-inch high) and broad: style-appendages elongated, subulate-linear or narrower: akenes flat, with strong marginal nerves and sometimes a single lateral nerve.

A'. linariifólius, L. Stems 6 to 20 inches high, puberulent, strict, very leafy up to the heads : leaves widely spreading (except the small ones on the branchlets), narrowly linear, mucronate, about an inch long, green, smooth except the hispidulous-ciliolate or scabrous acufe margins; uppermost more or less passing into the rigid acutish bracts of the pluriserial campanulate or somewhat turbinate involucre : rays deep violet. $-A$. linariffolius \& $A$. rigi$d u s$, I. Spec. ii. 874 ; Bart. Fl. Am. Sept_iii. t. 104 ; Bertol. Misc. Bot. v. t. 6. A A pulcherrimus, Lodd. Bot. Cab. i. t. 6. Chrysopsis linariifolia, Nutt. Gen. ii. 152. Diplostephium linariifolium, Nees, Ast. 199. Diplopappus linariffolius (Hook. Fl., Torr. \& Gray, Fl.) \& D. rigidus, Lindl. in DC. Prodr. v. 277. - Dry sandy or gravelly soil, Newfoundland to Wisconsin and Texas. A variety with white rays is occasionally seen. 
A. scopulórum, Gray. Scabro-puberulent and somewhat cinereous : stems tufted, rigid, only a span high, terminated by a solitary pedunculate head: leaves short ( 3 to 6 lines long), rigid, from oblong to linear or the lowest spatulate, the broader obtuse with an abrupt mucro, callous-margined : involucre broadly campanulate; its bracts imbriçated in about 3 series, scabro-puberulent, lanceolate, acuminate: rays half-inch long, light violet: outer pappus sometimes distinctly squamellate.-Proc. Am. Acad. xvi. 98. Chrysopsis alpina, Nutt. Jour. Acad. Philad. vii. 34, t. 3, fig. 2. Diplopappus alpinus, Nutt. 'Trans. Am. Phil. Soc. vii. 304 ; Torr. \& Gray, Fl. 1. c. - Rocky Mountains, Montana and Wyoming, to W. Nevada and the border of California ; first coll. by Wyeth.

A. stenómeres, Gray. More slender, 6 to 10 inches high, green, minutely scabrous: solitary naked pedunculate head larger: leaves all linear (half to full inch long, a line wide), acutely mucronate, hardly margined: involucre broad; its bracts barely in two moderately unequal series, linear, acute or acuminate, thinnish, often pubescent : rays pale violet, over half-inch long: outer pappus setulose. - Proc. Am. Açad. xvii. 209. - Rocky Mountains of Montana and Idaho, Burke, Watson.

* * Head smaller (a third to a quarter inch high) and narrow: the disk-flowers sometimes hardly more numerous than those (12 to 15 ) of the ray: style-appendages ovate and obtuse: akenes less compressed, lightly few-nerved: outer pappus of few or indistinct unequal short bristles.

A. ericæefólius, Rотнrock. About a span high, strigosely canescent or hispidulous and glandular-scabrous, much branched: branches erect or diffuse, terminated by somewhat pedunculate heads: leaves commonly hispid-ciliate, erect or little spreading, 3 to 6 lines long; lowest spatulate and tapering into a petiole; upper from linear to nearly filiform, piliferous-mucronate : bracts of the involucre in about 3 series, lanceolate, acute or apiculate, thinnish, scarious-margined: rays purple or violet, sometimes white. - Rothrock in Bot. Gazette, ii. 70, \& Wheeler Rep. vi. 152. Inula? ericoides, Torr. in Ann. Lyc. 'N. Y. ii. 212. Eucephalus ericoides, Nutt. in Trans. Am. Phil. Soc. 1. c. 299 . Diplopappus ericoides, Torr. \& Gray, Fl. ii. 182; Gray, Pl. Fendl. 69, var. hirtella, a hispid form. -Dry hills, Kansas and Texas to Utah, Arizona, and border of California; first coll. by James. (Adj. Mex.)

Var. ténuis, Gray. Much less or not at all hispid : branches filliform and diffuse: all the upper leaves minute. - New Mexico, Wright, \&c. (Adjacent Mex. to San Luis.)

\$10. Orthómeris. Pappus simple: bracts of the involucre imbricated and appressed, destitute of foliaceous or herbaceous tips, often scarious-edged or more or less dry: rays fertile. - Gray, Proc. Am. Acad. xvi. 98. \$ Orthomeris with part of § Oxytripolium, Torr. \& Gray, Fl.; Benth. \& Hook. Gen. l. c.

* Involucre well imbricated, of small and narrow bracts, greener than in others of this section (much as in Aster proper): low and slender herbs (a foot or less high), leafy-stemmed, branching above; with mostly linear erect and entire leaves, and several small white-rayed heads: akenes somewhat 4-5-angled or nerved.

A. ptarmicoídes, Torr. \& Gray. Rather rigid, 6 to 20 inches high in a tuft from short and thickish rootstocks, from smooth or minutely scabrous to hirtellous-puberulent, bearing a corymbiform cyme of several or numerous heads: leaves of firm texture, linear or the lower spatulate-lanceolate, lucid both sides, the broader ones nervose: bracts of the campanulate or somewhat turbinate involucre oblong-lanceolate, obtuse, thickish, rather rigid: rays 2 to 4 lines long, bright white, broadish: style-appendages acutely lanceolate-subulate : pappus white, of rather rigid bristles, longer ones manifestly clavellate at tip : akenes very glabrous, hardly at all compressed.-Fl. ii. 160. Chrysopsis alba, Nutt. Gen. ii. 152. Doellingeria ptarmicoides, Nees, Ast. 183. Diplopappus albus, Hook. Fl. ii. 21. Hleleastrum album, DC. Prodr. ఛ. 264, excl. syn. Willd. Aster albus, Eaton \& J. Wright, Man. Bot. 146, not Willd. herb. \& Spreng. Syst. (which is A. Amellus). Eucephalus albus, Nutt. Trans. Am. Phil. Soc. vii. 299. - Rocky banks and bluffs, W. New England (S. Hadley, Ma.ss.), to Illinois, the Saskatchewan, and the mountains of Colorado ; first coll. by $N$ uttall. Depauperate plants sometimes ondy 2 or 3 inches high, and monocephalous.

Var. Georgiánus, GraY. Taller and slender, over 2 feet high : lowest leaves 5 or 6 inches long, sometimes with 2 or 3 coarse denticulations : heads and rays rather small..Proc. Am. Acad. xvi. 98; Chapm. Fl. Suppl. 627. - Upper Georgia, near Rome, Chapman. Nearly the same from open woods of N. W. Arkansas, F. L. Harvey. 
Var. lutéscens. Rays pale yellow, small. - A. lutescens, Torr. \& Gray, F1. 1. c. Diplopappus albus, var. lutescens, Hook. 1. c. D. lutescens, Lindl. in DC. 1. c. - Saskatchewan, on dry limestone rocks of Red River, Louglas, a broadish-leayed scabrous-puberulent form. Englewood, N. Illinois, $E$. J. Hill, a slender and smooth form, with numerous and unusually small heads.

A. Lemmóni. Slender, from filiform rootstocks, somewhat strict, smooth and glabrous, bearing a few rather scattered heads: leares not rigid nor lucid, not nervose; cauline somewhat gramineous, narrowly linear and attenuate (larger 4 or 5 inches long, a line or two wide), on flowering branches gradually reduced to subulate-attenuate; radical shorter, lanceolate-oblong or spatulate: involuere ( 3 lines high) equalling the disk, of about 3 series of thin linear and acute or acuminate bracts : rays 2 lines long: pappus of soft and slender bristles: akenes minutely canescent. - Along mountain streams in s Arizona: Santa Rita Mountains, Pringle, and Huachuca Mountains, Lemmon.

* * Involucre rather loosely imbricated, of thin narrowly linear-lanceolate attenuate-acute bracts in not more than 3 series: akenes glandular, several-nerved: stems leafy, a foot or two high from filiform creeping rootstocks, bearing several or sometimes solitary long-peduncled middlesized heads : leaves mostly pinnately veined, thin or thinnish, from lanceolate to oblong-ovate. Northern Atlantic species.

A. acuminátus, Mıснх. Somewhat pubescent or puberulent: stem leafless below, leafy and somewhat corymbosely branched above, or often simple, sometimes flexuous: leaves membranaceous, 3 to 6 inches long, mostly oblong with cuneiform-attenuate base and slender acuminate apex, sharply and coarsely dentate, primary veins abundant and conspicuous: heads usually several and corymbiform-paniculate, barely half-inch high: rays linear, white. or tinged purplish: style-appendages lanceolate-subulate, slender: akenes narrow. - Fl. ii. 109 ; Hook. Bot. Mag. t. 2707, \& Fl. ii. 9; Torr. \& Gray, Fl. ii. 157, not Nees. A. divaricatus, Lam. Dict. i. 305 (herb. Juss.), not L. A. diffusus, var. acuminatus, Pers. Syn. ii. 447. Diplostephium acuminatum, DC. Prodr. v. 273. - Deep and cool woods, S. Labrador to Pennsylvania, and along the mountains to Georgia.

A. nemorális, Ait. Somewhat puberulent: stem slender, very leafy above, sometimes simple and bearing a single slender-pedunculate head, often corymbosely or somewhat umbellately branched above, the branches similarly monocephalous: leaves from oblong-lanceolate to broadly linear, an inch or two long, acutish or obtuse, tipped with a callous point, entire or slightly few-toothed, scabrous above; those of the flowering branches or peduncles linearsubulate and scattered : involucre of more numerous lifear-subulate puberulent bracts: rays broadly linear, lílac-purple: style-appendages broadly lanceolate: akenes broader. - Kew. iii. 198; Nutt. Gen. ii. 154; Torr. \& Gray, 1. c. A. uniflorus, Michx. F1. ii. 110, small and simple-stemmed form. A. ledifolius, Pursh, Fl. ii. 544. Galatella nemoralis, Nees, Ast. 173. - Bogs and swamps, Newfoundland and Hudson's Bay to New Jersey.

* * Involucre closely and regularly appresserl-imbricated in several series of ovate or ovatelanceolate dry and chartaceous (sometimes purplish-tinged) bracts : akenes oblong, conpressed, more or less pubescent: stems leafy to the top, bearing several or rarely solitary pedunculate heads: leaves mostly pinnately veined, sessile, from lanceolate to oblong-ovate, commonly entire. Rocky Mountain and Northwestern species. - Eucephalus, Nutt.

+ Style-appendages subulate, equalling or longer than the stigmatic portion: involucral bracts all thin and dry, acute or acutish, commonly tomentose-ciliate, at least when young: akenes rather broad and flat, hirsute, becoming glabrate at maturity: stems mostly simple and 2 or 3 feet high, striate-angled: heads showy: rays purple or violet.

A. Engelmánni, Gray. Commonly rather tall and robust, green, slightly puberulent to glabrous : leaves thin, ovate-oblong to broadly lanceolate ( 2 to 4 inches long), loosely veined, the larger sometimes with a few small acute teeth, upper commonly tapering at apex iuto a slender or cuspidate acumination: heads (fully half-inch high), hemispherical, either racemosely disposed on slender axillary peduncles or somewhat thyrsoid-cymose: involucral bracts mostly acute or acuminate; some outer ones loose, narrow and partly herbaceous, or with loose pointed tips; inner purplish : rays about half-inch long: style-appendages attenuate-subulate: akenes obovate-oblong with narrowish summit. - Am. Joux. Sci. ser. 2, xxxiii. 238, without char. A. elegans, var. Engelmanni, Eaton, Bot. King Exp. 144. - Rocky Mountains, Utah and Wyoming to the Brit. boundary and in the Cascades, Washington Terr. ; first coll. by H. Engelmann and Lyall. 
Var. ledophýllus, Grax. Stem lower (not over 2 feet high), rather strict: leaves smaller (inch or two long), cottony-tomentulose beneath, at least when young; lower obtuse and merely mucronate, uppermost with slender cuspidate point usually developed. - Proc. Am. Acad. viii. 388. A. ledophyllus, Gray, Proc. Am. Acad. xvi. 98, without char. - Mount Hood at 4,000 feet and upward, Hall, Howell, Mount Paddo (Adams), Suksdorf. Seemingly distinct, but passes into the type and into the following variety.

Var. glaucéscens. Stem mostly slender, 1 to 3 feet high, in the larger plants more branched above and bearing rather numerous corymbosely disposed heads: leaves somewhat glaucous, wholly glabrous (except the minute ciliolation of the species), lanceolate, 2 or 3 inches long, 3 to 7 lines wide, uppermost usually attenuate-cuspidate: heads smaller or less broad: involncre of fewer and closer bracts. - Washington Terr. : on Mount Paddo, and Sincoe Mountains, Suksdorf, Howell. N. California, mountains of Siskiyou Co., Greene, Pringle, distributed as $A$. elegans, which it approaches.

A. élegans, Torr. \& Gray. Slender, 1 to 3 feet high, mostly scabro-puberulent: leaves thickish, pale, lanceolate (inch or two long), erect, the upper apiculate-mucronate, the veins inconspicuous: heads several at summit of simple stem or branches, comparatively small and few-flowered (4 or 5 lines high): involucral bracts all close and conspicuously woollyciliate, barely acute, outer ovate, none with pointed tips : rays rather few, about 4 lines long: style-appendages linear-subulate, hardly acute. - Fl. ii. 159; Eaton, l. c. (a somewhat ambiguous form). Eucephalus elegans, Nutt. Trans. Am. Phil. Soc. vii. 298. - Mountains of Wyoming and Montana to N. Nevada and E. Oregon; first coll. by Nuttall.

+ + Style-appendages obtuse and short-oblong, shorter than the stigmatic portion: involucral bracts firmer; all the outer obtuse, not ciliate nor scarious-margined: akenes narrower, merely pubescent.

A. glaúcus, Torr. \& GraY. Throughout smooth and glabrous, glaucescent or pale: stems a foot high from extensively creeping filiform rootstocks, branching, bearing several or numerous paniculate heads : leaves thickish, lanceolate $(1$ to 3 inches long, a quarter to half inch broad), rather obtuse, when dry reticulate-venulose both sides: involucre 3 lines high, imbricated in about 3 ramks : rays bright violet, 4 to 6 lines long. $-F l$. ii. 150; Eaton, l. c. Eucephalus (Lagatea) glaucus, Nutt. l. c.-Rocky Mountains, Wyoming to Colorado and Utah.

* * * * Inrolucre less imbricated, hemispherical; the bracts in few ranks and in the typical species somewhat equal, partly greenish, with or without scarious margins: pappus-bristles not clavellate-thickened at tip: low-stemmed or acaulescent, from a thick and sometimes ligneous caudex or rootstock, with solitary or few pedunculate heads, and rather large and numerous rays: leares thickish, narrow, one-nerved or nerrose, entire. - Xylorrhiza, Nutt. Traus. Am. Phil. Soc. vii. 298. § Orthomeris, Xylorrhiza, Torx. \& Gray, 1. c.: also Benth. \& Hook. Gen. ii. 273, excl. syn. Rhinactina (which has a double pappus) \& Arctogeron (which has the characters of Erigeron with somewhat too imbricated involucre). Western montane species.

+ Genuine species, with comparatively large (half-inch high or more) and showy heads, and thickish leaves : pappus-bristles rather rigid.

* Heads terminating short leafy stems which arise from creeping and ligneous rootstocks: invoIucral bracts acuminate and mucronate-tipped : style-appendages triangular- or lanceolate-subulate, not attenuate, shorter than the stigmatic portion : akenes oblong, very villous. - Xylorrhiza, Nutt.

A. Párryi, Gray. Tomentose-pubescent and cinereous, a span high : leaves mostly spatulate and obtuse with a mucronate point, an inch or more long: heads usually solitary on peduncle surpassing the leaves, very broad: bracts of the involucre oblong-lanceolate, densely cinereous-pubescent: rays white, over half-inch long. - Am. Nat. viii. 212. - Rocky Mountains in Wyoming, on marshy flats of Sandy Creek, Green River, \&c., Parry, A. J. McCosh.

A. Xylorrhíza, Torr. \& Grar. Less pubescent.and glabrate, 4 to 8 inches high: leaves from narrowly spatulate-lanceolate to linear ( 1 or 2 inches long, I to 3 lines wide); the upper commonly equalling the 1 to 3 peduncles: heads smaller: involucral bracts more attenuate: rays "pale red" or "pale rose-color," 4 lines long. - Xylorrhiza villosa \& $X$. glabriuscula, Nutt. Trans. Arn. Phijl. Soc. n. ser. vii. 297, 298. Aster Xylorrhiza \& A. glabriusculus, Torr. \& Gray, l. c. 158; the latter a more leafy-stemmed form. - Clayey soil and on rocks, Rocky Mountains of Wyoming, toward the sources of the Platte; first coll. by Nuttall. Laramie Plains, Parry. 
+ Head (broad and large for the plant) solitary on the simple and scapiform few- and snallleaved stems, which with the cluster of narrow radical leaves rise from a thickened caudex: involucral bracts linear, acutish, rather loose, of ten tomentulose when young: the plants otherwise glabrous and smooth: rays numerous, purple or violet; style-appendages slender and acute, usually more than twice the length of the stigmatic portion: akenes narrow: pappus strongly denticulate.

A. Andersóni, Grır. Scapiform stems a span to a foot high, erect: radical leaves ligulate-linear or slightly broader upward, gramineous, mostly acute (2 to 10 inches long, 2 or 3 lines wide), nervose when dry; upper cauline reduced to scattered subulate bracts: head broad (fully half-inch high and wide): style appendages filiform: akenes oblong-linear, softvillous. - Proc. Am. Acad. vii. 352, \& Bot. Calif. i. 325. Engeron Andersonii, Gray, 1. c., vi. 540. - Wet subalpine meadows, along the whole length of the Sierra Nevada, California and borders of Nevada; first coll. by Anderson.

A. pulchéllus, Eatos. Scapiform stems spreading and assurgent, 2 to 4 inches long: radical leaves from lingulate-spatulate to narrowly linear, an inch or two long, obtuse, nerveless, in the larger western form often 3 or 4 lines wide near apex, and hearls as large as those of A. Andersoni; in the smaller more eastern form only a line wide and hoads smaller: style-appendages linear-subulate: akenes linear, striate, glabrate, at least below. Bot. King Exp. 143, t. 16, the small and slender form, published in 1871. A. alpigenus, Gray, Proc. Am. Acad. viii. 389 (1872), the larger form first collected by Tolmie, and published as Aplopappus alpigenus, Torr. \& Gray, Fl. ii. 241, the rays supposed to be yellow, whereas they are violet. - On the higher mountains, viz. Ranier, Paddo, and Hood, of Washington Terr. and Oregon, rediscovered by Hall, Howell, Suksdorf, Mrs. Barratt, and the smaller form on Blue Mountains, E. Oregon, Cusick, those of N. Nevada, Watson, also Rocky Mountains of Wyoming and Montana, Hayden, Parry, Scribner.

+ + Ambiguous species, with small heads (2 or 3 lines high) few or solitary, terminating very slender leafy stems or branches; and leaves small and slender: style-appendages ovate-subulate, about the length of the s' igmatic portion : akenes compressed, hispidulous-pubescent, 2-3-nerved: pappus rather scanty and fragile (therefore near to Erigeron, but with the style-tips of Aster): small and many-stemmed from a somewhat ligneous caudex, nearly glabrous.

A. Watsóni, Gray. Cespitose, 2 to 4 inches high; the filiform stems mostly monocephalons: leaves filiform-linear, or the lower and larger (inch long) with spatulate-dilated apex; npper very small: bracts of the involucre lanceolate, acute, commonly purplish-tinged, 2-3seriate: rass white or purplish: style-appendages ovate or triangular and acuminate-subulate. - A. glacialis, in part, Eaton, Bot. King Exp. 142 (no. 509), also mixed with specimens of A. pulchellus. - Monntains of N. Nevada, Wahsatch Mountains at the hearl of American Fork; first coll. by Watson.

A. arenarioídes, Entov. Stems tufted on a woody caudex, almost filiform, 6 to 9 inches high, sparingly branched above, or bearing 2 to 4 heads : leaves filiform-linear, even the lower (inch or two long) only obscurely dilated upward: uppermost reduced to minute subulate bracts; bracts of the involucre linear, rather rigid, unequal and 3-seriate: rays white or bluish: style-appendages ovate-subulate, merely acute. - Proc. Am. Acad. viii. 647. Erigeron stenophyllum, Eaton, Bot. King Exp. 152, t. 17, not Gray. - Wahsatch Mountains, above Cottonwood Cañon, 8,000-9,000 feet, Watson.

* * * * Involucre (except in A. pauciflorus) well imbricated and with short outer bracts disposed to pass into scale-like bracts of the peduncle: herbs or shrubby plants, maritime or of alkaline soil; the leares more or less fleshy or reduced to scales. - $\$$ Oxytripolium in part (the perennial species), Torr. \& Gray.

- Heads rather large (about half-inch high), with showy violet rays: involucre well imbricated in sereral ranks: leaves long and narrow, entire, moderately fleshy: very glabrous herbs of the Atlartic coast. (Here also A. imbricatus. Walp. Rep. ii. 574, Tripolium imbricatum, Nutt., and the true T. conspicuum, Lindl. in DC, of Chilı; see Proc. Am. Acad. xvij. 210.)

A. Chapmáni, Tork. \& Gray. Stem simple and slender, 2 or 3 feet high, from in thickish caudex, bearing a few simple slender monocephalous branches at summit: leaves rigid when dry, linear, or radical spatulate-linear (these 5 to 9 inches long, inclucling the long attenuate base), obscurely nerved when dry; cauline becoming subulate-filiform and erect, and reduced on the branches to minute bracts: involucre campanulate, equalling the disk; its rather firm bracts mostly oblong-lanceolate, acute or mucronate: style-appendages ovate- 
subulate: akenes oblong, 7-10-nerved : pappus rather rigid. -Fl. ii. 161 ; Chapm. Fl. 205. Pine-barren swamps, W. Florida, Chupman, Curtiss.

A. tenuifólius, L. Stem simple or paniculately branched above, a foot or two high from a weak and slencler rootstock, often flexuous, somewhat sparsely leafy : leaves rather fleshy, at least thickish, linear, tapering to both ends, acute ; the lower (2 or 3 lines wide) with long tapering base; upper subulate-attenuate: involucre turbinate; its bracts lanceolate-subulate and attenuately very acute: style-appendages linear-subulate: akenes narrow, 5-ribbed, hispidulous-pubescent : pappus soft. - Spec. ii. 873 (excl. syn. Plul..) \& herb.; Gray, Proc. Am. Acad. viii. 647. A. flexuosus, Nutt. Gen. ii. 154; Torr. \& Gray, 1. c. A. sparsiflorus, Pursh, Fl. ii. 547 ; Ell. Sk. ii. 346, not Michx. A. Tripolium, Walt. Car. 210. - Salt or brackish marshes, coast of Mass. to Florida. This is one of the plants of Clayton which by the character in Gronov. Fl. Virg. was referred by Linnæus to A. linifolius.

+ Heads rather small (quarter-inch high), with conspicuous violet or purple rays: little in-
bricated involucre with peduncles and upper part of stem viscid-glandular: wholly herbaceous,
western, might be sought among the Glandulusi of true Aster.

A. pauciflórus, Nutr. Stem 6 to 20 inches high from a slender creeping rootstock, simple and bearing few heads, or branching above and with several corymbosely disposed shortpeduncled heads: leaves moderately fleshy, linear, or radical subspatulate or elongatedlanceolate, entire, uppermost reduced to short sparse bracts : bracts of short hemispherical involucre rather fleshy and green, moderately unequal and rather loose, in only 2 or 3 ranks: style-appendages lanceolate-subulate: akenes narrow, compressed, striate-nerved, appressedpubescent. - Gen. ii. 154, \& Trans. Am. Phil. Soc. vii. 292 ; Torr. \& Gray, Fl. ii. 164. A. caricifolius, HBK. Nov. Gen. \& Spec. iv. 92, t. 333. Tripolium subulatum, Nees, Ast. 167; Líndl. in Hook. Fl. ii. 15, \& DC Prodr. v. 254. T. caricifolium, Schaner in Linn. xix. 721. - Wet saline soil, Saskatchewan and Dakota to New Mexico, Utah, and Arizona. (Mex.)

Var. gracíllimus, Grax, Pl. Wright. ii. 76, a very slender form, with leaves almost filiform; from New Mexico, Wright.

+ + Heads small or rather small, with close imbricated involucre and whole herbage smooth
and glabrous: branching plants with lignescent base, or even shrubby, all of the Southwestern
borclers and Mexican, and in saline soil.
+ Low and spreading or tufted, with merely lignescent base, leafy: rays purple or violet, rather
conspicuous, about 3 lines long.

A. blepharophýllus, GraY. Loosely surculose-tufted, with ascending flowering stems a span or two high : leaves fleshy, conspicuously hispid-ciliate with strong bristles; those of creeping sterile shoots and rosulate tufts linear-spatulate, half-inch long; of the branching flowering stems much smaller, short-linear, and upper ones reduced to minute and merely bristle-tipped scales : heads 3 lines high : involucre turbinate; its bracts dry and pale, ovateoblong to lanceolate, rather obtuse, carinate-one-nerved: rays 10 to 14 : style-appendages short-subulate: akenes obscurely striate-nerved, not compressed, sericeous. - Pl. Wright. ii. 77. - Las Playas Springs, New Mexico, Wright.

A. ripárius, HBK. A foot or two high from a somewhat lignescent base, diffusely branched: branches terminated by solitary heads (of 4 or 5 lines in height and equally broad): leaves linear and entire, or lowest spatulate and incisely few-toothed, an inch or less long, on the branches toward the heads gradually rednced to small subulate bracts: involucre shorter than the disk; its numerons well-imbricated bracts narrowly lanceolate and with subulateacuminate greenish tips: style-appendages subulate, rather short: akenes pubescent, obscurely striate: pappus rufous. - Nov. Gen. \& Spec. iv. 92, the rays said to be white, which is probably a mistake, and the involucre subsquarrose, but it is not so, though the onter may be a little loose. A. Sonorce, Gray, Pl. Wright. ii. $76 .-$ S. Arizona, west of the Chiricahui Mountains, Wright. (Mex., Humboldt.)

+ Taller, much branched, rigid, woody at base, with small beads terminating the branchlets: rays small (a line or two long) and white or none: anomalous species.

A. carnósus, GRAY. Glancescent or pale, 2 or 3 feet high; the rigid slender stems diffusely and at length intricately much branched: lower leaves linear aud very fleslyy, an inch or less long; upper and those of the branchlets reduced to small or minute subulate scales: heads 3 or 4 lines high : involucre campanulate or turbinate, of lanceolate acute chartaceous bracts : rays wanting: style-appendages linear-subulate: akenes sericeous-pubescent. - Lino- 
syris? carnosa, Gray, PI. Wright. ii. 80. Bigelovia intricata, Gray, Proc. Am. Acad. xvii. 208, a slender form, with smaller heads. - Saline arid region, S. Arizona, Wright, to California, in the Mohave Desert, Parry, Greene, Pringle, Parish, and near Visalia, Congdon.

A. spinósus, Bente. Base of stem usually persistent and woody, sending up ( 3 to 8 feet long) slender and lithe striate green branches, resolved into paniculate branchlets, terminated by small heads : cauline leaves small, linear or spatulate-lanceolate, entire, mostly few and fugacious, some of them with soft subulate spines in or above their axils; those of the branchlets reduced to subulate scales or wanting: involucre hemispherical, 2 lines high, of small and thinnish subulate-lanceolate bracts, imbricated in about 3 series: rays white, 2 lines long: style-appendages subulate-triangular, mucl shorter than the stigmatic portion: akenes glabrous. - Pl. Hartw. 20; Torr. \& Gray, Fl. ii. 165; Gray, Pl. Lindh. ii. 219. Banks of streams, or in moist ground, S. W. Texas to Arizona and S. California, common; first coll. by Berlandier. (Mex.)

A. Pálmeri, Grsy. Decidedly shrubby, with the habit of a small-leaved Baccharis, 3 or 4 feet high, very much branched throughout: branchlets slender, striate-angled, terminated by the small heads : leaves apparently not fleshy, narrowly linear (of the branches an inch or less long), entire: involucre equalling the disk, barely 3 lines high, of closely imbricated narrowly oblong obtuse rather dry bracts: rays 6 to 10, a line long : disk-flowers about 20 : akenes sericeous-pubescent. - Proc. Am. Acad. xvii. 209. Perhaps rather of the W. Indian genus Gundlachia, Gray, Proc. Am. Acad. xvi. 100.-S. Texas, at Corpus Christi Bay, Palmer.

\section{Series II. Biennials and annuals.}

§11. Oxrtripótrom. Involucre of § Orthomeris; the bracts thin and narrow, linear-lanceolate or linear-subulate, gradually very acute or acuminate, commonly greenish above or in the centre, but without herbaceous tips, imbricated in few series, the outer successively shorter, all erect-appressed: rays at least equalling the disk, numerous, often more numerous than the disk-flowers (revolutely coiled in drying): style-appendages lanceolate-subulate: akenes narrow, more or less pubescent, few-nerved: pappus fine and soft: glabrous and smooth annuals, chiefly of saline soil, paniculately branched, bearing numerous small heads, with bluish or purplish rays, and with entire narrowly lanceolate or linear leaves, on the branchlets reduced to subulate bracts. - Gray, Proc. Am. Acad. xvi. 98. Tripolium § Oxytripolia, DC. Prodr. v. 253, excl. spec. Tripolium § Astropolium, Nutt. in Trans. Am. Phil. Soc. n. ser. vii. 296. Aster § Oxytripolium, Torr. \& Gray, Fl. ii. 161, in part. The two species are quite distinct in the Atlantic U. S., but seemingly confluent in Mexico and S. America.

A. exílis, ELL. Mostly slender and diffusely branched above : principal cauline leaves linear ( 3 or 4 inches long, 1 or 2 lines wide, lowest sometimes broader and lanceolate, rarely with a few serratures): heads 3 lines high: bracts of the involucre linear-subulate or more lanceolate and acuminate : rays 15 to 40 , bluish or puxple, rather conspicuous (about 2 lines long), nsnally much surpassing the pappus: disk-flowers generally more numerous.-Ell. Sk. ii. 344; Torr. \& Gray, Fl. ii. 163: believed to be the species here described; but the original of herb. Ell. is now lost. A. divaricatus, Torr. \& Gray, l. c., not L., \&c. A. subulatus, Michx. Fl. ii. 111, in part. Tripolium subulatum, Nees, Ast. 157, in part; DC. Prodr. 1. c. 254, excl. var. boreale. Tripolium divaricatum, Nutt. Trans. Am. Phil. Soc. 1. ‥ 296. Subsaline or even not at all brackish moist soil, S. Carolina to Texas, Arizona, and California; on the southern borders occurs with very short ligules. (Mex., W. Ind., \&c.)

Var, austrális, the commoner Mexican and S. American form of this polymorphous and widely diffused species, is less diffuse, less slender, often broader-leaved, and with larger heads, the involucral bracts broader, less acute, and greener or purplish-tinged. $-A$. subulatus, Less. in Linn. vi. 120. Erigeron multiflorum, Hook. \& Arn. Bot. Beech. 87. Tripolium conspicurm of anthors, but not the original of Lindley. - Coast of Oregon and California (at Visalia, in the interior, Congdon, a form with unusually large heads), \&c. (Mex. to Chili, Brazil, \&c.) 
A. subulátus, Mrcix. Stouter, only a foot or two high, with short usually purplish stems and branches: leaves somewhat fleshy, linear-lanceolate (lower 4 to 6 inches long, 2 to 4 lines wide), or the upper linear passing into subulate: heads narrower, cylindraceous, 4 lines high: bracts of the involuere linear-subulate with much attenuate apex : rays 25 to 30 , purplish, very small and inconspicuous, hardly surpassing the disk, with ligule very much shorter than the tube, often surpassed by the (not very copious) mature pappus, more numerous than the (10 to 15 ) disk-flowers. - Fl. ii. 111, partly (char. "ligulis minimis," \& hab.); Nutt. Gen. ii. 154. Tripolium subulatum, Nees, DC., \&c., in part. Aster linifolius, Torr. \& Gray, El. ii. 162, not L., not even as to the syn. "Gron. Virg." cited (which belongs to $A$. tenuifolius, p. 202). - Salt marshes, from New Hampshire to Florida. Closely connects with the following section.

§ 12. Conrzópsis. Involucre campanulate, of 2 or 3 series of linear or oblong bracts, nearly equal in length; the outer foliaceous or herbaceous and loose, resembling the rameal leaves; the inner more membranaceous or scarious: rays small and not longer than the mature pappus, or the ligule wanting; the female flowers mostly in more than one series and more numerous than the hermaphrodite; these with slender corolla, its limb 4-5-toothed: style-appendages lanceolate: akenes narrow, not compressed, 2-3-nerved, appressed-pubescent: pappus simple, very soft: low and branching leafy-stemmed annuals (of W. North America and N. E. Asia, and of moist subsaline soil), nearly glabrous, except that the linear (or the lowest spatulate) chiefly entire leaves are more or less hispidulous-ciliate; the numerous rather small heads in well-developed plants disposed to be racemose-paniculate. (Char. from the two genuine species, which are intermediate between the Oxytripolium section, A. subulatus connecting them, and Conyza.) - Gray, Proc. Am. Acad. xvi. 99. Aster § Oxytripolium, subsect. Conyzopsis, Torr. \& Gray, Fl. ii. 162. Brachyactis, Ledeb. Fl. Ross. ii. 495; Benth. in Hook. Ic. Pl. xii. 6 (excl. spec.), \& Gen. PI.; Gray, Proc. Am. Acad. viii. 647 , \& Bot. Calif. i. 326 .

A. frondósus, Torr. \& Gray. A span to a foot or more high, branching from the base, when low usually spreading, when taller the branches bearing numerous spicately paniculate heads (of 4 lines in height): outer bracts of the involucre linear-oblong, obtnse, wholly foliaceous and loose, numerous: rays in anthesis exserted, a line long, linear, pinkish-purple, always longer than the style, but equalled or surpassed by the mature copious pappus. Fl. ii. 165. Tripolium frondosum, Nutt. Trans. Am. Phil. Soc, n. ser. vii. 296. A. angustus, Gray, Pl. Wright. ii. 76; Eaton, Bot. King Exp. 144, not Torr. \& Gray. Brachyactis ciliata, var. carnosula, Benth. in Hook. Ic. Yl. xii. 6. B. frondosa, Gray, Proc. Am. Acad. 1. c.; Bot. Calif. 1. c. - Borders of springs, pools, \&c., Rocky Mountains of Idaho to the Sierra Nevada, California, and the Rio Grande in New Mexico.

A. angústus, Torr. \& Gray. Leares commonly narrower: bracts of the involuçre all linear, acute: corolla of the ray-flowers reduced to the tube and much shorter than the elongated style, or rarely with a rudimentary ligule? - Fl. ii. 162. Crinitaria humilis, Hook. F1. ii. 24. Linosyris? humilis, Torr. \& Gray, 1. c. 234. Erigeron ciliatus, Ledeb. Fl. Alt. iv. 92, \& Ic. t. 100. Conyza Altaica, DC. Prodr. v. 380. Tripolium angustum, Lindl. in Hook. Fl. ii. 15, \& DC. I. c. 254. Brachyactis ciliata, Ledeb. Fl. Ross. ii. 495; Benth. I. c. (excl. var.); Gray, Proc. Am. Acad. viii. 647. (The poor figure in Ledeb. Ic. 1. ¿. represents a ligulate female flower, which accords with neither specimens nor character.) - Saline wet ground, Saskatchewan to Utah and Colorado, eastward to Minnesota, and now extending to Chicago, \&c. (N. Asia.)

§ 13. MaCHerAnthíra. Involucre pluriserially imbricated, hemispherical or campanulate; the bracts linear, coriaceous below, and with herbaceous or foliaceous spreading tips : rays numerous and conspicuous, violet or bluish purple: akenes narrowed downward, compressed, few-nerved, and the faces somewhat 
striate: receptacle alveolate, the alveoli toothed or lacerate: style-appendages from linear-lanceolate to filiform-subulate: pappus copious and simple, of rather rigid unequal bristles: leafy-stemmed and branching biennials (sometimes more enduring, but no rootstocks, stolons or buds below the crown), or occasionally annuals (W. N. American and Mexican): the showy heads terminating the branches: involucre either canescent or somewhat viscid or glandular: leaves from sparingly. dentate to bipinnately parted, the teeth or lobes apt to be bristletipped. - Gray, Proc. Am. Acad. viii. 647, \& Bot. Calif. i. 322. Macharanthera, Nees, Ast. 224 ; Gray, Pl. Wright. i. 20. Dieteria, Nutt. Trans. Am. Phil. Soc. vii. 300 ; Torr. \& Gray, Fl. ii. 99.

* Anomalous, seemingly perennial and multicipital, but otherwise of this section.

A. Coloradoénsis, Grat. A span or less high, forming a tuft of short few-leaved stems on a strong tap root, canescently pubescent, not at all glandular: leaves spatulate or oblanceolate (about an inch long), coarsely dentate, the teeth tipped with conspicuous bristles: heads solitary, broadly hemispherical, half-inch high: involucral bracts small and numerous, well imbricated, subulate-lanceolate, rather close : rays 35 to 40 , riolet-purple, barely halfinch long: akenes turbinate, short, densely canescent-rillons, half the length of the comparatively rigid pappus. - Proc. Am. Acad. xi. 76 ; Rothrock in Wheeler Rep. vi. 149, t. 7. Common in South Park, Colorado, Porter, Canby, Greene, \&c. Also San Juan Pass, at 12,000 feet, Brandegee.

* * Genuine species, with annual or biennial but never truly perennial root.

+ Involucre densely hispidulous as well as viscid, very squarrose: akenes glabrous or glabrate: pappus slender: heads large and broad (the disk two-thirds to full inch in diameter): herbage green, not canescent, glabrate: leaves from incisely dentate to entire, their teeth or tips obscurely if at all mucronate-setigerous : rays bright violet, showy: root biennial or somewhat more enduring.

A. Pattersóni, Gray. A span or two high, branched from the summit of the tap root: stems or branches with soft or cottony-tomentulose pubescence, or glabrate: leaves thickish, spatulate or lingulate, entire or coarsely few-toothed, none widened at base: heads solitary or few : involucral bracts lanceolate: rays about 30, fully half-inch Iong. - Proc. Am. Acad. xiii.' 272, excl. var. Macheranthera canescens, var. alpina, Porter \& Coulter, Fl. Colorad. 59. - Moist ground along streams, Gray's Peak, Colorado ; first coll. by Parry, then by Patterson, \&c.

A. Bigelóvii, GraY. A foot or two high, robust: stem leafy, branching above, roughishhirsute to glabrate; the flowering branches or peduncles glandular-hirsute, terminated by showy large heads: leaves oblong or lanceolate, irregularly and sometimes incisely dentate, sometimes entire; radical lanceolate-spatulate; cauline oblong to lanceolate, usually with broadish partly clasping base: involucral liracts very numerous, linear-attenuate or the prolonged and much recurved tips almost filiform: rays very many, an inch or less long. Pacif. R. Rep. iv. 97, t. 10. A. Townshendi, Hook. f. Bot. Mag. t. 6430 (wrong as to the broadly obovate style-appendages figured and described); Robinson, Garden, xvii. t. 228. Southern Colorado and New Mexico, Bigelow, Brandegee, Rusby, \&c. Very handsome in cultivation.

+ + Involucre from nearly glabrous to glandular-puberulent or canescent, not rarely viscid, but not hirsute or hispidalous: heads less ample: akenes densely pubescent.

* Leares at most incisely dentate, rather rigid: root disposed to be biennial or somewhat more enduring. - Dieteria, Nutt.

A. gymnocéphalus, Gray. Stem erect, simple or branched from a rather slender root, commonly hirsute or hispidulous, equably leafy to the top : branches bearing solitary usually naked-pedunculate middle-sized heads: leaves spatulate-oblong to lanceolate; cauline short (inch or less long), usually obtuse, copiously serrate or denticulate with spinulose-setigerous teeth: involucre depressed-hemispherical, half-inch or less high; its bracts linear-subulate with the tips squarrose: rays purple, 4 or 5 lines long: receptacle fimbrillate. - Proc. Am. Acad. xv. 32 ; Hook. f. Bot. Mag. t. 6549. Aplopappus gymnocephalus, DC. Prodr. v. 346, \& A. blephariphyllus, Gray, Pl. Wright. i. 97 ; the ray-flowers having been thought to be yellow. 
Macharanthera setigera, Nees in Linn. xix. 722.-Dry ground S. W. borders of Texas, Wright, Havard. (Mex.)

A. canéscens, Pursir. Commonly a foot or two high and loosely much branched, even from the indurated root, bearing numerous paniculate heads, sometimes dwarf and with simple contracted inflorescence, pale and cinereous-puberulent or minutely canescent, or greener and glabrate: leaves lanceolate to linear or the lower spatulate, from entire to irregularly dentate, or occasionally laciniate, the rigid teeth mostly with mucronate-setulose tip : heads when numerous 4 or 5 lines and when fewer half-inch high: involucre turbinate to hemispherical, of rigid usually well-imbricated bracts : rays violet, 4 or 5 lines long: akenes narrow, canescent. - Fl. ii. 547; Gray, Bot. Calif. i. 322. A. biennis, Nutt. Gen. ii. 155. Dieteria.canescens, pulverulenta, divaricata, viscosa, \& sessiliflora, Nutt. Trans. Am. Phil. Soc. vii. 300 ; Torr. \& Gray, Fl. ii. 100. Macharanthera canescens, Gray, PI. Wright. ii. 75 ; Eaton, Bot. King Exp. 146. - The forms taken as the type of this polymorphous species are cinereous, rigid, when well developed bearing numerous heads : bracts of the involucre regularly imbricated in numerous ranks, coriaceous and appressed, with the green tips short and spreading, seldom at all viscous or glandular. - Open and sterile ground and sandy banks of streams, Saskatchewan to the eastern parts of Brit. Columbia, on the plains south to W. Texas, also eastern side of the Sierra Nevada to Arizona. (Adj. Mẹx.)

Var. víridis. A green form, hardly rigid, of less arid situations, either sparsely scabropuberulent or almost glabrous : involucral bracts looser, either with short and ascending or longer and squarrose-spreading tips, sometimes rather hispidulous-glandular. -Machoranthera canescens, var. glabra, Gray, P1. Wright. i. 89, \&c. Aster Pattersoni, var. Hallii, Gray, Proc. Am. Acad. xiii. 272, is rather a subalpine form of this. - W. burders of Texas to Utah.

Var. latifólius. Green, minutely soft-pubescent, 2 feet or more high : leaves thinnish, nearly membranaceous, comparatively large, sometimes spatulate-oblong and over half-inch wide: heads large and few : involucre hemispherical; tips of its bracts mostly attenuatesubulate and squarrose-spreading, eanescent and obscurely glandular. - Dieteria asteroides, Torr. in Emory Rep. 141. Macheranthera canescens, var. latifolia, Gray, Pl. Wright. ii. 75. - New Mexico and Arizona, in moist ground; passes into var. tephrodes.

Var. viscósus. Canescent or cinereous: leaves narrow, rather rigid; the apper mostly entire and the lower coarsely dentate : involucre campanulate or turbinate, squarrose; the prominent (either short or elongated) foliaceous tips of the bracts viscid-glandular, either spreading or recurved. - Dieteria viscosa \& D. sessiliflora (rays probably only abnormally if ever at all "ochroleucous"), Nutt. 1. c.; Torr. \& Gray, 1. є. D. incana, Torr. \& Gray, l. c. Diplopappus incanus, Lindl. Bot. Reg. t. 1693 (form with little viscidity to involucre); Hook. Bot.' Mag. t. 3882 (involucre very foliaceous-squarrose).-Arid districts, Wyoming to California.

Var. tephródes. More or less canescent, especially the hemispherical involucre of the large heads; the bracts with elongated and subulate-attenuate foliaceous tips, not glandular; the hoary pubescence sometimes looser. $-A$. incanus, Gray, Bot. Calif. i. 322. - S. California, Arizona, and New Mexico.

- + Leaves 1-3-pinnately cleft or parted, not rigid: involucre hemispherical, its bracts mostly looser : akenes more strongly striate: root commonly aunual: stem diffusely branched. Macharanthera, Nees, 1. c. Dieteria § Pappochroma, Nutt., excl. spec.

A. tanacetifólius, HBK. Pubescent, often rather viscid, very leafy, commonly a foot or two high: lowest leaves 2-3-pinnately parted ; uppermost simply pinnatifid or on the flowering branchlets entire; lobes short, setulose-mucronate: heads half-inch high: bracts of the involucre narrowly linear, with slender mostly linear-subulate spreading foliaceous tips, or the outermost almost wholly foliaceous: rays numerous (half-inch long or more), bright violet: akenes rather broad, villous. - Nov. Gen. \& Spec. iv. 95. A. chrysanthemoides, Willd. in Spreng. Syst. iii. 538. Machoeranthera tanacetifolia, Nees, Ast. 224; Hook. Bot. Mag. t. 4624; Gray, Pl. Wright. i. 90. Chrysopsis (Pappochroma) coronopifolia, Nutt. Jour. Acad. Phílad. vii. 34. Dieteria coronopifolia, Nutt. Trans. Am. Phil. Soc. vii. 300; Torr. \& Gray, 1. c. - Moist ground, Nebraska to Texas, Arizona, and borders of California. (Mex.)

Var. pygmǽus, a low and small form, seemingly a precocious state, with less dissected leaves, rather smaller heads, and much shorter foliaceous tips to the involucral bracts, seems to connect this with the following. - Machoeranthera canescens, var. humilis \& var. pygmcea, Gray, P1. Wright. ii. 74. - New Mexico, Wright. 
A. parviflórus, Gray. Glabrous, somewhat viscid, low and slender: leaves narrow, simply pinnatifid, barely inch long; the lobes short-linear, obtuse, hardly mucrunate: heads 3 or 4 lines high: involucre closer; the bracts with short oblong or ovate-lanceolate acute green tips: rays 3 lines long: akenes canescently sericeous. - Bot. Calif. i. 322, note. Machceranthera parviflora, Gray, Pl. Wright. i. 90. - New Mexico from the Rio Grande to W. Arizona, Wright, Thurber, \&c.

49. ERIGeroN, L. Fleabane. ( ${ }^{\circ} \rho$ and $\gamma$ '́ $\rho \omega \nu$, old man in spring.) - A rather large genns of herbs or barely suffrutescent plants, verging on the one hand to Aster, on the other to Conyza, and only arbitrarily to be separated on the lines of junction; the heads disposed to be solitary and long-pedunculate; rays (occasionally absent in certain species, uniformly wanting in two or three others) violet, purple, white, rarely ochroleucous (or in anomalous species even clear jellow!); disk-flowers yellow, not changing to purple: akenes commonly 2-nerved. - L. Gen. ed. 2, 400 (Erigerum in ed. 1, after Dodoens, who had Groundsel in view, and this form may explain how the name was taken for neuter by Linnæus); Torr. \& Gray, Fl. ii. 166; Benth. \& Ilook. Gen. ii. 280, excl. § Oritrophium (which must belong either to Celmisia or Aster); Gray, Proc. Am. Acad. xvi. 86. Erigeron, Trimorphaca, Phalacroloma, Stenactis, \&c., Cass. Erigeron, Stenactis, Phalacroloma, Polyactidium (Polyactis, Less.), Heterochata, \& Woodvillea, DC. Prodr. (Genera founded on the pappus and number of the rays, mostly unavailable even for good subgenera.) The series here commences with Asteroid and ends in Conyzoid forms.

§ 1. Ecerígeron. Rays elongated and conspicuous, or in a few species uniformly wanting, in one or two (E. compositus, $E$. concinnus) occasionally abortive: no rayless female flowers between the proper ray and disk.

* Perennials, commonly dwarf from a multicipital caudex, alpine or rarely alpestrine, with comparatively large and mostly solitary heads: involucre loose or spreading, and copiously lanate with long multiseptate hairs: rays about 100, narrow: leaves entire.

+ Whole herbage gnaphalioid-lanate : pappus double; the short outer multisquamellate.

E. Muirii, Gray. A span high, densely clothed with long and soft white (apparently persistent) floccose wool ; stems simple and monocephalous, rather leafy : leaves lanceolate-spatulate (an inch or two long), or uppermost narrowly lanceolate: involucre squarrose, as of the following species: rays white, a third of an inch long. - Proc. Am. Acad. xvii. 210.Cape Thompson, Alaska, John Muir.

++ Herbage green, with or without villous or hirsute pubescence: pappus nearly simple.

E. uniflórus, L. Stems an inch to a span or two high, strictly monocephalous, few-leaved, often naked and pedunculiform at summit : radical leaves spatulate or oblanceolate (inch or two long); cauline lanceolate to linear : involucre usually hirsute as well as lanate, occasionally becoming naked; the linear acute bracts rather close, or merely the short tips spreading: rays purple or sometimes white, 2 or 3 or rarely 4 lines long. - Fl. Lapp. t. 9, f. 3 , \& Spec. ii. 864; Hook. Fl. ii. 17; Torr. \& Gray, Fl. ii. 169 ; Ledeb. Fl. Ross. ii. 490; Reichenb. Ic. Fl. Germ. xvi. 914. E. alpinus \& Hieracium pusillum, Pursh, Fl. ii. 532, 502. E. pulchellus, var., \& E. alpinus, in part, DC. Prodr. v. 287. E. erioceplıalus, J. Vahl, I1. Dan. t. 2298, is either this or possibly a form of the next. - Labrador to Arctic coast, and Unalaska, south to the Sierra Nevada, California, and mountains of Colorado, in the alpine region. Forms with a comparatively hirsute involucre occur in the Rocky Mountains; and some are not well distinguished from the next. (Greenland, Eu., N. Asia to Kamts.)

Æ. lanátus, Hook. Stems about a span high from a multicipital caudex, scapiform or fewleaved, monocephalous : radical leaves spatulate to obovate, about half-inch long, tapering into a narrowed base or into a slender margined petiole; some primary ones occasionally palmately 3-lobed; cauline one or two, small and linear, or hardly any; head not larger than 
that of $E$. uniflorus, and involucre similar, but densely soft-lanate: rays rather broader, 3 lines long, white. - Fl. ii. 17, t. 121; Torr. \& Gray, Fl. ii. 168. E. grandiflorus, var. lanatus, Gray, Proc. Am. Acad. xvi. 92. Aster glacialis, Torr. \& Gray, Fl. ii. 503, not Nutt. - Alpine summits of the Rocky Mountains in Montana and Brit. America, Drummond, Fremont, Bourgeau, and of the Cascades, Lyall. (Lyall's plant may have yellowish rays, and pass into Aplopappus Brandegei.)

E. grandiflórus, Hook. Stems a span or two high, rather stout, usually several-leaved and monocephalous: radical leaves obovate-spatulate, an inch or so long; canline oblong to lanceolate, usually half-inch or less long: heads larger: involucre half-inch high, very woolly; its linear and attenuate-acuminate bracts squarrose-spreading or the tips recurved: rays violet or purple, a third to half inch long. - Fl. ii. 18, t. 123; Torr. \& Gray, l. c.; Eaton, Bot. King Exp. 184 (a somewhat abnormal form, in the Uinta Mts.) - Rocky Mountains, in or near the alpine region, from British Columbia (Drummond) to Colorado, where it sometimes bas fewer and linear cauline leaves, and approaches $E$. uniflorus.

Var. elátior, GraY. A foot or two high, leafy up to the 1 to 4 pedunculate heads, pubescent, but hardly hirsute : leaves oblong to ovate-lanceolate, 2 to 4 inches long; cauline closely sessile by a broad base: involucre fully half-inch high: rays half-inch long. - Am. Jour. Sci. ser. 2, xxxiii. 237, \& Proc. Am. Acad. xvi. 92. - Subalpine and lower, in the Rocky Mountains of Colorado; first coll. by Parry.

* * Submaritime perennial: heads of the largest, the disk a full inch in diameter: involucre rather loose, villous with long multiseptate hairs: rays about 100, rather broad, Aster-like: pappus simple: leaves obovate or spatulate, ample, mostly entire, graveolent. - Woodvillea, DC., color of ray-flowers mistaken.

E. glaúcus, KER. A span to a foot high, viscidulous and more or less pubescent, producing a tuft of radical leaves from a rather fleshy crown, and some ascending monocephalous or occasionally branching stems : leaves glaucescent or pale green, but hardly glaucous, somewhat succulent; larger radical 3 or 4 inches long and an inch wide, rarely 2-3-toothed; upper cauline few and small: rays half-inch long, bright violet: akenes 4-nerved. - Bot. Reg. t. 10 ; DC. Prodr. v. 284 ; Torr. \& Gray, Fl. ii. 172; Gray, Bot. Calif. i. $330 . \quad$ E. maritimum \& F. hispidum, Nutt. Trans. Am. Phil. Soc. vii. 310, E. squarrosus, Lindl. Bot. Reg. xxvii. misc. 44? Aster Bonariensis, Spreng. Syst. iii. 528. A. Californicus, Less. in Linn. vi. 121; Hook. \& Arn. Bot. Beech. 146 ; DC. 1. c. 228. Stenactis glauca, Nees, Ast. 275. Woodvillea calendulacea, DC. I. c. 318. - Along the Pacific coast, within the influence of salt water, Oregon to S. California, flowering for most of the year; probably first coll. by Menzies.

* * * True perennials from rootstocks or a caudex, neither stoloniferous-surculose nor flagelliferous: involucre from hispid or villous to glabrous, but not lanate, in the first species loose and spreading: all Western or Northern species. - Part of $\S$ Phoenactis, Nutt. Trans. Am. Phil. Soc. vii. 310 ; Benth. \& Hook. Gen. ii. 280.

+ Comparatively tall and large, a foot or more high except in alpine or depauperate forms, leafystemmed, glabrous to soft-hirsute: leaves rather ample. entire or occasionally few-toothed: heads pretty Jarge, with usually very numerous rays: montane or alpestrine.

+H Aster-like; the rays comparatively broad: involucre rather loose: heads solitary, or on larger plants few and corymbosely disposed: pappus simple.

E. salsuginósus, Gray. Rootstocks short and thickish: stem commonly 12 to 20 inches high, the summit or peduncles lanate-pubescent or puberulent: no bristly or hirsute hairs: leaves very smooth and glabrous or glabrate, bright green, thickish; radical and lower cauline leaves spatulate to nearly obovate, with base attenuate into a margined petiole; upper cauline ovate-oblong to lanceolate, sessile, conspicuously mucronate or apiculateacuminate; uppermost small and bract-like : bracts of the involucre loose or eren spreading, linear-subulate or attenuate, viscidulous, at most puberulous (or at some northern stations sometimes pubescent) : disk over half an inch in diameter: rays 50 to 70 , purple or violet, half-inch or more long. - Proc. Am. Acad. xvi. 93. Aster salsuginosus, Richards. in Frankl. Journ. App. ed. 2, 32; Hook. Bot. Mag, t. 4942 ; DC. Prodr. v. 229; Torr. \& Gray, Fl. ii. 150. A. Unalaschensis, I.ess. ex Bongard, Sitch. 148 ; DC. 1. c. 228. - Wet ground, Kotzebue Sound and Unalaska, and along the higher mountains southward to California, Utah, and New Mexico; first coll. by Richardson.

Var. angustifólius, Grar. A span to a foot high : radical and lower cauline leaves from narrowly spatulate to lanceolate (only 3 or 4 lines broad), somewhat scabrous on mar- 
gins; upper cauline linear-lanceolate, small : rays about 40. - Proc. Am. Acad. 1. c. Aster salsuginosus, var. angustifolius, Gray, Bot. Calif. i. 325. - Mountains of Washington 'lerr. (Brandegee) to the Sierra Nevada, California, as far south as Kern Co., Lemmon, Mrs. Austin, Matthews, \&c. Passes in to

Var. glaciális. A span high, few-leaved, monocephalous: leaves as of the type (of which this is a reduced alpine form), but smaller. - Aster glacialis, Nutt. Trans. Am. Phil. Soc. vii. 291 ; Torr. \& Gray, Fl. ii. 155. - Alpine region of the Rocky Mountains ; first coll. by Nuttall in Wyoming.

E. Howéllii. Rootstock filiform: stem a foot high, equably leafy, monocephalous : leaves membranaceous, glabrous and smooth; radical obovate, slender-petioled; cauline mostly ovate and with broad half-clasping base (larger ones 2 inches long and an inch wide), sometimes one or two sharp denticulations, mucronate-acuminate: involucre, \&c, nearly of the foregoing: rays only $\mathbf{3 0}$ to 35 , two-thirds inch long, u line or two wide, white. - E. salsuginosus, var. Howellii, Gray, Proc. Am. Acad. xvi. 93. - Oregon, in the Cascade Mountains, Houcell.

E. Coúlteri, T. C. Porter. Rootstock slender : stem 6 to 20 inches high, equably leafy, bearing solitary or rarely 2 or 3 rather slender-pedunculate heads : leaves mernbranaceous, obovate to oblong, either entire or serrate with several sharp teeth, pilose-pubescent to glabrous, cauline inconspicuously mucronulate: disk of the head about half an inch wide: involncre less attenuate and spreading than that of $E$. salsuginosus, obscurely viscidulous but hirsute (as also the peduncle) with spreading hairs: rays 50 to 70 , rather narruwly linear, half-inch or more long, white, varying to purplish. - Porter \& Coulter, Fl. Colorad. 6l; Rothrock in Wheeler Rep. vi. 154 ; Gray, Proc. Am. Acad. xvi. 93. - Rocky Mountaius of Colorado, at about 10,000 feet, Coulter, \&c., of Utah, Ward, Jones, \&c., and Sierra Nevada, California, Brewer, Bolander, Greene.

\# Less Aster-like: rays 100 or more and narrow: involucre closer: pappus more or less double, but the exterior minute, setulose or subulate-squamellate: stems chicfly erect, tufted, generally leafy to the summit, and bearing few or several heads: leaves entire. (Species hard to discriminate, montane, but never alpine.) - $\$$ Phanactis, Nutt. Trans. Am. Phil. Soc. l. c., in part.

E. speciósus, DC. Sparingly and loosely hirsute or with a few scattering hairs: stems mostly 2 feet high, very leafy to the top: leaves lanceolate, acute (3 to 8 lines wide), sparsely ciliate; lowest more or less spatulate: involucre hirsute-pubescent, or sometimes almost glabrous : rays half-inch to almost an inch long, violet. - Prodr. v. 284, \& vii. 274; Torr. \& Gray, Fl. ii. 173. E. glabellus, var. mucronatus, Hook. Fl. ii. 19. Stenactis speciosa, Lindl. Bot. Reg. t. 1577; Hook. Bot. Mag. t. 3067. - British Columbia to Oregon and perhaps $\mathrm{N}$. California, near the coast.

E. macránthus, Nuтr. From hirsute-pubescent to nearly glabrous: stem 10 to 20 inches high : leaves from lanceolate to ovate; upper often reduced in size: involucre glabrous or nearly so, but commonly minutely glandular: rays half-inch long (heads not larger, as the name would imply, but rather smaller than those of the preceding): short outer pappus more conspicuous, sometimes nearly squamellate. - Trans. Am. Phil. Soc. 1. c.; Torr. \& Gray, 1. c. E. grandiflorum, Nutt. Jour. Acad. Philad. vii. 31, not Hook. - Rocky Mountains, from Wyoming to New Mexico and S. W. Utah, at 8,000 to 10,000 feet in the southern portions of its range.

E. glabéllus, Nuxr. From partly glabrous to copiously hirsute, disposed to be naked above: stems 6 to 20 inches high: leaves lanceolate or the lowest somewhat spatulate; upper linear-lanceolate and gradually reduced to subulate bracts : heads in the typical forms considerably smaller than those of the two preceding species: involucre strigosely hirsute or pubescent: rays violet, purple, and rarely white, a third to half an inch long: outer pappus setulose. - Gen. ii. 147, \& Jour. Acad. Phílad. 1. c. ; Hook. Bot. Mag. t. 2923, \& Fl. ii. 19 (excl. var. $\gamma$ ) ; Torr. \& Gray, l. c., with vars. asper \& pubescens. E. asper, Nutt. 1. c., a somewhat ronghish-hirsute form. E. pulchellus, Hook. Fl. ii. 19, partly. - Minnesota and Sas katchewan to the Rocky Monntains, and southward to Colorado and Utah. Occurs in various forms; the small or slender northern forms of the plains naked-stemmed and simple; some of the larger more equably leafy and approaching the preceding, others by the copious pubescence leading to the ambiguous

Var. móllis, GraY. Somewhat cinereous with a soft and short spreading pubescence, a foot or two high, leafy to the top : leaves oblong-lanceolate: cinereous pubescence of the 
involucre soft and spreading.-Proc. Acad. Philad. 1863, 64, \& Proc. Am. Acad. 1. c.Colorado Rocky Mountains, at 8,000 to 9,000 feet; first coll. by Parry, Hall, \&c. Perhaps a distinct species.

+ + Low, rarely a foot high, conspicuously hispid or hirsute with spreading bristly hairs: leaves entire, narrow: involucre close: rays numerous, occasionally wanting in one species : pappus conspicuously double, but least so in the first species.

* Sparingly branched stems several or numerous from the crown of a tap root, more or less leafy: heads middle-sized: disk a third to half an inch in diameter: involucre hispid: rays 50 to 80 , long and narrow, soon deflexed, occasionally wanting in the second species.

E. púmilus, Nutr. Radical and lower cauline leaves from spatulate-linear to lanceolate (a line or two wide); upper linear: rays white (4 lines long): outer pappus of short bristles little or not at all thicker than the inner ones and more or less intermixed with them. Gen. ii. 147; Torr. \& Gray, Fl. ii. 174. E. hirsutus, Pursh, F1. ii. 742, not Lour.-Dry upper plains, Dakota to Colorado, and in the Rocky Mountains, west to Utah.

E. concínnus, Torr. \& Grax. Like the preceding, but usually with more dense and shaggy hirsuteness and less rigid leaves: stems not rarely somewhat copiously branched: rays violet or blue, rarely white: outer pappus conspicuous and squamellate or paleaceous (the palex varying from subulate to oblong!). - Fl. ii. 174 ; Eaton, Bot. King Exp. 151, with var. condensatus, a dwarf and condensed form with monocephalous stems, and conmonly wide (but fewer) paleæ to the pappus. E. strigosus, var. hispidissimus, Hook. Fl. ii. 18, chiefly. Distasis? concinna, Hook. \& Arn. Bot. Beech. 350. - Arid regions between the western slopes of the Rocky Mountains and the Sierra Nevada and Cascades, from Wyoming to New Mexico and Brit. Columbia to Arizona.

Var. aphanáctis, Grar. Discoid, the rays being nearly destitute of ligule or wanting. - Proc. Am. Acad. vi. 540. - Colorado to Nevada and the borders of California.

++ ++ More branched and leafy, over a span high; with smaller heads, fewer rays, and somewhat naked involucre more imbricated: anomalous Texano-New-Mexicun species.

E. Bigelóvii, Gray. Cinereous-hispidulous, diffusely branched from the base, leafy up to the short-pedunculate scattered heads: leaves small, spatulate-lanceolate or upper linear (less than inch long), lowest more spatulate and petioled: bracts of the hemispherical involucre rather rigid, lanceolate, acuminate, obviously of 2 or 3 lengths, the outer sparingly hispidulous : rays 40 to 50 , purple or violet ( 3 lines long): outer pappus of slender-subulate squamellæ, about a third the length of the inner bristles. - Bot. Mex. Bound. 78. - On the Rio Grande near Fronteras, at the borders of Texas, New Mexico, and Chihuahua, Wright, Bigelow.

E. Brandegéi. A very anomalous and imperfectly known plant, green, sparsely hispidulous-hirsute, less branched: radical leaves spatulate-linear; cauline linear and small, or upper minute: bracts of involucre short-linear, almost naked : rays 30 or more, white: outer pappus of coriaceous squamellæ which are commonly confluent with the scanty bristles of the inner, perhaps abnormal : only one specimen seen. - Adobe plains, S. W. Colorado, on the borders of New Mexico, Brandegee.

+++ Tufted stems very short and densely leafy, bearing simple and monocephalous scapiform or few-leaved flowering stems (about a span high) : head proportionally large: rays 25 to 50 , not very narrow, 3 or 4 lines long: leaves narrowly spatulate-linear.

E. poliospérmus. Leaves hispid throughout, an inch or more long, filiform-spatulate, the broader summit a quarter or half a line wide: head half-inch high: involucre of rather loose and slender hispidulous bracts. rays about 25, blue-violet or white: akenes densely white-villous. onter pappus slender-squamellate, fully as long as the breadth of the akene, covered by the copious white silky hairs of the latter. - Umatilla, Oregon, Howell, and Washington Terr., in the Wallawalla region, Brandegee, Tweedy. Resembles the next.

E. Chrysópsidis. Hispid, also with some minuter pubescence : leaves spatulate-linear, an inch or two long, commonly a full line wide at summit: involucre rather hirsute : rays 40 to 50, "golden yellow": akenes barely pubescent or hirsutulous ; outer pappus less conspicuous, merely setulose: otherwise very like the preceding.-Chrysopsis hirtella, DC. Prodr. v. 327. E. ochroleucus, var. hirtellus, Gray, Proc. Am. Acad. xvi. 90. - Stony hills and in wet clay on mountain sides, E. Oregon and adjacent Washington Terr., Douglas, Cusick, Nevius, Howell. Must be retained in Erigeron (of which it has the involucre and style), notwith- 
standing the pure yellow rays, which also occur in $E$. peucephyllus. It can hardly pass into $E$. ochroleucus.

+++ Dwarf, cespitose from a multicipital caudex, with monocephalous flowering stems, often scapose : radical leaves dissected: pappus simple.

E. compósitus, Porsh. From hirsute to glabrate, with slender margined petiole setoseciliate: radical leaves much crowded on the crowns of the caudex, usually 1-3-ternately parted into linear or short and narrow spatulate lobes, the few on the erect flowering stems 3-lobed or entire and linear: involucre (3 or 4 lines high) sparsely hirsute: rays from 40 to 60 , not very narrow, white, purple, or violet, mostly 3 or 4 lines long. - Fl. ii. 535 ; Fl. Dan. xii. 1999 ; Hook. in Trans. Linn. Soc. xiv. 374, t. 13, \& Fl. ii. 17; DC. Prodr. v. 288 ; Torr. \& Gray, Fl. ii. 167. E. pedatus, Nutt. Trans. Am. Phil. Soc. vii. 308. Cineraria Lewisii, Richards. in Frankl. Journ. App. ed. 2, 32. - Alpine and alpestrine districts of the Rocky Monntains, and of the Sierra Nevada, from S. Colorado and California to Brit. Columbia and arctic sea-coast. (Greenland and Spitzbergen.)

Var. discoídeus, Gr.1r. Rays wanting or abortive: head commonly smaller. Am. Jour. Sci. ser. 2, xxxiii. 237 ; Eaton, Bot. King Exp. 148. - Same range as the radiate form, often accompanying it; first coll. by Parry, \&c.

Var. trifidus, Grir. Small blade of leaves simply 3-5-fid : the lobes from oblong to obovate. - Proc. Am. Acad. xvi. 90. E. trifidus, Hook. Fl. ii. 17, t. 120, - Rocky Mountains, N. Colorado to Brit. Columbia; first coll. by Drummond, later by J. MI. Coulter and Canby.

Var. pinnatiséctus, GRAT, 1. c. Usually a large form: numerous violet-purple rays 5 lines long: leaves pinnately parted into 9 to 11 linear and entire or rarely 2-3-cleft divisions. - Mountains of Colorado, from South Park to the Sierra Blanca; first coll. by Hall.

E. Prínglei, Gray. Smooth and glabrous, densely cespitose from a lignescent multicipital caudex: radical leaves laciniate-pinnatifid into 3 to 5 short-lanceolate or broadly subulate pointed lobes; those of the ascending ( 2 or 3 inches long) flowering stems linear, entire, 5 or 6 in number: involucre hardly 3 lines high, glabrous : rays 20 or 30 , purple or whitish, 3 lines long. - Proc. Am. Acad. xvii. 210. - Cliffs of Mount Wrightson, Santa Rita Mountains, Arizona, Pringle.

++++ Dwarf or low species, alpine or alpestrine, entire-leaved, cespitose from multicipital caudex, no fine or cinereous pubescence, monocephalous: leares few on the simple stems, at least the radical broader than linear: rays rather numerous and not very narrow : pappus simple or nearly so.

\# Involucre glabrous but pruinose-glandular, brownish-purple: alpine and Aster-like, smooth and green.

E. leiómerus. A span high from the somewhat surculose branches of the caudex, smooth and very glabrous (or some minute hairiness at least on the petioles) : leaves bright green, mainly radical and spatulate, very obtuse (larger about inch long, with tapering base or petiole of at least equal length), from 2 to 6 lines wide; cauline only 2 or 3 and smaller : involucre 3 lines high, not unlike that of $E$. salsuginosus, but close, the bracts lanceolate and not attenuate: rays about 40, linear, violet, 3 or 4 lines long. - Aster glacialis, Eaton, Bot. King Exp. 142, but hardly that of Nuttall (which is rather a high alpine form of $A$. salsuginosus, to which this is related). Comes close to the next species, to which it has been referred. - Rocky Mountains of Colorado, Utah, and Nevada, in the alpine region; first coll. by Parry, Hall \& Harbour, Watson.

++ Involucre hirsute or pubescent, greenish: herbage not strigulose nor cinereous.

E. ursínus, Eatox. A span or two high, loosely cespitose: lenves duller green, mostly smooth and glabrous, but their margins more or less hirsute-ciliate, spatulate to narrowly oblanceolate; cauline ones lanceolate or linear and acute: involucre ( 3 lines high) and naked summit of flowering stem hirsute-pubescent : rays 40 or 50, purple, narrowly linear, 3 lines long. - Bot. King Exp. 148; Gray, Bot. Calif. i. 327.-Alpine and subalpine region, Rocky Mountains, Wyoming to S. Colorado, Uinta Mountains, Utah, and on Mount Dana, California; first coll. by Watson.

E. radicátus, Hook. A span high or less, densely tufted : leaves all spatulate-linear or somewhat wider (broadest only a line or two wide), hirsute or hirsutely ciliate, or sometimes 
almost naked, then glabrous; no glandular roughness: involucre more or less villous-pubescent (barely 3 lines high) : rays white or purplish, 2 or 3 lines long. - Fl. ii. 17. E. nanus \& E. radicatus, Nutt. Trans. Am. Phil. Soc. vii. 308. - Alpine or subalpine in the Rocky Mountains, from British America (Drummond, Macoun) to Wyoming, S. Colorado, aud Utah, Nuttall, Parry, \&c.

E. glandulósus, T. C. Porter. Cespitose from a stout caudex, a 'span to almost a foot high, rigid, minutely granulose-glandular or' glandular-scabrous (but sometimes obsoletely so), and with sparse hirsute or hispid hairs, especially on the margins of the leaves: these thickish, spatulate to linear-oblanceolate, 1 to 3 inches long; upper cauline small : head comparatively large, 4 or 5 lines high: involucre glandular or viscid as well as pubescent: rays 40 or 50, violet or purple, 4 to 6 lines long: an obscure outer setulose pappus. - Porter \& Coulter, Fl. Colorad. 60; Gray, Proc. Am. Acad. xvi. 90. - Bleak mountain-tops, alpestrine and subalpine, and sometimes descending to lower levels, Colorado, J. M. Coulter, Hall \& Harbour, Greene, \&c. Some forms approach $E$. pumilus.

+++++ Various Rocky Mountain to Pacific species, with entire leaves, none truly alpine, none hispidly hirsute (except very rarely some spreading bristly hairs fringing base of leaves): involucre close, disposed to be somewhat imbricated and rigid: rays not very numerous, in several species uniformly wanting.

t+ A span or two high from a simple or multicipital caudex: leaves only few and narrow on the weak and ascending simple or sparingly branched flowering stems; but radical ones with obovate or spatulate blade, only half-inch long, contracted into a petiole of at least equal length, cinereously puberulent or canescent: heads only 3 or 4 lines high: rays 18 to 30 , pale violet or purple: akenes compressed, 2-3-nerved: pappus near.]y simple.

E. asperugíneus, Gray. Cinereous with minute roughish pubescence : stems commonly simple from the slender caudex, monocephalous: involucre obscurely hirsute, a single series of equal bracts : rays 18 or 20. - Proc. Am. Acad. xvi. 91. Aster asperugineus, Eaton, Bot. King Exp. 142. - Utah, in the E. Humboldt Mountains, Watson, M. E. Jones.

E. téner, GrAx, 1. c. Canescent with very fine and close or almost imperceptible pubescence (either silvery-whitish or becoming greener): stems several from a stouter caudex, weak and ascending, bearing single or 2 or 3 heads: involucre minutely canescent; its narrow and close bracts unequal, somewhat in 2 or 3 ranks: rays 25 to 30 . $-E$. ccespitosum, var. tenerum, Gray, Bot. Calif. i. 328. - High mountains of Utah, N. W. Nevada, and of the Sierra Nevada on the borders of California, Watson, Brewer, \&c., to those near the sources of the Sacramento, Pringle, Red Rock Creek, and of Wind River, Montana, Watson, Dr. Forwood.

+ +- A span to near a foot high, cespitose on a stout multicipit l caudex, silvery-canescent, with simple and monocephalous or rarely somewhat branching stems: leaves from narrowly spatulate to linear: rays 40 or 50, white or purple changing to white: akenes slender and nearly terete, 5-10-nerved or striate: pappus double; the outer subulate-setulose and conspicuous.

Æ. cánus, Gray. Silvery appressed pubescence obviously strigulose under a lens, that of the involucre loose and spreading: stems 4 to 9 inches high, leafy: linear cauline leaves gradually diminishing upward; radical spatulate lanceolate or narrower: head 4 lines high: rays narrow, 3 lines long: akenes glabrous, striately 8-10-nerved.-Pl. Fendl. 67, \& Proc. Am. Acad. viii. 650. - Dry and gravelly hills, Northern New Mexico and Colorado; first coll. by Fendler. Also on the Platte in Wyoming, Geyer.

P. argentátus, Gray. Silvery white pubescence throughout very close and fine, the separate hairs undistinguishable: stems 6 to 12 inches high: radical leaves very densely clustered, linear-spatulate or broader, inch or two long; cauline scattered and much smaller: head broad, fully half-inch high: rays rather broad and large, half-inch long: immature akenes sericeous-pubescent or villous, 5-8-nerved. - Proc. Am. Acad. viii. 649. E. ccespitosum, Eaton, Bot. King Exp. 153, in small part (no. 549), not Nutt. - Arid interior region, Utah and Nevada, Watson, Miss Searls, Ward, Palmer, M. E. Jones.

* + A foot or less high from a thick multicipital caudex, more or less branching and leafy, minutely silvery-canescent (the pubescence fine and short): leaves all narrowly linear: rays 30 to 50, elongated (large for the involucre of about 3 lines high), purple or sometimes white: akenes narrow, 4-nerved, disposed to be tetragonal.

E. Paríshii. Rigid and rather stout, at length somewhat corymbosely branched: leaves spatulate-linear (largest 2 lines wide or nearly so), rather short: heads short-peduncled: 
involucre cinereous-puberulent and glandular: rays nearly half-inch long, purple: diskcorollas beset with some sparse and short minute hairs: akenes sparsely hirsute: pappus conspicuously double; outer setose-squamellate. - Rocky cañons, borders of the Mohave Desert, S. E. California, Parish.

E. Utahénsis, GrAY. Slender, but rigid, with sparse branches from dense clumps : leaves narrowly linear or almost filiform (larger 2 inches long and barely a line wide) : heads slender-peduncled: involucre canescent : rays fully half-inch long: disk-corollas sparsely hirsute toward the base: immature akenes villous : pappus alınost simple; the outer being scanty and setulose, hardly distinguishable from the villous hairs of the akene. - Proc. Am. Acad. xvi. 99. E. stenophyllus, var.? tetrapleurus, Proc. Am. Acad. viii. 650. - Rocky hills in the arid region of S. Utah, Mrs. Thompson, Parry, Palmer. This and the preceding are showy species, nearly related to,$E$. argentatus, all with a close and somewhat imbricated involucre.

++++ Either low or comparatively tall, leafy-stemmed or subscapose: akenes compressed, 2-nerved, rarely 3-nerved.

$=$ Heads radiate: leaves all narrowly linear to filiform, the broadest not over a line wide: pubescence either cinereous or obscure. (Also one or two of the following subdivision are sometimes very narrow-leaved.)

a. Involucre of the ample head balf-inch high, of linear and equal bracts; and rays half-inch long.

E. stenophyllus, GRır. Green and glabrate, but obscurely strigulose-puberulent when young: stems simple and monocephalous, less than a foot high, naked and pedunculiform at summit: leaves mostly 2 inches long, hardly widening upward; upper ones sparse aud smaller: bracts of involucre somewhat hirsute-pubescent and glandular: ovary villous: pappus simple or nearly so. - Pacif. R. Rep. iv. 42 ; Proc. Am. Acad. viii. 650, \& xvi. 89. Hills on the Pecos, N.W. Texas, Bigelow. A smaller plant from Fort Wingate, New Mexico, Mattheus, may belong here, but has merely hirsutulous young akenes.

b. Involucre only 2 or 3 lines high, of shorter and unequal somewhat imbricated bracts: rays 2 to 4 lines long:

E. filifólius, Notr. Canescent or cinereous throughout with very fine close pubescence, no loose hairs: stems slender, a span to two feet high from lignescent slender base or branched rootstock, leafy, usually paniculately branched and bearing several or rather numerous heads: leaves linear-filiform or quite filiform (some lower ones ocrasionally dilated upward to a line in width and flat): involucre canescent: rays 30 to 50 , rarely even 80 , purple, violet, or white, 3 or 4 lines long: akenes slightly pubescent or glabrate: pappus simple, of fragile and indistinctly scabrous bristles. - Trans. Am. Phil. Soc. vii. 328; Torr. \& Gray, Fl, ii. 177; Gray, Proc. Am. Acad. xvi. 89. Diplopappus flifolius, Hook. Fl. ii. 21, is either this or the next. Chrysopsis canescens, DC. Prodr. v. 328. - Rocky or dry ground, from Brit. Columbia, mostly east of the Cascades, and Idaho, to the Sierra Nevada in California and Nevada; first coll. by Douglas.

E. peucephýllus, Gray. Low, with flowering stems is span or two high from broad depressed tufts, simple and with naked summit or peduncle monocephalous or occasionally forking and 2-3-cephalous, cinereous-puberulent or glabrate: leaves filiform or lowest slightly dilated upward (to not over half a line in breadth) : involucre hirsute-pubescent or glabrate: rays 20 or 30 , usually short ( 2 or 3 lines long), pale blue to cream-color or pure yellow: pappus manifestly double, the outer squamellate. - Proc. Am. Acad. xvi. 89. - Dry hills, from Brit. Columbia (and east to Cypress Hills, Macoun) to the Sierra Nevada in California and adjacent Nevada, east to Idaho.

c. Involucre 3 or 4 lines high, of equal bracts: rays of equal length.

E. ochroleucus, Nutr. Low, a span or two high, somewhat cespitose on the caudex, from cinereous-pubescent to glabrate, and attenuate lower part of the leaves not rarely sparsely hirsute-ciliate: stems usually simple, naked above and monocephalous, occasionally with one or two additional heads: leaves rather rigid, narrowly linear, the radical (2 or 3 inches long) often a line wide at the upper part: involucre tomentose or hirsute-pubescent: rays 40 to 60 , "ochroleucous," white, or purplish (not known to be yellow) : outer pappus setulose. - Trans. Am. Phil. Soc. vii. 309 ; Torr. \& Gray, Fl. ii. 178; Gray, Proc. Am. Acad. xvi. 89, excl. var. E. pumilus, Hook. Lond. Jour. Bot. vi. 242 , in part, not Nutt. E. canescens, Parry in Jones Exp. no. 139, canescent form. Diplopappus linearis, Hook. Fl. 
ii. 2l ? - Gravelly hills and plains, N. Wyoming and Montana to Idaho, Nuttall, Spalding, Geyer, Parry, \&c.

$==$ Heads rayless : leaves filiform to narrowly spatulate-linear, chiefly from the multicipital caudex: dwarf flowering stems more or less scapiform and monocephalous.

E. Bloómeri, Gray. Densely cespitose, cinereous-puberulent or glabrate and pale : radical leaves 1 to 3 inches long, the larger dilated upward sometimes to a line or more in width; cauline few and nearly filiform: scapiform flowering, stems 2 to 6 inches high: head almost half an inch high : involucral bracts equal, linear-lanceolate, soft-villous or canescent : akenes glabrate, oblong-linear, flat: pappus whitish, simple. - Proc. Am. Acad. vi. 40, \& Bot. Calif. i. 328 ; Eaton, Bot. King Exp. 148. - Stony ground, mountains of Nevada to Idaho, and from the Sierra Nevada, California, to E. Oregon; first coll. by Bloomer. Habit of the last preceding species, to which it is most allied.

$$
===\text { Heads radiate: leaves from narrowly linear to oblong. }
$$

u. Stems naked above, more commonly simple and monocephalous, only a span or two high: pappus simple.

E. Nevadénsis, Gray. Stems numerous from a multicipital caudex, erect, a span to nearly a foot high: leaves all lanceolate or linear; radical 1 to 4 inches long, 1 to 4 lines wide, strigulose-cinereous; uppermost small and subulate: head always solitary, half-inch high : involucre villous-pubescent, sometimes glabrate; its bracts equal : rays rather broadly linear, white or pale blue, 4 to 6 lines long: akenes comparatively large: pappus rather coarse. - Proc. Am. Acad. viii. 649; Bot. Calif. i. 328. E. ccespitosus, var. grandiflorus, Eaton, Bot. King Exp. 153, in part. - Sierra Nevada, California, and W. Humboldt Mountains, Nevada, at 5,000 to 8,000 feet; first coll. by Bloomer, Watson, \&c. Appears to pass into the somewhat doubtful

Var. pygmóous, Gray, 1. c. Dwarf, subcaulescent: leaves spatulate-linear, an inch or more long, a line or so wide, more minutely pubescent or cinereous, and glabrate: head considerably smaller: involucre slightly hirsute : rays purple. - Sierra Nevada, California, above Ebbett's Pass (at 9,500 feet) and Mono Pass (10,750 feet), Brewer. Also Mount Dyer, Plumas Co. (a connecting form), Mrs. Austin.

E. Eatóni, Gruy. Stems several from the crown of a strong tap root, slender and weak, diffuse, 3 to 9 inches long, simple or with 2 or 3 monocephalous branches: leaves all linear, thickish, minutely strigulose-pubescent; radical about 2 inches long and the broadest 2 lines wide: heads only 3 lines high : bracts of the sparsely hirsute involucre little unequal: rays seldom over 20, at most 3 lines long, white or purplish. - Proc. Am. Acad. xvi. 91. E. ochroleucus, Eaton, Bot. King Exp. 152, not Nutt. - Rocky Mountains of Colorado and Wyoming, and the Uinta and Wahsatch Mountains in Utah; first coll. by Watson and Eaton.

b. Stems more leafy and disposed to branch, but sometimes monocephalous : pubescence cinereous: outer pappus setulose, sometimes rather manifest, sometimes obscure or none.

E. cæspitósus, Nutr. Low, a span to rarely a foot high, many-stemmed and ascending or spreading from a stout multicipital caudex, from cinereous to canescent with dense and fine short pubescence' (this generally spreading and soft, sometimes hispidulous, rarely fine and appressed, at least on young parts) : stems of smaller plants monocephalous: radical leaves spatulate to lanceolate, and cauline lanceolate-oblong to linear (half-inch to 2 inches long) : heads short-peduncled, 3 or 4 lines high : bracts of the involucre rather unequal : rays 40 or 50 , linear, 3 or 4 lines long, white, sometimes tinged with rose-color. - Trans. Am. Phil. Soc. vii. 307 (a small and low form); Torr. \& Gray, Fl. ii. 179. Diplopappus canescens (Erigeron canescens, Torr. \& Gray, 1. c.) \& D. grandiflorus (E. coespitosus, var. grandiflorus, Torr. \& Gray, l. c.), Hook. Fl. ii. 21, the latter a large form. - Mountains and high plains, Saskatchewan and Montana to Utah and borders of New Mexico, and eastern part of the Sierra Nevada, California. A variable species. Western forms come near to the next.

E. corymbósus, NuтT. Taller, often a foot or two high, erect from creeping rootstocks, soft-cinereous or sometimes hispidulous with the mostly spreading short pubescence: radical leaves narrow-lanceolate or spatulate-lanceolate (largest 3 or 4 inches long and 3 or 4 lines wide), 3-nerved; cauline linear and narrow: heads sometimes solitary, usually several and corymbosely disposed on short slender peduncies : involucre 3 lines high, canescently pubescent : rays 30 to 50, mostly narrow and 3 to 5 lines long, blue or violet, apparently sometimes white. - Trans. Am. Phil. Soc. vii. 308; Torr. \& Gray, I. c.; Gray, Bot. Calif. i. 329. 
- Mountains of Montana to those of Washington Terr. and sparingly of California ; first coll. by Nuttall. A soft-pubescent form, subalpine in Washington Terr, and E. Oregon, Cusick, Brandegee, has white rays ; a similar one, coll. by Lyall near the British boundary, has blue rays. Nuttall's character of achenium, "nearly smooth and striate," does not accord with his specimens.

E. Bréweri, Grar. A span to a foot high from slender rootstocks, slender, erect or ascending, leafy up to the solitary or several and corymbosely disposed heads, scabrouscinereous with minute spreading pubescence: leaves small (the largest barely inch long), narrowly spatulate or uppermost nearly linear, obtuse: heads 3 or 4 lines ligh: involucre glabrous or minutely granulose-glandular; its bracts unequal, obtuse: rays 12 to 20 , violet, 3 lines long. - Proc. Am. Acad. vi. 541, \& Bot. Calif. 1. c.-Open woods of the Sierra Nevada, California, from Kern Co. to Shasta; first coll. by Brewer and Torrey.

c. Stems (commonly from slender rootstocks) leafy, mostly branched above and bearing few or several heads: pubescence not cinereous nor spreading, either strigose or none: pappus essentially simple.

E. decúmbens, Nctr. Slender, commonly low or spreading, 6 to 18 inches high, strigulosepubescent or puberulent, or glabrate: leaves linear or sometimes linear-spatulate (radical not rarely 4 to 6 inches long and only a line or two wide, sometimes 3 lines wide): involucre minutely hirsute or pubescent: rays 15 to 40 , white, purplish, or violet-tinged. - Trans. Am. Phil. Soc. 1. c. 309; Torr. \& Gray, 1. c. - Mountains, from Montana and Utah to Oregon and northern part of the Sierra Nevada, California; first coll. by Douglas and Nuttall.

E. foliósus, Notr. A foot or two high, smooth and glabrous, or with some minute rough. ish hairs, usually branched above, and bearing seattered or loosely corymbose heads : leaves linear, obtuse, the larger an inch or two long and 2 or 3 lines wide, but of ten much narrower: heads hemispherical, 3 or 4 lines high: involucre of somewhat unequal bracts, either minutely puberulent-strigose or glabrous, rarely hirsute : rays 20 to 40, narrow, 3 to 5 lines long, violet or purple, rarely white. - Trans. Am. Phil. Soc. l. c., \& P1. Gamb. 117; Gray, Bot. Calif. i. 329 (excl. var, inornatus), \& Proc. Am. Acad. xvi. 88. E. Douglasii, Torr. \& Gray, Fl. ii. 177. E. decumbens, Benth. Pl. Hartw. 316, not Nutt. Diplopappus occidentalis, Hook. \& Arn. Bot. Beech. 350. - Sparsely wooded ground, common nearly throughout California, especially in the western parts ; first coll. by Douglas. Nuttall's name was given to the broader-leaved form. This passes freely into

Var. stenophyllus, GraY, 1. c. A common form, with leaves from only a line wide to slender and filiform. - E. stenophyllus, Nutt. Pl. Gamb. 176, not Gray. - Same range, and equally common.

Var. tenuíssimus. Slender, small-leaved : leaves nearly all filiform, erect or ascending; the longest only an inch long; upper gradually shorter, becoming setaceous-subulate: heads much smaller. - San Diego Co. on the Mexican border, and within Lower California, Parry, Palmer, Orcult.

$$
====\text { Heads wholly rayless: stems leafy to the summit: pappus simple. }
$$

E. inornátus, Grax. Commonly glabrous throughout and smooth, or with some sparse hirsute pubescence: stems 10 to 20 inches high, erect: leaves from broadly to narrowly linear (an inch or two long, a line or two wide): heads usually several and cymosely disposed at the summit of the stem, short-peduncled, 3 lines high: involucre campanulate; its brants unequal and somewhat imbricated, very glabrous. - Proc. Am. Acad. xvi. 88. E. foliosus, var. inornatus, Gray, Bot. Calif. i. 330. - Pine woods, Sierra Nevada and coast ranges of California to those of E. Oregon and Washington Territory; first coll. by Newberry. Comes near some forms of $E$. foliosus, but rayless.

Var. angustátus. Leaves very narrowly linear or almost filiform: heads few or scattered and paniculate. - Red Mountain, Mendocino Co., California, Kellogg \& IJarford, and Napa Co., Greene.

Var. viscidulus. Low and stouter: heads fewer and largex (4 lines high): leaves spatulate-linear, shorter (seldom an inch long) : stems and peduncles occasionally hirsutepubescent, and as well as the leaves commonly more or less viscid. - Mountains of northern part of California, Kellogg \& Harford, Pringle.

E. súpplez, GRAX. Villous-hirsute: stems decumbent or ascending from a slender rootstock, mostly simple, a span to a foot long, terminated by single and very broad 15 to 6 
lines high) short-peduncled heads: leaves spatalate-lanceolate or uppermost linear, mucronate-apiculate (an inch or two long) : involucre villous; its bracts linear-lanceolate, equal. Proc. Am. Acad. vii. 353, \& Bot. Calif. i. 330. - N. E. California, in Humboldt and Mendocino Co., Bolander, Pringle; the latter a nearly erect form.

E. míser, Grar. Cespitose from a thickish caudex or rootstock, canescently villous: stems ascending, 3 to 5 inches high, leafy up to the solitary or few and small ( 3 lines high) heads : leaves from oblong-spatulate to short-linear ( 4 to 8 lines long): involucre glabrate or minutely glandular, short; its bracts lanceolate or linear, acute : flowers comparatively few. Proc. Am. Acad. xiii. 372, \& Bot. Calif. ii. 445. - On Mount Stanford and vicinity, in the Sierra Nevada, California, Lobb, Kellogg, Greene, \&c. : fl. late.

++++++ S. Arizonian, with diffusely branched and trailing stems, very leafy branches, bearing very small heads, soft-cinereous pubescence, and lower leaves commonly : $3-5$ lobed or toothed: pappus simple.

F. Lemmóni, Gray. Stems a foot or two long, apparently from slender creeping rootstocks: leares half-inch long or less, spatulate; upper all entire, lower tapering into more or less of a petiole, many of them 1-5-toothed or incisely lobed: heads terminating short branchlets, short-peduncled: involucre 2 lines high: rays of about same length, 40 or 50, light purple. - Proc. Am. Acad. xix. 2. - Tanner's Cañon, Huachuca Mountains, S. Arizona, Lemmon.

+++++++ Northeastern species, smooth and slender, erect, from filiform rootstocks, leafy-stemmed, entire-leaved; with small and Aster-like heads of only 20 or 30 rays: pappus quite simple.

E. hyssopifólius, Mrctx. Nearly glabrous, a span to a foot high, sparingly branched: branches terminated by a solitary slender-peduncled head: leaves small and numerous, linear or lower somewhat spatulate, thinnish, entire, an inch or less long : rays 3 lines long, white or tinged with purple. - Fl. ii. 123; Gray, Proc. Am. Acad. xvi. 87. Aster graminifolius, Pursh, Fl. ii. 545; DC. Prodr. v. 227 ; Torr. \& Gray, Fl. ii. 156. Galatella graminifolia, Hook. Fl. ii. 15. - Moist and rocky banks, Newfoundland and New Brunswick to Hudson's Bay, northern borders of New England to Lake Superior and Slave Lake; first coll. by Michaux.

* * * Perennial by rosulate offisets, producing a scapiform stem from a rosette of radical leaves: heads small and Aster-like, bearing only 20 or 30 rays: disk convex, only 3 lines broad: akenes mostly 4-nerved : pappus quite simple: S. Atlantic species. - $\$$ Erigeridium, Torr. \& Gray.

E. nudicaúlis, Mickx. Glabrous or glabrate: scapiform stems solitary or occasionally several from the rosette of obovate or spatulate thickish and sparingly denticulate leaves: cauline leaves few and small, or merely bracts: heads several, corymbosely cymose : rays white and pinkish, 2 or 3 lines long. - Pursh, 1. c. Erigeron (Erigidium) vernus, Torr. \& Gray, Fl. ii. 176. E. integrifolius, Bertol. Misc. Bot. vi. t. 3, not Bigel. Aster vernus, L. Spec. ii. 876. Doronicum lavifolium, Walt. Car. 205? Stenactis verna, Nees, Ast. 275; DC. l. c. 299. - Low pine barrens near the coast, Virginia to Florida and Louisiana : fl. spring.

* * * * Perennial by biennial rosulate offsets borne on apex of stoloniform creeping rootstocks, or some species probably biennial: leaves membranaceous, commonly serrate or dentate: heads middle-sized or small, with glabrate involucre: rays numerous: pappus quite simple: species not montane.

+ Rays not very narrow, not more than 60 or 70 .

E. bellidifólius, M兀ru. Stoloniferous-cespitose, making rosulate offsets from slender subterranean shoots, villous-hirsute: flowering stems usually a foot or more high, simple, naked above and bearing 3 to 9 (or, when depauperate, only single) umbellately cymose middle-sized heads: radical leaves cuneiform-obovate or spatulate, mostly coarsely fewtoothed, on very short-winged petioles; cauline few, oblong or lanceolate: bracts of the involucre appressed: rays violet or bluish-purple, a third to half inch long: akenes almost glabrous. - Willd. Spec. iii. 1958; Sims, Bot. Mag. t. 2402; Torr. \& Gray, Fl. ii. 170. E. pulchellus, Michx. Fl. ii. 124, excl. syn. Gronor; Darl. Fl. Cest. ed. 2, 492; Hook. Fl. ii. 19, excl. var. - Damp ground, borders of woodlands; Canada to Illinois and Louisiana: fl. spring.

E. Oregánus, GRAY. Perhaps only biennial, pubescent: rosulate tufts many-leaved, sending up weak or diffuse leafy stems of a span or two in length, bearing solitary or few rather 
small heads: leaves spatulate, or the radical cuneate-obovate; these an inch or two long, coarsely 3-5-toothed or incised; cauline more entire, inch long: rays pale purple, quarterinch long. - Proc. Am. Acad. xix. 2.-Oregon, along the Columbia River under overhanging cliffs in Multnomah Co., Howell.

+ + Rays very narrow, almost filiform, and numerous (much over 100): disk only 3 or 4 lines broad: stems scattered, erect, either from a biennial root or from a biennial or winter-annual offset.

E. Philadélphicus, L. Soft-hirsute, a foot or two high: stem striate-angled: leaves oblong, or lowest spatulate or obovate; npper cauline half-clasping, obtuse, sparingly and coarsely serrate or entire : peduncles thickened under the head: rays pink, about 3 lines long. - Spec. ii. 863; Willd. Spec. iii. 1957; Torr. \& Gray, Fl. ii. 171, not Michx., Ell., \&c. E. purpureum, Ait. Kew. iii. 186, DC. 1. c. E. pulchellus, var., Hook. Fl. ii. 19 (N. W. Am.).Moist fields and border of woodlands, Hudson's Bay to Florida, Texas, California, and Brit. Columbia: fl. summer.

E. quercifólius, LAM. Pubescent with short spreading hairs, sometimes cinereous, about a foot high : radical and lowest cauline leaves obovate or spatulate, from repand to siunatepinnatifid: heads smaller than in the preceding: rays barely 2 lines long, from bluish or purplish to white. - IIl. t. 681, f. 4 ; Poir. Dict. vii. 490; Reichenb. Ic. Lxot. t. 134 (?); Torr. \& Gray, 1. c. E. Philadelphicus, Michx. Fl. ii. 123; Ell. Sk. ii. 396; DC. 1. c., not L. - Low grounds, S. Carolina to Florida and Texas; $\mathrm{fl}$. spring.

****** Perennial by rooting from decumbent or creeping leafy stems or stolons: rays very numerous and narrow: heads solitary, slender-peduncled.

E. répens. Cinereous-pubescent : stems prostrate or ascending from the slender root; prostrate ones rooting at the nodes: leaves obovate or broadly spatulate with cuneate base tapering into a petiole, obtusely and deeply 5-9-toothed or almost lobed: peduncles scapiform, 4 to 8 inches long: involucre 4 lines high: rays 3 lines long, white: pappus simple. $-E$. scaposus, Torr. \& Gray, Fl. ii. 170; Gray, Pl. Lindh. i. 11, but harclly the Mexican E. scaposus nor E. longipes, DC. E. scaposus, var? cuneifolius, Gray, Proc. Am. Acad. xvi. 94.Sandy sea-coast, Texas, Berlandier, Drummond, Lindheimer, Wright, \&c. (Probably also on the Mexican side of the Rio Grande.)

E. flagelláris, Grar. More or less cinereous with fine appressed pubescence: stems slender, diffusely decumbent and flagelliform but leafy, some prostrate, many at length rooting at the apex and proliferous: leaves small, entire; radical spatulate and petioled; those of the branches passing to linear (from an inch to 3 lines long): peduncles 2 to 5 inches long: head barely 3 lines high : rays white or purplish: pappus double, the outer subulate-setulose. - Pl. Fendl. 69; Rothrock in Wheeler Rep. vi. 153. E. dirergens, Hook. Lond. Jour. Bot. vi. 242. E. divergens, var., Gray, Pl. Wright. - Banks of streams, W. Texas and New Mexico to Colorado and S. W. Utah; also north to the Upper Platte; first coll. by Fendler.

******* Annuals or sometimes biennials, leafy-stemmed and branching: heads conspicuously radiate, except in one species.

+ Akenes narrow, little compressed, with a broad and whitish truncate apex and a simple capillary pappus: heads small (only 3 lines high): rays 40 to 70 , not very narrow.

E. Bellidiástrum, Nutr. A diffusely or loosely branched annual, a span or two high, cinereous-pubescent: leaves entire, spatulate-linear or the lowest broader (an inch or less long): heads paniculate, short-peduncled: rays light purple. - Trans. Am. Phil. Soc. vii. 307; Torr. \& Gray, Fl. ii. 170; Gray, Proc. Am. Acad. viii. 648. - Low grounds, plains of Nebraska to New Mexico; first coll. by Nuttall.

+ + Akenes compressed, 2-nerved: pappus more or less double; outer short and subulatesquamellate or sometimes coroniform; inner often fragile or deciduous.

+ Leares entire, sometimes dentate or lower inciselyr lobed, not dissected. - Phalacroloma, Torr. \& Gray, Fl. ii. 175.

= Rays of the middle-sized or rather large heads num-rous, well exserted, and with pappus like the disk-flowers: leaves all entire: Southwestern species.

E. Rúsbyi. Hirsute-pubescent or hispidulors, but green : stems a foot high from probably annual or biennial root, sparingly branched, somewhat diffuse or spreading, equably leafy: cauline leaves oblong-lanceolate, acute, closely sessile by a broad base, about an inch long; 
radical not larger, obovate or spatulate, slender-petioled: heads solitary, terminating the branches, on rather slender peduncles: involucre broad, 3 lines high, slightly pubescent: rays about 50, apparently white, 4 lines long, not very narrow: pappus indistinctly double, the outer short and setulose. - Mogollon Mountains, New Mexico, Rusby.

E. Arizónicus, Grax. Cinereous-hirsute throughout: stem 2 feet high from an annual root, strict, with simple branches, leafy: leaves oblong-lanceolate and. sessile, or lower obovate-oblong and petioled, an inch or two long: heads solitary and short-peduncled, terminating the branches, half-inch high and broad: involucre hirsute: rays 80 to 100, white, 4 or 5 lines long: outer pappus very conspicuous, setose-squamellate. - Near Tanner's Cañon in the Huachuca Mountains, S. Arizona, Lemmon.

$==$ Rays of the small heads rather numerous but small, shorter than or barely equalling the flowers of the convex disk. Verges to $\$$ Comotus.

E. incómptus. A foot or two high, branched from the base, slender and erect, hirsute with short spreading pubescence, leafy: leaves narrowly linear (half-inch or inch long, a line or less wide), or lower narrowly spatulate-lanceolate and attenuate into slender petiole: heads slender-peduncled: involucre 2 lines high, shorter than the hemispherical disk: rays either very numerous or fewer, slender, with ligule only a line long, bluish or purplish: outer pappus conspicuons, subulate-squamellate, longer than the breadth of the glabrate akene; inder scanty and rather deciduous. - Carysito, Lower California, near the U. S. border, within which it probably occurs, C.R. Orcutt.

$==$ Rays of the small heads only 30 or 40 , well exserted, white, not very narrow, barely

3 lines long, and with pappus as in the disk-flowers: leaves narrow, entire.

E. modéstus, Gray. A foot or less high and much branched from an indurated but annual root, slender, rigid, cinereous-hirsute or hispid: branches terminated by the small (2 lines high) slender-pedunculate heads: upper leaves linear and lower narrowly spatulate, about an inch long. - PI. Fendl. 68 (excl. syn.) \& Pl. Lindh. ii. 220. - Dry and sterile rocky plains, W. and N. W. Texas, Lindheimer, Wright, \&c.

$===$ Rays of small or barely middle-sized heads very numerous (about 100), narrow, with pappus like the disk-flowers; the inner of rather scanty bristles; outer of short subulate squamelle: leaves from entire to sparingly lobed.

E. divérgens, Torr. \& Gray. Diffusely branched and spreading, a foot or less high, cinereous-pubescent or hirsute: leaves linear-spatulate or the uppex linear and the lowest broader (these 2 to 4 lines wide, sometimes laciniately toothed or lobed) : heads 2 or 3 lines high, and the white or purplish or sometimes violet rays equally long: involucre hirsute: reeptacle in age commonly very convex. - Fl. ii. 175; Gray, Pl. Fendl., Pl. Wright., \&c. E. strigosus, var., Hook. Fl. ii. 18, in part. E. (Oligotrichium) divaricatus, Nutt. Trans. Am. Phil. Soc. 1. c. 311. - Low plains and river-banks, Nebraska to W. Texas, Washington Texr., and California. (Adj. Mex.)

Var. cinéreus, GraY, 1. c. Dwarf and flowering almost from the root, with the earliest heads on slender almost scapiform peduncles; or leafy and later heads shorterpeduncled: pubescence soft and cinereous. - E. cinereus, Gray, Pl. Fendl. 68. E. nudiflorus, Buckley in Proc. Acad. Philad. 1861, 456. - W. Arkansas to Arizona. (Adj. Mex.)

E. ténuis, Torr. \& Gray. Branched from the annual or biennial root, ascending or erect, a span or two high, somewhat hirsute or pubescent: leaves oblong-spatulate or lanceolate, and the lowest obovate ( 4 to 6 lines wide), occasionally few-toothed or sinuate-lobed: heads little over 2 lines high: involucre nearly glabrous: rays white and purplish. - Fl. ii. 175. E. quercifolium, Nutt.; DC. Prodr. v. 285, not Lam. E. Brazoensis, Buckley, 1. c. - Low grounds, Arkansas, Louisiana, and Texas.

$====$ Rays of the small heads not excessively numerous, nor very narrow (2 or 3 lines long), white or barely purplish-tinged; the bristles of their pappus commonly wanting or very few: outer pappus a short crown of distinct or partly united slender squamelli, persistent after the fragile inner pappus has fallen: tall and erect winter annuals or biennials, leafy, branched above, bearing corymbosely cymose or paniculate heads, commonly produced all summer: leaves green, sometimes serrate or the lower incised: weed y species, of wide distribution; the two generally distinct in the Atlantic States, hardly so on the Pacific side. - Phalacroloma, Cass. Dict. xxxix. 404.

E. ánnuus, Pers. Sparsely hirsute with spreading hairs, 2 to 5 feet high: leaves membranaceous, from ovate to broadly lanceolate, mostly serrate, lower often very coarsely so: 
involucre commonly beset with some bristly hairs. - Syn. ii. 431 ; Hook. Fl. ii. 20; Torr. \& Gray, Fl. ii. 175. E. heterophyllus, Muhl. in Willd. iii. 1956; Pers. 1. c.; Pursh, Fl. ii. 148 ; Bart. Veg. Mat. Med. t. 21. E. strigosus, Bigel. Fl. Bost. ed. 2, 302, not Muhl. Aster annuus, L. Hort. Cliff. \& Spec. ii. 875. Pulicaria annua, Gærtn. Fruct. ii. 462. Diplopappus dubius, Cass. Bull. Philom. 1817 \& 1818. Stenactis dubia, Cass. Dict. xxxvii. 485. S. annua \& S. strigosa (excl. syn.), DC. Prodr. v. 299. Phalacroloma acutifolium, Cass. Dict. xxxix. 405. - Fields and open grounds, common from Canada to Virginia: also in Oregon, \&c., in a form quite intermediate between this and the following. (Nat. in Eu.)

E. strigósus, MонL. Pubescence appressed, either sparse and strigose or close and minute: stem seldom over 2 feet high: leaves of firmer texture, lanceolate and the upper entire; lower from spatulate-lanceolate to oblong, often sparingly serrate : involucre with few or no bristly hairs. - Willd. Spec. l. c. ; Ell. Sk. ii. 394; Hook. 1. c. ; Torr. \& Gray, 1. c. E. nerrosum, Pursh, 1. c., not Willd. E. ambiguus, Nutt. Gen. ii. 147. E. Philadelphicus, Bart. Veg. Mat. Med. t. 20. E. integrifolius, Bigel. 1. c. Doronicum ramosum, Walt. Car. 205. Phalacroloma obtusifolium, Cass. Dict. xxxix. 405. Stenactis ambigua, DC. 1. c. - Dry open grounds, Canada and Saskatchewan to 'Texas, Oregon, and California. Passes into or mixes with the preceding. Occurs rarely with abortive rays, var. discoideus, Robbins, in Gray, Man. ed. 5, 237.

Var. Beyríchii. A slender form, with minute and sometimes almost cinereous pubescence, smaller heads, and rays from white to pale rose-color. - Torr. \& Gray, 1. c. E. Beyrichii, Hort. Berol. Stenactis Beyrichii, Fisch. \& Meyer, Ind. Sem. Petrop. v. 27. Phalacroloma Beyrichii, Fisch. \& Meyer, 1. c. vi. 63. - Nebraska to Arkansas and Texas, perhaps first coll. by Beyrich.

+ + Leaves pinnately parted into narrow divisions : rays rery numerous (100 or more) and narrow: pappus alike in ray and disk; the bristles of the inner very deciduous; the short squamellæ of the outer more or less confluent into a multidentate crown. - Original of Stenactis, Cass. ex Benth. Polyactis, Less. Syn. Comp. 188. Polyactidium, DC. Prodr. v. 281.

E. Neo-Mexicánus, Grar. A foot or two high from a biennial or winter-annual root, leafy, paniculately branched, hispidulous or hispid with spreading bristly hairs: divisions of the cauline leaves 3 to 9, linear or linear-spatulate, obtuse, of the radical shorter and broader: rays white or purplish-tinged, narrowly linear, 4 or 5 lines long. - Proc. Am. Acad. xix. 2. E. delphinifolius, Gray, Pl. Wright. ii. 77; Rothrock in Wheeler Rep. vi. 153 (where the root is said to be perennial, which needs confirmation), not Willd. - Hillsides, New Mexico and Arizona, Wright, Thurber, Palmer, Rothrock, Lemmon.

E. Delphim fólics, Willd. (Stenactis, Cass., Polyactidium, DC.), from which Bentham first distinguished our very similar species, appears to be wholly Mexican, has appressed pubescence and more numerous as well as more slender rays.

§ 2. Trmorpha. Rays inconspicuous or slender, numerous, sometimes not exceeding the disk: within them a series of rayless filiform female flowers (commonly none in the last species) : leaves entire or nearly so. - Trimorphaa, Cass. Dict. xxxvii. \& liv.

* Stems low from a truly perennial rootstock, mostly simple and monocephalous: ray-corollas bearing a few long and articulated hairs on the upper part of the tube: short outer pappus manifest.

E. alpinus, L. A span or so high, 1-3-cephalous: herbage and involucre more or less hirsute: leaves entire; lowest spatulate, uppermost usually linear: rays purple, about twice the length of the pappus. - Spec. ii. 864 ; Engl. Bot. t. 464; Fl. Dan. t. 292; Hook. Fl. ii. 18, excl. vars. ; Reichenb. F1. Germ. xvi. t. 914. - High region of Northern Rocky Mountains, Drummond, only specimen seen is not certain. (Eu., N. Asia.)

* Stems a span to a foot or more high from a biennial or sometimes more enduring root, the larger plants branching and bearing several or numerous somewhat paniculately disposed heads : pappus nearly or quite simple.

E. ácris, L. More or less hirsute-pubescent, varying towards glabrous (not glandular): canline leaves mostly lanceolate, the lower and radical spatulate: involucre hirsute: rays slender, equalling or moderately surpassing the disk and pappus, purple: filiform female flowers numerous. - Spec. ii. 863 ; Engl. Bot. t. 1158 ; Reichenb. 1. c. t. 917 ; Blytt, Norg. 
Fl. 561. E. alpinus \& E. glabratus, in part, Hook. Fl, 1. c. Trimorphoea vulgaris, Cass. Dict. liv. 324. - Anticosti to Labrador, Saskatchewan, \&c., to Brit. Columbia and Oregon, and in the Rocky Mountains south to Colorado and Utah. (Eu., N. Asia.)

Var. Drøbachénsis, BLYтT, 1. c. Somewhat glabrous, or even quite so: involucre also green, naked, at most hirsute only at the base, often minutely viscidulous: slender rays somewhat slightly exserted, sometimes minute and filiform and shorter than the pappus. $-E$. Drebachensis, O. Mueller, Fl. Dan. t. 874 ; Fries, Summa Scand. 182; Reichenb. Ic. Fl. Germ. xvi. t. 916. E. elongatus, Ledeb. Fl. Alt. iv. 91, \& Fl. Ross. ii. 487. E. Kamtschaticus, DC. Prodr. v. 290. E. glabratus, Hook. Fl. ii. 18, mainly, not Hoppe. - New Bruns wick and the north shore of Lake Superior to the Arctic Circle and Kotzebue Sound, south along the Rocky Mountains to Colorado and Utah, at about 10,000 feet. Clearly passes into the other form. (Eu., N. Asia.)

Var. débilis. Sparsely pilose: stems a span to a foot high from an apparently perennial root, slender, 1-3-cephalous : leaves bright green; radical obovate or oblong; cauline spatulate to lanceolate, short: involucre sparsely hirsute or upper part glabrate, the attenuate tips of the bracts spreading: rays in flower rather conspicuously surpassing the disk. Northern Rocky and Cascade Mountains, Montana, Canby, Sargent, at Woodruff's Falls, the tips of involucral bracts strongly recurved. Mount Paddo, Suksdorf, Howell. Also Hudson's Bay, Burke, and N. Labrador, named by Steetz, E. Droebachensis, var. hirsutus. Passing into that species or form.

E. armeriæfólius, Turcz. Sparsely hispid-hirsute or the leaves glabrous and most of the (narrowly linear and elongated) cauline bristly-ciliate: inflorescence more racemose and strict: involucre sparsely hirsute : rays filiform, extremely numerous, slightly surpassing the disk, whitish, no filiform rayless flowers seen (even in Siberian specimens, though described by Turczaninow). - Cat. Baik. \& DC. Prodr. v. 291 ; Ledeb. Fl. Ross. ii. 489 ; Gray, Proc. Am. Acad. viii. 648, \& Bot. Calif. i. 326. E. lonchophyllus, Hook. Fl. ii. 18. E. glabratus, var. minor, Hook. l. c., partly. E. racemosus, Nutt. Trans. Am. Phil. Soc. I. c. 312.- Saskatchewan and along the Rocky Mountains to Colorado, mountains of S. Utah, Nevada, and the Sierra Nevada, California. (N. Asia.)

§3. CAsnótus, Nutt. Rays of the small and narrow seemingly discoid (and mostly thyrsoid-paniculate) heads inconspicuous, little if at all surpassing the disk or pappus; the narrow ligule always shorter than its tube, often shorter than the style-branches, or even obsolete: disk-flowers sometimes few, with usually 4-toothed corolla: annuals or biennials, with the aspect of Conyza, and passing into that genus: the pappus in the genuine species simple: bracts of the involucre not rarely somewhat unequal and imbricated. - Gen. ii. 148 ; Benth. \& Hook. Gen. ii. 281.

* Floccose-lanuginous with white wool, destitute of either hirsute or viscid pubescence.

E. eriophýllus, Grax. A foot or two high, bearing few heads on almost leafless branches: lower leaves spatulate-oblong; obtuse, serrate near the apex (inch long); upper linear, entire: involuere glabrate ( 3 lines high) : corollas purplish, not exceeding the pappus: akenes oblong-obovate, flat, callous-margined : pappus completely simple, somewhat deciduous in a ring. - PI. Wright. ii. 77. - S. Arizona, on the Sanoita, Wright.

* * Lightly arachnoid, but green and at length naked, somewhat viscid-pubescent.

E. subdecúrrens, SchdLtz Bip. A foot or two high, strict, bearing numerous heads in a virgate racemiform leafy thyrsus : leaves oblong-linear or lanceolate (inch or less long), sparingly dentate, or the lower sometimes sinuate-laciniate, the base partly adnate-clasping: involucre (2 lines high) sparsely hirsute with viscid hairs: flowers whitish : ligules very short: disk-flowers 6 to 10 : pappus scanty, somewhat decidnous in a ring. - Conyza subdecurrens, DC. Prodr. v. 379. C. Coulteri, Rothrock in Wheeler Rep. vi. 155, not Gray. - Arizona, on Mount Graham at 9,000 feet, Rothrock. (Mex., Schaffner, Parry \& Palmer, \&c.)

* * Pubescence hirsute or hispid, neither lanate nor viscid, very leafy.

+ Introduced weed: heads fully 3 lines high.

E. LINIFóLIUs, Willd. A foot or two high, rather strict, bearing loosely paniculate heads, hirsute, also somewhat scabrous with minute appressed pubescence : upper leaves narrowly 
linear, mostly entire, narrowed downward; lowest broader, incisely toothed or laciniate. involucre cinereous-pubescent: ligules very small, shorter than the style and the at length ferruginous pappus. - Spec. iii. 1955 ; Benth. Fl. Austr. iii. 495. E. ambiguus, Schultz Bip. in Phyt. Canar. ii. 208. E. Bonariensis, DC. Prodr. v. 289, in part. Conyza ambigua, DC. Fl. Franc. \& Prodr. 1. c. C. sinuata, Ell. Sk. ii. 323. - Waste grounds, coast of S. Carolina to Florida. (Intr. from tropics.)

+ + Indigenous weeds; but the common species now cosmopolitan: heads only 2 lines high: involucre almust glabrous : leaves commonly more or less hispid-ciliate.

F. Canadénsis, L. From sparsely hispid to almost glabrous : stem strict, I to 4 feet high, with numerous narrowly paniculate heads, or in depauperate plants only a few inches high and with few scattered heads: leaves linear, entire, or the lowest spatulate and incised or few-toothed : rays white, usually a little exserted and surpassing the style-branches. - Spec. ii. 863; Fl. Dan. t. 292 ; Torr. \& Gray, Fl. ii. 167. E. paniculatus, Lam. Fl. Franc. E. pusillus, Nutt. Gen. ii. 148, a depauperate form. E. strictum, DC. Prodr. v. 289, a strict and setose-hispid form. Senecio ciliatus, Walt. Car. 208. - Open or waste grounds, throughout temperate N. America, especially the warmer parts. (Nat. in Eu., \&c.)

E. divaricátus, Mrснx. Low (a span to a foot high), diffusely much branched, somewhat fastigiate: leaves all narrowly linear or subulate, entire: rays purplish, rarely surpassing the style-branches or the pappus. - Fl. ii. 123; Nutt. 1. c. ; Torr. \& Gray, 1. c. - Open grounds and river banks, Indiana to Minnesota, Nebraska, and Texas.

50. CONYZA (Tourn., L. in part), Less. (Name used by Dioscorides and

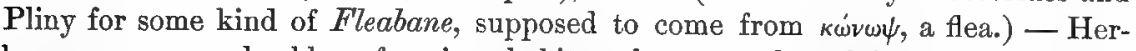
baceous or some shrubby, of various habit; what were the original species belong to Inula, \&c., those now referred to it are of warm regions, and approach the Canotus section of Erigeron. - Benth. \& Hook. Gen. ii. 283.

C. Coúlteri, Gray. Apparently annual, a foot or two high, commonly branched, bearing numerous small heads in a mostly crowded thyrsoid leafy panicle, viscidly pubescent or partly hirsute with many-jointed hairs: cauline leaves linear-oblong, the lower spatulateoblong and with partly clasping base, from dentate to laciniate-pinnatifid (an inch or two long): involncre 1 or 2 lines high, hirsute with rather soft spreading hairs, considerably shorter than the soft pappus: flowers whitish; the numerous female with an entire corollatube barely half the length of the style; hermaphrodite flowers only 5 to 7. - Proc. Am. Acad. vii. 355, \& Bot. Calif. i. 332. C. subdecurrens, Gray, Pl. FendI. 78, \& Pl. Wright. i. 102, not of DC. Erigeron discoideus, Kellogg, Proc. Calif. Acad. v. 55. E. subdecurrens, Gray, Bot. Mex. Bound. 78. - River-bottoms, \&c., W. Texas and Colorado to Arizona and California. Much resembling $C$. subdecurrens, DC., which, from the more developed corolla of the ray, is referred to Erigeron, but has also a different pubescence. (Adj. Mex.)

Var. tenuisécta. Greener, extremely leafy: leaves pinnately or even somewhat bipinnately parted into linear lobes: heads smaller and very numerous in an ample panicle. - S. Arizona, near Fort Huachuca, Lemmon. Apparently growing with the ordinary form.

51. BÁCCHARIS, L. (Named after Bacchus, unmeaningly.) - Shrubs, undershrubs, or some perennial herbs; with alternate simple leaves, sometimes reduced to scales, and the branches commonly striate or sulcate-angled, bearing small heads of white or whitish or yellowish flowers. A huge American genus, chiefly tropical and S. American. - Benth. \& Hook. Gen. ii. 286; Gray, Proc. Am. Acad. xvii. 212.

$\S 1$. Pappus of the fertile flowers very copious and pluriserial, elongated in fruiting, soft: akenes 5-10-costate: stems herbaceous from a lignescent or more woody base: leaves linear, 1-nerved: receptacle flat and broad, naked. Here also B. juncea, of S. Brazil (Arrhenachne, Cass., Stephananthus, Lehm.), and B. Seemanni, of Mexico. - Gray, Proc. Am. Acad. xvii. 211. 
B. Wríghtii, Gray. Very smooth and glabrous, a foot or two high, diffusely branching, sparsely leaved: slender branches terminated by solitary heads: leaves small; uppermost linear-subulate : involucre campanulate, 4 or 5 liwes high; its bracts lanceolate, gradually acuminate, conspicuously scarious-margined, with a green back: pappus fulvous or sometimes purplish, four times the length of the scabrous-glandular 8-10-nerved akene.-Pl. Wright. i. 101, \& ii. 83. - W. Texas to S. Colorado and Arizona. (Adj. Mex.)

B. Texána, GrAY. Glabrous, a foot or more high, with many nearly simple rigid stems from a woody base, leafy to the top, where it bears a few somewhat corymbosely disposed heads : leaves an inch or two long, rather rigid: involucre 3 lines long, of firmer and narrower merely acute bracts : akenes smoother. - Pl. Fendl. 75, \& Pl. Wright. I. c. Linosyris Texana, Torr. \& Gray, Fl. ii. 232, male plant. Aplopappus linearifolius, Buckley in Proc. Acad. Philad. 1861, 457. - Texas, forming large patches in dry prairies, Berlandier, Drummond, Wright, \&c.

§ 2. Pappus of the fertile flowers more or less copious, but uniserial or nearly so, conspicuously elongating in fruiting, soft and fine, mostly flaccid and bright white: akenes 10-nerved: branching shrubs, glabrons or nearly so, usually viscous with a resinous exudation : leaves sometimes lobed or angulate-dentate: heads glomerate or paniculate: receptacle naked and flat.

* Eastern species, of the coast or along streams in subsaline soil: shrubs 3 to 12 feet high.

B. halimifólia, L. Cauline leaves from dilated-obovate to oblong with cuneate base, attenuate into a petiole, laciniately or angulately 3-9-toothed, those of the flowering branchlets becoming lanceolate and mostly entire: heads in pedunculate and paniculate glomerules ( 3 to 5 together): involucre of the male heads only 2 lines long, of oblong-ovate obtuse bracts; of the female rather longer and narrower, the inner bracts linear-lanceolate and acute. - Spec. ii. 860; Michx. Fl. ii. 125; Duham. Arb. i. t. 60. - Sea-coast, New England to Florida and Texas. (W. Ind.)

B. glomeruliflóra, Pers. Brighter green: leaves mostly cuneate-obovate or the upper. most spatulate, less petioled or sessile, merely angulate-toothed : heads larger, sessile or in very short-peduncled glomerules in the axils of the upper leaves: involucre of both sexes campanulate, pluriserially imbricate, of obtuse bracts. - Syn. ii. 423; Pursh, Fl. ii. 523. B. sessitiflora, Michx. Fl. ii. 125; Ell. Sk. ii. 320, not Vahl. - Swamps near the coast, N. Carolina to Florida. (Bermuda.)

B. salícina, Torr. \& Grar. Leaves mostly subsessile, from oblong to linear-lanceolate, sparingly toothed, rarely entire: heads or glomerules pedunculate: involucre of both sexes campanulate (nearly 3 lines long), of mainly ovate and acutish bracts. - Fl. ii. 258. B. salicifolia, Nutt. Trans. Am. Phil. Soc. vii. 337.-Colorado (banks of the Arkansas, \&c.) to W. Texas, on the Rio Grande, near El Paso.

B. angustifólia, Mrchx. Rather strict: leaves narrowly-linear (larger 2 or 3 inches long, a line or two widle), entire or with few denticulations; and some lower ones broadly lanceolate and more serrate: heads or glomerules short-pedunculate, amply paniculate: involucre 2 lines long, of oblong-ovate or lanceolate bracts, the outer obtuse, innermost acute. - Fl. ii. 125; Ell. 1. c.; Torr. \& Gray, 1. c. B. salicina, Gray, P1. Wright. i. 101, not of ii., nor Nutt. - Brackish marshes, \&c., S. Carolina to Florida, and to Texas on the Rio Grande; also S. Arizona, Lemmon. (Adj. Mex.)

* Western species (Pacific coast to Arizona): branches smooth or nearly so, striate-angled.

B. piluláris, DC. Either depressed, spreading on the ground, or more erect and sometimes 4 feet high, leafy up to the glomerate sessile heads: leaves short (seldom over inch long), obovate and cuneate or roundish, very obtuse, sessile, coarsely few-toothed or some entire: involucre nearly hemispherical, 2 lines long; its bracts oval and oblong, all but the innermost very obtuse: flowers bright white: fertile pappus not over 4 lines long. $-B$. pilularis \& B. consanguinea, DC. Prodr. v. 407, 408; Torr. \& Gray, Fl. ii. 259; Benth. Bot. Sulph. 25. B. glomeruliflora, Less. in Linn. vi. 506; Hook. \& Arn. Bot. Beech. 147. - Near the coast, Monterey, California, to Oregon.

B. Emóryi, Gray. Erect, with slender branches, 2 to 15 feet high : cauline leaves mostly oblong or the lower broader, with attenuate or cuneate base and the larger somewhat 
petioled, more or less triplinerved, often with 2 to 4 short lobes or teeth; those of the branches from oblanceolate to linear, mostly entire, l-nerved: heals somewhat nakedly paniculate on the branchlets, short-pedunculate or the giomerules more or less pedunculate: involucre campanulate or oblong, 3 or sometimes 4 lines long, mostly of firm coriaceous and obtuse bracts; the outermost oval, inner oblong, the innermost thin, linear and acutish: pappus of male flowers bearded towards the tip; of the female in fruit half-inch long. - Bot. Mex. Bound. 83, \& Bot. Calif. i. 333, described from mere branches. B. pilularis, Nutt. Trans. Am. Phil. Soc. 1. c., partly, not DC. B. salicina, Rothr. in Wheeler Rep. vi. 156, \& Bot. Calif. ii. 456, partly. - Along watercourses, from Los Angeles southward, through Arizona and in S. Nevada and Utah.

B. sarothroídes, Grar. Erect, fastigiately much branched, 10 to 15 feet high : leaves all nearly linear, entire, 1-nerved, rigid, small; the larger (less than inch long and 2 lines wide) narrowed at base; those of the slender and strongly striate-angled branchlets commonly sparse and minute: heads loosely paniculate, terminating ultimate naked branchlets, small: involucre of the male campanulate, hardly 2 lines long; of the female rather oblong, only about 10-flowered; short outer bracts ovate or oval, very obtuse, innermost thin and broadly linear : clavellate tips of male pappus naked: female pappus in fruit 3 lines long. - Proc. Am. Acad. xvii. 211. - S. California, from San Diego to the Mexican line, Sutton Hayes, Palmer. Has been confounded with B. Emoryi and B. sergiloides. (Adj. Mex.)

* * Species of Mexican border, with branchlets terete, less striate, pruinose-scabridous.

B. pteronioides, DC. Diffusely branched : leaves small (rarely half-inch long), crowded and fascicled on the branchlets, from lanceolate-spatulate to linear, thickish, nearly veinless, the larger 2-6-dentate: heads singly terminating very short densely leafy branchlets, which are crowded in a virgate or racemose way along the branches: involncre 3 lines long, campanulate; the outer bracts orate or oblong: pappus of the male flowers not at all clavellate; of the female in fruit 4 lines long, not much surpassing the corolla. - Prodr. v. 410. B. ramulosa, Gray, P1. Thurb. 301, \& Bot. Mex. Bound. 84. Aplopappus ramulosus, DC. 1. c. 350. Linosyris (Aplodiscus) ramulosa, Gray, Pl. Wright. i. 97, \& ii. 80. - New Mexico and Arizona. (Mex.)

§ 3. Pappus rather rigid and scanty, short, not elongated with age, of the fertile flowers even in fruit not surpassing the style : akenes 10 -nerved (the 5 primary nerves sometimes the more prominent): fertile corollas regularly cleft at apex into 5 subulate lobes: some chaff among the flowers on the sometimes elevated receptacle similar to the innermost involucral bracts : branches broom-like.

B. sergiloídes, Grax. Suffuticose, glabrous, 3 to 5 feet high, very much branched; the slender and partly herbaceous branches and branchlets strongly striate-angled and naked, bearing a few small leaves and paniculate mostly short-pedunculate heads: larger leaves spatulate, entire, rarely 2-4-toothed (the larger seldom over half-inch long): heads 2 or 3 lines long: bracts of the involucre small, oblong or lanceolate, rather obtuse, of firm texture: fertile pappus barely twice the length of the mature akenes. - Bot. Mex. Bound. 83, Pacif. R. Rep. iv. 101, \& Bot. Calif. i. 333, partly, and not well characterized. - Arid districts of S. F. California and adjacent Nevada to S. W. Utah, Bigelow, Wheeler, Palmer, Parish, \&c. Varies in the amount of imbrication of the involucre, and the number of chaffy scales; when these are numerous the receptacle becomes conical and the disk very convex.

$\S 4$. Pappus of the fertile flowers not flaccid, little if at all elongated in fruit, not very copious: akenes only 5-nerved, sometimes 4-nerved. Southwestern, chiefly Pacific species.

* Scabro-puberulent or pubescent throughout, not glutinous : fruiting pappus manifestly surpassing the style: heads loosely paniculate: bracts of the involucre scarious-margined from a green or greenish back or centre, acute or acuminate : stems herbaceous from a woody or merely lignescent base, 2 or 3 feet high : leaves not rigid.

B. brachyphýlla, Gray. Minutely scabro-puberulent, diffusely much vranched, slender: leaves small, entire, mostly linear, 1-nerved, the larger cauline seldom over half-inch long, on the branchlets mostly becoming minute and scale-like: heads 3 lines long, 12-15-flowered: 
involucre of oblong-lanceolate or broader bracts : pappus in fruit 3 lines long. - Pl. Wright. ii. 83. - Rocky ground, S. Arizona to San Bernardino Co., California, Wright, Palmer, Parry.

B. Plúmmeræe, Gray. Loosely pubescent, moderately branched : leaves linear-oblong, obtuse, irregularly and acutely serrate, the larger an inch or two long, obscurely 3-nerved: heads 4 lines long: involucre of linear bracts: akenes somewhat compressed and puberulent, obscurely 5-nerved: pappus in fruit 4 lines long. - Proc. Am. Acad. xv. 48, \& Bot. Calif. ii. 456. - S. W. California, in mountain ravines behind Santa Barbara and Santa Monica, Miss Plummer, Parish, \&c.

* Glabrous or nearly so and smooth, sometimes glutinous: pappus in fruit slightly if at all surpassing the style.

+ Bracts of the 15-30-flowered involucre from oblong to linear, rather firm and with green centre or costa: receptacle flat: leaves comparatively smull and rather rigid, serrate with rigid or spinulose teeth.

B. thesioídes, HBK. A foot or two high from a woody base: branches rigid and slender: leaves linear-lanceolate or sometimes broader and narrowed to base, nearly or quite sessile, rather closely and evenly ciliately spinulose-serrate (the larger an inch or rarely 2 inches long), prominently 1-nerved, sometimes with obscure lateral nerves: heads 2 lines long, numerous in a corymbiform or an oblong naked panicle: pappus of the male flowers obscurely if at all thickened upward.-Nov. Gen. \& Spec. iv. 61 ; DC. Prodr. v. $419 . \quad$ B. ptarmicafolia, DC. 1. c. B. ptarmicoefolia? or thesioides, Gray, Pl. Wright. ii. 83.-S. Arizona, Wright, Lemmon. (Mex.)

B. Bigelóvii, GraY. Stems more copiously and loosely branched: leaves less rigid, from linear to oblong and the broader ones sometimes petioled, irregularly serrate, commonly obtuse: heads larger, more cymose: bristles of the male pappus thickened and barbellate at the tip. - Bot. Mex. Bound. 84. B. ptarmicafolia? Gray, 11. Wright. ii. 83. - Woods and shaded hillsides, in Arizona and New Mexico, Bigelow, Wright, Thurber, Lemmon, Rusby. (Adj. Mex.)

B. Havárdi. Stems copiously branched, slender: leaves hardly at all rigid; lower linearoblanceolate and tapering into a slender petiole, laciniate-pinnatifid into several irregular slender-subulate lobes; those of the branchlets narrowly linear, 2-3-toothed or entire: heads loosely paniculate, only the male known, these barely 2 lines high, about 15-flowered: involucral bracts oblong: bristles of the pappus rigid, clavellate. - Guadelupe Mountains, western borders of Texas, Havard.

+ + Bracts of the involucre narrowly oblong or linear-lanceolate, thin and pale with greenish centre : heads short and broad, many-flowered : receptacle hemispherical or broadly conical!

B. Douglásii, DC. Herbaceous nearly or quite to the ground, 3 to 5 feet high, loosely branched: leaves glutinous, not rigid, either entire or serrulate with minute and very acute denticulations, triplinerved from near the base, ovate-lanceolate (the larger 4 to 6 inches long) or the upper lanceolate, with attenuate-acute apex, the base contracted into a short margined petiole: heads numerous and densely cymose at the summit of naked branchlets, 3 lines long: involucral bracts erose-ciliate: female pappus barely 2 lines long, soft; male somewhat clavellate and barbellate above. - Torr. \& Gray, Fl. ii. 259, excl. syn. Nutt., \&c.; Gray, Bot. Calif. i. 333. B. Douglasii \& B. Hoenkei, DC. 1. c. $400 \& 401$, the latter from Monterey in California. B. glutinosa, Hook. \& Arn. Bot. Beech. 147? - Moist or wet ground, California, from San Francisco southward, and southeastward to San Bernardino.

+++ Bracts of the involucre broader, thin-chartaceous, rather dry, with narrow scarious margins, at least the inner ones yellowish or tawny, destitute of green centre or distinct costa ; the outer bracts ovate, inner oblong: heads many-flowered: receptacle flat: stems very leafy up to the corymbosely paniculate or cymose inflorescence, more terete than in the preceding species: leaves lanceolate, willow-like, acute at both ends, either denticulate-serrate or entire, subsessile.

B. glutinósa, Pers. Stems herbaceous above but woody toward the base, 3 to 10 feet high: branches somewhat striate-angled: leaves elongated-lanceolate, serrate with few or several scattered teeth on each side, more or less distinctly 3-nerved from near the base ( 3 or 4 and the larger 5 or 6 inches long): heads mostly 3 lines long or the male smaller, numerous and corymbosely cymose at the summit of comparatively simple stems or branches: involucre 
stramineous. - Syn. ii. 425; Hook. \& Arn. Bot. Beech. i. 31 (Molina viscosa, Ruiz \& Pav. Syst. 207). B. glutinosa, B. carulescens, \& B. Alamani, DC. Prodr. 1. c. 402, 403. B. Pingraea, Nutt. Trans. Am. Phil. Soc. 1. c. 337, excl. syn. B. glutinosa \& B. ccerulescens, Gray, Bot. Calif. i. 333. - Along streams and in moist ground, S. California, from Los Angeles southward, and through Arizona to S. Colorado and the borders of Texas : H. late in autumn. (Mex. to Chili.)

B. vimínea, DC. Stems truly shrubby, 6 to 12 feet high, producing short lateral flowering branches, these terete and minutely striate: leaves lanceolate, entire or some sparingly denticulate, obscurely 3-nerved, 2 or 3 inches long, or much smaller on the flowering shoots: heads usually 4 lines long, hemispherical, in small cymose clusters terminating numerous lateral branchlets: involucre tawny.-Prodr. v. 400; Gray, Bot. Calif. i. 333.- Along streams, California, from Monterey southward and to San Bernardino Co.: flowering in carly spring; the foliage persisting all winter.

\section{Tribe IV. INULOIDE瓜, p. 57.}

52. PLÚCHEA, Cass. (For the Abbé $N . A$. Pluche, an amateur naturalist of the latter part of the eighteenth century.) - Warm-temperate or tropical plants ; with alteruate pinnately veined leaves, and heads of flesh-colored or dull purple flowers, cymosely or paniculately disposed or rarely solitary at the summit of the stem or branches._Cass. Bull. Philom. 1817, \& Dict. Sci. Nat. xlii.; Benth. \& Hook. Gen. ii. 290.

§ 1. Berthelótia. Pappus of the hermaphrodite-sterile (or rarely fertile) flowers of more rigid bristles with clavellate-dilated tips: involucre chartaceocoriaceous; the innermost narrowly linear and deciduous with the flowers. Very leafy sericeous-canescent shrubs. - Gray, Proc. Am. Acad. xvii. 212. Berthelotia, DC. Prodr. จ. 375.

P. boreális, Gray, 1.c. (Cachimilda, Arrow-wood.) Shrub several feet high, much branched, willow-like, very leafy up to the cymulose-glomerate heads, silvery with the very close and fine appressed pubescence: leaves entire, linear-lanceolate, sessile, acute at both ends: involucre campanulate; its outer bracts ovate, obtuse, tomentose: bristles of the pappus of the central flowers little stouter than of the others, but with abruptly enlarged tips, not united at base: style of the same entire. - Tessaria borealis, Torr. \& Gray, in Emory Rep. (Notes of Reconnoissance, 1848) 143; \& Sitgreaves Rep. 162, t. 5 ; Gray, PI. Fendl. 75, Pl. Wright. i. 102 (§ Phalacrorline), \& Bot. Calif. i. 384. Polypappus sericeus, Nutt. Pl. Gamb. 178. - Sandy banks of streams, from the Rio Grande on the western borders of Texas to S. California: Al. summer.

§ 2. Strlininus. Pappus of both kinds of flowers fine and similar, more or less soft, none of the bristles at all thickened at tip: bracts of the involucre thin or thinnish: corolla of the hermaphrodite flowers somewhat enlarged upward: heavy-scented herbs, or in the tropics shrubby, somewhat pubescent and glandular, with membranaceous or slightly succulent pinnately-veiny leaves, commonly with some callous-mucronate teeth: heads cymose-clustered: flowers dull purple, in late summer or autumn. - Stylimnus \& Gynema, Raf. in Jour. Phys. 1819, \& Ann. Nat. 1820, 15. Leptogyne, Ell. Sk. ii. 322, as subgenus. Pluchea (Stylimnus) \& 3, DC. Prodr. v. 451.

The first of the following species may fairly retain the now established name, rather than have a new one made; but Conyza bifrons was founded by Linnæus on European Inula, viz. on Hermann's figure, which in ed. 2 he refers to that genus, and on one of Plukenet's (mistaken for Canadian), which is certainly I. bifrons, as his herbarium shows. Of the many names for our second species, 
one of De Candolle's, which continues the principal Linnæan specific name, is to be preferred. Conyza Carolinensis, Jacq., is Pluchea odorata, wrongly attributed to Carolina.

P. bífrons, DC. Stems nearly simple, 2 or 3 feet high from a perennial root: leaves veiny, acutely denticulate, from oblong to lanceolate, commonly obtuse at both ends ( 2 to 4 inches long), partly clasping or closely adnate-sessile: heads glomerate in leafy-bracted sessile clusters: involucral bracts lanceolate. - Prodr. 1. c. ; Torr. \& Gray, Fl. ii. 260, excl. syn. L.! Baccharis foctida, L. Spec. 861, as to pl. Gronov. B. viscosa, Walt. Car. 202. Conyza bifrons, Pursh, Ell. l. c., \&c., not L. C. amplexicaulis, Michx. Fl. ii. 126. C. uliginosa, Pers. 'Syn. ii. 427. - Wet soil, Cape May, New Jersey, and through the low country to Keys of Florida (where is a very narrow-leaved variety, Conyza angustifolia, Nutt. Jour. Acad. Philad. vii. 109 ?), and Texas. (W. Ind.)

P. camphoráta, DC. Stems 2 to 5 feet high from an annual (not perennial) root: leaves from oblong-ovate to oblong-lanceolate, acute or acuminate at botb ends, denticulate or dentate ( 3 to 8 inches long), the larger distinctly or indistinctly petioled; primary veins often evident, but veinlets obscure : heads numerous and crowded in naked convex or corymbiform cymes, commonly short-pedicelled : involucral bracts from ovate to lanceolate, often tinged with purple._Erigeron camphoratum, L. Spec. ed. 2, 1212 (Gronov. Virg. ed. 1, 96, Clayt. no. 165). Baccharis foetida, L. Spec. ed. I, 861, as to syn. Dill., not as to Gronov. Conyza Marilandica, etc., Dill. Elth. t. 88, fig. 104, \& C. Americana frutescens, etc., Dill. 1. c. t. 89. C. Marylandica, Michx. 1. c. C. Marilandica \& C. camphorata, Pursh, Fl. ii. 523; Ell. I. c. G./nema dentata, viscida, \&c., Raf. Ann. Nat. 159. Pluchea Marilandica \& P. petiolata, Cass. Dict. 1. c. P. Marilandica, feetida, camphorata, also (W. Ind.) $P$. purpurascens \& $P$. glabrata? DC. 1. c. P. foetida, camphorata, \& purpurascens, Torr. \& Gray, F1. ii. 261. - Salt marshes and moist saline soil, Mass. to Florida, Texas, Arizona, and coast of California : in shady places or less saline soil, with leaves thinner and more petioled, and involucre almost glabrous, when it is $P$. petiolata, Cass. (Adj. Mex., W. Ind.)

53. PTEROCAƯLON, Ell. Brack-Roот. (Птєрóv, wing, and кav入ós, stem.) - Mostly perennial herbs, the typical species American; with one exception all tomentose-canescent except the upper face of the sessile pinnately veined leaves, these decurrent on the whole stem, forming wings; small sessile heads spicate at the summit of the stem and virgate branches; the flowers usually white or whitish, in summer. - Ell. Sk. ii. 323 ; DC. Prodr. v. 453. Chlenobolus, Cass. Dict. Sci. Nat. xlix. 348.

P. pycnostáchyum, ELL. 1. c. Roots fasciculate and tuber-like or fusiform, black : stem 2 feet high, mostly simple: leaves from oblong to lanceolate, minutely denticulate: heads crowded in a dense and continuous spiciform naked thyrsus (of 3 to 8 inches in length): involucre lanate-tomentose. - Torr. \& Gray, Fl. ii. 262. Conyza pycnostachya, Michx. Fl. ii. 126. Chlonobolus pycnostachyus, Cass. 1. c. Gnaphalium undulatum, Walt. Car. 203.Dry pine barrens, near the coast, N. Carolina to Florida.

P. virgátum, DC. Root fusiform and fibrose (perhaps biennial): stem slender, simple or with virgate branches: leaves linear and very acute, entire, or the lower cauline lanceolate and obscurely serrulate, the venation hardly apparent: heads narrow, in separated glomerules; these forming a virgate and elongated interrupted spike-like inflorescence : involucre appressed-tomentose, or the subulate inner bracts glabrate. - Prodr. v. 454. Gnaphalium virgatum, L. Amoen. Acad. v. 405. Conyza virgata; L. Spec. ed. 2, 1206, with syn. Chloenobolus virgatus, Cass. 1. c. - Open pine woods near Houston, Texas, Lindheimer. (W. Ind., Mex.)

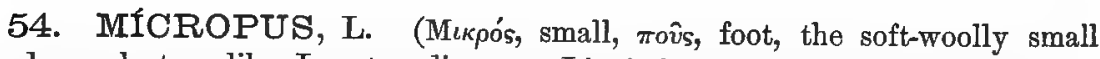
heads or clusters like Leontopodium, or Lion's-foot, on a small scale.) - Low floccose-woolly annuals, with alternate entire leaves, belonging to the Old World, except our Pacific coast species. - Gærtn. Fr. t. 164; Schkuhr, Handb. t. 267; 
Benth. \& Hook. Gen. ii. 297 (excl. § 3, 4); Gray, Proc. Am. Acad. viii. 651, \& Bot. Calif. i. 335. - Our species, of the section Bombrcildsina (with woolly fructiferous bracts smooth and crestless), approach Stylocline and Filago in the points which distinguish them from the European species.

M. Califórnicus, Fiscr. \& Merer. Slender, erect, 6 to 12 inches high: leaves mostly linear: fructiferous bracts 5 or 6 , at length firm-coriaceous, somewhat half-obcorclate or halfobovate in outline, straight anteriorly, and with the soon erect beak-like tip largely scarious. -Ind. Sem. Petrop. 1835, 42 ; Torr. \& Gray, Fl. ii. 264 ; Gray, Bot. Calif. 1. c. . 1 . (Rhyncholepis) angustifolius, Nutt. Trans. Am. Phil. Soc. n. ser. vii. 339. - Plains and open ground from S. California northward, toward the coast, to Oregon. Heads vary in the wool, from long and copious, as in $1 \%$. bombycinus, to short, as in the subjoined

Var. subvestítus, Gray, Bot. Calif. 1. c. Small; the wool of the bracts all short and wholly appressed. - Arroyo Grande near Monte Diablo, California, Brewer.

M. amphíbolus, Gray. Resembles the more loose-woolly forms of the preceding: female flowers about 10, somewhat imbricated on an oblong receptacle; their fructiferous bracts membranaceous or merely chartaceous at maturity, the beak an ovate almost wholly hyaline appendage which in flower is almost as long as the body and inflexed, at maturity porrect: sterile flowers subtended by some linear thin chaff, and with a pappus of a few bristles. Proc. Am. Acad, xvii. 214. - California, Walnut Creek near Martinez, Brewer, and coll. (probably in same district) Kellogg \& Harford, distrib. 416.

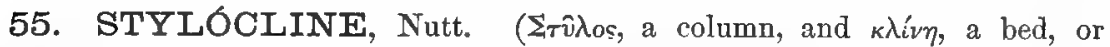
receptacle, from the form of this.) - Floccose-woolly annuals, a span or less in height, branched from the base, erect or spreading, with entire alternate leaves and more or less glomerate heads. - Nutt. Trans. Am. Phil. Soc. n. ser. vii. 338; Gray, Proc. Am. Acad. viii. 652, \& Bot. Calif. i. 336. Micropus $\$ 3 \& 4$, Benth. \& Hook. Gen. ii. 296. - Includes, besides the following species, S. (Diplocymbium) Griffithii of Afghanistan, most related to our second and very distinct section.

§ 1. Eustrlócline, Gray, 1. c. Fertile flowers numerous; their chaffy bracts pluriserially and closely imbricated in an ovoid head, thin, with at least the broad tips hyaline (barely a green midrib or centre), ovate in outline, promptly falling from the receptacle after maturity along with the loosely enclosed akene; those subtending the sterile flowers all scarious-hyaline and deciduous. Pappus of a very few capillary bristles generally present with the sterile flowers. - Stylocline, Nutt. 1. c.

S. gnaphalioídes, Notr. 1. c. Leaves broadly linear or the upper oblong, obtuse: fructiferous bracts broadly ovate, moderately woolly on the back, almost wholly hyaline-scarious, a firmer central portion at base saccate-conduplicate and enclosing the narrowly obovate oblique laterally compressed akene. - Gray in Pacif. R. Rep. iv. 101, t. 13, \&c. - Open grounds, California from the Stanislaus sonthward ; first coll. by Nuttall.

S. micropoídes, GraY. Leaves somewhat narrower and rather acute: heads more woolly, appearing less scarious and imbricated; fructiferous bracts having a narrower oblong-ovate hyaline tip, the oblong body densely long-woolly, without hyaline expanded margins, but wholly enwrapping the nearly straight and slightly compressed akene. $-\mathrm{Pl}$. Wright. ii. 84, \& Bot. Calif. I. c. Micropus Grayanu, Hemsl. Bot. Centr.-Amer., name only. - Arid plains, S. California through S. Nevada and Arizona to New Mexico; first coll. by Wright.

$\S 2$. Ancistrockrrents, Gray. Fertile flowers 5 to 9 , loosely disposed on the slender receptacle; their enclosing bracts cymbiform, of firm texture except the narrow hyaline tip, tardily if at all deciduous at maturity; the few sterile flowers involucrately subtended by about 5 larger open bracts; these herbaceo-coriaceous, 
ovate-lanceolate, tapering into a rigid and incurved-uncinate cusp, persistent and at length stellately spreading: akene obovate-fusiform and obscurely obcompressed (the pericarp distinct from the seed and obsoletely few-nerved!), loosely enclosed in the involutely closed bracts: no pappus to sterile flowers: no involucre outside the fructiferous bracts. - Proc. Am. Acad. viii. 652.

S. filagínea, GraY, 1. c. Erect or diffuse, appressed-lanate: leaves from linear to spatulate: heads capitate-glomerate, the hooked empty bracts at maturity 2 lines long. - Ancistrocarphus filagineus, Gray, Proc. Am. Acad. vii. 356. - Open ground, California from Mendocino Co. (Bolander) to the Mohave Desert (Parry, Lemmon), and northward to Union Co., Oregon, Cusick. Between Stylocline and Evax.

56. PSILOCÁRPHUS, Nutt. ( priate name.) - Small and diffuse or depressed and much branched annuals (Pacific American), floccose; with most of the leaves opposite, and globose heads comparatively large and apt to be solitary at the forks and ends of the branches. Fructiferous chaff at length deciduous with the enclosed akene, or opening ventrally so that this is shed. Uppermost leaves involucrate around the sessile head. - Nutt. Trans. Am. Phil. Soc. 1. c. 340 ; Torr. \&. Gray, Fl. ii. 265 ; Gray, 1. c. Bezanilla, C. Gay, Fl. Chil. iv. 109, t. 46.

P. Oregánus, Nuтt. Loosely lanate, erect or spreading, becoming a span high, but beginning to flower close to the ground: leaves mostly linear: heads when well formed 3 lines in diameter, and fructiferous bracts a line and a half long. - Gray, Bot. Calif. ii. 336. $P$. Oreganus, globiferus (excl. syn.), \& brevissimus (excl. syn.), Nutt. 1. c., the last two depauperate early-flowered states. - W. California, from Los Angeles to Oregon, and even to Boise City, Idaho, Wilcox.

Var. elátior, GRAY, l. c. A robust well-developed form, 5 or 6 inches high, with larger leaves three-fourths inch long, and heads 4 lines broad. - Near Portland, Oregon, Hall, Kellogg.

P. tenéllus, Nuxr, 1. c. Canescent with a finer and elosely appressed wool, slender, diffusely much branched, usually depressed and matted: leaves commonly spatulate, sometimes all linear, 3 or 4 lines long: heads 2 lines in diameter, the more vesicular fructiferous bracts a line long. - Gray, Bot. Calif. ii. 336. - Common through W. California to Washington Territory.

57. EVAX, Gærtn. (Name, unexplained by Gærtner, used as a joyous exclamation in Plautus, said by Wittstein, on the authority of old editions of Pliny, to be the name of an Arabian chief who wrote to the Emperor Nero about simples.) - Mostly dwarf and depressed annuals, or some typical species of the old World perennials, floccose-woolly, represented in N. America by the following aberrant groups.

$\S 1$. Hesperevax, Gray. Bracts of the oblong involucre and those of the receptacle subtending the female flowers from oblong to obovate, chartaceous, becoming coriaceous, persistent, barely concave: receptacle at length slendercolumnar from a broader base, sparsely villous; the female flowers and bracts crowded at its base; the summit bearing a circle of 3 to 5 or 7 more herbaceous or coriaceous obovate or rotund tomentulose open bracts, subtending a few male flowers; these with a 2-cleft style but no ovary: akenes pyriform-obovate, somewhat obcompressed, very smooth. - Pacif. R. Rep. iv. 101, t. 11, Proc. Am. Acad. viii. $651, \&$ Bot. Calif. i. 337.

E. cauléscens, GraY, l. c. Either annual or biennial, canescent with appressed or somewhat flocculent wool: leaves spatulate. Occurs ander various forms, of which the typical, 
var. PETIolata, is comparatively stout and large; the blade of the leaves 6 to 15 lines long, tapering into petioles of an inch or two in length : the heads in their axils glomerate at the rout, therefore stemless (E. acaulis, Greene, in Bot. Gazette, vii. 256), or on the summit of a simple stem or simple branches from the base, an inch or two high. - Psilocarphus caulescens, Benth. Pl. Hartw. 319. - Gravelly or alluvial soil, California, ou the Sacramento, \&c., Hartueg, Bigelou, Kellogg, Parry, and others.

Var. sparsiflóra. More caulescent and branching: leaves similar but smaller, rarely inch long (including the slender petiole), scattered on branching stems of at length 2 inches high, none rosulate at the base: heads in their axils accordingly scattered, narrowly oblong. - Sontheastern part of California, San Luis Obispo and San Diego, Brewer, Parry, Cleveland, \&c.

Var. brevifólia. Either depressed and rosulate, or with stems an inch or two high : leaves small and short-petioled, seldom over a quarter to half inch long. - Northern part of the State, Humboldt and Mendocino Co., Bolander, Kellogg, \&c.

Var. mínima. A very exiguous form of the preceding variety, in the early and depressed state, but tending to be subcaulescent; the largest leaves barely half-inch long and hardly a line wide. - Stylocline acaule, Kellogg in l'roc. Calif. Acad. vii. 112, exceedingly starved specimens, just coming into flower, coll. Dr. Eisen, at Fresno. The whole structure exactly of $E$. caulescens, and sterile flowers not "single," but 6 or 7 , surrounded by 5 to 7 firm but not yet enlarging bracts.

§2. DiapḱRIA. Bracts of the involucre thin; of the female flowers scarious, from oval to oblong-linear, barely concave, at maturity deciduous from the merely convex receptacle; those of the 2 to 5 staminate flowers (which have an undivided style and no ovary) similar or with woolly tips, or partly herbaceous, and somewhat embracing the flowers; no central prolongation to the receptacle: akenes obcompressed, smooth or very minutely papillose: heads small, aggregated in terminal foliose-involucrate glomerules. - Diaperia, Nutt. Trans. Am. Phil. Soc. vii. 337 ; Benth. \& Hook. 1. c. 298, extended. Diaperia \& Filaginopsis, Torr. \& Gray, Fl. ii. 263, 264.

E. prolífera, Nutr. Rather stout: stem often a span high, simple and erect, or with ascending branches from the base, bearing numerous small spatulate leaves and a capituliform glomerule (commonly half-inch in diameter), whence proceed 1 to 3 nearly leafless branches similarly terminated, sometimes again proliferous : heads cylindraceous or ublung-fusiform: fructiferous bracts chartaceo-scarious, oval or oblong, mainly naked ; those embracing staminate flowers more herbaceous and woolly-tipped, of firmer or more herbaceous texture: staminate flowers each ou a filiform stipe representing an abortive ovary: habit of Filago Germanica.-DC. Prodr. v. 459. Diaperia prolifera, Nutt. Trans. Am. Plill. Soc. 1. c. 337 ; Torr. \& Gray, Fl. ii. 264. - Dry or exsiccated ground, Arkansas to 'Texas, Colorado, and north to Dakota; first coll. by Nuttall.

E. multicaúlis, DC. Diffusely branched from the base, rather slender: capituliform glomerules much smaller and less foliose-involucrate: leaves oblanceolate or spatulate (3 or 4 lines long): heads globular or ovoid (only a line or two in diameter): involucre and apex of the receptacular bracts densely implexed-lanate; those of the female flowers narrowly oblong, of the male spatulate; these sessile without vestige of ovary. - Prodr. v. 459. Filaginopsis multicaulis, Torr. \& Gray, 1. c., \& Pacif. R. Rep. ii. t. 3. Micropus minimus, DC. 1. c. 461, a depauperate form. Diaperia multicaulis, Benth. \& Hook. Gen. ii. 298. - Low or exsiccated alluvial ground, common from Texas and the borders of New Mexico even (coll. Lemmon) to the Mohave Desert in S. E. California. (Adj. Mex., Berlandier, Gregg.)

Var. Drummóndii. A slender form, commonly with some long woolly hairs on the limb or on the tube of the staminate corollas. - Filaginopsis Drummondii, Torr. \& Gray, 1. c. Diaperia Drummondii, Benth. \& Hook. 1. c. - E. Texas and Louisiana, in moist ground, Drummond, Hale, \&c.

\$3. Calrmm Sndra. Bracts of the simple involucre and of the female flowers mostly scarious, narrowly spatulate-oblong, plane, externally villous-lanate; of 
the five central hermaphrodite flowers shorter and broad, very woolly, involute around the lower half of the flower; all at length deciduous: hermaphrodite flowers also fertile, with funnelform 4-toothed corolla and linear-oblong obtuse style-branches : receptacle hemispherical: akenes of both kinds of flowers very smooth, obovate-oblong, obscurely obcompressed, the terminal areola larger and more evident, at least in the perfect flowers: heads small, axillary. - Calym mandra, Torr. \& Gray, Fl. ii. 262.

E. cándida. A span or two high, slender, and with commonly simple branches, silvery white throughout with appressed wool: heads usually few in a foliose-involucrate cluster and sessile or nearly so in the axils of the spatulate or lanceolate leaves. - Calymmandra candida, Torr. \& Gray, 1. c., \& Pacif. R. Rep. ii. t. 2. Diaperia candida, Benth. \& Hook. Gen. ii. 298. - Alluvial or sandy ground, E. Texas, Drummond, Berlandier, Wright, \&c., and in the northwestern part of the State, Pope.

58. FILÁGO, Tourn. (Filum, a thread, in allusion to the cottony wool.) - Low annuals, mainly of the Old World, mostly erect and with the habit of the preceding. Ours have no pappus to the outer flowers. - DC. Prodr. vi. 247; Benth. \& Hook. Gen. 299.

$\S 1$. Receptacle subulate; its pluriserial and well-imbricated bracts merely concave, subtending the loose akenes. - Gifola, Cass.

F. Germatica, L. (Соtтon-Rose, Hrarba Impia of the old herbalists.) A span to a foot high, erect, thickly beset with lanceolate commonly erect leaves, terminated by a capituliform globose glomerule of many heads, whence proceed a similar branch or branches, as if proliferous: heads ovate-oblong; its bracts ovate-lanceolate, acuminate. -FI. Dan. t. 2787. -Dry fields, New York to Virginia. (Nat. from Eu.)

§2. Receptacle somewhat obconical or convex; its deeply concave or boatshaped fructiferous bracts rather few, more or less enclosing the somewhat oblique akenes, loose or stellately spreading at maturity: glomerules smaller and looser. - Oglifa, Cass. (The indigenous Pacific American species are peculiar, as connecting with Styloctine and Micropus.)

F. Califórnica, Nutr. Erect, leafy throughout, a span or two high, with the habit of $F$. arvensis: heads ovate, somewhat angular : bracteate female flowers 8 to 10 ; their bracts (or all but the innermost) broadly ovate and deeply boat-shaped, somewhat arcuate-incurved, very woolly, not herbaceous on the back, with a broadish and obtuse hyaline tip; inner bracts oblong, merely concave, nearly glabrous : akenes narrowly oblong, almost terete, minutely and obscurely papillose-granular: pappus of the upper female and hermaphrodite flowers copious, of the embraced akenes none. - Nutt. Trans. Am. Phil. Soc. 1. c. 405, with var. tomentosa. F. Californica \& F. parvula, Torr. \& Gray, Fl. ii. 432. Gnaphalium filaginoides, Hook. \& Arn. Bot. Beech. 359. - Open ground throughout California and to S. Utah.

F. depréssa, Gray. Diffusely branched from the root, depressed-spreading: internodes all short, even the lower little longer than the glomerules of the oblong-ovate heads: bracteate female flowers 5 or 6 ; their bracts narrower and straighter, somewhat herbaceous on the back: akenes obovate, smooth, sometimes the uppermost bracteate ones also with pappus. - Proc. Am. Acad. xix. 3. - San Bernardino Co., S. California, in the desert at Hot Springs, Parry, Parish.

F. Arizónica, Gray. Diffuse or at first erect, with widely spreading branches; the proliferous ones of elongated filiform internodes, widely separating the glomerules: bracteate female flowers 10 to 15 ; their bracts of firmer texture, ovate, open on the face: akenes clavate-oblong and arcuate, very smooth. - Proc. Am. Acad. viii. 652. - Arizona to San Diego Co., California, and Lower California, Smart, Parry, \&c.

F. GÁlitCA, L., forming the section Logria (Logfia subulata, Cass.; characterized by the low and nearly plane receptacle, pentagonal-conical heads, about two-ranked female flowers, 
the akenes of the outer ones completely and firmly enclosed in the at length indurated base of the subtending bract), has been found at Newcastle, California, by Mrs. Curran, probably a weed of grain-fields or a waif.

F. Répens and F. TexAxa, Scheele in Linn. xxii. 164, of Rœmer's collection in Texas, are not identified; probably are not of this genus.

59. ANTENNÁRIA, Gærtn., R. Br. (Bristles of male pappus likened to the antenna of certain insects.) - Perennial, mostly low, canescently and often floccosely woolly herbs (occasionally glabrate), of north temperate and arctic zones, with whitish or purplish flowers; the bracts of the involucre pearly white or rose-color, or brownish, never yellow. - Gartn. Fruct. ii. 410, t. 167 (excl. spec.) ; R. Br. in Linn. Trans. xii. 122; Benth. \& Hook. Gen. ii. 301.

$\S 1$. Bristles of the male pappus hardly at all thickened but minutely barbellulate near the apex: akenes (in the first species) oblong-linear, obscurely 2-3nerved, puberulent; the short hairs with 2-lobed and at length biuncinate tip, after the manner of Townsendia: bracts of the campanulate or somewhat turbinate involucre brownish, not radiant.

A. dimórpha, Torr. \& Gray. Depressed, cespitose from a stout multicipital caudex, bearing rosulate clusters of spatulate leaves : hearls solitary and subsessile at the crown, or raised on a sparsely-leaved stem of an inch or less in height: male head 4 lines high, with broad and obtuse involucral bracts; female becoming half to three-fourths inch long, the inner bracts narrow and long-attenuate iuto a lyyaline acuminate tip : pappus of the fertile flowers of long and fine smooth (not denticulate) bristles. - F1. ii. 431 ; Eaton, Bot. King Exp. 186 (var. Nuttallii \& var. macrocephala); Gray, Bot. Calif. i. 339. Gnaphalium (Omalothecu, IIeterophania) dimorphum, Nutt. Traus. Am. Phil. Soc. vii. 405. - Dry hills, from eastern base of the Rocky Mountains, in Wyoming, \&c., to the Sierra Nevada in California, and north to Brit. Columbia.

A. flagelláris, GrAY. Simpler, from a small caudex or biennial root, bearing smaller and fewer-flowered heads than the preceding and in the same manner, also copious naked and filiform stolons of a span or less in length, either as declined scapes bearing at their apex a head rosulately involucrate by small leaves, or rooting and forming a rosulate offset: leaves small, all narrowly linear: bracts of the female involucre less attenuate. - Proc. Am. Acad. xvii. 212. A. dimorpha, var. flayellaris, Torr. \& Gray in Wilkes Exped. xvii. 366. - Dry rocks, Washington Territory and throughout E. Oregon, Pickering \& Brackenridge, Cusick, Howell.

A. stenophylla, Grar, 1. c. Sterns erect from a suiterranean caudex, slender, 4 to 6 inches high, without stolons, leafy, terminated by a capituliform glomerule of 2 to 4 heads: leaves very narrowly linear or almost filiform, attenuate to both ends (the larger 3 inches lung), silvery-woolly: heads barely 3 lines long: involucral bracts in both sexes broadish and obtuse, dark brown, or in the male the inner ones with white tips: akenes (two thirds of a line long), minutely hirtellous-scabrous : female pappus scanty, only a line long; male pappus nearly of the preceding. - A. alpina? var. stenophylla, Gray in Bot. Wilkes Exped. l.c. - Banks of the Spipen River, Washington Terr., Pickering \& Brackenridge. High hills, Union Co., E. Oregort, Cusick.

$\S 2$. Bristles of the male pappus stouter, with thickish and clavate or scariousdilated tips.

* Not surculose by stolons, a span or more high: female heads narrow, cylindraceous or clavate: akenes glandular.

A. Géyeri, Grax. Branched from a lignescent base, commonly stout, thickly woolly: stems very leafy to the top, bearing few or several somewhat spicately or cymosely disposed rather large heads: leaves spatulate or oblanceolate, less than inch long: involucre very woolly at base; of the female heads commonly 4 lines long, of the male shorter; the inner in both with conspicuous rose-purple or sometimes ivory-white tips, which in the latter are obtuse, in the 
former narrower and rather acute: bristles of the male pappus moderately clavate. - Pl. Fendl. 107, \& Bot. Calif. i. 340. Gnaphalium alienum, Hook. Lond. Jour. Bot. vi. 251. Hills, Washington Terr, to N. California; first coll. by Geyer.

A. microcéphala, Gray. Simple-stemmed, slender, silvery-woolly: lower leaves spatulate; uppermost small and linear: heads rather numerous, small, loosely paniculate: involucre nearly glabrous throughout, fuscous, of the narrow female heads 3 lines long, of the broader male heads 2 lines long, the somewhat colored (whitish or purplish) tips scarious and inconspicuous: bristles of the male pappus with much dilated tips. - Proc. Am. Acad. x. 74, \& Bot. Calif. 1. c. - Dry eastern slope of the Sierra Nevada, in California and Nevada, Stretch, Lemmon, \&c.

* * Not surculose-stoloniferous: stems simple from the subterranean branching caudex, rather strict, leafy, naked at summit, and bearing a mostly compound-cymose cluster of broad heads: inner bracts of the male involucre all with conspicuous ivory-white papery obtuse tips; those of the female with hardly any tips and more scarious: herbage silvery-lanate: larger lower leaves 3-nerved.

A. luzuloídes, Torr. \& Gray. Closely silky-woolly: stems slender, a span to a foot high : leaves all narrowly linear, or some of the lowest narrowly lanceolate-spatulate, small uppermost linear-subulate: heads small (2 lines, or the female barely 3 lines long), several or numerous: involucre glabrous nearly or quite to the base; the inner bracts in the female heads obtuse : akenes glandular : the spatulate and as it were petaloid tips of the male pappus obtuse. - Fl. ii. 430 ; Gray, Bot. Calif. 1. c., excl. var. - Oregon, Washington Terr., and borders of Brit. Columbia, east to Wyoming.

A. argéntea, Bentr. Larger, 8 to 16 inches high: lower leaves all spatulate (the larger 4 or 5 lines wide) : heads numerous in a more compound cyme, broader (fully 3 lines long): involucre in both sexes whiter than in the preceding species; innermost bracts of the female acutish : tips of male pappus eren more dilated. - Pl. Hartw. 319. A. luzuloides, var. argentea, Gray in Pacif. R. Rep. iv. 54, \& Bot. Calif. 1. c. - California, in the Sierra Nevada, from Siskiyou Co. to the Yosemite district.

A. Carpáthica, R. Br. Floccosely white-woolly, rather stout: lower leaves spatulatelanceolate and the upper linear: heads broad, 3 or 4 lines long: involucre conspicuously woolly at base, more or less livid, except the white tips to the bracts of the male; the iuner bracts of the female commonly acutish and thin-scarious: akenes smooth and glabrous. The typical plant 2 to 6 inches high, with a simple close cluster of 3 to 7 heads, or even a solitary head: bristles of the male pappus gradually and moderately enlarged upward. Hook. Fl. i. 329 ; DC. Prodr. vi. 269; Torr. \& Gray, Fl. ii. 430; Reichenb. Ic. Fl. Germ. xvi. t. 951. Gnaphalium Carpathicum, Wahl. Fl. Carp. 258, t. 3. - Labrador (a monocephalous form!) and Anticosti, and from the northern Rocky Mountains to mountains of Oregon and Washington Terr. (Eu., N. Asia.)

Var. pulchérrima, Hook. 1. c. Stems 6 to 18 inches high: leaves mostly larger, the radical often half-inch or even almost an inch wide: heads more numerous, often in a compound cyme: bristles of the male pappus with more strongly and abruptly or even scariously dilated tips! - Rocky Mountains at lower elevations, extending to New Mexico, Oregon, and Brit. Columbia; first coll. by Drummond. Passes into the typical form as to stature, and even as to pappus.

* * Surculose-proliferous by either subterranean or humifuse and leafy shoots or stolons, in the first species least so.

$$
\text { + Heads in a cymose cluster, sometimes solitary: involucre woolly at base. }
$$

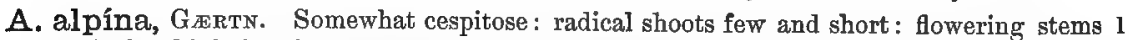
to 4 inches high, bearing 2 to 5 heads, sometimes (var. monocephala, Torr. \& Gray) a single head: radical leaves spatulate, half-inch long: involucre 3 lines high, livid-brownish; the inner of the male heacls with whitish oblong tips, of the female wholly livid and scarious and from acutish to acuminate: akenes glandular. - Less. in Linn. vi. 221 ; Hook. l. c.; IDC. 1. c. ; Torr. \& Gray, 1. c. ; Fl. Dan. t. 2786. A. monocephala, DC. 1. c., depauperate form. A. Labradorica, Nutt. Trans. Am. Phil. Soc. 1. c. 406. Gnaphalium alpinum, L.; Reichenb. Ic. Pl. Crit. viii. t. 750. - Labrador and northward to Behring Strait and Aleutian Islands, and southward on the high mountains to Colorado and to California beyond the Yosemite. (Greenland, Eu.) 
A. dioíca, Gerrtw. 1. c. Freely surculose and forming broad mats: flowering stems 2 to 8 or even 12 inches high, bearing few or numerous heads: radical leaves from obovate to spatulate (half-inch to nearly inch long), rarely glabrate above: lracts of the involucre in both sexes with colored (white or rose-colored) and obtuse papery tips: akenes smooth and glabrous or sometimes minutely glandular. (Polymorphous.) - Hook. 1. c.; Torr. \& Gray, 1. c. Gnaphalium dioicum, L., \&c. A. hyperborea, Don, Engl. Bot. t. 2640, a glabrate form. A. partifolia, Nutt. l. c. (A. dioica, var. parvifolia, Torr. \& Gray, l. c.); form with small and very silvery leaves, and involncral bracts rarely of yellowish tinge. - Moist or dry ground, Newfoundland and Labrador, and through the Rocky Mountain region (alpine, subalpine, and lower along the streams), thence southward to New Mexico and S. California, and northwestward to Alaska. (Eu., Asia.)

Var. congésta, DC. l. c. A form too little dereloped, with heads sessile in a rosulate tuft of leaves terminating depressed stems, like the sterile creeping ones, occurs on Sierra Blanca, S. Colorado, at 13,000 feet: and similar but more caulescent forms, from mountains of S. Utah, California, Wyoming, \&c.

A. plantaginifólia, Hoor. l.c. Freely surculose by long and slender sparsely leafy stolons, the offsets biennial: flowering stems more scapiform, 6 to 18 inches high, bearing small linear or lanceolate leaves and a cluster of several heads : radical leaves from roundish ovate to obovate and spatulate, the larger an inch or two long (besides the petiole), soon glabrate and green above, silvery-canescent beneath with a completely panuose coating, 3-5-nerved (but the nerves not rarely obsolete): involucre very woolly at hase; inner bracts of the male heads with oval or ublong obtuse ivory-white tips, of the larger (4 to 6 lines long) female heads with white or whitish narrow and acute tips: akenes minutely glandular. -Torr. \& Gray, Fl. 1. ث. 431. A. plantaginea, DC. 1. c. Gnaphalium plantaginifolium, L. G. pluntagineum, Murr. Syst. 748; Pursh, Fl. ii. 525. G. dioicum, var. plantaginifolium, Michx. Fl. ii. 128. - Dry hills and shaded grounds, Hudson's Bay to Florida, Texas, and New Mexico, and northwestward to British Columbia and Washington Territory. - Var. monocephala, Torr. \& Gray, is an occasional form, with a single head ; from Louisiana. On the Blue Ridge in Virginia, A. H. Curtiss collected the male of a remarkably small-headed and small-leaved form.

+ + Heads loosely paniculate: involucre almost glabrous.

A. racemósa, Hook. 1. c. Stoloniferous in the manner of the preceding, lightly woolly, becoming glabrate: flowering stems 6 to 20 inches high, slender, sparsely leafy, bearing few or numerous racemosely or paniculately disposed heads, nearly all slender-pedunculate : leaves thin; the radical broadly oval, an inch or two long, olsscurely 3-nerved at base, rather veiny; lower cauline oblong; upper small and lanceolate: involucre scarious, brownish; the male 2 or 3 lines long, of obtuse bracts, the inner obscurely white-tipped ; female 3 or 4 lines long, of narrow and mostly acute bracts: akenes glabrous. - Torr. \& Gray, 1. c. - Moist woods, Rocky Mountains along the British border, south to Wyoming, and west to the Cascade Mountains, \&c.; first coll. by Drummond.

60. ANÁPHALIS, DC. Everlasting. (Said by DC. to be an ancient Greek name of some Gnaphalioid plant, and that it may be taken as an anagram of the very similar genus Gnaphalium.) - Chiefly perennial herbs, all but our species Asiatic: fl. late summer. - Benth. \& Hook. Gen. ii. 303. Anaphalis \& Antennaria § Margaripes, DC. Prodr. vi. 270, 271.

A. margaritácea, Bentr. \& Ноoк. 1. c. Commonly a foot or two high, in tufts, very leafy, the white floccose wool rarely becoming tawny: leaves ( 2 to 5 inches long) from rather broadly to linear-lanceolate, soon glabrate and green above, the broader ones indistinctly 3-nerved: heads numerous, corymbosely cymose: bracts of the involncre very numerous, almost wholly pearly white, radiating in age. - Gnaphalium margaritaceum, L.; Engl. Bot. t. 2018. G. Americanum, \&c., Clusius, Hist. i. 327, fig. 3. Antennaria margaritacea, R. Br. in Linn. Trans., \&c. - Dry fields and open woods, Newfoundland to the Aleutian Islands, and through the northern and cooler portions of the United States, extending south to the higher mountains in Colorado (a var. subalpina, dwarf, broad-leaved, and with few glomerate heads), and the mountains of California. (N. E. Asia. Nat. in Eu.) 


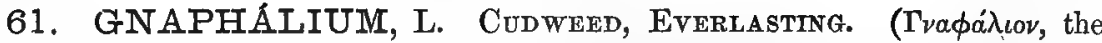
Greek and also Latin name of these or similar plants). - Floccose-woolly herbs (of most parts of the world); with sessile and sometimes decurrent entire leaves, and cymosely clustered or glomerate heads of whitish or yellowish flowers. Involucre not rarely colored, but seldom yellow. Receptacle usually flat. Akenes terete or flattish, mostly nerveless. Fl. summer and autumn. - Torr. \& Gray, Fl. ii. 426 ; Benth. \& Hook. Gen. ii. 305.

$\S 1$. Eugraphólum. Bristles of the pappus not at all united at the base, falling separately.

* Involucre woolly only at base, mainly scarious, in ours from white to brownish straw-color or rarely tinged with rose, not yellow: heads paniculately or corymbosely cymose or glomerate at summit of the leafy stem and branches: more or less fragrant herbs, erect, a foot or two high from an annual or biennial or sometimes perennial root: akenes in our species smooth and glabrous.

+ Leaves not at all decurrent, narrowed at base: hermaphrodite flowers very few: akenes sometimes lightly 3-4-nerved: stems freely branching, rather slender, 1 to 3 feet high.

G. polycéphalum, Michx. Erect from an annual root, somewhat aromatic: branches either glabrous when the white wool is detached, or minutely viscid-pubescent when it is caducous: leaves thinnish, lanceolate or sometimes linear, mucronately acute or acuminate, often with finely undulate margins, soon bare and green and commonly viscid-puberulent or glandular above : heads in numerous rather close paniculately or cymosely disposed glomerules: involucre dull white, soon with a rusty tinge; its thin bracts oblong, obtuse. - Fl. ii. 127; DC. Prodr. vi. 227 ; Torr. \& Gray, l. c. G. obtusifolium, L. Spec. ii. 851, a false name taken from the char. and figure of the doubtful plant of Dill. Elth. (but the figure of Morison is good and its leaves acute), changed in Lam. Dict. ii. 755 to $G$. conoideum, founded on the same ambiguous figure. - Open woods and dry ground, Camada to Wisconsin and south to Texas. (Mex.)

G. Wríghtii, Gray. Diffusely much branched from an apparently perennial root, persistently white-woolly, not glandular : leaves from spatulate to lanceolate (an inch or two long): heads ( 2 lines long) very numerous in small cymosely paniculate glomerules on loose spreading or divergent branchlets: involucre turbinate, grayish-white, very woolly at base; its bracts thin, oblong, obtuse, but most of them (at least the inner) with an acnte apiculation. -Proc. Am. Acad. xvii. 214. G. microcephalum, Gray, Pl. Wright, i. 124, \& ii. 99, not Nutt. - Dry ground, W. Texas and Arkansas to New Mexico and Arizona; first coll. by Wright. (Adj. Mex.)

+ + Leaves more or less adnate-decurrent at base, persistently white-wooll 5 , slightly if at all glandular or heavy-scented.

G. Arizónicum, Gray. Grayish-woolly : stems slender, strict, a foot high from an annual root: cauline leaves narrowly linear (inch and a half long, a line wide), slenderly decurrent; lowest short and somewhat spatulate: heads (2 lines or more long) very numerous and glomerate, the clusters fastigiate-cymose: involucre narrowly oblong, brownish; its thin bracts mostly lanceolate and acute. - Proc. Am. Acad. xix. 3. - S. A rizona, in dried beds of streams near Fort Huachuca, Lemmon.

G. microcéphalum, Nuтт. Slender, more loosely branched from an apparently perennial root: leaves linear or lower spatulate-lanceolate, with slenderly decurrent base : heads (2 or 3 lines long) rather few or loose in the paniculately or cymosely disposed glomerules : involucre from turbinate to campanulate, bright white; its bracts ovate or oblong (except the innermost), obtuse, though described by Nuttall as "acute."-Trans. Am. Phil. Soc. n. ser. vii. 404. - Along water-courses, S. California to Oregon; first coll. by Nuttall.

G. Sprengélii, Hook. \& ARN. Stems usually stout, 6 to 30 inches high from an annual or biennial root: leaves lanceolate or linear, or the lowest narrowly spatulate, densely whitewoolly, or sometimes more thinly floccose, the short decurrent bases or adnate auricles rather broad: heads (3 lines long and wide) in single or few (rarely numerous and cymose) close glomerules terminating the stem or few branches: involucre hemispherical, white or with barely greenish-yellowish tinge, becoming slightly rusty in age; its bracts thin, oval and 
oblong, obtuse. (Slender forms resemble G.luteo-album of the Old World, which has duller or sordid heads and scabrous-pubescent akenes. A slender form in New Mexico, \&c., nearly approaches the Mexican $G$. gracile, HBK., which has yellowish involucre.) - Bot. Beech. 150; Torr. \& Gray, Fl. ii. 427; Gray, Bot. Calif. i. 341. C. Chilense, Spreng. Syst. iii. 480, ex Less. in Linn. vi. 525, but not Chilian. G. luteo-album, Hook. Fl.; Nutt. Trans. Am. Phil. Soc. 1. c. (var. occidentale), \&c. - Moist or dry ground, from N. Oregon to S. California, and eastward to W. Texas. (Mex.)

+++ Leares obviously adnate-decurrent, the upper face at least becoming naked and green in age and with the stem glandular-pubescent or glandular-riscid: herbage strongly balsamicscented.

+ Root apparently aunual or biennial.

G. decúrrens, Ives. Stem stout, 2 or 3 feet ligh, corymbosely branched at summit, and bearing crowded cymosely disposed glomerules of broad heads: leaves very numerous, lanceolate or the upper linear, white-woolly beneath or rarely glabrate: involucre broadly campanulate, white, usually becoming rusty-tinged; the thin-scarious bracts ovare and oblong, acutish, only the innermost linear-lanceolate and acute. - Am. Jour. Sci. i. 380, t. I ; Torr. Compend. 288; Hook. Fl. i. 328 ; DC. Prodr. vi. 236; Torr. \& Uray, 1. c.; Gray, Bot. Calif. i. 346. - Rather open and dry ground, New England to Pennsylvania, Upper Michigan, Colorado, also Texas, New Mexico, and to Brit. Columbia and Washington Terr.

Var. Califórnioum, GRAr, 1. c. Bracts of the involucre more pearly white : leaves usually shorter. - G. Californicum, DC. 1. c.; Torr. \& Gray, 1. c., excl. var. - Throughout the western part of California, and to San Bernardino Co. Foliage sometimes wholly green.

G. ramosíssimum, NuTT. Greener than G. decurrens, soon glabrate, and more glandular-viscid: stem 2 to 6 feet high, paniculately and fastigiately much branched above: leaves smaller, linear: heads amply and rather loosely paviculate, small (commonly 2 lines long), comparatively few-flowered: involucre turbinate; its bxacts fewer, narrower, white or tinged with rose. - Pl. Gamb. 172; Gray in Wilkes Exped. xvii. 363, \& Bot. Calif. 342. G. Sprengelii, var. erubescens, Nutt. Trans. Am. Phil. Soc. 1. c., a form with rosy bracts. G. Californicum, var., Torr. \& Gray, 1. c. - Thickets, \&c., W. California, from the Sacrar mento to Los Angeles; first coll. by Nuttall.

$+\%$ Root lignescent-perennial.

G. leucocéphalum, Grar. Very white with close wool, except the upper face of the leaves: stems a foot or two high, strict, mostly simple, very leafy: cauline leaves all narrowly linear, small (not over 2 inches long, a line or two wide), attenuate-acute, commonly erect, hardly broader at the short-decurrent base, viscid-glandular above: heads in a rather close cyme: involucre broadly campanulate, much imbricated, pure pearly white; the bracts thin-papery, ovate and oblong, obtuse. - Pl. Wright. ii. 99.-Dry water-courses, western borders of Texas to Arizona and S. California, Wright, Thurber, Parish, \&c.

* * Involucre less imbricated, more involved in wool, the scarious tips of the nearly equal bracts comparatively inconspicuous and dull-colored: heads glomerate and leafy-bracteate, only a line or so in length: low and branching annuals, a few inches or rarely a foot high: akenes in the same species either smooth or scabrous. Species perhaps confluent.

G. palústre, Nutr. Loosely floccose with long wool, erect, at length diffuse or weak . leaves ( 3 to 5 lines wide) spatulate or the uppermost oblong or lanceolate: tips of the linear involucral bracts white, obtuse.-Gray, Bot. Calif. i. 342. G. palustre \& G. gossypinum, Nutt. Trans. Am. Phil. Soc. 1. c.; Torr. \& Gray, Fl. ii. 427, 428. - Common in all moist grounds, from Washington Terr. to S. California, east to Wyoming and New Mexico.

G. uliginósum, L. (CuDwexd.) Appressed-woolly, soon diffusely branched: leaves spatulate-linear or the lower spatulate-oblanceolate: involucral bracts brownish to the tip or soon becoming so, acutish or obtuse, the outermost oblong. - Fl. Dan. 859 ; Engl. Bot. 1194 ; DC. Prodr. vi. 230 . - Low or wet ground, a common weed, from Newfoundland to Virginia and west to the Mississippi; seemingly introduced from Eu. Also in Oregon and Brit. Columbia, where the preceding appears to pass into this. (Eu., N. Asia.)

G. stríctum, GraY. Appressed-woolly: stem strict and simple, a span to a foot high, sometimes branching or with ascending stems from the base: leaves all linear, seldom a line wide: heads in spicately disposed glomerules in the axils or on short lateral branches: invo- 
lucral bracts with brownish or somewhat whitish tips, obtuse. - Pacif. R. Rep. iv. 110 ; Rothr. in Wheeler Rep. vi. 157. - Eastern Rocky Mountain region, from Wyoming to New Mexico, and to Mount Agassiz, Arizona; first collected by Fremont.

* * Involucre of the few and naked heads nearly glabrous, brown : female flowers comparatively few, only twice or thrice the number of the hermaphrodite: akenes broader and flaiter: small and low alpine perennial. - Omalotheca, Cass., DC.

G. supinum, Vill. Cespitose: leaves white-woolly, mainly in radical tufts, linear, less than inch long, 2 or 4 on the (inch to span high) simple slender flowering stems, which bear 2 to 7 spicately disposed heads. - Delph. iii. 192; Engl. Bot. t. 1193; Hook. Fl. i. 329; Torr. \& Gray, 1. c. G. pusillum, Hænke; Schkuhr, Handb. t. 267. Omalotheca supina, DC. Prodr. vi, 245. - Alpine region of the White Mountains, N. Hampshire, and Labrador. (Greenland, Eu., Asia.)

§ 2. Gamocheta. Bristles of the pappus united in a ring at base and deciduous together from the akene: heads spicately or sometimes capitately glomerate, the lower glomerules leafy bracteate: involucre brownish, purplish, or sordid. Gamochata, Wedd. Chlor. And. i. 151.

* Northern (also European) species, perennials : stems strict and simple: akenes fusiform, hispidulous-pubescent.

G. Norvégicum, Gunner. A span or two high, silvery-woolly throughout: leaves spatulate-lanceolate, acute; the radical often 6 inches long and half-inch wide; cauline sparse: heads in the upper axils and in an oblong spike: involucre 3 lines long, dark brown or the bracts with a lighter centre. - Fl. Norveg. 105 (Fl. Dan. t. 254); Syme, Iingl. Bot. t. 744. G. sylvaticum, Smith (not L.); Torr. \& Gray, Fl. ii. 429. G. sylvaticum, var. fuscatum, Wahl. ; DC. Prodr. vi. 232. G. fuscum, Lam. Dict., not Scop. - Labrador; Mount Albert, Lower Canada, Allen. (Greenland, Eu.)

G. sylváticum, L. A span to a foot or more high, more leafy : leaves linear or the lowest linear-oblanceolate, glabrous or glabrate above: heads numerous in an elongated and leafy virgate-spiciform inflorescence : involucre light-colored; the bracts usually only brownishtipped or with a brown spot below the hyaline-scarious tip. — Spec. ii. 856 ; Fl. Dan. t. 1229 ; Syme, 1. c., t. 743. G. rectum, Smith, Engl. Bot. - New Brunswick, roadsides and muddy shores of the Bay of Chaleurs, Fowler, Macoun. Perhaps introduced. (Eu., N. Asia.)

* * More southern, and wholly American, annuals or biennials, chiefly of the sea-coast or near it.

G. purpúreum, L. Canescent with a silvery dense and close coating of white wool, sometimes becoming flocculent, simple or branched from the base: stems erect or ascending, 6 to 20 inches high: leaves spatulate, obtuse, usually becoming glabrate and green above: heads in a cylindraceous or oblong or in a more elongated spiciform inflorescence: involucre (2 lines long) brownish, often tinged with purple: akenes sparsely scabrous. - Spec. ii. 854 (pl. Gronov. \& Dill. Elth.); Michx. Fl. ii. 127 ; Torr. \& Gray, Fl. ii. 428; Klatt in Linn. xlii. 140. G. spicatum, spathulatum, stachydifolium, \& falcatum (narrow-leaved form), Lam. Dict. ii. 757, \&c. G. Americanum (Mill. Dict.?), Willd. Spec. iii. 1887. G. Pennsylvanicum, Willd. Enum. 867. G. hyemale, Walt. Car. 203. G. Chamissonis, DC. Prodr. vi. 233. G. ustulatum, Nutt. Trans. Am. Phil. Soc. 1. e., ex char. And many other extra-NorthAmerican synonyms: polymorphous. - Coast of Mass. to Texas, and interior of Arkansas; also Washington Terr. to S. California and Arizona, in saline soil. (Mex., S. Amer.)

62. INULA, L. (Old Latin name of Elecampane.) - A large and varied Old World genus, chiefly of perennial yellow-flowered herbs, with alternate simple leaves, sometimes tomentose, but not floccose-woolly. Section Corvisartia (Helenium, Adans., not L., Corvisartia, Mérat \& Cass.) consists mainly of

I. Helondum, L. (Elecampane, i. e. Enula campana of the herbalists.) A coarse and tall herb, in tufts from large perennial (bitter-mucilaginous) roots : leaves large, especially the petioled ovate radical ones, denticulate, tomentose beneath; cauline sessile, partly clasping: heads very large, solitary or few terminating the stem or flowering branches: outer bracts of the involucre ovate and foliaceous; inner smaller, obovate and spatulate, obtuse : rays very 
many, long and slender: akenes 4-sided, glabrous. - Fl. Dan. t. 728 ; Lam. Ill. t. 680; Sibth. Fl. Græc. t. 873. - Roadsides and pastures, escaped from gardens, and well established in the older States. (Nat, from Eu.)

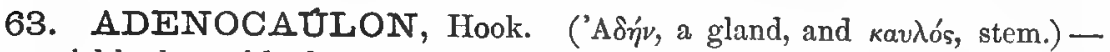
Perennial herbs; with alternate and dilated leaves on long and margined petioles, slender stems naked and paniculately branched above, and bearing very small heads of whitish flowers; the peduncles, \&c., beset with stalked glands (whence the name) like those of the akenes but less stout. Floccose wool caducous, except on the lower face of the leaves. - Hook. Bot. Misc. i. 119, t. 15, \& Fl. i. 308; Maxim. Fl. Amur. 152; Gray. Proc. Am. Acad. viii. 653, \& xvii. 214.

A. bícolor, Hook. I. c. Stem 1 to 3 feet high, leafy below : leaves ample, deltoid-cordate, coarsely sinuate-dentate or repand or slightly lobed, early glabrate and green above, white with the thin cottony wool beneath : bracts of the involucre 4 or 5 in a single series, ovate, reflexed in fruit, several times shorter than the (4 to 6) club-shaped akenes. - Gray, Bot. Calif. i. 335. - Damp woods, California to Brit. Columbia and east to Lake Superior: f. summer. Quite distinct from the Chilian, less so from the Amur-Himalayan species.

\section{Tribe $\nabla$. HELIANTHOIDE正, p. 59.}

64. PLUMMMRA, Gray. (Sara Plummer, now Mrs. J. G. Lemmon, the discoverer. She and her husband have shared together the toils, privations, and dangers of arduous explorations in the wilds of Arizona and California, as well as in the delights of very numerous discoveries: so that wherever the name of Lemmon is cited for Arizonian plants, it in fact refers to this pair of most enthusiastic botanists.) - Proc. Am. Acad. xvii. 215. - Single species.

P. floribúnda, GRAr, l. c. Erect and rather stout herb, apparently from a biennial root, 2 or 3 feet high, nearly glabrous, with bitter-aromatic odor and savor, fastigiately and corymbosely mach branched above: branches terminating in loose cymes of numerous pedunculate heads: leaves all alternate, 1-3-ternately parted into filiform Iobes, impressed-punctate: involucre only 2 lines long: corollas golden-yellow; those of the ray nearly glabrous, of the disk densely puberulent-glandular. - S. Arizona, in Apache Pass, Mr. \& Mrs. Lemmon.-Corollas, involncre, odor, \&c., nearly of Actinella, sect. Picradenia.

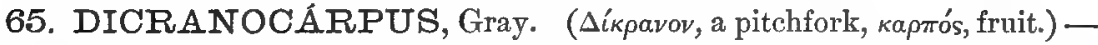
Mem. Am. Acad. v. 322 (Pl. Thurb.), \& Bot. Mex. Bound. 85. - Single species.

D. parvifórus, Grax, l. c. Branching annual, a foot or less high, nearly glabrous : leaves all opposite, 1-2-ternately divided into filiform lobes, or the uppermost nearly simple: heads more or less pedunculate and paniculate, terminating slender branches, in flower a line long, yellowish: Iongest akenes 4 lines and their horns often 3 lines in length. - Heterospermun dicranocarpum, Gray, Pl. Wright. i. 109. - W. Texas, near the Pecos, Wright. (Adj. Mex., Parry, Palmer.)

66. GUARDIOLA, Humb. \& Bonpl. (The name of a Spanish naturalist.) - Perennial herbs (of Mexico and its northern borders), glabrous, branching; with merely serrate and commonly petiolate veiny leaves; the branches terminated by the cymulose-clustered heads of white flowers. - Pl. Equin. i. 144, t. 41 ; Gray, Pl. Wright. i. 110; Benth. \& Hook. Gen. ii. 347. Tulocarpus, Hook. \& Arn. Bot. Beech. 298, t. 63.

G. platyphylla, GrAY. Somewhat glaucous, 2 or 3 feet high, corymbosely branched: leaves roundish-ovate, very obtuse, rigidly denticulate or dentate, commonly subcordate (the 
larger 3 or 4 inches long), very short-petioled: involucre narrow, 5 linés long : corollas pure white and anthers bright green. - Pl. Wright. ii. 91. - S. Arizona, Wright, Thurber, Schott, Lemmon, \&c. : fl. summer.

67. POLYMNIA, L. (Name of the muse Polyhymnia, shortened.) Perennial herbs (Atlantic-American), or some S. American species shrubby or arborescent, 'commonly viscid-pubescent and heavy-scented, of coarse habit; with mostly opposite ample and membranaceous lobed or angulate leaves, commonly with margined petioles, or auriculate-appendaged at the insertion, and loosely paniculate heads of yellow or yellowish flowers, or the rays sometimes white; in summer. - Gen. ed. 4, 396 ; Lam. Ill. t. 711; Gærtn. Fruct. t. 174; DC. Prodr. v. 514. Alymnia, Neck. Polymniastrum, Lam.

§1. Eupolýmia. Akenes somewhat obcompressed and trigonous-obovoid, tricostate (namely with marginal and ventral nerves or ribs), not striate: heads rather small.

P. Canadénsis, L. Viseid-pubescent, 2 to 5 feet high: slender branches bearing loosely paniculate somewhat nodding heads of honey-yellowish flowers: leaves thin-membranaceous; uppermost (sometimes alternate) deltoid-ovate or somewhat hastate; lower variously pinnately lobed or the larger ones parted, acuminate, sharply denticulate, occasionally sinuatedentate: disk of the head about 4 lines in diameter: loose outer bracts ovate-lanceolate or narrower: flowers yellowish; those of the ray 5, their ligule commonly minute or abortive, so that the head is discoid: akenes smooth and glabrous or sparsely puberulent, and with a narrow apiculate-protuberant epigynous disk: disk-corollas with abruptly much dilated campanulate throat and ovate lobes. - Amœn. Acad. iii. 15, t. 1, fig. 5, \& Spec. ii. 926 ; Lam. 1. c.; Michx. Fl. ii. 147; DC. Prodr. v. 515. P. Canadensis, var. discoidea, Gray, Man. ed. 3, 248. - Shaded and damp hillsides along streams, Canada to Pennsylvania and Missouri and in the higher $\Lambda$ lleghanies to Carolina. Southward commonly with more evident rays and passing to

Var. radiáta. Ligules developed, dilated-cuneate, a fourth to full half an inch long, 3-lobed, not rarely surpassing the disk, nearly white. - P. Canadensis, Torr. \& Gray, Fl. ii. 272, mainly, from the character, excl. syn. Poir. \& Lam. (which belong to a S. American species). - Extends to Hot Springs, Arkansas, F. L. Harvey.

§ 2. UvED ́́lIA, DC. Akenes somewhat laterally compressed, very stout, rather oblique, and their whole surface closely and strongly striate-nerved. (Here $P$. variabilis, Poir., Polymiastrum, Lam., i. e. all of $\S$ Alymnia, DC., excepting the original $P$. Canadensis.)

P. Uvedália, L. Commonly pubescent, not viscid, stout, 4 to 10 feet high : leaves ample (the larger a foot or two long and nearly as broad), of deltuid-ovate outline and 3-ribbed above the cuneate-decurrent base, 3-5-lobed, or the smaller only angulate-sinuate: heads somewhat cymosely paniculate, short-peduncled; the disk half-inch or more in diameter: outer involucral bracts broadly ovate: rays 10 to 14, with ligules bright yellow, linear-oblong to oval, usually half-inch in length, but sometimes hardly developed: akenes 3 lines long, glabrous: disk-corollas with cylindraceous throat and short lobes. - Spec. ed. 2, ii. 1303 (Pluk. Alm. t. 83, f. 3; Moris. Hist. iii. 6, t. 7, f. 55); Torr. \& Gray, 1. c. Osteospermum Uvedalia, L. Spec. ed. 1, ii. 923. - Fertile or moist grounds, New York to Florida and west to Missouri and Texas.

68. MELAMPÓDIUM, L. (Mé $\lambda a s$, black or dark, and toús, foot, i. e. black-footed, an ancient name of Black Hellebore, from the root; unmeaningly transferred to these plants.) - Branching herbs, of the warm parts of America, the greater number Mexican; with opposite mostly sessile leaves, and pedunculate heads terminating the branches or in the forks. Rays in some short, in 
others conspicuous. - Gærtn. Fruct. t. 169 ; R. Br. in Linn.'Trans. xii. 104; DC. Prodr. ¥. 517 ; Benth. \& Hook. Gen. ii. 349.

* Perennial and the base slightly lignescent: akene with apex exposed at the hooded orifice of the fructiferous bract: rays plane, conspicuously exserted, comparatively ample, tardily deciduous from the akene, white!

M. cinéreum, DC. Branched from the base, a span to a foot high, rather slencler, cinereous or even silvery-canescent with a fine and mostly close pubescence, or greener and becorning strigulose: leaves linear or the lower lanceolate or spatulate, entire or undulate, or even sinuate-pinnatifid : peduncles slender: ligules 5 to 9 , cuneate-oblong, 2-3-lobed at apex, 3 to 6 lines long: bracts of the involucre ovate, appressed, slightly united at base: fructiferous bracts ( 2 lines long, including the hood) turbinate, nearly terete, somewhat incurved, muricate with sharp tubercles; its hood about the length of the body and very much wider, imperfectly cupuliform, nearly smooth, callous-thickened or becoming suberose, its truncate and usually even margin commonly incurved.-Prodr. v. 518 (excl. habitat); Gray, Pl. Fendl. 78, Pl. Wright., \&c. $M$. leucanthum, Torr. \& Gray, Fl. ii. 271. - Open ground, W. Arkansas and Texas to Arizona. (Adj. Mex.)

Var. ramosíssimum. (M. ramosissmum, DC. 1. c. by the char, but habitat and number of distribution of this and of $\boldsymbol{M}$. cinereum were interchanged in the Prodromus!) More loosely pubescent and diffusely branching: heads mostly smaller: hood of the fructiferous bracts with the less thickened margin little or not at all involute, sometimes erose or denticulate and bearing a mucro or short (seldom "uncinate") cusp. - Southern borders of Texas, Berlandier, Palmer. (Adj. Mex.)

* Annuals, commonly low, erect, branching, with linear or oblong mostly entire leares : akene with merely the apex exposed at the summit of the enclosing fructiferous bract: ray and diskcorollas yellow. Our species all quite alike in foliage and habit.

M. híspidum, HBK. Hispidulous-hirsute, sometimes a foot high : rays very small, barely a line long" outer involucral bracts oval, distinct to the base; fructiferous bracts truncate and not at all appendaged at the somewhat oblique summit, more or less tuberculate on the back and sides. - Nov. Gen. \& Spec. iv. 273, t. 399 ; DC. 1. c. 520; Gray, Pl. Wright. ii. 85. -S. Arizona, Wright, Lemmon. (Mex.)

M. cupulátum, Gray. Somewhat hispidulous-pubescent: rays small but exserted, 2 lines long: outer involucral bracts connate to above the middle into an obtusely. 5-lobed hemispherical or saucer-shaped cup: fructiferous bracts nearly of the preceding. - Proc. Am. Acad. viii. 291. - Borders of S. Arizona, on the Mexican side, Schott. (Mex.)

M. longicórnu, Gray. Sparsely hispidulous: rays exserted, oblong, when well developed 3 lines in length and as long as the involucre, the outer bracts of which are distinct: fructiferous bracts more nervose, little tuberculate or smooth, the summit cupulately produced and gradually extended exteriorly into a circinnate or revolute horn or rigid awn, fully as long as the body, longer and more attenuate than in $M$. sericeum, and sericeouspubescent along the outside. - Mern. Amer. Acad. (PI. 'Thurb.) v. 321, \& Bot. Mex. Bound. 85. - S. Arizona, Thurber, Schott. (Adj. Mex.)

69. ACANTHOSPERMUM, Schrank. ("Akav $\theta \alpha$, a prickle or thorn, and $\sigma \pi \dot{\epsilon} \rho \mu \alpha$, seed, i. e. prickly-fruited.) - Homely annual weeds, much branched from the base; with opposite dentate leaves, in their axils and in the forks small subsessile or short-peduncled heads of yellowish flowers; the (4 to 7) bur-like involucral bracts enlarging in age. Natives of the tropics, one or two species becoming naturalized. - P1. Rar. Hort. Monac. t. 53; DC. Prodr. v. $521 . \quad C e n-$ trospermum, HBK. Nov. Gen. \& Spec. iv. 270, t. 397.

A. халтhiof́des, DC. 1. c. Diffusely procumbent or creeping: stems pubescent: leaves small (about inch long), mostly obovate, narrowed at base into a short petiole : fructiferous involucral bracts narrowly oblong, longitudinally sulcate, truncate, thickly beset especially along the angles with uniform and small hooked prickles. $-A$. Brasilum, Schrank, l. c.? a hirsute form. Melampodium australe, Lofl., L. Centrospermum xanthioides, HBK. 1. c. Roadsides and waste grounds, S. Carolina to Florida, \&c. (Nat. from S. Amer.) 
A. Húmile, DC. Larger, commonly erect, hirsute: leaves wing-petioled or sessile by a cuneate base: fructiferous bracts somewhat 3-angled, not grooved, armed (besides the prickles) with one or two long spines from the truncate summit. $-A$. humile \& $A$. hispidum, DC. 1. c. Melampodium humile, Swartz, Prodr. 114. Centrospermum humile, Less. Syn. 217. - Ballast-weed, about Philadelphia and New York; naturalized at Pensacola. (Nat. from W. Ind.)

70. SfLPHIUM, L. ROSIN-WEED. ( belliferous plant in $\mathbf{N}$. Africa which produced a gum-resin, transferred by Linnæus, in his accustomed way, to an American genus.) - Tall and coarse perennials (all of Atlantic U. S.) ; with resinous juice, thick roots, commonly large leaves, and ample pedunculate heads of yellow flowers (one species with white rays!), produced in summer and autumn. - Torr. \& Gray, Fl. ii. 275 ; Benth. \& Hook. Gen. ii. 350 .

* Stem square, leafy to the top: bases of the leaves or of their winged petioles cupulate-connate.

S. perfoliátum, L. (CUP-PLANT.) Stem 4 to 8 feet high, commonly very smooth and glabrous: leaves either smooth or scabrous, sometimes hirsute-pubescent beneath, orate or the upper ovate-lanceolate (the larger a foot or more long), dentate or denticulate with mucronate teeth; upper ones united by their broad bases and lower by winged petioles into a perfoliate cup: heads terminating the loosely cymosely disposed flowering branches, on naked peduncles : involucre short-campanulate, half or two-thirds inch high; outer bracts ovate, from erect to somewhat squarrose-spreading : rays inch long: akenes either with deep or shallow notch, the narrow wings being produced either into very small obsolete or prominent triangular teeth. - Spec. ed. 2, ii. 1301 ; Gouan, Hort. Monsp. 462 ; Hook. Bot. Mag. t. 3354 ; Torr. \& Gray, I. c. S. connatum, L. Mant. 574, a form with branches. somewhat hispid. S. tetragonum \& S. scabrum, Mœnch, Meth. 606. S. conjunctum, Willd. Enum. 633. S. Hornemanni, Schrad. Hort. Gœtt.; DC. Prodr. v. 514. S. erythrocaulon, Bernh. in Spreng. Syst. iii. 630.-Alluvial soil, Michigan and Wisconsin to Upper Georgia and Louisiana. Common in cultivation; variable but characteristic.

* Stem from obtusely quadrangular to terete, leafy : leaves all or some of them opposite, entire or serrate, not connate-perfoliate,

+ All but the lower sessile, and either all opposite or the upper pairs occasionally disjoined: akenes with is broad wing and a deep narrow noteh: stems 2 to 4 feet high, rigid, very leafy to the top.

S. integrifólium, Micnx. Stem smooth or scabrous, sometimes rough-hispidulous : leaves entire or denticulate, lanceolate-ovate or ovate-lanceolate; all the upper ones closely sessile by a broad and roundish or subcordate partly clasping base, and tapering from below the middle to an acute apex, scabrous above, from nearly glabrous and smooth to cinereouspubescent beneath, 3 to 5 inches long, commonly of firm texture: heads somewhat corymbose, nearly all short-peduncled : involucre over half-inch high; its bracts mostly ovate and spreading: akenes broadly obovate, the body 4 lines long, the scarious wing a line or so wide, at least toward the summit. - Fl. ii. 146; Torr. \& Gray, Fl. ii. 279, hardly of Ell. S. lovigatum, Pursh, as to char. S. speciosum, Nutt. Trans. Am. Phil. Soc. vii. 341, a very smooth form, the var. lave, Torr. \& Gray, 1. c. - Prairies, \&c., Wisconsin and Illinois to Arkansas and Texas, and possibly to W. Georgia.

S. aspérrimum, Ноок. Commonly taller: stem rough-hispid: leaves of the preceding but more scabrous: heads generally larger: akenes with broader wings, the triangular apical portions 2 or 3 lines high. - Comp. Bot. Mag, i. 99. S. radula, Nutt. Trans. Am. Phil. Soc. 1. c. S. scaberrimum, Torr. \& Gray, Fl. ii. 279, var. $\gamma$, hardly Ell. - Plains of Arkansas, Louisiana, and Texas.

S. scabérrimum, ELL. Stem and commonly both sides of the leaves hispid: leaves in remoter pairs, thinner, oblong or ovate, all but the uppermost rather coarsely serrate and with narrowed or even short petiole-like base (the larger 4 to 6 inches long): heads fewer, more pedunculate: rays inch long: outermost involucral bracts smaller: akenes including broad wing nearly orbicular in outline, half-inch in diameter. - Sk. ii. 462 ; Torr. \& Gray, Fl. ii. 279, excl. var. $\boldsymbol{\gamma}$. - W. Georgia to Louisiana and E. Texas. 
+ Leaves rather few on the slender stem, the lower slender-petioled, often alternate: akenes with the broad wings of the precerling.

S. grácile, Grax. Hispidulous: stem 12 to 30 inches high, rather naked, terminated by solitary or few mostly long-pedunculate heads: leaves membranaceous, ovate-oblong or oblong-lanceolate, acute at both ends, denticulate; radical and lower cauline ample (5 to 9 inches long); upper cauline from 2 inches to half-inch long: involucre of nearly equal and rather few oblong bracts: akenes orbicular or very broadly oval, broadly winged, and with a comparatively shallow notch. - Proc. Am. Acad. viii. 653. - Prairies of Middle Texas, Drummond, Lindheimer, Hall, \&c. Sometimes the leaves are all alternate and the petioles of the one or two principal cauline 2 or 3 inches long, equalling the blade.

+++ Leaves numerous on the stem, varying from opposite to alternate or the middle onea verticillate, only upper and alternate ones (if any) strictly sessile by a broad base: akenes witl narrow wings and a comparatively shallow open notch; awn-like pappus-teeth usually evident and not rarely partly separate from the wing.

S. Asteríscus, L. Stem 2 to 4 feet high, commonly hispid : leaves from ovaté-oblong to oblong-lanceokate, coarsely and irregularly dentate or serrate, or some entire, scabro-hispidulous or hispid, all the upper not rarely alternate, seldom any verticillate; upper commonly sessile by a rounded or partly clasping base; lower short-petioled: heads solitary or few on leafy branches: involucre foliaceous and squarrose (half-inch high), hirsute or hispidulous : akenes obovate-oval. - Spec. ii. 920 (Dill. Elth. t. 37, f. 42) ; Michx. Fl. ii. 146; DC. Prodr. v. 512; Torr. \& Gray, Fl. ii. 278. - Dry sandy soil, common from Virginia and Tennessee to Florida and Louisiana.

Var. lævicaúle, DC., l. c. Stem smooth and glabrous, either throughout or up to the branches. - Torr. \& Gray, 1. c. S. scabrum, Walt. Car. 217. S. reticulatum, Mœnch, Meth. 607, fide syn. L. S. Asteriscus, var. scabrum, Nutt. Gen. ii. 183. S. dentatum, Ell. Sk. ii. 468 ; Torr. \& Gray, 1. c. S. lanceolatum, Nutt. Trans. Am. Phil. Soc. vii. 341, a narrow-leaved form. S. Asteriscus, var. dentatum, Chapm. Fl. 221. - S. Carolina to Georgia and Alabama.

S. trifoliátum, L., l. c. Stem 4 to 7 feet high, very smooth and glabrous, terıninated by naked corymbiform panicles of numerous usually slender-peduncled heads: leaves lanceolate, varying to oblong ovate, and from entire to sparsely serrate, from almost glabrous and smooth to scabrous or hispidulous-puhescent, seldom alternate, a part of them usually 3-4nately verticillate, commonly acute at base and the upper subsessile, lower tapering into margined petioles : involucre somewhat campanulate, narrower and usually smaller than in the foregoing; the bracts hardly foliaceous, smooth and glabrous, except the ciliate margins: akenes broadly obovate-oval. - Hook. Bot. Mag. t. 3355; Torr. \& Gray, 1. c. S. trifoliatum, ternatum, \& atropurpureum, Retz in Willd. Spec. iii. 2333. S. ternifolium, Michx. Fl. ii. I46. -Dry woodlands, Penn. and Ohio, and through the upper country to Alabama.

Var. latifólium. Stem 2 to 4 feet high: leaves broader, seldom more than upposite: heads fewer and broader. $-S$. loevigatum, Ell. Sk. ii. 465 (perhaps Pursh, Fl. ii. 578, but his character points to S. integrifolium); Torr. \& Gray, 1. c. - W. Georgia, Alabama, and low country of S. Carolina; and broad-leaved northern forms are similar.

* * Stem terete, almost leafless and scapiform, bearing a loose panicle of slender pedunculate heads: involucre nearly hemispherical, of rounded mostly erect and coriaceo-herbaceous bracts: radical leaves ample, long-petioled, cordate at base: cauline when present all alternate and slender-petioled : herbage almost glabrous and smooth, or the leaves hispidulous and papillosescabrous. (True Rostr-WEEDs.)

S. compósitum, Michx. Stem slender, 2 to 6 feet high, commonly glaucous: radical leaves of roundish-cordate or reniform or more ovate cireumscription, 6 to 12 inches long or broad: heads small and numerous: involucre a third or rarely half inch high: rays small and scattered, 4 lines long: akenes roundish-obovate and with wing broadened above, so as to form a deep notch, with which the two subulate pappus-teeth are confluent, sornetimes narrowly winged so that the summit is barely emarginate and minute pappus-teeth nearly free. - I'orr. \& Gray, F1. ii. 276. The first-describcil form (var. Michauxii, \& var. ovatifolium, Torr. \& Gray, l. c.) has the leaves varying from deeply sinuate-pinnatifid to pinnately or somewhat ternately divided into 3 to 7 divisions, which are again sinuate-lobed; for this the specific name is appropriate, being $S$. compositum, Michx. Fl. ij. 145 ; Ell. 1. c.; DC. 1. c., and $S . l a$ ciniatum, Walt. Car. 217, not. L. S. nudicaule, M. A. Curtis in Bost. Jour. Nat. Hist. i. 127, 
a form passing into var. reniforme, Torr. \& Gray, 1. c., has rounder leaves, some only sinuatedentate, others deeply palmately cleft. S. elatum, Pursh, Fl. ii. 579. S. terebinthinaceum, Ell. Sk. ii. 463, not Jacq. S. reniforme, Raf. Med. Fl. ii. 283; Nutt. Trans. Am. Phil. Soc. vii. 341. - Pine woods and barrens, N. Carolina to Florida.

S. terebinthináceum, JACQ. (PraIrie Dock.) Stem 4 to 9 feet high, bearing several or numerous large heads: leaves of thick and firm texture, cordate-oblong or sometimes ovate-oblong, a foot or two long (besides the long petiole), dentate with very many small teeth, becoming rough in age: involucre nearly an inch high: rays an inch or more in length: akenes obovate, narrowly winged, merely emarginate and obscurely 2-toothed at summit. - Hort. Vindob. i. t. 43 ; L. f. Suppl. 383; Gæertn. Fruct. ii. 445, t. 171; Schk. Handb. t. 262 ; Hook. Bot. Mag. t. 3525; Torr. \& Gray, 1. c. - Prairies and dry open woodlands, Ohio and Michigan to Iowa and south to W. Georgia and Louisiana.

Var. pinnatífidum, GRAY. Leaves laciniately or sinuately pinnatifid. - Man. ed. 1, 220. S. pinnatifidum, Ell. 1. c. - Ohio and W. Georgia, not common.

* * * Stem terete (striate when dried), bearing alternate deeply pinnatifid or bipinnatifid coriaceous leaves, and sessile or short-peduncled large heads racemosely disposed along the naked summit, and bracteate: involucre rigid; its bracts ovate, thickened and at length coriaceous at base, with equally long or longer and spreading foliaceous acumination: rays numerous: herbage scabrous-hispidulous or hispid, very rough when dried._Compass-Plants.

S. laciniátum, L. Stem 3 to 6 and even 12 feet high : radical leaves (a foot or two long) long-petioled, once or twice pinnately parted or below divided, the divisions and lobes lanceolate to linear; cauline with petiole simply dilated at base, or with stipuliform and sometimes palmatifid appendages; upper sessile and reduced to bracts: involucre inch or more high and broad: rays numerous, inch or two long, bright yellow: akenes half-inch long, oval, glabrous or nearly so, with narrow wing widening upward and an open shallow notch; no awns. - Spec. ii. 919; L. f. Dec. 5, t. 3 ; Jacq. f. Ecl. 1, t. 90 ; Torr. \& Gray, 1. c.; Meehan, Nat. Flowers, ser. 2, ii. t. 46 ; Hook. f. Bot. Mag. t. 6534. S. spicatum, Poir. Suppl. v. 157. S. gummiferum, Ell. Sk. ii. 460. - Prairies, Wisconsin to Dakota and south to Alabama, Kansas, and Texas. Leaves vertical and, especially the radical ones, disposed to place the edges north and south, - in respect to which there is abundant literature. See Alvord in Am. Naturalist, xvi. 626.

S. albiflórum, Gray. Low, a foot to barely a yard high, very scabrous : leaves rigid, as broad as long, more disposed to pedate division; dilated base of petiole entire: tips of involucral bracts seldom surpassing the disk: rays white, about inch long: akenes puberulent; the narrow wing produced and dilated at summit into somewhat triangular teeth which are adnate to a pair of subulate and more or less projecting awns, the notch narrow. - Proc. Am. Acad. xix, 4. - On cretaceous rocks, W. \& N. Texas, Reverchon.

71. BERLANDIERA, DC. ( $J$. L. Berlandier, a Genevese bqtanist and collector, explored parts of Texas and Mexico, died at Matamoras in 1851.) - Perennial herbs (of the southeastern borders of the U. S.); with canescent or cinereous herbage, thick roots, alternate leaves, and pedunculate heads: the rays yellow : involucre radiately expanding in fruit. Fl. spring and summer. Prodr. v. 517 ; Benth. Pl. Hartw. 17 ; Torr. \& Gray, Fl. ii. 280.

* Stems leafy up to the inflorescence of mostly rather numerous and short-peduncled heads: leaves crenate, some or all the cauline cordate; radical oblong.

B. Texána, DC. Hirsute-tomentose; the pubescence not pannose, that of the (2 or 3 feet high) very leafy stem commonly hirsute or villous, the coarser hairs many-jointed: cauline leaves from oblong-cordate to subcordate-lanceolate, greenish, merely cinereous beneath, somewhat scabrous above; upper closely sessile, lower short-petioled: heads usually fastigiate-cymose. - Prodr. 1. c. ; Deless. Ic. Sel. iv. t. 26 ; Torr. \& Gray, l. c. B. longifolia, Nutt. Trans. Am. Phil. Soc. vii. 342. - Margin of woods and hillsides, Texas (first coll. by Berlandier), W. Louisiana and Arkansas to S. W. Missouri. Leaves of Betonica.

Var. betonicifólia, Torr. \& GRAY, 1. c. A form with most of the cauline leaves petioled, and the peduncles hirsute with purplish hairs. - Silphium betonicifolium, Hook. Comp. Bot. Mag. i. 99. - Louisiana, Drummond. 
B. tomentósa, Nutr. 1. c. Canescent throughout with soft and close pannose tomentum, no hirsute or villous hairs, when glabrate hardly at all scabrous : stem a foot or two high, rarely only a span high: leaves all obtuse, green above, generally whitish beneath; radical and lower cauline elongated-oblong and petioled; upper cauline usually ovate-oblong or oval, sometimes subcordate-orate, short-petioled or sessile. heads fewer, in low specimens almost solitary and longer-peduncled. - Torr. \& Gray, Fl. ii. 282. B. pumila, Nutt. 1. c. Silphium pumilum, Michx. Fl. ii. 146. S. tomentosum, pumilum, \& reticulatum? Pursh, Fl. ii. 578, 579. S. Asteriscus, var. pumilum, Wood, Bot. 442. Polymnia Caroliniana, Poir. Dict. v. 505. Dry pine barrens, N. Carolina to Florida, Arkansas, and Missouri.

Var. dealbáta, Torr. \& Grar, 1. c. More robust and leafy, 2 or 3 feet high, branching at summit and bearing more numerous and shorter-peduncled heads: cauline leaves broader and more sessile, densely white-tomentose beneath; lower broadly cordate, upper often deltoid (with or without a subcordate base), either obtuse or acute. - Texas, Drummond, Hall, Reverchon, a very soft-canescent form. Varies into a less canescent state, approaching $B$. Texana, the leaves scabrous above (var. $\gamma$, Torr. \& Gray, I. c.), Arkansas, Louisiana, and Texas.

* * Stems commonly low and with long monocephalous pecluncles; the earliest often produced from near the root, and scapiform, the later from leafy stems or branches: leaves variable, all attenuate at base, disposed to be pinnatifid or ly rate.

B. subacaúlis, Nutr. 1. c. Barely cinereous with minute often hispidulous pubescence (or the peduncles sometimes hirsute), soon green, becoming a foot or so high and leafy: leaves of oblong-linear or oblong-spatulate outline, irregularly sinuately or lyrately pinnatifid, with short obtuse lobes: akenes narrowly obovate-oval, merely carinately costate on the inner face. - Torr. \& Gray, Fl. ii. 282. Silphium subacaule, Nutt. in Am. Jour. Sci. v. 301 ; DC. Prodr. v. 512. S. Nuttallianum, Torr. Ann. Lyc. N. Y. ii. 216, as to syn. - Florida, in dry pine barrens; first coll. by Ware.

B. Iyráta, Benth. Canescent with minute white or gray tomentum: leaves at length greenish above, variously lyrate-pinnatifid; the lateral lobes oblong or narrower, obtusely dentate, sometimes incised: akenes obovate, the costa of the inner face strongly carinate. - Pl. Hartw. 17; Gray, Pl. Fendl. 78, \& Pl. Wright. i. 103. B. incisa, Torr. \& Gray, Fl. ii. 282. Silphium Nuttallianum, Torr. Ann. Lyc. N. Y. ii. 216, excl. syn. - Plains and hills, W. Texas and Arkansas to Arizona. '(Mex.)

Var. macrophýlla. Radical leaves often a foot long, lanceolate-oblong or spatulate, either merely crenate or pinnatifid at base: later flowering stems sometimes 2 or 3 feet high. - S. Arizona, Lemmon.

72. CHRYSÓGONUM, L. (Greek name of some plant in Dioscorides.

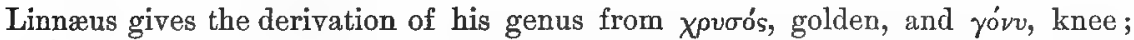
of no obvious application.) - Gærtn. Fruct. ii. 436, t. 174; Lam. Ill. t. 713 ; DC. Prodr. v. 510; Torr. \& Gray, Fl. ii. 274; Benth. \& Hook. Gen. ii. 350, excl. syn. Moonia, \&c.; Gray, Proc. Am. Acad. xvii. 216. Diotostephus, Cass. Dict. xlviii. 543. - Single species: fl. spring and summer.

C. Virginiánum, L. Perennial from creeping rootstocks and sometimes by runners, pubescent, often hirsute, flowering acaulescently from the ground, also with stems a span to a foot high, bearing 3 or 4 pairs of long-petioled leaves; these ovate, mostly obtuse and crenate; cauline rarely subcordate and equalling or shorter than their petioles, or the radical obovate with cuneate attenuate base: peduncles solitary in the forks and terminal, all but the radical ones elongated: involucre one-third and yellow rays half inch long. - Spec. ii. 920 (Pluk. Alm. t. 83, f. 4, \& 242, f. 3) ; Walt. Car. 217; Michx. Fl. ii. 148; Torr. \& Gray, 1. c. C. Virginianum \& C. Diotostephus, DC. 1. c. Diotostephus repens, Cass. 1. c. - Dry ground, S. Pennsylvania to Florida. Varies considerably according to age and season, usually low when blossoming begins.

Var. dentátum, Grar. Leaves deltoid-ovate, acute, coarsely dentate-serrate, the tip and teeth, also the tips of the bracts of the outer involucre, terminated by a more conspicuous callous mucro. - Bot. Gazette, viii. 31.- High Island at the falls of the Potomac above Washington, J. Donnell Smith, Ward, Vasey. 
73. LINDHEIMERA, Gray \& Engelm. (Ferdinand Lindheimer, the discoverer of this neat plant, now prized in cultivation, and remarkable for its golden yellow rays simulating a 5-petalous flower.) - Proc. Am. Acad. i. 47, Jour. Bost. Nat. ITist. vi. 225, \& Pl. Lindh. ii. 225. Single species.

L. Texána, Gray \& Engelm. 1. c. At leugth 2 feet high from an annual root, hirsute or hispid, branching above, bearing loosely cymose-paniculate usually slender-pedunculate heads: lower leaves spatulate to cuneate-ovate, alternate, coarsely sinuate-dentate; upper ovate to ovate-lanceolate, with a broad closely sessile base, acuminate, commonly entire, mainly opposite, their edges and also the peduncles usually beset with some small tackshaped glands: ligules half-inch or more long. - Open woods and bottoms of the upper Guadalupe River, \&c., Texas, Lindheimer, Wright.

74. ENGELMÁNNIA, Torr. \& Gray. (George Engelmann, an eminent botanist, died while this volume was printing, Feb. 4, 1884, æt. 75.) - Torr. \& Gray in Nutt. Trans. Am. Phil. Soc. vii. 343, \& Fl. ii. 283. Angelandra, Endl. Gen. Suppl. iii. 69. - Single species, in structure nearer to Parthenium than to Silphium. Fl. summer.

E. pinnatífida, ToRR. \& GraY, 1. c. A foot or two high from a stout perennial root, roughish-hirsute or hispid, branching above, and bearing somewhat paniculately disposed heads of golden-yellow flowers on mostly slender naked peduncles: leaves all alternate, deeply pinnatifid; radical and lower canline short-petioled and their linear or oblong lobes sometimes sparingly lobulate; upper cauline sessile and with broad base: head about 4 lines high: rays half-inch or more long: akene rough-hispidulous. - Torr. in Marcy Rep. t. 11; Meehan, Nat. Flowers, ser. 2, i. t. 2. E. Texana, Scheele in Linn. xxii. 155. - Prairies and rocky hills, Arkansas and Louisiana to Texas and Arizona. (Adj. Mex.)

75. PARTHÉNIUM, L. (Ancient mame of some plant, from $\pi a \rho \theta$ évos, virgin.) - Herbaceous or suffruticose (all E. American), bitter-aromatic; with small heads of whitish flowers; in summer. - Gærtn. Fruct. t. 168; DC. Prodr. v. 531 ; Torr. \& Gray, Fl. ii. 284 ; Benth. \& Hook. Gen. ii. 351.

$\S 1$. Parthenístrum (Nissole), DC. Ligule more or less evident: caulescent, usually branching, with alternate leaves either dentate or variously lobed or divided: heads corymbosely or paniculately cymose.

* Herbaceous, with membranaceous once or twice pinnatifid leaves, and habit of Ambrosia.

P. Hysteróphorus, L. A foot or two high, from an annual root, diffuse, strigosely púbescent, sometimes also hirsute, geverally green: heads in a loose and open naked panicle: cauline leaves of broadly ovate outline, pinnately parted into 5 to 9 mostly narrow again pinnatifid lobes; of the flowering branches linear or lanceolate and entire or few-lobed: pappus of 2 rather large and roundish scales. - Spec. ii. 988; Bot. Mag. t. 2275. Argyrochota bipinnatifida, Cav. Ic. iv, 54, t. 378 . Villanova bipinnatifida, Ort. Dec. iv. 48, t. 6 . (P. lobatum, Buckley in Proc. Acad. Philad. 1861, 457, should be this, by its " annual root," rather than the following.) - Waste grounds, Florida to 'Texas, where it may be indigenous, but probably introduced from within the tropics : also an imported ballast-weed as far north as Philadelphia. (Mex., Trop. Am.)

P. Iyrátum. A foot high from a truly perennial root, canescent or cinereous with fine and close sometimes also loose hirsute pubescence, erect: heads corymbosely crowded, more pubescent: leaves of obovate or oblong outline, lyrately pinnatifid, the lobes short and oblong. - P. Hysterophorus, var. lyratum, Gray, Proc. Am. Acad. xvii. 216. - Texas, in the southern and western parts, Berlandier, Lindheimer, Wright, Reverchon, \&c. Equally allied to the preceding species and to the Mexican P. confertum, Gray. (Adj. Mex.)

* Fruticose or suffrutescent, with firmer and more simply lobed leaves.

P. incánum, HBK. Decidedly shrubby, 1 to 3 feet high, much branched, canescent with fine tomentum: leaves mostly obovate in outline, sinuately pinnatifid into 3 to 7 oblong or 
roundish and obtuse lobes: heads numerous, paniculate-cymose: ligules commonly longer than broad: pappus a pair of short-subulate erect or at length spreading awns. - Nov. Gen. \& Spec. iv. 260, t. 391 ; Gray, Pl. Wright. i. 103. P. incanum \& P. ramosissimum, DC. Prodr. v. 532. - Dry hills, W. Texas to Arizona. (Mex.)

P. argentátum, Grar. Suffrutescent, a foot high, silvery-canescent with close tomentum: branches erect, rather leafless above, bearing comparatively large and fow heads (of 2 lines in diameter): leaves lanceolate to spatulate in outline, some entire or incisely 2-3-toothed; the larger incisely pinnatifid into 2 to 7 acute lateral lobes: pappus a pair of lanceolate chaffy awns. - Bot. Mex. Bound. 86. - S. W. borders of Texas, Bigelow. (Adj. Mex., Parry, Palmer. Produces a gum or resin in Mexico.)

* * Perennial berb, with larger heads and leaves; the latter undivided, thickish.

P. integrifólium, L. Stout, 1 to 3 feet high, minutely pubescent, corymbosely branched above, the branches terminated by a dense cyme of many heads (these a quarter-inch high): leaves ovate-oblong or narrower, thickly crenate-dentate, rarely doubly dentate or somewhat incised, hispidulous-scabrous, prominently veiny from a strong midrib; raclical a foot or more long and tapering into a petiole; upper cauline closely sessile and broad at base: pappus a pair of small chaffy teeth or scales. - Spec. ii. 988 (Dill. Elth. t. 225 ; Pluk. AIm. t. 53 \& 219) ; Lam. Ill. t. 766 ; Willd. Hort. Berol. t. 4 ; Torr. \& Gray, l. c. - Dry ground, Marylaud to Illinois and Texas.

§ 2. Bolóphytcm, Torr. \& Gray. (Bolophyta, Nutt.) Ligule wanting, the corolla being reduced to a truncate tube, which is obscurely notched at back and front: acaulescent cespitose perennial.

P. alpínum, Torr. \& Gray, l. c. Densely tufted on a thick branching caudex, depressed, rising only an inch or two high: leaves crowded, silvery-canescent with a fine appressed pubescence, and villous in the axils, spatulate-linear, barely inch long, entire: heads solitary and nearly sessile among the leaves: pappus a pair of oblong-lanceolate membranaceous scales. - Bolophyta alpina, Nutt. Trans. Am. Phil. Soc. n. ser. vii. 347. - Rocky Mountains in Wyoming (at 7,000 feet), on rocks near the Three Buttes, Nuttall.

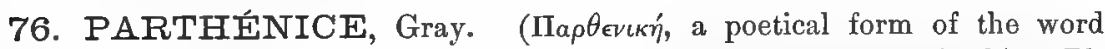
from which the name of the preceding nearly'related genus is derived.) - Pl. Wright. ii. 85 ; Benth. \& Hook. Gen. 352. - Genus of a single species, allied also to the succeeding genus.

P. móllis, Gray, 1. c. Annual, with odor aud savor of Artemisia, 4 to 6 feet high, paniculately branched, minutely puberulent-cinereous throughout, wholly destitute of any coarser pubescence: leaves membranaceous, all alternate, ovate, some of the larger (as much as 10 or 12 inches long) subcordate, acuminate, irregularly or doubly dentate, long-petioled: heads small ( 2 lines broad), numerons in loose axillary and terminal somewhat leafy panicles, mostly pedicellate : flowers greenish-white. - Hillsides and along streams, S. Colorado to Arizona, Wright, Thurber, Lemmon, \&c. Fl. autumn.

77. IVA, L. (An unexplained name.) - American herbs or shrubs; with entire or dentate or dissected leaves, at least the lower ones opposite, and small spicately or racemosely or paniculately disposed or scattered and commonly nodding heads: fl. summer. - Lam. Ill. 766; Grertn. Fruct. t. 164; DC. Prodr. v. 529. Iva \& Cyclachana (Fresen.), Torr. \& Gray, Fl. ii. 285; Benth. \& Hook. Gen. ii. 352.

§1. Crclachena. Heads naked-paniculate, inconspicuously bracteate: corolla of the 5 fertile flowers a very short rudiment or none: leaves membranaceous, from incisely serrate to dissected, mostly petioled: flowers somewhat inclined to polygamo-diøcious through abortion of the ovaries: annual herbs. -Cyclachana, Fresen. Ind. Sem. Hort. Frano. 1836, \& Linn. xii. ; Torr. \& Gray, 1. c. 285. 
* Heads nearly sessile, crowded in narrow spiciform clusters which are aggregated in a panicle.

I. xanthilfólia, Noтr. Tall and coarse ( 3 to 5 feet high), pubescent, at least when young: leaves mainly opposite, long-petioled, broadly ovate, ample, coarsely or incisely serrate, acuminate, 3-ribbed at base, puberulently scabrous above, and when young canescent beneath: panicles axillary and terminal : involucre depressed-hemispherical, biserial; outer of 5 broadly ovate herbaceous bracts; inner of as many membranaceous dilated-obovate or truncate ones, which are strongly concave at maturity and half embrace the obovate-pyriform and glabrate akenes (on the apex of which sometimes persists a minute crown answering to the obsolete corolla, or this wholly absent). - Gen. ii. 185. I. (Picrotus) xanthiifolia \& paniculata, Nutt. Trans. Am. Phil. Soc. vii. 347. Cyclachona xanthiifolia, Fresenius, 1. c.; Torr. \& Gray, Fl. ii. 286. Euphrosyne xanthiffolia, Gray, Pl. Wright. ii. 85.-Alluvial ground or along streams, Saskatchewan and Nebraska to New Mexico, Utah, and Washington Terr. ; first coll. by Nuttall.

I. dealbáta, Gray. A foot or two high, canescent with floccose wool except the elongated and narrow terminal panicle: leaves in greater part alternate, soft-tomentose, reticulateveiny ( $1 \frac{1}{2}$ to 3 inches long), from obscurely angulate-toothed to laciniately pinnatifid, cuneately or abruptly contracted at base into a short winged petiole: heads only a line long: involucre of only 5 obovate concave somewhat herbaceous bracts : corolla of fertile flowers a short cup or ring: akenes pyriform, roughish and glandular. - Pl. Wright. i. 104. - Valleys of S. W. Texas, Wright, Bigelow. (Adj. Mex., Thurber, \&c.)

* * Heads pedicellate, in looser panicles, more or less leafy-bracteate: habit and foliage of Euphrosyne.

I. ambrosiæefólia. A foot or two high, hirsute or villous-hispid, paniculately branched: leaves almost all alternate, thin, twice or thrice pinnately parted into small oblong lobes: involucre of 5 broadly ovate herbaceous outer bracts, and as many smaller obovate thinscarious inner ones: corolla of fertile flowers a mere vestige: akenes turgid-obovate. Euphrosyne ambrosicefolia, Gray, Pl. Wright. i. 102, ii. 85. - W. borders of Texas and adjacent New Mexico, Wright. (Mex.)

$\S 2$. Iva proper. Heads spicately or racemosely disposed in the axils of leaves or foliaceous bracts, and nodding: fertile flowers with evident corolla. - Iva, Torr. \& Gray, Fl. ii. 286 ; Benth. \& Hook. Gen. l. c.

* Heacls in terminal and solitary or paniculate compact squarrosely bracteate spikes: leaves not coriaceous : root annual.

I. ciliáta, WILLD. Rather stout, 2 to 6 feet high, strigose-hispidulous and hispid : leaves nearly all opposite, ovate, acuminate, sparsely serrate, the base abruptly contracted into a hispid petiole: spikes strict, 3 to 8 inches long; their bracts lanceolate and ovate-lanceolate, foliaceous, surpassing the at length deflexed heads, hispid-ciliate, as are the 3 or 4 (rarely 5) herbaceous and unequal distinct or partly united bracts of the involucre: akenes about 3 , obovate, moderately flattish. - Spec. iii. 2386; Pursh, Fl. ii. 580 ; 'Torr. \& Gray, Fl. ii. 287. I. annua, Michx. F1. ii. 184, not L., unless possibly the detailed illustration by Schmidel should represent a state of it much altered in cultivation. Ambrosia Pitcheri, Torr. in Hook. Comp. Bot. Mag, i. 99, with a var. having linear and much elongated bracts to the spike.-Moist alluvial ground, Illinois to Nebraska, and south to Louisiana, Texas, and New Mexico. (Adj. Mex., Berlandier.)

* Heads more loosely disposed in the axils of ordinary leaves, or upper ones commonly in the axils of foliaceous bracts,

+ Rather many-flowered; the fertile flowers 5 or rarely fewer: perennials or shrubby, with thickish and firm somewhat flesby or coriaceous leaves.

+ Bracts of the fleshy-herbaceous involucre 6 to 9 , imbricated in two or more ranks; and those among the numerous sterile flowers linear-spatulate.

I. imbricáta, WALT. A foot or two high from a suffrutescent base, honey-scented, smooth and glabrous or nearly so: stems thickish, ascending: leaves mainly alternate, fleshy, from spatulate-oblong to narrowly lanceolate, sessile, some of the larger ( 1 or 2 inches long) sparingly serrate: heads large for the genus ( 3 or 4 lines long), commonly pedunculate, the lower surpassed by and the upper surpassing the subtending leaves: involucre hemisphericalcampanulate, the outer bracts orbicular: sterile flowers many, the fertile 2 to 4: akenes 
obovate-oval, turgid. - Car. 232; Michx. Fl. ii. 184; Torr. \& Gray, 1. c. - Sands of the sea-shore, Virginia to Florida and Louisiana. (W. Ind.)

++ Bracts of the simpler involucre 5 or 4 ; those among the several or rather numerous sterile flowers reduced to linear filiform chaft: herbage minutely or sparsely strigulose or nearly glabrous, rarely more pubescent: leaves opposite and alternate.

I. frutéscens, L. (Marsh Elder, High-water Shrub.) Shrubby, or on the northern coast nearly herbaceous, erect, 3 to 8 feet high, much branched: canline leaves oval or oblong, 3 to 5 inches long, serrate, 3-nerved at base, petioled; those of the branches lanceolate and tapering to each end, and in the upper part of the inflorescence reduced to linear bracts mostly surpassing the heads: bracts of the involucre distinct, orbicular-obovate. - Amœn. Acad. iii. 25, \& Spec. ii. 989; Walt. Car. 232 ; Lam. Ill. t. 166, f. 2 ; Michx. Fl. ii. 184; Torr. \& Gray, Fl. ii. 287. - Brackish muddy shores and beaches along the sea-coast, from Massachusetts to Texas.

I. Hayesiána, Grar. Suffrutescent, 2 or 3 feet high, with ascending rather simple branches : leaves obovate-oblong or spatulate, or the small uppermost lanceolate, obtuse, entire, nearly sessile; the larger 2 inches long; upper little or not at all surpassing the heads: involucral bracts distinct, roundish. - Proc. Am. Acad. xi. 78, \& Bot. Calif. i. 614. - Brackish soil, San Diego Co., California, Sutton Hayes, Palmer, G. R. Vasey.

I. axilláris, PuRsH. Herbaceous from somewhat woody creeping rootstocks; the stems or branches nearly simple, ascending, a foot or two high: leaves from obovate or oblong to nearly linear, obtuse, mostly entire, sessile, rarely over inch long, even the uppermost usually much surpassing the mostly solitary heads in their axils : bracts of the hemispherical involacre connate into a 4-5-lobed or sometimes parted and sometimes merely crenate cup.Fl. ii. 743; Nutt. Gen. ii. 185; Hook. Fl. i. 309, t. 106 ; Torr. \& Gray, 1. c. - I. arillaris (bracts almost separate) \& I. foliolosa (bracts much united), Nutt. Trans. Am. Phil. Soc. 1. c. 346. - Sandy saline soil, Saskatchewan and Dakota to New Mexico, and west to Brit. Columbia and California.

Var. pubéscens, Gray. Villous with lax spreading hairs: involucre turbinate and almost entire.-Bot. Wilkes Exped. xvi. 350, \& Bot. Calif. i. 343. - California, along the Bay of San Francisco.

+ + Heads 3-6-flowered, small (about a line long), very numerous, subsessile, all surpassed

by the narrow-linear or filiform mostly alternate subtending leaves: slender erect annuals, with elongated or virgate flowering branches: chaffy bracts filiform. - \$ Monachana, Torr. \& Gray, l. c.

I. microcéphala, Notr. Nearly glabrous, 2 or 3 feet high, even the lower leaves narrowly linear (an inch or two long, a line wide), those subtending the loosely disposed hemispherical heads spreading: involucre of 4 or 5 distinct bracts: fertile and sterile flowers each about 3 . - Trans. Am. Phil. Soc. 1. c.; Torr. \& Gray, 1. c. - Dry pine barrens, E. and Middle Florida, Baldwin, Chapman, Palmer, Curtiss.

I. angustifólia, Nurt. Strigulose-scabrous or somewhat hirsute, 2 to 4 feet high: lower leaves lanceolate, acute at both ends (larger inch and a half long, 3 or 4 lines wide), some of them sparingly serrate; those of the branches from linear to filiform, the bracteal ones ascending: heads more crowded and spicate, turbinate: involucral bracts united by scarious edges into a cup: fertile flowers usually solitary; the sterile 2 to 5 : anther-tips cuspidateapiculate.-DC. Prodr. v. 529, \& Trans. Am. Phil. Soc. 1. c.; Torr. \& Gray, l.c. - Gravelly banks or beds of streams, Arkansas, Louisiana, and Texas. (Adj. Mex.)

§3. Chorisíva. Ileads scattered, lateral and ebracteate on leafy branches: fertile flowers with evident corolla.

I. Nevadénsis, M. E. Jones. Low and diffusely branched annual, leafy to the top, cinereously hirsute-pubescent: leaves obovate in outline, pinnately 3-i-parted into oblung or obovate obtuse lobes: heads small, sessile along the branches or rarely in the axil of a leaf: involucre of 3 nearly distinct ovate-oblong and very obtuse foliaceous bracts, considerably surpassing the 8 to 10 male and 3 or 4 female flowers; the latter subtended and akene partly enwrapped by as many roundish and hyaline interior bracts; their truncate corolla beset and fringed by long hairs. - Am. Naturalist, xvii. 973, but akenes not "finely striate." - Near Hawthorne, Nevada, M. E. Jones. - Insignificant but singular species, with the aspect of Franseria Hookeriana. 


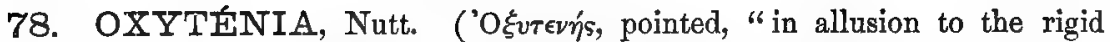
narrow foliage.") - Pl. Gamb. 172 ; Benth. \& Hook. Gen. ii. 3ə̃3 ; Gray, Bot. Calif. i. 343. - Single species, Artemisia-like in habit; fl. autumn.

O. acerósa, Nutr. l. c. Shrubby, but soft-woody, 3 to 5 feet high, canescent, with erect branches sometimes leafless and rush-like: leaves when present alternate, pinnately 3-5-parted into long fliform divisions, or uppermost entire: heads numerous (2 lines long), in dense panicles. - Dry plains, S. W. Colorado to S. E. California, Gambel, Wheeler, Brandegee, \&c.

79. DICÓRIA, Torr. \& Gray. ( $\Delta$ is, twice, used for two, and kópls, a bug, from the aspect of the two akenes of the original species.) - Emory Rep. 143, \& Bot. Mex. 86, t. 30; Gray, Proc. Am. Acad. xi. 76, \& Bot. Calif. i. 615.

D. canéscens, Torr. \& GraY, 1. c. Herb a foot to a yard high, with annual root, stem becoming liguescent at base and widely branched, herbage canescent with appressed pubescence and the branches hispid, becoming green and scabrous in age : lower leaves opposite, lanceolate and oblong, coarsely toothed or laciniate; upper alternate, ovate or roundish, all petioled: heads sparsely and irregularly racemose-paniculate, along slender nearly leafless branchlets, nodding in fruit: fertile flowers 2 : inner bracts of the involucre pelatoid-scarious (yellowish white), orbicular and deeply concave, accrescent in fruit (becoming 3 or 4 lines long), then inflated-saccate and loosely or partly enclosing the laciniately wing-margined akene, falling with it. - Desert washes, S. E. California and adjacent Arizona to S. Utah.

D. Brandegéi, Grar, 1. c. Strigulose-canescent, diffusely and alternately branched (base of stem unknown): leaves of the branches oblong-lanceolate or partly spatulate, obtuse, mostly entire, an inch or less long and with slender petiole: heads sparse, racemose-paniculate; some all male: corollas sparsely hirsute: fertile flower solitary; its dilated-cuneate hyaline subtending bract hardly accrescent or surpassing the outer involucre: akene naked and exserted, bordered with pectinate callous teeth connected by an indistinct scarions margin. - Sandy bottoms of the San Juan, near the boundary between Colorado and Utah, Brandegee. Little Colorada, N. Arizona, Rusby, in flower only.

80. HYMENOCLEA, Torr. \& Gray. (' $Y_{\mu} \eta^{\prime} v$, membrane, used for wing, and $\kappa \lambda \varepsilon^{\prime}(\omega$, to enclose.) - Two known species, of low and much branched shrubhy plants, minutely canescent, or else glabrous and smooth; with slender diffuse branches, bearing profuse scattered or glomerate paniculate small heads, the two sexes intermixed, or the female in lower axils: leaves all alternate and linear-filiform; the lower sparingly and irregularly pinnately parted: fl. summer and autumn. - Pl. Fendl. 79 ; Gray, Pl. Wright. i. 104, Bot. Calif. i. 343.

H. Sálsola, ToRR. \&.GRAY, 1. c. Fructiferous involucre fusiform, strobilaceous; the ample orbicular silvery-scarious wings spirally alternate, imbricated over each other, radiately spreading when mature and dry. - Torr. Pl. Fremont (Smiths. Contrib.) 14, t. 8. - Saline soil in the desert region, S. California, adjacent Arizona, and Nevada; first found by Fremont.

H. monogýra, TorR. \& GrAY, 1. c. Fructiferous involucre smaller (2 lines long), winged only at the middle by a whorl of obovate or rhombic-reniform radiating scales of smaller size. - S. California through Arizona to S. W. Texas; first coll. by Coulter. (Adj. Mex.)

81. AMBRÓSIA, Tourn. RAGWEed. (Ancient Greek and also Latin name of several plants, as well as of the food of the gods.) - Weedy or coarse herbs ; with mostly lobed or dissected opposite and alternate leaves, and dull inconspicuous flowers; in summer. Sterile heads racemose or spicate, and with no subtending bracts; the fertile below, commonly in small clusters in the axils of leaves or bracts : fl. summer and autumn. - Lam. Ill. t. 765 ; Gærtn. Fruct. t. 164 ; Schk. Handb. t. 292 ; Torr. \& Gray, Fl. ii. 354. - Fructiferous nut-like involucre called for shortness "fruit." 
§ 1. Cercómeris, Torr. \& Gray, 1. c. Sterile heads densely spicate, closely sessile; the involucre turbinate and half-truncate, the inner margin bearing a large lanceolate-acuminate hispid lobe, which by the deflexion of the head is strongly recurved and partly covers the orifice of the involucre, the bractless spike thus appearing as if retrorsely bracteate; fertile heads commonly solitary in axils below: leaves closely sessile by partly clasping base.

A. bidentáta, Micnx. Roughish-hirsute annual, 1 to 3 feet high, fastigiately branched above, very leafy up to the stout (span long) spikes: leaves mostly alternate, lanceolate, commonly with an acute lobe or tooth on each side near the broad base, thence tapering gradually to.a point, usually entire: fertile involucre in fruit oblong, somewhat prismatic, the 4 strong angles or ribs terminating in acute strong spines of half the length of the spinelike beak: sterile heads about 10 -flowered. -Fl. ii. 182 ; Pursh, Fl. ii. 581 ; Torr. \& Gray, Fl. ii. 292. - Prairies and alluvial ground, Hlinois and Missouri to Texas. (Adj. Mex.)

§2. Ambrosia proper. Sterile heads racemose or spicate: sterile involucre commonly saucer-shaped or open-campanulate, with a several-toothed or truncate border : fertile flowers usually glomerate in axils below.

* Involucre of sterile heads unilaterally 3-ribbed: no chaff on the receptacle: Ieaves palmately eleft, ample, petioled.

A. trífida, L. Tall and stout annual, 3 to 12 feet high, or even higher, roughish-hispidulous, or partly hispid or hirsute, sometimes almost glabrous: leaves all opposite, very deeply 3-lobed or the Iower 5-lobed; the lobes ovate-lanceolate, acuminate, serrate (in the larger leaves a span or more in length); petioles of the upper commonly wing-margined: sterile racemes long and dense : fertile heads clustered and as if involucrate by short bracts : fruit (matured fertile involucre) very thick and indurated, 4 or 5 lines long, obovoid-turbinate or obpyramidal, with 5 or sometimes 6 or 7 strong ribs or angles terminating above in spinous tubercles around the base of the conical beak. - Spec. ii. 987 (Moris. Hist. iii. sect. 6, t. 1, f. 4); Michx. l. c.; DC. Prodr. r. 527 ; Torr. \& Gray, l. c. - Moist alluvial banks of streams, Canada and Saskatchewan to Florida, Missouri, Nebraska, \&c.

Var. integrifólia, TorR. \& GRAY, 1. c. A depauperate form, with oblong or ofallanceolate undivided leaves, and mostly solitary sterile racemes: spinous tubercles of the fruit less developed. - A. integrifolia, Muhl. in Willd. Spec. iv. 375. - New York to Illinois and Virginia.

A. áptera, DC. Very like the preceding, equally tall : petioles not margined; larger leaves commonly 5-lobed, and the middle lobe often 3-cleft: sterile racemes more numerous and paniculate : fruit smaller, 2 or 3 lines long, more obovoid, 4-8-ribbed, and with 4 to 6 short or obsolete tubercles. - Prodr. v. 527; Gray, Pl. Lindh. ii. 226. A. trifida, var. Texana, Scheele in Linn. xxii. 156. - Low grounds, Texas to New Mexico and S. W. Arizona ; first coll. by Berlandier.

* * Inrolucre of sterile heads not costate, indistinctly radiate-veined: receptacle with some filiform or sometimes mere dilated chaff: leares opposite and alternate (in the adjacent Mexican A. cheiranthifolia, Gray, Bot. Mex. Bound. 87, entire and canescent), mostly 1-3-pinnatifid or dissected.

A. artemisiæfólia, L. (Roman Wormwood, Ragweed, Bitter Weed.) Annual, variously pubescent or hirsute, paniculately branched, a foot or two high, sometimes taller: leaves thinnish, bipinnatifid or pinnately parted with the divisions irregularly pinnatifid or sometimes nearly entire, on the flowering branches often undivided: sterile heads more or less pedicelled: fruit not 2 lines long, short-beaked, armed with 4 to 6 short acute teeth or spines. (Varies much, occasionally the sterile inflorescence abnormally fertile.) - Torr. \& Gray, Fl. ii. 291. A. artemisiafolia \& A. elatior, L. Spec. 987, 988. A. absynthifolia \& A. paniculata, Michx. Fl. ii. 183. A. heterophylla, Muhl. in Willd. Spec. iv. 378. Iva monophylla, Walt. Car. 232. - Dry ground, a weed of cultivated and waste grounds, Nova Scotia to Saskatchewan, Texas, California, and Washington Terr. (W. Ind. \& Mex. to Brazil.)

A. longístylis, Nutr. Trans. Am. Phil. Soc. I. c. 344, - known only from Nuttall's specimen from "Rocky Mountains," described as having pinnatifid leaves, and conglomerate fertile flowers with styles about an inch long, - needs verification. 
A. híspida, Pursit. Perennial, spreading from a suffrutescent base, strigose-hispidulous or hispid and hirsute: leaves all petioled, twice and thrice pinnatifid or interruptedly pinnately divided into numerous short and small oblong ultimate lobes: sterile raceme commonly solitary and elongated: fruit with a stout short beak and commonly 4 short acute tubercles. - Fl. ii. 743, the original in herb. Sherard was probably from Bahamas. A. crithmifolia, DC. Prodr. v. 525; Torr. \& Gray, 1. c. - Sandy sea-shore, Florida. (W. Ind.)

A. psilostáchya, DC. Perennial from slender running rootstocks, stouter than A. artemisicfolia, 2 to 6 feet high, with strigose and some loose hirsute pubescence: leaves thickish; upper simply and lower twice pinnatifid; the lobes mostly lanceolate and acute: sterile heads commonly short-pedicelled: fruit mostly solitary in the axils below, turgid-obovoid, less than 2 lines long, rugose-reticulated, obtusely short-pointed, either wholly unarmed or (sometimes on the same plant) with four short either blunt or acute tubercles. - Prodr. v. 526; Gray, Pl. Wright. ii. 86, \& Bot. Calif. i. 34t. A. Peruviana, DC. 1. c, as to pl. Mex., hardly of Willd. A. coronopifolia, Torr. \& Gray, Fl. ii. 291. A. Lindheimeriana \& A. glandulosa, Scheele in Linn. xxii. 156, 158. - Moist prairies and beds of streams, Illinois and Saskatchewan to Texas, Arizona, and California. (Mex.)

A. púmila, Gray. Perennial, a span or two high from slender running rootstocks, canescent throughout with a dense and close silky pubescence, very leafy: leaves nearly all alternate and long-petioled, 2-3-pinnately parted into linear-oblong crowded lobes: sterile heads in a short spike: fruit obovoid, pubescent, muticous, a line long (rarely two are connate at base). - Proc. Am. Acad. xvii. 217. Franseria pumila, Nutt. Trans. Am. Phil. Soc. l. c. 344 ; Gray, Bot. Calif. i. 345, ii. 615. Hemiambrosia, Delpino, Stud. Comp. Artemis. 57. San Diego, California, Nuttall, \&c., recently coll. by Cleveland in fruit.

82. FRANSÉRIA, Cav. (Ant. Franser, a physician and botanist in Madrid in the time of Cavanilles.) - Herbs or shrubby plants (all American); with chiefly alternate leaves, some species with habit of Ambrosia and near it in character, others with the fruiting involucre nearly that of Xanthium. - Cav. Ic. ii. 78, t. 200 ; Willd. Hort. Berol. i. t. 2; DC. Prodr. v. 224; Torr. \& Gray, Fl. ii. 292. Franseria, Hemixanthidium, \& Xanthidium, Delpino, Stud. Comp. Artemis. 58-67.

$\S 1$. Spines of the fruiting and 1-2-flowered involucre comparatively few, conical, subulate, or flattened with the inner face more or less concave, usually straight or merely incurved. - $\$$ Acantholana, DC.

* Herbaceous perennial: fruiting involucre seldom over a line long, in the same plant bearing either one or two flowers.

F. tenuifólia, GraY. Erect, 1 to 5 feet high, leafy to the top, hispid, variously pubescent, or glabrate: leaves mostly 2-3-pinnately parted or dissected into narrowly oblong or linear lobes, and the narrow primary rhachis often with some interposed small lobes, the terminal elongated : sterile racemes commonly elongated and paniculate: fertile heads in numerous glomerules below, in fruit minutely glandular, usually 2-flowered, obovate with narrow obpyramidal base, armed with 6 to 18 short and stout incurving spines, their tips almost always hooked, and an excavated cartilaginonsly bordered areola above each. (Larger leaves often 5 inches long or more.) - Pl. Fendl. 80, Pl. Wright. i. 104 (var. tripinnatifida), Bot. Mex. Bound. 87, \& Bot. Calif. i. 346. Ambrosia longistylis, Gray, Pl. Fendl. 79, as to no, 407, perhaps of Nutt. Ambrosia tenuifolia, Spreng. Syst. iii. 851? A. confertifora \& A. fruticosa (excl. var.), DC. Prodr. v. 525, 526. Xanthidium tenuifolium, Delpino, 1. c. 62. - Moist grounds, from Texas to N. Colorado, S. California, and southward. (Mex., Hawaii, \&c.)

* * Herbaceous, with fruiting involucre 3 or 4 lines long at maturity, and longer stout or broad spines: stems low.

F. Hookeriána, Nurr. Diffusely spreading from an annual (or perennial?) root, freely branched, hirsute-pubescent or hispid, sometimes canescent with strigose-sericeous pubescence when young : leaves of ovate or roundish circumscription ( 1 to 3 inches broad) and bipinnatifid, or the upper oblong and pinnatifid: sterile racemes solitary or paniculate : fruit- 
ing involucre armed with flat and thin lanceolate-subulate smooth and glabrous long and straight spines, seemingly always 1-flowered. - Torr. \& Gray, Fl. ii. 294. F. Houkeriana \& montana, Nutt. 1. c. Hemixanthidium, Delpino, 1. c. 60. Ambrosia acanthicarpa, Hook. Fl. i. 309. - Plains and along streams, Saskatchewan to Washington Terr., California, Arizona, and W. Texas.

F. bipinnatifida, Nutr. Procumbent, with stems 2 or 3 feet long from a perennial root, somewhat hirsute: leaves of ovate circumscription (an inch or two long), 2-3-pinnately parted into oblong-linear divisions and small oblong lobes, canescent with soft tomentum or fine hirsute-sericeous pubescence: sterile spike or raceme dense, of rather large heads: fraiting involucre ovate-fusiform, armed with rather short and thick but flattish tuberculelike spines, their acute tips sometimes incurving. - Trans. Am. Plil. Sòc. vii. 507; Torr. \& Gray, l. c. F. Lessingii, Walp. Rel. Meyen. 268. - Sands of the sea-coast, Washington Terr. to S. California.

F. Chamissónis, Less. Leares cuneate-oborate or oblong-orate with a cuneate base, 3-5-nerred at base, obtusel5 serrate, the lower often laciniate-incised; otherwise as the preceding, or the 2-flowered fruiting involucre rather thicker, the spines broader and more canaliculate. - Torr. \& Gray, 1. c. (with var. cuneifolia); Gray, Bot. Cal. i. 345. F. Chamissonis, var. malvafolia, Less. in Linn. vi. 507; DC. 1. c. F. cuneifolia, Nutt. 1. c. - Sandy seabeaches, Brit. Columbia to California.

F. díscolor, Nuтr. 1. c. A foot or less high, erect from perennial slender creeping rootstacks: leaves canescently tomentose beneath, green and glabrate above, interruptedly bipinnatifid, oblong in outline, comparatively large (the lowest often 6 inches long); the lobes usually short and broad: sterile racemes commonly solitary: fruiting involucre ovoid, 2-flowered, canescent, armed with rather short conical-subulate very acute and straight spines. - Torr. \& Gray, 1. c. From station and char. probably Ambrosia tomentosa, Nutt. Gen. ii. 186. Xanthidium discolor, Delpino, 1. c.-Plains, \&c., Nebraska to Wyoming, Colorado, and New Mexico.

F. tomentósa, Gray. A foot high, rather stout, erect from an apparently perennial base or rootstock, canescent with a dense sericeous tomentum: leaves very white beneath, cinereous above, pinnately 3-5-cleft or parted ; the terminal division large, oblong or broadly lanceolate, serrate; upper lateral similar but smaller; lowest commonly very small and entire: fruiting involucre 3 lines long, turgid-ovoid, 2-flowered, nearly glabrous; the short spines conical-subulate, very acute, and the very tip usually uncinate-incurved. - P1. Fendl. 80, \& Pacif. R. Rep. iv. 102. - Along streams or river-beds, Kansas and E. Colorado, Fendler, Bigelow, Hall.

* * * Shrubby, low (1 to 3 feet high), much branched, canescent with a fine and close white tomentum, which is sometimes partly deciduous with age: sterile heads and fertile glomerules not rarely intermixed in short racemes or clusters.

* Fruiting involucre mostly 2-flowered, smooth and glabrous, or barely puberulent; its spines flattened and dilated at base, mostly straight-pointed.

F. dumósa, GRAY. Divergently much branched, very canescent : leaves small, 1-3-pinnately parted into oblong or roundish (1 or 2 lines long) obtuse lobes: fertile involucre globular; its spines long, tapering from a broadish flat base to a slender aristiform point. - Frem. 2d Rep. 316, Bot. Mex. Bound. 86, \& Bot. Calif. i. 345. F. albicaulis, Torr. Pl. Frem. 16. Arid region, from S. E. California to S. Utah and S. Axizona; first coll. by Coulter.

F. deltoídea, Torr. Somewhat less woody, and less densely canescent-tomentulose: branches erect or spreading; leaves all undivided, from rhomboid-ovato or oblong to deltoid or obscurely hastate, minutely and often cloubly crenate-serrate, an inch or less long, rather slender-petioled: fruiting involucre of the preceding, but the spines shorter and broader, flatter, lanceolate-subulate.-P1. Frem. 15; Bot. Mex. Bound. 87 ; Bot. Calif. 1. c. - Xanthidium rhombophyllum, Delpino, 1. c. ? - Arid regions of Arizona, and perhaps adjacent part of California, Fremont, Parry, Schott, Palmer, \&c. (Can hardly be F. chenopodiifolia, Benth., of Lower California.)

++ Fruiting involucre only one-flowered, villous-lanate!

F. eriocéntra, GRAX. Rigidly much branched, canescent with very minute tomentum: leaves soon green and glabrate above, cuneate-oblong to lanceolate, from sinuately few-toothed or lobed to sparingly and irregularly laciniate-pinnatifid, ncarly sessilo ly astenuate base: 
fruiting involucre with single subulate beak as long as the body, the latter bearing about 10 rather long rigid subulate-acerose spines, these nearly equalled by the long whitish wool. Proc. Am. Acad. vii. 355, \& Bot. Calif. ii. 345. Here also belongs the flowerless specimen coll. by Newberry, mentioned under $F$. artemisioides in the Colorado Expedition of Ives; and this is probably the nearest relative of $F$. chenopodiifolia, Benth. - Arid region, S. E. California and adjacent Nevada, Cooper, Newberry. Arizona and S. Ltah, Parry, Palmer, Lemmon.

§ 2. Spines of the larger and 2-4- (commonly 3-) flowered involucre very numerous, comparatively slender, and conspicuously uncinate-tipped in the manner of Xanthium. (But the S. American F'. artemisioides has stout spines.) $\S$ Xanthiopsis, DC. l. c.

F. ambrosioídes, CAv. Shrubby, 4 or 5 feet high, cinereous-pubescent: leaves rather long-petioled, oblong-lanceolate, mostly truncate or subcordate at base, acuminate, irregularly dentate or serrate, 2 to 4 inches long; petiole naked : fruit ovoid, nearly half-inch and slender prickles 2 lines long. - Ic. ii. 79, t. 200 (excl. syn.); Gray, Bot. Calif. i. 346. Xanthidium ambrosioides, Delpino, Stud. Comp. Artemis. 63.-Arizona, Bigelow, Palmer, Pringle, \&c. (Lower Calif., Mex.)

F. ilicifólia, Gray. Shrubby, at least the branches hirsute, very leafy: leaves rigidly coriaceous, scabrous, reticulate-veiny, sessile, somewhat clasping, oblong-ovate, coarsely dentate, the teeth and apex spinose: heads ovoid, those seen only 2-celled. - Proc. Am. Acad. xi. 77. - Cañons beyond the southern border of San Diego Co., California, Palmer. Gila Desert, Arizona, Lemmon, foliage only.

83. XÁNThIUIM, Tourn. Cockle-Bur, Clot-Bdr. (Old Greek name of some plant the fruit of which, in the time of Dioscorides, was used to dye the hair yellow.) - Coarse annuals, chiefly American, of the warmer region, but now widely dispersed weeds; with branching stems, alternate and usually lobed or toothed leaves, and mostly clustered heads of greenish or yellowish flowers, in terminal and larger axillary clusters of both sexes, the male uppermost; the lower of few or solitary female heads in axils of leaves: $f$. summer and autumn. - Gærtn. Fruct. t. 164 ; Schkuhr, Handb. t. 291 ; Benth. \& Hook. Gen. ii. 355 .

$\S 1$. Leaves cordate or ovate, 3-ribbed from the base, with dentate margins and often incised or lobed, on long petioles: axils unarmed: fruiting involucre with two prominent indurated beaks. - $\$$ Euxanthium, DC. Prodr. v. 523. - Perhaps all derivatives of a single species.

X. STRUMARIUM, L. A foot or two high: fruiting involucre half to two-thirds inch long, glabrous or puberulent; the beaks straight and rarely at all hooked at maturity, and spines rather slender. - Spec. ed. 2, ii. 1400; Fl. Dan. t. 270; Schkuhr, Handb. t. 291. - A weed of barnyards and in cult. grounds. (Sparingly nat. from Eu.? or Ind.?)

X. Canádense, MrLL. Stouter: stem often punctate with brown spots : fruiting involucre about an inch long, densely beset with rather long prickles, the stout beaks at maturity usually hooked at the tip or incurved, the surface and base of the prickles more or less hispid, sometimes glabrate. - Dict. ed. 8, first after L. Spec. $X$. majus Canadense, Herm. Lugd. 635. X. elatius Americanum, etc., Moris. Hist. iii. 604, sect. 15, t. 2, fig. 2. X. Carolinense, etc., Dill. Elth. ii. 432, t. $231 . \quad X$. orientale, L. I. c., in part. $X$. Americanum, Walt. Car. 231. X. macrocarpum, var. glabratum, DC. Prodr. 1. c. X. $\bar{X}$ strumarium, var. Canadense, Torr. \& Gray, FI. ii. 294. - Alluvial shores and waste grounds, from Texas to Saskatchewan, Nevada, and California : perhaps extended northward by man's indirect agency. In brackish soil it becomes

Var. echinátum. A form, usually dwarf, with still denser and longer prickles, these conspicuously hirsute or hispid. $-X$. echinatum, Murr. Comm. Goett. vi. 32, t. 4 ; Torr. \& Gray, Fl. ii. 294. $X$. maculatum, Raf. in Am. Jour. Sci. i. 151. $X$. macrocarpum, DC. Fl. Fr. Suppl. 356, \& Prodr. l. c. Sandy sea-shores and on the Great Lakes. (S. Am.) 
§ 2. Leaves attenuate to both ends and short-petioled; their axils triply spiniferous. - $\$$ Acanthoxanthium, DC.

X. spinósum, L. A foot or two high, much branched: leaves ovate-lanceolate with cuneate base, the larger 3-lobed or incisely pinnatifid, glabrate and green above, white-tomentose beneath: axils bearing long and slender 3-parted yellow spines: fertile involucres solitary or few in upper axils, cylindraceous, half-inch long, obtuse, armed with short weak prickles, inconspicuously 1-2-beaked or pointless. - Lam. Ill. t. 655, f. 4 ; DC. 1. c. - A weed of S. Atlantic States and Pacific coasts, occasionally about seaports northward to Massachusetts. (Nat. from Trop. Am.)

84. ZINNIA, L. (Dr. J. G. Zinn, of Göttingen, who figured the original species as a Rudbeckia.) - American, chiefly Mexican, herbs or suffruticulose plants; with opposite and mostly sessile entire leaves, single heads terminating the branches, and showy flowers, the bright-colored rays long enduring: fl. summer. - Gen. ed. 6, 437; Gærtn. Fruct.t. 172; Gray, Pl. Wright. i. 105. Zinnia \& Diplothrix, DC. Prodr. v. 534, 611.

§ 1. Euzínnia. Herbs, mostly anņual (some species perennial) : leaves from ovate to linear : ray-flowers several or numerous, usually without pappus. - Pl. Wright. 1. c.

Z. pauciflóra, L. Erect annual : leaves from lanceolate to oblong-ovate, commonly with subcordate base, scabrous: peduncle sometimes enlarging and hollow: involucre narrowcampanulate: ligules from obovate to narrowly spatulate, red, purple, or yellow: akenes of the disk 1-awned, sometimes with a rudiment of a second awn or tooth. - Webb, Spic. Gorg. 141. Z. pauciflora \& Z. multiflora, L. Spec. ed. 2, 1269 (L. f. Dec. t. 12). Z. tenuiflora, Jacq. Ic. Rar. t. 590, with narrow ligules. Z. revoluta, Cav. Ic. iii. 25I. Z. leptopoda \& probably Z. bicuspis, DC. Prodr. v. 535. Z. intermedia, Engelm. Bot. Wisliz. 23. - Louisiana to Texas, but probably introduced, Arizona, apparently indigenous. (Mex., S. Am., and now widely dispersed.)

§ 2. Drplóthrix. Suffruticulose and tufted perennials: leaves narrow and rigid, connate-sessile, usually crowded: ray-flowers commonly few, and their akenes 2-4-aristate: head conspicuously pedunculate only in $Z$. juniperifolia. P1. Wright. l. c. Diplothrix, DC.

* Ligules shorter than or little surpassing the disk, sometimes wanting: stems mainly herbaceous. -\$ Heterogyne, Gray, Pl. Wright. l. c.

Z. anómala, GrAy. Scabrous-hispid: stems or branches very numerous from a ligneous base and root, 4 to 8 inches high: leaves linear (half-inch to inch long, less than 2 lines wide), one-nerved, obscurely 3-nerved at base: peduncle shorter than the uppermost leaves: involucre oblong or campanulate (half-inch long): ligules 4 to 6 , oval or oblong, 1 to 3 lines long, yellow or orange, occasionally the whole corolla wanting; hispid style-branches of the disk-flowers acuminate-subulate. - Pl. Wright. i. 106, t. 10, \& ii. 86. - S. W. Texas, Wright. (Mex. near Saltillo, Palmer, with broader involucre.)

* Ligules (4 or 5) ample, dilated-obovate or roundish, at maturity much surpassing the disk, light yellow or sulphur-color, becoming white in age: involucre narrow: stems or branches a span or more high from the stout woody base or branching caudex.

Z. grandiflóra, Nттт. Scabro-hispidulous: leaves linear, 3-nerved at base: involucre usually 4 lines long: ligules at maturity 5 to 8 lines long: style-branches of the disk-flowers attenuate-subulate. - Trans. Am. Phil. Soc. n. ser. vii. 348; Torr. \& Gray, Fl. ii. 298; Torr. in Emory Rep. t. 4 (style incorrect); Gray, 1. c. - Plains and bluffs, E. Colorado to S. W. Texas and Arizona.

Z. púmila, GRAT. Cinereous-puberulent: leaves very narrowly linear (hardly half-line wide, half-inch or less long), one-nerved : involucre 2 or 3 lines long, and ligules 2 to 4 lines: style-branches of disk-flowers with short triangular-subulate tips. - Pl. Fendl. 81, Pl. Wright. 1. c. - High plains and table-lands, S. W. Texas to Arizona. (Adj. Mex.) 
Z. acerósa, Gray. Cinereous-pubescent or glabrate : leaves acerose-filiform, very obscurely one-nerved, half-inch or more long: ligules 3 to 6 lines long: style-branches with subulateovate tips. - Pl. Wright. 1. c. Diplothrix acerosa, DC. Prodr. v. 611.-Hills, S. W. Texas, Wright. (Adj. Mex.)

85. SANVITÁLIA, Lam. (Sanvitali, name of a noble Italian family.) - Mostly low and branching herbs, of Mexico and its border; with opposite and more or less petioled leaves, almost always entire, and rather small heads terminating the branches, ours and most of the species annuals. - Jour. Hist. Nat. ii. (1792), 176, t. 33 ; Ill. t. 686 ; Cav. Ic. iv. 31 , t. 351 ; DC. Prodr. v. 628. Lorentea, Ort. Dec. iv. 42 , t. 5 .

$\S 1$. Involucre of 2 or 3 series of bracts, their tips commonly herbaceous: fructiferous receptacle from flat to strongly conical; its chaffy bracts soft or shorter than the flowers: disk commonly dark purple or brownish: rays yellow or turning whitish in age: ray-akenes mostly triangular; the comparative smoothness, granulation, or murication of disk-akenes inconstant.

S. ocymoídes, DC. A span or two high, diffusely spreading, hispidulous or hirsute: leaves oval, obtuse, abruptly contracted into the petiole: ligules shorter than the akene and shorter than the three slender-subulate diverging awns: disk-akenes all wingless, quadran. gular-compressed, sometimes 1-2-awned. - S. ocymoides \& $S$. tragicefolia, DC. 1. c. - South. ernmost border of Texas on the Rio Grande, Berlandier, Schott. (Adj. Mex.)

S. procúmbens, Lam. 1. c. (S. villosa, Cav. Ic. 1. c.), a Mexican species not uncommon in cultivation, has conspicuous ligules much exceeding the awns at their base, and flattened diskakenes, some of them winged and 1-2-aristellate, some not; and the receptacle, at first barely convex, may become even acutely conical in age. S. acinifolia, DC. 1. c., appears to be only a form of it.

S. ANG USTIFólia, Engelm. in Gray, Pl. Wright. i. 112, of Northern Mexico, has similar alsenes and similar receptacle, but rays nearly as short as those of S. ocymoides; the chaff of the receptacle disposed to be rigid-tipped as in the following.

$\S 2$. Involucre a single series of dry bracts: fructiferous receptacle strongly and acutely conical; its chaffy bracts conspicuous and with rigid cuspidate tips: rays white: disk pale: leaves rarely denticulate.

S. Abérti, GraY. Erect, at length a foot high, with ascending branches, minutely pubescent or hispidulous, glabraté : leaves lanceolate or nearly linear, 3-nerved, narrowed into a margined petiole: rays 1 to 3 lines long: akenes all corky-thickened; those of the ray almost terete, narrowly 4-sulcate, bearing 3 very short and stout nearly conical awns or tubercles; of the disk compressed-quadrangular, wingless, awnless, or sometimes minutely uniaristellate. - Pl. Fendl. 87, \& Pl. Wright. i. 111. - S. W. Texas, New Mexico, and S. Arizona.

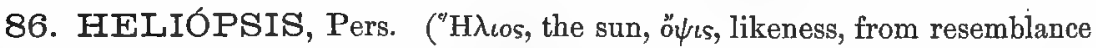
to the Sunflower.) - American perennials (or a Mexican and South American species annual); with loosely branching stems, ovate or oblong and veiny mostly serrate 3-ribbed or triple-ribbed leaves, on naked petioles, and pedunculate showy heads; the rather numerous rays yellow, and the disk yellowish. FI. summer and autumn. - Syn. ii. 473; Torr. \& Gray, Fl. ii. 302 ; Benth. \& Hook. Gen. ii. 358 .

H. læevis, Pers. Smooth and glabrous or nearly so throughout, 3 or 4 feet high : leaves bright green, thinnish, oblong-ovate or ovate-lanceolate from a truncate or slightly cuneate. decurrent base, acuminate, coarsely and sharply serrate with numerous teeth (3 to 5 inches long): heads somewhat corymbose : rays broadly linear, an inch long, at length marcescent and decaying away: akenes wholly glabrous and smooth, the summit wholly truncate or obscurely 2-4-toothed. - Pursh, Fl. ii. 563; Dunal, Mem. Mus. v. 55; Hook. Bot. Mag. t. 3372; 
Torr. \& Gray, 1. c., excl. vars.; Meehan, Nat. Flowers, ser. 2, ii. 42. Buphthalmum helianthoides, L. Hort. Ups., \& Spec. ii. 904 ; Michx. Fl. ii. 130; L'Her. Stirp. t. 45. Silphium helianthoides, L. Spec. ii. 920, pl. Gronov. S. solidaginoides, L. Spec. 1. c. Rudbeckia oppositifolia, L. Spec. 1. c. 907, pl. Gronov. Helianthus lavis, L. Spec. ed. 2, 1278, excl. syn. Gronov, which is Bidens chrysanthemoides. Helepta grandiflora, \&c., Raf. Neog. - Dry or moist ground, Canada to Florida.

H. scábra, Duxal. Hispidulous-scabrous, especially the leaves, 2 to 4 feet high: leaves from broadiy ovate and subcordate to ovate-lanceolate, the upper occasionally entire: rays oblong, nearly or quite an inch in length: akenes smooth, but the angles above pubescent when young, the summit usually bearing an obscure or evident and irregular coroniform chaffy pappus, or sometimes 2 or 3 conspicuous and rigid teeth! Otherwise as in the foregoing, into which it may pass. - Mem. Mus. l. c. 56, t. 4; Hook. Fl. i. 310 ; DC. Prodr. v. 550, excl. syn. H. canescens, Don. H. lavis, var. scabra, Torr. \& Gray, Fl. ii. 303.W. New York to Saskatchewan, Missouri, and Arkansas.

H. grácilis, Nutr. Slender, a foot or two high: leaves ovate-lanceolate to lanceolate (2 or 3 inches long), and with somewhat cuneate base, hispidulous-scabrous or almost smooth: heads very much smaller, barely 3 or 4 lines high, and the fewer (5 to 10) rays 5 to 8 lines long: akenes of $H$. scabra. - Trans. Am. Phil. Soc. n. ser. vii. 353. H. loevis, var, minor, Hook. Comp. Bot. Mag. i. 98. H. leveis, var. gracilis, Torr. \& Gray, Fl. ii. 303.- Dry and shaded ground, Georgia and W. Florida to Louisiana and Arkansas, Gates \& Jewett, Drummond, Curtiss, \&c.

H. parvifólia, GRAY. Slender, a foot or two high, from cinereous-puberulent and somewhat scabrous to nearly glabrous and green: leaves deltoid-lanceolate or rhomboid-lanceolate or approaching deltoid-ovate, irregularly dentate with few or several teeth, or some entire, an inch or two long: head barely half-inch high: rays oval or oblong, half or two-thirds inch long: akenes glabrous but dull and rugulose-scabrous, the summit evenly truncate. Pl. Wright. ii. 86; Rothr. in Wheeler Rep. vi. 159. H. buphthalmoides, Gray in Bot. Mex. Bonnd. 88, not Dunal. - Cañons and beds of streams, Arizona, Wright, Thurber, \&c. (Lower Cal. \& adj. Mex.)

H. вuphthalmof́des, Dunal, of Mexico and S. America, and H. Ansua, Hemsley (which may be the $H$. canescens, HBK., that being said to have an annual root, as has Parry \& Palmer's no. 431), have puberulent or papillose-pubescent akenes.

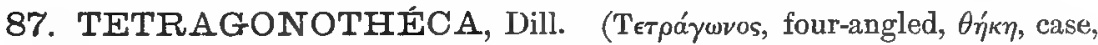
i. e. involucre.) - Erect perennial herbs, all N. American, with striate stems; the leaves all opposite, mostly sessile or connate-amplexicaul, thinnish, dentate or sinuate-pinnatifid; heads rather large, on slender peduncles terminating the stem or branches; both disk- and ray-corollas light yellow, nervose (the ligules 5 to 10 -nerved, and the usual 5 nerves of the throat of the disk-corollas not rarely doubled), marcescent and persisting almost to the maturity of the akenes. Fl. summer. - Dill. Elth. ii. 378, t. 283; Linn.; Benth. \& Mook. Gen. ii. 367. Tetragonotheca \& Halea, Torr. \& Gray, Fl. ii. 303, 304.

$\S 1$. Akenes very thick, obscurely 4-sided or almost terete, wholly destitute of pappus : tube of the corolla villous below: stem simple : involucre very saliently 4-angled in the bud.

T. heliánthoides, L. Villous with somewhat viscid hairs: stem a foot or two high : leaves ovate or rhomboid-oblong, closely sessile by a narrow base, dentate, 4 to 6 inches long: lubes of the involucre and 6 to 9 rays about an inch long. - Spec. ii. 903; DC. Prodr. v. 552; Torr. \& Gray, 1. c. Polymnia Tetragonotheca, L. Syst.; Abbot, Ins. \& P1. Georg. ii. t. 69; Schkuhr, Handb. t. 263. Silphium Tetragonotheca, Gærtn. Fruct. t. 171.-Dry ground, Virginia to Florida.

§ 2. Akenes distinctly 4-sided and the sides striate (somewhat pubescent), moderately narrowed from the truncate summit to base: pappus plurisquamellate 
or sometimes wanting: stems more branching: involucre ovoid and less angled in the bud. - Halea, Torr. \& Gray, l. c.

T. Texána, Gray \& Engelm. Minutely pubescent or glabrate: stems slender, a foot or two high, sometimes freely branched: cauline leaves laciniately pinnatifid or incised, 2 or 3 inches long; the lower tapering into margined connate petioles; upper with winged petioles or bases dilated at insertion and usually connate around the stem into a toothed disk: peduncles elongated ( 4 to 9 inches Iong): lobes of the involucre and 7 to 9 rays half-inch long: tube of the corollas glandular: pappos none, or very minute, or sometimes of numerous subulate squamellæ of length nearly equalling the breadth of the akene. - Proc. Am. Acad. i. 48. Halea Texana, Gray, Pl. Fendl. 83, \& Pl. Lindh. ii. 227. Tetragonosperma lyratifolium, Scheele in Linn. xxii. 167. - Rocky ground, Texas, Lindheimer, Wright, \&c." (Adj. Mex., Berlandier, Palmer.)

T. Ludoviciána, Grar. Glabrous or nearly so: stem rather stout, 2 to 4 feet high, usually leafy to the top: leaves ovate or oblong, ample (the larger 4 to 7 inches long), saliently and acutely dentate, the lowest on winged petioles, upper all connate by mostly broad bases into a large perfoliate disk: peduncles mostly longer than the leaves: corollas with tube somewhat pubescent: ligules 10 to 12, oval, less than half-inch long: akenes (over 2 lines long) crowned with a conspicuous pappus of rigid oval or oblong chaffy scales in length equalling the breadth of the truncate summit. - E. Hall, List Pl. Tex. 13, no. 328. Halea Ludoviciana, Torr. \& Gray, 1. c. - Sandy soil, Louisiana (Hale, Leavenworth) \& Texas.

Var. repánda. Depauperate or dwarf form; flowering sometimes from near the ground; the leaves therefore petioled, and the upper with perfoliate disk of united bases of the petioles, nearly as in $T$. Texana: peduncles elongated as in that species; so that it is as it were intermediate between the two. - Halea repanda, Buckley in Proc. Acad. Philad. 1861, 458. - Texas, near Corpus Christi, Buckley. W. of San Antonio, Palmer; an alltumnal state, flowering as seedlings.

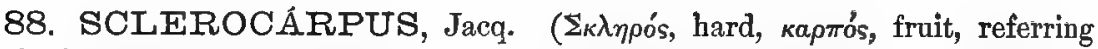
to the indurating enclosing bracts.) - Strigose-pubescent herbs (the original species African, the others mostly Mexican); with branching stems, terminal pedunculate heads of yellow flowers, and alternate or opposite leaves: fl. summer. - Act. Helv. ix. 34, t. 2, \& Ic. Rar. t. 176; Benth. \& Hook. Gen. ii. 364 . Aldama, Llav. \& Lex. Nov. Gen. Descr. i. 14. Gymnopsis, DC. Prodr. v. 561, in part.

S. uniseriális, Benтr. \& Ноoк. 1. c. Annual, a foot or two high, loosely branched: leares all alternate, slender-petioled, deltoid- or rhombic-ovate, or uppermost lanceolate, coarsely dentate, the strigose pubescence of the lower face canescent: loose involucral bracts nearly in a single series; corollas orange; ligules 5 to 9 , oval or oblong: fructiferous bracts cartilaginous or bony, terete, roughish, in age often tuberculate.-Gymnopsis uniserialis, Hook. Ic. t. 145; Torr. \& Gray, Fl. ii. 316 ; Revue Hort. 1853, t. 14; Belg. Horticole, 1854, t. 20. Aldama uniserialis, Gray, Pl. Lindh. ii. 228. - Moist or shady ground, Texas, Berlandier, Drummond, \&c. (Mex.)

89. ECLfPTA, L. (Name from $\epsilon^{k} \kappa \lambda \epsilon i \pi \omega$, to be deficient, i. e. in pappus.) - Insignificant herbs, of the warmer regions, chiefly of shores; with opposite leaves, and scattered small heads of whitish or yellowish flowers; in summer.Mant. Alt. 157 ; DC. Prodr. v. 489.

F. álba, Hasskart. Annual, 1 to 3 feet high, or often procumbent and smaller, minately strigose-pubescent: leaves lanceolate or oblong, sparingly serrate, sessile or the lower somewhat petioled: peduncles from the upper axils, sometimes equalling the leaves, sometimes shorter than the heads : ligules not surpassing the disk, white : akenes of the disk at length corky-margined, truncate at summit or 4-denticulate when young. - Pl. Jav. Rar. 528. E. erecta \& $E$. prostrata, L. Mant. Alt. 286. $E$. procumbens \& $E$. brachypoda, Michx. Fl. ii. 129. E. species 1-8, DC. l. c. Cotula alba, L. Syst., \& Verbesina alba, L. Spec. Eupatoriophalacron, Dill. Elth. t. 113. Amellus Carolinianus, Walt. Car. 313. - Shores and river-banks, New Jersey to Texas. (All subtropical countries.) 


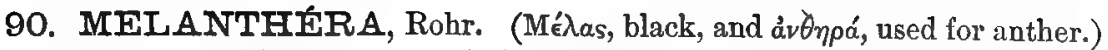
- Scabrous herbs (chiefly tropical American); with quadrangular branching stems, opposite and sometimes lobed petioled leaves, and pedunculate heads: corolla white and anthers blackish in the genuine (rayless) species. Fl. summer. - Rohr, Skriv. Nat. Selsk. Kiob. 1792, ii. 213; DC. Prodr. v. 544. Melananthera, Michx. Fl. ii. 106.

M. hastata, Michx. l. c. Stem 3 to 6 feet high from a perennial root, spotted : leaves from ovate to ovate-lanceolate, or uppermost lanceolate, some of them commonly and variously hastately 3-lobed, unequally serrate: bracts of the involucre broadly lanceolate, of the receptacle spinescently acuminate: heads in fruit half-inch in diameter. - DC. Prodr. v. 545. M. trilobata, panduraformis, \&c., Cass. Dict. xxix. 485. Bidens nivea, L. Spec. ii. 833 (Dill. Elth. t. 46, 47). Athanasia hastata, Walt. Car. 201. - Moist ground, near the coast, S. Carolina to Louisiana. (Mex., W. Ind., \&c.)

M. deltoídea, Michx. 1. c. Leaves ovate to deltoid or obscurely hastate: heads smaller: bracts of the involucre ovate, of the receptacle only mucronate.-DC. 1. c. M. urticafolia, Cass. 1. c. M. Linncei, HBK. Bidens nivea, L. I. c. as to Dill. Elth. t. 47, f. 3. Calea aspera, Jacq. Ic. Rar. t. 583. - S. Florida. (W. Ind. to S. Am.)

M. lanceoláta, Bentr. A foot or two high: leaves lanceolate (1 to 3 inches long, 2 to 5 lines wide), somewhat serrate: bracts of the involucre oblong-ovate, of the receptacle cuspidately mucronate, short: disk about 4 lines in diameter. - Vidensk. Medel. 1852-3, 88. $M$. microphylla, Steetz in Seem. Bot. Herald, I56 (same year?). M. angustifolia, A. Rich. ex Griseb. Cat. Cub. 154. - S. Florida, Garber, \&c. (W. Ind., Centr. Am.)

91. VARILLA, Gray. (Native Mexican name of this and some similar plants.) - Shrubby or suffrutescent, glabrous ; with linear and narrow entire and sessile thickish or fleshy leaves, and pedunculate rather small heads, either corymbosely cymose or solitary; the flowers yellow. - Pl. Fendl. 106, \& Pl. Wright. i. 123. - Two known species.

V. Mexicána, Gray, l. c. Shrub about 5 feet high, much branched : branches very leafy, terminated by a cyme of numerous short-peduncled heads : leaves not succulent, linear ( 1 to 3 inches long, at most 2 lines wide), attenuate to both ends, opposite : involucre somewhat turbinate, 2 lines long, half the length of the rather narrow head: pappus of 5 to 10 or 15 slender short bristles (which commonly bear 3 or 4 salient setulose denticulations), somewhat irregular, in length fully equal to the diameter of the akene. - Coahuila, near Parras, Gregg, Wislizenus, Palmer, \&c., not yet found within U. S. (Mex.)

V. Texána, Gray. Low, suffrutescent, much branched and very leafy at base: leaves very succulent, terete, mostly alternate, obtuse: head larger, solitary on a long terminal and minutely bracteate peduncle: involucre not turbinate, very much shorter than the broadly ovoid conical disk : pappus none. - Pl. Wright. i. 103. - Saline soil, from the Nueces to the Rio Grande, S. Texas, Wright, Trecul, Bigelow, Palmer. (Adj. Mex.)

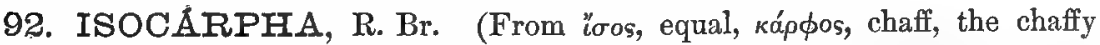
bracts of the receptacle and of the involucre similar.) - Tropical American herbs; with small heads of white or whitish flowers, either solitary or glomerate at the summit of a naked peduncle. - Trans. Linn. Soc. xii. 110; Benth. \& Hook. Gen. ii. 365. Dunantia, DC. Prodr. จ. 626.

I. oppositifólia, R. BR. 1. c. Pubescent: stems slender, 1 to 3 feet high from a perennial (?) root, paniculately branched: leaves opposite, lanceolate, narrowed to both ends, triplinerved, entire or sparingly denticulate: heads commonly in threes, in fruit 4 or 5 lines long, narrow, with turbinate involucre : bracts of the involucre aud receptacle pointed, becoming rigid and the receptacle columnar. - Calea oppositifolia, L. Dunantia Achyranthes, DC. Prodr. v. 672; Deless. Ic. Sel. iv. t. 37. - S. borders of Texas on the Rio Grande, Schott. (Adj. Mex., W. Ind.) 


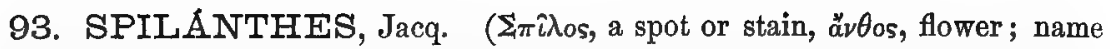
ordinarily without application.) - Usually spreading or creeping herbs (mainly tropical); with opposite and merely serrate leaves, rather small heads on peduncles terminating the stem and branches, the rays when present yellow or white, the disk-flowers yellow: herbage of some species acrid to the taste. Fl. summer. - Jacq. Amer. t. 214, Hort. Vind. t. 135, \& Ic. Rar. t. 584; Schreb. Gen. 1266; DC. Prodr. v. 620. Spilanthus, L. Mant. 475; Grertn. Fruct. ii. t. 167. - Our species is of the section Acmella, DC. (Acmella, Pers. Syn. ii. 472), having evident ligules.

S. répens, Michx. Perennial by the creeping base, slender, spreading or ascending, from hirsute-pubescent to almost glabrous: stems'slender, a foot or two long: leaves from lanceolate to oblong-ovate, an inch or two long, from sparsely denticulate to serrate, abruptly or sometimes gradually contracted at base into a petiole: peduncles 2 to 4 inches long: bracts of the involucre oblong-lanceolate, mostly obtuse : rays 8 to 12 , yellow, rather shorter than the obtusely ovoid disk - receptacle at length subulate-conical: akenes oblong, less than a line long, not flat, most of them tuberculate-roughened in age and minutely hispidnIous, the margins not more so than the sides: pappus none or occasionally one or two minute awns. - Fl, ii. 131 ; DC. Prodr. v. 623 . S. repens \& S. Nuttallii, Torr. \& Gray, Fl. ii. 356. Anthemis repens, Walt. Car. 211; Pursh, Fl. ii. 562. Acmella repens, Pers. Syn. 1. c. A. repens \& A. occidentalis, Nutt. Gen. ii. 171. - Low or wet ground, S. Carolina to Florida, Arkansas, and Texas.

94. ECHINÁCEA, Mœnch. ('Exîvos, hedgehog, or sea-urchin, in allusion to the spinescent bracts of the receptacle.) - Atlantic N. American perennial herbs; with thick and black roots of pungent taste (used in popular medicine under the name of Black Sampson), rather stout erect stems, undivided somewhat nervose leaves, the lower long-petioled, and solitary large heads on long peduncles terminating the stem and few branches; in summer. Rays from flesh-color to rose-purple or crimson, much elongating with age: disk purplish. - Meth. 591; Cass. Dict. xxxv., xlvii., \&c.; DC. Prodr. v. 554, excl. sp. Mex. Brauneria, Necker. Heliochroa, Raf. Neog. 1825, no. 35, \&c.

E. purpúrea, Mœrch. Commonly smooth and glabrous, or the leaves hispidulons and rough, sometimes the stem also hispid, 2 feet or more high: leaves ovate-lanceolate or the lower ovate from a broad base, commonly denticulate or acutely serrate, most of them abruptly contracted into a margined petiole, some of the middle occasionally opposite; lower often 3-5-plinerved involucre well imbricated: ligules (rarely almost white), at first an inch long and broadish, in age often elongated to 2 inches or more. - Torr. \& Gray, Fl. ii. 305, with varieties. E. purpurea \& E. serotina, DC. Prodr. v. 554. Rudbeckia purpurea, L. Spec. ii. 907 (Catesb. Car. t. 59 ; Pluk. Alm. t. 21, \&c.); Bot. Mag. t. 2; Schkuhr, Handb. t. 259 ; Bart. Fl. Am. Sept ii. t. 64. R. serotina, Sweet, Brit. Fl. Gard. t. 4, \& Lodd. Cab. $\checkmark$ t. 1539 (R. purpurea, var. serotina, Nutt. Gen. ii. 178), the hirsute or hispid form, which is R. hispida, Hoffm., and R. speciosa, Link. Enum., ex DC. Heliochroa Linnarana, elatior, amoena, furcata, \&c., Raf. Neog. 1. c. - Rich or deep soil, Virginia and Ohio to Illinois and Louisiana.

E. angustifólia, DC. Hispid, either sparsely or densely, a foot or two high, mostly simple: leaves from broadly lanceolate to nearly linear, entire, 3-nerved, all attenuate at base, the lower into slender petioles; bracts of the involucre in only about 2 series: heads and flowers nearly of the preceding (the fruiting disk often an inch high), or sometimes very much smaller. - Prodr. 1. c. ; Torr. \& Gray, Fl. ii. 306; Hook. Bot. Mag. t. 5281 ; Sprague, Wild Flowers of Amer. t.25. . E. pallida \& E. sanguinea, Nutt. in Trans. Am. Phil. Soc. n. ser. vii. 354. Rudbeckia pallida, Nutt. in Jour. Acad. Philad. vii. 77. - Prairies and barrens, Saskatchewan and Nebraska to Texas, and east to Illinois, Tennessee, and Alabama; in several forms; some too near the preceding. 
95. RUDBECKIA, L. Coneflower. (The two Professors Rudbeck, father and son, predecessors of Linnæus at Upsal.) - N. American herbs, chiefly perennial; with alternate leaves, either simple or compound, and commonly showy pedunculate heads terminating stem and branches; the rays yellow, rarely with brown-purple base, in one species wholly crimson, the disk from fuscous to purplish black. Fl. summer. - Gærtn. Fr. t. 172. Rudbeckia \& Dracopis, Cass. 1. c.; DC. l. c. ; Torr. \& Gray, Fl. ii. 307, 316.

$\S 1$. Ecridbéckia. Akenes prismatic-quadrangular, when laterally compressed yet with a salient angle or rib on the lateral faces: bracts persisting on the receptacle. - Rudbeckia, Cass., \&c.

* Disk from hemispherical to globose or oblong-ovoid, dark-purple (at least the corollas) or brown: akenes (not rarely becoming somewhat curved) inserted by a central or slightly oblique basal areola.

+ Leaves elongated-linear, as it were gramineous, but rigid, nervose, shining, entire: chaffy bracts of the receptacle flrm or rigid, carinate-concave, commonly mucronate from the thickish obtuse summit, rather shorter than the subtended flowers: style-tips conical-capitate: disk dark brown, globular, becoming ovoid in fruit: stems rush-like and striate, 2 feet or more high from a perennial root, bearing solitary rather small heads on long naked peduncles: rays in one species dark crimson!

R. atrórubens, Мгтт. Either glabrous or sparsely and minutely strigulose : stems rigid, nearly simple, few-leaved: leaves rather obtuse, often purplish; radical and lowest cauline often a foot long, a quarter to half an inch wide: involucre a few small subulate-linear bracts : rays 9 or more, oblong, half-inch long, dark crimson; fructiferous disk two thirds of an inch long, its receptacle fusiform-conical; its chaffy bracts thick and firm, oblong, tipped with a short rigid mucro: akenes equably quadrangular, straight and with centrally basal insertion, a line and a half long, inclnsive of the short cupulate and obscurely 4-toothed pappus.-Jour. Acad. Philad. vii. 80. Echinacea atrorubens, Nutt. Trans. Am. Phil. Soc. l. c. 354 ; Torr. \& Gray, Fl. ii. 306 (with var. graminifolia); Chapm. Fl. 226. - Borders of pine-barren ponds, Georgia and Florida, in the low country (also Arkansas, according to Nuttall), Wray, Chapman, Mohr, \&c.

R. bupleuroídes, Shutru. Perfectly glabrous and smooth, divergently branching: leaves pale green, attenuate-acute; the larger 7 or 8 inches long, 2 or 3 lines wide: heads smaller; disk even when fructiferous hemispherical or globular : rays bright sulphur-yellow, over halfinch long: chaffy bracts of the receptacle less rigid, obtuse with obscure or blunt mucro: akenes somewhat curved and with rather oblique insertion, 2 lines long, inclusive of the deep cupulate and irregularly dentate pappus. - Coll. Rugel distrib. by Shuttleworth; Chapm. Fl. Suppl. 629. R. Mohrii, Gray, Proc. Am. Acad. xvii. 217. - W. Florida. Wet pine barrens near St. Marks, Rugel, 1843. Margin of the Dead Lakes, near Iola, C. Mollr.Makes approach to $R$. nitida, var. longifolia.

++ Leaves broad, various in form, thinnish, veiny : chaffy bracts of the receptacle merely concave, thinnish, not rigid, acuminate into a slender almost awn-like cusp, about equalling the flowers; the whole disk black-purple: style-tips conical-capitate : root biennial.

R. tríloba, L. Bright green, sparsely hirsute or hispidulous, or the freely branching stem glabrous and smooth, 2 to 5 feet high: radical leaves commonly cordate, slender-petioled; cauline ovate-lanceolate or broader, with cuneate subsessile base, coarsely serrate, acuminate, or the upper lanceolate and nearly entire, the lower divergently 3-lobed or 3-parted: heads short-peduncled: involucre foliaceous, soon reflexed; its bracts linear or mostly so, unequal, nearly in a single series: rays 8 to 10 , half-inch to inch long, deep yellow, sometimes particolored, the basal portion orange or even brown-purple : disk depressed-globular, becoming ovoid at maturity (about half-inch in diameter), glabrous, the upper part of the chaffy bracts and the flowers dark purple: akenes equably quadrangular: pappus a minute crown or border. - Spec. ii. 907 (pl. Gronov., Pluk., \&c.); Michx. Fl. ii. 144 (excl. var.); Bot. Reg. t. 525; Bart. Fl. Am. Sept. i. t. 24 ; Torr. \& Gray, l. c. R. triloba, subtomentosa (as to herb. \& pl. Virg.), \& aristata, Pursh, Fl. 575. Peramibus hirtus, Raf. Ann. Nat. 14. Centrocarpha triloba (at least as to "paleis acuminato-aristatis," though the rest of the character refers to 
R. subtomentosa) \& C. aristata, Don in Sweet, Brit. Fl. Gard. ser. 2, under t. 87. - Dry or moist ground, Penn. and Michigan to Illinois, and south to Georgia and Louisiana, but mostly affecting the mountains.

Var. rupéstris. Large; cauline leaves often 4 or 5 inches long: rays 9 to 13, an inch to inch and a half long, pure orange-yellow to the base: in habit approaching $R$. subtomentosa. - R. rupestris, Chickering in Bot. Gazette, vi. 188. - Rocky slopes of the Roan and other mountains on the borders of $\mathrm{N}$. Carolina and Tenn., Chickering, \&c.

Var. pinnatíloba, Tork. \& GRAY, l. c. A peculiar form, slender : leaves small; many of the radical and lowest cauline pinnately 5-7-parted; upper ones seldom inch long: heads small, with rays at most half-inch and disk a quarter-inch long. - W. Florida, Chapman.

+++ Leaves from lanceolate to ovate or broader: chaffy bracts of the receptacle pointless (obtuse or rarely acute), linear, concave or carinate-canaliculate, somewhat shorter than the diskflowers : akenes nearly equably quadrangular, or in a few species moderately compressed: involucre foliaceous and variable, soon reflexed: disk very obtuse.

+ Cauline leaves or some of them 3-cleft or parted: disk of the head dull brownish: rays yellow, sometimes with dark base : root perennial: receptacle anisate-scented.

R. subtomentósa, Pursh. Cinereous with short and mostly soft pubescence, 2 to 5 feet high, branching above, leafy; leaves nearly all petioled, acutely serrate, veiny, ovate, or the terminal lobe ovate and the lateral oblong or lanceolate: peduncles not much elongated: rays numerous, becoming inch and a half long: disk hemispherical, becoming higher, halfinch broad; its bracts cinereous-puberulent and somewhat glandular at the obtuse tips: pappus a short crenately toothed crown. - F1. ii. 575; Torr. \& Gray, l. c. R. triloba, var., Michx. Fl. ii. 144. R. odorata, Nutt. Jour. Acad. Philad. vii. 78. R. tomentosa, Ell. Sk. ii. 453 , as to syn. \& char. Centrocarpha triloba, Don in Sweet, l. c., as to syn. and part of the char. - Prairies and open moist grounds, Illinois to Arkansas and Texas.

+ ++ Leaves undivided (rarely laciniate-dentate): stems more simple.

$=$ Style-tips slender-subulate: bracts of the receptacle hispid or hirsute at and near the acutish summit: akenes small, equably quadrangular, wholly destitute of pappus: annuals or biennials, hispid with spreading bristly bairs.

R. bícolor, Nuтx. A foot or two high from an annual root, simple or branching, slender or not very stout: leaves from lanceolate to oblong or the lower obovate, mostly obtuse and nearly entire, an inch or two long, indistinctly triplinerved, nearly all sessile: peduncles rarely elongated: rays half-inch to barely inch long, either pure yellow, or with brown purple spots at base, or the lower half deep blackish-purple : disk black. - Jour. Acad. Philad. vii. 81 ; Torr. \& Gray, 1. c. - Pine woods or sandy soil, Arkansas, Texas, and sparingly E. to Georgia. Often confounded with small forms of the next, and with $R$. fulgida. (Adj. Mex.)

R. hírta, L. Stouter and larger, 1 to 3 feet high from a biennial or sometimes annual root, rough-hispid and hirsute: leaves from oblong to lanceolate, sparingly serrate or nearly entire, slightly triplinerved, 2.to 5 inches long, the lower narrowed into margined petioles: rays when well developed an inch or two long, golden yellow, sometimes deeper colored toward the base : disk at first nearly black, in age dull brown, becoming ovoid in fruit. Spec. ii. 907 (Dill. Elth. t. 218); Michx. Fl. ii. 143, mainly; Sweet, Brit. Fl. Gard. t. 82 ; 'Torr. \& Gray, l. c., chiefly. R. gracilis (Herb. Banks.?), Nutt. Gen. ii. 178? a depanperate form. R. discolor, Ell.? not Pursh. R. serotina, Nutt. Jour. Acad. Philad. vii. 80, at least the cult. plant described, fide herb. Acad. Philad. R. strigosa, Nutt. Trans. Am. Phil. Soc. vii. 354, a hairy and short-rayed form. - Dry and open ground, Saskatchewan and W. Canada to Florida, Texas, and Colorado: naturalized in grass-fields in Eastern States: flowering early as a biennial.

$==$ Style-tips short and thickened, obtuse (in $R$. mollis narrower and sometimes acutish): pappus more or less manifest: perennials.

a. Chaffy bracts of the receptacle obtuse and glabrous or nearly so, with blackish-purple tips of the same hue as the corollas, so that the hemispherical at length globose-oroid disk is deep blackpurple: rays golden yeliow, not rarely orange toward the base: akenes small, equably quadrangular: pappus a very short commonly 4-toothed crown.

R. fúlgida, Art. Hispid or hirsute, a foot or two high : leaves from narrowly to oblonglanceolate, mostly entire, lowest and radical spatulate-lanceolate and tapering into slender petioles : foliaceous bracts of the involucre often ample and equalling or sometimes balf the 
length of the 12 to 14 fully inch-long rays : disk over half-inch in dismeter. - Ait. Kew. iii. 251 ; Bot. Mag. t. 1996 ; Bart. Fl. Am. Sept. i. t. 54, \& iii. t. 98 (both figures doubtful); Torr. \& Gray, l. c., partly. R. chrysomela, Michx. Fl. ii. 143. R. discolor, Pursh, Fl. ii. 574, DC. 1. c., hardly of Elliott. - Dry soil, Pennsylvania? and Virginia to Louisiana and Texas, west to Missouri; flowering rather late.

R. spathuláta, Mrснx. Strigulose: stem slender, 8 inches to 3 feet high : leaves obovate or spatulate, or the uppermost lanceolate, denticulate or sparingly serrate, their pubescence wholly appressed and short; radical and lowest cauline leaves mostly roundish at summit, at base abruptly contracted into a winged petiole, or even subcordate: peduncle usually elongated : inrolucre commonly shorter and rajs fewer and broader than in the preceding, and disk smaller. - Fl. ii. 144; Nutt. Gen. ii. 178. R. Heliopsidis, A. H. Curtiss, coll. no. 1427, not Torr. \& Gray. $R$. fulgida, Torr. \& Gray, 1. c,, var. $\gamma, \& \beta$ in part. - Pine woods, Virginis to Tennessee and Florida.

R. speciósa, Wenderoth. Sparsely strigulose or hispid, or glabrate: stem 1 to 3 feet high, usually with spreading branches terminating in long naked peduncles: leaves ovatelanceolate or the upper elongated-lanceolate, bright green, irregularly serrate or some laciniately dentate, acute or acuminate; radical and lower cauline oblong or orate, 3-5nerved, abruptly contracted into long margined petioles: rays 12 to 20, elongated, at length inch and a half long: disk two-thirds to three-fourths inch high at maturity, the tips of the purple chaffy bracts sparingly or obscurely ciliate: akenes larger and longer than in the related species (line and a half long), more curved. - Ind. Sem. Hort. Marb. I828, \& in Flora, 1829, i. Suppl. 30 ; Schrad. in DC. 1. c.; Torr. \& Gray, 1. c.; Gard. Chron. 1881, ii, 372, fig. 72. Probably R. aspera, Pers. Syn. ii. 477. $R$. fulgida, Meehan, Nat. Flowers, ser. 2, i. t. 14. - Moist ground, Penn. to Michigan, Arkansas, and upper part of Alabama. Long cultivated in gardens as $R$. fulgida, \&c.

b. Chaffy bracts of the receptacle with the obtuse tips canescently puberulent or pubescent, and the flowers duller purple; the disk therefore browner.

1. Cauline leares all closely sessile or partly clasping, not nervose: bristly style-tips little thickened: akenes small : pappus very short or obsolete.

R. móllis, ELL. Cinereous, the leaves with fine and close pubescence, the (2 or 3 feet high and usually branching) stem with hirsute or villous hairs, leafy: leaves spatulate-oblong, obtuse, obscurely serrate, somewhat triplinerved ( 1 to 3 inches long): rays 12 to 20, at length inch and a half long and disk fully half-inch high. - Sk. ii. 453; Torr. \& Gray, l. c. R. spathulata, Pursh, Fl. ii. 574.-Dry soil, Georgia and Florida.

2. Cauline leares mostly petioled: heads small: quadrangular akenes only a line long: pappus an obscure crown or hardly any.

R. Heliópsidis, Torr. \& Gray. Almost glabrous, 2 feet high, rather slender, branched above : leaves oblong-ovate, somewhat serrate, triplinerved and with a pair of nearly basal nerves, abruptly contracted, the upper into short and wing-margined, the lower into long and naked petioles : peduncles rather short and corymbose : involucre much shorter than the at length globular disk (which is hardly half-inch high): rays light yellow, 10 or 12, an inch or less long. - Fl. ii. 310. - Pine woods, Columbus, Georgia, Boykin. Cherokee Co. and Lee Co., Alabama, Buckley, J. Donnell Smith.

3. Cauline leaves mostly petioled and like the radical 3-5-nerved; the veinlets reticulated: heads large and showy; the soon drooping light yellow rays 1 or 2 inches long, and the hemispherical at length somewhat conical receptacle becoming three fourths of an inch high: involucre rather small: akenes somewhat compressed: pappus a conspicuous cup-shaped irregularly dentate or crenate crown: stem 2 or 3 feet high, usually simple, and head long-peduncled.

R. alismæfólia, ToRR. \& Gray. Glabrous or minutely scabrous: leaves oval, obtuse or sometimes acute, obscurely repand-dentate or entire, 3 to 6 inches long, abruptly contracted into the petiole: rays 10 to $15 .-$ Fl. ii. $310 .-$ Plains and open pine woods, S. Arkansas, W. Louisiana, and adjacent Texas, Leavenworth, Hale, Drummond.

R. grandifióra, C. C. Gmenis. Hispidulous and scabrous thronghout: leaves more rigid, ovate to oval-lanceolate or uppermost lanceolate, commonly acute or acuminate at both ends, sparingly serrate or denticulate, 4 to 9 inches long: rays 20 or more. - Hort. Bad. Carlsr. 1811 ; DC. 1 . c. 556 (with some erroneous characters as to chaff and pappus, taken from a plant of $R$. hirta); Torr. \& Gray, 1. c. Centrocarpha grandiflora, Don in Sweet. Brit. Fl. 
Gard. ser. 2, t. 87, but has not the character of his genus, which was founded on $R$. triloba. - Dry plains, Arkansas and W. Louisiana.

* * Disk from globular to cylindrical, greenish, fuscous, or yellowish ; its chaffy bracts navicular or more conduplicate, truncate or obtuse, little surpassing the mature akenes, sometimes decidnous from the receptacle at full maturity: style-branches with short and truncate-capitate or obtuse tips: akenes comparatively large and somewhat compressed, inserted by a more or less oblique or lateral areola, the more lateral when the receptacle is elongated: root in all perennial.

+ Rays several or numerous, an inch or two long, drooping, pure yellow: bracts of receptacle pubescent at summit.

+ Leaves entire or barely dentate: disk when well developed at length columnar, an inch or two long, three-fourths inch thick; the receptacle bodkin-shaped: akenes about 3 lines long: pappus a conspicuous irregularly toothed or denticulate cup: herbage completely glabrous and smooth, or sometimes slightly scabrous in age: stems simple or nearly so, and the long-peduncled heads solitary or few : involucre comparatively small. - \$ Macrocline, Torr. \& Gray, Fl. ii. 312.

R. nítida, Nutr. Stem 2 to 4 feet high: leaves bright green, commonly lucid, thincoriaceous, nervose-ribbed, mostly acute, denticulate or entire; radical and lower cauline ovate-spatulate to lanceplate-oblong, tapering into long margined petioles, upper cauline sessile, oblong to lanceolate, 3 to 6 inches long. - Jour. Acad. Philad. vii. 78; Torr. \& Gray, Fl. ii. 313. R. lavigata? Nutt. Gen. 178, not Pursh. - Wet ground, lower part of Georgia to Florida and Texas ; first coll. by Nuttall.

Var. longifólia. Leaves elongated-lanceolate or broader, attenuate to both ends, sparingly dentate or repand-denticulate, more nervose-veiny, in age sometimes minutely scabrous; radical and lowest cauline 8 or 10 inches long, an inch or more broad in the middle. - R. glabra, DC. Prodr. v. 556. - Near Savannah, Georgia, according to herb. DC. Tuskegee, Alabama, Beaumont. Manatee, Florida, Garber.

R. máxima, Nurr. Stem 4 to 9 feet high, and whole plant smooth and glaucous: leaves from broadly ovate to oblong, mostly obtuse, repand-denticulate or entire, with numerous pinnate veins, the larger a foot or less long; upper cauline subcordate-clasping. - Trans. Am. Phil. Soc. vii. 354; Torr. \& Gray, 1. c. - Moist pine woods and plains, Arkansas, Louisiana, Texas ; first coll. by Nuttall.

H Leaves more or less dentate, sometimes 2-lobed at base: pappus a conspicuous crown deeply cleft into four irregular chaffy lobes: Pacific species!

R. Califórnica, Gray. Pubescent, slightly scabrous: stem simple, 2 to 4 feet high, bearing a solitary long-peduncled head: leaves from ovate to oblong-lanceolate, the upper sessile by a narrow base : rays from half-inch to $2 \frac{1}{2}$ inches long, surpassing the loose linear bracts of the involucre: disk from short-oblong to cylindraceous (becoming sometimes 2 inches long); its bracts canescent at summit: akenes flattish. - Proc. Am. Acad. vii. 357, \& Bot. Calif. i. 347. - California; moist ground in the Sierra Nevada ; first coll. by Bridges.

++4 All or most of the cauline leaves 3-7-cleft or divided: pappus a short 4-toothed or nearly entire crown: disk from globular or even hemispherical to oblong-cylindraceous in age, dull yellowish; the tip of the chaffy bracts canescent.

R laciniáta, L. Glabrous and smooth, sometimes mainutely hispidulous-scabrous, at least on the margins and upper face of the leaves: stem 2 to 7 feet high, branching above : leaves veiny, broad, incisely and sparsely serrate; radical commonly pinnately 5-7-foliolate or nearly so, and divisions often laciniately 2-3-cleft; lower cauline 3-5-parted, upper 3-cleft, and those of the branches few-toothed or entire: involucre loose and irregular, foliaceous: rays soon drooping, few or several, oblanceolate. - Spec. ii. 906 (Cornuti, Canad. t. 179, \&c.); Michx. Fl. ii. 144; Bart. Fl. Am. Sept. i. t. 16 ; Torr. \& Gray, l. c. R. laciniata, quinata, \& digitata, Mill. Dict. ed.6. R. laciniata \& digitata, Ait. Kew. iii. 251 ; DC. 1. c. - Moist ground, commonly in thickets, Canada to Florida, and westwardly from Montana to New Mexico and Arizona. A variable species, of which an extreme form is

Var. húmilis. A foot or two high, simple or branching, commonly slender, glabrous : radical leaves diverse, some of them undivided or with roundish divisions : heads smaller; the rays seldom inch long and globular disk barely half-inch high. - Probably $R$. levigata, Pursh, 1. c. - Alleghany Mountains from Virginia to Georgia and Tennessee, common in open woods, \&c., at 4,000 to 6,000 feet. 
R. heterophylla, TorR. \& Grat. Cinereous-pubescent: stem 2 to 4 feet high, slender, bearing several somewhat corymbose short-peduncled small heads: leaves coarsely and rather obtusely serrate; some of the radical cordate-obicular and undiviled, others with 3 ovate undivided leaflets, the terminal petiolulate, lower cauline 3-5-parted; upper all ovate, coarsely toothed, nearly sessile : rays an inch or less long: disk in fruit globose and barely half-inch high. - Fl. ii. 312 ; Chapm. Fl. 228. - Swamps, Middle Florida, Chapman.

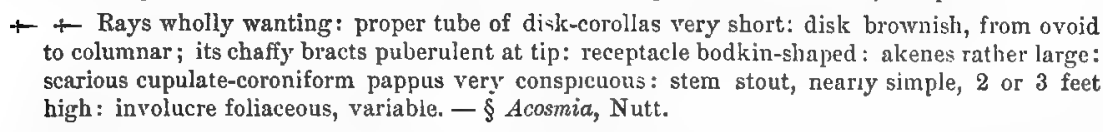

R. occidentális, Nutr. Nearly glabrous and smooth, or somewhat scabrous-puberulent: leaves undivided, ovate or ovate-lanceolate, acuminate, entire or irregularly and sparingly dentate ( 4 to 8 inches long); upper sessile by a dounded or subcordate base; lower abruptly contracted into a short winged petiole, rarely a pair of obscure lateral lobes: disk in age becoming inch and a half lung, and akenes 2 lines long. - Trans. Am. Phil. Soc. vii. 355 ; Torr. \& Gray, 1. c. - Woods along streams, Rocky Mountains of Wroming to Idaho and Oregon; first. coll. by Nutall. Sierra Nevada in Butte Co., California (B?duell), \&c.

R. montána, Gray. Smoother, somewhat glaucous, tall and very stout: leaves (8 to 12 inches long) pinnately parted into 3 to 9 oblong-lanceolate divisions, or the lanceolate uppermost cauline with 2 to 4 narrow lateral lobes: disk cylindraceous or cylindrical, at length often 3 inches long and an inch in diameter: akenes with the deep coroniform pappus 3 or 4 lines long. - Proc. Am. Acad. xvii. 217. - Rocky Mountains of Colorado, E. Hall, Brandegee, the latter in the Elk Mountains.

§2. Dracópis. Akenes nearly terete, not angled, minutely striate, destitute of pappus, inserted by an obliquely lateral areola, and subtenderl by navicular bracts, which are more or less deciduous in age. - Dracopis, Cass., DC., \&c.

R. amplexicaúlis, VAHL. A foot or two high from an annnal root, smooth and glabrous, somewhat glaucous, leafy; the branches terminated by solitary rather showy heads : leaves strictly one-ribbed, reticulate-veiny, from entire to sparingly serrate; lower oblong-spatulate and sessile by a tapering base; upper oblong and ovate with cordate-clasping base: involucre of a few small foliaceous bracts: rays oblong, half-inch or mоте long, yellow, often with a brown-purple base: disk brownish, cylindraceous in age: receptacle slender: akenes small, minutely rugulose-roughened transversely between the sulcate strix. - Act. Hafn. ii. 29, t. 4 (1793); Schkuhr, Handb. t. 259; Pursh, Fl, ii. 573. R. amplexifolia, Jacq. Ic. Rar iii. t. 592 (1793). R. perfoliata, Cav. Ic. t. 252. R. spathulata, Nutt. Gen. ii. 178 (excl. hab.), not Michx. Dracopis amplexicaulis, Cass. Dict. xxxv. 273; DC. Prodr. v. 558; Torr. \& Gray, Fl. ii. 316. - Low grounds, Louisiana and Texas. (Adj. Mex.)

96. LEPACHYS, Raf. ( $\Lambda \epsilon \pi i s$, a scale, and $\pi \alpha \chi \dot{v} s$, thick, the upper part of the bracts of the receptacle thickened.) - Herbs (Atlantic N. American); with pinnately divided or parted alternate leaves, and terminal long-peduncled showy heads, the drooping rays mostly broad, yellow or partly brown-purple; the disk at first grayish, the truncate inflexed tips of the chaff canescently pubescent; disk-corollas yellowish turning fuscous. Heads redolent with anisate odor when bruised. Chaffy bracts commonly marked with an intra-marginal purple line or spot, containing volatile oil or resin. Fl. summer. - Less. Syn. 225 ; Torr. \& Gray, Fl. ii. 313. Lepachys \& Ratibida, Raf. in Jour. Phys. 1819, 100. Obeliscaria, Cass. Dict. xlvi. 401 (1825); DC. Prodr. v. 558.

$\S 1$. Akenes with convex or obscurely angled faces: root perennial. - Obeliscaria, Cass.

* Style-tips lanceolate-subulate: rays large and long.

L. pinnáta, Torr. \& Gray, 1. c. Strigulose-pubescent and scabrous, 3 to 5 feet high, slender: leaves 3-7-foliolate, and the leaflets lanceolate or broader, usually sparsely serrate, sometimes lobed, the uppermost commonly confluent:- rays pure yellow, oblong-lanceolate, 
often 2 inches long or more, very much exceeding the at length short-oblong disk: ehaffy bracts of the receptacle becoming much corky-thickened at the enlarging summit : ovary not rarely wing-margined; akenes subcuneate-oblong, the inner margin acute and salient, and produced at summit into a short rounded tooth, which is occasionally aristellate-pointed. L. pinnatifida \& L. angustifolia, Raf. 1. c. Rudbeckia pinnata, Vent. Cels. t. 71 ; Smith, Exot. Bot. i. t. 38 ; Bot. Mag. t. 2310 . R. digitata, Willd. Spec. iii. 2247, excl. syn. $R$. tomentosa, Ell. Sk. ii. 453, as to herb., hardly of char. Obeliscaria pinnata, Cass. 1. c.; DC. 1. c. - Dry prairies, W. New York to Michigan and Iowa, south to W. Florida and Louisiana.

* * Style-tips short and obtuse: rays oval or oblong, mostly shorter than the fruiting disk, not rarely particolored with brown purple: akenes commonly with a scarious and more or less eiliate margin or sometimes narrow wing to the inner edge: divisions or lobes of the leaves mostly entire.

I. Tagétes, Gray. A foot high, branching, leafy, strigulose-cinereous : leaves thickish, mostly with 3 to 7 narrowly linear rather rigid lobes: heads rather short-peduncled : rays few, a quarter to half an inch long: disk globose to barely oblong, half-inch high: pappus of one or sometimes two subulate or awn-like deciduous teeth, and no intermediate squamellæ. - Pacif. R. Rep. iv. 103. Lepachys columnaris, var. Tagetes, Gray, P1. Wright. i. 106. Rudbeckia Tagetes, James in Long Exped. ii. 68. R. globosa, Nutt. Jaur. Acad. Philad. vii. 19, \& Trans. Am. Phil. Soc. 1. c. 355. Obeliscaria Tagetes, DC. 1. c.-Alluvial plains, Arkansas to W. Texas and New Mexico; first coll. by James.

L. columnáris, TorR. \& GRAx, 1. c. Strigose-scabrous, a foot or two high, branching from the base, terminated by long peduncles bearing a showy head: divisions of the cauline leaves 5 to 9 , from oblong to narrowly linear, sometimes 2-3-cleft: rays commonly an inch long or more, normally all yellow: disk at length columnar and inch or more long: pappus of the preceding, but usually a series of minute and delicate squamellæ around the broad flat summit. - Rudbeckia columnaris, Pursh, Fl. ii. 575; Bot. Mag. t. 1601 ; Hook. Fl. i. 311 ; Sprague, Wild Flowers of Amer., 43, t. 8. Ratibida sulcata, Raf. l. c. R. columnaris, Don, Brit. Fl. Gard. n. ser. iv. 361. Obeliscaria columnaris, DC. 1. c. - Plains and prairies, Saskatchewan to the Rocky Mountains, and south to Texas and Arizona.

Var. pulchérrima, Torr. \& GraY, 1. c. Differs only in having a part or even the whole upper face of the ray brown-purple; varies southward into more slender and branching forms, some with rays reduced to a quarter-inch. - Obeliscaria pulcherrima, DC. 1. c. Ratibida columnaris, var. pulcherrima, Don, 1. c. t. 361. - Nebraska to Arizona and Texas. (Adj. Mex.)

§ 2. Akenes completely flat: style-tips slender-subulate, very hispid: root probably annual or biennial. — \$Lophochana, Torr. \& Gray, 1. c.

L. peduinculáris, Torr. \& GRAY. Strigose-scabrous or pubescent and somewhat cinereous, 2 or 3 feet high, including the naked peduncle of a foot or more: leaves rather large, irregularly bipinnately parted or pinnately parted and some of the lobes incisely pinnatifid or toothed, these oblong-linear or broader: rays obovate, an inch or less long and pure yellow, or sometimes only quarter-inch long and particolored: disk cylindrical, the largest an inch and a half long: akenes broadly and somewhat obliquely obovate, with no nerve or elevation on the face, from narrowly to broadly winged and squamellate-fimbriate on at least the inner edge, deeply notched at summit by an extension into two chaffy teeth, the inner one large and triangular-subulate, the outer smaller, and the notch fringed with small irregular squamella. - Fl. ii. 315. - Low ground, Texas, Drummond, Wright, \&c.

Var. pícta, GRAY. Pubescence more cinereous: leaves simply and lyrately pinnately parted into fewer ( 5 to 7 ) divisions; these incised, the larger terminal one ovate-oblong or obovate: rays barely half-inch long, brown-purple with yellow edge: disk becoming inch and a half long. - Pl. Wright. i. 107. L. serrata, Buckley in Proc. Acad. Philad. 1861, 457. - Texas, near the coast, and in sandy woods, Wright, Buckley, Ball.

97. WEDÉLIA, Jacq. (Prof. G. W. Wedel, of Jena, in the latter part of the 17th century.) - Tropical herbs or undershrubs, mostly of sea-shores; with opposite leaves, and lateral or terminal pedunculate heads of yellow flowers. One species has reached our southernmost coast. 
W. carnósa, Pers. Perennial herb, slightly strigose-hispidulous, glabrate: stem extensively creeping, sending up erect branches: leaves fleshy, mostly sessile, cuneate-oblong to obovate, somewhat serrate, often with some coarse teeth or 3 to 5 short lobes: rays golden yellow, 3-toothed, little surpassing the oblong foliaceous involncral bracts: akenes (3 lines long including the cupulate pappus) much thickened and muricate-scabrous at maturity, the attenuate base compressed and sharp-edged. - Syn. ii. 490; DC. Prodr. v. 538; Griseb. Fl. W. Ind. 371. Silphium trilobatum, L. Spec. ed. 2, ii. 1302 (Plum. ed. Burm. t. 107, f. 2; Sloane, Jam. t. 155, f. 1). Buphthalmum repens, Lam. - Biscayne Bay, S. E. Florida, Curtiss. (W. Ind., S. Am.)

98. BORRICHIA, Adans. (Ole Borrich, a Danish botanist of the 17 th century.) --Shrubs or suffruticose and more or less fleshy plants of the sea-coast, canescent, or becoming glabrate and green; with opposite entire or denticulate leaves tapering somewhat into a petiole, and rather large heads of yellow flowers on terminal peduncles: fl. summer.-Fam. ii. 130 ; DC. Prodr. v. 488.

B. arboréscens, DC. Shrub 4 feet or less high, fleshy, much branched: leaves spatulatelanceolate, rigidly mucronate, veinless : involucre appressed : bracts of the receptacle obtuse or barely mucronate. - Prodr. 1. c. Asteriscus, \&c., Dill. Elth. t. 38, f. 43. Corona-solis frutescens, \&c., Plum. ed. Burm. t. 16, f. 2. Buphthalmum arborescens, L. Spec. ed. 2, ii. 1273. - Sandy shores and Keys, S. Florida. (W. Ind. to Peru.)

B. frutéscens, DC. Less woody, more permanently canescent; the simpler stems 1 to 3 feet high: leaves fleshy-coriaceous, from obovate to spatulate-lanceolate, sometimes dentate: bracts of the inrolucre smaller and looser, spreading in age; of the receptacle spinulosecuspidate. - Prodr. I. c.; Torr. \& Gray, Fl. ii. 268. Asteriscus frutescens, \&c., Dill. Elth. t. 38, f. 44. Chrysanthemum fruttcosum, \&c., Catesb. Car. i. t. 93. Buphthalmum frutescens, L. Spec. ii. 903; Walt. Car. 212. - Sandy sea-coast, Virginia to Texas. (Mex., \&c.)

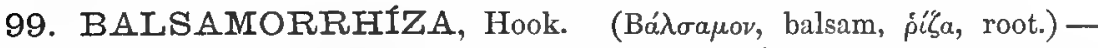
Low perennials (all of Central and Western N. America); with thick and deep roots, which exude a terebinthine balsam, and send up a tuft of radical leaves, mostly on long petioles, and short simple few-leaved flowering stems or naked seapes, bearing large and mostly solitary heads of yellow flowers; the rays ample and numerous. Cauline leaves when present alternate or occasionally opposite, petioled. The root, when peeled (to get rid of the terebinthine rind) and baked, is an article of food to the aborigines, and the akenes are also eaten. - Fl. i. 310 (under Heliopsis); Torr. \& Gray, Fl. ii. 300 ; Gray, Pl. Fendl. 81.

$\S 1$. Ligules becoming thin-papery, and persistent on or very tardily deciduous from the canescently pubescent akenes. - Kalliactis, Gray, l. c.

B. Careyána, Grax, 1. c. Cinereous-pubescent, slightly scabrous: flowering stems a foot high, bearing 3 or 4 small lanceolate leaves and 2 to 7 racemosely disposed heads: leaves subcoriaceons, entire, reticulated; the radical cordate-lanceolate, a span or more in length: involucre half-inch or more high; ligules oval, hardly inch long, abruptly contracted into a very short but distinct tube: style-branches of the disk-flowers subulate and very hispid thronghout. - Sandy plains on the Clearwater, Idaho, fl. May, Spalding. Rediscovered on the Wallawalla, Washington Terr., 1883, by Brandegee, with the rays deciduous from the mature fruit.

§2. Ligules deciduous in the ordinary manner: akenes glabrous: stems or scapes terminated by solitary or sometimes 2 or 3 heads.

* Leaves entire or merely serrate; the principal ones cordate or with cordate base and long-petioled. - § Artorkiza, Nutt. Trans. Am. Phil. Soc. vii. 350. Espeletia, Nutt. Jour. Acad. Philad. vii. 39, not Humb. \& Bonpl.

B. aagittáta, Nстт. Silvery-tomentulose or canescent, and the involucre white-woolly: radical leaves from cordate-oblong to hastate, entire or nearly so (4 to 9 inches long, the 
base 2 to 6 inches wide, on petioles of greater length); the few and inconspicuons cauline from linear to spatulate: scape at length a foot or more high: rays 1 to nearly 2 inches long. - Gray, Bct. Calif. i. 348. B. sagittata \& B. helianthoides, Nutt. Trans. Am. Phil. Soc. 1.c.; Torr. \& Gray, 1. c. Espeletia helianthoides \& E. sagittata, Nutt. Jour. Acad. Philad. vii. 38, t. 4. Buphthalmum sagittatum, Pursh, Fl. ii. 564.- Rocky Mountains of Colorado to Montana and Brit. Columbia, the border of California, and S. Utah. Young stalks, root, and seeds used for food by the Indians. Outer bracts of the involucre sometimes oblong-lanceolate, foliaceous, and surpassing the disk (as in Pursh's original); or all more imbricate and conformed, the outer shorter.

B. deltoídea, Nutr. Trans. 1. c. Green, more or less pubescent or glabrate : leaves broadly cordate to cordately ovate-lanceolate, sometimes nearly deltoid, from irregularly serrate to entire, 4 to 10 inches long: scape with small lanceolate or rarely ovate leaves, not rarely 2-3-cephalous: rays an inch or more long. - Torr. \& Gray, 1. c.; Gray, Bot. Calif. 1. c. $B$. glabrescens, Benth. PI. Hartw. 317. - Idaho and Brit. Columbia to S. California.

B. Bolánderi, Grax. Green, glabrate: stems stout, a span or two high, and bearing 2 or 3 subcordate nearly entire leaves, similar to and as large as the radical ones: principal involucre of the short-peduncled head a single or double series of ovate-lanceolate foliaceous bracts, over an inch long: apparently disk-akenes flattened.-Proc. Am. Acad. vii. 356, \& Bot. Calif. 1. c. - California, at Auburn, and on the Sacramento, Fremont, Rich, Bolander.

* Leaves not cordate and entire, varying from laciniately dentate to pinnately or bipinnately divided: heads solitary on a uaked scape, or scapiform stem bearing a pair of small opposite leaves towards the base: thick caudex or root exceedingly balsamic-resiniferous. Perhaps all forms of one polymorphous species. - E Eubalsamorrhiza, Nutt.

B. macrophýlla, Nurr. Green, not at all canescent, glabrate, except the ciliate margins of the leaves, usually minutely glandular-viscidulous: leaves ample, ovate or oblong in outline, a span to a foot long, some with only one or two lobes or coarse teeth, most of them pinnately parted into broadly lanceolate and commonly entire lobes (of 2 or 3 inches in length): scapes a foot or two high: bracts of the involucre from narrowly lanceolate to spatulate and foliaceous, an inch or two long, nearly equal, either half or fully the length of the rays. - Trans. Am. Phil. Soc. vii. 350; Torr. \& Gray, Fl. ii. 301 ; Eaton, Bot. King Exp. 168. - Rocky and Wahsatch Mountains, Wyoming to Utah, Nuttall, Fremont, Watson.

B. terebinthácea, Nutr. Slightly and minutely if at all canescent: leaves from green and glabrate to minutely hispidulous-scabrous, or barely hirsutulous at margins, at length rigid and reticulate-veiny, oblong-lanceolate and with cuneate or truncate base (4 to 8 inches long, 1 to 3 wide), spinulosely dentate or sometimes crenate-dentate, or some laciniate-incised, or even pinnatifid: scapes a span to a foot high: involucre lanate-tomentose, of numerous and narrow linear-lanceolate and attenuate loose and nearly equal bracts, an inch long. Trans. Am. Phil. Soc. vii. 349 (name only); Gray, Pl. Fendl. 82. B. Hookeri, var., Torr. \& Gray, 1. c. Heliopsis? terebinthacea, Hook. Fl. ii.310? - W. Idaho to E. Oregon, in hard or stony ground, Douglas, Spalding, Nevius, Cusick.

B. Hoókeri, Nurr. 1. c. Canescent with fine sericeous or more tomentose pubescence, but not at all hirsute: scapes and leaves a span to a foot high; the latter lanceolate or elongatedoblong in outline, pinnately or bipinuately parted into lanceolate or linear divisions or lobes, or some of them only pinnatifid or incised : involucre from canescently puberulent to lanate; its bracts from linear- to oblong-lanceolate, either unequal and well imbricated or sometimes the outermost foliaceous and enlarged. - Torr. \& Gray, 1. c., excl. var.; Eaton in Bot. King Exp. 1. c. Heliopsis? balsamorrhiza, Hook. I. c. - Hills and rocky plains, eastern parts of Washington Terr. to Nevada and W. California; first coll. by Douglas.

Var. incána. Densely white-tomentose : leaves often of broader outline. - B. incana, Nutt. 1. c. 350 ; Torr. \& Gray, 1. c. - Wyoming and Montana to northern parts of California ; first coll. by Nuttall.

B. hirsúta, Nutr. l. c. Green, roughish-hirsute or hispidulous, not tomentose nor canescent: leaves lanceolate in ontline, pinnately parted or divided, the divisions ( 9 to 15 lines in length) incisely toothed or again pinnatifid, soon rigid: scapes a span to a foot high: involncre birsute-pubescent or glabrate, of narrowly lanceolate or more attenuate bracts. Torr. \& Gray, 1. c.; Eaton, 1. c. - Utah to Brit. Columbia and N. E. California, in the dry region; first coll. by Douglas and Nuttall. 
100. WYETHIA, Nutt. (Nathaniel $J$. Wyeth, who collected the species on which the genus was founded, and with whom Nuttall subsequently crossed the continent.) - Stout and mostly low perennials (W. North-American); with more or less balsamic or resiniferous juice, ample and undivided pinnately veined alternate leaves (commonly entire), and large heads of mostly yellow flowers. (Thick roots and seeds were food of the Indians.) - Jour. Acad. Philad. vii. 38, \& Trans. Am. Phil. Soc. vii. 351 ; Gray, Proc. Am. Acad. viii. 654. Alarçania, DC. Prodr. v. 537.

* Rays from "pale yellow" or dull straw-color to white. - The original Wyethia, Nutt.

W. helianthoídes, Noтr. A span to a foot and a half high, simple and with a single large head, or rarely 3 or 4, hirsute: leaves from oval to broadly lanceolate, denticulate or entire, 4 to 8 inches long, mostly narrowed at base into a short margined petiole : heads an inch high : bracts of the involucre narrowly lanceolate, numerous : rays nearly 2 inches long : akenes 4 lines long, either prisnatic-quadrangular or flattish, 12-nerved: pappus shorter than the width of the akene, sometimes minute, chaffy-coroniform and cleft into few or several teeth. - Jour. Acad. Philad. I. c. t. 5 ; Gray, 1. c. - Northern Rocky Mountains, in moist valleys, S. W. Montana to E. Oregon, Wyeth, Nevius, Cusick, Watson, Scrilner.

* * Rays bright yellow. - Alarçonia, DC. (Dedicated to the memory of Hernando de Alarçon, a noble Spanish navigator, who, in 1540, first visited and carefully surveyed the coast of California.)

+ Involucre of the very large and broad heads foliaceous; the spreading outer bracts ovate or oblong, commonly 2 inches or more in length, much surpassing the disk (which is of about equal breadth) and often exceeding the rays: akenes very stout and thick, half-inch long, with counparatively obtuse angles, crowned with a large chaffy-coriaceous calyciform pappus, which is cleft into unequal teeth or lobes: cauline leaves short-petioled.

W. helenioídes, Notr. I. c. Very stout, 2 or 3 feet high, floccosely tomentose, glabrate in age: leaves oblong and ovate, mostly entire, radical a foot or two and upper cauline 6 to 8 inches long: akenes pubescent toward the summit. - Gray, Pl. Fendl. 82, Proc. Am. Acad. 1. c., \& Bot. Calif. i. 349. Alarçonia helenioides, DC. 1. c.- - Hillsides around and near San Francisco Bay, California; first coll. by Douglas.

W. glábra, Grar. A foot or two high, glabrous or nearly so, balsamic-riscid: leaves of the preceding in size and shape, or narrower, sometimes serrate: akenes glabrous. - Proc. Am. Acad. vi. 543, viii. 654, \& Bot. Calif. 1. c. - W. California, from Marin Co. southward, Andrews, Brewer, \&c.

+ + Involucre of the smaller heads (about inch or less high) narrower and fewer-flowered, usually campanulate; the outer bracts even when foliaceous seldom surpassing the disk: akenes less thick, 3 to 5 lines long.

+ Glabrous and smooth throughont, usually balsamic-viscid: leaves thickish, lanceolate to oblong, upper sessile, lower tapering into margined petioles: outer bracts of the narrowish involucre disposed to be foliaceous.

W. amplexicális, Nutr. A foot or two high, robust: leaves mostly lanceolate-oblong, entire or denticulate; radical often a foot or more long; upper cauline (a span or so long) partly clasping by a rounded or somewhat narrowed base: heads solitary or several, shortpeduncled: involucral bracts broadly lanceolate, acute or obtuse, one or two outer ones occasionally foliaceous and larger: rays inch and a half long: akenes with a conspicuous crown cleft into acute teeth, and sometimes a small awn. - Trans. Am. Phil. Soc. 1. с.; Torr. \& Gray, 1. c. Espeletia amplexicaulis, Nutt. Jour. Acad. Philad. vii. 38. Silphium? lave, Hook. Lond. Jour. Bot. vi. 244. - Moist valleys and plains, Rocky Mountains from Colorado to Montana, west to Nevada and Brit. Columbia. Pe-ik of the Indians.

W. longicaúlis, Gray. Nearly resembles preceding, taller, rather slender: leares lanceolate, even uppermost with tapering base and not clasping: heads solitary or paniculate, on long and slender peduncles: outer series of involucral bracts oblong or somewhat spatulate, foliaceous, mostly surpassing the inner and the disk: rays only inch long: akenes with a short erosely denticulate crown. - Proc. Am. Acad. xix. 4.-Prairies of E. Humboldt Co., California, Rattan. 
++ Glabrous, but scabridous and balsamic-viscid: leaves ovate, abruptly petioled, coriaceous.

W. retículata, Gresne. Habit of W. ovata, only puberulent-hispidulous without tomen. tum, leafy up to the corymbosely disposed heads: cauline leaves ovate or subcordate, shortpetioled (4 down to 2 inches long), 3-5-plinerved, and with veins and veinlets much reticulated, shining; those of flowering branches small, oblong, 3-nerved: heads hemispherical, little over half-inch high: bracts of involucre oblong-linear, obtuse, short; outer foliaceous and loose, sometimes one or two enlarged: rays apparently few and rather small: akenes compressed-quadrangular, glabrous (barely 3 lines long) : pappus an extremely short erosedenticulate crown; no awn. - Bull. Calif. Acad. i. 9. - Banks of Sweetwater Creek, El Dorado Co., California, Mrs. Curran.

++ Tomentose or woolly, but sometimes glabrate in age: leaves all petioled and becoming coriaceous, ample, even the cauline 4 to 7 inches long.

$=$ Involucre hemispherical, of numerous broadly lanceolate bracts, not surpassing the disk: rays numerous, 20 to 24 .

W. ováta, Torr. \& Gray. Canescent with a soft not floccose tomentum, 2 or 3 feet high from running rootstocks, commonly branching : leaves ovate, the cauline subcordate and with acute apex, somewhat triplinerved; veinlets not much reticulated: pappus a chaffy, several-toothed crown. - Emory Rep. 143 (1848, wholly overlooked); Gray, Proc. Am. Acad. vii. 357, \& Bot. Calif. 1. c. - California, on the western side of the Sierra Nevada.

$=$ = Involucre narrower, campanulate; the outer bracts larger than the inner and more or less surpassing the disk: rays fewer: leaves at length firm-coriaceous and the veinlets cunspicuously reticulated.

W. móllis, Gray. White with floccose wool when young, more or less glabrate in age, I to 3 feet high, bearing solitary or few heads : leaves oblong and ovate, with either rounded or truncate or cuneate base : rays 10 to 15, over an inch long: akenes minutely pubescent at summit: pappus a truncate chaffy crown, and 2 or in the ray 3 to 5 subulate awns. - Proc: Am. Acad. vi. 544, viii. 655 , \&c. - Sierra Nevada, especially on the eastern side, from Sierra Valley to Virginia City, Nevada, and westward to the Yosemite; first coll. by Anderson.

W. coriácea, Grax. Sericeons-tomentose, stout, 1 to 3 feet high: leaves rigid, broadly ovate or oval, obtuse or apiculate, somewhat triplinerved, even the upper cauline (5 to 7 inches long) seldom longer than their petiole: rays 5 to 9 , hardly surpassing the involucre: pappus a short obtusely 4-6-cleft crown. - Proc. Am. Acad. xi. 77, \& Bot. Calif. i. 616. San Diego Co., California, on the Mesa Grande, \&c., Palmer, Parish.

++ ++ + Hirsutely more or less pubescent, often somewhat balsamic-glutinous: leaves elongated-lanceolate, tapering to both ends, or the upper and sessile cauline broader: bracts of the involucre mostly foliaceous or herbaceous, Ianceolate or broader, equalling the disk.

W. angustifólia, Nutr. A span to 2 feet high, and the radical leaves about as long, these occasionally denticulate or serrate, often undulate: involucre fully inch high, loose or spreading: head solitary: rays mostly numerous, inch and a half long : pappus a short and chaffy fimbriolate-cleft crown, and one or two or in the ray 3 or 4 elongated subulate awns, one of them about the length of the akene. - Gray, Proc. Am. Acad. viii. 655, \& Bot. Calif. 1. c. W. angustifolia \& W. robusta, Nutt. 1. c.; Torr. \& Gray, Fl. ii. 299. Helianthus longifolius, Hook. Fl. i. 312; Hook. \& Arn. Bot. Beech. 353. H. Hookerianus, DC. Prodr. Alarçonia angustifolia, DC. Prodr. v. 537.-Plains and hills, commonly in moist ground, Washiugton Terr. to Monterey Bay, California.

W. Arizónica, Grar. A foot high, bearing a single or few and smaller heads : leaves oblong-lanceolate: involucre of fewer and more erect bracts: rays 8 to $12:$ pappus a very naxrow crown, extended into 3 or 4 stout subulate teeth, or into one or two short awns. Proc. Am. Acad. viii. 655 ; Rothrock in Wheeler Rep. vi. 161, t. 9 ; Meehan, Nat. Flowers, ser. 2, ii. t. 37. - Near streams and springs, S. Colorado to S. Utah and Arizona, Palmer, Bishop, Siler, Rothrock, \&c.

+++++ Hispidulous, very scabrous, narrow-leaved : involucre more imbricated, squarrose.

W. scábra, Hook. A foot or two high (root unknown), rigid: cauline leaves linear, thick, 4 to 6 inches long, half-inch wide, sessile, attenuate-acute, the few veius confluent into lateral undulate nerves: involucre nearly hemispherical; its bracts imbricated in 3 or 4 series, all the outer with a coriaceous ovate-oblong appressed base, which is acuminate into a longer subulate filiform spreading very hispid-scabrous appendage : rays several, half-inch 
long: akenes acutely angled and with few or obscure intermediate nerves, very smooth, the 3 or 4 angles extended into a pappus of as many short and blunt tceth, which are barely coroniform-confluent at base. — Lond. Jour. Bot. vi. 245; Gray in Pacif. R. Rep. iv. 102, \& Proc. Am. Acad. viii. 655. - S. Colorado and New Mexico to Utah and Wyoming, Geyer, Bigelow, Parry, Ward, \&c.

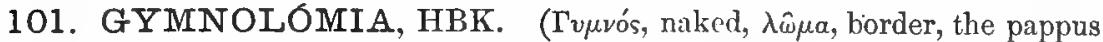
obsolete or none.) - Herbs or frutescent plants (of Mexico and adjacent countries), resembling the smaller-flowered species of Helianthus; with erect branching stems, alternate or opposite leaves, and heads of yellow flowers (or the disk brownish); the peduncles terminating the branches: fi. summer. - Nov. Gen. \& Spec. ir. 217, t. 373, 374; Benth. \& Hook. Gen. ii. 363. Gymnopsis, DC. Prodr. v. 561, in part.

* Annuals : receptacle of the head conical and the disk high : bracts of the rather simple involucre linear. - Heliomeris, Nutt.

G. Pórteri, Grar. A foot or two high, slender, paniculately branched, sparingly hispid, otherwise nearly glabrous: leaves nearly all alternate, narrowly lanceolate or linear, entire: rays 5 to 8, oval or obovate (half-inch or more long), deep orange yellow : disk in age oblongconical; its chaffy bracts oblong-lanceolate or the outer ovate, cuspidate-acuminate, striate, merely concave at maturity : fructiferous receptacle almost columnar : akenes turgid-obovate, very obscurely quadrangular, dull, somewhat puberulent, with small terminal areola, one of the angles or nerves sometimes slightly margined or umbonate at the summit: style-tips subulate and hispid. - Proc. Am. Acad. xii. 59 ; Meehan, Nat. Flowers, ser. 2, ii. t. 35. - Rudbeckia? Porteri, Gray, Pl. Fendl. 83. - Northern Georgia, known only on the isolated granite rock called Stone Mountain, near Atlanta, where it abounds; first coll. by Prof. Porter.

G. multiflóra, Bexth. \& Hook. A foot to a yard high, strigulose-pubescent or scabrous, sometimes also hispid, often much branched: leaves from narrowly linear to lanceolate, rarely broader, either alternate or mainly opposite, entire or obscurely denticulate: rays 10 to 15 , golden yellow : disk hemispherical, in age little more elevated and receptacle obtusely conical; its bracts obtuse or the inner acute with soft acumination: akenes smooth, compressed, with convex or obtusely angulate sides: style-tips short and obtuse. - Benth. \& Hook. ex Rothrock in Wheeler Rep. vi. 160, \& Hemsl. Biol. Centr.-Am. ii. 162. Heliomeris multiflora, Nutt. 1. c.; Gray, Pl. Fendl., Pl. Wright. ii. 87, with var. hispida, \&c. - Sandy banks of streams, \&c., W. Texas to Wyoming, Nevada, and Arizona. Very polymorphous: the root not perennial as was supposed. An indigenous specimen coll. by Lemmon in Arizona has disk-corollas all converted into rays or radiatiform ampliate lobes. (Mex.)

G. tríloba, Grar. Much branched, over 2 feet high (root not seen), obscurely puberulent, no hispid bristles: leaves roundish in general outline, 3-lobed, with subcordate or truncate base, short-petioled, the lobes short and broad: rays 12 or more, oblong-linear, elongated: disk hemispherical : receptacle low-conical: akenes of the preceding but more oblong. Proc. Am. Acad. xvii. 217. - Mountains of S. Arizona south of Rucker's Valley, Lemmon.

* Perennial or frutescent: disk and receptacle low.

G. tenuifólia, Bentr. \& Hook. Shrubby, much branched, 2 or 3 feet high, scabrouspuberulent, very leafy : branches terminated by solitary long-peduncled heads : leaves alternate and the lower opposite, canescent beneath, pinnately or pedately parted into 3 to 7 narrow linear lobes, or the uppermost very narrow and entire, the margins mostly revolute: bracts of the involucre subulate-linear: rays 10 to 16 : disk convex: chaffy bracts of the receptacle truncate-obtuse: akenes smooth, quadrangular-compressed. - Ex Hemsl. Biol. Centr.-Am. 1. c. Heliomeris tenuifolia, Gray, Pl. Fendl. 84, Pl. Wright, \&c. - S. W. Texas, Wright, Havard. (Adj. Mex., Berlandier, Gregg, \&c.)

* * Annual: receptacle and disk barely convex: habit of Encelia and Helirnthus.

G. encelioídes, GRAr. A foot or two high from an annual root, strigose-canescent and the branching stem hispid: leaves ovate-oblong or obscurely deltoid, rather obtuse, nearly entire, mostly long-petioled, the lower opposite: heads barely half-inch high : involucre biserial; outer bracts all equal and equalling the disk, oblong-lanceolate, acute, white with soft 
but at length hispid pubescence, longer and larger than the nearly linear interior ones : rays 10 or 12, oval, showy, golden yellow, less than an inch long: disk-corollas with dark purple tips: akenes obovate-oblong, below sparsely and toward the summit thickly villous with slender hairs: pappus none, or a few very delicate setiform squamellw shorter than the hairs of the akene. - Proc. Am. Acad. xix. 4.-S. E. California, at Aqua Caliente, in the Mohave Desert, Parish.

102. VIGUIERA, HBK. (Dr. A. Viguier, botanist, of Montpellier.) Ierbaceous or sometimes suffruticose plants (of the warm parts of America); with only the lower or rarely all the leaves opposite, yellow-flowered heads of only medium size (in our species), on peduncles at the summit of the branches, the akenes usually pubescent. - Nov. Gen. \& Spec. iv. 224, t. 379 ; Benth. \& Hook. Gen. ii. 375. IViguiera, Leighia (Cass.), \& Harpalium (Cass.), in part, DC. Prodr. v. 578-584.

* Disk of the head at maturity elevated or strongly convex (but at first often low) and the receptacie conical: root probably annual or biennial.

V. helianthoídes, HBK. Minutely hispidulous-pubescent or scabrous, green, or sometimes cinereous: stem 2 to 7 feet high, slender, paniculately branched above: leaves alternate or occasionally either upper or lower opposite, slender-petioled, mostly thin, ovate, acuminate, sometimes very broadly ovate (the larger 4 to 6 inches long and 3 or 4 wide), sometimes ovate-lanceolate, from slightly to coarsely serrate, triplinerved from near the base: heads paniculate, usually slender-peduncled: involucre only 3 lines high, shorter than the disk, nearly simple, of subulate or linear bracts : rays 7 to 10 , obovate or oblong, over half-inch long: chaffy bracts of the receptacle somewhat cuspidately mucronate or acuminate: akenes villous-pubescent : palex a pair on each side between the chaffy awns, erose or fimbriolate at the truncate summit. - HBK. 1. c.; Benth. \& Hook. 1. c. V. helianthoides, Sagrceana, laxa, brevipes, and probably $V$. microcline, triguetra, also with little doubt $V$. dentata (Spreng., the Helianthus dentutus, Cav. Ic. iii. 10, t. 220), DC. Prodr. v. 579. V. Texana, Torr. \& Gray, Fl. ii. 318. Helianthella latifolia, Scheele in Linn, xxii. 160. - Shady or more open grounds, Texas to Arizona. (Mex., Cuba.)

V. canéscens, DC. Less tall, more rigid, commonly cinereous: leaves coriaceous, entire or nearly so, from broadly ovate to oblong-lanceolate; the lower opposite: chaff of the receptacle more cuspidate $\hat{?}$ rays saffron-yellow: akenes canescently sericeous. - Prodr. $v$. 579. - S. Arizona, Pringle, a greener form, and in adjacent Mexico, Palmer. (Mex.)

* Disk flattish or convex: receptacle at maturity flat or hardly conical.

+ Herbaceous to the base from a probably perennial root, not canescent nor tomentose.

V. cordifólia, Gray. Hispid or bispidulous and scabrous: stem rather stout, 2 or 3 feet high, leafy to the top, commonly branched above: leaves mostly all opposite, occasionally some alternate, subcordate-ovate or deltojid, acute, serrate or denticulate, 3-ribbed from the base, either sessile or short-petioled, rough; veinlets reticulated: heads mostly corymbose and short-peduncled: involucre campanulate, fully half-inch long, equalling the barely convex disk, commonly lanceolate and acuminate, erect, in 2 or 3 series : chaffy bracts of the receptacle gradually acuminate: akenes narrowly cuneate-oblong, almost equalled by the chaffy awns; the intermediate palex equalling the breadth of the akene, narrowly oblong, rigid. - Pl. Wright. i. 107, ii. 88. - Near water-conrses, W. Texas to Arizona, Wright, Schott, Lemmon, \&c. (Mex., Schaffiner.)

+ + Shrubby or lignescent at base, low, not tomentose: leaves hispidulous-scabrous, mostly alternate, rigid.

V. laciniáta, Grar. Branching: leaves lanceolate or obscurely hastate, from laciniatepinnatifid to nearly entire, abruptly petioled, an inch or two long, beneath with very prominent pinnate veins: branches bearing several cymosely disposed and pedunculate heads: involucre nearly half-inch high; its bracts lanceolate or the outermost ovate, acute or acuminate: rays half-inch long: akenes sparingly pilose, glabrate: pappus-awns chaffy: the intermediate chaffy paleæ laciniate or erose. - Bot. Mex. Bound. 89, \& Bot. Calif. i. 354, - San Diego Co., California, Schott, Newberry, Clevelund, \&c. (Lower Calif.) 
V. Parishii, Grenere. Branched from the base and diffuse; the nearly simple slender flowering branches (sometimes rather canescently pubescent) bearing mostly solitary pedunculate heads : leaves ovate, small (half-inch to barely inch long), somewhat serrate, shortpetioled: involucre broad: its bracts lanceolate: akenes more villous : awns as long as the akene and chaffy-dilated only near the base; the palex much laciniate. - Bull. Torr. Club, ix. 15. - Desert region of W. Arizona and S. E. California to the coast at San Luis Rey, Newberry, Palmer, Parry \& Lernmon, Parish, W. G. Wright, Greene.

+++ Herbaceous? perennials, white-tomentose or canescent (at least the foliage): involucre of rather short imbricated bracts.

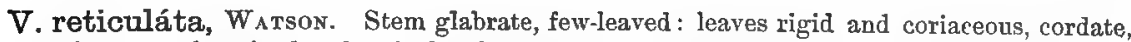
entire, strongly veined and reticulated beneath, 2 inches long, petioled, canescent with short rather silky pubescence: heads small ( 3 or 4 lines high), several in the corymbiform clusters: rays 3 lines long: subulate chaffy awns only twice the length of the laciniate paleæ of the pappus. - Amer. Nat. vii. 301. - Telescope Mountain, Nevada, Wheeler.

V. tephródes, Grar. Silvery-white with close-pressed sericeous-hirsute (not tomentose) pubescence, which is probably somewhat deciduous: leaves alternate, ovate-oblong or the upper rather deltoid-lanceolate, entire, thickish, 3-ribbed at base and obscurely veiny, less than inch long, slender-petioled: heads few or solitary, less than half-inch high : akenes (or rather ovaries) short, with villous-ciliate margins and rather glabrous sides, about the length of the lanceolate awned palex, the short intermediate palex dissected into almost setiform squamella.-Proc. Am. Acad. xrii. 218. Helianthus (Harpalium) tephrodes, Gray, Bot. Mex. Bound. 90. Viguiera nivea, Gray, Bot. Calif. i. 354, excl. syn. Benth. \& syn. Kellogg. -S. E. California, at Mirasol del Monte, in the Colorado Desert, Schott.

V. uanát., Gray, Proc. Am. Acad. xvii. 218 (Bahiopsis lanata, Kellogg, Proc. Calif. Acad. ii. 35), of Lower California, with very pannose dense tomentnm, is of the genus, but is not Encelia nivea, Benth.

V. tomentósa and V. DeltofoeA, Gray, Proc. Am. Acad. v. 161, are other species of Lower California.

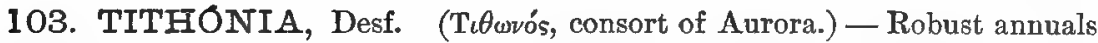
(all Mexican); with alternate petioled and 3-ribbed often 3-lobed ample leaves, and large heads of yellow flowers on long and stout upwardly thickened peduncles. Ligules entire or nearly so. Bracts of the receptacle rather rigid, striate, cuspidate or aristate. Akenes oblong or narrower, compressed-quadrangular: the pappus either deciduous or persistent. - Desf. Ann. Mus. i. 49, t. 4 ; Benth. \& Hook. Gen. ii. 374. - The following was collected so near the southwestern boundary of the U. S. that it is here introduced.

T. Thlurberi, Grar. Comparatively small and slender, 2 feet high, slightly hispid : leaves ovate, serrate, undivided : head only half-inch high, with little exserted orange-colored rays : bracts of the involucre lanceolate or oblong, with short foliaceous tips: akenes narrow: squamellie of the pappus linear-oblong, coriaceous, the awns nearly smooth. - Proc. Am. Acad, riii. 655. T. tubaformis, Gray, Bot. Mex. Bound. 90, not Cass., which is a far larger and showy species. - Magdalena, State of Sonora, Mex., near Arizona, Thurber.

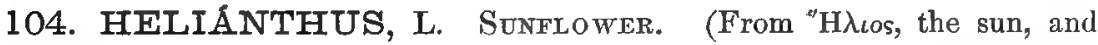
$\ddot{a} \nu \theta_{0 s}$, flower.) - Annual and perennial American herbs, almost all N. American, usually tall or coarse; with the lowest and sometimes all the leaves opposite and simple; heads pedunculate and terminating the stem or branches, produced in summer or autumn, with yellow rays (wanting in one or two species), and either yellow or dark purple disk-flowers: chaffy bracts of the receptacle either entire or 3-toothed: throat of the disk-corollas not rarely 10-nerved. Pappus normally of a thin and acuminate or awn-pointed palea from each of the two principal angles of the akene, or rarely an additional one: intermediate squamellæ present 
only in a few species, and then inconstant, or else mere appendages or lateral portions of the 2-paleaceous pappus. Juice of the stem resinous. - Schkuhr, Handb. t. 528 ; Torr. \& Gray, Fl. ii. 318; Benth. \& Hook. Gen. ii. 376, excl. syn. of Flourensia in part.

H. PadCIFL6rus, Nutt. Gen. ii. 177, of "Lower Louisiana," with narrow serrate leavez, and ovate closely imbricated bracts to the involucre, has not been identified.

§1. Annuals: involucre spreading; its bracts attenuate to a point: disk brownish or dark purple: receptacle flat or nearly so: leaves petioled, 3-ribbed from or near the base, all but the lower usually alternate.

* Stem erect, commonly robust: chaffy bracts of the receptacle mostly 3-cleft at apex, the longer middle lobe lanceolate or linear and somewhat hirsute or hispid. Species of difficult limitation, apparently confluent.

H. argophyllus, Torr. \& GrAY. White with soft and silky wool, which is sometimes floccose, in age more or less deciduous: leaves slightly serrate: otherwise as in the larger indigenous forms of the following. - Fl. ii. 318; Rev. Hort. 1857, 431 with figure. - Texas; first coll. by Drummond. Disk often inch and a half broad, and rays as long. Degenerates in cultivation apparently into

H. ánnuus, L. (Сомmor Striflower.) Robust, when well developed tall, hispid, hispidulous, or scabrous: stem often spotted or mottled: leaves ovate and the lower cordate, serrate, the larger 6 to 12 inches long, the blade of the cauline ones longer than their petiole: bracts of the involucre from broadly ovate to oblong, aristiform-acuminate, below hispidly ciliate : disk in the wild plant commonly an inch or more in diameter. - Spec. ii. 904 (excl. habitat, for it came not from Peru, nor even from Mexico); Lam. Ill. 706 ; Gray, Bot. Calif. i. 353. H. lenticularis, Dougl. Bot. Reg. t. 1225; DC. Prodr. v. 586; Torr. \& Gray, l. c. H. tuboxformis, Nutt. Gen. ii. 177 ; Ind. Sem. Gœett. 139. H. ovatus, Lehm. Ind. Sem. Hamb. 1828, \& Linn. v. 376. H. erythrocarpus, Bartl. H. macrocarpus, DC. Prodr. 1. c., a race of the garden Sunflower with larger and light-colored akenes, long cult. in Russia, \&c., for food and oil. H. multiflorus, Hook. Fl. i. 313, excl. syn. (For history, \&c., see Decaisne in Fl. des Serres, xxiii,, and Gray \& Trumbull in Am. Jour. Sci. ser. 3, xxiii. 245.) - Plains and alluvial grounds, Saskatchewan to Texas, and west to Washington Terr. and California. (Adj. Mex.) Fruit from early times collected by the N. American Indians for food and hair-oil; the plant cultivated for these uses. Gigantesque forms everywhere commonly cultivated for ornament.

H. petioláris, Nurr. A foot to a yard high, more slender, loosely branching, strigose-hispidulous, rarely hirsute: leaves oblong-lanceolate or ovate-lanceolate, entire or sparingly denticulate, barely acute, $\mathbf{I}$ to 3 inches long, cuneately attenuate or the lower abruptly contracted into a long and slender petiole: bracts of the involucre lanceolate or oblong-lanceolate, with acute and mucronate or sometimes more attenuate tips, seldom at all ciliate: disk half-inch or more in diameter. - Jour. Acad. Philad. ii, 115; Sweet, Brit. Fl. Gard. ser. 2, t. 75 ; DC. 1. c.; Torr. \& Gray, 1. c. H. patens, Lehm. Ind. Sem. Hamb. 1828, \& Ind. Schol, 1828, 19. H. integrifolius, Nutt. Trans. Am. Phil. Soc. vii. 366. - Dry plains, Saskatchewan to Texas, west to Oregon and Arizona: seemingly passes into the preceding species.

Var. canéscens, Gray, P1. Wright. i. 108. Leaves whitened with a fine and close strigulose-sericeous pubescence; the lowest ovate, all or most of them with blade longer than the petiole. - S. W. Texas and New Mexico; first coll. by Wright. A very similar variety from Nebraska, $H$. Engelmann.

* * Stem erect, not tall: chaffy bracts of the receptacle entire or with a pair of sinall lateral teeth, and the apex prolonged into a naked cusp or awn: bracts of the involucre hirsute or hispid with long spreading hairs, oblong or lanceolate, mostly attenuate-acuminate.

H. scabérrimus, Benrir. A foot or two high : stem rather stout, branching, scabroushispid: leaves from ovate to oblong-lanceolate, from rather coarseiy serrate to entire, 2 to 5 inches long, the base cuneately or more abruptly contracted into the petiole, both faces either slightly or strongly scabrous: disk about two-thirds inch in diameter, and rays of about equal length: cusp of the chaff mostly subulate-aristiform and equalling the developed diskflowers. - Bot. Sulph. 28, not Ell. H. Bolanderi, Gray, Proc. Am. Acad. vi. 544, \& Bot. 
Calif. i. 353. - California, from San Francisco Bay northward, Hinds (who got it at Bodegas), Bridges, Bolander, Mrs. Ames.

H. exillis, Grar. A foot or so high, slender, commonly hirsute: leaves lanceolato and ovate-lanceolate, sparingly denticulate, tapering into a slender petiole: heads from half to nearly full size of those of the preceding: cusp of the chaff a slender awn, surpassing the disk-flowers. - Proc. Am. Acad. vi. 545, \& Bot. Calif. 1. c. - Plains throughout the northern part of California. (The specimen from Owen's Valley, I'an LIorn, is probably a depauperate $H$. petiolaris.)

* * * Stems branched from the base, diffuse or decumbent, slender.

H. débilis, Nort. Scabrous to hispiclulous or hispid: stems a foot to a yard long: leaves " from ovate to deltoid or obscurely hastate, occasionally subcordate, thiunish, 1 to 3 inches long, repand-denticulate to sparingly lobulate-dentate, slender-petioled : bracts of the involucre lanceolate and gradually subulate-acuminate: disk half-inch or more in diameter; its chaffy bracts with truncate or 3-toothed summit, the middle tooth aristiform-subulate : rays half-inch or more long. - Trans. Am. Phil. Soc. vii. 367; Torr. \& Gray, l. c. 320; the coast form. H. procex, Engelm. \& Gray, Pl. Lindh. i. 13, form with more hispid stem. - Sandy shores of Florila, W. Louisiana, and E. 'Texas.

Var. cucumerifólius. A larger form, usually with purple-mottled stems, leaves irregularly serrate with salient teeth, more commonly subcordate, the larger 4 or 5 inches long, and the ampler (15 to 20 ) rays an inch or more long. $-H$. cucumerifolius, Torr. \& Gray, 1. c. 319. H. Lindheimerianus, Scheele in Linn. xxii. 159? - Sandy soil, often in woods, Texas, common westward.'

§2. Perennials : receptacle convex, or in some at length low-conical: lower leaves almost always opposite.

* Involucre loose (about half-inch high), more or less squarrose in age, of subulate-lanceolate or narrower mostly attenuate-acuminate and almost equal bracts: disk (upper part of corollas) commonly but not always dark purple or turning brownish: all but the lower leaves linear or filiform and strictly one-nerved: slender creeping rootstocks, no tubers.

H. orgyális, DC. Stem smooth and glabrous, often 10 feet high, very leafy to the top: leares mostly alternate, from long-linear ( 8 to 16 inches long, commonly 2 to 4 lines wide), or the lowest lanceolate, to almost filiform, slightly papillose-scabrons, the lower narrowed into a petiole and sometimes serrulate: bracts of the involucre filiform-attenuate, those of the receptacle entire: akenes oblong-obovate with a rounded summit, 3 lines long. - Notul. Pl. Rar. Genev. 12, \& Prodr. v. 586, excl. syn.; Torr. \& Gray, Fl. ii. 320. H. giganteus, var. crinitus, Nutt. Gen. ii. 177? - Dry plains, Nebraska to Arkansas and Texas, west to S. E. Colorado.

H. angustifólius, L. Scabrous, sometimes hispidulous: stems 2 to 6 feet high, rather sparsely leafy, slender: leaves thickish, entire, when dry with revolute margins: cauline sessile (the upper hardly narrowed at base), 3 to 7 inches long, mostly 2 or 3 lines wide, paler and smooth or sometimes canescent beneath, many of them opposite; radical somewhat spatulate or lanceolate: bracts of the involucre lanceolate and acute or attenuateacuminate: rays numerous, inch long: disk generally dark-purple: receptacular bracts entire or 3-toothed: akenes (barely 2 lines long) with broad truncate apex. - Spec. ii. 906; Walt. Car. 216 ; Michx. Fl. ii. 141 ; Bot. Mag. t. 2051 ; Bart. Fl. Am. Sept. t. 105 ; Torr. \& Gray, Fl. ii. 320. Coreopsis angustifolia, L. 1. c. 908 ; Mill. Ic. t. 224,'f. 2 ; and Rudbechia angustifolia, L. Spec. ed. 2, 1281. Leighia bicolor, Cass. Dict. xxv. 436. - Wet ground, pine barrens of New Jersey and Kentucky to Florida and Texas.

* * Involucre closer, of more imbricated and unequal inappendiculate bracts, none of them foliaceous: disk mostly dark-colored or dusky : leaves from lanceolate to ovate, rarely linear: herbage not tomentose nor conspicuously cinereous : Atlantic United States species, one of them reaching the Rocky Mountains.

+ Stems glabrous and very smooth or merely scabrous, leafy: leaves narrowly to broadly lanceoIate: chaff of receptacle entire, merely mucronate.

H. Floridánus, Gray. Stem from 2 to 6 feet high: leaves thinnish, bright green above, sparsely hispidulous-scabrous, lanceolate, sparingly or obscurely denticulate, somewhat triplinerved near the base, 2 to 4 inches long, 5 to 9 lines wide toward the base, often short-peti- 
oled ; uppermost commonly alternate: bracts of the involucre from oblong-ovate to lanceolate and either acute or acuminate, glabrous, shorter than or sometimes equalling the yellowish or at length brownish disk; its bracts nearly glabrous: rays about an inch long, oblong. Chapm. Fl. Suppl. 629. H. angustifolius, var. with broader leaves and yellow disk, Chapm. F1. 229 ; Curtiss, distrib. 1437. - N. and E. Florida, Chapman, Palmer, Garber, Curtiss; flowering late.

H. ciliáris, DC. Glaucous : stems a foot or two high, very leafy : leaves nearly all opposite and sessile, lanceolate, varying to ovate-lanceolate or to linear, thickish, with undulate or repand margins, either very smooth and naked, or hispidulous with some scattered bristles, at least along the margins: bracts of the involucre ovate or oblong, obtuse or abruptly mucronulate, hirsutely ciliate: chaff of the brownish disk pubescent at tip : rays few or several, not surpassing the disk, sometimes none. - Prodr. v. 587; Gray, Pl. Fendl. 84, Pl. Wright. i. 108. - Linsecomia glauca, Buckley in Proc. Acad. Philad. 1861, 458. - Low and brackish ground, S. W. Texas, on the Rio Grande, and Arizona, Berlandier, Wright, 'Thurber, \&c. (Adj. Mex.)

+ + Stems somewhat hirsute, scapiform and monocephalous: leaves roundish : chaff of receptacle with entire cuspidate-acuminate tips: rays commonly wanting: akenes rather fiat, emarginate-2-toothed at summit: an anomalous species. - Echinomeria, Nutt.

H. rádula, TorR. \& GRAY. Leaves hirsute or hispid, denticulate, triplinerved, mostly sessile; radical orbicular, 2 or 3 inches long, in a rosulate cluster; canline 2 or 3 pairs near the base of the (foot or two high) simple stem, obovate with narrowed base, or above reduced to some narrow and minute ones: involucral bracts broadly lanceolate or oblong, acute, brownish-purple, as is the disk : the few rays when present little exserted : akenes with the unusually acute margins produced above more or less into a sort of tooth: pappus snall. - F1. ii. 321. Rudbeckia radula, Pursh, Fl. ii. 575. R. apetala, Nutt. Jour. Acad. Philad. vii. 77. Echinomeria apetala, Nutt. Trans. Am. Phil. Soc. vii. 356. - Low pine barrens, Georgia, Alabama, and Florida.

+++ Stem and (mostly opposite and triplinerved) leaves more or less hispid, hirsute, or scabrous (or forms of the last species smoother): chaff of receptacle entire or some 3-toothed at the apex, pointless : rays numerous and conspicuous.

\section{+ Disk of the head dark purple or brownish.}

H. heterophyllus, Nurr. Stem slender, 1 to 3 feet high, naked above, bearing a single showy head: leaves hispid, entire; radical oval to spatulate-oblong; cauline 3 or 4 pairs and some minute ones above, narrowly lanceolate or linear, sessile, the lower with long taperiug base: bracts of the involucre lanceolate, acuminate, ciliate: rays about 20, inch and a half long. - Jour. Acad. Philad. vii. 74; Hook. Comp. Bot. Mag. i. 98, partly; Torr. \& Gray, 1. c. - Low pine barrens, Georgia to Florida and Louisiana, toward the coast.

H. atrórubens, L. Stems stouter, sometimes leafy, sometimes few-leaved, 2 to 4 feet high, bearing few or several rather small heads: leaves hispid and scabrous, veiny, commonly thinnish, from roundish-ovate or rarely cordate to oblong-Ianceolate, often serrate, contrarted below into winged petioles, lower a span to a foot long, uppermost small and bract-like: bracts of the involucre oval or obovate, obtrise, ciliolate: rays 10 to 16, rarely inch long. - Spec. ii. 906, \& ed. 2, 1279 (Dill. Elth. t. 94; Martyn, Hist. Pl. Rar. t. 20) ; Ait. Kew. iii. 250; Michx. Fl. ii. 140, in part; Torr. \& Gray, l. c., not Lam., nor Bot. Mag., Bot. Reg., \&c. H. sparsifolius, Ell. Sk. ii. 415. H.-silphioides, Nutt. Trans. Am. Phil. Soc. vii. 366. - Open woods, Virginia to Florida, Arkansas, and Louisiana.

H. rígidus, DESF. A foot or two (rarely 6 to 8 feet) high, rigid, sparingly branched : leaves very firm-coriaceous and thick, both sides hispidulous-scabrous, shagreen-like, entire or serrate, lightly triplinerved but indistinctly and 'sparingly veined; lower oblong and ovatelanceolate, attenuate at base into short winged petioles; upper mostly lanceolate: heads comparatively large, showy (disk three-fourths inch high): involucre pluriserially imbricated; its bracts mainly ovate, obtuse or acutish, rigid, appressed, densely and minutely ciliate: rays numerous, generally inch and a half long: akenes oblong-obovate, 3 lines long: pappus of two large ovate-lanceolate paleæ, and sometimes two or four rather stout intermediate paleæ! more commonly none. - Cat. Hort. Par. ed. 3, 184; Torr. \& Gray, F1. ii. 322. H. atrorubens, Michx. 1. c., in part ; Bot. Reg. t. 508; Bot. Mag. t. 2668; DC. Prodr. v. 586. H. diffusus, Sims, Bot. Mag. t. 2020. H. Missuricus, Spreng. Syst. iii. 618, name in place of 
diffusus. H. scaberrimus, Ell. Sk, ii. 423. H. Missouriensis (Schweinitz) \& H. crassifolius, Nutt. Trans. Am. Phil. Soc. 1. c. Harpalium rigidum, Cass. Dict. Sci. Nat. xx. 200; DC. Prodr. v. 583, founded on the form with intermediate palex to the pappus. Plains and prairies, Saskatchewan and Michigan to W. Georgia, Texas, and eastern part of Colorado. Sometimes the disk-corollas are at first yellow!

$$
\text { + Disk yellow. (Here the Californian H. gracilentus would be sought.) }
$$

H. lætiflórus, PErs. Resembles tall forms of the preceding, similarly scabrous or hispid, leafy: leaves commonly thinner, mostly oval-lanceolate, acuminate at both ends, 4 to 10 inches long, more or less serrate: heads usually several and rather short-peduncled: disk half-inch high: bracts of the involucre imbricated in only 2 or 3 series, from ovate- to oblong-lanceolate, acuminate or attenuate-acute, hirsutely ciliate or ciliolate, occasionally a little hirsute on the back: rays numerous, the larger inch and a half long, - Syn. ii. 476 ; DC. Prodr. v. 586, excl. syn. Ell.; Torr. \& Gray, l. e. H. atrorubens, Lam. Dict. iii. 86, not L. - Prairies and barrens, Indiana, Illinois, Wisconsin.

Var. tricúspis, Torr. \& Grax, 1. c. Leaves less serrate: chaff of receptacle more commonly 3-toothed. - H. tricuspis, Ell Sk. ii. 422. W. Georgia, ex Elliott. Needs confirmation.

H. púmilus, Nutr. Hispid and scabrous thronghout: stems simple, a foot or two high, bearing 5 to 7 pairs of leaves and a few rather short-peduncled heads: leaves mostly ovatelanceolate, acute, entire or nearly so ( $1 \frac{1}{2}$ to 4 inches long), rigid, abruptly contracted at base into a short margined petiole: involucre less than half-inch high, white-hirsute or scabrohispidulous; its bracts imbricated in about 3 series, oblong-lanceolate, acutish : rays about inch long. - Trans. Am. Phil. Soc. vii. 366 ; Gray in Am. Jour. Sci. ser. 2, xxxiíi. 239. Eastern Rocky Mountains and adjacent plains of the Platte, \&c., from Wyouning to Colorado, Nuttall, Hayden, Geyer, Parry, Hall \& Harbour, \&c.

H. occidentális, Riddell. Stem slender, 2 or 3 feet high, sometimes smooth and glabrous, usually leafy only at and near the base: radical and lowest cauline leaves ovate to lanceolate-oblong, entire or denticulate, contracted at base into long margined petioles, minutely hirsute or hispidulous, moderately scabrous; upper cauline a few remote pairs, subsessile, lanceolate, and bract-like, of an inch or half-inch in length : heads few or sometimes solitary, small: bracts of the involucre ovate to lanceolate, acute or acuminate, glabrous, or the margins sometimes ciliate, snmetimes naked : rays half-inch to nearly inch long: akenes when young and at summit prbescent. - Suppl. Cat. Ohio Pl. (1836), 13; Torr. \& Gray, I1. ii. 323. H. heterophyllus, Short, Cat. Kentucky PI. Suppl. 3 ; Hook. Comp. Bot. Mag. i. 98 , partly, not Nutt. - Prairies and oak barrens, in dry ground, Michigan to Kentucky and Missouri.

Var. plantagineus, Torr. \& Grar, 1. c. Minutely puberulent and slightly or not at all scabrous: leaves rather more rigid: involucre obscurely ciliolate or naked. - Texas, Drummond, Lindheimer, Wright. (Adj. Mex.)

Var. Dowelliánus, Torr. \& Gray. Like the preceding, but leafy to the middle or higher, the leaves larger and mostly ovate, and stem sometimes branching. - Fl. ii. 504. H. Dowellianus, Curtis in Am. Jonr. Sci. xliv. 82.-Mountain region in the southwestern part of North Carolina, Curtis, Buckley, \&c.

* * Involucre looser and the bracts disposed to be more taper-pointed, or elongated, or foliaceous (closer and shorter in some species): disk except for the dark anthers yellow or yellowish.

+ Canescent or cinereous, at least the foliage, with soft and fine appressed (but not tomentose) pubescence: leaves all opposite, sessile, merely serrulate: heads middle-sized: bracts of the involucre imbricated; their attenuate tips seldom or little surpassing the disk: Atlantic species.

H. cinéreus, Torr. \& GRAY, A foot or twyo high, barely cinereous throughout with minute and slightly scabrous appressed pubescence: stem simple, somewhat equably. leafy, bearing one or two slender-pedunculate small heads: leaves coriaceous, Ianceolate-oblong, acute; lower ( 3 inches long) contracted into a rather long narrowed base; uppermost (about inch long) ovate-lanceolate with a broad sessile base: involucre half-inch high; its bracts Ianceolate-subalate, canescent: rays 10 or 12, two-thirds inch long. - Fl. ii. 324, excl. var. - Texas, Drummond. Heads little larger than those of $H$.occidentalis, of which it may be a hybridized offspring. 
H. móllis, LAM. Canescent throughout: stems 2 or 3 feet high, very leafy, when young villous, in age often hirsute or hispid, simple and with solitary or few rather large heads, or branched above and more floriferous : leaves ovate-lanceolate or ovate with a cordate closely sessile or a clasping base, attenuate-acute or acuminate, 3 to 5 inches long, whitened with a soft pubescence, or the upper face becoming greener and scabrous: involuere two-thirds inch high, villous or sericeous : rays 15 to 25 , an inch or more long. - Dict. iii. 85 (1789); DC. Prodr. v. 587; Torr. \& Gray, 1. c., not Willd., \&c. H. canescens, Michx. Fl. ii. 140. H. pubescens, Vahl, Symb. ii. 92 (1791); Willd. Spec. iii. 2240; Ell. Sk. ii. 418 ; Hook. Comp. Bot. Mag. i. 98. - Dry barrens, Ohio to Iowa and south to W. Georgia and Texas. Well-marked species, but passes into a greener or less pubescent and somewhat scabrous variety.

++ Soft-villous rather than tomentose (varving to merely pubescent) as to the lower face of the mostly alternate ample leaves, but the tall stem villous hirsute or even hispid: heads jather large: involucre loose and long: disk grayish: the corolla-lobes as well as the tips of the chaff externaily hirsute!

H. tomentósus, Mrchx. Stems stout, 4 to 9 feet high, branching : leaves thinmish, ample (the larger cauline a foot long), from ovate to oblong-lanceolate, acuminate at both ends, mostly somewhat petioled, sparingly serrate, upper face scabrous : heads nearly inch high and broad: bracts of the involucre linear-lanceolate and long-attenuate into almost filiform tips, externally hirsute, especially the margins, squarrose-spreading, often much surpassing the disk, outermost sometimes large and foliaceous : rays pale yellow, an inch or more long. - Fl. ii. 141 ; Ell. Sk. ii. 424 ; Torr. \& Gray, l. c. H. pubescens, Bot. Reg. t. 524, but not that of Hort. Kew., \&c. H. squarrosus, Nutt. Trans. Am. Phil. Soc. vii. 367. H. spathulatus, Ell. Sk. ii. 421, a form with mostly opposite leaves and less prolonged involncral bracts. Moist woods, Illinois? and Virginia to Georgia and Alabama, most common along the mountains, in the lower country with leaves less pubescent beneath.

+++ Leaves mostly scabrous both sides (in one sometimes soft tomentose-canescent beneath), the upper disposed to be alternate and not triplinerred, mostly petiolate and not broad: heads middle-sized.

+ Atlantic species : involucre loose or squarrose; its bracts linear-subulate or gradually attenuate from a narrowish base to a slender point, all nearly of the same length, equalling or surpassing the dull yellow disk: all producing slender creeping rootstocks and also forming one or more fleshy thickened roots (like tap-roots) at base of stem.

H. grosse-serrátus, Muxtevs. Stem very smooth and glabrous, commonly glaucous, 6 to 10 feet high, beaxing numerous rather cymosely disposed and short-peduncled heads : leaves (not rarely some even of the uppermost opposite) slender-petioled, thinnish, oblong-lanceolate or narrower, or some of the cauline almost deltoid-lanceolate, gradually acuminate, sharply serrate (sometimes with long salient teeth), or upper merely denticulate, slightly scabrous above, whitish and minutely tomentulose or soft-puberulent beneath; larger cauline commonly 8 to 10 inches and the petiole an inch or two long: heads fully half-inch high, and deep yellow oblong rays over an inch long: bracts of the involucre mostly slender. - Sel. Sem. Hort. Lovan., \& Linn. xiv. Suppl. 133; Torr. \& Gray, Fl. ii. 326. - Dry plains and prairies, Ohio to Dakota, Missouri, and Texas. Eastward the smaller-leared forms seem to pass into $H$. giganteus.

Var. hypoleúcus. Leaves almost silvery-canescent with fine and dense soft tomentum, the larger with either cuneate or truncate base. - Texas, Drummond, Lindheimer, Wright. (Var. $\gamma$, Torr. \& Gray, in part.)

H. gigantéus, L. Stem hispidulous or scabrous, or below smooth, 3 to 10 feet high, commonly one or more of the roots becoming thick and tuber-like; the larger plants brauching above, bearing scattered heads: leaves lanceolate or oblong-lanceolate, green and more or less scabrous both sides, tapering to base and summit, short-petioled or subsessile, minutely serrate or denticulate, occasionally nearly entire, commonly only 3 to 5 inches long: heads of the preceding or smaller: rays pale yellow, barely inch long. - Spec. iii. 249; Willd. Spec. iii. 2242 ; DC. I. c.; Torr. \& Gray, Fl. ii. 325; exc1. $\beta$. H. altissimus, L. Spec. ed. 2, ii. 1278 ; Jacq. Hort. Vind. t. 162. H. gigas, Michx. Fl. ii. 141. A low and mainly northern form is $H$. tuberosus, Parry in Owen Rep. Minnesota Surv. 614, and $H$. subtuberosus, Bourgeau in herb. Hook.; "the Indian Potato of the Assiniboine tribe," the so-caller "edible tubers" (which were also long ago noted by Douglas) being tuber-like thickened. 
roots. - Moist or wet ground, Canada to Saskatchewan, and south to Alabama and Louisiana. Very variable: the var, ambiguus, Torr. \& Gray, l. c., is intermediate between this species and $H$. divaricatus, probably a hybrid.

H. Maximiliáni, Schrader. Hispidulous-scabrous: stem stout, 2 or 3 (and even 10 to 12) feet high, below 'mostly rough-hispid: leaves almost all alternate, thickish, becoming rigid, very scabrous above, lanceolate, acute or acuminate at both ends, mostly subsessile, all entire or sparingly denticulate: heads comparatively large, short-peduncled, terminating somewhat simple stem or branches, and later in the axils of many of the cauline leaves: involucre of more rigid bracts : rays numerous, often inch and a half long, golden yellow: flowering late. - Ind. Sem. Hort. Goett. 1835 ; DC. Prodr. vii. 290 ; Torr. \& Gray, Fl. ii. 325; Gray, Pl. Lindh. i. 41 (with var. asperrimus, which is merely a rougher form); Meehan, Nat. F1. ii. t. 37. - Rich prairies and plains, west of the Mississippi, and from Saskatchewan and Minnesota to Texas.

+ Pacific species: leaves mostly lanceolate, broader toward the base and tapering to an acute or acuminate apex, short-petioled or subsessile: involucre of narrow or small bracts : rays about inch long.

$=$ Bracts of the involucre linear- or lanceolate-subulate, attenuate, fully equalling the disk, herbaceous, loose or soon squarrose-spreading: stem usually smooth and glabrous, except at the summit.

H. Nuttállii, Torr. \& Gray. Stem slender, 2 to 4 feet high, commonly simple: leaves lanceolate or the upper linear ( 3 to 6 inches long, 3 to 9 lines wide, in small plants not rarely all opposite), serrulate or entire: heads half-inch high: bracts of the involucre naked or somewhat hirsute at base: disk-corollas slightly pubescent toward the base: paleæ of the pappus long and narrow. - F1. ii. 324. H. Californicus, Nutt. in herb., not DC. - In wet soil, Rocky Mountains, from western part of Wyoming and Utah to Oregon, Washington Terr., and interior of Brit. Columbia.

H. Paríshii, Grax. Resembles the preceding, 6 to 15 feet high: leaves elongated-lanceolate, softly cinereous-puberulent or even canescent beneath, scabrous above: heads half-inch high and rays 10 to 18 lines long: bracts of the involucre linear-subulate, longer than the disk, villous toward the base: disk-corollas with a silky-villous ring or two tufts above the short proper tube: paleæ of the pappus slender-subulate. - Proc. Am. Acad. xix. 7. - S. E. California, in wet places and along streams at San Bernardino, Parish; fl. autumn.

H. Califórnicus, DC. Tall, 3 to 8 feet high, usually branching : leaves lanceolate, entire or serrate (the larger 4 to 10 inches long, sometimes an inch or two wide): heads mostly two-thirds inch high: rays over an inch long when well developed: bracts of the involucre slightly hirsute or naked : disk-corollas canescently puberulent toward the base: akenes very glabrous : palea of the pappus broadly lanceolate. - Prodr.v. 589 ; Torr. \& Gray, Fl. ii. 325 ; Gray, Bot. Calif. i. 353. H7. giganteus, var. insulus, Kellogg, Proc. Calif. Acad. v. 17.California, along streams, from San Francisco Bay southward.

Var. Utahénsis ( $H$. giganteus, var. Lituhensis, Eaton, Bot. King Exp. 169) seems rather to be a form of $H$. Californicus, with thin and smoother leaves, and involucre more hirsute. - Wahsatch Mts., Parley's Park, Utah, Watson.

Var. Mariposiánus. Leaves ample; upper cauline ovate or oblong-lanceolate, entire ( 7 or 8 inches long by 2 or more wide): pappus not rarely of 4 linear-lanceolate palex of nearly equal length, or two often reduced and short. - Banks of the Merced at Clark's Ranch, Mariposa Co., California, Bolander.

$$
==\text { Bracts of the involucre broader and short, erect. }
$$

H. graciléntus, Gray. Stem 2 to 5 feet high, rough-hispidulous, the slender branches glabrous or scabrous: leaves thickish, scabrous and commonly hispidulous both sides, sparingly denticulate or entire; lower cauline from broadly to ovate-lanceolate, triplinerved near the base, which is abruptly contracted into a short margined petiole; upper lanceolate: heads slender-peduncled, half-inch high : bracts of the involucre imbricated in about 3 ranks, thickish, ovate or oblong-lanceolate, acute or apiculate-acuminate, shorter than the disk, scabrous-puberulent, nsually ciliolate : chaff of receptacle with puberulent obtuse or abruptly acutish tips, below often purplish: rays 12 to 16, about inch long. - Proc. Am. Acad. xi. 77, Bot. Calif. i. 616. - Low plains and along water-courses, San Diego Co. to San Bernardino Co., California, Pulmer, Parry \& Lemmon, Parish, \&c. 
+t +t Imperfectly known Pacific species, probably perennial, with foliaceous involucre.

H. Douglásii, Torr. \& Gray. Stems branching, ascending, hispidulous : leaves alternate; upper rhomboid-oblong to spatulate-lanceolate, tapering into winged petioles, obtuse, entire, inch or two long: head half-inch high : bracts of the involucre almost all foliacoous, hispidulous; outer narrowly oblong, mostly obtuse, reflexed or spreading, longer than the disk, innermost shorter, erect, acute or somewhat acuminate: rays barely half-inch long: chaff of receptacle entire. - Fl. ii. 332. - California, Douglas (nentioned in Bot. Beech. 253); near Santa Clara, Sinclair, in Bot. Sulph. as "H. Californicus."

++++ Leaves all or most of them opposite, at least the cauline, or in $H$. tuberosus, \&c., the upper alternate, all triplinerved or 3-nerved: Atlantic species.

t+ Heads remarkably small, only 4 or 5 lines high and rather narrow, loosely paniculate: rays only 5 to 8 , seldom inch long: sten and spreading branches slender: leaves scabrous above, puberulent or canescent-tomentulose beneath.

H. parviflórus, Bernt. Stem smooth and glabrous, 3 to 6 feet high : leaves thin, nearly membranaceous, ovate-lanceolate or narrower, cuneately or almost truncately contracted at base into a half-inch or inch long partly margined petiole, gradually attenuate-acuminate, serrulate, sometimes more serrate ( 4 to 7 inches long, the larger inch or two wide near the base), pale and when young tomentulose or puberulent beneath; bracts of the campanulate involucre subulate-lanceolate, shorter than the comparatively few-flowered disk, the tips loose or squarrose: rays 5 or 6, commonly half-inch but sometimes nearly inch long. Spreng. Syst. iii. 617 (1826, \& probably somewhat earlier), not of HBK. Nov. Gen. \& Spec., 1820 (H. micranthus, Spreng.), which perhaps is not of the genus. H. divaricatus, Michx. Fl. ii. 141 ; Ell. Sk. ii. 428, not L. H. strumosus, var. pallidus, Ell. 1. c., ex Torr. \& Gray. H. trachelizfolius, Hook. Comp. Bot. Mag. i. 98. H. microcephalus, Torr. \& Gray, Fl. ii. 229. - Moist woods and along streams, Pennsylvania to Illinois, Upper Georgia, Arkansas, and Louisiana.

Var. attenuátus. Leaves narrowly lanceolate, $\mathbf{5}$ inches long, at most half-inch wide, very scabrous above, therefore connecting with the following. - Dry woods, near 'Tallulah Falls, Georgia, 'I. Donnell Smith.

H. Schweinítzii, Torr. \& Grax. Stem hispidulous or minutely strigose-pubescent, 2 to 5 feet high: leaves of thicker texture, shagreen-scabrous above, canescently tomentulose beneath, lanceolate (the larger 4 to 7 inches long, inch or less wide) and with more tapering less petioled base, serrulate or nearly entire : involucre hirsute : rays 6 to 8 , half-inch long. - Fl. ii. 330 ; Chapm. Fl. 231. - Dry ground, W. North Caroliua to Middle Georgia.

+ Heads small, half-inch or less high, few or scattered, sleuder-peduncled: rays 6 to 10: whole plant glabrous and smooth! except perhaps the edges of the leaves and involucral biacts: involucre campanulate, of thickish smooth bracts; the outer lanceolate with gradually attenuatesubulate spreading tips; inner ovate-lanceolate or broader, somewhat acuminate, erect: akenes a little hairy at the summit: usually but not always one or two conspicuous acute squamelle or short palex on each side between the lanceolate or ovate principal palex of tho pappus, sometimes united with their base (like stipules), caducous with them.

H. longifólius, Pursh. Stem 3 to 7 feet high, simple: Ieaves elongated linear-lanceolate ( 3 to 8 inches long, quarter to half inch wide), thickish, mostly entire, sessile, lowest cauline and radical tapering into slender margined petioles : rays about 10, narrow, half-inch long: chaff of the receptacle glabrous, commonly 3-toothed, narrow: proper palex of the pappus 2 or 3, the squamellæ thin and small. - Fl. ii. 571 ; Ell. Sk. ii. 417 ; Torr. \& Gray, Fl. ii. 431. Leighia longifolia, Nutt. Trans. Am. Phil. Soc. vii, 365. - W. Georgia, in wet soil, Lyon, \&c. Little known; no sufficient specimens seen.

H. lævigátus, TorR. \& GRAY. No creeping rootstocks and no fleshy-thickened roots : stem 2 to 5 feet high, glaucous: leaves lanceolate, very acute, subsessile, thickish, pale beneath, sparsely serrulate or the upper entire : rays 6 to 8 , broad, usually inch long, bright yellow: chaff of the receptacle entire, more or less pubescent on the back: squamellæ or intermediate palea of the pappus rather large and firm, half or a quarter the length of the lanceolate or ovate proper paleæ, sometimes wanting. - Fl. ii. 330; Gray, Man. 256. - Alleghany Mountains in Virginia and N. Carolina. Occurs in two forms; one slender, simple, 2 or 3 feet high, with narrow leaves 3 to 5 inches long, half-inch or less broad (this possibly may be $H$. longifolius): the other larger, 4 to 6 feet high, branching, with ampler leaves, the larger canline ovate- or oblong-lanceolate and 2 or 3 inches wide, and rays over an inch 
long, and it would appear to pass into $H$. strumosus except for the remarkable smoothness. Bracts of the involucre minutely ciliolate.

+++ Heads middle-sized, at least balf-inch high: rays usually but not always more than 10, an inch or more long: plant multiplying by creeping rootstocks. (Species difficult of extrication, either confluent or mixed by intercrossing.)

$=$ Cauline leaves all sessile and even somewhat connate by a more or less narrowed base, those of the floweriug branches not rarely alternate, none more than serrulate, no lateral basal ribs.

H. doronicoídes, L.ir. Minutely pubescent and somewhat scabrous: stem 3 to 7 feet high: leaves ovate-ablong, narrowed from below the middle to both ends, moderately so below, lightly or indistinctly triplinerved much above the base, 4 to 8 inches long: involucre of loose subulate-linear and slender pointed bracts, soft-pubescent or hirsute: rays 13 to 18 , a third to half inch broad, sometimes inch and a half long: ovary and akene glabrous. Dict. iii. 84; Torr. \& Gray, Fl. ii. 327, in part, excl. syn. Vahl, \&c., not of Gray, Man. H. pubescens, Hook. Bot. Wag. t. 2778, not Vahl. H. cinereus? var. Sullirantii, Torr. \& Gray, 1. 1. 324, appears to be a form of this. - Dry Ground, Ohio to Missouri, \&c.

$==$ Cauline leaves sessile or nearly so by a rounded or subcordate and 3-nerved base, thence gradually narrowed to the slender apex, of rather firm texture: heads and rays comparatively small.

H. divaricátus, L. Stem simple to the summit or nearly, a foot to a yard high, mostly slender, rigid, usually smooth and glabrous below and hispidulous-scabrous at summit, bearing few short-peduncled heads: leaves green and scabrous both sides, appressed-serrulate, all the canline opposite and horizontally divaricate (whence the name), commonly 4 or 5 inches long, and at base an inch or two wide: head only half-inch high . bracts of the invo lncre lanceolate-subulate, usually hirsute-ciliate: rays 8 to 12, at most an inch long. - Spec. ii. 906 (excl. syn. Moris. Hist. sect. 6, t. 7, f. 66) ; Ait. Kew, iii. 250; Willd. Spec. iii. 2244; Torr. \& Gray, Fl. ii. 329. H. truncatus, Schweinitz in Ell. sk. ii. 416. Chrysanthemum Virginianum, \&c., Moris. Hist. sect. 6, t. 3, f. 62? - Dry and sandy or gravelly soil, Canada and Saskatchewan to Florida and Louisiana.

$===$ Cauline leares short-petioled or upper subsessile, serrulate or serrate with small erect teeth, or the upperniost entire, all triplinerved from near the base.

H. hirsútus, RAF. Stem simple or branched at summit, 2 to 4 feet high, rigid, commonly smooth below, rough and hispidulous abore: leaves oblong-lanceolate and ovate-lanceolate, subsessile or short-petioled with a roundish or broad abrupt and rarely subcordate or sometimes rather cuneate base, thence gradually tapering to the point in tile manner of $I I$. dix aricutus, scabrous above, somewhat so and little paler benoath: bracts of the involucre usually broadly lanceolate and acuminate, ciliate, unequal, commonly erect and not surpassing the (lisk : rays 12 to 15, rather broad, fully inch loug. - Anu. Nat. (1820), 14; DC. Prodr. v. 591 ; Torr. \& Gray, Fl. ii. 329. H. diversifolius \& $I$. hispidulus? Ell. Sk. 1. c. - Dry or moist soil, Ohio to Wisconsin and south to Georgia and Texas.

Var. trachyphyllus, Torr. \& Grar, l. c., a form from Arkansas, with thick rery rough leaves, and larger heads with squarrose involucre.

Var. stenophýllus, Torr. \& Grar, l.e, a small form, with narrow lanceolate leaves almost sessile by a somewhat contracted base. - II. strumosus, var.? leptophyllus, 'lorr. \& Gray, l. c., may be the same with smoother stem. - Louisiana and Texas.

H. strumósus, L. Rootstocks long and slender, often branching, thickened often into a narrow fusiform tuber at the apex: stem usually branching, 3 to 6 feet high, glabrous and very smooth and often glaucous, but summit and branches not rarely hispidulous: leaves oblong- or ovate-lanceolate, or the lowér sometimes ovate, acute or acuminate, slightly serrate or some of them entire, bright-green and somewhat papillose-scabrous above, whitish beneath (either with or without minute tomentum), abruptly contracted or more tapering into a margined petiole (the larger 5 to 8 inches long and 2 wide): hearls rather small (half-incls high), but the rays ample, 9 to 15, commonly oblong, an inch to inch and a half long : bracts of the involucre rather broadly or ovate-lanceolate, acuminate, sometimes with attenuate sprending tips, rarely surpassing the disk, ciliate, either glabrous or pubescent on the back: pappus not rarely with intermediate squamella, either free or adnate to the base of the palex. Spec. ii. 905 ; Ait. Kew. iii. 249; Torr. \& Gray, 1. c. UI.lcevis, Walt. Car. 215? H. neglectus, Otto, in Berlin Garden, is either a glabrous form of this, or is H. lavvigatus. - Open woods and banks, Canada to Wisconsin, Georgia, and Arkansas. 
Var. móllis, Torr. \& GrAY, l. «. Leaves canescently tomentulose beneath, not rarely subcordate, commonly larger (upper cauline not rarely 6 to 8 inches long): involucre looser, the luracts mostly with prolonged attenuate tips: there are similar forms without the pubescence, except when young. $-H$. mollis, Willd. Spec. iii. 2240, excl. syn. Michx.; Hook. Bot. Mag. t. 3689, not Lam. H. macrophyllus, Willd. Hort. Berol. t. 70, \& Enum. 920.Mass. to Iowa; commoner westward.

H. tracheliifólius, WILLD. Resembles the two preceding: leares thinner, nearly of the same rather dull green hue both sides, all distinctly short-petioled, lower more sharply serrate: involucre of the following, i. e. the bracts all loose and spreading, linear-attenuate, hirsute, surpassing the disk, sometimes much prolonged and attenuate-foliaceous. - Spec. iii. 2241, \& Enum. 920. II. prostratus, Willd. l. c. 2242, a weak form, decumbent in cultivar tion. - Moist or dry ground, Penn.? and Ohio to Wisconsin and Illinois.

$===$ Cauline leaves more conspicuously petioled, prominently serrate, thinnish or soft, veiny, commonly broad, the upper disposed to be alternate : stems mostly branching: involucral bracts loose, hirsute-ciliate.

H. decapétalus, L. Rootstocks rather slender, branching, more or less tuberous-thickened at apex: stem smooth and glabrous below, 2 to 5 feet high; the branches slightly pubescent or scabrous: leaves usually membranaceous, ovate or oblong-ovate, acuminate, saliently serrate, green both sides, either smooth and glabrous or above papillose-scabrous and slightly scabrous below, 4 to 8 inches long, the truncate or somewhat cuneate base abruptly contracted into a winged or naked petiole: bracts of the involucre narrowly lanceolate-linear or linear, thin, often foliaceous and surpassing the disk: rays 8 to 10 or more, light yellow, only an inch long. - Spec. ii. 905 ; Ait. 1. c.; Willd. 1. c.; Hook. Bot. Mag. t. 3510; Torr. \& Gray, 1. c. H. frondosus, L. Amœn. Acad. iv. 290, \& Spec. ed. 2, ii. 1277, merely a form with foliaceous involucre. H. strumosus, Willd. 1. c. 2422 ; Ell. Sk. ii. 420. HI. tenuifolius, Ell. 1. c., thin-leaved form of shady places. - Banks of streams and moist woods, Canada to Michigan, Illinois, Kentucky, and Georgia, in the upper country.

Var. multiflórus? H. multiflorus, L. 1. c.; Bot. Mag. t. 227, known only in cultivation, from early times; must have been derived from $H$. decapetalus. It has short and thick rootstocks, somewhat firmer leaves, on naked petioles, larger heads, more numerous bracts to the involucre, and 20 or more rays. The more common form of it in gardens is dwarf, and the disk filled with transformed ligulate flowers.

H. tuberósus, L. (Jerusalem Artichore.) Stem usually pubescent or hirsute, 5 to 10 feet high, branching at summit: leaves mostly alternate on the branches, and sometimes on the upper part of the stem, ovate or subcordate, sometimes oblong, acuminate, thickish membranaceous, dull green, minutely pubescent and occasionally cinereous beneath, soon scabrous above: bracts of the involucre lanceolate, attenuate-acuminate, hirsute, at least the margins toward the base: rays often inch and a lalf long, 12 to 20 : bracts of the receptacle hirsute-pubescent on the back: akenes more or less pubescent at summit and margins, mostly long and slender - horizontal rootstocks enlarging at apex into either oval or fusiform fleshy tubers (in cult. large and oblong or roundish, sweet and edible). - L. Spec. ii. 905 (excl. habitat); Jacq. Hort. Vind. t. 161; Trumbull \& Gray in Am. Jour. Sci. ser. 3. xiii. (May, 1877), 347 ; Decaisne in Fl. Serres, xxiii. 1881. H. doronicoides, Torr. \& Gray, Fl. ii. 327, in part; Gray, Man. 257, not Lam. - Moist alluvial ground, Upper Canada to Saskatchewan, and south to Arkansas and middle parts of Georgia. Was cultivated by the aborigines, and the tubers developed; now widely dispersed under cultivation. Among the various indigenous forms the following may be distinguished.

Var. subcanéscens. Mostly dwarf (about 2 feet high), comparatively small-leaved, rough-hispiclulous or scabrous, but the lower face of the leaves whitish with soft and fine pubescence. - Plains of Minnesota, Dakota, \&c., Kennicott, C'oues, Ward, sometimes with well-developed tubers. Also, a larger form with narrower leaves, near St. Louis, Missouri, Engelmann, \&c.

H. DEalbAtus. A foot or two high from a frutescent base, canescent with fine appressed pubescence: leaves ovate to oblong, obtuse, entire or repand, 3-nerved at the rounded or abruptly contracted base (about inch long), rather long-petioled; lower opposite, upper alternate: head solitary, terminating simple stems or few branches, slender-peduncled, barely half-inch high : involucre short-campanulate, canescent, of oblong-linear obtuse bracts, shorter than the fuscous disk: rays 4 or 5 lines long: akenes turgid, sericeous-pubescent. - Lower California, 
Belding, 1875. At All-Saints Bay, 70 miles below the U. S. boundary, Parry, 1883; perhaps therefore within the U.S. A singular species, with aspect of a Viguiera, but a caducous pappus of two lanceolate palere and no squamellæ.

105. FLOURÉESIA, DC. (M. J. P. Flourens, a distinguished physiologist.) - Founded on two homogamous northern Mexican species, of very distinct habit and character, shrubby, almost glabrous, somewhat resiniferous-viscid, much branched, with alternate entire leaves, either corymbed or paniculate shortpeduncled heads from upper axils, and whitish or yellowish flowers. 'To these the founder added two Chilian radiate species, viz. $F$. corymbosa, which is a Viguiera ( $I^{\prime}$. Poppigii); and $F$. thurifera (Helianthus thurifer, Molina), which may probably remain as a subgenus, Diomedia, Bertero and Colla, not Cass. DC. Prodr. v. 592, excl. no. 2 ; Gray, Proc. Am. Acad. xix. 7.

F. cérnua, DC., 1. c. Very branching and leafy shrub, with the aromatic bitterness and odor of hops, 3 to 6 feet high: branches puberulent: leaves obovate and oblong, half to inch and a half long, acute at both ends, dull, obscurely veiny: heads seldom half-inch long, subsessile in the axils or terminating paniculate branchlets, soon nodding: involucre campanulate, shorter than the disk, of lanceolate erect imbricated bracts, with some outer and spreading foliaceous ones passing into leaves: tips of the short style-branches much dilated, wider than high: awns of the pappus rigid, half the length of the appressed-villous akene, the slenter squamellæ not surpassing the villous hairs. - Gray, Pl. Wright. i. 114, \& ii. 89. Helianthus cernurus, Benth. \& Hook. Gen., ex Hemsl., but it is not really so referred, nor has it any likeness to that genus. - Arid hills and plains, W. Texas to Arizona, Wright, Lemmon, \&c. (Adj. Hex., Berlandier, Gregg, \&c.)

F. La drifólia, DC. 1. c., of N. E. Mexico, Berlandier, Palmer, is larger, with oblong and more veiny lucid leaves ( 2 to 4 inches long, on distinct petioles), corymbosely clustered heads of twice or thrice the size, \&c. ; may occur on the Lower Rio Grande.

106. ENCELIA, Adans. (Christopher Encel, wrote upon oak-galls.) Herbs or some under-shrubby (all American, chiefly subtropical); with alternate or opposite leaves, commonly with rather showy radiate heads of flowers on naked peduncles; the rays mostly yellow, occasionally wanting; the disk yellow or brownish. Chaffy bracts of the receptacle usually soft and mainly scarious. Benth. \& Hook. Gen. ii. 378. Encelia, Simsia (Pers.), \& Armania (Bertero), DC. Prodr., with Geraa, Torr. \& Gray, \& Barrattia, Gray \& Engelm. Neglecting the pappus, which is inconstant, the four sections may be reduced to two.

\$1. Euencélia. Akenes densely long-ciliate: upper and commonly most of the leaves alternate: petioles naked.-Encelia, Adans. Fam. ii. 128. Pallasia, I'Her. ex Ait., not L. f. Geraa, Torr. \& Gray, \&c.

* Shrubby or ligneseent at base, wish herbaceous flowering branches: leaves from ovate to oblonglanceolate, mostly entire.

E. Mr'cropiflla, Gray, Proc. Am. Acad. xv. 37, \& xix. 7, of Northern Mexico, makes the nearest approach to Flourensia, and commonly has a biaristellate pappus.

E. alméscens, Gray, 1. c. viii. 658, of Sonora in Mexico, Palmer, appears to be more herbaceous than the following species; the akenes less strongly villous on the edges, except next the summit, and the faces pubescent : pappus biaristellate. It may be expected in S. Arizona.

E. Halimifólia, CA . Ic. iii. 6, t. 210 (Pallasia grandiffora, Willd. Spec. iii. 2261), from "Nova Hispania," i. e. Mexico, probably from the Pacific side. This resembles E. Californirr, and, being described as having green and glabrous leaves and ciliate involucral bracts, is very probably identified in a plant collected on the Xaqui River, Sonora, by Palmer, perhaps not far below the Mexican border of Arizona. It is probably also E. conspersa, Benth. Bot. SuIph., of Lower California. 
E. Califórnica, Nuтt. Woody only at base, 2 to 4 feet high, strong-scented, minutely pubescent and sometimes cinereons when young, at least the foliage glabrate and green: leaves from ovate to oblong-lanceolate, rarely denticulate or toothed, about 2 inches long: heads commonly solitary and large, the disk nearly inch broad, brownish or purplish : involucre white-villous: rays 16 to 20 , an iuch or more loug, golden yellow: akenes oborate, with very shallow notch and no pappus; the margins very long-villous. - Trans. Am. Pliil. Soc. vii. 357; Torr. \& Gray, N1. Ii. 317 ; Gray, Bot. Calif. i. 351. - Dry ground, California near the coast, from Santa Barbara to San Diego, thence east to the borders of Arizona, where is a smaller-flowered form, $E$. conspersa, Gray, Bot. Mex. Bound. 88, not Benth. ?

E. farinósa, Grax. Shrubliy, except the nearly leafless flowering branches or corymbosely branched peduncles, 2 to 5 feet high. leaves (and the leafy branches) silvery-white with a close furfuraceous tomentum, ovate or ovate-ollong, obtuse, contracted at base into a rather long petiole ' heads somewhat paniculate, smaller; the disk only half-inch broad, yellowish. involucre short, barely pubescent rays 6 to 10 , only half-iuch long: akenes obovate, with a deep notch and no pappus. - Emory Rep. 143, \& Bot. Calif. 1. c. E. nvea, Gray, Bot. Mex. Bound. 88, not Benth. - Dry hills, S. E. California and Arizona; first call. by Coulter.

E. frutéscens, Gray. Shrubby below, 2 or 3 feet high, with widely spreading monocephalous branches, lispidulous-scabrous and at least the branches cinereous: leares ovate or oblung, obtuse, half-inch or an inch long, abruptly petioled mostly from a rounded base: heads rather long*peduncled, variable in size: rays either none, few, or numerous, but short (quarter to half inch long) and 3-4-lobed: akenes very long-villons on the margins, with a small narrow notch at summit pappus either nove or of two delicate long-villous awns. Proc. Am. Acad. viii. 657, \& Bot. Calif. 1. c. Simsia (Gercea) frutescens, Gray, Bot. Mex. Bound. 89. - Gravelly hills and ravines, S. Utah, Arizona, and S. E. California ; first coll. by Fremont.

\footnotetext{
* Herbaceous perennial. leaves linear, entire.
}

E. scapósa, Gray. Minutely scabrous-puberulent, a foot or more high : leaves all crowded at and near the base of the slender scapiform and simple monocephalous stem, rather rigid, entire, 2 or 3 inches long, a line or two wille: involucre loose: rays several, obovate or cuneiform, half-inch or less long, 3-toothed: akenes (immature) very villous all over, as also the pappus of two chaffy awns. - Proc. Am. Acad. xix. 7. Simsia? (Gerca) scaposa, Gray, Pl. Wright. ii. 88. - New Mexico, and stony hills between the Mimbres and the Rio Grande, Wright.

* * * Herbaceous from an annual or biennial ront (at least the first species): leaves apparently all alternate, somewhat dentate: awns of the pappus large and conspicuous, thick at base, continuous from the rather strong and very villous inargins of the cuneate akene. - Gercea, Torr. \& Gray, Proc. Am. Acad. v. 48 ,

E. eriocéphala, Grar. A foot or two high, hirsute with white hairs: stem simple or branched from the annual root, leafy below, nearly leafless toward the somewhat paniculate heads : leaves cuneate-obovate or ovate-oblong; luwer tapering into margined petioles, uppermost reduced to sparse subulate bracts: heads about half-inch high: bracts of the involucre linear-lanceolate, green, but the lower half and the margins very white with long villous pubescence: rays 12 or more, cuneate-obovate or spatriate, half-inch or more long, golderf yellow: akenes cuneate, sligltily emarginate between the thick-based awns. - Proc. Am. Acad. viii. 657 ; Bot. Calif. 1. c. Gercea canescens, Torr. \& Gray, Proc. Am. Acad. v. 48. Simsia (Gerca) canescens, Gray, Pl. Fendl. 85. - Low grounds and sand-hills, through the arid region of W. Arizona and adjacent parts of Nevada and S. E. California; first coll. by Coulter, then by Fremont.

Var. paniculáta. A greener and less hairy form, paniculately branched; the numerous heads of only half the ordinary size. - S. Arizona, Pringle.

E. víscida, Grar. A foot or two high, branching, leafy up to the usually short simple peduncles, viscid-glandular and hirsutely villons : leaves thinnish; cauline all ovate or oblong, obtuse, closely sessile and clasping by an auriculate or cordate base; lower ones and base of stem not seen : heads nearly an inch high and broad; bracts of the viscid involucre oblong, obtuse, at length much shorter than the yellow disk: rays none: akenes narrowly cuneate, truncate between the awns. - Proc. Am. Acad. xi. 78, \& Bot. Calif. i. 616. - Mountains of Sau Diego Co., California, Palmer, Parish. 
§2. Símsı. Akenes naked, at least not strongly ciliate: leaves usually opposite or the upper alternate, broad, usually serrate, sometimes 3-5-lobed, not rarely auriculate-dilated at the insertion: herbs. - Simsia, Pers. Barrattia, Gray \& Engelm., merely wants the pappus.

* Root annual: petioles all naked at base: some uppermost leaves alternate.

E. exaristáta, GraY. Stem 2 feet or more high, rather slender, minutely glandular-pubernlent and sparsely villous-hirsute, naked at summit and bearing loosely paniculate heads: leaves ovate and oblong-ovate, barely serrate, rarely somewhat incised, on narrowly margined petioles: heads half-inch high, rather narrow: bracts of the involucre lanceolate; outer series villous-hirsute, more than half the leugth of the narrow and granulose-glandular inner ones: rays 4 to 9 , not surpassing the disk: akenes rery smooth and glabrous throughout, obovate, slightly emarginate at summit, destitute of pappus, or not rarely with two minute vestiges of awns. - Hemsl. Bot. Biol. Centr.-Am. ii. 183, \& Proc. Am. Acad. xix. 8. Simsia lagasceeformis, Gray, Pl. Wright. 1. 107, not DC. S. exaristata, Gray, Pl. Wright. ii. 87. - Valleys along water-courses, Western Texas to Southern Arizona, Wright, Thurber, Lemmon. (Mex. ?)

* Root perennial, thick and flesby-tuberous: leaves all opposite, even on the branclies, on margined or narrowly winged petioles, these united at base on each side by a fuliaceous appendage, the two often connate into an amplexicaul disk.

E. cálva, Grar. Scahrous-pubescent and often hispildulous: stem 2 or 3 feet high, with opposite branches, terminating in long and naked monocephalous peduncles: leaves deltoidovate and subcordate, often hastately 3-lobed, irregularly dentate: involurre hemispherical, half-inch high, hirsute and hispid, outer bracts foliaceous and somewhat squarrose: rays 15 to 20 , half-inch long: akenes wholly smooth and glabrous, obcordate-oval, without vestige of pappus. - Proc. Am. Acad. xix. 8. Barrattia calva, Gray \& Engelm. Proc. Am. Acrd. i. 48. Simsia (Barrattia) calva, Gray, Pl. Lindh. ii. 228. - Rocky hills and edges of oak woods, Texas, Lindheimer, Wright, \&c. (Adj. Mex., Berlandier.)

E. subaristáta, Grax, 1. c. Too closely like the preceding, sometimes more canescently hispid: akenes minutely pilose-pubescent, ciliolate toward the summit, bearing two rigid scabro-hispidulous awns, which are half the length of the akene or often reduced to mere rudiments. - Simsia subaristata, Gray, Pl. Fendl. 84. - S. W. 'Texas, Wright, Palmer. (Monterey, Mex., Gregg, \&c.)

107. HELIANTHÉLLA, Torr.\& Gray. (Helianthus with altered termination, the principal species resembling that genus.) - Perennial (N. American) herbs, of diverse habit, commonly simple-stemmed and entire-leaved: rays yellow: disk either yellow or purplish-brown. - Fl. ii. 233; Gray, Proc. Am. Acad. xix. 9.

§ 1. ENCELIóPsis. Silvery-canescent, scapose, with large heads (disk an inch broad and flat), thick-leaved: chaffy bracts of the receptacle soft and scarious: akenes flat, oblong-cuneate, very villous, with narrow callous margins and summit, the latter bordered between the short subulate awns by a very short fringe of membranaceously confluent squamellæ. Anomalous species.

H. nudicaulis, GraY. Cespitose, with a stout multicipital caudex, densely tomentulosecanescent: leaves all radical and rosulate-tufted, obovate or orbicular, obtuse, an inch or more long, abruptly contracted into a longer margined petiole: scapes naked, nearly a foot high, monocephalous: bracts of the involucre all canescent and lanceolate, numerous in 2 or 3 series, equal: rays 20 or more, linear, about inch long: disk-corollas also yellow; the short ovate teeth hispidulons-pubescent outside: immature akenes 4 lines long, including the short awns, which do not surpass the villosity. - Proc. Am. Acad. xix. 9. Encelia (Gerca) nudicaulis, Gray, Proc. Am. Acad. viii. 656.- S. W. Utah, Capt. Bishop. Candelaria, Lismeralda Co., Nevada, Shockley.

H. argophýlla, GRAT, I. c. Said to be " 2 or 3 feet high, leafy, with cauline leaves similar to the radical ones"; these very white with the dense silvery tomentum, rhomboid-obovate 
or cuneate and acute: mature akene 5 lines long. - Tithonia argophylla, Eaton, Bot. King Exp. 423. Encella (Gercea) argophylla, Gray, Proc. Am. Acad. viii. 656. - S. W. Utah, near St. George, Palmer. Incompletely known. Perhaps the two are not specifically different.

§2. Helianthécla proper. Habit somewhat of Wyethia, leafy-stemmed: leaves from lanceolate to ovate, mostly triplinerved above the tapering base, and commonly venulose-reticulated, varying from opposite to alternate : rays broad: tube of the disk-corollas usually nearly half the length of the throat, and the short ovate lobes more or less puberulent: akenes flat, from cuneate-obovate and emarginate to slightly obcordate: style-appendages obtuse, mostly short and spatulate or oblong.

* Chaffy bracts of the receptacle soft and scarious: akenes with some long villous hairs on the margins and sometimes on the faces.

+ Heads showy, large or middle-sized, solitary, or some later ones in the axils of bract-like leaves below: bracts of the involucre loose and lanceolate-attenuate or linear, more or less foliaceous, conspicuously hirsute-ciliate: disk yellowish, with dark anthers.

H. quinquenérvis, Gray. Somewhat hirsutely pubescent or almost glabrous : stems solitary or scattered, 2 to 4 feet high: leaves mostly opposite, oblong- or ovate-lanceolate, acuminate, 4 to 9 inches long, triplinerved below the middle and commonly with a lower pair at some distance, uppermost sessile, lower ones tapering into margined petioles, and the lowest (a foot or more long) into longer petioles: head mostly long-peduncled, ample, the disk a full inch in diameter: bracts of the involucre lanceolate, more or less foliaceous: rays 15 to 20 , pale yellow, commonly inch and a half long: akenes cuneate-obovate and obscurely obcordate, 4 lines long, with margins and commonly a part of the faces longvillous: pappus of 2 slender awns, of half the length of the akene, and nearly thrice the length of the squamellæ, which form a conspicuous finely dissected fringe. - Proc. Am. Acad. xix. 10. Helianthus quinquenervis, Hook. Lond. Jour. Bot. vi. 247. Helianthella uniflora, Gray in Proc. Acad. Philad. 1863, 65; Porter \& Coulter, Fl. Colorado, 71 ; Eaton in Bot. King Exp. 170; not Torr. \& Gray, Fl., except as to one of Nuttall's specimens of Leighia uniflora, but not the original from Wyeth. - Rocky Mountains from Dakota and Montana to S. Colorado.

Var. Arizónica. Akenes obovate, even 5 lines long, with delicate awns rarely twice the length of the broader squamellæ. - Northern Arizona, Woodhouse, and S. W. Arizona, Lenmon.

H. Párryi, Grax. Hispidulous-hirsute: stems numerous from a thickened root, a foot high, rather sleader: leaves mostly alternate, more rigid, lanceolate and an inch or two long, or the lowest and radical oblong-spatulate and of double the size: heads and rays barely half the size of the preceding: pappus of fimbriately dissected squamellæ only, or with a pair of slender awns not surpassing these. - Proc. Acad. Philad. 1863, 68; Porter \& Coult. Fl. Colorado, 71. - Rocky Mountains of Colorado and northern part of New Mexico, at 8,000 to 10,000 feet, Parry, Hall, \&c.

H. MexicÁna, Gray, Proc. Am. Acad. xi. 37, of San Luis Potosi, Mexico, ranks between the preceding and the following, but is nearer the former; has solitary heads, dark brownish disk of 4 lines in diameter, broad rays half-inch long, and almost linear leaves.

++ Heads small: involucre more imbricated: rays few and hardly surpassing the dark-purple

H. microcéphala, Grar. Hispidulous-scabrous: stems numerous from a greatly thick-" ened root, a foot or less high, slender, somewhat paniculately or corymbosely branched at summit and bearing several heads: leaves rigid, all but the lower alternate; radical lanceolate-spatulate; upper cauline nearly linear and sessile, inch long: involucre somewhat campanulate, 3 or 4 lines high; its bracts linear-oblong, mostly obtuse : rays not over 3 lines long: immature akenes villous, at least at the summit: pappus of several slender squamellx intermixed with the long hairs, longer than the breadth of the ovary, two marginal ones often extended and awn-like.-Proc. Am. Acad. xix. 10. Encelia (Geroa) microcephala, Gray, Proc. Am. Acad. viii. 657. - Borders of Colorado and adjacent New Mexico and Utah, north to Rabbit Valley, Newberry, Brandegee, Ward. 
* * Chaffy bracts of the receptacle rather firm-chartaceous: stems a foot or two high.

H. Douglásii, Torr. \& Grax, extended. Hirsute-pubescent with spreading hairs, at least the upper part of the stem : leaves mostly opposite and oblong-lanceolate; upper sessile or nearly so: disk of the head an inch broad: involucre hirsute: rays an inch long: akenes obovate, more or less ciliate-fringed: pappus a pair of elongated awns with more or less chaffy-dilated base, or sometimes (as in the original specimen) reduced to this base, and with mostly conspicuous squamellæ. $-H$. Douglasii, 'Torr. \& Gray, Fl. ii. 334. H. lanceolata, Torr. in Wilkes Ex. Exped. xvii. 354, hardly of Torr. \& Gray, Fl. - Dry ground, W. Idaho and E. Oregon and Washington Terr., Louglas (awns of pappus reduced, perhaps not constantly), Spalding, Cusick, Brandegee. Ciliation of ovary and akene variable, sometimes wanting except near the summit.

H. uniflóra, Torr. \& Grar, 1. c. Minutely pubescent or somewhat scabridous, or glabrate: leaves more commonly opposite, sometimes all alternate, oblong-lanceolate ( 2 to 5 inches long); lower short-petioled : involucre pubescent or slightly hirsute: rays a full inch long: akenes more or less ciliate: pappus a pair of long awns and rather conspicuous squamellæ. Gray, Proc. Am. Acad. xix. 10. H. lanceolata, Torr. \& Gray, 1 c. (Leighia lanceolata, Nutt. Trans. Am. Phil. Soc. vii. 365, which is said by Nuttall to have three or more heads, but of which we have only two or three flowers, is probably of this species). H. multicaulis, Eaton in Bot. King Exp. 170, small form. Helianthus uniforus, Nutt. Jour. Acad. Philad. vii. 37, \& Leighia uniflora, Nutt. Trans. Am. Phil. Soc. 1. c., by char. and genuine specimens. - Rocky Mountains, Montana and E. Idaho to S. Utah, Wyeth, Burke, Watson, IF ard, \&c.

H. Califórnica, Grax. Minntely seabrous-puberulent or almost glabrous: stems slender, rarely bearing 2 or 3 small heads : leaves more commonly alternate, lauceolate, nearly all tapering into slender or distinct petioles: rays half-inch or more long, usually little surpassing the involucre: akenes obovate, wholly glabrous, the roundish summit slightly notched at maturity, minutely 2-aristellate and with very short squarnellæ, but whole pappus often obsolete in age, margins very obscurely ciliolate near the summit. - Pacif. R. Rep. iv. 103 ; Bot. Calif. i. 352. - California, from Napa Valley to the Sierra Nevada, from the heads of the Sacramento to Mariposa Co. ; first coll. by Bigelow.

§3. Psecdo-Helínteos. Habit of the narrow-leaved Helianthi: slender and leafy-stemmed: leaves all linear and one-nerved, with revolute margins, alternate, hispidulous-scabrous: bracts of the involucre linear-attenuate, hispid, squarrose-spreading: rays long and narrow: style-appendages of the disk-flowers long and slender, hirsute: chaffy bracts of the receptacle rather rigid, obscurely 3-toothed at the apex: akenes less flat, the lateral angles being usually developed, or even quadrangular.

H. grandiflóra, Torr. \& Gray, 1. c. Stem 3 or 4 feet high (the base unknown): leaves somewhat broadly linear (2 lines wide by 2 inches or more long), strongly papillose-scabrous above : head nearly three-fourths inch high and broad: rays 16 to 20 , inch and a half long: immature akenes broadly oblong, glabrous below, the acute almost winged margins produced on each side at apex into a chaffy tooth, and one or both of these commonly extended into a chaffy persistent awn, the salient border connecting them villous and minutely multisquamellate - E. Florida, Leavenw:orth, Burrows. Mature akenes not seen.

H. tenuifólia, Torr. \& Grax, l. c. Stem 2 feet or more high, more slender and simple from a narrow somewhat moniliform horizontal tuber: leaves nearly filiform: head one half smaller: rays 10 to 15 , an inch or more long: akenes slightly pubescent, quadrangular and moderately or the outer very little compressed, the anterior and posterior angles narrowly and acutely margined, these two and sometimes the other angles surmounted by a subulate or triangular short persistent chaffy and pointed tooth, and with some minute intermediate squamellie. - Sandhills and dry pine barrens on and near the Apalachicola River, Florida, Chapman, Mohr.

108. ZEXMENIA, Llave \& Lex. (Anagram of Ximenez, the genus being likened to Ximenesia.) - Mexican genus of numerous species, two of them reaching U. S., perennial herbs or some rather shrubby; with mostly opposite 
leaves, and heads of yellow flowers, of moderate or small size, in ours solitary on slender peduncles terminating the branches. Ray-akenes commonly triquetrous and 3-awned; those of the disk either much compressed or thicker, with winged or bordered margins, but the wings variable. Style-branches of the hermaphrodite flowers with acute hispid tips.--Nov. Veg. Descr. i. 13 ; Gray, Pl. Wright. i. 12 ; Benth. \& Hook. Gen. ii. 373. - The genuine species (Lasianthaa, Zucc., Lipochata Americane, DC.) form a marked group: some others too nearly approach Wedelia on the one hand, and Verbesina on the other.

Z. brovifólia, Grax. Much branched and below shrubby, 2 or 3 feet high, strigose-scabrous or hispidulous, and the branches cinereous : leaves (alternate on the branches!) small, less than an inch long, ovate and oval, mostly entire, short-petioled: heads solitary on slencler peduncles terminating the branches, half-inch high: involucre between hemispherical and campanulate, of broad mostly ovate bracts imbricated in 3 or 4 series, the outer looser and partly foliaceous: rays 5 to 9, small: corolla-lobes glabrous: akenes obovate, flat, some nearly marginless, some at maturity conspicuously callous-winged, slightly narrowed at summit between the wings or margin and the subulate-attenuate awns; between the bases of these the free or partly united squamellæ are conspicuous, yet sometimes obsolete in age. - Pl. Wright. i. 112, \& Bot. Mex. Bound. 92. - Rocky banks, S. W. Texas, Wright, Parry, Palmer. (Adj. Mex.)

Z. híspida, GRAY. Herbaceous and branched or many-stemmed from a barely lignescent base or root, strigose-hispid, about 2 feet high: branches terminated by solitary longpeduncled heads: leaves sessile or nearly so, lanceolate or the lower rhomboid-lanceolate, acute or acuminate and with acute or cuneate base, irregularly more or less serrate, sometimes with a pair of coarser salient teeth or lobes above the base: involucre biserial; the outer bracts more loose and foliaceous, lanceolate from a broader base, as long as the oblung inner ones: rays 7 to 9, orange-yellow, barely half-inch long: corolla-lobes puberulent-ciliolate: akenes obovate, either narrowly or (when well developed) broadly winged, or sometimes winged only near the summit, appearing obcordate, the pappus in the centre of the notch, consisting of a somewhat elevated cupule of united firm squamellx and one or two (or in the ray 3) variable awns, these occasionally abortive or little exceeding the squamellæ; usually an appressed fleshy scale or protuberance on each side of the base of the akene. - Proc. Am. Acad. xix. 10. Wedelia hispida, HBK. Nov. Gen. \& Spec. iv. 214, t. 371 (poor details, front flowers only); Bot. Reg. t. 543 (details copied from HBK.); DC. Prodr. v. 539, excl. syn. Cav.; Benth. \& Hook. Gen. ii. 370. Stemmodontia scaberrima, Cass. Diet. xlvi. 407. Lipochoeta (Catomenia) Texana, Torr. \& Gray, Fl. ii. 357; Gray, Pl. Lindh. ii. 229. Zexmenia Texana, Gray, Pl. Wright. i. 112. Wirtgenia Texana, Schultz Bip. in Seem. Bot. Herald, 304. - Dry ground, common in Texas. (Mex.)

Z. podocéphala. Herbaceous from a lignescent root, 2 or 3 feet high, rough-hirsute or hispidulous: stems with few and slender branches, terminated by solitary long-peduncled heads : leaves ovate, nearly sessile by a rounded base, obtuse or acute, serrate, thinnish, very veiny (the larger 3 or 4 inches long): head and involucre nearly of the preceding, but corolla-lobes hispidulous: akenes obovate, with narrow at length callous wings, more or less confluent with the rather long awns; the intermediate squamellæ small and distinct, absolutely wanting in the original specimens of Wright, on which was founded Verbesina podocephala, Gray, Pl. Wright. ii. 92, and of Schott, but obvious in specimens of Rothrock and Lemmon. - S. Arizona.

109. VERBESINA, L. partly, Less. (Unmeaning name.) - American herbaceous or more or less shrubby plants; with heads of yellow or rarely white flowers. - Benth. \& Hook. Gen. Pl. ii. 379, with part of Actinomeris, Verbesina, Ximenesia, DC.

§ 1. VerbesinfRIA, DC. Heads narrow, mostly small, cymosely clustered or paniculate: involucre imbricated in two or more series, the bracts not elongatedfoliaceous: rays (rarely wanting) few or several, styliferous and usually fertile: 
disk from flattish to low conical : awns of the pappus not hooked : ours all perennial herbs. - Gray, Proc. Am. Acad. xix. 11.

* Akenes wholly wingless : receptacle nearly flat: flowers yellow, the rays 1 to 5 , lanceolate: leaves opposite.

V. occidentális, WALT. Green and minutely pubescent or glabrous, 4 to 7 feet high, with erect narrowly 4-winged branches, leafy up to the short peduncles of the corymbosely paniculate open cymes: leaves ovate and the uppermost oblong-lanceolate, acuminate, acutely serrate, the larger about 8 inches long, contracted into a margined petiole: involucre oblong, 4 or 5 lines high: akenes obovate-oblong, pubescent. - Car. 213. E Siegesbeckia, Michx. Fl. ii. 134; DC. Prodr. v. 616 ; Torr. \& Gray, Fl. ii. 358. Siegesbeckia occidentalis, L. Spec. ii. 900, \& Pl. Gronov. V. Phøthusa, Cass. Dict. li. 476, \& lix. 149; DC. Prodr. I. c., but there are no squamellæ. Phathusa Americana, Gærtn. Fruct. ii. 425, t. 169, f. 3, hairs at summit of akene exaggerated, and awns missing. P. borealis, Spreng. Syst. iii. 591 . Coreopsis alata, Pursh, Fl. ii. 567, therefore Actinomeris alata, Nutt. Gen. 181. - Borders of woods and banks, S. Penn. to nlinois and Florida.

* Akenes or most of them broadly winged at maturity, but variable : receptacle convex to conical : flowers both of ray and disk white or whitish; the antbers blackish : rays 3 to 5 , obovate, short: lear"es alternate.

V. Virgínica, L. Minutely tomentose-pubescent or puberulent, 3 to 6 feet high : stem or branches winged or wingless: leaves green and glabrate or minutely hispidulous-scabrous above, cinereous to canescent beneath, ovate or the upper narrower, from denticulate to coarsely serrate, contracted below iuto a winged petiole: heads small, 3 or 4 lines high, crowded on the irregular branches of the compound paniculate naked cyme: bracts of the involucre lanceolate, rather obtuse, erect, pubescent: awns of the pappus slender, sometimes obsolete. - Spec. ii. 901 ; Walt. l. c. ; Michx. l. c. ; DC. 1. c.; Torr. \& Gray, 1. c. 359. V. paniculata, Poir. Dict. viii. 456. $V$. microptera, DC. l. c.; akenes sometimes but not always imperfectly winged. $\quad V$, polycephala, DC. l. c., rather robust form. $\quad V$, villosa, Nutt. Trans. Am. Phil. Soc. vii. 370, a tomentose form. V. Texana, Buckley in Proc. Acad. Philad. 1861, 458. - Rich dry soil, Penn. ?'and Illinois to Florida and Texas. (Mex.)

Var. laciniáta. Leaves variously and irregular sinuate- or laciniate-lobed, rarely almost to the midrib; the principal lobes 3 to 5. - Siegesbeckia laciniata, Poir. Dict. vii. 158. Verbesina laciniata, Nutt. Gen. ii. 170. V. sinuata, Ell. Sk. ii. 411 ; DC. 1. c. ; Torr. \& Gray, 1. c. - Along the coast, S. Carolina to Florida.

§2. Preróphxton. Heads (solitary or scattered) comparatively broad: involucre more or less imbricated, all or at least the inner bracts erect or appressed: disk convex to oval and the akenes all erect in fruit; the receptacle from convex to conical: rays several to numerous, either neutral or styliferous (even in the same species), but almost always infertile: akenes flat: awns of the pappus not hooked, often obsolete or wanting: perennial herbs. - Gray, Proc. Am. Acad. xix. 12. Part of Pterophyton, Cass., \& of Actinomeris, Nutt.

* Stems wholly wingless and marginless: leaves long and linear, not decurrent: bracts of the involucre narrow, the outer loose and disposed to become foliaceous.

V. longifólia, Grar. Stems slender, smooth and glabrous, 2 or 3 feet high, very leafy, branching at summit and bearing several heads: leaves alternate or some 2-3-nate, sessile, scabrous, reticulate-veiny and with prominent midrib, 4 to 9 inches long, quarter to half inch wide : head hemispherical, half-inch high, with flattish disk, often subtended by one or two linear leaf-like bracts: involncral bracts linear: rays about 15, neutral, inch long: akenes obovate, smooth, with narrow wing, a shallow noteh, and no awns or rarely a rudimentary one. - Proc. Am. Acad. xix. 12. Actinomeris longifolia, Gray, Pl. W right. ii. 89. - Mountains of S. Arizona, Wright, Rothrock, \&c.

* * Stems wholly wingless: leaves ovate to oblong, sessile, not decurrent, mostly opposite: bracts of the involucre broader and closer: rays not rarely styliferous.

V. Wríghtii, GraT, 1. c. Scabrous and mostly hispidulous: stems stout, 1 to 3 feet high, somewhat branching, bearing few or solitary long-pedunculate showy heads: leaves from 
broadly ovate to oblong, thickish, serrate, triplinerved : heads hemispherical, three-fourths inch high: bracts of the involucre oval or oblong, obtuse, in 2 or 3 series : rays about 12 , oval or oblong, sometimes inch long, rarely wanting: akenes obovate, smooth, with either broad or narrow wings, and only minute callous teeth for pappus, or some of the inner with short awns : receptacle low. - Actinomeris Wrightii, Gray, Pl. Fendl. 85, \& Pl. Lindh. ii. 229; Rothr. in Wheeler Rep. vi. 162, t. 8. - Rocky ground, W. Texas to Arizona, Wright, Thurber, \&c. (Adj. Mex.)

V. Wárei, GrAY, 1. c. Scabrous, somewhat hispidulous : stem slender, a foot or two high, simple, leafless at the peduncle-like summit, which bears one or two small heads: leaves 4 or 5 pairs, narrowly oblong, obtuse at both ends, obscurely serrulate, reticulate-veiny, lucid; the upper very small: bracts of the involucre oblong-lanceolate, shorter than the ovoidconical fruiting disk: "rays 3 or 4," small : akenes oblong, with narrow or rather broad wings, connected by an obscure epigynous border: pappus of 2 minute teeth or none. Actinomeris pauciflora, Nutt. in Am. Jour. Sci. v. 301, \& (\$ Achata) Trans. Am. Phil. Soc. vii. 364 ; Torr. \& Gray, I. c. But there is a $V$. paucifora of Hemsley in Mexico. - Florida, in low pine barrens near the coast, Ware, Chapman.

V. nudicaúlis, GRAY, l. c. Scabrous-hirsute and hispidulous, 2 or $\mathbf{3}$ feet high; the naked sumnit of the stem or branches bearing a few mostly pedunculate small heads: leaves in numerous pairs, dull green, elliptical-oblong, obtuse at both ends or the apex acutish, acutely and irregularly serrate, loosely pinnately veined : bracts of the involucre oblong-linear, short: disk in fruit merely convex: rays 7 to 12 , linear, an inch or more long, the head only quarter-inch wide: wings of the akene often one or both wanting, sometimes rather conspicuous : pappus 2-aristellate or obsolete. - Helianthus? aristatus, Ell. Sk. ii. 428. Actinomeris nudicaulis, Nutt. Trans. Am. Phil. Soc. 1. c.; Torr. \& Gray, 1. c. — Dry sandy woods, Georgia, Alabama, and Florida.

* * * Stems winged by decurrence of the more or less broad sessile leaves. Leaves in our species only pinuately-veined: stems 2 or 3 feet high, simple or with sparing flowering branches.

V. heterophýlla, Gray, l. c. Hispidulons-seabrous, below somewhat hirsute: lower leaves nearly all opposite, approximate, oblong or oval, obtuse, sometimes acute, minutely serrate ( 1 to 3 inches long), indistinctly veiny, decurrent into wings; those toward the naked summit and on the slender flowering branches small, lanceolate, soon reduced to linear bracts: heads somewhat paniculate, barely half-inch high in fruit, then with strongly convex disk: bracts of the involucre barely in 2 series, small, lanceolate; those of the receptacle very similar, rigid : rays 5 to 10, linear : akenes obovate, narrowly winged, 2-aristellate. - Actinomeris heterophylla, Chapm. in Bot. Gazette, iii. 6. - Dry pine barrens, E. Florida, Chapman, Garber, Curtiss. Related to the preceding.

V. helianthoídes, Micux. Pubescent, stouter : stem usually winged up to the short peduncles: leaves alternate, or rarely some of the lower opposite, ovate-lanceolate or ovate, acuminate, serrate, transversely veiny-scabrous above, canescently soft-pubescent beneath, at least when young: heads few, fully half-inch high; the disk and receptacle at maturity either strongly convex or conical: involucre of 2 or 3 series of erect lanceolate bracts: rays 8 to 15 , inch or more long: akenes somewhat pubescent or scabrous, rather broadly winged, 2-aristellate. - Fl. ii. 134 ; Pursh, Fl. ii. 565. Actinomeris helianthoides, Nutt. Gen. ii. 181 ; Ell. Sk. ii. 413 ; DC. Prodr. v. 575, \& vii. 290 (vars. Nuttallii \& Elliottii); Torr. \& Gray, 1. c. A. oppositifolia, DC. Prodr. vii. 1. c., not of Fresenius? - Prairies and open woods, Ohio to Iowa, Georgia, and Texas; first coll. by Michaux.

§ 3. XIMENfisia. Heads (solitary or scattered) broad: involucre of spreading linear and foliaceous equal bracts: disk and receptacle merely convex: rays numerous and conspicuous, usually fertile: akenes flat; the awns not hooked: root annual. - Ximenesia, Cav.

V. encelioídes, BENTH. \& Hook. A foot or two high, freely branching, pale and cinereous or sometimes canescent with fine and soft appressed pubescence: leaves mostly alternate, and the upper face green, from ovate or cordate to deltoid-lanceolate, variously serrate or laciniate-dentate, some with nearly naked, most with winged petioles, and these commonly with auriculate-dilated appendage at base: heads large, the disk three-fourths inch in diameter: rays 12 to 15 , inch long, deeply 3-cleft at summit: akenes obovate, mostly broadly 
winged and with short setiform awns; the outermost often awnless and pubescent, sometimes rugose and thick-winged. - Ximenesia encelioides, Car. Ic. ii. 60, t. 178; DC. Prodr. v. 627 (under several varieties); Torr. \& Gray, 1. c. Pallasia serratifolia, Smith in Rees Cycl. - Low grounds, Texas and S. Colorado to Arizona: also Florida, where it was probably introduced. Now widely dispersed in warm regions and cult. (Mex.)

110. ACTINÓMERIS, Nutt., partly. (From åkтis, a ray, and $\mu \epsilon \rho i ́ s$, a part.) - Tall perennials, of the Atlantic U. S.; the somewhat simple stems (4 to 8 feet high) leafy to the top, below mostly winged in the manner of Verbesina by decurrent prolongations from the base of the leaves; these alternate or some lower ones occasionally opposite, lanceolate or broader, acuminate at both ends, pinnately veined, serrate, thinnish : heads loosely corymbosepaniculate: flowers yellow or white, produced in late summer. - Gray, Proc. Am. Acad. xix. 11. Actinomeris, spec. 1, Nutt. Gen. ii. 181, \& § 1, 2, Torr. \& Gray, Fl. ii. 335.

A. squarrósa, Nлтт. 1. c. Heads with 2 to 8 irregular yellow rays; disk-flowers yellow: involucral bracts linear to narrowly spatulate: akenes mostly with broad and firm wings: pappus of 2 or in marginal akenes 3 awns. - Ell. Sk. ii. 413 (excl, var. alba) ; Torr. \& Gray, l. c. (forms alternifolia and oppositifolia, the latter of rare occurrence); Meehan, Nat. Fl. i. t. 39. A. alternifolia, DC. Prodr. v. 575. A. oppositifolia, Fresenius, Ind. Sem. Hort. Francf. 1836, an occasional form. Coreopsis alternifolia, L. Spec. ii. 909 ; Jacq. Hort. Vind. t. 110. C. procera, Ait. Kew. iii. 253. C. acuta, Pursh, Fl. ii. 569? Verbesina Coreopsis, Michx. Fl. ii. 134. - Rich or alluvial soil, either moist or dry, W. New York to Iowa, south to Florida and Louisiana. Wholly wingless-stemmed specimens occasionally occur.

A. álba, Torr. \& Gray, l. c. Rather smoother: heads smaller: rays none; disk-flowers dull white: akenes oftener wingless or narrowly winged: awns of the pappus not rarely 3 or 4, and commonly some interposed small ones or aristellate squamellw! $-A$. squarrosa, var. alba, Nutt. 1. c.; Ell. 1. c. A. alternifolia, var. alba, DC. 1. c. Athanasia paniculata, Walt. Car. 201. Verbesina Coreopsis, var. alba, Michx. I. c. - Alluvial soil, S. Carolina to Louisiana, near the coast: rare in herbaria. Specimens from Dr. Mellichamp, S. Carolina, all exhibit the squamellate-aristellate pappus, not before known in this genus.

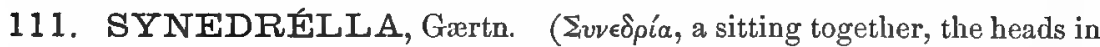
the original species being collected at the nodes.) - Tropical annuals; with branching stems, opposite and more or less serrate petioled leaves, and small heads of yellow flowers, the rays short. - Fruct. ii. 456, t. 171; Hook. Exot. Fl. t. 60. Synedrella, Oligogyne in part, \& Calyptrocarpus (Less.), DC. Prodr. v. 629.

S. viális, GRAT. Diffuse or procumbent, slender, strigulose-hirsute or more hairy : leaves ovate, about inch long: heads only 3 lines long, solitary or scattered, some subsessile, others slender-peduncled : principal bracts of the involucre 4 or 5 , ovate or oblong: rays 5 to 8 , with oblong exserted ligule: akenes or many of them tuberculate-scabrous at maturity, some of the outer occasionally trigonal, mostly flattened, and with or more commonly without a coriaceous and thickish undulated wing-like border, the central ones narrower and marginless : pappus of 2 or sometimes 3 rigid diverging awns, with occasionally one or two additional teeth or squamellæ, arising from an obscure border.-Proc. Am. Acad. xvii. 217. Calyptracarpus vialis, Less. Syn. 221, \& Linn. ix. 269. Oligogyne Tampicana, DC. Prodr. v. 629; Deless. Ic. Sel. ix. t 38; Gray, Pl. Wright. i. 111 . Zexmenia hispidula, Buckley in Proc. Acad. Philad. 1861, 458. - Waysides and waste grounds, southern borders of Texas. (Mex., S. Am. ?)

112. COREOPSIS, L. TICKSEED. (Kó $\iota s$, a tick, and ö $\psi \iota s$, resemblance, from the form of the akene.) - Herbs, mostly Eastern North American and opposite-leaved, of various habit; with pedunculate heads terminating the branches; the rays commonly showy, yellow, particolored, or sometimes rose- 
colored : fl. summer and autumn. - Gen. no. 981; Torr. \& Gray, Fl. ii. 338; Benth. \& Hook. Gen. ii. 384, partly.

C. Aspera, Pursh, Fl. ii. 570, and C. Flexicaúlis, Raf. in Med. Rep., are not identified, and probably not of the genus.

§ 1. Calliópsis. Style-tips truncate or obtusely short-conical : akenes not villous-ciliate: outer involucre small, short and calyculiform, except in the last species: rays obovate or cuneate, inclined to be palmately 3-4-toothed or lobed. — Calliopsis, Coreoloma, \& Cosmella, Torr. \& Gray, FI.

* Perennials, with rose-red rays and yèllow disk-flowers: akenes oblong, nearly straight, smooth. - §Cosmella, Torr. \& Gray.

C. rósea, Nரтr. Nearly glabrquus, a foot or less high from slender creeping rootstooks, branched, leafy, bearing numerous small and short-peduncled heads : leaves opposite, linear or nearly so and entire, or the lower 2-3-toothed or 3-parted: involucre 2 or 3 lines high: rays rose-color, coarsely 3-toothed or lobed: akenes with merely callous margins and an obscure entire border at summit. - Gen. ii. 179 ; Bart. Fl. Am. Sept. t. 12 ; Torr. \& Gray, Fl. ii. 348 ; Torr. Fl. N. Y. i. t. 57. Calliopsis rosea, Spreng. Syst. iii. 611. - Grassy swamps, coast of Mass. to Delaware and Georgia.

C. nudáta, Notr. 1. c. Very smooth and glabrous: stem 2 to 4 feet high from a thick or tuberous rootstock, rush-like, below bearing some alternate terete and filiform-subulate leaves (the larger a foot long), above some scattered smaller ones, gradually reduced to bracts, the naked summit forking and bearing a few slender pedunculate heads: involucre 4 or 5 lines high: rays showy, obscurely lobed, bright purplish rose-color, inch long: akenes with fimbriately or pectinately dissected wings, and two short upwardly hirsute subulate awns. - Torr. \& Gray, 1. c.; Hook. f. Bot. Mag. t. 6419. — Pine-barren swamps, Florida.

* * Perennials, with yellow rays, dark purple disk-flowers, and mostly entire leaves: akenes oblong or elliptical, straight, with fimbriate border or dissected wings and a pair of awns. $\S$ Coreoloma, Torr. \& Gray, excl. first species. \$ Rlabdocaulis \& Eublepharis, Nutt. Trans. Am. Phil. Soc. vii. 359 , excl. sp.

+ Stems not rarely alternate-leaved throughout, strict; the summit or flowering branches (bearing solitary or scattered heads) naked and rush-like, their leaves being reduced to small subulate bracts: cauline thickish and rather fleshy, especially when near brackish water, all tapering or contracted at base.

C. gladiáta, WALT. Glabrous, or young leaves not rarely pilose-pubescent: stem terete, 2 to 4 feet high, all the upper part naked : principal leaves alternate, from broadly obovateoval to lanceolate-linear, obtuse, scarious-edged; lower 3 to 6 inches long, with long margined petiole dilated and partly clasping at insertion: involucre 4 or 5 lines high : rays commonly inch long: mature akenes bordered by a strong pectinate fringe, and surmounted by 2 short rigid awns or teeth which may not surpass the fringe. - Car. 215 ; Nutt. Gen. 1. c.; Ell. Sk. ii. 244; Torr. \& Gray, Fl. ii. 347. C. dichotoma, Michx. Fl. ii. 137, mainly and by the char. Moist pine barrens, S. Carolina to Florida, in the low country, commoner near the coast.

C. angustifólia, Arт. Wholly glabrous: stem slender, mostly quadrangular, 1 to 3 feet high: leaves narrower and smaller than in the foregoing, sometimes all opposite; lower spatulate-lanceolate and the upper spatulate-linear: heads and rays smaller, the latter about half-inch long: akenes with narrow lacerate fimbriate wings and slender setiform awns. Ait. Kew. iii. 253; Torr. \& Gray, 1. c. C. dichotoma in part, Michx. 1. c. C. linifolia, Nutt. Jour. Acad. Philad. vii. 75. C. (Rhabdocaulis) linifolia \& angustifolia, Nutt. Trans. Am. Phil, Soc. 1. c. - Moist pine barrens or swamps, N. Carolina to Florida and Texas.

$$
++ \text { Stems leafy to near the summit, and the leaves opposite. }
$$

C. integrifólia, Poir. Nearly glabrous, 2 or 3 feet high: leaves ovate or oblong, entire, only inch and a half long, rounded at base; upper almost sessile; lower abruptly petioled: rays three-fourths inch long: akenes not seen : ovary minutely serrulate-hispidulous on the margin, minutely awned. - Suppl. ii. 353; DC. Prodr. v. 570 ; Torr. \& Gray, Fl. ii. 347, rnainly. - Carolina, Bosc (originals in herb. Poir., now of Cosson, \& herb. DC.), S. Carolina, Ravenel, and Georgia, Decatur Co., Chapman. Too little known. Ligules said by Poiret to be linear-oblong and entire, which does not accord with our specimens, nor with the group. 
* * Annuals or biennials, one has been thought perennial, with opposite leaves, yellow or particolored rays, and dark-purple or brown disk-flowers: akenes short, with entire scarious wings or none, incurved at maturity, one or both faces sometimes becoming papillose or tuberculate-roughened, or in some remaining smooth: heads scattered-paliculate: herbage glabrous or wearly so, except in C. Drummondii. - \$Calliopsis, Torr. \& Gray, slightly extended.

+ Rays pure yellow: pappus a pair of conspicuous slender awns (or these rarely abortive): leaves from entire to 3-parted or simply pinnately divided. - Coreopsidium, Torr. \& Gray.

C. Leavenwórthii, Torr. \& Gray. Annual, sometimes seemingly perennial, slender, 1 or 2 feet high: lower leaves or their 3 to 7 divisions from broadly linear to spatulate-lanceolate: rays barely half-inch long: wings of the akene on each side as wide as the body, equalled or surpassed by the distinct erect awns. - Moist ground in pine barrens, Flopida; first coll. by Leavenworth.

Var. Gárberi. Very remarkable form, more robnst, all the cauline leaves pinnately 5-7-parted or divided into shorter and broader divisions; the termiual one from obovate to lanceolate-oblong. - Tampa, Florida, Garber: perhaps in over-luxuriant condition.

+ + Rays with base or lower part brown-purple: pappus none or minute: leaves all 1-2-pinnately divided.

C. Atkinsoniána, Doogl. Root "perennial" or annual, flowering in autumn, stem 2 to 4 feet high: lobes of the leaves linear or nearly so: akenes with a narrow wing, sometimes a mere scarions margin, and usually a pair of distinct short subulate teeth for pappus. Lindl. Bot. Reg. t. 1376; Torr. \& Gray, 1. c. 346. Calliopsis Atkinsoniana, Hook. Fl. i. 311. - River banks, Oregon, Washington Terr., and east to Dakota ; first coll. by Douglas.

C. cardaminefólia, Torr. \& GRAY. Root anuual: stem a span to 2 feet high: lobes of the lower or radical leaves oval to lanceolate, sometimes linear; of the upper mostly linear: rays rarely half-inch long: akenes with a moderately broad wing, with which is sometimes connected two obscure teeth. - Fl. 1. c., with var. lineariloba, the narrowest-leaved form. Calliopsis cardaminefolia, DC. Prodr. v. 568. - Low grounds, W. Louisiana and Texas to Kansas and New Mexico. (Adj. Mex.)

$+\div$ Akenes wingless: pappus none or an obscure border: annuals.

C. tinctória, Nutт. Glabrous, 2 or 3 feet high: radical and some lower cauline leaves 2-pinnately divided into lanceolate or linear divisions; upper with 3 to 7 linear divisions: outer involucre short and close: rays from half to three-fourths inch long, sometimes base only, sometimes nearly all crimson-brown : akenes oblong, thinnish, moderately incurved. Jour. Acad. Philad. ii. 114 ; Bart. Fl. Am. Sept. t. 45; Bot. Mag. t. 2512 ; Bot. Reg. t. 846 ; Brit. F1. Gard. t. 72 ; Torr. \& Gray, 1. c. "Calliopsis bicolor, Reichenb. Mag. t. 70." C. tinctoria, DC. 1. c. 568 ; Hook. Bot. Mag. t. 3511 , var. atropurpurea. - Low ground, Saskatchewan and Minnesota to Louisiana, Texas, and Arizona. Common everywhere in gardens.

C. Drummóndii, Torr. \& GRAY, 1. c. Low, pubescent with many-jointed lax hairs, sometimes glabrous: divisions of the radical and lower cauline leaves from roundish-ovate to oblong-lanceolate; of the uppermost sometimes linear: peduncles inclined to be solitary terminating stem and branches: outer involucre of loose and spreading more foliaceous bracts, little shorter than the inner : rays broad, sometimes inch long, brown-purple only at base: akenes oval or obovate, thick, much incurved at maturity, a cartilaginous margin bordering the inner face. - C. diversifolia, Hook. Bot. Mag. t. 3474, not DC. Calliopsis Drummondii, Don, Brit. Fl. Gard. ser. 2, t. 315. - Sandy soil, Texas; first coll. by Drummond. Common in cultivation.

Var. Wríghtii. Lobes of the leaves narrower, linear and the broadest linear-oblong: heads smaller : akenes circinately incurved. - Pl. Wright. ii. 90. - Rocky hills on the San Pedro, W. Texas, Wright.

§ 2. Leáchia. Style-tips hispid or hirsute and abruptly produced into a cusp or acute cone : akenes nearly orbicular, incurved at maturity, some or all of them becoming papillose or muriculate at maturity, often developing a callus at base and apex of the inner face (this varying greatly even in the same head) : pappus of two small chaffy teeth, or none: outer involucre little shorter and more herbaceous than the inner : rays cuneate, palmately $3-5$-lobed or toothed, mostly yellow, 
as also the disk-flowers : narrow chaffy bracts of receptacle attenuate-filiform at apex : heads usually showy, on long and simple peduncles: leaves all opposite, entire or pinnately 3-7-parted, mostly petioled. - Leachia, Cass. Dict. x., xxv., lix. Coreopsides, Mœnch. Chrysomelea, Tausch. § Eucoreopsis, Leachia, Torr. \& Gray.

* Root annual: style-tips almost truncate and with a short conical point : rays with some brownpurple lines or spots toward the base: leaves long-petioled. Transition to preceding section.

C. coronáta, Hook. Sparsely hirsute-pubescent or mainly glabrous, a foot or two high, lax : leaves entire or the lower 3-5-parted, obovate and spatulate-oblong, the lateral divisions when present small : bracts of the outer involucre lanceolate or oblong-lanceolate : rays an inch or less long, bright yellow, with deeper or orange hue at base, above which are delicate brownish-purple markings, thus forming a sort of corona : akenes with a rather broad wing and a pappus of 2 minute squamellate teeth. - Bot. Mag. t. 3460 (not L.); Torr. \& Gray, Fl. ii. $345 .-$ E. Texas, Berlandier, Drummond, Lindheimer, \&c. Rather common in oruamental cultivation.

* * Root apparently perennial: style-tips with conspicuous cusps: rays sometimes brown-purple at base: heads small: cauline leares hardly petioled, very slender.

C. Harveyána. A foot or more high, smooth and glabrous: stems slender, branching above: leaves pinnately parted into 3 to 7 and upper often palmately parted into 3 to 5 filiform divisions (no broader than the rhachis) ; lowest cauline and radical petioled and the divisions narrowly linear: involucre about 3 lines high : bracts of the outer involucre narrowly lanceolate-linear, little shorter than the inner: rays 3 or 4 lines long; disk-flowers brownish in age: akenes orbicular (only a line long), outer narrowly winged (and the wing occasionally laciniate-dentate), mostly muricate-roughened; inner smooth and wingless or nearly so; callus small or none : pappus a pair of obtuse short squamella. - Arkansas, on cliffs near Fort Smith, Prof. F. L. Harvey.

* * Root perennial, or in the first species sometimes annual: rays yellow throughout (the larger inch long): style-tips with conspicuous cusp: calli of the akene often very large: pappus a pair of small denticulate or fimbriolate squamellæ, which become subulate teeth, sometimes deciduous or obsolete; at least lower leaves slender-petioled : species apparently confluent.

+ Wings of the akene thin-scarious, outspread, broad when well developed.

C. grandiflóra, Nutr. Glabrous except the hirsute-ciliate petioles, rarely sparsely pilose, a foot or two high: radical and some lower cauline leaves lanceolate or spatulate and entire; upper or sometimes all the cauline 3-5-parted or divided, the divisions lanceolate or linear, or even almost filiform, sometimes again 2-3-parted: heads, \&c., nearly of the next, usually larger: akenes with more conspicuous squamellate or paleaceous pappus. - Hort. Barclay \& Trans. Am. Phil. Soc. vii. 358 ; Sweet, Brit. Fl. Gard. t. 175 ; DC. Prodr. v. 572 ; Torr. \& Gray, Fl. ii. 344, with the vars. longipes \& sulintegrifolia. C. longipes, Hook. Bot. Mag. t. 3586 ; DC. 1. c. C. Boykiniana \& C.heterophylla, Nutt. Trans. Am. Phil. Soc. 1. c. - Low grounds, Georgia to S. Missouri and Texas. Variable species: involucre 5 to 7 lines high: rays half-inch to inch long: foliage diverse.

C. lanceoláta, L. Low, only a foot or two high, including the long and simple naked peduncles: leaves ordinarily a few pairs, oblong-spatulate to lanceolate or nearly linear, obtuse, thickish, all entire, or rarely 1 or 2 small lateral lobes : rays commonly inch long and half-inch broad, sometimes smaller : pappus very small or obsolete. - Spec. ii. 908 (Martyn, Hist. Pl. t. 26 ; Dill. Elth. t. 48) ; Michx. Fl. ii. 136; Torr. \& Gray, Fl. ii. 344. Leachia lanceolata, \&c., Cass. Chrysomelea lanceolata, Tausch. - In rich or sandy damp soil, W. Canada and Illinois, Virginia, \&c., to Florida and Louisiana. The ante-Linnæan figures well represent the species; the type glabrous or nearly so, except hirsute ciliation: passes into

Var. angustifólia, ToRr. \& Gray, 1. c. (var. glabella, Michx. 1. c., partly); a low form, with narrow leaves ( 2 to 4 lines wide) all crowded on the abbreviated stems, and scapiform peduncles about a foot long. - Shore of L. Superior to Florida.

Var. villósa, Mrcex. 1. c. Leaves spatulate-obovate to oblong-lanceolate or oblong, villous-hirsute with many-jointed hairs, as also lower part of the stem. $-C$. crassifolia, Ait. Kew. iii. 253; Ell. Sk. ii. 434. C. oblongifolia, Nutt. Jour. Acad. Philad. vii. 76. Ilinois to Florida. 
C. pubéscens, ELt. Taller, 1 to 4 feet high, more leafy, from pubescent to nearly glabrous: leaves thickish, oblong, or the lower oval-obovate and the upper oblong-lanceolate, often all entire, some not rarely with 2 or even 4 small lanceolate lateral lobes or divisions : heads usually smaller than in the preceding: akenes similar.-Sk. ii. 441; Chapm. Fl. Suppl. 630. C.auriculata, Schk. Handb. t. 260 ; DC. Prodr. 1. c.; Torr. \& Gray, Fl. ii. 343, in part $(\gamma \& \delta)$, and of old gardens. Leachia trifoliata, Cass.? - Virginia to S. Illinois, Missouri, and south to Florida. In the middle or low couutry southward only a slender form, usually with lateral loles to upper leaves; in the mountains a larger plant in all its parts, with larger leaves 3 to 5 inches long, 1 or 2 inches wide, all entire, or a few 3-parted, the var. $\gamma$, Torr. \& Gray, Fl. 1. c.

+ + Wings of the akene narrow, strongly involute and callous-thickened at maturity.

C. auriouláta, L. Lorv and weak, stoloniferous, below commonly villous-hirsute : stems a foot or so high, including the long and slender peduncle, often simple: leaves of few pairs, ovate to round-oval, only an inch or so long, entire and some with a pair of smaller basal lobes, all but the upper slender-petioled: head comparatively small : rays little more than half-inch long: akenes by involution of margins oulong and umbilicate. - Spec. ii. 908 (Pluk. Alm. t. 242, f. 4, and perhaps t. 83, f. 5 ; Moris. Hist. iii. sect. 6, t. 3, f. 45); Michx. Fl. ii. 138; Ell. 1. c. (var. diversifolia); Torr. \& Gray, 1. c., as to typical form, but the akenes were then unknowa. C. diversifolia, DC. Prodr. v. 57l, excl. syn. - Wooded ground, Virginia and Kentucky to the borders of Florida.

§3. Edcoreópsis. Style-tips produced into a cusp or acute cone: akenes straight or little incurved, oblong, with narrow wing or none; no calli on the inner face : rays mostly entire or slightly toothed (yet sometimes 2-3-cleft) at the apex, pure yellow: disk-corollas yellow (sometimes dull, rarely turning brown): leaves opposite, in some seemingly verticillate. - Torr. \& Gray, Fl., excl. Leachia.

* Perennials, mostly low (a foot or two high), leafy to the summit: leaves sessile, palmately divided or cleft, but never serrate, not veny: involucre becoming rigid, its bracts all united at the base; outer oblong-linear, erect, about the length of the inner: rays from oblong to lanceolate : chaff of the receptacle linear-filiform and persistent: akenes oblong, narrowly wing margined: pappus 2-toothed or 2-aristellate, or obsolete: stems and branches striate-angled when dry. - \$ Gyroph yllum, Nutt.

+ Leaves 3-cleft to or below the middle, but not to the base, which has a 3 -nerved midrib.

C. palmáta, Nuтiт. Glabrous, rigid: stem nearly simple : leaves cuneiform in outline; the undivided basal portion little wider than the rather broally linear lobes, which are either simple or again 1-3-lobed, the margins scabrous: rays obovate-oblong akenes oblong. Gen. ii. 573; Torr. \& Gray, Fl. ii. 342. C. pauciflora, Lehm. Ind. Sem. Hort. Hamb. 1833, \& Linn. x. Suppl. 76. C. pracox, Fresenius, Ind. Sem. Hort. Francf. 1838. Calliopsis palmata, Spreng. Syst. iii. 611. - Plains and prairies, Winnipeg and Wisconsin to Illinois, Lonisiana, and W. Texas; first coll. by Nuttall.

+ + Leaves divided to the base, the pair thus imitating a whorl of six, or the uppermost simple, rarely some of the lower also simple.

C. verticilláta, L Glabrous, slender: leaves 2-3-ternately dissected into very narrowly linear or nearly filiform lobes : heads small : rays narrowly ollong: disk-corollas dull yellow: akenes obovate-cuneiform. - Spec. ii. 907; Lam. Dict. ii. 108; Michx l. c. (var. tenuifolra); Bart. Fl. Am. Sept. t. 73; Torr. \& Gray, 1. c. C. tenuifolia, Ehrh. Beitr. vii. 168; Willd. Spec. iii. 2252; Schk. Handb. t. 260; DC. l. c. - Moist ground, Upper Canada and Maryland to upper parts of Carolna and Arkansas.

C. delphinifólia, LAM. Stouter than the preceding: divisions of the leaves fewer and wider; the middle one once or its midlobe again 3-parted, lateral ones 2-parted or simple; lobes all linear, 2 lines wide: disk-flowers brown!-Dict. ii. 108 ; DC. 1. c. ; Torr. \& Gray, 1. c. C. verticillata, Ehrh. I.c.; Willd. 1. c.; Bot. Mag. t. 156; Schk. Handb. t. 260. C. verticillata, var. linearis, Michx. 1. «. - Pine woods, \&c., Virginia to Alabama and the borders of Florida.

C. senifólia, MIchx. Stem stouter and often taller (2 or 3 feet high): leaves divided into 3 commonly oblong-lanceolate or ovate-lanceolate and entire sessile divisions (of $1 \frac{1}{2}$ to $3 \frac{1}{2}$ 
inches in length and half-inch to inch wide), thus closely imitating a whorl of six: diskflowers dull yellow: akenes obovate-elliptical, 2-toothed at summit by extension of the broadish wing, the teeth sometimes aristellate-pointed. - Fl. ii. 128; Pursh, FI. ii. 568; Nutt. in Jour. Acad. Philad. vii. 77; Torr. \& Gray, l. c. C. major, Walt. Car. 214 ? - Dry and usually sandy woodlands, N. Carolina to Florida. The typical form is softly and minutely pubescent. Passes into the following

Var. stelláta, Torr. \& Gray, l, c. Smooth and glabrous throughout: divisions of the leaves from oblong to broadly lanceolate, sometimes rather attenuate at base (rarely, or in a monstrosity, the middle one 3-cleft !), sometimes a part or even all the leaves entire! $-C$. stellata (Soland. in herb. Banks), Nutt. Jour. Acad. l. c. C. senifolia, Hook. Bot. Mag. t. 3484. C. Emleri, Ell. Sk. ii. 435, the abnormal entire-leaved form. - Upper country and mountains, Virginia and Kentucky to Georgia. Passes, especially in the lower country, to

Var. rígida, Nutr. Divisions of the leaves lanceolate, mostly attenuate at base, from 2 to 3 or 4 lines wide, mostly quite glabrous. - Gen. ii. 180. C. Wrayi, Nutt. Jour. Acad. 1. c. C. delphinifolia, var rigida, Torr. \& Gray, 1. c. - S. Carolina to Florida, in the low and middle country. Narrowest-leaved forms closely approach $C$. delphinifolia.

* * Perennial, tall : leaves petioled and pinnately 3-5-divided, except the uppermost: otherwise nearly as the preceding. - §Chrysostemma, Torr. \& Gray. Chrysostemma, Less., DC.

C. trípteris, L. Smooth and glabrous, or leaves minutely pubescent: stem strict, 4 to 8 feet high, simple, with corymbose or fastigiate flowering branches : leaflets lanceolate, rather obtuse, 2 to 5 inches long; the pinnate veins connected by an obscure vein just within the scabrous margin : heads half-inch or less high, and oblong rays almost inch long: disk-flowers dull yellow turning brownish : akenes with narrow wings obscurely lacerate or denticulate at surnmit: no proper pappus : heads when bruised anise-scented. - Spec. ii. 908 (Moris. Hist. sect. 6, t. 3, f. 44); Michx. Fl. ii. 138; Torr. \& Gray, l. c. Anacis tripteris, Schrank, ex DC. Chrysostemma tripteris, Less. Syn. 227; DC. Prodr. v. 568 ; Hook. Bot. Mag. t. 3553. - Near streams, in rich soil, Penn. to Wisconsin and Louisiana.

* * Perennial, tall : leaves short-petioled, undivided, copiously pinnately veiny and serrate: style-tips conical-pointed: akenes oblong-lanceolate, wingless, the narrow truncate apex destitute of teeth or any kind of pappus: flowering late. $-\S$ Silphidium, Torr. \& Gray.

C. latifólia, Micrx. Glabrous and smooth, or pubescent, 3 to 5 feet high, leafy and simple to near the top: leaves membranaceous, 6 to 9 inches long, ovate or oval, acuminate at both ends, short-petioled; the long-mucronate teeth callous-tipped: heads several or numerous: involucre half-inch high, narrow; bracts of the onter loose and herbaceous, linear, more or less shorter than the thin and narrowly oblong inner ones, hardly united at base: rays narrowly oblong, entire, over half-inch long: disk-corollas yellow, barely brownish in age: akenes nearly 4 lines long. - Fl. ii. 137; Torr. \& Gray. Fl, ii, 341. - Higher mountains, N. Carolina to Georgia.

* * * Annuals, late-flowering, some perhaps biennial, leafy-stemmed and branching: leaves thinnish, petioled, pinnately 3-7-parted or divided, rarely undivided, these or their divisions pinnately veiny and incised or serrate, the principal veins often running to the sinuses: heads numerous: bracts of the involucre mostly distinct to the base; the outer loose and spreading or reflexed, ustally foliaceous, irregular, sometımes numerous: rays obovate-oblong, almost always entire, conspicuously many-nerved. disk-flowers dull yellow: anthers black : akenes wingless or obscurely margined, obovate or cuneate-oblong, unicostate on each face, straight, more or less 2-dentate or 2-aristate, sometimes the lateral ribs produced at summit into a tooth or awn. - § Diodonta, Torr. \& Gray. Diodonta, Nutt. Trans. Am. Phıl. Soc. vii. 360 . (Transition to Biclens: differing only in the absence of retrorse barbs to the awns of the pappus, and some species hybridizing with those of Bidens.)

+ Heads radiate: rays golden yellow: bracts of the outer involucre about 8 , not longer than the inner: akenes cuneate-oblong or obovate-cuneate, somewhat angulate-thickened on the faces, obscurely ciliate or naked-margined.

C. aúrea, Ait. Glabrous or nearly so, 1 to 3 feet high : leaves various, more commonly $3-7$ divided, with lanceolate divisions or leaflets incisely serrate or lobed, or upper leaves undjvided: rays half or two-thirds inch long. akenes broadly cuneate, only one or two lines long, slightly hairy, bearing two very short and rather divergent and blunt chaffy teeth, and rarely obscure ones from the lateral angles. - Ait. Kew. iii. 252; Torr. \& Gray, Fl. ii. 339. C. coronata, L. Spec. ed. 2, ii. 1281, as to herb., but excl. syn. Plum. (from which the "foliis 
lineatis," \&c., is taken) \& Vaill.; Walt. Car. 215 ; name best not restored. Diodonta mitis, aurea, \& leptophylla, Nutt. Trans. Am. Phil. Soc. 1. c. 360. - Wet ground, Virginia to Florida. The original $C$. aurea is a form with some of the upper leaves lanceolate and entire, lowermost of 3 leaflets. Extreme forms are : var. subintegra, Torr. \& Gray, with all or most of the leaves undivided and lanceolate (C.arguta, Pursh, Fl. 567, \& C. inbiuna, Nutt. Jour. Acad. Philad. vii. 75); var. leptophylla, Torr. \& Gray, l. c., with leaves or their few divisions elongated linear, only a line or two wide (Diodonta leptoplyyla, Nutt. Trans. Am. Phil. Soc. l. c.), a brackish coast form; and var. incisa, Torr. \& Gray, 1. c., with nearly all the leaves 3-7-divided and the divisions incised or coarsely serrate ( $C$, mitis, Miclix. Fl. ii. 138, \& tho C. coronata of herb. Linn.), the form which approaches or passes into the following.

C. trichospérma, Michx. Glabrous or nearly so, a foot or two (rarely' 3 to 5) high: leaves almost all 3-5-divided into lanceolate coarsely serrate or pinnately incised divisions : rays oval-obovate, two-thirds to three-fourths inch long: akenes narrowly cuneate-oblong, sparsely hairy or glabrate, about 4 lines long and barely a line wide, or the outer somewhat broader and shorter, bearing a pair of strong subulate pointed erect teeth, commonly equal in length to the breadth of the summit of the akene. - Fl. ii. 139 ; Torr. \& Gray, Fl. ii. 340 , C. aurea, Lindl. Bot. Reg. t. 1228. Diodonta coronata, Nutt. 1. c. - Wet ground, coast of Mass. to Virginia and N. E. Georgia. Also shore of L. Erie to Illinois; where is a

Var. tenuíloba. Tall, much branched: divisions of the leaves from narrowly lanceolate to linear: akenes smaller (outer barely 3 lines long), and with shorter somewhat spreading teeth: approaching C. aurea. - Peat bogs, Indiana and Illinois, Vasey, Stewart, \&c.

++ Heads radiate: rays golden yellow, sometimes inch long: akenes obovate, very flat, with very thin margins hispid-ciliate: leaves all $3-7$-divided or parted; the divisions serrate, incised, or some again cleft: herbage somewhat pubescent or glabrous. (Hybrids of these with Bidens frondosa or others are not uncommon.)

C. aristósa, Michx. Stem 1 to 3 feet high: divisions of the leaves lanceolate, acuminate: bracts of the outer involucre 8 to 10, barely ciliate, not surpassing the inner: akene with a pair of slender upwardly scabrous awns of 'ts own length, or these rarely wanting. - F1. ii. 140; Torr. \& Gray, 1. c.; Hook. f. Bot. Mag. t. 6462. C. aristata, Willd. Spec. iii. 2253. Diodonta aristosa, Nutt. 1. c.-Swamps, Michigan to Iowa, Missouri and W. Louisiana: Southwestward with the var. mutica (the awns wanting), there disposed to pass into the next.

C. involucráta, Notr. Heads rather larger: bracts of the outer involucre i2 to 20 , mostly surpassing the inner, slender, hispid on the back and margins: akenes with 2 short acute teeth. - Jour. Acad. Philad. vii. 74; Torr. \& Gray, 1 c. Diodonta involucrata, Nutt. Trans. Am. Phil. Soc. 1. c. - W. Illinois to Kansas and Texas.

\footnotetext{
+++ Heads without rays, or rarely a rudimentary one, short-pedunculate: disk dull yellow: outer involucre of 3 to 5 irregular foliaceous bracts, some or most of them surpassing the head: herbage glabrous or nearly so: leaves slender-petioled.
}

C. bidentoídes, NurT. Rather stout, 1 to 4 feet high, with ascending branches: leaves undivided, lanceolate, acuminate, serrate, tapering at base into the long petiole: heads oblong, half to three-fourths inch long, and outer involucral bracts sometimes inch and a half long, resembling uppermost leaves; bracts of inner involucre with somewhat petaloid margins and tips - akenes cuneate-linear, 4 or 5 lines long, more or less exceeding the two setiform. upwardly hispidulous awns, rarely vestiges of awns from lateral nerves. - Torr \& Gray, Fl. ii. 339. Diodonta (Heterodonta) bidentoides, Nutt, Trans. Am. Phil. Soc. vii 361. - Muddy shores of Delaware River and Bay, from above Philadelphia. first coll by Nutall.

C. discoídea, Torr. \& GraY, 1. 七. Slender, with widely spreading branches, a foot or two high: leares membranaceous, irregularly serrate; uppermost undivided and rhomboidlanceolate ; lower divided into 3 sessile or petiolulate leaflets : heads campanulate, a quarterinch high : akenes narrowly cuneiform, 2 or 3 lines long, the two subulate teeth rather than awns mostly shorter than the width of its summit. - River borders and swamps, Connecticut and N. New York to Ohio, Virginia, and Texas.

113. BIDENS, Tourn. Bdr-Marigold. (Lat. bidens, with two teeth or prongs: name from the adjective, i. e. planta bidens, therefore feminine.) - Herbs, of wide distribution, chiefly American; with opposite elther simple or compound 
leaves, and solitary or paniculate heads of mostly yellow (sometimes white, rarely purple) flowers; in summer or autumn. - Linn. Gen. no. 932 ; DC. Prodr. v. 593 ; Benth. \& Hook. Gen. ii. 387.

§1. Platrcarp fa, DC. Akenes flat, from obovate to cuneiform, not at all contracted at the summit, 2-4-awned: outer involucre foliaceous and spreading: veins of the leaves commonly terminating in the sinuses: ours annuals.

* Heads erect, rayless, or rarely with one to five small rays, these usually shorter than the disk and therefore inconspicuous: disk greenish yellow: leaves mostly petioled.

B. frondósa, L. (Sтrck-тight.) Glabrous or somewhat hairy, branching, 2 to 6 feet high: leaves except the uppermost pinnately 3-5-divided into lanceolate or broader sharply serrate and pinnately veiny commonly petiolulate leaflets: outer involucre often very leafy: akenes obovate or oblong, more or less hairy (the hairs of the margin ascending except near the summit), 2-awned. - Spec. ii. 832; Torr. \& Gray, Fl. ii. 351. - Shady or moist ground, preferring manured soil, Florida and Texas to Saskatchewan and Brit. Columbia, everywhere common, and with the habit of a naturalized weed. Near Philadelphia, along with this and Coreopsis bidentoides, occurs a form with upwardly hispidulous awns, doubtless a hybrid.

B. connáta, Murt. Glabrons, a foot or two high, loosely branched : leaves either all undivided, oblong or broadly lanceolate, acuminate at both ends, sharply serrate, tapering into margined petioles or the upper sessile; or some with a pair of lateral divisions which are sessile and decurrent on the petiole: akenes oblong-cuneate or the outermost obovate, nearly glabrous but retrorsely hispid-ciliate, commonly 3-awned. - Willd. Spec. iii. I718; DC. l. c.; Torr. \& Gray, l. c. B. tripartita, Bigel. Fl. Bost. ed. 2, 294, not L. B. petiolata, Nutt. Jour. Acad. Philad. vii. 99, a thin-leaved small-headed form; while var. comosa, Gray, Man. 261, is a stout and larger-headed form with very leafy involucre. Slender forms imitate Coreopsis discoidea. - Wet ground, Canada to Illinois, Missouri, and Georgia.

* Heads disposed to nod after anthesis, commonly with conspicuous rays: leaves all sessile and undivided; upper pairs somewhat connate round the stem: margins of the cuneate akenes and the rigid awns retrorsely aculeolate-hispid.

B. cérnua, L. Stem glabrous or setulose-hispid, from a span to a yard high: leaves oblonglanceolate, coarsely and irregularly sharply serrate: heads conspicuously nodding after anthesis, commonly surpassed by the foliaceous outer involucre: rays ovate or oval, little surpassing the disk or wanting: akenes usually 4-awned. - Spec. ii. 832 (discoid); Willd. Spec. iii. 1716 ; Schk. Handb. t. 235; Fl. Dan. t. 841 ; Torr. \& Gray, Fl. ii. 352, with var. elata, a large form of the Pacific coast. B. quadriaristata, var. dentata, Nutt. Trans. Am. Phil. Soc. 1. c. 368. Coreopsis Bidens, L. l. c. 908, radiate form. - Wet ground, from Hudson's Bay and Saskatehewan to the Pacific coast, and in the Atlantic States south to Virginia and Missouri ; at some stations seemingly introduced. (Eu, N. Asia.)

B. chrysanthemoídes, Mrchx. Glabrous, often decumbent at base, a foot or two high: leaves lanceolate, rather minutely and evenly serrate: heads rather large, little or not at all nodding: outer involucre seldom surpassing the inner, conspicuously surpassed by the oval or broadly oblong (usually inch-long) rays: akenes 2-4- (more commonly 2-) awned. - Fl. ii. 136; Willd. Spec. iii. 1717; Torr. \& Gray, 1. c. ; Sprague, Wild Flowers of Amer. 131, t. 30. B. quadriaristata, DC. l. e. B. helianthoides, HBK. Nov. Gen. \& Spec. iv. 230. Helianthus loevis, L. Spec. ii. 906, viz. Pl. Gronov. Fl. Virg., ed. I, 104 (not of ed. 2). Coreopsis Bidens (\& C. perfoliata?), Walt. Car. 215. - Wet grounds, Canada to Florida, Arizona, and California. (Mex., S. Am.)

§ 2. Psilocarpla, DC. (Ceratocephalus, Vaill.) Akenes narrow, lineartetragonal; the outer almost always shorter and more truncate at apex than the inner, which generally taper upward, but are not distinctly rostrate: outer involucre seldom foliaceous or enlarged.

* Leaves mainly divided into 3 to 5 ovate merely serrate divisions or leaflets: rays when present white: annuals, at least with us, varying from pilose-pubescent to nearly glabrous: akenes 4 to 5 
or even 6 lines long, in the same plant either smooth with sparing bristles, or the outer becoming tuberculose and rough.

B. leucántha, Willd. Leaves of rather firm texture, some undivided and ovate; these and the 3 or occasionally 5 ovate or oblong-ovate divisions evenly serrate, more or less lineately veiny: heads corymbosely paniculate on rather short pecluncles : rays obovate, bright white, 5 to 8 lines long, rather showy. - Spec. iii. 1719; Torr. \& Gray, 1. c. B. striata, Sweet, Brit. Fl. Gard. t. 237 ; Hook. Bot. Mag. t. 3155. Coreopsis leucanthema, L. Amon. Acad. iv. 291. C. leucantha, L. Spec. ed. 2, ii. 1282; Desc. Fl. Ant. t. 583. C. coronata, L. l. c. 1281, as to syn. Plum. t. 53, f. 2. - Common in S. Florida. (W. Ind., Mex.)

B. pilósa, L. Stem sometimes tall, usually weak: leaves thin; leaflets 3 to 5, irregularly serrate, sometimes incised, or the lower divisions occasionally 3-lobed: heads fewer and scattered : rays commonly none, at most inconspicuous and yellowish-white. - Spec. ii. 832 (but the cited figure, Dill. Elth. t. 43, probably belongs to $B$. frondosa); Willd. l. c. Coreopsis alba, L. Spec. ii. 908 (Herm. Parad. t. 124? excl. syn. Pluk.). Bidens Californica, DC. Prodr. v. 599; Torr. \& Gray, Fl. ii. 354. Variahle, and the slender forms in warm countries seeming to pass into B. bipinnata. $-\mathrm{S}$. California and Arizona, introduced? (Mex. to Chili, W. Ind., and all tropics.)

* * Leaves all once to thrice 3-5-nately parted or divided into oblong or linear ultimate lobes: root in ours annual.

+ Heads narrow: rays inconspicuous and yellowish or none: akenes long and slender, at least the central ones much surpassing the involucre.

+ Lobes of the thin leaves from oblong to lanceolate: heads slender-peduncled.

B. bipinnáta, L. (Spanisf Needles.) Primary and secondary divisions of the leaves rather ovate or deltoid-lanceolate in circumscription, and the lobes mostly acute: akenes all slender, the inner ones 5 to 9 lines long, outermost moderately shorter and thicker: awns 3 or 4, sometimes only 2.-Spec. ii. 832 ; Michx. ii. 135 ; Torr. \& Gray, 1. c. -Damp thickets and waste ground; a common and disagreeable weed, New England to Florida and Arizona. (Trop. Am., \&c.)

B. Bigelóvii, Grax. Lobes of the leaves linear-oblong, mostly obtuse : innermost akenes 5 or 6 lines long, 2-3-awned; outermost of half that lengtl or less, stouter, 2-corniculate, or with a pair of short awns, or even with none. - Bot. Mex. Bound. 91. B. tenuisecta, in part, Gray, Pl. Wright. i. 109. - S. W. Texas to S. Arizona, first coll. by Wright and Bigelow.

$$
+\div \text { Lobes of the leaves linear. }
$$

B. tenuisécta, GRAY. A foot or two high, branched from the base, sparsely hirsute or glabrous: leaves 2-3-ternately or pinnately dissected into narrow linear lobes (of a line or more in width): heads on naked rather long and stout peduncles, many-flowered, 4 or 5 lines high in flower: involucre hirsute, especially at base: akenes glabrous, 2-awned; inner 5 lines long, with tapering summit; outermost 3 lines long, stouter and with broad summit and asually short awns: rays yellow, mostly surpassing the disk. - Pl. Fendl. 86. - Along water-courses, Colorado, New Mexico, and Arizona; first coll. by Fendler.

B. Lemmóni. A foot or less high, slender, with short branches, smooth and glabrous: leaves twice ternately parted into entire obtuse rather broadly linear lobes (a line or two wide) ; the uppermost simply 3-5-parted, subtending the mostly sessile 5-9-flowered cylindraceous and glabrous heads: akenes nearly of the preceding, but the outer nearly like the inner: rays apparently none. - S. Arizona, in Apache Pass, Lemmon.

B. heterospérma, Grax. Slender, glabrons, paniculately much branched: leaves once or twice ternately parted into filiform-linear (half-line wide) lobes: heads on slender peduncles, few-flowered, in flower barely 3 lines long: rays apparently none: akenes 2-3-awned, smooth; the inner 4 or 5 lines long, outermost only 2 lines long and their short awns caducous. - Pl. Wright. ii. 90. - S. Arizona : raised from seed coll. by Wright (thought to come from New Mexico): rediscovered in Apache Pass by Lemmon.

++ Heads broader, many-flowered, and with comparatively large deep yellow rays: akenes all short, hardly surpassing the involucre.

B. prócera, Dos. Erect and tall from an annual or biennial root, glabrous: leaves twice or thrice parted into narrow linear lobes (mostly of an inch or more in length and less than a line wide): heads corymbosely paniculate: outer involucre small and inconspicuous, 
merely spreading: rays oval (in ours half-inch long, in Mexican sometimes an inch): disk in fruit only 4 lines high, comparatively broad: outer akenes narrowly cuneate-oblong and only 2 lines long, innermost 3 lines long and cuneate-linear, apex not attenuate: awns 2, strongly barbed, of half or a third the length of the akene. - Bot. Reg. t. 684 (1822); DC. Prodr. v. 603 ; Gray, Proc. Am. Acad. xix. 16. B. feniculifolia, DC. 1. c. (probably); Gray, Pl. Wright. ii. 90; Rothr. Wheeler Rep. vi. 165. B. feruloefolia, Hemsl. Bot. Biol. Centr.Am. ii. 202, mainly, not Jacq. - Arizona, Wright, Thurber, Lemmon. (Mex.)

* * *eaves some undivided, some 3-5-parted into lanceolate or linear divisions : root perennial.

B. heterophylla, ORT. Glabrous or nearly so, often tall: leaves of firm texture and with ascending veins, mostly serrate with erect teeth, from oblong to lanceolate and tapering into a petiole, sometimes all undivided, commonly some 3-parted or the upper 5-parted into lanceolate or linear lobes: heads in flower 3 and in fruit about 5 lines high: rays broadly obovate, half to three-fourths inch long, deep yellow : akenes cuneate-linear, the inner ( 3 lines long) little longer than the outermost, 2-3-awned.-Dec. 99, t. 12; DC. Prodr. v. $597 . \quad B$. arguta, HBK. Nov. Gen. \& Spec. iv. 231 ; DC. 1. c. B. longifolia, DC. 1. c.-S. Arizona, along streams, Pringle, Lemmon. (Mex.)

Var. Wríghtii. Base of stem and lower leaves unknown: upper leaves and (when divided) their divisions lanceolate-linear, entire or nearly so, the longer 4 or 5 inches long and 3 or 4 lines broad. - P1. Wright. ii. 90 (as nnnamed doubtful var.); Rothrock in Wheeler Rep. vi. 165.-S. Arizona, Wright, Rothrock, Lemmon. Seemingly an extreme form of a variable species.

§3. Hydrocarpea. Akenes almost terete, cartilaginous, truncate at both ends, bearing 3 to 6 very long and rigid acerose awns, which are smooth below, the upper part densely and retrorsely hispidulous: aquatic: submersed leaves filiformly dissected: rays conspicuous, yellow.

B. Béckii, Torr. Submersed stems much elongated in deep water, thickly beset with the almost capillary ternately multifid leaves; emersed summit bearing a few pairs of oblonglanceolate serrate leaves, or the lower pinnatifid: head short-peduncled : bracts of the involncre oblong: rays obovate, over half-inch long: mature akenes half-inch and the rigid diverging awns an inch or less long, very persistent. - Torr. in Spreng. Neu. Entd. ii. 135, Syst. iii. 455, \& Fl. N. Y. i. 388, t. 58. - In slow-llowing streams and ponds, Canada to New Jersey and Missouri ; first coll. by $L . C$. Beck.

114. CÓSMOS, Cav. (Kóoros, an ornament.) - Tropical American herbs, chiefly Mexican, too near Bidens; for there is one yellow-rayed species, and certain species with purple rays have hardly a beak to the akenes. - Ic. i. 9, t. 14, 79; DC. Prodr. v. 606; Benth. \& Hook. Gen. ii. 387. Cosmea, Willd. Spec. iii. 2250.

C. CAODÁTJS, HBK. Apparently annual: leaves twice pinnately parted into lanceolate acute lobes: rays rose-colored, seldom much surpassing the involucre: akenes fusiform, with beak longer than the body (in all nearly inch long), 2-awned. - HBK. Nov. Gen. \& Spec. iv. 240; Torr. \& Gray, Fl. ii. 349. - Key West, Blodgett. (Evidently introduced from W. Ind.)

C. Bipinșítus, Cav. 1. c. t. 14. Annual: leaves pinnately divided into narrowly linear or almost filiform lobes: heads very showy, the deep rose-colored rays commonly an inch or more long: akenes smooth and glabrous throughout, with abrupt beak very much shorter than the body, or in some flowers reduced to a mere neck: awns 1 to 3 , short (Mexico); in var. EXARISTÁTUS, DC. l. c., the awns wholly wanting. - The var., S. Texas, near Marfa, on an abandoned ranch (base of stem becoming lignescent), Havard. (Mex.)

C. parviflórus, HBK. Annual, slender: heads smaller, with either white or rose-colored rays half to a quarter of an inch long: beak of the akenes slender, usually half the length of the body, scabrous, 2-3-awned: otherwise as preceding, into which it may pass. Nov. Gen. \& Spec. iv. 241. C. bipinnatus, var. parviflorus, Gray, Pl. Wright. ii. 90. Coreopsis parvifora, Willd. Spec. iii. 2551. Bidens Humboldtii, Schultz Bip. in Bot. Herald, 307.S. W. Texas to Arizona. (Mex.) 
115. HETEROSPERMUM, Cav. (Heterosperma. "Etєpos, other, in sense of unlike, $\sigma \pi \dot{\epsilon} p \mu a$, seed.) - Small or slender annuals (from the Mexican border southward), mainly glabrous, branching; with opposite pinnately or ternately dissected or sometimes undivided leaves, and small heads of yellow flowers; the 3 to 5 rays little exserted. - Cav. Ic. iii. 24, t. 267 ; HBK. Nov. Gen. \& Spec. iv. 245, t. 383, 384 ; DC. Prodr. $\nabla .632$.

H. pinnátum, Cav. l. c. About a foot high : leaves pinnately 3-7-parted into linear divisions, which are either all entire or some of them again 2-3-parted : heads slender-peduncled, about 3 lines long: outer involucre of 3 to 5 linear foliaceous bracts, hispidly ciliate at base, and overtopping the thin and oval striate inner bracts: outer akenes oval, at maturity cymbiform or becoming oblong by inflexion of the callous wing, destitute of pappus ; innermost commonly infertile, subulate, attenuate into a scabrous beak, bearing a pair of short deciduous awns. - Willd. Spec. iii. 2129; DC. Prodr. v. 632. H. tagetinum, Gray, P1. Fendl. 87, \& Pl. Wright. ii. 91, a form with simply pinnate leaves often marked with glandular spots, the awns sometimes wholly wanting or caducous. - W. Texas to Arizona. (Mex.)

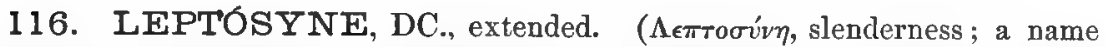
applicable to the original, but not to most of the species here associated, except as to the leaves and their divisions.) - Herbaceous or suffruticose plants (of California and Arizona), smooth and glabrous; with alternate or opposite and usually rather fleshy ternately or pinnately divided or dissected leaves, and showy pedunculate heads, both disk and ray flowers bright yellow. IIabit of Coreopsis (which it represents on the western side of the continent), but mostly with pistillate rays, and always with a ring on the tube of the disk-corollas or at its junction with the throat. - Gray, Proc. Am. Acad. xvii. 218. Leptosyne, DC. Prodr. v. 531, with Agarista, DC. 1. c. 569. Coreocarpus \& Acoma, Benth. Bot. Sulph. 28, 29, t. 16, 17. Leptosyne \& Pugiopappus, Gray (Pacif. R. Rep. iv. 104), Bot. Calif. i. 354.

§1. Euleptóstne. Akenes callous-winged and commonly meniscoidal at maturity, a small or obscure saucer-shaped cup in place of pappus : rays pistillate and commonly fertile, obovate, more or less 3-lobed: style-tips of the diskflowers capitellate either with or without a minute setiform cusp: low annuals, with all but the lowest leaves alternate, and long or scape-like monocephalous peduncles: bracts of the outer involucre linear or lanceolate, loose. - Leptosyne, DC. 1. c.

L. Douglásii, DC. A span to a foot high, leafy only at or near the base: leaves once to thrice parted into nearly filiform divisions: rass half-inch or more long: ring of the diskcorollas usually digtinctly bearded: akenes thickened at maturity (at least the more fertile outer ones) and corky-winged, also corky-ridged down the inner face, roughened nearly throughout with capitellate or clavate short and rigid bristles: pappus-cup somewhat conspicuous. - Prodr. v. 531 ; Torr. \& Gray, Fl. ii. 355 ; Gray, Bot. Calif. i. 356. L. Californica, Nutt. Trans. Am. Phil. Soc. vii. 363, \& L. Newberryi, Gray, Proc. Am. Acad. vii. 358, Bot. Calif. 1. c.; state with young akenes or infertile inver ones thin-winged, and ring of corollatube less bearded. - California (from Monterey to San Diego and San Bernardino) and adjacent Arizona; first coll. by Douglas: flowering early.

L. Stillmáni, Gray. Stouter, more leafy below: lobes of the leaves linear, a line or more broad: ring of the disk-corollas beardless: akenes somewhat obovate, quite smooth and naked on the back, becoming papillose or tuberculate on the inner face, at least along the slightly ridged centre, the corky wing more or less rugose. - Bot. Mex. Bound. 92, \& Bot. Calif. i. 356. - California, from San Francisco Bay northward and eastward; first coll. by Stillinan. 
§2. Tuckerminnia. Akenes plane, oblong, smooth and glabrous, with obscure wing-like margin : pappus none or sometimes the margins continued into an acute tooth or short naked awn: rays fertile, oblong, obscurely toothed at the apex: ring of disk-corollas beardless: perennial, with more fleshy leaves and thickened succulent stem or caudex: the heads Jarge and showy.-Tuckermannia, Nutt. Trans. Am. Phil. Soc. 1. c. 363.

L. marítima, Gray. Stems low, fleshy-herbaceous from a thick base or caudex: branches terminating in monocephalous peduncles of a span to a foot in length: leaves bipinnately divided into narrowly linear lobes of a line or two in width: rajs 16 to 20 , an inch or more long, and disk commonly an inch in diameter. - Proc. Am. Acad. vii. 358, \& Bot. Calif. 1. c.;

to Regel, Rev. Hort. Tuckermannia maritima, Nutt. 1. c. ; Torr. \& Gray, Fl. ii. 355; Torr. Bot. Mex. Bound. 92, t. 31. Coreopsis maritima, Hook. f. Bot. Mag. t.6241. - S. Coast of California, at San Diego and on the adjacent islands.

L. gigantéa, KeLlog G. Fleshy-woody stem 2 to 8 feet high, 1 to 5 inches thick, leafy at top: leaves twice or thrice pinnately divided into filiform lobes: heads smaller (disk halfinch in diameter) on short corymbosely. clustered peduncles: inner bracts of the involucre with prominent midrib. - Proc. Calif. Acad. iv. 198; Gray, Bot. Calif.' i. 356. - California, on the mountains near Sta. Barbara and San Miguel, and islands off the coast; first coll. by Coulter. May be a form of the preceding, but seemingly is quite distinct. (Guadalupe Island, Palmer.)

§ 3. Pugropáples. Akenes dimorphous; those of the ray- or outermost diskflowers very like those of the preceding section (oval, flat, glabrous), either fertile or sterile; those of the disk also flat, but narrowly oblong, marginless, clothed at least on the margins with long and soft-villous hairs (which are bidentate at apex under a lens), bearing a conspicuous pappus of a pair of linear triquetrous palex: annuals with the habit and otherwise the character of Euleptosyne; the ample golden yellow rays multinervose, commonly styliferous, not rarely fertile, yet sometimes neutral or with mere included rudiment of style. - Agarista, DC. Prodr. v. 569 ; Torr. \& Gray, Fl. ii. 337, not Don. Pugiopappus, Gray, Pacif. R. Rep. 1. c., \& Proc. Am. Acad. vi. 545, viii. 659.

L. Bigelóvii, Grar. A foot or less high, with the habit of $L$. Douglasii, leafy only at base, and with long often scapiform peduncles: leaves once or twice ternately or quinately parted into narrow linear lobes: involucre half-inch or less high; its outer bracts linear or nearly so, inner oblong-ovate: rays obovate or quadrate-oblong, half to two-thirds inch long, 10-12nerved : ring of disk-corollas beardless: ray-akenes oblong, with narrow callous-winged margin ; disk-akenes elongated-oblong, very villous at the margins, sparsely so or naked on one or both faces, twice the length of the palex of the pappus. - Pugiopappus Bigelovii \& $P$. Breweri, Gray, Proc. Am. Acad. viii. 660, \& Bot. Calif. 1. c., the former clescribed from immature and incomplete specimens, in which the villosity of the disk-akenes was little develuped. - Southern part of California, from San Buenaventura and Tejon to the Mohave Desert.

L. calliopsídea, Gray. A foot or two high, rather stout and leafy, with peduncles a span long: lobes of the leaves narrowly linear, sometimes incised : heads rather large and broad: bracts of the outer involucre broadly ovate, thick, a little shorter than the narrowly ovate inner ones: rays broadly cuneate-obovate, commonly an inch long and three-fourths inch wide, 15-20-nerved: ring of the disk-corollas pubescent: ray-akenes broadly oval, distinctly thin-winged; disk-akenes cuneate-oblong, little longer than the paleæ of the pappus, very long villous on the margins and inner face. - Agarista calliopsidea, DC. Prodr. $\mathbf{v}, 569$; Torr. \& Gray, 1. c. Coreopsis calliopsidea, Bolander, Cat. Pl. San Francisco. Pugiopappus calliopsideus, Gray Proc. Am. Acad. \& Bot. Calif. 1. c. Leptosyne maritima, Rev. Hortic. 1873, 330, tab. - Moist hillsides and plains, California, from the Sacramento southward.

Var. nána. A span or so high, with more seapiform peduncles, leaves crowded at base, heads and rays smaller, outer involucre comparatively shorter, and ray-akenes narrower or less margined. - San Bernardino Co. at Mohave Station, \&c., Lemmon, Pringle. 
§4. Coreoc氏rpos. Akenes nearly of Euleptosyne, but mostly with tuberculate rather than winged margins, and some of them bearing a pair of sometimes retrorsely hispid awns; those of the ray-flowers mostly fertile: style-branches of the disk-flowers produced into a subulate appendage: outer involucre of a few small inconspicuous bracts: annuals or suffruticose perennials; with branching stems, opposite leaves, and small cymose or paniculate heads on short slender peduncles.-Coreocarpus \& Acoma, Benth. Bot. Sulph. l. c. Coreocarpus, Benth. \& Hook. Gen. ii. 384.

L. Arizónica, Grar. Stems 2 or 3 feet high, and paniculately branched from a woody base, rigid, slender: leaves 3-5-parted into mostly entire linear acute lobes: heads loosely cymose, 3 or 4 lines long: outer involucre of 1 to 3 small loose bracts; inner of 6 to 8 ovate ones in two ranks: rars 5 or 6 , about 3 lines long: disk-corollas with a bearded ring: akenes narrowly oblong, with faces either smooth or papillose-muriculate, and margins beset with a wing which is wholly dissected into a pectinate tubercular fringe (in the manner of Coreopsis, $\$$ Coreoloma), the inner and less fertile or infertile marginless, some without pappus, others bearing either one or two short and setiform awns, which are either naked or sparingly denticulate, the denticulations spreading or a few of them recurved.-Proc. Am. Acad. xvij. 218. - Along streams in the Santa Catalina Mountains. Southern Arrzona, Lemmon, Pringle.

L. Partheniofoes (Coreocarpus parthenioides, Benth. Bot. Sulph. t. 16), L. HeterocArpa (C. heterocarpus, Gray, Proc. Am. Acad. v. 162), and L. Dissécta (Acoma dissecturn, Bentlı. L. c. t. 17) are species of Lower California, insufficiently known.

117. THELESPERMA, Less. (® $\eta \lambda \dot{\eta}$, a nipple, $\sigma \pi \dot{\epsilon} \rho \mu \alpha$, seed, from the papillosity of some of the akenes.) - Perennial, sometimes annual or suffrutescent herbs (of the Great Plains, and one on the Pampas of S. Amer.), smooth and glabrous; with habit of Coreopsis, opposite usually finely dissected leaves, and pedunculate heads; the rays normally golden yellow, disk-flowers yellow, sometimes purplish or brownish. - Less. in Linn. vi. 511; Gray in Kew Jour. Bot. i. 252, \& Pl. Wright. i. 109. Cosmidium, Torr. \& Gray, in Nutt. Trans. Am. Phil. Soc. 1. c., \& F1. ii. 350.

* Lobes of the disk-corollas linear or lanceolate, longer than the short-campanulate throat: styleappendages with cuspidate or subulate tips: pappus evident: chaff of receptacle falling with and partly embracing the akenes.

T. BCABrosioldes, Less, of the Pampas in S. America, closely represents $T$. gracile, but has more filiform foliage and longer-awned pappus.

Cosmidium BurridgeAnum of the gardens is a hybrid of $T$. filifolium and Coreopsis tinctoria, acquiring its brown-purple rays from the latter.

T. filifólium, GrAx. A foot or two high from an annual or biennial root, loosely branching, leafy : leaves not rigid, bipinnately divided into filiform lobes no wider than the rhachis: bracts of the outer involucre 8 , subulate-linear, almost equalling or more than half the length of the inner, which are connate only to the middle: rays broad, over half-inch long: disk usually purple turning brownish : outer akenes becoming coarsely papillose on the back; the stout triangular-subulate pappus-scales not longer than the width of the akene. - Kew Jour. Bot. i. 252, \& Pl. Wright. i. 109. Coreopsis trifida, Lam. Ill. t. 704 ; Poir. Suppl. ii. 353, ex tab. C. flifolia, Hook. Bot. Mag. t. 3505. Cosmidium filifolium, Torr. \& Gray, Fl. ii. 350. - Dry uplands and plains, Arkansas to Texas.

T. ambiguum, GRAY. A foot high, perennial and spreading by creeping rootstocks, rather rigid, usually more naked above or with longer peduncles: cauline leaves less compound; the lobes from filiform to narrowly linear; bracts of inner involucre connate to or above the middle: rays rarely wanting; otherwise as the preceding. - Proc. Am. Acad. xix. 16. T. filifolium, Gray, Pl. Wright. i. 109, \& ii. 90, chiefly. - Plains and hills, W. Texas to New Mexico, Colorado, and Montana. 
T. grácile, Gray, 1. c. More rigid, a foot or two high from a deep perennial root, less branched, naked above : leaves once or twice 3-5-nately divided or parted into filiform-linear or broader lobes, or some upper ones filiform and entire: bracts of the outer involucre 4 to 6 , very short, ovate or oblong; of the inner one connate to above the middle, the edges of their lobes slightly scarious: disk mostly yellow, scarcely brownish after anthesis: akenes less papillose or roughened, the breadth of the summit exceeded by the subulate awns: rays usually none, rarely present and 2 or 3 lines long. - Bidens gracilis, Torr. Ann. Lyc. N. Y. ii. 215. Cosmidium gracile, Torr. \& Gray, 1. c.-Plains, Nebraska and Wyoming to W. Texas and Arizona. (Adj. Mex.)

* * Lobes of disk-corollas from ovate to oblong, decidedly shorter than the cylindraceous throat; the proper tube also shorter than in the foregoing: pappus shorter and more coroniform, destitute of retrorse bristles or hairs, or wanting.

+ Leafy-stemmed, branching, herbaceous to the ground: style-appendages subulate-tipped.

T. subsimplicifólium, Grar. Stems slender, rigid, 1 to 3 feet high: leaves sometimes all entire and filiform ( $1 \frac{1}{2}$ to 3 inches long), sometimes 3-5-parted into filiform entire lobes: outer bracts of the involucre oblong to linear, short: rays half-inch long: akenes shortfusiform: pappus 2 minute slightly hairy teeth, or obsolete. - Bot. Mex. Bound. 90. T. simplicifolium, Gray, Kew Jour. Bot. 1. c. Cosmidium simplicifolium, Gray, Pl. Fendl. 86. Rocky prairies, Texas to Arizona. (Adj. Mex.)

+ + Low, branching from a lignescent base, very leafy below, sending up long and naked or scapiform peduncles: outer involucre short and small: akenes fusiform, more incurved at maturity.

T. subnúdum, Gray. Rather stout: leaves thickish and rigid, once or twice ternately parted into linear or lanceolate lobes: peduncles 4 to 10 inches long: head rather large (half-inch high): rays sometimes none, sometimes ample (the larger two-thirds inch long and over half-inch wide): style-appendages subulate-tipped: pappus a minute 4-5-toothed naked crown, or obsolete. - Proc. Am. Acad. x. 72. Includes also T. subsimplicifolium, var. scaposum, Gray, coll. Parry, \&c. - New Mexico, S. Utah, and N. Arizona, Palmer, Parry, Ward. Also apparently Green River, Wyoming, Parry, a plant referred to T. gracile.

T. lóngipes, GraT. Fastigiately much branched at the woody base, very leafy: leaves 3-5-parted into filiform divisions which are usually no wider than the rhachis: pednncles filiform, wholly simple, 5 to 10 inches long: head small (quarter-inch high), rayless : styleappendages tipped with a very short cone : akenes barely 2 lines long, arcuate at maturity, falling free from the chaff: pappus quite obsolete. - Pl. Wright. i. 109; Rothrock in Wheeler Rep. vi. 164. - Dry hills and barks, W. Texas and Arizona, Wright, Rothrock (not showing the woody stems), Lemmon. (Mex., Schaffner.)

1 18. BALDWINIA, Nutt., in the form of Balduina. (Dr.Wm. Baldwin, collaborator with Elliott, died early.) - Apparently biennials or annuals (of S. Atlantic States), mostly glabrous or minutely puberulent; with alternate entire leaves, puncticulate in the manner of Helenium and veinless, and solitary or corymbosely paniculate heads of yellow flowers, or those of the disk sometimes purplishtinged : fl. late summer and autumn. - Nutt. Gen. ii. 175; Ell. Sk. ii. 447; Benth. \& Ilook. Gen. ii. 391. Baldwinia and Actinospermum (Ell.), Torr. \& Gray, Fl. ii. 388. (True affinity rather with the Helenioidea.)

B. uniflóra, Nuтr. 1. c. Stem rather stout, simple or simply branched, 1 to 3 feet high from a perhaps "perennial" root, with terminal usually elongated peduncle bearing a solitary large head: leaves obtuse, spatulate, or the upper linear : bracts of the involucre numerous, in about 4 series, thickish, at first appressed: rays 20 to 30, cuneate-linear, 3-toothed at truncate apex, inch or more long : concreted chaff of receptacle truncate: akenes cylindraceous-obconical, with pappus of 7 to 9 narrowly oblong palew of nearly its length. - Ell. Sk. ii. 447. - Low pine barrens, S. Carolina to Florida and Louisiana; first coll. by Bartram.

B. multiflóra, Nutr. l. ৬. Slender, from an annual or biennial root, branching above, very leafy up to the several or numerous slender pedunçles, glabrous or sometimes sparsely hirsute : leaves all narrowly linear: heads small ( 3 or in fruit 5 lines high): bracts of the 
involucre fewer and narrow: rays 8 or 10 , cuneate, half-inch long, $3-4-$ lobed at summit: alveoli cuspidate-toothed at the angles: akenes stipitate, turbinate, the flat summit crowned with the pappus of about 12 radiate and orbicular-obovate paleæ. - Actinospermum, Ell. 1. c. A. angustifolium, Torr. \& Gray, l. c. Buphthalmum angustifolium, Pursh, Fl. ii. 564. - Sandhills, Georgia and Florida; first coll. by Bartram.

119. MARSHALLIA, Schreb. (Humphiry Marshall, author of the earliest indigenous work on the sylva of $\mathrm{N}$. America.) - Low and smooth nearly glabrous perennials (of S. Atlantic States); with fibrous roots, commonly simple stems, and solitary pedunculate (Armeria-like) heads of rose-purple or white glandularpuberulent flowers, with blue anthers, produced in spring or summer: peduncle puberulent: leaves alternate, entire, mostly 3-nerved, but not manifestly veiny. - Gen. ii. 810; Torr. \& Gray, Fl. ii. 390. Persoonia, Michx. Fl. ii. 104, not Smith. Trattenickia, Pers. Syn. 403, not Willd. Therolepta, Raf.

* Leaves thickish, mostly obtuse, all but the upper tapering below into a slender sessile base or margined petiole; radical spatulate.

M. angustifólia, Pursh. Sometimes 2 feet high and branching above. cauline leares linear, or the uppermost linear-subulate; radical spatulate : bracts of involucre narrow, mostly acute, rigid, head only half-inch high : corollas pale purple : akenes minutely pubescent or at maturity glabrous, longer than the pappus. - Fl. ii. 520; Ell. Sk. ii. 316 (\& var. cyananthera); Torr. \& Gray, 1. c. Athanasia graminifolia, Walt. Car. 201. Persoonia angustifolia, Michx. l. c. Trattenickia angustifolla, Pers. 1. c.-Low pine barrens, N. Carolina (and Tennessee?) to Florida and Louisiana.

M. cæespitósa, Nuтt. More tufted, a foot high or less, either leafy only at base and with scapiform pednocle, or sparsely leafy-stemmed and sparingly branching: leaves spatulatelinear, or somewhat lanceolate and the upper linear: bracts of involucre narrow-linear, acute or acutish: head two-thirds inch or more high: corollas pale rose-color or. white : akenes obpyramidal, villous on the angles, shorter than the pappus. - Nutt. in DC. Prodr. $r .680$; Hook. Bot. Mag. t. 3704 ; Torr. \& Gray, 1. c. - Calcareous soil, Arkansas to Texas; first coll. by Berlandier and Nuttall.

M. lanceoláta, Pursh. A foot or less high, commonly leafy only at base and with scapiform simple peduncle: leaves lanceolate, oblanceolate, or spatulate, 3 to 6 lines wide: bracts of involucre oblong-linear or lanceolate, obtuse: akenes elongated-turbinate, pubescent, much longer than the pappus. - Fl. ii. 519; Ell. l. c.; Torr. \& Gray, l. c. Persoonia lanceolata, Michx. 1. c. Trattenickia lanceolata, Pers. 1. c. - Open dry woods, N. Carolina to Florida, preferring the upper districts.

Var. platyphylla, M. A. Corris. Leafy-stemmed, sometimes 2 feet high, with spatulate-oblong leaves 2 to 6 inches long, all obtuse. - Chapm. F1. 241. - Moist or wet ground, N. Carolina, \&c., from the middle country westward.

* Leaves thinner, conspicuously 3-nerved; cauline acuminate.

M. latifólia, Pursh, 1. c. A foot or so high, leafy to the middle or more: cauline leaves oblong- or ovate-lanceolate, sessile by a merely narrowed base, gradually acuminate, 2 or 3 inches long: bracts of the involucre linear, acute or acutish, rigid. - Torr. \& Gray, 1. c. Athanasia trinervia, Walt. 1. c. Persoonia latifolia, Michx. l.c., t. 43. Trattenickia latifolia, Pers. 1. c. Marshallia Schreberi, Tratt. Arch. Gen. i. 108. - Moist soil, Virginia to Mississippi, along the middle country.

120. GALINSÓGA, Ruiz \& Pav. (M. Galinsoga, a Spanish physician and botanist.) - Annuals of Tropical America, the common species now widely disseminated.

G. parviflóra, CAv. A foot or two high, loosely branching, slender, somewhat pubescent: leaves thin, ovate, acute, serrate, 3-nerved from near the base, petioled: heads 2 lines long, slender-peduncled from the summit of the branches, somewhat paniculate: rays whitish, barely exserted : disk-flowers yellow : pappus usually of 8 to 16 short paleæ. - Ic. iii. 41, t. 281 ; DC. Prodr. v. 677 ; Gray, Man. 264 ; Reichenb. Ic. Fl. Germ. t. 983. - Open or waste grounds, 
perhaps indigenous to New Mexico and Arizona, an introduced weed about gardens in the Northern States. In indigenous plants of the Southern border (var. Caracasana, \& var. semicalia, Gray, Pl. Wright. ii. 98) pappus 'of the ray much reduced or wanting. (Mex., S. Amer.)

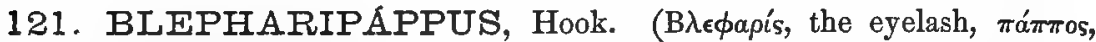
seed-down, from the fringed paleæ of the pappus.) - A single but variable species. (Transition to the Madiea.)

B. scáber, Hook. Annual, a span to a foot high, loosely branched, puberulent and scabrous, and with some hispid hairs, above more or less glandular : leaves alternate, narrowly linear. with revolute or involute margins when dry, entire: heads short-peduncled, terminating the paniculate branchlets, 3 to 5 lines high: both rays and disk-flowers white: anthers brownish-purple. - Fl. i. 316 ; Torr. \& Gray, Fl. ii. 391 ; Gray, Bot Calif. i. 358. Ptilonella scabra, Nutt. Trans. Am. Phil. Soc. 1. c. 386. - Dry plains and mountains, interior of Oregon, Idaho, \&c., to Nevada and the Sierra Nevada, California.

Var. subcálvus, Grar, Bot. Calif, 1. c. Pappus both of ray and disk obsolete or recluced to hyaline vestiges, - Eastern borders of California, Lemmon, Matthews, \&c.

Var. lávis, GRAY, l.c. Slender, with filiform branches, almost smooth: heads few. flowered. - Califoruia, Bridges. Taken for Hemizonia in Gen. P1. ii. 395.

122. MÁdIA, Molina. TARweEd. (Madi, the Chilian name of the com mon species.) - Glandular and viscid herbs, mostly heavy-scented; with leaves entire or merely toothed, some or all of them alternate; heads axillary and terminal; the yellow flowers vespertine or matutinal, closing in sunshine: in summer. - Molina, Chil. ; Cav. Ic. iii. 50, t. 298 ; Don in Bot. Reg. ; Benth. \& Hook. Gen. ii. 393. Madaria (DC.), Madariopsis, Madorella, Amida, Anisocarpus, \& Harpacarpus, Nutt. Trans. Am. Phil. Soc. l. c.

- § 1. Madf́ria. Ligules exserted and conspicuous: disk-flowers sterile or partly fertile: disk-corollas pubescent, except in the first species : herbage hirsute, the upper part minutely glandular. - Gray, Proc. Am. Acad. ix. 188, \& Bot. Calif. i. 358.

* Annual, low and slender, with mostly alternate leaves and small heads: pappus both to ray and disk-Howers!

M. Yosemitána, PARry. A span or more high: leaves linear, entire: heads slenderpedunculate, 2 lines high: ray-flowers 5 to 10, with ligules a line or two long: disk-flowers 3 to 10, sterile: corollas nearly glabrous: bracts of the involucre with short and narrow tips; of the receptacle 4 to 8 , more or less connate by their margins : ray-akenes semi-obovate or slightly lunate, bearing an evident pappus in the form of a ciliolate crown: pappus of the disk-flowers of about 5 sparsely barbellate awns, nearly equalling the corolla. - Gray, Proc. Am. Acad. xvii. 219. - California; near Fresno, Eisen; at the foot of the upper Yosemite Fall, Parry (few-flowered form); near Auburn, Murcus E. Jones, a larger form, with 8 to 10 rays and about as many disk-flowers.

* * Perennial, taller, with larger heads and some or most of the leaves opposite, occasionally dentate: a manifest pappus to the disk-flowers, of plumose-lacerate or fimbriate palex. - Anisocarpus, Nutt. Trans. Am. Phil. Soc. vii. 388.

M. Nuttállii, Grax. Stem slender, a foot or two high: leaves linear-lanceolate: heads sparsely paniculate, 4 lines high, usually slender-peduncled: involucral bracts 8 to 12 , with short inconspicuous tips: exserted ligules 3 to 5 lines long: only ray-akenes fertile; these obovate-falcate, much compressed, with sides many-striate and nearly nerveless : pappus of sterile disk-flowers of small oblong paleæ. - Proc. Am. Acad. l. c. viii. 391, ix. 188, \& Bot. Calif. i. 358. Anisocarpus madioides, Nutt. 1. «.; Torr. \& Gray, Fl. ii. 403. - Woods, from Monterey, California, to Brit. Columbia; first coll. by Nuttall.

M. Bolánderi, GraY, 1. c. Stem 2 to 4 feet high : leaves linear (the longer 7 to 10 inches long, 4 lines wide): heads half to three-fourths inch ligh : involucral bracts and rays 12 
to 16 ; bracts of the receptacle linear and unconnected: ray-akenes linear-falcate, 1-2-nerved on the narrow faces, commonly with a rudiment of pappus: disk-akenes numerous, straighter, all the outer ones fertile, all with a pappus of slender palex, which are either little or much shorter than the corolla. - Anisocarpus Bolanderi, Gray, Proc. Am. Acad. vii. 360. - Woods of the Sierra Nevada, California, from Mariposa to Plumas Co.; first coll. by Bolander, and northward to Scott Mountains, Pringle.

* * Annual, with showy heads, chiefly alternate leaves, and no pappus : pubescence riscid as well as hirsute or hispid.

M. radiáta, Kellogg. Stem stout, 2 or 3 feet high: larger leaves broadly lanceolate, denticulate: bracts of the involucre 10 to 20 , with short tips: rays as many, half-inch long, obtusely 3-toothed-: disk-flowers very numerous on a nearly flat glabrous receptacle, all but the central ones fertile, somewhat clavate and 4-angular, straightish: ray-akenes narrowly obovate-falcate, flat, tipped with a minute reflexed beak ! - Proc. Calif. Acad. iv. 190; Gray, Bot. Calif. i. 359. - California, near the mouth of the San Joachin River, Bolander.

M. élegans, Dos. Stem less stout, a foot or two higl, or in depauperate forms only a span or two, above sometimes copiously beset with stipitate viscid glands, sometimes these almost wanting: leaves linear or lanceolate, mostly entire: bracts of the involucre 5 to 15 , with linear tips: rays acutely 3-lobed, yellow throughout or with a brown-red spot at base: diskflowers more numerous than the rays, on a convex hirsute-fimbrillate receptacle, all sterile: fertile akenes obliquely oborate-cuneate, nearly nerveless, depressed-truncate aind wholly beakless at summit. - Don in Bot. Reg. t. 1458; Gray, l. c. M. viscosa, var., Hook. Fl. ii. 24, not Cav. Madaria elegans \& M. corymbosa (with var. hispida?), DC. Prodr. v. 692. M. elegans, Hook. Bot. Mag. t. 3548. Mf. corymbosa, Endl. Iconogr. t. 36. M. racemosa, Nutt. Trans. 1. c. - Hills and plains, throughout California, Oregon, and the borders of Nevada; first coll. by Douglas.

\$2. Eбм́́dia. Ligules inconspicuous or short, from twelve to one, or rarely none: disk-flowers few or numerous and fertile: the corollas pubescent: pappus none: receptacle flat, smooth: glandular and viscid heavy-scented annuals. Gray, 1. c. Madia, Madariopsis, Madorella, \& Amida, Nutt. 1. c.

M. satíva, Molina. Commonly robust, I to 3 feet high, pubescent with slender somew hat riscid hairs and beset with pedicellate very viscid glands : leaves from broadly lanceolate to linear: heads commonly short-peduncled or sessile and rather scattered, 5 or 6 lines high: rays 5 to 12, with honey-yellow ligules about 2 lines long: disk-akenes cuneate-oblong and quadrangular, being prominently one-nerved on the faces (2 lines long), those of the ray somewhat falcate-obovate, either with or without an obrious nerve on the sides. - Don in Bot. Reg. 1. c.; DC. Notul. Jard. Genev. \& Prodr. 1. c.; Torr. \& Gray, Fl. ii. 404. MI. sativa (with false char.) \& $\mathbf{M}$. mellosa (which would have been the better name to use), Molina, Chil. ed. 1, 354. M. viscosa, Cav. Ic. iii. 50, t. 298. M. mellosa, Jacq. Hort. Schœub. iii. 29, t. 302. M. stellata, Fisch. \& Meyer, Ind. Sem. Petrop., few-flowered form, like that figured by Jacquin. - Oregon and California. (Chili.)

Var. congésta, Torr. \& Gray, 1. c. The common Tarweed near the coast, stout, branching, very sticky: heads mostly crowded or glomerate at the end of the branches, many-flowered; the rays from 8 to $12 .-M$. capitata, Nutt. I. c. Nearly M.viscosa, Cav. l. c. - Fields and waysides throughout the western portion of California and Oregon; probably an introduction from Chili, or the contrary.

Var. racemósa, Grax, l. c. Slender, simple-stemmed, with fewer-flowered heads somewhat racemosely disposed: disk-akenes flatter and nerve less distinct. $-M$. racemosal Torr. \& Gray, 1. c. Madorella racemosa, Nutt. 1. c. - Oregon to Idaho, interior of California, and Nevada. Approaching the fewer-flowered Chilian M. mellosa, Jacq., \&c., perhaps passing into the next.

M. dissitiflóra, ToRr. \& Gray, 1. c. Slender, a foot or two high, often loosely branching, moderately viscid: heads 3 or barely 4 lines high, scattered or loosely paniculate : rays 5 to 8 : disk-flowers few : akenes shorter and broader (a line or two long), also thicker, not angled nor with the sides evidently nerved.-M. sativa, var. dissitiflora, Gray, 1. c. Madorella dissitiflora, Nutt. 1. c. Sclerocarpus gracilis, Smith in Rees Cycl.? - Not uncommon throughout Oregon and California. 
M. glomeráta, Hook. A foot or so high, rigid, very leafy, hirsute, glandular only toward the inflorescence : leaves narrowly linear : heads glomerate: rays 2 to 5 or sometimes none, not surpassing the abont equal number of disk-flowers : akenes (2 lines or more long) narrow, those of the disk 4-5-angled; of the ray somewhat curved and 1-nerved on each face. - Fl ii. 24; Gray, 1. ¿. Amida hirsuta \& A. gracilis, Nutt. 1. c. ; Torr. \& Gray, 1. c.-Rocky Mountains of Colorado to Saskatchewan, Washington Terr, Oregon, and the Sierra Nevada in California.

§3. HARPeCÁRPUS. Ligules very short and inconspicuous, not surpassing the solitary fertile disk-flower, all destitute of pappus : corolla glabrous. - Gray, 1. c. Harpacarpus, Nutt. 1. c. 389.

M. fílipes, GrAY, 1. c. Slender annual, a span to a foot or more high, hirsute, glandular above, paniculately branched; the small heads (a line or two long) on long filiform peduncles: leaves narrowly linear: bracts of the involucre 4 to 8 , lunate and strongly carinate in fruit, almost destitute of free tips, hispid-glandular: bracts of receptacle united into a 3-5toothed cup: ray-akenes obovate-lunate, the tip somewhat pointed by a small epigynous disk: disk-akene straight and obliquely obovate.-Sclerocarpus exiguus, Smith in Rees Cycl.? Harpacarpus madarioides, Nutt. 1. c. H. exiguus, Gray, Bot. Mex. Bound. 101.Open grounds, from S. California to British Columbia near the coast, and eastward to Idaho.

123. HEMIZONÉLLA, Gray. (Diminutive of Hemizonia.) - Little annuals of Pacific N. America; with somewhat the aspect and characters of the Harpacarpus section of Madia, hirsute-pubescent and above glandular, diffusely branching: leaves linear, entire, opposite or some of the upper alternate: heads in the forks and cymosely clustered, terminating the branchlets, short-peduncled, small (a line or two in length); the very small corollas yellow. Involucre glandular-hispid on the back. - Proc. Am. Acad. ix. 189, \& Bot. Calif. i. 360. Hemizonia § Hemizonella, Gray, Proc. 1. c. vi. 548.

H. Durándi, GRגy. A span high: earliest heads slender-peduncled: akenes narrowly oblong-obovate or somewhat fusiform, manifestly obcompressed with the inner face slightly angulate, tipped with a short but conspicuous incurved beak. $-H$. Durandi \& $H$. parvula, Gray, Proc. Am. Acad. ix. 189. Hemizonia Durandi \& H. parvula, Gray, Proc. Am. Acad. vi. 549. - Dry ground, California, from the Yosemite Valley to Washington Territory; first coll. by Pratten.

H. mínima, Gray, l. c., with syn. An inch or two high: peduucles all shorter than the heads : ray-akenes obovate, less incurved, much obcompressed, the beak obsolete or a minute inflexed apiculation. - Dry sterile soil, California, through the eastern ranges of the Sierra Nevada, from Mariposa Co. northward, Brewer, Matthews, \&c.

124. HEMIZÓNIA, DC. TARWEED. (Composed of $\ddot{\eta} \mu \iota$, half, $\zeta \dot{\omega} v \eta$, girdle, from the half-enclosed ray-akenes.) - Californian herbs, nearly all annuals or biennials, usually glandular, viscid, and heavy-scented; with alternate or sometimes opposite leaves, and middle-sized or small heads of yellow or white flowers, the anthers commonly brownish. Fl. summer or later. - Torr. \& Gray, Fl. ii. 396 ; Benth. \& Hook. Gen. Pl. ii. 394; Gray, Proc. Am. Acad. ix. 190, xix. 17, \& Bot. Calif. i. 361. Hemizonia, Hartmannia, in part, \& Calycadenia, DC. Prodr. v. 692-695.

§1. Euhemizónia, Gray, 1. c. Ray-akenes only fertile, obovate-triangular, with depressed terminal areola hardly eccentric, glabrous, smooth and even: disk-akenes abortive and without pappus : annuals, a foot or so high; with entire or merely denticulate and mostly linear leaves, and white or yellow flowers : rays 3-lobed. - Hemizonia, DC. (the typical species of both sections). 
* Akenes rounded on the back and with u rentral angle, destitute or nearly so of busal stipe: rays exserted but rather short: chaffy bracts none or hardly any among the inner flowers: leaves narrow, quite entire, or rarely a few salient denticulations. (Ambiguous species, with the habit, but not the akenes, of Madia.)

H. Wheéleri, Gray. Loosely branching, slender, green, slightly pubescent, minutely glandular above: heads scattered : rays 5 or 6 , bright yellow: marginal bracts of the receptacle distiuct. - Bot. Calif. i. 617; Rothrock in Wheeler Rep. vi. 361, t. 10.-Olanche Mountains, of the southern Sierra Nevada, California, Rothrock.

H. citriodóra. Simple-stemmed, with short-pedunculate corymbosely panicled heads, or loosely branched above and heads more scattered, "lemon-scented," cinereously villous-hirsute and above with small pedicellate glands interspersed: rays 8 or 9, greenisll-yellow: marginal bracts of the receptacle lightly united into a cup. - Madia citriodora, Greene, Bull. 'Torr. Club, ix. 63. - Northern California, from Siskiyou Cu., Greene, to Placer and Sacramento Co., Bolander (1865), Mrs. Curran. With specimens from the latter a less villous and more glandular form, Madia anomala, Greene, ined.

* Akenes oborate-triangular, with a dorsal and two lateral angles, the ventral face broad and nearly plane, surface smooth and shining, base usually extended into a small inflexed stipe, with a whitish callous at its insertion (but sometimes the stipe short or obsolete and the callus at the very base of the akene): receptacle claffy throughout: rays either white or light yellow in the same species, opening only in bright sunshine.

+ Heads terminating paniculate or usually corymbosely cymose branches.

H. congésta, DC. Soft.hirsute or villous, hot not lanate, sightly glandular toward the clustered or scattered heads: bracts of the involucre with lanceolate foliaceous tips, little surpassed by the rays: marginal bracts of the receptacle either lightly connate or nearly distinct: inflexed stipe of the akene conspicuous. - Prodr. v. 692; Gray, 1. c. (not of Pacif. R. Rep. iv. 109, which proves to be young Lagophylla). - California, near San Francisco, Douglas, $G$. R. Vasey. Specimens formerly referred to this still little-known species belong to the following.

H. luzulæfólia, DC. Villous, and below even sericeous-lanate, at least when young, above becoming very viscid-glandular and corymbosely or paniculately branched: lower leaves elongated, 3-5-nerved: bracts of the involucre with short and broadish herbaceous tips: marginal bracts of the receptacle united into a cup: rays 5 to 10 , rather large, white, sometimes tinged with pink, or not rarely pale yellow (var. lutescens, Greene, Bull. Torr. Club, ix. 16) : stipe of akene as in the preceding, or shorter, or obsolete. - Prodr. l. c.; Gray, l. c. H. sericea, Hook. \& Arn. Bot. Beech. 356. H. rudis, Benth. Bot. Sulph. 31, a very branching and late-flowering form. - Dry open grounds, throughout western part of California, very common from San Francisco Bay to Monterey. Varying greatly.

++ Heads disposed to be sessile along simple branches.

H. Clevelándi, Greene. More slender, below villous with long spreading hairs, not lanate: leaves all narrowly linear, mostly one-nerved: heads smaller, nearly all after the terminal one subsessile in the axils or on short leafy branchlets, thus as it were spicately or racemosely disposed: rays white: akenes and flowers as in the smaller-headed form of the preceding. - Bull. Torr. Club, ix. 109. - California, from Mendocino Co. (Kellogg) to Lake Co., Bolander, Cleveland.

§ 2. Hartmánnia, Gray, 1. c. Ray-akenes opaque and often rugose or tuberculate (rarely smooth and shining), very gibbous, turgid, the terminal areola from the summit of the inner angle or face, and by gibbosity commonly intraapical, raised on a little beak (rostellum) or apiculation: flowers in all yellow: ours annuals. - Hartmannia (excl. spec.) \& part of Hemizonia, DC. Prodr.

H. Frutéscens, Gray, Proc. Am. Acad, xi. 79, \& Bot. Calif. i. 361, an outlying species from Guadalupe Island, off Lower California, is remarkable for having a woody-based stem, and is probably the only species that is really perennial. This and

H. Strefétsu, Gray, 1. c. xii. 162, from San Benito Island, Lower California, are the only known representatives of the genus beyond the limits of this Flora. 
* Receptacle conical or convex, many-flowered, all the disk-flowers subtended by narrow and mostly quite distinct chaffy bracts, some of them not rarely fertile: ray-flowers usually numerous and in more than one series, with short and yellow ligules; their akenes obovate-triangular, with very oblique apiculation, usually smoothish: rigid and branching annuals; with some or all of the lower leaves incisely pinuatifid, and the uppermost clustered around the sessile heads. - Hartmannia § Olocarpha, DC. Prodr.

+ Leaves and bracts not pungent, but the upper gland-tipped.

H. macradénia, DC. Stout, hirsute, viscid-glandular, very leafy: upper leaves linear, entire or laciniately dentate; those of the branchlets and axillary fascicles linear-subulate, truncately gland-tipped: some of these and most of those crowded around the sessile glomerate heads, also the bracts of the involucre and even those of the conical receptacle, beset with stipitate tack-shaped glands: heads fully half-inch in diameter: pappus none. - Prodr. v. 693 ; Hook. \& Arn. Bot. Beech. 356 ; Torr. \& Gray, Fl. ii. 400 ; Gray, Bot. Calif. i. 363. Dry open ground, from the Bay of San Francisco southward. An unpleasantly scented Tarweed.

+ - Upper leaves or their lobes and the bracts of the involucre rigid, pungently pointed, none gland-tipped.

H. Fítchii, Gray. Villous-hirsute, somewhat viscid, above beset with small scattered tackshaped glands: leaves some (even of the lower) entire and elongated linear-acerose, very pungent, some of the lower once or twice pinnately parted: bracts of the involucre subulate; those of the receptacle pointless, soft, beurded with long villous hairs: disk-akenes sterile, with pappus of 8 to 12 linear palex, fringed or bearded at tip, somewhat united at base, nearly equalling their corolla. - Pacif. R. Rep. iv. 109, \& Bot. Calif. I. c. - Common in California north and east of Sacramento; first coll. by Rev. Mr. Fitch.

H. Párryi, Greene. Sparsely or slightly hirsute, sometimes minutely viscid-glandular: leaves short; lower sparingly pinnatifid; upper subulate-acerose, as also the tips of the involucral bracts; those of the receptacle thin, villous on the margin, acute or obtuse, but neither pointed nor rigid: sterile disk-akenes with a pappus of 3 to 5 narrowly linear slender, pointed naked palex which equal the corolla. - Bull. Torr. Club, ix. 16. (Has been inexcusably confounded with the preceding and following.) - Not uncommon in California from Lake Co. to San Bernardino Co., Torrey, Parry, Parish, \&c.

H. púngens, Torr. \& Grax. Hirsute or hispid, sometimes only slightly so, hardly at all viscid or glandular: cauline leaves pinnatifid or the lower bipinuatifid, and the lobes short; those of the branchlets and fascicles entire, lanceolate or linear-subulate, with very pungent tips, those around the head little surpassing it: bracts of the receptacle also pungently pointed: pappus to disk-flowers none.-Fl. ii. 399 ; Bot. Calif. 1. c. Hartmannia pungens, Hook. \& Arn. Bot. Beech. 357 ; Hook. Ic. Pl. t. 334. - Dry hills and fields, from San Francisco Bay southward; first coll. by Douglas.

* * Receptacle fiat or nearly so, naked among the disk-flowers, which are surrounded by a circle of connate or sometimes distinct bracts : rays golden yellow and with glandular ustally slender tubes: some of the pubescence glandular or viscid: no large tack-shaped or terminal truncate glands.

+ Rays 12 to 24 , oblong-cuneate; their akenes occupying more than one series, obscurely rugose: disk-flowers as numerous, with wholly sterile or abortive ovary, and small plurisquamellate pappus or none.

H. corymbósa, Torr. \& Gray, l. c. Erect, corymbosely branched above, hirsute, with or without short-pedicellate glands intermixed : lower or sometimes most of the cauline leaves pinnately parted into linear lobes; those of the branches narrowly linear: heads rather large (a third to half inch high): rays 15 to 25 , oblong-cnneate : bracts of receptacle well united into a cup: akenes 4-5-nerved or angled (the nerve of the inner face indistinct or wanting), and with beak short and stont: disk-pappus setosely plurisquamellate. $-H$. angustifolia, Benth. Pl. Hartw., not DC. H. macrocephela, Nutt. Pl. Gamb. 174. H. balsamifera, Kellogg, Proc. Calif. Acad. ii. 64, t. 13. Hartmannia corymbosa, DC. Prodr. v. 694. - W. California, in low grounds, common from San Francisco Bay to San Luis Obispo; first coll. by Douglas.

H. angustifólia, DC. Diffuse, a span to a foot high, hirsutely puluescent and glandular, becoming viscid: cauline leaves all linear, small, entire: heals corymbosely pauiculate or 
scattered: rays 12 to 15 : bracts of the receptacle less united, or almost separate: akenes 3-nerved, with prominent upturned beak: disk-pappus minute and squamellate or nearly wanting. - Prodr. v. 692 ; Torr. \& Gray, Fl. ii. 398 ; Gray, Bot. Calif. i. $362 . \quad$ H. multicaulis, Hook. \& Arn. Bot. Beech. 355 ? H. decumbens, Nutt. Pl. Gamb. 175. - W. California, in open grounds, from San Francisco Bay southward; first coll. by Douglas.

Var. Bárclayi, Gray, Proc. Am. Acad. ix. 190, \& Bot. Calif. 1. c. (excl. pl. Brewer), from Monterey, Barclay, has more conspicuous laciniate pappus to disk-flowers.

$+\quad$ + Rays 8 to 20 , broadly cuneate or quadrate: disk-flowers more numerous, with well-formed and often fertile ovary and a conspicuous pappus of coriuceous oblong obtuse paleæ, which are hirsute at summit and margins, and even on the back : stems erect, paniculately branched, 2 feet or more high, very leafy.

H. floribúnda, GraY. Minutely glandular-pubescent and viscid, not hirsute : cauline leaves all linear, small, entire: heads disposed to be racemose-paniculate on the brauches: rays about 20; their akenes in more than one series, somewhat tuberculate-rugose, obscurely 4-angled, with very short straight beak: disk-akenes numerous, with pappus of 5 to 8 broadish paleæ shorter than the proper tube of the corolla. - Proc. Am. Acad. xi. 79, \& Bot. Calif. i. 616. - California, southern part of San Diego Co., Palmer, Cleveland.

H. paniculáta, Gray. More diffusely branched, below commonly hirsute, the branchlets and heads viscid-glandular ' cauline leaves laciniate-pinnatifid; those of the branches entire or 2-3-dentate, linear, small; of the flowering branchlets mostly very small and bract-like, erect: heads sparsely paniculate, barely 3 lines high: involucral bracts minutely densely glandular: rays about 8 ; their akenes coarsely rugose or pitted on the back: receptacular bracts connate or distinct: disk-flowers about 11 ; their well-formed akenes with a pappus of 8 or 10 oblong paleæ which exceed the proper tube of the corolla.-Proc. Am. Acad. xix. 17. - Santa Barbara Co. to San Diego Co., Brewer, Parish, Jared. Includes plant of coll. Brewer, referred in Bot. Calif. to $H$. angustifolia, var. Barclayi.

+++ Rays 5 (rarely 3, 4, or 6), broadly cuneate or quadrate: disk-flowers not over 6, surrounded by mostly 5 receptacular bracts, which are usually more or less connate; their akenes generally sterile, the palex of their pappus not hirsute: stems paniculately branched, a foot or two high, some taller: lower cauline leaves pinnatifid; upper and rameal entire, small.

H. Kellóggii, Greene. Hirsute, sparsely so above, bearing short-pedicelled loosely paniculate heads : cauline leaves mostly pinnately-parted or toothed: involucre quarter-inch high ; the bracts hirsutely glandular on the back, broadly lanceolate: rays fully 3 lines long: bracts of the receptacle rather broad, well united into a cup : ray-akenes tuberculate-rugose (a line or more long), bearing a rather strongly lateral and slender curved (almost sigmoid) beak: sterile disk-akenes with pappus about equalling the tube of their corolla, composed of lacerately truncate palex, which are mostly connate to wear their summits. - Bull. Torr. Club, x. 41. - Central California near Antioch (Kellogg), and along the San Joaquin Valley, Greene.

H. Wríghtii, Grar. Hirsute below, 1 to 3 feet high, with widely-spreading branches, when much branched decumbent; the slender or filiform branchlets terminated by pedicellate heads: lower cauline leaves laciniate-pinnatifid; those of the brancllets mostly minute and very viscid-glandular, as is the involucre; its bracts ovate-lanceolate; those of the receptacle partly united: ray-akenes obscurely tuberculate-rugose, with short beak: sterile disk-akenes with pappus of 8 or 9 oblong firm palex, their summit erose-laciniate. - Proc. Am. Acad. xix. 17. - S. California, about San Bernardino, W. G. Wright, Parish, Parry. Found also as a waif near San Francisco, Greene. Heads always scattered, and most of them on pedicels of fully their own length.

H. fasciculáta, Torr. \& Grar. More or less hirsute or hispid below, a span to 2 feet high, commonly with rather rigid ascending glabrate or viscid-glaudular branches, bearing usually fasciculate-clnstered sessile small heads: cauline leaves mostly pinnately parted or laciniate; uppermost on the branches subulate-linear and rather crowded about the heads or clusters: bracts of the involucre narrowly lanceolate, either glabrous or glandular-hispidulous; of the receptacle lightly united or nearly free : ray-akenes either smoothish or at length transversely rugose, apiculate with a small very short beak; disk-akenes chiefly sterile, with conspicuous pappus of 8 ог 10 narrowly oblong or linear lacerate-tipped paleæ. - Fl. ii. 397 ; Gray, 1. c. H. glomerata, Nutt. Trans. Am. Phil. Soc. 1. c. Hartmannia fasciculata, DC. 
Prodr. 1. c. - Dry ground, W. California, common from Monterey to San Diego; first coll. by Coulter, Douglas, \&c. Passes into

Var. ramosíssima. Diffuse, sometimes decumbent: upper leaves mostly entire: heads less fascicled or all scattered: akenes at maturity rugose. - H. ramosissima, Benth. Bot. Sulph. 30; Gray, Bot. Mex. Bound. 100, \& Bot. Calif. i. 362. - Same range, and to San Bernardino Co.

Var. Lóbbii (H. Lobbii, Greene, Bull. Torr. Club, ix. 109, founded on a single specimen, coll. by Lobb, thought to come from near Monterey) appears to be nothing more than a tall and slender form of this species, with stem 2 feet high, long and slender branches, very small and numerous leaves on the branchlets, rays reduced to 3 or 4 , and disk-flowers to about the same number, each subtended and partly enclosed by a free bract. But specimens hardly sufficient.

* * Receptacle flat: all the flowers subtended and akenes partly enclosed by bracts; the corolla-tubes glandular: ligules yellow and broad, 5 to 8 : ray-akenes somewhat 5-nerved or angled, i. e. ventral face somewhat curinate-angled, with short upturned beak: disk-flowers 8 to 15 , with akenes mostly sterile and destitute of pappus: slender virgately branched or paniculate anmuals, with lowest cauline leaves commonly laciniate-dentate, the upper all small and linear, none of them at all pungently pointed, but those of the branchlets tipped with a sessile truncate gland.

H. Heermánni, Greene. Viscid and somewhat pubescent or hirsute, heavy-scented, paniculately branched, 1 to 3 feet high, the minute leaves of the diffuse flowering branchlets rather scattered : involucre nearly hemispherical; its bracts (and rays) 5 to 9, viscid-pubescent and copiously beset with pedicellate glands; the terminal gland inconspicuous : beak and stipe of ray-akenes somewhat conspicuous: disk-flowers 10 to 15 . - Bull. Torr. Club, ix. 15. $H$. macradenia, Jurand, Pacif. R. Rep. v. I0, not DC. H. ramosissima, in part, Rothrock in Wheeler Rep. vi. 365. - Southern part of California, from Santa Barbara to Keru Co., \&c., first coll. by Heermann.

H. virgáta, GraY. Less pubescent and viscid or nearly glabrous, the stem or long branches virgate and bearing numerous racemosely or somewhat paniculately disposed heads on short densely foliolose branchlets; their leaves Heath-like, line long, all glandular-truncate : involucre campanulate or in age oblong; its mostly 5 bracts becoming coriaceous, with stout involute tip bearing a large truncate gland, the back nearly glabrous and sparsely. beset with some stout pedicellate glands or gland-tipped processes : stipe of ray-akene hardly any, and its beak short: disk-flowers 7 to 10. - Bot. Mex. Bound. 100, \& Bot. Calif. i. 363. - Califoruia, from Lake Co. to Los Angeles, \&c. ; first coll. by Fremont.

§-3. Calycadénia, Gray, l. c. Ray-flowers few ( 1 to 7 ), with very broad palmately 3-lobed or parted ligule; their akenes mostly dull, obovoid-triangular and little oblique; the terminal areola scarcely if at all eccentric: disk-flowers surrounded by a circle of herbaceous bracts (forming a kind of inner involucre), which are connate into a cup or rarely separable; their akenes well formed and the outer not rarely fertile (then hairy), turbinate-quadrangular or slightly obcompressed, straight, bearing a conspicuous paleaceous pappus: annuals, with entire narrowly linear leaves, often becoming filiform by revolution of the margins; those of the axillary fascicles and clusters near the heads usually tipped with tack-shaped or when dry saucer-shaped conspicuous glands, which are either sessile or short-stipitate, sometimes similar glands along their backs or edges: heads as it were involucrate by some bract-like leaves. - Calycadenia, DC. Prodr. v. 695 .

* Wholly destitute of tack-shaped glands, paniculately and duffusely much branched and heads scattered: rays 3-parted down to the slender tube, and disk-corollas cleft into oblong-linear lobes; both white: ray-akenes almost beaked. -Osmadenia, Nutt.

H. tenélla, GrAy. Slender, 6 to 18 inches high, sparsely hirsute-pubescent or hispid, and filiform branchlets minutely viscid-glandular: leaves almost filiform: involucre cylindraceous-campanulate: ray-flowers 3 to 5 ; their akenes rugose, short-stipitate and abruptly rostellate-apiculate: disk-flowers 5 ; their pappus of 4 or 5 lanceolate palex tapering into 
stout rough awns, and as many intermediate short and lacerate-truncate ones. - Proc. Am. Acad. ix. 191, Bot. Calif. l. c. Osmadenia tenella, Nutt. 'Trans. Am. Phil. Soc. vii. 392. Calycadenia tenella, Torr. \& Gray, Fl. ii. 402. - Found only near San Diego, California ; first by Coulter and Nuttall.

* * Tack-shaped or saucer-shaped glands borne at least by the leaves next the heads and those fascicled in the axils: stem strict or with ascending branches: disk-corollas long and narrow, 5-toothed: ray-ikenes truncate at summit, and with a depressed or sometimes slightly protuberant terminal areola; no basal stipe: anthesis commonly (or perhaps always) vespertine or matutinal.

+ Heads very few-flowered and narrow, spicately and sparsely scattered along flexuous simple branches: flowers white or rose-tinged.

H. pauciflóra, GRAX, 1. c. A foot or less high, with spreading filiform branches, sparsely hirsute, glabrate: heads solitary and sessile in the axils of small remote leaves; these and the floral ones sparsely hispid near the base: ray-flowers solitary or 2, the ligule 3-parted: disk-flowers 3 in a 3-lobed cup; their pappus of 5 subulate-awned and 5 small truncate paleæ: ray-akenes glabrous : tack-shaped glands small and sparse, short-stalked. - Calycadenia pauciflora, Bot. Mex. Bound, 100. - California, from unrecorded station, Fremont. Also Lakeport, Lake Co., Pringle.

+ + Heads many-flowered, loosely paniculate or racemosely scattered along the slender spreading branches: flowers yellow: plant remarkably glabrous.

H. truncáta, Gray, 1. c. A foot or two high: leaves rather lacid and thickish, some of them hispidulous-scabrous, or the lower with a few bristles, and those next the heads occasionally setose-ciliate, otherwise very smooth: glands mostly only terminal, large and subsessile: heads oval-campanulate, 4 or 5 lines long: ray-flowers 5 to 8 , with ovate-oblong boat-shaped involucral bracts and giabrous triangular-obpyramidal akenes: bracts of the receptacle 7 to 9 , lightly connate to the top into a truncate cup, at length separable: diskflowers 10 to 20 ; their pappus of 7 to 10 oblong and somewhat erose fimbriate pointless paleæ, much shorter than the akene, sometimes obsolete.-Calycadenia truncata, DC. Prodr. 1. c.; Torr. \& Gray, 1. c. - California, from near San Francisco Bay nortlward into Oregon ; first coll. by Douglas.

+++ Heads 8-15-flowered, in axillary and terminal short-pedunculate clusters on the strict stem or branches: pubescence all soft and short, grayish.

H. móllis, GRAr, l. c. A foot or two high, the stem only puberulent: leaves cinereouspubescent; those of the fascicles and around the heads and the bracts tipped with a short stalked dark gland, also some on the back: ray-flowers 3 to 5 , with sometimes white sometimes yellow 3-parted ligules on a short slender tube: chaff of receptacle forming a 6-8toothed cup : ray-akenes obpyramidal, glabrous: disk-flowers 5 to 10 , with pappus of 5 or 6 subulate-awned palex nearly twice the length of the akenes, and one or two small pointless ones.-H. anqustifolia, Durand, in Pacif. R. Rep. 1. c., not DC. Calycalenia mollis, Gray, Proc. Am. Acad. vii. 360. - Sierra Nevada, California, in the foothills up to 4,000 feet in Verced Co. and Tuolumne Co.; first found with bright white rays, later with yellow also, by Lemmon, \&c.

++++ Heads several-many-flowered, mostly glomerate or spicately paniculate on the strict stem or branches, in depauperate slender plants solitary in the axils: leaves rather rigia: pubescence setose-hirsute or hispid, at least on the margins of the upper leaves: lobes of the disk-corollas sometimes strongly and sometimes sparsely and obscurely hispidulnus-glandular or barbellate on the outside.

H. Douglásii, Gray, l. c., partly. Whitish-hirsute and hispid: tack-shaped glands not rare on the margins as well as the tips of many of the leaves, mostly none on the bracts of the involucre and receptacle: flowers yellow or white and purplish-tinged: akenes silky-villous, at least when young, but often glabrate : pappus a little shorter than the disk-corolla, of 10 or sometimes 12 narrow linear-lanceolate paleæ which are gradually attenuate into an awnlike point, as long as or longer than the akenes, or 2 or 3 of them not rarely shorter or pointless. -Calycadenia villosa, DC. 1. c.; Torr. \& Gray, 1. c., founded on slender and too young specimens of coll. Donglas. H. hispida, Greene, Bull. Torr. Club, ix. 63 ; a robust form, 1 to 3 feet high, with yellow flowers; coll. near Atwater Station, Merced Co., by Greene and Parry. H. spicata, Greene, Bull. Torr. Club, ix. 16, a dwarf form, with white flowers; coll. 
by the same at Milton. - Desiccated plains, from Lake Co. to Merced Co., California; first coll. by Douglas, in immature and depanperate specimens. As polymorphous as the vext species.

H. multiglandulósa, GraY, l c. Hirsute or hispid, also puberulent: tack-shaped glands usually abunclant on the back of the bracts of the involucre and of the receptacle: flowers white, sometimes purplish-tinged: ray-akenes glabrous or glabrate, short and broadly obpyramidal-obovate, glabrous or soon glabrate: pappus much shorter than the disk-corolla and shorter than the akenes, of 10 or rarely 12 unequal paleæ, 5 of them oblong- to lanceolatesubulate and attenuate at summit into an awn-like point, the others obtuse or erose-truncate.-Calycadenia multiglandulosa \& C. cephalotes. DC. Prodr. v. 695.-Common in Califoruia, especially in the Great Valley and north of the Bay of San Francisco. Runs into many and various forms. The type of the species has the heads or clusters sessile and not much crowded in the axils of the leaves along the virgate stem or its basal branches: odor said to be disagreeable.

Var. cephalótes. Stouter, with heads densely glomerate at the summit of the stem and in approximate axils, sometimes appearing later in remoter axils : herbage heavy-scented. $-H$. cephalotes, Greene in Bull. Torr. Club, ix. 110. Calycadenia cephalotes, DC. 1. c. A common form: odor said to be balsamic.

Var. spársa. Slender, lax, a span to a foot high : lower and sometimes all the leaves opposite: heads usually solitary in a few axils; the terminal glands on the bracts few.H. Fremonti, Gray, Proc. Am. Acad. ix. 191. (Calycadenia Fremonti, Gray, Bot. Mex. Bound. 100.) H. oppositifolia, Greene, Bull. Torr. Club, 1. c. - Valley of the Sacramento, Fremont, Mrs. Bidwell, Parry, \&c.

§ 4. Brepharizónia, Gray. Ray-flowers 7 to 10, with 3-lobed ligules: diskflowers 10 to 20; outer ones subtended by one or two series of linear receptacular bracts : akenes of disk disposed to be fertile and nearly like those of the ray, except in their pappus of about 20 short and stout densely plumose awns: rayakenes elongated-turbinate, hardly oblique, sericeous-hirsute, about 10-nerved, with broad and depressed terminal areola, this obscurely coroniform-bordered. - Proc. Am. Acad. ix. 192, \& Bot. Calif. i. 366.

H. plumósa, Grat, 1. c. Strongly ill-scented annual, 2 to 5 feet high, paniculately branched, hirsute-pubescent, above most copiously beset with very viscid tack-shaped glands: cauline leaves linear, entire; those of the branchlets very small, oblong or oval, bract-like : heads racemosely paniculate, broad ( 4 or 5 lines long) : involucral bracts short, very glandular: pappus in the original specimens nearly half the length of the diskakenes. - Calycadenia plumosa, Kellogg, Proc. Calif. Acad. v. 49. - Banks and dried beds of streams, near Stockton, California; the original discoverer unknown; recently collected by Lemmon, \&c.

Var. subplumósa. Pappus only one quarter the length of the disk-akenes, or even hardly longer than the diameter of their summit: heads more sparse, terminating loosely paniculate branches. - Near Stockton, apparently same habitat as that of the original species, Parry, Mrs. Curran.

125. ACHYRACH ENA, Schauer. ("Axvpov, chaff, and achanium, the botanical name of the fruit of Compositæ, \&c. : relates to the very chaffy pappus.) - Del. Sem. Hort. Vratisl. 1837; DC. Prodr. vii. 292; Torr. \& Gray, Fl. ii. 392 ; Benth. \& Hook. Gen. ii. 396. Lepidostephanus, Bartl. Ind. Sem. Hort. Gœtt. 1837. - Single species, a Californian annual.

A. móllis, Scha ter, 1. c. A span to a foot high, erect, villous-pubescent, slightly glandnlarviscid : leaves alternate, or the lower opposite, long and narrowly linear, entire or the lower laciniate: heads solitary and long-peduncled, terminating the stem and fastigiate branches, an inch or less long: corollas whitish or yellowish and turning brownish : pappus and diskakenes each quarter-inch long: in fruit and when mature and dry the akenes with their spreading pappus diverging, forming a globular silvery-chaffy head, resembling that of Thrift. 
-Lepidostephanus madioides, Bartl. 1. c.-Open grounds; f. in spring, throughout the western part of California; first coll. by Douglas.

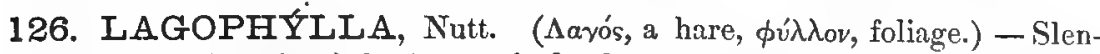
der (Pacific N. American) herbs, paniculately much branched, usually more or less cinereous with sericeous pubescence (this so long and copious on the crowded upper leaves of the original species as to have suggested the generic name, from some likeness to a hare's foot): leaves narrow, entire or nearly so, the lower opposite, upper alternate, sometimes bearing small tack-shaped glands: heads small, with "pale yellow" or white and rose-tinged rays, apparently vespertine. Bracts and chaff promptly deciduous with the matnre akenes, leaving the naked receptacle terminating and little thicker than the peduncle. - Trans. Am. Phil. Soc. ]. c. 390 ; Torr. \& Gray, Fl. ii. 402.

§1. Holozóxia. Perennial and spreading by creeping scaly rootstocks: pubescence all short: heads naked, scattered, mostly slender-peduncled: corollas white or purplish-tinged: chaff of receptacle connate into a 9-12-toothed cup: ray-akenes bearing a shallow entire or denticulate cupule in place of pappus (as sometimes in Layia) : ovary of sterile disk-flowers occasionally bearing 2 to 5 nearly capillary naked bristles, which are very caducous, sometimes almost equalling the corolla. - Holozonia, Greene, Bull. Torr. Club, ix. 122, 146.

L. filipes, Grar. Rootstocks elongated, rigid, partly sheathed by the approximate pairs of connate scales: stems diffusely branched: filiform branchlets and peduncles glabrous or sparsely glandular : cauline leaves linear, minutely soft-villous; those of the branchlets minute, oblong, commonly beset with short-stipitate dark glands: involucre loosely villous; its bracts little longer than the clavate-obovate obscurely 5-nerved akene, which bears a conspicuous white sancer-shaped cupule. - Pacif. R. Rep. ir. 109, Bot. Mex. Bound. 101, \& Bot. Calif. i. 367. Hemizonia flipes, Hook. \& Arn. Bot. Beech. 356; Torr. \& Gray, Fl. ii. 359. Holozonia filipes, Greene, Bull. Torr. Club, 1. c, where the peculiar characters were pointed out, and not unnaturally taken to be generic. - Rocky hills near streams, Napa Co. to Mendocino Co.; first coll. by Douglas.

§2. Lagopirylla proper. Annuals: heads subtended by bracteal leaves which may sometimes imitate an outer involucre, disposed to be sessile and glomerate, or at length short-peduncled: no cupule or pappus to the akenes: chaff or bracts of the receptacle mostly quite distinct: stems below smooth and glabrous, or early glabrate.

* Green or barely cinereous, not canescent: heads loose or scattered : ligules much exserted, pale yellow?

L. dichótoma, BexrrI. Stem a foot or two high, dichotomously paniculate; the branchlets puberulent: leaves sparse; cauline spatulate, occasionally dentate, strigulose-pubescent; of the branchlets short, hirsute-ciliate, as also the broadish bracts of the involucre, and with small and sparse or no glands: akenes obovate, much obcompressed, no nerve or keel to the ventral.face. - Pl. Hartw. 317 ; Gray, Bot. Calif. i. 366. - Plains of Feather River, on the Sacramento, and-Lake Co., California, Hurtweg, Fitch, Bigelow, Mrs. Curran.

L. glandulósa, GRAX. Stem virgately paniculate, slender, a foot or two high: leaves cinereons-puberulent, linear or the radical spatulate-lanceolate, entire, sometimes even the lower as well as the small and scattered upper ones (also the branchlets) beset with small tack-shaped glands, sometimes these all but or quite absent: bracts of the involucre and the outer subtending bracts resembling the ordinary leaves, and inconspicuously if at all ciliate: akenes nearly of the following. - Proc. Am. Acad. xvii. 219. - Not rare from Butte Co, to Mariposa, Mrs. Bidwell, G. R. Vasey, Lemmon, Mrs. Curran, Congdon. Badly named, the glands inconstant in this, and occasionally seen in all the species. 
* * Typical species : leaves canescent with soft silky pubescence: the short ones subtending the crowded heads conspicnously and densely ciliate with very soft villous hairs, and back occasionally beset with sessile or short-stipitate glands: involucral bracts comose-ciliate at the sides (along the line of infolding): ligules short, pale yellow according to Nuttall, but certainly sometimes if not always purplish or rose-color: akenes clavately obovate-oblong, carinate down the ventral face: stems at length becoming naked below by the early fall of the older leaves. Lagophylla, Nutt.

L. ramosíssima, Notr. Slender, paniculately much branched, 6 to 30 inches high : leaves entire; radical and lowest cauline obovate-spatulate; upper lanceolate or linear, obtuse; uppermost linear-oblong: heads 3 lines long, glomerate in small and at length rather scattered irregular clusters : akenes only a line and a half long. - Trans. Am. Phil. Soc. vii. 390 ; Torr. \& Gray, Fl. ii. 402; Gray, Bot. Calif. i. 367, mainly. L. minima, Kellogg, Proc. Calif. Acad. v. 53. - Dry ground, common through California, and to Washington Terr., Nevada, and W. Idaho; first coll. by Nuttall.

L. congésta, Greene. Robust, a foot to a yard high, with short branches and larger heads in thick glomerules: akenes 2 lines long. - Bull. Torr. Club, x. 87. Hemizonia congesta, Gray in Pacif. R. Rep. iv. 109 (immature), not DC. - From Marin Co. to the Sierra Nevada and to Mendocino Co, California, Bigelow, Torrey, Lemmon, Greene, Mrs. Curran. Chaff of receptacle not found to be "united into a cup": perhaps only a gigantesque form of the preceding species.

127. LÁYIA, Hook. \& Arn. (Thomas Lay, naturalist in Beechey's Voyage.) - Annuals, of California and adjacent parts; with chiefly alternate leaves, and branches terminated by usually showy heads of flowers, in spring and early summer : disk-corollas sparsely hispidulous or hirsute on the lobes, yellow: rays yellow or white. - Bot. Beech. 148 \& 357 (not 182); Torr. \& Gray, Fl. ii. 393; Gray, Pl. Fendl. 103, \& Bot. Calif. i. 368. Madaroglossa \& Oxyura, DC. Prodr. v. 693, 694. Eriopappus, Arn. in Lindl. Introd. Nat. Syst. ed. 2, 443. Callichroa, Fisch. \& Meyer, Ind. Sem. Hort. Petrop. ii. 31. Calliglossa, Hook. \& Arn. Bot. Beech. 356. Calliachyris, Torr. \& Gray, in Bost. Jour. Nat. Hist. v. 110.Certain species are so much alike in their whole aspect and structure that the technical characters which alone distinguish them may be expected to give way.

$\S 1$. Madarogcóssa, Gray, Pl. Fendl. 1. c. Pappus of about 10 to 20 stout bristles, which are long-plumose or villous below the middle: akenes all narrow and somewhat clavate, mostly with an obvious almost cupulate epigynous disk, at least in the ray: receptacle naked and pubescent among the disk-flowers: herbage hispid or hirsute, somewhat viscid, above beset with scattered stipitate blackish glands. - Madaroglossa, DC. l. c. Layia, Hook. \& Arn.

* Rays bright white (sometimes tinged with rose), large and conspicuous, commonly half to threefourths inch long, 3-lobed: lower leaves lanceolate or linear, laciniate-pinnatifid or incised, upper narrower and entire: pubescence more or less hispid or hirsute and with scattered shortstipitate dark glands, especially toward the heads: lobes of the disk-corollas with some sparse hispid hairs: pappus bright white.

I. glandulósa, Hoor. \& ARv. A span to a foot or more high, diffusely branched : dark glands sometimes abundant, sometimes scarce: rays 8 to 13 : villous hairs of the pappusbristles copious, the outer straight and erect, the inner soon crisped and interlaced into a woolly mass. - Bot. Beech. 358; Torr. \& Gray, l. c. L. Neo-Mexicana, Gray, PI. Wright. ii. 98, a form with vestiges of pappus to ray-akenes. Blepharipappus glandulosus, Hook. FI. i. 316. Eriopappus glandulosus, Arn. 1. ¿. Madaroglossa angustifolia, DC. Prodr. v. 694, ex Hook. \& Arn. - Barren ground, British Columbia to S. California and the Mexican border, and east to Idaho and New Mexico. Variable, sometimes with stems almost glabrous, sometimes with hairs of the pappus less copions.

Var. rósea, GRAY, Bot. Calif. i. 368 , a rare state with rose-purple rays. - Ojai, California, Peckham, Pulm?r. 
L. heterótricha, Hook. \& ARN. 1. c. Generally larger and more erect: dark glands copious : rays 10 to 18 : long-villous hairs of the pappus-bristles less abundant, all erect, the inner woolly ones wanting. - Gray, 1. c. Madaroglossa heterotricha, DC. 1. c.; Hook. Ic. Pl. t. 326. - California, from the Lower Sacramento Valley southward.

* * Rays apparently white, but small and inconspicuous, little if at all surpassing the disk : pappus dull white.

L. carnósa, ToRr. \& Gray. Dwarf, barely a span high, diffusely branched from the base, somewhat pubescent: dark glands few or wanting: leaves succulent, spatulate to linearoblong, an inch or less long, some sinuate-pinnatifid: pappus-bristles sparsely plumose with straight villous hairs: akenes of the ray also pubescent!-Fl. ii. 394; Gray, Bot. Calif. l. c. Madaroglossa carnosa, Nutt. Trans. Am. Phil. Soc. vii. 393. - Sands of the California seabeach, from San Diego to Marin Co., Nuttall, Parry, Bigelow.

* * Rays as well as disk-flowers yellow, or the former rarely white-edged.

+ Pubescence hirsute rather than hispid: inner hairs on the pappus woolly and interlaced in the manner of $L$. glandulosa, but mostly less densely so.

L. élegans, Torr. \& Grar, 1. c. Diffuse: sțipitate glands small and sparse : leaves linear; the lower pinnately toothed or parted into linear lobes: rays 10 to 12 , half-inch long: pappus white or whitish, its copious villous hairs much shorter than the aristiform bristles. Gray, Pl. Fend1. 103, \& Bot. Calif. i. 369. Madaroglossa elegans, Nutt. Trans. Am. Phil. Soc. vii. 393. - Common from Sayta Barbara Co. southward to San Bernardino, California, Nuttall, Cleveland, Parish, \&c. ; also in the northern part of the State at Ukiah, Kellogg.

++ Pubescence hispid; the stem often dark-spotted at the base of the papilla of the stronger bristles: hails on the pappus less copious, all straight and erect: stems and branches mostly upright.

L. hieracioídes, Hook. \& AnN. 1. c. Leaves from linear to oblong, mostly laciniate-dentate: rays 10 to 15 , small and short, little surpassing the disk : pappus dull white or rusty. - Gray, 1. c. Madaroglossa hieracioides, DC. 1. c. - California, from San Mendocino Co. to Santa Barbara, \&c. ; first coll. by Louglas.

L. gaillardioídes, Hook. \& ARN. Leaves more commonly laciniate-pinnatifid: heads usually larger: rays 10 to 20, orange-yellow, half to three-fourths inch long: pappus dull white or rusty. - Bot. Beech. 357 (Tridax? gaillardioides or Layia, Bot. Beech. 148); Torr. \& Gray, Fl. ii. 393; Gray, Bot. Calif. i. 369. - Common in W. California, from Mendocino Co. to Tejon; first coll. by Lay.

§2. Callichróa, Gray, 1. c. Pappus of 5 to 25 naked aristiform bristles, or rarely wanting: otherwise as in the preceding. - Callichroa, Fisch. \& Meyer, Ind. Sem. Hort. Petrop. 1. c.

L. pentachǽta, Gray. Somewhat hirsute and viscid-pubescent, hardly hispid, erect, a foot or two high, paniculately branched; stipitate glands minute and sparse: cauline leaves mostly pinnatifid and the lower laciniately bipinnatifid; the lobes narrowly linear: rays ample, half-inch or more long, golden- or orange-yellow: disk-akenes minutely pubscent or glabrate: pappus of 5 or rarely fewer rigid and smooth bristles, sometimes even wholly wanting in certain specimens apparently of very same parentage. - Pacif. R. Rep. iv. 108, t. 16 ; Bot. Calif. i. 369. - California, along the foothills of the Sierra Nevada, from Placer to Fresno Co., Bigelow, Bolander, Parry.

L. platyglóssa, Grar. Usually more hirsute and lower: stipitate glands small and sparse cauline leaves linear, simply pinnatifid into short linear lobes, noost of the upper entire rays half-inch long, light yellow, commonly with white tips to the Jobes: disk-akenes silkyhirsute: pappus of 15 to 20 upwardly scabrous stout awn-like bristles, only a little shorter than the corolla. - Pl. Fendl. 1. c.; Bot. Calif. 1. c. Callichroa platyglossa, Fisch. \& Meyer, Ind. Sem. Hort. Petrop. 1. c., \& Sert. Petrop. t. 5 ; Don, Brit. Fl. Gard. ser. 2, t. 373 ; Hook. \& Arn. 1.c.; Hook. Bot. Mag. t. 3719; Torr. \& Gray, Fl. ii. 395. Madaroglossa (Callicleroa) hirsuta \& angustifolia, Nutt. Trans. Am. Phil. Soc. 1. c. - Common in low grounds throughout W. California.

Var. breviséta, Gray, Bot. Calif, i. 370. Pappus only half the length of corolla and of the young akene: canline leaves mostly pinnatifil. - S. California, in the vicinity of Los Angeles, Bigelow. 
§ 3. Calliglóssa, Gray, 1. c. Pappus wanting or of few or several flattened awns or paleæ (instead of bristles), either naked or with long hairs only at base. - Calliglossa, Hook. \& Arn., with Oxyura, DC. \& Lindl.

* Rays pure white: only marginal receptacular bracts present: pappus aristiform: habit of $L$. glandulosa : a few small stipitate glands on the upper leaves and involucre.

L. Douglásii, Hook. \& ARN. Low, sparingly hirsute or hispid: radical leaves pinnatifiddentate; upper linear and entire: rays rather short, broad, 3-cleft : lobes of disk-corolla hirsute outside : akenes narrow, those of the disk villous-pubescent : pappus of about 10 minutely scabrous linear-subulate flat palex, nearly equalling disk-corolla; their margins toward the base scantily beset with long and straight villous hairs. - Bot. Beech. 358; Gray, Proc. Am. Acad. ix. 194. - Gravelly banks, between the Dalles and Great Falls of the Columbia River, Douglas (the pappus in the specimen fulvous by discoloration); Austin, Nevada, 1882, $M$. E. Jones (pappus bright white). Probably only a form of $L$. glandulosa with more paleaceous and almost uaked pappus.

* Rays yellow at base, white or pale at summit: bracts of the involucre lanate-ciliate at the basal margins where infolded around the akene: both ray-and disk-akenes mostly oblongobovate.

- Pappus of 7 to 12 broadish naked palex: disk-akenes more or less villous-birsute. - Calliachyris, Torr. \& Gray.

L. Jonésii, GraY. Somewhat hispidulous and viscid, a few small and sessile dark glands on and near the involucre: leaves hispidulous-ciliate, narrowly linear, simply pinnatifid, and npper ones 3-lobed or entire : heads rather small : rays only quarter-inch long: receptacular bracts only marginal: palex of the pappus ovate or oblong-ovate, acuminate, often erosedenticulate, not longer than the tube of the corolla. - Proc. Am. Acad. xix. 18. - San Luis Obispo, California, M. E. Jones.

L. Fremónti, GrAY, A foot high, minutely pubescent, not glandular: leares not ciliate, nearly all pinnately parted into oblong-linear or spatulate short lobes: rays ample, half to three-fourths inch long: receptacular bracts to many of the flowers: paleæ of the pappus from ovate to oblong-lanceolate, tapering into a subulate awn, nearly equalling the corolla, the margins entire, accompanied by a few free long-villous hairs, which much exceed those of the surface of the akene. - Pl. Fendl. 103, Bot. Calif. i. 370. Calliachyris Fremonti, Torr. \& Gray, Jour. Bot. Nat. Hist. Soc. v. 140. - California, upper valley of the Sacramento to Tuolumne Co.; first coll. by Fremont.

+ + Pappus subulate-aristiform anu unequal and naked, or none: chaffy bracts to most of the disk-flowers: herbs loesely erect or diffuse (about a foot high), not glanduliferous, with herbage glabrous or minutely pubescent, but the margin of the leaves and yet more the base of the bracts strongly hispidulous-ciliate: lower leaves pinnately parted or lobed; upper entire: heads showy, with ample usually particolored rays.

L. Calliglóssa, Grax, 1. c. Akenes villous-pubescent or partly glabrate : pappus of usually several (10 to 18 ) very unequal and rigid subulate awns, which are somewhat scabrous or silightly hirsute near the dilated base, the marginal ones rather shorter than the corolla, the smaller hardly half as long. - Oxyura chrysanthemoides, Lindl. Bot. Reg. t. 1850; Fisch. \& Meyer, Hort. Petrop. t. 6. Calliglossa Douglasii, Hook. \& Arn. Bot. Beech. 356 . Callichrva (Calliglossa) Douglasï, Torr. \& Gray, Fl. ii. 396. - California, common around San Francisco Bay; probably first coll. by Douglas.

Var. oligochæeta, GraY, Bot. Calif. 1. c. Pappus reduced to the two marginal awns (and these sometimes slender) and to some intermediate rudiments or small awns: leaves less lobed. - Petaluma, Santa Rosa, and elsewhere, north of Bay of San Francisco, Newberry, Bolander, \&c.

L. chrysanthemoídes, Gray, 1. c. Alenes wholly glabrous, broader, with no epigynous disk (the base of corolla covering the top of the ovary) : no pappus: receptacle becoming convex: otherwise quite like the preceding species. - Oxyura chrysanthemoides, DC. (in Lindl. Syst. Nat. \&) Prodr. v. 693, not of Bot. Reg. Tollatia chrysanthemoides, Endl. Gen. Suppl., \& Walp. Repert. ii. 631. Hartmannia ciliata, DC. Prodr. v. 694. - California, not rare near San Francisco; first coll. by Douglas. 
Tribe VI. HELENIOIDE $Æ$, p. 70.

128. CLÅPPIA, Gray. (Dr. A. Clapp, author of a Synopsis of the Medicinal Plants of the U. S.) - Bot. Mex. Bound. 93 ; Benth. \& Ilook. Gen. ii. 413, \& Ic. Pl. xi., partly. (The excluded C. aurantiaca, Benth. Ic. Pl. t. 1104, is a Dysodia, apparently wanting the oil-glands.) - Single species.

C. suædæfólia, GraY, l. c. Suffruticose, a foot high, widely branching, not punctate nor glandular: leaves alternate, fleshy, terete, linear, entire, or the lower pinnately 3-5-parted, sessile: head (half-inch in diameter) pedunculate, terminating herbaceous branchlets: flowers doubtless yellow. - Benth. Ic. Pl. t. 1105.-S. Texas; on the Rio Grande at Laredo, Berlandier. Alkaline flats of the Pecos, Havard.

129. JAÚMEA, Pers. (I. H. Jaume St. Hilaire, a French botanist.) Herbs or suffruticose plants (mainly S. American); with opposite entire leaves, and terminal pedunculate heads of yellow flowers. - Syn. Pl. ii. 397; Benth. \& Hook. Gen. ii. 397 (including Coinogyne, Less., Espejoa, DC., Chæethymenia, Hook. \& Arn., \&c.); Gray, Bot. Calif. ii. 371. Kleinia, Juss., not L.

J. carnósa, Gray. Procumbent or ascending perennial herb, fleshy, glabrous, leafy to the short-pedunculate head: leaves spatulate-linear, almost terete, about inch long: head halfinch long, fleshy: rays 6 to 10, linear, not surpassing the disk: receptacle conical: akenes glabrous, destitute of pappus. - Wilkes Exped. xvii. 360, \& Bot. Calif. i. 372. Coinogyne carnosa, Less. in Linn. vi. 520; Torr. \& Gray, Fl. ii. 410. - Salt marshes and sea-beaches, Brit. Columbia to California; probably first coll. by Chamisso.

130. VENEGÁSIA, DC. (Michael I'enegas, a Jesuit missionary, early writer upon California.) - Prodr. v. 43 ; Benth. \& Hook. Gen. ii. 397. - Single species, yellow-flowered.

V. carpesioídes, DC. 1. c. Large perennial herb, with glabrous leafy branches: leaves alternate, slender-petioled, membranaceous, ovate and subcordate, mostly denticulate, veiny, somewhat puberulent or atomiferous : heads terminal and from upper axils, short-peduncled, inch broad, and the about 15 rays an inch long. - Gray, Bot. Calif. i. 372. Partheniopsis maritima, Kellogg, Proc. Calif. Acad. v. 100. - Rocky banks of streams, coast of California, from Santa Barbara southward ; first coll. by Douglas and Coulter : fl. summer.

131. RIDDELLIA, Nutt. (Prof. John L. Riddell, author of a Synopsis of the Flora of Western States.) - Low and corymbosely branched woolly herbs (Texano-Arizonian); with alternate and spatulate or linear leaves, the cauline entire, and small heads of yellow flowers; the ligules large in proportion, becoming pale or whitish in age and thin-papery; fl. summer. In habit not unlike Zinnia § Diplothrix of the same regions. Bracts of the involucre distinct, but connivent-erect, and connected by the intricate wool so as to seem connate.Trans. Am. Phil. Soc. n. ser. vii. 371; Gray, Pl. Fendl. 94, \& Bot. Calif. i. 372. Psilostrophe, DC. Prodr. vii. 261.

* Rays at maturity half-inch long: akenes and pappus glabrous, or the former with few and short scattered hairs: perennial.

R. tagetína, Nctr. l. c. Loosely or somewhat villosely lanate, sometimes glabrate in age, rather widely branched : radical and even lower cauline leaves often laciniate-pinnatifid : heads numerous, mostly cymosely clustered and short-peduncled: palex of the pappus oblonglanceolate, entire, usually obtuse, half or three-fourths the length of the disk-corolla. - Torr. in Emory Rep. t. 5; Gray, Pl. Fendl. 94. - W. Texas to E. Colorado and Arizona; first coll. by James. 
Var. sparsiflóra. Heads more scattered and slender-peduncled: paleæ of the pappus linear-lanceolate, mostly acute. - S. Utah, Bishop, Mrs. Thompson.

R. Coóperi, Grax. Canescent with close and matted tomentum, no villous hairs, or the wholly entire narrow leaves glabrate: stems much branched from a ligneous base: heads scattered, slender-peduncled : paleæ of the pappus from broadly oblong to lanceolate, eroselaciniate at summit or nearly entire, less than half the length of the disk-corolla. - Proc. Am. Acad. vii. 358, \& Bot. Calif. ii. 373. - Gravelly plains and banks, S. E. California to S. Utah and Arizona; first coll. by Dr. Cooper.

* * Rays at maturity only a quarter of an inch in length: akenes and pappus long-villous: biennial or annual?

R. arachnoídea, GrAY. Loosely lanate: stem and branches rather strict: foliage of $R$. tagetina: heads clustered, short-peduncled: arachnoid hairs even longer than the somewhat turbinate akenes: paleæ of the pappus subulate-lanceolate, their margins and apex more or less deliquescent into long and arachnoid hairs. - Pl. Fendl. 94. Psilostrophe gnaphalioides, DC. 1. c. - Western Texas along the Rio Grande, Wright, \&c. (Adj. Mex., Berlandier, Gregg, \&c.)

132. BAILEYA, Harvey \& Gray. (Jacob Whitman Bailey, the pioneer in microscopical research in U. S.) - Soft and densely floccose-woolly annuals or biennials, of the Texano-Arizonian district; with alternate leaves, the lower once or twice pinnatifid, and terminal long-pedunculate solitary heads of yellow flowers, the large and persistent rays deflexed in age: fl. summer.-Pl. Fendl. 105 ; Proc. Am. Acad. ix. 195.

B. pauciradiáta, HARv. \& GRAY, 1. c. Villosely and floccosely lanate, a foot or so high, loosely paniculately branched, leafy : leaves sparingly, laciniate-pinnatifid or the upper entire, linear : heads small, short-peduncled : involucre quarter-inch high and broad : ligules 5 or 6 , roundish-oval, 3 or 4 lines long: disk-flowers 10 to 25 : akenes subclavate, with slightly narrowed summit, strongly many-nerved, muriculate-scabrous, obscurely resinous-atomiferous. - Gray, Bot. Calif. i. 373. - Sandy deserts, S. E. California and adjacent Arizona, Coulter, Schott, Cooper, Parish. Still rare.

B. multiradiáta, HARv. \& Grar, 1. c. Densely floccosely white-tomentose, at length much branched from the base and leafy: radical and lower leaves spatulate or broader, mostly laciniate-pinnatifid or sparingly bipinnatifid ; uppermost small, spatulate-linear, entire: heats on slender and often long peduncles: involucre mostly half-inch broad: ligules 25 to 50 , cureate-oblong or at length broader and nearly quadrate, 5 or 6 lines long: disk-flowers very numerous : akenes oblong-prismatic and obscurely striate, broadest at the truncate apex, minutely scabrous and resinous-atomiferous. - Torr. in Emory Rep. t. 6 ; Rothrock in Wheeler, Rep. vi. 175. B. pleniradiata \& B. multiradiata, Pl. Fendl. 1. c., Bot. Calif. 1. c.; the former the commoner form, branching and leafy, with more numerous and smaller heads. - Plains, from W. Texas to S. Utah, Arizona, and the borders of S. E. California ; first coll. by Coulter. (Adj. Mex.)

Var. nudicaúlis. More simple-stemmed, or branched only from a stout (biennial?) base: leaves more divided: peduncles elongated, sometimes scapiform : head larger.B. multiradiata, Harv. \& Gray, 1. c., mainly. - Same range, or more southern. (Adj. Mex.)

133. WHITNEYA, Gray. (Josiah D. Whitney, Director of California Greological Survey.) - Proc. Am. Acad. vi. 549, ix. 195, \& Bot. Calif. i. 374. Single species, yellow-flowered; perhaps most related to Arnica.

W. dealbáta, Grax, l. c. Low perennial herb, from filiform rootstocks, with aspect of Arnica, canescent with minute and close tomentum: stems simple or sparingly branched, bearing 2 to 4 pairs of opposite entire leaves, and solitary few slender monocephalous peduncles: radical leaves obovate or oblong-spatulate, obtuse, 3-nerved, 2 or 3 inches long; upper small, lanceolate : head half-inch high : rays inch or more long. - Sierra Nevada, California, in Mariposa Co., at 5,000 feet or higher; first coll. by Brewer and Bolander. 
134. LAPHÅMIA, Gray. (Dr. Increase Allen Lapham, of Wisconsin, died in 1875.) - Low suffruticulose perennials, Texano-Arizonian, growing in crevices of rocks, mostly with petioled and dentate or laciniate small leaves, the upper alternate, rarely all opposite; small heads of yellow (rarely white?) flowers, either cymosely disposed or singly terminating the branches: fl. spring and summer. - Pl. Wright. i. 99, t. 9 ; Benth. \& Hook. Gen. ii. 398, excl. spec.

L. Peninstuderis, Greene, Bull. Calif. Acad. i. 8, is an extra-limital species (with rather large and radiate heads and no pappus) from Lower California.

§ 1. Pappóthrix, Gray, l. c. Pappus of about 20 unequal rigid hispidulous bristles, hardly as long as the somewhat quadrangular-compressed akene, shorter than the corolla: rays none: disk-flowers 12 to 15 ; the corolla with short proper tube and cylindraceous throat: bracts of the involucre 5 to 8 , linear-oblong, nearly plane: stems slender, a span or more high and much branched from the stout woody base: leaves mostly opposite, as broad as long, abruptly slender-petioled: short-peduncled heads rather scattered.

L. rupéstris, GrAT, 1. c. Pubescent, slightly viscid, leafy to summit:- leaves (half-inch long) sometimes crenately sometimes strongly and acutely dentate or almost laciniate: pappus much exceeding short proper tube of the corolla. - S. W. Texas, Wright, Biyelow.

L. cinérea, Gray. Tomentose-canescent: leaves more orbicular, almost entire: pappus hardly surpassing the proper tube of the corolla, which is more than half the length of the short-cylindraceous throat: akenes sometimes 4-nerved. -Bot. Mex. Bound. 82. - Rocks along Escondido Creek, S. W. Texas, Bigelow.

§ 2. LaPhímia proper, Gray, 1. c. Pappus of a solitary very slender bristle (very rarely a pair from the same angle), or none: akenes flatter: disk-flowers 15 to 20 ; their corollas with longer and glandular tube. - Monothrix, Torr. in Stansb. Exped. 389, t. 7.

* Involucre 15-20-flowered, of nearly as many plane and linear pubescent bracts : leaves nearly orbicular in outline, palmately lobed or dissected, not punctate, the lower opposite.

L. Lemmóni, Gray. Depressed and diffuse, much branched, hardly a span high, villosely pubescent, leafy throughout : leaves a quarter or third of an inch in diameter and with petiole of equal length, obtusely 3-lobed and the lobes coarsely crenate-dentate: heads ( 3 or 4 lines long) short-peduncled : rays none: akenes canescently puberulent : pappus a very delicate bristle, or occasionally a pair from the same angle, little surpassing the proper trube of the corolla, or often none. - Proc. Am. Acad. xvi. 191. - Southern Arizona, near Camp Lowell, Lemmon.

Var. pedáta, GRAY, 1. c. Leaves pedately parted and cut into narrow lobes. - With the other form, also on the Chiricahua Mountains, Lemmon.

* Involucre 15-25-flowered, rather narrow, glabrous, of thinnish nearly plane luracts, 2 or 3 lines long: herbage merely puberulent: leaves mostly angulate-toothed or incised, the lower opposite: heads commonly corymbosely cymose and pedunculate.

L. halimifólia, Gray. Stems a span or more high and crowded on a thick woody candex : leaves coriaceous, resinous-punctate or atomiferous, somewhat viscid, broadly ovate or rhombic, seldom inch long, laciniately dentate, abruptly long-petioled: rays 4 to 6 , with broad and short ligules little longer than the tabe: pappus none.-Pl. Wright. l. c. 99, t.9.-S. W. Texas, Wright, Bigelow.

L. angustifólia, GRAY. Leaves lanceolate or rhombic-lanceolate, tapering into margined petioles, laciniately 1-5-toothed or lobed: heads less numerous, scattered : rays none: otherwise much like the preceding species. - Pl. Wright. 1. c. \& ii. 81.-S. W. Texas, on high and rocky hills of the Pecos, Wright, Havard, the latter's specimens connecting with var. laciniata, Gray, Bot. Mex. Bound. 82, which proves to be only a form with long and weak stems, hanging from rocks on the Rio Grande, Bigelow, Schott. 
L. Lindheímeri, Grar. Stems a foot or less high from a thick woody base: leaves thinner, oblong or ovate, glabrous, few-toothed or some entire, contracted at base into a short petiole: heads loosely cymose: rays 3 to 6 , very short, sometimes none: pappus a single slender bristle equalling the proper tube of the corolla. - Pl. Wright. i. 101. - Rocky banks of the Guadalupe, near New Braunfels, Texas, Lindheimer.

* * * Involucre 35-50-flowered, of numerotis carinate-concave bracts, somewhat puberulent or glandular on the back: herbage minutely puberulent: leaves thickish.

+ Flowers said to be white: leaves mostly opposite, numerous up to the heads, dentate.

L. Pálmeri, GRAY. Scabrous-puberulent: leaves broadly ovate or deltoid-rotund, rigid, coarsely 5-7-dentate or laciniate-lobed, half-inch long, veiny, abruptly short-petioled : heads somewhat crowded on the fastigiate flowering branches, little surpassing the upper leaves: involucre campanulate, about 35 -flowered; its bracts linear, somewhat pubescent: rays none: pappus a bristle of the length of the akene and a little shorter than the corolla. - Proc. Am. Acad. xiii. 372. - Cañons at Beaver-dam, N. W. Arizona, pendulous from rock-crevices, Palmer, who notes that the flowers are "creamy white."

+ + Flowers yellow: leaves small, 2 to 4 lines long, mostly orbicular, more entire, the upper alternate, scattered: heads solitary and naked, terminating the loose branchlets, nearly hemispherical.

L. megacéphala, WArsos. Base of stem and lower leaves unknown; those of flowering branches all very small, alternate, short-petioled: involucre about 50-flowered; its bracts lanceolate-linear, minutely glandulax: rays none: pappus none.-Am. Nat. vii. 301.S. Nevada, Wheeler.

I. Stansbúrii, Grar. Stems slender and Iax from a woody base: lower leaves opposite and on petioles of their own length ; upper alternate, also slender-petioled : involucre 35-40flowered, its bracts fewer and broader, lanceolate-oblong, nearly glabrous: rays 6 to 10 , conspicuous, oblong: pappus a bristle somewhat shorter than the disk-corolla. - Pl. Wright. i. 101 ; Eaton in Bot. King Exp. 164. Monothrix Stansburii, Torr. in Stansb. Rep. 389, t. 7. - Rocks on Stansbury Island, \&c., Salt Lake, Utah; first coll. by Stansbury.

§3. Díthrix. Pappus a pair of stouter naked bristles, one from each angle of the akene: head only 6-8-flowered.

L. bisetósa, Torr. Hispidulous-puberulent, minutely resinous-atomiferous and punctate: stems 1 to 3 inches high from the woody base: leaves mostly alternate, coriaceous, spatulateovate, obscurely few-toothed (quarter-inch long including the petiole): heads solitary and sessile: rays none: involucre ( 3 lines long) with bracts broadly linear, slightly pubescent, carinate-concave at base: flowers proportionally large : corolla (whitish or pale yellow?) with glandular tube one-third the length of the campanulate cylindraceous throat: akenes hispidulous-puberulent, the narrow marginal nerves naked : rigid awns rather shorter than the akene, more than half the length of the corolla. - Gray, Pl. Wright. ii. 106. - On the Rio Grande, Texas, in a cañon below Presidio del Norte, Parry.

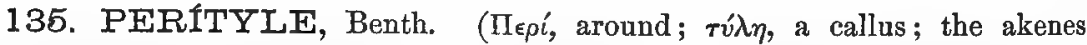
callous-margined.) - Californian and Mexican herbs, the genuine species mostly annuals; with petiolate dentate or palmately-lobed leaves, lower opposite, upper alternate, and small or middle-sized pedunculate heads terminating the branches: disk-flowers yellow (or sometimes white?) : rays when present yellow or white. Bot. Sulph. 23 \& 119, t. 15 ; Gray, Pl. Fendl. 77, Proc. Am. Acad. ix. 194, \& Bot. Calif. i. 396.

P. IncÁnA, Gray, Proc. Am. Acad. xi. 78, from Guadalupe Island, off Lower California, is an outlying anomalous species: all the others are as follows.

$\S 1$. Crown of the pappus an entire or undulate firm and shallow border: akene hardly ciliate: suffruticulose : transition to Laphamia.

P. dissécta, GraY. Dwarf, 3 or 4 inches high from the woody base, cinereous-pubescent, very leafy: leaves with blade (quarter-inch long) equalled by the petiole, round-cordate in 
outline, pedately cleft or parted and dissected into short linear lobes: heads subsessile, 3 or 4 lines high: involucre campanulate, of numerous narrow linear bracts: rays none: diskflowers about 20 (perhaps white) : akenes linear-oblong, minutely cinereous-hirsute, and the cartilaginous margins somewhat more hirsute; a short scabrous awn from one angle, of nearly half its length, or this wanting: style-branches slender-subulate, not short and obtuse, as said in Proc. Am. Acad. ix. 195. - Laphamia dissecta, Torr. in Pl. Wright. ii. 81. - Rocks at Presidio del Norte on the Rio Grande, between Texas and Mexico.

\$2. Genuine species: pappus a crown of hyaline lacerate squamellæ, either somewhat united at base or distinct, rarely obsolete.

* Suffruticulose perennial, with commonly dissected leaves: rays and perhaps disk-flowers also white.

P. coronopifólia, Gray. Cinereous-puberulent, many-stemmed from the woody base, a foot or less high, slencler, leafy: leaves small, somewhat pedately or pinnately once or twice divided or parted into linear or narrow spatulate lobes, or some coarser and merely trifid: heads disposed to be paniculate, 3 lines high: rays as long, broadly oblong, coarsely 3 -toothed at apex : style-tips slender-subulate: akenes narrowly oblong, glabrate on the faces, densely hirsute-ciliate: awns 2, little shorter than the corolla. - Pl. Wright. ii. 82, \& Bot. Mex. Bound. 82. - Rocks on mountain-sides, New Mexico and Arizona; first coll. by Wright. Varies with roundish merely incisely-cleft leaves.

* Herbaceous, chiefly and perhaps all with annual root, loosely branching, and bearing scattered pedunculate heads : leaves often palmately cleft.

+ Akenes thin-margined, hispidulous or hirsutely ciliate: crown of pappus minute or obsolete and awns wanting: style-appendages short, acute. (Perhaps extra-limital.)

P. Fitchii, Torr. Tiscid-pubescent: leaves and involucre nearly of the following species: akenes unknown: ovaries apparently destitute of pappus. - Pacif. R. Rep. iv. 100. - "California, Rev. A. Fitch," in herb. Torr. Probably from the islands : imperfect, seemingly winter specimens. (To this apparently is to be joined var. PALMER, P. Emoryi of coll. Palmer, no. 44, which has the whole aspect and foliage of $P$. Californica, var. nuda, but akenes narrowly oblong, somewhat falcately oblique, with a short pappus of numerous squamellæ united into an erose-denticulate crown. - Guadalupe Island off Lower California.)

+ + Akenes callous-margined and densely ciliate with long beard: pappus-crown more conspicuous: awns rarely wanting.

* Style-branches with short and obtuse or acute minutely hirsute appendages: rays 6 to 12, short, the oblong or broader ligule little longer than the tube, perhaps always white.

P. Califórnica, Вемтн. Somewhat hirsutely pubescent, also viscid and glandular: leaves broadly ovate or roundish-cordate, incisely lobed or more deeply 3-5-cleft and the lobes coarsely dentate: heads fully 3 or 4 lines high and broad: bracts of the involucre narrowly oblong: akenes oblong, densely hispid-villous on the margins, crowned with conspicuous squamellæ, and with a single more or less barbellate awn of about the length of the akene. Bot. Sulph. 23, t. 15. P. Emoryi, Torr. in Emory Rep. (1848), 142; Gray, Bot Calif. i. 397, furm with usually more rounded lobed and incised leaves. - Desert-region of the Mohave and Gila, S. E. California and W. Arizona. (Lower California, Guadalupe Ișland, \&c. Now found by many collectors.)

Var. núda, Gray, Bot. Calif. 1. c., under P. Emoryi. Awn of the pappus none: otherwise as in the P. Emoryi form. - P. nuda, Torr. Pacif. R. Rep. iv. 100. - With the aristate form and commoner. (Lower Calif.)

P. plumigera, Gray. Flowering branches only seen, small-leaved, viscid-glandular: heads much smaller than in the preceding (narrowish, barely 3 lines high): akenes oval-oblong, the margins very densely long-villous : awn solitary, longer than the akene, sparsely barbellatehispid. - Pl. Fend1. 1. c. - "California," probably Arizona, Coulter. Possibly a late-flowering form of the preceding.

P. microglóssa, Bentr. Merely puberulent, obscurely glandular above: leaves broadly ovate with subcordate or truncate base, or upper somewhat hastate, incisely dentate, often 3-5-lobed : heads 3 lines high : akenes obovate or obovate-oblong, with broad summit, villousciliate margins, and a pair of delicate awns, which barely equal the breadth of the akene and are twice or thrice the length of the crown of squamellæ. - Bot. Sulph. 119; Hemsl. Biol. 
Centr.-Am. Bot. ii. 210. P. Californica, Gray, Proc. Am. Acad. v. 159, not Benth. P. Acmella, Gray, P1. Fendl. 77, \& Bot. Calif. 1. c., with P. Californica, mainly. Spilanthes PseudoAcmella, Hook. \& Ara. Bot. Beech. 150. Boltonia § Dichetophora sp., Benth. \& Hook. Gen. ii. 269. - California, from Monterey? southward, Lay \& Collie, Coulter, Parish. (Mex.)

Var. effúsa. Very much branched from the annual root, paniculately floriferous: leaves and heads smaller (the former half-inch or so, the latter only 2 lines high): akenes correspondingly small, narrowly obovate-oblong. - Santa Catalina Mountains, S. Arizona, Pringle.

* +t Style-branches tipped with setaceous-filiform acute hispidulous appendages: rays with narrow ligules, or wanting in one species: disk-corollas slender, with long and narrow throat: akenes oblong: pappus of a rather conspicuous crown of squamellæe and one long and delicate awn: heads 5 lines high: bracts of the involucre linear: perhaps perennials or with lignescent base, not improbably all of one species.

P. leptoglóssa, Gray. Minutely puberulent or glabrate, not at all glandular: leaves roundish-subcordate, coarsely and donbly crenate-dentate (half to three-fourths inch long): rays oblong-linear, 4 lines long : akenes (a line long) linear-oblong, with comparatively short hispid ciliation, the setiform awn shorter than the disk-corolla. - Pl. Fendl. 77; Bot. Calif. 1. c. - "California," Coulter, more probably from Arizona.

P. Párryi, Grar. Minutely pubescent and obscurely viscid: leaves reniform-cordate, crenately dentate and often lobed (the larger inch broad) : rays oblong, barely 2 lines long: akenes (a line and a half long) oblong, strongly hirsute-ciliate: awn of the pappus nearly equalling the disk-corolla. - P1. Wright. ii. 106. - S. border of Texas, or on the Mexican side, in a cañon of the Rio Grande below Presidio, Parry. Also mountains on the Texan side, Havard.

P. aglóssa, Gray, l. c. Somewhat puberulent, obscurely viscid: leaves roundish, with subcordate or truncate base, mostly 3-5-cleft and coarsely dentate (the larger 2 inches broad): bracts of the involucre very narrowly linear: rays none: akenes narrowly oblong, with rather short and dense hirsute ciliation: awn of the pappus equalling the disk-corolla. Cañon of the Rio Grande, with or near the preceding, Parry.

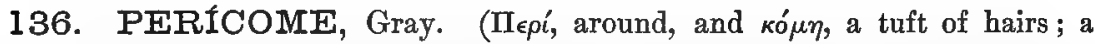
coma of long hairs all round the margin of the akenes.) - Pl. Wright. ii. 82; Benth. \& Hook. Gen. ii. 406. - The latter authors indicate a Mexican radiate species, of anomalous character, which they associate with the typical

P. caudáta, Grax, 1. c. Rather tall widely branching perennial herb, strong-scented, very minutely puberulent: leaves opposite, long-petioled, green and membranaceous, minutely somewhat resinous-atomiferous, triangular-hastate ( 2 to 5 inches long), with sparingly crenate-dentate or entire margins, caudately long-acuminate, as also in less degree are the basal angles: heads numerous in terminal corymbiform cymes, half-inch or less high; flowers golden yellow, conspicuously longer than the glabrous involucre: akenes linear-oblong; the flat faces glabrous, the nerviform margins densely villous-bearded: pappus a crown of hyaline squamellæ which are more or less connate and fimbriate-lacerate at summit, the fringe dissected into bristles or hairs somewhat simulating those of the margin of the akene; also sometimes a slender awn from one or both margins of the akene. - Rocky cañons, \&c., S. Colorado, New Mexico, and Arizona; first coll. by Wright, Bigelow, \&c. Fl. late summer and autumn.

137. EATONELLA, Gray. (Prof. Daniel Cady Eaton, author of Ferns of N. America, the Compositce of King's Expedition, \&c., grandson of Amos Eaton for whom was named the genus Eatonia.) - Very floccose-lanate annuals, of California and adjacent Nevada; with mostly alternate leaves and small sessile heads of yellow or white flowers: fl. spring or early summer. Bot. Calif. i. 379, as subgenus under Actinolepis ; Proc. Am. Acad. xix. 19.

E. nivea, Grar, l. c. Depressed in a small tuft from a slender root, an inch or so high, subcaulescent, densely leafy, white with long and loose wool: leaves obovate-spatulate, entire, 
equalling or surpassing the sessile heads : involucre of about 8 narrowly oblong bracts, subtending as many ray-flowers: ligules hardly exceeding the disk: disk-corollas 5-toothed: akenes all compressed and with only marginal callous nerves, linear-oblong, the dark faces polished and shining, the comose long and soft villous hairs of the margin bright white: pappus a pair of comparatively large opaque palea, of broadly ovate or quadrate form (the insertion of the two occupying the whole circumference of the akene), sparingly laciniatedentate or erose at summit, and the middle produced into a subulate naked awn which nearly equals the 4-toothed corolla. - Burrielia nivea, D. C. Eaton, Bot. King Exp. 174, t. 18. Actinolepis (Eatonella) nivea, Gray, Bot. Calif. i. 379. - Sterile hills of the eastern side of the Sierra Nevada; in the Pah-Ute Mts., Nevada, Watson, and Surprise Valley, E. California, Lemmon.

E. Congdóni, Gray. A span or two high, loosely branching, sparsely leaved, floccosely lanate: leaves-oblong linear, sparsely sinuate-dentate or repand: heads short-peduncled or nearly sessile at the summit of the stem : involucre of 5 or 6 oval-oblong herbaceous bracts: ray-flowers none: disk-corollas 4-toothed : akenes oval (the faces at first pubescent, at length glabrate), the outermost triangular-obcompressed, the others compressed and flat: pappus of 2 to 4 very thin and hyaline erose-laciniate awnless palex, not exceeding the long villosity, forming a crown. - Proc. Am. Acad, xix. 20. - California, at Deer Creek, Tulare Co., Congdon, and on the San Joaquin, Parry.

138. MONOLOPIA, DC. (Movóגomos, single husk, alluding to the uniserial involucre.) - Annual herbs, Californian, clothed with floccose wool; with alternate (or only lower sometimes opposite) sessile leaves, and comparatively large pedunculate heads of golden yellow flowers terminating the stem and few branches. - Prodr. vi. 74; Hook. Ic. P1. t. 343, 344. Spiridanthes, Fenzl in Endl. Gen. Suppl. ii. 105.

§1. MonolópIs proper. Ray-corollas with ample coarsely 3-4-toothed or lobed ligule, and bearing at base on the opposite side of the style a roundish denticulate appendage: leaves undivided, strictly sessile or partly clasping by a broadish base. - Bot. Calif. i. 383.

M. májor, DC. l. c. A foot or two high, rather stout and simple; the floccose white wool tardily decidnous: leaves from linear to lanceolate-oblong, repand-serrate to entire: bracts of the broad (half-inch high) involacre united to above the middle, the lobes triangularovate: ligules 6 to 10 lines long: akenes glabrous or nearly so at maturity. - Hook. Ic. Pl. t. 344, \& Bot. Mag. t. 3839 ; Gray, Bot. Calif. l. c. Hologymne Douglasii, Fisch. \& Meyer, Ind. Sem. Hort. Petrop. viii. 64. - Common in low ground, through W. California.

Var. lanceoláta, GraY, Bot. Calif. 1. c. A mere form, with bracts of involucre distinct to near the base. - $\boldsymbol{M}$. lanceolata, Nutt. Pl. Gamb. 175. Near Los Angeles, \&c.

M. grácilens, Grar. A foot or more high, slender, loosely paniculately branched, bearing scattered small heads: involucre only quarter-inch high; its oval or ovate bracts distinct to the base: akenes only a line long.-Proc. Am. Acad. xix. 20. - California in the coast ranges, near New Almaden and Santa Cruz, Bolander, Torrey, Isaman, Pringle.

§ 2. Pseudo-Búnia. Ray-corollas destitute of internal appendage, barely 3-toothed at apex: leaves all alternate, commonly laciniately cleft, narrowed at base into more or less of a petiole. - Bot. Calif. l. c.

M. mínor, DC. I. c. Loosely lanate, a span or more high: cauline leaves 3-5-cleft into linear lobes: heads 3 lines high: bracts of the involucre about 10, somewhat in 2 series, oblong, separate to below the middle : ovary glabrous. - Hook. Ic. PI. t. 343. - California, Douglas. Not since detected.

M. Heermánni, Durand. Whitened with a close and fine flocculent tomentum, which is deciduous, the foliage glabrate and green in age, a span or two high, branching: leaves pinnatifid or pinnately parted into linear lobes or dirisions, or some of the cauline bipinnatifid: heads 3 or 4 lines high: involucral bracts distinct nearly to base : akenes sericeouspuberulent or glabrate. - Pl. Pratten. in Jour. Acad. Philad. ser. 2, iii. 93. M. bahiofolia, 
var. pinnatifida, Gray, Bot. Calif. i. 383. - Foothills of the Sierra Nevada, California, from Calaveras to Tulare Co., Heermann, Pratten, Congdon. Also near Auburn, Bolander.

M. bahiæfólia, Bектн. Smaller than the foregoing, and with similar flocculent tomentum; the simple monocephalous stems only 2 inches high: leaves small (at most half-inch long), spatulate to linear, entire, or lower ones 3-lobed: head hardly 3 lines high: involucral bracts distinct to the middle : immature akenes sparsely pubescent. - Pl. Hartw. 317 ; Gray, Bot. Calif. i. 383, excl. var. - Valley of the Sacramento, Hartweg. Probably depauperate specimens.

139. LASTHENIA, Cass. ( $\Lambda \alpha \sigma \theta \epsilon i$, a courtesan, who was a pupil of Plato: name given, by some freak of the founder, to a genus of three Western American plants.) The Chilian $L$. obtusifolia has comparatively few-flowered nearly or quite homogamous heads, and a less developed receptacle. - Low and slender annuals, mostly quite glabrous and slightly succulent; with opposite and linear or narrowly lanceolate mostly entire leaves, their sessile bases connate round the stem; the yellow-flowered heads pedunculate, terminating the stem and branches. - "Opusc. Phyt. iii. 88 "; DC. in Lindl. Bot. Reg. t. 1780, 1823, \& Prodr. v. 664 ; Torr. \& Gray, Fl. ii. 377.

§1. Lasthenia proper. Pappus paleaceous: heads discoid; the ligules not surpassing the involucre or the short glabrous disk-corollas, therefore wholly inconspicuous. - Rancagra, Pœpp. \& Endl. Nov. Gen. \& Spec. i. 15, t. 24, 25.

L. glabérrima, DC. 1. c. Somewhat fleshy : stems ascending, a span to a foot long: heads on long peduncles which are enlarged at summit, nodding after anthesis : leaves elongatedlinear: involucre about 15-toothed : corollas all shorter than the minutely puberulent oblonglinear akenes: pappus of 5 to 10 rigid palex, two or three of them with subulate or shortawned points, the others erose or laciniate. - Torr. \& Gray, 1. c. ; Gray, Bot. Calif. i. 384. Wet meadows near brackish water, along the coast of California and Oregon.

§ 2. HologínNe. Pappus wanting: rays large, conspicuously exserted: disk-corollas fully as long as the akene; their lobes sparsely papillose-barbellate outside, as in Monolopia. - Gray, Bot. Calif. 1. c. Hologymne, Bartl. Ind. Sem. Goett. 1837, 1839. Xantho, Remy, in Ann. Sci. Nat. ser. 3, xii. 191. Lasthenia, Lindl. Bot. Reg. l. c.

L. glabráta, Lixdu. Somewhat fleshy, sometimes slightly pubescent: stems erect: leaves shorter : peduncles somewhat enlarged under the erect head: involucre more hemispherical: ligules 3 to 6 lines long: akenes narrowly obovate-oblong with acutish edges, smooth and glabrous.-DC. Prodr. v. 665; Hook. Bot. Mag. t. 3730 ; Torr. \& Gray, 1. c. L. glabrata \& L. Californica (a smaller form, mistaken for preceding species which DC. had so named), Lindl. Bot. Reg. t. 1780, 1823. Hologymne glabrata, Bartl. l. c. Monolopia glabrata, Fisch. \& Meyer, Sert. Petrop. 1835. - Moist grounds throughout W. California.

Var. Coúlteri. A smaller form: akenes smaller and narrower, with obtuse edges, sprinkled with minute rough points or glands. - Saline marshes, S. California, Coulter (no. 338), Brewer, Cleveland, Pringle.

140. BURRIELIA, DC., partly. (Andrés Marcos Burriel, a Spauish Jesuit and historian, who, in 1758, wrote a History of California, and edited the account by Venegas of the establishment of its missions.) - Prodr. v. 664; Benth. \& Hook. Gen. ii. 398: now reduced to one of the three original species. Perhaps too near the following somewhat earlier-published genus.

B. microglóssa, DC. 1. c. Slender annual, a span high, hirsute: leaves an inch long and barely a line wide, entire : involucre 3 lines high, equalling the yellow flowers. - Low ground, from San Francisco Bay to San Bernardino, California ; fl. spring; first coll. by Coulter and Douglas. 
141. BAERIA, Fisch. \& Meyer. (In honor of the eminent Russian zoölogist, Karl Ernst von Baer.) - Californian annuals, or one perennial species ; with opposite and entire or pinnately dissected and sessile leaves, sometimes connate at the base; and slender-pedunculate heads of yellow flowers terminating the branches: fl. spring and early summer. - Ind. Sem. Hort. Petrop. ii. 29, Jard. Petrop. t. 6, \& Sert. Petrop. t. 7; Don in Sweet, Brit. Fl. Gard. ser. 2, t. 395; Benth. \& Hook. Gen. ii. 399; Gray, Proc. Am. Acad. ix. 196, Bot. Calif. i. 375, \& Proc. Am. Acad. xix. 21. Burrielia in part, DC. Prodr. v. 664; Torr. \& Gray, FI. ii. 378, excluding the typical species. Dichata \& Ptilomeris, Nutt. 'Trans. Am. Phil. Soc. n. ser. vii. 382, 383. Dicheta \& Hymenoxys, Torr. \& Gray, Fl. ii. 379, 380.

§ EObaÉria. Pappus of uniform (or mainly uniform) and entire awned or pointed paleæ or chaffy-based awns, or wanting (even present or absent in the very same species): receptacle muricate-roughened: ligules mostly conspicuous: leaves linear and entire, except in one species. - Burrielia, Torr. \& Gray, 1. c., excl. B. microglossa.

* Akenes slenderly subclavate-linear: style-tips abruptly terminated by a conspicuous narrowsubulate appendage which usually surpasses the broad basal portion: receptacle slender-subulate and elongated in the manner of Burrielia: heads small: involucral bracts and oval rays 5 , or sometimes only 4.

B. leptálea. Wholly glabrous : stems filiform, a span high : leaves nearly filiform, quarter to half inch long: involucre 2 lines high : ligules mostly as long: anther-tips filiform: pappus of $\mathbf{2}$ or 3 scabrous flattened awns with gradually dilated base. - Burrielia leptalea, Gray, Proc. Am. Acad- vi. 546, \& Bot. Calif. i. 375. - Monterey Co., valley of the Nacismento, Brewer, and the Salinas, Greene. Known only as an exiguous vernal plant: probably also occurs in a larger form.

B. débilis, Greene in herb. Minutely pubescent: stems weak, 6 to 10 inches long: leaves flaceid, linear, the largest inch and a half long: involucre 2 or 3 lines bigh: ligules hardly over a line long: anther-tips ovate-lanceolate: pappus of 3 or 4 firm ovate-lanceolate and awned palex, or in some heads none, then the akene with narrower apex. - Plains of Fresno and mountains of Kern Co., Greene.

* * Akenes more clavate, with scanty aristiform pappus or commonly none, then less truncate or slightly contraeted at summit, either glabrous or minutely papillose-glandular in same species: style-tips capitate and mostly with a small apiculation: receptacle conical: large-flowered and with some hirsute pubescence, a foot or so high unless depauperate: rays and plane involucral bracts 7 to 12. - Baeria, Fisch. \& Meyer, 1. c.

B. macrántha, GraY. Apparently perennial, rather stout, with peduncles 4 to 8 inches long: leaves more or less 3 -nerved and obtuse, 2 or 3 lines wide (the lower 4 to 8 inches long), hispidly ciliate, at least toward the base : head about half-inch high and broad : involacre of about 12 hirsute-pubescent thickish-herbaceous bracts: ligules half to three-fourths inch long. - Proc. Am. Acad. xix. 21. B. chrysostoma, var. macrantha, Gray, Proc. Am. Acad. ix. 196, \& Bot. Calif. 1. c. Burrielia chrysostoma, var. macrantha, Gray, Pacif. R. Rep. iv. 106. - Coast of California, north of San Francisco Bay to Humboldt Co., Andrews, Bigelow, Bolander.

Var. pauciaristáta, GRAT, l. c. Clearly perennial, often only 6 inches high : leaves shorter, hispid-ciliate: ligules only 4 or 5 lines long: pappus when present of 1 to 3 subulate chaffy awns rather than palex, little shorter than the akene.-Coast of Mendocino Co., Bolander, Pringle.

B. chrysóstoma, Fiscr. \& Merer, 1. c. Annual, slender : leaves narrowly linear (a line or less wide): heads 3 or 4 lines high: bracts of the broad involucre 7 to 12, in depauperate plants sometimes fewer: ligules 3 or 4 lines long: pappus (perhaps always) none.-Don, Brit. Fl. Gard. ser. 2, t. 395; DC. Prodr. v. 254; Gray, Bot. Calif. i. 375, excl. var. Burrielia chrysostoma, Torr. \& Gray, Fl. ii. 379. - Moist ground, common almost throughout California. 
* * Akenes more cuneate and broad at the summit, usually but not always pappose, more or less 4-angular, not glandular, mostly canescent-hispidulous : receptacle conical or cylindraceous: heads middle-sized or smaller.

+ Some hirsute or strigulose pubescence, but no woolliness: style-tips capitate, without any obvious apiculation: plants slender, a span to a foot high according to situation and season: pappuspaleæ 1 to 5.

B. grácilis, Gray. Bracts and rays 10 to 12, when depauperate 5 or 6 : ligules 2 or 3 lines long: akenes almost equalled by the pappus; this in type specimens of 3 or 4 awns from small lanceolate paleæ. - Proc. Am. Acad ix. 196, \& xix. 21. Burrielia gracilis, DC. Prodr. v. 664. B. hirsuta, Nutt. Trans. Am. Phil. Soc. n. ser. vii. 381, a state destitute of pappus. - Common in W. California, especially southward, and W. Arizona : variable. Extreme variations are

Var. aristósa, GRAY, 1. c., with awns very gradually and slightly widened downward, or in some flowers wanting. - Burrielia gracilis, Hook. Bot. Mag. t. 3758.

Var. tenérrima, with pappus-awns of the preceding, but usually fewer: depauperate form: bracts and rays only 5 or 6. - Probably Burrielia tenerrima, DC. Prodr. v. 664.

Var. paleácea, Gray, l. c., with awns more or less abruptly dilated at base into a conspicuous oval or ovate palea, occasionally wanting, rarely one or two of the palea awnless. - Burrielia longifolia \& B. parviflora, Nutt. 1. c.

B. cúrta, Gray. Bracts and rays 8 or 10: pappus of 4 or 5 ovate or oblong pointless palex (or rarely of a single one), in length not exceeding the breadth of the akene, or in some plants obsolete or wanting: leaves all filiform-linear: heads 2 or 3 lines high and wide.Proc. Am. Acad. xix. 21. - Southeastern California, near San Bernardino, W. G. Wright, Lemmon.

++ Glabrous except some fine deciduous woolliness: leaves and involucral bracts more or less fleshy-thickened: heads about 4 lines high, many-flowered: style-tips ovate or capitate, and with a conical or subulate apiculation or appendage: pappus of firm ovate or deltoid palex abruptly attenuate-awned, about equalling the akene.

B. Clevelándi, GRıY. Leaves linear, a line wide, obtuse, entire : involucral bracts 8 to 12, plane: pappus-paleæ only 2, slender-awned.-Proc. Am. Acad. xix. 22. - San Diego, Cleveland. Too little known.

B. carnósa, Greene. Leaves filiform, entire: involucral bracts about 7, with a strong carinate midrib: pappus of 4 or 5 subulate-awned palex. - Bull. Torr. Club, x. 86. - Bay of San Francisco, in salt marsh at Vallejo, Greene.

B. platycárpha, Grar. Leaves narrowly linear to filiform, some laciniate-pinnatifid: involucral bracts 6 or 7, manifestly 3-nerved at base, middle nerve at length carinate-thickened : pappus-paleæ 5 to 7, slender-awned. - Proc. Am. Acad. ix. 196, xix. 22. Burrielia platycarpha, Gray, Bot. Mex. Bound. 97. - Lower Sacramento and Byron Springs, Stillman, Greene.

§ 2. Dich ta. Pappus of two forms both in ray and disk, i. e. of truncate or muticous paleæ alternating with awned ones or naked awns, or wanting in some species : receptacle, \&c., of $\S 1$ : involucral bracts more obviously carinate-concave in middle, the concavity partly embracing subtended akene, disposed to be deciduous with it at maturity of the fruit: heads not large ( 3 or 4 lines high): leaves from entire to laciniate-pinnatifid in the same species. - Gray, Proc. Am. Acad. ix. 196, \& xix. 22. Dichata, Nutt. Trans. Am. Phil. Soc. vii. 383; Torr.\& Gray, l. c.

B. marítima, GRAY. Low and diffuse, glabrate: leaves oblong-linear, inch long, entire, or lowest sparingly laciuiate-toothed: head rather narrow: involucral bracts and short orbicular rays 6 or 8: pappus of 3 to 5 slender-subulate awns and at least as many small and narrow laciniate squamellæ or paleæ. - Proc. Am. Acad. ix. 196. Burrielia maritima, Gray, Proc. Am. Acad, vii. 358. - Farallones Islands, off San Francisco, Gruber. 
B. Fremónti, GRAY, 1. c. Erect, slender, a span or two high, somewhat hirsute-pubescent: leaves some narrowly linear and entire, the others palmately or pedately 3-5-parted above into linear lobes: bracts of the broad involucre 10 to 12 : rays as many or fewer, with oval ligules seldom surpassing the disk: pappus of about 4 slender awns and as many or more numerous narrow small palew, or rarely none. - Dichceta Fremontii, Torr. in Pl. Fendl. 102. Burrielia (Dichceta) Fremontii, Benth. P1. Hartw. 317.- Lower valley of the Sacramento to San Francisco Bay; first coll. by Fremont.

B. uliginósa, Grar, l.c. A span to a foot or more high, at length loosely branched and diffuse, villous-tomentose when young, commonly glabrate: leaves linear or ligulate (the larger 4 to 10 inches long), laciuiate-pinnatifid and the linear segments sometimes again cleft, or the upper occasionally entire; involucral bracts and oblong exserted rays 10 to 13 : pappus sometimes none, commonly of 2 or 3 stout chaffy awns, and as many or twice as many shorter broad and truncate laciniate-fimbriate paleæ. - Dichoeta uliginosa, Nutt. Trans. Am. Phil. Soc. 1. c. 383; Torr. \& Gray, Fl. ii. 380. - Wet ground or in shallow water, San Francisco Bay to Santa Barbara; first coll. by Coulter.

Var. ténera, Grax. Depauperate, on drier soil, 2 to 6 inches high: leaves linear, entire, or some of the lowermost laciniate: rays oval or oblong, little or not at all exceeding. the disk: palex and awns each usually 2 , the former very broad and quadrate, or splitting into 2 or 3.- Proc. Am. Acad. xix. 22. Dichata tenella, Nutt. 1. c.; Torr: \& Gray, 1. c. With the ordinary form: also at Tulare Station, Parry.

§3. Ptilómeris. Pappus wholly of awned or of muticous and commonly erose palex, or sometimes wanting: receptacle not muricate-roughened, rather scrobiculate : involucral bracts in fruit curinate at centre outside, plicate-concave within, and at length deciduous with the subtended akene, as in $\$$ Dichata: heads of the same: leaves all pinnately or lower ones bipinnately parted into linear and attenuate divisions: not woolly, mostly somewhat glandular, diffuse. - Proc. Am. Acad. xix. 23. Hymenoxys (Hook.), Torr. \& Gray, Fl. ii. 380, not Cass. Ptilomeris, Nutt. Trans. Am. Phil. Soc. vii. 382. Actinolepis § Ptilomeris, Benth. \& Hook. Gen. ii. 399 ; Gray, Proc. Am. Acad. ix. 197, \& Bot. Calif. i. 378. Baeria § Ptilomeris, Gray, Proc. Am. Acad. xix. 21, 23.

* Rays 6 to 8, oblong, short-exserted: involucral bracts ovate-oval: receptacle either acutely or obtusely conical, glabrous: heads small (barely 3 lines high): plants a span high, minutely pubescent, obscurely if at all glandular, with filiform-linear divisions to the leaves: the two following perhaps forms of one species.

B. affininis, Gray. Pappus of 8 or 10 oblong or lanceolate paleæ with laciniate-setulose margins, fally equalling the corolla tube, some or most of them produced into an awn almost equalling disk-corolla, or in the ray blunt and awnless. - Proc. Am. Acad. xix. 23. Ptiloneris affinis, Nutt. Pl. Gamb. 174. - S. California, from Los Angeles to San Bernardino, Gambel, Nevin, Parish.

B. tenélla, GRAT, 1. c. Pappus of 6 to 10 short and firm quadrate or broadly cuneate paleæ, with the truncate muticous summit denticulate or nearly entire, not surpassing the tube of the corolla. - Ptilomeris tenella, Nutt. P1. Gamb. 173. Actinolepis tenella, Gray, Bot. Calif. i. 378, mainly. - Los Angeles, California, Gambel, Parry.

* Rays 10 to 15 , elongated-oblong, exserted: involucral bracts oblong-lanceolate : receptacle acutely conical, minutely and sparsely pubescent: plants minutely glandular-pubescent, diffusely branched, a span to near a foot high, perhaps all varieties of one, the difference being mainly in the pappus.

B. coronária, GrAy, l. c. Pappus of 8 to 12 lanceolate or oblong denticulate palex, all tapering into awns, little shorter than disk-corollas, or some in the ray awnless: rays nearly half-inch long. - Ptilomeris coronaria \& P. aristata, Nutt. in Trans. Am. Phil. Soc. vii. 382. Shortia Californica, Nutt. in garden catalogues. Hymenoxys Californica, Hook. Bot. Mag. t. 3828 ; Torr. \& Gray, 1. c., with var. coronaria. Actinolepis (Ptilomeris) coronaria, Gray, Proc. Am. Acad. ix. 197, \& Bot. Calif. 1. c. - California, Nuttall. Not since collected, but common in cultivation, especially in France. 
B. anthemoídes, GRAT, I. c. More glandular, and with somewhat more fliform divisions to the leaves: pappus wanting. - Ptilomeris (Ptilopsis) anthemoides, Nutt. l. c. Hymenoxys calva, Torr. \& Gray, Fl. l. c. Actinolepis (Ptilomeris) anthemnoides, Gray, Bot. Calif. I. c. San Diego, California, Nuttall, and near Julian City, Bolander.

B. mútica, GRAY, 1. c. Like the preceding, probably the pappose state of it : pappus of 6 to 8 quadrate-oblong paleæ, the obtuse or truncate summit erose. - Ptilomeris mutica, Nutt. l. c. Hymenoxys mutica, Torr. \& Gray, l. c. Actinolepis (Ptilomeris) mutica, Gray, Bot. Calif. l. c. - San Diego, California, Nuttall, Cleveland.

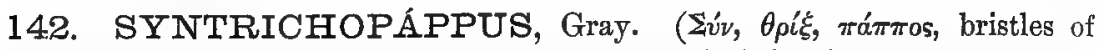
pappus united.) - Low and small Californian and Arizonian winter annuals, floccose-woolly, mostly alternate-leaved, branched from the base; with shortpeduncled heads terminating the branches; flowers all yellow or rays sometimes rose-red. - Pacif. R. Rep. iv. 106, t. 15, Bot. Calif. i. 394, \& Proc. Am. Acad. xix. 20.

S. Fremónti, GrAY, l, c. About a span high, loosely floccose: leaves spatulate or linearcuneate, often 3-lobed at summit: involucre 3 lines high, of about 5 broadly oblong bracts: rays 5, rather large: flowers all golden yellow: pappus bright white. - Desert plains, S. E. California, adjacent Nevada, S. Utah, and Arizona; first coll. by Fremont.

S. Lemmóni, Grar. Smaller, slender, lightly woolly, glabrate in age: leaves spatulate or linear, entire: involucre of 6 to 8 narrowly oblong bracts : rays small, rose-purple and white or white-edged; disk-corollas pale yellow: pappus none.-Proc. Am. Acad. xix. 20. Actinolepis Lemmoni, Gray, Proc. Am. Acad. xvi. 102. - S. E. California, on the Mohave Desert, Lemmon. Summit of Cajon Pass, Parish.

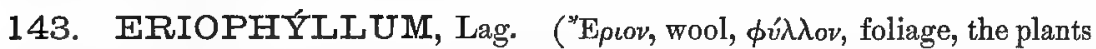
woolly.) - Mostly floccose herbs, rarely suffruticose (of W. N. America and probably in northern parts of Mexico); with alternate or partly opposite leaves, and peduncled or sometimes sessile heads; the flowers wholly yellow, or one or two with rose-purple rays, one rayless. - Nov. Gen. \& Spec. 28 ; Dougl. in Bot. Reg. t. 1167; Gray, Proc. Am. Acad. xix. 24. Eriophyllum \& Phialis, Spreng. Gen. 631. Trichophyllum, Nutt. Gen. ii. 166; Hook. Fl. i. 315. Bahia, DC. Prodr. v. 656, in part; Torr. \& Gray, Fl. ii. 374, partly, not Lag. Actinolepis, DC. Prodr. v. 655 .

§ 1. Actinólepis. Low and diffuse winter-annuals, with short-peduncled or sessile heads only 2 or 3 lines high: involucral bracts few, distinct to the base, herbaceous or chartaceous in age: anther-tips from ovate-lanceolate to linearsubulate. - Gray, Proc. Am. Acad. xix. 24. Actinolepis, DC., Benth. \& Hook. Gen. ii. 399 ; Gray, Proc. Am. Acad. ix. 198, \& Bot. Calif. i. 377, excl. § Ptilomeris.

* Heads sessile or nearly so in the forks, or at summit of branches, then subtended by a leaf or glomerate, 2 lines high, wholly yellow-flowered: receptacle fiat or barely convex: anther-tips ovate-lanceolate, obtuse: leaves small, spatulate, commonly 3-lobed or 3-toothed at summit. Actinolepis, DC. 1. c., founded on specimens with infertile disk-flowers.

E. multicaúle, GRA Y, l. c. Whitened with rather close cottony wool, sometimes denudate in age : stems slender, at length much branched, a span high, most of the internodes exceeding the leaves: rays 3 to 5, obovate, a line long: akenes glabrate: pappus of 10 to 15 rather firm narrowly subulate or almost aristiform palex, or sometimes wanting in all or some of the disk-flowers, especially when these are infertile; then their style is only minutely forked at the apex. - Actinolepis multicaulis, DC. Prodr. v. 656; Hook. Ic. t. 325 ; Torr. Bot. Mex. Bound. t. 33. - Southern California to Arizona, from Santa Barbara to Tueson, in low ground; first coll, by Coulter and Douglas. 
E. Prínglei, Grar, 1. c. More loosely and copiously woolly, depressed, inch or two high, flowering almost from the base: rays none: flowers all fertile: akenes villous: pappus of about 10 much larger wholly silvery-scarious oblong-lanceolate and pointless erose palere.Gravelly plains from the Mohave Desert in S. E. California to Tucson, Arizona, Palmer, Lemmon, Pringle, Parish.

* * Heads pedunculate, terminating the branches, 3 or 4 lines high : receptacle convex or conical: plants 3 to 5 inches high, erect and at length diffuse, with mostly entire leaves.

- Rays about 5, inconspicuous: disk-flowers not numerous: anther-tips orate-oblong, obtuse.

E. nubígenum, Grenne. Densely white-woolly: leaves lanceolate-spatulate (about halfinch long): heads short-peduncled, narrow: involucre of 5 oblong bracts : rays with oval ligule, hardly exceeding the disk-flowers, yellow: receptacle with conical centre: pappus of about 10 oblong or narrow nerveless and obtuse erose thinnish paler, half the length of the corolla, one third that of the akene. - Gray, I'roc. Am. Acad. xix. 25. - On Cloud's Rest, above the Yosemite, at 9,000 feet, Mrs. Curran.

+ + Rays 5 to 9, exserted and ample, oval or oblong: disk-flowers more numerous: anther-tips narrow and slender : receptacle higll-convex or obtusely low-conical.

E. Wallácei, Gray. Thickly clothed with cottony wool: leaves obovate or spatulate, occasionally 2-3 toothed at apex : pappus of 6 to 10 short-oval or obovate obtuse and pointless nerveless palex, of firm texture and opaque: style-tips somewhat subulate-conical: corollas all yellow.-Proc. Am. Acad. xix. 25. Bahia Wallacei, Gray, Pacif. R. Rep. iv. 105. Actinolepis Wallacei, Gray, Proc. Am. Acad. ix. 198. - Plains, from San Diego Co., California (first coll. by $W . A . W$ allace), to adjacent Arizona and S. Utah. A var. with pale purple and white rays (Bahia rubella, Gray, Bot. Mex. Bound. 95), S. E. California, Parry.

E. lanósum, Grar, 1. c. More thinly and floccosely woolly: leaves spatulate-linear, entire: pappus of about 5 oblong and rather firm nerveless and obtuse palex and as many alternating paleaceous awns of double the length: style-tips obtuse and sometimes with a minute cuspidate apiculation : rays white or rose-color. - Burrielia (Dichata) lanosa, Gray, Pacif. R. Rep. iv. 107. Actinolepis lanosa, Gray, Proc. Am. Acad. ix. 198. - Dry plains, S. E. California to Arizona and S. Utah; first coll. by Bigelow.

§2. Trichophíludu. Larger, erect: heads when clustered small, when solitary commonly rather large: involucral bracts of firm texture: rays and diskflowers golden yellow; tube of corolla commonly glandular or hairy : anther-tips ovate, mostly obtuse: akenes linear or cuneate-linear, glabrous or nearly so : pappus of short opaque and firm werveless and pointless paleæ, sometimes very small, rarely obsolete or wanting. - Gray, Proc. Am. Acad. xix. 25. Trichophyllum, Nutt. l. c. Phialis, Spreng. 1. c., but involucre seldom gamophyllous.

* Suffruticose or suffrutescent, leafy to the top, branching: heads small, compactly corymbosely cymose, short-peduncled: ligules roundish-oval, only a line or two long : pappus of oblong-linear paleæ much shorter than the akene: leaves mostly lobed or divided, and the margins revolute.

E. stæchadifólium, LAG. I. c. Canescent with close-pressed pannose tomentum, at length partly denudate, 1 to 4 feet high from a woody base : leaves once or twice pinnately parted into linear divisions and rhachis, or the upper linear with a pair of lateral lobes, or some of them entire, upper face soon glabrate and green: heads 3 or 4 lines high, numerous in rather loose paniculate clusters: involucre cylindraceous-campanulate; its bracts 8 to 10 , linear-spatulate to narrowly oblong, thinnish: receptacle convex, alveolate-toothed: rays 6 to 8: palex of the pappus 8 to 12, the four over the angles of the akene rather longer. Helenium stcechadifolium, Spreng. Syst. iii. 574. Bahia artemisiofolia, Less. in Linn. vi. 253; DC. Prodr. v. 657; Torr. \& Gray, 1. c. B. stcechadifolia, DC. 1. c. 656 (with wrong halitat, the plant of Hænke coming from Monterey, California); Nutt. Trans. Am. Phil. Soc. l. c. (with var. Californica). Lagasca's original appears to have been a branch of the form with uppermost leaves entire. - Coast of California, from San Francisco to Santa Barbara.

E. confertiflórum, GrAY, 1. u. Similarly white-woolly, a foot or two high, with slender and more strict stems naked at summit: leaves small, of mostly cuneate outline, pinnately or somewhat ternately once or twice 3-7-parted into narrow linear divisions: heads 2 lines 
high, several or numerous in a compact cymose cluster, mostly short-peduncled or subsessile : involucre oval or obovoid-oblong, of about 5 broadly oval thin-coriaceous bracts : receptacle convex or low-conical in the centre, not alveolate : rays 4 or 5 : paleæ of the pappus 8 to 14 . - Bahia confertiflora, DC. 1. c. 657 ; Torr. \& Gray, l. c. - Hills, California, common from near the coast to the Sierra Nevada.

Var. trifidum, GraY, l. c. A form with small short leaves, simply 3-5-cleft into oblong or short-linear lobes. - B. trifida, Nutt. Trans. Am. Phil. Soc. 1. c. ; Torr. \& Gray, 1. c. B. confertiflora, var. trifida, Gray, Bot. Calif. 1. c. - With the ordinary form. Autumnal specimens, coll. by Parish, on the San Bernardino Mountains, are tomentose with longer and looser wool.

Var. laziflórum, Grax, 1. c. Heads loosely fastigiate-cymose and mostly slenderpeduncled. - Bahia tenuifolia, DC. 1. c. - California, Douglas (herb. DC.), Coulter. An ambiguous form with larger heads and rays, coll. at San Bernardino, Parish.

* Herbaceous, commonly and perhaps always perennials: heads larger, mostly solitary or scattered and conspicuously pedunculate: receptacle from convex or low conical to flat (evern in the same species): ligules 6 to 13 , from quarter to half inch long, oblong or oval: leaves variable.

+ Akenes glabrous, glabrate, or sparsely appressed-pilose, not glandular.

E. crespitósum, Dougc. Floccosely white-woolly, many-stemmed from the root: leares in age with upper face often glabrate; lower ones from spatulate or cuneate to roundish in outline, from incisely 3-5-lobed to pinnately parted, or the upper varying to linear and entire: involucral bracts 8 to 12 , oblong or oval: tube of disk-corollas mostly hirsute-glandular and longer than the pappus, which is variable, sometimes very short, sometimes obsolete. - Lindl. Bot. Reg. t. 1167 (but the gamophyllous involucre of the figure is seldom found); Gray, l. c. Actinella lanata, Pursh, Fl. ii. 560. Helenium lanatum, Spreng. Syst. iii. 574. Trichophyllum lanatum, Nutt. Gen. ii. 167; Hook. Fl. i. 315. Bahia lanata, DC. Prodr. v. 657; Torr. \& Gray, F1. ii. 375 , incl. var. tenuifolia (which is not $B$. tenuifolia, DC., but merely the most slender form of the present species). - Moist or dry ground, common from Montana to Brit. Columbia, and thence to $\mathrm{S}$. California, under very various forms, which are indefinable as species. Taking as the type the original of Pursh and Nuttall, with rather slender stems a foot or more high, principal leaves somewhat palmately pinnatifid into narrow divisions, or incisely cleft, and heads rarely half-inch high, the main divergent forms are:-

Var. latifólium, Grar, l. c. The opposite extreme in foliage: stems commonly 2 feet long, branched and lax when growing in shade : leaves thin, dilated, from rhombic or cuneate to oblong-lanceolate, 3-5-lobed and incised or dentate, the lobes from oblong to broadly lanceolate: peduncles comparatively short: rays 9 to 13 : corolla-tube either sparsely or densely hirsute with gland-tipped hairs, much longer than the pappus, the rounded palex of which do not exceed the breadth of the narrowly oblong-cuneate or narrower glabrous akenes, commonly very short and forming a kind of crown, sometimes quite obsolete (as occurs in other forms also). - Bahia arachnoidea, Fisch. \& Lallement, Ind. Sem. Hort. Petrop. 1842 ; Gray, Pl. Fendl. 100, \& Bot. Calif. i. $382 . \quad$ B. latifolia, Benth. Bot. Sulph. 30. Eriophyllum cospitosum, Bot. Reg. t. 1167, is nearly this. - California, near the coast, in or near Redwood forests, from Humboldt Co. to Santa Cruz. Bahia lanata, var. brachypoda, Gray, Bot. Calif. l. c., is a sea-shore form of this, with leaves thickish under exposure, heads clustered and remarkably short-peduncled, and pappus larger. Forms connecting with var. integrifolium occur in the Sierra, in groves of Sequoia gigantea.

Var, achillæooídes, Grax, I. c. Leaves pinnately parted or eleft, with the 3 to 5 divisions mostly narrow and laciniately incised or pinnatifid: heads somewhat corymbosely collected and rather short-peduncled: involucre hemispherical, 3 or 4 lines high; rays and involucral bracts 9 to 13 : akenes sparsely pubescent or glabrate. - Bahia achilleoides, DC. 1. c. B. lanata, var. arhillooides, Gray, Bot. Calif. 1. c. - California, near the coast.

Var. grandiflórum, Grax, l. c. Rather strict and stout, densely woolly: leaves all linear or the lower narrowly lanceolate or spatulate, laciniate-serrate or entire, or some parted into a few narrowly linear divisions: heads solitary and long-peduncled: involucre half-inch high, hemispherical, densely woolly, of 10 to 13 bracts : rays as many, large : akenes usually somewhat pubescent : corolla-tube sparsely hirsute-glandular. - Bahia lanata, Benth. Pl. Hartw. 317. B. lanata, var. grandiflora, Gray, Bot. Calif. 1. c. - California, valley of the Sacramento. (Guadalupe Island, off Lower California.) 
Var. leucophýllum, Gra , l. c. Smaller, a span to a foot high, rather strict : leaves narrow, entire or sparingly cleft or parted : heads solitary, long-peduncled : involucre campanulate, 4 or 5 lines high, of about 8 oblong bracts : pappus in the typical plant of narrow lanceolate paler, four of them twice the length of the others, but this is inconstant. - Bahia leucophylla, DC. 1. c. - Brit. Columbia to N. California, and east to Idaho.

Var. integrifólium, Grar, 1. c. Low, often dwarf, cespitose-tufted, 3 to 10 inches high : leaves from narrowly spatulate or oblanceolate and entire to more dilated and 3-lobed at summit, or at base and on sterile shoots cuneate and incisely lobed: heads rather long-peduncled : involucre, \&c., of the preceding, sometimes smaller and of only 6 bracts: palex of the pappus mostly of same length, about equalling the very glandular but not hirsute corollatube: akenes glabrous, rarely somewhat glandular-atomiferous near the summit. - Trichophyllum integrifolium, Hook. Fl. i. 316. T. multiflorum, Nutt. Jour. Acad. Philad. vii. 37. Bahia integrifolia, DC. 1. c.; Gray, Bot. Calif. 1. c. B. multiflora, Nutt. Trans. Am. Phil. Soc. 1. c. B. leucophylla, Torr. \& Gray, 1. c., in part. B. cuneata, Kellogg in Proc. Calif. Acad. v. 49, a form passing into the preceding. - Rocky Mountains in Montana and Wyoming to Brit. Columbia and along the higher portions of the Sierra Nevada, California, south to San Bernardino Co.

++ Akenes like the corolla-tube glandular: stems less than a foot high, slender.

E. grácile, GRAY, l. c. Loosely floccose-woolly : leaves so far as known all very narrowly linear and entire (an inch or two long, half-line wide) : head on a long slender peduncle: involucre nearly 4 lines high, campanulate, of about 10 oblong bracts: rays about 8 : receptacle nearly flat, alveolate-dentate: akenes slender, 2 lines long: paleæ of the pappus oblong or quadrate, exceeding the breadth of the akene. - Bahia gracilis, Hook. \& Arn. Bot. Beech. 353; Torr. \& Gray, 1. c.; Gray, Bot. Calif., in part. - S. Idaho, on Snake River, Tolmie. Not since seen.

E. Watsóni, Grar, l. c. Canescent with fine and close tomentum, fastigiately branched : leaves cuneate or spatulate in outline, with taperiug slender base or petiole, 3-lobed at summit: involucre 3 lines high, short-campanulate, of 6 or 7 oval bracts : rays 5 to 7 : receptacle conical, naked: akenes shorter and thicker: pappus a crown of truncate laciniate-dentate palex, decidedly shorter than the breadth of the akene. - Bahia leucophylla, Eaton, Bot. King Exp. 173, in part. B. gracilis, Gray, Bot. Calif. 1. c., in part. - N. Nevada, at Robert's Station, at 6,000 feet, Watson.

* * Annuals, with leaves apparently all alternate, and small pedunculate heads terminating the lax slender branches: receptacle conical; pappus a crown of small paleæ, not longer than the breadth of the summit of the akene, sometimes very short or obsolete: style-tips conical.

E. ambíguum, Grar, l. c. Somewhat loosely floccose-woolly, or denudate: stems branching from the decidedly annual root, 3 to 10 inches high: leaves from spatulate to linearlanceolate (an inch or less long), entire, or 3-toothed or lobed, especially the broader sometimes dilated-cuneate lowermost: involucre campanulate, 3 lines high, of 6 to 9 oblonglanceolate bracts, which are either distinct to the base or lightly coherent for two thirds their length: rays 5 to 9 , oblong or oval: tube of the corollas glandular-hirsute : akenes pubescent or the inner ones glabrous. - Lasthenia (Monolopia) ambigua, Gray, Proc. Am. Acad. vi. 547. Bahia Wallacei, Gray in Jour. Bost. Nat. Hist. vii. 145, not of Pacif. R. Rep. B. parviftora \& B. (Pseudo-Monolopia) ambigua, Gray, Bot. Calif. i. 382. - S. I. California, near Tejon, Xantus, Van Horn, Parry, and near Hot Springs, San Bernardino Co., Parish.

144. BÅHIA, Lag. (Juan Francisco Bahi, Professor of Botany at Barcelona.) - Suffruticose or mostly herbaceous plants (of Rocky Mountain district, Mexico, and Chili), not lanate but in some canescent; with opposite or sometimes alternate leaves, and small or middle-sized pedunculate heads of yellow flowers terminating the branches. - Lag. Nov. Gen. \& Spec. 30 ; Gray, Proc. Am. Acad. xix. 26. Stylesia, Nutt. Trans. Am. Phil. Soc. n. ser. vii. 377, founded on the original Bahia. Species of Bahia, Less. Syn. 238; DC. Prodr. v. 656 ; Benth. \& Hook. Gen. ii. 402. Achyropappus, HBK. Nov. Gen. \& Spec. iv. 257, t. 390, not Bieb. Species of Schkuhria \& of Villanova, Benth. \& Hook. Gen. 403, 404. 
Amauria, Benth. Bot. Sulph., of Lower California, insufficiently known, is perhaps an epappose Bahia.

$\S 1$. Suffruticose (B. ambrosioides, Lag., of Chili) or herbaceous from a perennial sometimes lignescent root: paleæ of the pappus 4 to 8 , obovate or spatulate, with rounded or truncate scarious summit, and thickened base or imperfect costa : leaves dissected or cleft, the lower opposite.

B. oppositifólia, Nurt A span or two high, fastigiately branched and many-stemmed, herbaceous to the base, very leafy up to the short-peduncled heads, cinereous with fine close pubescence : leaves mostly opposite, petioled, palmately or pedately 3-5-parted into linear divisions little broader than the margined petiole: head 4 or 5 lines high : bracts of the involucre oblong or oval, comparatively close (the outer obscurely carinate-one-nerved): rays 5 or 6, oval, hardly surpassing the disk-flowers : akenes slender, glandular: pappus half the length of the corollartube, the palex narrowly obovate, with strongly opaque centre evar nescent near the summit. - Torr. \& Gray, Fl. ii. 376; Gray, P1. Fendl. 99. Trichophyllum oppositifolium, Nutt. Gen. ii. 167. - Sterile hills and plains, Nebraska to Colorado and the borders of New Mexico.

B. absinthifólia, Bentr. About a foot high from an herbaceous root or barely suffrutescent base, diffusely branched, tomentulose-canescent, and with sparsely corymbose-paniculate heads on slender peduncles: leaves opposite and the upper alternate, pedately or sometimes pinnately 3-5-parted into narrowly linear or lanceolate divisions and lobes: involucre more lax; its bracts oblong-spatulate or lanceolate with narrowed base: rays 9 to 12, lanceolate-oblong, much exceeding the disk: akenes slender, pubescent: pappus nearly equalling the proper corolla-tube, its paleæ more dilated and broadly thin-scarious above. Pl. Hartw: 18. - Arizona, near Tucson, Palmer, Lemmon. (Forms almost as slender and narrow-leaved as the plant of Northern Mexico.)

Var. dealbáta, GRax. Perhaps more lignescent at base, more whitened with fine pannose tomentum: leaves less divided, commonly only 3-cleft into lanceolate or linearoblong lobes, or some lower ones oblong-lanceolate and entire. - Pl. Wright. i. 121; Proc. Am. Acad. xix. 27. B. dealbata, Gray, Pl. Fendl. 99. - Dry plains, W. Texas to Arizona. (Adj. Mex.)

\$ 2. Herbaceous from a perennial caudex: leaves all alternate and entire, coriaceous: paleæ of the pappus about 10, linear-lanceolate, and with a distinct excurrent or percurrent costa. — $\$$ Platyschkuhria, Gray.

B. nudicaúlis, Grar. Cinereous-puberulent and glabrate, upper part of the scapiform stem and involucre minutely glandular, a span or two high : leaves nęarly all radical, oval or spatulate-oblong (an inch or more long), tapering into a slender petiole: heads solitary or few and somewhat corymbosely paniculate, nearly half-inch high: involucre hemispherical, of about 10 oblong bracts: rays 6 to 9, oblong: pappus fully half the length of the cuneatelinear sparsely hairy akene; the thin margins of the palex of the pappus erose, and the short-excurrent awn barbellate-hispidulous. - Proc. Am. Acad. xix. 27. - Schkuhria (Platyschkuhria) integrifolia, Gray in Am. Nat. viii. 213, \& Proc. Am. Acad. ix. 198, excl. var. Wind River Mountains, N. W. Wyoming, Parry.

B. oblongifólia, GRAX, 1. c. Smaller: stems sparsely leafy almost to the 3-cephalous naked inflorescence: leaves narrowly oblong: head only 4 lines high, narrow : paleæ of the pappus firmer, smoother, and with entire edges, little shorter than the glabrate akene. Schkuhria integrifolia, var. oblongifolia, Gray in Am. Nat. l. c. - On the San Juan and Rio Colorado, near their junction, S. E. Utah or adjacent Colorado, Newberry, Brandegee.

§3. Annuals, with once or twice palmately or pedately divided leaves: akenes mostly hirsute along the slender attenuate base, at least on the angles. - Achyropappus, HBK.

* Leaves mainly opposite, at least all the lower ones, their divisions narrowly linear: pappus of broad and very obtuse paleæ, scarious above, callous-thickened and opaque at base, as in $\S 1$ : ray-flowers occasionally wanting. - Gray, Proc. Am. Acad. xix. 27. Achyropappus, HBK., DC. 
B. Bigelóvii, GRAY. Slender, a foot high, diffuse, strigose-puberulent : leaves 3-parted and the divisions sometimes 2-3-parted into linear-filiform segments and lobes : peduncles elongated, filiform : involucre hemispherical, 2 lines high; its bracts 8 or 9 , oval and tapering to both ends, viscidly hirsute : rays as many, oblong: tube of disk-corollas hirsute with wiscid hairs; throat broadly cyathiform: palex of the pappus broadly cuneate-obovate, half the length of the corolla-tube, callous-thickened only at base. - Bot. Mex. Bound. 96; Proc. Am. Acad. xix. l. c. Schkuhria (Achyropappus) Bigelovii, Gray, Proc. Am. Acad. ix. 199. - S. W. Texas, in the valley of the Limpio, Bigelow.

B. Neo-Mexicána, Grax. A span or more high, minutely puberulent : leaves 3-7-parted into narrow linear divisions; uppermost little shorter than the slender peduncles: involucre of about 10 sparingly pubescent spatulate bracts : rays none: disk-corollas small, with glandular tube, almost equalled by the obovate palex of the pappus, which are much thickened at and near the base.-Proc. Am. Acad. xix. 27. Schkuhria Veo.Mexicana, Gray, Pl. Fendl. 96, \& Proc. Am. Acad. ix. 199. Amblyopappus Neo-Mexicanus, Gray, Pacif. R. Rep. iv. 106. - Northern New Mexico and S. Colorado, Fendler, Bigelow, Parry, \&c.

* *. Leares mainly opposite, with linear divisions: flowers perhaps white: palere of the pappus lanceolate and with a complete costa.

B. Woodhoúsii, Gray. Low, cinereous-puberulent: peduncles hardly longer than the heads: leaves thickish, 3-parted, and the middle divisions sometimes with a pair of lateral lobes: involucre 3 lines high; its bracts 8 or 9, oblong-obovate, obtuse: rays 8 or 9 , with oblong ligules a line or two long, hardly surpassing the disk-flowers : palea of the pappus 8 to 10 , with hyaline margins and a strong opaque costa, which reaches the acute apex. Proc. Am. Acad. xix. 28. - Achyropappus Woodhousii, Gray, Proc. Am. Acad. vi. 546. Schkuhria Woodhousii, Gray, Proc. Am. Acad. ix. 199. - Northern part of New Mexico, Ir. Troodhouse.

* * Leares all or mostly alternate, naked-petioled, 2-3-ternately divided or parted; the divisions from linear-spatulate to obovate, comparatively short: heads loosely cymose-paniculate at the naked summit of the erect stems, hemispherical, yellow-flowered, with oblong or obovate exserted rays: paleæ of the pappus oblong to narrowly lanceolate, with a distinct procurrent or excurrent costa, or the pappus wanting: akenes tetragonal-clavate, or those of the ray slender obpyramidal with 4 sides.

+ Tube of the disk-corollas glandular but not hirsute; lobes ovate or oblong, shorter than the dilated throat: pappus present.

B. pedáta, Gr.4. A foot or two high, cinereous-puberulent : leaves pedately divided, commonly into 3 petiolulate obovate or cuneate segments, of which the lateral are 2-parted and the middle 3-7-lobed; the lobes obovate or broadly oblong, short : heads 5 lines high : bracts of the involucre oblong, obtuse, shorter than the disk: rays about 12 , oblong : paler of the pappus 10 to 12, spatulate-oblong, with costa vanishing near the obtuse or retuse summit. Pl. Wright. i. 23, \& Proc. Am. Acad. xix. 28. Schkuhria (Achyropappus) pedata, Gray, Proc. Am. Acad. ix. 199. - S. W. Texas, on the Limpio and Rio Grande, Wright, Bigelow.

B. biternáta, Gray. More pubescent and slender: leaves biternately dissected into linear and obtuse or somewhat spatulate segments and lobes, the primary ones slightly petiolulate : heads 4 lines high: bracts of the involncre obovate: rays 8 or 10 , broadly obovate: palex of the pappus 12 to 14 , longer and narrower, about equalling the corolla-tube, those of the outer flowers obovate and obtuse, with costa evanescent below the apex; of the inner flowers longer, elongated-lanceolate, and with costa excurrent into an awn-like cusp; in intermediate flowers of intermediate character. - Pl. Wright. ii. 95, \& Proc. Am. Acad. I. c. Schkuhria (Achyropappus) biternata, Gray, Proc. Am. Acad. ix. 199. - Borders of W. Texas and adjacent New Mexico, Wright, Bigelow, Thurber. May pass into the preceding.

++ Tube of disk-corollas viscid-hirsute; the limb cleft into narrow lobes which are much longer than the throat and little shorter than the tube: pappus none.

B. chrysanthemoídes, Grar. Taller and stouter, 1 to 4 feet high, puberulent or below glabrous, above with the flowering branches and short peduncles glandular-pubescent and viscid: leaves 1-3-ternately divided or parted; the lobes from oblong and obtuse to nearly linear: heads 5 or 6 lines high and broad: bracts of the involucre 16 to 20, crowded, from oblong-lanceolate to obovate-oblong, most of them conspicuously acuminate: rays as many, obovate-oblong: akenes obscurely striate on the four narrow faces, the whole apex covered 
by the base of the corolla: - Proc. Am. Acad, xix. 28. Amauria ? dissecta, Gray, P1. Ferdl. 104. Villanova chrysanthemoides, Gray, P1. Wright. ii. 96. - Along mountain water-courses, Colorado to S. Arizona; first coll. by Fremont.

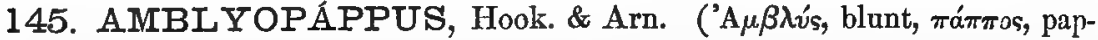
pus.) -Jour. Bot. iii. 321 ; Benth. \& Hook. Gen. ii. 406.'A Aromia, Nutt. Trans. Am. Phil. Soc. vii. 395. Infantea, Remy, in Gay, Fl. Chil. iv. 257, t. 48. Low annual (of Chili, and Schkuhria pusilla, Wedd., is perhaps a second species in Bolivia), probably introduced into California.

A. pusíllus, Hook. \& ARn. l. c. A span or two high, nearly glabrous, balsamic-viscid, paniculately or corymbosely branched, with small short-peduncled heads terminating the branches: leaves linear and alternate, entire or lower pinnately 3-5-parted and opposite: involucre 2 lines high, equalling the yellowish flowers. - Aromia tenuifolia, Nutt. 1. c. Infuntea Chilensis, Remy, in Gay, 1. c. - Around San Diego, California, and southward. (Chili.)

146. SCHKÚHRIA, Roth. (Christian Schkuhr, of Wittenberg.) Slender and paniculately much branched annuals (Mexican and Andean), somewhat pubescent, never tomentose; the small pedunculate heads of yellow (rarely purplish) flowers terminating the branchlets: leaves alternate, or the lower opposite, pinnately 3-7-parted or uppermost entire, the divisions and rhachis filiform. Herbage sometimes minutely resinous-atomiferous and the leaves impressed-punctate. - Roth, Catalecta Bot. i. 116 ; Cass. ; Less., \&c. Tetracarpum, Mœnch, Meth. Suppl. 241. Schkuhria \& Hopkirkia, DC. Prodr. v. 654, 660. Schkuhria, Benth. \& Hook. Gen. ii. 403, in part, excl. Achyropappus, \&c. - Our species, and S. Wislizeni of Northern Mexico, form a section (the genus Hopkirkia, DC.), with leaves more commonly only 3-parted and on the branches entire, heads only 3-5-flowered, with a single ray-flower or none: obpyramidal akenes in length only about double the width of the summit, their angles very densely long-villous, some hairs also on the faces: scarious tips of involucral bracts purple-tinged: stems diffusely corymbose-paniculate.

S. Hopkírkia, Gray. Pappus equalling the corolla; its paleæ all alike, ovate-oblong, with percurrent costa projecting as a cusp: faces of the akene conspicuously 3-nerved. - Pl. Wright. ii. 94. Hopkirkia anthemidea, DC. Prodr. v. 660.-S. Arizona, Wright, Lemmon. (Northern Mex., Hanke.)

S. Wrightii, Grax, 1. c. Pappus shorter than the corolla; its paleæ all obovate and obtuse or erose-truncate, destitute of costa, merely thickened at very base : akenes rather less thick and faces less striate. - S. Arizona, Wright, Thurber, Lemmon.

147. HYMENOTHRIX, Gray. (From i $\mu^{\prime} \dot{\gamma}^{\prime}$, membrane, $\theta \rho i \xi$, bristle, the pappus a combination of awn and thin palea.) - Herbs of Arizona and vicinity, glabrous or somewhat pubescent; with probably annual or perhaps perennial root, branching stems of 1 to 3 feet high, alternate leaves once to thrice parted into linear divisions or lobes, and numerous corymbosely cymose heads (about one-third inch high); the corollas yellow or white and purple, strikingly different in the two species.

H. Wislizéni, Gray. Glabrous: lobes of the leaves often spatulate-linear and broadish: heads radiate: involucre of comparatively narrow acutish and yellow-tinged bracts, hardly any accessory ones: corollas yellow; those of the disk with oblong lobes only half the length of the narrowly obconical throat: style-tips pointless: akenes rather slender, barely pubescent: pappus-awns' narrowly margined below, naked and hispidulous above. - Pl. Fendl. 
102, \& Pl. Wright. ii. 97 ; Rothrock in Wheeler Rep. vi. 168. - River-bottoms, \&c., S. Arizona and New Mexico; first coll. by Wislizenus. (Adj. Mex.)

H. Wríghtii, Gray. Leaves with very narrow linear or almost filiform divisions, the lower cauline hirsute: heads broader: involucre of obovate-oblong and very obtuse purpletinged bracts, and a few smaller narrow accessory ones: rays none: disk-corollas white or purplish, 5-parted almost down to the narrow tube into oblong-linear widely spreading lobes : style-tips with a slender-subulate cusp: akenes broader, villous: pappus of broader palex and smoother awned tips. - Pl. Wright. ii. 97 ; Torr. in Sitgreaves Rep. t. 6 ; Rothrock, 1. c. - Along streams, S. Arizona, Wright, Thurber, \&c. (Lower California, Orcutt.)

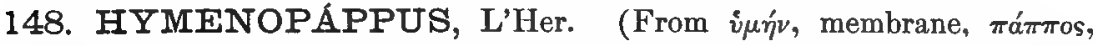
pappus, the latter of hyaline paleæ.) - North American and North Mexican herbs (chiefly of the prairies and plains), perennial, biennial, or some perhaps winter annuals, mostly floccose-tomentose and with sulcate-angled erect stems, alternate 1-2-pinnatifid or parted leaves, the lower sometimes entire, and corymbosely cymose or solitary pedunculate middle-sized heads of white or yellow flowers. Leaves in some species evidently impressed-punctate. When the corolla is deeply cleft the nerves of its lobes are deeply intramarginal. Fl. spring. "L'Her. Diss. cum icon."; Michx. FI. ii. 103 ; Cass. Dict. lv. 266, 279 ; DC. Prodr. v. 658 ; Gray, Proc. Am. Acad. xix. 29.

* Lobes of the white corolla as long as the short-campanulate or crateriform throat; the tube long and slender, much exceeding the short pappus: stamens with even the filaments mostly exserted: akenes merely pubescent, clavate-obpyramidal, with much thickened summit and stipitiform base: involucre of comparatively lax and partly white-petaloid bracts: heads corymbiformcymose and rather numerous, on short peduncles: comparatively Eastern species, biennials, 1 to 3 feet high.

- Pappus of very small oborate or roundish nerveless palex forming a crown, much shorter than the breadth of the summit of the merely pubescent akene, often minute, even obsolete: floccose or pannose tomentum thin, sometimes deciduous.

H. scabiośeus, L’Hez. Leafy to the top, thinly tomentose: radical leaves pinnately parted or occasionally entire, cauline irregularly 1-2-pinnately parted into broadly or narrowly linear lobes: heads about 5 lines high : the broad involucre somewhat radiate-expanded, its mainly white bracts roundish-obovate, at first surpassing the disk : akenes short-pubescent. - Michx. Fl. ii: 104; Torr. \& Gray, Fl. ii. 372. Rothia Carolinensis, Lam. Jour. Hist. Nat. i. 16, t. 1 , \& Ill. t. 667 . - Sandy pine-barrens, Middle Florida to S. Carolina, and west to Illinois and Texas.

H. corymbósus, Torr. \& Gray. More slender, smaller, and glabrate, naked above: lower leaves 2-pinnately and the small upper ones mostly simply parted into narrowly linear acute divisions and lobes: heads 3 or 4 lines high: bracts of the involucre much smaller, shorter than the flowers, obovate-oblong, the petaloid summit only greenish-white: akenes puberulent. - Fl. ii. 372. - Prairies, Nebraska to Arkansas and Texas. 'The var. Nuttallii, Torr. \& Gray, as to plant in herb. Torr., belongs here, but the $H$. tenuifolius of Nuttall in other herbaria is Pursh's species.

++ Pappus of larger spatulate-obovate palex, in length vearly equalling the breadth of the summit of the villous-pubescent akene, partly traversed by a callous-thickened axis or obscure costa.

H. artemisizélíus, DC. Pannosely or somewhat floccosely white-tomentose, or somewhat denudate in age: leaves from simply pinatifid or lyrately few-lobed, and sometimes quite entire (lanceolate or oblong), to bipinnately parted into broadly linear or narrowly oblong obtuse divisions and lobes: heads 4 lines high: bracts of the involucre obovateoblong, about equalling the disk-flowers, dull white, lower half green. - Prodr. v. 658; Torr. \& Gray, Fl. ii. 372. - Texas; first coll. by Berlandier.

* Lobes of the corolla more or less shorter than the throat: pappus conspicuous, of spatulate or narrow palex, which have a manifest costa or thicker opaque axis, this evanescent near or below the obtuse or retuse apex: akenes villous: involucre greener, less petaloid. 
- Stems leafy, from a biennial root a foot or two high: heads rather numerous and corymbosely cymose, on rather short slender periuncles: corolla-tube slender, throat short, and lobes rather long.

H. flavéscens, Grax. Densely white-tomentose, sometimes glabrate in age: leaves once or twice or even thrice pinnately parted; the divisions or lobes from narrowly to rather broadly linear: heads 4 or 5 lines high: bracts of the involucre roundish-obovate or ovate, with greenish-white or barely yellowish margins: corolla from yellowish to yellow, and short-campanulate throat almost equalled by the lobes: akenes rather short-villous: palex of the pappus spatulate, usually ouly half the length of the slender corolla-tube. - Pl. Fendl. 97, \& Pl. Wright. i. 121, ii. 94 (excl. the last var.); Rothrock in Wheeler Exped. vi. 167, where one form is printed "H. canescens." $H$. robustus, Greene, Bull. Torr. Club, ix. 63, stout specimens of the form with finely much divided leaves and somewhat reduced pappus. - Sandy plains and valleys, W. 'Texas and New Mexico to Arizona. (Adj. Mex.)

H. tenuifólius, Pursh. Lightly tomentose, or soon glabrate and green: leaves rather rigid, once or twice (or radical thrice) pinnately parted into very narrowly linear or filiform divisions, their margins soon revolute: heads only 3 or 4 lines high: involucre more erect and close; its bracts oblong-obovate, greenish with whitish apex and margins : corolla dull white; its lobes moderately shorter than the throat: palea of the pappus shorter than the corolla-tube, oblong-spatulate: akenes long-villous. - Fl. ii. 742; Nutt. Gen. ii. 139; DC. Prodr. v. 658; Torr. \& Gray, 1. c.-Plains, from Nebraska to Arkansas, Texas, and apparently also in Utah.

+ + Stems clustered on a perennial caudex, leafy below, naked above, bearing few or solitary comparatively large heads.

H. filifólius, Hook. Tomentose-canescent, or somewhat denudate and glabrate: stems a span to a foot high, sometimes scapiform : leaves nearly of $H$. tenuifolius, or of more filiform rigid divisions: heads a third to half inch high: bracts of the involucre oblong or obovateoblong, largely green or else white-woolly, the tips whitish or purplish-tinged: corolla yellowish-white or sometimes clear yellow, its reflexed lobes or teeth very much shorter than the throat: akenes very long-villous: paleæ of the pappus equalling or much shorter than the tube of the corolla, but commonly equalled by the villosity of the akene. - Fl. i. 317, but the pappus is not "extremely minute." $H$. flifolius \& $H$. luteus, Nutt. Trans. Am. Phil. Soc. 1. c.; Torr. \& Gray, Fl. 1. c. H. tenuifolius, Eaton in Bot. King Exp. 173.-Rocky Mountain plains, from Nebraska and Montana to New Mexico, mountains of Arizona, and southern borders of California. The forms referable to $H$. luteus are more white-tomentose, have shorter and more crowded lobes to the leaves, and southward have almost scapiform stems. Northeasteru forms are greener, more leafy, and with smaller heads, approaching H. tenuifolius.

* * Lobes of the honey-colored or yellow corolla much shorter than the throat: akenes broad, the faces almost destitute of nerves: pappus obsolete or wanting: root perennial: fl. July-Oct.

H. Mexicánus, Grax. Densely floccose-tomentose, sometimes denudate in age, a foot or two high from a thick root or caudex : radical leaves from lanceolate to spatulate, and from entire to pinnately parted, the lobes entire; upper cauline leaves linear or lanceolate, often entire: heads few or several and loosely corymbose-paniculate, 4 lines high: bracts of the involucre oval or ovate, green' with yellowish tips: akenes slightly pubescent and glabrate. - Proc. Am. Acad. xix. 29. H. flavescens, var.? Gray, Pl. Wright. ii. 94. - Mountain ravines, New Mexico, Wright, Greene, Rusby. (Mountains near San Luis Potosi, Mexico, these certainly perennial, Schaffiner.)

149. FLORESTINA, Cass. (Probably dedicated to a female friend.) Slender annuals (of Mexico and its northern borders), leafy-stemmed, loosely paniculately branched, pubescent and above beset with stipitate glands: all but the lowest leaves alternate, petiolate, simply palmately or pedately divided into entire segments, rarely entire: heads loosely paniculate, quarter-inch high: flowers white or flesh-color, in summer. - Bull. Philom. 1815, \& Dict. xvii. 155, t. 86 ; DC. Prodr. v. 655, excl. spec. - Consists of the Mexican F. pedata. Cass., and the following. 
F. tripteris, DC. 1. c. Lowest leaves commonly ovate or oblong and entire; others of 3 oval or oblong or the upper linear leaflets : tips of involucral bracts and flowers usually dull white : anther-tips acutish. - Gray, Pl. Wright. i. 121. - S. Texas; first coll. by Berlandier. (Adj. Mex.)

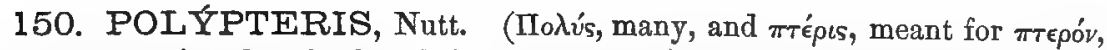
wing; many-winged or feathered, i. e. the pappus.) - Southeastern N. American herbs (entering Mexico), more or less scabrous-pubescent; with undivided and mostly entire petiolate leaves, all or the upper alternate, and loosely corymbosecymose or paniculate and pedunculate heads of rose-purple or flesh-colored flowers, in summer and autumn. - Gen. ii. 139 ; Ell. Sk. ii. 314 (not of DC., which was a Gaillardia); Nutt. Trans. Am. Phil. Soc. ser. 2, 377 ; Gray, Proc. Am. Acad. xix. 30. Part of Palafoxia, Less., DC., \&c.

$\S 1$. Heads homogamous, middle-sized or small : bracts of the involucre herbaceous up to the small sphacelate colored tip: corollas 5-parted nearly down to the slender tube: akenes narrowly obpyramidal: root annual. (Nearest to $F$ lorestina.)

P. callósa, Gray, 1. c. Slender, paniculately branched, a foot or two high : leaves linear, sligbtly petioled: peduncles glandular: involucre turbinate, 10-12-flowered, quarter-inch high, of 8 or 10 linear-oblong bracts : akenes minutely pubescent or glabrous: paleæ of the pappus all short, obovate or roundish, with costate-thickened centre seldom reaching the obtuse or erose and retuse apex, occasionally minute or wholly wanting. - Stevia callosa, Nutt. Jour. Acad. Philad. ii. 121 ; Bart. FI. Am. Sept. t. 46. Florestina callosa, DC. Prodr. v. 655. Palaforia callosa, Torr. \& Gray, Fl. ii. 369. - Low or dry ground, Arkansas to Texas; first coll. by Nuttall.

P. Tezána, Gray, l. c. Stouter: leaves from lanceolate-linear to lanceolate-oblong (at least below), distinctly petioled : peduncles less glandular : involucre campanulate or broader, 20-30-flowered, 3 to 5 lines high, of 8 to 12 spatulate-oblong bracts: palex of the pappus from oblong-ovate to oblong-lanceolate, with slender nearly complete or slightly excurrent costa, sometimes almost as long as the akene, in the outer flowers often much shorter. Palafoxia Texana, DC. Prodr. v. 124; Torr. \& Gray, Fl. l. c.-River-banks, Texas; first coll. by Berlandier. (Adj. Mex.)

\$2. Heads heterogamous, larger, with palmately 3-lobed rays: disk-corollas parted not quite to the filiform tube: bracts of the involucre herbaceous up to the small and narrow sphacelate colored tip: akenes slender: root annual.

P. Hookeriána, GraY, 1. c. Stouter, 1 to 4 feet high, above glaudular-pubescent and somewhat viscid: leaves from narrowly to broadly lanceolate, mostly 3-nerved below : involucre many-flowered, broad, half-inch or more high, of 12 to 16 lanceolate bracts in two series, the onter looser and often wholly herbaceous, inner with purplish tips : ray-flowers 8 to 10 , the deeply 3-cleft rose-red rays half-inch long, but sometimes reduced or abortive: pappus in the ray a crown of 6 to 8 short and obtuse rather rigid spatulate palex; in the disk of narrowly lanceolate thin palea, traversed by an excurrent costa, attenuate at apex into a slender point or short awn, nearly of the length of the akene. - Stevia sphacelata (Nutt.), Torr. in Ann. Lyc. N. Y. ii. 214, Palafoxia Texana, Hook. Ic. Pl. t. 148, not DC. P. Hookeriana, Torr. \& Gray, Fl. ii. 368; Hook. f. Bot. Mag. t. 5549, with var. subradiata, a reduced state. - Sandy plains of Nebraska to Texas. (Adj. Mex.)

§ 3. Heads homogamous, rather large: corollas with the base of 5-parted limb forming a short-campanulate throat: involucre more imbricated and whitishscarious, glabrous : akenes slender: root perennial. - Polypteris, Nutt.

P. integrifólia, NuTr. Not glandular: stems 2 to 5 feet high, fastigiately corymbose at summit, almost glabrous: leaves scabrous, lanceolate and obtuse, upper ones linear, lowest spatulate-oblong to obovate: heads fully half-inch high, many-flowered : principal bracts of 
the involucre obovate-spatulate, very obtuse, thin, mainly whitish, some. outer or accessory bracts narrower and shorter, partly herbaceous: corollas white or flesh-colof: palex of the pappus little shorter than the akenes, linear-lanceolate, gradually attenuate, more or less pointed by the excurrent tip of the strong costa. - Gen. ii. 139; Ell. Sk. ii. 314, not DC. Paleolaria fastigiata, Less. Syn. 156. Palafoxia fastigiata, DC. Prodr. v. 125. P. integrifolia, Torr. \& Gray, Fl. ii. 269. - Pine barrens, Georgia and Florida; first coll. by $D_{r}$. Baldwin.

151. PALAFÓXIA, Lag. (José Palafox, noted Spanish general.) - Herbaceous or suffruticose plants (of Mexico and the U. S. borders); with branching stems, rather large scattered or loosely cymosely disposed pedunculate heads of flesh-colored or whitish flowers; the leaves linear to oblong, alternate, entire, the lower short-petioled. - Nov. Gen. \& Spec. 26 (Elench. Hort. Madr. 1815); Gray, Proc. Am. Acad. xix. 31. Palafoxia in part, Less., DC., Benth. \& Hook.

P. Latiforia, DC. Prodr. v. 125, of Southern Mexico, is unknown to us, and by its opposite cordate leaves and obovate involucral bracts is probably of some other genus.

* Anomalous species, connecting with Polypteris.

P. Feáyi, Gray. A foot or two high, suffruticose at base, very leafy to near the summit, minutely scabrous - leaves short (little over inch long), oblong or ovate-oblong and rounded at both ends, or uppermost lanceolate and acutish, thickish, 3-nerved at base: heads corymbosely cymose, over half-inch high: involucre campanulate, about half the length of the flowers; its bracts spatulate-linear, at apex truncate-obtuse and somewhat purplish-sphacelate: corollas with oblong lobes fully half the length of the cylindraceous throat: pappus shorter than the corolla-tube and several times shorter than the glabrate akene, of 8 oblong rigid pointless lacerately scarious-edged palea (comparable with those of some outermost flowers of the following).-Proc. Am. Acad. xii. 59, xix. 31.-Coast of S. Florida, in sandy soil, Feay, Chapman, Curtiss, no. 1507.

* * Genuine species, with narrow and paniculately scattered heads, narrowly linear involucral bracts, these in age usually concave and applied to the subtended akenes.

P. lineáris, LaG. 1. c. Flowering as an annual, but becoming perennial and frutescent, strigose-cinereous and partly hirsute or hispid, slender flowering branches sometimes glanduliferous: leaves linear, or lower ones lanceolate, more or less canescent: heads about inch long, 15-30-flowered (or by depauperation 10-12-flowered) · corolla-lobes oblong-linear, half the length of the throat: pappus of 4 (sometimes 5) linear hyaline palex with strong and rigid excurrent costa, and little shorter than the slender akenes, or sometimes 2 to 4 additional and shorter blunt ones, or in the outer flowers all reduced, short, and of firmer texture, with imperfect costa, or abortive. - DC. Prodr. v. 124; Hook. Bot. Mag. t. 2132. Ageratum lineare, Cav. Ic. iii. 3, t. 205. Paleolaria carnea, Cass. Bull. Philom. 1816, \& Dict. P. leucophylla, Gray, Proc. Am. Acad. viii. 291, \& Bot. Calif. i. 388, a shrubby form with reduced pappus, from seeds of which were raised plants having nearly the ordinary pappus of the species, which, although flowering as an herb with seemingly annual root along the Mexican border, was originally described as shrubby. - On the Colorado near Fort Yuma, \&c., S. California, and Arizona. (Mex.)

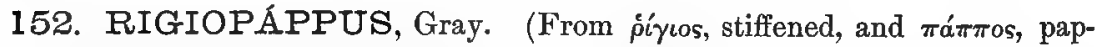
pus.) - Proc. Am. Acad. vi. 548, Bot. Calif. i. 387 ; Benth. \& Hook. Gen. ii. 406. - Single but variable species.

R. leptócladus, Grax, 1. c. Slender annual, a span to a foot high, minutely hirsute-pubescent to almost glabrous, paniculately or subcorymbosely branched : branches commonly filiform, elongated, and leafless below, smooth, simple or proliferous, bearing solitary heads: leaves all alternate, very narrowly linear, sessile, erect, entire, those of the branches near the heads small and subulate : involucre 3 lines high : flowers yellow but often changing to purple or whitish: paleæ rather than awns of the pappus from half to two-thirds the length of the akene, 3 to 5 , occasionally only 2 or 1, or rarely wanting. - Dry ground, interior region of Washington Terr. to the middle of California and Nevada ; first coll. by Lyall. 
Var. longiaristátus. A small form: involucre only 2 lines high: pappus of (mostly 3) more slender awns, subulate-dilated at base, much longer than the corolla, rather longer than the akene. - Rattlesnake Bar, California, Mrs. Curran.

153. CH Æ̇NÁCTIS, DC. (Xaivw, to gape, and ákтis, ray, the enlarging orifice and limb of the marginal corollas in most species simulating a kind of ray.) - Herbaceous or rarely suffrutescent (Western N. American); with alternate mostly pinnately dissected leaves, and pedunculate solitary or sometimes cymosely disposed heads of yellow, white, or flesh-colored flowers. Pappus more commonly shorter or of fewer palex in the outer flowers. Akenes pubescent, rarely glabrate. - Prodr. v. 659 ; Benth. \& Ilook. Gen. ii. 401; Gray, Proc. Am. Acad. vi. 545, x. 73 .

§ 1. Снænactis proper. Pappus of entire or merely erose persistent paleæ, rarely obsolete: akenes more or less tetragonal or terete, slender.

* Corollas yellow, the marginal ones with enlarged throat and limb, somewhat unequally or as if palmately 5-lobed: annuals, mostly winter annuals, flowering in spriug.

+ Pappus of 4 (rarely if ever " 5 or 6 ") nearly equal narrowly oblong or oblong-lanceolate acutish palex, at least the inner attaining to the throat of the corolla.

C. lanósa, DC. Floccosely white-woolly when young, flowering from near the base with ( 3 to 8 inches) long naked peduncles, the earliest scapiform: leaves thickish, simply pinnately parted into a few narrowly linear (rarely again parted) lobes no wider than the rhachis, or uppermost entire: heads half-inch high: involucral bracts nearly linear: marginal flowers moderately ampliate, not surpassing the disk. - Prodr. 1. c.; Torr. \& Gray, Fl. ii. 370; Gray, Bot. Calif. i. 389. - California, common from Monterey southward to San Bernardino, \&c.

C. glabriúscula, DC. Taller, stouter, more caulescent, a foot or more high, thinly floccose, at length denudate, branching above, and with stout sometimes elongated peduncles bearing solitary heads of two-thirds to three-fourths inch high: leaves with more numerous and irregular lobes: bracts of the involucre broader, thickish, glabrate, obtuse : marginal corollas with much ampliate and more palmate limb, surpassing the disk. - Prodr. 1. c.; Gray, 1. c. C. denudata, Nutt. Pl. Gamb. 177. The var. megacephala, Gray, Pacif. R. Rep. iv. 104, is merely a larger form. - California, from valley of the Sacramento southward.

C. tenuifólia, Nuтr. Somewhat white-tomentulose when young, glabrate, loosely branched, often diffuse, bearing scattered or paniculately disposed heads (a third of an inch high) on short slender peduncles : leaves once or twice pinnately parted into irregular and small linear or oblong or sometimes nearly filiform lobes : involucral bracts narrow, rather rigid: limb of marginal corollas short, not surpassing the disk. - Trans. Am. Phil. Soc. 1. ․ 375 ; Torr. \& Gray, 1. c.; Gray, Bot. Calif. 1. c. C. filifolia, Gray, Pl. Fendl. 98, the most slender-leaved form. On the sea-shore occurs an opposite extreme, witl primary divisions of the leaves pinnatifid into very short and thickish lobes. - Coast of California, from Santa Barbara to San Diego; also San Bernardino.

$$
++ \text { Pappus of very obtuse mostly unequal paleæ, or obsolete. }
$$

C. heterocárpha, Grax. Lightly floccose, soon denudate, a span or two high, simple or sparingly branched: leaves pinnately or sometimes bipinnately parted into irregular and unequal rather crowded and short divisions and lobes: heads half-inch high, mostly on rather long peduncles terminating stem and branches: bracts of the involucre broadly linear or sometimes wider: limb of the marginal flowers conspicuously ampliate, surpassing the disk: pappus of inner flowers of 4 elliptical-oblong palex fully half the length of the corolla, and with 4 or fewer alternate outer and roundish very short ones, but these occasionally wanting; in the outermost flowers all shorter or very short. - Pl. Fend1. 98, \& Bot. Calif. 1. c. Var. tanacetifolia, Gray, 1. c. (C. tanacetifolia, Gray, Proc. Am. Acad. vi. 545), proves to be only a stunted and condensed form. - California, from the Upper Sacramento and Lake Co. to San Bernardino Co.; first coll. by Hartweg.

C. Névii, Gray, Proc. Am. Acad. xix. 30. Dwarf, rather stout, puberulent, or leaves nearly glabrous: peduncles short: marginal corollas little ampliate : pappus of a few minute denti- 
form vestiges : otherwise resembles the preceding, so far as an insufficient specimen shows. - Coll, in Idaho, 1876, Nevius.

* Corollas white or pale flesh-colored.

+ Marginal ones with throat and limb manifestly enlarged, and unequally 5-lobed or even palmately ligulate: bracts of the involucre linear, obtuse or acutish: pappus of 4 palex: winter aunuals.

C. Fremónti, Gray, 1. c. Glabrate, the slight woolliness caducous, or glabrous, except the puberulent or hispidulous peduncles, a foot or less high, rather stout: leaves thickish, narrowly linear, many entire, some with 2 to 5 similar linear lobes: heads half or two-thirds inch high, terminating rather simple erect branches : bracts of the involucre thickish, rather acute, with prominent midrib : marginal corollas comparatively large and conspicuous, lignlately palmate, not rarely developing a cuneate almost equally 4-5-cleft ligule (of 3 lines in length): paleæ of the pappus linear-lanceolate, nearly equalling disk-corolla, with manifestly thickened axis at base forming a vanishing costa. - Desert of the Mohave and Lower Colorado, California, and adjacent Nevada and Arizona, Fremont (imperfect specimen), Newberry, Parish, Lemmon, \&c. Partly confounded in Bot. Calif. with the next.

C. stevioídes, Hoor. \& ArN. Floccose-tomentose, glabrate in age, seldom a foot high, freely and loosely branched, bearing numerous somewhat cymosely disposed heads (of halfinch in height) on short slender peduncles: leaves 1-2-pinnately parted into short linear lobes, uppermost rarely entire: bracts of involucre narrowly linear, obtuse, with obscure midrib: marginal corollas with moderately ampliate unequally 5-lobed limb, not surpassing the disk: paleæ of the pappus scarcely thickened at base, those of the inner flowers oblong-lanceolate and shorter than the corolla, of the outer ones ovate or oblong, often unequal, sometimes much shorter. - Bot. Beech. 353 ; Torr. \& Gray, Fl. ii. 371 ; Eaton in Bot. King Exp. 172. - Dry interior region, Utah and S. Idaho, to eastern side of Sierra Nevada and through Arizona; first coll. by Tolmie.

C. brachypáppa, GraY. Resembles the preceding : leaves perhaps thicker : heads broader: involucral bracts with prominent midrib: paleæ of pappus alike in inner and outermost flowers, quadrate or slightly cuneate, very truncate, not longer than the short proper corollatube, barely one fourth the length of the akene. - Proc. Am. Acad. viii. 390, \& Bot. Calif. i. 389. - S. E. Nevada, in the Pahranagat Mountains, Miss Searls.

+ + Marginal corollas little enlarged, nearly regular: receptacle commonly with a few fimbrilla or bracts in the form of setifor'm awns: bracts of the receptacle very narrowly linear, cuspidately or setaceously acuminate: pappus of 4 paleæ: winter annuals, minutely puberulent, with no woolliness.

C. carphoclínia, Gray. A foot or less high, diffusely much branched, slender, bearing numerous scattered heads (barely half-inch high) on short filiform peduncles : leaves 1-2-pinnately parted into almost filiform lobes: involucre 30-40-flowered: awns on the receptacle 5 to 10 among and nearly equalling the flowers, rigid, persistent: paleæ of the pappus ovatelanceolate, acute or acuminate, and little or moderately shorter than the inner corollas, or in the outer much shorter, occasionally very short. - Bot. Mex. Bound. 94, \& Bot. Calif. I. . - Arid districts, W. Arizona and S. Utah to S. E. California; first coll. by Gen. Thomas.

C. attenuáta, Grax. More slender, with narrow 15-20-flowered heads: ray-corollas hardly at all enlarged: hardly any fimbrillæ on the receptacle: paleæ of the pappus very short, broadly obovate-cuneate and truncate: otherwise nearly like the preceding.-Proc. Am. Acad. x. 73, \& Bot. Calif. 1. c. - Ehrenberg, Arizona, Janvier, through Canby.

+++ Marginal corollas not larger than the others (or only slightly so in $C$. Xantiana). receptacle quite naked: involucral bracts pointless, narrowly linear, rather loose, the midrib obvious: pappus of 4 conspicuous palex and usually 2 to 4 small alternating outer ones: leaves simply pinnately parted, with divisions entire or merely 1-2-toothed: winter annuals.

C. Xantiána, Grax. Stont, often a foot or more high, tomentulose when young, some glabrate: ascending simple branches terminated by large (three-fourths to inch long) solitary many-flowered heads on thick often fistulous peduncles: leaves with a few narrowly linear distant lobes, or some entire : corollas with short oval or oblong lobes a little bearded externally, or in the margin rather broader and more spreading, but equal : anthers partly exserted (in the manner of the genus) : pappus of 4 lanceolate paleæ little shorter than the corolla, and of as many very short obovate or obcordate ones.-Proc. Am. Acad. vi. 545, 
x. 74, \& Bot. Calif. i. 390, with var. integrifolia, which is more slender, fewer-flowered, and usually entire-leaved. C.glabriuscula, var. megacephala, Gray, Jour. Bost. Nat. Hist. Soc., vii. 146, not Pacif. R. Rep. - Eastern California and adjacent Nevada, from 'Iejon to Carson, \&c., Dr. Horn, Anderson, Lemmon.

C. macrántha, Eaton. A span high, rather simply branched from the base, canescently tomentulose, partly glabrate: leaves short, with linear or oblong-linear lobes usually approximate: heads 12-20-flowered, mostly short-peduncled, or the earlier on longer naked peduncles from near the base of the stem : bracts of the involucre thinnish, more or less tomentose: corollas half to three-fourths inch long, narrow, externally puberuient, all alike; the 5 short teeth linear-oblong, ascending or barely spreading: anthers wholly included in the throat, the tips lanceolate: pappus of 4 linear-oblong paleæ barely half the length of the corolla, and 2 to 4 very short cuneate-oblong ones, but these occasionally obsolete or wanting. - Bot. King Exp. 171, t. 18; Gray, Bot. Calif. 1. c. - Hills in the desert region, W. Nevada to $\mathrm{S}$. Utah and the Mohave in California ; first coll, by Watson.

\footnotetext{
++++ Marginal corollas not distinctly larger than nor different from the others (the lobes if slightly larger still regular): bracts of many-flowered involucre linear or somewhat spatulate, obtuse, sometimes one or two loose and shorter outer ones: pappus of 8 to 14 mostly equal and large obtuse paleæ: biennial, perennial, or suffrutescent plants: $\mathrm{A}$. summer. $-M a c r o-$ carphus, Nutt.
}

C. Douglásii, Ноок. \& ARN. Canescent with a fine somewhat fioccose or pannose tomentum, or sometimes early glabrate, a span to a foot or more high from a biennial or more enduring root: leaves mostly of broad outline and bipinnately parted into crowded short and very obtuse divisions and lobes: heads from half to three-fourths inch long, in larger plants several or numerous and corymbosely cymose: paleæ of the pappus from linearligulate to narrowly oblong and from half to three-fourths the length of the corolla, or in marginal flowers shorter and broader. - Gray, Proc. Am. Acad. x. 74, \& Bot. Calif. 1. c. C. Douglasii \& C. achillecefolia, Hook. \& Arn. Bot. Beech. 354; Torr. \& Gray, Fl. I. c.; Torr. in Stansb. Rep. t. 6. Mymenopappus Douglasii, Hook. Fl. i. 316; DC. Prodr. v. 658 ; Macrocarphus Douglasii \& .1. achilleafolius, Nutt. Trans. Am. Phil. Soc. n. ser. vii. 376. Dry plains and mountains, Montana to New Mexico, west to Washington Terr. and California. From S. E. California, Palmer, an incomplete specimen of a peculiar large and glabrate form, with sparser divisions to the leaves, and shorter spatulate-oblong palex of pappus. Very variable species.

Var. alpina. Dwarf, 3 to 5 inches high, consisting of a rosette or thick tuft of leaves with very approximate divisions, and naked or scapiform stems, bearing mostly solitary heads, surmonnting the subterranean branches of a multicipital perennial caudex or rootstock. Alpine region of the Rocky and Cascade Mountains in Colorado and Wyoming, of the Sierra Nevada, California, and north to Washington Terr. Seems distinet from the following.

C. Nevadénsis, Gray. Very dwarf, in small tufts surmounting filiform branches of subterranean rootstocks, mostly growing in volcanic scorix or ashes: leaves small (half to barely inch long), densely white-woolly, crowded, obovate or flabelliform-cuneate in outline, once or twice pinnatifid or parted into obovate or spatulate-linear lobes: peduncles inch or less long, bearing a solitary rather narrow head. - Bot. Calif. i. 391. Hymenopappus Nevadensis, Kellogg, Proc. Calif. Acad. v. 46. - Alpine region of the Sierra Nevada, California, from Shasta and Lassen to the sources of the San Joaquin, Kellogg, Muir, Lemmon, \&c.

C. santolinoídes, Greene, in herb. Subcaulescent perennial: leaves all crowded on short tufted shoots from a slightly ligneous crown, white-tomentose, linear in outline, with broadish rhachis thickly beset with small (line or so long) oblong obtusely few-iobed and crispate divisions: peduncles scapiform, 4 to 6 inches high, simple or once or twice forked, glandular and viscid: head half-inch high, rather narrow: pappus of 8 or 10 linear-ligulate palex, a little shorter than the corolla.-San Bernardino Mountains, above Bear Valley, S. E. California, Parish.

C. suffrutéscens, Gray. Canescently tomentose, a foot or more high from decumbent woody stems: leaves pinnately parted into 5 to 7 narrowly linear entire or rarely 1-2-toothed divisions : heads solitary or scattered, on slender peduncles, three-fourths inch high : pappus of 10 to 13 linear or narrowly ligulate-oblong paleæ a little shorter than the corolla, or in the outermost flowers considerably shorter. - Proc. Am. Acad. xvi. 100. - California, on the 
rocky banks of the Sacramento, below Mount Shasta; Lemmon (perhaps a mistake as to habitat); S. E, California, south of San Jacinto Mountains, Parish.

§2. ACARphta. Pappus of deciduous and fimbriate paleæ, or wanting: akenes obovate- or linear-clavate, hardly angled, blackish : involucre viscid: corollas whitish or ochroleucous, all alike or nearly so, the marginal not obviously ampliate: annuals. - Acarphrea, Gray, Pl. Fendl. 98 ; characterized anew in Proc. Am. Acad. xix. 30.

C. artemisiæfólia, Gray. A foot or two high, paniculately branched, furfuraceouspubescent, somewhat viscid, above glandular-hirsute, especially the naked summit and peduncles and involucre of the loosely cymose-paniculate heads : leaves 2-3-pinnately divided or parted into short linear or oblong lobes : involucre broadly, campanulate, half-inch high, many-flowered; its bracts lanceolate-linear, acute: akenes linear-clavate, flattened, hardly at all angled, the sides minutely impressed-striate; epigynous disk small and obscurely annulate. - Proc. Am. Acad. x. 74, \& Bot. Calif. l. c. Acarphaea artemisicefolia, Gray, Pl. Fendl. 98, \& Bot. Mex. Bound. 95, t. 32. - San Diego Co., California; first coll. by Coulter.

C. thysanocárpha, Gray. Slender and low annual, paniculately branched, viscid-puberulent, with some early deciduous villosity, sparsely leafy up to the subsessile small heads: leaves narrowly linear, entire: involucre barely 3 lines high, of few linear-oblong and viscidulous bracts, 7-10-flowered: akenes clavate-obovate, obscurely angled : pappus about half the length of the corolla, of 8 or 9 nearly equal thin spatulate palex which are erosely fimbriate quite down to their unguiculate base, deciduous. - Proc. Am. Acad. xix. 30. - Sierra Nevada in Kern Co.? California, at 9,800 feet, Rothrock, no. 345. Apparently depauperate or unseasonable specimens of a peculiar plant; coll. Sept.

154. HƯL SEA, Torr. \& Gray. (The late Dr. G. W. Hulse, U. S. Army.) - Herbs, of the Sierra Nevada and its continuations, viscid-pubescent and balsamic-scented, most of the species when young floccose-woolly; with alternate mostly sessile entire or dentate or pinnatifid leaves, and solitary or scattered large heads of yellow flowers, or rays sometimes purple; in summer. - Bot. Mex. Bound. 98; Pacif. R. Rep. vi. 77, t. 13; Bot. Calif. i. 385.

* More or less floccose-woolly when young, and denudate in age: upper leaves reduced in size and bract-like on the naked flowering branches or peduncles : root perennial, or in the first species perhaps biennial.

H. Califórnica, Torr. \& Gray, 1. c. Robust, 2 feet or more high, leafy, bearing several paniculately disposed heads, when young whitened by long and soft loose wool: leaves entire or nearly so ; lower spatulate or lingulate, uppermost ovate-lanceolate to linear : inyolucre two-thirds inch high and broad; its bracts very numerous, linear, gradually acute, villose-lanate: rays very many, with linear ligule half-inch long: paleæ of the pappus quadrate-oblong and somewhat equal, or the two over the principal angles longer, erose-denticulate at summit. - Gray, Bot. Calif. i. 386. - S. California, in mountains of San Diego Co., Parry, and (near Campo, June, 1880), Parish, G. R. Vasey.

H. vestíta, Gray. Commonly a foot or less high from a rosette of pannosely white-tomentose spatulate leaves (either entire or lyrately dentate, tardily somewhat denudate); the flowering stems sometimes scapiform and monocephalous, commonly sparsely leaved below and bearing two or three slender pedunculate heads: involucre half-inch high, of mostly broadly lanceolate viscid-pubescent bracts : rays little surpassing the disk-flowers, sometimes shorter, or even wanting, yellow or changing to reddish : pappus of conspicuous and silvery quadrate erose-toothed palex, either nearly equal or two rather longer. - Proc. Am. Acad. vi. 547, \& Bot. Calif. i. 387. (Forms have been distributed under the names of $\boldsymbol{H}$. Parryi, Gray, and $H$. callicarpha, S. Watson.) - S. E. California ; volcanic hill south of Mono Lake, Brewer, low, scapiform, with large head: San Jacinto Mountain, San Diego Co., 1882, Parish. Mohave country, San Bernardino Co., Parry, 1876, form with dentate or almost pinnatifid leaves. Also a more leafy and branched form, 2 feet high, with more deciduous wool and rather longer rays, Parish. 
Var. pygmǽas. Depressed, rising only 2 inches high, the head subsessile in the tuft of leaves : rays saffron or rose-colored. - San Bernardino Co., on the summit of Greyback Mountain, Lemmon, W. G. Wright, and Bear Valley, Parish.

H. álgida, Grar. A span or two high from a deep perennial rootstock, the villous or cottony wool caducous, viscid pubescence remaining: stem simple, stout, terminated by a solitary short-peduncled large hend: leaves linear-lingulate, irregularly dentate, sometimes with large salient teeth; lower crowded ( 2 to 5 inches long, quarter to half inch wide), upper gradually smaller and sparser: involucre almost inch high and broad; its bracts linear, attenuate-acute, lax, villose-lanate and viscid: rays very numerous, linear, nearly half-inch long, yellow: pappus short, not exceeding the breadth of the akene, equalled by its hairs; the palex deeply fimbriate-lacerate. - Proc. Am. Acad. vi. 547, Bot. Calif. i. 386. - California, on the higher summits of the Sierra Nevada, from Mount Dana southward, Brewer, Bolander, Muir, on Mount Whitney up to 13,700 feet, Rothrock.

H. nána, Grax. A span high from long branching rootstocks rising through volcanic ashes and scorix, villous-lanate when young, viscid-pubescent : leaves crowded around base of the thickish (inch or two long, or sometimes very short) monocephalous peduncle, oblong spatulate, pinnatifid or incised, mostly tapering into a margined petiole: involucre half-inch or more high, of lanceolate bracts : rays about 30 , yellow, broadly linear, nearly half-inch long: paleæ of the pappus (either broad or apparently splitting into narrower ones) usually longer than the breadth of the akene, equalled by its villous hairs, incisely or fimbriately lacerate. - Pacif. R. Rep. vi. 76, t. 13, Bot. Calif. 1. c. - Volcanic peaks of the Cascade Mountains, Oregon, Newberry, Cusick, to Washington Terr., Suksdorf.

Var. Lárseni, Grar, Bot. Calif. 1. c. More woolly even in age, and leaves somewhat scattered on the flowering stems, even up to the head: rays smaller. - California, in volcanic ashes on peaks of northern part of the Sierra Nevada, such as Shasta and Lassen; first coll. by Lemmon and Larsen.

* * Apparently quite destitute of floccose wool from the first, but with some long and soft manyjointed and viscidulous hairs: stems mostly simple, equably leafy to the top, bearing solitary or somewhat racemosely disposed short-pedunculate heads: paleæ of the pappus conspicuous, oblong or narrower, the two over the angles longer.

H. heterochróma, Grar. Rather stout, sometimes over 2 feet high from an annual root: leares oblong, saliently dentate: involucre two-thirds or three-fourths inch high, of linearlanceolate attenuate-acute bracts : rays very numerous, 3 or 4 lines long, rose-purple, sometimes inconspicuous or obsolete: tube of disk-corollas hirsute: shorter paleæ of the pappus truncate-lacerate. - Proc. Am. Acad. vii. 369, \& Bot. Calif. l. c. - California, from the Yosemite, Bolander, to the mountains of San Bernardino Co., Lemmon, Parish.

H. brevifólia, GRAY, 1. c. Slender, a foot high from an annual or possibly perennial root, the stem or simple branches bearing a solitary comparatively small and narrow head: leaves small (the largest inch and a half long), spatulate-oblong, denticulate: involucre half-inch high, of linear rather loose bracts : rays only 10 or 12, 3 or 4 lines long, light yellow: palea of the pappus rather entire. - California, along the Merced in and near the Yosemite Valley, Bolander, \&c.

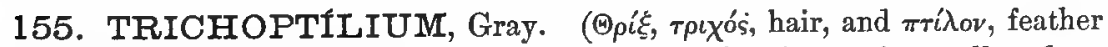
or plumage, the pappus-paleæ feathery-dissected.) - Single species, yellow-flowered winter annual; fl. spring.

T. incísum, Gray. Diffusely branched, low and spreading, loosely floccose-woolly, also somewhat pubescent and glandular: leaves oblong-rhomboidal or cuneate-lanceolate, incisely and acutely dentate, alternate or the lower opposite: heads scarcely half-inch high, on slender peduncles terminating stem and branches. - Bot. Mex. Bound. 97, Pacif. R. Rep. v. t. 5, \& Bot. Calif. i. 395. Psathyrotes incisa, Gray, PI. Thurb. 322. - Arid district of the Mohave, Lower Colorado, and Gila, W. Arizona and S. E. California ; first coll. by Fremont.

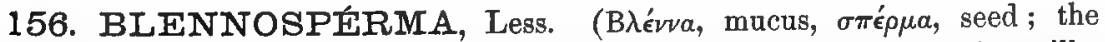
akenes developing copious mucus when wetted; that is, the club-shaped papillæe then swell up through imbibition, open at the apex, or else split into two valves, and emit a pair of uncoiling filaments of extreme tenuity, in the manner of 
Crocidium, to which this anomalous genus is perhaps most related.) - Low and small annuals, of two species, one Chilian, the other Californian. - Less. Syn. 267 ; Torr. \& Gray, Fl. ii. 272 ; Remy in Gay, Fl. Chil. iv. t. 48; Benth. \& Ilook. Gen. ii. 404. Apalus, DC. Prodr. v. 507. Coniothele, DC. 1. c. 531.

B. Califórnicum, Torr. \& GrAY, 1. c. A span or two high, at length diffusely branched, glabrous or nearly so, with pedunculate heads terminating the branches: leaves alternate, pinnately parted into narrowly linear usually entire lobes: heads a third to half inch in diameter when expanded: flowers pale yellow, with ligules 2 or 3 lines long, or the alternate ones sometimes destitute of corolla: disk-flowers shorter than the involucre: style-branches of fertile flowers broad. - Coniothele Californica, DC. Prodr. v. 531. - Moist ground, Upper Sacramento to San Diego, California: fl. summer; first coll. by Douglas.

157. ACTINELLA, Pers., Nutt. (Changed from Actinea, from ákтís, ray.) - Low herbaceous or rarely suffruticose plants (all American); the herbage usually impressed-punctate and often resinous-atomiferous, bitter-aromatic, genererally Chamomile-scented; leaves all alternate and narrow or with narrow lobes; the heads of yellow flowers commonly slender-pedunculate. - Pers. Syn. ii. 469 (Actinea, Juss. Ann. Mus. Par. ii. 425, t. 61, a S. American form, somewhat approaching Helenium, but not to be combined with Cephalophora, which is a reduced rayless Helenium); Nutt. Gen. ii. 173, \& Trans. Am. Phil. Soc. n. ser. vii. 378; Torr. \& Gray, Fl. ii. 381 ; Gray, Proc. Am. Acad. xix. 31. Hymenoxys, Cass. Dict. lv. 278; DC. Prodr. v. 661. Actinella, Hymenoxys, and a part of Cephalophora, Benth. \& Hook. Gen. ii. 413-415.

A. (Plateiléma) Pálmeri, Gray, Proc. Am. Acad. xviii. 109, xix. 31, is an outlying species, of Northern Mexico, remarkahle for its few and broad and nearly herbaceous involucral bracts, convex receptacle, and truncate laciniate palex of the pappus.

$\S 1$. Eua Ctinélla. Involucre of numerous herbaceous or nearly membranaceous (not rigid) nearly equal and similar bracts, distinct to the base : receptacle obtusely conical or hemispherical : heads mostly solitary on long or scapiform peduncles, rarely sessile in the cluster of leaves: rays inclined to persist and turn pale: akenes silky-villous: pappus of 5 to 7 hyaline paleæ. - Gray, 1. c.

* Winter annual or at most biennial, caulescent, entire-leaved : receptacle conical.

A. linearifólia, TorR. \& GRAY. Slender, a span to a foot high, sometimes strict and nearly simple, generally diffusely branched, villous-pubescent and glabrate: leaves linear or the lowest somewhat spatulate: peduncles filiform, a span long: head 3 lines high: rays 4 lines long: palex of the pappus ovate, abruptly acuminate-awned. - Fl. ii. 383 . Hymenoxys linearifolia, Hook. Ic. t. 146; DC. Prodr. vii. 243. - Texas and borders of Louisiana, in sandy soil ; first coll. by Drummond. (Adj. Mex.)

* Perennials, mostly with multicipital caudex, commonly lanate in the axils of the radical leaves.

- Leaves except in one form of the first species quite entire, all on the crowns of the caudex, which bear a simple scapiform peduncle (or none): receptacle obtusely or low conical: involucre villous-lanate: palex of the pappus hyraline from broadly ovate to oblong, mostly traversed by an indistinct costa, and usually produced at apex into an awn: well-formed heads 4 to 6 lines high, and rays as long.

A. scapósa, Nutr. In the typical form somewhat like the preceding in aspect, especially when leafy along the base of the scape, loosely villous and glabrate, rather sparsely cæspitose, the branches of the caudex being slender and often ascending : leaves linear to lanceolate or some of the earlier ones spatulate, not rarely laciniate-lobed: scape a span to a foot high. Trans. Am. Phil. Soc. l. c.; Torr. \& Gray, Fl. ii. 382. Cephalophora (Actinella) scaposa, DC. Prodr. จ. 663. Gaillardia Romeriana, Scheele in Linn. xxii. 161. A. lanuginosa, Buckley in Proc. Acad. Philad. 1861, 459. - Rocky prairies, \&c., Texas to New Mexico ; first coll. by Berlandier. (Adj. Mex.) 
Var. lineáris, Nттт. 1. c. Leaves all narrowly linear and entire, more rigid. - Texas to New Mexico, and the borders of Colorado: broader-leaved and dwarfer forms very like glabrate A. acaulis. (Adj. Mex.)

A. acaúlis, Nutr. Densely cespitose, the branches of the caudex short, thick, and crowded, canescently villous or sericeous, sometimes more naked: leaves thickish, all entire, from spatulate to nearly linear, commonly short (half-inch to 2 inches long), densely crowded on the caudex: scape half-inch to 6 inches high: rays 3 to 5 inches long (rarely wanting). Gen. ii. 173 ; Torr. \& Gray, l. c.; Eaton in Bot. King Exp. 174. A. lanata, Nutt. Trans. Am. Phil. Soc. 1. c.; Torr. \& Graj, 1. c., a loosely villous form. Galardia acaulis, Pursh, Fl. ii. 743. Cephalophora (Actinella) acaulis, DC. 1. c. - Rocky Mountains and the bordering plains and bills, Dakota to Montana, and south to New Mexico, W. Nevada, and Arizona. Passes into

Var. glábra, GRAY, Man. ed. 5, 263. Leaves green, spatulate-linear, from sparingly villous or glabrate to nearly glabrous, even to the base and axils. - A. glabra \& A. Torreyana, Nutt. l. c.; Torr. \& Gray, Fl. ii. 382. - Rocky hills and bluffs, Wyoming Terr. to New Mexico and Utah. Also on an ancient mound at Joliet, Illinois, Scammon, W. Boott, probably adrentive.

A. depréssa, Torr. \& Grar. Pulvinate-cespitose: leaves densely crowded on the very thick dense branches of the caudex, spatulate-linear, half-inch long, either sericeous-canescent or glabrate: head strictly sessile, immersed among the long-villous bases of the leaves. P1. Fendl. 100, with var. pygmae, a diminutive silky-canescent form. - Mountains of W. Colorado or E. Utah, Fremont, Ward, and the small variety, Raton Mountains, Gordon. Perhaps a state of $A$, acaulis.

+ + Leaves all quite entire, crowded on the caudex, also scattered along the simple or sparingly branched stems: peduncles slender: heads, \&c., of the preceding subdivision.

A. argéntea, Gray. Commonly rather stout, a span to a foot ligh, silvery-canescent with appressed silky pubescence: lower leaves spatulate and oblanceolate, uppermost linear : heads 4 or 5 lines high and rays 5 or 6 lines long, but sometimes of less than half this size : palex of the pappus 5 , from broadly ovate or obovate to oblong, with manifest costa produced into an awn which usually about equals the disk-corolla. - Pl. Fendl. 100; Rothrock in Wheeler Rep. vi. 173. - Hills of New Mexico; first coll. by Fendler.

A. leptóclada, Grar. A span or two high, more slender, sparsely and more loosely silkyvillous, glabrate, the narrower (sometimes all narrow-linear) leaves and lower part of the stems not rarely glabrous: heads usually smaller than of the foregoing. - Pacif. R. Rep. iv. 107. - New Mexico and S. W. Colorado to Arizona? Bigelow, Newberry, Brandegee, \&c.

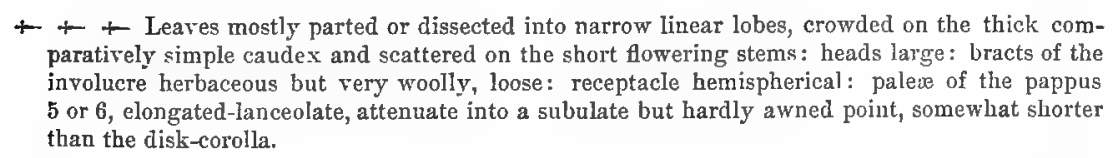

A. Brandegéi, T. C. Porter. Leaves glabrate, with 2 or 3 lobes toward the upper part, or some entire, narrowly linear, only 2 or 3 on the somewhat scapiform simple flowering stem (of a span or more in height): head therefore conspicuously pedunculate, half-inch high and wide : involucral bracts lanceolate : rays 12 to 16,3 or 4 lines long. - Gray, Proc. Am. Acad. xiii. 373. A. grandiflora, var. glabrata, Porter \& Coulter, Fl. Colorad. 76. Alpine region of the Sangre de Christo and adjacent mountains of S. Colorado, Parry (1867), Brandegee, Gray \& Hooker.

A. grandiflóra, ToRr. \& GRAY. $\Lambda$ span or two high, very stout, floccose-woolly, tardily somewhat glabrate in age: stem simple or branching below, leafy: leaves with petiole scarious-dilated at base, lower ones 2-3-ternately or quinately parted, upper with 3 to 5 simple lobes: involucre about an inch broad, very woolly; its bracts linear: rays 30 or more, over half-inch long: plants generally growing singly and the caudex on a perpendicular root, as if biennial. - Bost. Jour. Nat. Hist. Soc. v. 110 ; Gray, Am. Jour. Sci. xxxiii. 240. Alpine region of the Rocky Mountains from Montana to Colorado; first coll. by Fremont.

A. Chrysanthemoídes and A. insígnis, Gray, Proc. Am. Acad. xix. 32, of Mexico (large and tall species, with much divided leaves, and at most biennial roots), rank next to $A$. grandiflora. 
§ 2. Hrmenóxys. Involucre double or of two distinct series of coriaceous or rigid erect bracts, the outer more commonly connate at base: leafy-stemmed herbs; ours all with ray-flowers. - Gray, Pl. Fendl. 101, \& Proc. Am. Acad. xiii. 373, \& xix. 32. Hymenoxys, Cass. Dict. lv. 278 (founded on a rayless South Amer. species; DC. Prodr v. 661 ; Benth. \& Hook. Gen. ii. 415.

* Simple-stemmed and monocephalous or nearly so, perennial: pappus-paleæ elongated and pointed.

A. Bigelóvii, Grar. Habit of A. leptoclada, loosely woolly, tardily glabrate: stems strict and slender, 6 to 15 inches high from an apparently multicipital caudex, terminated by a single long-pedunculate head, rarely with one or two branches: leaves all very narrowly linear, rigid, not perceptibly punctate, some of them with a pair of subulate lobes, the others quite entire : head half-inch high: involucre hemispherical; its bracts all lanceolate, acute, coriaceous, about 12 in each series, distinct; those of the inner a little longer, scariousmargined, and attenuate-cuspidate : rays about 12, half-inch long : receptacle obtusely lowconical : palex of the pappus about 10, subulate-lanceolate, nearly equalling disk-corolla, with more or less evident costa, gradually attenuate into an aristiform cusp.-Pl. Wright. ii. 97, \& Bot. Mex. Bound. 99. - Pine forests in the mountains of New Mexico, Bigelow, Newberry, Palmer, Greene.

* * Stems branching above and bearing numerous or several heads.

+ Most of the leaves entire, some 3-cleft: pappus of about 5 broad and truncate palez.

A. Rúsbyi, Gray. Green and glabrous or nearly so: stems a foot or more high from a lignescent perhaps biennial root, strict, fastigiately branched at summit into a cyme of many small ( 3 lines high) heads: leaves rigid, linear; upper cauline all entire; lower and the long and narrow radical ones some entire, some 3-cleft: outer involucre shorter than inner, of 7 or 8 thickish subulate-lanceolate coriaceous bracts, connate only at very base: ligules 2 or 3 lines long, quadrate: paleæ of the pappus rather firm, quadrate or broadly cuneate and truncate, without costa, not surpassing the proper tube of the disk-corolla. - Proc. Am. Acad. xix. 33. - Grassy slopes of the Mogollon Mountains, New Mexico, Rusby.

+ + Leaves all or mostly 1-3-ternately parted.

++ Paleæ of the pappus oblong or roundish, pointless, mostly thin and hyaline: heads rather large: outer involucre more or less cupulate: rays laciniate at apex : root apparently perennial.

A. Vaséyi, Grax. Nearly glabrous, a foot high: leaves once or twice 3-parted into linear lobes: heacls rather numerous and fastigiately cymose: involucre narrowly campanulate, 4 lines high; outer nearly equalling the inner, united high up into a 7-9-toothed cup: palese of the pappus oblong or broadly lanceolate, more or less obtuse, about half the length of the disk-corolla. -Proc. Am. Acad. xvii. 219, xix. 33. - Organ Mountains, New Mexico, G. R. Vasey.

A. Coóperi, GraY. Puberulent; 2 feet or more high, paniculately branched above and with more scattered heads: lower leaves twice ternately or quinately and the upper simply 3-5nately parted into (mostly inch long) nearly filiform lobes of hardly more width than the rhachis : involucre almost hemispherical; outer of 6 to 10 bracts which are united only toward the base: palex of the pappus ovate or quadrate-oblong, with very obtuse erose summit, not half the length of the disk-corolla. - Proc. Am. Acad. vii. 394, xix. 33.

+ +- Paleæ of the pappus orate to lanceolate, attenuate into a slender point or awn, fully half the length of disk-corolla.

A. biénnis, GrAy. Mostly stout and a foot or more high from a tap root, probably never more than biennial, cinereous-puberulent, sometimes more hoary, sometimes green and glabrate : leáves simply 3-5-parted into narrow linear lobes: heads loosely cymose, hemispherical : involucre about 4 lines high; bracts of its outer series 12 to 14 , plane or barely carinate-thickened at base, nearly distinct: rays about as many, half to full inch long when well developed, narrowly cuneate: paleæ of the pappus ovate-lanceolate, from acuminate to cuspidate. - Proc. Am. Acad, xiii. 373 ; also part of A. Richardsonii, Bot. Calif. i. 394, \&ce. A. Richardsonii, var, canescens, Eaton, Bot. King Exp. 175, a hoary and dwarf form. - Arid mountain districts of Utah, Nevada, and on the borders of California and Arizona, Watson, Ward, Lemmon, Palmer, \&c. 
A. Richardsónii, Nurt. A span to a foot high, in tufts from a multicipital perennial caudex, obscurely puberulent or nearly glabrous, woolly in the axils of radical leaves, fastigiately cymose, polycephalous: upper leaves mostly once and lower twice ternately parted into long and simple filiform-linear lobes, rather rigid: involucre campanulate, 2 or 3 lines high, 6-9-angled; the 6 to 9 bracts of the outer strongly carinate, united for the lower quirter or third: rays broadly or sometimes narrowly cuneate, 2 to 4 lines long: paleæ of the pappas attenuate-acuminate. - Trans. Am. Phil. Soc. vii. 379; Torr. \& Gray, 1. c.; Gray, Pl. Fendl. 101, with var. floribunda, a tall and full-tlowered form. Picradenia Richardsonii, Hook. Fl. i. 317, t. 108. - Plains, Saskatchewan and E. Oregon to Utah and New Mexico.

A. odoráta, Grar. Diffuse and at length much branched from an annual root, a span to 2 feet high, with scattered small heads terminating leafy branches: leaves once to thrice ternately parted into filiform lobes, not rigid: involucre campanulate, rigid; outer of 7 or 8 oblong bracts, united at base: paleæ of the pappus aristately attenuate. - Pl. Fendl. 101, Pl. Wright. i. 122, \& Proc. Am. Acad. xix. 33. Hymenoxys odorata, DC. Prodr. v. 661; Deless. Ic. iv. t. 42. Philozera multiflora, Buckley, Proc. Acad. Philad. 1861, 459. - Open ground, Texas to S. California; also sparingly in Kansas, where it is probably naturalized. (Mex.)

158. HELÉNIUM, L. SNeeze-Weed. (Ancient Greek name of Elecampane, or some other plant, which was said to be named after the wise Helenus, son of Priam.) - N. American and Mexican herbs, erect, mediocre or tall; with alternate simple leaves, which are sometimes decurrent, commonly resinous-atomiferous (therefore bitter-aromatic) and impressed-punctate, and with pedunculate heads of usually yellow or occasionally brownish-tinged flowers, produced in summer or autumn. - DC. Prodr. v. 667 ; Benth. \& Hook. Gen. ii. 413, with the synonymy (except Amblyolepis, and adding Hecubaa); Gray, Proc. Am. Acad. ix. 202. Helenium, Leptopoda (Nutt.), and Hecubcea, DC. Prodr., to which Cephalophora (Cass.), § 1, DC., should be added.

§1. Oxínepis. Rays fertile, numerous, long and narrow: disk-corollas with moderately long proper tube: pappus of elongated paleæ: bracts of the involucre numerous in two series, tardily reflexed in fruit: leaves not decurrent on the stem. - Gray, Proc. Am. Acad. ix. 205. Dugaldea, Cass. Oxylepis, Benth. Pl. Hartw. 87.

H. Hoopésii, GrAY. Slightly tomentose or pubescent when young, soon glabrate: stem stout, 1 to 3 feet high, from a strong perennial root, leafy, bearing several or sometimes solitary large heads: leaves thickish, entire, oblong-lanceolate, or the lower spatulate with long tapering base, somewhat nerrose: rays becoming inch long, tardily reflexed : disk half to three-fourths inch high, hemispherical : receptacle in fruit ovoid-hemispherical: paleæ of the pappus ovate-lanceolate, long attenuate-acuminate, a little shorter than the corolla. Proc. Acad. Philad. 1863, 65, Proc. Am. Acad. ix. 205, \& Bot. Calif. i. 392. - Rocky Mountains, Montana to New Mexico, Arizona, and Sierra Nevada, California; first coll. by Thomas Hoopes.

§ 2. Euhelfiniou. Rays fertile (rarely sterile, occasionally wanting), with cuneate or oblong soon drooping rays: disk-corollas with proper tube very short or reduced to a mere ring: palex of the pappus not dissected: involucre comparatively simple and small, of slender linear or subulate often unequal bracts, soon reflexed: plants from glabrous to puberulent, leafy-stemmed, mostly branching. - Gray, 1. c.

* Root annual: leaves all filiform-linear, not decurrent on the stem or branches.

H. tenuifólium, Nurr. Glabrous, slender, fastigiately much branched, very leafy up to the slender peduncles: leaves mostly entire : rays often half-inch long, much surpassing the globular disk : receptacle depressed-hemispherical (a line and a half in diameter): paleæ of 
the pappus ovate, abruptly tipped with a longer awn which equals the villous akene and is little shorter than the disk-corolla. - Jour. Acad. Philad. vii. 66; Hook. Comp. Bot. Mag. i. 98; Torr. \& Gray, Fl. ii. 385; Meehan, Native Fl. ii. t. 10. - River bottoms, \&c., Arkansas to Mississippi, Florida, and Texas: becoming a naturalized weed throughout Southern Atlantic States.

Var. bádium, GRAY. Disk dull purplish brown (instead of yellow): lower leaves sometimes pinnately parted, the radical into short linear or even somewhat oblong entire or few-toothed lobes. - Proc. Am. Acad. xviii. 108. - Texas, E. Hall, Reverchon, Palmer.

* * Root annual, or at most biennial: leaves broader, at least some of them decurrent and forming wings on the stem and branches: rays in several species occasionally particolored with brownish-red.

- Paleæ of the pappus obtuse or at least pointless, destitute of costa.

+ Rays present: disk and receptacle in fruit elongated.

H. quadridentátum, LABILL. Loosely paniculate: lower leaves incisely pinnatifid; upper lanceolate, entire: heads with oval disk becoming oblong, half-inch long, surpassing the rays : receptacle cylindraceous-oblong: disk-corollas more commonly 4-toothed: pappus of very short roundish-oval palex. - Act. Soc. Nat. Hist. Par. i. 22, t. 4 ; Lam. Ill. t. 688 ; Lindl. Bot. Reg. t. 598; DC. Prodr. v. 666. H. quadripartitum, Link, Enum. ii. 338? Rudbeckia alata, Jacq. Ic. Rar. t. 593. Tetrodus quadridentatus, Cass. Dict. lv, 272.-Low ground, Carolina to Texas, near the coast; adventive in ballast-heaps to Philadelphia. (Mex.)

$$
+ \text { + Rays present: đisk globular. }
$$

H. élegans, DC. Strict, slender: leaves narrowly lanceolate and entire, or lowermost broader and sometimes slightly toothed: heads of the smallest ( 2 or 3 lines high), with brownish or purplish disk, equalled or surpassed by the pure yellow or particolored or sometimes largely brownish-purple rays: receptacle barely hemispherical: pappus minute, the roundish-ovate palex decidedly shorter than the breadth of the akene.-Prodr. v. $667 . H$. microcephalum, var. bicolor, Torr. \& Gray, Fl. ii. 385. H. microcephalum, Curtiss, distrib. 1513. - Moist ground, W. Lonisiana and Texas; first coll. by Berlandier. (Adj. Mex.)

H. microcéphalum, DC. Freely branching: leaves lanceolate or oblong, the lower denticulate or repand-toothed: heads with yellow or fuscous disk ( 3 or 4 lines high) much surpassing or sometimes equalled by the rays: receptacle conical-ovate: palex of the pappus ovate, short, but nearly half the length of the akene. - Prodr. v. 667; Gray, Proc. Am. Acad. ix. 202, in part. H. heterophyllum, DC. 1. c. as to Berland. 2113 from Reynosa, not of char. H. Texanum, Buckley in Proc. Acad. Philad. 1861, 460, to which aristate pappus is wrongly assigned. - Moist ground, Texas; first coll. by Berlandier. (Adj. Mex.)

H. amphíbolum, Gray. Stouter, freely branching : upper leaves lanceolate to linear and entire; lower varying to oblong and toothed or laciniate-pinnatifid: heacls with fuscouspurplish globose disk ( 3 or 4 lines in diameter), equalled or surpassed by the yellow rays: receptacle more than hemispherical : palex of the pappus roundish and very small, as in II. elegans. - Proc. Am. Acad. ix. 202. H. Mexicanum, DC. Prodr. v. 666, by the char., not HBK. - Southern borders of Texas, on the Rio Grande, at Presidio and Eagle Pass, Havard. (Adj. Mex.)

H. ooclinium, Gray. Freely branching, rather stout: leaves lanceolate, usually more or less dentate or denticulate: heads with yellowish and fuscous ovate-globose disk ( 5 or 6 or rarely 4 lines high), longer than the yellow rays: receptacle ovoid-conical (acutish or obtuse): palea of the pappus comparatively large, ovate, obtuse, often almost the length of the akene, sometimes with traces of a costa or of a mucro. - Proc. Am. Acad. ix. 202. - Southern borders of Texas, along the Rio Grande, at Presidio and (with smaller heads) at Eagie Pass, Havard. (Northern Mex.)

$$
+++ \text { Rayless. }
$$

H. Thúrberi, GraY. Slender, puberulent, freely branched, 2 or 3 feet high : leaves mostly linear-lanceolate, entire, the lowest broader and denticulate or rarely laciniate: heads globose-ovoid, 3 or 4 lines high, fuscous : receptacle relatively large, broadly ovate: pappus of ovate obtuse palex, about one third the length of the corolla and of the akene. - Proc. Am. A cad. xix. 32. - S. Arizona, Coulter (359, distributed as of California), Thurber (wrongly referred to $H$. puberulum in Bot. Mex. Bound.), Pringle, Lemmon. 
+ - Palex of the pappus acuminate, mucronately cuspidate, or awned, the costa commonly manifest: heads with globose disk and semi- or sub-globose receptacle: herbage puberulent.

H. MexicÁnum, HBK. (H. rarium, Schrader), by some said to be perennial, has paleæ of the pappus from apiculate to aristellate-acuminate. To it may belong Coulter's no. 357 (specimeu too incomplete), ticketed "California," but probably belonging to his Mexican collection.

H. pubérulum, DC: Mostly tall, freely branching, and witl long monocephalous peduncles: leaves lanceolate or the lower broader, all entire: heads about half-inch in diameter : rays one, two, or sometimes three lines long, equalling or exceeding the small involucre, rarely obsolete: palez of the pappus ovate, short-awned, not half the length of the corolla. Prodr. v. 667 ; Torr. \& Gray, Fl. ii. 385 ; Gray, Bot. Calif. i. 393. H. pubescens, Hook. \& Arn. Bot. Beech. 355, not Ait. H. Californicum, Link. Ind. Sem. Berol. 1840? H. decurrens, Vatké, Ind. Sem. Berol. 1875. H. Mexicanum, Gray, Pacif. R. Rep. iv. 107, probably. Cephalophora decurrens, Less. in Linn. vi. 517; DC. Prodr. v. 663. - Moist or wet ground, California, common.

H. laciniátum, Grar. A foot or two high, more cinereous: leaves lanceolate or linear, pinnatifid-dentate or laciniate, or the upper entire: heads 4 or 5 lines in diameter: rays as in the preceding: involucre commonly more conspicuons: paleæ of the pappus more than half the length of the corolla. - Proc. Am. Acad. ix. 203, \& Bot. Calif. 1. c. - S. E. California and adjacent Arizona, Coulter, \&c. (Adj. Mex.)

* * Root perennial : rays sterile, either neutral or with abortive style and akene: ligules equalling or exceeding the globular disk: receptacle orate: leaves mostly narrowly decurrent on the stem and branches: palex of the pappus aristate-acuminate, hardly half the length of the diskcorolla: heads on short slender peduncles.

H. nudiflórum, Nстт. Somewhat puberulent, 1 to 3 feet high, with leafy branches and corymbosely disposed heads: leaves from narrowly lanceolate to oblong, entire, or the radical obovate or spatulate and dentate: rays half to three-fourths inch long, either pure yellow or partly (sometimes wholly) brown-purple, once or twice the length of the brownish or purplish disk : receptacle ovate, in age acutish, but sometimes rounder and very obtuse. Gray, Proc. Am. Acad. ix. 203, excl. syn. H. parviflorum. H. nudiflorum \& II. micranthum, Nutt. Trans. Am. Phil. Soc. 1. c. 384. H. quadridentatum, Hook. Comp. Bot. Mag. i. 98. H. atropurpureum, Kunth, Ind. Sem. Berol. 1845, 21, purple-rayed state. H. Seminariense, Featherman in Louisiana Univ. Rep. 1871. Leptopoda brachypoda, Torr. \& Gray, Fl. ii. 388; Curtiss, distrib, a very slender and small-rayed form. - Low ground, N. Carolina and Ininois to Arkansas and Texas; and naturalized eastward. Hybridizes with $H$. autumnale.

H. parviflórum, Nurr. 1. c. Glabrate or glabrous, much branched and with scattered small heads: leaves broadly lanceolate, with contracted base, sparingly denticulate, very narrowly decurrent on the branches: disk and rays yellow, the former 3 or 4 lines in diameter; the latter 3 to 5 lines long, styliferous: receptacle short-ovate. - Georgia, Nuttall (a specimen named by him is ticketed Alabama); in a swamp near Macon, J. Donnell Smith. Seemingly quite distinct. Simple-stemmed and low specimens with larger heads, Delaware Co., Penn., verge rather to $H$. autumnale.

* * * Root perennial: rays fertile and conspicuous: stem or branches more or less winged by the decurrent leaves: receptacle from half to two-thirds splerical: pappus with the paleæ acuminate-aristate, not rarely somewhat lacerate or with one or two setiform teeth.

- Heads corymbose at summit of very leafy stem and branches; the disk globose: leaves mostly serrate or denticulate: flowering late.

H. autumnále, L. Nearly glabrous or mizutely pubescent: stem narrowly winged, 2 to 6 feet high: leaves lanceolate to ovate-oblong: heads about half-inch in diameter, usually equalled by the rays: pappus commonly half or two-thirds the length of disk-corolla. Spec. ii. 866 ; Lam. Ml. t. 688 ; Schkuhr, Handb. t. 250 ; Bart. Fl. Am. Sept. t. 26 ; Hook. Bot. Mag. t. 2994; Torr. \& Gray, Fl. ii. 384. H. longifolium, Smith in Rees Cycl. H. pumilum, Willd. Enum. Suppl. 60, may be a common dwarf form. H. pubescens, Ait. Kew. iii. 287. H. canaliculatum, Lam. Jour. Hist. Nat. ii. 213, t. 35, \& H. tubuliflorum, DC. Prodr. v. 666, a state with tubulose ligules. H. altissimum \& H. commutatum, Link, Ind. Sem. Berol. 1840. H. grandiflorum, Nutt. Trans. Am. Phil. Soc. vii. 384, larger-flowered form. H. montanum, Nutt. l. c. - Wet ground, Canada to Georgia, Texas, and westward to Brit. Columbia and Arizona; the var. grandiflorum, with rays three-fourths inch long, only in the northwest. 
+ + Heads solitary or few on long (sometimes foot long) peduncles, terminating the stem or lax branches; disk depressed-globose or almost hemispherical : leaves en ire.

H. Bigelóvii, Gray. Almost glabrous : stem simple or loosely branched, 2 or 3 feet high: leaves from narrowly to oblong-lanceolate, the radical oblong-spatulate, elongated : peduncles mostly slender: disk of the head three-fourths globose at maturity, two-thirds to threefourths inch in diameter, equalled by the rays: palex of the pappus ovate-lanceolate or subulate and awn-pointed, considerably shorter than the corolla. - Pacif. R. Rep. iv. 107, Proc. Am. Acad. ix. 205, \& Bot. Calif. i. 393. - Wet ground, California, not rare from Lake

Co. to San Bernardino Co.; first coll, by Bigelow.

H. Bolánderi, Gray. Somewhat furfuraceous-pubescent : stems stout, often simple, 1 or 2 feet high: leaves oblong to ovate-lanceolate, or lowest obovate : peduncles thick, commonly npwardly enlarged and fistulous: disk of the head decidedly broader than high, inch or more wide: rays often inch long: paleæ of pappus lanceolate or subulate, with slender awn, almost equalling disk-corolla. - Proc. Am. Acad. vii. 358, ix. 204, \& Bot. Calif. 1. e. Low grounds near the coast, northeastern part of California, Bolander, \&c.

§3. LEPtópoda. Rays neutral, very numerous, mostly surpassing the linear bracts of the involucre, cuneate, 3-5-cleft, yellow, as are also mostly the flowers of the broad disk: pappus of thin-scarious wholly nerveless sometimes lacerate or fimbriate paleæ: simple-stemmed perennials (sometimes biennials?), from slender or filiform rootstocks; virgate stem continued into an unusually long solitary peduncle, the apex of which is mostly turbinate-thickened under the large and broad head: leaves narrowly or not at all decurrent. - Gray, Proc. Am. Acad. ix. 204. Leptopoda, Nutt. Gen. ii. 174; Ell. Sk. ii. 445 ; Torr. \& Gray, Fl. ii. 386 , excl. §2.

* Receptacle ovate-conical and the disk semi- to sub-globose: involucre soon reflexed and the rays (over half-iuch long) drooping in the manner of Euheltnium: nearly glabrous, with somewhat elongated-lanceolate mostly entire cauline leaves, but no conspicuons radical tuft: akenes more or less hairy on the ribs.

H. Curtísii, Gray. Stem slender, 2 or 3 feet high : disk of the head half-inch in diameter, surpassed by the rays: paleæ of the pappus almost entire, obovate, muticous, about one third the length of the disk-corolla. - Proc. Am. Acad. 1. c. Leptopoda integrifolia, M. A. Curtis in Torx. \& Gray, Fl. ii. 387, under L. brevifolia, var. - Near Raleigh, N. Carolina, M. A. Curtis.

H. fimbriátum, GRAY, 1. c. Less slender: disk two-thirds or three-fourths inch broad, equalled by the rays: palex of the pappus broad, dissected from summit to beyond the middle into many capillary bristles. - Gaillardia fimbriata, Michx. Fl. ii. 142. Leptopoda fimbriata, Torr. \& Gray, Fl. l. c. - Low pine barrens, Florida and Texas.

* Receptacle and disk depressed-hemispherical or flatter: involucre and rays merely horizontal or tardily recurved: flowering stem usually from a rosulate cluster of radical leares: cauline leaves gradually diminished upward, the uppermost usually bracteiform and subulate, all somewhat fleshy.

H. Nuttállii, GRaY, 1. c. A foot or more high, with nearly the foliage of the preceding and head of the following: ovary and akene glabrous and glandular-atomiferous: paleæ of the pappus oval or oblong, more or less erose or lacerate, muticous, or some of them aristellate. - Leptopoda Helenium, Nutt. Gen. ii. 174, excl. syn.? L. denticulata, Nutt. Trans. Am. Phil. Soc. vii. 372. L. decurrens, Machride in Ell. Sk. ii. 446, form with denticulate leaves. - Damp ground, S. Carolina to Florida and Louisiana.

Var. incísum, GraY, 1. c. Leaves incised or sinuate-pinnatifid in the manner of the following. - Leptopoda incisa, Turr. \& Gray, Fl. ii. 387. - Georgia, Le Conte.

H. vernále, Waut. Somewhat puberulent or tomentulose and viscidulous, a foot or two high: principal leaves in a radical tuft, spatulate-lanceolate or narrower, 4 to 6 inches long, from repand-denticulate to incisely pinnatifid; upper cauline small, linear-subulate and bract-like: disk of the head two-thirds or three-fourths inch broad, yellow: akenes pubescent: paleæ of the pappus obovate or spatulate, with larerate or fimbriolate-toothed summit. - Walt. Car. 210; Gray, Proc. Am. Acad. ix. 205. Leptopoda puberula, Macbride in Ell. 
1. c.; Torr. \& Gray, 1. c., with var. pinnatifida. L. pinnatifida, Schweinitz; Nutt. Trans. Am. Phil. Soc. 1. c. - Pine barren swamps, N. Carolina to Florida.

H. brevifólium, Gray, l. c. More glabrous : leaves shorter and entire or nearly so, lower and radical spatulate: head smaller, with brownish or purplish disk: akenes pubescent: paleæ of the pappus nearly entire. - Leptopoda brevifolia, Nutt. Trans. Am. Phil. Soc. 1. c.; Torr. \& Gray, 1. c., excl, var. - Pine barren swamps, N. Carolina to Alabama.

159. AMBLYOLEPIS, DC. (Composed of å $\mu \beta \lambda v^{s}$, blunt, and $\lambda \epsilon \pi i s$, scale; from the pappus.) - Prodr. v. 667. - Single species, exhaling the odor of Melilot in drying: $\mathrm{fl}$. all summer.

A. setígera, DC. 1. c. Annual, a foot or so high, sometimes glabrous and very smooth, sometimes villous with very long hairs rising from minute papillæ, especially along the margins of the leaves: stem loosely branching below, terminated by long monocephalous peduncles : leaves membranaceous, bright green, entire; radical oblong-spatulate with long tapering base; cauline oblong or ovate, with rounded or subcordate half-clasping base and mucronate-acuminate tip: head large: flowers all golden yellow: rays almost inch long, 3-4-lobed : palea of the pappus 5, about half the length of the akene, broadly ovate, silveryscarious, entire and nerveless, very obtuse, or in some outer flowers short-acumainate. - Gray, Pl. Wright. i. 121. - Prairies of 'Texas; first coll. by Berlandier. (Adj. Mex., Palmer.)

160. GAILLÁRDIA, Fougéroux. (M. Gaillard de Merentonneau.)N. American herbs (and one extra-trop. S. Amer.), chiefly of the Atlantic side; with alternate sometimes resinous-atomiferous and impressed-punctate leaves, and ample and showy Scabious-like heads on terminal or sometimes scapiform peduncles; the flowers often fragrant, yellow or reddish-purple; in summer. - Mem. Acad. Sci. Par. 1786, 5, t. 1, 2; DC. Prodr. v. 651; J. Gay in Ann. Sci. Nat. ser. 2, xii. 56. Galardia, Lam. Dict. ii. (1786), 590, \& Ill. t. 708; Michx. Fl. ii. 142 ; Nutt. Gen. ii. 175. Calonea, Buchoz, Ic. (1786), t. 126, ex DC. Virgilia, L'Her. \& Smith, not Lam. Guntheria, Spreng. Syst. iii. 356.

$\S 1$. Style-branches tipped with short (in ours naked) appendage of only once to thrice the length of the penicillate tuft: lobes of disk-corolla short and obtuse: rays sometimes fertile, often none: akenes villous all over: winter annuals or at most biennials. - Guntheria, Spreng. Syst. iii. 356, 449, and Cercostylis, Less. Syn. 239 ; an extra-tropical S. American species. Agassizia, Gray \& Engelm. Proc. Am. Acad. i. 50, \& Jour. Bot. Nat. Hist. vi. 229.

G. comósa, Gray, Proc. Am. Acad. xviii. 109, xix. 34, of Coahuila, Mexico, is a third species of this section: it has truly fertile rays, exceedingly long hairs to the akene which nearly cover the short-awned pappus and at length almost equal the disk-corolla, and very short soft fimbrillæ to the receptacle; the head on a naked scape.

G. símplex, Scheere. Leaves all in a radical cluster or a few near the base of the simple (foot or two long) monocephalous scape, commonly spatulate, from pinnatific to coarsely dentate or some entire: head globose in fruit: involucre of about 2 series of short and narrow bracts: flowers heliotrope-scented : rays none or imperfect and irregular and styliferous, or but few fully developed and neutral: villous hairs of the akene little surpassing the base of the large palex of the pappus, these 6 to 11, their slender awns at length surpassing disk-corolla. - Scheele in Linn. xxii. 160. G. tuberculata, Scheele, 1. c. 349, is apparently the subcaulescent and more radiate form. Agassizia suavis, Gray \& Engelm. 1. c.-Rocky prairies of Texas; first coll. by Lindheimer and Wright.

$\S 2$. Style-branches tipped with a long hispid or hispidulous filiform appendage: rays neutral, in first species sometimes wanting. - Gaillardia, Foug., DC., \&c. 
* More or less pubescent or hirsute with many-jointed hairs, leafy-stemmed: leaves not coriaceous: bracts of the involucre (at least the outer and larger) mainly foliaceous and spreading, la ceolate or narrower: disk-flowers apt to turn brown or dark-purple: villous hairs covering the akene mainly at its base or below the broad summit: palex of the pappus slender-awned.

+ Fimbrillæ of the receptacle obsolete or reduced to very short soft teeth: corolla-lobes caudately acuminate from a short broadish base.

'G. lanceoláta, Mrснх. Minutely or somewhat cinereously pubescent, not hirsute, about 2 feet high from an annual or perhaps perennial root, virgately branched: leaves rather small, from spatulate-lanceolate to linear, entire or slightly or sparsely serrate: outer bracts of the involucre lax and herbaceous to the base: rays rather few and sparse, half or two. thirds inch long, 3-cleft into narrow lobes and with slender tapering base, sometimes obsolete or wanting: flowers sweet-scented : the disk commonly dark and the rays yellow or coppercolored with dark veins. -Fl. ii. 142; Gray, l. c.; Torr. \& Gray, F1. ii. 365, not DC. Galardia bicolor, Pursh, Fl. ii. 572 (excl. syn. and it cannot be Leysera Caroliniana, Walt.); Nutt. 1. c.; Ell. Sk. ii. 449. Polypteris integrifolia, DC. Prodr. v. 659, excl. syn. - Dry piue barrens, S. Carolina to Florida, Kansas, and Texas.

++ Fimbrillæ of the receptacle setiform or subulate-aristiform, mostly surpassing the akenes.

+ Lobes or teeth of disk-corolla subulate-acute and usually tipped with a seta or cusp, externally beset with long and beaded hairs: rays usually numerous and when well developed contiguous or overlapping, short-cuneate at base: pappus aristate even in the ray-flowers: bracts of involucre callous at base, more or less hirsute, as also the herbage.

G. aristáta, Punsf. Perennial; often 2 feet or more high: leaves of firm texture, lanceolate or broader, or lower spatulate, from entire to laciniate-dentate or sinuate-pinnatifid: rays all yellow, in the largest heads inch and a half long: setiform fimbrillæ sometimes little shorter than disk-corollas. - Fl. ii. 573; Lindl. Bot. Reg. t. 1186; Hook. Bot. Mag. t. 2940, \& Fl. i. 315 ; DC. Prodr. v. 652 ; Gay, 1. c. ; Torr. \& Gray, l. e. G. bicolor, Hook. Fl. 1. c., excl. syn. G. bicolor, var. aristata, Nutt. Gen. ii. 175; Hook. Bot. Mag. sub t 3368. G. rustica, Cass. Dict. xviii. 20 ; Desf. Cat. $G$. lanceolata, DC. 1. c., excl. syn. - Plaius, Saskatchewan to Brit. Columbia and Oregon, south to S. Coloracio, New Mexico, and even the borders of California?

G. pulchélla, Forg. l. u. Annual, a foot or less high, diffusely branched at base : leaves softer, from entire to pinnatifid: rays two-colored, lower part red-purple or darker, the upper or teeth yellow, at most inch long: lobes of disk-corolla more attenuate: fimbrilix rather stouter, hardly surpassing the mature akenes. - Cass. Dict. xviii. 19 ; DC. 1. c.; Gay, 1. c.; Torr. \& Gray, l. c. G. bicolor, Lam. Dict. ii. 590, \& Inl. t. 708; Sins, Bot. Mag. t. I602 (as to figure); Hook. Bot. Mag. t. 3551 (var. Drummondii, integerrima). G. Drummondii, DC. Prodr. v. 652. Virgilia helioides, L'Her.; Smith. Exot. Bot. i. t. 37. - Plains, Louisiana, Arkansas, and Texas to Arizona. (Adj. Mex.)

Var. pícta. Form with somewhat succulent leaves, when growing near the sea-shore: fimbrillæ of the receptacle shorter and stouter, more or less subulate. - G. bicolor, var. Drumbmondii, Hook. Bot. Mag. t. 3368. G. picta, Don, Brit. Fl. Gard. ser. 2, t. 267 ; Gay, l. c.Texas, in low grounds. Common in gardens.

++ Teeth of the disk-corolla short and broad, obtuse, pointless or obscurely apiculate: involucre more or less callous at base.

$=$ Akenes destitute of villous hairs (glabrous or glabrate) at the upper part, and not overtopped by the basal villi : fimbrillæ of the receptacle setiform, equalling or surpassing the akenes: leaves undivided.

G. amblyodon, Gar. Annual, a foot or two high, leafy to the top, mostly hirsute : leaves oblong or the lower spatulate, all sessile by an auriculate base, denticulate or the upper entire: bracts of the involucre hirsute-ciliate, outer with conspicuous erect callous base; rays numerous and contiguous, oblong-cuneate, throughout brownish red or maroon-color, an inch or less long: ray-pappus awnless. - Ann. Sci. Nat. 1. c.; Torr. \& Gray, Fl. ii. 367; Gray, Chloris Am. Bor. (Mem. Am. Acad. iii.) 32, t. 4; Meehan, Nat. Fl. ii. t. 46. - Sandy prairies of Texas; first coll. by Drummond.

G. Mexicána, Gray. A foot or less high from a perennial root, with the habit of $G$. lanceolata, minutely pubescent, naked above, with long rather rigid peduncles : leaves lanceolate. rather small, entire, or the lowest cauline and radical sparingly dentate or laciniate: head 
rather small (disk barely half-inch in diameter) : rays rather sparse and narrow, half-inch - or less long, yellow and brownish: teeth of disk-corolla oblong: akenes with rather short and scanty villosity, surpassed by the numerous setiform fimbrillæ. - Proc. Am. Acad. xix. 34. G. pulchella, var., Gray, Pl. Wright. i. 120, along with plants mentioned as G. lanceolata. - Hills of the Rio Frio, S. W. Texas, Wright. (Adj. Mex. to San Luis.)

$==$ Akenes densely long-villous all over: fimbrillæe subulate-setaceous : rays yellow: peduncles scapiform or from short leafy stems, 5 to 10 inches long: sume or even all the leaves pinnatifid, but very variable.

G. pinnatífida, Torr. Perennial, cinereous-pubescent: leaves sometimes linear or with linear lobes, sometimes spatulate and sinuate or even entire: pappus-paleæ lanceolate. Ann. Lye. N. Y. ii. 214 ; Torr. \& Gray, l. c. - Plains, W. Texas to Colorado and Arizona; first coll. by James. (Adj. Mex.)

G. Arizónica. Annual, greener: leaves less frequently pinnatifid and with only oblong lobes: pappus-paleæ obovate-oblong, very obtuse or retuse. - High plains of S. Utah and Arizona, Palmer, Parry, Greene, Pringle. Has been confounded with the preceding.

* Glabrous or nearly so, thick-leaved, impressed-punctate, low, perennial from a stout multicipital caudex: rays and disk-flowers both yellow: bracts of involucre more coriaceous, mostly ovate or oblong and with short herbaceous tips: teeth of disk-corolla short, ovate, obtuse: akenes moderately villous all over.

G. spathuláta, Grsy. Hardly a foot high, leafy-stemmed, branched from the base : leaves spatulate, entire, inch long, uppermost gradually smaller: head barely half-inch in diameter : rays few and small : pappus with awns surpassing disk-corolla: finbrillæ setaceous-attenuate, shorter than the akenes. - Proc. Am. Acad. xii. 59. - Rabbit Valley, Utah, Ward.

G. acaúlis, Grar. Leaves all clustered on the thick caudex, ovate and obovate, somewhat spatulate, contracted into slender petioles, entire or sparingly dentate : scapes a span to a foot high: head larger : rays more numerous, over half-inch long, rather narrow and with narrow lobes: pappus with short awns not equalling the disk-corolla: fimbrillæ subulate, shorter than the akenes. - Proc. Am. Acad. xi. 73. - S. W. Utah and adjacent Arizona, at Mokiak Pass, \&c., Parry, Palmer.

161. SARTWELIA, Gray. (In honor, now in memory, of Dr. Henry $P$. Sartwell.) - Annuals (of the Texano-Mexican border), glabrous, a foot or two high, leafy, fastigiately branched, and bearing very numerous small heads (only 2 lines high) of yellow flowers in corymbiform cymes; the leaves all narrowly linear or filiform, entire, rather fleshy, opposite, slightly connate at base. - Pl. Wright. i. 122, t. 6, \& Proc. Am. Acad. xix. 34.- Two species.

S. Flavériæ, GRAY, 1.c. Leaves nearly filiform: pappus a truncate cupule. $-\mathbf{S}$. W. Texas, on the Pecos, \&c., Wright, Thurber, Harard.

S. Mexićsas, Gray, Proc. Am. Acad. xviii. 107, xix. 34 (coll. Palner in Northern Mexico), has less filiform leaves, and a pappus of nearly distinct palex, with which as many longer delicate awns alternate.

162. FLAVERIA, Juss. (From flavus, yellow; plants used to dye yellow.) - Glabrous herbs (mainly tropical-American), mostly annuals; with small and fascicled or glomerate heads of yellowish or yellow flowers, and opposite sessile leaves, the broader ones 3 -nerved. Akenes mostly smooth and glabrous. - Gen. 186; Benth. \& Hook. Gen. ii. 409. Flaveria \& Broteroa (Brotera, Spreng.), DC. Prodr. v. 635. Vermifuga, Ruiz \& Pav. Prodr. 114, t. 24.

$\S 1$. Involucre 4-15-flowered, composed of 3 to 5́ principal bracts.

* Heads more or less clustered in broad and open naked-pedunculate compound terminal corymbiform cymes: leaves somewhat fleshy : involucre of 5 bracts : corollas except in the last species nearly or quite glabrous.

F. chloræfólia, Grar. Glaucous, 1 to 3 feet high: leaves entire, from ovate-oblong to lanceolate, broadest (half to fully an inch broad) and connate or connate-perfoliate at base: 
heads about 12-flowered, 3 lines long: no ray. (A few flowers once seen with a pappus of 4 thin palex!) - Pl. Fendl. 88, \& Pl. Wright. 114. - Low grounds, on and near the Rio Grande, S. W, Texas, Wright, Parry, Bigelow. (Adj. Mex., Wislizenus, Gregg, Palmer.)

F. longifólia, Gray, 1. c. Rather stout, 1 to 3 feet high, pale: leaves from linear to lanceolate, broadest or not narrowed at the closely sessile base, 2 to 5 inches long, entire or with rare spinulose denticulations: heads in very ample cymes, 10-15-flowered, often 3 lines long: no ray: bracts of the involvcre broad. - Gymnosperma? oppositifolium, DC. Prodr. v. 312. - Not yet found on the Texan side of the Rio Grande. (Adj. Mex.)

F. lineáris, LAG. Rather slender, a foot or two high: leaves from narrowly linear to lanceolate, or sometimes lower oblong-lanceolate (and inch broad), all contracted above the somewhat connate bases, sometimes denticulate: heads smaller and more glomerate, 5-8flowered, commonly uniligulate. - Nov. Gen. \& Spec. 33 ; Torr. \& Gray, Fl. 360. F. maritima, HBK. Nov. Gen. \& Spec. iv. 285. F. tenuifolia, Nutt. Jour. Acad. Philad. vii. 81. Selloa nudata, Nutt. in Am. Jour. Sci. v. 300 ; therefore Gymnosperma nudatum, DC. Prodr. v. 312. - Coast and Keys of S. Florida ; first coll. by Ware. (Cuba \& Bahamas.)

* Heads in closer subsessile or short-pedunculate or foliose-involucrate chiefly terminal glomerules: involucre of mostly 3 bracts, narrow, 3-5-flowered or some only 2-flowered, commonly uniligulate: disk-corollas sparsely hirsute at base.

F. angustifólia, Pers. Erect, a foot or two high : leaves from linear to lanceolate, serrulate or entire, lightly 3-nerved, sessile by broadish or little contracted base : ligule somewhat exceeding the disk. - Syn. ii. 489 ; DC. Prodr. v. 635 ; Gray, Pl. Fendl. 88 . Milleria angustifolia, Cav. Ic. iii. 12, t. 223. - Alkaline ground, S. W. Texas to E. Colorado and New Mexico. (Mex.)

F. Contrayérba, Pers., is S. American, spreading to W. Indies, and possibly to within our borders, has mostly oblong-lanceolate leaves contracted at base and conspicuously 3-nerved, more glomerate heads, and ligule not exceeding the disk or wanting.

§ 2. Involucre 1-2-flowered, of 1 to 3 unequal bracts : heads densely glomerate. - Broteroa, DC., corrected from Brotera, Spreng. in Schrad. Jour. Bot. (1800), ii. 186 , t. 5 .

F. repánda, LAG. 1. c. Divergently branched annual: leaves obovate to oblong-lanceolate with narrowed petiole-like base, strongly 3-nerved, acutely serrate : glomerules of many confluent heads, sessile in the forks and involucrate at end of the branches, outermost heads commonly of a single short-ligulate flower. $-F$. Contrayerba, Gray, Pl. Wright. i. 114, not Pers. Brotera Contrayerba, Spreng. 1. c. B. trinervata, Pers. Syn. ii. 498. B. Sprengelii, Cass. Dict. xxxiv. 304. Nauenbergia trinervata, Willd. Spec. iii. 2393. Broteroa trinervata, DC. Prodr. v. 636. - S. W. borders of Texas, Wright. (Mex., \&c.)

163. POROPHÝLLUM, Vaill. (П'ópos, a passage or pore, $\phi v ́ \lambda \lambda o v$, leaf, the foliage or involucre appearing as if punctate on account of the translucent oil-glands.) - Herbaceous or suffrutescent plants (of the warmer parts of America), usually glaucous; with alternate or opposite undivided leaves, and pedunculate heads of yellow or purplish flowers. Oil-glands present in the involucre when wanting in the leaves, in the form of dots or stripes. - L. Hort. Cliff. 494; Adans. Fam. ii. 122 ; DC. Prodr. v. 647, excl. § 2, 3. Kleinia, Jacq. Stirp. Am. $21 \tilde{0}$, t. 127 , not L.

* Annual, with broad crenate-repand leaves on slender petioles : bracts of cylindrical involucre 5: corollas purplish, with filiform tube several times longer than the throat and limb: akenes filiform or slender-fusiform.

P. macrocéphalum, DC. A foot or two high: leaves roundish-oval to oblong (or some of the lowest narrower), about the length of the petiole: peduncles enlarged above, clavate and fistulous: head inch long: bracts of involucre obtuse: akenes much longer than the pappus. - Prodr. v. 468; Gray, Pl. Wright. ii. 93.-Rocky hills and ravines, Arizona, Wright, Thurber, \&c. (Mex.) 
* Perennial (as to N. American species), with narrow entire sessile leaves, glaucescent, much branched, 1 to 3 feet high.

P. grácile, Bentr. Lignescent at base, with slender striate branches : odor pungent, "Fennel-like": leaves narrowly linear with tapering base, or uppermost filiform of subulate, or all filiform : involucre cylindraceous, half-inch long; its bracts 5, oblong or linear-oblong, obtuse, scarions-margined, often slightly purple-tinged: corollas dull white and purple, with tube as long as the narrowish throat and short triangular-lanceolate lobes : akenes attenuate at apex, rather longer than the pappus. - Bot. Sulph. 29; Gray, Bot. Calif. i. 399. P. Greggii, Gray, Pl. Wright. i. 120, in part, \& ii. 94. - Arid plains, S. W. Texas to San Diego Co., California. (Lower Calif., Adj. Mex.)

P. scopárium, Grax. Shrubby at base, with slender rush-like branches: leaves thick and firm, linear-subulate and filiform, narrow at base, mucronate-apiculate : involucre campanulate, 4 or 5 lines high, of 7 to 9 broadly lanceolate greenish bracts, one third to half shorter than the mature pappus: corollas yellow, with very short obtuse teeth, and narrow throat much longer than the proper tube (i. e. below the insertion of the stamens) : akenes nut attenuate at apex, fully equalled by the pappus. - Pl. Wright. i. 120, ii. 94, \& Proc. Am. Acad. xviii. 108. P. Greggii, Gray, Pl. Wright. l. c., as to pl. Gregg, a stouter form. - Rocky banks and plains, S. W. Texas and New Mexico; first coll. by Wright. W. borders of Texas, Havard. (Adj. Mex.)

P. AMPlexicaúle, Engelm. in Pl. Wright. l. c., of adjacent Mexico, is stouter, less branched, with solitary and larger heads, and fleshy-coriaceous leaves lanceolate, tapering from a partly clasping base, all but the uppermost opposite: bracts of the involucre 8 to 10, half-inch long.

164. CHRYSACTINIA, Gray. (Xpvoós, gold, ákтis, ray, from the golden yellow rays, which distinguish the genus from the preceding.) - Pl. Fendl. $93, \&$ Pl. Wright. i. 119. - Single species, with resinous-aromatic odor.

C. Mexicána, Grar, 1. c. Fruticulose, about a foot high from a stout base, much branched, very leafy: leaves alternate, Heath-like, thick or almost terete, short-linear or filiform, with narrowed base, cuspidate-mucronate, entire, with abundant round oil-glands : heads on slender peduncles terminating the branches, a third of an inch high: bracts of the involucre lanceolate, hardly longer than the akenes, usually bearing a single large and prominent infra-apical oil-gland : disk-corollas with short proper tube and long cylindrical throat (in the way of Porophyllum scoparium and $P$. amplexicaule) : akenes shorter than the pappus. Rocky ground, W. Texas and adjacent New Mexico; first coll. by Gregg. (Mex.)

165. NICOLLÉTIA, Gray. (Memory of $J . N$. Nicollet, astronomer and explorer of the region between Upper Mississippi and Missouri Rivers.) - Perennial herbs ; with alternate leaves irregularly pinnately parted, and leafy branches terminated by large heads of purple or flesh-colored flowers, or disk-corollas at first yellow. - Rep. Fremont 2d Exped. 315, Pl. Wright. i. 119, \& Bot. Calif. i. 398.

N. occidentális, GraY, l. c. Stout, somewhat fleshy, a foot or two high : branches leafy up to the head : leaves with numerous or several short lanceolate-subulate or linear setosely tipped lobes: involucre three-fourths inch long, of 8 to 12 bracts: ligules oblong, little surpassing the disk. - Sandy banks and plains of the Mohave Desert region, S. E. California; first coll. by Fremont, who made his earliest exploration under Nicollet.

N. Edwárdsii, Gray. More slender, a span or two high: leaves attenuate-linear, fewlobed: heads somewhat naked-pedunculate : involucre turbinate at base, half-inch long, of 8 or 9 bracts: ligules much exserted, elongated-oblong, dentate or denticulate at the truncate summit, commonly half-inch long. - PI. Wright. i. 119, t. 8, \& Bot. Mex. Bound. 93.Sandy banks and plains, S. W. Texas and adjacent New Mexico, Bigelow, Parry. (Adj. Mex., Dr. Edwards, Palmer. Lower Calif., Streets.)

166. DYSODIA, Cav., as Dyssodia. ( $\Delta v \sigma \omega \delta i a$, an ill smell.) - Herbs or suffrutescent plants, of N. America and Mexico, mostly strong-scented; with alternate or opposite leaves, and solitary or rarely somewhat paniculate heads of 
yellow or orange flowers, sometimes turning purplish or reddish. - Anal. Cienc. Nat. vi. 334 ; Lag. Nov. Gen. \& Spec. 29 (mainly) ; Cass. Dict. xxv. 396 ; DC. Prodr. v. 639 (excl. § 5 and incl. Clomenocoma \& Lebetina, Cass.); Benth. \& Hook. Gen. ii. 409 (but not excl. § Gymnolcena, DC.) ; Gray, Proc. Am. Acad. xix. 37. Boebera, Willd. Spec. iii. 2125.

D. Anthemidifólia, Benth. Bot. Sulph., of Lower California, is of a peculiar section (Boberastrum, Gray, 1. c.), with simple and more open involucre, broad conspicuous rays, stylebranches nearly of Bcebera, and pappus with the paleaceous part more conspicuous, the lower bristles on the sides much reduced in size.

§ 1. Eudysódia, Gray, 1. c. Involucre calyculate with some external loose bracts: style-branches (at least in our species) tapering into slender-subulate appendages: teeth of the corolla usually narrow: heads comparatively large, pedunculate, and terminating naked branches: perennials; ours obviously frutescent at base, very glabrous, and with glabrous akenes which are shorter than the pappus; this of rather scanty bristles; the receptacle minutely if at all fimbrillate.

D. Coóperi, Grax. Stout, a foot or two high : leaves all alternate, sessile, thickish, short (the larger less than inch long), from broadly ovate to lanceolate, acute, spinulose-dentate, many with a pair of stipule-like small lobes at base, mostly glandless: head broad, inch high : principal bracts of the involucre 20 to 30 . distinct, subulate-acuminate; accessory ones small and subulate: rays little surpassing the disk orange or turning purplish. - Proc. Am. Acad. ix. 201, \& Bot. Calif. i. 398. - Dry ravines of the Mohave Desert, S. E. California, Cooper, Palmer, Lemmon, Parish.

D. porophylloídes, Gray. Stems 1 to 3 feet high from a woody base, with numerous spreading slender branches: leaves partly alternate, 3-5-parted; the lower petioled and with cuneate to lanceolate entire or incised divisions; upper sessile and the divisions linear-subulate, not setigerous: head narrower, half to three-fourths inch high: principal bracts of the involucre 14 to 20 , linear, abruptly acute or mucronate, commonly slightly united below: rays few and inconspicuous, yellow. - Pl. Thurb. in Mem. Amer. Acad. v. 322, \& Bot. Calif. 1. c. - Dry hills and mesas, S. E. California and Arizona; first coll. by Thurber.

D. SPECrósa, Gray, Proc. Am. Acad. v. 163, is a species of Lower California, allied to the preceding, with opposite trifoliate leaves, and mostly petiolulate leaflets.

D. canceldata, Gray, Proc. Am. Acad. xix. 38 (Lebetina, Cass.), is a species very closely related to $D$. porophylla, DC. (and with similar abruptly short-appendiculate style-appendages), but the pappus is anomalous in having an outer series of short and blunt and wholly naked palex. Common in the northern part of Mexico, reaching so near the Texan border that it may be expected within it.

§ 2. Bđ́BERA, DC., excl. spec. Involucre regularly calyculate with accessory bracts: style-branches with very short conical tips: corolla-teeth short, ovate: palex of the pappus multicapillary : akenes pubescent : receptacle merely pubescent or puberulent: rather low herbs (the two Mexican species perennials, with naked-peduncled conspicuously radiate heads); all with opposite pinnately divided leaves, and some pubescence.

D. chrysanthemoídes, LAG. Much branched and ill-scented annual, leafy up to the subsessile or short-pedunculate small heads leaves 1-2-pinnately parted into linear lobes: involucre purplish-tinged or greenish, campanulate, of 8 or 10 scarious-tipped oblong bracts, and some linear loose accessory ones : rays few and incunspicuous, not surpassing the disk. - Nov. Gen. \& Spec. 29 ; DC. 1. c.; Torr. \& Gray, Fl. ii. 362. D. glandulosa, Cav. D. fastigiata, DC. 1. c., excl. syn. Tagetes papposa, Vent. Hort. Cels. t. 36; Michx. Fl. ii. 132. Babera chrysanthemoides, Willd. Spec. iii. 2125. B. glandulosa, Pers. Syn. ii. 459. - Allnvial soil Minnesota to Louisiana and southwest to Arizona: now spreading eastward in the Atlantic States as a weed. (Mex.) 
167. HYMENATHERUM, Cass. (' $Y \mu \eta^{\prime} \nu$, membrane, $\dot{\alpha} \theta \dot{\rho} \rho$, awn, the paler of the pappus awned.) - Low herbs or suffruticulose plants (chiefly of the Mexican borders), of various habit, mostly pleasant-scented; with alternate or opposite leaves, and small or barely middle-sized usually radiate heads of yellow flowers. - Cass. Bull. Philom. 1817, 1818, \& Dict. xxii. 313; Gray, Pl. Fendl. 88, \& Pl. Wright. i. 115 ; Benth. \& Hook. Gen. ii. 410. Hymenatherum (excl. § 2), Dysodia \& Aciphyllaca, \& Gnaphaliopsis, DC. Prodr. Now adding Thymophylla, Lag. (slightly earlier published name, but obscure), \& Lowellia, Gray, with muticous pappus. Vide Proc. Am. Acad. xix. 40.

§1. Aciphyllesa, Gray. Paleæ of the simple pappus numerous (18 to 20), above resolved into about 5 or the alternate ones into 3 capillary bristles, like those of Dysodia (to which it makes transition): heads sessile or nearly so at the end of the woody branchlets: leaves entire, opposite. - Pl. Wright. i. 115.

H. acerósum, Grar, l. c. Shrubby, a span to a foot high from a thick base, rigid, exceedingly branched: branches barely puberulent: leaves filiform-acerose, usually with shorter ones fascicled in most of the axils : heads 3 or 4 lines high: involncre with copious large oil-glands, subtended by uppermost pair of leaves or by a few shorter subulate foliaceous bracts : rays oblong. - Dysodia? (Aciphyllcea) acerosa, DC. Prodr. v. 641. Aciphylloea acerosa, Gray, Pl. Fendl. 91. - W. borders of Texas to Arizona toward the Mexican boundary, Wright, \&c. (Mex.)

§ 2. Drsodiórsis, Gray, 1. c., excl. spec. Paleæ of the simple pappus only 10, rigid, not longer than the thickish akene, much shorter than disk-corolla, some entire with a single awn, others with 3 aristate-subulate tips : heads loosely foliose-calyculate: leaves alternate.

H. tagetoídes, GRAT, 1. c. A rigid annual, and becoming perennial, glabrous, a fout or so high, fastigiately branched at summit: leaves narrowly linear, 2 or 3 inches long, rigid, laciniately and spinolosely dentate or almost pinnatifid: heads indistinctly peduncled, less than half-inch high: involuere rigid; its bracts obviously imbricated, but connate almost to the tip : rays oblong, conspicuous. - Dysodia tagetoides, Torr. \& Gray, Fl, ii. 361. - Low prairies, Texas; first coll. by Drummond.

§ 3. Euhruenathérum, Gray, 1. c. Paleæ of the pappus 10 to 20 , all or the inner ones 1-3-aristate, and the awns about equalling or surpassing the diskcorolla: heads naked at base, or with some small and scanty subulate accessory bracts. (See also § 4.)

* Rays inconspicuous and few, with ligule not surpassing the disk or the double and dimorphous pappus; this of 10 rigid palere in each series, inner with stout awns.

H. Neo-Mexicánum, Grax. A slender erect annual, a foot or less high, glabruus, fastigiately branched above : leaves mostly pinnately parted into a few linear-filiform entire divisions; lower opposite, upper alternate : heads short-peduncled : involucre turbinate, 3 or 4 lines high, of 5 to 7 oblong connate bracts, subtended by 2 to 4 filiform-subulate bractlets: akenes appressed-villous at the attenuate base, shorter than the inner pappus, the oblonglanceolate paleæ of which are cleft into 3 scabrous rigid awns, the middle one longer; those of the short outer pappus oblong-spatulate, retuse. - Proc. Am. Acad. xix. 40. Adenophyllum Wrightii, Gray, Pl. Wright. ii. 92. - Hillsides, New Mexico, Wright.

* * Rays exserted and conspicuous, oblong: awns of the pappus capillary or slender-setiform.

+ Most of the paleæ of the nearly homomorphous pappus 3-awned, lateral awns shorter: glabrous Ieafy-stemmed herbs, either annuals or slender-rooted subperennials: upper leaves all alternate.

H. polychǽtum, Gray. Low, diffusely much branched from an annual root, leafy to near the numerous short-peduncled heads: leaves not rigid, pinnately parted into several short-filiform obtuse and pointless divisions : involucre barely 3 lines high, 10-16-toothed: 
pappus of 18 or 20 very narrow palex, of 2 or 3 lengths, the smaller attenuate into a short single awn, the larger into a much longer capillary awn, with a delicate short one at each side of its base, or rarely an additional pair of setæ. - Pl. Wright. i. 116.-Prairies, S. W. 'Texas and New Mexico, Wright. (Chihuahua, adj. Mex., Thurber.)

H. Wríghtii, Gray. Erect or diffuse, a foot or less high from a firm annual or perhaps perennial root: branches rather simple, bearing few or solitary heads on peduncles 1 to 3 inches long : leaves not rigid, narrowly linear or almost filiform (an inch or more long), setnlose-mucronate, many entire, some with 1 to 3 small subulate lobes: involucre fully 3 lines high, 16-20-toothed: paleæ of the pappus 10, all slenderly 3-awned from a short lanceolate base; lateral awns with subulate base, half the length of middle one.-Pl. Fendl. 89, Pl. Lindh. ii. 229, \& Pl. Wright. 1. c. - Prairies of Texas, Wright, Lindheimer, \&c.

H. tenuílobum, DC. Diffusely branched and spreading from a seemingly annual but sometimes more enduring root: branches a span to a foot long: heads on filiform (1 to 4 inches long) peduncles: leaves rather rigid, all pinnately parted into 7 to 11 subulate-filiform setulose-mucronate divisions (of only 2 to 4 lines in length) : involucre 3 lines high, about 12-toothed: paleæ of the pappus 10, more rigid, all nearly similar and bearing two lateral and a middle longer stouter awn, the latter hardly longer than the lanceolate paleaceous portion (which, however, sometimes splits away from the awn on each side), rarely one or two smaller lateral setæo or cusps. - Prodr. v. 642. H. tenuifolium, Gray, Pl. Wright. 1. c., not Cass. - S. Texas along and near the Rio Grande, Berlandier, Wright, \&c. (Adj. Mex.)

+ + All 10 palex of the pappus nearly similar and tapering into a single short awn, and the larger mostly 2-setulose: leaves acerose.

H. Thúrberi, Grar. Habit and character of a more leafy-stemmed form of $B$. pentachotum: paleæ of the pappus not distinctly in two series, all narrowly lanceolate, alternate shorter ones subulate-awn-pointed, the others with awn rather shorter than the palex, and a pair of obscure or more manifest setulose teeth at its base.-Proc. Am. Acad. xix. 41. H. tenuifolium, var.? Gray, Pl. Wright. ii. 93. - Texas or adjacent New Mexico, on the Mexican border near El Paso, Wright. Corralitas, Thuber. (Apparently also Northern Mexico, Parry.)

++ Pappus manifestly double and dimorphous, of 10 scarious palex; the 5 outer shorter, spatulate or oblong, obtuse and pointless; inner lanceolate or oblong, bearing a single awn, of equal or greater length, between a pair of cusps or subulate or sometimes aristellate teeth.

t+- Low and diffuse suffruticulose perennials, minutely cinereous-pubescent or glabrate, not woolly, much branched from the base: leaves rigid or rigidulous, pinnately parted into few or several mostly filiform or acerose entire divisions, subulate or setulose-mucronate at tip: heads on elongated filiform peduncles.

H. Hartwégi, Grax. A span. or two high, nearly herbaceous and glabrous : leaves chiefly opposite, of few rather long filiform-acerose divisions: heads numerous: involucre 'rather narrow, 2 lines high, almost naked at base : outer paleæ of pappus subcoriaceous, with truncate summit obscurely denticulate. - Pl. Wright. i. 117. H. Berlandieri, Benth. Pl, Hartw. 18, not DC. - W. Texas to S. Arizona, Wright, Lemmon. (Mex.)

H. pentachǽtum, DC. Decidedly suffruticulose, low, diffuse, cinereous-puberulent, sometimes glabrate and rather shining, sometimes the foliage canescent with short and fine spreading pubescence: leaves rigid, upper alternate, divisions slender subulate-acerose: involucre from broadly campanulate to hemispherical, 2 or 3 lines high: outer paleæ of the pappus thinnish, usually erose at summit. - Gray, PI. Wright. i. 117. II. pentachatum (the onter pappus overlooked) \& $H$. Berlandieri, DC. Prodr.. . 642. - Dry hills, Texas (first coll. by Berlandier) to Arizona and S. Utah : very variable. (Mex.)

H. Trecullii, Grax. Diffuse, nearly herbaceous, almost glabrous, with loose elongated leafy branches and very scattered heads: leaves perhaps rather succulent, pectinately parted into linear-subulate equal short ( 2 or 3 lines long) divisions, which are rather narrower than the rhachis: involucre (3 lines high) and pappus of the preceding. - Proc. Am. Acad. xix. 42. - S. E. Texas, Trécul, in herb. Mus. Paris.

++ Low and densely floccose-lanate and soft-leaved annual. - Gnaphaliopsis, DC.

H. Gnaphaliópsis, Gray. Depressed or diffusely spreading, clothed even to the involucre with dense white wool in the manner of a Cudweed, leafy up to the sessile or short-peduncled solitary heads: leaves mostly alternate, spatulate, entire, barely half-inch long: involucre 
quarter-inch high : rays oval, short : receptacle flat and wholly naked : paleæ of inner pappus narrowly lanceolate. - Pl. Fendl. 90 (as $H$. gnaphalodes) \& 115 ; Pl. Wright. 1. c. Gnaphaliopsis micropoides, DC. Prodr. vii. 258. - Hills and plains, S. Texas, Wright, Havard, \&c. (Adj. Mex.; first coll. by Berlandier.)

§4. Thrmoptflla, Gray. Paleæ of the pappus 5 to 12 , truncate and muticous (yet in one species occasionally some are short-awned!), somewhat coriaceous, distinct or cupulately connate. - Proc. Am. Acad. xix. 42. Thymophylla, Lag. Nov. Gen. \& Spec. 25 ; Gray, Pl. Fendl. 91, \& Pl. Wright. i. 119, t. 7 ; Benth. \& Hook. Gen. ii. 410 (as Thymophyllum).

* Fruticulose plants, with habit and character of the acerose-leaved genuine species of Bymenatherrm, but white tomentose, and rays in one species wanting.

H. setifólium, Gray, l. c. (Thymoplylla setifolia, Lag. l. c., on which the long imperfectly known genus was founded), may possibly reach our limits. It has a canescent involucre, no rays, and normally pappus of 5 or 6 distinct quadrate palea. But in some specinens of Parry and Palmer's no. 516 occurs an inner alternating series of longer and narrower aristate paleæ, - completely invalidating Lagasca's genus.

H. Gréggii, Grax. A span or two high in dense tufts: branches thickly leafy up to the filiform glabrate peduncles: leaves white-tomentose, short, Heath-like; lower 3-7-parted, upper entire, setaceous: involucre campanulate, glabrous, naked at base: rays 10 to 12, short, but distinctly exserted, sometimes wanting: paleæ of the pappus united into an entire truncate cup. - Proc. Am. Acad. xix. 42. Thymophylla Greggii, Gray, Pl. Fendl. 92 (specimen apparently rayless), \& Pl. Wright. i. 309, t. 7, radiate. - S. W. Texas, on the Pecos, \&c., growing in large bunches, Wright. (Adj. Mex., Gregg.)

* * Annual, wholly glabrous, wholly resembling $H$. polychatum and its near allies, except the pappus. - Lowellia, Gray.

H. aúreum, Grar. A span or two high, erect or diffuse, much branched, bearing numerons short-peduncled heads: leaves mostly alternate, pinnately parted into 7 to 9 linear-filiform pointless divisions : involucre broadly campanulate, 3 lines high : rays about 12, oblong, 3 lines long: pappus of 6 or 8 quadrate or oblong and erose-truncate palex, in length little exceeding the breadth of the akene. - Proc. Am. Acad. xix. 42. Lowellia aurea, Gray, Pl. Fendl. 89, \& Pl. Wright. i. 118. - Plains of Colorado to W. Texas; first coll. by Fendler, next by Wright.

168. TAGETES, Tourn. (A name of the early botanists for the "French" or "African Marigold" of the gardens, T. patula, and its larger form, T. erecta, L. Fuschius says it was applied by Apuleius to the Tansy: some derive the word from Tages, an Etruscan deity.) - Mexican and S. American herbs, mostly annuals, strong-scented, branching; with opposite and sometimes alternate leaves, in one species nearly entire, in most pinnately divided, having copious oil-glands, bearing large and showy or small and comparatively inconspicuous heads of mostly yellow or orange flowers, in cultivation some flamecolored or reddish. - Inst. 488, t. 278; L. Gen.; DC. Prodr. v. 642 ; Gray, Proc. Am. Acad. xix. 42.

T. LGCIDA, Cav., the species with simple and narrow sessile leaves, and cymose heads with 2 or 3 rather showy rays, may yet be found within our Mexican border. One of our two indigenous species has handsome exserted rays, the other has inconspicuous rays and the most slender heads in the genus.

T. Lemmóni, Gray. Nearly glabrous, 2 or 3 feet high from a perennial root, lignescent at base, rather slender, fastigiately branched, bearing numerous cymosely disposed heads on slender short peduncles: leaves all opposite, 3-7-foliolate; leaflets lanceolate-linear or sometimes lanceolate-oblong, with attenuate base, serrulate, not setiferous (an inch or two long), sometimes a minute lower pair: involucre turbinate-campanulate, 4 lines high: rays 6 to 8 , nearly half-inch long, obovate-oblong: lobes of the disk-corolla nearly beardless: pappus 
much shorter than the akene, of 1 to 3 subulate and one or two shorter truncate pales. Proc. Am. Acad. xix. 40, 42.-S. Arizona, in the Huachuca Mountains, Lemmon.

T. micrántha, CAv. Slender, diffusely much branched, Anise-scented, a span to a foot high from an annual root, with loosely paniculate slender-peduncled heads: leaves linearfiliform, 3-5-parted, or some of the lowest undivided, not serrate: involucre fusiform, about half-inch long, few-flowered; rays 1 to 3 , the oval pale yellow or white ligules only a line long: akenes slender, glabrate, longer than the pappus of 2 oval or truncate thin palex and 2 longer awns. - Ic. iv. 31, t. 352; DC. Prodr. v. 646; Gray, Pl. Wright. ii. 93. - Dry ground, New Mexico and Arizona, Wrighl, Rothrock, \&c. (Mex.)

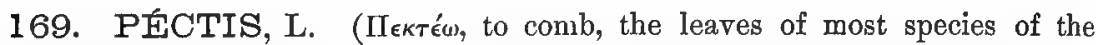
genus pectinately setiferous. It is an ancient Latin name of some plant, appropriated to this genus by Linnæus.) - Herbs, all American, mostly low and spreading, usually glabrous, heavy-scented; with narrow opposite leaves conspicuously dotted with round oil-glands; and with mediocre or small heads of yellow flowers, occasionally turning purplish, slender rigid bristles fringing at least the base of the leaves, or rarely quite wanting.

§1. Eupḱctrs. Pappus of a few paleæ or slender awns with or without a dilated or chaffy base, or in some (and occasionally in all) of the akenes reduced to a paleaceous crown, or to a few squamellæ, or obsolete: base of the leaves copiously setiferous. - Gray, Proc. Am. Acad. xix. 44. Pectis § Pectidopsis \& Eupectis, Gray, Pl. Wright. i. 83. Pectidopsis, Pectis (excl. spec.), and part of Lorentea, DC. Prodr. v. 98-101.

* Pappus paleaceous, conspicuous: the palex (in ours 4 or 5 or 6 in the disk, 2 or 3 in the ray) mostly prolonged into awns or subulate points: bracts of involucre 4 to 6 , broad or broadish: ours annuals.

P. prostráta, $\mathrm{CAv}_{\mathrm{A}}$. Procumbent or prostate: leaves oblanceolate or spatulate-linear (seldom inch long) : heads sessile or nearly so: disk-flowers 5 or 6 : paleæ of the pappus ovatelanceolate or narrower, thin, often unequal, short-awned. - Ic. t. 324; DC. Prodr. v. 100 ; Gray, Pl. Wright. i. 83. Chthonia prostrata, Cass. Dict. ix. 173.-S. W. Texas to Arizona. (Mex., W. Ind.?)

P. ciliáris, L. Erect or diffuse, sometimes a foot high: leaves linear-oblanceolate or narrower, commonly inch loug: heads nearly sessile: disk-flowers 4 to 8 : paleæ of the pappus lanceolate-subulate tapering into a slender awn, more rigid and equal than in the preceding. - Spec. ed. 2, 1250. - Coast and keys of S. Florida, Blodgett, Grarber. (W. Ind.)

P. linifólia, LEss. Erect, diffusely branched, slender, a span to a foot high: leaves narrowly linear, inch long: heads on minutely bracteate filiform (commonly inch long) peduncles: involucre (2 lines long) of narrower bracts: paleæ of the pappus ovate or ovate-lanceolate, abruptly long-awned, or some nearly awnless. Varies with peduncles not longer than the head. - Less. in Linnæa, vi. 709 (excl. syn.); DC. 1. c. 99 (excl. syn.); Griseb. F. Brit. W. Ind. 378, not L. - S. Florida, Blodgett, Garber, Curtiss, \&c. (W. Ind.)

* * Pappus pauciaristate; viz. of 1 to 5 or 6 upwardly scabrous (usually slender and setiform but rigid) awns, at most dilated only at very base, with or without a short chaffy crown of connate or separate squamella, sometimes reduced to this, the awns being absent: bracts of the short-cylindraceous rather many-flowered involucre linear, at length with involute margins partly surrounding outer akenes: low and much branched annuals, with slender narrow-linear leaves, bearing a few bristles next the base.

- Heads subsessile or short-peduncled, more or less fastigiate or cymose at the end of the branches: bracts of the involucre about. 8 .

P. tenélla, DC. A span or more high: pappus of 3 to 6 slender awns, not much shorter than the akene: no squamellæ or crown. - Prodr. v. 99 ; Gray, Bot. Mex. Bound. 73. - S. Texas, Berlandier, Thurber, Havard. (Adj. Mex.)

P. angustifólia, Torr. A span or two high, lemon-scented: pappus a crown of 4 or 5 mostly connate squamellæ, and not rarely one or sometimes two slender usually short awns 
-Ann. Lyc. N. Y. ii. 214; Gray, Pl. Fendl. 61, Pl. Wright. i. 82, \& Bot. Mex. Bound. 1. c. P. fastigiata, Gray, Pl. Fendl. J. c. Pectidopsis angustifolia, DC. 1. c.; Torr. \& Gray, Fl. ii. 62. - Dry hills and plains, Texas to Colorado and Arizona; first coll. by,James. (Adj. Mex.)

++ Herds scattered or solitary, on filiform (one or two inches long) peduncles terminating stem and diffuse branches: involucral bracts obtuse, at length more or less infolding ray-akenes: plants a span or two high: leaves shorter than or equalling the internodes, au inch or two long.

P. fílipes, Grar. Lemon-scented, at length much branched: leaves narrowly linear : involucre narrow, of 5 narrowly oblong bracts : ligules 2 lines long: pappus both in disk and rayflowers of 2 or 3 (rarely one) rigid subulate awns, shorter than or equalling disk-corolla, with thickened bases and usually very short and blunt interposed squamellx, sometimes all coroniform-concreted, or some disk-flowers destitute of pappus. - P1. Fendl. 62, \& Pl. Wright. ii. 69. P. Jaliscana, Hemsl. Bot. Biol. Centr.-Am. in part, not of Hook. \& Arn. (as Taliscana) as was supposed. - Common from S. W. Arizona (probably not California) to S. W. Texas; first coll. by Coulter.

P. Rúsbji, Greene, in herb. "Mint-scented": leaves linear, thickish : involucre campanulate, of 7 to 9 oblong very obtuse bracts: ligules 3 lines loug: pappus in ray-flowers of two or more slender awns; in disk-flowers a conspicuous crown of numerous setaceouspointed squamelix more or less concreted at base: flowers more mumerous than in the proceding. - Beaver Creek, N. Arizona, Rusby.

§ 2. Pестóthrix. Pappus of numerous capillary bristles (at least in most of the disk-flowers) and no paleæ. - Gray, 1. c.

* Pappus barbellate-setose, uniserial, but occasionally reduced to a crown of squamellæ: annual.

P. pappósa, Grax. A span to a foot high, diffusely or divaricately much brazched from the base: leaves very narrowly linear, elongated (the larger 2 inches long, barely a line wide), very few bristles at their base: peduncles once to thrice the length of the heads: involucre of 7 to 9 linear bracts: akenes sparsely hispidulous with short capitate bristles: pappus shorter than the disk-corolla, normally of 12 to 18 unequal capillary bristles, which are strongly but rather sparsely barbellate, sometimes (especially in the ray) reduced to a setulose or squamellate crown, or quite obsolete. - Pl. Fendl. $62 ;$ Pl. Wright. ii. $69 . \Gamma$. tenella, Rothrock in Wheeler Rep. vi. 17], not DC. - S. California, Arizona, Utab, and New Mexico; first coll. by Coulter.

* * Pappus of merely scabrous capillary bristles, with shorter outer ones more or less in a separate series: ours perennial.

P. lóngipes, Gray. Low and much branched from a perennial root, forming spreading or depressed tufts: leaves crowded, linear, conspicuously setiferous at base: perluncles elongated, often scape-like, 3 or 4 inches long: involucre campanulate, 3 lines high, manyflowered, of 12 or 13 linear bracts: rays as many, 3 or 4 lines long: pappus of the rayflowers setosely 2-aristate; of the disk multisetose, i. e. of 20 or 30 upwardly denticulate capillary bristles, the longer equalling disk-corolla, and of some small more attenuate outer ones. - P1. Wright. ii. 70; Rothrock, 1. c., but root not annual. - S. Arizoua; first coll. by Wright, Thurber, \&c.

§ 3. Pectídicm. Pappus when developed of few ( 1 to 4 or 5 ) subulate and rigid mostly corneous and persistent awns, or reduced to a crown or vestige in some flowers. — $\$$ Pectidium \& Heteropectis, Gray, Pl. Wright. i. 83.

* Diffuse low annuals, puberulent, with setiferous leaves: corneous divergent awus of the pappus retrorsely barbed, in the way of Bidens. - Heteropectis, Gray, 1. ᄂ.

P. Coúlteri, Gray. A span or less high, very diffuse, slender: leaves narrowly linear, setiferous merely at base, only half-inch long: peduncles twice or thrice the length of the head : involncre cylindraceous, 2 lines high, 10-20-flowered, of 5 linear-oblong bracts : serrulate-hispid awns of the pappus 3 or 4 in the ray, 2 or 3 in the disk. - Pl. Fendl. 62. - Arizona (probably not California), Coulter, Palmer.

'P. MUltisḱt A, Benth. Bot. Sulph. 20 (Lower California, Hinds, Xantus), is larger, with broader and serrulate leaves, all the teeth and the apex bristle-tipped; outer akenes with 2 or 3 retrorsely hispid awns; inner with a single awn and a short crown. 
* * Erect and comparatively tall annual, with leaves sparingly if at all setiferous at base: akenes all with 2 or 3 corneous and subulate diverging smooth awns (rarely an ascending denticulation): rays small, turning purplish. - Pectidium, DC.

P. punctáta, JACQ. A foot or more high, paniculately branched, very smooth : leaves linear, with copious small oil-glands: heads slender-peduncled, quarter-inch long: involncre cylindrical, few-flowered, of 4 or 5 narrow bracts, involute in age. - Stirp. Amer. t. 128; L. Spec. ed. 2, 1250 ; Griseb. l. c. P. linifolia, L. Amœn. Acad. v.407, \& Spec. 1. c., founded on pl. of Browne and Sloane. Pectidium punctatum, Less. in Linn. vi. 706; DC. 1. c. 98. - S. W. Arizona, Palmer, Smart, Lemmon. Not yet seen from Florida, where it would rather be expected. (W. Ind., S. Calif., Galapagos.)

* * Erect and rather tall perennial, with leaves wholly destitute of bristles: pappus in some flowers of one or two conspicuous erect and smooth paleaceous awns or rigid aristiform palex, and 2 or 3 rigid squamellæ, or sometimes all reduced to a crown of corneous squamellx, or nearly obsolete: rays conspicuous, turning purplish.

P. imbérbis, Grax. Wholly smooth and glabrous: stems a foot or two high, paniculately branched, rather rigid and junciform, sometimes few-leaved: leaves narrowly linear, quite entire, sparingly punctate with oil-glands: heads half-inch long, slender-pedunculate: involucre cylindrical, of 5 or 6 linear obtuse bracts, with margins strongly involute in age : rays 5: disk-flowers 5 to 7, with lobes of cotolla bearing a large dark gland. - Pl. W right. ii. 70; Rothrock in Wheeler Rep. vi. 172.-S. Arizona, Sanoita Valley, Wright, Rothrock, \&c. (Adj. Mex.)

\section{Tribe VII. ANTHEMIDEÆ, p. 77.}

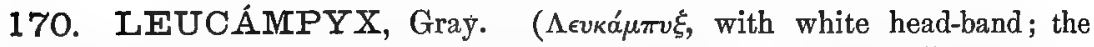
circle of bracts of the head white-bordered.) - Benth. \& Hook. Gen. ii. 422; Porter \& Coulter, Fl. Colorad. 77 ; Rothrock in Wheeler Rep. vi. 175, t. 12. Single species.

L. Newbérryi, Gray in Porter \& Coulter, 1. c. Perennial herb, a foot or two high, with the aspect and some of the characters of Hymenopappus (except the rays), flocculent-woolly, glabrate in age: leaves 2-3-pinnately parted into filiform-linear segments: heads few or several at the naked summit of the stem : involucre nearly half-inch broad : rays three-fourths inch long, obscurely 3-lobed at summit, at first yellow, soon changing to cream-color or white: akenes 2 lines long, turning black. - Cañons, \&c., S. W. Colorado, Newberry, Porter, Brandegee. Also W. New Mexico, Loew.

171. ÁNTHEMIS, L. Chamomile. (Ancient Greek and Latin name of Chamomile.) - Herbs, usually with pinnately dissected leaves, and rather large heads on peduncles terminating the branches; disk-flowers yellow; rays white, rarely yellow, fertile, except in the first species. A large Old-World genus, one or two species naturalized.

A. Cótuda, Y. - (Mayweed.) Annual weed, of the section Maruta, has receptacle of the head conical, destitute of bracts near the margin, bristly ones at the centre: rays mostly neutral, white, sometimès abortive: akenes 10-ribbed, rugose or tuberculate: stem low: leaves finely 3-pinnately dissected : herbage unpleasantly strong-scented, acrid. - Spec. ii. 894; Barton, Veg. Mat. Med. t. 14. Maruta foetida, Cass. Dict. xxix. 174. M. Cotula, DC. Prodr. vi. 13. - Common in waste grounds and along roadsides; fl. late summer and autumn. (Nat. from $\mathrm{Eu}$.)

A. ARténsis, L. (Firld Chamomile.) Anuual weed, not unpleasantly scented : leaves 1-2pinnately parted into linear-lanceolate lobes: heads rather long-peduncled : bracts of involucre obtuse, whitish-scarious: receptacle conical; its bracts lanceolate, acuminate: rays white: akenes with a very short slightly toothed margin in place of pappus. - Engl. Bot. t. 602; Fl. Dan. t. 1179; DC. Prodr. vi. 6. - Old fields, sparingly established in the Atlantic States, Oregon, \&c. (Nat. from. Eu.) 
A. Nóbruss, L., the officinal Chamomile, a low perennial, with pleasant azomatic filiformly dissected foliage, not uncommon in gardens, is said to be occasionally spontaneous, but rarely.

A. TINCTórta, L., - an erect herb, rather stout, with large heads, yellow rays, or occasionally pale or partly white, and quadrangular akenes, - has sometimes escaped from gardens.

172. ACHILLÉA, Vaill. Yarrow. (After Achilles.) - Perennial herbs; with small and corymbosely cymose heads of white, yellow, or sometimes rosecolored flowers, at least in the ray; disk commonly yellow. - Linn. Gen. no. 661. Ptarmica \& Millefolium, Tourn. Ptarmica \& Achillea, DC.-Many Old-World species, very few American, all perennial.

$\$ 1$. Heads rather narrow: receptacle at length elevated. - Ackillea, DC.

A. Millefólium, L. (Mrlforl or Yarrow.) From villous-lanate to glabrate: stems simple, a foot or two (on high mountains a span) high: leaves elongated and narrow in outline, sessile, bipinnately dissected into numerous small and linear to setaceous-subulate divisions : heads numerous, crowded in a fastigiate cyme: involucre oblong; its bracts pale or sometimes fuscous-margined, or even wholly brownish: rays 4 or 5 , about the length of the involucre, white occasionally rose-color. - Very variable; in grassy fields of Atlantic States greeu and more or less glabrate, and with open foliage (perhaps introduced from Europe); northward and on mountains mostly lanate (var. lanata, Koch), with divisions of the narrow leaves much crowded; including $A$. gracilis \& $A$. occidentalis, Raf. in DC. Prodx. vi. 24 ; A. tomentosa, Pursh, Fl. ii. 319. A. lanulosa, Nutt. Jour. Acad. Philad. vii. 36 ; A. setacea, Schwein. in Long Exped. ii. 119. Form with dark involucre, A. Lillefolizm, var. nigrescens, E. Meyer, P1. Labrad.; A. borealis, Bong. Veg. Sitch. 149. Ptarmicrt brealis, I)C. - Common from Labrador to Alaska, south to Texas and California. (All N. hemisphere.)

§ 2. Heads broader: involucre campanulate : receptacle low.-Ptarmica, Tourn., DC.

A. multiflóra, Hook. Villous-pubescent, soon glabrate: stem strict, 2 feet high: leaves linear, closely pectinate-pinnatifid into lanceolate-subulate minutely denticulate lobes, the sinuses extending fully half-way to the midrib: heads in rather a close cyme: rays 10 or 12 , very short and small, white. - Fl. i. 318; 'Torr. \& Gray, Fl. ii. 409. A. Ptarmiru, Richards. in Frankl. Journ. 33. - Saskatchewan to Fort Franklin and Behring Strait; first coll. by Richardson and Drummond.

A. Ptármica, L. (SNezzewort.) A foot or two high, loosely branching above, bearing more loosely disposed and pedunculate heads : leaves glabrous, linear, finely and closely serrate: rays 8 to 12 , comparatively large, roundish, white. - Fl. Dan. 643 ; Engl. Bot. 757 ; Pursh, F1. ii. 552. Ptarmica vulgaris, Blackw. Ilerb. t 256; DC. Prodr. vi. 23. - "Open lry swamps, Canada and New York," Pursh. The latter habitat unsupported. New Brunswick, apparently indigenous in Restigouche and Kent Counties, Fowler. Locally uaturalized in Mass. and Michigan. (Eu., N. Asia.)

173. MATRICÁRIA, Tourn., L. (Name given by the herbalists, from mater or matrix, to herbs of reputed medicinal virtues.) - Herbs, chiefly of Europe and Asia; with finely once to thrice dissected leaves, and pedunculate heads, the disk-flowers yellow, those of the ray white, or occasionally (and in one of our species constantly) wanting. - Benth. \& Hook. Gen. ii. 427.

$\S 1$. Akenes obpyramidal, with 3 strong and thick (lateral and facial) ribs. Tripleurospermum, Schultz Bip. Chamamelum, Visiani ; Boiss., in part.

M. inodóra, L. Nearly scentless, annual, an arctic form apparently biennial or perennial: leaves 2-3-pinnately divided into filiform or narrow linear lobes: heads large : rays half to three-fourths inch long: receptacle at length ovate: pappus a minute entire or 4-toothed border. - Fl. Suec. ed. 2, 297; DC. Prodr. vi. 52 ; Torr. \& Gray, Fl. ii. 412. Chrysanthemum inodorum, L. Spec. ed. 2, 1253 ; Fl. Dan. t. 696 ; Schk. Handb. t. 253. Pyrethrum inodorum, Smith, Engl. Bot. t. 676; Hook. Fl. i. 320. Tripleurospernum inodorum, Schultz Bip. Tara- 
cet. 31. - Arctic searcoast to Alaska and the Hudson Bay country, commonly in a dwarf and monocephalous form with blackish involucre (var. nana, Torr. \& Gray, 1. c., Chrysanthemum grandiflorum, Hook., Pyrethrum inodorum, var. nanum, Hook. Fl. l. c.), occasionally wanting the ray, var. eligulata, Seem. Bot. Herald, 33. The common taller and branching European form is naturalized in some parts of Canada and Maine. (Eu., Asia.)

$\S 2$. Akenes more terete, with 3 to 5 slender often unequal or indistinct ribs, the surface commonly developing mucilage when wetted.

M. Сinмoмílla, L. Annual, a foot or two high, quite resembling Anthemis Cotula, aromatic: heads 3 lines high, and rays of the same length: bracts of the iurolucre oblong, fuscous: receptacle ovate-conical or oblong in age: akenes small, with an obscure border and usually no distinct pappus; the inner face unequally 5-ribbed.-Curt. Fl. Lond. v. t. 63; Schk. Handb. t. 253. - Waste grounds, S. New York and New Jersey. (Nat. from Eu.)

Var. cononata, GAY, ex Boiss. Akenes of the ray and commonly most of the disk furnished with a conspicuous thin-scarious cleft and toothed and sometimes unilateral pappus, not rarely surpassing the tube of the corolla. $-M$. coronata, Gay in Koch, Fl. Germ. ed. 2, 416. M. Courrantia, DC. 1. c. 72 ; Webb, Phyt. Canar. ii. t. 89. M. pyrethroides, DC. 1. c., from Mex. Courrantia chamomilloides, Schultz Bip. in Webb, Phyt. Canar. ii. 278. Cult. fields, S. Texas, Bigelow. (Adj. Mex.)

M. discoídea, DC. Annual, somewhat aromatic, glabrous, a span to a foot high, very leafy : leaves 2-3-pinnately dissected into short and narrow linear lobes: heads all shortpeduncled : bracts of the involucre broadly oval, white-scarious with greenish centre, hardly half the length of the well-developed greenish yellow ovoid disk: receptacle high-conical: akenes oblong, somewhat angled, with an obscure coroniform margin at summit, this occasionally produced into one or two conspicuous oblique anricles of coriaceous texture. - Prodr. vi. 50; Torr. \& Gray, Fl. ii. 413. M. tanacetoides, Fisch. \& Meyer, Ind. Sem. Petrop. vii. 52. Santolina suaveolens, Pursh, Fl. ii. 520. Artemisia matricarioides, Less. in Linn. vi. 210. Tanacetum matricarioides, Less. Syn. 265. T. suaveolens, Hook. Fl. i. 327, t. 110. $T$. pauciflorum, DC. 1. c. 131, not Richards. Cotula matricarioides, Bong. Veg. Sitch. 150. Lepidoiheca (Lepidanthus) suaveolens, Nutt. Trans. Am. Phil. Soc. n. ser. vii. 397. - Open ground, W. California to Unalaska and Behring Island, east to Montana, and becoming naturalized in the Atlantic States near railroad stations. (N. Asia; nat. in N. Eu.)

174. CHRYSÁNTHEMUUM, Tourn., L. (Old Greek name, Xpvбáv-

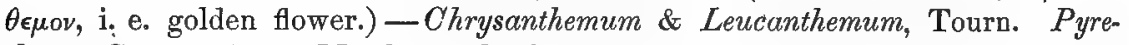
thrum, Gærtn., \&c. - Mostly an Old-World genus, only a small portion of the species with yellow rays: fl. summer.

C. SEGÉTUM, L. (CoRn-ChrTsanthemum or CoRn-MARYGold of Europe), is a ballast-weed at New York and Philadelphia, and is in fields at Oakland, California. This and C. conoNÁriUm, L., are genuine Chrysanthemums, annuals, with golden yellow rays as well as diskflowers, and 3-sided or 3-winged ray-akenes.

C. SinÉnse and C. ÍNDICUs, L., of China and Japan, are the parents of the autumn-flowering perennial Chrysanthemums of gardens and houses, and form a peculiar section of the genus.

C.? NAXum, Hook. Fl. i. 320, is Blennosperma Californicum.

§ 1. Prréthrum, Benth. \& Hook. Herbaceous or suffruticulose perennials; with compuratively large and broad heads, either solitary or loosely corymbose : rays usually conspicuous: akenes all equably 5-10-costate. - Pyrethrum, Gærtn. Pyrethrum, Lencanthemum, Plagius, \&c., DC. Tanacetum in part, Schultz Bip.

* Rays described as yellow, but perhaps white, short: leaves bipinnately dissected into many small linear lobes.

C. bipinnátum, L. Slender, a span to a foot high from a creeping rootstock, villous or glabrate, bearing usually a solitary head of half-inch diameter : rays obovate, little surpassing the merely convex disk: pappus a short crown. - Spec. ii. 890; founded on Gmel. Fl. Sibir. ii. 205, t. 85, f. 1. Pyrethrum bipinnatum, Willd. Spec. iii. 2160; DC. Prodr. vi. 60. Tanacetum Kotzebuense, Bess., ex DC. 1. c. 131. T. bipinnatum, Schultz Bip. Tauacet. 48. - 
Cape Espenberg, Arctic Amer., Eschscholtz. Yukon Valley, Alaska, L. II. Turner, a glabrate form. (E. Asia to Russ. Lapland.)

* * Rays white, elongated: heads solitary, mostly long-peduncled: leaves undivided or merely pinnatifid.

C. Leccánthemdu, L. (Ox-eye Daisy, Whiteweed.) Glabrous, a foot or two high from a creeping base or rootstock, simple or sparingly branched : cauline leaves spatulate, and the upper gradually narrower, becoming small and linear, pinnately dentate or incised, partly clasping at base; radical broader, petioled: head broad and flat: rays inch long: pappus none. - Fl. Dan. 994; Engl. Bot. 601. Leucunthemum vulgare, Lam. Fl. Fr. ii. 137; DC. Prodr. vi. 46. - Common weed in pastures and meadows through Atlantic States, \&c.; here and there met with in similar situations quite to the Pacific. Occurs occasionally with abortive, deformed, or tubular and laciniate rays. (Nat. from Eu.)

C. árcticum, L. Nearly or quite glabrous, rather fleshy, a span to a foot high: leaves cuneate, with long tapering base or petiole, crenately toothed or incised at summit, sometimes 3-5-lobed; uppermost small and linear, nearly entire: bracts of the involucre broad, brown-margined : rays nearly inch long: pappus none. - Spec. ii. 889 ; Pursh, F1. ii. 526 ; Willd. Hort. Berol. t. 33. Leucanthemum arcticum, DC. 1. c.; Torr. \& Gray, Fl. ii. 412. Coasts, Hudson's Bay and arctic shores to Arctic Alaska and islands. (Kamtschatka and Japan to Lapland.)

C. integrifólium, RICHaRDS. Villous when young: stem simple and scapiform from a leafy tufted base, 2 to 4 inches high: leares linear or slightly spatulate, entire: bracts of involucre oblong, blackish : rays less than half-inch long: pappus none. - App. Frankl. Journ. ed. 2, 33 ; Hook. in Parry Voy. \& Fl. i. 319, t. 109. Leucanthemum integrifolium, DC. 1. c. ; Torr. \& Gray, l. c. - Arctic sea-coast; first coll. by Parry and Richardson. (Arctic Asia.)

* * Rays white, broad: heads globular-depressed, comparatively small, loosely corymbosecymose: leaves bipinnately parted or cleft.

C. Parthénidu, Pers. (Feferfew.) Much branched, puberulent, leafy: leaves thin, pinnately parted, and the oval or oblong divisions pinnatifid or incised and toothed: rays oval or obovate, 2 or 3 lines long (in cultivation sometimes all the disk-flowers changed into rays) : pappus a minute crown. - Benth. Brit. Flora, ed. 4, 250. Matricaria Parthenium, L.; Fl. Dan. t. 624. M. odorata, Lam. Pyrethrum Parthenium, Smith. Leucanthemum Parihenium, Godron; Gray, Man. Tanacetum Parthenium, Schultz Bip. - Roadsides and waste grounds, sparingly in Atlantic States; escaped from cult. (Nat. from Lu.)

§ 2. Grmnócline, Benth. \& Hook. (Gymnocline, Cass.). Consists of perennial species, with small and corymbosely disposed rather narrow heads, resembling Achillea except in the naked receptacle, and when discoid or nearly so making transition to Tanacetum. An outlying member of this group is

C. Balsámita, L, with its rayless or discoid form, var. ravacetof́des, Boiss. (Costmarr, Mint-Gerani u, of the gardens), is beginning to escape to roadsides in a few places. It is known by its sweet-scented herbage, barely serrate oblong leaves, and yellowish flowers; when the rays appear they are white. (Adv. from Asia.)

175. SOLIVA, Ruiz \& Pav. (Dr. Salvador Soliva, of Spain.) - Small and depressed herbs, mostly if not all annuals and S. American; with mainly alternate and petioled pinnately dissected leaves; the heads of greenish flowers sessile in the axils or forks. - Prodr. 113, t. 24. Soliva a, Cass. Dict. xxix. 177. Gymnostyles, Juss. Ann. Mus. Par. iv. 258, t. 61.

S. séssilis, RuIz \& PAv. Villous, or the leaves glabrate; these twice divided; primary divisions 3 to 5 , petiolate, parted into 3 to 5 narrow lanceolate lobes: heads depressed : akenes broadly obovate, thin-winged, the wings entire or sometimes panduriform-excised near the base, spinulose-pointed at summit, in some the wings reduced to an acute margin: persistent style long and stout. - Syst. 215; DC. Prodx, vi. 143. S. daucifolia, Nutt. Trans. $\Lambda \mathrm{m}$. Phil. Soc. 1. c. 403; Torr. \& Gray, Fl. ii. 425; Gray, Bot. Calif. i. 406. Gymnostyles Chilensis, Spreng. Syst. iii. 500. - Moist ground, coast of California, from Santa Barbara to Mendocino Co. (Chili, whence probably introduced.) 
S. NASTURTifólia, DC. I. c. Much depressed, spreading, small : leaves glabrate, pinnately parted into 5 to 9 oblong divisions of about a line in length; these entire or the lower fewtoothed : heads globular: akenes small, very numerous, villous at apex, cuneate, the margius much thickened and tuberculate-rugose: style short and slender. - Torr. \& Gray, l, c. Gymnostyles nasturtiifolia, Juss. Ann. Mus. iv. 262, t. 61, f. $2 . \quad$ G. stolonifer a, Nutt. Gen. ii. 185 ; Ell. Sk. ii. 473. - A humble weed, near dwellings, coast of N. Carolina to Georgia. (Nat. from Buenos Ayres.)

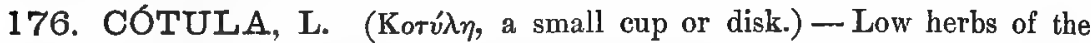
southern hemisphere, one or two naturalized in the northern, strong-scented; leaves alternate, lobed or dissected; flowers yellow: ours more or less perennial by creeping base, or annual. - Benth. \& Hook. Gen. ii. 428.

C. coronopifóris, L. Somewhat succulent, nearly glabrous : ascending stems often a font high : leaves lingulate-linear, laciniate-pinnatifid, or uppermost entire, the base clasping or sheathing: head much depressed, a third to half inch broad: female flowers a single row, on flattened pedicels which lengthen in fruit, their akenes bordered with a thick spongy wing and notched at both ends: disk-akenes with wing reduced to a thickened border. - Lam. Ill. t. 700 ; Dill. Elth. t. 23 ; DC. Prodr. vi. 28. - Wet ground, thoroughly established on the coast of California, and on some water-courses in the interior: a rare ballast-weed on the Atlantic coast. (Nat. from S. Afr.)

C. Austrális, Hook. f. Slender, diffusely branched, somewhat pubescent: leaves 2-pinnately dissected into linear lobes: heads small : female flowers in 2 or 3 rows, their akenes distinctly pedicelled; those of the disk less so. - F1. N. Zeal. i. 128; Gray, Bot. Calif. i. 405. Strongylosperma australe, Less.; ])C. 1. c. 82. - Waste ground, coast of California. Kellogg, Cleveland. Oregon, E. Hall. (Sparingly nat. from Australia.)

177. TANACETUM, Tourn. Tansy. (Name of the old herbalists, of quite uncertain derivation.) - Chiefly perennials, of the northern hemisphere, strong-scented, alternate-leaved, yellow-flowered. Disk-flowers 5-toothed. - Torr. \& Gray, Fl. ii. 414.

$\S 1$. Robust erect perennials, leafy to the summit: leaves 2-3-pinnately dissected into very numerous divisions and lobes; also with interposed small ones on the main rhachis: pappus coroniform-dentate : receptacle fat, quite naked. $\S$ Eutanacetum \& Omalotes. DC. Prodr. vi. 128. 83.

T. vUlgáre, L. (COMMON TANST.) Acrid-aromatic, glabrous or somewhat pubescent, 2 or 3 feet high: divisions and lobes of the leaves decurrent-confluent, the teeth cuspidate-acuminate: heads numerous and crowded in the corymbiform cymes, 3 to 5 lines broad, depressedhemispherical: ray-corollas terete, inconspicuous, with oblique 3-toothed limb.-Escaped from gardens to roadsides, \&c., in Atlantic States and Canada. (Nat. from Eu.)

T. Huronénse, Nuтr. Comparatively sweet-aromatic, villous when young, sometimes glar brate, commonly a foot high: leaves with fewer interposed segments on the rhachis; lobes and teeth narrowly oblong to linear, mucronate or acuminate: heads much fewer $(1$ to 5$)$ and larger; the disk convex, half-inch broad: corollas of female flowers with a flattish tube and a 3-5-lobed limb, which not rarely expands into a cuneate rather obvious ligule (thus making a transition to Chrysanthemum and showing relationship to C. bipinnatum). - Gen. ii. 141; Torr. \& Gray, FI. ii 414. T. Douglasii, DC. Prodx. vi. 128. T. pauciflorum, Richards. A pp. Frankl. Journ. ed. 2, 30; Hook. Fl. i. 327, not DC. T. boreale, Nutt. Trans. Am. Phil. Soc. n. ser. vii, 401, not Fischer in DC., which is rather a form of T. vulgare.Banks of streams, \&c., N. Maine (Goodale), New Brunswick, and Lake Superior to Hudson's Bay, west to Washington Terr. and Oregon on the coast.

T. camphorátum, Less. Pleasantly camphoric-aromatic, villous-tomentose, at least when young, glandular, robust, 1 or 2 feet high : pinnæ and segments of the leaves much crowied ; the latter oval or short-oblong, entire or crenately few-lobed, rounded-obtuse, at most calloseapiculate, usually with revolute margins: heads several in a corymbiform cluster, short- 
peduncled, hemispherical, the flat or at length low-convex disk half-inch broad : disk-corollas with flattened tube and 3 small lobes, not surpassing the disk-flowers, regularly 3-5-toothed, not at all liguliform. - Linnæa, vi. 521. T. Huronense, Nutt. Trans. Am. Phil. Soc. 1. c., in part; Torr. \& Gray, Fl., in part; Gray, Bot. Calif. i. 402. T. elegans, Decaisue in Fl. Serres, ser. 2, xii. t. 1191. Omalanthus camphoratus, Less. Syn. 260; Hook. Fl. i. 321, as to pl. Calif. only. Omalotes camphorata, DC. Prodr. vi. 83. - Sea-beaches, San Fraucisco, California ; first coll. by Menzies, next by Chamisso.

\$2. Low perennials : slender stems more naked above, bearing rather small globular heads : leaves less dissęcted or entire : corolla of disk-flowers not oblique nor dilated at summit, regularly 2-4-toothed: akenes usually utricular : pappus obsolete or none: receptacle convex or conical. - \$ Spheromeria, Torr. \& Gray, 1. c. 415. Spharomeria, Nutt. Trans. Am. Phil. Soc. n. ser. vii. 402.

* Herbaceous to the thickened root: leaves dissected: receptacle densely fimbrillate-hirsute.

T. potentilloídes, Gray. Silvery-sericeous : stems decumbent or ascending, a span to a foot long, the naked summit bearing a few slender-peduncled somewhat corymbiforno-paniculate heads (of 3 or 4 lines in diameter) : radical leaves 2-3-pinnately and cauline 1-2-pinnately parted into rather few mostly linear lobes: bracts of the involucre roundish-ovate or obovate.- Proc. Am. Acad. ix. 204 ; Bot. Calif. 1. c. Artemisia potentilloides, Gray, Proc. Am. Acad. vi. 551. - Eastern ranges of the Sierra Nevada, California and adjacent Nevada, Lemmon, Anderson.

* * Suffrutescent at base, erect: leaves simply or pedately cleft or entire: receptacle not hirsute, sometimes conical: heads only 2 lines broad. - Sphceromeria, Nutt.

T. diversifólium, EAton. Glabrous, very smooth, 8 to 15 inches high, leafy : leaves some narrowly linear and entire, 1-nerved, some pinnately or pedately parted: heads several or rather numerous in a corymbiform cyme, slender-peduncled: female flowers 8 or 10, with 3-4-toothed corolla. - Bot. King Exp. 180, t. 19. - Utah, in the American Fork Cañon; first coll. by Watson.

T. cánum, EArox. Silvery with minute close tomentum, a span or two high : lower leavea cuneate and 3-lobed or 3-cleft; upper linear-lanceolate, mostly entire: heads few or several, very short-peduncled or in clusters of 2 or 3 terminating the short branches of the cyme: female flowers 4 to 8, with a truncate obscurely toothed corolla. - Bot. King Exp. 179, t. 19, f. 8-14; Rothrock in Wheeler Rep. vi. 366. - Nevada, in a cañon of E. Humboldt Monntains, Watson. Olanche Mountain, S. E. California, Rothrock.

T. Nuttállii, Torr. \& Gray. Silvery-canescent, loosely cespitose, a span high: leaves short, mostly broadly cuneate with tapering base, obtusely $3-5$-lobed at the broad summit; those of the flowering stems usually oblong or linear and entire : heads few, somewhat panicnlate or loosely clustered; some of them slender-pedunculate: involucre rery scarious. Fl. ii. 415. Spharomeria argentea, Nutt. Trans. Am. Phil. Soc. vii. 402. - Rocky Mountains of N. Wyoming, Nuttall, Parry.

T. capitátum, Torr. \& Grar, l. c. Silvery-canescent, densely cespitose, a span high: leaves simply or pedately 3-5-parted into linear lobes, or some of them only 3-cleft at summit: flowering stems scapiform or 2-4-leaved : heads 10 or more, sessile in a globose glomerule. - Sphceromeria capitata, Nutt. Trans. Am. Phil. Soc. 1. c.-Rocky Mountains of N. Wyoming, Nuttall, Parry.

178. ARTEMísia, Tourn., L. Wormwood, Sage-brush, Mugwort. (Ancient name of Mugwort, in memory of Artemisia, wife of Mausolus.) Herbs and low shrubs (chiefly of the northern hemisphere, and most abundant in arid regions), bitter-aromatic; with alternate leaves, and small paniculately disposed heads, commonly nodding, at least when young; the flowers yellow or whitish, or turning brownish, usually sprinkled with resinous globules. Anthers commonly tipped with subulate-acuminate appendages, in the manner of Am brosia, but not inflexed.-. Besser in DC. Prodr. vi. 93. Artemisia, Abrotanum, \& Absinthium, Tourn. 
§ 1: Dracúnculus, Bess.-Heads heterogamous ; the disk-flowers hermaphrodite but sterile, their ovary abortive, and style mostly entire, peltate-penicillate at tip : receptacle not hairy. - Oligosporus, Cass.

* Akenes and flowers beset with long cobwebby and crisped hairs: spinescent undershrub. Picrothamnus, Nutt.

A. spinéscens, Eaton. Stout and densely branched, rigid, 4 to 18 inches high, villoustomentose : leaves small, pedately 5-parted and the divisions 3-lobed; lobes spatulate: heads globose, racemosely glomerate on short and leafy brancllets, which persist as slender spines: bracts of the involucre 5 or 6, broadly obovate: female flowers 1 to 4 ; hermaphrodite-sterile fowers 4 to 8, their corolla ventricose-campanulate from a narrow base. - Bot. King Exp. 180, t. 19, f. 15-2l ; Gray, Bot. Calif. i. 404. Picrothamnus desertorum, Nutt. Trans. Am. Phil. Soc. n. ser. vii. 417 ; Torr. \& Gray, Fl. ii. 289. - Whole desert region of Wyoming, Utah, Nevada, and Idaho, reaching the borders of California ; first coll. by Douglas (incomplete specimens), then Nuttall.

* Akenes nearly glabrous: receptacle except in last species hemispherical or orate : no spines. + Biennial herb: leaves all filiform.

A. caudáta, Michx. Glabrous, with one or more strict stems, 2 to 6 feet high: leaves 1-3pinnately divided into slender filiform lobes: heads small (a line in diameter), very numerous in an ample elongated thyrsus. - Fl. ii. 129; Nutt. Gen. ii. 144; Torr. \& Gray, Fl. ii. 417. - Sandy ground, Canada to Texas near the coast, Illinois to Saskatchewan and Kansas.

+ + Perennial herbs, the last two or three species sometimes frutescent at base: heads manyflowered.

+ Leaves dissected.

A. Canadénsis, Mrcerx. A foot or two high from a perennial (or sometimes biennial?) root: glabrous or mostly with at least the radical and sometimes all the leaves either sparsely or canescently silky-pubescent: leaves mustly 2-pinnately divided into narrow linear or almost filiform but plane lobes, of thickish texture: heads 1 or 2 lines long, very numerous in a compound oblong or pyramidal virgate panicle (in reduced specimens northward fewer in a simple panicle): involucre greenish, glabrous or rarely pubescent. - Fl. ii. 129 (northern form with heads 2 lines broad); Nutt. 1. c. ; Torr. \& Gray, 1. c. ; Besser, Dracunc. 90, \& DC. 1. c., partly (mixed with $A$. caudata). A. peucedanifolia, Juss. Herb. ; Besser, l. c. 29 (A. Canadensis ferulaceo-folio, Vaill.), spec. Herb. Tourn., DC. 1. \&. 99, excl. pl. Mitch. A. campestris, Pursh, Fl. ii. 521 ? excl. syn. ; Richards. App. Frankl. Journ. A. desertorum, in part, Bess. in Hook. Fl. A. commututa, Bess. Dracunc. 68, \& in DC. Prodr. vi. 98. A. Pacifica, Nutt. Trans. Am. Phil. Soc. 1. c. 399 ? - Rocky banks and plains, N. New England to Hudson's Bay, west to the Pacific in Washington Terr, and south in the Rocky Mountain region to New Mexico, Utah, and Arizona. (N. W. Asia.)

A. boreális, PaLL. A span or two high from a stout caudex: stems simple : leaves silkypubescent or silky-villous; radical and lower 1-2-ternately or pinnately divided into linear lobes; uppermost linear and entire or 3-parted : heads (2 lines broad) comparatively few, crowded in a narrow (rarely compound) spiciform thyrsus with leaves interspersed: involucre pilose or glabrate, pale-fuscous to brownish. - It. iii. 129, t. hh, f. 1 ; Bess. Dracunc. 78, \& in DC. 1. c. 98; Torr. \& Gray, 1. c. A. spithamoea, Pursh, Fl.,ii. 522. A. violacea, Ledeb. Ic. Fl. Alt. t. 475. - Arctic America, Labrador to Alaska, and Rocky Mountains to Colorado in the alpine region. (Greenland, N. Asia.)

Var. Wormskióldii, Bess. Taller, 10 to 16 inches high, with more numerous heads in looser or compound narrower thyrsus. - Dracunc. 83, \& Hook. 1. c. 327. A. Groenlandica, Wormsk. Fl. Dan. t. 1585, small specimen. - Hudson's Bay and mountains of Lower Canada (where it seemingly passes into A. Canadensis, in coll. Allen) to Washington Terr. and N. Alaska. (Greenland, N. E. Asia.)

A. pedatífida, Noxr. Cespitose, with a stout lignescent caudex, very dwarf, canescent throughout with a fine and close pubescence: leaves chiefly crowded iu radical tufts and on the base of the (inch or two high) rather naked flowering stems, once or twice 3-parted into narrowly spatulate or nearly linear obtuse entire divisions: heads (hardly 2 lines broad) few, loosely spicately or racemosely disposed, canescently pubescent: heads 12-15-flowered; the hermaphrodite-sterile flowers with style barely 2-lobed at summit and no ovary. - Trans. 
Am. Phil. Soc. vii. 399 ; Torr. \& Gray, F1. ii. 419. - Arid grounds in the Rocky Mountains of Wyoming, Montana, and Idaho, Nuttall, Fremont (without flowers), Parry. Has been wrongly referred to the following section of the genus.

A. pycnocéphala, DC. A foot or two high, either herbaceous or with a woody base, densely silky-villous, even to the involucre, robust: leaves 1-3-pinnately parted into rather few and short linear or spatulate lobes: heads numerous (2 lines broad), glomerate in an elongated and interrupted spiciform leafy thyrsus. - Gray, Bot. Calif, i. 404. A. pycnocephala \& A. pachystachya, DC. 1. c. 99 \& 114 ; Torr. \& Gray, 1. c. A. pycnostachya, Nutt. 1. c., error in name. Oligosporus pycnocephalus, Less. in Linn. vi. 524. - Sea-shores, California, from Monterey to Humboldt Co.; first coll. by Chamisso.

++ Leaves mostly entire, occasionally some 3-cleft, or the lowest even more divided: base of stems rather lignescent.

A. glaúca, Pacl. Minutely silky-pubescent or canescent, sometimes glabrate and glaucous : stems strict, a foot or two high: leaves rather short, from linear- to oblong-lanceolate: heads nearly of the next, into which it probably passes. - Willd. Spec. iii. 1331; Bess. Dracunc. 55, \& DC. 1. s. A. glauca, var. fastigiata, Bess. 1. c. A. dracunculoides, var. incana, Torr. \& Gray, Fl. ii. 416. - Saskatchewan and Minnesota, Drummond, Nicollet, Kennicott.

A. dracunculoídes, Pursu. Glabrous, wanting the scent and taste of A. Dracunculus, which it much resembles: stems 2 to 4 feet high, either virgately or paniculately branched: leaves narrowly or sometimes more broadly linear: heads very numerous in a compound and crowded or open and diffuse panicle. - Pursh, Fl. ii. 742; Torr. \& Gray, Fl. ii. 416. A. Dracunculus, Pursh, Fl. ii. 521. A. cernua, Nutt. Gen. ii. 143. A. inodora, Hook. \& Arn. Bot. Beech. 150. A. Nuttalliana, Bess. in Hook. Fl., \&c., shorter-leaved form, with lower leaves more freely 3-cleft. - Plains, Missouri to Saskatchewan and Brit. Columbia, and from Texas to Arizona and California. Polymorphous.

A. LEw ́́sr, Torr. \& Gray, Fl. ii. 417, appears to be a fictitious species. The plant referred to $A$. Santonica by Pursh is wholly obscure. The specimen in herb. Michaux, with no indication of source, which Besser made a var. Americana of A. variabilis, Tenore, is without much doubt European. The plant of Engelmann, referred to by Besser in Linnæa, xv. 111, is an imperfect specimen, probably of $A$. Canadensis.

+++ Suffruticose: heads very small and numerous, few-flowered.

A. filifólia, Torr. Minutely canescent, even to the 3-6-flowered involucre, 1 to 3 feet high, with virgate rigid branches, very leafy : leaves all slender filiform, commonly 3-parted; the upper and those in axillary fascicles entire: heads crowded in an elongated leafy panicle: receptacle small, not pilose. - Ann. Lyc. N. Y. ii. 211 ; Torr. \& Gray, Fl. ii. 417; Torr. in Marcy Rep. t. 12. A. Plattensis, Nutt. Trans. Arn. Phil. Soc. vii. 397.-1'lains, Nebraska to New Mexico and western borders of Texas ; first coll. by James.

§ 2. Euartemísia. Heads heterogamous; the disk-flowers hermaphrodite and fertile, with 2-cleft style. - $§$ Abrotanum \& Absinthium, Bess.

* Akenes oboroid or oblong, wholly destitute of pappus: receptacle beset with long woolly hairs. -§Absinthium, Bess.

A. scopulórum, Gray. Herbaceous, a span or two high from a stout multicipital caudex, silky-canescent: stems simple, bearing 3 to 12 spicately or racemosely disposed hemispherieal (rarely solitary) heads: radical and few lower cauline leaves pinnately 5-7-divided, and divisions 3-parted into spatulate-linear lobes; uppermost simply 3-5-parted or entire : involucre 2 lines broad, villous, 18-30-flowered; its bracts brown-margined: corollas hirsute at summit. - Proc. Acad. Philad. 1863, 66 ; Eaton, Bot. King Exp. 184. - Alpine region of the Rocky Mountains in Colorado, Utah, and Wyoming; first coll. by Parry, Hall \& Harbour. Var. monocephala, Gray, 1. c., is merely a form with single head.

A. frígida, Willd. Herbaceous from a suffrutescent base, silky-canescent and silvery, about a foot high: stems simple or branching, bearing numerous racemosely disposed heads in an open panicle: leaves mainly twice ternately or quinately divided or parted into linear crowded lobes, and usually a pair of simple or 3-parted stipuliform divisions at base of the petiole: heads globular, barely 2 lines in diameter: involucre pale, canescent, its outer bracts narrow and herbaceous : corollas glabrous. - Spec. iii. 1838 (Gmel. Fl. Sibir. t. 63); Pursh. Fl. ii. 521 ; Ledeb. Ic. Fl. Alt. t. 462 ; Bess. in Hook. Fl. i. 321. A. sericea, T'utt. Gen. ii. 
143. A. virgata, Richards. in Frankl. Journ. - Plains and mountains, Saskatchewan to Minnesota and W. Texas, west to Idaho, Nevada, New Mexico, \&c. (N. Asia.)

A. Absínthium, L. (Wormwood.) Frutescent, paniculately branched, 2 or 3 feet high, bearing numerous small heads in leafy panicles: leaves 2-3-pinnately parted into lanceolate or oblong obtuse and entire or sparingly incised lobes: involucre canescent, of one or two loose and narrow herbaceous bracts and several roundish and scarious : corollas glabrous. Spec. ii. 848; Engl. Bot. t. 1230. Absinthium vulgare, Lam. Fl. Fr.; Gærtn. Fr. t. 164. Roadsides, escaped from gardens, Newfoundland to New England. Also Moose Factory, Hudson's Bay. (Nat. from Eu.)

* Akenes broad or broadish and truncate at summit, commonly bearing a minute or even a conspicuous squamellate or coroniform-dentate pappus, therefore having the character of Tanacetum, but the heads paniculate: receptacle glabrous or barely pubescent. (Here belongs A. Australis, Less., of Hawaian Islands, as well as the anomalous A. Chinensis, L.) - Crossostephizu, Less. Artemisia § Tanaceum, Nutt.

A. Califórnica, Less. Shrubby, with habit of $A$. Abrotanum, 4 or 5 feet high, paniculately branched, minutely canescent or cinereous : leaves 1-2-pinnately parted into few filiform lobes not wider than the rhachis, or uppermost entire: heads very numerous in leafy panicles: involucre hemispherical, many-flowered, about 2 lines broad: akenes 3-5-ribbed, with a minute squamellate crown at the broal summit. - Linn. vi. 523; Hook. \& $\Lambda$ rn. Bot. Beech. 150; Torr. \& Gray, Fl. ii. 424 ; Gray, Bot. Calif. i. 403. A. Fischeriana, Besser, Abrot. 21 ; DC. Prodr. vi. 105. A. abrotanoides, Fischeriana, \& foliosa, Nutt. Trans. Am. Phil. Soc. vii. 397, 399. California, along the coast, from San Francisco Bay southward and to San Bernardino Co. ; first coll. by Menzies.

* * Akenes obovoid or oblong, with small epigynous disk, wholly destitute of pappus : receptacle not villous. — $\$$ Abrotunum, Bess.

A. Abrótandm, L. (Soutinkn wood), cultivated in old gardens, has become spontaneous in a few places from New York southward.

A. Prócera, Willd., a less shrubby and finer-leaved species, has escaped from gardens at Buffalo, New York.

$$
\text { + Annuals and biennials. }
$$

A. Annua, L. A tall and much branched glabrous species, native to Asia, with a very ample and loose panicle of small heads, and leaves 2-pinnately divided into oblong deeply pinnatifid segments. - Naturalized in waste places around Nashville, Tennessee.

A. biénnis, WILLD. Wholly glabrous, inodorous and nearly insipid: stem strict, 1 to 3 feet high, leafy to the top, bearing close glomerules of small heads in the axils from toward the base of the stem to the somewhat naked and spiciform summit: leaves 1-2-pinnately parted into lanceolate or broadly linear laciniate or incisely toothed lobes; or the uppermost small, sparingly pinnatifid and less toothed. - Phytogx. 1794, 11, \& Spec. iii. 1842 (excl. hab. New Zeal.); Pursh, Fl. ii. 522; Nutt. Gen. ii. 144; Bess. in Hook. Fl.; DC. Prodr. vi. 120; Torr. \& Gray, 1. c. A. Hispanica, Jacq. Ic. Rar. i. t. 172, not Lam. - Open grounds, Hudson's Bay to Oregon and Colorado; also in Utah and S. Califorvia : common also from Ohio and Tennessee to Missouri, probably by immigration, now spreading to the seaboard. (Kamtschatka, N. India.)

$$
++ \text { Perennials, some fruticulose. }
$$

+ Heads many-flowered, collected in a single capitate glomerule or dense cluster: dwarf, arctic, with leaves mainly in radical tufts. (Nearly related species.)

A. Senjavinénsis, Bess. Cespitose-proliferous, very densely villous with long hairs, which on the radical tufts conceal the foliage: leares much crowded in the tufts, and scattered on the flowering stems, cuneate or oblong, simply 3-5-cleft into oblong or lanceolate lobes: heads in a dense villous glomerule, fuscous: involucral bracts sphacelate : corolla glabrous. - Abrot. 65 (as Semavinensis), Suppl. in Bull. Mosc. ix. 64, \& DC. Prodr. vi. 116. A. androsacea (characteristic name), Seem. Bot. Herald. 34, t. 6 (founded on A. glomerata, Hook. \& Arn. Bot. Beech. 125, not Ledeb.); Hook. f. Arct. P1. 331, - Kotzebue Sound, Beechey. (Adj. Asia, Arakamtchetchene Island, Wright.)

A. glomeráta, LEDEB. Silky-canescent with mostly close short pubescence : leaves usually twice or thrice ternately parted and cleft into lanceolate or spatulate lobes: heads cymoseglomerate, fuscous or pale: flowers sparsely pilose, at least the summit of the corolla. - 
Mem. Acad. Petrop. v. 564 ; Bess. Abrot. 63; DC. Prodr. vi. 116; Torr. \& Gray, Fl. ii. 423. A. globularia, Ledeb. Fl. Ross. ii. 588, in part. A. leontopodioides \& A. corymbosa (form with heads pedunculate), Fisch. in Bess. Abrot. \& DC. 1. c. - Arctic Alaska, Seemann, Muir. (Adj. Asia.)

A. globulária, Char. Canescently pubescent: leaves once or twice ternately parted intu linear or broader lobes: heads globular- or somewhat racemiform-capitate, both involucre and flowers dark purplish-brown, the latter glabrous. - Cham. in Bess. 1. ¿.; DC. 1. c. $A$. Senjavinensis, Ledeb. Fl. Ross. ii. 588, at least in part, not Bess. Perhaps an extreme arctic form of $\boldsymbol{A}$. Norvegica, as was suspected by Maxim. Diagn. Pl. Jap., \& Dec. xi. 534. Arctic Alaska and islands. St. Paul's Island, Mrs. Macintyre. (Adj. Asia.)

T. + Heads many-flowered, broad (2 to 5 lines in diameter), several or rather numerous and loosely racemose or paniculate on mostly simple stems of a foot or less in height: subarctic and subalpine, with dissected leaves and no cottony tomentum.

A. Richardsoniána, Bess. A span to near a foot high, with rather slender ascendiug stems from a cespitose caudex: leaves silvery-canescent with fine very close-pressed pubescence; radical twice ternately or quinately divided or parted into oblong-linear or narrower lobes (of only 2 or 3 lines in length); cauline sparse, mostly trifid : heads comparatively small (2 lines high), several or rather numerous in a strict and simple racemiform inflorescence, fuscous : corollas pilose or sometimes glabrous. - Suppl. 64, \& DC. 1. c. 117 ; Torr. \& Gray, Fl. ii. 422. A. arctica \& A. caspitosa, Bess. in Hook. Fl. j. 323, 324. - Arctic coast to Bear Lake (Richardson, \&c.), northern Rocky Mountains, and Mount Ranier, Washington Terr., Tolmie. (From the char. probably A. heterophylla, Bess. Abrot., which is said to be A. trifurcata, Steph. in Spreng. Syst. iii. 488, and to occur in Arct. Amer. as well as Arct. Asia to Kamtschatka.)

A. Norvégica, Fries. Rather stout, 5 to 25 inches (commonly a foot) high, from villous or sericeous-pubescent to glabrate: leaves twice 3-7-nately parted into linear or lanceolate or more dilated segments: heads large (commonly 4 or 5 lines broad), loosely racemose or racemose-panicnlate, most of them long-peduncled: bracts of the involucre broadly brownmargined : corollas yellow or turning brown, loosely pilose, rarely almost glabrous. - Fries in Liljeb. Fl. 1815, Novit. ed. 1, 56, ed. 2, 265 ; Reichenb. Ic. Crit. i. 74, t. 89 ; Bess. Abrot. 76 ; DC. 1. c. A. rupestris, Fl. Dan. t. 801 , not L. A. Chamissoniana, var. saxatilis, Bess. l. c. \& Hook. Fl. i. 324. A. Richardsoniana, Gray, in Am. Jour. Sci. ser. 2, xxxiii. 239, not Bess. A. arctica, Gray, in Proc. Acad. Philad. 1863, 66. - Alpine and subalpine region of the Rocky Mountains, from lat. $62^{\circ}$ to S. Colorado, Utah, and the Sierra Nevada, California. (N. E. En.)

Var. Pacífica. Robust, glabrons or glabrate up to the heads, sometimes two feet high : leaves broader; their divisions from lanceolate to cuneate, commonly laciniate. - A. longepedunculcta, Rudolphi, ex Bess. Abrot. 77. A. arctica, Less. in Linn. vi. 213; Hook. \& Arn. Bot. Beech. 125 ; DC. Prodr. vi. 119 ; Torr. \& Gray, Fl. ii. 423. A. Chamissoniana, Bess. in Hook. Fl. l. c. (mainly), \& Abrot. 77, t. 4, of which the largest and coarsest-leaved form is his var. Ochotensis! - Arctic coast to the Aleutian Islands, \&c., in various forms. (Adj. E. Asia.)

A. Párryi, Gray. Rather stout, a foot or less high, wholly glabrous, leafy up to the loosely paniculate inflorescence of numerous short-peduncled heads: leaves 2-3-pinnately parted into mostly linear thickish lobes: involucre 2 or 3 lines broad, its bracts greenish with brownish margins and with the corollas glabrous. - Proc. Am. Acad. vii. 361. - Mountains of Colorado, at Sangre de Cristo Pass, 11,000 feet, Parry, Brandegee.

+ + + Heads many-flowered, large and broad ( $\$$ lines long), in a racemose-glomerate and thyrsoid inflorescence, white-tomentose as well as the herbage.

A. Stelleriána, Bess. A foot or two high from a creeping lignescent base, robust, densely white-tomentose, the tomentum of the stem cottony: leaves obovate or spatulate in outline, sinuately or incisely pinnatifid; lobes obtuse: corolla glabrous: akenes a line and a half long, oblong, not contracted at summit; the coat utricular. - Abrot. 79, t. 5; DC. 1. c. A. Chinensis, Pursh, Fl. ii. 521, not L. \&c. - This may be what Pursh saw in herb. Lambert, from N. W. America, probably from Pallas. It is indigenous from Kamtschatka to Japan, and not improbably on the American coast. Singularly, it grows wild in large tufts on Iynn Beach, Massachusetts! Also of Sweden, Fl. Dan, t. 3045. 
++++ Heads comparatively small (1 to 3 lines high and broad), variously paniculate, 12-many-flowered: flowers glabrous: herbs, or occasionally suffrutescent at base, mostly whitened (at least when young and on the lower face of the leaves) with cottony tomentum.

$=$ Tall, with numerous amply paniculate heads, strict stems, and undivided elongated-lanceolate or linear leaves (the lowest sometimes 'cleft), 3 to 7 inches long: involucre oblong.

A. serráta, Nutr. Stems 6 to 9 feet high, very leafy: leaves green and glabrous above, white-tomentose beneath, lancedate or uppermost linear, all serrate with sharp narrow teeth, pinnately veined, the earliest sometimes pinnately incised: heads rather few-flowered, less than 2 lines long, greenish, hardly pubescent. - Gen. ii. 142. A. Ludoviciana, var. serrata, Torr. \& Gray, Fl. ii. 420. - Prairies and low grounds, Illinois to Dakota; first coll. by Nuttall.

A. longifólia, Nutr. 1. c. Stem 2 to 5 feet high : leaves entire, at first tomentulose, but usually glabrate above, white tomentose beneath, linear or linear-lanceolate ( 1 to 5 lines wille), entire; veins obsolete: heads usually canescent, 2 or 3 lines long. - Torr. \& Gray, Fl. ii. 419, not Bess. Rocky banks, Minnesota and Nebraska to Saskatchewan and Montana; first coll. by Nuttall, or by Lewis \& Clarke, if perhaps A. integrifolia of Pursh.

$==$ Moderately tall or sometimes low: leaves various, more or less eleft or divided, or when entire cumparatively short, not filiform or very narrowly linear. Species of very difficult discrimillation.

u. Involucre canescently lanate-tomentose.

A. Ludoviciána, Nutr. A foot to a yard high, simple or with virgate branches, sometimes paniculate, completely and somewhat flocculently white-tomentose, or upper face of leaves sometimes early glabrate'and green: leaves from linear-lanceolate to oblong, sometimes nearly all undivided and entire; commonly the lower with a few coarse teeth or incisions, or 2-3-cleft, or irregularly 3-5-parted into lanceolate or linear entire lobes: heads glomerately paniculate, not over 2 lines long: involucre campanulate or in fruit ovoid, 12-20flowered. - Torr. \& Gray, Fl, ii. 420 (excl. var. serrata); Bess. Revis. Artem. in Linn. xv. 104; Gray, Bot. Calif. i. 404. A. Ludoviciana (with incised or subpinnatifid leaves) \& $A$. !maphalodes (with undivided leaves), Nutt. Gen. ii. 143. A. integrifolia, Pursh, 1. c., at least in part, not L. A. Purshiana, Bess. Abrot. 59, \& Hook. Fl. i. 323. A. Douglasiana, Bess. 1. c., an entire-leaved less white-tomentose Western form. A. Hookeriana, Bessi. 1. c.; the plant taken to be this, of "Rocky Mts., Saskatchewan, \&c., Drummond," in herb. Hook., but not ticketed, is a tall and large-leaved form. - Plains and banks, Saskatchewan to Texas, east to Illinois and Upper Michigan, and west to Brit. Columbia, California, and Arizona. The Wild Sage of Lewis \& Clarke, at least in part. (Adj. Mex.)

$b$. Involucre not lanate (at least when fully developed), from pilose-pubescent or minutely cauescent to glabrate or glabrous : divisions of the leaves broad or narrow, but not filiform.

A. Mexicána, Willd. Intermediate between preceding and following, paniculately branched, 2 to 4 feet high, less tomentose: leaves narrow-lanceolate to linear, commonly attenuate, some 3-5-cleft or parted; radical cuneate, incisely pinnatifid or trifid - heads very numerous in an ample loose panicle, many pedicellate, I to 2 lines long: involucre campanulate, arachnoid-canescent or glabrate, largely scarious, 10-20-flowered. - Spreng. Syst. iii. 490 ; Less. in Linn. v. 163 ; DC. Prodr. vi. 114 ; Bess. Revis. 1. c. 106. A. Indica, var. Mexicana, Bess. Abrot. 56. A. vulgaris, var. Americana, Bess. in Linn. xv. 105. A. vulgaris, var. Mexicana, Torr. \& Gray, Fl. ii. 421. A. Ludoviciana, in part, Gray, Pl. Wright. ii. 98. A. cuneifolia? \& A. Lindheimeriana, Scheele in Linn. xxii. 162, 163. A. Ludoviciana, var. Mexicana, forma tenuifolia, Gray, P1. Wright. ii. 98, from New Mexico, \&c., is a very narrowleaved variety, with strict panicle. - Dry plains, Arkansas and Texas to Arizona and S. W. Nevada. (Mex.)

A. vulgáris, L. (Mugwort.) Paniculately branched : leaves white with cottony tomentum beneath, green and soon glabrate or glabrous above, usually bipinnately cleft or parted and laciniate, and the lobes lanceolate or coarser; upper sometimes linear: heads numerous and glomerate-paniculate, 2 lines long: involucre mostly oblong-campanulate, scarious, sparingly arachnoid but usually glabrate. - Michx. Fl. ii. 128 ; Pursh, Fl. ii. 522 ; Torr. \& Gray, Fl. 1. c., excl. var. Mexicana. - The common European form is apparently indigenous at Hudson's Bay, \&c., and is naturalized in Canada (A. Indica, Canadensis, Bess. in Hook. F1.) and Atlantic States. (Eu., Asia.) 
Var. Tilésii, Leder. Robust, leafy to the very summit: heads glomerate, fuscous: involucre broadly campanulate, arachnoid-cottony when young, but glabrate, many-flowered: leaves coarsely cleft and laciniate, the lobes lanceolate, attenuate-acute, - Fl. Ross. ii. 586. A. Tilesii, Ledeb. Mem. Acad. Petrop. v. 568; Bess. Lbrot. 70; Less. in Linn. vi. 214 ; DC. 1. c.; Torr. \& Gray, l. c. - Arctic coast to Unalaska. (Adj. E. Asia.)

Var. Califórnica, Bess. Less branched or simple-stemmed, with more naked panicle: heads of var. Tilesii or smaller, or at maturity sometimes oblong, glabrate. - Bess. in Linn. xv. 91 (founded on A. integrifolia, Less.); Torr. \& Gray, 1. c.; Gray, Bot. Calif. i. 404. A. heterophylla, Nutt. Trans. Am. Phil. Soc. vii. 400. A. Tile sii, var, elatior, Torr. \& Gray, Fl. ii. 422. - Northern Rocky Mountains to Alaska, south to the coast of California and in the Sierra Nevada.

A. franserioídes, Greene. Habit of A. vulgaris, glabrous throughout, or minutely and obscurely cinereous-puberulent: stem rather stout, 2 or 3 feet high: leaves comparatively ample, green above, pale and barely cinereous beneath; lower bipinnately and upper simply pinnately parted into lanceolate-oblong obtuse entire or 2-3-cleft divisions and lobes : heads numerous, loosely racemose on the branches of the leafy elongated panicle, 2 or 3 lines broad: involucre greenish, glabrous, low-hemispherical, 30-40-flowered. - Bull. Torr. Club, x. 42. A. discolor, Torr. \& Gray in Pacif. R. Rep. ii. 126; Rothrock in Wheeler Rep. vi. 176, not Dougl. - Roubidean's Pass, Mountains of S. Colorado, Gunnison. Pinos Altos Mountains, New Mexico, Greene. Mount Graham, Arizona, Rothrock.

A. díscolor, Dougl. A foot high, mostly slender, from a lignescent slender caudex, glabrous or glabrate except the lower face of the leaves: these white with close cottony tomentum (which is rarely deciduous), 1-2-pinnately parted into narrow linear or lanceolate entire or sparingly laciniate divisions and lobes: heads glomexate in an interrupted spiciform or virgate panicle, 1 or 2 lines high : involucre hemispherical-campanulate, greenish and scarious, glabrous or soon becoming so, 20-30-flowered. - Dougl. in herb. Hook.; Bess. Suppl. \& DC. Prodr. vi. 109; Torr. \& Gray, 1. c.; Gray, Bot. Calif. i. 404. A. Ludoviciana \& A. Michanxiana, Bess. Abrot. 38, 71, \& in Hook. Fl. I. c., not Nutt.-Mountains of Brit. Columbia and Montana to Ltah, Nevada, and the Sierra Nevada in California.

Var. incómpta. A stouter form, with coarser and less dissected leaves, having mostly broader (sometimes short-oblong) lobes, or the upper entire. - A. incompta, Nutt. Trans. Am. Phil. Soc. vii. 400. - Rocky Mountains from Montana and Wyoming to Washington Terr., Nevada, and the Sierra Nevada in California.

$===$ Not tall, sometimes low, herbaceous or suffrutescent at base: leaves or their divisions

narrowly linear, simple, small : heads 15-20-flowered, in a narrow thyrsoid or spiciform panicle.

A. Lindleyána, Bess. A foot or two, rarely only a span high, slender, with thin flocculent tomentum soon deciduous, or persisting on the lower face of the mostly entire leares (these inch or less long, a line or much less wide, the lower occasionally with 2 or 3 smail lobes): heads barely 2 lines high, loosely spicate on the simple stem or pauiculate branches of the inflorescence: involucre sparingly pubescent or glabrate, pale fuscous. - Abrot. $35, \&$ in Hook. l. c., described from herb. Liudl. A. pumila, Nutt. Trans. Am. Phil. Soc. 1. c. 399, it dwarf state. - Sandy banks of the Columbia River and its tributaries, Idaho, Oregon, and Washington Terr., Douglas, Nuttall, Hall (distrib. as A. discolor?), Brandegee. Also on the sands of the sea-shore near the Straits of Juan de Fuca, Douglas.

A. Wríghtii, GraY. Cinereous or canescent with minute pubescence, or radical shoots sometimes white-tomentose, 10 to 20 inches high, very leafy up to the strict virgate panicle: leaves pinnately 5-7-parted into very narrow linear and by revolution filiform entire divisions: heads numerous and crowded: involucre minutely cinereous-canescent, glabrate in age. - Proc. Am. Acad. xix. 48. - Plains of S. Colorado and adjacent New Mexico, Wright (no. 1279, P1. Wright. ii. 98, mention only), Palmer, Greene, Rothrock (no. 539), Brandegee.

$====$ Pinnately parted leaves mostly attenuate-filiform: heads simply and loosely racemose-spicate.

A. Prescottiána, Bess. Much branched from the base, a foot or two high, slender, glabrous or early glabrate. lower leaves cuneate-linear and incised or clcft at apex, slightly tomentose beneath; most of the cauline pinnately parted into 5 to 7 delicate filiform divisions (of an inch or less long) : involucre glabrous, hemispherical, about 15-flowered. - Abrot. 72, \& in Hook. 1. c. — "Quicksand River, near the Grand Rapids of the Columbia," Douglas. 
Described by Besser from herb. Lindl., here from herb. Hook. . A peculiar and little known species, to which Douglas had applied the appropriate name of A. leptophylla.

+++++ Heads small and narrow, very few-flowered: flowers glabrous: stems woody at base: habit of the following section.

A. Bigelóvii, Gray. Silvery-canescent throughout, a foot high: leaves from oblong- to linear-cuneate, mostly 3-toothed at the truncate apex, about half-inch long: heads very numerous and crowded in the oblong or virgate thyrsiform panicle, tomentose-canescent, containing only one or two hermaphrodite and as many female flowers, all fertile. - Pacif. R. Rep. iv. 110.- - Rocky banks and cañons, Colorado, on the Upper Canadian and Arkansas, common where the latter leaves the mountains; first coll. by Bigelow.

§ 3. Seriphídium, Bess. Heads homogamous, the flowers all hermaphrodite and fertile: receptacle not hairy. - Gray, Proc. Am. Acad. xix. 49.

* Anomalous species of Southwestern border, tall, mainly herbaceous, 3 , to 5 feet high, with ample and naked compound panicles; the heads nodding in anthesis, as is common in the genus.

A. Paríshii, Gray. Frutescent, cinereous-puberulent: leaves linear and entire, below passing into elongated slender-spatulate and with 3-toothed apex : panicle a foot or two long, loose: heads mostly pedicellate (2 lines long): involucre oblong-campanulate, canescent, 6-7-flowered: akenes sparsely arachnoid-villous! - Proc. Am. Acad. xvii. 220. - Interior of Los Angeles Co., California, Parish.

A. Pálmeri, Gray. Wholly or nearly herbaceous, obscurely puberulent; but leaves white beneath with close cottony tomentum, pinnately 3-5-parted into long narrowly linear entire lobes, their margins revolute: heads glomerate on the branches of the open panicle, hemispherical, less than 2 lines in diameter: involucre greenish, about 20-flowered; many of the flowers subtended by scarious-hyaline bracts of the receptacle!-Proc. Am. Acad. xi. 79, \& Bot. Calif. i. 618. - Jamul Valley, 20 miles south of San Diego, on the borders of California and Lower California, Palmer, Miss Bird.

* * SAGE-BRUSH or SAGE-BuShes, low shrubs, or fruticulose, canescent or silvery with very fine and close tomentum: heads glomerate or strict in the paniculate or spiciform inflorescence, not nodding even when young: corollas sometimes turning reddish,

$$
\text { + Foliose-spicate: heads solitary in the axils, surpassed by the rigid leaves. }
$$

A. rígida, Gray. A span to a foot high from a thick woody base or short stem, producing a plofusion of rigid and slender rather simple fastigiate branches, leafy to the very top: leaves also rigid, silvery-canescent, filiform-linear, 3-5-parted or cleft, or some of the upper and fascicled ones entire (even the lower rarely inch long), most of them subtending a sessile head: involucre oblong to campanulate, 5-12-flowered, less than 2 lines long; bracts oval, hyaline-margined. - Proc. Am. Acad. xix, 49, A. trifida, var. rigida, Nutt. Trans. Am. Phil. Soc. vii. 398. - On high rocky ridges, N. E. Oregon and adjacent Idaho, Nuttall (without flowers), Cusick.

++ More naked-paniculate or thyrsoid, at least the upper heads or clusters exceeding the subtending leaves; these not rigid.

+ Heads comparatively small and few-flowered, mostly oblong, one or two lines long: involucral bracts rather firm in texture, well imbricated, the outer successively shorter: leaves seldom over an inch long, mostly shorter.

A. arbúscula, Nutr. Dwarf, a span or rarely a foot high, with a stout base and slender flowering branches: leaves short, cuneate or flabelliform, 3-lobed or parted, with the lobes obovate to spatulate-linear, sometimes again 2-lobed; those subtending the heads usually entire and narrow: panicle strict and comparatively simple and naked, often spiciform and reduced to few rather scattered sessile heads : involucre 5-9-flowered. - Trans. Am. Phil. Soc. 1. c. ; Torr. \& Gray, Fl. ii. 418 ; Laton, Bot. IKing Exp. 182; Gray, Bot. Calif. i. 405.High mountains and elevated arid plains, Wyoming and Utah to Idaho and the Sierra Nevada, California. Two forms, passing into each other (both coll. by $N$ uttall, \&c.); one with involucre more campanulate, 7-9-flowered; in the other oblong and only 4-5-flowered; sometimes the inflorescence simply spiciform, sometimes freely naked-paniculate.

A. tridentáta, NurT. 1. c. Larger, I to 6 (or even 12) feet high, much branched: leaves cuneate, obtusely 3-toothed or 3-lobed, or even 4-7-toothed, at the truncate summit, upper- 
most cuneate-linear: heads densely paniculate: involucre 5-8-flowered, its outer or accessory tomentose-canescent bracts short and ovate. - Torr. \& Gray, l. c.; Eaton, 1. c. - Plains and also on the drier mountains, Montana to Colorado, Washington Territory, and eastern slope of the Sierra Nevada, California, immensely abuudant, the characteristic Sage-brush or Sagewood of the region.

Var. angustifólia, Gray. Leaves all narrow ; lower spatulate-linear, barely 3-toothed at the roundish summit; upper entire and more linear, a line or less wide: heads small: shrub 3 or 4 feet high, with foliage too like that of the following species, but involucre of A. tridentata. - Proc. Am. Acad. xix. 49. - Arid plains, S. Idaho and W. New Mexico to the Mohave Desert and the southern borders of San Diego Co., California.

A. trifida, N'tr. I. c. A foot or two high, sometimes lower, much branched : leaves 3-cleft and 3-parted; the lobes and the entire upper leaves narrowly linear or slightly spatulatedilated: heads numerous in the contracted leafy panicle, or spicately disposed on its branches: involucre 3-5-flowered, rarely 6-9-flowered, its outer or accessory bracts oblong to short-linear or lanceolate. - Torr. \& Gray, Fl. ii. 419 (excl. var.); Eaton, l. c. - Plains and valleys, Wyoming and Utah to Washington Terr. and the Sierra Nerada, California.

- Heads somewhat larger and broader, glomerate-paniculate, 7-14-flowered: involucre shortcampanulate; inner bracts more scarious: stems low, suffruticose.

$=$ Pubescence looser, furfuraceous-tomentose : inner bracts of the involucre narrow.

A. Bolánderi, Grax. A foot or two high: leaves all narrowly linear, half a line wide, acutish, entire, or some with one or two slender lobes: heads numerous, densely glomeratepaniculate, 14-flowered, mostly equalled or surpassed by one or two linear-subulate herlbaceous accessory bracts. - Proc. Am. Acad. xix. 50. - A. trifida, in part, Gray, Bot. Calif. i. 405. Mono Pass, in the eastern part of the Sierra Nevada, California, Bolander.

$==$ Canescent pubescence minute and very close: bracts of the involucre broad.

A. cána, Pursh. A foot or two high, freely branched, silvery-canescent: leaves lanceolatelinear or narrower, somewhat tapering to both ends, an inch or two loug, entire, rarely with 2 or 3 acute teeth or lobes; margins not revolute: heads glomerate in a leafy contracted panicle, 6-9-flowered, rarely 5-flowered, usually with one or two linear subulate accessory bracts. - Fl. ii. 521 ; Bess. in Hook. Fl. \& DC. Prodr. vi. 105; Torr. \& Gray, 1. c. A. Columbiensis, Nutt. Trans. Am. Phil. Soc. 1. c. - Plains, Saskatchewan to Montana, Dakota, and Colorado; common only northward.

A. Rothróckii, Gray. A foot or less high, less canescent or cinereous: leaves (inch or less long) from cuneate and obtusely 3-lobed at dilated summit to spatulate-lanceolate or the upper linear, sometimes all entire: heads (2 or 3 lines long), glomerate-paniculate, 9-12flowered: proper bracts of the involucre all ovate or oval, glabrate. - Bot. Calif. i. 618; Rothrock in Wheeler Rep. 366, t. 13 ; Gray, Proc. Am. Acad.xix. 50. A. trifida, Gray, l. c. 405, in part. - California, in the eastern and southern part of the Sierra Nevada, Rothrock, Bolander, \&c., and S. Utah, Ward, Parry.

\section{TRIBE VIII. SENECIONIDE 2, p. 79.}

179. TUSSILÅGO, Tourn. Coltsfoot. (Tussis and ago, allays cough.) - Single species, indigenous to Europe and Asia, naturalizerl in N. America.

T. Fárfara, L. Low perennial herb, cottony-tomentose; with extensively creeping rootstocks, sending up in earliest spring a scape beset with alternate lanceolate bracts, and terminated by a head of yellow flowers; later developing rounded-or angulate-cordate irregularly dentate leaves on long and stout radical petioles, glabrate in age. - Wet grounds, a common weed in N. Atlantic States and Canada. (Nat. from Eu.)

180. Petasites, Tourn. Butrer-Btr, Sweet Coltsfoot. (Пє́тajos, a broad-brimmed hat, alluding to the large and broad leaves.) - Perennial herbs, of the northern temperate zone; with thickish and mostly creeping rootstocks, sending up scapiform and foliose-bracteate simple flowering stems, and ample 
radical leaves on strong petioles, cottony-tomentose or glabrate; the flowers whitish or purplish, in spring. - Gærtn. Fruct. ii. 406, t. 166 ; Grenier \& Godr. Fl. Fr. ii. 89; Reichenb. Ic. Fl. Germ. t. 896-901; Benth. \& Hook. Gen. ii. 438. Nardosmia (Cass.) \& Petasites, DC. Prodr. v. 205, 206.

\section{$\S 1$. No ligule to female flowers: an introduced plant. - Petasites, DC.}

P. VULGÁRIS, DESF. Rootstock very stout: leaves at maturity very large, round-cordate, angulate-dentate and denticulate: heads racemosely disposed: flowers purplish. - Tussilago Petasites, L. - In cult. and waste grounds, spreading in the vicinity of Philadelphia, C. E. Smith. (Nat. from Eu.)

$\S 2$. Female flowers with distinct ligules: rootstocks in ours slender and creeping: leaves developing with or soon following the whitish blossoms, in spring. Nardosmia, Cass.; so named from the fragrant flowers of the original species.

P. sagittáta, Grar. Leaves from deltoid-oblong- to reniform-hastate, from acute to rounded-obtuse, repand-dentate, very white-tomentose beneath, when full grown 7 to 10 inches long: heads short-racemose becoming corymbose: ligules equalling or shorter that the disk. - Bot. Calif. i. 407. Tussilago sagittata, Pursh, Fl. ii. 332. Nardosmia sagittata, Hook. Fl. i 307 , and apparently a part of $N$. frigida, Hook, - Wet ground, Hudson's Bay to Fort Franklin, west to the Rocky Mountains in Brit. Columbia, and south to those of Colorado.

P. frígida, Frixs. Leaves small ( 1 to 3 or 4 inches long), rounded- or oblong-cordate to reniform-hastate, sometimes evęn truncate at base, angulately or more deeply and sinuately lobed, the lobes entire: heads few, corymbose. - "Syll. 20," \& Sum. Veg. Scand. 182. Tussilago frigida, L.; Fl. Dan. t 61, not of Pursh, whose plant from Canada and New England is either fictitious or the succeeding species. T. corymbosa, R. Br. in Parry Voy. \& Richards. App. Frankl. Journ. Nardosniia angulosa, Cass. Dict. xxxiv 188. N. frigida $\& N$. corymbosa, Hook. 1. c., at least mainly. - Arctic coast and west to Kotzebue Sound, the Aleutian Islands, \&c. (N. Eu. \& Asia.)

P. palmáta, Grar. Leaves ( 7 to 10 or even 18 inches broad) round-reniform in outline, palmately 7-11-cleft to beyond the middle or deeper; the lobes oblong-lanceolate to oblongcuneate, laciniate-dentate: scape multibracteate, bearing rather numerons heads. - Bot. Calif. i. 407. Tussilago palmata, Ait. Kew. ii. 188, t. 2; Pursh, 1. c. Nardosmia palmata, Hook. l. c.; Torr. \& Gray, 1. c. - Wet woodlands, Newfoundland and Labrador, Canada, New England, and Wisconsin to Brit. Columbia and California. (E. Asia.)

181. CACALIOPSIS, Gray. (Kakaגía, ancient Greek name of Coltsfoot? and ö $\psi$, likeness; from resemblance, if not to the ancient Cacalia, at least to that of ' (ournefort. - Proc. Am. Acad. xix. 50. - Single known species.

C. Nardósmia, Gray, 1. c. Robust perennial, a foot or two high, floccose-woolly, at length glabrate: leaves considerably resembling those of Petasites palmata, alternate, long-petioled, all but 2 or 3 radical, orbicular-cordate or flabellate, 5-9-cleft or rarely parted; the lobes or divisions rather broad, incisely lobed or dentate: heads (an inch high) few or several, pedunculate, corymbosely or racemosely disposed at the naked summit of the stem: corolla pure yellow: flowers honey-scented. - Cacalia Nardosmia, Gray, Proc. Am. Acad. vii. 361. Adenostyles Nardosmia, Gray, 1. c. viii. 631, \& Bot Calif. i. 301, following Benth. \& Hook. -Open pine woods, California from Mendocino Co. northward (Bolander, Kellogg, Greene) to Oregon and Washington Terr., Suksdorf, Howell.

182. LUINA, Benth. (Anagram of Inula, which this genus approaches.) - Hook. Ic. P]. t. 1139 ; Benth. \& Hook. Gen. ii. 438. - Single species.

L. hypoleúca, BeNTH. 1, c. Herbaceous and simple-stemmed from a stout woody rootstock, white with appressed tomentum: stems hardly a foot high, equably leafy up to the corymbiform cyme of several small heads: leaves ovate or oval, alternate, sessile, entire, inch or less long, nervose-veiny and reticulated, the upper face soon glabrate and green, 
involucre 4 lin 3 high, nearly equalling the light yellow corollas. - Gray, Proc. Am. Acad. ix. 206, \& Bot. Calif. i. 409. - Cascade Mountains, on the border of Brit. Columbia, L,; all. . Yakima Co., Washington Terr., Brandegee.

Var. Califórnica, Grar, l. c. More densely woolly, and upper face of the leares tardily glabrate: corolla-lobes shorter. - W. Californit, on Chimney Rock, Mendocino Co. (and, according to the ticket, behind Santa Cruz), Kellogg.

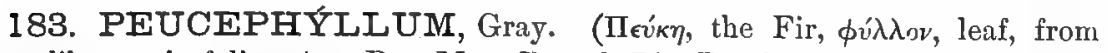
some likeness in foliage.) - Bot. Mex. Bound. 74; Benth. \& Iook. Gen. ii. 438. Psathyrotes § Peucephyllum, Gray, Proc. Am. Acad. ix. 206. - Single species.

P. Schóttii, Grır, I. c. Shrub 2 to 10 feet high, glabrous but resinous-riscid and balsamic', very much branched, rigid (the stem at base often 3 inches in diameter, including the rougl bark) : branches and branchlets very leafy up to the terminal heads: leaves alteruate and some fascicled in the axils, nearly terete, half-inch to inch long, as it were acerose but bluntish and not very rigid, minutely impressed-punctate; the lower sometimes 3-parted: heads barely half-inch high : corollas dull yellowish, with the teeth becoming fuscous , anthers included or half-exserted. - Psathyrotes Schottii, Gray, Proc. Am. Acad. ix. 206, \& Bot. Calif. i. 409. - Desert region of S. E. California and adjacent Arizona; first coll. by Schott and Newberry; later by Parry, Lemmon, Pringle, \&c.

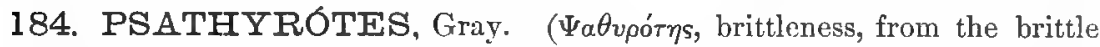
stems and branches.) - Low and pubescent or scurfy winter annuals (of Nevada and Arizona); with round-cordate or ovate petioled leaves, and rather small heads of yellowish flowers, sometimes turning purplish. - Pl. Wright. ii. 100; Proc. Am. Acad. vii. 363; also Proc. Am. Acad. ix. 206, \& Bot. ('alif. i. 409, excl. § 2. Tetradymia § Polydymia, Torr. in Emory Rep. 1848, 145. Bulbostylis (Psathyrotus), Nutt. Pl. Gamb. in Jour. Acad. Philad. n. ser. i. 179.

$\S 1$. Divaricately much branched, spreading or depressed, leafy; with solitary heads in the forks, either erect or nodding on short or slender peduncles: corollitis more or less woolly at summit: style-branches glabrous, or with some very minute pubescence at or toward the tip.

P. ramosíssima, Grat. Lanate, at least the stems and branches, and the young leaves covered with dense and somewhat scurfy white tomentum: leaves long-petioled, roundish, subcordate or almost cuneate at base, coarsely crenate (half-inch wide): outer bracts of the involucre 5, spatulate-obovate, much larger than the inner, the upper part spreading and foliaceous : corollas plainly yellow: akenes short-turbinate, densely long-villous. - Proc. Am. Acad. vii. 363, \& Bot. Calif. 1. c. P. annua, Gray, Pl.'Thurb. 323, \& Bot. Mex. Bound. 102, in part. Tetradymia (Polydymia) ramosissima, Torr. in Emory Rep. l. c. - Gravelly hills and rocks, along the Mohave and Gila, S. E. California and throughout adjacent $\lambda$ rizona; first coll. by Emory.

P. ánnua, Gray. Furfuraceous-canescent or cinereous: leares more dentate, seldom cordate, commonly wider than long: outer bracts of the involucre ovate-oblong or narrowr'? less foliaceous, rather shorter than the inner, erect: corollas more slender, pale yellow, changing sometimes to purplish: akenes oblong-turbinate, densely villous; pappus rather less copious. - Pl. Wright. ii. 100, Proc. Am. Acad. vii. 364, \& Bot. Calif. 1. c. Bulbostylis (Psathyrotus) annua, Nutt. 1. c. - Saline plains, Nevada, eastern borders of Califormia, S. Utah, and adjacent Arizona; first coll. by Gambel.

P. pilífera, GrAY. Minutely furfuraceous-tomentose: leaves dilated rhombic-obovate or roundish with cuneate base, entire; their margin and sometimes upper face and long petiole beset with very long and soft (probably viscid) many-jointed hairs : heads narrower: outcr bracts of cylindraceous involucre oblong-linear, herbaceous only at summit: young aliencs oblong, short-hirsute: style-branches dorsally somewhat pubescent for some distance below the truncate tip. - Proc. Am. Acad. xix. 50. - Southern Utah, near Kanab, Mrs. Thompson, Parry. 
§ 2. Scapose, erect: corollas nearly glabrous throughout: style-branches flatter, very obtuse, externally minutely hirsute over most of the back.

P. scapósa, GrAY. Leaves all at or near the base, ovate or roundish, almost entire, shortpetioled, at first loosely white-tomentose, at length glabrate: scapes or naked peduncles several, 3 or 4 inches high, bearing 3 to 7 corymbosely disposed heads, glandular-pubescent, as also the campanulate involucre: bracts of the latter all somewhat herbaceous; outer ones broadly linear or barely oblong, equalling and not unlike the inner: akenes oblong-turbinate, hirsute: pappus about half the length of the corolla. - Pl. Wright. ii. 100, t. 13.Borders of Texas, New Mexico, and Chihuahua, near El Paso, on the Rio Grande, Wright. (Adj. Mex.)

185. BARTLÉTtA, Gray. (John R. Bartlett, Commissioner of the Mexican Boundary Survey, in which this plant was discovered.) - Pl. Thurb. in Mem. Amer. Acad. v. 324 ; Bot. Mex. Bound. 102. - Single species.

B. scapósa, Grax, 1. c. Slender winter-annual, almost glabrous, flowering almost from the base by monocephalous scapes of 6 to 9 inches high, and later by similar peduncles terminating sparsely leafy branching stems: leaves slender-petioled, roundish or subcordate, membranaceous, repand-dentate, some 3-5-lobed: head half-inch or less high: involucre pubescent: flowers yellow: pappus rather fragile, little longer than the akene. - New Mexico, near El Paso, perhaps only below the Mexican boundary, Thurber, Schott, G.R. Vasey. (Adj. Mex.)

186. CROCIDIUM, Hook. (Diminutive formed from крóкๆ, loose thread or wool, alluding to the wool which usually persists in the axils of the leaves.) Fl. Bor.-Am. i. 335, t. 118; Torr. \& Gray, FI. ii. 448; Benth. \& Hook. Gen. ii. 440. - Single species; $f$. early spring.

C. multicaúle, Hоoк. 1. c. Small winter annual, a span or two high, flocculent-woolly when young, soon mostly glabrate, producing many simple stems from the tuft of obovate or spatulate few-toothed sessile or short-petioled radical leaves : cauline leaves small, lanceo. late to linear: head slender-pedunculate, rather small, but showy; the ray and disk deep golden yellow. - Plains and hills, British Columbia and Idaho to the northern part of California; first coll. by Douglas.

187. HAPLOESTHES, Gray. ('A $\pi \lambda$ óos, simple, é $\sigma \theta$ '́s, garment, the involucre of unusually few pieces.) - Pl. Fendl. 109, Pl. Wright. i. 125, \& Bot. Mex. Bound. 102. — Single species.

H. Gréggii, GraY, l. c. Somewhat fleshy, herbaceous or suffrutescent, a foot or two high, fastigiately branched, glabrous, leafy up to the loose cymes of a few slender-pedunculate naked heads: leaves all opposite, very narrowly linear or filiform, entire; the lower connate at base: heads 2 or 3 lines high: flowers yellow: ligules 1 or 2 lines long. - Saline soil, S. E. Colorado and W. Texas to the Mexican border, Wright, Bigelow, Parry, \&c. (Adj. Mex.; first coll. by Gregg.)

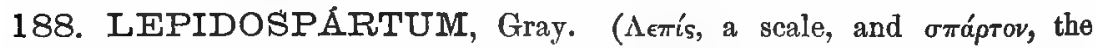
Broom plant.) - Proc. Am. Acad. xix. 50. - Single species.

L. squamátum, GrAr, l. c. A rigid Broom-like shrub, 4 or 5 feet high; seedling plants floccose-tomentose and with spatulate entire alternate leaves of half-inch or more in length; but the primary branches and whole subsequent growth glabrous or nearly so, and beset with small and thickish appressed green scales in place of leaves: heads terminal or more commonly spicate-paniculate on the slender branchlets, 3 to 5 lines long: involucre very glabrous, 10-18-flowered : corollas pale yellow. - Linosyris squamata, Gray, Proc. Am. Acad. viii. 290. Tetradymia (Lepidosparton) squamata, Gray, Proc. Am. Acad. ix. 207, \& Bot. Calif. i. 408; var. Breweri \& var. Palmeri are mere varying forms. Carphephorus junceus, Durand in Pacif. R. Rep. v. 8, not Penth. Has been mistaken also for a Baccharis. - Dry 
hills and arid plains, from Los Angeles Co., California, to Arizona; first coll. by Meermann and by Brewer.

189. TETRADYMIA, DC. (Teтpódvuos, four together, the heals of the principal species only 4-flowered.) - Low and rigid shrubs (of the arid interior of N. America), sometimes spinescent, canescently tomentose; with alternate and sometimes fascicled narrow and entire leaves, rather large cymose or clustered heads of yellow flowers, and a copious white pappus. - Prodr. vi. 540; Deless. Ic. Sel. iv. t. 60 ; Torr. \& Gray, Fl. ii. 447.

§ 1. Ectetradfmia. Involucre 4-flowered, of 4 or 5 bracts: pappus extremely copious: akenes either very villous, glabrate, or glabrous, varying even in the same species: undershrubs, a foot or two high.

T. canéscens, DC. Permanently canescent with a dense close tomentum, unarmed, fastigiately branched : leaves from narrowly linear to spatulate-lanceolate, an inch or less long: heads half to three-fourths inch long, most of them short-pedunculate. - P'rodr. 1. c.; Deless. Ic. iv. t. 60. - Hills and plains, along with Artemisia rridentata, N. Wyoming and Brit. Columbia to New Mexico, Arizona, and eastern borders of California. Passes freely into

Var. inérmis, Gray, Bot. Calif. i. 408. A form with shorter and crowded branches, shorter leaves more iuclined to spatulate and lanceolate, and smaller heads. $-T$. inermis, Nutt. Trans. Am. Phil. Soc. vii. 415; Torr. \& Gray, 1. c. - The commonest and almost the only form eastward.

T. glabráta, Grar. Whitened with looser at length deciduous tomentum, unarmed: branches more slender, spreading: leaves at length naked and green, primary ones slendersubulate, cuspidate, on young shoots appressed, half-inch long; those of fascicles in their axils spatulate-linear, fleshy, pointless: heads mostly short-pedunculate: involucre often glabrate: akenes as far as known very villous. - Pacif. R. Rep. ii. 122, t. 5 ; Eaton, Bot. King Exp. 193; Gray, Bot. Calif. i. 408. - Common in Ltah and to the eastern borders of California and S. E. Oregon; first coll. by Beckwith.

T. Nuttállii, Torr. \& GraT. Pubescence and foliage of T. canescens, var. inermis, bearing rigid divergent spines in place of primary leaves; leares of the axillary fascicles mostly spatulate: heads more glomerate. - Fl. I. c.; Eaton, l. c. T. spinosa, Nutt. l. c., not Hook. $\&$ Arn. - Ctah and Wyoming or S. Idaho, Nuttall, Watson.

§ 2. Lagotháminds, Torr. \& Gray, 1. c. Involucre 5-9-flowered, of 5 or 6 broader bracts : proper pappus less copious, reduced nearly or quite to a single series of bristles, which are covered by a false pappus of the extremely long very soft and white woolly hairs which densely clothe the akene: shrubs 2 to 4 feet high, at least the branches densely white-tomentose. - Lagothamnus, Nutt. Trans. Am. Phil. Soc. vii. 416.

T. spinósa, Hook. \& ARs. Branches divaricate, rigid, bearing rigid and straight or recurved spines in place of primary leares: secondary leaves fascicled in their axils, small, fleshy, linear-clavate, glabroüs or glabrate: heads scattered, pedunculate, fully half-inch long: pappus of compraratively rigid capillary bristles, somewhat surpassing the wool of the akene. - Bot. Beech. 360 ; Torr. \& Gray, 1. c. ; Gray, Bot. Calif. 1. c. - Lagothamnus microphyllus \& L. ambiguus, Nutt. Trans. Am. Phil. Soc. vii. 416. - S. Wyoming and Utah to Idaho, E. Oregon, and along the soatheastern borders of California to border of Arizona.

T. comósa, Grdr. Branches erect, elongated : primary leares linear, soft, floccose-tomentose; the earlier 2 or 3 inches long and 2 lines wide, plane; those of the branches often filiform and deciduous, some of the upper changed to long and soft spines; fascicled secondary leaves wanting, or fewer and like those of $T$. spinosa: heads corymbose or glomerate at the summit of the branches: pappus finer and more scanty, concealed by the long wool of the akene.-Proc. Am. Acad. xii. 60; Bot. Calif. ii. 458. - N. W. borders of Nevada (Lemmon), San Bernardino and San Diego Counties, California, Parry, Lemmon, Parish, Cleveland. 
190. RAILIARDÉLLA, Gray. (Diminutive of Raillardia, an allied Hawaian genus of shrubs.) - Perennial and mostly scapose herbs of the Sierra Nevada, California, intermediate between the Senecionidece and the Helenioidea. Leaves entire, narrow; cauline alternate or none: head solitary, with yellow flowers; in summer. - Proc. Am. Acad. vi. 5̃ōo (§ of Raillardia), \& in Benth. \& Hook. Gen. ii. 442 ; Bot. Calif. i. 416.

$\S 1$. Genuine species, with creeping rootstocks, producing rosulate clusters of spatulate-lanceolate or narrower thickish leaves, and occasionally one or two small ones near the base of the otherwise naked elorgated simple scape, which is terminated by the solitary (commonly inch long) head: pappus-bristles 15 to 20 or more, conspicuously short-plumose, white : no hirsute pubescence, but involucre and upper part of scape glandular.

R. argéntea, GrAY, 1. c. Rootstocks extensively creeping, somewhat lignescent: leaves silvery with a silky tomentum, inch or two long: scape 2 to 4 inches high : head narrow, in depauperate specimens 7-8-flowered, but nsually about 15 -flowered : no rays. - High Sierra Nevada (9,000 to 11,000 feet) from the San Bernardino Mountains to Lassen, Brewer, Greene, Lemmon, \&c.

R. scapósa, Gray, l. c. Somewhat pubescent, but no tomentum, glabrate: leaves 1 to 4 inches long: scape 4 to 10 inches high: involucre cylindraceous, in depauperate plants 10-12-flowered, in others 20-30-flowered : corollas light yellow. - Sierra Nevada above and east of the Yosemite, at 8,000 to 9,000 feet; first coll. by Brewer and Bolander; the latter found some specimens with incipient rays, connecting with

Var. Eiseni. A small form: heads with 3 or 4 deformed rays. $-R$. Eiseni, Kellogg in herb. Calif. Acad. - Mountains of King's River, Fresno Co., G. Eisen.

R. Pringlei, Greene. Rootstock stout and branching: leaves glabrous and smooth, thickish, some obseurely denticulate, 3 or 4 inches long, 3 or 4 lines wide: scape 10 to 18 inches high: involucre campanulate, about 40-flowered, of correspondingly numerous and more distinct bracts : flowers orange-yellow, 6 to 10 of them conspicuously radiate : pappus-bristles rather fewer (15 to 18) and rather less plumose than in the foregoing. - Bull. Torr. Club, ix. 17. - High mountains of N. California, west of Mount Shasta, Pringle.

$\S 2$. Anomalous species, hirsute, leafy-stemmed, perhaps some of the central flowers infertile.

R. Muírii, GraY. About a foot high, roughish-hirsute, leafy below, sparsely so and bearing stipitate glands toward the summit: leaves inch long, lanceolate-linear, acute, closely sessile; radical ones unknown: heads terminal and one or two lateral, half-inch high, wholly discoid : involucre campanulate, hirsute, its narrow bracts distinct to the base : akenes oblong with tapering base : pappus of 11 or 12 somewhat more aristiform and rather less plumose bristles than in preceding species. - Bot. Calif. ii. 618. - In the Sierra Nevada, probably southwarl, but station unknown, Muir. Too little known.

191. ÁRNICA, L. (Thought to be a corruption of Ptarmica.)-Perennial herbs, of the northern temperate and arctic zones; with erect stems, either quite simple or branching above, opposite leaves (or upper occasionally alternate), and comparatively large long-pedunculate heads of yellow flowers; the rays usually elongated, rarely wanting. Anthers yellow except in the last species. Fl. summer. - Gærtn. Fr. t. 173; Schkuhr, Handb. t. 248; Torr. \& Gray, Fl. ii. 449.

* Radical leaves roundish and sessile in an ample rosulate cluster. Atlantic U. S.

A. nudicaúlis, Nutr. Hirsute: stem robust, I to 3 feet high, simple and bearing few heads, or loosely paniculate with many: leaves denticulate or nearly entire; radical 2 to 5 inches long; cauline only one or two remote pairs up to the inflorescence, small, oval, closely sessile: rays half-inch long, - Gen. ii. 164; Ell. Sk. ii. 333; DC. Proll. ri. 318; Torr. \& 
Gray, l. c. A. Claytoni, Pursh, FI. ii. 527. Doronicum acaule, Walt. Car. 205. D. nudicaule, Michx. Fl. ii. 121. - Pine barreas, \&c., Penn. to Florida.

* Radical leares mostly cordate at base, on slender or sometimes winged petioles: rootstocks slender and creeping. Pacific and Rocky Mountain species.

+ Rays wanting or rarely some rudiments: cauline leaves sometimes by disjunction alternate, some of them petioled, irregularly dentate: heads rather numerous, paniculate.

A. parviflóra, Grdx. A foot high, slender, pubescent, even the peduncles but slightly glandular: leares narrowly deltond or oblong, truncate or abrupt at base, an inch or two long: involucre 4 or 5 lines high, about 20-flowered; its linear bracts sparsely pubescent: akenes not pubescent, minutely glandular. - Proc. Am. Acad. vii. 363, \& Bot. Calif. i. 415. - California, in Humboldt Co., Bolander. Also at some station north of San Francisco Bay, G. R. Vasey.

A. discoídear, Bentr. A foot or two high, stouter, more or less villons and viscid : rarlical and lowest cauline leaves from ovate with truncate or abruptly cuneate base to cordate, not rarely wing-petioled: involucre half-inch high, 30-50-flowered, usually very villous and glandular; its bracts lanceolate or linear: akenes pubescent.-Pl. Hartw. 319; Gray, Bot. Calif. 1. c., with a part of A.cordifolia. - Wooded hills in the coast ranges of California, from San Luis Obispo Co. northward to Tashington Terr.; first coll. by Hartweg. Northwardly seems to pass into $A$. cordifolia.

++ Rays conspicuous and elongated, rarely wanting: cauline leaves all opposite, in one or two or at most three pairs, broad, usually membranaceous, dentate or denticulate.

A. cordifólia, Hook. A foot or two, or when alpine a span or two high, pubescent, or the stems hirsute and peduncles villous: lower cauline as well as radical leaves long-petioled, deeply cordate, yet sometimes only ovate; upper cauline small, sessile : heads few, in smaller plants solitary: involucre two-thirds inch long, pubescent or villous: rays commonly inch long: akenes more or less hirsute.-Fl. i. 331 ; Torr. \& Gray, Fl. ii. 450. A. macrophylla, Nutt. Trans. Am. Phil. Soc. 1. c. 407. Senecio Cumingii, Klatt in Alh. Nat. Hist. Gesellsch. xv. 9, is either this or the next. - Woods and high mountains, Brit. Columbia, and mountains near Saskatchewan, to those of Colorado, Utah, Nevada, and eastern borders of the Sierra Nevada, California.

Var. eradiáta is an ambiguous form; with smaller and rayless heads, and oblongovate at most subcordate leaves. - E. Oregon, Montana, \&c. Transition to A. Parryi.

A. latifólia, Boxg. Minutely pubescent or commonly glabrous, with smaller heads than the preceding: only radical leaves cordate or subcortate and petioled; cauline 2 or 3 pairs, equal, orate or oval, usually sharply dentate, closely sessile by a broad base, or lowest with contracted base: akenes commonly glabrate or glabrous. - Veg. Sitch. 147 ; 'Torr. \& Gray, 1. c. A. Menziesii, Hook. Fl. i. 331, t. 111. - Pine woods, Alaska and Brit. Columbia to Oregon, and Rocky Mountains to Colorado and Utah; first coll. by Menzies.

Var. viscídula. Viscidly pubescent: cauline leaves less broad at base: heads rather larger: akenes pubescent. - High Sierra Nevada, California, Greene, Pringle. And a very similar plant from Sitka.

* * No corlate leaves; radical leaves petioled, tapering or sometimes abrupt at base: rootstocks usually creeping and slender. Western and Northern species.

- Leafy to the top: cauline leaves very seldom less than 4 pairs, and the upper not conspicuously diminished: heads several or few, or in smaller plants solitary".

t+ Heads all with rays half-inch or more long: plants a foot or two high: the species confluent.

A. amplexicaulis, Nurr. Slightly pubescent or almost glabrous: leaves from ovate to lanceolate-oblong, acute or acuminate, all the cauline sessile by a half-clasping base, saliently and very acutely dentate: akenes hirsute-pubescent. - Trans. Am. Phil. Soc. vii. 408 ; Torr. \& Gray, 1. c. - Woods and shaded rocks, Oregon to Brit. Columbia, Nuttall, Lyall, Wallace, \&c. Broad-leaved forms much resembling the preceding, except in more leafy stems and want of cordate radical leaves : narrower-leaved forms nearly pass into the sncceeding.

A. Chamissónis, Less. From tomentulose- or villous-pubescent to nearly glabrous : leaves oblong or oblong-lanceolate, denticulate or dentate, acute or obtuse; lowest tapering into a margined petiole, upper broad at base. (sometimes ovate-lanceolate) and somewhat clasping: akenes hirsute-pubescent. - Less. in Linn. vi. 238; DC. Prodr. vi. 317 ; 'Torr. \& 
Gray, 1. c. partly ; Gray, Bot. Calif. 1. c. A. mollis, Hook. Fl. i. 231 ; Torr. \& Gray, Fl. 1. c.; Torr. Fl. N. Y. t. 60, a form with comparatively few and mostly broad leaves. A. lanceolata, Nutt. Trans. Am. Phil. Soc. 1. c. A. latifolia, Gray, Bot. Calif. ii.,458, \& i. 415, in part, almost glabrous broad-leaved form. - Lnalaska and Sitka to the Sierra Nevada, California, and mountains of Utah and Colorado; east to L. Superior, Mount Washington, and the mountains of Lower Canada. A form with comparatively uarrow leaves, N. Maine and Lower Canada, Goodale, Allen, \&c.

A. longifólia, EAтon. Many-stemmed in a tuft, minutely puberulent: cauline leaves elongated-Ianceolate, tapering to both ends, entire or denticulate, somewhat nerrose ( 3 to 6 inches long), lower with narrowed bases connate-vaginate; heads corymbosely disposed, shortpeduncled: akenes minutely glandular, not hairy. - Bot. King Exp. 186. - On rocks, in the mountains, at 9,000 feet, from above Summit (Jones, Pringle) to Kern Co. (Rothrock) in California, Clover Mountains, Nevada (Watson), and Wahsatch Mts. (Jones) in Utah.

A. foliósa, NuTr. Tomentose-pubescent, strict: leaves lanceolate, denticulate, nervose; upper partly clasping by narrowish base, lower with tapering bases connate: heads shortpeduncled, rarely solitary; akenes hirsute-pubescent or glabrate. - Trans. Am. Phil. Soc. vii. 407 (excl. var. nana); Gray, Bot. Calif. i. 416. A. Chamissonis, Torr. \& Gray, l. c., in part. A. montana, Hook. Fl. 1. c., in part. - Wet meadows and mountain-sides, Saskatchewan to Oregon, N. California, and southward along the Sierra Nevada, and in the Rocky Mountains south to Colorado.

Var. incána, Grax, Bot. Calif. 1. c. White with very soft floccose tomentum. - Wet meadows, mostly in water, in the Sierra Nevada, California and adjacent Nevada; first coll. by Brewer and Torrey.

+ Heads rayless: stems leafy even on the flowering branches.

A. viscósa, Gruy. A foot or less high, fastigiately branching, very viscid-pubescent: leaves small (inch or less long), ovate-oblong, entire, closely sessile, but not connate at base: involucre 4 lines high, considerably shorter than the (25 or 30 ) flowers : corollas pale yellow: akenes glandular-hirsute. - Proc. Am. Acad. xiii. 374, \& Bot. Calif. ii. 458. - N. California, on Mt. Shasta at 8,000 feet, Gray \& Hooker.

+ + Less leafy: cauline leaves one or two (rarely three) pairs, and the upper mostly small.

+ Heads rayless, mostly 3 to 5 and rather short-peduncled at the naked summit of the stem.

A. Párryi, GrAr. A foot or less high, slender, simple, somewhat hirsutely pubescent and above glandular: leaves membranaceous, commonly denticulate; radical oval to ovateoblong ( 1 to 3 inches long), abruptly or cuneately contracted at base into a short margined petiole; canline remote: involucre hirsute and glandular, half-inch or less high: occasionally some outermost corollas ampliate: akenes glabrous or with a few sparse hairs. - Am. Nat. viii. 213. A. angustifolia, var. discoidea, latifolia, Gray in Am. Jour. Sci. ser. 2, xxxiii. 238. A. angustifolia, var. eradiata, Gray, Proc. Acad. Philad. 1863, 68. - Rocky Mountains. from Colorado (on the borders of alpine region) to Wyoming, in the Wahsatch, Utah, and west to Oregon and Washington Terr.; first coll. by Parry.

+ Heads conspicuously radiate, solitary or very few, mostly long-peduncled.

$=$ Anthers yellow, as in all the preceding species: tube of disk-corollas hirsute.

A. Nevadénsis, GraY. Half a foot high, puberulent, sometimes cinereous: leaves all oval or oblong, mostly obtuse, entire or a few small denticulations (inch or two long), obscurely triplinerved or 3-nerved at base; radical roundish to obovate, either abruptly contracted or tapering into slender petiole: involucre half-inch high : akenes minutely pubescent and glabrate. - Proc. Am. Acad xix. 55. - Sierra Nevada, California. Lassen's Peak, Mrs. Austin, cinereous form, with rays almost inch long, bears resemblance to Whitneya. Peaks south of Summit, at 9,000 feet, Pringle, greener, roundish-leaved, with rays half-inch long.

A. alpína, Otin. A span to 18 inches high, pubescent, hirsute, or at summit villons, strict, simple and monocephalons, occasionally 3-cephalous : leaves thickish, from narrowly oblong to lanceolate, or the radical oblong-spatulate and small uppermost linear, entire or denticulate, 3-nerved; bases of the cauline hardly at all connate: akenes hirsute-pubescent, rarely glabrate. - "Murr. Syst. Veg., 1774" (according to Fries, but not found there), "Olin, Monogr. Arnic. Upsaliæ, 1799," ex Fries, Summ. Veg. Scand. 187; Wahl. Fl. Suec. ii. 530; Gray, Bot. Calif. i. 416. A. angustifolia, Vahl, Fl. Dan. t. 1524 ; DC. Prodr. vi. 317 ; Torr 
\& Gray, Fl. ii. 449. A. plantaginea \& A. fulgens, Pursh, Fl. ii. 527. - Labrador and north to the arctic coast, west to the Aleutian Islands, south to the Sierra Nevada, California, and to Colorado in the Rocky Mountains; the southern forms comparatively large and broadleaved. (N. Eu., Greenland.)

Var. Lessíngii, Tonn. \& Grar, l. c., perhaps from Kotzebue Sound, is a thinner. leaved form, of lax habit; the akenes only sometimes glabrous, and the anthers not "blackish." - A. alpina, Less. in Linn. vi. 235 ; Herder, Pl. Radd. ii. 110. (N. E. Asia.)

$==$ Anthers black: leaves broad: Lead large, solitary. High Northwestern species.

A. Unalaschénsis, Less. Robust, a span or two high, hirsute or villons: leaves oblong, mostly acutish and ooviously serrate or denticulate with subulate callous teeth : disk-corollas glabrous or nearly so: akenes slightly hairy or glabrate. - Linn. vi. 235 ; Herder, 1. c. Unalaska, and other Aleutian Islands, Behring Island, \&c.; first coll. by Chamisso.

A. obtusifólia, Less. 1. c. Taller or longer-pedunculate, pubescent or glabrate : leaves oblong or spatulate, very obtuse, almost or quite entire, nervose: disk-corollas "glabrous" or upper part of the tube hispidulous : akenes glabrous : resembles $A$. montana. - Unalaska, Chamisso. Shumagin Islands, Harrington.

192. SENÉCIO, Tourn. Groundsel. (Old Latin name of Groundsel, from senex, old man, in allusion to the hoary pappus.) - One of the largest known genera, very widely dispersed over the world, most of the species (all of ours) herbs; with alternate leaves, and 5ellow-flowered heads of middle or rarely larger size: fl. spring and summer. Minute short hairs or papillæ on the akenes of most species swell and emit a pair of spiral threads when wetted. Before wetting the akenes may be really or apparently glabrous, and after wetting become canescent. - Less. Syn. 391 ; DC. Prodr. vi. 340; Benth. \& Hook. Gen. ii. 446, partly. - Arrangement wholly artificial.

S. Canadénsis, L., Spec. ii. 869, and Cineraria Canadensis, L. Spec. ed. 2, ii. 1244 (to which Nutt., Gen. ii. 165, gave the name of S. Kalmii), were said to be of "Canada, Kalm." They are not so indicated in the Linnæan herbarium: both are probably South European specimens. The first belongs to $S$, artemisicefolius, Pers.; the second is a thinner-leaved form of Cineraria maritina, L., the S. Cineraria, DC. - Cineraria Carolinensis, Walt. Car. 207, is undeterminable.

S. ciliátus, Walt. Car. 208, is probably only Erigeron Canadense, L.

S. Floccifferds, DC. Prodr. vi. 426, is Malacothrix oltusa, Benth.

S. Cinerária, DC., the Desty-Milier of house-cultivation, has been found wild on the beach of San Francisco Bay, California, at Alameda.

S. JACoBśa, L., of Europe, has become a weed in some parts of Nova Scotia and Canada.

S. PÁcmeni, Gray, a peculiar frutescent species of Guadalupe Island, off Lower California, is quite beyond our limits.

$\S 1$. Perennials (one or two suffruticose); with pubescence, if any, of a tomentose character, mostly floccose and when deciduous leaving the surface smooth and naked, never viscid nor obviously hirsute.

* Heads an inch or distinctly over half-inch high, very many-flowered.

+ Disk-corollas deeply 5-toothed: heads of the largest.

S. Rugélia, GraY. Lightly floccose-tomentose when young, soon glabrate: stems simple, a foot high from a creeping rootstock, bearing 3 to 5 naked slender-pedunculate somewhat racemosely disposed heads : leaves membranaceous; radical and lowest cauline ovate, denticulate, 2 to 5 inches long, long-petioled; others small and few, bract-like, sessile : involucre not calyculate, of about 12 linear-lanceolate thickish glabrous bracts: rays none: pappus rather sordid. - Proc. Am. Acad. xix. 54. Rugelia nudicaulis, Shuttlew. in coll. Rugel; Chapm. Fl. 246. - Woods, Smoky Mountains, N. Carolina and Tennessee, Rugel, Buclcley. Style-branches capitellate-truncate and pubescent at summit, and a few obscure minute hairs on the back. 
S. Pseudo-Árnica, Less. Floccosely white-tomentose, more or less glabrate in age: stem stout, 6 to 30 inches high, equably very leafy to top, bearing solitary or several curymbosely disposed heads on stout bracteolate peduncles : leaves oblong-lingulate or the lower spatulate, denticulate or dentate, 5 to 8 inches long, sessile by a partly clasping auriculate base : involucre calyculate by few or several slender-subulate loose accessory bracts: rays numerous, half-inch or more long: pappus dull white. - Less. in Linn. vi. 240; Hook. Fl. i. 334, t. 113 ; DC. Prodr. vi. 358 ; Torr. \& Gray, Fl. ii. 446 . Arnica maritima, L. Spec. ii. 884; Pursh, Fl. ii. 528. A. Doronicum, Pursh, l. c. - Sea-beaches, \&c., Newfoundland, New Brunswick, and border of Maine to Labrador, and west to the Aleutian Islands. (N. Asia.)

+ + Disk-corollas merely 5-toothed. Rocky-Mountain and more Western species.

+ Heads radiate.

- Alpine species of the Rocky Mountains.

S. Soldanélla, Grax. Apparently glabrous from the first, a span high, somewhat succu-lent: leaves mostly radical and long-petioled, from round-reniform to spatulate-obovate, denticulate or entire; cauline one or two or none: head solitary, erect, two thirds to nearly a full inch high : involucral bracts lanceolate and a very few calyculate ones : rays 6 to 10 , oblong, quarter-inch long. - Proc. Acad. Philad. 1863, 67; Porter \& Coulter, Fl. Colorad. 83. - High alpine region, mountains of Colorado, Parry, Hall \& Harbour, Coulter, \&c.

S. ampléctens, Gra . Lightly floceose-woolly at first, soon glabrate, a foot or so high, few-several-leaved, terminated by one or two long-pedunculate nodding heads : leaves thinner than in the foregoing, from denticulate to conspicuously and sharply dentate; radical obovate to spatulate, tapering into a winged petiole; cauline as large or larger $(4$ to 6 inches long), oblong or narrower, half-clasping or more, the upper by a broad base: involucre over half-inch high, of linear bracts and id few loose calyculate ones: rays linear, inch long or more, acute or acutely 2-3-toothed at tip. - Am. Jour. Sci. ser. 2, xxxiii. 240, \& Proc. Acad. Philad. 1. c. - Alpine and subalpine region, Rocky Mountains, Colorado; first coll. by Parry.

Var. taraxacoídes, Gray. Only a span or two high, with fewer and smaller cauline leaves; these and the radical commonly spatulate and with tapering base, not rarely laciniately subpinnatifid : head smaller, even down to half-inch, and with rass of only the same length. - Proc. Acad. Philad. 1863, 67; Eaton, Bot. King Exp. 192. - High alpine, in the mountains of Colorado and Nevada; first coll. by Parry. The most dwarf forms are very unlike the type.

$$
=\text { Not alpine: scapiform stem low, strict and strictly monocephalous. }
$$

S. Actinélla, Greene. Floccosely white-tomentose, glabrate in age : simple stem 6 to 10 inches high, bearing several small and appressed linear bract-like leaves and an erect head of two thirds of an inch in height: radical leaves in a rosulate tuft, obovate-spatnlate, denticulate, subcoriaceous, an inch or more long including the cuneate narrowed base or short winged petiole: involucral bracts subulate-linear: rays 9 to 12 , rather conspicuous, broadly linear. - Bull. Torr. Club, x. 87.-N. Arizona, near Flagstaff, Rusby.

$===$ Not alpine, with leafy stems a foot to a yard high, and several or few or sometimes solitary erect heads. (Here S. Clarkianus, if the heads were a little Iarger.)

S. Whippleánus, GraY. Probably floccose when young, sprinkled with less deciduous araneose hairs: stem robust, apparently 3 or 4 feet high, naked above, with an ample loose cyme: leaves ample ( 6 or 8 inches long), sinuately or laciniately pinnatifid, the lobes few and irregular; cauline sessile: peduncles mostly elongated, naked: involucral bracts fleshythickened, oblong-linear, abruptly acuminate; a very few loose and small slender calyculate bracts: rays half-inch long. - Proc. Am. Acad. xix. 54, without char. S. eurycephalus, var. major, Gray, Pacif. R. Rep. (Bot. Whipp.) iv. Il1. - Lower Sierra Nevada, at Murphy's, Calaveras Co., California, Bigelow. Further specimens needed. The broad heads nearly three-fourths inch high.

S. Mendocinénsis, Gray. Lightly arachnoid-floccose, soon glabrate : stem robust, 2 or 3 feet high, leafy below, naked above, bearing a corymbiform cyme of several heads on sparsely setaceous-bracteolate peduncles: leaves somewhat succulent, irregularly repanddenticulate to dentate ; radical and lower 3 to 6 inches long, oval to oblong-lanceolate, tapering into margined petioles; upper lanceolate from a broad sessile base, above reduced to 
subulate bracts : involucral bracts linear-subulate, and with several loose and slender calyculate ones: rays oblong, seldom half-inch in length.-Proc. Am. Acad. vii. 362, \& Bot. Calif. 1. c. 413. - Plains, Mendocino to Humboldt Co., California, Bolunder, Kellogg, Harford.

S. Greénei, Grar. Lightly floccose-tomentose, seldom a foot high, simple, bearing 1 to 3 short-peduncled heads: leaves (about inch long) coarsely dentate; radical ruundish, with abrupt or somewhat cuneate base, coarsely crenate-dentate, slender-petioled; cauline few, sessile, upper lanceolate and entire, sometimes all small and bract-like: heads two-thirds inch long: bracts of involucre linear, no outer calyculate ones: rays deep orange, half-inch or more long: style-tips of disk-flowers conspicuously penicillate-margined and with a central cusp. - Proc. Am. Acad. x. 75, \& Bot. Calif. i. 412. - Wooded mountain-side, near the Geysers in Lake Co., California, Greene.

S. megacéphalus, Nutr. About a foot high, loosely floccose-woolly, tardily glabrate, leafy: leaves entire, lanceolate, or the radical spatulate-lanceolate and tapering into a petiole, and uppermost cauline attenuate, thickish (obscurely glandular under the wool?): heads 1 to 3 , short-peduncled ( 8 lines to an inch high) ; involucre calyculate by some very loose and setaceous-subulate elongated accessory bracts; sometimes the true bracts and peduncles bear a few hirsute hairs besides the loose wool : rays over half-inch long. - Trans. Am. Phil. Soc. 1. t. 410; Torr. \& Gray, Fl. ii. 438. - Mountaius of Idaho, Nuttall, Watson, and Rocky Mountains, at 5,000 to 8,000 feet, near British Boundary, Lyall, Canby.

+ Heads rayless, nodding: some sparse crisped hairs in place of tomentum: caudex hardly any; the root a cluster of fibres.

S. Bigelóvii, Gray. Robust, 2 or 3 feet high, leafy up to near the racemiform or simply paniculate inflorescence, pubescent with some sparse crisped hairs when young, and with mere traces of arachnoid caducous wool, at length glabrate: leaves from elongated-oblong to lanceolate, denticulate or more dentate, acute or acuminate; radical and lower cauline 3 to 6 inches long, abrupt at base and naked-petioled, or tapering into a winged petiole or partly clasping base; upper lanceolate with partly clasping base: heads in small plants few or solitary, in larger ones several, nodding on their perluncles: involncre very broadly campanulate; its bracts lanceolate, thickish; a few small and loose subulate accessory bractlets at base. - Pacif. R. Rep. iv. 111; Porter \& Coulter, Fl. Colorad. 83; Rothrock in Wheeler Rep. 178. With var. Hallii, Gray, Proc. Acad. Philad. 1. c. (more sessile-leaved), and var. monocephalus, Rothrock, l. c. (smallest form).-Mountains of Colorado, New Mexico, and Arizona, at 8,000 to 10,000 feet ; first coll. by Bigelow.

* Heads middle-sized or small (half-inch or less).

+ Nodding on the paniculate pedicels in anthesis, rayless, a few loose setaceous or subulate bractlets at their base: very early glabrate or quite glabrous leafy-stemmed plants: leaves at most dentate, all either petioled or attenuate at base.

S. Rúsbyi, Greexe. Stem 2 to 4 feet high: leaves very obscurely pruinose-puberulent under a lens, ovate-lanceolate, callous-denticulate; the lower ( 3 to 6 inches long) with abrupt or truncate base and winged petiole with dilated and somewhat auriculate half-clasping insertion; upper cuneately contracted into the winged petiole; the small uppermost closely sessile, attenuate-acuminate: heads ( 4 or 5 lines high) less nodding than in the next, almost hemispherical. - Bull. Torr. Club, ix. 64, at least as to pl. Rusby. - New Mexico, in the Mogollon Mountains, Rusby. Apparently in Santa Catalina Mountains, Arizona, Lemmon, but specimens insufficient. Nearly related to the following: root nearly of the preceling.

S. cérnuus, GRay. Quite glabrous, usually more slender, 2 or 3 feet high : leaves lanceolate or the larger oblong-lanceolate, entire, denticulate, rarely with a few scattered coarser teeth, all tapering at base into a barely margined petiole, or upper into a narrowed not clasping base: heads ( 4 to almost 6 lines long) several or numerous in the panicle, most of them decidedly nodding: involucre narrow-campanulate: flowers pale yellow. $-\Delta \mathrm{m}$. Jour. Sci. ser. 2, xxxiii. 10; Porter \& Coulter, Fl. Colorad. 82. - Mountains of Colorado, wholly below the alpine region; first coll. by Parry.

++ Heads erect, mostly radiate, occasionally rayless in same species.

t+ Stem frutescent below.

S. Lemmóni, Grax. Loosely much branched, early glabrate and smooth : main stems decidedly woody: branches slender, spreading, very leafy below, nearly naked at sunmit, 
bearing several or numerous loosely cymose slender-pedunculate heads: leaves somewhat succulent, lanceolate, irregularly and sparsely dentate with salient teeth, attenuate below and with a dilated cordate-clasping base, or the lower tapering into a naked petiole; uppermost small, linear, entire: heads 4 or 5 lines high : rays about 12 ; disk-flowers 20 or more.Proc. Am. Acad. xvii. 220. - Santa Catalina Mountains, S. Arizona, Lemmon.

+ + Stems herbaceous, numerously leafy to the top: leaves all rounded-subcordate and angu-
lately somewhat lobed, palmately veined and reticulate-venulose, petioled: heads small and
numerous in a compound cyme.

S. Hartwégi, Bentr. Flocculent-tomentulose when young, or nearly glabrous : stems 2 or 3 feet high from a somewhat tuberous rootstock : leaves chartaceo-membranaceous (2 to 4 inches broad, and petiole inch or two long), the margin with 7 to 9 short angulate lobes or coarse teeth, and sinuses dentieulate: veinlets minutely reticulated : heads 3 or 4 lines long, crowded: involucre narrow-campanulate, 12-20-flowered; its bracts lanceolate, short: rays few. - Pl. Hartw. 18, form with leaves tomentulose beneath. S. Seemanni, Schultz Bip. in - Seem. Bot. Herald, 311, glabrous form. - Cañons, S. Arizona, near Fort Huachuca, Lemmon. (Mex. ; of a Mexican type unlike any other N. American.)

++++ Stems numerously and nearly equably leafy to the top: leaves pinnately veined, not conspicuously reticulated, from entire to laciniate-dentate, never divided or dissected, nor narrowly linear: glabrous, or very early glabrate and smooth, seldom a vestige of wool at anthesis.

$=$ Low, alpine: heads subsolitary, radiate.

S. Fremónti, Torr. \& GraY. Many-stemmed from a thickish caudex, a span to a foot high: leaves thickish, from rounded-obovate or spatulate to oblong (inch or sometimes 2 inches long), obtuse, obtusely or acutely dentate, sometimes even pinnatifid-dentate, lower abruptly contracted into a winged petiole; uppermost sessile by broadish base: heads halfinch high, short-peduncled, subtended by a few short loose bractlets : rays 3 to 5 lines long. - Fl. ii. 445. - Alpine region of the Rocky Mountains (first coll. by Fremont), from near Brit. boundary to S. Colorado, Utah, and Lassen's Peak, California : passing to

Var. occidentális, Gray. More slender, with rounder leaves and heads longerpeduncled; in high alpine stations becoming very dwarf, and flowering almost from the ground. - Bot. Calif. i. 618. - Sierra Nevada, California, at 10,000 to 12,000 feet, Rothrock, \&c. Also Rocky Mountains of N. Wyoming and Montana, at 7,000 to 8,000 feet, Lyall, Parry, very dwarf.

$==$ Rather low, with numerous cymosely paniculate and small heads, always rayless.

S. rapifólius, Nurr. About a foot high: leaves ovate or oblong, throughout very sharply and unequally dentate, rather fleshy; radical tapering into a petiole, cauline mostly clasping by a broad subcordate base : heads 3 lines high, about 15-flowered : involucral bracts 8 to 10 , narrowly oblong. - Trans. Am. Phil. Soc. vii. 409: Torr. \& Gray, Fl. ii. 441. - Rocky Mountains, Wyoming, about the sources of the Platte, Nuttall, Fremont, \&c.

$==$ Tall, with corymbosely cymose and radiate heads : involucre setaceously few-bracteolate, campanulate or narrower: leaves nearly membranaceous.

S. trianguláris, Hook. Rather stout: stem simple, 2 to 5 feet high, bearing several or somewhat numerous heads in a corymbiform open cyme: leaves all more or less petioled and thickly dentate (sometimes minutely so, sometimes with long lanceolate-subulate and very salient teeth), deltoid-lanceolate, or the lower triangular-hastate or deltoid-cordate, and uppermost lanceolate with cuneate base: heads about half-inch high : involucre campanulate, mostly 25-30-flowered; the oblong-linear rays 6 to 12. - Fl. i. 332, t. 115; Torr. \& Gray, Fl. ii. 441 ; Eaton, Bot. King Exp. 189 ; Gray, Bot. Calif. i. 414. S. longidentatus, DC. Prodr. vi. 428. - Wooded districts in wet ground, Saskatchewan to Washington Terr., south to the higher mountains of Colorado and through the Sierra Nevada, California.

S. Huachucánus, Gray. Two or three feet high, somewhat branching: leaves ovate- to oblong-lanceolate, acuminate, minutely denticulate ; lower cauline ( 4 to 6 inches long) tapering into a winged petiole, upper partly clasping by a broad subcordate base: heads fastigiately cymose, small, about 4 lines high : involucre cylindraceons-campanulate, 15-18-flowered : the small rays 3 or 4. - Proc. Am. Acad. xix. 54. - High bluffs near Fort Hiuachuca, S. Arizona, Lemmon.

S. sérra, Hook. Strict, 2 to 4 feet high, very leafy, sometimes simple and bearing rather few somewhat large (half-inch long) heads, commonly branching at summit, then bearing 
numerous corymbosely paniculate smaller heads: leaves ( $t$ to 6 iuches long) all lanceolate and tapering to both ends, sessile by a narrow base (or the lowest oblong-spatulate and taperiug into a short petiole), usually with whole margin thickly serrate or serrulate with very acute salient teeth: involucre oblong-campanulate, 20-30-flowered : rays 5 to 8 , oblong-linear, sometimes fully half-inch long. - Fl. i. 332 (Torr. \& Gray, Fl. ii. 441, as to wame only, the char. taken from $S$. longidentatus, DC., wrongly referred, and syu. belonging to $S$. triangularis); Gray, Proc. Acad. Philad. 1863, 68, under S. Andinus?-Mountains, from Wryoming to Idaho and S. Colorado; first coll. by Douglas. The form with the very serrate leaves of the original of Douglas, but with much fewer and larger heads, mountains of Colorado, Fremont, Hall \& Harbour, Parry, Rothrock (under S. Andinus). Passes into

Var. integriúsculus. Heads smalles (usually only 3 or 4 lines high) and narrower, fewer-flowered: leaves minutely serrate or denticulate, or the upper entire, sometimes all entire or nearly so, generally shorter and smaller, or broader and not acuminate. - S. Andinus, Nutt. Trans. Am. Phil. Soc. 1. c.; Torr. \& Gray, 1. c.; Gray, Bot. Calif. 1. c. S. lanceolatus, Torr. \& Gray, Fl. ii. 440, an entire-leaved form. - Common from Wyoming to E. Oregon, and in the mountains of Nevada and the borders of California; perhaps first coll. by Nuttall.

++++ Stem not numerously but somewhat equably leafy up to the inflorescence: leaves all entire or denticulate: involucre fleshy-thickened!

S. crássulus, Grir. A foot or less high, glabrous apparently from the first: stem rather stout, 5- $i$-leaved, bearing 3 to 8 pedunculate rather large (fully half-inch high) and thick heads : leaves oblong-lanceolate, of rather firm texture, apiculate-acute, 2 to 5 inches long; radical and lowest cauline spatulate or obovate-oblong, narrowed into a short winged petiole; upper sessile by partly clasping or decurrent base: involucre broadly campanulate, 40-50flowered, of 12 or more lanceolate to oblong fleshy-thickened but thin-edged bracts, the base also much thickened, the whole becoming conical and multangular in fruit: rays about 8 , oblong, - Proc. Am. Acad. xix. 54. S. integerrimus, Gray, Am. Jour. Sci. 1. c., \& Proc. Acad. Philad. 1863, 67, not Nutt. S. lugens, var. Hookeri, Eaton, Bot. King Exp. 188, in part. - Subalpine, Rocky Mountains of Colorado (first coll. by Parry) to the Wahsatch in Utah (Watson), and in N. Wyoming, Parry.

++++ Stens either few-leaved or with the upper leaves (and sometimes most of the cauline) reduced in size; the infloreseence therefore naked: none with narrow linear leaves (except one scapose species).

= Plant tall and simple-stemmed, with a coarsely fibrous cluster of roots, perhaps not perennial: leaves fleshy-coriaceous, all entire or barely denticulate.

S. hydróphilus, Nutr. Very glabrous and smooth, sometimes glaucous: stem robnst, 2 to 4 feet high, strict: leaves lanceolate, with strong midrib and obsolete veins; radical oblanceolate and stout-petioled, sometimes a foot long and nearly two inches wide; upper canline sessile or partly clasping: heads numerous in a branching corymbiform cyme, 5 lines high, short-pedicelled: involucre narrowly campanulate, slightly bracteolate; its bracts 8 to 12 : disk-flowers 15 to 30 ; rays 3 to 6 and small, sometimes none. - In water or very wet ground, especially in brackish water, Montana to Brit. Columbia, south to Colorado, and west to San Francisco Bay, California.

$==$ Plants mostly in clumps or tufts, or from tufted or creeping rootstocks.

u. Stems commonly robust, from it foot or rarely less to 3 or even 5 feet high, bearing mostly numerous heads in a cyme: involucre sparingly calyculate: leaves from entire to dentate, only in the last species at all laciniate, none really cordate nor with permanent tomentum. Western species, none truly alpine.

1. Glaucous or glaucescent, apparently quite glabrous throughout from the very first: heads many-flowered.

S. Clevelándi, Grenne. Stems rather rigid and slender, a foot or two high from firm creeping rootstocks: leaves subcoriaceous, entire, obtuse, with veins almost obsolete, spatulate or rarely obovate; radical and lower cauline an inch or. two long, tapering into much longer slender petioles; upper cauline few and smaller, with shorter petioles: heads 4 or 5 lines high : involucral bracts subulate-linear: rays 6 to 8 and short, sometimes fewer, occasionally none. - Bull. Torr. Club, x. 87. - Springy ground, Lake Co., California, Cleveland, Pringle. 
S. Toluccánus, DC. Prodr. vi. 428; Gray, Proo. Am. Acad. xriii. 110: apparently a common Mexican species.

Var.microdóntus. About 2 feet high from a short rootstock or caudex: leaves thickish and firm; radical obovate to oblong, obscurely veiny, mostly acute, numerously denticulate, 2 to 6 inches long, tapering into shorter wing-margined petioles; cauline sessile, few and oblong-lanceolate toward the base of the stem, or commonly only one or two small and bract-like ones on a scapiform stem, these subtending the rather few-headed branches of the cyme: heads nearly half-inch high: involucral bracts linear: rays 6 to 10, conspicuous. - Pinos Altos Mountains, New Mexico, Greene. Mountains of S. Arizona, Pringle, Lemmon. Agrees with a specimen of coll. Seemann, N. W. Mexico, but not well with $S$. Toluccanus, var. modestus, Schultz Bip. in Bot. Herald, 211. Approaches very smooth forms of $S$. lugens.

2. Not glaucous, usually more or less woolly-pubescent when young, and the wool sometimes tardily deciduous, often quite glabrate and green at flowering time: heads many-flowered: rays 8 to 12 , conspicuous.

S. integérrimus, Notr. Leaves oblong-lanceolate, or the radical elongated-oblong, quite entire or denticulate; upper ones reduced and bract-like, attenuatessubulate from a dilated base : heads several, umbellately cymose, commonly half-inch high: involucral bracts narrow, acute or acuminate. - Gen. ii. 165, \& Trans. An. Phil. Soc. 1. c.; Torr. \& Gray, Irl. ii. 439. -Dakota to Wyoming and Saskatchewan; first coll. by Nuttall.

S. Iúgens, RICHARDs. Lightly floccose-woolly when young, in the typical form early glar brate and bright green : stem 6 inches to 2 feet high, few- and small-leaved and naked above, terminated by a cyme of several or rather numerous heads (these about 5 lines high): radical and lower cauline leaves spatulate, varying to oval or oblong, either gradually or alruptly contracted at base into a winged or margined short petiole, usually repand- or callous-denticulate; upper cauline lanceolate or reduced and bract-like: bracts of the campanulate involucre lanceolate, with obtuse or acutish commonly blackish-sphacelate tips: rays 10 or 12, conspicuous. - App. Frankl. Journ. ed. 2, 31; Hook. Fl. i. 332, t. 114; Torr. \& Gray, Fl. ii. 439 ; Eaton, Bot. King Exp. 188, var. Hookeri, chiefly, \& var. Parryi. S. campesiris, Hook. f. Aret. P1. 294, 332, partly. Cineraria pratensis, Herder, PI. Radd. ii. 127, in part.Low or moist grounds, Subarctic America to Kotzebue Sound ? through the whole Rocky Mountains to New Mexico, and west to California. In various forms.

Var. foliósus, Grax, Bot. Calif. i. 413. Floccose wool usually persistent up to flowering, and vestiges remaining to near maturity: stem seldom over a foot high, stouter, more leafy to near the inflorescence : leaves comparatively large, oblong to broadly lanceolate: heads often very numerous and crowded in the corymbiform cyme, then narrower: tips of involucral. bracts conspicuously blackish. - S. exaltatus, Nutt, var. minor, Gray, Am. Jour. Sci. 1. c. 406 . S. lugens, var. exaltatus, Eaton, 1. c. - Mountains of Colorado and Utal, from base up to 10,000 or 12,000 feet; first coll. by Parry.

Var. exaltátus, GraY, l. c. Lightly floccose when young, and not rarely with looser and more persistent scattered hairs: stem stout, 1 to 3 or even 4 or 5 feet high: leaves thickish ; radical longer-petioled, from spatulate-lanceolate to obovate or ovate, the broader ones abrupt and sometimes even subcordate at base; cauline occasionally laciniate-dentate: heads mostly numerous in the cyme. - S. exaltatus, Nutt. Trans. Am. Phil. Soc. 1. c. 410; Torr. \& Gray, l. c. - Wet ground, Brit. Columbia and Idaho to California, where it connects with the next species.

Var. ochroleúcus. Rays yellowish-white: otherwise like broader-leaved forms of the preceding, some radical leaves subcordate. - S. cordatus, Nutt. 1. c. 411, probably, but color of flowers not noted. - Open woods, on Columbia River, Klikitat Co., Washington Terr., Suksdorf.

3. Like the preceding, but with fewer-flowered heads and fewer or no rays: upper leaves occasionaliy incised.

S. aronicoídes, DC. Robust, lightly floccose when young, and usually with some deciduous villosity, 1 to 3 feet high: leaves variable, from broadly ovate to oblong, repand-denticulate to coarsely dentate, or cauline sometimes pinnatifid-laciniate: heads mostly smaller than in preceding, often only 10-12-flowered : rays when present only one or two and short. -Prodr. vi. 426; Torr. \& Gray, Fl. ii. 441 ; Gray, Bot. Calif. i. 414. - S. exaltatus, var. 
uniflosculosus, Gray, Pacif. R. Rep. iv. 111. - Low grounds, common in California ; first coll. by Douglas. Connects with $S$. lugens, var. excultatus.

b. Stems low and simple, bearing a solitary or few comparatively large heads: involucre not at all calyculate: leaves entire or merely dentate; radical and lower ones spatulate to obovatc. Arcticalpine species, loosely cottony-woolly, tardily glabrate.

S. Hoókeri, Torr. \& Gray. Perhaps a less arctic variety of the next, bearing 3 to 5 closely corymbose heads, or a var. of $S$. campestris of the Old World, but ovaries and akenes glabrous. - Fl. ii. 438. S. integrifolius, Hook. Fl. i. 334, ex'l. syn. S. campestris, Hook. f. Arct. Pl. 395, partly. Cineraria integrifolia, Richards. 1. c. - Aretic and Subarctic America and high-northern Rocky Mountains, Richardson, \&c.

S. frígidus, Less. A span or two high, 3-5-leaved, bearing a solitary head, sometimes 2 or 3 : leaves spatulate, or the radical rounded-obovate and cauline lanceolate from a broad or narrow sessile base, these sometimes dentate: involucre half-inch high, usually villous with some purplish hairs, especially at the thickened base or summit of the peduncle: rays rather numerous, becoming half-inch long: ovaries and akenes glabrous or sparscly hairy. - Less. in Linn. vi. 239 ; Hook. Fl. i. 334, t. 112 ; Torr. \& Gray, Fl. ii. 445. Cineraria frigida, Richards. l. c.; Hook. \& Arn. Bot. Beech. 126; Herder, 1. c. 124. C. atropurpurea, Ledeb. ex DC., \&c. - Newfoundland? and Labrador, Arctic coast to Kotzebue Sound, \&c. (N. E. Asia.)

c. Stems low, only 2 to 6 inches high, scapiform: leaves clustered on the rootstock or caudex, entire or crenate; those of the scape few and very small, reduced to mere bracts: involucre slightly calyculate. Rocky Mountain species, chiefly alpine or subalpine.

1. Leaves linear, not thick: akenes papillose-hirtellous.

S. Thúrberi, Grix. Leaves densely tufted on the branches of the multicipital caudex, about inch long, barely a line wide toward the apex, tapering into a slender base, entire or nearly so, tomentose-canescent, tardily glabrate: scapes glabrate, 4 to 6 inches high, bearing 2 to 5 heads; these 4 or 5 lines high: rays 7 to 10, 3 lines long. - Proc. Acad. Philad. 186.3, 68. S. canus, var. pygmaus, Gray, Bot. Mex. Bound. 103. - Mountain-sides, Santa Rita del Cobre, New Mexico, Thurber, Bigelow.

2. Leaves thick and coriaceous, tapering into a petiole, crowded on the multicipital caudex, nearly veinless, even the midrib obscure: akenes glabrous.

S. Werneriæélólius, Grar. Woolly and canescent, tardily glabrate: leaves quite entire, erect or ascending, from spatulate-linear ( 2 or 3 inches long, including the petiole-like base, by 2 or 3 lines wide) to elongated-oblong (inch long and half-inch wide) and short-petioled, the margins sometimes revolute: scape a span high, rather stout, bearing 2 to 8 heads; these 4 or 5 lines high: rays 10 or 12, oblong, 2 lines long, rarely few or wanting. - Proc. Am. Acad. xix. 54. S. aureus, var. wernerioefolius, Gray, Proc. Acad. Philad. 1863, 68; Porter \& Coulter, Fl. Colorad. 81.- Mountains of Colorado, alpine, in coniferous wuods near the upper linit of trees, and in the alpine region, mostly on the upper waters of Clear Creek, Hall \& Harbour, Greene, Coulter, \&c.

S. petrǽus, KLATT, Glabrous or early glabrate: leaves from orbicular-obovate or oval (a quarter to half an inch long) to cuneate-oblong (largest inch long), entire or 3-7-crenatetoothed at the broad summit, abruptly petioled: scapes 1 to 3 inches high, bearing solitary or several clustered heads; these 4 or 5 lines high: rays 6 to 10, golden yellow, 3 lines long. - Abhand. Nat. Gesellsch. Halle, xv. (1881). S. aureus, var. alpinus, Gray, Am. Jour. Sc:. n. ser. xxxiii. 11 ; Porter \& Coulter, 1. c. S. aureus, var. borealis, mainly, Gray, Bot. Calif. i. 412. - Alpine region of the Rocky Mountains in Colorado (first coll. by Parry), of Utah ( $W$ ard ), and highest peaks of the Sierra Nevada, California, Brewer, \&c. Approaches the preceding on one hand, and SS. aureus, var. borealis, on the other.

3. Leaves round-cordate, crenate, purple-tinged beneath, slender-petioled, more or less clustered at the base of the scape: akenes glabrous: plants very glabrous.

S. renifólius, Porter. Two inches high from filiform creeping rootstocks: leaves thickish, resembling those of Ranunculus Cymbalaria, rounded-subcordate or reniform, only about half-inch wide, coarsely 5-7-crenate: scape or pecluncle little surpassing the leaves, bearing a solitary comparatively large (half-inch long) head: rays about 8 , oblong, 4 lines long.Porter \& Coulter, Fl. Colorad. 83. - High alpine region on Whitehouse Mountain, in Central Colorado, at 13,000 feet, J. M. Coulter. 
S. Cardamíne, Grense. Scapes a span or two high, slender, bearing solitary or 2 or 3 small (about 4 lines high) heads, and below one or two very small oblong-cordate clasping pinnatifid-dentate bract-like leaves : radical leaves orbicular-cordate, repand-crenate, thinnish, inch or two in diameter, on long slender petioles: rays about 8, pale yellow. - Bull. Torr. Club, viii. 98. - New Mexico, on the higher slopes of the Mogollon Mountains, Greene.

d. Stems low (2 to 6 inches high) and slender, 1-2-cephalous, few-leaved: leaves mostly lyratepinnatifid. High northern species.

S. resedifólius, Less. Glabrous or soon glabrate: stems simple: earlier radical leaves roundish or subcordate, crenate or crenately lobed, later ones lyrate-pinnatifid, slenderpetioled, all or the terminal lobes crenate-incised: heads 4 or 5 lines high: involucre very obscurely bracteolate: rays 5 lines long: style-branches commonly with slender cusp: akenes either papillose-hirsute or glabrous. - Less. in Linn. vi. 243; Hook. Fl. i. 333, t. 117 ; Torr. \& Gray, Fl. ii. 445. Cineraria lyrata, Ledeb. Fl. Alt. iv. 102 ; Reichenb. Ic. Bot. Crit. ii. t. 101. - From Great Bear Lake, \&c., near the Arctic Circle, to Kotzebue Sound and the Aleutian Islands. (N. Asia.)

Var. Columbiénsis. Heads rayless: stems often sparingly branched and 2-4leaved. - Mucklung River, British Columbia, Mr. Mackay.

e. Stems a foot or two high (or in reduced forms lower), bearing some leaves and corymbosely cymose (only when depauperate solitary) heads: involucre sparingly or inconspicuously calyculate, or nearly naked at base: foliage various. Not arctic nor alpine, except perhaps one variety of S. aureus: usually some floccose tomentum, at least when young.

1. Leaves all entire, rarely a tooth or a few obscure denticulations, and narrowed at base.

S. fastigiátus, Nutr. Cinereous with a fine and close pannose tomentum, or glabrate: stems strict, simple, 1 or 2 feet high, terminated by a fastigiate cyme of several heads, or sometimes with branches terminated by single and rather larger heads : leaves lanceolate or spatulate-lanceolate, obtuse, about 2 inches long; upper often linear; lower cauline and the sometimes oblong radical tapering into slender petioles: heads 4 or 5 lines high : rays conspicuous: akenes glabrous. - Trans. Am. Phil. Soc. vii. 410 ; Torr. \& Gray, Fl. ii. 439. - Plains of Oregon, Washington Terr., and adjacent Idaho; first coll. by Nuttall.

Var. Laýneæ. Stems disposed to branch, and the branches to bear 2 or 3 or sometimes solitary heads, of half-inch in height: leaves mostly apiculate-acute. $-S$. Laynea, Greene in Bull. Torr. Club, x. 87. - Sweetwater Creek, El Dorado Co., California, Mrs. K. Layne-Cüran.

2. Leaves from entire or serrate to pinnatifid in the same species, none pinnately divided: rays occasionally wanting. Species of perhaps impossible limitation.

S. cánus, Hook. Permanently canescent with paunose tomentum, or at length flocculent, but rarely at all glabrate: stems from a span to a foot or rarely 2 feet high : leaves sometimes all undivided or even entire, the radical and lower from spatulate to oblong or roundish-oval (half-inch to thrice that length) and slender-petioled, sometimes laciniate-toothed or pinnatifid (either the upper or lower ones, or both) : heads 4 or 5 lines high: akenes very glabrous (in figure of Hooker hispidulous on the angles): style-tips usually with central cusp. - Fl. i. 333, t. 116 ; Torr. \& Gray, 1. c. ; Gray, Bot. Calif. i. 412. S. integrifolius, Nutt. Gen. ii. 165. Cineraria integrifolia minor, Pursh, Fl. ii. 528. S. Purshianus, Nutt. Trans. Am. Phil. Soc. vii. 412. S. Howellii, Greene, Bull. Torr. Club, viii. 98. - Rocky banks, Saskatchewan and Dakota to the mountains of Colorado, west to Brit. Columbia, Oregon, Nevada, and the Sierra Nevada as far as Kern Co., California. - A notable and dubious form, low and stout, with comparatively large heads and always undivided leaves, abounds in the mountains of Colorado, at the upper limit of trees.

S. tomentósus, Mrcux. Canescent or cinereous with a close or at length floccose and more or less deciduous wool: stems rather stout, commonly 2 feet high: leaves thickish, oblong; crenate or sometimes entire; the larger radical ones ample, 5 or 6 inches long, on elongated stout petioles and with stout midrib; cauline similar and smaller or lyrate-pinnatifid, often few and small: heads, \&c., of the next species : akenes always hispidulous, at least on the angles. - Fl. ii. 119; Ell. Sk. ii. 329; Torr. \& Gray, Fl. ii. 443. S. integrifolius, var. heterophyllus, Nutt. Gen. ii. 165. Cineraria heterophylla, Pursh, F1. ii. 528.Open or sparsely wooded moist ground, Delaware to Florida and Arkansas ; first coll. by Michaux. 
S. aúreus, L. Very early glabrate, usually quite free from wool at flowering (in spring or early summer) and a foot or two high from small rootstocks: radical leaves mostly rounded and undivided, and cauline lanceolate and pinnatifid or laciniate : most polymorphous species, of which the typical form is bright green, 1 to 3 feet high, surculose by slender rootstocks: leaves thin; principal radical ones roundish, cordate or truncate at base, crenate-dentate ( 1 to 3 inches in diameter), on long slender petioles; lower cauline similar, with 2 or 3 lobelets on the petiole, or lyrately divided or lobed; others more laciniate-pinnatifid and lobes often incised ; uppermost sparse and small, with closely sessile or auriculate-dilated incised base; heads rather numerous, 4 or 5 lines high: rays 8 to 12, conspicnous, rarely wanting: akenes quite glabrous. - Spec. ii. 870; Michx. Fl. ii. 820 ; Ell. Sk. î. 331 ; DC. Prodr. vi. 432 ; Torr. \& Gray, Fl. ii. 442; Sprague, Wild Flowers, 77, t. 15, the normal form. S. gracilis, Pursh, Fl. ii. 529; DC. 1. c., a slender or depauperate form. S. fastigiatus, Schwein. in Ell. 1. c. - Swamps and wet banks, usually in shaded ground, Newfoundland to Florida, Texas, and to Brit. Columbia and the Sierra Nevada, California.

Var. obovátus, Torr. \& Grax, l. c. Radical leaves of thicker texture, rotund with abrupt or truncate base, or obovate and cuneate-contracted into a short margined petiole, or the earliest in the rosulate tufts almost sessile and humifuse: otherwise as in the typical form. - S. obovatus, Mulı. in Willd. Spec. iii. 1999; Pursh, 1. c.; Ell. 1. c. S. Elliottii, Turr. \& Gray, Fl. ii. 443, a form with the early radical leaves more plantagineons and very short-petioled. - More open and moist grounds, Canada to Indiana and Georgia, in the upper country, characteristically developed southward.

Var. Balsámitæ, Torr. \& Gray, l. c. Less glabrate, not rarely holding more or less wool until fruiting: depauperate stems a span or two, larger fully 2 feet high : principal or earliest radical leaves oblong, sometimes oval, commonly verging to lanceolate, inch or two long, serrate, contracted into slender petioles; the succeeding lyrately pinnatifid : heads usually rather small and numerous: akenes almost always hispidulous-pubescent on the angles. - S. Balsamitre, MuhI. l. c.; Pursh, 1. c. S. Plattensis, Nutt. Trans. Am. Phil. hioc. 1. c. 413, a robust and larger-leaved western form, verging toward S. tomentosus. S. aurers, var. lanceolatus, Oakes in Hovey's Mag., \& Torr. \& Gray, 1. c., an attenuated form of this, or of the type, growing in shady swamps. S. pauperculus, Michx. Fl. ii. 120, depauperate form. - Rocky or nearly dry ground, Canada to 'Texas, and northwestward to Brit. Columbia.

Var. compáctus. A span or two high, in close tufts, rather rigid, when young whitenel with fine tomentum, glabrate in age : radical leaves oblanceolate or attenuate-spatulate, entire or 3-toothed at apex, or pinnatifid-dentate, an inch or more long, thick and firm at maturity; cauline lanceolate or linear, entire or pinnatifid: heads rather numerous and crowded in the cyme, rather small : ovaries papillose-hispidulous on the angles. $-S$. aurens, var. borealis, Gray, Pl. Wright. i. 125, \& Proc. Acad. Philad. 1863, 68, in part. -N. W. Texas ( $W$ right) to the base of the mountains in Colorado, Hall \& Harbour, Greene, \&c. ; mostly in saline soil.

Var. boreális, Torr. \& Grax, 1. c. A foot down to a span high, at summit bearing either numerous or few heads; these not rarely rayless : leaves thickish; radical from roundish with abrupt or even truncate base to cuneate-obovate and cuneate-spatulate, half-inch to inch long, slender-petioled; cauline seldom much pinnatifid : akenes glabrous. - S. elongatus, pauciflorus, \& Cymbalaria? Pursh, Fl. ii. 529, 530. S. aureus, var. foliosus, \&c., Hook. 1. c. S. aureus, var. borealis \& var. discoideus, Torr. \& Gray, 1. c. S. cymbalarioides \& S. debilis, Nutt. Trans. Am. Phil. Soc. 1. c. 408, 412. - Labrador to Brit. Columbia, Oregon, the high Sierra Nerada in California, and mountains of Nevada, Utah, and Colorado, where are forms undistinguishable from the following.

Var. cróceus, Gray. A span to a foot or two high, glabrous or early glabrate leaves somewhat succulent; radical oblong to roundish, sometimes lyrate; cauline very various : heads usually numerous in the cyme: flowers saffron-colored or orange, at least the rays, or these sometimes wanting.-Proc. Acad. Philad. 1863, 68; Porter \& Coulter, Fl. Colorad. 82; Eaton, Bot. King Exp. 190, \& S. Fendleri of the same. S. aureus, var. multtlobatus, Gray, Bot. Calif. i. 411, in part. - Wet ground, high mountains of Colorado, Utah, Nevada, north to Montana, and sparingly in the Sierra Nevada; first coll. by Parry, \&c.

Var. subnudus. Wholly glabrous or glabrate, slender, a span or two high, bearing 2 or 3 small cauline leaves and a solitary head, or not rarely a pair : radical leaves few. spatulate or obovate, sometimes roundish, half-inch or less long, occasionally lyrate : cauline incised or sparingly pinnatifid: rays conspicuons. $-S$. subnudus, DC. Prodr. vi. 428 ; Nutt. 
1. c.; Torr. \& Gray, 1. c. Here perhaps S. Cymbalaria, Pursh, Fl. ii. 530. - Wet ground on mountains, Wyoming to Brit. Columbia, Oregon, and sparingly in California. The most depauperate form.

S. Féndleri, Grar. Very canescent with pannose or floccose wool, in age tardily glabrate : stems rather stout, 5 to 15 inches high, leafy, the larger plants branching: leaves oblonglanceolate or narrower; radical sometimes almost entire, more commonly like the canline sinuately pectinate-pinnatifid or even pinmately parted, the short oblong divisions incisely 2-4-lobed: heads mostly numerous and crowded, small (3 or 4 lines high): rays rather numerous: akenes and ovaries glabrous. - Pl. Fendl. 108, Pacif. R. Rep. iv. 111, \& Proc. Acad. Philad. 1. c. - Dry ground, mountains of New Mexico and Colorado, at 6,000 to 8,000 feet, Fendler, Bigelow, Parry, \&c.

S. Neo-Mexicánus, Gray. More or less canescent with looser tomentum, in age glabrate: stems robust, a foot or two high (often from a simple thickish caudex), few-leaved, simple or often branching above, and bearing loose cymes of comparatively large (often half-inch) heads: leaves thickish (inch or two long); radical oblong-obovate to spatulate, with cuneate or tapering base, sometimes coarsely few-toothed only at summit, many lyratepinnatifid, with few or several pairs of small lateral lobes; cauline similar or more pinnatifid, and the lobes incisely few-toothed: rays 12 to 16 , in larger heads half-inch long: akenes sometimes hispiclulous-papillose, sometimes quite glabrous. - Proc. Am. Acad. xix. 55. Has been variously referred to $S$. Fendleri, to doubtful forms of $S$. aureus, \&c. - Mountains and wooded hills of New Mexico, Fendler, Wright, Thurber, Henry, Greenc, \&c. Arizona, Lemmon, Pringle. San Bernardino Mountains, California, Parish.

S. Arizónicus, Grexne. Lightly and loosely floccose-woolly when young, early glabrate and green : stems a foot or two high, sometimes from a thick perpendicular candex : leaves mainly in the radical tuft, thickish, ovate to oblong-obovate (commonly 2 or 3 inches long), dentate with mucronate teeth, often with rounded or subcordate, but some with cuneate base, with or without one or two pairs of small lobes on the petiole; lower cauline leaves one or two and usually lyrate-pinnatifid, upper very small and bract-like: heads loosely cymose, 5 or 6 lines high : rays 9 to 12, conspicuous. - Bull. Torr. Club, x. 87.- Arizona, Palner, Pringle (referred to a form of $S$. aureus), Rusby.

3. Leaves all or mainly bipinnately dissected into narrow lobes. Atlantic species.

S. Millefólium, Torr. \& GrAY. Early glabrate: stems slender, a foot or two high, bearing a corymbose cyme of rather numerous heads: these 3 lines high: radical and cauline leaves similar (or the earliest less dissected), the very numerous lobes linear-oblong or narrow ( 1 to 3 lines long), thickish: small upper leaves narrow and more simply dissected: rays few, a line or two long. - Fl. ii. 444. - Sides of precipitous mountains, North and South Carolina, especially at Table Mountain, S. Carolina, and vicinity ; first coll. by Fraser.

4. Leaves mostly once pinnately divided or parted, and again lobed or incised. Pacific species.

S. Bolánderi, GraY. Glabrous or early glabrate: stems weak and slender, 6 to 30 inches high from slender creeping rootstocks: leaves thin and membranaceous, mostly petioled; early radical orbicular, subcordate, palmately 5-9-lobed or crenate-incised; others pinnately divided into 5 to 9 distinct leaflets, or upper lobes confluent with rounded terminal one, all obtusely incised: heads several, loosely cymose, 4 or 5 lines high : rays 5 to 8 , rather long, Proc. Am. Acad. vii. 362, \& Bot. Calif. i. 411. - Sandstone bluffs and in Redwoods, Mendocino Co., California, Bolander, Rattan, to Cascade Mountains, Oregon, Kellogg, Howell.

S. eury céphalus, Torr. \& GRAY. Floccose-woolly when young, sometimes early glabrate : stems robust, 1 to 3 feet high, corymbosely branching above, bearing several or numerous loosely cymose heads: leaves irregularly pinnately parted or the lower divided, radical mostly lyrate; divisions of the cauline from cuneate to linear-lanceolate, variously lobed or incised, mucronately tipped : heads hardly at all calyculate, fully half-inch high, commonly as broad, but sometimes half smaller: rays 10 to 12, the larger half-inch long. - Gray, in Pl. Fendl. 109, \& Bot. Calif. i. 411, excl. var. major, Pacif. R. Rep. iv. 111. - Low grounds, California north of the Bay of San Francisco, and on Monte Diablo; first coll. by Fremont and Hartweg.

S. eremóphilus, Richards. Stems freely branching, leafy up to the inflorescence: leaves mostly oblong in outline, laciniately pinnatifid or pinnately parted, the lobes usually incised or acutely dentate: heads numerous in corymbiform cymes, 4 or 5 lines high, short-pedun- 
cled : involucre campanulate or narrower, minutely bracteolate; proper bracts commonly purple-tipped: rays 7 to 9,2 or 3 lines long: akenes either minutely papillose-cinereous or glabrous. - App. Frankl. Journ. ed. 2, 31; Hook. Fl. i. 334 ; Torr. \& Gray, Fl. ii. 444 ; Eaton, Bot. King Exp. 192. - Shady moist ground, from Mackenzie River and Saskatchewan, along the Rocky Mountains to those of New Mexico, Utah, and Arizona; first coll. by Richardson. In cañons of S. Arizona, a form with narrowest and even linear lobes to the leaves, coll. Lemmon.

+++++++++ Stems leafy, numerously or somewhat equably so up to the top, all pinnately lobed or parted, or when entire narrowly linear.

= Leaves comparatively broad, pinnatifid and laciniate : early glabrate if not glabrous.

S. Clarkiánus, Grar. Stems stgict and simple, 3 or 4 feet high, striate-angled: leaves lanceolate; cauline 4 to 7 inches long, sessile, simply pinnatifid or laciniate-dentate; the salient lobes or teeth lanceolate or triangular, very acute: heads several, cymose or somewhat paniculate, fully half-inch high, short-peduncled: involucre of subulate-linear bracts, and several more slender loose calyculate ones: rays 4 or 5 lines long, narrow. - Proc. Am. Acad. vii. 362, \& Bot. Calif. i. 413. - Moist ground, in the Sierra Nevada, California, at 8,000 to 9,000 feet, Yosemite to Kern Co., Bolander, Rothrock, \&c.; first coll. at Clark's Ranch.

$==$ Leaves or their divisions from linear to filiform, or broader toward the base of the stems.

S. Douglásii, DC. Lignescent and sometimes decidedly shrubby at base, many-stemmed, a foot or two or southward eren 5 or 6 feet high, either white-tomentose or glabrate and green: leaves thickish, sometimes all entire and elongated-linear (mostly 2 to 4 lines long and 1 or 2 lines wide), more commonly pinnately parted into 3 to $\gamma$ linear or nearly filiform entire divisions : heads several or numerous and cymose, from a third to half an incls high, obscurely bracteolate, the proper bracts linear: rays 8 to 18, a third to half an inch long: akenes canescent with a fine strigulose pubescence. - Prodr. vi. 429 ; Torr. \& Gray, Fl. ii. 443 ; Gray, Bot. Calif. i. 411. S. Regiomontanus, DC. 1. c. (Monterey, California), \& probably S. stoechadiformis, DC. S. longilobus, Benth. PI. Hartw. 18; Gray, PI. Fendl. 108. S. filifolius, Nutt. Trans. Am. Phil. Soc. vii. 414. S. Riddellii, S. flifolius, \& S. spartioides, Torr. \& Gray, l.c. S. fastigiatus? Gray, Pl. Wright. ii. 99, a peculiar and abnormal broader-leared form. - Open plains and hills, Nebraska to Texas, S. Utah, Arizona, S. California, and northward near the Pacific coast to Lake Co.

\section{§2. Perennial? viscidly pubescent: heads conspicuously radiate.}

S. Párryi, Gray. Rather stout, a foot or two high, branching, sparsely leafy to the inflorescence, pubescent with short and spreading and some longer viscid hairinesi: root not seen : leaves irregularly dentate, oblong or the lowest spatulate, auriculate-clasping at base : heads cymose or somewhat paniculate, about half-inch long: involucre sparsely calyculate: akenes strigulose-canescent. - Bot. Mex. Bound. 103. - S. E. California on the San Bernardino and San Francisco Monntains, Lemmon, Greene. First coll. within the Mexican lines, on the Rio Grande in Chihuahua, below San Carlos, Parry.

\section{§3. Annuals or biennials.}

* Indigenous species, of Sonthern range: heads conspicuously radiate: akenes seldon glabrous.

S. ampulláceus, Hook. Lightly floccose or araneose-woolly when young, glabrate and smooth: stem mostly stout, a foot or two high, leafy to near the summit: leaves all undivided, repand-dentate or entire ( 1 to 6 inches long), ovate or oblong; lowest obovate with tapering wing-petioled base; upper mostly clasping with broad base: heads rather numerous in naked loose cymes: involncre (4 lines high) calyculate-bracteolate, cylindraceous, becoming thickened and conoidal after anthesis: rays 7 to 9, oblong: akenes canescent. - Bot. Mag. t. 3487 ; Torr. \& Gray, Fl. ii. 440; Gray, Pl. Lindh. i. 42. -Sandy prairies, Texas ; first coll. by Drummond.

S. Califórnicus, DC. Early glabrate if not glabrous, slender, a foot or so high: leaves lanceolate, linear, or the lower oblong, varying from clenticulate to pinnatificl, the lobes short and obtuse, all but the lowest auriculate-sessile or clasping at base (one or two inches long): heads several and loosely paniculate or cymose at the naked summit of the stem: involucre broadly campanulate, 3 or 4 lines high, nearly naked at base : rays oblong, 3 or 4 lines long: akenes canescent. - Prodr. vi. 426; Torr. \& Gray, 1. c.; Gray, Bot. Calif. i. 410. S. Coro- 
nopus, Nutt. Trans. Am. Phil. Soc. 1. c.; Torr. \& Gray, 1. c.; a form with leaves deeply and even doubly pinnatifid. - Low ground, California, from Santa Barbara southward. (Lower Calif.)

S. multilobátus, Torr. \& Gray. Early glabrate and smooth, a foot or two high from a winter-annual or biennial root, nuked and often branching above, bearing numerous corymbosely cymose heads: radical and lower cauline leaves lyrate, and the divisions dentate; upper pinnately parted, their mostly numerous divisions narrowly cuneate, incised or 2-3lobed at the apex: involucre 3 lines high, nearly or quite naked at base: rays 3 or 4 lines long: akenes slightly hispidulous or glabrate. - Yl. Fendl, 109, excl. var. pl. Coulter, which . is probably S. Douglasii S. Tanipicanus, Gray, Pl. Wright. ii. 89, perhaps also i. 109. S. aureus, var. multilobatus, Gray, Bot. Calif. 1. c., partly. - S. Utah, Arizona, and western borders of Texas, Fremont, Wright, Palmer, \&c.

S. lobátas, Pers. (BuTter-weded.) Lightly floccose-tomentose when very young, early glabrous, very smooth, soft-suceulent or tender: stem fistulous, 1 to 3 feet high, sometimes depauperate and slender, commonly branching, and bearing compound or paniculate cymes: leaves lyrately parted or divided, irregular and variable; divisions from roundish to cuneato or oblong, obtusely sinuate-lobed or toothed: involucre barely 3 lines high, nearly naked at base: rays 6 to 12 : akenes minutely hispidulous on some of the angles. - Syn. ii. 436 ; Ell. Sk. ii. 332 ; Torr. \& Gray, l. c. S. lyratus, Michx. Fl. ii. 120, not L., \&c. S. glabellus, Poir. Dict. vii. 102. S. Carolinianus, Spreng. Syst. iii. 559. S. Mississippianus, DC. Prodr. vi. 427. S. densiflorus, Martens, Bull. Acad. Brux. viii. 67. S. Schweinitzianus, Nutt. in Trans. Am. Phil. Soc. vii.411. S. imparipinnatus, Klatt in Naturf. Gesellsch. Halle. xv. - Wet grounds, in the low country, N. Carolina to Texas, common. (Adj. Mex.)

* * Indigenous, of northern range: heads obviously radiate: akenes glabrous: pappus elongated.

S. palústris, Hook. Loosely woolly or villous with long and many-jointed hairs, in age sornetimes glabrate : stem 6 to 20 inches high from an annual or biennial root, leafy, usually stout: leaves broadly lanceolate, from sinuate-dentate to pinnatifid-laciniate, cauline sessile by a cordate or auriculate partly clasping base: heads crowded in a glomerate or corymbiform cyme, in flower only 4 lines long, and with short light-yellow rays, in fruit with pappus half-inch or more long : involucre naked at base. - Fl. i. 334; DC. Prodr. vi. 363 ; Torr. \& Gray, Fl. ii. 438. S. Kalmii, Less. in Linn. vi. 244, not Nutt., which is only a changed name for Cineraria Canadensis, L. Cineraria palustris, L. Spec. ed. 2, 1243-; Fl. Dan. t. 573; Schkuhr, Handb. t. 246. C. congesta, R. Br. in Parry, Voy., Richards., \&c., only an arctic and woolly conclensed form, var. congestus, Hook. 1. c. - Wet ground, N. Wisconsin, Iowa, and Minnesota to the Arctic sea-coast, N. Alaska, \&c. (N. Asia, Eu.)

* * Naturalized annual weeds from Europe: rays none or minute.

S. syLvATICUs, L. Slender, glabrate or somewhat pubescent, a span to a foot or more high: leaves usually pinnatifid : heads 3 or 4 lines high, narrow, nearly naked at base, bearing a few rays with inconspicuous ligule not surpassing the disk: akenes canescent. - Engl. Bot. t. 748 ; Fl. Dan. t. 869. - Waste grounds, of sparing occurrence in Nova Scotia and coast of California. (Nat. from. Eu.)

S. vulgáris, L. (Groundsen.) Stouter, more branchy and leafy to the top, glabrate: leaves incisely pinnatifid, the oblong or roundish lobes and the sinuses sharply toothed: heads thicker, 4 or 5 lines high : tips of the involucral bracts and the short calyculate ones at base blackish : rays none: akenes canescently puberulent. - Engl. Bot. t. 747; Fl. Dan. t. 513; Pursh, Fl. ii. 528. - Waste grounds and cult. fields, not rare on both the Northern Atlantic and Pacific coasts. (Nat. from Eu.)

S. vrscósus, L. Coarser, viscid-pubescent, strong-scented : leaves once or twice pinnatifid : heads rather larger, more pedunculate: involucre sparingly and slenderly bracteolate at base, its bracts not black-tipped : rays with inconspicuous ligule : akenes glabrous. - Engl. Bot. t. 32 ; Fl. Dan. t. 1230. - Waste grounds on coast of New England, near Providence and Boston. (Nat. from Eu.)

193. CACÁlia, L. Indian Plantain. (Ancient Greek name of some Senecioneous plant, perhaps Coltsfoot.) - Perennial herbs, not fleshy (some shrubby in the tropics), natives of America and Asia in the northern hemisphere, 
with aspect mostly unlike Senecio. Leaves petioled. Our species all smooth, glabrous, and akenes glabrous: f. summer. - L. Gen. ed. 4, 362 (partly); DC. Prodr. vi. 327 (with Psacalium, \& excl. § 3,4); Gray, Proc. Am. Acad. xix. 51.

$\S 1$. Involucre in ours of rather many bracts, calyculate with some small loose ones, and many-flowered: corolla-lobes shorter than the throat: receptacle plane.

C. suavéolens, L. Nearly glabrous : stem striate-angled, 3 to 5 feet high, leafy up to the corymbiform cyme of numerous heads : leaves hastate and on margined or winged petioles, or uppermost merely truncate or cuneate at base, acutely and often cloubly dentate : proper bracts of the involucre about 12 : flowers 25 to 30 : corolla-lobes fully half the length of the throat: style-branches capitellate-truncate. - Spec. ii. 835 ; Walt. Car. 195; Michx. Fl. ii. 96; Schkuhr, Handb. t. 236; Torr. \& Graj, Fl. ii. 434. Senecio suaveolens, Ell. Sk. ii. 328. - Moist and shaded ground, W. New England to Michigan and Illinois, and along the mountain region to $W$. Florida.

C. Hastáta, L., which reaches Kamtschatka, is said to have been collected in Sitka by four collectors (see Herder in Pl. Radd. iii. 108); but Stewart's plant, named by Herder, is Prenanthes alata, and probably the others likewise.

§ 2. Involucre of about 5 narrowly oblong or linear bracts and as many flowers : receptacle commonly with a fleshy projection or 2 or 3 thickish fimbrillæ in the centre: corolla-lobes longer than the throat: heads numerous in corymbose cymes. — $\$$ Conophora, DC.

* Leaves merely lobed, pedately ribbed, veiny: plants glabrous and smooth.

C. renifórmis, Murl. Green, not at all glaucous: stem angled, 4 to 9 feet high: leaves slightly angulate-lobed, repand-dentate, ample; radical dilated-reniform, often 2 feet wide ; upper cauline subcordate or flabelliform: corolla parted down almost to the proper tube. - Muhl. in Willd. Spec. iii. 1735 (where the heads are vrongly said to be many-flowered); Pursh, Fl. ii. 518 ; Torr. \& Gray, Fl. ii. 435. - Rich and damp woods, Penn. to Carolina and Tennessee along the mountains.

C. atriplicifólia, L. Glaucous : stem terete, 3 to 6 feet high, naked at summit: leaves of firmer texture, lobed or incised, but not dentate ; radical from round-reniform to subcordateovate (larger 6 inches broad); cauline angulate-cordate or triangular, or with cuneate base and 3 to 7 laciniate lobes, to rhombic-lanceolate and entire in the uppermost: cymes open: corolla-lobes fully twice the length of the throat. - Spec. ii. 835; Walt. 1. c.; Michx. 1. c.; Pursh, 1. c. ; Schkuhr, Handb. t. 236; Torr. Fl. N. Y. i. 401, t. 59. C. atriplicifolia, etc., Moris. Hist. iii. sect. 7, t. 15, f. 7. C. gigantea, Nees \& Schauer, Ind. Sem. Vratisl. 1841, \& Linnæa, xvi. 216. Senecio atriplicifolius, Hook. Fl. i. 332, with var. reniformis. - Moist or dry ground, W. Canada and New York to Florida, west to Michigan and Mlinois.

C. diversifólia, Torr. \& Gray. Not glaucous: stem striate, 2 or 3 feet high: corollalobes a little longer than the oblong-campanulate throat: otherwise nearly as in the preceding, into which it may pass. - Fl. ii. 435. - River swamps in Middle Florida, Chapman. S. Carolina, Ravenel.

* Leaves from sinuately dentate to entire, 3-7-nerved or triplinerved: plants glabrous and smooth : style-tjps with or without a short setiform central cusp.

$$
\text { + Corolla-lobes moderately longer than the oblong-campanulate throat. }
$$

C. Floridána, Gray. Not glaucous: stem 3 or 4 feet high, rigid, striate-angled: leaves thickish, ovate or oblong, obtuse, cuneate-contracted at base into a margined petiole, 3-5nerved from or near the base, obtusely dentate (cauline 2 or 3 , and radical 5 or 6 inches long): cymes open, irregular. - Proc. Am. Acad. xix. 52. - Coast of Florida, Palmer, Chapman.

++ Corolla parted down almost to the proper tube: stems comparatively naked above, bearing loose fastigiate-corymbose cymes.

C. ováta, Ell. Somewhat glaucous: stem terete: 3 or 4 feet high: leaves thinnish, from oval, or radical broadly ovate, to oblong or upper cauline oblong-lanceolate, obtuse or acute, entire or with a few irregular teeth; uppermost sessile; lower and radical nervose at base and triplinerved above it, the nerves commonly diverging. - Ell. Sk. ii. 310 ; 'Torr. \& Gray, 
1. c.-Damp woods, Georgia and W. Florida to Louisiana. It is impossible to determine whether this or the next is Walter's C. ovata.

C. tuberósa, Nutr. Green, not glaucous : stem 2 to 5 feet high from "a napiform root" or stock, striate-angled: leaves thiokish, from oval to oblong-lanceolate, entire or denticulate, or rarely repand-centate, conspicuously 5-7-nerved from base, and the nerves parallel and continued to the apex; radical plantagineous, 3 to 8 inches long, contracted or tapering at base into (sometimes foot long) petioles; lower cauline similar, upper comparatively few and small. - Gen. ii. 138; Torr. \& Gray, Fl. ii. 436. C. paniculata \& C. pteranthes, Raf. Ann. Nat. 1820, 14. C. ovata, Walt. Car. 196? from char., not Ell. - Wet prairies, \&c., W. Canada and Wisconsin to Alabama.

C. lanceoláta, Notr. Somewhat glaucous: stem terete, 2 or 3 feet high, slender: leaves all lanceolate and lightly 3-5-nerved, or even linear and 1-3-nerved, thickish, entire, sometimes 2 or 3 laciniate teeth or small lobes: hends and cymes of the preceding or fewer. Gen. 1. c.; Ell. 1. c.; Torr. \& Gray, 1. c. C. hastata? Walt. 1. c. 195 ? - Wet pine barrens, \&c., S. Carolina to Florida and Louisiana.

* * Leaves decompound: stem and branches slightly pubescent: corolla divided down to the proper tube into linear lobes somew hat exceeding it in length.

C. decompósita, Gray. Stem slender, 3 feet high, floccose-woolly at base, naked and paniculately branched above, bearing numerous small (4 or 5 lines high) heads in open corymbiform cymes: leaves large (radical 2 feet high including the petiole), 3 or 4 times pinnately divided into linear chiefly entire lobes, the primary and secondary divisions more commonly alternate: involucre about half the length of the (5 or 6 ) flowers. - Pl. Wright. ii. 99. Senecio Grayanus, Hemsl. Biol. Centr.-Am. Bot. ii. 241.-Mountains of S. Arizona, Wright, Lemmon.

194. ERECHTITES, Raf. FirewEed. (Name of a Groundsel by Dioscorides.) - Coarse and homely annuals (Eastern American, and some in New Zealand and Australia); with rank smell, alternate leaves, and cymosely or paniculately disposed heads of whitish or dull yellow flowers. - DC. Prodr. vi. 294; Benth. \& Hook. Fl. ii. 443. Neoceis, Cass.

巴. hieracifólia, RAF. Glabrous or with some hirsute pubescence: stem commonly stout, 1 to 6 feet high, sulcate, leafy to top : leaves of tender texture, lanceolate or broader, sessile, acute, acutely dentate, or some incised or pinnatifid, upper commonly with auriculate partly clasping base: heads half-inch high, cylindraceous, rather fleshy, setaceously bracteolate: pappus white. - DC. Prodr. l. c ; 'Torr. \& Gray, Fl. ii. 434. E. (hieracifolia,) prcalta, elongata, \&c., Raf. Fl. Ludov. \& in DC. Senecio hieracifolius, I. Spec. ii. 866. Cineraria Canadensis, Walt. Car. 207? - Moist woods and copses, a common weed in enriched soil, and especially where woods have been recently burned away (fl. late summer), Newfoundland and Canada to Louisiana. (Extends to S. Amer.)

\section{TRIbe IX. CYNAROIDE $Æ$, p. 81.}

195. SAUSSUREA, DC. (Theodore, and his father Horace Benedict Saussure, eminent Genevese naturalists.) - Perennials of the northern temperate and arctic zones; with middle-sized heads of purple or violet-blue flowers. Ann. Mus. Par. xvi. t. 10-13, \& Prodr. vi. 532 ; Benth. \& Hook. Gen. ï. 471. - Ours all have the distinct and deciduous outer pappus of true Saussurea: fl. late summer.

S. alpina, DC. 1. e. Low, 2 to 12 inches high, with few cymose-glomerate heads, loosely arachnoid-tomentose and glabrate: leaves from narrowly to oblong-lanceolate or even broader, all narrowed at base, denticulate, sometimes entire: bracts of the involucre chartaceo-membranaceous, acutish or acute, outer shorter: usually some setose chaff of the receptacle among the flowers. - Torr. \& Gray, Fl. ii. 452 ; Reichenb. Ic. Fl. Germ. t. 816, 
\&c.; Herder, Pl. Radd. iii. 36. S. angustifolia, DC. 1. c. S. monticola, Richards. App. Frank. Journ. ed. 2, 29. S. multiflora, Richards. 1. c., ed. 1.-Mackenzie River to Arctic coast and Kotzebue Sound. (Eu., N. Asia.)

Vaṙ.. Ledeboúri. More glabrate : leaves from sinuately or laciniate-dentate to entire: involucre looser; its bracts mostly attenuate-acuminate, less uncqual, or the outermost prolonged to the height of the inner: chaff of the receptacle either sparse or wanting. S. alpina, Hook. Fl. i. 303, in part. S. Ledebouri, Herder, 1. c. 41 . S. subsinuata, nuda, \& Tilesii, Ledeb. Ic. Fl. Alt. t. 60,61, 62. S. subsinuata, Seem. Bot. Herald, 35, t. 7. S. acuminata, Turcz. in DC. 1. c. 636, exactly S. nuda, Ledeb. 1. c. - Northern Rocky Mountains in the alpine region to Kotzebue Sound and Alaskan islands; in this country the commoner form and manifestly passing into $S$. alpina. (Adj. Asia.)

S. Americána, EAtox. Tall, 2 or 3 feet ligh, leafy, lightly arachnoid when young, soon glabrate, bearing numerous corymbosely cymose heads: leaves membranaceous, denticulate or dentate, ovate and oblong-ovate, acute or acuminate; radical and lower cauline subcordate and on slender margined petioles ( $t$ inches long); upper sessile with acute base; uppermost lanceolate: heads half to three-fourths inch long: involucre cylindraceous or somewhat turbinate, pubescent, 10-1 $\boldsymbol{i}$-flowered; its bracts thin-coriaceous, 5-6-ranked, all pointless and obtuse; outer successively shorter, ovate: corollas "dark blue " or "purple": receptacle bearing more or less copious setiform chaff ["naked" according to Eaton]. - Bot. Gazette, vi. 283. - Mountains of Eastern Oregon, Cusick, and Simcoe Mountains, Washington Terr., T. J. Howell. Related to the W. Asiatic S. latifolia, Ledeb., and S. grandifolia, Maxim., especially to the latter, which has an equally copious outer pappus.

196. ÁRCTIUM, L. Bटridock. ("A lucre?) - Coarse and rank biennials, of the Old World, unarmed, except the hooked tips of the involucral bracts forming the bur; with large and roundish mostly cordate leaves, the lower on stout petioles, and middle-sized heads of pink or purplish flowers, in summer. - Benth. \& Hook. Gen. ii. 466. Lappa, Tourn., Juss., Gærtn., DC., \&c.

A. LÁPA, L. Plant 3 to 5 feet high, with somewhat cymosely disposed heads : leaves mostly green and glabrous above, whitish with cottony down beneath: in the larger form, var. MÁJCs (Lappa major, Gærtn., Arctium majus, Schkuhr), the bur an inch or more in diameter, its bracts all spreading and glabrous or nearly so. - Common in waste or manured ground, near dwellings. (Nat. from Eu.)

Var. tomentósum (A. Bardana, Willd., Lappa tomentosa, Lam.), a more woolly form ; with bracts of involucre cottony-webbed. - Rare in N. America.

Var. úfus (A. minus, Schkuhr, Lappa minor, DC.), with smaller and only slightly webby heads; these more paniculate, and innermost bracts or awns of the bur erect. Varies with laciniate leaves. - Not uncommon. All the forms are vile weeds.

197. CÁRdUUUS, Tourn., L., partly. Plumeless Thistle. (Ancient Latin name of Thistle.) - Old World genus, one species locally naturalized.

C. Nutans, L. (Musk Thistue.) Biennial, 1 to 3 feet high, green: stem sinuately and interruptedly winged: head solitary, nodding: corollas crimson-purple. - Fl. Dan. t. 675 ; Reichenb. Ic. Germ. t. 877. - On the Susquehanna near Harrisburg, Pean. (Nat, from Eu.)

C. CRfspus, C. acanthof́nes, and C. Pycxocéphalcs, L., occasionally appear as ballastweeds or waifs at seaports.

C. PECTINAtus, L. Mant, 279, grown in the Upsal Garden, from unknown source, said by Willdenow to come from Pennsylvanian seeds, but doubtless not American, is referred by Sprengel to $C$. defloratus.

198. CNÍCUS, Tourn., L., partly. Plumed Thrstle. (Latin name of Safflower, changed from кvฑิкоs, of Dioscorides, applied by the herbalists and early botanists to Thistles.) - Stout herbs (of the northern hemisphere); with sessile leaves, commonly with prickly teeth and tips, and large or middle-sized 
heads; the flowers red, purple, or rose-color, rarely white or yellowish, in summer. Many hybridize! - L. Gen. ed. 6, 409 (where the char. is pappus plumosus, and in Spec. ed. 2, two years earlier, C. benedictus is referred to Centaurea); Willd. Spec. iii. 1662; Benth. \& Hook. Gen. ii. 468. Cirsium, DC. Fl. Fr. ed. 3, iv. 110, \& Prodr. vi. 634, not Tourn.

\section{\$ 1. Naturalized from Europe : one species with diœcious heads.}

C. arvénsts, Hofrm. (Chanada Thistle). Perennial and spreading by creeping rootstocks, a foot or two high, corymbosely branching, usually glabrate and green: stem and branches wingless: leaves lanceolate, pinnatifid and toothed, furnished with abundant weak prickles · heads loosely cymose, less than inch high, dioecious; in male plant ovate-globular, and flowers (rose-purple) well exserted; in female oblong-campanulate and flowers less projecting: bracts of involucre all appressed, short, and with very small weak prickly points: only abortive anthers to the female flowers. - Fl. Germ. iv. 180; Pursh, Fl. ii. 506. Serratula arvensis, L. Spec. ii. 820; Fl. Dan. t. 644. Carduus arvensis, Curt. Fl. Lond. t. 57; Engl. Bot. t. 975 . Cirsium arvense, Scop. Fl. Carn.; DC. Prodr. vi. 643; Torr. Fl. N. Y. i. 408, t. 61 ; Reichenb. Ic. Fl. Germ. t. 842. Breea arvensis, Less. Syn. 9. - Meadows, pastures, and waste grounds, from Newfoundland through the Northern and Middle Atlantic States: too common weed. (Nat. from $\mathrm{Eu}$.)

C. canceoratus, Hofrm. 1. c. (Common Thistle of fields.) Biennial, 3 or 4 feet high, with large heads (almost 2 inches high) terminating somewhat leafy branchlets, cottony-tomentose when young, becoming green, more or less villous or hirsute: leaves lanceolate, deeply pinnatifid and with lanceolate lobes, rigidly prickly; npper face strigose-setulose; base decurrent on the stem into interrupted prickly wings : bracts of involucre arachnoid-woolly, lanceolate and mostly attenuate into slender and rigid prickly-pointed spreading tips: flowers rose-purple, hermaphrodite. - Willd. Spec. iii. 1666 ; Pursh, 1. c. Carduus lanceolatus, L.; Engl. Bot. t. 107; Fl. Dan. t 1173. Cirsium lanceolatum, Scop. I. c.; DC. 1. c.; Reichenb. Ic. Fl. Germ. t. 826. - Pastures and waste grounds, Newfoundland and Canada to Georgia (very common northward; ; also in Oregon. (Nat. from Eu.)

$\S 2$. Indigenous species, all but one Alaskan species endemic, all or mostly biennials.

* Bracts of the oroid or hemispherical involucre appressed-imbricated and the outer successirely shorter, all with loose and dilated fimbriate or lacerate white-scarious tips. - Echenais, Cass., DC.

C. Americánus, GraT. A foot or two high, branching above : branches bearing solitary or scattered naked heads: leaves white-tomentose beneath, lanceolate or broader, sinuately pinnatifid, or some merely dentate, others pinnately parted, weakly prickly: heads erect, inch high: principal bracts of the involucre naked-edged or merely fimbriate-ciliate (not setosespinuliferous) below, and the dilated scarious apex as broad as long, fimbriate-lacerate, tipped with barely exserted cusp or mucro ; innermost with lanceolate nearly entire scarious tips: flowers ochroleucous: stronger pappus-bristles dilated-clavellate at tip.-Proc. Am. Acad. xix. 56, without char. C. carlinoides, var. Americanus, Gray, Proc. Am. Acad. x. 48, \& Bot. Calif. i. 420, excl. syn. Nutt., \&c. Echenais carlinoides, var. nutans, Gray, Proc. Acad. Philad. 1863, 69. - Lower mountains of Colorado and New Mexico to the coast of California. (A hybrid with C. undulatus? with red-purple flowers and purplish tips to involucral bracts, is from Pinos Altos Mountains, New Mexico, Greene.)

* * Bracts of the involucre mostly loose, not appressed-imbricated nor rigid, tapering gradually from a narrow base to a slender-prickly or muticous apex; outer not very much shorter than the inner, wholly destitute of dorsal glandular ridge or spot,

- Some with scarious or fringed tip or margins, at least the innermost, slightly or not at all prickly-pointed (except accessory leafy ones) : leaves not decurrent on the stem, moderately prickly: Rocky Mountain and Western species.

C. Párryi, Gray. Green, lightly arachnoid and villous when young, 2 feet or so high : leaves lanceolate, sinuate-dentate : heads (inch high) several and spicately glomerate or more racemosely paniculate, more or less bracteose-leafy at base: accessory and outer proper bracts or some of them pectinately fimbriate-ciliate down the sides, innermost with more or less 
dilated or margined mostly lacerate-fimbriate tips : corollas pale yellow; the lobes longer than the throat: pappus of fine soft bristles, none of them obviously clavellate. - Proc. Am. Acad. x. 47; Rothrock in Wheeler Rep. vi. 180. - Rocky Mountains in Colorado and Utah, at about 8,000 feet; first coll. by Parry. Appears to hybridize with C'. eriocephalus, \&c.

C. remotifólius, GraY, 1. c. Loosely arachnoid-woolly when young, 3 to 8 feet high: leaves from sinuately to deeply pinnatifid, more or less whitened by the loose tomentum beneath even in age : heads (inch and a half high) pedunculate, scattered, naked or nearly so at base: involucre lightly arachnoid and glabrate; the bracts attenuate, the outer into a weak small prickle; the inner or some of them with a scarious (from broadly subulate to ovate-lanceolate) entire or sparingly lacerate tip: corolla ochroleucous, its lobes much shorter than the throat: pappus of coarser bristles, the strongest with conspicuously clavellate tips. - Carduus remotifolius, Hook. Fl.i. 302. Cirsium remotifolium, DC.; Torr. \& Gray, Fl. ii. 460. C. stenolepidum, Nutt. Trans. Am. Phil. Soc. vii. 419. - Along streams, Columbia River, from the Yakima district, Washington Terr., to the coast, and to Mendocino Co., California. Here no. 559 Kellogg \& Harford (not "Hall \& Harbour"), doubtfully re ferred to $C$. Americanus in Bot. Calif. i. 421, a form most approaching the latter speeies.

++ None of the involucral bracts with fimbriate or scarious-dilated tips, or obscurely so in the first species.

* Proper bracts nearly all tipped with a slender acicular prickle, also somewhat viscidly longwoolly: leaves narrow, well armed with prickles: stem a foot or two high, leafy: pappusbristles not clavellate-tjped. Rocky-MIountain species.

C. Hookeriánus, Grar, 1. c. Arachnoid white-woolly, hardly glabrate, stout : leaves pinnatifid; the short lobes rather distant, sparsely prickly; base little or not at all decurrent: heads few and sessile in a terminal cluster, or scattered, inch and a half high, somewhat bracteose-leafy at base: proper bracts tapering from a broadish base into a rather rigid subulate prickly point: corollas white or whitish. - Carduus discolor, var. $f$. albis, Hook. Fl. i. 302. Cirsium Hookerianum, Nutt. Trans. Am. Phil. Soc. vii. 418. - Upper wooded and subalpine region of the Rocky Mountains, north of lat. 48 ${ }^{\circ}$, Douglas, Bourgeau, \&c.

C. eriocéphalus, Gray, 1. c. Loosely arachnoid-woolly and partly glabrate, very leafy : leaves pinnatifid into very numerous and crowded and numerously prickly short lobes, the base decurrent on the stem into prickly wings: heads (inch long) several, sessile, and crowded in a leaf-subtended at first nodding glomerule; the subtending leaves and the involucral bracts densely long-woolly (or the inmost bracts glabrous), all very slender-prickly : corollas light yellow or yellowish. - Cirsium eriocephalum, Gray, Proc. Acad. Philad. 1863, 69; Eaton, Bot. KRing Exp. 196, excl. var. - Alpine region of the Rocky Mountains, at the head of Clear Creek and its tributaries; first coll. by Parry.

$+\div$ Proper bracts of the involucre tapering into an almost innocuous weak and short prickle or soft point: leaves green both sides, glabrate, mostly membranaceous, not decurrent on the stem, except the lower of the last species. Pacific species, with middle-sized or small heads.

C. édulis, Grax, I. c. Stem robust and somewhat succulent, 3 to 6 feet high, pubescent, leafy to the top: leaves oblong or narrower, from slightly to deeply sinuate-pinnatifid, weakly prickly-ciliate: heads (the larger inch and a half high) scattered or few in a cluster, usually bracteose-leafy at base: involucre conspicnously arachnoid-woolly when young, partly glabrate in age : corollas dull purple or whitish; the lobes much shorter than throat, filiform in the dried state and capitellate-callous at apex!-Bot. Calif. i. 420. Cirsium edule, Nutt. 1. c. ; Torr. \& Gray, 1. c. - Low grounds, British Columbia to W. California.

C. Hállii, Gray. Glabrate and green: stem slender, 2 or 3 feet high, moderately leafy: leaves pinnatifid, the lobes and teeth rather strongly prickly : heads solitary and pedunculate, or 2 or 3 in a small terminal cluster (inch or more high), more or less bracteose-leafy at base: involucre sparingly arachnoid when young, soon glabrate, the attenuate tips of all but the ontermost innocuous: corollas rose-purple, varying to white; the lobes linear, plane, obtuse. - Proc. Am. Acad. xix. 56. - Oregon, Hall (310, was referred to C. edulis), to $\mathrm{S}$. California (San Bernardino Co., Lemmon, \&c.) and S. Utah, Mrs. Thompson.

C. Kamtscháticus, MAxrm. Glabrate and green, leafy up to the naked and short-pedunculate (inch high) heads: leaves oblong-ovate or oval, from barely dentate to incisely pinnatifid, 6 to 10 inches long, weakly prickly; lower decurrent on the stem into narrow prickly wings: involucral bracts all attenuate-subulate from a narrow base, arachnoid-pubescent 
when young or glabrate: corolla-lobes narrowly linear, apiculate: larger pappus bristles clavellate. - Mel. Biol. ix. 310. Cirsium Kamtschaticum, Ledeb. in DC. Prodr. vi. 644, \& Fl. Ross. ii. 736. - Atkha, one of the Aleutian Islands, Lieut. Turner. Said to be " 7 feet high": corollas whitish: anther-tips slender, as in pl. Kamts., and longer than in var.? Grayanus, Maxim., of Japan. (Kamtschatka to Japan.)

+++ Proper bracts of the involucre not at all prickly, but the large (2 inches bigh) heads conspicuously and numerously bracteose-leafy at base. Atlantic species.

C. horrídulus, Pursu. Arachnoid when young, glabrate with age, 1 to 3 feet high, the larger plants branching and bearing several heads: leaves elongated-lanceolate, not decurrent, pinnatifid, strongly prickly: head about 2 inches high, surrounded by a whorl of 8 to 30 linear or lanceolate numerously and strongly prickly leaves, which usually equal in length the involucre of gradually attenuate weak-pointed minutely scabrous bracts: flowers pale yellow, rarely purple (var. Elliotti, Torr. \& Gray). - Fl. ii. 507; Ell. Sk. ii. 272; Gray, Proc. Am. Acad. x. 40. C. spinosissimus, Darlingt. Fl. Cest. ed. 2, 438. Cirsium horridulum, Michx. Fl. ii. 90; DC. Prodr. vi. 651. C. megacanthum, Nutt. in Trans. Am. Phil. Soc. vii. 421, large form. Carduus spinosissmus, Walt. Car. C. horridulus, Pers. Syn. ii. 390.Sandy or gravelly soil, New England, near the coast, to Florida and Texas.

* * Bracts of the involucre moderately unequal or the lower not rarely about equalling the upper, more rigid and imbricated at base, but most of them with more or less herbaceous spinescent-tipped spreading upper portion, and no glandular dorsal ridge. Rocky Mountain and Pacific species.

+ Heads (only inch high) few or several and sessile in a terminal cluster: stem leafy to the top.

C. Eatóni, GrAy. A foot or so high, mostly simple, loosely arachnoid-woolly or glabrate: leaves pinnatifid or pinnately parted into short lobes, mostly very prickly, either green and glabrate or remaining whitish-woolly beneath: involncre rather narrow, from arachnoidciliate to glabrate or apparently glabrous; its principal bracts erect, with broadish appressed base, abruptly attenuate into the subulate-acerose slightly herbaceous spinescent portion, outermost little shorter than the inner: corolla whitish, its lobes considerably shorter than the throat. - Proc. Am. Acad. xix. 56. Cirsium eriocephalum, var. leiocephalum, C. foliosum, $\&$ C. Drummondi in part, Eaton in Bot. King Exp. 195, 196. - Mountains of Utah (Uintah and Wahsatch) and of Colorado, from 8,000 to 11,000 feet, also in Humboldt Mountains, Nevada, Watson, Jones, Hall \& Harbour, \&c.

- + Heads solitary terminating the stem or branches (involucre usually long-woolly when young, but sometimes glabrate), hemispherical,

$$
\text { + Middle-sized: flowers white or pale purple: anther-tips deltoid. }
$$

C. Andréwsii, Gruy. Probably tall, branching; the loose wool deciduous except from the heads: stem strongly striate: upper leaves laciniate-pinnatifid and with narrowly lanceolato prickly lobes: bracts of the involucre with coriaceous oblong-ovate base, greenish at short upper part, where it is abruptly contracted into an aristiform spinescent appendage: corollas apparently whitish; the lobes fully twice the length of the throat. - Proc. Am. Acad. x. 45, \& Bot. Calif. i. 420. - W. California, Andrews, station unknown.

C. Califórnicus, GraY, l. c. Tall and branching, with white wool more or less deciduous: leaves from sinuately to deeply pinnatifid, moderately prickly: principal bracts of the involucre with somewhat foliaceous and subulate spinescent summit, sometimes very conspicuous, sometimes smaller and attenuate more directly into the prickle: corollas cream-color, white, or rarely purple; lobes shorter than the throat. - Cirsizm Californicum, Gray, Pacif. R. Rep. iv. 112. - California, from the Stanislaus (where first coll. by Bigelow) to San Diego and San Bernardino and adjacent Arizona. A variety of forms here assembled, some with larger heads and more leafy-bracted involucre passing to the next.

+ +t Large heads, the larger fully 2 inches high and broad: slender corolla-lobes considerably longer than the throat: herbage and commonly squarrose involucre copiously white-woolly, sometimes glabrate in age: anther-tips narrow and acuminate.

C. Neo-Mexicánus, Gray, 1. c. Stout, 2 to 4 feet high: spinescent rigid tips to the principal involucral bracts half to nearly full inch long: corollas from white to pale purple: node on the style generally manifest and obscurely bearded: otherwise as the next, into which it seems to pass. - Cirsium Neo-Mexieanum, Gray, Pl. Wright. ii. 101. C. canescens, 
Gray, Pl. Fendl. 110, not Nutt. - Plains of S. Colorado, New Mexico, and Arizona; first coll. by Fendler, Wright, \&c.

C. occidentális, Grar, 1. c. Mostly stout, 2 to 5 feet high, very white with thick coating of cottony wool: leaves from sinuate-dentate to pinnatitid, not very prickly: involucral bracts sometimes narrow and herbaceous-acerose from a little dilated base, sometimes with broader more coriaceous base, or the outer with lanceolate-subulate tips: corollas red or crimson (the longer inch and a half long): style destitute of node. - Carduus occidentalis, Nutt. Trans. Am. Phil. Soc. vii. 418. Cirsium Coulteri, Gray, Pl. Fendl. 110; Eaton in Bot. King Exp. 195. - S. Oregon and W. California to San Diego and the Molhave; first coll. by Coulter. Varies much in the size of the heads; these in some plants only inch and a half long, narrower, and involucre glabrate; its outer bracts successively shorter, with lanceolate-subulate squarrose green tips; approaching $C$. Californicus and also the following section.

* * * Bracts of the involucre regularly and chiefly appressed-imbricated in numerous ranks; the outer successively shorter, not herbaceous-tipped or appendaged, except that the innermost (which are all muticous or innocuous) are in one or two species obviously scarious-tipped.

+ Heads oblong or cylindraceous, showy ( $1 \frac{1}{2}$ to 2 inches long): flowers bright red or crimsonpink: involucral bracts comparatively jarge, not at all glandular on the back; inner ones all erect and purplish-tinged. Arizonian and Californian.

+W White with cottony wool, which is tardily if at all deciduous, 1 to 3 feet high.

C. Andersóni, Gray, l. c. Slender, rather lightly and loosely woolly: leaves lightly prickly, sinuate-pinnatifid, rather sparse: heads naked-pedunculate: involucral bracts comparatively loose and erect, all gradually attenuate from a narrow base; outermost ripped with a small weak prickle: corolla bright pink-red; its slender lobes about equalling the throat: style considerably prolonged above the very obscure node. - Dry hills, E. California, adjacent Nevada, and S. W. Idaho; common along the Sierra south to the Yosemite and Kern Co.; first coll. by Anderson.

C. Arizónicus, Gray, l. c. More densely white-woolly, branching and leafy: leaves sinnate or pinnatifid; lobes prickly-pointed: heads more numerous, less peduncled: involucral bracts well imbricated, soon glabrate; outer coriaceous, ovate-oblong to ovate-lanceolate, abruptly contracted into a rigid prickle of rarely over their own length, inner attenuate: corolla crimson-purple or carmine; its lobes twice the length of the throat: style produced at tip to only 4 or 6 times its diameter above the manifest node. - Cirsium undulatum, var., Gray, Pl. Wright. ii. 101. - Sandy or gravelly places, Arizona and S. W. Utah; first coll. by Wright and by Thurber.

+ + Green and glabrous or very early glabrate, 3 or 4 feet high.

C. Rothróckii, Grax. Stout, branching, leafy to the top: leaves from incisely pinnatifia to pinnately parted, conspicuonsly prickly: heads rather thicker than in the foregoing: involucre similar, but longer prickly (prickles sometimes even three-fourths inch long) corolla and style similar, or node of the latter less evident. - Proc. Am. Acad. xvii. 220 (form noted by Rothrock in Wheeler Rep. under C. Arizonicus).- Cañons of S. Arizona, Rotkrock, Lemmon.

+ - Heads broad, mostly large: flowers from rose-purple to white: involucre glabrous or early glabrate, the light arachnold wool caducons; its bracts rather large, chartaceous or coriaceous, not at all glandular on the back, outer tipped with a short weak prickle or innocuous cusp, innermost wholly unarmed and not rarely scarious-tipped.

+ Eastern species: leaves equally green both sides : anther-tips broadish.

C. pumilus, Torr. Somewhat villous-pubescent: stem stout, mostly simple, a foot or two high (rarely taller) and bearing 1 to 3 large heads: leaves oblong or lanceolate, commonly pinnatifid, copionsly prickly and setose-ciliate: heads full 2 inches high, often leafy-bracteose at base, arachnoid when young: involucral bracts mostly lanceolate: corollas rose-purple, occasionally white, with lobes shorter than throat: flowers distinctly fragrant. - Compend. 282; Bigel. Fl. Bost. ed. 2, 292; Gray, Proc. Am. Acad. x. 40; Sprague, Wild Flowers, 138, t. 32. Carduus odoratus, Muhl. Cat. 70; Darlingt. Fl. Cest. ed. 1, 85. C. pumilus, \& var. hystrix, Nutt. Gen. ii. 130. Cirsium pumilum, Spreng. Syst. iii. 375; DC. Prodr. vi. 651 ; Torr. \& Gray, 1. c. - Open ground, Mass., near the coast, to Penn. and New Jersey. 
++ Western species: leaves either green both sides or deciduously white-woolly beneath : involucral bracts plane: anther-tips narrow, very acute.

C. quercetórum, Gray. Lightly villous-arachnoid when young, soon glabrate: stem stout, a foot or less high, bearing few or several thick heads: leaves mostly petiolate (the larger a foot long), pinnately parted and the oblong divisions often 3-5-cleft, strongly or weakly prickly; involucral bracts thickish-coriaceous, closely imbricated in numerous ranks; outer only mucronately cuspidate or with short prickle (outermost only about 3 lines long); innermost obscurely scarious at tip: corollas purplish or whitish, the lobes equalling or longer than the throat. - Proc. Am. Acad. x. 40, \& Bot. Calif. i. 418. - Dry hills, at Oakland and vicinity, California, Kellogg, Bolander, \&c.

C. Drummóndii, Gray, 1. c. Green and somewhat villous-pubescent, or when young lightly arachnoid-woolly (at least the lower face of the leaves), either stemless and bearing sessile heads in a cluster on the crown, or caulescent and even 2 or 3 feet high, with solitary or several loosely disposed heads: leaves from sinuate or almost entire to pinnately parted, moderately prickly: larger heads fully 2 inches high: involncral bracts thin-coriaceous or chartaceous, mostly acuminate, weak-prickly pointed or innocuous, innermost with more scarious and sometimes obviously dilated and erose-fimbriate tips: corollas either white or sometimes rose-purple, with lobes usually shorter than the throat. - Carduus pumilus, Hook. Fl. i. 302, excl. syn. Cirsium Drummondii, Torr. \& Gray, Fl. ii. 459. - From Fort Franklin, wear the Arctic Circle, to the Saskatchewan, along the Rocky Mountains to Colorado and Utah, west to Oregon, and south along the Sierras to S. California. Polymorphous and of very wide range.

Var. acauléscens, GrAy, l. c. Smaller, with heads (solitary or several on the crown, encircled by the radical leaves) only inch and a half long, or less, and proportionally narrow: outer involucral bracts with a longer but rather weak prickle. - Cirsium acaule, var. Americanum, Gray, Proc. Acad. Philad. 1863, 68. - Mountains of Colorado to the Sierra Nevada in S. California.

C. foliósus, Grar, l. c. More woolly, usually also villous when young: stem stout, leafy to the cluster of a few sessile heads, a span or two high: leaves commonly elongated, linearlanceolate, laciniately dentate, arachnoid-tomentose beneath: heads broad, inch and a half high, leafy-bracteose: involucre nearly of the preceding: corollas pale or white, with lobes equalling or longer than the throat. - Carcluus foliosus, Hook. Fl. i. 303. Cirsium foliosum, DC. Prodr. vi. 654. - Prairies of the northern Rocky Mountains, Drummond. Idlaho, Burke, Spalding.

C. scariósus. White with cottony tomentum, at least the lower face of the leaves: stem about a foot high : leaves of lanceolate outline, mostly pinnately parted into lanceolate longprickly lobes; upper face sometimes villous, sometimes only cottony and early glabrate: heads nearly of preceding, 2 or 3 in a sessile cluster, or solitary on short leafy branches: innermost bracts of involucre commonly with more conspicuous erose or entire scarious tips: corollas pale or white. - Cirsium scariosum, Nutt. Trans. Am. Phil. Soc. vii. 420. - Rocky Mountain plains, Wyoming and Utah, Nuttall, Ward, Palmer, \&c. Has been referred to C. Americanus and (in Proc. Am. Acad. xix. 56) to C. foliosus.

++ Species of Mexican border, with dense white tomentum, smaller and obscurely carinate outer involucral bracts, and blunt very scarious tips to the inner: anther-tips very acute.

C. Wheéleri, Gray. Stem slender, 2 or 3 feet high, white with close cottony wool, as is the lower face of the leaves: these narrowly lanceolate or linear, sparingly laciniate-pinnatifid, glabrate and green above, slightly prickly: head solitary, nearly 2 inches high, naked at base : outer involucral bracts firm-coriaceous, much appressed, carinate-thickened down the middle of the back, abruptly tipped with a small weak prickle; inner with conspicuous scarious or scarious-edged and erose tip or appendage: corolla crimson-purple; its lobes much longer than throat. - Proc. Am. Acad. xix. 56. - Rocky Cañon, south of Camp Apache, Arizona, Rothrock, in Wheeler Exped., where it was referred to C. undulatus.

+++ Heads large or comparatively small : fowers usually rose or flesh-colored: involucral bracts closely appressed, coriaceous or thickish, commonly with a glandular or viscid ridge, short line, or a broader spot on the back near the summit.

+ Canescent, at least the lower face of the leaves white-tomentose, very rarely glabrate in age: heads naked, solitary or scattered. 
- Leaves pinnately parted into narrow and linear mostly entire divisions : anther-tips attenuatesubulate.

C. Pítcheri, Torr. A foot or two high, with herbage persistently white-tomentose throughout: lower leaves a foot or so long, with divisions (2 to 4 inches long, 2 or 3 lines wide) either entire or some again pinnately parted into shorter lobes, weakly prickly-tipped; the winged rhachis not wider than the divisions: heads few or solitary, 2 inches high: involucre glabrate; the bracts rather small, viscid down the back, tipped with small short prickle: corollas ochroleucous. - Torr. in A. Eaton, Man. ed. 5, 180; Gray, Proc. Am. Acad. x. 42. Cirsium Pitcheri, Torr. \& Gray, Fl. ii. 456. - Sand-banks on the shores of the Great Lakes from the head of Lake Michigan northwestward, and in Dakota, Suckley; first coll. by Dr. Pitcher.

$==$ Leaves from undivided to pinnately parted, the lobes lanceolate or broader, disposed to be white-tomentose above as well as below : prickle on cusp of the principal involucral bracts more or less rigid and pungent.

a. Bracts of the involucre minutely scabrous-ciliolate.

C. Gráhami, Gray. Stem 3 to 8 feet high : leaves elongated-lanceolate (larger ones a foot or more long), from repand-dentate to sinuate and pinuatifid (sometimes delicately, sometimes strongly prickly), upper face at length glabrate and green: heads $1 \frac{1}{2}$ to 2 inches high: involncre glabrate and greenish; the bracts lanceolate-subulate, tipped with a short rigid cusp rather than prickle, the margins at least of the principal ones minutely scabrous-ciliolate : corollas crimson-red: anther-tips attenuate-subulate. - Proc. Am. Acad, xix. 57. C. undulatus, var. Grahami, Gray, Proc. Am. Acad. x. 43. Cirsium Grahami, Gray, Pl. Wright. ii. 102 ; Hook. Bot. Mag. t. 2885. - Wet ground, Arizona, Wright, Thurber, Lemmon.

b. Bracts of the involucre smooth and naked, or else tomentose on the margins.

C. ochrocéntrus, Grar. Resembles the next following species, usually taller, even to 6 or 8 feet high, the white tomentum mostly persistent: leaves commonly but not always deeply pinnatificl and armed with long yellowish prickles: heads 1 or 2 inches high: principal bracts of the involucre broader and flatter, the viscid line on the back narrow or not rarely obsolete, tipped with a prominent spreading yellowish prickle: corollas purple, rarely white.-Proc. Am. Acad. xix. 57. C. undulatus, var. ochrocentrus, Gray, P'roc. Am. Acad. x. 43. Cirsium ochrocentrum, Gray, PI. Fendl. 110. - Plains, \&c., W. Texas to Colorado, the eastern Sierra Nevada, and Arizona. (Adj. Mex.)

C. undulátus, Grax. A foot or two high, persistently white-tomentose: leaves rarely pinnately parted, moderately prickly: heads commonly inch and a half high: principal bracts of the involncre mostly thickened on the back by the broader glandular-viscid ridge, comparatively small and narrow, tipped with an evident spreading short prickle: corollas rosecolor, pale parple, or rarely white; its lobes equalling or surpassing the throat in length: anther-tips attenuate-subulate. - Proc. Am. Acad. x. 42, excl. var. ochrocentrus, \& var. Grahami. Carduus undulatus, Nutt. Gen. ii. 130. C. discolor, Hook. Fl., in part. Cirsium Douglasii, DC. Prodr. vi. 643, excl. habitat. C. Hookerianum, Hook. Lond. Jour. Bot. vi. 253, not Nutt._- Plains, \&c., from Lake Huron and Minnesota to Saskatchewan, west to Oregon, south to Kansas and New Mexico.

Var. canéscens, Gray, 1. c., is merely a form with smaller heads, sometimes not over an inch high, the leaves varying from ciliately spinulose-dentate to deeply pinnatificl. Cirsium canescens \& C. brevifolium, Nutt. Trans. Am. Phil. Soc. vii. 421. - Miunesota to New Mexico and S. Utah.

Var. megacéphalus, GRAY, 1. c. Stouter form, usually broader-leaved, with broad heads 2 inches or more high, - Minnesota and Texas (where coll. by Berlundier) to Idlaho.

C. Bréweri, GraY, 1. c. Usually both very white-tomentose and tall (5 to 10 feet high): leaves mostly elongated-lanceolate, conspicuously prickly: heads paniculate, sometimes very numerous, subsessile, merely inch high, or when solitary inch and a half high: bracts of the globular involucre much appressed, firm-coriaceous, the tip externally bearing an oval or oblong greenish viscid-glandular spot; outer ones ovate to oblong, abruptly tipped with a rather slender spreading prickle : corollas pale purple or whitish, the lobes shorter than the throat: anther-tips deltoid, merely acute. - Springy soil, Sierra Nevada from Lake Tahoe and Mendocino Co., California (first coll. by Anderson and Brew'er), to E. Oregon, Cusick, \&c. Also, less white-woolly, San Juan, Monterey Co., Brewer, leading to the var. 
Var. Vaséyi. Perhaps a distinct species, only arachnoid-tomentose and greenish, even glabrate in age. - California, in Plumas and Sierra Co., Lemmon, Mrs. Ames. A remarkably glabrate form, with involucral bracts obscurely glandular, and tipped with very short prickle, growing in dry soil exposed to the sun, Tamalpais, G. R. Vasey. Also a robust form, equally glabrate and green, with the glandular spot on the involucral bracts conspicuous and narrow : in salt marshes, Sujsin Bay, Greene.

$===$ Leaves in the same species from undivided to pinnately parted, and the lobes from ovate to lanceolate, upper face soon glabrate and green: involucral bracts tipped with weak setiform prickles or sometimes hardly any: anther-tips subulate, very acute: corolla fleshcolored, rarely white.

C. altíssimus, WILLd. Stem branching, 3 to 10 feet high : leaves in the typical form ovate-oblong or narrower, sometimes with merely spinulose-ciliate slightly toothed margins, sometimes laciniate-cleft or sinuate, or lower ones deeply sinuate-pinnatifid, weakly prickly: heads one and a half to two inches high : involucral bracts firm-coriaceous, abruptly tipped with a spreading setiform prickle, the short outermost ovate or oblong: roots fascicled and not rarely tuberous-thickened below the middle, in the manner of Dahlia. - Willd. Spec. iii. 1671 ; Ell. Sk. ii. 268 ; Gray, Proc. Am. Acad. x. 42. Carduus altissimus, L. Spec. ii. 824. Cirsium altissimum, etc., Dill. Elth. i. 81, t. 69. C. altissimum \& C. diversifolium, DC. Prodr. vi. 640. - Borders of woods, and in open ground, common from New York to Wisconsin, Florida, and Texas.

Var. filipéndulus, Grax, Proc. Am. Acad, xix. 56. Smaller, 2 or 3 feet high: roots tuberiferous : leaves commonly deeply pinnatifid : heads few, only inch and a half high. - Cirsium filipendulum, Engelm. in Gray, Man. ed. 5, 273. C. Virginianum, var. $\delta$ ? Torr. \& Gray, l. c. - Prairies and Live-oak thickets, Texas and Colorado. (Adj. Mex.)

Var. díscolor, GRAY, l. c. Stem 2 to 6 feet high, freely branching: leaves nearly all deeply pinnatifid into lanceolate lobes, or those of upper leaves linear : heads fully inch and a half high. - C. discolor, Muhl. in Willd. Spec. iii. 1670; Ell. 1. c.; Bigel. Fl. Bost. ed. 2, 292. Carduus discolor, Nutt., Darlingt., \&ce. Cirsium discolor, Spreng. Syst. iii. 373; DC. 1. c.; Torr. \& Gray, 1. c. - Borders of fields and thickets, Canada and New England to Illinois and Georgia.

C. Virginiánus, Porsir. Stem slender, 2 or 3 feet high, simple or branching: leaves narrow, varying as in the preceding: heads more naked-pedunculate, only an inch long: involucral bracts small and narrow, thinner, tapering into a very weak short spreading bristlelike prickle, sometimes hardly any : flowers rose-purple. - Fl. ii. 506; Ell. 1. c. Carduus Virginianus, L. 1. c.; Jacq. Obs. iv. t. 99 ; Nutt. 1. c. Cirsium Virginianum, Michx. Fl. ii. 90; DC. 1. ¿.; Torr. \& Gray, Fl. ii. 457, excl. last var. C. Texanum, Buckley in Proc. Acad. Philad. 1862, imperfect specimen, apparently of this species. - Pine woods and dry banks, Virginia to Texas.

+ Green or with only light and thin arachnoid tomentum, this at length mostly deciduous: involucre innocuous or nearly so. Atlantic species.

= Heads only inch high, loosely somewhat paniculate: principal bracts of the involucre conspicuously viscid-glandular on the back, more or less cuspidate-tipped : stems branching, 2 to 8 feet high.

C. Nuttállii, GraY, 1. c. Early glabrate : stem slender, below winged by decurrence of the leaves: these when young lightly arachnoid beneath and often villous with jointed hairs above, deeply pinnatifid and with narrow lobes, slender-prickly: heads rather narrow: invoIucre nearly glabrous, of very small and narrow thinnish bracts, the lower ones acicularmucronate: corollas white or pale purple. - Carduus glaber, Nutt. Gen. ii. 129 ? but if so, hardly from New Jersey. Cnicus glaber, Ell. Sk. ii. 270. Cirsium Nuttallii, DC. Prodr. vi. 651. - Dry ground, S. Carolina to Florida, toward the coast. Nearly related to $C$. Virginianus.

C. Wríghtii, Gray, 1. c. Robust and tall, with thin arachnoid wool tardily deciduous from the ample (foot or more long) sinuate or pinnatifid weakly prickly leaves : heads in a naked panicle, hemispherical : bracts of the involucre small; outer ones subulate, cuspidate-tipped : corollas white, or possibly flesh-color: larger pappus-bristles strongly clavellate at tip. Cirsium Wrightii, Gray, Pl. Wright. ii. 101.- Near springs, S. W. Texas and E. Arizona, Wright. 
$==$ Heads large, oblong or cylindraceous, commonly solitary and pedunculate: involucral bracts comparatively large, gradually acuminate into a mucronate cusp o1 weak and slort prickle, glabrate, the viscid dorsal ridge narrow: corollas purple: leaves when young canescently floccose-woolly beneath, oblong-linear or narrowly lanceolate.

C. repándus, EcL. A foot or two high, leafy: leaves mostly undulate-lobulate, ratler densely prickly at margins: heads inch and a half long: involucre narrow-campanulate. Sk. ii. 269; Gray, 1. c. Cirsium repandum, Michx. Fl. ii. 89; DC. Prodr. vi. 651. Carduus repandus, Pers. Syn. ii. 386, C. Virginianus, Walt. Car. 195 ? - Dry pine barrens, N. Carolina to Florida.

C. Lecóntei, Gray. Stem slender but rigid, commonly simple and bearing a single conspicuously pedunculate head (of full 2 inches in height): leaves sparsely dentate or pimnatifidlobulate, with scattered prickles : iuvolucre cylindraceous. - Proc. Am. Acad. x. 39. Cnicus Virginianus, Hook. Comp. Bot. Mag. i. 48. Cirsium Lecontei, Torr. \& Gray, El. ii. 458. Wet pine barrens, Georgia to Florida and Louisiana; first coll. by Le Conte.

$===$ Heads inch and a half high, rather broad: involucre arachnoid-woolly; its printipal bracts broad and pointless. Atlantic species.

C. múticus, Pvrsi. Obscurely arachnoid when young and with some villosity : stem 3 to 8 feet high, branching above : leaves deeply pinnatifid, sparsely weak-prickly, glabrate : involncre sometimes glabrate in age: bracts with broad and short viscid ridge or spot just beneath the obtuse or acutish sometimes mucronulate apex, lowest ovate or oblong and very short, innermost linear: flowers rose-purple. - Gray, 1. c. C.glutinosus, Bigel. Fl. Bost. ed. 2, 291, not Lam. Cardus muticus and perhaps C. glaber, Nutt. Gen. ii. 129. Cirsium muticum, Michx. Fl. ii. 89 ; DC. 1. c.; Torr. \& Gray, Fl. ii. 458, excl. syn. of the var.?, which is a more rigid form, growing in open ground. C. Bigelovii, DC. 1. c. - Low ground and shady swamps, Newfoundland to Saskatchewan, Florida, and Louisiana.

199. ONOPORDON, Vaill. Cotton Thistle. (Old Greek name, meaning Asses' Thistle.) - Large and stout biennials of the Old World, one sparingly naturalized; fl. late summer,- DC. Prodr. vi. 617. Onopordum, L.

O. ACÁxthIOr, L. White with cottony wool: stem 3 to 9 feet high, branching, winged throughont by decurrence of the large oblong sinuate-lobed and prickly leaves; wings sinuate, very prickly: heads pretty large: involucre globular, arachnoid or partly glabrate; bracts rigid, subulate and prickly tipped, squarrose: corollas light purple or paler: pappus fuscous, scabrous, not twice the length of the slightly rugose akene. - Fl. Dan. t. 909 ; Engl. Bot. t. 907. - Waste grounds near dwellings and roadsides in Atlantic States, not abundant. (Nat. from Eu.)

200. SILYBUM, Vaill. Milk Thistle. ( $i \dot{i} \lambda \nu \beta$ s, ancient Greek name of an edible-stemmed Thistle, perhaps the present plant.) — Single species.

S. Marínum, Gartw. Prickly-leaved biennial or annual, glabrate or nearly glabrous ; with ample sinuate or pinnatifid green leaves, blotched with white along the veins: corollas rosepurple, deeply cleft. - Escaped from gardens in a few places, also a ballast-weed, disposed to be naturalized southward, especially in California: fl. summer. (Adv. from Eu.)

201. CentaUREA, L. Star Thistle, \&c. (Kevtavpelov, plant of the Centaurs, name applied by the herbalists to two or three widely different genera.) - An immense genus in the Old World, one species only indigenous to $\mathrm{N}$. America, two or three in Chili. - Centaurea \& Carbenia (Adans.), Benth. \& Hook. Gen. Pl. ii. 477, 482.

§ 1. Carbéria. Akenes terete, strongly many-striate, with lateral scar, the corneous margin at summit 10-dentate: pappus double, each of 10 aristiform bristles, outer longer and naked, inner short and fimbriolate: anthers with elongated cartilaginous terminal appendages, which are connate to their blunt tips: 
hear surrounded by large and leafy accessory bracts. - Carbeni, Adans. Fam. ii. 116. Cnicus, Gærtn., DC., not L.

C. Benedfcta, L. (Blessed Tirstle.) Low and branching annual, hirsute or pubescent: leaves prominently reticulated, sinuate-pinnatifid or laciniate-dentate, the teeth or margins weakly prickly; lower attenuate at base; upper narrowly oblong, partly clasping by broad base: heads sessile, inch and a half high, equalled by the oblong involucral leaves: proper involucre of thin-coriaceous bracts in few ranks, all or most of them abruptly tipped with an aristiform or spinescent and pectinately prickly spreading appendage : receptacle very densely setose with long and soft capillary bristles : corollas light yellow : longer bristles of the pappus alternating with inner and with the teeth of the akene. - Spec. ed. 2, ii. 1296; Sibth. Flora Græca, t. 906. Cnicus benedictus, l. Spec. ed.1, i. 826; Gærtn. Fruct. ii. t. 162 ; DC. Prodr. vi. 606 ; Torr. \& Gray, Fl. ii. 455. - Waste grounds, at seaports and elsewhere near dwellings, in the Southern Atlantic States and in California; not common. (Nat. from Eu.)

§ 2. Centaurea proper. Akenes more or less compressed or quadrangular: pappus of indefinite (either scanty or numerous) bristles or narrow paleæ: involucre globular or ovoid.

* Old World species, sparingly naturalized, with comparatively small heads: scar or insertion of akene lateral.

+ Bracts of the involucre (or some of them) armed with a rigid spine or prickle, and also more - or less spinulose along its sides or base: cartilaginous appendages terminatiug the anthers commonly elongated and connate: ours annuals, none witl the marginal corollas enlarged. Calcitrapa, Juss.

C. Calcítrapa, L. (Star Thistre.) Low, much branched, diffusely spreading, green, glabrate or hairy : leaves narrow, laciniate-pinnatifid; uppermost somewhat involucrate-crowded at base of the sessile heads: principal bracts of the involucre becoming corneous, armed with a widely spreading very long and rigid spine, which bears 2 or 3 spinules on each side at base : corollas purple or purplish : pappus wanting. - Engl. Bot. t. 125; Torr. \& Gray, Fl. ii. 454. - Sparingly established at seaports from New York southward, chiefly as a mere ballast-weed. (Nat. from Eu.)

C. solstitiális, L. Erect, a foot or two high, canescent with cottony wool : radical leaves lyrate-pinnatifid; cauline lanceolate and linear, mostly entire, decurrent on the branches in narrow wings : heads naked, somewhat pedunculate: intermediate bracts of the globular involucre tipped with a long spreading spine, having one or two spinules at base; outermost bearing a few small palmate prickles; innermost only scarious-tipped : corollas yellow : pappus double; outer of short and squamellate, inner of longer bristles. - Engl. Bot. t. 243; Reichenb. Ic. Fl. Germ. t. 795 ; Gray, Bot. Calif. i. 421. - Near San Francisco and San Diego, California, sparingly introduced. (Nat. from Eu.)

C. Medtí́nsis, L. Erect, 2 to 4 feet high, paniculately branched, cinereous-pubescent, somewhat woolly at first : radical leaves lyrate-pinnatifid; cauline lanceolate or linear, mostly entire, narrowly decurrent on the branches: heads smaller, sessile or 1-2-leaved at base: principal bracts of involucre bearing a spreading slender spine of about their own length, which is pectinately spinulose towards its base ; innermost with simply spinescent tip; outermost usually with the central spine reduced and the spinules palmate: corollas yeilow: pappus of very unequal rigid bristles or squamellæ: akene lightly costate. - Sibth. Flora Græca, t. 909 ; Reichenb. Ic. Fl. Germ. xv. t. 796 ; Gray, Bot. Calif. l. c. - Fields, California and Arizona, rather common. (Nat. from Eu.)

+ + Bracts of the involucre unarmed, most of them terminated by a scarious discolored fimbriate-ciliate or lacerate appendage. - Jacea, Platylophus, Cyanus, \&c., Cass.

+ Perennials, with rose-purple flowers: pappus obsolete.

C. Nigra, L. (KNapweed, Hardieads.) A foot or two high, branching, roughish-pubescent: leaves lanceolate and entire, or lower sparingly toothed: most of the involucral bracts with strongly pectinately ciliate-fringed blackish appendages, these only conspicnous : flowers all hermaphrodite, marginal ones not enlarged or rarely so. - Fl. Dan. t. 606; Engl. Bot. t. 278. — Fields, Newfoundland to E. New England. (Nat. from Eu.) 
C. JACEA, L. Heads usually larger: brownish appendages of the involncral bracts merely lacerate : marginal flowers neutral and with enlarged palmate corollas, forming conspicuous false rays: otherwise like the preceling. - Fl. Dan. t. 519; Reichenb. Ic. Fl. Germ. xv. t. 754, 755. - Charlotte, Vermont, Pringle. Near New York, \&c., as a ballast-weed. (Nat. from Eu.)

+ + Annual, with blue flowers, varying to white or purple: pappus of unequal bristles about the length of the akene.

C. Cfands, L. (Buuebottle.) Slender, branching, a foot or two high, whitened when young with floccose wool: leaves linear, entire, or lower toothed, sometimes pinnatifid: heads naked on slender peduncles: involucral bracts rather narrow, fringed with short scarious teeth: marginal flowers neutral, with much enlarged radiatiform corollas. - Engl. Bot. t. 277; Reichenb. 1. c. t. 768. - Escaped from gardens sparingly in the Atlantic States. (Nat. from. Eu.)

* * American species: heads large: scar or insertion of akene obliquely basal: bracts of involucre unarmed, the appendage conspicuously pectinate-fimbriate: anther-appendages distinct. Plectocephalus, Don.

C. Americána, Nurt. Annual, nearly glabrous : stem stout, commonly simple, 2 to 6 feet high, striate-sulcate, thickened under the naked head: leaves entire or mostly so, oblonglanceolate, mucronate: involucre inch or inch and a half in diameter; its very numerous bracts all with conspicuously fringed scarious appendages: flowers rose-color or flesh-color; the hermaphrodite ones forming a disk of 1 to 3 inches in diameter; the nentral marginal ones (with their very narrow lobes an inch long) forming an ample ray: style filiform, entire to the minutely 2-dentate stigmatic tip: pappus of copious similar but unequal bristles longer than the akene. - Jour. Acad. Philad. ii. 117; Barton, Fl. Am.-Sept. t. 50; Reichenb. Ic. Exot. t. 132 ; Fl. Serres, iv. t. 327 ; Meehan, Nat. Flowers, ser. 2, ii, t. 17. C. Nuttallii, Spreng. Syst. iv. 298. C. Mexicana \& C. Americana, DC. Prodr. vi. 575. Plectocephalus Americanus, Don, Brit. Fl. Gard. ser. 2, t. 51. - Plains of Arkansas and Louisiana to Arizona; first coll. by Nuttall. (Adj. Mex.)

Tribe X. MUTISIACEA, p. 82.

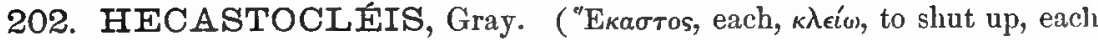
flower in an involucre of its own). - Proc. Am. Acad. xvii. 220. - Single species.

H. Shockléyi, Grat, l.c. Low and glabrous shrub, with rigid branches, and rigid leaves of two sorts; cauline small, linear-lanceolate or subulate, cuspidate-tipped, and on the sides usually a few spiniform teeth, also fascicled on axillary spurs; floral ones 3 or 4 in a whorl or cluster, larger (half-inch or more long) and oval or ovate, papyraceous, reticulated, margined with sparse slender prickles, forming a loose external involucre around a fascicle of few or sereral sessile heads (these about 5 lines long and fusiform) : flower apparently dull white. - Esmeralda C.o., W. Nevada, in an arid desert region, W. S. Shockley. By the style and habit evidently Mutisiaceous rather than Cynaroideous.

203. GOCHNÁTIA, HBK. (F. C. Gochnat, of Strasburg.) - American shrubby plants; with coriaceous leaves usually entire and tomentose beneath, and white or whitish flowers. - Nov. Gen. \& Spec. iv. 19, t. 309. Gochnatia \& Moquinia (at least in part), DC.; Benth. \& Hook. Gen. ii. 490.

G. hypoleúca, Gray. Rigid shrub, 6 to 8 feet high : leaves oblong or oval, very shortpetioled, commonly inch or more long, glabrous and bright green above, finely, whitetomentose beneath (like an Olive-leaf) as also the brauchlets: heads in sessile somewhat thyrsoid-paniculate fascicles, half-inch or less long: involucre cylindraceous, 5-7-flowered: bracts ovate and oblong, outermost very short: flowers white, all hermaphrodite! - Proc. Am. Acad, xix. 57. Moquinia hypoleuca, DC. Prodr. vii. 23. - Southern Texas, between the Rio Frio and the Nueces, Palmer. (Adj. Mex.; first coll. by Berlandier.) 
204. CHAPTÁLIA, Vent. (J.A. C. Chaptal, an eminent chemist.) Perennial herbs (all American), chiefly stemless, low, and floccose-tomentose; with leaves in a radical tuft, persistently canescent beneath, glabrate above; scapes naked; heads at first nodding; flowers white or purplish, or the rays rose-purple: fl. spring and summer.

$\S 1$. Akenes of female flowers merely attenuate into a neck; those of hermaphrodite flowers all abortive: scapes elongated. - Chaptalia, DC.

C. tomentósa, VENT. Leaves spatulate or oblanceolate, thickish, entire or retrorsely denticulate, white beneath with dense matted tomentum: scapes a span to a foot high: rays broadly linear, commonly purple: akenes glabrous. - Hort. Cels. t. 61 ; Pursh, Fl. ii. 577 ; Sims, Bot. Mag. t. 2257 ; DC. Prodr. vii. 41 ; Torr. \& Gray, Fl. ii. 464. Perdicium semiflosculare, Walt. Car. 204. Tussilago integrifolia, Michx. F1. ii. 121. Gerbera Walteri, Schultz Bip. in Seem. Bot. Herald, 313, - Moist pine barrens, N. Carolina to Florida and E. Texas.

$\S 2$. Akenes of all the flowers fertile, and with slender usually filiform beak: corollas of hermaphrodite flowers sometimes hardly bilabiate, of innermost female flowers somewhat so: scapes elongated. - Leria, DC.

C. nútans, Hemsi. Leaves obovate or oblong, sometimes lyrate-sinuate, thin, beneath white with more cottony or even arachnoid and partly deciduous tomentum: scapes a foot or two high : rays small and narrow, little exserted: akenes pubescent or glabrate, the beak as long as the body.- - Bot. Biol. Centr.-Amer. ii. 255. Tussilago nutans, L. Amœn. Acad. v. 406 (Plum. ed. Burm. t. 41, f. 1). Leria lyrata, Cass. Dict. xxvi. 102. L. nutans, DC. Ann. Mus. Par. xix. 68, \& Prodr. 1. c. 42. Gerbera nutans, Schultz Bip. 1. c.-Wooded grounds, Texas to New Mexico and Arizona. (Mex., W. Ind., S. Am.)

205. PERÉIA, Lag. (Lorenzo Perez, of Toledo, pharmacist and writer on materia medica in the sixteenth century.) - Perennial herbs, all American (Texan, Californian, and southward, chiefly along the Andes), not lanate, except at the base of the stem, mostly with reticulated leaves, often setulose-ciliate or spinulose; heads solitary or cymose or paniculate; the corollas rose-purple to white, rarely blue, never yellow. - Amœn. Nat. i. 31 ; Gray, Pl. Fendl. 110, \& Pl. Wright. i. 126; Benth. \& Hook. Gen. ii. 500. Perezia, Clarionea (Lag. ined.), Homoianthus, Dumeritia (Less., not Lag., nor DC. Ann. Mus.), Proustia § Thelecarpaca, \& Acourtia (Don), DC. Prodr., \&c. Drosia, Cass. - § Euperezra (Perezia, Lag. 1. c., Clarionea \& Homoianthus, DC.), of S. American species, is distinguished by radiate heads, the corollas of marginal flowers having elongated and conspicuously liguliform outer lip, the two lobes of the inner much shorter and smaller.

$\S$ Acoúrtia, Gray, Proc. Am. Acad. xix. 58, has flowers nearly or quite homomorphous, the marginal corollas with 3-toothed outer lip hardly ever longer than the two lobes of the inner: flowers commonly fragrant: involucre usually naked at base: leaves coriaceous or papyraceous, reticulated: usually a tuft of wool at base of the stem. - Acourtia, Don in Trans. Linn. Soc. xvi. 203 ; DC. Prodr. vii. 6ō. Perezia, Llav. \& Lex.; Less.; DC. 1. c. 62. Dumerilia, Less. \& DC. 1. c. 66, not Lag., nor Cass. Of few Chilian, numerous Mexican, and the following Texano-Californian species.

* A span or two high: heads (half-inch to inch long) single or few, 20-30-flowered : flowers purple.

P. runcináta, LAG. Acaulescent, scabrous-puberulent or glabrate: rootstoclis apparently

short, sending down tuberous-thickened fascicled roots: radical leaves runcinate-pinnatifid, 
4 to 8 inches long, thin-papyraceous; lobes rounded, copiously fringed with spinulose teeth, margined-petioled : scapes naked, equalling the leaves, bearing solitary or a few pedunculate heads: bracts of the involucre rather few in three series, lanceolate, setaceous-acuminate: pappus rather sordid. - Lag. in herb. ex Don; Gray, Pl. Fendl. 110, Pl. Wright. 1. c. Clarionea runcinata, Don in Trans. Linn. Soc. xvi. 207 ; DC. 1. c. - Dry ground, E. \& S. Texas, Wright, Hall, \&c. (Adj. Mex.)

P. nána, GraY. Leafy-stemmed, glabrous : rootstocks slender, creeping : first leaves small and scale-like; principal cauline leaves firm-chartaceous, orbiculate, dilated-obovate, or ovate (inch or two long), coarsely spinulose-dentate, sessile or partly clasping the slender stem : heads mostly sessile, solitary and terminal : bracts of involucre 3 or 4 series, thinnish, acutish; the short outer ones ovate, innermost lanceolate, mucronulate: pappus white. Pl. Fendl. 111. - Dry plains and rocky bluffs, S. W. Texas to Arizona, Wright, Palmer, \&c. (Mex., first coll. by Gregg.)

* Taller, 1 to 3 feet high, branching, especially abore, leafy up to the corymbiform polycephalous inflorescence: leaves closely sessile by sagittate-cordate or sometimes truncate base, densely and spinulosely denticulate: heads 5-15-flowered, narrow, half-inch or less long, subsessile and fasciculate-crowded or short-pedicelled, quite naked at base: involucral bracts thinnish, not very many, in only three series: flowers rose-purple and sounetimes white in the same species: pappus white, soft.

+ Involucre 8-15-flowered; its bracts not attenuate-acuminate.

P. Wríghtii, Gray. Glabrous throughout, or obscurely puberulent, but smooth: leaves thin, oblong to nearly ovate (larger 4, smaller I or 2 inches long), often unequally or doubly dentate: heads 8-12-flowered: involucral bracts all pointless and obtuse, or the narrow innermost barely acutish: corollas pale rose to whitish. - Pl. Wright. i. 127, ii. 102; \& Proc. Am. Acad. xix. 60. P. Arizonica, Gray, Bot. Calif. i. 422, a form of drier districts, rather more rigid, the involucral bracts all rounded-obtuse. P. Coulteri, Gray, Proc. Am. Acad. xv. 40, as to pl. Parry \& Palmer, no. 234. - Rocky hills and ravines, S. W. Texas to S. Arizona; first coll. by Coulter, then by Wright. (Mex., Schaffner, Parry \& Palmer.)

P. microcéphala, Grar. Scabro-puberulent and minutely resinous-glandular: leaves more chartaceous, oblong, commonly obtuse, finely and closely denticulate $\cdot$ heads 10-15flowered, larger than in preceding (over half-inch long when well leveloped) : involucral bracts scaberulous on the back, abruptly acute or mucronate-acuminate: corollas rose-color. - Pl. Wright. i. 127, \& Bot. Calif. i. 422. Acourtia microcephala, DC. Prodr. vii. 66. - California, on hills back of Monterey? (Douglas), Santa Barbara, and San Diego.

+ + Inrolucre 5-6 flowered; bracts attencate-acuminate: fully developed heads half-inch long.

P. Thúrberi, Gray. Scabro-puberulent, viscidulous-glandular: leaves firm-chartaceous, oblong-ovate, deuticulate and partly doubly dentate (larger 5 to 8 inches long): involucral bracts lanceolate, gradually tapering to a very acute point, scaberulous extermally: corollas sometimes deep rose-color, sometimes white. - PI. Thurb. in Mem. Am. Acad. v. 324, \& Proc. Am. Acad. xix. 59.-S. Arizona, on rocky hills, Thurber, Lemmon.

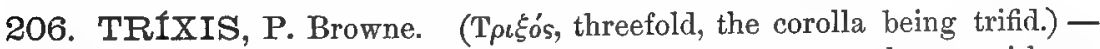
American, chiefly subtropical, fruticose or perennial herbaceous plants ; with entire or merely denticulate leaves, and paniculately or corymbosely cymose heads, of moderate size; the corollas yellow or sometimes whitish. - Hist. Jam. 312; Lag. Amœn. Nat. i. 35. Perdicium, L., in part.

T. angustifólia, DC. Suffruticose, fastígiately or corymbosely much branched, a foot or two high, sericeous-puberulent, from subcanescent to glabrate, somewhat resinous-atomiferous, leafy up to the heads: leares sessile, rather rigid, from broadly to very narrowly lanceolate, entire or denticulate with sparse mucroniform teeth (2 or 3 inches long): heads simply fascicled or singly terminating leafy branchlets, half-inch and more long, 9-12-flowered, subtended by a few lanceolate or linear bracteiform leaves which do not exceed the 8 or 10 linear-lanceolate and equal proper bracts of the involucre; these in age gibhous and indurated at base: receptacle copiously villous: corollas golden yellow; outer lip of the marginal ones quarter-inch long: pappus barely fulvous. - Prodr. vii. 69 ; Gray, Pl. Wright. i. 128, ii. 102. T. frutescens, Gray, Bot. Mex. Bound. 103, vars. T. Californica, Kellogg 
in Proc. Calif. Acad. ii. 182, fig. 53, with some seeming monstrosities. T. corymbosa, Gray in Coll. Pringle, \&c.; but that species should have petiolate leaves and loosely corymbose heads. - Hills and cañons, S. W. Texas to Arizona, Wright, \&c. Founded on Mexicau specimens with narrow leaves revolute when dry. (Mex.)

Var. latiúscula. Leaves lanceolate, plane, commonly glabrate and greener, from 4 to nearly 12 lines wide, thence varying into the narrow-leaved form. - Gray, Pl. Wright. ii. 102. T. suffruticosa, Wats. Bot. Calif. ii. 459. - Cañons, S. New Mexico to San Diego Co., California, Wright, Palmer, Greene, Lemmon, \&c.

T. FRUtéscens, P. Browne, which the broad-leaved forms of the preceding species nearly approach, was collected by Berlandier near Matamoras, but has not yet come from Texas.

\section{TRIBE XI. CICHORIACEA, p. 83.}

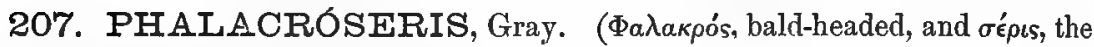
Greek name of some kind of Cichoriaceous plant). - Proc. Am. Acad. vii. 364; Bot. Calif. i. 423. — Single species.

P. Bolánderi, Gray, 1. c. Glabrous and acaulescent perennial, with thickish root : leaves lanceolate, entire, clustered on the caudex, slightly succulent: scape perfectly naked, a span to a foot high: solitary head half-inch high: flowers deep yellow, in summer. - California, in wet mountain meadows of the higher Sierra Nevada, Mariposa Co.; first coll. by Torrey and by Bolander.

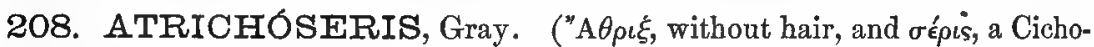
riaceous plant.) - Malacothrix § Anathrix, Gray, Proc. Am. Acad. ix. 213, \& Bot. Calif, i. 435. - Single species.

A. platyphylla. Winter annual, wholly glabrous, somewhat glaucous: leaves all or chiefly in a rosulate radical tuft, broadly cuneate or obovate, mostly rounded at summit, sessile, spinulose-denticulate, somewhat veiny (inch or two long); those of stem reduced to very small scattered bracts : stem slender, a foot or two high, at summit deliquescent into a diffuse cymose panicle of few or numerous slender-pedunculate heads: involucre quarterinch high, about half the length of the corollas (these white or with purple base): akenes 2 lines long, at maturity nearly equalling the narrow and open bracts of the involucre, white, sometimes with 4 or 5 very thick corky ribs and much smaller alternate ones, sometimes more terete and obscurely costate, the truncate summit wholly destitute of the border of Malacothrix, its areola sinall: receptacle rather fleshy, scrobiculate. - Malacothrix? platyphylla, Gray, 1. c. - Gravelly deserts of the Mohave, S. W. California, to the southern borders of Utah, Cooper, Palmer, Parry, Parish.

209. LÁMPSANA, Tourn. (Ancient Greek name, of obscure deriva-

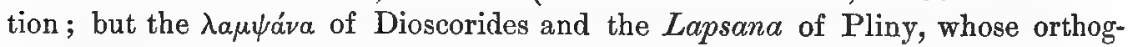
raphy was followed by Linnæus, were Cruciferous plants.) - Yellow-flowered and leafy-stemmed branching annuals of the Old World, one sparingly naturalized: fl. summer.

L. COMMÚNis, L. (NipPlewort.) A foot or two high, hirsutely pubescent or glabrate: leaves ovate, repand-dentate, or lower lyrate and uppermost oblong : heads loosely paniculate: involucre 2 or 3 lines high. - Roadsicles, in a few places, Peun. to New England, more abundant in Canada, also on the Columbia River. (Nat. rom Eu.)

210. APOGON, E11. ('A $\dot{\omega}^{\prime} \gamma \omega \nu$, beardless, i. e. no pappus.) - Low annuals of the Southern Atlantic States, glaucescent, mostly glabrous, a span to a foot high, branching from the base, bearing scattered rather small heads on slender peduncles: flowers yellow, in spring and early summer. Leaves variable, lanceolate or lower oblong, from entire or repand to dentate, or radical lyrate-pin- 
natifid, uppermost closely sessile, often seemingly opposite.-Sk. ii. 267 ; DC. Prodr. vii. 78 ; Torr. \& Gray, Fl. ii. 466.

A. húmilis, ELL. 1. c. Peduncles naked, or rarely with some obscure glandular-bristly hairs under the head: this in fruit only 2 lines high: corollas pure yellow, little longer than involucre: akenes oblong-obovate. - DC. 1. c.; Torr. \& Gray, 1. c., in part. A. lyratum, Nutt. Jour. Acad. Philad. vii. 71, \& Trans. Am. Phil. Soc. n. ser. vii. 424. Serinia caspitosa, Raf. Fl. Ludov. 149, cited in DC. 1. c. 261, should be either this or the next. - Open ground, S. Carolina to Texas and Arkansas.

A. grácilis, DC. 1. c. Sometimes slender and strict, not rarely more robust than the preceding, often some bristly hairs on the stem and lower lenves : peduncles usually glandularhispid some way below the head; this commonly 3 lines high in fruit: corollas orange, conspicuously exserted, twice the length of the involucre : akenes rather thicker and obtuser at apex, sometimes an obseure vestige of pappus! - A. humilis, Nutt. Trans. Am. Phil. Soc. l. c., not Ell. - Rocky prairies, \&c., 'Texas; first coll. in a very slender form by Berlandier. Grows with the preceding, keeping distinct.

A. Wríghtii. Resembling slender and narrow-leaved form of the preceding (such as Berlandier's original specimens) : rather diffuse : heads equally small: akenes larger and thicker (over half-line long), little contracted at either end, and with comparatively large areola (yet less than the full breadth of the akene), this bordered by obscure vestige of pappus. Possibly a hybrid between $A$. gracilis and Krigia occidentalis. - E. Texas, Wright, in fruit.

211. KRfGIA, Schreb. (David Krig, or Krieg, an early collector in Maryland and Delaware.) - Low herbs of Atlantic U. S., glabrous or somewhat hispidulous; with small or middle-sized heuds of yellow flowers, terminating slender naked peduncles or scapes; these not rarely glandular-hispidulous at summit: fl. in spring or summer. - Gen. Pl. 532, Benth. \& IIook. Gen. ii. 507. Krigia \& Cynthia, Don; Torr. \& Gray, Fl. ii. 467, 468.

§ 1. Cŕmbia, Torr. \& Graj, l. c. Acaulescent annuals: bracts of the involncre 5 to 8 , oblong-lanceolate, in fruit becoming broader and firmer, erect and navicular-carinate, with a conspicuous midnerve, or sometimes 2-3-nerved: akenes turbinate, mostly 5 -paleaceous and 5-aristate.

$\mathrm{K}$. occidentális, Nгтт. Scapes a span or more high, commonly glandular-lispidulous, at least toward the summit: leaves obovate to lanceolate, entire, lyrately lobed or pinnatifid: heads 2 or 3 lines high: akenes transversely rugulose: palex of the pappus conspicuous, ronnded-obovate; bristles or rather awns alternating with these and over the stronger angles of the akene sometimes equalling it in length, sometimes not surpassing the palex, sometimes (var. mutica, Torr. \& Gray) obsolete or wanting. - Jour. Acad. Philad. vii.,104, \& Trans. Am. Phil. Soc. vii. 427; Torr. \& Gray, Fl. ii. 468 . K. nervosa, Hook. Ic. Pl. iii. t. 227, \& $K$. bellioides, Scheele in Linn. xxv. 257 , normal form, with pappus-awns double the length of the paleæ. - Prairies of Arkansas and Texas; first coll. by Nuttall.

§2. Eukrígia, Torr. \& Gray, 1. c. Acaulescent and subcaulescent winter annual; bracts of the involucre 9 to 18 , thin, remaining narrow and nearly nerveless, reflexed after the fall of the narrowly turbinate somewhat 5-angular akenes: pappus of 5 to 7 (commonly 5) roundish short paleæ. and of as many alternating nearly capillary long bristles. - Krigia, Schreb., \&c.

K. "Virgínica, WrLLD. Varying much in size; often sparsely hispidulous: scapes 2 or 3 inches or at length a foot or more high, slender, not rarely caulescent below: leaves from spatulate-obovate to lanceolate or linear, from few-toothed or entire to pinnately parted: heads 3 or 4 lines high: pappus-bristles fully twice the length of the akenc. - Spec. iii. 1618. K. Virginica, dichotoma, \& Caroliniana, Nutt. Gen. ii. 127. K. leptophylla, DC. Prodr. vii. 88, slender form. Hyoseris Virginica, L. Spec. ii. 809; Lam. Jour. Hist. Nat. i. 22, t. 12; Walt. Car. 193; Michx. Fl. ii. 88. Hyoseris Caroliniana, Walt. 1. c.? Sandy ground, Canada to Florida and Texas: fl. from spring to autumn. 
§ 3. Crnthia. Caulescent or acaulescent perennials, glaucescent, comparatively large-flowered: involucre of the preceding section: akenes less turbinate, of 10 to 15 smaller and more squamellate oblong palex and 15 or 20 slender capillary bristles. - Cynthia, Don in Edinb. Phil. Jour. xii. 305 ; DC. Prodr. vii. 89 ; Torr. \& Gray, 1. c. Adopogon, Neck. Elem. i. 55.

K. Dandélion, Nutr. Scapigerous, or at length leafy-stemmed only next the ground: crown bearing uval or globose tubers on filiform stolons: leaves lanceolate or almost linear, from denticulate to laciniate-lobed or pinnatifid: scapes 6 to 18 inches high, naked: head about half-inch high. - Gen. ii. 127 ; Ell. Sk. ii. 267. Tragopogon Dandelium, L. Spec. ed. 2, ii. 111. Hyoseris major, Walt. Car. 194. H. angustifolia, Michx. Fl. ii. 87. Troximon Dandelion, Pers. Syn. ii. 360. Cynthe Dandelion \& C. Boscii, DC. Prodr. vii. 89. C. lyrata, Nutt. Joux. Acad. Philaci. vii. 69. K'́rigia Caroliniana, Hook. Comp. Bot. Mag. i. 100, a slender form. - Moist ground, Maryland to Florida, Arkansas, and Texas.

K. montána, Nutr. 1. c. Caulescent or subcaulescent from short cespitose rootstocks, not tuberiferous: peduncles simple and naked, a span to a foot long: leaves from oblong to linear, from entire to pinnatificl, thickish : head smaller than of the preceding. - Hyoseris montana, Michx. Fl. ii. 87. Cynthia Dandelion, var. $\gamma$, Torr. \& Gray, Fl. ii. 469. C. Dandelion, Meehan, Nat. Flowers, ser. 2, ii. t 35. - Crevices of rocks, Alleghany Mountains (Blue Rilge), N. and S. Carolina, and Georgia; first coll. by Michaux.

K. amplexicaúlis, Nutr. 1. c. Caulescent, not tuberiferous, glaucous: stem a foot or two high, 1-3-leaved, bearing one or two or few somewhat umbellate heads on moderately long peduncles: leaves obloug or oval, obtuse, entire, repancl and denticulate, or radical somewhat lyrately lobed; these contracted into winged petioles; cauline partly clasping by a broad base: heads a third of an inch high. - Trayopogon Virginicum, L. Spec. ii. 789. Hyoseris amplexicaulis, Michx. Fl. ii. 87. H. bifora, Walt. Car. 194? H. prenanthoides, Willd. Spec. iii. 1618. Cynthia Virginica, Don, 1. c.; Torr. \& Gray, 1 c. C. amplexicaulis, Beck, Bot. 168; Darl. Fl. Cestr. 441. C. Griffilhii, Nutt. Jour. Acad, Philad. vii. 69, with lower leaves runcinate-lyrate. Luthera Virginica, Schultz Bip. in Linn. X. 257. - Moist banks, New York to Minnesota and Colorado, south to Georgia.

212. CICHÓRIUM, Tourn. Succory, Chiccory, Endive. (Arabic name Latinized.) - Old World herbs, fl. summer.

C. Intries, L. (Chiccorr) Deep-rooted perennial, more or less hirsute, at least below, with rigid stout branches: radical leaves runcinate; cauline oblong or lanceolate, commonly dentate: those of flowering branches mostly reduced and scale-like, subtending solitary or clustered sessile heads, or some heads raisel on a fistulous peduncle : flowers showy, matutinal, closing by midlay, sky-blue, varying occasionally to purple or white - Roadsides, common in E. New England, and in a few places westward. (Nat. from Eu.)

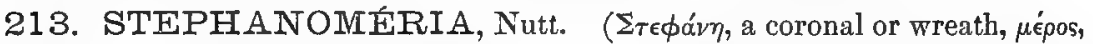
a division; no particular application.) - W. N. American peremnials or annuals, mostly smooth and glabrous; with branching or rarely virgate and often rigid or rush-like stems, small or merely scale-like leaves on the flowering branches, and usually paniculate small or middle-sized heads of rose-colored or flesh-colored flowers, open only in early morning. - Trans. Am. Phil. Soc. vii. 427 ; Torr. \& Gray, Fl. ii. 722 ; Benth. \& Hook. Gen. ii. 533 (excl. Rafinesquia); Gray, Bot. Calif. i. 427. Jamesia, Nees in Pl. Neuwied Trav. 16, not Torr. \& Gray.

$\S 1$. Altóseris, Gray. Heads large for the genus, about 12-flowered: involucre somewhat imbricated, the outer bracts being of 2 or 3 lengths : receptacle alveolate, and the short alveoli fimbriolate-hirsute: pappus-bristles 12-20, shortplumose for their whole length, sordid or almost fuscous. - Proc. Am. Acad. vi. 552, Bot. Calif. 1. c., \& Proc. Am. Acad. xix. 60. 
S. cichoriácea, Grar. 1. c. Perennial, 1 to 4 feet high, comparatively stout, when young sometimes tomentulose leaves resembling those of Chiccory, lanceolate, sparsely denticulate to runcinate-laciniate: involucre half-inch high: heads sessile along naked branclies: mature akenes short-linear, smooth, lightly and acutely 5-angled. - Rocky hills and cañons through the southern portious of California, Dr. Horn, Parish, Pringle.

§2. Stephanoneria proper. Heads 3-20-flowered : receptacle quite naked : involucre slightly imbricated by having one or two intermediate bracts, especially in the earher species, or only calyculate at base: pappus setose and plumose thronghout or only above the middle, the lower part of the bristle either slender to base opr sometimes paleaceous-dilated. — Gray, l. c. 61.

* Heads fully half-inch high, 10-20-flowered, somewhat corymbosely disposed,

+ Terminating leafy stems and branches: pappus sordid or grayish, of 10 or 12 rather long-rlumose bristles: akenes smooth and even, with slender ribs or angles: plants a span to a foot high from perennial roots; involucre obscurely imbricated, 10-12-flowered.

S. Párryi, Grar. Rather stout, willely branched from the base: leaves thickish, deeply runciuately pimatifid; those of the flowering branchlets rather numerous up to the head, small, somewhat spinulose-lobed: pappus-bristles rather stout, naked (and often united in twos or threes) at base. - Proc. Am. Acall xix. 61. - Arid clistricts, near St. George, S. Utah, Parry. Borders of the Mohave Desert, S. E. California, Palmer, Pringle.

S. lactucína, Grix. Rather slender, with erect branches, leafy up to the nearly naked peduncles : leaves linear or narrowly lanceolate, entire or with a few salient teeth: pappusbristles slender and plumose to the base.-Iroc. Am. Acad. vi. 552; Bot. Calif. 1. c. Woods of the Sierra Nevada, California, from Mariposa Co. to Shasta, Newberry, Brezcer, Bolander, \&c.

$$
\text { + + Heads naked-paniculate: pappus bright white: involucre merely calyculate. }
$$

S. Phúrberi, Gray. Simple-stemmed from a probably biennial root, a foot or two high: leaves mainly at and near the base, runcinate-pinnatifid, inch or two long; those of the naked stem and few corymbosely-paniculate branches reduced to lincar-subulate or inconspicuous bracts: heads rather few: involucre narrow, 16-20-flowered. bristles of the pappus 20 to 30 , soft and slender, very plumose to base. - Pl. Thurb. in Mem. Am. Acad. v. 325, \& Bot. Mex. Bound. 105. - New Mexico and adjacent Arizona, Thurber, Bigelow, IIenr!, Greene, \&c.

S. elÁtA, Nutt. Pl. Gamb. 173, - said to be probably perennial and blue-flowered, simplestemmed, 3 or 4 feet high, with very narrow linear leaves, about 10-flowered heads, involucre (6-8-phyllous) and branches sprinkled with resinous dats, and plumose white pappus, coll. at Santa Barbara, California, - remains quite obscure.

* * Heads quarter to third inch high, or sometimes higher, narrow, mostly 5-flowered (flowers from 3 to 6 , ocensionally 8 or 9 ), and with about the same number of involucral bracts: mature akenes either smooth and even between the ribs, or rugose, or tubercular-thickened, sometimes in the same species. $-J$ cmesia, Nees, 1 . c.

* Perennials, paniculately or fastigiately branched from thick and tortuous roots or a lignescent base, with striate and rush-like branches, small-leaved or nearly leafless above: pappus-bristles not at all squamellate-appendaged or dilated at base.

S. runcináta, Nutr. Comparatively stout and rigid, a foot or two high, with spreading branches: heads mostly 4 or 5 lines high aud scattered along the branches: lower leaves runcinate-pinnatifid, commonly lanceolate; upper linear or reduced to scales: pappus dull white, plumose only to near the base.-Torr. \& Gray, F1. ii. 472 ; Gray, P1. Fendl. 112. S. runcinata \& S. heterophylla, Nutt. Trans. Am. Pliil. Soc. l. c., at least in part and by char, but poor specimens, seemingly confused with next. Prenarthes runcinata, James in Long Exped. P.? pauciflora, Torr. Ann. Lyc. T. Y. ii. 210.-Plains, Nebraska to Wyoming, N. W. Texas, Arizona, and S. California ; first coll. by James.

S. minor, Nutr. 1. u. More slender and with ascending branches bearing usually terminal and smaller heads: canline leaves all-slender, often filiform: pappus white, very plumose down to base. - Torr. \& Gray, 1. c. Prenanthes? tenuifolia, Torr. l. c. Lygodesmia minor, Hook. Fl. i. 205, t. 103 A. Janesia pauciflora, Nees in Nenwied Trav. 516 (16).-Plains and mountains, from borders of Brit. America to those of Texas, Arizona, the Sierra Nevaria 
in California, and Washington Terr. Generally of more northern range than the foregoing, not throughout distinguishable, perhaps has been rightly combined with it.

S. myrióclada, EATON. Very slender stems and tortuous filiform branches very numerous and fastigiately crowded in an erect tuft, a foot or two high, terminated by scattered small heads: leaves linear and very small: involucre 2 and 3 lines long (of 4 or 5 as well as " 3 " narrow bracts) and 3-5-flowered : akenes pluristriate at maturity : pappus white, its bristles naked or merely hirsute below the middle or at the base. - Bot. King Exp. 198, t. 20. - Dry rocky ridges, Thousand Spring and Goose Creek Valleys, Nevada, Watson. Hawthorne, Nevada, M. E. Jones.

++ Biennial, or probably perennial with long and slender subterranean shoots: pappus bright white; the bristles long-plumose to base, which is not at all paleaceous-dilated.

S. Wríghtii, GraY. A foot or two high, slender, with single corymbosely paniculate stems: cauline leaves mostly filiform and entire; those of the radical tuft linear to spatulate and laciniate-pinnatifid : heads nearly half-inch long, 5 -flowered, sparse, pedunculate, terminating slender branches: akenes smooth on the salient ribs and narrow intervals, contracted at summit: pappus long-plumose. - Proc. Am. Acad. xix. 60. S. runcinata, var., Gray, Pl. Wright. ii. 103, no. 1301. - W. Texas, in pebbly bed of Howard's Creek, Wright (without the elongated root or shoot), and adjacent New Mexico, Bigelow. Apparently same from N. A rizona, Rusby, seemingly perennial from long and filiform subterranean shoots.

+++ Annual, strictly erect: pappus white ; the brisiles plumose to base, not paleaceous-dilated.

S. virgáta, Benth. Stem rigid, 1 to 4 feet high : heads 3 or 4 lines long, mostly subsessile or short-peduncled, spicately or thyrsoidly disposed along the naked upper part of virgate stem or similar branches, but sometimes more loosely paniculate on open branchlets: upper leaves linear, small and entire; lower oblong or spatulate, ofteu sinuate or pinnatifid: involucre 4-8-flowered, originally described as "8-10-flowered": akenes subclavate or oblong, rugose-tuberculate between the narrow ribs: pappus moderately plumose. - Bot. Sulph. 32 ; Gray, Proc. Am. Acad. l. c. S. paniculata, chiefly, Eaton, Bot. King Exp. 198, t. 20, f. 5 ; Gray, Bot. Calif. i: 428. Possibly (from habitat not improbably) S. elata, Nutt. Pl. Gamb. 173; but flowers not blue, and no resinous dots on involucre and branchlets. California, common from San Bernardino and San Diego Co., to Oregon, east to Nevada and Utah.

++++ Annual, strictly erect: pappus grayish or fuscous; its bristles short-plumose nearly or quite to the more or less paleaceous or squamelliferous base.

S. paniculáta, Nutr. Stem erect from an annual root, a foot or two high, bearing numerous narrow 3-5-flowered hearls in an elongated narrow or more open panjcle, or else more strictly disposed on virgate branches: leaves linear or the lower lanceolate: akenes nearly of the preceding: pappus decidedly different. - Trans. Am. Phil. Soc. vii. 428; Torr. \& Gray, Fl. ii. 473. - Plains of Idaho, and probably Northern Nevada, to E. Oregon, Nuttall, IIall, Cusick, \&c.

+++++ Annuals or biennials: bristles of the white or whitish pappus plumose above but naked below the middle, at base more or less dilated or abruptly paleaceous, or else with one or two adnate squamellæ or bristly teeth at or near insertion: akenes thick-ribbed and tuberculate-rugose at maturity: stems paniculately and often divergently branched, bearing scattered squamulose-peduncled heads. - \$ Hemiptrlium, Gray, Bot. Calif., in part only.

S. exígua, NurT. A foot or two high, with slender branches and branchlets, but stem not rarely robust (therefore ill named from depauperate specimens): radical and lower cauline leaves pinnatifid or bipinnatifid, those of the branches mainly reduced to short scales: involucre 3 to 5 lines long, with commonly 5 flowers, " 3 or 4 " when depauperate, rarely 6 or 8 in strong plants: bristles of the pappus 9 to 18 , their more or less dilated and paleaceous or thickened bases commonly a little comnate in 4 or 5 phalanges and often 1-2-setulose on each side. - Trans. Am. Phil. Soc. 1. c. 428; Torr. \& Gray, Fl. ii. 473 (attenuated form); Eaton, Bot. King Exp. 198, t. 20, f. 6, 7; Gray, Bot. Calif. i. 428. Hemiptilium Bigelovii, Gray, Bot. Mex. Bound. 105, a stout form. - Interior of Wyoming to the Upper Rio Grande on the border of Texas, west to Nevada and E. California.

S. pentachærta, Eaton. A span or two or even 2 or 3 feet high, like the preceding, or divaricately branched from the base: pappus of 5 or sometimes 7 bristles, all distinct to the base, which is little dilated, plumose only above the middle. - Bot. King Exp. 199, t. 20, 
f. 8-10; Gray, Proc. Ant. Acad. xix. 63. - Desert region, W. Nevada, Watson, Shockley. Edge of desert at San Felipe, San Diego Co., California, Parish.

§ 3. Hemiptílium, Gray, 1. c., xix. 63. Heads 5-flowered, small : receptacle naked : involucre merely calyculate: pappus of 4 to 6 narrow and rigid paleæ (rather than awns), not longer than the akene, sparsely short-plumose toward the summit, fuscous. - Hemiptilium, Gray, Bot. Mex. Bound. 105, excl. spec.

S. Schóttii, Grar. Probably annual, with habit of S. paniculata or S. exiqua, slender: loosely paniculate, 3 lines long: involucre of 4 or 5 thinnish bracts and 2 or 3 small calyculate ones: ligules barely 3 lines long: akenes less than 2 lines long, rather narrow, 4-5augled, tapering very slightly from truncate summit to base, minutely scabrous between the smooth angles. - Bot. Calif. i. 427. - Hemiptilium Schottii, Gray, Bot. Mex. Bound. 1. c. Arizona, on the Gila River, Schott. Not since collected.

214. CHATADELPHA, Gray. (Xait $\eta$, bristles, and ả $\delta \in \lambda \phi \dot{\eta}$, sister, the bristles or awns of pappus as it were 5-adelphous.) - Proc. Am. Acad. ix. 218; Rothrock in Wheeler Rep. 182, t. 15. - Single species.

C. Wheéleri, GKAY, 1. c. Much branched from a perennial root, flexuous and fastigiate, with aspect of Stephanomeria, or more of Lygodesmia, a foot or two ligh : leaves narrowly linear, entire, uppermost reduced to subulate scales: heads solitary terminating the branchlets: involucre half-inch and more high, somewhat exceeded by the pappus. - W. Nevada, on the borders of Arizona, Wheeler. Near Pyramid Lake, Lemmon.

215. RAFINÉSQUIA, Nutt. (Constantine S. Rafinesque Schmalz, a noted botanist.) - Glabrous and branching slightly succulent and Sonchus-like winter annuals (Californian and New Mexican), leafy; with pinnatifid leaves, reduced on the flowering branches to herbaceous bracts: the heads rather large, with showy white or rose-tinged flowers, mostly matutinal. - Nutt. Trans. Am. Phil. Soc. vii. 429; Gray, Pl. Wright. ii. 103, \& Bot. Calif. i. 429.

R. Califórnica, Norr. l. c. Mostly robust, 2 or 3 feet high, paniculately branching, bearing numerons heads: leaves oblong (larger 4 to 6 inches long); cauline partly clasping: involucre thickened at base (half to three-fourths inch high), of 12 to 15 principal bracts and some spreading calyculate ones: ligules comparatively short: beak of the akenes very slender, as long as the body : pappus dull white. - Torr. Bot. Mex. Bound. t. 34, figure not good. - Moist or shaded ground, common in California toward the coast : a smaller-flowered form in N. W. A rizona, Palmer:

R. Neo-Mexicána, Gray. A foot or less high, more slender, bearing few but larger and more showy heads and much smaller leaves, the lower of these often runcinate: involucre narrow, more cylindraceous, sometimes inch long, little thickened at base, of fewer bracts : ligules large and conspicuous (half-inch and more long), white or tinged with flesh-color: beak of akene more gradually tapering, therefore stouter, rather shorter than the body : pappus bright white, of firmer bristles, the plume somewhat arachnoid. - Pl. Wright. l. c. Sand-hills, \&c., in the desert region, S. E. California to S. Utah and New Mexico on the Rio Grande ; first coll. by Wright.

216. TRAGOPÓGON, Goat's-BEARD, SALsify. (Tpáyos, goat, $\pi \dot{\omega} \gamma \omega v$, beard.) - Old World biennials or rarely perennials, glabrous; with long taproot; entire and grass-like nervose leaves clasping at base; long and stout peduncles commonly thickened and fistulous under the large head; the flowers yellow or purple, closing at noon or earlier. - Two species sparingly naturalized, one of them cultivated.

T. porrifólite, L. (SAlsift, Otster-plant.) Commonly 2 or 3 feet high: peduncle strongly clavate-thickened and fistulous for 2 or 3 inches beneath the head, which becomes 
3 inches high: flowers violet-purple, mostly surpassed by the involucre: ontermost akenes squamellate-muricate. - Sparingly in fields and near dwellings, as an escape from cultivation in the Atlantic States, a naturalized weed in California and Oregon. (Nat. from Eu.)

T. PRAténsis, L. (Goat's-BEard.) A foot or two, or the larger form a yard high: leaves with broader base: peduncles little enlarged except close under the head : flowers yellow, equalling the involncre, sometimes longer. - Sparingly found in fields, \&c., New England to New Jersey and Wisconsin. (Nat. from Eu.)

217. ANISOCOMA, Torr. \& Gray. ("Avıбos, unequal, kó $\mu \eta$, tuft of hair; from the pappus.) - Jour. Bost. Soc. Nat. Hist. v. 111, t. 13 ; Eaton, Bot. King Exp. 197 ; Gray, Bot. Calif. i. 430. — Single species.

A. acaúle, Torr. \& GraY, 1. c. Low winter annual, glabrous, except a dense white tomentum on the edges of the pinnately lobed and often runcinate leaves: these all in a rosulate radical cluster (inch or two long): scapes numerous, naked, a span high: head about inch high: ligules conspicuous, light yellow. - Pterostephanus runcinatus, Kellogg, Proc. Calif. Acad. iii. 20, f. 4, badly characterized. - Jry plains and hills, of the eastern part of the Sierra Nevada, from Sierra Co. to the Mohave, Califormia, and adjacent Nevada; first coll. by Fremont.

218. HYPOCH\&RIS, L. (A name of Theophrastus for some plant of this tribe.) - Old World and S. American herbs; with yellow flowers; one species sparingly introduced.

H. GLÁBRA, L. Nearly glabrous; a rosulate tuft of oblong-spatulate sinuate-dentate leaves from an annual root, sending up branching scapes a span to a foot high, bearing a few middle-sized heads : involucral bracts lanceolate : outermost akenes truncate, inner slenderbeaked: bristles of the somewhat sordid pappus arachnoid-plumose, but naked at tip, also some fine and shorter naked ones in an outer series. - Fields, E. California. (Nat. from Eu.)

H. RADICATA, L., which is hirsute and has all the akenes rostrate, is an occasional ballastweed, at Philadelphia and New York.

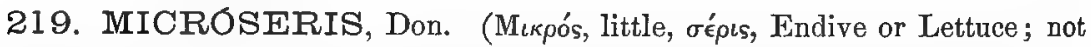
an apposite name for our larger species.) - W. and S. American (but almost all Californian) annuals, biennials, or some perennials, glabrous or inerely furfuraceous-puberulent, acaulescent or subcaulescent; with heads of yellow flowers terminating naked scapes or elongated simple peduncles, commonly nodding before expansion. Foliage very variable. - Don in Phil. Mag. xi. 388 (1832); Gray, Proc. Am. Acad. ix. 207, \& Bot. Calif. i. 423. Bellardia, Colla in Mem. Acad. Taurin. xxxviii. 40, t. 34. Lepidonema, Fisch. \& Meyer, Ind. Sem. Petrop. 1835. Fichtea, Schultz Bip. in Linn. x. 255. Calais, DC. Prodr. vii. 85; Gray, Pacif. R. Rep. iv. 121. Phyllopappus, F. Muell. in Linn. xiv. 507. Uropappus \& Scorzonella, Nutt. Trans. Am. Phil. Soc. vii. 426. Microseris \& Scorzonella, Benth. \& IIook. Gen. ii. 506, 533.

$\S$ 1. Ptilóphora, Gray, 1. c. Pappus of 15 to 20 white and soft plumose bristles with paleaceous base: akenes linear-columnar, of same diameter from base to summit : stems more or less branching and leaf-bearing: perennials, with fusiform biennial roots.

M. nútans, Gray. Slender, a foot or so high : fusiform roots either fascicled or solitary: leaves from entire and spatulate-obovate to pinnately parted into narrow linear lobes : heads 8-20-flowered, slender-peduncled: involucre cylindraceous, of 8 to 10 linear-lanceolate gradually acuminate principal bracts and a few short loose calyculate ones : bristles of pappus several times longer than the oblong scale at the base. - Proc. Am. Acal. ix. 208. Scorzo- 
nella nutans (Geyer), Hook. Lond. Jour. Bot. vi. 253. Ptilophora nutans, Gray, Pl. Fendl. 113. Calais (Ptilophora) nutans, Gray, Pacif. R. Rep. iv. 112. Stephanomeria intermedia, Kellogg. Proc. Calif. Acad. v. 39. - Wet grassy grounds, borders of Brit. Columbia and Montana to S. W. Colorado, Ltah, and the higher Sierra Nevada, California: fl. spring.

M. májor, Grax, l. c. Stouter, often more than 2 feet high, apparently thicker-rooted: heads larger, sometimes inch high : involucre of more lanceolate bracts imbricated in three lengths: pappus rather less plumose: leares oblong-lanceolate, entire or sparingly laciniate. - Ptilophora major, Gray, Pl. Fendl. 113. Calais major, Gray, Pacif. R. Rep. 1. c. 114. Idaho, Utah, \&c.; first coll. by Spalding.

Var. laciniáta, Grar, 1. c. Lower: leaves pinnately parted and laciniate. - Calais graciloba, Kellogg, Proc. Calif. Acad. I. c. - W. Idaho, Spalding. Mendocino Co., California, Kellogg.

§ 2. Scorzonílda, Gray, 1. c. Pappus (somewhat sordid) of 5 to 10 attenuate bristles with paleaceous base, or of short palere bearing long bristles, these either subplumose or naked : akenes truncate at summit, slightly attenuate downward only : involucre loosely imbricated in 2 or 3 series, many-flowered : perennials or biennials, often branching from base and somewhat leafy-stemmed: root fusiform. - Scorzonella, Nutt., Benth. \& Hook. 1. c.

* Pappus-bristles barbellate or short-plumose, not more than 4 times the length of the entire lanceolate palea: akenes slender.

M. sylvática, Gray, 1. c. A foot or so high, not rarely simple and monocephalous : leaves from broadly lanceolate to linear, laciniate-pinnatifid: head almost inch high: involucral bracts mostly abruptly acuminate from an oval or oblong base: awn-like bristles of the pappus (commonly 10) almost or quite plumose. - Scorzonella sylvatica, Benth. Pl. Hartw. 320. Calais (Anacalais) syliatica, Gray, Pacif. R. Rep. iv. 113. - California, in woods of the Sacramento and its tributaries, Hartweg, Bigelow, Kellogg \& Harford.

Var. Stillmáni, Grax, I. c. Sometimes several-stemmed from the base and with leaves pinnately parted into long linear lobes: involucral bracts lanceolate and more gradually slender-acuminate: pappus-bristles (5 to 10) merely barbellate under a lens: akenes smooth, obscurely costate. - California, on the Sacramento, \&c., Stillman, Bigelow. Near San Francisco, Samuels, G. R. Vasey.

* Pappus-bristles (10, sometimes 8) naked, barely denticulate or scabrous, entire or neariy so, several or many times longer than the small palea: akenes columnar or rather slender: heads large or middle-sized, with elongated ligules: involucre not reflexed at the fall of the akenes, its bracts with loose and conspicuously acuminate or attenuate tips: stem sometimes scapiform, often few-leaved and branching. - Scorzonella, Nutt. (Foliage variable, as in the genus generally: species too nearly connected.)

\section{+ Heads and leaves of the largest.}

M. prócera, Grar. Glaucous: stem robust, 2 or 3 feet high, branching: leaves chiefly oblong and apiculate-acuminate, denticulate or entire, rarely laciniate-lobed; larger cauline 6 to 8 inches long and one or two wide; radical oblong-lanceolate, commonly a foot long: involucre a full inch or more high and broad; outer bracts broadly ovate with abrupt acumination; innermost lanceolate-acuminate: akenes nearly 3 lines long: paleæ of the pappus lanceolate or oblong-lanceolate, acute, about one fourth the leugth of the awn. - Proc. Am. Acad. xix. 64. M. laciniata, var. procera, Gray, Proc. 1. c. ix. 209, \& Bot. Calif. i. 424. Calais glauca, var. procera, Gray, Proc. Am. Acal. vii. 364.- - Hillsides, W. California, from Sonoma Co. northward to Klamath, Oregon, Torrey, Bolunder, Kellogg, Kronkhite.

+ + Heads and leaves less ample and stem less robust, a foot or less to two feet high.

M. laciniáta, Grax. Rather stout, glaucescent: leaves laciniate-pinnatifir into attenuate lobes, or sometimes entire; radical 4 to 10 inches long: involucre an inch or less high; its bracts as in the preceding, or nearly all with broad dilated base: akenes columnar, 2 lines long: paleæ of the pappus deltoid or triangular-ovate, not longer than breadth of the akene, abruptly tipped by an awn or bristle 8 or 9 times longer. - Proc. Am. Acad. ix. 209, excl. var. procera. Hymenonema? laciniatum, \& perhaps also II.? glaucum, Hook. Fl. i. 301. Scorzonella laciniata, Nutt. Trans. Am. Phil. Soc. vii. 426. Calais (Scorzonella) laciniata, 
Gray, Pacif. R. Rep. iv. 112 - Alluvial ground, Washington Terr. and Oregon to N.W. California ; first coll. by Douglas. Some forms are to be distinguished from the smaller of the preceding by the pappus only.

M. leptosépala, GRAX. Slender, a foot or less high : leaves from linear to narrowly lan. ceolate, and from entire to attenuate-pinnatifid: heads comparatively small and fewerflowered : involucre only half-inch high, of fewer bracts reduced almost to two series; outer ovate or oblong with abrupt acumination, inner lanceolate-attenuate: akenes more slender: palex of the pappus (often only 8) ovate-lanceolate or narrower, a quarter or fifth of the length of the akene, tapering from base gradually into the awn. - Proc. Am. Acad. ix. 209, Bot. Calif. 1. c. in part only, \& Proc. Am. Acad. xix.64. Scorzonella leptosepala (\& S. glauca), Nutt. 1. c. Hymenonena? glaucum, Hook. 1. c.? Calais laciniata, Gray, Proc. Am. Acad. viii. 208, pl. Hall:-Low grounds and meadows, Washington Terr. \& Oregon, along the Columbia River, Garry? Nuttall, Hall, Suksdorf.

M. Bolánderi, Grax. Slender, a foot or two high: leaves from narrowly linear-lanceolate to somewhat spatulate, entire or with a few small salient linear lobes; radical a span to a foot long including the margined petiole : involucre half to two-thirds inch high; its bracts all gradually lanceolate-attenuate from a broadish base, or some small outermost ovate and abruptly acuminate : palex of the pappus ( 8 to 10) little exceeding the breadth of the akene, broadly ovate, mostly obtuse, abruptly tipped by the long slender awn. - Proc. Am. Acad. xix. 64. Calais Bolanderi, Gray, Proc. Am. Acad. vii. 365. Microseris leptosepala, Gray, Proc. Am. Acad. ix. 209, in part, \& Bot. Calif. i. 425, as to Californian plant. - Swamps, Mendocino and Humboldt Co., N. W. California, Bolander, Kellogg, Rattan, Pringle. Apparently same from Seattle, Washington Terr., Mrs. Summers

* * * Pappus-bristles or awns 5, not over thrice the length of the palea, rising from an apical cleft, rather strongly denticulate.

M. Párryi, Gray. Furfuraceous-pubernlent: leaves all radical, lanceolate, a span long, from entire to laciniate-pinnatifid: scape 7 inches high: involucre campanulate, half-inch higlh, of ovate and oblong and hardly acuminate bracts : ligules little exserted. - Proc. Am. Acad. ix. 209, \& Bot. Calif. 1. c. Calais Parryi, Gray, Pacif. R. Rep. iv. 122, \& Bot. Mex. Bound. 104. - S. California, near San Diego, Parry. Kuown only from scanty and imperfectly developed specimens; perhaps not of this section.

$\S 3$. CALAIS. Pappus of $\check{5}$ scarious awn-tipped paleæ (in one species sometimes fewer or deciduous, and with only minute palea at base of the capillary awn): involucre either sparingly imbricated or merely calyculate, of thinnish bracts, the principal ones lanceolate: acaulescent or subcaulescent annuals, with leaves very variable in all the species, some narrow and entire, some laciniatetoothed, some very commonly pinnatifid or parted into slender lobes. - Calais, DC. Prodr. vii. 85.

* Paleæ of pappus acutely bifid or bidentate at apex by early splitting away from the base of the awn, which thus rises from the notch: akenes more or less slender and narrower upward, but not rostrate, for the slender seed reaches nearly to the apex : acaulescent, with slender scapes and middle-sized or smaller heads. - Calais § Calocalais, DC. 1. c.

$$
+ \text { Awn very long in proportion to the paleæ of the pappus. }
$$

M. macrochæeta, Gray, 1. c. Subcaulescent: scapes or peduncles sometimes even 2 feet high : involucre narrow, 8 or 10 lines high; its bracts attenuate-acuminate, outermost fully half the length of the inner: forming akenes decidedly contracted toward summit: pappuspaleæ thin, small, cleft quite to the middle from the first, bearing a long and weak capillary awn. - Calais macrochacta, Gray, P1. Fendl. 112, \& Pacif. R. Rep. iv. 113. - S. W. Idaho (Spalding), and California along the coast from San Francisco (Bigelow) to San Diego (Nuttall, Cleveland); but mature fruit still unknown.

++ Awn short in proportion to the lanceolate paleæ, which about equal the akene: larger heads inch or more high: involueral bracts less acuminate, the few outer of variable length: scapes or scapiform peduncles rising from a span to even 2 feet in height.

M. linearifólia, Gray, l. c. Peduncle more or less thickened upward and in strong plants fistulous under the oblong head: leaves sometimes almost villous-pubescent when young: 
akene attenuate above almost into a beak : pappus silvery white; very delicate awn barely half the length of the more deeply notched palea. - Calais linearifolia, DC. 1. c., excl: syn. Uropappus linearifolius \& U. grandiflorus, Nutt. Trans. Am. Phil. Soc. vii. 425. - Open low grounds, throughout California, to Nevada, Arizona, and New Mexico.

M. Lindléyi, Grax, 1. c. Peduncle little or not at all thickened upward: akene gradually and slightly attenuate toward the summit: pappus sordid; palew bearing a stronger and more exserted awn from a shallow notch, sometimes those of the marginal flowers villous, and their akenes pubescent. - Calais Lindleyi, DC. 1. c., excl. syn. Cropappus Lindleyi \& U. heterocarpus, Nutt. 1. c. - California, from San Francisco Bay to San Diego; apparently less common than the preceding.

* Palex of the sordid or merely whitish pappus entire, surmounted by the awn, conspicuous except in the second species: scapes slender, a span to 18 inches high: akenes mostly upwardly scabrous on the 10 equal ribs, occasionally the outermost villons. - Calais $§$ Eucalais, DC., \&c.

+ Akenes attenuate-fusiform, the upper and slightly narrowed half not occupied by the seed!

M. attenuáta, Greese. Leares mostly pinnately parted into narrow linear lobes: scapes a span or two high: involucre half-incli high, barely calyculate at base: pappus of the length of the akenes (nearly 4 lines); the palex oblong-lanceolate, about half the length of the awn, externally either lightly or conspicnously villous. - Proc. Am. Acad. xix. 65. California, at Berkeley and hills north of Monte Diablo, Greene.

- + Akenes from slender-subclavate to turbinate, the cell filled by the seed.

+- Palex of the pappus rery small (not over balf-line long) or obsolete, glabrous, and the slender bristles fragile or deciduous.

M. aphantocárpha, Gray, 1. c. Involucre merely calyculate : akenes (1 $\frac{1}{2}$ to 2 lines long) oblong-clavate, with usually some constriction or rounding of the summit, shorter than the rigid capillary awns of the pappus: these merely deltoid-dilated at base, or hardly so. Calais aphantocarpha, Gray, Proc. Am. Acad. vi. 552. - California, in Alameda and Contra Costa Co.; first coll. by Brewer.

Var. tenélla, Grar, 1. c. Depauperate in the original specimens: bristles of pappus 2 to 5, sometimes with manifest broadly-ovate palea at base, sometimes deciduous. - Calais (Aphanocalais) tenella, Gray, Pacif. R. Rep. iv. 114, t. 17.-Same range, and along the Napa and Lower Sacramento; first coll. by Bigelow \& Fitch.

$$
+ \text { Palex of the pappus conspicuous, persistent. }
$$

$=$ Akene (with truncate summit) little over a line long and the long-awned palex of the pappus of not more than half its length, both glabrous: head small.

M. élegans, Greene, in herb. A span to a foot high, slender : head in fruit less than halfinch high: akenes tapering gradually from very summit to base: palex of the pappus ovatedeltoid or sometimes rather narrower, either obscurely emarginate or more attenuate into a slender awn of about 4 times the length: sometimes a minute villosity covering the truncate summit of the akene. - California, common in Contra Costa Co., Hall, Lemmon, Parry, Greene, \&c. Between M. aphantocarpha and $\boldsymbol{M}$. Bigelovii.

$==$ Akenes 2 or 3 lines long, some of the outermost not rarely villous : palere of the pappus seldom shorter, in the same species and even in the same head disposed to be either glabrous or scabro-puberulent, or externally villous.

M. acumináta, Greene. A span or two high: head in fruit about inch high: akenes apparently all glabrous, slenderly somewhat fusiform-turbinate (obscurely contracted between middle and summit), almost 3 lines long, not half the length of the pappus : palex narrowly lanceolate, gradnally attenuate into a rather shorter awn. - Bull. Torr. Club, x. 88. Calais Douglasii, Gray, Pacif. R. Rep. iv. 113, not DC. - California, on Mark West's Creek, Bigelow (has passed for the following species; pappus nearly glabrous). Foot-hills of the Sierra Nevada, Mrs. Curran, with palea minutely silky-villous externally.

M. Bigelóvii, Gray. A span to a foot or more high : head half-inch or more high : involucre inclined to be somewhat imbricated : akenes oblong-turbinate, not contracted under the truncate summit, only 2 lines long; outermost sometimes villous: paleæ of the pappus oblongto ovate-lanceolate, mostly if not always glabrous, or scaberulous, varying considerably in size, only half or a third the length of the awn.-Proc. Am. Acad. ix. 209. Calais Bige- 
lovii, Gray, Pacif. R. Rep. iv, 164, t. 17.-Common in the district around San Francisco Bay, California, and south to Tulare Co,; first coll. by Bigelow.

M. Douglásii, GrdY. Rather coarser: scapes 8 to 20 inches high: head broad: akenes oblong-turbiuate, thickish, obviously contracted under the summit, nearly 3 lines long; outermost usually white-villous: palea of the pappus ovate to orbicular ( 2 lines high and often as wide), firm-scarious, commonly imbricated or convolutely overlapping, abruptiy acute or retuse at the apex, a half or a third the length of the awn, sometimes glabrous, sometimes densely villous outside. - M. Douglasii \& $M$. cyclocarpha, with var. eriocarpha, Gray, Proc. Am. Acad. ix. 210. Calais Douglasii, DC. Prodr. vii. 85; Hook. \& Arn. Bot. Beech. 361. C. cyclocarpha, Gray, Pacif. R. Rep. iv, 115, t. 18. C. eriocarpha, Gray, Proc. Am. Acad. vi. 552. - W. California, from Humboldt Co. to San Francisco Bay, and southward; perhaps first coll. by Douglas.

M. platycárpha, GrAr, 1. c. A span to a foot high, slender: head half-inch or less high: proper bracts of involucre rather few and broad (ollong) : akenes turbinate, tapering gradually from the broad summit to base; outermost densely short-villous: paleæ of the pappus ovate, 2 lines long, somewhat longer than the akene, abruptly acuminate into a short awn or cusp. - Calais platycarpha, Gray, Pacif. R. Rep. 1. c. - Hills around San Diego and San Luis Rey, Parry, Cleveland, Pringle, \&c. (Lower Calif., Parry, \&c.)

$\S 4$. Nothocḱlais. Pappus of 20 to 24 narrowly linear-lanceolate silverywhite palex, occupying two or more series, with obscure mid-nerve, very gradually attenuate into a slender awn: akenes atteuuate-fusiform: seed not reaching to the tapering summit: bracts of the oblong-campanulate involucre narrowly lanccolate, nearly equal, in about two series: perenuial from a thick caudex. Intermediate between Microseris and Troximon! - Gray, Proc. Am. Acad. xix. 65.

M. troximoídes, Gray. Acaulescent or nearly so: leaves tufted on the caudex, rather fleshy, narrowly linear-lanceolate, entire or undulate, 4 to 6 inches long: scapes a span to a foot high: involucre three-fourths inch high: ligules somewhat elongated: mature akenes half-inch long: pappus somewhat longer, its almost setiform palex a quarter of a line wide below. - Proc. Am. Acad. ix. 211. - Wooded hills and open plains, Montana and Idaho (first coll. by Spalding), Washington Terr. and Oregon to N. W. California.

220. LEÓNTODON, L. partly, Juss. HAwritr. ( $\Lambda$ éwv, lion, ódoúc, tooth, from the toothed leaves.) - Low perennials of the Old World, one naturalized in N. E. America, belonging to section Oporinia, Koch, having simple pappus of a single series of plumose bristles, and the unopened heads not drooping.

L. autumxális, L. (FAll Dandelion.) Short rootstock or caudex præmorse: leaves lanceolate, more or less pinnatifid, somewhat pubescent with simple hairs: seapes 5 to 15 inches high, sometimes simple, commonly once to thrice forked : peduncles clavate-thickened under the pubescent much calyculate involucre: akenes all alike. - Apargia autumnalis, Hoffm. Fl. Germ. iv. 113 ; Schk. Handb. t. 220; Pursh, Fl. ii. 497. Oporinia autumnalis, Don in Edinb. Phil. Jour. vi. 309 ; DC. Prodr. vii. 108. - In grassy grounds, Newfoundland to E. New England and sparingly to Peдn.; fl. June to Nov. (Nat. from Eu.)

L. HísPidus, L., with double pappus, the outer of short naked bristles, and L. Irf́rus, L., with both kinds of bristles plumose, and a paleaceous crown to outermost akenes, are sparing. ballast-weeds at the ports of New York and Philadelphia.

220. PICRIS, L. (Greek name for some bitter herb of this suborder,

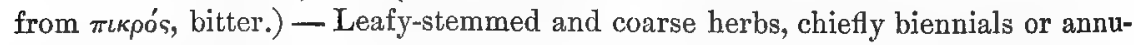
als, and of the Old World, with aspect of the larger kinds of Hieracium, roughbristly, yellow-flowered. - Benth. \& Hook. Gen. ii. 511. Picris \& Helmintha, Juss. Gen. 170.

P. gremaciof́des, L. Rather tall, hispid, and some of the bristles minutely glochidiate, corymbosely branched : leaves lanceolate or broader, with partly clasping base, irregularly 
dentate : heads half-inch or more high : outer bracts of the involucre broader and spreading : akenes oblong, with 5 broad ribs and little or no beak: pappus of unequal sparsely plumose bristles, deciduous in a ring. - Lam. Ill. t. 648; Reicheub. Ic. Fl. Germ. t. 1375. - Introduced in a few places (as in Illinois, Hall), and as a ballist-weed. (Nat. from Eu.)

Var. Japónica, Regel. Very hispid with dark bristles, even to the invalucre. $-P$ Japonica, Thuub. Fl. Jap. 299. P. Kamtschatica, Ledeb. Mem. Aciul. 1814, \& Fl. Alt. iv. 159. P. Davurica, Fischer \& Hornem. Hort. Hafn. Suppl. 155. - Sitka, l/ertens, according to Herder. (Occurs on Behring Island, off Kamtschatka, as well as on the mainland, Japan, \&c.)

P. (Helmítha) Echioínes, L., of the Old World., is a ballast-weed of occasional appearance near New York and Philadelphia : it is known by the ovate and subcorlate foliaceons cuter bracts of the involucre, 3 to 5 in number, and by the narrow inuer ones becoming thickened at base in age; also by the slender beak to the akene and a densely plumose pappus.

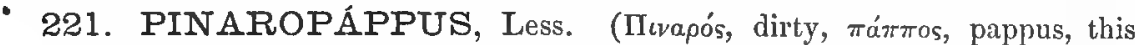
being sordid or fuscous.) - Syn. 143; DC. Prodr. vii. 99. — Single species.

P. róseus, Less. 1. c. Glabrous and glaucescent deep-rooted perennial - stems scapiform with a few minute bracts, and monocephalous, or leafy below with a few naked branches, slender, rather rigid : leaves lanceolate and eutire, and some pinnatifid : involucre over lalfinch high : ligules conspicuous, rose-tinged or almost white. - Troximon Romerianum, Scheele in Linn. xxii. 165. - High and rocky prairies, Texas, Lindheimer, Wrighl, \&c. (Mex.)

222. CALYCÓSERIS, Gray. (Kádv乡̧, a cup, alluding to the shallow cup at summit of akene, $\sigma \dot{\epsilon} \rho \iota s$, a Cichoriaceous plant.) - New Mexican and Californian winter annuals, low, branching from the base, glabrous below and glaucescent; with leaves pinnately parted into narrow linear lobes, and showy rather large heads terminating the branches; the ligules elongated; peduncles sparsely or copiously hispid with tack-shaped glands. Fl. spring. - Pl. Wright. ii. 104, - t. 14, Bot. Mex. Bound. 106, \& Bot. Calif. i. 431.

C. Wríghtii, Gray. Flowers rose-color: akenes with thick and broad somewhat rugulose ribs and thickish beak. - Fl. Wright. 1. c. t. 14. - New Mexico from the Rio Grande to Arizona and S. Utah; first coll. by Wright.

C. Párryi, Grar. Flowers yellow : akenes more slender, 5-angled by the acute ribs, with narrower beak and smaller apical cup. - Bot. Mex. Bound. 1. c.; Bot. Calif. 1. c. - San Diego Co., California, to S. Nevada and adjacent Utah; first coll. by Parry.

223. MALACÓTHRIX, DC., extended. (Maגakós, soft, $\theta$ pí́, hair.) W. N. American herbs, leafy-stemmed or sometimes scapose; with pedunculate heads usually nodding before anthesis : flowers yellow or white, sometimes becoming purplish-tinged; in spring and early summer. - DC. Prodr. vii. 192; Torr. \& Gray, Fl. ii. 485 ; Gray, Pl. Fendl. 113; Benth. \& Hook. Gen. ii. 518; Gray, Proc. Am. Acad. ix. 213, \& Bot. Calif. i. 432, excl. § 3.

§1. MaLAcólepis, Gray, 1. c. Involucre very broad, of silvery-scarious bracts with only a linear central portion green, regularly imbricated in several series; the short outer ones orbicular; inner from oval to oblong-lanceolate: receptacle bearing slender persistent bristles: corollas white, closed in sunshine, purplishtinged in fading: broad-leaved annual.

M. Coúlteri, GraY, 1. c. A foot or two high, rather stout, glabrous: leaves oblong or spatulate, upper cauline ovate or cordate and clasping, sparsely laciniate-dentate: heads terminating loose branches, short-peduncled, hemispherical, over half-inch high: akenes acutely about 15-ribbed and 4-5-angled, the summit obscurely denticulate by projection of the ribs: one or two stouter pappus-bristles more persistent. $-\mathrm{S}$. California, from the Mohave desert to San Luis Obispo, \&c. ; first coll. by Coulter. 
§ 2. MALACótHrix proper. Involucre of narrow and acute or acuminate bracts, only narrowly scarious-margined, much less imbricated: bristles on the receptacle sparing, or fragile and deciduous, rarely none. - Leptoseris, Leucoseris, \& Malacomeris, Nutt.

* Annuals: flowers light yeilow, sometimes purplish in fading.

+ Simply scapose, with solitary large head, about 3-serially imbricated involucre, and herbage long-woolly when young. - Malacothrix, DC.

M. Califórnica, DC. Leaves once or partly twice laciniately pinnatifid into narrow linear or almost filiform lobes, when young woolly with long and loose very soft hairs (whence the generic name), as also is the base of the broadly campanulate (two-thirds inch high) involucre; the outer bracts slender-subulate : delicate bristles of the receptacle generally present: akenes narrow, lightly striate-costate, the acutish base with a small concave callus: outer pappus of 2 persistent bristles and between them some minute pointed teeth: scape a foot or less high, bractless or nearly so. - Prodr. vii. 192 ; Gray 1. c., excl. var. glabrata, Eaton. Open grounds, California, from the Sacramento valley to San Diego; first coll. by Douglas.

+ + Subcaulescent or more leafy-stemmed, more or less branching, early glabrate or glabrous: involucral bracts nearly or wholly of two lengths; the outer (or calyculus) short, proportionally broader and loose. - Leptoseris, Nutt.

+ Heads comparatively large, and on elongated or the earlier on scapiform peduncles: leaves and their divisions long and slender, nearly as in the preceding species.

M. glabráta. Erect, or with ascending branches from the base, these leafy, often again branching and bearing a few lateral as well as terminal heads: involucre fully half-inch high, glabrous, or outer bracts sometimes tomentulose-canescent when young: flowers, \&c., as in M. Californica. - M. Californica, var. glabrata, Eaton, Bot. King Exp. 201 ; Gray, Bot. Calif. 1. c. M. Torreyi, Gray, Proc. Am. Acad. ix. 213, as to "slender narrow-leaved form." - Dry eastern portion of the Sierra Nevada in California and Nevada, to S. E. Utah and Arizona; first coll. by Anderson.

+ Heads smaller, with broadish campanulate involucre seldom less than half-inch high, short-peduncled on the leafy usually spreading branches: lower leaves oblong, rather short, pinnatifid, with short and dentate lobes; teeth and lubes commonly callous-mucronate: plants a span to a foot high.

M. Torréyi, Gray. Akenes linear-oblong, 5-angled by as many salient often almost winglike ribs, a much less prominent pair in each interval: outer pappus of 2 to 5 or sometimes 8 stouter persistent bristles, between the thickish bases of which are minute teeth: bracts of the involucre acuminate: peduncles commonly with some sparse gland-tipped hairs. - Proc. Am. Acad. ix. 213, \& Bot. Calif. i. 433. M. sonchoides, Torr. in Stansb. 1Rep. 392 ; Gray, Pl. Wright. ii. 105, in part; Eaton, Bot. King Exp. 201, not Torr. \& Gray. - Low grounds, Utah to W. Nevada and S. E. Oregon, probably to California; first coll. by Stansbury.

M. sonchoídes, Torr. \& Grat. Akenes linear-oblong, 15-striate-costate, somewhat angled by 5 moderately stronger ribs, the summit with a 15-denticulate white border: no persistent bristles : involucral bracts rather broader, merely acute : branches more diffuse: rhachis of the principal leaves as well as lobes dentate. - Fl. ii. 486; Gray, l. c. M. abtusa, Eaton, l. c., in part. Leptoseris sonchoides, Nutt. Trans. Am. Phil. Soc. vii. 428. - Plains of W. Nebraska to New Mexico, Nevada, and adjacent California and Arizona; first coll. by Nuttall.

M. Féndleri, Gray. Akenes cylindrical, equably 15-costate, dark-colored; the summit bordered by a shallow cupulate crown, its margin entire, white within : no persistent pappusbristles or only one. - Pl. Wright. ii. 104, Bot. Mex. Bound. 106, \& Proc. Am. Acad. ix. 213. - E. New Mexico to S. E. California, Fendler, Bigelow, Wright, Lemmon, \&c.

+++ Heads small, numerous and loosely paniculate on slender erect and rather naked stem and branches: involucre seldom over 3 lines high, narrower, fewer-flowered: the tips of the bracts commonly sphacelate or purplish.

M. XANTI, Gray, 1. c., the only outlying species of the genus (Cape San Lucas, Lower California, Xantus), is 2 feet high, with leaves mainly radical and lyrate-pinnatifid, panicle very naked, narrow involucre 4 lines high, akenes obtusely 15 -ribbed, five ribs moderately stronger, cupulate apex obtusely 5 -toothed, outer pappus of 3 to 5 very slender persistent bristles. Heads larger than in either of the following. 
M. Clevelándi, Gray. Akenes oblong-linear, minutely striate-costate, 4 or 5 of the ribs slightly more prominent: outer pappus of one persistent bristle and a couspicuous circle of narrow white setulose teeth: leaves narrow, only some of the radical pinnatifil. - Bot. Calif. i. 433. - From Antioch (Mrs. Curran) to Santa Barbara and San Diego in California (first coll. by Cleveland); also mountains of Arizona.

M. obtúsa, Benth. Akenes obovate-oblong, obtusely angled by 5 rather prominent ribs, the others delicate or obscure, the apex somewhat contracted and its border entire: no persistent pappus-bristles : remains of tomentum in axils of leaves, \&c. : radical leaves thickisl, spatulate-oblong, sinuate-dentate or pinnatifid; the teeth or lobes short-oblong, sometimes very obtuse: corollas (white?) in dried specimens purplish-tinged. - Gray, 1. c. M. obtusa, \& M. parvifiora, Benth. P1. Hartw. 321. Senecio flocciferus, DC. Prodr. vi. 426. - California, from Monterey to Humboldt Co. and in the Yosemite; first coll. by Douglas and Hartweg.

$$
\text { * * Suffrutescent-perennial: "flowers yellow." - Malacomeris, Nutt. }
$$

M. incána, Torr. \& GraY. Low, white-tomentose: leaves in tufts on short basal shoots, pinnatifid, with short lobes: flowering branches scape-like, a few inches high, bearing one or two rather large heads : involucre broadly campanulate: no persistent pappus-bristles. FI. ii. 486. Malacomeris incana, Nutt. Trans. $1 \mathrm{~m}$. Phil. Soc. vii. 435. - Island in the bay at San Diego, California, Nuttall, who only has collected it, and in imperfect specimens.

* * Somewhat suffrutescent and leafy paniculately branching pereunials: flowers white (changing to rose-color?): involucre broadly campanulate (nearly half-inch high), manyflowered; the loose calyculate bracts numerous, subulate, passing into similar bractlets on the peduncle: receptacle obscurely dentate-alveolate, no bristles detected: no persistent exterior pappus-bristles. - Leucnseris, Nutt.

M. saxátilis, Torr. \& Grar. Minutely tomentose when young, soon glabrate, somewhat succulent, a foot or two high: leaves lanceolate or the lower spatulate, either entire or laciniate-pinnatifid: heads terminating the paniculate branches: akenes narrowly oblong, 10-15costate, at maturity somewhat 4-5-angled by the stronger ribs : apex slightly contracted, bearing a very short multidenticulate white border. - Gray, Proc. Am. Acad. \& Bot. Calif. 1. c. M. saxatilis \& 11 . commutata, Torr. \& Gray, 1. c., excl. syn. Senecio flocciferus. Leucoseris saxatilis \& $L$. Californica, Nutt. Trans. Am. Phil. Soc. vii. 440, 441. Hieracium? Californicum, DC. Prodr. vii. 235. Sonchus? C'alifornicus, Hook. \& Arn. Bot. Beech. 361. - Coast of California at Santa Barbara and southward; first coll. by Coulter. Passes on the mountains and in the interior district into

Var. tenuifólia. Early glabrate or glabrous: stems slender, not succulent, 2 to 4 feet high, with long and slender loosely-paniculate branches, bearing slender-pedunculate heads (of equal or smaller size): leaves narrowly lanceolate to linear, or on branchlets almost filiform. - M. tenuifolia, Torr. \& Gray, 1. c.; Gray, Bot. Calif. l.c. Leucoseris tenuifolia, Nutt. 1. c. - Mountain-sides and cañons, Santa Barbara to San Diego, also Tejon, Saı Bernardino, and Arizona; first coll. by Coulter.

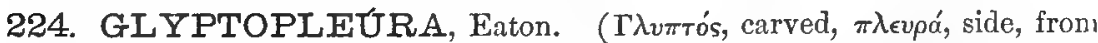
the sculpturing of the akenes.) - Winter annuals of the Utah-Nevada desert, many-stemmed and depressed, forming flat and leafy tufts, only an inch or two high; with thickish and oblong runcinate leaves on margined petioles: heads rather large for the size of the plant: fl. spring. - Bot. King Exp. 207, t. 20; Gray, Proc. Am. Acad. ix. 209, \& Bot. Calif. i. 431.

G. margináta, EA Tos, 1. c. Corollas white, turning pink in fading, little exserted : lobes and mostly whole margin of the leaves densely scarious-fringed, this white border mainly cut into short obtuse teeth, only pectinate-setiform on the leaves subtending the heads. - Western borders of Nevada, from the Truckee to Candelaria (Watson, Lemmon, Shockley), and to the Mohave desert in Califurnia, Parish.

G. setulósa, Gray, 1. c. Corollas yellow changing to pink, much exserted (half to threefourths inch): white margin of the leaves less conspicuous, mainly composed of distinct subulate or acicular white teeth. - St. George, S. Utah, to the Mohave desert, Parry, Palmer, Parish, \&c. 
225. APARGIDIUM, Torr. \& Gray. (Likeness to Apargia, a sort of Dandelion.) - Fl. ii. 474; Gray, Bot. Calif. i. 439. - Single species.

A. boreále, Torr. \& Gray, 1. c. Glabrous and slender perennial: leaves wholly radical, linear-lanceolate, entire or nearly so, thinnish: scapes at Iength a foot high: involucre half to three-fourths inch high : corollas deep yellow, conspicuous. - Apargia borealis, Bongard, Veg. Sitch. 146. Leontodon boreale, DC. Prodr. vii. 102. Microseris borealis, Schultz Bip., ex Herder in Pl. Radd. iii. (4), 28. - Wet meadows and bogs, Alaskan Islands (Mertens, \& ${ }^{\circ}$.) to Mendocino Co., California. Mature akenes not yet seen.

226. HIERĀCIUM, Tourn. HAWKWEED. (The Greek and Latin name, from $i \in \rho a ́ \xi \xi$, a hawk.) - A huge European genus, and with a moderate number of peculiar American species; perennial herbs, often with toothed but never deeply lobed leaves; heads in ours from small to barely middle-sized, paniculate, rarely solitary; the flowers yellow, in one species white, produced in summer and autumn, usually open through the day. - Frolich in DC. Prodr. vii. 198; Fries, Symb. Hist. Hier. (1848), \& Epicrisis Hier. (1862); Benth. \& Hook. Gen. Pl. ii. 516; Gray, Proc. Am. Acad. xix. 65. Sections after Fries.

H. KÁLMI, L. The original in the Linnæan herbarium is some wholly undetermined plant, probably not at all from Pennsylvania,'nor from America, certainly not of this genus.

§1. Pilosélla, Fries. Involucre not distinctly calyculate nor regularly much imbricate: pappus a single series of delicate bristles: akenes oblong, truncate: natives of the Old World.

H. aurantíncrm, L. Somewhat stoloniferous from the tufted rootstocks, long-hirsute and above setose-hispid as well as setulose-glandular, the involucre especially with dark hairs: leaves radical and near the base of the simple scape or peduncle: heads (four lines high) in a naked cymose cluster: flowers deep orange-color to flame-color: pappus whitish. - Jacq. FI. Austr. t. 410; Fl. Dan. t. 1112 . - Escaped from gardens to roadsides and fields in several places, New England and New York. (Nat. from Eu.)

H. PRÁĺtum, Vill. Glaucous, 2 feet or more high: stems scapiform, leafy only near the base, and there (as also the lanceolate leaves) sparsely beset with bristly hairs: heads rather numerous in an open cyme: involucre about three lines high. - A form of this appears to be established, along fences and field borders, near Evans Mills and Carthage, N. New York, L. F. Ward. (Nat. from En.)

§ 2. Archier fciux, Fries. Involucre of the comparatively large heads irregularly more or less imbricated: pappus of more copious and unequal bristles: akenes columnar, truncate: chiefly natives of the Old World.

\footnotetext{
* Stem scapiform, or only with a leaf or two above the base.
}

H. Mdróncis, L. The form called $H$. pracox, Schultz Bip., or nearly: leaves thin, oval or oblong, obtuse, incisely clentate toward the subcordate base: scapiform stem a foot or less high, bearing few or several cymose heads: involucre 4 or 5 lines high, dark-glandular. Open woodlands near Brooklyn, New York, Merriam. Also apparently in Lower Canada. (Nat. from Fu.)

H. vulgátum, Fries. Habit of the preceding, or more leafy: leaves from 'oblong to broadly lanceolate, mostly acute at both ends, decurrent on the petiole: heads few, rather smaller than in the foregoing. - Novit. ii. 258, Symb. Hier. 115, \& Epicr. 98; Reichenb. Ic. Fl. Germ. xix. t. 1526, 1527. II. sylvaticum, Smith (that of L. is xather H. murorum); Fl. Dan. t. 1113 ; Schlecht. in Tinn. x. 87. H. molle, Pursh, Fl. ii. 503, not Jacq. - Labrador, Kohlmeister, \&c. Canada, on shores of the Lower St. Lawrence (Macoun), there perhaps introduced. (Greenland, Eu., N. Asia.)

H. ALPÍxu, L., which has only a single large and dark-haired head, is in Greenland only, beyond our range. 
* * Stem leafy to the top (a foot to a yard high), benring short-pedunculate broad heads : involucre half-inch high, or sometimes smaller: no stolons or running rootstocks: no cluster of leaves at base of the developed stems; cauline leaves all closely sessile : receptacle conspicuously fimbrillate-dentate: ligules not ciliate.

H. umbellátum, L. A foot or two high, strict, bearing a few somewhat umbellatcly disposed heads: leaves narrowly or sometimes broadly lanceolate, nearly entire, sparsely denticulate, occasionally laciniate-dentate, all narrow at base: involucre usually livid, glabrous or nearly so; outermost bracts loose or spreading. - Fl. Dan. t. 680 ; Fl. Lond. vi. t. 58 ; Richards. App. Frankl. Journ. ed. 2, 29 ? in part; Fries, 1. c. H. Canadense, var. angustifolium, Torr. \& Gray, Fl. ii. 476, in part. H. macranthum, Nutt. Trans. Am. Phil. Soc. vii. 446. H. rigidum? Fries in Epicr. 134. - N, shore of Lake Superior to the Rocky Mountains, and northward. (Kamtschatka, N. Asia, Eu.)

H. Canadénse, Micnx. Taller, robust, with corymbosely or paniculately cymose heads: leares from lanceolate to ovate-oblong, acute, sparsely and acutely dentate or even laciniate, at least the upper partly clasping and broad or broadish at base : involucre usually pubescent when young, glabrate, occasionally glandnlar; the narrow outermost liracts loose : pappus sordid.-Fl. ii. 86; Torr. \& Gray, 1. c. H. virgatum, fasciculatum, \& macrophyllum, Pursh, Fl. ii. 504. H. Kalmii, Spreng. Srst. iii. 646; Bigel. Fl. Bost.; Torr. Compend., \&c., not L. H. scabriusculum, Schwein. App. Long Exp. H. prenanthoides, Hook. Fl. i. 300, not Vill. H. helianthifolium, Frolich in DC. 1. c. 225 . H. corymbosum, Fries, symb. Hier. 185 , as to pl. Newfoundl. ? also H. auratum, Fries, l c. 181, \& Epicr. 124; these being thin-leaved forms of shady places. - Open woods in dry soil, Newfoundland? and New England to Penn., north to the Mackenzie River, west to Oregon and Brit. Columbia, northwardly passing iuto H. umbellatum. (Greenland, N. Eu., if also $H$. cracatum, Tries.)

§. Stenotméca, Torr. \& Graj, 1. c. Involucre a series of equal bracts and a few short calyculate ones, usually narrow and few-many-flowered: pappus of more or less scanty equal bristles: akenes in a few species slender or tapering to the summit. (Name therefore more applicable to the involucre than to the akenes.) - Fries, I. c. Stenotheca, Monnier, Ess. Hierac. 71, there restricted to species with attenuate akenes. Species of Pilosella, Schultz Bip. in Flora, 1862, $433-440$.

* Atlantic species, all yellow-flowered and with sordid pappus.

- Akenes columnar, at maturity not at all attenuate upward: panicle not virgate.

$\div$ Heads 15-20-flowered, narrow, effusely paniculatc, on divergent or divaricate slender pedicels: stem leafy, sometimes almost leafless in depauperate plants.

H. paniculátum, I. Slender, 1 to 3 feet high, usually leafy up to the sparse compound panicle, nearly smooth and giabrous (except some villosity at base of stem), not glanclular: leaves thin, lanceolate or broader, tapering to both ends, sparingly denticulate or salientdentate: peduncles and pedicels filiform, an inch or more long: involucre 3 or 4 lines long, of 8 to 14 narrow principal bracts. - Spec. ii. 802 ; Michx. Fl. ii. 86; Torr. \& Gray, Fl. ii. 478. - Open dry woods, Canada and Xew England to upper parts of Georgia and Alabama. H. venosum, var. caulescens, Arvet-Touret, and II. Sullivantii, Arvet-Touvet, Spicil. Hier. (1881), 11, are seemingly depauperate forms of this.

+++ Heads 15-40-flowered, narrow-campanulate or oblong, on erect or ascending slender pedicels, in a naked and very loose corymbifurm-paniculate cyme.

H. venósum, L. (RATTLEsxans-wEED.) Slender: stem leafless from a depressed radical rosette, or 1-2-leaved alsove it, a foot or two high, glabrous or nearly so, branching above into a lax corymbiform cyme of few or sereral heads: leaves obovate to spatulate-oblong, mostly denticulate, subsessile, commonly purple-veined and sparsely setose-villous : involucre 4 lines long, 15-35-flowered (or even only 12-flowered), of 10 to 14 principal bracts and very few bractlets, either glabrous or with the peduncles beset with some small glaudular hairs: akenes short, strictly columnar, even when young. - Spec. ii. 800 (founded on the syn., but the "scapo crassissimo" of Gronovius unaccountable); Willd. Spec. iii. 1570 ; Torr. \& Gray, 1. c.; Fries, 1. c. H. Gronorii, L. 1. c. 802 , as to herb. \& descr. (but not the Gronovian plant); Willd. 1. c.; Michx, 1. c., in part, the var. subcaulescens, Torr. \& Gray, 1. c. II. subnudum, 
Frol. in DC. vii. 218, chiefly. Stenotheca venosa, Monnier, Ess. Hier. 72.-Open pine yoods and sandy barrens, Canada and Saskatchewan to Georgia and Kentucky.

H. M'ariánum, W ILld. Larger, 2 or 3 feet high, few-several-leaved, pilose-hirsute below, branching at summit into a very open cymose panicle of several or numerous 20-43-flowered heads : leaves obovate-oblong with tapering base; radical erect or ascending, attenuate below into petioles, rarely at all purplish-veiny : peduncles and pedicels commonly minutely whitishtomentulose, also usually the base of the involucre, at least when young, and beset with few and sparse or more copious glandular bristles : akenes slender-columnar, with tapering summit when forming, but not so at maturity. - Spec. iii. 1572, partly (\& as to syn. H. Marianum, \&c., Pluk. Mant. 102, t. 420, f. 2, whence the name); Frol. in DC. Prodr. vii. 217. $H$. Gronovii, var. subnudum, in part, \& some of H. scabrum, Torr. \& Gray, Fl. ii. 447. H. Carolinianum, Fries, Symb. Hier. 145, \& Epicr. 151. II. Rugelii, Arvet-Touvet, Spicil. Hier. (1881), 11, by the char. - Dry and open woods and clearings, New England to Penn. and Georgia. Various forms almost fill the interval between the preceding and the following species.

+++ Heads 40-50-flowered, thickish (and the tumid-campanulate involucre 4 or 5 lines bigh), on shorter and rather rigid spreading pedicels, and somewhat crowded in a convex or barely flat-topped cyme: no rosulate tuft of radical leaves at flowering time.

H. scábrum, Mrснx. Robust, 2 or 3 feet high, mostly leafy up to the inflorescence, hirsutely hispid below, glandular-hispid abore: whole inflorescence and mostly base of involucre densely beșet with dark glandular bristles and with some fine grayish tomentum: leaves obovate to spatulate-oblong, obtuse, denticulate, pubescent or hirsute, sessile by a narrow base : akenes exactly columnar. - Fl. ii. 86 ; Pursh, Fl. ii. 504 ; Torr. \& Gray, Fl. ii. 476; Fries, l. c. H. Marianum, Willd. 1. c., in part (as to one specimen); Bigel. Fl. Bost. ed. 2, 288; Ell. Sk. ii. 263. - Dry open woods, Canada to Lake Superior, Missouri, and to Georgia.

+ + Akenes fusiform or with tapering summit: heads 15-30-flowered, on short and ascending pedicels disposed in a narrow thyrsiform or almost virgate panicle: glandular-bristly hairs on peduncles and cylindraceous involucre either scanty or numerous: radical leaves generally present at flowering time, and clestitute of colored reins, oblong-obovate, all more or less longpilose or setiferous, especially along the midrib beneath.

H. Gronóvii, L. Stem strict, 1 to 3 feet high, leafy (3-12-leaved) below, continued nearly through the virgate or thyssiform panicle : pubescence mainly soft-setose, the stronger bristles from papilla: cauline leaves oval or oblong, closely sessile mostly by a broad base; lowest and radical obovate or spatulate with attenuate base or short petiole : involucre 3 or 4 lines long, 15-20-flowered: akenes fusiform, with gradually tapering beak-like summit: pappus dirty whitish. - Spec. ii. 802, as to pl. Gronov. (excl. remarks and pl. herb., which are of H. venosum); Michx. Fl. (var. foliosum); Monnier, Ess. Hiex. 30 ; Torr. \& Gray, Fl. ii. 677, not of Willd., Frol. in DC., \&c. H. Marianum, Fries, Symb. Hier. 147, \& Epicr. 152, not Willd., except perhaps in small part. Stenotheca Mariana, Monnier, 1. c. 72? S. subnuda, Monnier, l. c. t. 2, £. 5 ; depauperate form (var. subnudum, Torr. \& Gray), with narrow panicle reduced to a few heads. H. Gronovii, var. hirsutissimum, Torr. \& Gray, 1. c., is the most setose-hirsute form, with narrow panicle a foot or more long: and from that character, either this or the next must be $H$. Peninsylvanicum, Fries, Symb. Hier. I50, \& Epicr. 156; yet the alsenes described are like those of H. Marianum, Willd. - Sandy ground, and open dry woods, Canada? to Florida, Missouri, and Louisiana.

H. longípilum, Torr. Stouter, leafy to near the middle of the stem, and with linearlanceolate or subulate bracts up to the narrow panicle: pubescence mainly setose and most abundant; the bristles from a small papilla, upright, commonly half-inch to even an inch long, fulvous or rufous, denticulate: leaves spatulate-oblong or upper lanceolate, thickish, the radical commonly present in a tuft at flowering time: involucre 5 or 6 lines long, 20-30flowered, oblong-campanulate, and with short perluncles more or less tomentalose as well as glandular: akenes fusiform, but much less tapering upward than in the preceding: pappus at maturity fuscous. - Hook. Fl. i. 298 (note); Torr. \& Gray, Fl. ii. 477 ; Fries, l. c. H. barbatum, Nutt. Jour. Acad. Philad. vii. 70, \& Trans. Am. Phil. Soc. vii. 446, not Tausch. - Open woods and prairies, Michigan to Nebraska and Texas.

Var. spathulátum (Pilosella spathulata, Schultz Bip. in Flora, 1862, conjectured by the author to be a variety of Hicracium scabrum), collected on Tuscarora Mountain, in the 
Alleghanies of Penn., Porter and Traill Green, seems to be a depauperate form of the present species, with stem naked and leafless except near the base, and bristly hairs not so long: but heads in the specimens barely in blossom, and akenes unknown.

* * Rocky Mountain and Pacific species. (Involucre in most cases less obviously double than in the Eastern species; the calyculate bracts sometimes unequal or emulating the interior, or else obsolete.)

- Crinite-hirsute with long and whitish or yellowish shaggy denticulate hairs, especially on both sides of the entire leaves, on the branching leafy stems and panicle, and commonly but not always on the involucre also: flowers yellow: akenes columnar and short, not at all narrowed upward, at most a line and a half long, shorter than the sordid pappus.

H. Scoúleri, Hook. Robust, a foot or two high : long and soft setose hairs commonly from small papillæ: leaves lanceolate or spatulate-lanceolate ( 3 to 6 inches long) : panicle irregular or branching: heads half-inch high: involucre somewhat furfuraceons and glandular, also sparsely or copiously beset with long bristly hairs: pappus whitish. - Fl. i. 298, \& Torr. \& Gray, Fl. ii. 478, partly (some specimens of coll. Scouler distributed being H. cynoglos. soides, and the plant from "Pennsylvania, Schueinitz" of Hooker, being H. Gronovii); Eaton, Bot. King Exp. 199. - Montana to Oregon and Brit. Columbia, southeast to the Wabsatch Mountains, Utah.

H. hórridum, Fries. Low (a span to a foot high), in tufts, branched from the caudex: softer villous hairs not from papilla: leaves lingulate-lanceolate or spatulate-oblong, lowest petioled: panicle corymbiform-cymose, of numerous small and rather narrow heads: invoIucre 3 lines high, sometimes nearly naked, oftener beset with scattered and long bristly hairs: pappus fuscous. - Epicr. Hier. 154; Arvet-Touvet, 1. c. 19. H. Breweri, Gray, Proc. Am. Acad. vi. 553, \& Bot. Calif. i. 440. - On rocks, in the higher Sierra Nevada, California, from Shasta to San Bernardino Co.; first coll. by Bridges, next by Brewer.

H. Rexícinda, Fries, Epicr. 153, would seem to be only a taller and simpler-stemmed form of the preceding, with widely open panicle and long-hirsute involucre. Described from a specimen in herb. DC., from mountains of California, Bridges.

++ Crinitely long-villous with soft-woolly and blackish smooth hairs, which involve the heads, \&:e, but are wanting to lower leaves; no stellular pubescence aud no glands: Howers yellow: pappus fuscous.

H. tríste, Chas. A span or two high: stem simple, few-leaved, bearing solitary or mostly 2 to 4 somewhat racemosely disposed heads: radical leaves obovate to spatulate, entire, green and glabrate, or with sparse pale hairs; cauline oblong, upper ones and stem more or less villous-lanate: heads half-inch high : livid involucre and peduncles densely clothed with the very long dark-brown or partly grayish soft wool: akenes short-columnar. - Cham. in herb. Willd.; Spreng. Syst. iii. 640 ; Frol. in DC. Prodr. vii. 209 ; Torr. \& Gray, Fl. ii. 458, partly; Fries, 1. c. - Aleutian Islands to Behring Strait; first coll. by Chamisso and Eschscholtz.

+++ Dark-hirsute (verging to naked) and somewhat glandular (also whitish with short stellular-tomentum) on the involucre: leaves and lower part of scapiform stems not even pilose (but glabrous or at most puberulent): flowers yellow: pappus sordid.

H. grácile, Honк. Pale green, in tufts: leaves nearly all in radical clusters, obovate- to oblong-spatulate ( 1 to 3 inches long) and attenuate into petioles, entrre or repand-denticulate: stems or scapes slender, 8 to 18 inches high, cinereous-tomentulose above, bearing few or several racemosely disposed livid heads, the lower linear-bracteate: involucre about 4 lines high, usually blackish-hairy at base in the manner of the preceding, but the hairs much shorter than the head, also (as on the peduncles) some more setulose and glandular ones: akenes short-columnar. - Fl. i. 298; Fries, 1. c., not of Froel., which is later. H. arcticum, Frel. in DC. Prodr. vii. 209. H. Hookeri, Steud. Nomen. ed. 2, 763. H. triste, in part, Torr. \& Gray, Fl. ii. 478. H. triste, var. gracile, Gray, Bot. Calif. i. 441. - Alaska (Norfolk Sound, ex Froelich), Brit. Columbia, Northern Cascade and Rocky Mountains, and south to those of Utah and Colorado. Passes into

Var. detónsum. A span to nearly a foot high, with rather smaller heads : dark hirsute hairs wholly wanting, or only some smaller ones on the involucre. $-H$. triste, var, detonsum, Gray, Bot. Calif. 1. c. - Mountains of Brit. Columbia to those of Colorado, and alpine region in the Sierra Nevada, California, at some stations accompanying the typical form. 
++++ Not crinite (yet sometimes scattered bristles on the involucre and panicle), but at least the radical leaves and base of stem sparsely or eren thickly setose-hirsute with long spreading hairs.

+ Flowers white: stems leafy and in larger plants loosely branching, depauperate or subalpine plants even scapose: involucre 18-30-flowered: akenes linear-columnar (only a line and is half long), not at all narrowed upward: pappus sordid: leaves entire or denticulate.

H. albiflórum, Ноок. A foot to a yard high, smaller plants with simple and larger with compound open corymbiform-paniculate cyme: leaves oblong, thin ( 2 to 4 or laiger 5 to 6 inches long), upper with usually narrowed sessile base, lower tapering into petiole: involucre narrow-campanulate, 4 or 5 lines high, of linear-lanceolate bracts, pale or livid, mostly glabrous or nearly so, not rarely a few bristly hairs. - Fl. i. 298; Torr. \& Gray, Fl. ii. 479; Fries, Symb. Hier. 143; Gray, Bot. Calif. i. 440.-Open dry woods, Rocky Mountains, from lat. $56^{\circ}$ to Colorado and Utah, and Brit. Columbia to mountains of S. California; first coll. by Drummond. H. Vancouverianum, Arvet-Touvet, Spicil. Hier. 10 (at least specimens coll. Lyall distributed from Kew as " $\mathrm{H}$. Scouleri"), is of this species, and doubtless whiteflowered.

- Flowers yellow : stems more or less leafy, except in var. of $H$. cynoglossoides: involucre 15-30-flowered, oblong-campanulate, of rather numerous narrow and acute or acutish bracts: akenes columnar, not at all tapering upward, not over a line and a half long: pappus from sordid to dull white.

$=$ Leaves or many of them salient-dentate: pappus whitish.

H. argútum, Nutr. A foot or two high, slender, hirsute with long shaggy hairs at base of stem, glabrous or merely puberulent above and throughout the very lax diffuse naked panj. cle : leaves numerous at and near the base of the stem, broadly lanceolate (or radical oblongspatulate), acute or acuminate, tapering into margined petioles, larger ones 4 inches long, hilf or two-thirds inch wide, each margin with 4 or 5 salient triangular teeth; upper ones linear and entire, much reduced in size ( 1 to 3 lines wide): peduncles elongated and with the involucre more or less dark-glandular, sometimes a few scattered dark hairs. - Trans. Am. Phil. Soc. vii. 447. - Hills behind Santa Barbara, California, Nuttall (specimen not seen), Rothroek, who found it in Bartlett's Cañon, young, color of flowers uncertain; Santa Lucia Mountains, Purry, an almost naked-stemmed form with radical leaves merely denticulate, the involucre and peduncles less glandular and more scurfy-puberulent; corollas certainly yellow. Also coll. by Henke? if Pilosella arguta, Schultz Bip. in Flora, 1862, 438.

H. Paríshii, Grar. Leafy up into the narrowly oblong panicle, puberulent above, with no glandular hairs or stipitate glands: lower leaves shaggy-hirsute (along with base of stem), elongated-lanceolate (5 to 8 inches long, half-inch or more wide), tapering to the base or margined petiole, with 5 to 8 salient teeth to each margin; upper leaves linear-lanceolate, entire, those subtending lower branches of panicle ( 2 inches long) little shorter than they: peduncles seldom much longer and often shorter than the heads : involucre pale, granulosepuberulent. - Proc. Am. Acad. xix. 67. - Rock-crevices, San Bernardino Mountains, S. E. California, Parish.

$$
==\text { Leaves all entire, or merely repand, or slightly denticulate. }
$$

H. Rúsbyi, Gresne. Leafy-stemmed, 2 feet or more high, bearing numerous compoundpaniculate heads: stem hirsute below, above smooth and glabrous up to the rather shortpeduncled heads : leaves all elongated-oblong; cauline little diminished in size upward ( 3 or 4 inches long), quite entire, mostly half-clasping at base : involucre 3 lines high, pale, barely puberulent: akenes short-columnar, blackish: pappus sordid. - Bull. Torr. Club, ix. 64; Gray, Proc. Am. Acad. xix. 69. - Mogollon Mountains, New Mexico, Rusby.

Var. Wríghtii, GRAx, 1. c. More robust and branching: bristles of the stem truly hispid from papilliform base: branches and even peduncles setulose-hispidulous, and the latter obscurely glandular: sometimes a few small bristles near the tips of the involucral bracts: pappus dull white. - Crepis ambigua, Gray, Pl. Wright. i. 129, not Pl. Fendl. - W. borders of Texas, between the Limpio and the Rio Grande, Wright.

H. cynoglossoídes, Arvet. Stem a foot or less high (either from naked base or more commonly a radical tuft of leaves), simple, 2-several-leaved, bearing few or several cymosely disposed heads, setose-hirsute or hispid at base, either hispidulous or glabrous above : leaves lanceolate to spatulate-oblong; at least the lower conspicuously setose-hirsute; upper some- 
times glabrons: involucre 4 or 5 lines high, glandular, sometimes as also peduncles glandular-hispidulous: akenes rather short-columnar: pappus whitish. - Gray, Proc. Am. Acad. xix. 68. H. Scouleri, Hooker, in herb. \& distrib., partly; Torr. \& Gray, Fl. ii. 478, \& Gray, Bot. Calif. 1. c., mainly, not Hook. Fl. H. cynoglossoides, Arvet-'Touvet, Spicil. Hier. 20, founded on undeveloped specimen of Parry's N. Wyoming coll. no. 188. E. Hall's Oregon coll. 523 consists of this and $H$. Scouleri mixed. - N. W. Wyoming and Montana (Porter, Parry) to Washington Terr. and Oregon (first coll. by Tolmic, \&c.); also Siskiyou Co., California, Greene, passing to

Var. nudicaúle, Grar, 1. c. Leaves all in the radical tuft, or only one or two very small and bracteiform on the (8 to 12 inch high) glabrous scape. - Northern Sierra Nevada, California, Lemmon, Mrs. Austin, the latter on Lassen's Peak.

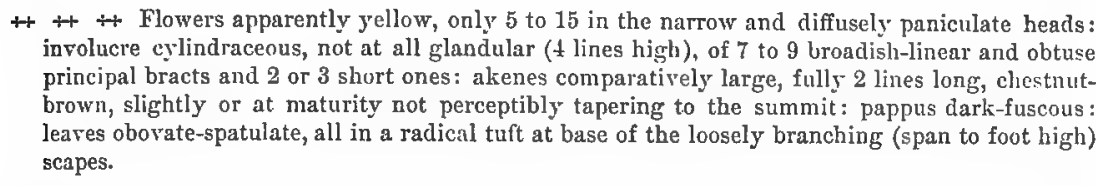

H. Bolánderi, Grar. Radical leaves sparsely or densely long-hirsute, no other pubescence, scapes and involucre smooth and glahrous. - Proc. Am. Acad. vii. 365, But. Calif. i. 440, \& Proc. Am. Acad. xix. 68. - Mountains of California, Humboldt Co., Bolander. Near headwaters of the Sacramento, Pringle. Sierra Co., Lemmon. Only Bolander's specimen has akenes narrowed npward.

H. Gréenei, Grar. Radical leaves villous-hirsute, also canescent-tomentose on both sicles with stellular pubescence: scape with peduncles and involucre cinereous-tomentose. - I'roc. $\Lambda \mathrm{m}$. Acad. xix. 69. - Pine woods of Scott's Mountains, Siskiyou Co., N. California, Greene.

$+++\div$ Flowers yellow, 20 to 30 in the oblong heads: akenes fusiform, tapering gradually to a narrow summit, fully as long as the white or whitish and softer pappus: stems scapiform, bearing one or two small leaves toward the base and subulate bracts subteuding pedunclcs or simple branches of the panicle: leares of radical tuft obovate to spatulate, obtuse, entire or minutely denticulate, contracted into short wing-margined petioles. - $\$$ Chionoracium, Schultz Bip. in Bonplandia, 1861. Crepidispermum, Fries, Symb. Heteropleura, Schultz Bip. in Flora, 1861, 434. (Transition to Crepis.)

H. Prínglei, Grax. Strictly scapose, completely destitute of setose hairs and of glands : leaves wholly rosulate, very villous-lanate both sides, obovate (2 or 3 inches long) : scape very slender, a foot or more high, minutely soft-pubescent, as also the involucre, loosely paniculate above, bearing few (4 or 5 lines long) and scattered heads : forming akenes somewhat narrowed upward: young pappus soft, bright-white. - Proc. Am. Acad. xix. 69. - S. Arizona, on Santa Rita Mountains, Pringle, Lemmon. Specimens too young.

H. Féndleri, Schultz Bip. Subscapose, not rarely one or two leaves toward base of the simple or paniculately branching stem, sparsely setose-hirsute, not at all lanate, not glandular or only obscurely so on the peduncles: radical leaves spatulate or broader; cauline verging to lanceolate, reduced above to linear bracts: heads few and racemiform-paniculate, or more numerous and corymbosely disposed, rather long-pedunculate: involucre half-inch high, of 16 to 24 linear bracts and some short ones, puberulent or glabrate, with or without scattered setose hairs: akenes $2 \frac{1}{2}$ to fully 3 lines long, tapering from near the base to summit (at maturity the alternate nerves usually thicker than the others), sometimes reddish, at length commonly blackish: pappus copions, soft, sordid-whitish. - Bonplanclia, ix. 173; Gray, 1. ¿. Crepis ambigua, Gray, P1. Fendl. 114.- New Mexico, Fendler, Wright, G. R. Vasey. Colorado, Parry, Hall \& Harbour.

Var. díscolor, Gray, l. c. Radical leaves (sometimes large, roundish, and over 2 inches broad) purple beneath: pappus nearly pure white.-Santa Rita and Huachuca Mountains, S. Arizona, Lemmon, Pringle, the latter distributed as Hieracium erythrospermum, Greene, ined., which is the following.

Var. Mogollénse, Gray, 1. c. Leaves narrower, hardly if at all pnrple-tinged: bristly hairs disposed to be shorter: peduncles minutely and sparsely glandular-setulose: involucre smaller (only 5 lines high) : immature akenes reddish: pappus pure white. $-H$. brevipilum, Greene in Bull. Torr. Club, ix. 64, first distributed as "Hlieracium erythrosper. mum." - Mogollon Mountains, New Mexico, Rusby. 
++++++ Flowers white or flesh-colored: akenes slender-columnar, hardly narrowed upward, about the length of the bright white soft pappus: stem leafy. (Transition to Crepis.)

H. cárneum, Greene. Wholly glabrous and smooth except below: stem slender, 2 feet or more high, loosely paniculate-branched, glaucescent, its base and the oblong or lanceolate subsessile radical leaves beset with long villous-setiform hairs : cauline leaves narrowly-lanceolate to linear, entire, very smooth, some of the lower sparsely piliferous : heads scattered in the corymbiform or irregular panicle: involucre campanulate, 4 or 5 lines high, pale, of narrow linear-lanceolate bracts, 15-20-flowered: corollas light rose-color: akenes 2 lines long. - Bot. Gazette, vi. 184; Gray, 1. c. 69.-Mountains of New Mexico, Greene. Also coll. by Bigelow or Wright. Huachuca Mountains, S. Arizona, Lemmon.

H. Lemmóni, Gray. Villously or hirsutely setose throughout up to the racemiform close thyrsus: stem simple, 2 feet or more high, very leafy: leaves thinnish, lanceolate-oblong, denticulate with callous or glandular teeth; cauline partly clasping, acnte; lowest oblongspatulate, 4 to 7 inches long, tapering into winged petioles; those of radical cluster wanting: heads numerons and crowded in the oblong thyrsus, 4 lines high, 12-20-tlowered: involucre glabrous or nearly so, not glandular, not longer than the canescently puberulent peduncles; its principal bracts narrowly linear, greenish-livid, obtuse : corollas short, seemingly white: akenes hardly 2 lines long, slender, obscurely if at all narrowed upward when mature but obviously so when younger: pappus less copious than in the precediug, bright white. Proc. Am. Acad. xix. 70. - S. Arizona, at Bear Spring, Cave Cañon, near Fort Huachuca, Lemmon. A species of Mexican type, of the group Thyrsoidea of Eries.

H. ABscrssum, Less., a Mexican species (with habit of H. Lemmoni, but less leafy), probally also including $H$. thyrsoideum, Fries, is said, in Fries, Epicrisis, 150, to come from "Texas ar Malpays de la Joyas" (an unrecognized locality), and from "Alabama."

227. CRÉPIS, L. (Name used by Pliny for some now unknown plant, from $\kappa \rho \eta \pi i s$, a boot or sandil.) - Chiefly a European genus, of annuals or perennials, with soft white pappus and narrow-necked or beaked akenes, some with truncate or merely upwardly attenuate akenes; the involucre apt to be thickened at base, and leaves to be pinnatifid. Flowers in all ours yellow. - Torr. \& Gray, Fl. ii. 487 ; Benth. \& Hook. Gen. ii. 513.

* Annuals or hardly biennials, sparingly introduced from Europe : akenes beakless or nearly so: bracts of involucre thickening and becoming more or less rigid at base after anthesis.

C. vfness, L. A foot or two high, erect or ascending: leaves from dentate to laciniate-pinnatifd, spatulate to lanceolate; cauline with sagittate somewhat clasping base: heads slender-peduncled, small: involucre 3 or 4 lines high: akenes oblong, 10-striate, smooth, slightly and about equally contracted at both ends. - Vill. Fl. Delph. iii. 142. C. polymorpha, Wallr.; DC. Prodr. vii. 162, mainly. Malacothrix crepoides, Gray, Pacif. R. Rep. xii. 49, \& Crepis Cooperi, Gray, Proc. Am. Acad. ix. 214, a small and diffuse somewhat nakedstemmed form, with scattered heads. - At landings and near towns on the Columbia River, Oregon and Washington Terr., probably at first a ballast-weed. (Nat. from Eu.)

C. тест́́num, L. Usually more slender: leares narrow, less or not at all sagittate at base: akenes fusiform, with gradually attenuate summit, upwardly scabrous on the ribs. - A ballast-weed at New York Harbor. In fields at Lansing, Michigan. (Nat. from Iu.)

C. вí́nnis, L. Generally larger, more pubescent or hirsite, leafy-stemmed: leaves runcinatepinnatifid, or some of the lower spatulate and barely dentate; cauline with sagittate-dentate base: involucre 4 to 6 lines high, broadly campanulate, somewhat canescently pubescent and hispidulous: akenes oblong with narrower summit, 13-striate, smooth. - Engl. Bot. t. 149; DC. Prodr. vii. 163 (excl. var. Americana); Reichenb. Ic. Fl. Germ. t. 1439. - Waste grounds, Vermont, Pringle. (Nat. from Eu.)

* * Perennials, indigenous westward or northward : akenes beakless or short-beaked.

+ Low or depressed, branched from base, glaucescent and wholly glabrous, bearing numerous clustered and narrow short-peduncled heads: involucre cylindrical, 8-14-flowered, of 8 to 10 smooth and narrowly linear obtuse equal bracts, in a single series (unchanged in fruit except by thickened midrib close to the base in $C$. nana), and 3 or 4 short calyculate ones at base: akenes 
narrow, 10-striate, the summit with a more or less dilated disk bearing the soft deciduous pappus. - Youngia, Ledeb., \&c., not Cass.

C. nána, Richards. Forming depressed tufts on slender creeping rootstocks: leaves chiefly radical (inch or two long, including petiole or attenuate base), oborate to spatulate, entire, repand-dentate, or lyrate, commonly equalling the clustered scapes or stems: heads in fruit half-inch high or nearly: akenes linear, unequally costate, obscurely contracted uncler the moderately dilated pappiferous disk. - App. Frankl. Journ. ed. 2, 92; Hools. App. Parry Voy. 397, t. 1, \& Fl.1. 297 ; Torr. \& Gray, Fl. ii. 488. Hievacium, etc., Gmel. Fl. Sibir. ii. 20, t. 7. Prenanthes pygmea, Ledeb. in Mem. Acad. Petrop. v. 553. P. polymorpha, Ledeb. Fl. Alt. iv. 144. Barkhausia nana, DC. Prodr. vii. 156. Youngia pygmea, Ledeb. Fl. Ross. ii. 838. - Arctic coast and islands, and alpine mountain summits south to Colorado and the Sierra Nevada in California. (N. Asia.)

C. élegans, Hook. Many-stemmed from a perennial tap-root, a span to a foot high, diffusely branched : leaves entire or nearly so; radical spatulate, cauline from lanceolate to linear: heads smaller or narrower than in the preceding: akenes linear-fusiform, minutely scabrous on the equal narrow ribs, attenuate into a short slender beak, which is discoid dilated at summit. - FI. i. 297; DC. Prodr. vii. 172; Torr. \& Gray, 1. c. Barkhausia elegans, Nutt. Trans. Am. Phil. Soc. vii. 435. - Saskatchewan district to Dakota and Montana; first coll. by Drummond.

+ + More robust and taller, with scapiform or few-leaved stems and larger heads: akenes thicker, not discoid-dilated at the insertion of the pappus.

+ No furfuraceons or canescent pubescence: foliage mostly glabrous: involucre campanulate, many-flowered; its bracts lanceolate or linear, acute, little thickened below after flowering: thick root possibly biennial, probably perennial: heads few or several and loosely corymbosely cymose: pappus not remarkably copious. - Crepidium, Nutt.

C. glaúca, Torr. \& Grar. Usually scapose, a foot or two high, glancescent or glaucons: radical leaves from obovate-spatulate to lanceolate, from entire to laciniate-pinnatifid: involucre 4 lines high, glabrous or nearly so, as also the peduncles: akenes oblong, with slightly narrowed summit, strongly and evenly 10-costate. - Fl. ii. 488 ; Eaton, Bot. King Exp. 203; Gray, Bot. Calif. i. 436. Crepidium glaucum, Nutt. Trans. Am. Phil. Soc. vii. 436. - Moist and saline ground, Saskatchewan and Nebraska, Utah and Nevada. Probably Arizona (Rothrock), but specimen too young and leafy, and peduncles sparingly hispidulous-glandular. Crepidium caulescens, Nutt. 1. c., is probably a somewhat leafy-stemmed form.

C. runcináta, Torr. \& Grar, 1. c. Not glaucous or slightly so, a foot or two high: radical leares obovate-oblong to oblong-lanceolate, from repand to runcinate-pinnatificl with short lobes or teeth; cauline none, or small and narrow at the forks: involucre half-inch high or smaller, pubescent, often hirsute, sometimes (with peduncles and upper part of scape) glandular-hispidulous: akenes narrowly oblong, moderately narrowed upward, somewhat evenly 10-costate. $-C$. biennis, var., Hook. Fl. i. 297, not L. C. biennis, var. Americana, DC. Prodr. vii. 163. Hieracium runcinatum, James in Long Exped. i. 453; Torr. in Ann. Lyc. N. Y. ii. 209. Crepidium runcinatum, Nutt. 1. c. - Saskatchewan to Montana and south to Colorado and Utah, in subalpine swamps; first coll. by James.

C. Andersóni, Gray. Not glaucous, a foot or more high; leaves laciniately pinnatifid or dentate, but not runcinate: involucre half to three-fourths inch high, cinereous-pubescent, of broader and firmer bracts, more imbricated, outermost oblong- to ovate-lanceolate : akenes fusifurm, unequally 8-10-costate, tapering into a short but manifest beak. - Proc. Am. Acad. vi. 553, \& Bot. Calif. i. 436. - Eastern Sierra Nevada, California and adjacent Nevada, in low grounds: a form with a cauline leaf or two in uplands; first coll. by Anderson.

+ + Furfuraceous- or cinereous-pubescent, at least the foliage, sometimes also hirsute, deeprooted perennials, more or less leafy-stemmed : akenes oblong to fusiform, beakless, 10-12-costate: pappus of very copious bristles, persistent: bracts of involucre at length with more or less thickened or carinate midrib, at least the base: leaves usually laciniate-pinnatifid. - Crepis $\$$ Leptorheca \& Psilochenia, Nutt. Trans. Am. Phil. Soc. vii. 437, but false character of akenes of the latter, and outer flowers not sterile. Species difficult.

$=$ Principal bracts of the narrow involucre and flowers 5 to 8 : no hirsute pubescence: pappus moderately copious and soft.

C. acumináta, Nuтt. 1. c. Minutely cinereously-puberulent below, but green : stem slender, 1 to 3 feet high, 1-3-leaved, bearing a fastigiate or corymbiform cyme of numerous 
small heads: leaves elongated, slender-petioled, oblong-lanceolate in outline, laciniate-pinnatifid, tapering to both ends, the apex usually into a lanceolate or linear tail-like prolongar tion (of 2 or 3 inches in length); the lobes also mostly linear-lanceolate, rarely short: involucre narrow-cylindraceous, a third to half inch long, rarely over 6-flowered, theinflorescence smooth and glabrous: the few calyculate bractlets minute and often tomentulose: akenes at maturity fusiform, considerably longer than the pappus, lightly striate-costate, moderately attenuate at summit. - Torr. \& Gray, FI. ii. 489 ; Torr. in Stansbury Rep. 392, t. viii. (akene too rostrate); Eaton, Bot. King Exp. 204, hardly of Gray, Bot. Calif. - Dry ground, Montana and Wyoming to E. Oregon, southward to Utah and mountains of S. E. California; first coll. by Nuttall.

C. intermédia. Habit and foliage of the preceding, or less tall, more cinereous-puberulent, usually with fewer heads : involucre half-inch or more long, canescently puberulent; its bracts in age more carinate by thickened midrib, the calyculate ones less minute: akenes acutely 10-costate at maturity, oblong-fusiform, slightly attenuate upward, longer than or equalling the pappus. - C. acuminata, Gray, Bot. Calif. 1. c., partly. Rocky Mountains in Colorado to the Sierra Nevada, California, and north to the interior of Washington Terr. and borders of British Columbia. Appears to pass both into preceding and following.

Var. grácilis. A very slender form, with rhachis and apical prolongation as well as lobes of the leaves attenuate-linear. $-C$. occidentalis, var. gracilis, Eaton, Bot. King Exp. 203, mainly.

Var. pleurocárpa. Leaves runcinately dentate, or subpinnatifid, or some entire, not prolonged at apex : akenes merely oblong, hardly narrowed upward, shorter than the pappus, very saliently 10-costate. - Mountains about headwaters of the Sacramento, N. California, Pringle, coll. 1881, taken as a well-marked species: but the coll. 1882 , distributed as " C. pleurocarpa, Gray," accords both as to leaves and akenes with C. intermedia.

$=$ Principal bracts of involucre 9 to 24 and flowers 10 to 30 : pappus exceedingly copious and pluriserial, rather harsher.

C. occidentális, Nutr. Often hirsute as well as canescent, rather robust, a span to a foot or so high, commonly leafy-stemmed and branching: leaves oblong-lanceolate or broader in outline, variously laciniate-pinnatifid or incised, apex seldom much prolonged : heads few or several, mostly on stout peduncles: involucre half to two-thirds inch high, oblong-cylindraceous to campanulate, canescent: akenes (4 or 5 lines long, longer than the pappus) usually with tapering summit and acute ribs. - Jour. Acad. Philad. vii. 29; Torr. \& Gray, F1. 488; Gray, Bot. Calif. i. 435. Psilochenia occidentalis, Nutt. Trans. Am. Phil. Soc. 1. e. - Plains of Nebraska and Wyoming to Washington Terr., and south to the mountains of Colorado and California. Varies widely, as into

Var. costáta, Grar, Bot. Calif. 1. c. Low and stouter form, with broader heads, and no hirsute pubescence : involucre oblong, of 10 to 14 bracts: akenes thicker, oblong, sometimes hardly at all narrowed at summit and more saliently costate. - Utah, on Stansbury Island, Watson.

Var. Nevadénsis, Kellogg. Stout, a span or two high, hirsute as well as canescent, or canescent only : leaves broad, disposed to be laciniately bipinnatifid : heads solitary or few, on stout peduncles: involucre campanulate; its principal bracts 16 to 20 : akenes gradually narrowed to summit. $-C$. occidentalis, var. Nevadensis \& var. subacaulis, Kellogg, Proc. Calif. Acad. v. 50. Var. costata in part, \& var. Nevadensis, Gray, Bot. Calif. 1. c. High Sierra Nevada, California, Kellogy, Lemmon, \&c.

Var. criníta, Gray, Bot. Calif. l. ¿. Stout, a span to a foot high, barbately and above somewhat viscidly hirsute even to the involucre; this from broadly campanulate to oblong, 20-30-flowered: akenes (as far as seen) oblong, strongly costate, obscurely narrowed at summit. - Sierra Nevada from Sierra Co., Lemmon, Mrs. Ames, to Siskiyon Co., Greene. Also collected by the Wilkes Expedition, in Washington Territory, or perhaps rather N. California.

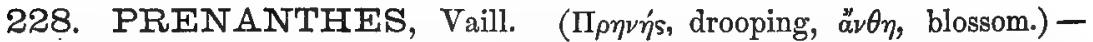
Perennial herbs, the original a European species, with loosely paniculate heads, few-nerved akenes, and soft bright white pappus. But the American species all belong to the following well-marked subgenus, 
§1. NÁbalUs, Endl., with more contracted inflorescence, dull-colored flowers, more nerved akenes (only in the last species tapering at summit), and stiffer sordid pappus. (North American \& North Asiatic.) - Nabalus, Cass. Dict. xliii. 281 ; Hook. Fl. i. 293 ; Torr. \& Gray, Fl. ii. 480. Harpalyce, Don, in Edinb. Phil. Jour. vi. 305 , not DC. Fl. late summer and autumn.

* Heads 20-35-flowered, comparatively broad, corymbosely paniculate: leaves mostly wingpetioled.

P. crepidínea, Michx. Miuutely pubescent or partly glabrous : stem stout, 5 to 9 feet high, branching above, leafy up to the short branches of inflorescence: leaves ample, ovate-deltoid, or radical hastate and uppermost oblong, acutely or laciniately dentate: involucre half to two-thirds inch long, oblong-campanulate, sparsely hirsute: flowers ochroleucous: akenes finely 12-15-costate, four or five of the ribs stronger : pappus sordid, - Fl. ii. 84. Harpalyce crepidina, Don ex Steud. Nabalus crepidineus, DC. Prodr. vii. 241 ; Torr. \& Gray, 1. c. 483. - Rich soil, Penn. and western borders of New Tork to Illinois and Kentucky ; first coll. by Michaux.

* * Heads 8-15-flowered, narrow, crowded or sometimes scattered in an elongated racemiform or thyrsoid-virgate inflorescence which terminates the simple (1 to 5 feet high) stem: cauline leaves sessile; radical and lower tapering into winged petioles, not cordate or deltoid; all simply pinnately veined: root usually fusiform-thickened or tuberous, simple or palmately branched.

+ Thyrsus hirsute or pubescent: heads little or not at all drooping, on pedicels much shorter than the involucre, 12-14-fiowered: alienes at maturity about 15-nerved, somewhat angled by four or five of the nerves being stronger: stems leafy up to the strict thyrsus: leaves ordinarily only denticulate, lower spatulate-oblong to obovate.

P. áspera, Micux. 1. c. Minutely scabrous-pubescent or below puberulent: upper leaves lanceolate, not clasping: thysus a foot or two long: involucre roughish-hirsute: flowers yellowish cream-color. $-P$. Illinoensis, Pers. Syn. ii. 366; Pursh, F1. ii. 500. Chondrilla Illinoensis, Poir. Suppl. ii. 331. Nabalus Illinoensis, DC. Prodr. vii. 242. N. asper, Torr. \& Gray, 1. c. - Prairies and barrens, Ohio and Kentucky to Iowa and Louisiana; first coll. by Michaux.

P. racemósa, Michx. 1. c. Leaves and stem glabrous and glaucous: upper cauline leaves lanceolate to ovate, partly clasping, the broader ones by cordate or auriculate base: thyrsus a span to 2 feet long: involucre rather loosely hirsute: flowers purplish. - Harpalyce racemosa, Don ex Steud.; Beck, Bot. 168. Nabalus racemosus, DC. 1. c. ; Torr. \& Gray, 1. c. Moist or low ground, N. Maine and Canada, also New Jersey, to Saskatchewan and the Rocky Mountains, south to Colorado; first coll. by Michaux.

Var. pinnatífida. Large: leaves all lyrately or laciniately pinnatifid. $-V$. racemosus, var., Torr. \& Gray, 1. c. - Hackensack Marshes, New Jersey, Carey.

++ Thyrsus and whole plant smooth and glabrous: heads pendulous and more pedicellate, in a looser racemiform thyrsus, 8-12-flowered: akenes about 5-nerved or angled, the intermediate nerves obscure.

P. Mainénsis. About two feet high, leafy up to and into the panicle : leaves nearly those of $P$. racemosa, but thinner and less glaucous; the radical ovate, commonly with abrupt or rounded base; upper subtending clusters of the interrupted narrow thyrsus: heads all drooring both before and after anthesis, resembling those of the following species. - Shore of the St. John's River, at St. Francis, N. Maine, Pringle. Growing with or near P. racemost. And a looser form of the latter, "very common on the St. John's River," Goodale, is somewhat between the two; so that this may be a hybrid of $P$. racemosa with $P$. serpentaria.

P. virgáta, Micrx. 1. c. Glaucescent, very smooth, 2 to 4 feet high, very strict: radical and lower leaves oblong-lanceolate, deeply sinnate-pinnatifid or pinnately parted, and divisions sometimes lobed or few-toothed; upper not clasping, decreasing to linear-lanceolate and entire, and to small subulate bracts of the naked and slender ( 1 or 2 feet long) racemiform inflorescence: flowers whitish or pale flesh-color: pappus sordid-stramineous. Willd. Spec. iii. 1533; Pursh, 1. c.; Ell. Sk. ii. 258. P. autumnalis, \&c., Gronov. Fl. Virg. ; Walt. Car. 193. P. simplex, Pursh, 1. c. Harpalyce virgata, Don ex Steud.; Beck, 1. ¿. Nabalus virgatus, DC. 1. c. ; Torr. \& Gray, 1. c. - Moist ground in pine barrens, New Jersey to Florida, in the low country. 
* * Heads 5-18-flowered, sometimes racemose, usually paniculate, commonly pendulous: leaves diverse, but the cauline nearly all petioled; lower and radical or some of them cordate, or hastate, or truncate at base: rout mostly fusiform-thickened or tuberous, as in the preceding: akenes obscurely or minutely striate and sometimes 3-4-costate or angled.

$\leftarrow$ Involucre cylindraceous, distinctly calyculate with very short and ovate to triangular-subulate appressed scale-like bracts : principal bracts with their covered margins white-scarious in dried specimens. Species variously called White LetTuce, Lion's-Foot, Ratrlesnake-root, GALL-OF-THL-EARTH.

+- Pappus cinnamon-brown: stem tall, generally purplish.

P. álba, L. Glabrous, often glaucescent, 2 to 5 feet high, rather stout: leaves sometimes all deltoid-hastate and nearly dentate, on slender winged petioles, or uppermost oblong with tapering base, or most of them 3-5-lobed or parted : inflorescence thyrsoid-paniculate: involucre 8-12- (rarely 5-) flowered, commonly purplish-tinged: flowers dull white: pappus reddish-brown. - L. as to Hort. Cliff. \& Syn. Pluk., not of herb.; Michx. Fl. ii. 83, in part (not of herb. proper); Sims, Bot. Mag.t. 1079 ; Pursh, Fl. ii. 499; Bigel. Fl. Bost. ed. 2, 286. P. rubicunda, Willd. Spec. iii. 2537, excl. syn.; Pursh, 1. c. P. suavis, Salisb. Parad. Lond. t. 85. P. Miamensis, ovata, \& proteophylla, Riddell, Syn. W. Pl., to be divided between this and following species. Harpalyce alba, Don ex Steud.; Beck, 1. c. Nabalus trifoliolatus, Cass. Dict. xxxiv. 95. N. suavis, DC. I. c. 241. N. albus, Hook. F1. ii. 294, chiefly; Torr. \& Gray, Fl. ii. 480, excl. var. - Open oak-woods and sandy or gravelly ground, Canada and New England to Saskatchewan, Illinois, and the upper country of Georgia, \&c.

+ + Pappus sordid straw-color or whitish: leaves diversely variable, assuming all the forms of the preceding species.

P. serpentária, Pursh. Commonly 2 feet high, glabrous or a little hirsute-pubescent: stem sometimes purple-spotted, rather stout: inflorescence corymbosely thyrsoid-paniculate; the heads mostly glomerate at summit of ascending or spreading flowering-branches or peduncles: involucre green, rarely purplish-tinged, 8-12-flowered : flowers purplish, greenish white, or ochroleucous. - Fl. ii. 499 , t. 24 ; Ell. Sk. ii. 261. P. alba, L. Spec, as to Pl. Gronov.; Walt. Car. 193 ; Ell. Sk. ii. 259. Harpalyce serpentaria, Don, 1. c.; Beck, l. c. Nabalus trilobatus, Cass. Dict. 1. c. ? N. serpentarius (Hook. 1. c.), N. trilobatus, \& N. Fraseri, DC. 1. c. (N. glaucus, Prenanthes glauca, Raf. Fl. Lud. 57, \& Esopon glaucum, Raf. 1. c. 149, has no foundation.) - Open grounds, commonly in sandy or sterile soil, New Brunswick and Canada to Florida.

Var. nána. Stem more simple and strict, 6 to 16 inches high, smooth and glabrous: inflorescence contracted; often sessile or subsessile clusters of heads in the axils of most of the cauline leaves: involncre livid-greenish. $-P$. alba, var. nana, Bigel. FI. Bost. 1. c. Nabalus nanus (also $N$. serpentarius, var. lavis), DC. 1. c. ; Torr. \& Gray, l. c. A form with leaves pedately parted into narrow divisions is probably $N$. trifoliolatus, Cass. - Mountains of N. New England to Canada, S. Labrador, and Newfoundland.

Var. barbáta. Sometimes hirsutulous-pubescent: leaves from oblong to deltoidhastate, from denticulate to sinuate-lobed, upper not rarely sessile: involucre sometimes sparingly and sometimes copiously beset with bristles. $-P$. crepidinea, Ell. Sk. ii. 259, not Michx. Nabalus integrifolius (Cass. 1. c. 96, with "subsagittate" leaves), \& N. Fraseri in part, DC. 1. e. N. Fraseri, var. integrifolius \& var. barbatus, Torr. \& Gray, Fl. ii. 481. N. (\& Prenanthes) Roanensis, Chickering in Bot. Gazette, v. 155, vi. 191, a mountain form, a span to a foot high, with most of the leaves hastate-deltoid, and bristles on the involucre copious and conspicuous. - Mountains of N. and S. Carolina to Alabama; apparently first coll. by Fraser, then by Macbride; the high mountain form by Chickering on Roan Mountain. Occasionally a few of these setose hairs are found on the involucre of ordinary $P$. serpentaria, and in this variety some heads are almost destitute of them.

P. altíssima, L. Commonly 3 to 7 feet high, slender, not glaucous, glabrous or nearly so (in open ground sometimes purple-stemmed and hispidulous !) : leaves thin, disposed to be hastate, deltoid, or cordate, sometimes ovate, and denticulate or dentate; lower not rarely from 3-lobed to pedately 5-parted: panicle elongated and loose, very commonly subsessile clusters in the axils of many cauline leaves: involucre narrow-cylindrical, greenish, always glabrous, 5-6-flowered: flowers greenish-ochroleucous. - Spec. ii. 797, from ehar., syn. Pluk. (Alm. t. 317) \& Vaill., and perhaps herb. ( $P$. alba, L. herb., specimen from Kalm, is either this or 
P. serpentaria.) Harpalyce altissima, Don, 1. c.; Beck. l.c. Nabalus cltissimus, Hook. Fl. i. 294 ; DC. l. c. ; Torr. \& Gray, l. c., with named varieties, ovatus, cordatus ( $N$. cordatus, Hook., Prenanthes cordata, Willd. Hort. Berol. t. 25), deltoideus $(N$. deltoideus \& $N$. cordatus, DC. 1. c., Prenanthes deltoideus, Ell. l. c.), \& dissectus, all too trausitional for preservation. - Woods and shaded banks, Newfoundland to Saskatchewan, Pennsylvania, and to the mountains of Georgia.

+ + Involucre campanulate-oblong, of livid or greenish bracts nearly or quite destitute of scarious margins, imperfectly calyculate by 2 or 3 irregular and loose linear accessory bracts, less pendulous than in the preceding: pappus sordid-whitish: plants glabrous or a little pubescent.

P. Boóttii. A span or two high, simple, several-leaved, bearing 7 to 15 racemosely disposed heads: leaves deltoid-oblong and obtuse, or somewhat hastate and the upper acute, on margined petioles, uppermost lanceolate, all entire or denticulate, the lamina unly an inch or so long: involucre half-inch long, of 10 to 15 obtuse and rather unequal proper bracts, 10-18flowered: flowers dull white. - Prenanthes alba, var. nana, Bigel. Fl. Bost. l. c., in part. Nabalus Boottii, DC. Prodr. vii. 241 ; Torr. \& Gray, 1. c. 482.-Alpine region, mountains of Maine, New Hampshire, Vermont, and N. New York; first coll. by Boott and Bigelow.

P. aláta. A foot or two high, the larger plants branching: leaves hastate-cleltoid, acute or acuminate, sharply and irregularly dentate, abruptly contracted or some of the upper cuneately decurrent into winged petioles, or small uppermost narrower and sessile by a tapering base: heads loosely and somewhat corymbosely paniculate: involucre of 8 to 10 bracts, 7-15flowered: flowers purplish : akenes slender, 3 or almost 4 lines long, at least sometimes with tapering summit! - Sonchus hastatus, Less. in Linn. vi. 99; Bong. Veg. Sitch. 146. Nabalus alatus, Hook. Fl. i. 294, t. 102 ; Torr. \& Gray, Fl. ii. 483. Mulgedium hastatum, DC. Prodr. vii. 250. - Unalaska and other Aleutian Islands to Oregon; first coll. by Chamisso, \&c. (Adj. Asia.)

Var. sagittáta. Leaves sagittate or hastate, with the basal lobes mostly slender and prolonged: heads in a virgate panicle: involucre narrower, pale green (not livid), very glabrous, subtended by more numerous slender calyculate bracts: immature akenes little over 2 lines long, not tapering at summit. - Rocky Mountains, N. Montana, in Jocko Cañon, Watson. Üpper Flathead, C'anby \& Sargent.

229. LYGODESMIA, Don. ( $\Lambda$ v́yos, a pliant twig, and $\delta \dot{\epsilon} \sigma \mu \eta$, bundle, from the vimineous fasciculate stems of the typical species.) - N. American herbs, mostly smooth and glabrous; with usually rush-like rigid or tough stems, linear or scale-like leaves, and terminal or scattered heads which are always erect; the flowers pink or rose-color, produced in spring or summer. - Don, in Edinb. Phil. Jour. vi. 305 ; DC. Prodr. vii. 198 ; Torr. \& Gray, Fl. ii. 484; Benth. \& Hook. Gen. 530; Gray, Proc. Am. Acad. ix. 217. Genus somewhat polymorphous.

$\S 1$. Erect perennials, with striate-angled junciform stems and branches, not spinescent, and terminal solitary heads: akenes slender, terete, almost filiform, slightly tapering to summit, 4-8-nerved or at maturity nerveless: pappus soft and copious, whitish or sordid.

L. júncea, Dos, l c. Fastigiately much branched from the deep-rooted base, about a foot high : leaves persistent, small, somewhat nervose; lower lanceolate-linear from a broadish base, inch or two long; upper reduced to small subulate scales: involucre at most half-inch long, 5-flowered : ligules a quarter or third of an inch long. - Hook. Fl. i. 295, t. 103; Torr. \& Gray, 1. .. Prenanthes juncea, Pursh, Fl. ii. 498; Nutt. Gen. ii. 123.-Plains of the Saskatchewan and Minnesota to the Rocky Mountains, New Mexico, and eren in Nevada, Watson.

L. grandiflóra, Torr. \& GraY. Stems separate or few from the root, simple below, a span to a foot high; the larger plants leafy, corymbosely branched above, and bearing few or numerous short-pedunculate heads : leaves all entire, of firm and thickish texture, linearattenuate, 2 to 4 inches long, only the very uppermost reduced to scales: involucre fully three-fourths inch long, 5-10-flowered: ligules of equal length, showy, rose-red.-F]. ii. 485. 
L. juncea, var. dianthopsis, Eaton, Bot. King Exp. 200, the well-developed and taller form, leafy to the top. Erythremia grandiflora, Nutt. Trans. Am. Phil. Soc. vii. 445, dwarf form. - Gravelly hills or slopes, W. Wyoming (first coll. by Nuttall), Utah about Salt Lake (first coll. by Stansbury), and S. Utah.

L. aphýlla, DC. 1. c. Stems mostly solitary from the root, slender and quite rush-like, 2 feet or so high, naked or nearly so, once or twice forked above, and bearing solitary long. peduncled heads : leaves rather fleshy, chiefly radical or near the ground, filiform, elongated, entire, or with one or two rare teeth; upper reduced to minute scales at the forks: involucre (mostly 10-flowered) and rose-colored ligules each two-thirds to three-fourths inch long. Torr. \& Gray, 1. c. ; Chapm. Fl. 251. Prenanthes aphylla, Nutt. Gen. ii. 123 ; Ell. Sk. ii. 261. Erythremia aphylla, Nutt. Trans. Am. Phil. Soc. 1. c. 446. - Dry pine barrens, S. Georgia and Florida ; first coll. by Baldwin.

Var. Texána, Torr. \& Gray, l. c. Stouter : leaves more numerous, from filiform and usually with 2 or 3 lateral lobes to linear (2 lines broad) and sparingly pinnately lobed, also some smaller leaves on the stem : some Texan specimens nearly like those of Florida. - Rocky hills and plains, Texas; first coll. by Berlandier, Drummond, \&c.

§ 2. Diffuse and spinescent perennial, with flexuous branches not striate-angled: pappus rigidulous, whitish, of unequal bristles. - $\$$ Pleiacanthus, Nutt.

L. spinósa, Nuтт. 1. c. Stems slender and rigid, low, much branched from an indurated and matted-woolly base, otherwise glabrous: branchlets divergent, spinescent, bearing minute scales in place of leaves and lateral very short-peduncled heads : lower cauline leaves linear, entire, thickish, above soon reduced to scales : involucre 3-5-flowered; its proper bracts not more numerous, rather loose, lanceolate; the unequal and more imbricated calyculate ones comparatively broad and large: akenes much shorter than the pappus, not at all narrowed upward, 4-5-costate. - Torr. \& Gray, 1. c. ; Eaton, Bot. King Exp. 200; Gray, Bot. Calif. 441. - Gravelly hills and plains in the arid district, S. Idaho to S. Nevada and the eastern borders of California ; first coll. by Nuttall.

\section{§3. Paniculately branched annuals, not spinescent: pappus white and soft.}

L. rostráta, Gray. Stem erect, 1 to 3 feet high, striate, leafy, corymbose-paniculate : leaves narrowly linear, attenuate to both ends, entire, obscurely 3-nerved; cauline 3 to 7 inches long, barely 2 lines wide; nppermost slender-subulate: heads numerous, on scaly-bracteolate erect peduncles: involucre over lalf-inch high, 8-9-flowered, of as many very narrowly linear bracts and a few short calyculate ones : rays small and narrow, probably purplish : akenes slender-fusiform, 4 or 5 lines long, distinctly attenuate at summit but not truly rostrate, 5-8striate, longer than the soft rather dull-white pappus. - Proc. Am. Acad. ix. 217. L. juncea, var, rostrata, Gray, Proc. Acad. Philad. 1863, 69. - Plains along the eastern base of the Rocky Mountains, from the Saskatchewan (Cypress Hills, Macoun) to Wyoming and Colorado, where first coll. by Hall \& Harbour.

L. exígua, Gray, 1. c. A span or two high, effusely paniculate from the base, bearing numerous small heads terminating short-filiform divergent branchlets or peduncles: branches not striate: radical leaves spatulate or oblong (about inch long), from nearly entire to runcinate-pinnatifid; cauline small and entire, soon reduced to minute bracts : involucre oblong, 2 lines high, 4-5-flowered, of as many narrowly oblong bracts and one or two very small calyculate ones: akenes not 2 lines long, gradually tapering from the truncate summit to base, broadly 4-5-costate, or rather narrowly 4-5-sulcate, somewhat longer than the bright white pappus. - Prenanthes exigua, Gray, Pl. Wright. ii. 105. - Stony hills, S. E. New Mexico, Wright. S. W. Utah, Parry, Palmer. Mohave Desert, S. E. California, Parish.

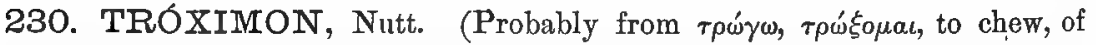
no obvious application to this, or to the factitious genus, partly Krigia, partly Scorzonera, for which Gærtner coined the name.) - N. American with one or two S. American herbs, acaulescent or nearly so, with a cluster of sessile or subsessile radical leaves, and simple scapes bearing a head of yellow or rarely purple fiowers, in summer. Occasionally in one species some chaffy bracts among the 
flowers. - Nutt. in Fras. Cat. \& Gen. ii. 127 ; Benth. \& Hook. Gen. ii. 522 ; Gray, Proc. Am. Acad. ix. 215, Bot. Calif. i. 437, \& Proc. Am. Acad. xix. 71. Troximon \& Macrorhynchus (Less.), DC., Torr. \& Gray, Fl. ii. 489, 491.

§1. Eutróximon. Akenes more or less linear, beakless, or tapering gradually into a short and thickish beak, on which the nerves or ribs of the body are prolonged to the apex : pappus rigidulous : perennial from a strong caudex.

* No beak to the akene, its moderately short contracted summit of the same texture as the body and equally 10-costate: involucral bracts somewhat equal, all tapering to a slender acumination, the onter from an oblong or ovate-lanceolate base, glabrous: corolla yellow : root perennial.

T. alpéstre, Gray. Dwarf from an elongated rootstock or caudex, glabrous : leaves diverse (2 or 3 inches long), narrowly spatulate or lanceolate and pinnately lobed or incised, or parted into narrow linear divisions: scape 2 or 3 inches high, weak: involucre campanulate, 7 or 8 lines high; the bracts in about 2 series: akenes $2 \frac{1}{2}$ lines long, equalled by the slender uniform pappus-bristles. - Proc. Am. Acad. xix. 70, 71. - On Mount Paddo, Washington Terr., Suksdorf, 1880. Summit of Cascade Mountains, Oregon, L. F. Henderson.

T. cuspidátum, Persh. Glancescent, tomentulose when young, a span or two or the scape at length a foot high from a thickened caudex : leaves entire, elongated linear-lanceolate and upwardly linear-attenuate, thickish, often nervose, mostly tomentulose-ciliate (2 to 5 lines wide): involucre about inch high; its bracts in 2 or 3 series: akenes 3 or 4 lines long when mature, rather shorter than the unequal rigidulous pappus. - Fl. ii. 472; Torr. \& Gray, 1. c.; Gray, Man. 277, \& Proc. Am. Acad. ix. 215. T. marginatum, Nutt. 1. c. - Prairies of W. Mlinois and Wisconsin to Dakota; first coll. by Nuttall and Bradbury. Stronger pappus-bristles gradually and slightly widened toward the base.

* * Akenes with apex tapering gradually into a rather stout and nerved beak which is shorter than the body. - \$ Nothotroximon, Gray, Bot. Calif. l. c., partly.

T. barbellulátum, Greene in herb. Slender, not glaucous: leaves linear-lanceolate, laciniate-pinnatifid into a few short and narrow lobes, or some entire: involucre narrow, orer half-inch high, rather few-flowered; its 10 to 12 bracts nearly equal, Ianceolate, acuminate, glabrous : flowers yellow: akenes with the beak (of fully half the length of the fusiform body) 3 lines long, about the length of the soft distinctly barbellulate pappus. - Castle Lake, near Mount Shasta, California, C. H. Dwinelle, from Greene.

T. glaúcum, Noxt. Usually a foot or two high, rather stout, pale or glaucous, either glabrous or with loose pubescence: leaves linear to lanceolate, from entire to sparingly dentate or sometimes laciniate, 4 to 12 inches long: involucre commonly an inch high and many-flowered; its bracts lanceolate or broader; outer series shorter, often pubescent, or even villous : akenes with the beak 5 or 6 lines long, longer than the pappus, the copious and rather rigid bristles of which are (as in most species) only denticulate-scabrous. - Nutt. in Fras. Cat. \& Gen. ii. 128; Pursh, 1. c. ; Sims, Bot. Mag. t. 1667 ; Torr. \& Gray, 1. c. Macrorhynchus glaucus, Eaton, Bot. King Exp. 204. - Grassy plains, Saskatchewan and Dakota to Brit. Columbia, and mountains of Utah and Colorado; first coll. by Nuttall and Bradbury.

Var. parviflórum. A small and slender form: leaves only 2 to 6 inches long: scape a span to a foot high: head smaller and narrower. $-T$. parviflorum, Nutt. Trans. Am. Phil. Soc. vii. 434. Macrorhynchus cynthioides, Hook. Lond. Jour. Bot. vi. 256 ? - Plains of Nebraska and Wyoming to the mountains of New Mexico.

Var. laciniátum, GRAY, Bot. Calif. 1. c. Dwarf (a span or two high), with the small heads of the preceding variety, varying to larger, glabrous or glabrate, when young often cinereous-pubescent throughout: rays sometimes purplish externally or in fading: leaves mostly of lanceolate outline and laciniate-pinnatifid. - Mountains of Colorado and New Mexico to the higher Sierra Nevada, California. Larger forms pass into the next.

Var. dasycéphalum, Torr. \& Grar. Commonly robust, with large and broad heads; the involucre inch broad as well as high, and from villous to cinereous-pubescent, sometimes early glabrate : receptacle not rarely bearing a few chaffy bracts among the flowers : leaves from elongated-lanceolate to oblong-spatulate (the broadest even inch and a half wide), from entire to laciniate or rarely pinnatifid: scape from a span to 2 feet high. - Ammogeton scorzonerafolium, Schrad. Ind. Sem. Hort. Goett. 1833 ; DC. Prodr. vii. 98. Troximon glaucum, Richards. App. Frankl. Jour.; Hook. Bot. Mag. 3462. T. pumilum, Nutt. 
Trans. Am. Phil. Soc. 1. c, a dwarf form. T.taraxacifolium, Nutt. 1. c., a larger form. Dakota to Saskatchewan and to near Arctic coast, south to the mountains of Colorado, west to the Sierra Nevada and Washington Terr. on the mountains. Passes through smoother and narrowish-leaved forms to the type of this polymorphous species.

§ 2. MaCrorminchus. Akenes with a slender and mostly filiform nerveless beak and soft pappus. - Macrorhynchus, Torr. \& Gray, Fl. l. c. Trochoseris, Endl. Gen., \& Pœpp. \& Endl. Nov. Gen. \& Spec. iii. 56, t. 263. Troximon in part, Stylopappus, Cryptopleura, \& Kymapleura, Nutt. Trans. Am. Phil. Soc. vii. 430,434 .

* Perennials, with akene acute or tapering at summit

+ Into a beak not longer or little longer than the cylindraceous or narrowly fusiform body.

T. aurantíacum, Hook. Loosely soft-pubescent and glabrate: leaves from linear-lanceolate to spatulate, thinnish, entire, or sparingly laciniate-dentate, occasionally pinnatifid: scape from a span to a foot or more high: involucre oblong to campanulate, 7 to 9 lines high; its bracts from broadly to narrowly lanceolate and acute, or outer and looser ones oblong and obtuse: flowers orange, commonly changing to brownish red or purple: akenes thickish, 3 or 4 lines long, and the firm beak only 2 or 3 lines long: pappus somewhat rigidulous. - Fl. i. 300, t. 104. T. roseum, Nutt. Trans. Am. P'hil. Soc. 1. c., a small form. Macrorhynehus aurantiacus, Fisch. \& Meyer, Ind. Sem. Hort. Petrop. 1837? M. troximoides, Torr. \& Gray, Fl. ii. 491. - Mountain prairies and banks of streams, northern Rocky Mountains to Brit. Columbia and Oregon, perhaps California, and mountains of Colorado.

Var. purpúreum, Grax. Leaves apparently thickish, laciniate, and with the purpletinged involucre very glabrous or glabrate: "flowers purple."-Proc. Am. Acad. xix. 72. Macrorhynchus purpureus, Gray, P1. Fendl. 114. - Along Santa Fé Creek, New Mexico, Fendler. A similar form in mountains of Colorado.

T. grácilens, Gray. Resembles slender forms of preceding : leaves mostly entire, flaccid, from lanceolate to nearly linear, or some narrowly spatulate : scape 10 to 18 inches high: head and involucral bracts narrow: flowers deep orange : akenes fusiform-linear, 3 or 4 lines long; the very slender beak 4 or 5 lines long : pappus soft, but not flaccid. - Proc. Am. Acad. xix. 71. - Cascade Mountains of Oregon and Washington Terr., Lyall, Nevius, Suksdorf, Brandegee. Rocky Mountains in N. Wyoming, Forwood.

Var. Greènei, Gray, l. c. A dubious form, smaller : leaves narrowly linear, with a few linear lobes. - N. California, in Scott Mountains, Siskiyou Co., in dry open ground at about 7,000 feet, Greene.

T. Nuttállii, Grar. Resembles broad-leaved forms of $T$. glaucum, robust: leaves thickish, from spatulate to lanceolate, from sparingly dentate to pinnatifid, a span to near a foot long (the thick midrib nervose when dry): scape 6 to 20 inches high: head broad, an inch or more high : involucre more or less pubescent: flowers yellow: thickish akene and beak each 3 or 4 lines long. - Proc. Am. Acad. ix. 216, \& Bot. Calif. i. 438 (excl. pl. Nevius). Stylopappus elatus, Nutt. 1. c. 433. Macrorhynchus elatus, Torr: \& Gray, l. c. M. grcuntiflorus, Eaton, Bot. King Exp. 206. Troximon aurantiacum, Gray, Bot. Calif. 1. c., as to Calif. plant. - Low or moist ground, Oregon, and the Sierra Nevada in California to S. Ltah; perhaps first coll. by $N$ uttall.

T. apargioídes, Less. Low and tufted from a multicipital lignescent caudex, glabrate: leaves linear or narrowly lanceolate, entire or with a few salient teeth or lobes, or pinnatifid with sparse linear divisions: scapes a span or two high: head half-inch high: involucre campanulate; outer bracts at least pubescent: akenes and beak each $1 \frac{1}{2}$ to 2 lines long: pappus soft, dull white.-Linnæa, vi. 594; Gray, Bot. Calif. 1. c., partly. - Sandy soil on and near.the coast, San Francisco Bay, \&c., California ; first coll. by Chamisso.

+ + Beak slender-filiform or almost capillary, 2 to 4 times the length of the short-fusiform or oblong akene (this rarely over 2 lines long): pappus soft and fine, rather flaccid: flowers all yellow. - Stylopappus, Nutt. 1. u.

t+ Pappus about the length of the beak, whitish.

T. húmile, GraY. Leaves hirsutely pubescent, from spatulate and repand-dentate or lyratepinuatifid to lanceolate or broader in outline and pinnately parted into linear lobes: scapes 
from a span to a foot high, slender: involucre permanently villous with apparently somewhat viscid hairs : ligules exserted : closed head in fruit from half-inch to hardly inch high : filiform beak only about twice the length of the whitish akene. - Proc. Am. Acad. xix. 72. Leontodon hirsutum, Hook. Fl. i. 296, therefore Taraxacum hirsutum, Torr. \& Gray, Fl. ii. 494, ex char. Barkhausia Lessingï, Hook. \& Arn. Bot. Beech. 145, excl. syn, Macrarhynchus Lessingii, Hook. \& Arn. 1. c. 36I, excl. syn., for it is not Lessing's plant described in Linnæa. 1\%. humile, Benth. Pl. Hartw. 320, a small form. M. Harfordii, Kellogg, Proc. Calif. Acad., a larger form. Troximon apargioides in part, Gray, Bot. Calif. 1. c. - California near the coast, from Monterey to Washington Terr. Variable in size, the flowering head sometimes nearly as large as in $T$. grandiforum.

* Pappus much shorter than the almost capillary beals, usually bright white.

T. laciniátum, Grax, 1. c. Smootl and glabrous, or with sparse soft pubescence: leaves elongated-lanceolate, laciniate-dentate or commonly deeply pinnatifid into linear lobes: scapes a foot or two high: involucre glabrous or glabrate, or base of the outer of the lancsolate bracts tomentose: closed head in fruit not over inch high: akene 2 and beak 5 to 7 lines long. - Stylopappus laciniatus (original specimen, and one like it from Vancouver's Island, Lyall, small and with small immature heads, but apparently of the species) and especially var. longifolius, Nutt. 1. c. Macrorhynchus laciniatus, \& var., Torr. \& Gray, l. c. Troximon grandiforum, var. tenuifolium \& var. laciniatum, Gray, Bot. Calif. 1. c.-Low ground, Brit. Columbia to Oregon, and California to San Francisco Bay or nearly.

T. grandiflórum, Grax. Leares hirsutely or cinereous-pubescent, or glabrate, spatulate to lanceolate, sinuate-dentate to laciniate-pinnatifid, or even pinnately parted: scapes stout, a foot or two high: involucre broad, usually well imbricated; the bracts lanate or tomentose when young, often glabrate in age: ligules short: head in fruit an inch to inch and a half high: akene 2 and capillary beak 6 to 8 lines long. - Proc. Am. Acad. ix. 216, \& Bot. Calif. 1. c., excl. vars. Stylopappus grandiflorus, Nutt. 1. c. Macrorhynchus grandiftorus, Torr. \& Gray, I. c. - Plains and moist hillsides, Washington Terr. to S. California, toward the coast. Some forms seem to pass into the preceding.

* * Perennial, with habit of the last preceding species : akene abruptly long-beaked from a broad truncate summit.

T. retrórsum, Grar, 1. c. Villous-tomentose when young: leaves pinnately parted into linear-lanceolate usually retrorse lobes, the terminal lobe long and narrow, all callous-tipped: scapes about a foot high: involucre narrowly oblong, $1 \frac{1}{2}$ to 2 inches high when mature; its narrow linear bracts hardly surpassed by the soft white pappus : ligules short : akene 3 lines and filiform beak about an inch long. - Mfacrorhynchus retrorsus, Benth. Pl. Hartw. 30 ; Gray, in Wilkes Exp. xvi. 373. Mr. angustifolius, Kellogg, Proc. Calif. Acad. v. 47.Open pine woods, California, from Mendocino and the Upper Sacramento to mountains of San Bernardino; first coll. by Pickering \& Brackenridge, then by Hartweg. Also in S. WV. Idaho, Nevius.

* * Annuals, slender, mostly low, occasionally subcaulescent: flowers yellow. - Macrorhynchus, Less. Syn. 137, but "achenium plano-obcompressum" is erroneous. Kymapleura in corrig. (Macrorhynchus in text) \& Cryptopleura, Nutt. Trans. Am. Phil. Soc. vii. 430.

T. heterophýllum, GREENE. Somewhat villosely or hirsutely pubescent, or glabrate: leaves from spatulate to linear-lanceolate, denticulate to pinnatifid: scapes a span or two (rarely a foot) high: involucre oblong-campanulate, half to three-fourths inch high; its bracts erect, lanceolate or narrower; outer decidedly shorter than the glabrous inner ones, more or less pubescent with simple or gland-tipped hairs (not villous): akenes various but at most 2 lines long, usually fusiform; filiform beak fully 3 lines long, mostly longer than the white or whitish pappus. - Bull. Torr. Club, x. 88; Gray, Proc. Am. Acad. xix. 72. T. Chilense, Gray, Proc. Am. Acad, ix. 216, \& Bot. Calif. i. 439. Macrorhynchus heterophyllus \& Cryptopleura Californica, Nutt. 1. c. .1T. Californicus \& M. heterophyllus, Torr. \& Gray, El. ii. 493. M. Chilensis, Hook. Lond. Jour. Bot. vi. 256. - Open and low ground throughout California, at least near the coast, to Brit. Columbia, and east to Utah. - Varies mainly in the akenes; these generally glabrous, occasionally outer ones pubescent or hirsute; sometimes all alike and from 10-striate to acutely 10-costate; sometimes the outer ones more acutely or even alately costate, and passing into the following forms described by Nuttall, even taken as of different and peculiar genera, but they afe rather conditions than.varieties 
Var. Kymaplefra, Grecne, 1. c. Outermost and sometimes all of the akenes thicker and blunter or truncately obtuse by the development of the ribs into wings, which become sinuously undulate, corering the whole surface. $-M$. (Kymapleura) heterophyllus, Nutt. 1. c., changed in corrig. to Kymapleura heterophylla. - Common in California, with other forms.

Var. Cryptopleúra, GreENe, 1. c. Some marginal akenes becoming utricular and lightly nerved, enlarging to almost a line in diameter. - Cryptopleura Californica, Nutt. l. c. - With other forms, less common.

231. TARÁXACUM, Haller. Dandelion, i. e. Dent de Lion. (Ta-

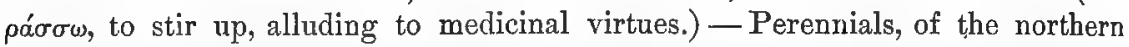
hemisphere, sending up in spring, from a rosulate cluster of runcinate-pinnatifid or lyrate radical leaves, naked fistulous scapes, which elongate with and after anthesis of the showy head of yellow flowers: involucre reflexed at maturity of the fruit, which, with the expanded pappus, raised on the elongated beak, is displayed in a globose body. The common and only North American, but very polymorphous species, is the following.

T. officinále, W siser . Root vertical : leaves from spatulate-oblong to lanceolate, from irregularly dentate to runcinate-pinnatifid : akenes oblong-obovate or narrower, squamulose or spinellose-muricate towarl the summit, abruptly contracted into a conical or pyramidal apex, which is prolonged into a filiform beak of twice or thrice the length of the akene. In the orainary form of the fields the involucral bracts arc obscurely or not at all corniculate, and the calyculate bracts are linear, elongated, and recurved; leaves usually lobed. - Weber (not Wiggers) Prim. Pl. Holst. 56; Vill. Dauph.; Koch, Fl. Germ., \&c. T. Dens-leonis, Desf. Fl. Atl. ii. 228; DC. I'rodr.; 'Torr. \& Gray, Fl. ii. 494. Leontodon Taraxacum, L. L. officinatis, Withering. L. vulgare, Lam. - Common everywhere in fields and yards, an introduction from Europe: perhaps nowhere here indigenous, but it comes even from Modoc Co., California. (Eu., Asia, \&c.)

Var. alpínum, КосH. Onter involucral bracts ovate to broadly lanceolate, sprealing, none conspicuously corniculate. - Leontodon alpinus, Hoppe. Taraxacum latilobum, DC. Prodr. vii. 494? - Labrador to Brit. Columbia, and southward along higher mountains to Colorado, Utah, and California.

Var. glaucéscens, Kocır. Onter involucral bracts lanceolate to linear, looscly erect or spreading, inner ones and sometimes outer with a corniculate appendage below the tip: leaves generally glaucesceut. - T. corniculatum and T. ceratophorum, DC. l. c. Leontodon ceratophorum, Ledeb. Ic. Fl. Alt. t. 34. - Unalaska, \&c. (Adj. Asia, Greenland.)

Var. lívidum, Kocir. Outer involucral bracts ovate to ovate-lanceolate, all apt to be dark-colored in drying, obscurely or not at all corniculate: leaves from denticulate to runcinate-dentate, sometines pinnatifid. $-T$. palustre, DC., \&c. T. Tanceolatum, Poir. T. montanum, Nutt. Trans. Am. Phil. Soc. vii. 430, not Meyer \& DC. Leontodon lividus, Walds. \& Kit. - Rocky Mountains, south to New Mexico, north to Arctic coast and islands, and the Aleutian Islands, in various forms. (N. Asia, Eu., Greenland.)

Var. scopulórum. Minute : leaves and scape an inch or less long: head 3 or in fruit even 5 lines high, narrow, few-flowered: outer involucral bracts lanceolate, rather loose; inner somewhat corniculate. - T. Icerigatum, Gray, Proc. Acad. Philad. 1863, 70، - Highest alpine region of the Rocky Mountains in Colorado, Hall \& Harbour, Brandegee.

T. piryatocárpum, J. Vahi in Fl. Dan. t. 2297, of Greenland, is near var. lividum, but the akene is broad and its beak shorter.

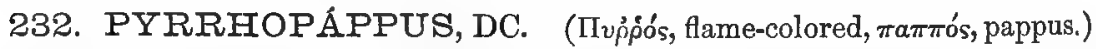
- Atlantic N. American and adjacent Mexican herbs; with leafy or sometimes scapiform stems, undiviaed or pinnatifid leaves, and rather large slender-pedunculate heads of golden yellow flowers, produced in late spring and summer. Principal bracts of the involucre always more or less corniculate behind the tip, in the manner of certain forms of Dandelion. - Prodr. vii. 144 (excl. S. African sp.) ; Torr. \& Gray, Fl. ii. 495; Benth. \& Hook. Gen. ii. 523. 
* Scapose, monocephalous, perennial by roundish tubers.

P. scapósus, DC. 1. c. Hirsutulous-pubescent, low and simple: globular tuber (tlirecfourths inch in diameter) sending up a slender caudex, bearing at the surface of the ground a cluster of pinnatifid leaves and scapes of a span or two high: the latter simple and waked, sometimes a bract or small leaf uear the base: head seldom an inch high in fruit: calyculate bracts of involucre short and small, subulate; principal ones obscurely corniculate at tip; flowers citron-yellow: pappus fulvous. $-P$. grandiflorus, Nutt. Traus. Am. Plil. Soc. l. c. 430; Torr. \& Gray, 1. c.; Engelm. \& Gray, Pl. Lindh. i. 42. Barkhausia grandiflora, Nutt. Jour. Acad. Philad. vii. 69.- Prairies of Arkansas and Kansas; first coll. by Pitcher. Texas; first coll. by Berlandier.

* * More or less leafy-stemmed and branching : heads moderately long-pedunculate.

- Leaves diversely pinnatifid, Iaciniate, sinuate-dentate, or some upper ones entire.

P. Caroliniánus, DC. Annual or biennial, freely branching, 2 to 5 feet high, nearly glabrous, but peduncles and involucre mostly cinereous-puberulent: upper leaves when undivided usually elongated lanceolate and gradually attenuate to the tip : flowers very bright yellow: fruiting heads fully inch high: calyculate bracts setaceous-subulate, loose, half or a third the length of the principal ones; these conspicuously corniculate at the apex: pappus rufous. - Torr. \& Gray, 1. c.; Nutt. Trans. Am. Phil. Soc. 1. c, with var. maximus. P. mutticaulis, Curtiss, Distrib. N. Am. Pl. 1623, not 1DC. Leontodon Carolinianum, Walt. Car. 192. Scorzonera pinnatifida, Michx. Fl. ii. 89. Chondrilla lcevigata, Pursh, Fl. ii. 497. Barkhausia Caroliniana, Nutt. Gen. ii. 126; Ell. Sk. ii. 251. - Diy ground, Maryland to Florida, Arkansas, and Texas.

P. multicaúlis, DC. 1. c. A foot or two high from a thickened apparently perennial root (but flowering first season), less leafy, at length many-stemmed from base and diffuse or ascending: leaves seldom large: head in fruit two-thirds to three-fourths inch high: calyculate bracts of involucre short and subulate: pappus rufous or fulvous. - Texas (first coll. by Berlandier), New Mexico (Newberry, Greene, Rusby), and Arizona (Lemmon), the latter a dwarf and very narrow-leaved form. (Mex., where $P$. pauciflorus and even $P$. Sesseanus are probably forms of it.)

$$
++ \text { Leaves all undivided, narrow: stems junciform. }
$$

P. Rothróckii, Grax. Glabrous, or involucre obscurely puberulent: stems 1 to 3 feet high, slender, erect from a thickened perenuial root: leaves narrowly lanceolate or linear, entire or merely denticulate ( 3 to 9 inches long, $1 \frac{1}{2}$ to 4 lines wide); radical ones spatulatelanceolate: caljculate bracts of involucre short and subulate: head in fruit only two-thirds inch ligh: pappus sordid-whitish. - Proc. Am. Acad. xi. 80; Rothrock in Wheeler Rep. vi. 181, t. 14. - Mountains of S. Arizona, Rothrock, Lemmon.

233. CHONDRfLLA, L. (Name by Dioscorides, of unexplained meaning, for some gummiferous plant.) — Old World herbs, perennials or biennials; with virgate or rush-like stems and branches, leafy below, and small heads of yellow flowers; one species introduced.

C. Júxcea, L. Hirsute towards the base, 1 to 3 feet high, glabrous above: lower leaves runcinate; upper linear and entire, those on the long slender branches reduced to linear-subulate bracts: heads scattered or in small clusters and nearly sessile along the branches: akenes somewhat clavate, bearing a circle of scales at base of the filiform beak. - Old fields and banks, S. Maryland and N. Virginia, common about Washington. (Nat. from Eu.)

234. LACTÚCA, Tourn. Letruce. (Ancient Latin name, from lac, milk, referring to the milky juice.) - Mostly tall herbs (of the northern hemisphere); with leafy stems, and paniculate middle-sized or small heads of yellow, blue, or sometimes whitish flowers, in summer. Involucre in ours glabrous and smooth. - Benth. \& Hook. Gen. ii. 524, excl. § 5, 6. Lactuca \& Mulgedium, Cass., DC., \&C. 
§ 1. Scariola, DC. Akenes very flat, orbicular to oblong, abruptly produced into a filiform beak of softer texture, which bears the soft white pappus on its dilated apex : involucre cylindraceous or in fruit conoidal, glabrous : ours biennials or sometimes annuals.

* Introduced : heads 6-12-flowered: akenes several-nerved, margined.

L. Scaríl一, L. Strict, 2 to 6 feet high, glancous-green, glabrous except lower part of stem, which has stiff bristles : leares becoming vertical by a twist, lanceolate to oblong, with spinulose-denticulate margins, sometimes sinuate-toothed, sometimes pinnatifid; midrib beneath beset with weak prickles rather than bristles; base sagittate-clasping: panicle open: heads small: flowers pale yellow: beak about the length of the obovate-oblong striate-nerved akene. - Waste ground, becoming common in Atlantic States near towns and habitations. (Nat. from Eu.)

* * Indigenous : heads 12-20-flowered : akenes blackish, obscurely scubrous-rugulose, lightly onenerred on the middle of each face, sometimes with obscure nerves toward the distinct thin margins; the beak a litule shorter or longer than the body: most of the cauline leaves partly clasping by a sagittate or auriculate base.

+ Involucre irregularly calyculate, but little imbricated, hardly over half-inch long. Species seemingly confluent.

L. Canadénsis, L. (Fire-weed, Wild Lettdee, Trdmpet-weed.) Glabrous, glalcescent: stem strict, 4 to 9 feet high, very leafy up to the elongated narrow panicle: leaves mostly sinuate-pinnatifid, 6 to 12 inches long, with margins entire or sparingly dentate, and midrib naked or rarely some sparse bristles: involucre half-inch or less high: flowers pale yellow: akenes broadly oval, rather longer than the beak. - Spec. ii. 796; Gray, Man. 280. L. Caroliniana, Walt. Car. 193? L. longifollia, Michx. Fl. ii. 85. L. elongata, Mubl. in Willd. Spec. iii. 1523; Pursh, Fl. ii. 252 ; Hook. Fl. i. 296 ; Torr. \& Gray, l. c., var. longifolia. Galathenium elongatum, Nutt. Trans. Am. Phil. Soc. vii. 443. Sonchus pallidus, Willd. Spec. iii. 1521; Pursh, 1. c., founded wholly on char. of Lactuca Canadensis, L. - Rich moist grounds, Nova Scotia and Canada to.Saskatchewan, south to the upper part of Georgia. Specimens from a grain-field in Sierra Valley, California, probably introduced with grain.

L. integrifólia, BigeL. Glabrous, less leafy, 3 or 4 feet high, loosely branched above, or heads loosely paniculate: leaves oblong-lanceolate, acuminate (larger 7 to 10 inches long, $1 \frac{1}{2}$ to 3 inches broad), whitish beneath, denticulate, sometimes quite entire, all undivided, midrib naked: involucre barely half-inch long: flowers yellow or purplish-tinged: akenes oval, longer than the beak. - Fl. Bost. ed. 2, 287; DC. I. c. 137, not Nutt. L. sagittifolia, E11. Sk. ii. 253. L. elongata, var. integrifolia, Torr. \& Gray, 1. c. L. Canadensis, var. integrifolia, Gray, Man. 1. c. Galathenium integrifolium and partly G. salicifolium, Nutt. 1. c.Open grounds, New England to Illinois and Georgia.

L. hirsúta, Muru. Stems 2 or 3 feet high, rather few-leaved, often reddish, the naked summit paniculate-branched or bearing a loose panicle of heads, the base commonly hirsute: leaves hirsute on both faces, or glabrous except the hirsute or hispid midrib, mostly runcinate-pinnatifid, with narrow rhachis; cauline 3 or 4 inches long: involucre rather over halfinch long: flowers yellow-purple or dull red, or sometimes whitish: akenes oblong-oval, about the length of the beak. - Cat. \& in Nutt. Gen. ii. 124. L. sanguinea, Bigel. Fl. Bost. ed. 2, 287. L. elongata, var. sanguinea \& var. albiflora, Torr. \& Gray, 1. c. L. Canadensis, Gray, Man. 1. c. Galathenium sanguineum, \& G. Floridanum, Nutt. 1. c. $\rightarrow$ Dry and open ground, E. Massachusetts to Louisiana and 'Texas.

L. graminifólia, Micux. Perhaps perennial, glaucescent and glabrous, or merely hispid on the midrib beneath, or hirsute in the manner of the foregoing species: stern slender, 2 or 3 feet high, terminating in a naked loose panicle of comparatively large heads: leaves elongated-linear or linear-lanceolate ( 4 to 12 inches loug, 2 to 5 lines wide), rather rigid, entire, or with spreading or deflexed lobes, or the radical spatulate-lanceolate and pinnatifid: involucre 6 or 7 lines long, with outer bracts broader and more imbricated : flowers purple or pale blue, varying to white or yellow: alsenes elliptical-oblong, longer than the beak. Fl. ii. 85 ; Ell. Sk. ii. 253; DC. Prodr. vii. 134; Torr. \& Gray, 1. c. L. elongata, var. graminifolia, Chapm. Fl. 252. L. graminea, Spreng. Syst. iii. 659. Galathenium graminifolium \& G. salicifolium in part, Nutt. 1. c. - Dry and fertile soil, S. Carolina to Florida and 'Texas; also New Mexico and Arizona. 
- + Involucre more imbricated, commonly three-fourths inch high; outermost and intermediate bracts ovate and orate-lauceolute.

L. Ludoviciána, DC. Glabrous, leafy to the open panicle, 2 to 5 feet high : leaves all oblong and auriculate-clasping, 3 or 4 iuches long, sinuate-pinnatifid, somew lat spinulosely dentate, more or less bristly-ciliate, more or less hispiclulous-setose on the midrib beneatl: peduncles squamose-bracteolate: fluwers yellow: akenes oblong-oval, about equalled by the filiform beak. - Prodr. vii. 141 ; Torr. \& Gray, 1. c. Sonchus Ludovicianus, Nutt. Gen. ii. 125. Galathenium Ludovicianum, Sutt. Trans. Am. Phil. Soc. 1. c. - Moist or dry bauks of lakes and streams, Dakota, Vuttull, Geyer. Iowa, Lithur. Black Hills of the Platte, Hayden. Rio Limpio, S. W. Texas, Bigelow.

§ 2. LACTUCÁSTRLi. Akenes lanceolate-oblong, flat, marginless, tapering into a beak nearly like that of the preceding section, but not longer than the breadth of the body : root perennial: involucre well imbricated, glabrous.

L. pulchélla, DC. A foot or two high, very glabrous, glaucescent, leafy up to the open corymbiform panicle: leaves from linear-lanceolate to narrowly oblong, entire or runcinatedentate, or some lower ones pinnatifid; cauline sessile, with base not auriculate-clasping, disposed to be vertical: branches of the loose panicle and peduncles squamose-bracteolate: involucre two-thirds inch high, 15-20-flowered; its outer bracts ovate-lanceolate: flowers bright blue or violet-purple: akenes barely 2 lines long, striate-nervose; the tip of short beak soft and usnally whitish. - Prodr. vii. 134; Gray, Bot. Calif. i. 442. L. integrifolia, Nutt. Gen. 1. c., not Bigel. Sonchus pulchellus, Pursh, Fl. ii. 502. S. Sibiricus, Richards.; Hook. Fl. i. 293, not L. Mulgedium pulchellum, Torr. \& Gray, F1. ii. 497. .11. pulchellum \& M. heterophyllum, Nutt. 'Trans. Am. Phil. Soc. vii. 441. - Alluvial ground, Upper Michigan to the Hadson's Bay region in lat. $60^{\circ}$, south to New Mexico, west to Brit. Columbia and mountains of Nerada and adjacent California.

§3. MrLGÉDICx. Akenes thickish, oblong, with some strong ribs and nerves, contracted at summit into a stout short beak mainly of the texture of the body, or into a mere (even obscure) neck under the dilated pappiferous apex : involucre (glabrous, 15-25-flowered) and habit of § Scariola, or more branching: glabrous biennials or annuals, with or without some hairs or weak bristles on the midrib and veins beneath, commonly with bluish flowers. - Here characterized for the American species only of Mulgedium, Cass. (Agathyrsus, Don), leaving the older name, Cicerbita, Wallr., for the OId World species of less affinity to true Lactuca.

* Flnwers light blue : pappus bright white: cauline leaves on margined or winged petioles, not clasping nor auriculate at insertion: heads loosely paniculate.

L. Floridána, Gærтx. Sten 3 to 7 feet high: leaves deeply lyrate-pinnatifid; lobes simply or doubly dentate, lateral ones ovate, terminal dilated-deltoid and acuminate : involucre half-inch long: akenes acuminate into a manifest beak. - Gartn. Fruct. ii. 262, name, but the akenes figured, t. 158, probably from herb. Banks, are of L. leucophoca. Sonchus Floridanus, L. Spec. ii. 795; W'illd. Spec. iii. 1520; Michx. Fl, ii. 85, in part; Ell. Sk. ii. 225. Mulgedium lyratum, Cass. Dict. xxxiii. 297. M. Floridanum, 1)C. Prodr. vii. 249; Torr. \& Gray, Fl. ii. 498, excl. vars. Agathyrsus Floridanus, Beck, Bot. 171 . Galathenium Floridanum, Nutt. Trans. Am. Plil. Soc. 1. c. 443.-Alluvial ground and along streams, Penn. to Illinois, Florida, and Texas.

L. acumináta, Gray. Leares from ovate-oblong to oblong-lanceolate, acuminate at both ends, or cauline not rarely sagittate or hastate, sharply and sometimes doubly serrate, occasionally some of the lower cleft at base, forming a pair of lateral lobes: involucre 5 lines high : akenes beakless and with hardly a neck: otherwise nearly like the preceding. - Proc. Am. Acad. xix. 73. J.. villosa, Jacq. Hort. Schøenbr. iii. t. 367; Beck, Bot. 170, but the plant mostly glabrous or nearly so. Sonchus acuminatus, Willd. Spec. iii. 1521; Ell. 1. c. $S$. Floridanus, Michx. 1. c., in part. IInlgedium acuminatum, DC. 1. c.; Torr. \& Gray, 1. c.Borders of woodlands, New York to Hinois and Florida. 
* * Flowers bluish to yellowish or whitish: pappus sordid or fuscous : upper cauline leaves sessile by a mostly narrowed but auriculate or partly clasping base: heads in a pyramidal more crowded panicle. - Mulgedium $\$$ Agalma, DC. 1. c., in part.

L. leucophóa, Gray, 1. c. Stem 3 to 12 feet high, stout, leafy up to the panicle: leaves ample, sinuately or runcinately pinnatifid, coarsely and irregularly or doubly dentate: involucre oblong, 5 lines high . akenes narrowed at summit into a short but manifest neck. -

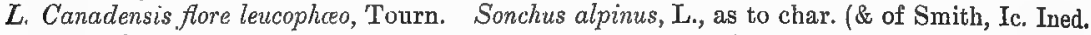
t. 21), \& S. Canadensis, L., as to habitat, owing to transposition by Linnæus. S. spicatus, Lam. Dict. iii. 401, excl. syn. Walt. S. racemosus, Lam. 1. c. 400. S. biennis, Monch, Meth. 545. S. leucopharus, Willd. Spec. iii. 1520, excl. syn. Walt. S. Floridanus, Ait. Kew. iii. 116, from fruit of which is probably that of Lactuca Floridana, Gærtn. t. 158. S. acuminatus, Bigel. Fl. Bost. ed. 2, 290. S. pallidus, Torr. Compend. 279. Agathyrsus leucophaus, Beck, Bot. 170. Mulgedium leucophceum, DC. 1. c., Nutt. 1. c. (\$ Leucomela); Torr. \& Gray, Fl. ii. 499. M. multiflorum, DC. 1. c. Sonchus multiflorus, Desf. Cat. (and so Galathenium mult, florum, Nutt. 1. c.) is, from sessile canline leaves, probably this species. - Moist gromds and border of woods, Newfoundland to Canada, Iowa, mountains of Carolina and Tennessee, and northwestward to coast of Oregon and Brit. Columbia.

Var. integrifólia. Leaves undivided (simulating those of L. acuminata, but sessile), or the lower sinuate-pinnatifid. - Mulgedium leucophreum, var. integrifolia, Torr. \& Gray, 1. c. - Ohio, Lea. Canton, Illinois, Wolf.

L. MACRophŕlLA, Sonchus macrophyllus, Willd., is not known in this country, and is doubtless an Old World species.

L. ALr fYA, Sonchus alpinus, L., is not American. For an account of the early confusion between this and $L$. leucophea, see the latter species, supra, and Torr. \& Gray, Fl. ii. 500.

235. SONCHUS, Tourn. Sow-Thistle. (The ancient Greek name.) - Herbs of the Old World, some species now widely diffused, the following naturalized in N. America. Stems leafy: leaves somewhat spinulosely or ciliately dentute: flowers yellow, in summer: pappus white.

* Coarse annual weeds, of cultivated soil and around dwellings; with mostly runcinately or lyrately pinnatifid leaves, of tender texture, beset with soft spinulose serratures; upper cauline auriculate-clasping, and lobes ovate or oblong: heads about half-inch high, somewhat corymbose-paniculate, on short peduncles; these sometimes setose-glandular: akenes flat, thin-edged, oblong-obovate.

S. oLerÁCEUS, L. Leaves with soft or harlly spinulose teeth; auricles of the canline ones acute: akenes striate-nerved and transversely rugulose-scabrous. - Common in yards and gardens. (Nat. from Eu.)

S. Ásper, Vili. Teeth of the leaves longer and more prickly; auricles of the clasping base rounded: akenes smooth, 3-nerved on each side, nıargined. - Torr. \& Gray, Fl. ii. 501, with syn. S. Carolinianus, Walt. Car. 192; Ell. Sk. ii. 255. S. spinulosus, Bigel. Fl. Bost. ed. 2, 292. - More common westward and southward, widely dispersed, even to remote districts.

* * Slender annual; wi h leaves pinnately parted into narrow lobes.

S. TeNérimus, L. A foot or two high, with rather few and scattered pedunculate heads, glabrous: lobes of the leaves mostly linear or narrowly lanceolate, somewhat spinulosely denticulate: akenes narrow, thickish, rugose-scabrous. $-S$. tenuifolius, Nutt. Trans. Am. Phil. Soc. vii. 438. - San Diego, California, Nuttall, Orcutt. (Nat. from Eu.)

*** Strong-rooted perennial, with deep yellow flowers; alsenes thickish:

S. ARvensis, L. Rootstocks creeping: stems 2 feet high, naked at summit, bearing few or several and corymbosely paniculate showy heads. leaves runcinate-pinnatifid or some undivided, denticulate-spinulose, cauline partly clasping at base: peduncles and involucre more or less glandular-bristì: : head almost inch high: akenes oblong, about 10-costate, rugulose on the ribs. - On shores and banks of streams, in several places in N. Atlantic States, and Salt Lake City, Utal. (Nat. from Eu.) 


\section{SUPPLEMENT TO VOL. I. PART II.}

\section{ADDITIONS AND CORRECTIONS.}

\section{RUBIACE无.}

26. GÁLIUM. P. 35, add, after the mention of Asperula:-

SherÁrdi ARV́risis, L., according to Macoun, has been found wild in several places in Canada.

G. Dasycarpum, Nees, Pl Neuwied Trav 11 (510), collected on the Missouri at the mouth of the Yellowstone, and briefly described, is wholly obscure. It is likened to $G$. boreale. - The following is a somewhat anomalous species, perhaps to stand after G. multiflorum.

G. Catalinénse. Herbaceous perennial, hispidulous-puberulent or glabrate, unarmed: stems erect, 3 or 4 feet high, mostly simple with short flowering branches which little surpass the larger leaves; its nodes usually with a tumid ring. Ieaves in fives or fours, narrowly oblong, obtuse, mucronate, one-nerved (rarely by the union of two leaves 2-nerved), either sessile by a contracted base or short-petioled; at the insertion within bearing some obscurely glandular bristle-shaped appendages: flowers on short slender pedicels, perhaps polygamous: corolla white (2 lines in diameter): young fruit sometimes naked and smooth, sometimes beset with soft and straight bristles of about the length of the body. - Island of Santa Catalina off Los Angeles, California, W. S. Lyon.

\section{COMPOSIT艮.}

To the Synopsis of Genera add, at the end of the Inuloidec, p. 59 :-

63․ DIMERESIA. Heads 2-flowered, homogamous. Involucre 2-phyllous. Pappus plumose, early deciduous.

Tribe VIII. SENECIONIDE正, p. 79. An additional division is required for an outlying genus, $\mathrm{\nabla rz}:-$

Style-branches attenuate: involncre imbricated: often some chaffy bracts on the receptacle. - Subtribe Liaber, Benth. \& Hook.

178 ${ }^{1}$. BEBBIA. For the characters see p. 453.

\section{BRICKELLIA, Ell.}

B. Nevínii, Gray. (Next to B. mecrophylla, p. 106.) White-tomentose, almost as in $B$. incana, frutescent : leaves ovate or oval (larger ones only half-inch long): heads 30-40-flowered: outer bracts of the involucre resembling the small rameal leaves, equally tomentose: otherwise nearly like B. microphylla. - Proc. Am. Acad. xx. 297. - S. California, near Newhall, Nevin. 
17. CARPHEPHORUS, Cass. The section $\S 2$. Kunniordes, and the species under it to be suppressed. Vide $163^{1}$, Bebbia, p. 453.

\section{PENTACH ATA, Nutt.}

P. aúrea, Notr., p. 120. Add syn. . P. paleacea, Greene, Bull. Calif. Acad. i. 189. The "triangular palea at base" of the pappus-bristles is evident in most specimens, from Nuttall's onward.

P. Lýoni. Hirsute, at least the margins of the plane linear or spatulate-linear leaves, 4 to 7 inches high, with the sparing ascending branches leafy up to the head or short peduncle: involucre hirsute; its bracts linear-lanceolate and of gearly equal length, green, with narrow scarious margins: pappus-bristles 9 to 11 or commonly $12 !-S$. California, at San Pedro, Los Angeles Co., and Catalina Island, W. S. Lyon. An anomalous species, evidently allied to $P$. aurea, notwithstanding the involucre and the more numerous pappus-bristles, which are repugnant to the generic name.

\section{CHRYSOPSIS, Nutt.}

C. graminifólia, Notr., p. 121. A probable synonym is Erigeron Carolinianum, Walt. Car. 205.

C. gossypína, Notr., p. 122. Here may belong Erigeron squarrosum, Walt. 1. c. But C. gossypina, Nees, Pl. Neuwied Trav. 14, must be $C$. villosa.

C. Wrightii. Ammodia, near C. Breweri, p. 124. Pubescent with fine soft hairs: bracts of the involucre all partly herbaceous, and the inner nearly equalling the flowers: corollas with limb slightly hairy outside: stigmatic portion of the style-branches not much longer than broad, several times shorter than the subulate-linear appendage: outer pappus scanty and obscure; inner extremely copious. - S. California, on the San Bernardino Mountains, at 11,500 feet, W. C. Wright.

\section{APLOPÁPPUS, Cass.}

A. Orcúttii, Gray, Proc. Am. Acad. xx. 297, an extra-limital species of Lower California, connects the rayless A. squarrosus, p. 125, with the radiate Pyrrocomoid species. And the following connects these with the Arnicella group.

A. Howéllii. Before A. uniflorus, p. 128. A span or two in height, branching from base into ascending ferv-leaved monocephalous stems, sericeous-tomentose, glabrate in age: leaves all narrowly lanceolate and acute, entire, or rarely a denticulation : head and involucre pearly of $A$, uniflorus, the bracts of the latter of equal length and rather obtuse: style-appendages long and slender in the manner of $A$. carthamoides: akenes also elongated (oblong-linear) but pubescent, nearly as long as the rigid pappus. - On Stein's Mountain, S. E. Oregon, June, 1885, Howell, Cusick.

A. spinulósus, DC., p. 130. Add syn.. Sideranthus spinulosus, "Fraser ex Steud."; Nees, Pl. Neuwied Trav. 15 (515).

A. Júnceus, Greene, Bull. Acad. Calif. i. 190, S. W. border of California, is one of those forms intermediate between $\boldsymbol{A}$. gracilis and the polymorphous $\boldsymbol{A}$. spinulosus.

34. LESSINGIA, Cham. P. 161, add: Pappus not rarely of awns rather than capillary bristles (especially in depauperate heads), then correspondingly fewer and sometimes irregularly concreted at base in pairs or phalanges. The species are polymorphous and not readily limited.

L. ramulósa, Grar, p. 162. Tack-shaped glands abound on the margins of the leaves whenever these are rigid: pappus-bristles inclined to unite at base into five phalanges.

Var. adenóphora. Tack-shaped glands conspicuous, even on involucral bracts: heads only about 8-flowered: pappus of few bristles in 5 paleaceous-aristiform phalanges, or 
some of these reduced to a rigid awn. $-\dot{L}$. adenophora, Greene, Bull. Calif. Acad. i. 190. Colnsa Co., California, M/rs. Layne-Curran.

L. leptóclada, Gray, p. 162. Pappus of fewer and more rigid bristles in the reduced forms, such as the

Var. microcéphala, Gray, the most attenuate form, with only 5-flowered or even 3-flowered small heads. - Proc. Am. Acad. vii. 351, \& Bot. Calif. i. 308, with var. tenuis. L. nemaclada, Greene, 1. c. 191. - Not uncommon.

L. nána, Grar, var. cauléscens, p. 163. Add syn. : L. Parryi, Greene, 1. c. Almost exactly the typical plant (which also occurs in the same region), except that, in addition to the subradical heads, some eler ated 3-4-cephalous shoots have developed.

48. ASTER. P. 172, \&c. The following omitted names to be added in their places, chiefly as synonyms.

A. IxтybÁcers, Kunth \& Bouché, Adn. Ind. Sem. Hort. Berol. 1845, \& Ann. Sci. Nat. ser. 3, v. 358, according to au original specimen, is A. Tartaricus, L. f., wrongly taken for North American.

A. Salscgixósos, Less. in Limn. vi. I24 (not Richards.), is A. Sibiricus, L., fide Herder.

A. Gravéolexs, Nutt. Trans. Am. Phil. Soc. ser. 2, vii. 294, is a syn. of A. oblongifolius, Nutt., on p. 178.

A. PubÉscexs, Nees, Syn. Ast. 16 (1. heterophyllus, var. Nees, Ast. 55), is a form of A. sagittio folius, Willd., p. 182.

A. Pinifólios, Nees, Syn. Ast. 29 (referred to 1. Tradescanti in Nees, Ast. 103), seems to be $A$. polyphyllus, Willd, p. 184.

A. AyGústus, Nees, Syn. Ast. 26 (referred, along with A. rigidulus, Syn. Ast. 29, to A. bellidiflorus in Nees, Ast. 97, seems to be a cultivated form of $\boldsymbol{A}$. paniculatus, Lam., p. 187 .

A. Éminess, Nees, Ast. 87, is a mixture. The leading form is either $A$. junceus, Ait. (cited by Nees as a synonym), or $A$. paniculatus, to which some of the varieties seem to belong; the var. Levigatus is our $A$. Tovi-Belgii, var. leevigatus (to which his synonym points); other forms are more obscure. Belgii.

A. Luxúrians (Spreng. Syst. iii. 538), Nees, Ast. 538, is a broad-leaved form of $A$. Novi-

A. dybellátus, Mill,, should have the syn. supplied: Doellingeria umbellata, Nees, Ast. 178, a broad-leaved form.

A. virgátus, Nees, Syn. Ast. 27 (not Ell.), is a form of A. Novi-Belgii, L., p. 189.

The above determinations from Nees were derired from a set of cultivated Asters supplied by Nees to Hohenacker (either directly or indirectly), thence to Dr. Klatt, who obligingly gave them to the author.

A. Hárdent, Porter in Hayden, Geol. Rep. 1871 (published 1872), 485, is a syn. of $A$. pulchellus, Eaton, p. 201.

\section{ERÍGERON, L. On p. 214, after E. Bloomeri, add:-}

E. nudátus, Grat. Like E. Bloomeri, but quite glabrous and smooth: leaves thickish, narrowly spatnlate-linear, obtuse, much shorter than the simple (span high) monocephalous scape: involucre of thickish and green lanceolate bracts somewhat in two series: akenes obovate-oblong, sparsely pubescent: pappus whitish, simple. - Proc. Am. Acad. xx. 297.Dry hillsides, Waldo, S. W. Oregon, Houtll.

E. glaúcus, KER, p. 208. Here probably belongs E. sq̆uarrosus, Lindl. Bot. Reg. xxvii. misc. 44. No specimen has been found in the herbarium of Lindley.

E. púmilus, Nutr., p. 210. Add syn.: E. sulcatus, Nees, P1. Neuwied Trav. 13, according to the character.

E. Chrysópsidis, Grax, p. 210. Rays vary from yellow to cream-color and even white, according to Sulsdorf. 
E. inornátus, var. angustátus, Grar, p. 215. Add syn. : E. angustatus, Greeue, Bull. Calif. Acad. i. 88: perhaps a distinct species, but appears to connect with var. viscidulus.

E. Oregánus, Gray, p. 216. On both sides of the Columbia River, up to and beyond the Cascades, Mrs. Barrett, Suksdorf. Truly perennial, forming a stout caudex and strong root, not stoloniferous; the rosulate tufts appressed to the bare rocks, which it affects

E. Philadélphicus, L., p. 217. In California the rays are commonly paler, not rarely white.

56. PSILOCÁRPHUS, Nutt. P. 228, add after line 4: Very few or commonly no empty involucral bracts. Species revised as follows:-

* Leaves all (even those subtending the heads) tapering below, and midrib not prominent: herbage and (small) heads canescent with close wool: 1ructiferous bracts not over a line long.

P. tenéllus, Nutr. At length much depressed, the woolliness cottony and becoming flocchlent: leares spatulate, a quarter or rarely half an inch long: akenes (half-line long) obovateoblong. - Trans. Am. Phil. Soc. n. ser. vii. 341 ; 'Torr. \& Gray, Fl. ii. 266. - California, common in low grounds throughout the western part of the State.

P. Oregánus, Nттт. 1. c. More erect and silky-lanate: leaves nearly linear, attenuate below, half-inch long: akenes oblong-cylindraceous. (On p. 228 partly confounded with the preceding.) - Along and near the Columbia River, Oregon and Washington Terr., Nuttall, Howell, Sulcsdorf, Mrs. Barrett.

* * Leaves little and those subtending the heads seldom at all narrowed at base; the midrib of the latter (in dried specimens) comparatively strong: herbage and especially the heads loosely floccose-lanate, least so in the first species.

P. elátior. Erect and caulescent, or at length with branches spreading, 3 to 6 inches high, commonly robust, and with large ( 3 or 4 lines broad) very leafy-subtended heads, lightly arachnoid-woolly, the wool of the fructiferous bracts shorter and mostly close : leaves lanceolate- or sulspatulate-linear, sometimes an inch long: akenes cylindraceous. $-P$. Oreganus, Gray, Proc. Am. Acad. viii. 390. P. Oreganus, var. elatior, Gray, Bot. Calif. i. 336, \& Syn. Fl. supra, 228. On the Columbia River, from the Willamette to Hood River, E. Hall, Kellogg \& Harford, Suksdorf. Also, Boise City, S. W. Idaho, Wilcox, ambiguous between this and the preceding.

P. brevíssimus, Nutr. Dwarf, with solitary or few and very woolly heads : leaves oblong or lanceolate, 2 to 5 lines long, seldom surpassing the developed heads : akenes cylindrical or slightly clavate. - Trans. Am. Phil. Soc. vii. 340, excl. syn.; exceedingly depauperate specimens from the banks of the Columbia River, Nuttall. Also "California," Kellogg \& Harford, no. 417, less depauperate, half-inch high or more. N. California, in fields on Chico Creek, Gray, 1885, half-inch to two inches high, with large and very woolly terminal head or glomerule of heads ; the akenes a line long! The scarious beak to the fructiferous bracts, which Nuttall thought to be wanting in his exiguous specimens, is small and deciduous.

P. globíferus, Noтr. Branched from the base and spreading or prostrate: leaves linear or narrowly spatulate, becoming glabrate; uppermost little surpassing the very woolly heads: akenes oburate-oblong, scarcely over half a line in length. - Trans. Am. Phil. Soc. l. c., excl. syn. - Coast of California, from Santa Barbara (Nuttall, \&c.) to Los Angeles (Nevin) and San Diego, Cleveland.

P. Curlénsis (Micropus globiferus, Bertero, DC. Prodr. v. 460, and Bezanilla Chilensis, Remy in Gay, Fl. Chil. iv. 110, t. 46, f. 1) has somewhat similar akenes, but mainly ovate leaves.

$63^{1}$. DIMERÉSIA. New genus, to be appended to the Inuloidere, on p. 59 and p. 237: (Name $\Delta \iota \mu \epsilon \rho \eta^{\prime}$, of two parts or members.)-Heads 2-flowered, homogamous; the flowers hermaphrodite; the involucre of two herbaceous oblong concave bracts, a little united at base, each subtending and almost enclosing a flower. Corolla tubular, regular, 5-toothed. Anthers sagittate at base, the narrow auricles little extended. Style-branches narrowly linear, obtuse, uot ap- 
pendaged; the bordering stigmatic lines extending to and around the naked apex. Akenes clavate-pyriform, glabrous, many-striate, with small epigynous areola bearing a pappus of 20 stout and long-plumose bristles in a single series, these united at base in a ring and early deciduous together.

D. Howéllii. An acaulescent and depressed little herb, from an apparently annual taproot, somewhat woolly but early glabrate; the thickish and obovate or oval entire and 3-5nerved leaves all crowded in a rosulate tuft at the surface of the ground, bearing among and between them, on very short and crowded branches, nunerous small subsessile heads in a depressed tuft: flowers purplish or flesh-color. - On Stein's Mountain in S. E. Oregou, Jnne, 1885, T. Howell, and rather later, Cusick.

\section{MELAMPÓDIUM, L. P. 239, at end of genus, add:-}

* * * Coarse and broad-leared annual: akene wholly enclosed in its indurated bract: ray and disk-corollas yellow.

M. PERFolí́tín, HBK. Mostly glabrous, divergently branched, bearing slender peduncles in the forks: leaves large, rhombic-ovate, serrulate, contracted below as if into a winged petiole, the bases of the pairs connate around the stem, forming a kind of cup : fructiferous bracts lanate-obovate, compressed, smooth and unarmed, except a few small tubercular points at and near the apex. - Nov. Gen. \& Spec. iv. 274; DC. Prodr. v. 520. Alcina perfoliata, Cav. Ic. i. 10, t. 15. Wedelia perfoliata, Willd. Polymnia perfoliata, Poir. - Waste grounds in Los Angeles, California. (Nat. from Mex.)

\section{SILPHIUM, L. After S. perfoliatum, p. 240, add:-}

* * 1 Stem square, but branches terete: leaves not cupulate-connate; cauline petioled, all opposite.

S. brachiátum, Gatrixger. Stem ( 3 to 5 feet high) and very slender brachiate branches smooth, glabrous, glaucous : leaves somewhat hispidulous-scabrous, thin; cauline hastate- or deltoid-lanceolate ( 4 to 8 inches long), slightly dentate, on rather long and barely margined or naked petioles; those of the branches small and very distant, sessile, ovate-lanceolate, entire; uppermost reduced to small bracts: heads small (half-inch or so high), on long and slender peduncles : involucral bracts ovate: rays 6 to 8 : akenes ovate-orbicular, narrowly winged, with barely emarginate summit. - Bot. Gazette, ix. 192; Gray, Proc. Am. Acad. xx. 297. - S. E. Tennessee, on the Cumberland Mountains near Cowan, Gatlinger, coll. 1867.

S. Asteríscus, L., p. 241. Add the following:-

Var. angustátum. A slender form, hispid: leares oblong-lanceolate; all the cauline (except the much reduced uppermost) tapering at base into more or less of a petiole: akenes obovate-orbicular. - Chattahoochee, Florida, A. H. Curtiss.

\section{FRANSERIA, Cav.}

F. tenuifólia, Grar, p. 250. Add syn. : Ambrosia tenuifotia, Gren. \& Godr. Fl. Fr. ii. 395 (but fruit wanting in spec. Cusson), not of Spreng. Syst., if that is rightly taken by Baker in Fl. Bras. vi. ${ }^{3}$ 150, t. 49, for a coarse-leaved annual plant, apparently too like A. polystachya. Three species of the southwestern borders now to be added to the section ACantholana, viz. :-

F. cordifólia, Grax. (Ed. 1, 445.) Herbaceous, with merely suffrutescent base, erect, 2 or 3 feet high, cinereous-puberulent: leaves thin, roundish-cordate or subcordate, obscurely 3-5-lobed, serrate, an inch or two long, slender-petioled, sometimes one or two small appendages or lobes at or near the summit of the petiole: heads loosely paniculate on slender rather naked branches: fertile involucre 2 or 3 lines long, minutely granulose-puberulent, bearing 4 or 5 short and stout subulate spines. - S. Arizona, in the mountains near Tucson, Pringle, Parish. 
F. flexuósa, Grar. Widely branched from a woody base, canescently puberulent or gla. brate in age: branches slender, flexuous: leaves coriaceous, short-petioled, deltoid-lanceolate and laciniate-ientate, or upper lanceolate with cuneate base, feather-veined, the tapering tip and coarse teeth somewhat spiunlose: heads naked-paniculate on the branches: fertile invo* lucres pubescent, armed with 7 or 8 stout-subulate and widely spreading straight spines, 2-3-flowered. - Proc. Am. Acad. xx. 298. - Cañon Cantillas, within the borders of Lower California, Orcutt.

F. chenopodifólia, Benth. To stand between $F$. deltoidea and $F$. eriocentra, habit of the former: leares broadly ovate or subcordate, rather slender-petioled, crenate-serrate, rarely somewhat incised, an inch broad, minutely white-tomentose, upper face glabrate: fertile involucres glomerate, subglobose, 2-3-flowered, tomentose-lanate, but the numerous subulate divergent spines naked. - Bot. Sulph. 26. - All Saints Ba ${ }_{5}$, in Lower California, Orcutt. Hinds found it farther south, at Bay of Magdalena. Probably may reach the U. S. border.

\section{GYMNOLÓMIA, HBK.}

G. tríloba, GRAY, p. 269, has a thick perennial root, and should be transferred to the second division, after $G$. tenuifolia.

G. encelioídes, Gray, and the division under which it stands, are to be suppressed, as also Viguiera tephrodes, p. 271 . See Helianthus, infra.

104. HELIÁNTHUS, L. After $H$. debilis, p. 273, add:-

H. tephródes, GrAy. Annual, strigose-canescent, or the stem and branches more loosely hispidulous: leaves ovate-lanceolate or ovate-oblong, obscurely denticulate or entire (an inch or two long), soft strigose-canescent both sicles, rather long-petioled: heads short-peduncled: involucre 4 or 5 lines high, of oblong-lanceolate acute bracts: rays broadly oblong: bracts of the receptacle nearly entire and glabrous: akenes linear-oblong, thickish, silky-hairy at least above : pappus of two oblong or linear caducous small and thin paleæ, which sometimes do not surpass the hairs of the akene. - Bot. Mex. Bound. 90, \& Proc. Am. Acad. xx. 298. Viguiert nivea, Gray, Bot. Calif. i. 354, exc1. syn. V. tephrodes, Gray, \& Gymmolomia encelioides (Proc. Am. Acad. xix. 4), Gray, supra, 269, 271. - Southern borders of California and Arizona about the head of the Gulf, Schott, Parish. (Adj. Sonora, Pringle.)

H. Olivéri, Gray. Perhaps next II. Parishii, p. 277, tall and stout (10 or 12 feet high), leafy to the top, remarkable for its soft-villous and even tomentose pubescence and no roughness: leaves all alternate, lanceolate ( 4 to 7 inches long), tapering to an acute point, and at base into a short and margined petiole, nearly entire, obscurely triplinerved near the base: involucre also villous, of linear-subulate bracts, not surpassing the disk: rays an inch long: palea of the pappus subulate from a broad base. - Proc. Am. Acad. xx. 299. - S. California, in low grounds between Los Angeles and Santa Monica, J. C. Oliver.

H. Dealbátus, Gray, p. 280. Collected in excellent specimens by E. L. Greene, 1885, on Cape San Quentin, Lower California; the foliage very silvery and soft with the dense pannose tomentum. From the habitat, the Encelia-like aspect, and the whole description, this is eridently Encelia nivea, Benth. Bot. Sulph. 27, the new specimens with peduncles even longer than described, and the bracts of the involucre come near to ovate-lanceolate. The small and narrow paler of the pappus are so very caducous from the ovary that Bentham orerlooked them.

\section{HELIANTHÉLLA, Torr. \& Gray.}

H. Califórnica, GraY, p. 285. Add syn. : H. Nevadensis, Greene, Bull. Calif. Acad. i. 90, the state with small awns and intermediate exiguous squamellæ more developed; but traces of both are found in the original of coll. Bigelow, sometimes whole pappus obsolete from the first.

118. BALDWINIA, Nutt.

B. uniflóra, Netr., p. 302. Add syn. : Viguiera glandulosa, Bertol. Misc. Bot. vii. 45. 
122. MÁdIA, Molina.

M. Yosemitána, PArry, p. 304. Add syn. . M. Rammii, Greene, Bull. Calif. Acad. i. 90, the larger and fully developed form, sometimes 18 inches high foccurring aloug the western base of the Sierra Nevada), the original of Parry being the most depauperate.

\section{HEMIZÓNIA, DC.}

H. citriodóra, Gr.ı, p. 307. Add to syu. : Madia citriodora, Greene, Bull. Torr. Club, ix. 63, \& Bull. Calif. Acad. i. 91. To habitat add : Hood River, Oregon, Mrs. Burett, Klickitat Co., Washington Terr., Suksdorf. Instead of the statement about .Madia anomalu, add:

H. anómala. More hirsute and viscid than the preceding, destitute of soft villons pubescence, not at all lemon-scented : rays " 3 to 5, greenish-yellow" - bracts of receptacle unconnected : akenes of disk and ray similar, larger than in related species (2 lines long), turgid oval, obscurely gibbous, subterete, very oltuse or retuse at both ends, wholly destitute of terminal apjculation and of basal stipe or callus, not at all angled, or in ray-akenes a very obscure ventral ridge. - Madia anomala, Greene, Bull. C'alif. Acad. i. 91. - California, on hills and mountains in El Dorado and Lake Co., Mrs. Layne-C'urran. The alsenes confirm the reference of the preceding species with the present one to Euhemizonia.

H. Streétsii, Gray, mentioned on p. 307 , to be introduced on p. 308 , before H. corymliosa. Erect or ascending, at length much branched, 5 to 15 iuches high, more or less hirsute, destitute of glands, usually rery leafy up to the numerous corymbosely crowded heads: lanes linear, obtuse, short (the larger only inch and a half long), entire or with a few coarse short teeth: heads 3 or 4 lines high: involucral bracts short and linear; those of the receptacle $\mathbf{1 5}$ or more in a circle, slightly united below : rars 14 to 20 : disk-flowers numerons : akenes of the ray rugose-tuberculate at maturity, indistinctly triangular, with a prominent upturned beak; those of the disk sterile, bearing a pappus of about Io subulate-linear palere of half the length of the corolla. - Proc. Am. Acad. xii. 162, from dwarf or early specimens. Islands of California, Santa Catalina, Lyon, San Clemente, Nevin \& Lyon. (Lower California on San Benito Island, Dr. Streets.)

\section{LÁYIA, Hook. \& Arn.}

L. heterótricha, Hook. \& Ans., p. 315. Pubescence all short and fine; hispid or hirsute hairs none or few in the original specimens, but moderately developed in a form which is distinguished from $L$. glandulosa, chiefly by the want of crisped wool to the pappus.

Var. májor. Robust, the copious pubescence all short: heads and rays large : pappus more or less deciduous from the disk-akenes in a ring at maturity (which the original of the species also shows). - L. graveolens, Greeve, Bull. Calif. Acad. i. 92. - California ; near Antioch, Kellogg, and Tehachapi Pass, Mrs. Layne-Curran.

$137^{1}$ CROCKERIA, Greene. Next to Eatonella, p. 323. (Dedicated by the discoverer to Charles Crocker, Esq., of San Francisco, one of the most liberal promoters of botanical exploration in California and adjacent regions.) Habit, involucre, flowers, and receptacle essentially of Lasthenia § Hologymne. Akenes oval-obovate, very flat and the plane sides nerveless, glabrous; margins with a distinct filiform nerve, and very densely ciliate with short and pyriform or clavate rather rigid more or less glandular hairs; apex truncate. Pappus none.

C. chrysántha, Greexe, Bull. Calif. Acad. i. 93. A span or two high from a slender annual root, nearly glabrous, not at all woolly: leaves all opposite, linear, entire: heads a quarter-inch high: involucre nearly hemispherical, shorter than the disk; the 12 to 14 ovate bracts cupulate-connate to the middle: rays and numerous disk-flowers golden yellow, and quite like those of Lasthenia glabrata. To refer the plant to that genus seems impracticable. - Valley of the San Joaquin, California, in alkaline soil near Lake Tulare, April 15, 1884, E. L. Greene. 
138. MONOLÓPIA, DC.

M. májor, DC., p. 323 . Add : Regel, Gart. Fl. xx. 162, t. 690.

\section{LASTHÉN.IA, Cass.}

L. glabráta, Lindu., var. Coulteri, p. 325. Add syn. : L. Coulteri, Greene, Bull. Calif. Acad. i. 192.

\section{BAtria. At close of § Eubaeria, p. 326, add:-}

B. Pálmeri, GraY. Paleæ of the disk-flowers mostly 5 , all alike, ovate, firm, attenuate into a stout awn, erose-laciniate or denticulate; those of the ray-flowers commonly awnless or depauperate or obsolete: otherwise nearly like a large form of B. gracilis. - Bot. Calif. i. 376, \& Proc. Am. Acad. xix. 22, where it is not well placed in the section Dichceta. - Guadalupe Island, off Lower California, Palmer, Greene, extra-limital.

Var. Clementína. Heads rather smalier: pappus alike and awned in ray and diskflowers, the paleæ sparingly erose-laciniate or only denticulate!-On San Clemente, off Southern California, Nevin \& Lyon, 1885. An ambiguous form.

\section{ERIOPHÝLLUM, Lag.; § TRIChOPHYLLUM, p. 329, add:-}

E. Nevínii. Stem about 3 feet high, decidedly woody below : leaves comparatively large, eqnally white-tomentose both sides, twice pinnately parted into narrow and very obtuse seg. ments and lobes: corymbiform and compound cymes naked-peduncled, of very many and much crowded heads : bracts of the involucre mostly 3-4-nerved : receptacle wholly naked: rays not surpassing the disk-flowers: pappus of 4 to 6 often unequal palex. - Island of San Clemente, off San Diego, California, on rocks overhanging the sea, Nevin \& Lyon, April, 1885. Near to $E$. stcechadifolium.

E. cæespitósum, Dougl., p. 330 . Add syn.: Egletes Californicus, Kellogg, Proc. Calif. Acad. i. 56.

\section{BÁHIA, Lag.}

B. Woodhóusii, GraT, p. 333. Rediscovered at Albuquerque, New Mexico, by Marcus E. Jones.

\section{CH સૈNÁCTIS, DC.}

C. heterocárpha, GRAT, p. 339, var. cúrta. Pappus of only 4 oval or broadly oblong palex, either equal or one of them longer, but not over a third or fourth of the length of the corolla. - Ventura Co., California, in the upper part of the Santa Clara Valley, Gray \& Farlow, 1885.

C. Névii, GraY, p. 339. Now collected in good condition in John Day's Valley, S. E. Oregon, by Howell. Plants rather slender. Akenes terete, clavate, surmounted by a short and thickish obscurely denticulate crown, which is an epigynous disk rather than pappus.

C. Cusíckii. Of the white-flowered division having marginal flowers enlarged, very low, diffusely branched, floccose-tomentulose, soon glabrate : leaves rather fleshy, all entire, spatulate-linear : peduncles short: bracts of the involucre broadly linear, midrib obscure: pappus of 10 linear-oblong nearly equal paleæ, about the length of the tube of the corolla. - Sandy hills of the Malheur, Baker Co., E. Oregon, 1885, Cusick.

C. suffrutéscens, GraY, p. 341, includes two species, both suffrntescent perennials. The char. of this is: Tomentose-canescent: branches simple from a decumbent ligneous stem, erect, bearing a solitary long-peduncled head : leaves pinnately parted into narrowly linear entire lobes: head nearly an inch high: palex of the pappus 10, oblong-lingulate.-Proc. Am. Acad. xvi. 100, \& Syn. Fl. 1. c. in part, distinguished in Proc. Am. Acad. xx. 299. Sand-washes of the Upper Sacramento, California, year Mount Shasta, Lemmon, 1879. 
C. Paríshii, Gray. Minutely canescent: stems branching from a suffrutescent base and bearing few heads : leaves pinnately parted into short and partly entire linear lobes : heads hardly over half an inch high: paleæ of the pappus 13 to 15 , linear. - Proc. Am. Acad. xx. 299. - On the southern borders of California, south of the San Jacinto Mountains, Parish, 1882, and near Hanson's Ranch below the boundary, Orcutt, 1884.

\section{HYMENATHERUM, Cass. Add on p. 357 :-}

§21. Heterochrónea. Paleæ of the simple pappus 10 , little shorter than the slender akene and the disk-corolla, lanceolate, resolved above into 5 or 7 awns, the central one longer, and the lateral successively shorter: rays white!

H. concínnum. Depressed and spreading from the annual root, mostly glabrous, glaucescent: leaves chiefly alternate, thickish, pinnately parted into narrowly linear obtuse and pointless divisions : heads sessile and clustered at summit of the short leafy branchlets: involucre 12-14-toothed, nearly naked at base : rays 10 or 12 , the showy oblong ligules (2 lines long) bright white; the disk-flowers yellow. - Arizona, on the mesas near Tucson, 1884, Pringle. - A handsome species, anomalous for its heterochromous flowers; and in other respects serving to connect the first two sections with true Hymenatherum.

\section{ARTEMÍSIA, Tourn.}

A. scopulórum, GRAY, p. 369. Strike out var. monocephala, and add:-

A. Pattersóni. More dwarf and white-tomentose, but sometimes glabrate in age: leaves 3-5-parted or cleft, or uppermost entire : beads much larger and broader, solitary or 2 to 5 , 40-50-flowered: corollas glabrous : receptacle extremely long-woolly. $-A$. scopulorum, var. monocephala, Gray. - Lower alpine region of the Rocky Mountains in Colorado, first coll. by Parry in 1862, and noted as distinct, and now well distinguished by Patterson.

\section{TETRADÝMIA, DC. § EdTETRADTMia, p. 379, add :- -}

T. stenólepis, Greere. Very white-tomentose with appressed wool, armed with long and slender leaf-spines; also bearing from narrowly spatulate to linear-subulate primary leaves: heads fully half-inch long, 5 -fiowered, bracteate with one or two small narrow leaves: bracts of the involucre linear or broader, rigid and thick: akenes pubescent when young; pappus copions, rather rigid. - Bull. Calif. Acad. i. 92. - S. E. California, at Tehachapi Pass and Antelope Valley, IIrs. Layne-Curran, J. C. Oliver. Habit of the second, but characters of the first section of the genus.

1901. BÉBBIA, Greene. (Michael S. Bebb, of Illinois, specially notable for his knowledge of Willows.) - Heads homogamous, 20-30-flowered; flowers all hermaphrodite and fertile. Involucre campanulate, shorter than the disk; its bracts imbricated in two or three series, oblong or ovate, appressed; outermost short ones nearly herbaceous; inner partly or wholly scarious and obscurely nervose when dry, a few of the innermost among the outer flowers. Receptacle otherwise naked, flat. Corolla with short proper tube and elongated upwardly enlarging throat, 5-toothed; the teeth ovate, spreading, hispidulous outside. Stylebranches slender and produced into indistinct subulate hispidulous appendages. Akenes somewhat turbinate, hirsute, obsoletely 5-nerved and many striate. Pappus of 15 to 20 rigid short-plumose bristles in a single series. - Greene in Bull. Calif. Acad. i. 179. Carphephorus, § Kuhnioides, Gray, p. 113.

B. júncea, GreEne, l. c. Shrubby at base, fastigiately much branched, a yard or less high ; flowering branches rush-like, herbaceous or mainly so, mostly leafless and alternate, bearing solitary or scattered heads : leaves few or sparse; lower opposite, oblong to linear, the lar- 
ger often laciniate and petioled; upper small and linear, or reduced to subulate minute scales: flowers golden yellow, sweet-scented (somewhat as in those of Acacia Farnesiana).Carphephores junceus, Benth. \& p. 113. B. atriplicifolia (Carphephorus atriplicifolius, Gray, 1. c.) of Lower California is probably the same, and var. aspera, Greene, l. c., is a common hispiclulous state. - Rocky places, in cañons, \&c. in the arid regions of Arizona and S. E. Califoruia (Lower Calif., first coll. by Hinds). Evidently an outlying representative of the subtribe Liabec.

\section{SENECIO, Tourn.}

S. aúreús, var. Balsámitæ, p. 391. Add syn.. S. ceratophyllus, Nees, Pl. Neuwied Tray. 12.

S. Neo-Mexicánus, Gray, p. 392. S. Austinœ, Greene, Bull. Calif. Acad. i. 93, is probably a form of this, from the northeastern borders of California, in Modoc Co., Mrs. Austin.

S. Lyóni. (Next after S. eremophilus, p. 393.) Obscurely suffrutescent, and somewhat succulent, early glabrate except the persistent dense tufts of wool in the axils: leaves once or twice prinnately parted into linear obtuse segments and lobes, glabrous above, minutely woolly-pubescent beneatb: peduncle bearing a few pedicellate heads (these 4 to 6 línes high and radiate): pedicels and involucre sparingly subulate-bracteolate. - Island of San Clemente, off S. California, on cliffs by the sea, Nevin \& Lyon, April, 1885.

S. Califórnicus, DC. Growing in sand along the sea-shore (San Diego and southward) it becomes succulent and dwarf, when it is $S$. ammophilus, Greene, Bull. Calif. Acad. i. 193.

At the end of the genus, p. 394, add :-

*** * Indigenous winter-annual : heads with few and minute ray-flowers, or noue.

S. Mohavénsis. Glabrous, branching from the base, leafy up to the loose corymbiform panicle: leaves soft and thickish, ovate or oblong, sinuate-dentate or sparingly incised, cauline with auriculate or cordate-clasping base: heads slender-peduncled, 4 lines high : involucre narrow-campanulate, 18-20-flowered; calyculate bracts few and inconspicuous: ray-flowers when present mostly difformed and biligulate, not surpassing the disk: akenes canescent. S. E. California in the Mohave region, near the Colorado, Lemmon. (Also within the borders of Sonora, Mex., Pringle.)

\section{STEPHANOMERIA, Nutt.}

S. coronária, Greene, Bull. Calif. Acad. i. 194, Santa Lucia Mountains, Brandegee, by the character seems too like $S$. exigua, Nutt., p. 414.

\section{MICRÓSERIS, § SCORzonella. At end, p. 418, add:-}

M. Howéllii, Gray. A foot or more high from a fusiform root, slender, bearing solitary or 2 or 3 heads: leaves (only 2 or 3 lines wide) elongated-linear and attenuate, some bearing a few attenuate refracted lobes; involucre half-inch high, narrow, 15-20-flowered ; its bracts all acuminate; inner oblong-lanceolate and all nearly equal; outer much shorter and mostly ovate: akenes 3 lines long, narrower at base: pappus of 8 or 10 conspicuous and firm lanceolate palea, which nearly equal the length of the akene and bear a denticulate-scabrous awn of hardly greater length!-Proc. Am. Acad. xx. 300, where by some mistake the pappus is quite wrongly described. - Waldo, S. W. Oregon, June, 1884, Howell. Ambiguous between the sections Scorronella and Calais, with pappus-paleæ of the latter, except in number, but perennial or biennial from a fusiform root, and the habit of a slender M. leptosepala.

\section{MALACÓTHRIX, DC.}

M. Coulteri, GraY, p. 421. Anthesis vespertine or matutinal, the heads closed at midday.

M. insuláris, Greene. Intermediate between $\S$ Malacolepis and Malacothrix subsection Malacomeris, annual, glabrous, a foot or two high : leaves oblong-lanceolate, laciniate-pinna- 
tifid, the lobes alınost linear : involucre well imbricated, less than half-inch high ; outermost bracts ovate, innermost linear, all scarious with green or purplish tip and centre: corolla yellow: receptacle almost destitute of bristles : akenes 15-ribbed, five of the ribs angulateprominent: one or two stronger pappus-bristles persistent. - Bull. Calif. Acad. i. 194. S. California, on Coronados Islands, off San Diego, Greene.

M. foliósa. Between M. obtusa and $M$. incana, p. 423, with habit of $M$. saxatilis, but an an. nual, with nuch smaller heads of yellow flowers, glabrous: stem a foot or two high, erect, much branched, very leafy even to the branchlets : leaves lanceolate, most of them laciniatepinnatifid, 2 to 4 inches long, uppermost linear-attenuate : heads short-peduncled, 3 to 5 lines high : bracts of the involnare lanceolate, rather obtuse : akenes somewhat equally 10-costate: pappus wholly deciduous, leaving neither bristles nor crown. - Islaud of San Clemente, off Southern California, Nevin \& Lyon, April, 1885. - Connects the Leucoseris of Nuttall with his Leptoseris.

M. saxátilis, Tork. \& Grar, p. 423. L'nder this may be more than one species, not only the $\boldsymbol{M}$. tenuifolia, Torr. \& Gray, but also a larger-flowered one, $\boldsymbol{M}$. altissima, Greene, Bull. Calif. Acad. 1. s., of mountaius of İern Co., IIrs. Layne-Curran, said to be anuual (but not seen here): probably same from Ojai, Peckham. But the characters are not yet clear.

\section{HIERÁCIUM, Tourn.}

H. longípilum, Torr., p. 426. Cancel the var. spathulatum, which should be trausferred to

H. Mariánum, Willd., var. spathulátum. A mountain form, with leaves all or mainly radical and unusually barbate-hispid. - Pilosella spathulata, Schultz Bip. in Flora, 1862. - Tuscarora or Two-top Mountain, Penn., Porter and Traill Green.

H. Brandegéi, Greene, Bull. Calif. Acad. i. 194. Santa Lucia Mountains, Brandegee, fide Greene, which we have not seen, appears to be the same as the plant of the same district, coll. G. R. Tasey (not Parry as stated), and referred to $B$. argutum, Nutt., on p. 428. 



\section{N D E X.}

NAMES of orders are in CAPITALS; of suborders, tribes, \&c., in small capitals; of admitted genera and species, in ordinary Roman type; of synonyms, as also of subgenera, sections, and all species merely' referred to, in Italic type.

Abrotanum, 369.

Absinthinm, 369. vulgare, 370.

Acamptopappus, $5 \pm, 124$

Shockleyi, 124 .

sphærocephalus, 124.

Acantholosna, 250.

Acanthospermum, 60, 239.

australe, 239

Brasilum, 239 .

hispidum, 240.

humile, 240.

xanthioides, 239.

Acanthoxanthium, 253.

Acarphea, 3 $\div$ :2. artemisicefolia, $3 \pm 2$.

Acheta, 288.

Achillea, 78, 363.

borealis, 363 .

gracilis, 363 .

lanulosa, 363

Millefolium, 363

multiflora, 363 .

occidentalis, 363 .

Ptarmica, 363.

tomentosa, 363

Achyrachæna, 69, 312.

mollis, 312 .

Achyraa, 124

Achyropappus, 332. Woodhousei, 333 .

Aciphyllkea, 357. acerosa, 357

Acmella occidentrilis, 258. repens, 258.

Acoma dissectum, 301.

Acosmia, 263.

Acurrtina, 408

microcephala, 409 .

Actinea, 344

Actinella, $75,344$.

acaulis, 345 .

argentea, 345 .

bienn is, 346 .

Bigelovii, 346 .

Brandegei, 345.

chrysanthemnides, 345 .

Cooperi, 346.

depressa, 345 .

glabra, 345

grandifora, 345 .

insignis, 345 .

lanata, 330,345 .

lanuginosa, 344.

leptoclada, 345 .

linearifolia, 344 . odorata, 347.

Palmeri, 344

Richardsonii, $3 \pm 7$.

Richardsonii, 346.

Rusbyi, 346.

scaposa, 344 .

Torreyana, 345.

Vaseyi, 346.

Actinaphuria, 129.

Actinolepis, 328.

anthemoides, 328.

coronaria, 327.

lanosa, 329.

Lemmoni, 328.

multicaulis, 328.

inutica, 328 .

nivea, 323.

tenella, 327 .

IVallacei, 329.

Actinomeris, 67, 289.

alata, 287 .

alba, 289 .

alternifulia, 289.

helianthoides, 288.

heterophyila, 288.

longifolia, 287 .

nudicaulis, 288

oppositifolia, 288, 289.

pauciflora, 288 .

squarrosa, 289.

Wrightiii, 288.

Actinospermum, 302. angustifulium, 303.

Adenocaule 5.59

Adenocaulon, 59, 237

bicolor, 237

Adenophyllum Wrightï, 357.

Adenostyles Nardosmia, 376 .

Adoporon, 412

Adoxa, 7,8 .

Moschatellina, 8 .

Ethulire uniflora, 92

A garistr, 299, 300 . criliopsidea, 300.

Agassizia, 351.

szo a vis, 351.

Agnthyrsus, 443 .

Floridanus, 443. leucophasus, 444

Ageratum, 51, 93.

altissimum, 101.

cclestinum, 93 .

conyzoides, 93 .

corymbosum, 93 .

lineare, 338.

littorale, 93 . maritimum, 93.

Mexicanum, 93.

punctatum, 92 .

Wrightii, 92

Alarconia angustifolia, 268. helenivides, 267.

Alcina perfoliata, 449

Aldama uniserialis, 256.

Alloseris, 412.

Alymnia, 238.

Amruria, $332^{\circ}$

dissecta, 334 .

Amblyolepis, 76, 351. setigera, 351 .

Amblyopappus, 73, 334. Neo-Mexicanus, 333. pusillus, 334 .

Ambrosia, 63, 248

absynthifolia, 249.

acanthicarpa, 251.

aptera, 249

artemisixfolia, 219 .

bidentata, 249 .

cheiranthifolia, 249.

confertiflora, 250.

con'unopifolia, 250

crithmifolia, 250.

elatior, 249.

fruticosa, 250.

glandulosr, 250.

heterophylla, 249.

hispida, 250 .

integrifolia, 249

Linolheimeriana, 250.

longistylis, 249 .

lon ristylis, 250 .

priniculata, 249.

Peruviana, 250.

Pitcheri, 246.

psilostachya, 250 .

pumila, 250.

tenuifolia, $250,449$.

tomentosa, 251.

trifida, 249.

АмвROSIE. 62 , 62.

Amellastrum, 172.

Amellus Carolinianus, 256. spinulosus, 130. villosus, 123.

Amida gracilis, 306 . hirsutn, 306.

Ammodia, 124. Oreqana, 124.

Ammogeton

scorzonerafolium, 437.

Amphiaclivris, $53,116$. 
dracunculoiaes, 116.

Fremontii, 116.

Amphipappus Fremontii, 116.

Anacalais, 417 .

Anacis tripteris, 294.

Anaphalis, 59, 233. margaritacea, 233.

Ancistiocarphus, 227. filaginers, 228.

Angelandra, 244.

Anisocarpus Bolanderi, 305. madioides, 304.

Anisocoma, 85, 416 . acaule, 416 .

Anotzs lanceolatu, 26.

Antenuaria, 58, 231. alpina, 232.

alpina, 231

argentea, 232.

Carpathica, 232.

dimorpha, 231.

dioica. 233 .

flagellaris, 231.

Geyeri, $2 \dot{3} 1$.

hyperborea, 233.

Labradorica, 2:32.

luzuloides, 232.

margaritacea, 233.

microcephala, 232.

monocephala, 232.

parvifolia, 233.

, lantaginea, 233.

plantaginifolia, 233.

Jacemosa, 233.

stenophylla, 231

AxтHeMne. $77,362$.

Anthemis, 78, 362 .

arvensis, 362.

Cotula, 362

nobilis, 363 .

repens, 258.

tilictoria, 363 .

Apalus, 344.

Apargia autumnalis, 420 . borealis, 424 .

A pargidium, 86, 424 . boreale, 424 .

Aparine, 35.

Aphanostephus, 55, 163.

Arizonicus, 163.

Arkansanus, 164

humilis, 164 .

pilosus, 163.

ramosissimus, 163.

ramosus, 164 .

Riddellii, 163.

Aphantochceta, 119. exilis, 120 .

Aplodiscus, 125, 142.

Aplopappus, 54, 125, 446. acaulis, 132

alpigenus, 201.

apargioides, $12 \bar{\imath}$.

arenarius, 130.

armerioides, 132.

aureus, 129.

baccharoides, 160.

Berberidis, 126 .

blephariphyllus, 205

Bloomeri, 134.

Brandegei, 132.

canescens, 123.

carthamoides, 126.

cervinus, 134

ciliatus, 125. croceus, 128.

cuneatus, 133.

discoiders, 143.

divaricatus, 130.

ericuides, 133 .

florifer, 168.

Tremonti, 128.

gracilis, 130.

Greenei, 135.

gymnoceplealus, 205.

Hinkei, 170.

Hallii, 129.

hirtus, 127.

Hookerianus, 131.

Howellii, 446.

integrifolius, 128.

inuloides, 128.

lanceolatus, 129.

lanceolatus, 127.

lanuginosus, 131.

laricifolius, 133.

linearifolins, 132

linearifolius, 222.

Lyalli, 131.

junceus, 446.

Macronema, 135.

Menziesii, 143 .

mollis, 135 .

monactis, 133 .

multicaulis, 129.

nanus, 134 .

Nuttallii, 125.

Oreuttii, 446.

l'almeri, 133.

paniculatus, 127.

Parryi, 131.

- pinifolius, 134.

phyllocephalus, 130.

pygmæus, 131.

racemosus, 126.

ramulosus, 142, 228.

resinosus, 134 .

rubiginosus, 130.

spharocephalus, 124.

spinulosus, 130,446 .

squarrosus, 125 .

stenophyllus, 132

suffruticosus, 135 .

tenuicaulis, 129.

tortifolius, 173 .

uniflorus, 128.

Watsoni, 134.

Whitneyi, 127.

Aplostephium canum, 170.

Apogon, 84, 410.

gracilis, 411.

humilis, 411 .

lyratus, 411.

Wrightii, 411 .

Archierncium, 424

Arctium, 82, 397.

Bardana, 397.

Lappa, 397.

majus, 397 .

minus, 397.

Arctngeron, 200.

Argyrocheta bipinnatifua, 244.

Armania, 281.

Arnica, 81,380

alpina, 382

amplexicaulis, 381 .

angustifolia, 382.

Chamissonis, 381.

Chamissonis, 382.

Claytoni, 380. cordifolia, 381 .

discoidea, 381.

Doronicum, 384.

fol iosa, 382.

fulyens, 383.

lanceolata, 382.

latifolia, 381.

latifolia, 382.

longifolia, 382.

macrophylla, 381

mreritima, 384.

Menziesii, 381.

mollis, 382 .

montana, 382.

Nevadensis, 382 .

nudicaulis, 380 .

obtusifolia, 383 .

Parryi, 382.

parviflora, 381.

plantaginen, 383 .

Unalaschensis, 383 .

viscosa, 382.

Arnicella, 128.

Aromia tenuifulia, 334.

Arrhenachne, 221.

Arrow-wood, 10, 225.

Artemisia, 78, 367. abrotanoides, 370 .

Abrotanum, 370.

Absinthium, 370 .

andrusacea, 370 .

anmua, 370.

arbuscula, 374.

arctica, 371.

biennis, 370 .

Bigelovii, 374.

Bolanderi, 375 .

borealis, 368 .

cospitosa, 371.

Californica, 370.

campest ris, 368.

cana, 375 .

Cauadensis, 368.

capillifolia, 97.

caudata, 368.

cernua, 369.

Chamissoniana, 371.

Chinensis, 371.

Columbiensis. 375 .

commutata, 368 .

conymbosa, 371.

cuneifolia, 372.

desertorum, 368 .

discolor, 373 .

Douglasiana, 372.

dracunculoides, 369.

Dracunculus, 369 .

filifolia, 369.

Fischeriuna, 370 .

foliosa, 370 .

franserioides, 373.

frigida, 369 .

glauca, 369.

globularia, 371 .

clomerata 370 .

gnaphalodes, 372.

Grenlandica, 368.

heterophylla, 371, 373.

Hispanica, 370.

Hookeriana, 372.

incompta, 378.

Intica, var., 372.

inodora, 369

integrifolin, 372, 373 .

leptophylla, 374. 
leontopodioides, 371. Lewisii, 369.

Lindheimeriana, 372.

Lindleyana, 373.

longepedunculaia, 371 . longifolia, 372 .

Ludoviciana, 37.

Ludoviciana, 373.

matricarioides, 364 .

Mexicana, 37.2.

Michauxiana, 373.

Norvegica, 371.

Nuttaliana, 369.

pachyslachya, 369 .

Pacifica, 368.

Palueri, 374.

Parishii, 374

Parryi, 371.

Pattersoni, 453.

pedatifida, 368 .

peucedanifulia, 368 .

Plattensis, 369.

potentilloides, 36 .

Prescottiana, 373.

procera, 370.

pumila, 373.

Purshiana, $3 \bar{\imath} 2$

pycnocephala, 369 .

pycrostachya, 369 .

Richardsoniana, 371 .

rimida, 374.

Rothrockii, 375 .

rupestris, 371.

Santonica, 369.

scopulorum, $369,4 \overline{3} 3$.

scopulorum, $4 \overline{3} 3$.

Semavinensis, 370 .

Senjavinensis, 370 .

Serjavisensis, $3 \mathbf{i}$.

serrcea, 369.

serrata, 372 .

spinescens, 368 .

spithamae 368 .

Stelleriana, 371.

Tilesii, 37:3.

tridentata, 374

trifida, 375 .

trifila, 374, 375 .

trifurcata, $3^{71}$.

variabilis, 369.

violacea, 368.

virgata, 370

vulgaris, 372.

Wrightii, 373 .

Artichoke, 82, 280.

Artorhiza, 265 .

Asperula odvrata, 35.

Aster, 56, 172.

abbseviatus, 194.

acuminatus, 199

acuminatus, 194

adnatus, 180

adscendens, 191.

adscendens, 192, 193.

adullerinus. 189.

cestivus, 188, 189, 192.

alatus, 180.

albus, 198.

alpigenus, 201.

alpinus, 173.

amethystinus, 185.

amoenus, 195.

ampiexicaulis, 178, 180, 183 .

amplus, 194.

amygdalinus, 196, 197.
Andersonii, 201.

Andinus, 191.

angustus, 204.

anyustus, 447 .

anomalus, 181.

annuนs, 172, 219.

arenarioides, 201.

argenteus, $17 \mathrm{~s}$.

argutus, 189.

artemisioflorus, 187.

asperrimus, 178.

asperugineus, 212.

asperulus, 181.

attenuatus, 183.

auritus, 180

azureus, 181.

Baldwinii, 182.

bellidiflorus, 188.

bicolor, 140.

biennis, 179, 185, 206.

biflorus, 176.

bifroms, 187.

Bigelovii, 205.

blindus, 195.

blepharophvllus, 202, 205.

Bloomeri, 178 .

Bonariensis, 208.

borealis, 188.

Bostoniensis, 185.

bracteolatus, 191.

brumalis, 189

carulescens, 188.

ccespitosus, 190.

Californicus, 208.

campestris, 178 .

Canbyi, 193

canescens, 206.

caricifolius, 202.

carneus, 188, 192.

carnosus, 202.

Carolinianus, 179.

Chanissonis, 190.

Chapmani, 201.

Chilensis 190.

chrysanthemoides, 206.

ciliatus, 172 .

ciliatus, 180, 185.

ciliolatus, 18:2.

Collinsii, 172.

Coloradoensis, 205.

commutatus, 185.

concinutus, 183.

concinnus, 178.

concolor, 180.

confertus, 183, 195.

consanquineus, 196.

conspicuus, 177.

conyzoides, 171.

cordifolius, 182 .

cordifolius, 174, 128.

curidifolius, 186.

cornifolius, 197.

Cornuti, 194.

corymbosus, 174.

Curtisii, 177.

Cusickii, 195.

cyaneus, 183.

denudatus, 191.

dichotomus, 197.

diffusus, 186 .

diffusus, 186, 187, 199.

discoideus, 144.

divaricatus, 172, 174, 197, 199 ,

divergens, 186.

diversifolius, 181.
Douglasii, 192.

Douglasii, 193, 194.

dracunculoides, 188.

Drummondii, 182.

dumosus, 185 .

dumosus, 18t, 186.

Durandir, 190

elegans, 200 .

eleyans, 176, 184, 199.

Elliotti, 194.

elodes, 100

eminens, 188, 189, 190, 447.

Engelmanui, 199.

ericæfolins, 198.

ericoides, 184.

ericoides, 185, 186.

ervngiifolius, 173.

Espenber'gensis, 176.

exilis, 203.

exscripus, 168.

falcatus, 185.

fulcatus, 190, 191.

Fendleri, 178.

flaginifolius, 170.

firmus, 195.

flexuosus, 202.

floribundus, 189.

foliaceus, 193.

foliolosus, 186.

fragilis, 186, 187.

Fremonti, 191.

frondosus, 204.

glabellus, 184 .

glabriusculus, 200.

glacialis, 201, 208, 209, 211.

glaucescens, 183.

glaucus, 200.

gracilentus, 183.

gracilis, 176.

gruminifolins, 216.

grandiflorus, 178.

grandiflorus, 174.

graveolens, 447 .

Greenei, 188.

gymnocephalus, 205.

Hallii, 191.

IIaydeni, 447.

hebecladus, 185.

Herveyi, 175.

hesperius, 192

heterophiyllus, 182, 447.

hiemalis, 189.

hirsuticaulis, 187.

hirtellus, 182.

hispidus, 195.

horizontalis, 187.

humilis, 197.

hyssopifolius, 172.

imbricatus, 201.

incanus, 206.

infirmus, 197.

integrifolius, 177.

intybaceus, 447 .

junceus, 188.

junceus, 188.

Kingii, 178.

Kumleini, 179

lavifatus, 183, 189.

levis, 183.

Lamarckianus, 188.

lanceolatus, 188.

latifolius, 175 .

lrixifolius, 188, 189, 192.

laxis, $188,189$.

leucanthemus, 187. 
ledifulius, 199.

ledophyllus, 200.

Lemmoni, 199.

linariifolius, 197.

Lindleyanus, 182.

linifoluus, 172, 202, 204.

longifolius, 188.

longifolius, 189, 190, 192.

lucidus, 195.

lutescens, 199.

luxurians, 447 .

macrophyllus, 175.

Marylandicus, 171.

Menziesii, 190.

microphyllus, 180.

mirabilis, 175 .

miser, $172,183,186,187$.

modestus, 179 .

montanus, 176,179 .

multiceps, 179 .

multiflorus, 185 .

multiflorus, 186, 191.

mutabilis, 172 .

mutabilis, 183, 189.

mutatus, 179.

Neesii, 190.

nemoralis, 199

Novæ-Angliæ, 178.

Novi-Belsii, 189, 447

Novi-Belyigi, 192

nudiflorus, 176.

Nuttallii, 178, 191.

obliquus, 188.

obIongifulius, 178,447 .

obovatus, 196, 197.

occidentalis, 192.

onustus, 188,189

Oolentangiensis, 181.

Oreganus, 192

pallens, 194

Palmeri, 203.

paludosus, 174 .

paniculatus, $18 \pi, 447$.

paniculatus, 181, 182, 189.

Parryi, 200

parviflorus, 207.

parviflor'us, 187.

patens, 180

patentissimus, 180.

Pattersoni, 205.

Pattersoni, 206.

patulus, 194.

pauciflorus, 202.

pauciflorus, 184.

pendulus, 186.

Pennsylvanicus, 183.

peregrinus, 196.

phlogifolius, 180

phyilolepis, 179.

pilosus, 184, 185

pinifolius, 447 .

pulitus, 183 .

poly phyllus, 184, 447.

Porteri, 184

proealtus, 188, 189.

precox, 182, 194.

prenanthoirles, 194.

Prescottii, 176.

ptarmicoides, 198.

pubescens, 447.

pulchellus, 201, 44i.

pulcherrimus, 197.

puniceus, 195.

puniceus, 194

purpuratus, 183. pygmæus, 196.

racemosus, 186.

radula, 176 .

radula, 177, 190.

radulinus, 177 .

ramulosus, 185, 191.

recurvatus, 187, 188.

Reeresii, 184.

reticulatus, 197.

Richardsonii, 176.

rigidus, 172, 197.

rigidulus, 188.

riparius, 202.

roseus, 178.

rubricaulis, 183.

sagittifolius, $182,447$.

sayittifolius, 181.

salicifolius, 188 .

saliciffolius, 188, 189.

salignus, 188.

salsuginosus, 196, 208, 209,

Saycenus, 179.

scuber, 181.

scabrosus, 172.

scandens, 179 .

scoparius, 185.

scopulorum, 198.

secundifior us, 186.

sericeus, 179.

serotinus, 189.

Shastensis, 174.

Shortii, 181.

Sibiricus, 176, 447.

simplex, 188, 192.

solidagineus, 171 .

solidaginoides, 171.

Sonora, 202

sparsiflorus, 186, 202.

spathulatus, 191

speciosus, 176.

spectabilis, 176.

spectabilis, 190.

spinosus, 203.

spinulosus, 174 .

spurius, 178.

squariosus, 180 .

squarrulosus, 189.

stemomeres, 198.

stenophyllus, 188.

strictus, 170, 188.

subasper, 188.

subspicatus, 193.

subulatus, 204.

subulatus, 203.

surculosus. 176.

tanacetifolius, 206.

tardiflorus, 194.

tardiflorus, 189.

tenuifolius, 202

tenuifolius, 184, 186, 187, 188.

thyrsiflorus, 190.

Tilesii, 196.

tomentellus, 170 .

tortifolius, 173 .

tortifolius, 172.

Tawnshendii, 205.

- Tradescanti, 187.

Tradescanti, 186, 188, 194.

Tripolium, 202.

turbinellus, 183

umbellatus, 196, 447.

Unalaschensis, 179, 196, 208. undulatus, 181.

undulatus, 180

uniflorus, 199. urophyllus, 182

vยrnus, 172, 216

versicolor, 183.

villosus, 184.

vimineus, 186.

vimineus, 183, 194, 195.

virgatus, 183.

virgatus, 184, 447.

viryineus, 189.

Watsoni, 201.

Wrightii, 173.

Xylorrhiza, 200.

AsteroIde E $_{1}$ 52, 114.

Astrantlinum integrifolium, 163 .

Astropolium, 203.

Athanasia graminifolia, 303.

hastati, 257.

paniculata, 289

trinzervia, 303

Atrichoseris, 84, 410 . platyphylla, 410 .

Aurelia, 117

amplexicaulis, 118.

decurrens, 119 .

BACCHARIDEF, 57 .

Baccharis, 57, 221.

Alamani, 225.

angustifolia, 222.

Bigelovii, 224.

brachyphylla, 223 .

corulescens, 225.

consanzrinea, 222

Douglasii, 224.

Emoryi, 222.

f'atida, 226.

glomeruliflora, 222.

ylomeruliflora, 222

glutinosa, 224.

glutinosa, 225.

Hankei, 224.

halimifolia, 222.

Harardi, 224.

juncea, 221.

pilularis, 222.

pilularis, 223.

Pingrcea, 225.

Plummeræ, 224.

ptarmicafolin, 224.

pteronioides, 223.

ramulosa, 223.

salicifolia, 222.

salicina, 222.

salicina, 223.

sarothroides, 223.

Seemanni, 221.

sergiloides, 223 .

sessiliflor'a, 222.

Texana, 222

thesioides, 224 .

veneta, 143.

viminea, 225 .

viscosa, 226 .

Wrightii, 222.

Baeria, 72, 325 .

affinis, 327.

anthemoides, 328 .

carnosa, 326.

chrvsostoma, 325.

Clevelandi, 326 .

coronaria, 327.

curta, 326.

debilis, 325

Fremonti, 327.

gracilis, 326. 
leptalea, 325 . macrantha, 325 . maritima, 320 .

mutica, 328.

Palmeri. 452.

platycarpha, 326.

tenella, 327 .

uliginosa, 327.

Bahia, 73, 331

absinthifolia, 332

achillooides, 330 .

ambigun, $33 \mathrm{~L}$.

ambrosioides, 332

arachnoidea, 330 .

artemisias folia, 329 .

Bigelovii, 333.

biternata, 333 .

chrrsanthemoides, 333 .

confertiflora. 330

cuneata, 331

dealbata, 332

gracilis, 331

integrifolia, 331.

lanatr. 330 .

latifolia, 330 .

leucophylla, 331 .

multiflora, 331 .

Neo-Kexicana, 333.

nudicaulis, 332.

oblongifolia, 332.

oppositifolia, 332.

parviftora, 331

pedata, 333 .

rubella, 329

stechndifolia, 329.

tenuifolia, 330

trifida, 330 .

Wullacei, 329, 331.

Woodhousii, 333, 452 .

Bahiopsis lan'ta, 271 .

Baileya, $71,318$.

multiradiata, 318 .

panciradiata, 318. pleniradiata, 318.

Baldwinia, 68, 302 .

multiflora, 302 .

uniflora, 3(12, 450 .

Balsamorrhiza, 66, 295.

Bolanderi, 266.

Carevana, 265.

deltoidea, 266.

glabrescens. 266.

helianthoides, 266.

hirsuta, 266.

Hookeri, 266.

incana, 266.

macrophylla, 266.

sagittata, 265.

terebinthacea, 266.

Barkhausia Caroliniana, 441. elegans, 431.

granififtora, 441

Lessingii, 439 .

nana, 431.

Barrattia, 283.

calva, 283.

Bartlettia, 80, 378 .

scaposa, 378 .

Bebbia, 445, 453. juncea, 453 .

Bedstraw, 35.

Bellardir, 416.

Belis, 55, 163.

integrifolia, 163.

Mexicana, 163. perennis, 163.

xanthocomvides, 163.

Berlandiera, 61, 242 .

incisa, 243.

longifolia, 242.

lyrata, 243.

pumila, $2 \pm 3$

subacaulis, 243.

Texana, $2+2$.

tomentosa, 243.

Berthelotia, 225.

Betckea, 44. 46, 47 . major, 47.

samolifolia, 47

Bezanilla, 228, 448 .

Bidens, 68, 2915.

arguta, 248.

Beckii, 298.

Bigelovii, 297.

bipinnata, 297.

Californica, 297.

cernua, 296

chrysanthemoides, 296.

connata, 296.

ferula folit, 298.

faniculifolia, 298.

frondosa, 296 .

gracilis, 302.

helianthoides, 296.

heterophylla, 298.

heterosperma. 297

Humboldtii, 298.

Lemmoni, 297.

leucantha, 297.

longifolia, 298.

niver, 297.

petiolata, 296.

pilosa, 297 .

procera, 297.

quadriaristata, 296.

striata, 297.

tenuisecta, 297.

tipartita, 296.

Bigelovia, 54, 135.

acradenia, 142.

albida, 137.

arborescens, 141.

Bigelovii, 137.

Bolanderi, 136.

brachrlepis, 141.

ceruminosa, 138 .

Cooperi, 141.

coronopifolia, 142.

coronopifolia, 143.

depressa, 137.

diffusa, 141.

Douglasii, 139.

aracunculoides, 139 .

Drummoudi i, 142.

Engelmanni, 137.

graveolens, 139 .

Greenei, 138.

Hartwegi, 143.

Howardi, 136 .

intricata, 203.

lanceolata, 140.

leiosperma, 139.

juncea, 138.

Menziesii, 143.

Missouriensis, 139.

Mohavensis, 138 .

Nevadensis, 136.

nudata, 141

paniculata, 138.

Parishii, 141.
Parryi, 136.

pluriftora, 142.

pulchella, 137.

rupestris, 133.

spathulata, 133.

teretifolia, 138 .

tridentata, 143.

uniligulata, 154

Vaseyi, 140.

veneta, 142.

virgata, 141

viscidiftora, 140

Wrightii, 142

Biotia, 174.

commixta, 175, 176.

corymbosa, 174.

glomerata, 175.

latifolia, 175.

macrophylla, 175.

Schreberi, 175 .

Blazing Stur, 109.

Blennosperma, $60,343$. Californicum, 344 .

Blepharipappus, 69,304 .

glandulosus, 314.

scaber, 304.

Blepharizonin, 312.

Blepharodon, 129.

Bluebottle, 407 .

Bluets, 24.

Bcebera, 356 .

chrysanthemoides, 356.

glandulosa, 356 .

Baberastrum, 356 .

Bulophyia, 245. alpina, 245.

Bolophytum, 2tō.

Boltonia, 56, 166 asteroides, 166. diffusa, 166. glastifolia, 166. latisquama, 166

Bombycilona, 227.

Boneset, 99.

Borreria, 33.

Domingensis, 34 .

micrentha, 34.

parriflora, 34

subulatr, 33 .

Borrichia, 66, 265 .

arborescens, 265

frutescens, 265.

Bouvardia, 19, 23.

angustifolin, 24

coccinea, 24.

hirtella, 24.

Jacquini, 24.

ovata, 23.

quaternifolin, 24.

splendens, 24.

ternifolia, 24

triphylla, 23.

Brach yachyris, 115. Euthamio, 115.

Brachyactis, 204. cilicta, 204

frondosa, 204.

Brachyrchæta, 53, 54, 161. cordata, 161.

Brachycome xanthocomoides, 166. Brachyris, 115.

Califon'nica, 115 .

divaricatn, 115.

dracunculoirles, 116.

Euthamia, 115. 
microcephala, 115, 116. ovatifolia, 161. paniculata, 115. ramosissima, 116.

Bradburia, 53, 120 hirtella, 120.

Brauneria, 2,8.

Breea arvensis, 398.

Brickellia, 51, 103. atractyloides, 104. bacchariclea, 106 . betonicæefolia, 107 . brachyphylla, 108. Californica, 106. cordifolia, 105.

Coulteri, 105.

Cumingii, 124.

crlindracea, 107.

dentata, 106

Fendileri, 96.

floribunda, 105.

frutescens, 108.

grandiflora, 105.

Greenei, 104.

hastata, 104.

incana, 104.

laciniata, 106.

Lemmoni, 107.

linifolia, 104.

longifolia, 108.

microphylla, 106 .

Mohavensis, 104.

multiflora, 108 .

Nevinii, 445 .

oblongifnlia, 104.

oliganthes, 107.

parvila, 107.

Pringlei, 107.

reniformis, 106.

Riddellii, 108.

Rusbri, 106.

simplex, 105.

spinulosa, 108.

squamulosa, 108.

tenera, 106.

Wislizeni, 10 ?.

Wrightii, 106.

Wrightii, 105

Brotera Contrayerba, 354. Sprengelii, 354

trinervata, 354.

Broteroa trinervata, 354.

Bulbostylis, 104 .

annua, 377

Californica, 106.

Crvanillesii, 106.

deltoides, 100. microphylla, 106. oliganthes, 107.

Buph thalmum anfrustifolium, 303. rrborescens, 265.

frutescens, 265.

helianthoides, 255. repens, 265.

sagittatum, 266.

Burdock, 397

Bur-Marigold, 295.

Burrielia, 72, 324 . chrysostoma, 325

Fremonti, $32 \bar{r}$.

gracilis, 326 .

hirsuta, 326 .

linosa, 329.

leptalea, 325.

\section{longifolia, 326.}

maritima, 326.

microglossa, 324 .

nivea, 323.

parviflora, 326 .

platycarpha, 326 .

tenerrima, 320 .

Bush Honeysuckle, 18.

Butter-bur, 375.

Butter-weed, 394.

Button Snakeroot, 109.

Cacalia, 81, 394. atriplicifolia, 395. cordifolia, 94.

decomposita, 396.

diversifolia, 395 .

Floridana, 395.

gigantea, 395

hastata, 395.

hastata, 395, 396.

lanceolata, 396.

Nardosmia, 376.

ovata, 395.

ovata, 396 .

paniculata, 396.

pteranthes, 396.

reniformis, 395 .

suaveolens, 395 .

tuberosa, 396 .

Cacaliopsis, 79, 376. Nardosmia, 376.

Cachimilla, 225.

Connotus, 220.

Calais, 418.

aphantocarpha, 419 .

Bigelovii, 419.

Bolanderi, 418.

cyclocarpha, 420 .

Douglasii, 419, 420 .

eriocarpha, 420.

glauca, 417

graciloba, 417 .

laciniata, 417, 418 .

Eindleyi, 419.

linearifotia, 419 .

macrochreta, 418 .

major, 417.

nutans, 417

Parryi, 418.

platycarph.a, 420

sylvatica, 417.

tenella, 419 .

Calea aspera, 257. oppositifolia, 257.

Calliachyris Fremonti, 316.

Calliastrum, 175.

Callichroa, 315.

Douglasii, 316.

platyglossa, 315.

Calliglossa Douglasii, 316.

Calliopsis, 290.

Atkinsoniana, 291.

bicolor, 291

cardamine folia, 291.

Drummondii, 291.

palmata, 293.

rosea, 290 .

tinetoria, 291.

Calocalais, 418.

Crlonea, 351.

Calostelma, 109.

Calycadenia, 310.

cephalntes, 312 .

Fremonti, 312. mollis, 311

multiglandulosa, 312

paruciflora, 311.

plumosa, 312

tenella, 311.

truncata, 311 .

villosa, 311 .

Calycoseris, 86, 421 .

Parryi, 421.

Wrightii, 421.

Calymmandra, 229.

candida, 230.

Calyptrocarpus vialis, 289.

Canada Thistle, 390.

C.APRIFOLIACE E, 7 .

Caprifolium, 16.

bracteosum, 18.

ciliosum, 16.

Douglasii, 17.

flavum, 17.

Fraseri, 17.

hispidulum, 18.

glaucum, 18.

gratum, 18.

occidentale, 16.

parviflorum, 18.

pubescens, 17.

sempervirens, 16.

Carbenin, 405.

Cardoon, 82.

Carduinee, 82.

Carduus, 82, 397.

acanthoides, 397.

altissimus, 404

a'vensis, 398.

crispus, 397.

discolor, 399, 403, 404.

foliosus, 402 .

glaber, 404, 405.

horridulus, 400 .

lanceolatiss, 398.

muticus, 405 .

nutans, 397.

occidentalis, 401.

odoralus, 401.

pectinatus, 397.

pumilus, 401, 402.

pycnocephalus, 397.

remotifolius, 399 .

repandus, 405.

spinosissimus, 400 .

undulatus, 403.

Viv'ginianus, 404, 405.

Carminatia, 51, 103 . tenniffora, 103.

Carphephorus, 52, 112. atriplicifolius, 113.

bellidifolins, 113 .

corymbosus, 113.

junceus, 113.

junceus, 378 .

Pseudo-Liatris, 113.

tomentosus, 113

Carphochæte, 52, 109.

Bigelovii, 109.

Cartesia centauroides, 88.

Carthamus loevis, 88.

Catesbæa, 20, 28. parviflora, 28.

Catomenia, 286

Centaurea, 82, 405.

Americana, 407.

Americana, 88.

benedicta, 406 .

Calcitrapa, $40 \mathrm{~s}$. 
Cvanus, 407 .

Jacea, 407.

Melitensis, 406 .

Mexicana, 407.

nigra, 406.

Nuttallii, 407.

solstitialis, 406 .

Centauridium Drunmondii, 125.

Centaurines, 82.

Centrocarpha aristitn, 260. grandiflora, 261 . triloba, 259, 260

Centrospermum humile, 240. xanthioides, 2:39.

Cephalanthus, 20, 29.

occidentalis, 29. salicifolius, 29.

Cephalophore acaulis, 345 . decumens, $3+9$. scapos $\pi, 3+1$.

Ceratocephalus, 296.

Cercomeris, 249.

Cercosiytis, 351.

Chrenactis, $74,339,452$. achilleafolia, 341 . artemisixfolia, 342 . attenuata, 340 . brachypappa, 340 . carphoclinia, 340 .

Cusickii, 452.

denudata, 339.

Douglasii, 341 .

filifolic 339 .

Fremonti, $3+0$

glabriuscula, 339 .

glabriusculı, 341 .

heterocarpha, 339, 452 .

lanosa, 339.

macrantha, 341 .

Nevadensis, 341 .

Nevii, 339, 452.

Parishii, 453.

santolinoides, 341.

sterioides, 340 .

suffrutescens, 341,452

tanacetifolia, 339.

tenuifolia, 339 .

thysanocarpha, 342

Xantiana, 340 .

Chætadelpha, 84, 415 .

Wheeleri, 415 .

Chatrnthera asteroides, 165.

Chathymenia, 317.

Chætopappa, 55, 165. asteroides, 165 .

modesta, 165

Parryi, 16 .

Chamadapohne, 31.

Chamamelum. 363.

Chamomile, 362, 363 .

Chaptalia, 83,408 . nutans, 408. tomentosa, 408.

Chiccory, 412.

Chiococca, 21, 30 parvifolia, 30 racemosa, 30 .

Chionoracium, 429.

Chlanolobus pycnostachyus, 226. virgatus, 226.

Chondrilla, 87, 441. Illinoensis, 433.

juncea, 441 .

iavigatr, 441.

Chorisiva, 247.
Chrysactinia, 77, 855 .

Mexicana, 355 .

Chrysanthemum, 78, 364. arcticum, 365 .

Balsamita, 365 .

bipinnatum, 364

Crrolininnum, 166.

yrandiflorum, 364.

Indicum, 364

inodorum, 363.

integrifolium, 365 .

letucanthemum, 3655 .

nanum, 364 .

Parthenium, 365.

segetum, 364 .

Sinense, 364.

Chrysastrum, 144.

Chrysocoma acaulis, 91.

coronopifolia, 97.

dracunculoides, 139

gigantea, 90 .

graminifolia, 90, 161.

grareolens, 139, 142.

nauseosa, 139.

nudata, 141.

tomentosa, 89 .

virgata, 141.

Chrysogonum, 61, 243. Diotostephus, 243.

Virginianum, 243.

Chrysoma, 161. pumila, 160. solidaginoides, 161. uniligulata, 154.

Chrysomelea, 292. lanceolata, 292.

Chrysopsis, 53, 121, 446. acaulis, 132 .

alba, 198.

alpina, 198.

amygdalina, 196.

argentea, 121.

aspera, 121.

Bolanderi, 123.

Breweri, 124.

cespitosa, 132

canescens, 123, 213.

coronopifolia, 206.

decumbens, 122

dentrita, 122

divaricate, 130 .

echioides, 12:

falcata, 123.

foliosa, 123.

gossypina, 122, 446.

graminifolia, 121, 446

hirtella, 210.

hispida, 123 .

humilis, 197.

hyssopifolia, 122.

Lamrirckii, 130.

linarizifolia, 197.

Mariana, 122.

mollis, 123.

obovata. 197.

oligantha, 121.

Oregana, 124

pilosa, 124.

pinifolia, 121.

scabra, 121.

scabrella, 122.

sessiliforce, 123.

trichophylla, 122.

villosa, 122 .

Wrightii, 446.
Chrysostemma tripteris, 294.

Cherysothamnopsis, 136.

Chrysothamnus, 136, 137.

depressus, 137.

dracunculvides, 139.

lenceolatus, 140 .

pumilus, 140.

speciosus, 139

visciditlonus, 140.

Chthonia inostrata, 360 .

C'ICHORIACLE, 83,410 .

Cichorium, 84, 412 . Intybus, 412 .

Cinchova Caribea, 23. Caroliniana, 23. Jamaicensis, 23.

Cinchonaces, 19.

Cineraria atropurpurea, 389. Canalensis, 383, 394, 396.

Carolinensis, 383.

congesta, 394 .

tivigida, 389.

heterophylla, 390.

inlegrifolia, 389, 390.

Lewisii, 211.

lys'ata, 390.

maritima, 383

palustris, 394. pralensis, 388.

Cirsium, 398.

acaule, 402 .

altissinum, 404 .

arrense, 398 .

Bigelurii, 405.

brevifolium, 403.

C'alifornicum, 400.

canescens, 400,403.

Coulteri, 401.

discolor, 404 .

diversifolium, 404.

Douqlasii, 403.

Drummondii, 400, 402.

eciule, 399.

eriocephalum, 399, 400.

flipendulum, 404.

foliosum, 400, 402.

Grahami, 403.

Hookerianum, 399, 403.

horridulum, 400 .

Kamtschaticum, 400.

lanceolatum, 398.

Lecontei, 405 .

megacanthum, 400 .

muticum, 405 .

Neo-Mexicrnum, 400.

Nuttallii, 404.

ochrocentrum, 403.

Pitcheri, 403.

pumilum, 401.

remotifolium, 399.

reprndum, 405.

scariosum, 402.

stenolepidum, 399.

Texrnum, 404

undulatum, 401, 403.

I'ivrinionum, 404

Wrightri, 404.

Clappia, $70,31 \%$.

aurantirca, 317.

suæedæfolia, 317.

Clarionen, 408. runcinatr, 409.

Clavigera, 104

brachyphylla, 108.

dentuta, 108. 
Riddellii, 108.

Cleavers, 35.

Clomenocuma, 356.

Clot-bur, 252.

Cuicus, 82, 397.

altissimus, 404 .

Americanus, 398.

Andersonj, 401.

Andrewsii, 400.

Arizonicus, 401 .

arvensis, 398.

benedictus, 406 .

Breweri, 403.

Californicus, 400.

carlinoides, 398.

Drummondii, 402.

Eatoni, 400 .

edulis, 399.

eriocephalus, 399.

foliosus, 402 .

glaber, 404.

ghutinosus, 405.

Grahami, 403.

Hallii, 399 .

Hookerianus, 399.

horridulus, 400 .

Kamtschaticus, 399.

lanceolatus, 398.

Lecontei, 405.

muticus, 405 .

Neo-Mexicanus, 400.

Nuttallii, 404.

occidentalis, 401.

ochrocentrus, 403.

Parryi, 398.

Pitcheri, 403

pumilus, 401.

quercetorum, 402.

remotifolius, 399.

repandus, 405.

Rothroekii, 401.

scariosus, 402.

spinusissimus, 400 .

undulatus, 408.

Virginianus, 404.

Virginicnus, 405 .

Wheeleri, 402.

Wrightii, 404 .

Cockle-bur, 252

Coelestina, 93.

ctgerutoides, 93.

cremlea, $93,102$.

corymbosa, 93.

maritima, 93.

COFFEACE

Coinogyne carnosa, 317.

Coleosanthus, 104.

Coltsfoot, 375.

Compass-plant, 242.

COMPOSIT $2,48,445$.

Cone-flower, 259.

Coniothele Californica, 344.

Conoclinium, 102.

betonicum, 102.

coelestinum, 102.

dichotomum, 102

dissectum, 102.

rigidum, 95 .

Conophorn, 395.

Conyza, 57, 221.

Altaica, 204.

ambigua, 221

amplexicaulis, 226.

angustifolia, 226.

asteroides, 171. bifoliata, 172 .

bifrons, 226.

camphoratu, 226.

Carolinensis, 226.

Coulteri, 221.

Coulteri, 220.

linifolise, 171.

Marylandica, 226.

pycnostachya, 226.

sinuata, 221.

subdecurrens, 220, 221.

uliginosa, $226^{\circ}$. viryata, 226.

CONYZE

Conyzopsis, 204.

Coral-berry, 13.

Coreocarpus heterocarpus, 301. parthenioides, 301.

Corevloma, 290.

COREUPSIDE $\pi, 6 \tau$.

Coreopsides, 292

Coreopsidiun, 291.

Coreopsis, 68, 289.

acuta, 289.

alata, 287.

alba, 297.

alternifolia, 289.

ambiguce, 295.

angustifolia, 290 .

angustifolia, 273.

aryuta, 295.

a'istala, 295.

aristosa, 295.

aspera, 290.

A trinsoniana, 291.

aurea, 294.

aurea, 295.

auriculata, 293.

auriculata, 293.

Bidens, 296.

bidentoides, 295.

Buykiniana, 292.

calliopsidea, 300 .

cardaminefolia, 291.

coronata, 292.

coronatà, 294, 295, 297.

crassifolia, 292.

delphinifolia, 293.

delphinifolia, 294.

dichotoma, 290.

discoidea, 295.

diversifolia, 291, 293.

Drummondii, 291.

filifolia, 301 .

flexicaulis, 290.

gladiata, 290

grandiflora, 292.

Harveyana, 292

heterophylla, 292.

integrifolia, 290.

involucrata, 295 .

lanceolata, 292.

latifolia, 294.

Leavenworthii, 291.

leucantlka, 297.

leucanthema, 297.

linifolia, 290 .

longipes, 292.

major, 294.

maritima, 300

mitis, 295.

nudata, 290.

oblon rifolia, 292.

Emleri, 294.

palmata, 293. parviflora, 298.

pauciflora, 298.

perfoliata, 296.

precox, 293.

procera, 289

pubescens, 293.

rosea, 290.

senifolia, 293.

stellata, 294.

tenuifolia, 293.

tinctoria, 291.

trichosperma, 295.

trifida, 3n1.

tripteris, 294

verticillata, 293.

verticillata, 293.

Wrayi, 294.

Corethrogyne, 56, 170 .

Californica, 170.

detonsa, 170 .

filaginifolia, 170 .

incana, 170.

obovata, 170.

spathulata, 170.

tomentella, 170.

virgata, 170.

Corn Marygold, 364.

Corn Salad, 44.

Corvisartia, 236

Cosmidium Burridgeanum, 301. filifolium, 301.

gracile, 302.

simplicifolium, 302

Cosmos, 68, 298.

bipinnatus, 298.

caudatus, 298.

parviflorus, 298

Costmary, 365 .

Cotton-Rose, 230.

Cotula, 78,366 .

alba, 256.

australis, 366 .

coronopifolia, 366 .

matricarioides, 364.

Coum antia chamomilloides, 364.

Cranberry-Tree, 10.

Crepidium caulescens, 431. glancum, 431. эuncinatum, 431.

Crepiuisper'mum, 429

Crepis, 86, 87, 430 .

acuminata, 431 .

acuminala, 432 .

ambigua, 428429 .

Andersoni, 431 .

biennis, 430 .

biennis, 431.

Cooperi, 430.

elegans, 431.

glauca, 431 .

intermedia, 432.

nana, 431.

occidentalis, 432 .

occidentalis, 432 .

pleurocarpa, 432 .

polymorpha, 430 .

runcinata, 431 .

tector'tum, 430 .

virens, 430 .

Crinitaria humilis, 204.

viscidiflora, 140.

Critoní Kuhnia, 103.

Crocidium, 80, 378.

multicaule, 378

Crockeria chrysantha, 72, 451. 
Crossostephium, 370.

Cruciata, 35.

Crusea, 22, 32. allococca, 33

subulata, 33.

Vrightii, 33.

Cryptopleura, 439. Californica, 440.

Crvptostemma calendulacea, $\overline{82}$.

Cudweed, 234.

Cup-plant, $2 \pm 0$.

Cyanus, 406.

Cyclachæna, 245. xanthiifolia, 246.

Cylindrocephala, 94.

Cymbia, 411.

Cynara, 82.

Cryaruidex, 81, 396.

Cynthia, 41-2.

amplexicaulis, 412.

Boscii, $41-2$.

Dandelion, 412 .

Griffithii. 412.

lyrata, 412.

Virginica, 412 .

Dandelion, 420, 440.

Demetria glutinosn, 119. spathulata, 117.

Dent de Lion, 440.

Diaperia, 229. candida, 230 . Drummondii, 229. mulicaulis, 229. prolifera, 229.

Dichneta, 326.

Fremonti, 327

tenellh, 327.

uliginosa, 327.

Dichatophora, 55, 165 . campestris, 166 .

Dicoria, 63, 248. Brandegei, 248. canescens, 248 .

Dicranocarpus, 60, 237. parviflorus, 237.

Diervilla, 8,18 .

Acadiensis, 19.

Canadensis, 19.

humilis, 19.

lutea, 19.

sessilifolia, 19.

Tournefortit, 19. trifida, 18.

Dieteria, 205.

asteroides, 206.

canescens, 206.

coronopifolia, 236.

divaricata, 206.

gracilis, 130 .

incana, 206.

pulverulenta, 203.

sessiliflora, 206.

spinulosa, 130.

viscosa, 206 .

Dimeresia, $445,448$.

Howellii, 449.

Diodia, 22, 34 .

glabra, 34.

hirsuta, 34 .

teres, 35.

tetracocca, 33 .

telragona, 35.

tricocca, 33

Virginiana, 35 .
Virginica, 35.

Diodunta, 294.

aristosa, 295.

aurea, 295.

bidentoides, 205.

coronata, 295.

involucrata, 295.

leptophylla, 295.

mitis, 245.

Diomeder, 281.

Divlost phins repens, 243.

Diploprpprus albus, 198.

alpinus, 198.

amyylalinus, 196, 197.

canescens, 214.

cornifolius, 197.

dubius, 219 .

ericoides, 133, 198.

filifolizus, 213 .

graminifolius, 121.

grandiflorus, 214.

hispiclus, 123.

incanus, 206.

leucophyllus, 170 .

linarifolius, 197.

linearis, 213.

lutescens, 199.

Mrrianus, 12:.

ubovatus, 197.

occidentalis, 215 .

pinnatifidus, 130.

rigillus, 197.

scaber, 121.

sericeus, 121.

trichophyllus, 122.

umbellatus, 196.

villosus, 123.

Diplostelma bellioides, 165.

Diplostephium acuminatum, 199. amygdalinum, 196.

boreale, 197.

canum, 170 .

cornifolium, 197.

dichotomum, 197.

linarïfolium, 197.

obovatum, 197. umbellatum, 196.

Diplothrix, 253. acerrost. 251.

DIPSACACEA, 47.

Dipsacus, 47.

fullonum, 48 . sylvestric, 48 .

Distrisis concinna, 210. heterophylla, 165. modesta, 165.

Distreptus, 88.

Dithrix, 320.

Dockmackie, 10.

Dœllingeria, 196. amygdalina, 197.

crimifolia, 197.

obovata, 197. ptarmicoides, 198.

Donia. 117.

ciliata, 125.

glutinosa, 118, 119.

inuloides, 117.

lanceolata, 129.

squarrosa, 118.

uniflora, 128

Don'onicrzm acaule, 381.

glutinosum, 119

lavifolium, 216.

nudicaule, 381. ramosum, 210.

Dracopis, 263.

amplexicaulis, 263.

Dracunculus, 368.

Dufresnia, 44.

Dugaldea, 347

Drihamelia, 28.

Dumerilia, 408.

Dunantia Achyranthes, 257.

Dysodia, 77, 355.

aceros $\pi, 357$.

anthemidifolia, 350 .

cancellata, 356,

chrysanthemoides, 356 .

Cooperi, 358.

fistigiata, 356.

glandulosa, 356 .

porophylloides, 356.

speciosa, 356.

tanetioides, 357 .

Dysodiopsis, 357.

Eatonella, 72, 322.

Congdonii, 323.

nirea, 322 .

Echenais carlinoides, 398.

Echinacea, 65, 258. angustifolia, 258. atrorubens, $2,90$.

pallida, 258.

purpurea, 2.58. sanguinea, 258. serotina, 258.

Echinomerin apetala, 274.

Eclipta, 64, 256.

alba, 256.

brachypoda, 256.

erceta, 256.

integrifolia, 163. procumbens, 256. prostrata, 256.

Egletes Arkansana, 164 Californicus, 452 .

humilis, 164.

ramosissima, 164.

Flecampane, 236.

Elephantopus, 50, 88.

Carolinianus, 88.

elatus, 88.

nudatus. 88 .

nudicaulis, 88,89 .

scaber, 88, 89.

tomentosus, 88 .

Elephantosis, 88.

Encelia, 67, 281.

albescens, 281.

argophylla, 284.

Californica, 282

calva, 283.

conspersa, 281, 282.

eriocephala, 282.

exaristata, 283

farinosa, 282

frutescens, 282 .

halimifolia, 281.

microcepteala, 284

microphylla, 281.

nivea, $282,450$.

nudicaulis, 283.

scaposa, 282.

subaristata, 283.

viscida, 282.

Enceliopsis, 283.

Endive, 412.

Engelmannia, 61, 244. 
pinnatifida, 244.

Texana, 244.

Enula Campana, 236.

Erechtites, 81, 396 .

elongata, 396.

hieracifolia, 396.

prceulto, 396.

Ereicotis, 27.

Eremiastrum, 56, 171. bellioides, 171.

Evicameria, 132.

diffusa, 141.

erecta, 134 .

microphylla, 133.

nana, 134.

resizosa, 134.

Erigerastrum, 196

Erigeridium, 216.

Erigeron, 56, 207, 447.

acris, 219.

alpinus, 219.

alpinus, 207, 220.

ambiguns, 219, 221.

Andersonii, 201.

angustatus, 448 .

annuus, 218.

argentatus, 212.

Arizonicus, 218.

armeriæfolius, 220.

asper, 209.

asperugineus, 212.

Bellidiastrum, 217.

belliclifolizu, 216 .

Beyrichii, 219.

Bigelovii, 210.

Bloomeri, 214.

Bonariensis, 221.

Brandegei, 210.

Brazoensis, 218.

Breweri, 215.

crspitosus, 214.

ccespitosus, 212, 214

camphoratzs, 226.

Canarlensis, 221.

canescens, 213, 214.

canus, 212.

Carolinianus, 161, 446.

Chrysopsidis, 210, 447

ciliatus, 204.

cinereus, 218.

compositus, 211 .

concinnus, 210.

corrmbosus, 214

Coulteri, 209

decumbens, 215.

decumbens, 215.

delphinifolius, 219.

delphinifolius, 219 .

discoideus, 221.

divaricatus, 221.

divaricatus, 218.

divergens, 218.

divergens, 217.

Douglasii, 215.

Droebaehensis, 220.

Eatoni, 214

elongatus, 220.

eriocephalus, 207.

eriophyllus, 220 .

filifolius. 213.

ftagellaris, 217.

florifer, 168.

foliosus, 215.

glabellns, 209.

glabratus, 220. glandulosus, 212.

glandulosus, 121.

glaucus, 208, 447 .

grandiflorus, 208.

grandiflorus, 208, 209.

heterophyllus, 219

hirsutus, 210.

hispitus, 208.

Howellii, 209.

hyssopifolius, 216 .

incomptus, 218.

inornatus, 215,448 .

integrifolius, 216, 219.

Kamtschaticus, 220.

lanatus, 207.

leiomerus, 211.

Iemmoni, 216.

linifolius, 220 .

lonchophyllus, 220.

longipes, 217.

macrauthus, 209.

maritimus, 208.

miser, 216 .

modestus, 218.

Muirii, 207.

multiflorus, 203.

nanus, 212.

Neo-Mexicanus, 219.

nervosus, 121.

Nevadensis, 214.

mudatus, 447.

nudicaulis, 216.

nudiflorus, 218.

ochroleucus, 213.

ochroleucus, 210, 214

Oreganus, 216, 448.

paniculatos, 221.

Parishii, 212.

pedatus, 211.

peucepiryllus, 213.

Philadelphicus, 217 .

Philadelphicus, 217, 219, 448.

pilosus, 122.

poliospermus, 210.

Pringlei, 211.

pulchellus, 207, 209, 216, 217.

pumilus, 210, 447 .

pumilus, 213.

purpureus, 217.

pusillus, 221.

quercifolius, 217.

quercifolius, 218.

racemosus, 220.

radicatus, 211.

repens, 217.

Rusbvi, 217.

salsuginosus, 208.

salsuginosus, 209.

scrposus, 217.

speciosus, 209.

squarrosus, 208, 446, 447.

stenophyllus, 213.

stenoph yllus, 201, 213, 215.

strictus, 221

strigosus, 219.

strigosus, 210, 218, 219.

subdecurrens, 220

subdecurrens, 221.

sulcatus, 447.

supplex, 215 .

tener, 212.

tenuis, 218

trifidus, 211.

uniflorus, 207.

ursinus, 211.
Utahensis, 213.

vernus, 216.

Eriocarpum grindelioides, 126.

Eriopappus glandulosus, 314.

Eriophyllum, 72, 73, 328, 452 .

ambiguum, 331.

cæspitosuin, 330, 452.

confertiflorum, 329 .

gracile, 331.

lanosum, 329.

muticicaule, 328 .

Nevinit, 452.

nubigenum, 329 .

Pringlei, 329 .

stæchadifolium, 329 .

Wallacei, 329.

Watsoni, 331.

Erithalis, 21, 30.

fruticosa, 30 .

odorifera, 30

Ernodea, 21, 31. littoralis, 31 .

Erythremia aphylla, 436. grandiflora, 436 .

Esopon glaucum, 434 .

Lispejoa, 317.

Espeletia amplexicaulis, 267. helianthoides, 266. sagittata, 266.

Eublepharis, 290.

Eucephalus, 199.

albus, 198.

elegans, 200.

ericoides, 198.

glaucrs, 200.

EUINULEE, 59.

EUP'ATORIACE.玉, 50; 91.

Eupatoriophalacron, 256.

Eupatorium, 51, 94. ageratifolium, 100 . ageratifolium, 101 ageratoides, 101.

album, 98.

altissimum, 99 .

altissimum, 101.

ambiguum, 97, 48 .

amœnum, 96.

aromaticum, 101.

Berlandieri, 100, 101.

betonicum, 102 .

Bigelovii, 96 .

Bnickellia, 105.

Bruneri, 96.

calocephalum, 95

cassin'folium, 98 .

ceanothifolium, 101.

coelestinum, 102.

compositifolium, 97 .

concinnum, 95 .

conyzoides, 95.

cordatum, 101.

cordiforme, 101.

coronopifolium, 97 .

crassifolium, 97, 102

Cubense, 101.

cuneatum, 100 .

cuneifolium, 98

dissectum, 102.

divergens, 95.

dubium, 96.

falcatum, 96.

Fendleri, 96.

fœeniculaceum, 97 .

funiculoides, 97

floribundum, 95. 
Fraseri, 101.

fusco-rubrum, 96. glandulosum, 98. glastifolium, 114. glaucescens, 98. grasudiflonem, 105. Greggii, 102.

Hartwe gi, 102.

heteroclinium, 95. hyssopifoliun, 98. incarnatum, 101.

ivefolium, 95 .

levigat um, 96 .

lanceolatum, 99.

leptophyllum, 97.

leucolepis, 98.

Lindheimerianum, 100.

linearifolium, 98 .

luteum, 102.

maculatum, 95, 96.

Marrubium, 99 .

Maximiliani, 95.

melissoidles, 101.

mikanioides, 97.

mullinerve, 100.

obovatum, 99.

obscurum, 95 .

occidentale, 100.

odoratum, 95, 101.

oliganthes, 107.

Oreyanum, 101.

ovatum, 99.

Parryi, 96.

parviftorum, 97, 98, 99.

pauperculum, 102.

perfoliatum, 99 .

pilosum. 99 .

pinnatifidum, 97.

pubescens, 99.

punctatum, 96.

purpureum, 95.

pycnocephalum, 100.

racemosum, 97.

resinosum, 100

Rothrockii, 102.

rotundifolium, 99 .

Sabeanum, 95.

sagittatum, 94.

salviafolium, 100.

scabridum, 99.

scandens, 94.

Schiedennum, 100.

semiserratum, 98.

serotinum, 97 .

sessilifolium, 99

solidaginifolium, 97.

Sonore, 100.

speciosum, 109.

stigmatosum, 98.

suaveolens, 101.

ternifolium, 96.

teucrifolium, 99 .

tortifolium, 98.

trifoliatum, 95.

truncatum, 99, 100.

urticcefolium, 101.

verbencefolium, 99 .

verticillatum, 95 .

villosum, 100 .

violaceum, 102.

Wrightii, 100 .

Euphrosyne ambrosiafolia, 246. xanthiifolia, 246 .

Eurybia commixta, 175.

corymbosa, 174 . glomerata, 175.

Schreberi, 178

Jussice, 175.

macrophylla, 175.

Euthamia, 160. graminifolia, 160. occidentalis, 160 .

tenuifolia, 161

Euthamiopsis, 141.

Evax, 58, 228.

candida, 230.

caulescens, 228.

multicaulis, $\geq 29$.

prolifera, 229y.

Everlasting, 233, 234.

Exostema, 19, 23. Caribaum, 2:3.

Exostemma, 23.

Fedia, 44 .

amarella, 45.

chenopodifolia, 45.

Fagopyrum, 45.

longifolia, 46 .

Nutlellii, 46

olitorin, 44.

patellaria, 46.

radiata, 45 .

stenocarpa, 45 .

umbilicata, 45 .

Woodsiana, 45 .

Feverwort, 12

Fichtea, 416.

Filagines, 57.

Filaginopsis Drummondii, 229. multicaulis, 229.

Filagn, 58, 230.

Arizonica, 230.

Californica, 230 .

depressa, 230 .

Gallica, 230.

Germanica, 230.

parvula, 230.

repens, 231.

Texana, 231

Fireweed, 396.

Flaveria, 76,353 .

angustifolia, 354

chloræfolia, 3.5. 3 .

Contrayerba, 354 .

linearis, 354.

longifolia, 354 .

maritima, 354 .

repanda, 354 .

tenuifolia, 354

Flaveriefe, 76 .

Fleabane, 207.

Florestina, 74, 336 . callosa, 337. tripteris, 337 .

Flourensia, 66, 281. cernua, 281.

con'ymbosa, 281

Iaurifolia, 281.

thur'ifer'a, 281.

Fly Honeysuckle, 15.

Franseria, 63, 250, 449. albicaulis, 251.

ambrosioides, 252 .

artemisioides, 252 .

bipinnatifida, 251 .

Chamissonis, 251.

chenopodiifolia, (251, 252)

cordifolia, 449 .

cuneifolia, 251. deltoidea, 251.

discolor, 251.

dumosa, 251.

eriocentra, 251.

flexuosa, 450 .

Hookeriana, 250.

ilicifolia, 252.

L'ssingii, 251 .

montana, 251.

pumila, 250.

tenuifolia, 250,449 .

tomentosa, 251 .

Fuller's Teasel, 48 .

Gaillardia, 76, 351 .

acuntis, 353 .

acaulis, 345 .

amblyodon, 352 .

arjstata, 352

Arizonica, 353

bicolor, 352

comosa, 351.

Drummondii, 352

Iancenlata, $3 \bar{n} 2$.

Iexicana, 352.

picta, 352 .

pinnatifida, 353

pulchella, 352 .

pulchella, 33.3.

Romerima, 344.

rustict, 352.

simplex, 351.

spathulata, 353.

tuberculata. 351

Galarciia, 351.

Galatella graminifolia, 216. nemoralis, 199.

obtusifolia, 171.

Galathenium elongatum, 442

Flor:danum, 442,443 .

graminifolium, 443

integrifolium, 442 .

Ludovicianum, 443.

multiflorum, 444.

salicifoliun, $442,443$.

sanguineum, 442.

Galinsoga, 69, 303. parviflora, 303

Galissogied 68.

Galium, 23, 35, 445 .

acutisism

Andrewsii, 41.

Anglicum, 36.

angustifolium, 39 .

A parine, 36.

Arlcansanum, 38.

asperrimum, 39 .

asprellum, 39.

Bermudianum, 37

Bermudiense, 37.

bifolium, 36 .

Bloomeri, 40.

Bolanderi, 41.

boreale, 38 .

boreale, 37.

brachiatum, 37, 39 .

Brandegei, 38.

Californicum, 41.

Catalinense, 445.

circezans, 37.

Claytoni, 38.

concinnum, 38.

cuspidatum, 39.

dasycarpum, 445.

Fendleri, 41. 
hispidulum, 42.

hispidum, 42.

hypotrichium, 40.

Kantschaticum, 37 .

lanceolatum, 37 .

latifolium, 38 .

Littellii, 37.

margaricoccum, 41.

Matthewsii, 40 .

micruntlum, 39.

microphyllum, 41.

Mollugo, 35.

multiflorum, 40 .

Nuttallii, 41.

obovatum, 37.

obtusum, 38.

Parisiense, 36.

parritlurum, 39.

Penrisylvanicum, 39.

pilosum, 37.

proliferum, 37.

pubens, 40.

punctatum, 37 .

puncticulosum, 40 .

purpureum, 37.

Rothrockii, 39.

rubioides, 38.

septentrionale, 38.

spinulosum, 39.

stellatum, 40.

strictum, 38

suaveolens, 39 .

suffruticosum, 41.

Texanum, 36.

Texense, 36.

tinctorium, 38.

Torreyi, 37 .

tricorne, 36 .

trifidum, 38.

trifloru1n, 39.

uncinulatum, 36 .

uniflorum, 41 .

Vaillantii, 36.

verum, 35.

virgatnm, 36.

Wrightii, 39

Gall-of-the-earth, 434 .

Gamochota, 236.

Garberia, 52, 112. fruticosa, 112 .

Gardenia florida, 29. clusice folia, 29.

Randia. 29.

Genipa, 20, 29. clusixfolia, 29

Georgia Bark, 23.

Gercea, 281, 282. canescens, 282.

Gerbera nutans, 408 . Walteri, 408

Glyptopleura, 86, 423 . marginata, 423. setulosa, 423 .

Gerberese, 83

GNAPHALIE $2 E, 58$.

Gnaphaliopsis micropoides, 359.

Gnaphalium, 59, 234.

alienum, 232.

alpinum, 232.

Americanum, 236

A rizonicum, 234.

Californicum, 235.

Carpathicum, 232.

Chamissonis, 236.

Chilense, 2350. conoideum, 234.

decurrens, 235.

dimorphum, 231.

dioicum, 283.

falcatum, 236.

flaginoides, 230.

gossypinum, 235.

hyemale, 236.

leucocephalım, 235 .

luteo-album, 235.

margaritaceum, 233.

microcephalum, 234.

Norvesicum, 236.

obtusifolium, 234.

palustre, 235 .

Pennsylvanicum, 236.

plantagineum, 233.

plantaginifolium, 233.

polycephalum, 234.

purpureum, 236.

pusillum, 236.

ramosissimum, 235.

rectum, 236.

sputhulatum, 236.

spicatum, 236.

Sprengelii, 234.

Sprengelii 235 .

stachydifolium, 236.

strictum, 285.

supilum, 236.

sylvaticum, 236.

sylvaticum, 236.

uliginosum, 238.

ustulatum, 236.

virgatum, 226.

W'rightii, 234.

Goat's-beard, 415, 416 .

Gochnatia, 83, 407. hypoleuca, 407.

GochindTIE, 83.

Gulden-rod, 143.

Greenella, 55, 164.

Arizonica, 164.

discoidea, 164.

Grindelia, 53, 116.

anyustifolia, 117 .

Arizonica, 118.

arguta, 118.

coronopifolia, 117.

costata, 117

cuneifolia, 118.

discoiden, 119

glutinosa, 119.

grandiflora, 118.

hirsutula, 117.

humilis, 119.

humitis, 119.

integrifolia, 117.

integrifolia, 118.

inuloides, 117.

lanceolata, 118.

latifolia, 119 .

microcephala, 117, 118.

nana, 119.

nuda, 118.

Oregana, 118.

Pacifica, 119.

robusta, 119.

rubricaulis, 117

squarrosa, 118.

squarrosa, 119.

siricta, 117.

subdecurr $n s, 118$.

Texana, 118.

virgata, 118.
GroundseI, 383, 394.

Guardiola, 60, 237.

platyphylia, 237.

Guettarda, 21, 29.

ambigua, 30.

Blodgettii, 30 .

elliptica, 30 .

scabra, 30.

Gum-plant, 116, 119.

Guntheria, 351

Gutierrezia, 53, 115.

Berlandieri, 116.

Californica, 115 .

divaricata, 115.

eriocarpa, 116.

Euthamiæ, 115.

Lindheimeriana, 116.

linearifolia, 115.

microcephala, 115 .

microphylla, 115.

spharncephala, 115.

Texana, 116.

Gymnocline, 365 .

Gymnolana, 356.

Gymnolomia. 66, 269.

encelioides, 269, 450.

multiflora, 269 .

Porteri, 269.

tenuifolia, 269.

triloba, 269, 450 .

Gymnopsis, 269.

uniserialis, 256.

Gymmosperma, 52, 11

corymbosum, 114.

multiflorum, 114.

nudatum, 354.

oppositifolium, 354

scoparium, 114.

Gymnostyles Chilensis, 365. nasturticfolia, 366 . stolonifera, 866 .

Gynema, 225. dentata, 226.

viscida, 226.

Gyrophyllim, 293.

Halea Ludoviciana, 256. repanda, 256 . Texana, 256.

Hamelia, 20, 28. coccinea, 28 patens, 28.

Haploesthes, 80, 378. Greggii, 378.

Haplopappus, 125.

Hardheads, 406.

Harpacarpus exiguus, 306. madarioides, 306.

Harpalium, 270, 271. rigidum, 275.

Harpalyce, 433.

alba, 434 .

altissima, 435 .

crepidina, 433 .

racemosa, 433.

serpenlaria, 434.

virgata, 433.

Hartmannia, 307. ciliata, 316.

corymbosa, 308 .

fasciculata, 309. pungens, 308.

Hawkbit, 420.

Hawkweed, 424. 
Hecastocleis, 83, 407. Shockleyi, 407.

Hectorea villosissina, 121.

Hecubra, 347.

Hedyotis acerosa, 27.

angustifolia, 26.

auricularia, 28.

Boscil, 27.

carulea, 24.

calycosa, 26

ciliolata, 26 .

gentianoides, 24.

glumerata, 28.

Halei, 28.

humifusr, 26, 27.

lanceolata, 20

longifolin, 26.

minima, 25.

rotund folia, 25.

rubra, 25 .

serpyllifolia, 24 .

stenophylla, 26, 27.

umbellata, 26.

Virginica, 28

Heleastrum, 173 .

album, 193.

paludosum, 174 .

HeLeNIE, 7 , 7

HeLENTOIDE $\notin, 70,317$.

Helenimm, 76, 347 .

altissimum, 349 .

amphibolum, 348.

atropurpureum, 349 .

antumnale, 349 .

Bigelorii, 350

Bolanderi, 350.

brevifolium, 351 .

Californicum, 349.

canaliculatum, 349 .

commutatum, 349 .

Curtisii, 3500.

decurrens, 349 .

elegans, $3 \pm 8$.

fimbriatum, 350 .

grandiflorum, 349 .

Hoopesii, 347 .

lanalum, 330 .

longifolium, 349 .

Mexicanum, 349 .

Mexicanum, 348, 349.

micranthum, 349 .

microcephalum, 348 .

montcrnum, 349 .

nudiflorum, 349 .

Nuttallii, 350 .

ooclinimm, 348 .

parviflorum, 349 .

puberulum, 349 .

pubescens, 349 .

pumilum, 349 .

quadridentatum, 348 .

quadriclentatum, 349.

quadripartitum, 348 .

Seminariense, 349.

stachadifolium, 329 .

tenuifolium, 347.

Thurberi, 348.

tubuliflorum, 349 .

varium, 349 .

vernale, 350 .

Helepta grandiflora, 255.

Helianthella, 67, 283.

argophylla, 283.

Californica, 285

Douglasii, 285 . grandiflora, 285 .

Intifolia, 270.

Mexicana, 284

microcephala, 284.

Nevadensis, 450 .

nudicaulis, 283 .

Parryi, 284.

quinquenervis, 284.

tenuifolia, 285.

uniflora, 28.j.

unitlor'a, 284.

HELIAYTHOIDE.E, 59, 237 .

Helianthus, $66,271,450$. altissimus, 276

angustifolius, 273.

annuus, 272 .

argopbyllus, 272

aristatus, 288.

atrorubens, $\geq 74$.

atrorubens, 274, 275.

Bolanderi, 2T.2.

Californicus, 277 .

canescens, 276 .

cernuus, 281.

ciliaris, 274 .

cinereus, 275.

cinzereus, 279.

crassifolizs, 275.

cucumerifulius, 273.

dealbatus. 280,450 .

debilis, 273 .

decapetalus, 280.

dentatus, 270

diffusus, 274.

divaricatus, 279 .

divaricalus, 278 .

diversifolius, 279 .

doronicoides, 279.

doronicoides, 280.

Douglasii, 278.

Dowellianus, 275.

e)"ythrocarpus, 272.

exilis, 273 .

Floridanus, 273.

frondosus, 280.

giganteus, 276.

giganteus, 273, 277.

gigas, 276.

gracilentus, 277.

grosse-serratus, 276.

heterophyllus, 274 .

heterophyllus, 275 .

hirsutus, $2 \div 9$.

hispidulus, 279.

Hookerianus, 268.

integrifolius, 272.

lætillorus, 275 .

lævigatus, 278.

lavis, 255, 279, 296.

lenticularis, 272 .

Lindheimerianus, 273.

longifolius, 278 .

longifolius, 268

macrocarpus, 272.

macrophyllus, 280.

Maximiliani, 277.

microcephalus, 278

Jfissouriensis, 275.

Missuricus, 274.

mollis, 276.

mollis. 280.

multiforus, 272, 280

neglectus, 279.

Nuttallii, 277.

occidentalis, 275.
Oliveri, 450 .

orgvalis, 273.

ovitus, 272

Parishii, 277 .

parvitlorus, 276.

patens, $2 \div 2$.

pancitlorus, 272.

petiolaris, 272 .

precux, 273.

prostratus, 280.

pubescens, 276, 279 .

punilus, $27 . \overline{3}$.

quinquenervis, 284

radula, $2-i t$.

rigidus, 274 .

scaberimus, 272 .

scaberimus, 275.

Scliweinitzii, 278.

silphioides, 274.

spar'sifurus, 274.

spathulatus, 276 .

squarrosus, 276.

strumosus, $27 \mathrm{~T}$.

strumosus, 278, 279, 280.

subluberosus, 276.

tenuifolius, 280.

tephrodes, 4 in.

tephrodes, 271

thurifer, 281.

tomentosus, 276 .

tracheliifolius, 280

tracheliifulius, 278 .

tricuspis, 275 .

truncatus, 279.

tubaformis, 272

tuberosus, 280 .

tuberosus, 2 \% 6.

Uliochroa anzona, 258

elation, 258.

furcata, 258.

Linnouna, 258.

Heliomeris muliffora, 269. tenuifolia, 269 .

Heliopsis, 64, 254.

annua, 25.5.

Balsamorrhiza, 266.

buphthalmoides, 255 .

buphthalmoides, 255.

canescens, 255.

gracilis, 255

lævis. 254.

parvifolia, 25.

scabra, 255 .

terebinthacea, 266.

Helmintha, 420 .

Helogyne, 93.

Hemiachyris Texana, 116.

Hemiambrosia, 250.

Hemiptilium, 415.

Bigelorii, 414.

Schottii, 415 .

Hemixuntlidium, 250, 251.

Hemizonella, 69, 306.

Durandi, 306 .

minima, 306.

parvula, 306

Hemizonia, 69, 306. angustifolia, 308 . anqustifolic, 311 .

balsamifera, 308 .

cephalotes, 312.

citriodors, 307, 451.

Clevelandi, 307.

congesta, 307.

congesta, 314 . 
corymbosa, 308. decumbens, 309 . Douglasii, 311. fasciculata, 309 . filipes, 313.

Fitchii, 308.

floribunda, 309 .

Fremonti, 312 .

frutescens, 307.

glomerata, 309.

Heermanni, 310.

hispida, 311 .

Kelloggii, 309 .

Lobbii, 310 .

luzulafolia, 307.

macradenia, 308

macradenia, 310.

macrocephala, 308.

mollis, 311 .

multicaulis, 309.

multiglandulosa, 312

oppositifolia, 312 .

paniculata, 309.

Parrvi, 308.

pauciflora, 311 .

plumosa, 312

pungens, 308.

ramosissima, 310.

rudis, 307.

sericea, 307.

spicata, 311

Streetsii, 307, 451.

tenella, 310 .

truncata, 311.

virgata, 310 .

Wheeleri, 307.

Wrimhtii, 309 .

Herba Impia, 230.

Hesperastrum, 174

Hesperevax, 228.

Heterochota, 207.

Heterochromea, 453.

HETEROCHROME $\mathrm{AE}$, 54 .

Heterodonta, 245 .

Heterogyne, 253.

Heteropectis, 361 .

Heterophania, 231.

Heteropleur'a, 429.

Heterosperma, 299.

Heterospermum, 68, 299.

dicranocarpum, $23 \%$.

pinnatum, 299

tarletinum, 299.

Heterotheca, 53, 120. Chrysopsidis, 121.

fioribunda, 121 .

grandiflora, 121.

Lamarckii, 120.

Lamarckici, 130.

latifolia, 121.

leptogloss $x, 121$. scabra, 121 .

Hieracium, 86, 424.

abscissum, 430

albiflorum, 428 .

alpinum, 424 .

arcticum, 427.

argntum, 428.

aurantiacum, 424 .

auratum, 425 .

brrbatum, 426 .

Bolanderi, 429 .

Brardegei, 455 .

brevipilum, 429.

Breweri, 427.
Californicum, 423.

Canarlense, 425 .

Canadense, 425 .

carnetum, 430.

Carolinianum, 426.

corymbosum, 425 .

cynoglossoides, 428.

erythrospermum, 429 .

fasciculatum, 425 .

Fendleri. 429.

gracile, 427.

Greenei, 429.

Gronovii, 426 .

Gronovii, 425, 426, 427 .

helianthifolium, 425 .

Hookeri, 427.

horridum, 427.

Kalmii, 424.

Kalmeii, 425.

Lemmoni, 430 .

longipilum, 426, 455 .

macranthum, 425 .

macrophyllun, 425 .

Marianum, 426, 446, 455 .

Marianum, 426 .

molle, 424 .

murorum, 424.

paniculatum, 425.

Parishii, 428.

Pennsylvanicum, 426.

pricaltum, 424.

proscox, 421.

prenanthoides, 425.

Pringlei, 429.

pusillum, 207.

relicinum, 427.

rigidum, 425 .

Rugelii, 426 .

runcinatum, 431 .

Rusbvi, 428.

scabriusculum, 425 .

scabrum, 426.

scabrum, 426 .

Scouleri, 427.

Scouleri, 429.

subnudum, 425.

Sullivantii, 425 .

sylvaticum, 424 .

thyrsoideum, 430 .

triste, 427.

triste, 427 .

umbellatum, 425 .

Vancouverianum, 428.

venosum, 425 .

venosum, 425 .

viryatum, 425 .

vulgatum, 424 .

High Cranberry, 10.

High-water Shrub, 247.

Hobble-bush, 9.

Hofmeisteria, 51, 93 . pluriseta, 93

Hologymne, 324

Durglasii, 323.

glabrata, 324.

Holozonia, 313 . flipes, 313.

НомоCHвоме ब, อ̆ 2 .

Homoinathus, 408 .

Homopappus, 126. argutus, 127.

glomeratus, 127

inuloides, 128.

multiflorus, 129.

paniculatus, 127. racemosus, 127.

spathulatus, 149.

squar"osus, 125.

Honeysuckle, 141.

Hopkirlia anthemoides, 334.

Horse-Gentian, 12.

Houndstongue, 113.

Houstonia, 20, 24.

acerosa, 27.

angustifolia, 26.

carulea, 24

ciliolata, 26.

coccinea, 24.

fasciculata, 27 .

firuticos $\alpha, 26$.

humifusa, 25.

Linncei, 24, 25.

longifolia, 26.

minima, 25.

patens, 24.

pubescens, 26.

purpurea, 26

pusilla, 24.

rotundifolia, 25.

rubra, 25.

rupestris, 26.

serpyllifolia, 24.

subriscosa, 25 .

tenuifolia, 26.

varians, 26.

Wrightji, 26

Hulsea, 75, 342 .

algida, 343 .

brevifolia, 343 .

Californica, 342.

crllicarpha, 342 .

heterochroma, 343.

nana, 343.

Parjyi, 342.

vestita, 342 .

Hydrocarpoa, 298.

Hynenatherum, $77,357,453$.

acerosum, 357

aureum, 359.

Berlandieri, 358.

concinnum, 453 .

Gnaphaliopsis, 358.

gnaphalodes, 359.

Greggui, 359.

Hartwegi, 358.

Neo-Mexicanum, 357.

pentachætum, 358.

polychætum, 357

setifolium, 359 .

tagetoides, 357 .

tenuifolium, 358 .

tenuilobum, 358 .

Thurberi, 358.

Treculii, 358.

Wrightii, 358

Hymenoclea, 63, 248.

monogyra, 248.

Salsola, 248.

Hymenonema glaucum, 417, 418 . laciniatum, 417.

Hymenonappus, 74, 235. artemisiæfolius, $\mathbf{3 3 5}$.

corymbosus, 335 .

Douglasii, 341 .

filifolius, 336 .

flavescens, 336 .

luteus, 336.

Mexicanus, 336.

Nevadensis, 341.

robustus, 336 . 
scabiosæus, 335. tenuifolius, 336 . tenuifolius, 336 .

Hymenothrix, 73, 334 . Wislizeni, 334 . Wrightii, 335.

Bymenoxys, 346 . Californica, 32T. calva, 328. linearifolia, 344. mutica, 328 . odorata, 347 .

Hyoseris amplexicaulis, 412 . angustifolia, 112 . bitora, 412 .

Caroliniana, 411. major, 412. montana, 412 . prenanthoides, 412

Hypochœris, 85, 416. glabra, 416. radicata, 416 .

Ianthe, 197.

Iudian Currant, 13.

Indian Plantain, 394.

Infuntia Chilensis, 334.

Innocence, 24.

Inula, 59, 236 .

argentea, 121.

divaricata, 130 .

ericoides, 198.

falcuta, 122

glandulosa, 122.

glutinosa, 119.

gossypina, 122.

graminifolia, 121.

Helenium, 236.

Mariann, 122

scabra, 121 .

serrata, 117.

subaxillaris, 121.

INULOIEE $, 57,225$.

Iron-weed, 89.

Isocarpha, 65, 257. oppositifolia, 257.

Isocoma vernonioides, 143.

Isopappus, 130.

divaricatus, 130.

Hookerianus, 131.

Iva, 62, 245 .

ambrosiæfolia, 246.

angustifolia, $24 \overline{6}$.

annua, 246.

axillaris, 247.

ciliata, 246.

dealbata, 246 .

fuliolosa 247 .

frutescens, $2 \pm 7$.

Hayesiana, 247 .

imbricata, 246.

microcephala, 247.

monophylla, 249.

Nevadensis, 247.

paniculata, 246.

xanthififolia, 246.

Ixora Americana, 24 ternifolia, 24.

Jacea, 406 .

Jamesia, 412, 413. pauciftora, 413

Jaumea, 70, 317. carnosa, 317.

JAUMIE $\pi, 70$.
Jerusalem Artichoke, 280. Joe-Pye Weed, 95.

Kalliactis. 265.

Keerlia. 55, 164.

bellidifolia, 164.

effusa, 165 .

ramosa, $16 t$.

skirrobasis, 164.

Kelloggia, 22, 31 galioides, 32

Kleinia, 317, 354

Knapweed, 406 .

Knoxia, 31.

Krigia, 84, 411.

amplexicaulis, 412 .

bellioides, 411 .

Caroliniana, 411, 412

Dandelion, 412.

dichotoma, 411.

leptophylla, 411.

montana, 412.

nerrosa, 411 .

oecidentalis, 411 .

Kuhnia, 51, 103.

Critonia, 103.

eupatorioides, 103.

frutescens, 103.

ylutinosa, 99, 103.

leptophylla, 103.

macrantha, 103.

.Iaximiliani, 103.

paniculatr, 103.

rosmarinifolia, 103.

Schaffneri, 103.

suaveolens, 103.

Kuhnioides, 113.

Kymapleura, 439 heterophylla, 440 .

LABIATIFLOR.E, 50, 82.

Lactuca, 87, 441 .

acuminata, 443 .

alpina, 444 .

Canadensis, 442.

Canadensis, 444.

Crrolinianr, 442.

elongata, 442, 443 .

Floridana, 443 .

Floridana, 444

graminea, 443.

graninifolia, 442.

hirsuta, 442 .

integrifolia, 442.

integrifolia, 443.

leucophrea, 444.

longifolia, 442 .

Ludoviciana, 443.

macrophylla, 444.

pulchella, 443.

sagittifolia, 442 .

sanguinea, 442

Scariola, 442

villosa, 44 .

Lactucastrum, 443.

Lagatea, 200.

Lagophyl]a, 70, 313. congesta, 314 .

dichotoma, 313

filipes, 313 .

glandulosa, 313.

ramosissima, 314.

Lagothamnus, 379. ambiguus, 379 . microphyllus, 379.

Lampsana, 84, 410. communis, 410 .

Laphamia, 71, 319. angustifolia, 319 .

bisetosa, 320 .

cinerea, 319 .

dissecta, 321 .

halimifolia, 319 .

Lemmoni, 319.

Lindheimeri, 320 .

meracephala, 320 .

Palmeri, 320.

peninsularis, 319 .

rupestris, 319 .

Stansburii, 320 .

Lappa major, 397. minor, 397 .

tomentosa, 397.

Lapsana, 410 .

Lusianthoe, 286.

Lasthenia, $72,324$.

ambiyua, 331.

Californica, 324.

Coulteri, 452.

glaberrima, 324.

glabrata. 324. 452.

obtusifolia, 324.

Laurestinus, 9 .

Layia, $70,314,451$.

Calliglossa, 316.

carnosa, 315.

cirrvanthemoides, 316.

Douglasii, 316.

elegans, 315 .

Fremonti, 316 .

gaillardioides, $\mathbf{3 1 5}$.

glandulosa, 314

graveolens, 451.

heterotricha, $315,451$.

Jonesii, 316.

Neo-Mexicann, 314.

pentachreta, 315.

platyglossa, 315 .

Leachia, 291.

lanceolata, 292.

trifolinta, 293.

Lebetina, 356 .

Leighia, 270

bicolor, 273.

linceolata, 285.

longifolia, 278.

uniflora, 284. 285

Leontrodon, 85, 420 .

alpinus, 440 .

autumnalis 420

boreale, 424 .

Carolinianum, 441.

ceratophorum, 440.

hirsutum, 439

hirtus, 420 .

hispidus, 420 .

lividus, 440 .

officinalis, 440 .

Taraxacum, 440.

vulgare, 440.

Lepachys, 66, 263 .

ant,ustifolia, 264.

columnaris, 264.

peduncularis, 264.

pinnata, 263.

pinnatifich 264.

serrata, 264.

Lepidanthus, 364.

Lepidaploa, 89. 
Lepidonema, 416

Lepidospartum, 80, 378. squamatum, 378 .

Lepidostephanus madioidts, 313.

Lepidutheca suciveolens, 364.

Leptoclinium fruticosum, 112

Leptogyne, 225.

Leptopoda, 350

brachypoda, 349.

brevifolia, 350, 351.

decurrens, 350 .

denticulata, 350 .

fimbriata, 350.

Helenium, 350.

incisa, 350 .

integrifolia, 350.

pinnolifida, 351.

puberula, 350.

Leptoseris, 422.

Californica, 423 .

saxctilis, 423 .

sonchoides, 422.

Leptosyne, 68, 299.

Arizonica, 301.

Bigelovii, 300.

Californica, 299.

calliopsidea, 300.

Douglasii, 299.

gigantea, 300 .

heterocarpa, 301.

maritima, 300.

Nexberryi, 299.

parthenioides, 301.

Stillmani, 299.

Leptotheca, 431.

Leria lyrata, 408. nutans, 408.

Lessingia, 54, 161, 446.

adenophora, 447.

Germanorum, 1 ri2.

glandulifera, 162.

leptoclada, 162, 447.

nana, 163,447 .

nemaclada, 447 .

Parryi, 447 .

ramulosa, 162, 446.

virgata, 162 .

Lettuce, 441.

Leucampyx, $78,362$.

Newberryi, 302

Leucanthemum arcticum, 365. integrifolium, 365 . Parthenium, 365.

vulgare, 365 .

Leucocoma, 172 .

Leucopsidium Arkansanum, 134. hunile, 164.

Leucopsis, 123.

Leucoseris, 422 tenuifolia, 423

Leysera Caroliniana, 352.

Liatris, 52, 109.

acidota, 110.

aspera, 110.

bellidifolia, 113.

Boylkini, 110.

brachystachys, 111.

Chapmanii, 112

corymbosa, 113.

cylindracea, 109.

cylindrica, 110.

dubia, 111.

elegans, 109.

flexusesa, 110

fruticosa, 112.
Garberi, 112.

gracilis, 110.

graminifolia, 111.

oraminifolia, 110.

heterophylla, 110 .

intermedia, 109.

lavigata, 112.

lanceolata, 111.

macrostachya, 111.

mulcronata, 110.

odoratissima, 113.

oppositifolia, 95 .

paniculata, 113.

pauciflora, 112

prucift'sculosa, 112.

pilosa, 111.

propinqun, 111.

pumila, 111.

puluctata, 110.

pycnostachya, 110.

radians, 109.

resinose, 110, 111.

scariosa, 110 .

secunda, 112.

sessiliftorc, 111.

sphoroiden, 110.

spicata, 111.

squamosa, 113.

squarrosa, 109.

squarrulose, 110.

stricta, 110.

tenuifolia, 112.

tomentosa, 113.

umbellate, 90.

virgata, 111.

Walteri, 113

LIGULIFLOR

Lindheimera, 61, 244.

Texana, 244.

Linnxa, $7,13$. borealis, 13.

Linosyris, 136.

albicaulis, 139.

arborescens, 141.

Bigelovii, 138.

Bolanderi, 130 .

carnosa, 202.

ceruminosa, 138.

coronopifolia, 142.

dentata, 143 .

clepressa, 137.

Drummondii, 142.

graveolens. 139.

heterophylla, 142.

hirtelln, 142 .

Howardi, 136.

humilis, 204.

lanceolata, 140

Mexicana. 143.

Parryi, 136.

pluriftora, 142.

pulchella, 137.

ramulosa, 223.

sermulata, 140

Sonoriensis, 141.

squamata, 378.

teretifuliu, 138.

Texana, 222.

viscidiflora, 138, 139, 140.

Wrightii, 142.

Linsecomia glauca, 274 .

Lion's-foot, 434.

Lipochceta Texanu, 286.

Loqfic subulate, 230 .

Lonicera, 8, 14 alba, 30 .

albiflora, 18.

Bi'eweri, 15.

carulea, 15.

Californica, 18.

Canndensis, 15.

Caroliniana, 16

ciliata, 15.

ciliosa, 16.

ciliosa, 18.

conjugialis, 15 .

Diervilla, 19.

dioica, 17.

Douglasii, 17.

dumosa, 18.

flava, 17.

flava, 17.

hirsuta, 17.

hispidnla, 18.

glauca, 17 .

grata, 17

Goldii, 17.

intermedia, 16.

interrupta, 18.

involucerata, 16.

Ledebourii, 16.

microphylla, 18.

Mociniana, 16.

oblongifolia, 15.

occidentalis, 16.

parifiora, 17.

pilcsa, 18.

pubescens, 17 .

sempervirens, 16.

subspicata, 18.

Sullivantij, 17.

Symphoricarpos, 13.

Tartarica, 16.

Utahensis, 13.

velutina, 15 .

villosa, 15,17 .

Virginiana, 16.

LONICERE $A, 7$.

Luphochona, 264.

Lurentea, 254, 360 .

Lowellia aurea, 359 .

Luina, 79, 376.

hypoleuca, 376.

Luthera Virginica, 412.

Lygodesmia, 87, 435 .

aphylla, 436 .

exigua, 436.

grandiflora, 435.

juncea, 435.

juncer, 436 .

minor, 413 .

rostrata, 436.

spinosa, 430 .

Macharanthera, 204.

canesctns, 205, 206.

grandiflura, 125.

parvifiora, 207.

setigera, 206.

Shastensis, 174.

tanacetifolia, 206.

Macrocarplius achilleafolius, 341.

Douglasii, 341 .

Macrohoustonia, 24

Macronema, 135.

dissoidea, 135.

saffruticosa, 135.

Macrorhynchus, 438 .

angustifolius, 439. 
aurantiacus, 438 . Californicus, 439 . Chilensis, 440. cynthioides, 437 . elatus, 438. glaucus, 437. yrandiflorus, 438, 439. Harfordii, 439 . heterophyllus, 439. humile, 439 . laciniatus, 439 . Lessing $\ddot{i}, 439$. purpureus, 438. retrorsus, 439. troximoides, 438.

Mudaria, $30 \pm$. conymbosa, 305. elegans, 305. racemosa, 305 .

Madariopsis, 305.

Madaroglosea, 314 angustifolia, 314, 315. carnosa, 314

elegans, 315.

heterotricha, 315. hieracioides, 315 . hirsuta, 315.

Madder, 35

Madia, 69, 304, 451. anomala, 307, 451 .

Bolanderi, 304. capitata, 305 . citriodora, 307. 451. dissitiflora, 305 .

elegans, 305 . filipes, 306. glomerata, 306. mellosn, 305 .

Nuttallii, 304

radiata, 305 .

Rammii, 451

sativa, 30 ప.

stellata, 30ว.

viscosa, 305.

Yosemitana, 304, 451 .

MADIE, 69.

Madorelle dissitiflora, 305. racemosa, 305.

Malacolepis, 421.

Malacomeris, 423 incana, 423 .

Malacotbrix, 86, 421 .

altissima, 45,5

Californica, 422.

Californica, 422 .

Clevelandi, 423.

commutata, 42,3 .

Coulteri, 421, 454 .

crepoides, 430 .

Fendleri, 422

foliosa, 455 .

glabrata, 422 .

incana, 423.

insularis, 454

obtusa, 423.

obtusa, 422 .

parviftora, 423.

platyphylla, 410 .

saxatilis, 423, 455.

sonchoides, 422 .

sonchoides, 422

tenuifolia, 423 .

Torreyi, 422

Torreyi, 422.

$\mathrm{X}$ anti, 422 .
Mallostoma acerosa, 27.

Maryacola parvula, 93.

Marsh Elder, 24i.

Marshallia, 68, 303 . angustifolia, 303. exspitosa, 303. lanceolata, 303. latifolia, 303. schreberi, 303.

Ifaruta Cotuln, 362. fotida, 362

Matricaria, 78, 363. asterioides, 166.

Chamonila, 364. cirronata, 364. Courrantia, 364. discoidea, 364. glastifoli', 166. inodora, 363. odorata, 365.

Parthenium, 365. pyrethroides, 364 tinncetoides, 364

Iratthiola, 29. scabra, 30 .

Nayweed, 362.

Yegalastrum, 173.

IVEA JIPODIE 60

Melampodium, 60, 238, 449 . australe, $2: 39$.

cinereum, 239.

cupulatum, 239

hispidum, 239.

leucanthum, 239 .

longicornu, 239.

perfoliatum, 449 . ramosissimum, 239 .

Melananthern, 257.

Jelanthera, 65, 257 . angustifolin, 257. deltoidea, 257.

hastata, 257.

lanceolata, 257.

Linnai, 257.

mic)ophylla, 257.

pandurceformis, 257.

triloba, 257. urticafolia, 257.

1 icrageratum, 92.

Micropus, 58, 226. amphibolus, 227. an qustifulius, 227 . Californicus, 227. Grayana, 227. minimus, 229.

Microseris, 85, 416. acuminata, 419 . aphantocarplia, 419 .

attenuata, 419.

Bigelovii, 419 .

Bolanderi, 418.

borealis, 424.

cyclocarpha, 420 .

Douglasii, 420 .

elegans, 41 .9.

Howellii, 454.

Iacinjata, 417.

leptosepala, 418 .

leploseprela, 418 .

Iindle $\mathrm{i}, 419$.

linearifolia, 418 .

macrochrta, 418.

nutans, 416 .

Parryi, 418.

platycarpha, 420 . sylyatica, 417 .

troximoides, 420 .

Mikunia, 51, 94.

artemisioides, 97.

concolvalucea, 94.

cordifolia, 94.

yonoclada, 94. menispermoiden, 94. pubescens, 94.

rubiginosa, 94 .

scandens, 94 .

sucveolens, 94

Milfuil, 363.

Milk 'lhistle, 405.

Millerin anyustifolia, 354.

Milleirie.e, 59.

Mint Geranium, 365.

Mist-flower, 102 .

Mitchella, 22, 31. repens, 31. undulata, 31.

Milracarpium, 32.

Mitucarpum, 32

Mitracarpus, 32.2. breviflorus, 32 . linearis, 32.

Molina viscust, 225.

Wonachana, 247.

Jonolopia, 72, 323. bahixefolia, 324 . glabrata, 324.

gracilens, 323.

Heermanni, 323.

linceolnta, 323 .

major, 323, 452 . minor, $32: 3$.

Monoptilon, 55, 165. bellidiforme, 165

Minothrix Stansburii, 320.

Iforuinia hypoleuca, 407.

ITurinda, 21, 29.

Roioc, 29.

Mugwort, 367, 372 .

Wulgedium, 443.

acuminatum, 444.

Floridanum, 443.

hestatum, 435 .

heterophyllum. 443.

leucophazum, 444.

lyratum, 443.

multiflorum, 444 .

pulchellum, $4 \pm 3$.

II TISIACE. $82,40 \overline{7}$.

Myrstiphyllum, 30.

Nabalus, 433.

alatus, $4: 35$.

albus, 434 .

altissimus, 435 .

asper, 433.

Boottii, 435 .

corrlatus, 435 .

crepidlineus, 433 .

deltoideus, 435 .

Froseri, 434 .

ylaucus, 434.

Illinoensis, 433.

integrifolius, 434. nonus, 434.

racentosus, 433.

Roanensis, 434.

serpenturius, 4.34.

trifoliolatus, 434.

trill,batus, 434

virgalus, 433. 
Nardosmia angulosa, 376. curymbosa, 376. firigida, 376 . palmata, 376. sagittata, 376.

Nassauvie.te, 83.

Nauenberria trinervala, 354

Neocis, 398

Nicolletia, 77, 355, 446. Edwardsii, 355. occidentalis, 355 .

Nipplewort, 410.

Nothocalais, 420.

Obeliscaria colnmnaris, 264 pinnata, 264. pulcherrima, 264. Tagetes, 264.

Odontucarpha, 115.

Onlif'a, 230 .

oldenlandia, 20, 27. acerusa, 27. andustifolita, 27.

Boscii, 27.

ccerulea, 24.

glomerata, 27.

Gieenei, 27.

Halei, 28.

humifust, 26.

pentandra, 28.

purpurea, 26.

retundifolia, 25.

rubra, 25

serpyllifolia. 24.

subviscosa, 25

uniflora, 28.

Oligogyne Tampicana, 289

Oligosporus, 368. pycnocephalus, 369.

Oligotrichium. 218.

Olocarpha, 308

Omalanthus comphoratus, 367.

Omalotes camphoratus, 367.

Omalotheca, 231, 236. supina, 236.

Onopordon, 82, 405 . acanthium, 405 .

Onopordum, 405 .

Oyurinia, 420. autumnalis, 420

Oritrophium, 175.

Orthomeris, 198.

Osmadenia tenella, 311.

Osmia, 94.

Osteospermum Uvedalia, 238.

Ox-eye Daisy, 365.

Oxylepis, 347 .

Oxytenia, 62, 248. acerosa, 248 .

Oxytripolinm, 203.

Oxyura chrysanthemoides, 316. Oyster-plant, 415.

Palafoxia, 74, 338. callosa, 337 .

fastiviata. 338 .

Feayi, 338.

Hovkeviana, 337

integrifulia, 338 .

latifolin, 338.

leucophylla, 338 .

linearis, 338

Texana, 337

Paleolaria carnen, 338. fastiginta, 338.

Pallasia, 281. grandiflora, 281

serratifolia, 289.

Prppochroma, 206.

Pappothrix 319.

Partheniastrum, 244.

Parthenice, 62, 245.

mollis, 245.

Parthenium, 62, 244.

alpinum, 245 .

argentatum, 245.

Hysterophorus, 244.

incanum, 244.

integrifolium, 245.

lobatum, 244.

lyratum, 244.

ramosissimuni, 245.

Partridge-berry, 31

Patrinia ceratoplyylla, 43. longifolia, 43.

Pectidium, 361.

punctatum, 362

Pecticlopsis angustifolia, 361.

Pectis, 77, 360 .

angustifolia, 360 .

ciliaris, 360

Coulteri, 361.

fastigiata. 361 .

filipes, 361 .

imberbis, 362

Jaliscana, 361 .

linifolia, 360,362 .

longipes, 361.

multiseta, 361

papposa, 361 .

prostrata, 360

punctata, 362

Rusbyi, 361 .

tenella, 360 .

tenella, 361 .

Pectothrix, 361.

Pentachæta, 53, 119, 446. alsinoides, 120 .

aphantochceta, 120.

aurea, 120, 446.

exilis, 120 .

pracilis, 120

Lroni, 446.

Pentodon, 6, 28. Halei, 28.

Pentotis, 28.

Perumibus hirtus, 259.

Perdicium, 409. semiflosculare, 408.

Perezia, 83, 408. Arizonica, 409 .

Coulteri, 409.

micrncephala, 409 .

nana, 409 .

runcinata, 408 .

Thurberi, 409 .

Wrightii, 409

Pericome, $71,322$. caudata, 322 .

Perityle, 71, 320.

Acmella, 322.

aglossa, 322 .

Californica, 321 .

Californica, 321, 322

coronopifolia, 321.

dissecta, 321.

Emoryi, 321

Fitchit, 321.

incana, 320 .

leptoglossa, 322.

mieroglossa, 322 . nuda, 321.

Parryi, 322.

plumigera, 321.

Perityle a 71 .

Persoonia angustifolia, 303. lanceolata, 303.

latifolia, 303

Petasites, 79, 375

frigida, 376 .

palmata, 376.

sagittata, 376 .

vulgaris, 376 .

Pencepliyllum, $79,377$.

Scliottii, 377.

Phonactis, 207, 208, 209.

Phoethusa Americana, 287. borealis, 287.

Phalacrocline, 225.

Phalacroloma, 207, 218. acutifolium, 219 .

Beyrichii, 219.

obtusifolium, 219.

Phalacroseris, 84, 410. Bolanderi, 410 .

Phinlis, 328, 329.

Philozera multiflora, 347.

Phyllacrocephala, 94.

Phyllactis obovata, 42.

Phyllopappus, 124, 416 .

Phyllotheca, 123.

Picracienia Richardsonii, $\mathbf{3 4 7}$.

Picris, 85, 420.

Davurica, 421.

echioides, 421.

hieracioides, 420 .

Japonica, 421 .

Kamtschatica, 421.

Picrothannus desertor'um, 368.

Picrotus, 246.

Pilosella, 424. arguta, 428. spathulata, 426, 455 .

Pinaropappus, 85,421 . roseus, 421.

Pinckneya, 19, 23 puluens, 23.

pubescens, 23.

Pinknea pubescens, 23.

Pityopsis, 121.

argentea, 121

falcata, 122.

graminifolia, 121.

pinifolia, 122.

Plagius, 364.

Plateilema, 344.

Platycarpoea, 296.

Platylophus, 406.

Platyschkuhria, 332

Plectocephalus Americanus, 407.

Plectritis, 46.

brachys'emon, 47

capitata, 47 .

congesta, 47

macrocera, 46.

major, 47.

samolifulia, 47 .

Pluchea, 57, 225.

bifi'ons, 226.

borealis, 225 .

camphorata, 226.

foetida, 226.

glabrata, 226.

Marylandica, 226.

petiolata, 226.

purpurascens, 226. 
Plucheines, 57.

Plummera, 59, 237. fioribunda, 237.

Polyactidium, 207, 219.

Polyactis, 207, 219.

Polydymia, 377.

Polymnia, 60, 238.

Canadensis, 238.

Curoliniana, 243.

perfoliata, 449 .

Tetragonotheca, 255.

Uvedalia, 238.

Polynniastrum, 238.

Polypappus sericeus, 225.

Polypteris, 74,337 .

callosa, 337.

Hookeriana, 337.

integrifolia, 337. integrifolia, 352 .

Texaun 337.

Porophyllum, 76, 354. amplexicaule, 355 .

gracile, 355.

Greggti, 355. macrocephalum, 354.

Prenanthes, 87, 432 .

alata, 435.

alba, 434 .

alba, $43 \pm, 435$.

altissima, 434

aphylla, 436 .

aspera, 433.

autumnalis, 433.

Boottii, 435.

cordata, 435 .

crepidinea, 433 .

crepidinea, 434

deltoidea, 435 .

exigua, 436.

glauca, 434 .

Illinoensis, 433.

juncea, 435 .

M[ainensis, 433.

Miamensis, $47 \pm$.

ovata, 434 .

pauciflora, 413.

polymorpha, 431.

proteophylla, 434.

рудтюа, 431.

racemosa, 433 .

Roanensis, 434 .

rubicunda, 434 .

runcinata, 413 .

serpentaria, 434 .

simplex, 433 .

suavis, 434

tenuifolia, 413.

Prionopsis, 125.

Chapmanii, 174.

ciliata, 125.

Proustia, 408.

Pacalium, 397.

Psathyrotes, 80, 377. annua, 377 .

incisa, $3+3$.

pilifera, 377 .

ramosissima, 377 . scaposa, 378 .

Pseudo-Bahia, 323.

Pserdo-Monolopia, 331.

Psilactis, 56, 170.

asteroides, 171.

brevilingulata, 171.

Coulteri, 171.

Psilocarpcea, 296.
Psilocarphus, 58, 228, 448.

brevissimus, 448 .

brevissimus, 228.

Chilensis, 448.

elatior, 448.

globiferus, (228, 448.

globifer'us, 228.

Oreganus, $228,448$.

tenellus, 228, 448 .

Psilochana, 431. occidentalis, 432.

Psilostrophe gnaphaliodes, 318.

Psychotria, 21, 30. chimarroides, 31. lanceolata, 31 .

nervosa, 31

oligotricha, 31

rufescens, 31.

tenuifolia. 31

undata, 30.

Psychotrophum, 30.

Ptarmica borealis, 363. vulgaris, 363 .

Pterocaulon, 57, 226. pycnostachyum, 226.

virgatum, 226.

Pteronia Caroliniana, 109.

Pterophyton, 287.

Ptilomeris, 327.

affinis, 327.

anthemoides, 328.

aristata, 327 .

coronaria. 327.

mutica, 328 .

terella, 327.

Ptilunella scabra, 304.

Ptilophora, 416.

major, 417.

nutans, 417 .

Pugiopappus, 300.

Bigelorii, 300.

Breweri, 300.

calliopsideus, 300 .

Pulicaria annua, 219.

Pyrethrum, 364

bipinnatum, 364 .

inodorum, 363.

Parthenium, 365.

Pyrochata, 170.

Pyrrhopappus, 87, 440.

Carolinianus, 441.

grandiflorus, 441.

multicaulis, 441 .

multicaulis, 441 .

pauciflorus. 441.

Rothrockii, 441.

scaposus, 441 .

Sesseanus, 441.

Pyrrocoma arouta, 127. carthamindes, 126. foliosa, 128.

glomerata, 127.

grintelioides, 125.

Menziesii, 143.

paniculata, 127.

racemosa, 127.

radiata, 126.

Ratinesquia, 85, 415.

Californica, 415, 446

Neo-Mexicana, 415.

Ragweed, 248.

Raillardella, 81, 380.

argentea, 380 .

Eiseni, 380.
Muirii, 380.

Pringlei, 380.

scaposa, 380 .

Raillardia, 380.

Rancarua, 324 .

Randia, 20, 28.

aculeata, 28.

clusicefolia, 29.

latifolia, 29.

mitis, 29.

Xalapensis, 29.

Ratibida columnaris, 264. sulcata, 264.

Rattlesnake-root, 433, 434.

Relbunium, 35, 40, 41 . microphyllum, 41 polyplocum, 41.

Rhabdocaulis, 290.

Rhinactina, 200.

Rhyncholepis, 227.

Richardia, 22, 32 . pilosa, 32 . scabra, 32.

Richardsoniu scabra, 32.

Riddellia, 71, 317. arachnoidea, 318.

Cooperi, 318.

tagetina, 317.

Rindeltie $\pi, 71$.

Rigiopappus, 74, 338. leptocladus, 338 .

Roioc, 29.

Rosalesia, 104.

Rosin-weed, 240, 241.

Rothia Carolinensis, 335 .

Rubia, 35.

Brownei, 42.

peregrina, 42.

tinctoria, 35 .

Walteri, 42.

RUBIACE $A$, 19.

Rudbeckia, 65, 259. alata, 348 .

alismæfolia, 261.

amplexicaulis, 263.

amplexifolia, 263.

angustifolia, 273.

apetala, 274 .

aristata, 259.

aspera, 261.

atrorubens, 259.

bicolor, 260.

bupleuroides, 259.

Californica, 262.

chrysomeln, 261.

culumnaris, 264.

digitata, 262, 264

discolor, 260, 261.

fulgida, 260 .

fulgida, 261.

glabra, 262.

globosa, 264.

gracilis, 260.

grandiflora, 261

Heliopsidis, 261.

Heliopsidis, 261.

heterophylla, 263.

hirta, 260 .

hispilla, 258.

laciniata, 262.

lovigata, 262.

maxima, 262.

Mohri, 259.

mollis, 261.

montana, 263. 
nitida, 262.

occidentalis, 263.

odoratc, 260.

oppositifolia, 255.

pallida, 258.

perfolicta, 253

pinnata, 264.

Porteri, 269.

purpureen, 258.

quinata, 262.

radula, 274.

rupestris, 260.

serotina, $258,260$.

spathulata, 261.

spathulata, 263.

speciosa, 261.

speciosa, 258.

striyosu, 260.

subtomentosa, 260 .

Tagetes, 264.

tomentosi, 260, 264.

triloba, 259.

Rugelia nudicaulis, 383.

Sage-brush, 367, 374.

Sagre-bush, 374 .

Salsity, 415.

Sambucers, 7.

Sambucus, 7, 8.

Canadensis, 8.

planca, 9 .

humilis, 9.

melanocarpa, 8.

Mexicana, 9 .

nigra, 9 .

pubens, 9.

pubescens, 9

racemosa, 8 .

velutind, 9 .

Santolina suaveolens, 364.

Sanvitalia, 64, 254.

Aberti, 254 .

acinifolio, 254.

ancustifolia, 254.

ocymuides, 254.

procumbens, 254.

tragicefolin, 254. viliosa, 254 .

Sartwellia, 76, 353 . Flaveria, 353.

Mexicana, 353.

Saussurea, 82, 396.

acuminata, 397 .

alpina, 396.

Americana, 397.

angustifolia, 397.

Ledebunri, 397.

monticola, 397.

nuda, 397.

subsinuata, 397.

Scabiosa atropurpurea, 47.

Sicabious, 47.

Scariola, 442

Schkuhria, 73, 334.

Bigelovii, 338.

biternata, 333 .

Hopkinkia, 334.

integrifolia, 332.

Neo-Mexicına, 333.

pednta, 333 .

pusilla, 334

Wislizeni, 334

Woodhousii, 333.

Wrightii, 334 .

Sclerocarpas, 64, 256. exigurus, 306.

gracilis, 305 .

uniserialis, 256.

Sclerolepis, 51, 92.

verticillata, 92

Scorzonella, 416, 417. glauca, 418.

laciniata, 417 .

leptosepala, 418.

nutans, 417.

sylvatica, 417.

Scorzonera pinnatifida, 441.

Selloa glutinosa, 114. nudata, 354.

Senecio, 81, 383.

Actinella, 384.

ammophilus, 454.

amplectens, 384 .

ampullaceus, 393 .

Andinus, 387.

Arizonicus, 392.

aronicoides, 388 .

atriplicifolius, 395 .

attreus, 391.

aureus, 389, 394.

Austince, 454.

Balsamitæe, 391.

Bigelovii, 385.

Bolanderi, 392

Californicus, $393,454$.

campestris, 388, 389.

canus, 390 .

canus, 389.

Cardamine, 390.

Carolinianus, 394.

ceratophyllus, 454 .

cernuus, 385 .

ciliatus, 221, 383 .

Cineraria, 383 .

Clarkianus, 393.

Clevelandi. 387.

Coronopus, 393

crassulus, 087 .

Cumingii, 381.

Cymbalaria, 391, 392.

cymbalarioides, 391.

debilis, 391.

densiflorus, 394.

Douglasii, 393.

Elliottzi, 39t.

elongatus, 391.

eremophilus, 392 .

eurycephalus, 392.

eurycephalus, 384.

exaltatus, 388.

fastigiatus, 390 .

fastigiatus, 391, 393.

Fendleri, 392.

filifolius, 393

flocciferus, 383, 422.

Fremonti, 386 .

slabellus, 394.

Grayanus, 346.

Greenei, 385.

Hartwegi. 386.

hieracifolius, 396.

Hookeri, 389.

Howellii, 390 .

Huachucanus, 386 .

hydrophilus, 387 .

imparipinnatus. 394

integerrim us, 388 .

integerrimus, 387.

integrifolius, 380,390

Jacobæa, 383 .
Kalmii, 383, 394

lanceolatus, 387

Laynea, 390.

Leinmoni, 385.

lobatus, 394.

longidenlatus, 386.

longilubus, 393.

lugens, 388 .

luggens, 387.

Lyoni, 454 .

lyratus, 394.

megacephalus, 385 .

Mendocinensis, 384 .

Millefolium, 392.

Mississippianus, 394.

Mohavensis, 454.

multilobatus, 394.

Neo-Mexicanus, 392, 454.

obovatus, 391.

Palmeri, 383.

palustris, 394 .

Parryi, 393.

pauciflorus, 391.

pauperculus, 391.

petræus, 389.

Plattensis, 391.

Pseudo-Arnica, 384.

Purshianus, 390 .

rapifolius, 386.

Regiomontunus, 393.

renifolius, 389 .

resedifolius, 390 .

Riddellii, 393.

Rugelia, 383.

Rusbyi, 385.

Schweinitzianus, 394.

Seemanni, 386.

sel'ra, 386.

Soldanella, 384.

spartioides, 393.

stochadiformis, 393.

suciveolens, 395 .

subnudus, 391.

sylvalicus, 394.

Trmpicanus, 394.

Thurberi, 389.

Toluccanus, 388.

tomentosus, 390.

triangularis, 386 .

viscosus, 394.

vulgaris, 394

werneriæfolius, 389 .

Whippleauus, 384.

SENECIONIDH de, 79, 375.

Sericocarpus, 56, 171.

conyzoides, 171.

Oregonensis, 172.

rigidus, 172

solidagineus, 171.

tortifolius, 172 .

Sericophyllum, 121.

Serinia caspitosa, 411.

Seriphidium, 374

Serratula arvensis, 398.

Carolinensis, 91.

compta, 111.

glauen, 89.

Noveborncensis, 89.

pilosa, 111.

praalia, 89

scariosa, 110.

speciosa, 109.

spicata, 111.

squarmosa, 109.

Seven-Years' Apple, 29. 
Shortia Califurnica, 327.

Sirleranthus spinulosus, 446 . Silphium, 61, 240, 449 .

atbiflorum, $2+2$.

asperrimum, 240.

Asteriscus, 211, 449.

Asteriscus, $2 \pm 3$.

atropurpureum, 241.

betonicifulium, 242 .

brachiatum, 449 .

compositum, $2 \pm 1$.

conjunctum, 240.

connatum, 240 .

dentatum, 241

elatum, 242.

erythrocaulon, 240.

gracile, 241.

gummiferum, 242

Hornemanni, 24).

integrifolium, 240.

lasvigatum, 240, 241

lanceolatum, 211.

laciniatum, 242.

laciniatum, $2 \pm 1$.

mudicaule, 241.

Nultallianum, 243.

pumilum, 243.

perfoliatum, $2+0$.

pinnatifidum, 242

radula, 240 .

reniforme, $2+2$.

reticulatum, 241, 243.

scaberrimum, 240.

scabrum, 240, 241.

speciosum, 240.

spicatum, $2+2$.

subacaule, 243.

tetragonum, 240

trifoliatum, $2+1$

ternatum, $2+1$.

ternifolium, 241.

terebinthinaceum, 242.

tomentosum, 243.

Simsia 283

calva, 283.

canescens, 282.

exaristata, 283.

frutescens, 282.

lagascaformis, 283.

lanceolata, 285.

scaposa, 282

subaristata, 283.

Sneezewort, 363 .

Snowberry, 13, 30 .

Solidago, 54, 143 .

alba, 146 .

altissima, 151, 153, 157

anbigua, 143, 146 .

amplexicaulis, $15 \%$.

amplexicaulis, 160.

anyulata, 152.

angusta, 145

angustifolia, 150.

argentea, 145 .

arguta, 154.

arguta, 145, 155.

aspera, 153.

asper'ata, 152, 153.

asperula, 153 .

axillaris, 145.

Azorica, 149.

bicolor, 146.

Bigelovii, 146.

Bonttii, 154.

brachyphylla, 154.
Buckleyi, 147.

cresia, 145.

Californica, 158.

Californica, 147.

Canadensis, 157.

carinata, 149.

calnosa, 14!.

C'lapmani, 151.

ciliaris, 155 .

cinerascens, 158.

Clelioe, 143 .

compacta, 147.

conferta, 158.

confertiflora, 148 .

confertitlora, 144.

confinis, 149 .

cordata, 161.

corymbosa, 159.

corymbosa, 144, 148.

Curtisii, 146.

decemflora, 158, 159.

diffuse, 141

Drummondii, 159.

dubia, 143 .

elata, 14t, $15 \%$.

Elliottii, 153.

elliptica, 143.

elliptica, 15.3.

elongata, 15i.

elongat", 153, 156.

eminens, 157.

erecta, 144, 146, 152 .

fistulosa, 151.

Arbellata, 145 .

flabelliformis, 145.

flavovirens, 150 .

flexicaulss, 145.

fragrans, 143, 156.

Frankii, 152 .

fuscata, 144.

Gattingeri, 156 .

genisturdes, 150.

gigantert, 156.

glaberrimn, 155.

glabra, 156

glomerata, 147.

glatinosa, 148.

gracilis, 1 t5.

gracillima, 150 .

graminifulia 161

grandiftorn, $144,159$.

Guiradonis, 151.

hirsuta, 146.

hivta, 153.

hispida, 146, 158.

Houghtoni, 160.

humilis, 148.

humilis, 153.

incana, 158.

integerviona, 149.

intervifolia, $1+9$.

juncea, 155 .

lovigata, 149.

lanata, 146.

lanceolata, 160.

lancifolia, 145 .

laterifors, 143, 153, 187.

latifolia, 145 .

lntifolin, 143.

latissimifolia, 143.

Leavenworthii, 156.

levocarpa, 147.

lepida, 157.

leptocephala, 161.

limonifolia, 149.
Lindheimeriang, 147

linoides, 150, 154.

lithospermifolia, 144, 149 .

livida, 144,145 .

lungifolia, 157.

maciophylla, 147.

macrophylla, 145.

Marshalli, 156.

Mexicana, 149.

Missouriensis, 155.

Missouriensis, 156.

mollis, 157, 1 158.

monticola, 146.

Buhlenbergii, 155.

multiflora, 1.53 .

multiradiata, 147.

nana, 158.

neglecta, 154 .

nemoralis, 158 .

nitida, 160 .

Noveborracensis, 1 $1 \pm 3,1 \pm 9$.

nutans, 157.

obovatr, 150 .

occidentalis, 160 .

odora, 150.

Ohioensis, 159

patula, 152.

pauciflora, 144 .

panciflosculosa, 161

petiolaris, 144

petiolaris, 146, 147, 149, 152 158.

pilosa, 151.

pilosa, 153.

Pifcheri, 156.

procera, 157.

pubens, 146.

puberula, 150.

puberula, 158.

pulverulenta, 150.

puncticulairt, 151.

pyjamidata, 151.

radula, 158 .

recurvata, 144, 145.

recurvata, 153

reflexu, 157.

retrorsa, 151.

Ricldellii, 160.

rigrida, 159 .

vigidula, 153.

rotundifolia, 159.

rugosa, 153 .

rupestris, 156.

snlicina, 152.

Sarothre, 115

scaberrimn, 159.

scrbra, 152, 153, 157.

scribrida, 157.

Schraderi, 145.

sempervirens, 149 .

sempervirens, 149, 1 j2.

serotina, 156 .

serotina, 155 .

Shortii, 156.

sparsifinra, 159.

spathulata. $1 \pm 8$.

speciosa, 152.

speciosa 147.

spectabilis, 151.

splescelatert, 161 .

spiciformis, $1+9$.

spithamrea, 147 .

squarrosa, 144.

squar'rosa. 144.

stricta, 149. 
stricta, 148, 152, 157.

tenuifolia, 161 .

Terrie-Nova', 154.

thyrsoidea, 147.

Tolmieana, 151.

tortifolia, 151 .

uliginosa, 151.

uliginose, 154.

ulmifolia, 153 .

ulmifolia, 159.

velutina, 158.

verna, 152.

verrucosa, 143, 155 .

villosa, 151, 153 .

viminea, 146, 149 .

Virgaurea, 148.

Virgaurea, 147, 148

virgata, 150.

Virminiana, 153 .

Soliva, 78,365 .

daucifolia, 365 .

nasturtiifolia, 366 .

sessilis, 366 .

Solivcea, 365.

Soncbus, 87, 444.

acuminatus, 444.

alpinus, 444.

arvensis, 444

asper, 444 .

biennis, 444.

Californicus, 423.

Canadensis, 444.

Carolinianus, 444.

Floridanus, 443, 444.

hastatus, 435 .

leucophoeus, 444 .

Ludiovicianus, 443.

macrophyllus, 444

multiflorus, 444 .

oleraceus, 414 .

pallidus, 442, 444.

pulchellus, 443.

racemosus, 444.

Sibiricus, 443.

spicatus, 444

spinulosus, 444.

tenerrimus, 444.

tenuifolius, 444

Sow-Thistle, 444.

Sparganophorus verticillatus, 92. Spermacoce, 22, 33.

Chapmanii, 34 .

diodina, 35 .

glabra, 34

hirta, 34 .

involucrate, 33

parviflora, 34

podocephala, 34

Portoricensis, 34

pygmaet, 34 .

subulata, 33 .

tenuior, 34 .

tetracocca, 33.

Virginiana, 35.

Spharomeria argentea, 367. capitata, 367.

Spilanthes, 65,258 .

Nuttallii, 258.

occidentalis, 258.

Pseudo-Acmella, 322.

repens, 258.

Spilanthus, 258.

Spiridanthes, 323.

Stachelina elegans, 109.

Starkea pinuata, 130.
Star Thistle, 405.

Starwort, 172.

Staurospermum, 32.

Stemmodontia scaberrima, 286.

STELLAT 2 , 23.

Stenactis. 207, 219. ambiyua, 219.

annua, 219.

Beyrichï, 219.

dubia, 219.

glauca, 208.

speciosa, 209.

strigosa, 219.

verna, 216.

Stenotheca, 425 .

Mariana, 426 .

submuda, 426 .

venosa, 426

Stenotus, 131.

acaulis, 132.

armerioides, 132.

coespitosus, 132

florifer, 168.

linearifolius, 132.

multicaulis, 129 .

pygmoeus, 131.

Stepliananthus, 221.

Stephanomeria, 84, 412.

cichoriacea, 413 .

coronaria, 454 .

e]ata, 413 .

exigua, 414.

heterophylla, 413 .

intermedia, 417.

lactucina, 13.

minor, 413.

myrioclada, 414.

paniculata, 414.

Parryi, 413.

pentachæta, 414

runcinata, 413.

Thurberi, 413.

Schottii, 415 .

virgata, 414.

Wrierhtii, 414.

Stevia, 51.91.

amabilis, 91.

angustifolia, 92 .

callosa, 337 .

canescens, 92.

ivcefolia, 92.

Lemmoni, 92.

macella, 91 .

micrantha, 91.

Plummeræ, 92.

punctata, 92.

salicifolia, 92.

sphacelata, 337.

virgata, 92 .

Stick-tight, 296.

Stokesia, 50, 88.

cyanea, 88

Strigia, 103.

Strongylosperma australe, 366.

Strumpfia, 21, 31.

maritima, 31

Stylesia, 331.

Stylimnus, 22.5.

Stylocline, 58, 227.

acaulis, 229 .

filaginea, 228

gnaphalioides, 227.

micropoides, 227.

Stylopappus, $4: 99$ elatus, 438. grandiflorus, 439.

lacinuatus, 439 .

Succory, 412.

Sunflower, 271.

Suprago, 109.

Sweet Scabious, 47.

Symphiotrichium unctuosum. 189.

Symphoria conglomerata, 13.

elongata, 14.

glomerata, 13 .

heterophylla, 14.

occidentalis, 13.

racemosa, 13.

Symphoricarpos, 7, 13.

ciliatus, 14.

longiflorus, 14.

mollis, 14.

montanus, 14.

occidentalis, 13

oreophilus, 14.

parviflorus, 13.

racemosus, 13.

rotundifolius, 14.

spicatus, 13.

vulgaris, 13 .

Synedrella, 67, 289

vialis, 289 .

Syntrichopappus, 73, 328.

Fremonti, 328.

Lemmoni, 328.

Tagetes, 77, 359 .

Lemmoni, 359.

lncida, 359.

micrantha, 360 .

papposa, 356.

Tagetin:Ac, 76.

Tanacetum, 78, 366.

bipinnatum, 364 .

boreale, 366 .

camphoratum, 366 .

calpum, 367.

capitatum, 367.

diversifolium, 367.

Douglasii, 366 .

eleyans, 367.

Hurnnense, 366.

Huronense, 367.

Kotzebuense, 364.

matricarioides, 364.

Nuttallii, 367.

Parthenium, 365.

pauciflorum, $364,366$.

potentilloides, 367 .

suaveolens, 364 .

vulgare, 366

Taraxacum, 87, 440 .

ceratophorum, 440.

corniculatum, 440 .

Dens-Leonis, 440 .

hirsutum, 439 .

lavigatum, 440.

lanceolatum, 440

latilobum, 440 .

montrnum, 440

officinale, 440 .

palustre, 440.

phymatocarpum, 440.

Tarweed, 304, 306 .

T'easel, 47.

Tessaria borealis. 225 .

Tetracarpum, 334

Tetradymia, 80, 379, 453 . canescens, 379 . comosa, 379. 
glabrata, 379. iner'mis, 379.

Nuttallii, 379. ramosissima, 377 . spinosa, 379 .

squamata, 378 . stenolepis, 453.

Tetragonosperma lyratifolium,

Tetragonotheca, 64, 255 .

helianthoides, 255.

Ludoviciana, 256

Texana, 256 .

Tetrodus guadridentatus, 348 .

Thelecarpoea, 408.

Thelesperma, 68, 301 .

ambiruom, 301 .

filifolium, 301

gracile, 302.

longipes, 302.

simplicifolium, 302 .

subnudum, 302

subsimplicifolium, 302.

Therolepta, 303.

Thistle, 397 .

Thoroughwort, 94, 99.

Thymelea, 31 .

Thymophylla, 359 .

Greggii, 359

setifolia, 359

Thymophyllum, 359

Tickseed, 289.

Tinker's-weed, 12.

Tithonia, 66, 271.

argophylla, 284.

Thurberi, 271

tubof formis, 271 .

Tollatia chrysinthemoides, 316.

Townsendia, 56, 166.

Arizonica, 169.

condensata, 167

eximia, 167 .

Fendleri, 167.

florifer, 167.

Fremontii, 169.

glabella, 169

grandiflora, 167

incana, 169.

Mexicana, 169.

Partyi, 167.

Rothrockii, 168.

scapigera, 168 .

sericea, 168.

spathulata, 169

strigosa, 169.

strigosa, 168.

Watsoni, 168.

Wilcoxiana, 168.

Wrightii, 173

Traganthes, 97.

Tragopogon, 85, 415 .

Dandelium, 412.

porrifolius, 415 .

pratensis, 416 .

Virginicum, 412.

Trattenickia angustifolia, 303 . lanceolata, 303. latifolia, 303.

Trichocoronis, 51, 92. rivularis, 93

Wrightii, 92.

Trichophyllum, 329. integrifolium, 331 lanatum, 330

multiflorum, 331 oppositifolium, 332 .
Trichoptilium. 75, 343. incisum, 343 .

Tridax gaillardioides, 315

Trilisa, 52, 113. odoratissima, 113. paniculata, 114

Timorphas, 219. vulgaris, 220 .

Tiiosteospermum, 12.

Triosteun., 7, 12. angustifolium, 12. majus, 12.

minus, 12 .

perfoliatum, 12.

Tripleurospermum, 363. inodorum, 363.

Triplopappus, 196.

Tripolium angustum, $20 \pm$. caricifolium, 202.

conspicuum, 201, 203.

divaricatum, 203

frondosum, 204.

imbricatum, 201.

occidentale, 192.

Oreganum, 192.

paludosum, 174.

subulatum, 202, 203, 204.

Trixis, 83, 409 .

angustifolia, 409

Californica, 409

corrymbosa, 410.

frutescens, 410 .

frutescens, 410 .

suffruticosa, 410

Trochoseris, 438.

Troximon, 86, 87, 436 . alpestre, 437 .

apargioides, 438 .

apargioides, 439 .

aurantiacum, 438 .

aurantiacum, 438 .

barbellulatum, 437 .

Chilense, 439 .

cuspidatum, 437 .

glaucum, 437 .

gracilens, 438.

grandiflorum, 439 .

grandiflorum, 439.

heterophyllum, 439

humile, 438 .

laciniatum, 439.

marginatum, 437

Nuttallii, 438.

parviflorum, 437.

pumilum, 438 .

retrorsum, 439 .

Romerianum, 421.

taraxacifolium, 438 .

Trumpet Honevsuck]e, 16.

Trumpet Weed, 95.

TUBULIFLORA, 49.

Tuckernuannir, 300.

gigantea, 300 . mavitima, 300.

Tulocarpus, 237.

Tussilago, 79,375 .

corymbosa, 376

Farfara, 375.

frigida, 376 .

integrifolia, 408 .

nutans, 408 .

prlmata, 376

Petasites, 376.

sagittata, 376

Twin-flower, 13.
Uropappus, 416.

grandiflorus, 419.

heterocarpus, 419

Lindleyi, 419.

linearifolius, 419 .

L'vedalia, 238.

Vaccinium album, 16.

Valeriana, 42.

Arizonica, 43.

capitata, 43 .

ciliata, 43.

dioica, 43 .

edulis, 43 .

locusta, 44, 45 .

pauciflora, 43 .

scandens, 44.

Sitchensis, 43.

sorbifolia, 44

sylvatica, 43.

VALERIANACE $\mp, 42$.

Valerianella, 42,44 .

amarella, 45

anomala, 47 .

aphanoptera, 47.

carvulea, 44.

chenopodifolia, 45 .

congesta, 47.

Fregopyrum. 45 .

longiflora, 46 .

macrocera, 46 .

Nuttallii, 46.

olitoria, 44.

patellaria, 46.

radiata, 45 .

rhombicarpa, 44

samolifolia, 47 .

stenocarpa, 45 .

triquetra, 45 .

umbilicata, 45 .

Woodsiana, 45 .

Vanilla-plant, 113.

Varilla, 65, 257.

Mexicana, 257.

Texana, 257.

Venegasia, 70, 317. carpesioides, 317.

Verbesina, 67, 286 .

alba, 256.

Coreopsis, 289.

encelioides, 288.

helianthoides, 288.

heterophylla, 288.

laciniata, 287.

longifolia, 287.

microptera, 287.

nudicaulis, 288.

occidentalis, 287.

preniculata, 287.

Phocthusa, 287.

podocephala, 286.

polycephala, 287.

Siegesbeckii, 287.

Texana, 287

rillosa, 287.

Virginica. 287.

Warei, 288.

Wrightii, 287.

Verbesinaria, 286.

VERBESINEA, 64.

Vermifuga, 253.

Vernonia, 50, 89.

altissima, 90.

ancustifolia, 90 .

Arkansana, 89. 
Baldwinii, 90 .

corymbosa, 90 .

fasciculata, 90 .

Jamesii, 90 .

Lettermani, 90.

Lindheimeri, 91.

Noveboracensis, 89 .

oligophylla, 31 .

ovalifolia, 90 .

proaitta, 89,90

scaberrima, 91.

spharoidea, 90 .

tomentosa, 89

VerNoniacede, 50, 58.

Viburnum, 7,9 .

acerifolium, 10 .

acerifolium, 10.

alnifolium, 10.

cassinoides, 11.

cassinoides, 12.

densiflorum, 10.

dentatum, 11 .

dentatum, 10 .

edule, 10.

elljpticum, 10.

grandiflorum, 10.

lovigatum, 12 .

Lantana, 10.

lantanoides, 9 .

Lentago, 12.

molle, 11.

nudum, 11.

obovatum, 12.

opuloides, 10.

Opulus, 10.

Oxycoccus, 10.

pauciflorum, 10.

prunifolium, 12.

pubescens, 11 .

pyrfolium, 11, 12.

Rafinesquirınu, 11.

scabrellum, 11 .

stuamatum, 11

Tinus, 9.

trilobum, 10.

villosum, 11.

Viguiera, 66, 270.

brevipes, 270.

canescens, 270

cordifolia, 270 .

deltoidea, 271

dentata, 270.

glandulosa, 450 .

helianthoides, 270 .

laciniata, 270. lanata, 271.

laxa, 270.

microcline. 270.

niver, 271, 450.

Parishii, 271.

reticulata, 271.

tephrodes, 271, 450 .

Texana, 270

tomentosa, 271.

triquetra, 270 .

Villanova bipinnatifida, 244 chrysanthemoides, 334.

Virga-aurea, 144.

Virgaurea, 144 .

Virgitia, 351.

helioides, 352.

Wayfaring Tree, 9.

Wedelia, 66, 264 .

carnosa, 265.

hispida, 286.

perfoliata, 449 .

Weigela, 18.

White Istruce, 434.

Whiteweed, 365.

Whitneya, 71, 318. dealbata, 318 .

Wild Coffee, 12.

Wirtgenia Texana, 286.

Wolf-berry, 13.

Woodbine, 14.

Woodruff, 35.

Woodvillea, 207, 208. calendulacea, 208

Wormwood, 367, 370.

Wrethia, 66, 267. amplexicaulis, 267. angustifolia, 268.

Arjzonica, 267.

coriacea, 268.

glabra, 267.

helenioides, 267.

helianthoides, 267.

longicaulis, 267.

mollis, 268

ovata, 268.

reticulata, 268

robusta, 268.

scalora, 268.

W' ythe-rod, 11.

Xanthidium ambrosioides, 252. discolor, 251.

rhombophyllum, 251.

tenuifolium, 250.
Xanthiopsis, 252.

Xanthisma, 54, 124.

Texanum, 124.

Xanthium, 63, 252.

Americanum, 252.

Canadense, 252.

Carolinense, 252.

echinatum, 252.

macrocarpum, 252.

maculatum, 252

spinosum, 25.2 .

strumarium, 252 .

$X \pi n t h o, 324$.

Xanthocephatum, 53, 114 Benthamianum, 114. gymnospermoides, 114. sericocarpum, 114.

Wrightii, 114

Xanthocoma, 114.

Ximenesia, 288.

encelioidtes, 289.

Xylor'tiza "ylabriuscula, 200. villosa, 200.

Xylosteon, 14.

Xylosteum ciliatum, 16. involucratum, 16. oblongifolium, 15 Solonis, 15.

Trirtaricum, 15

villosum, 15 .

Yarrow, 363.

Youngia py.gmaea, 431.

Zexmenia, 67, 285.

brevifolia, 286.

hispida, 286.

hispidula, 289.

podocephala, 286 .

Texana, 286 .

Zinnia, 63, 253.

acerosa, 254

anomala, 253.

bicuspis, 253.

grandiflora, 253.

intermedia, 253.

juniperifolia, 253

leptopoda, 253.

multiflora, 253.

pauciflora, 253.

pumila, 253.

revoluta, 253.

tenuiftora, 253.

ZINNIEE, 63. 


\section{SYNOPTICAL}

\section{FLORA OF NORTH AMERICA:}

\section{By ASA GRAY, LL.D.,}

F.M. R S. \& L.S. Lond., R.I.A. Dubl., Phil. Soc. Cambr., Roy. Soc. Upsala, Stockholm, Göttingen, Edinb.; Roy. Acad. Sci. Munich, \&c.; Corresp. Imp. Acad. Sci. Se. Petersburg, Roy. Acad. Berlin, and Acad. Sci. Inssit. France.

FISHER PROFESSOR OF NATURAL HISTORY (BOTANY) IN HARVARD UNIVERGITY.

VOL. II. - PART I.

GaMOPETAL坐 AFTER Composites.

SECOND EDITION.

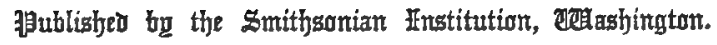

NEW YORK:

IVISON, BLAKEMAN, TAYLOR, AND COMPANY.

LONDON : WM. WESLEY, 28 ESSEX ST., STRAND,

AND TRÜBNER \& $\mathrm{CO}$.

LEIPSIC: OSWALD WEIGEL.

JAXUARY, 1886. 



\section{P R E F A C E.}

THIS volume commences where the Flora of North America by Torrey and Gray stopped, thirty-five years ago, namely at the close of the great order of Compositæ; and the present part comprises the remaining Gamopetalæ. It is intended to complete this Synoptical Flora in two volumes, of about 1200 pages each; the first to cover the ground which was gone over in the work referred to (now wholly out of print as well as antiquated), that is, to contain the orders from Ranunculaceæ to Compositæ, newly elaborated. The next ensuing part of the present volume will be devoted to the Apetalæ and Gymnospermæ, and the final portion to the Monocotyledones and the Vascular Cryptogamia.

Botanists will need no particular explanation of the plan of this work. Geographically it comprises the United States and all the North American continent and islands northward, Greenland excluded. The series of Natural Orders adopted is that of Bentham and Hooker's Genera Plantarum. The generic characters are given synoptically, but with essential completeness, at the beginning of each order. The characters. of sections of genera, when of comparatively high rank, are designated by the sectional mark $(\S)$ and printed in the larger type; and those of first importance, such as may be termed subgenera, are distinguished by having a substantive name. Subsections, and also primary divisions when of low rank, are in small type. Such subdivisions are very freely made, for convenience of analysis and to save repetition of identical phrases under the included species; and they are preferred to artificial keys to the species, because enabling these to be grouper more naturally. If somewhat less facile for rapid determination, they are more exhaustive and less liable to mislead; and they permit the ultimate specific 
characters to be more simply diagnostic. In monotypic genera, it has been found more convenient to give the details under the species, in the form of a specific character. Throughout the work, from the order down to the species or variety, the endeavor is to avoid repetition of statement.

The names of introduced species, sufficiently established to claim a place in our flora, are printed in small capitals, as are such adventitious or extraneous species as require mention.

In the accentuation of generic, sectional, and specific names, no attempt is made (as in the Manual of Botany of the Northern United States and other works) to mark the quality of the accented vowel, but only to designate the syllable upon which the principal accent falls.

Compactness being essential, only the leading synonymy and most important references are given, and these briefly. All deficiency in this respect will be amply supplied by the Bibliographical Index to North American Botany, prepared at the Harvard University Herbarium by. Sereno Watson, and now in course of publication by the Smithsonian Institution. The first part of this most important adjunct to the present work, which is just issued, gives the full bibliography of the Polypetalæ (the subject of the first volume of Torrey and Gray's Flora of North America, published in 1838 and 1840), with revision, critical corrections, and additions up to the present time. Its continuation may be expected to proceed pari passu with this Flora.

\section{Harvard University Herbarium,}

Cambridge, Massachusetts, April 10, 1878.

IN this edition many corrections have been made upon the electrotype plates; but larger ones are given in the Supplement, along with additions of new material and the re-elaboration of old. Page 68 and pages 389-392 have been reconstructed, and a full Index is added.

January 1, 1886. 


\section{O N T E N T S.}

\begin{tabular}{|c|c|c|c|c|c|c|c|c|c|c|c|c|}
\hline & & & & & & $P_{A G E}$ & & & & & & $\begin{array}{r}\text { PAGE } \\
152\end{array}$ \\
\hline & . & & & & & 1 & HYDROPHYLLACE $A$ & . $\cdot$ & - & - & & 152 \\
\hline CEA & & & . & - & & 1 & BORRAGINACE年 & . & . & & & 177 \\
\hline & & & • & & & & Costoltulace.de & & . & • & & \\
\hline - & · . & - & . & . & & 14 & OLANACE & r & . & . & & 224 \\
\hline & 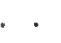 & . & . & & & 50 & SCROPHCLARIACEA, & & & & & \\
\hline$E$ & & 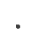 & . & & & 51 & $E$ & . & . & & & \\
\hline E & & & . & & & 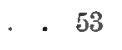 & ULARIACE $A$. & & . & . . & & 14 \\
\hline & & . & . & . & & 5 & BIGI & & & & & \\
\hline & & - & . & & 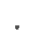 & 6 & $P_{E}$ & & & & & \\
\hline - & & . & . & 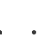 & . & 66 & ×. . & & . & & & \\
\hline . & - & . & . & & & 69 & 承 & . & . & & & \\
\hline$\approx$ & . & . & . & & . & - & - & ${ }^{\circ}$ & & & & \\
\hline 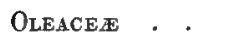 & & & . & & & 72 & E. & • & & & & $34-2>$ \\
\hline $\boldsymbol{E}$ & & & . & & & 7 & $\boldsymbol{E}$ & . & - & & & \\
\hline & & & & & & 5 & & & & & & \\
\hline & - & & · & & & .1 & & & & & & \\
\hline & & & - & & & 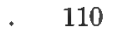 & 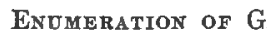 & YAMOPI & & & & \\
\hline NIACEX & & & & & & 128 & NDEX $\ldots$. & & & & & \\
\hline
\end{tabular}





\title{
SY NOPTICAL
}

\section{FLORA OF NORTH AMERICA.}

\section{Drvision II. GaMOPETALOUS DICOTYLEDONOUS PLANTS}

\author{
CONTINEED AFTER COMPOSITE.
}

\section{ORDER LXXIV. GOODENIACE $\mathbb{E}$.}

Shrcbiy or herbaceous plants, chiefly with alternate leaves and no proper stipules, most resembling Lobeliacea, especially in having the corolla cleft down between two of the lobes more deeply than between the rest; but without milky juice, the anthers separate, and a cup-like indusium around and at first enclosing the stigma. Mainly Australian and Oceanic, one or two species of the following genus reaching or overpassing the northern tropic.

1. SC AOLA, L. (Diminutive of scceva, a left-handed person; application obscure.) Calyx adnate to the 2 -celled ovary; the limb 5-cleft or a mere border around the base of the epigynous 5-lobed corolla, the tube of which is cleft down one side to the base; its lobes valvate-induplicate in the bud. Stamens 5, epigynous, or lightly connected with the base of the corolla, alternate with its lobes, distinct. Ovules solitary or a pair in each cell, erect. Fruit drupe-like, or when dry nut-like. Flowers in axillary cymes, or sometimes solitary.L. Mant. 145̃ ; Benth. \& Hook. Gen. ii. 539.

S. PIumiéri, Vahl. Low and shrubby, with fleshy obovate entire leaves, woolly-bearded in the axils, otherwise smooth: limb of the calyx a truncate border: corolla white, an inch long; the tube as long as the lobes, very woolly inside. - Lobelia, Plum. Ic. t 165; Catesb. Car. i. t. 79. - Seashore, S. Florida. (W. Ind., S. Afr., S. Asia.)

\section{ORDER LXXV. LOBELIACE E.}

Herbs (out of the tropics), the juice usually milky and acrid, with alternate simple leaves, no stipules, racemose inflorescence, and perfect 5 -merous flowers; having the calyx-tube adnate to the ovary, epigynous irregular corolla and stamens, the latter as many as the lobes of the corolla and alternate with them, and 
usually both syngrenesious and monadelphous. Limb of the calyx divided down to the ovary, which is wholly inferior or sometimes a large part free; its lobes generally persistent. Corolla (with the stamens) inserted just where the calyx becomes free from the ovary, its lobes mostly valvate or induplicate in the bud, commonly deeper cleft or completely split down between two of the lobes, the cleft mostly on the upper side (next the axis of inflorescence) in the open blossom, but becoming so by a twist; in the early bud the cleft looks toward the bract. The 5 petals occasionally disposed to separate from below upward, and the limb to be bilubiately irregular. Filaments generally free from the corolla, sometimes more or less adherent to its tube: anthers 2-celled, introrsely dehiscent, firmly united around the top of the style into a ring or short tube (except in an anomalous tribe). Ovary 2-celled with placentre projecting from the axis, or sometimes 1-celled with 2 parietal placentæ. Style entire: stigma commonly 2-lobed, girt with a rim of hairs. Ovules and seeds mostly indefinitely numerous, small, anatropous. Embryo small or narrow, straight, in the axis of fleshy albumen. (Too near the Campanulacece, and nearly passing into them, therefore united by recent authors; but as there are two dozen genera, agreeing in the indefinite inflorescence, irregular corolla, and mostly in the syngenesious anthers, it seems best to retain the order.)

Trine I. CYPHIE $\mathbb{E}$. Anthers entirely separate, merely surrounding the stigma.

1. NEMACLADUS. Caly $x$ partly or wholly free. Corolla bilabiately irregular; lower lip 3-, upper 2-lobed or parted. Filaments monadelphous above the middle: anthers oval, glabrous. Style incurved at tip : stigma capitate, 2-lobed, obsoletely annulate. Capsule 2-celled, 2-valved from top, 20-40-seeded.

Tride II. LOBELIE.E. Anthers syngenesious. Corolla truly gamopatalous, at least above, in ours distinctly bilabiate, two lobes turned away from the other three.

* Corolla open down to the base on one (the apparently upper) side.

2. LOBETIA. Calyx-tube short. Corolla with tube commonly straight; the lobe each side of the cleft ereet or turned backwards ; the three others larger and soncwhat combined to form the spreading or recurved (apparently) lower lip. Stamens free from the tube of the corolla, monadelphous except near the base. Capsule thin-walled, 2-celled, many-seeded, loculicidally 2 -valved at the top or free upper part.

* Corolla with a closed tubc : capsule wholly inferior.

3. PALMERELLA. Calyx-tube turbinate; the lobes slender, Corolla with an elongated linear and straight tube, not at all dilated at the throat; the short limb abruptly spreading; two lobes small, spatulate-linear and recurving; the three larger obovate or oblong and slightly united at base. Filaments more or less adnate to the corolla up to near the throat, then monarielphous and free, or farther adnate on one side only: anthers oblong; the three larger naked; the two shorter tipped with a tuft of very unequal stout bristles. Stigma, ovary, and probably capsule as in Lobelia.

4. LAURENTIA. Calyx-tube turbinate or oblong. Corolla witl its tube as long as the limb, which is like that of Lobelia. So are the stamens, pistil, \&c. Capsule short, 2 -valved at the summit.

5. DOWNINGIA. Calyx-tube very long, stalk-like. Corolla with a very short tube, and an ample bilabiate limb; lips spreading, the larger 3-lobed and broad; the two distinct divisions of the smaller narrower. Anther-tube incurved: one or both of the sliorter anthers tipped with a stout bristle-like point; the others naked. Ovary at first two-celled. Capsule very long and linear, crowned with the foliaceous and linear caly $x$-lobes, terete or 2-3-angled, early becoming 1-celled with 2 parietal and many-seeded filiform placentæ, remaining closed at the narrow apex, dehiscent longitudinally by from one to three long fissures or valves.

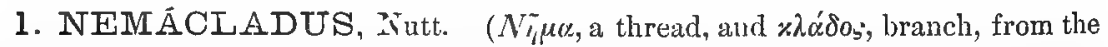
very slender stem and brancles.) - Two small annuals a span high, at length excessively branched and diffuse: leaves minute; the radical obovate; cauline reduced to subulate bracts: pedicels capillary, racemose on zigzag branches: corolla flesh-color. - Gray in Jour. Linn. Soc. xiv. 28. 
N. ramosissímus, Nutt. Glabrous, except the minutely pubeseent tuft of radical leaves: calyx 5-cleft; its tube turbinate, adnate to the lower third of the ovary and roundish capsule, which does not exceed the rather unequal lobes: corolla short (a line long), soon separating into 3 or 5 parts or petals : filaments monadelphous above: seeds oblongoval. - Pl. Gamb. (Trans. Am. Phil. Soc. n. ser. viii.), 254 ; Torr. Hex. Bound. 108, t. 35. Gravelly or sandy soil, California to New Mexico.

N. longiflórus, Gray. Radical leaves more canescent: calyx 5-parted, free from and much shorter than the narrow oblong capsule, its lobes equal : corolla narrower, firmly gamopetalous, fully 3 lines long, 3 or + times longer than the calyx : filaments long-monadelphous : seeds short-oval. - Proc. Am. Acad. xii. 60.-S. California, Wallace, Lemmon.

2. LOBÉLIA, L. (Commemorates Lutthias de l' Obel, latinized Lobelius, an early Flemish herbalist.) - Ours herbs, flowering in summer, some of them showy; common in the Atlantic, almost absent frow the Pacific United States. Tube of the corolla more or less disposed to split up in age into three pieces or into its five petals; at least the two shorter anthers with a bearded tuft at tip.

$\S 1$. Hoxochícus, A.DC. Lips of the corolla somewhat equal; one of them 3-toothed, the other 2-parted: flowers long-peduncled from the axil of leaves or large leafy bracts, in ours red and yellow : perennials.

L. laxiflóra, HBK., var. angustifólia. Tall and brancling: leaves lanceolate or even linear, 3 or 4 inches long, denticulate : peduncles 2 to 4 inches and corolla an inch long: calyx-lowes hardly longer than the tube. - L. persicafolia, HBK., not Iam. $L$. Curanillesii, Mart.; Hook. Bot. Mag. t. 3600. - Danp ground, just below the Mexican border of Arizona, north of Arispe, Thurber. (Mex.) A form intermediate in the breadth of the leaves between the var. and the L. Cavanillesii, Cav. Ic. t. 518, or the plant cultivated as Siphocampylus bicolor. Anthers sometimes long-hirsute externally, sometimes nearly naked.

§2. ErtobeliA. (Eulobelia, Hemipogon, \& Holopogon, Benth. \& Hook.) Larger lip of the corolla 3-parted or 3-cleft and spreading or dependent; the other two lobes either erect or turned backward: flowers racemose or spicate.

* Flowers bright red, large and showy, on crect or ascending pedicels in a virgate raceme : larger anthers naked at tip: perennial froni slender ofishoots, the llowering plants dying throughout in autumn.

L. cardinális, L. (Cardivalflower.) Minutely pubescent or glabrous: stem 2 to 4 feet high, commonly simple: leaves from oblong-ovate to oblong-lanceolate, tapering to both ends, irregularly serrate or serrulate : lower bracts leafy: tube of calyx and capsule hemispherical, much shorter than the subulate linear lobes: tule of the corolla about an inch long: seeds oblong, rugose-tuberculate: the intense red of the corolla varying rarely to rose-color or even white. - Bot. Mag. t. 320 ; Bart. Med. Bot. t. 48. - Wet ground, New Brunswick to the Saskatchewan, Florida, and the borders of Texas.

L. spléndens, Willd. More slender, glabrous or nearly so: leaves lancenlate or almost linear, glandular-denticulate, all but the lower sessile: seeds less tuberculate: otherwise very like the preceding. - Hort. Berol. t. 86, the corolla-lobes larger and longer than in wild specimens. L. Texensis, Raf. Ann. Nat. (18:39) 20. - Wet grounrls, Texas and through New Mexico and Arizona to southern borders of San Diego Co., California, Palmer. Also Mexico. Lobes of the corolla in our plant (as in many Mexican) only 8 to 6 lines long. Anthers sometimes a little hairy on the back.

* * Flowers bluc or partly white, sometimes varying to white: tips of the three larger anthers naked or stsort-bearded, or rarely with a tuft like the other two.

+ Flowers rather large (tube of the corolla half or over a 1 linel of an inch long), spicate-racemose: capsule short and broad: stems leaf $y^{*}$ : plants perennial, mostly by offsots.

$\rightarrow$ Leaves short and small (about half an incli long), thickish, very numerous up to the inflorescence, and passing into foliaceous bracts.

L. brevifólia, Nutt. Glabrous or minutely pubescent: stem virgate and simple, a foot or two high: leaves rather fleshy, strongly toothed, mostly 2 lincs broad; the lowest 
obovate or spatulate; the upper oblong-linear, often crowded and widely spreading or reflexed, sometimes even pinnatifid-toothed, the teeth callous: spike-like raceme few many-flowered: short pedicels mainly appressed and equalied by the short foliaceous bracts: calyx-lobes lanceolate or ovate-lanceolate, strongly and pectinately toothed, auriculate-appendaged at base, fully half the length of the puberulent tube of the corolla: anthers all hairy above, but only the two shorter with conspicuous beard at tip: capsule very short. - A.DC. Prodr. vii. 377; Bertol. Misc. x. 28. L. crassiuscula, Hook. Comp. Bot. Mag. i. 100. - Open pine barrens, Louisiana, Alabama, and Florida; flowering late. Tube of the corolla nearly half an inch long.

+t Leaves rather large and broad ( 1 to 5 inches 'Iong), from ovate to broadly laneeolate, numerous; the upper passing into foliaceous bracts: lip and upper part of the tube of the corolla glabrous within.

L. syphilitica, L. Somewhat pubescent with scattered hairs: stem rather stout, very leafy, 2 or 3 feet high: leaves thinnish, lanceolate or oblong and tapering to both ends, irregularly serrate or repand-denticulate (the larger 5 or 6 inches long): spicate raceme leafy below, a span to a foot long: calyx-lobes mostly hairy or ciliate, moderately shorter than the tube of the corolla, the sinuses conspicuously appendaged by deflexed auricles: larger anthers wholly naked at tip. -Dill. Elth. t. 242 ; Jacq. Ic. Rar. t. 597 ; Bot. Reg. t. 587.

6 L. glandulosa, Lindl. Bot. Reg. xxxii. t. 6 o. - Wet grounds, Canada to Georgia, Louisiana, and west to Kansas and Dakotah. Runs into some varieties: var. Ludoviciana, A.DC., is a south-western smoother form, with thickish leaves : there are also garden hybrids. Auricles of the calyx sometimes reaching the base of the ovary, sometimes short. Corolla bright light blue, rarely varying to white or purple; its tube broader than in the following, half an inch long.

L. pubérula, Michx. Soft-pubescent with very short and fine hairiness, 2 feet high: leaves from ovate to oblong, mostly obtuse and an inch or two long, pale or slightly hoary, callous-denticulate or more toothed; the upper passing into ovate foliaceous lower bracts of the strict and virgate spike-like raceme: flowers mostly crowded, becoming horizontal on the short appressed pedicels : calyx-lobes lanceolate, little shorter than the tube of the corolla (about 4 lines long, rarely shorter in proportion); the auricles at the sinuses short and rounded, commonly very short, often inconspicuous: larger anthers minutely short-bearded at tip : ovary generally hirsute. - Fl. ii. 152. L. amona, Ell. ? A.DC. Prodr. vii. 377, not Michx. L. glandulosa, Engelm. \& Gray, Pl. Lindh. i. 14.Damp sandy grounds, New Jersey to Illinois, Florida, and Texas. Passes insensibly into

Var. glabélla, Hook. (Bot. Mag. ts 3292, not of Ell.): a greener form, with slender, more glabrous, and usually more naked virgate spike, glabrous calyx, \&c, and flowers more secund. - L. glandulosa, var. obtusifolia, A.DC. I. c.; Bertol. Misc. x. 29. - N. Carolina to Florida and Texas.

L. amóna, Michx. Green and glabrous throughout, or nearly so: stem 1 to 4 feet high, in the larger plants leafy to the virgate raceme: leaves thinnish, oblong-lanceolate or narrower, mostly tapering to both ends, 2 to 4 inches long, irregularly serrate or denticulate; the upper passing into conspicuous lanceolate or linear bracts; these often glandular-denticulate, and the foliaceous lower ones equalling the flowers: calyx-lobes long and very slender, little shorter than the narrow tube of the corolla, from filiform- to linear-subulate, commonly quite entire, little widened and not auriculate at base: larger anthers wholly naked or merely puberulent at tip: ovary glabrous: lobes of the large lip of the corolla broadly ovate. - L. syphilitica, Walt. Car. 218; Juss. Ann. Mus. xviii. t.1, f.1. L. puherula, var. glabella, Ell. Sk. i. 267. L. glandulosa, var. glabra, A.DC. I. c. L. colorata, Don, Brit. Fl. Gard. n. ser. t. 180, and L. horlensis, A.DC. 1. c., are a hybrid form of this. - Deep swamps, N. Carolina to Florida. Raceme a span to a foot long; tube of bright blue corolla half an inch long. Calyx-lobes sometimes with a few teeth; the sinuses absolutely naked, or sometimes obscurely bordered. - To this belongs Clayton's plant referred by Gronovius to $L$. Cliffortiana, $L$.

Var. obtusáta. Cauline leaves oblong, obtuse, and almost entire: spicate raceme virgate and naked: calyx-lobes subulate, shorter, only half the length of the tube of the corolla: larger anthers densely very short-pubescent at tip. $-L$. amona, Chapm. Fl., in part. - Mirlde Florida, Chapman.

Var. glandulífera. A foot or two high, often slender and sparsely leaved, below sometimes hirsute-pubescent; leaves from oval to lanceolate-oblong, an inch or two long, 
mainly obtuse and the margins beset with glandular salient teeth : raceme secund, slender and loosely or few-flowered: bracts mostly shorter than the calyx; these and the slender calyx-teeth beset with slender gland-tipped teeth or lobes: sinuses of the calyx sometimes decidedly auriculate-appendaged: anthers as in the preceding var. or more hairy. $-L$. glandulosa, A. DC. in part. - Moist grounds, S. Virginia to Florida and Alabama. - These three forms clearly run together.

+++ Leaves long ( 2 to 5 inches) and narrow; the upper few and sparse: lip of corolla pubescent at base: usually a pair of glands or small glandular bractlets toward the base of the short pedicel.

L. glandulósa, Walt. Glabrous, or sometimes stem sparsely and often the calyx-tube densely hirsute: stem slender, 1 to 4 feet high: leaves thick and smooth, bright green, lanceolate or linear ( $1 \frac{1}{2}$ to 4 lines wide), callous- or glandular-denticulate: raceme or spike loosely few-many-flowered, secund, often as it were long-peduncled: bracts linear and subulate, more strongly glandular-toothed: calyx-lobes subulate, half the length of the tube of the corolla, bearing few or numerous salient gland-bearing teeth or lobes, or occasionally quite entire; the sinuses not auriculate-appendaged: tube of the light blue corolla 5 or 6 lines long: anthers all bearded at the tip. - Ell. Sk. i. 26.); A. DC. 1. c. (excl. vars.); Chapm. Fl. 25t. L. crassiuscula, Michx. Fl. i. 252 ; Nutt. Gen. ii. 70. - Pine-barren swamps, S. Virginia (Bailey) to Florida: fl. autumn.

+ + Flowers smaller or small : tube of the corolla not exceeding 2 or 3 lines in length.

+ Stem scape-like and mostly simple, hollow: leaves all or mainly in a rosulate cluster at the base, fleshy: bracts of the raceme shorter than the pedicels: lobes of the calyx subulate and entire, the sinuses naked or nearly so: fibrous-rooted and mostly aquatic very glabrous perennials, with pale blue or whitish tlowers half an inch long.

L. paludósa, Nutt. A foot or two or even 4 feet high: stem in the larger plants sometimes branching above and bearing several few-many-flowered racemes: leaves flat, from linear-spatulate to oblong, repand-denticulate or entire (1 to 9 inches long), sometimes scattered along the lower part of the stem: corolla pubescent at the base of the lip inside. -A. DC. l. c. 376. - In water (but foliage emerged), Delaware to Florida and Louisiana.

L. Dortmánna, L. Scape a span to a foot high, naked except a few fleshy bracts: leares in a radical tuft, linear, fleshy, terete, hollow and with a longitudinal partition: raceme loosely few-flowered: lower lip of the corolla almost naked. - Fl. Dan. t. 39. - Borders of ponds, often immersed, New England to Penn., and to subarctic Amer. (Eu.)

* + Stem leafy, mostly simple, strict, and continuert juto a more or Jess ped unculate and elongated virgate and naked spike-like raceme: leaves from lanceolate to obovate, barely denticulate or repand : lip prominently 2 -tuberculate within at base.

= Flowers or at leact the capaules horizontal, secund, scattered in the slender raceme. large for the section. the tube of the corolla $3 \frac{1}{2}$ to 2 lines long.

L. Ludoviciána, Gray. Glabrous, 2 or 3 feet high (from a perennial ? root), slender : leaves lanceolate, acute, or the lowest spatulate and obtuse, merely denticulate, thickish, an inch or two long (not over 4 lines broad), all with tapering base and the lower petioled: raceme loosely 5-20-flowered: flowers commonly puberulent: corolla balf an inch long: calyx with nearly.hemispherical tube; its lobes ovate-lanceolate, or rather cordate-lanceolate, being rounded auriculate at the sinuse's (their margins entire or obscurely fewdenticulate), only half the length of the tube of the corolla, and hardly longer than the capsule: larger anthers densely hirsute at and near the summit, but with no bearded tuft. - Proc. Am. Acad. xii. 60. - Wet prairies, W. Louisiana, Hale. Texas near Houston, Lindheimer. Tube of the corolla fully a quarter of an inch long: barely a trace of pubescence on the base of the lip. The five short auricles at the sinuses of the calyx broad and entire. Intermediate, as it were, between $L$. paludosa and the following.

L. appendiculáta, A.DC. Nearly glabrous, or the strong angles of the slender stem above scabrous, a foot or two high from an apparently annual or biennial root, not rarely branching: leaves thin, mostly denticulate or repand, an inch or two long, obtuse, the lowest obovate, the others oval or ollong and mainly sessile by a broad base: spike-like raceme very slender, several-many-flowered: corolla a third of an inch long: calyx with turbinate tube; its lobes linear-acuminate from a broader base, minutely hispid-ciliate, equalling the tube of the corolla, their bases sagittatcly extended into the deffexed auricles, which are sometimes subulate and all 10 distinct, but more commonly united partially or wholly into 5 lolses which not rarely cover the tube: base of capsule hemispherical, much 
shorter than the calyx-lobes : larger anthers slightly hirsute on the back, but naked at tip. - Prodr. vii. 376. - Moist grounds, W. Louisiana, Arkansas, and E. Texas: flowering early. Tube of the bluish corolla 2 to $2 \frac{1}{2}$ lines long. Calyx-appendages, as in all these species, very variable.

$==$ Flowers or at least the fruit-bearing pedicels ascending, mostly very numerous and hardly secund in the elongated and virgate spike-like raceme: tube of the corolla barely 2 lines long: upper leaves passing into bracts in the strunger plants: calyx-lobes loose and spreading in flower.

L. leptóstachys, A. DC. Calyx-tube short-turbinate and in fruit becoming hemispherical, the sinuses each with a pair of subulate or linear strictly deflexed appendages, which mostly soon equal or even exceed the tube; otherwise as the next. - Prodr. vii. 376. - Sandy dry soil, Ohio to Illinois and Missouri, and Virginia to Georgia : fl. early summer.

L. spicáta, Lam. Puberulent: stem virgate, 1 to 4 feet high (from a biennial? root): leaves pale, barely denticulate, obtuse; the radical and lowest obovate, 1 to 4 inches long; the upper spatulate, gradually smaller, and at length linear-oblong or lanceolate and bractlike: spike-like raceme from 3 to 18 inches long: tube of the calyx turbinate; the lobes subulate or linear-subulate and shorter than the tube of the (light blue, pale, or rarely white) corolla; the sinuses not appendaged. - Dict. iii. 587. L. Claytoniana, Michx. Fl. ii. 153. L. pallida, Muhl. Cat., Ell., \&c. L. goodenioides, Willd. Hort. Berol. t. 30 . L. nivea, Raf. Ann. Nat. 1820, 15, white-flowered form. - Gravelly or sandy and mostly dry soil, N. New England to Saskatchewan, Louisiana and Arkansas: fl. through summer.

Var. parviflóra, a small form, with calyx-lobes broadly subulate, and pale corolla only 3 lines long. - L. pallida, Muhl.? - Swamps, Lancaster, Penn., Porter : fl. June.

Var. hirtélla, a western form, with somewhat scabrous pubescence, and minutely hirsutely ciliate bracts and calyx-lobes, the latter subulate-linear and fully as long as the tube of the corolla. - Chiefly towards and beyond the Mississippi.

++++ Stem very leafy, simple and strict, continued into a rery leafy-bracted spike: leaves and bracts laciniate-toothed : lips of the corolla of nearly similar lobes, smootl and naked : seeds with a very smootl and eren coat.

L. fenestrális, Cav. Annual or at most biennial, 2 or 3 feet ligh, nearly glabrous, or the sharp decurrent angles of the stem hairy: leaves oblong or lanceolate, all the upper partly clasping and acuminate, passing into the similar bracts of the long spicate inflorescence, these mostly exceeding the crowded flowers: calyx-tube obovate; the lobes linear and mostly witl some slender teeth: tube of the corolla 2 lines long, surpassing the stamens and style: Iarger anthers short-bearded at tip. - Ic. vi. 8, t. 512; Lindl. Bot. Reg. xxiv. t. 47. L. pectinata, Engelm. in Wisliz. Rep. 108. - S. W. Texas to Arizona and Mexico.

++++ Stems leafy, often paniculately branched: flowers loosely racemose: sinuses of the calyx not appendaged: mainly biennials or amnuals.

- Cauline leaves chiefly linear, entire or merely denticulate : capsule not inflated.

u. Tube of the corolla fully 3 lines long: perennial from filiform rootstocks.

L. gruína, Cav. Puberulent or glabrous: stems nearly simple, slender, a foot or two high: leaves all lanceolate or linear, acute, denticulate, an incls or two long: raceme mostly slender-peduncled and few-flowered: calyx-lobes slender-subulate, shorter than the tube of the corolla. - Arizona, in the Sierra Blanca, at $7000 \mathrm{feet}$ Rothrock. Flowers smaller than in Mexican specimens; the tube of corolla only 3 lines long. (Mex.).

$b$. Tube of the bright blue (rarely varying to white) corolla not over 2 lines long; the two superior

lobes small and narrow: plants mainly glabrous, slender and erect: inflorescence disposed to become paniculate.

L. Bóykini, Torr. \& Gray. Perennial : stem a foot or two high from a creeping rootstock, fistulous, mostly simple: leaves all small and seattered, filiform or nearly so, an inch or less long and above reduced to setaceous bracts: filiform pedicels rather longer than the flower, spreading: calyx-lobes setaceous-subulate, spreading, very much longer than the short tube, which in fruit is rounded at base: mature capsule half superior: seeds shortoval, rough-rugose. - A. DC. Prodr. vii. 374; Chapm. Fl. 255. - Pine-barren swanjs in shallow water, S. Carolina, Georgia, and Florida, beginning to flower in May.

L. Cánbyi, Gray. Perennial from offsets ? or annual, 2 feet high, the larger plants paniculately branched above, obscurely puberulent, scabrous or nearly smooth: leaves linear, remotely denticulate-glandular, an inch or two long, a line or two wide : racemes elongated, often leafy at base: pedicels naked, erect or ascending, shorter than the bracts or the flower: calyx-lobes subulate-linear, denticulate-glandular, hardly longer than the wholly 
inferior oblong-turbinate capsule: seeds oblong-obovate, rugose-reticulated. - Man. ed. 5. 284. - Wet swamps, New Jexsey, Delaware, and S. Carolina : fl, late summer. Corolla about 4 lines long. Capsule 2 lines long.

L. Kálmii, L. Biennial or perhaps perennial from small rosulate offesets, a span to a foot or more high, often paniculately branching, glabrous and smooth or below slightly hairy: radical and lowest cauline leaves oblanceolate or spatulate, and the upper linear, an incli or two long: racemes loosely and mostly few-Howerct, often leafy at base or panicled: pedicels equalling or longer than the flowers, mostly 2-glaudular or minutely bracteolate above the middle: calyx-lobes subulate, a little longer than the broadly turbinate tube: capsule shorter and blunter at base than in the preceding, or even roundish, wholly inferior: seeds oblong, reticulated. - Bot. Mag. t. 22:'s. - Wet banks, Low'r C'anada and IIudson's Bay to L. Winnipeg, and to s. New York and l'enl., but rare southward.

L. Nuttállii, Roem. \& Schult. Annual, or at most biennial, very slender, a foot or two high, simple or sparingly and Joosely branched above: leaves an inch or less in length; the radical ones oblong or oval; the others from lanceolate to lincar, denticulate-glandular: racemes slender: pedicels mostly longer than the bract and shorter than the flower; the minute bractlets, if any, near the base: calyx-lobes subulate, considerably slorter than the tube of the pale blue corolla: capsule short and broad, obtuse or rounded at base, half superior: seeds 'oborate-oval, roughish, these as well as the flowers only half the sizc of those of $L$. Canbyi. - Torr. Fl. N. Y. i. 240. L. yrarlis, Nutt. Gen. ii. 77. L. Kalmii, var. gracilis, Bart. Fl. i. t. 34. - Moist pine barrens, New Jersey and Penn. to Georgia. Whole corolla 3 or at most 4 lines long, - To this belongs the Rapuntium minimum fore pallido caeruleo; Clayt., Gronur. Fl. Virg. ed. ?. 134. $=$ Leaves chiefly ovate or oblong and more or less serrate or tootlied: root annual: stems
brauching.

«. Capsule not inflated, partly or sometimes mainly superior: pedicels of the pedunculate raceme slender: leaves mostly petioled.

L. Cliffortiána, L. Glabrous or slightly and minutely hairy, a foot or so high: leaves ovate or slightly cordate, obtusely toothed or repand, petioled, or the upper lanceolate and sessile: pedicels filiform, Ionger than the flowers: calyx-tube obconical; the lobes subulate and shorter than the tube of the corolla : capsule ovoid, obtuse, nearly the upper half free: seeds oval, very smooth and shining. - Hort. Cliff. t. 26, \& sp., excl. syn. Gronov.; Michx. Fl. ii. 152? (Therefor L. Mirhurri, Nutt. Gen?) - Occasionally met with in the S. Atlantic States, in waste or cult. grounds: probalbly introduced from Trop. Amer.

Var. Xalapénsis differs in the fully two-thirds free and rather more oblong capsule (which does not, as in $L$. micrantha, much exceed the calyx-lobes), and the stems are weakcr or diffuse.-L. Xalapensis, HBK. - Peninsula of Florida (Canby, E. Pulmer, \&c.); perhaps introduced from $W$. Ind. and Mex.

Var. brachýpoda, a remarkable and distinet form, with cauline leaves from obovatespatulate to lanceolate, and pedicels ( 2 or at most 3 lines long) rather shorter than the flower or the capsule, which is that of genuine L. Cliffortiona. $-L$. Briturlimi, Torr. Mex. Bound. 107, hardly of A.DC. - S. W. Texas, IT right, Parry. Adjacent parts of Mexico, Berlandier, \&c. (No. 3177 of the latter may be L. Berlandieri, A.DC., but is from Matamoras, not Tampico: it has long filiform pedicels and seems to be a depauperate form of the true L. Clifforticua.)

L. Feayána, Gray. Slender, a span high, diffusely branched from the base, glabrous throughout: leaves small (a quarter to half inch long), repaneldenticulate, roundish or obovate, or the small uppermost spatulate or lanceolate and sessile: raceme loosely 4-10flowered: pedicels as long as the flower, twice or thrice the length of the subulate bract: calyx-tube and capsule broadly obconical; the latter two-thircls inferior, its free apex about the lengtl of the subulate calyx-lobes; these only half the length of the tube of the bright blue corolla: anthers glabrous (except the bearded tips of the shorter ones): seeds oblong, with a rough cellular coat. - Proc. Am. Acad. xii. 60. - E. \& S. Florida, Lr. Feay, Dr. E. Palmer, Mrs. Treat. Tube of the corolla under 2 lines long. Pedicels 2 to 4 lines long.

$b$. Capsule inflated, wholly inferior, longer than the pedicels: leaves sessile.

L. infláta, L. (Iroix Touscco) Pubescent, a foot or two high, branching above, and the spike-like but loose racemes paniculate: leaves ovate or oblong (an inch or two long), obtusely toothed, veiny; the upper forming foliaceous bracts: uppermost bracts linear- 
subulate as long as the pedicels: corolla pale blue or whitish, 2 lines long, hardly surpassing the subulate-linear calyx-lobes : turgid capsule oval, 4 lines long, glabrous, transversely veiny between the ribs: seeds oblong, roughish and reticulated. - Act. Ups. 1741, 23, t. 1; Schk. Handb. t. 269 ; Barton, Med. t. 16 ; Bigelow, Med. t. 19 ; 'Torr. Fl. N. Y. t. 63. - Open rather dry grounds, Hudson's Bay to Saskatchewan, and to Georgia and Arkansas. Herbage very acrid, formerly much employed in empirical medicine; an acridnarcotic poison.

3. PALMERÉLLA, Gray. (Named for the discoverer, Dr. Edward Palmer.) - A single species. - Proc. Am. Acad. xi. 81, \& Bot. Calif. i. 619.

P. débilis, Gray, l. c. A glabrous apparently perennial herb: stems simple or branched above, 2 feet ligh, slender and rather weak or spreading, very leafy: cauline leaves lanceolate or linear-lanceolate, about 2 inches long, entire or remotely denticulate, very acute; the uppermost passing into foliaceous or at length slender-subulate bracts of the few-many-flowered raceme: pedicels rather slender: lobes of the calyx slender or setaceous-subulate, much longer than the tube, about half the length of the tube of the blue corolla. - In the Tantillas Cañon, just below San Diego Co., California, Palmer. Corollatube whitish, three-fourths of an inch long, tomentose within, in age disposed to split up from below as in most Lobelias, and the filaments then separating, the sinus between the small lobes completely closed, and the filaments most adnate on that side: three larger lobes deep violet-blue, 3 or 4 lines long. Mature fruit not seen.

Var. serráta, Gray; a form with inflorescence and tube of the corolla somewhat puberulent; all but the upper leaves acutely serrate; the lowest broader, spatulate and obovate. - Bot. Calif. 1. c. ; Rothrock in Wheeler Rep. 1877, t. 16. - Valley of Ojai Creek, Ventura Co., California, Rothrock.

4. IAURENTIA, Micheli. (In honor of M. A. Laurenti, Professor at Bologna early in the 18th century.) - Low herbs, with the aspect and characters of the small species of Lobelia, excepting the closed tube of the corolla: flowers blue. Mainly S. Europe, Africa, and S. America : some have ovary almost free. - A.DC. Prodr. vii. 409; Benth. \& Hook. Gen. ii. 549. Porterella, Torr. in Hayden Rep. 1872, 488.

L. carnósula, Benth. Annual, rooting in the mid, glabrous, 1 to 5 inches high, rather succulent : lea ves oblong-linear or lanceolate, entire, sessile, a quarter to half inch long: flowers axillary and above corymbose or racemose, long-pedicelled : caly x-loles somewhat foliaceous, linear, obtuse, equalling the oblong-obconical or clavate tube, and also that of the corolla : seeds elongated-oblong, smooth. - Gray, Bot. Calif. i. 444 . Lobelia carnosula, Hook. \& Arn. Bot. Beech. 362. Porterella carnosula (carnulosa), Torr. 1. c.; 1’arry in Am. Nat. viii. 177. Muddy borders of ponds and streams, from California in the Sierra Nevada to Utah and Wyoming. Limb of corolla deep blue with a white or yellowish throat; three larger lobes round-obovate, 2 or 3 lines long; the other two small and lanceolate.

5. DOWNINGIA, Torr. (In memory of $A$. $J$. Downing, distinguished in landscape gardening, pomology, and horticulture.) - Low and mostly showyflowered annuals (of Oregon, California, and one in Chili); with entire and sessile slightly succulent small leaves, the upper passing into bracts to the axillary sessile flowers, which, on account of the very long and slender calyx-tube and ovary, seem to be racemose or corymbose. Corolla blue, with white or yellowish throat or broad blotch on the large lip. Capsule sometimes twisted. Seeds oblong, very smooth. - Pacif. R. Rep. iv. 116 ; Benth. \& Hook. l.c. Clintonia, Doug].; Lindl. Bot. Reg. t. $12+1$.

D. élegans, Torr. Stems a span to a foot long: leaves from ovate to lanceolate, acute (4 to 10 lines long) : larger lip of the corolla moderately 3-lobed, the other lobes lanceolate: seeds short-oblong. - Clintonia elegans, Dougl. ; Lindl. Bot. Reg. t. 1241. C. corymbosa, A.DC. Prodr. vii. 347, a more leafy form. - Wet ground, N. California to Washington Terr., and 
Nevada to Idaho. Large lip of corolla a fourth to half inch long and broad. Capsule often 2 inches long.

D. pulchélla, Torr. Mostly lower or weaker-stemmed: leaves more linear and obtuse: large lip of the corolla deeply 3-lobed; the other two lobes oblong-ovate: seeds elongatedoblong. - Clintonia pulchella, Lindl. Bot. Reg. t. 1909; Brit. Fl. Gard. ser. 2. t. 412. - Wet banks, California, nearly through the State, and in the borders of N. Nevada and Oregon. Large lip of corolla much broader than long ( 9 or 10 by 5 or 6 lines); all the lobes intense blue; the large centre mostly white. - Very like the preceding; both cultivated as ornamental annuals.

\section{ORDER LXXVI. CAMPANULACE}

Herbs, with bland milky juice, alternate simple leaves, no stipules, and regular 5 -merous flowers; the tube of the calyx adnate to the 2-5-celled many-ovuled ovary; the corolla and 5 stamens (alternate with its lobes) inserted where the calyx becomes free, or the latter adnate merely to the base of the corolla; fruit a many-seeded capsule, rarely baccate. Calyx persistent, usually divided down to the ovary. Corolla valvate, induplicate, or rarely imbricate in the bud. Stamens mostly distinct: anthers with 2 parallel cells, introrse. Style one, almost always pubescent or puberulent for some distance below the 2 to 5 introrse stigmas. Ovules anatropous, on placentæe projecting from the axis. Seeds small, usually smooth. Embryo straight in the axis of fleshy albumen. Flowers often showy; the corolla commonly blue or in the same species white, and withering rather than deciduous. In fertilization proterandrous; the anthers opening in the bud, discharging their pollen upon the style, where it accumulates upon the collecting hairs or pubescence; the stigmas (then firmly conniving) maturing and diverging much later, receiving only pollen conveyed from flower to flower by insects.

TRIBE I. SPHFNOCLE.E. Corolla imbricated in the bud, bearing the short stamens. Style destitute of collecting hairs. Flowers simply spicate, centripetal.

1. SPHENOCLEA. Flowers all alike. Calyx with 5 roundish lobes; the short tube adnate almost to the depressed summit of the ovary. Corolla short-campanulate, 5-lobed, deciduous, bearing the stamens on the lower part of its tube. Style very short: stigma capitate-2-lobed. Capsule globular and cuneate at base, 2-celled, with stipitate placentæ, circumscissile just below the calyx-lobes, which fall with the lid. Seeds very numerous, oblong.

Tribe II. CAMPANULE $æ$. Corolla mostly valvate or induplicate in the bud, and stamens free or adnate to its very base. Style below the stigmas clothed with pollencollecting hairs. Inflorescence mostly centrifugal, sometimes centripetal.

* Capsule opening by a perforation at the apex within the calyx.

2. GITHOPSIS. Flowers all alike and corolliferous. Tube of the calyx club-shaped, strongly 10-ribbed, adnate up to the very summit of the ovary; limb of 5 long and linear foliaceous lobes. Corolla tubular-campanulate 5-lobed. Filaments short, dilated at the base: anthers long, linear. Ovary 3-celled: stigna 3-lobed. Capsule club-shaped, coriaceous, crowned with the rigid calyx-lobes of its own length, strongly striate-ribbed, manyseeded, opening when the persistent base of the style falls away by a round hole in its place. Seeds fusiform-oblong. - Annual.

* Capsule dehiscent by one or more small valvular openings on the sides, usually over a partition, rarely disposed also to split septicidally.

3. SPECULARIA. Flowers in Amer. species dimorphous; the earlier ones smaller, with undeveloped corolla, and close-fertilized in the bud. Calyx-lobes in these flowers commonly 3 or 4 , in the ordinary corolliferous flowers 5 , narrow : calyx-tube more or less elongated and narrow, usually prismatic. Corolla short and broad, rotate when expanded or nearly so, 5-lobed or 5-parted. Anthers linear. Stigmas and cells of the ovary 3, sometimes 2 or 4 . Capsule prismatic or elongated obconical, or cylindraceous; the valvular openings either near the summit or near the middle. - Annuals. 
4. CAMPANULA. Flowers all alike and corolliferous. Calyx-lobes 5, narrow, its tube short and broad. Corolla campanulate or nearly rotate, 5-lobed or 5-parted. Filaments dilated at base: anthers oblong or linear. Stigmas and cells of the ovary 3 to 5 . Capsule mostly short, opening on the sides or near the base by 3 to 5 small uplifted valves or perforations.

* * Capsule bursting indefinitely on the sides by the giving way of the thin walls.

5. HETEROCODON. Flowers dimorphous in the manner of Specularia. Calyx with large and leaf-like ovate lobes, 3 or 4 in the earlier, 5 in the later flowers, much longer than the obpyramidal tube. Corolla open campanulate, 5-lobed. Stamens, style, \&c., as in Campanula. Capsule 3-celled, 3-angled, very thin and membranaceous. Seeds numerous, oblong, obscurely triangular. - Anmual.

1. SPHENOCLÉA, Gærtn. ( $\Sigma \varphi i v$, a wedge, and $x \lambda^{i} \varepsilon^{\prime} \omega$, to shut up, the bases of the crowded capsules becoming wedge-shaped by mutual pressure.) - A single species, native of tropical Africa or Asia, dispersed over the warmer parts of the world.

S. ZEYLÁnici, Gærtn. Glabrous and somewhat succulent annual, a foot or more high: leaves entire, from obovate to lanceolate, tapering into a petiole: flowers closely sessile in a dense terminal pedunculate spike, small, each subtended by a short bract and pair of bractlets: corolla white, a line or so wide, slightly exceeding the calyx. - S. Pongatium, A.DC. Prodr. vii. 548. Pongatium Indicum (Juss.), Lam. - Low grounds, nat. in Louisiana.'

2. GITHOPSIS, Nutt. (From the resemblance of the calyx to that of Githago, the Corn Cockle.) - Nutt. Trans. Am. Phil. Soc. 11. ser. viii. 258; Benth. \& Hook. Gen. ii. õ59; Gray, Bot. Calif. 1. 446. - Single species.

G. specularioídes, Nutt. Small annual, 2 to 10 inches high, hirsute or glabrate : leaves small, linear-oblong, coarsely toothed, sessile: flowers simply terminating the stem or branches, or becoming lateral, strictly erect: corolla blue: rigid capsule tapering into a very short and stout peduncle. $-G$. calycina, Benth. Pl. Hartw. 321. G. pulchella, Vatké in Linn. xxxviii. 714. - Open grounds, California, toward the coast, and Oregon. Calyxlobes from near half to three-fourths inch long, rigidly 1-nerved, sometimes few-toothed. The form named $G$. calycina has short corolla, exceeded by the long calyx-lobes; the $G$. pulchella, longer corolla surpassing the calyx-lobes.

3. SPECULÁRIA, Ileister, A.DC. (Speculum Veneris, i. e. Venus's Looking-Glass, an early popular appellation of the common European species.)Annuals, with leafy slender stems, and sessile or short-peduncled flowers, 1-2bracteolite, terminal or in the axils of the leaves. Corolla blue or purplish. The American species, differing from those of the Old World chiefly in the dimorphism of the flowers, are not to be generically separated. - Triodanis (not Triodallus), Raf., founded on specimens with only the close-fertilized flowers yet appearing. Dysmicodon, section of Specularia, Endl., but the true character unnoticed. Dysmicodon \& Campylocera, Nutt. 1. c.

§ 1. Canipylócera, Gray. Flowers dimorphous. Stigmas 2 to 4. Capsule slender, straight or curved, occasionally twisted, in the close-fertilized flowers at least disposed to split longitudinally into valves, sometimes by abortion onecelled.-Proc. Am. Acad. xi. 82. Campylocera, Nutt. 1. c.

S. leptocárpa, Gray. Minutely hirsute and roughish or nearly glabrous: stems (a span or two high) virgate, mostly simple or branched from the base: leaves lanceolate: flowers closely sessile in their axils: stigmas 2 or 3 : cells of the ovary as many, or in the lower close-fertilized flowers only one with a parietal placenta: calyx-lobes of the lower flowers 3: capsules nearly cylindrical (half to three-fourths inch long, only a line thick), inclined to curve and rarely to twist, opening by one or two uplifted valves near the summit; the lowest also often spliting longitudinally from the summit: seeds obiong. - Proc. Am. Acad. l. c. Campylocera leptocarpa, Nutt. 1. c. Specularia (Campanula) 
Linsecomii, Buckley, Proc. Acad. Philad. 1801, 460. - Lrkansas to W. Texas and Colorado. Leaves an inch long or less. Expanded corolla half to three-fourths inch wide.

S. Lindheímeri, Vatké. Larger than the last: stems erect or diffuse ( 1 to 3 feet long), paniculately branched above: leaves oblong-lanceolate or the lower oblong or spatulate: flowers subsessile or short-peduncled, commonly terminating branchlets : stigmas "; or 4 : cells of the ovary as many: calyx-lobes even in close-fertilized flowers 5, about the length of the ovary: capsules angular, narrowed to the base, mostly straight, not twisted, opening by 2 or 3 downwardly turned or irregularly bursting small valves below the summit, and afterwards somewhat disposed to be septicidal: seeds almost orbicular, flattened. - Linn. xxxviii. 713; Gray, 1. c. Campanula Coloradoense, Buckley, l. c. - W. Texas, on the Colorado and Guadaloupe, \&c. Larger leaves two inches long. Expanded corolla sometimes an inch broad.

§2. Dysuicónon, Endl. Flowers dimorphous. Capsule rather short, straight, not disposed to split. - Dysmicodon, Nutt. l. c.

S. biflóra, Gray. Stem slender, mostly simple or branched from the base, minutely and retrorsely serrulate-hispid on the angles : leaves sessile, ovate or oblong, or the upper reduced to lanceolate bracts, sparingly somewhat crenate: flowers sessile, singly or in pairs in the axils: the lower and close-fertilized ones with 3 or 4 short subulate or ovate calyxlobes; the upper with 4 or 5 longer lanceolate-subulate calyx-lobes shorter than the developed corolla: capsule oblong and eylindraceous or slightly fusiform, obscurely ribbed, the 2 or 3 valvular openings close under the calyx : seeds lenticular. - Proc. Am. Acad. l. c. Campanula biflora, Ruiz. \& Pav. Fl. Per. ii. 55, t. 200, f. 6. C. Monteridensis, spreng.? C.. Ludoviciana, Torr. ined. C. intermedia, Engelm. in Nutt. 1. c. Dysmicodon C'alifornicum \& D. ovutum, Nutt. I. e. Specularia ovata, Vatké, l. c.-Open grounds, often with the next, S. Carolina to Texas and Arkansas; also in California. Leaves half an inch or less in length, the uppermost shorter than the flowers. (S. Am.)

S. perfoliáta, A.DC. Stems commonly stouter and simple ( 8 to 20 inches high), very leafy throughout, hirsute or hispid on the angles, sometimes smoother: leaves round-cordate and clasping, mostly crenate, veiny : flowers sessile singly or clustered in the axils: calyxlobes of the close-fertilized flowers 3 or 4 and short, of the later and corolliferous flowers as long as the ovary: capsule oblong or somewhat obconical; the 2 or 3 valvular openings at or below the middle: seeds Ienticular. - Torr. FI. N. Y. i. 428, t.65. Campanula perfolicata, L.; HBK. Nov. Gen. \& Sp. t. 265. ( $\therefore$ amplexicrmlis, Michx., \&c. Dysmicodon perfoliatum, Nutt. 1. c.-Open gravelly ground, Canada to Texas, Utah, and Oregon. (Mex., \&c.)

4. CAMPÁNULA, Tourn. Bell-Flower, Hare-Belt. (Italian Campana, a bell.) - Flowers mostly showy or pretty and blue or white, in summer. Seeds smooth. A very large genus, dispersed over the northern hemisphere, but scanty in North America. Ours all have a 3-celled ovary, and all but one on our north-western borders have naked sinuses to the calyx. "Canterbury-bells" of the gardens, C. Medium, represents the section with reflexed appendages in the sinuses of the calyx, covering the tube, and the cells to the ovary as many as lobes to the corolla.

$\S 1$. Calyx with deflexed appendages at the sinuses more or less covering the tube: our species perennial and the stigmas and cells of the ovary 3 .

C. pilósa, Pall. Stems an inch to a span high, 1-flowered, when young woolly-pubescent: leaves mainly radical, from ovate to spatulate-lanceolate, crenate; the cauline from lanceolate to linear: calyx-lobes ovate-lanceolate: corolla an inch or more long, open-campanulate, internally soft-bearded; its tube longer than the lobes and surpassing the calyx. -Roem. \& Sch. Syst. v. 148; Ledeb. Ic. t. 209; IIerder in Radde, Reis. iv. 6. C. dasyantha, Bieb. Cauc.; Reichenb. Ic. Crit. i. t. 85; A.DC. Camp. t. 10, f. 4. C. Pullasiana, Roem. \& Sch. 1. c. C. Altaica, A.DC. 1. c. 229 , t. 10, f. 3.-Alaska, Aleutian Islands, and northward. (Kamtschatka and Siberia.) 
$\S 2$. Calyx wholly destitute of appendages at the sinuses: stigmas and cells of the ovary 3 , rarely varying to 4 or even 5 .

* Style not longer than the corolla, straiglt: root perennial in all the North American species.

+ Openings of the capsule near its summut: low and mostly one-flowered, arctic-alpine or subalpine.

C. lasiocárpa, Cham. An inch to a span high, rather slender: leaves denticulate or laciniate with subulate salient teeth; the radical spatulate or oblong, mostly acute, and slender-petioled; cauline few and lanceolate or linear: calyx-tube obconical, villous; its lobes lanceolate-linear, laciniate-toothed: corolla between half and an inch long, broadly oblong-campanulate, glabrous within; its tube twice the length of its lobes and surpassing the caly x : capsule turbinate. - Linn. iv. 39 ; Hook. Fl. ii. 28. C. algida, Fischer in A.DC. Camp. 338, t. 11, f. 4. - Summit of high northern Rocky Mountains (Drummond); N.W. Coast and Islands. (Kamtschatka.)

C. uniflóra, L. Chiefly glabrous, 1. to 4 inches high : leaves small (an inch or less long), entire or nearly so, thickish; the lowest spatulate or oblong, obtuse, uppermost linear: flower small (4 to 6 lines long), rather slender-peduncled: calyx-tube often pubescent, nearly as long as the lobes, which are from fully to half the length of the bluish corolla: capsule cylindraceous or clavate (half inch long). - Fl. Lapp. t. 9; Fl. Dan. t. 1512. - Arctic regions from Labrador to Aleutian Islands, and south to the Colorado Rocky Mountains. (N.W. Eu., N. E. Asia.)

++ Openings of the capsule at or near its base.

++ Rather coarse and large, pubescent, many-flowered European species, escaped from cultivated ground and sparingly naturalized near the Northern Atlantic coast.

C. Rapunculoídes, L. Minutely roughish-pubescent: stem 1 to 3 feet high, simple or at length branching: leaves more or less crenate and acuminate; the lower and radical ones cordate and long-petioled; upper lanceolate and passing into bracts of the loose virgate mostly one-sided true raceme : corolla oblong-campanulate deeply 5-lobed (an inch long), blue: capsule globular, nodding on a short pedicel. - Fl. Dan. t. 1327. - Roadsides and fields, Canada to Penn. (Nat. from Eu.)

C. glomeráta, L. Pubescent, a foot high : leaves serrulate; the lowest and radical cordate-oblong and slender-petioled; the others closely sessile, ovate-lanceolate or oblong: flowers sessile in a few terminal and upper axillary ciusters, exceeding the leafy bracts: corolla (an inch long) oblong-campanulate: capsule erect, opening near the base. - Fl. Dan. t. 1328. - Roadsides, E. Massachusetts : rare. (Nat. from Eu.)

++ Slender or low species, with filjform rootstocks, mostly glabrous, one-several-flowered (inflorescence centrifugal): peduncles or pedicels slender,

= When several racemosely disposed on the simple smooth stem : capsule nodding: radical leares roundish or ovate and often cordate, at least on sterile shoots. (HARE-rELLs.)

C. Scheúchzeri, Vill. Stem a span to a foot high, 1-4-flowered, more commonly 1flowered: cauline leaves linear or narrowly lanceolate, sessile, not rarely denticulate; lowest cauline spatulate: flower-bud nodding: campanulate corolla half to three-fourths inch long, little or moderately exceeding the slender linear-subulate caly x-lobes. - Prosp. 22 (1779), \& Dauph. ii. 503, t. 10 ; Koch, Syn. 538. C. linifoliu, Willd.; A.DC. 1. c., \&cc., in part, not Lam. (1785). C. dubia, A.DC. Camp. 286. C. Langsdorfiana, Gray in Am. Jour. Sci. xxxiv. 254. - Alpine and subalpine or subarctic, Newfoundland and Labrador, and Alaska; Rocky Mountains down to Colorado, Parry, E. Hall. The latter specimens strictly 1-flowered, with the base or lower part of the leaves hirsute-ciliate, and calyx-lobes sparingly denticulate. (Eu., N. Asia.)

Var. heterodóza. Stems more diffuse and Ieafy: cauline leaves from lanceolate to ovate-lanceolate ( 2 or 3 to even 5 lines wide), often sharply denticulate, nearly all tapering into margined petioles; the radical round-cordate or ovate (sometimes an inch in diameter): corolla two-thirds to a full inch long: slender calyx-lobes more spreading or even reflexed, especially in fruit. - Vest in Roem. \& Sch. Syst. v. 98; Bong. Sitk. 144. C. Langsdorffiana, Fischer. C. linifolia, var. Langsdorffiana, A.DC. Camp. 279, in part. C. linifolia, var. heterodoxa, Ledeb. Fl. Ross. ii. 888. C. pratensis, A.DC. 1. c. 287? excl. var. - Newfoundland, Pylaie; Alaska and islands to the Shumagins.

C. rotundifólia, L. Stems diffuse or erect, a foot or two long, or sometimes dwarfer, 1-9-flowered: orbicular or cordate slender-petioled leaves only on radical shoots; cauline 
leaves linear: flower-buds erect on the slender pedicel : campanulate corolla from half to even an inch long: calyx-lobes setaceous-subulate. - Fl. Dan. t. $855 \& 1080^{\circ}$. - C $C^{\prime}$ petiolata, A.DC. l. c., is apparently this rather than the foregoing. - Rocky banks through the subarctic regions, and common northward, ranging south to the Alleghany Mountains, New Mexico, and the northern borders of California. Calyx-lobes from a third to half the length of the bright blue corolla, and erect or spreading; or sometimes nearly equalling it, almost filiform, and widlely spreading after the flower opens. (Eu., N. 1 sia.)

$==$ Peduncles when several cymose or paniculate, erect in blossom and fruit: angles of the weak stem and midrib or margins of leaves commonly retrorsely scabrous : flowers small.

C. aparinoides, Pursh. Stem a foot or two high, almost filiform, equally leafy to the top; its sharp angles rough with almost prickly short retrose bristles: so also the midrib beneath and the margins of the lanceolate or linear sessile leaves: flower-buds drooping: corolla open-campanulate, deeply 5-cleft (the lobes 2 lines-long or less): calyx-lobes triangular, short, about equalling the tube of the pale blue or whitish corolla. - Fl. i. 159 . C. erinoides, Muhl., Nutt., \&c., not L. - Wet grassy grounds, Canada to Georgia, and from the Saskatchewan to the mountains in Colorado. Leaves varying from linear, and 20 lines long by one wide, to lanceolate-oblong, less than an inch long and 3 lines wide.

C. Floridána, Watson, in herb. Glabrous and smooth throughout: stems filiform, simple or sparingly branched, a span high; leaves from oblong to linear-lanceolate, remotely serrulate, almost sessile, about half an inch long: flowers few, terminating the stem or branches: corolla 5-parted, blue, somewhat rotate; the clivisions ovate-lanceolate, equalled by the slender lanceolate-linear sinooth and spreading calyx-lobes. - E. and S. Florida: Pease River, Dr. Feay; and Indian River, \&c., Dr. E. Palmer. Calyx lobes 2 to at length 4 lines long.

C. linnæifólia, Gray. A span to a foot high, simple or sparingly branched at summit: leaves from roundish to ovate-oblong, obtuse, crenately serrate, nearly sessile, half inch or less long; the margins and the sharp angles of the stem retrorsely hispid-ciliate: flowers solitary terminating the branches: corolla pale blue, campanulate, 5-cleft (barely half inch long), its tube somewhat exceeding the broadly lanceolate caly $\mathrm{x}$-lobes, which are retrorsely ciliolate like the leaves: capsule globular. - Proc. Am. Acad. vii. 366, \& Bot. Calif. i. 448. Wahlenbergia Californica, Kellogg, Proc. Calif. Acad. ii. 158? - Swamps, Mendocino Co., California, Bolander, \&c.

* Style filiform and straight, exceeding the narrow campanulate corolla : capsule hemispherical or short-turbinate, the openings near the middle or base: leaves sharply or laciniately serrate: root perennial: intlorescence centrifugal,

$$
\text { + Racemiform. Pacific species. }
$$

C. Scoúleri, Hook. Glabrous or a little pubescent, stems slender, a span to a foot or so long, at length spreading, often branching: leaves from ovate to lanceolate, mostly tapering at base into a margined petiole : flowers more or less panicled, on long filiform pedicels : corolla oblong in the bud, rather longer than the slender calyx-lobes, somewhat deeply 5-cleft (4 lines long); its lobes ovate-oblong. - A.DC. Camp. 312; Hook. Fl. i. 28, t. 125. - Open coniferous woods, Puget Sound to the mountains in N. California.

C. prenanthoídes, Durand. Glabrous or roughish-puberulent: stems more erect, a foot or two high: leaves more numerous and shorter (half to an inch or so long), more copiously and sharply serrate, from ovate-oblong to lanceolate; the cauline mainly sessile: flowers racemose, scattered or clustered, generally numerous, short-pedicelled: corolla slender-cylindrical in the bud, twice the length of the slender calyx-lobes (5 or 6 lines long), almost 5-parted; its lobes narrowly lanceolate and 2 to 4 times the length of the tube.-Jour. Acad. Philad., n. ser. ii. 93; Gray, Proc. Am. Acad, 1. c. \& Bot. Calif. i. 448. C. flifiora, Kellogg, Proc. Calif. Acad. ii. 5. C. Roczi, Regel, Animad. Pl. Hort. Petrop. 1872, 6. - Coniferous woods and open grounds, California, along the coast from Monterey to Mendocino Co., and through the northern part of the Sierra Nevada. Capsule thinwalled, and with broad and retuse base.

$$
++ \text { Effusely paniculate. Alleghany; species. }
$$

C. divaricáta, Michx. Glabrous: stems paniculately branched, 1 to 3 feet high, slender: leaves oblong to linear-lanceolate, acuminate at both ends, strongly or laciniately serrate in the middle, slightly petioled ( 2 or 3 inches long) : panicle very open and compound: filiform pedicels as long as the flowers: corolla pale blue, campanulate, barely 3 lines long; its 
lobes and the subulate calyx-teeth considerably shorter than its tube. - C. flexuosa, Michx. Fl. i. 109, appears to be only a low form of this from the higher mountains. - Rocks and banks, along the Alleghanies from Virginia and E. Kentucky to Georgia.

* * Long tiliform style dechined and upwardly curved, much exceeding the rotate corolla: capsule oblong-clavate, sessile, erect; the openings close to the summit: inflorescence truly spicate (centripetal): root annual or at most biennial.

C. Americána, L. Sparsely hairy or almost glabrous: stem mostly simple, a yard or two high : leaves thin and large, ovate and ovate-lanceolate or the lowest cordate, petioled; upper passing into bracts of the elongated and loosely many-flowered virgate spike: corolla white or blue, almost 5-parted; its lobes ovate or ovate-lanceolate, half an inch long, exceeding the divergent subulate-setaceous calyx-lobes: capsules half an inch long. C. olliqua, Jacq. Schoenb. t. 336. C. acuminata, Michx. Fl. i. 108. C. declinata, Moench. C. Illinoensis, Fresenius, a branched state witl paniculate leafy spikes, which is not uncommon. - Shaded low ground, W. New York to Iowa, south to Georgia and Arkansas.

C. PLANIFlórA, Lam. (C. nitida, Ait.), long ago described from cultivated specimens, vaguely attributed to North America, is wholly unknown in the wild state; apparently allied to C. persicafolia, L., and not N. American.

5. HETEROCÓDON, Nutt. ( ${ }^{\circ} \mathrm{E} \tau \epsilon \rho o s$, different, and $* \omega \dot{\delta} \omega v$, a bell, from the two kinds of campanulate flowers.) - $\mathbf{A}$ single species, near Campanula, to which Bentham joins it. - Nutt. in Trans. Am. Phil. Soc. n. ser. viii. 255.

H. rariflórum, Nutt. A delicate little annual, sparsely hirsute: stems filiform, diffusely spreading, leafy, branching: leaves orbicular with cordate partly clasping base (a fourth to half inch long), coarsely many-toothed: flowers solitary, terminal and lateral, also axillary; the later ones only with well-developed pale blue corolla, which barely exceeds the ovate and sparingly toothed foliaceous calyx-lobes; these one to three lines long. - Shady and grassy places, Vancouver's Island to California and Nevada, along the coast ranges and the Sierra Nevada.

\section{ORDER LXXVII. ERICACE正.}

Trees, shrubs, or some perennial herbs, with simple and undivided leaves destitute of stipules and commonly alternate, symmetrical (4-5-merous) and perfect flowers, either regular or occasionally irregular, stamens free or nearly free from the corolla and as many or more commonly twice as many as its lobes or petals, the anthers 2-celled and in most opening by pores (in many awned or otherwise appendaged), the pollen composed of 4 united grains (except in the fourth suborder and a part of the third), and the style single. Calyx imbricated or sometimes valvate in the-bud, free and the corolla and stamens hypogynous, except in the first suborder. Corolla not rarely 5- (or 4-) petalous, in the bud imbricated or in some convolute. Anthers introrse, or in the Pyrolinea primarily and normally extrorse, but in anthesis introrsely inverted! Ovary 4-10-celled (or the cells rarely 3 or 2 and fewer than the petals), with placenta in the axis (a tribe of Monotropere excepted); the ovules numerous, generally very numerous, sometimes solitary, anatropous. Stigma not rarely girt with a ring, entire or merely lobed; only in Clethra is the apex of the style 3-cleft. Fruit capsular, baccate, or drupaceous. Embryo small or minute, in fleshy albumen; the cotyledons small and short or undeveloped. (Ericacea, Vacciniacer, Pyrolacer, \& Monotropece of authors, all merging into one large family.)

Suborder I. VACCINIEA. Calyx-tube adnate to the ovary (or to the greater part of it), which in fruit is baccate, either a true berry or drupaceous, crowned with the calyx-teeth. Corolla always gamopetalous, and with the disk 
epigynous. Anthers erect, introrse; the cells partly separate or prolonger at apex into a tip or a tubular appendage, where they open by a pore or chink. Pollen-grains compound, of four unitel gruins. Stigna not indusiate. Sieeds with a close and firm coat. - Shrubby or suffrutescent, with scaly buds : leaves all alternate.

* Ovary wholly inferior: herbage not aromatic.

1. GAYLUSSACIA. Ovary 10-celled, 10-ovuled. Fruit baceate-drupaceous, with 10 seed-like mutlets.

2. VACCINIUM. Ovary 4-5 celled, or by false-partitions from the back of these cells 8-10 celled : orules numerous. Fruit a berry; its cells several-many-seceled.

* * Ovary at first one third to one half superior: herbage aromatic as in (ruultheriu.

3. CHIOGENES. Ovary and white berry t-celled, many-seeded. Corolla short-"'impanulate, 4-cleft. Stamens 8: anthers awnless, t-cuspidate at apex.

Stborder II. ERICINE.E. Calyx free from the ovary. Corolla gamopetalous, rarely polypetalous or nearly so, hypogynous. Disk generally annular or 8-10-lobed. Anthers upright, introrse. Pollen-grains compound. Shrubs or small trees.

Tribe I. ARBUTEe. Fruit fleshy, either baccate or drupaccous. Corolla urceolate or globular, 5-toothed or rarely 4 -toothed, deciduous. Stimens twice as many as the corolla lobes, included. Buds scaly. Leares alternate.

4. ARBUTUS. Anthers compressed, bearing a pair of reflexed awns on the back, each cell opening at the apex anteriorly by a terminal pore. Ovary. 5- (rarely 4 -) celled, ripening into a granular-coated and many-seeded berry, with firm endocarp.

5. ARCTOSTAPHYLOS. Wrary 4-10-celled, with solitary ovules in the cells, in fruit forming a drupe with as many seed-like nutlets or a solid stone.

Tribe II. ANDROMEDE.F. Fruit a loculicidal chiefly 5-celled and many-seeded capsule; the ralves usually bearing the partitions, which separate from the persistent placentiferous axis or columella. Corolla gamopetalous, deciduous. Stitmens twice the number of the corolla-lobes (mostly 10), more or less included. Leaves mainly alternate.

* Anther-cells opening through their whole length, not appendaged: stigma 5-lobed; the lobes adnate to a surrounding ring or cup.

6. EPIG ÆEA. Calyx of 5 nearly distinct and strongly imbricated dry and scarions scpals. Corolla salver-form, 5-lobed. Stamens 10, mostly equalling the tube of the corolla: filaments filiform : anthers linear-oblong, blunt.

* * Anthers opening only at the top: stigma usually entire.

+ Calyx becoming fleshy and baccate in fruit, enclosing the small capsule.

7. GAULTHERIA. Calyx 5-cleft ; its lobes imbricated. Corolla ovate-urceolate to campanulate. Stamens 10: filaments dilated towards the base : capsule deeply umbilicate; placentæ ascending.

++ Caly $\mathrm{x}$ unchanged and dry under the capsule.

the Thes or sepals valvate or open in the bud, never overlapping.

8. ANDROMEDA. Corolla from globular-urceolate to cylindraceous, 5-toother or 5-lobed. Ovary and capsule 5-celled, umbilicate: placentae borne on the summit or middle of the columella; the seeds pendulous or spreading in all directions.

H+ Sepals or calyx-lobes more or less imbricated, at least in the early bud.

$=$ Corolla cylindraceous or conical-urceolate, 5 -toothed : anthers fixed toward their base : leaves plane, usually large and broad : capsule not thickened at the dorsal sutures.

9. OXYDENDRUM. Calyx short, early open, naked at base. Corolla minutely canescent. Anthers linear, unappendaged, narrower than the broadly subulate filaments; the cells opening by a long chink. Capsule ovoid-pyramidal: placenta on the short columella at the base of the cells. Seeds all ascending or erect, scobiform, with lonse reticulated eoat extended at each end much beyond the linear nucleus. Bracts and bractlets minute and deciduous. 
10. LEUCOTHOE. Calyx slightly or in one section much imbricated. Filaments subulate: anthers oblong, obtuse, blunt; the cells opening by a terminal pore or chink, either pointless, or 2-mucronate, or sometimes 1-2-awned from the apex: filaments subulate. Capsule depressed-globose, 5-lobed; valves mostly thin, entire; placentæ borne on the summit or upper part of the columella. Seeds pendulous or in all directions; the coat various but usually loose.

11. CASSANDRA. Calyx of rigid and much imbricated ovate sepals, subtended by a pair of similar bractlets. Filaments subulate (glabrous): anthers awnless; the cells tapering into a tubilar beak, which opens by a pore at the apex. Capsule depressedglobose: pericarp in dehiscence separating into two layers; the chartaceous epicarp loculicidally 5-valved; endocarp cartilaginous, at length 10-valved; sutures not thickened; placentæ on the summit of the short columella. Seeds imbricated in 2 rows, compressed and obtusely angled; the smooth and shining coat much thickened on the side next the placenta.

$=$ Corolla open-campanulate, 4-5-lobed or parted : anthers short, fixed nearly by their apex : fruticulose and heath-like, with small thick or acerose mostly imbricated leaves.

12. CASSIOPE. Calyx ebracteolate, of ovate imbricated sepals. Anther-cells each opening by a large terminal pore, and tipped by a slender recurved awn. Capsule globose or ovoid, 4-5-valved; the valves 2 -cleft. Seed-coat thin and close.

Trne III. ERICEAE. Fruit a loculicidal or sometimes septicidal 4-5-celled capsule. Corolla gamopetalous, marcescent-persistent; the lobes convolute in the bud. Stamens twice the number of the corolla-lobes (8, rarely 10). Heath-like leatres commonly opposite or verticillate.

13. CALLUNA. Corolla campanulate, 4-parted, shorter and less conspicuous than the 4 concave colored sepals, both scarious and persistent. Anthers with a pair of auriculate appendages on the back; the cells opening by a long chink. Ovary 8-angled: ovules numerous, pendulous: style filiform. Capsule globose-4-angular, septicidally 4-valved.

TrIBE IV. RHODODENDRE现. Fruit a septiciclal capsule; the valves (except in Leiophyllum, \&c.) in dehiscence separating from the persistent placentiferous columella. Corolla deciduous, its lobes or petals chiefly imbricated in the bud. Anthers destitute of awns or appendages. Stigma not rarely surrounded by a ring or border. (Rhodorece Don, name changed by Maximowicz, because Rhodora falls into Rhododendron.)

* Anthers opening by a pore or chink at the apex of cach cell.

+ Corolla gamopetalous: scaly leaf-buds none: flowers from the axils of coriaceo-foliaceous persistent (seldom scale-like or scarious) bracts, or rarely from those of ordinary leaves: filaments and style filiform: capsule globular, 4-5-valved from above.

14. BRYANTHUS. Corolla from campanulate to ovoid, 4-6-lobed; the lobes simply imbricated in the bud. Stamens 8 to 10 , straight. Leaves heath-like, alternate but crowded.

15. KALMIA. Corolla crateriform or saucer-shaped, with a short narrow tube, 5-lobed, 10-saccate below the limb. Stamens 10; the short anthers lodged in the sacs of the corolla in the bud, so that the filaments are strongly recurved when this expands. Capsule tardily septicidal. Leaves alternate, opposite, or whorled, flat.

++ Corolla gamopetalous: buds, at least flower-buds, scaly-strobilaceous; the thin or scarious scales caducous or deciduous: capsule 4-5-valved (or sometimes more) from apex to base: seeds usually (but not always) scobiform, having the loose coat produced or appendăged at both ends : calyx often much reduced or obsolete.

16. MENZIESIA. Flowers usually 4-merous. Corolla from globular-urceolate to cylindraceous, 4-toothed or lobed. Calyx bristly-ciliate. Stamens included, mostly 8: filaments subulate: anthers mostly linear-sagittate; the cells opening by an oblique pore or short chink. Style included : stigma truncate. Capsule short.

17. RHODODENDRON. Flowers almost always 5-merous. Corolla various (but not contracted at the orifice), lobed or cleft, or even parted, often somewhat irregular. Stamens sometimes as few as the corolla-lobes, more commonly of twice the number, usually declined: filaments filiform or slender-subulate: anthers short; the cells opening by a terminal orbicular pore. Style filiform: stigma capitate or somewhat lobed.

+++ Corolla polypetalous or very nearly so: filaments filiform: seeds scobiform or linear: placenta borne on the summit of the persistent columella.

18. LEDUM. Calyx 5-lobed or parted, small. Petals oval or obovate, widely spreading. Stamens 5 to 10 . Capsule oval or oblong, 5-celled, 5-valved from the base upward; the columella slender. Flowers umbellate or corymbose from separate strobilaceous buds. 
19. BEJARIA. Calyx 4-5-lobed. Petals obovate or spatulate, somewhat erect. Stanens 12 or 14 . Capsule depressed-globose, $6-7$-lobed, $6-7$-ralred from above; the columella short. Flowers (in ours) racemose: no strobilaceous buds.

* Authers opening longitudinally from the apex nearly or quite to the base of the cells: corolla of distinct petals, or in Loiselewia j-cleft: no thin-scaly strobilaceous buds : leares entire: capsule $3-5$ - (rarely $2-)$ valved from above.

+ Low and small-leaved evergreens : coriaceous persistent leaves mostly opposite : flowers small, corymbose or fascicled: pedicels subtenled by coriaceous folinceous persistent scales or bracts: caly $x$ 5-parted: style and slenclei filaments not declined: anthers globose-didymous: seeds oval, with a thin close coat.

20. LEIOPHYLLUM. Petals 5, obovate-oblong, spreading. Stamens 10 : filaments and style filiform, exserted. Placenta borne on the middle of the columella, but carried away with the 2 or 3 valves in dehiscence.

21. LOISELEURIA. Corolla broadly campanulate, ileeply 5-cleft. Stamens 5: filaments and style stout-filiform and included. Capsule $2-3$-valved, and valves at length 2 -cleft; the placentæ left on the columella.

+ + Erect shrubs, with deciduous alternate leaves : flowers larger, from leafy shoots of the season: anthers oblong: filaments flat and subulate or linear: style long, nore or less declined and incurved, thickened at the apex and annulate around the discoid stigma: placentæ persistent on the short colunella: seeds with a loose cellular or fungous coat.

22. ELLIOTTIA. Petals (3 to 5$)$ mostly 4, long and narrow. Stamens as many or twice as many: filaments short. Flowers in conspicuous terminal racenes or panicles.

23. CLADOTHAMNUS. Petals 5, obloug, spreading, equalled by the somewhat foliaceous sepals. Stamens 10 : filanents dilated below. Capsule 5-6-celled, depressed-globose. Flowers solitary, terminating short leafy branches or sometimes axillary.

Stborder III. PYROLINEE. Calyx free from the ovary. Corolla polypetalous, hypogynous, deciduous. Anthers erect and extrorse in the bud, with apex often pointed, emarginate or 2 -horned at base, where each cell opens by a pore, in anthesis mostly introrsely resupinate on the filament, so that the really basal pores become apical and the point or apex basal. Disk obsolete or obscure. Fruit a loculicidal capsule. Seeds with a loose cellular coat. Sepals and petals imbricated in the bud; the former persistent. (Proc. Am. Acad. xij. 61.)

Trise I. CLETHRE.E. Shrubs or trees. Pollen-grains simple. Ovary and capsule of the כ-merous flower 3-celled. Stigmas '3, distinct, over the placentæ. Embryo cylindraceous, as in Ericinece.

24. CLETHRA. Petals 5, obovate or obcordate. Stamens 10: anthers sagittate and pointed, after inversion obsaggitate, the diverging lobes opening by a chink or large pore. Style filiforn, persistent, commonly ?-cleft at the apex: stigmas thickishı and truncate. Capsule globose or 3-lobed, 3-valved, and the valves at length 2-cleft; the many-seeded porrect placentæ remaining attached to the upper part of the columella.

Tribe II. PYROLEE. Herbs or nearly so, from perennial slender rootstocks, glabrous, with evergreen foliage, one species lextfless. Pollen-grains compround. Cells of the ovary and capsule as many as the petals or sepals (5, or rarely 4): valves of the capsule remaining attached to the columella. Seed-coat very loose and cellular, enclosing a small nucleus. Enmbryo very minute.

* Stems leafy : flowers corymbose or sometines solitary : stigma orbicular-peltate, barely 5-crenate, concealing the very short olxonical style, which is immersed in the unbilicate summit of the ovary and capsule: the latter dehiscent from above downwards: valves not woolly on the edges.

25. CHIMAPHILA. Petals 5, widely spreading, regular, orbicular, concave. Stamens 10: filaments short, dilated and mostly hairy in the midlde.

* Scape naked or leafy only at hase: style mostly elongated.

26. MONESES. Flowers solitary, sometimes 4-merous, regular. Petals wiclely spreading, orbicular. Stanens 10, or sometinies 8: filaments subulate, naked. Style straight : stigma large, peltate, and with 5 or sometimes 4 narrow (at first erect, at length radiating) lobes. Valves of the capsule not woolly on the elges. 
27. PYROLA. Flowers in a raceme, 5-merous. Petals concave or incurved and more or less converging. Stamens 10, of ten declined: filaments subulate, naked. Style often declined or turned downward: stigma 5-lobed or toothed and annulate. Capsule depressedglobose and 5-lobed, umbilicate at apex and base, dehiscent from the base upward; the adges of the valves colbwebly when opening.

Scborver IV. MONOTROPE $\mathbb{E}$. Calyx free from the orary. Pollengrains simple. Capsule loculicidal. - Ierbaceous root-parasites or saprophytes, scaly, destitute of all green herbage, one closely related to Pyrolea, one to Ericinea, the others more peculiar. (Proc. Am. Acad. vii. 370.)

'Гribe I. ELMIONOTROPEX. Ovary j-celled, or sometimes 4-celled; the placente projecting from the thick central columella.

* Anthers extrorse, in flower becoming introrsely pendulous : corolla none.

28. ALLOTROPA. Calyx of 5 roundish sepals, marcescent under the capsule. Stamens 10: anthers didymous, on lorrg and slender filaments : cells opening by a chink from the apparent apex to the middle. Disk none. Style short: stigma large, peltate-capitate. Cansule globose. Seeds scobiform, linear.

* Anthers introrse or introrsely pendulous from the first: corolla gamopetalous, and with the calyx persistent or marcescent,

+ Globular-ovate, with 5 short recurved lobss or teeth: anthers 2-awned.

29. PTEROSPORA. Calyx deeply 5-parted. Corolla globular-urceolate; the lobes convolute or mostly so in the bud. Stamens 10, inclutecl : filaments subulate-filiform: anthers ovate-didymous, introrse, erect, or in bud hurizontal-inflexed, fixed near the base, there dorsally 2-awned; the slender awns deflexed; the cells opening lengthwise. Disk none. Style short: stigina 5-lobed. Capsule depressed-globular, 5-lobed. Seeds broadly winged from the apex.

+ + Corolla campanulate, with barely spreading lobes, rather ficsliy: anthers muticous: seed-coat reticulated, but confornied to thee nucleus: sepals 5 , oblong, erect, nearly equalling the corolla, persistent: filaments slender.

30. SARCODES. Stamens 10, shorter than the cylindraceous-campanulate corolla : anthers linear-oblong, erect, inserted above the base; the two cells strictly combined throughout, the whole apex opening by a large introrsely oblique terminal pore. Disk none. Ovary low-conical and 5-fobed: style columnar, rather long: stigma capitate and somewliat 5-lobed. Capsule depressecl-5-lobed. Seeds oval and with a small conical protuberance at the apex.

31. SCHWEINITZIA. Stamens 10, hardly shorter than the oblong-campanulate corolla, this 5 -gibhous at lase: anthers short, somewhat didlynous, introrsely pendulous, being attached dorsally near the apex; the saccate cells opening by the while apex as a large pore. Disk 10-crenate. Ovary globose-ovate: style short and thick: stigna large, 5 -sided, umbilicate.

* * * Anthers innate or transverse on the apex of the filament, opening across the top; the cells more or less confluent: corolla 4-5-petalous and with the sepals or bractlets tardily decilluous.

32. MONOTROPA. Sepals of 2 to 5 lanceolate bract-like scales. Corolla of 4 to 6 erect and oblong or spatulaté scale-like fieshy petals, whiclu' are gibbous or saccate at base. Stamens twice the number of the petals : filaments filiform-sululate: anthers somewhat reniform; the valves moderately or very dissinilar. Disk 8-12-toothed; the teeth defexed. Style columnar, tulualar: stigma funnelform, with obseurely crenate margin. Capsule ovoid; the columella very thick and fleshy. Seeels immumerable, very small, scobiforn; nucleus minute in the loose-cellular elongated coat.

Tribe II: PIJEURICOSPORE.E. Ovary one-celled or spuriously 4-5-celled; the 4 or 5 placentre parietal and 2-lamellate. Disk none or obscure: anthers linear or oldong, erect, introrse, fixed by the base to the long and slender filaments, opening longitudinally.

33. PLEURICOSPORA. Calyx complete, of 4 or 5 oblong-lanceolate scale-like sepals, their margins fimbriate-laciniate. Corolla of 4 or 5 oblong and finlbriate-lacerate plane petals, resenbling but rather shorter than the sepals. Stamens 8 or 10, glabrous : filaments ligulate-filiform: anthers linear, apiculate; the colls opening from base to apex into two equal valves. Ovary ovate, strictly one-eelled: style columnar: stigma depressedcapitate or somewhat funnelforn. Capsule fleshy? Seeds obovate, with a snootl or polished close c'nat. 
34. NEWBERRYA. Calyx incomplete, of 2 bract-like entire sepals. Corolla tubularurceolate, 4-5-lobed, marcescent. Stanems 8 or 10 : filmments filiform, long-hairy above the middle: anthers oblong; the cells opening from apex to base into two une Ovary ovate, contracted at apex into a long style, tipped with a depressecl-capitate umbilicate and pervious stigma: placentæ 4, with broad divergent lamellæ, which meet at aljacent edges, ovuliferous on both sides, giving the appearance of four axterior cells surrounding a central larger one.

1. GAYLUSSÁcia, HBK. Heckleberry. (In honor of a distinguished French chemist, Gay-Lussac.) - Shrubs (of Eastern N. and S. America); with either evergreen or deciduous leaves, commonly glandular or resinous-atomiferous, flowers in lateral racemes from separate scaly buds, bracteate and often bracteolate pedicels, reddish or greenish or white corolli, and edible fruit. Flowering in spring; fruit ripe in summer, blue or black. - Torr. Fl. N. Y. i. 448; Gray, Chloris (Mem. Am. Acad.iii.), 51, « Man. Bot. Decachæna, Torr. \& Gray in Am. Jour. S.i. xlii. 43 (1841). Decamerium, Nutt. in Trans. Am. Phil. Soc. n. ser. viii. 260 (1843).

$\S 1$. Leaves thick and evergreen, somewhat serrate, destitute of resinous atoms.

G. brachýcera, Gray. Very smooth and glabrous, the young parts barely puberulent, a foot high or less: branches angled: leaves oval (half to full inclh long): racemes in the axils, short, almost sessile, of few crowded flowcrs: bracts and bractlets scaly, caducous: corolla cylindraceous-campanulate, white or flesh-color, 2 lines long: anthers slightly pointed, shorter than the ciliate filament. — Man. ed. 1, 2.59. Taccinium brachycerum, Michx. Fl. i. 2:34. F. buxifolium, Salisb. Parad. t. 4; Bot. Mag. t. 928 ; Bot. ('al). t. 618. - Wooded hills, Alleghanies, from Perry Co., Penn. (Baird), to Virginia. Susnex Co., Delaware, A. Commons. Leaves like those of Dwarf Box.

$\S 2$. Leaves decirluous, entire, more or less sprinkled with minute resinous or waxy atoms : racemes from axils of the former year.

* Leaves thickirh and almost coriacenus, green both siles, the upper face shining: bracts foliacerus and persintent: anthers with filifum tubular appondages loniger than the cells and almist equalling the corolla.

G. dumósa, Torr. \& Gray. A font or two high from a creeping base, somewhat hairy and glandular: leaves obovate-oblong or lanceolate-spatulate, veiny, conspicuously mucronate: racemes loose: bracts oval, as long as the slender 2-bracteolate pedicels: ovary either glandular-pubescent or hairy: corolla campanulate, white or rose-red : fruit lolack, mostly pulseseent, watery and rather insipid. - Gray, Man. l. c. G. hirtella, Torr. Fl. N. Y. i. 448. Vucciniun dumosum, Andr. Bot. Rep. t. 112; Bot. Mag. t. 1106; Dunal ín DC. Prodr.

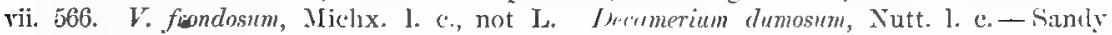
swamps, Newfoundland, and along the coast to Florida and Louiniana; southward enpecially passing freely into

Var. hirtélla, Gray, 1. c. Branclalets and especially racemes and ovary, and sometimes the leaves, glandular-hirsute or hispid. $-r_{r}$. hirtella, Kintzsch in Linn. xiv. 48. Vuccinium hirtellmen, Ait. Kew. ed. 2, ii. :3,j; Dunal, 1. c. - Chiefly Southern States.

* Leares thinner, dull or paler: bracts much smaller, deciduous.

+ Branches slender and widely spreading; flowers in very loose racemes, on long liliform pedicels: corolia lyetween globular and campanulate, greenish-purplish, 2 lines or less in length.

G. frondósa, Torr. \& Gray. Glabrous, or puberulent when young, from :3 to 6 feet ligh, with light gray branches: leaves oblong or oval-obovate, obtuse or retuse, pale, whitish and very veiny beneath: bracts tardily deciduous: anthers with rather long tubular tips: fruit dark blue and glaucous, sweet and edible (Bhye Tavgle or Blde

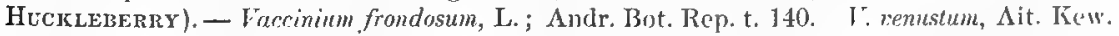
ed. 1, ii. 11. V. glaucum, Michx. 1. e. V. de ramerncurpm, Dunal, 1. c. exel. syn. Wang. Decamerium frondosum, Nutt. l. c. - Low and shaded grounds, coast of New Hampshire and mountains of Penn. to Kentucky, Louisiana, and Florida.

Var. tomentósa, a form with foliage and shoots tomentose-pubescent. - Vaccinium tomentosum, Pursh, ined. - Georgia, Enslin. E. Florida, Dr. E. Palmer. 
G. ursína, Torr. \& Gray. Somewhat pubescent, 2 to 4 feet high : leaves green and membranaceous, lanceolate-obovate or oblong, acuminate (2 to 4 inches long), loosely veiny : bracts rather scaly, caducous: anthers with very short tips: fruit reddisl, turning black, insipid (Bedr Huckleberry).-Gray, Chloris, 49, t. 10 ; Chapm. Fl. 258. Vaccinium ursinum, M. $\Lambda$. Curtis in A.ner. Jour. Sci. xliv. 82. - Moist woods, confined to the mountains of the southern part of North Carolina and adjacent parts of South Carolina, Curtis, Buckley, \&c.

+ + Branches erect: flowers short-peclicelled in short sessile racemes: corolla orate-conical and 5-angular, becoming campanulate or cylindraceous, reddish, as are the scale-like caducous ovate bracts.

G. resinósa, Torr. \& Gray. A foot to a yard high, rigid, glabrous or minutely pubescent, when young very clammy: leaves yellowish-green, from oval to lanceolate-oblong, commonly obtuse, mucronulate, of rather firm texture and paler beneath when mature: racemes secund, drooping, b-8-flowered: corolla 2 or 3 lines long: anthers with tubular tips : fruit black, rarely varying to white, without bloom, pleasant (the common HuckLEberry or Black HuckleberRY of the market). - Vaccinium resinosum, Ait. Kew. 1. c.; Michx. Fl. i. 232 ; Bot. Mag. t. $1288 . \quad$ V. parviflorum, Andr. Bot. Rep. t. 125. Andromeda baccatu, Wang. Amer. 111, t. 30, fig. 69. Decamerium resinosum, Nutt. I. c. - Rocky woodlands and swamps, Newfoundland to Saskatchewan and south to Upper Georgia. The only species in the northern Mississippi States, where it is rare.

\section{VACCiNiUm, L. Blueberry, Bilberry, or sometimes Huckle-} Berry, and Cranberry. (Classical Latin name.) - Shrubs or suffruticose plants (chiefly of the northern hemisphere), with either deciduous or evergreen leaves; the flowers white or reddish, either solitary in the axils, or in racemes or fascicles, mostly nodding. Corolla small, of thinnish texture, and various in form. Stamens 8 or more, commonly 10 : filaments usually hairy or ciliate: anthers awned on the back or awnless, opening by a terminal hole or slit of the tubular apex of each cell. Flowers in spring: berries ripe in summer or autumn, sweetish or sometimes acid, mostly edible. - Vaccinium \& Oxyeoccus, Pers.; Benth. \& Hook, Gen. ii. 573, 575. The following are excluded, viz.:-

V. mucronatum, L., which was founded, not on "one of the Mespilus or Pyrus tribe," as Smith opined, but on a fruiting specimen of Nemopanthes Canadensis.

V. ALBUM, L., founded on a specimen of Lonicera cilictu, from Kalm, who sent it as a Vuccinium with white berries.

V. Ligustrinum, L., founded on a specimen of Andromeda paniculatu, also from Kalm.

V. GLABRUM, Wats. Dendr. Brit. t. 125, d., probably Gaylussacia resinosu.

V. овтusum, Pursh, from Oregon, collected by Menzies, probably Gaultheria Myrsinites.

V. numirusum, Graham in Edinb. Phil. Jour. 1831, 8, probably also Gicultheria Myrsinites.

§1. Batodéndron, Gray. Corolla open-campanulate, 5-lobed: anthers tipped with long and slender tubes, and 2-awned on the back : ovary and (hardly edible or mawkish) berry spuriously 10-celled (ripening in autumn) : leaves deciduous, but of rather firm texture: flowers axillary and solitary or in leafy-bracted racemes, slender-pedicelled: bractlets minute or none. - Chloris, 1. c. 52.

* Flower articulated with its peclicel: anthers included: berry black, many-seeded. (Batodendron, Nutt. Trans. Am. Phil. Soc., ser. 2, viii. 261.)

V. arbóreum, Marshall. (Farkle- or Sparikle-berry.) Shrub 6 to 25 feet high, with spreading branches, glabrous or somew hat pubescent : leaves thinnish-coriaceous, very smooth and shining alove, reticulate-veiny, obscurely glandular-denticulate or entire, from obovate or round-oval to oblong: flowers profuse, axillary along the branches and leafyracemose: corolla white, moderately 5-lobed: awns of anthers more than half the length of the tubular tips: berry globose, small, with a dry rather astringent pulp. - Arbust. 157; Lodd. Bot. Cab. t. 1885. V. diffusum, Ait.; Bot. Mag. t. 1607. V. mucronatum, Walt., not L. 
Batodendron arboreum, Nutt. l. c., \& Sylv. iii. 43. - Sandy soil, Florida and Texas to N. Carolina and $s$. Illinois. There is an unusually narrow-leaved form in Texas.

* Flower not articulated with the pedicel : anthers much excerted: hurry greenish or yellowish, ripening few and proportionately large seets. (Picrococcus, Nutt. i. c.)

V. stamíneum, L. (DEerierry.) Shrub 2 or 3 fect high, with divergent branches, minutely pubescent, or at length glabrous: leaves pale and dull or glaucous, especially beneath, from oval to lanceolate-oblong: ovary glabrous: flowers nearly all axillary: corolla dull purplish or yellowish-green, deeply 5-cleft: awns of the anthers very much shorter than the elongatel tubes: berry large, jeir-shaped or globular, mawkish. - Andr. Bot. Rep. t. 263. V. elecatum, Solander; Dunal, in I) ('. 1. c. 507 (excl. var.) V. cilbum, Pursh, Fl. i. 28, not L. Picrococcus stamineus, elecatus, \& Floridanus, Nutt. 1. c. - Dry woods, Maine to Michigan and south to Florida and Louisiana: rare west of the Alleghanies. ( $l^{*}$. Kunthianum, Klotzsch, the $V$, stamineum, HBK. t. 35;, has much shorter anther-tubes, and a hairy ovary.)

§ 2. Cyanocóccts, Gray. (Blteberry.) Corolla from cylindraceous to campanulate-oblong or ovoid, כ-toothed: filaments hairy: anthers inclucled, awnless: ovary and berry completely or incompletely 10-celled by a spurious partition or projection from the back of each carpel: berry blue or black with at bloom, juicy, sweet aucl edible, many-scerled: flowers (white or rose-color) in fascicles or very short racemes, developed with or a little before the leaves from large and separate scaly buds, short-pedicelled: scaly bractlets as well as bracts mostly caducous or decidnous. (Atlantic North-American with one exception.)

* Exergreen leaves coriaceous : bracts of timer texture, reddish, and tardily decjeluous.

V. nítidum, Andr. Diffusely much branched and very leafy, a foot or two high: leaves thick-coriaceous, shining, at least above, slightly veined, from obovate to oblanceolateoblong, a futurth to half inch long, obscurely dentuculats aurl glandular: calyx-teeth and almust persistent bracts 1,1, li h antl very obtuse: corolla rose-red or turning white, rather short and broad ( 2 lines long): berry "somewhat pear-shaped, black." - Bot. Rep. t. 480 ; Dunal in ICC. 1. c. ; Chapm. Fl. 259. - Low pine barrens, Florida and Georgia. Near to or passing into the next.

V. Myrsinites, Lam. A span to 2 feet high, much branched: branchlets, \&c., when young puberulent: leaves from obovate and obtuse to oblong-lanceolate and acute or spatulate, often cuspidate, from a thircl tn a full inch long, sometimes denticulat $r$, morlerately coriaceous, mostly shining above, dull or pact and sometimes glaucious undirncall, more veiny: bracts from ovate to lanceolate, less persistent; calyx-teeth acute or acuti-l: corolla at length cylindraceous, 2 or, lines long, soon white: "luerry globose, blue." Dict. i. 73; Michlx. Fl. i. 29n; I'ursh, Fl. i. 290 (with vars. lanceolulum and oltusum); Dunal, l. c.; Chapm. l. c. V. nitidum, var. decumbens, Sims, Bot. Mag. t. 1550 ? - Sandy pime barrens, Florida to Louisiana and N. Carolina.

Var. glaúcum. A low form, with snall leaves dull or glaucous above and very glaucous beneath, at least when young. - Ncw Orleans? (I)ummond) to Alabama, \&e.

* Leaves thinner, deciduous: scaly brarts more deciluous.

+ Corolla when developed cylindrical or cylindraceous. Snuthern species, the leaves far southward sometimes persisting until flowering the next spring.

$\nabla$. formósum, Andr. Two or 3 feet high: leaves ovate or oblong, entire fan inch or two long), smooth and bright green above, either glabrous or pubescent beneath, of firmer texture than in the others of the section : flower-clusters loose: calyx and tardily deciduous bracts red or reddish : corolla rose-red, 4 or 5 lines long. - Bot. Rep. t. 97. - Georgia or Florida, "Win. Fomm," James Reed: specimens by the latter witl flower-clusters in the axils of persistent leaves. Related to large-leaved forms of the preceding, and may probably pass into the next.

* Virgátum, Ait. Low, or a yard or so high, more or less pubescent: leaves from ovate-oblong to cuneate-lanceolate, or oblong-lanccolate, usually acute or pointed and minutely serrulate, thinnish, lucid at least above, commonly an inch or so in length : flowerclusters sometimes virgate on naked branches : bracts more deciduous: corolla rose-color, 
3 or 4 lines long: berry black, sometimes with a bloom. - Hort. Kew. ed. 1, ii. 12; Andr. Bot. Rep. t. 181; Hook. Bot. Mag. t. 3522. V. liqustrinum, Pursh, not L. V.fuscatum, Ker. Bot. Reg.t. 302 (not Ait.), a form with deep rose-colored flowers, and red pedicels and bracts, approaching $\boldsymbol{V}$. formosum. - Swamps, Florida to S. Carolina and Louisiana.

Var. tenéllum, a low form, mostly small-leaved, with nearly white flowers in shorter or closer clusters: corolla barely 3 lines long and less cylindrical. - V. tenellum, Ait. Kew. 1. c.; Chapm. Fl. 260. V. galezans, Michx. Fl. i. 232. V. galiformis, Smith in Rees. Cycl. Virginia to Arkansas and southward.

Var. parvifólium, a peculiar form, with leaves half to three-fourths inch long, entire or nearly so, mostly oblong and obtuse; stem slender, 3 to 8 feet high : flowers also small. -V. myrtilloides, Ell. Sk. i. 500, not Michx., nor Hook. V. Elliottii, Chapm. 1. c. - S. Carolina to Arkansas and Louisiana. An ambiguous form.

+ - Corolla shorter and broader, from ovate-urceolate to at most oblong-campanulate, white or obscurely rose-colored.

+ Orary and berry glabrous, as in the gentis generally : scarious bracts and bractlets early deciduous. (Edible Blutberries or BulE Huckleberiries.)

V. Pennsylvánicum, Lam. Dwarf, a span to a foot or more high, with green and warty stems, mostly glabrous, and branches: leaves oblong-lanceolate or oblong, green and somewhat shining both sides, glabrous, or not rarely hairy on the nidrib beneath, distinctly serrulate with bristle-pointed tecth: flowers very short-pedicelled: corolla campanulate $w^{i+h}$ nifice sliglitly cuntracted, barely $2 \frac{1}{2}$ lines long: berries ripening early, large and sweet, bluish-black and glaucous. - Dict. i. 72 ; Michx. Fl. i. 223 ; Hook. Bot. Mag. t. 3434; Gray, Man. ed. 1, 261. V. myrtilloides, Michx. 1. c. V. tenellum, Pursh, Fl. i. 288, not Ait. V. ramulosum \& T. humile, Willd. Enum. Suppl. 20? V. multiflorum, Wats. Dendr. Brit. t. 125? - Dry hills and woods, from Newfoundland to Saskatchewan and southward to New Jersey and Illinois; commoner northward. The lowest and earliest-fruited of the blueberries.

Var. angustifólium, Gray, 1. c. (V. anyustifolium, Ait. l. c.), a more dwarf form, a span or less high, with lanceolate leaves. - V. salicinum, Aschers. in Flora, 1860, 319, not Cham. - Labrador and Hudson's Bay, Newfoundland, and alpine region of the White Mountains of New Hampshire.

V. Canadénse, Kalm. A foot or two high, with branchlets and both sides of the clliptical or oblong-lanceolate entire leaves downy with soft spreading pubescence : flowers few in the clusters: corolla shorter ( 2 lines Iong), greenish-white, and more open-campanulate: otherwise as in the preceding. - Ricliards. in Frankl. ed. 2, 12; Hook. Fl. ii. 32, \& Bot. Mag. t. 3446. V. ulbum, Lam. 1. c., not L. - Swamps or low woods, Hudson's Bay to Bear Lake and the northern Rocky Mountains, south to N. New England, mountains of Penn. and Illinois. Named by Kalm in herb. Leche, now in herb. Banks.

V. vacíllans, Solander. A foot or a yard high, glabrous: branchlets yellowish-green: leaves obovate, oval, or broadly oblong, entire or nearly so, pale or dull, commonly glau'ous, at least beneath: flowers in rather loose clusters: corolla oblong-campannate or with obscurely narrowed orifice, 2 or 3 lines bong, about the length of the pedicel: calyxlobes proportionally large and roundish: berries bluish-black with a bloom, ripening later than the common low blueberries. - Gray, Man. 1. c.; Torr. Fl. N. Y. i. 445. V. virgatum, Bigelow, not Ait. Ir. Pennsyhanicum, Torr. Fl. N. U. S. i. 416, excl. char., not Lam.Dry or sandy woodlands and rocky places, New England to N. Carolina and Missouri. Flowers generally on the leafless summits of the twigs, more greenish or yellowish than those of the next, and apt to be tinged with red. The commoner species of the Northern and Middle States west of the Alleghany Mountains.

$\nabla$. corymbósum, L. Tall, 5 to 10 feet high : branchlets yellowish-green turning brownish: leaves from ovate or oblong to elliptical-lanceolate: flowers more commonly racemosely than corymbosely clisposed on the naked twigs: corolla from turgid ovate- to cylindraceous-campanulate, 3 or 4 lines long, commonly shorter than the pedicels, 3 or 4 times the length of the lax calyx-lobes: berries blue-black with a copious bloorn (except in one var.), ripening later than the preceling. - Smith in Rees Cycl. no. 13; Gray, Man. l. c. $V$. disomorphum, Michx. 1. c. - Swamps and low woods, from Newfoundland and Canada through the Atlantic U. S. to Louisiana, but rare in the Mississippi region. The

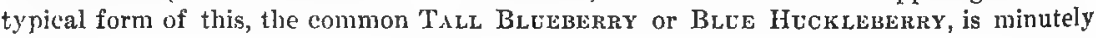


more or less pubescent when young, sometimes perfectly glabrous (var. glabrum, Gray, Man.), and commonly soon becoming so; the leaves with naked entire margins. 'There are numerous gradations between the following forms:-

Var. amónum, Gray, a form witl ciliate-serrulate or bristly-ciliate leaves, ratler bright green both sides: pubescence sliglıt or sparse. - Mau. ed. 5, 292. I'. amonum, Ait. l. c.; Andr. Bot. Rep. t. 138; Bot. Reg. t. 400. V. corymbosum, var. fuscatum, Hook. Bot. Mag. t. 3433? F. Maricmum, grandiflorum \& elongatum, Wats. Dendr. Brit. ? - Mainly in the Middle Atlantic States.

Var. pállidum, Gray, l. c., a pale and very glaucous or glaucescent form, with or without some pulbescence, generally low; otherwise nearly as in the preceding. $-V$. patlidum, Ait. 1. c.; Gray, Man. ed. 1, 262. I. albiflorum, Hook. Bot. Mag. t. :3128. I. Constabkei, Gray in An. Jour. Sci. xlii. 42; Chapm. 1. c. - Common through the Alleghanies southward, mostly on the tops of the higher nountains, and 2 to 4 feet high.

Var. fuscátum, a tall form, with the mature and entire leaves fuscous-pubescent beneath: flowers virgately somewhat spicate on the naked flowering twigs. - Ir. fuscatum, Ait. 1. c. - Alabama and Florida to Arkansas and Louisiana.

Var. atrocóccum, Gray, 1. c., the most distinct form, with the permanently and at length rusty puhescent leaves of the foregoing, lut with a more diffuse habit, rather snaller flowers, and berries purplish-black, without any bloom. - I' fuscatum, Gray, Man. ed. 1, 262. V. clisocurpum, Bigelow, Bost. ed. 2, 151. - Conmon from N. England to Penu.

+-+ Orary and berry glandular-hirsute: bracts less scarious and more persistent.

V. hirsútum, Buckley. I foot or two high: branchlets, entire orate leaves, and even the oroid-campanulate corolla pubescent with soft and short persistent spreading hairs: style hairy: hirsute berries bluish-black. - Am. Jour. Sei. xlv. 175; Chapn. l. c. - Mountains of Cherokee Co., $\mathrm{N}$. Carolina, Buckley. Rare and little known: the local name is Bear Huckleberky.

§3. Euviccínicy, Gray. (Bilberry.) Corolla from ovate to globular and more or less urceolate, 4-5-toothed, rose-color or nearly white : filaments glabrous : anthers 2-awned on the back, included: ovary and berry 4-5-celled, with no false partitions: leaves deciduous: flowers on drooping pedicels, solitary or two to four together, developing with or soon after the leaves.

* Flowers 2 to 4 in a fascicle, or sometimes solitary, from a distinct scaly bud, in the mamer of Cymocoectu, more commonly t-merons and 8-androus: leaves quite entire, and usually almost sessile: limb of the calyx deeply 4-5-parted : berries blackish-blue with a bloom.

V. vliginósum, L. $\Lambda$ span to a foot or two high, much branched, glabrous or minutely puberulent: leaves thickish, mostly pale or glaucescent, obovate, oval, or oblong-cuneate, obtuse or retuse, reticulate-veiny, especially beneath, half inch or more long: corolla ovateor globular-urceolate: berry proportionally large, sweetish. - Fl. Dan. t. Reichenb. Ic. Germ. xvii. t. 1168. V. pulhescens, Hornem. Fl. Dan. t. 1516. $\quad r$. genullherioides, Bigel. Aretic America to the alpine region of the mountains of New England, New York, and shore of Lake Superior, westward to Oregon and Alaska. (Eu., Asia.) In our northern regions low, in Oregon sometimes even 4 feet high.

Var. mucronátum, Herder. Depressed-cespitose: leaves small, bright green both sides, conspicuously reticulated, usually roundish, abruptly mucronate or cuspidate. - Alaska and Aleutian Islands to Behring Straits.

V. occidentále, Gray. A foot or more high, glabrous: leaves thinner, glaucescent, obscurely veiny. from oval to obovate-oblong or oblanceolate, obtuse or acutisl (half to three-fourths inch long): flower mostly solitary from the scaly bud: corolla oblong-ovate ( 1 or 2 lines long) : berry small, barely 3 lines in diameter. - Bot. Calif. i. 451. - Sierra Nevada of California at 5-7000 feet, from Mariposa to Mt. Shasta, and Uinta Mts., Utah.

V. salícinum, Cham. Depressed-cespitose: leaves cuncate-lanceolate and acuminate (4 to 8 lines long), tapering into a kind of petiole, briglit green, coarsely reticulated beneatli, entire: flowers solitary: "corolla cylindraceous-urceolate, 8 lines long." - Spreng. Syst. Cur. Post. 147, \& Linn. i. 525 (not Aschers. in Flora, 1860, 369), - Lnalaschka, in moss, Chamisso. Perhaps this is only a renuarkably narrow-leaved form of $V$, uliginosum, var. mucronatum. 
* * Flowers solitary in the earliest axils, ustally 5-merous and 10-androus : calyx less or very slightiy lobed.

- Dwarf and cespitose : branches not angled.

V. cæespitósum, Michx. Glabrous or nearly so, 3 to 6 inches high: leaves from obo. vate to cuneate-oblong, obtuse or rarely acutish, thickly serrulate, brigit green both sides, reticulate-veiny (one to three-quarters inch long): corolla ovate or ovoid-oblong: berry proportionally large, blue with a bloom, sweet. - Hook. Fl. ii. 33, t. 126; \& Bot. Mag. t. 3429. - Hudson's Bay and Labrador, alpine summits of White Mountains of New Hampshire, and Colorado Rocky Mountains to Alaska.

Var. arbúscula. Erect and a foot high, much branched : leaves obovate, thicker, little exceeding half an inch in length: flowers and berries rather smaller. - Sierra Nevada, California, in Plumas Co., Mrs. Austin. In Oregon passes into the ordinary form and into the following.

Var. cuneifólium, Nutt. $\Lambda$ span to near a foot high, busliy: leaves spatulatecuneate and with rounded apex, passing in one form (var. angustifolium, Gray, Proc. $\Lambda$ n. Acad. viii. 393) to spatulate-lanceolate and acute; the earliest not rarely entire. - Mem. Am. Phil. Soc. n. ser. viii. 262. - Mountains of Colorado and Utah to California, British Columbia, and east to Lake Superior.

$$
+ \text { + Low : branches sharply angled and green: leaves small. }
$$

V. Myrtíllus, L. (Whormleberkr, Bilberkr) A foot or less high, glabrous: leaves ovate or oval, thin, shining, serrate, conspicuously reticulated-veiny, and with a prominent narrow midrib) (in ours half to two-thirds inch long): limb of caly $x$ almost entire : corolla globular-ovate: berries black, nodding. - Sclık. Handb. t. 107; Reichenb. Ic. Gern. l. c. t. 1169; Hook. Fl. ii. 33. V. myrtilloides, Watson, Bot. King Exp. 209, not of others. Rocky Mountains, extending as far south as Colorado and N. E. Utall, and north-west to Alaska. (Eu., Asia.)

Var. microphýllum, Hook. 1. c.; a remarkable diminutive form, 3 to 6 inches higlı: leaves 2 to 4 lines long: corolla proportionally small, a line long: berries at first "light red." - Higher Rocky Mountains, south to Colorado and Utah, and in the Sierra Nevada, California, down to 7000 feet.

$$
+++ \text { Mostly taller or tall, with spreading branches. }
$$

V. myrtilloídes, Hook. (Gray). Glabrous or glabrate, 1 to 5 feet higlı : branchlets slightly angled : leaves ovate or oval and oblong, sharply serrulate, membranaceous, green both sides, but not shining, loosely reticulate-veiny, an inch or two long, the larger or later mostly acute or acuminate: limb of calyx entire: corolla depressed-globular or semiglobose-urceolate (nearly 2 lites long and broad, yellowish or greenish-white with a purple tinge): pedicel erect in fruit: berry purplish-black, rather acid. - Gray, Man. ed. 5, 291. V. myrtilloides, partly, Hook. FI. ii. 32, \& Bot. Mag. t. 34 $\mathbf{f}$ (excl. syn. Ait., \&c. and var. rugrdum), not Michx.! (which is V. Pennsyluanicum, var. angustifolium). V. memliranaceum, Dougl. ined.; Torr. Bot. Wilkes Exp. 377, the larger-leaved coast form (V. myrtilloides, var. membranaceum, Hook. 1. c.).-Damp woods, Lake Superior to the coast of Oregon and British Columbia. - There is nothing to prevent the retention of this specific name, going back only to Hooker, and excluding the original of Michaux.

V. ovalifólium, Smith. Glabrous and glaucescent, 4 to 12 feet high, straggling: branchlets more or less angled: leaves oval, mostly obtuse or rounded at both ends, merely. mucronulate, entire or with a few irregular serratures, pale or glaucous, at least beneatli (one or two inchies long): corolla globose-ovoid: pedicel nodding in fruit : berries blue with a bloom. - Rees Cycl.1. c.; Hook. Fl. ii. 33, t. 127; Gray, Man. 1. e. V. Chamussonis, Bong. Sitk. 525, - Woods, Lake Superior (on the south shore, Robbins), and Oregon to Unalaschka. (Japan.)

V. parvifólium, Smith, l. c. Glabrous, glaucescent, 6 to 12 fect higl and straggling : branches and branchlets slender, sharply and conspicuously angled, green, articulated: leaves oblong or oval, obtuse or rounded at both ends, pale and dull, especially beneath, entire, one to three-quarters inch long: calyx 5-lobed: corolla globular: pedicel nodding in fruit: berries light red, rather dry, hardly edible. - Hook. 1. c. t. 128. - Sliady and low woods, northern part of California, near the coast, to Alaska and Aleutian Islands.

$\S 4$. Vitis-IDÁA, Koch. Corolla, ovary, \&c., as in the preceding section: filaments hairy: anthels awnless (at least in ours): leaves coriaceous and per- 
sistent: flowers in short racemes or clusters from separate buds : bracteate and 2-bracteolate.

\section{* Flowers 5-merous, 10-androus.}

V. ovátum, Pursh. Frect evergreen shrub, 3 to 5 feet high, rigid : branchlets pubescent: leaves thick iud firu, very uumerous, from oblong-ovate to oblong-lanceolate, acute, minutely and acutely serrate, glabrous or nearly so, bright green both sides, an inch or so long; the veins obscure or hidden: flowers in short and close axillary clusters : bracts 'unl bractlets deciduous: corolla campanulate, 2 lines long, rose-color or flesh-color, barely thrice the length of the triangular acute reddish calyx-lobes: berries reddish turning black, small, sweetish. - Fl. i. 290 ; Lindl. Bot. Reg. t. 18j5. V.lanceolatum, Dunal in DC. 1. c. 570, a narrow-leaved form. ILetagonia (Pyxothamnes) ovata, Nutt. 1. c. - Vaneouver's Island to Monte:ey, \&c., California, on hills near the coast.

V. crassifólium, Andr. Procumbent, the trailing slender stems 2 or 3 feet long, glabrous or nearly $s n$ : leaves small, a quarter to half inch long, from oval to narrowly oblong, sparsely mucronate-serrulate or entire, shining: flowers few and almost sessile in small axillary clusters: bracts scaly-coriaceous, persistent : corolla globose-campanulate, nearly white: anther :lls barely pointed at apex: berries black. - Bot. Rep. t. 105 ; Bot. Mag. t. 1152 ; Chapm. Fl. 259. I. carnosum, Pers. Syn. i. $479 . \quad$ V. myntifolium, Michx. FI. i. 229. Metagonia myrtifolia, Nutt. 1. c. -- Sandy bogs, N. Carolina to Georgia, near the coast. Habit of Cranberry.

$$
\text { * Flowers 4-merous, 8-androus. }
$$

V. Vitis-Idǽa, L. (Cowberry, Močstain Cranberry.) Almost glabrous, tufted, 3 inches to a span or more higl from creeping stems; leaves crowcled, obovate or oval, emarginate (a quarter to over half inch long), shining above, paler and bristly dark-dotted beneath; the margins revolute, entire or obscurely serrulate: flowers crowded in a short and terminal secund and nodding raceme: bracts reddish, nearly persistent: corolla white or rose-color, open-campanulate, rather deeply 4-lobed: berries dark red, acid and bitterish, edible when cooked (a fair substitute for cranberries), - Fl. Dan. t. 40 ; Lodd. Bot. Cab. t. 616. I. punctulum, Lam. - Round the Arctic circle, south to the coast and mountains of N. New-England, and Lake Winipeg; on the western coast south to Britisl Columbia. (Greenland to Japan.)

\$5. Oxrcóccuss. (Oxycoccus, Pers.) Corolla deeply 4-cleft or 4-parted; the lobes linear or lanceolate-oblong and reflexed: anthers exserted, awnless, with very long terminal tubes: ovary and berry 4-celled, destitute of false partitions: Howers axillary and terminal, nodding on long filiform pedicels, appearing in early summer ; fruit maturing in autumn.

* Erect sbrubs, with deciduous membranaceons lenves and berries of Euvaccinium, but corolla of true Oxycoccus : flower solitary in the axils : pedicel bractless but minutely 2-bracteolate at base: corolla conical-rostrate in the bud, deeply 4-cleft: filaments villous. ( $V$. Jopmicum of Miquel is a very nearly related Japanese species.) - Vaccinium § Oxycoccoides, Benth. \& Hook.

V. erythrocárpon, Michx. Divergently branching slirub, 1 to 4 feet ligh, slightly pubescent : leaves oblong-lanceolate or ovate-oblong, acuminate, finely serrate with bristletipped teeth, thin, bright green both sides, veiny, acute or merely obtuse at base ( $1 \frac{1}{2}$ to 3 inches long): pedicel about half the length of the leaf: corolla flesh-color (about half inch long) : berry light red, turning nearly black at full maturity, watery, slightly acid. Fl. i. 227. Oxycoccus erectus, Pursh, Fl. i. 264. O. erythrocarpus, Ell. Sk. i. 447.-Danip woods in the higher Alleghanies, Virginia to Georgia.

* * (Craxberre.) Trailing and creeping lignescent plants, with filiform stems, and small persistent leaves with entire revolute mamgins and the lower face whitened : filiform perlicels 1 to 4 from a terminal scaly bud, erect, and bearing a flesh-colored or pale rose-colored fiower nodding from its apex : corolla conjical-cylindraceous in the bud, deeply 4-parted : filaments puberulent: berry rerl and acid. - Oxycoccus (Pers.), Benth. \& Hook.

V. Oxycóccus, L. (Small Cranberpy.) Stems very slender, creeping: Ieaves ovate, acute, 2 to 4 lines long; the margins much revolute: pedicels 1 to 4 in a fascicle from a terminal and not proliferous thin-scaly bud: filaments commonly fully half the length of the anthers: berry globose, a quarter to a third of an inch in diameter, often spotted when 
young. - Fl. Dan. t. 80 . Oxycoccus palustris, Pers. 1. c. O. vulgaris, Pursh, 1. c. Schollera Oxycoccus, Roth. - Sphagnous swamps, around the subarctic zone, from Newfoundland and Labrador south to mountains of Pennsylvania, to the Saskatchewan district, and to Alaska. (Greenland to Japan.)

V. macrocárpon, Ait. (Large Amer. Cranberry.) Stems stouter, 1 to 4 feet long, and with more ascending branches: leaves oblong or narrowly oval, obtuse, a third to half inch long; the margins less revolute; veins evident: pedicels several and somewhat race. mose, the firmer scaly bracts separating as the bud develops above into a proliferous leafy shoot: filaments one third the length of the anthers: berry ovoid or oblong, half to threefourths inch long (variable in shape and size, much larger than in the preceding). - Ait.

6. Kew. ed. 1, ii. 13, t. 7; Bot. Mag. t. Emerson, Mass. Rep. ed. 2, t. 30. V. Oxycoccus, var. oblongifolius, Michx. l. c. Oxycoccus macrocarpus, Pursh,.1. c.; Bart. Fl. i. t. 17.-Bogs, \&c., Newfoundland to N. Carolina, through Northern States and Canada to Saskatchewan. Said by Ilooker to abound at the mouth of Columbia River?

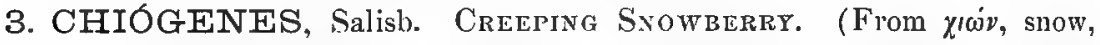
and g'vos, offspring, in allusion to the snow-white berries.) - Flowers very small and inconspicuous, solitary in the axils of the small Thyme-like leaves, on short nodding peduncles; a pair of large ovate persistent bractlets under the calyx. 'Tube of the latter arnate to the lower half of the ovary, or rather more; the limb 4-parted. Corolla little exceeding the calyx, 4-cleft, greenish-white. Stamens 8 , included, inserted on an 8-toothed disk: filaments very short and broad: cells of the anther ovate-oblong, separate, neither awned on the back nor producerl into tubes, but each minutely 2-pointed at the apex, and opening by a large chink down to the middle or lower. Style columnar. Berry globular, crowned by the 4 short calyx teeth, largely inferior, the calyx-tube being now almost wholly adnate. Seeds rather uumerous, obliquely obovate, with a close and firm coriaceous minutely reticulated coat. - Genus naturally related rather to Ganltheria and Pernettya than to Vaccinium, except in the adnation of the calyx.

C. hispídula, Torr. \& Gray. A slender trailing or creeping evergreen, with the hahit of Cranberry, the aroma and taste of Wintergreen or Sweet Birch: filiform branches strigose-hispid: leaves ovate, with rounded or obtuse base and revolute margins, thickcoriaceous, 2 to 4 lines long, short-petioled, glabrous, except the scatteresl rusty bristles of the margins and lower surface: bractlets foliaceous and almost equalling the flower: white berry also minutely bristly, slightly spicy but otherwise insipid, ripe late in summer. -Torr. Fl. N. Y. i. 450, t. 68; Gray, Man. ed. 1, 262. C. serpyllifolia, Salisb. Trans. IIort. Soc. Lond. ii. 94. Vaccinium hispidulum, L. (excl. syn.); Michx. Fl. i. 228, t. 23. Arbutus filiformis, Lam. Dict. i. 228. A. thymifolia, Ait. Kew. ed. 1, ii. 72. Oxycoccus hispidulus, Pers.; Nutt. Gen. i. 251. Gaultheria serpullifolia, Pursh, Fl. i. 283, t. 13 (bad). G. hispiclula, Mulll. Cat.; Hook. Fl. ii. 36. Glyceyphylla hispidulu, Raf. in Am. Month. Mag. 1819. Phederocurpus serpyllifolus, G. Don, Syst. iii. 841; Dunal in DC. 1. c. 577; Klotzsch in Limn. xxiv. 67 (char. bad). - Sphagnous swamps and damp woods, Newfoundland to the northern Rocky Mountains, and in the Atlantic States south to the cooler parts of New Jersey and Pennsylvania, thence along the Alleghanies to North Carolina.

C. JA PONICA, a second species (C. hispidula, Miquel), the representative in Japan, has obovate or oval leaves, all acute or tnpering at base.

4. ÁRBUTUS, Tourn. (Classical Latin name.) - Low trees or shrubs (of S. Europe and W. America from Oregon to Mexico); with evergreen and coriaceous alternate petiolate leaves, and white or flesh-colored small flowers in a terminal cluster of racemes or panicles. Bracts and bractlets scaly. Calyx small, 5-parted. Corolla from globular to ovate. Ovary on a hypogynous disk : ovules crowded on a fleshy placenta projecting from the inner angle of each cell. Style rather long: stigma obtuse. Berry more or less eatable. 
A. LaCrifolia, L.f. Suppl. 238, may be Pizmus Caroliniana, but is indeterminable. A. Laxceolata, Lam. Dict. i. 22 $\bar{i}$, is possibly the sime, but has no valid foundation, having been described solely from a sterile branch of some cultivated slırub of uncertain origin. A. Acadiensis, L., founded on a phrase cited from Tournefort, which cannot be found, is wholly obscure.

A. Menziésii, Pursh. (MadroÑa.) Tree 80 to 100 feet high, with trunk a foot or two in diameter in northern habitats, a shrub in its southern: bark close and smooth by exfoliation, turning brownish-red: leaves oval or oblong, entire or serrulate, paler beneath, 3 to 5 inches long: spicate racemes minutely pubescent: corolla globular, white: berries dry, somewhat drupaceous, hardly entable, orange-color.-Hook. Fl. ii. 36; Nutt. Sylv. iii. 42, t. 95; Newberry in Pacif. R. Rep. iv. 23, fig.; Gray, Bot. Calif. i. 452. A. procera, Dougl. Bot. Reg. t. 175:). A. laurifolia, Lindl. Bot. Reg. Xxv. t. 67 (small-leaved MLexican form), not L. f. 1. Texana, Buckley in Proc. Acad. Plilad. Dec. 1861 ; Vasey, Cat. Forest Trees, U. S. 17, the small-leaved form of Texas and Mexico, possibly distinct, but apparently a mere form of the Pacific species. - Puget Sound and southward through the coast-region of California to Arizona? and W. Texas. (Mex.)

\section{5. arctostáphylos, Adans. Bearberry, Maxzanita. (Com-}

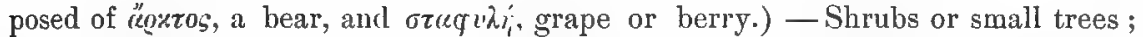
with alternate leaves, and small mostly white or rose-colored flower's, chiefly in racemes, spikes, or panicles, both bracteate and bracteolate. Flowers nearly as in the preceding genus, but less rarely 4 -merous, and ovules solitary in the cells, which become bony nutlets or combine into a few-several-celled stone; the drupes somewhat bitter or astringent, or in Californian species subacid and more or less edible. Leaves in the erect species almost always more or less vertical by a twisting of the petiole.' Fl. spring. - Gray in Pacif. R. Rep. iv. 116; Benth. \& Hook. Gen. ii. 581.

§1. Arctócs. Flowers preceding the thin and deciduous leaves: fruit juicy.

A. alpína, Spreng. Depressed or prostrate and tufted, rising little above the ground, glabrate: leaves obovate with a tapering base, conspicuously rugose-reticulated, ciliate when young : flowers few in a fascicle from a terminal lax-scaly bud: drupe rather large, black, containing 4 or 5 stones. - Syst. ii. 287 ; DC. Prodr. vii. 584. Arbutus alpina, L. ; Fl. Dan. t. 73 ; Engl. Bot. t. 2030. - Arctic America, south to Newfoundland and alpine summits in New England ; also northern Rocky Mountains and Aleutian Islands. (Arcticalpine round the Old World.)

§2. UVA-ÚRST. Leaves coriaceons and evergreen, in erect species inclined to be vertical, and the bark mahogany-color: drupe smooth, mealy; its nutlets separate or separable, or irregularly coalescent: bracts persistent and usually becoming rigid. - Xerobotrys, Nutt. in Trans. Am. Phil. Soc. n. ser. viii. 267. Daphnidostaphylis, Klotzsch in Linn. xxiv. 80.

* Depressed-trailing or creeping, green, glabrous or minutely pubescent, no bristly hairs: flowers rather few in siniple small clusters, 2 lines long: ovary and reddish fruit glabrous: nutlets 1nerved on the back.

A. Uva-tursi, Spreng. (Beargerry.) Leaves oblong-spatulate, retuse, an inch or less long', tapering into a petiole : fruit insipid. - A. officinalis, Wimmer, Koch. Arbutus Uvaursi, L. Fl. Lapp. t. 6; Bigel. Med. Bot. t. 6. Daphnidostaphylis Fendleriana, Klotzsch in Linn. xxiv. 81. - Rocky or sandy ground, Penn. to New Mexico, N. California, and north to the arctic circle. (Arctic-montane Eu. \& Asia.)

A. Nevadénsis. Leaves obovate or oval to lanceolate-spatulate, cuspidate-mucronate, thicker, abruptly petioled: berries subacid. $-A$. pungens, var. (small Manzanita), Gray, Bot. Calif. i. 453. - Sierra Nevada, California, common at 8-10,000 feet. Rising only a few inches, or at most a foot above the surface of the ground, from rigid procumbent main stems: apparently there are no transitions into $A$. pungens, which is sometimes found at the same altitudes. 
* Erect low shrubs, witl mostly clustered short racemes or spikes: flowers only a line or two long: leares half inch or at most an inch long.

A. púmila, Nutt. $\Lambda$ foot or less high, tomentulose: leaves pale, oblong-obovate, obtuse or retuse, sometimes obscurely mucronulate, entire, short-petioled: fruit unknown. Trans. Am. Phil. Soc. n. ser. vii. 266; Gray, Bot. Calif. 1. c. Daphnidostaphylis pumila, Klotzsch, l. c.-Monterey, California, Nuttall, Rich. Not yet met with by recent collectors.

A. Hoókeri, Don. A foot or two high, diffuse, puberulent or glabrate: leaves green, ovate or oval, cuspidately mucronate or acuninate, sometimes spinulose-denticulate, slender-petioled : fruit glabrous, 2 lines in dianeter, reddish. - Syst. iii. 836. Arbutus pungens, Hook. \& Arn. Bot. Beech. 144. Androneda? venulosa, DC. Prodr. vii. 607. Xerobotrys venulosus \& Arctostıphylos acuta? Nutt. in Trans. Amer. Phil. Soc. 1. c. A. pungens, partly, Gray, Bot. Calif. i. 453, into which it may pass. But the smaller forms seem quite distinct, and the drupes are very small. - Monterey, \&c., California.

A. nummulária, Gray. A foot or two ligh, nearly glabrous, excepting scattered setose bristles on the branches and short petioles, very leafy: leaves mostly broadly oval with both ends rounded or the base slightly cordate, usually entire, bright green : fruit unknown. - Proc. An. Acad. vii. 360, \& Bot. Calif. 1. c. - Mendocino plains, California, Bolander.

* * Erect shrubs or low trees, with short clusteredd racemes: flowers 3 or 4 lines long and drupes 4 or 5 lines in diameter, yellowish turning reddish: leaves 1 to 3 inches long.

A. Andersónii, Gray. Long and spreading bristles copious on the branchlets, \&c. (along with fine pubescence) : leaves thin, bright green, glabrous, lanceolate-oblong to ovate-lanceolate, with a sagittate or cordate base, sessile or very short-petioled, conspicuously spinulose-serrulate or rarely entire: drupes depressed, densely clothed with exceedingly viscid-tipped bristles. - Proc. Am. Acad. xi. 83, \& Bot. Calif. 1. c. - Santa Cruz, California, under Redwoods, Anderson.

A. tomentósa, Dougl. Tomentose or pubescent when young, and the branchlets, \&c., usually bristly: leaves pale, coriaceous, oblong-lanceolate to ovate, entire or sparingly spinulose-serrulate, petioled; the base acutish, rounded or subcordate : ovary hirsute: drupes minutely puberulent or becoming glabrous. (Runs into endless forms, of which one has narrow-oblong and rather small leaves, acutish at base, apparently comecting with the next species.) - Lindl. Bot. Reg. t. 1791. A. cordifolia, Lindl. 1. c. Arbutus tomentosa, Pursh. Fl. i. 282; Hook. Fl. ii. 36, t. 130, \& But. Mag. t. 3320. Andromeda? bracteosa, DC. Prodr. vii. 607. Xerobotrys tomentosus, cordifolius, \& arqutus, Nutt. in Trans. Am. Phil. Soc. n. ser. viii. 268, - Dry hills, from Puget Sound to San Diego Co., California, and Arizona. The berries are used in California in infusion for a subacid drink. Nutlets 8 to 10 , either all separate or some united in pairs.

A. púngens, HBK. GIabrous or minutely tomentose-pubescent, 3 to 20 feet high : leaves thick and rigid, green or glaucescent, oblong-lanceolate to round-ovate, conmmonly mucronate-cuspidate, entire, obtuse or rounded at base, slender-petioled: pedicels glabrous: drupes smooth and glabrous: nutlets thick-walled, carinate or thickened on the back, sometines firmly coalescent. - Nov. Gen. \& Spec. iii. 278, t. 259; Hook. Bot. Mag. t. 2987; Lindl. Bot. Reg. xxx. t. 17; Torr. in Emory Rep. t. 7; Gray, Bot. Calif. i. 453, in part. Daphnidost t)hylis pungens, Klotzsch, l. c. - Arizona and S. Utah to California. (Mex.)

Var. platyphylla, the commoner MANzanita in California, especially northward, reaching Oregon, Nevada, and Utah: leaves pale or glaucescent, oblong to orbicular, 1 to 2 inches long, commonly muticous. - Arctostaphylos glauca, Watson, Bot. King, 210, \&c., not Lind1. A. pungens, Gray, l. c., partly.

§ 3. Xycocóccus. Leaves coriaceous and evergreen, entire : drupe not warty, ovoid-globose, with a thin pulp and a thick completely solid woody or bony 1-6celled putamen. - Xylococcus, Nutt. 1. c. vii. 258.

A. glaúca, Lindl. Ereet, 8 to 24 feet high, wholly glabrous except the glandular-pubescent slender pedicels : leaves, \&c., as of A. pmmgens, var. platypluylla, or paler : drupes half an inch or more in diameter, minutely glanclular, sometimes viscid, with a thin flesh around the solid mucronate-apiculate stone: seeds and cells 4 to 6 , or by abortion fewer, very small in proportion to the size of the putamen. - Bot. Reg., under 1791; Grav, Bot. Calif. i. 454-California, commoner from Monterey southward. Except by the larger and solid drupe hardly distinguishable from the common glaucous variety of $A$. pungens. 
A. bícolor, Gray. Shrub 3 or 4 feet high: leaves petioled, not vertical, oblong-oval, thin-coriaceous, pinnately-veined, 1 or 2 inches long, white-tonentose beneath, as are the ovate obtuse bracts and much imbricated sepals: pedicels very short: corolla rose-color, 3 or 4 lines long: filaments filiform: drupe 3 or 4 lines in diameter. - Proc. Am. Acad. vii. 366, \& Bot. Calif. l. c. Sylucucrus bicolor, Nutt. 1. c. - San Diego Co., California, Nuttall, Cooper, Cleveland, \&c. Fl. February.

A. Clevelándi. More pubescent: leaves sessile, narrower, acuminate, margins more revolute: inflorescence leafy: bracts and sepals acute: corolla 4 lines long, equalled by the pedicels : fruit unknown. (When the fruit becomes known, it may refer this recently discovered species to the following section.) - Potrero, San Diego Co., California, Cleveland. Fl. Sept.

\$. Comarostápurus. Leaves coriaceous, evergreen : drupe with granulate or warty surface and a solid few-celled putamen. - C'omarostaphylis, Zucc.

A. polifólia, HBK. Shrub 5 to 8 feet high, glabrous: leaves linear-lanceolate, pale beneath: flowers in a loose terminal raceme or panicle: caly $x$-lobes triangular and acute: corolla reddish, ovoid: drupe dark purple, small. - Nov. Gen. \& Spec. iii. 277, t. 258; Torr. Mex. Bound. 108. - California, on the southern boundary, and Mexico.

6. EPIG 2 A, L. Mayflower. (Formed of ' $\varepsilon \pi i$, upon, $\gamma \tilde{\eta}$, the earth, from the mode of growth.) - Prostrate or somewhat creeping; the short slender stems barely shrubby, rusty-bristly, leafy only toward the summit of the flowering shoots; the leares petioled, alternate, thin-coriaceous, veiny, pale green, persistent, round-oval or elliptical, mostly cordate, entire. Flowers in earliest spring, almost sessile in a short and close terminal cluster, bracteate and 2-bracteolate; the somewhat scale-like persistent bracts equalling the calyx. Sepals ovate-lanceolate and acuminate, nearly scarious and often purplish. Lobes of the corolla oval, either quincuncially imbricated in the bud or imbricate-convolute. Capsule a depressed-globose and somewhat 5 -angled, bristly, thin-walled. Seeds numerous on the much-projecting placentæ, round-oval, with a close and thin reticulated coat. The flowers are heteromorphous and inclined to be diøcious or diœcio-dimorphous. Those with fully polliniferous anthers seldom set fruit: their stigmas short, erect, slightly projecting beyond the margin of the 5-toothed ring (to the teeth of which they severally are adnate); the style sometimes longer than the stamens and projecting, sometimes shorter and included. Fully fertile flowers on other plants; their style (as in the former sort sometimes long and exserted, sometimes shorter and included) with stigmas elongated and much surpassing the ring, shortlinear, glutinous, radiately divergent; their stamens either slightly polliniferous, or reduced to abortive filaments, or even wanting. - Gray, Man. ed. 5, 293, \& Amer. Jour. Sci. ser. 3, xii. 74.

E. répens, L. (Mayflower, Trailixg Arbutus, Ground Laured.) Flowers mostly numerous or several in the cluster, spicy-fragrant: corolla rose-color to almost white, bearded inside; its tube more or less exceeding the calyx. - Lam. Ill. t. 367; Andr. Bot. Rep. t. 102; Bot. Reg. 3, t. 201 ; Brit. Fl. Gard. ser. 2, t. 384. - Gravelly or sandy woodlands in the shade of evergreens, Newfoundland westward to Saskatchewan, and south to Kentucky and Florida. (The other and very nearly related species is E. Asiatica, Maxim., of Japan.)

7. GAULThERIA, Kalm, L. Aromatic Wintercreen. (Dedicated by Kalm to "Dr. Gaultier" of Quebec, whose name, as appears from the records, was written Gaultier. The genus therefore should not be written Guallheria, (Scop., \&c.), nor Gualteria, Gautiera, \&c., as by others. If changed at all, the right 
orthography would be Gaultiera.) - Shrubs or almost herbaceous plants (Asiatic and American); with broad evergreen leaves, shining above, and usually spicyaromatic in flavor, axillary white or rose-colored nodding flowers in early summer, succeeded by red or blackish "berries," consisting of the at length baccate calyx enclosing the capsule. Cells of the anthers opening by a terminal pore, and commonly tipped with two points or awns. Stigma truncate or obtuse, entire. Disk 10-toothed or of 10 scales. Ovary and capsule depressed, umbilicate, commonly 5-lobed: placentre ascending, although often borne toward the summit of the short columella. Seeds very many, with a close shining coat. Pedicels or calyx bracteolate.

* Corolla short-campanulate, 5-lobed: filaments glabrous : apex of the anthers obscurely 4-pointed.

G. Myrsinítes, Hook. Cespitose-procumbent or depressed, a few inches high : leaves orbicular or ovate, denticulate with minute bristle-tipped teeth (half inch to inch and a half long): pedicels solitary in the axils, very short, 3-5-bracteolate: fruit scarlet, with pine-apple flavor. - Fl. ii. 35, t. 129. Vaccinium humifusum, Graham in Edinb. Phil. Jour. 1831, 8. - Rocky Mountains from Colorado northward and in Utah, and northern borders of California, to Brit. Columbia. One form glabrous or nearly so, with small round leaves; another with rusty hirsute hairs on the stem and calyx, and larger ovate leaves.

* Corolla orate or urceolate, 5-toothed : filaments hairy : anthers 4 -awned at the summit.

G. procúmbens, L. (Wintergreen, Checkerberry, Boxberry.) Nearly glabrous and as if herbaceous: slender but ligneous stems extensively creeping, generally underground, sending up flowering shoots a span high: leaves crowded towards the top, obovate and oval, mucronate, more or less serrulate with bristly-tipped teeth: pedicels mostly solitary in the axils, 2-bracteolate close under the calyx: fruit red, this and the foliage aromatic-tasted, with flavor as of Sweet Birch, but warmer. - Lam. Ill. t. 367; Andr. Bot. Rep. t. 316; Bigelow, Med. Bot. ii. 27, t. 12 ; Bot. Mag. t. 1966. Gautiera procumbens, Torr. Fl. N. Y. i. 433. - Low woods under evergreens, Newfoundland to L. Superior and subaretic Amer, and through the Atlantic States southward to upper Georgia.

G. Shállon, Pursh. (Salat.) Shrubby, a foot or two high, with rather stout spreading stems: branches, pedicels, and even the corollas-glandular-hairy or pubescent: leares ovate or obscurely cordate, acuminate, strongly serrulate ( 2 to 4 inches long) : racemes from large both terminal and axillary chartaceous-scaly buds, elongated, many-flowered, secund : scaly bracts persistent: pedicels 2-bracteolate below the middle: corolla large for the genus ( 3 or 4 lines long), viscid: fruit purple becoming black, eaten by Indians under the name of "shallon" (Lewis \& Clark) or salal. - Fl. i. 284, t. 12; Hook. Bot. Mag. t. 2843, \& Fl. ii. 35; Lindl. Bot. Reg. t. 1411. - Shady woods, Brit. Columbia along and near the coast to the mountains behind Santa Barbara, California.

8. ANDROMEDA, L. (Fancifully named in allusion to the fable of $\Delta n$ dromeda. See the poetical account by Linnæus, under the original species, in Fl. Lapp. 126.) - Shrubs ; with evergreen or deciduous and broad or rather narrow mostly petioled leaves, and umbellate-fascicled or paniculate racemose flowers, in spring or early summer; all of the northern hemisphere. Calyx naked at base, usually very early open in the bud, 5-parted or of nearly separate sepals, the edges of which do not overlap even at the base. Corolla white or rose-color. - Gray, Man. ed. 2, 253, \& ed. 5, 295. Andromeda, Zenobia (Don), Pieris (Don), \& Lyonia (Nutt.), Benth. \& Hook. Gen. ii. 587.

§ 1. EuAndrómeda. Corolla globose-urceolate : calyx small, deeply ó-parted, early open: filaments bearded and not appendaged: anthers short; each cell surmounted by a slender ascending awn: placentæ attached next the summit of the columella: seeds turned in all directions, oval, with a smooth and shining crustaceous coat. - Andromeda, Don, DC., Benth. \& Hook. 
A. polifólia, L. Shrub a foot or so high, glabrous and glaucous: the firm-coriaceous and evergreen Rosenary-like leaves from linear to linceolate-oblong, with strongly revolute margins, white beneath: flowers (eariy spring) in a small terminal umbel: pedicels from the axils of ovate persistent scaly bracts, naked. - Fl. Lapp. t. 1, f. 3; Fl. I)an. t. 54. A. rosmarinifolia, P'ursh, Fl. i. 2!)1. A. glaucophylla, Link, Enum. i. 394. - Wet bogs, \&e., from New Jersey and Pennsylvania, and on the Pacific side from Norfolk Sound to the arctic coast. Capsule in the American specimens more or less depressed, in the European higher than broad. (Eu., N. Asia.)

§. Zexóbra. Corolla opeu-campanulate, obtusely 5-lobed: calyx barely 5puted, thickish, with the thin margins valvate in the early burl : filaments naked, abruptly dilated at base: anther's lanceolate; each cell surmounterl by a pair of slender asceuding awns: capsule depressed-globose, obtusely J̆-lobed, and somewhat carinate at the dorsal sutures: placente on the middle of the very short columella: seeds oval, angled, with a rather soft minutely reticulaterl coat. Zenobia, Dou, \&c.

A. speciósa, Michx. Shrub 2 to 4 feet high, glabrous, often glaucous: leaves coriaceous, but deciduous, oval or oblong (an inch or two long), commonly crenulate or sparsely serrulate, reticulate-veiny: flowers in umbel-like fascicles from axillary buds, mostly racemose on naked branches of the preceding year: pedicels naked, drooping: calyx-lobes triangular, short: corolla white (a third of an inch high and wide). Yraties from bright green to chalky-white with a dense glaucous bloom. - Fl. i. 2.50; l'ursh, Fl. i. 294; Lodd. Cab. t. 551. A. nitida, Sims, Bot. Mag. t. 970. A. cussinefolia nuda, Vent. Cels., 1. 60. Zenobia speciosa, Don, l. c. The following relate to the var. pulverulenta, Michx., i.e. the white glaucous form: Andromeda pulverulenta, Bartr. Trav. 476, with plate; Sims, Bot. Mag. t. 667. A. cassinefolia pulverulenta, Vent. Maln. t. 79. A. dealbata, Lindl. Bot. Reg. t. 1010, a state with corolla 5-parted. - Low pine-barrens, Florida to N. Carolina.

§3. Portúna. Corolla ovate-urceolate, 5-toothed: calyx deeply 5-parted; the lobes firm-coriaceous and thick-edged, ovate-lanceolate, strictly valvate in the bud: filaments not appendaged: anthers oblong; the cells each with a slender deflexed awn on the back at the junction with the filament: capsule globose, not thickened at the sutures: placenta borne on the summit of the columella: seeds mostly scobiform: flowers in axillary and terminal racemes, formed during the preceding summer, remaining naked until early the following spring, when the (white) blossoms unfold: pedicels minutely bracteate and 2-3-bracteolate: leaves coriaceous, evergreen. - Portuna, Nutt. 1. c. Pieris $\$$ Portuna \& \$ Phillyreoides, Benth. \& Hook. l. c. (Here also belong A. Cubensis, Griseb., A. Japonica, 'Thunb., and A. formosa, Wall.)

A. floribúnda, Pursh. Slırub 2 to 6 feet high, very leafy: young branchlets, \&\&., strigose with rusty or dark hairs: leaves thinnish-coriaceous, lanceolate-oblong, acute or acuminate, minutely serrulate and bristly-ciliate, rounded at base, somewliat glandulardotted beneatl ( 2 inches long): racenes crowded in a terminal short panicle, densely flowered: corolla (3 lines long) strongly 5-angled and at base 5-saccate, twice the length of the calyx : seeds linear-oblong with a very loose cellular coat, large, all pendulous from the sumnit of the cell. -Fl. i. 299; Bot. Mag. t. 1566; Bot. Reg. t. 807. A. (Leucothoe) monluna, Buckley in Amer. Jour. Sci. xlv, 172. Leucothoe, forlbunda, Don, 1. c. Zenobia foribunda, DC. 1. c. Portuna floribunda, Nutt. 1. c. - Moist shaded hills, in the Alleghanies, Virginia to Georgia.

A. phillyreifólia, Hook. Shrub a foot or two high, nearly glabrous : branches slender, alternately leafy and scaly-bracteate: leaves firm-coriaceous, oblong or lanceolate-oblong, obtuse, more or less serrulate or few-toothed near the apex (an inch or two long) : racemes solitary and axillary, loosely 4-12-flowered : bracts deciduous: corolla ovoid, not angled, twice the length of the calyx: seeds small and short, borne on all sides of the placentr, which occupy the middle of the cells of the depressed-globular umbilicate capsule; the 
minutely reticulated coat conformed to the nucleus. - Ic. Pl. t. 122; Lindl. Bot. Reg. xxx. t. 36; Chapm. Fl. 262. Pieris phillyreifolice, DC. Prodr. vii. 599. - Wet pine barrens, W. Florida, especially Apalachicola.

\$ 4. Piŕris. Corollat from ovate-urceolate to cylindraceous, 5-toothed: calyx of 5 nearly distinct and early open sometimes herbaceous sepals: filaments narrow, usually pubescent or ciliate, 2 -setose or 2 -toothed at or below the apex (these teeth or awn-like appendlages spreading or recurved, rarely obsolete) : authers oblong, awnless: dorsal sutures of the 5-angular capsule with more or less of a thickened ridge (sometimes separating in dehiscence) : placentae usually borne about the middle of the columella and of the cells: seeds scobiform or oblong and with a loose thin coat. - Pieris $\$ 1 \& \S 4$, Benth. \& Hook. l. c. - Original Pieris, Don, is Asiatic, with racemes chiefly terminating leafy branches; and the seeds pendulous. The two American, of subsection MARIa (Pieris $\$$ Maria, Benth. \& Hook.), bear the flowers in axillary umbels or fascicles, the pedicels scariousbracteate and bracteolate at base; and the placentæ as low as the middle of the columella; the seeds therefore in all directions. All combine into one subgenus in structure of flower, capsule, and bisetose filaments.

* Leaves thick-coriaceous and evergreen: sepals thickish and rigid, purplish: flowers honeyscented, in early spring.

A. nítida, Bartr. (Fetren-Bush.) Very glabrous, 2 to 6 feet high, and with acutely triangular branchès: leaves Myrtle-like, rigid, bright green, very shining above, puncticulate beneath, ovate to lanceolate-oblong, acuminate, entire, the minutely revolute edge bordered by an intramarginal nerve: flower-clusters in the axils of the persistent leaves of the preceding year: corolla oroid-cylindraceous with contracted orifice ( 3 or 4 lines long, from white to rose-red) : filaments nearly glabrous, bearing the setiform small appendages close to the sumnit: style abruptly fusiform-thickened above the middle: capsule ovoidglobose, little exceeding the calyx. - Bartram, Cat. \& in Marsh. Arbust. (1785) 8; Walt. Car. 137 ; Michx. Fl. i. 252. A. lucida, Lam. Dict. i. 157 (1783), not Jacq. A. conacea, Ait. Ǩew. ed. 1 (1789), ii. 70 ; Sims, Bot. Mag. t. 109j. A. Mariana, Jacq. Ic. Rar. iii. t. 465, not L. A. marginata, Duham. Arb. ed. nov. i. 188, t. 40. A. myrtifolia, Salisb. A.obovata, Raf., a form with smaller and rhombic-obovate obtuse leaves. Lyonia marginatu, Don. Leucothoe coriacea, 1)C., excl. syn. A.rhomboidalis? L. marginata, Spach. - Low pine barrens, N. Carolina to Florida and Louisiana. (Cuba: A. lacustris, C. Wright.)

* * Leaves almost membranaceous, deciduous: flowers (late spring or summer) consequently on leafless brauches of the previous year, in the manner of Zenobia: sepals thinner, larger, and nearly foliaceous, deciduous with the leaves! (Leucothoe $\$$ Maria, DC.)

A. Mariána, L. (Stagger-iusir.) Glabrous or slightly pubescent, 2 to 4 feet high: leaves oblong or oval, olstuse or acute at both ends, entire, loosely veiny ( 1 to 3 incles long): fascicles of nodding flowers racemose on naked shoots: corolla cylindraceous-campanulate with slightly narrowed orifice, white or pale rose-color (almost half inch long): filaments hairy outside; their very small setose appendages below the summit, occasionally obsolete or wanting: capsule ovate-pyramidal, truncate at the contracted apex; the placentæ low down. - Sims, Bot. Mag. t. 1579; Duham. l. c. t. 37; Gray, Man. ed. 5, 296. A. pulchella, Salisb. Lyonia Mrariana, Don, l. e. Leucothoe Mariana; DC. I. e. - Low grounds, Rhode Island to Florida along the low country; also Arkansas and Tennessee. Foliage said to be poisonous to lambs and calves.

§ 5. LYónia. Corolla from globular to urceolate, pubescent ar glandular : calyx 5- (rarely 4-) cleft; the valvate lobes early open, short: filaments flat, pubescent; these and the short anthers both destitute of appendages or awns: capsule as in the preceding section, i. e. with ribs at the dorsal sutures which are more or less separable in dehiscence: placentr on the apex of the columella and at the top of the cells : seeds all pendulous, narrow, scobiform, having a loose 
and thin cellular-reticulated testa : flowers (small and white) racemose or fascicled : bracts minute and deciduous. - Lyonia, Nutt. Gen. i. 266 ; Benth. \& Hook. Gen. ii. $\check{5} 87$.

* Lepidote-scurfy, not pubescent: flowers fascicled in the axils of persistent coriaceous leaves.

A. ferrugínea, Walt. Low shrub, or taller and arborescent: leaves rigid, cuneatc-obovate, rhombic-obovate, or cuneat ('-oblong, entire, with revolute margins ( 1 or 2 inclies long), smooth and slining above, or obscurely lepidote when young, grayish or ferrugineouslepidote beneath, much exceeding the flower-clusters: capsule ovil-pentagonal, barely 2 lines long. - Car. 138; Michx. Fl. i. 252; Vent. Malm. t. 80. A. ferrugines de 1. rigide, Pursh, Fl, i. 295; Lodd. Cal. t. 430. Lyonia ferruginea \& L. rigida, Nutt. 1. c. - Michaux's two forms are pretty well marked, viz. var. crborescens, with narrower less reticulated leaves, usually crowded; and var. fruticosa, with sparser leaves conspicuously reticulated, mostly cuneate-obovate or rhomboilal. To this belongs $A$, rhomboidulis, "Veill." in Duham. $\Lambda$ rb. ed. nov. i. 192, therefore Leucothoe rhomboidulis, Don, 1. c. - Sindy pine barrens, S. Carolina to Florida. (WW. Ind. \& MIex. ?)

* *omewhat pubescent, but not scurfy : leaves deciduous : Howers racenose-panicled.

A. ligústrina, Muhl. Shrub 3 to 10 feet high, much branched : pubescence minute: leaves from obovate or broadly ovate to lanceolate-oblong ( 1 or 2 inches long), thinnish, obscurely serrulate or entirc: racemes few-leaved at base, or mainly from separate buds (in summer), crowded in naked or leafy panicles: pedicels either scattered or fascicled: corolla globose, barely 2 lines long : capsule glolular : seeds oblong, oltune at each end. Ell. Sk. i. 490; Torr. Fl. 421; Girny, Man. l. (: A. preniculate, Nit.; Micllx. Fl. i. 254, partly, not L. (except as to syn. Pluk.). A. racemosa, Lam., not L. Vaccinum ligustrimum, L. Spec. i. 351. Lyonia paniculata, Nutt. I. c. L. ligustrime, DC. 1. c. L. paniculata, capmerefolier, selicifolia, \& multiftora, Wats. Dendr. t. 37, 12ר, 128. - Wet grounds, Canada to Florida and Arkansas.

Var. pubéscens. A form cinereous with dense and soft fine pubescence. - 1. frondosa, Pursh, Fl. i. 295 (anthers not awned in specimen of herb. Enslin); Fill. 1. c. $\boldsymbol{A}$.

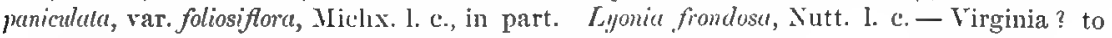
Georgia.

9. OXYDENDRUM, DC. Sorlel-tree, Sour-wood. (Composed of

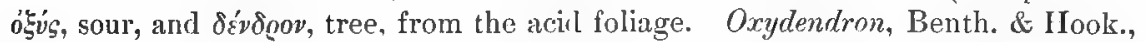
but DeCandolle's form follows the analogy of Epidendrum.) $-\Lambda$ single species, with Peach-like foliage: fl. summer.

O. arbóreum, DC. Tree 15 to 40 feet high: leaves membranaceous and deciduous, oblong or lanceolate (4 to 6 inches long), acuminate, serrulate, glabrous, or at first glaucous, veiny, slender-petioled: inflorescence a panicle of many-flowered racemes terminating the leafy shoots of the season, appearing in early summer: flowers tardily opening: corolla from cylindraceous- to ovate-conical (3 lines long), white, minutely pubescent. - Prodr. vií. 601 . Andromeda arborea, I. (Catesb. Car. t. 71); Sims, Bot. Mag. t. n05; Michx. f. Sylv. iii. t. 7; Bart. Fl. Am. Sept. 1, t. 30. Ly/gnia arborea, Don, 1. c.-Rich woods, Penn., Ohio, and along the Alleghany region to Florida.

10. LEUCÓTHOË, Don. (Mythological; the name of one of the fifty daughters of Nereus.) North and Sonth American and Japanese shrubs, of various habit; with entire or serrulate leaves, and racemose chiefly white flowers. - Don in Edinb. Jour. xvii. 159; Gray, Man. 1. c. Leucothoe \& Agrrista (at least mainly), Benth. \& Hook. Gen. ii. 5xt, i86. (Algrista of I)on is evidently founded on the Mauritius and Bourbon species, the section Agauria. DC.. genus Agauria, Benth. \& Hook., to which are added S. American species, all or chiefly belonging to Leucothoe.)

\$1. Fuleccothoe. Calyx not bracteolate, "s-parted; the divisions usually only early or slightly overlapping, herbaceous or membranaceous: anthers awl- 
less: leaves coriaceous and evergreen: bractlets at or near the base of the pedicels; these articulated with the flower.

* (Nearest Gaultheria.) Racemes dense and spike-like, sessile in the axils of persistent leaves of the former season, developing in spring, at first resembling catkins: the ovate concave scal. persistent bracts being imbricated, little shorter than the pedicels : filaments minutely scabrous, jearly straight: anther-cells obscurely or manifestly binucronate : stigma large, depressed-capitate and 5-rayred. Glabrous shmbs with green erect and recurving branches, and serulate leaves bright green and slining above and loosely pinnately reined.

L. axilláris, Don. Stems 2 to 4 feet high; often minutely pubescent when young: leaves from oval to oblong-lanceolate ( 2 to 4 inches long), mostly with an abrupt acumination, serrulate mainly toward the apex with cartilaginous or somewhat spinulose teeth: petioles very short: sepals broadly ovate and obviously imbricated. - Gray, Man. l.c.; Chapm. Fl, 261 ; also DC. Prodr. vii. 601, excl. var. \& habitat. Andromeda axilltris, Lam. Dict. i. 157 ; Ait. Kew. ed. 1, ii. 69; Duham. Arb. ed. nov. i. t. 39. - Low grounds, Virginia to Florida and Alabama toward the coast; not in the mountains.

L. Catesbǽi, Gray. Shoots longer ( 3 to 6 feet) and more recurving, glabrous: leaves ovate-lanceolate to lanceolate and tapering into a long and slender acumination, serrulate throughout with appressed strongly ciliate-spinulose teeth (4 to 7 inclies long), conspicuously petioled: sepals ovate-oblong, not overlapping in the flower: capsule chartaceous, depressed, strongly lobed: seeds oval, flat, with a loose cellular-reticulated coat much larger than the nucleus. - Man. ed. 2, 252, \& ed. 5, 294. Andromestre C'utesurei, Walt. Car. 137; Willd. Spec. ii. 613 (excl. syn. Catesb.); Sims, Bot. Mag. t. 1055; Lodd. Bot. Cal. t. 1320. A. Wutheri, Willd. Enum. 453. A. lanceolutu, Desf.? A. axilluris, Michx. Fl. i. 253, chiefly. A. uxilluris, var. longifolia, Pursh, Fl. i. 293; Hook. Bot. Mag. t. 2357, hardly Lam. A. spinulosc, Pursh, l. c., excl. habitat. Leucothoe spinulosu, Don, l. c.; IDC. l. c., excl. syn. Duham, \&c. - Moist banks of streans, Virginia to Georgia, along and near the mountains. (l'ursh characterized the two species, but transposed the habitats.) Flowers later than the other, and with the unpleasant odor of chestnut-blossoms.

* * Racemes lonse and few-flowered in the axils of the prersistent reticulated leaves: bracts and bractlets minute: pedicels slender: filaments pubescent, sigmoid-curved toward the apex (in the manner of Brazilian species ): anthers nearly pointless : stigma small.

L. acumináta, Don. (PIPE-wood.) Shrub 3 to 12 feet high, with spreading hollow branches, glabrous, or pulerulent when young: leaves ovate-lanceolate, gradually acuminate, with callous entire or obscurely serrulate margin, rouncled at base, short-petioled; the midrib only prominent; the veins and veinlets all minute and finely reticulated: racemes shorter than the leares: calyx very short and small at base of the cylindraceous ( 1 or 5 lines long) corolla : capsule coriaceous: seeds oblong, pendulous. - Andromeda acuminata, Ait. 1. e.; Smith, Exot. Bot. t. 89. A. lusida, Jacq. Ic. Rar. i. t. 79. A. populifolia, Lam. Dict. i. 159. A, reficulate, Walt. Car. 137. A. laurina, Michx. Fl. i. 253.Sandy swamps, coast of S. Carolina to E. Florida.

* * Racemes clustered in a terminal naked panicle: bracts and bractlets small and scarious or whitish: pedicels short: tilanents glabrous, slender, straight: anther-cells 2-mucronate: stigma rather small, 5-rayed.

L. Davísiæ, Torr. Slırub 3 to 5 feet high, very leafy, nearly glabrous: leaves oblong, obtuse at both ends, obscurely serrulate, hright green ( 1 to 3 inches long): racemes nearly sessile, slender, many-flowered : flowers recurved-pendulous (3 lines long): divisious of the deeply parted whitish calyx ovate-oblong, obtuse, not overlapping in the flower: seeds pendulous, oblong, flat, scobiform, the thin reticulated coat being much Iarger than the oval nucleus, and its margin densely fimbriate with clavate-oblong liair-like cells. - Gray, Proc. Am. Acad. vii. 400, \& Bot. Calif. i. 455; Hook. f. Bot. Mag. t. 6247. - California, in the Sierra Nevada, Plumas and Nevada Counties, Lolb, Miss N. J. Duris, \&e.

§2. Ecвótrus. Calyx bibracteolate; the persistent bractlets and distinct sepals firm-chartaceous, ovate or ovate-lanceolate, acuminate, nuch imbricated, (whitish or redlish) : corolla cylindraceous: filaments glabrous, straight: anthercells 1-2-awned from the apex: stigma merely truncate: placenta short and porrect: leaves membranaceous and deciduous : flowers in secund spike-like racemes, which mostly terminate the brauchlets, formed early in summer, remaining naked 
and undeveloped until late in the ensuing spring, when the flower-buds complete their growth and the blossoms expand: bracts foliaceous-subulate, deciduous at flowering: the short pedicels articulated with the rhachis. - Gray, Man. l. c. Eubotrys, Nutt. in Trans. Am. Phil. Suc. n. ser. viii. 269. (Between Euleucothoe and the genus Cassandra. The two Japanese species agree with this subgenus only in foliage.)

L. racemósa, Gray. Shrub 4 to 10 feet high: branches erect: leaves oblong or ovallanceolate, acute, serrulate, somewhat pubescent when young and on the midrib beneath: racemes or spikes mostly solitary, erect or ascending: sepals lanceolate-ovate, very acute : anther-cells each 2-awned: capsule coriaceous, not lobed: seeds angled and wingless, the shining smooth coat conformed to the nucleus. - Man. ed. 2. 2,52, ed. 5, 2:4. Andromedu racemosa \& 1. paniculutn (chiefly), L. Spec. 394. 4. spicata, Wats. Denur. t. 313. Lyonia racemosa \& Leucothoe spicata, Don, 1. c. Zenobia racemustz, DC. 1. c. Cussandra racemosa, Spach, Hist. Veg. ix. 478. Eubotrys racemosa, Nutt. l.c.-Varies with awns of anthers very short. - Moist thickets (Canada, Pursh, but most doubtful), Missachusetts near the coast to Florida and Louisiana.

L. recúrya, Gray, 1. c. Lower than the foregoing, and with divaricate branches: leaves more acuminate: racemes spreading or recurved: sepals ovate: anther-cells 1-awned: capsule chartaceous, strongly depressed and j-lobed: seeds flat, with a broadly winged loose cellular coat. - Andromeda (Zenobia) recurca, Buckley in Am. Jour. Sci. xlv. 172. Dry hills in the Alleghany Mountains, Yirginia to Alabama.

11. CASSÁNDRA, Don. Leather-Leaf. (Mỵthological: Cassandra was the daughter of Priam and Hecuba.) - A single good species.

C. calyculáta, Don. A low and much branched shrub, a foot or two high, with recurving branches: leaves coriaceous and persistent, very short-petioled, oblong, obtuse, obsoletely serrulate, dull green and lepidote-scurfy, an inch or so in length: flowers on short recurved pedicels in the axils of the upper leaves, these becoming gradualiy smaller and bract-like : calyx and bractlets rusty-lepidote: flowers formed in summer and expanding early the next spring: corolla cylindraceous-oblong, 5-lobed, white, 2 or 3 lines long: capsules small. - Andromerlı calyculatu, L.; Pall. Fl. Ross. t. 71 ; Sims, Bot. Hag. t. 1286 ; Lodd. Cab. t. 530 \& 862. Thamcedaphne colyrulata, Mcench. Lymiu calyculata, Reichenb. Bogs, through the cooler parts of the Northern Atlantic States, and in the Alleghanies to Georgia; N. Illinois to Newfoundland; Kotzcbue's Sound. (N. Eu. \& N. Asia.)

Var. angustifólia is a remarkable form, unknown in an indigenous condition : leaves linear-lanceolate, and the somewhat revolute margins undulate or crisped : bractlets acute: sepals more pointed. - Andromeda culyculata, var. anqustifolia, Ait. Kiew. ed. 1, ii. 70 . A. angustifolia, Pursh, Fl. i. 2!1. A. crispa, Desf. Cat.; Guimp., Otto, \& IIayne, Holz. t. 51."North America and Siberia," Hort. Kew. "Carolina to Georgia," Pursh; but that is a random guess.

12. CASSIOPE, Don. (Cassiope was the mother of Andromeda.)-Arctic-alpine fruticulose evergreens, resembling Heaths or Lycopodium; with small or minute and imbricaterl or crowded entire and veinless leaves, often opposite or whorled, and solitary flowers nodding on the apex of an erect naked peduncle. Sepals ovate, thickened at base. Corolla white or rose-color. Style thickened at base or conical. Placentr many-seederl, pendulous from the summit of the short columella : seeds with a thin close coat. - DC. Prodr. vii. 610.

* Leares loose or spreading, narrow, flattish : peduncle terminal: corolla deeply cleft: style conical.

C. Stelleriána, DC. Diffusely spreading, with the habit of Empetrum: leaves oblonglinear, obtuse, widely spreading, obscurely serrulate (less than 3 lines long) : peduncle very short: corolla 4-5-parted. - Andromeda Stelleriana, Pall. Fl. Ross. 58, t. 74: Ilook. Fl. ii. 37, t. 131. Erica Stelleriana, Willd. Mrnziesia empetriformis, Pursh, Fl. i. 265, not Snith. Bryanthus Stelleri, Don, Syst. iii. 833. - N. W. Coast, Sitka to Behring Straits. 
C. hypnoídes, Don. Cespitose, 2 to 4 inches high, with the habit of a moss or small Lycopodium: leaves somewhat erect, loosely imbricated, linear-acerose; a line long: peduncle stender: corolla deeply 5-cleft. — Edinb. Phil. Jour. xvii. 157. Andromeda hypnoides, L. Spec. 393, \& Fl. Lapp. t. 1; Fl. Dan. t. 10; Pall. 1. c. t. 73; Hook. Bot. Mag. t. 2936. _ Alpine summits of the mountains of N. New England and New York, Labrador, \&c. (Greenland, Lapland, Arct. Siberia.)

* Leaves appressed-erect, closely imbricated in four ranks, thick, boat-shaped or triangular, ovate or oblong in outline: peduncles lateral: corolla 5-lobed: style slender, but slightly thickened downward.

C. lycopodioídes, Don. Very low or creeping stems filiform : leaves barcly a line long, roundish on the back, not ciliate: peduncles filiform. - Ledeb. Fl. Ross. ii. 912. Andromeda lycopodioides, Pall. 1. c. t. 72 ; Hook. 1. c. - Aleutian Islands to Oregon, Cusick.

C. Mertensiána, Don. Stouter, with rigid ascending stems and fastigiate branches, a foot or less in height, resembling the next: leaves $1 \frac{1}{2}$ or 2 lines long, glabrous, carinate and not furrowed on the back: pedicels rather short. - DC. l. c. ; Gray, Bot. Calif. ii. 456. Andromeda Mertensiuna, Bong. Sitk. 152, t. 5. A. cupressina, Hook. Fl. ii. 38. - Sitka, \&c., northern Rocky Mountains, and along the Cascade Mountains to the Sierra Nevada, California, as far south as Mount Dana.

C. tetrágona, Don. Stems ascending, a span or two high, with fastigiate branclies: leaves $1 \frac{1}{2}$ to 2 lines long, thick, and with a deep furrow on the back, often pubescent when young: parts of the flower sometimes in fours. - Andromeda tetragona, L. ; Fl. Dan. t. 1030 ; Pall. l. c. t. 73, f. 4; Hook. 1.c. \& Bot. Mag. t. 3181. - Northern Rocky Mountains, and Cascade Mountains in Oregon, to the arctic regions. (Greenland round to Kamtscluatka.)

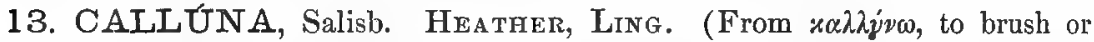
sweep, brooms being made of it.) - Grayish-evergreen undershrub, with no scaly buds, minute opposite leaves imbricated in four ranks on the branches, and very numerous small flowers in the upper axils, subtended by two or three pairs of bractlets, the inner scarious. - Single species.

C. vulgáris, Salisb. A foot or less liigh, in broad tufts, more or less whitish-tomentose or glabrate: branches 4-sided by the imbricated leaves: these minute, 3-sided, grooved on the back: flowers appearing in summer, crowded on the branchlets, as if spicate or racemose, commonly secund, rose-colored or sometimes white. - Linn. Trans. vi. 317; Reichenb. Ic. Germ. xvii. t. 1162; Gray, Man. el. 5, 297. C. Atlantica, Seem. Jour. Bot. iv. 305, t. 53. Erica vulgaris, L. ; Lam. Ill. t. 287 ; Engl. Bot. t. 1013. - Low grounds, Massachusetts, at Tewksbury ( $T$. Dawson) and W. Andover (.James Mitchell); Cape Elizabeth, Maine (Pickard); and less rare in Nova Scotia, Cape Breton, Newfoundland, \&c. (Iceland, the Azores, N. Eu. to W. Asia.)

ERfCA cinérea and F. T'́rrralix, European Heaths, have been found wild on Nantucket, Mass., in one or two small patches : singular waifs.

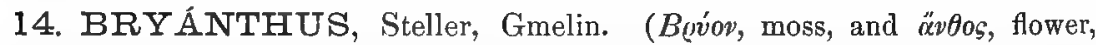
because growing among mosses.) - Heath-like fruticulose evergreens (all areticalpine); with alternate much crowded linear-obtuse leaves (half an inch or less in length), articulated with the stem, grooved beneath or margins revolute-thickened. Flowers umbellate or racemose-crowded at the summit of the branches: the pedicels glandular and bibracteolate at base. Sepals 4 or 5 , sometimes 6 , imbricated, persistent. Anthers.oblong, opening at top by oblique chinks. Seeds oval or oblong; the coat close and rather firm. Flowers in summer, from purple to ochroleucous. - Gray, Proc. Am. Acad, vii. 377, \& Bot. Calif. i. 456 . Bryanthus \& Phyllodoce, Maxim. Rhod. As. Or. 4, 5 ; Benth. \& Hook. Gen. ii. 595.

B. Gmelini, Don, the typical species, and the only one not yet found in America, may be expected on the American, as it belongs to the opposite, side of Behring Straits. It has the cluster of few flowers raised on a naked peduncle, and an open 4-parted corolla. 
\$1. Parabryantuts. Corolla open-campanulate, 5-cleft or 5-lobed : calyx glabrous: flower racemose-clustered: pedicels subtended by foliaceous and rigid bracts : leaves almost smooth, with strougly revolute thickened margins. - Gray, Bot. Calif. l. c. Bryanthus, in part, Hook. \& Benth. Gen. 1. c. Plyyllodoce, in part, Maxim. l. c.

B. Bréweri, Gray. A span to a foot high, rigid: leaves 3 to 7 lines long: pedicels numerous, at first shorter than the flowers: corolla rose-purple, almost saucer-shaped, 5-cleft fully to the middle, large for the genus, the spreading lobes 2 lines long: stamens ( 7 to 10$)$ and style soon much exserted. - Proc. Am. Acad. vii. :37. - Sierra Nevada at about 10,000 feet. Flowers comparatively large and showy.

B. empetrifórmis, Gray, l. c. A span or so high : leaves similar to those of the preceding, or rough at the margin: pedicels fewer and more umbellate: corolla rose-color, much smaller (between 2 and 3 lines long), campanulate, barely 5 -lobed; the lobes much shorter than the tube: stamens included: style either included or exserted. - Menziesia empetriformis, Smith in Linn. Trans. x. 280; Pursh, Fl. i. 264; Graham in Edinb. Pliil. Jour. \& Bot. Mag. t. 3176; Hook. Fl. ii. 40. M. Grahami, Hook. l. c. Plyllodoce empetriformis, Don, Syst. iii. 783. - Rocky Mountains from Iat. $50^{\circ}$ to $42^{\circ}$, and Mount Shasta, California to Y'ancourer's Island.

Var. intermédius (Menziesia intermedia, Hook. l. c.), apparently a form with corolla approaching cylindraceous and sepals rather acute. - Northern Rocky IIountains, Drummond, Lyall.

§2. Phyllónoce. Corolla ovate, contracted at the orifice, 5 -toothed: calyx glandular-pubescent : stamens and style included: pedicels umbellate; the bractlets scarious and bracts thinnish: leaves more scabrous-ciliolate or roughish. Phyllodoce, Salisb. Parad. Lond. 36; DC. 1. c., in part; Benth. \& Hook. I. c.

* Flowers purple, rarely rose-color, 2 to 6 in the umbel, or sometines solitary.

B. taxifólius, Gray, l. c. Barely a span high: leaves with acute scabrous-ciliolate edges: pedicels minutely glandular: sepals ovate-lanceolate, acuminate: corolla from urceolate-oblong to ovoid, glabrous, as are the filaments. - Andromeda taxifolia, Pall. Fl. Ross. i. 5t, t. T2 ; Fl. Dan. t. 57. A. ccerulea, L. Fl. Lapp. t. 1, f. 5, but corolla not blue. Menziesia ccerulea, Swartz in Linn. Trans. x. 377, t. 30. Phyllodoce taxifolia, Salisb. 1. c.; DC. I. c. - Alpine mountain summits of New Ilampshire and Maine; also Labrador. (Greenland, X. Eu. to Japan and Kamtschatka.)

* * Flowers from white or whitish to sulphur-color.

B. Aleúticus, Gray, l.c. $\Lambda$ span or more high : leaves of the preceding: pedicels ( 7 to 15) and base of the acutish sepals very glandular: corolla almost globose, glabrous, whitish: filaments glabrous. - Menzirsia Aleutica, Spreng. Syst. ii. 202; Cham. in Linn. i. 515; Hook. 1. c.; not Bong. Phyllodoce Pallusiana, Don, \& DC. l. c. (as to pl. Cham., Andromeda ccerulea, var. viridiflora, Pall. herb.?); Maxim. Rhod. As. Or. 6. - Unalaschka and Alaska. (Kamtschatka to Japan.)

B. glanduliflórus, Gray, l. c. A span or two high: leaves similar or thicker-edged: pedicels ( 3 to 8 ) and acuminate sepals glandular-hirsute: corolla turgid-ovate, glandular, sulphur-color: filaments puberulent. - IIenziesia glanduliftora, Hook. Fl. ii. 40, t. 132. $M$. Aleutica, Bong. Sitk. 154, t. 3 (poor), not of Spreng. - Rocky Mountains, lat. $49^{\circ}$ to $56^{\circ}$, and west to Sitka.

15. KÁLmia, L. Anerican Laurel. (Peter Kalm, a pupil of Linnzus, who travelled in Canada and $\mathrm{N}$. States, and became professor at Abo.) - N. American shrubs and one W. Indian; with evergreen entire leaves, and umbellate clustered or rarely scattered showy flowers, either rose-colored, purple, or white: no scaly leaf-buds nor thin scaly-bracted flower buds; the bracts ovate to subulate, coriaceous or firm and persistent. Calyx is-parted or of 5 sepals, imbricated in the bud. Limb of the corolla in the bud strongly 10-carinate from the pouches 
upward, the salient keels running to the apex of the lobes and to the sinuses, the limb imbricated in the bud. Anthers free and on erect filments in the early bud, in the full-grown bud received in the pouches of the corolla, and the filaments bent over as the corolla enlarges, and still more when it expands, straightening elastically and incurving when disengaged, thereby throwing out the pollen : anther-cells opening by a large pore, sometimes extending into a chink. Stigma depressed. Capsule globular, 5-celled: placentæe pendulous or porrect from the upper part of a small columella. Seeds with a thin and mostly close coat.

$\S 1$. Flowers in simple or clustered umbels, fascicles, or corymbs : calyx persistent under the capsule: leaves and branches glabrous or nearly so.

* Inflorescence compound: branchlets terete : capsule depressed, tarclily septicidal : seeds oblong.

K. latifólia, L. (Laurel, Carrco-Bush, \&c.) Widely branching shrub 3 to 10, or in S. Alleghanies even 30 feet high, with very hard wood: leaves alternate or occasionally somewhat in pairs or threes, oblong or elliptical-lanceolate, acute or acutish at both ends, petioled, bright green : inflorescence very viscid-pubescent: flowers produced in early summer; the corymbose fascicles numerous and crowded in compound terminal corymbs: corolla rose-color to white, viscid, three-fourths inch in diameter : capsules viscid-glandular; the almost closed valves or pieces generally carrying with them the placenta. - Sims, Bot. Mag. t. 175; Schk. Handb. t. 116; Michx. f. Sylv. ii. t. 68; Bigel. Med. Bot. i. 133, t. 13. (Catesb. Car. ii. t. 98; Trew, Ehret. t. 38.) - Rocky hills or northward in damp grounds, commonly where wooded, Canada, Maine to Ohio and Tennessee, and chiefly along the mountains to W. Florida.

K. angustifólia, L. (Sheer Ladret, Lambill, Wickr.) Shrub 2 or 3 feet high, simple: leaves mostly in pairs or threes, oblong, obtuse, petioled, an inch or two long, light green above, dull or pale beneath: inflorescence lateral from the early growth of the terminal shoot, puberulent, slightly glandular: flowers in early summer, not half as large as in the foregoing, purple or crimson: capsules not glandular, on recurved pedicels. - Sims, Bot. Mag. t. 331. (Catesb. Car. iii. t. 17 ; Trew, Ehret. t. 18.) - Hillsides, Newfoundland and Hudson's Bay to the upper part of Georgia.

K. cuneáta, Michx. Low shrub, somewhat pubescent: leaves oblong with cuneate base, almost sessile and chiefiy alternate, mucronate (an inch long) : inforescence lateral, few-flowered, nearly glabrous: sepals ovate, obtuse: corolla white or whitish, one-third inch in diameter. - Fl. i. 257; Nutt. Gen. 1. 268; Loud. Arb. fig. 1143. - Swamps, eastern part of N.\& S. Carolina (not in the mountains, as said Pursh) : little known.

* * Inflorescence a simple terminal umbel or corymb: branchlets 2-edged : capsule oroit-globose, freely dehiscent from the summit; the valves 2 -cleft at apex; placentr left on the summit of the columella: seeds linear, with a loose cellular coat.

K. glaúca, Ait. Shrub a foot or two high, wholly glabrous, mostly glaucous: leaves all opposite or rarely in threes, almost sessile, oblong or linear-oblong, or appearing narrower by the usual strong revolution of the edges, glaucous-white beneath (an inch or less long): flowers in spring, lilac-purple, half to two-thirds inch in diameter: bracts large: sepals ovate, scarious-coriaceous, much imbricated. - Hort. Kew. ed. 1, ii. 64, t. 8; Sims, Bot. Mag. t. 177 ; Lodd. Cab.t. 1508. K. polifolia, Wang. Act. Nat. Ber. v. t. 5. Var. rosmarinifolia, Pursh, is merely a state with very revolute leaves : var. microphylla, Hook. Fl. a small alpine form, a span high, with leaves barely half inch long. - Bogs, Newfoundland and IIudson's Bay to Pennsylvania, and on the western coast at Sitka, \&c., extending down the Rocky Mountains to Colorado, and down the Sierra Nevada to Mt. Dana, California, in the depauperate alpine form or variety.

$\S 2$. Flowers mostly scattered and solitary in the axils of ordinary leaves; these small and, with the branches and foliaceous sepals, hirsute: capsule shorter than the calyx: placentre remaining upon the columella: seeds oval or ronndish, and with a close and firmer coat. (The Cuban $K$. ericoides, with rigid Heath-like leaves, has inflorescence approaching the first section, and sepals apparently persistent.) 
K. hirsúta, Walt. Ibout a foot high, branching freely : leaves nearly sessile, plane, oblong or lanceolate, a quarter to half inch long: flowers scattered and axillary, produced through the sunimer, on pedicels longer than the leaves: sepals ovate-lanceolate and leaflike, as long as the rose-purple corolla (this barely half inch in diameter), at length deciduous, leaving the old capsules bare.-Bot. Mag. t. 138. K. ciliulu, Bartram, Trav. - Low pine barrens, S. E. Virginia to Florida.

16. MENZIÉSIA, Smith. (Archibald ILenzies, assistant surgeon in Vanconver's royage, 1791-95, brought the original species from the $\mathrm{N}$. W. coast.) Deciduous-leaved shrubs, of N. Am and Japan; with the foliage of the Azaleas, lut with small and mostly dull-colored 4-merous flowers (the corolla barely lobed. in ours a quarter inch long, lurid-purplish), developed at the same time as the leares, from separate strobilaceous buds, which terminate the branches of the preceding year; the pedicels nodding in flower, erect in fruit. Leaves alternate, membranaceous, glandular-mucronate. Capsule short: placeute attached to the whole length of the co'umella. Flowers in early summer. - Smith, Ic. Pl. 59; Salisb. Parad. Lond. 44; Maxim. Rhod. As. Or. 7.

* Seeds with tail or appentlage at each end as long as the nucleun: capsule smooth and naked or nearly so, inclined to obovate: tilaments more or less ciliate below.

M. glabélla. Strigose-chaffy scales wanting, or very few on young petioles and midrib bencatlı: leaves obovate, mostly obtuse, barely mucronate-tipped, glaucescent and glabrous or nearly so beneath (an inch or two long), sprinkled with some small appressed hairs above, the obscurely serrulate margins minutely ciliolate: pedicels naked or somewhat

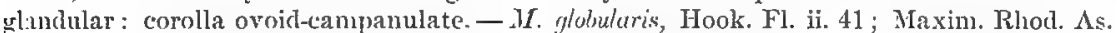
Or. l. ('., not Salisb. II. ferruyinea, Gray in Proc. Am. Acad. viii. 39:3. - Rocky Mountains, lat. $49^{\circ}-56^{\circ}$ (Drummond, Bouryeau), thence to Washington Territory and Oregon, Lyall, Tolmie, E. Hull.

* * Seeds merely apiculate or very short-tailed : capsule orate: filaments glabrous.

M. globuláris, Salisb. Straggling or loosely branched shrub 2 to 5 feet high (like the others), more or less chaffy : leaves olovate-ollong, usually obtuse, prominently glandularmucronate, strigose-hirsute especially above, glaucescent bcneatl : pedicels glandular: corolla globular-ovate becoming ovate-campanulate: capsule beset witl slort gland-tipped bristles. - Pursh, 1. c. M. Smithii, Michx. Fl. 1. 235. II. ferruginea, var. (globularis), Sims, Bot. Mag. t. 15i1; Gray, Man. ed. 2 \& 3. M. pulost, Juss. in Ann. Mus. i. 56 . Asalme pulosu, Miclıx. in Lam. Jour. Nat. Mist. i. 110. - Woods, through the Alleghany Mountains, from Pennsylvania to Georgia. Most like the preceding, but the seeds very different; the snill calyx conmonly more distinctly 4-lobed. Leaves an inch or two long.

M. ferrugínea, Smith. Strigose-chaff not rare on young parts: leaves oblong or lanceolate-obovate, acute or acutish at both ends, prominently glandular-mucronate, more ciliate witl glandular bristles, rusty strigose-hirsute above, merely paler beneath (somewhat blackening in drying): pedicels bristly-glandular: corolla oljlong-ovate and lsecoming cylindraceous. - Pursh, Fl. i. 264; Hook. 1. c.; Maxim. 1. c.-Woods, coast of Oregon to Alaska and. Aleutian Islands. (Kamtschatka ?)

17. RHODODÉNDRON, L. Rose Bay, Azalea, \&c. (The ancient Greek name, meaning rose-tree.) - Shrubs or small trees, of diverse habit and character, with chiefly alternate entire leaves: the principal divisions have been receiver as genera, but they all run together. Only five are N. American out of the eight subgenera of Maximowicz, Rhod. As. Or. 13. (Rhododendron \& Azalea, L.) - The first two subgenera are very anomalous.

§1. Therorhódion, Maxim. Flowers one or two terminating leafy shoots of the season; the thin bud-scales of the shoot deciduous only with the annual leaves : corolla rotate, divided to the base on the lower side: stamens 10. 
R. Kamtscháticum, Pall. A span high: leaves thin and chartaceo-membranaceous, sessile, obovate, or the upper oval, very obtuse, nervose-veined and reticulated, bristly ciliate, shining: sepals large and foliaceous, deciduous : corolla rose-purple, deeply 5-cleft, nearly an inch long: capsule thin. - Fl. Ross. i. 48, t. 33; Hook. Fl. ii. 43. Rhodothamnus Kamtschaticus, Lindl. in Paxt. Fl. Gard. i. t. 22. - Alaska and Aleutian Islands to North Japan, \&c.

§ 2. Azaleastrum, Planchon, Maxim. Inflorescence lateral; the flowers from the same bud as the leafy shoot or from separate 1-3-flowered lateral buds below: scales carlucous: leaves deciduous: corolla rotate or approaching campanulate: stamens 5 to 10 .

R. albiflórum, Hook. Shrub 2 or 3 feet high, with slender branches, pubescent with slender strigose or silky and some short glandular hairs when young, nearly glabrous in age: leaves membranaceous, oblong, pale green: flowers from separate small buds of the axils of the previous year, nodding on short pedicels : sepals membranaceo-foliaceous, oval or oblong, half the length of the white 5-cleft corolla, as long as the ovoid capsule: stamens 10 , included : filaments bearded at the base: stigma peltate-5-lobed. - Fl. ii. $4 \dot{3}$, t. 133, \& Bot. Mag. t. 3670. - Woods of the northern Rocky Mountains and Oregon to British Columbia. Corolla less than an inch long.

§3. Azálea, Planchon, Maxim. Inflorescence terminal; with the umbellate flowers from a separate strobilaceous bud, terminating the growth of the previous year, surrounded at the base by lateral and smaller leaf-buds, developing in spring or early summer; the thin-scaly bud-scales and bracts caducous or early deciduous : leaves deciduous, glandular-mucronate : calyx small, sometimes minute: corolla chiefly funnelform, glandular-viscid outside: stamens (5 to 10) and style more or less exserted and declined. - Azalea, L. chiefly, DC. \&c. (with Rhodora, Duhamel).

* Strobilaceous flower-buts of numerous much imbricated scales: corolla with conspicuous funnelform tube, slightly irregular limb, and acute oblong lobes: stamens (chiefty 5) and style longexserted. True Azaleas.

+ Pacitic States species: flowers more or less later than the leaves.

R. occidentále, Gray. Shrub 2 to 6 feet high : branches not bristly : leaves obovateoblong, nearly glabrous at maturity, but ciliate, thickish, bright green and shining above (1 to 3 inches long): lobes of the 5-parted calyx oblong or oval: corolla white or barely with a rosy tinge and a pale yellow band on the upper lobe, often $2 \frac{1}{2}$ inches long: capsule oblong, three-fourths inch long. - Bot. Calif. i.458. R. calendulaceum, Hook. \& Arn. Beech. 362. Azalea occidentalis, Torr. \& Gray, Pacif. R. Rep. iv. 116. - California, western foothills of the Sicrra Nevada through the length of the State, and in the coast ranges, along streams. Fragrance of blossoms sweet, but slightly unpleasant.

++ Atlantic States species (commonly called Swamp Hoxeystckles), all from 3 to 10 feet high and the l'aves from obovate to oblong-oblanceolate. - Species of Rlududendron, Torr. Fl. N. \& M. States (1824), 424.

- Flowers appearing later than the glabrous leaves, deliciously fragrant.

R. arboréscens, Torr. Few strigose or chaffy bristles: leaves (fragrant in drying) merely ciliolate, slightly coriaceous when mature, bright green and shining above, glaucescent beneath: corolla white or tinged with rose, fully 2 inches long; the tube and the conspicuous narrow-oblong calyx-lobes sparsely glandular-bristly : stamens and style red. Fl. N. \& M. States, 425. Azalea arborescens, Pursh, Fl. i. 152; Gray, Man. ed. 1, 268. A. fragrans, Raf. Ann. Nat. 12. - Alleghany Mountains, Pennsylvania to North Carolina. Foliage exhales the odor of Anthoxanthun in drying.

R. viscósum, Torr. Branchlets and midrib of the leaves beneath more or less chaffybristly: leaves more ciliate, an inch or two long, clull or liardly shining above, pale beneatli: calyx very small : corolla white, or with a rosy tinge, sometimes varying to reddish, the outside very glandular-riscid. - Fl. N. \& M. States, l. c., \& Fl. N. Y. i. 439, t. 66. Azulea viscosa, L. (Catesb. Car. i. t. 57); Michx. Fl. i. 150; Emerson, Mass. Rep. ed. 2, 
t. 24.- Swamps, Canada and Maine to Florida and Arkansas. Runs into manifold varieties; the following being those most marked:--

Var. glaúoum. Leaves glaucous-wlitened beneatl, dull and sometimes glaucous above also. - Azalea viscosa, var. glauca, Michx. L. c. A. glauca, Lam. Ill. t. 110. R. glaucum, Don, l. c. Form more strigose-hispid is A. hispida, Pursh, l. c. (R. hispidum, Torr. l. c.) A. scubra, Loddiges, \&c. - New England to Virginia.

Var. nítidum. Leaves oblanceolate, brighter green botl sides: stems a foot to a yard high. - R. nitidum, Torr. 1. c. Azalea nitida, Pursh, l. c.; Lindl. Bot. Reg. t. 414. Mountains, New York to Virginia.

$+\div$ Flowers earlier and less fragrant, preceding or accompanying the leaves; these soft-pubescent beneath and more membrauaceous, 1 to 3 inches long; the midrib and the branchlets either slightly or not at all chaffy-strigose or hispid: calyx usually very small.

R. nudiflórum, Torr. l. c. Corolla from light rose-color or flesh-color to rose-purple; the viscid tube as long as or rather longer than the limb. - Azalea nudiflora, L. Spec. ed. 2, 214 ; Sims, Bot. Mag. t. 180 ; Emerson, 1. c. t. 24 . A. lutea, L. Spec. ed. 1. A. periclymenoides \& A. canescens, Michx. 1. c. A.bicolor, Pursh, l. c. Rhododendron canescens, bicolor, \&c., Don, I. c. - Swamps, low grounds, or shaded hillsides, Canada to Florida and Texas. Tarying much in color, \&c., at the south sometimes passing into yellow. Many hybrid forms are in cultivation.

R. calenduláceum, Torr. 1. c. Corolla from orange-yellow to flame-red; the tube mostly hirsute-glandular, shorter than the ample limb: mature leaves more tomentose beneath. - Azalea calendulacea, Michx. Fl. i. 151; Pursh, I. c.; Bot. Mag. t. 1721, 2143. Woods in the Alleghany Mountains, from Pennsylvania to Georgia, extending southward into the middle country.

* Strobilaceous flower-buds of fewer and early caducous scales: corolla irregular, with a short or hardly any tube, anteriorly divided to the base; the limb equalling the 10 stamens and style. - Rhodor a, Dulnamel, in Linn. Gen.

R. Rhodóra, Don. A foot or two higl, the young parts sparingly strigose-hairy: flowers somewhat preceding the leaves, short-pedicelled: calyx very small: corolla less than an inch long, purplish-rose-color, bilabiately parted or divided; the posterior lip 3-lobed; the anterior of two oblong-linear and recurving nearly or quite distinct petals: leares oblong, pale, glaucescent, more or less pubescent. - Syst. iii. 848; Maxim. 1. c. Rhodorä Canadensis, L. ; L'Her. Stirp. i. 161, t. 68; Lanı. Ill. t. 364 ;. Bot. Mag. t. 474; 1)uliam. Arb. ed. nov. iij. 53; Emerson, 1. c. t. 25. Rhodora congesta, Mœencl.. Rhododendron pulchellum, Salisb. - Cool bogs, New England to mountains of Pennsylvania and northward to Newfoundland: fl. May. Mature leaves 1 to $2 \frac{1}{2}$ inches long, glandularmucronulate. Flowers rarely white, sometimes variably or variously cleft or divided, or the lower petals more united to the upper lip.

§4. Ezrhododéndron. Inflorescence terminal; the umbellate or somewhat corymbose flowers from a separate strobilaceous bud (of mostly numerous and well-imbricated caducous scales), terminating the growth of the previous year; the leaf-buds lateral and below: leaves coriaceous and persistent: calyx various, usually small or minute: corolla mostly 5-lobed and little irregular: stamens (commonly 10) and style rarely exserted, somewhat declined, or sometimes equally spreading: flowers mostly large and showy, in early summer. - Eurhododendron \& Osmothamnus (DC.), Maxim. 1. c.

* Not lepidote, glabrous or soon becoming so; the pubescence of young parts (if any) scurfytomentose and deciduous: leaves ample and thick-coriaceous: stems and branches stout and erect: flowers many in the cluster, mostly developing earlier than the leaf-buds: seeds scobiform or scarious-appendaged at one or both ends.

+ Pacific species: pedicels wholly glabrous: calyx lobes very short and rounded.

R. Califórnicum, Hook. Shrub 3 to 8 feet high, glabrous: leaves broadly oblong, 3 to 6 inches long, obtuse with a mucronate or short-acuminate point, acute or acutish at base: corolla rose-purple, broadly campanulate (over an inch long); the broad lobes undulate: ovary rusty-hirsute.- Bot. Mag. t.4863; Gray, Bot. Calif. i. 458. - Woods, California from Mendocino Co. extending into Oregon (E. Hall). Corolla much resembling that of $R$. Catawliense. 
R. macrophýllum, Don. Shrub 10 to 15 feet high : leaves oblong, acute at both ends, 5 to 8 inches in length, thinnish : corolla white, less than an inch long; its lobes oblong: ovary bristly hirsute. - Syst. iii. 843; Torr. Bot. Wilkes Exp. 382. R. maximum, Hook. Fl. ii. 43, excl. syn. \&c. - Woods, Puget Sound to Washington Territory. A little known species.

$$
++ \text { Atlantic States species : pedicels glandular or pubescent. }
$$

R. máximum, L. (Great L.dURel or Rose Bay.) Shrub or small tree 6 to 35 feet high: leaves elongated- or lanceolate-oblong, acute or short-pointed, narrowed toward the mostly acute base, 4 to 10 inches long, commonly whitish beneath : pedicels viscid : calyxlobes oval, equalling the glandular ovary : corolla pale rose-color or nearly white, greenish in the throat on upper side and with some yellowish or reddish spots, campanulate, an inch long, rather deeply 5-cleft into oval Lobes: capsule short. - Catesb. Car. iii. t. 17 ; Lam. Ill. t. 364 ; Bot. Mag. t. 951 ; Michx. f. Sylv. i. t. 67 ; Bigel. Med. Bot. iii. t. 51 . R. purpureum \& R. Purshii, Don, 1. c. (varying in color of flower, \&c.).-Danp woods, rare in Nova Scotia, New England and bordering part of Canada, common through the Alleghanies on steep banks of streams, \&c., New York to Georgia. Flowering toward nidsummer, simultaneously witl the growth of the leafy shoots.

R. Catawbiénse, Michx. Shrub 3 to 6 (rarely 20) feet high : leaves oval or broadly oblong, mostly obtuse or rounded at both ends, 3 to 5 inches long: pedicels rusty-pulescent when young, glabrous in age: caly $x$ and its lobes very short: ovary oblong, rusty-pubescent: corolla lilac-purple, broadly campanulate, an inch and a half high, with broad roundish lobes: capsule narrowly oblong. - Fl. i. 258; Bot. Mag. t. 1671. Higher mountains, Virginia to Georgia: fl. at beginning of summer. Largely hybridized with other species, and varied in cultivation.

* Lepidote-dotted or scurfy with scattered peltate scales: stems mostly spreading or diffuse: flowers fewer or few in the umbel: seeds (in ours and in most species) with a close coar, barely apiculate at either end?

+ Southern species: stems 3 to 6 feet high, with slender and often recurving branches: even the outside of the sliort-funnelform corolla sprinkled with the resinous globules or dots: stamens 10: Hower-buds ovate or oblong and well imbricated.

R. punctátum, Andr. Diffuse, the slender branches recurved or spreading: leaves lighter green and thimner-coriaceous, oblong or oval-lanceolate, acute or somewliat acuminate at both ends, 2 to 5 inches long: flowers developed later than or with the leaves of the season (in early summer), copious : corolla rose-color, an inch long, short-funnelform with an ampie widely expanded limb and rounded-obovate slighitly undulate lobes, exceeding the stamens and style: capsule resinous-dotted: seeds oval. - Bot. Rep. t. 36; Vent. Cels. t. 15; Bot. Reg. t. 37. R. minus, Michx. Fl. i. 258. - Eastern portion of the Alleghany Mountains from N. Carolina to Georgia, and extending to the eastern frontier of the latter State on the Savannalı River at Augusta. Corolla often darker-spotted and greenish in the throat.

R. Chapmánii. More erect and rigid: leaves firm-coriaceous, oval or oblong, obtuse, seldom an inch and a half long, duller, more crowded, short-petioled : flowers developed earlier than the leafy shoots of the season: corolla rose-color, spotted within, more narrowly funnelform; the tube longer than the limb; lobes somewhat ovate, shorter than the stamens and style: seeds narrowly oblong. - R. punctatum, var., Chapm. Fl. 266. - Sandy pine barrens, W. Florida, Chapman.

+ + Arctic-alpine species, small and depressed: corolla rotate-campanulate, deeply 5-cleft, not lepidote or resinous-dotted: stamens 5 to 10 : flower-buds globular and less imbricated.

R. Lappónicum, Wahl. Divergently branched from the base, prostrate or a span or two high: leaves a quarter to half an inch long, firm-coriaceous, oval or oblong, obtuse: umbels 3-6-flowered: corolla purple, with darker spots within, half inch long: stamens 5 to 8 , rarely 10. - Fl. Suec. 249; DC. Prodr. vii. 724; Hook. Bot. Mag. t. 3106 . Azalea Lapponica, L. ; Fl. Dan. t. 906. - Alpine region of the mountains of N. New York and New England, Labrador to the northern Rocky Mountains and aretic coast, west to Norton Sound and Unalaschka (Eschscholtz). (Greenland to Arct. Asia.) R. parvifolium, Adams (Azalea Lapponica, Pall.), or at least the N. W. American form referred to it by Maximowicz, seems hardly different; and all the American and Greenland specimens have the filaments bearded or pubescent at base. 
18. LÉDUM, L. Labrador Tea. (-1; $80 v$, ancient name of the Cistus.) - Low shrubs, with alternate persistent leaves entire and more or less resinous dotted, slightly fragrant when bruised. Flowers white, developed in early summer from separate and mostly terminal buds, their scales and bracts well imbricated, thin and caducous. Stamens and the (persistent) style fully as long as the petals. Stigma obscurely annulate. Pedicels slender, recurved in fruit. - We have all the species.

* Leaves denscly tomentose beneath, the wool soon ferrugineous, and the margins strongly revolute: inflorescence all terminal.

L. palústre, L. A span (in the aretic form) to 2 fuet high : leaves linear (half to inch and a half long): stamens 10: capsule short oval. - Fl. Dan. t. 10:1 ; Lodd. Cab. t. 560.Bogs, Newfoundland, Labrador, and through the arctic regions to Alaska and Aleutian Islands. (N. Eu. \& Asia.)

Var. dilatátum, Wahl. : approaching the next, having broader leaves and sometimes long-oval capsules. - N. W. Coost, Sitka, \&c.

L. latifólium, Ait. \& foot to a yard high, erect: leaves oblong or linear-oblong (an inch or two long), commonly half inch wide, very obtuse: stamens 5 to 7 : capsule oblong, acutish. - Lam. Ill. t. 363; Jacq. Ic. Rar. t. 404. L. Groenlandicum, Retz. Scand. L. palustre, var. latifolium, Michx., \&e. L. Canudense, Lodd. Cab. t. 1049. - Newfoundland and Labrador (Greenland), through the wooded regions to Puget Sound, and south in the Atlantic States to Wisconsin and Pennsylvania.

* * Leaves glabrous both siles: inflorescence sometimes also lateral. - Ledlodendrun, Nutt.

I. glandulósum, Nutt. Shrub 2 to 6 feet high, stout: leaves oblong or oval, or approaching lanceolate (one or two inches long), pale or whitish and minutely resinous. atomiferous beneath : inflorescence of ten compound and crowded : calyx 5-parted : capsules oval, retusc. - Trans. Am. Phil. Soc. n. ser. viii. 270; Gray, Bot. Calif. i. 459. - Woods and swamps, coast of California from Mendocino Co. northward, and through the Sierra Nevada ; thence north and east to Br. Columbia and northern Rocky Mountains.

19. BEJÂRIA, Mutis. (Written Befaria by the younger Linnæus, \&c., but originally "Bejaria, Mutis, ex Zea, Annal." iii. 151. Zea was a pupil of Mutis, and he declares that the name was given in honor of Bejar, professor of Botany at Cadiz, and an intimate friend of Mutis.) - All but the following species tropical American.

B. racemósa, Vent. Shrub 3 or 4 feet high, evergreen : branches sparsely hispid : leaves alternate, sessile, oblong, coriaceous, glabrous, pale: flowers in pedunculate and sometimes paniculate naked racemes terminating leafy branches: bracts and bractlets subulate, deciduous: calyx obtusely 7-lobed; petals spatulate, white tinged with red, an inchl long. Hort. Cels, t. 51 ; Ell. Sk. i. 533. Befaria paniculata, Michx. Fl. i. 280, t. 26. Pine barrens, Florida and Georgia near the coast: fl. summer.

20. LEIOPhyLlUM, Pers. Sand Mrrtle. (Aeios, smooth, qúlion, leaf, from the smooth and shining foliage.) - A single species, varying considerably : flowering late in spring; the coriaceous scales or bracts resembling reduced leaves.

L. buxifólium, Ell. Shrub resembling Dwarf Box in miniature, a span or two high, very glabrous, mucl branched, thickly leafy: leaves alternate or opposite, oblong or oval, veinless, a fourth to half inch long, slightly petioled : flowers profuse, in terminal umbelliform corymbs : corolla white or rose-color (3 or 4 lines broad) : anthers brown or purple. - L. buxifolium \& L. serpyllifolium, DC. Prodr. vii. 730. L. thymifolium, Don, Syst. iii. 851. Ledum buxifolium, Bèrg. in Act. Ups. 1777, t. 3, f. 1; Michx. Fl. i. 260 ; Lodd. Cab. t. 52. L. thymifolium, Lam. Ill. t. 363 . Dendrium buxifolium, Desv. Jour. Bot. i. 36. Ammyrsine buxifolia, Pursh ; Lind1. Bot. Reg. t. 531. Fischera buxifolia, Swartz in Act. Mose, v. 16. Sandy pine barrens, New Jersey to Florida, and the mountains of Carolina. The state 
(L. serpyllifolium, DC.) with "capsules.sparsely puberulent" or often granulate-roughish is chiefly suthern, and on the mountains passes into

Var. prostrátum. Depressed-tufted, with the habit of Loiseleuria: leaves mostly oval and deeper green: capsules from smooth and nearly even to sparsely muricate with soft projecting points or processes. - (Gray, in Amer. Jour. Sci. xlii. 36.) L. prostratum, Loud. Arb. 1155 ; DC. 1. c. - Summit of Roan Mountain, and of other high mountains of Carolina.

21. LOISELEÚRIA, Desv. (Loiseleur-Delongchamps, a French botanist.) - A single, arctic-alpine species, which was included by Linnæus in Azalea, but is most unlike.

L. procúmbens, Dest. Fruticulose and cespitose, depressed, glabrous, evergreen: leaves nearly all opposite, rather crowded on the branches, distinctly petioled, oval or oblong, thick-coriaceous, veinless, 2 to 4 lines long, with thick midrib beneath and revolute margins : umbel 2-5-flowered from a terninal coriaceo-foliaceous bud ; the scales or bracts persistent : pedicels short : corolla rose-color or white (2 lines high), barely twice the length of the purplish sepals. - Jour. Bot. i. 35 ; DC. Prodr. 1. c. Azalea procumbens, L. Spec. \& IIl. Lapp. t. 6, f. 2 ; Fl. Dan. t. 9 ; Pall. Fl. Ross. t. 70, f. 2 ; Pursh, Fl. i. 154 (excl. pl. Grandfather Mt., which is Leiophyllum); Lodd. Cab. t. 762. Chamoeledon procumbens, Link, Enum. i. 211. - Alpine region of White Mountains, New Hampshire; also Labrador, Arctic America to high N. W. coast and islands. (Greenland, Eu., N. Asia.)

22. ELLIÓTTIA, Muhl. (Dedicated to Stephen Elliott, author of Sketch of the Botany of S. Carolina and Georgia.) - Identified with a Japanese genus, Tripetaleia, Sieb. \& Zucc., forming a rather polymorphous but marked genus of three species and as many sections, as arranged in Benth. \& Hook. Gen. ii. 598.

E. racemósa, Muhl. Shrub 4 to 10 feet high, glabrous, witl slender branches : leaves short-petioled, oblong, mostly acute at both ends, about 2 inches long, mucronate witl a gland, thinnish, pale beneath, lightly veiny : raceme or racemose panicle loosely many-flowered, a span to a foot long: bracts and bractlets minute, scarious, very caducous: calyx very short, 4-lobed: corolla white, half inch long; the petals 4, spatulate-linear, valvate or nearly so at base and imbricated at summit in the bud, in blossom recurved-spreading: stamens 8: anthers somewhat sagittate, erect; the cells callous-mucronate: style little declined, incurved at apex: ovary not stipitate. (Parts of the flower rarely in fives?) Muhl. in Ell. Sk. i. 448 ; Chapm. Fl. 273 ; Baill. Adans. i. 205. - Wet sandy woods, on or near the Savannah River, at Waynesboro' (Ellioft), and near Augusta (Wray, and recently Berckmans) in Georgia; and on the S. Carolina side of the river near Hamburg, on David L. Adams' place (Olney, 1853) : rare and local : fl. carly summer.' Fruit still unknown.

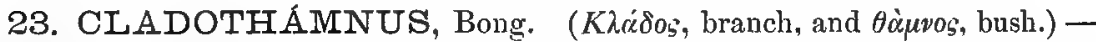
Bong. Veg. Sitk. 37, t. 1; Benth. \& Hook. Gen, ii. 598. Tolmiea, Hook. Fl. ii. 44. - A single species.

C. pyrolæflórus, Bong. Tall shrub with many virgate branches, glabrous, leafy: leaves obovate-lanceolate, glandular-mucronulate, almost sessile, thin, an inch or so long, pale : flower nodding on a short pedicel : petals redaish, hardly half inchl long. - DC. Prodr. vii. 722. Tolmiea occidentalis, Hook. 1. c. - Low woods, Washington Territory to Alaska.

24. CLEThRA, Gronov. White Alder. (Kij; $\theta_{\varrho} \alpha$, ancient Greek name of the Alder, which the original species somewhat resembles in foliage.) - Shrubs or small trees; with alternate leaves, in ours serrate and deciduons, and white flowers in simple or panicled chiefly terminal racemes; these usually canescent with a stellate pubescence. Bracts subulate, deciduous: bractlets none or caducous. Leaf-buds of few scales or naked. Capsule in ours nearly enclosed in 
the calyx. Petals imbricated (or sometimes nearly convolute) in the bud. Filaments usually subulate: anthers fixed near the middle, in the bud extrorse, after expansion becoming introrse. Stigmas over the cells according to Baillon, Adans. i. 201. Fl. summer.

C. alnifólia, L. (Sweet Pepperrosh.) Shrub 3 to 10 feet high : leaves cuneate-obovate or oblong, sharply serrate, entire toward the base, prominently straight-veined, short-petioled: racemes erect, mostly panicled : filaments glabrous: Howers spicy-fragrant. - Lam. Ill. t. 369; Schk. Handb. t. 118; Michx. Fl. i. 260. (Alnifolia Americana, \&c., Pluk. Alm. t. 115, f. 1; Catesb. Car. 1, t. 66.) C. dentata, Ait. Kew. ed. 1, ii. 73, with strongly serrate leaves. C. paniculata, Ait. l. c., with less toothed cunente-lanceolate leaves green and glabrous both sides. C. scabra, Pers. Syn. i. 482, with leaves somewhat scabrous above and more or less pubescent beneath, as is common. - Wet woods and swamps, Maine to Florida, at the north only along the coast.

Var. tomentósa, Michx., l. c. More or less hoary: leaves tomentose-canescent beneath. - C. lomentosa, Lam. Dict. ii. 46 ; Hook. Bot. Mag. t. 374 4. C. incana, Pers. 1. c. C. pubescens, Willd. Enum. 455. - S. Atlantic States, passing into the other forms.

C. acumináta, Michx. Tall shrub or small tree: leaves ample (3 to 7 inches long), oval or oblong, acuminate, closely and sharply serrate almost to the base, with somewhat curved veins and rather long petioles, almost glabrous : racemes mostly solitary, nodaing: caducous bracts longer than the flowers: filaments hirsute, usually also the base of the petals within the capsule hirsute. - Bart. Fl. Am. Sept. iii. t. 71; Lodd. Cab. t. 1427. C. montana, Bartram; Duham. Arb. ed. nov. v. 130. - Woods of the Alleghanies, Virginia to Georgia.

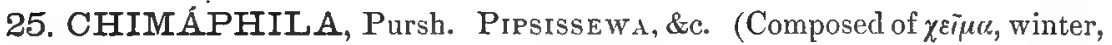
and $p\left(\lambda \varepsilon^{\prime} \omega\right.$, to love, being a sort of "Wintergreen.") - Low, with running lignescent stolons, thick and shining toothed leaves either scattered or often imperfectly opposite or verticillate on the short ascending stems, narrowish : a few fleshcolored or white fragrant waxy-looking flowers on a terminal naked peduncle, produced in early summer. Petioles short. Calyx כ̌-parted. Cells of the anther oblong, with a short narrow neck under the orifice, imperfectly 2-locellate, at least when young. Stigma very broad, obscurely 5-radiate. Bracts scaly. - We have all the species, except one in Japan, near C. Menziesii.

C. umbelláta, Nutt. (Pipsissew., Prince's Pine.) A span or two high, very leafy in irregular clusters or whorls, often branched: leaves cuneate-lanceolate, with tapering base, sharply serrate, not spotted, shining: peduncle 4-7-flowered: bracts narrow, cleciduous: filaments hairy on the margins only. - Bart. Mat. Mled. i. t. 1; Hook. Fl. i. 49. C. corymbosa, Pursh, Fl. i. 300. Pyirala umbellata, L. ; Lam. III. t. 367; Fl. Dan. t. 1336; Bot. Mag. t. 778; Bigel. Med. Bot, t. 21. P. rorymbosa, Bertol. Misc. iii. 12, t. 3. - Dry and especially coniferous woods, Canada to Georgia, west to the Pacific from Br. Columbia to California. (Mex., Eu., Japan.)

C. Menziésii, Spreng. A span high, sparingly branched from the base: leaves from ovate to oblong-lanceolate, acute at both ends, small (6 to 18 lines long), sharply serrulate, the upper surface often mottled with white: perluncle 1-3-flowered: bracts ovate or roundish : filaments slender, with a round dilated portion in the middle villous: flowers smaller, about half inclı in diameter. - Syst. ii. 317; Hook. l. c. t. 138; Gray, Bot. Calif. i. 459. Pyrolk Mlenziesui, R. Br.; Don in Wern. Trans. v. 245. - Coniferous woods, British Columbia to California.

C. maculáta, Pursh, 1.c. (Spotted Winterareer.) A span or more in height, more simple : leaves oblong- or ovate-lanceolate, obtuse at base (an inch or two long), sparsely and very sharply serrate; the upper surface variegated with white: peduncle 2-5-flowered: bracts linear-subulate: filaments villous in the middle: flower comparatively large, threefourths incl in diameter. - Bart. Fl. An. Sept. i. 40, t. 11 ; Radius, Diss. Pyr. t. 5, f. 2; Torr. Fl. N. Y. 1, t. 70. Pyrola maculata, L. ; Bot. Mag. t. 897. - Dry woods, Canada to Georgia and Mississippi. 


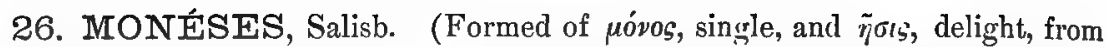
the solitary handsome flower.) - Cells of the anther oblong, abruptly constricted under the orifice into a conspicuous short-tubular neck, in the bud completely bilocellate, so that the anther appears equally 4-lobed. Capsule not depressed, opening from above downward. - A single species.

M. uniflóra, Gray. Herb with 1-flowered scape 2 to 4 inches high, a cluster of roundish and serrulate thin leaves at base, on a short stem or the ascending summit of a filiform rootstock : corolla white or tinged rose-color, about two thirds inch in diameter (in early summer). - Gray, Man. ed. 1, 273; Alefeld in Linn. xxviii. 72. M. grandiflora, Salisb., Don, l. c. Pyrola uniftora, L. ; Fl. Dan. t. 8 ; Engl. Bot. t. 146 ; Reichenb. Ic. Germ. xvii. t. 1156. M. reticulata, Nutt. in Trans. Am. Phil. Soc. n. ser. viii. 271. - Deep moist woods, Labrador to Oregon, south to Pennsylvania, \&c., and along the mountains to Colorado, Utah, \&c., north to the aretic regions. (Eu. to N. E. Asia.)

27. PÝrola, Tourn. Wintergreen, Shin-leaf. (Name said to be a diminutive of Pyrus, Pear-tree.) - Acaulescent herbaceous evergreens ; with a cluster of round or roundish leaves, and some scarious scales on the ascending summit of slender subterranean rootstocks (one species leafless): scape more or less scaly-bracted, bearing a raceme of white, greenish, or purplish nodding flowers, in summer. (Almost all N. American). - Pyrola (Actinocyclus, Klotzsch), Amelia, \& Thelaia, Alefeld in Linn. xxviii. 8.

$\S 1$. AmÉLia, Benth. \& Hook. Style straight and short: stigma peltate, large, obscurely 5-lobed: stamens equally connivent around the pistil: anthers not narrowed below the openings: hypogynous disk none: petals orbicular, naked at the base, globose-comnivent. - Amelia, Alefeld, 1. c. (P. media, of the Old World, connects with § Thelaia.)

P. mínor, L. Leaves orbicular, thinnish, obscurely serrulate or crenulate, an inch or less long: scape a span high, 7-15-flowered : pedicels short, rather crowded : style much shorter than the ovary, included in the globose white or flesh-colored corolla. - Fl. Dan. t. 55; Raclius, Diss. l’yrol. 15, t. 1; Reichenb. Ic. Germ. xvii. t.1155. P. rosed, Smith, Engl. Bot. t. 2543 ; Radius, l. c. t. 2. Amelia minor, Alefeld, l. c. - Cold woods, Labrador, White Mountains of New Hampshire, Lake Superior, Rocky Mountains from New Mexico, Oregon, and nortlıward to the arctic regions. (Greenland to Kamtschatka.)

§ 2. FupÝrorA. Style straight and long: stigma peltate-5-lobed, large; the lobes at length radiately much projecting beyond the ring or border: stamens and oblong petals equally connivent around the pistil: a pair of tubercles on the base of each petal : anthers as in the preceding : hypogynous disk 10-lobed. - Pyrola, Alefeld. Actinocyclus, Klotzsch.

P. secúnda, L. Inclined to be caulescent from a branching base: leaves thin, ovate, serrulate or crenate, an inch or two long: scape a span long: flowers numerous in a secund spike-like raceme: pedicels at first merely sprearling, in fruit recurved: petals greenishwhite, campanulate-connivent. - Fl. Dan. t. 402 ; Engl. Bot. t. 517 . - Rich woods, Nortlern Atlantic States to Labrador, and the mountains of Colorado and California, thence far northward. (Mex., N. Eu. to Japan.)

Var. púmila, a smaller form, with rounded leaves half inch or little more in diameter, and 3-8-flowered scape. - J. A. Paine, Cat. Pl. Oneida Co., N. Y.; Gray, Man. ed. 5, 302.Peat bogs of elevated regions in Central New York; also Labrador, Alaska, \&c. (Greenland.)

§3. Thel ÁiA, Benth. \& Hook. Style strongly declined or decurved, and toward the apex more or less curved upward, longer (or becoming longer) than the concave somewhat campanulate-connivent or partly spreading petals: stigma 
much narrower than the truncate and usuilly excavated apex of the style, which forms a ring or collar; its 5 lobes at first very short and even included, in age commonly protruding, connivent or more or less concreterl: stamens declinedascending: anthers more or less contracted under the terminal orifices, so as usually to form a neck or short prolongation, the other extremity with either a prominent or often an obsolete mucro: hypogynous disk none. - Thelaia, Alefeld, l. c.

* Anomalous, perhaps monstrous: petals and leaves acute: flowers ascending.

P. oxypétala, C. F. Austin. Leaves ovate, coriaceous, an inch or less in length and shorter than the petiole: scape 7 or 8 inches high, naked, 7-9-flowered: calyx-lobes triangular-ovate, acute, short: petals greenish, lanceolate-oblong, acuminate (nearly 3 lines long), campanulate-connivent: stamens slightly declined: anthers remaining extrorse, obscurely produced at the openings, the other end conspicuously 1-mucronate: style slightly curred; lobes of the stigina not projecting. - Gray, Man. ed. 5, 302. - Delaware Co., New York, on a wooded hill near Deposit, C. F. Austin, 1860. Not since found.

* Leaves orbicular, oral, or oblong: petals from orbicular to oblong, very obtuse.

+ Calyx-lobes very short and obtuse or rounded, appressed to the greenish-white corolla.

P. chlorántha, Swartz. Leaves small (half to an inch in diameter), orbicular or nearly so, coriaceous, not shining, shorter than the petiole : scape 4 to 8 inches high, $3-10$-flowered: anther-cells with distinctly beaked tips. - Act. Holm. 1810, 190, t. 5; Nutt. Gen. i. 273 ; Lodd. Bot. Cab. t. 1542 ; Hook. Fl. ii. 46, t. 134. P. asarnfolia, Radius, Diss. 2;, t. 4; Torr. Fl. N. \& M. St. i. 433, not Michx. - Rather dry woods, Labrador to Pennsylvania, Rocky Mountains in Colorado, California? to Br. Columbia, and north to subaretic regions. (Eul., X. Asia?) The E. Asian species allied to this is $P$. renifolia, Maxim.

Var. occidentális. Leaves thinner and inclined to ovate. $-P$. occidentalis, $\mathrm{R}$. Br. in herb. Banks; Don in Wern. Trans. v. 232. Thelaia occidentulis, Alefeld, 1. c. 36, t. 1, f. 6 (excl. stamens, which apparently belong to $P$. secunda, var. minor?). - Alaska to Kotzebue's Sound, Nelson, \&c. Rocky Mountains, Bourgeru.

++ Calyx-lobes ovate and acute, short: leaves membranaceous, Ionger than their petioles.

P. ellíptica, Nutt. Leaves oval or broadly oblong, $1 \frac{1}{2}$ to $2 \frac{1}{2}$ inches long, acute or merely roundish at base, plicately serrulate: scape a span or more high, loosely several-manyflowered : corolla greenish white: anther-tips hardly at all beaked. - Gen. i. 27:3; Radius, l. c. t. 5, f. 1; Ilook. I. c. 47, t. 135. P. rofundifolia, Michx. in part. Thelaia elliptica, Alefeld, l. c. 47, t. 1, f. 5. - Rich woods, Canada to Br. Columbia, and through the N. Atlantic States to the mountains of New Mexico. (Japan.)

$$
+++ \text { Calyx-lobes from ovate and acute to lanceolate: leaves coriaceous. }
$$

P. rotundifólia, L. Leaves generally orbicular or broadly oval, $1 \frac{1}{2}$ to 2 inches long, obscurely crenulate or entire, shining above, mostly shorter than the slender petioles: scape a span to a foot high, several-many-flowered, scaly-bracteate: bracts lanceolate or ovate-lanceolate: calyx-lobes lanceolate to ovate-lanceolate, lax or with spreading tips, usually half or one third the length of the white or sometimes flesh-colored petals : anthers with oblong cells contracted into a very short neck under the orifice: the mucro at base either short and distinct or obsolete. - Lam. IIl. t. 367, f. 1 ; Engl. Bot. t. 213; Schk. Handb. t. 119; Gray, Man. ed. 2, 259, ed. 5, 301. Thelaia rotundifolia, asarifolia, bracteosa, intermedia, \& grandiftora, Alefeld, 1. c. - Sandy or dry woods, from upper Georgia, New Mexico, and California to the aretic regions. (Eu. to Kamtschatka.) With the following varieties or forms, all but the last of which pass into each other freely.

Var. incarnáta, DC. A rather small form : flowers from flesh-color to rose-purple: calyx-lobes triangular-lanceolate. - Coldwoods and bogs, Northern New England to the Aleutian Islands.

Var. asarifólia, Hook. Leaves round-reniform, orbicular-subcordate, or inclined to oblate-orbicular: scape slender: calyx-lobes from ovate-lanceolate to ovate, one third to one fourth the length of the flesh-colored or rosecolored or rarely white petals. - Fl. ii. 46. P. asarifolia, Michx. FI. i. 251, in part; DC. Prodr. vii. 779 (excl. syn. Bigel., Torr., Nutt., \& Muhl.) ; Gray, Man. ed. 1, 272. - Not uncommon northward and westward to the Rocky Mountains. 
Var. uliginósa, Gray. Calyx-lobes shorter, usually broadly ovate, sometimes obtuse: leaves from subcordate to obovate, generally dull: flowers rose-colored or purplc. - Man. ed. 2, 259. P. uliginosa, Torr. Fl. N. Y. i. 452, t. 69. P. obovata, Bertol. Misc. iii. 11, t. 2. - Cold bogs, northward nearly across the continent: distinguished from the preceding with reddish flowers only by shorter and broader calyx, and leaves seldom with a sinus at basc.

Var. bracteáta, Gray. Like the preceding forms, but larger: leaves commonly 2 or 3 inches long and thinnish, sometimes variegated with whitish bands: scape often a foot or more high; the scaly bracts large and conspicuous : anthers (as in all these forms, but especially in this) distinctly mucronate at base: calyx-lobes triangular-lanceolate, acute or acuminate, commonly half the length of the rose-colored or purplish petals. Bot. Calif. i. 460. P. bracteata, Hook. 1. c. P. elata \& bracteata, Nutt. 1. c. 270. - Coniferous woods of California to $\mathrm{Br}$. Columbia; the prevailing or exclusive form.

Var. púmila, Hook. l. c. A remarkable low variety: leaves firm-coriaceous, an inch or much less in diameter: scape 3 or 4 inches high, 5-10-flowered: flowers proportionally large, white: calyx-lobes oblong-lanceolate or linear-oblong. $-P$. Granlandica, Hornem. Fl. Dan. t. 1817. P. grandifora, Radius, l. c. 27, t. 3 ; Alefeld, l. c. t. 2, f. 12. P. rotundifolia, var. grandiftora, DC. 1. c.-Labrador to Mackenzie River along the arctic coast. (Greenland.)

P. pícta, Smith. Leaves firm-coriaceous, dull, commonly veined or blotched with white above, pale or sometimes purplish beneath ( 1 to 21 inches long), from broadly ovate to spatulate or narrowly oblong, all longer than the petiole; the margins quite entire, or rarely remotely denticulate: rootstocks rigid and often branched or clustered: scapes a span or more high, 7-15-flowered: bracts few and short: calyx-lobes ovate, not half the length of the greenish-white petals : cells of the anther with a distinct neck or beak below the orifice. - Rees Cycl.; Don, l. c. ; Hook. Fl. ii. 47; Gray, Bot. Calif. i. 460. P. dentata, - Smith, l. c.; Hook. l. c. t. 136; a common form with narrow and erect leaves, remotely but seldom strongly denticulate. Thelaia spathulata, Alefeld, 1. c. - Nootka Sound to California, and east to Wyoming and S. Utah. In the drier regions often very small-leaved.

* * Leafless, from deep scaly-toothed branching rootstocks, doubtless parasitic.

P. aphýlla, Smith. Scapes a span to a foot high, subulate-bracteate, reddish or lurid: raceme several-many-flowered: calyx-lobes ovate, acute, very much shorter than the obovate white petals: anthers tubular-beaked under the orifice of the cells; deflexed style almost straight. - Hook. Fl. ii. 48, t. 137 ; Gray, Bot. Calif. i. 461. - Thelaia caphylla, Alefeld, 1. c. - Coniferous woods, California to Puget Sound. According to Nuttall, there are sometimes, "on infertile shoots, a few small, ovate or lanceolate, greenish leaves." These not since seen; but there is such a form of the preceding species.

28. ALLÓTROPA, Torr. \& Gray. (Alגorooros, in another manner, the flowers not turned to one side as in Monotropa.) - A single species, connecting the Pyrolece with the Monotropece.

A. virgáta, Torr. \& Gray. Herb reddish or whitish, rather fleshy, a span or two high: simple erect stem thicker at base, there densely and above more sparsely scaly : lower scales ovate; upper lanceolate, passing into linear bracts of the virgate many-flowered spike: flowers 2-bracteolate. - Gray in Pacif. R. Rep. vi. 81, Proc. Am. Acad, vii. 368, \& Bot. Calif. i. 461 ; Torr. Bot. Wilkes Exp. 385. - Under oaks, \&c., Cascade Mountains, Washington Terr., to the Sierra Nevada, California.

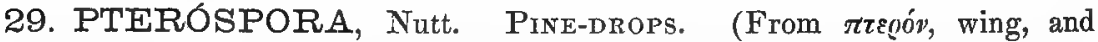
$\sigma \pi o g(x$, seed, alluding to the remarkable wing of the seed.) - Capsule becoming nearly naked in age; the thin valves persistent after dehiscence, being fixed by the partitions to the columella, in the manner of Pyrola, \&c. Seeds innumerable (as in the tribe), on the pendulous placentx; the nucleus oroid, with a nearly close thin coat, apiculate at both ends, the upper apiculation bearing a broad and hyaline rounded or reniform and reticulated wing, which is many times larger than the body of the seed. - A single species. 
P. andromedéa, Nutt. A chestnut-colored or purplish herb, glandular and clammypubescent: simple stem 1 to 3 feet high, bearing small and scattered lanceolate scales: raceme long and many-flowered: pedicels slender, spreading, soon recurved: corolla white, a quarter inch long, somewhat viscid. - Gen. i. 386 ; Lindl. Coll. t. 5 . - Under pines and oaks, N. W. New England, Canada, and Pennsylvania to Br. Columbia and California: fl. summer.

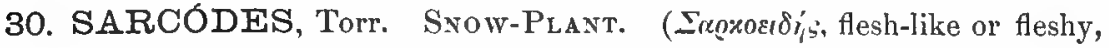
from the appearance of this singular plant.) - Torr. Pl. Frem. in Smithson. Contrib. iii. 17, t. 10. - A single species.

S. sanguínea, Torr. Stout fleshy herb, a span to a foot high, of flesh-red color, somewhat glandular-pubescent, thickly clothed and when young imbricated with the firm fleshy scales: lower scales ovate; upper narrower, more scattered, and above passing into linear bracts of the thick spike or raceme which subtend and mostly exceed the reddish flowers : pedicels erect, the upper ones very short: corolla glabrous, half inch long. - Pl. Frem. l. e.; Chatin, Anat. t. 55; Benth. \& Hook. Gen. ii. 607 ; Gray, Bot. Calif. i. 462.California, in coniferous woods of the Sierra Nevada, 4-9,000 feet, shooting up and flowering soon after the snow melts away.

31. SCHWEINfTZIA, Ell. Sweet Pine-sap. (Named in honor of the late Louis David von Schweinitz.) - Flowers exhaling the odor of violets, produced in spring. Anthers in the young flower-bud turned at right angles to the filament, so that apex and base are directed right and left; in anthesis becoming vertical. - A single species.

S. odorata, Ell. Plant light brown, in tufts, 2 to 4 inches high, glabrous, beset with thinnish ovate or oblong scales, and similar bracts, spicately several-flowered: spike nodding in flower, erect in fruit: corolla flesh-color, ic quarter inch long. - Ell. in Nutt. Geu. addend. \& Sk. i. 478; Gray, Chloris, 15, t. 2. S. Caroliniana, Don, Syst. iii. 867. Monotropsis odorata, Schweinitz in Ell. 1. c. - Moist woods, Maryland (near Baltimore) to North Carolina in and near the mountains, parasitic on the roots of herbs or on decaying vegetable matter.

32. MONÓtropa, L. Indian Pipe, Pine-sap. (Móvos, one, and zoózos, turn, the summit of the stem in flower turned to one side or drooping.) - White, tawny, or reddish scaly and fleshy herbs, a span or two high; the clustered stems rising (in summer) from a thick and matted mass of fibrous rootlets, one-severalflowered; the summit of the stem straightening in fruit. - Comprises two very distinct subgenera, in Benth. \& Hook. Gen. ii. 607 restored as genera.

§1. Euroxótropa. (Indian Pipe.). Plant inodorous, 1-flowered: scales' passing into an imperfect or irregular calyx of 2 to 4 loose sepals or perhaps bracts; the lower ones rather distant from the flower: anthers opening at first by 2 transverse chinks, at length 2-valved; the valves almost equal and equally spreading: style short and thick: edge of the stigma naked.

M. uniflóra, L. Smooth plant a span or so high, waxy-white (blackish in drying), rarely flesh-color: nodding flower two-thirds inch long: petals 5, rarely 6. - Iam. Ill. t. 352; Bart. Fl. Am. Sept. iii. t. 86, f. I; Hook. Exot. FI. t. 85; Torr. Fl. N. Y. t. 71; Chatin, Anat. t. 50. M. uniflora \& M. Morisoniana, Michx. Fl. i. 266. M. Morisoni, Pers. (Moris. Hist. iii. 502 (12), t. 16, f. 5; Pluk. Alm. t. 209, f. 2.)-Damp woods, nearly throughout the U. S., Brit. Amer., \&cc. (Mex., Japan to India.)

§ 2. Hrpópitys. (Pine-sap.) Plant often violet-scented, commonly pubescent, at least above, racemosely 3 -several-flowered : terminal flower earliest and usually 5-merous and the lateral 3-4-merous: sepals less bract-like, as many as 
the petals: the latter saccate at base: anthers more reniform; the cells completely confluent into one, which opens hy very unequal valves, the larger broad and spreading, the other remaining erect and contracted: style longer: stigma glandular or hairy on the margin. - Hypopitys, Dill., Scop., \&c.

M. Hypópitys, L. A span or at length a foot high, tawny or flesh-colored: scales and bracts entire or slightly erose: flowers less than half inch long; the lateral 4-petalous and 8-androus. - Lam. Ill. t. 362; Fl. Dan. t. 232; Schk. Handb. t. 316; Reichenb. Ic. Germ. t. 1152. M. lanuginosa, Michx.; Torr. Fl. N. Y. i. 457, t. 72. Hypopitys lutea, Dill. H. multiflora, Scop. H. Europaea \& H. lanuginosa, Nutt. Gen. i. 271. - Under amentaceous and coniferous trees, Canada to Florida and Louisiana, west to Oregon and Br. Columbia. (Mex., Japan to $\mathrm{Eu}$.)

M. fimbriáta, Gray. Near a foot in height: obovate-cuneate upper scales and bracts and spatulate sepals laciniately or erosely fimbriate: lateral flowers commonly g-petalous and 6-androus. - Proc. Am. Acad. viii. 629, \& Bot. Calif. i. 463. - Cascade Mountains in Oregon, E. Hall. (Mistaken for Pleuricospora fimbriolata in Proc. Ant. Acad. viii. 394.)

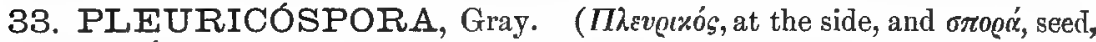
alluding to the parietal placentation.) - A single known species.

P. fimbrioláta, Gray. Light brown or whitish plant, with the aspect of Monotropa $\mathrm{H}_{y-}$ popitys, but stouter, a span high, glabrous or nearly so, clothed with imbricated scales: lowest scales ovate, firm, entire; upper passing into the narrower and lanceolate scariousmargined and lacerate-fringed bracts of the dense and erect cylindraceous spike: corolla white or whitish, not exceeding the bracts, barely half inch long. - Proc. Am. Acad. vii. 369, \& Bot. Calif. i. 463 (not of Proc. Am. Acad. viii. 394, which is Monotropa fimbriata).California, in the Mariposa grove of Sequoia gigantea, Bolander.

34. NEWBERRYA, Torr. (Dedicated to the discoverer, Professor J. S. Newberry, a geologist and naturalist, much devoted to fossil botany.) - Benth. \& Hook. Gen. ii. 606. A single species.

N. congésta, Torr. Plant brownish, glabrous, a span high : scales crowded or loosely imbricated, oval or oblong, thinnish, with obscurely erose margins; the upper forming similar bracts of the somewhat depressed head of numerous flowers: corolla hardly half inch long; its lobes within and the style hairy. - Ann. Lyc. N. Y. vii. 55; Gray, Bot. Calif. i. 464. Hemitonies congestum, Gray, Pacif. R. Rep. vi. 81, t. 12 ; char. and figure incorrect as to the anthers, and the name inapplicable. - Cascade Mountains, in Des Chutes Valley, S. Oregon, Newberry. Washington Territory, station unknown, George Gibbs.

\section{ORDER LXXVIII. LENNOACE AE.}

Root-parasitic leafless herbs, scaly and fleshy, with much the aspect of Monotropece, but with stamens inserted in or near the throat of the tubular corolla, and the polymerous ovary peculiar, the cells being at least double the number of the other parts of the 5-10-merous regular and perfect flower, and uniovulate; the fruit drupaceo-polycoccous. Sepals 5 to 10 , linear or filiform. Corolla hypogynous, tubular or slightly funnelform, marcescent, 5-8-lobed, the lobes plicateimbricated in the bud. Stamens as many as the corolla-lobes and alternate with them: filaments very short: anthers 2-celled, introrse; the cells opening longitudinally: pollen simple, 3-sulcate. Disk none. Ovary depressed-globose, 1228-celled (doubtless of half as many 2-locellate carpels, surrounding a thick axis): style slender : stigma crenulate or somewhat lobed. Ovule horizontal, anatropous or somewhat amphitropous; the orifice superior. Fruit depressed-globular, with 
a thin fleshy at length dry epicarp which ruptures transversely, as if circumscissile, liberating the ring of numerous seed-like nutlets: these are crustaceous, lenticular, and separable. Seed with a very thin proper coit: albumen farinaceous and oily: embryo (according to Solms) minute, globular and undivided, i. e. as in Monotropece. - Torr. in Ann. Lyc. N. Y. viii. 56 ; Solms-Laubach, Abhand. Nat. Halle, xi. 1-60; Benth. \& Hook. Gen. ii. 621.

Lennon (Corallophyllum, HBK.), the remaining genus of this small and very singular natural order, is Jexican, with coralloid branching stems, and the stamens in two sets; the cells of the anther divergent.

1. PHOLISMA. Flowers sessile and densely spicate. Sepals 0, rarely 5, linear, naked, shorter than the corolla; the short lobes of the latter mostly 6 , undulate-plicate, spreading. Stamens 6 or sometimes 5, in a single row : anthers oblong, the cells parallel. Fruit 18-24-celled.

2. AMMOBROMA. Flowers short-pedicelled, thickly covering the expanded and hollowed receptacle. Sepals mostly 10, filiform, plumose-hairy, pappus-like, equalling the corolla; the mostly 6 lobes of which are erect, retuse, hardly plicate. Stamens 6 to 10 in a single row. Anthers, pistils, \&c., as in Pholisma.

1. PHOLfSMA, Nutt. (From podis, a scale, referring to the scaly stem.) - Single species.

P. arenárium, Nutt. Herb brownish or reddish, with simple stems, in clumps, a span or more high, somewhat glandular-puberulent, stout, beset with short and narrow scattered scales: spike dense, oblong or cylindraceous (an inch or two long): flowers purplish (4 lines long), rather longer than the linear bracts. - Hook. Ic. t. 626; Gray, Bot. Calif. i. 461. - Sandy soil, Monterey to San Diego, California, Nuttall, \&c. Parasitic on the roots of Eriodictyon tomentosum, according to $D$. Clereland, also apparently upon those of some Clematss. Flowers produced in spring. Nutlets half a line long, oval. Albumen of the sced oily. Embryo not seen.

2. AMMOBROMA, Torr. (Formed of $\ddot{\mu \mu \rho \varsigma, ~ s a n d, ~ a n d ~ \beta o w ~} \mu \alpha$, food.) Single species.

A. Sonóræ, Torr. Root of tortuous fibres : stems simple, 2 to 4 feet long (but mainly buried in sand), three fourths to an inch and a half in cliameter, fleshy, gradually tapering upward, but at summit dilated into an obconical dilated receptacle of 2 inches in diameter, funnelform inside and lined with the flowers: scales lanceolate, acute, appressed, or on the receptacle reflexed : corolla purple, 4 lines long: ovary about 20-celled. - Mem. Am. Acad. v. 327, \& Ann. Lyc. Nat. Hist. N. Y. viii. 51, t. 1; Gray, Bot. Calif. i. 464; Solms-Laubach, 1. c. t. 1.-Desert sand-hills, Adair Bay, near the head of the Gulf of California, beyond the limits of the United States, Col. A. B. Gray. Arizona, between Pilot Knob and Cook's Wells, Schuchard. The plant upon the roots of which it is parasitic is unknown. The roasted stems are edible and even luscious; they are said to be an important article of food of the Papigos Indians.

\section{ORDER LXXIX. DIAPENSIACEÆE.}

Low perennial herbs or suffruticulose tufted plants, wholly glabrous or nearly so, with alternate simple leaves, no stipules, regular and symmetrical 5-merous flowers, except the pistil which is 3 -merous and the ovary 3 -celled, stamens adnate to the corolla or connate with each other, those opposite its lobes when present reduced to sterile appendages (staminodia), anthers mostly transversely or obliquely dehiscent, pollen simple, and capsule and seeds of Ericacece. Flowers perfect, solitary or racemose. Caly $x$ and corolla imbricated in the bud, hypogynous, or with slight adnation to base of ovary; the former persistent, the latter deciduous. 
Filaments commonly dilated. Style one: stigma 3-lobed, not indusiate. Ovules indefinite, on projecting axile placentæ, anatropous or nearly amphitropous. Capsule coriaceous, loculicidally 3-valved, with or without a persistent columella. Embryo small and terete in fleshy albumen; the cotyledons very short. - Gray, Proc. Am. Acad. viii. 246; Maxim. Mél. Biol. ix. 18; Benth. \& Hook. Gen. ii. 618. Diapensiacer, Lindl., as to our Tribe I., with Galacineæ, Don, as to Galax.

TRIBE I. DIAPENSIË危. Suffruticulose depressed evergreens, crowded with small entire and nerveless coriaceous leaves. Sterile filaments or staminodia none : fertile filaments adnate to the campanulate corolla up to the sinuses: anthers 2-celled. Capsule with persistent columella bearing the placentæ. Calyx conspicuously bracteolate, strongly imbricated. Flowers solitary.

1. PYXIDANTHERA. Flowers sessile on short leafy branchlets. Sepals thin-chartaceous. Anther-cells transversely 2-valved, the lower valve cuspidate-pointed. Seeds globular, amphitropous, with a close pitted coat.

2. DIAPENSIA. Flower (or at least fruit) on a scape-like peduncle. Sepals broad and coriaceous. Anther-cells muticous, divergent, obliquely 2-valved. Seeds oval or by pressure cubical, anatropous, with a nearly close and reticulated coat.

Tribe II. GALACINE E. Acaulescent, with creeping rootstocks sending up longpetioled round-cordate or oblong evergreen leaves, and a scape bearing racemose or clustered or rarely solitary flowers. Staminodia opposite the lobes of the corolla. (Besides the following genera are Schizocodon of Japan, near to Shortia, and Berneuxia of Thibet, between the latter and Diapensia.)

3. SHORTIA. Calyx strongly imbricated and scaly-bracteolate; the sepals many-striate. Corolla open campanulate, 5 -lobed; the lobes undulate-crenate. Stamens distinct: anthers 2-celled; the cells obliquely dehiscent: staminodia small and scale-like, artnate to base of corolla, incurved over the ovary. Style filiform: stigma obscurely 3-lobed. Capsule globular: partitions borne on the valves and separating from the persistent columella, which bears the placentæ. Seeds globular or ovoid with a close granulate coat.

4. GALAX. Calyx rather strongly imbricated, minutely 2-bracteolate, 5-parted; the oblong divisions nerveless. Corolla of 5 entire oblong petals, distinct, except that their bases are adnate to the base of the monadelphous stamen-tube, which is ovate-cylindraceous, 10-lobed above; the lobes alternate with the petals very short and antheriferous; those opposite the petals (i. e. the staminodia) longer, linear-spatulate, petaloid: anthers subsessile, thickened, rounded and granulate on the back; the polliniferous part introrse and small, somewhat beak-like, one-celled, transversely 2-valved. Style very short: stigma obscurely 3-lobed. Capsule ovate; the placentiferous columella at length more or less 3-parted. Seeds angular, with a loose coat tapering upward.

1. PYXIDANTHÉRA, Michx. Flowering Moss. ( $\Pi v v_{\xi}^{\text {cis }}$, a small box. and ćr $\theta$ rige, anther, the latter opening as by a lid.) - Fl. i. 152, t. 17 ; Gray, Bot. Text Book, ed. 2, 436, fig. 785-790; Lindl. Veg. Kingd. 606, fig. 410; Hook. Bot. Mag. t. 4ว992. — Single species.

P. barbuláta, Michx. A small prostrate and creeping evergreen, leafy throughout, loosely branching: leaves lanceolate or somewhat narrowed below, subulate-acuminate, when young pubescent at base, much crowded, a quarter inch long: flowers abundant (in early spring), closely sessile: corolla white or tinged with rose, open-campanulate; its lobes $(2$ lines long) cuneate-obovate, retuse and obscurely erose: filaments ligulate.Diapensia ceneifolia, Salisb. Parad. Lond. 105; Pursh, Fl. i. 148. D. barbulata, Ell. Sk. i. 229. - Pine barrens, mostly in sand, New Jersey and N. Carolina.

2. DIAPENSIA, L. (Said to be an ancient Greek name of Sanicle, somewhat altered, applied in a wholly meaningless way to the present genus.) - Arctic- . alpine, containing a Himalayan species (Hook. f. Kew. Jour. Bot. ix. t. 12), and the following. 
D. Lappónica, L. Plant forming very dense cushion-like tufts, glabrous: leaves imbricated on the short shoots, cartilaginous, spatulate ( 3 to 5 lines long), with mostly revolute margins: peduncle at length an inch or two long: sepals and 2 or 3 bractlets oval, rigid : corolla white, open campanulate; the tube ( 2 lines long) not longer than the caly $x$, nearly equalled by the rounded lobes: filaments linear. - Fl. Lapp. t. 1; Wahl. Fl. Lapp. t. 9; Fl. Dan. t. 47 ; Bot. Mag. t. 1108. - Labrador, Alpine summits of White Mountains, New Hampshire, Mount Mansfield, Vermont, and N. W. arctic coast. (Greenland eastward to Japan.)

3. SHORTIA, Torr. \& Gray. (Dedicated to the late Dr. Charles W. Short, of Kentucky.) - Gray in Amer. Jour. Sci. xlii. 48, ser. 2, xlv. 402, \& Proc. Am. Acad. viii. 246; Maxim. Mél. Biol. ix. 19; Benth. \& IIook. Gen. ii. 620.Two species, one Japanese, from which the character of the corolla, stamens, \&c., were drawn by Maximowicz.

S. galacifólia, Torr. \& Gray. Rootstocks slender and apparently stoloniferous : leaves ( 2 inches wide) orbicular, moderately cordate and retuse, repand-serrate and the teeth mucronate: peduncles in fruit a span high, not surpassing the long petioled leaves, scaly bracteate towarls the summit: style elongated, persistent. - High mountains of $\mathrm{N}$. Carolina, Michaux. In fruit only.

4. GÁLAX, L., Sims. (If from $\gamma^{\prime}(\hat{\lambda})$, milk, an unmeaning name.) - Linn. Gen. ed. 5, 93, excluding all the charucter and the synonymy; these wholly of Viticella, Mitchell, which is Hydrophyllum appendiculatum. Anonymos s. Belvedere, Clayt. Virg. ed. 1, 25, with goot character, which is wholly omitted by Gronovius himself, in Fl. Virg. ed. 2, because quite incongruous with the generic character of Galax by Linnæus. - Single species.

G. aphýlla, L. Glabrous herb, with reddish creeping and matted rootstocks, scnding up leaves and scape: leaves round-cordate, thickly crenate-dentate, veiny, thin but persistent over winter, rather shining, $1 \frac{1}{2}$ to 3 inches broad, long-petioled: scape a foot or two high, slender and very naked, almost bractless : raceme virgate and spike-like: bractlets minute, deciduous: flowers numerous, small : corolla 2 lines long, white. - Spec. i. 200 (excl. syn. Mitch.); Sims, Bot. Mag. t. 754 (where the true char. gen. first appears with the name); DC. Prodr. vii. 776. Erythrorhiza rotundifolia, Michx. Fl. ii. 36. Blanfordia cordata, Andr. Bot. Rep. t. 343. Solenandria cordifolia, P. de Beauv, ex Vent. Malm. t. 69, - Wooded hillsides and in mountains, Virginia to Georgia; fl. early summer.

\section{Order LXXX. PLUMBAGINACE E.}

Herbs, occasionally somewhat woody, agreeing with Primulacen in having the stamens isomerous with the petals or divisions of the corolla and opposite them; the filaments adnate only to their base or completely hypogynous; the free ovary one-celled, with a solitary auatropous ovule pendulous on a slender funiculus which rises from the base of the cell; styles 5 and distinct or united; the single seed with a large and straight embryo surrounded by (or sometimes destitute of) a sparing mealy albumen. Chiefly affecting saline soil. Leaves alternate, mostly rosulate. Flowers regular and symmetrical, 5-merous, perfect. Calyx gamosepalous, costate, plaited at the sinuses, persistent. Corolla with claws to the nearly distinct petals, or these united into a tube, convolute or rarely imbricated in the bud. Anthers 2-celled, opening longitudinally. Disk none. Fruit dry, utricular or akene-like, sometimes dehiscent by a lid or by valves. Innocent, with astringent roots or rootstocks. 
TRIBE I. STATICEÆ. Calyx with open limb scarious, colored, strongly plicate. Petals (long-unguiculate) and filiform styles distinct or united only below.

1. STATICE. Flowers cymose-spicate, secund. Styles wholly separate. Leaves flat.

2. ARMERIA. Flowers capitate-glomerate. Styles mostly united at the very base, stigmatose down the inner side. Leaves usually slender, with no distinction of blade and petiole.

Tribe II. PLUMBAGINEA. Calyx with erect teeth or lobes, and merely scarious sinuses. Claws of the petals completely united into a tube. Style filiform, 5-cleft at the apex; the slender lobes stigmatic within.

3. PLUMBAGO. Calyx tubular, beset with glands. Corolla salver-form with a long tube. Stamens free from the corolla. Leafy-stemmed.

1. STÁtice, Tourn. Sea-Lavender, Marsh-Rosemary. (The ancient Greek name, referring to the use as an astringent.) - Large genus in the Old World, very sparingly represented in the New, in N. America only by the section Limonium, in which the styles are stigmatose down the inside; the 1-3-flowered spikelets about 3 -bracteate, i.e. 1-bracteate and 2-3-bracteolate; leaves all radical and 1-ribbed. Fl. late summer.

S. Limónium, L. Root thick and woody, reddish: leaves thickish and rather fleshy, oblong, spatulate or obovate-lanceolate, tapering into a long or rather long petiole, obtuse or retuse, and usually mucronate-tipped: scapes a foot or two high, loosely paniculate: the branches spreading or rather erect: spikelets either crowded or soon rather scattered: extcrior or true bract ovate, herbaceous with scarious margin, much shorter and smaller than the obtuse or retuse broadly scarious innermost bractlet: flowers lavender-color: calyx hirsute on the angles below; the lobes ovate-triangular and acute, and usually a tooth in each sinus. - In various forms widely distributed over the world, mainly in salt marshes of the coast. Ours are

Var. Califórnica. Leaves thinnish, retuse or obtuse and muticous: scape 2 feet or more high: branches of the ample panicle densely floriferous at the summit, the spikelets almost imbricated in short cymose spikes: innermost bract only twice the length of the outermost. - Bot. Calif. i. 466. S. Californica, Boiss. in DC. Prodr. xii. 468. - S. W. Texas (C. Wright) to California. Resembles dense-flowered European S. Limonium.

Var. Caroliniána, Gray (Man. 313). Inflorescence more paniculate than corym. bose; the 1-3-flowered spikelets soon separate or rather distant on the branching slender spikes: bracts more unequal: calyx-Iobes usually very acute or acuminate- $-S$. Caroliniana, Wait. Car. 118; Bigel. Med. Bot. ii. 51, t. 25; Boiss. 1. c. S. Limonium, Torr. Fl. i. 329 , \& Fl. N. Y. ii. 17. - Labrador to Texas. The Southern plant thinner-leaved, with mucro often obsolete, branches of the spike filiform, and scattered spikelets small, slender, and only 1-2-flowered: the northern forms with more fleshy veinless leaves, the mucro conspicuons, flowers and 2-3-flowered spikelets larger, in closer less spreading spikes; the snaller state nearly approaching the European var. Bahusiensis (S. Bahusiensis, Fries).

S. Brasiliénsis, Boiss. Leaves oblong, rounded or retuse at the apex, thinnish : scape (a foot or two high) and spreading branches of the panicle slender: spikelets 1-3-flowered, slender, more or less remote in the spreading spikes: bractlets very unequal : flowers white or whitish: calyx perfectly glabrous; the lobes ovate and acutish. - DC. I. c. - Coast of N. Carolina to Florida. (Mex.? Brazil to Patagonia.)

Var. angustáta. Leaves linear or nearly so, tipped with an awn-like mucro, fleshy : spikelets sparse. - Pine Key, Florida, in a salt marsh, Blodgett. Leaves 2 or 3 inches long besides the petiole, 2 or 3 lines wide.

2. ARMERIA, Willd. Thrift, Sea Pink. (The monkish Latin Flos Armeria, applied to a Pink, and transferred to Thrift). - Low and stemless herbs, of the Old World, with one variable species widely dispersed in the New and familiar in cultivation; the narrow leaves much crowded on the crown or 
short tufted stems, 1-5-nerved, persistent; scapes simple and naked, terminated by a compact glomerule of rose-colored or white short-pedicelled flowers, surrounded and subtended by scarious bractlets aud bracts; the lower of the latter empty and forming an involucre, the two lowest extended downward at base into appendages forming a reverse sheath to the apex of the scape. Calyx more dry and scarious than in Statice, at base oblique or decurrent on the pedicel. Dilated bases of the filaments adnate to the slightly united bases of the petals. Styles hairy below. Fl. early summer.

A. vulgáris, Willd. (Conmox Thrift.) Leaves narrowly linear, flat or flattish, more or less 1-nerved: scapes a span to a foot high: bricts very obtuse: calyx at base simply decurrent on the pedicel; the tube 10-nerved, hairy at least on the stronger nerves or angles; the lobes blunt or cuspidate. - Situtice Armeria, L. Armeria vulgaris, maritima \& alpina, Willd. Enum. 133. A. Labradorica, arctica \& sunguinolenta, Wallr. Armer.; Boiss. in DC. A. andina, Pœpp., \& var. Californica, Boiss. I. c. - Through Arctic America to Labrador on the Atlantic and to California on the Pacific coast; in various forms, the Californian tall form recurring in Chili and Patagonia. (Èu., N. Asia.)

3. PLUMBÁGO, Tourn. Leadwort. (Latin name, from the lead-colored flowers of some species.) - Herbs, or rather woody plants, some of them sarmentose, and cult. in conservatories for the handsome Phlox-like blossoms, leafy;

: leaves with the sessile base or that of petiole commonly auriculate-clasping; the flowers in a terminal spike. Calyx valvate and corolla convolute in the bud. Glands of the calyx stipitate. - Species mainly tropical.

P. scándens, L. Suffrutescent, decumbent or climbing, much branched: branches sulcate-striate: leaves ovate-lanceolate, not auricled at base: caly $x$ with 5 hooked teeth : corolla white. - Boiss. in DC. Prodr. xii. 692. P. Floridena, Nutt. in Am. Jour. Sci. v. 290. - S. Florida : perhaps introduced from W. Ind. (Trop. Amer.)

\section{ORdER LXXXI. PRIMULACE Æ.}

Herbs, with simple leaves, regular and symmetrical perfect flowers, remarkable for having the stamens of the sume number as the lobes of the corolla and opposite them (inserted on the tube or base), and a 1-celled ovary surmounted by an undivided style and stigma, and containing few or numerous (mostly amphitropous) ovules, sessile on a free central placenta. Calyx and corolla hypogynous, except in Samolus, in which they cohere below with the base of the ovary. But Glazx, with a partly colored calyx, is apetalous and the stamens perigynous; Coris (which belongs to the Old $W_{\text {orld }}$ ) has irregular calyx and corolla; and rudiments of a second series of stamens (staminodia) appear in Samolus and Steironema. Submersed leaves pinnately divided, and the ovules anatropous in Hottonia. Flowers 4-8-merous, commonly 5-merous. Calyx usually persistent, and the lobes imbricated in the bud. Anthers introrse. Fruit capsular. Seeds with copious fleshy albumen and a small straight embryo.

Tribe I. HOTTONIE 2 . Ovary wholly free : ovules fixed by the base, anatropous. Aquatic: immersed leaves pectinate.

1. HOTTONIA. Corolla short-salverform; limb 5-parted, the Iobes imbricated in the bud. Capsule globular, more or less 5-valved, many-seeded. Flowers verticillate and racemose.

Tribe II. PRIMUlE free : ovules fixed by the middle, amphitropous or half-anatropous. 
* Scapigerous or tufted: flowers chiefly 5-merous, umbellate or solitary : capsule dehiscent (at least at the apex) by valves: lobes of the corolla imbricated (or sometimes partly convolute) in the bud.

+ Stamens exserted, connivent in a cone, monadelphous.

2. DODECATHEON. Corolla 5-parted with very short tube, and dilated thickened throat; the long and narrow divisions (with the caly $x$-lobes in flower) reflexed. Stamens inserted on the throat of the corolla: filaments short and flat, monadelphous (but separable above in age): anthers lanceolate or linear. Style filiform, exserted: stigma small. Placenta columnar, many-seeded.

++ Stamens included, distinet, with short filaments and short and blunt anthers: corolla salverform or funnelform.

3. PRIMULA. Corolla with tube surpassing or at least equalling the calyx, and spreading mostly obcordate or emarginate lobes. Style filiform. Capsule many-seeded. Leaves all radical.

4. DOUGLASIA. Corolla with tube equalling or surpassing the caly $x$, somewhat inflated above; the throat more or less contracted and 5-foruicate beneath the sinuses; lobes entire. Style filiform. Ovary 5-ovuled. Capsule turbinate, 1-2-seeded. Leaves imbricated or crowded on tufted stems.

5. ANDROSACE. Corolla short; its tube shorter than the calyx ; the throat constricted. Style mostly short. Ovules and seeds numerous or few. Flowers sinall.

* Leafy-stemmed: corolla rotate or somewhat so, and the divisions convolute or sometimes involute in the bud, in Glaux none: leaves entire.

+ Capsule dehiscent vertically by valves or irregularly, mostly globose.

6. TRIENTALIS. Flowers 7-merous (rarely 5-6- or 8-merous. Corolla completely rotate, without a tube, deeply parted; the divisions convolute in the bud, ovate to lanceolate and pointed. Filaments long and filiform, united at their insertion into a very short ring: anthers linear, recurving when old. Style filiform. Leaves clustered at the summit of the simple stem.

7. STEIRONEMA. Flowers 5-merous. Corolla rotate, with no proper tube, deeply parted, and the sinuses rounded; the divisions ovate, cuspidate-pointed, erose-denticulate above, each separately involute or convolute around its stamen! Filaments distinct or nearly so on the ring at the base of the corolla: anthers linear and arcuate in age, nearly as in Trientalis: sterile filaments (staminodia) 5, interposed between the fertile ones, subulate. Capsule 10-20-seeded. Flowers nodding on the slender peduncles. Leaves opposite, destitute of dots. Calyx valvate in the bud.

8. LYSIMACHIA. Flowers 5-merous (or casually 6-7-merous). Corolla rotate (or short funnelform in some foreign species); the divisions entire, convolute in the bud. Filaments more commonly monadelphous at base: anthers oblong or oval. No staminodia or vestige of sterile stamens. Capsule few-several-seeded. Herbage commonly glandular-dotted. Stems leafy throughout. Calyx lightly imbricated or valvate in the bud.

9. GLAUX. Flowers 5-merous. Corolla none. Calyx with 5 petaloid lobes, which are imbricated in the bud and equal the campanulate tube. Stamens on the base of calyx, alternate with its lobes: filaments slender: anthers cordate-ovate. Style filiform: stigma capitate. Capsule 5-valfed at apex, few-seeded. Leafy throughout: leaves mainly opposite: nearly sessile flowers solitary in the axils.

+ + Globose capsule circumscissile, the top falling off as a lid : seeds nunerous.

10. ANAGALLIS. Corolla completely rotate, 5-parted; the rounded lobes convolute in the bud, exceeding the 5-parted calyx. Stamens on the base of the corolla: filaments bearded or pubescent : anthers broadly oblong.

11. CENTUNCULUS. Corolla with a globular tube and a 4-5-lobed limb, shorter than the calyx; lobes acute. Stamens on the tube of the corolla : filaments short and subulate, beardless : anthers ovate or cordate.

TriBe III. SAMOLEÆ. Ovary connate at base with the base of the calyx : ovules as in the preceding tribe.

12. SAMOLUS. Flowers 5-merous. Corolla perigynous, nearly campanulate; the rounded lobes imbricated in the bud. Fertile stamens 5 , on the tube of the corolla, with short filaments and cordate anthers. Staminodia or sterile filaments 5 in the sinuses of the corolla, or in one species wanting. Style short or slender: stigma obtuse or capitate. Capsule ovate or globular, 5-valved at the apex, many-seeded. Caulescent, alternateleaved, with racemose flowers. 
1. HotTónia, L. Featherfoil. (In memory of Prof. Peter Hotton of Leyden.) - Rooting, often floating, glabrous, branching, with air-bearing fistulous stems and peduncles. Sepals linear. Corolla white. Filaments short. Stigma capitate. Capsule membranaceous. Flowers dimorphous in the manner of Primula in the European species, the earlier cleistogamous in the following.

H. infláta, Ell. Leafy stems and especially the internodes of the emersed flowering ones or peduncles much inflated (the lattor often as thick as fingers) : proper leaves dissected into long and numerous filiform divisions; whorled bracts linear or spatulate, entire, a quarter inch long, mostly exceeding the pedicels: corolla only a line or two long, with short lobes as well as tube, not equalling the calyx; the throat open: style short. - Sk. i. 231 ; Nutt. Gen. i. 120. H. palustris, Pursh, \&c., not L. - Shallow water, Massachusetts to Louisiana : fl. summer.

2. DOdeḉtheon, L. Shooting Star, Auer. Conslip. (Fanciful name, from $\delta \omega \delta \delta \varepsilon \alpha x$ and $\theta \varepsilon o i$, twelve gods; the specific name of the original and, as we suppose, the only species commemorates Dr. Richard Mearl, and was given as generic by Catesby.) - Flowers few or numerous in an umbel, terminating a naked scape, in late spring or summer, handsome, resembling the solitary flower of Cyclamen: corolla from pink-purple to white. Calyx erect in fruit, enclosing the lower part of the ovoid or fusiform crustaceous capsule.

D. Meádia, L. Perennial herb, with fibrous roots: leaves crowded on a thickish crown, generally spatulate-oblong or oblanceolate and entire or nearly so, sometimes repand, obtuse, below tapéring into more or less of a margined petiole, in the typical or Atlantic form 3 to 9 inches long; while the scape is from a span to 2 feet ligill; and the flowers from few to many in the umbel: bracts of the involucre linear or subulate, small: pedicels slender and nodding with the flowers, erect in fruit. (Flower rarely 4-merous.) - Meadia, Catesb. Car. iii. t. 1; Ehret, Pl. Sel. t. 12. D. Meadia \& D. integrifolium, Michx. Fl. i. 123. D. integrifolium, Hook. Bot. Mag. t. 3622. Dianthus Carolinianus, Walt. Car. 140. - The Atlantic plant, in moist and shaded grounds, Michigan and Ponn, and through the upper country to Georgia, thence to Arkansas and Texas. Westward the species extends to California and Behring Straits, under very various forms and varieties, which may be generally classified as follows (after Bot. Calif. i. 467) ; the Pacific forms generally having shorter or blunter anthers than the Atlantic or typical D. Meadia, L.

Var. brevifólium. Leaves from obovate or ovate to broadly spatulate, half inch to an inch and a half long, abruptly contracted into a petiole; scape 3 to 12 inches high, fewmany-flowered: capsule seldom exceeding the minutely glandular calyx. $-D$. ellipticum, Nutt. ex Durand, Pl. Pratt. in Jour. Acad. Philad. 11. ser. ii, 95. D. integrifolium, Benth. Pl. Hartw. 322. - Common in W. California. Forms nearly answering to this, or larger-leaved, occur in Arkansas, Kentucky, and Pennsylvania.

Var. lancifólium. Leaves oblanceolate or elongated-spatulate, 3 to 10 inches long, the short margined petiole included, quite entire, mucronate: pedicels and caly $x$ commonly minutely glandular; lobes of the latter lanceolate or triangular-lanceolate, nearly equalling the short-ovoid capsule. - D. Jaffrayi of the English gardens. - Wet mountain meadows of California, especially in the Sierra Nevada.

Var. alpínum. Like diminutive forms of the preceding, with shorter as well as smaller leaves (half inch to an inch and a half long): scape 2 to 10 inches long, 1-4flowered : pedicels and calyx glabrous. - High Sierra Nevada to the Rocky Mountains.

Var. macrocárpum. A large and stout form, emulating the common Atlantic plant: leaves thickish (rarely laciniate-toothed), tapering gradually into a rather slort petiole : capsule oblong or even fusiform, 6 to 9 lines long, about double the length of the narrow calyx-lobes. - W. California to Alaska.

Var. frigidum. Leaves from obovate to oblong, very obtuse, mostly entire, an inch or two in length, with short or long and slender petiole: scape a span or two high, fewseveral-flowered: lobes of the calyx longer than the tube, from broadly lanceolate to almost ovate, shorter than the oblong capsule. - Hook. Bot. Mag. t. 5871; Wats. Bot. 
King, 214. D. frigidum, Cham. \& Schlecht. in Linn. i. 217; Seem. Bot. Herald, 38, t. 9.Behring Straits (both sides and islands) to the Rocky Mountains and high Sierras.

Var. latílobum. Leaves thin, ovate or oval, repand or undulate-toothed, longpetioled: scape a span to a foot high, 1-several-flowered: calyx-lobes ovate or triangularovate, not longer than the tube, about half the length of the oblong capsule. - Var. frigidum, Watson, I. c., in part. D. dentatum, Hook. Fl. ii. 110 ? - Cascade Mountains, British Columbia or Washington Terr. to Wahsatch Mountains, Utah.

3. PRimULA, L. Prinrose. (Late Latin, from primula veris, the first in spring, i. e. to blossom.) - Flowers in some species, but not in others, dimorphous, i.e. in different individuals either with elongated style and low-inserted stamens, or with short included style and stamens inserted high in the throat, so that the tips of the anthers show in the orifice of the corolla. Few N. American species of this large Old World genus, and none of 'the True Primrose or Cowslip set, with thin rugose-veiny leaves. All perennials, chiefly with fibrous roots from a short crown: ours glabrous or nearly so.

* Flowers small; the tube of the salverform corolla not over 2 or 3 lines long and little surpassing the calyx; lobes obcordate; throat with more or less of a callous ring or processes. Species passing into each other, probably reducible to two.

P. farinósa, L. More or less white mealy on the leaves, calyx, \&c., at least when young: leaves from cuncate-lanceolate to obovate-oblong or spatulate, denticulate, an inch or less long, tapering into a short margined petiole : scape 3 to 9 inches high : umbel few-severalflowered, close: pedicels seldom equalling the flower, sometimes very short: corolla from flesh-color to lilac, with yellowish eye; the lobes cuneate-obcordate, rather distant at base, 2 or 3 lines long. Varies with mealiness sparing or deciduous. - Fl. Dan. t. 125; Curt. Lond. ii. 21 ; Engl. Bot. t. 6. P. Scotica, Hook. in Curt. Lond. iv. t. 133; Engl. Bot. t. 2608, form with almost capitate umbel. - Labrador, Nova Scotia and Maine, Lake Superior, Rocky Mountains from Colorado northward, through Arctic America. (Antarctic Amer,, Eu., N. Asia.)

P. Mistassínica, Michx. Green, without mealiness or with mere traces of it, small and slender: leaves half inch long, with or without a short petiole, spatulate or obovate, repand or toothed: scape 2 to 5 inches high, 1-8-flowered: lobes of the flesh-colored corolla from broadly to narrowly obcordate, $1 \frac{1}{2}$ or 2 lines long. - Fl. i. 124; Pursh, Fl. i. 137; Lehm. Prim. 63, t. 7; Hook. Bot. Mag. t. 2973; Gray, Man. 314. P. stricta, Hornem. Fl. Dan. t. 1385. P. ITornenanniana, Lehm. 1. c. 55. P. pusilla, Hook, in Edinb. Phil. Jour. vi. 322, t. 11, Exot. Fl. t. 68, \& Bot. Mag. t. 30\$0; Sweet, Br. Fl. Gard. ser. 2, t. 5. - Wet banks and shores, N. New England and New York to Lake Superior and N. Rocky Mountains to the Arctic Sea. (Greenland, N. Eu.)

P. boreális, Duby. Between the preceding and the next: very slender : leaves nearly of the latter, but only 3 to 5 lines long: scape 1-5-flowered: lobes of the purple corolla oblong, barely 2 lines long, deeply notched.-DC. Prodr. viii. 43; Herder in Radde, iv. 114. - Alaska and Islands to Kotzebue's Sound, \&c. (Greenland, being apparently $P$. Eqalikcensis, Hornem. Fl. Dan. t. 1511.)

P. Sibírica, Jacq. Green, not at all mealy: leaves round-ovate, oval, or obovate, entire or nearly so, a quarter to a full inch long, slender-petioled: scape a span high, fewflowered: bracts of the involucre almost spur-like at base: lobes of the lilac-colored corolla broadly and usually deeply obcordate, 3 to 5 lines long; the throat broadened. Misc. i. 161; Lehm. Prim. t. 5; Hook. Fl. ii. 121, \& Bot. Mag. t. 3167, 3445 ; Trautv. Imag. Fl. Ross, t. 30, mainly. P. integrifolia, Gunner, ex Oed. Fl. Dan. t. 188, not L. $-P$. Finmarkica, Jacq. 1. c.; Fries, Sum. Scand. 198. - Arctic Amer. (Richardson) to the high N.W. coast and islands. (Greenland to Kamtschatka.)

* Flowers larger: tube of the corolla from 3 to 6 lines long, the throat open and unappendaged.

+ Leaves entire or merely denticulate, clustered on the short erect subterranean crown.

P. angustifólia, Torr. Small: scape 1-flowered, one or two inches high, equalling the lanceolate-spatulate obtnse entire short-petioled leaves: involucre of one or two minute bracts: lobes of the lilac-purple corolla obovate, emarginate ( 3 or 4 lines long); the tube 
hardly exceeding the narrow teeth of the oblong calyx. - Ann. Lyc. N. Y. i. 34, t. 3, \& ii. 235. - Alpine region of the Rocky Mountains in Colorado and New Mexico, James, \&c.

P. Párryi, Gray. Large, sometimes obscurely puberulent: leaves rather succulent, spatulate-oblong or oblanceolate, 4 to 12 inches long, often denticulate: scape a span to a foot high, 5-12-flowered: bracts of the involucre subulate, much shorter than most of the pedicels : caly $\mathbf{x}$ ovoid-campanulate, glandular, conmonly reddish; the lanceolate-subulate lobes as long as the tube, rather longer than the ovoid capsule: corolla crimson-purple with yellow eye; the round-obovate lobes (about 5 lines long) emarginate or obcordate; the tube not exceeding the calyx. - Imer. Jour. Sci. scr. 2, xxxiv. 257 ; Watson, Bot. King; 213; Hook. f. Bot. Mag. t. 6185. - Margins of alpine brooks, through the higher Rocky Mountains of Colorado (Parry, \&c.), to those of Nevada and Arizuna. The most showy species.

P nivális, Pall. Resembles the preceding, but runs into much smaller fortns: leaves from one to $u$ inches long, thickish, either entire or closely denticulate: umbel 2-10flowered: bracts of the involucre ovate-subulate: pedicels usually short: calyx-lobes oblong or broadly lanceolate, shorter than the oblong capsule: corolla lilac-purple; the lobes oblong or oval, entire ( 3 or 4 lines long); the tube funnelform and surpassing the calyx. - "It. appx. t. G, f. 2," ex Ledeb. Fl. Ross. Hii. 10; Cham. \& Schlecht. in Linn. i. 215; Hook. \& Arn. Bot. Beech. 12!. - Unalaschka to Behring Straits and St. Paul's Island; chiefly the small form, var. pumila, Ledeb. 1. c. (N. Asia.)

+ + Leares more or less cuneate. coarsely toothed around the apex or sometimes laciniate, of firm and thickish texture: bracts of the involucre subulate: pedicels and deeply cleft calyx obscurely glandular.

P. cuneifólia, Ledeb. Leaves all rosulate-clustered on the thick short crown, obovatecuneate, coarsely laciniate-toothed ( 3 to 12 lines long), mostly narrowed at base into a long and slender petiole: scape 2 to 4 inches high, 1-several-flowered : corolla purple; the lobes deeply 2-cleft ( 3 to 5 or even 6 lines long), as long as the funnelform tube. - Mem. Acad. Petersb. (1814) v. 522, \& Fl. Ross. 1. c. P. saxifragafolia, Lehm. Prim. 89, t. 9; Cham. \& Schlecht. 1. c. - Aleutian Islands to Behring Straits. (N. E. Asia.)

P. suffrutéscens, Gray. Leaves thickly crowded on ligneous-fleshy and tufted creeping stems or rootstocks (of a span or so in length), thick, cuneate-spatulate, 5 - 7 -toothed at summit, long-attenuate below into a margined petiole: scape 2 to 4 inches long, severalflowered: corolla red-purple; the lobes (three lines long) obovate and emarginate or slightly obcordate, about equalling the tube, - Proc. Am. Acad. vii. 3i0, \& Bot. Calif. i. 468. Crevices of rocks, alpine region of the Sierra Nevada, Califormia.

4. DOUGLÁsiA, LindI. (Named for Drrid Douglas, of Scotland, an indefatigable explorer of N. W. Amer. Botany.) - Depressed and tufted little herbs; the stems branching or proliferous, suffrutescent, or at least persistent; the leaves small, linear, imbricated or rosulate on the branches, or some of them scattered and alternate. Flowers solitary or somewhat umbellate, small. - Lindl. in Brande Jour. Sci. 1827 (not 1828 as generally cited), 383, \& Bot. Reg. t. 1886; Gray, Proc. Am. Acad. vii. 371 ; Benth. \& Hook. Gen. ii. 632. Aretia, Gaud., Koch, \&c., not L. Gregoria, Duby, Bot. Gall. 182×, 583, \& DC. Prodr. viii. 45, as to No. 1, namely the D. Vitaliana, of Europe, which has yellow flowers: in ours they are rose-purple.

* Flowers umbellate-clustered from the uppermost rosulate tuft of leaves: tube of the corolia longer than the calyx.

D. nivális, Lindl. Canescent with fine close pubescence, 3 or 4 inches high, repeatedly 3-4-chotomous: leaves nearly all in proliferous rosulate tufts, not ciliate, rather obtuse, 3 to 6 lines long: lobes of the corolla oval, shorter than the tube, 2 lines long. - Bot. Reg. t. 1886. Androsace linearis, Graham in Edinb. Phil. Jour. July, 1829. - Rocky Mountains, in Iat. $52^{\circ}$, \&c., at 12,000 feet, Douglas.

D. árctica, Hook. Glabrous : leaves ciliate with short and simple hairs. - Fl. ii. 120. D. nivalis, var. glabra, Duby, in DC. 1. c. 47. - Arctic seashore between the Mackenzie and the Coppermine, Richardson. 
* Flowers solitary terminating the leafy shoots : tube of the corolla barely equalling the calyx: leaves more or less imbricated in the manner of $D$. Vitaliana.

D. montána, Gray. Pulvinate-cespitose, an inch or two high, nearly glabrous : leaves subulate, minutely somewhat ciliate, 2 lines long, somewhat interruptedly imbricate-clustered: pedicel not longer than the flower, 1-2-bracteolate near the calyx: corolla-lobes cuneate-obovate, 2 lines long. - Proc. Am. Acad. vii. 371.-Rocky Mountains around Helena City, Montana, M. A. Brown. Owl Creek Mts., Wyoming, J. D. Putnam.

5. ANDRÓSACE, Tourn. (Ancient Greek name of some sea-plant or zoöphyte, curiously transferred to these little plants of the mountains.) - Snall annuals or perennials, of various habit, numerous in species in the Old World, few in the colder regions of the New : fl. summer.

* Perennials, proliferously brancheil at base and cespitose: leaves rosulate-imbricated at the base of the many-flowerecl scapes: capsule usually few-seeded: umbel several-flowered.

A. Chamæjásme, Host. Leaves in more or less open rosulate tufts, from lanceolate to oblong-spatulate or ovate, carinate-1-nerved ( 3 to 6 lines long), at least their margins with the scape ( 1 to 3 inches high) and somewhat capitate umbel villous with many-jointed hairs: corolla white with yellowish eye ( 3 or 4 lines in diameter). - Koch, Syn. ed. 2,671; Hook. Fl. ii. 119. A. carinata, Torr. in Ann. Lyc. N. Y. i. 30, t. 1; Sweet, Brit. Fl. Gard. ser. 2, t. 106 . A. villosa, var. latifolia, Ledeb. Fl. Alt. ; Herder, Bot. Radde, iii. 118. Indeed it may pass into A. villosa, L. - Alpine region of the Rocky Mountains from Colorado northward to the aretic coast, Behring Straits and islands. (N. E. Asia to Eu.)

* Annuals, acaulescent, with slender root, an open rosulate circle of leaves, and naked scapes, bearing an involucrate few-many-flowered umbel : capsule many-seeded : corolla white, small.

+ Calyx-tube obpyramidal in fruit, whitish witl conspicuous green teeth, which mostly surpass the capsule.

A. occidentális, Pursh. Minutely pubescent, not over 3 inches high: radical leaves and those of the conspicuous involucre oblong-ovate or spatulate, entire, sessile: scapes diffuse: bracts of the involucre ovate or oblong: lobes of the calyx triangular-lanceolate: oblong or deltoid, as long as the tube, still longer in fruit, foliaceous : lobes of the corolla oblong, shorter than the calyx. - Fl. i. 137; Nutt. Gen. i. 118. - Banks of the Missouri from the mountains down to St. Lowis, and extending down the Mississippi, and into Illinois : also Utah, Colorado, and New Mexico.

A. septentrionális, L. Almost glabrous: leaves lanceolate or oblong-lanceolate, narrowed at base (often into a sort of winged petiole), from irregularly denticulate to laciniatetoothed: scapes erect, usually numerous, 2 to 10 inches high: bracts of the small involucre subulate: umbel several-many-flowered: pedicels filiform, mostly long: lobes of the calyx mostly shorter than the tube, rather shorter than the obovate lobes of the corolla, from triangular to subulate-lanceolate, acute. - Lam. Ill. t. 98, f. 2; Fl. Dan. t. 7 ; Bot. Mag. t. 2021. A. elongata, Richards., not L. A. linearis, Graham in Edinb. Phil. Jour. 1829? Rocky Mountains, both high alpine (and small), and at much lower elevations, New Mexico and Nevada to the arctic sea coast: also N. W. coast. (Kamtschatka to Eu.)

Var. subulifera. Lobes of the calyx slender-subulate, as long as the tube, surpassing the corolla. - Rocky Mountains near Boulder City, Colorado, H. G. French. San Bernardino, California, Parry \& Lemmon.

+ + Calyx-tube hemispherical in fruit; the short teeth barely greenish and rather shorter than the globular capsule.

A. filifórmis, Retz. Glabrous: leaves, scapes (1 to 4 inches high), and pedicels nearly as in the preceding or more capillary: flowers less than a line and globose capsule only a line long: calyx-teeth broadly triangular, shorter than the very small corolla. - Obs. ii. 10 ; DC. Prodr. viii. 53 ; Reichenb. Ic. Germ. xvii. t. 69; Gray, in Proc. Acad. Philad. 1863, 70. - Rocky Mountains, from Colorado and Utall to Wyoming. (N. Asia.)

6. TRIENTÁLIS, L. Star-FLower, ChickWEed-Wintergrreen. (Latin, for the third of a foot high.) - Low and glabrous perennials; the simple stem, from filiform rootstock somewhat tuberous-thickened at apex, bearing scat- 
tered small scales or small leaves below, and a cluster or apparent whorl of larger leaves at summit; these veiny, entire or obscurely serrulate, nearly sessile. Peduncles filiform in some of the upper axils, one-flowered, in spring. Sepals slender, linear-lanceolate, united only at base. Corolla white or pinkish. Capsule with about 5 revolute valves. Seeds few, rather large, covered with a white cellular-reticulated pellicle, remainiug for some time fast on the placenta in a globular mass. - The following are all the known species.

T. Americána, Pursh. Stem very naked below, unequally 5-9-leaved at summit, a span high : leaves lanceolate, acuminate at both ends : divisions of the white corolla finely acuminate. - Bart. Fl. Am. Sept. ii. t. 47. T. Europcea, Michx. T. Europcen, var. Americana, Pers., \& rar. angustifolia, Torr. Fl. 1. 363. - Damp woods, from Labrador to the Saskatchewan and the mountains of Yirginia.

T. Europáa, L. Stem either naked or with a few scattered leaves below the cluster of obovate or lanceolate-oblong obtuse or abruptly somewhat pointed leaves: divisions of the white or pink corolla abruptly acuminate or mucronate. - Alaska, \&c. (Eu. to N. E. Asia.)

Var. árctica, Ledeb. Tery like small specimens of the Old World plant, 2 to 4 inches high, with obtuse or retuse leaves, the larger barely an inch long, and gradually decreasing ones down the upper part of the stem: corolla white. - T. arctica, Fischer in Hook. Fl. ii. 121. T. Europrea, Cham. \& Schlecht. - Mountains of Oregon to Mleutian Islands and Behring Straits.

Var. latifólia, Torr. Stem naked below in the manner of $T$. Americana ; the whorl or cluster of 4 to 7 oblong-obovate or oval mostly acute leaves ( $1 \frac{1}{2}$ to 4 inches.long), rarely proliferous : corolla from white to rose-red. - Pacif. R. Exp. iv. 118; Gray, Bot. Calif. i. 469. T. latifolia, Hook. l. c. - Woods, W. California to Vancouver's Island.

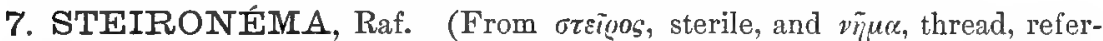
ring to the presence of staminodia alternating with the fertile stamens.) Leafy-stemmed perennials, glabrous except the ciliate petioles, destitute of glands or dots; the leaves all opposite, but mostly in seeming whorls (in the manner of Trientalis) on the flowering branches; the slender peduncles as in Trientalis; so also the corolla except that it is rellow. Filaments and bottom of the corolla granulose-glandular. Fl. summer. - Raf. in Ann. Gen. Phys. Bruxelles, vii. (1820) 192 ; Baudo in Ann. Sci. Nat. ser. 2, xx. 346; Gray in Proc. Am. Acad. xii. 62. Lysimachia § Seleucia, Bigel. Bost. ed. 2, 74. Lysimachia § Steironema, Gray, Man. ed. 1, 283.

* Leaves membranaceous, pinnately veined even when linear, at least the lower ones petioled: corolla sulphur-yellow.

S. ciliátum, Raf. Stem erect, 2 to 4 feet high, mostly simple: leaves ovate-lanceolate or oblong-ovate, gradually acuminate ( 5 to 2 inches long), and mostly with rounded or subcordate base, minutely ciliate; the long petioles hirsutely ciliate : corolla exceeding the calyx, about three quarters inch in diameter,-Gray, Proc. Am. Acad. 1. c. Lysimachia ciliata, L. ; Engl. Bot. t. 2922, \& ed. Syme, t. 1.j43; Reichenb. Ic. Germ. xvii. t. 1086. L. quadrifolia, var., L. Syst. \& Mant. - Low grounds and thickets, Nova Scotia to Georgia, and west to Br. Columbia and New Mexico. (Sparingly nat. in Eu.)

S. radícans, Gray. Stem slender and branching, soon reclined, the weak long branches often rooting in the mud: leaves smaller than in the foregoing, especially on the branches, not at all cordate, not ciliate, the margined petioles slightly so : caly x-lobes broader (ovatelanceolate) and equalling the corolla, which is only a third of an inch in diameter. - Lysimachia radicans, Hook. Comp. Bot. Mag. i. 177. - Swamps, W. Virginia to Arkansas and Louisiana.

S. lanceolátum, Gray. Stens erect, a foot or two high, simple or paniculately branched, somewhat angled; leaves lanceolate or linear, an inch or two long, tapering into a short and margined ciliate petiole or attenuated base; the radical and sometimes lowest cauline from oblong to orbicular, small : corolla about two thirds inch in diameter; its divisions 
conspicuously erose and cuspidate-acuminate, slightly exceeding the lanceolate calyxlobes. - Proc. Am. Acad. 1. c. S. heterophylla, Raf. 1. c. S. florida, Baudo, l. c., chiefly. Anagallis lutea, \&c., Pluk. Alm. t. 333, f. 1. Lysimachia lanceolata, Walt. Car. 92. L. hybrida \& heterophylla, Michx. Fl. i. 126. L. ciliata, var., Chapm. Fl. 280. L. decipiens, Bertoloni, Amon. - Low grounds and thickets, western parts of Canada to Florida, and Nebraska to Louisiana. Polymorphous; the extremes in the following varieties, the first of which verges to the two preceding species.

Var. hybridum. Cauline leaves mostly petioled, from oblong to broadly linear. Lysimachia lanceolata, var. hybrida, Gray, l. c. L. hybrida, Michx. 1. c. L. heterophylla, Ell., Nutt., \&c. - Commoner northward and westward.

Var. angustifólium. Stems more branched, a span to 2 feet high : cauline leaves linear, acute at both ends, more sessile, a line or two broad. $-L$. angustifolia, Lam. Ill. i. 440, not Michx. L. heterophylla, Michx. l. c. L. quadriflora, Ell., hardly of Bot. Mag. The more marked form mainly southward.

* Leaves of firmer texture and nearly veinless, mainly sessile : corolla deeper yellow.

S. longifólium, Gray, 1. c. Glabrous: stems simple or very sparingly branched, slender, quadrangular, a foot or more high: cauline leaves all narrowly linear and sessile, mostly obtuse ( 2 to 4 inches long, $1_{\frac{1}{2}}$ to $2 \frac{1}{2}$ lines wide), lucid, the midrib prominent beneath, the margins narrowly revolute: corolla three fourths inch wide; the divisions somewhat obovate, longer than the calyx. - S. longifolia? \& S. revoluta, Raf. l. c. Lysimachia quadrifora, Sims, Bot. Mag. t. 660, inappropriate name. L. longifolia, Pursh, Fl. 1. 135 (at least chiefly); Duby in DC. 1. c. (excl. habitat Carol.); Gray, Man. ed. 2, 273; Torr. Fl. N. Y. ii. $10 . \quad L$. revoluta, Nutt. Gen. l.c. L. angustifolia, Gray, Man. ed. 1, not Lam. - Banks of streams, Lake Winnipeg to Niagara, and Wisconsin to W. Virginia; apparently not farther south.

8. LYSIMÁCHIA, 'Tourn. Loosestrire. (In honor of King Lysimachus, or from $\lambda \dot{v} \sigma \iota s$, release from, $\mu \dot{\alpha} \chi \eta$, strife.) - A genus of wide distribution, but very few species in America, and these rather polymorphous. Ours are perennials; fl. summer.

\$1. Lysimachia proper. Corolla yellow, strictly rotate, and deeply parted, with hardly any tube, and no teeth between the lobes: stamens more or less monadelphous at base, often unequal in length: leaves opposite or verticillate, or some abnormally alternate.

* Flowers (middle-sized) in a teminal and naked thyrsoid panicle: corolla destitute of dots and colored streaks : ovules rather numerous.

L. Fráseri, Duby. Almost glabrous: stem 3 to 5 feet high, sulcate-angled: leaves in whorls of 3 or 4 , ovate to oblong-lanceolate, acutely acuminate ( 3 to 5 inches long), more or less reddish-dotted, mostly acute at base, very short-petioled; the upper smaller and commonly only opposite: panicle many-flowered, minutely glandular: bracts small and subulate: divisions of the calyx linear-lanceolate, valvate in the bud, margined by a narrow reddish line, moderately shorter than the obovate obtuse divisions of the corolla: glandular filaments somewhat unequal, united into a cup at base: anthers narrowly oblong, arcuate in age.-DC. Prodr. vii. 65. L. lanceolata, Pursh, Fl. ii. 729, ex herb., not Walt. - S. Carolina (Catesby in herb. Sherard, and Fraser in herb. IDC.); Columbus, Georgia, Boykin; Lookout Mountain, Tennessee, Dr. Allen. A striking: and rare species, of the $L$. vulgaris section, most related to $L$. Duhurica of N. E. Asia.

* * Flowers (small) in a virgate terminal raceme or in the upper axils : stem erect: leaves punctate with pellucid and at length dark-colored dots: corolla dark-clotted or streaked; the divisions longer than the narrow lanceolate sepals: filaments couspicuously monadelphous at base and glandular, unequal: anthers barely oblong: capsule 1-5-seeded, sometimes 10-15-ovuled. Tridynir, Raf. 1. c. L. \$ Cassandra, Bigel. 1. v.

L. quadrifólia, L. Stem a foot or two high, simple, leafy throughout, somewhat pubescent : leaves in whorls of 4 , sometimes of 3,5 , or 6 , rarely only in pairs or partly scattered, oblong-lanceolate or the lower ovate, more or less acuminate (1 to 3 inches long), equal, and with flowers on filiform pedicels from most of the upper axils, or sometimes the upper reduced to foliaceous bracts and the flowers loosely racemose: divisions of the corolla 
ovate-oblong (2 lines long) : ovules 10 to $18 .-\mathrm{I}_{\text {. }}$ Spec. i. 147 (not of Syst. Veg., where it is confounded with L. ciliata, L.) ; Lam. Ill. t. 101, f. 2. L. Luten, \&e., Pluk. Amalth. t. ts, f. 3. L. punctata, Walt. L. hirsuta, Michx. - Sandy or gravelly soil, New Brunswick and Canada to Wisconsin and Georgia.

L. asperulæfólia, Poir. A foot or more high, mostly glabrous: leaves in whorls of 3 or 4, or some opposite, ovate-lanceolate from a broad closely sessile base, 3-5-ribbed, glaucous beneath, an inch or so in length; the upper ruduced to bracts of a small leafy-bracted raceme: pedicels not longer than the flowers: divisions of the corolla lanceolate, 3 or 4 lines long. - Diet. Suppl. iii. 47 (wrongly said to come from Egypt); Duby in I)C. I. c. L. Herbemonti, Ell. Sk. i. $2: 22$; Chapm. l. c. - Pine woods, N. Carolina to Georgia.

L. strícta, Ait. A foot or two high, glabrous, soon branched, very leafy; the axils bearing fascicles of small leaves or sometimes torose bulblets : leaves opposite and occasionally alternate, lanceolate, acute at both ends, nearly veinless; the upper mostly abruptly reduced to linear or subulate uracts of a long and closely many-flowered virgate raceme: pedicels filiform, longer than the flowers: divisions of the corolla lanceolate or oblong, 3 lines long. - Hort. Kew. ed. 1, i. 199. L. vulgaris, Walt. Car. 92. L. racemosa, Lam.; Michx. Fl. i. 128. L. bulbifera, Curt. Bot. Mag. t. 104 . Viscum terrestre, I. Spec. ii. 1023, bulbiferous and flowerless. - Tet ground, Newfoundland to Saskatchewan and Upper Georgia.

Var. prodúcta, Gray, with a long and loose foliaceous-bracted raceme, gradually passing into ordinary leaves subtending filiform pedicels : flowers rather larger. - L. racemosa, Michx. 1. c. (herb.), in part. - New York and Michigan.

Var. angustifólia, Chapm. Leaves all narrowly lanceolate and linear, a line or two broad : raceme rather few flowered. $-L$. angustifolia, Michx. l.c. L. Loomisii, Torr. in Croom, Cat. Pl. Newbern, 46. - Low country, N. Carolina to Georgia.

* * Flowers (rather large), solitary in the axils of ordinary leaves : corolla not dark-dotted nor streaked : filaments slightly monadelphous at base.

L. voumclárit, L. (Moneywort.) Glabrous: stems prostrate and creeping: leaves orbicular, short-petioled: sepals cordate-ovate, valvate and reduplicate in the bud, nearly equalling the corolla. Sparingly naturalized, escaped from gardons into moist grounds in N. Atlantic States. (Eu.)

§2. Nacmbúrgra. Corolla with hardly any tube deeply 5- (or even 6-7-) parted into linear divisions (light yellow and somewhat purplish-dotted), and with a small tooth interposed in each sinus: filaments distinct, slender, equal : leaves opposite, those at the base of the stem reduced to scales. - Nanmburgia, Hocnch. Thyrsanthus, Schrank.

L. thyrsiflóra, L. Glabrous or becoming so: stem a foot or two high from a slender rootstock, naked below: leaves lanceolate, sessile: peduncles only from 2 or 3 pairs of lower axils, much shorter than the leaf, bearing several or numerous small flowers in a dense head or oblong spike: capsule glandular-dotted, few-seeded.-Engl. Bot. t. 176; Fl. Dan. t. 517. L. capitata, Pursh, Fl. i. 135. - Wet bogs, Pennsylvania to Canada and northward, thence west to Oregon and Alaska. (Eu. to Japan.)

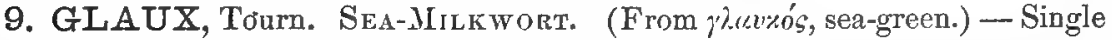
species. Flowers dimorphous as to reciprocal length of filaments and style.

G. marítima, L. A somewhat succulent little herb, glabrous and glaucous or pale, perennial by slender running rootstocks: stems a span or less high, erect or spreading, very leafy: leaves from oval to oblong-linear, a quarter to half inch long, entire, sessile: calyx-lobes oval, purplish or white. - Sialt marshes along both sea-coasts, from New England and from California northward; also in the interior west of the Mississippi, in subsaline soil : fl. summer. (Eu., Asia.)

10. ANAGĀLLIS, Tourn. Pimpernel. (Ancient Greek name, probably from '́d $\nu \alpha$, again, and $a^{\prime} \gamma \dot{\alpha} \lambda \lambda \omega$, to delight in.) - Low herbs, mainly annuals and of the Old World, one indigenous to Chili, one widely naturalized round the 
world: flowers on slender pedicels from the axils of the entire leaves, middlesized or small, in summer.

A. ARvínsis, L. Annual, glabrous : stems spreading: leaves ovate, sessile (half to a full inch long, mostly shorter than the pedicels), opposite, in threes, or sometimes the uppermost alternate: calyx-lobes narrow, nearly equalling the red, purple, or blue (rarely white) corolla; the divisions of which are minutely denticulate or glandular-ciliate. - Waste grounds, especially in sandy soil, naturalized both on the Atlantic and Pacific coast. (Eu., Asia, Afr.)

11. CENTÚNCULUS, Dill. CrafFweed. (The meaning obscure.) Very small glabrous annuals, with mainly alternate leaves, and solitary inconspicuous flowers in their axils, in summer.

C. mínimus, L. Stems ascending, 2 to 6 inches long, slender : leaves ovate, obovate, or in ours often spatulate-oblong, contracted or tapering at base (2 or 3 lines long), all but the lowest sessile: flowers nearly or quite sessile in the axils, 4-merous, sometimes 5merous: calyx-lobes lanceolate-subulate, fully equalling the capsule. -Fl. Dan. t.177; Reichenb. Ic. Germ. xvii. 1082 ; FI. Bras. Prim. t. 23. C. lanceoldus, Michx. Fl. i. 93. - Low grounds, Illinois to Florida and Texas (wanting in N. E. States), and west to Oregon. . (Eu., S. Amer.)

12. SÁMOLUS, Tourn. Brookweed, Water-Pimpernel. (Celtic name, according to Pliny, the meaning unexplained.) - Low and glabrous herbs; with alternate entire leaves, and small white flowers in simple or panicled racemes; in summer. One species cosmopolite; most of the others in the southern hemisphere. Ours either anuual or perennial, with fibrous roots.

S. Valerándi, L. Stems erect or ascending, branching from the base, leafy up to the raceme: leaves obovate, thinnish; the lower tapering into a petiole: pedicels ascending, bractless, 1-bracteolate near the middle: caly $\mathrm{x}$ adherent to the middle of the ovary and capsule; the lobes ovate, half the length of the short-campanulate corolla; this only a line long, the sinuses bearing inflexed sterile filaments. - Engl. Bot. t. 703.-Near Philadelphia, \&c. ; introduced in ballast. (Eu., Afr., Asia.)

Var. Americánus, Gray. More branched with age, becoming slender and diffuse, with elongating and loose paniculate racemes of mostly smaller flowers on more filiform and spreading pedicels: capsules sometimes one-half smaller. - Man, ed, 2, 274, \&c. S. foribundus, HBK.; Gray, Man. ed. 1, \&c. - Wet places, especially along brooks, N. Canada to Florida, Texas, Oregon, and California. (Mex., S. Amer.)

S. ebracteátus, HBK. Leafy stems short: leaves fleshy, obovate, spatulate, or oblongoblanceolate, the lower tapering into a winged petiole and decurrent: racemes longpeduncled or as if on a scape (a span or two high) : pedicels without bract or bractlet: calyx almost 5-parted, adherent only to the base of the ovary and capsule : corolla oblongcampanulate (about 2 lines long), with tube longer than the lobes: sterile filaments none. - Nov. Gen. \& Spec. ii. 223, t. 129; Torr. Ann. Lyc. N. Y. ii. 236; Chapm. Fl. 282. S. longipes, Hook. ex Shuttleworth in Bot. Zeit. 1845, 222. Samodia ebracteata, Baudo in Ann. Sci. Nat. ser. 2, xx. 350. - Saline and brackish soil, Florida to Texas and Upper Arkansas. (Mex., W. Ind.)

\section{ORDER LXXXII. MYRSINEACE无.}

Shrubs or trees, with the floral characters of Primulacea, i. e. stamens of the number of the petals or corolia-lobes and opposite them, undivided style and stigma, and a one-celled ovary with a free central placenta, bearing few or numerous peltate amphitropous ovules. These are generally immersed in the placenta, and only one usually matures into a seed. This is globose, with a thin 
coat, and a copious cartilaginous albumen. The fruit is pea-shaped, usually drydrupaceous, never capsular. Leaves simple, mostly alternate, without stipules, commonly marked with some immersed dots or short lines, containing at first pellucid but at length dark resinous matter; these also appearing in the flower, especially in the corolla. (There are similar dots or lines in Lysimachia, of the preceding order.) No milky juice. Flowers small and the corolla short, rotate or campanulate. -1 tropical order, sparingly reaching the southern borders of the United States.

Tribe I. MIRSINE.E. Calys perfectly free. No staminodia. Ovules usually immersed in the fleshy placenta, only one maturing into " seed which fills the cavity of the fruit.

1. MYRSINE. Flowers mostly polygamo-diœcious, in axillary or lateral fascicles. Corolla 4-5-parted, imbricated in the bud. Inthers short and usually blunt.

2. ARDISIA. Flowers in panicles, either terminal or from the upper axils. Corolla rotate, 5 - (rarely 4-6-) parted; the lobes convolute in the bud, or sometines one wholly exterior. Anthers lanceolate-sagittate, pointed ; the cells dehiscent from the apex downward.

Tribe II. THEOPHRASTE.E. Calyx perfectly free. Staminodia or sterile stamens in the throat at the sinuses of tha corolla. Orules numerous, not immersed in the placenta, maturing few or numerous seeds.

3. JACQUINIA. Calyx 5-cleft, with lobes rounded and much imbricated. Corolla shortsalverform or campanulate; lobes rounded, imbricated in the bud: it rounded petaloid appendage (representing a sterile stanien of the outer series) in each sinus. Stamens 5, inserted low down on the tube of the corolla: filaments subulate: anthers oblong or ovate, extrorsely dehiscent. Fruit ovoid or globose, leathery, pointed with the base of the style. Seeds few, imbedded in the mucilage of the placenta. Embryo with ovate cotyledons and slender radicle.

1. MYRSINE, L. (An anrient Greek name of Myrtle.) - Shrubs or trees; with glabrous coriaceons leaves, small whitish flowers, and small dry berrylike fruits.

M. Rapánea, Roem. \& Schult. Shrub or small tree: leaves thickish (2 inches or more long), oblong-ohovate, obtuse or retuse, entire, narrowed at base into a short petiole: flowers sessile or nearly so in numerous small sessile clusters; the cluster in age raised on a short scaly-imbricated axis or spur: flowers 5-merous: drupe 2 lines in diameter, obscurely pedicelled. - Syst. jv. 509 (following indication of R. Br. Prodr.); A.DC. Prodr. viii. 97 ; Miq. in Fl. Bras. ix. 307, t. 50-52. 11. Aloribunda, Griseb. Fl. W. Ind. 39:3. M. Floridana, A.DC. I.c.; Chapm. Fl. 277. Rapanea Guyanensis, Aubl. Guian. i. 121, t. 46; the large and tropical form. Samara foribunda, Willd. Sp. i. 665. - Florida Keys, Blodgett, Hassler. (W. Ind. to S. Brazil.)

2. ARDISIA, Swartz. (From $\ddot{\alpha} 0 \delta$ s $s$, the point of a thing, referring to the pointed anthers, which are often connivent around the acute style, forming a prominent cusp in the centre of the flower.) - $\mathbf{A}$ large and wide-spread tropical genus, with white or rose-colored corolla, and white, red, or blue berry-like fruits. Our only species differs from the most of the genus in having the corolla-lobes sinistrorsely overlapping, instear of the contrary direction, or occasionally with one lobe wholly outside and one inside, as often happens in this astivation.

A. Pickeríngia, Torr. \& Gray. Shrub 5 to 9 feet high, glabrous: leaves from oborate to lanceolate-oblong, glaucescent, entire ( 2 to 4 inches long), contracted at base into a petiole: panicle broad, many-flowered: lobes of the corolla oval, soon reflexed, commonly dark-lined, 2 lines long: style filiform: fruit as large as peas. -A.DC. l.c. 124; Chapm. Fl. 277. Cyrilla paniculata, Nutt. in Amer. Jour. S'i. v. 290. Pickeringia paniculata, Nutt. in Jour. Acad. Philad. vii. 1. - E. Florida. (Mex. \& W. Ind.) 
3. JACQUINIA, L. (In honor of Nicolas Joseph Jacquin.) - Tropical American trees or shrubs; with thick coriaceous entire leaves, and white or yellow flowers in terminal or axillary raccmes, corymbs or fascicles.

J. armilláris, L. Glabrous : leaves cuneate-spatulate or obovate-oblong, obtuse or retuse, sometimes mucronulate, nearly veinless, the margins somewhat revolute: flowers racemose or rather corymbose, white. - Jacq. Amer. 53, t. 39; Miq. in Fl. Bras. ix. t. 27. - E. Florida and Key West on the coast: perhaps introduced. (W. Ind., S. Amer.)

J. púngens, Gray. Shrub 8 to 12 feet high, glabrous, or the branchlets puberulent: leaves crowded, very rigid, some imperfectly verticillate, linear-lanceolate, veinless, minutely punctate beneath, with revolute margins, and tipped with a long pungent cusp: flowers few or solitary at the end of the branchlets, short-pedicelled : corolla orange : fruit globose, half to three fourths inch in diameter. - Pl. Thurb. in Mem. Am. Acad. v. 325. - Mountains near Ures (Thurber), and elsewhere in Sonora, N. W. Mexico (Palmer); probably reaching the borders of Arizona, but not received from within our limits. Related to $J$. ruscifolia.

\section{ORDER LXXXIII. SAPOTACE $\mathbb{E}$.}

Shrubs or trees, with perfect flowers, agreeing with the foregoing order in having fertile stamens of the same number as the (proper) lobes of the corolla and opposite them, and inserted on its tube, in the short corolla, undivided style and stigma; differing in the few-several-celled ovary with solitary anatropous or amphitropous ovules, and a comparatively large seed with a crustaceous or bony testa (containing a large straight embryo with or without albumen), with broad and flat or sometimes fleshy-thickened cotyledons; and the juice in most is milky. Flowers regular and small, in axillary clusters. Calyx free, of 4 to 7 distinct sepals, which are strongly imbricated. Corolla hypogynous, 4-7-cleft, and the lobes imbricated in the bud, often with as many or twice as many accessory internal lobes or appendages borne on the throat. Staminodia (answering to series of stamens) commonly present, alternate with the true corolla-lobes and sometimes in the form of sterile filaments, or squamiform, or petaloid. Filaments of fertile stamens subulate or filiform, generally short: anthers oftener extrorse; the cells opening longitudinally. Fruit baccate, commonly by abortion 1-celled and 1 -seeded; when several-seeded, the bony seeds are laterally flattened and disposed in a ring around a thickened axis. Leaves alternate, simple and entire, pinnately veined, mostly coriaceous: stipules small and caducous or none. Pubescence when present silky or tomentose, composed of malpighiaceous or stellate hairs. - Tropical or subtropical, except our species of Bumelia. Fleshy fruit of some edible. Juice of certain trees of the order yields gutta-percha. Seed albuminous in all ours excepting Bumelia.

* Calyx simple, i. c. of mostly 5 sepals in a single series, but strongly imbricated.

+ No internal appendages to the corolla and no staminodia.

1. CHRYSOPHYLLUM. Corolla bearing 5 stamens, otherwise naked within. Ovary 5-10-celled. Seeds 1 to 10 , attached by an elongated hilum.

++ Staminodia one in each sinus of the corolla, but no other internal appendages or divisions.

2. SIDEROXYLON. Staminodia more or less unlike and smaller than the lobes of the corolla. Ovary 2-5-celled. Berry drupe-like, usually 1-seeded.

+++ Both staminodia and appendages or accessory lobes of the corolla present and petaloid; the latter one to each side of the proper corolla-lobes (or these 3-parted), therefore geminate in the sinuses outside of the staminodia: flowers white: anthers 
extrorse, versntile: fruit cherry-like, with thin pulp, containing a mostly solitary erect seed (from a 5-ovuled ovary); the scar small and basilar or nearly so.

3. DIPHOLIS. Petaloid staminodia mostly erosely or fimbriately toothed. Seed with copious albumen; the embryo in its axis with flat cotyledons.

4. BUMELIA. Petaloid staminodia entire or denticulate. Seed destitute of albumen; the cotyledons very thick and fleshy, commonly consolidated.

* * Calyx double, of 6 or 8 sepals in two series; the outer almost valvate and enclosing the inner and thimner.

5. MIMUSOPS. Corolla of 6 or more exterior proper lobes, and twice as many similar appendages, a pair in each sinus outside of a thin seale-like or petaloid staminodium. Anthers sagittate, extrorse. Ovary 6-8-celled. Fruit baccate, maturing one or few sceds.

1. CHRYSOPHYLLUM, L. S'TAR-APPLE. (Formed of $\chi \varrho v 0{ }^{\prime}$ ', gold, and gúd. $o v$, leaf, from the golden sheen of the lower face of the leaves.) - Handsome trees of tropical regions; with the leaves in the commoner species green and glabrous above, and beneath resplendent with a golden or copper-colored silky pubescence, traversed by fine and close parallel transverse vins: flowers small in axillary fascicles: fruit fleshy and commonly edible.

C. Caxíto, L., the common Star-apple of the IV. Indies, if spontaneous in Florida, is doubtless an iatroduced tree. It has an 8-10-crenate stigma and an 8-10-celled large and globose edible fruit, as large as an apple; the foliage undistinguishable from the following.

C. olivifórme, Lam. Small tree: leaves oval; the lower face (also young shoots, pedicels, and (aly $\mathrm{x}$ ) silky-tomentose and shining with the copper-colored or golden pubescence : corolla white; its tube seldom exceeding the calyx; stigma 5-crenate: fruit ovoidoblong, 1-seeded, blackish when ripe, insipid. - Dict. i. 552 ; Descourt. Fl. Ant. ii. t. 71 ; Griseb. Fl. W. Ind. 398 . C. monopyrenum, Swartz; Hook. Bot. Mag. t. 3303; Miq. in Fl. Bras. vii. 94. - S. Florida and Key West, Blodgett, Chapman. (W. Ind.)

2. SIDEROXYLON, L. (Composed of oínoos, iron, and gúdov, wood, from the hardness of the latter.). - A wide-spread tropical genus, of which a single W. Indian species has reached Florida.

S. mastichodéndron, Jacq. (Mistic-tree.) Rather large tree, glabrous: leaves thinnish, oval, with undulate margins, rounded or bluntish at apex, acutish at base, shining above ( 2 to 4 inches long), on slender (inch long) petioles: flowers crowded in lateral or axillary fascicles much shorter than the petioles: calyx barely puberulent, half the length of the 5-parted rellow corolla : staminodia lanceolate, with a subulate tip, nearly entire: ovary glabrous, 5-celled : fruit plum-like, 1-seeded, "yellow." - Coll. ii. t. 17, f. 5 (Catesb. Car. ii. t. 75); Gærtn. f. Carp. Suppl. 125, t. 202 ; A.DC. Prodr. viii. 181. S. pallidum, Spreng.; A.DC. 1. c.; Chapm. Fl. 274. Bumelia pallida, Swartz. B. faetidissima, Nutt. Sylv. iii. 39, t. 94. - Key West (Blodgett) and Charlotte Harluor, Florida. (W. Ind.)

3. DIPHOLIS, A. DC. (Formed of $\delta i s$, double, and podis, scale, from the pair of appendages in the sinuses of the corolla.) - Three W. Indian species, with the aspect and seeds of Sideroxylon, one of them extending to Sjuthern Florida.

D. salicifólia, A. DC. Tree 60 feet high: leaves oblong-lanceolate, acuminate, glabrous, tapering into a petiole: flowers in axillary fascicles: short pedicels and caly $\mathrm{x}$ rusty silky-pubescent : staminodia oval, erose-toothed, as long as the linear or subulate exterior appendages: anthers oblong: fruit the size of a pea.-Prodr. l. c. 188 , \& Deless. Ic. v. 40 (corolla-lobes and appendages too much fringe-toothed); Griseb. Fl. W. Ind. 401 ; Miq. in Fl. Bras. vii. t. 18. Achras salicifolia, L. Bumelia salicifolia, Swartz. - Keys of S. Florida, Blodgett. (W. Ind.)

4. BUMELIA, Swartz. (Ancient Greek name of a kind of Ash, unmeaningly transferred to this genus.) - Shrulss or small trees (of Atlantic U. S. and 
tropical America) ; with very hard wood, small white flowers fascicled in the axils of the leaves, in summer, and a black cherry-like fruit. Axils often spiny: therefore in $\mathbf{S}$. States popularly called BuckthorN. Leaves in ours mostly deciduous, and staminodia nearly as large as the proper corolla-lobes.

* Pedicels, calyx, and lower face of the leaves clothed with silisy or somewhat tomentose pubescence; the upper face of the leaves finely venulose-reticulated: pedicels longer than the short petioles: fruit 4 or 5 lines long, oral.

B. ténax, Willd. Shrub or small tree, 12 to 30 feet high, with divergent branches: pubescence silky and close-pressed, yellowish or at first whitish, shining: leaves from oblanceolate or spatulate to cuncate-obovate, obtuse ( $1 \frac{1}{2}$ to $2 \frac{1}{2}$ inches long): fascicles very many-fiowered: staminodia ovate. -Willd. Spec. i. 1085; Nutt. Sylv. iii. 39, t. 92. B. chrysophylloides, Pursh, Fl. i. 155. B. reclinatn, Chapm. Fl. 275? Sideroxylon tenax, L. Mant. 48. S. sericeum, Walt. Car. 100. S. chrysophylloides, Michx. Fl. i. 123. Chrysophyllum Carolinense, Jacq. Obs. iii. t. 54. - Sandy soil, const of N. Carolina to Georgia.

B. lanuginósa, Pers. Shrul or tree, sometimes even 40 feet high, less spiny; the pubescence looser, more tomentose, and not shining: leaves from oblong-obovate to cuneate-ohovate: fascicles 6-18-flowered: staminodia obscurely denticulate: otherwise in the most eastern forms very like the foregoing; in the western with paler or sparser down to the leaves, or this partially deciduous in age so as to approach the next. - Syn. i. 287; Pursh, l. c. B. tomentosa, lanuginosa, \& oblongifolia (Nutt. Gen.), A.DC. l. c. B. oblongifolia \& B. ferruginea, Nutt. Sylv. 1. c. 33. B macrocarpa, Nutt. Sylv. iii. 37 , must be this or the preceding. B. arborea (not Texana, as in ed. 1), Buckley, Proc. Acad. Pbilad. 1861, 461, a glabrate and thin-leaved form. Sideroxylon tenax, Walt. 1. c. S. lanuginosum, Michx. Fl. i. 122. - Woods, Georgia and Florida to S. Illinois and W. Texas. - The Western forms (B. oblongifolia, Nutt., B. arborea, Buckley) are less pubescent, and in the drier districts pass into

Var. rígida. More spiny, the coriaceous leaves little over inch long, from obovate to cuneate-oblanceolate: seeds sometimes narrower at base and mottled. - B. spinosa, Watson, Proc. Am. Acad. xi. 112, not DC.? B. pauciflora, Engelrn. in distrib. Pringle. $-\mathrm{S}$. Texas (Wright, Palmer) to S. Arizona, Pringle, Lemmon. (Adj. Mex.) * * Pedicels and calyx glabrous: leaves nearly glabrous or soon becoming so, fnely venulose-
reticulated, thinnish.

B. lycioídes, Pers. Shrub or low tree: leaves from oblanceolate to oblong-obovate, lucid, 1 to 5 inches long, lower face sometimes whitish-pubescent when young: fascicles very many-flowered, about the length of the petioles : staminodia ovate, obscarely denticulate : fruit short-ovoid, 3 to 5 lines long. - Syn. i. 237 ; Gærtn. f. Carp. iii. 127, t. 202, f. 5 ; Loud. Arb. t. 1016; Nutt. Sylv. iii. t. 91. Sideroxylon lycioides, L. (excl. hab.); Michx. Fl. ii. 122. S. decandrum, L. Mant. 48 ? S. loeve, Walt. l. c. - Low grounds, E. Virginia and $\mathbf{S}$. Illinois to Florida and Texas.

B. reclináta, Vent. Low shrub, decumbent or spreading, spiny : leaves an inch or less long, cuneate-spatulate or obovate, obtuse or retuse: flowers commonIy fewer. - Choix, t. 22. B. lycroides, var. reclinata, ed. 1. Sideroxylon reclinatum, Michx. Fl. i. 122. - Coast of Georgia and E. Florida.

* * * Glabrous throughout: leaves thicker, small, with only obscure veins.

B. angustifólia, Nutt. Shrub or small tree : leaves from spatulate or linear-oblanceolate to broadly obovate-cumeate, very obtuse, fleshy-coriaceous : fascicles few-many-flowered: lanceolate appendages to the corolla and ovate-lanceolate staminodia acute, denticulate : fruit oblong-oval, 6 to 9 lines long, edible: seed oblong. - Sylv. ini. 38, t. 93; Radlk. in Sitz. Acad. Bavar. xix. 481. B. parvifolia, Chapm. Fl. 275, not A. DC. B. reclinata, Torr. Bot. Mex. Bound. 109, not Vent. B. cuneata, ed. 1, not Swartz. - Shores of Florida and S. E. Texas. (Adj. Mex.)

5. MIMUSOPS, L. (Formed of $\mu \iota \mu \dot{w}$, an ape, and oै $\psi(s$, appearance, but the likeness is not apparent.) - Trees of the tropics; with coriaceous leaves, having slender and inconspicuous transverse veins and minutely reticulated vein- 
lets, pedicels in axillary fascicles, corolla immersed or nearly so in the double calyx, and a plum-like edible fruit.

M. Síeberi, A.DC. Tree 30 feet high: leaves elliptical-oblong or inclining to obovate, retuse, glabrous and green both sides ( 2 to 4 inches long), slender-petioled; midrib stout: fascicles several-flowered : corolla whitish, 6-parted; its slender appendages 12 : staminodia short, triangular, nearly entire: fruit the size of a pigeon's egg, brownish or yellowish when ripe, pleasant. - Prodr. viii. 204; Chapm. Fl. 275. Mr dissecta, Griseb. 1. c., as to W. Ind. pl. Achras mammosa, Sieber, Coll., not L. A. Zapotilla, var. parciffura, Nint. Sylv. iii. 28, t. 90. - Key West, Florida, Blodgett, Palmer. Said to be conmon; probably indigenous. (W. Ind.)

Achras SApota, L., the Sappadilla or Naseberry of the West Indies and Central America (for a variety of which Nuttall mistook the above tree), appears not to have reached Florida.

\section{ORDER LXXXIV. EBENACEÆ.}

Trees or shrubs, with limpid juice, alternate entire leares, and diocious or polygamous (rarely completely hermaphrodite) regular flowers; the staminate with at least twice or thrice as many stamens as there are lobes to the short gamopetalous hypogynous corolla (usually convolute in the bud), and inserted on its tube or base, their anthers introrse; the pistillate flowers mostly with some imperfect stamens; the several-celled ovary with one or two anatropous ovules suspended from the summit of each cell ; the fruit a berry, maturing one or more large and bony-coated seeds. These have a cartilaginous albumen, and a rather small straight embryo, with foliaceous cotyledons and a mostly slender radicle. Calyx persistent, often foliaceous and accrescent. Filaments short. Hypogynous disk wanting. Styles as many or hilf as many as the cells of the ovary, 2 to 8 , distinct or partly united: stigmas sometimes 2-parted. Stipules none. Flowers axillary, articulated with the pedicels. Wood very hard; that of several species of Diospyros furnishes ebony. - Iliern, MIon. Eben. in Trans. Cambr. Phil. Soc. xii. part i. - A small order, of warm regions, nearly two thirds of the species belonging to the following genus.

1. DiOSPÝROS, L. Date-Pltu, Persmanon. (dó; togós, Jove's grain.) - Calyx 4-5-lobed, enlarging under the fruit. Corolla campanulate, shortsalverform or urceolate. Ovary $1-1-2$-celled; a pair of ovules in each cell. Berry maturing only 4 to 8 oblong bony flattened seeds. Flowers essentially diøcious; but the fertile flowers (commonly solitary in the axils) may have sterile stamens more or less polliniferous; the sterile flowers much smaller, usually racemose or clustered, and with more numerous stamens. - A large genus, widely dispersed, but the greater portion Asiatic: fruit edible.

D. Virginiána, L. (Commox Persimmox.) Tree 20 to 70 feet high, with a rough bark: leaves thickish-membranaceous, more or less pubeseent when young, commonly soon glabrate, oval (2 to 5 inches long): sterile flowers in threes: calyx 4-parted: corolla 4lobed, greenish-yellow, thickish, glabrous : stamens 16, in pairs, somewhat pubescent; the sterile ones of the fertile flowers 8 : styles 4, 2-lobed at apex: ovary 8-celled, nearly glabrous : fruit plum-like, an inch in diameter, excessively astringent when green, yellow when ripe, and when frosted sweet and luscious. - Gartn. f. Carp. Suppl. t. 207; Michx. f. Sylv. ii. t. 99 (Catesl. Car. ii. t. 76). D. concolor, Moneh. D. pulescens, Pursh, Fl. i. 265 (var. microcarpa, Raf. Med. Fl.). - Woods and fields, Rhode Island? and New York near the coast, also from Ohio to Iowa, and south to Florida and Louisiana: fl. early summer: fr. Oct. (Too near the N. Asiatic D. Lotus, L.) 
D. Texána, Scheele." (Mexican Persimmon.) Shrub or tree 10 to 29 feet high, widely much branched, with smooth bark and heary white wood: leaves cuneate-oblong or obovate, rounded at apex, often retuse (an inch or two long), almost sessile, tomentose, as also the branchlets: flowers silky-tomentose outside; sterile few in a fascicle: calyx 5-6parted: stamens 16 to 20 in two ranks, glabrous; none in the fertile flowers: ovary and young fruit pubescent, 8-celled: stigmas 4, each 2-lobed: fruit globose, black, luscious (ripe in August), with 3 to 8 triangular seeds. - Linnæa, xxii. 145: Torr. Mex. Bound. 109 ; Hiern, Mon. Eben. L. c. 239. - Woods along streams, Southern and Western Texas. (Adjacent parts of Mex.)

\section{ORDER LXXXV. STYRACACEAE.}

Shrubs or trees, with alternate simple leaves, and mostly perfect regular flowers, having at least twice as many stamens as the petals or lobes to the corolla, borne on its tube or base, or sometimes inserted with it; the filaments monadelphous or $4-5$-adelphous at base; style and stigma one; calyx more or less adnate to the 2-ó-celled ovary; the fruit or its cells one-seeded; seed anatropons, with a mostly straight embryo in copious fleshy albumen. Calyx either imbricated or open in bud.' Anthers introrse or innate. Disk none. Ovules solitary, in pairs, or few in each cell, most of them aborting in the fruit. Style filiform. - A small order, in warm regions; but nearly half the genera are represented in the United States. - Gray, Mem. Am. Acad. v. 334; Benth. \& Hook. Gen. ii. 667.

Tribe I. SYMPLOCINEE. Stamens in several series: anthers short, innate. Calyx-lobes imbricated in the bud. Pubescence simple. Embryo terete.

1. SYMPLOCOS. Calyx 5-lobed; the tube adnate to the 2-5-celled ovary. Corolla 5-parted, or nearly 5-petalous. Stamens very numerous, with filiform filaments, usually a cluster adnate to the base of each petal. Ovules mostly a pair suspended from the summit of each cell. Fruit a small dry drupe or nut-like, mostly 1-celled and 1-seeded.

Tribe II. STYRACE IE. Stamens definite in a single series: anthers linear or oblong, adıate, introrse. Pubescence more or less stellate or scurfy. Calyx-lobes or teeth mostly very short or obsolete, open in the bud. Cotyledons flat or foliaceous.

2. HALESIA. Calyx-tube obconical or obpyramidal, 4-ribbed, adnate to the 2-4-ceiled ovary; the short truncate limb 4-toothed. Corolla campanulate, 4-cleft, or sometimes nearly 4-petalous, convolute or imbricated in the bud. Stamens 8 to 16 : filaments flattened, more or less monadelphous in a ring at base and somewhat adnate to the base of the corolla. Ovules 4 in each cell, the upper pair ascending, the lower pendulous. Fruit dry-drupaceous or at maturity nut-like, 2-4-winged, within bony, 1-4-celled, pointed with the persistent base of the style. Seeds single in each cell, cylindrical, with a thin coat.

3. STYRAX. CalyX-tube campanulate; its base adnate only to the lower part of the primarily 3-celled ovary; the truncate limb of very small or obsolete teeth. Corolla 5petalous or 5-parted, or rarely 4-8-parted; the lobes or petals imbricate, or nearly convolute, or valvate in the bud. Stamens double the number of the lobes of the corolla or rarely fewer: filaments flat, in ours borne on the base of the corolla, either monadelphous or nearly distinct: anthers linear. Ovules several in each cell, ascending. Fruit usually globular, becoming one-celled and dry, coriaceous or crustaceous, sometimes 3-valved from the top. Seed mostly solitary, filling the cell, erect, with a bony smooth coat.

1. SÝMPLOCOS, Jacq. SWét-LEAF. ( $y^{\prime} \mu \pi \lambda o \% 0 s$, connected, referring to the stamens, which in some are bighly monadelphous.) - Shrubs or small trees (American and Asiatic); with pinnately veined leaves, which commonly turn yellowish in drying and yield a yellow dye; the flowers axillary and yellow. - Jacq. Stirp. Amer. 166; L. Gen. 677. Hopex, Garden; L. Mant. 15.

S. tinctória, L'Her. Shrub 4 to 18 feet high: leaves rather coriaceous, oblong, acute or acuminate, obscurcly more or less serrate ( 4 or 5 inches long), soon glabrate and shining 
above, pale and pubescent beneath, tardily deciluous, or far south more persistent : flowers in sessile fascicles from the axils of the preceding year, 6 to 16 in a cluster, scaly-bracteate, the scales deciduous: calyx-tube turbinate: petals oblong, obtuse, barely connected at base and bearing the stamen-clusters: ovary :-celled: fruit nut-like, oblong, half inch or less long. - Linn. Trans. i. 176; Willd. Spec. iii. 1436. Hopea tinctoria, L. Mant. 105; Michx. f. Sylv. iii. 9. - In rich soil, Delaware (Commons) to Florida and Louisiana ; H. spring. Flowers fragrant. Leaves sweet to the taste and in antumn greedily deroured by cattle and horses (hence called Horse-sighr); also used for yellow dye.

2. HAlfisia, Ellis. Syotwdop or Silver-bell Tree. (Commemorates Stephen Hales of England, author of Yegetable Statics, \&c.) - Small trees of the Atlantic Lnited States; with partly stellate soft pubescence: leaves rather large, ovate-oblong, acuminate, more or less denticulate, slender-petioled, deciduous; flowers showr, drooping on slender pedicels, in fascicles (or rarely very short racemes) from the axils of fallen leaves of the preceding year, produced in spring at leating-time; corolla white. Thin testa of the seerl adherent to the pericarp; the delicate inner coat adherent to the albumen. - (Pterustyrax, Sieb. Z Zucc, of Japan, referred to this genus by Beutham and Ilooker, although nearly related, is better kept distinct, on account of the terminal paniculate inflorescence, quinary flowers, and thinner small fruit.) - Ellis in Phil. Trans. li. t. 22: ; L. Gen. no. 596.

H. díptera, L. Tall shrul or small tree: leaves ovate or inclined to obovate, when fullgrown thinnish and renulose-reticulated (4 to 6 inches long): corolla three-fourths inch long: stamens 8 to 16 , mostly 8 , sometimes free: ovary rarely 4-celled: fruit oblong (2 inches long), 2-winged; its strongly angled body tapering into a long stipe within the wing. - ispec. ed. 2, 636; Cav. Diss. vi. t. 187; Lodd. Cab. t. 1172. H. reticulata, Buckley in Proc. Acad. Philad. 1860. - Rich woods, Georgia and Florjda to Louisiana. Flowers larger and more numerous and showy than in the next.

H. tetráptera, L. Small tree (or in the mountains even a large tree): leaves oval or ovate-oblong: corolla half inch long: stamens 10 to 16 : ovary 4-celled: fruit ellipsoidal, equally 4-wing-angled, over an inch long. - (Catesb. Car. i. t. 64.) Lam. Ill. t. 204 ; Cav. 1. c. t. 186 ; Bot. Mag. t. 910 ; Lodd. Cab. t. 1173 . - Woods and along streams, W. Virginia and Illinois to Florida, mostly along and near the mountains.

H. parvifióra, Michx. Foliage of H. tetraptera, but smaller : corolla 4 or 5 lines long: fruit an inch or less in length, narrowly 2 -winged, the oblong-clavate body with stipe included in the acute base of the wing. - Fl. ii. 40, not Lindl. Bot. Reg., which is Styrax Americana. - Georgia and Florida.

3. STYRAX, Tourn. Storax. (Greek Itvere, ancient nume of the tree

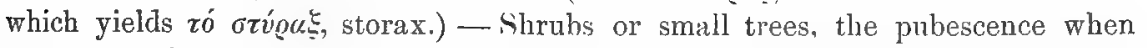
present scurfy or stellular. Leaves deciduous, at least in our species; the flowers (in spring) racemose, subcorymbose or somewhat rymulose, or sometimes solitary, from the axils or summit of the branchlets. Corolla white, in ours campanulate or more open, of petals distinct to the base or nearly so, soft and tomentulose or puberulent, at least outsirle. Ovary 3 -celler at base, with a thick placenta, which divides and becomes obsolete at the summit. A widely dispersed genus, chiefly of warm regions. - Gray, Mem. Am. Acal. 1. c., Proc. vi. 326, \& Minl. ed. 5, 309; Benth. \& Fook. 1. c.

$$
\text { * Petalin nearly valvate in the bud, a third to barely half inch long. }
$$

S. Americána, Lam. Shrub 4 to 8 feet high, glabrous or nearly so throughout : leaves small ( 1 to 3 inches long), bright green, commonly entire, oblong or oval, mostly acute at both ends, often acuminate: flowers single or in very few-flowered racemes, nodding: peduncles or branchlets minutely glandular, not hoary 5 -to thed calyx and sometimes 
the pedicel glandular-dotted : petals lanceolate-oblong, nearly glabrous. - Dict. i. 82 ; Gray, Man. 1. c. S. leeve, Walt. Car. 140 . S. glabrum, Cav. Diss. vi. 500, t. 188; Michx. Fl, ii. 41 . S. lcevigatum, Ait. Kew. ii. 75; Bot. Mag. t. 921 . Halesia parviflora, Lindl. Bot. Reg. t. 952 ? - Along streams, Virginia to Florida, Louisiana, and Arkansas.

* * Petals lightly but decidedly imbricaten or convolute in the bud, minutely soft-puberulent outside, barely half inch long: calyx and infloreseence with the lower face of the leaves more or less camescent.

S. pulverulénta, Michx. Low shrub : leaves as in the preceding, but more or less pubescent or scurfy and hoary beneath, rarely 2 inches long on flowering stems : flowers geminate in the axils on short branchlets and in short terminal racemes, fragrant : pedicels not longer than the calyx: petals oblong-lanceolate. - Fl. ii. 41; Ell. Sk. i. 505. - Pinebarren swamps, S. Virginia to Florida and Texas.

S. grandifólia, Ait. Shrub from 4 to 12 feet high: leaves membranaceous, oval or obovate, usually denticulate, green and glabrous above, canescently pubescent or tomentose beneath, the larger 3 to 6 inches long: flowers mainly in loose naked racemes of 3 to 6 inches in length, or some in leafy-bracted clusters, larger than in the preceding: petals more overlapping in bud, oblong, fully half inch in length. - Lodd. Cab. t. 1016 (poor); Michx. Fl. ii.41, as S. grandiflorum. S. officinale, Walt., not L. - Rich woods, S. Virginia to Florida.

* * Petals conspicuously orerlapping in the bud, obovate or broadly oblong, two thirds to three fourths inch long: short peduncle terminating the branches or short lateral branchlets, corymbosely 1-4-flowered: bracts minute: style long and filiform.

S. platanifólia, Engelm. Shrub 12 feet high, green and glabrous or nearly so : leaves roundish, with subcordate or truncate broad base and slender petiole, undulate or angulatetoothed, or even sinuate-lobed, sometimes abruptly acuminate, reticulate-veiny ( 2 to 4 inches in diameter): even the pedicels and calyx glabrous or nearly so. - Torr. in Smiths. Contrib. vi. 4, note. - Wooded bottoms, Texas, Lindheimsr, Wright, \&c.

S. Califórnica, Torr. Shrub 5 to 8 feet high, with scurfy stellular pubescence, at first hoary, sometimes soon green and glabrate: leaves oval, entire or sparingly undulate (an inch or two long), short-petioled: pedicels with the calyx and corolla minutely canescent: style becoming an inch long. - Smiths. Contrib. 1. c. \& Pacif. R. Rep. iv. 118; Gray, Bot. Calif. i. 470. - W. side of the Sierra Nevada, California, Fremont, \&c. Bony seed as large as a small cherry.

\section{ORDER LXXXVI. OLEACE无.}

Trees or shrubs, rarely almost herbaceous, with colorless bland juice, opposite (rarely alternate) leaves destitute of stipules, perfect or dicecious and regular flowers (gamopetalous, 2-4-petalous, apetalous, or even achlamydeous); with stamens 2 to 4 , mostly 2 and fewer than the parts of the corolla, distinct; the free ovary 2-celled; style one or none; anatropous ovules mostly one or two pairs in each cell ; seeds with a rather large straight embryo (its cotyledons flat or planoconvex) in firm fleshy albumen, or sometimes exalbuminous.

Forsythia viridissima and F. suspensa, of Japan and China, cultivated ornamental shrubs, noted for their very early yellow blossoms, are peculiar in having numerous ovules.

SYringa, the Lilac, of the Old World, becomes spontaneous in a few places.

Ligdstrum vULGare, the Privet, used for ornamental hedges, is also occasionally found wild in the vicinity of towns in the Eastern Atlantic States, and may claim to be a really naturalized plant.

Olea Europ zeA, the Olive, has long been planted in the southern part of California.

Tribe I. FRAXINE E. Fruit entire, dry, indehiscent, winged, a samara. Seed suspended.

1. FRAXINUS. Flowers diœeious or polygamous, sometimes perfect. Calyx very small, 4 -cleft or irregularly toothed, or entire, or wanting. Petals none, or 4 and either separate 
or united in pairs at the very base. Stamens 2, sometimes 3 or 4 . Fruit by abortion mostly 1-celled and 1-seeded, rarely 2-seeded; the wing mainly terminal.

Tribe II. OLEINE.E. Fruit fleshy and indehiscent, a drupe or rarely a berry, not lobed. Seed suspended or pendulous. Leares simple.

* Flowers apetalous, diocious or polygamous.

2. FORESTIERA. Calyx minute, 4-parted or toothed, sometimes wanting or deciduous. Corolla none, or rarely one or two sinall deciduous petals. Stamens 2 to 4 : anthers ovate or oblong. Ovary ovate, with 2 ovules in each cell : style slender: stigma somewhat 2-lobed. Drupe 1-seeded.

* * Flowers complete, sometimes polygamous : parts of the calyx and corolla 4.

3. CHIONANTHUS. Calyx 4-cleft, persistent. Corolla of 4 long and linear petals, which are plane in the bud with slightly induplicate margins, and united only and often slightly at the base. Stamens 2, rarely 3, short. Style short. Ovules a pair in each cell. Drupe mostly 1-seeded. Embryo in copious flesly albumen : cotyledons flat.

4. HESPEREL ZEA. ('alyx of 4 somewhat colored sepals, imbricated in the bud, deciduous. Corolla of 4 spatulate unguiculate petals, imbricated at summit in the bud, acerescent, deciduous. Stamens 4, hypogynous: filaments subulate : anthers oblong, mucronulate. Style stout: stigma thick, 2-lobed. Uvules a pair in each cell.

5. OSMANTHUS. Calyx 4-cleft, short, persistent. Corolla short, 4-cleft; the lobes broad and obtuse, imbricated in the bud. Stamens '2 (rarely 1 ). on the short tube of the corolla, included: anthers ovate. Style short: stigma small, entire. Ovules a pair in each cell. Drupe globose or óvoid, mostly 1-seeded.

Tribe III. JASMINE.E. Fruit didymons or septicidally 2-partible. Seeds ascending or erect. Parts of calyx and corolla $\bar{\jmath}$ or more.

6. MENODORA. Calyx 5-15-cleft, persistent; the lobes mostly linear. Corolla from rotate to salverform; limb 5-6-parted, the lobes imbricated in the bud. Stamens 2, rarely 3: anthers oblong or nearly linear. Ovary emarginate: style slender: stigma usually capitate or 2 -lobed. Orules 4 (or in a $S$. Amer. species only 2 ) in each cell. Fruit a didymous or 2-parted at length membranaceous capsule, circumscissile at or near the middle. Seeds usually a pair in each cell, large, with a thickened and spongy outer coat : no albumen. Leaves often alternate!

1. FRÁXINUS, Tourn. Ash. (Classical Latin name.) - Trees; with rather light tough wood, cliefly opposite and odd-pinnate leaves, and small flowers, in panicles, developed in spring. Petals when present narrow, induplicate-ralvate in the bud, white: anthers yellow, large in proportion. Stigma 2-lobed. Ovules a pair from the summit of each cell, only one usually fertile; the oblong seed filling the cell of the samara or key-fruit. Bark of shoots ash-color. Winter-buds of few and usually dark-colored thickish scales. (Shape of the wing of samara variable, not rarely some are 3 -winged and 3-celled.)

Orves AMericsys, Pursh, \&c., is probably only Fraxinus Ormus, L., and wrongly thought to be American. A host of nominal species of Ash which were named by Bosc, characterized mainly by the foliage, and upon which his herbarium throws little or no light, must pass unnoticed.

$\S 1$. Orxcs, Pers. Flowers 2-4-petalous, polygamous (many perfect), in loose panicles, which mostly terminate leaf-bearing branches or spring from the axils of new leaves.

* Petals 2: style manifest: Californian.

F. dipétala, Hook. \& Arn. Small tree, glabrous: lcaflets 5 to 9 , oval or oblong, obtuse, serrate, mostly petiolulate, an inch or two long: panicles usually clustered on short lateral spurs, naked or subtended by one or two leaves: calyx truncate and somewhat toothed: petals oblong-obovate, equalling the linear anthers: fruit from linear-ollong to spatulate-oblong (usually an inch long), the flat body several-nerved on each side and with sharp edges. - Bot. Beech. 362, t. 87; Gray, Bot. Calif. i. 472. Omus dipetala, Nutt. Sylv. iii. 66, t. 101 . Chionanthus fraxinifolius, Kellogg, Proc. Calif. Acad. v. 18. - Western part of California. 
Var. brachýptera, a form with short obovate fruit, only half to three-fourths inch long, and the terminal part of the wing only half the length of the body. - Borax Lake, California, Torrey.

Var. trifolioláta, Torr. Leaves (only the uppermost known) 1-3-foliolate : leaflets small, an inch or less long, coriaceous, obsoletely serrate : fruit rather small. - Bot. Mex. Bound. 167. - Mountains south of the boundary between Upper and Lower California, Parry.

* Petals (always?) 4: style none or hardly any: North Mexican and Texan species, with small and minutely punctate leaflets, and small panicles chiefly terminating short 1-2-leaved lateral branchlets: flowers of the second species unkllown.

F. cuspidáta, Torr. Shrub 5 to 8 feet high, with slender branches, glabrous: leaflets 5 to 7 , lanceolate or orate-lanceolate and gradually acuminate into a cuspidate tip, or some of them ovate or oval and obtuse or even emarginate, acutely and sparsely few. toothed or entire, petiolulate (half to a full inch or more in length): petiole slightly margined between the leaflets: calyx deeply 4-cleft or 4-toothed: corolla 4-parted, half inch long; the lobes long-linear, several times exceeding the oblong anthers: stigma sessile: fruit spatulate-oblong or obovate-oblong (half inch long), its wing rather shorter than the flattened nerveless body. - Bot. Mex. Bound. 166. - South-western Texas, on the Rio Grande from the great cañon upwards, Parry, Wright, \&c., in fruit. New Mexico, Palmer, in flower.

F. Gréggii, Gray. Shrub 5 to 9 feet high, glabrous, with slender mostly terete branches : leaflets 3 to 7 , from narrowly spatulate to oblong-obovate, obtuse, obtusely few-toothed or entire, plane, firm-coriaceous, veinless or nearly so (a half to nearly an inch long), sessile: petiole wing-margined between the leaflets : fruit 6 to 8 lines long, oblong-linear, the retuse apex tipped with a very short distinct style. - Proc. Am. Acad. xii. 64. F. Schiedeana; var. parvifolia, Torr. l. c. - On limestone, S. W. Texas, Schott, \&c. Adjacent parts of Mexico, Gregg, Bigelow, Parry.

\$2. Fraxinf́ster, DC. Flowers apetalous, in mostly denser panicles (especially the staminate), which are developed from separate buds from upper axils of the preceding year, or on the leafless base of shoots of the season.

$$
\text { * Flowers polygamous : leaves mostly simple! }
$$

F. anómala, Torr. Shrub or low tree, more or less soft-pubescent when young: leaves thin-coriaceous, ovate, rotund, or cordate, rarely obcordate, entire or partly serrate, manyveined (an inch or two long), sometimes 2-3-foliolate with similar sessile leaflets : panicles short: calyx campanulate, erose-toothed, longer than the ovary: anthers linear-oblong: fruit oblong ( 7 to 10 lines long), winged from the base, the flattened striate-nerved body as long as the terminal part of the wing. - Watson, Bot. King, 283. - S. Utal, Newberry, Palmer, Bishop, \&c.

* * Flowers dioecious; the pistillate rarely with abortive stamens; the staminate reduced to 2 or 4 stamens with a minute or cibsolete calyx or none: leaves 3-11-(mostly 5-9-) foliolate.

- Leaflets petiolulate: anthers linear-oblong, mucronate or apiculate: small calyx to fertile flowers present and persistent, sometimes deciduous in $F$. quadrangulcta.

+ Fruit winged only from the summit or upper part of the terete or nearly terete body, $=$ Which is marginless; the wing wholly terminal.

F. pistaciæfólia, Torr. Small tree, either velvety-pubescent or nearly glabrous : leaflets 5 to 9 , short-petiolulate, sometimes subsessile, small (one or two inches long), from lanceolate to oval, entire or somewhat serrate: fruits small and crowded, spatulate (either broadly or narrowly), the terete body ( 3 to 5 lines long) somewhat clavate, about equalling and sometimes exceeding the wing. - Pacif. R. Rep. iv. 128, \& Bot. Mex. Bound. 166. - S. W. Texas to Arizona. (Adjacent Mex.)

Var. coriácea. A rigid form of arid districts : leaflets 3 to 5 , firm-coriaceous, usualiy more serrate. $-F^{\top}$. velutina, Torr. in Emory, Rep. 1848, 149 , a velvety-tomentose form. F. coriacea, Watson in Am. Nat. vii. 302, excl. pl. coll. Bigelow. - Arizona, Emory, Wheeler.

F. Americána, L. (White Asi.) Large timber-tree: branchlets and petioles glabrous: leaflets 7 to 9 , from ovate to oblong-lanceolate, mostly acuminate, entire or sparsely serrate or denticilate ( 3 to 5 inches long), pale or whitish and often pubescent beneath: fruit usually about an inch and a half long; the body oblong and cylindraccous, completely 
terete, barely acute at base, merely 1-nerved at what would be the margins, half or thrice shorter than the lanceolate or oblanceolate wing. - Spec. ed. 2, 1510, excl. syn. Catesb.; Muhl. in N. Schrift. Berl. iii. (1801); Michx. f. syiv. t. 118 (excl, fruit, which is apparently that of $F$. viridis); Torr. Fl. N. Y. ii. 12.5, t. 89 (on plate $F$. acuminata); Emerson, Rep. Trees, ed. 2, t. 12. F. acuminata, Lam. Dict. ii. 5t:2. F. Nuve-. Lnglia \& F. C'irolinianu? Wangenheim. F. alba, Marsh. Arbust. 51. $F$. juglandifulit, Lam. 1.c.? \& Bose in Mem. Inst. 1808, 209. F. epiptera, Michx. Fl. ii. 256. F. Conadensis, Grortn. Fruct. i. 122, t. 49. F. discolor, Muhl. Cat.111. - Rich or moist woods, Canada to Florida and Louisiana. Very valuable timber-tree : fruit rariable in size and shape of wiug, but that of the terete cylindraceous body quite constant. Monocious flowers have been met with.

Var. microcárpa. Fruit (seemingly full grown but seulless) remarkably small, half to two thirds inch long. - F albicans, Buckley in Proc. Acad. Philad. 18t;, partly. $F$. Curtissii, Vaser, (at. Trees U. S. 20. - Eufaula, Alabama (Curtiss), \&c.

Var. Texénsis. Low tree, glabrous throughout: leaflets mostly 5, slender-petiolulate, from ovate to broadly oval, $1 \frac{1}{2}$ to 2 inches long, either rounded at apex or slightly acuminate: fruit small, two-thirds to barely an inch long, the wing hardly double the length of the body. $-F$. albicans, Buckley, l. c., in part. F. pistaciafolict, E. Hall, List. Pl. Tex. no. 527. F. coriacea, Watson, l. c., as to pl. Bigelow, "Devil's Run Cañon," Texas (not "Arizona"), a form with remarkally long-petiolulate leaves of firmer texture, without flowers or fruit. - Texas, on rocky hills, from Austin to Devil's River, near the Rio Grande. Perhaps a distinct species.

$==$ Bodry of the fruit more slender, tapering gradually from summit to base, more or less margined upward by the decurrent wing.

F. pubéscens, Lam. (RED Asir.) Tree of middle or large size: inner face of the outer bark of the branches red or cinnamon-color when fresh: young parts velvetypubescent, commonly permanently so: leaflets as of the preceding, or else longer and narrower, the lower face and the petioles more tomentose: fruit commonly $1 \frac{1}{2}$ to 2 inches long; its body more than half (or even little less than) the length of the linear or spatulate wing. - Dict. ii. 548 ; Walt. Car. 254 ; Muhl. in N. Schrift. Berl. 1. c.; Gray, Man. ed. 5, 402. F. Pennsylianica, Marsh. Arbust. 51. F. nigra, DuRoi. F. tomentosa, Michx. f. Srlv. t. 119. F. oblongocarpa, Buckley, l. c. - Low grounds, Canada to Dakotah, and south to Florida; rare west of Ohio.

F. víridis, Michx. f. (Greex AsH.) Small or middle-sized tree, glabrous: leaflets 5 to 9 , bright green both sicles, or barely pale beneath, from oblong-lanceolate to ovate, mostly acuminate and sparsely and sharply serrate or denticulate (2 to 4 inches long): fruit nearly as in the preceding or with a rather more decurrent wing (from 9 to 18 lines long). - Sylr. t. 120, excl. fruit (which must belong to $F$. Americana); Bosc, 1. c. ; Gray, Man. ed. 2, 358. F. concolor, Muhl. Cat.; Torr. Fl. N. Y. (on plate, F. puhescens in letter-press) t. 90 . F. juglandifolia, Willd. Spec. iv. 1104. F. Caroliniana (Tilld.?), Pursh, Fl. i. 9. F. expansa, Willd. Baum. 150. - Along streams, Canada and Dakotah to Florida, Texas, and Arizona? Pale-leaved forms, with some pubescence on the veins of the leaflets beneath, pass into the preceding.

Var. Berlandieriána. Leaflets's to 5, with a more cuneate base : wing of the fruit rather wider and more decurrent on the body.-F. Berlandieriana, DC. Prodr. viii. 278. $F$. trialata, Buckley, l. c, a state with 3 -winged samara. - Texas. (Cuba?)

++ Fruit with compressed and wing-margined body.

F. platycárpa, Michx. (WVTER Ash.) Tree of middle size, glabrous or pubescent: branchlets terete: leaflets 5 to 7 , ovate or oblong, acuminate, sharply serrate or entire, conspicuously petiolulate: fruit elliptical, obovate, or spatulate (one or two inches long), contracted below into a stalk-like base, each face with an impressed midnerve, not rarely 3-winged. - Fl. ii. 256; Michx. f. Sylv. t. 124; Chapm. Fl. 370. F. Carolinensis, \&c., Catesb. Car.i. t. 80, F. Caroliniana, Lam. 1. c.? F. excelsior? Walt. Car. 254. F. Amoricana, Marsh. Arbust. 50. F. pallida, Bosc, 1. c. F. pauriflora, Nutt. Sylv. iii. 61, t. 100. $F$. triptera, Nutt. l. c., with 3-winged samara. $F$. Nittallii \& $F^{\prime}$. nigrescens, Buckley, in Proc. Philad. Acad. 1860 \& 1862. - Deep river-swamps, Virginia to Louisiana. (Cuba.)

F. quadranguláta, Michx. (Brit Asf.) Largetimber-tree, the inner bark yielding a blue color to water, glabrous : branchlets square : leaflets 7 to 11 , ovate-oblong to lanceolate, acuminate, sharply serrate ( 3 or 4 inches long), short-petiolulate, when young often pubes- 
cent beneath: fruit linear-oblong or cuneate-oblong (one or two inches long, 4 to 7 lines wide), not stipitate and oftener not narrowed at base, lightly several-nerved on both faces, somewhat twisted when mature; the minute calyx at length deciduous or obsolete. Fl. ii. 225; Michx. f. Sylv. t. 123. - Dry rich woods, Michigan to Tennessee.

++ Lateral leaflets sessile: common petiole angled: anthers short-oblong.

$$
=\text { Calyx small, persistent. }
$$

F. Oregána, Nutt. Tree of middle or ample size, with wood like that of White Ash, the foliage and shoots villous-pubescent, at least when young: leaflets 5 to 7 , lanceolateoblong to oval, entire or nearly so ( 2 to 4 inches long), veiny, the upper surface soon glabrous : fruit with nearly clavate and slightly compressed body, the margined edges gradually widened upwards into the longer oblanceolate wing (of an inch or less in length). Sylv. iii. 59, t. 99; Gray, Bot. Calif. i. 472. F. pulbescens, var., Hook. Fl. ii. 51. F. latifolia, Benth. Sulph. 33. - Along streams, Washington Terr., near the coast, to California. $==$ Calyx wanting: the flowers wholly naked.

F. sambucifólia, Lam. (BLACK Asfr.) Small or middle-sized tree, with very tough and fissile wood; glabrous, except bearded hairs along the midribs beneath: leaflets 7 to 11, green and of similar hue both sides, oblong-lanceolate from a roundish base, gradually acuminate, finely and acutely serrate ( 3 to 5 inches long), the pinnate primary veins of numerous pairs : fruit lanceolate-oblong or linear-oblong, flat throughout, finely nervose, the acutely margined body of the same breadth as the wing. - Dict. ii. 549; Muhl. 1.c.; Michx. f. Sylv. t. 122 ; Emerson, Rep. Trees, ed. 2, ii. 381, t. 13. F. nigra, Marsh. Arbust. 51. - Swamps and wet banks, Nova Scotia to Wisconsin, the mountains of Virginia and Kentucky. Bruised foliage exhales the odor of Elder. Remarkable for the total absence of calyx.

2. FORESTIERA, Poir. (M. Forestier, a French physician.) - Shrubs (North American and W. Indian); with opposite simple leaves, inconspicuous flowers, in early spring, from imbricated-scaly axillary buds, and small dark-colored drupes; the putamen thin. Fascicles or panicles very short, few-flowered; the staminate sessile and in a sessile globular scaly glomerule : the bracts or bud-scales deciduous. Branches minutely warty. - Tulasne in Ann. Sci. Nat. ser. 3, xv. 265. Adelia, Michx. Borya, Willd. Bigelovia, Smith. Piptolepis, Benth.

* Leaves membranaceous and deciduous, not porulose, mostly minutely serrate: flowers from axils of the preceding year.

F. acumináta, Poir. Shrub somewhat spinescent, 5 to 10 feet high, glabrous throughout: leaves ovate-lanceolate and ovate-oblong, conspicuously acuminate, slender-petioled, $1 \frac{1}{2}$ to 4 inches long: fertile flowers several in a panicle: caly $x$ obsolete or caducous : drupe (when forming fusiform acuminate, and somewhat arcuate) elongated-oblong. - Dict. Suppl. ii. 664; Gray, Proc. Am. Acad. iv. 363, excl. var. Adelia acuminata, Michx. Fl. ii. 225, t. 48. Borya acuminata, Willd. Spec. iv. 711. Forestiera ligustrina, Willd. ex char. \& hab.; Gray, Man. ed. 2, 358, not Poir. - Wet and shady river-banks, W. Illinois and Missouri to W. Georgia and Texas. The habitat of this and of $\dot{F}$. ligustrina must have been transposed in Michaux's Flora.

F. Neo-Mexicána, Gray. Shrub 6 to 10 feet high, glabrous : leaves spatulate-oblong, obtuse or obtusely acuminate, short-petioled, obtusely or obsoletely serrulate, an inch long : fertile flowers in sessile fascicles: calyx minute and rather persistent: drupe obtuse, short-oblong or ovoid. - Proc. Am. Acad, xil. 63. F. acuminata, var. parvifolia, Gray, Proc. Am. Acad. iv. 364. - New Mexico, and adjacent borders of Texas and Colorado, Fendler, Wright, Palmer, Brandegee.

Var. Arizónica. Young shoots and foliage soft-pubescent; only earliest leaves seen, those entire. - Near Prescott, Arizona, Palmer.

F. ligústrina, Poir. More or less pubescent with short spreading hairs: leaves obovate or oblong with narrowed base, short-petioled, appressed-serrulate, rounded at apex, usually an inch long: fertile flowers in simple fascicles: calyx almost obsolete: drupe short-ovoid, sessile: putamen smooth and even. - Gray, Proc. Am. Acad. iv. 364, partly. Adelia ligus- 
trina, Miclıx. l. c., excl. hab. Borya ligustrina, Willd. 1. c., but character wrongly altered, as also by Poiret, 1. c. - Tennessee to Florida, \&c., lut not Illinois.

F. pubéscens, Nutt. Soft-pubescent: fertile flowers and oblong drupes pedicellate: putamen striate: otherwise like the preceding. -- Trans. Am. Phil. Soc. n. ser. v. 177. F. ligustrina, var. pubescens, Gray, 1. c. - Florida, Arkansas, and Texas.

* Leaves coriaceous (very small), not porulose.

F. sphærocárpa, Torr. Low shrub; leaves obiong or oval, obtuse, obscurely crenulate, minutely soft-pubescent, half inch long, short-petioled, mainly crowded at the tip of the branchlets: drupe globular, very short-pedicelled. - Bot. Mux. Bound. 168. - S. W. Texas, in dry ravines of the Rio Limpio, Bigelow.

* * Leaves coriaceous, porulose-punctate beneath, often persistent until flowers develop in their axils, or eren to the maturicy of the fruit,

+ Their margins plane, often serrulate.

F. reticuláta, Torr., l. c. Glabrous throughout: leaves ovate or almost oblong, with rounded base and obtuse or acute mucronulate apex, short-petioled, firm-coriaceous, lucid above, conspicuously venulose-reticulated, an inch or more long: fascicles few-flowered and very short in the axils of persistent leaves: drupe short-ovoid. - Western borders of Texas, Wright, Bigelow, Schott.

++ Margin of the leaves narrowly revolute, entire.

F. porulósa, Poir. Much branched shrub, glabrous: leaves thin-coriaceous, obovateoblong to lanceolate, tapering at base into a short distinct petiole, obtuse or rounded at apex (one or two inches long), the scattered and spreading veins manifest: drupes shortoblong, short-pedicelled. - Gray, 1. ¿., excl. vars. Myrica segreguta, Jacq. Obs. ii. 273, \& Ic. Rar. t. 625. Idelia porulosa, Michx. 1. c. Borya porulosa, Willd. l. c. Forestiera Jacquiniana, Didrichson, Ind. Sem. Hamb. 1838, \& Linn. xxvii. 737. - S. Florida : rare. (W. Ind.)

F. angustifólia, Torr. Densely branched and rather large slurub, glabrous: leares firm-coriaceous, linear or spatulate-linear ( 6 to 12 lines long and 1 to 3 wide), sometimes linear-oblong (short and 4 lines wide), very obtuse, veinless or nearly so: flowers not rarely hermaphrodite, few in the close cluster: drupe ovate, acute, very short-pedicelled. - Bot. Mex. Bound. 168. F. porulosa, var. ? angustifolia, Gray, l. c. - Texas, from Matagorda Bay and New Braunfels southward to Mexico.

F.. PHillyreioídes, Torr. 1.c. (Piptolepis phillyreioides, Benth. Pl. Hartw. 29), of Mexico (Hartweg, Gregg, \&c.), appears to have leaves destitute of the pore-like punctuations, smaller than those of $F$.porulosa, but similar in form and venation, the lower face more or less pubescent, and the drupes oblong.

3. CHIONÁNTHUS, L. Fringe-tree. (From $\chi \omega \omega$, snow, and $\alpha \nu \theta o s$, blossom, alluding to the snow-white and light clusters of flowers.) - Shrubs or low trees (the genuine species E. North American and Chinese); with simple and entire opposite deciduous leaves, and loose compound panicles of white flowers, in early summer, from the uppermost axils of the leaves of the preceding year. Petals sometimes nearly separate or separable, oftener united (but irregularly) to about twice the length of the small calyx, in cultivation occasionally 5 or 6. - Gray, Proc. Am. Acad. v. 231 ; Benth. \& Ilook. Gen. ii. 677.

C. Virgínica, L. Somewhat pubescent: leaves oval or oblong, 3 to 6 inches long, shortpetioled: panicles drooping, with very slender branches and pedicels and usually some foliaceous bracts : petals an inch long, acute: fruit black or bluish, with thin pulp, globular, half inch or more long. - (Catesb. Car. t. 68.) Lam. Ill. t. 9; Lodd. Bot. Cab. t. 1264. - Along streams, S. Pennsylvania to Florida and Texas.

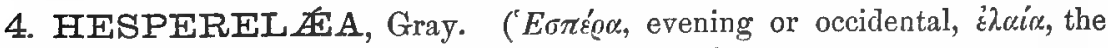
olive-tree.) - Proc. Am. Acad. xi. 83. - Single species.

H. Pálmeri, Gray. Small tree, glabrous : leaves opposite, entire, coriaceous, oblong, veiny : flowers sulphur-colored, crowded in a terminal compound panicle : pedicels short, 
articulated; petals twice the length of the sepals: fruit not seen, but evidently drupaceous. - Guadalupe Island, off Lower California (beyond the limits of this Flora), $D_{r}$. E. Palmer.

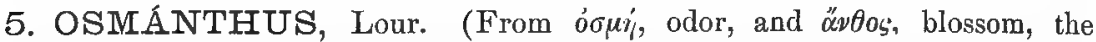
flowers fragrant.) - Shrubs and small trees (of E. United States, Pacific Islands, and N. E. Asia); with evergreen chiefly opposite leaves, and small flowers in axillary clusters. Genus founded on the Chinese $O$. fragrans, cultivated as a house-plant for its deliciously fragrant small blossoms; now distinguished from Olea by the imbricated instead of valvate rstivation of the corolla. - Benth. \& Hook. Gen. ii. 677.

O. Americánus, Benth. \& Hook. (Devil-wood.) Tall shrub or small tree, glabrous: bark whitish: leares firm-coriaceous, lanceolate-oblong, tapering into a short petiole, entire, briglit green, shining above ( 3 to 6 inches long), much longer than the panicles of dull white (polygamous or even diœcious) flowers: drupe small, dark purple. - Ligustrum laurifolio, \&c., Catesb. Car. i. 61, t. 61. Olea Americana, L. Mant. 24; Michx. Fl. ii. 222; Michx. f. Sylv. iii. t. 6, -N. Carolina to Florida near the coast : fl. spring.

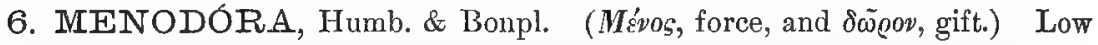
shrubby, suffruticose, or nearly herbaceous plants (American and one S. African); with simple entire or pinnately lobed leaves, many of them alternate, and conspicuous flowers terminating the branches, or becoming lateral, or sometimes loosely corymbosely cymose: $\mathrm{fl}$. in spring or summer: corolla in ours yellow. - Pl. Equin. ii. 98, t. 110 ; Gray in Am. Jour. Sci. ser. 2, xiv. 43; Benth. \& Hook. l. c. Bolivaria, Cham. \& Schlecht. in Linn. i. 207. Calyptrospermun, Dietr. Spec. i. 226.

§1. Bolivária. Corolla with short or very short tube; its lobes blunt or hardly acute; the throat commonly bearded within: filaments filiform: anthers pointless. (§ Bolivaria \& § Menodora, Gray, l.c.)

* Calyx-lobes rather short, 5 or 6 , rarely some intermediate ones: leaves entire.

M. spinéscens, Gray. Thorny shrub, 2 to 4 feet high, rigid, divergently brąnched, obscurely puberulent: leaves alternate, spatulate-linear and very small, commonly reduced to minute scales or sears on the main branchlets: flowers small, almost sessile, terminating short shoots: calyx-lobes a little shorter than the light yellow corolla, the oblong lobes of which (a line and a half long) are rather shorter than the funnelform tube: capsule of 2 almost separate and diverging obovoid divisions. - Proc. Am. Acad. vii. 388, \& Bot. Calif. i. 471. - Nevada and adjacent borders of California, Anderson, Cooper.

M. scopária, Engelm. Shrubby at base, the slender branches herbaceous, glabrous or nearly so: leaves linear or lanceolate, entire; or the lower oblong or obovate, the upper mainly alternate: flowers sparsely corymbose, short-peduncled : calyx-lobes at first little longer than the tube of the almost rotate corolla (lobes of the latter ovate and 3 or 4 lines long): divisions of the capsule globular. - Bot. Calif. 1. c. - S. E. California, Arizona, and adjacent parts of Mexico. Related to $M$. integrifolia of Buenos Ayres, and to the next.

* * Calyx-lobes 7 to 15 , slender, linear or subulate: corolla nearly rotate, its obovate lobes much longer than the tube.

M. scábra, Gray. Herbaceous from a woody branching base, a span to a foot high, Flax-like, whole herbage or at least the lower part puberulent-scaurous: leaves mostly alternate, linear or the lower oblong, chiefly entire, 4 to 10 lines long: flowers rather numerous: peduncles remaining erect: lobes of the bright yellow corolla obovate, 3 or 4 lines long. -Am. Jour. Sci. l. c.; Torr. Pacif. R. Rep. vii. t. 7. -W. Texas to N. New Mexico and S. Arizona.

M. heterophýlla, Moricand. Nearly herbaceous, diffusely spreading, a span high, almost glabrous but roughish : leaves mostly opposite and pinnately 3-7-cleft or parted; 
the lobes and uppermost leaves linear: flowers sparse: lobes of the corolla obovate, 3 to 5 lines long, light yellow, sometimes purplish outside: short peduncles recurved in fruit. DC. Prodr. viii. 316; Gray, 1. c. Bolizaria Grisebachii, schecle in Linn. xxv. 25t. - Dry or rich soil, Texas. (Adjacent Mex.)

§ 2. Mexodorópsis, Gray, 1. c. Corolla salverform with a long tube, glabrous within; the oval or orate lobes mucronate-acuminate: anthers almost sessile in the throat, apiculate: flowers vespertine, odorous, bright yellow: calyx with about 10 setaceous lobes, exceeding the fruit: habit of M. scabra.

M. longiflóra, Gray. Glabrous, numerous almost simple herbaceous stems a foot or more high from a woody and branching base: leaves linear or lanceolate (an inch or less long), smooth, entire (or some of the lowest rarely bcleft), the upper commonly alternate: flowers several and cymose: tube of corolla $1 \frac{1}{2}$ to 2 inches long, slightly widening to the summit; the lobes half an inch long. - Am. Jour. Sci. 1. c. 45. - S. \& W. Texas, Lindheimer, Tright.

M. púbens, Gray, l.c. Pubescent throughout with soft and spreading hairs: leaves rather broader: otherwise nearly resembling the preceding. - Valley of the Pecos, western part of Texas, Wright.

\section{ORDER LXXXVII. APOCYNACEA.}

Herbaceous or woody plants, with milky and mostly acrid juice, simple and entire pinnately-reined leares, either alteruate, opposite, or verticillate, no stipules, and perfect regular 5 -merous flowers; the calyx free from the ovary or nearly so, imbricated in the bud and persistent; the lobes of the gamopetalous corolla conrolute and often twisted in the bud; stamens as many as the corolla-lobes and alternate with them; anthers introrsely dehiscent; pollen of ordinary loose but often glutinous grains; two carpels either distinct or united into a 2-placentiferous ovary; a single common style, surmounted by a single stigma; the proper stigmatic surface a ring underneath a thickened or lengthened sterile terminal portion. Ovules few or numerous, amphitropous or sometimes anatropous. Seeds with or without a coma. Embryo straight and rather large, in sparing albumen. Anthers distinct, but connirent around the stigma, and not rarely adhering to it (by a process from the base of the connective). Inflorescence various : peduncles either terminal or axillary.

Neridu Ole.ander, L., escaping from gardens and yards, inclines to be spontaneous in Florida and Louisiana.

Thevetia neriffolia, Juss., of Tropical America, grows on Key West, doubtless introduced.

TRIBE I. PLCMERIEAE. Anthers free (unconnected with the stigma); the cells polliniferous to the pointless and usually rounded base. Oraries 2, connected only by the common (filiform) style. Corolla sinistrorsely convolute in the bud, in our genera unappendaged and salverform, with tube more or less dilated at summit. (Calyx in ours small, and anthers from ovate to oblong-lanceolate.)

* Anthers blunt, on very short filaments, inserted and included in the throat or enlarged summit of the tube of the corolla, which is villous or hispidulous : seeds not comose.

$$
\text { + Disk none: leaves alternate. }
$$

1. VALLESIA. Corolla conspicuously constricted at the orifice. Stigma clavate or cylindrical. Carpels drupaceous in fruit, oblong or clavate and curved, 2-4-ovulesl, 1-seeded. Seed erect : radicle inferior. Shrubs.

2. AMSONIA. Corolla slightly or decidedly constricted at the villous throat. Stigma girt underneath by a reflexed cup-like membrane; the apex truncate-capitate or didymous. Carpels many-ovuled, becoming slender terete and often torose follicles, erect, several- 
seeded. Seeds cylindraceous or oblong, obliquely truncate at both ends, in a single row; the coat corky. Herbs.

++ Disk of 2 oblong or linear glands alternate with the carpels : leaves opposite.

3. VINCA. Corolla callous-constricted at the orifice; the lobes broad. Stigma a viscid ring between a rotately dilated upper and a lower hairy or bearded sterile portion, the upper truncate and often 2-apiculate, the lower subtended by a reflexed membranous ring or cup. Carpels few-many-ovuled, in fruit narrow terete follicles. Seeds oblong, truncate, with rough-granulate coat. Radicle superior.

* * Anthers acute, inserted at or below the middle of the tube : disk none : seeds comose.

4. HAPLOPHYTON. Calyx 5-parted; the lobes linear-subulate. Corolla salverform with open throat; its tube about the length of the obovate lobes. Anthers short-sagittate with the short bases rounded. Style rather short: stigma cylindraccous, 2-lobed at apex, unappendaged. Follicles filiform, striate, several-seeded. Seeds linear-fusiform, fixed by the middle, sessile, furnished with a deciduous coma at both ends.

Tribe II. ECHITIDE E. Anthers with the cells produced into a sterile appendage at base, connivent around the stigma and adherent to it by a point at the base of the polliniferous portion. Ovaries 2, united only by the common style or stigma, in fruit follicles containing (at least in ours) comose seeds. Lobes of the corolla almost always dextrorsely convolute, and the leaves opposite. (Stamens in all ours included.)

* Calyx-tube by means of a thickish disk adnate to the back of the ovaries below: corolla appendaged witlfin : style hardly any.

5 APOCYNUIM. Calyx small, deeply 5-cleft. Corolla campanulate, 5-lobed, toward the base bearing 5 small triangular-subulate appendages alternate with the stamens and inserted rather higher. Stamens on the base of the corolla: filaments very short, broad: anthers sagittate, acute. Disk fleshy at base, the free summit 5-lobed. Stigma ovoid, obscurely 2-lobed. Follicles slender, terete. Seeds numerous, with a long coma at apex: albumen little.

* * Calyx wholly free: style filiform, girt below by a ring which is commonly extended into a reflexed entire or 5-lobed membranous cup or appendage, less conspicuous in no. 9 : seeds numerous and comose at the apex.

$$
\text { + Stems erect, not twining. }
$$

6. CYCLADENIA. Calyx 5-parted, naked within; the lobes slender. Corolla funnelform with dilated throat, in the base of which are 5 minute callous appendages, one behind each stamen; lobes ovate or obovate, not twisted in the bud. Stamens borne on the base of the dilated portion of the tube: anthers sagittate, on short filaments, the tips and the basal lobes slender-cuspidate. Disk an entire shallow cup encircling the base of the ovaries. Stigma capitate-5-angled and truncate, girt by a conspicuous 5-lobed reflexed membrane. Follicles lanceolate, turgid, smooth. Seeds ovate, narrowed at the apex under the copious coma.

7. MACROSIPHONIA. Calyx 5-parted, multiglandular at base within; the lobes slender. Corolla salverform, with a long tube and enlarged cylindraceous or funnelform throat; the lobes broad, dextrorsely convolute but sometimes sinistrorsely twisted in the bud, often crisped. Stamens borne in the throat: filaments short: anthers oblong or sagittate-lanceolate, mostly obtusely tipped, and the basal appendages obtuse. Disk of 5 fleshy and distinct or partly united scales. Stigma thickened and firm, 5-costate, with entire or 2-cleft small apex, the base appendaged with 5 reflexed lobes or a 5 -cleft membrane. Follicles long and slender, terete. Seeds oblong.

+ + Stems twining, or at least sarmentose : calyx gland-bearing at base within : corolla. wholly destitute of internal scales or appendages; the lobes usually more or less twisted (to the left, i. e. contrary to the overlapping) in the bud: filaments very short: disk mostly 5 -lobed or of 5 glands : follicles long and slender.

8. ECHITES. Flowers comparatively large. Corolla salverform, funnelform, or with abruptly dilated campanulate throat. Appendage of the stigma conspicuous and reflexed, in the form of a reversed membranous cup or of 5 strong lobes. Inflorescence simple or nearly so.

9. TRACHELOSPERMUM. Flowers comparatively small. Corolla salverform or somewhat funnelforn. Tips of the sagittate and gradually acuminate anthers sometimes exserted; the basal lobes acute. Apex of style more or less thickened or obconical under the narrow or inconspicuous ring of the stigma. Seeds linear, beakless. Inflorescence open-cymose. 
1. VALLÉSIA, Ruiz \& Pav. (Francis Vallesio, a Spanish physician.) Glabrous shrubs; with alternate leaves, and small terminal or soon lateral cymes of small flowers. Calyx not glanduliferous within. - Prodr. Fl. Per. 28, t. 5. The principal species is -

V. gläbra, Cav. Leaves coriaceous and somewhat fleshy, shiming, almost veinless, oblong or oblong-lanceolate, acute, short-petioled, about 2 inches long : corolla white, 3 lines long: drupes half inch long, dry, slender, often single. - Ic. iii. t. 297. V. dichotoma, Ruiz \& Par. (Fl. Per. ii. 26, t. 151) \& V. chiococcoides (HBK.); A. DC. Prodr. viii. 349. - Key West, Florida. (W. Ind. to Lower Calif. and Chili.)

2. AMSONIA, Walt. (Dedicated to Charles Amson.) - Perennial herbs (E. North America and Japan); with very numerous membranaceous and alternate leaves, varying from ovate to linear, and rather compact small cymes of blue or bluish flowers in a terminal thyrsus: $f$. spring and early summer. Inside of the tube of the corolla below the stamens beset with reflexed hairs. Liber of tough fibres, as in Apocynum, \&c.

$\S 1$. Stigma with depressed-capitate or truncate entire apex: corolla not constricted under the limb : eastern species.

A. Tabernæmontána, Walt. About 3 feet high, glabrate: leaves from ovate to lanceolate, acuminate ( 2 to 5 inches long), distinctly petioled, pale beneath : calyx very small : corolla in the bud slender-beaked by the convolute limb; its lobes lanceolate, becoming linear and as long as the tube; the latter at first mostly villous at the enlarging summit: follicles slender, 2 or 3 inches long. - Car. 98; A.DC. Prodr. viii. 385. (Tabernamontana Amsonia, L.) A. latifolia, Michx. Fl. i. 121; Bot. Reg. t. 151. A. tristis, Smith in Rees Cycl. A. salicifolia, Pursh, Fl. i. 184; Bot. Mag. t. 1873; A.DC. l. c., with var. ciliolata. -Low grounds, N. Carolina and Illinois to Florida and Texas.

A. angustifólia, Michx. Stems ( 1 to 3 feet high) and commonly inflorescence and leaves (or at least their margins) when young villous with loose hairs, these deciduous : leaves much crowded, linear-lanceolate to narrowly linear (an inch or two long, half line to 4 lines wide), indistinctly petioled, the margins at length somewhat revolute: calyx small and short: corolla glabrous outside; its funnelform tube (3 or 4 lines long) little longer than the ovate-oblong or at length linear-oblong lobes: follicles slender and even, 2 to 5 inches long. - Fl. i. 121 ; Pursh, 1. c. Taberncemontana angustifolia, Ait. Kew, ed. 1, i. 300 (1789). Amsonia ciliuta, Walt. Car. (1788), 98 ; A.DC. 1. c. ; Chapm. Fl. 360; a deceptive specifie name, and barely the older. - Dry soil, N. Carolina to Florida and Texas.

Var. Texána. A foot or two high from creeping woody subterranean shoots, completely glabrous: leaves of firmer texture, lanceolate-oblong to linear:- Texas, in rocky prairies and at the base of limestone hills, Pope, Lindheimer, E. Hall, \&c.

\$2. Stigma apiculate with two distinct obtuse lobes above the truncate body: tube of the corolla clavate, being constricted (at least in bud) under the conspicuously shorter limb; calyx deeply 5-parted into slender-subulate lobes (2 or 3 lines long): stems lower, more branching, and bearing smaller or simpler cymes: western species.

* Follicles torose, inclined to break into thickish articulations: corolla rather short.

A. brevifólia, Gray. About a foot high, glabrous: leaves thickish, ovate, varying above to lanceolate, nearly sessile by a narrowed base ( 8 to 18 lines long): lobes of the corolla ovate or becoming oblong, 2 or 3 lines long, nearly half the length of the tube; the throat bearded only within the constricted orifice: mass of the stigma between the ring and the apical lobes longer than wide: follicles 2 or 3 inches long, thickish, irregularly moniliform, chartaceous, and disposed to break into one-seeded joints. - Proc. Am. Acad. xii. 64. - Southern Utah and W. Arizona to the border of California, 1/rs. Thompson, Parry, Palmer.

A. tomentósa, Torr. A foot or more high, cinereous-tomentose or puberulent, varying to glabrous : leaves from lanceolate to narrowly linear, sessile : lobes of the corolla oblong; 
2 or 3 lines long, fully half the length of the tube; orifice bearded : mass of the stigma between the ring and the lobes broader than high : follicles as in the preceding? - Frem. Rep. ed. 2, 316, \& Bot. Mex. Bound. 158. - Sandy plains and ravines, W. border of Texas to S. Utall, Fremont, Wright, Lis. Thompson, \&c.

* * Follicles slender and continuous: iube of the corolla much longer than the lobes.

A. Pálmeri, Gray. Glabrous or nearly so, a foot or two high : leaves narrowly lanceolate or linear, sessile ( $1 \frac{1}{2}$ to 3 inches long): clusters simple and few-flowered: lobes of the white corolla ovate, $1 \frac{1}{2}$ to 2 lines long, about a quarter the length of the tube, which is reflexed-bearded within almost to the base: mass of the stigma didymous, puberulent, divided almost down to the ring. - Proc. An. Acad. l. c. - Arizona, Palmer.

A. longiflóra, Torr. Minutely scabrous or even scabrous-pubescent, or above glabrous : leaves linear, sessile ( $\frac{1}{2}$ to 2 lines wide, 1 to 2 inches long): lobes of the corolla narrowly oblong, white, a quarter the length of the greenish-purple clavate tube; this over an inch long and glabrous within except toward the summit: body of the stigma trochleate, much longer than wide, surmounted by the small and short lobes. - Bot. Mex. Bound. 159. Rocky ravines, W. Texas and New Mexico on the Rio Grande, and adjacent Mexico.

3. VINCA, L. Periwinkle. (Ancient Latin name, of obscure meaning.) - Flowers handsome, usually axillary. Juice hardly milky. - Two distinct subgenera: §1. Pervinca; herbaceous and procumbent or creeping Old World species, blue-flowered, anthers with wide connective, and carpels only 6-8-ovuled; includes $V$. minor, L., the common. Periwinkle of the gardens and the related species. §2. Lochnera, A.DC.; low and erect shrubby plants, with white or rose-colored corolla, anthers with narrow connective and carpels several-seeded; represented by the following species.

V. rósea, L. Low erect shrub, puberulent: leaves oblong, short-petioled: flowers almost sessile: tube of corolla an inch long, the narrowly dilated upper portion with a nectariferous pit (externally salient) behind each anther; the throat with a hairy ring over the tips of the stamens and a slighter one at the narrow orifice; lobes obovate, shorter than the tube, white with a pink eye, sometimes all rose-color or white, showy. - Bot. Mag. t. 248. - Lochnera vincoides, Reichenb. - S. Florida: possibly native. Widely distributed as a weed in the tropics; cult. as a house-plant. (Trop. Amer.)

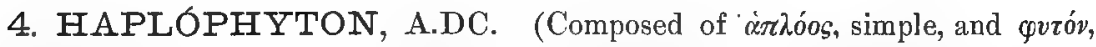
plant, alluding to the want of calycine glands and disk.) - DeCandolle was not aware of the double coma, and Benth. \& Hook. (Gen. ii. 722) wrongly assign to it adnate anthers with empty tails, referring it to the Echitidea. Single species.

H. cimícidum, A.DC. Herbaceous or nearly so from a suffrutescent base, slender, a foot or two high, branching, somewhat cinereous-puberulent: leaves hispidulous-scabrous, opposite and alternate, lanceolate or ovate-lanceolate, short-petioled, an inch or two long: flowers terminating the branches, short-peduncled: corolla sulphur-color, half inch or more long; the lobes as long as the tube. - Prodr. viii. 412 ; Torr. Bot. Mex. Bound. 159. - S. Arizona, in crevices of rocks, Wright, Schott, Thurber. (Mex., Guatemala, Cuba.)

5. APÓCYNUM, Tourn. Dogb.九ne, Indian IIEmp. (Ancient Greek name for Dogbane; áxó, far from, xíwy, dog.) - Perennial herbs (of northern temperate zone), pale or glaucescent; the liber very tough-fibrous; and the leaves opposite, oval or oblong, mucronate-tipped. Flowers (in summer) small, in terminal minutely subulate-bracteate cymes, white or rose-color. Follicles 2 to 7 inches long, slender-pointed, often deflexed.

A. androsæmifólium, L. A foot to a yard high, glabrous, or rarely soft-tomentose, branched above: branches widely spreading: leaves ovate or roundish, distinctly petioled: 
cymes loose, spreading, naked and mostly surpassing the leaves: corolla flesh-color, opencampanulate ( 3 or 4 lines long) with revolute lobes; the tube exceeding the ovate acute calyx-lobes. - Spec. i. 213 ; Lam. Ill. t. 176; Bot. Mag. t. 280 ; Bigel. Med. t. 36. - Borders of thickeis, Canada to Georgia, New Mexico, California, and Brit. Columbia. Var. incanum, A.DC., is the lowny-leaved form, not uncommon northward.

Var. púmilum, a vегy low and peculiar round-leaved form, comnon from California to Brit. Columbia.

A. cannábinum, L. Erect or ascending, glabrous or sometimes soft-pubescent : branches ascending, leafy to the top: leaves from oval to oblong and even lanceolate, from shortpetioled to sessile, with a rounded or obscurely curclate base: cymes erect, densely flowered ; corolla greenish-white or slightly flesh-color, smaller than in the preceding, with almost erect lobes, and tube not longer than the lanceolate calyx-lobes. - ijec. l, c.; Hook. Fl. t. 139 ; Gra . Han. ed. 5, 39.1. 1.hypericifolium, Ait. Kew. ed. 1, i. 304; Hook. 1. c. t. 140; form with mostly sessile and sometimes subcordate leaves. A. Sibiricum, Jacq. Vind. iii. t. 66. A. pubescens, R. Br. in Wern. Soc. i. 67 ; the downy form. - Hoist grounds and banks of streams, same range as the preceding, and more southem; occurring in a much greater number of forms, hardly to be distinguisherl as named varieties.

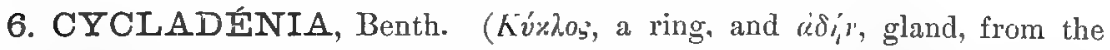
circular glandular disk around the pistil.) - Low perennial herlus (Californian); with a creeping rhizoma sending up a simple stem, hardly a span high, and bearing 2 or 3 pairs of opposite petiolite leares, of a thickish texture, aud one or two slender terminal or apparently axillary peduncles, with a few rose-purple flowers on slender pedicels, developed in spring. - Pl. Hartw. 322.

C. húmilis, Benth. Glabrous and green, or pruinose when young: leaves ovate or obovate, thickish, 1 to 3 inches long: calyx-lobes from lanceolate to nearly linear: corolla three-fourths inch long. - Yuba to Shasta Co., California, in the inountains, IIartweg, Brewer, \&c.

C. tomentósa, Gray. Densely tomentose-pubescent throughout: leaves ovate and oblong, 2 or 3 inches in length: calyx hirsute. - Bot. Calif. i. 474. - Plumas Co., California, with the preceding, Lemmon.

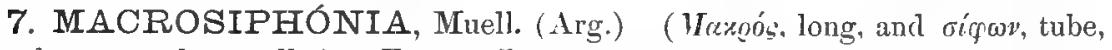
in reference to the corolla.) - Erect suffrutescent or more woody plants (of Mexico, Texas, and Brazil); with rather simple stems or branches, numerous opposite or sometimes verticillate leaves, and proportionally large showy flowers, either terminal or becoming lateral, ou short peduncles or pedicels; the corolla commonly soft-puberulent or tomentose outside. Follicles erect. - Mart. Fl. Brás. vi. 137, t. 4:2, t:3 ; Benth. \& I-Iook. Gen. ii. 727. - Flowers in ours white or externally tinged with rose-color, vespertine, fragrant, in spring or summer; the leaves very short-petioled.

M. Berlandiéri. A foot or two high, shrubby, white-tomentose: leaves from oval or cordate-ovate to orbicular (an inch and more long), becoming greenish and merely pubescent above, the diverging veins at length conspicuous : corolla merely puberulent outside, its slender tube (with the cylindraceous-dilated throat) 3 to 5 inches long, many times exceeding the calyx and the round-obovate (nearly inch long) lobes. - Echites marrosiphon, Torr. Bot. Mex. Bound. 158, t. 43. - Rocky soil, W. Texas and adjacent parts of Mexico, Berlandier, Wright, Lindheimer.

M. Wríghtii. slender, branching, a foot high, soft-puberulent: leaves narrowly lanceolate, acute, white-tomentulose beneath, glabrous or nearly so above: tube of the corolla and its cylindraceous throat each half inch or more in length, tomentulose, the lobes half inch long. $-W$. Texas, in mountains heyond the Iimpio, Wright.

M. brachysiphon. A span to a foot high, branching, minutely puberulent, green or barely cinercous : leaves oblong or ovate, acute or mucronate-pointed, or some rounded at 
the apex (half to barely an inch long): corolla minutely puberulent outside; its somewhat funnelform throat and the obovate lobes as well as the narrow tube each about half an inch in length. - Echites brachysiphon, Torr. 1.c. - Suuthern New Mexico and Arizona, Wright, Schott, Thurber, Palmer, Rothrock.

8. ECHITES, P. Browne, L. ('Exitns is the serpent-stone; application to this genus obscure.) - Twining woody plants; with opposite leaves, and terminal or lateral peduncles, bearing racemosely or sometimes simply cymosely disposed flowers, of ample size; the corolla white, rose-color, or more commonly yellow. Nearly all tropical American, barely reaching the south-eastern shores of the United States, in three species belonging to as many genera of Mueller, hesitatingly adopted by Bentham; perhaps better as two, viz., the following, here arranged as subgenera.

$\S 1$. Mandevílene. Corolla with cylindrical or cylindraceous tube abruptly dilated above into an inflated- or oblong-campanulate wide throat. - Mandevillea, Lindl. (Amblyanthera, Muell.), with Rhabdadenia \& Urechites, Muell.

E. Andréwsii, Chapm. Glabrous or occasionally pubescent, low, usually twining: leaves oval or oblong, often mucronate (about 2 inches long): peduncles corymbosely 3-5-flowered: lobes of the calyx as long as the proper corolla-tube, linear-subulate : corolla yellow ( 2 inches long and the limb as broad); the much enlarged throat oblong-campanulate, hardly thrice the length of the narrow tube, little longer than the ovate spreading lobes: anthers abruptly produced at apex into a long linear-filiform appendage: seeds with a long filiform beak, the lower half of which is naked, the upper plumosely comose. -F1. 359 (1860). Eclites suberecta, Andr. Bot. Rep. t. 187; Sims, Bot. Mag. t. 1064, not Jacq. E. neriandra, Griseb. Fl. W. Ind. 415 (1864). E. Catesbaei, Don? Neriandra suberecta, A.DC. Prodr. viii. 422. Urechites suberecta, Muell. in Linn. xxx. 444, in part?S. Florida and Keys, Blodgett, Palmer. - E. suberecta, Jacq. \& Griseb., is hardly distinguishable except by the longer throat and shorter lobes of the corolla, and the unappendaged anthers! (W. Ind.)

E. Sagrái, A.DC. Much smaller than the preceding: leaves half to barely an inch long, the margins more revolute: peduncles longer than the leares, somewhat racemosely flowered: caly x-lobes ovate-subulate and much shorter than the tube of the yellow (barely inch long) corolla, the lobes of which are half the length of the throat: anthers bluntish, unappendaged: beak of the seed plumosely-comose to the base. - Prodr. viii. 450 ; Griseb. 1. c. Rhabdadenia Sagrcei, Muell. 1. c. 435. - Pine Key, Florida, Blodgett. (W. Ind.)

§2. Euechíres, A.DC. Corolla truly salverform, i.e. cylindrical up to the limb, but the upper half (above the insertion of the stamens) abruptly somewhat larger. - Echites \& Stipecoma, Muell.

E. umbelláta, Jacq. Glabrous, twining: leaves ovate or oval (2 inches long), mucronate or short-pointed, slightly cordate: peduncles exceeding the leaves, somewhat umbellately 8-7-flowerer : caly $\mathrm{x}$ short : corolla greenish-white, 2 inches long, narrow-tubular: the tube abruptly swollen a little below the middle, thence tapering upwards, 4 times the length of the roundish lobes: anthers rigid, slender-hastate, bluntish and unappendaged at tip : coma sessile on the top of the seed.-Amer. Pict. t. 29 (Catesb. Car. i. t. 58); Chapm. 1. c.; Griseb. 1. c. - S. Florida. (W. Ind.)

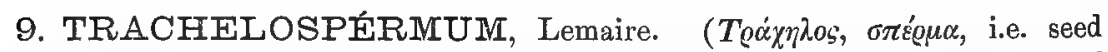
with a neck: unhappily it has none or hardly any: the proposer, ignorant of this, gave the name in reference to Rhynchospermum.) - Twining shrubby plants ; with oval or oblong opposite short-petioled leaves, and small or smallish flowers in terminal or lateral loose cymes : corolla white or greenish-white. - "Lemaire, Jard. Fleur. i. t. 61 ; Moore \& Henfr. Mag. Bot. ii. 113 ; "Benth. \& Hook. Gen. 
ii. 720 ; name changed from Rhynchospermum, Lindl. (not Reinw., nor A.DC., nor is there a beak to the seed). Parechites, Miq., Gray in Mem. Am. Acad. vi. 403. 'To this (Japanese, Himalayan, and Malayan) genus is here referred, somewhat dubiously, the following.

T. diffórme. Climbing 10 or 15 feet high, somewhat pubescent when young or glabrous : stems slender: leaves from ovate or oval to lanceolate, acuminate, membranaceous ( $1 \frac{1}{2}$ to 3 inches long): peduncles shorter than the leaves: flowers rather numerous in open cymes, short-pedicelled : corolla cream color, 4 lines long; the ovate lobes much shorter than the cylindraceous tube with its consilerably dilated throat: style obscurely dilated under the narrow membranous ring of the stigma: follicles long ( 6 to 9 inches) and slender. Echites difformis, Walt. Car. 98; Bart. Fl. Am. Scpt. i. t. 10. E. puberula, Michx. Fl. i. 120. Forsteronia difformis, A.DC. Prodr. viii. 437. Secondatia, Benth. \& Hook. 1. ᄂ. - Riverbanks, Virginia to Florida and Texas: fl. spring and summer.

\section{ORDER LXXXVIII. ASCLEPIADACE $Æ$.}

Characters of Apocynacea as to herbage and general structure of flowers and fruit; distinguished by the peculiar aggregation and cohesion of the pollen into granulose or waxy masses (pollinia), one or sometimes two in each anther-cell, and connected with the stigmil or rather stigmatic disk in pairs or fours by means of 5 glands or corpuscles, which alternate with the anthers. Estivation of the corolla often valvate or nearly so. A corona (crown) of five parts or lobes usually present between the corolla and the mostly monadelphous stamens, and adnate either to the one or the other. Hypogynous disk within the stamens none. Styles distinct up to the common stigmatic mass, or none. Fruit always of 2 follicles, or by abortion of one ovary solitary, several-many-seeded; the seeds almost always bearing a long and soft coma at the apex. Radicle superior. Stems herbaceous or merely shrubby, not rarely twining. Leaves almost always opposite or whorled, destitute of stipules. Inflorescence terminal, pseudo-axillary, or sometimes axillary, cymose, often umbelliform. Bracts small or minute. The tube of monadelphous filaments, commonly named gynostegium (a term which has been applied also to the anther-portion), we call the column.

Períploca Greci, L., a woody climbing plant of the Old World, in ornamental cultivation, and in one or two places inclined to be spontaneous, represents the tribe or suborder Periplocere, with granulose pollen loosely aggregated in two masses in each anther-cell. All the American genera have a single firn-waxy pollen-mass to each anther-cell, i.e. they belong to the suborder AsclepiaDes.

Tribe I. CYNANCHE.E. Anthers tipped with an inflexed or sometimes erect scarions membrane; the polliniferous cells lower than the top of the stigma : pollinia suspended, attached in pairs (one of each adjacent cell of different anthers) to the corpuscle or gland.

* Crown (corona) or appendages to the corolla or andrœcium none.

1. ASTEPHANUS. Calyx destitute of glands. Corolla urceolate or short-campanulate, 5-cleft; the lobes slightly and dextrorsely convolute: stamens inserted on the base of its tube. Top of the stigma obtusely conical or more elevated. Follicles smooth.

* * Crown double; the exterior annular, interior of 5 flat fleshy or hood-like scales or processes.

2. PHILIBERTIA. Calyx minutely 5-glandular within. Corolla open-campanulate or (in all ours) rotate; the lobes dextrorsely convolute, narrowly overlapping. Exterior crown a membranaceous ring adnate to the base of the corolla; interior of 5 scales adnate to the base of the usually very short stamen-tube or column. Top of stigma flat or umbonate, or with a short 2-cleft beak. Follicles rather thick, smooth, acuminate. 
* * Crown single, sometimes with accessory processes or denticulations alternate with the anthers: calyx 5-parted, mostly small, commonly bearing some minute glandular processes at base within.

+ Stems erect or merely decumbent, never twining : corolla rotate, ö-parted, dextrorsely valvate-convolute in the bud (the lobes obscurely or more manifestly overlapping by their edges, or at least by their tips) : body of the stigma 5-angular or 5-lobed, flattopped: crown consisting of distinct cucullate or hollowed nectariferous appendages (cuculli or hoods), one opposite each anther : anthers margined with mostly corneous and salient wings.

+ Hoods remote from the anthers, at the base of the long column.

3. PODOSTIGMA. Corolla oblong-campanulate, 5-parted nearly to the 5-angular base ; the lobes erect, oblong, obtuse. Hoods of the crown short, somewhat incurved, and the margins involute, forming pitcher-shaped nectariferous bodies. Column (and enclosed styles) slender, almost as long as the corolla : five small processes under and alternating with the short anthers. Wings of the latter widening downward to the truncate acuteangled base. Follicles linear-fusiform, unarmed.

++ Hoods approximate to the anthers: corolla in anthesis patent or reflexed.

$=$ Hoods cristate- or corniculate- appendaged within.

4. ANANTHERIX. Corolla reflexed in anthesis. Column under the hoods very short but distinct. Hoods as long as the corolla and far longer than the anthers, ascending, oblong-clavate with incurved summit, mainly solid, with narrow bilamellate ventral margin widening to and rounded at the summit, there enclosing a narrower and pointless lamelliform crest. Anthers of membranous texture throughout; their papery (instead of corneous) wings much broadened downward and horizontally truncate at base. Caudicles almost capillary, more than double the Iength of the oblong pollinia! Leaves * opposite.

5. ASCLEPIODORA. Corolla rotate-spreading in anthesis. Hoods basilar, inserted over the whole very short column, spreading and arcuate-assurgent, little surpassing the anthers, slipper-shaped and the rounded apex fornicate, hollow and with a thickish fleshy back, traversed (at least the upper part) by a salient crest which near the apex divides the cavity. Anther-wings (corneous) narrowed at base, angulate above the middle if at all. Caudicles shorter than the pyriforn pollinia. Leaves commonly alternate.

6. ASCIEPIAS. Corolla almost always reflexed in anthesis. Hoods involute or complicate, not fornicate, bearing a horn or crest-like (pointed or rarely pointless) process from the back or toward the base within, either sessile next the corolla or elevated on a column which is shorter than the anthers. Corneous anther-wings widening down to the base, usually triangular, the salient base being truncate or semihastate, or not rarely broadly rounded. Leaves opposite, sometimes varying to alternate or verticillate.

$==$ Hoods wholly destitute of crest or appendage within : corolla reflexed in anthesis.

7. ACERATES. Hoods involute-concave or somewhat pitcher-shaped. Anther-wings widened or angulate if at all near or above the middle, thence narrowed to the base. Otherwise as Asclepias. Leaves prevailingly alternate or scattered.

8. SCHIZONOTUS. Hoods saccate, dorsally bivalvular, cleft posteriorly from apex to base, the ventral side adnate to the whole length of the column. Leaves opposite. Anthers, \&c., of Acerates.

9. GOMPHOCARPUS. Hoods various, open ventrally or at the top. Anthers, \&c., of Asclepias.

+ + Stems twining (at least in ours) : corolla 5-parted or deeply cleft : crown of distinct or united plane or concave processes, or rarely cup-shaped.

+ The 5 divisions abruptly pointed, 2-3-lobed or appendaged at the apex.

10. ENSLENIA. Corolla erect-campanulate; lobes ovate-lanceolate, slightly dextrorseoverlapping in the bud. Crown nearly sessile at base of the anthers; its divisions distinct, thin, oblong, the abrupt or truncate apex bearing a long-ligulate or awnlike (single or) double appendage. Pollinia elliptical. Stigma with an elevated 2-lobed tip. Antherwings, follicles (smooth, ovate), seeds, \&c.; nearly of Asclepias.

11. ROULINIA. Corolla rotate-spreading. Crown 5-parted; its divisions simply and abruptly acuminate or ligulate-tipped. Anther-wings tuberculiform and short. Stigma flat-topped. Otherwise nearly as the preceding.

++ Divisions or lobes of the crown not tipped with any appendage or prolonged middle lobe: follicles smooth.

12. METASTELMA. Calyx short and the lobes obtuse. Corolla usually campanulate, 5-cleft or 5-parted; the lobes strictly valvate in the bud, commonly papillose-puberulent 
or bearded within. Crown of 5 flat or slender and distinct scales or processes, borne either on the corolla or the column. Stigma with flat top or with a mere apiculation at the centre.

13. MELINIA. Calyx-lobes narrow and acute, Corolla with thin-edged lobes slightly overlapping in the bud. Crown of 5 distinct fleshy scales at the base of the column. Stigma abruptly long-rostrate, the beak entire.

14. VINCETOXICUM. Corolla rotate or somewhat campanulate, 5-parted; the lobes dextrorsely overlapping or nearly valvate in the bud. Crown on the short column or at its junction with the corolla, cup-shaped or annular and usually 5-10-lobed or parted, or of 5 distinct plane scales, not appendaged. Stigma with flat or obtusely conical top.

Tribe II. GONOLOBE正. Anthers usually with short if any scarious tip, and borne on the margin of or close under the disk of the stigma; the cells opening more or less transversely. Pollinia horizontal or nearly so, otherwise as in the preceding tribe, but usually smaller.

15. GONOLOBUS. Corolla rotate or rarely campanulate, 5-parted or 5-lobed; the lobes dextrorsely convolute in the bud: crown annular or cupulate, entire or lobed, rarely di. vided. Stigma flat-topped.

ASTEPHANUS, R. Br. (Aotíqavos, crownless.) - Slender and smallered herbaceous or suffrutescent plants, chiefly of the southern hemisphere. ath. \& Hook. Gen. ii. 747 .

A. Uțahénsis, Engelm. Perennial from a thick root, low, nearly glabrous: stems filiform, twining: leaves filiform-linear, acute : short peduncles umbellately 3 -5-flowered : corolla dulf yellow, little longer than the calyx, campanulate (a line high and wide); the lobes ovate, somewhat cucullate with points inflexed, papillose-puberulent internally : follicles long-acuminate: surface of the seed rough-granulate. - Am. Naturalist, ix. 349.Dry sandhills, St. George, S. Ctah, Parry. Hardy ville, Arizona, Palmer.

2. PHILIBERTIA, HBK., Benth. \& Hook. (J. C. Philibert, author of some French elementary botanical works.) - Perennial herbaceous or shrubby twining plants (of warmer $\mathrm{N}$. and S. America) ; with petiolate leaves, and usually dull-colored or parti-colored fragrant flowers: peduncles umbellately severalmany-flowered: fl. summer. - Benth. \& Hook. Gen. ii. 750. Sarcostemma, as to spec. Amer., IIBK., Decaisne in DC., \&c. Corolla in our species deeply 5cleft or parted (= Śarrostemma, HBK.), the lobes commonly ciliate.

* Column manifest, rather longer than the tumid scales of the inner crown on its summit.

P. unduláta, Gray. Low-twining, glabrous or cinereous-puberulent, pale: leaves thickish, from lanceolate and gradually acuminate to linear from a hastately cordate base ( 2 or 3 inches long), the margins undulate-crisped : peduncle 6 -10-flowered, longer than the petiole and pedicels : corolla dull purple, glabrous above, half inch in diameter; the lobes ovate; outer crown saucer-shaped; follicles 4 or 5 inches long. - Proc. Am. Acad, xii. 95. Surcostemma undulata, Torr. Bot. Mex. Bound. 161. - W. Texas and New Mexico, Parry, Bigelow, Wright, \&c.

* Column none or very short and inconspicuous: peduncles about equalling or surpassing the plane leaves: follicles tomentulose or glabrate.

P. Torreyi, Gray. Freely twining, densely pubescent with soft spreading hairs : leaves cordate-lanceolate and acuminate or sagittate, an inch or more long: peduncle 10-15flowered: corolla apparently white, two-thirds to three-fourths inch in diameter; the lobes little shorter than the pedicel, broadly ovate, obtuse, externally puberulent, strongly villose-ciliate, outer and inner crowns contiguous. -Proc. Am. Acad. xii. 64. Sarcostemma elegans, Torr. 1. c., not Decaisne. - Rocky hills, S. W. Texas, on the Rio Grande and its tributary the Cibolo, Parry, Bigelow. - P. elegans is less pubescent, with smoother corolla purple in part within, the lobes narrower, and a short column developed between the thick and prominent outer crown and the inner.

P. cynanchoídes, Gray, 1. c. Tall-climbing (8 to 40 feet), glabrous or glabrate: leaves from decply cordate to sagittate or almost hastate, abruptly cuspidate or short-acuminate, 
1 to $2 \frac{1}{3}$ inches long: peduncle 15-25-flowered : pedicels filiform and much longer than the flowers : corolla white or whitish, scarcely half inch in diameter, smoothish; the lobes oblong-ovate, acutish, somewhat ciliate: crowns separated by a very short column. - Sarcostemma cynanchoides, Decaisne in DC. Prodr. viii. 540. S. bilobum, Torr. 1. c., not Hook. \& Arn.? Gonolobus viridiflorus, Torr. in Ann. Lyc. N. Y. ii. 219, not Nutt., and probably not from "St. Louis." - Along rivers, Texas to S. Utah and Arizona. (Adjacent Mex.)

P. lineáris, Gray, l. c. Slender, low twining or when young erect, puberulent or glabrate: leaves narrowly linear, acute or nearly so at both ends, short-petioled (an inch long): peduncle exceeding the leaves, 8-10-flowered : corolla yellowish, purplish, or whitish, barely puberulent, a third inch in diameter; the lobes ovate: crowns contiguous. - Sarcostemma lineare, Decaisne, 1. c., \& in Pl. Hartw. 25. - S. Arizona. (Mex.)

Var. hirtélla. Cinereous-pubescent throughout with short spreading hairs, little climbing: leaves as in the original species in form and size: sepals more slender. - Sarcostemma heterophyllum, var. hirtellum, Gray, Bot. Calif. i. 478. - Fort Mohave, California, on sandy river-banks, Cooper, \&c. Hardy ville, Arizona, Palmer.

Var. heterophýlla. More twining, glabrous, merely puberulent or above pubescent : leaves 1 or 2 inches long, 1 or 2 lines wide, some tapering into the petiole, some with rounded and more with somewhat dilated or auriculate-cordate or truncate base: corolla smoother, half inch in diameter. - Sarcostemma heterophyllum, Engelm. in Torr. Pacif. R. Rep. v. 363, \& Bot. Mex. Bound. l. c. (with var.?); Gray, Bot. Calif. 1. c.-California, from San Luis Rey, San Diego, \&c. to Arizuna.

P. viminális, Gray, l.c. Glabrous or nearly so, freely twining: leaves thickish, from ovate-oblong to lanceolate, cuspidate-acuminate, obtuse or rounded at base, short-petioled (an inch or two long), shorter than the many-flowered peduncle: corolla half an inch or more in diameter, white; the lobes ovate, puberulent outside. - Asclepias viminalis, Swartz, Prodr. 53; Willd. Spec. i. 1270 (Sloane, Jam. t. 131, f. 1). Sarcostemma Brownii, G. F. Meyer, Fl. Essseq. 139; Griseb. Fl. W. Ind. 419. S. clausum, Decaisne, 1. c. S. crassifolium, Chapm. Fl. 368. - Keys of Florida. (W. Ind. to Guiana.)

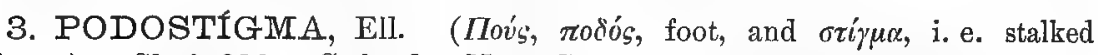
stigma.) - Sk. i. 326. Stylandra, Nutt. Gen. i. 170. — Single species.

P. pubéscens, Ell. 1. c. Peremial herb, a span to a foot high from a thickened root: stem erect, simple or sparingly branched : leaves opposite, linear-lanceolate, nearly sessile: peduncles terminal and axillary, short, umbellately several-flowered: flowers greenishyellow, fragrant, 4 lines long: follicles tomentulose. -Deless. Ic. v. t. 65 ; Chapm. Fl. 366. Asclepias pedicellata, Walt. Car. 106. Stylandra pumila, Nutt. 1. c. - Low pine barrens, N. Carolina to Florida: fl. summer.

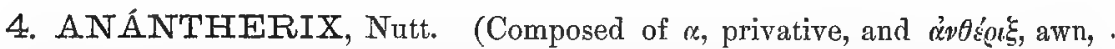
i. e. destitute of the horn of Asclepias.) - Single species, being Anantherix, Nutt. Gen. i. 169, not of Trans. Am. Phil. Soc. ser. 2, v. 201, except as to the first species.

A. connívens, Gray. Stem erect, 2 feet high from a perennial root, minutely pubescent above: leaves opposite, sessile, oblong ( $1 \frac{1}{2}$ to $2 \frac{1}{2}$ inches long), or the uppermost small and lanceolate, transversely veined, rather fleshy : umbels 2 to 6 along the naked summit of the stem, several-flowered: lobes of the greenish corolla ovate, 5 lines long: hoods whitish, incurved-conniving over the stigma; a pair of small and narrow internal appendages before the base of each: byaline anther-tips elongated: follicles not seen. - Proc. Am. Acad. xii. 66. Asclepias connivens, Baldw. in Ell. Sk. i. 320 (1817). Anantherix viridis, Nutt. Gen. I. c. (1818), but not Asclepias viridis, Walt. Acerates connivens, Decaisne in DC. Prodr. viii. 521. - Wet pine barrens of Georgia and Florida: fl. summer.

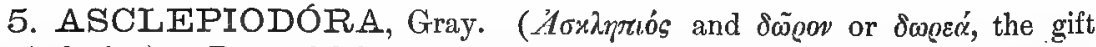
of Asclepios.) - Perennial herbs (of Atlantic N. America), rather low and stout, often decumbent; distinguished from Asclepias by the anther-wings and hood, the latter with a crest answering to the horn of that genus, from the original Anan- 
therix by the same characters. Leaves mainly alternate or scattered. Flowers proportionally large: corolla-lobes ovate, greenish. Follicles ovate or oblong and acuminate, usually bearing some scattered soft-spinulose projections, arrect on recurved or sigmoid pedicels. - Proc. Am. Acad. xii. 66. Anantherix in part, Nutt. in Trans. Am. Phil. Soc. 1. c. Acerates in part, Decaisne, l. c.

A. víridis, Gray, l. c. About a foot high, almost glabrous, very leafy to the top : leaves from ovate-oblong to oblong-lanceolate, mostly obtuse, short-putioled, 3 or 4 inches long: umbels few and corymbose or clustered, sometimes solitary : corolla globular-ovate in bud; the lobes a third to half inch long: hoods purplish or violet, about half the length of the corolla-lobes, lower than the anther-column : wings of the anthers narrow, hardly angulate above, and below less prominent than the connectives : pollinia narrow, little longer than their caudicles. - Asclepias viridis, Walt. Car. 107. Podostigma? viridis, Ell. Sk. i. 327. Anantherix paniculatus, Xutt. Trans. Am. Phil. Soc. I. c. A. Torreyanus, Don, Syst. iv. 146. Asclepias longipetala, Scheele in Linn. xxi. \%57. 1cerates paniculata, Decaisne, 1. c. 521.Prairies and dry barrens, S. Carolina to Texas, New Mexico, and westward of the Alleghanies north to Illinois.

Var. angústior, a lower form, with smaller and oblong-linear leaves, and rather more assurgent hoods. - Anantherix paniculatus, var. angustior, Engelm. ined. - Texas, Lindheimer, E. Hall.

A. decúmbens, Gray, l. c. Scabrous-puberulent: leaves firmer in texture, from Ianceolate to linear, tapering to the apex: umbel solitary : corolla depressed-globular in bud, 4 or 5 lines long, hardly twice the length of the yellowish or dark-purplish hoods, which overtop the somewhat depressed anther-column: anther-wings salient, especially at the broader and strongly angulate upper portion: pollinia pyriform, short-caudicled. - Anantherix decumbens, Nutt. 1. c. (\& in Torr. Ann. Lyc. N. Y. ii. 219, without name). -A. Nuttallianus, Don, Srst. iv. 147. Acrates decumbens, Decaisne, I. c. Asclepias brevicornu, Scheele, l. c. 756. - Dry plains, Arkansas and Texas to New Mexico and Utah. Follicles always smooth? (Adjacent Mex.)

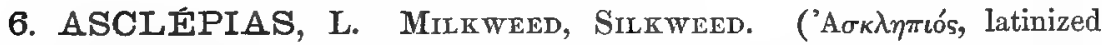
Esculapius, applied by the ancient herbalists to various plints of the present and the preceding order.) - Herbs, rarely woody at base (American, mainly North American with one or two Africas): upright or merely spreading stems from deep and thickish perennial roots: leaves opposite varying to verticillate, or sometimes alternate or irregularly scattered. Flowers (in summer) umbellate; the peduncles terminal and lateral, usually between the petioles. Stem often marked with decurrent lines of pubescence. Follicles soft-echinate or warty in two or three species, otherwise naked. Coma of the seeds often wanting in $A$. perennis. Corolla not reflexed in A. Feayi. - Benth. \& Hook. Gen. ii. 75 5 ; Gray, Proc. Am. Acad. xii. 66.

$\S 1$. Hoods sessile, broader or at least not attenuate at base; the horn or crest various, but conspicuous : anther-wings broudest and usually angulate-truncate and salient at base.

* Corolla and hoods. orange-color: follicles arrect on a deflexed fruiting pedicel, naked : leaves mostly irregularly alternate, seldom truly opposite: juice of stem not milky!

A. tuberósa, L. (ButTerfly-weed, Plecrisy-Root.) Hirsute or roughish-pubescent, a foot or two high, very leafy to the top: leaves from lanceolate-oblong to linear-lanceolate, sessile or slightly petioled : umbels several and mostly cymose at the summit of the stem, short-peduncled: column short: hoods narrowly oblong, erect ( 2 or 3 lines long), deep bright orange, much surpassing the anthers, almost as long as the purplish- or slightly greenish-orange oblong corolla-lobes, nearly equalled by the filiform-subulate hom: follicles cinereous-pubescent. - (Dill. Elth. t. 30, f. 31.) Bot. Tieg. t. 76; Bart. Med. t. 22 ; Bigel. Med. t. 26. Dry and especially sandy soil, Canada to Florida, Texas, and Arizona. 
Var. decúmbens, Pursh, a form with reclining stems, broader and more commonly opposite leaves, and umbels from most of the upper axils, racemosely disposed. $-A$. decumbens, L. Spec. 216; Sweet, Br. Fl. Gard. ser. 2, t. 24, but flowers too red. - Ohio to Georgia, \&c. (A hybrid between A. tuberosa and A. incarnata was found in South Carolina by Dr. Mellichamp.)

* * Corolla bright red or purple: follicles naked, fusiform, arrect on the cleflexed fruit-bearing pedicel, except in the first and last species: leaves opposite, mostly broad. (A. quadrifolia might be sought here.)

+ Hoods bright orange, raised on a distinct column: plants glabrous.

A. Curassávica, L. A foot or two high, becoming somewhat woody at base: leaves oblong-lanceolate, thin, short-petioled, 2 to 4 inches long: peduncles not longer than the leaves : lobes of the scarlet corolla ovate: hoods ovate, equalling the anthers, shorter than their subulate incurved horn: follicles and fruiting pedicels erect. - (Herm. Par. t. 36 ; Dill. Elth. t. 30, f. 33.) Bot. Reg. t. 81.-S. Florida and Louisiana: perhaps introduced from Tropical America.

A. paupércula, Michx. Stem 2 to 4 feet high, remotely leafy above or naked at the peduncle-like summit, which bears solitary or few pedunculate naked umbels : leaves elongated-lanceolate or linear and tapering to both ends, 4 to 10 inches long, nearly sessile, thickish, very smooth except the roughish margins: flowers rather few (5 to 12) in the umbels, large (fully half inch long when the narrowly oblong lobes of the deep red corolla are reflexed) : bright orange hoods obovate or broadly oblong, not twice the length of the anthers, much exceeding the incurved horn. - A. lanceolata, Walt. Car. 105. - Marshes near the coast, New Jersey to Florida and Texas.

++ Hools purple or purplish: umbel mostly many-flowered.

+- Flowers rather large; the hoods about a quarter inch long and clouble the length of the anthers: lobes of the corolla dull-colored outside, deep-colored within: leares transversely veined, 3 to 8 inches long.

A. rúbra, L. Glabrous, 1 to 4 feet high, somewhat remotely leafy : leaves from ovate to lanceolate, sessile or almost so, tapering from near the rounded or obscurely cordate base to an acuminate apex, bright green: umbels solitary (terminal and from the uppermost axils) or 2 to 4 raised on a nalked common peduncle: corolla-lobes and hoods lanceolateoblong, purplish-red, or the hoods obscurely orange-tinged; the horn of the latter long, very slender, straightish: column short but manifest. - Spec. 217 (founded on pl. Clayt. no. 263, Gronov. Fl. Virg., with upper leaves accidentally alternate); Gray, in DC. Prodr. \& Man. ed. 1,368. A. polystachia, Walt.? A. cordata, Walt.? A.laurifolia, Michx. Fl. i. 117. A. acuminata, Pursh, Fl. i. 182. A. periplocifolia, Nutt. Gen. i. 167. - Moist grounds, New Jersey and Penn. to Florida and Louisiana.

A. purpuráscens, L. Stem 1 to 3 feet high, leafy to top : leaves ovate-oval or oblong, short-petioled, tomentulose beneath, soon glabrous above: peduncles shorter than the leaves: corolla dark and deep (sometimes dull) purple within; the lobes oblong: hoods pale red or purple, oblong or somewhat ovate; the horn short-subulate from a broad base, falcate-incurved : column extremely short. - Spec. 214 (Dill. Elth. 32, t. 28, f. 31); Willd. Spec. i. 1265 ; Decaisne in DC. viii. 464 ; Torr. Fl. N. Y. ii. 120, t. 85 . A. amana, L. Spec. 217 (pl. Dill. l. c. 31, t. 27, f. 30); Michx. 1. c.; Sweet, Brit. Fl. Gard. ser. 2, t. 82.Dry ground, New Fngland to Wisconsin and Tennessee. Habit of A. Cornuti.

+ Flowers small; the hoods a line long and equalling the anthers: veins of the leaves ascending: milky juice scanty.

A. incarnáta, L. Nearly glabrous or a little pubescent: stem 2 or 3 feet high, very leafy to the top, sometimes branching: leaves oblong-lanceolate, short-petioled ( 3 to 5 inches long), obtuse or acutish at base: peduncles somewhat corymbose at or near the. summit of the stem, shorter than the leaves : corolla from deep rose-purple to flesh-color; the lobes oblong ( 2 lines long) : column narrow, more than half the length of the broadly oblong obtuse pale hoods; these a little exceeded by their slender uncinate-inicurved horn: follicles only 2 or 3 inches long, erect on erect pedicels. - (Cornuti, Canad. t. 93.) Jacq. Vind. t. 107; Bot. Reg. t. 250; Decaisne, l. c. excl, syn. in part. A. amcena, Brongn. in Ann. Sci. Nat. xxiv. t. 13, anal. - Swamps, Canada to Saskatchewan and Louisiana.

Var. pulchra, Pers., the form with copious and somewhat hirsute pubescence, and usually broader leaves (lanceolate to oblong) of ten subcordate at base. $-A$. incarnata, $\mathrm{L}$. 
as to Hort. Cliff.; Michx. 1. c. A: pulchra, Ehrhart; Sweet, Brit. Fl. Gard. ser. 2, t. 18. With the smooth form.

Var. longifólia. Leaves elongated- or linear-lanceolate, 4 to 7 inches long, a third to half inch wide, glabrous or with minute pubescence: stems 4 to 6 feet high: flowers paler. - A. tuberosa, Torr. in Pacif. R. Rep. vii. 18. - Texas to New Mexico.

* * Corolla and crown greenish, yellowish, white, or mcrely purplish-tinged : leaves opposite or sometimes whorled, or the upper rarely alternate or scattered.

+ Follicles echinate with soft spinous processes and densely tomentose, large ( 3 to 5 inches long) and rentricose, orate and acuminate, arrect on deflexed pedicels: leaves large and broad, shortpetioled, transversely veined: stems stout and simple, 2 to 5 feet high.

A. speciósa, Torr. Finely canescent-tomentose, rarely glabrate with age : leaves from subcordate-oval to oblong, thickish : peduncles shorter than the leaves: pedicels of the many-flowered dense umbel and the calyx densely tomentose: flowers purplish, large: corolla-lobes ovatè-oblong, 4 or 5 lines long: hoods 5 or 6 lines long, spreading, the dilated body and its short inflexed horn not surpassing the anthers, but the centre of its truncate summit abruptly produced into a lanceolate-ligulate thrice longer termination: column hardly any: wings of the anthers notched and öbscurely corniculate at base. - Ann. Lyc. N. Y. ii. 218. A. Donglasii, Hook. Fl. ii. 58, t. 142, \& Bot. MIag. t. 4113. - Along streams, Nebraska to Arkansas, and west to S. Ltah, California, and Washington Territory.

A. Cornúti, Decaisne. (Comos MiLkweed.) Finely soft-pubescent or tomentulose: leares green and early glabrate above, oval or oblong, obtuse or roundish at base: peduncles little longer than the very numerous pubescent pedicels: corolla dull purple or greenish-purple, rarely alinost white; the lobes ovate, three or four lines long: hoods whitish, orate, rather longer than the anthers, with a tooth on each side below the middle; the subulate horn short and incurved: column short. - Prodr. 1. c. 564; Torr. Fl. N. Y. ii. 119. A. Syriaca, L. (Cornuti, Canad. t. 90) ; Spenner in Nees Gen. Germ. fasc. 21, t. 1-3. - Canada to Saskatchewan and N. Carolina, chiefly in fields.

++ Follicles minutely warty-echinate along the tapering apex, otherwise as in the succeeding: wings of the anthers emarginately bicorniculate at base.

A. Sullivántii, Engelm. Glabrous throughout, a yard high, leafy to the top: leaves opposite, thickish, oblong, with subcordate or rounded base, nearly sessile ( 4 or 5 inches long): umbels terminal and from the uppermost axils, short-peduncled, rather. manyflowered: flowers flesh-colored: corolla-lobes oval, 5 lines long: column short: hoods oval, with a gibbosity on each side near the base, almost truncate at summit, a third longer than the anthers; the falcate-subulate horn rising from near the base, horizontally and slightly exserted from the middle. - Gray, Man. ed. 1, 366, ed. 5, 395. - Low grounds, Ohio (Sullivant) to Kansas (Fremont). Follicle 3 to 5 inches long, ovate-lanceolate, nearly glabrous, smooth, except small and soft conical warty processes scattered along the beak.

+++ Follicles wholly unarmed and smooth throughout, either glabrous or tomentulose-pubescent.

+- Arrect or ascending on the deflexed or decurved fructiferous pedicels.

= Unbel solitary on the perfectly simple strict stem, elevated on a naked terminal peduncle: leares all closely sessile, broad, transversely veined: plant glabrous and pale or glaucous: follicles fusiform: anthers either bicorniculate or salient-angled at base of the wing.

A. obtusifólia, Michx. Stem 2 or 3 feet high: leaves undulate, oblong or elliptical, 3 to 5 inches long, with rounded or retuse apex and cordate-clasping base: peduncle 2 to 12 inches long: umbel loosely many-flowered: corolla dull greenish-purple; the Iobes oblong, 4 lines long: column as high as broad: hoods flesh-color, erosely truncate and somewhat toothed at the broad summit, hardly exceeding the anthers, shorter than the falcate-subulate incurved horn: anther-wings bicorniculate at base in the manner of $A$. Sullivantii. - Fl. i. 113; Decaisne, 1. c. 565. A. purpurascens, Walt. Car. 103.-Dry or sandy soil, New England to Florida, Texas, and Nebraska.

A. Meádii, Torr. A foot or two high: leaves plane and even, ovate-lanceolate, or rarely lanceolate, obtuse or acute, rounded at the sessile base, rough-margined, $1 \frac{1}{2}$ to 3 inches long: peduncle 2 to 4 inches long: umbel 6-20-flowered: corolla greenish-yellow; the lobes ovate, 3 or 4 lines long: column very short: hoods purplish, with rounded-truncate entire summit and a tooth at the inner margins, exceeding the anthers and the subulate inflexed horn: anther-wings with entire but descending salient angle at base. - Gray, Man. ed, 2, addend. 704, ed. 5, 397. - Dry ground, Illinois, S. B. Mead, Iowa, Vasey, \&c. 
$==$ Umbels usually more than one and on peduncles overtopping or equalling the leaves: stem tall and simple: leaves broad, resembling those of the three preceding species.

A. glaucéscens, HBK. Glabrous up to the peduncles, and inclined to be glaucous: leaves as of $A$. obtusifolia, but only slightly undulate, $2 \frac{1}{2}$ to 4 inches long: umbels 2 to 4 or rarely solitary, many-flowered : pedicels pubescent or villous, rather short : corolla greenishwhite; the lobes ovate, 3 or 4 lines long: column very short: hoods obovate-truncate, about equalling the anthers, with fleshy gibbous-incurved back and (white?) petaloid sides, the whole length within occupied by a broad and thin crest, which is 2-lobed at the summit, the outer lobe broad and rounded, the inner a short and triangular-subulate nearly included horn. - Nov. Gen. \& Spec. iii. 1900, t. 227 ; Decaisne in DC. 1. c. 565. A. Sullivantii, Torr. Bot. Mex. Bound. 162, wholly? - S. W. Texas and New Mexico (but the only specimen in herb. Torr. from "Plains near the Rio Limpio"), Bigelow. (Mex.)

$==$ Crmbels more than one, on peduncles longer than the orbicular leaves or than the much abbreviated stem.

A. nummulária, Torr. Clustered stems an inch or two high : leaves in 2 or 3 approximated pairs, orbicular, mucronate, thickish, canescently tomentose, glabrate witlı age: peduncles $1 \frac{1}{2}$ to 2 inches long, many-flowered: corolla greenish-white; the lobes ovate, 2 lines long: column liardly any: hoods ovate, a little longer than the anthers: the horn short and stout: follicles ovate-lanceolate, tomentulose. - Bot. Mex. Bound. 163, t. 45. New Mexico, Bigelow, Thurber, \&c. (Adjacent Mex.)

$===$ Umbels mostly more than one: peduncle not orertopping the leaves (except perhaps in $A$. cinerea), sometimes none.

a. Leaves broad (from orbicular to oblong-lanceolate), proportionally large: hoods broad. little if at all overtopping the anthers: stems from a foot to a yard or more in heiglt, except the first species.

1. Glabrous or some minute pubescence or tomentum on young parts, no floccose wool.

A. cryptóceras, Watson. A span or two high, almost completely glabrous : stems decumbent: leaves 3 or 4 pairs, ovate-orbicular witl mucronate apiculation, glaucescent, 1 or 2 inches long, very short-petioled: flowers large, all at the summit, few in each of the 2 or 3 umbels: the lateral of these sessile, the terminal short-peduncled: lobes of the grecnish-yellow corolla ovate, 5 lines long: column none: hoods flesh-colored, saccateovate, abruptly and minutely bi-acuminate, equalling the anthers, enclosing the falcatesubulate horn: follicles ovate. - King Exped. 283, t. 28 . Acerates latifolia, Torr. in Frem. Rep. ed. 2, 317. - Utah, W. Nevada, and Idaho, Nuttall, Fremont, Watson, \&c.

A. amplexicaúlis, Michx. Glaucous and glabrous : stems decumbent, a foot or two long: leaves in numerous rather crowded pairs, cordate-ovate and clasping, obtuse, succulent, whitish-veiny, 3 to 5 inches long: peduncles about half the length of the leaves, longer than the numerous slender pedicels: lobes of the greenish-purplish corolla oblong, 3 lines long: column very short: hoods white, obovate-truncate, nearly enclosing the triangular-arcuate crest-like horn : follicles ovate-lanceolate. - Fl. i. 113 ; Ell. Sk. i. $322 . A$. humistrata, Walt. Car. 105, except "floribus rubris." - Dry sandy barrens, North Carolina to Florida.

A. Jamésii, Torr. Farinose-puberulent when young, soon green and glabrous: stem stout, erect or ascending, a foot or more high: leaves about 5 pairs, approximate, remarkably thick and large (when dry coriaceous, the larger 4 to 6 inches long), orbicular or broadly oval, often emarginate and with a mucronation, subcordate at base, nearly sessile, copiously transversely veined: umbels 2 or 3 , all or mostly lateral, densely manyflowered, on peduncles shorter than the pedicels: flowers greenish: lobes of the corolla ovate, 4 or 5 lines long: column very short but distinct: hoods barely equalling the anthers, broad, with truncate entire summit, which is equalled by the upper margin of the falciform-triangular crest, the apex of which extends into a shart.subulate horn partly over the top of the stigmatic disk: follicles turgid-ovate, barely acute, $2 \frac{1}{2}$ or 3 inches long. - Bot. Mex. Bound. 162. A. obtusifolia, var. latifolia, Torr. in Ann. Lyc. ii. 117. - Plains of Colorado to W. Texas and E. Arizona.

A. phytolaccoídes, Pursh. Bright green and glabrous : stem 4 or 5 feet high : leaves membranaceous, from oval to ovate-lanceolate, acuminate at both ends, short-petioled, 4 to 8 inches long: peduncles ( 1 or 2 inches long) seldom longer than the numerous filiform lax pedicels : corolla greenish; the lobes ovate or oblong, 4 lines long: column short: 
hoods white or pale, flesh-colored, broad and erect, rather shorter than the anthers, truncate horizontally, the truncate margin somewhat erose or toothed and with a slender tooth at the inner angles, much surpassed by the erect or slightly incurvecl slender-subulate horn: follicles fusiform and slender-acuminate, at length glabrous. - Fl. i. 180; Decaisne in DC. 1. c. A. Syriaca, var. exaltata, L. Spec. ed. 2, 313. 1. mivea, sinss, Bot. Mag. t. 1181, not L. A. exaltata (acuminata), Muhl. Cat. 28. - Shaded and moist ground, New England to Wisconsin and south to Georgia in the mountains.

A. variegáta, L. A foot or two high: leaves 3 to 7 pairs, thinnish (the middle ones sometimes 4-nate), oval or ovate, or the upper oblong, obtuse at both ends, mucronateapiculate or short-acuminate, not rarely somewhat undulate, lright green and glabrous above, pale and sometimes tomentulose beneath (at least when young), 3 to 6 inches long, conspicuously petioled: peduncles 1 to 3 , terminal and subterminal, short, equalling or exceeding the very numerous pedicels of the compact umbel, both usually tomentulose: flowers white with some pink or purple at the centre, i. e. on the distinct column and base of the corolla: lobes of the latter ovate or oval, 3 lines long: hoods globular-ventricose from a narrow base, spreading, overtopping the short anthers and stigmatic disk; the semilunate subulate horn horizontally short-exserted : follicles fusiform and long-acuminate. -Spec. 215, \& ed. 2, 312 (founded on syn. Dill. \& Pluk.) ; Walt. Car. 104; Sims, Bot. Mag. t. 1182; Ell. l. c.; Decaisne, 1. c. (excl. syn. Hook.) ; Gray, Man. l. c. ; Torr. Fl. N. Y. t. 86. A. nivea, L. as to syn. Gronov. \& herb. A. citrifolia, Jacq. Coll. \& Ic. Rar. t. 343. A. hybrida, Michx. 1. c. - Dry shaded grounds, S. New York and Ohio to Florida, Arkansas, and W. Louisiana.

2. Tomentose or pubescent, South Atlantic States or New Mexican species: umbels all lateral, short-peduncled : flowers greenish: follicles tomentose or canescent.

A. tomentósa, Ell. Tomentulose or merely soft-pubescent, sometimes minutely so : stems a foot or sometimes a yard high, very leafy above: leaves from oval-obovate to oblong-lanceolate, obtuse or short-acuminate at both ends, 2 to 4 inches long, rather conspicuously petioled: umbels 3 to 10 in alternate axils, very short-peduncled, loosely many-flowered: lobes of the corolla ovate, 3 or 4 lines long: column very short: hoods oval-obovate, obliquely truncate, decidedly shorter than the broadly-winged anthers; the broadly subulate horn ascending and moderately exserted at the upper interior angle: "follicles lanceolate." - Sk. i. 520 ; Chapm. Fl. 363. A. aceratoides, M. A. Curtís in Am. Jour. Sci. ser. 2, vii. 407. - Dry sandy barrens, N. Carolina to Florida.

A. arenária, Torr. Lanuginous-tomentose, in age glabrate: stems about a foot high, stout, ascending, thickly leaved: leaves coriaceous when old, obovate or oval and retuse or the lower ovate, with rounded or subcordate base, somewhat undulate, distinctly petioled, 2 to 4 inches long: umbels rather densely many-flowered, shorter than the leaves: lobes of the greenish-white corolla oval, 5 lines long: column nearly half the length of the anthers: hoods about as broad as high, surpassing the antlıers, truncate at base and summit, the latter oblique and notched on each side near the inner angle, which forms an obtuse tooth; horn with included ascending portion or crest broadly semilunate as high as the hood; the abruptly incurved apex subulate-beaked, horizontally exserted, or the slender termination ascending: follicles oblong-ovate and long-acuminate, tomentulose. - Bot. Mex. Bound. 162. - Colorado, on sand-banks of the Cpper Canadian and Red Rivers (Bigelow, Marcy) to New Mexico, W"islizenus, \&c. - Allied to A. .Jamesï.

3. Floccose-lanuginous or tomentose-canescent, Western species; the dense wool not rarely deciduous with age: stems stout, 1 to 4 feet ligh : leares occasionally alternate, large ( 2 to 6 inches long): umbels terminal and lateral, many-flowered: follicles (where known) ovate.

A. Fremónti, Torr. Canescently tomentose with short and fine wool, or the stem (a foot or less high) puberulent: leaves oval or oblong, obtuse, retuse, or apiculate-acute, often subcordate, smooth-edged, distinctly petioled: umbels 1 or 2 , on peduncles not longer than the lanuginous pedicels: lobes of the whitish corolla oblong-ovate, 3 lines long: column very short: hoods nearly erect, equalling the anthers, somewhat evenly truncate and the inner angles produced into an acute or obtusish tooth, with no notch behind it; the subulate apex of the broad lorn inflexed and a little exserted. - Pacif. R. Rep. vi. 87, name only. - California, on the Upper Sacramento, Fremont, Veubery, \&c. Follicles when young densely canescent-tomentose, in age glabrate. Herbage with the pubescence of the preceding rather than of the following species. 
A. erósa, Torr. Canescent with fine and appressed white wool when young, or the sten only puberulent: leaves glabrate and green with age. sessile, ovate to ovate-lanceolate, acuminate, coriaceous, the base rounded or slightly cordate, the margin scarious-cartilaginous and rough with minute irregular denticulation or erosion: umbels numerous, on peduncles equalling (or the lower exceeding) the lanuginous pedicels : lobes of the greenishwhite corolla oval, fully 3 lines long, merely hoary and soon glabrate outside: column distinct: hoods yellowish, with a duplication on each side at the edge below, erect and nearly horizontally truncate, rather surpassing the anthers; the falcate or claw-shaped horn attached below the middle and longer than the hood, incurving orer the disk of the stigma : ovaries glabrous: follicles canescent when young, often glabrate at maturity.Bot. Mex. Bound. 162, glabrate state. A. leucophylla, Engelm. in Am. Naturalist, ix. 349; Gray, Bot. Calif. i. 476 , in the canescent-lanuginous state. - Arizona on the Gila (Schott, Thurber) to S. Utah (Parry) and San Diego Co., California, Cooper, Palmer.

Var. obtúsa, a form with elliptical and very obtuse leaves and scanty woolliness. A. leucophylla, var. obtusa, Gray, l.c. - Bartlett's Cañon, interior of Santa Barbara Co., California.

A. eriocárpa, Benth. Densely floccose-woolly, even to the calyx, the loose wool hardly deciduous except from the angled stem below: leaves not rarely ternate and the uppermost alternate, elongated-oblong or the upper lanceolate, obtuse or subcordate at base, short-petioled, 4 to 8 inches long: umbels few or several, all on stout peduncles mostly longer than the pedicels: flowers dull white: corolla at first woolly outside; the lobes ovate, 3 lines long: column short but distinct: hoods shorter than the anthers, rather spreading, ventricose, oblately semiorbicular in outline and open round to near the middle of the back, the summits produced inwardly into an acute angle or tooth, barely enclosing the falciform acute horn: ovaries glabrous or merely the summit or the styles villous: "follicles densely woolly," according to Benth. Pl. Hartw. 323. - California, in dry ground, from near Monterey (II Irtweg) to San Diego Co.

A. vestíta, Hook. \& Arn. Densely floccose-woolly, usually even to the outside of the corolla, the white wool deciduous in age: leaves from ovate to oblong-lanceolate, very acute or acuminate, often subcordate, short-petioled or the upper sessile, 4 to 6 inches long: umbels 1 to 4, the terminal usually peduncled, the lateral all sessile: corolla greenish-white or purplish; the lobes ovate, 3 lines long: column very short: hoods nearly erect, ventricose, slightly surpassing the anthers, entire at the back of the somewhat truncate summit, auriculate-extended at the inner angle, the auricles or angles involute; the vomer-shaped crest rather than horn attached up to the summit of the hood, blunt, not exserted: an interior crown of 10 tooth-like processes in pairs between the hoods : ovaries glabrous : follicles at first canescent. - Bot. Beech. 363 (not Bot. Mag. t. 4106); Gray, Bot. Calif. i. 476. A. eriocarpa, Torr. in Pacif. R. Rep. iv. 128, not Benth. - Dry ground, California, from the Sacramento to San Diego Co. and the Moliave.

b. Leaves narrow (lanceolate or linear, 1 to 3 inches Iong), green and ncarly glabrous; the veins oblique: stems branching, ascending, a span or two high: hoods obtuse, shorter or little longer than the anthers: corolla-lobes oblong-ovate, about 2 lines long: column hardly any: follicles ovate, acute or acuminate, when young tomentose-canescent.

A. brachystéphana, Engelm. Stems 6 to 10 inches high, very leafy, cinereous-puberulent or tomentose when young, the inflorescence more floccose-tomentose: leaves from lanceolate with a broader rounded base to linear, short-petioled (sometimes 3 inches long), when young often cinereous-tomentulose beneath, very much surpassing the (3 to 8 ) fewflowered nmbels : peduncles as long as the pedicels or much shorter : flowers lurid-purplish : hoods only half the length of the anthers, erect, strongly angulate-toothed at the front; the tip of the erect subulate horn exserted. - Torr. Bot. Mex. Bound. 163. - Dry sandy soil, from Wyoming Terr. and Colorado to W. Texas and Arizona. (Adjacent Mex.)

A. involucráta, Engelm. Minutely pubescent when young, glabrate, a span or less in height: clustered stems spreading: leaves from lanceolate with roundish or subcordate base to linear. with acute base, short-petioled (occasionally alternate), tomentose on the margins ; the uppermost involucrating the mostly solitary sessile or short-peduncled 10-20flowered umbel and conmonly overtopping it; flowers greenish-white or purplish-tinged: hoods ovate, moderate-longer than the anthers; the short incurved horn slightly exserted from about their middle. - Torr. Bot. Mex. Bound. 163. - Sandy soil, New Mexico and Arizona. (Adjacent Mex.) 
c. Leaves extremely narrow, sessile: hoods thrice the length of the anthers, slender, acute, open.

A. macrótis, Torr. Glabrous or nearly so: stems barely a span high, numerous and much branched from a suffrutescent thickened base: leaves narrowly linear with revolute margins, almost filiform, an inch or more long: umbels $3-\bar{y}$-flowered, terminal and lateral, short-peduncled or sessile: pedicels little longer than the purplish or greenish flowers: corolla-lobes ovate, 2 lines long: column hardly any: hoods with ovate erect base as long as the anthers, above contracted into a gradually attenuate twice longer subulate spreading portion, the apex incurving; the broad horn short and blunt, with barely exserted apcx: follicles orate-lanceolate, an inch long. - Bot. Mex. Bound. 16t, t. 45. - Rocky hills along the Rio Grande, borders of Texas, New Mexico, and Chihuahua, especially near El Paso, Bigelow, Parry, Wright.

d. Leaves from ovate to oblong, mostly pubescent or puberulent: stems erect, a foot or more high : hoods obtuse, twice cr thrice the length of the anthers, not tapering to base, entire at summit,

1. Involute-concare or more open; the falcate or subulate horn free at or below the midale of the hood, and incurred or inflexed orer the stigmatic disk : follicles tomentose or soft-pubescent.

A. ovalifólia, Decaisne. Tomentulose-pubescent: stem rather slender: leaves thinnish, from ovate or oval to ovate-lanceolate, mostly acute, rounded at base, distinctly petioled ( $1 \frac{1}{2}$ to $: 3$ inches long), glabrate with age, at least the upper face, the midrib as well as primary veins slender, and veinlets reticulated: umbels few, loosely 10-18-flowered, on peduncles which seldom equal the pedicels, or sometimes sessile: corolla greenisll-white with purplish outside; the lobes oblong-ovate, 2 or 3 lines long: hoods oval or broadly oblong in outline, not auriculate at base, the inner margins below the middle extended into a large acute tooth or lobe; the horn broad and rather short: anther-wings rounded and entire or minutely and obscurely notched at the prominent base. - DC. Prodr. viii. 567 (excl. habitat) ; Gray, Man. ed. 5, 396. A. variegata, var., Hook. Fl. ii. 252, t. 141. A. Nuttalliana, Gray, Man. ed. 2, 352, 704. - Saskatchewan, Lake Winnipeg, and Dakotah to N. Tlinois and Wisconsin, in oak-openings and prairies.

A. Hállii, Gray. Puberulent, glabrate : stem stout : leaves thickish, ovate-lanceolate or oblong-lanceolate with rounded base and rather acute apex ( 3 to 5 inches long), shortpetioled, the stout midrib and the slightly ascending straight veins prominent underneath : umbels few and corymbose, many-flowered, on peduncles somewhat longer than the pedicels : corolla greenish-white and purplish; the lobes oblong, 3 lines long: hoods elongated-oblong in outline ( 3 lines long), entire, hastately 2 -gibbous above the narrower base, a little surpassing the sickle-shaped horn: anther-wings even and unappendaged at base. - Proc. Am. Acad. viii. 69. A. ovalifolia, Gray in Proc. Acad. Philad. March, 1863, 75, coll. E. Hall. n. 480. - Colorado, near Denver? E. Hall. Head-waters of the Arkansas, Brandegee, \&c. Follicles tomentulose, glabrate. In aspect resembles $A$. Sullivantii, but with some pubescence, and base of the anther-wings destitute of the corniculation.

A. obováta, \#ll. Cinereous with soft pubescence or tomentum on the lower face of the leaves: stem a font or two high : leaves oval or oblong, only the lower-obovate, somewhat undulate, mucronate-apiculate, rounded or subcordate at base, very short-petioled ( $1 \frac{1}{2}$ to 3 inches long), the midrib stout, the veins transverse and slender: umbels ( 3 or 4 at the upper axils) almost sessile, densely 10-14-flowered: lobes of the yellowish-green corolla oblong, 3 or 4 lines long, half the Iength of the pedicels : hoods purplish, oblong, strictly erect ( 3 or 4 lines long), involute so that the thin inner edges meet for almost their whole length, dorsally hastately bigibbous above a short contracted base, thence narrowly wingappendaged upward and inward for some length, a pair of broad and short fleshy internal auricles at very base within; horn narrowly falcate, fleshy; the exserted upper part of the free portion strongly inflexed, subulate; upper or dorsal face canaliculate-concave: anther-wings bicorniculate at the basal angle (in the manner of A. obtusifolia and A. Sullivantii).—Sk i. 321 ; Decaisne, 1. c. 570 (excl. syn. Torr.); Chapm. Fl. 363.- Dry ground, S. Carolina, near the coast, to Florida and Louisiana.

2. Hoods Iaterally much compressed, mainly solid, with a narrow dorsal keel and a broader ventral wing; the latter bearing two semi-obovate lamellse, its broad upper part enclosing a lamelliform crest of equal width, which bears a short subulate exserted horn at the inner angle.

A. nyctaginifolia, Gray. Roughish-puberulent, apparently a foot high and ascending: leaves rhombic-ovate, with ascending and branching veins, 2 or 3 inches long, rather longpetioled: umbels all lateral, very short-peduncled, 4-20-flowered: pedicels equalling the 
petiole: lobes of the greenish corolla oblong (half inch long) : column hardly any below the greenish white hoods, which are little shorter than the petals, almost thrice the length of the anthers, barely retuse at apex; the truncate upper edge of the crest erose; the exserted horn from its inner angle thin-subulate, a line long: auricles at base of the hood very small, roundish : anther-wings broadly rounded at base: follicles not seen.-Proc. Am. Acad. xii. 70. - Rock Spring, Providence Mountains, S. E. California, Palmer.

++ Follicles pendulous on recurving pedicels, at least not erect: leares subulate-filiform or wanting on the junciform naked stems : hoods elongated, broader upward.

A. subuláta, Decaisne. Cinereous-puberulent or soon glabrous and glaucous : stem 3 or 4 feet high, nalked and rush-like or bearing a few nearly filiform leaves, usually fewbranched above: umbels terminal and lateral, 5-20-flowered, on peduncles mostly shorter than the pedicels: flowers yellowish-white: lobes of the corolla oblong, 4 or 5 lines long: column distinct: hoods purplish, narrowly oblong-panduriform, erect, twice the length of the column, entire, a narrow crest adnate up to the apex, above dilated and inwardly pointed by a very short and blunt subulate horn; 10 short internal appendages forming a pair of fleshy auricles within the base of eacl hood: follicles fusiform and long-acuminate, 4 inches long, smooth. - DC. Prodr. viii. 571; Torr. in Pacif. R. Rep. v. 362, t. 7. - Desert region of S. E. California and W. Arizona. (Lower Calif., W. Mex.?)

++++ Follicles erect on erect fruiting pedicels, fusiform : Jeaves not rarely verticillate, in one species commonly alternate: hoods moderately if at all exceeding the anthers.

= Leaves from ovate to broadly lanceolate, glabrous or nearly so, thin, rather slender-petioled: corolla white or pinkish.

A. quadrifólia, L. A foot or two high, simple, usually leafless below : leaves 3 or 4 pairs, or commonly a whorl of four in place of each middle pair, ovate to ovate-lanceolate, acuminate, 2 to 4 inches long: umbels 2 to 4 , loosely many-flowered: peduncle seldom longer than the slender pedicels: corolla from light pink to almost white; the lobes $2 \frac{1}{2}$ lines long, oblong: column short: hoods white, twice the length of the anthers, ovateoblong, a salient tooth or lobe on each margin toward the base; horn short, very broadly falcate-subulate, incurved over the anther-tips. - Jacq. Obs. t. 33 ; Barton, Fl. Am. Sept. ii. t. 43 ; Lodd. Bot. Cab. t. 1258. A. vctilla, Raf. in Am. Month. Mag. iv. 39 (1818), ex Neob. 62. - Dry soil, Canada and Wisconsin to N. Carolina and Arkansas.

A. perénnis, Walt. Stem a foot or two high, commonly branching, leafy throughout, sometimes rather woody at base: leaves all opposite, from orate to oblong-lanceolate, mostly acuminate at both ends, 2 to 4 inches long: umbels several and rather small, on peduncles of about twice the length of the pedicels : flowers white throughout: lobes of the corolla 1 or 2 lines long, oblong : column narrow, half to three fourths of a line long: hoods oval, entire, erect, not twice the length of the column, hardly surpassing the anthers, one third shorter than their straightish or falcate almost filiform horn: seeds not rarely destitute of coma. - Car. 107 ; Gray, Man. ed. 5, 396 ; Chapm. Fl. $365 . A$. debilis, Michx. Fl. j. 116, in part; the Obs. relates to A. quadrifolia. A. parviflora, Ait. Kew. i. 307 ; Pursh, Fl. i. 180 ; Decaisne, 1. c. Matalea? lavis, Nutt. in Am. Jour. Sci. v. 291. - Muddy shores, \&c., from S. Indiana and Illinois, and from Carolina to Florida and Texas.

Var. párvula, barely a foot high, and leaves an inch or two long. - Torr. Bot. Mex. Bound. 164. - Head of Rock Creek, W. Texas, Bigelow, Wright.

A. NíveA, L. (Dill. Elth. t. 29, \& Plum. Ic. t. 30), is a W. Indian species (Griseb. Fl. W. Ind., excl. syn. Bot. Mag.), very near $A$. perennis, but corolla greenish-white, hoods longer than the anthers, the wings of which become auriculate-undulate next the base, and are not overtopped by the horn. "Louisiana," Grisebach, l. c.; but this is probably a mistake.

A. virgata, Lag. Gen. \& Spec. 14, Sweet Brit. Fl. Gard. ser. 2, t. 85 (A. angustifolia, Hort. Bcrol., Roem. \& Sch., \& A. linearis of gardens, A. linifolia, HBK. ?) is a nearly related species, with white or rose-tingerl corolla, anther-wings plane, and narrow leaves as of the succeeding section, probably only Mexican. See Proc. Am. Acad. xii. 70.

$==$ Leaves from elongated-lancenlate to filiform, sessile or nearly so, glabrous.

a. Corolla reflexed (as in the genus generally): horn of the hoods subulate and exserted.

1. Column conspicuous, at length about half as long as the anthers.

A. Mexicána, Cav. Stem 3 to 5 feet high : leaves in whorls of 3 to 6 , or uppernost and lower opposite, sometimes also in axillary fascicles, linear or narrowly lanceolate ( 3 to 6 
inches long, 2 to 6 lines broad): umbels corymbose, denscly many-flowered, on peduncles longer than the pedicels: flowers greenish-white, sonetimes tinged with purple: corollalobes oblong, 2 lines long: hoods broadly ovate, entire, shorter than the anthers, exceeded by the stout-subulate incurved horn. - Cav. Ic. i. 42, t. 58 ; Gray, Proc. Am. Acad. xii. 71. A. fascicularis, Decaisne in DC. Prodr. viii. 569; Gray, Bot. ('alif. i. 475. A. marrophylle, Nutt. Pl. Gamb. 180. - Dry or moist ground, Oregon and C'aliforuia, to Ncrada and Arizona. (Mex.)

A. verticilláta, L. Stems a foot or two ligh, slender, very leafy: leaves mostly in whorls of 3 to 6 , or some scattered, filiform-linear and with revolute margins ( 2 to 4 inches long): umbels numerous, small, many-flowered, on peduncles longer than the pedicels: corolla greenish-white; the lobes oblong, "2 lines long: hoods white, broadly ovate and entire, with somewhat auriculate involute base, barely equalling the anthers, much shorter than their elongated-subulate falca te-incurved horn. - (Pluk. Alm. t. 336.) IIook. Fl. t. 144; Lodd. Cab. t. 1067 ; sweet, Brit. Fl. Gard. t. 144; Decaisne, l. c. (excl. var. linifolia); Torr. Fl. N. Y. t. 87. A. jalioides, IIBK. Nor. Gen. \& Spec. iii. 188. - Dry soil, Canada to Nobraska and south to Florida, Texas, and New Mexico. (Mex.)

Var. púmila, Gray, l. c. A span or more high, many-stemmed from a fascicled root: leaves much crowded, filiform; peduncles seldom longer than the pedicels. - Dry pluins, Nebraska to Kansas and New Mexico.

Var. subverticilláta, Gray, I. c. Stems single, 1 to $2 \frac{1}{2}$ feet high: leaves all opposite or barely in threes, 3 to 5 inches long, 1 to 3 lines wide, flatter, the margins less or little rerolute: horus sumetimes rather less exserted. - A. verticillata, var. galioides, Torr. Bot. Mex. Bound. 16t, chiefly, hardly of Decaisne. 1. linearis, Scheele in Linn. xxi. 758. A. verticillata, var. linifolia, Engelm. ined., but not A. linifolia, HBK. (which may rather be $A$. virgata, Balb.), nor of Decaisne, l. c., which seens to be a mixture of two or three species. - W. Texas and New Mexico. (Adjacent Mex.)

A. Lixária, Cav., with the aspect of the foregoing, has the horn short and nearly included in the hood, a very short column, and turgid-ovate follicle arrect on the deflexed pedicel: enumerated in Torr. Mex. Bound. 1. c., from Northern Mexico, but not yet found very near the U. S. boundary.

2. Column manifest, but not higher than broad.

A. quinquedentáta, Gray. A span or two high: leaves all opposite, narrowly linear and elongated, resembling those of $A$. verticillata, var. subverticillata: umbels 4-10-flowered: peduncle longer than the pedicels: lobes of the greenish-white corolla oval, $2 \frac{1}{2}$ or 3 lines long: hoods white, about the length of the anthers, conduplicate, somewhat quadrate in outline, the keeled back ending below in a truncate salient base, the truncate summit prominently and acutcly 5-toother ; horn adnate up to the summit, falcate, ending in a small acute dorsal tooth and in an inflexed and moderately exserted subulate proper apex. - Proc. Am. Acad. xii. 71. A. verticillata, var. galioides, Torr. 1. c. in part. - Prairies or rocky hills on the San I'edro River, W. Texas, Wright (1089). Fruit unknown; but, according to Engelmann, it may be arrect on a decurved pedicel, as in $A$. Linaria.

A. angustifólia, Ell. Winutely puberulent, or the foliage glabrous : stems a span to a foot long, decumbent or ascending, very leafy : leaves irregularly alternate or the lower opposite, narrowly linear ( $1 \frac{1}{2}$ to 4 inches long, 1 to 3 lines wide), the margins little if at all revolute: umbels 1 to 3 , terininal, many-flowered: perluncle usually much longer than the pedicels : lobes of the greenish corolla oval, barely 2 lines long: hoods (purplish, " nearly orange-colored," Ell.) ovate, entire, considerably surpassing the anthers, longer than the broad subulate horn, which is inflexed-exserted from the middle. - Sk. i. 325. A. tubrosa? Walt. fide Ell. A. longifolia, Michx. herb., in part. A. Michauxii, Decaisne, 1. c. 569 ; Chapm. F1. 365. (Elliott's name was published in 1817, earlier than the homonyms.) - Low pine barrens and sand-hills, S. Carolina to Florida.

A. viridula, Chapm. Nearly glabrous : stem slender, erect, a foot or two higlı: leaves all opposite, narrowly linear or (when with revolute margins) filiform, ercet or ascending (1 to ? inches long), surpassing the short-peduncled 5-12-flowered umbels: lobes of the yellowish-green corolla oblong, 2 lines long: hoods oblong, one third longer than the anthers, the margins with an auriculate incurved tooth below the middle, otherwise entire, longer than the subulate incurved horn. - FI. 362. - Wet pine barrens near Apalachicoln, Florida, Chapman. 
3. Column none.

A. cinérea, Walt. Glabrous or nearly so : stem very slender, a foot or two high : leaves all opposite, spreading, very narrowly linear ( 1 to 3 inches long, half to a line wide); umbels terminal and subterminal at the naked summit of the stem, loosely 5-7-flowered: filiform drooping pedicels longer than the peduncle : corolla dull purplish outside, ash-color within; the lobes tardily reflexed, oval, 3 lines long: hoods considerably shorter than the anthers, broader than high, truncate at the back, the involute inner angles extended in a triangular acute ascending lobe, which exceeds the broad triangular horn. - Car. 105; Ell. Sk. I. 325 ; Chapm. 1. c. - Low pine barrens, S. Carolina to Florida.

\section{b. Corolla and calyx merely rotately spreading, not reflexed.}

A. Feáyi, Chapm. Stem filiform, erect, a foot or two high: leaves all opposite, in 4 to 6 pairs, spreading, linear-filiform ( 2 to 4 inches long, barely half a line wide), glabrous, often wanting above at the 2 or 3 approximate short-peduncled 3-5-flowered umbels: corolla white; the lobes oblong or at length narrower, 3 or 4 lines long : column none: hoods white and petaloid except a thickish midrib, barely as long as the sagittate-based anthers,'spreading, concave, entire; in place of horn a semioval entire crest or plate adnate to the middle of the back within : follicles not scen.-Gray, Proc. Am. Acad. xii. 72. - Tampa, Florida, Leavenworth (in herb. Torr.), Dr. Feay, Dr. Garber.

§ 2. Podostrmma, Gray. Hoods long-stipitate, their stalks adnate to nearly the whole length of the antheriferous column, surpassing the anthers; the crestlike process adnate to the nearly open lamina: anther-wings broader and somewhat angulate about the middle: umbels all lateral. - Proc. Am. Acad. xii. 72.

A. longicórnu, Benth. A span to a foot or more high, minutely and somewhat hirsutely pubescent: leaves all opposite, from ovate to oblong-lanceolate, obtuse, 2 to 4 inches long, petioled: umbels short-peduncled or nearly sessile, several-many-flowered: flowers yellowish-green: corolla-lobes a fourth to half inch long, oblong: hoods with stalk-like portion twice the length of the gradually dilated whitish somewhat 2-3-lobed or toothed lamina; the process infra-apical and divided into 2 short subulate and fleshy horns; the exterior horn barely equalling the apex of the hood ; the inner twice longer, incurved and somewhat exserted: follicles arrect on the deflexed pedicel, ovate-oblong, acuminate, at first canescent or pubescent or roughish. - Pl. Hartw. 24 ; Decaisne, l. c. 570. A. Lindheimeri, Engelm. \& Gray, P1. Lindh. ii. 42. - Texas and New Mexico. (Mex., Nicaragua.)

§ 3. Nothacerátes, Gray. Anther-wings widening to the broadly rounded base and conspicuously auriculate-notched just above it: hoods sessile, with a narrow wholly adnate internal crest terminating in a minute horn: habit of Acerctes : pollinia short and thick, arcuate-obovate.

A. stenophýlla, Gray. Puberulent, but foliage glabrous : stems slender, a foot or two high, simple: leaves long and narrowly linear ( 3 to 7 inches long, 1 to $2 \frac{1}{2}$ lines wide), with scabrous and more or less revolute margins and a strong midrib; the upper alternate and the lower opposite: umbels several, short-peduncled or subsessile, 10-15-flowered: pedicels about twice the length of the greenish flowers: corolla-lobes oblong, 2 lines long: column very short: hoods whitish, erect, equalling the anthers, oblong, conduplicate-concave, the base of each inner margin appendaged by a cuneate erosely truncate lobe, the apex 2-lobed and the narrow internal crest exserted in the sinus in the form of an intermediate tooth: interior crown of 5 very small 2 -lobed processes between the bases of the anthers : follicles slender-fusiform and long-acuminate, erect on the ascending pedicel. - Proc. Am. Acad. xii. 72. Polyotus anqustifolius, Nutt. in Trans. Am. Phil. Soc. ser. 2, v. 201. Acerates angustifolia, Decaisne, 1. c. 522 . - Dry prairies, W. Arkansas and N. Texas to Nebraska and Colorado. Connecting link between Asclepias and Acerates.

7. ACERÁTES, Ell. (Formed of $\alpha$, privative; and xégos, a horn.) - Atlantic U. S. perennial herbs, resembling Asclepias; with comparatively small flowers greenish or barely tinged with purple, in summer. Umbels many-flowered, sessile or short-peduncled. Distinguished only by the total absence of horn or 
crest to the hoods, and by the wings of the anthers not angulate nor dilated (but rather tapering) at base. - Ell. Sik. i. 316 (1817); Engelm. mss.; Gray, Proc. Am. Acad. l. c. Polyotus, Nutt. in Trans. Amer. Phil. Soc. 1. c. Gomphocarpus in part, Bentl. \& Hook. Gen. ii. 754.

* Mass of anthers and stigma globular. not equalled by the loods : column below the hoods evident: leaves mainly alternate-scattered, very numerous.

A. auriculáta, Engelm. Glabrous up to the inflorescence: stem 2 or 3 fcet high, slender: leaves linear-filiform ( $t$ to 6 inches long, a third to a line and a half wite), their scabrous margins not revolute: umbels several, lateral: pedicels short : column below the hoods very short: hoods oval or quadrate, emarginately or sometimes 3-crenately truncate, the involute margins at base appendaged with a pair of remarkably large and broad auricles: anther-wings narrow and of equal breadth from top to bottom : pollinia elongatedoblong, not tapering upward. - Engelm. in Bot. Mrex. Bouud. 100. - Prairies and rocky ground, from S. Texas and New Mexico to Colorado. Unless the characters are noted, very likely to be confounded with Asclepias (Nothacerates) stenophylla.

A. Iongifólia, Ell. Minutely hirsutely scabrous-pubescent, or smoothish : stems 1 to 3 feet high, erect or ascending : leaves from linear to elongated-lanceolate ( 3 to 8 inches long, 1 to 6 lines wide) : umbels few or numerous, terminal and lateral : pedicels slender : column rather conspicuous below the hoods: these purple or purplish, oval, obtuse, entire, unappendaged, adnate by the ventral margins to the whole upper half of the column, therefore pitcher-like, rising barely to the middle of the anthers : anther-wings semi-rhombic, more attenuate to base: pollinia (as generally in the genus) with tapering apex. - sk. i. 817 ; Decaisne in DC. Prodr. viii. 522. Lsclepias longifolia, MLicllx. Fl. i. 116, mainly. A. Floridana, Lam. Dict. i. 284. A. incarnata, Walt. Car. 106, not L. Polyotus longifolius, Niutt. in Trans. Am. Phil. Soc. v. 522. - Moist prairies and pine-barreus, Florida to Texas, and north to Ohio and Wisconsin. Varies greatly in height, length of peduncles, foliage, \&c.: a Florida form has few or single slender-peduncled unbels, and smaller flowers.

* * Mass of anthers and stigma longer than broad, almost equalled by the hoods, the short insertion of which covers the very short column: leaves not rarely opposite, mostly broader.

A. viridiflóra, Ell. Tomentose-puberulent, becoming glabrate, or the foliage somewhat scabrous : stem a foot or two high : leaves oval or oblong and obtuse or retuse (one or two inches long), or sometimes narrower and longer and also acute, commonly mucronate, occasionally undulate: umbels 2 to 5 or sometimes solitary, mostly lateral and subsessile, dense: pedicels little over double the length of the reflexed narrowly oblong lobes of the greenish corolla : hoods sumewhat fleshy, lanceolate-oblong, witl small auricles at base much involute and concealed, otherwise entire, alternated by as many short and roundish or glandlike small internal teeth: anther-wings semi-rhomboid above, with a much longer tapering base. - Asclepias viridiflora, Raf. in \£ed. Rep. xi. 360 , \& Desv. Jour. Bot. i. 22:27; Pursh, Fl. i. 181; Torr. Fl. 281 (excl. var. obovata); Hook. Fl. ii. 5,3, t. 143. Polyotus heterophyllus, Nutt. l. c.-Dry sterile soil, Tew England and Canada to Saskatchewan, and south to Florida and Texas. Runs into

Var. lanceoláta, with lanceolate leaves $2 \frac{1}{2}$ to 4 inches long. - Asclepias lanreolata, Ives in Amer. Jour. S.i. iv. 2:52, with plate. A. ririllffora, var. lanceolata, Torr. 1. c.; Hook. l. c., dextral figure. With the broader-leaved form.

Var. lineáris, with elongated linear leaves and low stems : umbels often solitary. Winnipeg Valley to New Mexico.

A. lanuginósa, Decaisne. Hirsute rather than wonlly: stems a span or two high, terminated by a single pedunculate umbel: leaves frequently alternate or scattered, from oblong-ovate to lanceolate ( 1 to 3 inches long), with roundish base: pedicels 3 or 4 times the length of the oblong lobes of the greenish corolla: hoods purplish, broadly oblong, obtuse and entire, involute auricles at base obscure if any; the alternating internal teeth or lobes small and emarginate: anther-wings broadest and obtusely angulate below the middle (approaching those of Asclepias) : fruit not seen.-Gray, Man. ed. :3, \& ed. 5. A. monocephnla, Lapham in Gray, Man. ed. 2, addend. Asclepiuslanuginosa, Nutt. Gen. i. 168. A. Nuttalliana, Torr. in Ann. Lyc. N. Y. ii, 218. Polyotus lanuginosus, Nutt. in Trans. Am. Phil. Soc. 1. c. - Prairies, Wisconsin and N. Tllinois, Lapham, Vasey, \&e., to the Missouri at White River, Nuttall, and the Yellowstone, Mr. Allen. 


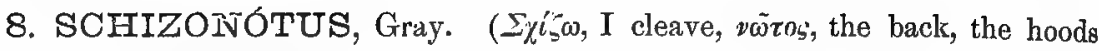
of the crown open posteriorly as if split down the back; in which it differs from Acerates.) — Single species.

S. purpuráscens, Gray. Herb a span to a foot high, canescently puberulent: leaves opposite, cordate (an inch or. more long), thickish: umbels 2, terminal, densely manyflowered on peduncles longer than the pedicels : corolla reddish purple outside, flesh-color within; the oblong lobes a line and a half long; the pale hoods about the same length: anther-wings lunate.-Proc. Am. Acad. xii. 66. Gomphocarpus purpurascens, Gray, Proc. Am. Acad. x. 76, \& Bot. Calif. i. 477 ( $\$$ Schizonotus). - California, on an open mountain summit in Lake Co., Greene (Mr. Towle): fl. June.

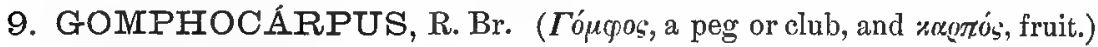
- Old World and chiefly African genus, to which these two Californian species are technically referred; distinguished from Asclepias merely by the absence of horn or crest to the hoods. - Benth. \& Hook. 1. c., excl. Acerates \& Anantherix.

G. cordifólius, Benth. Glabrous: stem 2 or 3 feet high: leaves orate or ovate-lanceolate with cordate clasping base, acute, opposite or rarely in threes, 2 to 5 inches long: umbels 1 to 4 , loosely many-flowered; slender filiform pedicels equalling or shorter than the peduncles : calyx villous-pubescent : corolla dark red-purple; the lobes oval or oblong, 3 or 4 lines long: hoods erect on the summit of the short column, purplish, thin, ventricose, with dorsally truncate summit produced at the ventral margins into subulate slender ascending cusp, equalling the anthers, a narrow fissure down the ventral side : follicles ovatelanceolate, smooth and glabrous, arrect on the deflexed fruiting pedicels. - Gray, Bot. Calif. i. 477. Acerates cordifolia, Benth. Pl. Hartw, 32:3. A. atropurpurea, Kellogg, Proc. Calif. Acad. i. 65. Asclepias "ecornutum," Kellogg, 1. c. 55. - California, common in dry ground through the great valley and foot-hills.

G. tomentósus, Gray, I. c. Tomentose up to the calyx or outside of the corolla with soft floccose matted wool, resembling Asclepias vestita : stem 2 or 3 feet high, angled : leaves opposite (rarely somewhat scattered), ovate or oblong, acute or acuminate (2 to 4 inches long), mostly rounded at base, short-petioled: umbels terminal and lateral, sessile or nearly so, loosely several-flowered: corolla greenish or dull purplish; the lobes 4 lines long: hood attached to the summit of the short distinct column, ventricose and rounded, spreading, reaching to near the middle of the anthers, pointless, open, and as if 2-valved across the top and to the middle of the back. - Acerates tomentosa, Torr. Bot. Mex. Bound. 160, t. 44. - Dry hills, California, from Monte Diablo to San Diego Co.

Var. Xánti, Gray, l. c., distinguished only by the hoods; these somewhat oval, and depending, so that the fissure becomes as if dorsal, and extends two-thirds down. - Fort Tejon, Xantus. Ojai, Santa Barbara Co., Dr. Peckham.

10. ENSLÉRIA, Nutt. (Aloysius Enslen, an Austrian botanist, who collected in the Atlantic U. S. early in the century.) - Perennial twining herbs (N. and S. American); with membranaceous and cordate opposite leaves, and whitish flowers in small axillary pedunculate cymes.

E. álbida, Nutt. Tall-climbing, glabrous, with some slight pubescence: leaves somewhat hastately cordate, slender-petioled, acuminate-tipped : cymes 15-30-flowered : appendages of the crown 2-awned: anther-tips erect, longer than the body of the anther: ligulate awn-like appendages of the crown geminate.-Gen. i. 164; Decaisne in DC. 1. c. 518 ; Deless. Ic. v. t. 63 . - River banks, S. Pennsylvania and Virginia to Illinois, Missouri and Texas: fl. summer.

11. ROULINIA, Decaisne. (Dr. Roulin, a French naturalist.) - Twining plants (Texas to Buenos Ayres), with the habit of Enslenia. - DC. Prodr. viii. 516 ; Deless. Ic. v. t. 62.

R. unifária, Engelm. Aspect and growth of Enslenia albida: leaves deeply cordate, with rounded basal lobes of the larger ones incurved, abruptly slender-acuminate: cymes 
10-20-flowered, somewhat paniculate or racemiform : flowers greenish-white, hardly 3 lines in diameter: corolla-lobes oblong, thickish-edged: divisions of the crown short (hardly at all exceeding the anthers), merely and obtusely 3-lobed at the apex; the middle lobe at most twice the length of the lateral ones, obtuse or emarginate: follicles oblong, thick, 3 or 4 inches long. - Torr. Bot. Mex. Bound. 160. Gonolobus unturius, Scheele in Linn. xxi. 760 , the insignificant specific name from the pubescence in a line down the stem, in a manner most common in the order. - Along streams, Texas, Lindheimer, Iright, \&c.

12. METASTÉLMA, R. Br. (Formed of $\mu \varepsilon \tau \dot{\alpha}$, change of, and $\sigma \tau \varepsilon \dot{\lambda} \mu \alpha$, girdle or crown, having 5 processes or scales in place of the ordinary crown.) Twining perennial herbs or somewhat woody plants (American and mainly tropical), usually slender, and with small opposite leaves. Flowers small in axillary umbelliform clusters, white or sometimes greenish.

\$1. Ecretastelan, Benth. \& Hook. Crown borne on the base of the corolla or of the short or else obsolete column.

M. FráserI, Decaisne in DC. Prodr. viii. 513, "Carolina? Fraser," was probably West Indian, perhaps same as $1 \%$. albiflon, Griseb., doubtless not Carolinian.

M. barbígerum, Scheele. Glabrous : stems slender: leaves from ovate-oblong to narrowly lanceolate, cuspidate-acuminate, rounded at base, glandular at base of midrib: peduncles shorter than the petiole and the 3 to 5 pedicels, often very short : corolla (nearly 2 lines long, greenish outside), 5-parted; the lobes linear and strongly white-villous inside: scales of the crown slender-subulate, on the base of the corolla, a little surpassing the anthers: column extremely short. - Linn. xxi. 760 ; Torr. Bot. Mex. Bound. 159. - Open woods and rocky banks, Texas. (Adjacent Mex.)

M. Blodgéttii, Gray. Nearly glabrous : stems filiform : leaves narrowly lanceolate, very acute (half inch or more long, a line or so wide), rounded at base, short-petioled: peduncle very short or obsolete, 3-0-flowered: pedicels about the length of the flower (one line): corolla cleft almost to base; the lobes oblong-lanceolate, within densely penicillate-bearded just below the apex, glabrous or witl a few sparse hairs below: scales of the crown slender-subulate, inserted on the base of the corolla, half the length of its lobes, hardly surpassing the anthers: column distinct but shorter than the anthers. - Proc. Am. Acad. xii. 73. M. parviflorum, Chapm. Fl. 367, not R. Br. - Pine Key, S. Florida, Blodyett. (Probably also W. Indian.)

M. Califórnictar, Benth. Sulph. 33, t 18, is from Bay of Magdalena, Lower California, nearly under the tropic.

$\S 2$. Epíciox, Griseb. Crown borne on the summit of the elongated column close to the anthers.

M. Bahaménse, Griseb. Nearly glabrous : leaves round-oval to oblong (an inch or less long), mucronate-cuspidate, slender-petioled: peduncles equaling or slightly surpassing the petiole, 3-6-flowered: corolla 2 lines long, campanulate; the lobes ovate-oblong, densely puberulent along the broad thickened margins: column 3 or 4 times the length of the anthers, 5-wing-angled at base: scales of the crown oblong-falcate, laterally compressed and internally carinate, equalling the anthers. - Cat. Cubens. 174. M. Cubense, Griseb. Fl. W. Ind. 417, not Decaisne. M. Schlechtendalii, Chapm. Fl. 366, not Decaisne. - Keys of Florida, Blodgett. (Bahamas.)

13. MELINIA, Decaisne. (From $\mu i_{i} \lambda$ cvos, yellowish, the color of the small flowers.) - Two or three extra-tropical $s$. American species, which have cordate leaves and slender peduncles; to which is appended the following, doubtfully, for its habit is that of Metastelma.

M. angustifólia, Gray. Nearly glabrous : stems filiform, branching from a ligneous base, a foot or two long, spreading, more or less twining: Ieaves opposite, narrowly linear ( 9 to 20 lines long, a line or less wide), acute, distinctly petioled : peduncles 1-2-flowered, hardly longer than the flowers : calyx-segments lanceolate-acuminate, nearly equalling the campanulate 5-parted corolla: scales of the crown spatulate-oblong, nearly plane, half the 
length of the corolla-lobes, surpassing the column under the anthers : terminal membrane of the latter oblong, longer than their cells, slightly surpassed by the slender columnar entire beak to the stigma: young follicle tapering from the base.-Proc. Am. Acad. xii. 73. Metastelma? angustifolia, Torr. Bot. Mex. Bound. 159. - Ravine at Santa Cruz, Sonora, near the southern boundary of Arizona, Wright. Corolla a line long, smooth within, except a minute and apparently glandular tuft at the base of the midrib, and the obscurely puberulent recurved tips; the sides below narrowly but distinctly conroluteoverlapping in restivation. Scales of the crown wholly separate, inserted at the junction of the corolla with the column.

14. VINCETOXICUM, Mœnch. (Old herbalist name of the typical species, from vinceus, that which serves for binding, and toxicum, a poison, i.e. poisonous bindweed.) - Herbaceous perennial or under-shrubby plants (of the Old and New Worlds); with twining or erect stems, mostly opposite leaves, and small or minute flowers, usually dull-colored. - A polymorphous and rather loosely defined genus, as extended in Benth. \& Mook. Gen. ii. 761 ; the indigenous North American (and most other American) species forming a distinct subgenus.

\$1. Seútera. Crown of 5 thin or thinnish scales or processes, either distinct or barely united at base: corolla-lobes narrowly or sometimes obscurely overlapping. - Lyonia, Ell., not Nutt., but rather earlier. Seutera, Reichenb. Consp. 131. Amphistelma, Griseb.

$\mathrm{V}$. palústre. Stems filiform, herbaceous, freely twining upon rushes and saline grasses: leaves linear, acute, fleshy (an inch or two long, a line or two wide) : peduncles longer than the leaves, umbellately several-many-flowered: corolla greenish, with ovate-lanceolate acuminate lobes nearly 2 lines long: scales of the crown oblong-obovate, retuse or emarginate, nearly half the length of the corolla, slightly surpassing the deeply sagittate-based anthers, distinct or very nearly so : stigma with obtusely conical apex. - Ceropegia palustris, Pursh, Fl. i. 181. Lyonia maritima, Ell. Sk. i. 316. Cynanchum angustifolium, Nutt. Gen. i. 164. Seutera maritima, Decaisne in DC. 1. . 590. Amphistelma salinarum, C. Wright in Griseb. Cat. Cubens. 175. - Salt marshes along the coast from North Carolina to Texas: fl. summer. (W. Ind.)

V. scopárium. Stems filiform, much branched, ligneous below, the branches diffuse and more or less twining, becoming leafless and rush-like: leaves slender-linear, thin, very acute: umbels sessile and few-flowered: flowers very small (only a line long), greenish: corolla-lobes lanceolate, almost valvate in the bud: scales of the crown much shorter than the anthers, ovate, hardly united at base. - Cynanchum scoparium, Nutt. in Am. Jour. Sci. v. (1822) 291. Cynoctonum? scoparium, Chapm. Fl. 367. Amphistelma filiforme, Griseb. Fl. W. Ind. 418. A. ephedroides \& graminifolium (probably), Griseb. Cat. Cubens. 174. Metastelma filiforme, C. Wright, in Sauvalle, Fl. Cubana, 120. - Dry soil, E. Florida. (W. Ind, Mex. ?)

§. Vincetoxicux proper. Crown more fleshy and cup-like, almost entire, lobed, or sometines 5-parted: stems erect or feebly twining.

V. NíGRTM, Mœnch, of Europe, with feebly twining stems, ovate acute leaves, and peduncled cymes of blackish-purple flowers ( 3 or 4 lines in diameter), the saucer-shaped crown crenately 5-lobed and with obscure interposed denticulations - sparingly occurs as a weed in and near gardens, New England to Penn., but does not deserve a place in our flora.

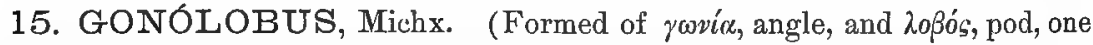
of the original species having costate-angled follicles.) - Perennial herbs, or in warmer regions shrubby (all. American) ; with twining or trailing stems, usually cordate opposite leaves, and mostly umbellate cymes or small fascicles of dull or dark-colored flowers, produced in summer, succeeded by follicles which generally resemble those of Asclepias. - Fl. i. 119 ; Gray, Proc. Am. Acad. xii. 73, 74. 
\$1. Diстүólobrs, Gray, l.c. Corolla reticulated and sometimes rugulose with a fine network of colored veins; the lobes commonly broad or roundish: crown single. (The species mainly tropical and rather large-Howered.)

G. reticulátus, Engelm. High-climbing, hirsute (especially the stems) with spreading and reddish bristly hairs, minutely somewhat glandular: leaves (1 $1 \frac{1}{2}$ to 4 inches long) deeply cordate with incurved auricles, acute or acuminate: pedincles equalling or exceeding the slender petiole and sometimes longer than the leaf, 5-9-flowered, thrice the length of the flawer : corolla lurid green, with purplish venation, half inch in diameter, glabrous within, somewhat hairy without; the lobes broadly ovate or obovate: crown a narrow entire ring around the base of the distinct column: stigma circular: follicles fusiform and long-acuminate, 3 to 5 inches long, strongly muricate. - Gray, 1. c. G. granulatus, Torr. Bot. Mex. Bound. 165, not Scheele. - Thickets and rocky banks, Texas to E. Arizona. (Monterey, Mex.)

§2. Есgохóloв us, Gray, 1. c. Corolla not venulose-reticulated (at least not conspicnously); the lobes from ovate-acuminate to linear: crown simple, unappendaged within, inserted at the junction of corolla and column or higher on the latter: angles of the stigma little or not at all salient: stems herbaceous, usually freely twining. (Pubescence variable, especially the hirsute and spreading or reflexed hairs, which often occur on the stems, petioles; and sometimes on the leaves.)

* Peduncles umbellately or sometimes more cymosely few-many-flowered: corolla rotate, 5parted; the lobes stellately spreading or recurving,

+ Thickish in texture, dull or dusky yellowish-green, sometimes turning lurid-purplish within, at least toward the base; the bud conical-acuminate, at least the outside (as well as calyx, pedicels, and short peduncle) glabrous: crown a low and undulately 10-lobed fleshy disk at base of short column under the stigma: anthers narrowly bordered at summit with a scarious membrane which overlies the edge of the stigma: follicles unarmed, glabrous, 3-5-costate or angled, fleshy and when mature and dry of spongy texture.

G. suberósus, R. Br. Leaves cordate with an open and shallow or sometimes deeper and narrow sinus, acuminate, minutely pubescent, glalurate, or sometimes hairy ( 3 to 5 inches long): umbels :3-9-flowered, much shorter than the petiole : corolla broadly conical and with abrupt acumination, twisted in the bud; its lobes ovate or becoming triangularlanceolate, acute, of thickish and firm texture, dusky, minutely whitish-pubescent inside, but sometimes glabrate, hardly double the length of the calyx-lobes, - Men. Wern. Soc. (name only) \& Hort. Kew. ed. 2, ii. 82 (1811) ; Gray, Proc. l. c., not Decaisne. Cynanchum suberosum, L. Spec., as to Dill. Elth. i. 308, t. 229, f. 296 . Iincetoxicum gonocrerpos, Walt. Car. 104, at least in part. Gonolobus macrophyllus, Chapm. Fl. i. 368, not Michx. - Virginia to Florida, along and near the coast.

G. lǽvis, Michx. Usually less pubescent or hairy : leaves (in the typical form) oblongcordate with a deep and narrow but open sinus, conspicuously acuminate (3 to 6 inches long): umbels 5-10-flowered, barely equalling the petiole: corolla rather elongated-conical in the bud, not twisted; its lobes ( 3 to 5 lines long) narrowly or linear-lanceolate, obtuse, glabrous inside, 3 or 4 times the length of the calyx. - Fl. ii. 119; Gray, Man. ed. 5, 399. - Mississippi to Arkansas and E. Texas. Passes freely into

Var. macrophyllus. Leaves broadly cordate, and with the rounded basal lobes approximate or even overlapping, abruptly acuminate, the larger often 2 or 10 inches long and 7 or 8 broad, the under side commonly soft with a fine and short or sometimes granularglandular pubescence: calyx-lobes often ciliolate toward the apex. $-G$. macrophyllus, Michx. l. c. G. viridiflorus, Nutt. Gen. i. 163; therefore ${ }^{\prime}$. Vuttallii, Decaisne in DC. Prodr. viii. 598. G. tilicefolius, Decaisne, l. c. 596. Gr. granulatus, Scheele in Iinn. xxi. 759. Tincetoxicum gonocarpos, Walt. Car. 104, in part. - Virginia and Carolina to Texas, Kentucky and Missouri.

+ - Corolla thinner in texture, mostly purple or whitish; the lobes obtuse: crown cupulate, as high as the anthers: membrane of the latter inconspicuous or obsolete. or not inflected over the edge of the stigma: peduncle with the umbel or cymnse cluster equalling or surpassing the petiole : follicles ovate-lanceolate, terete, muricate: stems in all varialsly hirsute: caly' $x$ and outside of the corolla more or less pubescent or puberulent. 
+4 Crown fleshy, the border merely crenate.

G. oblíquus, R. Br. Leaves from rounded- to ovate-cordate with a narrow sinus, abruptly acuminate ( 3 to 8 inches long): umbel many-flowered, sometimes cymosely compound or geminate : corolla in the bud oblong-conical; its lobes linear-ligulate $(5$ or 6 lines long, barely a line wicle), crimson-purple inside, dull or greenish and minutely pubescent outside: margin of the crown 10-crenulate, with the intermediate crenatures sometimes 2-dentate. - Rœm. \& Schult. Syst. vi. 64; Bart. Fl. Am. Sept. iii. t.99; Gray, Man. ed. 5 , 399. G. hirsutus, Nutt. Gen. i. 163, not Michx. G. macrophyllus, Decaisne, 1. c., chiefly, not Michx. Gonolobium hirsutum, Pursh, Fl. i. 179. Cynanchum obliquum, Jacq. Coll. i. 148, \& Ic. Rar. t. 341. C. discolor, Sims, Bot. Mag. t. 1273; therefore Gonolobus discolor, Rœm. \& Schult. l. c. C. hirtum, L.?, as to Apocynum scandens Virginianum, etc., Moris. Hist. iii. 611, t. 3, fig. 61. - Mountains of Virginia (and Carolina?) to Pennsylvania, Ohio and Kentucky. Anthers with a distinct dorsal membrane which barely reaches the edge of the stigma.

Var. Shórtii, apparently a form with dull purplish and larger flowers (corolla-lobes a line and a half wide), said to have the scent of Calycanthus-blossoms. - Dry woods, near Lexington, Kentucky, Short, Peter.

G. hirsútus, Michx. Commonly more hairy : leaves nearly as the preceding, the basal lobes sometimes overlapping: peduncles fewer-flowered: corolla in the bud ovate; its lobes elliptical-oblong, 3 or 4 lines long, barely puberulent outside, dull or brownish-purple: margin of the crown obtusely 10-crenate. - Fl. i. 119 (excl. syn. Walt.); Gray, Man. l. c., excl. syn. in part. Apocymum hirsutum, etc., Pluk. Alm. 37, t. 76. - Maryland and Virginia to Tennessee and Florida. Corolla in dried specimens showing some reticulate venation.

$4-+$ Clown of thinner texture, 5-lobed and with intermediate geminate or 2-cleft longer teeth: peduncle commonly longer and inflorescence more cymose or umbellate-clustered: leaves, \&c., as in the preceding species: flower-bud oblong, barely puberulent outside.

G. Carolinénsis, R. Br. Corolla brownish-purple; the lobes oblong or linear-oblong, 4 or 5 lines long: crown undulately and very obtusely 5-lobed and with a longer bifid subulate process in each sinus which equals or somewhat surpasses the stigma. - Rœm. \& Schult. 1. c. 62; Ell. Sk. i. 328 (excl. fruit); Gray, Proc. Am. Acad. 1. c. G. lirsutus, Sweet, Br. Fl. Gard. t. 1. Cynanchum Carolinense, Jacq. Coll. ii. 228, \& Ic. Rar. t. 342 . Vincetoxicum acanthocarpos, Walt. Car. 104, ex char. - S. Carolina to Louisiana and Arkansas.

G. Baldwiniánus, Sweet. Corolla whitish, thin in texture; the lobes less spreading, oblong or becoming spatulate, 4 or 5 lines long: crown almost membranaceous, deeply cleft; the 5 broader lobes quadrate, with the summit cornmonly emarginate; in their sinuses a pair of slender linear-subulate processes of about double the length, which prominently surpass the stigina. - G. macrophyllus, Ell. Sk. i. 327 ("corolla obseure. yellow"), not Michx. G. Curolinensis, Nutt. Gen. i. 163 ("flowers yellowish"), not R. Br. G. hirsutus, Lodd. Cab. t. 365 ? - Georgia and Alabama (Buckley, "flowers white") to N. W. Arkansas, Engelmann; "flowers whitish with offensive odor." Transition to Polymeria of Decaisne.

* * Flowers solitary and subsessile in the axils : corolla deply 5-cleft: anthers prominent and more separate from the stigma.

G. sagittifólius, Gray. Barely puberulent, small and low, but twining: leaves rather flesiyy (a quarter to half inch long, and with petiole of half the length), sagittate, with auricles obtuse or rounded: corolla "yellow," glabrous, $2 \frac{1}{2}$ lines Iong; the lobes lancealatelinear: crown at the base of corolla, entire and saucer-shaped : follicles lanceolate, smooth and nearly glabrous. - Proc.. Am. Acad. xii. 77.- Mountain sides along the Rio Limpio, Western Texas, Wright. A peculiar species, in Bot. Mex. Bound. confounded with G. parvifolius.

§3. Chтнамália, Gray, 1. c. Corolla not conspicuously venulose-reticulated, campanulate or rotate: crown appendaged or crested within, or else double (the internal appendages being free), inserted at the junction of the column with the corolla, or more adnate to one or the other: anthers more prominent and distinct from the stigma (not rarely with short corneous wings in the manner of Asclepias): flowers small : stems mostly low and little or not at all twining. - Chthamalia (at least in part) \& Lachnostoma, in part, Decaisne in DC. l. c. Lachnostoma, Benth. \& Hook. in part, not HBK. (The first species nearly wants the technical character.) 
* Peduncles none, or merely a terminal one by the reduction of uppermost leaves to bracts: pedicels 2 or 3 in a fascicle, as long as the flower: "stems a foot or two long, procumbent or diffuse, not twining.

G. pubiflórus, Engelm. Soft-pubescent and somewbat hirsute: leaves (about an inch long) broadly cordate or reniform, on petioles hardly longer than the basal lobes, the upper acute or sometimes acuminate: pedicels rather shorter than the flower: corolla campanulate, 5-cleft barely to the middle ( 3 lines long); its lobes oblong-ovate, very villous inside: crown globular cup-shaped, higher than the anthers and acutely 5-angled stigma, thinnish, obscurely 5-lobed at the involute somewhat plaited summit ; the lobes undulate-truncate and with a prominent callous tip, obscurely glandular within, and the tube within traversed with 5 light salient (or almost obsolete) ribs or erests; also 5 small adnate auricles at very base within: follicles "uval, smooth." - Pl. Lindh. i. 44 ; Torr. Bot. Mex. Bound. 165. G. prostratus, Baldw. in Ell. Sk. i. 329, not R. Br. Chthamalia pubiflora, Decaisne in DC. 1. c. 605. Georgia, on sandhills of the Altamaha River, \&c., Lyon, Baldwin, Le Conte : rare.

G. biflórus, Nutt. Hirsute-villous: leaves cordate (an inch or so in length), on slender petioles much longer than basal lobes, the upper triangular-cordate, uppermost occasionally reduced and bract-like : pedicels in pairs or sometimes solitary, nearly equalling the petiole :

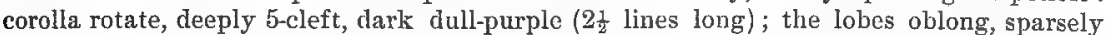
pubescent both sides: crown saucer-shaped, 5-lobed, and the sinuses occasionally 2-3-denticulate; the lobes traversed within by a salient canaliculate crest, which at base is adnate to the base of the column and at summit extends into a conspicuous callous acumination which incurves over the edge of the stigma: follicles muricate.-Torr. 1. c. 165. Chthamalia bifiora, Decaisne, 1. c. - Arkansas (Nuttall, \&c.) and Texas.

Var. Wríghtii, a form with corolla almost 5-parted into oblong-linear lobes: the callous acumination of the crown shorter, and the large and stout follicles lirsute as well as muricate. - E. Texas, Wright.

G. cynanchoídes, Engelm. Pubescent and somewhat hirsute: leaves cordate (an inch or two long) on short petioles mostly longer than the basal lobes, the upper often ovate-lanceolate and subcordate, uppermost not rarely reduced to bracts; the inflorescence thus becoming somewhat racemose-clustered at naked summit: pedicels also in pairs from a few of the axils below, rather longer than the petiole: corolla rotate-campanulate, dark greenish-purple (2 limes long), almost 5-parted; its lobes ovate or oblong, somewhat pubescent outside, glabrous within: crown saucer-shaped, thick, 5-lobed; the lobes broad and rounded, with a callous obscurely 3-crenulate margin, appendaged inside by a prominent crest or ligule; which is free and obtuse at apex, channelled below, and at base decurrent on the column: anther-tips (as in preceding) partly inflexed over the stigma: follicles orate, sparsely short-muricate, pubescent. - Pl. Lindh. i. 43; Torr. 1. c.-Dry prairies, Arkansas and Texas, Berlandier, Drummond, Lindheimer, \&c.

* * Peduncles none: flowers solitary (or rarely geminate) and nearly sessile in the axils of the very small and somewhat hastate leaves: stems low but twining.

G. parvifólius, Torr. Puberulent, much branched, sparingly climbing : leaves thickisl, deltoid or hastate, 2 to 5 lines long, and rather long-petioled: corolla globose in the bud, barely a line and a half long, dull yellow, glabrous throughout, nearly rotate, deeply 5-lobed; , the lobes ovate, obtuse : crown at the base of the very short column, fleshy, deeply 5-lobed; the lobes broadly ovate, obtuse or emarginate, spreading, almost equalling the undivided portion of the corolla, concave, appendaged by a broad and wholly adnate thin crest which is connected with the base of the very short column, and at tip within is extended into a minute projecting tooth. - Bot. Mex. Bound. 166 (excl. fruit); Gray, Proc. Am. Acad. xii. 78. - S. W. Texas, in a cañon of the Rio Grande below Mount Carmel, Parry. Fruit unknown, that described belonging to $G$. scrittifolius.

G. hastulátus, Gray, l. c. Canescently pubescent: filiform stems freely twining: leaves mostly hastate, 2 or 3 lines long, slender-petioled: corolla narrowly oblong in the bud, 2 lines long, whitish, glabrous, 5-parted; the lobes ligulate-linear : crown borne on the summit of the distinet column close to the anthers, of 5 white and thinnisl Asclepias-like hoods, which are complicate-concave, acutely 3 -toothed at summit, its internal crest free at the apex, falcate, and extended into a subulate process which is inflexed orer the stigma: follicles fusiform, sparsely muricate. - Lachnostoma hastulatum, Gray, Bot. Calif. i. 620. Tantillas Cañon, below the southern boundary line of California, Palmer. 
* * Peduncles at the axils shorter than the leaf and umbellately 3-5-flowered: corolla 4 lines Iong: crown cup-shaped, crenately lobed: stem twining or trailing, 2 to 4 feet long.

G. prodúctus, Torr. Minutely pubescent: leaves sagittate-cordate, or the broadest with somewhat reniform base, and above gradually tapering-acuminate (an inch or two long), the rounded and mostly incurved auricles much shorter than the slender petiole: peduncles about the length of the petiole: corolla oblong-campanulate, as long as the pedicel, dull greenish-purple, puberulent outside, nearly glabrous within, 5-cleft to rather below the middle; the lobes linear-oblong, somewhat erect: crown nearly equalling the anthers and stigma, thinnish, inserted at base of the short column, and connected with it by 5 membranaceous lamellæ or crests (2-toothed at the upper edge, which only is free) opposite the short lobes, the cavity of the crown thus as it were 5-celled: follicles ovate, smooth. - Bot. Mex. Bound. 185. - W. Texas to Arizona. (Adjacent Mex.)

* * * Peduncles at the axils and terminal, filiform, surprassing the leaves, somewhat racemosely several-flowered : corolla a line long: crown laciniate and double : stems not twining.

G. parviflórus, Gray, 1. c. Hirsute-pubescent: stems much branched from the tuberous base, a span or more high : leaves thinnish, ovate or the lower almost orbicular, not cordate, often undulate, an inch or less long, short-petioled, the upper acute or acuminate: slender peduncles 1 to 4 inches long: flowers short-pedicelled: corolla rotate, purplish, glabrous, 5-parted; the lobes ovate, becoming lanceolate: crown free from the column, membranaceous, 5-parted; the lobes each deeply cleft into a pair of slender subulate processes and before their base each augmented with a similar and rather longer free one, all of them surpassing the stigma and more or less connivent over it: follicles large, ovate, pubescent, tuberculate-muricate. - Lachnostoma? parviflorum, Torr. Bot. Mex. Bound. 165. - S. W. Texas, Wright, Schott.

\section{ORDER LXXXIX. LOGANIACE AE.}

Herhs, shrubs, or within the tropics trees, a few climbing, destitute of milky juice; distinguished by having, along with a free 2-celled ovary and axile placentæ, opposite (occasionally verticillate) simple leaves, and stipules between their bases, or a stipular line or narrow membrane in their place; the flowers regular and 4-5-merous, with stamens on the tube or throat of the corolla alternate with its lobes; pollen of ordinary loose grains; style one; stigma terminal; amphitropous or anatropous seeds, and embryo rather small in copious albumen. Therefore mainly like Rubiacea, but with a superior ovary, while they also variously approach Apocynacece, Gentianacea, and even Scrophulariacea. The greater part tropical.

Tribe I. GELSEMTEA. Stigmas 4, the apex of the style being twice 2-cleft.

1. GELSEMIUM. Calyx 5-parted, imbricated. Corolla open-funnelform, 5-lobed; the lobes broad and imbricated in the bud. Stamens 5, on the tube of corolla : anthers linear or oblong and sagittate. Style filiform; the 4 lobes stigmatose inside. Ovules numerous in each cell, on linear placentæ. Capsule elliptical, compressed contrary to the narrow partition, septicidal; the conduplicate valves at length 2-cleft at the apex. Seeds several or numerous in each cell, winged. Embryo straight or slightly curved in fleshy albumen; the ovate flat cotyledons much shorter than the slender radicle.

TrIbe II. LOGANIE 无. Stigma single, entire or barely 2-lobed. Ovules numerous.

* Corolla valvate in the bud, 5-lobed: capsule didymous or 2-lobed: herbs.

2. SPIGELIA. Calyx 5-parted; the lobes narrow, usually very slender. Corolla tubularfunnelform or salverform, 15-nerved. Stamens 5: anthers linear or oblong, 2-lobed at base. Style filiform, articulated near or below the middle, the upper part often hollow, above puberulent or pubescent. Ovules numerous in each cell, on a peltate stipitate placenta. Capsule didymous, somervat compressed contrary to the partition, circumscissile above the cupule-like persistent base, and 2-coccous, the carpels soon loculicidally 2valverl. Seeds few, peltate, angled by mutual pressure, closely packed on the placenta into a globular mass. Embryo short and straight in fleshy or cartilaginous albumen. 
3. MITREOLA. Calyx 5-parted; the lobes lanceolate. Corolla small, urceolate, bearded in the throat. Stamens 5, short: anthers cordate. Ovary 2-celled and with a broad tip: style short, early dividing into two from the base, united by a common stigma, soon wholly separate and divergent. Capsule divaricately 2-lobed or 2-horned at summit, dehiscent by the ventral suture of eith lobe. Seeds numerous, small, on stipitate placentro. Embryo linear, nearly the length of the fleshy albumen.

* * Corolla imbricated in the bud, 4-lobed, sometimes 5-lobed : embryo small and straight in fleshy albumen. Pentamerous tlowers occasionally occur.

+ Calyx deeply 4-5-parted : capsule loculicidal : annual herb.

4. POLYPREMUM. Corolla campanulat', bearded in the throat, shorter than the subulate foliaceous sepals. Stamens 4, inserted low on the tube of the corolla, included: anthers ovate. Style short: stigma capitate, entire or obscurely z-lobed. Capsule globular-ovoid but slightly compressed contrary to the partition and didymous, loculicidally 2-valved and at length somewhat septicidal. sueds numerous on oblong placentre ascending from near the base of the partition, minute, smooth.

+ + Calyx 4-toothed or 4-cleft : capsule septicidal, globose or oblong; valves mostly 2cleft at apex and separating from the united placentre : shrubs, with leaves often dentate!

5. BUDDLEIA. Calyx campanulate. Corolla rotate-campanulate for sometimes salverform) ; the lobes ovate or orbicular. Anthers 4, sessile or almost so in the throat or tube of the corolla, ovate or oblong-cordate.

6. EMORYA. Calyx oblong, 4cleft; the lobes linear-subulate. Corolla salverform, with tube somewhat enlarged above; the short lobes ovate. Stamens exserted: filaments filiform and elongated, inserted on the middle of the tube: anthers cordate-oblong. Style very long and filiform.

1. GELSÉmIUM, Juss. "Tellow Jessauine" of S. States. (Gelsemino, an Italian name of the Jessamine.) - Twining and glabrous shrubby plants, with a mere line marking the place of the minute glandular caducous stipules, connecting the bases of the opposite or sometimes ternate entire leaves; the flowers showy, in ours heterogone-dimorphous, fragrant, produced in spring. - Two E. Asian species and the following.

G. sempérvirens, Ait. Stems slender, climbing high : leaves evergreen, thin-coriaceous, shining, oblong- or ovate-lanceolate ( $1 \frac{1}{2}$ to $2 \frac{1}{2}$ inches long) : peduncles very short, axillary, scaly-bracteolate, cymosely 1-3-flowered: corolla deep yellow, over an inch long: stigmas of one form and anthers of the other protruding: capsule deeply sulcate down the flat sides, cuspidate-pointed. - Gelseminum seu Jasminum lnteum odoratum, etc., Catesb. Car. i. 53, t. 53. Bignonia semperiirens, L. Spec. ii. 623. Anonymos sempervirens, Walt. Car. 99. Gelsemium nitidum, Michx. Fl. i. 120. G. lucidum, Poir. "Herb. Amat. 3, t. 169."-Woods and low grounds, E. Virginia to Florida and Texas. (Mex.)

2. SPIGELIA, L. Pink-Root. (Adrian Spiegel, latinized Spigelius, a Dutch botanist of the 17th century.) - Herbs, rarely suffruticose (all American), usually low; with membranaceous and more or less pinnately veined entire leaves, and small interpetiolar stipules or a transverse membranous line. Upper portion of the style usually, but not always, furnished with pollen-collecting hairs: the stigma terminal, usually emarginate or 2-lobed: lower part or base of the style persistent. - Our species glabrous, or merely scabrous-puberulent on the veins, \&c. : stems 4-angled: flowering in early summer.

$\S 1$. Flowers showy, unilateral-spicate on the single or sometimes geminate or umbellate and naked terminal peduncles of a scorpioid inflorescence: bracts minute and subulate or wanting : corolla red or pink, elongated-tubular, not plicate and the edges of the lobes slightly or not at all turned outward in the bud: anthers and especially the summit of the style exserted; the articulation of the latter low down: root perennial, fibrose. 
S. Marilándica, L. Indias Prrs, \&c. Stem a foot or two high : leaves from ovatelanceolate to ovate and acuminate, 2 to 4 inches long, closely sessile by a rounded base, one or two pairs of veins basal : inflorescence 1-2-spicate, short-pedunculate : corolla scarlet outside, yellow within, an inch and a half long; the tube somewhat clavate, four times the length of ovate-lanceolate lobes. - Mant. 338; Bot. Mag. t. 80; Lodd. Cab. t. 930 ; Bigel. Med. ii. t. 14. (Catesb. Car. ii. t. 78.) Lonicera Marilandica, L. Spec. - Woodlands, New Jersey to Wisconsin and Texas.

§ 2. Flowers smaller, naked spicate as in the preceding: corolla white or purplish, funnelform; the limb more or less plicate in the bud with the edges of the lobes turned outward: anthers and style included.

S. gentianoídes, Chapm. Stem a span to a foot high from a perennial root, roughish : leaves ovate and the lower roundish, an inch or more long : spike few-flowered : corolla an inch long; the ovate-lanceolate lobes rather erect. - A.DC. Prodr. ix. 5; Chapm. Fl. 182. - Light soil, W. Florida, Chapman.

\$3. Flowers small, terminal and in the forks of leafy branches, mostly shortpeduncled : corolla nearly salverform, white or nearly so; the limb plicate in the bud and the edges turned outward: anthers and style included; the latter articulated in the middle, its tubular upper portion beset with collecting hairs fully half way down : root annual? - Coelostylis, Torr. \& Gray.

S. loganioídes, A.DC. A span or more high, ascending: leaves oval, sessile (half to three-fourths inch long): sepals narrowly linear and with the scarious margins denticulate: corolla 4 or 5 lines long, somewhat funnelform: capsule with minutely granulate surface (not lineolate) : seeds smoothish. - Prodr. ix. 4. Colostylis loganioides, Torr. \& Gray in Endl. Iconogr. t. 101 (beard on the style represented too short), \& Fl. N. Am. ii. 44. E. Florida, near Fort King, \&c., Dr. Burrows, Rugel, Buckley.

S. Lindheímeri. A span high, diffusely much branched from the base, puberulentscabrous: leaves from ovate-oblong to lanceolate (an inch or less long), acutish at base, the lower somewhat petioled: sepals linear and the scarious margins conspicuously denticulate: corolla salverform, 4 lines long: capsule minutely lineolate: seeds at maturity tuberculate-rugose as well as minutely pitted. - Prairies of W. Texas, Lindheimer, Wright.

S. Texána, A.DC. l.c. About a foot high, nearly smooth and glabrous : leaves ovate- to lanceolate-oblong, thinner and larger (one or two inches long), mostly acute at both ends, the lower somewhat petioled: sepals setaceous-subulate, only one-nerved; the margins very obscurely serrulate-scabrous: corolla salverform, half inch long: capsule smooth, not lineolate: seeds minutely rugulose and punctate. - Colostylis Texana, Torr. \& Gray, 1. c. - E. Texas, Drummond, Lindlheimer, Wright, \&c.

3. MITRÉOLA, L. (Diminutive of mitra, a turban or mitre, from the shape of the capsule.) - Glabrous low herbs (E. American, Asiatic and Australian), ours annuals; with entire leaves, small entire stipules between them, and very small white flowers unilaterally spicate on the naked branches of the terminal cyme: fl. summer. - Cynoctonum, Gmelin.

M. petioláta, Torr. \& Gray. A foot or two high: leaves membranaceous, from oblong-lanceolate to ovate ( 1 to 3 inches long), acute, narrowed at base into more or less of a petiole. - Fl. N. Am. ii. 45; A.DC. Prodr. ix. 8; Progel in Mart. Fl. Bras. vi. t. 82, fig. 1. Ophiorhiza Mitreola, L. Spec. i. 150; Swartz, Obs. t. 3. O. lanceolata, Ell, Sk. i. 238. Anonymos petiolata, Walt. Car. 108. Cynoctonum petiolatum, Gmel. Syst. 4. Mitreola ophiorhizoides, A. Rich. Mém. Soc. Nat. Hist. Par. i. 63, t. 3, includes both our species. - Wet grounds, E. Virginia to Texas. (Mex., W. Ind., \&c.)

M. sessilifólia, Torr. \& Gray, I. c. Stems more simple and virgate: leaves thicker and firmer in texture (half inch or more long, and veins more prominent), roughish-margined, from round-oval to oblong, sessile : flowers and fruit smaller and more crowded. Anonymos sessilifolia, Walt. 1. c. Cynoctonum sessilifolium, Gmelin, 1. c. Ophiorhiza Mitreala, 
Michx. Fl. i. 148. O. ovalifolia, Muhl. Cat. O. Croomii, Curtis in Bost. Jour. Nat. Mist. i. 128. Var. anqustifolia, Torr. \& Gray, l. c., is a depauperate state of the narrower-leaved form. -Moist ground, N. Carolina to Florida and Louisiana.

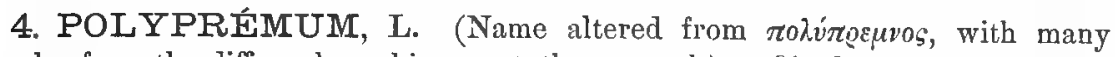
trunks, from the diffuse branching next the ground.) - Single species, an insignificant weed: fl. late summer.

P. procúmbens, L. A span or more high, much branched from an annual (sometimes almost ligneous) root, glabrous; the rigid stems erect or ascending rather than procumbent, 4-angled, repeatedly branching: leaves narrowly linear or almost acerose, half inch or more long, the uppermost gradually reduced to bracts, their margins obscurely scabrous, their bases united by a membranous stipular line: flowers sessile in the forks or somewhat cymose at the summit of the branches : inconspicuous corolla barely a line long, white. Act. Ups. 1741, p. 78 ; Lam. Ill. t. 71. P. Linneei, Michx. Fl. i. 83. - Sancly soil, Penn. (adventive), Maryland to Texas. (Mex., W. Ind.)

5. BUDDLÉIA, Houston. (Adam Buddle, an early English botanist, who corresponded with Ray.) — Shrubs, or some arborescent, a few herbaceous (mainly tropical), usually canescent or tomentose with floccose or furfuraceous stellate down; the leaves sometimes dentate, the petioles connected by a transverse stipular line, or by more evident stipules. Flowers commonly small, and crowded into capitate clusters or cymules, which are variously disposed; rarely some are 5 -merous; the corolla in our few (chiefly Mexican) species very short.

* Flowers in comparatively loose and very numerous clusters, disposed in an ample and naked terminal panicle.

B. Humboldtiána, Rœm. \& Schult. Minutely ferrugineous-tomentose : leaves oblong- or ovate-lanceolate, acuminate, denticulate, 3 inches long, rounded at base, rather long-petioled, copiously pinnately-veined, in age glabrate above: flowers a line and a half long. - Benth. in DC. Prodr. x. 438. B. acuminata, HBK. Nov. Gen. \& Spec. ii. 349, t. 187, not Poir. - Mexican borders of S. W. Texas and New Mexico, Thurber, \&c. (Mex.)

B. LANCEOLÁTA, Benth., with smaller and narrower leaves tapering to base, and simpler contracted inflorescence, also inhabits Northern Mexico, and may reach the boundary. B. свотолоides, Gray, Proc. Am. Acad. $\mathbf{1 6}$ 165, is from Lower California, under the tropic.

* Flowers in numerous and small dense pedunculate heads, disposed in a virgate raceme.

B. racemósa, Torr. Stems 1 to 3 feet high, loosely branching, nearly glabrous : leaves from ovate-oblong to oblong-lanceolate with a truncate or obscurely hastate base, irregularly crenate-dentate, mostly obtuse, thinnish, 2 to 4 inches long, short-petioled, green and glabrous above, puberulent-canescent beneath: raceme of heads a span to a foot long: heads about a quarter inch in diameter, on shorter or longer peduncles: corolla little exceeding the tomentulose calyx. - Bot. Mex. Bound. 121.- Rocky banks, W. Texas. Lindheimer, Riddell, Wright, \&c.

Var. incána, Torr. 1. c. Leaves barely an inch long, fulvous-cancscent-tomentose beneath. - San Pedro River, W. Texas, Wright.

* * Flowers in solitary or geminate heads or capitate clusters: leaves, branches, and heads densely soft-tomentose thronghout.

B. marrubiifólia, Benth. I. c. Much branched, canescent or ferrugineous : leaves obovate or oval with cuneate base, arcuate, about half inch long, short-petioled, the dense tomentum somewhat velvety: flowers in a globose terminal head (half inch in diameter) on a short peduncle, "odorous : corolla golden yellow turning orange red." - Torr. Bot. Mex. Bound. 121. - S. Texas on the Rio Grande. (Mex.)

B. scordioídes, HBK. Much branched, ferrugineous-tomentose: leaves narrowly oblong or cuneate-linear, nearly sessile, obtuse, coarsely crenate, rugose, an inch or less Iong: dense clusters of flowers sessile in the axils of all the upper leaves, the pair combined around the stem into a globular head. - Nov. Gen. \& Spec. 1.c. t. 183; Torr. 1. c. S. E. Texas to Arizona. (Mex.) 
6. EMORYA, Torr. (In honor of Major, now General, W. H. Emory, the U. S. Commissioner of the Mexican Boundary Survey in which the plant was discovered.) - Single known species.

E. suavéolens, Torr. Shrub 3 to 6 feet high, much branched, somewhat pulverulent or puberulent: the leaves canescent beneath, somewhat deltoid or hastate, sinuate-dentate with a few coarse teeth, obtuse, petioled, half inch or more long: inflorescence a narrow and pedunculate thyrsus or panicle: flowers pedicellate, loose and rather few, sweetscented: corolla over an inch long, "greenish-white or yellowish;" the roundish lobes only a line or two long. - Bot. Mex. Bound. 121, t. 36 ; Benth. \& Hook. Gen, ii. 794. Cañons of the Rio Grande, Texas, below Presidio, Parry.

\section{ORDER XC. GENTIANACE}

Herbs, with bitter colorless juice, and (the Menyanthea excepted) with opposite or rarely verticillate simple and entire sessile leaves, no stipules, perfect and regular flowers, persistent calyx and often marcescent corolla, the latter (with one or two exceptions) dextrorsely convolute in the bud, a one-celled free ovary with two parietal many-ovuled placentæ, or the whole parietes ovuliferous, a single style with usually 2-lobed or 2-lamellate stigma, and the capsule dehiscent through the placentæ. Seeds indefinitely numerous, or rarely few, anatropous, commonly - small, and with a minute embryo in fleshy albumen. Stamens, as in all the related orders, borne on the tube or base of the corolla, as many as its lobes and alternate with them: anthers in our genera 2-celled and opening longitudinally. Style rarely cleft, at least the divisions stigmatose down the inner face of the lobes. Plants almost all glabrous and smooth throughout, and the flowers cymose or simply terminal. Ovary in all our genera one-celled, or half two-celled by introflexion of the placentre (in some exotic genera 2-celled). The Menyanthece differ almost ordinally in the foliage and æstivation. Obolaria and Bartonia are remarkable for the imbricated astivation of the corolla: the sepals of the latter are reduced to two: their lower leaves or scales are often alternate.

Stborder I. GENTIANE无. Leaves always simple and entire, sessile (except some radical ones), never alternate, except in one Swertia. Estivation of the corolla never valvate.

\section{* Lobes of the corolla convolute in the bud.}

+ Style filiform, usually deciduous from the capsule : stigma bilamellar or bicrural, but the divisions at first often connivent as if united, the flowers being proterandrous: seeds numerous, with a close and reticulated or foveolate coat.

+ Calyx 4-toothed and 4-angled: anthers cordate-ovate and unchanged in age.

1. MICROCALA. Corolla short-salverform, bearing the 4 short stamens in its throat. Stigma as if compressed-capitate, but of 2 flabelliform lobes which at length separate.

+4 +- Calyx 5-12- (or in Erythrcea sometimes 4-) cleft or parted : anthers oblong to linear, mostly twisting or curving in age : placentæ more or less intruded.

2. ERYTHRAA. Parts of the flower 5 or sometimes 4. Calyx-lobes narrow and carinate. Corolia salverform with either a short or rather long tube. Filaments slender: anthers oblong or linear, commonly exserted, twisting spirally in one or two turns after anthesis. Style filiform: stigmas from oblong to flabelliform. Capsule from oblong-ovate to fusiform.

3. SABBATIA. Parts of the flower 5 to 12 . Corolla rotate. Filaments filiform, rather short: anthers linear or elongated-oblong, soon arcuate, recurved, or revolute. Style 2cleft or 2-parted ; the lobes filiform, compressed-clavate or spatulate, introrsely stigmatose for most of their length. Capsule globose or ovoid, thick-coriaceous or at first fleshy. 
4. EUSTOMA. Parts of the flower 5, rarely 6. Calyx-lobes long-acuminate, the midrib carinate. Corolla campanulate-funnelform. Filaments filiform-subulate: anthers oblong, versatile, straight or recurving in age. Style filiform, nearly persistent : stigma of 2 broad oblong or oval lamella. Capsule oral or oblong.

+ + Style short or subulate and persistent, or none: anthers remaining straight.

+- Corolla without nectariferous pits or large glands : flowers usually 4-5-merous.

5. GENTIANA. Calyx commonly with a membranous or spathaceous tube. Corolla funnelform, campanulate, or salverform (or some rotate); the sinuses with or without plaits or appendages. Stamens inserted on the tube of the cornlla. Style very short or none: stigma of 2 spreading (rarely united) lamella, persistent. Seeds very numerous, not rarely covering the whole parieces of the thin capsule.

6. PLEUROGYNE. Calyx deeply 4-5-parted. Corolla rotate, 4-5-parted; the divisions acute, a pair of scale-like appendages on their base. Stamens on the base of the corolla: anthers introrse, versatile. Style none: stigmas decurrent down the sutures. Capsule lanceolate or oblong, not stipitate. Seeds extremely numerous, near the two sutures.

+ Corolla with one or two nectariferous pits, spots (glands), or an adnate scale to each lobe: caly $\times$ 4-5-parted: seeds comparatively large.

7. SWERTIA. Corolla rotate, 5- (rarely 4-) parted; the lobes lextrorsely convolute in the bud. Style none, or very short: stigma "2-lamellate or 2-lobed. Capsule ovate; the placentæ not intruded. Leares sometimes alternate.

8. FRASERA. Corolla rotate, 4-parted; the lobes dextrorsely convolute in the bud, bearing a single or double fringed gland, and sometimes a fimbriate crown at base. Stamens on the very base of the corolla : filaments subulate, often monadelphous at base, occasionally with some interposed small bristles or seales. Ovary ovate, tapering into a distinct and often slender (but sometimes very short) persistent style: stigma small, 2-lobed or nearly entire. Capsule coriaceous, comnonly flattened; the placentæe or edges of the valves not intruded. Sceds comparatively few, compressed, commonly smooth and margined. Leaves verticillate or opposite.

9. HALENIA. Corolla campanulate, 4-5-cleft; the lobes sinistrorsely convolute, mostly erect; underneath each a hollow nectariferous spur or gibbous projection, which is glandular at bottom (sometimes obsolete) : no fringes nor crown. Filaments slender, inserted on the tube of the corolla. Ovary and capsule ovate-oblong; the placentæ more or less introflexed : style very short or none: stigmas 2 . Ovules and close-coated seeds oval or globular, in a single series on the margin of the valves.

* Lobes of the corolla imbricated in the bud, i.e. 4, two exterior and two interior: no appendages: ovules and extremely numerous minute close-coated seeds covering the whole parietes of the ovary and capsule: stamens inserted in or little below the sinuses of the corolla: anthers ovate-sagittate: foliage hardly any or discolored.

10. BARTONIA. Calyx deeply 4-parted; the sepals lanceolate-subulate, carinate. Corolla deeply 4-cleft, somewhat campanulate. Filaments slender, much longer than the anthers. Stigma nearly sessile, of 2 erect or closed short lobes. Capsule oblong, acute, 2-valved,

11. OBOLARIA. Caly $\mathrm{x}$ of 2 foliaceous spatulate sepals! Corolla oblong-campanulate, 4-cleft; the lobes oval-oblong or in age spatulate. Filaments not longer than the anthers. Ovary rather thick-walled, and with four thicker equidistant projections, making the cavity cruciform: style distinet: stigma bilamellar. Capsule membranaceous, 2-valved or rupturing irregularly.

Scborder II. MENYANTHEAE. Leaves all alternate and mostly petioled, sometimes trifoliolate, or crenate. AEstivation of the corolla induplicate-valvate. Seed-coat crustaceous. Marsh or aquatic perennials: flowers heterogonous.

12. MENYANTHES. Calyx 5-parted. Corolla somewhat funnelform or campanulate, 5-cleft; the lobes widely spreading, fimbriate-bearded or crested on the face. Stamens on the tube of the corolla: anthers sagittate, versatile. Hypogynous glands 5. Ovary surmounted by a long style: stigma bilamellate, 2-lobed. Capsule globular, tardily 2valved or irregulariy bursting across the top. Seeds rather few and large, orbicular and compressed; the close crustaceous coat smooth and shining. Flowers on a scape.

13. LIMNANTHEMUM. Calyx 5-parted. Corolla almost rotate and deeply 5-cleft; the lobes naked on the face (but sometimes fimbriate on the broadly induplicate margins). Stamens inserted on the base of the corolla. Style short or none. Capsule ovoid or oblong, indehiscent or irregularly bursting. Flowers (in ours) as if borne on a filiform petiole. 
1. MICROCALA, Link. Compounded of $\mu * x o o_{s}$, small, and $x \eta^{\prime} \lambda \gamma$ or $x \alpha \lambda o^{\prime}$, beautiful: should have been Microcalia, but that proper form of the name was preoccupied. - One European species and the following: fl. in spring.

M. quadranguláris, Griseb. A little annual, with simple or branching filiform stem, 2 or 3 inches high: branches or peduncles 1-flowered: leaves 2 or 3 pairs, oval or oblong, 2 or 3 lines long: calyx at first oblong-canpanulate; in fruit broader, truncate at top and bottom, strongly 4-angled; the teeth short and subulate: corolla saffron-yellow, 3 lines long. -DC. Prodr. ix. 63; Progel in Mart. Fl. Bras. vi. 213, t. 68, fig. 3; Gray, Bot. Calif. i. 480. Exacum quadrangulare, Willd. Spec. i. 636. E. inflatum, Hook. \& Arn. in Jour. Bot. i. 283. Cicendia quadrangularis, Griseb. Gent. 157. - Open moist ground, coast of California, from Mendocino Co., southward. (S. Amer.)

2. ERythr AُA, Renealm. Centaury, Canchalagua. (From égvogós, red, the flowers being mostly red or rose-color.) - Low herbs (of various parts of the world), mainly annuals and biennials; the flowers small or middle-sized, but commonly numerous, in summer. Corolla-lobes becoming narrower with age.

E. chironiondes and E. speciosa, Gray, Bot. Calif. i. 479, are Mexican species, not yet found near our borders, forming a section (the genus Gyrandra of Grisebach) with tube of the corolla rather shorter than the ample lobes, and an oval capsule. All our species have a longer and narrower capsule (elongated-oblong or cylindraceous), and a longer tube to the corolla. Our $E$. venusta, as to the corolla, is the connecting form.

* Flowers spicately disposed along the rather simple branches and sessile in the few forks.

E. SPICÁA, Pers. Strictly erect, a foot or less high: leaves oblong: tube of the rose-colored corolla hardly longer than the calyx-lobes, twice the length of the rather narrow lobes. - E. Pickeringii, Oakes in Hovey Mag. Chironia spicata, Smith, Fl. Græc. t. 238. Coast at Nantucket, Mass. (Oales), and Portsmouth, Virginia (Rugel). (Nat. from Eu.)

* * Flowers cymose or paniculately scattered; our's all rose-red, and with broad stigmas.

+ European species sparingly naturalized in the Atlantic United States: stigmas broadly oval or obovate: lobes of the corolla oblong, obtuse.

E. Centaúrion, Pers. Strictly erect, a span to a foot high : leaves oblong, the lowest forming a rosulate tuft at the root: flowers cymose-clustered, at least the middle ones sessile: lobes of the corolla 2 or 3 lines long. - Waste grounds, shores of Lake Ontario (Oswego, New York) and Lake Michigan, Babcock: rare. (Nat. from Eu.)

E. Ramosíssima, Pers. Lower, more slender, diffusely branched: leaves from oval to lanceolate, the lowest not rosulate: flowers effusely cymose, pedicelled: lobes of the corolla only 2 lines long. $-E$. pulchella, Fries, Novit. ii. 31 (Grisebach's var. pulchella, merely a small form). E. Muhlenbergï, Griseb. in DC. Prodr. ix. 60, as to pl. N. Y. and Penn. Exacum pulchellum, Pursh, Fl. i. 100? Chironia pulchella, Muhl. Cat. 23. - E. Pennsylvania, New Jersey, \&c. : rare. (Nat. from Eu.)

++ Species indigenous from Texas to California: stigmas cuneate or flabelliform and truncate: no rosulate tuft of radical leaves.

+ Flowel's small : lobes of the corolla only $1 \frac{1}{2}$ to $2 \frac{1}{2}$ lines long, much shorter than the tube: anthers oblong.

E. Texénsis, Griseb. Slender, diffusely much branched above into a loose paniculatecorymbose cyme: leaves linear or the lowest Ianceolate and the uppermost reduced to subulate bracts: flowers all slender-pedicelled: corolla (apparently light rose-color) with very slender tube ( 4 or 5 lines long), and lanceolate-oblong lobes ( 2 lines long), which become lanceolate-linear, longer, and acute: seeds globose-ovoid. - DC. 1. c. 98.-Texas, common on rocks and hills.

E. floribúnda, Benth. Almost a foot high, corymbose-cymose at summit, rather strict and closely flowered: leaves oblong or the upper lanceolate: flowers short-pedicelled or in the forks nearly sessile: lobes of the light rose-colored corolla oblong and becoming lanceolate, at most 2 lines long and 3 or 4 times shorter than the tube: anthers short-oblong (shorter than in any other of this section and the stigmas smaller): seeds globular-ovoid. - Pl. Hartw. 322; Gray, Bot. Calif. i. 480. - California, on the Sacramento and its tributaries, IIartweg, \&c.

E. Muhlenbérgii, Griseb. A span or less high, at length fastigiately branched from the base, cymosely flowered at summit: leaves oblong, obtuse; the floral lanceolate : ped- 
icels short or hardly any in the forks; the lateral of ten as long as the flower, but 2-bracteolate at summit: lobes of the rose-red corolla oval, very obtuse or retuse, in age merely oblong, 2 or almost 3 lines long: seels short-oval. - DC. l. c. 60, as to California plant only; Benth. Pl. Hartw. 322 ; Gray, Bot. Calif. i. 480. - Western part of C'alifornia, and south-east to the Mohave.

E. Douglásii, Gray. Slender, a span to a foot high, loosely and paniculately branched, usually sparsely flowered: leaves from oblong to linear, mostly acute: flowers all on strict and slender peduncles or pedicels: lobes of the pink corolla oblong, obtuse, at most 2 lines long, nearly half the length of the tube: seeds globular.-Bot. Calif. i. 480. E. Nuttallii, Watson, Bot. King, 270, partly ; Gray, Proc. Am. Acad. viii. 398. Cicendiu exaltata, Griseb. in Hook. Fl. ii. 69, t. 157, wrongly described. - Oregon and California to $\mathrm{L}^{\mathrm{t}}$ ah and Wyoming.

B. Nuttállii, Watson. Like the preceding: lobes of the rather larger corolla more ovate, acutish, sometimes nearly 3 limes long: seeds fewer, and much larger (a third of a line long), oblong. - Bot. King, 276, t. 29, mainly. - Nevada, Idaho, and Utah, Nuttall, $H$. Engelmann, ITatson.

+ Flowers larger: corolla-lobes $3 \frac{1}{2}$ to 6 lines long, but more or less shorter than the tube: anthers linear.

$=$ Corolla-lobes narrow, in age by involution becoming acuminate: branching and inflorescence fastigiate-cymose : filaments and style very slender.

E. trichántha, Griseb. A span or less ligh: leaves from oblong-oval to lanceolate: flowers in dense cymes, those in the forks all sessile or nearly so: corolla-lobes oblonglanceolate becoming linear-lanceolate, $3 \frac{1}{2}$ or 4 lines long: stigmas small: seeds oval-oblong. - DC. 1. c. 60 (excl. var.) ; Gray, Bot. Calif. i. 479. - Dry ground, W. California.

E. Beyríchii, Torr. \& Gray. A span to a foot high, slender, at length fastigiately much branched: leaves linear (an inch or more long, a line or much less in width), the uppermost nearly filiform : flowers very numerous and all pedicellate : corolla-lobes linearoblong and becoming linear, 5 lines long: seeds globular. - Torr. in Marcy Rep. 291, t. 13. E. trichantha, var. angustifolia, Griseb. in DC. 1. c.-Arkansas, Beyrich, Marcy. Texas, Wright, Lindheimer.

$==$ Corolla-lobes broader and obtuse, little shorter than the tube: inflorescence loose : flowers all pedicellate : seeds globular.

巴. calycósa, Buckley. Paniculately or somewhat cymosely branched, a span to 2 feet high: leaves from narrowly oblong to lanceolate or linear: pedicels mostly as long as the calyx or the whole flower: lobes of the corolla oval or oblong, $3 \frac{1}{2}$ to 5 lines long ; the tube usually equalled by the calyx. - Proc. Acad. Philad. 1862, 7. - W. Texas and New Mexico, Wright, Buckley, \&c. (Adjacent Mex.)

Var. nána. A span high, with leaves all linear and inflorescence corymbose-cymose: approaching $E$. Beyrichii, but corolla-lobes only ; or 4 lines long and broadly oblong. Stony hills, W. Texas, Wright (no. 1662), Woodhouse.

Var. Arizónica. Stems or branches a foot or so long, lax : inflorescence racemosely paniculate or as if racemose: calyx-lobes mostly shorter than the tube of the corolla. S. Utah and Arizona, Whelen, Palmer, \&c.

E. venústa, Gray. A span or so high : leaves from ovate to oblong-lanceolate : flowers somewhat cymose or paniculate, on short or sometimes long pedicels: lobes of the corolla oval or obovate, becoming oblong, deep pink, 4 to 6 lines long, about the length of the yellowish tube, which is equalled by the calyx. - Bot. Calif. i. 479. E. trichantha, Durand in Pacif. R. Rep. v. t. 9, not Griseb. E. chironioides, Torr. Bot. Mex. Bound. 156, t. 42, mainly, excl. syn. - Dry hills, California, common from Plumas Co. southward.

3. SABBÁTIA, Adans. (Liberatus Sabbati, an early Italian botanist.) Atlantic North American biennials or annuals; with mostly showy rose-colored or white flowers (in summer and autumn), terminating the branches or in cymes. Calyx in most species deeply parted. Corolla usually with a yellowish or discolored eye. Style closed in early anthesis, and commonly turned to one side of the flower (and sometimes spirally twisted), later erect and its branches or stigmas diverging. Seeds very numerous and small, globular, pitted. 
§1. Flowers 5-merous (or only occasionally some of them 6-7-merous) : anthers from apically recurved to helicoid.

* Branches all opposite : flowers corymbosely or paniculately cymose, short-pedicelled. - Calyx very small, merely 5-toothed.

S. macrophylla, Hook. Glaucous : stem simple, terete, 2 or 3 feet high : leaves rather distant, thickish, nearly erect, ovate or ovate-lanceolate with cordate-clasping 3-5-nerved base, acute or mucronate-acuminate ( 1 to 3 inches long); the uppermost reduced to small subulate bracts: cymes flat-topped, naked and in a naked terminal corymb or compound cyme: pedicels short and filiform: teeth of the small calyx subulate and shorter than the tube : corolla white; the lobes oblong, 3 or 4 lines long: style not cleft to the middle. Hook. Comp. to Bot. Mag. i. 171; Griseb. in DC. 1. c. 50 ; Chapm. Fl. 353. - Wet pine barrens, Georgia to Florida and Louisiana.

+ + Calyx with long and slender or linear lobes: stem more or less 4-angled.

+- Corolla white, fading yellowish : style 2-parted, its divisions spatulate-linear.

S. lanceoláta, Torr. \& Gray. Stem simple, 2 or 3 feet high, bearing a terminal and naked corymbose cyme: leaves much shorter than the internodes (an inch or so long), from ovate to lanceolate, 3-5-nerved, the floral reduced to subulate bracts : pedicels mostly short but slender: calyx-lobes almost filiform, more than half the length of the corolla : Iobes of the latter obovate-oblong, a third to half inch long. - Gray, Man. ed. 1, 356; Chapm. Fl. 353. Chironia lanceolata, Walt. Car. 95. C. cymosa, Lam. Ill. i. 479, therefore Sabbatia cymosa, Don, Syst. C. paniculata, Michx. Fl. i. 146, partly. Sabbatia paniculata, var. latifolia, Pursh, Fl. i. 138. S. corymbosa, Baldw. in Ell. Sk. i. 283. - Wet pine-barrens, New Jersey to Florida.

S. paniculáta, Pursh. Stem a foot or two high, freely branching; the branches cymosely few-many-flowered and uppermost cymes corymbose: leaves from linear to lanceolate-oblong, obtuse; the floral mostly linear and acute: pedicels very short to the central flowers: calyx-lobes not more than half the length of the corolla: lobes of the latter spatulate-oblong, 3 lines long. - Fl. l. c. (var. angustifolia, \& excl. syn. Swertia difformis, L.); Gray, I, c., not Ell. Chironia paniculata, Michx. l. c. partly, and as to char. - Moist or dry ground, Virginia to Florida.

++ Corolla rose-color, varying to white: style cleft to the middle, its lobes slightly clavate.

S. brachiáta, Ell. Stem slightly angled, a foot or two high : leaves from lanceolateoblong to linear, mostly obtuse, obscurely 3-nerved at base: inflorescence thyrsiform-paniculate; the lateral cymes naked-pedunculate and about 3-flowered: calyx-lobes narrowly linear, shorter than or nearly equalling the light rose-color or nearly white corolla: lobes of the latter obovate-oblong, half inch long. - Sk. i. 284; Chapm. 1. c. S. concimna, Wood, Class-Book, 451. Chironia angularis, var. angustifolia, Michx. l. c.-Dry or low grounds, Indiana and $\mathrm{N}$ : Carolina to Louisiana and Florida.

S. anguláris, Pursh. Stem quadrangular with sharp angles, 2 feet high, paniculately branched above; the branches leafy : leaves cordate-ovate and clasping, 3-5-nerved: numerous and crowded branches few-flowered, pyramidally or somewhat corymbosely cymose: calyx-lobes linear, much shorter than the corolla: lobes of the latter deep rose-color, obovate, fully half-inch long. - Ell. l. c. ; Bigel. Med. t. 57; Bart. Med. t. 24; Torr. Fl. N. Y. ii. t. 83. Chironia angularis, L. ; Michx. 1. c., var. latifolia. - Rich soil, W. Canada to Florida and Louisiana.

* Branches alternate or the lower opposite: foliaceous calyx-lobes longer and hardly narrower than the lobes of the corolla: flowers not rarely 6-7-merous: style 2-parted.

S. calycósa, Pursh. Stem a span to a foot long, lonsely branching: leaves from oblong to broadly lanceolate, narrowed at base: peduncles scattered, I-flowered, mostly elongated, occasionally short: calyx-lobes from linear to spatulate, resembling upper leaves, half inch or more long, not rarely double the length of the obovate-spatulate lobes of the rosecolored or almost white corolla. - Bot. Mag. t. 1600. Chironia dichotoma, Walt. Car. 93. C. calycosa, Michx. 1. c. Gentiana calycina, Lam. Dict. ii. 638. Sabbrtia gracilis, var. Cubensis, Griseb. Pl. Wright. Cub. ii. 521. - Sea-coast and near it, Virginia to Texas. (Cuba.)

* * Branches alternate: calyx-lobes slender, seldom exceeding the obovate lobes of the corolla: peduncles more or less elongated and seattered, naked, 1-flowered. 
+ Calyx-tube prominently 5-costate, nearly or quite enclosing the retuse capsule: corolla $1 \frac{1}{2}$ to 2 inches in diameter.

S. campéstris, Nutt. A span or two high, divergently branched above: lęves ovate with subcordate clasping base, somewhat :j-j-nerved, one-half to an inch long, those of the branches lanceolate: peduncles about 2 inches long: calyx-lobes narrowly linear-lanceolate, acute, half to three-fourths inch long, equalling the broad lobes of the lilaccolored corolla; angles of its campanulate tube below the sinuses acute and wing-like in flower, thickened in fruit: style very deeply 2-cleft. - Trans. Am. Phil. Soc. n. ser. v. 197; Hook. Bot. Mag. t. 5015. S. formosa, Buckley in Proc. Acad. Philad. 1862, 7. - Prairies of Arkansas and Texas. Very showy.

++ Calyx-tube very short, girling the base of the capsule, not conspicuously costate : plants loosely paniculate-branching: corolla bright rose-colqr or pink, with white varieties, or the last white.

S. stelláris, Pursh. Leaves rather fleshy, from oblong to lanceolate and the uppermost narrowly linear: calyx-lobes subulate-linear, from half to nearly the full length of the corolla-lobes: eye or star of the corolla conspicuous : style nearly 2-parted. - Fl, i. 137. S. gracilis, Ell. 1. c., not Salisb. Chironia stellata, Muhl. Cat. - Brackish marshes, coast of Massachusetts to Florida. Appears to pass into the next.

S. grácilis, Salisb. Stems more slender : branches and peduncles filiform : leaves linear and the uppermost filiform or setaceous: calyx-lobes very slender and as long as those of the corolla (6 to 9 lines long): style 2-cleft to the middle.-Parad. Lond. t. 32 ; Pursh, l. c.; Griseb. in DC. 1. c. 49 ; Chapm. Fl. 354. Chironia gracilis, Michx. 1. c. C. campanulata, L. Spec. 190 ?, but not from "Canada." - Brackisl marshes and river banks, Nantucket (an ambiguous form), and New Jersey to Florida and Louisiana, extending inland to the mountains of Georgia. (Cuba.)

Var. grandiflóra. Stem more rigid and erect: lower leaves fleshy: flower much larger; the corolla-lobes from three-fourths to nearly a full inch long. - Coast of E. Florida, Leavenworth, Buckley, Palmer, \&c.

S. FHllióttii, Steud. Effusely and paniculately much branclıed, a foot or two high: leaves small; the lower cauline (half inch or less long) thickish, from obovate to lanceolate; upper narrowly linear and rather longer; those of the filiform flowering branehes setaceous-subulate: flowers numerous: lobes of the calyx slender-subulate, about twice the length of the tube, very much shorter than the spatulate-oblong or oblanceolate lobes of the (apparently always white) corolla; the corolla-lobes only 5 or 6 lines long: style 2-parted.-Chapm. Fl. 5:34. S. paniculata, Ell. Sk. i. 282 (ex char.), not Pursh. Swertia difformis, L. Spec. i. 226 ? - Pine barrens on the coast (S. Virginia?) S. Carolina to Florida. (Bahamas.)

\section{§2. Flowers 8-12-merous, most commonly 9-11-merous, large and showy,}

* Solitary on naked somewhat paniculate peduncles : anthers at length coiled into a helix.

S. chloroídes, Pursh. Stem a foot or two high, loosely and sparingly branched above: leaves oblong-lanceolate, or the lowest oblong-spatulate and the uppermost linear: calyxlobes subulate-linear, about half the length the spatulate-obovate lobes of the (rose-purple or sometimes white) corolla: divisions of the decply-cleft style linear-clavate. - Torr. Fl. N. Y. ii. t. 84 Chironia dodecandra, L. Spec. i. 190 ; Walt. l. c. Chlora dodecandra, I. Syst. Chironia chloroides, Michx. El. i. 147. - Margin of pine-barren ponds along the coast, Massachusetts to Florida and Alabama. Corolla about 2 inches in cliameter.

Var. strícta. Stem more rigid, 1-few-flowered : leaves all linear._Chironia decandra, Walt. 1. c. ? - S. Carolina? Alabama, and Florida.

* Capitate-clustered or sometimes solitary flowers sessile and leafy-bracted: calyx-tube turbinate: anthers of firm texture, slightly curved. - Lapithea, Griseb.

S. gentianoídes, Ell. Stem strict, a foot or two high: radical leaves in a rosulate tuft, obovate or oblong: cauline very narrowly linear, $1 \frac{1}{2}$ to 3 inches long, a line or two wide; the uppermost involucrating the terminal cluster of 3 to 5 or sometimes one or two nearly sessile flowers; occasionally one or two in lower axils : calyx-lobes lanceolate-subulate, very much shorter than the spatulate corolla-lobes, these 6 to 10 lines long: style 2-cleft at the apex, the lobes spatulate.-Sk. i. 286 ; Chapm. Fl. 354. S. oligophylla, Featherman in Univ. Mississip. Rep. 1871. Lapithea gentianoides, Griseb. in DC. 1. c. 48. - Margin of pine-barren ponds, Georgia and Florida to Texas. 
S. Boýkini, Gray. A foot high, nearly simple : cauline leaves lanceolate-oblong or the lower elliptical, 3-nerved (an inch or two long); the uppermost lanceolate: flowers 1 to 7 in the clustex; the bracts oval or oblong: calyx-lobes lanceolate, much shorter than the corolla; lobes of the latter oblong-obovate, half inch long. - Chapm. Fl. 354. - Middle or Upper Georgia, Boykin (in herb. Torr.) ; also in herb. Muhl. Little known.

S. símplex, Bertol. Misc. x. t. 3, is Rhexia stricta.

4. EUTSTOMA, Salisb. (From $\varepsilon^{j}$, $\sigma \tau o$, $\mu \alpha$, good mouth, i.e. mouth of good size, alluding to the open-mouthed corolla.) - Glaucous and large-flowered annuals; with more or less clasping and connate thickish leaves, slender terminal and more or less paniculate one-flowered peduncles, and bluish purple corolla varying to white; the lobes commonly erose-denticulate. - Only the following species.

F. exaltátum, Griseb. Lower than the next species: leaves oblong: lobes of the corolla nearly oblong (barely an inch in length), twice the length of the tube: style little longer than the stigmas: capsule elliptical-oblong, very obtuse.-DC. Prodr. ix. 51; Lindl. Bot. Reg. xxxi. t. 1:3 ; Gray, Bot. Calif. i. 621. Gentiana exaltata, L. Spec. ed. 2, 331; Descourt, Ant. t. 15. Lisianthus exaltatus, Lam. Ill. i. 478. L. glaucifolius, Jacq. Ic. Rar. t. 33. Eustoma silenifolium, Salisb. Parad. Lond. t. 34; Don, Syst. iv. 211, excl. syn. Nutt. Urananthus glaucifolius, Benth. Pl. Hartw. 46. - Southern borders of the United States, from Florida and Texas to California. (Mex., W. Ind.)

E. Russelliánum, Griseb. 1. c. A foot or two high : leaves from ovate- to lanceolateoblong: lobes of the ample lavender-purple corolla obovate (inch and a half long), 4 times longer than the tube: style elongated: capsule oblong, usually pointed: anthers hardly curving in age. - Lisianthus glaucifolius, Nutt. in Trans. Am. Phil. Soc. n. ser. v. 197, not Jacq. L. Russellianus, Hook. Bot. Mag. t. 3626. - Nebraska to Texas. Very showy.

Var. grácile. Smaller : leaves lanceolate: capsule not pointed. - E. gracile, Engelm. in FI. Calif. 1. c. - S. Texas, Berlandier, \&s. (Mex.)

5. GENTIÁNA, Tourn. Gentian. (Gentius, king of Illyria.) - Erect herbs (of the cooler parts of the world); with chiefly sessile leaves, and conspicuous flowers of various colors, produced in summer or autumn; commonly expanding only in sunshine or at mid-day. Seeds in most of our species exceedingly numerous and borne over the whole inner surface of the capsule (as first remarked by the late Prof. H. J. Clark, in Gray, Man. ed. 2, 1856, 345). Herbage and especially the roots very bitter.

§1. Gentranḱlla. Corolla (not rotate) destitute of extended plaits or lobes or teeth at the sinuses: anthers usually versatile (introrse, at length retrorsely reversed) : stigmas distinct or only casually united : root annual in all ours except in G. barbellata. - Gentianella, \&c., Borkhausen.

* (Fringed Gentiays.) Flowers large or middle-sized, solitary, mostly 4-merous: corolla campanulate-funmelform, its lobes usually fimbriate or erose, not crowned: a row of glands between the bases of the filaments. - $\$$ Crossopetalum, Frolich, Grisebach.

- Flower on a naked and usually long peduncle teminating the stem or branches, not bracteate at base: filaments naked : root annul: calyx (except in $G$. simplex) ovate-acuminate in the bud and with acutely carinate lobes, the two exterior longer as well as narrower and more acuminate, the tube sharply angled by the decurrent keels.

+ Corolla enclosed in the ventricose wing-angled calyx?

G. ventricósa, Griseb. A foot high: leaves ovate-oblong: calyx ovoid and 4-wingangled; the two external lobes much acuminate; the two internal barely acute, rather longer than the campanulate deeply 4-cleft corolla: ovate-oblong lobes of the latter regularly "crenate-fimbriate" (or in the figures sharply serrate): ovary not stipitate. - Gent. 259, in Hook. Fl. ii. 65, t. 152, \& DC. Prodr. ix. 102. - Grand Rapids of the Saskatchewan, between Cumberland House and Hudson's Bay, Drummond. Little known and not since collected: apparently described and figured from undeveloped specimens, perhaps nearly related to $G$. crinita. 
++ Corolla (sky-blue, occasionally white) conspicuously longer than the wingless calyx: autumn-flowering.

G. crinita, Frcel. A foot or two high, often paniculate-corymbose, leafy : leaves lanceolate or ovate-lanceolate from a rounded or subcordate partly clasping base: salient narrow keels of the calyx-lobes conspicuously decurrent on the tube: corolla 2 inches long; its lobes cuneate-obovate, strongly fimbriate around the summit, less or hardly so down the narrowing sides: capsule fusiform, conspicuously stipitate: seeds squamulose-roughened. -Gent. 112; Bot. Mag. t. 2031 ; Bart. Fl. Am. Sept. iii. t. 80. G. ciliuta Americana, L. G. fimbriata, Andr. Bot. Rep. t. 509. Gentianella crinita, Don, Syst. ivi. 179. - Low grounds, Canada to Dakotah and southward to the mountains of Georgia.

G. serráta, Gunner. Stem 3 to 18 inches high: leaves linear or lanceolate-linear: P. corolla an inch to an inch and a half long; its lobes oblong or spatulate-obovate, erosely fimbriate or toothed around the summit and sides, or sometimes either part nearly bare: - capsule short-stipitate: seeds and calyx nearly as in $G$. crinita. - Fl. Norveg. 10 (also mander G. ciliata, 88, t. 2), \& Fl. Dan. t. 317 ; Fries, Sumn. Scand. 190; Gray, Bot. Calif. i.

.4481. G. detonsa, Rottb. Act. Hafn. x. 254, t. 1; Griseb. 1.c.; Torr. Fl. N. Y. ii. t. $82 . G$. ciliata, Pall. Fl. Ross. ii. t. 92, not L. G. barbata, Erol. Gent. 114. G. brachypetala, Bunge,

F Consp. Gent. in Mem. Mosq. 1829, 225, t. 1. - Wet grounds, Newfoundland, Canada, and

N. W. New York to Saskatchewan and northward, and west to Colorado and W. Nevada, mainly the larger and most fimbriate form, G. detonsa, var. barbata, Griseb., \&c. (Siberia to Norway and Greenland.)

Var. grándis, a form with stem 2 feet high or more, and corolla 2 inches long, a portion only of the sides of the lobes coarsely fimbriate. $-G$. detonsa. Torr. Bot. Mex. Bound. 157. - S. E. Arizona, between Barbacomori and Santa Cruz, Thurber, Wright. (Perhaps G. crinita, var. Cervantesii, Griseb. in DC. 1. c. Mexico.)

Var. holopétala, Gray, a small or slender form, 2 to 16 inches high, with comparatively long peduncles: corolla an inch or more long, its lobes entire or merely erose-denticulate round the summit. - Bot. Calif. i. 481. - Sierra Nevada, California, at 5,000 to 10,000 feet, and Oregon.

G. simplex, Gray. Stem 2 to 10 inches high, simple, bearing 2 to 4 pairs of lanceolate or linear-oblong leaves ( 3 to 9 lines long) and a single slender-pedunculate flower: calyxtube and lobes hardly at all angled or carinate; the latter nearly equal and similar : corolla an inch long; its oblong-spatulate lobes entire or erose-dentate and sometimes a fringe of a few bristly teeth low down on the sides: capsule stipitate: seeds smooth but longitudinally striate, narrow, wingless when mature, except a cellular appendage at both ends. Pacif. R. Rep. v. 87, t. 16, \& Bot. Calif. 1. c. - Higher parts of the Sierra Nevada, California, to adjacent portion of Oregon.

+ + Flower 2-bracteate under or near the calyx: filaments ciliate-bearded below the middle: caly $\mathrm{x}$ hardly at all angled or carinate: root perennial.

G. barbelláta, Engelm. Stems single or in pairs from the slender fusiform root or caudex, 2 to 5 inches high: leaves rather thick and fleshy, obtuse, with roughish callous margins; the radical spatulate (an inch or two long) or slender-petioled; the 2 or 3 cauline pairs spatulate-linear, or the uppermost narrowly linear and connate at base: flowers one to three, sessile or nearly so between the involucrate foliaceous bracts: calyx-lobes subulate-triangular : corolla bright blue, an inch to an inch and a half long, about twice the length of the calyx, deeply 4-cleft; the lobes oblong, erose-denticulate above, conspicuously fimbriate along the middle: capsule short and not stipitate: seeds squamuloseroughened. - Trans. Acad. St. Louis, ii. 216, t. 2.-Alpine region of the Rocky Mountains in Colorado, Parry, \&c. Related to G. ciliata of Europe.

* * Flowers smaller, 4-5-merous : corolla somewhat funnelform or salverform when expanded; the lobes entire (rarely with a few denticulations), their base sometimes crowned with setaceous filaments: capsule seldom stipitate: seeds with a very close thin and smooth coat. - Endotricha, ete., Froel. \$ Amarella, Arctophila, \&c., Griseb.

- Peduncles elongated and naked from a very short stem, 1-flowered: throat of corolla crowned; no glands at its base: edges of leares and sépals smouth.

G. tenélla, Rottb. An inch to a span high: leaves (2 to 6 lines long) oblong or the lowest spatulate: calyx deeply 5-(sometimes 4 -) parted; the lobes foliaceous, oblong to ovate, usually unequal : corolla $2 \frac{1}{2}$ to 4 lines long, double the length of the calyx (more lengthened in fruit), blue; its lobes ovate-oblong, rather obtuse, little shorter than the 
tube: fimbriate crown conspicuous at the throat. - Act. Hafn. x. 436, t. 2, fig. 6 ; Frol. l. c. 96 ; Reichenb. Ic. Germ. t. 1045. G. glacialis, A. Thomas in Vill. Delph. i1. $532 . \quad G$. Koenigii, Gunner, Fl. Norv. 102. G. dichotoma, Pall. Fl. Ross. ii. 116. G. borealis, Bunge, Gent. 1. c. 251, t. 10, fig. 2. - High alpine region of the Rocky Mountains in Colorado (Parry), Utah (L. Ward), and Idaho, Nuttall. Unalaschka and Kotzebue Sound, \&c. (Kamtschatka to Greenland.)

+ + Peduncles sliort or none, terminal and lateral on a comparatively elongated stem, the angles of which are acute or wing-margined.

+- Setaceous-fimbriate crown on the base of the corolla-lobes usually conspicnous and rather copious, sometimes reduced to a few setre, or rarely evanescent: glands at the base of corolla obscure or wanting: margins of the leaves and of the conspicuous foliaceous calyx-lobes minutely scabrous.

G. auriculáta, Pall. A span or two high: leaves oblong-lanceolate or the upper ovate: calyx-tube turbinate, longer than the 5 (or rarely 4) lobes; these nearly equal and similar, cordate-ovate, or the inner merely ovate: corolla violet-blue, 9 or 10 lines long; its lobes ovate. - Fl. Ross. ii. 102, t. 92, fig. 1; Griseb. 1. c. - Islands between N. E. Asia and America, and even on the N. W. American coast, according to Pallas; but not since found. (Kamtschatka, E. Siberia, \&c.)

G. heterosépala, Engelm. A span or two high, rather simple and racemosely few. flowered: leaves ovate-lanceolate or oblong: calyx very unequally 5-parted; two of the lobes large and foliaceous, ovate, acute, equalling the tube of the pale blue corolla ( 4 to 6 lines long); the other 3 linear-subulate and shorter: setæ of the crown copious, united below into a membrane on the base of each corolla-lobe: capsule sessile. - Trans. Acad. St. Louis, i. 215, t. 8; Watson, Bot. King, 278. - Utah, in Uinta and Wahsatch Mountains, $H$. Engelmann, Watson. New Mexico in the Sandia Mountains, Bigelow.

G. Wrightii. Nearly 2 feet high : stem virgate, simple, with strict racemiform inflores. cence: leaves thickish, ovate-oblong or elliptical (less than an inch long), erect, most of the (about 12) pairs below the flowering portion nearly equalling the internodes, connate at base: flowers rather numerous, 10 lines long: calyx very deeply 5-cleft; its short tube 10-costate (the ribs answeriug to the sinuses strongerj; the lobes somewhat unequal and with strongly scabrous margins, all lanceolate, rather shorter than the tube of the campanulate-funnclform white corolla: the latter not glandular at base; its lobes ovate, one-third the length of the tube, each with a crown of about 15 long and distinct setæ: capsule short-stipitate. - Accidentally named G. quinqueflora in Torr. Bot. Mex. Bound. 157. S. E. Arizona, in springy ground near Santa Cruz, Wright.

G. Amarélla, L. From 2 to 20 inches high: leaves from lanceolate to narrowly oblong, or the lowest obovate-spatulate: inflorescence disposed to be racemiform: calyx 5-cleft (or rarely 4-cleft) below the middle; the lobes lanceolate or linear, equal or one or two of them longer, all shorter than the mostly blue corolla: the latter half inch or more long; its lobes oblong, obtuse, or becoming acute: capsule sessile. - Fl. Dan. t. 328; Reichenb. Ic. Germ. t. 1046; Griseb. 1. c. ; Herder in Radde, iv. 145. G. pratensis, Frœl. l. c. (Eu., Asia.)

- Var. acúta, Hook. f. Calyx almost 5-parted: crown usually of fewer and sometimes very few setæ. - Engelm: l. c.; Herder, l. c. G. acuta, Michx. Fl. i. 177; Griseb. 1. c.; Engelm. l. c. 214, t. 9, fig. 6 (var. nana, a dejauperate high alpine form). G. Amarella, Richards. App. Frankl. Journ.; Watson, Bot. King, l. c. G. plebeja, Cham. in Bunge, Gent. 1. c. 250, t. 9, fig. 5. - Labrador and Lower Canada to Alaska, and south along the Rocky Mountains to New Mexico, in the Sierra Nevada of California, and thence far northward. (N. Asia, \&c. Mex.)

Var. strícta, Watson, 1. c. Stem (sometimes 2 to 4 feet high) and branches strict, remotely leafy: leaves thickish, the cauline lanceolate-linear: flowers numerous, commonly 4-merous, smaller: caly x rather less deeply cleft: corolla 3 to barely 5 lines long, whitisl, little longer than the unequal calyx; setæ of the crown sometimes very few or even wanting ; glands at base of the tube not rarely evident: seeds smaller. - G. acuta, var. stricta, Griseb. in Hook. Fl. \& DC. 1. c. G. arctophila, var, densiflora, Torr. in Frem. Rep. 94, not Griseb. - Mountains of Nevada, Idaho, and Wyoming. (Mex.)

Var. ténuis. Same as var. stricta, but calyx very deeply parted, according to figure and description of $G$. tenuis, Griseb. Gent. \& in Hook. Fl. 1. c. 63, t. 151.-Mackenzie River and Bear Lake, Richardson. Not since found. Seta of the crown 3 to each lobe and conspicuous, or wanting. 
$4+$ Setaceous-fimbriate crown, Sc., as in the preceding subdivision; but glunds on the base of the corolla more or less manifest: calyx-lobes very small and short on the truncate spatliaceous
tube.

G. Wislizéni, Engelm. A foot or less high, with the habit and many-flowered thyrsoidpaniculate inflorescence of $G$. quinqueflora, but smaller in all its parts : leatves from lanceolate to ovate (an inch or less long), with obtuse or subcordate base: calyx barely half the length of the tube of the corolla; its scarious tube ( $1 \frac{1}{2}$ lines long) split down one side, in age sometimes dejected, much longer than the 5 unequal linear herbaceous teeth : corolla nearly salverform, pale purplish, 4 or 5 lines long; its lobes oblong-ovate, copiously fringed above the base: capsule sessile: seeds globose. - Trans. Acad. St. Louis, ii, 215, t. 7. Sierra Blanca, S. Arizona, Rothrock, a broad leaved form, the glands less evident. (Adjacent Mex., Wislizenus.)

++ No crown to the corolla ; but its lobes tipped with a setiform point or sharp acumination and the glands at bottom of the tube manifest. - $\$$ Arctophila, Griseb. $=$ Dwarf species of high northern or alpine regions : cauline leaves only 2 to 4 rather distant pairs:
calyx 4-5-parted.

G. aúrea, L. Leaves ovate, 5-7-nerved; the margins and those of the spatulate-lanceolate calyx-lobes smooth : corolla yellow, violet, or commonly white, 4 lines long, little surpassing the calyx; its lobes almost as lon'g as the campanulate tube. - Fl. Dan. t. 344 ; Herder, 1. c. 155 . G. involucrata, Rottb. in Act. Hafn. x. 314, t. 1, fig. 2. G. Aleutica, Cham. \& Schlecht. in Linn. i. 1¡o, fide Herder. G. Tnalaschkensis, Cham. in Bunge, 1. e. 240, t. 9, fig. 2. - Unalaschka, \&c. Also Sitka, according to Herder. (High northern Siberia to Lapland, Iceland, and Greenland.)

G. propínqua, Richards. Stem slender, 2 to $T$ inches high, mostly branched from the base: leaves from oblong to lanceolate and the lowest spatulate, obscurely 3 -nerved, the edges and those of the calyx smooth: flowers chicfly 4-merous and rather slender-pedicelled: lobes of the calyx unequal; two of them ovate or oblong, the others linear-lanceolate, the larger rather shorter than the tube of the corolla: the latter bluish, narrow, 4 to 9 lines long, its lobes ovate or in age lanceolate, sometimes erose-denticulate. - App. Frankl. Journ. 734 ; Griseb. 1. c.; Hook. Fl. t. 150; Herder, 1. c. G. Rurikiana, Cham. \& Schlecht. in Linn. i. 176. G. setiflora, Bunge, I. c. t. 9, fig. 4.-Labrador to Bear Lake, the northern Rocky Mountains, Kotzebue Sound, \&c. (Adjacent Asia.)

Var. densiflóra, Griseb, I. s., in alpine swamps of the Rocky Mountains (I)rummond), a more condensed and leafy plant, occurring with the ordinary form, is said to differ from the preceding species only in the inequality of the calyx-lobes.

G. arctóphila, Griseb. Stem an inch to a span high: leaves ovate-oblong or the lowest obovate; the elges and especially those of the calyx-Iobes scabrous: corolla 7 to 10 lines long; the round-ovate lobes more acuminate-cuspidate: otherwise very like largeflowered G. propinqua (to which Herder refers it). - Gent. 251, \& in Hook. Fl. ii. 61, t. 149, with a var. densiflora, having cordate-ovate leaves, and two of the calyx-lobes unusually large. - Arctic sea-coast, Richardson. The variety in the alpine region of the northern Rocky Mountains, Drummond.

$$
\Longrightarrow=\text { Taller and leafy : calyx 5-cleft: capsule slender-stipitate. }
$$

G. quinqueflóra, Lam. A foot or two high; the larger plants branching : leaves ovatelanceolate, with subcordate partly clasping base, 3-7-nerved, the upper acute or cuspidate-acuminate: inflorescence thyrsoid-paniculate; the clusters, $3-j$-flowered: calyx one fifth or fourth the length of the narrow funnelform bright blue corolla; its lobes linearsubulate: corolla half to three fourths inch long; its lobes ovate-triangular, short. - Dict. ii. 643; Froel. Gent. 51; Griseb. 1. c. G. quinquefolia, L., doubtless meant for quinqueflora. G. amarelloides, Pursh, Fl. i. 186. - Moist hills, Canada, Maine to Michigan, and along the Alleghanies to Florida.

Var. occidentális, Gray. Sometimes 2 or 3 feet high and paniculately much branched: inflorescence more open : calyx-lobes more foliaceous, linear or lanceolate, unequal, reaching to the middle of the broader funnelform corolla. - Man. ed. 1, 359, ed. 5, 387. G. quinqueflora, Hook. Bot. Mag. t. 3496, mainly. - Ohio to Minnesota and south to Tennessee and Louisiana.

Var. parviflóra, Raf., collected in Virginia, Kentucky, \&c. (Griseb. in DC. 1. c. 100), is a depauperate and small-flowered state of the preceding variety, and is G. amarelloides, Michx. Fl. i. 175. 
§ 2. Pneumon $́$ nthe. Corolla (funnelform or salverform) plicate at the sinuses, the plaits more or less extended into thin-membranaceous teeth or lobes: no crown nor glands : stigmas distinct: flowers almost always j-merous : capsule more or less stipitate. - Pneumonanthe, Necker. \$ Pneumonanthe, Chondrophylla, Coelanthe, Tretrorhiza, \&c., Griseb.

* Root annual, and habit of the preceding section: leaves marginless : flowers cymose: calyx short, 5-cleft : anthers oblong-linear, introrse, remaining erect.

G. Douglasiána, Bong. A span high, slender, cymosely branched: leaves ovate; the lowest rosulate; the cauline of few remote pairs and somewhat cordate ( 2 to 4 lines long): corolla white, a third to half inch long; its lobes oblong, shorter than the funnelform tube, not double the length of the conspicuous and equally broad 2-cleft accessory lobes in the sinuses: capsule stipitate, obovate, ancipital above: seeds proportionally large (a line Iong), elongated-oblong, with a close coat, apiculate at both ends. - Veg. Sitka, 38, t. 6 ; Griseb. in Hook. Fl. ii. 60, t. 148. - Alaska to Oregon.

* Root annual or biennial in our species: dwarf and small plants : leaves small and with white cartilaginous or scarious margins: flowers solitary and terminal: caly $x$ narrow, 4-5-toothed: corolla salverform when expanded; the lobes or plaits in the sinuses broad and emarginate: anthers cordate, versatile: seeds oblong, with a close coat. - \$Chondrophylla, Bunge, Griseb.

G. húmilis, Stev. Stems single or numerous from the slender root, 1 to 5 inches long, erect or ascending: leaves glaucescent and broadly white-margined; the radical orbicular or ovate and rosulate (a quarter to half inch long) ; cauline linear-oblong, erect, connatesheathing, 2 or 3 lines long: corolla whitish or dull-colored; its tube little exceeding the calyx; the limb half inch in diameter: capsule clavate-obovate, at length exserted on a long and stout stipe much beyond the flower. - Act. Mosq. iii. 258; Griseb. 1. c. ; Engelm. in Trans. Acad. St. Louis, ii. 217, t. 9, fig. 1-5. G. aquatica, Pall. Fl. Ross. ii. t. 97, fig. 2, not L. G. Fremontii, Torr. in Frem. Rep. 94. - Grassy banks of streams in the Rocky Mountains, Wyoming to Colorado. (Asia.)

G. prostráta, Hæenke. Stems weaker than in the preceding and when elongated the lateral ones often procumbent: leaves ovate, less erect, greener, and less white-margined: flower (in the American plant always? and in the European sometimes) 4-merous : corolla azure-blue, in fruit enclosing the linear-oblong rather short-stipitate capsule. $=$ Jacq. Coll. ii. 66, t. 17, fig. 2 ; Griseb. l. c.; Engelm. l. c. t. 9, fig. 9-14. (var. Americana); Herder, l. c. G. nutans, Bunge, 1. c. t. 11, fig. 2. - Alpine regions of the Rocky Mountains, from Colorado northward, and to Kotzebue Sound, Aleutian Islands, \&c. (N. E. Asia to Tyrolese Alps. Antarc. Amer.)

* * Root perennial : flowers comparatively large, mostly, short-peduncled or sessile: anthers linear or oblong, more or less extrorse, remaining erect: usually a pair of bracts under the flower. $-\S$ Pneumonanthe, Griseb.

+ Rocky-Mountain and Pacific species: anthers unconmected, seldom connivent. + Dwarf, 1-5-flowered: cauline leaves only 2 to 4 pairs.

G. glaúca, Pall. Stem 2 to 4 inches high : leaves oval, glaucous, 3 to 5 lines long : calyx campanulate; its teeth shorter than the tube: corolla blue, half inch or more long; its tube cylindraceous, and ovate obtuse lobes short; the short lobes of the plaits ovate and entire: seeds oval, irregularly 3-4-wing-crested. - Fl. Ross. ii. 104, t. 93, fig. 2 ; Griseb. in Hook. Fl. ii. 58, t. 147. - Higher and northern Rocky Mountains to Kotzebue Sound. (Kamts. to Siberia.)

G. frígida, Hænke. Stems 1 to 5 inches high, 1-3-flowered: leaves linear, varying to Innceolate or spatulate, thickish, 1 to 3 inches long, the pairs connate-sheathing at base: calyx-tube obconical, longer then the oblong-linear lobes: corolla funnelform, an inch and a half long, yellowish-white or tinged with blue, purplisl-dotted; the lobes short and broad; the plaits entire and broad but slightly extended at summit: seeds with a loose cellular coat extended into crested longitudinal ridges. - Jacq. Coll. ii. 13; Frol. Gent. 39, t. 1 ; Griseb. in DC. 1. c., with var. algida. Gelgida, Pall. Fl. Ross. ii. 107, t. 95, a large form. G. Romanzovii, Ledeb. in Bunge, l. c. t. 11, fig. 1. - Alpine region of the Rocky Mountains in Colorado and Utah, Parry, \&\&. St. Paul and Shumagin Islands, Harrington, Elliott, \&c. (Kamts. to Carpathian Mts.)

G. Newbérryi, Gray. Stems 1-flowered, 2 to 4 inches long, and ascending from the axils of the rosulate-radical leaves: these obovate or spatulate, an inch or more long; 
cauline leaves much smaller, connate-sheathing; the lowest obovate, the uppermost lanceolate: calyx-lobes lanceolate or oblong, nearly the length of the oblong-campanulate tube: corolla broadly funnelform, inch and a half long, pale blue, white within, greenish dotted; its lobes ovate, mucronate; the interposed appendages 2-cleft or laciniate, subulate-tipped: seeds round-oval, smooth, broadly vinged. - Proc. Am. Acal. xi. 84, \& Bot. Calif. i. 482. F. calycosa? Gray in Pacif. R. Rep. vi. 86. - Sierra Nevada, California, in or near the alpine region, from Mariposa Co. north to s. Oregon, Newberry, Brewer, \&c.

\footnotetext{
++ Low: stems several from the same caudex: cauline leaves 6 to 16 pair, more or less connate or even sheathing at base; the uppermost involucrate around the sessile terminal flower or 3-5-flowered cluster: corolla campanulate-funnelform, blue, $1 \frac{1}{4}$ to $1 \frac{1}{2}$ inclien long; the lobes broadly ovate, and the appendages at the sinuses 2-cleft or laccrute.
}

G. setígera, Gray. Stems stout, about a foot long, decumbent: leaves thick and pale, oval or the upper oblong, very obtuse, an inch or less long; the pairs all with a connatesheathing base, the two uppermost involucrate around and covering the base of the solitary flower: calyx-lobes oral, about the length of the tube: corolla almost campanulate; the appendages of the plaits small and short, produced into 2 or 3 capillary bristles which nearly equal the lobes: forming seeds orbicular, winged. - Proc. Am. Acad. xi. 84, \& Bot. Calif. 1. c. - California, on Red Mountain, Mendocino Co., in damp soil, Bolander.

G. calycósa, Griseb. Stems erect, a span to a foot high : leaves ovate 6 to 15 lines long), commonly equalling or exceeding the internodes; the lowest pairs usually smaller and with connate-sheathing base, the upper hardly so; the involucrate uppermost leaves somewhat exceeding the caly $\mathbf{x}$ of the commonly solitary flower: calyx-lobes ovate or oblong, or even subcordate, about the length of the turbinate tube : corolla oblong-funnelform, its appendages in the sinuses triangular-subulate, laciniate, or 2-cleft at the tip, shorter than the broadly ovate lobes: seeds lanceolate, acuminate, wingless. - Gent. l. c. \& Hook. Fl. t. 146; Gray, Bot. Calif. 1. c. - Varies with stems only 2 to 4 inches high, and small leaves crowded (var. stricta, Griseb. 1. c.); also with taller and more slender stem 2-3-flowered, occasionally with one or two axilliary conspicuously pedunculate flowers subtended by a pair of smaller bracts. - California (Sierra Nevada, Bridges, Brewer, Lemmon), Oregon (Tolmie), and Rocky Mountains, lat. $42^{\circ}-49^{\circ}$, Porter, Lyall.

G. Párryi, Engelm. A span or more high: leaves glaucescent, thickish, ovate, varying' to oblong-lanceolate, three-fourths to inch and a half long, most of the pairs with somewhat sheathing base; the upper 2 or 3 involucrating the 1 to 5 flowers, concealing the caly $\mathrm{x}$ and sometimes almost equalling the (bright purple-blue) corolla: lobes of the caly $\mathrm{x}$ short-linear, small, moderately or nuch shorter than the campanulate (sometimes spathaceous-cleft) tube: appendages at the sinuses of the corolla narrow, deeply 2-cleft, little shorter than the obovate lobes: seeds lanceolate, wingless, obtuse or less acute than in $G$. calycosa, which the broad-leaved forms of this much resemble. - Trans. Acad. St. Louis, ii. 218, t. 10; Watson, Bot. King, 279. G. calycosa, var. Parryi, Herder, 1. c. 178. - Alpine and subalpine regions in the Rocky Mountains, New Mexico, Colorado, Utah, and N. E. Nevada, Parry, \&c.

+++ Stems either tall or low, many-leaved: flowers not involucrate: style manifest.

= Corolla (blue or bluish) oblong-campanulate, with broadly ovate lobes more or less narrowed at base, and the intervening plaits or lobes entire: calyx-lobes usually from ovate to lanceolate, equalling or longer than the tube: seeds wingless.

G. platypétala, Griseb. Stems a span high, ascending, densely leafy above, bearing a single sessile flower: leaves ovate-roundish, recurved-spreading: lobes of the 5-parted calyx ovate, acute: campanulate tube of the blue corolla twice the length of the calyx; its short lobes somewhat reniform, mucronate ( 2 lines long and 3 wide), double the length of the triangular acute and entire plaits. - Gent. 191, \& in Hook. 1. c.; DC. 1. c. - "Sitka, Kotzebue." The char. from Grisebach. Referred to $G$. calycusa by Herder, and it must resemble its smaller form; but the sinus-plaits are said to be entire.

G. Menziésii, Griseb. 1. c. Stems a foot or less high, slender: leaves from narrowly oblong to lanceolate (inch and a half or less long), somewhat 3-nerved: flowers one or two, short peduncled or sessile : caly $x$ according to Grisebach spathaceous and the lobes obsolete, in our specimens with oblong-lanceolate foliaceous lobes (5 lines long) equalling the turbinate-oblong tube: corolla an inch long; its lobes 3 lines long and wide; its plaits truncate and obscurely 2-3-crenate: seeds ovate-lanceolate or oblong, barely acute or both 
ends obţuse.- G. sceptrum, var. humilis, Engelm.; Gray, Bot. Calif. i. 488. - Bogs, W. Oregon (Menzies, E. Hall) to Mendocino Co., California, Bolander.

G. scéptrum, Griseb. l. c. Sten erect, 2 to 4 feet high, simple or short-branched above, few-several-flowered: leaves from ovate to oblong-lanceolate ( $1 \frac{1}{2}$ to 3 inches long), indistinctly 3-7-nerved: calyx-lobes unequal, lanceolate to ovate-oblong: corolla $1 \frac{1}{4}$ to 2 inches long, sometimes greenish-dotted; its loles nearly 4 lines long and wide; its plaits truncate or with barely rounded entire summit: seeds narrowly layceolate and with scarious acumination. - Hook. Fl. t. 145; Gray, Bot. Calif., excl. var. - W. Oregon to Brit. Columbia.

$=$ Corolla (blue or bluish) funnelform, with orate lobes not narrowed at base; the plaits extencled into conspicuous laciniatc-toothed or cleft appendages, which sometimes almost equal the lolves: margins of the leaves scabrous: seeds surrounded by a distinct and rather broad wing, ovate or oblong.

G. Oregána, Enggelm. Stems erect and rather stout, a foot or two high, sometimes more slender and ascending: leaves ovate, sometimes ovate-oblong ( 1 to $1 \frac{1}{2}$ inches long): flowers few at the summit, or occasionally several and racemose-scattered : bracts oblong or ovate: calyx-lobes from oblong- to ovate-lanceolate, as long as the tube: corolla broadly funnelform, over an inch long; its short lobes roundish. - Engelm. in herb. G. affinis, var. ovata, Gray, Bot. Calif. i. 483, - Brit. Columbia and W. Idaho (Lyall, Spalding) to Oregon (Nevius, \&c.) and W. California. Foliage and corolla somewliat as in G. calycosa, but the sualler forms nearly approaching $G$. affinis.

G. affinis, Griseb. Stems clustered, a span to a foot high, mostly ascending: leaves from oblong or lanceolate to linear: flowers from numerous and thyrsoid-racemose to few or rarely almost solitary : bracts lanceolate or linear : calyx-lobes linear or subulate, unequal and variable, the longest rarely equalling the tube, the shorter sometimes minute: corolla an inch or less long, rather narrowly fumnelform; its lobes ovate, acutish or mucronulate-pointed, spreading. - Gent. l. c. \& DC. 1. c. 114; Watson, Bot. King, 279; Gray, 1. c., excl. var. - Rocky Mountains from New Mexico and Colorado, and from the Sierra Nevada, California, to British Columbia, thence east to the Saskatchewan.

++ Upper Mississippi-valley species: flowers almost sessile, 2-bracteate under the calyx: corolla open-funnelform with conspicuously spreading lobes: anthers merely connivent, soon separate: seeds conspicuously winged, oblong, all attached at or near the suturies.

G. pubérula, Michx. About a foot high, mostly single-stemmed from the root, very leafy, at least the upper part of the stem, with the margins and midrib of leaves and sepals minutely puberulent-scabrous: leaves rigid, from oblong-lanceolate (or the lower oblong) to lanceolate-linear, an inch or two long: flowers solitary or several and clustered: calyx-lobes linear-lanceolate or subulate-linear, about the length of the tube : corolla bright blue, $1 \frac{1}{2}$ to 2 inches long; the ovate lobes (a fourth to even half inch long) widely spreading in anthesis, twice the length of the 2-cleft and sometimes laciniate-toothed appendages. - Fl. i. 176 (descr. not good as to corolla); Gray, Man. ed. 2, 347, ed. 5, 389. (G. Saponaria, var. puberula, ed. 1.) - Dry prairies and barrens, Ohio, Kentucky, and Kansas to Wisconsin and Minnesota.

+++ Atlantic U. S. species (one or two crossing the Mississippi): seeds covering the whole parieties of the capsule: style manifest, in most conspicuous.

t+ Corolla campanulate-funnelform, with the short lobes little if at all spreading in anthesis : anthers cohering in a ring or short tube: stem usually several-flowered: flowers sessile or very short-peduncled and 2-bracteate under the calyx, clustered at summit and often in upper axils. $=$ Calyx-lobes and bracts ciliolate-scabrous: seeds winged or appendaged.

G. Ellióttii, Chapm. Puberulent-roughish in the manner of the preceding, a span to n foot or more high, slender: leaves from lanceolate to ovate-lanceolate, or the lower ovate, an inch or less long, the broadest subcordate: flowers 1 to 3 terminal, and sometimes also in the axils, sessile, leafy-bracted: calyx-lobes lanceolate or broader, foliaceous, twice or thrice the length of the tube, ciliolate-scabrous: corolla bright blue, 1 to $1 \frac{1}{2}$ inches long; the broadly ovate obtuse lobes ( 3 lines long) hardly twice the length of the broad and 2cleft erose-dentate or somewhat fimbriate appendages : seeds conspicuously winged, ovateor oblong-lanceolate in outline. - Fl. 356, specially the var. parvifolia, " $G$. Catesbrei, Ell. not Walt." according to Chapman. Perhaps an extreme form of the next; but the Florida plant appears to be quite distinct. $-\mathrm{S}$. Carolina? to Florida.

G. Saponária, L. Stem a foot or two high, smooth, or somewhat scabrous above: leaves from ovate-lanceolate or oblong to broadly lanceolate, 2 or 3 inches long, more or less nar- 
rowed at base: caly $\mathbf{x}$-lobes from linear to spatulate or oblong, mostly equalling and sometimes exceeding thettube : corolla light blue, an inch or more long, its broad and roundish short lobes erect, little and often not at all louger than the bcleft and many-toothed inter. vening appendages: seeds nearly as in the preceding. - Spec. i. 2-2s (Moris. IIist. iii. 484, sect. 12, t. 5, fig. 4 ; Catesb. Car. i. t. 70); Griseb. l. c. (excl. var.) G. ('utesbut, Walt. Car. 109; Bot. Mag. t. 1039. G. Elliottii, var.? latifolia, Chapm. 1. c.-Moist woods, W. Canada and New York to Florida and Louisiana. A somewhat polymorphous species.

G. Andréwsii, Griseb. Stems stout, a foot or two high, smooth: leaves from ovate- to broadly lanceolate, gradually acuminate, contracted at base, 22 to 4 inches long: calyxlobes lanreclate to orate, usually spreading or recurved, shorter than the tube: corolla as the preceding but more oblong and the lubes obliterated or obsolete, the truncate and usually almost closed border mainly consisting of the proninent fimbriate-dentate intervening appendages: seeds with a conspicuous wing, oblong in outline. - Gent. 287, \& in Hook. Fl. ii. 5.3 (with var. linearis, which is merely a narrower-leaved state); Gray, Man. 1. c. G. Saponariu, Frœl. Gent. 32; Ell. 1. c.; Bart. Fl. Am. Sept. iii. t. 79 . G. C'atesbcei, Andr. Bot. Rep. t. 418. - Moist ground, New England and Canada to Saskatchewan, and south to the upper parts of Georgia. Corolla from bright to pale blue, with white plaits, sometimes all white. $=$ Calrx-lobes and bracts (also leares) smooth and naked on the margins (or sometimes rery
minutely ciliolate-scablous under a lens, especially the lower part of the bracts) : seeds distinctly
wingesl: flowers in a leafy-involucrate capirate cluster, aud often solity or clustered in upper
axils.

G. álba, Muhl. Smooth throughout: stem stout, 2 feet high: leaves ovate-lanceolate or oblong-lanceolate and gradually acuminate from a cordate-clasping base, 2 to 4 inches long: flowers usually rather numerous in the compact terminal cluster: calyx-lobes ovate or subcordate, acute, reflexed-spreading, shorter than the tube: corolla dull white and commonly tinged with yellowisly or greenish, often an inch and a half long, like that of G. Saponaria, but more campanulate and open; its ovate lobes twice the length of the broad and erose-toothed appendages. - Cat. ed. 2, 29, \& Fl. Lancast. ined.; Nutt. Gen. i. 172; Gray, Man. ed. 1, 360, ed. 5, 388. G. ochroleuca, Sims, Bot. Mag. t. 15.21; Griseb. in DC. 1. c., in part; Torr. Fl. N. Y. l. c., not Froel. G. flavida, Gray in Am. Jour. Sci. ser. 2, i. 80.- Low grounds and mountain meadows, W. Canada and Lake Superior, south to Illinois, Kentucky, and the mountains of Virginia, east to Penn. and New York? Begins to flower early in August.

G. lineáris, Frœel. Smooth throughout: stem slender and strict, a foot or two high : leaves linear or narrowly lanceolate, $1 \frac{1}{2}$ to 3 inches long, 2 to 5 lines wide, and with somewhat narrowed base: flowers 1 to 5 in the terminal involucrate cluster, and often solitary in one or two axils below: caly $x$-lobes linear or lanceolate, shorter than the tube : corolla blue, an inch or more long, narrow-funnelform; the erect lobes roundish-ovate and obtuse, 2 lines long, a little longer than the triangular acute and entire or slightly 1-2-toothed appendages. - Gent. 37 ; Pursh, Fl. i. 186, excl. syn. Michx. G. Pneumonanthe, Michx. Fl. i. 176; Bigel. Bost. ed. 2, 105, not L. G. Pseudo-pneumonanthe, Rœem. \& Sch. Syst. vi. 146. G. Saponaria, var. linearis, Griseb. l. c. (excl. syn. G. Catesbcei, Ell., \& $G$ puberula, Michx., \& char. foliis margine scabris); Torr. Fl. N. Y. ii. 106, t. 81; Gray, Man. ed. 5, 389. G. Saponaria, var. Froelichii, Gray, Man. ed. 1, 360. - Bogs, along the Alleghanies of Maryland and Penn. to northem New York and New England, New Brunswick (Fowler), and towards Hudson's Bay (Michaux). Distinctly different from $G$. Pneumonanthe of the Old World in inflorescence, corolla, and distinctly winged seeds.

Var. lanceoláta. Leaves lanceolate, or the upper and involucrate ones almost ovate-lanceolate ( 1 or 2 inches long and even half inch wide): appendages of the sinuses of the corolla sometimes very short and broad. - G. rubricaulis, Schwein. in Keating, Narr. Long Exped. Mississip. - Minnesota and along Lake Superior. Also Herkimer Co., New York, Paine. Approaches narrow-leaved forms of $G$. alba.

$==$ Calyx-lobes and bracts with smooth or nearly smooth margins: seeds oval and completely wingless, even marginless.

G. ochroleúca, Frrœl. Smooth, rather stout, a span to a foot high, often branching: leaves obovate or the upper oblong, all conspicuously narrowed at base, 1 to 3 inches long, pale : flowers sessile or nearly so in terminal and sometimes lateral leafy clusters : calyxlobes linear, unequal, longer than the tube; the longer little exceeded by the somewhat 
open-funnelform greenish-white corolla, which is greenish-veiny and often purplish-striped (and $1 \frac{1}{2}$ inches long); its lobes triangular-ovate and acute, much exceeding the triangular oblique and entire or sparingly toothed appendages. - Gent. 35 ; Pursh, l. c. ; Ell. Sk. i. 340; Griseb. 1. c. partly; Gray, Man. 1. c. G. Virginiana etc., Pluk. Alm. t. 186 (poor). G. villosa, L. Spec., i. e. pl. Gronov., but it is glabrous. G. Saponaria, Walt. Car. 109, not L. G. incarnata, Sims, Bot. Mag. t. 1856. G. intermedia, Sims, Bot. Mag. t. 2303. G. serpentaria, Raf. Ann. Nat. 13? - Dry or damp grounds, Pennsylvania to Florida and Louisiana.

it+ +t+ Corolla more funnelform and with longer spreading lobes: anthers connivent but not connected: flowers solitary on the stem or occasional branches, commonly peduncled and naked.

G. angustifólia, Michx. Smooth : stems scattered, a span or two Tong, slender, ascending, commonly simple: leaves narrowly linear, thickish, an inch or two long, a line or two wide; the lower narrowed downward; the uppermost smaller and sometimes forming bracts to the flower: calyx-lobes resembling the uppermost narrow leaves, longer than the tube: corolla 2 inches long, deep and brilliant azure-blue, somewhat brown-dotted_within (also a snow-white variety with a greenish hue outside) ; the lobes ovate, half inch long, widely spreading in anthesis, much longer than the broad and conspicuous laciniate appendages: seeds slender, wingless. - Fl. i. 177 ; Ell. 1. c. ; Chapm. Fl. 356. G. purpurea, Walt. Car. 109, not L. G. porphyris, Gmelin. G. frigida, var. Drummondii, Griseb. in DC, 1. c. 111, the white-flowered variety from Florida. - Low pine-barrens, New Jersey (not "Canada") to Florida. A most beautiful species.

6. PLEUROGYNE, Eschsch. (Formed of $\pi \lambda \varepsilon v \varrho o ́ n$, rib or side, and $\gamma^{\prime} v \eta^{\prime}$, female; from the remarkable stigmas, which, instead of terminating the ovary, occupy the greater part of the length of the two sutures below its apex.) - Small annuals of cold regions in the northern hemisphere, of three or four nearly related species. Genus more related to Swertia than to Gentiana, the appendages to the corolla, as in the former, adnate and apparently glandular at base. Linnæa, i. 188 (1826), Lomatogonizm, Braun in Flora, 1830, 221.

P. rotáta, Griseb. Stems 2 to 10 inches high, the smaller simpler and 1-flowered; the larger either simple and racemosely several-flowered or fastigiately much branched : leaves linear or lanceolate, or the radical ones short and spatulate: sepals similar to the upper leaves, in ours mostly narrowly linear; the longer equalling the blue or whitish corolla: lobes of the latter ovate becoming oblong-lanceolate, 4 or 5 lines long, bearing at base a pair of glandular and scale-like processes : ovary and capsule linear-oblong or lanceolate, nearly marginless. - Griseb. Gent. 309, \& Hook. Fl. ii. 65; DC. Prodr. ix. 122 ; Herder, 1. c. 181. Swertia rotuta, L. ; Pall. Fl. Ross. ii. t. 89, fig. 1, 2. Gentiana sulcata, Willd. Spec. i. 1351. G. rotata, Frœl., Bunge, \&c. - Labrador and Hudson's Bay to the high north-west coast, Kotzebue Sound, \&c., and Rocky Mountains south to lat. $39^{\circ}$ : in the latter always the slender-leaved form, var. tenuifolia, Griseb. (Kamts. to Greenland.)

P. Carinthíaca, Griseb. Low, few-flowered: leaves shorter and usually ovate: sepals from ovate to oblong-lanceolate, much shorter than the corolla: ovary and capsule oblongovate, distinctly margined. (Alps of Eu., east to N. E. Asia.)

Var. pusílla. Leaves lanceolate or spatulate : sepals oblong-lanceolate, after anthesis becoming as long as the ovate corolla-lobes and the oblong-ovate capsule. - (Near var. Stelleriana, Griseb., G. Stelleriana, Cham., Swertia rotata, Pall. 1. c. as to fig. 3 ; but leaves not ovate, \&:..). Swertia pusilla, Pursh, Fl. i. 101. Pleurogyne Purshii, Steud. Nom. - Labrador and alpine region of the White Mountains of New Hampshire, according to Pursh, the latter station very doubtful. Rivière du Loup, E. Canada, Dr. Thomas. ·(Himalayas, Lapland.)

7. SWÉRTIA, L. (Emanuel Sweert, a German herbalist.) - The genuine species are simple-stemmed perennials, occasionally with alternate leaves, the lower tapering at base into a margined petiole; the inflorescence thyrsoid; the flowers blue, varying to white, in summer. Seeds flat, commonly margined.

S. perénnis, L. A span to foot or more high : lowest leaves oblong or obovate-spatulate (2 to 4 inches long), tapering into a long petiole; upper cauline few and narrower, 
sessile; some commonly alternate: inflorescence racemiform or narrowly paniculate, fewmany-flowered : flowers 5-merous : sepals narrowly lanceolate: lobes of the corolla (4 to 6 lines long) oblong-ovate becoming lanceolate, the base bearing a pair of nectariferous pits which are crested with a fringe. - Engl. Bot. t. 1041; Fl. Dan. t. 2017; Jacq. Fl. Austr. iii. t. 243. - Ours the var. obtusa, Griseb. ( $S$. obtusa, Ledeb.), with obtuser lower leaves and corolla-lobes, but passing into the other and European form. - Rucky Mountains in Colorado, Ctah, \&c., and Alaska. (N. E. Asia to Eu.)

8. FRASERA, Walt. (John Fraser, of Great Britain, made collections in this country 1785-96, published Walter's Flora Caroliniana.) - Large and stout herbs, or some smaller and more slender; with single erect stem from a mostly biennial and thick bitter root, verticillate or opposite leaves, the broader ones commonly somewhat nervose, thyrsoid or paniculate-cymose inflorescence, and copious flowers, produced in summer. Calyx-lobes from linear to ovate. Corolla dull white, yellowish, or bluish, and commouly dark-dotted, mostly of firm texture, not "decidnous" but marcescent. Flowers seldum, if ever, כ̃-merous. Species all N. American, and all but one western; the genus mostly well marked in aspect, but in floral character distinguished from Swertia only by the distinct style; and this is very short in $F$. Parryi and $F$. thyrsiflora.

* Leaves marginless : a single round gland upon each corolla-lobe; no crown at base: capsule (as far as known) strongly flattened parallel with the valves: seeds orbicular, wing-margined : stem large and stout: sepals narrow, almost the leugth of the corolla.

F. thyrsiflóra, Hook. Stem 2 or 3 feet high: leaves in pairs or threes, oblong or spatulate-obovate, the cauline 3 or 4 inches long: flowers in a dense interrupted thyrsus: sepals subulate-linear ( 4 lines long) : lobes of the pale blue corolla ovate-oblong, thin, bearing the gland near the base: style short and conical, in some flowers hardly any! - Kew Jour. Bots iii. 288, where the flowers are said to be 5-merous! F. Carolinensis, Hook. Fl. ii. 66. Suertia fastigiata, Pursh, Fl. i. 101. - Idaho and interior of Oregon, on the tributaries of the Columbia, Levis, Douglas, Geyer, Sspalding. Rare and little known. Pursh's plant seen in herb. Lambert, where the true station is recorded: "in moist and wet places on the Quamash flats, June 4, 1806," at which date Lewis and Clarke were on the Kooskooskie (now Salmon) River, near which the species was collected by Spalding: the flowers in both 4-merous. Douglas's and Geyer's specimens not seen.

F. Carolinénsis, Walt. Stem 8 to 8 feet high: leaves mostly in fours, 12 to 4 inches long; the radical and lowest spatulate-oblong; uppermost lanceolate; those of the ample and open thyrsoid-paniculate inflorescence often only opposite and small or reduced to bracts: flowers mostly slender-pedicelled: sepals narrowly lanceolate : corolla ochroleucous and with brownish-purple dots; its broadly oblong lobes bearing the large and longfringed gland below the middle: style slender-subulate: stigma of 2 oval lobes. - Car. 87; Torr. Fl. 187, \& Fl. N. Y. ii. 89. F. Walteri, Michx. Fl. i. 97 ; Bart. Med. ii. t. 35. Swertia difformis, L. herb., not Spec. - Rich dry soil, W. New York to Wisconsin and Georgia. Thick bitter root has been used as a tonic, under the name of American Columbo.

* * Leaves marginless: a pair of oblong glands on each corolla-lobe and a separate crown below them: capsule compressed contrary to the deep-boatshaped or almost conduplicate valves: seeds oblong, flat, margined : sepals narrow-linear, equalling the corolla.

F. speciósa, Dougl. Stem stout, 2 to 5 feet high, very leafy : leaves in fours and sixes, nervose; the radical and lowest cauline obovate or oblong, 6 to 10 inches long; the upper lanceolate and at length linear: flowers very numerous in a long leafy thyrsus : the slender pedicels and peduncles at length strict: lobes of the greenish-white or barely bluish and dark-dotted corolla oval-oblong, acutish, half inch long, bearing the pair of contiguous and densely long-fringed glands about the middle, and a distant transversely inserted and setaceously multifid scalelike crown near the base: usually some minute setæe betwcen the bases of the filaments: style subulate, shorter than the ovary.-Griseb. Gent. 329, in Hook. Fl. ii. 66, t. 153, \& DC. 1. c. 131; Watson, Bot. King, 279; Gray, Bot. Calif. i. 484. Tessaranthium radiatum, Kellogg, Proc. Acad. Calif. ii. 142. - In the mountains, Wyoming to Oregon, and south to New Mexico and the Sierra Nevada of California. 
* * Leaves with cartilaginous white margins, thickish, lanceolate or linear: glands on the corolla-lobes solitary, but sometimes 2-lobed.

+ Capsule turgid; its valves strongly convex: seeds elongated-oblong, thickish, scabrous, marginless: corolla-lobes with a double longitudinally adnate crown confluent with the gland: inflorescence loosely paniculate.

F. paniculáta, Torr. Stem 2 or 3 feet high: cauline leaves linear, opposite (about 3 pairs): flowers in a loose and ample panicle, slender-pedicelled: sepals ovate, barely half the length of the whitish corolla: lobes of the latter oblong, obtuse, 2 or 3 lines long, bearing a plane and roundish discolored gland about the middle, which is lightly fringed round the border, its base confluent with a pair of coronal crests, which are adnate down the lobe, bilamellate and strongly ciliate fimbriate above, tapering and tubular below: filaments distinct to the base: style slender-subulate: stigma very small. - Pacif. R. Rep. iv. 126. - N. Arizona, sand bluffs at Inscription Rock in the Zuñi country, Bigelow. Habit of the two following species. What was described as a pair of glands rather belongs to the crown.

+ + Capstrle compressed parallel with the flat or flattish valres: seeds as far as known flat, smooth, and acute-margined.

+ Inflorescence ample and effusely paniculate; the pedicels longer than the flowers: corolla white or yellowish with scattered dark dots, of rather firm texture and enduring; the lobes acuminate or mucronate, longer than the ovate-lanceolate sepals.

F. Párryi, Torr. Stem stout, 2 or 3 feet ligh, including the large and very compound pyramidal or corymbose panicle: leaves in pairs or occasionally in threes, lanceolate, or the radical oblong, 3-nerved, 3 or 4 inches long; the upper becoming much shorter, often ovate-lanceolate, and soon reduced to small bracts: lobes of the white corolla ovate, becoming oblong, half inch long, bearing a large and Iunate-obcordate conspicuously fringed gland about on the middle, the base naked and destitute of a crown: some very minute setæ at the base of the filaments : style distinct, but only one fourth the length of the ovary: stigma small. - Bot. Mex. Bound. 156, \& Pacif. R. Rep. iv. 126 ; Gray, Bot. Calif. i. 484. Southern and eastern part of San Diego Co., California, to the borders of Arizona, Coulter, Paryy, Palmer.

F. albomargináta, Watson. Stem more slender, 1 to 3 feet high, including the ample and very compound broad cymose panicle: leaves in fours and sometimes opposite, linear, or the lower and radical oblanceolate, and the uppermost reduced to subulate bracts subtending the long branches of the panicle: lobes of the greenish-yellow corolla ovate, becoming oblong, cuspidate-acuminate, 3 or 4 lines long, twice the length of the sepals, bearing the obcordate moderately villous-fringed gland about on its middle, this decurrent into a longitudinally adnate crown with fringed free margins and a somewhat hooded base: style slender : stigma small. - Bot. King, l. c. ; Gray, Bot. Calif. 1. c. - S. Utah and S. Nevada, Palmer, Miss Searls, Parry. Leaves with conspicuous silvery-white and commonly undulate border.

++ Inflorescence a virgate interrupted thyrsus of 3 to 5 pairs of sessile (or the lower shortpeduncled) dense cymes, forming a series of glomerate clusters: pedicels very short: leaves nurrow and gramineous, merely opposite; the cauline only 3 to 5 pairs : corolla lavender-blue, of thin texture: the lobes ovate or oblong becoming narrower, 3 or 4 lines long, rather longer than the subulate-lanceolate sepals; the fringed gland elongated, extending from the base to near the micldle, saccate and with a longe) and coarser fringe at base: crown stamineal, consisting of a conspicuously laciniately parted or nearly entire scale between the filaments: style slender, twice the length of the ovary: stigma entire: capsule flat, few-sceded.

F. nítida, Benth. Completely glabrous, a foot or more high, slender: leaves linearlanceolate ( 2 to 4 lines wide, the upper 2 , and the radical 6 or 8 , inches long), those subtending the upper flower-clusters reduced to small bracts: corolla sometimes greenishspotted; the lobes barely acute, bearing an elongated oblong obtuse gland: thin scales between the filaments ovate or oblong-linear, entire or sparingly laciniate, longer than the ovary. - Pl. Hartw. 322 ; Torr. Pacif. R. Rep. iv. 126; Gray, Bot. Calif. 1. c. - Foothills of the Sierra Nevada, California, to the Dalles in Oregon.

F. albicaúlis, Doug1. Very minutely pruinose-puberulent: sepals rather longer and narrower: corolla-lobes ovate-lanceolate and acuminate; the gland oblong-linear: scales between the filaments more or less dissected into setiform processes: otherwise as the preceding. - Griseb. 1. c., \& Hook. Fl. ii. 67, t. 15.t. - Interior of Oregon and Idaho, on the eastern waters of the Columbia, Dourglas, Geyer, Spalding. 
9. HALÉNIA, Borkh. (John Halen, who wrote of Kamtschatka plants.) Low herbs (of N. Asia and America); with opposite leaves, and smill terminal and axillary often panicled cymes of usually 4-merous flowers; the corolla whitish, bluish, or yellowish. Occasionally or in some flowers the spurs or nectariferous gibbosities are wanting or nearly so.

H. defléxa, Griseb. Annual, 6 to 18 incles high: radical leaves obovate or spatulate and petioled; cauline oblong-lanceolate to ovate, acute, $3-5$-nerved (an inch or so long): sepals lanceolate or spatulate and acuminate : corolla dull whitish or purplish, 3 or 4 lines long; the lobes triangular-ovate and acute; spurs deflexed or obliquely desconding, thickish, considerably shorter than the corolla. - Gent. 32t; Hook. Fl. ii. 67, t. 155. Swertia corniculata, Michx. Fl. i. $\bigcap_{\bar{i}}$, not L. S. deflexa, Suith in Rees. Cycl. S. Mlichauriana, Roem. \& Sch. Syst. vi. 130. - Damp and cool woods, N. Maine and New York to Lake Superior and northern Rocky Mountains, Labrador, \&c.

Var. Brentoniána, a depressed form, with rather shorter and thicker spurs. $-H$. Brentoniana, Griscb. l. c. ; Hook. l. c. t. 156. - New foundland and Labrador. H. heterantha, Griseb. l. c., \& Hook. l. c. t. 156 , also Newfoundland, appears to be nearly the same, with some corollas spurless.

H. Rothróckii, Gray. Annual, a span or two high, loosely flowered : leaves linear: pedicels slender: sepals linear-lanceolate: corolla bright yellow, 4 or 5 lines long; the lobes ovate; spurs divaricate and slightly ascending, shorter than the corolla. - Proc. Am. Acad. xi. 84; Rothrock in Whecler Rep. t. 21. - Arizona, on Mount Graham, Rothrock.

10. BARTÓNIA, Muhl. (Prof. Benjamin Smith Barton, of Philadelphia, one of the earliest teachers of botany in the U.S.) - Small and-filiform annuals or biennials, of Atlantic C. S. ; with fibrous root, simple or paniculately branching stems, leaves reduced to subulate appressed scales or bracts, and small pedunculate scattered flowers with white corolla. - Willd. in N. Schrift. Berl. iii. 144 (1801) ; Torr. Fl. 185 ; Benth. \& Hook. Gen. ii. 818. Certaurella, Michx. Fl. i. 97, 1803. Andrewsia, Spreng. Syst. i. 428.

B. tenélla, Muhl. A span to a foot high, rather rigid : flowers racemose or racemosepanicled, barely 2 lines long: lobes of the yellowish-white corolla oblong, little longer than the calyx (sometimes twice as long): ovary 4-angled and the cell somewhat cruciform. - Willd. l. c.; Gray, Man. ed. 5, 389. Sayina Virginica, L. Centaurella paniculata, Michx. l. c. t.12, fig. 1. C. autumnalis, Pursh, Fl. i. 100 ; Griseb. l.c. Centaurium autumnale, Pers. Syn. i. 137. Andrewsia autumnalis, Spreng. l. c. Centaurella Moseri, Steud. Nom.; Griseb. in DC. Prodr. ix. 121, an occasional form, with leaves or scales and branches mostly alternate. - Open woods, Newfoundland to Wisconsin and Louisiana; flowering late.

B. vérna, Muhl. A span high or less, corymbosely or racemosely 1-9-flowered, the stem weaker or less rigid: Iobes of the white corolla obovate-spatulate, 3 or 4 lines long, very obtuse, thrice the length of the calyx : ovary compressed. - Centaurella verna, Michx. l. c. fig. 2; Griseb. 1. c. C. vernalis \& C. cestivalis, Pursh, 1. c. Centaurium vernum, Pers. l. c. Andrewsia. verna, Spreng. l. c. - Bogs, S. Virginia to Florida and Louisiana; flowering in early spring.

11. OBOLÁRIA, I. (OBo)ós, a small Greek coin, from the rounded leaves.) - Gray, Chloris, 21, t. 3. - Single species.

O. Virgínica, L. Herb a span or less in height from a tufted fibrous perennial root, of dull purplish-green hue and rather fleshy texture, simple or sparingly branched above : Iower leaves reduced to obtuse loose scales; upper ones cuneate-obovate, about half inch long and wide: flowers usually in threes and nearly sessile in the axils and terminating the stem and branches, white or purplish, 4 lines long, produced in spring. - Spec. ii. 632 (Gronov. Virg.); Darl. Fl. Cest. ed. 1, 21, t. 2; Bart. Fl. Am. Sept. iii. t. 90; Reuter in DC. Prodr. xi. 45; Gray, 1. c., \& Man. ed. 5, 890 . Orobanche Virginiana, etc., Moris. Hist. iii. 504, sect. 12, t. 16, fig. 23 ; Pluk. Alm. t. 209, fig. 6. - Moist woods, New Jersey to Illinois and south to Georgia and Texas. 
12. MENYÁNTHES, Tourn. Buckbean. (Ancient name, from $\mu \eta^{\prime}$, month, and $\alpha 2 v 0 s$, flower, some say from its flowering for about that time.) - Bogperennials (of the cooler parts of the northern hemisphere); with long and thickish creeping rootstocks, bearing either trifoliolate or reniform leaves on long petioles, with scarious sheathing base, and a naked erect several-many-flowered scape; fl. in spring or early summer. - Benth. \& Hook. Gen. ii. 819.

M. trifoliáta, L. Petioles and scape a span or two high, stout: leaf divided into 3 oval or oblong-obovate pinnately veined entire or repand leaflets : flowers racemose: corolla white or tinged with rose; the tube longer than the calyx; the upper surface of the lobes copiously fimbriate-bearded. - Lam. Ill. t. 100 ; Fl. Dan. t. 541 ; Bigel. Med. t. 46 ; Reichenb. Ic. Germ. t. 1013, - Bogs, Newfoundland and Labrador to Penn., Ohio, and northward: also Rocky Mountains to California and Aleutian Islands. (Japan to Eu. and Greenland.)

M. Crista-gálli, Menzies. Petioles and scape at length slender and a foot or two high: leaf reniform and sometimes emarginate, crenate! ( 2 to 4 inches wide): flowers in a simple or 1-2-forked cyme: corolla white; its tube not longer than the calyx; the lobes naked but with a medial crest. - Hook. Bot. Misc. 1. 45, t. 24 . Villarsia Cristagalli, Griseb. 1. c. Marshy ground, coast of $\mathrm{Br}$. Columbia to Alaska, Menzzes, Mertens, \&c.

13. Liminántheimuim, Gmelin. Floating Heart. (From hívi, marsh or pool, and $\not * v \theta \varepsilon \mu o \nu$, blossom.) - Perennial fibrous-rooted water-plants (of temperate and tropical regions); with proliferous or stoloniferous growth; the leaves orbicular or ovate and deeply cordate, entire or repand, floating; the flowers in our species as if umbellate-fascicled on the petiole, produced all summer, sometimes polygamous. Stolons sometimes tuberiferous.

L. lacunósum, Griseb. Petioles and stolons filiform, much elongated: leaves orbicular-cordate, an inch or two long, mostly quite entire: umbel of flowers borne near to the base of the leaf, often accompanied by a fascicle of thickened and short spur-like rootlets : corolla white, a third to half inch in diameter; its broadly oval lobes naked (except a crest-like yellowish gland at base), twice the length of the lanceolate calyx-lobes: style none: seeds numerous, smooth and even. - Gent. 347, \& in DC. Prodr. ix. 141, in part; Gray, Man. ed. 1, 363, ed. 5, 390. Villarsia lacunosa, Vent. Choix, 9 ; Pursh, Fl. i. 139, excl. syn. V. cordata, Ell. Sk. i. 230, a fitter name. - Shallow- ponds, \&c., Canada to Florida and Louisiana.

L. trachyspérmum, Gray, l. c. Larger: petioles, \&c., stouter: leaves cordate-orbicular, 2 to 6 inches in diameter, with margins sometimes repand, of thick texture, the discolored lower surface reticulate-veined, spongy and pitted: umbel usually destitute of thickened rootlets : expanded corolla three-fourths inch wide : style none : seeds roughened. -L. lacunosum, var. australe, Griseb. Gent. 1. c. Anonymos aquatica, Walt. Car. 109. Villarsia aquatica, Gmel. Syst. i. 447. V. trachysperma, Ell. l. c. Menyanthes trachysperma, Michx. Fl. i. 126. - Ponds and streams, Maryland (Canby) and Virginia to Florida and Texas.

\section{ORDER XCI. POLEMONIACE A.}

Herbaceous or rarely shrubby plants, with bland colorless juice, simple or divided leaves and no stipules, perfect and regular 5-merous flowers except that the free ovary is trimerous (3-celled with placentæ in the axis); the persistent calyx imbricated, and the corolla dextrorsely convolute (and not plicate) in the bud; the fruit a 3-celled loculicidal capsule, usually with a thick placental axis; the few or many seeds small, amphitropous or nearly anatropous, with a thin or soft coat, commonly developing mucilage when wetted; the embryo straight and rather large in the axis of a fleshy or harder albumen, the cotyledons flat or flattish and rather broad. Stamens on the corolla alternate with its lobes, distinct. 
Style one, 3-lobed or cleft; the introrse stigmas (or lobes of the style stigmatic down the inner face) sleuder. Iypogynous disk generally manifest. Almost exclusively American, and remarkable among the hypogynous gamopetalous orders for the 3 -merous pistil, but in 2 or 3 species of Gilia 2 -merous. The corolla is not always perfectly regular, and the $\overline{5}$ stamens are very commonly unequal in length or insertion. Cobca, common in cultivation, is very exceptional in the order, climbing by tendrils belonging to pinnate leares, and its capsule septicidal. — Gray, Proc. Am. Acad. viii. 247 ; Benth. \& Hook. Gen. ii. 820.

* Stamens unequally inserted on the tube of the corolla, not declined.

1. PHLOX. Corolla strictly salverform, with slender tube and narrow orifice. Filaments very short and unequally inserted: anthers mostly included. Orules solitary or few in each cell. Seed unaltered when wetted. Leaves opposite and entire.

2. COLLOMIA. Corolla tubular-funnelform or salverform, with an open orifice, from which the unequally inserted filaments commonly protrude. Ovules solitary or numerous. Seed-coat developing mucilage and projecting uncoiling spiral threads (spiricles) when wetted, except in one species. Leaves mostly alternate, and pinnately incised or divided.

* Stamens equally inserted in or below the throat or sinuses of the corolla.

3. LCESELIA. Corolla tubular or funnelform, somewhat irregular, the limb being more or less unequally cleft; the naked filaments declined. Otherwise as Gilia.

4. GILIA, Corolla from campanulate to funnelform and salverform, regular. Filaments not declined, naked (rarely pubescent) at base. Ovules and seeds from solitary to numerous. Leaves various.

5. POLEMONIUM. Corolla from funnelform to nearly rotate, regular. Filaments more or less declined and usually pilose-appendaged at base, slender. Ovules and seeds few or several in each cell. Calyx herbaceous, not scarious below the sinuses nor the lobes costate, accrescent. Leaves all alternate, pinnate or pinnately parted.

1. PHLOX, L. (Ancient Greek name of Lychnis, from $q i \hat{\alpha} \xi$, flame.) - N. American herbs, or a few suffrutescent. chiefly peirennials, many cultivated for their ornamental blossoms. Cauline leaves sessile and opposite, or some of the upper varying to alternate. Flowers cymose, showy, from blue-purple or lilac to crimson and white; the calyx narrow, and the corolla strougly convolute in the bud. Most species with long filiform style about equalling or surpassing the corolla-tube, but some with short included style, perhaps by dimorphism; but only in $P$. subulata have both forms been found in the same species.

$\S 1$. Perennial herbs of the Atlantic States, with flat (broad or narrow) leaves, and solitary ovules.

* Stem strictly erect (smooth or sometimes rough): cymules compact, numerous, in a pyramidal or corymbose panicle or elongated thyrsus : pedicels very short: corolla with entire rounded lobes: fi. summer.

P. paniculáta, L. Stem stout, 2 to 4 feet high : leaves oblong-lanceolate and ovatc-lanceolate, acuminate, tapering at base, or the uppermost more or less cordate: panicle ample, pyramidal-corymbose: calyx-teeth subulate-setaceous: corolla pink-purple varying to white.-Spee. i. 151; Lam. Ill. t. 108; Gray, 1. c. 249. P. undulatn, Ait. Kaw. i. $205 . \quad P$. cordata, Ell.; Sweet, Brit. Fl. Gard. ser. 2, t. 19. P. acumintta, Pursh; Bot. Mag. t. 1880. 'P. corymbosa, Swect, l. c. t. 114. P. scalma, Sweet, Brit. Fl. Gard. t. 248, P. Sickmanni, Lehm. in Act. Nat. Cur. xiv. t. 46. P. derussata, Hortul. (Some of the above smooth, others rough or hairy forms.) - Open woods, Penn. to Illinois, Louisiana, and Florida.

P. maculáta, L. Stem more slender, $1 \frac{1}{2}$ to 2 feet high, commonly purple-spotted: leaves very smooth, thickish; the lower lanceolate and the upper nearly ovate-lanceolate from a rounded or cordate base: panicle narrow and usually long: calyx-teeth triangularlanceolate, short: corolla pink-purple.-Spec. i. 152; Lam. Ill. t. 108; Jacq. Vind. t. 127. P. pyramidalis, Smith, Exot. ii. t. 87; Sweet, Brit. Fl. Gard. t. 283, with P. reflexa, Sweet, 1.c. t. 232, \& P. penduliflora, Sweet, Brit. Fl. Gard. ser. 2, t. 48, robust cultivated forms. - Kich woodlands and along streams, N. Penn. to Iowa and Florida. 
Var. cándida, Michx., is a white-flowered form, commonly with spotless stem. P. suaveolens, Ait. 1. c., fide Benth. P. tardiflora, Penny, fide Benth. P. longifora, Sweet; l. c. ser. 2, t. 31 . Wikh the ordinary form.

* * Stems, at least the flowering ones, ascending or erect: cymules corymbed or sometimes simple: flowers chiefly pedicelled: lobes of the corolla broad, obovate or obcordate.

+ Calyx-teetl lanceolate or triangular-subulate: whole plant glabrous or nearly so, never viscid: stems ascending or erect: pedicels equalling or shorter than the calyx: lobes of the pink or rosered corolla rounded and entire : fl. early summer.

P. ováta, L. Stems rather low, ascending from a decumbent or creeping base: leaves ovate or oblong-lanceolate, the uppermost often subcordate and the lowest tapering into a margined petiole: calyx-teeth short and broad, ovate or triangular-lanceolate acute.Bot. Mag. t. 528; Gray, 1. c. P. Carolina, L. Spec. ed. 2, i. 216; Bot. Mag. t. 144 a taller form, with narrower more tapering leaves and pointed calyx-teeth, approafhing the next species. P. latifolia, Michx. Fl. i. 143. P. triflora, Sweet, Brit. Fl. Gard. t. 29.-Open woods, from Alabama northward in the mountain region to Pennsylvania.

P. glabérrima, L. Stems taller and erect: leaves lanceolate or linear-lanceolate, or the uppermost narrowly ovate-lanceolate, tapering gradually to an acute point, firm in texture, almost veinless, bright green and glossy above, often with revolute margins: calyx-teeth triangular- or lanceolate-subulate, very sharp-pointed. - Spec. l. c. 152; Sweet, Brit. Fl. Gard. ser. 2, t. 36 ; Benth. in DC. 1. c. P. revoluta, Aikin in Eaton, Man.-Prairies and open woodlands, N. Virginia and Ohio to Wisconsin and south to Florida.

Var. suffruticósa, a form with more rigid stems, either smooth or scibrous, or the inflorescence strongly rough-puberulent, and the upper leaves broadly lancelolate, verging to narrow-leaved forms of the preceding species. $-P$. suffruticosa, Willd. Enum. 200; Bot. Reg. t. 68. P. nitida, Pursh, Fl. ii. 730. P. Carolina, Sims, Bot. Mag. t.1344, Sweet, -Brit. Fl. Gard. t. 190, not L. P. triflora, Michx. Fl. i. 143? P. carnea, Sims, Bot. Mag. t. 2155, smooth form. P. Carolina, var. nitida \& var. puberula, Benth. in DC. 1. c. - Georgia and Tennessee to Florida and Louisiana.

++ Calyx-teeth long and slender: flowering stems erect, ascending, or sometimes spreading, at least the summit and the calyx more or less hairy or glandular-pubsscent: fl. in spring.

+ No runners or prostrate sterile shoots.

P. Floridána, Benth. Stems erect and strict, a foot or two high, slightly hairy or nearly glabrous below, as are the lanceolate-linear or broadly linear rather rigid leaves, the summit and the corymb glandular: teeth of the glandular-pubescent calyx lanceolatesetaceous: lobes of the light purple corolla roundish-obovate, entire.-Prodr. l. c. 304; Chapm. Fl. 309. - Dry open woods, Florida, Chapmana, Ruggel. Foliage, \&c., nearly as in the preceding, the calyx approaching the following.

P. pilósa, L. Villous-hairy, pubescent, or sometimes glabrate: stems erect, slendèr (a foot or two high): leaves linear or lanceolate, usually tapering gradually from near the sessile base to the acute point: corymb at length loose: teeth of the hairy more or less viscous calyx subulate-setaceous or awn-like : lobes of the (pink, purple, rose, or sometimes white) corolla obovate and entire. - Sims, Bot. Mag. t. 1307 ; Lodd. Cab. t. 1251. P. aristata, Michx.; Lodđ. Cak. t. 173̈1; Torr. Fl. N. Y. ii. t. 80. P. cuspidata, Scheele in Linn. xxiii. 139. - Dry or sandy woods, prairies, \&a, from New Jersey to Iowa and Saskatchewan, and south to Florida and Texas. Very variable as to foliage and pubescence. Slender southern forms pass into

Var. detónsa, Gray. Smoother or almost glabrous, but corymb and calyx more or less pubescent : except in the calyx nearly approaches narrow-leaved forms of $P$. glaberrima. --Proc. Am. Acad. l. c. P. cristata, Benth., partly.-Alabama and Florida to Texas.

P. amóna, Sims. Softly villous-pubescent, or sometimes hirsute: stems ascending, simple (a span or two high): leaves erectish, short, oblong-lanceolate or nearly linear, seldom acute, the uppermost subtending or involucrating the compact cymose cluster: calyx-teeth narrow-subulate, very acute, but not awn-tipped: lobes of the (purple or pink, seldom white) corolla (half inch long) almost equalling the tube, obovate, entire, or rarely emaginate. - Bot. Mag. t. 1308; Gray, Proc. Am. Acad. 1. c. 251. P. pilosa, Walt., Michx., \&., not L. P. pllosa, var. Walteri, Gray, Man. ed. 2. P. Walteri, Chapm. Fl. I. c. $P$. procunbens, Gray, Man. ed. 5, 372, not Lehm. P. involucrata, Wood, Classbook, 1861, 568. - Hills and dry barrens, Virginia and Kentucky to Florida. 
++ Sterile shoots from the base creeping or decumbent: leaves comparatively broad, and with the stems and calyx softly more or less viscid-pubescent: pedicels rather slender.

P. divaricáta, L. Stems diffuse or ascending, the sterile shoots decumbent or somewhat creeping and bearing ovate sessile leaves : cauline leaves oblong- or ovate-lanceolate, rather acute: cyme open: calyx-teeth slenderly linear-subulate: lobes of the bluish or lavendercolored ( 1 to $1 \frac{1}{2}$ inches wide) corolla cuneate-obcordate or barely emarginate (Bot. Mag. t. 163, \& P. Canadensis, Sweet, Brit. Fl. Gard. t. 221), or not rarely quite entire (var. Laphamii, Wood. P. glutinosa, Buckley in Am. Jour. Sci. xlv. 177, as to specimens, but flowers not "red or scarlet.") - Damp woods, W. Canada and New York to Iowa, Florida and Arkansas. Corolla with the sinuses open. Style (always?) very short.

P. réptans, Michx. Stems weak and slender; the sterile long and prostate or creeping, runner-like, bearing obovate or roundish leaves with narrowed base; the flowering erect, a span or more high, bearing 3 or 4 pairs of oval or oblong mostly obtuse leaves : cyme simple, few-flowered : caly $x$-teeth linear-subulate: lobes of the purple or violet corolla roundish, mostly entire, about half the length of the tube. - Vent. Malı. t. 107. P. stolonifera, Sims, Bot. Mag. t. 563; Sweet, Brit. Fl. Gard. ser. 2, t. 293 . - Damp woods of the Alleghany region and near it, Pennsylvania to Kentucky and Georgia. Corolla-tube an incl long; style long, the stigmas and some of the stamens often more or less projecting.

* * : Stems diffuse and branching, slender, low (a span high): flowers scattered or barely cymulose, peduncled; the peduncles often elongated: lobes of the corolla narrowly cuneate and bificl: calyx-lobes subulate-lanceolate: fl. spring.

P. bífida, Beck. Minutely pubescent: leaves linear (an inch or two long, a line or two wide), glabrate: lobes of the pale violet-purple corolla 2- (2arely 3-) cleft to or below the middle into oblong or nearly linear diverging segments. - Am. Jour. Sci. xi. 167; Gray, Man. ed. 5, 373. - Prairies of Illinois and Missouri.

P. Stellária, Gray. Very glabrous : leaves barely somewhat ciliate at base, linear (an inch or two long, a line or more wide), acute, rather rigid: flowers scattered, mostly longpeduncled : lobes of the "pale blue or almost white" corolla bifid at the apex into barely oblong Iobes. - Proc. Am. Acad. 1. c. 2.52. - Cliffs of Kentucky River (above Lexington?), in fissures of the most precipitous rocks, Short. S. Illinois, G. H. French, \&c. Bases of the fliform and tufted or creeping stems rigid and persistent.

$\S 2$. Suffruticulose and creeping-cespitose, evergreen, east of the Mississippi, with mostly crowded and fascicled subulate and rigid leaves: lobes of the corolla at most obcordate : $f$. early spring.

P. subulátz, L. (Grousd or Moss Pink.) Depressed, forming broad mats, pubescent, when old glabrate; leaves squarrose-spreading, ciliate, varying from lanceolate- or subulate-linear to almost acerose, 4 to 10 lines long: flowers mostly slender-pedicelled: calyxlobes subulate: lobes of the (pink, purple, or white) corolla obcordate or rarely entire: ovules solitary or in pairs (or rarely 3) in each cell. (Style generally long and ovules solitary.) - Jacq. Fragm. t. 44; Bot. Mag. t.411, \& t. 415 (as setacea). P. setacea, L., form with slender leaves. $P$, nivalis, Lodd. Bot. Cab. t. 780 ; Sweet, Brit. Fl. Gard. t. 185: style short; and ovules commonly (but not always) 2 or rarely 3 in each cell, and corolla white. $P$. Hentzii, Nutt., a state of the last with lobes of the corolla entire or nearly so. $P$. aristata, Lodd. I. c. t.1731, a white-flowered variety. - Rocky bare hills and sandy banks, S. New York to Michigan, Kentucky and Florida. Very variable species.

P. Procúxrexs, Lehm. (Ind. Sem. Hamb. 1828 ; Sweet, Brit. Fl. Gard. ser. 2, t. 7 ; Lodd. Cab. t. $1722 ; P$. subulata, var. latifolia, Benth. in DC. 1. c.), is unknown as a wild plant, and is apparently a hybrid between $P$. sululata and $P$. amona.

$\S 3$. Suffruticulose or suffrutescent, rarely herbaceous to the ground, natives of the Rocky Mountain region and westward, chiefly with narrow or minute and thickish-margined leaves, and branches or peduncles mostly one-flowered, in spring and summer. (Species most difficult, passing in to one another.)

* Densely cespitose and depressed, mostly forming cushion-like crargreen mats or tufts ; the short leaves ( $1 \frac{1}{2}$ to 5 lines long) crowded up to the solitary and sessile (or in the last species short-peduncled) flowers, and also fascicled. scarious-connate at base, the old ones marcescent: ovules solitary in each cell. The earlier species of the spries most depressed. pulvinate, and imbricateleaved; the last looser, Jonger-leaved and approaching the next subsection. 
+ Leaves more or less beset or ciliate with cobweb-like or woolly hairs,

+ Very short, broadish or scale-like, soft, barely mucronate, appressed-imbricated: plants very depressed, moss-like, forming pulvinate tufts: lobes of the corolla entire.

P. Richardsónii, Hook. Rather loosely tufted : leaves oblong-lanceolate, 3 lines long, sparsely lanate above, and with thickened reflexed margins; the marcescent older ones lax and spreading: tube of the "brilliant lilac" corolla nearly twice the length of the calyx, the broadly cuneate-obovate lobes 3 lines long, - Hook. Fl. ii. 73, t. 160. - Aretic seacoast, Richardson, Pullen.

P. bryoídes, Nutt. Habit somewhat of Selaginella rupestris, copiously lanate: leaves (even the marcescent ones) very densely appressed-imbricated in 4 strict ranks on the loosely tufted branches, scale-like, ovate- or triangular-lanceolate, minute (only $1 \frac{1}{2}$ lines long), with rather inflexed margins : tube of the corolla considerably longer than the calyx, its cuneate lobes barely a line and a half long. - Pl. Gamb. 153. - High Rocky Mountains in Wyoming, lat. $42^{\circ}-45^{\circ}$, Nuttall, Parry.

P. muscoídes, Nutt. Like the preceding, more resembling some canescent moss; the branches much tufted, very short; leaves less strictly quadrifarious and less lanate, ovatelanceolate, mucromulate: tube of the corolla not" surpassing the calyx. - Jour. Acad. Philad. vii. 42, t. 6, fig. 2. - Rocky Mountains, at the sources of the Missouri, Wyeth.

++ Leaves subulate or acerose, somewhat rigid, less appressed: plants forming broad mats, 2 to 4 inches high.

P. Hoódii, Richards. Sparsely or loosely lanate, becoming glabrate; leaves subulate, rather rigid, erect, somewhat loosely imbricated : tube of the (white?) corolla not exceeding the calyx; its lobes obovate, entire, 2 to $2 \frac{1}{2}$ lines long. - Frankl. Journ. Appx. t. 28. Sandy plains and hills of the Saskatchewan, \&c., from lat. 54, and along the Rocky Mountains down to the south-west part of Wyoming.

P. canéscens, Torr. \& Gray. More lanate and canescent: leaves subulate, imbricated, soon recurved-spreading above the appressed base ( 3 to 5 lines long); tube of the white corolla at length exceeding (often about twice the length of) the calyx; the obovate lobes entire or emarginate, 3 or 4 lines long. - Pacif. R. Rep. ii. 8, t. 6; Watson, Bot. King, 259. - Rocky Mountains of Wyoming and Colorado to the Sierra Nevada in California and New Mexico. Apparently passes into the preceding.

\footnotetext{
+ + Leaves rigid (one thind to half inch long), destitute of woolly or cobwebby hairs, the margins naked or ciliate with rigid or rather soft hairs: plants either densely or loosely tufted; the leaves mostly less crowded.
}

P. cæspitósa, Nutt. Leaves linear-subulate or oblong-linear, commonly much crowded, hispid-ciliate, otherwise glabrous or with some short glandular-tipped rigid hairs: corolla witl tube somewhat exceeding the calyx; its lobes obovate, entire, 3 lines long.-Jour. Acad. Philad. vii. 41, t. 6, fig. 1. - Var. rigida, Gray, in Proc. Am. Acad. 1. c. 254, is a depressed form, with acerose-subulate at length recurved-spreading rigid leaves. $P$. rigida, Benth. in DC. - Var. condensata, Gray, 1. c., is a very dwarf, pulvinate-tufted form, with short and erect closely imbricated leaves, only 2 or 3 lines long; and is $P$. Hoodii, Gray, Enum. Pl. Parry (298) in Am. Jour. Sci. - Rocky Mountains of Colorado, Montana, \&c., to Oregon and the high Sierra in California. Laxer narrow-leaved forms pass into the next.

P. Douglásii, Hook. Less densely tufted, either pubescent or nearly glabrous : leaves acerose or narrowly linear-subulate, less rigid and usually less crowded, often spreading, their margins hirsutely-ciliate next the base or naked: flowers subsessile or short-peduncled: corolla (purple, lilac, or white) with tube more or less exceeding the calyx, and obovate entire lobes about 3 lines long. - Hook. FI. ii. 73, t. 158; Gray, Proc. Am. Acad. 1. c. - Eastern and western sides of the Rocky Mountains, from Montana to Utah, west to Oregon and the borders of California. Passes into the subjoined forms.

Var. diffúsa, Gray, 1. c., with more loosely spreading or cespitose-decumbent stems, and lax spreading leaves, growing in moister places. $-P$. diffusa, Benth. Pl. Hartw. 325. - Western slope of the Sierra Nevada and Cascade Mountains, California to British Columbia.

Var. Iongifólia, Gray, l. c., a rigid form, of more arid regions, and long and narrow less fascicled leaves (linear-filiform or acerose, 5 to 8 lines long, either ascending or spreading), approaching $P$. longifolia. - W. Nebraska to Oregon and N. E. California. 
* * Losely tufted or many-stemmed from a merely wondy-persistent base, or wholly herbaceous, with linear or lanceolate (or rarely ovate) spreading (approximate or sometimes distant) leaves, which are little if at all fascicled in the axils: flowers slender-peduncled, solitary or somewhat cymulose.

+ Style long and slender, often equalling or almost equalling the tube of the corolla.

\# Arctic, with rather flaccid leaves and stems.

P. Sibírica, L. Mostly villous-pubescent, especially on the margins of the narrow linear leaves, depressed and loosely cespitose, less than a span high: tube of the corolla little longer than its obcordate or emarginate lobes, seldom surpassing the calyx: ovules 2 in each cell. -(Gmel. Fl. Sib. iv. t. 46, fig. 2.) Trautv. Imag. t. 24. - Kotzebue Sound. (N. E. Asia.)

+ + Temperate, inhabiting the plains and mountains from the borders of British Columbia southward: leares and commonly erect or ascending stems more firm or rigid : calyx-tube between the strong ribs scarious, inclined to be membranaceous and more or less replicate, forming intervening angles: the narrowly subulate and mostly rigid teeth shorter than the tube of the rose-colored or sometimes white corolla.

P. linearifólia, Gray. Glabrous, above sometimes minutely hirsute-pubescent, corymbosely much branched from a ligneous base, a span or more high : leaves very narrowly linear (an inch or two long, about a line wide) : calyx-tube mostly saliently 5-angled from the broader base by the strong replication of the white-membranaceous sinuses; the lobes nearly acerose: tube of the corolla little exceeding the calyx; the obovate-cuneate lobes entire or barely retuse: ovules 2 in each cell. $-P$. speciosa, var. linearifolia, Hook. Kew. Jour. Bot. iii. 289, mostly. P. speciosa, Lindl. Bot. Reg. t. 1351 ; Benth. in DC. 1. c. - From the Dalles to the upper waters of the Columbia, Douglas, Spalding, Geyer, \&c.

P. longifólia, Nutt. Nearly glabrous or pubescent, much branched or many-stemmed from a ligneous base, 3 to 8 inches high: calyx more or less angled by' the white-membranaceous replicate sinuses : leaves mostly narrowly linear ( 1 to $2 \frac{1}{2}$ inches long) : lobes of the corolla oborate- or oblong-cuneate, entire or retuse: ovules almost always solitary in each cell. - Jour. Acad. Philad. vii. 41. P. speciosa, var., Hook. Fl. ii. 72. P. humilis, Dougl.; Benth. 1.c. . a small and short-peduncled form, sometimes apparently passing into $P$. Douglasii, var. longifolia. - From the eastern side of the Rocky Mountains, MIontana to Colorado, west to Nevada and Oregon, and north to British Columbia or nearly : southwestward passing into

Var. Stansbúryi, Gray, l. c. Conspicuously pubescent throughout, or sometimes glabrate, generally stouter and more open in grow th: leaves from linear to linear-lanceolate: pubescence of the branches and calyx viscid or glandular: corolla mostly pink or rose-color, and its tube commonly twice the length of the calyx; the lobes emarginate or erose at the apex : ovales sometimes a pair in one or two of the cells. - P. speciosa, var.? Stansburyi, Torr. Bot. Mex. Bound. 145. - Utah and Nevada to New Mexico and Arizona. Passes into

Var. brevifólia, Gray, 1. c., a depressed or dwarf form; with leaves 9 to 4 lines long, rigid and with more cartilaginous margins, at least the lower lanceolate or ovate-lanceolate: peduncles either short or none, or elongated. - From Dakotah (Black Hills) to $\mathrm{N}$. California and Arizona.

P. adsúrgens, Torr. Glabrous, except the slender peduncles and scarcely replicateangled caly $\mathrm{x}$, which are glandular-pubescent: stems diffuse and ascending, slender (a span or two long): leaves ovate-lanceolate and ovate, acute, 5 to 10 lines long, all but the lower much shorter than the internodes: tube of the corolla nearly twice the length of the calyx; its lobes obovate, entire (about 5 lines long) : ovules solitary in each cell. - Gray, Proc. Am. Acad. viii. 256. - Cascade Mountains, Oregon, Prof. A. Wood, C. W. Cusick.

++ Style very short, mostly shorter than the ovary and the linear sticmas: calyx-tube cylindraceous, the thin-membranous portion between the ribs not projecting into salient angles.

P. speciósa, Pursh. Above somewhat viscid-puberulent or glandular, below often glabrous, a foot to even a yard high; the branches ascending from a shrubby base: leaves lanceolate or linear (an inch or two long); the upper especially broadest at base: flowers corymbose: corolla rose-pink or nearly white; its tube little exceeding the calyx; its lobes obcordate: ovules solitary. - Gray, Proc. 1. c. \& Bot. Calif. i. 486. P. speciosa, var. latifolia, Hook. Kew. Jour. Bot. 1. c. P. divaricata, Durand. Pl. Pratten., not Michx. P. occidentalis, Durand. in Pacif. R. Rep. iv. 125: a broad-leaved form. - Interior plains of 
the upper Columbia to the foothills of the Sierra Nevada, California. In the larger Californian specimens, the corolla is an inch or more in diameter.

Var. Sábini, Gray, l. c. Differs only in the lobes of the corolla being entire or barely retuse (obovate with a narrowed cuneate base). - P. Sabini, Dougl. in Hook. 1. c.; Benth. l. c. P. speciosa, var. elatior, Hook. Fl. ii. 72. - Spokan River, Douglas, Lyall.

Var. Woodhoúsei, Gray, l. c. Small form, a span high, with linear leaves not broadened at base, and a much smaller corolla; its cuneate-obcordate lobes only 4 lines long. - $P$. nana, Torr. in Sitgreaves Rep., not Nutt. - Arizona, near Williams Mountain, Dr. Woodhouse.

P. nána, Nutt. Glandular and roughish-pubescent, loosely and copiously branching from a somewhat ligneous base, a span or more high: leaves linear (an inch or two long), those of the branches often alternate: flowers scattered or somewhat corymbose: corolla rose, "red" or "white," with tube somewhat exceeding the calyx; its ample and broadly cuneate-obovate or roundish lobes entire or nearly so (about half inch long): ovules 2 or often 3 in each cell. - Pl. Gamb. 153; Gray, Proc. 1. c. 256. P. triounlata, Thurber in Bot. Mex. Bound. 145. - Var. glabella, Gray, 1. c., is merely a less pubescent or glabrate form, less branched and more erect, the leaves narrower and all opposite. - New Mexico, especially on the Rio Grande, and adjacent borders of Colorado and Texas.

$\$$ 4. Annuals, all Texan, more or less pubescent with viscous or glandular many-jointed hairs: leaves linear or oblong, most of the upper ones alternate: calyx at length splitting almost to the base, the linear or subulate-lanceolate lobes setaceous-tipped: style shorter or not longer than the stigmas: ovules in each cell 1 to 5 : seeds with somewhat wing-like angles.

P. Drummóndii, Hook. Loosely branching, villous and glandular: leaves mostly oblong or lanceolate, mucronate-pointed; the upper commonly half-clasping by a broader somew hat cordate base : flowers mostly in crowded. cymose clusters : calyx-lobes lanceolatesubulate, soon recurved : corolla red, varying to rose, purple, or white; the lobes broadly obovate, entire or nearly so (about half inch long); the tube usually pubescent: ovules solitary in the cells. - Bot. Mag. t. 3441; Bot. Reg. t. 1949 ; Br. Fl. Gard. ser. 2, t. 316. Texas, especially in the eastern districts, and everywhere familiar in gardens.

Var. villosíssima, Gray. A very villous and viscous form, with more scattered flowers of large size, and barely spreading calyx-lobes: lobes of the pale corolla half inch long and broad. - Proc. Am. Acad. 1. c. 257. - S. Texas on the Nueces, Wright:

Var. ténuis, Gray, l. c. A small and slender form, much less pubescent; witl mostly linear or almost glabrous leaves (about an inch long), rather narrower instead of dilated at the base, and an open cyme of small flowers : lobes of the pink or purple corolla only 2 to 4 lines long. - Common in Eastern Texas, Drummond, Lindheimer, Wright. Seemingly very distinct.

P. Roemeriána, Scheele. Loosely branched from the base, a span or more high, sparsely hirsute or glabrate (except the calyx-tube): leaves lanceolate, or the oblong or spatulate lower ones often glabrous except the margins : flowers solitary or sparse: calyxlobes linear, merely spreading : corolla pink or rose-colored; the glabrous tube not exceeding the calyx, about half inch long, shorter than the ample roundish-obovate entire lobes: ovules in each cell 4 or $5 !$ - Tinnær, xxi. 752. P. macrantha, Buckley, in Proc. Acad. Philad. 1862, 5. - Texas, near San Antonio, \&c., on high prairies. Commonly. with most of the leaves alternate!

2. COLLÓMIA, Nutt. (Kó2גa, glue or gluten, the seeds when wetted mucilaginous.) - Annuals or biennials of the western region, some with showy flowers worthy of cultivation. Lower leaves usually opposite. - Nutt. Gen. i. 126 ; Gray, Proc. Am. Acad. viii. 258.

§1. Eucollómia, Gray. Ovules solitary or in the last species 2 or 3 in each cell: corolla salverform or almost so: annuals, more or less viscid-pubescent or glandular. - Collomia, Benth. in DC. Prodr., with one Navarretia. (C.gracilis 
alone wants the spirieles, which are so conspicuous on the seed-coat of the genuine species, in which they were first detected.)

* Calyx obconical : leaves sessile, entire or sometimes sparingly incised.

+ Flowers capitate-crowded and leafy-bracted, or a few of them scattered.

C. grandiflóra, Dougl. Erect, a foot or two high : leaves linear- or oblong-lanceolate, or uppermost lance-ovate : calyx-lobes broad and obtuse : corolla buff or salmon-color, narrow-funinelform, an inch long, showy. - Lindl. Bot. Reg. t. 1174; Hook. Bot. Mag. t. 2894. -Plains, \&c., from the Rocky Mountains, lat. $48^{\circ}$, to Nevada and California. Var. tenuifolia, Benth., is a form with more slender corolla.

C. lineáris, Nutt. More branching and in age spreading, a span or two high: calyxlobes triangular-lanceolate, acute: corolla half inch long, from lilac-purple to nearly white, very slender, little enlarged at the throat; the limb small. - Gen. i. 126; Lindl. Bot. Reg. t. 1166; Hook. Bot. Mag. t. 2893. - Lake Winnipeg and Mackenzie River (and even New Brunswick, on the const, Fowler, perhaps a chance introduction), west to the Pacific, and south to California and Colorado. Passes into

Var. subuláta, Gray, l. c. A low and slender form, diffusely branching from the base: leaves narrow and acute: flowers few in the lower forks: calyx-lobes attenuatesubulate; the tips almost awnlike from a broad base, ratlier longer than the tube. - C. tinctoria, Kellogg, Proc. Acad. Calif. iii. 17, t. 2. - Nevada and adjacent parts of California and Oregon.

$$
+ \text { Flowers scattered, all solitary in the forks. }
$$

C. tenélla, Gray. Slender, 3 or 4 inches high, loosely branclied, viscid: leaves linear with a long tapering base, obtusish : flowers solitary in all the forks, remote, almost sessile: calyx-lobes rather broadly triangular, acute, shorter than the broadly turbinate tube, about half the length of the narrow purplish corolla, this 3 or 4 lines long. - Proc. 1. c.; Watson, Bot. King, 262 , \& Bot. Calif. i. 488. - Dry hills, Utah and Nevada to eastern and northern parts of California.

* Calyx rounded at base: leaves sessile, entire, the lower oftener opposite : flowers rather loosely cymose or scattered. The mucilage-cells of the seed-coat wholly destitute of spiral fibres!

C. grácilis, Dougl. At length corymbosely much branched and spreading, 2 to 6 inches high : leaves lanceolate, or linear or the lowest oval or obovate : corolla 5 lines long, purple or violet; the narrow tube yellowish and seldom longer than the subulate-linear lobes of the deeply-cleft calyx. - Benth. in Bot. Reg. no. 1622, \& DC. Prodr. ix. 308. Gilia gracilis, Hook. Bot. Mag. t. 2924. Collomia micrantha, Kellogg, l. c. fig. 3. - Colorado and New Mexico and from Brit. Columbia south to Arizona. (W. S. Amer.)

* * * Calyx obtuse or acute at base : leaves all alternate and mostly incised or pinnately divided, all the lower petioled: corolla pinkish-purple, slender, half inch or less long, twice or thrice the length of the calyx.

C. gilioídes, Benth. Stems loosely branching, exect or diffuse, a span to 2 feet long: leaves nearly simply eut or parted into lanceolate or narrowly oblong divisions: flowers loose or scattered: calyx obtuse or rounded at base, deeply cleft; the lobes linear-subulate: stamens moderately unequal in insertion : ovules solitary or rarely in pairs: capsule globular. - Gray, Proc. Am. Acad. 1. c. (with var. glutinosa) \& Bot. Calif. l. c. C. gilioides \& C. glutinosa, Benth. l. c., the latter a more viscid state of this variable species. Gilia divaricata, Nutt. Pİ. Gamb. 15.5, it slender form.

C. heterophýlla, Hook. Iow, diffuse: leaves thin, mostly pinnatifid with the lobes again incised, or bipinnatifid, some of the uppermost less cut or even entire and bractlike, subtending the more or less capitate or looser clusters of flowers: calyx acute at base, cleft barely to the middle; the lobes ovate-lanceolate: stamens very unequally inserted: orules 2 or 3 in each cell : capsule ellipsoidal. - Bot. Mag. t. 2895; Bot. Reg. t. 1347. Courtoisia bipinnatifida, Reichb. Ic. Exot. t. 208. Gilia Sessei, G. Don. Navarretia héterophylylld, Benth. in DC. 1. c. - Brit. Columbia to California : common.

\$2. Phlogfnthea, Gray, 1. c. Ovules numerous, i. e. 6 to 12 in each cell: filaments unequal as well as unequally inserted, sometimes a little declined: biennials (sometimes perhaps perennials), or annuals, slightly if at all viscid. (Species of Gilia, sect: Ipomopsis, Benth.) 
* Cauline leaves simply pinnately parted into few ( 3 to 7 ) narrow-linear or often almost filiform divisions, very numerous, all alternate: inflorescence thyrsiform or panicled: corolla salverform, with tube little if at all dilated upward.

C. Cavanillesiána, Don. Biennial (or perhaps perennial southward) with a somewhat woody base, more or less pubescent, virgately branched: flowers in small clusters in a narrow or raceme-like leafy thyrsus : pedicels very short or none: corolla white, ochroleucous, or tinged with purple, only half inch long; the tube 2 or 3 times the length of the calyx; the sinuses somewhat unequal; lobes oblong: filaments moderately unequally inserted high in the considerably funnelform-expanded throat: anthers roundish : ovulcs 5 to 7 in the cells. - Syst. iv. 247; Gray, 1. c. 260. Phlox pinnata, Cav. Ic. t. 528 . Cantua glomeriflora, Juss. A'nn. Mus. Par. iii. 110. Gilia glomeriflora, Bentl. 1. c. G. multiflora, Nutt. Pl. Gamb. 1. c. - New Mexico and W. Texas to Arizona. (Mex.)

C. Thúrberi, Gray. Resembles the preceding in foliage and growth, but only minutely pubescent : inflorescence more spicate : flowers much larger: corolla blue or lilac, showy, salverform; the tube an inch or rather more in length, very slightly and gradually dilated upwards, 3 or 4 times the length of the calyx and of its orbicular lobes: filaments in the throat: anthers short-oblong: ovules 8 or 9 in each cell. - Proc. Am. Acad. 1. c. 261. New Mexico, near the Santa Rita coppermines, and in Arizona, Thutrber.

C. longiflóra, Gray, 1. c. Annual, glabrous, loosely paniculate-branched: divisions of the leaves long and slender: flowers loosely somewhat corymbose on slender peduncles: corolla white, strictly salverform and Phlox-like, showy; the tube often an inch and a half long, with narrow orifice; lobes orbicular or ovate (sometimes abruptly pointed): filaments very unequally inserted into the upper part of the tube, or 2 or 3 of them in the throat: anthers elongated-oblong: ovules 10 or 12 in each cell. - Cantua longiflora, Torr. in Ann. Lyc. N. Y. ii. 221. Gilia longiflora, Don, Benth., \&c. - W. Nebraska and Colorado to borders of Texas, and Arizona; common in pine forests.

* Leaves mostly entire, narrowly linear, scattered: corolla truly funnelform.

C. leptálea, Gray. Slender annual, 2 to 18 inches high, minutely glandular, otherwiso glabrous, branching into an effuse panicle: leaves 6 to 20 lines long, or the uppermost reduced to small subulate bracts, the lower sometimes with 2 or 3 small lobes: peduncles filiform or capillary : calyx small; its lobes subulate : corolla pink-red, 5 to 10 lines long; its slender tube longer than the calyx, and rather abruptly expanded into a wide funnelform throat of about the length of the oval spreading lobes. - Proc. Am. Acad. l.c. \& Bot. Calif. i. 488. Gilia capillaris, Kellogg in Proc. Calif. Acad. v. 46. - California ; conmon on moist or wet banks in the Sierra Nevada, \&c. A delicate species; the corolla in shape like that of Gilia tenuiflora.

3. LOESELIA, L. (John Laesel, of the 16th century, author of a Flora Prussica, \&c.) - Somewhat shrubby or suffruticulose plants (of Mexico and adjacent districts); with more or less rigid and commonly spinulose-toothed or spinulose-ciliate leaves, and the uppermost forming conspicuous bracts to the clustered flowers. But the following species form a section, Giliopsis, connecting with Gitia, having more scattered flowers, hardly any bracts, and very narrow leaves (all alternate), merely with rigidly mucronate tips. Limb of the corolla irregular by one of the lobes being separated by deeper sinuses from the others; the cuneate lobes erosely truncate or 3-denticulate: filaments incurved below the apex. - Gray, Proc. Am. Acad. xi. 86.

L. tenuifólia, Gray. Much branched from a somewhat woody perennial base, a span to a foot high, nearly glabrous: leaves linear-acerose, entire, or the lower and larger with 2 or 3 spreading subulate lobes: flowers rather crowded at the summit, the branches short-pedicelled : calyx-lobes subulate : corolla bright red, narrowly tubular-funnelform, an inch long; the tube 3 or 4 times the length of the lobes: capillary filaments and style conspicuously exserted: ovules 8 or 10 in each cell. - Bot. Calif. i. 500, \& Proc. 1. c. - Cantillas Moun. tains, on the lower border of San Diego Co., California, Mr. Dunn, Palmer.

I. effúsa, Gray. Diffusely much branched and rigid from an apparently annual root, a foot high, nearly glabrous : leaves all entire and fliform or very narrowly linear, short 
(a quarter inch or less long): flowers effusely paniculate : calyx-teeth short and broadly triangular: corolla pink purple, short-funnelform, 5 lines long; its lobes fully as long as the tube, unequal, about equalling the incurved filaments and style.-Proc. Am. Acad. l. c., \& Bot. Calif. i. 621. - With or near the preceding species, Palmer.

4. GILIA, Ruiz. \& Pav. (Dedicated to Philip Gil, who helped Xuarez to write a treatise on exotic plants cultivated at Rome.) - North American, chiefly Western, with a few S. American species; several cult. for ornament. Flowers in some species, especially in $\S 3$ and $\S 9$, tending to dimorphism, mainly in the length of the style. A polymorphous genus: most of the sections have been taken for genera, but they lack definiteness. - Gray, Proc. Am. Acad. viii. 261.

Series I. Leaves either opposite or palmately divided to the sessile base, usually both; their divisions fiom narrowly linear to filiform: seed-coat in many species mucilaginous when wetted, but destitute of spiricles.

§1. Dactruophýllư, Gray, 1. c. Corolla campanulate, rotate, or short-funnelform; the lobes obovate: filaments slender: ovules numerous or sometimes few in each cell : seed-coat when wetted developing more or less mucilage-cells from beneath the epidernis: low or slender annuals, loosely and mostly rather small-flowered : leaves opposite or the upper alternate.

* Flowers subsessile or short-pedicelled in the forks of the stem, at length crowded: calyx deeply cleft or parted, the lobes unequal : corolla campanulate with harlly any proper tube (the tilaments inserted on its base); lobes entire or nearly so: plants barely 2 inches high, with 3-7-parted leaves.

G. Párryæ, Gray. Pubescent, much branched from the base, forming a tuft: leaves short, 5-7-parted; the divisions linear-ace rose (barely quarter inch long): calyx deeply 5cleft; lobes acerose with broad thin-scarious margins: corolla (white, yellowish or purple, half an inch long) with broadly ovate somewhat pointed lobes as long as the undivided portion; the throat below each crowned as it were by a broad adnate and emarginate or obcordate scale: anthers oblong: capsule oval-oblong, many-seeded: seeds angular, not mucilaginous when wetted. - Proc. Am. Acad, xi. 76. G. Kennedyi, Porter in Bot. Gazette, ii. 77. - Desert Plains, S. E. California : near the head of the Mohave, Lemmon, Parry, Palmer. Kern Co., W. L. Kennedy. Dedicated to M/rs. Parry, one of the botanical party which discovered it. A handsome pygmy annual; remarkable for having appendages to the corolla not unlike those of many $H y d r o p h y l l a c e c e$.

G. demíssa, Gray. Less pubescent, diffusely branching, forming a depressed tuft: leaves 3-parted, or some of them simple (half inch long); the divisions acerose: calyx 5parted: corolla (white, sometimes purplish, 3 lines long) with obovate obtuse lobes and a naked throat: anthers oval : ovules 6 or 7 in each cell. - Proc. Am. Acad. viii. 263, \& Bot. Calif. i. 489; Rothrock in Wheeler Rep. t. 19. - Desert plains, S. E. California and W. Arizona to S. Utah, first collected by Fremont, next by C'ooper.

* Flowers loose or scattered or slender or capillary pedicels : calyx barely 5-cleft: corolla shorlfunnelform or approaching rotate, and with entire lobes: the filaments inserted in the throat: antherg oval: leares 3-7-parted, more or less hispidulous, or rarely glabrous. - Gilia $\$$ Dactylophyllum, Benth. in DC.

$\checkmark \quad \checkmark$ G. liniflóra, Benth. Erect, at length diffuse, 6 to 18 inches high, nearly glabrous: leaves Spurrey-like; the divisions nearly filiform: flowers paniculate: pedicels 5 to 15 lines long: corolla white or barely flesh-colored, somewhat rotate; its throat pubescent at base of the filaments; the obovate lobes thrice the length of the narrow tube, 3 to 5 lines long in the larger forms: ovules in the cells 6 to 8 . - Benth. in Bot. Reg, no. 1622, \& DC. 1. c. 315; Hook. f. Bot. Mag. t. 5895. - California ; rather common; passing freely into

Var. pharnaceoídes, Gray, l. c., a smaller form, with capillary diffuse branches and flowers of only half the size. - G. pharnaceoides, Benth. I. c.; Hook. Fl. ii. 74, t. 161. - California to Brit. Columbia and eastward to the Rocky Mountains; the smallest states strikingly different from the original $G$. liniflora.

G. pusilla, Benth. 1. c. Small, diffuse, 2 to 6 inches high, very slender : divisions of the leaves filiform-subulate or acerose ( 3 to 5 lines long): capillary pedicels 5 to 10 lines long: 
corolla purplish with yellow throat or nearly white, broadly shont-funnelform, 2 lines or more long; the obovate lobes equalling or longer than the campanulate throat and short proper tube: filaments nearly glabrous at base, inserted below the sinuses: ovules 3 to 5 in each cell. - Gray, Proc. Am. Acad. 1. c. - The proper species, witl corolla parely exceeding the calyx, Guadalupe Island and Lower California, Palmer, Orcutt, \&c. (Chili.)

Var. Califórnịca, Gray, l. c. Corolla with larger lobes, 2 or 3 lines long, and twice the length of the calyx. - Bot. Calif. i. 490. G. flipes, Benth. P1. Hartw. 325. California to Oregon.

G. Bolánderi, Gray, l. c. Like the variety of the foregoing; but the tube of the (blue- or purple-tinged) corolla long and narrow, almost equalling the narrow cylindraceous calyx-tube, rather longer than the oblong labes along with the very shont and slightly dilated throat: filaments inserted just below the sinuses, glabrous : ovules 2 to 5 in each cell. - California, on dry hills, Sonoma Co., to the Sierra Nevada, Bolander, A. Wood, Mrs. Austin, Mrs. Ames. Corolla 3 or 4 lines long; but the comparatively small lobes only a line and a half long. Longer pedicels an inch or so in length.

G. aúrea, Nutt. Diffusely branched, 2 to 4 inches high: divisions of the hispidulous leaves narrowly linear, barely 3 lines long: pedicels seldon longer than the flower, somewhat cymose: corolla mostly yellow, open and short-funnelform; the rounded obovate widely spreading lobes about as long as the obconical throat and the very short proper tube: filaments inserted just below the sinuses, glabrous at base: ovules about 10 in each cell. - Pl. Gamb. 155, t. 22 ; Gray, 1. c.-From Sta. Barbara, California, to Arizona and New Mexico. Corolla with the limb a third to half inch in diameter when fully expanded, bright or light yellow, sometimes purplish in the throat; or, in

Var. decóra, Gray, l. c., white or pale violet, with or without brown-purple in the throat. - California (Fremont, Brewer, \&c.) and through Arizona to New Mexico.

* * Flowers terminating the branches, rather short-pedicelled: corolla short-funnelform, its ample lobes fringe-toothed or denticulate: leaves all undivided and opposite - Fenzli, , Benth. Gilia § Dianthoides, Endi.

G. dianthoídes, Endl. Branching from the base, 2 to 5 inches high, more or less pubescent: leaves narrow-linear: corolla an inch or more long, lilac or purplish usually with darker or yellowish throat; the slender nearly included glabrous filaments inserted towards its base: ovules 12 to 20 in each cell. - Atakt. t. 29 ; Hook. Bot. Mag. t. 4876. Fenalia dianthiflora, Benth. in Bot. Reg. 1. c. F. speciosa (a large-flowered form), \& $F$. concinna (a depauperate state), Nutt. Gamb. 157. - California, from Santạ Barbara and the islands southward. A showy little plant, varying greatly in the size and hue of the flowers; the corolla-lobes in one form (coll. Coulter) only minutely erose-denticulate.

§ 2. LnNÁNTHus, Endl., Benth. Corolla salverform; the narrow tube about equalling the cylindrical tube of the caly (which is white-scarious, except the ribs, prolonged into acerose-linear teeth) ; the broadly cuneate-obovate lobes commonly minutely or obsoletely erose or crenulate, strongly convolute in the bud: stamens included in the tube of the corolla: filaments inserted below its middle, slender: ovules 20 to 40 in each cell : capsule cylindraceous or oblong: erect and slender glabrous annuals, about a span high or taller, with leaves all opposite, filiform or nearly so, 3-5-divided, or the lower simple, sometimes nearly all simple, especially in depauperate specimens: flowers mostly showy, white or nearly so, terminal or in the forks and subsessile. - Linanthus, Benth., formerly.

G. dichótoma, Benth. Flowers showy; the lobes of the corolla from half to nearly an inch long: anthers linear: seeds roundish, with a very loose arilliform external coat, not developing mucilage when wetted.-DC. 1. c. 314 ; Gray, 1. c. Linanthus dichotomus, Benth. in Bot. Reg. l. c. Gilia Linanthus, Steud. Nom. - California and Arizona; common westward. Leaves all entire only in some depauperate specimens.

G. Bigelóvii, Gray. 'Flowers inconspicuous; the lobes of the corolla not over 2 lines long, hardly surpassing those of the calyx and only half or one-third the length of its tube: anthers oval: seeds oval or oblong, with a close coat, freely developing mucilage when wetted. - Proc. Am. Acad. 1. c. 265 ; Watson, Bot. King, t. $25 . \quad$ G. dichotoma, yar. paryiflora, Torr. Bot. Mex. Bound. 147. $-W$. borders of Texas to E. California. 
§3. Leptásiphon, Endl., Benth. Corolla salverform, with the tube mostly filiform and elongated; the very short throat commonly abruptly more or less cyathiform-dilated: stamens inserted in the throat or orifice: anthers short: oxules numerous: annuals, mostly low or slender, with opposite narrow leaves, and handsome but commonly small flowers crowded into a capitate leafy-bracted cluster. (Style either very long and more or less exserted, or rather rarely short and included, in different individuals of the same species.) - Leptosiphon, Benth.

* Palmately-leaved genuine species, hairy, leafy-stemmed; commonly with leavas fascicled in the axils and all 5-7-parted; their divisions linear-tiliform: filaments slender, exserted more or less from the throat of the corolla, shorter than its entirc lobes: ovules 6 to 10 in wach cell.

- Large-flowered, and the tube of the corolla only equalling or little exceuding the obovate lobes.

G. densiflóra, Benth. Rather stout and large, often strict: numerous divisions of the leares filiform, somewhat rigid: tube of the lilac or nearly white corolla (half inch long) little if at all exserted beyond the calyx, and villous-hirsute bracts. - Gray, Proc. l. c. Leptosiphon densiftorus, Benth. in Hort. Trans. viii. t. 18; Lindl. Bot. Reg. t. 1725 ; Hook. Bat. Mag. t. 3578. Gilia Leptosiphon, Steud. Nom. Varies with corolla-tube a little more exserted, when it is G. grandiflora, Steud. \& Benth. I, c. and Leptosiphor grandiflorus, Benth. in Bot. Reg. - California; common towards the coast.

++ Slender-flowered; the filiform tube of the corolla 2 to 6 times the length of the lobes; these from 4 to less than 2 lines long, oval or ovate. Species difficult to detine.

G. brevicula, Gray. A span high, corymbosely branched, minutely pubescent and above glandular : leavès few and short (quarter of an inch long): tube of the corolla only 5 to 9 lines long, but much exceeding the calyx and bracts, hardly twioe the length of the (purple or violet) lobes: otherwise much like the next. - Proc. Am. Acad. xii. 79. Southeastern California, on the Mohave River, Palmer.

G. androsácea, Steud. A span to a foot high: corolla much exserted beyond the hirsute or villous-ciliate bracts and subtending leaves, lilac, pink, or nearly white with yellow or dark throat; its tube an inch or less long, thrice the length of the lobes (limb 8 to 10 lines in diameter)..-Gray, 1. c. \& Bot. Calif. i. 491. Leptosiphon androsaceus, Benth. in Hort. Trans. viii. t. 18; Hook. Bot. Mag. t. 3491 ; Lindl. Bot. Reg. t. 1710. - California; common west of the Sierra Nevada.

Var. rosácea, Gray. A dwarf and tufted form, with rose-red corolla, varying however into other hues, - Bot. Calif. 1. c. Leptosiphon parvifloms, var. rosaceus, Hook. f. Bot. Mag. t. 586:3. - Near San Francisco, Kellogg.

Var. detónsa, Gray, 1. c. Slender and almost glabrous form, the bracts and leaves merely hispidulous-ciliate. - Western part of California, Bridges, Brewer. A less marked form occurs on the borders of Nevada, Anderson.

G. micrántha, Steud. Slender, a span or so high: tube of the corolla extremely slender, three-fourths to inch and a half long, 4 to 6 times longer than the lobes; these 2 or 3 lines long: pubescence of the bracts, \&c., short and soft, rarely hirsute-ciliate. - Gray, Proc. 1. c. excl. syn. var. rosaceus, Bot. Mag. Leptosiphon parviforus \& L. luteus, Benth. in Bot. Reg. Gilia micrantha \& G. lutea, Benth. in DC. 1. c. - California; common through the western part of the State. Flower from purplish or lilac to cream-color, sulphur-yellow, and even golden yellow (var. aurea, Benth. Pl. Hartw.).

Var. longitúba ( $G$. longituba, Benth. Pl. Hartw. 324) is one of the larger-flowered forms, apparently passing into $G$. androsacea. - Monterey, Hartweg, \&c.

G. tenélla, Benth. Mostly depressed, small : tube of the corolla less slender in proportion to the size of the limb ( 6 to 9 lines long, the lobes only $1 \frac{1}{2}$ ): bracts and leaves hispiduIous-ciliate. - Pl. Hartw. 325. Leptosiphon bicolor, Nutt. Pl. Gamb., chiefly. - Puget Sound to Santa Barbara, California. Has been confounded with the two foregoing. Corolla dull purple, or pink, with yellow throat.

G. ciliáta, Benth. Rigid, rough, 4 to 12 incles high, the taller stems virgate : tube of the corolla slightly or not at all exserted beyond the very hirsute or hispid-ciliate bracts and subtending leaves ( 6 to 9 lines, and the lobes only $1 \frac{1}{2}$ lines long): caly $x$-lobes acerose. -Pl. Hartw. 1. c.; Gray, l. c. - California, reaching into Nevada, \&c. Greyish with short pubescence on the stems, and longer both rigid and softer spreading hairs fringing the leares and bracts. Corolla rose or violet, fading to white. 
* * Entire-leaved, wholly glabrous, very dwarf: anthers sessile in the throat of the corolla, the cuneate lobes of which are somewhat undulate-toothed or 1-3-dentate at the broad apex: ovules 10 to 16 in each cell.

G. nudicáulis, Gray. Very glabrous, an inch to a span high, at length branching from the base: stem (a long internode), leafless from the cotyledons up to the inflorescence, which is a close head or glomerule subtended by an involucre of several ovate-lanceolate or lanceolate foliaceous bracts : corolla white, pink, or yellow; the tube 3 or 4 lines long and thrice the length of the calyx, rather longer than the lobes. - Proc. Am. Acad. viii. 266 ; \& Bot. Calif. i. 492 . Collomia nudicaulis, Hook. \& Arn. Bot. Beech. 309. - Sandy plains, in spring, interior of Oregon and Nevada to Colorado.

§ 4. Siphonélis , Gray. Like Leptosiphon, but tube of corolla not surpassing the calyx, and its throat more funnelform, ovules only 2 or 4 in each cell, and flowers less glomerate: perennials, more or less woody or suffrutescent at base, cinereous-puberulent or the $3-\overline{7}$-parted leaves glabrate : caly $\mathrm{x}$ cylindraceous, firmherbaceous, soon 5-parted; the abrupt margins of the lanceolate-subulate lobes and the sinuses not at all scarious: corolla white, with yellow throat, obovate lobes ( 3 or 4 lines long), and tube externally puberulent: filaments short, slightly exserted: anthers short. - Siphonella, Nutt. herb.

G. Nuttállii, Gray. Stems or branches a span to a foot high, rather simple, terminated by a dense leafy cluster of flowers: divisions of the leaves narrowly linear (6 to 9 lines long), mucronate: ovules a pair in each cell. - Proc. Am. Acad. viii. 267; Watson, Bot. King, 265, t. 26. - Western side of the Rocky Mountains of Colorado and Utah to Arizona, S. California, and Washington Terr.

G. floribúnda, Gray. Taller and more slender, paniculately or corymbosely branched : the copious flowers in rather loose cymose clusters, often pedicelled . divisions of the leaves very slender, almost acicular or filiform: ovules 4 in each cell. - Proc. Am. Acad. 1. c., \& Bot. Calif. i. 492. - San Diego Co., California, on the southern borders, and east to Arizona, Coulter, Palmer, \&c. Upper leaves rarely alternate.

§5. Leptodíctylon, Benth. Corolla salverform, with tube more or less exceeding the calyx; the throat somewhat funnelform-dilated: filaments short, inserted in or below the throat: anthers short, included: ovules numerous in each cell: seeds with a close coat, developing neither spiricles nor mucilage when wetted : perennials or undershrubs, commonly tufted, very leafy : leaves all alternate, except in one species, and much fascicled in the axils, palmately 3-7-parted, acerose or subulate, rigid and pungent: flowers showy (rose, lilac, or white), solitary and sessile or few in a cluster at the summit of short branches or branchlets. - Leptodactylon, Hook. \& Arn.

* Leaves all opposite: stems or branches almost herbaceous from a woody base.

G. Watsóni, Gray. Roughish-puberulent and glandular, or at length smoothish : slender branches a span high from the woody caudex: leaves not much fascicled, widely spreading; the slender acerose divisions (6 to 8 lines long) often shorter than the internodes; calyx-lobes barely half the length of the tube: corolla nearly white (with purplish throat); its tube and lobes each half inch long: anthers at the orifice: ovules 10 or more in each cell. - Proc. Am. Acad. l. c.; Watson, Bot. King, 265, t. 26. - Rocky hills, Utah, Watson.

* * Leaves all alternate, or sometimes the lower opposite: stems decidedly woody.

G. Califórnica, Benth. Branches and very crowded soon widely spreading leaves tomentose-pubescent, or rather villous when young: corolla (rose or lilac, its ample limb an inch and a half in diameter) with broadly wedge-obovate lobes, their margin often minutely erose: anthers linear-oblong, included in the upper part of the tube: ovules 20 or more in each cell. - DC. Prodr. 1. c. Leptodactylon Californicum, Hook. \& Arn. Bot. Beech. 349, t. 89; Hook. Bot. Mag. t. 4872. - Dry hills, W. California, south to San Bernardino Co.

G. púngens, Benth. Branches and mostly erectish or little-spreading leaves viscidpubescent, puberulent, or glabrate: corolla rose, white, or "yellow" (Dougl.), the lobes 
narrower and only half as large as in the preceding: anthers in the throat, oblong: ovules 8 or 10 in each cell. - Proc. Am. Acad. 1. c. G. pungens \& G. Hookeri, Benth. in DC. l. c. - Plains of the Upper Platte and Columbia to Arizona and E. California. Widely variable. The original Cantua pungens, Torr. Ann. Lyc. N. Y. ii. 26 (_Egochloa Torreyi, Don), of the Platte, is a low glabrate form.

Var. cæspitósa, Gray, l.c. (Leptodactylon ccespitosum, Nutt. Pl. Gamb.), is a low and dense form, imitating Phlox Douglasii in growth. - Scott's Bluffs, W yoming, Nuttall.

Var. Hoókeri, Gray, l. c. (Pllox Hookeri, Dougl. in Hook. Fl. ii. 73, t. 159, \& G. Hookeri, Benth.), is taller, with sparser more rigid leaves, and viscid-pubescent flowering shoots. - Interior of Oregon, California, \&c. Flowers not found to be "yellow."

Var. squarrósa, Gray, l. c.' A foot or two high, with virgate branches, beset with stouter and more rigid recurred-spreading pungent leaves. - Dry interior region, Nevada to Idaho and Washington Terr.

Series II. Leaves alternate and pinnately incised, cleft, or divided, or rarely entire, occasionally some of the lowermost opposite : filaments slender : seed-coat (as in Collomia) when wetted mucilaginous and sending out threads containing each a spiral coil (spiricle), except in a few species.

§ 6. NAVARRÉtia, Gray, 1. c. Flowers capitate-crowded and densely foliaceousbracted (in the last species less so): lobes of the calyx and of the mostly (sometimes nearly palmately) multifid bracts rigid and acerose-pungent or spinulose, often laciniate or unequal: corolla slender, tubular-funuelform or almost salverform, and with rather small oval or oblong lobes : filaments inserted in or below the throat: authers short: stigmas and cells of the ovary sometimes reduced to 2 : low and much-branching annuals, sometimes glandular-viscid, never white-woolly; with chiefly 1-2-pinnately divided or cleft leaves, their lobes commonly subulate and pungent. - Navarretia, Ruiz \& Pav., Benth.

* Leaves and bracts, or some of them, more than once pinnately parted, i. e. their primary divisions incised or parted.

- Orules and seeds numerous ( 8 to 12 ) in each cell : stamens included in the throat of the corolla commonly unequal in length and slightly so in insertion: herbage very glandular-riscid and unpleasantly aromatic-scented.

G. squarrósa, Hook. \& Arn. Rather stout and rigid, often a foot high : upper leaves and bracts spinescent: tube of the small blue (or sometimes whitish) corolla rather shorter than the mostly entire calyx-lobes. - Bot. Beech. 151; Gray, Proc. Am. Acad. 1. c. 269. G. pungens, Hook. Bot. Mag. t. 2977. Hoitzia squarrosa, Esch. Egochloa pungens, Benth. in Bot. Reg. 1. c. Nararretia squarrosa, Hook. \& Arn. 1. c. 368. N. pungens, Hook. Fl. ii. 75. Plains of California and Oregon; a common fetid weed.

+ + Ovules varying from 1 to 2 or 3 to 4 in each cell: stamens exserted out of the throat of the corolla, at length mostly equalling the lobes : herbage less viscid or glandular, in some not at all so.

G. cotulæefólia, Steud. Rigid, a span to a foot high, pubescent or below glabrate, above mostly minutely glandular : leaves chiefly 2-pinnately parted; the subulate divisions of the upper and of the bracts spinescent: tube of the violet-blue or white corolla hardly longer than the lobes of the sparsely villous calyx; the throat funnelform: ovules solitary or rarely a pair in each of the (frequently only 2) cells of the ovary. - Epochloa pubescens \& cotulofolia, Benth. in Bot. Reg. Navarretia pubescens \& cotulafolia, Hook. \& Arn. 1. c.; Benth. in DC. 1. c. - California ; common westward, on dry hills: exhales the odor of Anthemis Cotula.

G. intertéxta, Steud. Erect or widely branched, low and rather stout, neither viscid nor glandular: stem retrorsely pubescent: leaves mainly glabrous, with divaricate acerosespinescent divisions sparingly divided or simple: flowers densely glomerate: tube of the caly $\mathrm{x}$ and base of the bracts strongly villous with white spreading hairs; its lobes equalling the white corolla: ovules and seeds 3 or 4 in each cell. - Navarretia intertexta, Hook. I. c. Plains of Columbia River to California and the Rocky Mountains. Corolla 3 or 4 lines long, the stamens equalling its lobes. 
G. mínima, Gray. Depressed, often forming broad tufts (half inch to 2 inches high), glabrate: leaves acicular and with simpler and fewer divisions than the preceding: tube of the calyx white-hairy in the broad sinuses, as long as the unequal lobes, which equal or exceed the white conlla : ovules 1 to 3 in each cell. - Proc. Am. Acad. 1. c.; Wastson, Bot. King, 266. Navarretia minima, Nutt. Pl. Gamb. 160. - Interior of Oregon and Nevada to Colorado and Dakota, in very arid districts. Corolla a line and a half long; the atamens mostly shorter than its lobes.

G. Bréweri, Gray. Erect or at length much branched and diffusely spreading, an inch to a span high, very minutely glandular-puberulent all over: flowers less glomerate: leaves with mostly simple acicular-subulate divisions: caly x-lobes similar to these, narrowly subulate, about equalling the yellow corolla, 3 or 4 times the length of the tube (which is even shorter than the capsule): ovules 1 or 2 in each cell. - Proc. Am. Acad. 1. c. \& Bot. Calif. i. 494; Watson, 1. c. - Sierra Nevada, California (Bvewer, \&c.), and through the interior to Utah and Wyoming. Corolla 3 or 4 lines long.

G. leucocéphala, Gray,'l. c. Slender, a span or less high, seldom rigid, not glandular, glabrous, except some woolly pubescence at the summit of the stem and of the thin ealyxtube: leaves soft; their often simple divisioms slender; those of the bracts barely pungent: corolla white, longer than the calyx (4 lines long): stamens considerably exserted: ov rules 2 in each cell. - Navarretia leucocephala, Benth. Pl. Hartw. 324. - California, on the Sacramento and its tributaries, and Mendocino $\mathrm{Co}$., in low grounds.

* Leaves simply pinnatifid or ineised, or many of them entire.

+ All slezder and filiform, except the bracts of the small heads, which are more or less palunately 3-5-cleft: corolla rather slender, 3 or 4 lines long: stems slender, not over a span high, diffusely branched : often with proliferous filiform branches.

G. divaricáta, Torr. Not glandular-viscid, glabrate; the bracts and especially the calyx woolly-pubescent: divisions of the uppermost leaves and the similar bracts acerose: corolla purple or apparently yellowish: ovules 5 to 7 in each cell. - Gray, Proc. Am. Acad. viii. 270, \& Bot. Calif. i. 494. - California, from Lake Co. to Mariposa Co., up to 8000 feet in the Sierra Nevada.

G. filicaúlis, Torr. More paniculate, glandular-viscid but not pubescent: upper leaves filiform or setaceous and entire: bracts somewhat cuneate and the lobes pungent; the inner shorter than the violet corolla: ovules solitary or at most a pair in each cell. - Gray, l. c. - California, Mariposa Co. to Butte Co.

+ + Leaves broader and rigid, linear or lanceolate, with spinulose lobes; the floral ones dilated at base and often cartilaginous: stems stout, 2 to 8 inches high: flowers densely glomerate: corolla violet or purple, a third to half inch long, about twice the length of the subulate spinescent calyx-lobes.

G. viscídula, Gray, 1. c. Viscid-pubescent, at length much branched : cauline leaves slender and laciniate-pinnatifid or parted into setaceous-subulate ascending lobes; the floral and bracts only moderately dilated: ovules 1 to 4 in each cell. - Navarretia viscidula, Benth. Pl. Hartw. 325, a small form. - Dry hills, California, from Santa Barbara to the Sacramento and east to the foothills of the Sierra Nevada.

G. atractyloides, Steud. Pubescent and very viscid, also very rigid, especially the leaves and bracts; these lanceolate or the uppermost even ovate, all pinnatifid, and with divaricate subulate-spinescent lobes: flowers less glomerate: ovules 6 or 7 in each cell. Egochloa atractyloides, Benth. in Bot. Reg. 1. c. Navarretia atractyloides, Hook. \& Arn. Bot. Beech. 368 ; Benth. in DC. Prodr, ix. 310. - California, from Santa Cruz to San Diego Co., in open and dry ground.

+++ Depressed, an inch or two high, at length prostrate, hardly if at all viscid: leaves upwardly cilated : fowers comparatively loose and scattered : corolla half to two thirds inch long, tubular-funnelform, much exceeding the calyx.

G. setosíssima, Gray. Pubescent or glabrate, strikingly setose; the very long white bristles terminating the lobes of the ealyx and the 3 to 7 lobes or teeth of the narrowly cuneate or linear leaves, and scattered or sometimes clustered down their sides: corolla white, purple, or mottled; the limb slightly irregular: ovules 3 to 10 in each cell. - Proc. Am. Acad. 1. c. 271, \& Bot. Calif. 494. Nanarretia setosissima, Torr. \& Gray, Bot. Ives Colorad. 22. N. Schottii, Torr. Mex. Bound. 145 (G. Schottii, Watson, Bot. King); an early and depauperate form. - Deserts of S. E. California, to W. Arizona and S. Utah, first collected by Coulter. 
§ 7. HuGŔLia, Gray. Flowers capitate-glomerate and foliaceous-bracted: the 3-5-cleft bracts and calyx densely implexed-woolly; lobes of the latter acerose or subulate and cuspidate or pungent: corolla salverform; the lobes ovate or oblong: filaments filiform, exserted: anthers deeply sagittate: herbage floccoselanate, at least when young, neither glandular nor viscid: leaves or their simple divisions very narrow and mostly rigid. - Hugelia, Benth. in Bot. Reg. l. c. Gilia \$Collomioides \& \& Pseudocollomia, Endl., Benth. in DC.

* Woody-based and rigid perennial : corolla violet-blue : ovules few or several in each cell.

G. densifólia, Benth. Canescent-lannte when young, glabrate with age : tufted stems a span to a foot or more high from a ligneous base, leafy to the top, simple or sparingly branched: leaves rigid, mostly pinnatifid or incisely laciniate into short-subulate spinulose lobes : flowers densely capitate-glomerate: tube of the corolla (half inch long) twice or thrice the length of the calyx: anthers sagittate-linear. - DC. Prodr. ix. 311 ; Gray, l. c. (Hugelia densifolia, Benth. in Bot. Reg.), a short and stout form, with crowded leaves. $G$. elongata, Steud.; Benth. l. c., a taller and looser form, with cells of the ovary usually only 2-3-ovulate. - California near the coast, from Santa Clara Co. southward, and thence to W. Arizona and S. Nevada.

* Herbaceous, and the root annual or biennial: leaves or divisions nearly or quite filiform. + Corolla violet, blue, or purple, or fading to white: ovules few (but seldom if ever solitary) in
the cells.

G. virgáta, Steud. White-floccose becoming glabrate: stem slender, either simple and virgate (a span to a foot high) or with virgate branches from the base and paniculately branched above: leaves slender-filiform; the lower mainly entire and the upper rarely more than 3-parted: flowers usually in rather small capitate clusters : corolla blue or lavender; the tube 4 to 6 lines long, surpassing the acerose calyx-lobes: anthers linear-sagittate, a line long. - Hugelia virgata, Benth. l. c.; Hook. Ic. t. 200. - California, on dry hills from Monterey southward, and east to Arizona.

Var. floribúnda, Gray. A remarkable form, with corymbose branches terminated by much larger and very many-flowered capitate clusters : most of the leaves (even the lower) pinnately :-7-parted: corolla-lobes 3 or 4 lines long. - Proc. Am. Acad. 1. c., \& Bot. Calif. i. 495. - Santa Clara Co. to San Diego Co., Wallace, Brewer, Palmer.

G. floccósa, Gray. More branched and generally lower than the foregoing, 2 to 12 inches high, similarly floccose-woolly, at length diffuse or spreading: corolla from violetblue to whitish; its tube 3 or 4 lines long, surpassing the subulate calyx-lobes: anthers narrowly oblong, fully half a line long. - Proc. Am. Acad. 1. c. \& Bot. Calif. i. 495, excl. syn. "Hugelia lutea, Benth." - Dry plains and desert, southern and easteru portions of California and S. E. Oregon to Utah and Arizona.

G. filifólia; Nutt. Flowers smaller; the lobes of the corolla seldom over a line in length, and its tube hardly if at all exceeding the calyx and bracts : anthers cordate-oval, a quarter or third of a line long: otherwise like small forms of the preceding. - Pl. Gamb. 156; Gray, l. c. - Santa Barbara and San Isabel, California, to the Rio Colorado.

Var. diffúsa, Gray, 1. c. A diffuse form, barely a span high; the leaves commonly rather shorter and less slender. - Interior of Nevada and Arizona to the western frontier of Texas.

$$
+ \text { + Corolla yellow: ovules solitary in the cells. }
$$

G. Iutéscens, Steud. A span high, closely resembles $G$. floccosa except in the above particulars, and the bright sulphur-yellow corolla only 3 lines long; its tube not exserted and lobes hardly exceeding a line in length: anthers elongated-oblong: capsule oval, $3-$ seeded. - Benth. in DC. 1. c. 311. Hugelia lutea, Benth. in Bot. Reg. 1. c. - W. California ; back of Monterey? Douglas. Back of San Simeon, Palmer, confirming the yellow color of the corolla.

8 8. Elaphócera, Nutt. Flowers capitate-congested oí sometimes more loosely cymose, more or less foliaceous-bracted : bracts and calyx-lobes commonly cuspidate or aristulate (but not pungent), and pubescent or ciljate with long and many-jointed somewhat viscid hairs : corolla (white or barely purplish) salver- 
form; the tube little exceeding the calyx; its lobes oval or oblong: stamens shorter than the corolla-lobes, inserted in or near the sinuses: biennials, shortlived perennials, or annuals, low or dwarf, more or less woolly-pubescent when young: leaves simply pinnatifid or entire.

* Leaves all entire, acerose-subulate or filiform: filaments slender. (Approaches § Hugelia.)

G. Wríghtii, Gray. Stems rigid, virgate, a foot high from an indurated or woody base or perennial? root, very leafy to the top: leaves rigid, cuspidate-tipped: flowers capitate-crowded: braets ovate-lanceolate, the larger ones sparingly laciniate, tipped with an awn-like cusp, as are the subulate calyx-lobes; these slightly shorter than the tube of the corolla: ovules 3 or 4 in each cell (4 lines long). - Proc. Am. Acad. viii, 273. - W. Texas, on the Rio Grande 40 to 60 miles below Eil Paso, Wright.

G. Gunnisóni, Torr. \& Gray. Annual, a span high, slender, at length almost glabrous, loosely paniculate-branched: leaves scattered, linear-filiform: bracts short, lanceolate, entire, tipped (like the triangular calyx-lobes) with a short cusp: flowers capitellate; the heads terminating slender peduncle-like branches : tube of the corolla slightly longer than the calyx and longer than its lobes: ovules 2 or sometimes 3 in each cell. - Pacif. R. Rep. ii. 129, t. 9. - S. E. Utah, Kreusfeldt, Newbery, Brandegee.

* * Leaves all or most of them pinnately parted into few narrow linear divisions, or sometimes all entire: filaments short: tube of the corolla not at all or at length slightly excceling the calyx: flowers densely capitate-clustered: perennials of short duration or biennials; the base of the simple or clustered stems or root hard and ligneous.

G. spicáta, Nutt. Stems rather stout, erect, simple, or several from the fusiform root, a span or two high: capitate flower-clusters crowded in an elongated virgate and spike-like thyrsus : leaves thickish, almost filiform, some about 3-cleft, occasionally all entire, barely mucronate: corolla-lobes oblong-ovate, shorter than the tube: anthers subsessile in the throat: ovules 4 to 6 in the cells. - Benth in Kew Jour. Bot. iii. 290 ; Gray, l. c. G. spicata \& G. trifida, Nutt. Pl. Gamb. 156. - Rocky Mountains, Wyoming to Colorado and Utah.

Var. capitáta, Gray, l. c. A dwarf form: leaves nearly all entire: thyrsus short and capituliform: filaments as long as the anther: approaches the next species. - Alpine region, from Black Hills in Dakota to Colorado.

G. congésta, Hook. Stems erect or spreading (3 to 12 inches ligh) from a tufted base, bearing single terminal or few and corymbose capituliform cymes: leaves witlı 3 to $7 \mathrm{mu}$ cronate divisions, or some of them entire: lobes of the corolla oval, nearly as long as the tube, which does not exceed the usually aristulate-tipped caly x-lobes : exserted filaments at length as long as the anthers: ovules 2 to 4 in each cell. - Hook. Fl. if. 75, \& Ic. t. 235. Wyoming and Colorado east of the Rocky Mountains to Oregon and the Sierra Nevada, California. Tube of the white corolla not over 2 lines long.

Var. crebrifólia, Gray, I. e. Depressed; the tufted stems 2 or 3 inches long, crowded with small entire leaves, and terminated by a single capitate cluster. - G. crebrifolia, Nutt. 1. c. - Mountains of Colorado and Utah. Connected with G. congesta by some intermediate forms.

G. iberidifólia, Benth. Leaves more rigid than in the preceding and the lobes euspidate-tipped, as also the bracts : capitate cymes corymbose : filaments shorter: ovules solitary in each cell. - Hook. Kew Jour. Bot. iii. 290. - Scott's Bluffs and Blackwater, North Platte, Nebraska and Wyoming, Geyer, H. Engelmann. Perhaps only a form of G. congesta.

* * * Leaves pinnatifid, trifid, or some of them entire: flowers cymulose-glomerate and leafy bracted, or at length loose: low annuals, branching from the base, only a span high : calyx-lobes aristulate-cuspidate.

G. púmila, Nutt. Stems loosely woolly, at least when young, leafy : leaves narrowly linear, entire or most of then 2-4-parted into diverging linear lobes, mucronate: tube of the corolla slender, about thrice the length of its lobes and twice the length of the aristulate-tipped caly x-lobes: filaments slender, inserted in the sinuses, exserted, shorter than the lobes of the corolla: ovules about 6 in each cell. - Pl. Gamb. 156; Gray, 1. c. G. trifida, Benth. in Kew Jour. Bot. iii. 291. - W. Texas, and New Mexico to W. Nebraska, and west to the Sierra Nevada. Tube of the corolla 3 or nearly 4 lines long; the limb small.

G. polýcladon, Torr. Stems puberulent or sparsely pubescent, diffuse, very few-leaved: leaves pinnatifid or incised; the lobes short, oblong, abruptly spinulose-mucronate, those 
subtending the cymose cluster longer than the flowers : tube of the corolla hardly exceeding the aristulate-mucronate calyx-lobes: anthers in the throat, on very short filaments: ovules 2 in each cell. - Bot. Mex. Bound. 147; Watson, Bot. King, 268. - Western Texas to Utah and W. Nevada. Corolla a line or two long, white with a tinge of rose-color.

§ 9. Ipoxópsis, Benth., partly. Flowers thyrsoid-paniculate, inconspicuously bracted or ebracteate : corolla scarlet or red, with white varieties, narrowly tubularfunnelform, gradually and regularly enlarging upward, very much surpassing the subulate calyx-lobes and its own ovate or lanceolate spreading or recurving lobes : stamens iuserted in the throat or below the sinuses of the corolla, not longer than its lobes: anthers oval or short-oblong: ovules numerous : biennials, not woolly, and usually showy-flowered. - Ipomopsis, Michx. Ipomeria, Nutt.

* Stem virgate, leafy: leaves pinnately parted into filiform or narrowly linear divisions: inflorescence contracted.

G. coronopifólia, Pers. (Standing Crpress.) Glabrous or barely pubescent: stem 2 to 6 feet high, very leafy throughout: divisions of the leaves and rhachis nearly filiform, acute and mucronate : flowers very numerous in a long and narrow compact thyrsus or panicle, inodorous : calyx-lobes setaceous-subulate, as long as the tube : corolla an inch or an inch and a half long, scarlet (within yellowish and dotted with red); the lobes ovate, moderately spreading,' barely exceeding the slender filaments : seeds not developing mucilage nor spiral threads when wet, but with a lax reticulate-cellular outer coat! -- Lindl. Bot. Reg. t. 1691. Polemonium rubrum \& Ipomaea rubra, L. Cantua thyrsoidea, Juss. C. pinnatifida, Lam. C. coronopifolia, Willd. C. elegans, Poir. Ipomopsis elegans, Michx.; Smith, Exot. t. 13. Ipomeria coronopifolia, Nutt. Gen. i. 124. Gilia Floridana, Don (Cantua, Nutt.), \& $G$. Beyrichiana, Bouché, are mere forms.-Dry sandy soil, South Carolina and Florida to Arkansas and Texas. Common in gardens.

G. aggregáta, Spreng. Somewhat pubescent: stems 2 to 4 fcet high, less leafy, sometimes loosely branching: leaves thickish, with narrowly linear mucronulate divisions: thyrsoid narrow panicle loose or interrupted ; the (fragrant) flowers sessile in small mostly short-pedunculate clusters: calyx commonly glandular; its lobes subulate: corolla from scarlet to pink-red (rarely white), with narrow tube; the lobes ovate or lanceolate, acute or acuminate, widely spreading, soon recurved: filaments slender: seeds when wotted developing mucilage and spiricles. - Syst. i. 626; Don, Brit. Fl. Gard. ser. 2, t. 218; Gray, l. c. Cantua aqgregata, Pursh. (Ipomeria aggregata, Nutt.) C. coronopifolia? \& $C$, aggregata, Torr. Ann. Lyc. N. Y. ii. 220. Ipomopsis elegans, Lindl. Bot. Reg. t. 1281. Gilia pulchella, Dougl. in Hook. Fl. ii. 74 ; Benth. 1. c.-W. Nebraska to W. Texas, New Mexico to Oregon, E. California and Arizona. (Adjacent Mex.) More or less heterogone-dimorphous: both stamens and style included (and the style shorter) in some individuals, both exserted (and the style longer) in most. Varies greatly: the extremes being

Var. attenuáta. Corolla-lobes lanceolate, tapering gradually from the very base into a slender acumination : caly x-lobes equally slender. - Colorado, in Middle Park, Parry. A white-flowered form, with stamens and style included.

Var. Bridgésii, Gray, l. c. Stems low (6 to 18 inches) and diffuse or spreading, as if from a perennial root: corolla bright red; its lobes oblong-ovate and merely acute: calyx-lobes shorter and broader, from subulate-lanceolate to deltoid: lobes of the leaves thicker and obtuse. - California, through the Sierra Nevada.

* Stem low, loosely paniculate-branched: upper leaves reduced to bracts.

G. subnúda, Torr. Glandular-puberulent, a span or two high: leaves all undivided, mainly crowded at the indurated base, spatulate or oblong and tapering into a margined petiole, sparsely and irregularly dentate; the few upper linear and entire; the uppermost subulate and minute: flowers rather crowded in a few small clusters: calyx-lobes subulate, about the length of the campanulate tube: corolla orange or scarlet; the tube (half inch Iong) thrice the length of the ovate obtuse lobes: anthers included in the throat on very short filaments: seeds developing mucilage and spiricles. - Gray, Proc. Am. Acad. viii. 276. - Arizona and S. Nevada to New Mexico, Newberry, Stretch, Paliner.

G. Háydeni, Gray. Almost glabrous, above slightly glandular, a span or more high, effusely much branched, somewhat corymbose: radical leaves pinnatifid; those of the 
branches linear and subulate, bract-like; entire: flowers mainly pedicellate: calyx-lobes subulate, shorter than the tube: corolla rose-red, slender; the tube (half inch long) several times longer than the obovate lobes: anthers subsessile in the throat: ovules only 6 in each cell: seeds fewer, neither spirilliferous nor mucilaginous when wetted. = Proc. Am. Acad. xii. 79. - S. W. Colorado or adjacent Utah, on the San Juan, Brandegee.

\$10. GrLÍNDRA, Gray. Flowers thyrsoid-paniculate and hardly bracted; rather small: corolla bluish or white, salverform; the tube hardly double the length of the calyx and little longer than its own obovate lobes: these surpassed by the slender and much exserted filaments: anthers short: ovules about 6 in each cell : seeds destitute both of mucilage and spiricles: glandular-puberulent and rather low biennials, with simply pinnatifid leaves, the radical in a dense rosulate tuft: calyx-lobes triangular.

F. stenothýrsa, Gray. Stem simple, virgate, very leafy up to the racemiform narrow thyrsus: leaves pinnately cleft into short oblong lobes: bracts small and entire: stamens moderately exserted : corolla somewhat funnelform, apparently white, nearly' half inch long. - Proc. Am. Acad. viii. 276. - Uinta Mountains, Utah; Fremont.

G. pinnatifida, Nutt. Stem simple or loosely branching, a span to 2 ' feet high : inflorescence open-paniculate, ofteri compound: leaves pinitately parted into linear or narrowly oblong 'lobes; these sometimes again 1-2-lobed; stamens conspicuously exserted (3' lines long, inserted just under the sinuses): corolla strictly salverform, pale blue or violet, or the narrow tube white (this and the lobes 2 or 3 lines long). - Gray, 1. c. - Rocky Mountains, common from S. Wyonting through Colorado (and Utah ?) to New Mexico.

\$ 11. Microgília, Benth. Flowers scattered, very small : corolla white, salverform: stamens inserted on and included in the tube: ovules solitary in the cells: much-branched annuals, with filiform or slender-subulate and entire (or sometimes 3-parted) small leaves: calyx short-campariulate, 5-toothed.

G. minutiflóra, Benth. Glabrous, or minutely glandular-puberulent above : stem erect, a foot or two high, with many virgate and rigid slender branches: upper leaves all reduced to minute subulate appressed bracts; the lower longer and some of them 3-parted: flowers terminating and also sparsely spicately disposed along the branchlets, 2 lines long: tube of the corolla about twice the length of the calyx and of its own lobes: filaments slender: capsule oval: seed oblong.-DC. Prodr. ix. 315. Collomia (Picrocolla) linbides, Nutt. Pl. Gamb. 159. - Interior of Oregon (or now Idaho, not "California"), Douglas. Wyoming on the Upper Platte, Nuttall, Fremont.

G. tenérrima, Gray. Minutely and sparsely glandular, low, effusely miuch branched: branches filiform: leaves entire: flowers Ioosely panicled, on slender divergent perlicels, minute: capsule globular (barely a line long): seed turgid oval. - Proc. Am. Acad. viii. 277; Watson, Bot. King, 270. - Utah, Bear River Valley, near Evanston (in fruit), Wdtson.

§ 12. Eugília, Benth., Gray. Flowers scattered, crowded, or rarely capitateglomerate, inconspicuously bracted or ebracteate: corolla from funnelform to nearly rotate: stamens usually inserted in or just below the sinuses of the corolla, not exceeding its lobes (or rarely moderately so): filaments slender: leaves various, all or chiefly alternate.

* Orules solitary in the cells : corolla funnelform with slender elongated tube and rather abruptly dilated throat (in the manner of $\S$ Navarretia, but no pungent or even mucronate tips to calyxlobes or leaves): sinuses of calvx somewhat replicate : very depressed small perennials; with flliform rootstocks and crowded leaves, among which the violet or purplish flowers are solitary and subsessile in the forks or axils.

G. Lárseni, Gray. Filiform creeping rootstocks elongated: stems rising only an inch or two above ground: leaves pedately 5-7-parted or the upper 3-cleft, rather surpassing the flowers, soft-pubescent: corolla half inch long, with tube slightly exceeding the calyx ; its rounded lobes somew hat surpassing the stamens and style. - Proc. Am. Acad. xi. 84, \& Bot. Calif. i. 497. - California, on Larsen's Peak, in loose volcanic ashes, Lemmon, John Larsen. 
G. débilis, Watson. An inch or two high, minutely pubescent: leaves oblong, 2-3lobed or entire, tapering into a short petiole, shorter than the flowers: corolla two thirds inch long; the tube exceeding the calyx: lobes of the latter conspicuously 3-nerved: stamens more or less and the style prominently exserted: "seed without mueilage or spiricles." - Am. Naturalist, viii. 302 ; Rothrock, in Wheeler Rep. t. 19. - S. Utah, Wheeler.

* Ovules and seeds few or numerous in the cells.

+ Root annual.

++ Corolla more or less funnelform, having a distinct tube: corolla from blue to purplish or sometimes white: flowers in the first species much crowded and short-pedicelled, in the last sirattered.

= Seeds developing mucilage and spiricles when wetted, mostly numerous : leaves once to thrice pinnately divided or cleft: herbage somewhat pubescent or glabrate.

G. capitáta, Dougl. Stem slender, a foot or two higl, nearly glabrous : leaves 2-3-pinnately divided into slender or even filiform-linear lobes: flowers numerous in dense capitate clusters terminating long naked peduncles : calyx glabrous or nearly so: corolla light blue ( 4 or 5 lines long); its tube about the length of the narrowly oblong or lanceolate-linear lobes and the nearly glabrous caly $\mathrm{x}$, only slightly dilated at the throat: stamens inserted in the very sinuses of the corolla. - Hook. Bot. Mag. t. 2698; Lindl. Bot. Reg. t. 1170; Brit. Fl. Gard. t. 287. - T. California and Oregon. Common in gardens.

G. achilleæfólia, Benth. Generally more pubescent and rather stouter than the pre. ceding, and the head-like flower-clusters larger and less compact: flowers larger: calyx more or less woolly; its lobes with short recurved tips : lobes of the violet-blue or lavender. purple corolla obovate or broadly oblong; its throat abruptly and amply dilated. - Bot. Reg. no. 1622, \& Prodr. 1. c. 311; Hook. Bot. Mag. t. 5939; Gray, Bot. Calif. i. 447. Common throughout W. California.

G. multicáulis, Benth. I.c. A span to a foot high, at length diffuse: leaves mostly twice pinnately parted into narrow linear lobes: flowers fewer and in a less dense shorterpeduncled cluster than the preceding, some of the pedicels in fruit equalling the calyx: corolla (4 lines long) violet; its proper tube shorter than the calyx, and its obovate or ovate lobes not longer than the fumnelform throat: capsule ovoid.-Gray, Bot. Calif. i. 408. G. achillecefolia, Lindl. Bot. Reg. t. 1682 ; Hook. Bot. Mag. t. 3440 ; Brit. Fl. Gard. n. ser. t. 280, not Benth. G. millefoliata, Fisch. \& Meyer, Ind. Sem. Petrop. 1838, 35, a diffuse and small-flowered form. G. stricta, Scheele in Linn. xxi. 755. Polemonium capitatum, Eschsch. in Mem. Acad. Petrop. 1826? - California, very common throughout the western part of the State.

Var. ténera, Gray, l.c., a depauperate and attenuated form, in dry and poor soil, with peduncle more loosely 3-5-flowered, or even 1-flowered. - G. stricta, Liebm. Ind, Sem. Hafn. 1853? - With the ordinary form.

G. trícolor, Benth. A span to a foot or two high, mostly slender, paniculately branched, at length diffuse : leaves (as of the preceding or more slender) and calyx, \&c., usually more viseid-pubescent: flowers few or several and short-pedicelled or subsessile in cymulose rather short-peduncled clusters : corolla (half inch long) twice or thrice the length of the calyx, with very short and yellowish proper tube, ample campanulate-funnelform throat , marked with deep brown-purple, and lilac or violet roundish lobes which surpass the stamens. - Hort. Trans. viii. t. 18; Lindl. Bot. Reg. t. 1701; Brit. Fl. Gard. n. ser. t. 264 ; Hook. Bot. Mag. t. 3469. - California, throughout the western part of the State: common in cultivation.

G. latiflóra. A span or two high, effusely paniculate, glabrous, and the inflorescence and calyx sparsely glandular: radical leaves simply pinnatifi, linear-lanceolate (an inch or two long), with short ovate or triangular and cuspidate-tipped lobes; the cauline few and small or minute, all but the lowest entire and subulate : paniculate cy me very loose : pedicels equalling or shorter than the flower: corolla ( 7 to 11 lines long) purple with yellowish or brownish throat, dilated-funnelform, abruptly contracted below into a narrow tube which slightly exceeds the calyx; its lobes rounded-obovate: capsule ovoid. - G. tonuflora, var. latiflora, Gray, Proc. Am. Acad. viii. 278, \& Bot. Calif. 1. c. - California, San Diego and Los Angeles Co., Fremont, Wallace, Palmer (402).

G. tenuiflóra, Benth. A foot or more high, slender, loosely paniculate above : radical and lower leaves bipinnately parted or divided, or simply divided and the narrow divisions 
incised, the lobes short; the upper becoming simple, small and entire: branches loosely few-flowered: pedicels shorter than the flower : corolla ( 7 to 9 lines long) rose-color with violet throat, narrowly funnelform or even trumpet-shaped; its slender tube fully thrice the length of the calyx : capsule ovoid-oblong. - Ijindl. Bot. Reg. t. 1888; Gray, l. c., excl. var. - California, from Monterey southward.

G. inconspícua, Dougl. Mostly low, a span to a foot or more high, usually with slight woolly pubescence when young, and viscidglandular, branching from the base: leaves mostly pinnatifid or pinnately parted, or the lowest bipinnatifid, with short mucronate-cuspidate lobes; the uppermost becoming small, subulate, and entire : flowers either somewhat crowded and subsessile or at length loosely panicled and some of them slender-pedicclled: corolla violet or purplish ( 3 to 5 lines long), narrowly funnelform, with proper tube shorter or slightly longer than the calyx. - Hook. Bot. Mag. t. 2883 (corolla too salverform); Benth. in DC. 1. c.; Gray, 1. c. G. parviflora, Spreng. Syst. i. 626. Cantua parviflora, Pursh, Fl. ii. 730. Ipomopsis inconspicua, Smith, Exot. t. 14. - Wyoming to the western border of Texas, and west to California and British Columbia. Very variable in size and form of corolla, passing into

Var. sinuáta, Gray, 1.c. Corolla larger, at least in proportion to the calyx, becoming thrice its length, with tube more exserted and throat and lobes more ample. - G. sinuata, Dougl.; Benth. in DC. I. c. G. arenaria, Benth. 1.c.-Oregon and California to New Mexico. Some forms approaching the two preceding.

$==$ Seeds destitute of mucilage and spiricles when wetted, numerous: leaves nearly all radical, barely pinnatifid or toothed; the cauline mainly reduced to small subulate bracts of the open compound panicle, which is about a span high : some flowers with very short, other's with slender pedicels, in the manner of $G$. inconspicua and related species.

G. leptoméria, Gray. Minutely somewhat glandular-viscid : radical leaves oblong or broadly lanceolate (an inch or more long), incisely toothed or simuate-pinnatifid; the obtuse teeth or lobes minutely mucronate-cuspidate : cymose panicle effuse: flowers inconspicuous: corolla whitish, 2 or 3 lines long, fully twice the lengtli of the calyx, slenderfunnelform, and with very small acute lobes: capsule ovoid, equalling or surpassing the triangular acute caly x-teeth. - Proc. 1. c. \& Bot. Calif. i. 498; Watson, Bot. King, 270, t. 26, fig. 6-11. - Interior desert region, Nevada and Utah, Watson, Parry, Lemmon.

G. latifólia, Watson. Viscid-pubescent and above glandular: radical leaves oval or roundish (an inch or two long), distinctly petioled, repand-dentate and the broad short teeth slender-spinescent: panicle loosely many-flowered: corolla pinkish, $2 \frac{1}{2}$ lines long, cylindraceous, little longer than the calyx; its lobes acute: capsule oblong, comparatively large (3 lines long), somewhat exceeded by the spinescent-subulate caly x-lobes. - Am. Naturalist, ix. 347, - S. Utah, Parry.

$$
\text { ++ Corolla campanulate or rotate : pedicels slender or filiform, scattered. }
$$

$=$ Western species, diffuse and slender, barely a span high: pedicels becoming horizontal or at length refracted.

G. microméria, Gray, 1. c. Nearly glabrous, glandless, effusely much branched: branches filiform: radical and lower leaves pinnatifid, and the lobes obtuse; the upper linear and entire: pedicels capillary, half inch long, axillary or opposite the leaves : flower barely a line long: corolla campanulate, white, a little longer than the 5-cleft calyx : capsule globular: seeds few, not mucilaginous.-Watson, l.c. fig. 12-14. - N. W. Nevada, Watson, Lemmon.

G. filifórmis, Parry. Completely glabrous and smooth: stem erect; the branches filiform and spreading: leaves all filiform or nearly so and entire: scattered capillary pedicels (from 1 to 11 lines long) at length refracted : corolla cream-color, very open-campanulate, 2 lines long, deeply 5-cleft, exceeding the 5-parted calyx; its lobes truncate and obscurely erose-denticulate: capsule globular: seeds rather few, mucilaginous but not spirilliferous when wet.-Gray, Proc. Am. Acad. x. 75. - St. George, S. Utah, Parry. Perhaps this species belongs to the $\S$ Dactylophyllum; but all except the lowest leaves are alternate.

G. campanuláta, Gray. Minutely pubescent when young, obscurely viscid, diffusely branched from the base, depressed: leaves lanceolate; the lower sparingly pinnatifidtoothed; the upper small and entire: pedicels not longer than the flower: corolla white, oblong-campanulate, 3 or 4 lines long, twice the length of the 5-parted calyx, moderately 
5-lobed : stamens inserted next the base: anthers oblong: ovules about 7 in each cell. Proc. Am. Acad. viii. 279; Watson, 1. c. fig. 16-18. - W. Nevada, on the banks of the Truckee River, Watson.

$==$ Texan and Mexican : pedicels erect or ascending, loosely and effusely paniculate: seeds mucilaginous and spirilliferous when wetted, rather numerous.

G. incísa, Benth. Merely puberulent: stems slender aud weak, diffusely branched from the base, a foot or two high, leafy: leaves thin; the radical and lower cauline slenderpetioled, roundish-ovate or obovate, acutely and incisely toothed or lyrately cleft; the upper lanceolate, sparsely laciniate; uppermost linear, more entire, sessile, and gradually reduced to subulate bracts : pedicels an inch or two long, rigid: corolla rotate, deeply 5. cleft (white or blue, half inch or less in diameter), deeply 5-lobed; the lobes ovate: filaments filiform: anthers oblong-oval. - DC. Prodr. ix. 312. G. Lindheimeriana, Scheele in Linn. xxi. 753. - Shady banks and thickets, Texas. (Mex.)

++ Root perennial or base of stems lignescent.

* Corolla (as far as known) rotate and blue: leaves rigid.

G. rigídula, Benth. Glabrous or viscid-glandular : stems a span or so high, slender and diffusely branched from a stout lignescent base: leaves mostly pinnately (or the uppermost nearly palmately) parted or cleft into few or several lanceolate-linear or subulate lobes: pedicels scattered, an inch or less long: corolla completely rotate (是 to $1 \frac{1}{4}$ inches in diameter), 5-parted; its lobes obovate: filaments filiform: anthers elongated-oblong: ovules and seeds several in each cell. - DC. 1. c.; Gray, Proc. Am. Acad. viii. 280 . G glandulosa, Scheele, l. c., one of the viscid-glandular forms. (Corolla opening wide in afternoon sunshine, closing at sunset, Lindheimer.) - Rocky plains and hills, Texas and New Mexico. (Adjacent Mex.)

Var. acerósa, Gray, l. c. More dwarf, rigid, and suffruticose : branches very leafy: the leaves all with slender-subulate or acerose and somewhat pungent divisions: pedicels short: flower rather smaller: anthers barely oblong. - Northern New Mexico and borders of Texas to Arizona. (Adjacent Mex.)

G. cæespitósa, Gray. Depressed-cespitose, with a stout lignescent caudex : leaves nearly all densely crowded on the very short tufted/shoots, viscid-puberulent, spatulate or somewhat lanceolate, entire, thickish, half inch long or less: flowering shoots scape-like, 1 to :3 inches high, 1-5-flowered: flowers short-pedicelled: calyx narrow, 2 lines long, 5-cleft; the lobes slender-subulate : corolla and stamens not seen : ovules few in each cell. - Proc. Am. Acad. xii. 80. - Rabbit Valley, Utah, on barren sandstone cliffs, at 7000 feet, $L . F$. Ward. - Its proper place in the genus quite uncertain, perhaps next $G$. subnuda.

$+t$ Corolla tubular-funnelform: habit and foliage wholly of Polemonium confertum, var. mellitum, but stamens straight.

G. Brandegéi, Gray. Very viscid with glandular pubescence, pleasantly odoriferous, cespitose : stems a span to near a foot high, simple: leaves all pinnate, elongated-linear in circumscription; the radical crowded and with short dilated and scarious sheathing petiole; the cauline scattered and similar: leaflets very small and numerous, 2 lines long, from oval to oblong-linear, sessile, some simple, others 2-parted and so appearing verticillate : flowers several in a short,and racemiform leafy thyrsus : corolla golden yellow, trumpet-shaped, an inch or less long, more than twice the length of the oblong or cylindraceous obtusely 5lobed calyx; its lobes oval and short: the stamens included in its throat (not declined or curved): anthers roundish: ovules few in each cell. - Proc. Am. Acad. xi. 85. - San Juan Gap, and Waggon-wheel Gap, on the Rio Grande, S. W. Colorado, on the face of high perpendicular cliffs, $T$. S. Brandegee.

Var. Lambórnii. Corolla lurid-yellowish or greenish. - Alpine region of Sierra Blanca, S. Colorado, R. H. Lamborn, A. Gray.

5. POLEMóniUm, Tourn. Greek Valerian, Jacob's Ladder.

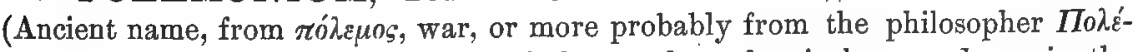
$\mu \omega y^{\prime}$ ) - Herbs, of the cooler parts of the northern hemisphere, and one in the southern; the leaflets or divisions of the pinnate leaves sessile and not serrate. Inflorescence racemiform, thyrsiform, or cymulose-paniculate; the upper pedicels ebracteate. Flowers blue or white, rarely purplish, usually showy, produced in 
summer. Anthers commonly oblong in the bud, oval in the blossom. Hypogynous disk fleshy and saucer-shaped, somewhat crenate. Seed-coat developing mucilage and spiricles when wetted. Genus marked rather by habit than character, the first and last sections too near Gilia.

$\S 1$. Corolla strictly or even narrowly funnelform; its tube more or less exceeding the oblong or cylindraceous calyx, prominently longer than the lobes: filaments uaked or nearly so and not dilated at base, usually inserted on the middle of the tube, or occasionally adnate higher : leaflets very small and crowded, so as seemingly to be verticillate: inflorescence capitate-congested or spiciform : cespitose perennial. (Transition to Gilia.)

P. confértum, Gray. A span or more high from a tufted rootstock, glandular-pubescent and viscid, musky-fragrant : radical petioles conspicuously scarious-dilated and sheatl-ing at base: leaflets 1 to 3 lines long, mostly 2-3-divided, and so appearing as if in fascicles or whorls; the divisions from round-oval to oblong-linear : flowers densely crowded, honeyscented : corolla deep blue, from half to a full inch long; its roundish lobes $2 \frac{1}{2}$ or 3 lines long: ovules about 3 in each cell. - Proc. Acad. Philad. 1863, 73, Proc. Am. Acad. vii. 280, \& Bot. Calif. i. 500; Watson, Bot. King, 271; Robinson, Garden, 1876, with a colored plate. P. viscosum, Nutt. Pl. Gamb. 154, in small part. - Alpine region of the Rocky Mountains from lat. $49^{\circ}$ southward to Colorado, Utah, Nevada, and in the high Sierra Nevada, California.

Var. mellítum, Gray, l. c. Usually a taller form : inflorescence more lax and leafy, becoming spiciform or racenıse : corolla pale or sometimes white, fully an inch long, more narrowly funnelform; the lobes only one third or fourth the length of the tube. - With the ordinary form in Wyoming, Colorado, and Utah.

§ 2. Corolla campanulate-funnelform, with tube not surpassing the open campanulate calyx and shorter than the ample spreading limb: filaments usually dilated and pilose-appendaged at base: inflorescence open and with very few bracts : leaflets simple and entire, sometimes confluent: root perennial.

* Low, about a span high from cespitose-branching and mostly thickened rootstocks: flowering stems only 1-3-leaved: flowers cymulose: leaflets seldom half an inch long.

P. viscósum, Nutt. Dwarf and with thick densely tufted rootstocks, viscid-puberulent: leaflets very numerous and crowded or even imbricated, thickish, ovate or roundish, at most a line and a half long: flowers in a rather close cymulose cluster : corolla blue or whitish, barely twice the length of the calyx, its rounded lobes ( 2 lines long) about the length of the included tube: filaments not appendaged at base. -PI. Gamb. 154 (mainly, excluding what relates to the "elongated lanceolate segments of the calyx"); Gray, Proc. Am. Acad. l. c. - High Rocky Mountains, towards the sources of the Platte, Nuttall.

P. húmile, Willd. More slender, and from somewhat creeping rootstocks, more or less viscid-pubescent: leaflets 15 to 21 , from round-oval to oblong, 2 to 6 lines long: flowers rather few in the clusters: corolla blue or purplish; its ampler rounded lobes much longer than the short included tube: filaments pilose at the dilated base: ovules 2 to 4 and seeds 1 or 2 in each cell. - Rom. \& Sch. Syst. iv. 792; Cham. in Linn. vi. 562. A polymorphous or complex species, of which the large-flowered high northern form, with rather long viscid pubescence about the calyx, \&c., may be taken as type, after Chamisso, viz. his $P$. humile and his var. macranthum. P. Richardsonii, Graham in Bot. Mag. t. 2800. P. lanatum, Fischer. P. capitatum, Bentl. in DC. Prodr. ix. 317, mainly (excl. syn. Lindl. Bot. Reg., which belongs rather to $P$. carveleum; also excluding the original of Eschscholtz, from California, which must be Gilia multicaulis or G. achillecefolia). P. pulchellum, var. macranthum, Ledeb. Fl. Ross. iii. 85. - Arctic coast to St. Paul's and Shumagin Islands. (Kamts. to Spitzbergen.) Lobes of the corolla often 5 lines long.

Var. pulchéllum. Viscid pubescence mostly minute, or the leaflets of ten nearly glabrous and naked: flowers smaller : the lobes of the corolla only 3 or 2 lines long, violet or lavender blue, in some forms nearly white. (Varies in small-flowered forms with style and even stamens exserted.) $-P$. pulchellum, Bunge, in Ledeb. Fl. Alt. i. 233, \& Ic. Ross. 
t.20. P. moschatum, Wormskiold. P. humile, Lindl. Bot. Reg. t. 1304. P. pulcherrimum, Hook. Bot. Mag. t. 2979, a more viscid, lax or diffuse, and small-flowered form; the corolla violet, varying to white, its lobes narrower. - N. W. and Arctic coast, and southward along the Rocky Mountains to Colorado and the Sierra Nevada. (Kamts. \& Niberia.)

* Taller, from slender rootstocks or roots: leaves and leaflets larger.

+ Orules 6 to 12 in each cell : stem erect, 1 to 3 fect high : leaflets numerous and mostly approximate, not rarely confluent or the rhachis winged: seeds in the same species either wing-angled
or marginless: corolla blue, varying to white.

P. cærúleum, L. Either glabrous or viscid-pubescent: stem mostly strict and virgate, 1 to 3 feet high, 5-10-leayed : leaflets from linear-lanceolate to oblong-ovate (9 to 20 lines long): flowers numerous in a naked and narrow thyrsus or panicle: calyx cleft to or beyond the middle: corolla an inch or considerably less in diameter: elongated style usually considerably and stamens often somewhat longer than the corolla. - Fl. Dan. t. 255; Reichenb. Ic. Germ. t. 18:31; Gray, Man. ed. 5, 371. - Wet or moist ground; very rare in the $\mathrm{X}$. Atlantic States (in swamps in New York, viz. Schoharie Co., Dr. Howe, Delaware Co., B. D. Gilbert, Herkimer Co., Clinton, also Warren Co., New Jersey, Porter ; a form with rather open-panicled inflorescence and broadish leaflets); but common in western wooded mountain districts, viz. from Colorado Rocky Mountains to California, Oregon, and far nortluward. (N. Asia, Eu.)

Var. acutiflórum, Ledeb., is a high northern and reduced form, a foot to a span high, with few and large flowers, and ovate more or less acute corolla-lobes, which exceed the stamens and sometimes even the style. $-P$. acutiflorum, Willd. in Rœm. \& Sch. 1. c.; DC. Prodr. l. c. - High N. W. coast and Aleutian Islands, \&c. (Siber., N. Eu.)

P. foliosissímum. Very viscid-pubescent throughout and strong-scented: stem a foot or more high, very leafy throughout: leaflets from lanceolate to ovate-lanceolate (seldom an inch long): flowers corymbose-cymose, smaller than those of the preceding: corolla commonly white or crean-color, sometimes violet, twice the length of the calyx, which is 5-cleft to or beyond the middle: style and stamens not protruding. $-P$. coeruleum, var.? pterosperma, Benth. in DC. Prodr. ix. 317 ; but the seeds, as in $P$. caruleum, are either marginless or wing-margined. P.cceruleum, var. foliosissimum, Gray, Proc. Am. Acad. viii. 281. Rocky Mountains of New Mexico, Colorado, and Wyoming, and west to Utah and Idaho. Some forms approaching the preceding species; but it is more like P. Mexicanum, Cerv., which is loosely branched, and has the violet corolla little exceeding the calyx, the lobes of the latter barely half the length of the tube.

+ + Orules only 3 or 4 in each cell : stem lax or with cliffuse branches and open corrmbiforn or paniculate inflorescence: leaflets fewer ( 5 to 15 ) and rather large, membranaceou, only the ultimate at all confluent: herbage glabrous or slightly pubescent, neither viscid nor glandular: style and stamens rather shorter than the corolla.

P. cárneum. A foot or two high, rather stout: leaflets from ovate to oblong-lanceolate (often an inch and a half long): branches somewhat umbellately 3-5-flowered: calyx deeply 5-cleft; the lobes ovate-oblong: corolla salmon-color or flesh-color (fading to purplish), 8 to 12 lines long (the ample limb sometimes $1 \frac{1}{2}$ inches in diameter when fully expanded); its lobes rounded-obovate. - In mountain wools, Siskiyou Co., California, Greene. Also near San Francisco, Kellogg, G. R. T'usey.

P. réptans, L. A foot or less high, slender, weak and at length diffuse or spreading (but never creeping) : leaflets ovate- or lanceolate-oblong: flowers several and loosely paniculate-cymulose on the branches: calyx with ovate lobes shorter than its tube: corolla light blue, half inch or less in length. - Lam. Ill. t. 106; Bot. Mag. t. 1887. - Open woods, New York to Alabama and west to Minnesota and Missouri.

\$3. Corolla almost rotate, shorter than the broad and open deeply 5-cleft calyx : filaments almost naked at base: flowers scattered: root annual. (Another transition to Gilia.)

P. micránthum, Benth. Much branched from the base, slender, diffuse, more or less viscid-pubescent: stems or branches 3 to 8 inches long: leaflets 5 to 13 , obovate or lanceolate ( 2 to 4 lines long): peduncles mostly solitary opposite the leaves: corolla whitish, a line or two long: ovules 2 or 3 in each cell. - DC. Prodr. ix. 318; Gray, 1. c. - Springy ground, British Colunbia to California and Nevada : fl. in spring. (S. Chili, P. antarcticum, Griseb. ex Benth.) 


\section{ORDER XCII. HYDROPHYLLACE E.}

Herbs, or rarely shrubs, with watery insipid juice, alternate or sometimes opposite leaves, no stipules, mostly a scorpioid inflorescence in the manner of Borraginacea, regular 5-merous 5-androus flowers, with the stamens borne on the base or lower part of the corolla alternate with its lobes, a 2-merous ovary, and the two styles distinct or partly united (in Romanzoffia completely united into one): stigmas terminal. Ovules amphitropous or anatropous, from 4 to very many, pendulous, or when numerous almost horizontal. Hypogynous annular disk at the base of the ovary often conspicuous. Fruit a capsule, one-celled with two parietal placentæ, or incompletely 2-celled by the approximation or meeting of the placentæ (borne on semisepta), or even completely 2-celled by their union in the axis. Seeds with a close and usually reticulated or pitted testa, and a small or slender embryo in cartilaginous or firm-fleshy albumen. Scorpioid cymes sometimes complete, more commouly reduced to geminate or solitary false spikes or racemes (which in description may be termed spikes or racemes); the pedicels bractless. Calyx 5-parted, or of nearly distinct sepals. - Benth. in Linn. Trans. xvii. 267 ; A.DC. Prodr. ix. 287 ; Gray, Proc. Am. Acad. ix. 312, \& Bot. Calif. i. 501.

TRIBE I. HYDROPHYLLE $æ$ E. Ovary and capsule strictly 1-celled, lined with a pair of expanded, at first fleshy, at maturity thin and membranaceous placentæ, which form a lining to the pericarp, and enclose the 4 or more amphitropous ovules and seeds. Calyx sometimes appendaged at the sinuses. Corolla mostly convolute in the bud. Style more or less 2-cleft. Ovary hispid, at least at the apex. Capsule globose, loculicidal, i. e. dehiscent by the- dorsal sutures. Seeds by abortion commonly fewer than the ovules, globular, or angled by mutual pressure : albumen cartilaginous.

* Stamens and style mostly conspicuously exserted : calyx nearly unchanged in fruit: root perennial or biennial : leaves alternate.

1. HYDROPHYLLUM. Calyx early open, with or without a small appendage at each sinus. Corolla campanulate; the tube within bearing a linear longitudinal appendage opposite each lobe, with infolded edges, forming a nectariferous groove. Filaments and style long and filiform, the former bearded at the middle: anthers linear or oblong, inflexed in the bud. Seeds 1 to 4 ; the ovules only 4.

* * Stamens shorter than the corolla : calyx accrescent in fruit : root annual : lower and sometimes all the leaves opposite.

2. NEMOPHILA. Calyx with a reflexed appendage at each sinus. Corolla rotate or approaching campanulate, usually longer than the calyx; the base within mostly with 10 appendages. Anthers usually sagittate-oblong. Ovules 4 to 20 . Seeds commonly with a deciduous or more persistent caruncle.

3. ELLISIA. Calyx destitute of appendages at the sinuses, usually much enlarged under the fruit. Corolla campanulate, shorter or little longer than the calyx; the internal appendages minute or obsolete; lobes in æstivation either all convolute, or one exterior, or rarely quincuncial. Anthers oval or oblong. Ovules 4 to 8 . Seeds not carunculate.

Tribe II. PHACFLIEÆE. Ovary either strictly 1-celled or 2-celled by the meeting of the linear or lanceolate placentæ in the axis ; these separating in the loculicidal dehiscence, and borne on the middle of the semiseptiferous valves, or sometimes falling away. Calyx naked at the sinuses, deeply 5-parted. Corolla imbricated in the bud. Style from 2-parted to (rarely) entire; the branches at the apex or the stigmas obscurely if at all thickened. Ovary mostly hispid or pubescent, at least its apex. Albumen cartilaginous or firm-fleshy. 
* Leaves all opposite, entire : flowers cymose: style 2-cleft at the apex.

4. DRAPERIA. Calyx-lobes or sepals narrow-linear, equal. Corolla tubular-funnelform, with 5 short lobes, not appendaged within. Stamens unequal and somewhat unequally inserted low down on the tube of the corolla, included. Uvary 2-celled, with a pair of collateral ovules pendulous from near the apex of each cell. Style long and filiform. Capsule globose-didymous, membranaceous; the thin semi-septa commonly adnate to each valve, and the membranaceous central or placental portion falling with the four seeds.

* Leaves all or all but the lowest alternate: flowers cymose, scorpioid-racemose or spicate, or rarely in the forks.

+ Style 2-cleft, at least at the apex.

5. PHACELIA. Calyx-lobes all similar or nearly so. Corolla deciduous, not yellow. Stamens equally inserted low down on the corolla. Inflorescence scorpioid. (Ovules and seeds when reduced to a pair collateral and nearly as long as the cell.)

$\checkmark$ 6. EMMENANTHE. Corolla (yellow or yellowish and campanulate) persistent! Otherwise as Phacelia. Seeds several.

7. CONANTHUS. Calyx-lobes all similar, narrow. Corolla deciduous, funmelform, not appendaged; the slender filaments unequally inserted more or less high up on its tube. Stigmas capitellate. Seeds with a thin smoothish testa, 10 to 20. Flowers solitary and subsessile in the leafy forks of the stem. Habit of Nama.

8. TRICARDIA. Calyx-lobes or sepals very dissimilar; 3 outer large and cordate, 2 inner linear. Corolla broad-campanulate, deciduons. Stamens equally inserted on the base of the corolla. Ovary glabrous: ovules and seeds about 8 . Flowers racemose.

+ + Style and even the stigma entire: ovary glabrous.

9. ROMANZOFFIA. Calyx-lobes or sepals similar. Corolla funnelform or almost campanulate; the stamens inserted on the base of its tube, unequal. Style filiform: stigma small. Inflorescence scapiform, loosely racemose. Leaves round-reniform and crenatelobed.

* * Leaves (alternate) and 1-flowered peduncles all radical : style 2-cleft at apex.

10. HESPEROCHIRON. Calyx 5 (rarely 6-7-)parted; the lobes linear-lanceolate, occasionally unequal. Corolla campanulate or rotate, deciduous; the stamens inserted on the base of jts tube. Ovary pubescent. Leaves spatulate or oblong, entire.

Tribe III. NAME.E. Styles 2, distinct to the base; their tips or stigmas commonly clavate-thickened or capitate. Orary completely or incompletely 2-celled. Capsule loculicidal ; the valves bearing the (usually placentiferous) half-dissepiments on their middle. Seeds with firm fleshy albumen. Corolla imbricated in the bud, not appendaged within. Leaves simple, alternate, or sometimes imperfectly opposite. (Closely connected with the foregoing tribe through Draperia and Conanthus on the one hand, and Lemmonia on the other.)

* Ovules and seeds only 2 in each cell, one above the other: placentæ not transversely dilated or bilamellar.

11. LEMMONIA. Corolla short-campanulate. Filaments and styles short and included, subulate: the former equally inserted, abruptly dilated or as it were appendiculate at the very base: anthers cordate-didymous. Stignas small. Capsule membranaceous, 2valved. Seeds proportionally large, globular-obovate. Depressed annual.

* * Ovules and seeds numerous or several, on transverse lamelliform placentæ, which approximate or cohere in the axis of the ovary, but separate in the loculicidal dehiscence and are borne on the half-dissepiments or half-valves of the capsule.

12. NAMA. Corolla funnelform or somewhat salverform. Filaments and styles filiform, more or less included; the former commonly unequal and often unequally inserted, slightly and gradually if at all dilated at base. Capsule membranaceous; the valves and placentæ undivided. Ovules and usually the seeds numerous. Mainly low herbs or suffrutescent.

13. ERIODICTYON. Corolla funnelform or approaching campanulate. Filaments and style more or less included. Capsule crustaceous, 4 -valved, i. e. first loculicidal, then septicidal, thus splitting into 4 half-carpels, which are closed on one side, owing to the widely dilated placentæ, and partly open on the other. Seeds rather few, pendulous. Shrubby, with leaves mostly dentate.

Tribe IV. HYDROLEEस. Ovary and capsule completely 2-celled, and with large and fleshy inseparable placentæ; the dehiscence septicidally septifragal, or often 
irregular, leaving the thin dissepiment with the central placenta. Styles 2. Corolla nearly rotate, imbricatad in the bud. Seeds very numerous, with fleshy albumen. Leaves all alternate, simple and entire.

14. HYDROLEA. The only genus.

1. HYDROPHYLLUM, Tourn. WaterLeaf. (Formed of visou, water, and $\varphi v ́ d \lambda o v$, leaf, a name of no obvious application.) - North-American herbs; with petioled ample and lobed or divided alternate leaves, and cymose clusters of violet-blue or white flowers, in early summer.

§1. Irdropirclex proper. Perennial, with fleshy horizontal rootstocks: calyx naked at the sinuses, except occasionally in the last species.

* Leaves pinnatifid or pinnate : at least the calyx and inflorescence hispid.

+ Peduncles shorter than the petioles, generally shorter than the mostly dense inflorescence: anthers short-oblong.

H. macrophýllum, Nutt. Hispid or rough-hirsute, stout, 2 or 3 feet high: lower leaves commonly a foot long; the divisions oval or oblong, obtuse, 2 or 3 inches long, incisely toothed; the upper ones confluent: stout peduncles commonly forked: cymes very dense: calyx white-hispid, not deeply parted; its divisions triangular-subulate, tapering gradually from the broad base, loosely spreading: corolla dull white, half an inch long. Jour. Acad. Plilad. vii. 111. - Rich woods, Ohio to Virginia and Alabama, and west to the Mississippi.

H. capitátum, Dougl. Only a span or so in height, tufted: copious fascicled roots fleshy and almost as large as the short rootstocks : leaves longer than the stem, and with blade mostly shorter than the petiole, ovate or roundish in general outline, 2 or 3 inches long, softly hirsute or pubescent, pinnately 5-7-parted or at base divided; the divisions 2-3-lobed or cleft; the lobes oblong, obtuse and mucronate: flowers capitate-cymose: calyx very hispid. - Benth. in Linn. Trans. xrii. 273 (excl. Calif. pl. \&c.); A.DC. Prodr. ix. 289; Hook. Kew Jour. Bot. iii. 292 (var. pumilum); Watson, Bot. King, 249. - Hillsides, \&c., Washington Terr. to the Sierra Nevada, California, and Utah.

Var. alpínum, Watson, l. c. Nearly acaulescent in dense tufts : flowers distinctly pedicellate in a somewhat open cyme close to the ground: calyx densely white-hairy, but less hispid. - Eastern California and Nevada, in the higher Sierra Nevada and Humboldt Mountains.

+ + Peduncle elongated, surpassing the petiole and often surpassing the subtending leaf: anthers oblong-linear.

+ Cauline leaves elongated-oblong in general outline, pinnately parted or divided into 7 to 15 divisions.

H. occidentále, Gray. Pubescent, hirsute, or sparingly lispid, a foot or two high: divisions of the leaves oblong, an inch or two long, mostly incised or few-cleft, obtuse: peduncles rather slender: cymes mostly dense or capitate: calyx deeply parted, its divisions lanceolate and rather obtuse, more erect: corolla violet-purple, varying to white, a third inch long. - Proc. Am. Acad. x. 314, \& Bot. Calif. l. c. H. capitatum, Torr. Pacif. R. Rep. iv. 125, not Dougl. - Oregon (Nuttall) and N. \& W. California.

Var. Watsóni, Gray, l. c. Commonly low, sometimes almost stemless, soft-pubescent, especially the lower side of the leaves (which is sometimes eanescent), as also the sparsely hispid calyx: cyme sometimes open. $-H$. macrophyllum, var. occidentale, Watson, Bot. King, 248, mainly. - Sierra Nevada, California, to Utah, Anderson, Bolander, Watson, \&c.

Var. Féndleri, Gray, l.c. Pubescence mainly hirsute or hispid, not at all canescent or cinereous: divisions of the leaves inclined to ovate-lanceolate, acute or acuminate, incisely serrate: peduncle shorter: cyme rather open : corolla white or nearly so. - Shady ravines, Santa Fé, New Mexico, to Colorado, Fendler, Greene, T. M. Coulter, \&c.

$$
++ \text { + Cauline leaves orate in general outline, 3-5-parted or divided. }
$$

耳. Virginicum, L. Stem (a foot or two high) and bright green leaves almost glabrous, or with some scattered hairs: divisions of the leaves ( 2 to 4 inches long) ovate-lanceolate or rhomboid-ovate, acuminate or acute, coarsely incised-toothed; the lowest commonly 2-cleft and the terminal one often 3-lobed: peduncle usually once or twice forked: cyme 
at length open: calyx 5-parted to the very base into narrow linear and spreading hispidciliate divisions: corolla nearly white or sometimes deep violet, about a fourth of an inci long. - Lam. Ill. t. 97 ; Schkuhr, Handb. t. 35 ; Bot. Reg. t. 331 . - Rich woods, Canada to the mountains of Carolina and through the western States northward to Washington Ferr. and Alaska (violet-flowered form). - Flesliy rootstock strongly toothed by the persistent bases of former radical petioles.

* * Leaves palmately 5-7-lobed: calyx often bearing minute tectl in the sinuses.

H. Canadénse, L. A foot or less high from thickish and scaly-toothed rootstoclss, nearly glabrous or very slightly and sparsely hirsute even on the calyx: stems simple and nakel below, 1-2-leaved at the summit: leaves bright green, rounded and with a cordate base, $5-7$-cleft to near the middle; the larger ones 5 to 7 inches wide; the radical ones on stout petioles as long as the stem, not rarely furnished with several small and distant pinnately arranged lateral divisions: peduncles mostly shorter than the cauline petioles, comnonly forked: small cymes rather open: divisions of the decply 5-parted calyx narrowly lanceolate-linear : corolla open-campanulate, mostly greenish-white: filaments very villous. Lam. Ill. t. 97 ; Bot. Reg. t. 242. - Damp woods, Canada to the mountains of Carolina, and west to the Mississippi.

§2. DecÉмtu., Raf. Biennial : calyx appendaged with a reflexed lobe at each sinus, and somewhat accrescent under the fruit (in the manner of Nemoplitla, to which genus this approaches): stamens little longer than the open-campanulate corolla. - Viticella, Mitch. Nov. Gen. 62.

H. appendiculátum, Michx. A foot or so high, loosely branching, hirsute with long spreading hairs, and above minutely somewhat viscid-pubescent : radical leaves pinnately 5-7-parted or divided; cauline rounded, with truncate or cordate base, palmately $5-\bar{i}-$ angulate-lobed or the lower deeper cleft, somewhat dentate; the lobes very acuminate: peduncles exceeding the upper leaves : cymes loosely paniculate : pedicels filiform, equalling or longer than the calyx; the divisions of the latter lanceolate-subulate, spreading, broadening at base under the one-seeded fruit. - Fl. i. 13t. H. (Decemium) trilobum, Raf. FI. Ludov. 33. Decemium hirtum, Raf. Med. F1. ii. 215. Nemophila paniculata, Spreng. Syst. i. 569 ; Beck, Bot. 256. - Damp woodlands, Upper Canada to mountains of Carolina, aud west to Missouri and Wisconsin.

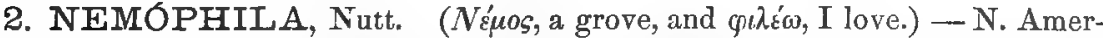
ican annuals, in California chiefly winter-annuals, diffuse, more or less hirsute, of tender texture; with opposite or alternate and usually pinnatifid leaves, oneflowered terminal or lateral peduncles, in one or two species inclined to be racemose, and white, blue, or violet corolla, which in one species only is shorter than the calyx. - Nutt. in Jour. Acad. Philad. ii. 179; Barton, Fl. Am. Sept. ii. t. 61 ; Gray, 1. c. 314, \& Bot. Calif. i. 503. (The larger-flowered species are common ornamental annuals in gardens.)

* Ovules 8 to 24 , maturing 5 to 15 seeds : leaves all or almost all opposite, surpassed by the slender peduncle. (All Californian.)

+ Seeds globular, smooth or minutely pruinose, with a very prominent papillæform caruncle.

N. maculáta, Benth. Leaves lyrately pinnatifid into 5 to 9 short lobes, or the uppermost somewhat cuneate and 3-lobed: corolla white, with a deep violet blotch at the apex of each of the broad lobes; its very broad scales partly free, hirsute-ciliate with long sparse bristles. - Lindl. in Jour. Hort. Soc. iii. 319, \& fig.; Pl. Hartw. 326 ; Paxt. Mag. xvi. t. 6 ; Fl. Serres, v. t. 431. - California, valley of the Sacramento to the Sierra Nevada. Corolla varying from 9 to 20 lines in diameter.

+ + Seeds oblong-oval, at maturity usually more or less tuberculate-corrugated or rugose: caruncle more deciduous.

N. insignis, Dougl. Leaves pinnately parted into 7 to 9 oblong and often 2-3-lobed divisions: corolla bright clear blue; the scales within its base short and roundish, partly free, hirsute with short hairs. - Benth. 1.c. 275, \& Trans. Hort. Soc. i. 479; Bot. Reg. 
t. 1713 ; Bot. Mag. t. 3485. N. Menziesii, var., Hook. \& Arn. Bot. Beech. 372.-Common nearly throughout California, flowering, like the other species, from early spring onward, Corolla from an inch or more down to little over half an inch in diameter.

N. Menziésii, Hook. \& Arn. Mostly smaller than the preceding: leaves pinnatifid into 3 to 9 lobes : rotate corolla from light blue to white, and commonly with dark dots or spots, especially towards the centre, or sometimes with a dark eye; the scales at its base narrow, wholly adherent, their free edge densely hirsute-ciliate: appendages to the calyx usually small. - Bot. Beech. 152, \& 372, first form; Gray, l. c. N. liniflora, Fisch. \& Meyer, Sert. Petrop. fol. \& t. 8, a large blue-flowered form, the corolla an inch wide. $N$. pedunculuta, Benth. 1. c. ; Torr. Bot. Mex. Bound. 142 (as to char. \& pl. coll. Coulter), a smallflowered form. N. atomaria, Fisch. \& Meyer, Ind. Petrop. 1835, \& Sert. Petrop. 1. c.; Bot. Reg. t. 1940 ; Bot. Mag. t. 3774. N. discoidalis, Hortul.; Fl. Serres, ii. t. 75, a cult. form, with the dark spots confluent into a uniform dark brown-purple eye, or almost covering the corolla (Regel, Gartenfl. 1864, t. 442). - Common in California, extending to Oregon. Corolla from half an inch to at most an inch in diameter; the larger forms many-ovulate and much resembling $N$. insignis; the smaller passing towards $N$. parviflora, and sometimes only 7-9-0vulate.

* * Ovules only 4, i. e a pair to each placenta: leaves all or mainly alternate : flowers mostly large: internal scales of the corolla very broad and partly free, conniving or united in pairs at the base of the filaments: seeds globose, with inconspicuous caruncle or none: peduncles rarely exceeding the leaves, or the later ones forming as it were a naked few-flowered corymb or raceme.

N. phacelioídes, Nutt. Sparsely hirsute, a foot or two high: leaves all but the earliest alternate, with naked petioles, 5-9-parted; the divisions oblong or oval, the larger ones 2-5-lobed: appendages of the calyx oblong or ovate, almost half the length of the lobes: corolla ample, blue; the appendages in throat hairy outside: seeds obscurely inpressed-punctate. - Nutt. in Jour. Acad. Philad. ii. 179, \& Trans. Am. Phil. Soc. n. ser. v. 192 ; Bart. Fl. Am. Sept. ii. t. 61 ; Bot. Mag. t. 2373 ; Bot. Reg. t. 740 ; Brit. Fl. Gard. t. 32. N. Nuttallii, Colla, Hort. Rip. App. i. t. 5. N. hirsuta \& N. pilosa, Buckley in Proc. Acad. Philad. - Low grounds, Arkansas and Texas. Corolla an inch or more in diameter, with white or pale centre.

N. auríta, Lindl. Hirsute, and the weak stems usually retrorsely hispid, a foot or two long: leaves all with dilated clasping base or winged petiole; the lowest opposite, deeply pinnatifid; the 5 to 9 oblong or lanceolate divisions more or less retrorse: appendages of the calyx small : corolla violet, from two-thirds to nearly an inch in diameter; its internal scales with erose and somewhat ciliate margins: seeds favose-reticulated. - Bot. Reg. $t$. 1601 ; Brit. Fl. Gard. n. ser. t. 338. - California, from the Sacramento Valley to San Diego. Upper pedurcles almost always bractless and at length racemose.

N. racemósa, Nutt. More slender and weak than the preceding: leaves shorter and with fewer divisions and a naked petiole destitute of auricled base: flowers only half the size, the upper ones racemose. - Gray, Proc. 1. c. \& Bot. Calif. 1. c. - San Diego, Nuttall; Island of Catalina, Dall and Baker. Leaves of ovate rather than linear outline. Corolla little longer than the calyx, only 4 or 5 lines wide.

* * * Ovules only 4, i. e. a pair to each placenta: lower leaves opposite, and the upper commonly alternate: flowers small or minute: corolla more campanulate; its internal scales delicate and nearly glabrous, or obsolete: seeds oval or globose, the caruncle at length evanescent: peduncles shorter than the leaves: plants small or slender, diffuse or prostrate, hirsute-pubescent.

+ Corolla, as in all preceding species, longer than the calyx.

N. parviflóra, Dougl. Leaves pinnately 3-9-parted or cleft, or below divided; the divisions obovate or oblong; the distinct lower ones either sessile or petiolulate, the upper confluent: appendages of the calyx rather conspicuous : corolla light blue or whitish, 3 to 5 lines in diameter; its lobes considerably longer than the tube; its oblong appendages manifest, wholly adherent by one edge : anthers oblong-sagittate : filaments filiform, inserted on the very base of the corolla. - Benth. 1. c. 275 ; Gray, I. c. N. parviflora \& $N$. pedunculata, Hook. Fl. ii. 79. N. heterophylla, Fisch. \& Mejer, l. c.; a larger-flowered form. - Shady places, British Columbia to California; common, and exceedingly variable in the foliage, size of corolla, \&c. Seeds from one to four, smooth and even, with obscure impressed punctures or pits, or becoming rather deeply, pitted or scrobiculate. All but the upper leaves mostly opposite. 
N. micrócalyz, Fisch. \& Meyer. Leaves pinnately 3-5-parted or divided, or the upper only 3-cleft; divisions obovate or cuneate, 2-3-lobed or incised, all approximate, commonly the whole leaf with a triangulate-reniform or cordate general outline: appendages of the calyx small and inconspicuous, in flower less evident than in fruit: corolla whitish or bluish, 1 to 2 lines long; its lobes shorter than the campanulate tube; the appendages (always?) obsolete: filaments short, inserted rather high on the tube of the corolla: anthers oval. - Sert. Petrop. 1. c.; Gray, Man. 368. N. evanescens, Darby, S. Bot. N. parviftora, A. DC. l. c., as to Louisiana plant. Ellisia microcalyx, Nutt. Trans. Am. Phil. Soc. l. c.; Hook. Comp. Bot. Mag. i. 172. E. ranunculacea, Nutt. l. c., ex char. - IIoist woods, Virginia to Florida, Arkansas, and Texas. Leaves prevailingly and often all but the lowest opposite. Seeds either globular or oval, when young minutely and sparsely pruinose with little papillæ, when old with impressed punctures.

++ Corolla decidedly shorter than the calyx.

N. breviflóra, Gray. A span or more high, at length diffuse: leaves sometimes all alternate, pinnately $3-5$-parted ; the divisions approximate, oblong-lanceolate, acute, entire, ( 3 to 9 lines long): peduncles seldom exceeding the petioles; appendages of the calyx nearly half the length of the proper lobes, both ciliate with long hirsute bristles: corolla whitish or tinged with violet, broadly short-campanulate; the lobes considerably shorter than the tube; internal appendages cuneate, the broad free summit fimbriatc-incised: style minutely 2-cleft at apex: seed solitary, almost filling the cell, globose, nearly smooth and even; the caruncle evanescent. - Proc. Am. Acad. xi. 315. N. parviflora, Watson, Bot. King, 249, excl. char. - Utah, in Parley's Park, Watson. Interior of Oregon, Tolmie, W. C. Cusick. When full grown, the habit is somewhat that of Florkea. Seed nearly 2 lines in diameter.

3. ELLISIA, L. (In honor of John Ellis, an English correspondent of John Bartram and of Linnæus, and who published the first account of Dionea, \&c.) North American annuals, with tender herbage, somewhat hirsute; the once to thrice pinnatifid leaves either all opposite or the upper alternate; peduncles solitary or racemose; corolla whitish, mostly small in comparison with the at length stellate calyx.

§1. Euellísia, Gray. Ovules in the manner of the tribe all on the inner face of the placentæ, a pair to each : seeds globose, uniform, alveolate-reticulated: leaves once pinnately parted.

F. Nyctélea, L. A span to a foot high, at lengtlı very diffuse: leaves on naked or barely margined petioles, the upper mostly alternate; the divisions 7 to 13 , lanceolate, acute, mostly 1-3-toothed or lobed: peduncles solitary in the forks or opposite the leaves, or some of the later ones racemose and secund: calyx-lobes lanceolate or at length ovatelanceolate, gradually acuminate, longer than the capsule : corolla cylindraceous-campanulate, rather shorter than the calyx: seeds very minutely reticulated. - (Moris. Hist. iii. 451, sect. 2, t. 28; Ehret in Act. Ups. i. 97, t. 5; Trew. P1. Sel. t. 99.$)$ Linn. Spec. erl. 2, 1662. E. ambigua, Nutt. Gen. i. 118, merely a slender form. Polemonium Nyctelea, L. Spec. ed. 1, \&c. - Damp and shady places, New Jersey to Virginia and west to Saskatchewan and Missouri; flowering through spring and summer.

E. membranácea, Benth. Weak, a foot or two long, sparsely beset with short hirsute or hispid hairs or bristles, otherwise glabrous: leaves mostly opposite, on narrowly winged or margined petioles; the divisions 8 to 9 , linear, obtuse, entire, or sometimes with a lobe: flowers chiefly bractless and becoming racemose on a terminal peduncle : caly $x$-lobes oblong or at length obovate, very obtuse, rather shorter than the open-campanulate corolla, not exceeding the capsule: seeds rather coarsely reticulated. - Benth. 1. c. 274; A. DC. 1. c.; Gray, Bot. Calif. i. 505. - California, from the Bay of San Francisco to San Diego. Flowers very much smaller than in the preceding: corolla 4 lines in diameter, one lobe outside in æstivation. Ovary beset with a few subulate bristles.

§ 2. EUCRÝPta, Gray, 1. c. Ovules a pair on the back as well as on the face of each placenta; the seeds of the two dissimilar, oval; the outer ones (usually 
solitary) flattened and hidden betwe $n$ its placenta and the valve: leaves twice or even thrice pinnately parted. - Eucrypta, Nutt. PI. Gamb. 159.

E. chrysanthemifólia, Benth. l. c. A foot or two high, erect, paniculately branched, more or less hirsute and scabrous: leaves opposite or the uppermost alternate, on short petioles auriculate-dilated at base, finely twice or thrice (or the uppermost once) parted or cleft into small and short lobes: flowers loosely racemose, the short filiform pedicels bractless : calyx-lobes ovate or broadly oval, about equalling the small striate-nerved capsule, shorter than the open-campanulate corolla: seeds oval; the ordinary ones ( 2 to 4 maturing) rugose-tubereulate, tercte, discharged upon dehiscence; a posterior one (or sometimes a pair) enclosed between each valve and the placenta which lines it, meniscoid, smooth, usually rather larger than the others. - Eucrypta paniculata \& E. foliosa, Nutt. 1. c. Phacelia micrantha, var.? bipinnatifldes, Torr. in Ives Colorad. Exped. Bot. 21. - California, from Contra Costa Co. to San Diego and to the borders of Arizona. Corolla and fruiting calyx about 3 lines in diameter, sometimes smaller. (Islands of Lower Calif.)

\section{DRAPERIA, Torr. (Dedicated to Professor Jolen William Draper of} New York, chemist and historian.) - A single species. Gray, Proc. Am. Acad. vii. 401 , x. 316 , \& Bot. Calif. i. 50 õ.

D. sýstyla, Torr. l. c. Low and diffuse or decumbent perennial herb, branching from sightly lignescent base, silky-hirsute and somewhat viscid, leafy : leaves all opposite, ovate, (ntire, pinnately veined, slender-petioled : flowers crowded in a pedunculate terminal once or twice 2-3-fid cyme; the unilateral spikes or racemes of which slightly elongate in age : sepals narrow-linear; corolla light purplish 4 or 5 lines Iong: capsule thin; the oval placental portion usually separating from the dissepiment in dehiscence: seeds oval and angled; the cont very minutely or obscurely reticulated. - Nama systyla, Gray, Proc. Am. Acad. vi. 37. - California, ravines and shaded hillsides, along the Sierra Nevada ; first collected by $L o b b$.

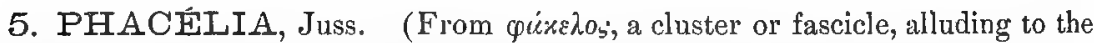
crowded flowers of the original species.) - Anuual or some few perennial herbs (all American, chiefly N. American); with alteruate simple or compound leaves, and more or less scorpioid cymes or so-called racemes or spikes. Corolla deciduous (as generally in the order), at least thrown off by the enlarging capsule (except in P. sericea!), blue, purple or white, never yellow, except the tube of certain species; the tube with or sometimes without appendages within; these when present generally in the form of 10 vertical folds or lamellar projections (borne on a lateral vein), in pairs, either adnate to or free from and alternate with the base of the slender filaments. Calyx-lobes commonly narrow, often wider upwards, more or less enlarging in fruit. Seed-coat reticulated or pitted. - Gray, Man. ed. 5, p. 369, \& Proc. Am. Acad. x. 316. Phacelia, Cosmanthus (Nolte), Eutoca (R. Br.), \& Microgenetes, A.DC. Prodr. ix. 292, 297.

$\S 1$. Euphacélia, Gray. Orules 4, i. e. a pair to each placenta: seeds as many or by abortion fewer, vertical; the testa areolate-reticulate or favose : lobes of the campanulate corolla entire (or rarely erose-dentate) ; the tube with 10 laminate appendages in pairs at the base of the stamens. - Phacelia, Juss., A.DC.

* Lower learcs and all the branches opposite: no hispid or hirsute pnbescence: spilkes or branches of the cyme hardly at all scorpioid: pedicels much shorter than the calyx. (An anomalous species.)

P. namatoídes, Gray. Annual, a span high, brachiately branched, glabrous and glaucous below, above glandular-pubescent: leaves narrowly-lanceolate, entire, tapering at hase, obscurely petioled; only the uppermost alternate, equalling or surpassing the rather loose spikes or branches of the cyme: sepals spatulate-linear, a little shorter than the 
narrow-campanulate blue corolla, exceeding the globular sparsely hirsute-pubescent capsule: stamens and at length deeply 2-parted style included: appendages at base of filament short: seeds alveolate-reticulated. - Proc. Am. Acad. x. 317, \& Bot. Calif. i. 506. Nama racemosa, Kellogg, Proc. Acad. Calif. v. 51. - California, in the Sicrra Nevada from Calaveras to Nevada Co., at Cisco, Summit Station, \&c., Bolander, Kcllogg. Corolla and capsule a line long.

* * Leares (as in the rest of the genus) all alternate: pubescence or some of it hispid or hirsute: spikes or branches of the cyme scorpioid and dense: pedicels short or hardly any (except in $P$. pedicellnta) : appendages of the corolla broad and salient, usually more or less united at the base of the filament.

- Leaves all simple and eutire, or some of the lower pinnately 3-5-parted or divided; the segments or leaflets entire: capsule orate, acute: seeds densely alveolate-punctate, upper end acutish.

P. circináta, Jacq. f. Hispid and the folinge strigose, and either green or canescent, a span to 2 feet high from a perennial or biennial root: leaves from lanceolate to ovate, acute, pinnately and obliquely straight-veined; the lower tapering into a petiole and commonly some of them with one or two pairs of smaller lateral leaflets: inflorescence hispid ; the dense spikes thyrsoid-congested: corolla whitish or bluish, moderately 5-lobed, longer than the oblong-lanceolate or linear calyx-lobes: filaments much exserted, sparingly bearded. - Eclog. 135, t. 91 ; Benth. 1. c.; A. DC. Prodr. 1. c., where see the older synonymy. (Aldea circinata, Willd. Enum.) P. heterophylla, Pursh, Fl. i. 140. P. Californica, Cham. in Linn. iv. 495. P. hastata, Dougl. in Hook. Fl, ii. 80. P. leucoplylla, Torr. in Frem. Rep. 93. $P$. canescens, Nutt. Pl. Gamb. 159, a dwarf very canescent state. - Dry ground, Dakota to British Columbia, New Mexico, and California. (S. to the Straits of Magellan.) Very variable: dwarf forms sometimes with a naked scape-like stem.

Var. calycósa, Gray, 1. c. Divisions of the calyx more foliaceous and ample, and in fruit with narrowed base, oblong to obovate-spatulate, reticulated. - California ; not rare in the western part of the State, under otherwise varying forms.

P. Bréweri, Gray, 1. c. Resembling the preceding but smaller and slender, from an annual root: corolla blue or violet, more broadly campanulate, nearly twice the length of the linear ealyx-lobes : filaments glabrous, a little shorter than the corolla. - Monte Diablo, California, on dry and soft sandstone, Brewer. Leaves seldom an inch long, exclusive of the petiole of the lowermost; many of them 3-5-parted; the lanceolate lobes ascending. Corolla barely 3 lines long.

P. húmilis, Torr. \& Gray. Annual, diffusely branched from the base, a span high, pubescent, or the inflorescence often hirsute: leaves spatulate-oblong or oblanceolate, rather obtuse; the lower rarely with one or two lateral ascencling lobes, the veins branching: spikes loosely paniculate or solitary, in age rather slender : pedicels either all very short, or the lower sometimes almost as long as the calyx: corolla indigo-blue, rather deeply lobed, surpassing the usually linear calyx-lobes: filaments moderately exserted, glabrous or sparingly bearded above. - Pacif. R. Rep. ii. 122, t. 7 ; Watson, Bot. King, 250. - Sierra Tevada, California, from Siskiyou to Mariposa Co, and E. Nevada. Leaves an inch or two in length. Corolla 2 or 3 lines long.

Var. calycósa, Gray. A strict and slender form: corolla apparently pale : calyxlobes larger and spatulate, as in the similar variety of $P$. circinata. - Proc. Am. Acad. \& Bot. Calif. i. 507. - E. side of the Sierra Nevada, near Mono Lake, Bolander.

+ + Leaves simple, all petioled, rounded-cordate, somewhat palmately lobed or incised, the lobes serrate.

P. malvæélía, Cham. Rather tall and stout, from an annual? root, hispid with spreading or reflexed stinging bristles, and the foliage more or less pubescent: leaves ( 1 to 3 inches in diameter) green and membranaceous, round-cordate, incisely 5-9-lobed, acutely toothed : somewhat palmately ribbed at base: spikes solitary or geminate: corolla ( 3 or 4 lines long) white, longer than the unequal linear and spatulate calyx-lobes: stamens exserted: seeds alveolate-scabrous. - Linn. iv. 494; Gray, 1. c. - California, Bay of San Francisco, Chamisso, Kellogg, G. R. Vasey.

+++ Leaves oblong or narrower in outline, pinnately toothed, lobed, or componnd, and the lobes or divisions toothed or incised: capsule globular or ovoid, obtuse : seerls with excavated ventral face divided by a salient ridge: annuals, or rarely biennials (or one perennial?), mostly with cymosely or umbellately or thyrsoid congested spikes.

to Calyx, \&c., not setose-hispid: stamens and style more or less exserted. 
$=$ Pedicels short, when any, and erect in the fruiting spike: divisions of the calyx entire, little exceeding the capsule: seeds minutely reticulated.

P. integrifólia, Torr. A span to 2 feet high, strict, viscid-pubescent or hirsute, very leafy: leaves ovate-oblong or lanceolate, sessile or the lower short-petioled with a commonly subcordate base, simply or mostly doubly crenate-toothed, sometimes incised: spikes crowded, at first thyrsoid: corolla narrow-campanulate, whitish or bluish: stanens and style long-exserted; the latter cleft to the middle: capsule short-ovoid. - Ann. Lyc. N. Y. ii. 222, t. 3, \& Bot. Mex. Bound. 143; Watson, 1. c.-Gypseous soil, Colorado and N. W. Texas to S. Utah and Arizona. (Adjacent Mex.)

Var. Pálmeri, Gray, 1. c. A strict form, apparently from a biennial root, more hirsute and viscid : leaves more acutely sinuate-toothed: inflorescence thyrsoid-contracted.S. Utah, Paliner, Siler, and intermediate forms by Parry and Ward.

P. crenuláta, Torr. A span or two high, often branched from the base and somewhat spreading, viscid-pubescent or hirsute: leaves mainly petioled, spatulate-obong, crenately toothed or pinnatifid, sometimes lyrate and the lowest divisions distinct or nearly so; the lobes crenulate-toothed: spikes soon open and spreading: corolla rotate-campanulate, bright violet or paler; the internal appendages very broad: stamens moderately exserted: style cleft far beyond the middle : capsule globular. - Watson, Bot. King, 251 ; Gray, l. c. - Rocky slopes, New Mexico to Arizona and N. W. Nevada. Flowers commonly deepcolored, half-inch in diameter, and showy, sometimes considerably smaller and paler.

P. glandulósa, Nutt. Viscid-pubescent and glandular, softly if at all hirsute, a span to a foot or more high : leaves irregularly and interruptedly twice pinnatifid, or below divided; the numerous lobes small, oblong, somewhat incised, obtuse : calyx-lobes oblong or spatulate: corolla (2 lines long) bluish, purplish; or white, with lobes shorter than the tube: stamens and 2-cleft style moderately or conspicuously exserted: sceds with the minute reticulations even. - Nutt. Pl. Gamb. 160 (very pubescent and viscid form); Gray, l. c. P. Popei, Torr. \& Gray, Pacif. R. Rep. ii. 172, t. 10 (less pubescent form, with corolla lobes quite entire). Eutoca glandulosa, Hook. Kew Jour. Bot. iij. 293. - Gravelly soil, N. W. Texas and Colorado to Arizona. (Mex.)

Var. Neo-Mexicána, Gray, 1. c. Lobes of the corolla either slightly or conspicuously erose-denticulate. - P. Neo-Mexicana, Thurber in Bot. Mex. Bound. 143. - Colorado and New Mexico.

P. congésta, Hook. Pubescent and commonly cinereous, hardly in the least viscid or glandular, a foot or more high: leaves pinnately 3-7-divided or parted, and with a few interposed small lobes; the main divisions oblong or oval, incisely pinnatifid or irregularly lobed; the lower ones mostly petiolulate and the upper confluent: calyx-lobes linear or somewhat spatulate: corolla blue ( 3 lines long); the lobes as long as the tube: stamens more or less exserted: seeds reticulate-scabrous, the fine sharp meshes being as it were toothed at the junctions. - Bot. Mag. t. 3452 ; A: DC. 1. c. 249 . P. conferta, Don. P. tanacetifolic, A. DC. I. c., as to pl. Tex. Berland. - Margin of thickets, \&c., throughout Texas. Not rarely cultivated.

$==$ Pedicels slender and horizontal, or divisions of calyx 3-5-lobed, much longer than the capsule, villous. Extra-limital species, of Lower California.

P. pedicelláta. A foot or less high, villous or soft-hirsute and glandular: root annual: leaves pinnately 3-5-divided; the divisions oval or oblong, incised and numerously toothed; the lower nearly sessile, the uppermost. confluent or larger and 3-cleft: flowers much crowded in short panicled or cymose-clustered racemes, small : pedicels filiform, about the length of the flower, somewhat deflexed in fruit: calyx-lobes linear or in age oblanceolate, entire, villous (as also the pedicel), hardly twice the length of the globular capsule : corolla apparently white (little over 2 lines long), moderately surpassed by the stamens and 2-cleft style; the internal appendages short and rounded: seeds rugose-reticulated and somewhat tuberculate at maturity. - Lower California, Dr. Thomas H. Streets.

P. phyllománica, Gray. A foot or two high from a rigid (and possibly perennial) base, very leafy, canescent with soft-tomentose and some longer villous pubescence, not glandular: leaves elongated-oblong in outline, pinnately parted or below divided; the divisions 9 to 18 pairs, linear-oblong, pinnatifid; the short lobes 1-2-toothed or entire: condensed spikes thyrsoid-crowded : flowers nearly sessile : calyx-lobes foliaceous, all or 2 or 3 of them pinnately 3-5-parted: corolla violet, a little longer than the calyx; the expanded 
limb 3 lines in diameter: stamens and style slightly exserted: fruit not seen. - Proc. Am. Acad. xi. 87. - Guadalupe Island, off Lower California (beyond our limits), Palmer.

Var. interrúpta, Gray, l. c. Lower, and with pubescence more villous or hirsute: leaves with fewer and sparser divisions (the larger crenately pinnatifid) and some very small interposed lobes. - With the other form.

+ Calyx more or less setose-hispid, in fruit usually much surpassing the capsule; the divisions entire, but often dissimilar: seeds farose-pitted or in age tuberculate: style 2-parted. (Species running together or ditticult to discriminate: leaves mostly 1-3-piunately divided and incised : corolla light violet or bluish, varying to white.)

P. tanacetifólia, Benth. Erect annual, roughish-hirsute or hispid, not glandular, or above slightly so, 1 to 3 feet high: leaves pinnately 9-17-divided into linear or oblonglinear once or twice pinnately parted or cleft divisions, all sessile or nearly so; the lobes mostly linear-oblong: spikes cymosely clustered, at length elongated : very short fruiting pedicels ascending or erect: calyx-lobes linear or linear-spatulate, not twice the length of the ellipsoidal capsule: stamens and style conspicuously exserted: seeds with very narrow pits bounded by thick walls. - Bot. Reg. t. 1696; Bot. Mag. t. $370 ;$; Brit. Fl. Gard. n. ser. t. 360. - California, very common, at least near the coast. Variable in foliage: the var. tenuifolia, Thurber in Bot. Mex. Bound., is a common form, with fine Tansy-like foliage. Common garden annual.

P. ramosíssima, Dougl. About 2 feet high, decumbent or ascending from a perennial root (according to $E$. L. Greene); the branches divergent, pubescent and more or less viscid or glandular, or above hispid: leaves 5-9-divided or parted into oblong or narrower pinnatifid-ineised divisions: spikes glomerate, short and dense, little elongated in age: flowers subsessile and in fruit ascending on the rhachis: stamens and style usually moderately exserted: appendages to the corolla with a merely acute free apex: calyx-lobes from linear-spatulate to obovate, twice or thrice the length of the ovate or short-ovoid capsule: seeds oblong. - Benth. in Linn. Trans. 1. c. 280; IIook. Fl. ii. 80 (but ovary not glabrous in original specimens); Gray, Proc. Am. Acad. x. 319, \& Bot. Calif. i. 508, excl. var. P. tanacetifolia, Thurber in Bot. Mex. Bound. 143. - Washington Territory and Oregon (through the dry interior) to San Diego Co., California, and Arizona. In some forms very near the foregoing.

P. híspida. A foot or less high from an annual root, diffusely branching, hardly viscid, setose-hispid with long and slender white bristles: leaves with fewer and coarser divisions than the preceding, the uppermost sometimes merely laciniate-incised: spikes soon loose and loosely paniculate, 2 or 3 inches long in fruit : flowers nearly all on short but manifest and slender horizontal pedicels: stamens and style equalling or barely surpassing the corolla: calyx-lobes narrowly linear with attenuated base, nearly equalling the corolla, in fruit 4 to 6 lines long and about 4 times the length of the globose capsule: seeds shortoval. - P. ramosissima, var. hispida, Gray, 1. c. - Western part of California, from Santa Barbara to San Diego, Nuttall, Wallace, Torrey, Cleveland. Bristles resembling those of Borage.

P. ciliáta, Benth. Erect or ascending, a span to a foot or more high from an annual root, more or less pubescent or sparingly hirsute above: stems scabrous : leaves pinnately parted, or the lower divided and the upper merely cleft; the divisions or lobes oblong, pinnatifid-incised: spikes rather short and in fruit rather loose: pedicels short or hardly any, ascending: stamens and the 2-parted style shorter than or not surpassing the corolla: appendages of the latter with pointed tips: calyx-lobes from lanceolate to ovate, more or less shorter than the white or bluish corolla, accrescent and becoming venosereticulated in age, then sparsely ciliate with short rigid bristles, 4 or 5 lines long, only twice the length of the ovate mucronate capsule: seedo oval, favose. - Linn. Trans. 1. c.; Gray, 1. c. - California, from the Sacramento and the vicinity of San Francisco to Monterey, apparently in shaded moist soil.

* * Flowers in loose and only slightly scorpioid racemes; the pedicels equalling or surpassing the flowers: appendages of the very open corolla Iong and rather narrow, villous on the edge, approximate between the stamens, from which they are remote: seeds with a rather fleshy obscurely areolate testa.

P. bipinnatífida, Michx. A foot or more high from a slender biennial root, erect, paniculately branched, hirsute-pubescent and above mostly viscid and glandular: leaves slender-petioled, green and thin, pinnately 3-7-divided; the divisions ovate or oblong-ovate, 
acute, coarsely and irregularly incised or pinnatifid; the lower short-petiolulate and the uppermost confluent : racemes loose, 7-20-flowered : pedicels spreading or in fruit recurved: calyx-lobes linear, loose, longer than the globular capsule: corolla rotate-campanulate, violet-blue, over half an inch in diameter, with rather short rounded lobes and very conspicuous internal appendages: stamens (bearded) and style usually more or less exserted. - Fl. i. 134, t. 16; Gray, Man. ed. 5, 369. - Shaded banks of streams, Ohio and Illinois to Alabama: flowering in June.

Var. brevístylis, Gray. A remarkable form, with corolla about one half smaller : style and especially the stamens not exserted. $-P$. brevistylis, Buckley, in Am. Jour. Sci. xiv. (1843) 172. - Alabama, Buckley, Nevius, \&c.

§ 2. Cosuánthus, Gray. Ovules and seeds of Euphacelia: corolla destitute of internal appendages, almost rotate; its lobes fimbriate: filaments (villousbearded) rarely longer than the corolla: ovary villous-hispid at the summit, otherwise glabrous: low annuals, with loosely racemose flowers in the manner of the last preceding species and of earliest of the next section. - Man. Bot. ed. 2, 328, \& 5,369. Cosmanthus, Nolte. Cosmanthus § Eucosmanthus, A.DC. in part.

P. Púrshii, Buckley. A span to a foot high, diffusely branched from the base, sparsely hirsute: cauline leaves pinnately 5-11-parted, the upper closely sessile; lobes oblong or lanceolate, acute: racemes rather many-flowered, sometimes forking: calyx-lobes linear: corolla light blue varying to white (half inch in diameter). - Buckley in Am. Jour. Sci. xlv. 172 ; Gray, Man. 1.c. P. fimbriata, Pursh, \&c. Cosmanthus fimbriatus, Nolte, A.DC. Prodr. ix. 297. - Moist wooded banks, W. Pennsylvania to Minnesota and Missouri, North Carolina and Alabama. - Pedicels filiform, 6 to 10 lines long. Perhaps only a variety of the next. Seeds as in the preceding.

P. fimbriáta, Michx. Weak and diffuse, a span high, less hirsute: cauline 3-7-cleft or lobed or the lower lyrately divided; the lobes obtuse or roundish : racemes ferv-flowered: perlicels filiform : calyx-lobes linear-oblong or spatulate: corolla white (only 3 or 4 lines broad), rather shorter than the stamens. - Fl. i. 134; Gray, Man. l. c. In woods of the higher Alleghany Mountains, Virginia to Alabama; flowering early.

Var.? Boýkini, Gray. More robust, evidently growing in more exposed soil: racemes rather many-flowered, at length strict, with fruiting pedicels erect and not longer than the calyx: corolla far less fimbriate, bluish. - Proc. Am. Acad. x. 320. - Upper part of Georgia, Boykin. Perhaps a distinct species, more likely a state of $P$. fimbriata, growing in a lower and warmer region.

§3. Cosyantroídes, Gray. Ovules and seeds 3 to 8 (rarely only a pair) on each placenta, the latter with reticulated testa: appendages of the rotately or open-campanulate corolla wanting, or very inconspicuous and remote from the stamens: capsule globular and pointless: low annuals of the Atlantic United States, early-flowering, hirsute-pubescent or glabrate, with mostly pinnatifid leaves, the upper closely sessile, simply racemose flowers, and somewhat villous-bearded filaments about the length of the blue or white corolla.

* Ovules 2 to 4 on each (at length decidtous) placenta: globose capsule thin-walled: slender and smoothish little annuals, with the aspect of Cosmunthus, but lobes of the corolla entire, its base with no appendages or only obscure vestiges. - Proc. Am. Acad. x. 320 .

P. glabra, Nutt. Slender, 3 to 8 inches high, glabrous except a few hirsute short hairs chiefly on the margins of the leaves and calyx: corolla 3 or 4 lines in diameter: calyxlobes in fruit little longer than the capsule, mostly oblong or oval: otherwise as in $P$. parviflora. - Trans. Amer. Phil. Soc. n. ser. v. 102 ; Gray, l.c. - Low prairies, Arkansas and Eastern Texas. Very like slender and smoother forms of the next, into which it probably passes. Ovules 4 in some flowers, 5 to 7 or 8 in others.

P. parviflóra, Pursh. A span or more high, sparsely hirsute or glabrate, branched from the base: radical and lowest cauline leaves lyrately pinnate, with 3 to 5 roundish leaflets or divisions, or sometimes simple and entire; the upper mostly sessile and 3-9parted or cleft into oblong or linear-lanceolate lobes : racemes loose, several-many-flowered; 
the spreading filiform pedicels longer than the fruiting calyx : corolla light blue or nearly white, 4 to 6 lines in diameter: calyx-lobes linear or lanceulate, in fruit nearly twice the length of the capsule (this only a line and a half long). - Fl, i.140; Gray, Man. l. c. (Pluk. t. 245, fig. 5.) Polemonium dubium, L. Eutoca partiflora, R. Br. in lichards. App. Frankl. Journ. 36 ; Benth. 1. c. Cosmanthus parviflorus, A.1)C. 1. c. Thacelia pusilla, Buckley, l. c., ex char. - Shaded places, Pennsylvania and Ohio to Carolina, Missouri, and Texas: the south-western and also Virginian forms passing into

Var. hirsúta, Gray. More hirsute and the stems less slender, apparently growing in more open or dry soil: corolla larger, 5 to 7 lines in diameter. - Proc. $\Lambda \mathrm{m}$. Acad. l. c. P. hirsuta, Nutt. 1. c. 191. - Prairies and barrens, south-western part of Missouri to castern Texas. Also similar forms from Giles Co., Virginia, and Stone Mountain, Georgia, Canby. Well developed capsule 2 lines long. Ovules only 4 in some flowers, 8 in others.

* Ovules (and commonly the seeds) about 8 on each placenta: plants stouter, with less divided leaves: restiges of appendages to the corolla sometimes manifest, in the form of very narrow lamellis approximate in pairs between the stamens.

P. patuliflóra, Gray. Rather softly cinereous-hirsute or pubescent, and the inflorescence somewhat glandular, branched from the base, a span to a foot high, erect or diffuse : leaves obovate or oblong (an inch or two long); the lowest lyrate-pinnatifid; the upper commonly only pinnatifid-incised, sessile: racemes lax, at length elongated; pedicels spreading or nodding, especially in fruit, 4 to 7 lines or more long: corolla deep blue with y'llow base, from half to three quarters inch in diameter; the lobes somewhat erose-denticulate : caly $x$ lobes lax or spreading, linear or somewhat lanceolate, occasionally becoming spatulate or obovate, sometimes twice the length of the rather thin-walled capsule.-Proc. Am. Acad. x. 321. Eutoca patuliflora, Engelm. \& Gray, Pl. Lindh. i. 45. Phacelia hispida, Buckley in Proc. Acad. Philad. 1861, 463. - Low prairies and thickets, Texas along and near the coast, Berlandier, Lindheimer, Wright, Buckley, \&c. Capsule $2 \frac{1}{2}$ lines long: placentæ at length deciduous: seeds apparently as in the next.

P. strictiflóra, Gray, 1. c. Shorter and stouter than the preceding, more cinereous-hirsute : leaves rather more pinnatifid (an inch or so long) : racemes in fruit strict and mostly dense, with pedicels erect and not longer than the capsule: corolla similar or ratlıer larger: calyx-lobes usually becoming spatulate: capsule firm-coriaceous (3 lines long): seeds round-oval, minutely alveolate-reticulated and coarsely more or less tuberculate-rugose! Eutoca strictiflora, Engelm. \& Gray, 1. c. - Sand-hills, San Felipe and Austin, Texas, Drummond, Lindheimer, E. Hall. Also Mississippi, Spillman. Perhaps a variety of the last, growing in more exposed soil. Capsule of firmer texture; the placenta inclincd to be adnate. In the seeds alone there is some approach to the character of the Mirrogenetes section.

§4. Gryмoв Ýthes, Gray. Ovules and seeds very numerous on the dilated placentr, descending or nearly horizontal ; the testa favose-pitted: appendirges of the rotate-campanulate corolla wholly absent: cansule ovate and pointed: style 2-parted: very glandular and viscid Californian annuals, with ovate dentate leaves, simple or sometimes geminate loose racemes, and very slender filaments (usually a little bearded at base) about the length of the corolla. - Proc. Am. Acad. x. 321. Cosmanthus § Gymnobythus, A.DC.

P. víscida, Torr. A foot or two high, branching, hirsute at base, very glandular above: leaves ovate or obscurely cordate, doubly or incisely and irregularly dentate (an inch or two long): corolla deep blue with purple or whitish centre, from half to nearly an inch in diameter. - Bot. Mex. Bound. 14?; Gray, 1. c. \& Bot. Calif. i. 513. Eutoca viscida, Benth. in Bot. Reg. t. 1808; Bot. Mag. t. 8572. Cosmanthus viscidus, A.DC. 1. ৬. 296. - Open soil, along the coast of California, from Santa Barbara southward. Calyx-lobes linear or becoming obscurely spatulate, about the length of the abruptly cuspidate-pointed capsule; the firm placentæo of which persist on the valves.

Var. albiflóra, Gray, 1. c., differs only in its white corolla. - Eutoca albiflora, Nutt. Pl. Gamb. 158. - Same range.

P. grandiflóra, Gray, 1, c. Very like the preceding, or disposed to be more hispid and robust: corolla purplish or white, an inch to an inch and a half in diameter. - Eutoca 
grandiflora, Bentl. in Linn. Trans. 1. c. 278. E. speciosa, Nutt. Pl. Gamb. 1. c. Cosmanthus grandiftorus, A.DC. 1. c. - California, from Santa Barbara Co. southward, Douglas, Nuttall, Peckham, \&c. Capsule 4 lines long, the cuspidate persistent and indurated base of the style a line in length.

$\S 5$. Whitc Ávia, Gray. Ovules and seeds numerous or rather few; the testa favose-pitted : appendages of the corolla reduced to 5 small truncate or emarginate scales, one adnate to the inner base of each capillary somewhat exserted filament: style 2-cleft above the middle: Californian annuals, with inflorescence and habit of the preceding section, but less glandular, and with longer petioles and pedicels, and looser racemes, the flowers showy. - Proc. Am. Acad. x. 321.

* Corolla large (purple or blue, varying to white in cultivation), with tube longer than the rounded lobes and much longer than the linear calyx-lobes: placentæ and seeds of preceding section.Whitlavia, Harvey.

P. Whitlávia, Graヌ, 1. c. About a foot high, loosely branching, hirsute and glandular: leaves ovate or deltoid, incisely toothed: corolla with cylindraceous ventricose tube usually an inch long, thrice the length of the lobes: appendages to the filaments hairy. - Whitlaria grandiflora (and W. minor), Harvey in Lond. Jour Bot. v. 312, t. 11, 12; Bot. Mag. t. 4813. - S. California, Coulter, \&c. Cultivated as an ornamental amnual.

P. campanulária. Lower: leaves subcordate, less deeply dentate: tube of the truly campanulate corolla half inch long, expanded at throat, barely twice the length of the lobes: appendages to the filaments glabrous and smaller; otherwise much resembles the preceding, and almost as showy. - S. California, San Bernardino Co., Parry and Lemmon. San Diego Co., Cleveland.

* Corolla rotate-campanulate, deeply-lobed, hardly twice the length of the narrow calyx-lobes: racemes very loose: pedicels filiform, widely spreading: herbage hirsute or somewhat hispid and glandular.

P. Párryi, Torr. A span or two high, rather slender: leaves ovate, irregularly and incisely doubly toothed or laciniate, or the lowest sometimes pinnately parted; the upper cauline longer than their petioles: corolla cleft beyond the middle, deep violet, two-thirds inch in diameter : filaments bearded: ovules on each placenta 20 or 30 and seeds 15 to 20 . — Bot. Mex. Bound. 144; Gray, l.c. - California, near Los Angeles and San Diego, Parry, Cooper, Davidson, \&c.

P. lónglpes, Torr. Slender, loosely branched: cauline leares roundish-oval or subcordate, coarsely and obtusely 5-8-toothed, about half inch long, all shorter than the petioles: corolla hardly half an inch long, apparently white, 5-cleft barely to the middle; ovules on each placenta 8 or 10, and the seeds fewer - Gray, l. c. - Santa Barbara Co., California, Torrey.

§6. Eútoca, Gray. Ovules and seeds several (6 to 12) or more numerous on each placenta; the testa areolate-reticulated or favose-pitted, but not transversely rugose: appendages of the mostly campanulate corolla in the form of 10 vertical salient lamellæ: capsule ovate or oblong. (Chiefly occidental, one or two boreal ; habit very various, several distinguished from analogous Euphacelice, \&c., only by the ovules and seeds.) - Man. ed. 2, 329, \& Proc. Am. Acad. x. 322. Eutoca, R. Br., excl. spec. Eutoca § Ortheutoca, A.DC.

* Perennials, or annuals, with conspicuously (in $P$. Bolanderi and $P$. Mohavensis more slightly) exserted stamens and dense scorpioid inflorescence: appendages of the open-campanulate corolla conspicuous and usually broad, more or less oblique, at base united in pairs with or across the base of the filament, forming a kind of sac behind it.

- Root annual: spikes solitary terminating the branches, or geminate: ovules only 4 to 9 on each placenta: anthers oval.

+- Low, a span or more high, diffusely branched, merely hirsute and with finer somewhat viscid pubescence: leares from ovate-oblong to linear-lanceolate, entire or rarely 1-2-toothed or incised, tapering at base into a short petiole: appendages to the corolla elongated-oblong and adnate up to the truncate summit: capsule ovate, acute.

P. Mohavénsis. Barely a span high: leaves lanceolate or the lowest linear-oblong (about an inch long): racemes at length an inch or two long and strict : short pedicels erect: 
calyx-lobes spatulate-linear: glabrous filaments and 2-parted style (3 or 4 lines long) slightly surpassing the purple corolla: ovules only 4 or 5 to each placenta. - South-eastern Califurnia, on the Mohave River, May, 1876, Palmer. Habit somewhat of $P$. Mlenziesii, but lower, more diffuse, less hispid, and with different appendages to the corolla, this fully 4 lines long.

Var. exílis, a slender form, more erect: leaves and calyx-lobes all linear and slightly broader upward: corolla only 3 lines long: seeds as in the next species. - Bear Valley on the Mohare slope of the San Bernardino Mountains, California, Parry \& Lemmon.

P. grísea, Gray. A span or two high, more cinereous with a sparse hirsute and a close finer pubescence, rather stout: leaves ovate or oblong: spikes more densely hirsute or even hispid, at length 4 to 6 inches long, densely flowered : calyx-lobes obovate-spatulate, little exceeding the capsule: corolla nearly white: filaments and 2-cleft style conspicuously exserted; the former minutely and sparsely retrorsely papillose or hirsute: ovules 5 or 6 to each placenta : seeds coarsely alveolate. - Proc. Am. Acad. xii. 80. - IV. California, on Pine Mountain, back of San Simeon Bay, Palmer, 1876.

* + Taller, setose-hispid; leaves pinnatifid and incised, petioled: appendages to the corolla large, free and pointed at apex.

P. loasæélia, Torr. A foot high, somewhat viscid-pubescent as well as hispid with long and stiff spreading bristles: leaves ovate or oblong, rarely subcordate, more or less pinnatifid, and the lobes acutely toothed or incised: spikes geminate : corolla short-campanuIate ( 3 lines long), little exceeding the linear-spatulate calyx-lobes; its internal appendages transverse and auriculate-incurved, with the free apex acuminate or cuspidate: naked filaments and 2-parted style conspicuously exserted: ovules 6 to 9 on each placenta: seeds angled, alveolate. - Bot. Mex. Bound. 1. c. ; Gray, Proc. Am. Acad. x. 323, \& Bot. Calif. i. 509. Eutoca loascefolia, Benth. 1. c. - California, near Monterey, Douglas, Parry. Little known, in aspect between $P$. malvafolia and $P$. ramosissima.

++ Root probably perennial : scorpioid inflorescence at length open and geminate-racemose: ovules and seeds about 50 on each dilated placenta: stamens hardly surpassing the very open corolla : leaves conspicuously petioled, incised.

P. Bolánderi, Gray. Hispid with slender bristles, also viscid-pubescent, especially above: stem stout, erect, a foot or two high, freely branching: radical and lower cauline leaves lyrate and oblong in outline, with one or two pairs of small and incised lateral divisions; the terminal division and the short petioled upper leaves ovate or oval ( 2 or 3 inches long), coarsely incised or lobed, truncate or subcordate at base: corolla nearly rotate when expanded and almost an inch in diameter, white; its appendages semi-obovate, almost as broad as long, distinctly connected at base in front of the adnate and sparingly bearded filaments: anthers oblong: style cleft nearly to the middle : capsule broadly ovate, acute, shorter than the lanceolate or at length spatulate lobes of the calyx. - Proc. Am. Acad. x. 322, \& Bot. Calif. i. 509. - Cottonaby Creek, 20 miles north of Noyo, Mendocino Co., California, Bolander. Lowest leaves 4 inches long, exclusive of the petiole. Cymes once to thrice forked; the short racemes at length open: pedicels 1 or 2 or sometimes the lower 3 lines long. Calyx 3 or at length 4 lines long, decidedly shorter than the ample corolla.

+++ Root perennial: spikes of the congested cyme once to thrice geminate or crowded at the summit of a terminal peduncle, short and densely-flowered: ovules and seeds rather few: appendages of the corolla very broad and obtuse: stamens and style conspicuously exserted: anthers linear or oblong: leaves all petioled, incisely lobed.

P. hydrophylloídes, Torr. A span or two high from slender subterranean shoots proceeding from a thickened stock or root, canescently pubescent, and above hirsute or hispid as well as glandular: leaves silky-pubescent both sides, slender-petioled, ovate or rhomboidal, an inch or two long, obtuse, incisely few-toothed or lobed, or sometimes the lowest lyrate, having one or two nearly detached small basal lobes or divisions: short spikes or racemes of the glomerate cyme not elongating: corolla violet-blue or whitish; its appendages semi-oval, united at base with that of the naked filament: anthers shortlinear: style almost 2-parted : capsule about the length of the calyx, abruptly mucronatepointed: seeds 6 to 8, angled. - Gray, Proc. Am. Acarl. vii. 400, x. 32?, \& Bot. Calif. 1. c.Dry sandy or gravelly soil in the Sierra Nevada, California, at 5-9,000 feet, from Mariposa to Sierra Co., Brewer, Bolander, Lemmon, \&c. Corolla 3 or 4 lines long: the appendages as in the following species, but hardly connected in front of the base of the filament. 
P. prócera, Gray. Erect, 3 to 7 feet high, minutely soft-pubescent; the summit of the simple stem glandular, but even the caly $\mathrm{x}$ not hispid: leaves green and membranaceous, 2 to 5 inches long, ovate-lanceolate and ovate, acute, mostly laciniate-pinnatifid or cleft; the lobes 2 to 4 pairs and acute: spikes of the glomerate or bifid cyme somewhat lengthened with age : corolla white or bluish; the semi-obcordate oblique appendages united over the base of the sparsely bearded filament : anthers oblong: style 2-cleft above the middle: capsule globular-ovate, hardly mucronate: seeds 10-18, wing-angled. - Proc. Am. Acad. x. 323, \& Bot. Calif. j. 509. - In mountain meadows of the Sierra Nevada, California, Nevada to Siskiyou Co., Bolunder, Lemmon, Greene. Flowers at length very short pedicelled: corolla cleft to the middle.

* * Perennial, with long exserted stamens and spiciform-thyrsoid inflorescence: appendages of the campanulate marcescent-persistent corolla conspicuous, oblong, rertical, wholly free from the filament : ovules moderately numerous.

P. serícea, Gray. A span to a foot high from a branching caudex, silky-pubescent or canescent, or the simple virgate stems and inflorescence villous-hirsute, rather leafy to the top : leaves pinnately parted into linear or narrow-oblong numerous and often again fewcleft or pinnatifid divisions, silky-canescent or sometimes greenish; the lower petioled; the uppermost simpler and nearly sessile: short spikes crowded in a naked spike-like thyrsus : corolla violet-blue or whitish, very open-campanulate, cleft to the middle : anthers short-oval: style 2-cleft at the apex: capsule ovate, short-acuminate, a little longer than the caly $\mathrm{x}$ and marcescent-persistent corolla, 12-18-seeded : seeds oval-oblong, terete, acutish, longitudinally costate and transversely alveolate, reticulated. - Am. Jour. Sci: ser. 2, (1862) xxxiv. 254, \& Proc. l. c.; Watson, Bot. King, 252. Eutoca sericea, Grahan ; Hook. Bot. Mag. t. 3003; \& Fl. ii. 79. E. pusilla, Lehm. Pugill. - Higher mountains of Colorado and Nevada, and north to British Columbia and the arctic region. Corolla 3, and stamens and style 7 to 10 lines long. Shallow alveolations of the seed in vertical rows.

Var. Lyállii, Gray. Low, less silky : leaves green and sparsely hirsute-pubescent, more simply pinnatifid; the lobes short and broad : inflorescence thyrsoid-capitate. - Proc. Am. Acad. x. 323. - Rocky Mountains in lat. 49\%, at 6-7,000 feet, Lyall, \&c.

* * Annuals, with stamens about the length of the rotate-campanulate corolla, and the densely-
flowered spikes or spike-like racemes thyrsoid-cymose or paniculate: appendages of the corolla
long and narrow, free at apex, and at base free from the (glabrous or slightly hairy) filaments:
anthers short: calyx-lobes linear: style 2-cleft at apex : capsule ovate, acuminate or acute.

P. Franklinii, Gray. A span to a foot or more high, soft-hirsute or pubescent: stem erect, simple or corymbose at summit: lower leaves petioled and pinnately or somewhat bipinnately divided or parted into numerous and short linear-oblong divisions or lobes, the upper sessile and less divided: spikes cymose-glomerate or crowded, little elongated in age : corolla pale blue or almost white : ovules 40 or more: capsule about the length of the calyx : seeds oval, minutely alveolate in vertical lines (nearly as in $P$. sericea, but the lines less conspicuous). - Man. ed. 2, 329, \& ed. 3, 370. Eutoca Franklinii, R. Br. 1. c. t. 27 ; Hook. Bot. Mag. t. 2985. - Shores of Lake Superior to Bear Lake, and on Snake River, southwestern Idaho.

P. Menziésii, Torr. A span to it foot high, at length paniculate-branched, hispid or roughish-hirsute, usually also minutely cinereous-pubescent: leaves mostly sessile, linear or lanceolate and entire, or some of them deeply cleft; the lobes few or single, linear or lanceolate, entire: spikes or spike-like racemes thyrsoid-paniculate, at length elongated and erect: corolla bright violet or sometimes white: ovules 12 to 16 : capsule shorter than the calyx : seeds oblong, coarsely favose-reticulated. - Watson, Bot. King, 252. HydrophylIlm lineare, Pursh, Fl. i. 134. Eutoca Menziesii, R. Br. 1. c. t. 27, fig. 1-5; Hook. Fl. l.c. \& Bot. Mag. t. 3762 ; Brit. Fl. Gard. ser. 2, t. 334. E. multiflora, Dougl. in Lehm. Pugill. \& Bot. Reg. t. 1180. E. heterophylla, Torr. in Stansb. Rep. - Open soil, Montana to Utah, and west to British Colunbia, Oregon, and the Sierra Nevada in California. Very floriferous and handsome : corolla half to three-fourths of an inch in diameter.

* * * * Annuals, with stamens shorter than (in $P$. divaricata sometimes equalling) the corolla, and spiciform or racemiform inflorescence.

+ Leaves pinnately compound, and seeds excavated and ridged on the ventral face, in the manner of $P$. congesta, tanacetifolia, \&c.

P. infundibulifórmis, Torr. A foot or so high, villous-hirsute or somewhat hispid, . viscid-glandular : leaves all petioled and pinnately divided; the divisions 5 to 11 , oval or 
oblong, incisely pinnatifid; the short lobes very obtuse or retuse, sometimes 1-2-lobed: spikes mostly cymose or geminate, elongated in fruit, dense; the pedicels very much shorter than the calyx: corolla pale purple or white, funnelform : the rounded and somewhat erose lobes not half the length of the tube; its appendages narrow-oblong, free from the stamens : ovules 8 to 12 on each dilated placenta: style 2-cleft at the tip : capsule oblong, very obtuse or retuse, membranaceous, about the length of the narrow spatulate calyx-lobes: seeds (about 20) oval, reticulated. - Bot. Mex. Bound. 144. - New Mexico, near the Santa Rita copper mines, Wright, Bigelow (and south into Chihuahua, Bigelow). Habit of $P$. congesta, \&c. Corolla nearly 3 lines long, narrow. Capsule 3 lines long.

$$
++ \text { Leaves simply pinnatitid ; the lobes short and obtuse. }
$$

+ Flowers crowded in at length elongated spikes : corolla small, white or nearly so.

P. brachyloba, Gray. A foot or two high, erect, roughish-pubescent, viscid-glanaular above: leaves elongated-oblong or spatulate, short-petioled; the 7 to 15 lobes entire or obtusely few-toothed: spikes solitary or geminate, at length much elongated and slender: pedicels very short : corolla campanulate; the lobes about half the length of the tube; its long and narrow appendages nearly free from the stamens: ovules about 6 on each placenta: style 2-cleft above the middle: capsule oblong-oval, very obtuse, membranaceous, shorter than the narrow spatulate caly $x$-lobes : seeds oval, reticulated. - Proc. Am. Acad. x. 324, \& Bot. Calif. I. c. Eutoca brachyloba, Benth. l.c. - California, near Monterey and Santa Barbara (Douglas, Brewer, Torrey), to San Diego Co. (Cleveland) and the Mohave region, Palmer.

++ +- Flowers loosely racemose, long-pedicelled : corolla (blue or purple or varying to white) opencampanulate, twice the length of the calyx; the appendages elongated, nearly free from the base of the usually sparsely bearded filament: low and diffuse, a span or less high, with the leaves mostly at or near the base.

P. Douglásii, Torr. Diffuse, pubescent and hirsute with mostly spreading hairs: leaves elongated-oblong or linear in outline, pinnatifid or pinnately parted into several or numerous pairs of lobes; the terminal lobe not larger nor parallel-veined: racemes at length elongated: pedicels filiform, mostly longer than the flower: calyx-lobes spatulate: appendages to the tube of the ample corolla semi-oblanceolate: style 2-cleft above the middle: ovules to each dilated placenta 12 to 14 : capsule ovate, mucronate : seeds rourdish-oval, scrobiculate. - Bot. Mex. Bound. 14:3 ; Gray, 1. c. Eutoca Douglasii, Benth. 1. c. - California, apparently rather common in the western part of the State south of Monterey. Habit somewhat of Nemophila insignis. Pedicels half an inch to an inch long, spreading. Corolla generally half an inch high, and proportionally broad when expanded.

P. Davidsónii, Gray. Resembles the preceding, but more hairy and hoary, the foliage with strigose, the racemes and calyx witlı villous-hirsute and spreading pubescence : leaves deeply pinnatifid into 2 to 4 triangular entire lateral lobes and a much larger oblong terminal one, the evident veins of which are nearly parallel with the midrib (in the manner of $P$. humilis and of the succeeding); some of the upper leaves occasionally entire : pedicels seldom longer than the fructiferous calyx, in age inclined to be recurved-ascending or sigmoid : calyx-lobes narrowly spatulate: appendages to the tube of the corolla semi-oval: ovules to each placenta 8 or 10. - Proc. Am. Acad. x. 324, \& Bot. Calif. i. 510, a depauperate and small-flowered form. - California, in Kern Co., Prof. Davidson, the small form above mentioned. San Bernardino Co., a larger form, with flowers fully the size of $P$. Douglasii, and limb or lobes of the corolla bright purple, Parry and Leminon.

++ Leaves entire (or the lower rarely 1-2-Iobed or toothed), petioled, not fleshy nor cordate, the reins somewhat parallel or converging: pubescence not glandular: flowers spicate-racemose: calyx hirsute or hispid with long spreading hairs: appendages of the tube of the corolla broader at base and united with the base of the (usually pubescent or sparsely bearded) filaments : capsule ovate, acute or mucronate, $6-16$ calyx-lobes: seed with favose-pitted or scrobiculate testa.

+ Corolla narrow, somewhat funnelform, little longer than the calyx, apparently pale or white, much exceeding the stamens.

P. circinatifórmis, Gray, 1. c. Erect, a span or so high, hispid and puberulent : leaves ovate and oblong-lanceolate, parallel-veined, somewhat strigose-hispid : racemes or spikes dense : style 2 -cleft above the middle : ovules 4 (or rarely more) to each placenta. - Éutoca phacelioides, Benth. 1. c. - California, Douglas (from whose collection only is the species yet known), probably from the vicinity of Monterey. Aspect of a small form of $P$. circinata. Corolla $2 \frac{1}{2}$ to 3 lines long. Fruiting calyx 5 lines long. 

++ Corolla broadly open-campanulate, violet or blue, not rarely nearly equalled by the stamens
and style.

P. cúrvipes, Torr. Diffuse, 2 to 4 inches high, hirsute and puberulent: leaves from oval to lanceolate, mostly shorter than the slender petiole: racemes simple, at length loose, the lower pedicels as long as the calyx : style cleft to the middle: ovules 8 or 10 to each placenta. - Watson, Bot. King, 252; Gray, 1. c. - Foothills of the desert region, W. Nevada (Carson City, Watson), and Owens Valley, California, Dr. Horn. Habit of $P$. humilis. Blade of the leaf 6 to 10 lines long. Corolla barely 3 lines high. Hispid calyx in fruit becoming 4 and 5 lines long. Pedicels from a line to 5 lines long in fruit; the lowest sometimes sigmoid-curved (deflexed and then ascending); and petiole sometimes "more or less abruptly curved," whence the specific name, which ordinarily seems rather inappropriate.

P. divaricáta, Gray, 1. c. Diffusely spreading, a span high, more or less hirsute and pubescent : leaves ovate or oblong, mostly longer than the petiole, occasionally 1-2-toothed or lobed at base, the veins curving upwards : spikes or racemes at length loose; the pedicels usually much shorter than the calyx: style 2-cleft at the apex: ovules 12 to 20 on each placenta (or rarely fewer ?). - Eutoca divaricata, Benth. 1. c. ; Lindl. Bot. Reg. t. 1784; Hook. Bot. Mag. t. 3706 . E. Wrangeliana, Fisch. \& Meyer; Don, Brit. Fl. Gard. ser. 2, t. 362, a form (var. Wrangeliana, A.DC.) with leaves inclined to be lobed or 1-2-toothed. - California, common about San Francisco Bay. Leaves 1 to 3 inches long. Flowers pretty large; the expanded corolla often three-fourths of an inch broad.

\footnotetext{
++++ Leaves entire or somewhat crenate-lobed or toothed, slender-petioled, the veins divergent or commonly obsolete: pubescence viscid or glandular: corolla narrow-cainpazulate or somewhat funmelform, the appendages of the tube linear or oblong and nearly free from the unequal glabrous filaments: style 2-cleft only at the apex. (Species peculiar to the interior desert region.)

+ Flowers and the very dense short spikes closely sessile: calyx equalling the narrow corolla: leaves thickish, spatulate-oblong.
}

P. cephalótes, Gray, l. c. Divaricately branching from the very base, nearly prostrate, more or less viscid-pubescent and the calyx, \&c., hispid-hirsute : leaves chiefly radical and at the bifurcations, apparently fleshy-coriaceous, nearly veinless, oblong or spatulate, entire (about half an inch long and tapering into the commonly longer petiøle): sessile spikes or heads radical and in all the forks, at length oblong: calyx-lobes spatulate-linear, twice the length of the oval obtuse 8-10-seeded capsule: seeds with a lax cellular-reticulated pellicle. - P. curvipes, Parry in Am. Naturalist, ix. 16, not Torr. - Southern Utah, Bishop, Mrs. Thompson, Parry. Corolla 2 lines long, cylindraceous, white or yellowish, with the short limb blue or purplish; the internal appendages linear. Earliest spike radical, much shorter than the subtending leaves; the first internode of the prostrate branches 2 to 4 inches long.

+4 Flowers not so crowded, more or less racemose: calyx conspicnously shorter than the somewhat open-fumnelform or campanulate corolla, a little longer than the obtuse capsule: leaves thickish, apparently fleshy-coriaceous, roundish or oval, the veins mostly obscure.

P. demíssa, Gray, 1. c. Diffusely branched from the base, less than a span high, viscidpuberulent or glabrate: leaves from orbicular to obscurely reniform or subcordate, entire or repand, half inch in diameter: flowers rather few and short-pedicelled in a sessile or very short-peduncled spike which is mostly shorter than the petioles and the internodes of the branches: corolla apparently white, barely 2 lines long, little exceeding the linear calyx-lobes; its short appendages narrowly oblong : capsule (2 lines long) short-oval, very obtuse, about 10 -seeded : seeds oblong, proportionally large, alveolate-reticulated. - New Mexico, Palmer.

P. pulchélla, Gray, 1. c. Diffusely branched, barely a span high, merely viscid-puberulent: leaves roundish-ovate or obovate, entire or crenate-toothed, obtuse or acutish at base, half an inch or less in length: flowers numerous in the at length elongated panicled racemes : pedicels mostly shorter than the calyx : corolla deep purple (with a yellowish base), commonly thrice the length of the spatulate calyx-lobes: capsule narrowly oblong, very obtuse, about 30-seeded. - P. crassifolia, Parry in Am. Naturalist, 1. c., not Torr. - Southern Utah, on gypseous clay knolls, Parry. A showy vernal species. Corolla 4 or 5 lines long, with an ampler limb than in the related species; the appendages conspicuous, semi-oval. Seeds not half the size of those of the preceding species, short-oval, pitted. 
P. pusilla, Torr. Very suall, not over 3 inehes high, simple or loosely branching, glandular-pubescent: leaves broally oval or oblong, entire, a quarter to half an inch long: flowers few in a loose raceme, on filiform pedicels : corolla white, not twice the length of the narrow linear or obscurely spatulate calyx-lobes: capsule narrow-oblong, obtuse and mucronulate, 18-24-seeded. - Watson, Bot. King, 25:; Griy, 1. e. - Western part of Nevada to the borders of California, "under sage-brush and junipers," Ir atson. Corolla hardly but capsule fully 2 lines long. Seeds somewhat pyriform, roughish-scrobiculate. Pedicels 1 to 5 lines long.

+++ Flowers loosely racemose in fully developed inflorescence: calyx shorter than the campanulite corolla, rather longer than the short-pointed capsule : leaves round-cordate and crenately lobed or repand, obscurely palmately veined.

P. rotundifólia, Torr. Diffusely branched, 2 to 4 inches high, glandular-hirsute : leaves crenately 7-13-toothed or cven lobed, mostly with a deep-cordate base (a quarter to a full incl long), usually much shorter than the petiole: pedicels shorter than the linear-spatulate calyx-lobes : corolla white: style obscurely 2-cleft at apex: capsule oval-oblong, abruptly pointed, 60-100-seeded. - Watson, Bot. King, 253; Gray, 1. c. - S. E. borders of California, near Fort Mohare, to \&. Utah and Arizona, Cooper, Palmer, Parry. Corolla '2 lines long. Capsule 2 lines long. Seeds globular, scrobiculate.

§7. Microgénetes, Gray. Ovules and seeds of the preceding section; but the latter oblong and strongly corrugated transversely (vermiculiform!) : style 2-cleft only at the apex : stamens unequal, included : corolla with internal appendages present or rarely wanting: low annuals, all W. American: leaves mostly pinnatifid. - Proc. Am. Acad. x. 326.

* Corolla short, almost rotate; the appendages 10 transverse plicæ in the throat, remote from the stamens! - \$ Belminthospermum, Torr. in herb.

P. micrántha, Torr. Slender, paniculately branched, a span or more high, minutely hirsute-glandular: leares membranaceous, pinnately parted into 5 to 9 obovate or oblong very obtuse and mostly entire lobes; the lower with margined petiole, the upper with dilated and sometimes auriculate partly clasping base: racemes geminate or panicled, very loose: pedicels as long as the calyx: corolla (bright blue with a yellowish tube, or sometimes pale) little exceeding the obovate or spatulate and enlarging calyx-lobes : capsule globular, obtuse, 20-24-seeded. - Bot. Mex. Bound. 144; Gray, 1. c., \& Bot. Calif. i. 511. - New Mexico and Arizona, from the Rio Grande near El Paso to S. Ltah, and the borders of California. Corolla barely 2 lines in diameter when expanded: no vertical appendages at the base of the stamens and on the intermediate veins, but a pair of completely transverse short and narrow folds high upon the short tube, stretching from the midvein of each lobe nearly to the lateral vein which springs from near its base. Style short, glabrous. Calyx in fruit 2 lines long. Seeds cylindraceous, incurved, very deeply rugose transversely and tuberculate.

* Corolla funneliorm or cylindraceous; the appendages vertical, long and narrow, united more or less to the base of the filaments (in the Chilian $P$. Cumingii obsolete): style more or less hairy below in our species : seeds minutely reticulated as well as coarsely corrugated: leaves chiefly pinnatifid, and the petioles naked. - Microgenetes, A.DC. Prodr. ix. 202. Phacelia § Euglypta, Watson, Bot. King, l. c.

+ Corolla white or pale purple, slightly longer than the little-dilated calyx-lobes, 2 or at most 3 lines long.

P. Ivesiána, Torr. About a span high, diffusely much branched from the base, hirsutepubescent and glandular: leaves pinnately parted into 7 to 15 linear or oblong and entire or incisely few-toothed lobes, rarely bipinnatifid: racemes loose, 6-20-flowered: narrow appendages of the corolla adnate to the filament only at base: capsule oblong, 16-24seeded. - Ives Colorad. Exped. Bot. 21; Watson, Bot. King, 2.). - Ctah, Nevada, and Arizona, from Salt Lake to the soutl-eastern horders of California. This species most resembles $P$. Cumingii, the ificrogenetes Cumingii, A.DC. Narrow calyx-lobes becoming 3 or 4 lines long, and conspicuously surpassing the capsule. Seeds over half line long, strongly rough-corrugated.

++ Corolla conspicuously longer than the calyx; the limb violet or blue-purple; the throat and tube yellow or whitisly. 
+- Leaves deeply once or twice pinnatifid: short fruiting pedicels erect: corolla half inch long: pubescence minute, more or less viscid.

P. Fremóntii, Torr. l. c. A span to a foot high, much branched from the base: leaves once pinnatificl into 7 to 15 oblong or obovate entire or obtusely $2-\hat{p}$-lobed divisions: flowers crowded in the at length elongated spiciform raceme: corolla broadly funnelform, double the length of the spatulate calys-lobes; the long and narrow appendages united below with the filament or almost free from it : capsule oblong: seeds 20 to 30 , strongly and somewhat evenly corrugated. - Watson, Bot. King, 253; Gray, 1. c. - S. Utah and Nevada to W. Arizona and Kern Co., California.

D. bicolor, Torr. 'Lower and more diffuse: leaves pinnately parted and the divisions again irregularly pinnatifid into small nearly linear lobes : spiciform racemes loosely 10-20flowered: corolla narrowly funnelform (sometimes 7 lines long), thrice the length of the narrowly linear and obscurely spatulate calyx-lobes; the long and narrow appendages united for more than half their length with the filament, forming a long tubular cavity behind it: capsule oval-oblong: seeds about 16 , shorter, minutely corrugated. - Watson, Bot. King, 255; Gray, l. c. - W. Nevada and adjacent parts of California in the Sierra Nevada, first collected by Anderson. The handsomest of the section.

$$
+ \text { Leaves merely pinnatifid-dentate: corolla only } 3 \text { or } 4 \text { lines long. }
$$

P. gymnóclada, Torr. Diffusely branched from the base, a span or less high, somewhat viscid-pubescent; the primary branches decumbent and with long naked internodes: leaves obovate or oblong, obtuse, coarsely and obtusely toothed (an inch or less long), mostly shorter than the petiole: spike several-flowered: short-funnelform corolla (rarely white) not twice the length of the linear or obscurely spatulate-hirsute calyx-lobes; its appendages united with the lower part of the filament: capsule globose-ovate, 8-16-seeded. - Watson, 1. c.; Gray, l. c. - W. Nevada and E. California, in the foothills of the Sierra Nevada and Humboldt Mountains, Watson, Lemmon.

P. crassifólia, Torr. Diffusely branched from the base, 3 or 4 inches high, viscidpubescent: leaves somewhat fleshy, oblong-ovate, scabrous ( 3 to 6 lines long), tapering into a short petiole; the lower with a few short obtuse teeth; the cauline entire: racemes rather loosely few-flowered; the short pedicels spreading: funnelform corolla fully twice the length of the linear calyx-lobes; the obscure appendages free from all but the very base of the filament: capsule ovoid, 6-8-seeded. - Watson, Bot. IKing, 255. - Reese River Valley, Nevada, Watson. Seeds rather strongly rugose, oblong, lialf a line long.

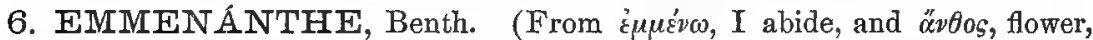
the corolla persisting.) - Low annuals (of California and Nevada), with much the habit and general character of certain sections of Phacelia, but the yellow or cream-colored campanulate corolla persistent (not carried off by the enlarging capsule). - Gray, Proc. Am. Acad. x. 328, \& Bot. Calif. i. 514.

§1. Mintítzia, Gray. Diffuse or depressed, and with the general characters of Phacelia § Microgenetes, except the persistent corolla : flowers small : calyxlobes broader upward: seeds more or less rugose transversely or obliquely, as well as minutely reticulated. - Miltilzia, A.DC. Prodr. ix. 296.

* Corolla bright yellow, merely 5-lobed, exceeding or at least equalling the calyx both in blossom and fruit, withering.persistent and enclosing the capsule; the tube within mostly with 10 narrow appendages: style persistent: herbage pubescent.

E. parviflóra, Gray. Depressed, densely pubescent and viscid : leaves deeply pinnatifiả : flowers crowded in short spikes or racemes, on very short pedicels : corolla not longer than the linear obscurely spatulate calyx-lobes: style hardly longer than the ovary : ovules 20 to 40 : seeds 15 to 20 . - Pacif. R. Rep. vi. 85, t. 15. - Shores of Klamath Lake, borders of California and Oregon, Newberry. Specimen poor. Except for the greater number of ovules and the shorter style (which may be inconstant), this would be referred to the next.

E. lútea, Gray. Diffusely branched, decumbent-spreading, more minutely pubescent, somewhat viscid but hardly or slightly glandular : leaves oblong or obovate, incisely fewlobed or toothed or pinnatifid: flowers rather crowded in short racemes; the lower pedicels often longer than the calyx: corolla exceeding the spatulate-linear calyx-lobes : style 
filiform, much longer than the ovary : ovules about 12. - Eutoca? lutea, Hook. \& Arn. Bot. Beech. 373; Hook. Ic. t. 35t. Miltitia lutea, A. DC. 1. c. Emmenanthe parviflora, Watson, Bot. King, 257, not Gray. _ S. E. borders of Oregon (Tolmie), and W. Nevada to the borders of California, Anderson, I"atson, Lemmon. Corolla nearly 3 lines long: the lincar appendages (like those of many Phacelia) plainly discernible in this and the preceding, but readily overlooked, slightly confluent below with the adnate base of the filaments. Hypogynous disk conspicuous, saucer-shaped, much larger and more free than in the preceding.

E. glandulífera, Torr. Very slender, :3 or 4 inches ligh, diffusely loranched, minutely glandular-pubescent and viscid: leaves"small (a quarter to half inch long), oblong or spatulate, incisely few-toothed or the upper entire: flowers numerous in slender spikes or racemes, mostly on very short pedicels : corolla narrow-campanulate, exceeding the linear calyx-lobes: style filiform: ovules 6 to 12. - Watson, Bot. King, l. c. - W. borders of Nevada, Anderson, Watson. Corolla 2 lines long: the appendages not found. Probably a mere form of the preceding.

* Corolla apparently nearly white, 5-cleft, short-campanulate, usually shorter than the calyx and capsule, investing the base of the latter at maturity, its internal appendages not mauifest: leaves mostly entire: capsule 8-10-seeded.

E. glabérrima, Torr. Tholly glabrous and glandless, diffuse or decumbent, a span or less high, much branched : leaves thickish, somew hat succulent, oblong-spatulate or obovate, entire, or the lower incisely 2-4-toothed (half an inch or more long), tapering into the petiole: flowers few or several, in short or at length elongated often geminate spikes or racemes; the short pedicels appressed: corolla not exceeding the spatulate or oblong thick calyx-lobes: style not longer than the wholly glabrous ovary: ovules 8 or 10: capsule pointed with the subulate indurated base of the style. - Watson, Bot. King, l. c. - Nevada, in the lower Humboldt and Reese River Valleys, Watson. Also N. Arizona, Newberry, being, according to Watson, the Eutoca aretioides of the botany of the Ives Expedition.

E. pusillla, Gray. Pubescent, an inch or two high, at length diffusely branched : leaves spatulate or oblong-lanceolate, entire or nearly so ( 2 to 5 inches long), tapering into a petiole of equal length: peduncles slender, loosely and racemosely 3-7-flowered; the earliest ones scapiform: pedicels spreading: corolla about half the length of the linear obscurely spatulate calyx-lobes and of the ovoid very blunt capsule: style very short, at length deciduous. - Proc. Am. Acad. xi. 87, \& Bot. Calif. i. 515. - North-western Nevada, Watson, Lemmon. Caly $\mathrm{x}$ in blossom one line, in fruit 2 lines long.

§ 2. Eunexaxтhe proper. Erect, with comparatively large and very broad cream-colored corolla : divisions of the caly $\mathbf{x}$ ample and broader downward (ovatelanceolate) : style deciduous: placentæ conspicuously dilated in the axis: seeds somewhat rugosely alveolate-reticulated.

E. penduliflóra, Benth. A span to a foot high, villous-pubescent and somewhat viscid: leaves pinnatifid into numerous short and somewhat toothed or incised lobes: racames panicled, mostly short and loose, at base occasionally bracteate: pedicels filiform, as long as the at length pendulous flowers: filaments slightly adnate to the very base of the broadly campanulate corolla: ovules about 16. - Linn. Trans. xvii. 281. - California, not rare from Lake Co. to San Diego, and east to S. Utah. (South to Guadalupe Island.) Corolla 5 lines Iong, with short rounded lobes, and no trace of internal appendages. Seeds oblong-oval, a line long.

7. CONÁNTHUS, S. Watson. Eutoca? § Conanthus, A.DC. (Name not

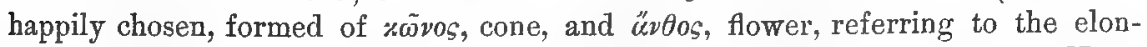
gated funnelform corolla.) - A single species, which would be referred to Nara except for the united styles; the flowers apparently 2-3-morphous as to length and insertion of style and stamens.

C. aretioídes, Watson. A small and depressed winter-annual, 2 or 3 inches high, repeatedly forked from the very base, forming a matted tuft, hirsute-hispid, copiously flowering through a long season: leaves spatulate-linear : flowers comparatively large and 
conspicuous, sessile in the forks, fully half inch long: corolla purple, funnelform, with rather long narrow tube and ample limb : calyx-lobes filiform-linear, not widehing upward, hispid with long spreading hairs: stamens unequally inserted: style 2-cleft at the apex, sometimes only slightly so: ovules about 20 : seeds usually fewer; the testa thin and translucent, smooth, or in age obscurely and sparsely excavated. - Bot. King, 256; Gray, Proc. Am. Acad. x. 329, \& Bot. Calif. i. 585. Eutoca aretioides, Hook. \& Arn. Bot. Beech. 374; Hook. Ic. t. 355. E.? (Conanthus) aretioides, A. DC. Prodr. ix. 295. Nama demissa, Gray, Proc. Am. Acad, viii. 283, in part. - Through the dry interior region, from Oregon to Arizona along the eastern borders of California. Style and filaments sometimes long and sometimes short in different plants, but not reciprocally so.

8. TRICÁRDIA, Torr. (From zol- three, and xagoik, heart, referring to the shape of the three larger sepals.) Sepals thin; the three exterior much enlarging after flowering, becoming somewhat scarious and finely reticulate-veiny. Corolla with the 10 narrow internal appendages free and rather distant from the filaments. - A single (Nevadan) species :-

T. Watsóni, Torr. Perennial herb, branched from the base; the ascending stems a span ligh, pubescent with long and soft cottony hairs, more or less glabrate with age: leaves all alternate, glabrate, entire; the radical and lower cauline spatulate-lanceolate, an inch or two long, and tapering into a conspicuous margined petiole; the upper much smalier, short-petioled or sessile and more oblong: flowers rather few, loosely racemose: short pedicels in fruit recurved : corolla purplish, about 3 lines wide, moderately 5-lobed: stamens and style included : larger sepals of the fruiting calyx becoming two-thirds of an inch long and wide, strongly cordate, much longer than the ovate pointed incompletely 2 celled capsule: ovules 4 to each placenta: "seeds a line long, oblong, slightly roughened." Watson, Bot. King, 258, t. 24. - Western Nevada, at Truckee Pass, Watson. Rio Virgen, S. Utah, Parry.

9. ROMANZÓFFIA, Cham. (Dedicated to Count Nicholas Romanzoff, the promoter of Kotzebue's voyage, in which the original species was discovered.) - Low and delicate perennial herbs, with the aspect of Saxifrage; the leaves mainly radical, all alternate, round-cordate or reniform, crenately 7-11-lobed, longpetioled; the lobes glandular-mucronulate. Scapes or flowering stems a span or less in length, racemosely or sometimes paniculately several-flowered; the pedicels filiform. Calyz-lobes oblong-linear or lanceolate. Corolla pale pink or purple, varying to white, delicately veiny. Ovary and retuse capsule 2-celled or nearly so: the placentr narrowly linear, many-seeded. Seeds oval: the testa alveolatereticulated.

R. Unalaschkénsis, Cham. Loosely somewhat pubescent: rootstock not tuberiferous: scape erect, 3 to 5 inches high; the erect or ascending pedicels shorter than the flowers: calyx-lobes herbaceous, a little shorter than the very short-funnelform corolla and equalling or surpassing the capsule: style short. —Cham. in Hor. Phys. Berol. 71, t. 14; Chois. Hydrol. t. 3; Gray, Proc. Am. Acad. x. 330. Saxifraga nutans, Don. - Unalaska and adjacent islands, Chamisso, Nelson, Harrington, Dall, \&c.

R. Sitchénsis, Bongard. Slightly and sparsely pubescent or glabrate: slender rootstocks tuberiferous: scapes filiforn; weak, a span long; the spreading pedicels longer than the flowers: calyx-lobes very glabrous, much shorter than the funnelform corolla, and shorter than the capsule: style long and slender. - Veg. Sitk. 41, t. 4; Torr. in Pacif. R. Rep. iv. t. 25 ; Hook. Bot. Mag. t. 6109 ; Gray, 1. c. - Sitka to the coast range of California, as far south as Redwoods occur, viz. to Monterey Co.

10. HESPEROCHIRON, S. Watson. (Hesperus, evening, used for western, and Chiron, a Centaur distinguished for his knowledge of plants, i.e. Western Centaury, the plant having been supposed to belong to the Gentian 
family). - Dwarf stemless perennials, or possibly biennials (IV. N. American), soft-pubescent; with entire spatulate or oblong leaves, on mostly elongated margined petioles, crowning the caudex or rootstock; and from their axils sending forth naked one-flowered peduucles, equalling or shorter than the leaves. Parts of the flower occasionally in sixes or sevens. Corolla purplish or nearly white; the tube and the base of the subulate filaments more or less hiiry or hirsute; the lobes often slightly unequal. Disk none. Base of the calyx obscurely adnate to the broad base of the conical-ovate ovary, which taper's into the rather stout style: stigmas minute. Orary 1-celled; the narrow placentæ projecting more or less on incomplete half-dissepiments: orules 20 or more to each placenta. Capsule loculicidal, 15-20-seeded. Seeds pretty large, with a somewhat fleshy minutely reticnlated testa. - A genus of doubtful affinity, but most probably Hydrophyllaceous. - Watson, Bot. King, 281; Gray, Proc. Am. Acad. x. 330, \& Bot. Calif. i. 516 ; Benth. \& Hook. Gen. ii. \$29.

H. Califórnicus, Watson. Leaves copious in a rosulate radical tuft: corolla somewhat oblong-campanulate; the lobes shorter than the tube. - Bot. King, 281, t. 30. Ourisia Californica, Benth. Pl. Hartw. 327. Hesperochiron latifolius, Kellogg in Proc. Calif. Acad. v. 44, a large form. - Hills and meadows, Sierra Nevada, California, from the Yosemite northward to Washington Terr., and east to the mountains of Utah. - Leaves an inch or two long, besides the petiole, into which the blade abruptly contracts or gradually tapers. Corolla from nearly half to three-fourths of an inch long in the largest specimens; the lobes oblong. Here belongs Nicotiana nana, Lindl. Bot. Reg. t. 883.

H. púmilus, T. C. Porter. Leaves fewer, crowning the rather slender rootstock: corolla nearly rotate; its lobes longer than the tube, which is densely bearded within. Hayden, Geol. Rep. 1872, 768; Gray, Proc. Am. Acad. x. 330. Villarsia pumila, Dougl.; Griseb. in Hook. Fl. ii. 70, t. 157. - Springy and marshy ground, mountains of Idaho to Oregon, Douglas, Geyer, Hayden, \&c. Also Plumas Co., California, Mrs. Austin.

11. LEMMÓNIA, Gray. (Named after John Gill Lemmon, the discoverer, a most ardent and successful explorer of E. Californian and Nevadan botany.) Proc. Am. Acad. xii. 162. Single species.

L. Califórnica, Gray, l. c. Small and depressed winter-annual, canescently pubescent, and the caly $\mathrm{x}$ white-villous: stem branched from the base, divergently and repeatedly dichotomous : leaves alternate, rosulate at base, and crowded at the summit of the branches; entire, spatulate and tapering into a short petiole, nearly veinless, 3 to 5 lines long: flowers sessile, solitary in the lower forks, cymose-glomerate at the leafy extremity of the branches: sepals very narrowly linear, not widening upward, in fruit 2 lines long and exceeding the short-oval retuse capsule : corolla apparently white, a line long, not surpassing the calyx, moderately 5-lobed : styles shorter or not longer than the ovary : placentæ or half-dissepiments narrow, adhering to the valves: seeds half a line long, somewhat rugosefoveolate in the manner of Conanthus. - Desert region of San Bernardino Co., California, about the sources of the Mohave River, May, 1876, J. G. Lemmon.

12. NÁMA, L. (Nö́uc, a stream or spring, in allusion to supposed place of growth of the original species.) - Chiefly low herbs, some few suffrutescent or woody-based (N. \& S. American and one Hawaian), of various habit; the corolla

- purple, bluish, or white ; the stamens sometimes equally, oftener unequally adnate to the base or lower part of the tube. (Besides the following there are several species in the bordering parts of Mexico.) - Gray, Proc. Am. Acad. v. 337, viii. 282, x. 330, \& Bot. Calif. i. 517, 621.

$\S 1$. Low annuals, merely pubescent or hairy : leaves entire: flowers terminal or lateral, or in the forks of the stem. 
* Leaves decurrent on the stem.

N. Jamaicénse, L. Diffusely spreading or prostrate, soft-pubescent: leares membranaceous (an inch or two long), broadly obovate or spatulate, tapering into a petiole-like base which is continued into wing-like margins of the stem: flowers mostly solitary, terminal and soon extra-axillary, short-pedicelled: corolla white, hardly longer than the narrow linear sepals : capsule narrow oblong. - Lam. Ill. t. 184; P. Browne, Jam. t. 18. - Low grounds, Texas, Florida. (W. Ind., Mexico.)

* Leaves not decurrent.

+ Cauline leaves all sessile, the upper by a more or less clasping base: villous-pubescent and somewhat viscid: seeds very numerous.

N. undulátum, HBK. Erect, diffusely branched, at length procumbent, leafy : branches a span to a foot long: leaves oblong; the upper with a broad sessile base, the lower spatulate: flowers commonly subsessile: corolla funnelform, somewhat longer than the linearspatulate sepals : capsule oblong, more or less shorter than the sepals: seeds oval, with a smooth and thin diaphanous coat, which is obscurely striate lengthwise and minutely pitted under a strong lens. - HBK. Nov. Gen. \& Spec. iii. 130. (Mexico.)

Var. macránthum, Chois. (Hydrol. 18, t. 2, fig. 1); a looser and less leafy form, with flowers (solitary or 2 and 3 together) on pedicels which vary from 1 to 5 lines long: corolla (4 or 5 lines long) almost twice the length, and capsule only about half the length of the spatulate-tipped sepals. - Gray, Proc. Am. Acad. x. 330. N. Berlandieri, Gray, Proc: Am. Acad. viii. 282. - Texas, along the Rio Grande near its mouth, and on the Mexican side of the river.

N. stenocárpum, Gray. Like the preceding, or sometimes with narrower leaves: pedicels, if any, short and rigid in fruit: capsule cylindrical, nearly linear (3 lines long), neariy equalling the narrow linear sepals: seeds short, angled by mutual pressure, with a thickish and opaque strongly reticulated and somewhat alveolate coat (only a quarter of a line long). - Proc. Am. Acad. x. 331. N. undulatum, Gray, 1. c. viii. 282, not HBK.Texas near the mouth of the Rio Grande, Berlandier. Along the northern borders of Mexicn to the province of Sonora on the borders of Arizona, Palmer.

++ Ieaves not at all clasping, more or less tapering at base, at least the lower petioled.

+ Corolla narrow-funnelform, mostly much longer than the calyx: seeds oval, with a thin and diaphanous close coat: Howers subsessile or short-peduncled.

N. híspidum, Gray. A span to a foot high, repeatedly forked, hispid or hirsute: leaves broadly or narrowly linear-spatulate, most of the cauline ones sessile: flowers lateral and solitary, or 3 to 5 in terminal unilateral nearly bractless clusters: sepals narrowly linear, very little if at all broadened upwards: capsule narrowly oblong, 30-40seeded : seeds smooth, very obscurely rugulose when highly magnified. - Proc. An. Acad. v. 339, \& Bot. Calif. i. 517. N. Jumaicensis, Engelm. \& Gray, Pl. Lindh., not Linn. $N$. dichotoma \& N. biflora, var. spathulata, partly, Torr. Bot. Mex. Bound. 147, \&c. - Plains and prairies, Texas to Arizona, and south-eastcrn borders of California. The extreme western form, with softer pubescence, sometimes has 3 or 4 styles and placentæ.

N. demíssum, Gray. Dwarf, diffuse or depressed, 2 or 3 inches high, hirsute-pubescent, sometimes hispid: leaves linear-spatulate, all or most of them tapering into a petiole: flowers subsessile in the forks: sepals very narrowly linear, not at all broader upwards: capsule short-oblong, 10-16-seeded: seeds much larger than in the preceding (oval or oblong, a quarter to a third of a line long).-Proc. Am. Acad. viii. 283 (mainly); Watson, Bot. King. 259, 460; Gray, Bot. Calif. i. 517. - Interior desert region, Washington Terr. to Nevada, and Utah (form with corolla, only 3 lines long); also S. Utah, Arizona, and the south-eastern borders of California; the latter forms with ampler purple or crimson corolla, 4,5 , or nearly 6 lines long. Filaments very unequally inserted, their adnate bases with somewhat free margins.

N. Coúlteri, Gray. Diffusely branched from the base, ascending, a span high, hirsutepubescent, somewhat viscid: leaves oblong-spatulate, the lower tapering into a petiole: flowers mostly in the forks and short-pedicelled: sepals with spatulate-dilated tips, not half the length of the narrow funnelform corolla: capsule narrowly oblong, 50-60-seeded: seeds short-oval, obscurely rugulose-pitted. - Proc. Am. Acad. viii. 283, \& Bot. Calif. 517. - "California," Coulter. But probably from Arizona or the adjacent part of Mexico. Corolla 5 lines long. 
++ Corolla short-funnelform, hardly exceeding the culyx : seeds with a thickisl opaque coat, coarsely pitted or scuptured.

N. dichótomum, Ruiz \& Pav. A Mexican and South American species, with oval or oblong-lanceolate leaves.

Var. angustifólium, Gray. Erect, a span high, minutely pubescent, glandular: stem repeatedly forked and with a nearly sessile flower in eacl fork: leaves narrow, linear or nearly so (an inch or less long, a line or two wide): sepals narrowly linear and slightly broadened upwards: capsule oblong-oval (nearly glabrous): seeds oval-oblong, marked with about 5 longitudinal rows of large pits, from + to 6 in each row. - Proc. Am. $\Lambda$ cad. viii. 284. - New Mexico, Fendler, Wright. Also Colorado, Hayden, Rothrock, Brandegee. Possibly a distinct species. Sometimes a weed of cultivated ground.

§2. Suffruticose and cespitose-procumbent, silky-woolly : leaves entire: flowers thyrsoid-glomerate: ovary and stylẹs hirsute.

N. Lóbbii, Gray. Leaves linear or somewhat spatulate, tapering to the base, nearly sessile (an inch or two long), more or less persistent; the older with revolute margins and becoming glabrate; the younger white with the soft villous wool : flowers clustered in the upper axils and at the summit, nearly sessile : sepals subulate-linear, more than half the length of the narrow funnelform (purple) corolla. - Proc. Am. Acad. vi. 37, viii. 285, \& Bot. Calif. 1. c. - Sierra Tevada, California, Lobb, Lellogg, Mis. Pulsifer-Ames, Lemmon, \&c. Forming dense and broad tufts, the older stems rigid and woody. Corolla half an inch long: the filaments unequally adnate high up. Fruit not seen.

$\S 3$. Perennial or woody-stemmed, erect, hirsute or hispid: leaves sessile, undulate or sinuate-dentate: Howers glomerate or spicate. (Approaching Wigandia, but with the narrowly funnelform corolla (also the capsule) of Nama.)

N. Rothróckii, Gray. A span or two high from an apparently deep perennial root, herbaceous, cinereous with a fine and somewhat viscid roughish pubescence, at least the inflorescence and calyx hispid with sharp spreading bristles: leaves lanceolate-oblong, almost pinnatifid; the pinnate veins running straight to near the sinuses between the strong teeth, there forking: flowers numerous in a capitate terminal cluster: sepals hardly dilated upward, half inch long, nearly equalling the corolla: ovary and capsule slightly hirsute: seeds rather few (almost a line long), oval, minutely reticulate-pitted. - Bot. Calif. i. 621; Rothrock in Wheeler Rep. t. 18. - Meadows on S. Kern River, California, Rothrock.

N. Párryi, Gray, l. c. Stem 6 feet high! below woody, over half inch in diameter and with a large brownish pith: leaves (as far as seen) linear, 2 or 3 inches long, 2 or 3 lines broad, villous-hirsute, numerously pinnate-veined, somewhat bullate; the margins revolute and undulate or repand: flowers unilateral and the fruit densely spicate on the few branches of the compact scorpioid cyme: sepals nearly filiform, little surpassing the oval capsule, barely 2 lines long: seeds oval (half line long), minutely reticulated. - S. E. California, on the Mohave slope of the San Bernardino Mountains (seen only in winter vestiges), Parry.

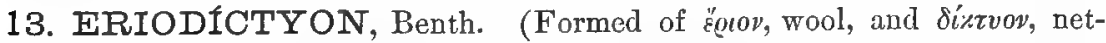
work, on account of the netted veins and woolliness of the under surface of the leaves.) - Low shrubs (California to New Mexico); with alternate pinnately veined and finely reticulated leaves, of firm or coriaceous texture, their margins mostly beset with rigid teeth, at base tapering into more or less of a petiole; the flowers scorpioid-cymose, forming a terminal usually naked thyrsus. Sepals narrow, not enlarging upwards. Corolla violet or purple, or sometimes white. Filaments adnate variably and sometimes very extensively to the tube of the corolla, usually sparsely hirsute. Ovary nearly or completely 2-celled by the meeting of the dilated placentr in the axis. Capsule small (a line or two long), globose-ovate, pointed. - Benth. Bot. Sulph. 35; Gray, Proc. Am. Acad. x. 313, $331, \&$ Bot. Calif. 1. c. 
E. tomentósum, Benth. 1. c. White-tomentose with a dense coat of short villous hairs, sometimes rusty-colored with age, 6 to 10 feet high: branches leafy to the top: leaves oblong or oval, rigid, obtuse (2 to 4 inches long): cymes at length broad: calyx densely and corolla slightly villous, the latter somewhat salverform and about twice the length of. the former. - Torr. Mex. Bound. 148, \&c. E. crassifolium, Benth. l. c., described from flowers with imperfect corollas. - Southern part of California, San Gabriel to San Diego and Tejon.

E. glutinósum, Benth. 1. c. Glabrate, glutinous with a balsamic resin, 3 to 5 feet high: leaves Ianceolate ( 3 to 6 inches long), irregularly more or less serrate, sometimes entire, whitened beneath between the reticulations by a minute and close tomentum, above glabrous : cymes in an elongated naked thyrsus : corolla tubular-funnelform (half an inch long), thrice the length of the slightly and sparsely lirsute calyx. - Wigandia Californica, Hook. \& Arn. Bot. Beech. 364, t. 88. - Dry hills, rather common in California. Infusion of the leaves in spirit used as a tonic, under the name of Yerba Santa.

E. angustifólium, Nutt. Glabrate and glutinous: leaves narrowly linear or narrowly lanceolate, rigid, and the margins at length revolute : corolla 2 or 3 lines long, short-funnelform or approaching campanulate: otherwise nearly as in the preceding. - Pl. Gamb.181. E. glutinosum, var. angustifolium, Torr. 1. c. - S. Nevada, Arizona, and adjacent parts of $\mathrm{New}$ Mexico. Leaves $1 \frac{1}{2}$ to 4 inches long, 1 to 3 lines wide.

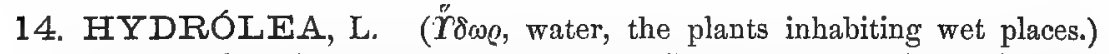
- Herbs, or rarely suffruticose plants (widely diffused in warm climates); with ovate or lanceolate.pinnately veined entire leaves, numerous on the stems, often with a spine in the axils, and clustered blue or rarely white flowers. Sepals distinct to the base. Corolla rotate or very open campanulate, 5-cleft. Stamens about the length of the corolla: filaments dilated at the insertion. Capsule globular; the fleshy or spongy placentæ very large. Seeds minute, generally striate-ribbed. Styles and placentæ occasionally varying to 3. - Ours appear to be perennials, flowering through the summer.

H. corymbósa, Ell. Spineless or nearly so: stem slender, a foot or two high, above minutely pubescent: leaves lanceolate, nearly sessile (an inch or so long), glabrous: flowers in a terminal corymbose cyme: sepals linear-lanceolate, villous-hispid; shorter than the corolla : filaments and styles long and filiform. - Sk. i. 336; A. W. Bennett in Jour. Iinn. Soc. xi. 275. - Pine-barren ponds, S. Carolina to Florida. Expanded corolla two-thirds of an inch in diameter.

H. affinis, Gray. More or less spiny, glabrous throughout or nearly so: stems ascending: leaves lanceolate, somewhat petioled ( 2 to 5 inches long): flowers in short axillary leafy-bracted clusters: sepals ovate, equalling the corolla: styles shorter than the capsule. - Man. ed. 5, p. 370. H. leptocaulis, Featherman, Louisiana Univ. Rep. 1871. - S. Illinois to Texas. Often confounded with the next.

H. Caroliniána, Michx. More or less spiny, sparsely villous-hispid or the leaves nearly glabrous: stem ascending: leaves lanceolate, short-petioled (3 or 4 inches long): flowers in short axillary clusters, or solitary in the upper axils: sepals linear or linearlanceolate, about the length of the corolla: styles shorter than the capsule. - Fl. i. 177. H. quadrivalvis, Walt. Car. 110, an older but false and deceptive name. H. paniculata, Raf. Neobot. 64. - N. Carolina to Florida and Lonisiana? (S. Amer.?)

H. ováta, Nutt. Spiny, minutely soft-pubescent and above slightly hirsute: stems a foot or two high, paniculately branched at summit: leaves ovate, sometimes ovate-lanceolate ( 8 to 20 lines long): flowers clustered at the end of the branches : sepals lanceolate, very villous-hirsute, shorter than the corolla; this an inch broad when expanded : filaments and especially the styles long and filiform. - Fl. Arkans. in Trans. Am. Phil. Soc. ser. 2, r. 196; Chois. Hydrol. t. 1; A. W. Bennett, l. c. 270. H. ovatifolia, Raf. Neobot. (1836), 64. H. Ludoviciana, Featherman, I. c. - Margin of ponds, Arkansas, W. Louisiana, and Texas. (S. Amer.) 


\section{ORDER XCIII. BORRAGINACEA.}

Mostly scabrous or hispid-hairy plants, with watery juice, entire and alternate (or partly opposite) leaves, no stipules, prevalently scorpioid inflorescence, and regular flowers (in Echium the corollia, \&c., irregular), the 5 or sometimes 4 stamens on the tube or throat of the corolla, as niany as and alternate with its lobes, a single style rising between the divisions of a deeply 4-parted ovary, or from the summit of an undivided one, the cells or lobes of which contain a solitary orule, the seed with little or no albumen, the embryo straight or rarely curved, its radicle superior or centripetal. Flowers perfect, generally j̃-merous. Calyx and corolla free; the lobes of the latter imbricated, convolute, or sometimes plicate or induplicate in the bud. Hypogynous disk usually present, but inconspicuous. Pistil of 2 biorulate carpels, although seemingly of 4 and uniovulate. Ovule anatropous or amphitropous. Fruit of 4 nutlets (or by abortion fewer), or a drupe containing 2 to 4 nutlets or cells, rarely reduced to one. - Some of the first great division have serrate and even incised leaves, and are trees or shrubs, of tropical or subtropical regions: these well distinguished from related orders by the superior radicle. The true Borraginacere are almost all herbs, mainly of temperate climates, with undivided style and eyen stigma, surrounded at base by the four distinct divisions of the ovary. Inflorescence and its nomenclature as in the preceding order.

I. Ovary undivided (or only laterally 4-lobed) and surmounted by the style.

Tribe I. CORDIE $\mathbb{E}$. Style twice bifid: stigmas terminal, not annular. Fruit drupaceous. Cotyledons longitudinally plicate or corrugated. Trees or shrubs, with leaves sometimes dentate.

1. CORDIA. Calyx tubular or campanulate, merely toothed or lobed. Corolla funnelform or salverform; the lobes and stamens sometimes more than 5. Stigmas clavate or capitate. Ovary and drupe 4-eelled, 4-seeded, or fewer by the abortion of some of the cells and seeds of the hard stone.

Tribe II. EHRETIE.E. Style once bifid or 2-parted (the divisions sometimes coalescent to the top): stigmas more or less capitate. Cotyledons plane. Trees, shrubs, or low herbs.

* Fruit drupaceous : ovules mostly amphitropous : trees or shrubs.

2. BOURRERIA. Calyx globular or ovoid, closed in the but, valvately splitting at the summit into 2 to 5 teeth. Corolla campanulate or short-funnelform. Drupe containing 4 more or less separable one-seeded nutlets.

3. EHRETIA. Calyx 5-parted or 5-cleft, imbricated or open in the bud. Corolla from short-funnelform to rotate. I)rupe usually containing 2 two-celled two-secded nutlets.

* Fruit dry: ovules anatropous, pendulous : herbaceous or suffruticulose plants.

4. COLDENIA. Calyx 5-parted, or in original species 4-parted; the divisions narrow. Corolla short-funnelform or nearly salverform, seldom much surpassing tle calyx; the lobes rounded, imbricated or sometimes partly convolute in the bud. Stamens included. Style 2-cleft or 2-parted. Ovary entire or laterally 4-lobed, 4-celled. Fruit separating at maturity into 4 one-seeded nutlets, or by abortion fewer, or in one species by suppression one-celled and one-seeded. Cotyledons thickish. Albumen none.

Trrae III. HELIOTROPIE E. Style entire, sometimes wanting : stimma peltateannular, forming a complete ring, surmounted usually by an entire or 2-lobed (from hemispherical to subulate) tip or appendage. Ovules pendulous. Seeds with a straight or incurved embryo, in sparing or copious albumen. Leaves entire, rarely denticulate. Inflorescence more or less scorpioid. 
5. TOURNEFORTIA. Fruit drupaceous. Shrubs or woody twiners, or rarely almost herbaceous. Otherwise nearly as Heliotropium.

6. HELIOTROPIUM. Calyx deeply 5-parted, persistent. Corolla salverform or funnelform, plaited and mostly imbricated in the bud. Stamens included : filaments short or none: anthers connivent, sometimes cohering by pointed tips. Ovary 4-celled, 4-ovuled. Fruit dry, 2- or 4-lobed, separating into 2 indurated 2-celled and 2-seeded closed carpels, or more commonly into 4 one-seeded nutlets. Seed sometimes with rather copious albumen, and, with the embryo, curved. - Low herbs or undershrubs; the flowers almost always small.

II. Ovary 4-parted (rarely 2-parted) from above into one-celled one-ovuled divisions surrounding the base of the undivided (rarely 2-lobed) style: stigma not annular, terminal.

TrIbe IV. BORRAGEE. Style entire, in Echium 2-cleft at the apex: stigma truncate or depressed-capitate, in a few species of Lithospermun tipped with a rudimentary terminal appendage. Ovules amphitropous or almost orthotropous and commonly ascending or erect, or when anatropous mostly pendulous. Nutlets 4 (or by abortion fewer), distinct, or sometimes at base united in pairs. Radicle superior or centripetal. Albumen none. Chiefly herbs, with somewhat mucilaginous watery juice and entire leaves. Flowers mostly near, but not in the axil of leaves or bracts, or bractless in scorpioid so-called spikes or racemes. Esstivation of the corolla imbricated, except when otherwise indicated. (The depressed or elevated disk, receptacle, or axis on which the nutlets are inserted, and from which they fall away, is called the gynobase.)

* Corolla and stamens regular : style entire, or sometimes barely 2-cleft at the very apex.

. + Ovary only 2-parted: fruit involved in a bur-like transformed portion of the calyx.

7. HARPAGONELLA. Calyx at first slightly but in fruit exceedingly unequal; three of the lobes nearly distinct: the remaining two more united, closely enwrapping the fruit, and becoming cornute with 7 to 9 divergent long and uncinately glochidiate soft-spinous processes, forming a bur. Ovule erect, anatropous. Nutlets one or sometimes both maturing, obovoid-oblong, thin-coriaceous, very smooth, obliquely fixed by the aarrowed base to the small depressed gynobase. Seed filling and conformed to the nutlet, erect or ascending. Radicle directed to the gynobase. Corolla, stamens, style, \&c., as in Pectocarya.

+ + Ovary 4-parted or 4-lobed: fruit of 4 nutlets, or by abortion fewer, subtended or surrounded by the unchanged or merely accrescent calyx.

* Nutlets divergent or divaricate (either radiately or in pairs), outwardly or backwardly extended much beyond the insertion (which is by a roundish or oblong areola or scar): seed accordingly horizontal or obliquely ascending, with radicle centripetal : but the anatropous ovule (and ovary-lobes) in flower erect or ascending. (Calyx deeply 5-cleft or parted, spreading or reflexed in fruit : corolla appendaged with strong fornicate processes almost closing the throat: stamens short, included.)

8. PECTOCARYA. Nutlets flat and thin (depressed-obcompressed), attached at the inner end underneath to the small depressed gynobase, either winged, laciniate-bordered, or pectinately setose around the thin margin; the bristles or prickles simply uncinate at tip. Style short: stigma capitate. Annuals, with minute white flowers imperfectly opposite the leaves.

9. CYNOGLOSSUM. Nutlets equally divergent, horizontal or obliquely ascending on a depressed or pyramidal gynobase, turgid, wingless, all over glochidiate-muricate, mostly separating (by an ovate or roundish scar at the upper end of the inner face) and carrying away an exterior portion of the indurated style from below upward, by which they are for a time pendulous. Stigma small, on a comparatively long style. Perennials or biennials, with flowers in usually bractless racemes.

+ + Nutlets erect and parallel with the style, or sometimes incurved,

$=$ Obliquely attached by more or less of the ventral face or angle, or by the base or prolongation of it, to

u. The more or less elevated (from low-conical or globular to subulate) gynobase which supports the style (and when narrow has been termed the base of the style), not stipitate, and the scar not excavated. 
10. ECHINOSPERMUM. Nutlets armed (either along a distinct margin or more or less over the whole back) with glochidiate prickles, forming burs. Calyx 5-parted, reflexed or open in fruit. Corolla short-salverform or somewhat funnelform, white or blue; the throat closed with prominent fornicate appendages.

11. ERITRICHIUM. Sutlets unarmed or rarely with a row of (non-glochidiate) prickles around the back, very rarely wing-bordered. Calyx 5-parted or deeply cleft, closed or not spreading in fruit (rarely circumscissile-decichous). Corolla with or occasionally without fornicate appendages at the throat, white or blue, in one species yellow!

12. AMSINCKIA. Nutlets crustaceous or coriaceous, unappendaged, triquetrous or ovatetriangular, attached below the middle to an oblong-pyramidal gynobase. Corolla salverform or tubular-funnelform, with a slender tube and open throat; the limb sometimes plicate at the sinuses, yellow. Style filiform: stigma capitate or 2-parted. Cotyledons each 2-parted.

b. Nutlets conspicuously stipitate, and the stipe more or less hollowed at the insertion upon the broadly pyramidal or globular gynobase.

13. ECHIDIOCARYA. Calyx 5-parted, lax in fruit. Corolla between short-salverform and rotate, slightly constricted at the more or less appendaged throat; the tube not exceeding the calyx, shorter than the roundish lobes. Filaments very short, inserted on the middle of the tube : anthers oblong, included. Style short: stigma capitate. Nutlets ovate-trigonous, oblique, acutely cristulate-muricate or rugose, dorsally and ventrally carinate, incurved-ascending on a stout stipe; the stipes either united in pairs or distinct. Leaves all alternate. Flowers white.

c. Nutlets sessile or obscurely stipitate on a flat or merely convex receptacle.

14. ANTIPHYTUM. Corolla (short), \&c., of Eritrichium. Nutlets crustaceous, ovate, rounded on the back and granulate or rugulose, carinate ventrally down to the flat roundish scar close to the base, which is either slightly protuberant and rather large, or smaller and somewhat stipitate: gynobase plane or barely umbonate by the base of the style. Flowers racemose, white, mostly bracteate. Leaves commonly opposite!

15. MERTENSIA. Corolla from tubular-funnelform or trumpet-shaped to almost campanulate, with open throat, bearing obvious or obsolete transverse folds for crests. Stamens with either flattened or nearly filiform filaments. Style filiform: stigma entire. Nutlets from somewhat fleshy to coriaceo-membranaceous, attached by a sniall or short scar just above the base to a barely or sometimes strongly convex gynobase. Perennials, often smooth and glabrous, with blue or rarely white flowers, mostly bractless.

$==$ Nutlets sessile and directly (usually centrally) attached by the very base to a plane gynobase;

$u$. The flat scar not excavated or perforate and bordered with a ring, mostly small.

16. MYOSOTIS. Corolla short-salverform or almost rotate; its throat contracted by transverse erests; the rounded lobes convolute in the bud! Anthers ovate or oblong. Nutlets small, ovoid, smooth and shining, thin-crustaceous; the scar small. Racemes mainly ebracteate.

17. LITHOSPERMUM. Corolla salverform, funnelform, or sometimes approaching campanulate, either naked or with pubescent lines or intruded gibbosities or low transverse crests at the throat. Filaments mostly very short: anthers short, included. Style slender : stigma mostly truncate-capitate or 2 -lobed. Nutlets ovoid, bony, either polished and white or dull and rough. Flowers all subtended by leaves or bracts.

18. ONOSMODIUM. Corolla tubular or oblong-funnelform, with open and wholly unappendaged throat; the lobes erect or hardly spreading, mostly triangular and acute; the sinuses more or less inflexed. Stamens not surpassing the corolla-lobes: filanents flat or dilated: anthers oblong-linear or sagittate, erect (sometimes in Mexican species becoming transverse). Style filiform or capillary, very long: stigma small and truncate, exserted before the corolla opens. Nutlets ovoid or globular, bony, smooth and polished, white. Flowers all subtended by leafy bracts.

b. The scar large and excavated, bordered by a prominent margin. (Old World plants.)

19. SYMPHYTUM. Corolla oblong-tubular, ventricose above the insertion of the stamens, or with campanulate-dilated limb, and with 5 short nearly erect lobes or teeth; the throat closed by 5 prominent lanceolate or linear papillose-margined scale-like appendages. Anthers lanceolate, more or less included. Style filiform: stigma small. Nutlets obliquely ovoid, crustaceous or coriaceous, the cartilaginous prominent ring denticulate at the edge.

* Corolla irregular with limb oblique and lobes unequal. (Old World genera.)

20. LYCOPSIS. Corolla somewhat salverform; the tube curved at the middle; the more or less spreading lobes rather unequal; the oblique throat closed with hispid for- 
nicate scales. Stamens and style included: stigma 2-lobed. Nutlets ovoid, oblique, coriaceous, coarsely reticulate-rugose, erect, almost laterally attached to a thickened protuberant gynobase; the scar large, oval, excavated or perforate, bordered by a thickened cartilaginous ring.

21. ECHIUM. Corolla funnelform, with dilated throat oblique and not at all appendaged; the lobes unequal, roundish, erect or slightly spreading. Stamens unequal and exserted: filaments filiform. Style long and filiform, 2-cleft at apex : stigmas small. Nutlets cartilaginous, rough or rugose, ovoid, acute, erect, fixed to the flat gynobase by a plane and maxginless scar.

Borrágo officinális, L. (BORAGE), with very rotate blue corolla, is a not uncommon annual in country gardens, but does not run wild. Omphalones linifolia, Mœnch, of S. Europe, is given in Hooker's Flora Boreali-Americana, on the strength of a specimen received from Newfoundland, to which it cannot be native, and the plant is rare in gardens, in which $O$. verrs is a hardy perennial, but it does not escape.

1. CÓRDIA, Plumier, L. (Valerius Cordus, a German botanist of the 16 th century.) - Tropical or subtropical trees or shrubs, the greater portion American. - Benth. \& Hook. Gen. ii. 838.

§1. Corolla large, an inch or two long, funnelform, deciduous; the tube longer than the cylindraceous calyx; its lobes and the stamens 5 to $12:$ drupe enclosed in the enlarged caly $\mathrm{x}$ : inflorescence open-cymose. $-\$$ Sebestenoides, DC.

C. Sebesténa, L. Tall shrub or small tree, scabrous-pubescent or smootlish: leaves ovate ( 4 to 8 inches long): flowers pedicelled: calyx not striate; the teeth irregular and obtuse: corolla varying from orange to flame-color, 5-8-lobed. - Bot. Rep. t. 157. C. speciosa, Willa., DC. - Keys of Florida. (W. Indies, \&c.)

C. Boissiéri, A.DC. Soft-tomentose: leaves oval or oblong-ovate, when old minutely rugose and somewhat scabrous above: caly $\mathrm{x}$ not pedicelled, somewhat campanulate and striate; the teeth often acute: corolla white with a yellow centre, 5-lobed, externally downy. - DC. Prodr. ix. 478; Torr. Bot. Mex. Bound. 135. - Southern frontier of Texas and New Mexico, Berlandier, Gregg, Schott, \&c. (Mex.)

$\S 2$. Corolla small or proportionally large, salverform or funnelform, deciduous : calyx short, not sulcate-striate; its lobes and those of the corolla as well as stamens no more than 5, sometimes 4 : flowers in our species capitate-glomerate, and the leaves serrate! - $\$ M y x a$, Endl.

C. globósa, HBK. Slurub hirsute or somewhat hoary: branches slender, spreading: leaves oblong-ovate, obtusely serrate (an inch or two long), the pinnate veins rather conspicuous and the upper surface often rugose: peduncle mostly short: calyx-teeth nearly filiform, longer than the tube: corolla funnelform, white ( 2 to 4 lines long), about twice the length of the ealyx. - Nov. Gen. \& Spec. iii. 76. Varronia globosa, L., \& V. bullata in part. Cordia bullata, DC. Prodr. ix. 496; Chapm. Fl. 329. - Keys of Florida, Blodgett, \&c. (W. Ind. to Isthmus.)

C. podocéphala, Torr. A foot or two high, woody only at base, minutely strigosehirsute, scabrous: branches slender, erect: leaves varying from ovate-lanceolate to linearlanceolate, narrowed at the base into a short petiole, coarsely serrate (an inch or two long): peduncles filiform, 2 to 4 inches long, bearing a small and very dense head: calyxteeth triangular-subulate or ovate, very much shorter than the tube: corolla broadly funnelform, white or pale purple (half inch or more long), its narrow tube hardly exceeding the calyx. - Bot. Mex. Bound. 135. - Lower Rio Grande, Texas to the borders of New Mexico, Wright, Bigelow, Schott, \&c. (Adjacent Mex.)

C. GRÉGII, 'Torr. 1. c., which is hardly of this section, is a Mexican species, found only at a considerable distance from our frontiers.

2. BOURRÉRIA, P. Browne. (Named after one Bourrer, a Nuremberg apothecary, not Beurrer, therefore the orthography Beurreria, Jacquin and others, is not to prevail over the original form.) - Tropical American trees and shrubs ; 
with white flowers in open terminal cymes. Lobes of the style not rarely coalescent even to the stigma. - Benth. \& Hook. Gen. Pl. ii. 840, excl. syn. Fymenesthes, Miers, which is a Cordia. Bourreria \& Crematomia, Miers, Bot. Contrib. ii. $230,242$.

B. Havanénsis, Miers. Shrub or small tree, glabrous or nearly so: leaves mostly obovate-oblong and acute at base (about 2 inches in length), bright green and shining above, coriaceous, entire : cyme loose : calyx at length campanulate, glabrous or puberulent, a little shorter than the tube of the corolla: style cleft only at the apex, or even quite entire : drupe as large as a pea, orange. - Bot. Contrib. ii. 238, t. 30 (Eliretia Havanensis, Willd.), with B. recurva \& B. ovata, Hiers, l. c. B. tomentosa, var. Haranensis, Griseb. (Ehretir tomentosa, Lam.), is probably a pubescent form of the same species. Pittonia similis, Catesb. Car. ii. t. 79. Ehretia Beurreria, Chapm. Fl. 329, not L. (the B. succulenta, Jacq.). Keys of Florida, Blodgett, \&c., a glabrous and smooth form. (W. Ind.)

Var. rádula. Upper face of the leaves tuberculate-scabrous or hispidulous from papillosities, the lower and the branchlets either glabrous or minutely pubescent. B. radula, Don, Syst. iv. 390; Chapm. 1. c.; Miers, 1. c. B. virgata, Griseb., not Swartz, ex Miers. Ehretia radula, Poir., ex Miers. - Keys of Florida, Blodgett, Palmer, \&c. (W. Ind.)

3. EHRÉtiA, L. (George Dionysius Ehret, a gifted botanical painter of the 18 th century.) - Trees or shrubs, chiefly tropical; with small white flowers in open cymes or panicles, or rarely almost solitary. - Beuth. \& Hook. 1. c.

E. ellíptica, DC. Tree 15 to 50 feet high: leaves oval or oblong, sometimes serrate, nearly smooth and glabrous or (with the branchlets and open cymes) minutely hirsute-pubescent and the upper face very scabrous : divisions of the calyx broadly lanceolate, acuminate, as long as the campanulate tube of the corolla: drupes yellow, globose, of the size of small peas (the thin pulp edible).- - Prodr. ix. 503; Torr. Hex. Bound. 136; Miers, Contrib. ii. 228, t. 85. - River-bottoms South-western Texas, Berlandier, Lindheimer, \&c. (Adjacent Mex.)

4. COLDENIA, L. (Dr. Cadwallader Colden, Colonial Lieut.-Governor of New York, a correspondent of Linnæus.) - Low herbaceous or suffrutescent plants, canescent or hispid; with small and mostly white flowers sessile and usually in clusters; the original species a prostrate annual, with usually 4 -merous flowers and coarsely toothed leaves, the strong simple veins of which run to the sinuses. (Lam. Ili. t. 89; Grertn. Fruct. t. 68, embryo wrongly figured.) Genus extended by the addition of several North and W. South American species, diverse in habit and minor characters, which might well form more than half as many subgeuera as there are species, but may be ranked under three. (Insertion of stamens probably both high and low in the same species.) - Gray, Proc. Am. Acad. v. 340, viii. 292, x. 48, \& Bot. Calif. i. 520 ; Benth. \& Hook. Gen. ii. 841.

$\S 1$ Eucoldenia, Benth. Fruit merely 4-sulcate; the nutlets with plane contiguous sides and thick crustaceous walls, or in one species reduced by abortion to a single cell: corolla not appendaged within: stamens equally inserted : veins of the leaves straight and simple. - Stegnocarpus \& Ptilocalyx, Torr.

C. canéscens, DC. Prostrate or procumbent, with somewhat ligneous perennial base, white-sericeous or tomentose : leaves (barely half inch long) ovate or oblong, entire, petioled, obscurely veined: flowers solitary or in small clusters at the axils or forks: calyx-lobes linear-lanceolate : fruit depressed-globose; the four thick-walled nutlets smooth and rounded on the back, obscurely rugose on the plane sides, pointless: embryo slightly curved. Prodr. ix. 559 (\$ Stegnocarpus); Gray, 1. c. Stegnocarpus canescens, Torr. Pacif. R. Rep. ii. 169, t. 7. - S. Texas to Arizona, Berlundier, Wright, \&c. (Adjacent Mex.) 
C. Grégrgii, Gray. Suffruticulose, a foot or two high, tomentose-canescent : leaves ovate or oval ( 2 to 4 lines long), short-petioled, almost veinless, entire, the margins revolute: flowers capitate-glomerate at the summit of the branches: calyx-lobes filiform from a broader base, elongated-plumose with long villous hairs : ovary obscurely 4-lobed; but the fruit even, ovate-oblong, by abortion 1-celled and 1-seeded, the walls comparatively thin, showing mere vestiges of three abortive cells : embryo straight. - Ptilocalyx Greggii, Torr. 1. c. 170, t. 8. - Rocky ravines, New Mexico, and south-western borders of Texas, Gregg, Wright, \&c. (Adjacent Mex.)

§ 2. FDDYA, Gray. Fruit deeply 4-lobed; the mature nutlets rounded and only ventrally united, thin-walled but crustaceous, rough-granulate: corolla not appendaged: stamens unequally inserted: narrow leaves with very thick midrib, veinless. - $E d d y a$, Torr. 1. c.

C. hispidíssima, Gray, 1. c. Suffruticulose, diffuse, soon procumbent, a span or two high, very setose-hispid, and with some minute cinereous pubescence: leaves fascicled, rigid, lanceolate, soon linear or acerose by strong revolution of the margins, dilated at base; the lower or primary ones petioled : flowers scattered: calyx-lobes linear, resembling the leaves: embryo straight. - Eddya hispidissima, Torr. 1. c. 170, t. 9.-Dry hills, \&c., W. Texas (Wright, \&c.) to Arizona and S. Utah.

§ 3. 'TrQuília, DC. Fruit deeply 4-lobed (or by abortion occasionally fewer); the thin-walled nutlets rounded and united only at the centre, smooth and shining: stamens equally inserted: leaves entire, petioled, veined. - Tiquilia, Pers. Galapagoa, Hook. f. - In our species ( $\$$ Tiquiliopsis, Gray, 1. c.), the corolla is appendaged within, and the cotyledons either 4-parted around or incumbent upon the radicle.

C. Nuttállii, Hook. Prostrate annual, repeatedly and divergently dichotomous, canescently pubescent, also sparsely hirsute or hispid: leaves ovate or rhomboid-rotund, 2 to 4 lines long and on longer petioles, with two or at most three pairs of strong and somewhat curving veins, and margins somewhat revolute: flowers densely clustered in the forks and at the ends of the naked branches: caly $x$-lobes linear, sparsely hispid, equalling the tube of the pink or whitish corolla: filaments shorter than the anthers, inserted nearly in the throat of the corolla, the tube of which bears 5 short obtuse scales near the base: nutlets oblong-ovate, marked with a linear and rhaphe-like ventral scar : cmbryo straight: cotyledons very deeply horseshoe-form, their elongated bases almost enclosing the radicle. - Kew Jour. Bot. iii. 296; Watson, Bot. King, 248; Gray, Bot. Calif. i. 520. Tiquilia brevifolia, Nutt.; Torr. Bot. Mex. Bound. 136, \& Wilkes Exped. xvii. 417, t. 12, under the name of T. Oregana. - Arid plaims, Arizona through Utah and E. California to Wyoming and Washington Terr.

C. Pálmeri, Gray. Apparently perennial or even suffruticulose at base, less prostrate, more canescent but not hispid or even hirsute: leaves obovate or ovate, about the length of their petiole, plicate-lineate by about 6 pairs of straight and strong veins : flowers fewer in the clusters: calyx less deeply cleft; the lanceolate lobes about half the length of the bluish corolla, which bears 5 salient plates above the base of the tube, extending to the insertion of the slender filaments : nutlets only one or two maturing, globular, with an orbicular scar: cotyledons very thick, somewhat hemispherical, not even cordate, incumbent on the radicle. - Proc. Am. Acad. vii. 292, \& x. 49; Watson, I. c. Tiquilia brevifolia, var. plicata, Torr. Bot. Mex. Bound. 136. - Sandhills on the Mohave and Colorado, E. California and W. Arizona, Emory, Schott, Cooper, Palmer.

5. TOURNEFORTIA, L. (Joseph Pitton de Tournefort, of France, the great botanist of the 17 th century.) - Shrubby, arborescent, or rarely nearly herbaceous plants; a rather large genus all round the world in and near the tropics, one or two extratropical. Flowers white, small, unilateral and as it were spicate on the scorpioid cyme-branches, usually destitute of bracts. A polymorphous and artificial genus, in a few species too nearly approaching the next. 
* Lobes of the small white corolla slender-subulate, valvate-induplicate in tho bud.

T. volúbilis, L. Slender shrub, with filiform sarmentose more or less twining branches, and minute usually rusty pubescence : leaves ovate or oblong-ovate, acute or acuminate, slender-petioled: spikes of the loose cyme filiform and divaricate : slender flowers merely 2 lines long: drupe 1-3mseeded. - Messersmidtia volubilis, Rœm. \& Sch. Syst. jv. 544; Miers Contrib. ii. 210. - Keys of Florida. (IV. Ind., \&c.)

* Lobes of the white corolla broad, more or less plicate in the bud and undulate.

T. móllis, Gray. Erect from a suffrutescent base, a foot or less in height, branching, canescently silky-tomentose: leaves deltoid- or rhombic-ovate, obtuse, and with undulate margins, rather long-petioled : flowers midtle-sized, crowded in a pair of naked peduncled spikes: tube of the corolla a little longer than the calyx, and longer than the rounded unduate or crenulate lobes: drupe globose-ovate, minutely tomentose, excavated at base, by abortion about 2-seeded.-Proc. Am. Acad. x. 50. Heliophytum molle, Torr. Bot. Mex. Bound. 138. - On the Rio Grande, Texas, at or opposite Presidio del Norte, Bigelow. Leaves about 2 inches long, including the petiole. Corolla apparently white, 3 lines long, the limb rather ample. Fruit probably fleshy in the living plant.

T. gnaphalódes, R. Br. Somewhat fleshy shrub, very white silky-tomentose through. out, thickly leafy: leaves spatulate-linear, obtuse: flowers densely clustered: corolla fleshy, downy outside: drupe ovate-conical, deeply excavated at base, with thin flesh, and 2 two-seeded nutlets. - Heliotropium gnaphalodes, Jacq. Amer. 25, t. 173. (Pluk. Alm. t. 193, fig. 5.) - Coast of Florida. (W. Ind.)

6. HELIOTRÓPIUM, Tourn. Tournsole, Heliotrope. (Ancient Greek name, not indicating that the flowers turn to the sun, but that they begin to appear at the summer solstice.) - Herbs, or low more or less shrubby plants, belonging mainly to the warmer parts of the world, represented in cultivation by the vanilla-scented $H$. Pertcianum, and in the southern part of the United States by several indigenous and two or three naturalized-species: fl. all summer. Gray, Proc. Am. Acad. x. 49 ; Benth. \& Hook. Gen. Pl. ii. 843.

§1. EúPLocA, Gray, I. c. Fruit didymous, solid; the two carpels each splitting into two almost hemispherical one-seeded nutlets, their internal face flat and smooth: embryo semicircular in rather copious albumen: corolla large, naked and not appendaged, strongly plicate in restivation: anthers slightly cohering by their minutely bearded tips: style long and filiform: cone of the stigma truncate and bearded with a penicillate tuft of strong bristles: flowers scattered.-E Euploca, Nutt.

H. convolvuláceum, Graj. Low spreading annual, strigose-hirsute and hoary, much branched: leaves lanceolate, or sometimes nearly ovate and sometimes linear, short-petioled: flowers generally opposite the leaves and terminal, short-peduncled: limb of the bright white corolla ample, angulate-lobed ; the strigose-hirsute tube about twice the length of the linear sepals: anthers inserted at or above its middle. - Mem. Am. Acad. vi. 403, \& Proc. v. 340. Euploca conzolvulacea, Nutt. in Trans. Am. Phil. Soc. ser. 2, v. 189 ; Hook. Tc. t. 651; Torr. in Marcy Rep. t. 15. E. grandiflora, Torr. in Emory Rep. 147. - Sandy plains, Nebraska to W. Texas. Soda Iake, S. E. California, Dr. Cooper. A showy plant; the sweet-scented flowers opening at sunset (. Yuttrall), in cultivation open nearly all day: tube of corolla (including the abruptly somewhat dilated throat, constricted at orifice) 4 lines long; the rotate border about half an inch broad; the wide sinuses not produced into teeth or appendages, but obscurely emarginate. Style fully thrice the length of the ovary: annular stigma obscurely 4-lobed; its strongly bearded terminal appendage rather longer, truncate or obscurely 2-lobed. Fruit somewhat pubescent or hairy.

§2. Euhelotropium. Fruit 4-lobed and separating at maturity into 4 onecelled one-seeded nutlets: style usually short: cone or tip of the stigma slightly bearded or naked, rarely obsolete: corolla plicate or induplicate in the bud; the 
lobes obtuse (with one exception) and usually broad : inflorescence in most species eithér distinctly or indistinctly scorpioid. — Euheliotropium \& Orthostachys, Benth. \& Hook. Gen. ii. 844. Heliotropium \& Schleidenia (Endl.), Fresenius in Fl. Bras. viii. 31, 33.

* Flowers all or some of them accompanied by bracts or leaves; when spicate, the so-called spikes not naked, nor conjugate or forking to forn a cyme, nor strongly coiled : anthers generally with tips connivent or cohering over the stigma. - \$Orthostachys, R. Br.; A.DC.; Bentl. \& Hook. Preslea, Mart. Schleidenia, Endl.

+ Stigma-tip elongated (sometimes 2-cleft): anther-tips lightly or only at first cohering: corolla with naked and open throat, white: leaves narrowly linear: nutlets globular, beakless, externally hispid or pubescent.

+- Divisions of the calyx similar, more or less shorter than the tube of the corolla: nutlets with a pair of pits on the inner face.

H. Gréggii, Torr. A span high, diffusely spreading from a slightly woody base, strigosecinereous: slender branches leafy : leaves narrowly linear, flat, about an inch long and a line wide: flowers short-pedicelled or almost sessile in an at first crowded and short scorpioid spike, with 'or often mainly without bracts: corolla with an ample and slightly 5-lobed limb: anthers long, acuminate, minutely bearded at tip: stigma-tip subulateconical, much thicker than the very short style, as well as much longer. - Bot. Mex. Bound. 137; Gray, Proc. Am. Acad. x.49. - Sandy or gravelly soil, western borders of Texas, New Mexico, and adjacent part of Mexico, first collected by $D r$. Gregg. Flowers very fragrant: corolla a third to nearly half an inch broad when expanded.

H. angustifólium, Torr. A span to a foot high, erect and densely branched from a woody base, strigose-canescent: branches rigid, very leafy: leaves very narrowly linear, with revolute margins, almost filiform when dry (4 to 9 lines long) : spike few-flowered, at length slender, nearly straight, bracteate at base or without bracts : flowers small, shortpeduncled: corolla salverform, with narrow canescent tube and 5-parted limb; the lobes ovate-lanceolate (acute!); hardly a line long, or half the length of the tube: anthers with mucronate glabrous tips : stigma-tip slender-subulate, longer and hardly broader than the rather long style. - Bot. Méx. Bound. 137. - South-western borders of Texas, Wrigh. (Adjacent Mex., Gregg.)

$4+$ Divisions of the calyx very unequal, the larger about the length of the corolla: nutlets witbout pits on the inmer face: inflorescence not in the least scorpioid.

H. tenéllum, Torr. A span to a foot high, erect from an annual root, paniculately branched, slender, strigose-canescent: leaves narrowly linear, with more or less revolut margins (about an inch long and a line wide) : flowers scattered, terminal, becoming lateral and axillary, on rather slender peduncles, inany of them bractless : limb of the corolla rather shorter than the narrow canescent tube; the lobes oblong or obovate, a line long: anthers oblong and with nearly naked blunt tips scarcely at all cohering: stigma-tip uarrowly subulate, 3 or 4 times the length of the short style. - Torr. in Marcy Rep. t. 14, \& Bot. Mex. Bound. 138. Lithospermum tenellum, Nutt. in Trans. Am. Phil. Soc. ser. 2, v. 189. L. anqustifolium, Torr. in Ann. Lyc. ii. 225, not Michx.-Open dry ground, Kentucky to Alabama, west to Kansas and throughout Texas.

+ + Stigma-tip conical or more slender : anthers cohering by minutely bearded tips: corolla appendaged and throat sometimes almost closed by a pubescent projection or gibbosity at or below the base of each fold of the sinuses: divisions of the calyx usually of unequal breadth: nutlets in our species beakless.

t- Diffuse or tufted, a span or less high: internal appendages of the corolla small roundish puberulent gibbosities low in the throat.

H. confertifólium, Torr. Suffruticulose, very much branched and tufted, silvery-white with a dense silky-hirsute pubescence: leaves crowded throughout and imbricated along the upper part of the branches, from narrowly oblong to linear, 2 or 3 lines long, equally white both sides, the margins somewhat revolute: inflorescence not in the least scorpioid: flower's sessile among the leaves, mainly glomerate with them at the end of the branches and hardly surpassing them: corolla pale purple; its silky-hairy tube hardly longer than the ealyx ; limb angulate-5-lobed, only 2 lines in diameter: style thrice the length of the ovary: annular stigma much broader than the subulate-conical tip. - Herb. Torr. $H$. limbatum \& var. confertifolium, Torr. Bot. Mex. Bound. 138, not H. limbatum, Benth. - Southwestern borders of Texas, Berlandier; Wright, \&c. (Adjacent Mex.) 
H. phyllostáchyum, Torr. Annual, diffuscly spreading, strigulose-hirsute: leaves oblong or broadly lanceolate, plane ( 3 to 7 lines long), obtuse, contracted abruptly at base into a short petiole, those subtending flowers similar: flowers small, loosely unilateralspicate along the branches, very short-peduncled, some bractless, others at the axils of leaves : caly $\mathbf{X}$-divisions unequal, lanceolate, in fruit one of them mostly ovate-lanceolate and larger: corolla white, hardly exceeding the calyx, its lobes ovate and the folds at the sinuses sometimes more or less extended into teeth: style very short: nutlets with 2 deep pits. - Bot. Mex. Bound. l. c., in part (1859). H. myosotoides, Chapm. Fl. 330 (1860). Rocky hills, southeastern part of Arizona, Wright. Fey West, Florida, Blodgett, Palmer. Flowers barely a line long. Fruiting-calyx becoming 2 lines long, the larger sepal fully twice the length of the depressed-globose fruit. The Mexican specimens of Berlandier referred to this by Dr. Torrey seem rather to belong to II. hispidum, HBK.

$==$ Erect, about a foot high : internal appendages of the throat of the corolla prominent and deflexell

H. polyphýllum, Lehm. Iany-stemmed from a ligneous base or root, minutely strigulose-cinereous: stems very leafy throughout: leaves linear-oblong or lanceolate, 3 to 7 lines long, very short-petioled or sessile : flowers approximate in a leafy slightly scorpioid spike: divisions of the calyx broadly lanceolate or one lanceolate-ovate: tube of the (mostly white) corolla not longer than the calyx, nearly equalling the moderately 5-lobed limb (this 3 or 4 lines in diameter); the strong folds of the sinuses produced at base into conical and pouch-like appendages : style short : nutlets 2-pitted on the inner face. - Lehm. Asper. 63, \& Ic. t. 8; Gray, l. c. H. glomeratum, A.DC. Prodr. ix. 550? H. bursiferum, C. Wright in Griseb. Cat. Cub. 211. Schleidenia polyphylla, Fresen. in Fl. Bras. l. c.E. Florida, Buckley, Palmer, \&c. (W. Ind. to Brazil.)

Var. Leavenwórthii, Gray, l. c. Stems a foot or two high, the larger plants decidedly shrubby : corolla golden yellow $-H$. Leavenworthii, Torr. ined., at least as to the original specimen. - Everglades of S. Florida, Leavenworth, Palmer, Garber, Appears to differ only in the yellow color of the corolla, which is remarkable.

* * Flowers bractless, in distinct unilateral scorpioid spikes, which are commonly in pairs or once or twice forked, forming the scorpioid cyme of this and related orders: anthers free. (Style none and the corolla mainly white in our species.) - \$ Euheliotropium, DC., \&c. Heliotropium, Fresenius, 1. c.

- Pubescent annuals, not fleshy: anthers pointless or mucronulate.

H. Europedr, L. A foot or so high, cinereous-pubescent, loosely branched: leaves oval or obovate, long-petioled: spikes in pairs or single, becoming slender: flowers small, scentless: stigma-tip long and slender-subulate, 2-cleft at apex. Waste grounds of Southern and rarely in Northern Atlantic States: nat. from Eu.

H. inundátum, Swartz. A foot or two high, strigose-cinereous, branching from the base: leaves spatulate-oblong, varying to oblanceolate (commonly an inch long), rather slender-petioled: spikes 2 or 4 in a cluster, filiform, hirsute: flowers very small, crowded (corolla barely a line or so long): stigma thick, surmounted by a short obtuse cone. Fl. Ind. Occ. i. 343; DC. Prodr. ix. 539. H. procumbens, canescens, \& cinereum, HBK. Nor. Gen. \& Spec. iii. t. 206. - Texas to the frontiers of California (Coulter). (S. Am. \& W. Ind.) The stems may become indurated, but the root is annual.

+ + Wholly glabrous perennial (or sometimes annual?), fleshy and glaucous : anthers acuminate.

H. Curassávicum, L. Diffusely spreading, a span to a foot high: leaves succulent, oblanceolate, varying on the one hand to nearly linear, on the other to obovate (an inch or two long): spikes mostly in pairs or twice forked, densely flowered: corolla with a rather ample 5-lobed limb ( 3 lines broad) and open throat (white, with a yellow eye, sometimes changing to blue!); the lobes round-ovate, rather shorter than the tube: stigma umbrellashaped, as wide as the glabrous ovary, flat, not surmounted by a cone! - Hook. Bot. Mag. t. 2669. - Sandy seashore from Virginia (or farther north as a ballast-weed), and from Oregon southward; also in the interior, chiefly in saline soils. (Widely distributed over most warmer parts of the world.)

§3. TinRídrur. Fruit at maturity more or less 2-lobed, and separating into 2 two-celled and two-seeded (or by abortion one-seeded) carpels, which may at length each split into 2 nutlets, with or without empty cavities or false cells: 
style very short or none: flowers in bractless scorpioid spikes, which are either solitary, geminate, or collected in a cyme. - Tiaridium, Lehm. Asper. 13 (1818); Cham. Heliophytum, D.C. Heliotropium § Heliophytum with Cochranea (Miers), Benth. \& Hook. Gen. ii. 844.

* Fruit didymous; the nutlets parallel.

H. ANChus żFólium, Poir. ; Fresen. in Fl. Bras. viii. 46 (which is Tournefortia heliotropioides, Hook. Bot. Mag. t. 3096, and probably also Heliophytum sidcefolium, DC.), is a low perennial, with oblong or lanceolate repand leaves, and a pedunculate close cyme of 3 or 4 spikes of bright violet-blue flowers, much resembling those of the Sweet Heliotrope (H. Peruvianum), but not sweet-scented, and the nutlets when fresh with a thin fleshy exocarp: stigma sessile and with a depressed cone. It is a native of Buenos Ayres and S. Brazil, is cultivated for ornament, occasionally appears among ballast-weeds at Philadelphia, and is becoming spontaneous in East Florida.

H. parviflórum, L. Annual, or becoming woody at base, more or less pubescent, a foot or two high: leaves oblong-ovate or ovate-lanceolate, acute or acuminate at both ends, - pinnately veined, slender-petioled, some of them opposite: spikes single or sometimes in pairs, filiform, 2 to 6 inches long: flowers small and crowded (a line long), white: fruit hardly a line long, blunt, commonly with no distinct empty cell. - Heliophytum parviforum, DC.; Fresen. l. c. 45, t. 10, fig. 6. - Keys of Florida and southern borders of Texas. (Mex., Trop. Amer.)

H. glabriúsculum, Gray. A span high, diffusely branching from a perennial and perhaps rather woody base, minutely and sparsely strigulose-pubescent: branches slender, leafy to the top: leaves green and except the midrib beneath nearly glabrous (an inch or less long), rather obtuse and sometimes undulate, hardly veiny, short-petioled: spikes rather short, solitary or forking: corolla white with a green eye; its tube longer than the calyx and about the length of the oval lobes (these a line long): fruit cinereous-pubescent; the nutlets turgid, by abortion often only 1-seeded, 3-4-toothed at summit, commonly with 3 empty cells or spaces. - Proc. Am. Acad. x. 50. Heliophytum giabriusculum, Torr. Bot. Mex. Bound. 139. - W. borders of Texas, Wright, Bigelow. (Adjacent Mex.)

* * Fruit mitre-shaped (whence the name Tiaridium, founded on the following species); its two lobes diverging: style deciduous.

H. Indicum, L. Coarse annual, hirsute, erect: leaves ovate or oval, sometimes rather cordate, on margined petioles, obscurely serrate or undulate: spikes mostly single, denselyflowered (becoming a span to a foot long): corolla bluish, the limb 2 or 3 lines in diameter: fruit glabrous; the nutlets acutely ribbed on the back, within a pair of large empty cells. Sims, Bot. Mag. t. 1837. Tiaridium Indicum, Lehm.; Cham. in Linn. iv. 452, t. 5. Heliophytum Indicum, DC.; Fresen. 1. c., t. 10, f. 4. - Waste grounds of the Southern Atlantic States, reaching to Illinois along the great rivers. (Nat. from India, \&c.)

7. HARPAGONELLA, Gray. (Diminutive of harpago, a grapplinghook.) - Single species with the aspect of Pectocarya, in company with which it grows. Corolla only a line long, white; the rounded lobes imbricate-convolute in the bud. - Proc. Am. Acad. xi. 88, \& Bot. Calif. i. 531; Benth. \& Hook. Gen. ii. 846.

H. Pálmeri, Gray, l. c. Small and insignificant annual, diffusely and rather simply branched from the base, strigulbse-hirsute: leaves linear; the upper or bracts lanceolate: flowers soon lateral and scattered, a little above and partly opposite the leaf, on short at length strongly recurved and rigid peduncles: body of the bur-ris fruiting calyx, oblong or fusiform, completely enclosing the solitary nutlet, or sométimes a pair. - (Guadalupe Island, off Lower California, Palmer.) Arizona, near Tucson, E. L. Greene. The two globular lobes of the ovary are unilateral, on the side of the style next the enveloping caly $\mathrm{x}$ lobes, and distinct; they apparently belong to different carpels, each of which wants the other half. Both carpels uniovulate and alike in flower, and both, according to Bentham, are sometimes fertile and enclosed together in the calyx. Sometimes one is excluded and naked, but falls away without maturing. 
8. PECTOCARYA, DC. (Compounded of $\pi \varepsilon \% \tau \delta_{s}$, combed, and ranvio, in place of xxovor, nut, referring to the pectimate border of the nutlets.) - Diminutive annuals, of the western coast of America, diffuse, strigose-hir'sute or canescent; with narrow linear leaves, and small and scattered flowers along the whole length of the stem, on rery short and sometimes recurved pedicels : corolla white, minute. - Meisn. Gen. 279 ; Benth. \& Ilook. Gen. ii. 847.

§1. Kтexospéraru. Nutlets bordered with a coriaceous undulate or laciniate wing, geminately divergent. - Ktenospermum, Lehm. Del. Sem. Hort. Hamb. 1837, without char. Pectocarya, DC. Prodr. x. 120 .

P. lineáris, DC. Diffuse : nutlets with narrowly oblong body (one or two lines long), surrounded by a broad wing, which is pectinately or laciniately and often irregularly parted or cleft into subulate teeth, ending in a delicate uncinate-tipped bristle: cotyledons oblong. - Benth. Gen. l. «. P. linearis \& P. Chilensis, DC. Prodr. 1. c. P. Chilensis, C. Gay, Fl. Chil. t. 52, bis, fig. 2. P. Chilensis, var. Californica, Torr. Pacif. R. Rep. v. 12t. P. lateriflora, Gray, Bot. Calif. i. 581, \&c., not DC. ('ymouldosstem lineare, Ruiz \& P'av. Fl. ii. 6. Dry gravelly soil, southern part of California, Ctah, and Arizona. (Chili.) One form, answering to $P$. linearis, DC., has coarsely cleft nearly plane wings; another, answering to $P$. Chilensis, DC., has narrower and more pectinate teeth to a somewinat incurved wing, and the nutlet arcuate-recurved in age.

P. penicilláta, A.DC., l. c. Yery diffuse and slender: nutlets with oblong body (a line "long) surrounded by a merely undulate or pandurate wing (incuived in age), its rounded apex thickly and the sides rarely or not at all beset with slender uncinate bristles : cotyledons oblong-obovate. - Cynoylossum penicillatum, Hook. \& Arn. Bot. Beech, :3ï1. - British Columbia (Macoun) to California and W. Nerada. (The Missouri habitat and the syn. of Nuttall, eited by $\mathrm{A}$. DeCandolle, belong to Echinospermum Redowskii.)

P. LAteriflora, DC., of Peru, has broadly obovate and less geminate nutlets, as noted by Bentham, with the wing dentate in the manner of $P$. linearis.

§ 2. GRctéLI... Nutlets broadly obovate and equably divergent (a line long), the wing or margin entire: cotyledons broadly obovate. - Gray, Proc. Am. Acad. xii. 81. Gruvelia, A.DC. Prodr. x. 119.

P. setósa, Gray, l. c. Hispid, as well as minutely strigose-pubescent, rather stout; caly $x$-lobes armed with 3 or 4 very large divergent bristles: nutlets bordered by a broadish (entire or obscurely undulate) thin-scarious wing; the faces as well as margins beset with slender uncinate-tipped bristles. - S. E. California, on the Mohave desert, Pulmer.

P. pusílla, Gray, I.c. Strigulose-canescent, slender: nutlets cuneate-obovate, wingless, and with a carinate mid-nerve on the upper face, the acute margin beset with a row of slender uncinate-tipped bristles. - Gruvelia pusilla, A.DC. Prodr. x. 119; ('. ('iay, Fl. Chil. 1. c. fig. 3. - Common about Yreka, in the northern part of California, apparently native, Greene. (Chili.)

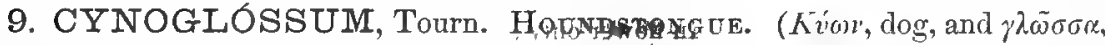
tongue, from the shape and soft surface of the lecaves of the commonest species.)

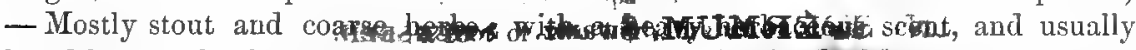
broad leaves, the lower

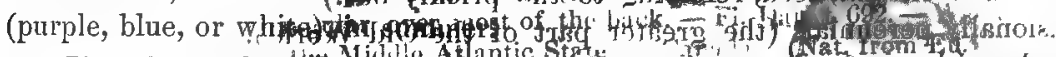

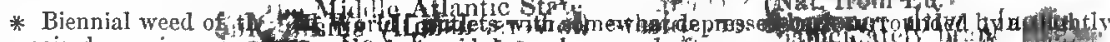
raised margin, asegafy

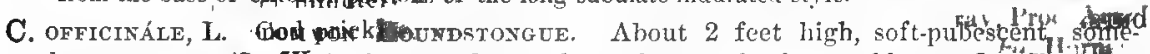

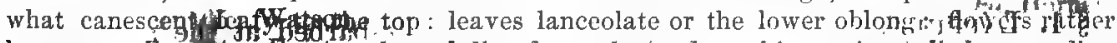

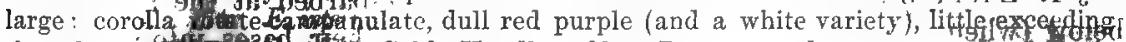
the calyx is stofe

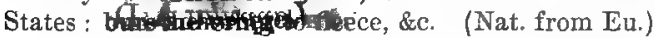


* * Perennial and indigenous: racemes elevated on a naked terminal peduncle: nutlets horizontal or nearly so, tumid, not margined,

+ Sepparating from the low-pyramidal gynobase and usually carrying away portions of the rather. short slender-subulate style.

C. Virgínicum, L. About 2 feet high, hirsute, few-leaved : radical and lowest cauline leaves oval or oblong ( 4 to 10 inches long) and rather abruptly contracted into a long margined petiole; the upper oblong or ovate-lanceolate, conspicuously cordate-clasping: common peduncle half a foot or so in length: tube of the corolla hardly longer than the calyx-lobes ( 1 or 2 lines long) and not longer than the comparatively ample (pale blue) lobes. - C. amplexicaule, Michx. Fl. i. 132. - Open woods, Upper Canada and Saskatchewan to Florida and Louisiana.

++ Nutlets horizontal on a very depressed gynobase, at separation free from the long and slender sts le: Pacific species, with violet or blue and rather large paniculate-racemose flowers.

C. occidentále, Gray. Hirsute-pubescent or in age almost hispid, about a foot high : lower leaves spatulate, tapering gradually into winged petioles; the upper from lanceolate to ovate and partly clasping : tube of the corolla longer than the lanceolate calyx-lobes, and twice or thrice the length of its own roundish lobes: style wholly filiform: nutlets very tumid, almost globular, 4 lines long. - Proc. Am. Acad. x. 58, \& Bot. Calif. i. 531. California, in the Sierra Nevada from Plumas Co. northward, Burgess, Lemmon, Mrs. Austin.

C. gránde, Dougl. Soft-villous-pubescent, hardly hirsute below, becoming glabrate in age, about 2 feet high : lower leaves ovate- or subcordate-oblong and acute or acuminate, 4 to 8 inches long, on margined petioles of about the same length; the upper smaller, from ovate to lanceolate, abruptly contracted into shorter winged petioles: tube of the corolla slightly exceeding the ovate calyx-lobes, and hardly longer than its own ample lobes (these 2 or 3 lines long): slender style thicker towards the base : mature fruit unknown. - Hook. Fl. ii. 85 ; DC. Prodr. x. 153; Gray, l. c. C. officinale, Hook. \& Arn. Bot. Beech. 152, not L. - In woods, from Monterey, California, to Washington Terr.

C. læeve. Smooth and glabrous, except some soft and apparently deciduous pubescence on the lower face of the leaves (which otherwise resemble those of $C$.grande), and more on the lanceolate divisions of the calyx: flowers few : lobes of the corolla ( 1 or 2 lines long) about half the length of the tube: filiform style hardly thickened downward: fruit not seen. - Plumas Co., California, Mrs. Pulsifer-Ames.

* * Perennials of doubtful genus (fruit unknown), with linear sessile leaves, bracteate racemes, rotate blue corolla, and short style.

C. ciliátum, Dougl. A foot or more high, canescently hirsute, the hairs on the lower part of the stem retrorse: leaves tomentose-hirsute, ciliate, 3-nerved; the lower 4 inches long and 2 lines wide, the upper an inch long: racemes subcorymbose : calyx-lobes lanceolate, obtuse : stigma capitate. - Lehm. Pug. ii. 24, \& in Hook. Fl. ii. 85, from which the above description has been compiled. - "Dry banks of mountain streams, Little Falls of the Columbia and upwards to the Rocky Mountains, Douglas."

C. Howárdi. Depressed-cespitose, sericeous-canescent with appressed pubescence : leaves mainly crowded on the tufted branches of the caudex, 5 to 8 lines long, spatulate-linear: flowering stems an inch or two high, 3-4-leaved, clensely few-flowered at the summit: bracts linear, equalling the linear calyx-lobes : corolla with rounded lobes (a line and a half long); fornicate appendages large; the tube very short: stigma truncate. - Rocky Mountains in Montana, Winslow J. Howand

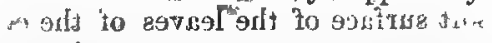

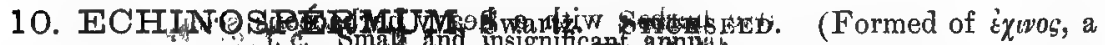

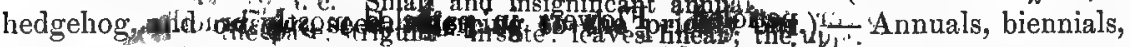

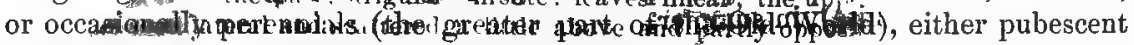

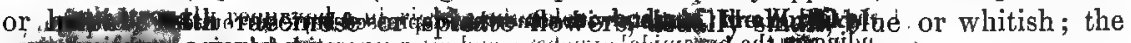

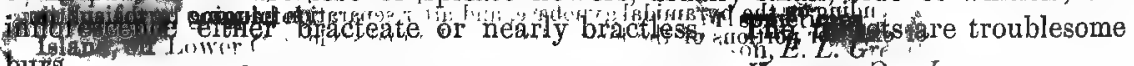

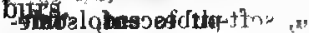

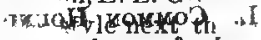

19)

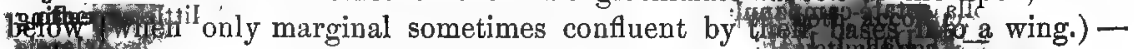
Dewpot, Monch. Echinospermum \& Homalocaryum \& 
* Racemes panicled, leafy-bracteate only at base, minutely bracteate or bracticss above: slender pedicels recurved or detexed in fruit: calyx-lohics lanceolate or oblong; shorter than the fruit, and at length reflexed under it: scar of the nutlets ovate or triangular, medial or infra-medial: gynobase short-pyramidal : biennials or anmuals, some perhaps perennials, pubescent or hirsute,
not hispid.

-r Corolla short-fumelform (blue); the tube surpassing the calyx, about the length of the lobes.

E. diffúsum, Lehm. A foot or so high: leaves oblong-lanceolate; or the lovest spatulate, narrowed at bnse into long wing-margined petioles; the upper sessile, from oblonglanceolate to ovate or cordate, passing into small bracts: racemes commonly loose and spreading : fruiting pedicels 3 to 5 lines long: limb of the bright blue corolla from half inch in diameter to much smaller: style slender: fruit a globose bur; the nutlets 3 lines long, delusely muriculate-scabrous, rather sparsely armed throughout with long and flattened prickles; the scar large and broadly ovate: gynobase broadly pyranidal. - Pug. ii. 23, \& in Hook. FI. ii. 83. E. nerrosum, Kellogg, Proc. Calif. Acad. ii. 146, fig. $42 . \quad E$. deflexum, var. floribundum, Gray, Bot. Calif. i. 511, in part. - Open woods, \&c., Oregon, and California, along the Sierra Nevada, where it is common.

+ + Corolla rotate (from blue to nearly white); its tube shorter than the calyx and the lobes.

E. floribúndum, Lehm., l. c. Rather strict, 2 feet or more high, or sometimes smaller : leaves from oblong- to linear-lanceolate; the lowest tapering into margined petioles: racemes numerous, commonly geminate and in fruit rather strict: nutlets with elongated triangular back naked ( 2 lines long), merely scabrous; and the margin armed with a close row of flat subulate prickles, their bases often confluent; scar smaller and narrowly ovate. - Hook. Fl. ii. 84, t. 164. E. deflexum, var, floribundum, Watson, Bot. King, 246; Gray, 1. c., mainly. E. subdecumbens, Parry in Proc. Davenport Acad. i. 148, a small form, said to be perennial. - Lake Winnipeg to British Columbia, and south to New Mexico and California. Limb of corolla varying from 2 to 5 lines in diameter.

E. defléxum, Lehm. Diffusely branched, a foot or so high : leaves from oblong to lanceolate: racemes lax, loosely paniculate : flowers soon sparse, smaller than in the preceding: nutlets smaller, and the mostly naked back (a line long) broader. - Asper. 120, \& in Hook. 1. c. Myosotis deflexa, Wahl. Act. Holm. 1810, 113, t. 4 ; Fl. Dan. t. 1568. - Saskatchewan, and Winnipeg Valley, Drummond, Bourgeau. Brit. Columbia, Lyall. Habit intermediate between the preceding and following; the American specimens having occasionally some few prickles developed from the rough-granulate dorsal face of the nutlets. Fruit as well as flowers about half the size of that of E.floribundum. (Siberia to Eu.)

E. Virgínicum, Lehm., l. c. Stem 2 to 4 feet high, erect, with long and widely spreading branches: radical leaves round-ovate or cordate, slender-petioled; cauline ( 3 to 8 inches long) ovate-oblong to oblong-lanceolate, acuminate at both ends; uppermost passing into lanceolate bracts : loosely paniculate racemes divaricate, filiform : pedicel and flower each about a line long: corolla slightly surpassing the caly $\mathbf{x}$, pale blue or white: fruit globular, 2 lines in diameter, armed all over with short prickles. - Myosotis Virginiana, L. Spec. 189. M. Virginica, L. Spec. ed. 2, 189 (Moris. Hist. iii. 449, sect. 11, t. 30, fig. 9). Cynoglossum Morisoni, DC. Prodr. x. 155. - Borders of woods and thickets, Canada to Alabama and Louisiana.

* * Spikes leafy-bracteate: pedicels erect or merely spreading, stout, shorter than the calyx: lobes of the latter little shorter than the small corolla, becoming foliaceous and often unequal, mostly exceeding the fruit: scar of the nutlets long and narrow, occupying most of the ventral angle, corresponding with the subulate gynobase: annuals, with rough or hispid pubescence: leaves linear, lanceolate, or the lower somew hat spatulate.

E. LÁPPULA, Lehm., l.c. Erect, a foot or two high, branched above; nutlets rough-granulate or tuberculate on the back, the margius with a double row of slender and distinct prickles, or these irregular over most of the back. - Fl. Dan t. 692. - Waste and cultivated grounds, from the Middle Ailantic States to Canada. (Nat. from Eu.)

E. Redówskii, Lehm., l.c. Erect, a span to 2 feet high, paniculately branched : nutlets irregularly and minutely muricately tuberculate; the margins armed with in single row of stout flattened prickles, which are not rarely confluent at base. - Gray, Proc. Acad. Philad. 1862, 165; Watson, Bot. King, 246, t. 23, fig. 9-12. Myosotis Redouskii, Hornem. Hort. Hafn. i. 174. E. internedium, Ledeb. Fl. Alt. \& Ic. ii. t. 180. (N. Asia.)

Var. occidentále, Watson, 1. c., the American plant, is less strict, at length diffuse, and the tubercles or scabrosities of the nutlet are sharp instead of blunt or round- 
ish, as in the Asiatic plant. - E. patulum, Lehm. in Hook. Fl. ii. 84 ; Torr. in Wilkes Exp. xvii. 418. E. Lappula, Hook. \& Arn. Bot. Beech., not Lehm. E. pilosum, Buckley in Proc. Acad. Philad. 1861. Cynoglossum pilosum? Nutt. Gen. i. 114. - Plains, Saskatchewan and Minnesota to Texas, and west to Arizona and Alaska.

Var. cupulátum, Gray. Prickles of the nutlet broadened and thickened below and united into a wing or border, which often indurates and enlarges, forming a cup (the disk becoming depressed), with margin more or less incurved at maturity, sometimes only the tips of the prickles free. - Bot. Calif. i. 530. E. strictum, Nees in Neuwied, Trav. App. 17 ; Torr. in Pacif. R. Rep. ii. 15, \& Bot. Mex. Bound. ]. c., not Ledeb. E. Redouskii, var. strictum, Watson, l. c. E. Texanum, Scheele in Linn. xxv. 260. E. scabrosum, Buckley, l. c. - Nebraska to Texas and Nevada, with the common form, into which it passes.

§2. Echinoglóchin, Gray. Prickles of the marginless nutlets (disposed without order over the back) beset for their whole length with short retrorse barbs; the scar next the base, ovate: calyx open but not reflexed in fruit: æstivation of the white corolla between convolute and imbricate (i. e. convolute except that one lobe is wholly interior); the fornicate appendages small: pedicels of the partly bracteate raceme erect, apparently articulated with the axis. - Proc. Am. Acad. xii. 163.

E. Greénei, Gray, l. c. Annual, with the habit of Eritrichium fulvum, diffusely branched from the base, a span high or more, strigulose-pubescent with whitish hairs, and the calyx silky-hirsute with fulvous-yellow hairs : leaves linear.(a line or more wide, the lower an inch or two long), obtuse : racemes simple or forked, rather loose, leafy or bracteate at base and occasionally above : flowers 2 lines long: calyx-lobes oblong-linear, obtuse, nearly equalling the corolla: dilated limb of the latter 2 lines wide or nearly: stamens low on the tube: nutlets a line and a half long, shorter than the calyx, ovate-trigonous, obtusely carinate on the back, acutely carinate ventrally down to the low scar, minutely tuberculate-scabrous throughout; the scattered barbed prickles terete, rather slender, a third to half line long. - Northern part of California, common about Yreka, E. L. Greene. An additional link between Echinospermum and Eritrichium, perhaps deserving the rank of a genus.

11. ERITRICHIUM, Schrader. (Composed of "govv, wool, and $\tau$ íxiov, small hair, the original species being woolly-hairy.) - Now a large genus of wide distribution, but most largely W. N. American, between Myosotis on one hand and Echinospermum on the other, not quite definitely distinguished from the latter. Lower leaves not rarely opposite. Flowers (spring and summer) white, in a few blue, only in the last species yellow. Calyx circumscissile and deciduous from the fruit in a few species, otherwise persistent. - A.DC. Prodr. x. 124, excl. spec.; Gray, Proc. Am. Acad. x. 55 ; Benth. \& Hook. Gen. ii. 8j0. Krynitzkia, Plagiobothrys, \&c., Fisch. \& Meyer.

§ 1. Eueritríchium, Gray, 1. c. Nutlets obliquely attached by the base of inner angle to a low-conical or pyramidal gynobase; the scar roundish or oblong, small : seed amphitropous. ascending : tube of the corolla not exceeding the calyx : pedicels not articulated with the rachis. * (Echinospermonde. Nutlets with a pectinate-toothed or spinulose dorsal border: cespitose

E. nánum, Schrader. "Cespitose in pulvinate tufts, rising an inch or two above the surface, densely villous with long and soft white hairs: leaves oblong, 3 to 5 lines long: flowers terminating very short densely leafy shoots, or more racemose on developed fewleaved stems of an inch or more in height, short-pedicelled, some of them bracteate: corolla with limb very bright cærulean blue, 2 or 3 lines in diameter : crest-like or winglike border of the nutlet various, mostly cut into slender teeth or lobes. (Alps of Eu.)

Var. aretioídes, Herder. More condensed: leaves varying from ovate to lanceolate: long villous hairs sometimes with papillose-dilated base, - Radde, Riesen, iv. 253; 
Gray, 1. c. E. aretioides, DC. Prodr. x. 125; Seemann, Bot. Herald, 87, t. 8. E. villosum, var. aretioides, Gray in Proc. Acad. Philad. 1863, 73; Watson, But. King, 211. Myosotis nana, Torr. in Ann. Lyc. N. Y. ii. 225. 1 I . aretivides, Cham. in Linn, iv, 44:3. - Ilighest Rocky Mountains of Colorado, Utah, and Wyoming, and north-west aretic coast and islands. Teeth or spines of the nutlets not rarely with a few bristly points, so that they would be glochidiate in the manner of Echinospermum if retrorse. The Rocky Mountain plant is very near the European, but whiter-villous. 'The form on the $N$. WV. coast more sparsely and less softly villous, passing into

Var. Chamissónis, Herder, l. «. A stouter form, with broader leaves imbricated on the stems, and the grey hairs commonly with papillose-dilated base. $-E$. Chamissonis, DC. 1. c. Myosotis villosa, Cham. 1. c. - Island of St. P'aul. (Adjacent Asia.)

* * (Mrosotidea.) Nutlets not appendaged, ovate, oblong, or trigonous: low and mostly diffuse or spreading annuals (in South America some perennials), sparsely or minutely hirsute: leaves linear ; the lower commonly opposite: flowers white, some bracteate, others racemose or spicate and bractless.

+ Flowers very small: corolla only a line long; the folds or appendages in its throat inconspicwous and smooth: stems diffuse or decumbent, a span or so in length.

E. plebéium, A.DC. Sparsely and minutely hirsute or glabrate : leaves lax (the larger 2 inches long and 2 lines wide): flowers scattered, on pedicels shorter than the calyx, which is open in fruit and the divisions foliaceous-accrescent: nutlets ovate-trigonous, a line long, coarsely rugose-reticulated, glabrous, sharply carinate ventrally down to the large ovate scar and dorsally only along the narrowish apex. - Gray, 1. c. Lithospermum plebeium, Cham. \& Schlecht. in Linn. iv. 446. - Aleutian Islands, Chamisso, Harrington.

E. Califórnicum, DC. Slender, more or less hirsute: leaves mostly smaller and narrower: stems flowering from near the base: flowers almost sessile, most or all the lower accompanied by leaves or bracts, at length scattered: calyx lax or open in fruit : nutlets ovate-oblong, transversely rugose and minutely scabrous or smooth, small ; the scar almost basal. - Prodr. x. 130; Watson, Bot. King, 242. Myosotis Californica, Fiseh. \& Meyer, Ind. Sem. Petrop. 1835. - Springy or muddy ground, through California and Oregon to New Mexico and Wyoming. Passes into

Var. subglochidiátum, Gray. Slightly succulent: lower leaves inclined to spatulate: nutlets when young minutely more or less hirsute or hispid, especially on the crests of the rugosities, some of these little bristles becoming stouter and appearing glochidiate under a lens! - Bot. Calif. i. 526. - E. California to Wyoming and Colorado.

++ Corolla surpassing the calyx, with comparatively ample limb $2 \frac{1}{2}$ to 4 or even 5 lines in diameter. therefore appearing rotate; the appendages in its throat conspicuous and yellowpuberulent: inflorescence more racemose: most of the lower leaves opposite, merely sparsely hirsute: calyx when young often ferrugineous-hirsute.

E. Scoúleri, A.DC. Slender, mostly erect, a span to a foot high : leaves narrowly linear (an inch or two long): flowers in geminate or sometimes paniculate slender naked spikes, most of them bractless: pedicels erect or ascending, from very short to at most a line long: calyx erect in fruit: nutlets rugulose, glabrous, half line long; the scar small. Gray, l. c. Myosotis Chorisiana, Lehm. in Hook. Fl. ii. 83, not Cham. M. Scouleri, Hook. \& Arn. Bot. Beech. 370. Eritrichium plebeium, Torr. in Pacif. R. Rep. iv. 124, not DC. $E$. Chorisianum, plebeium, \& part of Californicum, Gray in Proc. Am. Acad. viii. 397. - Comparatively dry soil, W. Oregon and California. Seems to pass into the next.

E. Chorisiánum, DC. At first erect, soon diffusely spreading or decumbent: larger leaves 2 to 4 inches long: flowers in lax usually solitary racemes, many of them leafybracted: pedicels spreading, sometimes filiform and 2 to 9 lines long, sometimes even shorter than the calyx : corolla more funnelform, its ample limb 3 to 5 lines in diameter: nutlets (half line long) minutely rugose-tuberculate; the scar narrow. - Gray, Proc. Am. Acad. x. 56, \& Bot. Calif. i. 525. E. connatifolium, Kellogg in Proc. Calif. Acad. ii. 103, fig. 51. Wyosotis Chorisiana, Cham. \& Schlecht. 1. c. - Wet ground, California along the coast and the bays of Monterey and San Francisco.

§ 2. Plagiobóthris, Gray, 1. c. Nutlets broadly ovate-trigonous, incurved (the narrowed tips conniving over the short style), rugose, attached by the middle of the concave or seemingly hollowed ventral face to a globular or short-conical gynobase, by means of a salient caruncle-like portion, which at maturity separates 
from a corresponding deep cavity of the side of the gynobase, and persists on the nutlet in place of the ordinary areola or scar (when only one nutlet matures it becomes incumbent) : seed amphitropous, attached above the middle of the cell: herbage villous-hirsute: caly $x$ in the original species at length circumscissile above the base! - Plagiobothrys, Fisch. \& Meyer, Ind. Sem. Petrop. 1835, 46; not well characterized, the fruit being probably immature.

* (Gexuina.) Mature nutlets very concave ventrally; the caruncle narrow and projecting, usually oral, each fitting into an orbicular cavity of the globular gynobase: low annuals, with small flowers, and villous or silky-birsute but not hispid calyx.

+ Nutlets dull or slightly shining, cartilaginous or coriaceous; the lines or ribs narrow and elevated, bounding depressed areolæ; the dorsal keel more or less salient.

E. fúlvum, A.DC. A span to a foot high; slender, branched from the leafy base, loosely Jirsute or merely pubescent: leaves linear or the lower and larger lanceolate or spatulate; the upper sparse and small: spikes at maturity nearly filiform, bracteate only at base: calyx, \&c., densely clothed with dark-ferruginous and some merely fulvous hairs, circumscissile from the mature fruit; the lobes narrow-lanceolate: limb of corolla 2 lines in diameter : nutlets (a line long) xugose with broad and shallow areolations. - Prodr. x. 132 ; Gray, 1. c. 57. Myosotis fulva, Hook. \& Arn. Bot. Beech. 38 (the Chilian plant, which has rather longer and narrower calyx-lobes), \& 369. Plagiobothrys rufescens, Fisch. \& Meyer, 1. c ; A.DC. 1. c. 134. P. canescens, Gray, Proc. Am. Acad. viii. 397 (no. 411, Hall). - Open grounds, California and Oregon, toward the coast. (Chili.)

E. canéscens, Gray, 1. c. Stouter and generally larger than the preceding, leafy, villous-hirsute; the pubescence whitish, even that of the calyx barely fulvous : leaves linear: caly $\mathrm{x}$ larger and with broader lanceolate lobes, less closed over the fruit and liardly if at all circumscissile: nutlets usually with more prominent transverse ribs. - Plagiobothrys canescens, Benth. Pl. Hartw. 326. - W. California and north to the Columbia River.

\section{++ Nutlets crustaceous, vitreous-shining or enamel-like at maturity; the lines bounding the long transverse and closely packed pugre very slender and impressed: low plants, seldom a span high: limb of corolla a line or two in diameter: calyx hardly if at all circumscissile at maturity.}

E. tenéllum, Gray, 1. c. Hirsute with rather soft hairs; those of the calyx more or less fulvous or rusty-yellowish: stems slender and erect: radical leaves in a rosulate tuft, oblanceolate or broadly linear; the cauline rather few and small: spike few-flowered and interrupted, leafy only at base: caly $x$-lobes triangular-lanceolate: nutlets (a line long) very shining, somewhat cruciate from the abrupt contraction at both base and apex, hollowed on the ventral face, the close and straight transverse wrinkles either smooth or sparsely and sharply muricate. - E. fulvum, Watsori, Bot. King, 243 ; Gray, Proc. An. Acad. viii. 397, not A.DC. Myosotis (Dasymorpha) tenella, Nutt. in Hook. Kew Jour. Bot. v. 295. - Northern California ta British Columbia, Nevada, and Idaho.

E. Torréyi, Gray, l. c. More hispidly hirsute, the hairs even of the calyx greyish, much branched from the root: stems diffuse or decumbent, leafy; the flowers mainly leafybracteate: leaves broadly oblong: nutlets rather larger than in the preceding and less shining, broadly ovate, not cruciate nor muricate but smooth (or next the margins obscurely tuberculate), the straight wrinkles rather broader; caruncle not projecting. - California, Sierra Nevada, near Yosemite Valley, Torrey. Sierra Valley, Lemmon; the latter a depressed and very leafy form, with scattered flowers, accompanied throughout by leaves.

* * (Ambigua.) Mature nutlets moderately incurved, affixed to the obtusely conical or pyramidal gynobase by a vertical narrow crest (answering to the caruncle) which occupies the middle third of the concave face of the nutlet (terminating above in the sharp ventral keel which extends to the apex); the carities of the gynobase oblong-ovate in outline: calyx, \&c., more or less setose-hispid.

E. Kíngii, Watson. Apparently biennial, villous-hirsute and more or less hispid : stems a span or so high, rather stout: leaves from spatulate or oblong to spatulate-linear: inflorescence at first thyrsoid; the flowers in short spikes or clusters which are commonly leafy at base: tube of the corolla not longer than the lanceolate calyx-lobes; its limb 4 lines in diameter, or sometimes one-half smaller: nutlets coriaceous, dull, irregularly rugose, not distinctly carinate on the back, fully a line long. - Bot. King, 243, t. 23 (in flower); Gray, Proc. Am. Acad. x. 60, \& Bot. Calif. i. 528. - Eastern portion of the Sierra Nevada, in Ne- 
vada and California; Truckee Pass, $l^{\top}$ atson, a larger-flowered form. Sierra Valley, Lemmon, a smaller-flowered form and with some fruit. Connects Plagiobothrys with the following section.

§ 3. KRyxítzmis, Gray. Nutlets ventrally attached from next the base to the middle or to the apex to the pyramidal or columnar or subulate gynobase; the scar mostly sulcate or slightly excavated: seed from amphitropous to nearly anatropous, commonly pendulous: corolla (except in the last species) white: calyx 5-parted, closed in fruit. - Krynitzkia, Fisch. \& Meyer, Ind. Sem. Petrop. 1841, 52. \$ Krynitzlia \& \$ Piptocalyx, Gray, 1. c.

* (EukryxizkiA.) Nutlets without acute lateral angles or margins, the sides more commonly rounded: corolla mostly small; the tube not surpassing the mostly setose-hispid calyx: anthers oval : root annual.

+ Calyx early circumscissile; the 5-cleft upper portion falling away, leaving a membranaceous some what crenate-margined base persistent around the fruit: corolla with naked and open throat: anthers mucronate: flowers all leafy-bracteate and sessile. - Piptocalyx, Torr.

E. circumscíssum, Gray. Depressed-spreading, very much branched from the annual root, an inch to a span high, whitish-hispid throughout: narrow linear leaves (a quarter to half inch long) and very small flowers crowded, especially on the upper part of the branches: nutlets oblong-ovate, smooth or minutely puncticulate-scabrous, attached by a narrow groove (with transverse basal bifurcation) for nearly the whole length to the pyramidal-subulate gynobase. - Proc. Am. Acad. x. 58, \& Bot. Calif. i. 527. Lithospermum circumscissum, Hook. \& Arn. Bot. Beech. 370. Piptocalyx circunscissus, Torr. in Wilkes Exp. xvii. 414, t. 12. - Desert plains, E. California to Utal, Wyoming, and Washington 'Terr.

++ Calyx neither circumscissile nor disarticulating from the axis in age; the lobes linearoblong, obtuse, nearly nerveless : the bristles short and even, not setose or pungent: corolla with minute if any appendages at the throat: nutlets attached for the whole length to a slencler columnar gyrobase by a groove which does not bifurcate nor sensibly enlarge at base: flowers all leafy-bracteate, short-pedicelled: style at length thickened!

E. micránthum, Torr. Hirsute-canescent, slender, 2 to 5 inches high, at length diffusely much branched : leaves linear, only 2 to 4 lines long: flowers in the forks, and much crowded in short leafy spikes, about equalling the upper bracts : corolla barely a line high, and its lobes one to two-thirds of a line long, obscurely appendaged at the throat: nutlets oblong-ovate, acute or acuminate, smooth and shining or clull and puncticulate-scabrous (half to two-thirds of a line long): style beconing thicker than the gynobase, or even pyramidal. -Bot. Mex. Bound. 141; Watson, Bot. King, 214. - Dry plains, western border of Texas through Utah and Arizona to E. California, where larger flowered specimens connect with

Var. lépidum. Less slender and more hirsute : corolla larger, its expanded limb 2 or 3 lines in diameter; the appendages or folds in the throat very manifest: nutlets nearly a line long, puncticulate-scabrous. - California, in San Diego Co., D. Cleveland.

+++ Calrx not circumscissile, 5-parted, conspicuously and often pungently bispid with lyrge stiff bristles, and the lobes usually with a stout midnerve; the whole calyx (or short perlicel) in several species inclined to disarticulate at maturity and to form a sort of bur, loosely enclosing the nutlets: inflorescence scorpioid-spicate, without or partly with bracts.

+ Grnobase slender and narrow: nutlets with narrow grooved scar, or continued into a groove above the attachment and so running the whole length of the ventral face: spikes when developed mainly bractless : leaves in all linear.

= Lobes of the fructiferous calyx very narrow; the strong bristles below reflexed and partly uncinate: appendages in the throat of the small corolla obsolete or wanting: only one nutlet usually maturing.

E. oxycáryum, Gray. Somewhat canescently strigulose-pubescent or above hirsute, slender, 6 to 20 inches high: leaves narrow: spikes dense in age, but slender, becoming strict, and with the sessile fruiting calyx appressed: this at most 2 lines long, thickly beset toward the base with stout reflexed bristles (of a line or less in length), the tips of some of them curving: nutlet ovate-acuminate or ovate-lanceolate, very smooth and shining, fully a line long, much surpassing the subulate gynobase and style, affixed to the latter only by the lower half or third of the narrow ventral groove. - Proc. Am. Acad. x. 58, \& Bot. Calif. i. 526. Myosotis flaccida, Hook. \& Arn. Bot. Beech. 369, ex Benth., not Dougl. Krynitzkia leiocarpa, Benth. PI. Hartw. (no, 1872), 326, not Fisch. \& Meyer. - Common in W. California. (Not seen from Oregon.) 
$==$ Lobes of fructiferous calvx very narrowly linear, twice or thrice the length of the nutlets, armed with remurkably long and straight spreading bristles : appendages in throat of corolla evident.

E. angustifólium, Torr. Hispid with spreading bristles, a span high, diffuse: leaves narrowly linear: spikes often geminate, dense and slender : corolla barely a line long and with a small limb: calyx-lobes almost filiform in age, seldom over a line long, beset with divaricate bristles of the same length: nutlets half a line long, ovate-triangular, with minutely granulate surface, all four maturing, little longer than the conical-subulate gynobase, to which they are attached by a narrow grooved scar with somewhat broader base. - Pacif. R. Rep. v. 363, \& Bot. Mex. Bound. 141. - South-eastern California and Western Arizona. (Lower Calif.)

E. barbígerum. Hispid and hirsute, stouter, a span to a foot high, freely branching : leaves broader: spikes solitary or paniculate, elongating; the flowers at length rather sparse and less secund: limb of the corolla sometimes 3 lines in diameter: calyx-lobes linear-attenuate, in fruit 3 or 4 lines long, thickly beset with long shaggy bristles (of $1 \frac{1}{2}$ to 2 lines length), which are sometimes accompanied with long white-villous hairs: nutlet commonly by abortion solitary, and a line or more in length, surpassing the style, avatetrigonous and somewhat acuminate, muricate-papillose, attached by the lower half and more to the subulate-columnar gynobase, the scar dilated at base (infertile ovary-lobes remaining on the gynobase, attached for almost their whole length). - $\mathbf{S}$. California, from Santa Barbara Co. to S. Utah and Arizona, Parry, Palmer, Smart, Rothrock, \&c. Has been confounded in imperfect specimens with the preceding and some of the following.

$===$ Lobes of the fructiferous calyx less attenuated, and the bristles less elongated: appenclages of the throat of the corolla conspicuous: all four nutlets usually maturing.

E. leiocárpum, Watson. Roughish-hirsute or hispid, with mostly ascending hairs, a span to a foot high, usually branching freely: spikes when elongated becoming rather loosely-flowered: $\operatorname{limb}$ of corolla 2 lines or less in diameter: fructiferous calyx-lobes seldom over 2 lines long, from narrowly lanceolate to narrow-linear ; nutlets ovate and oblongovate, very smooth and shining, a line or less long, somewhat surpassing the persistent style, attached from the middle downward to the subulate gynobase by a very slender scar which is divergently bifurcate at the very base. - Bot. King, 244 ; Gray, 1. c. -Echinospermum leiocarpum, Fisch. \& Meyer, Ind. Sem. Petrop. 1835, 36. Krynitzkia leiocarpa, Fisch. \& Meyer, Ind. Sem. Petrop. 1841, 52 ; A.DC. l. c. Myosotis faccida, Dougl. in Hook. Fl. ii. 82. - California to borders of British Columbia, and east to New Mexico and Saskatchewan. A wide-spread and also variable species.

E. muriculátum, A.DC. Stouter, leafy, more hirsute-hispid with spreading hairs, a foot or two high: spikes often geminate or collected in a 3-5-radiate pedunculate cyme: limb of corolla 2 or 3 lines in diameter: calyx-lobes lanceolate, in fruit only $1 \frac{1}{2}$ to 2 lines long and seldom twice the length of the nutlets: these ovate-triangular, obtuse, a line long, not equalling the style, dull or nearly so, muricate-papillose on the back and sometimes on the inner faces also, attached to the subulate gynobase for two-thirds of their length by a grooved scar which widens downward and is transversely dilated at base. Prodr. ix. 132. Myosotis muricata, Hook. \& Arn. Bot. Beech. 369. - California, Douglas (specimen, in flower only, wrongly referred, in Proc. Am. Acad. x. 50, to E. canescens), Brewer, Palmer (in fruit, San Buenaventura and back of San Simeon Bay), Coulter, Xantus, \&c.

Var. ambíguum. Fruit of E. muriculatum, or usually sparsely and more minutely murieulate, equally dull, equalling and usually somewhat surpassing the persistent style, yet occasionally shorter: in whole habit, sparse spikes, and generally the longer and narrower calyx-lobes agreeing with $E$. leiocarpum, of which there is also a form with lanceolate and shorter calyx-lobes. - E. muriculatum, Torr. Bot. Wilkes Exp. xvii. 416, t. 13; Gray, 1. c., mainly, $E$. angustifolium, Watson, Bot. King, 211, not Torr., at least not the original plant. - California and Nevada to Washington Terr.

+ + Gynobase broader, pyramidal or conical: nutlets with a correspondingly broader scar ( $E$. Texanum excepted): corolla small or minute (the limb only a line or two in diameter): calyx very hispid with yellowish ur fulvous bristles : rough-hispich annuals, with spikes loose in fruit, and mostly leafy-bracteate at base.

$$
=\text { Nutlets all fertile and alike, small : midrib of calyx-lobes not thickened. }
$$

E. pusíllum, Torr. \& Gray. Low (2 or 3 inches high) and slender: linear leaves mainly clustered at the root: flowers rather crowded in small spikes: calyx-lobes ovate- 
lanceolate: crests in throat of corolla inconspicuous: nutlets half a line long, ovate-triangular, strongly muricate-granulate on the rounded back, which is bordered by acute angles; the inner faces very smooth and concave when dry; the ventral angle beveled by the deltoid-lanceolate scar which terminates below the apex in a narrow groove: gynobase subulate-pyramidal. - Pacif. R. Rep. ii. 171. - North-western borders of Texas and adjacent New Mexico, Pope, Wright. Calyx in fruit about a line long, apparently not deciduous with the fruit.

E. híspidum, Buckley. A span or more high, greyish-hispid, diffusely much branched, even the loose paniculate spikes mostly leafy: leaves linear: flowers rather scattered: calyx-lobes lanceolate: crests in throat of the corolla rather conspicuous: nutlets half to two-thirds of a line long, triangular-ovate, without lateral angles, coarsely granulate (sometimes almost smooth) round to the deltoid or triangular-lanceolate excavated scar. - Proc. Acad. Philad. 1861, 462; Gray, Proc. Am. Acad. x. 59. E. heliotropioides, 'Torr. Bot. Mex. Bound. 140, mainly, excl. syn. DC. - Plains and sandy banks, W. Texas to New Mexico, extending into Mexico. Calyx a line long, closed at maturity, and deciduous with the enclosed fruit, like a bur.

$==$ Nutlets either solitary or dissimilar: calyx-lobes linear, obtuse, thickish, closed over the fruit ( 2 or 3 lines long); the midrib below becoming much thickened and indurated.

E. Texánum, A.DC. About a foot high, loosely branching, rough-hispid : leaves obovateoblong or spatulate, or the uppermost linear: spikes mostly leafless : flowers nearly sessile: caly $x$ in fruit separating by an articulation: nutlet usually only one maturing, fully a line long, oblong-ovate, rounded on the back, smooth and even, but ninutely puncticulate, fixed by a narrow scar from base to below the middle to a small conical-columnar gynobase. Gray, l. c. - Texas, about Austin, \&c., Drummond, Wright, E. Hall. Flowers smaller and midrib of the sepals less thickened than in the next.

E. crassisépalum, Torr. \& Gray. A span high, diffusely much branched from the base, very rough-hispid : leaves oblanceolate and linear-spatulate : flowers short-pedicelled, many or most of them bracteate: lobes of the persistent caly $x$ greatly thickened below in fruit: nutlets ovate, acute, rounded on the back, dissimilar, three of them muricate-granulate and one larger and smooth or nearly so (fully a line long), fixed to the conical-pyramidal gynobase from base to middle by an ovate-lanceolate excavated scar. - Pacif. $R$. Rep. ii. 171; Gray, Proc. I. c. - Plains, Western Texas and New Mexico to Nebraska and Saskatchewan. The larger and smooth nutlet, like the similar and only fertile one of $E$. Texanum, appears to be unusually persistent. Short pedicel thickened and indurated with the caly $x$ at maturity, disposed to separate tardily by an articulation.

* * (Ptrrygius.) Nutlets and flowers of the foregoing subsection; but the former (either all or three of them) surrounded by a conspicuous firm-scarious crenate or lobed wing: crests in the throat of the corolla rather sinall.

E. pterocáryum, Torr. Annual, slender, loosely branching, hirsute: leaves linear, or the lowest spatulate, often hispid : inflorescence at first cymose-glomerate, usually developing a pair of short spikes, mostly bractless : calyx-lobes oblong and in fruit ovate, erect, and with rather prominent midrib: corolla very small (its linb less than a line in diameter) : nutlets oblong-ovate, rough or granulate-tuberculate on the rounded back, affixed for nearly the whole length to the filiform-subulate gynobase by a narrow groove which widens gradually to the base; one of them commonly wingless and rounded at the sides; the others with lateral angles extended into a broad radiately striate wing with toothed or crenulate margins. - Wilkes Exp. xvii. 415, t. 13; Watson, Bot. King, 245; Gray, 1. ı. Dry interior region, from the plains of the Columbia River, Washington Territory, through Nevada and the borders of California to Arizona, New Mexico, and the borders of Texas. Fruiting calyx 2 lines long, rather sparsely hispid, very short-pedicelled, apparently not falling with the fruit. Nutlets a line and a half long, including the surrounding broadly ovate wing.

Var. pectinátum, Gray, l. c., has all the nutlets winged, and the wings pectinately cleft half way down. - S. Utah and Arizona, Parry, Palmer.

* * (Pseudo-Myosotis.) Nutlets triangular or triquetrous, with acute or even winged lateral angles, attached by half or nearly their whole length to the subulate or slendel-pyramidal gynobase: the scar very slender and usually with transversely dilated base: corolla with prominent fornicate crests at the throat, and near the base within annulate: biennials or perennials, mostly with thyrsiform and leafy-bracteate inflorescence. 
- Tube of the corolla not longer than the calyx and little if any longer than the lobes; a ring of 10 small scales or glands above the base within: anthers oval or oblong: style rather short.

+ Nutlets margined all round with a firm entire wing : plant setose-hispid: corolla small.

E. holópterum, Gray. About a foot high, perhaps from an annual root, loosely paniculate-branched, rather slender: leaves linear, an inch or so long, very rough with the papilliform bases of the rigid short bristles paniculate spikes rather few- and at lengtl loosely flowered: calyx and corolla about a line (and the former becoming 2 lines) long: immature nutlets ovate-trigonous, a line long, muriculate on the convex back, abruptly wing-margined (the wing nearly the breadth of the dorsal disk), attached for nearly the whole length to the conical-subulate gynobase. - Proc. Am. Acad. xii. 81. - Ehrenberg, Arizona, Palmer.

E. setosíssimum, Gray. Stem robust, 2 feet or more high from an apparently biennial root, nearly simple, very hispid (as is the whole plant) witl long and stiff but slender spreading bristles (with or without papilliform base), also cinereous with fine spreading hairs: leaves lanceolate-spatulate, the lower 4 or 5 inches long (including the tapering base or margined petiole): spikes in fruit elongated ( 3 or 4 inches long), dense and strict in a raked thyrsus : corolla 2 or hardly 3 lines long: anthers on short and thickened inflexed filaments : fructiferous caly $x$ fully 3 lines long; the lobes oblong-lanceolate, carinate by a strong midrib: nutlets obcompressed, almost 3 lines long, broadly ovate in outline, dull, merely scabrous on the back; the conspicuous wing much narrower than the disk and extended round the base; the scar narrow at base: gynobase elongated-subulate- Proc. Am. Acad. 1. c. - Shores of Fish Lake, Utah, at the elevation of 8,700 feet, L. F. Ward. Known only in fruiting specimens, which so much resemble E. glomeratum, var. virgatum, that intermediate forms may occur, and the great size, flatness, narrow-based scar, and conspicuous wing of the nutlets may prove inconstant.

$$
++ \text { Nutlets acutely triangular, wingless. }
$$

E. Jamésii, Torr. A span or two higl from a perennial root, rather stout, branched from the hard or lignescent base, canescently silky-tomentose and somewhat hirsute, becoming strigose-hirsute or even hispid in age: leaves oblanceolate or the upper linear, obtuse: spikes somewhat panicled or thyrsoid-crowcled, moderately clongating, bracteate: limb of the short and broad corolla about 3 lines wide : fruiting caly $x$ mostly closing over the depressed-globular fruit, which consists of 4 closely fitting very smooth and shining broadly triangular nutlets (hardly higher than wide).- Marcy Rep. 294, \& Bot. Mex. Bound. 140 ; Gray, 1. c. E. multicaule, Torr. 1. c., a more lispid form. Myosotis suffinticosa, Torr. in Amm. Iyc. N. Y. ii. 225. - Plains and sandy shores, western borders of Texas and New Mexico to Arizona and Wyoming. - Nutlets almost exact quarters of a sphere, or with angles more acute and sicles rather concave, attached by the inner angle, also with a short transverse scar at base.

E. glomerátum, DC. A span to a foot or more high from a biennial root, greyish-hirsute and hispid : leaves spatulate or linear-spatulate: inflorescence thyrsiform and mostly dense; the short and often forked lateral spikes at length commonly exceeding the subtending leaves: calyx very setose-hispid: limb of the corolla 3 to .5 lines in diameter: the crests truncate: nutlets forming an ovoid-pyramidal fruit; each triangular-ovate, sparsely more or less tuberculate-rugose on the back (a line long), with sharp lateral edges, and sulcate ventral angle extending into a broad basal scar. - Watson, Bot. King, 242, t. 23; Gray, l. c. Cynoglossum glomeratum, Pursh, Fl. ii. 729. Myosotis glomerata, Nutt. Gen. i. 112; Hook. Fl. ii. 82, t. 162. Rochelia glomerata, Torr. Ann. Lyc. N. Y. 1. c.; Nutt. in Jour. Acad. Philad. vii. 45. E. glomeratum, var. hispidissimum, Torr. Bot. Mex. Bound. 140, may be taken for nearly the original of Nuttall and Bradbury, of the Upper Missouri.-Plains of Saskatchewan to New Mexico and Utah. Two varieties mark the opposite extremes.

Var. húmile, Gray. Barely a span high, often tufted on an apparently perennial root: pubescence less hispid and generally canescent, at least the lower leaves; these spatulate, an inch or more long: thyrsus spiciform: pubescence and bristles of calyx either whitish or tawny yellow. - Proc. Am. Acad. x. 61. - Rocky Mountains from the British Boundary to Utalh, at 8000 feet, and higher parts of the Sierra Nevada, California. Passing on one hand into the typical form, on the other approacling the next species.

Var. virgátum, Porter. Very hispid, not at all canescent : stem strict, a foot or two high, flowering for most of its length in short and dense nearly sessile clusters, which 
are generally much shorter than the elongated linear subtending leaves and forming a long virgate leafy spike: nutlets less or slightly rugose on the back, at most a line and a half long. - Porter \& Coulter, Fl. Colorado, 102 ; Gray, l. c. E. glomeratum, Gray in Am. Jour. Sci. ser. 2, xxxiv. 225. E. virgatum, Porter in Hayden Rep. 1870, 479. - Along the base and eastern slope of the Rocky Mountains up to 8000 feet, Colorado, Parry, Hall, Porter, \&c. A well marked form, clearly biennial.

++ Tube of the salverform corolla longer than the calrx, and twice or thrice the length of the lobes; the ring within (at base of the tube', inconspicuous and truncate, its glands indistinct; crests of the throat large, ofteu elongated: anthers linear-ablong: style long and filiform: silkycanescent perennials, with contracted thyrsoid inflorescence. - Pseudomyosotis, A.DC,

E. fulvocanéscens, Gray. A span or so high, cespitose: leaves linear-spatulate or oblanceolate, silky-strigose or even tomentose; the lower with bright white and soft hairs; the upper and the thyrsoid glomerate inflorescence and calyx with fulvous-yellow nore hirsute hairs and some hispid bristles: corolla white: nutlets roughish or granulated. Proc. Am. Acad. x. 91, \& Bot. Calif. 1. c. E. glomeratum, var. ? fulvocanescens, Watson, Bot. King, t. 23, fig. T. - Mountains of New Mexico (Fendler, \&c.) to those of Nevada, and norti to Wyoming. Habit of the dwarf and hoary forms of the preceding species, with longer corolla, style, and anthers of the next.

E. leucophǽum, A.DC. A span to a foot high, many-stemmed from the lignescent base or root: leaves silky-strigose and silvery-canescent, lanceolate and linear, acute: spicate-glomerate inflorescence and calyx hirsute and hispid with spreading whitish or yellowish hairs and slender bristles : corolla cream-colored or yellow : style very long: nutlets ovate-triquetrous, smooth and polished, ivory-like, large ( $1 \frac{1}{2}$ or 2 lines long) : gynobase very slender. - Gray, 1. c. Myosotis leucophaea, Dougl. in Hook. Fl. ii. 82, t. 163. - Burren grounds, interior of British Columbia and Oregon, Southern Utah, and near Mono Lake, E. California. Anthers (always?) borne on the tube of the corolla close below the throat.

Rochelia Patexs, Nutt. in Jour. Acad. Philad. vii. 44, founded on a specimen collected by Wyeth on "Flat-Head River" in the Rocky Mountains, would seem to be an Eritrichium, but has not been identified, nor is the specimen to be found in the Academy's herbarium.

12. AMSINCKIA, Lehm. (In memory of Wm. Amsinck, a burgomaster of Hamburg and benefactor of the botanic garden.) - Rough-hispid annuals (W. N. American and one Chilian); with oblong or linear leaves, and scorpioid-spicate flowers, sometimes the lowest and rarely (in the last species) all leafy-bracteate; the corolla yellow, slender, with open throat, either wholly naked or with minute bearded crests. Stout bristles of the herbage commonly with pustulate-dilated base. Calyx-lobes in several species disposed to be occasionally united 2 or 3 together almost to the top. Flowers in most species all heterogone-dimorphous, at least in the insertion of the stamens; when these are high the throat of the corolla is quite naked. - Lehm. Del. Sem. Hamb. 1831, 7 ; Fisch. \& Meyer, Ind. Sem. Petrop. 1835, (1) 26 ; DC. Prodr. x. 117; Benth. \& Hook. Gen. ii. 851.

$\S 1$. Nutlets (resembling those of Eritrichium leucophreum, which is peculiar in its long and yellow corolla) ovate-triquetrous, straight, at maturity very smooth and polished, attached at the lower part of the sharp inner angle by a narrow scar, all three faces plane or nearly so.

A. vernicósa, Hook. \& Arn. A foot or more high, erect, sparsely setose-hispid: leaves from linear to ovate-lanceolate: tube of the light yellow corolld slightly longer than the calyx. - Bot. Beech. 370; DC. 1. c.; Gray, Proc. Am. Acad. x. 54, \& Bot. Calif. i. 525. - California, near the coast, Douglas, Coulter, \&c. Nutlets almost 2 lines long, in shape resembling a grain of buckwheat.

Var. grandiflóra, Gray. Robust, strongly setose-hispid, remarkably large-flowered, the more exserted and funnelform tube of the corolla almost half an inch Iong, and the limb ample: nutlets broader, rather concave on the back. - Bot. Calif. l. c.-Lower Sacramento, at Antioch, Kellogg. 
§2. Nutlets (not unlike those of Eritrichium $\$$ Plagiobothrys) rugose or muricate, dull, ovate-trigonous and somewhat incurved, carinate ventrally down to the short and broad usually somewhat protuberant scar.

* Nutlets crustaceous, tessellate-rugose: calyx-lobes obtuse..

A. tesselláta, Gray. Coarsely and strongly hispid, stout, a foot or two high : leaves from linear-lanceolate to oblong, mostly obtuse: tube of the orange-yellow corolla somewhat longer than the ferrugineous-hispid calyx (about 3 lines long) and much longer than the lobes: nutlets very broadly ovate, with narrowed apex and flattish back, thickly covered with granulate-warty projections which fit together in age, forming more or less conspicuous transverse lines or wrinkles; the scar toward the middle of the ventral face. - Proc. Am. Acad. \& Bot. Calif. 1. c. A. lycopsoides, Watson, Bot. King, 240, partly. Dry grounds, California from the Contra-Costa range through the interior to Nevada and S. Utah. Calyx-lobes either narrowly or rather broadly lanceolate.

* * Nutlets muricate or sharply scabrous, in uge sometimes loosely rugose. (Species difficult to discriminate.)

+ Calyx-lobes narrowly linear-lanceolate or linear, acutish, all over hispid and hirsute: leaves linear or lanceolate.

A. echináta, Gray, l. c. Stem strict, 2 or 3 feet high : corolla light yellow, about twice the length of the fulvous-hispid calyx, little dilated at the throat; the limb 2 or 3 lines in diameter: immature nutlets with the strongly convex and carinate back muricate with soft slender prickles and intermediate scabrous points, not rugose. $-\mathrm{S}$. E. California in the Mohave region, Cooper.

A. intermédia, Fisch. \& Meyer, 1. c. A foot or two high, branching: bristles even of the calyx whitish or barely fulvous: leaves from oblong-lanceolate to linear: corolla not above 3 lines long, little exceeding the calyx; the small limb hardly at all plaited: nutlets very convex and carinate on the back, muricate-scabrous and at maturity obliquely more or less rugose. - DC. 1. c.; Gray, Bot. Calif. 1.c. A. lycopsoides, Gray, Proc. Am. Acad. x. 54, in part; and of gardens. Benthamia lycopsoides, Lindl. (Introd. Nat. Syst.) in Hort. Soc. Lond. 1828 , \&c., thence becoming A. lycopsoides of cultivation, but probably not of Lehm. - California and W. Nevada to the borders of Brit. Columbia; a common and variable species.

A. spectábilis, Fisch. \& Meyer, 1. c. Mostly slender, a span (when depauperate) to a foot high: leaves mostly linear: tube of the bright orange corolla twice or thrice the length of the linear lobes of the ferrugineous-hispid caly $\mathrm{x}$, nearly half inch long, or sometimes shorter; the throat enlarging, and the limb conspicuously plaited in the bud (a third to half inch wide); anthers when high protruded from the throat: nutlets granulate-rugose, carinate and roundish on the back. - A. spectabilis \& $A$. Douglasiana, DC. I. c. - Open ground, California from San Diego to Plumas Co.

+ + Calyx loosely enclosing the fruit, more sparsely setose-hispid. greener and soft-herbaceous in texture; the lobes lanceolate or ovate-oblong, mostly obtuse, 2 or 3 of the lobes not rarely united.

A. lycopsoídes, Lehm. Loosely branched, soon spreading, sometimes decumbent, sparsely but strongly setose-hispid, the bristles on the foliage at length with very pustulate base: leaves greener, from lanceolate to ovate, the margins commonly undulate-repand: upper flowers mainly bractless: corolla light yellow, about 4 lines long, with tube little or considerably exceeding the calyx ; the throat little enlarged and limb 2 or 3 lines in diameter: anthers short, included : nutlets reticulate-rugose. - Del. Sem. Hamb. l. «., name only ; DC. Prodr. x. 117; Gray, Bot. Calif. i. 524. - Coast of California, from San Simeon Bay northward to Oregon. Passes into

Var. bracteósa, a smaller-flowered and more decumbent form (corolla 2 or 3 lines long and the limb a line or two broad), with most of the flowers subtended by a foliaceous bract. - Lithospermum lycopsoides, Lehm. Pug. ii. 28, \& in Hook. Fl. ii. 89, therefore properly the original of Amsinckia lycopsoides, Lehm. I. c. - San Francisco Bay to Puget Sound.

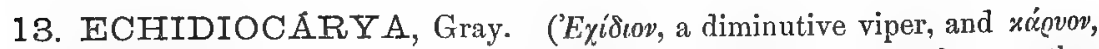
nut, the nutlets with the stalks resembling the head and neck of a snake or other reptile.) - Annuals or biennials of two species, with the habit of Eritrichium 
$\S$ Plagiobothrys, intermediate between that group and Antiphytum, hirsute, hardly hispid, branched from the base; the stems or branches diffuse, a span or two high; leaves spatulate-linear, all alternate; scorpioid spikes slender and at length remotely flowered, bractless, or with some scattered foliaceous bracts: white corolla with lobes sometimes almost convolute in the bul. - Gray in Benth. \& IIook. Gen. ii. 85̆4 ; Proc. Am. Acad. xi. 89, xii. 163.

E. Arizónica, Gray, 1. c. Lobes of the corolla a line or less long; the throat somewhat narrowed by rery small and rather obscure intrusive folds : mutlets attenuate and much compressed at apex, sparsely cristate-muricate, hardly longer than their thick basal stipes, which are united at base in pairs over the prominent receptacle, the pair with a very large excarated scar. - Arizona, on the Verde MIesa, Dr. simut. Also near Tucson, Greene.

E. Califórnica, Gray. Corolla larger; the orbicular lobes a line or two in length; the throat closed by strong and puberulent intrusive appendages: nutlets smaller (a line long), less acute, coarsely rugose-alveolate and the sharp elevated rugosities often echinulate; the stipes supra-basal, all four wholly distinct, laterally compressed, shorter than the diameter of the nutlet; the small caruncular scar concave. - Proc. Am. Acad. xii. 164. San Bernardino Co., S. E. California, Parry \& Lermon, no. 278, coll. $18 i$ U.

14. ANTIPHYTUM, DC., partly. (Aví, opposite, and cvvóv, plant; the leares in the typical species being all opposite, in this unlike most of the order.) - Restricted in Benth. \& Hook. Gen. Pl. ii. 859 to Brazilian species, all suffruticose and opposite-leaved, with short-stipitate areola to the nutlets. But the subjoined species exhibit the characters of the genus in a lesser degree. Gras, Proc. Am. Acad. x. 54. (In separating from the insertion, a delicate funicle-like process, which penetrated a minute central perforation of the scar, persists on the flat gynobase.)

A. heliotropioídes, A.DC. Woody perennial ? a foot or two high, paniculately much 'branched, softly strigose-hirsute anũ at least when young canescent : leaves linear, an inch or less long; the lower mainly opposite: flowers rather small and scattered, on filiform pedicels much longer than the calyx, the lobes of which are oblong-linear : corolla almost rotate, with conspicuous crests in the open throat: stigma capitate: scar of the nutlets large and sessile, but edged with an acute salient margin; the minute perforation above its centre. - Prodr. x. 122; Gray, 1. c. Eritrichium heliotropioides, Torr. Bot. Mex. Bound. 140 , as to the plant of Berlandier only. - San Carlos, on the MIexican side of the Rio Grande, close to Texas. Turgid nutlets only half a line long, not (as in the next) contracted behind the scar.

A. Horibúndum, Gray, l. c. Herbaceous fron a "perennial" or perhaps biennial root, a foot or two high, paniculately branched above, cinereous with fine and close and with a coarser nearly hispid pubescence: leaves perhaps all alternate, narrowly linear, an inch or so long; the upper gradually diminished to linear-subulate bracts: flowers very shortpedicelled, in short panicled racemes or spikes : lobes of the calyx linear-lanceolate, acuminate : corolla rotate-campanulate ( 3 lines in diameter), not appendaged in the throat: filaments longer than the anthers: stigma 2-lobed: nutlets granulate, acute; the salient ventral edge terminated a little above the base of the nutlet by the small and protuberant or slightly stipitate scar. - Eritrichium floribundum, Torr. l.c. - South-western Texas, on or near the Rio Grande, in the mountains of Puerte de Paysano, Bigelout. Flowers sometimes 6 -merous.

15. MERTENSIA, Roth. (Francis Charles Mertens, a German botanist, 1797.) - Perennials, of the cooler parts of the northern hemisphere, either glabrous and remarkably smooth, or with some soft or moderately scabrous pubescence; the leaves commonly broad, and the lowermost petioled; the flowers commonly handsome, blue, purple, or rarely white, paniculate-racemose or cymose, 
all pedicellate, the lowest occasionally leafy-bracteate. Fl. spring and summer. - DC. Prodr. x. 87; Gray in Am. Jour. Sci. ser. 2, xxxiv. 339, \& Proc. Am. Acad. x. 52 ; Benth. \& Hook. 1. c. (Stamens, in all but one of our species, protruding from the throat, but shorter than the limb of the corolla.)

§1. Stenhammária. (Steenhammera, Reichenb., wrongly written.) Nutlets very smooth and shining, acute, fleshy-herbaceous, in age becoming utricular; the

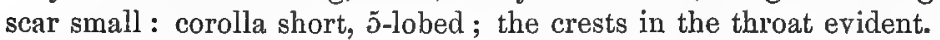

M. marítima, Don. Very smooth, pale and glaucous, much branched and spreading: leaves fleshy, ovate, obovate, or spatulate-oblong, an inch or two in lengtll, upper surface sometimes becoming pustulate: flowers small ( 3 or 4 lines long) on long and slender pedicels : tube of the blue or whitish corolla hardly as long as the limb and shorter than the ovate-triangular lobes of the calyx: filaments rather narrower and much longer than the anthers. - Syst. iv. 320. Cerinthe maritima, Dill. Elth. t. 65 . Pulmonaria maritima, L.; Lightfoot, Fl. Scot. i. 134, t. 7; Fl. Dan. t. 65. P. parviforc, Michx. Fl. i. 132. Lithospermum maritimum, Lehm. Asper. 291. Steenhammera maritima, Reich. Fl. Excurs. i. 387. Stenhammaria maritima, Fries, Summa, 12 \& 192. Hippoglossum maritimum, Hartw. ex Lilja in Linnæa, xvii. 111. - Sea-shore, Cape Cod to Hudson's Bay, and Puget Sound to Polar coasts. (Greenland, N. Eu., \& Asia.)

$\S 2$. Edmerténsia. Nutlets dull and with obtuse angles if any, wrinkled or roughish when dry. (Corolla commonly villous inside near the base, and below sometimes with a 10-toothed ring.)

* Corolla trumpet-shaped, with spreading border nearly entire; the plicate crests in the throat obsolete: filaments slender, much longer than the oblong-linear anthers: hypogynous disk produced into two opposite narrow lobes which become as higl as the ovary.

M. Virgínica, DC. Very smooth and glabrous, pale, a foot or two high: leaves obovate or oblong, veiny, or the lowest large and rounded and long-petioled : racemes at first short and corymbose: flowers on nodding slender pedicels: corolla purple and blue, an inch long, between trumpet-shaped and salverform, many times exceeding the short calyx. M. pulmonarioides, Roth, Cat. Pulmonaria Virginica, L.; Sims, Bot. Mag. t. 160. (Trew, Pl. Sel. t. 42.) - Alluvial banks, New York to Minnesota, S. Carolina in the mountains, and Tennessee: fl. spring; not uncommon in gardens.

* * Corolla (blue, rarely white) with conspicuously 5-lobed limb, which above the throat (i.e. the whole expanded upper portion) is usually open-campanulate; the small crests in the throat obvious and commonly puberulent or pubescent.

- Filaments enlarged, as broad as the anthers and shorter or only a little longer, always inserted in the throat of the corolla nearly in line with the crests: style long and capillary, generally somewhat exserled. (There are traces of some dimorphism as to reciprocal length of filaments and style, at least in one species.)

+ Tube of the corolla twice or thrice the length of the limb and of the calyx.

M. oblongifólia, Don, l. c. A span or so high, smooth or almost so: leaves mostly oblong or spatulate-lanceolate, rather succulent, and veins very inconspicuous: flowers in a somewhat close cluster : lobes of the 5-parted or deeply 5-cleft calyx lanceolate or linear, mostly acute: tube of the corolla 4 or 5 lines long, narrow; the moderately 5-lobed limb barely 2 lines long. - Hook. Kew Jour. Bot. iii. 295; Watson, Bot. King, 238. Pulmonaria oblongifolia, Nutt. in Jour. Acad. Philad. vii. 43. Lithospermum marginatum, Lehm. in Hook. Fl. ii. 86. - Mountains of Montana to the borders of British Colurnbia, and south to Nevada, Utah and Arizona, at 6-9,000 feet. On moist slopes; flowering early.

++ Tube of the corolla little or not twice longer than the throat and limb.

$=$ Stems mostly tall, 1 to 5 feet high: leaves ample and mainly broad, reiny; the upper with very acute or acuminate apex; the lowest ovate or subcordate (usually 3 or 4 inches long and long-petioled): calyx deeply 5-parted.

M. Sibírica, Don, 1. c. Pale and glaucescent, glabrous and smooth or nearly so, very leafy : cauline leaves oblong-or lanceolate-ovate, hirsute-ciliolate : short racemes panicled: calyx-lobes oblong or oblong-linear, obtuse, commonly ciliolate, half or a quarter the length of the tube of the bright light-blue corolla (this and the limb each about 3 lines long).-Gray, I. c. Pulmonaria Sibirica, L. Spec. i. 135, not Pall. P. denticulata, Roem. \& 
Sch. Syst. iv. 746. P. ciliata, James in Long Exped.; Torr. in Ann. Lyc. N. Y. ii. 224. Mertensia denticulata, Don, 1. c. M. ciliata, Don, 1. c.; DC. Prodr. x. 12. M. stomatechoides, Kellogg in Proc. Calif. Acad. ii. 147, fig. 43. - Along mountain streams from the Rocky Mountains in Colorado to the higher parts of the Sierra Nevada, California, and far northward. (E. Asia.)

Var. Drummóndii, Gray, 1. c. Dwarf, a span high : leaves oblong, sessile, only about an inch long, with barely denticulate-scabrous margins and obsolete veins: corolla only 5 lines long; the tube little if at all longer than the limb and hardly twice the length of the ovate-oblong obtuse lobes of the calyx. - Lithospermum Lrummondii, Lehm. Pugill. ii. 26, \& in Hook. Fl. ii. 86. Mertensia Drummondii, Don, Syst. iv. 319. - Aretic sea-shore, Richardson. Formerly and wrongly referred to $L$. alpina; but apparently an aretic variety of $\mathrm{H}$. Sibirica.

M. paniculáta, Don, l. c. Greener, roughish and more or less pubescent : cauline leaves ovate to oblong-lanceolate: racemes loosely panicled: calyx-lobes lanceolate or linear and mostly acute, hispid-ciliate or throughout hirsute, equalling or only half shorter than the tube of the purple-klue (6 or 7 lines long) corolla. - Gray, l. c. Pulmonaria paniculata, Ait. Kew. ed. 1, i. 181; Hook. Bot. Mag. t. 2680. P. pilosa, Cham. in Linn. iv. 49. P. pubescens, Tilld. in Rom. \& Sch. iv. 744? Lithuspermum Kamtschaticum, Turcz. in Bull. Mosc. 1810, 75. Mertensia paniculata, pilosa, pubescens? \& Kamtschatica, DC. 1. c. .11. Sibirica, Torr. in Wilkes Exp. xvii. 412 . Lithospermun corymbosum, Lehm. Pugill. ii, 27 , therefore 11 . corymbosa, Don, l. c. (Some forms connect with the preceding species, which is on the whole quite distinct.) - Hudson's Bay and Lake Superior, thence to the Rocky Mountains (south to Utah and Nevada), Alaska, Behring Straits. (N. E. Asia.)

Var. nivális, Watson, an alpine form, is span or so high, with thicker leaves only an inch long, and rather slender tube to the corolla: ambiguous between this species, I. oblongifolia, and the next. - Bot. King, 239. - High mountains of Utah, up to 12,000 feet, Watson.

$==$ Stems from a foot down to a span high: leaves smaller (one or two inches long), nearly reinless, obtuse or barely acute, pale or glaucescent.

M. lanceoláta, DC. Either glabrous or hirsute-pubescent, simple or paniculately branched: leaves from spatulate-oblong to lanceolate-linear: racemes at length loosely panicled: calyx-lobes lanceolate, acute, sometimes obtuse, ciliate or hirsute, or rarely glabrous, more or less shorter than the tube of the blue ( 5 or 6 lines long) corolla, which is hairy near the base within: filaments generally longer than the anthers. - Gray, Proc. Am. Acad. x. 53. Pulmonaria lanceolata, Pursh, Fl. ii. 729, rather large form. P. marginata, Nutt. Gen. i. 115. Lithospermum marginatum, Spreng. Syst. i. 547. Mertensia alpina, Gray in Am. Jour. Sci. 1. c., in part; Hook. f. Bot. Mag. t. 6178. - Hillsides, along the lower Rocky Mountains and their eastern base, from Dakota and Wyoming to northern New Mexico. A rariable species; the largest forms approaching too near the preceding; the smaller extremely different in appearance. Seemingly occurs in two forms as to length of style and filaments, the latter conspicuous in both forms.

Var. Féndleri, Gray, 1. c., is a (commonly hirsute) state, with calyx 5-cleft only to the middle. -.$M$. Fendleri, Gray in Am. Jour. Sci. l. c. - New Mexico (Fendler, Palmer) and Colorado.

+ + Filaments extremely short and narrower than the anthers, inserted either on the margin of the throat or about the middle of the tube (evidently heterogone-dimorphous): style in both kinds included.

M. alpína, Don, l. c. A span or more bigh, either nearly glabrous and smooth or pubescent: leaves oblong, somewhat spatulate or lanceolate, rather obtuse; the cauline sessile (1 or 2 inches long): flowers in a close or at length loose cluster: calyx 5-parted or deeply 5-cleft ; its lanceolate lobes equalling or rather shorter than the tube of the corolla, which hardly ever exceeds its limb: anthers nearly sessile, in the low-inserted form scarcely equalling the conspicuous crests of the corolla: style in this form reaching only to about the base of the anthers, in the other reaching almost to the mouth of the tube. - Gray in Am. Jour. Sci. l. c., mainly, \& Proc. Am. Acad. x. 53. Pulmonaria alpina, Torr. in Ann. Lyc. 1. c. Mertensia brevistyla, Watson, Bot. King, 239, t. 23, fig, 1, 2, the form with low anthers and short style. - Colorado Rocky Mountains, at 9-11,000 feet, and at lesser elevation in those of Utah. Corolla 3 or 4 lines long. 


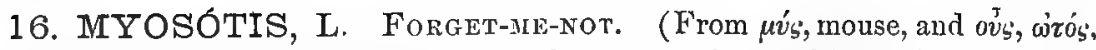
ear, i. e. mouse-ear, to which the leaves of some species are likened.) - Low and small or spreading herbs, usually soft-hairy ; with sessile cauline leaves, and small mostly blue flowers in at length elongated racemes, destitute of bracts. Stamens and style in the genuine species included. Fl. summer or spring.

* Calyx open in fruit, beset with fine and short appressed hairs. none of them hooked or glandulartipped: racemes very loose, with widely spreading pedicels: herbage green; the pubescence being rather sparse and short.

M. PALÚstris, Withering. (FoRgET-ME-Not.) Perennial by subterranean stolons: stems soon decumbent, rooting at base: leaves lanceolate-oblong: calyx-lobes triangular, much shorter than the tube: corolla with flat limb (3 or 4 lines in diameter), sky-blue with yellowish throat: nutlets somewhat angled or carinate ventrally. - Koch, Germ. 504; Syme, Engl. Bot. ed. 3, t. 1104. 1\%. scorpioides, var. palustris, L. \&c. - In wet ground, probably only where it has escaped from cultivation, and not indigenous. (Nat. from Eu.)

M. láxa, Lehm. Perenuial from filiform subterranean shoots, or perhaps annual : stems very slender, decumbent : pubescence all appressed : leaves lanceolate-oblong or somewhat spatulate: pedicels usually double the length of the fruiting calyx : lobes of the latter as long as the tube: limb of the corolla rather concave ( 2 or 3 lines broad, paler blue) : nutlets about equally convex both sides. - Asper. 83 ; Gray, Man. ed. 1, 338. M. caspitosa, var. laxa, DC. Prodr. x. 105. M. palustris, var. micrantha, Lehm. in Hook. Fl. ii. 81. M. palustris, var. laxa, Gray, Man. ed. 5, 365. M. Ingulata, Lehm. Asper. 110; Hook. f. Fl. Brit. Isl. 252 (M. cospitosu, Schultz; Syme, Engl. Bot. 1. c. t. 1103), a European form. - In water and wet ground, New York and Canada to Newfoundland. (N. Asia, Eu.)

* * Calyx closed or with lobes erect in fruit, beset with looser and some bristly hairs having minutely hooked tips.

M. sylvática, Hoffm. Perennial, not stoloniferous, hirsute-pubescent, either green or cinereous: stems erect: leaves oblong-linear or lanceolate; the radical conspicuously petioled : pedicels as long as the calyx or longer: calyx almost 5-parted, hirsute with erect hairs mixed near the base with some more spreading and hooked ones; the lobes merely erect or slightly closing in fruit: corolla with (blue or at first purple) flat limb, 3 or 4 lines in diameter: nutlets more or less margined and carinate ventrally at the apex. - Perhaps none of the typical form in N. America. (Eu., N. Asia.)

Var. alpéstris, Koch. Stems tufted, 3 to 9 inches high: racemes more dense: pedicels shorter and thicker, ascending, seldom longer than the calyx : nutlets larger. M. alpestris, Schmidt; Lehm. Asper. 86 \& in Hook. Fl. 1. c.; Syme, Engl. Bot. ed. 3, t. 1106. M. rupicola, Smith, Engl. Bot. t. 2559. - Rocky Mountains, from Colorado (in the higher alpine regions) and Wyoming (mainly with short pedicels) northward, and northwest to Kotzebue Sound. (N. Asia, Eu.)

M. arvénsis, Hoffm. Annual or sometimes biennial, loosely hirsute : stem erect, loosely branching, often a foot or more high : leaves oblong-lanceolate: racemes loose, naked and peduncled: pedicels spreading in fruit, longer or twice longer than the equal 5-cleft calyx, which is copiously beset with spreading hooked hairs : corolla blue (rarely white); the concave limb a line or so in diameter: calyx closed in fruit. - Lehm. Asper. 1.c.; Syme, l.c. t. 108. M. scorpioides, var. arvensis, L. M. intermedia, Link., DC. - Fields in low grounds, New Brunswick to Louisiana (?), rare, perliaps not native. (Eu., N. Asia.)

M. versf́color, Pers. Annual, slender, hirsute: leaves narrowly oblong: racemes slender, mostly naked at base: pedicels much shorter than the deeply and equally 5-cleft calyx: corolla yellowish, then blue, at length violet, not larger than in the preceding species, which it otherwise resembles. - Smith, Engl. Bot. t. 480; Syme, l. c. t. 1110, not Lehm. in Hook. Fl. - Fields, sparingly introduced (Delaware, Canby). (Nat. from Eu.)

M. vérna, Nutt. Annual or biennial, roughish-hirsute or hispid: stems erect, 3. to 9 inches high: leaves spatulate or linear-oblong: racemes strict, leafy at base: pedicels erect or appressed below but spreading toward the apex, equalling or shorter than the 5-cleft hispid unequal calyx : corolla white, small. - Gen. ii. in addit. unpaged; Gray, Man. ed. 5, 365. Lycopsis Virginica, L. Spec. i. 139, the plant of Gronov. Virg. Myosotis stricta, Gray, Man. ed. 1, not Link. M. inflexa, Engelm. in Am. Jour. Sci. xlvi. 98. Dry ground, E. New England to Florida, Texas, Missouri, \&c. 
Var. macrospérma, Chapm. Taller, looser, often a foot high : pedicels rather more spreading: flowers larger: the calyx sometimes 3 lines long, with lower caly $x$-lobes twice the length of the upper: nutlets larger in proportion. - Fl, 395. M. macrosperma, Engelm. l. c. II. versicolor, Lehm. in Hook. Fl. ii. 81. - Florida to Texas : also W. Ilaho, Oregon, and British Columbia; sometimes passing into the typical form.

17. LITHOSPÉRMUIM, Tourn. Gronwell. (From $\lambda i \theta o s ;$ a stone, aud $\sigma \pi \varepsilon \varepsilon^{\prime}(x$, seed.) - Chiefly herbs; with reddish roots, sessile leaves, and axillary or subaxillary or leafy-bracted flowers, developed in spring and summer, sometimes dimorphous as to length of style and height of insertion of anthers reciprocally. Calyx 5-parted. Strmens in our species with very short filaments. Stigma commonly single and truncate-capitate, sometimes as in $\$ 3$, capitate-2-lobed; in $L$. arvense there is a pair of stigmas below a slender bifid apex, a transition toward the mode in Heliotropiea.

$\S 1$. Annuals, with small at length widely scattered flowers: corolla white or whitish, little longer than the calyx.

L. ARVÉxsE, L. Slightly canescent with minute appressed hairs: stem loosely branching from the base, erect, a span to 2 feet high : leaves linear or lanceolate, with prominent midrib and obsolete lateral ribs: corolla funnelform, about 3 lines long; the throat with puberulent lines: nutlets dull, coarsely wrinkled and pitted, brownish. - Spec. 1;2; Fl. Dan. t. 456; Engl. Bot. 123. - Waste sandy grounds, not rare from Canada southward. (Nat. from Eu.)

L. Matamorénse, DC. Hirsute or hispid: stems much branched from the base and diffusely spreading, slender: leaves oblong, very obtuse (an inch or so long), at length rough: pedicels very short: corolla almost campanulate, 2 lines long, a prominent transverse crest at base of each lobe: nutlets at length shining but usually brownish and uneven, also coarsely pitted. - Prodr. x. 76. L. prostratum, Buckley in Proc. Acad. Philad. 1861. - Plains and river-banks, Texas, Berlundier, Wright, \&c.

§ 2. Perennials, with small or rather small flowers: corolla greenish-white or pale yellow, short; its tube hardly if at all longer than the calyx: mature nutlets bony, white and polished.

* Corolla with intruded crests in the throat: flowers sparse, or at least the fruits scattered: nutlets apt to be solitary.

+ Pubescence soft, fine, and short, only the upper face of the leaves becoming scabrous.

L. OfFicrsále, L. Copiously branching, z or 3 feet high: leaves lanceolate or ovate-lanceolate, acute, pale ( 2 inches or less long); a pair of lateral ribs more or less manifest: tube of the dull-white corolla considerably longer than the limb: style nearly equalling the stamens: nutlets less than 2 lines long. — Engl. Bot. t. 134; Fl. Dan. t. 1034. - Roadsides, Canada and New England. (Nat. from $\mathbf{E u}$.)

L. latifólium, Michx. More sparingly and loosely branched: leaves greener, ovate and broadly oblong-lanceolate, gradually acuminate, all acute and the lower tapering at base ( 2 to 5 inches long), with 2 to 4 pairs of ribbed veins: tube of the corolla little longer than the limb: style shorter than the stamens : nutlets globose-ovate, over 2 lines long. Fl. i. 131; Jacq. Eclog. t. 136. L. officinale, var. latifolium, Willd., \&c. - Open ground and borders of thickets, Upper Canada to Wisconsin and south to Virginia and Tennessee. Flowers yellowish-white, or sometimes light yellow, when it is $L$. lutescens of $\mathrm{N}$. Coleman in Cat. Pl. Grand Rapids, Michigan, 1874, 29.

+ + Pubescence hispid or rough-hirstute.

L. tuberósum, Rugel. Stem at first low, in age often more than 2 feet high, with some spreading branches : leaves ovate or oblong-lanceolate, or the large radical ones obovateoblong, mostly obtuse; the upper triple-ribbed, the others nervose-veined; bristles of the upper and even of the lower face at length with pustulate base: flowers short-pedicelled: corolla "yellowish-white," 2 or 3 lines long: nutlets globular, much shorter than the at 
length elongated-linear calyx-lobes: "roots bearing oblong tubers." - DC. Prodr. x. 76; Chapin. Fl, 332. - Florida, on rocky river-banks, Rugel, Chapman. Texas, Wright, Lindheimer, only in fruit. Larger leaves at length 4 to 6 inches long, and calyx-lobes in the Texan plant becoming almost half inch long.

* * Corolla nearly naleed at the throat, but obscurely puberulent and thickened under each lobe: inflorescence clense and very foliose.

L. pilósum, Nutt. Soft-hirsute and pubescent, pale or canescent : stems numerous from a stout root, a foot high, strict, mostly simple, very leafy : leaves linear and linear-lanceolate, 2 to 4 inches long, mostly tapering from near the base to apex; the lateral ribs or veins obscure: flowers densely crowded in a leafy thyrsus : corolla campanulate-funnelform, almost half an inch long, silky outside, dull greenish-yellow : style slender: nutlets broadly ovate, acute, smooth and polished, 2 to $2 \frac{1}{2}$ lines long. - Nutt. in Jour. Acad. Philad, vii. 43) Wats. Bot. King, 238. L. Torreyi, Nutt. 1. c. L. ruderale, Dougl. in Hook. Fl. ii. 89. - Hills and cañons, Montana and British Columbia to Utah and the eastern borders of California.

§3. Bátschia, Endl. (Puccoon.) Perennials, with long and deep red roots (filled with dyeing matter), very leafy stems, and mostly showy flowers: corolla yellow, much exceeding the calyx (except in cleistogenous or depauperate blossoms), more or less appressed-pubescent outside; the lobes commonly undulate or crenulate and sinuses plicate-infolded: pubescent crests in the throat apparent: stigma capitate-2-lobed: nutlets white, smooth and polished, the inner face rather conspicuously carinate. - Batschia, Gmelín.

* Corolla light yellow, rather small; later floral leares reduced to bracts, not surpassing the calyx.

L. multiflórum, Torr. Minutely strigose-hispid: stems virgate, often paniculate at summit, a foot or two high : leaves linear or linear-lanceolate : flowers numerous, short-pedicelled, the later spicate: corolla narrow (5 or 6 lines long), with very short rounded lobes and tube fully twice the length of the calyx ; the crests or folds in the throat inconspicnous. Watson, Bot. King, 238 (remark); Gray, Proc. Am. Acad. x. 51. L. pilosum, Gray in Am. Jour. Sci. ser. 2, xxxiv. 256, not Nutt. - Lower Rocky Mountains, Colorado to Arizona and W. Texas. Expanded limb of corolla 5-cleft, the minutely undulate rounded lobes only a line and a half long: ring at base of the tube sparingly bearded. Anthers in all known specimens inserted high in the throat and the style only half the length of the corolla; but a counterpart form may be expected.

* * Corolla bright and deep yellow or orange; the tube from one half to twice longer than the calyx, and the crests at the throat little if at all projecting or arching; the lobes barely undulate or entire: floral leaves or foliaceous bracts large, much surpassing the calyx. (Dimorphism as to height of insertion of stamens and length of style manifest.)

L. Califórnicum, Gray. Soft-hirsute, a foot high : leaves lanceolate or oblong : corolla hardly an inch long; its proper tube hardly twice the length of the calyx; its funnelform throat considerably longer than the very short lobes, almost destitute of crests; the glandular ring at base of the tube inconspicuous and naked. - Proc. Am. Acad. l. c., \& Bot. Calif. i. 522. $L$. canescens, Torr. in Pacif. R. Rep. iv. 124, not Lehm. - California, in Nevada and Plumas Counties, Bigelow, Lemmon, Mrs. Austin. Short-styled and high-stamened form only known.

L. canéscens, Lehm. (Puccoos of the Indians.) More or less canescent when young: stem hirsute, is span to a foot or more high: leaves oblong-linear or the upper varying to ovate-oblong, mostly obtuse, softly silky-pubescent, greener with age but not rough : corolla orange-yellow, with rather ample deeply 5-cleft limb, prominent crests in the throat, and glandular ring at the hase naked: flowers nearly sessile - Gray, Proc. l. c. L. canescens, \& L. sericeum, Lehm. Asper. 305, 306. Batschia canescens, Michx. Fl. i. 130, t. 14 ; Barton, Fl. Am. Sept. t. 58. Anchusa canescens, Muhl. Cat. - Plains and open woods, in sandy soil, Upper Canada and Saskatchewan to Alabama, New Mexico, and Arizona. Tube of the corolla 3 or 4 lines long; the well-developed limb about half an inch in diameter; in one form style about the length of the tube and stamens, inserted below its middle. - To this species also belongs L. sericeum, Lehm., but not Anchusa Virginica, L., which as to the Linnæan herbarium is not identified, as to the plant of Clayton's herb. is an Onosmodium, as to Morison's is probably L. hirtum, and as to Plukenet's may be either of the Puccoons. 
L. hírtum, Lehm., l. c. Hispid or hirsute, and at length rough, a foot or two high: leaves lanceolate or the lower linear and floral ovate-oblong: corolla bright orange, with ample and rotate deeply 5-eleft limb and prominent crests in the throat; the ring at base within bearing 10 rery hirsnte lobes or teeth: flowers mostly pedicelled: calyx-lobes elongated and linear-lanceolate. - Bufschia Carolinenses, Gmel. Syst. i. 315. B. Gmelini, Michx. 1. c. Anchusa hirta, Muhl. Cat. Lithospermum decumbens, 'Tor's. in Ann. Lyc. N. Y. ii. 22.j. L. Bejuriense, DC. 1. c. 79. - Pine barrens, \&c., Michigan to Minnesota, Virginia, Florida, Texas, and Colorado. - Tube of the intense orange corolla 4 or 5 lines long, the outspread limb sometimes almost an inch in diameter, but often half smaller. In some specimens, the stamens are inserted on the middle of the corolla and the style rises to the throat; in others, the style rises only to the uriddle and the stamens are in the throat.

* * Corolla bright vellow, salrerform; its tube in well-developed flowers 2 to 4 times the length of the calyx; the crests in the throat conspicuous and arching; the lobes undulate and nore or less erose: later towers cleistogenous. - Pentalophus, A.DC.

L. angustifólium, Michx. Erect or diffusely branched from the base, a span to a foot or more high, minutely scabrous-strigose and somewhat cinereous: leaves all linear: flowers pedicelled, leafy-bracted, of two sorts; the earlier and conspicuous kind with tube of the corolla an inch or less in length and the rounded lobes commonly crenulate-erose; later ones, and those of more diffusely branching plants, with inconspicuous or small and pale corolla, withuut crests in the throat, probably cleistogenous, the style shorter than the nutlets; in these the pedicels are commonly recurved in fruit: nutlets usually copiously impressed-punctate, conspicuously carinate ventrally. - Michx. Fl. i. 130 (the state with inconspicuous flowers); Bebb in Am. Naturalist, vii. 691. L. linearifolium, Goldie in Edinb. Phil. Jour. 18\%2, 319, the same state (unless possibly Goldie's plant is L. areense). L. breviflorum, Engelm. \& Gray, Pl. Lindh. i. 41, a similar state. Long-flowered plant is Batschia longiflora (Pursh, Fl. i. 132), \& B. decumbens, Nutt. Gen. i. 114. Lithospermun longiflorum, Spreng. L. incisum, Lehm. l. c.; Hook. Fl. ii. t. 165. L. ILandanense, Spreng.; Hook. l.c. t. 166, a small and smaller-flowered form. Pentalophus longiflorus \& P. Mandanensis, A.DC. Prodr. x. 87. - Dry and sterile or sandy soil, prairies and banks of streams, Illinois and Wisconsin to Saskatchewan and Dakota, south to Texas, and west to Utah and Arizona. Root thick and deep, abounding in violet-colored dye. Glandular ring at base of corolla naked. In the state with large and showy flowers, as far as known, the stamens are always borne at the upper part of the tube, and the filiform style is slightly exserted: but perhaps there is some heterogone-dimorphism. There are seemingly all stages between these conspicuous and the cleistogenous blossoms which are produced through the season.

18. ONOSMÓDIUM, Michx. ("Ovoo $\mu$, and $\varepsilon i \delta o s$, likeness, from the resemblance to the Old-World genus Onosma.) - Perennials (of the Atlantic States and Mexico, \&c.), rather stout and coarse, rough-hispid or hirsute; with nervose or costate-veined leaves, and leafy-bracteate flowers crowded in scorpioid spikes or racemes, when fruiting more separated; the bracts resembling the leaves. Fl. spring and summer, strongly proterogynous, the style early exserted. Corolla greenish-white or yellowish-green: a glandular 10-lobed ring adnate to the base of the tube within. Nutlets as in most Lithosperma. - Michx. Fl. i. 132. Onosmodium and Macromeria in part, Don ; DC. Prodr. x. 68 ; Benth. \& Hook. Gen. ii. 859. True Macromeria (exserta) has versatile anthers on cupillary and long exserted filaments.

$\S 1$ Macromerioides. Corolla 3 or 4 times the length of the calyx, narrow; the sinuses plane: filaments slender, longer than the linear-oblong obtuse anthers. - Macromeria, Don, \& DC. partly. (Gne or two Mexican species have the anthers promptly versatile or transverse; in ours they remain erect.)

O. Thúrberi. Somewhat sparsely strigose-lispid with short bristles (at least on the foliage) and minutely appressed-pubescent or when young canescent : stem simple, 2 or 8 feet high: leaves pinnately 5-7-ribbed; the cauline oblong-lanceolate or oblong (4 or 5 
inches long), passing into ovate bracts (at length an inch or two long) : leafy-racemose inflorescence in age elongated, many-flowered : pedicels 4 or 5 lines long: caly x parted to the base into narrow linear lobes (often an inch long) : corolla narrowly trumpet-shaped, 2 inches long, whitisl and densely villous outside, yellow inside; the lobes oblong-ovate, obtuse, nearly equalled by the erect anthers. - Macromeria viridiflora, Torr. Bot. Mex. Bound. 139, not DC, according to Ic. Mex. t. 904, which has broadly subcordate-ovate and acute corollalobes, giving the appearance of " excised sinuses," shorter and versatile anthers, \&c. - New Mexico, Thurber, Bigelow, Wright. Arizona, in dry woods, Rothrock. The portions of base of the corolla lobes which are interior in the bud are roundish-auriculate.

§ 2. Onosmodrum proper. Corolla seldom twice the length of the calyx; the lobes somewhat conduplicate in the bud; the sinuses gibbous-inflexed: filaments shorter (in our species very much shorter) than the mostly sagittate glandularmucronulate or acuminate anthers: leaves pimnately nervose-ribbed. - Onosmodium, Michx.

O. Bejariénse, DC. Stems 1 to 3 feet high, rather stout, hispid with spreading bristles : leaves oblong-lanceolate, 5-7-ribbed (the lower obtuse, upper acutish); upper surface appressed strigose-hispid, the lower more or less canescent with fine and soft pubescence: flowers short-pedicelled: corolla funnelform ( 6 to 9 lines long), about $t w i c e$ the length of the calyx, white; the greenish ovate-triangular acuminate lobes about one quarter the length of the tube, minutely pubescent externally and with some long hirsute hairs. Prodr. x. 70. O. Carolinianum, Torr. Bot. Mex. Bound. 1. c., not DC. - Border of thickets, nearly throughout Texas ; first coll. by Berlandier.

O. Caroliniánum, DC., l. c. Stout, 2 or 3 feet high, shaggy-hispid : leaves ovate-lanceolate and oblong-lanceolate, acute, 5-9-ribbed, generally hairy both sides : flowers nearly sessile: corolla short (4 or 5 lines long), yellowish-white, oblong-funnelform; its ovatetriangular acute lobes very hairy outside, and nearly half the length of the tube. - Lithospermum Carolinianum, Lam. Ill. \& Dict. Suppl. ii. 837. Purshia mollis, Lehm. Asper. 383. Alluvial grounds, Upper Canada to Georgia and Texas.

Var. mólle. A foot or two high; the pubescence shorter and less spreading or appressed : leaves mostly smaller (about 2 inches long), when young softly strigose-canescent beneath. - Onosmodium molle, Michx. Fl. i. 133, t. 15; Gray, Man. ed. 5, 362. Purshia mollis, Lehm. Asper. 382. - Illinois to Saskatchewan, Utah, and Texas.

O. Virginiánum, DC., 1. c. Strigulose-hispid throughout with mostly appressed short bristly hairs: stems rather slender, a foot or two high, often paniculate : leaves narrowly oblong or somewhat lanceolate, obtuse (1 to $2 \frac{1}{2}$ inches long), 3-5-ribbed: corolla yellowish, small (4 lines long); the lobes lanceolate-subulate, sparingly long-bristly outside, little shorter than the cylindraceous tube. - O. hispidum, Michx. 1. c. Purshia hispida, Lehm. l. c. Lithospermum Virginianum, L. - Hillsides and banks, New England to Florida and Louisiana. The specific names conferred by Michaux on this and the preceding species were replaced in the Prodromus by earlier ones under Lithospermum; which may be agreed to, Michaux's 0 . hispidum being far less hispid than $O$. Carolinianum, and $O$. molle is a misnomer except for the western variety (which cannot be separated) on which Michaux's species is founded.

19. SÝMPHYTUM, Tourn. Comfrer. (Ancient Greek and Latin name.) - Coarse perennial herbs ; with large and thick bitterish roots, mucilaginous juice, and loose or nodding racemose flower-clusters: bracts small or none. Fl. early summer. All of the Old World.

S. officinále, L. (Comfrey.) Two or 3 feet high from very thick roots, branching, rather soft-hirsute: cauline leaves long-decurrent on the branches, ovate-lanceolate and narrower, large : corolla yellowish-white, half inch long: style exserted : nutlets wrinkled or almost smooth. - Escaped from gardens into moist grounds sparingly in N. Atlantic States. (Nat. from Eu.)

S. Aspérrimum, Sims, a Caucasian species, with almost prickly stems, very scabrous leaves, and blue-purple flowers, is cultivated both as an ornamental and as a forage plant, and is not unlikely to run wild. 


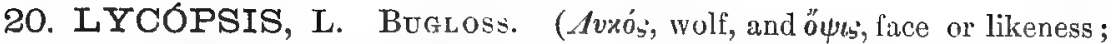
from some fanciful resemblance.) - Coarse setose-hispid annuals, of the old World, small-flowered and leafy-bracted, one species sparingly introduced into the Eastern Atlantic States.

L. ARrExsis, L. Rough and inelegant weed, a foot or two high, with spreading bristly hairs at length pustulate at base: leaves lanceolate, undulate-margined : flowers more or less racemose : corolla blue, or at first purple; the tube not longer than calyx; lobes barcly a line long. - Dry waste grounds, Canada to Virginia : scarce. (Nat, from Eu.)

21. ECHIUM, 'Tuurn. Viper's Bugloss, Bluewerd. (Old Greek name, from ' $" \chi$ 's, a riper; the shape of the nutlets likened to a snake's head.) - Biennials (or rarely shrubs), of the Old World; flowering in summer. One species an introduced weed.

E. vULGARE, L. Rough-hispid herb, a foot or two high: leaves lanceolate, or the upper linear, sessile: flowers in short lateral spikes disposed in a raceme-like thyrsus : corolla almost an inch long, showy, purple changing to deep blue (rarely pale). - Roadsides and meadows of the Middle Atlantic States. (Nat. from Eu.)

\section{ORder XCIV. CONVOLVUlaCE E.}

Herbs or shrubs, with stems generally twining or trailing, and many with milky juice; the leaves alternate and petioled, destitute of stipules; peduncles truly axillary, 1-flowered or cymosely "3-many-flowered; flowers regular and perfect, 5 -merous or rarely 4-merous, except as to the gynocium which is almost always 2-carpellary; calyx mostly of distinct and imbricated sepals, persistent; corolla either plicate and the plaits convolute, or induplicate-valvate, or sometimes imbricated in the bud, the limb either lobed or entire; stamens as many as the corolla-lobes and alternate with then, usually inserted low down on the tube; hypogynous disk commonly annular and manifest; ovary 2-celled or rarely 3-celled, with a pair of erect anatropous ovules in each cell, or spuriously 4-6-celled (each cell being more or less divided into a pair of 1-ovuled half-cells hy a false partition), or rarely 2-4-parted from above around the style in the manner of Borraginacea; style single or once or twice divided; stigmas terminal or introrse; fruit capsular or sometimes fleshy; seeds comparatively large, filled by a crumpled or plaited embryo involving or partly surrounded by a little mucilaginous or fleshy albumen, its cotyledons ample and foliaceous, or in Cuscuta a spiral embryo and no cotyledons. Cuscuta moreover is leafless. Nolanece form an exceptional tribe with several or many indehiscent carpels, narrow cotyledons, \&c., but are all South American, and connect with the following order. The present large order is well distinguished from all its allies by the character of the solitary or geminate seeds, size and nature of the embryo, and inferior radicle, along with the usually twining or trailing growth, alternate leaves, \&c.

TRIBE I. DICHONDRE 2 . Ovary divided into 2 or 4 carpels or almost separate lobes, surrounding a pair of basilar styles.

1. DICHONDRA. Corolla deeply 5-cleft or 5-parted, not plicate; the lobes imbricated in the bud. Filaments and anthers short. Ovary 2-parted, forming 2 indehiscent or irregvlarly bursting utricles in fruit: styles 2 or at base united into one, filiform: stigmas capitate. Seed by abortion solitary, globular, smooth. Embryo biplicate : cotyledons elongated-oblong. Creeping herbs. 
Tribe II. CONVOLVULE\&. Ovary entire. Plants with ordinary foliage, not parasitic.

* Corolla plicate at the sinuses and the plaits dextrorsely convolute : cotyledons broad, often emarginate.

2. IPOMOEA. Style undivided, terminated by it single capitate or 2-3-globose stigma, Corolla from salverform or funnelform to nearly campanulate. Capsule globular, 4-6- (or by abortion fewer-) seeded, 2-4-valved.

3. JACQUEIMONTIA. Style undivided : stigmas 2, ovate or oblong, thick but somewhat flattened. Otherwise as Ipomcea and Convolvalus, and intermediate between the two.

4. CONVOLVULUS. Style undivided or 2-cleft only at the apex: stigmas 2, from linearfiliform to subulate or ovate, when broad sometimes flattish. Stamens included. Corolla from funnelform to campanulate. Capsule globose, 2-celled, or sometimes imperfectly 4-celled by spurious partitions between the two seeds, or by abortion 1-celled, mostly 2-4-valved.

5. BREWERIA. Style 2-cleft or 2-parted; the divisions simple, each bearing a capitate stigma. Corolla, stamens, and capsule of Convolvulus.

6. EVOLVULUS. Styles 2, distinct or sometimes united below, each 2-cleft: stigmas linear-filiform or somewhat clavate. Corolla from funnelform to almost rotate. Otherwise like Convolvulus on a small scale, not twining.

* * Corolla not plicate in the bud, 5-cleft : cotyledons linear, biplicate, entire.

7. CRESSA. Styles 2, distinct, entire: stigmas capitate. Calyx of 5 nearly equal sepals, equalling the oblong-campanulate tube of the corolla ; the limb of the latter 5-parted into oblong-ovate lobes, lightly convolute-imbricate and somewhat induplicate in the bud. Filaments filiform, exserted from the throat of the corolla. Ovary 2-celled, 4.ovuled. Capsule by abortion often 1-seeded. Stems not twining.

Tribe III. CUSCUTEÆ. Ovary entire. Leafless parasitic twining herbs, destitute of foliage and of all green color; the spirally coiled filiform embryo even destitute of cotyledons. Corolla imbricated in the bud, appendaged below the stamens.

8. CUSCUTA. The only genus.

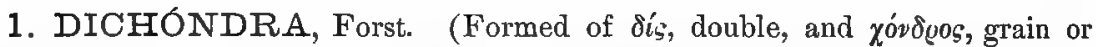
roundish mass, from the twin fruit.) - Small prostrate and creeping perennials (found almost all round the warmer parts of the world, but most in America); with filiform stems, slender petioles to the reniform or round-cordate entire leaves, and naked peduncles bearing a single small flower. Corolla greenish or yellowishwhite. Carpels pubescent. - Char. Gen. 39, t. 20. The following may be the only species.

D. répens, Forst. Soft-pubescent or slightly sericeous, but green or greenish: leaves mostly with a deep basal sinus: sepals obtuse, at length obovate with narrowed base or spatulate: corolla-lobes ovate, nearly glabrous. - Lam. Ill. t. 183; Smith, Ic. Ined. t. 8. D. sericea, Swartz, Prodr. 54, \& Fl. Ind. Occ. t. 11, a small and silky form. D. Carolinensis, Michx. Fl. i. 136, a large and greener form. D. repens, macrocalyx, \& sericea, Meissn. in Mart. Fl. Bras. vii. 357. - Wet ground, Virginia to Texas, near the coast, and Arizona. (Trop. \& S. Am., Asia, Oceanica, Australia, S. Africa.)

D. argéntea, Willd. Canescently sericeous and silvery : leaves mostly with a shallow sinus or even truncate, and with comparatively short petioles : sepals from oblong-oval to lanceolate: corolla-lobes oblong-lanceolate, acutish, villons outside. - Hort. Berol. 297, t. 81 ; Meissn. l. c. - S. Texas to Arizona. (Mex., S. Amer.)

2. IPOḾé, L. Morning Glory. (According to Linnæus, composed of $i \psi$, inos, and opotos, like; but $i \psi$ is a worm.) - A large genus, mainly of twining herbs, some prostrate, diffuse, or even erect: f. summer. Calyx not bracteate at base, but the outer sepals commonly larger. Limb of the corolla entire or barely 5-angulate, or slightly 5-lobed. Valves of the capsule usually septifragal. Cotyledons broad, commonly 2-lobed. Genus here taken in the 
extended sense, as in Meissn. in Mart. Fl. Bras. vii. 215, \& Benth. \& Hook. Gen. ii. 870 .

I. Leuchishı, Jacq., a South American species, is mentioned by Choisy in DC. Prodr. as having been collected by Charpentier in Arkansas; but we have it not.

I. Carolima, L. (Catesb. Car. ii. t. 91), belongs to the Bahamas and other West Indies, not Carolina.

Aniseia aurea, Kellogg, in Proc. Calif. Acad. iii. 229, with plate, is a 5-foliolate Ipomoea of Lower California, perhaps undescriberl, and the sane as no. 81 in the collection of Xantus, in the same district, which was referred to $I$. sinuutu, var, foliis integris, in Proc. Am. Acad. v. 165 .

§ 1. C.looníction, Griseb. Corolla salverform, ample, with very long tube, flat limb, and throat not dilated; in astivation contorted: sepals herbaceous, becoming coriaceous, the outer sometimes cornute-tipped : style capitate-didymous: ovules 4 , geminate in 2 cells, or commonly solitary in 4 : flowers white, opening at evening and for one night, fragrant. - Calonyction, Choisy.

I:Bona-nóx, L. Extensively twining, glabrous: stem lactescent, usually becoming muricate-tuberculose: leaves from ovate-cordate to hastate, entire or 3-5-lobed, acuminate: peduncles 1-7-flowered : outer sepals commonly with an infraterminal cusp or horn : corolla with slender tube 3 or 4 inches long and limb 4 or 5 inches wide, green externally between the plaits : stamens and style short-exserted : capsule ovate-conical, acute : seeds glabrous. - Andr. Bot. Rep. t. 403; Bot. Mag. t. 752. Calonyction speciosum, Choisy, Convolv. 59, \& in DC. Prodr. ix. $: 345$. $\rightarrow$ S. Florida, perhaps indigenous : cult, for ornament, especially southward. (Mex., W. Ind., S. Amer., and scattered through most tropical regions.)

§2. QT Ároclit, Meissn., \&c. Corolla salverform or with somewhat funnelform but narrow tube; the limb not contorted in the bud: sepals membranaceous or herbaceous: stamens and style more or less exserted: ovules solitary in the 4 cells, i. e. the 2 cells bilocellate by a spurious partition : flowers red, opening by day. (Ours glabrous annuals.) - Quamoclit, Tourn., Choisy.

I. QuÁmoclit, L. (Cypress-VINe.) Slender: leaves pinnately parted into linear-filiform divisions, short-petioled or sessile: peduncles few-flowered: corolla over an inch long, scarlet-red; the tube narrowly funnelform above; lobes ovate: scpals merely mucronate or blunt. (Hybridizes with the following.) - Lam. Ill. t. 104; Bot. Mag. t. 244. Quamom clit vulgaris, Choisy, \&c. - Cult. and sparingly spontaneous in S. Atlantic States. (Trop. Amer., \&c.)

I. coccínea, L. Rather tall-climbing : leaves slender-petioled, cordate, or with somewhat sagittate or hastate base, conspicuously acuminate, entire, or angulate, or 3-5-toothed: peduncles few-several-flowered : corolla 9 to 20 lines long, scarlet or verging to orange; the tube clavate; limb obscurely lobed, half to two-thirds inch wide: sepals mostly with slender appendage below the tip. - Sims, Bot. Mag. t. 221; Andr. Bot. Rep. t. 490. I. Iufeola, Jacq. Ic. Rar. t. 35, with orange-colored corolla. Quamoclit coccinea, Mœnch, Meth. 453; Choisy in DC. - River-banks, \&c., Middle and S. Atlantic States (apparently introduced, but well naturalized), and New Mexico and Arizona, where it is probably indigenous. (Trop. Amer., \&ce.)

Var. hederifólia. Leaves from angulate (or the earlicr quite entire) to 3-lobed or even 3-parted, or sometimes pedately 5-parted: corolla usually rather larger. - I. hederifolin, L.; Meissn. in Fl. Bras. vii. t. 76, fig. 1. I. sanguinea, Vahl, Symb. iii. 33 ; Bot. Reg. t. ?; Bot. Mag. t. 1769. Quamoclit hederifolia, Choisy. - W. Texas to Arizona. (Trop. Amer.)

§3. Euroyca. Corolla funnelform or nearly campanulate: stamens and style not exserted. - Ipomcea, Batatas, Pharbitis, \& Aniseia, Choisy. Ipomoea \& Pharbitis, Meissn.

* (Morizisg Grory.) Lobes of the stigma and cells of the ovary 3 (rarely varying to 2): sepals long and narrow, acuminate or attenuate upward, herbaceons. mostly bispid or hirsute below: corolla funnelform, purple, blue, and white: seeds glabrous. - Pharbitis, Chnisy. 
+ Root annual: flowers opening early in the morning, soon closing under sunshine. (All included under Convolvulus hederaceus, L., Hort. Clifí. \& Spec. ed. 1.)

I. hederácea, Jacq. Leaves deeply 3-lobed and deeply cordate; the lobes ovate or ovate-lanceolate, and the middle one narrowed at base, lateral ones sometimes repand 2-lobed: peduncles either short or very short, 1-3-flowered: pedicels none or hardly any: sepals (two-thirds to near an inch long) linear-attenuate from a dilated and densely Iong villous-hirsute base, in age the upper part recurved-spreading: corolla short-fumnelform, sky-blue with whitish tube, less than 2 inches long. - Ic. Rar. t. 36; Bot. Reg. t. 85; Meissn. 1. c. 228 ; but not the Convolvulus hederaceus, L. Spec. ed. 2, 219, at least as to the cited figures of Dill. Elth., but clearly C. Nil, L. 1. L., as to the lower figure cited (fig. 92), and therefore of Amer. authors. I. burbata, Roth, Cat. i. 37. Pharbitis hederacea, Choisy, 1.c. - Waste and cult. grounds, Penn. to Florida and Louisiana, barely naturalized north ward, perhaps indigenous far southward. (Trop. Amer. and now widely dispersed.)

I. Nru, Roth, Cat. i. 16, and of most botanists who distinguish $I$. hederacea, (Contolutlus Nil, L. 1. c., only as to fig. 91 in Dill. Elth., \& Bot. Mag. t. 188, and doubtless C. hederuceus, L., as to Dill. Elth. t. 81 , fig. 93), is an Old World species with larger and longer corolla (2 or 3 inches long), attenuate and erect calyx-lobes an inch long, the peduncle and pedicels short but distinct, the leaves less lobed, \&c. To this belongs Pharbitis triloba, Miq., and $P$. Nil, var. limbata, Hook, f. But. Mag. t. 5720, a cultivated plant. To it properly belongs the Oriental name $N i l$.

I. Mexicána. Slender : earlier leaves angulate-3-lobed or some entire; the others as in $I$. hederacea, or the middle lobe often broadest at base: peduncles slender (from half inch to 3 inches long), commonly equalling or even surpassing the petiole : fruiting pedicels ( 1 to 3) as long as the calyx : sepals (only half inch long) lanceolate, rather sparsely hirsute or hispid with comparatively short hairs, erect: corolla violet-purple, only an inch long, and limb an inch or so in diameter. - Convolvulus flore purpureo, \&c., Dill. Elth. t. 83, fig. 96, therefore in part C. hederaceus, L. . it might have taken this specific name had not another of the confused species been early taken up by Jacquin in Ipomcea. I. Nil, var. diversifolia, Choisy in DC. Prodr. ix. 343, viz. Pharbitis diversifolia, Lindl. Bot. Reg. t. 1988. I. Nil, Meissn. in Fl. Bras. I. c. 228, in part, \& t. 79, fig. 1. - New Mexico and Arizona, Fendler, Wright, Thurber, \&c. (Mex., \&c.) Nearer to the following than to the preceding.

I. purpúrea, Lam. (Common Mornixg Glory.) Leaves cordate, entire: peduncles elongated ( 2 to 5 inches long), 1-5-flowered: umbellate pedicels fully twice the length of the calyx, thickened and usually refracted in fruit: sepals lanceolate, half inch long, less hirsute : corolla about 2 inches long, violet, purple, or pink, varying to white and diversely variegated. - Comolvulus purpureus, L. ; Sims, Bot. Mag. t. 113, 1005, 1682. Pharbitis hispida, Choisy, l. c. - Cult. grounds, an escape from cultivation in the Atlantic States. Texas, Berlandier. San Diego Co., California (Cleveland), where it may be indigenous. (Mex., \&c., and widely dispersed.)

\section{++ Root perennial : flower's more diurnal?}

I. Lindheímeri. Finely appressed-pubescent (the stem retrorsely so), when young canescent: leaves deeply 5-cleft or 5-parted, all or the 3 interior lobes ovate or ovate-lanceolate with a much contracted base, the contracted portion often half the length of the dilated.lobe: peduncle slender, 1-2-flowered ( 1 to 3 inches long) : pedicels a quarter to half inch long: sepals lanceolate-linear from an at length broadish base, fully an inch long, erect, sparsely hirsute (all alike) : corolla light blue, elongated-funnelform with narrow tube, about $8 \frac{1}{2}$ inches long. - I. heterophylla, Torr. Bot. Mex. Bound. 149, not Ortega.Rocky soil, W. Texas to New Mexico, Lindheimer, Wright. (Adjacent Mex., Gregg.)

I. cathártica, Poir. Glabrous or nearly so, even to the calyx: leaves cordate, acuminate, entire, or some of them 3-lobed or deeply cleft: peduncles equalling the petiole, 1-5-flowered: outer sepals larger and ovatc-lanceolate, the inner narrowly lanceolate, all long-acuminate : corolla $2 \frac{1}{2}$ or 3 inches long, pink-purple or crimson. - Dict. Suppl. iv, 633 ; Griseb. Fl. W. Ind. 473. I. fastiginta, Chmpm. Fl. 439, not Sweet. Convolvulus pudibundus', Lindl. Bot. Reg. t. 999. Pharbitis cathartica, Griseb. 1. c. - S. Florida, Blodyett, Palmer. Perhaps introduced. (Bahamas to Brazil)

* * Stigma 2-lobed or entire: ovules only 4 and proper cells of the ovary only 2 , but these in some divided by cellular matter forming an additional partition between the two seeds: sepals membranaceous, or rather fleshy, or becoming coriaceous, mostly very much imbricated. 
- Creeping (or at least prostrate and not twining) perennials, glabrous or nearly so: flowers rather large, opeuing at morning.

I. Pes-cápræ, Sweet. Herbage succulent: leaves orbicular, mostly emarginate at both ends, 2-glandular at base, fleshy, pinnitely many-veined, 2 or 3 inches long, about equalled by the petiole: sepals oval, obtuse: corolla (nearly 2 inches long) broadly shortfunnelform, purple: mature capsule 2-celled: seeds rusty-pubsscent. - "Hort. Lond. ed. 2, 2s?;" Roth, Nor. Pl. 109 ; Desc. Ant. ii. t. 130. I. maritima, I. Br. ; Bot. Reg. t. :319. I. orbicularis, Ell. Sk. i. 257. Convolvulus Pes-capre \& Brasiliensis, L. - Drifting sands of the coast, Georgia to Texas. (Most tropical coasts.)

I. acetosæfólia, Rœm. \& Sch. Stem slender, extensively creeping and freely rooting: leaves slightly succulent, slender-petioled, cxceedingly various; the carlier oblong or subcordate, or emarginate at both ends, either entire or panduriform or 3-lobed; the others sometimes linear, sometimes deeply 3 -5-lobed or parted, and the lobes narrowed at base; lobes obtuse: peduncles 1-flowered : sepals oblong, mucronate or acuminate: corolla oblong-funnelform, white with yellowish throat, 11 to 2 inches long: capsule globose, thinwalled, half inch broad, 4-celled: seeds densely villous-woolly, globular. - Syst. iv. 246 ; Desc. Ant. ii. t. 145 ; Meissn. in Fl. Bras. vii. 2., t. 94. I. carnosa, R. Br. Prodr., ex Benth. Fl. Austr. iv. 120 . Conrolvuhs littoralis, L. C'acetoscefolius, Vahl, Eel. i. 18. ('. stoloniferus, Desr. in Lam. Dict. iii. 5.50; ('yr. Pl. Rar. i. 14, t. j. C. obtusilobus, Michx. Fl. i. 13!); Fll. 1. c. Batatas acetoscefolia \& littoralis, Choisy in DC. Prodr. ix. 3is8, excl. syn. I. longifalia, Benth. - Sandy sea-coast, $\therefore$. Carolina to Texas. (Most tropical shores.)

I. longifólia, Benth. Prostrate stems stout, 6 to 10 feet long : leaves thickish, shortpetioled, pinnately-veined, from linear- to oblong-lanceolate, entire, merely obtuse at base, mucronate at tip, 2 to 5 inches long: peduncle 1-flowered: sepals broadly oblong or oval, very obtuse: corolla very broadly open-funnelform, white with purple throat, 4 inches long, or when widely expanded 3 or 4 inches in diameter: capsule ovate, 2-celled, with firm-coriaceous valves, an inch long: seeds oblong, rather minutely hairy at the angles. Pl. Hartw. 16 ; Lindl. Bot. Reg. xxvi. t. 21; Torr. Bot. Mex. Bound. 149. I. Shumardi, Torr. in Marcy Rep. 191. - S. E. Arizona, Thurber, C. Wright. '(Adjacent Mex.)

I. Batáss, Lam., the Sweet Pot.ito of cultivation, belongs here, although it has the fleshy roots of the following, and the stems trail rather than creep: the leaves vary from cordate-hastate to deltoid, and from nearly entire to laciniate-lobed or parted. Origin unknown, unless from $I$. fastigiata of Trop. Amer.

++ Twining, or at first trailing, but not creeping: leaves cordate or sagittate, or with divisions broader than linear.

- Perennials, with immense fleshy-farinaceous roots: leaves cordate, entire, or some of them 3-5lobed: peduncles one-several-flowerest : sepals oblong or ovate, obtuse or merely mucronate, over half inch long: corolla over 2 inches long.

I. Jalápa, Pursh. Freely twining from a napiform or thick fusiform root (white, sometimes weighing 40 or 50 pounds), tomentulose-pubescent, at least the lower face of the shallow-cordate plicate-veiny repand or sometimes lobed leaves (these 3 to 5 inches long): corolla "opening at night," 3 or 4 inches long, white or light pink-purple; the narrow tube and throat 3 or 4 times longer than the calyx and deep purple : ovary imperfectly 4-celled : seeds densely clothed with long villous wool. - Fl. i. 146 ; Bot. Reg. t. 342, 621 ; Griseb 1. c. Convolvulus Jalapa, L. Mant. 43; Desf. in Ann. Mus. Par. ii. 126, t. 40, 41 ; Sims, Bot. Mag. t. 1572. Ipomøa macrorhiza, Michx. FI. i. 141. Conrol rulus macrorhizus, Ell. Sk. i. 352. Ipomeea Mechoacan, Nutt. in Am. Jour. Sci. . 289. I. Mirhurii, Swcet, l. c.; Chapm. Fl. 343. I. Purshii, Don, Syst. 1. c. Bntatns .I haya, Choisy, Convolv. \& DC. 1. c. 338. - Light sandy soil along the coast, S. Carolina to Florida. (Mex., W. Ind., \&c.) Apparently same as the Mexican false or Mechoacan Jalap, but root of the U. S. plant hardly purgative.

I. panduráta, Meyer. Glabrous or nearly so: stems trailing or twining : root very long and large (at length weighing 10 to 20 pounds): lcaves ( 2 to 4 inches long) usually cordate and entire, or some of the later angulate or panduriform-cordate, occasionally hastate-3-lobed: corolla rather broadly funnelform, 2 or 3 inches long, white with a darkpurple throat: ovary only 2-celled: seeds woolly on the angles. - lisieq. 100, as to name only; Ker, Bot. Reg. t. 588 ; Choisy, 1. c. 381 . Convolvulus megalorhizos, etc., Dill. Elth. 100, t. 85, fig. 99 . C. panduratus, L.; Sims, Bot. Mag. t. 1939; Ell. 1. c.; Barton, Med. t. 23. C. candicans, Solander in Bot. Mag. t. 1603, with somc minute pubescence of leaves. Var. 
rubescens, Choisy, l.c., is merely a longer-flowered form, from Kentucky; and Convolvulus ciliolatus, Michx. l. c., from Knoxville, Tennessee, is probably the same. - Dry ground, Upper Canada to Florida and Texas. There is a double-flowered state.

t+ Perennial with a thick ront: leaves all sagittate: peduncle mostly 1 -flowered: sepals as of
the preceding but barely half inch long: corolla proportionally very large.

I. sagittáta, Cav. Glabrous : stems slender: leaves deeply sagittate, otherwise entire, acute or acuminate; some with linear-lanceolate lobes; some (at least the earlier) larger and broader, with ovate-lanceolate outline and oblong obtuse basal lobes: corolla pinkpurple, 2 or 3 inches long; the tube with the narrowish throat very much exceeding the calyx: seeds somewhat villous on the back or sides. - Ic. ii. 4, t. 107; Desf. Fl. Atl. i. 177. I. sagittifolia, Ker, Bot. Reg. t. 437 ; Chapm. Fl. 344. Convolvulus Carolinensis, \&c., Catesb. Car. i. 35, t. 35. C. speciosus, Walt. Car. 93. C. sagittifolius, Michx. Fl. i. 138. - Salt marshes on the coast, N. Carolina to Texas. (Cuba, Spain and Barbary.)

+++ Perennials with roots not very large and thick, or annuals: corolla an inch and a half long or smaller.

= Calyx almost an inch long, large for the size of the corolla.

I. sinuáta, Ortega. Root perennial : stem (rather woody at base) and petioles hirsute with long spreading hairs from a papilliform base : leaves nearly or quite glabrous, 7-parted ; the divisions lanceolate or narrowly oblong, sinuately and laciniately pinnatifid or incised: calyx equalling the throat of the open-funnelform corolla (white with purple eye): seeds glabrous. - Dec. vii. 84 ; Choisy, l. c.; Chapm. 1. c. I. dissecta, I'ursh, not Willd. Convolvulus dissectus, L. Mant. 204 ; Jacq. Obs. iv. t. 28, \& Vind. ii. t. 159. - Near the coast in Georgia to Texas. (Trop. Amer.)

$$
==\text { Calyx in fruit over half inch long, setose-hispid. }
$$

I. barbatisépala. Apparently annual, glabrous except the calyx : leaves pedately 5-7. parted; the divisions lanceolate with narrowed base, an inch or two long, or the lateral ones mostly short, entire: peduncles 1-2-flowered, not longer than the petiole: sepals attenuate-linear from a broader base, nearly equal, in fruit 7 or 8 lines long, a third longer than the 2-celled 4-seeded globular capsule, the back strongly hispid with long and stout spreading bristles : corolla purple, less than an inch long: stigmas 2, globose: seeds glabrous or minutely scurfy. - W. borders of Texas; declivity of mountain near EI Paso, Wright (1849, no. 507). Calyx nearly as of $I$. hederacen, Jacq., but with stiffer beard.

$$
===\text { Calyx } 5 \text { to } 9 \text { lines long, completely glabrous : root perennial. }
$$

I. Thúrberi. Glabrous throughout, apparently with only low twining stems from a thickened root or tuber: leaves palmately or pedately and deeply 5-7-cleft (an inch or more in diameter); the widely divergent lobes triangular-lanceolate, or the one or three middle ones somewhat caudately prolonged, the narrow tip obtuse: peduncle short, 1-flowered, clavate in age: corolla, \&c., not seen : sepals in fruit 8 or 9 lines long, lanceolate-attenuate from a broader base, nearly twice the lengtl of the 4-celled 4-valved globular coriaceous capsule: seeds clothed with fine brownish somewhat furfuraceous pubescence. - Southeastern border of Arizona, near Santa Cruz, Thurber (no. 966), Wright.

I. trífida, Don. Much resembles I. commutata; but the root perennial, the pubescence shorter and softer, peduncles longer, and calyx glabrous. - Convolvulus trifidus, HBK. Nov. Gen. \& Spec. iii. 107. (Trop. Amer.)

Var. Torreyána. Nearly glabrous throughout, freely twining : leaves cordate, alsout 2 inches long; soine entire or merely angulate; most 3 -cleft, with ovate lobes, the lateral externally rounded: peduncles surpassing the leaves, umbellately 3 -10-flowered: pedicels il age muriculate-scabrous: sepals oblong-ovate or ovate-lanceolate, mucronate-acuminate, chartaceous, 5 lines long, not at all ciliate: corolla funnelform, pink or lilac-purple, over an inch long: capsule globular, chartaceous, simply 2-celled, either glabrous or sparingly pilose at tip, about equalling the calyx: seeds glabrous and very smooth. - I. commutata, Torr. Bot. Mex. Bound. 149, not Rom. \& Sch. I. fastigiata? Torr. 1. c., not Sweet. - W. and S. Texas, Wright, Bigelow, Lindheimer, Schott.

Var. Berlandiéri. Perhaps only a depauperate form: leaves smaller and deeper cleft, some almost 3-parted; the middle lobe lanceolate or ovate-lanceolate and longer, giving a somewhat hastate outline; the lateral divisions often 2-lobed or 2-3-cleft and their lobes acute: peduncles only an inch long. - Bejar, Texas, Berlandier. Referred by Choisy to 1 . commututa. 
$==\overline{C a l y x} 3$ to 6 lines long, thimnish, pilose or at least ciliate with some long and soft hairs rising from a more rigid or papilliform base, more or less longer than the snall and thinwalled globulur 2-colled capsule. which is sparsely pilose but sonietimes glabrate at the upper part: seeds glabrous: stems freely twining: root anuual.

I. commutáta, Rœm. \& Sch. Hirsute-pubescent or glabrate: leaves $(2$ or 3 inches long), cordate, some entire, some strongly 3-lobed with middle lobe ovate-lanceolate and acuminate; the lateral usually shorter and broader, sometimes again 2-lobed: peduncles slender, $1 \frac{1}{3}$ to 3 inches long, 1-3-flowered: sepals oblong, acuminate, 5 lines long: corolla an inch or more long, purple or pink. - Syst. iv. 228; Choisy, 1. c. Concoltulus Carolinus, L. Spec. i. 154 (Dill. Elth. 100, t. 84, fig. 98); Michx. Fl. i. 139 . Ipomoce ('arolina, Pursh, Fl. i. 145, not L., which is W. Indian. I. trichocarpa, Ell. sk. i. 2.58, which slightly antedates the name commutata, but is misleading, the fruit being not rarely glabrate or glabrous. Dry or low grounds, S. Carolina to Texas.

I. lacunósa, L. Slightly pubescent or hirsute, or nearly glabrous: leaves as the preceding or less lobed, more commonly ovate-cordate and entire, conspicuously acuminate: peduncles shorter: sepals commonly broader and mostly naked, except the long-ciliate margins : corolla half inch or so in length, narrow-funnelform, white or with a purple acutely 5-angulate border : globose capsule more turgid and pilose. - Spec. i. 161 (Dill. l. c. t. 87, fig. 102) ; Michx. 1. c.; Ell. 1. e. Convolvulus micranthus, Riddell, Syn. Fl. W. States, 70. - River banks and low grounds, Penn. to Llinois, S. Carolina, and Texas.

I. tríloba, L. Stems slender, sparsely pubescent: leaves usually glabrous, very deeply 3-lobed or alnoost 3-parted; the divisions mostly entire; the middle ovate or lanceolateovate with narrowed base; the lateral semicordate: peduncles usually elongated: sepals 3 lines long, oblong-ovate: corolla narrow, two-thirds inch long, resembling that of the preceding, but purple. - Choisy, l. c. 383; Chapm. Fl. 343. - Key West, Florida ; perhaps introduced. (Trop. Amer.)

$==\mathrm{C}=\mathrm{Calyx}$ only 2 lines long, naked and glabrous, shorter than the glabrous simply 2-celled thill-walled capsule: herbage glabrous throughout: root not seen.

I. Wríghtii. Stems very slender: leaves all digitately divirled into 5 narrowly lanceolate entire leaflets (all 12 to 18 lines long, or the lateral shorter, obtuse or acutish and mucronulate) : peduncles slender, 1-flowered, not exceeding the petiole: sepals ovate, very obtuse, equal : corolla pink or purple, narrowly funnelform, half inch long: capsule ovoid, 4 lines long: seeds globular, minutely and densely puberulent. - Texas, Wright, probably from the southern part of the State. Habit of I. quinquefolia, but leaves, corolla, \&c., different. A plant resembling it was collected by Dr. Palmer on the Yaqui River, in the northwestern part of Mexico, in which the leaves seem to be pedate, and the long filiform peduncles coil in the manner of tendrils.

I. cardiophylla. Very glabrous: leaves broadly cordate and with basal lobes somewhat incurved, entire, acuminate, an inch or two long : peduncles mostly 1-flowered and shorter than the slender petiole: sepals ovate, acute, thickish but scarious-margined, more or less muriculate-glandular on the back: corolla purple, three-fourths inch long, campanulatefunnelform above the narrow tube, which barely equals the calyx: capsule ovoid, half inch long; the thin valves finely lineolate: seeds oval, brownish-puberulent. - Western borders of Texas, in the mountains near El Paso, Wright. In calyx and foliage considerably resembling $I$. violacea.

+++ Stems erect or diffuse, feebly jf at all twining, never creeping or even prostrate: leaves or their dirisions all linear or narrower and entire.

+ Leaves simple and entire: flowers large: root perennial, immense, weighing from 10 to 100 pounds.

I. leptophýlla, Torr. Very glabrous: stems erect or ascending ( 2 to 4 feet high), and with recurving slender branches: leaves linear ( 2 to 4 inches long, 2 or 8 lines wide), shortpetioled, acnte : peduncles short, 1-2-flowererl : calyx :; or 4 lines long; the sepals brondly ovate, very obtuse, outer ones shorter: corolla pink-purple, funnelform, about 3 inches long: capsule ovate, an inch long: seeds rusty-pubescent. - Frem. Rep. 95, \& Emory Rep. 148, t. 11. Convolvulus Caddoensis, Buckley in Proc. Acad. Philad. 1862. - Plains of Nebraska and Wyoming to Texas and New Mexico: a striking and showy species, first collected, in Long's Expedition, by Dr. E. James, who singularly mistook it for an annual. Torr. in Ann. Iyc. N. Y. ii. 223. (Convolvulus.) 
++ Leaves palmately or pedately divided or parted,

$=$ Almost sessile and the divisions all simple : root perennial, an oblong tuber.

I. muricáta, Cav. A span or two high, erect, loosely branched, glabrous, slender : leaves of 5 (or sometimes pedately 7) narrowly linear or filiform mucronate-acute divisions or leaflets ( 6 to 10 lines long): peduncles shorter than the leaves, 1-flowered: sepals lanceolate-ovate, tuberculate-muricate on the back or midrib: corolla narrowly funnelform, crimson-purple, an inch long: capsule globose, nodding, hardly 3 lines long: seeds almost glabrous.-Ic. v. 52, t. 478, fig. 2 ; Torr. Bot. Mex. Bound. 150. Convolvulus capillaceus, HBK. Nov. Gen. \& Spec. iii. 97. - New Mexico and Arizona. (Mex., \&c.)

$$
==\text { Leaves distinctly petiolate : root annual: stems diffuse, filiform. }
$$

I. leptótoma, Torr. Diffuse or procumbent and feebly twining, a foot or two long, glabrous up to the pedicels: leaves pedately 5-7-parted into narrowly linear attenuateacuminate or acute divisions; the middle and longer one an inch or two long: peduncles slender, equalling or exceeding the leaf, 1-2-flowered: pedicels and lanceolate attenuateacuminate 3-nerved sepals hirsute: corolla funnelform, purple, over an inch long: capsule globose-ovoid, shorter than the calyx: seeds glabrous. - Bot. Mex. Bound. 150. - Arizona, Thurber, Wright, Palmer.

I. costelláta, Torr. 1. c. Erect and diffuse, at length procumbent or slightly twining, glabrous or minutely hirsute: leaves pedately 7-9-parted into linear or somewhat spatulate (or the upper into filiform) divisions of somewhat equal length (half to an inch long): peduncles filiform, surpassing the leaf, 1-3-flowered: sepals ovate-lanceolate or oblong, acute, glabrous (as is the pedicel), carinately 1-nerved or obscurely 3-nerved; the keel of the outer ones salient and often undulate-cristate or tuberculate : corolla narrowly funnelform, approaching salverform, a third or hardly half inch long, twice or thrice the length of the calyx, pink-purple or paler, with 5 short mucronate-pointed lobes : capsule globular, as long as the caly $x$ : seeds minutely puberulent. - S. Texas to Arizona. (Mex.)

3. JACQUEMÓNTIA, Choisy. ( Tictor Jacquemont, a French naturalist and traveller, died in India.) - A rather small genus, tropical or subtropical, mostly with the aspect of Convolvulus. Fl. summer. Seeds in ours roughish.

J. ABUTILof́des, Benth., to which belongs Dr. Kellogg's Aniseia azurea, is of Lower California. It is doubtful if either of the following are indigenous.

J. violácea, Choisy. Twining, pubescent or almost glabrous : leaves cordate or ovatelanceolate, cuspidate-acuminate: peciuncles slender, umbellately or cymosely severalflowered; sepals ovate, acuminate; the outer larger and subcordate : corolia short-funnelform, half inch long, violet. - Chapm. Fl. 344. Convolvulus violaceus, Vahl. C. pentanthos, Jacq. Ic. Rar. ii. t. 316 ; Bot. Mag. t. 2151. - Key West, Florida, Blodgett. (Trop. Amer.)

J. tamnifólia, Griseb. Erect or at length twining, fulvous-hirsute : root annual : leaves cordate and ovate, long-petioled, pinnately veiny: peduncles elongated, capitately manyfowered : glomerate cluster involucrate with foliaceous bracts : sepals subulate-linear, ferrugineous-hirsute, 5 lines long, nearly equalling the violet corolla. - Fl. W. Ind. 474; Meissn. in Fl. Bras. vii. 302. Ipomoea tamnifolia, L. (Dill. Elth. t. 318, fig. 414.) Convolvulus ciliatus, Vahl. C. tamnifolius, Ell. Sk. i. 258. - Cult. and waste grounds, from S. Carolina and Arkansas southward. (Trop. Amer.)

4. CONVÓLVULUS, L. Bindweed. (From convolvo, I entwine.) Herbs or somewhat shrubby plants (of many species, most of them in the Old World), either twining, erect, or prostrate; with small or rather large flowers (in summer), some opening at dawn, some in bright sunshine. - Convolvulus \& Calystegia, R. Br.; Benth. \& Hook. Gen. ii. 874.

$\S 1$. Calystégia. Stigmas from ovate or oval to oblong, thickish: solitary flower involucellate by a pair of persistent membranaceo-foliaceous broad bracts, which are close to the calyx and enclose or exceed it: corolla open in sunshine : ovary and capsule commonly somewhat one-celled by the imperfection of the par- 
tition : perennials, with fliform creeping rootstocks. - Calystegia, R. Br., Hook. \& Benth., \&c.

Calystegia Paradoxa, Pursh, Fl. ii. 729, which was described from Sherard's herbarium, and supposed to come from Virginia or Carolina, is not recognizable, and is certainly no true Calystegia.

C. Soldanélla, L. Glabrous, fleshy : stems low and mostly short, creeping or trailing: leaves reniform, entire or obscurely angulate, often emarginate, an inch or two wide, longpetioled : bracts roundish and obscurely cordate, not longer than the sepals : corolla pinkpurple, 12 to 18 lines long, short-funnelform: stigmas ovate. - Spec. i. 159; Engl. Bot. t. 314; Gray, Bot. Calif. i. 533. Calystegia Soldanella \& C. reniformis, R. Br. Prodr. 433. Sands of the Pacific coast, Puget Sound to California. (Most Pacific shores, Eu., \&c.)

C. spithamæuus, L. Soft-pubescent or tomentose : stem erect or ascending, or sometimes decumbent, as span to 2 feet long, mostly simple and not twining: Ienves short-petioled, oblong, with rounded or subcordate or sometimes short-sagittate base: bracts ovate, not auricled at base: corolla white, campanulate-funnelform, $1 \frac{1}{2}$ to 2 inches long: stigmas oval. - Spec. i. 158 ; Ell. Sk. i. 251. C. stans, Michx. Fl. i. 136 . Calystegia spithamcea \& C. tomentosa, Pursh, Fl. i. 434. C. spithamae, Hook. Exot. t. 97, but stigmas too narrow. - Dry and sandy or rocky soil, Canada to Wisconsin and south to Florida.

C. sépium, L. Glabrous, or more or less pubescent, freely twining : leaves slender-petioled, deltoid-hastate and triangular-sagittate ( 2 to 5 inches long), acute or acuminate; the basal lobes or auricles either entire or angulate-2-3-lobed: peduncles mostly elongated: bracts cordate-ovate or somewhat sagittate, commonly acute : corolla broadly funnelform, 2 inches long, white or tinged with rose-color: stigmas from oval to oblong, - Curt. Fl. Lond. t. 32 ; Engl. Bot. t. 313; Fl. Dan. t. $458 . \quad$ Calystegia sepium, R. Br. Prodr. 483; Reichenb. Ic. Germ. xviii. t. 1340. - Noist alluvial soil, or along streams, Canada and N. Atlantic States to Utah. (Eu., \&c.)

Var. Americánus, Sims. Corolla pink or rose-purple: bracts obtuse. - Bot. Mag. t. 732. C. sepium of Am. authors in large part. Calystegia sepium, var. rosea, Choisy in DC. Prodr. ix. 433. - Canada to Carolina and Oregon. (N. Asia.)

Var. répens. Corolla from almost white to rose-color: bracts from very obtuse to acute: herbage from minutely to tomentose-pubescent: sterile and sometimes flowering stems extensively prostrate : leaves more narrowly sagittate or cordate, the basal lobes commonly obtuse or rounded and entire. - Convolvulus repens, L. Spec. i. 158 (as to pl. Gronov., excl. syn. Plum. \& Rheede); Michx. 1. c. Calystegia sepium, var. pubescens, Gray, Man. ed. 5, 376. C. Cutesbeina, Pursh, Fl. ii. 729 ; Choisy, 1. c. - Canada? to Texas, and west to Dakota and New Mexico, on banks and shores. Sometimes with almost glabrous and thickish leaves; Calystegiasepium, var. maritima, Choisy, in part. (The species widely diffused over the world and variable.)

§. Stigmas linear or oblong-]inear, flat: bracts at the base of the calyx as in the preceding section or smaller, or various at the base of a short pedicel. Californian species.

C. occidentális, Gray. Glabrous or minutely pubescent : stems freely twining : leaves slender-petioled, from angulate-cordate with a deep and narrow sinus to sagittate or the upper hastate; the posterior lobes often 1-2-toothed : peduncles elongated, surpassing the leaf, sometimes proliferously 1-3-flowered : bracts at base of calyx ovate or obscturely cordate, membranaceous, equalling it or rather longer, mostly obtuse : corolla campanulatefunnelform, white or pinkish, 12 to 24 lines long: stigmas linear. - Proc. Am. Acad. xi. 89, \& Bot. Calif. i. 533. - Dry hills, W. California, from San Francisco Bay to San Diego.

Var. tenuíssimus, Gray, l. c., a form with narrowly hastate or sagittate leaves (only an inch or two long), the middle and mostly the basal lobes narrowly lanceolate: bracts ovate-oblong or ovate-lanceolate, acute or acuminate. - Santa Barbara and San Diego, Nuttall, Cooper, \&c.

C. Califórnicus, Choisy. Minutely and often densely pubescent: stems very short and erect from fliform rootstocks, flowering close to the ground, or at length with prostrate branches a span or even a foot long: leaves slender-petioled, from ovate or round-obovate to deltoid or subcordate and obtuse, or the later somewhat sagittate or hastate and acute 
(an inch or so long): peduncles shorter than the petiole: bracts at base of caly $\mathrm{x}$ oblong, obtuse, about equalling and somewhat resembling the outer very obtuse sepals : corolla broadly funnelform, $1 \frac{1}{2}$ to 2 inches long, white, crean-color, or flesh-color : stigmas linearoblong. - DC. Prodr. ix. 405; Gray, l. c. Calystegia subacaulis, Hook. \& Arn. Bot. Beech. 363. - W. California, on hills, \&c., from San Francisco Bay southward.

C. villósus, Gray, l. c. Densely velvety-tomentose throughout, mostly silvery-white, low : stems decumbent or prostrate, feebly if at all twining: leaves slender-petioled, from reniform-hastate to sagittate, an inch or less long; the basal lobes often angulate-toothed: peduncles shorter than the leaf: bracts at base of and equalling the calyx, oval or ovate, white-tomentose : corolla campanulate-funnelform, cream-color, an inch long: stigmas narrow-linear. - Calystegia villosa, Kellogg in Proc. Calif. Acad. v. 17. - Dry and sandy soil, California, Monterey Co., and Plumas Co. to Tejon.

C. lutéolus, Gray, l. c. Glabrous or soft-pubescent: stems a span or two long and ascending or more elongated and twining : leaves slender-petioled, from triangular- or deltoid-hastate to sagittate, an inch or two long : peduncles equalling or surpassing the leaves: bracts about their own length distant from the calyx, narrowly oblong varying to linearlanceolate, 2 to 4 lines long, much smaller than the chartaceo-coriaceous very obtuse unequal sepals, a second flower rarely in the axil of one of them (occasionally the bracts alternate): corolla 12 to 18 lines long, campanulate-funnelform, pale yellow (sometimes purplish or fading to purple?): stigmas linear. - Ipomoea sagittifolia, Hook. \& Arn. Bot. Beech. 151 (as to Calif. plant) ; Torr. in Pacif. R. Rep. iv. 127, the stigmas certainly linear! Convolvulus Californicus, Benth. PI. Hartw. 326, not Choisy. - California, from around San Francisco Bay northward, and in the foothills of the Sierra Nevada.

Var. fulcrátus, Gray, 1. c. Soft-pubescent: bracts foliaceous, hastate or sagittate, and short-petioled, resembling diminutive leaves, 3 to 6 lines long, about their length distant from the caly $x$ or sometimes closely subtending it. - Convolvulus arvensis, var. villosus, Torr. 1. c. -Foothills of the Sierra Nerada from the Stanislaus southward.

$\S 3$. Stigmas filiform or narrowly linear : no bracts at or near the base of the calyx.

* Procumbent or low-twining perennials : bracts of the 1-3-flowered peduncle small or minute and subulate: corolla an inch or less long, broadly short-funnelform.

+ Introduced species, nearly glabrous: leaves broad and entire.

C. ARVÉnsis, I. Mostly procumbent : leaves oblong-sagittate or somewhat hastate, an inch or two long; the basal lobes short and acute: bracts a pair at the base of the pedicel, small, subulate: corolla white, commonly tinged with rose: stigmas filiform. - Fl. Dan. t. 459 ; Reichenb. Ic. Germ. xviii. t. 1337. - Old fields, N. Atlantic States. (Sparingly nat. from Europe.)

+- Indigenous Texan species, cinereous-pubescent or canescent: leaves commonly lobed or dentate: flowers opening in afternoon sunshine: corolla ferrugineous-silky-hirsute outside in the bud.

C. hermannioídes. Sericeous-tomentulose: stems 3 to 5 feet long, mainly procumbent: leaves oblong or oblong-lanceolate, obtuse, and with sagittate or narrowly cordate base, $1 \frac{1}{2}$ to 3 inches long, repand- or sinuate-dentate, sometimes obsoletely so, rather shortpetioled; the veins not plicate-impressed above nor prominent beneath : peduncles rather Ionger than the leaves, 1-2-flowered: "sepals half inch long or nearly so, oval-oblong, mucronate and obtuse or barely acute: corolla white, an inch long, the border merely angulate. - C. Hermannice, Choisy in DC. l. c. as to Texan plant; Torr. Bot. Mex. Bound. 148, not of L'Her., which is Peruvian and Chilian. - Texas, in dry prairies. Narrow-leaved forms approach the next.

C. incánus, Vahl. Cinereous or canescent with a close and short silky pubescence (rarely greener and glabrate): stems filiform, 1 to 3 feet long, mainly procumbent : leaves polymorphous; some simply lanceolate- or linear-sagittate or hastate ( 1 or 2 inches long, 2 or 3 lines wide, obtuse and mucronate, entire, and with the narrow elongated basal lobes entire or 2-3-toothed); some pedate, having narrowly 2-3-cleft lateral Iobes or divisions, some more coarsely 3-5-parted, with lobes entire or coarsely sinuate-dentate; some of the carly ones ovate- or oblong-cordate and merely sinuate-dentate: peduncles 1-2-flowered, as long as the leaf : sepals a quarter inch long, oval, obtuse, or merely mucronate-tipped: 
corolla white or tinged with rose, half inch long, the angles salient-acuminate. - Symb. iii. 23 (1790). C. Bonariensis \& C. dissectus, Cav. Ic. v. t. 480 (1799). C. equitans, Benth. Pl. Hartw. 16. C. hastatus, Nutt. in Trans. Am. Plil. Soc. ser. 2, v. 194. C. lobatus, Engelm. \& Gray, Pl. Lindh. i. 44. C. glaucifolius, Choisy in DC. Prodr. ix. 412, but probably not Ipomoea glaucifolia, L., viz. Dill. Elth. t. 87, fig. 101, which is "glaucous and glabrous," - Dry prairies and hills, Arkansas and S. Colorado to Texas and Arizona. (Mex., Extra-trop. S. Amer.)

* Erect and much branched feebly twining perennial, glabrous throughout, small-leaved.

C. lóngipes, Watson. Stems slender, loosely much branched, a foot to a yard high: leaves mostly linear-hastate, short-petioled (an incls or two long, a line or two wide), thickish, veinless, entire, cuspidate-mucronate, the upper gradually reduced to linearsubulate bracts; these on the 1-flowered peduncles mostly alternate: sepals ovate, obtuse, often mucronulate, the outer shorter: corolla fully an inch long, broadly funnelform, glabrous throughout, white or cream-color: stigmas very uarrowly linear: seeds globular, minutely tuberculate. - Am. Naturalist, vii. 302 ; Gray, Bot. Calif. i. 534; Rothrock in Wheeler Rep. t. 20. - Arid desert region, S. Nevada and S. E. California, Lieut. Wheeler, Dr. Horn, Palmer.

5. BREWERIA, R. Br. (Samuel Brewer, an English Botanist or amateur of the 18th century.) - Chiefly perennial herbs, some suffruticose, of the warmer parts of the world, resembling Ipomoea and Convolvulus; with simple entire and usually short-petioled leaves, and the corolla mostly silky-pubescent or silky-hirsute outside in the bud, with angulate or obscurely lobed border: fl. summer and autumn.- Prodr. 487 ; Benth. \& Hook. Gen. ii. 877. Stylisma, Raf. in Ann. Sci. Phys. viii. 268; Choisy in DC. Prodr. ix. 450. Bonamia, Gray, Proc. Am. Acad. v. 336, \& Man. ed. 5, 376, not Thouars, in which the corolla is lobed and not plicate.

* Procumbent: peduncles very short and 1-flowered: capsule large: seed glabrous.

B. ovalifólia. Sericeous-canescent: leaves ovate or oval, mostly subcordate, an inch long: style 2-cleft above the middle: capsule globose, half inch in diameter, about the length of the broadly ovate sepals, by abortion 1-seeded. - Evolvulus? ovalifolius, Torr. Bot. Mex. Bound. 150. - S. W. borders of Texas, on the Rio Grande (the Mexican side) below San Carlos, Parry. Corolla not seen.

* * Procumbent slender perennials : peduncles slender and elongated, 1-5-flowered : flowers small: corolla almost campanulate: capsule small. - Stylisma, Raf., \&c.

B. humistráta. Sparsely pubescent or glabrate: leaves from elliptical and subcordate to narrowly linear (an inch or two long), mucronate, and the broader emarginate: peduncles 1-7-flowered: bracts shorter than the pedicels: sepals glabrous or almost so, oblong-ovate, acuminate: corolla white, half inch long: filaments hairy: styles united at base.-Convolvulus humistratus, Walt. Car. 94. C. patens, Desr. in Lam. Dict. iii. 547. C. trichosanthes, Michx. Fl. i. 137, partly. C. Sherardi, Pursh, Fl. ii. 730 ? C. tenellus, Lam. Ill. i. 459; Ell. Sk. i. 250. Evolvulus? Sherardi, Choisy. Stylisma erolmuloides, Choisy, 1. c., in part. S. humistrata, Chapm. Fl. 346. Bonamia humistrata, Gray, Man. ed. 5, 376. - Dry pine barrens, Virginia to Louisiana.

B. aquática. Soft-pubescent or cinereous-tomentulose : leaves from elliptical to subcordate-lanceolate, very obtuse, seldom over an inch long: peduncles 1-3-flowered: sepals strongly sericeous-pubescent, acute or acuminate : corolla rose-purple: filaments glabrous : styles distinct nearly to base. - Convolmulus aquaticus, Walt. 1. c.; Fll. l. c. C. trichosanthes, Michx. l. c., partly. C. erianthus, Willd. in Spreng. Syst. i.610. Stylisma aquatica, Chapm. 1. c. Bonamia aquatica, Gray, 1. c. - Wet pine barrens and margin of ponds, North Carolina to Texas.

B. Pickeríngii. Pubescent, or the leaves glabrate: these from narrowly spatulatelinear with acute and subsessile base to filiform-linear: peduncles seldom surpassing the leaves, 1-3-flowered: bracts foliaceous and exceeding the flowers: sepals villous-sericeous, ovate, obtuse, half the length of the ovate-conoidal capsule: corolla white, a third of 
an inch long, equalled by the almost glabrous filaments and the moderately 2-cleft style. - Convolvulus Pickeringii, Torr.; M. A. Curtis in Bost. Jour. Nat. Hist. i. 129; Gray, Man. ed.1, 319. Stylisma evolvuloides, var. angustifolia, Choisy in DC. 1. c. S. Pickeringii, Gray, Man. ed. 2, 335; Chapm. 1. c. Bonamia Pickeringii, Gray, Man. cd. 5, 376. - Dry pine barrens and prairies, New Jersey to North Carolina; Louisiana and Texas; also W. Illinois, H. N. Patterson.

6. EVOLVULUS, L. (From evolvo, I unroll, the name a counterpart of Convolvulus.) - Low and small herbaceous or suffrutescent plants (of the warm parts of the world, largely American); with erect or commonly diffuse or prostrate stems, not twining, entire leaves, one-few-flowered and sometimes paniculate peduncles, and small flowers, produced in summer and autumn. Corolla in ours almost rotate, white, rose-colored, or blue.

E. MonlenbÉk̨GIr, Spreng. Pugill. i. 27, habitat not given, is something not identified, and by "peduncles opposite the leaves" not of this order.

* Peduncles filiform, 1-3-flowered, mostly longer than the leaves: either perennials or annuals ?

E. alsinoides, $I$. Villous or hirsute, commonly with some long and spreading hairs: stems slender, diffuse or decumbent, a foot or two long: leaves from oval or oblong to lanceolate, somewhat petioled: pedicels at length nodding or refracted on the peduncle: corolla about 3 lines broad. - (Founded on the Asiatic plant, Burm. Zeyl. ii. t. 6, fig. 1, \& t. 9, fig. 1, and Rheede, Malab. xi. t. 64, apparently also indigenous to the New World, and diverse.) E. alsinoides, var. hirticaulis, Torr. Bot. Mex. Bound. 150. E. diffusus, Chapm. Fl. 345. - S. Florida and Texas, Blodgett, Berlandier, ITright, \&c. (All trop. regions?)

E. linifólius, L. Too like narrow-leaved and slender forms of the preceding, but the fine sericeous pubescence all appressed : leaves small and linear-Ianceolate, nearly sessile : blue corolla only 2 or 3 lines in diameter. - Spec. ed. 2, i. 392, founded on Convolvulus herbaceus, erectus, \&c., P. Browne, Jam. 152, t. 10, fig. 2, not Choisy in DC. - S. Arizona, near Tucson, Greene. (Mex., W. Ind., \&c.)

E. Arizónicus. Minutely sericeous or cinereous with fine appressed pubescence, paniculately branched: stems very slender, erect and diffuse or decumbent-spreading: leaves lanceolate or linear-lanceolate, subsessile or short-petioled ( 6 to 12 lines long, 2 or 3 wide); the upper reduced to bracts so that the inflorescence becomes paniculate: peduncles mostly 1-flowered: sepals ovate-lanceolate, acute: corolla blue or bluish, half inch in diameter when expanded. $-E$. alsinoides, Torr. l. c., partly. E. holosericeus, var. obtusatus, Torr. l. c., partly, excl. syn. - Sandy or dry prairies, Arizona and New Mexico; a common species of the region. (Adjacent Mex.)

E. mucronátus, Swartz. Glabrate and green, or when young sparsely villous-sericeous with appressed pubescence: stems decumbent or prostrate: leaves thickish, oval or round-obovate (about half inch long), short-petioled, the obtuse or retuse apex mucronate: peduncles barely surpassing or some shorter than the leaves: cornlla pale blue or white, 4 lines in diameter. - Griseb. Fl. W. Ind. 475; Meissn. 1.c. 345. E. glabriusculus, Choisy, Conv. 156 , \& in DC. l. c. 448 ; Chapm. 1. c. - South Florida, Blodgett. Perhaps E. nummularius, Nutt. Gen. i, 174 (not L.), on the Mississippi below New Orleans. (Trop. Amer.)

* * Peduncles or rather pedicels (bibracteolate at base, solitary and one-flowered) short, usually very short; the lower sometimes balf the length of the leaf, recurved in fruit: very low perennials.

+ Upper surface of the leaves green and glabrous, otherwise sericeous: corolla white or pale blue.

F. Seríceus, Swartz. Stems slender or filiform, a span or two high: leaves subsessile, lanceolate or linear-lanceolate (6 to 10 lines long), erect or ascending, mucronate-acuminate or acute; silky pubescence fine and close-pressed, sometimeś short, whitish or fulvous: sepals ovate-lanceolate : corolla 3 or 4 lines in diameter. - Prodr. 55, \& Fl. Ind. Occ. i. 576 ; Nutt. Gen. i. 174 ; Chapm. 1. c.; Choisy, 1. c.; Meissn. in Fl. Bras. vii. 353. Convolvulus erectus, herbaceus, \&c., P. Browne, Jam. 153, t. 10, fig. 3. E. holosericeus, Torr. 1. c. partly, not HBK. - Pine woods, \&c., Florida to Louisiana, Texas, and Arizona. The western forms with looser and longer hairiness. (Mex., W. Ind., S. Amer.) 
E. Díscolor, Benth. (E. holosericeus, var. obtusatus, Choisy, 1. c.), of Mexico, with shorter and procumbent or prostrate stems, ovate or oblong obtuse leaves, more villous pubescence and larger corolla, seems to be a good species, as Meissner also supposes; but is not found on our immediate borders. Dr. Torrey's plant so referred is mainly $E^{*}$. Arizonicus,

++ Buth sides of the leaves, stems, and calyz densely silky-villous.

E. argénteus, Pursh. Stems numerous from a lignescent base, rather stout and rigid, erect or ascending, a span or so high, very leafy: dense pubescence sometimes silverycanescent, usually fulvous or ferruginous: leaves from spatulate and obtuse to linearlanceolate and acute (a quarter to half inch long): pedicels very short: sepals lanceolatesubulate: corolla purple or blue (not "yellow" as says Pursh), 3 to 6 lines in diameter. Fl. i. 187, not R. Br.; Choisy, 1. c. ; Torr. 1. c. E. pilosus, Nutt. Gen. i. 1it (as additional name), \& in Trans. Am. Phil. Soc. ser. 2, v. 195, not Lam. E. Nuttallianus, Rom. \& Sch. Syst. vi. 198. - Sterile plains and prairies, Nebraska to Texas and west to Arizona. Pine Key, Florida, Blodgett, in small and insufficient specimens. (Adjacent Mlex.)

7. CRÉSSA, L. (Greek name for a female Cretan.) - Genus apparently of a single but very variable and widely diffused species.

C. Crética, L. Low canescent perennial, much branched from a lignescent base, erect or diffuse, a span or two high, very leafy: leaves entire, from oblong-ovate to lanceolate, sessile, 2 to 4 lines long : flowers subsessile or short-pedicelled in the upper axils, or the upper crowded as if in a leafy-bracteate spike: corolla white, 2 or 3 lines long, sericeouspubescent outside. - Lam. Ill. t. 183; Sibth. Fl. Græca, t 256. (S. Eu., Afr., S. Asia, Australia, \&c.)

Var. Truxillénsis, Choisy. A more silky-villous and stouter form, mostly largerleaved: capsule larger, 2 or 3 lines long. - Choisy in DC. 1. c. 440 ; Torr. l. c. C. Truxillensis, HBK. Nov. Gen. \& Spec. iii. 119. - On or near the sea-shore or in saline soil, California, and from Arizona to S. Texas. (Hawaian Islands, S. Amer., \&c.)

8. CỨSCUTA, Tourn.* Dodder. (Name said to be of Arabic derivation.) - Flowers 5 -merous, rarely 4 -merous, white or whitish, small, in loose or dense cymose clusters, usually produced late in the season. Calyx cleft or parted. Corolla from campanulate or somewhat urceolate to short-tubular, with the mostly spreading lobes between convolute and imbricated in the bud, not plicate, marcescent-persistent either at base or summit of the capsule. Stamens inserted in the throat of the corolla above as many scale-like lacerate appendages (scales); these rarely absent. Ovary globular, 2-celled, 4-ovuled. Styles distinct, or rarely united, persistent: stigmas globose, or in Old-World species filiform. Capsule 1-4-seeded, circumscissile or transversely bursting, or indehiscent. Seeds large, globular, or angular by mutual pressure. Embryo filiform, spirally coiled in the firm-fleshy albumen, wholly destitute of cotyledons, but the apex, or plumule, often bearing a few alternate scales, germinating in the soil, but not rooting in it, developing into filiform and branching annual stems of a yellowish or reddish hue, which twine dextrorsely upon herbs or shrubs, and become parasitic by means of suckers which penetrate the bark in contact, the base soon dying away. Small scales of the same color as the stem take the place of leaves and bracts. - Choisy in Mem. Genev. 1841 (cited "Cusc.") \& DC. Prodr. ix. 452 (1845); Engelm. in Am. Jour. Sci. xliii. (1842), 333, Gray, Man., \& Trans. St. Louis Acad. i. 453 (1859), here cited as "Cusc."

§1. Grámurca, Engelm. I. c. Styles (more or less unequal) terminated by peltate-capitate stigmas. - Grammica, Loureiro. (Comprises the greater part of the species of this large genus, almost all of them American and Polynesian.)

* Contributed by Dr. George Exgelian. 
* (Chistogrammica, Fngelm. 1. c.) Capsule indehiscent.

+ Calyx gamosepalous.

+ Ovary and capsule depressed-globose.

- Flowers in dense or globular clusters : corolla with short and wide tube, in age remaining at base of the capsule: styles mostly shorter than the ovary.

C. obtusiflóra, HBK. Stems orange-colored, coarse: lobes of calyx' and corolla rounded, as long as the tube : scales various. - Nov. Gen. \& Spec. iii. 122 ; Engelm. Cusc. 491. (Cosmop.)

Var. glandulósa, Fngelm. 1. c., the only form in our flora, has all parts of the flower ( 1 to $1 \frac{1}{4}$ lines long) dotted: scales large, equalling or exceeding the tube, deeply fringed. - Wet places, Georgia to 'Texas, on Polygonum, \&c. (W. Ind.)

C. chlorocárpa, Engelm. Stems coarse, orange-colored : lobes of calyx and corolla acute, often longer than the tube: scales small, 2 -cleft, often reduced to a few teeth. Gray, Man. ed. 1, 350, ed. 5, 378; \& Cusc. 494. C. Polygonorum, Engelm. in Am. Jour. Sci. xliii. 342, t. 6, fig. 26-29. - Wet places in the Mississippi Valley from Arkansas to Wis. consin; also in Penn. and Delaware, often on Polygonum. Flowers white, 1 to $1 \frac{1}{4}$ lines long; the thin capsule pale greenish-yellow.

C. arvénsis, Beyrich. Stems pale and slender, low : flowers smaller (scarcely a line long) : caly x-lobes obtuse, mostly very broad: those of corolla acuminate, longer than the tube, with inflexed points: scales large, deeply fringed.-Engelm. in Gray, Man. ed. 2, 336, ed. 5, 378, Cusc. 494, \& Fl. Calif. i. 535. Calyx often large and angled (var. pentagona, Engelm. 1. c., \& C. pentagona, Engelm. in Am. Jour. Sci. 1. c. 340, t. 6, fig. 22-24), sometimes smaller and papillose or glandular-verrucose (var. verrucosa, \& C. vervucosa, Engelm. l. c. fig. 25), and in a western form (var. calycina, Engelm. l.c.) larger-flowered, approaching the preceding species. - Rather dry soil, on various low plants, New York to Florida and Texas, Illinois and Missouri, California and Oregon: the varieties principally in Texas. (Mex., S. Amer.)

$==$ Flowers in paniculate often compound cymes: styles slender, mostly longer than the ovary.

C. tenuiflóra, Engelm. Stems coarse and yellow, usually rather high-climbing : flowers (a line or less long) on short thick pedicels, often 4-merous : lobes of calyx and corolla oblong, obtuse; the latter mostly shorter than the slender deeply campanulate tube: scales shorter than the tube, fringed : marcescent corolla capping the large capsule. - Gray, Man. ed. 1, 350, ed. 5, 378, \& Cusc. 497. C. Cephalanthi, Engelm. in Am. Jour. Sci. 1. c. fig. 1-6. - On tall herbs or shrubs, such as Cephalanthus, in wet places, Penn. (Porter) to Wisconsin, north to Saskatchewan, and south to Texas and Arizona. Readily distinguished from small-flowered forms of $C$. Gronovii by the depressed capsule covered by the corolla.

C. Califórnica, Choisy. Capillary stems low : flowers rather small, delicate, in loose cymes: lobes of the calyx acute : those of corolla lanceolate-subulate, as long as the campanulate tube or longer : scales none or rudimentary. - Cusc. 183 ; Hook. \& Arn. Bot. Beech. 364; Engelm. Cusc. 498, \& Bot. Calif. i. 535. (Independently published, in the same year, 1841, by Choisy and by Hook. \& Arn.) - California, on arid herbs, Eriogonum, \&c., in dry soil. Among various forms the following are the extremes.

Var. breviflóra, Engelm. l. c. Flowers scarcely over a line long, on shorter pedicels: calyx-lobes acuminate, equalling or surpassing the tube of the corolla : filaments and anthers short: style hardly longer than ovary: corolla marcescent at base of or around the 2-4-seeded capsule. - From the coast at Monterey, \&c., to the Sierra Nevada.

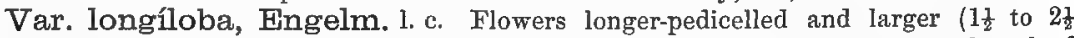
lines long): calyx-lobes often with recurved tips: corolla-lobes often twice the length of the tube: filaments and anthers more slender: styles much longer than ovary: capsule mostly 1-seeded, enveloped by the corolla. - Principally S. California and Arizona.,

+++ Ovary and capsule pointed; the latter enveloped or capped by the marcescent corolla.

$$
=\text { Flowers short-pedicelled or clustered. }
$$

C. salína, Engelm. Stems slender, low: flowers (1 $1 \frac{1}{2}$ to $2 \frac{1}{2}$ lines long) delicate white: calyx-lobes ovate-lanceolate, acute, as long as the similar but mostly broader and overlapping denticulate lobes and as the shallow-campanulate tube of the corolla: filaments about as long as the oval anthers: fringed scales mostly shorter than the tube, sometimes 
incomplete: styles equalling or shorter than the ovary : capsule surrounded (not covered) by the marcescent corolla, mostly 1-seeded. - Bot. Calif. i. 5830 . C'. subinclusa, var, abbreviata, \& C. Californica, var.? squamigera, Engeln. Cusc. 4!1, 500. - Saline or brackish marshes of the Pacific coast, on Salicornia, Suceda, \&c., California to Brit. Columbia, and eastward to Arizona and Utah. Intermediate between the preceding and following, distinguished from the former by larger flowers and the presence of infra-stamineal scales; from the latter by less crowded flowers, more open, and of more delicate texture.

C. subinclúsa, Durand \& Hilgard. Stems rather coarse: flowers sessile or shortpedicelled, at length in large (half to full an inch thick) and compact clusters, $2-\frac{1}{2}$ to $3 \frac{1}{2}$ or 4 lines long: calyx cupulate, fleshy; its lobes ovate-lanceolate, overlapping, much shorter than the cylindrical tube of the corolla: lobes of the corolla ovate-lanceolate, minutely crenulate, much shorter than the tube: oval anthers nearly sessile: scales narrow, fringed, reaching only to the nildile of the tube: slender styles longer than the ovary: capsule capped by the marceseent corolla, mostly 1-seeded. - Jour. Acad. Philad. ser. 2, iii. 42, \& Pacif. R. Rep. v. 11 ; Engelm. Cusc. 500, \& Bot. Calif. 1. c. - California, the most common species throughout the State, on shrubs and coarse herbs. The long and narrow tube of the corolla, only partially covered by the thick and mostly reddish calyx, readily distinguishes this species.

C. denticuláta, Engelm. Low stems capillary: flowers (about a line long) on short pedicels, in smali clusters : tube of the broadly campanulate corolla included.in the roundlobed denticulate calyx, and as Iong as its round-ovate lobes: oval anthers on very short filaments: scales reaching to the base of the stamens, denticulate at the rounded tip: styles as long as the ovary: stigmas very small, not much thicker than the style: capsule covered by the marcescent corolla, 1-2-seeded. - $A$ m. Naturalist, ix. :38, \& Bot. Calif. i. 536. - South-western Utah, in dry soil, on herbs and low shrubs, Parry.

$$
==\text { Flowers more pedicelled, in paniculate cymes. }
$$

a. Acute tips of corolla-lobes inflexed or corniculate.

C. decóra, Choisy (but name altered). Stems coarse: flowers fleshy and more or less papillose: lobes of the calyx triangular, acute; those of the broadly campanulate corolla ovate-lanceolate, minutely crenulate, spreading: scales large, deeply fringed: capsule enveloped by the remains of the corolla: seeds usually 4. - Engelm. Cusc. 502; Gray, Man. ed. 5, 378, \& Bot. Calif. 1. c.; the negative prefix in C. indecora, Choisy, omitted. (U. S. to Brazil.)

Var. pulchérrima, Engelm. 1. c. The larger form, with coarser stems, and conspicuous flowers $1 \frac{1}{2}$ to $2 \frac{1}{2}$ lines long and wide: anthers and stigmas yellow or deep purple. - C. pulcherrima, Scheele in Linn. xxi. 750. $\therefore$ neuropetala, Engelm. in Am. Jour. Sci. xlv. 75. - Wet prairies, on herbs and low shrubs, principally Lequminosce and Compositce (the largest-flowered forms in brackish soil on the Texan coast), Florida and especially in Texas, north to Illinois, and west to Arizona and California. (IV. Ind., Mex., Brazil.)

Var. indecóra, Fngelm. 1. c. Stems lower and more slender : flowers smaller, in looser paniculate clusters, often warty (C. verrucosa, Engelm. in Am. Jour. Sci. 1. c. xliii. 341, fig. 25) or papillose-hispid (C. hispidula, Engelm. l. c. xlv. 75). C. indecora, Choisy, Cusc. 182 , t. 3 , fig. 3, \& DC. 1. c. 457 . - Texas, \&c., first collected by Berlandier.

C. infléxa, Engelm. Similar to the preceding: flowers of the same structure, but smaller (only a line long), generally 4-merous: corolla deeper, with erect lobes, finally capping the capsule: scales reduced to a few teeth.-Cusc. 502, \& Gray, Man. ed. 5. C. Coryli, Engelm. in Am. Jour. Sci. xliii. 337, fig. 7-11. C. umbrosa, Beyrich, in part; Engelm. in Gray, Man. ed. 1, 351. - Open woods and dry prairies, on slurubs (hazels, \&c.) or coarse herbs, S. New England to Arkansas, and Nebraska.

C. RaCemósa, Martius, var. Chiliafa, Engelm. Stems coarse : flowers ( $1 \frac{1}{2}$ to 2 lines long) in loose panicles, thin in texture: tube of corolla deeply campanulate, widening upward; the spreading lobes shorter, acutish: scales large, deeply fringed. - Cusc. 505 , \& in Bot. Gazette, ii. 69. C. suaveolens, Seringe; Gay, Fl. Chil. iv. 448. C'. corymbosa, Choisy, Cusc. 180, not R. \& P. C. Hassiaca, Pfeiffer in Bot. Zeit. i. 705. - Introduced into California with seeds of Medicago satica, as also 40 years ago into Furope, whence, after causing much damage for several years, it has now disappeared. (Adv. from Chili.)

b. Obtuse lobes of the corolla spreading.

C. Gronóvii, Willd. Stems coarse, often climbing high: corolla-lobes mostly shorter than the deeply campanulate tube: scales copiously fringerl: capsule globose, umbonate. 
- Willd. Rel. ex Rœm. \& Sch. vi. 205; Choisy, Cusc. t. 4, fig. 1; Engelm. Cusc. 507, \& in Gray, Man. ed. 5, 379. C. Americana, L. Spec. i. 124, as to pl. Gronov. Virg. C. vulgivaga, Engelm. in Am. Jour, Sci. xliii. 338, t. 6, fig. 12-16. C. umbrosa, Beyrich, ex Hook. Fl. ii. 78. - Wet shady places, Canada to Iowa and south to Florida and Texas; the commonest and most diffused Atlantic species. Flowers sometimes 4-merous (from less than a line to 2 lines long, usually about $1 \frac{1}{2}$ lines) : calyx usually thick and warty, and corolla glandulardotted, very variable in size and compactness of clusters (sometimes 2 inches thick), and size of capsule (mostly 2 lines, sometimes 3 lines in diameter).

Var. latiflóra, Engelm. 1. c., is a form with flowers of more delicate texture, and shorter tube and longer lobes to the corolla. - C. Saururi, Engelm. in Am. Jour. Sci. I. c. fig. 17-21. - Common north ward.

Var. calyptráta, Engelm. 1. c., distinguished by the corolla eventually capping the capsule. - Louisiana and Texas.

Var. cúrta, Engelm. 1. c., perlıaps a distinct species, representing $C$. Gronovii west of the Rocky Mountains, and imperfectly known, has smaller flowers, with broad lobes of the corolla and calyx half the length of its tube, very short bifid scales, and styles much shorter than the ovary. - C. umbrosa, Hook. l. c., in part.

C. rostráta, Shuttleworth. Similar to the preceding: flowers larger (2 or 3 lines long), more delicate and whiter: lobes of the corolla and calyx shorter than its tube: slender styles longer: ovary bottle-shaped: capsule long-pointed. - Engelm. in Bost. Jour. Nat. Hist. Soc. v. 225, Cusc. 508; \& Gray, Man. ed. 5, 379. - Shady valleys in the Alleghanies, from Maryland and Virginia southward, on tall herbs, rarely on shrubs.

++ Calyx of 5 distinct and largely overlapping sepals, surrounded by 2 to 5 or more similar bracts: styles capillary: scales of corolla large and deeply fringed: capsule mostly 1-seeded, capped by the marcescent corolla.

$$
+ \text { Flowers on bracteolate pedicels, in loose panicles. }
$$

C. cuspidáta, Elngelm. Stems slender: flowers (1 $1 \frac{1}{2}$ to $2 \frac{1}{6}$ lines long) thin, membranaceous when dry : bracts and sepals ovate-orbicular and oblong lobes of the corolla cuspidate or mucronate, rarely obtuse, shorter than the cylindrical tube: styles many times longer than the ovary, at lengtl exserted. - Bost. Jour. Nat. Hist. Soc. v. 224, \& Cusc. 1. c. - Wet or dry prairies, on Ambrosia, Iva, some Leguninosce, \&c., Texas to Nebraska, occasionally straying down the Missouri as far as St. Louis (H. Eggert). The northern form has laxer inflorescence and fewer bracts under the calyx.

+ +- Flowers closely sessile in clensely compact clusters.

$=$ Bracts and sepals concave and appressed.

C. squarnáta, Engelm. Orange-colored stems slender: glomerules few-flowered,

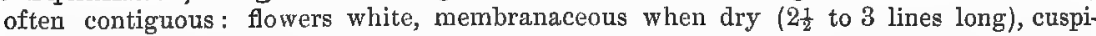
date or obtuse sepals and lanceolate acute lobes of the corolla, both shorter than the cylindrical upwardly widening tube: styles many times longer than ovary. - Cusc. 510 . -W. Texas and New Mexico. Common in the bottomlands on the Rio Grande from El Paso to Presidio del Norte. - Similar to the last, but the larger and whiter flowers are closely sessile.

C. compácta, Juss. Stems coarse : flowers (nearly 2 lines long) at length in continuous and often very thick clusters : orbicular bracts and sepals crenulate, nearly equalling or shorter, and ovate-oblong lobes much shorter than the cylindrical tube of the corolla: styles little longer than the ovary. - Choisy, Cusc. t. 4, fig. 2, \& in DC. Prodr. ix. 458; Engelın. 1. c. C. remotiflora \& C. fruticum, Bertol, Misc. x. 29. - Canada to Alabama along and west of the Alleghany Mountains, west to Missouri and Texas, in damp woods, almost always on shrubs. The original $C$. compacta of Jussieu's herbarium is a slender form, with smaller flowers and more exserted corolla: it is found from N. New York southward along the Alleghanies. The var. adpressa, Engelm. Cusc. 511 (Lepidanche adpressa, Engelm. in Am. Jour. Sci. xlv. 77, and probably C. acaulis, Raf. Ann. Nat. 1820, 13), is the common form westward. $==$ Bracts (8 to 15 ) and sepals with recurred-spreading and crenate tips.

C. glomeráta, Choisy. Stems coarse, orange-colored, soon witlering away, leaving dense flower-clusters closely encircling in rope-like masses the stems of the foster plant: sepals nearly equalling and its oblong obtuse lobes much shorter than the cylindrical upwardly widening tube of the corolla: styles several times longer than the ovary. - Cusc. 
184, t. 4, fig. 1, \& DC. 1. c. ; Engelm. Cusc. 510. C. paradoxa, Raf. 1. c.? Lepidanche compositanum, Engelm. in Am. Jour. Sci. xliii. 344, fig. 30-35. - Wet prairies, Ohio to Wisconsin, Kansas and Texas, mostly on Helianthus, Vernonia, and other tall Compositer. The rope-like twists, half to three-fourths inch thick, of white flowers with golden yellow anthers imbedded in a mass of curly bracts, have a singular appearance and justify Rafinesque's name, which probably belongs here.

* * (Ecgramica, Engelm. Cusc. 476.) Capsule more or less regularly circumscissile, usually cappet by the remains of the corolla: sty'les capillary and mostly much longer than the depressed
ovary.

+ Lobes of the corolla acute.

C. odontólepis, Engelm. Stems slender : flowers conspicuous ( $2 \frac{1}{2}$ to 3 lines long), on short pedicels in large clusters : lobes of the campanulate caly $x$ and of the tubular corolla ovate, acute, rather shorter than the cylindrical tube: scales hardly reaching to the base of the anthers, incisely dentate toward their rounded apex. - Cusc. 486. - Arizona, Wright, on Amaranthus. A large-flowered species, distinguished from the large-flowered Mexican forms of $C$. corymbosa by its acute lobes of calyx and corolla.

C. leptántha, Engelm. l. c. Stems low and capillary: flowers (2 to $2 \frac{1}{4}$ lines long), 4-merous, on slender fascicled pedicels: papillose calyx and lanceolate lobes of the corolla much shorter than the slender tube: scales incisely dentate and much shorter than the tube- - Mountains of W. Texas, on a prostrate Euphorbia (albo-marginata), Wright. The only N. American species (as far as known) with uniformly 4-nerous flowers.

C. umbelláta, HBK. Stems low and capillary : flowers (1 $\frac{1}{2}$ to 2 lines long) few together in umbel-like clusters, usually shorter than their pedicels: acute calyx-lobes and lanceolate-subulate lobes of the corolla longer than its shallow tube: scales deeply fringed and exceeding the tube: styles mostly little longer than the ovary. - Nov. Gen. \& Spec. iii. 121; Engelm. Cusc. 487. - Dry places, on low herbs (Portulaca, \&c.), from S. E. Colorado to Texas and Arizona. (Mex., \&c.)

$$
++ \text { Lobes of the corolla broad and obtuse. }
$$

C. applanáta, Engelm. Stems low and slender: flowers (a line or rather more in length) clustered on short pedicels: rounded lobes of calyx and corolla thin in texture, as long as the wide and shallow tube: scales deeply fringed, often exceeding the tube : styles scarcely longer than the ovary: marcescent corolla enveloping the depressed capsule. Cusc. 479. - On weeds, such as Ambrosia, Mirabilis, \&c., S. Arizona, Wright. Glomerules $\mathbf{3}$ or 4 lines thick, of ten strung together like beads. Capsule much broader than high.

C. Americkst, L. (Sloane, Jam. 85, \& Hist. i. 201, t. 128, fig. 4, and the plant in herb. L.) Coarse stems climbing high: flowers (a line or two long) very abundant, on short pedicels in globose clusters: calyx globular-cupulate, almost enclosing the corolla; the lobes of which are much shorter than the slender tube: anthers globular and almost sessile: scales short, more or less dentate: seed usually solitary. This S. American and West Indian species, easily known by its proportionally large calyx and small corolla, is here characterized because it may be looked for in South Florida.

§2. Monogrnḱlda, Engelm.1. c. Styles united into one: stigmas capitate: capsule circumscissile. - Monogynella, Desmoulins. (Consists of few species, of the largest size, mostly Asiatic, extending to Europe, S. Africa and N. America.)

C. exaltáta, Engelm. Stems thick, climbing high : lobes of the fleshy calyx and corolla orbicular, the former covering and the latter half the length of the corolla-tube: anthers sessile: scales small, bifid or reduced to a few lateral teeth : styles two-thirds united.Cusc. 513. - S. W. Texas, from the Colorado to the Rio Grande, on trees, such as Diospyros Texana, Ulmus crassifolia, Live Oak, \&c. Stems a line or two thick, climbing 10 to 20 feet high. Flower 2 lines long. Capsule $3 \frac{1}{2}$ to 5 lines long.

§ 3. Eucúsccta, Engelm. 1. c. Styles distinct, equal, bearing elongated stigmas: capsule circumscissile. (Old-World species.)

C. epílincm, Weihe. Stems slender, low : globular flowers (half line long) sessile in dense heads: corolla short-cylindrical, scarcely exceeding the broadly ovate acute calyx-lobes, surrounding the capsule: scales short and broad, denticulate: stigmas longer than the 
styles. - Archiv. Apoth. viii. 54; Reichenb. Ic. Crit. t. 693; Choisy, 1. c. C. densiflora, Soyer-Willem. in Act. Soc. Linn. Par. iv. 281. - Flax-fields of Lurope, doing much injury, occasionally appearing in those of the Atlantic States. (Adv. from Eu.)

\section{ORDER XCV. SOLANACE E.}

Herbs, shrubs, or even trees, commouly rank-scented, with watery juice, alternate leaves and no stipules; the inforescence properly terminal and cymose, but variously modified, sometimes scorpioid-racemiform in the manner of Borraginacere and Hydrophyllacea, the pedicels either not accompanied by bracts or not in their axils; flowers perfect aud regular (or only slightly irregular) and 5-4-merous; the stamens as many as and alternate with the corolla-lobes; these induplicatevalvate or plicate (rarely merely imbricate) in the bud; ovary wholly free, normally 2-celled with indefinitely many-ovuled axile placentr, and surmounted by an undivided style: stigma entire or sometimes bilamellar; ovules anatropous or amphitropous; fruit either capsular or baccate; embryo terete and incurved or coiled, or sometimes almost straight, in fleshy albumen, the cotyledons rarely much broader than the radicle. The leaves, although never truly opposite, are often unequally geminate, so as to appear so. Obviously distinguished from Convolvulacea by the greater number and the character of the seeds, less definitely so from Scrophulariacece by the regular flowers with isomerous stamens and plicate or valvate æstivation of the corolla, and centrifugal inflorescence, but in the last tribe nearly confluent with that order by the imperfection or abortion of one or three of the stamens, and some obliquity and bilabiate imbrication of the limb or lobes of the corolla. Nicandra has a regularly 3-כ-celled ovary; that of Lycopersicum, \&c., becomes several-celled in cultivation; that of Datura is spuriously 4-celled.

Bassovia? hebepoda, Dunal in DC. Prodr. xiii, 407, characterized from a specimen communicated to De Candolle by Teinturier of New Orleans, in fruit only, is a mere riddle. It is said to resemble Bassovia lucida.

Withania Morisoni, Dunal, 1. c., is doubtless not a Virginian or even a Mexican plant. From the figure it is likely to have been $W$. somnifera, as Dunal suggested.

Tribe I. SOLANE E. Corolla (mostly short) with the regular limb plicate or valvate in the bud, usually both, i.e. the sinuses or what answers to them plicate and the edges of the lobes induplicate. Stamens (normally 5) all perfect. Fruit baccate or at least indehiscent, sometimes nearly dry. Seeds flattened: embryo curved or coiled, slender; the semiterete cotyledons not broader than the radicle.

* Anthers longer than their filaments, either connivent or connate into a cone or cylinder: corolla rotate : calyx mostiy unchanged in fruit: parts of the flower 5 or varying to more, especially in cultivation.

1. LYCOPERSICUM. Anthers connate into a pointed cone, tipped with an empty closed acumination; the cells dehiscent longitudinally down the inner face. Otherwise as in the next, but leaves always pinnately compound.

2. SOLANUM. Anthers connivent or lightly connate: the cells opening at the apex by a pore or short slit, and sometimes also longitudinally dehiscent even to the base; the connective inconspicuous or obsolete.

* Anthers unconnected, mostly shorter than their filaments, destitute of terminal pores, dehiscent longitudinally.

+ Calyx not investing the fruit, nor much changing under it.

3. CAPSICUM. Calyx short, either truncate or merely 5-6-dentate. Corolla rotate, deeply 5-6-cleft, valvate in the bud, not plicate. Anthers oblong or somewhat cordate. Berry, or juiceless and thin-coriaceous pericarp, acrid-pungent, girt only at base by the nearly unchanged calyx. 
4. SALPICHROA. Calyx 5-parted or 5-cleft; the divisions narrow, herbaceous. Corolla from tubular to (in ours) short-urceolate, 5-lobed; the lobes short, valvate-induplicate in the bud. Stamens inserted high on the tube of the corolla! Berry globular or oblong.

5. ORYCTES. Calyx deeply 5-cleft; the lobes narrow, herbaceous. Corolla short-tubular or oblong, 5-toothed; the triangular lobes plicate in the bud, apparently erect. Stamens inserted on the base of the corolla, included: filaments filiform, unequal: anthers didymous. Berry apparently dry, globose, 10-20-sceded. Embryo apparently of this tribe, but not seen mature.

++ Calyx herbaceous and closely investing the fruit or most of it, not angled.

6. CHAM ESARACHA. Corolla rotate, 5-angulate, plicate in the bud. Filaments filiform: anthers oblong. Berry globose, filling the investing calyx, and its summit usually more or less naked. Pedicels solitary in the axils, refracted or recurved in fruit.

+++ Calyx becoming much enlarged and membranaceous-inflated, enclosing the fruit, reticulate-veiny,

+- Five-toothed or lobed, vesicular in fruit: ovary 2-celled.

7. PHYSALIS. Corolla rotate or rotate-campanulate, plicate in the bud, 5-angulate or obscurely 5-lobed. Stamens not connivent. Calyx in fruit 5-angled or 10-costate, and the teeth or short lobes connivent, completely and loosely enclosing the juicy berry. Pedicels solitary.

8. MARGARANTHUS. Corolla urceolate-globose and 5-angular-gibbous above a short narrow base, and with minutely 5-toothed contracted orifice, including the connivent stamens. Otherwise as Physalis.

+ Five-parted caly $x$ connivent-vesicular in fruit: ovary 3-5-celled.

9. NICANDRA. Corolla open-canupanulate, with entire or obscurely lobed border, strongly plicate in the bud. Filaments filiform, included, dilated into a pubescent scale at base. Calyx strongly 5-angled; the scarious-membranaceous and reticulated divisions cordate-sagittate, the deflexed auricles at the sinuses acuminate. Fruit globose, dry or nearly so at maturity. Pedicels solitary, recurved.

Tribe II. ATROPEA. Corolla with the regular limb imbricated in the bud, the sinuses little or not at all plicate. Stamens ( 1 or 5 ) all perfect. Baccate fruit and seeds as in the preceding.

10. LYCIUM. Calyx campanulate, irregularly 3-5-toothed or cleft, or somewhat truncate, valvate or nearly so in the bud. Corolla from campanulate to tubular-funnelform or salverform; the lobes oblong or roundish, plane. Stamens often exserted: filaments filiform: anthers short. Style filiform: stigma capitate or broadly 2-lobed. Berry globular or oblong, subtended by the calyx, few-many-seeded, rather dry. Seeds reniform or rounded, fiattened. Flowers either 5-merous or 4-merous.

'Trıbe III. HYOSCYAIIE.E. Corolla with the limb either plicate or imbricated in the bud. Stamens (5) all perfect. Fruit a capsule. Seeds and embryo as in the preceding tribes.

11. DATURA. Calyx prismatic or tubular, 5-toothed, in ours at length circumscissile near the base, the base remaining as a peltate border under the fruit (rarely splitting lengthwise). Corolla funnelform, with ample spreading border 5-10-toothed, convolute-plicate in the bud. Stamens included or slightly exserted: filaments long and filiform. Style long: stigrna bilamellar. Capsule muricate or prickly (rarely smooth), commonly firm and 4-valved from the top, sometimes fleshy and bursting irregularly at the top, 2-celled; the large many-seeded placentæ projecting from the axis into the middle of the cells and connected with the walls by an imperfect false partition, so that the ovary and fruit are 4-celled except near the top, and the placentæ as if borne on the middle of the abnormal partitions. Seeds large, reniform-orbicular.

12. HYOSCYAMUS. Calyx urceolate or tubular-campanulate with a 5-lobed limb, enlarged and persistent, becoming many-costate and reticulate-veiny, enclosing the capsule. Corolla short-funnelform, with an oblique 5-lobed limb, plicate-imbricated in the bud; the lobes sometimes conspicuously unequal, those of one side being smaller! Stamens more or less exserted and declined. Style filiform: stigma capitate-dilated. Capsule membranaceous, circumscissile towards the summit, which separates as a lid. Seerls less flattened.

Tribe IV. CESTRINE E. Cowolla (usually elongated) with the regular limb induplicate-valvate or induplicate-imbricated in the bud. Stamens (mostly 5) all perfect. Fruit either baccate or capsular. Seeds little or not at all flattened. Em- 
bryo either straight or only slightly curved; the cotyledons usually broader, than the radicle.

13. CESTRUM. Corolla salverform or tubular-funnelform; the short lobes induplicatevalyate in the bud. Filaments filiform: anthers short, explanate after dehiscence. Ovary usually short-stipitate, few-ovuled. Fruit a rather dry globular berry. Seeds few, or by abortion solitary, with a smooth testa: cotyledons usually broad and flat.

14. NICOTIANA. Corolla funnelform or salverform, plicate and somewhat imbricate in the bud. Filaments filiform, mostly included: anthers ovate or oblong, often explanate after dehiscence. Ovary normally 2-celled, with large and thick placentæ, bearing very numerous ovules and seeds. Style filiform: stigma depressed-capitate and of ten 2-lobed. Fruit a capsule, more or less invested by the persistent calyx, septicidal and also usually loculicidal at summit; the valves or teeth thus becoming twice as many as the cells, i.e. usually 4. Seeds very small, with granulate or rugose-foveolate testa : cotyledons little broader than the radicle.

Tribe V. SALPIGLOSSIDE irregular) plicate or induplicate and also more or less bilabiately imbricated, the two superior external. Stamens 5, conspicuously unequal, four being didynamous and the fifth smaller, the latter (and even one pair of the others) sometimes imperfect or abortive. Seeds globular or angular, not compressed. Embryo curved or nearly straight, with cotyledons usually broader than the radicle. (Transition to Scrophulariacece.)

* Stamens all five perfect (or rarely the fifth wanting), inserted low down on the funnelform or salverform corolla, included.

15. PETUNIA. Calyx 5-parted. Anther-cells distinct. Hypogynous disk fleshy. Stigma dilated-capitate, unappendaged. Capsule with 2 undivided valves, parallel with and separating from the placentiferous dissepiment.

16. BOUCHETIA. Calyx oblong-campanulate, 5-cleft, with narrow lobes. Corolla shortfunnelform. Anthers connivent; their cells somewhat confluent at summit. Hypogynous disk none or obscure. Stigma transversely dilated, somewhat reniform. Capsule at length 4 -valved. Seed-coat minutely reticulated.

* * Stamens 4 , didynamous, the fifth a sterile filament, included in the throat of the longtubed corolla.

17. LEPTOGLOSSIS. Calyx 5-cleft or 5-toothed. Corolla salverform, with slender tube and more or less gibbous ventricose throat, at base of which the stamens are inserted. Anthers somewhat reniform, confluent at summit; the upper pair much smaller, sometimes imperfect. Stigma or the style under it petaloid-dilated. Capsule membranaceous, 2-valved; the valves at length 2-cleft.

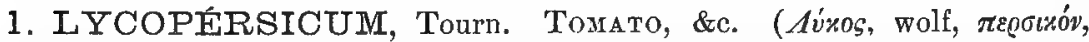
peach.) - Chiefly annuals, natives of the warmer parts of America; with once or twice pinnate leaves, rounded petiolulate leaflets, racemes (so called) of small flowers becoming lateral or opposite the leaves, articulated pedicels reflexed in fruit, and red or yellow pulpy berries, in cultivation esculent and often becoming several-celled.

L. esculéntum, Mill., var. cerasifórme. (Cherry-Tomato.) Annual, hirsute on the branches and more or less glandular: leaves interruptedly 1-2-pinnate; the larger leaflets incised and toothed, the interposed small ones rounder and often entire : calyx little shorter than the yellow corolla : inflorescence bractless : berry globose and even, small. $-L$. cerasiforme, Dunal. Solanum Lycopersicum, var., L. S. Pseudo-Lycopersicum, Jacq. Vind. t. 11. The normal form, probably, of the Tomato of the gardens: spontaneous on the southern borders of Texas (Berlandier, \&c.): introduced from Trop. Amer.

2. SOLÁNUMM, Tourn. Nightshade, \&c. (Late Latin name of Nightshade, probably from solamen, solace.) - Herbs or sometimes shrubs, of various habit; with the leaves (as in many other genera of the order) often geminate, the proper leaf being accompanied by a smaller lateral or extra-axillary (rameal) 
one, and the peduncles also extra-axillary or lateral. Flowers cymose, mostly after the scorpioid manner, or by unilateral suppression in appearance racemose, or rarely solitary, sometimes polygamous through the abortion of the pistil of many of the flowers. A rast genus, generally diffused over the temperate and warmer parts of the world, but sparingly represented in North America.

S. Virginiáxum, L. (founded on Dill. Elth. t. 267, and Pluk. Alm. t. 62, fig. 3), is some one of the very prickly exotic species and not of Virginian origin.

S. xnмxósux, L., a West Indian species, attributed to Virginia by Linnæus and succeeding authors, is unknown in the country. The less hairy S. aculeatissimum may sometimes have been taken for it. In Chapman's Flora a form of S. Melongena seems to represent it.

S. Texíncy, Dunal in DC. Prodr. xiii. 359, is probably not Texan, although raised from seed said to have been collected there. It is a plant of the Melongena (Aubergine or EggPlant) type, and is probably S. integrifolium, Poir. (S. . Ethiopicum, Jacq. Vind. t. 2, not L.), and according to Tenore his $S$. Lobelii. It has a 7-8-cleft calyx, and the fruit (from a solitary fertile flower) 5-10-celled.

S. Floridáxum, Dunal, 1. c. 306, taken up from an imperfect specimen so named by Shuttleworth in herb. DC., collected by Rugel at St. Mark's, Florida, is not identified, is probably some waif of ballast ground, and, having long-hairy and retrorse-prickly stems and pinnately parted leaves, cannot be a variety of $S$. Carolinense, to which Chapman referred it.

$\S 1$. Fruit naked, i. e. not enclosed in the accrescent calyx (in one species somewhat so): stamens all alike.

* Tuberiferous-perennial, pinnate-leaved: anthers blunt.

S. tuberósum, L. (Ротато-PL.1хт), var, boreále. Low, more or less pubescent : tubers about half an inch in diameter, sending off long creeping subterranean stolons: leaflets 5 to 7 , ovate or oval, and with only one or two interposed small ones, or sometimes none at all: peduncle few-flowered: corolla blue or sometimes white, angulate-5-lobed. $-S$. Fendleri, Gray in Am. Jour. Sci. ser. 2, xxii. 285; Torr. Bot. Mex. Bound. 151. - New IIexico, especially in the mountains, and southward: apparently not specifically distinct from the Potato-plant, which extends along the Andes to Chili and Buenos Ayres.

S. Jamésii, Torr. Low, a span or so in height: leaflets 5 to 9, varying from lanceolate to ovate-oblong, smoothish; the lowest sometimes mucll smaller, but no interposed small ones: peduncle cymosely few-several-flowered: corolla white, at length deeply 5-cleft: otherwise as in the last. - Ann. Lyc. N. Y. ii. 227; Gray, l. c. - Mountains of Colorado to New Mexico and Arizona. (Mexico, probably under several names.) Seems on the whole distinct; but Fendler's no. 669 belongs here, at least in part.

* Annuals (at least in our climate), simple-leaved, never prickly, but the angles of the stem sometimes minutely denticulate-asperate: anthers blunt: pubescence when present simple: flowers and globose berries small.

+ Leaves deeply pinnatifid.

S. triflórum, Nutt. Green, slightly hairy or nearly glabrous, low and much spreảding: leaves oblong and pinnatifid, with wide rounded sinuses; the lobes 7 to 9 , lanceolate, 3 or 4 lines long, entire or sometimes 1-2-toothed : peduncles lateral, 1-3-flowered: pedicels nodding: corolla small, white, a little longer than the 5-parted calyx: berries green, as large as a small cherry. - Gen. i. 128. - Plains from Saskatchewan to New Mexico, chiefly as a weed near habitations and in cultivated ground.

+ + Leaves varying from coarsely toothed to entire: flowers in small pedunculate umbel-like lateral cymes: corolla white and sometimes bluish: berries usually black when ripe, rarely red or yellowish, only as large as peas. (Section Morella, Dunal.)

S. nígrum, L. Low, green and almost glabrous, or the younger parts pubescent: leaves mostly ovate with a cuneate base, irregularly sinuate-toothed, repand, or sometimes entire, acute or acuminate: calyx much shorter than the corolla.-Includes many and perhaps most of the 50 and more species of Dunal in the Prodromus, weeds or weedy. plants, widely diffused over the world, especially the warmer portions. A. Braun's characters for several species, founded on the hairiness or smoothness of the filaments, length of the anthers and of the style, and whether the calyx is loosely appressed to the ripe berry or reflexed, do not hold out. Our common form, the true $S$. nigrum, has corolla only 
3 or 4 lines in diameter, filaments more or less hairy inside, style little if at all projecting, and fruiting calyx merely spreading. To this belongs mainly the following, referred to $\mathrm{N}$. America by Dunal : viz. S. pterocaulon, Dunal. (Dill. Elth. t. 275, fig, 356), S. crenato-dentatum, ptycanthum, and probably inops, DC. - Common in damp or shady, especially cultivated and waste grounds, appearing as if introduced. (Cosmopolite.)

Var, viclósum, ,Hill. L Low, somewhat viscid-pubescent or villous : leaves conspicuously angulate-dentate, small : filaments glabrous to the base: berries yellow. $-S$. villosum, Lam. - Ballast-grounds, Philadelphia, \&c. - Var. ALÁtum (S. alatum, Monch, S. miniatum, Benth.), a similar form, but with angled branches and red berries, has reached the shores of San Francisco Bay, California. (Adventive from S. Eu.)

Var. Dillénii. Taller and leaves mostly entire or merely repand: filaments more or less bearded, at least at the base: style exserted or sometimes not exceeding the stamens. -Dill. 1. c. fig. 355. S. Dillenii, Schult., Dunal, 1. c.; A. Braun, Ind. Sern. Hort. Berol. 1853. - Florida to S. America. Entire-leaved forms differ from the next only in the hairy filaments. $S$. Americamum, Mill. Dict., with glabrous leaves, should be the same, but $S$. Besseri, Weinm., to which Dunal refers it, is a canescently-puberulent variety, with rather large and entire leaves. (S. American.)

Var. nodiflórum. Slender, often tall : leaves entire, rarely few-toothed, acuminate: filaments glabrous : style generally exserted : caly $\mathbf{x}$ in fruit reflexed. $-S$. nodiflorum, Jacq: Ic. Rar. t. 326. - Texas and New Mexico to S. America. Seems to pass into

Var. Douglásii, Gray. Either herbaceous and annual, or southward decidedly with lignescent stem 3 to 5 or even 10 feet high: leaves variously angulate-toothed, or some nearly entire: flowers larger: corolla 5 to 8 lines in diameter, white, or sometimes light blue : filaments hairy inside : fruiting calyx erect. - Bot. Calif. i. 588. S. Douglasii, Dunal in DC. l. c. 48. S. umbelliferum, var. trachycladon, Torr. Pacif. R. Rep. vii. 17, a remarkably large form. - W. California.

S. GRÁcIle, Link. Cinereous-pubescent or puberulent, rather tall ( 2 or 3 feet high), with virgate spreading brancles : leaves ovate and ovate-lanceolate, acutish or obtuse, entire or nearly so: corolla white or bluish (about 5 lines in diameter): filaments slightly hairy inside : style exserted beyond the anthers: stigma rather large: calyx somewhat appressed to the (black) berry. - Hort. Berol.; Dunal, 1. c. 54, not Sendt. - Coast of N. Carolina, Curtis. Ballast-grounds near Philadelphia. (Nat. or adv. from Extra-trop. S. Amer.)

* * * Perennial and more or less woody, at least the base, never prickly: anthers merely oblong or linear-oblong, not tapering but very blunt at apex: leaves rarely geminate.

+ Pubescence of simple or in nne species of branching hairs, never stellate: cells of the anther opening by a short vertical slit at the apex, which extends downward usually for the whole length.

+ Corolla 5-parted: pedicels solitary or few in a lateral fascicle: common peduncle hardly any: berry large, scarlet.

S. Psecdo-Cápsicum, L. (Jerusalem Cherry.) Low erect shrub, with spreading branches, very leafy, glabrous: leaves oblanceolate or oblong, often repand, bright green and shining, narrowed at base into a short petiole: corolla white: berry globose, scarlet, rarẻly yellow, half inch or so in diameter. - Cult. for ornament, nat. in Florida, \&c., from Madeira, where probably it is not indigenous.

+ Corolla 5-parted or deeply cleft, violet, purple, or sometimes white: peduncles slender; terminal or sonn lateral, bearing several flowers in a paniculate or umbel-like cyme; the pedicels nodose-articulated at base: stems or branches mostly sarmentose or flexuous: leaves inclined to be cordate and often 3 -lobed: berries small, red.

S. Dolcamára, L. (Bittersweet.) More or less pubescent: shrubby stems climbing and somewhat twining several feet high: leaves ovate and acuminate, mostly slightly cordate, some with an auriculate lobe on one or both sides at base, which are sometimes nearly separated into small leaflets: corolla half inch in diameter: berry oval. - Curt. Lond. ii. t. 5 ; Bigel. Med. t. 18. - Near dwellings and in low grounds, Northern Atlantic States. (Nat. from Eu.)

S. triquétrum, Cav. Nearly glabrous: stems suffruticose, flexuous or sarmentose, hardly at all climbing, a foot to a yard high: branches angled but hardly triquetrous: leaves deltoid-cordate (and the larger 2 inches long), varying to hastate, and in smaller forms to hastate-3-lobed or even 5-lobed, with the middle lobe lanceolate or linear and prolonged (an inch or oniy half an inch long): cymes commonly, umbellately few- 
-flowered: pedicels in fruit clavate-thickened at summit: corolla nearly as the preceding: berry globose. - Ic. ii. 30, t. 259 ; Dunal, 1. c. 153, with the small-leaved variety. $S$. Londheimerianum, Scheele in Linn. xxi. 766. - Low grounds and thickets, W. Texas (Berlandier, Lindheimer, Wright, \&c.) to Arizona? Coulter. (Mex.)

+ + + Corolla angulate-5-lobed, ample and widely rotate, blue or violet, varying to white: peduncles mostly short, terminal or becoming more or less lateral, thickened often as if into a cupulate node at the articulation of the slender pedicels: "berries purple," the base covered by the appressed moderately accrescent calyx.

S. Xánti, Gray. Herbaceous nearly to the base, viscid-pubescent with simple hairs, or glabrate: branches slender: leaves ovate or ovate-oblong, thinnish, entire or undulaterepand, occasionally auriculate-lobed at the base, which is obtuse or rounded, or some of the upper acute, or the larger subcordate: cyme often forked: corolla about an inch in diameter.-Proc. Am. Acad. xi. 90, \& Bot. Calif. i. 539. - California, throughout the length of the State and into the borders of Nevada: confused in collections with the following species. Calyx lobes (as in that) ovate or triangular, equalling or shorter than the short and broad tube. Style much exserted. Pubescence of jointed viscid hairs, some of them gland-tipped.

Var. Wallácei, Gray, l.c. Leaves and flowers much larger; the former sometimes 4 inches long, and the violet corolla fully an inch and a half in diameter: branches and the forking cyme villous. - Island of Santa Catalina off San Pedro, California, Wallace. (Coulter's no. 586, without flowers, may be a glabrous form of this.)

S. umbelliferum, Esch. Woody below, tomentose-pubescent and cinereous with short many-branched hairs, sometimes glabrate: flowering branchlets mostly short and leafy: leaves rarely ovate and acute, commonly obovate and oblong, obtuse, entire, half inch to an inch or two long, more or less acute or narrowed at base, or the lower and larger ones rounded, on short petiole: umbels short-peduncled, few-several-flowered: corolla about three-fourths inch in diameter. - Esch. in Mem. Acad. Petrop. x. 281. S. Californicum \& $S$. genistoides, Dunal in DC. l. c. 86 ; the latter a starved and twiggy very small-leaved form, of arid soil or the dry season. - California, common from the foot-hills to the coast, producing handsome blue (rarely white) flowers throughout the season.

$\leftarrow+$ Pubescence of stellate hairs or down: cells of the anther opening only by a short terminal transverse slit or hole: corolla 5-parted, downy outside: peduncles usually terminal, erect, rather long and stout, bearing a many-flowered cyme.

S. verbascifólium, L. Shrub erect, very soft-tomentose throughout: leaves ovate, rounded at base (4 to 10 inches long), entire, very hoary beneath: corolla white, its lobes ovate: ovary woolly. - Jacq. Vind. i. t. 13. - Key West, Florida; also in Mexico near the Texan borders. (Tropics.)

S. Blodgéttii, Chapm. Shrub spreading, with rather slender branches, hoary with a fine somewhat furfuraceous and roughish pubescence: leaves narrowly oblong, obtusish at both ends ( 3 to 5 inches long), greenish and roughish above, soft and canescent beneath, entire: cyme twice or thrice forked: pedicels as long as the flower, erect in fruit: corolla white, deeply 5-parted, its lobes lanceolate (4 lines long) : ovary glabrous : berry green, turning red. - Fl. 349. - Key West, \&c., South Florida, Dr. Hasler, Blodgett, Palmer. Perhaps merely an unarmed form of some normally prickly species, allied to $S$. lancecefolium and S. igneum.

* * * * Perennials, or one or two introduced weeds here annuals, more or less prickly : anthers more or less elongated and tapering at the apex; the cells opening only by a terminal hole: berries in all our species glabrous.

+ Corolla deeply-5-parted and not plaited: leaves entire: scurfy down stellate: calyx 5-toothed: peduncles terminal or soon lateral: berries red.

S. Bahaménse, L. Shrubby, beset with straight and subulate tawny prickles: leaves lanceolate-oblong, obtusely pointed or obtuse (2 to 4 inches long), sometimes repand, stellate-scurfy with a minute roughish pubescence, which is denser but scarcely canescent beneath: flowers racemose, on slender pedicels which are recurved in fruit: divisions of the purplish or whitish corolla ( 3 or 4 lines long) linear with tapering tips, a little hairy. - Dill. Elth. t. 271, fig. 250. S. radula, Chapm., 1. c. not Vah1. - Keys of Florida, Blodgett, Palmer. (W. Ind.)

+ + Corolla 5-parted and not plaited: leaves sinuate-lobed or pinnatifid: no scurf, and the pubescence all of simple hairs: calyx deeply 5-cleft: anthers broadly lanceolate: peduncles 
lateral, short, few-flowered : berries smooth, becoming red or yellow. (Tropical American, sparingly introduced as weeds on and near the coast of Southern Atlantic States, growing as annuals.)

S. ACUleatissmum, Jacq. Villous with scattered long and weak jointed hairs, or soon nearly glabrate, beset (even to the calyx) with slender-subulate straight prickles: leaves pretty large, membranaceous, ovate or slightly cordate, mostly sinuate-pinnatifid: corolla white, its lobes ovate-lanceolate: berry globose: seeds very flat and thin, with a membranaceous border. - Jacq. Ic. Rar. t. 41. - Waste grounds, a weed near dwellings, from N. Carolina to Florida and Texas. (Nat. from tropics.)

+++ Corolla 5-cleft or angulate-5-lobed, plicate in the bud: pubescence all or partly stellate.

+ Indigenous perennials, a foot or two high, with deep running rootstocks : corolla violet, rarely white: anthers lanceolate or linear-lanceolate: pedicels recurved or reflexed in fruit: mature berries naked, merely subtended by the calyx.

S. elæeagnifólium, Cav. Silvery-canescent all over by the dense and close scurf-like pubescence, composed of many-rayed stellate hairs: stems often woody at base: prickles small and acicular, sometimes copious, sometimes nearly or wholly wanting: leaves Ianceolate and varying to oblong and to linear, rather obtuse, sinuate-repand or entire: cymes at first terminal, short-peduncled, few-fiowered: pedicels rather long: calyx 5angled, with slender lobes fully as long as the tube: corolla moderately 5-lobed, about an inch in diameter; the lobes triangular-ovate : ovary white-tomentose : berry globose, seldom half an inch in diameter, yellowish, or at length black. - Ic. iii. t. 243. S. leprosum, Ort. Dec. ix. 115; Dunal, Sol. t. 12, a prickly and sinuate-leaved form. S. flavidum, Torr. in Ann. Lyc. N. Y. ii. 227. S. Hindsianum, Benth. Sulph. 39. S. Texense, Engelm. \& Gray, Pl. Lindh. i. 45. S. Roemerianum, Schecle in Linn. xxi. 767. - Prairies and plains, Kansas to Texas, and west to S. Arizona. (Lower Calif., Mex., Extra-trop. S. Amer.)

S. Torréyi, Gray. Cinereous with a somewhat close furfuraceous pubescence composed of about equally 9-12-rayed hairs: prickles small and subulate, scanty along the stem and midribs, or sometimes nearly wanting: leaves ovate with truncate or slightly cordate base, sinuately 5-7-lobed ( 4 to 6 inches long); the lobes entire or undulate, obtuse, unarmed: cymes at first terminal, loose, 2-3-fid: lobes of the calyx (often 6) short-ovate with a long abrupt acumination: corolla an inch and a half in diameter; its lobes broadly ovate: berry globose, an inch in diameter, yellow when mature.-Proc. Am. Acad. vi. 44. S. platyphyllum, Torr. in Ann. Lyc. N. Y. ii. 227, not HBK. S. mammosum? Engelm. \& Gray, Pl. Tindh. i. 46. - Prairies, \&c., Kansas and Texas. - Anthers 4 to 5 lines long. Flowers large and handsome.

S. Carolinénse, L. Hirsute or roughish-pubescent with 4-8-rayed hairs, many of them with the central division elongated: prickles stout and subulate, yellowish, copious or rarely scanty: leaves oblong or sometimes ovate, obtusely sinuate-toothed or lobed or sinuate-pinnatifid: cymes or racemes simple, soon lateral, loosc, few-several-flowered: lobes of the calyx acuminate: corolla an inch or less in diameter, light blue or rarely white, the lobes ovate: berries about half inch in diameter, globose. - (Dill. Elth. t. 269; but the fig. of Jacq. Ic. Rar. t. 331 is dubious.) - Sandy soil and waste grounds, Connecticut and S. Illinois to Florida and Texas. Southward a troublesome weed in cult. grounds. Var. Floridanum, Chapm. Fl. 349 , is a mere form with deep-lobed leaves.

Var. hirsútum (S. hirsutum, Nutt. in Jour. Acad. Philad. vii. 109, S. pumilum, Dunal, l. c.), judging from an imperfect original specimen, is a depauperate and more hirsute variety, little prickly, with leaves merely repand and tapering to the base, as in the lowest leaves of $S$. Carolinense. S. Pleei, Dunal, l. c., may be a more developed state of the same, - Milledgeville, Georgia, Boykin, \&c.

++ Introduced annuals or more enduring and woody in the tropics, with partly simple pubescence: anthers lanceolate: racemose fructiferous pedicels merely spreading: ber'y wholly; or partly enveloped by the loose calyx.

S. sisvmbrifólium, Lam. Green, stout, villous-pubescent with simple more or less glandular and viscid hairs, mixed on the leaves with some few-rayed stellate hairs (their middle division elongated), much armed even to the calyx with long-subulate straight prickles: leaves deeply pinnatifid and the oblong lobes sinuate or even again somewhat pinnatifid: flowers several or numerous in terminal or soon lateral pedunculate racemes : corolla liglıt blue or white, an inch or more in diameter, 5-lobed: lobes of the 5-parted calyx lanceolate, becoming ovate-lanceolate and at length loosely and completely or incompletely surrounding the globose red berry: seeds minutely reticulate-pitted, - Dunal in DC. 1. c. S. vis- 
cosum, Lag. S. influtum, Hornem. S. Uranciefulium, Jacq. Ecl. t. 7. S. decurrens, Balbis. $S$. Ballisii, Dunal; Hook. Bot. Mag. t. 2828, 3954. S. Sabeanum, Buckley in Proc. Acad. Philad. 1862. - Waste grounds, Alabama, Georgia, Florida, and Texas: adventive or escaped from cultivation. (Brazil and Buenos Ayres.) - Calyx not greatly accrescent and not enclosing the berry in wild specimens, and in some later flowers of cultivated plants.

§ 2. ANDRócera. Fruit enclosed by the close-fitting and horridly prickly caly $x$ and even adhering to it: stamens and especially the style much declined: anthers tapering upwards, linear-lanceolate, dissimilar; the lowest one much longer and larger, and with an incurved beak : seeds thickish, coarsely undulaterugose: racemose pedicels erect in fruit: leaves 1-3-pinnatifid: annuals, sometimes woody below, armed with straight prickles. - Androcera, Nutt. Gen. i. 129. Nycterium, Vent. in part, but not the typical one, which has a naked fruit.

S. heterodózum, Dunal. Pubescent with glandular-tipped simple hairs, with a very few 5-rayed bristly ones on the upper face of the irregularly or interruptedly bipinnatifid leaves; their lobes roundish or obtuse and repand: corolla violet, an inch and a half or less in diameter, somewhat irregular, 5-cleft; the lobes ovate-acuminate: four anthers yellow, and the large one tinged with violet. - Sol. 235, t. 25 (small-flowered form cult. at Montpelier); HBK. Nov. Gen. \& Spec. iii. 47; Jacq. Ecl. ii. t. 101. S. (Nycterium) eitrullifolium, Braun, Ind. Sem. Frib. 1849 ; Torr. Bot. Mex. Bound. 152. - W. Texas and New Mexico. (Mex.) Leaves Watermelon-like in form and division.

S. rostrátum, Dunal. Somewhat hoary or yellowish with a copious wholly stellate pubescence, a foot or two high: leaves nearly as in the foregoing or less divided, some of them only once pinnatifid : corolla yellow, about an inch in diameter, hardly irregular, the short lobes broadly ovate. - Sol. 2:34, t. 24, \& in DC. l. c. 329 . S, heterandrum, Pursh, Fl. i. 156, t. 7. S. Bejariense, Moricand in DC. 1. c. Androcera lobata, Nutt. Gen. i. 129. - Plains of Nebraska to Texas. (Mex.) S. cornutum, Lam., of Tropical Mexico, should be known by its simple pubescence.

3. Cápsicum, Tourn. Cayenne Pepper. (Name conjectured to come from xártw, to gulp down, alluding to the pungency of the fruit used as a condiment, or from capsa, a pod, the pericarp of the larger-fruited species being dry at maturity and almost capsular.) - Herbs or shrubs, originally all American and nearly all tropical, green and commonly glabrous; with many-times forking stems, ovate and entire or merely repand thin and usually acuminate leaves, and small solitary or cymose flowers on slender (or when the fruit is recurved stouter) pedicels : corolla mostly white: anthers generally bluish; the red or yellowish berries (or in some cultivated forms vesicular pod-like fruits) charged with a very pungent aromatic acridity. - Fingerhuth, Mon. Caps. 1832.

C. Frutéscens, L. Shrub 2 to 4 feet high, with flexuose branches: berry ovate-oblong, obtuse, half an inch or more long, on an erect or inclined peduncle. - Key West, Florida. (Nat. from Trop. Amer.)

C. baccátum, L. (BIrd Peprer.) Shrubby, a foot or two high, with slender divergent branches: leaves slender-petioled: calyx more or less toothed in the flower, truneate in fruit: berry elliptical-globular or globose: peduncles in fruit erect. - Fingerh. 1. c. 19, t. 4, fig..6. C. microphyllhum, Dunal in DC. 1. c. 421 (sometimes small-leaved). -S. Texas to Arizona, indigenous. S. Florida, doubtless introduced. (Trop. Amer. and other tropical regions.)

4. SALPICHRÓA, Miers. ( $\Sigma^{\alpha} \alpha \pi t \gamma_{\xi}^{\xi}$, trumpet, and $\chi \varrho \omega ́ s$, complexion or color, the typical species having trumpet-shaped and handsome corolla; but in some it is urceolate and rather short, in ours especially so.) - South American, except the dubious

S. Wríghtii. Low herb, apparently perennial, pubescent with rather slender simple lairs: leaves membranaceous, ovate, entire (an inch or more long), slender-petioled: pedi- 
cels solitary or sometimes 2 or 3 together, soon deflexed : calyx lirsute (a line and a half becoming in fruit 2 or 3 lines long), divided to the base; the divisions lanceolate : corolla oblong and hardly longer than the calyx, naked within: dry berry globose, 4 lines in diameter: seeds flat, rugose, oval, with excised hilum. - Arizona on the Sonoita, Wright (no. 1692), with mature fruit and some undeveloped flower-buds; from the habit, calyx, seeds, and high insertion of the stamens referred to the present genus.

5. ORYCTES, S. Watson. ('O@úxzys, a digger, name given to this dubious plant because it grows in the country of the Digger Indians.) - A single species, known only from incomplete materials.

O. Nevadénsis, Watson. A low and insignificant winter-annual, 2 to 4 inches high, when young somewhat scurfy or pruinose-pubescent, rather viscid: leaves oblong-ovate or lanceolate, undulate, tapering at base into a petiole: pedicels 3 or 4 in a lateral fascicle, shorter than the flower: calyx-lobes lanceolate, obtuse, rather shorter than the corolla, about the length of the globose berry, loose: corolla 3 lines long, narrow, apparently cylindraceous, blue or purplish; the sinuses deeply induplicate in the bud: filaments somewhat hairy, inclined to be unequal in length; the longer ones and the filiform style nearly equalling the corolla : seeds orbicular, flattened, foveolate-reticulated. - Bot. King, 274, t. 28, fig. 9, 10 ; Benth. \& Hook. Gen. ii. 893; Gray, Bot. Calif. i. 542. - W Nevada, at the eastern base of the Virginia mountains, near the Big Bend of the Truckee, under Artemisia bushes, in spring, Watson.

6. CHAM Æ̇SÁRACHA, Gray. (Saracha is a tropical American genus, dedicated by Ruiz \& Pavon to Isidore Saracha, a Spanish Benedictine : the prefix $\chi\left(\alpha \mu x i^{\prime}\right.$, on the ground, makes the meaning low Saracha.) - Texano-Californian depressed perennials; with mostly narrow leaves, either entive or pinnatifid, and tapering into margined petioles, filiform naked pedicels, and either white, ochroleucous, or violet-tinged corolla; the close-fitting calyx in fruit obscurely if at all veiny. - Benth. \& Hook. Gen. ii. 891. Saracha § Chamasaracha, Gray, Proc. Am. Acad. x. 62.

* Stems branching, diffuse or at length depressed-procumbent: fruiting calyx almost globose: seeds thickish, rugosely favose.

C. Corónopus, Gray. Green, almost glabrous, or beset with some short and roughish hairs, diffusely very much branched: leaves lanceolate or linear with cuneate-attenuate base, varying from nearly entire to laciniate-pinnatifid : peduncles elongated: calyx more or less hirsute (the hairs often 2-forked at tip). - Bot. Calif. i. 540. Solanum Coronopus, Junal in DC. Prodr. 1. c. 64. Withania? Coronopus, Torr. Bot. Mex. Bound, 155. Saracha (Chamoesaracha) Coronopus, Gray, Proc. Am. Acad. x. 62. - Clayey soil, Texas to southern parts of Colorado and west to Arizona. (Adjacent Mex.) Corolla (yellowish), berry (nearly white), and fruiting calyx nearly as in the next species, with which some specimens seem to connect. To this probably belongs Saracha acutifolia, Miers in Ann. \& Mag. Nat. Hist. 1849, \& Ill. S. Am. Pl. ii. 19, described from an incomplete specimen in Coulter's collection, from California, or probably Arizona.

C. sórdida, Gray, l. c. Much branched from the root or base, somewhat cinereous with short viscid or glandular pubescence, which occasionally becomes furfuraceous, also more or less villous with longer hairs: leaves from obovate-spatulate or cuneate-oblong to oblanceolate, and from repand to incisely pinnatifid (or even with the lobes sinuate-incised): calyx when young viscid-villous. - Withania? sordida, Dunal in DC. 1. c. 456, Torr. 1. c. Solanum coniodes, Moricand ex Dunal, 1. c. 64. S. Linsecumii, Buckley in Proc. Acad. Philad. Saracha (Chamresaracha) sordida, Gray, Proc. Am. Acad. 1. c.-Dry or clayey soil, Texas and South-western Kansas to Arizona. (Adjacent Mex.) Corolla dull pale yellow or sometimes violet-purple, about half inch in diameter. Berry the size of a pea, all but the summit closely invested by the herbaceous calyx. Dunal's two plants are the same, both being rather hoary and less hairy forms 'of a very variable species. 
* * Stems very short and tufted on a branching rootstock : fruiting calyx hemispherical, open: seeds very flat, smoothish and minutely punctate.

C. nána, Gray. Seldom a span high, sometimes nearly acaulescent, minutely cinereous with appressed pubescence, not viscid: leaves crowded and large in proportion, oblongovate and ovate-lanceolate, mostly acute, entire or undulate, an inch or two long, and with the roundish or cuneate base abruptly contracted into a margined petiole of about equal length : peduncles mostly shorter than the petioles: rotate corolla white or bluish, 7 to 9 lines wide. - Saracha (Chamcesaracha) nana, Gray, Proc. l. c. - Sierra Co., California, at about 5,000 feet in the Sierra Nevada, Bolander, Lemmon.

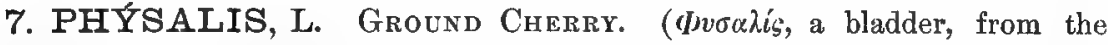
bladdery-inflated fruiting calyx which characterizes the genus.) - Herbs, chiefly American or of probably American origin; with entire, toothed, or lobed leaves, very commonly geminate, and solitary or sometimes geminate (rarely ternate) drooping or nodding pedicels ; the flowers small or middle-sized, white, yellow, or violet-purple: berries greenish, red, or yellow, often edible. - Gray, Proc. Am. Acad. x. 62 .

\$ 1. ChamePhysalis, Gray, l. c. Young parts sparsely (or on stalks and calyx densely) scurfy-granuliferous, otherwise quite glabrous: some leaves sinuate-pinnatifid : corolla flat-rotate: anthers short, yellow: seeds comparatively few and large, thickish and somewhat rugose-tuberculate round the back. (Habit nearly of Chamasaracha, but fruiting calyx of true Physalis.)

P. lobáta, Torr. Low and small, diffusely branched from a perennial root: leaves oblong-spatulate or obovate, from repand to sinuate-pinnatifid (an inch or two long), the base cuneately tapering into a margined petiole: pedicels commonly geminate, longer than the flower: corolla violet (probably never "yellow"), 6 to 9 lines in diameter, the centre with a 5-6-rayed white-woolly star: globular-inflated fruiting caly $\mathrm{x}$ strongly 5-angled, half inch or more long, with short bluntish teeth. - Ann. Lyc. N. Y. i. 226 (1826) \& Bot. Mex. Bound. 152. P. Sabeana, Buckley in Proc. Acad. Philad. 1861. Solanum luteoliflorm, Dunal in DC. Prodr. l. c. 64, at least as to var. subintegrifolium. - Plains, Texas to Colorado and W. Arizona.

§ 2. Physalis proper. Not granulose-scurfy: leaves never pinnatifid : corolla mostly rotately spreading from a somewhat campanulate throat or base: seeds with a thin and even margin.

P. Almekengr, L., the Winter Cherry of the south of Europe, with white 5-lobed corolla and a red berry in a calyx which turns red also, and

P. Peruviava, L., the Cape Gooseberry, with greenish-yellow corolla spotted by a brownpurple star in the centre, and a yellow berry, - both perennial-rooted species, - were introduced into cultivation several years ago, for their esculent fruit, under the name of Strawberry Tomato. But they have now mainly disappeared.

P. Carpentériı, Riddell, Cat. Fl. Ludov. (N. O. Med. \& Surg. Jour. viii. 758, 1852, name only), referred to Withania Morisoni, in Bot. Gazette, iii. 11, is some adventitious Athenaea.

* Corolla pure white or tinged with blue, wholly destitute of any dark centre, tomentose at the throat, proportionally large, widely rotate, with border almost entire: pubescence simple: fiuiting calyx ovate-globose.

P. grandiflóra, Hook. Annual, with stout erect stem 2 feet or more high, viscid-pubescent and young parts villous with some long and slender viscid hairs: leaves oblongovate or lanceolate-ovate, acute or acuminate, mostly entire: pedicels often in threes, shorter than the flower: calyx-lobes lanceolate: corolla often an inch and a half in diameter: anthers yellow, commonly with a tinge of violet: fruiting calyx less than an inch long, well filled and distended by the berry, the angles therefore obsolete, and the summit open. - Fl. ii. 90 ; Gray, Man., \& Proc. Am. Acad. x. 63, 381. - S. shore of Lake Superior to the Saskatchewan distriet, springing up in new clearings. Connects with Chamcesaracka through C. nana. 
P. Wríghtii, Gray. Annual, a span high, widely branched, nearly glabrous ; the appressed and rather sparse pubescence on pedicels and young parts very short and minute: leaves oblong or lanceolate-oblong, sinuate-toothed or repand, acute at base, about an inch long: pedicels filiform, longer than the flower and the fruiting calyx: corolla over half inch in diameter, apparently pure white: anthers with or without a tinge of violet: fruiting calyx half inch long, nearly filled by the berry. - S. W. Texas, on prairies of the San Pedro, Wright.

* * Corolla lurid greenish-white or yellow, mostly darker-colored or brownish in the centre, with or without a brown-purple eye, small or middle-sized, 3 to 10 lines in diameter.

+ Strictly annuals, glabrous or nearly so; the pubescence if any minute, and neither viscid nor stellate : anthers violet.

$\div$ Corolla small, 3 to 6 lines broad: fruiting calyx at first acutely angled and inflated, closing over, but at full maturity nearly replete with the greenish-yellow berry: stem and branches conspicuously angular: petioles long and slender.

P. obscúra, Michx. Branches widely diffuse : leaves broadly deltoid-ovate, mostly with truncate or subcordate base, unequally dentate, abruptly acuminate, membranaceous ( $1 \frac{1}{2}$ to 3 inches long): slender pedicels about half an inch long: corolla ( 3 or 4 lines broad) pale yellow with a dark eye: calyx deeply 5-cleft into lanceolate-subulate lobes, in fruit ovatepyramidal and acuminate (over an inch long), very smooth, with $\mathbf{5}$ strong keeled angles which are hardly obliterated at maturity, the 5 intermediate nerves much less distinct. Gray, Proc. Am. Acad. x. 64. P. obscura, var. glabra, Michx. Fl. i. 149. P. pruinosa, Ell. Sk. i. 279, not L. P. Brasiliensis, Sendtner in Mart. Fl. Bras. x. 133 ? - "Carolina," Michaux. Key West, Florida, Blodgett. Near Houston, Texas, E. Hall, no. 503.

P. anguláta, L. Erect, or at length declined or spreading, 2 to 4 feet long: leaves mostly ovate-oblong and with soinewhat cuneate base, coarsely and laciniately toothed (2 to 5 inches long) : slender pedicels an inch or more long : corolla ( 3 to 6 lines broad) greenish-white or yellowish and with no distinct eye : calyx-lobes shorter than the tube, triangular : fruiting caly $\mathrm{x}$ at first ovate-pyramidal and 10-angled, the 5 principal angles sharply keeled, at full maturity nearly replete and globose-ovate. - Dill. Elth. i. 13, t. 12. - Open rich grounds, through the Middle and Southern Atlantic States. (Widely diffused over tropical regions.)

Var. Linkiána, Gray, 1. c. Leaves with margin more laciniate-dentate; the irregular salient teeth lanceolate-subulate: caly $x$-lobes longer and narrower. $-P$. Linkiana, Nees in Linn. vi. 471. (Moris. Hist. iii. 526, sect. 13, t. 3, fig. 22, exaggerated.) - S. Atlantic States. (Trop. Amer.)

P. æquáta, Jacq. f. Erect, much branched, a foot or two high, the younger stems and branches a little hairy or pubescent: leaves ovate or oblong, repand or sinuate-toother (an inch or two long or rarely larger): pedicels very short (a line or two long): corolla ( 3 to 5 lines broad) light yellow with a brownish eye: calyx-lobes short and broadly ovatetriangular: fruiting calyx ovate-globose at maturity, about equally 10-nerved, an inch or considerably less in length. - Eclog. ii. t. 137 ; Nees, l. c.; Dunal, 1. c. P. Philadelphica, var. minor, Dunal, l. c. 450 . - Waste grounds, S. Texas and New Mexico to the border of California or near it. (Mex., W. Ind.)

+ + Corolla larger, 7 to $10 \mathrm{or}$ sometimes 12 lines broad: fruiting calyx at maturity replete and distended with the large reddish or purple berry, and open at the mouth, sometimes bursting.

P. Philadélphica, Lam. Erect stem and branches angled, 2 or 3 feet high: leaves obliquely ovate or oblong, repand-angulate and sometimes few-toothed ( 2 to 4 inches long): corolla greenish or yellowish with a dark eye : calyx-lobes broadly ovate or triangular, not longer than the tube; fruiting calyx globular, an inch in diameter. - Dict. ii. 101. $P$. chenopodifolia, Willd., not Lam. "P. atriplicifolia, Jacq. Fragm. t. 85." - In fertile soil, Pennsylvania to Illinois and Texas: sometimes cult. for the esculent fruit.

+ + Annuals or perennials, strong-scented, villous or pubescent with viscid or glandular simple hairs : fruiting calyx ovate-pyranidal and carinately 5-angled at maturity, closed, loosely enveloping the green or at length yellow berry : leaves ovate or cordate.

$$
\text { + Root annual : anthers violet. }
$$

P. pubéscens, L. A foot or two high, with at length widely spreading branches: leaves ovate or cordate, varying from nearly entire to coarsely and obtusely repand-toothed, sometimes becoming nearly glabrous except on the midrib and veins (commonly about 2 inches long): corolla barely half inch in diameter when expanded, dull yellow with a 
purplish brown eye: pedicels ( 3 to 5 lines long) much shorter than the fruiting mostly pubescent and viscid (inch to almost 2 inches long) calyx. - (Moris. Hist. iii. 527, sect. 13, 4, 3, fig. 24; Dill. Elth. t. 9, fig. 9.) P. obscura, var. viscido-pubescens, Michx. I. c. P. hirsuta \& $P$. pubescens, Dunal in DC. 1. c. P. viscosa? Ell. Sk. i. 279 . P. pruinosa, L. (from N. America?), is most probably a form of this with long pedicels and yellowish anthers, same as Dill. Elth. t. 9. - Low grounds, New York to Iowa, Florida, and westward from Texas to the borders of California. ('Trop. Amer., \&c.)

+ Perennial: anthers mostly yellow.

P. Virginiána, Mill. A foot or so high from slender and deep creeping subterranean shoots, at length spreading or decumbent, pubescent or hirsute-villous with (usually more or less viscid) many-jointed hairs: leaves ovate, occasionally subcordate, either repandly or saliently few-toothed or some nearly entire : corolla from three-fourths to a full inch in diameter, dull sulphur-yellow with a brownish centre: calyx-lobes narrowly triangular: pedicels half to an inch long, equalling or shorter than the fruiting calyx. - Dict. no. $4, \&$ Fig. Pl. 138, t. 206, fig. 1; Gray, Proc. Am. Acad. s. 65 (by mistake " $P$. Virginica"). $P$. heterophylla, Nees in Linn. vi. 463, excl. syn. Walt. "P. nutans, Walt. Car. 99?" ex Nees, l. c.; but no such name in Walter. $P$. heterophylla, nyctaginea, \& viscido-pubescens, Dunal, 1. c. $P$. viscosa, Gray, Man., not L. - Light or sandy soils, Upper Canada to Florida and Texas. This early name of Miller, taken up for the present species in Proc. Am. Acad. l. c., must from the size of the flower belong to it, or to a broad-leaved and hairy form of $P$. lanceolata. Miller's remark that "the root does not creep in the ground," is most applicable to the latter; but the color as well as size of the corolla and the "pale yellow" fruit, also the diffuse growth, best accord with this common species.

Var. ambígua, Gray, l. c. A coarse and very villous form with anthers violet! P. Pennsyluanica, Hook. Fl., at least in part. - Wisconsin (Lapham) to Saskatchewan, Bourgeau, Drummond, \&c.

P. hederæfólia, Gray, 1. c. A foot or less high, erect or at length diffuse from a thick perennial stock or root, densely viscid-pubescent or on young parts more or less villous, not unpleasantly scented: leaves roundish-cordate or almost reniform, or sometimes ovate, coarsely and obtusely angulate-toothed (three-fourths to an inch and a half in diameter): corolla half an inch in diameter: anthers yellow: calyx-lobes triangular: pedicels ( 2 to 4 lines long) shorter than the flower, much shorter than the fruiting calyx. $P$. Alkekengi? var. digitalifolia \& $P$. mollis, in part, Torr. Bot. Mex. Bound. 153.-Rocky hills, New Mexico to S. W. Texas, Arizona, and adjacent parts of Mexico. "Herbage destitute of the nauseous odor of the common viscid species, rather sweet-scented," Wright.

Var. pubérula, Gray, l. c. Pubescence short and minutely glandular, less viscid: stems inclined to be procumbent and leaves smaller. - Western borders of Texas, Wright.

P. Pálmeri. A span or two high from a thickish perennial stock, erect, viscid-pubescent with short jointed hairs : leaves ovate or deltoid-ovate, or the lowest rotund (rarely even subcordate), angulate-dentate with few obtuse teeth, the upper leaves acute (10 to 18 lines long): corolla light yellow with brownish centre, 7 or 8 lines in diameter: perlicels mostly longer than the flower: fruit not seen. - Rock Spring in the Providence Mountains, S. E. California, Pulmer. Apparently allied to the preceding.

+++ Perennials, not viscid, mostly low: anthers almost always yellow.

+ Very minutely cinereous-puberulent or glabrous throughout, no stellular pubescence whatever: corolla (yellowish) wholly destitute of a darker eye: leaves all cordate or broad and abrupt at base, thickish : pedicels long and filiform.

P. GLÁBrA, Benth. (not Martins \& Gal.), of Lower California, if found within the United States will be known by being completely smooth, and the leaves ovate- or hastate-lanceolate.

P. crassifólia, Benth. Minutely puberulent, or the leaves at length nearly glabrous: stems a span to a foot long, branching from the base, sometimes soon procumbent : leaves ovate or rounded-subcordate, repand or entire: pedicels commonly an inch long: corolla ochroleucous, half inch in diameter : fruiting caly $x$ an inch long, 5-angled. - Bot. Sulph. 40 ; Gray, 1. c. \& Bot. Calif. i. 541, the small-leaved form. - S. E. California and Western Arizona. (Lower Calif.)

Var. cardiophylla. A more upright form: leaves thinner and larger ( 6 to 15 lines long), sometimes with a few angulate and more prominent teeth. $-P$. cardiophylla, Torr. Bot. Mex. Bound. 153. - On or near the Rio Colorado, Fort Mohave, Fort Yuma, \&c. 
+ + Pubescence stellular or branching, at least on the calyx, \&c.: leaves all or most of them cordate or ovate with abrupt base : corolla usually with darker eye : anthers occasionally with a tinge of blue: fruiting calyx globose-ovate.

P. Féndleri, Gray, l. c. Pruinose-puberulent; the pubescence microscopically minute and partly simple, partly branched or stellular, sometimes a little glandular: stems a span to a foot high from a deep tuberous stock, slender, much branched : leaves small (an inch or less long), from deltoid-ovate or slightly cordate to ovate-lanceolate, and from repandundulate to coarsely sinuate-toothed, mostly acute : pedicels shorter than the flower : corolla half an inch in diameter. $-P$. mollis, Torr. Bot. Mex. Bound., in part. - Rocks and plains, New Mexico, Fendler, Thurber, Wright, Bigelow, Parry. Also S. Colorado.

P. móllis, Nutt. Softly cinereous-tomentose or canescent throughout with stellate or many-branched woolly hairs: stems a span to a foot or more high: leaves varying from ovate (or some of the lower obovate) to rounded-cordate, mostly obtuse, angulate-toothed or repand (an inch or two long), on slender petioles : pedicels usually filiform and equalling the petiole: corolla half to three-fourths inch in diameter: fruiting caly $x$ an inch or more long. - Nutt. in Trans. Am. Phil. Soc. ser. 2, v. 194 ; Torr. 1. c., in part; Gray, Proc. Am. Acad. x. 66. P. tomentosa, Dunal in DC. l. c.? not Walt. - Thickets and banks of streams, Arkansas (Nuttall, \&c.) and Texas. (Mex.) Sometimes very white-woolly (as in coll. E. Hall); but passing into

Var. cineráscens, Gray, l. c. Greenish; the pubescence much shorter and less dense, the hairs less compound: leaves roundish, rarely at all cordate, some of the lower with cuneate base : pedicels sometimes shorter. $-P$. Pennsylicanica, var. cinerascens, Dunal in DC. 1. c. 435. - Indian Territory (Palmer) and through Texas (Drummond, Schott, E. Hall, \&c.) to Mexico. Berlandier collected it at Matamoras.

to + + Pubescence stellular, or simple and somewhat rigid, or nearly none: leaves from oval

to lanceolate-linear and tapering into the petiole, or in the first species occasionally subcordate: style commonly clavate.

P. viscósa, L. Cinereous or when young almost canescent with short and soft stellalar or 2-3-forked pubescence: stems ascending or spreading from slender creeping" subterranean shoots, a foot or two long: leaves ovate or oval, varying to oblong and obovate, entire or undulate ( $1 \frac{1}{2}$ to 3 inches long): pedicels about the length of the petioles: corolla twothirds to three-fourths inch in diameter, greenish-yellow with a more or less dark throat: fruiting calyx globose-ovate, an inch or more long: berry yellow or orange. - Dill. Elth. t. 10; Jacq. Vind. t. 136; Michx. Fl. 1. 149; Gray, 1. c. P. Pennsylvanica, L. Spec. ed. 2, 1670, but not from Pennsylvania or near it. $P$. tomentosa, Walt. Car. 99. P. maritima, M. A. Curtis in Am. Jour. Sci. ser. 2, vii.407. P. Jacquini, Link, Enum. Berol. ; Dunal, l. c. P. Walteri, Nutt. in. Jour. Acad. Philad. vii. 112. - In sands on and near coast, Virginia (I.), N. Carolina to Florida. (Buenos Ayres, \&c.) Specific name from the viscous berry.

Var. spathulæfólia, Gray, l. c. Leaves spatulate or oblong-lanceolate, gradually tapering into the petiole.- P. pubescens, Engelm. \& Gray, Pl. Lindl. i. 19. P. lanceolata, var. spathulafolia, Torr. Bot. Mex. Bound. 1. c. - Sea beaches, Florida and Texas. Glabrate forms approach the next.

P. angustifólia, Nutt. Bright green, very minutely stellular-pubescent when young, or glabrous from the first, except a fine soft stellular pubescence on the margins of the leaves, or at least on the calyx-lobes: stems erect or ascending from filiform running shoots, a span to a foot or more high: leaves from oblong-lanceolate or oblanceolate to linear, tapering into a very short petiole ( $1 \frac{1}{2}-3 \frac{1}{2}$ inches long): corolla three-fourths inch in diameter when expanded: flowering calyx broadly campanulate and 3 or 4 lines long, the subglobose fruiting calyx seldom an inch long. - Jour. Acad. Philad. vii. 112; Gray, 1. c. - Sandy coast and Keys of IV. Florida.

P. lanceoláta, Michx. More or less hirsute-pubescent with short and stiff (or on the stem often longer and somewhat villous-hispid) tapering hairs, most of which are simple, a few 2-3-forked, varying to nearly glabrous: stems a span to a foot high from rather stout subterranean shoots, angled, somewhat rigid: leaves pale green, varying from oblongovate to narrowly lanceolate, and from sparingly angulate-few-toothed to undulate or entire, mostly acute at base or tapering into a short petiole: corolla ochroleucous with more or less dark eye, two-thirds to three-fourths of an inch in diameter: calyx (4 or 5 lines long) cormmonly hirsute, in fruit conical-ovate with sunken pyramidal base, 1 to $1 \frac{1}{2}$ 
inches long ; berry reddish. - Fl. i. 149 ; Ell. l. c. ; Dunal in DC. 1. c. ; Gray, l.c. P. pumila, Nutt. in Trans. Am. Phil. Soc. ser. 2, vii. 193. P. Pennsyluanica, Gray, Man. ed. 5, 382, in part, not Linn.? P. Elliotti, Kunze in Linn. xx. 33. - Dry open ground and bottoms, Lake Winnipeg to Florida and Texas, Colorado, Utah, and New Mexico. Calyx-lobes varying from triangular-lanceolate to ovate-triangular; fruiting calyx pyramidal-ovate, large.

Var. lævigáta, Gray, l. c. Glabrous or almost so throughout, or with some extremely short and pointed appressed rigid hairs on young parts, caly $x$, \&c., or on the margins of the leaves: petioles commonly longer. $-P$. longifolia, Nutt. in 'Trans. Amer. Phil. Soc. l. c. P. pumila? var. Sonore, Torr. Bot. Mex. Bound. l. c. - Nebraska to Texas, New Mexico and Arizona.

Var. hírta, Gray, l. c. A remarkable and ambiguous form, approaching $P$. mollis, var. cinerascens; much of the hirsute pubescence of the leaves being 2 -" -forked, as also are some of the villous-hispid abundant hairs of the stem. $-P$. Pennsylvanica, var., Gray in E. Hall's list, Coll. Tex. no. 501. - Wet woods, Houston, Texas, Drummond, E. Hall. Lawrence, Kansas, $J$. H. Carruth.

8. MARGARANTHUS, Schlecht. (Composed of $\mu \alpha \dot{\alpha} \alpha \alpha \rho o v$, a pearl, and \& $z$ fos, flower, from a fancied resemblance of the corolla.) - Resembles an annual Physalis on a small scale, except in the globular (livid or violet-tinged) corolla; the small berry wholly included in the globular and vesicular fruiting calyx, rather dry, 20-30-seeded. - Single species.

M. solanáceus, Schlecht. Nearly glabrous slender annual, a span to two feet high, erect, äivergently branched: leaves membranaceous, ovate and ovate-lanceolate, entire or somewhat repand, occasionally 1-2-toothed, an inch or two long, slender-petioled : pedicels short, recurving : corolla barely 2 lines and globular-conical fruiting caly $x+$ to 6 lines long. -Ind. Sem. Hort. Hal. 1838, \& Hort. Hal. Ic. i. t. 1; Torr. Bot. Mex. Bound. 154. $M$. tentis, Miers, Ill. ii. 74, t. 57, with more acute or acuminate leaves. - Southern and western borders of "Texas (Berlandier, referred to Physalis divaricata by Dunal in DC. Prodr. 1. c. 444) and New Mexico, Wright, Bigelow. (Mex.)

9. NICÁNDRA, Adans. Apple-of-Prru. (Nicander of Colophon.) - Single species, sparingly naturalized, from gardens : fl. summer.

N. Physalof́des, Grertn. Glabrous annual, 3 or 4 feet high, with the habit of an overgrown Physalis, and very smooth Stramonium-like leaves laciniate- or sinuate-lobed; pedicels solitary, recurved: flower rather showy: corolla blue or bluish (an inch long and with a broad nearly entire limb) : fruiting calyx over an inch long: included fruit so dry and thin-walled as to appear capsular. - Fruct. ii. 237, t. 131; Miers, Ill. ii. t. 43. Atropa physaloides, L. ; Jacq. Obs. t. 98. - Waste grounds near dwellings and old gardens. (Peru, and now dispersed through warm regions.)

10. LYCIUM, L. (Lycia, the country of the earliest-known species.) Shrubby plants (of warm-temperate and dry tropical regions), often spinose; the entire and usually narrow leaves commonly fascicled in the axils, often veinless. Flowers from greenish or white to purple, on solitary or fascicled terminal or axillary pedicels, in spring or summer. - Miers, IIl. S. Am. Pl. ii. 88; Gray, Proc. Am. Acad. v. 45, vii. 388 , \& viii. 292.

* Introduced from Old World, sparingly escaped from cultivation.

L. volgare, Dunal. (Matrimony-vine. Box-thonn.) Tall, the long and slender branches recurving or somewhat climbing, glabrous: spines few or none: leaves oblonglanceolate with a tapering base or somewhat spatulate: peduncles slender: corolla shortfunnelform, dull greenish-purple; the style and slender filaments equalling its lobes: berry oval, orange-red. - L. Barbarum, $\mathrm{T}_{\text {., }}$ in part. - Escaped into waste grounds and thickets in Penn., \&c. (Mediterranean region.) 
* * Indigenous, southern and western : berries red or reddish (one species excepted), globular. + Large-flowered: funnelform corolla nearly an inch long.

L. pállidum, Miers. Glabrous : stems and branches widely spreading, 2 to 4 feet high, spiny: leaves pale, spatulate and oblanceolate, an inch or two long: pedicels about equalling the deeply 5-cleft calyx : corolla greenish, tinged with purple; the lobes broad and rounded: filaments exserted: anthers tipped with a deciduous point. - Ill. 1. c. 108, t. 67 ; Torr. Bot. Mex. Bound. 154; Gray, Proc. Am. Acad. vi. 45. - New Mexico and Arizona: also S. Utah, Fremont, Fendler, \&c.

+- + Large calyx, with lobes commonly longer than or equalling the tube, foliaceous and obtuse: corolla half inch long or less: stamens included: herbage puberulent.

$$
i+\text { Flowers 4-merous. }
$$

L. Pálmeri, Gray. Apparently unarmed, with slender branches : leaves narrowly spatulate: flowers short-pedicelled, 4 or 5 lines long: calyx-lobes lanceolate, equalling the oblong-campanulate tube of the corolla, which is little longer than its oval lobes. - Proc. Am. Acad, viii. 292. - Yaqui River, W. Sonora, Mexico, added because it may reach Arizona.

++ Flowers 5-merous: corolla-lobes ovate, short, recurved-spreading.

L. Coóperi, Gray. Branches stout, and with some very short spines; leaves spatulate, minutely viscid-pubescent or puberulent, half inch or more in length: pedicels at least equalling the cylindraceous at length campanulate calyx, both hirsute or pubescent; the oblong-lobes of the latter more or less shorter than the tube: corolla narrowly funnelform, apparently white, half inch long, its lobes obtuse: filaments hairy at base: anthers oval, mucronulate. - Proc. Am. Acad. vii. 388, \& Bot. Calif. 542. South-eastern border of California and adjacent part of Arizona, Cooper, Palmer.

Var. pubiflóra. Corolla strongly pubescent outside : caly x shorter, - On the Mohave River, with the ordinary form, Palmer.

L. pubérulum, Gray. Stem 2 to 4 feet high, with slender divergent and spinescent branches: leaves obovate and oblong-spatulate, a quarter to half inch long, minutely and densely puberulent: flowers solitary and sessile in the fascicles of leaves: calyx-lobes oblong, much shorter than the tube of the corolla, twice the length of their own tube: corolla 4 or 5 lines long, tubular-funnelform, white, with the triangular-ovate acute lobes not longer than the abruptly dilated throat and tinged with greenish-yellow: filaments glabrous, inserted in the throat: anthers roundish-cordate.-Proc. l. c. vi. 46. - Borders of Texas and New Mexico, on the Rio del Norte, near El Paso, Wright.

L. mácrodon, Gray, l. c. Spiny: leaves spatulate-oblanceolate, glabrate, 2 to 4 lines long: pedicels at most a line and a half long: lobes of the minutely viscid calyx narrowly linear, twice the length of the short campanulate tube ( 3 lines long), half the length of the narrow corolla: filaments a little hairy at base : anthers oval-oblong. - California or Nevada? Fremont, 1849 : not since seen.

+++ Short-flowered; the tube and throat of corolla only a line or two long, and the limb comparatively large: calyx with short lobes or teeth or irregularly cleft: herbage glabrous or nearly so.

++ Corolla comparatively large, nearly half inch in diameter: leaves fleshy.

L.- Caroliniánum, Walt. Glabrous, 2 or 3 feet high, widely spreading, spiny : leaves linear-spatulate or so thickened as to be clavate, an inch or less long: pedicels slender: flower 4-5-merous: calyx short, irregularly cleft in age: corolla purple, its almost rotate limb deeply parted into oval lobes: slender filaments (woolly at base) and style elongated. - Car. 84; Michx. Fl. i. 95; Miers, 1. c. t. 71. L. salsum, Bartr. Trav. 9.- Salt marshes, S. Carolina to Texas.

+ Corolla small; the expanded limb under 3 lines wide, about equalled by the stamens: pedicels a line or two long or none: branches more or less spinescent: leaves linear-spatulate.

L. Califórnicum, Nutt. Slender stems very much branched, 2 feet high : leaves thickish and apparently fleshy-coriaceous, very small (1 to 3 lines long), from obovate or spatulate to nearly linear: pedicels sometimes hardly any : tube of the white corolla included in the campanulate 4 -toothed calyx ; its rotate 4-parted limb barely 2 lines in diameter. Gray, Bot. Calif. i. 542. - Clayey hill-sides, California, near San Diego, Nuttall (without flowers), Clevela id, Palmer. (Islands of Lower California.) 
L. parviflórum, Gray. Stems 2 to 4 feet high: leaves 2 to 5 lines long, narrow, not fleshy : corolla (2 lines long) funnelform, rather more than twice the length of the shortcampanulate often irregularly 2-3-cleft calyx; the 4 lobes very short: style at length much exserted. - Proc. Am. Acad. vi. 48. - Southern Arizona, Thurber.

L. barbinódum, Miers. Stouter, 6-10 feet high ; the old spurs or nodes densely shortwoolly: leaves linear-spatulate, 6 to 12 lines long: corolla (2 lines long) with narrow tube about equalling the commonly 2-3-cleft short calyx, abruptly enlarged into a broadly campanulate throat; the lobes 5, short, roundish. - Ill. 1. c. 115, t. 68, the corolla badly drawn and unlike the description. - N. W. Mexico (Seemann) and Magdalena, Sonora, Thusber (who says the berries are white and translucent); doubtless in adjacent Arizona.

L. BRÉvipes, Benth., and L. RICHII, Gray, are little known species of Lower California.

++++ Iong-flowered; the corolla tubular or when funnelform with tube and throat over two lines long and much exceeding the lobes, white, cream-color, or tinged with violet: stamens little if at all exserted.

$$
+ \text { Leaves, pedicels, and calyx puberulent: flowers } 5 \text {-merous. }
$$

L. Fremónti, Gray. Stem 2 to 4 feet high: leaves spatulate, 4 to 9 lines long : pedicels shorter than or barely equalling the cylindraceous calyx : corolla narrowly tubular-funnelform, 4 to 6 lines long, with very short ovate lobes: filaments nearly naked: style soon exserted. - Proc. An. Acad. vi. 46, \& Bot. Calif. i. 543. - S. E. California or Nevada, Fremont. Arizona, Palmer.

Var. Bigelóvii, Gray, l. c. Calyx shorter-campanulate : corolla broader and merely 4 lines long : flaments slightly hairy at base. - Williams Fork, N. Arizona, Bigelow.

L. gracílipes, Gray. Minute pubescence somewhat viscid or glandular: leaves small ( 2 to 6 lines long), spatulate or the smaller oblong-obovate, thickish : pedicels filiform, as long as the flower: calyx campanulate, short-toothed: corolla elongated-funnelform, half inch long, white with a violet tinge or sometimes deep violet; the lobes rounded-ovate, very obtuse, a line long: filaments inserted low in the throat, a little hairy at base: anthers and style not exceeding the corolla-lobes. - Proc. An. Acad. xii. 81. - Williams Fork, N. Arizona, Palmer.

++ Glabrous throughout, or merely some woolly pubescence on the spurs at the insertion of the leaves and pedicels: flowers in the same species either 5-merous or 4-merous.

$=$ Pedicels filiform, as long as the commonly 4-merous rather short funnelform corolla.

L. Berlandiéri, Dunal. Spiny, 3 to 8 feet high, with mostly slender branches : leaves spatulate-linear, 6 to 12 lines long: corolla 3 or 4 lines long, mostly thrice the length of the campanulate calyx which nearly includes its narrow proper tube; the lobes oval or oblong (a line long): filaments villous at base. - DC. Prodr. xiii. 520; Gray, Proc. Am. Acad. vi. 47. L. stolidum \& L. senticosum, Miers, 1. c. t. 68, 71. - S. Texas, Berlandier, Wright, to Arizona, Palmer.

$==$ Pedicels ( 1 to 3 lines long) shorter than the tubular-funnelform corolla: flowers copious.

L. Andersónii, Gray. Exceedingly branched, 2 or 3 feet high: leaves mostly very small ( 2 to 6 lines long), linear-spatulate or broader: calyx short-campanulate: corolla half inch long or nearly, tubular, very gradually widening upward; the expanded limb only 2 or 3 lines wide; its rounded lobes with nearly glabrous edges: filaments slightly hairy at base : berries bright red, "edible." - Proc. Am. Acad. vii. 388, \& Bot. Calif. 1. c. - Utah, S. Nevida, and N. Arizona, first collected by Anderson.

Var. Wríghtii, Gray. More leafy and sparsely flowered, spiny, smaller-flowered: corolla 4 or 5 lines long. - Bot. Calif. 1. c. L. stolidum, Torr. Bot. Mex. Bound, in part. L. Berlandieri, Gray, Proc. Am. Acad. vi. 47, in small part. - S. Arizona, Wright, Palmer.

L. Torréyi, Gray, l. c. More or less spiny, 4 to 8 feet high : leaves mostly larger than in the preceding, sometimes over an inch long and over 2 lines wide: pedicels 2 or 3 lines long: corolla 5 or 6 lines long, more funnelform; the limb about 4 lines wide, and the lobes tomentulose on the edges: filaments woolly at base: berries red, "not edible." - L. barbinode, Torr. in Pacif. R. Rep. v. 363, \& Bot. Mex. Bound. 154. - Western border of Texas, near El Paso, to S. E. California.

11. Datúra, L, Stramonium, Thorn-Apple. (From the Arabic name, Tatorah.) - Herbaceous plants, or some tropical species woody and arbo- 
rescent, of rank odor, and narcotic-poisonous qualities, natives of America and tropical Asia; with ovate leaves, and large flowers on short peduncles in the forks of the branching stems, produced through the season. Corolla commonly white or violet, usually more or less fragrant.

D. ARBórEa, the Tree-Stramonium, representing the section Brugmansia, with very large pendulous flowers, and oblong indehiscent fruit reflexed, cultivated in conservatories, may perhaps have become spontaneous on the southern borders of the United States.

$\S 1$. Caly x prismatic, 5 -toothed: border of the corolla with 5 acute teeth : capsule dry, 4-valved: seeds thickish, with a dark-colored and more or less rugose or pitted crustaceous coat : annuals, with flowers erect.

* Capsule strictly erect: seeds somewhat scrobiculate-rugose.

D. INÉRMIs, Jacq. Vind. iii. 44, t. 82 , which may sometimes be met with in waste ground, is very similar to $D$. Stramonium, but with a perfectly smooth and unarmed capsule.

D. Stramónium, L. (Сommon Stramonitum or Jamestown-weed.) Green, glabrous, 1 to 4 feet high: leaves sinuately and laciniately angled and toothed: corolla white, about 3 inches long: capsule thickly armed with short stout prickles, the lower ones mostly shorter. - A weed of waste grounds, common, especially in the Atlantic States. (Nat. from Asia?)

D. TAtula, L. Stem purple, commonly taller: corolla pale violet: prickles of the capsule all nearly equal: otherwise similar to the preceding. - Waste grounds in the Atlantic States. (Nat. from trop. Amer.)

D. QUercifólia, HBK. Green, and young parts commonly somewhat pubescent: leaves sparingly but mostly deeply sinuate-pinnatifid: corolla nearly as of $D$. Tatula : capsule armed with large and unequal flattened prickles, some of the upper not rarely an inch long (nearly as in $D$. ferox). - S. W. borders of Texas to Arizona. (Nat. from Mex.)

* * Capsule nodding: seeds rugose-tuberculate.

D. Díscolor, Bernh. More or less cinereous-pubescent, low : leaves sinuately or laciniately toothed : corolla white tinged with purple, 2 or 3 inches long: globose capsule and its stout large prickles pubescent. - Linn. (in Lit.) viii. 138; Gray, Proc. Am. Acad. v. 165. D. Thomasii, Torr. in Pacif. R. Rep. v. 362, \& Bot. Mex. Bound. 155. - Colorado, Arizona, and S. E. California. (Introd,? from Mex.)

$\S 2$. Calyx tubular, mostly 5-toothed: corolla large, 6 to 8 inches long; the border with 5 or 10 acute teeth : capsule nodding on the short recurved peduncle, globose, succulent, bursting irregularly at maturity: seeds flatter, with a softer and pale smoothish coat: flowers erect.

D. meteloídes, DC. Pruinose-glaucescent with minute puberulence or pubescence, a foot to 3 feet high from a (at least commonly) perennicl root: leaves unequally ovate, merely repand or nearly entire: calyx cylindrical, about 3 inches long: corolla white suffused with violet, sweet-scented, 7 or 8 inches long when well developed, the widely dilated and very open funnelform limb 5 or 6 inches in diameter, and with 5 slender subulate teeth: persistent base of the calyx narrow: capsule 2 inches in diameter, thickly muricate with short and equal prickles: seeds with a narrow and sometimes cord-like margin. - Dunal in DC. Prodr. l. c. 544 (the descr. and drawing of Moçino and Sesse wrong as to 10-dentate corolla); Gray in Bot. Mex. Bound. 154; Fl. Serres, t. 1266. D. Wrightii, Hortul. ; Regel, Gartenfl. viii. t. 260. D. Metel, var. quinquecuspida, Torr. in Pacif. R. Rep. vii. 18. - Along streams, S. W. Texas, on the Rio Grande, to Arizona and Santa Barbara, California. (Adjacent Mex.)

12. HYOSCYAMUS, Tourn. Henbane. (From iss, vós, a hog, and xúcuos, a bean, said to poison swine.) - Natives of the Old World, one species, the medicinal Henbane, sparingly introduced.

H. Níger, L. (Black Henbane.) Biennial with a fusiform root, or sometimes annual, viscid-pubescent or villous, heavy-scented (narcotic), a foot or two high: leaves oblong, 
sinuate-tootherl or somewhat pinnatifid, the upper all more or less clasping and partly decurrent; uppermost subtending the secund at length spicate flowers : corolla lurid-yellowish with reticulated purple veins. - Waste grounds and roadsides. (Nat. from Eu.)

13. CÉSTRUM, L. (Ancient Greek name of some plant, applied by Linnælis to this genus.) - Shrubs or low trees of tropical America. Leaves entire, short-petioled,- pinnately veined. Flowers variously clustered on axillary peduncles, or forming a terminal panicle or corymb the corolla narrowly tubularfunnelform or clavate: berries reddish or blackish. - Several are in cultivation, both day-blooming. and night-blooming, the latter very sweet-scented. One species is sparingly spontaneous in Florida, viz. -

C. DIÚRndm, L. Glabrous: leaves oblong, very bright green above: flowers sessile in a short close cluster on an axillary peduncle: corolla white, enlarging very gradually from base to summit, not narrowed at the throat, half an inch long, with lobes short and roundish, open through the day. (Dill. Elth. t. 154, fig. 186.) - Key West. (Adv. from W. Ind.)

14. NICOTIÁNA, Tourn. Toвacco. (In memory of John Nicot, who was thought to have introduced Tobacco into Europe.) - Herbs, or one peculiar species arborescent, mostly American, narcotic-poisonous, heavy-scented, usually viscid-pubescent; with entire or sometimes repand or pandurate leaves, and paniculate or racemose flowers.

§ 1. TABÁCuy, Don. Capsule septicidal, dividing the two placentre; the valves at length 2-cleft at the apex: leaves ample: flowers diurnal, naked-panicled: corolla funnelform with ventricose throat and acute or acuminate spreading lobes or teeth, purplish-red or rose-color, sometimes white in cultivation.

N. Tabácum, L. (Common Tobacco.) Tall annual, more or less glutinous-pubescent: leaves from ovate- to narrowly lanceolate, acuminate, the lower commonly 2 or 3 feet long: flowers pedicelled: corolla about 2 inches long. - Cult. from S. Amer,, and spontaneous in waste grounds along the south-western borders of the United States.

Var. cxocláta, Sendtner, a marked form, with long and narrow lanceolate gradually caudate-acuminate leaves, undulate below, and corolla-lobes caudate-acuminate. - Mart. Fl. Bras. x. 166. N. lancifolia, Willd, \& $N$. Ybarrensis, HBK. To this probably belongs the Yaqui Tobacco, found by Dr. Palmer cultivated in Arizona, and also N. caudata, Nutt. Pl. Gamb., at Monterey, California.

§ 2. Nicótra, Gray. Capsule septifragal, 2-4-valved (in anomalous forms several-valved); the thin dissepiment remaining with the entire central placenta: corolla mostly white or greenish. Ours annuals. - Benth. \& Hook. Gen. ii. 907.

* Corolla oblong-inflated, open throughout the day: leaves all broad and petioled.

N. ntestica, L. A foot or two high, very viscid-pubescent: leaves ovate or the lower rounder and subcordate, very obtuse (often a foot long): flowers thyrsoid-paniculate: calyx with broad round-ovate teeth, not equalling the globular at first merely 2-valved capsule : corolla about three-fourths inch long, lurid yellowish or greenish, not thrice the length of the calyx, inflated from a short narrow base and with contracted orifice; the short and rounded lobes reticulate-ieiny. - Bart. Fl. Am. Sept. i. 25; Reichenb. Ic. Fl. Germ. xx. t. 1626. - Spontaneous in waste grounds, rare, formerly cult. by Indians. Probably indigenous to the Old World, but of unknown nativity.

* Corolla salverform or tubular-funnelform : calyx-lobes narrow.

+ Leaves undulate-crisped or repand, or panduriform, all the upper more or less clasping: flowers vespertine: tube of the corolla almost fillform, $1 \frac{1}{2}$ to $2 \frac{1}{2}$ inches long: filaments very short, inserted in the throat: stem loosely branching, racemosely loose-flowered.

N. plumbaginifólia, Viv. Somewhat scabrous-pubescent or glabrate: cauline leaves sessile and with partly clasping base, undulate and sometimes even crisped along the margins; the lowest oblong or obovate-spatulate; the others oblong-lanceolate and acuminate, 
above passing into linear-subulate bracts: corolla greenish-white, less than 2 inches long, somewhat contracted between the limb and the subclavately dilated throat; the lobes 2 or 3 lines long, acute. - Dunal in DC. 1. c. 569.-Damp grounds around Matamoras, Ber. landier. Probably on the Texan side of the Rio Grande also. (Mex., W. Ind.)

N. repánda, Willd. Minutely pubescent or above glabrate, 2 or 3 feet high, with loose slender branches, extending into open racemose or somewhat paniculate naked inflorescence: leaves thin ( 3 to 6 inches long and 1 to 4 wide), ovate, or the lower obovate and sometimes panduriform, commonly repand; the lowest contracted into a winged petiole; upper deeply cordate-clasping: bracts minute or often wanting: calyx-lobes slender, fully as long as the short-campanulate acutely 10-ribbed tube: corolla with tube frequently 2 inches long, somewhat clavate or funnelform at the open throat; the spreading limb white, or sometimes tinged with rose, 7 to 12 lines in diameter; its lobes short and obtuse or acutish. - Lehm. Nicot. 40, t. 3 (depauperate); Dunal in DC. l. c., but not Hook. Bot. Mag. and perhaps not $N$. lyrata, HBK. N. pandurata, Dunal, 1. c. $N$. Roemeriana, Scheele in Linn. xxi. 767. - Low grounds, Texas. (Mex.)

+ + Leaves entire, or the margins sometimes obscurely undulate: filaments slender,

++ Equally inserted low down on the tube of the salverform corolla, which is not enlarged at the throat, and is very much longer than the small obtusely 5 -lobed limb.

$=$ Leares, even the lower, with more or less clasping base : flowers open throughout the day.

N. trigonophylla, Dunal. Viscid-pubescent: stem 1 to 3 feet high, simple or virgately branched: leaves all sessile or only the lower tapering into a winged petiole, and obovate-oblong; the upper oblong-lanceolate with a broader cordate half-clasping base, or some spatulate-lanceolate with a dilated auriculate-clasping base (1 to 4 inches long): inflorescence at length loosely paniculate-racemose, with the later bracts very small or wanting, and somewhat unilateral pedicels about the length of the calyx: caly x-lobes subulatelanceolate but rather obtuse, equalling the campanulate tube, attaining the middle of the corolla-tube, about equalling the 4-valved capsule, somewhat callous-margined: corolla greenish-white or yellowish, about three-fourths inch long, somewhat pubescent, a little constricted at the orifice; the tube slightly enlarging upward; the sinuately-lobed limb about 4 lines in diameter. -DC. Prodr. xi. 562; Gray, Bot. Calif. i. 545. N. multifora, Torr, in Pacif. R. Rep. v. 362, excl. "Nutt. Pl. Gamb." N. ipomopsiftora, Gray, Proc. Am. Acad. v. 166, and perhaps of Dunal, 1. c., but the figure in Moçino \& Sesse, Ic. Fl. Mex. ined. t. 909, represents a more funnelform corolla. N. glandulosa, Buckley in Proc. Acad. Philad. 1862, 166. - Texas to S. E. California. (Mex.)

N. Pálmeri. Viscid-tomentose throughout, except the corolla: stem apparently 3 feet high, loosely branched above: leaves as of the preceding, but acuminate and mostly with undulate margins, the larger 5 or 6 inches long : flowers sparsely racemose, short-pedicelled: caly $x$-lobes lanceolate-subulate, somewhat unequal, longer than the tube, half the length of the corolla, conspicuously surpassing the capsule: corolla white tinged with green, an inch long, neither constricted nor dilated at the orifice, externally somewhat pubescent: the conspicuously 5-lobed limb 6 or 7 lines in diameter. - Northern Arizona, on Williams Fork, Palmer (no. 433, coll. 1876).

$==$ Leaves not clasping : flowers vespertine, and closing before noon or under sunshine.

N. Clevelándi. Viscid-pubescent, or the stem (a foot or two high) villous : leaves ovate or the upper ovate-lanceolate ( 2 or 3 inches long); the lower obtuse and with margined petiole not dilated at base; the upper subsessile and gradually narrowing from a broad and rounded or truncate subsessile base into an acuminate apex: bracts lanceolate: flowers paniculate-racemose; calyx-Iobes linear, unequal; the longer fully twice the length of the tube, more than half the length of the corolla: the latter greenish-white tinged with violet, almost glabrous, an inch long, quite salverform; the somewhat 5-lobed limb half inch in diameter. - California, in dry bed of streams, Chollas Valley near San Diego, Cleveland, Palmer (no. 267, coll. 1875). Near Santa Barbara, Rothrock, a smaller-flowered form.

N. attenuáta, Torr. More or less viscid-pubescent, a foot or two high: leaves all on saked and mostly slender petioles and acute or merely obtuse at base; the lower ovate or oblong ( $1 \frac{1}{2}$ to 4 inches long); the upper from oblong-lanceolate and attenuate-acuminate to linear-lanceolate or linear: inflorescence loosely paniculate and naked above: pedicels short: calyx-teeth triangular-lanceolate or subulate, with thin edges, almost equal, much 
shorter than the tube, not over a line and a half long, and not surpassing the capsule: corolla dull white or greenish, glabrous, slender-salverform; the tube an inch to inch and a half long; the obscurely 5-lobed or angulate limb 4 to 6 lines in diameter. - Watson, Bot. King, 276, t. 27, fig. 1, 2; Gray, Bot. Calif. i. 545. - Dry ground, California and Nevada to Colorado. (Guadalupe Island off Lower California, Palmer, referred to $N$. Biyluiti.)

+++ Filaments more or less unequally inserted in the upper part of the tube of the tubular-funnelform or salverform but open-mouthed white corolla, which is respertine and open by day only in dull weather: capsule thin-walled : herbage viscid-pubescent, often minutely so.

$=$ Orary and ovate 4-ralved capsule 2-celled as in all the foregoing: diameter of the limb of the corolla less than the length of the slender tube.

N. Bigelóvii, Watson. A foot or two high : leaves oblong-lanceolate, sessile or nearly so; the lower ( 5 to 7 inches long) with tapering base; the upper ( 3 to $1 \frac{1}{2}$ inches long) more acuminate, with either acute or some with broader and partly clasping base: inforescence loosely racemiform, with all the upper flowers bractless: calyx-teeth unequal, linear-subulate, about equalling the tube, surpassing the capsule: tube of the corolla $1 \frac{1}{4}$ to 2 inches long, narrow, with a gradually expanded throat; the 5-angulate-lobed limb 12 to 18 lines in diameter. - Bot. King, 276, t. 27, fig. 3,4 ; Gray, Bot. Calif. 1. ᄂ. 546. N. plumbaginifolia? var. Bigelowii, Torr. Pacif. R. Rep.jv. 127. - California, from Shasta Co. to San Diego, and eastward to Nevada and the border of Arizona.

Var. Wallácei, a form with corolla smaller (the tube 12 to 16 lines long), and calyx-teeth shorter, but variable, sometimes hardly surpassing the capsule: upper leaves more disposed to have a broad and roundish or subcordate slightly clasping base : herbage, \&c., more viscid. - Near Los Angeles and San Diego, Wallace, Cleveland.

$==$ Ovary and capsule globular, 4-several-cellerl, at first somewhat succulent: the valves at maturity thin and rather membranous: corolla with ampler limb and proportionally shorter more funnelform tube. - Polydiclia, Don. Polydiclis, Miers.

T. quadriválvis, Pursh. A foot high, rather stout, more or less viscid-pulbescent, lowbranching: leares oblong or the uppermost lanceolate, and the lower ovate-lanceolate, acute at both ends, mostly sessile ( 3 to 5 inches long); the lowest larger and petioled: flowers few: calyx-teeth much shorter than the tube, about equalling the 4-celled for sometimes 3-celled 3) capsule: tube of the corolla barely an inch long, the 5-lobed limb an inch and a half or more in diameter; its lobes ovate and obtusish, veiny. - Sims, Bot. Mag. t. 1778; Lehm. Nicot. 45, t. 4 ; Nutt. Gen. i. 132 ; Gray, Bot. Calif. l. c. Polydiclis quadrivalvis, Miers, Ill: i. 164, \& ii. 55, 60, fig. 2-14. - Oregon, and cultivated by the Indians from Oregon to the Missouri: their most prized tobacco-plant. Perhaps a derivative of the preceding species.

Var. multiválvis, Gray, I. c. An abnormal form of cultivation (by aborigines), generally stouter, with calyx, corolla (often over 2 inches wide), and stamens 5-8-merous, and capsule several-celled, sometimes an inch in diameter. $-N$. multivalvis, Lindl. Bot. Reg. t. 1057. Polydiclis multivalvis, Miers, 1. c. t. 60, fig. 1 \& 9. - Oregon, probably known only as an escape from aboriginal cultivation.

N. NÁNA, Lindl. Bot. Reg. t. 833, Nierembergia nana, Miers, must be Hesperochiron Californicus.

15. PETÚNIA, Juss. (Petun is an aboriginal name of Tobacco.) - Viscid South American herbs, with entire leaves, the upper disposed to become opposite, and scattered flowers becoming lateral: two large-flowered species and their hybrids familiar in gardens; an inconspicuous small-flowered one is a naturalized weed, and perhaps indigenous along the southern borders of the U. S. It forms a peculiar section, and has received several generic names.

P. parviflóra, Juss. A small prostrate or diffusely spreading annual, much branched, more or less pubescent: leaves oblong-linear or spatulate, rather fleshy, seldom half an inch long, nearly sessile: peduncles very short : caly $\mathrm{x}$-lobes resembling the smaller leaves: corolla purple with a pale or yellowish tube, 4 lines long, funnelform; its short retuse lobes slightly unequal: capsule small, ovoid.-Juss. in Ann. Mus, ii. 216, t. 47; Miers, Ill. i. t. 23; Dunal. 1. ؛. 575. Nicotiana parviflora, Lehm. Nicot. 48. Lindernia Montevidensis, Spreng. Callibrachoa procumbens, Llav. \& Lex. Nov. Mex. Veg. ii. 3. Salpiglossis prostrata, Hook. \& Arn. Bot. Beech. 123. Leptophragma prostruta, Benth. mss. ex Dunal, 1. c. 578. - 
Waste grounds and coasts, S. Florida and Texas to California; also adventive at some seaports of the Atlantic States : an insignificant little weed. (S. Amer., \&c.)

16. BOUCHETIA, DC. (In memory of D. Bouchet, an obscure botanist of the south of France.) - Prodr. xiii. 589, in part; Benth. \& Hook. Gen. ii. 908. - Single species.

B. erécta, DC. 1. c. Much branched from a perennial root, ascending, a span high, minutely appressed-pubescent: leaves oblong-spatulate, or the lower oval and petioled, and the upper lanceolate and sessile, rather small: peduncles terminal or lateral and scattered: corolla white, 6 to 9 lines long, about twice the length of the calyx; the broadly funnelform limb deeply 5-lobed; lobes roundish. - Nierembergia anomala, Miers in Lond. Jour. Bot. iii. 175, \& Ill. i. 99, t. 20 ; Dunal in DC. 1. c. 528 ; Torr. Bot. Mex. Bound. 156 . N. staticafolia, Sendtner in Mart. Fl. Bras. x. 179. Leucanthea Rameriana, Scheele in Linn. xxv, 259. - Moist prairies and rocky hills, Texas. (Mex., S. Brazil, \&c.)

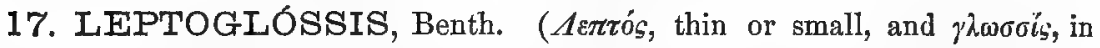
place of $\gamma$ thwizis, the mouth of the windpipe, the throat of corolla being narrow.) - Extra-tropical S. American herbs, resembling Nierembergia (which has 5 fertile stamens borne at and exserted from the orifice of the open saucer-shaped limb), but with tubular-funnelform throat, in the lower part or base of which the didynamous stamens are inserted. Besides the genuine species, a Texan and a Mexican species constitute a subgenus,

$\S 1$. BRACHYGLóssis, with strictly salverform corolla of Nierembergia; the long and filiform tube abruptly saccate-dilated just under the ample rotate limb: stigma rather narrowly 2-lobed, and the lobes alate-decurrent on the apex of the style : habit and foliage of Bouchetia. - Gray, Proc. Am. Acad. xii. 164.

L. Texána, Gray, l. c. Low perennial, diffusely much branched from a suffrutescent base, a span high, viscid-pubescent: leaves spatulate-obovate or oblong, acute (half inch long), narrowed at base, the lower into a short margined petiole: peduncles mostly shorter than the campanulate-funnelform 5-toothed calyx (the teeth deltoid) : corolla apparently white; the filiform tube 8 or 9 lines long; the almost regular broadly 5-lobed plane limb of about the same diameter; the very short campanulate throat hardly over a line in height and width: winged appendages under the stigma narrower than long: capsule only half the length of the 10-nerved calyx: seeds somewhat reniform, coarsely transverserugose, otherwise smooth. - Nierembergia (Leptoglossis) viscosa, \& Browallia (Leploglossis) Texana, Torr. Bot. Mex. Bound. 155, 156. - Rocky hills, W. Texas, Wright, Bigelow. (Adjacent Mexico, at San Carlos, Berlandier, no. 3194.) L. Coulteri, Gray, l. c., a nearly related Mexican species of this section, is minutely pubescent, and has ovate leaves on slender petioles, longer peduncle, calyx cleft to the middle, and rery broad wings to the apex of the style.

\section{ORDER XCVI. SCROPHULARIACEAE.}

Herbs, shrubs, or rarely small trees, with leaves either alternate or opposite and destitute of stipules, primary inflorescence centripetal and the secondary when developed centrifugal, perfect flowers with the bilabiately irregular corolla $\left(\frac{2}{3}\right)$ imbricated and not plicate in the bud, didynamous or diandrous stamens, 2-celled ovary with axile several-many-ovuled placentæ, usually capsular fruit, and anatropous or amphitropous seeds (generally numerous), with a small and straight or only slightly curved embryo in fleshy albumen, the cotyledons little if at all broader than the radicle. 'The calyx and corolla are mostly 5-merous, and the former persistent; but sometimes they are 4-merous, at least apparently, and 
either with or without all four stamens present; sometimes the corolla is nearly or quite regular, and even with all five stamens present and complete (uniformly so in Verbascum, abnormally in several species of Pentstemon); and the ovules are sometimes few and definite, rarely solitary. The posterior or superior stamen is the deficient or abortive one. Corolla wanting in one Synthyris. Style one and undivided : stigma either entire, or 2-lobed, or bilamellar (bilabiate); its lobes and the cells of the ovary anterior and posterior. Seeds comparatively small, rarely winged. - This large order has its tribes arranged by Bentham and Hooker (Gen. ii. 915) under three series, hardly to be regarded as suborders, the first of which closely connects with the preceding order, except as to inflorescence. The ambiguous Salpiglossidece are referred to that order.

I. (Pseudosolane.e.) Leaves all alternate. Inflorescence simply centripetal. Corolla hardly if at all bilabiate; the 2 posterior lobes external in the bud. All five stamens sometimes present and perfect.

Tribe I. LEUCOPHYLLEÆ. Corolla campanulate or short-funnelform; the lobes plane or merely concave.

1. LEUCOPHYLLUM. Calyx short, 5-parted; the lobes nearly valvate. Corolla with 5 rounded and spreading nearly equal lobes. Stamens 4 and didynamous, or rarely 5 and the fifth imperfect, included : anthers with cells confluent at the apex, at length divaricate. Stigma emarginate or bilamellar. Capsule 2-valved, and the valves at length 2cleft. Tomentose shrubs.

TRIBE II. VERBASCEÆ. Corolla rotate, with hardly any tube. Anthers by confluence 1-celled. (None indigenous to America.)

2. VERBASCUM. Stamens 5, all with anthers; all or the three superior filaments woolly-bearded. Style flattened and dilated at apex. Capsule globular or oblong, septicidally 2 -valved; the valves 2 -cleft at apex. Seeds very numerous, rugose.

II. (Antir Rhinides.) Leaves prevailingly opposite, at least the lower. Inflorescence when simple centripetal, when compound the partial centrifugal ; i.e. the peduncle cymosely few-several-flowered. Upper lip or lobes of the corolla external in the bud, with a few occasional and irregular exceptions. Fertile stamens very seldom more than four.

Tribe III. ANTIRRHINEA. Corolla bilabiate and more or less tubular; the base of the tube gibbous or saccate or spurred on the lower side, and the lower lip often with an intrusion (palate) at the throat. Capsule opening by irregular perforations or lacerate chinks, not by normal valves, many-seeded. Inflorescence simple and racemose, or the flowers solitary and axillary.

* Stamens 4, with more or less 2-celled fertile anthers.

3. LINARIA. Corolla with a spur at base (this rarely abortive) and a prominent palate nearly closing the throat. In the occasional monstrosity called Peloria, the corolla becomes regular by the production of 5 spurs and 5 regular short lobes.

4. ANTIRRHINUM. Corolla merely saccate or gibbous at base, otherwise nearly as Linaria, or the palate in some species much less prominent. Seeds destitute of any proper wing.

5. MAURANDIA. Corolla barely gibbous at base, nearly funnelform, ringent, with two longitudinal and commonly bearded intruded lines or plaits instead of palate. Capsule equal or hardly oblique. Seeds winged or wingless.

* Antheriferous stamens only 2 (the anterior pair); the posterior reduced to small abortive filaments.

6. MOHAVEA. Corolla with short tube merely giblous at base, and very ample bilabiate but somewhat campanulate-erect limb; the lips obovate-dilated or fan-shaped, the upper 2-lobed, the lower 3 -lobed and bearing a prominent but comparatively small palate, bearded down its middle; lobes all broad, erose-denticulate, and abruptly short-acuminate. Anthers of the two fertile stamens one-celled by confluence, Style slender and straight: 
stigma depressed-capitate. Capsule and the cyathiferous seeds of Antirrhinum $\S P_{\text {seudo- }}$ rontium.

Tribe IV. CHELONEÆ. Corolla more or less bilabiate and tubular, not saccate or otherwise produced at base anteriorly. Antheriferous stamens 4, and rudiment of the fifth commonly present. Capsule dehiscent by valves. Inflorescence normally compound (at least the peduncle 2-bracteate), and leaves opposite. (Chionophila is exceptional and of doubtful position, having flowers simply spicate, and the leaves sometimes alternate. In some species of Collinsia, the flowers are solitary in the axils on a bractless peduncle or pedicel.)

* Corolla gibbous or saccate on the upper or posterior side of the tube: ovules and seeds few or solitary in the cells: calyx deeply b-cleft, campanulate: peduncles or pedicels simple and ebracteate.

7. COLLINSIA. Corolla declined, deeply bilabiate; its upper lip 2-cleft, with lobes more or less erect and replicate; lower larger and 3 -lobed; its lateral lobes pendulous-spreading; middle one conduplicate into a keel-shaped sac which encloses the 4 declined stamens and style. Filaments long and filiform; the lower or anterior pair inserted higher on the corolla than the other: anthers round-reniform; their two cells confluent at the apex into one. Gland at base of corolla on the upper side represents the fifth stamen. Style filiform : stigma small, entire, or minutely 2-cleft. Capsule ovate or globose, at first septicidal; the valves soon 2-cleft. Seeds amphitropous and peltate, concave ventrally. Leaves undivided.

8. TONELLA. Corolla little declined, obscurely bilabiate, and the 5 more or less unequal lobes somewhat rotately spreading; the lower not enclosing the soon ascending stamens; tube slightly gibbous posteriorly. Ovules and seeds 1 to 4 in each cell, oval. Cauline leaves mainly ternately divíded or parted.

* * (Genuine Cheloneer.) Corolla-tube not gibbous posteriorly: ovules and seeds indefinitely numerous: calyx deeply 5-parted or of distinct sepals, imbricated: inflorescence mostly thyrsoidal, $i$.e the axillary clusters centrifugal or cymose, or when reduced to a single flower the peduncle or pedicel 2-bracteate: capsule septicidal.

- Sterile stamen represented by a scale on the upper side of the throat of the corolla.

9. SCROPHULARIA. Corolla short; the tube ventricose and globular or oblong; lobes 5 , unequal, four of them erect and the two posterior longer; the fifth or anterior reflexed or spreading. Stamens 4 , declined, usually included or shorter than the corolla lobes: anthers transverse and confluently 1-celled. Stigma entire or emarginate. Seeds marginless, rugose.

++ Filament of the sterile stamen conspicuous and elongated: corolla from ventricose-campanulate to elongated-tubular; the limb either obscurely or strongly bilabiate.

10. CHELONE. Seeds surrounded by a broad membranaceous wing. Otherwise nearly as Pentstemon. Anthers long-woolly as in the first division of that genus; the wool mainly confined to the inner face.

11. PENTSTEMON. Seeds angulate, marginless. Antheriferous stamens 4, declined at base, ascending above: filaments filiform : anther-cells either united or confluent at apex. Style filiform: stigma small, entire.

* * Corolla-tube not gibbous: ovules and seeds rather numerous : calyx not deeply cleft: inflorescence simply spicate: capsule at first loculicidal.

12. CHIONOPHILA. Calyx funnelform, thin-membranaceous becoming scarious, merely and obtusely 5-lobed. Corolla tubular, with slightly dilated throat and bilabiate limb, somewhat personate; upper lip ereet and slightly concave, barely 2-lobed, the sides somewhat recurved; lower with convex densely bearded base forming a palate, and 3 -lobed. the short lobes recurving. Stamens of Eupentslemon: cells of the anthers divaricate and confluent. Sterile filament small and short, or even minute, nalsed. Style filiform: stigma minute, entire. Capsule oblong, enclosed in the marcescent caly $x$ and corolla, loculicidally 2 -valved, and the valves soon septifragal and 2-parted; placental dissepiment flat. Seeds rather large, oblong, with a very loose and arilliform cellular-reticulated outer coat.

Tribe V. GRATIOLE E. Corolla from bilabiate to almost regular, not saccate or otherwise produced at base. Antheriferous stamens 2 or 4 : no rudiments of the fifth. Capsule dehiscent, many-seeded. Inflorescence simple and centripetal; the pedicels solitary in the axil of bracts or leaves and ebracteolate. Leaves opposite (or verticillate), or only the uppermost alternate. 
* Calyx prismatic and barely 5-toothed, or rarely campanulate and hardly 5-cleft : corolla more or less bilabiate: stamens 4.

13. MIMULUS. Corolla with either elongated or short tube; upper lip 2-and the lower 3 -lobed or parted; the former often erect and the sicles turned back; a pair of palatine ridges (either bearded or naked and more or less intrucled) running down the lower side of the throat. Stamens inserted low within the throat or on the tube. Anthers generally approximate in pairs, on filiform filaments; their cells divergent, either distinct or contluent at the apex. Style filiform: stigma bilamellar, or sometimes peltate by the union of the two dilated lips, or rarely even funnelform. Capsule enclosed in the calyx, loculicidal; the placentæ either firmly united, or in one section barely contiguous in the axis.

* * Caly x 5-parted: corolla more or less bilabiate: stamens 4, inserted below the throat, included : anther-cells distinct.

+ Sepals narrow and nearly alike : capsule septicidal or septifragal.

14. STEMODIA. Corolla with cylindraceous tube, somewhat erect and hardly 2-lobed upper lip, and more spreading lower one. Anther-cells separate and stipitate. Stigna 2-lobed. Capsule with valves soon 2-parted: placentæ left in the axis.

15. CONOBEA. Corolla nearly of the preceding, or more equally 5-lobed. Anther-cells distinct but not stipitate, parallel. Stigna bilamellar. Capsule septifragal; valves en tire or rarely 2 -cleft. Seeds striate.

++ Sepals unequal and imbricated; the posterior one considerably or much broader than the anterior; the two lateral interior and usually much narrower: capsule septicidal or loculicidal; the valves entire or 2-parted, separating from the undivided placentiferous colunn.

16. HERPESTIS. Corolla with short cylindraceous tube, and spreading lips; upper emarginate or 2-lobed; lower 3-lobed, plane. Anther-cells parallel or divergent. Capsule globose or ovate.

* * Calyx 5-parted or deeply 4-5-Jobed : antlieriferous stamens only 2,

- The posterior pair; the anterior pair sterile rudiments or sometimes wanting:-flowers not minute: corolla manifestly bilabiate; upper lip entire or 2-lobed; lower 3-cleft: sepals narrow, little unequal : stigma dilated and mostly bilamellar.

17. GRATIOLA. Corolla with cylindraceous tube and lips nearly of equal iength. Stamens both fertile (with anther-cells distinct) and sterile inserted below the throat and included. Capsule both loculicidal and septicidal; valves separating from the placentiferous column. Seeds striate and transversely reticulated.

i8. ILYSANTHES. Corolla with cylindraceous tube, or more dilated throat; upper lip erect and concave, 2-lobed; lower larger, spreading, with 3 broad nearly equal lobes. Fertile stamens inserted rather low down and somewhat included: sterile filaments inserted at the orifice and forked; one fork glandular and obtuse; the other smooth and naked, acute, sometimes reduced to a mere tooth, sometimes more elongater and even bearing the rudiment of an anther. Capsule ovoid or oblong, septicidal or septifragal; the valves entire, at length separating from the placentiferous column. Seeds foveolaterugose.

- The anterior pair of stamens antheriferous, at least only a single pair antlıerifcrous, and no rudiments of sterile ones: flowers minute: corolla only 4-lobed: anthers short, of roundish distinct cells.

19. MICRANTHEMUM. Calyx usually 4-cleft or 4-lobed. Corolla with very short tube, obscurely bilabiate; its upper lip short or almost none; the lower 3 -lobed and the middle lobe longer. Stamens inserted in the throat: filaments short, dilated or appendaged at base. Style short: stigma dilated or 2-lobed. Capsule globular, thin, becoming 1-celled by the vanishing of the partition, leaving the several-many-seeded placenta in the axis. Seeds oblong, minute.

20. AMPHIANTHUS. Calyx 5-parted, unequal. Corolla funnelform, with spreading 4cleft limb; lobes rounded, one of then larger. Stamens on the tube of the corolla, included: filaments filiform, not appendaged. Style subulate: stigma minutely 2-cleft. Capsule obcordate, compressed, loculicidal; valves bearing the partition. Seeds numerous, linear-oblong, striate, transversely rugulose.

* * * Calyx and corolla both 5-lobed and nearly regular: antheriferous stamens 4, nearly equal: no sterile filament.

21. LIMOSELLA. Calyx campanulate; the lobes short. Corolla between rotate and campanulate; its lobes oblong or ovate. Stamens borne on the tube of the corolla: filaments slender, unappendaged: anthers by confluence 1-celled. Style short: stigma depressed-capitate. Capsule globose-ovoid, 2-celled only at base; the large central placenta many-seeded. seeds ovoid, rugulose. 
III. (Rhinanthidex.) Leaves various. Inflorescence simply centripetal. Lower lip or lateral lobes of the corolla external in the bud. Stamens very rarely more than 4 .

Tribe VI. DIGITALEÆ. Corolla usually little if at all bilabiate; the lobes all plane, the lateral or one of them external. Anther-cells contiguous at apex and often confluent. Herbs, or some shrubs, none parasitic.

* Stamens 4 or sometimes 5, nearly equal: corolla short-campanulate or nearly rotate.

22. SCOPARIA. Sepals 4 or 5 , rather broad, imbricated. Corolla 4-cleft, densely hairy in the throat. Stamens 4 : anther-cells distinct. Style slightly clavate: stigma truncate. Capsule septicidal. Leaves opposite or verticillate.

23. CAPRARIA. Sepals 5, narrow, hardly imbricated. Corolla 5-cleft. Stamens often 5 : anthers sagittate or horseshoe-shaped; the cells confluent at apex. Style with thickened apex : stigma 2-lobed. Capsule 2-sulcate, loculicidal. Leaves alternate.

* * Stamens 2 (only abnormally 3 or 4), distant, straight, exserted, inserted at or below the sinuses between the two lateral and the posterior lobe of the corolla : style usually filiform, with terminal usually small-capitate stigma : capsule mostly compressed and obtuse or emarginate, few-many-seeded, loculicidal ; the valves tardily if at all separating from the placentiferous axis. (Hypogynous disk mostly conspicuous and crateriform or annular.)

24. SYNTHYRIS. Corolla from oblong- to short-campanulate, 4-cleft, more or less irregular (upper lobe longer), sometimes irregularly and variably parted, occasionally wanting. Sepals 4, oblong. Anther-cells parallel or somewhat divergent below, not confluent at apex. Placentæ short, chiefly at the centre of the valves. Seeds discoidal, orbicular or oval, with very close and strictly conformed smooth coat.

25. VERONICA. Corolla from rotate with very short or hardly any tube to salverform; its lobes 4 (or sometimes 5), one usually smaller. Anther-cells more or less confluent at the apex. Seeds various.

Tribe VII. GERARDIEAE. Corolla little or not at all bilabiate; the lobes all plane and mostly spreading, the anterior one external in the bud. Stamens 4: anther-cells distinct to the very apex, or sometimes one of them wanting. Capsule loculicidal, many-seeded. Herbs, most of them partially root-parasitic, and their green foliage inclined to blacken in drying: some African and Indian genera are wholly parasitic and destitute of green herbage, in the manner of Orobanchacea.

* Anthers by abortion 1-celled: corolla salverform; tube slender: flowers 2-bracteolate.

26. BUCHNERA. Calyx tubular or oblong, 5-10-nerved, 5-toothed. Corolla with straight or slightly curved tube, and almost equally 5-cleft widely spreading limb. Stamens didynanous : anthers approximate in pairs; the cell vertical. Style with somewhat clavate and entire apex. Valves of the oblong capsule separating from the placentiferous axis. Seeds with reticulated close coat.

* * Anthers 2-celled; the cells equal and parallel : pedicels ebracteolate.

+ Stamens equal or nearly so, more or less exserted : posterior lobes of the corolla united to near their middle.

27. SEYMERIA. Corolla short, somewhat campanulate or rotate, pale yellow, calyx 5 cleft or parted. Filaments short, usually woolly at base : anthers obtuse at base, not exceeding the corolla-lobes. Capsule globular or ovate, with more or less pointed and compressed apex. Seeds with a loose reticulated coat.

28. MACRANTHERA. Corolla (orange-color) salverform, with tube very much longer than the small lobes; its narrow orifice somewhat oblique; posterior and partly united lobes somewhat erect, the others soon reflexed. Calyx 5-parted; the divisions long and narrow. Stamens inserted toward the bottom of the corolla : filaments filiform, becoming conspicuously exserted, sparsely glandular-hairy, as are the linear-oblong anthers when young: cells of the latter acuminate at base. Style long and filiform: stigma simple or 2-cleft. Capsule glohose and bisulcate; the valves at length 2-cleft. Seeds obovate, lamellate-crested on the back.

$$
++ \text { Stamens conspicuously didynamous, shorter than the corolla. }
$$

29. GERARDIA. Corolla from campanulate to funnelform; the throat ampliate; limb 5-parted, and with the two posterior lobes often rather smaller or more united. Caly $x$ campanulate, $\tilde{5}$-toothed or 5-cleft. Stamens commonly more or less hairy: anthers more or less approximate in pairs. Style filiform : stigma clavate-thickened or flattened. Seeds usually angulate and with a rather loose coat. 
Tribe VIII. Euphrasifa. Corolla, manifestly bilabiate; the upper lip erect and concave or galeate, entire or emarginate, rarely 2-cleft; the lower 3-cleft, mostly spreading, external in the bud. Stamens 4 and didynamous, or rarely 2 , ascending under the upper lip: anther-cells distinct, sometimes one abortive or wanting. Style mostly filiform and stigma entire, rarely 2-lobed. Capsule loculicidal. Leafy herbs, not rarely drying blackish; these partially root-parasitic.

* Ovules and usually the seeds numerous.

- Anther-cells unequal or dissimilar; the outer one affixed by its middle; the other pendulous from its upper end, mostly smaller, sometimes sterile or deficient: seeds with a loose reticulated coat: leaves alternate or only the lowest opposite.

30. CASTILLEIA. Calyx tubular, laterally flattened, more or less cleft anteriorly or posteriorly or both; the lobes entire or 2-cleft. Corolla tubular, more or less laterally compressed, especially the elongated and conduplicate or carinate-concave and entire upper lip (galea); lower lip short and small, often very small, 3-toothed, 3-carinate or somewhat saccate below the short teeth; the tube usually enclosed in the calyx. Stamens 4 , all with 2 -celled anthers.

31. ORTHOCARPUS. Calyx tubular-campanulate, 4-cleft, or cleft anteriorly and posteriorly and the divisions 2-cleft or parted. Corolla mostly with slender tube; upper lip (galea) little longer and usually much narrower than the inflated 1-3-saccate lower one. Stamens 4 ; the smaller anther-cell sometimes wanting.

32. CORDYLANTHUS. Calyx spathaceous, diphyllous (anterior and posterior), or by the absence of the anterior division monophyllous. Corolla tubular, with lips commonly of equal length; the upper (galea) nearly as in Orthocarpus; the lower 3-crenulate or entire. Stamens of Orthocarpus, or sometimes the shorter pair wanting: anther-cells either ciliate or minutely bearded at base and apex. Style hooked at tip and somewhat thickened under the stigma. Seeds mostly few.

++ Anther-cells equal, parallel and alike in all 4 stamens.

t+ Flower 2-bracteolate under the calyx.

33. SCHWALBEA. Calyx tubular, 10-12-ribbed, oblique, 5-toothed; the posterior tooth much smaller; the 2 anterior united higher. Corolla with cylindraceous tube and lips of almost equal length; the upper erect and galeate, oblong, entire; lower erect-spreading, 2-plicate at base, obtusely 3 -lobed at summit. Stamens slightly didynamous : anthers oblong; the cells barely mucronulate at base. Seeds linear, with a loose hyaline coat, including a small nucleus.

+ Flowers ebracteolate.

34. EUPHRASIA. Caly $x$ tubular or campanulate, 4-cleft, and rarely with a fifth small posterior lobe. Corolla with dilated throat; upper lip erect, barely concave, 2-lobed, and the sides folded back ; lower larger, 3-lobed, spreading; its lobes obtuse or emarginate. Anther-cells mucronate at base. Seeds numerous, pendulous, oblong, longitudinally sulcate. Leaves opposite.

35. BARTSIA. Caly $x$ equally 4-cleft. Corolla with upper lip entire and sides not folded back. Seeds sulcate and with salient or alate ribs. Otherwise much as Euphrasia.

36. PEDICULARIS. Calyx various, cleft anterioriy and sometimes posteriorly. Corolla with cylindraceous tube and narrow throat, strongly bilabiate; upper lip (galea) compressed laterally, fornicate or conduplicate ; lower erect at base, 2-cristate above, 3-lobed; the lobes spreading or reflexed, the middle one smaller. Anthers transverse, approximate in pairs. Capsule compressed and often oblique or falcate, rostrate. Seeds numerous, various. Leaves mainly alternate or verticillate.

37. RHINANTHUS. Calyx ventricose-compressed, 4-toothed, inflated in fruit. Corolla with cylindraceous tube; galeate upper lip ovate, obtuse, compressed, entire at the apex, but with a minute tooth on each side below it; lower lip shorter, with 3 spreading lobes. Anthers approximate in pairs, transverse, pilose, nuticous. Capsule orbicular, compressed. Seeds few in each cell, orbicular, wing-margined. Leaves opposite.

* * Ovules only two in each cell, one sessile and ascending, the other stipitate and laterally attached: flowers ebracteolate: leaves opposite: flowers in our species scattered.

38. MELAMPYRUM. Calyx campanulate or short-tubular, 4-toothed; the teeth usually setaceous-acuminate, the posterior larger. Corolla with cylindraceous tube, enlarging at throat: galeate upper lip erect, compressed, obtuse, and with narrow replicate margins or a tooth to each; lower rather longer, erect-spreading, biconvex below. 3-lobed at apex. Stamens 4 : anthers approximate in pairs, nearly vertical; the cells equal and parallel, mucronulate at base. Capsule compressed, oblique or falcate: cells 1-2-seeded. Seeds smooth, strophiolate. 
1. LEUCOPHYLLUM, Humb. \& Bonpl. (Avvrós, light or white, and cúd dov, foliage.) - Low and much-branched shrubs (of Mexico and its northern borders), densely scurfy-tomentose with usually silvery-white wool; the flowers showy, on short bractless peduncles in the axil of the small obovate or roundish and short-petioled entire leaves; the corolla violet-purple. Fl. in spring and early summer. - Pl. Aquin. ii. 95, t. 109; Miers, Ill. ii. 76, t. 58.

L. Texánum, Benth. Shrub 2 to 8 feet high: leaves tomentose, obovate, half inch or more long, almost sessile : calyx-lobes lanceolate-oblong : corolla almost campanulate; the limb an inch in diameter, delicately soft-villous within. - DC. Prodr. x. 344 ; Gray in Bot. Mex. Bound. 115. - Southern borders of Texas, Berlandier, Wright, \&c. (Adjacent Mex.)

L. mínus, Gray, l. c. A foot or two high: leaves minutely silvery-canescent, obovatespatulate with long tapering base, half inch or less long: calyx-lobes linear: corolla with narrower and more funnelform tube and throat which much exceed the limb; this half inch in diameter, sparsely pubescent within. - South-western Texas, Wright, Bigelow, Parry.

2. VERBÁSCUMM, L. MulLein. (Altered from Barbascum, old Latin name.) - Coarse weeds, from Europe, mostly biennials; cauline leaves sessile and often decurrent on the stem: flowering in surnmer: flowers ephemeral. $\mathrm{Hy}$ brids abound.

* Woolly or scurfy, tall and stout: flowers yellow, occasionally white.

V. Thapsus, L. (Common Mulleir.) Densely woolly throughout: stem simple, 3 to 6 feet high, winged by the decurrent bases of the oblong nearly entire crowded leaves: flowers in a dense long spike, yellow : lower filaments mostly naked - Fields, a common weed in the Atlantic States, rare in the Pacific. A white-flowered form ( $V$. elongatum, Willd.), probably of hybrid origin, occurs occasionally. (Nat. from Eu.)

V. Lychnítis, L. (White Mulcein.) Clothed with fine somewhat mealy woolliness, often paniculate-branched at summit: leaves ovate, acute, somewhat crenate, not decurrent, the upper sûrface becoming naked and green: racemes panicled, close: filaments white-woolly. - Fields, N. Atiantic States, rather rare. (Nat. from Eu.)

* Slender, green, more loosely-flowered, filaments all bearded with violet woolly hairs.

V. Blattária, L. (Motr Muldein.) Below glabrous; the loose virgate raceme and calyx glandular: leaves oblong, obtuse, crenate or sometimes sinuate, not decurrent; the small upper ones ovate, acute, partly clasping: pedicels solitary and much longer than the linear-lanceolate calyx-lobes : corolla yellow or white and purple-tinged. - V. Claytoni, Michx. Fl. i. 148. Roadsides, Atlantic States. (Nat. from Eu.)

V. viRgÁtum, Withering. Somewhat pubescent or hairy as well as glandular, especially the raceme: pedicels often in twos and threes, not longer than the calyx-lobes: otherwise very like a taller form of the last. - California. (Nat. from Eu. by way of Mexico?)

3. LINÅRIA, Tourn. Toad-Flax. (Name formed from Linum, Flax.) - Herbs, chiefly natives of the Old World. Calyx 5-parted. Style filiform: stigma small, nearly entire. Leaves, \&c., very various. Fl. summer.

* Indigenous species, slender glabrous annuals or biennials; with entire leaves, linear and alternate on the erect flowering stems, smaller and oblong and mainly opposite or whorled on procumbent shoots or suckers from the base: small blue flowers in a naked terminal raceme.

I. Canadénsis, Dumont. Flowering stems nearly simple, 6 to 30 inches high: leares flat (a line or two wide): pedicels erect, not longer than the filiform and curved spur of the corolla. - Chav. Mon. Antirr. 149; Hook. Bot. Mag. t. 3473. Antirrhinum Canadense, L. ; Vent. Cels, t. 49. Linaria Texana, Scheele in Linn. xxi. 761, large-flowered form.Sandy or gravelly soil, Canada to Texas, California, and Oregon. (S. Amer., \&c.)

L. Floridána, Chapm. Flowering stem at length paniculately branching, a span or two high; its leaves filiform: pedicels spreading, filiform, sparsely and minutely glandular-hispid, much longer than the flower: raceme at length flexuous : spur very short and inconspicuous, subulate, slightly projecting below the calyx. - Fl. 290. - Sands of the 
coast, E. and W. Florida. Corolla much smaller than in the preceding, 2 or 3 lines long. Seeds shorter, paler, smoother, and less broadly truncate at apex.

$$
\text { * * Naturalized from the old World. }
$$

+ Perennial, erect, 1 to 3 feet high, glabrous, with narrow entire and alternate pale leaves, and yellow flowers in a terminal raceme.

L. volgAris, Mill. (Ramsted, Butter \& EgGs.) Leaves linear or nearly so, extremely numerous: raceme dense, often paniculate below : corolla an inch or more long, including the slender subulate spur: seeds winged.-Fields and road-sides, Atlantic States: a showy but pernicious weed. (Nat. from Eu.)

L. Genistifólid, Mill. Glaucous, paniculately branched: leaves lanceolate, acute: flowers smaller and more scattered : seeds wingless. - Sparingly naturalized near New York. (Adv. from Eu.)

+ + Annual, proumbent, and mucl branched, with broad and abruptly petioled veiny alternate leaves, and purplish and yellow small flowers from their axils.

L. Elátise, Mill. Spreading over the ground, slender, hairy: leaves hastate or the lower ovate, much surpassed by the filiform peduncles: calyx-lobes lanceolate, acute: corolla 3 or 4 lines long, including the subulate spur. - Sandy banks and shores, rather rare. Canada to Carolina. (Nat. from Eu.)

L. SPúRxa, Mill., like the preceding, but with roundish or cordate leaves and ovate or corlate caly $x$-lobes, and one or two other Old World species occasionally spring up in ballast or waste grounds near cities. L. Cymbalairia, Mill, a smooth and delicate creeping species, is common in cultivation, but seldom becomes spontaneous.

4. ANTIRRHINUM, Tourn. Snapdragon. (Avíg@ivov of Theophrastus, from the snout-like aspect of the flowers.) - Herbs, rarely shrubby, of very various aspect, indigenous to the warmer parts of the Old World and of North America and Mexico, in our species all or all but the lower leaves alternate. Calyx deeply 5-parted. Cells of the authers either distinct or more or less confluent.

§1. Oróntiur, Benth., partly. Capsule oblique, firm-coriaceous; the cells opening by a definite hole at the top: seeds cup-shaped on ventral face, with thickened incurved border, smooth and carinately one-ribbed on the back.

A. Oróstium, L. Annual, a span or two high, erect, slender, glandular-pubescent: leaves oblong-linear or lanceolate, entire : flowers subsessile: corolla purple or white, half inch long. - Cult. and waste ground, sparingly spontaneous in Atlantic States. (Nat. from Eu.)

§2. Psecdorónticm, Gray. Capsule not oblique, somewhat didymous, chartaceo-membranaceous; the equal cells irregularly bursting at the apex: seeds strongly cup-shaped; the body muriculate on the back and far smaller than the involute wing. - Proc. Am. Acad. xii. 81.

A. crathifervis, Benth. Bot. Sulph. 40, t. 19, of Lower California, appeurs to differ from the following in having linear-lanceolate sepals, of only half the length of the tube of the corolla, and a shallower cup to the seeds.

A. chytrospérmum, Gray, 1. c. Annual, viscid-pubescent : stem a span to a foot high: leaves ovate, entire, 3 to 9 lines long and contracted into a margined petiole: flowers axillary, short-peduncled: sepals oblong-lanceolate, equalling the tube of the purple corolla (this barely 3 lines long): cup of the seed several times larger than the body.Nhrenberg, Arizona, Palmer.

§3. Antirrhinfistrix, Chavannes. Capsule more or less oblique; the persistent style or its base bent forward: cells opening by one or two holes: seeds rugose-alveolate or tuberculate, similar on the two sides: palate of corolla closing the orifice or nearly so: leaves entire, pinnately.veined, and with short petioles or none. 
* Perennial OId World species.

A. MAJUs, L. (Common Snapdragon.) A foot or two high : leaves thickish, from oblong to linear, smooth: flowers short-pedicelled in a glandular-pubescent terminal raceme: corolla $1 \frac{1}{2}$ or 2 inches long, purple, rose, or white. - Sparingly escaped from gardens to road-sides in Atlantic States.

* * Indigenous Californian species, annual so far as the root is known, small-flowered: prominent palate closing the orifice of the corolla ; its upper lip spreading and lobes of the lower usually deflexed : filaments dilated at their apex. - \$ Scerorhinum, Graj, Proc. Am. Acad. vii. 372, but a misnomer, the palate not gaping.

+ Erect, in no way climbing, destitute of prehensile branchlets.

++ Flowers racemose-spicate, mostly rose-colored : capsule surmounted by a slender style : seeds fimbrillate-favose.

A. Vírga, Gray. Glabrous throughout: root not seen : stem strict, simple, 2 or 3 feet high: leaves thickish, linear-lanceolate; the lower 2 or 3 inches long, often 3 lines wide; the upper passing into filiform-subulate bracts of the long virgate spiciform raceme: flowers sometimes secund, soon horizontal : corolla with cylindrical tube (half inch long) fully twice the length of the lips and of the ovate-lanceolate sepals; sac at base mammæform: filaments viscid-hirsute; the dilated tips of the longer pair broader than the anther: capsules erect, ovoid, longer than the unequal sepals. - Proc. Am. Acad. vii. 373, \& Bot. Calif. i. 549. - W. California, Bridges, in flower. Mendocino Co. in fruit, G. R. Vasey.

A. glandulósum, Lindl. Very glandular-pubescent and viscid throughout: stem stout, branching, 3 to 5 feet high, very leafy : leaves lanceolate, mostly sessile, above gradually passing into bracts of the leafy dense spike or raceme; these equalling or shorter than the oblong tube of the corolla: sepals oblong-lanceolate, unequal; the longer equalling the capsule: filaments all moderately dilated upwards. - Bot. Reg. t. 1893; Benth. in DC. Prodr. x. 291. - Dry ground, California, from Santa Cruz south ward.

++ Flowers sessile or nearly so in the axils of all but the lowest almost uniform leares : corolla only 3 or 4 lines long, vellowish or dull purplish; the lips nearly the length of the tube; the sac prominent: sepals equal, linear, not longer than the ovate-globular capsule; the whole style indurated and persistent, stout at base.

A. cornútum, Benth. Viscid-villous, simply branched, a foot or so high : leaves linearoblong or lanceolate, obtuse (an inch long); the lower tapering into a short petiole: filaments all obliquely obovate-dilated at apex: style rather longer than the capsule: seeds echinate-favose. - Pl. Hartw. 328; Gray, Proc. Am. Acad. l. c.-Valley of the Sacramento, California, Hartweg.

A. leptáleum, Gray, l.c. Viscid-villous, mostly simple, a span or two high: leaves nearly linear, mainly sessile (the lowest less than an inch long, uppermost small and spatulate-oblong): shorter filaments hardly dilated at apex: style rather shorter than the capsule: seeds rugose-pitted. - A. cornutum, Durand in Pacif. R. Rep. v. 11, t. 10, not Benth. - California; Sierra Nevada from Mariposa Co. to Kern Co.

+ + Spreading or erect, branching, producing filiform and at length tortile axillary branchlets by which the plant is disposed to climb: calyx unequal: corolla (purple, violet, or yellowishwhite) short; both lips spreading, the lower usually conspicuously larger and as long as the tube.

+ Flowers in a naked spike or dense raceme : bracts minute.

A. Coulteriánum, Benth. Stem 2 to 4 feet high, gaining support by its numerous filiform tortile branchlets acting as tendrils, below glabrous, as also the (from linear to oval) distant leaves: inflorescence villous-pubescent with viscid and sometimes glandular hairs; the spike virgate, 2 to 10 inches long: pedicels shorter than the calyx: sepals linear or lanceolate, obtuse, the 3 upper a little longer, all shorter than the oval or ovateoblong glandular-pubescent capsule, which is twice the length of the style. - DC. Prodr. x. 5.92 ; Gray, l. c. - Santa Barbara Co. to San Diego, California. Corolla either violetpurple or white with yellowish palate; the lower lip with its great palate forming the larger part of the flower; the tube only 3 lines long, its sac broad and mammæform. Tendril-shoots mostly below, sometimes also in the lower part of the inflorescence.

\footnotetext{
+ +- Flowers (purple) scattered along the slender diffuse branches, or somewhat racemose but leafy-bracteate at the summit, often accompanied by tortile prehensile branchlets from the same axils : upper sepal conspicuously larger than the others: leaves short, from linear to ovate.

$=$ Peduncles shorter than the flower, mostly shorter than the calyx or hardly any: tube of the corolla rather longer than the lips: seeds tuherculate.
} 
A. vágans, Gray, 1.c. Very diffuse, sparsely setose-hirsute and often glandular, varying to nearly glabrous: leaves from lanceolate to oblong-ovate, thickish : flowers comparatively large (half inch long): sepals or at least the large and mostly oblong upper one equalling the tube of the corolla; the others linear: style slender, as long as the capsule. -Watson, Bot. King, 216, t. 21, fig. 5. A. Coulterianum, var. appendiculatum, Durand, 1. c. 11, t. 11. - California, common through the western part of the State.

Var. Bolánderi, Gray, l. c., a form with broader and thinner leaves, those of the tortile branchlets orbicular, and unusually large posterior sepal, grows mainly in the shade of Redwoods. A. Breweri, var. ovalifolium, Gray, Proc. Am. Acad. 1. c. 375, from the upper part of the Sacramento River, may be a depauperate form of this, with shorter calyx, approaching the following.

A. Bréweri, Gray, 1. c. Slender, at first erect, a foot or two high, minutely or softly viscid-pubescent : leaves from oblong-linear to oval (half to an inch long), obtuse: pedicels shorter than the calyx: flowers snull; the tube of the corolla (only 3 lines long) considerably longer than the moderately unequal sepals, rather narrowly saccate at base: style subulate, glandular, at length strongly deflexed, rather shorter than the capsule. California, common from Lake Co. to Plumas Co. and northward.

$==$ Peduncles more conspicnous: tube of the corolla not longer than the widely spreading lips, merely gibbous at base: the weakly tortile branchlets bearing small leaves.

A. Nuttalliánum, Benth. Softly viscid-pubescent, sometimes glabrous helow, at length diffusely much branched, 1 to 3 feet high : leaves ovate or subcordate (the largest an inch long), nearly all distinctly petioled: peduncles or at least the lower ones longer than the flowers, sometimes longer than the leaf and disposed to be tortile: sepals shorter than (or the ovate or oval posterior one equalling) the tube of the violet-colored corolla (this 2 or 3 lines long) : palate very prominent: seeds almost alately costate.-DC. Prodr. x. 592 ; Gray, l. c. - Common through S. California, near San Diego, \&c.

Var. effúsum, Gray. Slender stems climbing over bushes by tortile leafy branchlets, reaching 4 or 5 feet high : filiform peduncles mostly twice the length of the leaves: ribs of the seeds less wing-like. - Bot. Calif. i. 622. - S. E. California, in the Mohave region, Parry, Lemmon, Palmer.

A. Kíngii, Watson. Slender, mostly erect, a span to a foot or more high, somewhat hairy at base, above nearly glabrous : leaves from narrowly tanceolate to linear; the uppermost minute: pedicels at length equalling or exceeding the sparsely glandular calyx : corolla small ( 2 or 3 lines long, dull white); its tube half the length of the linear-oblong posterior sepal and about equalling the other sepals; the lips small: persistent style short and subulate, glabrous, half the length of the slightly oblique globular capsule: seeds favosetuberculate. - Bot. King, 215, t. 21, fig. 1-4. - N. W. Nevada to Utah, Watson, Lemmon, \&c.

§ 4. Mavrandélla, Gray, 1. c. Capsule and calyx equal or nearly so : seeds as in preceding : corolla with prominent palate partly or quite closing the orifice : herbs with entire or lobed leaves (all but the lower alternate), destitute of prelensile branchlets, but mostly climbing by tortile filiform petioles or peduncles, or by both, mainly glabrous. - Maurandia $\$$ Antirrhiniflora, Benth. in DC. 1. c.

* Annuals, with mostly lanceolate or linear short-petioled leaves, but long and filiform prehensile peduncles: caly $x$ rather shorter than the giobose capsule.

A. stríctum, Gray, 1. c. Erect, nearly simple, a foot or two high : lowest leaves ovatelanceolate; upper ones linear, or the upper floral filiform, much shorter than the tortile racemose peduncles: corolla violet-purple (nearly half inclı long), with hairy palate and gibbous base: capsule crustaceous, tipped with a straight style of equal length. - Maurandia stricta, Hook. \& Arn. Bot. Beech. 375; Benth. l.c.-California, near Santa Barbara, Douglas, Brewer.

A. Coóperi, Gray, l. c. Climbing 2 to 4 feet high by the long filiform peduncles (of 2 or 3 inches in length):-very slender stems at length much branched: lowest leaves ovate or oblong; the others linear; upper floral minute: corolla bright yellow (half inch long), conspicuously saccate at base, with hairy palate: style deciduous from the nearly membranaceous capsule: seeds rough-rugose and with 3 or 4 corky ribs. - Ravines near Fort Mohave, S. E. California, Cooper, Almendinger. S. Utah, Parry. 
A. fillipes, Gray, 1. c. More delicate than the preceding, and with broader more mernbranaceous leaves : capillary tortile peduncles equally long: flowers very small, "white." - Ives Colorad. Exped. Bot. 19. - Arizona, in desert arroyos of the Colorado, Newberry. Flowers perhaps imperfect, the corolla little exceeding the calyx. Perhaps a depauperate or attenuated state of the foregoing. * Perennial, climbing by the slender tortile petioles and axillary peduncles : calyx longer than

A. maurandioídes, Gray, l.c. Low or tall climbing: leaves triangular-hastate or the lower cordate-hastate; the lateral lobes often with a posterior tooth: corolla purple or sometimes white (half to an inch long), with a nearly closing palate: sepals lanceolate, very acute: style slender: seeds strongly costate, the ribs corky. - Usteria antirrhiniflora, Poir. Maurandia antirrhiniflora, Willd. Hort. Berol. t. 83; Bot. Mag. t. 1643; Benth. I.c. M. personata, Lagasca. - Texas to Arizona and the borders of California. Common in cultivation. (Mex.)

$\S$ 5̆. Gambécra, Gray; 1. c. Capsule and seeds of preceding section: stems erect and more or less shrubby, not climbing: palate of the tubular corolla somewhat prominent, but not closing the throat: most of the leaves opposite or in threes. - Gambelia, Nutt. Pl. Gamb. 149.

A. speciósum, Gray, 1. c. Shrub, 3 or 4 feet high, somewhat pubescent, leafy throughout: leaves oval or oblong, short-petioled, coriaceous: corolla "scarlet" or pink-red, liardly an inch long, thrice the length the lanceolate sepals, and the tube thrice the length of the narrow lips. - Gambelia speciosa, Nutt. 1.c. t. 22. - California, on the Island of Catalina, Gambell. (Guadalupe Island, Lower Calif., Palmer.)

A. júnceum, Gray, l.c. Shrubby slender stems glabrous, 2 feet high: leaves small, oblong-linear, or above hardly any: tube of the corolla 8 to 12 lines long. $-M$. juncea, Benth. Sulph. 41. - From San Diego southward (to the bay of Magdalena in Lower California, Hinds; also Cerroś Island, Dr. Streets).

5. MAURÁNDIA, Ortega. (Dr. Maurandy, a botanical teacher at Carthagena.) - Perennial herbs (Mexican and Arizonian), climbing by the slender tortile petioles and sometimes by the axillary peduncles; the leaves cordatetriangular or hastate, only the lower opposite; and showy purple or rose-colored or rarely white flowers. - Gray, Proc. Am. Acad. vii. 377. Maurandia (excl. $\S 1$ ) and Lophospermum (Don), Benth. in DC. Prodr. l.c. This comprises the two true Maurandias with wingless tuberculate seeds, Lophospermum, of one or perhaps two species, with seeds bordered by an irregular and lacerate wing; and the section Epixtphium, Engelm., with a narrow entire wing to the seeds, and capsule pointed by the subulate indurated style, containing the following species.

M. Wislizéni, Engelm. Glabrous, mostly low-climbing: leaves hastate, or some of them sagittate; the lowest obtuse, the others acuminate and with pointed basal lobes: peduncles short: corolla (pale blue, an inch long) with lips about half the length of the rather ample tube: sepals in flower linear-lanceolate, becoming in fruit triangular-lanceolate and gradually acuminate, much enlarged, rather rigid, very veiny-reticulated, and strongly saccate-carinate at base, enclosing the coriaceous globose-ovate capsule, and about the length of the sword-shaped indurated style: seeds compressed, oval, surrounded by a narrow entire wing, the sides chaffy-rugose. - Gray in Bot. Mex. Bound. 111. - New Mexico, on the banks of the Rio Grande, \&c., and adjacent borders of Mexico, Wislizenus, Parry, Wright, Bigelow.

6. MOHÁVEA, Gray. (Name of the river on the banks of which the plant was discovered by Fremont. It had been previously collected, in fruit ouly, by Dr. Coulter.) — Single species. 
M. víscida, Gray. Erect annual, a span to 2 fect high, corymbosely branched, pubescent and very viscid: leaves lanceolate, entire, 2 inches long, tapering to both ends, somewhat petioled; the lower opposite; upper alternate: flowers short-pedicelled: sepals lanceolate, acuminate, nearly equal: corolla inch and a half long, sulphur-colored, with some purple dots : capsule globular: seeds very numerous, oblong, smooth and even on the back; the ventral face deeply cup-shaped, with thickened somewhat corky sides. - Gravelly banks, S. E. California and adjacent parts of Arizona : fl. early spring.

7. COLLINSIA, Nutt. (Zaccheus Collins of Philadelphia, who published nothing, but was the most accurate botanist of his place and time.) - N. American winter-annuals, flowering early in spring and summer, low or slender; with simple opposite sessile leaves, or the lowest petioled and the upper verticillate, the uppermost often reduced to subulate bracts. Flowers handsome, in series of cymosely umbellate fascicles or in whorls, or sometiqnes solitary in the axils; the pedicels ebracteolate, and no common "peduncle. Corolla not rarely 2-colored. The stamens and style occasionally rise out of the sac of the corolla into a more erect position before all the pollen is shed. Ovules and seeds usually few (6 to 2) and sometimes solitary in each cell. - Nutt. in Jour. Acad. Philad. i. 190, t. 9 ; Gray, Proc. Am. Acad. xi. 91, \& Bot. Calif. i. ð53.

* Flowers short-pedicelled or almost sessile, verticillastrate-crowded, below in the axils of leaves, abwe in the axils of bracts: corolla balf to three-fourths inch long: sceds several or few, meniscoidal.

+ Corolla strongly declined; the much-inflated and gibbous saccate body (which we denominate the throat) full as broad as long, and forming an obtuse or right angle with the very short proper tube: gland short and small, sessile : upper pair of filaments more or less bearded toward the base: orules and seeds several.

C. bícolor, Benth. A foot or so high, from nearly glabrous to hirsute, or above viscidpubescent: leaves more or less dentate and oblong or lanceolate; the upper usually ovatelanceolate, sessile by a broad or subcordate and nervose base: pedicels shorter than the acute caly $x$-lobes, mostly several in the fascicle: corolla with lower lip violet or rose-purple and the upper paler or white (occasionally both white); saccate throat very oblique to the tube; recurved-spreading upper lip a little shorter than the lower : seeds rugose-reticulated. - Lindl. Bot. Reg. t. 1734; Don, Brit. Fl. Gard. ser. 2, t. 307 ; Hook. Bot. Mag. t. 3488. C. heterophylla, Graham, Bot. Mag. t. 3695, rare form with lower leaves 3-cleft. Moist grounds, common through the western part of California. Commonly cultivated.

C. tinctória, Hartweg. Like the preceding, but with more glandular and viscid brown or yellowish pubescence, which stains the fingers : flowers almost sessile: calyx-lobes lincar or ablong-linear, mostly obtuse: corolla yellowish, cream-color, or white, usually with some purple dots or lines; axis of saccate throat forming a right angle with the tube; the upper lip and its lobes very short: seeds smaller, rounder, and smootler, - Benth. Pl. Hartw. 328; Gray, Bot. Calif. 1. c. 553. C. barbata, Bosse in Verhand. Gartenb. Preuss. 18.;:, \& Bot. Zeit. xii. 905. C. septemnervia, Kellogg, Proc, Calif. Acad. ii. 224, fig. 69.('ommon in California, especially along the Sierra Nevada and its foot-hills.

++ Corolla less declined or oblique; the gibbons throat much longer than broad: stems only a span or two high: leaves crenate or obtusely dentate, obtuse, thickish, seldom over an inch long.

- Filaments and interior of corolla somewhat bearded : upper lip of the latter crestless, but with transverse callosity : calyx-lobes rather broad and obtuse.

C. bartsiæfólia, Benth. Puberulent and somewhat glandular, rarely hirsute-pubescent above: stem strict: leaves from ovate-oblong to linear: flower-clusters 2 to 5 or fewer: corolla purplish or whitish; its upper lip about the length of the curved gibbous throat; the lower with narrow base and emarginate or obcordate lateral lobes: gland sessile and elongated, porrect: seeds only a pair in each cell, smooth. - DC. Prodr. x. 318 ; Gray, l. c. C'. hirsuta, Kellogg, l. c. 110, fig. 34, a hirsute form. - Sandy soil, common through California, less showy than preceding.

C. corymbósa, Herder. Almost glabrous, cespitose-branching from base and diffuse or decumbent: leaves oblong or oval, very obtuse, rather fleshy: flowers mainly in a soli- 
tary leafy-bracteate capitate cluster: corolla straightish, white or ochroleucous; its upper lip blue or bluish and very short, the lobes being almost obsolete; lobes of elongated lower lip entire: gland small, oblong, compressed, short-stipitate: seeds 4 or 5 in each cell, rugose-reticulated. - Ind. Sem. Petrop. 1867, \& Gartenfl. 1868, 35, t. 568; Gray, Proc. Am. Acad. vii. 378, \& Bot. Calif. 1. c. - Shore of the northern part of California, Bolander, \&c. (Doubtless not "Mexico.")

+ Filaments and interior of corolla glabrous : upper lip of latter prominently fornicate-crested: flowers fewer: seeds about 4 , smooth.

C. Greénei, Gray. Slender and smaller, erect, glandular-puberulent: leaves oblonglinear, tapering to base, sparsely and coarsely dentate: flowers 2 to 6 in the clusters, on pedicels sometimes as long as the calyx : corolla violet-purple, 5 or 6 lines long; its uper lip much shorter than the oblong throat, about half the length of the lower; the crest under the origin of the limb developed into a pair of conspicuous callous teeth on each side; lateral lobes of lower lip small: gland small and sessile.-Proc. Am. Acad. x. 75, \& Bot. Calif. 1. c. - On rocks, Lake Co., California, Greene.

* Flowers slender-pedicelled, umbelliform-verticillate, or sometimes solitary.

+ Calyx-lobes acute, from lanceolate or even ovate to subulate, usually surpassing the capsule: plants glabrous, or the stems and pedicels puberulent, not glandular or viscid: leaves in the same species either somewhat serrate or entire: seeds about 4 , smooth or nearly so.

++ Eastern species : showy corolla half inch long, with very gibbous throat much shorter than the limb : upper filaments more or less bearded below.

C. Vérna, Nutt. 1. c. Stem 6 to 20 inches high: leaves ovate or oblong, or the lowest rounded and slender-petioled, and the upper ovate-lanceolate and partly clasping; the upper floral reduced to subulate-linear bracts: whorls about 6-flowered: pedicels filiform, longer than the flowers: throat of the corolla equalling the calyx-lobes; the ample lower lip bright blue; the upper white or purplish; lobes barely emarginate: gland subulate, porrect: seeds thick, not flattened, oblong, arcuate. - Sweet, Brit. Fl. Gard. t. 220; Hook. Bot. Mag. t. 4927. - Moist woods, W. New York and Penn. to Wisconsin and Kentucky.

C. violácea, Nutt. Lower: leaves thickish; the upper lanceolate : whorls $2-4$-flowered : pedicels as long as the flower: corolla violet; the upper lip much smaller than the lower; all the lobes obcordate. - Trans. Am. Phil. Soc. n. ser. v. 179; Gray, Proc. Am. Acad. xi. 93. Antirrhinum tenellum, Pursh, Fl. ii.421? - Arkansas, Nuttall, Pitcher. Little known species.

++ Western species, one extending north-eastward.

$=$ Flowers showy: corolla strongly declined; its saccate-ventricose throat shorter than the limb.

C. grandiflóra, Dougl. A span to a foot high: leaves thickish; the lowest roundish and petioled; upper from oblong to linear and sessile; the floral in whorls of 3 to 7 : pedicels in whorls of 3 to 9, about the length of the flower: calyx-lobes lanceolate gradually subulate-attenuate to a very acute point: corolla half to two-thirds inch long, white or purple with lower lip deep blue or violet; its very saccate throat as broad as long, almost or quite transverse with the tube, as long as the recurving (internally 2-callous) upper lip; lobes of the larger lower lip merely retuse or emarginate: filaments glabrous: gland sessile and capitate: seeds roundish, smooth. - Lindl. Bot. Reg. t. 1107; Gray, l. c. - Shady hills, \&c., from Mendocino Co. California to Brit. Columbia along the coast.

Var. pusílla. Small form, a span or more high : corolla only 4 or 5 lines long, more blue or violet throughout. - Plumas Co. California to Brit. Columbia.

C. sparsiflóra, Fisch. \& Meyer. More slender: upper leaves all lanceolate and linear, all opposite, or the uppermost small bracts in threes: pedicels solitary or some of the upper 2 or 3 in a whorl, sometimes longer than the flower: calyx-lobes from ovate to deltoid-lanceolate, acute: corolla 4 to 8 lines long, violet; the saceate throat very oblique but not transverse; upper lip hardly shorter than the lower: filaments hirsute below : gland sessile, elongated-subulate : seeds meniscoidal, acute-margined, obscurely reticulated. - Ind. Sem. Petrop. 1835, ii.33; Gray, l. c. C. solitaria, Kellogg, l.c. 10. - Rocky places, Cal'fornia, from San Francisco northward.

$==$ Flowers small, 2 or 3 lines long : corolla less declined or oblique; the oblong gibbous throat longer than the limb: stigma 2-cleft.

C. parviflóra, Dougl. About a span high, at length diffuse or spreading: leaves oblorg or lanceolate; the upper narrowed at base and entire; the floral often in whorls of 3 to 5 : 
pedicels solitary or above 2 to 5 in the whorl, usually longer than the flowers : calyxlobes lanceolate or triangular-subulate, usually almost equalling the blue (or partly white) corolla, hardly longer than the mature capsule: filaments glabrous: gland small, capitate, short-stipitate : seeds thickish, marginless. - Lindl. Bot. Reg. t. 1802; Hook. Fl. ii. 94 (misprinted C. pauciflora); Gray, l. c. - Shady moist grounds, Upper Michigan (shore of L. Superior) to the Pacific in Washington Territory, and south to Arizona and Utah. C. minima, Nutt. in Jour. Acad. Philad. vii. 47, of N. W. Rocky Mountains, is ambiguous, but apparently a dwarf and large-flowered form of $C$. parviflora, with corolla proportionally longer, 3 or 4 lines long.

+ + Calyx-lobes obtuse: corolla (blue) 3 or 4 lines long, fully twice the length of the calyx: filaments glabrous : gland subulate or conical: stem slender, only a span or so high.

++ Not glandular nor viscid : ovules and usually seeds 6 or 7 in each cell; the latter round-oval, when young discoidal, reticulated.

C. Párryi. Puberulent : stem strict, simple: leaves (less than an inch long) lanceolatelinear, obtuse; the upper mostly entire and closely sessile; the lowest smaller, narrowly oblong, crenate, petioled : pedicels solitary, in pairs, or the upper in threes, as long as the flowers: calyx-lobes oblong, equalling the moderately oblique throat of the deep blue corolla, not exceeding the capsule: lips of the corolla almost equal in length, not longer than the throat; the lobes emarginate. - San Bernardino Co., South-eastern California, Parry, Lemmon (no. 296).

+++ Filiform pedicels and upper part of the stems more or less glandular-pubescent and viscid: ovules solitary in the cells: seed oblong, thick, almust terete, somewhat arcuate, smooth : caly $x$ shorter than the throat of the corolla.

C. Chíldii, Parry, Herb. Stem mostly simple, puberulent: leaves thinnish; the lower obovate-rotund or oblong, obtusely more or less serrate, petioled; the upper oblong-lanceolate with narrowed base, subsessile : flowers rather few : pedicels and caly $x$ pubescent and partly glandular: lobes of the latter lanceolate or oblong, surpassing the capsule: corolla light blue; the oblong moderately oblique throat longer than the lips, the lobes of which are of about equal length and entire. - South-eastern California, in deep woods (of Libocedrus decurrens) in the San Bernardino Mountains, Parry \& Lemmon, H. S. Child. Also Kern Co., Kennedy.

C. Torréyi, Gray. Stem divergently much branched, very floriferous: slender branches and pedicels viscid-glandular: leaves thickish, linear with attenuate base and entire, or the lowest spatulate or oblong and petioled; fioral mainly reduced to subulate 3-4-nate bracts subtending whorls of 3 to 6 deep blue or violet flowers: corolla rather strongly declined, thrice the length of the calyx, the lobes of which are shorter than the capsule; upper lip equalling and the lower longer than the ventricose throat. - Proc. Am. Acad. vii. 378, \& Bot. Calif. 1. c. - California, in open woods, through the Sierra Nevada from Mariposa Co. northward to Siskiyou Co.

8. TONÉLLA, Nutt. (An unexplained and probably quite meaningless name.) - Two known species, slender annuals, small-flowered, with the habit of Collinsia. - Gray, Proc. Am. Acad. vii. 378, xi. 92, \& Bot. Calif. i. 555 .

T. collinsioídes, Nutt. Diffuse, nearly glabrous : filiform branches a span to a foot long: radical and lowest cauline leaves ovate or roundish ( 3 to 6 lines long), slenderpetioled, mostly entire; the others shorter-petioled or sessile, many of them 3-parted or else quite divided into oblong or lanceolate divisions or leaflets; the floral in whorls of three; uppermost simple and shorter than the slender filiform (solitary, geminate, or sometimes ternate) pedicels : flowers minute: corolla blue, a line long; its 5 lobes of equal length; the lower one transversely oval or roundish, very much larger than the oblong lateral and upper ones, and separated from them by deeper sinuses: ovules solitary in each cell : capsule exceeding the calyx. - Collinsia tenella, Benth. in DC. Prodr. x. 593; where the mss. name of Tonella collinsioides of Nuttall is cited. - N. California and Oregon, in shady places.

T. floribúnda, Gray, 1. c. Larger, a foot or two high : most of the cauline leaves $3-5-$ foliolate: whorls numerous in a loose elongated raceme, each of 3 to 7 flowers: corolla larger, more rotate, 3 or 4 lines broad, much exceeding the caly $x$, purple; the thrce lobes of 
the lower lip obovate and nearly alike, smaller than those of the 2-cleft upper lip : ovules and seeds 3 or 4 in each cell. - W. Idaho, Spalding, Geyer, \&c.

9. SCROPHULÁRIA, Tourn. Figwort. (A reputed remedy for scrofula.) - Rank herbs, chiefly perennials, of homely aspect; with mostly opposite leaves, and loose cymes of small flowers forming a narrow terminal thyrsus, in summer, proterogynous. Stamens in our species always shorter than the corolla.

* Corolla bright red, comparatively large, oblong-urceolate.

S. coccínea, Gray. Glabrous, a foot or two high : leaves deltoid-ovate, slender-petioled, coarsely dentate, sometimes doubly so: pedicels and calyx minutely glandular: corolla two-thirds to three-fourths inch long; the 2-cleft upper lip much longer than the lower: rudiment of sterile stamen obovate. - Bot. Mex. Bound. 111. - New Mexico, in mountains near Santa Rita del Cobre, Wryht, Bigelow.

* * Corolla lurid-purplish or greenish, 3 or 4 lines long, ventricose-ovoid.

S. nodósa, L. Nearly glabrous, 2 or 3 feet high : thyrsus naked or nearly so, elongated and open: leaves ovate or oblong-ovate, acute, and with rounded or subcordate base, sharply and of ten rather doubly serrate: cymes pedunculate: calyx-lobes broadly ovate, nearly marginless: rudiment of fifth stamen orbicular. (Eu., N. Asia.)

Var. Marilándica. Taller, sometimes 5 feet high : leaves larger and thinner, acuminate, often ovate-lanceolate, seldom at all cordate, mostly simply serrate : pedicels more slender. - S. Marilandica, L. S. lanceolata, Pursh, Fl. ii. 419, form with narrower leaves. - Damp grounds, Canada to Florida, and west to Utah and perhaps Oregon.

S. Califórnica, Cham. Leaves smaller, oblong-ovate, with truncate or cordate base, or the upper narrowly deltoid, acute, coarsely doubly toothed or sometimes laciniate-incised; the lower occasionally with a pair of detached lobelets near the summit of the petiole: thyrsus very loose, mainly naked: peduncles and pedicels minutely glandular: rudiment of fifth stamen spatulate or cuneiform, either roundish or acutish at base. - Linn. ii. 585; Gray, Bot. Calif. i. 552. S. nodosa, var., Benth. Pl. Hartw. 327. - Moist grounds, nearly throughout California, and in W. Nevada.

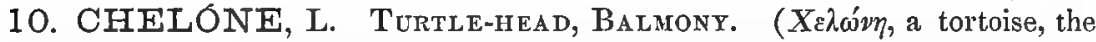
corolla in shape resembling the head of a reptile) - North American perennial herbs, glabrous or nearly so, large-flowered; the leaves opposite and acntely serrate. Seeds upwardly imbricated, compressed as well as broadly winged. Sterile filament shorter and smaller than the others. Capsule ovate: valves entire. Fl. late summer.

$\S 1$. Eucheróne. Flowers in axillary and terminal short and close spikes: bracts and bractlets imbricated, ovate or orbicular, concave, membranaceous, and the broad sepals similar: corolla (white or rose-color) strongly ventricose and with lips of about equal length; the upper broad and carinate-fornicate, almost entire, and from under its apex protrudes the recurved tip of the long filiform style; the lower moderately spreading, broad, 3-lobed, the middle lobe smaller, woolly in the throat: filaments woolly.

C. glábra, L. A foot or two (or in Illinois 6 or 7 feet) high: leaves from narrowly to rather broadly lanceolate ( 4 or 5 inches long, 4 to 12 lines wide), gradually acuminate, serrate with sharp appressed teeth, narrowed at base usually into a very short petiole: bracts not ciliate: corolla white, or barely tinged with rose, an inch long. - Spec. ii. 611; Bart. Fl. Am. Sept. iii. t. 76. C. glabra, alba, Pursh, \&c. - Wet places, Newfoundland to Saskatchewan and south to Florida.

C. oblíqua, L. A foot or two high, less strict or with spreading branches : leaves from broadly lancenlate to oblong ( 2 to 5 inches long), sometimes laciniately serrate, more veiny and duller, acute or obtusc at base, mostly short-petioled: bracts ciliolate: corolla deep and 
bright rose-color. - Syst. Nat. \& Syst. Veg.; Schk. Handb. t. 172 ; Bot. Reg. t. 175. ( foliis ovato-lanceolatis, \&c., Mill. Ic. t. 93. C. purpurea, Mill. Dict. C. glabra, var. purpurea, Michx., Pursh, \&c. C. glabra, var. lanceolata, Nutt. Gen. ii. 51. C. latifolia, Muhl. Cat., ex FII. Sk. ii. 127. - Damp or wet shady grounds, Illinois and Virginia to Florida. Varies between the preceding and following.

C. Lyóni, Pursh. About 2 feet high: leaves ovate or subcordate, acuminate (4 to 7 inches long), thin, evenly serrate, on rather slender naked petioles : bracts minutely ciliolate: corolla bright rose-purple. - Fl. ii. 737 ; Don, Brit. Fl. Gard. t. 293. C. major, Sims, Bot. Mag. t. 1684. - Wet ground, mountains of N. Carolina and Tennessee to Georgia.

§2. Nothochelóne. Flowers pedicellate, in a loose open terminal thyrsus: bracts and sepals lanceolate, acuminate: no bractlets under the calyx: corolla (violet-purple) with widely open orifice, a very short 2-cleft and not at all fornicate upper lip, and a 3-cleft spreading lower one; the throat and filaments glabrous: upper part of the filiform sterile filament hirsute. Accords with Pentslemon, except in the winged seeds.

C. nemorósa, Dougl. A foot or two high : herbage of rank somewhat unpleasant odor: leaves orate and ovate-lanceolate, acute, acutely dentate, 2 or 3 inches long; the cauline sessile or almost so by a truncate or subcordate base: peduncies 3-5-flowered, as long as the pedicels: corolla fully an inch long. - Lindl. Bot. Reg. t. 1211; Benth. in DC. 1. c. Pentstemon nemorosus, Trauttv. in Mem. Acad. Petrop. 1841, 250. - Woods along mountain streamlets, Washington Terr. to the northern borders of California, Newberiy, Greene.

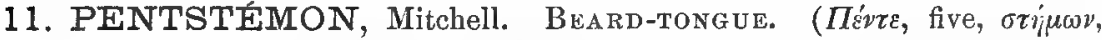
stamen, all five stamens being conspicuously present, the fifth as a sterile filament, which in rare instances, in several species, has been found to be antheriferous.) North American (a few Mexican and one N. E. Asian) perennials, mostly herbaceous, some suffruticose; usually with simple stems or branched from the base; the leaves opposite, rarely verticillate or very rarely the upper alternate; inflorescence from thyrsiform to almost simply racemose; and the flowers mostly handsome, in summer. - Nov. Gen. in Act. Phys. - Med. Nat. Cur. xiii. (1748) 36 ; Soland. in Ait. Kew. ii. 360 ; Benth. in DC. Prodr. x. 320, 593 ; Gray, Proc. Am. Acad. vi. 56, \& Bot. Calif. i. 5̃56. Pentastemon, Trauttv. in Mem. Acad. Petrop. 1841.

§1. Eupentstémon, Gray. Anther-cells soon divaricate or divergent, united and often confluent at the apex, dehiscent for their whole length or nearly.

* (ERInNrhêna.). Anthers densely comose with very long wool, in the manner of Chelone, peltately explanate in age: low and suffruticose, with coriaceous leaves.

P. Menziésii, Hook. A span or less to a foot high, woody at base: leaves commonly ovate, obovate, or oblong, a quarter to an inch long, rigidly serrulate or some cntire, glabrous or when young pubescent; the lower short-petioled: inflorescence mostly glandular or viscid-pubescent, racemose; the pedicels almost all 1-flowered, usually 1-2-bracteolate: sepals ovate-lanceolate or narrower and attenuate-acuminate: corolla (violet-blue to pinkpurple) an inch or more long, tubular-funnelform and moderately bilabiate, the upper lip deeply 2- and lower 3-cleft: sterile filament short and slender, hairy at apex or nearly naked.-Fl. ii. 98; Gray, Proc. Am. Acad. vi. 56 (var. Lewisii) \& Bot. Calif. i. 656. Gerardia fruticasa, Pursh, Fl. ii. 423 , t. 18. Pentstemon Levisii, Benth. in DC. Prodr. x. 321. - On rocks and mountain tops, Brit. Columbia through the higher Sierra Nevada of California, and Rocky Mountains of Idaho and Wyoming. Corolla at the north and on Mt. Shasta, \&c., bright violet or bluish. Passes into

Var. Newbérryi, Gray, a form with rose-purple or pink corolla.-P. Newberryi, Gray in Pacif. R. Rep. vi. 82, t. 14. P. Menziesii, var. Robinsoni, Masters in Gard. Chron. 1872, 969, fig. 227. - Sierra Nevada, California, the only form southward. 
Var. Douglásii, Gray, l.c., with entire and obovate-lanceolate or narrowly oblong leaves, and (as far as known) lilac-purple corolla, pink-red at base. $-P$. Douglasii, Hook. 1. c,, in fruit only. $P$. crassifolius, Lindl. Bot. Reg. xxiv. t. 16. - Interior of Oregon and Washington Terr. Passes into

Var. Scoúleri, Gray, 1. c. Leaves lanceolate, or even linear-lanceolate, acute; the larger $1 \frac{1}{2}$ to even 3 inches long, sparsely and acutely serrulate : corolla commonly inch and a half long, violet-purple. $-P$. Scouleri, Dougl. in Lindl. Bot. Reg. t. 1277. - Interior of Oregon to Brit. Columbia. A form (var. Lyalli, Gray, 1. c. 76) is 2 feet or more high, with remarkably long willow-like leaves.

* * (Fruticosi.) Anthers glabrous, dchiscent through the apex and explanate after dehiscence: stems branching and shrubby, at least below: leaves coriaceous or chartaceous, small or short, mostly very short-petioled : filaments all bearded or pubescent at base.

+ Corolia unknown: probably of this section.

P. microphýllus, Gray. Cinereous-puberulent and glabrate, much branched: primary leaves not seen; those of axillary fascicles only 2 lines long, obovate, obtuse, entire, thick-coriaceous : inflorescence racemose: sepals lanceolate-ovate, acute: persistent style (and therefore probably the corolla) short. - Torr. Pacif. R. Rep. iv. 119. - N. W. Arizona, on Willians Fork, Bigelow.

+ + Corolla red, long and narrow-tubular, an inch or more in length; its upper lip erect and the lower more or less spreading: inflorescence somewhat glandular, mostly compound: sterile filament bearded down one side.

P. cordifólius, Benth. Somewhat scandent over shrubs by long sarmentose branches, very leafy, scabrous-puberulent: leaves subcordate or ovate with truncate base, acutely serrate or denticulate, veined, an inch or less long: thyrsus short and leafy : peduncles several-flowered: sepals ovate-lanceolate: corolla scarlet; its tube near an inch and lips half inch long. - Scroph. Ind. adnot., \& DC. Prodr. x. 329. - California, common from Santa Barbara to San Diego.

P. corymbósus, Benth. Erect, a foot or two high, cinereous-pubescent or glabrate: branches leafy up to the naked and few-many-flowered corymbiform cyme: leaves oblong or oval, barely obtuse at base, obscurely or sparingly denticulate, somewhat parallelveined (half to 2 inches long): sepals lanceolate: corolla scarlet, an inch long. - DC. Prodr. X. 593; Gray, Bot. Calif. i. 557. - California, from Shasta Co. to Santa Cruz, \&c.

P. ternátus, Torr. Glabrous and the long virgate flowering shoots (2 to 4 feet long) glaucous : leaves linear-lanceolate, rigid, acutely serrate or denticulate with salient teeth ( 8 to 18 lines long); the upper ternately verticillate : flowers in a long racemiform thyrsus: sepals ovate-acuminate: corolla pale scarlet, an inch long and the lips about 3 lines long. - Bot. Mex. Bound. 115; Gray, 1. c. - Mountains of S. California, from Kern Co. southwarl.

+++ Corolla vellow or yellowish, merely tinged with purple, less than an inch long, with tube shorter than the ringent limb; upper lip fornicate and merely emarginate; the lower pendulousrecurved.

P. breviflórus, Lindl. Glabrous, 3 to 6 feet high, with slender or virgate branches leafy to the narrow many-flowered racemiform thyrsus : leaves lanceolate or oblong-lanceolate, denticulate, seldom if ever verticillate, an inch or more long: sepals ovate-lanceolate, acuminate: corolla yellowish with flesh-color, striped within with pink, about half incli long: upper lip beset with long and viscid hairs: sterile filament naked. - Bot. Reg. t. 1946; Gray, 1. c. P. carinatus, Kellogg in Proc. Calif. Acad. i. 62.-Dry hills and banks, California to the borders of Nevada, common on the flanks of the Sierra Nevada.

P. antirrhinoídes, Benth. Minutely cinereous-puberulent or glabrous, 1 to 5 feet high, much branched, very leafy : leaves small (barely half inch long), spatulate or oval, entire: inflorescence leafy-paniculate: peduncles 1-flowered, short: sepals broadly ovate: corolla ventricose, 8 to 12 lines long, unusially broad, lemon-yellow: sterile filament densely bearded on one side. - DC. Prodr. x. 694; Hook. Bot. Mag. t. 6157; Gray, 1. c. P. Lobbii, Illustr. Hort. 1862, t. 315. - S. California, San Diego Co., \&c.

++++ Corolla apparently purplish or flesh-color, not over half inch long, with tube and throat longer than the open lips : shrubby at base; the slender branches nore herbaceous.

P. Rothróckii. A span or two high, minutely puberulent, oval- or ovate-oblong, obtuse, mostly subcordate or truncate at subsessile base, usually undulate-dentate, 4 or 5 lines 
long: inflorescence loosely spiciform, leafy below : subsessile and mostly solitary 2-bracteolate flowers and their bracts or floral leaves commonly alternate: sepals ovate-lanceolate, puberulent, slightly if at all glandular: corolla 4 lines long, rather narrow, glabrous: sterile filament glabrous. - S. E. California, on Little Olanche Mountain, toward the sources of Kern River, at 10,400 feet, Rothrock.

P. Lemmóni, Gray. Glabrous up to the pedicels, 2 to 4 feet high, slender, rather remotely leaved: leaves ovate- or oblong-lanceolate, thinnish, acutely and sparsely serrulate, an inch or less long: thyrsus loose, leafy below : peduncles all opposite, slender, fewseveral-flowered: short pedicels and ovate-lanceolate sepals viseid-pubescent: corolla half inch long, somewhat campanulate-dilated above, viscid or glandular: filament strongly yellow-bearded. on one side of the curved apex. - Bot. Calif. i. 557. - California, from Mendocino to Plumas Co., Kellogg, Lemmon.

+++++ Corolla (white or purplish) nearly an inch long, oblonglempanulate from the base, hardly at all bilabiate.

P. frutéscens, Lamb. A span or less high from a woody (subterranean? or prostrate) stock : stems pubescent, leafy : leaves oblong, with somewhat narrowed base, denticulate, glabrous ( $1 \frac{1}{2}$ to 3 inches long, 7 to 12 lines wide): thyrsus terminal, 3-9-flowered: perlicels and lanceolate acuninate sepals villous and viscid: lobes of the corolla short and broad, nearly equal and equally somewhat spreading: lower part of the fertile filaments and most of the sterile one hirsute-bearded.-Linn. Trans. x. 250, t. 6, fig. 1; Pursh, Fl. ii. 428 (excl. hab.); Benth. in DC. Prodr. x. 321. - "Unalaschka, Pallas." Not since detected there, and perlaps a mistake. Certainly not found "on the nortl-west coast" by Lewis. (Kamtschatka and Japan!)

* * (Axbiglir) Anthers glabrons, reniform, not explanate in age, the line of dehiscence stopping a little short of the base of the cells: stem suffruticose and leaves thick-coriaceous.

P. baccharifólius, Hook. Glabrous, or the rigid branches obscurcly puberulent, 2 feet high, leafy below : leaves oblong, nearly sessile, rigidly and acutely dentate, almost veinless, an inch long; the uppermost abruptly reduced to small ovate bracts of the loose and racemose glandular inflorescence: peduncles 1-3-flowered : sepals ovate: corolla deep carmine-red, an inch long, broadly tubular and with a short moderately bilabiate limb; upper lip somewhat erect, 2-lobed; lower recurved and 3-parted : sterile filament naked. - Bot. Mag. t. 4627; Gray in Bot. Mex. Bound. 115, \& Proc. Am. Acad. vi. 58. - S. W. Texas, on the San Pedro River, Wright.

* * * (Eumigera.) Anthers glabrous (rarely villous); the cells deliscent from the base towards but not to the apex, consequently not explanate after dehiscence : corolla tubular, little ampliate upward, red : sterile filament mostly glabrous: herbs glabrous and usually glaucescent, glabrous even to the caly $x$ and outside of the corolla, or merely pruinose-puberulent: stems virgate and simple: leaves all entire; the cauline sessile or partly clasping: thyrsus elongated and virgate, loosely-flowered, racemiform or paniculate. - Elmigera, Reichenb. \$ Elmigera (Benth. in DC. I. c., excl. spec.), Gray in Proc. Am. Acad. l. c. + Corolla strongly bilabiate; upper lip erect and concave, 2-lobed at apex; lower reflexed and
3-parted: peduncles and pedicels mostly slender.

P. barbátus, Nutt. Usually tall, 2 to 6 feet high : leaves lanceolate or the upper linearlanceolate; the lowest and radical oblong or ovate: sepals ovate: corolla inch long, from light pink-red to carmine; base of the lower lip or throat usually bearded with long and loose or sparse yellowish hairs : anthers even in the bud divergent, sonn divaricate. - Gen. ii. 53 ; Benth. 1. c.; Lindl. Bot. Reg. xxv. t. 21, flesh-colored variety; Gray, Proc. Am. Acad. vi. 59. Chelone barbata, Cav. Ic. iii. 22, t. 242 ; Bot. Reg. t. 116. C. ruellioides, Andr. Bot. Rep. t. 34. Elmigera barbata, Reichenb, in Steud. Nom, - Mountains of Colorado and New Mexico; and commonly cult. (Mex.)

Var. Torréyi, Gray, l.c. (P. Torreyi, Benth. in DC. Prodr. 1.c.), a tall and usually deep scarlet-red-flowered form, with few or no hairs in the throat; but in cultivated and even in wild specimens the distinction vanishes. $-W$. borders of Texas to Colorado and New Mexico.

Var. pubérulus, Gray in Bot. Mex. Bound. 114, is pruinose-puberulent, otherwise like the preceding, - Guadalupe Cañon, Arizona, Thurber.

Var. trichánder, Gray, is also like a low form of var. Torreyi, except that anthers are beset with long woolly hairs! - Proc. Am. Acad. xi. 94. - S. W. Colorado, Brandegee.

Var. labrósus, Gray. A low and narrow-leaved form, with almost simply racemose flowers : corolla apparently red with a yellowish tube; the lips remarkably long $(\theta$ 
to 8 lines), the lobes of the lower very narrow. - Bot. Calif. i. 622. - S. E. California ; on Mt. Pinos, Kern Co. at 7,000 feet, Rothrock. San Bernardino Co., Parry \& Eemmon.

Var. Wiscizénr, Gray, Proc. Am. Acad. vi. 59 (P. coccineus, Engelm. in Mem. Wisliz. 107 ), known only from Chilhuahua, Mexico, is between $P$. barbatus and $P$. imberbis, having nearly the corolla of the latter, with the early divaricate anthers of the former.

++ Corolla obscurely bilabiate and the lobes hardly spreading: peduncles and pedicels short.

P. Eatóni, Gray. A foot or two high, hardly glaucescent: leaves from lanceolate to ovate; the upper partly clasping: thyrsus virgate and strict, simple; the peduncles very short, 1-3-flowered, and pedicels seldom much longer than the ovate-lancenlate sepals: corolla an inch long, bright carmine-red, tubular, hardly enlarged at the naked throat; its broadly oval lobes ( 2 lines long) all nearly alike except that the two of the upper lip are united higher: anther-cells usually (but not always) early divergent or divaricate, dehiscent for only three-fourths their length : sterile filament sometimes minutely bearded at the apex. - Proc. Am. Acad.,viii. 395, \& Bot. Calif. i. 560, but flowers in Wallace's collection, mistakenly referred to it, are of $P$. Clevelandi. $P$. centranthifolius, Watson, Bot. King, 219, not Benth. - Dry banks and cañons, Walsatch Mountains, Utah, to S. Nevada and Arizona. Intermediate in aspect between $P$. barbatus and $P$. centranthifolius.

* * * * (Specrosi.) Anthers with the diverging or divaricate and distinct cells dehiscent from base nearly or quite to, but not confluently thiough, the apex, not peltately explanate after dehiscence, either glabrous, hirsute, or rarely long-pilose: herbs with simple stems and closely sessile mostly very glabrous (rarely puberulent) entire cauline leaves : inflorescence never glandular-pubescent or viscid : flowers showy : corolla blue or violet, ventricose-ampliate above; the lobes of the moderately or slightly bilabiate limb roundish and equally spreading.

+- Corolla two-thirds to three-fourths inch long, funnelform, little ventricose.

P. Fremónti, Torr. \& Gray. A span or more high, minutely and densely pruinosepubescent: cauline leaves lanceolate or the lowest (like the radical) spatulate: thyrsus spiciform, virgate, rather densely flowered: peduncles and pedicels very slort: sepals oblong-ovate, acute, with irregular scarious margins : corolla very obscurely bilabiate; the lobes 2 lines long: anthers hirsute: sterile filament with dilated bearded apex. - Proc. Am. Acad. vi. 60. - Utah, "on the Uinta plains," Fremont.

Var. subgláber. A span to a foot high, merely puberulent below, glabrous above: upper leaves oblong-lanceolate: sepals conspicuously acuminate. - Idaho (in mountains near Fort Hall, Burke), \&c.

+ + Corolla an inch to an inch and a half in length, ventricose-ampliate above.

P. stríctus, Benth. Glabrous, or minutely pruinose, more or less glaucous: stem slender, virgate, 6 to 20 inches high : radical leaves from oval to spatulate; cauline narrowly lanceolate or" linear; floral reduced to small subulate bracts of the elongated narrow and loose thyrsus: peduncles and pedicels commonly slender: sepals ovate or oval, obtuse, not over 2 lines long, harely half the length of the narrow proper tube of the violet-purple or blue (about inch long) corolla; the throat of which is strongly ampliate: anthers either thickly or sparsely comose with very long flexuous hairs: sterile filament naked or with some similar slencler hairs. - DC. Prodr. x. 324. P. comarrhenus, Gray, Proc. Am. Acad. xii. 81. - Rocky Mountains of W. Wyoming to those of S. W. Utah. The original specimen (Fremont) is strict, with the inflorescence imperfectly developed, and no good corolla extant, the cauline leaves 2 or 3 inches long and 2 lines broad. The long and soft, but rather coarse hairs of the anther are not rarely a line and a half in length.

P. gláber, Pursh. Glaucous or glaucescent and very glabrous: stems ascending or erect, a foot or two high : leaves mostly oblong-lanceolate or the upper ovatelanceolate: thyrsus elongated and many-flowered: peduncles and pedicels short, commonly very short: sepals from orbicular-ovate and merely acute to ovate-lanceolate or strongly acuminate from a broadish base: corolla (1 to $1 \frac{1}{2}$ inches long) bright blue to violet-purple: anthers (and also the apex of sterile filament) from glabrous to sparsely hirsute; the cells dehiscent to or very near their apex. - Fl. ii. 728, \& Bot. Mag. t. 1672, \&c., under the form $P$. glabra. P. erianthera, Nutt. in Fras. Cat. \& Gen. ii. 53, not Pursh. F. Gordoni, Hook. Bot. Mag. t. 4319. P. speciosus, Dougl. in Lindl. Bot. Reg. t. Los; Brit. Fl. Gard. ser. 2, t. 259; a narrower-leaved form, with anthers and sterile filament commonly naked. $P$. Kingii, var. glauca, Kellogg in Proc. Calif. Acad. v. 39. - Plains of the Upper Missouri, in Nebraska and Dakota, to Colorado and Arizona, and west to the Sierra Nevada in California, and Oregon. - The following are extreme forms. 
Var. alpínus, Gray. A span high : cauline leaves from narrowly to broadly lanceolate: thyrsus abbreviated and few-flowered. $-P$. alpinus, Torr. in Ann. Lyc. N. Y. i. 35. - Alpine region of the Rocky Mountains, from the Yellowstone to Pike's Peak.

Var. Utahénsis, Watson. Stems a foot or two high, strict and slender (sometimes pruinose-puberulent): cauline leaves lanceolate, or even linear lanceolate, the lower tapering to the base: thyrsus virgate: sepals either narrower or much acuminate: sterile filament and usually the anthers hirsute. - Bot. King, 217. - Utah to Arizona and the borders of California, passing into the $P$. speciosus, Dougl., and the lower forms into the preceding variety.

Var. cyanánthưs, Gray. Usually tall and less glaucescent: leaves all broad; the cauline ovate or subcordate and ovate-lanceolate: thyrsus dense: sepals much acuminat' or narrow : corolla bright blue: anthers and sterile filament from hirsute to nearly glabrous.-Proc. Am. Acad. vi. 60. P. cyananthus, Hook. Bot. Mag. t. 44154 ; Watson, Bot. King, 1. c. - Rocky Mountains, Wyoming and Colorado to the Wahsatch in Utah. Seens rery distinct, but passes into $P$. glaber.

P. Wárdi, Gray. Low, a span or more high, minutely and densely cinereous-pubescent : leaves thick, oblong or the upper oblong-lanceolate: corolla externally pale and sparsely puberulent: anthers cartilaginous; the cells deliscent from the acutish base upward for little more than three-fourths of their length, glabrous: sterile filament also glabrous: otherwise like the preceding, of which it may be only a variety. - Proc. Am. Acad. xii. 82. - Glenwood, Utah, L. F. Ward.

* * **** (Gextrit) Anthers dehiscent from base to apex and through the junction of the two cells, slabrous (or merely hirtello-ciliate at lines of dehiscence), open after dehiscence. usually explanate in age, in the greater number confluently 1-celled: herbs, or rarely sutirutescent at base; the species of the first following subdivision approaching the preceding.

+ Glabrous throughout (or rarely minutely pruinose-puberulent or glandular) even to pedicels and calyx: leaves all entire. from linear to ovate, glaucous or pale: stems simple and erect: thyrsus virgate or contracted, with short or hardly any peduncles: five lobes of the corolla plane: anthers of cartilaginotus or coriaceous texture.

t- Corolla less than an inch long. lilac or mauve-purple, or verging to violet, abruptly campanulate-inflated, and the broad rather strongly bilabiate limb widely spreading or open.

P. secunditlórus, Benth. A foot or two high, including the clongated and racemiform strict many-flowered thyrsus : cauline leaves narrowly lanceolate (2 or 3 inches long and lines wide); radical spatulate: peduncles 1-3-flowered : sepals ovate or oblong, acute or obtuse, with somewhat scarious but entire margins: corolla with narrow proper tube of nearly twice the length of the calyx, abruptly dilated into the broadly campanulate throat of about one-third inch in height and width; this nearly equalled by the widely spreading lips; the lobes round-oval: sterile filament glabrous or minutely bearded at the dilated tip. - Prodr. x. 324. - Mountains of Colorado, common at 8 or 9,000 feet. A wellmarked and beautiful species.

P. Hállii, Gray. Allied to the foregoing, only a span or so high : leaves thickish, linear and linear-spatulate, or the lowest rather broader, obtuse: thyrsus short and more spiciform, 5-15-flowered, obscurely viscid : sepals broadly ovate and with widely scarious erose margins : corolla 7 to 10 lines long, broadly campanulate-inflated from a thickish and inconspicuous proper tube which is shorter than the calyx; bilabiate limb rather short: sterile filament short-bearded from the apex downward. - Proc. Am. Acad. vi. 71. - Colorado Rocky Mountains, at 10-12,000 feet (common on Gray's Peak), Hall \& Harbour, Parry, Greene, \&c.

Var. Arizónicus. An ambiguous form, almost a foot high, with flowers apparently intermediate between those of $P$. Hallii and $P$. secundiflorus, and sterile filament of the latter; but corolla lips shorter than the less abruptly expanded portion. - Mount Graham, Arizona, at 9,250 feet, Rothrock.

++ Corolla two-thirds or three-fourths inch long, from blue to lilac: the tube gradually and moderately dilated into the funnelform throat; lobes of the obscurely bilabiate 5-parted lint, short and widely spreading. (See also P. confertus, Watsoni, \&c., which, being glabrous and entire-leared, might be referred here.)

P. acuminátus, Dougl. Glaucous, 6 to 20 inches ligh, generally stout and rigid, leafy: leaves coriaceous, somewhat cartilaginous-margined; radical and lowest cauline obovate or oblong; upper cauline from lanceolate to broadly ovate, or the upper cordate-clasping, these mostly acute or acuminate: thyrsus strict, interrupted, leafy below, naked above; 
the clusters several-flowered, and peduncles and pedicels mostly very short: sepals ovate and acute or lanceolate: corolla lilac or changing to violet; the limb half or two-thirds inch in diameter: sterile filament mostly bearded at the dilated tip: capsule firm-coriaceous and acuminate.- Lindl. Bot. Reg. t. 1285 ; Hook. Fl. ii. 97 ; Benth. in DC. 1.c.; Gray, Proc. Am. Acad. vi. 61 (excl. syn. P. secundiforus), \& Bot. Calif. i. 559. P. nitidus, Dougl. ex Benth. in DC. l. c. P. Fendleri, Gray in Pacif. R. Rep. ii. 168, t. 5, \& Bot. Mex. Bound. 114, excl. syn. - Plains of the Saskatchewan and Upper Missouri to the interior of Oregon, and south to Nevada, New Mexico, and the western borders of Texas. (Adjacent Mex.) Seems to pass into

. cæerúleus, Nutt. Low: leaves (even the radical) all from lanceolate to narrowly linear (often 3 inches long and only a line or two wide): thyrsus spiciform and usually dense: sepals lanceolate-acuminate: corolla blue, varying occasionally to rose-lilac or white: sterile filament much bearded above. - Gen. ii. 52; Benth. in DC. 1. c.; Gray, 1. c. $P$. angustifolius, Nutt. in Fras. Cat.; Pursh, FI. ii. 738. - Plains of Dakota and Montana to Colorado at the base of the mountains.

+++++ Corolla an inch or less long, red, tubular or funnelform, hardly bilabiate; the roundish or short-oblong lobes all alike, except that the two upper are rather more united: sepals ovate or roundish, obtuse or acute: peduncles usually manifest and pedicels slender.

= Sterile tilament filiform, naked: corolla narrow-tubular, deep scarlet; lobes short, little spreading.

P. centranthifólius, Benth. Very glaucous : stem strict, leafy, 1 to 3 feet high: leaves thick, from ovate-lanceolate or the lowest oblong to lanceolate-linear, the upper with subcordate-clasping base: thyrsus virgate, elongated: corolla fully an inch long; the lobes ( 2 lines long) hardly longer than the width of the orifice. - Scroph. Ind. \& Prodr. 1. c.; Hook. Bot. Mag. t. 5142; Gray, 1. c. Chelone centranthifolia, Benth. in Hort. Trans.; Lindl. Bot. Reg. t. 1737. - Open grounds, California, from Monterey southward, and W. Arizona.

$==$ Sterile filament dilated at tip and retrorsely bearded down one side: corolla funnelform, and with rather large and rounded wilely spreading lobes.

P. puníceus, Gray. Very glaucous: stem stout, " 1 to 6 feet high," sparsely leafy: leaves thick, oblong or the lowest obovate and the uppermost ovate, sometimes connateperfoliate: thyrsus virgate, interrupted, many-flowered: corolla almost an inch long, narrowly funnelform, "brilliant scarlet;" the limb two-thirds inch in diameter. - Bot. Mex. Bound. 113, \& Proc. 1. c. - Guadalupe Cañon, Arizona, Thurber, E. K. Smith.

P. Párryi. Less glaucous : stem virgate, a foot or two high: leaves from oblong to narrowly lanceolate; the upper with auriculate or roundish partly clasping base; radical oblanceolate or spatulate: racemiform thyrsus more simple and fewer-flowered : corolla narrowly funnelform, half to three-fourths inch long, "bright pink" or cherry-red; the limb half inch in diameter. - P. puniceus, var.? Parryi, Gray, Bot. Mex. Bound. 1. c.Western Arizona, Parry, Palmer, Greene. Southern Nevada, Miss Searls, Palmer. Southern Utah, Parry. Some specimens of this have been referred to the preceding, some to the following species.

P. Wríghtii, Hook. Pale and somewhat glaucous or glaucescent: stems rather stout, a foot or two high: leaves oblong or the lowest obovate 2 to 4 inches long, an inch or so wide); upper cauline partly clasping by a roundish base: thyrsus virgate and elongated, loosely flowered: sepals when in bloom with spreading tips: corolla bright rose-color, about three-fourths inch long and with ampliate throat, the expanded limb three-fourths inch in diameter. - Bot. Mag. t. 4601 (corolla too deep red), Gray, 1. c.; Fl. Serres, vii. t. 685. - W. Texas and New Mexico, Wright, \&c.

++++ Corolla showy, inch and a half or more in length, ventricose-funnelform, somewhat bilabiate, the upper lip rather smaller: sterile filament hooked at apex: sepals ovate or oblonglanceolate, barely acute: thyrsus virgate, with hardly any common peduncles to the few-flowered clusters: leaves glaucous, thickish, broad; the upper and the floral rounded, all but the obovate radical ones clasping or perfoliate: stem 2 to 4 feet high.

P. grandiflórus, Nutt. Leaves all distinct at base : pedicels short: corolla lilac or lavender-blue, abruptly ventricose above the proper tube, which exceeds the calyx : sterile filament.minutely pubescent at the dilated apex. - Fras. Cat. \& Gen. 1. c.; Benth. l. c.; Gray, 1. c. P. Bradburii, Pursh, Fl. ii. 738. - Prairies, from Wisconsin, Minnesota, and Illinois to Nebraska and Kansas. Capsule almost an inch long. 
P. Murrayánus, Hook. Cauline leaves connate-clasping, and all the upper pairs united into an oval or orbicular concave disk : pedicels slender: corolla deep scarlet, gradually widening upward; the lobes rather small : sterile filament wholly glalırous. - Bot. Mag. t. 3472; Gray, l.c.-Prairies of E. Texas, collected first by Berlandier, then by Drummond, \&e.

++ Glabrous and glandless throughout. even to the calyx: leaves oblong or ovate, rigid, glaucescent, very acutely and as it were spinulosely dentate or denticulate with salient,teeth: cymes of the open elongated thyrsus pedunculate: flowers ample and showy; the corolla an inch long: sepals orate, short.

P. spectábilis, Thurber. Pale or glaucescent, 2 to 4 feet high : leaves thinnish-coriaceous, ovate or ovate-lanceolate or the lower oblong, acute; the upper pairs acuminate and their broad bases connate-perfoliate: thyrsus many-flowered, elongated-pyramidal or sometimes virgate, a foot or two long: peduncles and pedicels slender (half inch or more long) : corolla rose-purple or lilac with the ample limb usually violet or blue, a full inch long, with narrow proper tube twice the length of the calyx, then abruptly dilated into the campanulate-ventricose or broadly funnelform throat, moderately bilabiate; the oval or roundish plane lobes 3 or 4 lines long : sterile filament glabrous. - Gray in Pacif. R. Rep. iv. 19, \& Bot. Mex. Bound. 113 ; Hook. Bot. Mag. t. 5260. - Dry hills and plains, S. California (from San Gabriel) to Arizona and New Mexico.

P. Cleavelándi, Gray. Resembling the preceding in foliage and growth: but leaves less broad at base and commonly distinct, sometimes connate-perfoliate; the lower on naked petioles: thyrsus smaller and virgate : corolla crimson, three-fourths to a full inch long, much narrower, tubular-funnelform; its lobes $1 \frac{1}{2}$ or 2 lines long: sterile filament moderately bearded above on one side. - Proc. Am. Acad. xi. 94 \& Bot. Calif. i. 559. - S. E. California, San Diego Co., Cleceland, Palmer, and San Bernardino Co., at Cucamonga, long ago collected (panicles only) by Wallace, and now near San Bernardino, by Parry \& Lemmon. (Adjacent Mex.)

+++ Tery glabrous up to the loose elongated inflorescence and orate appressed sepals: leaves coriaceous, glaucous, orate or oblong-lanceolate, mostly spinulose dentate : corolla abruptly much enlarged and remarkably wide.

P. Pálmeri, Gray. Stems 2 or 3 feet high: leaves $1 \frac{1}{2}$ to 4 inches long; the lower petioled; upper from closely sessile to completely connate-perfoliate, and from very sharply dentate or denticulate to nearly entire: thyrsus pyramidal-racemiform, glandular or pruinose-puberulent: lower peduncles $2-3$-flowered, as long as the pedicels : corolla creamwhite and usually suffused or parti-colored with pink; the short narrow proper tube hardly surpassing the caly $\mathrm{x}$, very abruptly dilated into the ventricose-campanulate throat of about three-fourths inch in length and width at orifice; the lips broad; the upper erectish and 2-lobed; lower 3-parted, widely spreading, sparingly bearded at base: sterile filament long- and densely (yellow-) bearded above. - Proc. Am. Acad. vii. 378, \& viii. 291 ; Watson, Bot. King, 220 ; Hook. f. Bot. Mag. t. 6064 (very highly colored). - Arizona and S. Utah to W. Nevada and S. E. California.

++++ Puberulent or pubescent and above viscid or glandular: leaves from ovate to lanceolate-linear: thyrsus racemiform : cornlla ample, purplish; its proper tibe little if any longer than the lanceolate sepals, abruptly dilated into the ventricose-campanulate or broadly funnelform throat; the spreading limb obscurely bilabiate : sterile filament more or less long-bearded.

+ Corolla commonly 2 inches Inng: thyrsus lax and short: stem about a foot high: leaves large and broad, most of them acutely denticulate or serrate.

P. Cobǽa, Nutt. Soft-puberulent : leaves ovate or oblong, or the lower broadly lanceolate and the upper subcordate-clasping ( 2 to 4 inches long): corolla abruptly campanulateventricose above the narrow tube, from dull reddish purple to whitish, glabrous within: slender sterile filament sparsely bearded. - Trans. Am. Phil. Soc. n. ser. v. 182; Hook. Bot. Mag. t. 3465. - Prairies, Kansas to Texas.

++ ++ Corolla about an inch long: thyrsus strict, leafy below: stems a span or two high: leaves narrower, mostly entire, or the margins undulate.

P. Jamésii, Benth. Pruinose-puberulent: leaves all narrowly or linear-lanceolate ( $1 \frac{1}{8}$ to $3 \frac{1}{2}$ inches long) : corolla abruptly dilated into a broadly cyathiform-campanuiate throat, a little hairy within: sterile filament moderately bearded. - DC. Prodr. x. 325; Gray, Proc. Am. Acad. vi. 67. P. albidus, in part, Torr. in Ann. Lyc. N. Y. ii. 229, not Nutt. - Prairies, \&c., S. Colorado, New Mexico, and W. Texas. 
P. cristátus, Nutt. Pubescent, or above viscid-villous : leaves from linear-lanceolate to narrowly oblong ( 1 to 3 inches long): corolla more funnelform, being less abruptly dilated upward; its lower lip long-villous within: sterile filament more exserted, inordinately yellow-bearded. - Fras. Cat. \& Gen. ii. 52 ; Benth. 1. c. P. erianthera, Pursh, Fl. ii. 737, excl. syn., not Nutt. - Plains, \&c., Dakota to Nevada and S. Colorado.

+++++ Pruinose-puberulent and glandular or nearly glabrous: leaves all linear and entire, narrow at base: corolla large, nearly inch and a half long, funnelform, purple or violet, very obscurely bilabiate; the rounded lobes 2 or 3 lines long: sterile filament wholly glabrous: inflorescence very loose, sometimes simply racemose: sepals ovate or oblong.

P. dasyphýllus, Gray. A foot high, simple, densely puberulent, and the few-flowered simply racemose inflorescence glandular: pedicels alternate, bracteolate only at base: leaves 3 or 4 inches long, 2 or 3 lines wide (rarely shorter and wider); uppermost reduced to subulate bracts : sepals hardly acute. - Bot. Mex. Bound. 112, \& Proc. 1. c. - Eastern Arizona and New Mexico.

P. stenophýllus, Gray, 1. c. Glabrous or obscurely puberulent, 2 or 3 feet high : leaves 3 or 4 inches long and the larger only 2 lines wide, attenuate-acute; the uppermost and floral nearly filiform: thyrsus loosely paniculate: peduncles and pedicels slender: sepals acuminate. - Southern Arizona, Wright. (Adjacent Mex., Wishizenus.)

P. LANCEOLAtus, Benth., of Mexico, may reach our borders. It is minutely puberulent, has leaves mostly broader at base, racemose but not quite simple inflorescence, and a "red" corolla barely an inch long.

++++++ Puberulent, or viscid-pubescent, at least the inflorescence, or sometimes glabrous: leaves various: corolla from an inch down to 4 lines long, not abruptly campanulateventricose above, except in $P$. lavigatus: sepals usually narrow or acuminate.

+ Leaves from ovate to lanceolate, or the upper cauline when narrower widest at base, undivided: stems erect or ascending : thyrsus mostly many-flowered.

= Sterile filament bearded along one side, at least toward the apex.

u. Corolla hardly at all bilabiate, funnelform, with proportionally rather ample and nearly equal spreading lobes, white or whitish, often with a tinge of purple, two-thirds or three-fourths inch long and the limb about as broad: sterile filament thinly short-bearded: leaves entire or bartly and sparingly denticulate: thyrsus strict and verticillastriform-interrupted.

P. tubiflórus, Nutt. Wholly glabrous: stem 2 or 3 feet high, strict, naked above: leaves oblong or ovate-lanceolate; the floral shorter than the remote and densely-flowered clusters of the much interrupted virgate thyrsus: sepals ovate, merely viscid, only 2 lines long, very short in proportion to the rather slender tube of the corolla. - Trans. Am. Phil. Soc. ser. 2, v. 181; Benth. I. c. - Low prairies, Kansas and Arkansas. Still rare and insufficiently known. Thyrsus a span to a foot long, of several whorl-like clusters.

P. álbidus, Nutt. Viscid-pubescent, 6 to 10 inches high: leaves oblong-lanceolate or narrow: thyrsus strict, leafy below, of approximate few-several-flowered clusters : sepals lanceolate, densely viscid-pubescent, 3 or 4 lines long: corolla with shorter tube and more cyathiform throat. - Gen. ii. 53; Benth. 1. c. P. teretiflorus, Nutt. in Fras. Cat. $P$. viscidulum, Nees in Neuwied Trav, app. 18. - Plains, Dakota to Colorado and Texas.

b. Corolla more manifestly bilabiate; lower lip usually somewhat bearded or pubescent within.

1. Leaves ovate, all or most of them serrate: corolla bright blue or changing to purple, rather narrow, half or two-thirds inch long.

P. pruinósus, Dougl. Stem a foot high, pubescent: leaves from ovate to oblong, glaucescent, an inch or two long; the radical and lowest and also uppermost cauline commonly entire; the others acutely and rigidly dentate or denticulate: thyrsus virgate, interrupted: peduncles (several-flowered) and pedicels short; these and the lanceolate attenuate-acuminate sepals viscidly villous: lower lip of the deep blue corolla slightly hairy within. Lindl. Bot. Reg. t. 1280 ; Benth. 1. c. - Interior of Oregon and Washington Territory, Douglas, Lyall. Little known.

P. ovátus, Dougl. Stem 2 to 4 feet high, puberulent or pubescent: leaves ovate and the upper subcordate-clasping, all acutely serrate (or the radical rarely entire), bright green: thyrsus looser; the lower peduncles often longer than the clusters: sepals ovate or oblong, barely acute, glandular: lower lip of the purple-blue corolla bearded in the throat. - Hook. Bot. Mag. t. 2903 ; Brit. Fl. Gard. ser. 2, t. 211 ; Benth. 1. c. - Woods and banks, Oregon to Brit. Columbia and the western part of Idaho. 
2. Leaves from oblong or ovate-lanceolate to lanceolate, entire, or some denticulate, glabrous : corolla from a third to two-thirds of an inch in length.

P. attenuátus, Dougl. Stem strict, a foot or two high; the summit and inflorescence more or less pubescent and viscid: leaves narrowly oblong to lanceolate, or the upper sometimes ovate-lanceolate: thyrsus of the next species or less compact: sepals ovate- to oblong-lanceolate, acute or acuminate, narrowly scarious-margined, as long as the capsule: corolla narrowly funnelform, over half inch long, ochroleucous, sulphur-yellow, or sometimes violet or blue. - Lindl. Bot. Reg. t. 1295; Hook. Fl. ii. 97; Benth. I. c. - Interior of Oregon, Idaho, \&c. No indigenous specimens yet seen accord with the figure, in robustness, upper cauline leaves ovate-lanceolate and inch wide, and corolla 9 lines (or according to Bentham 9 to 11 lines) long. The plants referred here verge to the next, but have longer corolla, 6 or 8 lines long. The species is still uncertain.

P. confértus, Dougl. Glabrous throughout, or the inflorescence and calyx sometimes viscid-pubescent or puberulent, a foot or two high: leaves from oblong or oblong-lanceolate to somewhat linear, usually quite entire: thyrsus spiciform, interrupted, naked, of 2 to 5 verticillastriform dense many-flowered clusters (either subsessile or the lower peduncled): pedicels very short: sepals from oblong-lanceolate to broadly ovate, with broad scarious margins conmonly erose or lacerate, rather shorter than the capsule: corolla narrow, 4 to 5 or rarely 6 lines long, in the typical forms from ochroleucous to sulphur-color; lower hip conspicuously bearded within. - Lindl. Bot. Reg. t. 1260; Hook. l. c. ; Benth. 1. c. ; Gray, Proc. Am. Acad. vi. 72. - Moist or dry grounds, Northern Rocky Mountains to Oregon. The commoner state is

Var. cæruleo-purpúreus, Gray, 1.c. A foot or two high, rarely more, or in the higher mountains from 10 down to 2 inches high ; the latter with capituliform inflorescence: sepals very variable, commonly very scarious and erose, sometimes with a long herbaceous acumination: corolla blue-purple and violet. $-P$. procerus, Dougl. ex Graham in Edinb. Phil. Jour. 1829; Hook. Bot. Mag. t 2954; Lodd. Bot. Cab. t. 1616 ; Benth. 1. c. P. Tolmiei, Hook. Fl. ii. 97. P. micranthus, Nutt. in Jour. Acad. Philad. vii. 45. - Saskatchewan and along the Rocky Mountains to Colorado, west to Oregon and through the whole length of the Sierra Nevada, California.

P. Watsóni. Glaucescent and glabrous throughout, or inflorescence and calyx minutely puberulent, but neither glandular nor viscid : stems a foot or more high, ascending or weak: cauline leaves oblong-lanceolate to ovate-lanceolate, acute or acuminate (1 to 2 inches long, 4 to 9 lines wide) : contracted thyrsus rather loose: peduncles several-flowered; the lower slender : pedicels longer than the caly $x$ : sepals broadly ovate or orbicular with a small acumination, somewhat scarious-margined, little over a line long, barely half the length of the mature capsule : corolla narrowly funnelform, 6 to 8 lines long, violet-purple or partly white; lower lip almost glabrous within. - P. Fremonti, var. Parryi, Gray ex Watson, Bot. King, 218. - Mountains of W. Colorado, Utah, and Nevada (Fremont, Parry, Watson, Wheeler; Tasey, Ward, \&c.), to borders of Arizona, Palmer.

P. húmilis, Nutt. Stems a span or two high, glabrous or above with the inflorescence and flowers viscid-pubescent: leaves glaucescent, from oblong to lanceolate (an inch or more long); the cauline commonly denticulate: thyrsus strict and virgate, 2 to 4 inches long: peduncles (2-5-flowered) and pedicels short: sepals ovate or lanceolate and acuminate, lax: corolla rather narrowly funnelform, half inch long, deep-blue or partly white; lower lip somewhat hairy within. - Gray, Proc. 1. c.; Watson, Bot. King, 220. - Rocky Mountains from the British boundary to $\mathrm{S}$. Colorado, and west to the Humboldt Mountains in Nevada. The larger forms may pass into $P$. gracilis.

Var. brevifólius. A low and rather diffuse tufted form, with weak stems : leaves at most half inch in length; cauline elliptical-oblong; the radical oval or rotund : corolla light blue. - P. humilis, var.? Watson, 1. c. - Utah, in the Wahsatch Mountains, at 9,000 or 10,000 feet, Watson, Eaton.

3. Leaves from ovate-lanceolate to linear, often denticulate: corolla an inch or three-fourths inch long: cymes of the more or less open thyrsus pedunculate: sepals lanceolate, acute, marginless.

P. grácilis, Nutt. A foot or less high, glabrous or merely puberulent up to the more or less viscid-pubescent strict thyrsus: stems slender: cauline leaves mostly linear-lanceolate ( 1 to 3 inches long, the serrations when present very acute or subulate); the radical spatulate or oblong: peduncles 2-several-flowered : corolla tubular-funnelform or almost cylin- 
draceous, lilac-purple or sometimes whitish, three-fourths to nearly an inch long; the throat open. - Gen. ii. 52 ; Graham in Bot. Mag. t. 2945 ; Lodd. Bot. Cab. t. 1541; Benth. 1. c. $P$. pubescens, var. gracilis, Gray, Proc. l. c. partly. - Saskatchewan to Wyoming, and south in the mountains to Colorado. Intermediate between the preceding and following: distinguished from slender forms of the latter by the open mouth and nearly terete throat of the narrow corolla.

P. pubéscens, Solander. Stem a foot or two high, viscid-pubescent, or sometimes glabrous up to the inflorescence.: cauline leaves from oblong to lanceolate ( 2 to 4 inches long), usually denticulate; the lowest and radical ovate or oblong: thyrsus loosely-flowered, mostly naked, narrow : flowers drooping: corolla dull violet or purple, or partly whitish, an inch long, very moderately dilated above the short proper tube, carinateangled for the whole length of the upper and deeply plicate-bisulcate on the lower side, the upper part of the intrusive portion villous-bearded and forming a sort of palate; orifice crescentic or almost closed; the lips and their lobes short: sterile filament densely bearded far down. - Ait. Kew. ii. 360; Sims, Bot. Mag. t. 1424; Gray, l. c. excl. syn. P. lavigatus. Chelone hirsuta, L. C. Pentstemon, L. Mant. 415. Asarina caule erecto, \&c., Mill. Ic. t. 152. Pentstemon hirsutus, Willd. Spec. iii. 227. P. Mackayanus, Knowles in Fl. Cab. ii. 117, t. 74. $P$. longifolius, Scheele in Linn. xxi. 764? - Dry or rocky grounds, from Canada to Iowa and south to Florida and Texas.

P. lævigátus, Solander, 1. c. Mostly glabrous up to the glandular inflorescence: stem 2 to 4 feet high: leaves of firmer texture and somewhat glossy; cauline ovate- or oblong-lanceolate with subcordate-clasping base, 2 to 5 inches long: thyrsus broader: corolla about an inch long, white and commonly tinged with purple, abruptly campanulateinflated above the proper tube, more or less obliquely ventricose, obscurely angled down the upper side, not at all intruded on the lower; orifice widely ringent, sparingly slenderbearded at base of the lower lip: sterile filament thinly bearded above. - Sims, Bot. Mag. t. 1425; Michx. Fl. ii. 21 ; Pursh, Fl. ii. 427. Chelone Pentstemon, L. Spec. ed. 2, 850, excl. syn. Arduin, Moris. \&c.; Lam. Ill. t. 528. P. pubescens, var. multiflorus, Benth. in DC. 1. c. ( $P$. Ihigitalis, var. multiflorus, Chapm.); a small-flowered and small-fruited form, answering to the figure by Lam. P. glaucophyllus, Scheele in Linn. xxi. 763?-Moist or rich soil, Jenn. to Florida and westward, where the commoner form is

Var. Digitális. Stem sometimes 5 feet high: corolla larger and more abruptly inflated, white. - P. Digitalis, Nutt. in Trans. Am. Phil. Soc. n. ser. v. 181 ; Reichenb. Exot. v. t. 292 ; Hook. Bot: Mag. t. 2587 ; Benth. in DC. 1. c. 327 ; Gray, Man. ed. 5, 328. Chelone Digitalis, Sweet, Brit. Fl. Gard. t. 120. Penn. to Illinois, Arkausas, \&c.

P. glaúcus, Graham. Glabrous up to the inflorescence, more or less glaucous: stems dwarf or ascending, a span to a foot high: leaves thickish, oblong-lanceolate or the radical oblong-ovate (one or two inches long), entire or denticulate: thyrsus short and compact, either simple or compound, villous-pubescent and viscid or glandular : corolla dull lilac or violet-purple, less than an inch long, campanulate-ventricose above the very short proper tube, gibbous, not at all plicate-sulcate; the orifice widely ringent; the broad lower lip sparsely villous-bearded within : sterile filament bearded mostly at and near the apex only. - Edinb. Phil. Jour. 1829, 348; Lindl. Bot. Reg. t. 1286; Gray, Proc. l. c. P. glaber, var. stenosepalus, Regel in Act. Petrop. iii. 121 ? - Rocky Mountains north of $49^{\circ}$ (Drummond) to Wyoming and Utah; southward, chiefly in the form of

Var. stenosépalus, Gray, l. ¿. Sometimes over a foot high : thyrsus comparatively small and glomerate: sepals attenuate-lanceolate: corolla dull whitish or purplish. - Mountains of Colorado and Utah near the upper borders of the wooded region. $=\underset{\text { antheriferous in certain flowers. }}{=}$ Sterile filament with a few minute short hairs), sometimes completely

P. Whippleánus, Gray. Glabrous up to the inflorescence or nearly so: stems slender, a foot long, ascending from a decumbent base, leafy: leaves, membranaceous, ovate or ovate-oblong, entire or repand-denticulate, acute or acuminate, commonly 2 inches long; lower petioled; upper cauline closely sessile or partly clasping by a broad base: thyrsus loosely few-flowered: peduncles 2 to 5 , slender, 2-3-flowered: pedicels and the narrowly linear-lanceolate lax and attenuate sepals villous, somewhat viscid: corolla an inch long, campanulate-ventricose above the short proper tube, decidedly bilabiate; the lower lip longer than the nearly erect 2-lobed upper one, sparscly long-bearded within: stcrile fila- 
ment dilated, uncinate at tip. - Proc. Am. Acad. vi. 73. - New Mexico, Sandia Mountains, Bigelow. Corolla in size and shape, and probably color, resembling that of $P$. glaucus.

P. deústus, Dougl. Completely glabrous; the caly $\mathbf{x}$ at most obscurely granular-pruinose or glandular : stems a span to a foot high in tufts from a woody base, rigid: leaves coriaceous, from ovate to oblong-lincar or lanceolate (an inch or two long), irregularly and rigidly dentate or acutely serrate, or some of then entire; upper cauline closely sessile: thyrsus virgate or more paniculate, mostly many-flowered: peduncles and pedicels short: sepals from ovate to lanceolate, nearly marginless: corolla ochroleucous or dull white, rarely with a tinge of purple, half inch or less long, either narrowly or rather broadly funnelform; the short lobes widely spreading. - Lindl. Bot. Reg. t. 1318; Benth. 1. c. ; Gray, 1. c., \& Bot. Calif. i. 559 ; Watson, Bot. King, 22:2, who has seen the "filament bearded with yellow hairs." $P$. heterander, Torr. \& Gray, Pacif. R. Rep. ii. 123, t. 8, a narrowleaved form having the fifth filament in some flowers antheriferous. - Dry interior region, California, on the eastern side of the Sierra Nevada, and north to the borders of Brit. Columbia and Montana.

P. heterodóxus. A span or more high, leafy, glabrous nearly up to the inflorescence: leaves oval or oblong, obtuse, entire; the cauline closely sessile: thyrsus short, compact, viscid-pubescent : sepals lanceolate: corolla 7 lines long, narrow-tubular, hardly dilated up to the small limb, probably purplish: fifth filament filiform, resembling the others, in some flowers completely antheriferous. $-P$. Fremonti, Gray, Bot. Calif. i. 622 , not of Torr. \& Gray. - High mountain near Donner Pass, in the Sierra Nevada, California, Torrey. Species imperfectly known, from insufficient specimens.

++ Leares from linear-spatulate to obnvate, or the uppermost sometimes ovate, entire: stems low-cespitose or spreading, leafy to summit, often suftrutescent at base, few-flowered: corolia over half inch long, mostly purple or blue, narrowly funnelform: sterile filament bearded down one side.

$=$ Leaves green and mostly glabrous, broad, half to quarter inch wide.

P. Harboúrii, Gray. Tufted nearly simple stems 2 to 4 inches high, puberulent: leaves about 3 pairs, thickish, obovate, oval, or the uppermost sometimes ovate, these sessile by a broad base: thyrsus reduced to 2 or 3 crowded short-pedicelled flowers: sepals ovateoblong, villous and somewhat viscid: corolla little bilabiate, with rather broad cylindraceous throat and tube, barely twice the length of the round-oval lobes; lower lip bearded within. - Proc. Am. Acad. vi. 71. - High alpine region of the Colorado Rocky Mountains, Hall \& Harbour, Parry.

$=$ Leaves cinereous or canescent, a line or two wide: sepals lanceolate: corolla narrowly funnelform, mostly three-fourths inch long: flowering along the short stems in the axils of the leaves: short peduncles leafy-bracteolate, 1-3-flowered.

P. púmilus, Nutt. Canescent (even to the marginless sepals) with a dense and fine short pubescence: stems an inch or two high, erect or ascending, very leafy: leaves lanceolate or the lower spatulate (the latter, including the attenuate base or margined petiole, an inch or more long): corolla with regularly funnelform throat, glabrous within: sterile filament sparsely short-bearded, or more abundantly at the tip. - Jour. Acad. Philad. vii. 46; Gray, 1. c. 67. - Rocky Mountains in Montana? "on Little Goddin River," Wyeth. A small and few-flowered plant.

Var. Thompsónize. Cespitose, from half inch to 4 inches high, suffrutescent at base: stems copiously flowering for their whole length: lowest leaves obovate; upper lanceolate: corolla two-thirds to three-fourths inch long. - S. Utah, Mis. Thompson, Capt. Bishop (a dwarf and depressed form), also Siler, Palmer, a more developed and elongated form, with corolla àpparently bright blue.

Var. incánus. A small and very white-hoary form, few-flowered: leaves only 2 or 3 lines long, spatulate and obovate, more mucronate: corolla half inch long, slightly hairy within down the lower side, somewhat as in the next.-Pahranagat Mountains, S. F. Nevada, Miss Searls. S. W. Utah, Siler.

P. cæespitósus, Nutt. Minutely cinereous-puberulent, spreading, forming depressed broad tufts 2 to 4 inches high: leaves from narrowly spatulate to almost linear ( 3 to 8 lines long, including the tapering base or margined petiole): peduncles mostly secund and horizontal, but with the flower upturned: sepals more acuminate, and the margins below obscurely scarious: corolla tubular-funnelform, and the lower sile biplicate, the narrow folds sparsely villous within : sterile filament strongly and densely bearded. - Gray, Proc. 
Am. Acad. vi. 66; Watson, Bot. King, 219. - Rocky Mountains, Wyoming, W. Colorado, and Utah, Nuttull, Hall \& Harbour, Purry, Watson.

Var. suffruticósus. A span or more high from a stouter woody base: leaves from spatulate to obovate and more petioled, thicker, glabrate: sepals less acuminate: corolla and stamens not seen: probably a distinct species. - Utah near Beaver, Palmer, in fruit.

+++ Leares from narrowly linear-lanceolate with tapering base or linear-spatulate to filiform, entire: stems or branches racemosely several-many-flowered.

$=$ Stem herbaceous to the base, very simple, a foot or two high : corolla broad : sterile filament glabrous: peduncles mostly opposite.

P. virgátus, Gray. Minutely glandular-pruinose or glabrous : stem strict and elongated: thyrsus virgate: leaves all linear-lanceolate ( $1 \frac{1}{2}$ to 4 inches long) : peduncles short, $1-3-$ flowered: sepals ovate: corolla lilac with purple veins, three-fourths inch long, abruptly dilated into a broadly campanulate funnelform throat (as wide as long), distinctly bilabiate; the broad lips widely spreading: stamens nearly equalling the lips. - Bot. Mex. Bound. 112, \& Proc. Am. Acad. vi. 66. - New Mexico and Arizona, Fendler, Wright, \&c. Inflorescence and corolia in the manner of $P$. secundiflorus.

$==$ Stems or tufted branches mostly simple from a woody base (or herbaceous in the last species), low : sterile filament longitudinally bearded: short peduncles commonly alternate.

P. linarioídes, Gray, l. c. Cinereous, minutely pruinose-puberulent: stems much crowded on the woody base, filiform, rigid, very leafy, 6 to 18 inches high: leaves 6 to 12 lines long, from oblanceolate-linear (at most a line wide) to nearly filiform, mucronulate; the floral short and subulate: thyrsus racemiform or sometimes paniculate; only the lower peduncles 2-4-flowered: pedicel shorter than the ovate or oblong acuminate sepals : corollit lilac or purple, half inch or more long, with dilated-funnelform throat, less bilabiate than in the preceding; lower lip conspicuously bearded at base. - Arid grounds, New Mexico and Arizona, Wright, Thuber, Purry, \&c.

Var. Silleri. $\Lambda$ dwarf and suffruticulose form, with smaller and fewer flowers, mostly 1-flowered peduncles subtended by proportionally longer floral leaves, and the lower lip less bearded. - P. coespitosus, var., Parry in Am. Naturalist, ix. 346, a much reduced form. - S. Utah, Siler, Parry.

P. Gaírdneri, Hook. Cinereous-puberulent: stems a span high, rigid: leaves linear or the lower more or less spatulate, obtuse, half to full inch long: thyrsus short and simple: peduncles usually one-flowered: sepals oblong-ovate, glandular-viscid: corolla half inch long, narrowly funnelform, obscurely bilabiate, purple. - Fl. ii. 99; Gray, 1. c. - Dry interior of Washington Terr., Oregon, and W. Nevada.

P. laricifólius, Hook. \& Arn. Glabrous: lignescent caudex not rising above the soil : leaves very slender, when dry filiform (the larger a fourth of a line wide, and with margins revolute, an inch or less long), much crowded in subracical tufts and scattered on the ( 2 or 5 inch long) filiform flowering stems: flowers few, loosely racemose, slenderpedicelled : sepals ovate-lanceolate : corolla tubular-funnelform, half inch long; the small limb obscurely bilabiate. - Bot. Beech. 376; Gray, 1.c. - Interior of Oregon and Wyoming. $===$ Stems paniculately branching and slender, woody toward the base: cornlla betwean funnelform and salverform: sterile filament glabrous: peduncles slender, opposite, all the upper one-flowered.

P. ambíguus, Torr. Glabrous, a foot or two high, diffuse and often much branched: leaves filiform, or the lowest linear and the floral slender-subulate: inflorescence loosely paniculate: sepals ovate, acuminate: corolla rose-color and flesh-color turning to white; the rotately expanded limb oblique but obscurely bilabiate; lobes orbicular-oval; throat or its lower side somewhat hairy: sterile filament sometimes imperfectly antheriferous. Ann. Iyc. N. Y. ii. 228, \& Marcy Rep. t. 16; Gray, Proc. Am. Acad. vi. 64. - Plains of F. Colorado and New Mexico to S. Utah and Arizona. (Adjacent Mex.) Var. foliosus, Bentlı, l. $\varepsilon$., is an undeveloped state. Corolla in the typical form with a narrow and somewhat curved tube and throat, of half inch in length: but it passes into

Var. Thúrberi, Gray, l. c. (P. Thurberi, Torr. in Pacif. R. Rep. vii. 15), with shorter tube and more dilated throat. The two extremes of this have, in the larger forms, limb of corolla half inch in diameter with tube and throat together only 3 lines long (Arizona, Palmer, \&c.); in the smallest, corolla-limb only half the size, with tube and throat 2 or 3 lines long (Arizona and adjacent Mex., Wislizenus, Rothrock). New Mexico, Arizona, and S. Utah. 
++++ Leares pinnately parted into narrowly linear divisions!

P. disséctus, Ell. Merely puberulent : stem slender, 2 feet high : leaves in rather distant pairs; radical and lowest not seen; upper with 7 to 11 obtuse entire divisions, of barely half line in width, on a rhachis of equal breadth : thyrsus long-peduncled, umbelliform or triradiate, few-flowered: pedicels slender : sepals ovate-oblong: corolla "purple," 9 lines long, oblong-funnelform; the limb obscurely bilabiate: sterile filament bearded at the apex. - Sk. i. 129 ; Gray, 1. c. — Middle Georgia, "Jackson," Darby.

- $\$ 2$. Saccanthéri, Benth. Anthers sagittate or horseshoe-shaped; the cells confluent at the apex, and there dehiscent by a continuous cleft, which extends lown both cells only to the middle; the base remaining closed and saccate, sometimes hirsute, never lanate. Pacific-States species, herbaceous or some rather woody at base, mostly with ample and showy flowers.

* Soft-pubescent and riscid, with broad and thinnish leaves mostly serrate or denticulate.

P. glandulósus, Lindl. Sten rather stout, 2 or 3 feet high : radical leaves ovate or oblong, 6 or 8 inches long, dentate: cauline from cordate-clasping to ovate-lanceolate, acuminate, usually denticulate or few-toothed: thyrsus contracted and interrupted, leafy below: cymes short-pedunculate, few-several-flowered: sepals attenuate-lanceolate, lax: corolla lilac, over an inch long, with funnelfornt-inflated throat, and rather short broad and spreading lips: sterile filament glabrous. - Bot. Reg. t. 1262; Hook. Bot. Mag. t. 3688; Benth. in DC. Prodr. x. 330 ; Gray in Proc. Am. Acad. vi. 74. P. staticifolius, Lindl. Bot. Reg. t. 1770. - Mountain woods and along streams, Oregon and Washington Terr. to Idaho.

* * Glabrous or merely puberulent: leaves serrate, incisely dentate, or sometimes laciniate: sterile filament more or less hairy above : corolla funnelform and moderately bilabiate, lilac, purple, or light violet,

+ Over an inch long: calyx remarkably small.

P. venústus, Dougl. Very glabrous: stems rather strict and simple, a foot or two high, leafy: leaves thickish in texture, oblong-Ianceolate or the upper ovate-lanceolate, closely and subulately serrate (about 2 inches long): thyrsus naked, mostly narrow: peduncles 1-3-flowered: sepals ovate, acute or acuminate, only a line or two long, much shorter than the proper and narrow tube of the corolla: upper part of fertile filaments and of the sterile one (as also usually anthers and lobes of the corolla within) sparsely pilose. - Lindl. Bot. Reg. t. 1309; Benth. l. c.; Gray, l. c. P. amonus, Kunzè in Linn. xvi. littbl. 107 ? - Oregon and Idaho.

+ + Corolla barely or less than an inch long: calyx and pedicels mostly puberulent or viscidglandular: stems (a foot or two high) ascending or diffuse: thyrsus paniculate.

P. diffísus, Dougl. Leaves from ovate to oblong-lanceolate, or the upper subcordate, slarply and unequally and sometimes laciniately serrate ( $1 \frac{1}{2}$ to 4 inches long): thyrsus commonly interrupted and leafy: pedicels mostly shorter than the ovate or lanceolate and acuminate (sometimes laciniate-toothed) sepals: corolla three-fourths inch long: anthers glabrous : sterile filament villous-bearded above. - Lindl. Bot. Reg. t. 1132; Hook. Bot. Mag. t. 3645; Gray, 1. c. P. serrulatus, Menzies in Hook. Fl. ii. 95. P. argutus, Paxt. Mag. Bot. vi. 271, appears to be a form of this, connecting with the next species. - Wooded or rocky banks, Oregon to Brit. Columbia.

P. Richardsónii, Dougl. Stems often loosely branching: leaves ovate- to narrowly lanceolate in outline, from incised to laciniate-pinnatifid; the upper commonly alternate or scattered: thyrsus loosely panicled: sepals (ovate or oblong) and pedicels often glandular and viscid: corolla three-fourtls to an inch long: sterile filament sparingly villousbearded at apex. - Lindl. Bot. Reg. t. 1121; Hook. Bot. Mag. t. 3391 ; Loodd. Bot. Cab. t. 1641. - Bare rocks, \&c., Oregon and Washington Terr.

P. triphýllus, Dougl. Stems slender, about a foot high, usually simple: cauline leaves lanceolate or linear (an inch or so long), rigid, from denticulate to irregularly pinnatifid-laciniate; the upper sometimes ternately verticillate, sometimes alternate: thyrsus narrow, loosely paniculate : sepals lanceolate, acuminate : corolla comparatively small and narrow, half to two-thirds inch long: sterile filament densely bearded at apex. - Lindl. Bot. Reg. t. 1245; Benth. in DC. Prodr. 1. c. - Rocks, \&c., Oregon to British Columbia. 
* * Glabrous or merely puberulent: leaves all entire.

+ Corolla blue or violet, half inch long, slender-funnelform, moderately bilabiate : sterile filament lightly bearded.

P. graciléntus, Gray. Stems slender from a lignescent base, a foot or more high, rather few-leaved, naked above, terminating in a loose and rather simple paniculate thyrsus: leaves glabrous and green, lanceolate, or the upper linear and the lowest sometimes oblong, all narrowed at base: peduncles (and calyx) viscid-puberulent, 2-5-flowered; the lower elongated : pedicels short: corolla-lobes only 2 lines long, moderately spreading. Pacif. R. Rep. vi, 83, Proc. Am. Acad. vi. 75, \& Bot. Calif. i. 561.-Mountains; N. California and adjacent parts of Oregon and Nevada, at 5-8,000 feet.

+ + Corolla blue to purple, more ventricose-funnelform, short-bilabiate, two-thirds to an inch and a half long: sterile flament glabrous. (Species too nearly allied, mostly lignescent or rather slirubby at base.)

++ Inflorescence and calyx glandular or viscid-pubescent: thyrsus open-paniculate.

P. læbtus, Gray. A foot or so high, cinereous-pubescent or puberulent, above glandularpubescent: leaves lanceolate or linear-lanceolate and the lowest spatulate: sepals ovate or oblong, herbaceous : corolla an inch long, blue. - Jour. Bost. Nat. Hist. Soc. vii. 147, Proc. Am. Acad. 1. c., \& Bot. Calif. 1. c.-Open and dry grounds, California to the mountains above the Yosemite and apparently even to Siskiyou Co.

P. Rózli, Regel. Smaller, a span to a foot high, below glabrous or minutely puberulent: leaves all lanceolate or linear, or the lower oblanceolate: thyrsus either narrow or more diffuse and compound, with the branches divergent: corolla smaller (from half to two-thirds inch long) and narrower, pale blue or violet. - Act. Hort. Petrop. ii. 326, \& Gartenfl. 1872, t. 239 ; Gray, Bot. Calif. ii. 567. P. heterophyllus, var.? Torr. \& Gray in Pacif. R. Rep. ii. 122. - Drier parts of the Sierra Nevada, California, from Kern Co. to frontiers of Oregon and adjacent Nevada. Approaches smaller forms of the preceding.

++ Inflorescence and calyx, as well as foliage, perfectly glabrous or $\epsilon$ lse minutely puberulent without glandulosity: thyrsus usually narrow.

P. Kíngii, Watson. Hardly glaucous: stems a span or so high from the depressed ligneous base, leaty to the top, erect or ascending: leaves oblanceolate or lanceolate-linear, acutish or obtuse, mostly narrowed to the base, an inch or so long: thyrsus strict, 1 to 5 inches long: sepals ovate-lanceolate and sleuder-acuminate, equalling the capsule: corolla comparatively small (two-thirds inch long), "purple." - Nevada and Utah, from the W. Humboldt to the Wahsatch and Uinta Mountains, Watson, \&c.

P. azúreus, Benth. Glaucous, rarely pruinose-puberulent : stems erect or ascending, 1 to 3 feet high: leaves from narrowly to ovate-lanceolate or even broader, the uppermost wider at base: thyrsus virgate, loose, usually elongated : sepals ovate, with or without a conspicuous acumination : corolla from 1 to $1 \frac{1}{2}$ inches long, azure-blue verging or changing to violet, the base sometimes reddish ; the expanded limb sometimes an inch in diameter. P1. Hartw. 327; Gray, 1. c.; "Paxt. Fl. Gard. t. 64; Lem. Jard. Fl. t. 211; Moore, Mag. 1850 , t. 209." - Dry ground, California, apparently through the length of the State, common on the Sacramento, \&c. Founded on a rather narrow-leaved form, but varies greatly in the foliage.

Var. Jaffrayánus, Gray, 1. c. A low form: leaves oblong or oval, or the upper ovate-lanceolate or ovate, very glaucous: peduncles 1-5-flowered: flowers large. $-P$. Jaffrayamus, Hook. Bot. Mag. t. 5045. P. glaucifolius, Gray in Pacif. R. Rep. vi. 82. $P$. heterophyllus, var. latifolius, Watson, Bot. King, 222? - Northern part of California and through the Sierra Nevada, also eastward to the Wahsatch Mountains in Utah, if the syn. Bot. King is rightly referred.

Var. párvulus. Less than a foot high : leaves oblong and oval, barely an inch long: many-flowered thyrsus rather open: sepals broadly ovate: corolla hardly three-fourths inch long: would be referred to the preceding variety, except for the smaller flowers:Northern part of California, in mountains above Jackson Lake, at 8,000 feet, Greene.

Var. angustíssimus, the extreme narrow-leaved form : leaves narrowly linear or sometimes the uppermost narrowly lanceolate from a broad base. - Yosemite Valley, \&c.

Var. ambiguus, a rather tall form, paniculately branched and slender, with lanceolate and linear leaves all narrowed at base in the manner of the following species, but pale and glaucescent, and the corolla violet-blue (only an inch or less long) : sepals remarkably 
small, ovate, merely mucronate. - P. heterophyllus, Watson, Bot. King, 222. - Cañons of the Wahsatch Mountains, Utah, viz. of the Provo and American Fork, Watson, \&c.

P. heterophyllus, Lindl. Green, seldom glaucescent : stems or branches 2 to 5 feet high from a woody base, slender: leaves lanceolate or linear, or only the lowest oblonglanceolate, mostly narrowed at base: corolla an inch or sometimes more in length, with narrow tube rose-purple or pink, sometimes changing toward violet; the bud often yellowish: otherwise hardly distinguishable from narrow-leaved forms of the preceding. - Bot. Reg. t. 1899 ; Hook. \& Arn. Bot. Beech. 376; Bot. Mag. t. 3853; Gray, l. c._- Dry banks, through the western and especially the southern part of California.

+++ Corolla scarlet-red, tubular-funnelform, conspicuously bilabiate, an inch long: sterile filament glabrous.

P. Bridgésii, Gray. A foot or two high from a lignescent base, glabrous up to the virgate secund thyrsus, or pruinose-puberulent: leaves from spatulate-lanceolate to linear; the floral reduced to small subulate bracts: peduncles (1-5-flowered) and pedicels short: these and the ovate or oblong sepals glandular-viscid : lips of the narrow corolla fully onethird the length of the tubular portion; the upper erect and 2-lobed; the lower 3-parted and its lobes recurved: anthers deeply sagittate. - Proc. Am. Acad. vii. 379, \& Bot. Calif. i. 560. - Rocky banks, Sierra Nevada, California, from the Yosemite southward, on Williaus Mountain, N. Arizona, and S. W. Colorado (Brandegee).

P. Nuttálli, Beck in Am. Jour. Sci. xiv. 120, is wholly doubtful, perhaps P. lavigatus.

P. Cerroséxsis, Kellogg in Proc. Calif. Acad. ii. 19, from Cerros Island, off the coast of Lower California, is said to have a tubular yellow corolla, 3-nerved sepals, \&c. Probably not of this genus.

P. Canoso-Barbatem and P. rostriflordm, Kellogg in Proc. Calif. Acad. ii. 15, Californian species, remain wholly obscure.

12. CHIONÓPHILA, Benth. (Xínv, snow, and qí̀os, beloved, growing on snow-capped mountains.) - DC. Prodr. x. 351; Benth. \& Hook. Gen. Pl. ii. 942 . - Single species : fl. summer.

C. Jamésii, Benth. l. c. Dwarf perennial, glabrous or nearly so: leares thickish, entire, mostly radical in a tuft, spatulate or lanceolate, tapering into a scarious sheathing base; those on the scape-like ( 1 to 3 inches high) flowering stems one or two pairs, or occasionally alternate, linear: spike few-many-flowered, dense, mostly secund, imbricate-bracteate: bracts shorter than the flowers: corolla over half inch long, dull cream-color, in anthesis twice the length of the calyx, at length more nearly enclosed by it. - Gray in Am. Jour. Sci. ser. 2, xxxiii. 252. - Colorado Rocky Mountains, in the high alpine region, first collected by Dr. James, in Long's Expedition, on James', now Pike's Peak.

13. MímULUS, L. Monkey-Flower. (Latin diminutive of mimus, a mime, from the grinning corolla.) - Large genus, of wide dispersion, but far most largely N. American; with opposite simple leaves, and usually showy flowers from the axils, or becoming racemose by the diminution of the upper leaves to bracts. Chiefly herbs, one polymorphous species shrubby; fl. in summer; several cultivated for ornament. - Gray, Bot. Calif. i. 563, \& Proc. Am. Acad. xi. 95 ; Benth. \& Hook. 1. c. Mimulus, Diplacus (Nutt.), Eunanus, \& Herpestis $\S$ Mimuloides, Benth. in DC. Prodr.

§1. Ecvincs, Gray. Annuals, mostly very low, glandular-pubescent or viscid: flowers sessile or short-pedicelled: calyx 5-angled and 5-toothed; the angles and teeth more or less plicate-carinate: corolla in the typical species with long and slender tube: anthers approximate in pairs, forming crosses : upper part of style pubescent or glandular : stigma variable, not rarely funnelform or peltate-petaloid: placentæ separated in dehiscence and borne by the half-dissepiment on the middle of each valve. - Eunanus, Benth. in DC. 
* Capsule cartilaginous, 2-4-sulcate, tardily dehiscent, oblique or gibbous at base : calyx gibbous at base and very oblique at the orifice : corolla purple or violet, with spotted or variegated throat: leaves entire or obscurely few-toothed.

- Corolla-tube filiform and long-exserted, in the earlier state much longer than the stems, an inch or more in length. - Enoe, Gray in Pl. Hartw. 329. Mimulus $\S$ Enoe, Gray, Bot. Calif. i. 503 .

M. trícolor, Lindl. Leaves from oblong to linear, obscurely nerved, with narrowed base nearly sessile: calyx hardly gibbous at base, ampler toward the very oblique orifice: corolla about inch and a half long, with short-funnelform throat, lips of about equal length, and lobes similar: capsule short-oval or ovate, slightly compressed rather acutely angled before and behind: seeds obovate, oblique, much larger than in related species. Jour. Hort. Soc. Lond. iv. 222 (June, 1849); Gray, 1. c. Eunanus Coulteri, Gray in Benth. Pl. Hartw. 329, Aug. 1849. - California, from the valley of the Sacramento to Mendocino Co. and eastward, Plumas Co. Stem when beginning to flower only a quarter inch high, at length may reach 3 inches.

Var. angustátus, Gray, 1. c. Leaves small and linear or nearly so: more slender tube of corolla sometimes nearly 2 inches long. - Plumas to Placer Co., Bolander, \&c.

M. Douglásii; Gray, 1. c. Leaves ovate or oblong, the 3-5-nerved base contracted into a petiole: calyx soon very gibbous at base on upper side: lower lip of corolla very much shorter than the ample erect lower one, or even obsolete; the throat more amply funnel. form : capsule linear or linear-oblong, terete, 4-sulcate, gibbous or somewhat inflexed at the very base: seeds oval, small, apiculate at both ends, as in all the following species of the section: stigma very variable. $-M$. nanus, var, subuniforus, Hook. \& Arn. Bot. Beech. 378. Eunanus Douglasii, Benth. in DC. 1. c. 374. - California, on gravelly banks, throughout the length of the State. Stem from a quarter of an inch to 6 inches high: corolla an inch to one and a half inches long.

+ + Corolla-tube hardly exserted from the calyx: fowers not surpassing the subtending leaf.

M. latifólius, Gray, 1.c. Viscid-pubescent : stem a span high, loosely branching : leaves all broadly ovate or oval, slightly petioled, membranaceous, 5-nerved at base, 9 to 12 lines long: caly $\mathrm{x}$ in flower hardly oblique, in fruit very gibbous: corolla pink-purple, half to three-fourths inch long; the funnelform throat as long as the tube: capsule narrowly oblong, laterally sulcate. - Guadalupe Island, off Lower California, Palmer.

* Capsule coriaceous or membranaceous, symmetrical : calyx equal at base, campanulate or short-oblong: stigma peltate-funnelform, and entire or obscurely 2-lobed. - $\$$ Eunanus, Gray, Bot. Calif. i. 564 .

+ Corolla smail, 3 to 6 lines long; the tube slender and exserted: calyx-teeth nearly equal.

M. leptáleus, Gray, l. c. Viscid-puberulent, 1 to 3 inches high, at length much branched: leaves from spatulate-oblong to linear-lanceolate, 2 to 6 lines long: calyx-tecth ovate or triangular, not equalling the oblong-ovate obtuse capsule : corolla crimson, with filiform tube, small throat, and oblique limb $1 \frac{1}{2}$ to 3 lines wide. - California, in gravelly soil of the Sierra Nevada, at 5-8,000 feet.

t + Corolla ampler, half to fully three-fourths inch long, funnelform, with widely spreading limb and throat gradually narrowed downward into the included or partly exserted tube: stems frum an inch to a span oi more high. (Species nearly related.)

+ Calyx hardly at all oblique; the teeth almost equal in length.

M. Bigelóvii, Gray, l. c. Leaves oblong; the upper ovate, acute or acuminate: calyxteeth very acutely subulate from a broad base ( 2 or less lines long), half the length of the broadly campanulate tube, the anterior ones narrower; throat of the corolla cylindraceous, and the ample limb rotate (crimson with yellow centre): capsule oblong-lanceolate, acute or acutish, a little exceeding the calyx; the valves membranaceous. - Eunanus Bigelovii, Gray in Pacif, R. Rep. iv, 121. - S. California, W. Nevada, and S. Utah.

M. nánus, Hook. \& Arn. Leaves from obovate or oblong to lanceolate: calyx-teetl broadly lanceolate or triangular, acute (a line long), a quarter of the length of the tube: corolla sometimes rose-purple, sometimes yellow: capsule with tapering apex rather exceeding the calyx; the valves chartaceous. - Bot. Beech. 1. c. 378, (var. pluriforus); Gray, 1. c. Eunanus Tolmioei, Benth. 1. c. E. Fremonti, Watson, Bot. King, 226, not Benth.-Hills, \&c., Sierra Nevada, California and adjacent parts of Nevada and Oregon to Wyoming. 
Var. bícolor, Gray, 1.c. A doubtful and insufficiently known form; with throat of corolla short and abruptly dilated, dark purple; the limb yellow. - Eunumus bicolor, Gray, Proc. Am. Acad. vii. 381. - Iigh sierra Novada in Fresno Co., Brewer.

M. Fremónti, Gray, l.c. Leaves narrowly obiong or the lowest spatulate, obtuse: caly $\mathrm{x}$-teeth orate, obtuse or acutish (less than a line long), less than a quarter the length of the tube, surpassing the proper tube of the crimson corolla. - Eunanus Fremonti, Benth. 1. c. - California, from Santa Barbara Co. southward and eastward, first coll. by Fremont.

++ Calyx decidedly oblique at the orifice; the teeth unequal, reaching to the base of the funnelform throat of the corolla: stem rather slender: leaves quite cutire.

M. Párryi, Gray, l. c. Not pubeseent, minutely glandular, 2 to 4 inches high: leaves oblong or oblanceolate, half inch long: teeth of the campanulate caly $\mathrm{x}$ acute; the upper and larger one ovate; the others subulate from a broad base, a third or fourth the length of the tube: corolla yellow or pink, two-thirds inch long: capsule oblong-lanceolate, not surpassing the calyx. - St. George, S. Ltah, on gravelly hills, Parry.

M. Torréyi, Gray, l.c. Viscid-pubescent, a span to a foot high, simple or loosely branching: leares oblong or almost lanceolate, sometimes an inch long: calyx-teeth all broad and obtuse; the posterior one larger and barely a line long: corolla half to threefourths inch long, pink-purple: capsule chartaceous, lanceolate-oblong. -Eunanus Fremonti, Gray in Pacif. R. Rep. vi. 83, not Benth. - California, througl the Sierra Nevada, at 4,000 feet and upwards, from 2 Iariposa Co. northward, first coll. by Newberry.

+++ Corolla larse and wide, an inch or more long, with proper tube very short and included in the calyx: teeth of the latter very unequal: stem simpler and faller: "leaves often acutely dentate or denticulate with salient teeth. ('Transition to Eumimulus.)

M. Bolánderi, Gray, 1. c. A foot or less high, viscid-pubescent : leaves oblong, an inclı or two in length; the lower surpassing the flowers: teeth of the very oblique caly $\mathrm{x}$ lanceolate; the posterior and longer one 3 lines long and half the length of the oblong tube: corolla purple, an inch long, cylindraceous : capsule fusiform-subulate, somewhat coriaceous. - H. breripes, Gray in Pacif. R. Rep. iv. 120, not Benth. - California, in foothills and lower part of the Sierra Nevada.

M. brévipes, Benth. A foot or two high, very viscid-pubescent: leaves from lanceolate to linear, 1 to 4 inches long: caly $\mathrm{x}$-teetlı very unequal, acuminate; the posterior fully half the length of the broadly campanulate tube: corolla yellow, sometimes $1 \frac{1}{2}$ inches long, and the expanded limb nearly as broad, campanulate, with ample rounded lobes: capsule ovate, acuminate, firm-coriaceous. - DC. Prodr. x. 369; Gray, Bot. Mex. Bound. 116. - California, from Monterey to San Diego and San Bernardino.

§2. Díplaccs, Gray. Shrubby, glutinous; with flowers as of the following and capsule of the preceling section: tube of the funnelform corolla about the length of the narrow prismatic carinate-angled calyx: style glandular: stigma bilamellar: placentæe meeting but even in the ovary not united in the axis, in dehiscence borne on the linear firm-coriaceous valves. - Diplacus, Nutt. in Ann. \& Mag. Nat. Hist. i. 137 ; Benth. in DC. Prodr. x. 368.

M. glutinósus, Wendl. Shrub 2 to 6 feet high, nearly glabrous but glutinous: leaves from narrowly oblong to linear, from denticulate to entire ( 1 to 4 inches long); at length with revolute margins: flowers $1 \frac{1}{2}$ to 2 inches long, short-pedicelled : corolla usually buff or salnon-color, obscurely bilabiate; the spreading lobes laciniately toothed or notehed. Obs. 51; Jacq. Schœnbr. iii. t. 364; Gray, 1. c. M. aurantiacus, Curt. Bot. Mag. t. 354. Diplacus glutinosus \& D. Latifolius, Nutt. 1. c. D. stellatus, Kellogg, Proc. Calif. Acad. ii. 18. Rocky banks, \&c., Califormia, common from San Francisco southward. Runs into many varietics, such as

Var, puníceus, Gray, l. c. Flowers from orange-red to scarlet, often slender-perlicelled : corolla-lobes commonly obcordate. - Diplacus puniceus, Nutt. 1. c.; Hook. Bot. IIag. t. 3655. D. glutinosus, var. puniceus, Benth. in DC. 1. c. W. California.

Var. lineáris, Gray, l. c. Flowers very short-pedicelled, red-brown to salmoncolor: calyx commonly pubescent: leaves linear, more rigid, and revolute-margined. - $1 \%$. linearis, Benth. Scroph. Ind. 27. Diplacus leptanthus, Nutt. 1. c.; Benth. 1. c.-From Monterey southward. 
Var. bráchypus, Gray, 1. c. Flowers very short-pedicelled, salmon-color, large: calyx viscid-pubescent or villous: herbage often pubescent: leaves linear-lanceolate, mainly entire. - Diplacus longiflorus, Nutt. 1. c. - From Santa Barbara southward.

§3. Eumimulus, Gray. Herbaceous: proper tube of the corolla mostly included in the plicately carinate-angled 5-toothed calyx (the teeth traversed by the strong nerve): style glabrous : stigma bilamellar, the lobes or lips ovate or rotund and equal: placente remaining united in the axis of the capsule (or partly dividing, in $M$. rubellus completely), from which the thin and usually membraraceous valves tardily separate.

* Large-flowered and perennial western species: corolla $1 \frac{1}{\frac{1}{2}}$ to 2 inches long, red or rose-color, with cylindrical body longer than the limb: calyx oblong-prismatic; the short teeth nearly egual: anthers either villous or almost glabrous in the same species : pedicels elongated : capsule oblong: leaves several-nerved from the base: seeds with a dull and loose epidermis, longitudinally wrinkled.

M. cardinális, Dougl. Villous and viscid, 2 to 4 feet high : leaves ovate, or the lower obovate-lanceolate; the upper connate; all erose-dentate : corolla scarlet, with remarkably oblique limb; upper lip erect and the lobes turned back; lower reflexed: stamens exserted. - Lindl. Hort. Trans. ii. 70, t. 3; Brit. Fl. Gard. ser. 2, t. 358; Hook. Bot. Mag. t. 3560. - Along watercourses, through Oregon and California to Arizona.

M. Lewísii, Pursh. More slender, greener, and with minute or finer pubescence: Jeaves from oblong-ovate to lanceolate, denticulate: corolla rose-red or paler, with tube and throat proportionally longer; roundish lobes all spreading: stamens included. - Fl. ii. 427 , t. 20 ; Gray, 1. c. 1 . roseus, Dougl. in Bot. Reg. t. 1591 ; Hook. Bot. Mag. t. 335̄3; Brit. Fl. Gard. ser. 2, t. 210. - Shady and moist or wet ground, Brit. Columbia to California along the whole length of the Sierra Nevada, east to Montama and Utah.

* * Moderately large flowered eastern species, perennial.glabrous: corolla violet, at most an inch long, with narrow tube and throat more or less exceeding the nearly equal calyz, and personate limb: fruetiferous calyx oblong: leaves throughout pinnately veined: seeds not wrinkled. (Corolla rarely rarying to white, not very rarely with the lateral lobes of the lower lip exterior in the bud!)

M. ríngens, IJ. Stem square, 2 feet high : leaves oblong or lanceolate, closely sessile by an auriculate partly clasping base, serrate: pedicels longer than the flower : calyx-teeth subulate, slender: seed-coat rather loose, cellular. - Hort. Ups. 176, t. i. ; Lam. Ill. t. 523 ; Bot. Mag. t. 283. - Wet places, Canada to Iowa and south to Texas.

M. alátus, Solander. Stem somewhat wing-angled: leaves ovate to ovate-lanceolate, less acutely serrate, tapering at base into a margined petiole: pedicels shorter than the calyx: teeth of the latter short and broad with abrupt mucronate tips: seed-coat close and smooth. - Ait. Kew. ii. 361; Lodd. Bot. Cab. t. 410; Bart. Fl. Am. Sept. iii. t. 94. Wet places, W. New England to Illinois, and south to Texas.

* * * Small- or moderately large-flowered mainly western species: corolla from yellow or sometimes partly white to brown-red or crimson; the throat broad and open: seeds with a thin and smooth or shining (or in 1 . luteus duller and reticulate-striate) coat.

+ Leafy-stemmed, not villous, nor leaves pinnately veined, but with 3 to 7 primary veins from or near the base, and hardly any, or only weak ones, from above the middle of the midrib.

++ Calyx oblique at the orifice; the posterior tooth largest: leares mostly broad, dentate, at least the lower petioled: root fibrous.

= Perennial by stolons or creeping branches : upper leaves sessile by a broad or somewhat clasping base: lower lip of the corolla bearled at the throat.

M. Jamésii, Torr. \& Gray. Diffuse ard creeping, freely rooting, glabrate: leaves roundish and often reniform, from clenticulate to nearly entire ( 4 to 12 lines long), all but the uppermost with margined petioles: flowers all axillary and slender-pedicelled: corolla light yellow, 4 to 6 lines long: fructiferous calyx campanulate, about 3 lines long: seeds oval, shining, almost smooth. - Benth. in DC. l. c. 371 (with var. Fremontii); Gray, Man. ed, 2, 287. M. glabratus, Gray in Bot. Mex. Bound. 116, partly, hardly of HBK. In water or wet places, usually in springs, Illinois to Upper Michigan and Minnesota, west to the Rocky Mountains in Montana, thence south to New Mexico and Arizona. (Adjacent Mex.) 
Var. Tezénsis. Larger : leaves more ovate, seldom subcordate, usually more strongly or even laciniately dentate; the uppermost sometimes reduced, so that the later flowers become somewhat racemose. - $M$. glabratus, Bot. Mex. Bound. 1. c., mainly.-Texas, Wright, Lindheimer, \&c. Probably in drier soil : near $\mathbf{H}$. glabratus, of S. An. and Mex.

M. lúteus, L. Glabrous or puberulent: stems erect, ascending or with later branches spreading; the larger forms 2 to 4 feet high: leaves ovate, oval-oblong, roundish, or subcordate; the upper cauline and floral smaller, closely sessile, not rarely connate-clasping; all usually acutely dentate or denticulate; lower sometimes lyrately laciniate: inflorescence chiefly racemose or terminal: pedicels equalling or shorter than the flower: corolla deep yellow, commonly dark-dotted within, and the protuberant base of lower lip blotched with brown-purple or copper-color, in the largest forms from 1 to 2 inches long: calyx ventricose-campanulate, half inch or less long: seeds oblong, rather dull, striate-reticulated longitudinally. - Spec. ed. 2, 881; Bot. Mag. t. 1501, 3363; Bot. Reg. t. 1030, 1796; Andr. Bot. Rep. t. 661 ; Gray, 1. c. $M$. guttatus, DC. Cat. Monsp. 127 ; Hook. Fl. ii. $99 . M$. variegatus, Lodd. Bot. Cab. t. 1872.1 M. rivularis, Lodd. 1. c. t. 1575; Nutt. in Jour. Acad. Philad. vii. 47. M. lyratus, Benth. Scroph. Ind. 28, form with lower leaves laciniate at base. M. Scouleri, Hook. Fl. ii. 100 ; a narrow-leaved form. M. Smithii, Lindl. Bot. Reg. t. 1674. - Moist or wet ground, Aleutian Islands and Alaska to California, and east to and through the Rocky Mountains. (Along the Andes, \&c., to S. Chili.) Most variable and polymorphous: extreme forms are the following

Var. alpínus, Gray. A spán or so high, lax, leafy to top: stem 1-4-flowered: corolla $\frac{8}{4}$ to $1 \frac{1}{4}$ inches long: seeds oval : some leaves rather distinctly pinnate-veined above the middle!-Proc. Acad. Philad. 1863, 71; Watson, Bot. King, 224; Gray, Bot. Calif. i. 567. $M$. dentatus, Nutt. in DC. Prodr. l. c. 372, appears from an original specimen to be between this and M. moschatus, var. longiflorus. M. Tilingii, Regel, Gartenfl. 1869, 321, t. 631; plant which developed next year into a large many-flowered form, as figured in Gartenfl. 1870,290 , t. 665 (corolla distinctly personate by a palatine protuberance of base of lower lip, as is often seen in other forms). M. cupreus, Regel, l. c. 1864, t. 422 (throat of the corolla wide open). h. luteus, var. cuprea, Hook. Bot. Mag. t. 5478. - Alaska to high Sierra Nevada, California, and Colorado Rocky Mountains. (Chilian Andes.)

Var. depauperátus, Gray. Includes reduced or depauperate forms, flowering as slender annuals, 2 to 10 inches high, with leaves 3 to 6 lines long, fructiferous calyx 2 or 3 lines long, and corolla 3 to 7 lines long. - Bot. Calif. l. c. M. microphyllus, Benth. in DC. 1. c. 371. - Washington Terr. to California and the Rocky Mountains.

$$
=\text { Apparently only annual: leaves all petioled : pedicels long and filiform. }
$$

M. alsinoídes, Benth. Very glabrous: stems slender, at length diffusely branched, 3 to 12 inches long: leaves from rotund- to rhombic-ovate (from 4 to 16 lines long, besides the abruptly long-attenuate base or margined petiole), thin, the upper part salient denticulate: pedicels at length divaricate: corolla light yellow (or lower lip with a brown spot), 3 to 6 lines long; the limb small: calyx in flower narrow-cylindraceous, in fruit narrowoblong; its teeth all very short. - Benth. 1. c.; Gray, l. c. - Wet shady places, Oregon to British Columbia, \&c.

Var. mínimus, Benth. 1. c., consists of very small and depauperate forms, half inch to 2 inches high, with corolla 2 to 4 lines long. - Same range.

M. laciniátus, Gray, 1. c. Glabrous or slightly pubescent: filiform stem diffusely branched, a span or less high: leaves on filiform petioles, which mostly exceed the (quarter to half inch long) hastately 3-lobed or laciniately 3-5-cleft and obscurely 1-nerved blade, about equalling the pedicels: corolla yellow, 2 lines long: calyx in fruit ovate, 2 lines long: the teeth rather conspicuous. - Sierra Nevada, California, on a branch of the Merced at Clark's.

+++ Calyx equal or nearly so at the orifice, and the teeth almost alike : root annual.

$=$ Cauline leaves contracted at base into margined petioles.

M. Pulsiferæ, Gray, l. «. Viscid throughout, but hardly pubescent, a span high, loosely branching: leaves from broadly ovate to lanceolate-oblong, sparsely denticulate or entire, 3-nerved at base (half inch or more long), equalled or surpassed by the pericels: corolla yellow, 5 lines long: caly $x$ cylindraceous-campanulate, in fruit 3 or 4 lines long, with short ovate-triangular teeth. - California, in the northern part of the Sierra Nevada, on rocks, from Sierra Co. to Siskiyou Co., Bolander, Mrs. Pulsifer-Ames, Greene. 
$=$ Cauline leaves mainly closely sessile by a broad base.

M. inconspícuus, Gray. Glabrous, 2 to 7 inches high, simple or branched from the base: leaves ovate or ovate-lanceolate, "entire, somewhat 3-5-nerved (quarter to half inch long): pedicels as long as flower: corolla 5 lines long, with rather small limb, yellow or rose-color: fructiferous calyx oval, 4 or 5 lines long, appearing as if truncate; the teeth very short. - Pacif. R. Rep. iv. 120, \& Bot. Calif. l. c. - Damp hillsides or rocks, Los Angeles to the Sacramento, California, Bigelow, \&c.

$==$ Cauline leaves sessile or nearly so by a narrowed obscurely 3-nerved base : plants minutely viscid-pubescent or glandular, erect, branched from the base, from 2 to 10 inches high.

M. bícolor, Benth. Viscid-pubescent: leaves lanceolate or linear-oblong, sometimes spatulate, mostly denticulate, an inch long or less; the upper shorter than the pedicels: corolla half to three-fourths inch long, with ample limb, yellow, or lower lip commonly white : calyx narrowly oblong, purple-dotted, in fruit 4 lines long; the teeth comparatively large (a line long), triangular, acute.-Pl. Hartw. 328; Gray, Bot. Calif. i. 568. $M$. Prattenii, Durand in Jour. Acad. Philad. n. ser. ii. 98. - California, through the foot-hills of the Sierra Nevada.

M. Pálmeri, Gray. Viscid, but hardly at all pubescent: leaves lanceolate or the lower spatulate, mostly entire, half inch or so long, all shorter than the filiform pedicels: corolla nearly three-fourths inch long, ample-funnelform, crimson, thrice the length of the calyx; the lobes all about equal and equally spreading: fructiferous calyx 3 or 4 lines long, narrowly oblong; the teeth broad and obtusè. - Proc. Am. Acad. xii. 82. - S. E. California, on the Mohave River, Palmer, Parry \& Lemmon. Corolla in shape and color as of the Eunanus section, foliage, aspect, and capsule of the present group.

M. rubéllus, Gray. Viscid and sometimes pubescent: leaves from spatulate-oblong to linear, entire, rarely with a few salient teeth, a quarter to two-thirds inch long, commonly equalling the pedicels; the lower sometimes obovate or ovate: corolla 3 or 4 lines long, from one-third to twice the length of the calyx, yellow or rose-color, sometimes yellow varying or changing to crimson-purple: fructiferous caly $x$ oblong, 3 lines long; its teeth mostly short and obtuse. - Bot. Mex. Bound. 116, \& Bot. Calif. 1. c.; Watson, Bot. King, 225. M. montioides, Gray, Proc. Am. Acad. vii. 380, in part. - Gravelly moist banks, Washington Terr. to Arizona, Colorado, and E. New Mexico, chiefly in the mountains.

Var. latiflórus, Watson, 1. c. Stems an inch or two high: leaves from linear to oblanceolate : corolla yellow, half to two-thirds inch long, with slender exserted tube, funnelform throat spotted with brown-purple, and comparatively large limb, resembling that of $M$. bicolor. - M. montioides, Gray, l. c., mainly. - W. Nevada, on the eastern side of the Sierra Nevada, \&c., Anderson, \&c. Adopted in this form in Bot. Calif. 1. c.; but probably a distinct species.

++ Leafy-stemmed, villous and viscid, diffuse : leaves membranaceous, more or less pinnatelyveined and petioled, denticulate or serrate : corolla narrow, light yellow: calyx slightly if at all oblique; the teeth nearly equal.

M. floribúndus, Dougl. About a span high from an annual root, flowering from almost the lowest axils, at first erect, the lateral branches diffusely spreading: leaves ovate and the lower subcordate, an inch long or less; the upper shorter than the somewhat racemose pedicels : calyx short-campanulate, becoming ovate or oblong and truncate in fruit, 3 or 4 lines long; the teeth short and triangular: corolla 3 to hardly 6 lines long, about twice the length of the calyx: capsule globose-ovate, obtuse. - Lindl. Bot. Reg. $t$. 1125 ; Benth. in DC. 1. c. 372 ; Gray, 1. c. M. peduncularis, Dougl. in Benth. Scroph. Ind. 29. Capraria pusilla, Torr. in Ann. Lyc. N. Y. i. 36. - Moist soil, Rocky Mountains of Colorado and Wyoming to California and Oregon.

M. moschátus, Dougl. (Musk Plaxr.) More villous and viscous, musk-scented: stems spreading and creeping, thus perennial, a foot or so long: leaves oblong-ovate, an inch or two long, mostly exceeding the pedicels : calyx short-prismatic, oblong-campanulate in fruit, 4 or 5 lines long; the teeth half the length of the tube, broadly lanceolate and acuminate, somewhat unequal: corolla usually two-thirds inch long and barely twice the length of the calyx: capsule ovate, acute. - Lindl. Bot. Reg. t. 1118; Benth. 1. c.; Gray, 1. c. - Wet places, along brooks, British Columbia to California and Utah.

Var. longiflórus. Corolla elongated, reaching an inch in length, thrice the length of the calyx: later peduncles surpassing the leaves. - The usual form in California, also in Oregon. 
+++ Scapose, i. $\bullet$. peduncles scape-like: leaves 3-5-nerved, sessile.

M. primuloídes, Benth. Perennial by filiform stolons : leaves all radical in a rosulate tuft, or crowded on an upright stem of 1 to 3 inches in height, soft-villous when young, glabrate with age, from obovate to oblanceolate, sparsely and sharply serrate or nearly entire, from 5 to 16 lines long: filiform and often solitary pedicels ( 1 to 4 inches long) and cylindraceous caly $x$ glabrous: corolla golden-yellow, funnelform, a quarter to three-fourths inch long. - Seroph. Ind. 1. c., \& DC. l. c.; Regel, Gartenfl. 1872, t. 739; Gray, 1. c. Wet soil, througl the Sierra Nevada, California, at 6-10,000 feet, extending to the Blue Mountains of Oregon. Like the other species varies greatly in size of flower as well as in stature.

§4. Mrudooídes, Gray. Annual, with corolla of Eumimulus, capsule with the divided placentxe of Eunanus, but the calyx campanulate and 5-cleft; its tube not prismatic nor even carinate-angled, but almost nerveless; its lobes plane: stigma bilamellar. - Herpestis § Mimuloides, Benth.

M. pilósus, Watson. A span to a foot high, at length much branched, leafy, soft-villous and slightly viscid, rarely glabrate, flowering from near the base: leaves lanceolate or narrowly oblong, sessile, entire, obscurely 3-nerved at base; the lower surpassing and the upper hardly equalling the pedicels : calyx oblique at orifice; the tube somewhat 5 -sulcate below the sinuses; the posterior tooth equalling and the others shorter than the tube; all oblong or ovate, rather sliorter than the bright yellow ( 3 or 4 lines long) rather obscurely bilabiate corolla: lobes of the latter nearly equal, usually a pair of brown-purple spots on the lower: capsule oblong-ovate, acute. - Bot. King, 225; Gray, 1. c. M. exilis, Durand in Pacif. R. Rep. v. 12, t. 12 . Herpestis (Mimuloides) pilosa, Benth. in Comp. Bot. Mag. ii. 57, \& DC. 1. c. 394. - Gravelly soil along streams, nearly throughout California, and along the borders of Nevada to Arizona.

14. STEMÓDIA, L. (Name shortened by Linnæus from P. Browne's Stemodiacra, meaning stamens with two tips, in reference to the disjoined stipitate anther-cells.) — Chiefly tropical species, herbaceous or slightly shrubby, one reaching our borders.

S. durantifólia, Swartz. Annual with indurated base, or sometimes perennial, viscidpubescent : leaves either opposite or 3-4-nate, from oblong- to linear-lanceolate, serrate or denticulate, narrowed below and with somewhat dilated partly clasping base : inflorescence spiciform, leafy below: calyx 2-bracteolate: corolla purplish, quarter inch long. - Obs. p. 240; Benth. in IDC. Prodr. x. 383. Capraria durantifolia, L. Stemodia verticillaris, Link; Reichenb. Ic. Exot. ii. t. 149. - Wet grounds, S. Arizona. (Trop. Am.)

15. CONÓBEA, Aublet. (Unexplained name.) - Low or spreading annuals, all American; with opposite leaves, and small flowers on axillary pedicels, 2-bracteolate under the calyx. - Our species belong to

\$1. Levcóspora. Leaves pinnately 3-7-parted into cuneate-linear divisions: anther-cells completely disjoined but contiguous : seeds striate-costate. - Leucospora, Nutt., with Schistophragma, Benth. in Endl. Gen. \& DC. Prodr. x. 392.

C. multífida, Benth. 1. c. A span high, diffusely branched, minutely viscid-pubescent: pedicels as long as the greenisl-white and purplish corolla: sepals very slender: capsule ovate: seeds small, white, longitudinally costate.-Capraria multifida, Michx. Fl. ii. 22, t. 35. Stemodia multifida, Spreng. Syst. ii. 811. Leucospora multifida, Nutt. in Jour. Acad. Philad. vii. 87. Sutera multifida, Walp. Rep. iii. 271.-Along streams and shores, Ohio to Illinois, Arkansas, and Texas : also adventive below Philadelphia.

C. intermédia, Gray. More viscid-pubescent: pedicels shorter than the calyx : sepals narrowly linear-lanceolate; the posterior one rather longer: corolla larger ( 3 lines long): capsule ovoid-lanceolate: seeds larger, spirally costate, - Bot. Mex. Bound. 117. - New Mexico and Arizona, Wright, Rothrock. 


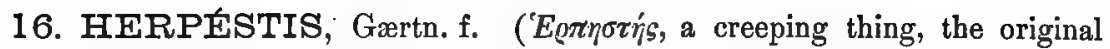
species creeping.) - Low herbs (chiefly American), commonly glabrous; with opposite leaves, and mainly axillary flowers, in summer.

$\S 1$. Corolla obviously bilabiate; the two posterior lobes being united to form the upper lip: pedicels and calyx ebracteolate: style dilated and 2-lobed at the apex, or stigma bilamellar. — $\$$ Mercadonia, Mella, \& Choetodiscus, Benth. in DC. Prodr. \& Gen. ii. 952.

* Erect or ascending glabrous perennials, drying blackish : leaves pinnately veined, mostly petioled and serrate or crenate: anther-cells divergent : style curved at apex : stigmas obovate.

H. nigréscens, Benth. A foot or two high, mostly erect, very leafy: leaves from oblong to cuneate-lanceolate, serrate, with entire tapering base ( 1 or 2 inches long): pedicels equalling and the upper surpassing the leaves: upper sepals oblong-lanceolate, not much broader than the narrowly-lanceolate lower ones: corolla whitish or purplish: valves of the capsule often 2-cleft. - Comp. Bot. Mag. ji. 56, \& DC. Prodr. x. 394. Gratiola acuminata, Walt. Car. 61 ; Ell. Sk. i. 15; Curtis, Pl. Wilmingt. in Jour. Bost. Nat. Hist. i. 130. - G. incequalis, Walt. l. c.? Gerardia cuneifolia, Pursh, Fl. ii. 422. Matourea nigrescens, Benth. in Comp. Bot. Mag. i. 173. - Wet places, Maryland (A. Hay), and North Carolina to Texas, along and near the coast.

H. chamædryoídes, HBK. A span or two high, generally diffuse or decumbent: leaves ovate or oblong, serrate (half or three-fourths inch long), mostly surpassed by the pedicels : upper sepal ovate; the lower ones ovate or oblong: corolla yellow. - Nov. Gen. \& Spec. ii. 369; Benth. 1. c. Erinus procumbens, Mill. Dict. Mercadonia ovata, Ruiz \& Pav.? Lindernia dianthera, Swartz. Microcarpcea Americana, Spreng. Syst. ii. 368. - Moist ground, Texas. (Mex., W. Ind., S. Amer.)

Var. pedunculáris (H. peduncularis, Benth. 1 c.) is founded on a form with erect and simpler stems, smailer and narrower leaves, and filiform pedicels of thrice their length. Texas, Drummond, also Berlandier, \&c. A similar form, but with diffuse or procumbent stems (H. peduncularis, Chapm. FI. 291), is from Key West, Florida.

* * Creeping, or ascending from a creeping base, stoloniferous-perennial, rather succulent: stems villous-pubescent or glabrate: leaves closely sessile and partly clasping, nervose from the base, entire or obscurely crenulate : capsule 4-valved: corolla blue or violet, varying to white.

+ Leaves pellucid-punctate, aromatic when bruised : ovary girt by a slenderly 10-12-toothed hypogynous disk : anthers somewhat sagittate : stigma dilated, obscurely 2-lobed : upper lip of corolla obcordate.

H. amplexicaúlis, Pursh. Stems a span to a foot or two long, creeping at base, then ascending and nearly simple, very leafy : leaves ovate, obtuse, half to nearly. an inch long, sometimes a little pubescent: pedicels shorter than calyx or hardly any: upper sepal cordate: corolla 5 lines long, ephemeral. - Fl. ii. 413; Benth. l. c. Obolaria Caroliniana, Walt. Car. 166. Monniera amplexicaulis, Michx. Fl. ii. 22. - Margin of pine-barren ponds, New Jersey (?) and Maryland to Louisiana.

++ Leaves not punctate : hypogynous disk obscure and entirc or none : anthers parallel : stigma 2-lamellar: upper lip of corolla merely emarginate.

H. répens, Cham. \& Schl. Glabrous, or summit of the creeping stems puberulent: leaves oval and with broad clasping base (quarter to half inch long) : pedicels about the length of flower and fructiferous calyx: upper and lower sepals broadly oval or subcordate, reticulate-veiny, in flower almost equalling the white or whitish corolla. Linnæa, v. 107; Griseb. Fl. W. Ind. 430. F. micrantha, Benth. 1. c., mainly (not Pursh, which is chiefly Micronthemun); Ell. Sk. ii. 105, ex char. Gratiola repens, Swartz, Fl. Ind. Occ. i. 39, \& Ic: t. 3. - Wet soil, S. Carolina, \&c. (W. Ind., Brazil.)

H. rotundifólia, Pursh. Larger: spreading and creeping stems usually villous-pubescent; leaves obovate or rotund, with cuneate-narrowed but partly clasping flabellately many-nerved base, often an inch long: pedicels longer than the flower (commonly in threes) : corolla blue, almost twice the length of the ovate and oval sepals. - Fl. ii. 418; Benth. 1. c. Monniera rotundifolia, Michx. 1. c. - Margin of ponds, Illinois and Missouri to Louisiana and Texas. (Possibly also in "S. Carolina and Georgia," but $H$. rotundifolia of Elliot is probably the $H$. amplexicaulis.) 
Hydhanthélium Egense, Poepp. of Brazil, with aspect of Herpestis, was picked up in New Orleans by the late $J$. Hale, and is enumerated in Mann's Catalogue, also by Chapman in Bot. Gazette, iii. 10 : but it is probably a ballast waif and transient.

$\S 2$. Corolla obscurely bilabiate; the limb being almost equally 5-lobed; tube somewhat campanulate: stamens hardly didynamous: anthers sagittate: stigma capitate. - Bramia, Lam. § Bramia, Benth.

H. Monniéra, HBK. Glabrous perennial, prostrate and creeping, somewhat fleshy: leaves spatulate to obovate-cuneate, entire or obsoletely somewhat toothed, sessile (4 to 8 lines long), nearly veinless: pedicels at length longer than the leaves, 2-bracteolate at apex: upper sepal ovate: corolla (4 or 5 lines long) pale blue. - Hook. Bot. Mag. t. 2557. H. cuneifolia, Pursh, Fl. ii. 418. H. Brownei, Nutt. Gen. ii. 42. Gratiola Monniera, L. Monniera cuneifolia, Michx. l. e.-River-banks and shores near the sea, Maryland to Texas. (Cosmopolite near the tropics.)

17. GRATIOLA, L. Hedge Hyssop. (From the Latin gratia, grace or favor, i. e. Herb-of-grace.) - Low herbs, of wide distribution; with opposite and sessile entire or dentate leaves, and solitary axillary pedicels, usually 2-bracteolate under the caly $\mathrm{x}$ : fl. summer.

§ 1. Gratiolária, Benth. Anther-cells transverse and separated by a membranaceous dilated connective: capsule ovate or globular: soft-herbaceous and diffusely branching, either annuals or fibrous-rooted perennials from a creeping base, growing in wet soil.

\section{* Sterile stamens wanting or reduced to minute rudiments.}

+ Calyx ebracteolate: Pacific species.

G. ebracteáta, Benth. A span high or less, erect, nearly glabrous, obscurely viscid: leaves lanceolate, entĩre, or sometimes sparingly and acutely denticulate : pedicels slender, in fruit strict: sepals foliaceous, 3 or 4 lines long, equalling the yellowish corolla, mostly surpassing the globular and somewhat 4.angled capsule: seeds oblong. - DC. Prodr. x. 595; Gray, Bot. Calif. i. 570. - Oregon and N. California.

+ + A pair of foliaceous bractlets close to the calyx and equalling it: Atlantic species, one extending westwarl to the Pacific.

* Pedicels filiform, equalling or exceeding the leaves: seeds oblong or oval.

$=$ Corolla golden yellow : capsule ovate-conical, acute, much exceeding the reflexed or spreading calyx.

G. pusílla, Torr. Minutely viscid, almost glabrous, slender, 2 or 3 inches high : leaves oblong-linear, obtuse, entire ( $1 \frac{1}{2}$ to 4 lines long): corolla 4 lines long; lobes retuse or emarginate: capsule 2 lines long: seeds comparatively large, obliquely obovate-oblong. Benth. in DC. Prodr. x. 402.-Arkansas and the adjacent parts of Texas, Leavenworth, Wright, \&c.

$=$ Corolla yellowish or whitish, commonly with a tinge of purple: capsule broadly or globoseovate, equalled by the calyx.

G. grácilis, Benth. 1. c. Glabrous or nearly so, small and slender, erect: leaves from oblong- to linear-lanceolate, entire or sparingly dentate: corolla 3 lines long: capsule globular, but acutish. - E. Texas, Drummond, \&c. Little known.

G. Floridána, Nutt. Glabrous or nearly so, erect, a span or two high : leaves oblonglanceolate or broader, entire or repand, sometimes remotely dentate, narrow at base (an inch long) : corolla 8 lines long, with yellowish tube 2 or 3 times the length of the calyx, and the rather large white lobes all emarginate: capsule broadly ovate-Jour. Acad. Philad. vii. 103; Benth. in DC. l. c. (with var.? intermedia, a form verging to next species); Chapm. Fl. 292. - Florida, Georgia, and Alabama. Tennessee, Gattinger.

G. Virginiána, L. Viscid-puberulent or more pubescent, or below nearly glabrous, divergently branched from the base, a span or less high: leaves commonly glabrous, oblong-lanceolate, acute, from entire to denticulate-serrate, mostly narrow at base (the larger an inch or two long) : corolla 4 or 5 lines long, with yellowish tube barely twice the 
length of the calyx; lobes nearly white, the two upper emarginate : capsule ovate- Spec. i. 17 ; Torr. Fl. 13; Benth. l. c. G. officinalis, Michx. Fl. i. 6, not L. G. Caralinensis, Pers. Syn. i. 14. G. neglecta, Torr. Cat. Pl. N. Y. G. Missouriana, Beck in Am. Jour. Sci. x. 253, the viscid form. Conobec borealis, Spreng. Syst. ii. 771. - Canada to Florida and Texas, and west (chiefly northward) to British Columbia, Oregon, and the eastern part of California.

+* +t Pedicels short, mostly shorter than the calyx: seeds linear.

G. sphærocárpa, Ell. Glabrous or nearly so: stem thick, erect or ascending from a procumbent creeping base, a span to a foot high: leaves from oblong-lanceolate to obovateoval, from acutely dentate to repand, narrow at base (an inch or two long): corolla 5 or 6 lines long, white: capsule globose, large (2 lines in diameter), pointless, usually somewhat surpassed by the calyx and bractlets. - Ell. Sk. i. 14; Benth. I. c.; Chapm. Fl, 292. G. araminata, Vahl, Enum. i. 92, not Walt. G. Virginica, Pursh, l. c., as to short pedicel, exel. syn. Gronov., \&c. G. Carolinensis, LeConte in Ann. Lyc. N. Y. i. 105. - Maryland and Illinois to Florida and Texas. Remarkable for the size and rotundity of the capsule, and the short pedicel. (Mex.)

* * Sterıle stamens conspicuously represented by a pair of filiform filaments with a minutely capitate tip : cauline leaves seldom at all narrowed at the partly clasping base : pedicels slender: stems all more or less creeping at base, and somewhat quadrangular above.

$$
+ \text { Corolla golden yellow. }
$$

G. aúrea, Muhl. Glabrous or obscurely viscid-puberulent: leaves lanceolate, mostly entire ( 5 to 10 lines long) : upper pedicels equalling the leaves: bractlets equalling the calyx, longer than the globose-ovate capsule: corolla half an inch long: sterile filaments short. - Cat. ed. 1, 1813; Pursh, Fl. i. 12 (but the sterile filaments overlooked), excl. syn.; Eil. Sk. 1. 13 ; Lodd. Bot. Cab. t. 1899 ; Benth. in DC. Prodr. x. 404. - Lower Canada to Florida, chiefly eastward.

++ Corolla white or purplish-tinged, and the tube yellowish within.

+- Bractlets conspicuous, either surpassing; equalling, or little shorter than the calyx.

G. officinális, L. Wholly glabrous : stem quadrangular, a foot or more high : leaves lanceolate, distinctly 3-nerved, entire or sparingly serrulate (an inch or more long), all exceeding the pedicels and flower: bractlets usually exceeding the caly $\mathrm{x}$ : corolla 8 or 10 lines long: sterile filaments elongated: capsule ovate, acute. - Schkuhr, Handb. t. 2; Fl. Dan. t. 363 ; Benth. 1. c. ; Chapm. l. c. (but corolla not "pale yellow"), not Michx. Georgia, LeConte, in herb. Torr. As this specimen is the only known authority, it is questionable whether it is really of American origin. (Eu., N. Asia.)

G. Viscósa, Schwein. Viscid-puberulent or pubescent, a span high, rather simple: leaves oblong or ovate-lanceolate, acutely dentate or denticulate, conspicuously clasping (one or two-thirds inch long), shorter than the pedicels: sepals and bractlets broadly or ovate-lanceolate: corolla 5 lines long: sterile filaments short: capsule shorter than calyx. - Le Conte in Ann. Lyc. N. Y. i. 106; Benth. 1. c. - N. Carolina and Kentucky to Georgia, in the upper country.

G. Drummóndi, Benth. 1.c. Puberulent and somewhat viscid, a span or two high: leaves lanceolate, acute, sparsely and acutely serrate (6 to 10 lines long), about equalling the pedicels: sepals and bractlets linear-subulate, much longer than the capsule: corolla from 5 to 6 lines long: sterile filaments short. - Chapm. Fl. 293. - Georgia to Arkanșas, Louisiana, and Texas.

$$
+++ \text { Bractlets minute or obsolete. }
$$

G. ramósa, Walt. Minutely viscid-puberulent, a span or more high : leaves lanceolate or linear-lanceolate, acute, serrate with sharp coarse teeth (6 to 10 lines long), equalling or shorter than the pedicels: sepals linear ( 2 or 3 lines long), half the length of the corolla: sterile filaments filiform. - Car. 61. G. Virginica, Lam. Ill. t. 16, fig. 2. G. quadridentata, Michx. Fl. i. 6 ; Ell. 1. c.; Benth. l. c. (this specific name later and no better than that of Walter). - S. Carolina to Florida.

§2. Sophronfanthe, Benth. 1.c. Anther-cells vertical, contiguous; the connective not dilated: herbs with erect and strict rigid stems, hirsute or hispid, growing in less wet soil: flowers subsessile, small : sterile filaments manifest, 
filiform, with minutely capitate tip : capsule oblong-conical, acuminate, about the length of the 2-bracteolate calyx: seeds oval or short-oblong: corollaw white or purplish-tinged.

G. pilósa, Michx. Stem a foot or two high from an apparently annual root: leaves ovate or ovate-lanceolate, sparingly and acutely denticulate, closely sessile by a broad base: corolla 3 or 4 lines long, little exceeding the calyx; the tube oblong. - Fl. i. 7 ; Pursh, 1. c.; Benth. 1. c.; Chapm. Fl. 293. G. Peruviana, Walt. l. c., not L. - New Jersey to Florida and Texas.

G. subuláta, Baldw. A span high from a ligneous perennial root, very leafy: leaves linear-lanceolate, obtuse, entire, with revolute margins, rigid: corolla half inch long, somewhat salverform; its slender tube nearly thrice the length of the calyx, marcescent and recurving in age. - Benth. in DC. 1. c.; Chapm. 1. c. Sophronanthe hispida, Benth. in Lindl. Introd. Nat. Syst. ed. 2, 445. - Coast of Florida, in sandy pine barrens.

G. MEGAlocárPA, Ell. Sk. i. 16, is a factitious species, established by Elliott wholly upon Pursh's G.acuminata, which is based upon Walter's character, but evidently confused with some other plant.

G. micríxtha, Nutt. in Am. Jour. Sci. v. 287 (E. Florida, Ware), is characterized as having an erect angulate stem, a foot high, lanceolate and serrate acute leaves attenuate at base, peduncles shorter than the leaves, ebracteolate calyx 4-parted, and stamens 4. Probably Scoparia dulcis.

18. ILYSANTHES, Raf. ("Ihvs, mud, and $\ddot{\alpha} v \theta \eta$, blossom.) - Low and rather small flowered annuals, or chiefly so, glabrous, branching; with opposite undivided leaves, all but the lowest sessile, and flowers on filiform ebracteolate pedicels, which are either axillary or by reduction of the leaves racemose or paniculate, in fruit usually refracted. Calyz-lobes narrow. Corolla violet or bluish, or partly white. Sterile filaments in ours glandular with a glabrous lateral lobe. Flowering all summer, in wet soil. - Raf. Ann. Nat. 1820, 13; Benth. in DC. Prodr. x. 418.

I. grandiflóra, Benth. 1. c. Stems creeping at base, leafy throughout: leaves roundish, entire, thickish: peduncles all much surpassing the leaves: corolla (3 or 4 lines long) about thrice the length of the calyx: lobe of sterile filaments rather long and borne below the middle. - Lindernia grandiftora, Nutt. Gen. ii. 43. - Eastern Georgia and Florida, Nuttall, Garber, \&c.

I. gratioloídes, Benth. l.c. Diffusely spreading from the base, or at first simple and erect, leafy: leaves ovate or oblong, often slightly and acutely few-toothed; the later ones reduced to bracts: corolla ( 3 lines long) hardly twice. the length of the calyx : lobe of sterile filaments short: capsule ovoid, equalling the calyx. - Capraria gratioloides, L. Spec. ed. 2,876. Gratiola anagallidea, Michx. Fl. i. 5. G. dilatata, Muhl. Cat. G. attenuata, Spreng. Syst. i. 39. G. tetragona, Ell. Sk. i. 15? Lindernia pyxidaria, Pursh, Fl, ii. 419, not Allioni. L. dilatata \& L. attenuata, Muhl. in Ell. Sk. i. 16; Bart. Fl. Am. Sept. i. 31. Herpestis callitrichoides, HBK. Ilysanthes riparia, Raf. 1.c. - Canada to Florida and Texas; also Oregon and California. (S. Am., E. Asia, and nat. in W. Eu.)

I. refrácta, Benth. l. c. Stems a span or two high, erect from a rosulate tuft of spatulate-oblong or obovate radical leaves (of an inch or less in length), filiform, below bearing one or two pairs of small and oblong or oblong-linear entire or obscurely serrate leaves, and above only linear-subulate bracts, which are many times shorter than the almost capillary racemose pedicels: corolla narrow ( 3 to 6 lines long), four times the length of the calyx : capsule oblong, from one half to twice longer than the calyx: root perhaps biennial. - Lindernia refracta, E11. Sk. i. 579. L. monticola, Nutt. Gen. addend. - Mostly on dripping rocks, Western $\mathrm{N}$. Carolina to Florida.

Var. saxícola. Apparently only a smaller form, barely a span high, with more leafy stems, shorter internodes, and capsule (as far as seen) little surpassing the calyx.Lindernia monticola, Muhl. Cat. 61? L. saxicola, M. A. Curtis in Am. Jour. Sci. xliv. 83. Ilysanthes saxicola, Chapm. Fl. 294. - Mountains of S. W. North Carolina to E. Florida. 
19. MICRÁNTHEMUUM, Michx. (Composed of $\mu$ reós, small, and $\ddot{\alpha} \nu \theta \varepsilon \mu o v$, flower.) - Creepiug or depressed small (American) annuals, in mud or shallow water, glabrous, branching, leafy throughout; the leaves opposite, rounded or spatulate, sessile, usually 3-5-nerved, entire. Flowers solitary in alternate axils, white or purplish, inconspicuous. - Gray, Man. ed. 5, 330. Hemianthus, Nutt., includes the species with limb of corolla as it were halved, the upper lip wanting or nearly so.

M. orbiculátum, Michx. Creeping freely: leaves roundish, 2 to 4 lines long: pedicels shorter than calyx : corolla white, hardly equalling the 4-cleft caly $x$; its upper lip or lobe manifest: stigma capitate. - Fl. i. 10, t. 2. M. emarginatum, Ell. Sk. i. 18. - N. Carolina to Texas. (S. Am.)

M. Nuttállii, Gray. Creeping, with ascending branches an inch or two high: leaves oblong-spatulate or oval-obovate, 2 or 3 lines long: pedicels equalling the campanulate 4-toothed calyx: corolla purplish or white, with obsolete upper lip; middle lobe of the lower lip linear-oblong, nearly twice the length of the lateral ones: appendage of the stamens nearly equalling the filament itself: stigma of 2 subulate lobes. - Man. ed. 5, 331. Herpestis micrantha, Ell. Sk. ii. 105? Hemianthus micranthemoides, Nutt. in Jour. Acad. Philad. i. 123, t. 6. - Tidal mud of rivers, New Jersey to Florida: Al. late summer and autumn.

20. AMPHIÄNTHUS, Torr. ( $A \mu \varphi \iota$, on both sides, $\ddot{x} \nu 00 s$, a flower; a blossom produced both at base and apex of the stem.) - Single species.

A. pusillus, Torr. A minute annual, glabrous, bearing a radical tuft of oblong or obovate leaves (each a line or two long) and a subsessile flower, also sending up a capillary scape an inch or two high and terminated by another similar flower subtended by a pair of leaves : corolla white. -Ann. Lyc. N. Y. iv. 82 ; Benth. in DC. 1. c. $425 .-$ Shallow pools on flat rocks, Upper Georgia, particularly on Stone Mountain, Leavenworth, Canby, \&c. . fl. early spring.

21. LIMOSÉLLA, L. Mudwort. (Limus, mud, and sella, seat.) Small annuals, or proliferous-perennial by stolons, glabrous (of wide distribution); with fibrous roots and a cluster of entire fleshy leaves at the nodes of the stolons, and short scape-like naked pedicels from the axils, bearing a small and white or purplish flower, in summer.

L. aquática, L. Tufts an inch or two high : clustered leaves longer than the pedicels, when scattered on sterile shoots alternate, in the typical form with a spatulate or oblong blade on a distinct petiole; this in mud rather short, in water elongating to the length of 2 to even 5 inches. - Reichenb. Ic. Germ. t. 1722. - From Hudson's Bay to S. Colorado and the Sierra Nevada, California, in brackish mud, and in fresh water; also on the Pacific coast? (Eu., N. Asia, Australia, S. Am.)

Var. tenuifólia, Hoffm. Leaves subulate or filiform, with little or no distinction of petiole and blade, seldom over an inch or so in length. - Gray, Man. 1. c.; Reichenb. Ic. Germ. I. c. L. tenuifolia, Nutt. Gen. ii. 43. L. subuluta, Ives in Am. Jour. Sci. 1. 74, with plate. L. australis, R. Br. Prodr. 443. - Brackish river-banks and shores. Canada to.New Jersey. (S. Am., Australia, Eu., \&c.)

22. SCOPARIA, L. (Scopa, twigs used for brooms.) - Tropical American undershrubs or herbs, much branched; with small and slender-pedicelled flowers in the axils of the opposite and verticillate leaves.

S. dúlcis, L. Annual or suffrutescent, almost glabrous : leaves from oblong-spatulate to narrowly lanceolate, tapering at base, the larger serrate and incised: sepals 4: corolla white, 3 lines wide. - Lam. Tll. t. 85: Gratiola micrantha, Nutt. in Am. Jour. Sci. v. 287? -S. Florida and perhaps on the Mexican border. (Mex., Trop. \& Subtrop. Am., and now in Asia, \&c.) 
23. CAPRÁRIA, L. (Caprarius, relating to goats, i. e. Goat-weed.Tropical American herbs or undershrubs; with rather small white or flesh-colored flowers, on slender often geminate pedicels, in the axils of the alternate serrate leaves. One species barely reaches our southern border.

C. biflóra, L. Suffruticose, 2 to 4 feet high, pubescent or glabrous : leaves oblong-lanceolate, sharply serrate above the middle: sepals linear-subulate, equalling the capsule. Key West, and S. Texas on the coast; the glabrous form, mostly 5-androus, C. Mexicana, Moricand in DC. (Tropical shores.)

24. SÝNTHYRIS, Benth. (From ov́', together, and $\theta v$ ou's, little door or valve, the valves of the capsule long adhering below to the short placentiferous axis.) - W. North American perennials, nearly related to Irulfenia of S. F. Europe and the Himalayas; but the anther-cells not confluent and seeds discoidal. Leaves largely radical and petioled; those of the simple stem or scape and the bracts all alternate. Flowers small, purplish or flesh-color, in a simple spike or raceme ; in summer. Stamens inserted close to the sinuses of the corolla. - DC. Prodr. x. 45 4, \& Gen. ii. 963.

$\S 1$. Ovules and seeds only a pair in each cell, on a short partition : capsule divaricately 2-lobed; the cells transversely oblong: seeds with thickish margins incurved at maturity: acaulescent, with naked scapes.

S. rotundifólia. Rootstock short and creeping, bearing a tuft of cordate-orbicular doubly crenate or crenate-incised leaves (glabrous or slightly hairy), and weak scapes hardly exceeding the petioles ( 3 or 4 inches long): pedicels of loose short raceme longer than the bluish flowers (about half inch long): sepals spatulate: corolla campanulate. - S. rentformis, Gray, Bot. Calif. i. 571, chiefly, not Benth. - Oregon, in shady coniferous woods of the Columbia and Willamette, Nuttall, E. Hall; and probably first collected in woods N. E. of Fort Vancouver by Gairdner.

Var. cordáta, a form with smaller and thicker almost simply crenate leaves of cordate outline. - S. reniformis, var. cordata, Gray, l. c. - Gravelly hillsides, Mendocino Co., California, Kellogg \& Harford.

$\S 2$. Ovules and usually seeds several or uumerous in each cell : capsule merely emarginate: seeds plane or meniscoidal, thin-edged.

* Flowers racemose rather than spicate : leaves of the preceding section : capsule orbiculate, much compressed, acute-edged.

S. renifórmis, Benth. 1. c. A span or so high : leaves orbicular-reniform, crenate and crenately somewhat incised, an inch or two in diameter: surpassed by the somewhat bracteate slender scape: pedicels mostly shorter than the bluish flowers: capsule truncate-emarginate. -Wulfenia reniformis, Dougl. in Hook. Fl. ii. 102, t. 71. (Fig. 3 represents the capsule much too long and too turgid.) - Oregon and Washington Terr. "Grand Rapids of the Columbia and Blue Mountains," Douglas.

Var. major, Hook. Leaves of thicker texture and with multilobulate margin, the lobelets crenate: raceme spiciform : capsule strongly emarginate. - Kew Jour. Bot. v. 257. - Idaho. Fertile northerly slopes of snowy mountains, highlands of Nez Percez, Geyer, in fruit. Porphyry Peak, Prof. Marcy, in flower.

* Flowers in a dense spike terminating a stouter and more or less bracteate or leafy scape or stem : rootstock or caudex short, thickish, not creeping: capsule turgid, from short-oval to elliptical, slightly emarginate or retuse.

- Leaves laciniately cleft or divided, all radical: corolla cylindraceous, considerably longer than the calyx, 4-cleft to the middle.

S. pinnatífida, Watson. Tomentulose-pubescent and glabrate: leaves slender-petioled, from round-reniform to oblong in circumscription, from palmately to pinnately 3-7parted or below divided, and the divisions again laciniately cleft or parted: scape sparingly bracteate, a span high: spike narrow: flowers subsessile: corolla whitish. - Bot. 
King, 227, t. 22, wrongly depicted with 2 styles! - Utah, in Wahsatch Mountains at 9,000 feet, Watson. S. Idaho, on mountains near Virginia City, Hayden.

Var. laciniáta. Leaves all of roundish or reniform outline, and laciniately manycleft to the middle or less. - Fish-Lake Mountain, Utah, 11,700 feet, L. F. Ward.

+ + Leaves undivided, merely crenate or crenulate: scape or stem leafy-bracteate.

+ Corolla mostly 2-parted, rarely 3-parted, and stamens inserted on its very base.

S. alpina, Gray. A span or only an inch or two high, early glabrate except the very lanuginous inflorescence : radical leaves oval or subcordate, an inch or so long on a longer petiole: base of stem or scape naked: spike very dense, oblong or cylindraceous: bracts and lanceolate sepals very long-woolly-villous at margins: corolla violet-purple, very unequal; its broad upper lip twice the length of the calyx, the 2-3-parted lower one small and included. - Am. Jour. Sci. ser. 2, xxxiv. 251. - Colorado Rocky Mountains in the alpine region, first collected by Parry.

S. plantagínea, Benth. A foot or less high, rather stout; tomentulose-pubescent when young, tardily glabrate: radical leaves oblong, rarely cordate, usually obtuse at base, pale or dull, 2 to 4 inches long: scape very leafy-bracteate: dense spike 3 to 5 inches long: bracts and ovate sepals glabrate and villous-ciliate: corolla purplish; its upper lip little exceeding the calyx, twice the length of the 2-3-lobed lower one. - Prodr. 1. c.; Gray, 1. c. - Rocky Mountains of Colorado and New Mexico, in subalpine woods, first collected in Long's expedition, by James.

S. Houghtoniána, Benth. A foot or two high, pubescent: radical leaves cordate or ovate, 2 or 3 inches long: scape or stem strict, very leafy-bracteate: spike 4 to 8 inches lung, dense, or at base open: bracts and oblong-lanceolate sepals soft-pubescent: corolla greenish or dull yellowish, not longer than the calyx, variously 2-4-parted; the divisions almost equal in length. - Gray, Man. ed. 5, 331. - Oak-barrens and prairies, Michigan and Wisconsin to W. Illinois. Rarely with 3-celled ovary, or 5-merous calyx, or 4 stamens, the additional pair later.

+ Corolla wanting: stamens inserted on the outside of the hypogynous disk.

S. rúbra, Benth. l. c. A span to a foot or more high, rather stout, more or less pubescent, and the spike ( 2 to 5 inches long) tomentose: radical leaves ovate or obscurely cordate ( 1 to 3 inches long), thickish; the cauline similar, but small and sessile: sepals oblong: capsule turgid. - Gymnandra rubra, Dougl. in Hook. Fl. ii. 103, t. 172, - Along streams, interior of Oregon to Brit. Columbia, Montana, and N. Utah. Name inappropriate: perhaps the stamens are reddish.

25. VERÓNICA, L. Speedwell, Brooklime. (Flower of St. Veronica?) - Herbs in all the northern temperate regions, \&c. (in Australia and New Zealand, in a peculiar section, shrubby or even arborescent, and with a turgid septicidal capsule), of various habit; the leaves opposite or verticillate, or sometimes the upper alternate, as are the bracts. Flowers small, racemose, spicate, or solitary in the axils, never yellow; in spring or summer.

$\S 1$. LEPTÁNDRA, Benth. in DC. Corolla salverform; the tube longer than the lobes: stamens and style much exserted, the former inserted low on the tube: capsule ovate, turgid, hardly at all compressed, not at all emarginate, dehiscent at apex by all four sutures, at length more loculicidal: seeds numerous, oval and terete, with minutely reticulated coat: tall perennials : leaves mostly verticillate: flowers in dense terminal and also upper axillary spikes, minutely bracteate. Leptandra, Nutt. Gen. i. 7. Eustachya \& Callistachya, Raf.

Leptandra angustifolia, Lehm. Del. Sem. Hamb. 1839 (Veronica angustifolia, Steud.), mistakenly said to have been raised from New Orleans seed, is V. tubifora, Fischer \& Meyer, of F. Siberia.

V. Virgínica, L. (Culver's Phrsic.) Nearly glabrous, or foliage pubescent; simple stems 2 to 6 feet high : leaves in whorls of 3 to 9 , lanceolate and slender-acuminate, some- 
times oblong, very closely and sharply serrate, 3 to 5 inches long : terminal spike 6 to 10 inches long, with commonly several shorter ones from upper axils : corolla white, sometimes bluish, - Spec. i. 9 (Pluk. Alm. t. 70, fig. 2) ; Hoffm. Comm. Gott. xv. t. 1; Thunb. Fl. Jap. 20 ; Michx. Fl. i. 5. Eustachya alba \& purpurea, \& Cullistachya Virginica, \&c., Raf. Leptandra Firginica, Nutt. 1. c. L. purpurea, Raf. Med. Bot. t. 59. Veronica Sibirica, L. Spec. ed. 2, 1. 12. V. .Japonica, Steud.; Miq. Prol. Jap. 50.-Moist woods and banks, from Canada and Winipeg Valley to Alabama and Missouri: fl. summer. (Japan and E. Siberia.)

§ 2. VERoniCA proper. Corolla rotate with very short tube: stamens at the upper sinuses : capsule from emarginate to obcordate-2-lobed : seeds more or less compressed anteriorly aud posteriorly, or plano-convex, or the inner face hollowed : low herbs.

* Perennials, stoloniferous or creeping at base: racemes in the axils of the opposite leaves.

+ Capsules many-seeded, turgil, orbicular and mainly enarginate: seeds merely compressed or plano-convex: lower part of stems rooting in shallow water : racemes commonly from opposite axils, loose and elongated : pedicels slender, widely spreading: corolla pale blue, often purplestriped.

V. Anagállis, L. Glabrous, or inflorescence glandular-puberulent: leaves sessile by broadish somewliat clasping base, and tapering gradually to the apex, oblong-lanceolate, entire or obscurely serrate. - Fl. Dan. t. 903; Engl. Bot. t. 781. - Canada to Illinois, New Mexico, and Brit. Columbia. (Eu., Asia.)

V. Americána, Schwein. Glabrous: leaves all or mostly petioled, ovate or oblong, truncate-subcordate at base, usually obtuse: pedicels more slender. - Herb. Hook.; Benth. in DC. 1. c. I. intermedia, Schwein. in Am. Jour. Sci. viii. 268, name only. V. Beccubunga of older Am. authors. V. Anagallis, Bong. Veg. Sitk., \&c. - Canada and N. Atlantic States to New Mexico, California, and Alaska.

+ + Capsule several-seeled, strongly compressed contrary to the partition: seeds very flat: racemes or spikes from alternate or sometimes from opposite axils: corolla mostly pale blue.

V. scutelláta, L. Glabrous: stem slender, ascending from a stoloniferous base, a span or two high: leaves sessile, linear or linear-lanceolate, acute, remotely denticulate (2 or 3 inches long): racemes several, filiform, flexuous: flowers scattered on filiform elongated and widely spreading pedicels : capsule biscutelliform, being deeply emarginate at apex and slightly at base. - Fl. Dan. t. 209; Engl. Bot. t. 782 ; Michx. 1. c. - Swamps, Hudson's Bay and N. Atlantic States to British Columbia and N. California. (Eu., N. Asia.)

V. Chay źprys, L. Stem ascending from a creeping base, pubescent, at least in two lines: leaves ovate or cordate, incisely crenate, subsessile: racemes loosely-flowered : pedicels little longer than calyx: blue corolla rather large: capsule triangular-obcordate. - Engl. Bot. t. 673. - Sparingly introduced into Canada, New York, and Penn. (Nat. from Eu.)

V. officinális, L. Soft-pubescent throughout: stems creeping and procumbent: leaves short-petioled or subsessile, obovate-oval or oblong, obtuse, serrate, pale (an inch long): spikes few, alternate or solitary, rarely from opposite axils, densely many-flowered: pedicels shorter than calyx : capsule obovate-triangular or cuneate, with a broad and shallow notch at the apex. - Fl. Dan. t. 248; Lam. Ill. t. 13; Engl. Bot. t. 765; Michx. 1. c. Dry hills and open woods, New England to Michigan, and south to the mountains of N. Carolina and Tennessee. (Eu., N. W. Asia.)

V. Kamtchática, L.f. Villous with somewhat viscid hairs: stems ascending, 1 to 8 inches long, bearing 3 to 5 pairs of leaves separated by short internodes: leaves 6 to 18 lines long, broadly oval, obscurely serrate, contracted into a short petiole-like base : peduncles 1 to 3 , erect, surpassing the leaves, somewhat corymbosely 3-8-flowered: pedicels about the length of calyx and bracts: corolla half inch or more in diameter, perhaps bright blue. - Suppl. 83. V. grandiflora, of Gærtn. in Comm. Act. Petrop. xiv. t. 18, not of Don, \&c. V. aphylla, var. (Willd. Spec. i. 60; Cham. \& Schlecht. in Linn. ii. 556) grandiflora, Benth. .in DC. Prodr. x. 476; Ledeb. Fl. Ross. iii. 245. - Kiska, one of the Aleutian Islands, Dall. (Kamtschatka and adjacent islands.)

* * Low perennials, with ascending or erect flowering stems terminated by a single raceme: cauline leaves above passing into bracts : seeds numerous, much compressed or somewhat meniscoidal. (Specimens disposed to turn dark in drying.)

V. FRUticulósA, L., of Europe, is in Greenland, beyond our limits. 
+ Capsule ovate, elliptical, or oblong, merely emarginate: stems erect from a slender creeping rootstock: leaves all sessile or nearly so : corolla blue or violet.

V. Cusíckii. A palm high, glabrous or pubescent: leaves ovate or oblong, entire (half to three fourths inch long); the pairs crowded up to the naked peduncle of the 3-9-flowered racene: pedicels slender, often as long as the flower and longer than the oblong-linear bracts : corolla 4 or 5 lines in diameter, with ample rounded lobes: these surpassed by the filiform filaments and style; the latter thrice the length of the deflorate calyx. - Alpine region of the Blue Mountains, W. Oregon, W. C. Cusick, a form with glabrous thickish leaves. Scott Mountains in N. California, at 8,000 feet, $E$. L. Greene, form with uarrower and hirsute-pubescent leaves, rarely with a denticulation or two. Nearly related to $V$. macrosternon of Bunge.

V. Stélleri, Pall. A palm high, hirsute, leafy up to the sessile corymbose raceme: leaves ovate, copiously crenate-serrate (three fourths inch long): pedicels slender, longer than the flowers: corolla as in the foregoing: stamens barely equalling its lobes: slender style not surpassing the calyx: "capsule ovate, hardly emarginate."-Rom. \& Sch. Syst. Mant. i. 102; Cham. in Linn. ii. 557; Benth. in DC. Prodr. x. 481. - Unalaska and other Aleutian Islands. (Kamtschatka and Curile Islands.)

V. alpina, L. A span or rarely a foot high, hirsute-pubescent or glabrate : leaves mostly shorter than the internodes of the simple stem, ovate to oblong, crenulate-serrate or entire (half to full inch long): raceme spiciform or subcapitate, dense, or interrupted below: pedicels erect, shorter than the calyx (at least in flower), much shorter than the bracts: corolla with comparatively small limb, 2 or 3 lines in diameter, surpassing the stamens and short style: capsule elliptical-obovate, emarginate. - Fl. Lapp. 7, t. 9, fig. 4 ; Spec. i. 11 ; Fl. Dan. t. 16; Benth. 1. c.; Ledeb. Fl. Ross. iii. 248. V. Wormskioldii, Rœm. \& Sch. Syst. i. 101 (villous inflorescence); Hook. Bot. Mag. t. 2975 (as var. of alpina), the larger-leaved and villous-pubescent form, commonest in N. America. V. nutans, Bong. Veg. Sitk. 39. Alpine regions, White Mountains of New Hampshire, Rocky Mountains and Sierra Nevada for nearly their whole length, and north to Labrador, subarctic regions, and Aleutian Islands. (Eu., Asia, Greenland.)

+ + Capsule oblately orbicular and obcordate : lower leaves short-petioled; upper sessile : corolla usually bluish or pale with blue stripes.

V. serpyllifólia, L. Glabrous or puberulent: stems creeping and branching at base, with flowering summit ascending 3 to 9 inches high: leaves oval or rounöish, entire or crenulate (half inch or less long); the upper passing into bracts of the leafy spiciform raceme: pedicels erect, as long as the calyx. - Fl. Dan. t. 492; Engl. Bot. t. 1075. Open and grassy grounds. Labrador to the mountains of Georgia, New Mexico, and across the continent to California and Aleutian Islands. (Eu., Asia, S. Am.)

* * Low annuals: flowers in the axils of ordinary or of the upper more or less reduced and commonly alternate leaves: corolla mostly shorter than the calyx. (All but the first naturalized from the Old World.)

++ Seeds flat or flattish, small and numerous: flowers very short-pedicelled, appearing somewhat spicate, the floral leaves being reduced or unlike the others.

V. peregrína, L. (NEckwEed.) Glabrous, or above minutely pubescent or glandular: stem and branches erect, a span or two high: leaves thickish; lowest petioled and oblong or oval, dentate; the others sessile, from oblong to linear-spatulate, mostly alternate; uppermost more bractlike and entire: capsule orbicular and slightly obcordate. $-V$. Marilandica, Murr. Comm. Goett. 1782, 11, t. 3, not L. V. Caroliniana, Walt. Car. 61. V. Xalapensis, HBK. - Low grounds, and a weed in damp cultivated soil, throughout the U. S. and Canada to Brit. Columbia. (S. Am., and now almost cosmopolite.)

V. Arvénsis, L. Pubescent, a span or two high, soon spreading: lower leaves ovate, crenate, short-petioled: floral sessile, lanceolate, entire: capsule broadly obcordate. - Cult. and waste ground, Atlantic States to Texas: rather rare. (Nat. from Eu.)

+ + Seeds fewer, cyathiform, much hollowed on the ventral face ( $\$$ Omphalospora, Bess.): prostrate or spreading annuals: flowers on slender at length recurving pedicels from the axils of ordinary and petioled leaves.

V. AGRÉstis, L. Pubescent: leaves from round-ovate or subcordate to oblong, crenate-serrate, about equalling the pedicels: sepals oblong, surpassing the small corolla: ovules numerous: capsule orbicular with a deep and narrow emargination, maturing few or solitary seeds. - Sandy fields, New Brunswick to Louisiana : rare. (Nat. from Eu.) 
V. Buxbaúmi, Tenore. More pubescent: leaves mainly roundish, crenate-dentate, shorter than the filiform pedicels: corolla larger, nearly half inch in diameter, blue: sepals divaricate in fruit, ovate-lanceolate: capsule broadly obcordate-triangular, with a widely open emargination, ripening several or rather numerous seeds. - Waste grounds, rare in Atlantic States. (Nat. from Eu.)

V. HEderafólia, L. Hairy : leaves roundish, often subcordate (half inch long), somewhat 3-5-lobed, commonly shorter than the pedicels: sepals triangular-subcordate, acute, at length erect: corolla small : capsule turgid, 2-lobed, 4-ovuled, 2-4-seeded. - Moist banks, New Jersey, Penn., \&c. , rather rare. (Nat. from Eu.)

V. Marilandica, L. Spec. i. 14 (Pl. Gronov. Fl. Virg.) is Polypremum procumbens.

V. Caroliniána, Poir, Dict. viii. 520, appears to be Mitreola petiolata.

V. REXIFórMis, Raf. in Med. Rep. \& Jour. Bot. i. 228, is not made out: perhaps V. hederefolia, but its flowers are not "subsessile," nor are they said to be so in the original character in Med. Repository.

V. Púrshir, Don, Syst. iv. 573 ( $\nabla$. reniformis, Pursh, Fl. i. 10), collected by Lewis and Clark "on the banks of the Missouri," is not identified, although described in detail ; probably not of this genus.

26. BƯCHNERA, L. (I. G. Buchner, an early German botanist.) - Erect perennials or biennials (of both worlds), drying blackish, scabrous; with undivided leaves, the lower opposite, and the upper gradually reduced to subulate bracts of a terminal spike; the flowers white, bluish or rose-purple, produced in summer.

B. Americána, L. Rougl-hispid: stem strict, 2 feet high: lowest leaves obovate or oblong, obtuse; the others from ovate-oblong to linear-lanceolate, coarsely and sparsely dentate, somewhat veiny, sessile : spike short, rather dense, or interrupted : caly $x$ not half the length of the tube of the purple (inch long) corolla: lobes of the latter cuneate-obovate, 3 or 4 lines long. - Spec. ii. 360; Michx. Fl. ii. 18; Benth. in DC. 1. c. 498. - Moist sandy or gravelly ground, Western New York and Wisconsin to Virginia, Arkansas, and Louisiana.

B. elongáta, Swartz. Scabrous, but seldom hispid, slender, a foot or more high, longnaked above: radical leaves obovate; lower oblong or lanceolate, obscurely or rarely dentate; upper linear: spike slender, often few-flowered: tube of purple ("blue or white") corolla not twice the length of the calyx; its rounded lobes not over 2 lines long. - Fl. Ind. Occ. ii. 1061 ; Benth. 1. c. - Pine barrens, S. Carolina to Florida and Texas. (W.Ind., S. Am.)

27. SEYMERIA, Pursh. (Henry Seymer, an English amateur-naturalist.) - Erect and mostly branching herbs (mainly of Atlantic States and Mexico, one in Madagascar!) ; annuals or some perennials; with copious and mostly opposite incised or dissected leaves, the uppermost reduced to bracts of the somewhat racemose or spicate and comparatively small yellow flowers, produced in late summer.

$\S 1$. Style filiform and long: stigma simple or slightly capitate: corolla glabrous within, except a line at the insertion of the stamens: anthers dehiscent from the apex and tardily to near the base: leaves small: stems paniculately much branched.

* Leaves filiformly dissected : corolla very deeply cleft; the lobes oblong.

S. tenuifólia, Pursh. Glabrous, or the branches puberulent, very slender, 2 to 4 feet high : leaves (half inch long) copiously 1-2-pinnately parted: pedicels filiform: corolla about 3 and capsule 2 lines long: calyx-lobes setaceous : filaments minutely woolly at base : anther-cells acutish. - FI. ii. 737 ; Benth. in DC. Prodr. x. 511. Anpmymos cassioides, Walt. Afzelia cassioides, Gmel. Syst. 827. Gerardia Afzelia, Michx. Fl, ii. 20. - Low pine barrens, N. Carolina to Florida and Texas.

* Leaves or their divisions linear or broader: corolla-lobes obovate or oval, about the length of the tube and throat: pedicels short. 
+ Capsule orate and gradually acuminate, 4 or 5 lines long, glabrous or nearly so: anthers sagittate, the cells very acute.

S. scábra, Gray. Hispidulous-scabrous, not glandular, slender, 2 feet high: leaves sparingly pinnately parted into few narrow linear divisions, or the upper few-lobed or entire : caly x-lobes subulate-linear : corolla glabrous. - Bot. Mex. Bound. 118. - Mountains near Rio Limpio, S. W. Texas, Wright.

+ + Capsule broadly ovate and merely acute, 2 lines long, glandular-hairy : anthers very obtuse.

S. pectináta, Pursh, l. c. Minutely viscid-pubescent or glabrate, about a foot high, slender: leaves pinnately parted into rather few short- or oblong-linear divisions, or the upper incisely few-toothed or entire: calyx-lobes linear: corolla hairy outside, especially in the bud. - Ell. Sk. ii. 122; Chapm. Fl. 297. - Dry sandy soil, N. Carolina to Florida and Alabama, and perhaps to Texas.

S. bipinnatisécta, Seem. Very glandular-pubescent and viscid, a foot or two high, stouter: leaves rather copiously 1-3-pinnately parted; the divisions from linear to oblong, small, often incisely toothed; even the bracts and sometimes the oblong-linear calyx-lobes lobed or incised : corolla somewhat glandular-pubescent outside. - Bot. Herald, 323, t. 59; Gray in Bot. Mex. Bound. 117, as var. Texana, with short pedicels, \&c.; but early flowers more slender-pedicelled. - W. and S. Texas, Lindheimer, Wright, Bigelow, \&c. (N. Mex.)

$\S 2$. Style short, with enlarged and compressed tip: corolla densely woolly within above the insertion of the very woolly filaments: anthers oblong, freely dehiscent to base : leaves ample. — § Brachygne, Benth.

S. macrophýlla, Nutt. Somewhat pubescent or glabrate; stems rather simple, 4 or 5 feet high: lower leaves pinnately parted, and the divisions lanceolate and incisely toothed or pinnatifid; upper leaves lanceolate or oblong, mostly entire: flowers very short-pedicelled in the axils of the upper leaves and bracts: calyx-lobes from oval to lanceolate, about the length of the tube: corolla barely half inch long; the ovate lobes not longer than the tube: capsule globose-ovate, with a flat mucronate point. - Gen. ii. 49 ; Bentl. in IC. 1. c. Gerardia mucrophylla, Benth. in Comp. Bot. Mag. i. 205. - River banks and copses, Ohio to Illinois, Arkansas, and Texas.

28. MACRANTHERA, Torr. (Mx*oós, long, and $\alpha \dot{\nu} \theta \eta \propto \alpha \dot{\alpha}$, word used for anther, but it is here the filaments which are long.) - Genus of a single species, most related to Esterhazya of Brazil. Fl. autumn.

M. fuchsioídes, Torr. Tall biennial, minutely puberulent or glabrate, 3 to 5 feet higl, with some strict virgate branches: leaves all opposite, short-petioled, from entire to pinnatifid or pinnately parted (the larger 4 to 8 inches long); uppermost reduced to linear or lanceolate bracts of the elongated virgate raceme: pedicels (near an inch long) divaricate or decurved with incurved apex, so that the flowers are erect: tube of the calyx very short and broad; the divisions distant, narrowly linear or somewhat spatulate, often pinnatifid-incised, rather shorter than the minutely puberulent orange-colored corolla : tube of the latter cylindrical, half to three-fourths inch long, slightly curved at summit; the lobes ovate, about 2 lines long: filaments with short and lax glandular beard: anthers less bearded or glabrate; the linear cells mucronate-pointed at base. - Comp. Bot. Mag. i. 208, \& Ann. Iyyc. N. Y. iv. 81 ; Benth. I. c., \& DC. Prodr. x. 513; Chapm. Fl. 297. Conradia fuchsioides, Nutt. Jour. Acad. Philad. vii. 88, t. 11, 12. Dasystoma tubulosa, Bertol. Misc. 18, t. 3. - Pine barrens, Georgia, Alabama, and Florida (not "Louisiana "), Dr. Gates, \&c.

Var. Lecóntei, Chapm. l. c. Calyx smaller, with subulate wholly entire lobes usually much shorter than the tube of the corolla : but passing into the preceding form.M. Lecontei, Torr. 1. c. 83, t. 4. - Lower Georgia, LeConte. Middle Florida, Chapman.

29. GERÁRDIA, L. (John Gerarde, the English herbalist of the 16th century.) - Annual or perennial erect and branching herbs (all American and mostly of Atlantic U. S.) ; with mainly opposite leaves, the uppermost reduced to bracts of the racemose or paniculate showy flowers. Corolla rose-purple or yellow; the former color rarely varying to white. Fl. late summer and autumn. 
§1. Dasýstoma, Gray, Man. Corolla more or less funnelform, yellow; the proper tube within, as also anthers and filaments, pubescent or villous-woolly: anthers all alike, hardly included; the cells aristate at base : rather tall and largeflowered perennials or biennials; with calyx-lobes sometimes foliaceous and incised, and comparatively broad leaves often incised or pinnatifid. (For rootparasitism, see Gray, Struct. Bot. t. 145.) -Dasystoma, Raf. in Jour. Phys. Ixxxix. 99 ; Benth. in DC. Prodr. x. 520.

* Pubescence partly glandular and viscid, especially on the slender pedicels and calyx; corolla pubescent outside: root biennial or annual.

G. pediculária, L. Paniculately much branched, 2 or 3 feet high, soft-pubescent or villous and viscid, or the foliage hardly so: leaves mostly sessile, an inch or two long, oblong- or ovate-lanceolate in outline, all pinnatifid; the divisions crowded and incisely pinnatifid or toothed : pedicels 4 to 12 lines long: caly $x$-lobes foliaceous, from linear to oblong, equalling or longer than the tube, often denticulate or incisely serrate : corolla from 1 to $1 \frac{1}{2}$ inches long. - Spec. ii. 611 ; Lam. Dict. ii. 529; Ell. Sk. ii. 121. Dasystoma pedicularia, Benth. in DC. l. c. - Canada and west to the Mississippi, south to Florida.

Var. pectináta, Nutt. A southern more villous and glandular form, with rather narrower leaves, and more foliaceous lobes of the calyx longer than its tube. -Gen. ii. 48. G. pectinata, Torr. in Benth. Comp. Bot. Mag. i. 206. Dasystoma pectinata, Benth. in DC. l. c.; Chapm. Fl. 298. - N. Carolina to Florida and Arkansas.

* No glandular pubescence : corolla glabrous outside : root perennial.

G. grandiflóra, Benth. Densely cinereous-puberulent: stem much branched, 2 or 3 feet high, leafy to the top: leaves somewhat petioled, ovate to oblong-lanceolate in outline, incisely and often lyrately pinnatifid, or the lower more divided and the upper merely laciniate-dentate ( 2 inches long): inflorescence leafy: pedicels shorter or rarely twice Ionger than the turbinate caly $x$-tube: lobes of the calyx lanceolate, entire or sparingly toothed, equalling or shorter than the tube: corolla inch and a half long. - Comp. Bot. Mag. l.c.; Gray, Man. ed. 5, 335. Dasystoma Drummondii, Benth. in DC. l. c. - Oak openings, \&c., Wisconsin and Iowa to Tennessee and Texas.

Var. integriúscula. A form with slender branches, bearing either sparsely serrate or entire leaves; or the lower laciniate-pinnatifid. - G. serrata, Torr., Benth. l. c. Dasystoma Drummondii, var. serrata, Benth. in DC. - W. Louisiana, Hale.

G. fláva, L. Densely puberulent and somewhat cinereous: stem nearly simple, 3 or 4 feet high : leaves ovate-lanceolate or oblong, obtuse, entire, or the lower sparingly sinuate-toothed or pinnatifid ( 2 to 4 inches long): pedicels very short: caly x-lobes oblong or lanceolate, entire, about the length of the tube : corolla inch and a half long, much dilated upward. Spec. ii. 610, as to syn. Gronov. \& Pluk., not herb.; Michx. Fl. ii. 19; Pursh, Fl. ii. 423; Torr. Fl. N. Y. ii. 47, t. 74. Dasystoma pubescens, Benth. in DC. 1. c. - Open woods, Canada to Wisconsin and Georgia.

G. quercifólia, Pursh. Glabrous : stem at first glaucous, 3 to 6 feet high, simple or commonly branching: lower leaves once or twice pinnatifid or incised ( 3 to 5 inches long) and the lobes acute; the upper often entire and lanceolate, acute: pedicels equalling or shorter than the calyx : corolla not rarely 2 inches long, more funnelform and narrower below than in the preceding. - Fl. ii. 423, t. 19. G. flava, L, as to herb. Rhinanthus Virginicus, L., as to Syn. Gronov. G. glauca, Eddy, Cat.; Spreng. Syst. ii. 807. Dasystoma quercifalia, Benth. in DC. 1. c. - Dry woods, from New England and W. Canada to Illinois and south to Florida and Louisiana.

G. lævigáta, Raf. Glabrous or obscurely puberulent, not glaucous: stem slender, a foot or two high : leaves lanceolate ( $1 \frac{1}{2}$ to 4 inches long); all the upper entire; the lower often incised or irregularly pinnatifid: pedicels and lobes of the calyx shorter than its tube: corolla much dilated above the short tube, an inch long and the limb fully as broad. Ann. Nat. (1820), 13. G. integrifolia, Gray, Man. ed. 1, 307, ed. 5, 335. Dasyystoma quercifolia, var,? integrifolia (\& var. intermedia?), Benth. in DC. 1. c. -Oak barrens, \&c., Penn. to Illinois and the mountains of Georgia.

G. pátula, Chapm. Obscurely pubescent or glabrate, not glaucous : stem weak and slender, loosely branching above, 2 or 3 feet long: leaves as of the preceding, but thinner: 
pedicels filiform, 8 to 15 lines in length, widely spreading, mostly longer than the bracts or upper floral leaves: calyx-lobes about twice the length of the tube, spreading: corolla funnelform, an inch and a quarter long. - Chapm. in herb. Dasystoma patula, Chapm. in Bot. Gazette, iii. 10, 1878. - Upper Georgia, in the mountains, on the banks of Horse-leg Creek, a tributary of the Coosa River, Floyd Co., Chapman.

§ 2. OтоPнÝlLA, Benth. Corolla short-funnelform with very ampliate throat, purple (rarely white), naked within, as also the filaments: anthers muticous, glabrous or sparingly villous ; those of the shorter stamens smaller : scabroushispid or hirsute annuals; with sessile entire or divided leaves, sessile flowers, and deeply cleft calyx. - Otophylla, Benth. in DC. l.c.

G. auriculáta, Michx. A foot or two high, branching above: leaves lanceolate or ovate-lanceolate, an inch or two long, sessile by a broad base, entire, or some (at least the upper) bearing an oblong or lanceolate lobe on each side at base: corolla seldom an inch long. - Fl. ii. 20; Gray, Man. ed. 5, 335. Seymeria auriculata, Spreng. Syst. ii. 810. Otophylla Michauxii, Benth. in DC. Prodr, x. 512. - Prairies and low grounds, W. Penn. to W. North Carolina, and west to Wisconsin and Missouri.

G. densiflóra, Benth. More hispid and rough, very leafy: leaves rigid, pinnately parted into 3 to 7 narrowly linear acute divisions; those subtending the densely spicate flowers similar and much crowded: corolla over an inch long. - Comp. Bot. Mag. i. 206. Otophylla Drummondi, Benth: in DC. 1. c. - Prairies, Kansas to Texas.

§ 3. Eugerardia, Benth. Corolla from short-funnelform to nearly campanulate, purple or rose-color (with one exception), varying occasionally to white: calyx-teeth or lobes short: anthers all alike; the cells either muticous or mucronulate at base: cauline leaves linear or narrower and entire, rarely reduced to mere scales; the radical rarely broader and sometimes incised: flowers from middle-sized to small ; the corolla externally and the anthers usually more or less pubescent or hairy : herbage glabrous or merely hispidulous-scabrous.

* Root perennial : leaves erect, very narrowly linear, acute: pedicels ereet, as long as floral leaves: calyx truncate: anther-cells mucronate-pointed at base.

G. Wríghtii, Gray. Very scabrous-puberulent: stems (a foot or two high) and virgate branches strict : leaves nearly filiform, with revolute margins : calyx-teeth short and subulate: corolla glabrous within (and stamens nearly so), three-fourths inch long, light yellow ! - Bot. Mex. Bound. 118. - Valleys and hillsides along the Sonoita, \&c., Arizona, Wright, Bigelow, Rothrock.

G. linifólia, Nutt. Glabrous and smooth: stems 2 or 3 feet high, sparingly or paniculately branched: leaves flat, thickish, a line wide: calyx-teeth minute: corolla an inch long, minutely pubescent outside, villous within and lobes ciliate: anthers and filaments very villous. - Gen. ii. 47 ; Benth. in DC. l. c. (not of Comp. Bot. Mag.); Chapm. Fl. 299. - Low pine barrens, Delaware to Florida. (Cuba, C. Wright.)

* * Root annual: stems more or less leafy: herbage blackish in drying except in the last. - Pedicels little if at all longer than the calyx and capsule: inflorescence racemose or spiciform. + Calyx-lobes as long as the turbinate tube, and the sinuses very acute.

G. heterophýlla, Nutt. Nearly smooth, a foot or two high, paniculately branched, or the branches virgate: leaves rather erect, thickish or rigid; the lowest 3-cleft or Iaciniate (according to Nuttall); the others narrowly linear, mucronate-acute, scabrous on the margins; those of the branchlets short and somewhat subulate: pedicels very short, alternate: calyx-lobes subulately attenuate from a broad base, very acute, in age spreading: corolla an inch or less long. - Trans. Am. Phil. Soc. n. ser. v. 180; Benth. Comp. Bot. Mag. i. 207, \& Prodr. 1. c. 517. - Prairies, Arkansas (Nuttall) and Texas.

+++ Calyx-lobes shorter than the tube, and mostly separated by broad or open sinuses.

G. áspera, Dougl. Stem and branches strict: leaves rather erect, strongly hispidulousscabrous, all filiform-linear: pedicels mostly equalling and sometimes moderately exceeding the calyx, erect, most of them alternate : calyx-lobes deltoid-subulate or triangularlanceolate from a broad base, acute, about half the length of the tube: anthers obscurely 
if at all mucronulate at base: capsule elliptical in outline, 4 lines long: otherwise nearly like a scabrous form of the next, into which it may pass. - Benth. in DC. 1. c. ; Gray, Man. 1. c. G. longifolia, Benth. in Comp. Bot. Mag. i. 208, not Nutt. - Plains and prairies, from Saskatchewan and Dakota to W. Arkansas, and east to Wisconsin and Illinois.

G. purpúrea, L. Commonly a foot or two high, with virgate rather spreading branches: leaves usually spreading, narrowly linear, either somewhat scabrous or smooth with merely scabrous margins: pedicels shorter than calyx, mainly opposite: teeth of the caly $x$ acute, from very short and distant to half the length of the broad tube (then with broad base and narrower sinuses): corolla an inch or less long: anther-cells cuspidatemucronate at base: capsule globular, 2 or 3 lines long. - Spec. ii. 610, in part (confounded with G. tenuifolia), \& of syn. Pluk., \&c.; Bart. Fl. An. Sept. iii. t. 97. G. maritima, var. major, Chapm. Fl. 300. - Low and moist grounds, Canada to Florida and Texas near the coast, also Great Lakes to Illinois, \&c. (Cuba.) A polymorphous species, of which the following are extreme forms.

Var. fasciculáta, Chapm. Usually taller, 2 to 5 feet high: leaves (and mostly branches) often alternate (and the cauline fascicled in the axils), rery scabrous, narrowly linear or nearly filiform: pedicels in great part alternate : corolla commonly a full inch long. - Fl. 300. G. fasciculata, Ell. Sk. ii. 115. - S. Carolina to Florida, Texas, and Arkansas, usually in brackish soil.

Var. paupércula. A span to a foot high, smoother : stem more simple or with stricter branches: pedicels mainly opposite: flowers decidedly smaller: corolla usually only half inch long, lighter rose-purple: caly $x$-teeth deltoid-subulate from a broad base, leaving comparatively narrower sinuses, sometimes over half the length of the tube. $-G$. purpurea, Sims, Bot. Mag. t. 2048; Hook. Fl. ii. 204. G. intermedia, Porter, in herb., a name to be adopted if a distinct species. - Lower Canada to Saskatchewan, and southward from coast of New England to Penn., N. Illinois and Wisconsin. A maritime form has many spreading branches.

G. marítima, Raf. A span or two high, with short branches from below, smooth: leaves fleshy, obtuse; the floral small: flowers accordingly in a more naked simple raceme: pedicels about the length of the calyx : teeth of the latter broad, short, and very obtuse: corolla glabrous, half inch, or in a Texan form (var. grandiflora, Benth., G. spiciflora, Engelm. Pl. Lindh. i. 19), three-fourths inch long: anther-cells mucronulate at base: capsule globular or oroid, 2 or 3 lines long. - N. Y. Med. Rep. ii. 361; Nutt. Gen. ii. 46 ; Benth. 1. c. G. purpurea, var. crassifolia, Pursh, Fl. ii. 42. - Salt marshes on the coast, Maine to Florida and Texas.

++ + Pedicels from once to thrice the length of the calyx, always much shorter than the corolla: inflorescence or ramification paniculate; some flowers appearing terminal: anthers mucronulate at base.

G. Plukenétii, Ell. Commonly 2 feet high, with many slender spreading branches: leaves all filiform, smooth or barely scabrous, seldom in fascicles, only some of the upper alternate: pedicels 2 to 4 lines long and alternate in upper axils, and solitary terminating leafy filiform branchlets: calyx truncate and with very short subulate teeth: corolla three-fourths to near an inch long, loosely long-villous in throat, as are the filaments and anthers.-Sk. ii.114. Antirrhinum purpureum, \&c., Pluk. Alm. 34, t. 12, fig. 4, poor. G. linifolia, Benth. Comp. Bot. Mag. i. 200, not Nutt. $G$. filifolia, var. Gatesii, Benth. in DC. 1. c. G. setacea, Chapm. Fl. 300, not Walt.? nor Ell.? nor Pursh, nor Nutt., \&c. Sandy or wet pine barrens, Middle Georgia, Alabama, and Florida. Larger leaves an inch long.

Var. microphýlla. Slender: cauline leaves setaceous, half inch or less long, rather few, and on the branchlets reduced to minute subulate bracts (mostly less than a line long): corolla half to two-thirds inch long, $-G$. aphylla, var. grandiflora, Benth. Comp. Bot. Mag. 1. c. - Louisiana, Drummond, Hale. Keys of Florida, Blodgett, \&c. Plukenet's figure (Alm. t. 12, fig. 4) may be rightly referred here; but it is not characteristic.

+++ Filiform pedicels about equalling or commonly exceeding the corolla in length : woolly anthers cuspidate or almost aristate at base.

+ Leaves all but the lowest cauline alternate and copiously fascicled in the axils.

G. filifólia, Nutt. Smooth, often 2 feet high, paniculately branched above, very leafy up to the loose paniculate-racemose inflorescence: leaves numerous in the fascicles, filiform 
and slightly clavate, rather fleshy, less than an inch long: pedicels mostly from an inch to half inch long: calyx-teeth short, triangular-subulate: corolla an inch or three-fourths long.-Gen. ii. 48; Ell. Sk. ii. 116; Benth. 1. c. (excl. var.); Chapm. 1. c.-L Low pine barrens, S. Georgia, Alabama, and Florida.

++ All or most of the cauline (or even the rameal) leaves opposite, and few or none fascicled in the axils,

$=$ Blackening more or less in drying: capsule globular, hardly surpassing the calyx.

G. setácea, Walt. Mostly scabrous, at least the setaceous-filiform leaves, and loosely and paniculately much branched: inflorescence more or less paniculate: pedicels ascending, from half to an inch and a half long: calyx-teeth subulate, from minute to a fourth of the length of the tube: corolla three-fourths to about an inch long, often pubescent outside; the margins of the lobes thickly lanose-ciliate: anther-cells short-aristate. - Car. 170 ; Pursh, Iil. ii. 422, excl. hab.; Nutt. Gen. ii. 47; Ell. 1. c.; not Bentl., nor Chapm. G. flifolia \& tenuifolia, var. fliformis (leptophylla in Comp. Bot. Mag. i. 209), Benth. 1. c. in part. G. tenuifolin, var. filiformis, Chapm. Fl. 300. - Pine barrens, \&c., South Carolina to Florida and Texas.

Var. longifólia (G. longifolia, Nutt. Trans. Am. Phil. Soc. n. ser. v. 180, G. flifolia, var. longifolia, Benth. in DC. 1. c.) is described from simple-stemmed specimens, collected on the "banks of the Arkansas," Nuttall, which have long (but not " 2 inch") leaves, setaceoussubulate calyx-teeth about half the length of the tube (not "nearly its length") as in some Texan specimens, and corolla barely three-fourths inch long.

G. tenuifólia, Vahl. Smooth or usually so, about a foot high, paniculately much branched, but the inflorescence racemose: leaves mostly narrowly linear and plane, equalling the lower but mostly shorter than the uppermost (half to inch long and commonly spreading) pedicels : calyx-teeth very short : corolla about half inch long, nearly glabrous outside, except the minutely ciliate margins of its nearly equal lobes: anther-cells cuspidatemucronate at base. - Symb. iii. 79, excl. syn. Pluk.; Pursh, 1. c.; Nutt. 1. c.; Bart. Fl. Am. Sept. iii. t. 82 . G. purpurea, L. in part (as to ped. filiformibus, \&c.). G. erecta, Walt. l. c.? ; Michx. Fl. ii. 20. - Low or dry ground, Canada and Minnesota to Georgia and Louisiana. This sometimes has very narrow leaves, approaching filiform : it varies on the otber hand into

Var. macrophýlla, Benth. Stouter: larger leaves $1 \frac{1}{2}$ to 2 inches long and almost 2 lines wide, scabrous: pedicels ascending: calyx-teeth usually larger; corolla little over half inch long. - Comp. Bot. Mag. i. 209. - Western Iowa to Colorado and W. Louisiana.

G. strictiflóra, Benth. Obscurely scabrous, excessively paniculate-branched, rigid, a foot or more high: leaves filiform-linear passing on the branches into subulate; these erect and half to quarter inch long, rigid, shorter than the erect or ascending (half to three-fourths inch) pedicels: calyx-teeth short but conspicuous, subulate, very acute: corolla half inch long or more: anther-cells aristulate at base.-Comp. Bot. Mag. \& Prodr. 1. c. - Texas, Drunimond, \&c.

G. divaricáta, Chapm. Smoothish throughout, very slender, a foot or so high, with numerous lax and long branches and elongated racemose inflorescence: leaves filiform, wiclely spreading; the larger over half inch long; upper gradually reduced to small setaceous bracts : pedicels opposite, divaricate, capillary, about inch long: calyx-teetl minute: corolla barely half inch long; the "two posterior lobes shorter, truncate, and erect:" anther-cells abruptly aristulate at base.-Fl. 299. G. Mettaueri, Wood, Class Book, 1861. - Low sandy pine barrens, W. \& S. Florida, Chapman, \&c.

$$
=\text { Herbage drying green. }
$$

G. Skinneriána, Wood. Somewhat scabrous : stem simple or paniculately branched, strongly striate, a span to 18 inches high, slender: leaves mostly filiform, ascending; the larger an inch long; those of the branches much smaller, the uppermost reduced to small bracts: pedicels racemose-paniculate, ascending, 4 to 8 lines long: calyx-teeth mostly minute: corolla a third to half inch long, glabrous outside, delicately ciliate, usually rosecolor. - Class Book, 1847, excl. syn. G. setacea, Benth. in Comp. Bot. Mag. \& DC. 1. c. ; Gray, Man., \&c., not of Walt., nor of Chapm. G. parvifolia, Chapm. Fl. (1860) 200. - Sandy low ground, coast of Massachusetts (W. E. Davenport, Mrs. Piper, but rare north-eastward), and Penn. to Iowa, and south to Florida and Louisiana. 
* * Root annual: stems leafless: cauline leaves represented by minute subulate scales.

G. filicaúlis, Chapm. 1. c. Smooth, glaucescent, apparently leafless: stem about a foot long, filiforn and weak, diffusely much branched; the elongated paniculate branchlets terminated by a flower or bearing a few short lateral pedicels : minute scales or bracts mostly opposite: calyx-teeth minute: corolla 3 to 5 lines long; the two posterior lobes more erect and shorter: anther-cells aristulate at base. $-G$. aphylla, var. filicaulis, Benth. in Comp. Bot. Mag. i. 210. G. Mettaueri, var. nuda, Wood, Class Book, 1861, 530, \& later G. nuda, Wood. - Low and grassy pine barrens of Florida and Louisiana, Drummond, Chapman, \&c.

G. aphýlla, Nutt. Smooth: slender stem 1 to 3 feet high, strict and simple below, about 4-angled, simple or mostly paniculate-branched above; radical leaves (rarely seen) small and oval or oblong, thickish, hispidulous, half inch or less long; cauline reduced to appressed subulate and mostly scattered minute scales: pedicels short, rather crowded in virgate mostly spiciform naked racemes: calyx-teeth minute: corolla 6 to 8 lines long, villous within; "the upper lobes reflexed:" anther-cells hardly mucronulate at base. - Gen. ii. 47 ; Ell. 1. c.; Benth. 1. c. excl. varieties; Chapm. 1. c. - Low and sandy pine barrens, coast of N. Carolina to Florida and Louisiana.

30. Castilléia, Mutis. Painted-Cup. (D. Castillejo, a botanist of Cadiz.) - Herbs (American, mostly N. American, and two in N. Asia); with alternate entire or laciniate leaves, passing above into usually more incised and mostly colored conspicnous bracts of a terminal spike; the flowers solitary in their axils and ebracteolate, red, purple, yellowish, or whitish; but the corolla almost always duller-colored than the calyx or bracts, mostly of yellow or greenish tinge. Fl. in summer. (Primary divisions generally received are not distinct enough for subgenera, except Epichroma of Mexico, with a finnelform calyx. Ours accordingly maty all be embraced in § Euchroma, Euchroma, Nutt. Gen. ii. 5.5.) - Gray in Am. Jour. Sci, ser. 2, xxxiii. 335, \& Bot. Calif. i. 573.

* Annuals or some biennials with fibrous root: at least the upper part of the bracts and sometimes of the calyx petaloid (bright red or scarlet, occasionally varying to yellowish): pubescence villous or soft-hir:ute.

+ Atlantic species, flowering in spring or early summer, a span to a foot high: floral leaves or bracts dilated: calyx equally cleft before and behind into 2 broad or upwardly dilated entire or retuse lobes: galea (upper lip) shorter than the tube of the corolla, little surpassing the calyx, much exceeding the short lower lip.

C. coccínea, Spreng. (Painted-Cup.) Biennial, at least northward: rosulate radical leaves mostly entire, obovate or oblong; cauline and bracts laciniate or $3-5$-cleft; the middle lobe of latter dilated: caly $x$-lobes quadrate-oblong. - Syst. ii. 775; Benth. in DC. Prodr. x. 259. Bartsia coccinea, L. Spec. ii. 602. (Pluk. Alm. t. 102, fig. 5.) Euchroma caccinea, Nutt. 1. c. - Low sandy ground, Canada and Saskatchewan to Texas.

C. indivísa, Engelm. Leaves lanceolate-linear and entire, or sometimes with 2 or 3 slender lateral lobes: bracts and calyx-lobes obovate-dilated, bright red. - Pl. Lindh. i. 47 ; Benth. in DC. 1. c. - Texas, Berlandier, Drummond, Lindheimer, \&c. Winter-annual, flowering in spring, no tuft of radical leaves surviving.

+- + Ultramontane and Pacific annuals, with virgate stems, mostly tall and slender: leaves 'and bracts all linear-lanceolate and entire; the latter or at least the upper with petaloid (red) linear tips : fiowers all pedicellate, the lower rather remote in the leafy spike : calyx gibbous and broarlest at base, ovoid or oblong in fruit, wholly green, about equally cleft before and behind to near the middle; the segments Janceolate and acute or acutely 2-cleft at apex: galea of the narrow and straight corolla rery much longer than the small not callous lip: capsule oblong.

C. mínor, Gray. A foot or two high: corolla half to three-fourths inch long, yellow: the oblong galea much shorter than the tube. - Bot. Calif. i. 573. C. affinis, var, minor, Gray, Bot. Mex. Bound. 119, \& Am. Jour. Sci. 1. c. - Wet ground, New Mexico and Nebraska to W. Nevada.

C. stenántha. Taller, 1 to 5 feet high: corolla linear, double the length of that of the preceding species; the slightly falcate and commonly reddish galea one-half longer than the tube. - C. affinis, Benth. Pl. Hartw. 329, in part (no. 1897); Gray, 1. c. in part.- 
Moist grounds, California from Monterey to San Diego, and through the southern part of the Sierra Nevada.

\section{* * Perennials.}

+ Calyx deeper cleft before than behind, tubular-cylindraceous, mostly cclored red, as are a part of the bracts: corolla large, an inch or two long, well exserted from the lower side of the spathaceous calyx and at length somewhat arcuate or faleate, exposing the protuberant and very short callous lip; its galea about equalling the tube: lower flowers commonly pedicellate.

C. aftinis, Hook. \& Arn. A foot or two high, mostly strict, villous-pubescent or glabrate: leaves narrowly lanceolate, entire, or some of the upper laciniate-toothed at apex; lower floral or bracts similar; upper shorter and broader, red : spike or raceme lax below: calyx narrowly cylindrical, red, an inch long, its anterior fissure hardly twice the depth of the posterior; narrowly oblong lobes acutely 2-cleft at apex : corolla $1 \frac{1}{4}$ to $1 \frac{1}{2}$ inches long. - Bot. Beech. 154, 380; Benth. in DC. 1. c., \& Pl. Hartw. no. 1896; Meyer, Sert. Petrop. ii. t. 15? - California, in moist grounds about San Francisco Bay, on the Sacramento, and south to Tejon, \&c.

C. láxa, Gray. A foot high, weak and slender, short-pubescent: leaves linear-lanceolate, entire, barely 2 inches long, 3-nerved, spreading: bracts similar or broader, the upper reddish : flowers few and crowded : calyx broadly cylindraceous, inch long, its anterior fissure not twice the depth of the posterior, both short; the lobes broad and broadly 2-toothed: corolla inch and a half long, nearly straight; its galea shorter than the tube.-Bot. Mex. Bound. 119 \& Am. Jour. Sci. 1. c. - Mountain side, southern border of Arizona near Santa Cruz, Wright.

C. oblongifólia. Two feet or more high, very leafy, densely villous or pubescent: leaves widely spreading, 5-nerved, 1 or 2 inches long, narrowly elliptical and very obtuse, or the uppermost oblong-ovate and acute: bracts similar, the upper reddish : spike manyflowered: calyx-lobes narrowly lanceolate or linear: corolla 2 inches long; somewhat falcate narrow galea as long as the tube; lip very protuberant and fleshy globular-saccate, its minute lobes subulate. - Southern borders of San Diego Co., California, Palmer. Collected along with $C$. miniata.

C. linariæefólia, Benth. Mostly tall and strict, 2 to 5 feet high, glabrous below, the several-many-flowered spike somewhat pubescent or villous: leaves linear, entire, or some of the upper sparingly laciniate, and the uppermost and bracts 3-parted, 1-3-nerved; divisions not dilated : calyx narrowly cylindrical, over an inch long, mostly red or crimson, sometimes pale; the anterior fissure very much deeper than the posterior; the long upper lip acutely 4-toothed or 2-cleft and the lobes 2-toothed: corolla $1 \frac{1}{2}$ or 2 inches long; its narrow falcate and much exserted galea as long as the tube.-DC. 1. c.; Gray, 1. c., \& Bot. Calif. i. 573. C. candens, Durand in Pacif. R. Rep. v. 12, a pubescent form. - Through the mountains of Colorado and Wyoming to New Mexico, Arizona, and Sierra Nevada of California.

++ Calyx about equally cleft before and behind: floral leaves or bracts more or less dilated and petaloid-colored (red or crimson, varying to yellowsh or whitish). + Pubescence never tomentose nor cinereous-tomentulose.

- Galea equalling or longer than the tube of the corolla; the lip very short.

C. latifólia, Hook. \& Arn. A foot or two high, diffusely branched from the base, villous-hirsute and viscid: leaves short (half inch or more), dilated-obovate or oval, very obtuse, some 3-5-lobed: spike leafy: calyx 2-cleft to the middle; the oblong-oborate lobes entire or emarginate, almost equalling the small (8 lines long) corolla. - Bot. Beech. 154. Coast of California. -

C. parviflóra, Bong. A span to 2 ·feet high, villous-hirsute, at least above: leaves variously laciniately cleft into linear or lanceolate lobes, or sometimes the cauline mainly entire and narrow (rarely oblong): calyx-lobes oblong atid 2-cleft at apex or to below the middle: corolla an inch or less long; only the upper part of the narrow galea exserted; the small lip not protuberant. - Veg. Sitk. 157; Gray, l. c. C. Toluccensis, Cham. \& Schlecht. in Linn. ii. 579? C. coccinea, Lindl. Bot. Reg. t. 1136. C. hispida, Benth. in Hook. Fl, ii. 105, \& DC. 1. c. 532 . C. Douglasii, Benth. in DC. 1. c. 530 ; narrow-leaved and large-flowered form of coast of California. Euchroma Bradburii, Nutt. in Jour. Acad. Philad. vii. 47. $\boldsymbol{E}$. angustifolia, Nutt. 1. c., a low and small-flowered subalpine form: same as C. desertorum, Gever, in Hook. Kew Jour. v. 258. - Dry or moist ground, Sitka to S. California and 
mountains of Arizona, east to Dakota and Colorado. A most polymorphous species, and the oldest name not a good one. Bracts, as in other species, varying from red to yellow or white.

C. miniáta, Dougl. A foot or two high, mostly simple and strict, glabrous or nearly so except the inflorescence: leaves lanceolate or linear, or the upper ovate-lanceolate, acute, entire (rarely laciniate-3-cleft): spike dense and short: bracts from lanceolate to oval, mostly bright red, rarely whitisl,, seldom lobed: calyx-lobes lanceolate, acutely 2-cleft: corolla over an inch long; the galea exserted, linear, longer than the tube; very short lip protuberant and callous, as deep as long, with ovate short teeth involute. - Hook. Fl. ii. 106 ; Benth. 1. c.; Gray, Bot. Calif. i. 574. C. pallida, var. Unalaschensis, Cham. \& Schlecht. 1. c., partly. C. pallida, var. miniata, Gray in Am. Jour. Sci. 1. c. 337. - Alaska to Saskatchewan and southward along the higher mountains through Colorado, Utah and Cali. fornia.

Ealea decidedly shorter than the tube of the corolla and not over twice or thrice the length of the lip.

C. pállida, Kunth. A foot or so high, strict, commonly villous with weak cobwebby hairs, at least the dense and short leafy-bracted spike, or below glabrous, not giandular or viscid : leaves membranaceous, mainly entire ; the lower linear; upper lanceolate or ovatelanceolate: bracts oval or obovate, partly white or yellowish, equalling the (half to inch long) corolla: calyx cleft to or below the middle and again more or less 2-cleft; the lobes oblong or lanceolate: galea 2 to 4 lines long, barely twice the length of the lip, its base not exserted from the calyx. - Syn. Pl. Equin. ii. 100 ; Benth. 1. c.; Gray, Bot. Calif. i. 57j. C. Sibirica, Lindl. Bot. Reg. under 925. Bartsia pallida, L. Spec. ii. 602. - Subarctic N. W. coast and islands, Chamisso, \&c. (Siberia.) Passes into

Var. septentrionális, Gray. A span to 2 feet high, sometimes almost glabrous: bracts greenish-white, varying to yellowish, purple, or red: lip smaller, from half to hardly a third the length of the galea. - Bot. Calif. 1. c. C. septentrionalis, Lindl. Bot. Reg. t. 925 ; Benth. 1. c. C. pallida, Hook. Kew Jour. Bot. v. 258. C. pallida, var. Unalaschensis, latifolia, Cham. \& Schlecht. 1. c. C. acuminata, Spreng. 1. c. Bartsia acuminata, Pursh, Fl. ii. 429. - Labrador, alpine summits of White Mountains and Green Mountains of New England, and north shore of Lake Superior, to the Rocky mountains of Colorado and Utah, and north-westward to Alaska, Aleutian Islands, \&c. Some larger forms appear to pass into C. miniata.

Var. occidentális, Gray. Dwarf and narrow-leaved form, 2 to 6 inches high: bracts comparatively broad, mostly incised or cleft, the tips and flowers whitish: lip about half the length of the rather broad galea. - Bot. Calif. l. c. C.occidentalis, Torr. in Ann. Lyc. N. Y. ii. 230; Benth. 1. c.- High alpine region of the Rocky Mountains, Colorado, and Sierra Nevada, California.

Var. Haýdeni. More slender, 3 to 5 inches high : linear lenves sometimes with one or two slender-subulate Iobes: bracts merely ciliate-pubescent, laciniately 3-5-cleft into linear lobes, bright crimson: lip not half the length of the galea. - Alpine region of the Sierra Blança, S. Colorado, Hayden, Hooker, \& Gray. Seemingly very distinct from C. pallida, but connected through the preceding variety.

C. viscídula. A span ligh, tufted, pubescent with very short stiff mostly glandulartipped hairs and somewhat viscid, only the dense naked spike with some short villous hairs: stems slender: leaves linear, attenuate, entire, or uppermost 3-cleft: bracts 3-5cleft, more or less dilated ; the upper rather shorter than the flowers, with reddish or whitish lobes: calyx-segments shorter than the cylindraceous tube, 2-parted into linear-lanceolate lobes: corolla three-fourths inch long; galea hardly one-third the length of the tube, twice the length of the lip; lobes of the latter elongated-oblong, equal in length to the ventricose obscurely 3-carinate but not callous lower portion. - Nevada, in the E. Humboldt Mountains, at 9,000 feet, Watson (part of no. 810 ).

C. Lemmóni. A span or more high, pubescent, and the dense oblong spike somewhat hirsute-villous, not glandular: leaves narrowly linear, entire or 3-cleft; uppermost more dilated and cleft: bracts 3 -cleft, the upper with reddish lobes and equalling the flowers: calyx-segments as long as the tube, oblong, petaloid, emarginate or barely 2-cleft at apex: corolla fully three-fourths inch long; galea oblong, about a quarter the length of tube, hardly twice the length of the ventricose lip; lobes of the latter ovate, rather shorter than 
the saccate portion, the 3 narrow obtuse keels or plicæ of which terminate under the lobes in as many conical gibbosities. - Sierra Co., California, probably in the alpine region, Lem. mon. Referred in Bot. Calif. to C. pallida, var. occidentalis. One of the transitions to the first section of Orthocarpus.

++ Herbage white-woolly throughout; the tomentum loose or flocculent with age: leaves linear and entire: bracts 3-parted; the divisions more or less spatulate-dilated and petaloid: calyxlobes broad and with rounded entire or slightly 2-lobed summit: corolla almost included, 7 to 9 lines long, slender; the narrow galea little shorter than the tube; lip very short.

C. foliolósa, Hook. \& Arn. A foot or two high, and many-stemmed from a woody base: woolly hairs intricately branched: leaves narrowly linear (inch or less long), crowded below and fascicled in lower axils: spike close: galea shorter than the tube of the corolla. - Bot. Beech. 154; Benth. 1. c.; Gray in Am. Jour. Sci. l. c. \& Bot. Calif. j. 574. - Dry hills, coast of California from San Diego to Mendocino Co.

C. lanáta, Gray. Apparently herbaceous to base, branching, white with appressed arachnoid wool: leaves larger (inch or two long); the galea longer than the tube: flowers larger, more scattered in the spike: corolla rather more exserted. - Bot. Mex. Bound. 118. - S. W. Texas to Arizona. (Adjacent Mex.)

+++ Tomentulose or cinereous-puberulent, or the stem only lanate-tomentose: bracts, \&c., conspicuously petaloid: primary calyx-segments 2-cleft or 2-parted into narrow usually acute lobes : corolla more exserted, inch long or over; galea shorter than the tube;

$=$ Lip very short; its lobes not longer than the more or less callous saccate portion.

C. íntegra, Gray. A span to a foot high: stem rather stout, tomentose : leaves cinereous-tomentulose, linear ( $1 \frac{1}{2}$ to 3 inches long, 1 to 3 lines wide), entire: bracts of the short spike linear- or obovate-oblong, red or rose-color, entire or sometimes incised : corolla inch and a quarter long; galea rather broad; lip strongly tri-callous, its lobes very short. -Bot. Mex. Bound. 119, \& Am. Jour. Sci. l. c. C. angustifolia, Gray, Bot. Mex. Bound. 118, in part, not Nutt. C. tomentosa, Gray, 1. c., a more tomentose form. - Dry grounds, W. Texas to Colorado and Arizona.

C. Lindheímeri. A span or two high, branched or many-stemmed from the base, cinereous-puberulent or the stem tomentulose: leaves narrowly linear, entire or sparingly laciniate, or the upper 3-5-cleft, as are the bracts of the dense spike; these mostly petaloid and dilated, from brick-red to rose-color or sulphur-yellow : calyx equally colored: corolla (inch or so in length) rather slender; the lobes of the lip ovate, not longer than the callous saccate portion - C. purpurea, Gray in Am. Jour. Sci. 1. c. 338, not Don \& Benth. - Stony or fertile mountain prairies, on the Pierdenales and Guadalupe, W. Texas, Lindheimer, \&c. Much more showy than the next, and with different corolla.

$==$ Lip of corolla with Ionger and narrow lobes, and base less saccate.

C. purpúrea, Don. A foot or less high, minutely cinereous-pubescent and the stem appressed-tomentose : leaves narrowly linear and entire, or mostly once or twice 3-cleft or laciniate, with divisions and lobes all narrowly linear: bracts similar or with cuneatedilated base; the broader lobes of the upper and the calyx magenta-color or purple: corolla (over an inch long) narrow; galea very much shorter than the tube, only twice the length of the lip: lobes of the latter elongated-oblong, plane and petaloid, very much longer than the obscurely saccate and not callous basal portion. - Syst. iv. 615; Benth. 1. c. Euchroma purpurea, Nutt. in Trans. Am. Phil. Soc. n. ser. v. 180.-Hilly prairies, Arkansas, Nuttall. E. Texas, Drummond (iii. no. 286 in part), Miss Hobart, Reverchon.

+++ Calyx deeper cleft before than behind: corolla either slender or small, with galea much shorter than its tube and lip comparatively long: bracts and calyx if colored at all yellowish : leaves or their divisions narrowly linear, rather rigid: stems numerous from the root.

+ + Lip of corolla half the length of the short galea, more or less trisacculate and little if at all callous below the narrow lobes: flowers yellowish or greenish white: clefts of the calyx moderately unequal.

= Cinereous-pubescent: leaves mostly 3-5-cleft and the slender divisions sometimes again 2-3cleft: bracts similar or with more dilated base, not even their tips colored.

C. sessiliflóra, Pursh. A span or two high, very leafy, cincreous-pubescent: leaves 2 inches or more long, with slender lobes, rarely entire: lobes of the tubular calyx slender: corolla exserted, about 2 inches long: lip with linear-lanceolate lobes very much longer than the obscurely saccate base. - Fl. ii. 738; Benth. 1. c.; Gray, 1. c. C. grandiflora, Spreng. Syst. ii. 775. Euchroma grandiflora, Nutt. Gen. ii. 55. - Prairies, Wisconsin and Illinois to Saskatchewan, Dakota, and south to W. Texas and New Mexico. 
C. breviflóra, Gray. Barely span high, more pubescent: lower leaves often entire and upper only 3-5-parted, an inch or so long: bracts of the dense spike more dilated, not surpassing the flowers: calyx ovoid-oblong; its lobes lanceolate: corolla little exserted, less than inch long: lip with somewhat callous oblong plicæ or saccate keels about the length of the oblong obtuse lobes. - Am. Jour. Sci. 1. c. 338. - Rocky Mountains of Colorado and Wyoming, in the alpine region, Nuttall, Parry, \&c.

$==$ Very glabrous up to the merely pubescent naked dense spike: cauline leaves all entire: bracts shorter than the flowers, dilated and 3-cleft; the lobes with petaloid yellow ssil tips.

C. linoídes. Stems strict, a foot high, rigid, branching at summit, very smooth, as also the rigid leaves (these 1 or 2 inches long, a line or less wide) : calyx and corolla nearly of C. breviffor $a$, the forner with narrower lobes and the latter only half inch long. - Clover Mountains, Nevada, Watson. In Bot. King, included under " C. pallida, var."

+ + Lip of corolla very short, globular-saccate and callous, and with very short orate lobes: anterior cleft of calyx deeper.

C. fláva, Watson. A foot high, with numerous slender stems, cinereous-puberulent, at least above, and the elongated spike more pubescent : leaves entire or the upper with one or two lobes: bracts 3-cleft and with dilated base; the upper and calyx yellowish: corolla hardly an inch long; narrow galea little shorter than the tube. - Bot. King, 230. Mountains of E. Utah and Wyoming, in and near the Uintas, Watson, Porter.

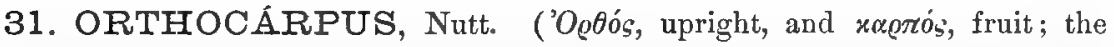
capsule not oblique as in Melampyrum.) - Low herbs, almost all annual (W. North American and one Chilian); with mainly alternate entire or 3-5-parted and laciniate leaves; the upper passing into bracts of the dense spike and not rarely colored, as also the calyx-lobes; the corolla yellow, or white with purple or rose-color, often much surpassing the calyx. Seeds numerous or rather few. Fl. spring and summer. - Benth. in DC. Prodr. x. 535; Watson, Bot. King, 230, 457 ; Gray, Bot. Calif. i. 575.

§1. Castilleioídes, Gray. Corolla with lip (i. e. lower lip) simply or somewhat triply saccate, and with conspicuous mostly erect lobes; the galea (i.e. upper lip) either broadish or narrow : anthers all 2-celled: bracts with more or less colored tips: seeds with very loose and arilliform cellular-favose coat. Bot. Calif. l. c.

* Root perennial: lips of the short and yellowish corolla more equal and less dissimilar than in any of the following; lower one rather obscurely saccate; galea broadish, obtuse : filaments glabrous. Transition to Castilleia.

O. palléscens, Gray. Cinereous-puberulent, not hairy: leaves 3-5-parted into linear lobes, or the lower entire : bracts similar with dilated base, or upper with shorter obscurely whitish or yellowish lobes : calyx deeply 2-cleft, with broad lobes merely 2-cleft at apex: corolla over half inch long. - Am. Jour. Sci. ser, 2, xxxiv. 339, \& Proc. Am. Acad. vii. 384, in part, but only as to Nuttall's Euchroma pallescens in herb. O. Parryi, Gray in Am. Naturalist, viii. 214. - Rocky Mountains of N. W. Wyoming to E. Oregon, Nuttall, Parry, Cusick.

O. pilósus, Watson. From soft-villous to hirsute-pubescent, a span or two high, very leafy: leaves of the precéding or more divided: bracts usually more dilated and colored, from yellow or whitish to dull crimson : calyx-segments deeply cleft or parted; the lobes linear. - Bot. King, 231 ; Gray, Bot. Calif. i. 576. O. pallescens, Gray, l. c., except as to Nuttall's plant. - Sierra Nevada, California, at 5-10,000 feet, to Oregon. Varies with lax and with rather rigid leaves, with soft-villous and with hirsute pubescence. \&c.

* Root annual : filaments glabrous: galea narrow and nearly straight, lanceolate-triangular or broadly subulate, naked: lip moderately ventricose and somewhat plicate-trisaccate for its whole length; the teeth or lobes conspicuous, erect, oblong-linear: capsule oblong or oval.

O. attenuátus, Gray. Erect, slender, a span or two high, hirsute-pubescent above: leaves lnear and attenuate, often with a pair of filiform lobes: spike virgate: lower flowers scattered: bracts with slender lobes barely white-tipped : corolla narrow throughout, 
half inch long, white or whitish : narrow teeth of purple-spotted lip nearly equalling the galea. - Pacif. R. Rep. iv. 121, \& Bot. Calif. 1. c. - Moist ground, San Francisco Bay to Puget Sound.

O. densifiórus, Benth. Erect or diffusely branched from base, 6 to 12 inches high, above soft-pubescent: leaves linear or linear-lanceolate, attenuate upward, entire or with a few slender lobes: spike dense, many-flowered, at length cylindrical, or lowest flowers rather distant: bracts 3-cleft, about equalling the flowers; their linear lobes and (8 to 10 lines long) corolla purple and white: teeth of the lip shorter than the galea. - Scroph. Ind. 13, \& DC. Prodr. x. 536; Gray, 1. c. - Coast of California, in low grounds, San Luis Obispo to Sonoma Co.

O. castilleioídes, Benth. 1. c. At length diffuse and corymbosely branched, 5 to 12 inches high, minutely pubescent, or below glabrate and above somewhat hirsute: leaves from lanceolate to oblong, commonly laciniate; the upper and bracts cuneate-dilated and incisely cleft, herbaceous, or the obtuse tips whitish or yellowish: spikes dense, short and thick: corolla nearly inch long, dull white or purplish-tipped; lip ventricose-dilated: seeds longer or larger than in the preceding. - Pine woods and low grounds near the seashore, from Monterey, California, to Puget Sound or nearly.

* * Root annual : filaments mostly pubescent: galea attenuate upward, densely bearded on the back with many-jointed hairs, uncinate or incurved at the obtuse tip, rather longer and very much narrower than the open-saceate lip, the sumnit of which under the short and small recumbent lobes is trisacculate and the midrle sacculus didymous: stignia very large, depressed-capitate: capsule orate. (Transition to $\S$ Triphysaria.)

O. purpuráscens, Benth. 1. c. Erect, rather stout, at length much branched from base, 6 to 12 inches high, hirsute: leaves with lanceolate base or body, and laciniately 1-2-pinnately parted into narrow linear or filiform lobes, or the upper palmately cleft: spike thick and dense: bracts equalling the (inch or less long) flowers, some what dilated : their lobes and calyx-lobes with upper part of corolla crimson to rose-color, or sometimes paler and duller. - California, common along and near the coast from Humboldt Co. southward.

Var. Pálmeri. Flowers smaller: galea more linear : filaments glabrous or almost so. - Arizona, near Wickenberg, Palmer.

§ 2. True Orthocarpus, Benth. Corolla with simply saccate lip inconspicuously or obsoletely 3-toothed, and moderately smaller ovate-triangular galea ; its small tip or mucro usually somewhat inflexed or uncinate: stigma small, entire: anthers all 2-celled: seed-coat very loose, costate-reticulated: root annual. - Orthocarpus, Nutt. Gen. ii. 56. Oncorrhynchus, Lehm.

* Bracts abruptly and strikingly different from the leaves, much dilated, entire or the lower with narrow lateral lobes, more or less petaloid (purplish), becoming papyraceous and imbricated in the dense fructiferous (oblong or at length cylindrical) spike, toward base often hispid-ciliatc, otherwise naked : corolla mostly rose-color: cauline leaves linear-attenuate; lower mostly entire and upper 3-5-parted.

O. pachystáchyus. A span high, scabrous-puberulent and the stem hirsute: bracts an

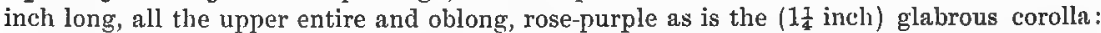
tube of the latter much longer than the calyx: galea with conspicuous and slender incurved tip: anther-cells linear-lunate, mucronate-attenuate at base, glabrous. $-N$. California, near Yreka, Siskiyou Co., Greene.

O. tenuifólius, Benth. More slender, taller, somewhat pubescent or hirsute: bracts about half inch long, oblong or oval, partly purplish: corolla purplish, half inch long, puberulent; the tube little surpassing the caly $x$; inflexed tip of galea minute and inconspicuous: anther-cells oblong, sparsely pubescent. - Scroph. Ind. 12, \& DC. 1. c.; Gray, Bot. Calif. i. 577. O. imbricatus, Torr, in Watson, Bot. King, 458. Bartsia tenuifolia, Pursh, Fl. ii. 429, excl. "flowers deep yellow," which must refer to O. luteus. - Dry ground, Montana to Brit. Columbia and south to the Sierra Nevada, California.

* * Bracts herbaceous, not colored, less or little different from the leaves, all 3- (rarely 5-) cleft and with acute lobes.

+ Spike dense or close, mostly many-flowered : seeds costate.

O. bracteósus, Benth. 1. c. Hirsute-pubescent: stem strict, a foot or less high : leaves as of the preceding or the upper broader: bracts of the thickish and dense spike broadly 
cuneate-dilated, shorter than the flowers, the divergent lobes broadly lanceolate: corolla rose-purple, half inch long; tube moderately longer than the calyx: galea with minute inflexed tip. - Gray, Bot. Calif. I. c. - Dry ground, Brit. Columbia to Oregon and northern portion of Sierra Nevada, California.

O. lúteus, Nutt. Pubescent and hirsute, sometimes viscid : stem strict, a span to a foot high: leaves from linear to lanceolate, occasionally 3-cleft: bracts of the dense spike broader or with more dilated base, completely herbaceous, mostly 3-cleft, about equalling the flowèrs: corolla golden yellow, less than half inch long, twice or thrice the length of the caly $\mathrm{x}$; tip of galea obtuse and straight. - Gen. ii. 57. 0. strictus, Benth. 1. c.; Hook. Fl. ii. 104, t. 172. - Plains, \&c., N. Minnesota and Saskatchewan to Colorado, eastern borders of California, and Brit. Columbia.

O. Tolmíei, Hook. \& Arn. Puberulent, a span or two high, loosely branched : leaves narrowly lanceolate-linear, chiefly entire: bracts of the small and short spikes little dilated, often 3-cleft, the upper shorter than the flowers : corolla bright yellow, half inclı long, 3 or 4 times longer than the calyx; minute tip of galea inflexed. - Bot. Beech. 379 ; Benth. in DC. Prodr. x. 536; Watson, Bot. King, 230. - Utah, in the Wahsatch Mountains, to S. Ilaho.

+ Spike looser, few-flowered : seeds with loose reticulated coat.

O. purpureo-álbus, Gray. Minutely pubescent, somewliat viscid, simple or branched, a span or two high: leaves entire or mostly 3-cleft, filiform: bracts similar or somewhat dilated at base: corolla three-fourths inch long, purple and often partly white, with tube twice or thrice the length of the calyx; tip of galea mucroniforn, inflexed. - Watson, Bot. King, 458; Bot. Calif. 1. c. - New Mexico and S. Utall, Woodhouse, Niwberry, Parry, Mrs. Thompson.

§3. 'TRIPhysária, Benth. Corolla with conspicuously trisaccate lip very much larger than the slender straight galea; its teeth minute or small; tube filiform or slender: stigma capitate, sometimes 2-lobed: bracts all herbaceous and similar to the leaves (or with somewhat colored tips in two species) : root annual. - Triphysaria, Fisch. \& Meyer, Ind. Sem. Petrop. ii. 52.

* Anthers 1-celled : lip of corolla saccately 3-lobed from the end: seed-coat close, conformed to the nucleus, apiculate at one or both ends.

+ Stamens early escaping from their enclosure in the less involute oblong-lanceolate galea.

O. pusillus, Benth. Small and weak or diffuse, branched from the base, a span or less high, somewhat pubescent: leaves once or twice pinnatifid and bracts 8-5-parted into filiform or setaceous divisions: flowers scattered, small and inconspicuous, shorter than the bracts : corolla purplish, 2 or :3 lines long; tube not surpassing the calyx; lip moderately 3-lobed, beardless: capsule globose.-Scroph. Ind. 12, \& DC. 1. c.; Gray, Bot. Calif. i. 578. - Low ground, San Francisco Bay to Oregon.

O. floribúndus, Benth. 1. c. Erect, a span or more high, branched above, almost glabrous: upper part of leaves pinnately parted into linear-filiform divisions, some again cleft: bracts of the mostly dense many-flowered spike 3-5-cleft and dilated at base ; upper ones not surpassing the calyx: corolla white or cream-eolor, half inch long; tube twice the length of calyx; lip with 3 divergent oval sacs, 2 hairy lines within; the teeth lanceolate, erect, scarious. - Gray, Bot. Calif. 1. c. Choropyron palustre, Behr in Proc. Calif. Acad. i. 62, 69? - Hillsides, California, around San Francisco Bay, \&c.

+ - Stamens more strictly enclosed in the acute involnte-subulate galea: lip of 3 obovate or globular-inflated sacs, not more than a quarter of the length of the filiform and mostly densely pubescent tube, the two folds separating the sacs within villous-borrled: flowers numerous in a rather dense spike: upper bracts not exceeding the calyx; lower and the leaves pinnately parted above the broader entire base into setaceous or filiform divisions.

O. eriánthus, Benth. I. c. Frect, a span or more high, fastigiately much branched, pubescent: corolla sulphur-color, with slightly falcate galea brown-purple: tube 6 to 8 lines long, thrice the length of the calyx. - Low grounds, coast of California, from Montercy northward.

Var. róseus, Gray, 1. c. Corolla rose-colored, or probably cream-colored changing to rose-purple; the tube shorter, - Triphysaria versicolor, Fisch. \& Meyer, I. c. ? - Sandy fields, Noyo, Mendocino Co., Bolander, \&c. 
O. faucibarbátus, Gray. Aspect of the preceding, but nearly glabrous up to the short-hirsute or appressed puberulent bracts, less branched: divisions of the leaves rather coarser: corolla apparently white, with smaller sacs and less beard within the lip; the straight galea pale. - Pacif. R. Rep. iv. 121; Bot. Calif. 1. 579. - Moist ground, San Francisco Bay to Mendocino Co., California.

* * Anthers 2-celled (lower cell mostly imperfect in the first two succeeding species): seed-coat loose and arilliform, coarsely reticulated.

+ Lip of corolla very broad ; its sacs deeper horizontally than long.

+ Galea truncate at tip : sacs small, somewhat conical : capsule oblong, obtuse.

O. grácilis, Benth. l. c. Minutely pubescent, or below glabrous, branched from the base: slender branches a span or more high : leaves mostly 3-parted, linear-filiform: upper bracts of the rather dense spike shorter than the flowers; the tips of their lobes purplishtinged : corolla pubescent, purplish (over half inch long); slender tube twice the length of the calyx: lip decidedly shorter than galea. - California, near San Francisco or Monterey, Douglas, Nuttall. Little known.

++ ++ Galea subulate: sacs ample, very ventricose: stem simple or few-branched: spike thickish and dense, at least above: capsule ovate.

O. campéstris, Benth. Glabrous below, but the calyx hirsute: stem 2 to 4 inches high: leaves and bracts narrowly linear and entire or nearly so: corolla white (9 lines long, and lip 2 lines deep): teeth of the lip scarious, slender, rather conspicuous. - Pl. Hartw. 329; Gray, l. c. - Fields, Butte and Plumas Co., California, Hartweg, Mrs. Ames.

O. lithospermoídes, Benth. Copiously hirsute above, pubescent below : stem a span to a foot high, strict, simple or with some erect branches, very leafy : leaves lanceolate or somewhat linear, 2-5-cleft or lowermost simple: bracts of the dense many-flowered spike cuneate-dilated and 3-5-cleft, about equalling the flowers: corolla an inch or less long, cream-color, often turning pale rose-color; sacs 3 lines deep; the teeth short and inconspicuous. - Scroph. Ind. \& DC. 1. c.; Gray, Bot. Calif. i. 579. - Moist and dry ground, California, from San Francisco Bay northward.

+ + Lip not so ample, surpassed by the subulate galea: sacs not deeper than long: stems strict and simple, or branched above: leaves or their lobes linear, mostly attenuated : spikes leafy: calyx-lobes slender: pubescence hirsute.

$$
+ \text { Corolla yellow; the saes nearly as deep as long. }
$$

O. lasiorhýnchus, Gray. Soft-hirsute: leaves mostly 3-parted and bracts 4-5-cleft: corolla an inch long, with filiform tube; lip 3 or 4 lines long; galea subulate-linear, densely white-villous. - Proc. Am. Acad. xii. 82.-S. E. California, on and near the Mohave River, Palner, Parry \& Lemmon.

O. lácerus, Benth. Rather soft-hirsute and above viscid: leaves pinnately and bracts palmately 3-7-cleft or parted: corolla half or two-thirds inch long; the lip only 2 lines long: subulate galea glabrous or merely puberulent. - Pl. Hartw. 329 ; Gray, Bot. Calif. i. 579. O. hispidus, Watson, Bot. King, 230, in part. - Dry ground, California ; common through the whole length of the Sierra Nevada, and valley of the Sacramento.

++ Corolla white or merely purplish; sacs longer than deep.

O. híspidus, Benth. Soft-hirsute rather than hispid: stem strict, mostly simple: leaves with few and slender divisions, or the lower entire: leafy spike virgate: calyx-lobes much shorter than the tube: corolla white, half inch long; lip barely a line deep.Scroph. Ind. \& DC. l. c., at least in part; Gray, Bot. Calif. l. c. - Low grounds, W. Oregon and northern part of California.

O. linearílobus, Benth. Hirsute or nearly hispid : stem stouter, more branched : divisions of the leaves and bracts long and slender; the latter equalling the densely spicate flowers, their tips sometimes purplish-tinged: calyx-lobes much longer than the tube: corolla three-fourths inch long (white or purplish?): sacs deeper than in the preceding at the upper part, narrowing gradually downward. - Pl. Hartw. 350; Gray, l. c. - N. California, in mountain pastures, \&c., Butte Co. to Mendocino Co., Hartweg, Bolcurder.

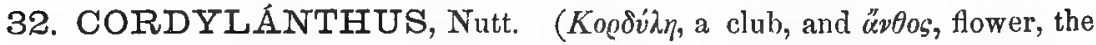
corolla somewhat clavate.) - W. North American branching annuals; with alternate and narrow leaves, either entire or 3-5-parted, and mostly dull-colored 
flowers in small terminal heads or clusters, or more scattered along the branches; the bracts and calyx not colored, and corolla seldom much surpassing the calyx. Seeds comparatively few and large, often apiculate or appendiculate at one or both ends. Fl. summer. - Benth. in DC. Prodr. x. 597 ; Gray, Proc. Am. Acad. viii. 381, \& Bot. Calif. i. 580; Watson, Bot. King, 420. Adenostegia, Benth. in Lindl. Nat. Syst. ed. 2, 445, \& in DC. Prodr. x. 537, but the name abandoned in the same volume for the more appropriate one of Nuttall.

\$1. Axisocheíl. Calyx diphyllous : corolla cleft to the middle; the lower lip only half the length of the upper, entire, hardly saccate: stamens 4, with one-celled anthers (and rarely a vestige of the lower cell): both divisions of the calyx 6-nerved: no gland at tip of leaves: corolla "bright yellow."

C. laxiflórus, Gray. A foot or two high, much branched, very hirsute, above somewhat viscid : leaves short, linear, entire, or the uppermost 3-cleft : flowers approximate or scattered on the leafy branchlets (8 lines long), either sessile and ebracteolate or shortpeduncled and 1-2-bracteolate: corolla little longer than the calyx: filaments villous below: seeds coarsely fitvose, not appendaged.-Bot. Mex. Bound. 120, \& Proc. Am. Acad. 1. c. 383. - Hills and ravines, Arizona, Thurber, Palmer, Rothrock. The habitat "Salt Lake, Utah, Fremont," needs confirmation.

§2. Adenostrigra, Gray, 1. c. Calyx diphyllous: corolla 2-lipped at summit; lower lip about equalling the upper, 3-crenate: flowers short-peduncled or subsessile, 2-4-bracteolate : upper leaves and bracts commonly with a depressed gland or callosity at the truncate or retuse apex: corolla greenish-yellow or purplish. Adenostegia, Benth. in DC. Prodr. x. 537.

* Corolla more exserted and conspicuous, fully inch long: stamens 4: anthers 2-celled: seeds coarsely farose.

C. Wríghtii, Gray. A foot or two high, loosely branched, almost glabrous, or above puberulent-scabrous: leaves setaceous-filiform, 3-5-parted; floral similar, the tips not dilated: flowers several in the mostly dense terminal heads: corolla purplish, with rather long lips: anthers villous. - Bot. Mex. Bound. 120, \& Proc. Am. Acad. 1. c. -S. W. borders of Texas to N. Arizona, Wright, Rothrock.

* * Corolla almost included, half to three-fourths inch long. (Natives of California and adjacent districts.)

+ Stamens 4: anthers 2-celled: filaments villous: both divisions of calyx 5-6-nerved; the posterior entire or emarginate.

$$
\div \text { Seeds rather numerous, about } 20 \text {, delicately favose. }
$$

C. ramósus, Nutt. l. c. A span or two high, diffusely much branched, cinereous-puberulent: leaves filiform, all but the lower usually 3-7-parted; no distinct apical gland or dilatation: flowers few in the small terminal heads or upper axils: corolla dull yellow, barely half inch long. - Watson, 1. c.; Gray, l. c. - Dry interior region of Oregon and W. Nevada, to Wyoming.

+ Seeds fewer and larger, mostly apiculate or appendiculate at one end; the coat close. minutely and closely lineolate with sinuous lines or reticulations, or at maturity smooth and eren through their obliteration: callous gland generally apparent at the tip of some of the upper leaves or bracts.

C. filifólius, Nutt. Tall, 1 to 3 feet high, loosely branched above, roughish-puberulent and somewhat viscid or nearly glabrous below, commonly more or less hispid above, especially the margins of the floral leaves: leaves 3-5-parted or some of the lower entire; the divisions from filiform to linear; those of the upper and the more dilated bracts usually broadening upward and with retuse tip: heads rather many-flowered, often proliferous: corolla purplish, over half inch long. - Benth. 1. ¿. Adenostegia rigida, Benth. in Lindl. Nat. Syst. \& DC. 1. c. 5:37. (Name replaced in the same volume by the then unpublished one of Nuttall.) - Dry and moist banks, throughout all but perhaps the northern part of California. Varies greatly in foliage, pubescence, \&c., but generally well marked by the hispid- or setose-ciliate bracts and floral leaves. 
Var. brevibracteátus, Gray, is glabrous up to the floral leaves, these hispid-ciliate with short bristles, also shorter and fewer, as are the flowers in the head. - Bot. Calif. i. 622. - Soda spring, Kern Co., Rothrock.

C. pilósus, Gray. Paniculately branched, 2 to 4 feet high, soft-villous throughout, somewhat viscid, no rigid hairs: leaves linear, all but the floral entire; these commonly 3-parted and with emarginate or callous-3-toothed tip: flowers few in the irregular terminal clusters, or some lateral and solitary; corolla yellowish or purplish, half inch or more long. - Proc. Am. Acad. vii. 383, \& Bot. Calif. i. 581. - W. California, in open dry ground from Santa Clara Co. northward.

Var. Bolánderi, Gray, l. c. Lower, less pilose, more viscid or glandular : flowers all scattered. - Mendocino Co., Bolander. Also from Plumas Co. to Tuolumne Co, in the foothills of the Sierra.

C. ténuis, Gray, 1. c. Effusely paniculate, a foot or two high, minutely cinereous-puberulent, at summit sometimes more pubescent and glandular: leaves very narrowly linear, entire : flowers scattered along the almost filiform branches, or some loosely clustered at their summit: flowers as of the preceding or smaller and the upper sepal narrower. - Dry ground, California from the mountains of Mendocino Co. to Lake Tahoe, and adjacent borders of Nevada. + - Stamens 2: anthers 1-celled: filaments nearly glabrous: posterior division of calyx only
2-nerved, 2-cleft at apex : seeds few, minutely farose.

C. capitátus, Nutt. A foot or two high, paniculately much branched, soft-pubescent and cinereous: leaves very narrowly linear, or those subtending the several-flowered terminal head broader and 3-5-cleft: corolla purplish, half inch long: capsule 8-seeded. Benth. l. c. 597; Watson, Bot. King, 231, 459; Gray, Bot. Calif. I. c. - S. Idaho and N. Nevada, Nuttall, Watson.

§3. Hemistégia, Gray, 1.c. Calyx monophyllous; the anterior division wanting: flowers strictly sessile in the axil of a clasping bract or leaf, ebracteolate: corolla purplish or yellowish: no callous gland at the tip of leaves: herbage not glandular: seeds (those of $C$. maritimus not seen mature) rather numerous, scarious-appendaged; the coat cellular-favose.

* Stamens 2: anthers 2-celled: filaments glabrous: seeds somewhat reniform.

C. móllis, Gray. Barely a foot high, rather stout, much branched, villous-hirsute: leaves and bracts oblong-linear, obtuse, entire or the upper laciniate-toothed or pinnatifid: flowers in a thickish short spike : corolla three-fourths inch long. - Proc. Am. Acad. viii. 384, \& Bot. Calif. 1. c. - Salt marshes of San Francisco Bay, California, around Vallejo, Wright, Greene.

* * Stamens 4: anthers of longer stamens 2-eelled, of the shorter with only the small lower cell: filaments glabrous or nearly so: leaves and even bracts all entire, pale or canescent; lower ones linear; upper, and especially the loosely imbricated bracts, lanceolate or broader and concave or somewhat conduplicate: inflorescence at first capitate, beconing short-spicate.

C. marítimus, Nutt. 1. c. A span or two high, corymbosely branched, cinereous-pubescent: leaves glabrate, slightly fleshy: pairs of filaments very unequal. - Gray, 1. c.California, in sandy salt marshes, from San Diego to San Francisco Bay.

C. canéscens, Gray, 1. c. A foot or less high, corymbosely much branched, canescent with soft and short villous pubescence: uppermost leaves and bracts from oblong- to ovate-lanceolate : smaller filaments sometimes obscurely hairy. - Saline soil, Sierra Nevada, on the eastern border of California to Salt Lake, Utah.

Var. Párryi. A slender form, with narrower bracts and sparser flowers: smaller filaments with some scattered hairs. - C. Parryj, Watson in Am. Naturalist, ix. 346. S. W. Utah, Parry, Palmer.

* * * Stamens 4: anthers all 2-celled: filaments villous: leaves and bracts mostly 3-5-parted into linear-filiform divisions : habit and inflorescence of $\$$ Adenostegio.

C. Kíngii, Watson. A foot or less high, diffusely branched, viscid-pubescent or villous : leaves 1 or 2 inches long: flowers loosely glomerate or somewhat scattered at the summit of the slender branchlets: calyx 4-6-nerved: corolla less than an inch long, purplish. Bot. King, 233, t. 22.-W. Nevada, Watson. S. Utah, Parry, Siler, S. W. Colorado, Brandegee. 
33. SCHW ÁLBEA, Gronov. Chaff-serd. (C. G. Schualbe, who wrote a tract on Sarsaparilla in 171j.) Clayt. Fl. Virg. ed. 1, 71. - Single species.

S. Americána, L. Perennial herb, minutely soft-pubescent: stem strict, 2 feet high, leafy : leaves sessile, ovate or oblong, 3-nerved, entire, an inch or more long; upper gradually reduced to bracts of the loose virgate spike: corolla full inch long, yellowish and purplish : bractlets linear. - Spec. ii. 606 (Pluk. Mant. t. 348, fig. 2) ; Benth. in DC. Prodr. x. 538. - Low sandy ground, Mass. to Louisiana, near the coast. Fi. early summer.

34. EUPHRÁSIA, Tourn. Exebright. (Greek for hilarity, from reputed power to restore impaired eye-sight.) - Genus of wide distribution, but only a single and insignificant $\mathrm{N}$. American species.

E. officinális, L. Low annual: leaves from round-ovate to oblong, incisely dentate; the upper with very strong sctaceous-tipped teeth; lowest crenate: galea and lobes of lower lip of the purplish or bluish corolla deeply emarginate. $-N$. E. coast of Maine and Canada: depauperate and small-flowered forms, perhaps introduced from Europe. Alpine region of White Mountains of New Hampshire, shore of L. Superior, northern Rocky Mountains to Aleutian Islands and far northward; chiefly the var. Tartarica, Benth. in DC. (E. latifolia, Pursh, FI. ii. 430); a low form with small flowers ( 2 or 3 lines long), and mostly rounded leaves (3 to 6 lines long): fl. summer. (Eu., N. Asia.)

35. BÁRTSiA, L. (Dr. I. Bartsch, an early friend of Linnaus, who died in Surinam.) - Herbs, the genuine species chiefly of mountains or cold regions, both of the Old and New World; with opposite sessile leaves, and subsessile flowers, in the upper axils and in a terminal leafy spike.

B. alpína, L. A span high, simple from a perennial root, pubescent, leafy : leaves ovate, crenate-dentate, half inch long: spike short: corolla over half inch long, purple, with obovate somewhat arching galea : anthers hairy on the back. - Spec. ii. 602; Engl. Bot. 361 ; Pursh, Fl. ii. 430. - Labrador. (Greenland, Arct. \& Alp. Eu.)

B. Odontítes, Huds. A span or two high from an annual root, branching, scabrouspubescent: leaves oblong-lanceolate, coarsely and remotely serrate: spikes elongated, loosely flowered, partly in the axils of ordinary leaves : corolla small, rose-red: anthers nearly naked. - Fl. Angl. 268; Engl. Bot. t. 1415. Euphrasia Odontites, L. Odontites rubra, Pers. Syn, ii. 150. - Coast of Maine and of Nova Scotia. (Sparingly nat. from Eu.)

36. PEDICULÁRIS, Tourn. Lousewort. (Pediculus, a louse; no obvious application, unless the herb was used as an insectifuge.) - Large genus, of perennial herbs, or rarely biennial or annual (as in $P$. palustris and $P$. euphrasioides); many arctic-alpine, rather few N. American, still fewer S. American. Leaves commonly pinnately cleft or dissected, mainly alternate; flowers in a terminal bracteate spike, rarely in a raceme or scattered; in spring or summer. Benth. in DC. Prodr. x. 560; Maxim. Diagn. in Bull. Acad. Petrop. x. 1877.

* Cauline leaves and flowerg verticillate or mostly so: calyx 5-toothed: galea toothless.

P. Menziésii, Benth. About 10 inches high, nearly glabrous, simple: leaves deeply pinnatifil or pinnately parted into oblong incisely toothed divisions: lower whorls of the spike rather distant: caly $x$ inflated-globose; the teeth short, ciliate, somewhat crested: tube of corolla exceeding the caly $x$; galea straightish, slightly if at all rostrate, shorter than the depending lower lip. - Prodr. 1. c. 563. - N. W. Coast, Menzies, in herb. Smith. Not identified : char. copied. Corolla of $P$. versicolor, but with much-dilated throat.

P. verticilláta, L. A span high, glabrate or above pilose: leaves 1-2-pinnately parted or pinnatifid into small ovate or oblong divisions or lobes: spikes interrupted: calyx-teeth entire or serrulate: corolla red (half inch long) : galea short, barely incurved at the blunt apex, nearly equalled by the Iower lip. - Jacq. Austr. iii. t. 206; Benth. l. c. ; Reichenb. Ic. Germ, t. 1762. - Alaska to arctic regions, and Aleutian Islands. (Asia, Eu.) 
P. Chamissónis, Stev. Commonly a foot high, robust, glabrous : leaves deeply pinnatifid; divisions lanceolate, serrate or incised: lower whorls of the spike remote: calyxteeth entire: corolla yellow (over half inch long); galea with incurved acuminate beak, becoming straitish.-Monogr. in Mem. Soc. Nat. Mosc. vi. 20, t. 4, fig. 1; Hook. Fl. ji. 107. P. Romanzovii, Cham. in Spreng. Syst. ii. 778. - Aleutian Islands, Chamisso, Dall, \&c. (Adjacent W. Asia.)

* *eaves alternate, or some occasionally opposite.

+ Galea produced into a filiform porrect or soon upturned beak; throat with a tooth on each side; tube of corolla nearly included in the 5-toothed calyx: leaves lanceolate in ontline, pinnately parted; the linear or lanceolate divisions acutely or laciniately serrate, or the larger again pinnatifid: stems simple, strict, from a span to a foot and a half high : spike dense and manyflowered, naked : corolla dull rose-red or crimson-purple.

P. Grcenlándica, Retz. Glabrous : spike 1 to 6 inches long : calyx-teeth short : beak of the galea half inclı or more long, twice the length of the rest of the corolla, deeurved on the accumbent lower lip, thence porrect and soon upwardly recurved. - Fl. Scand. ed. 2, 45; Fl. Dan. t. 1166 (with flowers not well developed); Torr. Ann. Lyc. N. Y. ii. 223; Hook. l. c. P. Groenlandica \& surrecta, Benth. 1. c. 566. P. incurnata, Retz, Fl. Scand. ed. 1, 117, \& Obs. iv. 27, t. 1 (representing well developed ascending beak), not Jacq. \&c. Wet ground, Labrador and Hudson's Bay to Alpine and subalpine Rocky Mountains, extending south to borders of New Mexico, west to Brit. Columbia, and south in the Sierra Nevada to King's River, California, Dr. Matthews. (Greenland.)

P. attóllens, Gray. More slender: spike loosely lanate-pubescent when young : flowers smaller: calyx-teeth nearly as long as the tube: corolla dull violet purple: galea much shorter than the broad lower lip, about half the length of the obtuse and abruptly upturned or retrocurved filiform beak, which is only 2 or 3 lines long. - Proc. Am. Acad. vii. 384, \& Bot. Calif. i. 582. - Wet ground, Sierra Nevada, California, from the Yosemite district to Placer Co., at 6-10,000 feet, Bridges, Brewer, \&c.

++ Galea of the (short, half inch long) white corolla produced into a slender elongated-subulate circinate-incurved beak, nearly reaching the apex of the broad lower lip: calyx cleft in front: whole plant glabrous.

P. contórta, Benth. A foot or less high, simple: leaves pinnately parted into linear incisely serrate lobes; the upper reduced to sinpler small bracts : spike naked, cylindrical, rather loosely many-flowered: galea with the slender beak almost circinate. - Hook. Fl. ii. 108, \& DC. 1. c. 575. - Mountains of Oregon and Idaho, Tolmie, Hayden, \&c.

P. racemósa, Dougl. A foot or so high, simple or sometimes branching, leafy to the top: leaves lanceolate, undivided, minutely and doubly crenulate (2 to 4 inches long): flowers short-pedicelled, in a short leafy raceme or spike, or the lower in remote axils and uppermost with bracts hardly surpassing the 2-toothed calyx: slender beak of galea hanate-deflexed. - Hook. 1. c., \& DC. 1. c. - Subalpine regions, British Columbia to N. California, Utah, and Colorado.

$+\leftarrow+$ Galea falcate and with a conical or thick-subulate beak, edentulate : leaves at least pinnatifid: flower about half inch long.

- Stems more or less leafy, low: leaves simply pinnatifid: corolla ochroleucous.

P. Lappónica, L. Merely puberulent: stems clustered, a span or more high, leafy up to the short close spike: leaves lanceolate, pinnatifid half way down in many and close small oblong and incisely toothed lobes: calyx cleft in front, minutely 2-toothed behind: galea erect, with abruptly incurved conical short beak. - Fl. Lapp. t. 4, fig. 1; Fl. Dan. t. 2 ; Pursh, Fl. ii. 309.-Labrador and Arctic America : apparently uncommon. (GreenIand, Lapland to Kamtschatka.)

P. Párryi, Gray. Glabrous, or the inflorescence slightly pubescent: stem a span or two high, very leafy at base, slightly so above : leaves linear-lanceolate in outline, deeply pinnately parted; the divisions linear-lanceolate, acute ( 2 or 3 lines long), closely callousserrate; uppermost leaves reduced to narrow linear bracts: spike dense, $1 \frac{1}{2}$ to 4 inches long: calyx 5-toothed; the teeth entire: corolla ochroleucous or more yellow; galea strongly falcate, with decurved subulate-conical beak, of about the length of the width of the galea. - Am. Jour. Sci. ser. 2, xxxiii. 250; Porter \& Coulter, Syn. Fl. Colorad. 97.Rocky Mountains, from Wyoming or Montana through Colorado to Utah, within and on the border of the alpine region. 
++ Stem scapiform, or sometimes bearing a pair of leares, low: leaves donbly pinnatifid: corolla probably purple: decurved or porrect narrow beak longer than the breadth of the galea: plants nearly gilabrous, only a span high.

P. pedicelláta, Bunge. Leaves pinnately parted, and the oblong or lanceolate divisions incisely pinnatifid; lobes very small, dentate: spike capitate and with one or two more distant pedicellate leafy-bracted flowers at base: calyx-lobes toothed or incised: corolla fully half inch long: lower lip much smaller than the galea. - Walp. Repert. iii. $4: 32$ (name only) \& in Ledeb. Fl. Ross. iii. 278; Maxim. 1. c. 111. P. nasuta, Bong. Sitk., not Bieb. P. subnuda, Benth. in DC. 1. c. 577. - Sitka, Mertens, \&c. Norfolk Sound, Eschscholtz. Also Labrador, according to Bunge, l. c.

P. ornithorhýncha, Benth. Habit, foliage, \&c., of the preceding, according to the character: "spike interrupted : caly $x$ ovate-inflated; the teeth nearly entire." - Hook. l, t. \& DC. 1. c. - "On Mount Ranier, Oregon, Tolmie." Said to be related to P. rostrata, but with more dissected leaves, having very acute lobes, and a smaller lip*

++++ Galea falcate, arcuate, or with apex more or less incurved, or anteriorly curvilinear; the beak very short and thick, or commonly none.

+ Stems branching from a biennial or perhaps annual root: flowers from the axils and in short terminal spilies: galea about the length of the lip, slender-bidentulate at the lower part of the apex.

P. euphrasioídes, Stephan. A span or more high, puberulent: leaves lanceolate; lower pinnately parted into lanceolate incisely serrate divisions; upper pinnatifid; uppermost closely crenate: calyx cleft in front and with 2 or 3 entire teeth behind : corolla half inch long, yellowish and purplish; galea little shorter than the tube, with a very short and truncate horizontal beak. - Willd. Spec. iii. 204; Reichenb. Iconogr. i. t. 14; Benth. 1. c. P. Labradorica, Houtt. Linn. Syst. viii. 39, t. 57. - Labrador to Behring Straits. (Kamts. to Greenland.)

P. palústris, L., var. Wlassoviána, Bunge. A foot high, glabrous : leaves all pinnately parted; the small segments oblong, incisely crenate: caly $x$ 2-cleft; lobes incisely cristate : corolla narrow, half inch long, purplish; lips much shorter than the tube; galea not at all rostrate, nearly straight, the anterior face curvilinear, a pair of minute additional denticulations at the throat. - Ledeb. Fl. Ross. iii. 28?; Maxim. 1. c. P. Wlassoviana, Stev. Monogr. 27, t. 9, fig. 1; Benth. 1. c. P. parvifora, Smith, ex Benth. - Hudson's Bay to Kotzebue Sound, and south to Oregon. (Siberia.)

+ +- Stems simple, from a perennial root, leafy, and along with the spike longer than the leaves. $=$ Atlantic States species, not alpine: leaves pinnatifid: spike short and dense.

P. Canadénsis, L. Hirsute-pubescent and glabrate, a span to a foot high: leaves oblong-lanceolate, rather deeply pinnatifid; lobes short-oblong, obtuse, incisely and the larger doubly dentate: spike leafy-bracteate : calyx cleft in front: corolla ochroleucous or tinged or variegated with purple, narrow, less than inch long; cucullate summit of the galea incurved, its slightly produced tip emarginate-truncate and below conspicuously cuspidatebidentate: capsule gladiate-lanceolate. - Mant. 86; Sims, Bot. Mag. t. 2506; Sweet, Brit. Fl. Gard. t. 67. P. gladiata, Michx. Fl. ii. 18, P. requinoctialis, HBK. Nov. Gen. \& Spec. ii. 332. - Moist woodlands and gravelly banks, Canada to the Saskatchewan, south to Florida, and west to the Colorado Rocky Mountains. (Mex.)

P. lanceoláta, Michx. Glabrous or sparsely pubescent: stem robust, 1 to 3 feet high: leaves not rarely opposite, thickish, lanceolate or oblong, moderately pinnatifid and the short and broad lobes doubly crenate-dentate, or the upper leaves merely crenate and the teeth minutely crenulate: leafy bracts shorter than the flowers: calyx 2-lobed; lobes crested with a roundish appendage : corolla straw-color, an inch long, rather broad; cucullate summit of the galea incurved and produced into a somewhat beak-like evenly truncate and edentulate apex: capsule ovate, oblique. -Fl. ii. 18; Benth. 1. c. 582. P. Virginica, Poir. Ilict. v. 126. P. pallida, Pursh, Fl. ii. 421. P. auriculata, Smith, ex Benth. Swamps, Connecticut to Virginia, Ohio and the Saskatchewan. Perhaps this is also $P$. resupinata, Pursh, 1. c., from Canada.

$$
==\text { Rocky Mountain species, tall or slender, not alpine. }
$$

a. Leaves undivided: galea bidentulate at tip, equalled by the lip.

P. crenuláta, Benth. Villous-pubescent, at length glabrate: stems a foot or less high: leaves oblong-linear or narrower, obtuse ( $1 \frac{1}{2}$ to 3 inches long), closely crenate and the 
broad crenatures minutely crenulate: spike short and dense: calyx cleft in front, 2-3toothed posteriorly: corolla whitish or purplish, three-fourths of an inch long, like that of $P$. Canadensis, but the teeth at the apex of galea less conspicuous. - Prodr. 1. c. 568; Porter \& Coulter, Fl. Colorad. 97. - Meadows and parks, Colorado Rocky Mountains, at 7 to 10,000 feet, Fremont, Fusey, \&c.

b. Leaves all pinnately parted and the lower divided, ample: divisions lanceolate or linear-lanceolate, acutely laciniate-serrate or the larger pimatifid: spike naked, many-flowered: bracts unlike the leaves: calyx 5-cleft; the lobes slender and entire: galea almost ştraight, cucullate at summit.

P. bracteósa, Benth. Glabrous, or the dense cylindraceous ( $1 \frac{1}{2}$ to 3 inch) and usually pedunculate spike somewhat pilose: stem 1 to 3 feet high: divisions of the leaves $\frac{1}{2}$ to 2 inches long, linear-lanceolate: bracts ovate, acuminate, shorter than the flowers: calyxlobes slender-subulate, equalling the tube : corolla less than inch long, narrow, pale yellow; galea much longer and larger than the lip, its cucullate summit slightly produced at the entire edentulate orifice, but not rostrate.-- Hook. Fl. \& DC. l. c. P. recutita, Pursh, Fl. ii. 425, probably. P. elata, Pursh? not Willd.-Mountain and subalpine woods, Saskatchewan to British Columbia, and south to Utah and the Colorado Rocky Mountains.

P. prócera, Gray. Puberulent: stem robust, $1 \frac{1}{2}$ to 4 feet high : leaves pinnately divided into lanceolate ( 1 to 3 inches long) and irregularly pinnatifid segments, or the uppermost deeply pinnately parted; lobes mucronately serrate or incised: bracts lanceolate, caudateacuminate, mostly longer than the flowers, serrate or denticulate, or the upper entire: spike 8 to 15 inches long: calyx-lobes lanceolate or subulate, much shorter than the tube: corolla about an inch and a half long, sordid yellowish and greenish-striate; galea hardly longer than the ample lip; its broad cucullate summit slightly incurved, hardly at all extended at the orifice, the lower angle with a short triangular tooth on each side: capsule broadly ovate. - Am. Jour. Sci. ser. 2, xxxiv. 251. - Low or wooded grounds of the Rocky Mountains in Colorado and New Mexico, at 8 or 9,000 feet. Leaves more compound, the bracts and calyx-lobes longer, and corolla larger than in the allied Siberian $P$. striata, Pall.

$$
===\text { Rocky-Mountain-alpine : stem few-leaved, only a span or so high.. }
$$

P. scopulórum. Glabrous, except the arachnoid-lanate dense oblong spike : calyx-teeth triangular-subulate, entire, membranaceous, very much shorter than the tube: galea of the reddish-purple (three-fourths inch long) corolla with its somewhat produced apex obliquely truncate, edentulate or produced on each side into an obscure triangular tooth: otherwise as the following. - P. Sudetica, var., Gray in Am. Jour. l.c.-Colorado Rocky Mountains, at 12 to 14,000 feet, Parry, Hall \& Harbour, \&c.

$$
====\text { Arctic-alpine, in America only in high northern regions. }
$$

(c. Galea falcate-incurved and with somewhat produced bidentulate summit.

P. Sudética, Willd. Glabrous, or the spike commonly hirsute-villous or lanate: stem a span high, few-leaved: leaves simply pinnately-parted; divisions lanceolate, incisely serrate or crenate; the teeth somewhat cartilaginous: spike dense, mostly short: calyxteeth lanceolate or linear, little shorter than the tube, serrulate: corolla purple ( 9 or 10 lines long); galea longer than the erose-crenulate lobes of the lip; the tooth at the lower side of truncate apex on each side conspicuous and cuspidate, sometimes shorter and triangular-acuminate. - Spec. iii. 209; Stev. Monogr. 44, t. 15; Reichenb. Iconogr. iv. t. 390, \& Ic. Germ. t. 1750; Bunge in Ledeb. 1. c. - Kotzebue Sound, St. Paul and St. Lawrence Islands, \&c. (Adjacent Arctic Asia, N. Siberia to Lapland, E. Alps.)

b. Galea less falcate or straightish, with rounded-obtuse summit not at all produced anteriorly, yet sometimes bidentulate: calyx 5-toothed: capsule acuminate, usually double the length of the calyx: spike dense, its evolution according to Maximowicz centrifugal or nearly coetaneous (but this hardly apparent), except in true $P$. Langsdorffi.

P. Langsdórffii, Fisch. Stem stout, glabrous below, at base bearing numerous leafiess brown scales, 3 to 8 inches high, including the at length elongated leafy-bracteate more or less hirsute or lanate spike: leaves pectinately pinnatifid or the radical parted into suall oblong denticulate lobes: bracts mostly like the upper leaves: calyx-teeth or most of them denticulate : corolla rose-color or purple (rarely yellowish, 9 or 10 lines long), with oblong-linear somewhat falcate galea longer than the lip, commonly with a slender tooth on each side below the apex: filaments all or one pair more or less pilose above: capsule gladiate-lanceolate. - Stev. Monogr. 49, t. 9, fig. 2; Hook. Fl. ii. 109; Ledeb. Fl. Ross. iii. 
288; Maxim. 1. c. P. purpurascens, Cham. in Spreng. Syst. ii. 781. - Aleutian and more northern Islands, Kotzebue Sound, \&e. (Adjacent N. E. Asia.) Evidently passes into

Var. lanáta. Spike conspicuously and densely lanate: galea rather shorter, nearly equalled by the lip, often edentulate: one pair of filaments glabrous : capsule ovate-acuminate. - P. Langsdorffi, var., Stev. 1. c. $P$. lanata, Willd, ex Cham. in Linn. ii. 583; Bunge, 1. c. P. arctica, R. Br. App. Parry, 280, ex char. P. hirsula, Benth. 1. c., in part. $P$. Kanei, Durand in Jour. Acad. Philad. n. ser. ii. 195. - Same range as the type on the north-west coast; also arctic coast and islands, and high northern Rocky Mountains. (Greenland, Nova Zembla, Arctic Asia.)

P. hirsúta, L. More sparsely-leaved, 2 to 10 inches high: leaves pinnately parted or divided down to the broad rhachis, which is almost as wide as the length of the (line long) divisions: spike capitate, lanate, or the caly $x$ rather hirsute: corolla smaller, not over half inch long, flesh-colored; the closed galea not excised or notched anteriorly: filaments all glabrous. - Fl. Lapp. t. 4, fig. 3 ; Fl. Dan. t. 1105; Bunge, l. c.-Arctic seacoast, Capt. Pary. (Greenland, Spitzbergen, Lapland, Arct. Siberia.)

P. flámmea, L. Rather sparsely-leaved, glabrate or glabrous, 2 to 4 inches high : leaves deeply pinnately parted; divisions crowded, ovate or oblong, incisely and doubly serrate (hardly 2 lines long): bracts of the narrow naked spike shorter than the pedicellate flowers, linear-lanceolate, merely denticulate: calyx-teeth lanceolate, unequal, much shorter than the cylindraceous tube: corolla narrow, half inch long, citron-yellow with crimson or dark purple tip to the oblong almost equal-sided but slightly arcuate galea, which much exceeds the small lip: filaments all glabrous. - Fl. Lapp. t. 4, fig. 2; Fl. I)an. t. 30, \& t. 1878; Bunge, l. c. - Labrador to the northern Rocky Mountains and northward. (Greenland, Arct. Eu.)

P. versícolor, Wahl. Like the preceding, mostly larger : calyx more deeply 5-toothed: corolla three-fourths inch long, with more arcuate and gibbous galea, dilated throat, and larger lip: two longer filaments hairy, - Veg. Helvet. 118 (not Fl. Suec.); Cham. \& Schlecht. in Linn. ii. 585; Hook, 1. c. ; Bunge, 1. c. - N. W. Coast? Island of St. Lawrence, Chamisso. (Arctic E. Asia to Himalayas and Siriss $\Lambda$ lps.)

+++ Stem scapiform, leafless or one-leaved, and with the head of few large flowers surpassing the radical leaves: galea edentulate : anthers muticous.

P. capitáta, Adams. Pubescent or glabrate: leaves pinnately divided; divisions ovate, pinnately incised and dentate: scape 1 to 4 inches high: bracts foliaceous: caly $x$ campanulate, 5-cleft; the lobes incisely dentate: corolla over an inch long, "white" or "yellow;" its tube little exserted; galea elongated, arcuate-incurved, of equal breadth throughout, obscurely produced at the orifice, twice the length of the lip: filaments glabrous. - Mem. Soc. Nat. Mosc. v. 100 ; Stev. Monogr. 1. c. 19, t. 3, fig. 2 ; Cham. \& Schlecht. 1. c.; Trautv. Imag. 55, t. $36 . \quad P$. Nelsoni, R. Br. in Richards. Frankl. App. 743 ; Hook. in Parry, App. 402, t. 1. P. verticillata, Pursh, Fl. ii. 426, not L. - Arctic seacoast, Kotzebue Sound, Unalaska, and more northern islands. (Arct. Asia.)

+++++ Stem short or hardly any: radical leaves exceeding the short spike or head: galea edentulate: anther-cells mucronate or aristate at base: lower lip nearly the length of the galea: calyx 5-cleft into lanceolate unequal lobes: capsule ovate, nearly included in the calyx.

P. semibarbáta, Gray. Nearly acaulescent, depressed, pubescent and glabrate: leaves ( 6 to 9 inches long) in a radical tuft and as bracts to the lowest flowers, on petioles mostly exceeding the irregular sessile spikes, twice pinnately parted or nearly so, and the oblong lobes laciniately few-toothed: corolla yellowish and purplish, pubescent outside, two-thirds inch long; the almost straight galea rounded obliquely at summit, not cucullate: longer filaments villous above the middle: anthers mucronate at base.-Proc. Am. Acad. vii. 385, \& Bot. Calif. i. 583. - Open woods of the Sierra Nevada, California, at 5 to 10,000 feet, south to San Bernardino Co.

P. centranthéra, Gray. Glabrous: leaves (2 to 5 inches Iong) moderately exceeding the short and dense spike, deeply pinnatifil; the ovate or oblong divisions doubly crenatedentate and their margins thickly bordered with minute white-cartilaginous teeth : bracts shorter than the flowers, similarly margined and toothed, or the upper and calyx-lobes nearly entire: corolla inch long, purple and yellowish; the galea slightly incurved and conspicuously cucullate at summit: filaments glabrous: anthers aristate at base. - Bot. Mex. Bound. 120.-W. New Mexico and S. Utah to S. E. California, Bigelow, Nervberry, Mrs. Thompson, Palmer, \&c. 
+++++ Galea completely straight and anteriorly rectilinear, edentulate, very much longer and larger than the depauperate lip, slightly broader upwards; the whole corolla therefore more or less clavate.

P. densiflóra, Benth. Pubescent or glabrate: stem stout, 6 to 20 inches high, leafy: leaves ample ( 4 to 12 inches long), of oblong outline, twice pinnatifid or pinnately parted, and the lobes laciniate-dentate; the irregular salient teeth cuspidate-tipped : spike at first very dense, oblong ( 2 or 3 inches long), in age looser and longer (sometimes a foot or more long); lower bracts leaf-like; uppermost almost entire and equalling or shorter than the short-pedicellate or sessile flowers: calyx deeply 5 -toothed; the teeth lanceolate or subulate : corolla scarlet-red, fully an inch long; lip a line or two long: filaments glabrous. - Hook. Fl. ii. 110, \& DC. l. c. 574 ; Gray, Bot. Calif. i. 583. P. attenuata, Benthr in DC. 1. c. - Dry hills, almost throughout California, at least in the western part of the State. A variable but most distinet species.

37. RHINÂNTHUS, L. Yellow-Ratrle. (Formed of giv, snout, and "an $\theta$ os, flower, now meaningless, for the species with beak to the upper lip of the corolla have been removed to another genus.) - Comprises a very few annuals of northern temperate zone; with erect stem, opposite leaves, and mostly yellow subsessile flowers in the axils, the upper ones crowded and secund in a leafybracted spike; in summer. Seeds when ripe rattle in the inflated dry calyx, whence the popular name.

R. Crista-gálli, L. About a foot high, glabrous, or slightly pubescent above: leaves from narrowly oblong to lanceolate, coarsely serrate; bracts more incised and the acuminate teeth setaccous-tipped: corolla barely half inch long, only the tip exserted; transverse appendages of the galea transversely ovate, as broad or broader than long: seeds conspicuously winged. - Spec. ii. 603, mainly ; Engl. Bot. t. 657. R. minor, Ehrl. Beitr. vi. 144. - Coast of New England, rare, and perhaps introduced. Alpine region of the White Mountains, New IIampshire, Labrador and Newfoundland, Lake Superior, Rocky Mountains, extending south to New Mexico, and north-west to Alaska and Unalaska; clearly indigenous. (Greenland, Eu., Asia.) Varies much in size, but apparently we have no R. major, Ehrls.

38. MELAMPÝRUM, Tourn. Cow-WhEAT. (The name, from $\mu$ '́l $\alpha$ s and

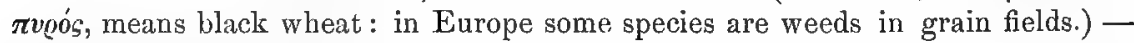
Low and branching annuals; with opposite leaves; chiefly European, one Atlantic N. American : fl. summer.

M. Americánum, Michx. Nearly glabrous, a foot or so high, loosely branched: leaves lanceolate or linear-lanceolate, short-petioled; lower entire; upper with abrupt base and one or two bristly-acuminate teeth, or nearly hastate: calyx-teeth longer than the tube, subulate-filiform, one-third the length of the slender pale yellow (barely half inch) corolla: flowers scattered in the axils of ordinary leaves. - Fl. ii. 16; Gray, Man. 338. M. lineare, Iam. Dict. iv. 23. M. latifolium, Muhl. Cat.; Nutt. Gen. ii. 58. M. sylvaticum, Hook. Fl. ii. 106, not L. M. pratense, var. Americrnum, Benth. in DC. Prodr. X. 584. M. brachiatum, Schwein. in Keating, Narr. St. Peter R. Appx. 115, a slender form. - Thickets, \&c., Hudson's Bay to Saskatchewan, and through Atlantic States, chiefly eastward, to the mountains of N. Carolina.

\section{Order XCVII. OROBANCHACE}

Root-parasitic herbs, destitute of green foliage (whitish, yellowish, reddish or brown), with alternate scales in place of leaves, the two (single or double) multiopulate placentæ parietal, and ovary consequently one-celled, the very small and innumerable seeds with a minute embryo having no obvious distinction of parts, otherwise nearly as Scrophulariacea. Flowers hermaphrodite, $\tilde{5}$-merous as to 
perianth, with didynamous stamens and the dimerous pistil of all the related orders, but the stigmas and the placentæ sometimes divided or separated so as apparently to be four: all the flower commonly marcescent-persistent. Corolla ringent. Anthers always 2-celled. Ovary ovoid, pointed with a mostly long style: stigma sometimes peltate or disc-shaped and entire, often bilabiate, occasionally 4-lobed, i. e. the anterior and posterior stigma each 2-lobed, and sometimes these lobes or half-stigmas combine laterally, forming two right and left stigmas which therefore are superposed to (instead of alternate with) the parietal placentæ. When the latter are four, it is because the half-placentæ are borne more or less within the margin of each carpel. Capsule 2-valved, each valve beariug on its face a single placenta or a pair. Hypogynous gland not rarely at the base of the ovary on one side. Flowers solitary in the axils of bracts or scales, sometimes on scapiform peduncles, sometimes collected in a terminal spike : evolution always centripetal.

* Flowers all alike and fertile.

+ Anther-cells deeply separated from below, mucronate or aristulate at base. - Foreign, sparingly introduced from Europe.

1. OROBANCHE. Flowers spicate, sessile. Calyx cleft before and behind almost or quite to the base into a pair of lateral and usually 2-cleft divisions. Corolla bilabiate; upper lip erect, "2-lobed or emarginate; lower spreading, broadly 3-lobed. Stanens included. Lobes of the stigma when distinguishable right and left.

$$
+\rightarrow \text { Indigenous and peculiar to North America. }
$$

2. APHYLLON. Flowers pedunculate or pedicellate, sometimes subsessile and thyrsoidspicate. Calyx 5-cleft; lobes nearly equal, acute or acuminate. Corolla somewhat bilabiate; upper lip more or less spreading, mostly 2 -lobed, lower spreading. Stamens included. Stigma peltate or somewhat crateriform, or bilamellar, the lobes anterior and posterior. Style deciduous. Placenta 4, either equidistant or contiguous in pairs.

3. CONOPHOLIS. Flowers in a dense simple scaly-bracted spike, 2-bracteolate. Calyx spathaceous, deeply cleft in front, posteriorly about 4-toothed. Corolla ventricose-tubular, strongly bilabiate; upper lip fornicatc and emarginate; lower shorter, spreading, 3-parted. Stamens somewhat exserted; the pairs little unequal (rarely the 5th stamen present). Stigma capitate, obscurely 2-lobed; the lobes anterior and posterior. Placentæ 4, almost equidistant. Seeds oval, with a thick coat.

$$
++ \text { Anther-cells closely parallel and muticous at base. }
$$

4. BOSCHNIAKIA. Flowers sessile in a dense simple scaly-bracted spike, ebracteolate. Calyx short, cupuliform, posteriorly truncate or obliquely shorter, and with 3 distant teeth in front. Corolla ventricose; upper lip erect or fornicate, entire; lower 3-parterl. Stamens slightly exserted. Stigma dilated and bilamellar (the lobes right and left) or 4 lobed. Seeds with a thin reticulated coat.

* Flowers dimorphous; lower cleistogamous; upper commonly infertile.

5. EPIPHEGUS. Flowers subsessile and spicately scattered along slender paniculate branches. Calyx short, 5-toothed. Corolla cylindraceous, slightly curved and upwardly enlarged, almost equally 4-lobed at summit; the rather larger upper lobe or lip fornicate or concave, barely emarginate. Stamens slightly exserted : anther-cells parallel, mucronate at base. Broad gland adnate to base of the ovary on the upper side. Style filiform: stigma capitate-2-lobed. Cleistogamous flowers short unopened buds : style liardly any. Capsule 2-valved at apex : a pair of contiguous placentæ on each valve. Seeds with a thin and shining striate-reticulated coat.

1. OROBÁNCHE, L. Broom-RAPE. ("ODoßos and d́yxóvi, a vetchstrangler.) - Old-World parasites, on roots of various plants, very numerous in species or forms, one species sparingly and probably recently introduced into the Atlantic United States.

O. Míror, L. Parasitic on clover, New Jersey to Virginia, a span to a foot high, pubescent, pale yellowish-brown, or witl purplish-tinged flowers in a rather loose spike: corolla half inch long. (Nat, from Eu.) 
2. APHÝLLON, Mitchell. CANCER-Root. (From $\alpha$ privative, and $\varphi v i \lambda$, foliage, i. e. leafless.) - North American and Mexican, brownish or whitish, low, commonly viscid-pubescent or glandular, and with violet-purplish or yellowish flowers. - Nov. Gen. in Act. Phys.-Med. Acad. Nat. Cur. viii. (1748), 221 ; Gray, Man. ed. 1, 290, \& Bot. Calif. i. 584; Benth. \& Hook. Gen. ii. 983.

$\S 1$. Gymnocaúlis, Benth. \& Hook. 1. c. Peduncles or scapes long and slender from the axils of fleshy loose scales of a short and commonly fasciculate rootstock or caudex, naked, not bracteolate under the flower: calyx regularly 5-lobed : corolla with elongated somewhat curved tube, and widely spreading somewhat equally 5-lobed limb, only obscurely bilabiate: stigma peltate and slightly bilamellar, broad and thin: placentre nearly equidistant: seed-coat thin and minutely reticulated. Fl. summer. - Aphyllon, Mitchell, 1. c. Orobanche § Gymnocaulis, Nutt. Gen. ii. 59. O. § Anoplon, Wallr. Orobanch. 66. Anoplanthus § Euanoplon, Endl. Gen. 727.

A. uniflórum, Gray. Scaly stem short and nearly subterranean, bearing few scapes (a span high): calyx-lobes mostly much longer than the tube, subulate, usually attenuate: corolla violet-tinged (and flower violet-scented, inch long); the lobes obovate and rather large. - Man. l. c. \& Bot. Calif. i. 584. Orobanche uniflora, L.; Bart. Med. Bot. t. 50. O. biflora, Nutt. 1. c. Phelipoea biflora, Spreng. Syst. ii. 818. Anoplanthus uniflorus, Endl. Iconogr. t. 72 (stigma wrong); Renter in DC. Prodr. xi. 41. Anoplon biflorum, Don, Syst. iv. 633. Damp woodlands, Newfoundland to Texas, California, and Brit. Columbia : flowers early.

A. fasciculátum, Gray, l.c. More pubescent and glandular : stem often emergent and mostly as long as the numerous fascicled peduncles, not rarely shorter : calyx-lobes broadly or triangular-subulate, not longer than the tube, very much shorter than the dull yellow or purplish corolla; lobes of the latter oblong and smaller. - Orobanche fasciculata, Nutt. 1. c.; Hook. Fl. ii. 93, t. 170. Phelipcea fasciculata, Spreng. 1. c. Anoplanthus fasciculatus, Walp. Repert. iii. 480; Reuter in DC. 1. c. - Sandy ground, Lake Michigan and Saskatchewan, southward west of the Mississippi to Arizona, and west to Oregon and California; on Artemisia, Eriogonum, \&c.

Var. lúteum, a very caulescent and short-peduncled form, with sulphur-yellow corolla, and whole plant light yellow. - Phelipcea lutea, Parry in An. Naturalist, viii. 214. - Wyoming, Parry. Parasitic on roots of grasses.

$\S 2$. NothaphÝLloN, Gray. Caulescent, and the inflorescence racemose, thyrsoidal, or spicate: pedicels or calyx 1-2-bracteolate: corolla manifestly bilabiate; upper lip less or not at all 2-cleft: stigma sometimes crateriform: seed-coat favose-reticulated: placentæ approximate in pairs.

* Flowers all manifestly pedicellate: corolla lobes oblong, spreading; upper lip less so.

A. comósum, Gray. Low, puberulent: short stout stem branching close to the ground: pedicels corymbose or paniculate-racemose, shorter than the (inch or more long) flower: bractlets one or two on the pedicel or sometimes at the base of the flower: calyx deeply 5-parted; lobes subulate-linear and attenuate, about half the length of the pink or pale purple corolla: anthers woolly. - Bot. Calif. i. 584. Orobanche comosa, Hook. Fl. ii. 93, t. 169 (but lobes of lower lip seldom so notched). Anoplanthus conosus, Walp. l. c. Phelipcea comosa, Gray in Pacif. R. Rep. iv. 118. - Dry hills, parasitic on Artemisia, \&c., Washington Terr. to California.

A. Califórnicum, Gray, 1. c. More pubescent and viscid, and with stouter and simpler stem, about a span lhigh: flowers crowded in an oblong dense raceme or thyrsus : pedicels shorter than calyx: bractlets close to the calyx, and with the subulate-linear lobes of the latter almost equalling the yellowish or purplish corolla; the lobes of which are shorter and less spreading: anthers glabrous or slightly hairy. - Orobanche Californica, Cham. \& Schlect. in Linn. iii. 134. Phelipoea Californica, Don. 1. c. P. erianthera, Watson, Bot. King, 225, not Engelm. - California and W. Nevada. Lower pedicels sometimes half inch long; upper very short. 
* Flowers nearly sessile or the lower ones short-pedicelled, simply spicate or thyrsoid: calyx bibracteolate, deeply 5-cleft into linear-lanceolate lobes: upper lip or all the lobes of the more tubular corolla less sprealing: whole plant viscidly pruinose-puberulent.

A. multifiórum, Gray, 1. c. A span or two high: calyx almost 5-parted, fully half the length of the ample (inch or more long) purplish corolla: anthers very woolly. - Orobanche multifora, Nutt. 1'l. Gamb. 179. Phelipoea Ludoviciana, Torr. Bot. Mex. Bound. 110, in part. $P$. erianthera, Engelm. in Proc. Am. Acad. vii. 3i2. - Gravelly plains and pine woods, W. Texas, New Mexico, and S. Colorado, to Arizona. (Adjacent Mex.)

A. Ludoviciánum, Gray, l.c. Rather less pubescent: spikes more frequently compound: calyx less deeply and somewhat unequally 5-cleft: corolla about half smaller; upper lip sometimes almost entire: anthers (before dehiscence) glabrous or nearly so. Orobanche Ludoviciana, Nutt. Gen. ii. 58. Phelipoec Ludoviciana, Walp. 1. c.; Reuter in DC. 1. c. - Illinois and Saskatchewan to Texas, thence west to Arizona and the south-eastern borders of California. (Adjacent Mex.)

* * Flowers subsessile or short-pedicelled, thyrsoid-paniculate. small, otherwise nearly as in the preceding section: stems with a thickened tubel-like squamose base: anthers glabrous: corolla yellowish, half inch long.

A. tuberósum, Gray, 1. c. Pruinose-puberulent, seldom a span high: short and dense spikes corymbose-glomerate at the summit of the thick stem : caly $x$-lobes lanceolate, longer than the tube. - Phelipoea tuberosa, Gray, Proc. Am. Acad. vii. 371. - Dry ridges, California, from Monterey to San Diego, and San Bernardino Co., Brewer, Palmer, Parry.

A. pinetórum, Gray, I. c. More pubescent : stem rather slender above the large tuberous base, a span to a foot high: flowers in a rather loose elongated panicle: calyx-lobes subulate from a broad base, not longer than the tube. - Orobanche pinetorum, Geyer in Hook. Kew Jour. Bot. iii. 297. - Oregon to British Columbia, on the roots of Fir-trees.

3. CONÓPHOLIS, Wallr. SQuaw-Root. (Kw̃vos, cone, and cpolis, scale, the young plant, clothed with the imbricated dry scales and bracts, not unlike a slender Fir-cone.) - Single species.

C. Americána, Wallr. Glabrous, simple, 3 or 4 and in fruit becoming 6 to 10 inches long, as thick as the thumb, light chestnut-colored, and with yellowish flowers: scales at first rather fleshy, at length firm-chartaceous. - Orobanch. 78 ; Endl. Iconogr. t. 81 . Orobanche Americana, L. f. Suppl. 88. - Oak woods, in clusters among decaying fallen leaves, New England to Michigan and Florida : fl. summer. (Mex.)

4. BOSCHNIÁKIA. C. A: Meyer. (In memory of Boschniaki, a Russian botanist.) - Short and thick, simple-stemmed from a tuberous caudex, brown, glabrous, scaly ; the sessile flowers each subtended by a scaly bract nearly equalling the corolla; the whole forming a mostly dense cylindrical spike. W. N. American, E. Asian and Himalayan: fl. summer.

* Calyx-teeth short and broad: placentre 2: scales (acutish) and corolla-lobes somewhat ciljate.

B. glábra, C. A. Meyer. $\Lambda$ span to a foot ligh : scales ovate: anterior calyx-tooth larger : lower lip of the ovoid ventricose corolla almost obsolete: filaments merely glandular at base. - Bong. Veg. Sitka, 158, where the genus was first described. Orobunche, \&c., Gmel. Sibir. iii. 216, t. 46. O. Rossica, Cham. \& Schlecht. in Linn. iii. 132. O. (Bosch.) glalra, Hook. Fl. ii. 92, t. 167. - Aleutian Islands and east to Slave Lake. (Japan, Siberia.) The reference in DC. Prodr. to E. United States and Mexico was an oversight.

B. Hoókeri, Walp. Smaller: scales oblong, rather sparse: spike short: lower lip of the oblong corolla fully half the length of the upper; its lobes ovate-oblong: filaments bearded at base. - Rep. iii. 479; Reuter in DC. 1. c. 39. Orobanche Luberosa, Hook. Fl. ii. 92, t. 168. - N. W. Coast, Menzies: not since seen.

* Calyx-teeth linear-subulate and longer than the tube: scales very broad and obtuse: piacentæ 4, equidistant.

B. strobilácea, Gray. $\Lambda$ span high or less, stout and thick, brownish-red, flowering almost from the base: scales much imbricated, orbicular and round-obovate: lower lip of 
the oblong (white and brownish-striped) corolla about as long as the upper; its lobes oblong, widely spreading: filaments densely bearded at base.-Pacif. R. IRep. iv. 118, \& Bot. Calif. i. 585. - California; on dry steep hills, S. Yuba, Biyelow. Santa Lucia Mountains, parasitiç on Manzanita-roots, Brewer. San Bernardino Co., Lemmon. (Mex.?)

\section{EPIPHÉGUS, Nutt. (Written Epifagus.) Beech-drops, Cancer-} Rоoт. (Composed of $\dot{\varepsilon} \pi i^{\prime}$, upon, and gryós, Beech, being parasitic on the roots of that tree.) - Single species.

E. Virginiána, Bart. Annual, slender, a foot or so high, with thickened base producing short filurous matted roots, glabrous, dull purple or yellowish-brown, paniculately branched: scales and bracts minute and sparse: cleistogamous flowers a line and capsules 2 lines long: developed corolliferous flowers along the upper part of the branches 3 to 6 lines long, purplish and whitish:-Comp. I'l. Philad. ii. 50; Gray, Man. l. c.; Reuter in DC. l. c. 4. E. Americanus, Nutt. Gen. ii. 60; Endl. Iconogr. t. 80 . Orolanche Virginiana, L. Leptumnium Virginianum, Raf. in Am. Month. Mag. 1819. Mylanche, Wallr. Orobanch. 75. - Beech woods, New Brunswick to Florida and Missouri : fl. autumn.

\section{Order XCVIII. LENTIBULARIACE A.}

Herbs, growing in water or wet soil, when terrestrial acaulescent, with scapes or scapiform peduncles simple and one-few-flowered, calcarate corolla always and calyx usually bilabiate, a single (anterior) pair of stamens, confluently onecelled anthers contiguous under the broad stigma, no hypogynous disk, and a free one-celled ovary with free central multiovulate placenta (either sessile or stipitate) which becomes a globular many-seeded capsule; the anatropous seeds with a close coat, no albumen, and filled by the apparently solid ellipsoidal or oblong embryo. Style short or none: stigma bilamellar, or the smaller anterior lip sometimes obsolete. Upper lip of the corolla commonly erect or concave, or the sides replicate, from entire to 2-lobed, interior in the bud; lower larger, spreading or reflexed, 3-lobed, with a palate projecting into the throat and a nectariferous spur beneath. Flowers always perfect. Capsule commonly bursting irregularly. - The following are the two principal genera. (For action of bladders of Utricularia and leaves of Pinguicula, see Darwin, Insectivorous Plants, p. 368-453.)

1. UTRICULARIA. Calyx 2-parted or deeply 2-lobed; lobes mostly entire, nearly equal. Upper lip of strongly bilabiate and more or less personate corolla erect. Filaments thick, strongly arcuate-incurved, the base and apex contiguous. Dissected foliage or stems of aquatic species bladder-bearing.

2. PINGUICULA. Calyx with upper lip deeply 3-and lower 2-cleft or parted. Corolla ringent or less personate, and the lobes all spreading. Filaments straighter: anthers nearly transverse. Terrestrial, with entire rosulate leaves next the ground.

1. UTRICULÁRIA, L. Bradderwort. (Utriculus, a little bladder.) - Cosmopolitan small herbs: terrestrial species with inconspicuous or fugacious radical leaves; aquatic with the dissected leaves, branches, and even roots, bearing little bladders, which are furnished with a valvular lid, and commonly tipped with a few bristles at orifice. Scapes one-flowered or racemosely several-flowered, in summer. - Lentibularia, Vaill.

$\S 1$. Scape bearing an involucriform whorl of dissected leaves, which are buoyant by ample inflated-bladdery petioles filled with air : cauline leaves of the immersed branching stems capillary-dissected and bladder-bearing, in the manner of the following section: roots few or none. 
U. infláta, Walt. Inflated petioles of the whorled leaves oblong or clavate, tapering to each end, the bases of the lower divisions also inflated; setaceous divisions pinnately multifid : scape 3-10-flowered, a span or so long: pedicels recurved after flowering: flowers rather large, yellow: spur conical-lanceolate, emarginate, appressed to and half the length of the lower lip: capsule apiculate with a short distinct style: seeds globular, squamose-echinate. - Car. 64; Ell. Sk. i. 20; A.DC. Prodr. viii. 4; Gray, Man. ed. 5, 318. U. ceratophylla, Michx. Fl. i. 12 ; LeConte in Ann. Lyc. N. Y. i. 73, t. 6, fig. 1. - Floating in still water, Maine to Texas along the coast.

$\$ 2$. Scape leafless, emersed from submersed or floating leafy stems, which are free swimming and mostly rootless in deep water, or in some sparingly rooting where the water is shallow: leaves dissected into capillary or filiform divisions, some or many of them (as also stems) bearing small bladders: chiefly perennial, or continued by hybernacular tuber-like buds set free in autumu.

* Cleistogamous flowers along the submersed copiously bladder-bearing stems.

U. clandestina, Nutt. Leaves of the slender stems repeatedly forked: scapes slender, 3 to 5 inches high, 3-5-flowered: corolla yellow, 3 lines long; lips nearly equal in length, the lower broader, somewhat surpassing the approximate thick and obtuse spur: cleistogamous flowers scattered on the leafy stems; their short peduncle soon deflexed: seeds (from the clandestine blossoms) depressed-globular; the coat minutely reticulated. - Herb. Greene, \& in Gray, Man. ed. 1 (1848), 287. U. striata, Tuckerm. in Am. Jour. Sci. xlv. 29, not of LeConte. $U$. geminiscapa, Benjamin in Linn. xx. 305? But that may be a form of $U$. intermedia. - Ponds, from New Brunswick and New England to New Jersey, near the coast.

* No cleistngamous flowers.

+ Pedicels (few or several) recurved in fruit: corolla yellow.

U. vulgáris, L. Stems long and rather stout, densely leafy: leaves 2-3-pinnately divided, very bladdery : bladders about 2 lines long: scapes a foot or less long, 5-16-flowered: corolla (half inch or more broad) with sides of lips reflexed; upper nearly entire, hardly longer than the prominent palate : spur conical, porrect toward the slightly 3-lobed lower lip, shorter than it, in the N. American plant (var. Americana) commonly narrower and less obtuse than in the European. - Lam. Ill. t. 14; Engl. Bot. t. 25:3; Fl, Dan. t. 138; Gray, Man. l. c. U. macrorhiza, LeConte, l. c.-Slow streams, \&c., Newfoundland and Saskatchewan to Texas, and west to California and Brit. Columbia. (N. Asia, Eu.)

U. mínor, L. Leaves scattered on the filiform stems, repeatedly dichotomous, small, setaceous: bladders barely a line long: scapes slender, 3 to 7 inclies high, 2-8-flowered: corolla pale yellow, 2 or 3 lines broad, ringent; upper lip not longer than the depressed palate of the lower: spur very short and obtuse, - Fl. Dan. t. 128; Engl. Bot. t. 254; A.DC. I. «. U. setarea, Hook. Fl. ii. 118, ex char. - Shallow still waters, Canada and Saskatchewan to New Jersey, mountains of Utah and Nevada, northern Sierra Nevada, and Brit. Columbia. (Eu., Siberia.)

\section{++ Pedicels erect in fruit, few and slender: corolla yellow.}

* Spur of corolla thick and conical, shorter than the lower lip and approximate to it.

U. gíbba, L. Branches delicate, root-like: leaves sparse, sparingly dissected, capillary, sparingly bladder-bearing: scape filiform, $1 \frac{1}{2}$ to 3 inches high, 1-2-flowered: corolla 3 lines broad; the lips broad and rounded. - Spec. i. 18 (Gronov. Fl. Virg.); Pursl, Fl. i. 116. $U$. pumila, Walt. Car. 64? Benjamin in Linn. xx. 313. U. fornicala, LeConte, I. c. $U^{T}$. minor, Torr. Fl. N. Y. ii. 21, not L. - Shallow water, Massachusetts to Alabama and Illinois. Apparently in a subalpine pond in Colorado, Gieene.

U. bipartíta, Ell. Sk. i. 22, from St. Jølnn's, S. Carolina, said to have "spur scarcely half as long as the corolla, very obtuse," and "lower lip of the calyx generally 2-cleft, sometimes divided to its base" (an anomalous character), has not been identified. +++ Spur of corolla narrower, equalling or little shorter than the lower lip.

= Scapes 2 to 4 inches high, 1-3-flowered: corolla less than half an inch broad.

U. biflóra, Lam. Floating or submersed stems filiform, small : dichotomously dissected leaves delicately capillary, usually copiously bladder-bearing: spur narrowly oblong, 
obtuse, porrect or curved upward: seeds somewhat scale-shaped, imbricated, smooth. Ill. i. 50; Poir. Dict. viii. 272; Vahl, Enum. i. 200 ; Ell. Sk. i. $23 . \quad$ U. pumila, Walt. l. c.? a rather earlier name, but uncertain. $U$. integra, LeConte, l. c. ex Ell. $U$. fibrosa, Chapm. Fl. 283, not Walt. \& Ell. - Ponds and shallow waters, S. Virginia? and S. Illinois to Texas.

$=$ - Scapes 4 to 12 inches high, slender, few-several-flowered: corolla over half inch broad: leaves dichotomously dissected: bladders wholly or mostly borne along leafless portions of the slender stems.

U. fibrósa, Walt. Leaves somewhat scattered, small and capillary, sometimes bladderbearing: scape $2-6$-flowered : lips of the corolla nearly equal, broad and expanded; upper undulate, concave, plicate-striate in the middle; lower slightly 3-lobed, with projecting emarginate palate and reflexed sides; equalled by the nearly linear obtuse or emarginate spur: seeds minutely muricate. - Car. 64 (ex char.); Vahl, l. c. ? Ell. Sk. i. 20. U. longirostris, LeConte in Ell. 1. c. 21. U. longirostris \& U. striata, LeConte in Ann. Lyc. N. Y. 1. c. $U$. bipartita, Chapm. Fl. 283. - Shallow ponds and pine-barren swamps, Long Island and New Jersey to Florida and Alabama.

U. intermédia, Hayne. Leaves crowded, 2-ranked, repeatedly dichotomous, rigid; the divisions filiform-linear, flat, with margins not rarely setaceous-serrulate: scape 1-4-flowered: lower lip of corolla very broad and with large palate, larger than the upper, somewhat exceeding the conical-subulate acute spur. - Schrad. Jour. i. 18, t. 5, \& Fl. Germ. i. 55 ; Vahl, 1. c.; Engl. Bot. t. 2489 ; Reichenb. Ic. Germ. t. 1824 . U. vulgaris, minor, L.; Oeder, Fl. Dan. t. 1262. - Shallow water, Newfoundland to New Jersey and Ohio, and thence far northward. Also Plumas Co., in the Sierra Nevada, California, Mrs. Austin. (N. Eu., N. Asia.)

$$
+++ \text { Pedicels erect in fruit, rather long: corolla violet-purple. }
$$

U. purpúrea, Walt. Leaves verticillate on the rather long and large free-floating stems, petioled, decompound; the divisions capillary, rather copiously bladder-bearing: scape a span or two long, 2-4-flowered : corolla over half inch broad; lower lip 3-lobed, its lateral lobes saccate and the central larger, about twice the length of the conoidal compressed spur: seeds globular, chaffy-muricate. - Car. 64 ? (doubtful, because the flowers are said to be small); Pursh, Fl. i. 15 ; LeConte, 1. c.; A.DC. l. c. 5 . U. saccata, Ell. Sk. i. 21, said to have been so named by LeConte. - Ponds, Maine and N. Penn. to Florida, mainly near the coast. (Cuba.)

$\S 3$. Scape leafless and solitary, the base rooting in the mud or bog, usually rising from or producing filiform and root-like creeping shoots, which bear slender subulate-gramineous (occasionally septate) simple leaves, or branches which take the place of leaves, to the lower part of which, as also to the colorless shoots, bladders are sparingly attached, usually fugacious or unnoticed, so that the flowering plant appears to be a leafless and naked scape only.

* Flower violet-purple, solitary and transverse on the summit of the scape: leaves of the rooting shoots sometimes furnished with a few capillary lobes.

U. resupináta, B. D. Greene. Scape filiform, a span high: corolla 4 or 5 lines long, deeply 2-parted; lips almost entire; upper narrowly spatulate; lower dilated and with a small palate: spur oblong-conical, very obtuse, ascending, shorter than and remote from the corolla, which appears as if resupinate: leaves an inch or so long, attenuate. - Hitchcock, Cat. Pl. Mass.; Bigel. Bost. ed. 3, 10; A.DC. Prodr. 1. c. 11; Gray, Man. ed. 1, 286, ed. 5, 319. U. Greenei, Oakes in Hovey, Mag. Hort. 1841. - Sandy bogs and borders of ponds, Maine to Rhode Island near the coast, $B$. D. Greene, Oakes, Olney.

* * Flowers mostly yellow, solitary or several : spur descending: leaves entire, terete : these and the bladclers seidom seen.

U. subuláta, L. Filiform radical shoots and leaves rather copious, but commonly evanescent: scape filiform, an inch to a span high, 1-9-flowered; the raceme becoming zigzag: pedicels slender: corolla 2 or 3 lines broad; lower lip plane or with margins recurved, equally 3 -lobed, much larger than the ovate upper one, nearly equalled by the oblong acutish appressed spur. - Spec. i. 18 (Gronov. Virg., ex herb. Clayt.); Pursh, 1. c. ; A. DC. l. e. 16. U. setacea, Michx. Fl. i. 12 ; Vahl, l. c. - Wet places in pine barrens, New Jersey to Florida and Texas near the coast. (W. Ind. to Brazil.) 
Var. cleistógama. An inch or two ligh, bearing one or two evidently cleistogamous purplish flowers, not larger than a pin's head: capsule becoming a line long. (Gray, Man. ed. 5, 320; Ell. Sk. i. 24.) - With the ordinary form. Pine barrens of New Jersey, J. A. Paine. Evidently also seen in Georgia by Elliott.

U. cornúta, Michx. Filiform radical shoots apparently none : leaves fasciculate, evanescent, rarely at all seen: scape strict, a span to a foot high, 1-10-Howered : pedicels very short, 2-bracteolate at base: corolla an inch long, including the long subulate acute spur; lower lip very large, the sides strongly recurved, and the central palate-like portion as if galeate, merely equalled by the obovate upper lip: sceds nearly smooth. - Fl. i. 12; Pursh, 1. c.; A. DC. 1. c. U. personata, LeConte, 1. c. ; Bertol. Misc. viii. 21 - Spliagnous or sandy swamps, Newfoundland to L. Superior and south to Florida and Texas. (Cuba, Brazil.)

2. PINGUfCULA, Tourn. Butrerwort. (From pinguis, fat, in allusion to the greasy-viscil surface of the leaves.) - Terrestrial acaulescent herbs, of moist or wet ground (in northern hemisphere and the Andes); with fibrous roots, broad and entire leaves in a rosulate radical tuft, their upper surface with a coating of viscid glands, to which insects, \&c., adhere, the margins slowly infolding under irritation; scapes naked, 1 -flowered, circinate-coiled in vernation. Upper lip of the corolla 2-and lower 3-lobed or parted; the lobes sometimes incised; the base anteriorly saccate, and the bottom of the sac contracted into a nectariferous spur.

* Corolla distinctly bilabiate, purple, violet, or rarely whitish ; upper lip decidedly smaller, 2-lobed or parted; lower 3 -parted; lobes mostly quite entire : boreal species.

P. villósa, L. Small : leaves oval, nearly glabrous, half inch long or less : scape villouspubescent, inch or two long: corolla (pale violet with yellowish-striped throat) 2 lines long, and with a slender spur of nearly the same length or half shorter. - Fl. Lapp. t. 12, fig. 2; Fl. Dan. t. 1021; E. Meyer, Labrad. 39; Reichenb. Iconogr. i. t. 82 ; Cham. in Linn. vi. 568. P. acutifolia, Michx. Fl. i. 11, the erect-rosulate oval and very acute leaves described are really the scales of a hybernacular bud, and the plant (with nuature fruit) had lost its leaves. - Labrador, Hudson's Bay, Northern islands and shores of the N. W. Coast. (Greenland, Arctic Eu., \& Asia.)

P. alpína, L. Somewhat glabrous: leaves oblong, barely inch long: scape 3 or 4 inches high: corolla (whitish) 4 lines long, and with a conical obtuse divergent incurving spur of less than half the length of the lower lip. - Fl. Lapp. t. 12, fig. 3; Fl. Dan. t. 453; Reichenb. 1. c. t. 81 ; Engl. Bot. t. 2747. - Labrador, Sleinhruer. Given by LeConte to herb. Collins. Specimen not wholly satisfactory, but apparently of this species, not elsewhere detected in America. (Eu. to Siberia.)

P. vulgáris, L. Minutely puberulent or alnıst glabrous : leaves ovate or oval, an inch or two long, soft-fleshy: scape 1 to 4 inches high: corolla (violet) about half inch long, with campanulate or short-funnelform boly abruptly contracted into a narrow linearcylindraceous (acutish or obtuse) and mostly straight spur (of about 2 lines in length). Oeder. Fl. Dan. t. 93 ; Engl. Bot. t. 70 ; Reichenb. 1. c. t. 84; Hook. Fl. ii. 118; Herder in Radde, iv. 96. P. grandiflora, Hook. 1. c. P. macroceras, Willd. ; Roem. \& Sch. Syst. Mant. i. 168; Cham. in Linn. vi. 568; A.DC. 1. c. 30 ; a longer-spurred and commonly largerflowered form (corolla from two-thirds to almost an inch long). $P$. microceras, Cham. l. e. ( $P$. macroceras, Reichenb. I. c. t. 82, fig. 169, 170), a depauperatc small-flowered and shorterspurred form of high northern region. - Wet rocks, Labrador, Northern New England and New York, L. Superior, \&c., to Alaskan coast and islands, and northward; the macroceras and microcercts forms north-westward. (N. E. Asia to Europe and Greenland.)

* * Corolla light violet, varying occasionally to white, less bilabiate, the sinuses equal except between the two lobes of the upper lip; the three lower lobes usually emarginate or obcordate: palate conical or cultriform, very protuberant, clotherl with a dense yellow or sometimes white beard: spur abrupt and narrow from base of a hhort conical sac: npper lip of stigma small, narrowly triangular; lower semi-orbicular: fi. springr. (P. carulera, Walt. Car, 63, covers one or both the following species, but the character is insufficient to secure the adoption of the name.)

P. púmila, Michx. Leaves half to full inch long, oval or ovate: scapes filiform, weak, 2 to 6 inches high: corolla a quarter to half inch long; spur acute, longer than the rather 
narrow saccate base; lobes retuse or enarginate; palate puberulent-bearded, conical, salient. - Fl. i. 11 ; Pursh, Fl. i. 14 ; Ell. Sk. i. 19. P. australis, Nutt. in Jour. Acad. Philad. vii. 103, the spur by no means "very short." - Low pine-barrens, Carolina to Florida and Louisiana.

P. elátior, Michx. Leaves oblong or spatulate-obovate, 1 to 3 inches long: scapes 6 to 12 inches high : corolla an inch long or considerably smaller; spur obtuse, mostly shorter than the saccate base; lobes obcordate; palate oblong, parallel with the throat, the short free apex more conspicuously bearded. - Fl. 1. c.; Vahl, Enum. i. 191; Pursh, l. c. ; Ell. 1. c. - Wet soil, Carolina to Florida and Alabama in the low country.

* * Corolla golcten yellow, not bilabiate, except tbat the two upper lobes are commonly more united, all or most of the lobes incisely 2 -4-cleft, equal: stigma of the preceding, or lips less unequal. - Brandonia, Reichenb.

P. lútea, Walt. Leaves from ovate to oblong-obovate, an inch or two long: scapes 5 to 12 inches high: corolla an inch or less long; the lobes longer than the short-campanulate tube with the saccate base, all or the lower and lateral usually 4-lobed or 2-cleft with the divisions obcordate, or variously sinuate; spur subulate, as long as the sac and tube; palate oblong, very salient, densely bearded. - Car. 63; Michx. 1. e ; Ker, Bot. Reg. t. 126 ; Ell. 1. ᄂ.; A.DC. Prodr. viii. 32. P. campanulata, Lam. in Jour. Hist. Nat. 1792, 336, t. 18, fig. 1. - Low pine barrens, N. Carolina to Florida and Louisiana.

Var. edéntula, A.DC., 1. c. (P. edentula, Hook. Exot. Bot. t. 16, cult. from Savannah), has lobes of corolla all simply and equally obcordate, shorter than the tube. Possibly a hybrid of $P$. lutea and $P$. pumila.

\section{ORDER XCIX. BIGNONIACE}

Trees or shrubs, either erect or scandent (very rarely herbs), with mostly opposite leaves, and large and showy flowers, with more or less bilabiate corolla, tetradynamous or diandrous stamens, single style and bilabiate stigma, and numerous anatropous ovules of the preceding orders; distinguished from them by the large and flat usually winged and transverse exalbuminous seeds, indefinitely numerous, on parietal placentr, or usually on a partition which separates from the two valves of the capsule in dehiscence, although in the ovary and when the ovules are in many rows the placentation often appears to be central; the cotyledons broad and thin, plane, commonly emarginate or 2-lobed, and the short straight radicle included in the basal notch. Capsule either loculicidal or septicidal, often siliquelike. Anthers 2-celled: suppressed stamens commonly represented by rudimentary filaments. Corolla bilabiately imbricated in the bud (in our genera, in a few others valvate). Calyx gamosepalous. Leaves compound, or in two of our genera simple; sometimes a pair of basal leaflets and sometimes an axillary pair of leaves imitate stipules. Chiefly a tropical and rather large order; but few North American.

* Leaves opposite, compound: perfect stamens 4: seeds transversely winged, hypogynous disk conspicuous : stems mostly scandent.

1. BIGNONIA. Calyx with undulate or barely 5-toothed margin. Corolla campanulate or cylindraceous-ampliate above the narrow and short proper tube, somewhat equally bilabiate-5-lobed. Anther-cells divergent, glabrous. Capsule linear, compressed parallel with the flat valves and partition, marginicidal and septifragal, a filiform margin usually separating all round both from the edges of the valves and the partition. Seeds attached in a single series on each side of both margins of the partition; the thin wing entire. Tendril-climbers.

2. TECOMA. Calyx distinctly 5-toothed. Corolla funnelform or somewhat campanulate above the short proper tube, somewhat bilabiately 5-lobed. Anther-cells divergent, glabrous or sparsely pilose. Capsule narrow, somewhat terete or turgid, loculicidal and septifragal; the valves contrary to the partition. Seeds imbricated in one or two or more series on eaclı side of the margins of the partition; the wing hyaline. Rootlet-climbing or ereet shrubs; flowers in terminal panicles or corymbs. 
* Leaves simple and entire : erect trees or slirubs: caly $x$ closed in the bud, bilabiately or irregularly dividing or bursting in anthesis: corolla-lobes undulate-crisped, hardly unequal: anthers glabrous; the cells narrow, divaricate: hypogynous disk obsolete: capsule long-linear, loculicidal, terete; valves contrary to the partition: secels narrow, in 2 or more series on each side of partition; lateral wings dissected into copious long hairs.

3. CATALPA. Corolla ventricose-ampliate above, somewhat oblique, bilabiate-5-lobed. Antheriferous stamens 2 , anterior, with filaments arcuate, and 3 rudimentary filaments (rarely 4 stamens antheriferous). Lenves mainly opposite and ovate or cordate.

4. CHILOPSIS. Corolla more funnelform; the lobes erose. Antheriferous stamens 4; also a rudimentary filament. Leaves oftener alternate or irregularly scattered, linear.

1. BIGNÓNIA, Tourn. (Commemorates the Abbé Bignon.) - A large tropical-American genus, with the following more northern one: fl. spring.

B. capreoláta, L. (Cross-vive.) Extensively climbing, glabrous: transverse section of older stems exhibiting a medullary cross: leaves of a single pair of ovate or oblong acuminate and subcordate entire leaflets and a compound tendril; accessory leaves or leaflets in some axils initate foliaceous stipules: pedicels in fascicles of 2 to 5 on axillary spurs: calyx membranaceous: corolla 2 inches long, orange-red without, yellow within: capsule 6 inches long, 9 lines wille; valves 1-nerved. - Spec. ii. 624 (Catesb. Car. ii. $t$. 82); Sims, Bot. Mag. t. 864 ; Jaeq. Schœenb. t. 363 ; Michx. Fl. ii. 25. Li. crucigera, ${ }^{\circ}$ L. as to syn. Clayt. \& Gronov. Virg.; Walt. Car. 169. - Woods, in low grounds, Virginia and S. Illinois to Florida and Louisiana.

2. TÉCOMA, Juss. Trumper-flower, or Trumpet-creeper. (Abridgment of the Mexican name, Tecomaxochitl.) - Genus (of late divided into several by monographers, but retained nearly intact by Benth. \& IIook. Gen. ii. 1044 , digitate species excluded) of several species, widely dispersed ; ours imparipinnate and the leaflets serrate, ovate, and acuminate. 'They have been referred to different genera or subgenera on account mainly of the number of ranks of seeds. Fl. summer.

T. radícans, Juss. Climbing by aerial rootlets: leaflets 9 to 11 : flowers corymbose: corolla tubular-funnelform, orange and scarlet, $2 \frac{1}{2}$ or 3 inches long: stamens not exserted: capsule lanccolate, slightly stipitate; valves very convex, acutely narrowly margined: seeds several-ranked. - DC. P'rodr. ix. 22:3; Nutt. Sylv. iii. t. 104; Bureau, Mon. Bign. t. 14. Bignoma redicans, L. (Catesb. Car. i. t. 65); Wangenheim, Amer. t. 26; Sims, Bot. May. t. 485; Schk. HandlJ. t. 175. Campsis radicans, Scem. Jour. Bot. \&c. - Moist soil, Penn. and Mllinois to Floridi and Texas : common in cultivation.

T. stáns, Juss. Erect shrub: leaflets 5 to 11, narrower or lanceolate, more incisely serrate: flowers racemose or paniculate : ealyx small : corolla more campanulate, yellow, incls and a half long: fifth stamen often with abortive anther: capsule linear, elongated, sessile; valves carinate-convex : seeds single ranked. - Hook. Bot. Mag. t. 3191 ; DC. l.c. 224. Bignonice stems, L. (Plum. Ic. Aner, t. 51); Jacq. Stirp. Amer. t. 176. Stenolobium stums, Seenl. Jour. Bot. i. 87; Bureau, 1. c. t. 13. - S. Florida (introduced?) and S. Texas to Arizona. (W. Ind., Mex., \&c.)

3. CATÁLPA, Scop., Walt. (Aboriginal name.) - There are a N. China and a Japanese species allied to our own, and a few somewhat anonalous West Indian species. Fl. summer; showy.

C. bignonioídes, Walt. Low or large tree, with spreading branches: leaves pubescent, at least beneath, anple, cordate, acuminate, rarely somewlat angulate-lobed, longpetioled: panicle large and loose, compound: lips of the calyx obovate, mucronate: corolla inch long and broad, white or nearly so, dotted with purple and yellow in the throat: pendulons slender capsules a foot long.-Car. 64 ; DC. 1. c. 226 ; Bureau, Mon. Bign. t. 25. C. cordifolia, Jaume in Dulıam. Arb. t. 5; Ell. Sk. i.24. C. syringrefolia, Sims, 
Bot. Mag. t. 1094; Pursh, Fl. i. 10. Bignonia Catalpa, L. (excl. syn.); Catesb. Car. i. t. 49; Michx. f. Sylv. ii. 64. - River banks, S. Illinois to Georgia, W. Florida, and Louisiana. Cult. north to New England.

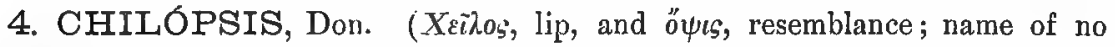
particular application.) - Single species.

C. salígna, Don. Shrub or low tree, 10 to 20 feet high, with hard wood, pubescent when young, soon glabrous: branches slender: leaves linear or linear-lanceolate, 4 to 6 inches long, of firm texture: lower leaves often opposite or verticillate: flowers in a short terminal raceme: corolla an inch or two long, white and purplish : capsule 6 to 10 inches long. - Edinb. Phil. Jour. ix. 261: G. Don, Syst. iii. 228 ; Gray, Bot. Calif. i. $587 . \quad$ C. linearis, DC. Prodr. ix. 227. Bignonia linearis, Cav. Ic. iii. 35, t. 269. - Water-courses in dry districts, S. Texas to S. California. (Mex.)

Crescéntia Cujére, L., the Calabash tree of the West Indies, the type of an anomalous tribe of this order, with indehiscent cucurbitaceous-like fruit, has been introducerl on the Keys of Florida, and in consequence has been figured by Nuttall, Sylv. iii. t. 103; but it has no claim to a place in our flora.

\section{Order C. PEDALIACE 㞼.}

Herbs, with mucilaginous or watery juice, chiefly opposite simple leaves, and flowers as of the preceding order (to which it has more usually been annexed), except in the structure of the ovary and fruit. Ovary either one-celled with two parietal intruded placentre expanded into two broad lamella or united into a central columella, or variously $2-4$-celled by the extension of the placenta and by spurious partitions from the wall. Fruit capsular, drupaceous, or nucumentaceous, few-many-seeded. Seeds wingless, mostly with a thick and close coat, filled by the large embryo ; the cotyledons thickish. - A small extra-European and mainly African order, or suborder, of warm climates, represented in the United States by one sparingly naturalized, and one or two probably indigenous species.

1. SESAMUM. Calyx herbaceous, 5-parted, persistent. Corolla ventricose-campanulate or funnelform; limb bilabiately 5-parted, spreading; upper lobes smaller. Stanens didynamous: anther-cells parallel. Stigmas linear. Fruit an oblong quadrangular and 4-sulcate capsule, septicidal at summit, spurionsly 4-celled, a false partition from the dorsal suture of each of the two carpels reaching the columnar placenta at the centre. Seeds numerous in a single series in each lualf-cell.

2. MARTYNIA. Calyx 1-2-bracteolate, membranacenus, somewhat bladdery-campanulate, 5-cleft, sometimes splitting anteriorly to base, decilluous. Corolla ventricose-funnelform or campanulate, somewhat oblique or decurved; the lobes of the bilabiately 5 parted limb broad, somewhat undulate, slightly unequal. Stamens 4, strongly didynamous, or sometimes only the anterior pair antheriferous: anthers tipped by a gland; the cells divaricate. Stigma bilamellar. Ovary one-celled, witls two parietal placentæ which meet in the axis and there diverge in broad lamellæ, bearing single or double rows of ovules. Fruit fleshy-drupaceous, tapering into an incurved beak: fleshy exocarp at maturity 2-valved and deciduous: endocarp fibrous-woody, scrobiculate, cristate at the sutures, 2-valved through the slender beak to the summit of the cells, indehiscent below; the cavity by the extension of the placentæ to the walls 4-locellate, and with a smali empty central cavity. Seeds rather numerous, oblong, large, with a thick and somewhat spongy tuberculate-rugose coat. Cotyledons obovate, flesliy: radicle very short.

1. SÉSAMUM, L. Bene, Oil-Plant. (From the Arabic semsen.)Chiefly African annuals; the following widely dispersed through cultivation.

S. Indrcum, L. Somewhat pubescent annual, 1 to 3 feet high, with mucilaginous juice and oily seeds: leaves ovate-oblong or lanceolate, petioled; lower often 3-lobed or divided: corolla white or tinged with rose, inch long: capsule velvety-pubescent. - Bot. Mag. 
t. 1688 ; Endl. Iconogr. t. 70; DC. Prodr. ix. 219. S. Indicum \& S. orientale, L., \&c. - Sparingly naturalized in the Gulf Atlantic States. Sceds yield a useful oil. (Adv. from Old World.)

2. MARTÝNIA, L. Unicorn-Plant. (Prof. John Martyn, of Cambridge.) - Diffuse and rank viscid-pubescent herbs (natives of America), of heavy odor; with ample rounded and subcordate petioled leaves, the lower usually opposite and upper alternate, and large flowers in short and loose terminal racemes: pedicels subtended by small bracts or none. Fl. summer.-Our species belong to § Proboscidea, having 4 perfect stamens and beak longer than the body of the fruit, and the calyx is more cleft anteriorly.

M. proboscídea, Glox. Coarse and heavy-scented annual: leaves cordate, roundish, often oblique, entire or obscurely undulate-lobed ( 4 to 12 inches in diameter): bractlets oblong-linear: corolla $1 \frac{1}{2}$ or 2 inches long, dull white, spotted within with some yellowish or purplish, also varying to light yellow : endocarp crested on the posterior suture only. Obs. 14, ex DC. Prodr. ix. 25:3; Sims, Bot. Mag. t. 1056; Pursh, Fl. ii. 428. M. annua, L. excl. syn. \& hab. If. Louisiana, Mill. Diet. \& Ic. t. 286. Banks of the Mississippi and lower tributaries to New Mexico. Also naturalized or cultivated about gardens farther north. (Mex., \&

M. frágrans, Lindl. Less stout: leaves from roundish to oblong-cordate, somewhat lobed and sinuate-dentate, 3 to 5 inches broad: corolla more campanulate, 1 or 2 inches long and wide, sweet-scented, from redllish- to violet-purple. - Bot. Reg. xxvi. misc., \& xxvii, t. 6; Hook. Bot. Mag. t. 4292. M. violacea, Engelm. Pl. Wisl. 101; Torr. Bot. Mex. Bound. 110, partly. - South-western borders of Texas and southern part of New Mexico, Wright, Bigelow. (Northern Mex.)

M. altheæfólia, Benth. Low and small : leaves seemingly all alternate, long-petioled, roundish-ovate and cordate, sinuately 3-7-lobed, 1 or 2 inches broad: bractlets linearoblong or oval: corolla inch and a half or less long, from buff- to chrome yellow, or whitish, mottled or dotted with brown and orange: endocarp armed with teeth on both sutures. - Bot. Sulph. 37. M. arenaria, Engelm. Pl. Wisl. 101; Torr. Bot. Mex. Bound. 110. S. W. Texas to S. Arizona, Wright, Bigelow, Palmer. (Lower California.)

\section{Order CI. ACANTHACEA.}

Chiefly herbs, with opposite simple leaves, no stipules, and didynamous or diandrous more or less bilabiate or irregular flowers with the general characters of Scrophulariacer, \&c. ; but corolla not rarely convolute in the bud; the anatropous ovules few and definite (from 2 to 8 or 10 in each of the two cells); fruit always capsular, 2-celled, elastically loculiciclal scattering the seeds; seeds without albumen (except sparingly in the first tribe), either globose, or orbicular and compressed and the hilum marginal, wingless, in most supported on the upper face of curved processes from the placentre (iudurated and persistent funiculi ?) called retinacula, the close coat not rarely developing mucilage and spiricles when wetted, in the manner of Polemoniacea. Cotyledons plane, orbicular with cordate base: radicle straight or accumbently incurved. Hypogynous disk conspicuous. Style filiform, undivided, with one or two small stigmas. Corolla from almost regular and 5-lobed (and then convolute in the bud) to deeply bilabiate (or in Acanthus with only a lower lip). C'alyx persistent, of 5 or sometimes 4 sepals, commonly unequal and more or less imbricated, sometimes united. Inflorescence various: flowers usually conspicuously bracteate and often 2-bracteolate. Stems commonly quadrangular. Cystoliths abound in the foliage. - A large 
and mainly tropical or subtropical order, one strongly marked tribe of which is represented in ornamental cultivation by Thunbergia, another sparingly so by the Acarthus of the Old World; the others have several North American representatives.

Tribe I. NELSONIE EE. Corolla imbricnted in the bud; upper lip exterior. Seeds small and giobular, attached by a small ventral papilliform funicle, without retinacula, not mucilaginous when wetted: embryo in a thin layer of albumen! (In char. nearest to Scrophulariacese, but capsule and habit of Acanthacece.)

1. ELYTRARIA. Calyx 4-parted; lower division sometimes 2-toothed. Corolla with cylindraceous tube, funnelform throat, and 5-lobed or somewhat bilabiate limb. Stamens 2: filaments very short, inserted low in the throat: anther-cells equal and parallel. Stigma 2-lobed. Ovules 6 to 10 in eacls cell. Capsule oblong, thinner and contracted at base, acute at tip. Seeds globular. Bracts of the solitary or fasciculate-clustered spikes and the similar scales of the scape imbricated, glumaceous.

Tribe II. Ruelliez. Corolla convolute (sinistrorsely) in the bud, either bilabiate or nearly regular. Seeds fiat, attached by the edge to retinacula. (Stamens in ours didynamous, the long and the short filarnent on each side contiguous or united at base by a memlrane; the anthers 2-celled, and the cells equal aud parallel : style with linear or subulate stigmatose apex, the posterior lobe wanting or reduced to a minute tooth, or rarely 2 equal narrow stigmas.)

* Corolla deeply bilabiate : capsule terete and 2-celled to the very base:

2. HYGROPHILA. Calyx deeply and almost equally 5-cleft or parted. Corolla narrow; lips erect at base and above (at least the lower) spreading, 2- and is-lobed. Anthers oblong, muticous. Capsule oblong-linear, several-seeded. Flowers sessile in the axils.

* * Corolla not obviously or only moderately bilabiate, the 5) lobes broad and roundish, spreading: capsule with the base more or less contracted into a solid short stipe.

3. CALOPHANES. Calyx deeply 5-cleft or parted; lobes elongated setaceous-acuminate or aristiform. Corolla funnelform, with aniple limb, either somewliat manifestly bilabiate, or with 5 equal broad and spreading lobes, the two posterior a little ligher united. Anthers mucronate, or at least nucronulate, or sometimes aristate at base. Ovules a single pair in each cell. Capsule oblong-linear, 2-4-seeded.

4. RUELLIA. Caly x deeply 5-cleft or parted; lobes mostly linear or lanceolate. Corolla with funnelform or campanulate throat on a narrow and sometimes elongated tube; the 5 ovate or rounded lobes nearly similar and spreading, or the posterior rather more united. Anthers muticous, oblong-sagittate. Ovules 3 to 10 in each cell. Capsule oblonglinear or clavate, several- (6-20-) seeded.

Tribe III. JUSTICIE $\mathbb{E}$. Corolla imbricated in the bud; the posterior lobes or lip interior. Seeds and capsule of the preceding tribe; in the last two genera the placentiferous half-portions separating below from the valve after dehiscence.

* Stamens 4, in the throat of the corolla: filaments short: anthers one-celled, ovate-lanceolate or oblong, muticous at base, their tips sometimes lightly coliering by a minute beard: corolla witl 5 plane obovate lobes, the two posterior usually united a little higher: stigma naked, truncate or obscurely funnelform : ovules 2 in each cell: calyx 5 -sepalous or 5-parted into narrow nearly equal divisions.

5. STENANDRIUM. Lobes of the salverform corolla all equally spreading. Low herbs.

6. BERGINIA. Posterior lobes of the corolla nearly erect, forming an upper lip, the 3 others larger and widely spreading. Anterior pair of filaments bearded on the inner side; antliers ovate-lanceolate. Seeds (mostly 2 ) rugose. Fruticulose.

* * Stamens 2 and no rudiments: anthers 2-celled : ovules 2 in each cell; capsule usu. ally more or less obcompressed, and with a conspicuous stipe-like solid base.

+ Placentæ not separating from the valves of the capsule.

+ Anther-cells equal, parallel and contiguous, nıuticous: limb of corolla somewhat equally 4-parted : slirubby plants: bracts and bractlets small and narrow or minute: calyx small, 5-parted or 5-cleft; the divisions narrow : stigma obscurely capitate or enrarginate: filaments filiform, inserted in the throat.

7. CARLOWRIGHTIA. Corolla with narrow tube shorter than the lobes; throat not dilated; limb 4-parted down to the tube; lobes entire, oblong, nearly similar, widely 
spreading and plane, or the posterior (interior in the bud) at first concave-infolded and less spreading. Stamens nearly equalling the corolla-lobes. Capsule ovate, acuminate, obcompressd, on a slender clavate stipe. Seeds very flat, minutely scabrous.

8. ANISACANTHUS. Corolla with elongated tube gradually somewhat wider at the throat; the 4 lobes similar, lanceolate, entire, erectisl recurving; the posterior (or upper lip) rather more deeply separated. Stamens and style equalling or exceeding the coroulalobes. Capsule ovate on the long clavate stipe. Seeds smooth or rugulose.

$\div+$ - Anther-cells unequal or unequally inserted, one lower than the other or oblique;

= The lower calcarate or mucronate at base: corolla manifestly bilabiate; upper lip erect and more or less concave, merely emarginate or '-lobed at apex, not surpassed by the stamens: these inserted in or near the throat: calyx 5-parted (sometimes 4-parted), small.

9. SIPHONOGLOSSA. Corolla with long-linear or filiform tube and short limb; lower lip broat and spreading, a-cleft. Anther-cells contiguous and parallel, but one higher.

10. BELOPERONE. Corolla deeply bilabiate, but with tube much longer than limb; throat narrow; lower lip 3-lobed at apex, erect-spreacling. Anther-cells somewhat unequal and oblique, on a more or less dilated connective. Seeds globular or thickened!

11. JUSTICIA. Corolla with short tube, and rather ampliate throat seldom longer than the limb; lower lip sprealing, 3-lobed. Anther-cells oblique and disjoined. Seeds, as far as known, flat.

$==$ Anthers muticous, or both cells rarely mucronulate at base: calyx deeply 5-parted into narrow or subulate divisions, the fiftl commonly smaller: stamens not surpassing the corolla.

12. DIANTHERA Corolla bilabiate; upper lip erect and concave or fornicate, entire or 2-toothed; lower spreading and 3 -lobed, with a rugose or venose-reticulated convex base or palate. Anther-cells ovate or oblong, not parallel, moderately or conspicuously disjoined on a dilated connective. Seels glabrous, smooth, or echinulate-scabrous. Bractlets small.

13. GATESIA. Corolla with slender tube, somewhat ampliate throat, and almost cqually 4-lobed spreading limb; lobes nearly similar, plane, ovate. Anther-cells oblong, contiguous and similar, but one a little lower and oblique. Stigma capitellate. Seeds glabrous, minutely rugulose. spikes short and dense: bracts and bractlets membranaceofoliaceous, 1-nerved and pinnately veined or triplinerved.

$+\div$ Placentæ, by rupture of half-partition from the base upward, at length separating and diverging or incurving: anther-cells muticous, or rarely one or both mucronulate at base: calyx small, dry, or somewhat glumaceous, 4-5-parted; the divisions subulate or linear-lanceolate, equal, or the innermost (posterior) smaller: corolla with narrow tube: filaments filiform.

14. TETRAMERIUMI. Flowers solitary (rarely 2 or 3 ) covered by a large and herbaceous primary bract, and subtended by two small and narrow bractlets. Corolla with an almost equally 4-parted limb, or somewhat bilabiate; the 3-parted and widely spreading lower lip rather more separated from the less spreading or rather erect and slightly concave entire and obovate or oblong upper lip. Anther-cells equal and parallel or nearly so, either contigunus or separated by a slightly dilated connective. Seeds flat, muriculate or papillose. Spikes strobilaceous, quadrifarious.

15. DICLIPTERA. Flowers not covered by primary bracts (of main axis), but involucrate (either singly or in a fascicle) by 2 valvately opposed and nearly equal or 4 less dilated and unequal herbaceous bractlets. Corolla deeply bilabiate; upper lip erect, con. cave or plane, entire or emarginate; Iower spreading, entire or 3-lobed at apex. Anthers with a narrow connective. Seeds either smooth or muriculate. Inflorescence various, not strobilaccous-spicate.

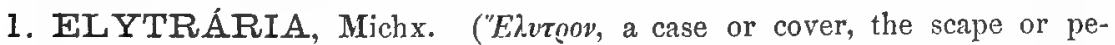
duncle and spike covered with jmbricated bracts.) - Low perennial herbs (chiefly tropical American); with leaves crowded at base of a naked scape or at summit of a short naked stem, tapering to the base, thinnish ; flowers small, solitary and sessile under the bracts; these and the scales of the scapes rigid-chartaceous or glumaceous, alternate! - Michx. Fl. i. 8 (1803); Vahl, Enum. i. 106 (1804), excl. spec.

E. virgáta, Michx. Acaulescent: leaves from oblong to elongated spatulate, obtuse (2 to $(\dot{i}$ inches long), with usually undulate margins: scape a foot or less high, bearing a short 
spike or a cluster of spikes: bracts ovate, cuspidate-acuminate : corolla white (3 or 4 lines long): seeds nearly smooth and even.-Fl. i. 9, t. 1; Vahl, l. c. ; not " $E$. Vahliana," as says Nees in DC. Prodr. xi. 63. Anonymos Carolinensis, Walt. Car. 69. Tubifora Carolinensis, Gmel. Syst. E. cupressina, Nees, 1. c. 65, if N. Amer.? - Low grounds, S. Carolina to Florida: fl. summer.

E. tridentáta, Vahl, l. c. Acaulescent or with proliferous low stems: leaves lanceolate or oblong, 2 or 3 inches long, clustered, as are the hardly longer peduncles or scapes, either at the root or at the summit of naked stems : spikes slender: bracts ovate, mostly scariousmarginel; the upper commonly tricuspidate or aristate: corolla purple. - Griseb. Fl. W. Ind. 451 ; Torr. Bot. Mex. Bound. 122. E. ramosa, frondosa, fasciculata, \&c., HBIr. ; Nees, 1. c. - Arizona and New Mexico, along the Mexican border. (Mex. to W. Ind. \& S. Brazil.)

2. HYGRÓPHILA, R. Br. (From 'vyós, moist, and qihic, affection; plants which affect wet places.) - A large tropical genus, of which a single species reaches the southernmost Atlantic States.

H. lacústris, Nees. Nearly glabrous : stem simple, 2 or 3 feet high from a creeping base: leaves lanceolate, sessile, entire (about 4 inches long), scabrous-ciliolate: flowers small, white: calyx-lobes and bracts subulate-lanceolate: anthers of the shorter stamens smaller.-DC. Prodr. xi. 86. Ruellia lacustris, Schlecht. in Linn. v. 96. $R$. justicicefora, Hook. Comp. Bot. Mag. i. 170. - Swamps, Texas and Louisiana, Drummond, Ricldell, Lindheimer, \&c. W. Florida, Saurman. (Mex.)

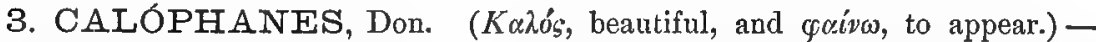
Low perennials, branched from the base, pubescent or hirsute, usually with proportionally large or showy axillary flowers, either solitary or usually clnstered and nearly sessile; the corolla blue or purplish, rarely white; its tube not longer than the calyx. Seeds as in Ruellia, or the hairs nearly destitute of rings or spiral fibres. Fl. summer.

* Eastern-Atlantic species: calyx deeply 5-parted : stems from slender creeping base or rootstocks : flowers solitary or few in the axils.

C. humistráta, Nees. Glabrous or almost so throughout, no hirsute hairs: stems weak, erect or decumbent from the creeping base: leaves thinnish, oblong-obovate or the uppermost oblong, narrowed at base into a petiole ( 6 to 18 lines long) : corolla white, barely half inch long, seldom longer than the obovate or oblong foliaceous bractlets; the tube very short: sepals setaceous-aristiform from an oblong-lanceolate base, little shorter than the corolla : anther-cells oblong, barely mucronulate.-DC. Prodr. xi. 108. Ruellia humistrata, Michx. Fl. ii. 23. Dipteracanthus (Calophanes) riparius, Chapm. Fl. 303, a Iuxuriant form. - Low grounds, S. Georgia and Florida.

C. oblongifólia, Don. Pubescent or soft-hirsute, sometimes glabrate: stems usually erect and sinple, a span to a foot high: leaves from narrowly oblong to oval, very obtuse, sessile (an inch or less long): corolla blue, sometimes purple-dotted or mottled, seldom an inch long, twice the length of the narrowly oblong bractlets; the tube shorter than the ample throat: sepals distinct almost to the very base, filiform-setaceous, hirsute, more than half the length of the corolla: anther-cells oblong-linear, aristulate. - Brit. Fl. Gard. ser. 2, t. 181 ; Nees, l. c. (Ruellia biflora, L. Spec. ii. 635, may be this, but it rests on a mere mention by Dillenius, 'without character.) Ruellia oblongifolia, Michx. Fl. ii. 23; I’ursh, Fl. ii. 420. Dipteraconthus biflorus, Nees in Linn. xvi. 294. D. oblongifolius, Chapm. 1. c. - Sandy pine barrens, S. Virginia to Florida. An almost glabrous large form in Florida.

Var. angústa. A reduced form, a span or so high, nearly glabrous, very leafy: leaves and flowers only half inch long, most of the former oblong-linear. - Dipteracanthus linearis, Claapm. 1. c.-S. Florida; Key West and Biscayan Bay, Blodgett, Palmer.

* * Texano-Arizonian species : caly'x 5-cleft.

C. lineáris. Hirsute with somewhat rigid and short hairs, or glabrate, not cinereous: stems erect and strict (a span to a foot high), or branched and diffuse : leaves from linearoblanceolate to oblong-spatulate ( 9 to 20 lines long), rather rigid: flowers usually folioseglomerate: bracts and bractlets similar to and equalling the subtending leaves and about 
equalling the corolla: calyx-lobes subulate-setaceous, more or less hispid-ciliate, hardly more than twice the length of the narrow tube: corolla purple? (10 lines long); the tube not longer than the abruptly ampliate throat: anther-cells linear-oblong, aristulate. Dipteracanthus (Calophtnes) linearis, 'T'orr. \& Gray in Pl. Lindl. i. 50. C. ovata, Benth. Pl. Hartw. 89, as to Texan sp.; Nees, 1. c.; surely not Ruellia ovalu, Cav. C. oblongifolia, var. Texensis, Nees, 1. c.; Torr. Bot. Mex. Bound. 122. - Dry ground, Texas (Berlandier, Drummond, Wright, \&c.) to the border of New Mexico. (Adjacent Mex.)

C. decúmbens. Cinercous-puberulent throughout, not at all hirsute, nor scabrous : stems mostly spreading on the ground: leaves spatulate, or the lowest obovate and the uppermost oblanceolate, with attenuate base, but hardly petioled (6 to 14 lines long): flowers few in the foliose-bracteolate clusters : setaceous-subulate calyx-lobes hardly twice the length of the tube: corolla purple ( 8 or 10 lines long); its tube double the length of the throat, nearly equalling the caly $x$-lobes : anther-cells oblong, mucronate. - Calophanes oblongifolia, Torr. Bot. Mex. Bound. 123, not Don. - Dry soil, western borders of Texas (Wright, \&c.) to S. Arizona, Thurber, Wright, Rolhrock, \&c. (Adjacent Mex.)

4. RUÉLLIA, Plum. (I. Ruel, or de la Ruelle, of France, early herbalist.) - Large genus, chiefly American and tropical, perennials; with mostly entire and broad leaves, and rather large flowers (in summer), usually violet or lilacpurple, solitary or commonly clustered in the axils or in evolute cymes; in several species the earlier or later blossoms cleistogamous. Seeds in many clothed with fine appressed hairs, which when wetted diverge and elongate, either marked with fixed spiral bands or developing spiricles. - Benth. \& Hook. Gen. ii. 1077. - Our species all rank under Ruellia proper (Cryphiacanthus and Dipteracanthus, Nees in DC.), with straight tube and almost or quite regular limb to the corolla, and included stamens. Both stigmas equally developed occasionally in $R$. strepens and $R$. ciliosa. Five stamens have been found in the latter.

* Flowers in open pedunculate crmes from upper axils and forming a terminal panicle : bracts and bractlets small, linear or subulate: capsule 8-12-seeded, narrow: hairs of the seed developing long spiricles when wetted.

R. tuberósa, L. Glabrescent or minutely pubescent, a foot or two high, with somewhat tuberous-thickened roots: leaves ( 2 or 3 inches long) with undulate or obscurely repanddentate margins, ovate-oblong or elliptical, and with base cuneate-contracted or decurrent into a rather long petiole: primary and secondary peduncles of the loose cyme siender: caly x-lobes subulate-filiform (half inch or more long), much exceeding the bractlets, lardly equalling the slender tube of the (inch and a half long blue or sometimes white) corolla, which is about as long as the funnelform-campanulate throat: capsule narrowly subclavate, 7 to 9 lines long, the stipitiform solid base mostly short but manifest. - Spec. ii. 6.3.5; Griseb. Fl. W. Ind. 452, but liardly of Desc. Ant. ii. t. 113. R. clandestina, L. l. c. (Dill. Elth. 328, t. 248.) R. humilis, etc., Plum. Nov. Gen. Amer. 12, t. 2. Cryphiacanthus Barbadensis, Nees in DC. 1. c. 197. Dipteracanthus nudiflorus, Engelm. \& Gray, Pl. Lindh. i. 21. - Riverbottoms, Texas. (W. Ind., Mex., S. Am.)

Var. occidentális. Rather large and tall: inflorescence and calyx conspicuously viscid-pubescent; the latter usually shorter than the tube of the (1t to fully 2 inch) corolla: leaves from glabrate to velvety-pubescent, mostly ovate and with more abrupt or even subcordate base, sometimes 6 or 7 inches long.-W. \& S. Texas, Berlandier, Wright. S. Arizona, Rothrock. "California" (or probably Arizona), Coulter. The two latter glabrate forms. (Mex.)

* * Flowers solitary or 3 and cymulose on an axillary peduncle as long as the leaf: bracts foliaceous: seeds and capsule of the succeeding; stems branching.

R. pedunculáta, Torr. Slightly puberulent, 2 feet high, with spreading branches: leaves ovate-oblong, acute, short-petioled ( $1 \frac{1}{2}$ to 3 inches long): peduncles spreading, slender, 1 or 2 inches long, bearing a pair of bracts similar to the leaves (half inch or more long) and equalling the caly $x$ and capsule of the single flower, or shorter than the similarly 2-bracteolate pedicels when they are developed: calyx-lobes subulate-filiform, pubescent, about the length of the narrow tube of the corolla: throat of the latter dilated-funnel- 
form : capsule puberulent. (Torr. in herb., unpublished.) - Dry woods, in W. Louisiana, J. Hale. Arkansas, Bigelow, Mrs. Harris. Corolla about an inch and a half long.

* * * Flowers subsessile and commonly glomerate in the axils, when short-peduncled with foliaceous primary bracts or bractlets : stamens of almost equal length: capsule at nost 8-seeded: short hispid hairs of the seed spreading when wet, containing a fixed spiral fibre or band, but no uncoiling spiricles.

+ Suffrutescent: leaves rigid : corolla white : capsule oblong, with hardly any stipe-like base,

R. Párryi. A span high, nuch branched from the lignescent base : leaves obovate-oblong, or the upper oblong-lanceolate, tapering into a distinct petiole, hispid-ciliate, otherwise glabrate, an inch or less long (the older have cystoliths): flowers mostly solitary in the axils, on a peduncle shorter than the petiole or subsessile: bractlets oblong, surpassing the slender-subulate often unequal calyx-lobes: tube of the corolla (incl long) slender, dilated at the summit into a small narrowly funnelform throat, which is shorter than the lobes. - Dipteracanthus suffruticosus, Torr. Bot. Mex. Bound. 122 (but there is a R. suffirticosa, Roxb.).- Soutl-western borders of Texas: at Presidio del Norte, Paryy, in flower. Valley of the Pecos, in fruit, Wright.

++ Herbaceous: stems mostly simple: corolla usually blue or violet, except in $R$. tubiflora: capsule more broadly clavate and obcompressed.

t+ Calyx-lobes filiform-attenuate, longer than the capsule: cleistogamous flowers seldom seen.

R. noctiflóra. Puberulent, or very young parts soft-villous, a foot or less high: leaves narrowly oblong ( 1 to 3 inclies long), mostly with tapering base, but sessile: bracts and bractlets of the solitary or few flowers linear-lanceolate: caly $\mathbf{x}$ generally soft-puberulent; its lobes somewhat linear-filiform and hardly widened at base (sometimes 18 lines long), barely half the length of the elongated (fully 2 inch) tube of the white corolla, the throat of which is funnelform. $-R$. tubiflorc, LeConte in $\Lambda$ nn. Lyc. N. Y. i. 142, not HBK. Dipleracanthus noctiflor's, Nees in DC. 1. c., partly; Chapm. Fl. 304.-Low pine-barrens, Lower Georgia, LeConte. W. Florida, Rugel, Chamman, \&c. S. Mississippi, Ingalls. Nightblooming?

R. ciliósa, Pursh. Usually hirsutt with long spreading hairs, especially the (about inch long) filiform attenuate caly x-lobes: leaves oblong or the lower oval (an inch or two long), almost sessile: tube of the blue corolla commonly twice the length of the calyx and of the limb with the obconical throat, the whole not rarely 2 inches long. - Fl. i. 420 ; Gray, Man. ed. 5, 3:39. Dipteracanthus ciliosus, Nees in Linn. xvi. 204, \& Prodr. 1. c., with var. hybridus, mainly. - Dry ground, Michigan and Illinois to Florida and Louisiana : in various forms.

Var. longiflóra. Pubescence sometimes cinercous, with or without long hirsute hairs: stems sometimes flowering when 2 or 3 inches high, sometimes tall and slender: leaves narrowly oblong or the lower obovate-spatulate, usually small: slender tube of corolla 1 or 2 inches long. $-R$. lumilis, Nutt. in Traus. Am. Phil. Soc. n. ser. v. 182. Justicia, with char. \& no name, Torr. in Ann. Lyc. N. X. ii. 235. Dipleracanthus Diummondii, Torr. \& Gray in Pl. Lindh. i. 50. D. noctiflorus, Nees, in DC. 1. c.., as to Texan pl. and var. humilis, also I). ciliosus, var. hybridus, in part. - Louisiana, Arkansas, and Texas.

Var. hýbrida. Either hirsute or cinereous-pubcscent, sometimes almost velvetypubescent: leaves from ovate to oblong, mostly with distinct petioles : tube of the corolla shorter than the throat and limb, sometimes shorter than the linear-setaceous calyx-lobes, which often want the hirsute hairs. - $R$. hybrida, Pursh, Fl. ii. 420; LeConte in Ann. Lyc. l. c. R. strepens, $I_{\text {. }}$ as to Dill. Eltl. t. 249 , at least in part. $R$. hirsula, Ell. Sk. ii. 109. Dipteracantlus ciliosus, var. hybridus, in part, \& D. Mitchllianus, Nees, I. c. D. strepens, var. Dillenie, Nees, l. c. - S. Carolina to Florida. Verges to the two following species.

Var. ambígua. Sparingly hirsute-pubescent or glabrate: leaves ovate-oblong, usually short-petioled, larger: tube of corolla little exceeding the hardly hirsute calyx.Dipleracanthus ciliosus, var. parviflorus, Nees, 1. c. - Virginia and Kentucky to Alabama. As if a hybrid between $R$. ciliosa and $R$. strepens, with aspect of the latter, but the calyx of the former.

R. Drummondiána. Cinereous-puberulent, tall : leaves ovate, 3 to 6 inches long, petioled: filiform-setaceous ancl canescent caly $x$-lobes (commonly an inch or more long) more or less shorter than the tube of the (inch and a half long) corolla. - Dipteracanthus Drummondianus, Nees in DC. 1. c. D. Lindheimerianus, Scheele in Linn. xxi. 764, 1848. - Texas, Diummond, Lindheimer. 

+ + Calyx-lobes lanceolate or linear, hardly surpassing the capsule: cleistogamous flowers
common.

R. strépens, L. Green and almost glabrous or pubescent, 1 to 4 feet high : leaves oblongovate or oblong, 2 to 5 inches long, mostly contracted at base into a short petiole: caly $\mathrm{x}$ sparingly soft-hirsute or ciliate: well-developed corolla $1 \frac{1}{2}$ or 2 inches long, with tube ahout the length of the campanulate-funnelform throat and limb. - Spec, ii. 634 (partly) \& Mant. 422; Schk. Handb. t. 177; Pursh, 1. c. Dipterucanthus strepens, Nees, 1. c., mainly. - Iry soil, Penn. to Wisconsin, Florida, and Texas.

Var. cleistántha. Leaves commonly narrower and oblong: flowers for most of the season cleistogamous. - Dipteracanthus (Meiophanes) micranthus, Engelm. \& Gray, Pl. Lindh. i. 49. D. strepens, var. strictus, Nees, 1. c., mainly. Hygrophila Illinoiensis, Wood in Bull. Torrey Club, $\nabla .41$. - Common with the ordinary form.

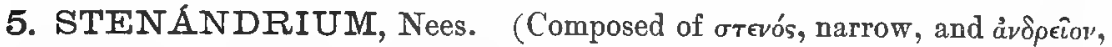
the hall for men, alluding to the narrow corolla?) - Low and small perennials, all American, commonly with leaves all at base of scapiform flowering stems; the flowers spicate; corolla rose-colored or purple.

S. dúlce, Nees. Hirsute-pubescent or glabrate : leaves all radical, oval or oblong, thickish, 9 to 16 lines long, either narrowed or abruptly contracted into a rather long naked petiole: scape equalling or shorter than the leaves, capitately few-flowered: bracts lanceolate, longer than the calyx, usually hirsute-ciliate (either nerveless or 3-nerved) : tube of the corolla narrow, rather longer than the calyx, the limb half inch or more in diameter: capsule clavate-oblong, somewhat terete. - DC. Prodr. xi. 282, with S. trinerve. Ruellia dulcis, Cav. Ic. vi. 62, t. 585, fig. 2. (Mex. to S. Chili.)

Var. Floridánum. Glabrous, only the upper bracts and bractlets lightly hirsuteciliate. - Indian River, E. Florida, Palmer.

S. barbátum, Torr. \& Gray. Very hirsute with long and shaggy white hairs, manystemmed from the root; a span or less high: leaves crowded, oblanceolate, attenuate at base into an indistinct petiole, above passing into the lanceolate and crowded foliaceous bracts of the rather many-flowered spike, which nearly equal the corolla: tube of the latter hardly longer than the calyx; limb over laalf inch in diameter: capsule ovate, obcompressed, not attenuate at base: seeds hispid. -Pacif. R. Rep. ii. 168, t. 4, \& Bot. Mex. Bound. 122. - Hillsides, western borders of Texas and adjacent parts of New Mexico, Wright, Gen. Pope, \&c.

6. BERGfiniA, Harvey. (In honor of Mr. Bergin, of Dublin.) - Benth. \& Hook. Gen. ii. 1096. A single species.

B. virgáta, Harvey. Low and branching, apparently suffruticose, minutely cinereouspuberulent: branches slender: leaves linear-oblong, nearly sessile (half inch long); the upper smaller and passing into obscurely 3-nerved bracts of the loose and interrupted spike: calyx rather longer than the bracts, 2-bracteolate: corolla probably white, less than half inch long; its lower lobe bearded at and below the base. - Gray, Bot. Calif. i. 588. - "California," Coulter. Probably Arizona: not since found.

7. CARLOWRIGHTIA, Gray. (Charles Wright, the discoverer of one species, the earliest explorer of the district it inhabits, a most assiduous and successful collector and investigator of the botany of several parts of the world.) Much branched undershrubs, minutely cinereous-puberulent or glabrate; with slender branchlets, small and narrow entire leaves, and rather small loosely spicate or paniculate-racemose flowers: corolla purple. - Gray, Proc. Am. Acad. xiii. 364.

C. linearifólia, Gray, l. c. A foot high, ericoid-leafy : leaves filiform-linear, 4 to 8 lines long; uppermost passing into similar bracts and bractlets of the somewhat paniculate inflorescence: cnlyx deeply 5-parted; the divisions similar to and equalled by the bractlets: 
lobes of the purple and almost rotate corolla oblong, 21 lines long, twice the length of the tube: filaments lirsute-puberulent: anthers sagittate, the cells at base very obtuse or retuse: stipe as long as the body of the capsule. - Shaueria linearifolia, Torr. Bot. Mex. Bound. 123: referred by Benth. \& Hook. Gen. ii. 1114, to Dianthera, but it cannot properly be included in that genus. - Western Texas; on hills between the Limpio Pass and the Rio Grande, Wright. Burro Mountains and Great Cañon of the Rio Grande, Bigelow, Parry.

C. Arizónica, Gray, 1. c. Apparently low, diffuse : leaves oblong or lanceolate, 2 or 3 lines long: flowers sparsely spicate on filiform branchlets: bracts subulate, shorter than the calyx: bractlets minute or none: calyx deeply 5-cleft; the lobes subulate: lobes of the bright purple corolla 4 lines long, thrice the length of the narrow tube, narrowly oblong, or the posterior broader above and with a yellow spot on the face, contracted below: filaments glabrous : anthers oblong: stipe shorter than the body of the capsule. - Arizona, on rocks near Camp Grant, Palmer, 1867.

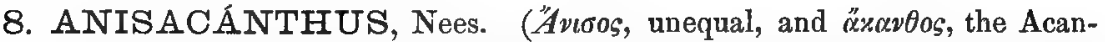
thus.) - Suffruticose or shrubby plants (of Mexico and its borders); with mostly lanceolate and entire petioled leaves, and usually loosely spicate or scattered red (an inch or more long) flowers : branches apt to be pubescent in alternate lines. Benth. \& Hook. Gen. ii. 1117.

A. púmilus, Nees. Low slırub, nearly glabrous: leaves lanceolate or linear-lanceolate (about 18 lines long); the larger short-petioled: calyx pubescent or tomentulose, 5-parted; the subulate or linear lobes about equalling the stipe of the capsule, which is not longer than the body : corolla red or reddish. - DC. Prodr. xi. 445. Drejera puberula, Torr. Bot. Mex. Bound, 123. - S. Arizona, Wright, Wheeler. Probably not distinct from A. virgularis, Nees, the Justicia coccinea, Cav. and J. virgularis, Salisb. (Mex.)

A. Thúrberi. Shrubby, 2 to 4 feet high: young parts minutely hirsute: leaves oblong or lanceolate (an inch or less long), thickish, subsessile: flowers more pedicellate, in short leafy clusters at the axils: calyx-lobes long-attenuate, equalling the pointed capsule, twice the length of its stipe: corolla red, more funnelform; its lobes little shorter than the tube. - Drejerr Thurberi, Torr. Bot. Mex. Bound. 124. - S. New Mexico and Arizona, Thurber, Capt. Smith, Palmer.

A. Wrightii. Suffruticose, 2 to 4 feet high, puberulent or the foliage glabrous, paniculately branched: leaves oblong or ovate-lanceolate, acute or acuminate (an incl or two long): spikes loosely paniculate, naked: lobes of the deeply 5-cleft calyx oblong-lanceolate, obtuse, very much (commonly thrice) shorter than the stipe of the pointed capsule (stipe 3 to 5 and capsule 3 or 4 lines long) : corolla purplish-red, inch and a half long, with lobes considerably shorter than tube. - Drejera Wrightii, Torr. 1. c. $-\mathrm{S}$. and W. Texas, between the Guadaloupe and the Rio Grande, Wright, \&c.

A. GréGGn, Drejera Greggii, Torr. 1. c., of northern part of Mexico, has leaves as the last species, but more pubescent and veiny, longer and slender corolla, with linear lobes longer than the tube, tomentose calyx 5-cleft only to the middle, and the single capsule seen is obovate and obtuse or retuse, on a stipe of thrice its length and double the length of the calyx.

9. SIPHONOGLOSSA, Oersted. ( $i^{\prime} \varphi \omega \nu$, tube, and $\gamma \lambda \tilde{\omega} \sigma \sigma \alpha$, tongue.) Herbaceous or barely suffrutescent, chiefly Mexican.

S. Pilosélla, Torr. Low, branching from a suffrutescent base, hirsute with scattered spreading hairs: leaves ovate or oval, subsessile ( 5 to 15 linés long): flowers mostly solitary in the axils: sepals 5, subulate: corolla pale blue or purple, with tube 8 or 9 and limb 3 or 4 lines long: lower anther-cell conspicuously mucronate-calcarate at base; upper less so at apex : seeds cordate-orbicular, rugulose. - Bot. Mex. Bound. 124. Adhaloda dipteracantha, Nees in DC. 1. c. 396. Monechma Pilosella, Nees, 1. c. 412. - Dry ground, Texas and S. New Mexico. (Adjacent Mex.)

S. longiflóra. Glabrous, or the slender stems cinereous-puberulent, barely a foot high: leaves lanceolate, glabrous, short-petioled, an inch or two long: flowers clustered in upper 
axils : corolla (white or yellowish-white) with tube inch and a half long: lower anthercell mucronate-appendaged at base. - Adhatoda? longiflora, Torr. Bot. Mex. Bound. 125. S. Arizona, Schott, Rothrock.

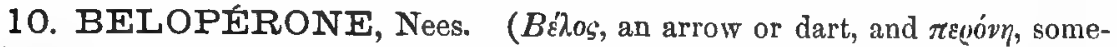
thing pointed.) — Shrubby plants ; with red flowers, all but the following tropical American.

B. Califórnica, Benth. Low shrub, with spreading often leafless branches, tomentose or cinereous-puberulent : leaves ovate, oval, or subcordate, petioled: racemes terminating the branches, short, several-many-flowered: bracts and bractlets small, deciduous: caly $x$ deeply 5-parted; lobes subulate-lanceolate: corolla dull scarlet, an inch long; both the lips oblong and truncate; lower 3-lobed at apex : anther-cells oval; lower mucronate at base: capsule obtuse, with broad and long stipe-like base obcompressed: seeds turgid, glabrous, coarsely rugose. - Bot. Sulph. 38; Gray, Bot. Calif. i. 588. Jacobinia Californica, Nees in DC. 1. c. 729. Sericographis Californica, Gray in Bot. Mex. Bound. 125. - Desert region along the southern borders of California, and Lower California.

11. JUSTICIA, Houston, L. (James Justice, a Scotch cultivator and amateur.) - A large and widely distributed genus, chiefly tropical, represented here by a single anomalous and little known plant.

J. Wrightii. A span or less high and much branched from a suffrutescent base, cinereouspuberulent: leaves rigid, 3 or 4 lines long, sessile; lowest obovate; upper linear-lanceolate, mucronate-acute : flowers solitary and sessile in the upper axils; bractlets similar to the subtending leaf : corolla purplish, 4 lines long, somewhat canpanulate; upper lip with a broad emargination and two short narrow lobes; lower larger with oval-obovate lobes: anthercells oblong; the lower abruptly short-calcarate; the upper smaller and mucronate at base (fruit nut seen : ovules 4). - Calcareous hills along the San Felipe, W. Texas, Wright (no. 445 of 1st coll.).

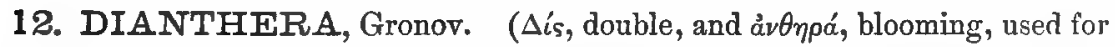
anther.) - Chiefly pereanial herbs, mostly American and of warm regions, various in inflorescence and habit: fl. summer. - Rhytiglossa, Nees in DC. Prodr. xi. 335.

\$1. Eudianthŕra. Flowers capitate or spicate on a long and naked axillary peduncle: bracts and bractlets subulate or linear: tube of the (purple or violet) corolla shorter or not longer than the limb: glabrous perenuials.

D. crassifólia, Chapm. Stem barely a foot high, simple or sparingly branched: leaves few in distant pairs, fleshy, linear, or the lowest spatulate-lanceolate and short, and the upper filiform and elongated (4 to 6 inches), about the length of the 2-6-flowered peduncles : corolla an inch long, bright purple: capsule (with the long stipe) of the same length. - Fl. 304. - Apalachicola, Florida, in wet pine barrens, Chapman.

D. Americána, L. Stem 1 to 3 feet high, sulcate-angled: leaves narrowly lanceolate, 3 or 4 inches long, tapering at base, subsessile: peduncles mostly exceeding the leaves, capitately several-flowered: corolla pale violet or whitish, less than half inch long; base of lower lip rugose. - Spec. i. 27; Gray, Man. ed. i. 293. D. ensiformis, Walt. Car. 63. Justicia linearifolia, Lam. Ill. i. 41. J. pedunculosa, Michx. Fl. i. 7. J. Americana, Vahl, Enum. i. 140. Rhytiglossa pedunculosa, Nees in DC. 1. c. 339. - In water, Canada to South Carolina, Arkansas, and Texas.

D. húmilis, Engelm. \& Gray. Stems a span to a foot high from a creeping base or rootstock, mostly slender : leaves from oblong or obovate-oblong to linear-lanceolate, sessile or slightly petioled, 1 to 3 inches long: flowers at length scattered in slender spikes on a peduncle shorter than the leaf : bract and bractlets much shorter than the 5 equal subulate-linear caly $\mathrm{x}$-lobes : corolla violet or pale purple, 4 or 5 lines long: anther-cells more or less mucronate at base. - Pl. Lindh. 1. 22. D. ovata, Walt. Car. 63; Chapm. Fl. 304 (with var. lanceolata \& angusta), a misleading name, as the leaves are never so broad. 
as ovate. Justicia humilis, Michx. Fl. i. 8; Pursh, Fl. i. 13; Vahl, Enum. i. $43 . \quad$ Rhytiglossa humilis, Nees, 1. c. $340 . \quad$ R. obtusifolia, Nees, 1. c. 338, as to N. Am. plant? - Muddy borders of streams, S. Carolina, near the coast, to Texas. Narrowest leaved forms much resemble the tropical $D$. pectoralis, which has smaller flowers and fifth sepal small.

D. parviflóra, Lrejera parviflora, Buckley in Proc. Acad. Philad. Dec. 1861, is like the preceding, so far as an imperfect specimen shows: but leaves shorter (an inch or so long), lanceolate from a broader and rounded subsessile base, the younger with a few hairs, and the inflorescence puberulent, with also some short-stipitate glands. - W. Texas, Buckley.

$\S 2$. Anomalous species, cinereous-pubescent: flowers small, in the axils of ordinary leaves and in slender spikes terminating the branches. (D. Sagraana, Griseb. with somewhat similar habit, is Justicia Sagreana, the lower anther-cell calcarate.)

D. parvifólia. Much branched from a somewhat woody root or base, a span or more high, erect or diffuse: leaves ovate, 3 to 8 lines long, petioled; upper axils floriferous: flowering branches mostly extended into slender sparsely-flowered spikes: bracts with bractlets and sepals subulate, small : corolla white or purple, 4 lines long; the lips nearly equal and about the length of the rather broad tube: anther-cells separated by a narrow connective, somewhat oblique and one a little lower. - Shaveria parifolia, Torr. Bot. Mex. Bound. 122. - Dry soil, W. Texas to New Mexico, Wright, Schott, Lindheimer, \&c. Referred to this genus on the authority of Benth. \& Hook. Gen. ii. 1114.

13. GATÉSIA, Gray. (In memory of Dr. Hezekiah Gates, who almost half a century ago made and distributed a collection of Alabama plants, upon one of which, viz. Petalostemon corymbosus, mistaken for a Composita, Bertoloni founded his genus Gatesia.) — Single species : fl. summer. - Proc. Am. Acad. xiii. 360 .

G. læte-vírens, Gray, 1. c. Perennial herb a foot or two high, puberulent or almost glabrous : stem when dry with a contracted ring above each node, as if articulated: leaves

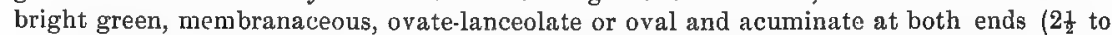
5 inches long), petioled: flowers in oblong and somewhat strobilaceous usually shortpeduncled spikes, both terminal and axillary: bracts oval or obovate with narrowed base, mucronate, hirsute-ciliate (half inch long): bractlets similar but smaller, about half the length of the clavate-oblong firm-coriaceous capsule: calyx somewhat glumaceous, deeply 5-parted; lobes setaceous-subulate, sparingly hirsute-ciliate, the innermost smaller: corolla white or flesh-color, almost salverform (about half inch and the lobes 2 lines long); stipelike base shorter than the body of the 4-seeded capsule. - Justicia late-virens, Buckley in Am. Jour. Sci. xiv. 176 (1843). Rhytiglossa viridiflora (meant for viridifolia), Nees in DC. Prodr. xi. 346. Dicliptera Halei, Riddell, Cat. Fl. Ludov. in N. Orl. Med. Jour. 1852; Chapm. Fl. 305. - Shady damp ground, Northern Alabama, Buckley, Cabell, Beaumont. Lookout Mountain, Tennessee, A.H. Curtiss. W. Louisiana, Hale. Eastern Texas, Wright. "Flowers opening in the night: corolla dropping early next day," Dr. Cabell. More allied to Tetramerium than to Dianthera, having only the capsule of the latter, and the bractlets of Dicliptera.

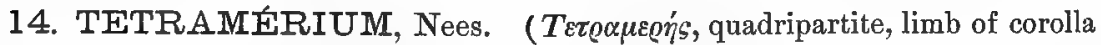
4-parted.) - Low perennial herbs, or barely suffrutescent at base (of and near Mexico); with oblong or ovate and petioled leaves, dense spike terminating stem and branches, its 4-ranked bracts imbricated and little exceeded by the (white or purplish) corollas. - Bot. Sulph. 147, \& DC. Prodr. xi. 467. (Henrya, Nees, referred here in Benth. \& Hook. Gen. ii. 1121, is distinguished by its small primary bract, or ordinary leaf in place of it, and conspicuous herbaceous bractlets, as of Dicliptera, which are usually vaginate and connate.)

T. híspidum, Nees, 1. c. Hirsute-pubescent, and the ovate or oblong strongly 3-5nerved spinulose-pointed bracts hispid: leaves oblong, 1 or 2 inches long: calyx 4-parted: lobes of the corolla shorter than its tube: seeds muriculate. $-T$. nervosum, var., Torr. Bot. Mex. Bound. 125. - S. Arizona to the borders of Texas. (Mex.) 
T. platystégium, Torr. 1. ¿. Seabrous-puberulent, not at all hirsute: leaves oblonglanceolate: bracts subcordate, mucronate-acuminate (half or two-thirds inch long), lightly 3-5-plinerved and veiny: bractlets minute and subulate: calyx 5-parted: tube of purple corolla longer than the narrowly oblong lobes: seeds muriculate-scabrous. $-\mathrm{S}$. borders of Texas, near Ringgold Barracks on the Rio Grande, Schott.

15. DICLIPTERA, Juss. ( $M \% \lambda i s$, two-valved, and $\pi \tau \varepsilon \varrho 0 \%$, wing : applies to the involucre of the typical species, but was explained to relate to the bipartition and separation of the two parts of each valve of the capsule after dehiscence.) - Chiefly herbs, dispersed over the warmer regions of the world. Fl. summer. Corolla often seemingly resupinate as relates to prinury axis, on account of the cymose inflorescence or the evolution of more than one flower in the involucre. Leaves petiolate. In the disruption of the valves of the capsule, the sides are usually carried away with the placentr, leaving only a stalk-like base.

§ 1. Eudiclíptera. Bractets of the flat involucre a single pair and broad, opposite : internal bractlets small and thin like the sepals : anther-cells oval, disjoined, one nearly over the other.

D. resupináta, Juss. A span to a foot or two high from an annual or perennial root, . nearly glabrous: stem 6-angled: leaves from ovate to lanceolate or oblong: involucres on naked simple or commonly trifid peluncles, 1-;-Howered, rotund- or deltoid-subcordate, rarely round-obovate, very flat, a third to half inch long and nearly as wide: lobes of the purple corolla oborate. - Ann. Mus. ix. 268; Nees in DC. Prodr. xi. 474; Torr. Bot. Mex. Bound. 125. Justicia sexangularts, Cav. Ic. iii. 2, t. 203. J. resupinata, Vahl, Enum. i. 114. Dicliptera thlusproides, Nees, 1. c.? S. Arizona (and California? Coulter), Thurber, Schott, Wright, \&c. (Mex.)

D. brachiáta, Spreng. A foot or two high, from almost glabrous to pilose-pubescent: stem 6-angled, rather slender, witl numerous spreading branches: leaves oblong-ovate, mostly acuminate, membranaceous ( 2 to 4 inches Iong), slender-petioled: involucres clustered in the axils and more or less paniculate, short-peduncled and subsessile, somewhat convex, or at length ventricose, its valves narrowed at base, 3 to 5 lines long, from broadly obovate with rounded summit to spatulate-oblong, often unequal, frequently mucronate or mucronulate: lobes of the purple or flesh-colored corolla clongated-oblong, half inch or less long, about the length of the slender curved tube.-Syst. i. 80 ; Nees, 1. c.; Chapm. Fl. 305. D. resupinata, Nutt. in Trans. $\Lambda \mathrm{m}$. Pliil. Soc. n. ser. v. 18:, not Vahl. D. glandulosa, Schecle in Linn. xxi. 76.j, a villous-pubescent form. - Sliady and moist ground, N. Carolina to Florida and Texas.

Var. attenuáta, a form with the involucral valves narrower, spatulate or oblong, and cuspidate-acuminate; and attenuate-acuminate leaves on long (sometimes 2 inch) petioles. -E. Texas, Wight. Also Arkansas, Nuttall: therefore his D. resupinuta, in part; but not according to his character "bracteis bivalvibus subcordatis."

§ 2. DActylostraium. Bractlets 2 and narrow, and at base supplemented by and sometimes partially concreted with a smaller and alternate pair, being the outer and larger of the internal bractlets: anthers oblong-sagittate, the cells usually parallel and equal : flowers loosely secund-spicate or paniculate : primary bracts small and subulate. - Dactylostegium, Nees in Fl. Bras., Oersted. § Dactylostegiae, Nees in DC. Prodr.

D. assúrgens, Juss. 1. c. Glabrous or puberulent: stem 1 to 3 feet high, with virgate branches: leaves ovate, acuminate, or the smaller upper ones oblong and obtuse: involucres chiefly sessile and rather sparse in the slender simple or paniculate spikes : principal bractlets of the involucre linear-spatulate, 4 or 5 lines long, 1-nerved, mucronate, nearly twice the length of the slender-subulate interior ones : corolla much exserted, an inch long, red or crimson, arcuate; the nearly entire lanceolate-oblong lips shorter than the upwardiy ampliate tube. - Nees in DC. 1. c. 489; Chapm. Fl. 305. Juslicia assurgens, L. (P. Browne, J $ı$ In. 110, t. 2, fig. 1.) - Eastern S. Florida. (W. Ind., Centr. Am.) 


\section{Orner CII. SELAGINACE}

Shrubs or herbs, of various habit, confined to the southern hemisphere, except two anomalous northern genera of dubious association, in character most like Verbenacece, but the solitary ovules anatropous and suspended, and the radicle of the terete straight embryo superior.

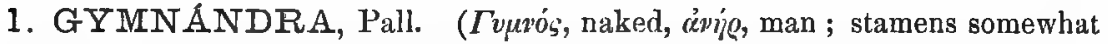
protruding.) - Calyx spathaceous, cleft anteriorly, entire or 2-3-toothed posteriorly. Corolla tubular, ampliate at the throat; limb 2-labiate; upper lip entire, erose-2-3-crenulate, or 2-cleft; lower usually longer, 2-3-cleft. Stamens 2, inserted in the throat of the corolla, not surpassing its lobes: anthers versatile, confluently 1-celled. Ovary 2-celled, 2-ovulate: style filiform and elongated: stigma subcapitate or 2-lobed. Fruit dry or slightly drupaceous, small, included in the caly $x$ and murcescent corolla, separating into two akene-like nutlets, or one of them often abortive. Seed suspended: embryo a little shorter than the fleshy albumen. - Perennial and subcaulescent glabrous herbs; with the aspect of Synthyris in Scrophulariacea (p. 285) ; rootstock somewhat creeping: leaves alternate; the radical obovate or oblong and petioled; those of the scapiform and simple flowering stem sessile: flowers in a dense terminal spike, each solitary and sessile in the axil of a bract: corolla bluish. A few montane and arctic Asiatic species, two of them reaching N. America. - Pall. It. iii. 710 ; Choisy in DC. Prodr. xii. 24 ; Bentl. \& Hook. Gen. ii. 1130.

G. Gmélini, Cham. \& Schl. Somewhat robust, a span to a foot high : radical leaves ovate or oblong, mostly obtuse at both ends, repand-crenate (2 to 4 inches Iong): cauline smaller, passing into bracts of the dense and thick oblong spike: stamens much shorter than the upper lip of the corolla, exceeding the style. - Linn. ii. 561; Hook. Fl. ii. 102. G. borealis, var., Pall. l. c. G. ovata \& reniformis, Willd. Lagotis glauca, Gærtn, in Nov. Comm. Petrop. xiv. 533, t. 18, fig. 2. (Bartsia gyminandra, Pursh, Fl. ii. 430, referred here as to plant of Columbia River, is probably Synthyris rubra.) - Unalaska, Popoff Islands, \&c., recently coll. by Harrington and Elliot. (Kants., \&c.)

G. Stélleri, Cham. \& SchI. 1. c. Slender and smaller : radical leaves oblong, acute, more attenuate at base, unequally and obtusely serrate: stamens about equalling the upper lip of the corolla, shorter than the style. - Hook. 1. c. G. minor, denlata, \& grachls, Willd. - Kotzebue Sound, Lity \& Collie. Arctic coast, Richardson. Perhaps Island of St. Lawrence, Chamisso. St. Paul's Island, Elliott. (Arctic Asia.)

\section{ORDER CIII. VERBENACE}

Herbs or shrubs (in tropical regions some are trees), with chiefly opposite or verticillate leaves, no stipules, bilabiate or almost regular corolla, with lobes imbricated in the bud, mostly didynamous stamens, single style with one or two stigmas, an undivided mostly 2-carpellary but more or less completely 2-4-celled (rarely 8-locellate) ovary, a pair of ovules to each carpel (one to each locellus or half-carpel); the fruit either drupaceous and 2-4-pyrenous, or dry and separating at maturity into as many nutlets; embryo straight, and in true Verbenacere with the radicle inferior. Phryma, appended to this order for lack of other affinity, is a notable exception. Albumen in our genera scanty or none. Inflorescence various. Foliage sometimes aromatic. 
Tribe I. PHRYMEAs. Ovary one-celled, and with a single erect or ascending orthotropous ovule. Seed without albumen. Radicle superior: cotyledons broad, convolute round their axis. Inflorescence centripetal.

1. PHRYMA. Calyx cylindraceous, bilabiate; upper lip of 3 setaceous-subulate teeth; lower of 2 short subulate teeth. Corolla with cylindrical tube equalling the upper lip of the calyx, and a bilabiate limb: upper lip almost erect, emarginate; lower much larger, spreading, 3-lobed. Stamens didynamous, included: anthers 2-celled, opening longitudinally'. Style slender: stigma 2-cleft. Fruit a dry akene in the bottom of the calyx. Calyx abruptly reflexed on the axis of the spike in fruit, strongly ribbed, and closed by the narrowing of the orifice: the long slender teeth hooked at the tip.

Tribe II. VERBENE.E. Ovary, or at least the fruit, with 2 to 8 cells or nutlets: ovules anatropous or nearly so, erect. Radicle accordingly inferior. Inflorescence centripetal and simple; the flowers in the spike commonly alternate: bractlets none. Leaves simple, sometimes divided, but not compound. Stamens in our genera included and distinctly didynamous.

* Flowers spicate or capitate.

- Calyx ampliate-globular and closed over the fruit.

2. PRIVA. Flowers slender-spicate. Calyx at first cylindraceous, with 5 ribs produced into short teeth, membranaceous and enlarging with and closely investing the dry indurated fruit, which splits into a pair of 2-locellate or by abortion 1-locellate nutlets. Corolla salverform, 5-lobed, obscurely bilabiate.

++ Calyx narrow, tubular, plicately 5-angled, 5-toothed, mostly enclosing the dry fruit: corolla salverform; limb somewhat equally or unequally 5-lobed: akene-like nutlets 1-celled, 1-seeded.

3. STACHYTARPHETA. Perfect stamens 2 (the anterior pair) and with divaricate rertical anther-cells: posterior reduced to sterile filaments. Stigma terminal, orbicular, subcapitate. Fruit separating into 2 oblong-linear nutlets.

4. BOUCHEA. Perfect stamens 4: anthers ovate, the cells parallel. Stigma 2-lobed, one lobe abortive, the other subclavate-stigmatose. Fruit separating into 2 nutlets. Seed linear.

5. VERBENA. Perfect stamens 4: anthers ovate; the cells nearly parallel. Stigma mostly 2-lobed; anterior lobe larger; posterior smooth and sterile. Fruit separating into 4 nutlets. +++ Calyx small and short: anthers short, the cells parallel : cells of the ovary and nutlets of the fruit 2 , one-seeded : style mostly short: stigma thickish, mostly oblique.

6. LIPPIA. Calyx 2-cleft or toothed, ovoid, oblong-campanulate or compressed and bicarinate, enclosing the dry fruit, which separates into 2 nutlets. Limb of corolla oblique or bilabiate, 4 -lobed.

7. LANTANA. Calyx very small and membranaceous, truncate or sinuate-toothed. Limb of the corolla not bilabiate, obscurely irregular, 4-5-parted; the broad lobes obtuse or retuse; tube slender. Fruit drupaceous, merely girt at base by the calyx, fleshy or juicy; its nutlets bony, mostly roughened.

* Flowers in open racemes, minutely bracteate: calyx tubular-campanulate, with trun. cate minutely 5 -toothed border: corolla salverform; the 5-parted limb sone what oblique or unequal : anther-cells parallel: ovules amphitropous: drupe juicy, containing 2 to 4 bilocellate 2-seeded bony nutlets : subtropical and tropical shrubs or trees.

8. CITHAREXYLUM. Caly $\mathrm{x}$ in fruit girting the base of the drupe. Stigmas 2. Nutlets 2. Sterile fifth stamen present, rarely antheriferous.

9. DURANTA. Calyx in fruit ampliate and enclosing the drupe. Corolla commonly curved. Stigma unequally 4-lobed. Nutlets 4 : seeds therefore 8 .

Tribe III. VITICEE. Ovary, embryo, \&c., of the preceding tribe. Ovules laterally affixed, amphitropous. Inflorescence centrifugal, cymose.

10. CALLICARPA. Flowers 4-merous (rarely 5-merous in calyx and corolla), nearly regular. Caly $\mathbf{x}$ short, sinuately toothed. Corolla with short or campanulate tube. Stamens 4, equal, exserted: anthers short; cells parallel. S'tyle elongated: stigma capitate or 2-lobed. Baccate drupe small, the base subtenderl by the calyx, containing 4 small 1-seeded nutlets or by abortion fewer. Cymes axillary.

TrIbe IV. AVICENNIEE. Ovary imperfectly 4-celled, with a central 4-winged columella bearing 4 pendulous amphitropous ovules, these and the solitary seed des- 
titute of any coats. Fruit fleshy-capsular. Seed consisting solely of a large embryo, which begins germination at or before dehiscence: radicle villous, inferior: cotyledons large, amygdaloid, conduplicate longitudinally: plumule conspicuous. Flowers glomerate (inflorescence centrifugal); the capituliform clusters variously disposed.

11. AVICENNIA. Calyx of 5 imbricated concave sepals. Corolla with short campanulate tube, and slightly irregular 4-parted spreading limb. Stamens 4, somewhat unequal and exserted. Style short or none. Stigmas 2. Fruit compressed, 2-valved.

1. PHRYMA, L. Lopsed. (An unexplained name, substituted by Linnæus for Leptostachya, Mitch. in Act. Phys.-Med. Nat. Cur. viii. 212, 1748.) Single species.

P. Leptostáchya, L. Perennial herb, 2 to 4 feet high, slender, somewhat pubescent: leaves ovate, acuminate, coarsely serrate; lower ones long-petioled: flowers small and inconspicuous, sessile in slender and filiform at length much elongated terminal spikes, purplish, each in the axil of a setaceous bract and subtended by a pair of minute bractlets, at length strictly reflexed; the fructiferous calyx, detaching at maturity, apt to adhere to fleece and clothing by the hooked tips of the awn-like teeth in the manner of a bur. Gærtn. Fr. t. 75; Lam. Ill. t. 516; Schauer in DC. Prodr. xi. 520. - Moist and open woods, Canada to Florida and Missouri: fl. summer. (Japan to Nepal.)

2. PRÍfA, Adans. (Name of unknown derivation.) - Homely perennial herbs of warm climates; with petioled coarsely serrate leaves, and terminal spikes of small dull flowers, in summer.

P. echináta, Juss. Somewhat pubescent: leaves ovate, somewhat cordate: flowers alternate in the slender spike : fruiting calyx hirsute with small hooked hairs: fruit ovate, 4-angled, splitting into 2 nutlets, each 2-seeded, spiny-toothed on the back. -Jacq. Obs. t. 24; Sloane, Jam. t. 110; Chapm. Fl. 206. - S. Florida. (Trop. Amer.)

3. STACHYTARPHETA, Vahl. (Name formed of $\sigma \tau a ́ x v 5$, spike, and

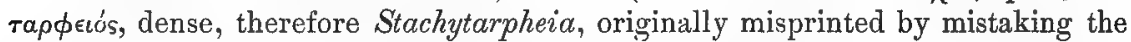
penultimate letter. Abbreviated to Stachytarpha by Link and some succeeding authors.) - Tropical herbs or undershrubs, chiefly American; with mostly serrate and sometimes alternate leaves, and dense terminal spikes; the flowers, or at least the fruiting calyx, often half immersed in longitudinal excavations of the stout rhachis, subtended each by a small and usually paleaceous bract.

S. Jamaicénsis, Vahl. Annual, but suffrutescent, glabrate: leaves oval or oblong, coarsely serrate, tapering into the petiole: spike as thick as a goose-quill, 6 to 10 inches long: bracts appressed, striate, aristulate-acuminate: flowers sunk in deep excavations of the thickening rhachis : caly $\mathrm{x}$ becoming compressed and 2-cleft: corolla blue, its border 4 lines broad.-Enum. i. 206 (Sloane, Jam. t. 107; Desc. Ant. vi. t. 692); Chapm. Fl. 308. Verbena Jamaicensis, L. - S. Florida. (W. Ind. to Guiana.)

4. BOÚCHEA, Cham. (Charles and Peter Bouché, Berlin gardeners.) Between the preceding and following genera, American, African, and Indian: flowers not immersed in the slender rhachis of the spike; in summer.

$\S 1$. Leaves petioled and serrate (as in the genus generally) : flowers small.

B. Ehrenbérgii, Cham. Annual, a span to 2 feet high, barely puberulent, brachiately branched: leaves ovate or oval: spikes short: flowers crowded: corolla little exserted, bluish, 3 lines long: tip of fruit exserted from the shortish tube of calyx. - Linn. vii. 253; Schauer in DC. Prodr. xi. 558; Torr. in Bot. Mex. Bound. 126. Verbena prismatica, Jacq. Ic. Rar. t. 208. - S. Arizona, Thurber, Wright. (Mex. \& W. Ind. to Venezuela.) 
§ 2. Leaves sessile or nearly so and entire: spikes lax : tube of (purple or white) corolla exserted, and limb 6 to 9 lines broad: fruit somewhat shorter than the narrow cylindrical calyx-tube. Peculiar species.

B. spatuláta, Torr. Suffrutescent, puberulent: branches terete, very leafy: leaves thickish, obovate, entire, obtuse, mucronate (9 lines long); upper ones passing into similar foliaceous bracts; uppermost lanceolate, about equalling the calyx. - Bot. Mex. Bound. 126. - S. W. Texas, cañon of the Rio Grande, near Mount Carmel, Parry.

B. linifólia, Gray. Fastigiately and alternately branched from a perennial or suffrutescent base, a foot or two high, glabrous and smooth: branches rigid, striate-angled and sulcate, very leafy: leaves linear-lanceolate, entire, acute at both ends, 1-nerved; uppermost passing into bracts of the loose spike: upper bracts subulate, much shorter than the slightly pedicellate striate calyx : throat of corolla funnelform. - Am. Jour. Sci. ser. 2, xvi. 98 ; Torr. l. c. - Dry bed or banks of the San Pedro and Rio Grande, S. W. Texas, Wright, Schott.

3. VERBÉNA, Tourn. Vervain. (Roman name of a sacred herb, of Celtic derivation.) - A large genus of herbs (or a few S. American species suffruticose), chiefly American, some mere weeds, some ornamental; fl. summer. Spontaneous hybrids abound, not here to be described; many are noted by Engelmann in Am. Jour. Sci. xlvi. (1843) 99.

$\S 1$. Flowers small or comparatively so, in narrow spikes: anthers unappendaged.

* Spikes filiform, with the flowers or at least the fruits scattered, naked, and the inconspicuous bracts shorter than the calyx.

$$
\text { + Leaves 1-2-pinnately cleft or incised, sessile or nearly so. }
$$

V. officriális, L. Annual, slender : stem glabrous or nearly so : leavęs minutely strigulose-pubescent, chiefly once or twice pinnatifid or 3-5-cleft; lower obovate, sometimes only incised, narrowed below into a tapering base; uppermost lanceolate: spikes very slender, solitary or panicled: bracts shorter than calyx : lobes of the small purplish corolla usually less than a line long. - Fl. Dan. t. 628 ; Lam. Ill. t. 17 . V. officinalis \& V. spuria, L. Spec. i. 18. - Road-sides and old fields, New Jersey to Texas, Arizona, and S. California. (Nat. from Eu., \&c.)

V. xútha, Lehm. Stouter and taller ( 2 or 3 feet high, from a perennial root?), hirsutepubescent: leaves more or less canescent, incisely pinnatifid or laciniate, or some of the lower 3-parted; lobes coarsely toothed: flowers more crowded in the strict spikes, larger: bracts equalling the calyx : lobes of the purple or blue corolla commonly a line and a half long. - Ind. Sem. Hamb. 1834, \& Linn. x. Literb. 115. V. strigosa, Hook, \& Arn. Comp. Bot. Mag. i. 176, not Cham. V. Luccana, Walp. Rep. iv. 23; Schauer in DC. Prodr. xi. 547. V. corrulea, Vatke in App. Ind. Sem. hort. Berol. 1876, 1. V. sororia, Don, Prodr. Fl. Nepal. 101, \& Brit. Fl. Gard. t. 202, is perhaps the same species. - Louisiana and Texas, southern borders of California. (Mex.)

++ Leaves merely serrate, or sometimes sparingly incised : root perennial.

V. urticæélólia, L. From minutely hirsute-pubescent to almost glabrous, 3 to 5 feet high: leaves thin, petioled, ovate to oblong-lanceolate, acuminate or acute, eveniy or doubly serrate: spikes slender-filiform, panicled, more or less sparsely flowered: bracts ovate, acuminate, shorter than the short calyx : corolla a line or two, and lobes only half a line Ing, white, sometimes bluish or purplish. - Waste or open grounds, Canada to Texas, \&c. (Trop. Am.)

V. polystáchya, HBK. Less tall, more scabrous, sometimes hirsute or hispid, paniculately branched : leaves from oblong to broadly lanceolate ( 1 or 2 inches long), sessile by a narrowed base or short-petioled, obtuse or acute, incisely serrate, occasionally somewhat lobed: spikes thicker and denser than in the preceding. - Gray, Bot. Calif. i. 608. V. polystachya, biserrata, \& veroniccefolia? HBK. Nov. Gen. \& Spec. ii. 274, \&c. V. Caroliniensis, Dill. Elth. ii. 407, t. 301, fig. 388: therefore V. Curolina, L. Spec. ed. 2, ii. 29, but not in Carolina. V. Caroliniana, Spreng. Syst. ii. 748; Hook. \& Arn. Bot. Beech. 156; Schauer in DC. 1. c. 546. California and Arizona : rare. (Mex.) 
V. Caroliniána, Michx. Cinereous-puberulent and scabrous-pubescent: stems mostly simple, ascending, from 6 inches to 2 feet high, including the commonly solitary long and virgate spike: leaves oblong and the lowest obovate, obtuse, sessile, finely and of ten doubly serrate : flowers in the upper part of the spike crowded : bracts subulate, equalling the calyx: corolla flesh-color; the lower lobe a line long, the others shorter. - Fl. ii. 13; Ell. Sk. ii. 99. Plryma Carolinensis, Walt. Car. 166. Verbena Caroliniana, Ray, and as to this at least V. Carolina, L., but seemingly not V. Carolinensis, Dill. Elth. V. carnea, Med, ex Schauer in DC. 1. c. 545. - Pine barrens, N. Carolina to Florida.

* * Spikes thicker or densely-flowered; the fruits crowded, mostly overlapping each other or imbricated : bracts inconspicuous, not exceeding the flowers: root peremnial.

- Pubescence short, sparse and hirsute or scabrous: spikes dense, strict, naked at base or more or less peduncled: stem erect.

V. angustifólia, Michx. l. c. Stem and spikes often simple, a foot or two high : lenves linear or Ianceolate, coarsely rugose-veiny, serrate, tapering into nearly sessile base: corolla purple or lilac (3 lines long). $-V$. rugosa, Willd. Enum. 633 . V. simplex, Lehm. Pugill. i. 37. - Dry or sandy ground, Massachusetts (Amherst) to Wisconsin and Florida.

V. hastáta, L. Tall, 3 to 6 feet high: leaves oblong-lanceolate, gradually acuminate, coarsely or incisely serrate, petioled, some of the lower commonly hastate-3-lobed at base: spikes numerous in a panicle : corolla blue. - V. paniculata, Lam.; Bot. Mag. t. 1102; name applied to the form which wants the 3-lobed leaves; the better but the later name for the species. - Canada and Saskatchewan to Florida, New Mexico, and (according to Torrey in Wilkes Exped. Bot.) California : chiefly waste grounds and road-sides. - Var. pinnatifida, Schauer (V. pinnatifida, Lam.), is a probable hybrid, of occasional occurrence.

+ + Pubescence softer and denser, commonly cinereons or canescent: spikes mostly sessile or leafy-bracted at base.

V. strícta, Vent. Erect, rather stout, a foot or two high: leaves cinereous with dense soft-hirsute-villous pubescence, thickish, rugose-veiny, ovate or oblong, nearly sessile, very sharply and densely mostly doubly serrate, rarely incised: spikes comparatively thick, dense both in flower and fruit, canescent: bracts subulate-setaceous, equalling the calyx: corolla blue (4 or 5 lines long): nutlets linear. - Hort. Cels, t. 53. V. rigens, Michx. Fl. ii. 14. V. cuneifolia, Raf. in Med. Rep. N. Y. xi. 260 ? - Barrens and prairies, Ohio to Dakota, Texas, and New Mexico, where a hybrid occurs between it and $V$. bracteosu. V. lanceolata, Beck in Am. Jour. Sci. xiv. 118, may be one of the hybrids between $V$. stricta and $V$. angustifolia which oecur at St. Louis.

V. prostráta, R. Br. Diffusely spreading, at length much branched, from soft-villous to hirsute: leaves obovate or oblong, with cuneate base tapering into a margined petiole, veiny, acutely incised and serrate, often 3-5-cleft: spikes solitary or somewhat clustered, elongated, hirsute or villous, dense when in flower: bracts subulate, shorter than the calyx: corolla violet or blue, 2 lines long: nutlets oblong. - Ait. Kew. ed. 2, iv. 41; Schauer, l. c.; Gray, Bot. Calif. i. 609. V. lasiostachys, Link; Hook. \& Arn. Bot. Beech. 156. - Plains and open grounds, throughout W. California. Very variable.

* * Spikes (either thickish or slender) sessile and bracteose, i. e. the rigid and somewhat foliaceous bracts, or some of them, surpassing the flowers: root annual or becoming lignescent-perennial.

V. bracteósa, Michx. Much branched from the base, diffuse or decumbent, hirsute: leaves cuneate-oblong or cuneate-obovate, narrowed mostly into a short margined petiole, pinnately incised or 3-cleft, and coarsely dentate: spikes terminating the branches, thick: lowest bracts often pinnatifid or ineised; the others lanceolate, acuminate, entire, rigid, sparsely hispid, all exceeding the flowers: corolla purplish or blue, very small : nutlets with a broad and strongly convex or 2-facetted granulate-scabrous commissure. - Fl. ii. 13; Hook. Bot. Mag. t. 2910. V. squarrosa, Roth, Catal. Bot. iii. 3. V.canescens? Chapm. Fl. 307, not HBK. - Prairies and open waste grounds, Wisconsin to W. Florida, and west to Oregon, California, and Arizona.

Var. brevibracteáta, a peculiar form, with dense spikes, most of the bracts little longer than the flowers, and the uppermost barely equalling them, in fruit all ascending or appressed. - W. Texas to Arizona. (Adjacent Mex.)

V. canéscens, HBK. Much branched from the base, ascending or erect, canescentlirsute: leaves oblong-lanceolate and cuneate-obovate, contracted into a margined base, rigid, sharply toothed, incised, or some of them pinnatifid: spikes solitary, filiform, mostly loosely-flowered : bracts subulate, the lower almost foliiform and more or less ex- 
ceeding the flowers, the uppermost ovate-lanceolate and only equalling them: corolla bluish (about 2 lines long): nutlets with a narrower almost suooth comnissure. - IIBIK. Nov. Gen. \& Spec. ii. 274 , t. 130. V. gracilis, Desf. Cat. ed. 3, 393. V. remota, Benth. Hartw. 21. $V$. Romericuna, Scheele in Linn. xxi. 755 ? - Dry open grounds, W. T'exas to S. California. (Mex.)

Var. Neo-Mexicána. Stems rather strict and slender : leaves bipinnately cleft or almost parted: bracts not longer than the caly $\mathrm{x} .-\boldsymbol{V}$, officinulis, var. hirsula, Torr. Bot. Mex. Bound. 28. - Borders of thickets near the Coppermines, New Mexico, Wright, Birgelow. $\Lambda$ ppears as if a hybrid between $V$. canescens and $V$. officinalis. S. Arizona, similarin foliage but with long bracts, Rothock.

§. Flowers more showy, at first depressed-capitate, becoming spicate in fruit: anthers of the longer stamens appendaged by a gland on the connective: tube of corolla at the upper part lined with reflexed bristly hairs, especially the anterior side: anther-cells slightly oblique or unequal. - Glandularia, Gmelin, Nutt. Billardiera, Monch. Shuttleworthia, Meissner. Uwarowia, Bunge.

* Gland of the anthers small and short, sometimes inconspicuous, on the mildle of the back: mainly fibrous-rooted perennials; but seedlings flowering as annuals: nutlets reticulate-ruggulose, mostly scabrous on the commissure. Species difficult to distinguish, apparently passing into each other.

V. ciliáta, Benth. Low or depressed, hirsute-pubescent or hispid, 3 to 10 inches ligh, diffusely spreading from an apparently annual root; the branches not ereeping nor rooting at base: leaves once or twice 3-cleft or parted and variously incisely lobed, 6 to 12 lines long, with cuneate base contracted into a margined petiole; lobes from linear to oblong: spikes short-peduncled or sessile, dense, at most oblong : fructiferous calyx oblong: $2 \frac{1}{2}$ or 3 lines long, with short subulate tecth: limb of the purple or bluish corolla 2 to 4 lines broad: gland of the anthers usually rery small. - Pl. Hartw. 21; Schauer in DC. Prodr. xi. 55?; Gray, Bot. Calif. i. 608. - Dry plains, W. Texas to Arizona and the southern border of California. (Mex.)

V. bipinnatífida, Nutt. A span to a foot higl, hispid-hirsute, perennial, rooting fron subterranean branches: leaves ( $1 \frac{1}{2}$ to 4 inches long), bipinnately parted, or 3 -parted into more or less bipinnatifid divisions; the lobes commonly linear or rather broader: spikes in age elongated. bracts setaceous-attenuate, mostly surpassing the calyx : teeth of the latter slender, subulate-setaceous from a broader base, unequal: limb of the bluish-purple or lilac corolla 4 or 5 lines broad; lobes obcordate: nutlets at maturity usually retrorsely muriculate-scabrous or hispidulous on the commissure. - Jour. Acad. Philad. ii. 123; Torr. in Ann. Lyc. N. Y. ii. 2:3:); Schauer in DC. 1. c. 553 . Glandularia bipinnatifida, Nutt. in Trans. Am. Phil. Soc. n. ser. v. 184. - Plains and prairies, Arkansas and Texas to the base of the Rocky Mountains in Colorado, \&c. Cult. as "V. montana."

V. Aublétia, L. $\Lambda$ foot or less high, branching and ascending from a creeping or rooting base, perenuial (as rightly said by Jacquin), slender, soft-pubescent, hirsute, or glabrate: leaves (1 or 2 inches long) ovate or ovate-oblong in outline, with truncate or broadly cuneate base tapering into a margined petiole, incisely lobed and toothed, often more deeply 3-cleft: spikes pedunculate, elongated in fruit: bracts subulate or linear-attenuate, shorter than or equalling the similar slender and unequal teeth of the narrow calyx: limb of the reddish-purple or lilac (rarely white) corolla half or two-thirds inch broad: commissure of the nutlets minutely white-dotted or nearly smooth. - Jacq. Vind. ii. 82, t. 176; L.f. Suppl. 86; Bot. Mag. t. 308; Michx. Fl. ii. 13; Bot. Reg. t. 294, t. 1925 (var. Drummondi); Schaucr in DC. 1. c. 554 . V. Obletia, Retz. V. lonyiflor, Lam. Buchnera Canadensis, L. Mant. 88. Glandularia Carolinensis, Gmel. Billardiera explanata, Mœnch. V. Lamberti, Sims, Bot. Mag. t. 2200; Schauer, 1. c.; form with narrower and more incised leaves. V. Lamberti, var. rosed, Don, Brit. Fl. Gard. ser. 2, t. 363, with large and light-colored corolla (three-fourths inch wide, fragrant). - Open woods and prairies, Florida to Illinois, Arkansas, and New Mexico. (Mex.) Cult., variously mixed.

* * Gland of the anthers oval, as high and almost as large as one of the cells : stem erect from an annual root.

V. Wríghtii. Hispidulous-pubescent: stem simple below, 2 feet high: leaves pinnately 3-7-parted or deeply cleft, contracted at base into a margined petiole; lobes mostly lan- 
ceolate, acute: fructiferous pedunculate spikes dense, oblong : fructiferous calyx with teeth very much shorter than the oblong tube: corolla light purple: nutlets, \&c., of $V$. Aubletia. - Near Frontera, on the borders of Texas, and adjacent New Mexico, and Chihuahua, Wright (no. 1504).

V. venósA, Gillies \& Hook., of S. America, one of the species cultivated for ornament, has escaped into prairies in the vicinity of Houston, Texas.

6. LfPPIA, L. (Dr. A. Lippi, killed in Abyssinia early in the 18th century.) - Herbs or shrubs (American, mainly southern, a few African, \&c., and one or two widely dispersed species); with spikes or heads of small flower's, in summer. Leaves often verticillate.

§1. Alóysia, Schauer, Benth. \& Hook. Flowers in slender and naked spikes, with small and narrow bracts:-calyx about equally 4-cleft, herbaceous, often densely hirsute, the tube not compressed: nutlets thin-walled: shrubs, with foliage commonly sweet-aromatic. - Aloysia, Ortega. '(L. citriodora, of Uruguay, with smooth calyx, \&c., is the Lemon Verbena shrub, of cultivation.)

L. 1ycioídes, Steud. Shrub 4 to 10 feet high, with long and slender branches, sometimes spinescent, minutely puberulent: leaves ( 3 to 12 lines long) lanceolate-oblong, obtuse, 1-nerved, scabrous above, pale beneath, veinless, small and entire on flowering branches, larger and incised or few-toothed on strong sterile sloots: spikes axillary, racemosepanicled, filiform : flowers white or tinged violet (fragrance of vanilla). - Schauer in Fl. Bras. ix. t. 36 \& DC. Prodr. xi. 574. Verbena ligustrina, Lag. Nov. Gen. \& Spec. 18. - Texas to Arizona and "California," Coulter. (Mex., Uruguay, \&c.)

L. Wríghtii, Gray. Shrub 2 to 4 feet high, witl many spreading slender branches, minutely canescent-tomentose: leaves ( 4 to 8 lines long) orbicular-ovate, crenate, rugose, abruptly short-petioled: spikes short-peduncled, densely flowered; calyx-teeth triangular: corolla white, glabrous within: "odor of Sage," - Am. Jour. Sci. ser. 2, xvi. 98 ; Torr. in Bot. Mex. Bound. 126:- S. W. Texas to Arizona, Thurber, Wright, Palmer, \&c. (Adjacent Mex., where var. macrostachya, Torr. I. c., approaches $L$. scorodonioides, HBK., of S. Am.)

§.2. Zaránia, Schauer, Benth. \& IIook. Flowers capitate or in short and dense spikes, subtended and imbricated by broad bracts.

* Bracts decussately 4-ranked, complicate-carinate, persistent: fluwers very small.

L. gravéolens, HBK. Shrubby, 2 to 4 feet high, cinereous with close pubescence : leaves ovate-oblong or oval, crenate reticulate-rugose, hirsute-pubescent above, canescent beneath, petioled: umbellate peduncles 3 to 6 in each axil, shorter than the leaves: bracts thin, ovate, acute, silky, shorter than the yellowish-white salverform corolla. - Nov. Gen. \& Spec. ii. 266; Schauer, l. c. L. Berlandieri, Torr. 1. c., not Schauer. - Texas, along and near the Rio Grande. (Mex., \&c.)

* * Bracts several-ranked. concave or flattish : calyx thin, more or less compressed fore and aft and the sides carinatc. $-\$ Z$ Zaponia, Schauer.

+ More or less shrubby, erect: heads on short axillary peduncles.

L. gemináta, HBK. l. c. Pubescent leaves ovate or oblong, closely serrate, triplinerved, pinnately veined, and with rugose-reticulated veinlets, minutely strigose above, canescently tomentose-pubescent beneath, petioled: peduncles mostly solitary in the axils, hardly longer than the petiole: head globular, at length cylindraceous : bracts broadly ovate, abruptly cuspidate-acuminate, villous-canescent, a little shorter than the purple or violet corolla. (Foliage with odor of citron.) - Verbena lantanoldes, L. - S. Texas on the Rio Grande. (Mex. to Uruguay.)

* * Herbacenus, procumbent or creeping: nubescence of fine and close hair's fixed by their middle and botll ends acute: peduncles chiefly axillary and slender: bracts closely imbricated : calyx strongly flattened fore and aft, with carinate margins, and cleft into 2 lateral more or less conduplicate lobes : limb of corolla manifestly bilabiate; the smaller upper one retuse or emarginate: pericarp crustaceous or corky, not readily separating into the two nutlets.

L. cuneifólia, Steud. Diffusely branched from a lignescent perennial base, procumbent (not creeping), minutely canescent throughout : leaves rigid, cuneate-linear, sessile, incisely 
2-6-toothed above the niddle, nearly veinless, the midrib prominent: peduncles mostly shorter than the leaves: heads at length cylindraceous, almost half inch thick: bracts rigid, broally cuneate, abruptly acuminate from the truncate or retuse dilated summit: calyx deeply 2-cleft ; the lobes oblong and emarginate, shorter than the tube of the (white?) corolla : fruit oblong-oval. - Torr. in Marcy, Rep. 293, t. 17. Zapania cuneifolia, Torr, in Ann. Lyc. N. Y. ii. 2:3t. - Plains, Nebraska to New Mexico and Arizona.

L. nodiflóra, Michx. Creeping extensively, some brancles ascending, "annual" or probably perennial, cinereous or greenish: leaves cuneate-spatulate or oblanceolate, sessile or nearly so, obscurely veiny or almost veinless, the long tapering base entire, sharply serrate from above the midule to the apex: peduncles filiform ( 1 to 4 inches long), much exceeding the leaves: heads cylindraceous in age, quarter inch thick : bracts mucronate or pointless: Iolves of the calyx linear-lanceolate: corolla rose-purple or nearly white, short: fruit globose or didymous. - Fi. ii. 15. Zapania nodiflora, Lam. Ill. t. 17. Verbena nodifora, L. ; Sibth. Fl. Græe. t. 553. - Low grounds, Georgia to Texas and southward: also California. (Cosmopolite in torrid zone.)

L. lanceoláta, Michx. 1. c. Like the preceling, and perlıps passes into it, but greener, minutely and sparsely strigulose: leaves thinner, mostly broader (name therefore inapt), varying from obovate and lanceolate-spatulate to ovate, narrowed at base mostly into a petiole, above sharply serrate, pinnately straiglit-veined; veins ending in the sinuses: corolla bluish-white. - Gray, Man. ed. 5, 341. L. reptans, HBK. 1. c.? Zapania lanceolala, Beck in Am. Jour. Sci. xiv. 284. - River banks, E. Penn. to Illinois and Missouri, south to Florida and Texas. (Mex.)

7. LANTÁNA, L. (An old name of a Viburnum, transferred by Linnæus, in view of some resemblance to this genus, which should have retained Plumier's name of ('amara). - Shrubs or undershrubby plants of warm regions; with mostly rugose and somewhat glandular-odorous pinnately veined petioled leaves (not rarely in threes), and axillary pedunculate heads of rather showy small flowers; in summer. Several species common in gardens, two or three indigenous to our southern borders.

\$1. Drupe thin-fleshed or somewhat dry, at least with nutlets contiguous and usually cohering more or less into a 2-celled putamen: stems never prickly. (Transition to Lippia.)

L. involucráta, L. Canescent, much branched: leaves obovate-oval or ovate, rounded at the apex, crenate, rugulose and veiny, scabrous above, soft-tomentose beneath, cuneate at base, rather slender-petioled : peduncles equalling or exceeding the leaf : head hemispherical or at length globose, not elongating: bracts silky, ovate, or the outermost sometimes oblong, these as long as the (white or lilac) flowers, and forming an involucre. S. Florida (L. incolucrate, var, Floridume, Clapm.; a form with long peduncles and white flowers). S. borders of Texas (L. odorata, var. Berlandieri, Torr. Mex. Bound. and L. parvifoliu, Raf. ${ }^{7}$ ): an form with less olstuse leaves and white flowers. L. odoratu, L. Syst., seems not distinct. (Trop. Am.)

L. canéscens, HBK. Cinereous-canescent throughout with fine and soft strigose pubescence: branches slender: leaves oblong-lanceolate or ovate-lanceolate and gradually acuminate, with cuneate base, somewhat appresserl-serrate, lineate-veined and minutely rugose, about the length of the slender peduncles: hearls ovoid, small, in age short-oblong: bracts ovate and ovate-lanceolate, acuminate; lax; the exterior larger, spreading and involucrate: corolla small, white. - Nov. Gen. \& Spec. ii. 25\%. Lippia pallescens, Benth. Hartw. 245. As yet collected only on the Coabuila (Mfexican) side of the Rio Grande, Berlandier, Bigelow. (Trop. Am.)

L. macrópoda, Torr. Cinereous with minute strigulose pubescence: stems slender, 1 to 3 feet higl, herbaceous almost or quite to the base: leaves ovate or ollong-ovate, acute, coarsely and sharply serrate, obtuse or somewhat cuneate at base, petioled, usually scabrous above and slightly canescent beneath, not at all rugose-reticulated, the primary veins conspicuous and running strajght to the sinuses : peduncles twice or thrice the length 
of the leaf ( 2 to 5 inclies long): heads globular, at length oblong : bracts ovate, cuspidateacuminate, nearly equalling the white or purple corolla; the outermost gradually larger but hardly forming an involucre. - Bot. Mex. Bound. 127.- S. W. borders of Texas (Wright, \&c.), and adjacent parts of Mexico, Gregg, Palmer.

§2. Drupe juicy; the 2 nutlets separated, at least at base. Stems sometimes prickly or hispid, but this very variable.

L. Cámara, L. Scabrous and more or less hirsute, 1 to 4 feet high : prickles on the stem short and hooked: leaves ovate or ovate-oblong, of ten subcordate, crenate-serrate, very scalorous above, scabrous-hirsute or softer-pubescent beneath (about 2 inches long): peduncles rigid, about the length of the leaf: head flat-topped in anthesis; the rhachis not elongating: Jracts lanceolate, strigose-hirsute, about half the length of the yellow at length orange or even flame-colored corolla. - Plum. Ic. t. 71; Dill. Elth. t. 56. L. horrida, var. parvifora, Schauer in DC. 1. c.; Torr. I.c.-S. Georgia and Florida, S. Texas and southward. (Trop. Am.)

8. CITHAREXYLUM, L. (Name composed of xifúgx, guitar or lyre, and $\xi u j$ in, wood, a translation into Greek of the colonial-English Fiddle-wood; but this name, unfortunately for the etymology, is an English corruption of the earlier French-colonial name, bois fidèle, meaning a wood trustworthy for strength.) - Tropical American shrubs or trees ; with somewhat coriaceous leaves, and small flowers on a filiform rhachis, each subtended by a minute bract.

C. villósum, Jacq. Soft-puTescent or glabrate: leaves oblong-obovate or oblong, entire or occasionally few-toothed above the middle, veiny and with fincly reticulated veinlets, shining and barely scabrous above, pale and sometimes soft-canescent beneath, biglandular at the narrowed base, tapering into the petiole : racemes declining, loose, but spike-like: flowers very short-pedicelled: corolla white, glabrous externally. - Coll. i. 72, \& Ic. Rar. t. 118; Chapm. Fl. 309. - Key West, S. Florida ; perhaps S. Texas, (W. Ind., Mex.)

9. DURÁNTA, L. (Castor Durantes, wrote upon W. Indian plants in the 16 th century.) -W. Indian and S. American shrubs, often armed with axillary spines; one has reached our borders.

D. Plumiéri, Jacq. Minutely pubescent or glabrate: branches 4-angled : leaves obovate, oblong, or ovate, mostly entire, contracted at base into a short petiole : racemes panicled, loose: lower bracts often leafy: calyx-teeth subulate from a broad base: corolla lilac: drupe yellow; the enclosing persistent calyx also yellowish, closed into a straight or contorted beak. - Jacq. Stirp. t. 176, fig. 76, \& Ic. Rar. t. 502; Bot. Reg. t. 244; Chapm. 1. c. D. spinosa \& D. inermis, L. ; the branches sometimes spiny, sometimes unarmed. D. Ellisia, Jacq. Amer. t. 176, f. 77, \& Hort. Schœenb. iii. t. 99; Bot. Mag. t. 1759. Ellisia acuta, L. Key West, S. Florida, Blodgett. (Trop. Am.)

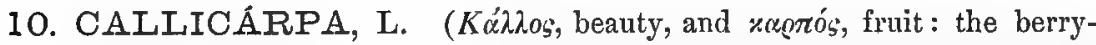
like drupes ornamental.) - A rather large E. Asiatic and American genus, chiefly of the warmer regions, one in the Atlantic States; fl. late summer. Pubescence stellular-branched or scurfy.

C. Americána, L. (French Mulberri.) Slrub low, witlı scurfy-stellate down and glandular-dotted : leaves ovate-oblong, acuminate, obtusely serrate, greenish above, whitish or rusty beneath, acute or cuneate at base : cymes shorter than the petiole, many-flowered: corolla bluish, lardly 2 lines long: fruit violet-colored. —Catesb. Car. t. 47; Lam. Ill. t. 69. Spondylococcus, Mitchell, Nov. Gen. Burchardice Americana, 1)uham. Arb. ed. 1, i. t. 44.Rich or moist grounds, Virginia to Texas. (W. Ind.)

11. AVICENNIA, L. White Mangrove. (Dedicated to Avicenna, the Latinized name of Jbusina, most illustrious of Arabian physicians; died in 
1037.) - Maritime evergreen trees, of tropical regions, spreading from creeping shoots; their opposite entire and mostly canescent coriaceous leaves connected at base by an interpetiolar line, giving the branchlets the appearance of being articulated : peduncles axillary and terminal, commonly cymosely trichotomous : flowers small, white or whitish, in late summer.

A. nítida, Jacq. Leares oblong or lanceolate-elliptical, glabrate and at length sometimes shining above: pecluncles ternate or tricliotomous: lobes of corolla minutely sericeous or tomentulose both sides: style as Iong as stamens. - Jacq. Amer. t. 112, fig. 1; Schauer in J)C. Prodr. xi. 699 ; Griseb. Fl. W. Ind. 502. A. tomentosa, Meyer, Essequib.; Nutt. Sylv. iii. 79, t. 10.), exscrted style shown. A. oblongifolia, "Nutt.?" Chapm. Fl. 310 : name not mentioned by Nuttall in Sylv. 1. c. - Keys and coasts of S. Florida, and mouth of the Mississippi. (W. Ind. to Brazil.)

A. Tosextósi, Jacq. l. c. fig. 2, with hardly any style, and corolla-lobes glabrous above, is in the Prodromus and in Chapman's Flora attributed to "Florida, Nuttall." But Nuttall's species figured under this name in the Sylva is clearly the A. nitida, and that is probably our only species.

\section{ORDER CIV. LABIAT}

Herbs or low shrubs, with aromatic herbage (usually dotted with small inmersed glands replete with volatile oil), with square stems, opposite simple leaves and no stipules; the perfect flowers with irregular more or less bilabiate corolla, didynamous or diandrous; filiform style mostly 2-cleft and 2-stigmatose at apex, aurl around its base the divisions of a 4-parted (sometimes only 4-lobed) ovary, which are uniovulate and ripen ințo akene-like nutlets, in the bottom of a gamosepalous calyx. Ovule and seed mostly amphitropous or anatropous, and erect. Embryo straight except in the Scutellarinea, with plane or plano-convex cotyledons and inferior radicle: albumen usually none or hardly any. Lobes of the corolla imbricated in the bud, the posterior or the upper lip exterior and the middle lobe of the lower lip innermost. Stamens borne on the tube of the corolla. distinct or rarely monadelphous; the fifth (posterior) stamen, and in diandrous flowers the adjacent pair also, not rarely represented by sterile filaments or rudiments: rarely the 4 fertile stamens equal. Hypogynous disk generally present, sometimes as (one to four) gland-like lobes. Pistil as in all the related orders dimerous, each carpel deeply 2-parted or 2-lobed. Inflorescence thyrsoidal; the general evolution of the clusters in the axils of leaves or primary bracts (these occasionally reduced to single flowers) centripetal; that of the clusters (cymes or glomerules) centrifugal. The pair of sessile clusters, one to each axil, having the appearance of a whorl (verticil) form what has been termed a verticillaster. Bracts or bractlets various. Leaves occasionally verticillate. Seed transverse and the radicle incurved in Scutellarinea. (The Ajugoidece connect with the tribe Viticese of the preceding order, and therefore are placed foremost. A larger proportion of our Labiate are Old World naturalized plants than of any other order.) - Benth. Lab. \& in DC. Prodr. xii. 26 ; Benth. \& Hook. Gen. ii. 1160 .

I. Nutlets rugose-reticulated, with introrsely very oblique or even ventral and comparatively large areola (scar of the attachment) : ovary merely 4-lobed or not deeply 4-parted. (Seeds in the tribe here represented, as in most of the order, exalbuminous.) 
Tribe I. AJUGOIDE 2 . Stamens ascending, mostly exserted from the upper side of the corolla, 4 in all our genera. Nutlets obovoid, dry. Ovule and seed more or less amphitropous: calyx 5-10-nerved.

* Limb of the corolla merely or hardly oblique, of 5 somewhat equal and similar lobes, therefore obscurely if at all bilabiate.

1. TETRACLEA. Calyx deeply 5-cleft, regular; the lanceolate lobes twice the length of the short turbinate tube. Corolla nearly salverform in anthesis, with narrow tube sur. passing the calyx; limb globular and erect (not oblique) in the bud; Iobes oval or oblongobovate, similar and equally spreading, the three lower obscurely more united at base. Filaments filiform, involute in bud, exserted : anthers cordate-oblong; cells permanently parallel and distinct. Ovary barely 4-lobed. Ovule and seed descending-amphitropous, i. e. attached above its niddle, rostellate at the micropyle. Areola of the nutlet very large and ventral.

2. TRICHOSTEMA. Calyx barely 5-cleft, either oblique or almost regular. Corolla with narrow tube and more or less oblique limb; the somewhat similar lobes oblong, more or less declined. Filanients spirally coiled in the oblique unopened limb, curved in anthesis, capillary, very long-exserted, didynamous, sometimes monadelphous at base: anther-cells divaricate or divergent, at length often confluent. Ovary deeply 4-lobed. Amphitropous ovule and seed ascending, being attached below the middle.

3. ISANTHUS. Calyx nearly equally 5-cleft, campanulate; lobes lanceolate. Corolla short; tube included in the cal $y \mathrm{x}$; throat somewhat campanulate; limb almost regularly 5 -parted; lobes obovate, not declined. Stamens slightly incurved-ascending, not longer than the corolla, didynamous: anther-cells at length divergent. Ovary deeply 5-lobed. Ovule and seed nearly anatropous and erect. Areola of nutlet introrsely basal.

* * Limb of corolla irregular, seemingly unilabiate; the upper lip being either split down or very short: stamens exserted from the cleft.

4. TEUCRIUM. Corolla deeply cleft between the two small lobes of the upper lip, which are united one on each side with the lateral lobes of the declined lower lip; middle lobe much larger. Anthers confluently one-celled. Nutlets with a broad introrse areola.

5. AJUGA. Corolla with very short and as if truncate upper lip ; the large and spreading lower lip with middle lobe emarginate or 2-cleft. Anther-cells less confluent.

II. Nutlets smooth or granulate; areola basal, small : ovary deeply 4-parted.

Tribe II. OCIMOIDEAE. Stamens declined toward or resting on the lower lip of the corolla, didynamous, all fertile. Corolla declined; lower lip apparently formed of the anterior lobe only, which is unlike the other somewhat equal four lobes.

6. OCIMUM. Calyx deflexed after flowering; its posterior tooth broad, orbicular or obovate, and with decurrent of ten wing-like margins; the 4 others narrower. Corolla with short tube, and flat or concave declined lower lobe. Disk enlarging into glands.

7. HYPTIS. Calyx mostly equally 5-toothed. Corolla with the lower lobe saccate, abruptly deflexed at the contracted and callous base. Disk entire or with a gland on the anterior side. Nutlets ovoid or oblong.

Tribe III. SATUREINEÆ. Stamens not declined; the posterior pair shorter or wanting: anthers (in ours) 2-celled; the cells distinct or more or less confluent, short. Corolla less strongly bilabiate and the lobes flatter than in succeeding tribes; upper lip not galeate or concave, except in Acanthomintha.

* Corolla with lower Iobe larger and pendent, fimbriate or lacerate-toothed, very unlike the 4 shorter and nearly equal lobes, which in appearance form the upper lip: stamens straight and long, livergent: anther-cells divaricate and contiguous, or at length somewhat confluent: flowers in terminal racemes.

8. COLLINSONIA. Calyx short, small in flower, enlarging and declined in fruit, about 10-nerved, mostly somewhat hirsute in the throat, bilabiate; the broader and at length flattish upper lip 3-tootherl; the lower 2-parted. Corolla elongated, somewhat funnelform, with a bearded ring inside at the insertion of the stamens. Stamens 2 or 4 , much exserted, spirally coiled in the bud.

* Corolla about equally 4-lobed, small and short, hardly irregular, but the upper lobe often broader than the others and emarginate: stamens erect, straight and distant: anther-cells parallel, destitute of any thickish connective: flowers capitate-glomerate, and the clusters sometimes confluent-spiked.

9. MENTHA. Stamens 4, similar and nearly equal. Calyx campanulate or short-tubular, and 5-toothed. Upper lobe of corolla sometimes emarginate. 
10. LYCOPUS. Stamens only 2 with anthers; the upper pair sterile rudiments or else wanting. Calyx campanulate, 4-5-toothed, naked in the thront. Upper lobe of corolla entire. Nutlets 3-sided, truncate at top, narrow at base, thickened-margined.

* * Corolla more or less evidently bilabiate; the upper lip erect, entire or emarginate, or in Monardella 2-cleft; the lower spreading and 3-cleft, destitute of bearded ring within, except in Poliomintha. Calyx striate-nerved or costate, not much changed after flowering.

+ Stamens distant and straight, often divergent, never convergent nor curved.

-Antheriferous stamens only 2; with or without abortive rudiments of the upper pair.

11. CUNILA. Caly $x$ ovate-tubular, equally 5-toothed, very villous in the throat, 10-13. nerved. Upper lip of corolla emarginate; the lower somewhat equally 3-cleft. Stamens long-exserted. Nutlets smooth.

+ + Antheriferous stamens 4, didynamous: calyx 15-nerved.

12. HYSSOPUS. Calyx tubular, equally 5-toothed, naked in the throat. Tube of corolla short : upper lip emarginate; the lower 3-cleft, its middle lobe larger and 2-cleft. Stamens exserted, divergent: anther-cells linear, divaricate.

$\div+-$ Antheriferous stamens 4, didynamous: calyx 10-13-(in 1/onardella 15-)nerved,

$=$ Naked in the throat: flowers capitate-verticillastrate, or sometimes sparser.

13. PYCNANTHEMUM. Calyx ovate-oblong or tubular; the 5 teeth equal, or the 8 upper more or less united. Corolla short, with entire or barely emarginate upper lip, and 3-cleft lower one; the lobes all short, ovate, obtuse. Stamens little unequal : anther-cells parailel.

14. MONARDELLA. Calyx tubular, narrow; the 5 teeth equal or nearly so. Corolla glabrous within; the 2-cleft upper lip and lobes of the 3-parted lower one all linear or narrowly oblong, plane. Stamens strongly or moderately unequal, exserted: anthercells often divergent or divaricate. Flowers densely capitate-verticillastrate in the manner of Monarda.

$==$ Calyx villous or hirsute-bearded in the throat: corolla short.

15. ORIGANUM. Calyx ovate-campanulate, in our (introduced) species equally 5-toothed. Stamens exserted. Flowers spicate- or capitate-verticillastrate, imbricated with broad colored bracts.

16. THYMUS. Calyx ovate, declined in fruit, villous in the throat, distinctly bilabiate; upper lip 3-toothed, spreading; lower 2-cleft, its divisions subulate and ciliate. Flowers scattered or crowded, the bracts inconspicuous.

$\div$ - Stamens ascending (at least the lower part) or arcuate, often more or less converging and sometimes ascending parallel under the erect upper lip of the corolla : connective of the anther commonly more or less thickened, sometimes separating the oblique or divaricate cells.

+ Calyx only about 10-nerved, naked in the throat, not declined nor gibbous: fertile stamens 4 .

17. SATUREIA. Calyx campanulate or short. Tube of the corolla short, or not exceeding the bracts.

+++ Calyx 12-15-nerved : upper lip of the corolla plane or slightly concave and straight, as in the tribe generally.

$$
\text { = Style beardless: anthers muticous. }
$$

a. Stamens 4, all antheriferous.

18. MICROMERIA. Caly $x$ oblong or tubular, terete, not gibbous nor declined, about equally 5-toothed. Corolla short, its straight tube usually shorter or hardly longer than the calyx. Stamens arcuate, shorter than the corolla.

19. CALAMINTHA. Calyx oblong or tubular, often gibibous, bilabiate; the upper lip 3-toothed or 3-cleft, the lower 2-parted. Corolla with a straight tube mostly exceeding the calyx, and a commonly enlarging throat. Stamens ascending parallel under or beyond the upper lip, or conniving in pairs.

20. MELISSA. Calyx oblong-campanulate, bilabiate as in the preceding, but the broad upper lip becoming flatter. Corolla rather short; its tube at base declined, then ascending, included in the caly $x$. Otherwise like Calanintha. Leaves ovate, serrate, veiny.

21. CONRADINA. Calyx, \&c., of Calamintha. Corolla with a narrow and straight tube rather shorter than the calyx, abruptly bent backwards at the throat, deeply bilabiate, ringent; the upper lip somewhat concave and incurved, emarginate or retuse; the lower dependent, contracted at the base, deeply 3-lobed; the lateral lobes roundish, the dilated 
middle one emarginate-2-lobed. Stamens arcuate-ascending under the upper lip, parallel : cells of the anther at length separated on a transversely dilated connective, their base bearing a small tuft of delicate villous hairs. Leaves linear, with entire revolute margins, one-ribbed.

b. Stamens 2 antheriferous, ascending parallel under the upper lip; the posterior pair either wanting or rudimentary, or with imperfect (rarely perfect and polliniferous) anthers: calyx tubular or tubular-campanulate, more or less villous-bearded in the throat.

22. POLIOMINTHA. Calyx cylindraceous or cylindrical, terete and regular, 13-15striate, bearded in the throat, equally 5 -toothed or nearly so. Corolla mostly with a hairy ring within the throat or tube; upper lip erect, emarginate; lower 3-cleft and spreading, the broader middle lobe emarginate. Posterior filaments mere subulate rudiments. Fruticulose and canescent.

23. HEDEOMA. Caly $x$ from tubular to oblong, usually gibbous, more or less bilabiate or unequally 5-toothed (the two lower teeth different and longer), mostly 13-striate, hairy or villous-bearded in the throat, which is commonly contracted in fruit. Tube of corolla naked: upper lip erect, entire or 2-lobed; lower 3-cleft, spreading. Posterior stamens either none, or sterile, or in the original species sometimes antheriferous! Low herbs.

$==$ Style bearded or villous, sometimes sparingly so: antheriferous stamens 4 or sometimes 2.

24. POGOGYNE. Calyx very deeply and unequally 5-cleft, at least the two longer (lower) lobes much longer than the campanulate or turbinate 15-nerved tube; throat naked. Corolla straight, tubular-funnelform; with short lips; the erect entire upper lip and the spreading lobes of the lower one oval and somewhat similar. Stamens ascending, and above somewhat approximate in pairs : anther-cells parallel and muticous : posterior filaments much shorter and sometimes sterile. Style more or less hirsute-bearded above. Flowers verticillastrate-glomerate and spicate: bracts and calyx strongly ciliate.

25. CERANTHERA. Calyx tubulose-campanulate, 13-nerved, noarly terete, villous in the throat, bilabiate; lips short; the upper recurved-spreading and entire or slightly 3-toothed; the lower scarcely longer and 2-cleft. Corolla with a straight narrow tube barely exceeding the calyx, an abruptly much-dilated short throat, and rather short and spreading lips; the upper one nearly entire, the lower 3-cleft. Fertile stamens 4 : filaments capillary, somewhat ascending, exserted, and above diverging : cells of the anther divaricate on a broad connective, aristate or pointed! Style long-exserted, pubescent. Leaves linear, entire.

+++ Calyx 13-nerved : upper lip of corolla concave, erect, straight, or a little incurved or fornicate, after the manner of the succeding tribes: bracteal leaves aristate-spinulose.

26. ACANTHOMINTHA. Calyx tubular-campanulate, 13-nerred, naked in the throat, strongly bilabiate; upper lip 3-toothed; lower 2-cleft, shorter; teeth all acerose-spinulose from a broader base; Corolla with tube exceeding the calyx, naked within; upper lip narrow, oblong; lower broad and spreading, 3-lobed; lobes short and rounded, middle one deeply and the lateral slightly emarginate, or all entire Stamens 4, inserted high in the ampliate throat: anterior pair fertile, ascending under the upper lip, bearing 2-celled anthers, the cells divaricate: posterior pair much shorter, with filiform filaments, and either abortive or smaller anthers. Style 2-lobed at apex; lobes or stigmas subulate, the posterior shorter. Nutlets smooth.

* * * Corolla obscurely bilabiate: a hairy ring at base of the tube within : calyx irregularly about 10-nerved, reticulate-veiny, enlarging and commonly inflated after flowering.

27. SPHACELE. Calyx campanulate, deeply and nearly equally 5-toothed, membranaceous at least in fruit, naked within. Corolla with a broad tube, and 5 broad or roundish and plane rather erect lobes, the lower one longest. Stamens 4 , distant, somewhat ascending: filaments naked: anthers somewhat approximate, the cells diverging. Leaves veiny.

TRIBE IV. MONARDE mentary or wanting), straight or commonly parallel-ascending; the anther with narrow usually oblong-linear cells, which are either widely separated on the upper and lower ends of a linear or filiform commonly filament-like connective (which is usually longer than the filament itself and articulated with it), or the lower cell wanting or difformed, or the two cells confluent into one linear cell. Corolla bilabiate.

* Anther dimidiate on the elongated filament-like connective, which is articulated with the filament, a fertile anther-cell at the ascending end, and sometimes one at the lower. Calyx bilabiate; its lower lip 2-cleft. 
23. SALVIA. Corolla with upper lip erect (entire, emarginate, or rarely 2-lobed above), straight or falcate, usually concave; the lower spreading, its middle lobe often emarginate. Stamens inserted in the throat of the corolla: connective commonly linear or filiform, transverse on the short (sometimes very short) and mostly horizontal filament, its descending or porrect portion continued beyond the articulation and either more or less dilated and naked, or bearing an abortive rudiment of the second anther-cell, or sometimes one which is polliniferous but unlike the upper one. Nutlets commonly developing mucilage and long spiricles when wetted.

29. AUDIBERTIA. Corolla with upper lip spreading, 2-lobed or emarginate; lower spreading and 3 -lobed, the middle lobe broad and emarginate. Filaments slender, exserted, seemingly simple and bearing a linear one-celled anther, or with an articulation, showing that the portion above the joint answers to a filiform connective, the lower end of which sometimes obliquely projects into a subulate point, but never bears even a trace of an anther-cell. Otherwise as Salvia, but the calyx (always naked in the throat) more deeply cleft in front, or oblique, or as it were spathaceous. Nutlets smooth, unchanged when wetted.

* Anther with both cells fertile and similar, contiguous and divaricate, more or less connate or confluent at their junction, so as to become or to initate a single linear cell, on a very small and inconspicuous dorsal connective: corolla with slender tube, and lips of somewhat equal length; the upper erect, linear or oblong, entire or barely emarginate; the lower spreading, 9-lobed, its middle lobe retuse or emarginate: stamens inscrted in the throat of the corolla, ascending, usually more or less projecting from the upper lip: calyx tubular, 13-15-nerved: inflorescence verticillastrate-capitate, dense, many-flowered, multi-bracteate: outer bracts and bractlets broad; inner from lanceolate to setaceous.

30. MONARDA. Caly $x$ elongated-tubular, mostly 15-nerved, regular or nearly so, almost equally 5-toothed, more or less villous-bearded or hirsute at the orifice. Corolla narrow or dilated at the throat; middle lobe of lower lip larger or longer than the lateral.

31. BLEPHILIA. Calyx shorter, naked in the throat, bilabiate; upper lip 3 - and the shorter lower one 2 -toothed; teeth aristiform or subulate. Corolla dilated at the throat; lower lip broader; its linear-oblong middle narrower than the roundish lateral lobes.

Tribe V. NEPETEE. Stamens 4, both pairs fertile; the posterior (inner or upper) pair surpassing the anterior. Corolla distinctly bilabiate. Calyx usually 15-nerved; the upper teeth or lip commonly larger or longer.

* Anthers separated or distant (not approximate in pairs); their cells parallel or nearly so.

32. LOPHANTHUS. Stamens divergent or distant, exserted; the upper pair usually declined; the lower or shorter pair ascending. Calyx tubular-campanulate, more or less oblique, 5 -toothed. Corolla with tube not exceeding the caly $\mathbf{x}$; upper lip nearly erect, 2-lobed at the apex ; lower spreading, its broad middle lobe crenate.

33. CEDRONELLA. Stamens parallel, ascending. Calyx campanulate or short-tubular, 5-toothed, the throat little oblique. Corolla with short lips; the flattish erect upper one 2-lobed; middle lobe of lower lip largest, commonly crenulate-erose and more or less 2-lobed.

* * Anthers more or less approximate in pairs ; their cells divaricate or divergent : filaments ascending, not exserted.

34. NEPETA. Calyx more or less oblique at the throat, equally (or somewhat unequally) 5-toothed. Corolla with tube narrow at base; throat dilated; upper lip somewhat concave, emarginate or 2-lobed; lower spreading, with middle lobe large.

35. DRACOCEPHALUM. Calyx equal at the throat, 5-toothed; the upper tooth (at least in ours) very much larger than the others, sometimes the 3 upper partly united. Corolla, \&c., of Nepela.

Trine VI. SCUTELlaRINEA, Visiani. Stamens 4, ascending and parallel; both pairs fertile; the anterior (lower or outer) pair longer and with anthers mostly onecelled by abortion (the other cell rudimentary or wanting); those of the posterior pair 2-celled. Corolla bilabiate; but with the small lateral lobes more connected with the galeate upper lip; lower lip therefore of a single lobe. Calyx bilabiate, closed in fruit; the lips entire. Upper fork of the style very short or none. Ovule campylotropous or amphitropous. Nutlets depressed or globular, rough-granulate or tuberculate: seed transverse. Embryo curved; the short radicle incumbent on one of the cotyledons! Herbage bitterish, little or not at all aromatic. 
36. SCUTELLARIA. Calyx in anthesis campanulate, gibbous, with a crest-like or casque-shaped projection (answering to the upper sepal) on the back, closed after the corolla falls, not inflated, at maturity of the fruit splitting to the base; upper part not rarely falling away; the lower persistent. Corolla with long exserted tube, naked within; its anterior lobe or lower lip with the sides recurved. Anthers ciliate-pilose. Nutlets very rarely wing-margined.

37. SALIZARIA. Calyx globular or at first oblong, barely repand-bilabiate, not appendaged or gibbous on the back, much enlarged after anthesis, becoming vesicular-inflated and reticulated. Nutlets depressed, tuberculate-roughened, marginless. Corolla, \&c., of Scutellaria.

Tribe VII. STACHYDEA, Benth. (Lab., with part of Scutellarinea.) Stamens 4; both pairs fertile, parallel and ascending under the concave and commonly galeate upper lip of the bilabiate corolla (or in Marrubium included in the throat); the anterior (lower or outer) pair longer (except in a Phlomis): anthers 2-celled or confluently somewhat 1-celled. Calyx 5-10-nerved, or veiny. Bitter-aromatic or with hardly aromatic herbage.

* Calyx reticulate-veiny, membranaceous or chartaceous, more or less inflated, deeply bilabiate; the lips flattened and closed in fruit; upper lip plane and broad: corolla with inflated throat from a more or less exserted tube.

38. BRUNELLA. Calyx oblong, somewhat 10-nerved; upper lip truncate, 3-toothed, its teeth very broad and short; lower 2-cleft, its teeth lanceolate. Corolla with assurgent tube, ringent lips, and slightly contracted orifice; upper lip galeate, entire; lower 3-lobed ; its middle lobe dependent, rounded, concave, denticulate. Filaments, at least of the upper pair, 2-toothed at the apex, one tooth naked, the other bearing the 2-celled anther, the cells of which are divaricate. Nutlets smooth and glabrous. Inflorescence verticillastrate-capitate or spicate.

39. BRAZORIA. Calyx short-campanulate, indistinctly nerved, mostly declined in fruit ; both lips broad; the upper 3-lobed and somewhat recurved; the lower 2-lobed and surrected in fruit. Corolla with inflated throat, broad and barely concave upper lip, and spreading 3-lobed lower one; its lobes short and roundish. Filaments simple: anthers with soniewhat divergent cells. Nutlets smooth, glabrous or pubescent. Inflorescence racemose-spicate.

* * Calyx more or less membranaceous and inflated or enlarged after flowering, obscurely nerved, but somewhat veiny, 3-5-lobed, not bilabiate, open: corolla showy ; throat inflated; upper lip more or less concave, not galeate: filaments more or less villous.

40. PHYSOSTEGIA. Calyx nearly regular, and equally 5-toothed; the tube campanulate or oblong, hardly nerved or veined, moderately turgid in fruit. Corolla gradually inflated upward; lips short; the upper erect, rounded, entire; lower somewhat spreading, 3-parted, its roumdish middle lobe emarginate. Anthers uniform; the cells nearly parallel, denticulate or slightly spinulose along the edges of the valves. Style almost equally 2-cleft at apex. Nutlets triquetrous, smooth and even. Flowers simply opposite in the spikes, one under each bract.

41. MACBRIDEA. Calyx tubular-campanulate or funnelform, 3-lobed; upper lobe narrower, oblong, entire, obtuse; the two others broad (each of two combined sepals) and 2 -lobed or entire. Corolla much inflated above, rather deeply bilabiate; upper lip roundish and fornicate, entire or nearly so; lower spreading, with 3 roundish lobes, middle one larger. Anthers unconnected, hairy on the face; cells divergent. Style equally 2-toothed at apex. Nutlets oblong, nervose. Inflorescence terminal and capitate, 2 or 3 flowers under each bract.

42. SYNANDRA. Calyx campanulate, inflated, membranaceous, deeply 4-cleft; the lobes lanceolate-subulate, somewhat equal; the 2 lower slightly smaller, the fifth or uppermost wanting. Corolla with narrow tube, inflated above into a very ventricose throat; upper lip somewhat fornicate, entire; lower widely spreading, 3-lobed, the middle lobe emarginate. Filaments very villous above : anthers nearly glabrous; the cells divergent, the contiguous ones of the upper stamens sterile and connate! Upper fork of the style very short. Nutlets smooth, ovatc-compressed, with lateral angles almost winged. Inflorescence simply and loosely leafy-spicate.

* * Caly $\mathrm{x}$ of firmer texture, distinctly 5-10-nerved or striate, 5-10-toothed.

+ Stamens included in the short tube of the corolla, the upper lip of which is merely concave.

43. MARRUBIUM. Calyx tubular-cylindraceous, strongly ribbed, and with 5 or 10 subulate or spinulose teeth. Tube of corolla included in the calyx; lips short; the upper 
erect and narrow, 2-lobed; lower spreading, 3-cleft. Anther-cells more or less confluent. Nutlets ovoid, smooth, obtuse. Leaves rugose.

++ Stamens ascending under the galeate upper lip of the corolla.

* Introduced and naturalized from the Old World: stamens not deflexed after anthesis.

44. BALLOTA. Calyx fumelforn-dilated at the throat or border, 10-nerved, 5-toothed in ours. Corolla nearly as in Stuchys. Filaments not appendaged.

45. PHLOMis. Calyx tubular, 5 -10-nerved, 5-toothed in ours. Upper lip of the corolla strongly galeate; thie lower spreading, 3-cleft. Upper pair of stamens (in our species rather longer) furnished with a subulate or hooked appendage at base !

46. LEONOTIS. Calyx tubular, 10-nerved, at length incurved above, oblique at the orifice, and with 5 or more unequal spinulose-tipped teeth, the upper one largest. Corolla slender; the upper lip erect or incurved and elongated, entire; lower short and spreading, 3-cleft, its middle lobe not larger. Filanents not appendaged at base: anthers approximate in pairs. Upper fork of the style very short. Flowers densely capitate-verticillastrate.

47. LEONURUS. Calyx turbinate, 5-nerved, with nearly equal truncate orifice, and 5 rigid and at length spreading subulate-spineseent teeth. Corolla short; upper lip oblong, entire. Filameits not appendaged: anther-cells parallel or sometimes divergent; valves naked. Nutlets smooth, truncate at apex. Leaves cleft or incised, veiny, all longer than the capitate-verticillastrate flowers.

48. LAMIUM. Calyx tubular- or turbinate-campanulate, somewhat 5-nerved, commonly oblique at the orifice; the 5 teeth subulate but not spinescent. Corolla dilated at the throat; upper lip ovate or oblong, fornicate, narrowed at base; lower lip spreading, its lateral lobes truncate down to the throat, or sometimes oblong, and with or without a tooth-like appendage; middle one broad, emarginate, contracted and as it were stipitate at base. Filaments not appendaged: anthers approximate in pairs; their cells oblong, divaricate, sometines lhairy; valves not ciliate. Nutlets truncate at the apex. Leaves mostly cordate.

49. GALEOPSIS. Resembles Lamin in habit and Stachys generally in flowers. But anthers transversely 2 -valved; the inner valve of each cell hirsute-ciliate, the outer and larger one naked.

+ +t Indigenous (cliefly): stamens all or the lower pair sometimes deflexed to the sides of the tliroat or contorted after anthesis.

50. STACHYS. Calyx tubular-campanulate or turbinate, 5-10-nerved, equally 5-toothed, sometimes the upper teeth larger and more or less united. Corolla with cylindrieal or cylindraceous tube, not dilatel at the throat; upper lip erect, more or less fornicate or concave, sometimes rather thrown back, entire or enargrinate; lower spreading, 3-lobed, its middle lobe larger. Filaments naked : anthers approximate in pairs; the cells either parallel or divergent. Nutlets obtuse at the apex, not truncate.

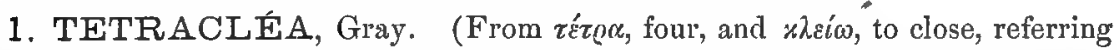
to the four distinct or closed nutlets of the fruit: first described as a Verbenaceous genus.) - Single species.

T. Coúlteri, Gray. Herb a foot or more higl from a perennial root or suffrutescent base, minutely puberulent: leaves petioled, ovate, nearly entire: flowers 2 or 3 on the short axillary peduncles, short-pedicelled, cream-colored, in sunmer. - Am. Jour. Sci. ser. 2 , xvi. 98; Torr. Bot. Mex. Bound. 134, t. 41; Benth. \& Hook. Gen. ii. 1220. - Rocky hills, S. W. Texas to Arizona. (Adjacent Mex.)

2. TRIChOSTÉmA, Gronov. (Trichostemma of some.) Blue-Curls. (From $\theta \omega ' \xi$, hair, and $\sigma \tau \tilde{\eta} \mu(\alpha$, for stamen, referring to the capillary filaments.) Iferbs or suffrutescent plants, sweet-aromatic or strong-scented, mostly low; with entire leaves, and commonly blue or violet corolla and stamens: fl. summer: all belonging to the $\mathrm{U}$. $\mathrm{S}$.

$\S 1$. Caly $\mathrm{x}$ very oblique and bilabiate; its 3 upper divisions twice or thrice the length of the lower two and united to above the middle: tube of the corolla shorter than the limb: flowers loose, 1 to 3 on slender bibracteate peduncles, or scattered on paniculate branches; the alar ones, becoming lateral and secund or 
decurved, appear as if resupinate, and have the two short teeth of the calyx uppermost: cismontane, low and paniculately branched annuals. - § Streptopodium, Benth.

T. dichótomum, L. Viscid with rather minute pubescence : leaves oblong or lanceoIate-oblong, obtuse, short-petioled: corolla blue or pink, sometimes white: stamens half inch long. - Spec. ii. 598; Bart. Fl. Am. Sept. iii. 93. T. pilosum, Roth. - Sandy fields, E. Massachusetts to Kentucky, Texas, and Florida.

T. lineáre, Nutt. Puberulent: leaves linear, sometimes nearly g]abrous: stems more slender: corolla rather larger: otherwise similar. $-T$, dichotomum, Roth. T. brachiatum, Lam., not L. T. linaricefolium, Bertoloni, Misc. xiii. t. 2.-Connecticut to Alabama and Louisiana, near the coast, in sandy ground.

§2. Calyx campanulate, regular, almost equally 5-cleft (as in Isanthus): far western species. — $\$$ Orthopodium, Benth.

* Tube of corolla not exceeding the calyx.

+ Peduncles (in the manner of the preceding) loosely 1-5-flowered and much longer than the leaves.

T. Arizónicum, Gray. Puberulent, a foot or less high from a ligneous perennial root: leaves ovate or oval, half inch long, short-petioled: pedicels as long as the calyx : bracts minute : calyx-lobes ovate or oblong, sometimes irregularly united: lobes of the blue or whitish çorolla 3 to 5 line, long, oblong-spatulate, very much longer than the tube, much shorter than the filaments. - Proc. Am. Acad. viii. 371. T. dichotomum, Torr. Bot. Mex. Bound. 134, not L. - S. Arizona, Wright, Rothrock.

++ Peduncles and pedicels slort; the inflorescence shorter than the leaves, which are similar to the summit of the stem, and are narrowed at base into short petioles : corolla small and inconspicuous: branching annuals.

T. micránthum. $\Lambda$ span higl, cinereous-pubescent : leaves lanceolate, not costate-veiny : peduncles about the length of the 3-7-flowered cymule: caly x-lobes little longer than the tube, nearly equalling the (only line long) corolla: stamens moderately exserted. - San Bernardino Co., California, in Bear Valley, Purry \& Lemmon.

T. oblóngum, Benth. A span to a foot high, soft-villous : leaves oblong or oval with narrowed base, membranaceous, costate-veined: glomerate cymules many-flowered, subsessile, villous : caly $\mathrm{x}$-lobes narrow, much longer than the tube, nearly equalling the ( 3 line) corolla : filaments 4 or 5 lines long. - Lab. 659; Gray, Bot. Calif. i. 606. - Oregon and California to Mariposa Co.

* * Tube of the corolla slender and exserted, longer than the limb: nutlets sometimes tuberculate.

+ Annuals, a span- to two feet high, leafy to the summit : leaves nerrose-costate : cymes severalmany-flowered, when fully developed the pedicels becoming secund-racemose in age : calyx-lobes ovate or triangular-lanceolate: tube of blue corolla about 3 and limb 2 lines long: stamens half an inch longer.

T. láxum, Gray. Diffusely branched, minutely soft-pubescent, rather sparsely leafy: leaves lanceolate and oblong-lanceolate, acuminate-obtusish ( 2 or 3 inches long), rather slender-petioled : cymes pedunculate, loose. - Proc. Am. Acad. vii. 387, \& Bot. Calif. 1. c. - California, from Sonoma Co, northward.

T. lanceolátum, Benth. l. c. More strict and simple, with ascending branches from the base: leaves crowded, sessile, lanceolate or the upper almost ovate-lanceolate, gradually tapering from near the broad base to a very acute tip, strongly 3-5-nervose (an inch or more long) : cymes subsessile or short-peduncled, dense, mostly undivided: calyx villous : corolla somewhat pubescent. - California, throughout the whole western part of the State, and north to Oregon.

++ Shrubby, taller: cymes in a naked terminal thyrsus : leaves Rosemary-like.

T. lanátum, Benth. l.c. Very leafy : leaves thickish, narrowly linear and with revolute margins, 1-nerved, glabrate and shining above, canescent-tomentulose beneath, sessile, many fascicled in the axils; uppermost reduced to bracts: thyrsus racemiform, interrupted; cymules short-peduncled or subsessile; whole inflorescence with calyx and even corolla clothed with dense violet or purple wool : corolla half inch long and filaments an inch or more longer. - Torr. Bot. Mex. Bound. 134, t. 40; Gray, Bot. Calif. i. 607. - Rocky places, California, from Santa Barbara southward. 


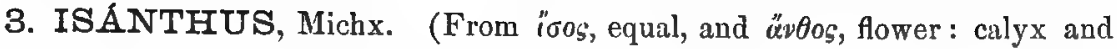
corolla vearly regular.) - Single species.

I. cærúleus, Michx. Low and erect annual, somewhat viscid-pubescent, pungently aromatic, copiously branched: leaves oblong-lanceolate or broader, acute at both ends, somewhat petioled: peduncles axillary, 1-3-flowered: corolla blue, 2 or 3 lines long, little exceeding the calyx. - Fl. ii. 3, t. so. Trichostema brachiatum, L. l.c. (Dill. Elth. t. 285.)-Dry or sterile ground, common from Canada to Georgia, Kentucky, and Texas: fl. all summer.

4. TEƯCRIUM, L. Geryander. (Teucer, first king of Troy.) - Less aromatic herbs or undershrubs, mainly of the Old World: fl. summer.

* Erect perennial herbs: leaves undivjded: flowers in naked terminal spikes or racemes, short pedicelled, 1 to 3 to each bract: caly $x$ canpanulate, moderately 5-lobed; two lower teeth triangular-subulate; three upper ovate: "nutlets globular and with a roundish scar.

T. Canadénse, L. Soft-pubescent to canescent-tomentose, 1 to 3 feet high: leaves obloug-ovate to oblong-lanceolate, sharply serrate, short-petioled: spike at lengtll 6 to 12 inches long: flowers short-pedicelled : corolla purple, rose, or sometimes eream-color, half inch long: calyx canescent, sometimes distinctly short-pubescent; the 3 upper lobes very obtuse. - Spec. ii. 56t. T. Virginicum, L. l. c. (pl. Gronov. Virg.); Schk. Handl. t. 155. Low grounds, Canada to Texas. (Mex.)

Var. angustátum. Leaves lanceolate, very acutely serrate (2 inches long, 8 to 6 lines wide): pubescence all minute. - Camp Grant, Arizona, Pulmer.

T. occidentále. Loosely pubescent, more branched, a foot or two high : leaves smaller ( 1 or 2 inches long), ovate-oblong to broadly lanceolate: corolla 4 or 5 lines long: calyx villous with viscid hairs; upper lobes acute or the middle one acuninate. - Nebraska, (Hayden, \&c.) to New Mexico (Fendler, Wright), Arizona (Pulmer), and on the Sacramento, California (T. Canadense, Torr. in Bot. Wilkes), collected there only by the Wilkes Expedition. ( $T$. inflatum, Swartz, has a globular fructiferous calyx, with upper lobes obtuse, nutlets angulate ventrally, \&c.)

* * Low and diffuse herbs: leaves multifid or incised, having snlitary perlicellate flowers in their axils; the uppermost more or less reduced or bract-like: caly $x$ almost 5-parted into subulatclanceolate equal lobes.

T. Cubénse, L. Glabrous or nearly so, branched from the annual root, about a foot high: leaves cuneate; the lower obovate-cuneate or rhomboidal and short-petioled, crenately incised, sometimes : $:-5$-cleft to the middle; upper sessile, palmately 3 -cleft or $3-5$ toothed, exceeding the flowers: corolla (pale blue or white, $;$ or 4 lines long) hardly exceeding the calyx: nutlets suberous-thickened, obscurely few-ribbed lengtliwise and punctate-impressed between the ribs. - . Iant. 80 ; Jacq. Stirp. t. 183 , f. 74 , \& Ous. t. 30. T. levigatum, Vahl, Symb. i. 40. - Texas to S. E. California. (W. Ind., Mex. to BuenosAyres.)

T. laciniátum, Torr. Glabrous or hirsute-pubescent, muclı branched from a lignescent perennial root, a span or so high : leaves pinnately 3-7-parted into narrow linear entire or 2-3-lobed or toothed divisions, rather rigid; the floral much crowded, 3-parted; upper equalling the flowers: corolla (pale blue or lilac, 6 to 10 lines long) with spatulate lower lobe nuch surpassing the calyx : nutlets not obviously costate. - Ann. Lyc. N. Y. ii. 2::31; Benth. in DC. Prodr. xii. 579. T. Culense, in part, Torr. Bot. Mex. Bound. 135. - Plains of Colorado to W. Texas and Arizona. (Adjacent Mex.)

5. ÁJUGA, L. (Formed of $\alpha$ privative, and $\zeta v y^{\prime} v$, a yoke, from the seeming absence of a yoke-fellow to the lower lip of the corolla.) - Low herbs of the Old World (Europe to Japan and Australia), one scantily naturalized in a few stations : fl. summer.

A. RÉptans, L. Perennial, a span or so high, with copious creeping stolons : leaves obovate or spatulate, sometimes repand-sinuate; cauline sessile; lowest and radical with long tapering base; floral approximate, subtending several sessile blue flowers. - Fields, Montreal, Canada, Maclagan. Saco, Maine, Goodale. (Eu., N. Asia.) 


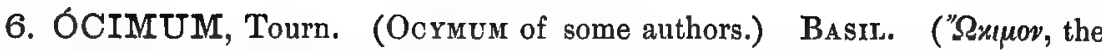
ancient Greek name.) - Sweet-aronatic herbs or suffrutescent plants, of warm regions, largely African and Brazilian.

O. Basíliccm, L., of the Old World, the Sweet Basil, is one of the sweet herbs of the gardens.

O. micránthum, Willd. Glabrate or nearly glabrous low annual: leaves long-petioled, ovate, nore or less serrate : flowers in terminal racemes, about 3 to each early deciduous small bract: calyx with large and roundish upper tooth, in fruit the decurrent wing extending down to the short pedicel : corolla white, 2 lines long: filaments separate, naked, toothless. - Enum. 630. O. Campechianum, Chapm. Fl., not Mill. - S. Florida, Key West. (W. Ind, S. Am.)

7. HÝPTIS, Jacq. ("T $\Upsilon_{\pi \tau \iota s}$, resupinate, or turned back, referring to the lower lobe of the corolla.) - A large genus in South America, a few species within our borders. Fl. summer.

* Herlss, minutely pubescent or smoothish, not canescent or white-woolly : flowers capitate or spicate: leaves slender-petiuler.

H. radiáta, Willd. Stems tall, mostly simple from a perennial root: leaves ovate-lanceolate, toothed, and with entire long-tapering base: axillary peduncles usually shorter than the leaf, bearing a many-flowered soft-puberulent capitate glomerule which is mostly shorter than its involucre of several lanceolate obtuse whitish bracts: calyx campanulate : its teeth lanceolate-subulate and rigid: corolla white, purple-dotted. — Spec. iii. 84 ; Poit. Ann. Mus. vii. t. 27. Clinopodium rugosum, L. - Low ground, from North Carolina towards the coast to Texas.

H. pectináta, Poit. Stem tall, commonly rough on the angles, branching: leaves longpetioled, ovate, serrate : flowers sessile in small capitate glomerules which become unilateral in age, these subulate-bracteate and crowded in a spiciform interrupted thyrsus: fruiting calyx with short-oblong tube a line in length, densely short-villous in the throat, Ionger than the erect setaceous teeth : corolla very small. - Ann. Mus. vii. 474, t. 30 ; Benth. in DC. Prodr. xii. 127. H. spicigera, Chapm. \& ed. 1. - S. Florida, Garber, Curtiss. (Nat.? from S. Amer.)

H. spicáta, Poit. Stem tall from an annual root, branching, rough-angled : leaves ovate, acuninate, unequally serrate: flowers in small capitate glomerules, which are shortpeduncled or sessile, and form interrupted and often paniculate terminal racemes or spikes: calyx cylindrical, with base somewhat inflated in fruit, then much exceeding the bracts; teeth subulate-setaceous, short, strict. - S. Florida. Ann. Mus. Par. vii. 474, t. 28, fig. 2; Bentl. in DC. Prodr. xii. 121. - (Mex., S. Am.)

H. POLYSTÁCHYA, HBK., allied to this, is said in Bot. Beechey, 156, but doubtfully, to have been collected in California.

* Slirubby, at least the calyx and short pedicels white-woolly with mány-branched implexed hairs: bracts inconspicuous.

H. Emóryi, Torr. Slırub 5 feet high, lavender-scented, furfuraceous-canescent: leaves ovate, crenate (incli or less long), rather slender-petioled: flowers on pedicels about the length of the lanate-furfuraceous calyx, in axillary short-peduncled cymes, and in denser somewhat paniculate clusters at the end of the branchlets: corolla violet, only 2 lines long. - Bot. Ives Colorad. Exped. 20; Gray, Bot. Calif. i. 591 . H. lanata, Torr. Bot. Mex. Bound. 129, excl. syn. - Arid region, S. E. California and Arizona. (Adjacent Mex.)

H. ÁLEIDA, HBK. of Mexico, not yet found within our borders (although a form of $H$. Emoryi has been mistaken for it), has more oblong leaves, and sessile glomerules crowded in terminal naked spikes.

H. Laniflóra, Benth. Bot. Sulph. t. 20, a remarkable species, with rotund and angulate- dentate glabrous leaves on slender petioles, open cymes on filiform peduncles, and very densely long-woolly calyx (the wool dendritic-branched), is known only from Cape San Lucas, in Lower California.

H. TEPHRódes, Gray, Proc. Am. Acad. v. 164, from the same place, collected by Xantus, is minutely canescent, except the furfuraceous calyx, and has subsessile lanceolate leaves, and paniculate inflorescence. 


\section{Collinsónia, L. Horse-Balm, Citronerda. (Peter Collin-} son of London, who corresponded with Linnæus and John Bartram, and received from the latter the original species.) - Odorous and large-leaved perenuials (of Atlantic North America); with thickened roots or rootstocks, ovate and serrate veiny leaves, mostly on long petioles, and simple or panicled naked terminal racemes of yellow or whitish flowers; mostly only a single naked pedicel to each small bract.

* Fertile stamens 2; upper pair rudimentary or obsolete: calyx-teeth all subulate-acute: flowers in late summer or autumn, on slender pelicels, solitary from the axil of each small subulate bract.

C. scabriúscula, Ait. Glabrate or minutely pulescent, 1 to 3 feet ligh from a tuberous stock, commonly leafless below : leaves small for the genus (2 or 3 inches long), broadly ovate, of ten rather scabrous above: corolla 3 or 4 lines long, yellowish or purple-spotted. - Ait. Kew. ed. 1, i. 47 (1789); Benth. Lab. \& in IC. Prodr. xii. 253. C. precox, Walt. Car. 65 ? (1788), but not early flowering. C. Luberosu, Michx. Fl. i. 17. C. scabra, Pers. Syn. i. 29 ; Pursh, Fl. i. 20 ; Lll. Sk. i, 35. C. oralis, P'ursh, 1. c., from the char.? - Open woods, S. Carolina to Florida and E. Arkansas.

C. Canadénsis, L. (IIorse-weed, Stone-root, \&c.) Glabrous, or the inflorescence glandular-puberulent, 2 to 4 feet high, leafy: leaves ample ( 4 to 9 inches long), from broadly ovate to oblong, rarely subcordate: racenes amply paniculate: calyx in flower a line, in fruit 4 or 5 lines long : corolla lemon yellow, lemon-scented, 5 or 6 lines long. Hort. Cliff. t. 5, \& Spec. i. 28; Torr. Fl. N. Y. t. 75 . C. decussuta, Moench, Meth. 379. C. ovalis, Pursh, l. c. \& herb., ex Benth. - Rich woods, Canada to. Wisconsin and south to Florida, chiefly in the upper country.

Var. punctáta. Inflorescence more puberulent and glandular: leaves minutely tomentose-pubescent beneath and more obviously punctate, - C. serolina, Walt. Car. 05. C. punctata, Ell. Sk. i. 36. - Rich soil, Carolina and Georgia, towards the coast.

* * Fertile stamens 4, usually 2 ascending and 2 descending: corollat rather broader, about hatf inch long, viscicl-pubescent: flowers carlier.

C. verticilláta, Baldw. Sten a foot high, leafless and glabrous below, at summit bearing two approximate pairs or a seeming whorl of thin and large ( 3 to 7 inch) ovate coarsely serrate and glabrous leaves: peduncle mostly simple and slender, viscid-pubescent, supporting a single raceme: bracts minute: lower pedicels often in pairs or threes: caly $x$-teeth all attenuate-subulate: corolla yellow or purplish, Fll. Sk. i. :37; Bentlı. Lab. \& in DC. 1. c. ; Chapm. Fl. 316. - Rich woods, western part of S. Carolina and Georgia to Tennessee and Mississippi : H, May.

C. anisáta, Sims. (Citronella, Frencir Ted.) Copiously viscid-pubescent, or the foliage glabrate, sweet-scented : stem 2 or 3 fect high, leafy : leaves ovate, rarely subcordate, obtusely serrate, veiny, somewhat rugose, 8 to 8 inches long: racemes paniculate: bracts ovate, conspicuous, mostly subtending single short pedicels : upper lip of ealyx with very broad and ovate mostly obtuse tectli; those of the lower lanceolate: corolla yellowish or cream-color. - Bot. Mag. t. 1213; I’ursh, FI. i. 21 ; Ell. Sk. i. 37. - S. Carolina to Alabama and Florida, chiefly in the middle country : fl. summer.

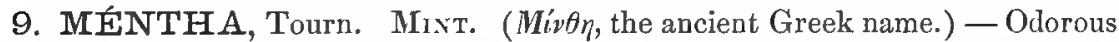
perennial herbs, mostly spreading by slender creeping rootstocks : calyx naked at the throat in our species. Flowers small, whitish or purplish, glomerate (in summer), not rarely gynodiccious, i.e. some individuals produce female flowers with impotent stamens instead of perfect ones.

* Introduced from the Old World, to which most of the species belong. Many hybrids.

t- Infiorescence terminal.

+ Densely capitate glomerules all much crowded in leafless narrow spikes: leaves either sessile or very short petioled.

M. sylvéstris, L. (Horse Mivt of Eu.) Finely pubescent or canescent: leaves from ovate-oblong to oblong-lanceolate, acute, sharply serrate, often glabrous above: spikes rather slender, canescently pubescent or cinereous. - Spec. ed. 2, ii. 804 ; Engl. Bot. ed. 
Syme, t. 1022. - Road-sides, \&c., Pennsylvania, Porter. Also a seeming hybrid between it and $\boldsymbol{M}$. viridis. (Nat. from Eu.)

Var. Alomecroídes, Baker. Intermediate between the above and the next species: leaves larger, more nearly sessile, broadly oval and obtuse, of ten subcordate, coarsely and sharply serrate, more veiny, but not rugose: spikes usually thicker; bracts broader. Baker in Seem. Jour. Bot. iii. 238; Hook. f. Fl. Brit. Isl. 279. M. aloperuroides, Ilull, ex Smith; Engl. Bot. ed. Syme, t. 1021. M. rolandifulia, Sole, Menth. Brit. t. 4, not L.Penn. and New Jersey, Porter, Parker, Leggett. (Nat. from Eu.)

M. Rotundiróla, L. Tomentose-canescent: stem strict: leaves from broadly elliptical to roundish-subcordate, sessile, rugose, rather finely serrate: spikes slender, not canescent. Reichenb. Ic. Germ. t. 1282 ; Engl. Bot. ed. Syme, t. 1020 . M. sylcestris, Sole, 1. c. t. 3, not L. - Atlantic States, at a few stations, Maine to Texas : rare. (Nat. from Eu.)

M. víridis, L. (SpenRmint.) Glabrous or nearly so: leaves oblong-lanceolate or oblong, sparsely and sharply serrate: bracts linear-lanceolate and subulate, conspicuous. - Wet ground, in cultivated districts. (Nat. from Eu.)

+ Less capitate glomerules in interrupted leafless spikes, or some in the axils of upper leaves: flowers distinctly pedicellate: leaves distinctly petioled: stems less ereet.

M. piperít, L. (Peppermint.) Glabrous, or in one variety somewhat hairy, very pungent-tasted: leaves ovate-oblong to oblong-lanceolate, acute, sharply serrate: spikes narrow, of numerous glomerules. - Along brooks, escaped from cult. (Nat. from Eu.)

M. AQUÁticA, L. Soft-pubescent or glabrate, the stem with reflexed hairs: leaves ovate, roundish, or subcordate: spikes oblong and interrupted or capitate, thick: calyx and usually the pedicels hairy. - M. citrata, Ehrh.; Engl. Bot. ed. Syme, t. 1029 (Венсамот Mint), a more glabrous and sweet-odorous variety. - Wet places, New England to Pennsylvania, \&c.; rare. (Nat. from Eu.)

Var. CRisps, Benth. A glabrous or glabrate form, with Iacerate-dentate and crisped leaves. - $M I$. crispu, L. ; Engl. Bot. ed. Syme, t. 1028. - Wet ditches, New Jersey, \&c. (Nat. from Eu.)

++ Inflorescence axillary, in dense verticillastrate glomerules, on stems leafy to the fop: leaves more or less petioled, ovate or oblong-ovate, pubescent or glabrate.

M. Arvénsis, L. Leaves obtusely serrate: calyx-tectl deltoid, acute or obtuse, about onethird the length of the campanulate tube: otherwise same as forms of the next, which passes into it. - Engl. Bot. ed. Syme, t. 1038. - New England, \&c., at a few stations. (Nat. from Eu.)

M. sitíva, L. Taller, generally more pubescent, the stem with reflexed soft hairs: leaves sharply serrate: calyx-teeth triangular-subulate, half the length of the cylindraceous tube, commonly hairy. - Engl. Bot. ed. Syme, t. 1031, 1032. Mf. gentilis, Smith in Linn. Trans. v. 208, \& Engl. Bot. t. 2118, a glabrate variety with only calyx-teetl hairy, and these longer. - Waste damp places, Mass. to Penn. ; uncommon. (Nat. from Eu.)

* * Indigenous : inflorescence axillary, consisting of distant sessile verticillastrate glomerules in the axils of leaves, as in the preceding species, the uppermost axils flowerless.

M. Canadénsis, L. Stem often simple: leaves varying from oblong-ovate to oblonglanceolate, sharply serrate, acute, generally tapering into the petiole: calyx hairy; the short teeth triangular-subulate. - Spec. ii. 577. - Wet places, through the Northern U. S. from Atlantic to Pacific, and Canada and Saskatchewan to New Mexico and California. Villous-hairy, with Pennyroyal odor: passes into

Var. glabráta, Benth., with leaves and stem almost glabrous, the former sometimes very short-petioled, and a sweeter scent, as of Monarda. - M. borealis, Michx. Fl. ii. 2. Similar range.

\section{LÝCOPUS, Tourn. Water Horehound, Bugle-weed, Gipsy-} wort. ( $\dot{v}^{\prime} * 0 s$, wolf, noüs', foot, wolf's-foot.) - Perennials, of wet or low ground (northern temperate and Australian), Mint-like, but bitter and only slightly aromatic; with sharply toothed or lobed leaves, and small white or whitish flowers in their axils, in sessile capitate-verticillastrate glomerules, the uppermost axils flowerless. Fl. summer. - Gray, Proc. Am. Acad. viii. 285. 
* Stoloniferous: long filiform runners produced in summer from the base of the stem, often tuberiferous at their apex.

+ Calyx-teeth 4 , or sometimes 5 , obtuse or barely acutish, as also the very short bracts, in fruit sborter than the nutlets.

L. Virgínicus, L. (BugLE-weEd.) Glabrous or somewhat pubescent: stem obtusely angled, 6 to 24 inches high: leaves ovate or oblong-lanceolate, coarsely serrate in the middle, acuminate at both ends, tupering into a short petiole: calyx-teeth ovate or lanceolate-ovate: sterile stamens minute rudiments. - Spec. i. 21; Raf. Med. Fl. t. 61. L. uniflorus, Michx, i. 14 (L. pumilus, Vahl, L. Virg. var. pauciforus, Benth.), a diminutive and northern few-flowered form, a span high. L. macrophyllus, Benth. Lab. \& in DC. I'rodr. xii. 17 (var. macrophyllus, Gray, l. c.), a tall and large-leaved form of Northern Pacific coast. - Labrador to Florida, Missouri, and nortl-westward to Brit. Columbia and Oregon.

++ Calyx-teeth 5 , or occasionally 4 , very acute, in fruit longer than the nutlets.

* Bracts minute: corolla nearly twice the length of the calyx: rudiments of posterior stamens very short, oval or lingulate: herbage glabrous or puberulent: stems 6 to 20 inches lijgh.

L. sessilifólius, Gray, 1. c. Stem ascending, rather acutely 4-angled: leaves all closely sessile, ovate or lanceolate-oblong (inch or two long), sparsely sharply serrate : calyx-teeth subulate, rigid. - L. Europeus, var. sessilifolius, Gray, Man. ed. 5, 345. - New Jersey, in pine barrens, late-flowering, Canby, Parker.

L. rubéllus, Mœnch. Sten rather obtusely 4-angled, erect or ascending: leaves ovateoblong or oblong-lanceolate, sharply serrate in the middle, attenuate-acuminate at botls ends ( 3 inches long), petioled: caly $x$-teeth triangular-subulate, not rigid-pointed. - Mœnch, Meth. Suppl. 446; Fresenius in Regensb. Flora, 1842; Benth. in DC. l. c. L. oblusifolius, Vahl? not Benth. L. Arkansamus, Fresenius, l. c. . puberulent form, with rather broader triangular-lanceolate less pointed calyx-teeth, the rudiments of sterile stamens varying from lingulate to linear-spatulate. L. Europecus, var. inlegrifolius, Gray, Man. 1. c. - Penn.? and Ohio to S. Carolina, Louisiana and Arkansas.

+ + Outer bracts conspicuous, very acute, of ten equalling the flowers: corolla hardly exceeding the caly: $\mathrm{x}$ : rudiments of sterile stamens slender and capitellate or clavate-tipped.

L. Iúcidus, Turcz. Stem strict, stout, 2 or 3 feet high, hirsute-pubescent or glabrate, acutely angled above: leaves lanceolate and oblong-lanceolate ( 2 to 4 inches long), acute or acuminate, very sharply and coarsely serrate with triangular-subulate ascending teeth, sessile or nearly so by an obtuse or acute base, coarsely punctate: calyx-teeth attenuatesubulate. (Siberia, Japan.)

Var. Americánus, Gray, l.c. Leaves dull, often minutely puberulent both sides: caly $\mathrm{x}$-teeth less rigid. - Bot. Calif. i. 592. L. obtusifolius, Benth. in DC. 1. c. ? - Saskatchewan to Kansas, Arizona, and California.

* * Not stoloniferous, but rootstocks more or less creeping: calyx-teeth 5 , cuspidate or spinulosetipped, rigisl, nearly equalling the corolla, in fruit surpassing the nutlets: subulate outer bracts often equalling the flowers.

L. sinuátus, Ell. Stem erect, 1 to 3 feet high, acutely 4 -angled, glabrous, roughish, or minutely pubescent : leaves oblong or lancelate ( $1 \frac{1}{2}$ or 2 inches long), acuminate, irregularly incised or laciniate-pinnatifid, or some of the upper merely sinuate or incisely toothed, tapering at base mostly into a slender petiole: calyx-teeth triangular-subulate and shortcuspidate : rudiments of sterile stamens slender, conspicuous, and with a globular or subclavate tip. - Sk. i. 187. L. Europaus, Walt. \&c. L. sinuatus, exullatus \& angustifolius, Ell. 1. c. L. vulgaris \& L. angustifolius, Nutt. Gen., without char. L. Europceus, var. sinuatus, Gray, Man. l. c. - N. Canada to Elorida, Texas, and west to Oregon and N. California.

L. Europáus, L., has less acutely angled stems, mostly broader and shorter subsessile leaves with less unequal teeth or lobes, subulate-spinulose calyx-teeth, and rudiments of sterile stamens obsolete or minute. - Occurs as a ballast-weed at Norfolk and Philadelphia, Durand, Parker. (Probably not yet nat. from Eu.)

11. CUNiLA, L. Dittany. (An ancient Latin name of some Labiate plant, applied by Linnæus to a small American genus.) - Perennials, with small purplish flowers, in summer. (Gray, Proc. Am. Acad. 8, 365.)

C. Mariána, L. Herbaceous, cymosely much branched, a foot high, glabrous except the nodes: leaves nearly sessile, ovate with subcordate or rounded base, serrate, much punc- 
tate flowers in peduncled loose cymes, rudiments of the upper pair of stamens generally apparent. - Spec. ed. 2, i. 30 ; Bart. Med. Bot. t. 42 ; Lodd. Bot. Cab. t. 1205 ; Sweet, Brit. El. Gard. t. 243 ; Torr. Fl. N. Y. t. 76. Satureia origanoides, L., ed. 1.-Dry soil, S. New York and Ohio to Georgia.

12. HYSSOPUS, Tourn. HYssor. (The ancient name, from a Hebrew word.) Only one species.

H. ofricinÁlis, L. Perennial herb, with somewhat woody base, virgate branches, lanceolate or linear entire leaves, and blue-purple flowers in small spiked clusters, in summer. Sparingly on roadsides eastward, and in California, escaped from gardens. (Nat. from Eu. and Asia.)

13. PyCNánthemUM, Michx. Mountain Mint or Basil. (From $\Pi v \%$ ós, dense, đ̈ $\nu \theta_{\varepsilon} \mu o v$, blossom: glomerate inflorescence.) - Perennial erect herbs (all N. American, and all but one eastern), pleasantly pungent-aromatic, branching above; with capitate-verticillastrate glomerules or dense cymes (commouly multibracteate) in the upper axils, or mainly cymosely terminal; flowers small, whitish or purplish, often purple-dotted, in summer. - Michx. Fl. ii. 7, with Brachystemum, 1. c. 5; Gray in Am. Jour. Sci. xlii. 44.

$\S 1$. Flower-clusters naked in a terminal corymbose cyme, small, rather dense; the proper bracts minute and loose : calyx short-tubular; the teeth equal : leaves sessile and small.

P. núdum, Nutt. Nearly glabrous; stem strict, 2 feet high : leaves oval, nearly entire, less than inch long, shorter than the internodes: calyx-teeth triangular, villous. - Gen. ii. 34. - Low pine barrens, N. Carolina? to Florida, Alabama, \&c.

§2. Flowers densely verticillastrate-cymose or glomerate, usually conspicuously much bracted: calyx oblong or short-tubular. (Many of the species difficult of discrimiuation, perhaps on account of hybridizing.)

* Bracts and equal calyx-teeth aristate-tipped, rigid, naked, equalling the corolla: leaves slightly petioled, rather rigicl.

P. aristátum, Michx. Minutely soft-puberulent, mostly canescent: leaves ovate- and lanceolate-oblong, sparingly denticulate; flower-clusters dense or capitate, terminal. - Fl. ii. 8, t. 33. P. verticillatum, Pursh, not Michx. P. setosum, Nutt. in Jour. Acad. Philad. vii. 100. Origanum incamum, Walt. - Pine barrens, New Jersey to Florida and Louisiana.

Var. hyssopifólium, Gray, 1. c. (P. hyssopifolium, Benth.): leaves narrowly oblong or almost linear, nearly entire, obtuse. - Virginia to Florida.

* Bracts and equal (or later species nearly equal) and similar calyx-teeth not aristate.

+ Leaves linear or lanceolate, nearly sessile, entire, mostly glabrous, very numerous throughout the stems and copious branchlets : capitate glomerules small and numerous, densely fastjgiatecymose, copiously imbricated with short appressed rigid and subulate-pointed or acute bracts, which do not exceed the equally 5-toothed calyx : lips of the corolla very short. (Brachystemum Virginicum, Hichx.)

P. linifólium, Pursh. Glabrous up to the canescent inflorescence, 2 feet high, slender: leaves linear, somew hat 3-nerved : bracts subulate or cuspidate-tipped from a broad base: calyx-teeth lanceolate-subulate, rigid-pointed. - Fl. ii. 409. Satureia Virginiana, L., as to syn. Pluk. Koellia capitata, Mœnch, Meth. 408. Brachystemum linifolizm, Willd. Enum. 623. Pycnanthemum tenuifolium, Schrad. Hort. Gott. 10, t. 4.-Dry ground, Massachusetts to Illinois, Florida, and Texas.

P. lanceolátum, Pursh, 1. c. Stem stouter and somewhat pubescent: inflorescence villous-canescent: leaves lanceolate or almost linear, nervose-veined, obtuse at base: bracts ovate or lanceolate: calyx-teeth ovate-deltoid, merely acute. - Satureia Virginiana, Herm. Parad. t. 218; L. Spec. ii. 567. Thymus Virginicus, L. Mant. 409. T. lanceolatus, Poir. Suppl. v. 305. Nepeta Virginica, Willd. Spec. iii. 56. Brachystemum lanceolatum, Willd. Enum. 623. Pycnanthemum Virginicum, Pers. Syn. ii. 128. - Dry ground, Mass. and Canada to Nebraska and Georgia. 
+ + Leaves from lanceolate to ovate sessile, or almost so, denticulate or sometimes entire, pinuately veined : flowers in larger and fewur less dense heads: verticillastrate glomertes subtended by fewer and looser bracts.

P. Califórnicum, Torr. Usually tomentose-canescent, rather stout: leaves ovatelanceolate or almost ovate, with rounded or subcordate sessile base; glomerules terminal and in the axils of 2 or 3 uppermost pairs of leaves, at first very dense $(6$ to 12 lines in diameter): bracts setaceous, lax: teeth of the calyx lanceolate-triangular, villous, 3 or 4 times shorter than the cylindraceous tube. - Jour. Acad. Philad. n. ser. ii. 99, \& Pacif. R. Rep. ir. 122; Gray, Bot. Calif. i. 592. California and borders of Nevada. Passes into

Var. glabéllum, not canescent : leaves and stens from pubescent to almost glabrous : inflorescence l'ss dense. - Torr. 1. c. - Lpper Sacramento, Bigelow, Brewer, \&c.

P. múticum, Pers. l.c. Puberulent, cinereous-pubescent, or glabrate but pale, much branched: leaves from lanceolate to ovate, subsessile, rather rigid, commonly obtuse at base; those subtending the (sometimes proliferous) dense capitate glomerules canescent: calyx-teeth ovate-deltoid or triangular-lanceolate, acute. - Brachystemum muticum, Michix. Fl. ii. 6, t. :32. Pyc. Arkansanum, Fresenius in Regensb. Flora, 1842, 325. - Maine to Florida and Arkansas. - Brachystemum verticillatum, Michx. 1. c. t. 31 (coll. at Pittsburgh, Penn.), is intermediate between the typical (eastern) plant, with short bracts, shorter and broader caly $x$-teeth, and leaves glabrate or minutely cinereous, and

Var. pilósum. Cinereous with looser pubescence: leaves thinner, oblong-lanceolate, mostly acute or acutish at base, sometimes ovate (Memphis, Fendler) : bracts and especially the rather narrower calyx-teeth canescent with more copious often villous pubescence. P. pilosum, Nutt. Gen. ii. 33; Gray, 1. c. - Ohio to Illinois and Arkansas. - Calyx often (but inconstantly) somewhat unequal, two or three of the teeth more united.

P. léptodon. Soft-pubescent, or glabrate below, loosely branched, tall: leaves membranaceous, green ( $1 \frac{1}{2}$ or 2 inches long), lanceolate or oblong-lanceolate, subsessile: glomerules larger and looser than in the preceding, canescent-hirsute: long-acuminate bracts and calyx-teeth slender-subulate, villous-hirsute. $-P$. pilosum, var. ? leptodon, Gray in Am. Jour. Sci. 1. c. - North-western N. Carolina and S. Missouri, Gray \& Carey, Geyer.-Perhaps a hybrid between $P$. muticum, var. pilosum, apd $P$. Tullia, var. dubium.

+++ Leares linear- or oblong-lanceolate, short-petioled, not even the uppermost canescent: flowers in mostly terminal capitate glomerules, which are dense even in fruit: calyx almost or quite equally 5-toothed, canescently pubescent, the teeth subulate. (Ambiguous species.)

P. Torréyi, Benth. Puberulent: stem strict, corymbose at summit; leaves narrowly lanceolate, green, glabrate, entire or slightly and sparingly denticulate: heads cymosecorymbed, small; the bracts subulate, mostly appressed : corolla rather large. - Prodr. l. c. 188 . P. Vinginicum, Nutt. Gen. 1. c. ? - Dry ground, S. New York to Pemsylvania.

P. clinopodioídes, Gray, l.c. Pubescent: leaves broadly or oblong-lanceolate, sharply denticulate or sometimes entire: heads fewer and larger: bracts loose, - Dry soil, S. New York to E. Pennsylvania.

* * Calyx distinctly bilabiate through the union of three teeth to form the upper lip: the teeth and the tips of the loose bracts if slender not rigid : flowers in dense flattened glomerate cymes, which are usually expanded with age: leaves membranaceous, mostly serrate, distinctly petioled, the uppermost more or less canescent: stems loosely branching.

P. Túllia, Benth. Rather stout, loosely more or less pubescent: leaves ovate- or lanceolate-oblong, acuminate, obtuse or acutish at base, somewhat serrate, thin (2 to 4 inches long), pale green both sides, only the uppermost tomentulose-whitened: calyx-teeth aristiform-subulate, equalling the tube in lengtl, above and the long-attenuate tips of the bracts setose-barbate. - Lab. 328, \& in DC. 1. c. 1. 87. Tullia Pycnanthemoides, Leavenworth in Am. Jour. Sci. xx. 243, t. 5. - S. Virginia and N. Carolina to Tennessee and Georgia, chiefly in and near the mountains.

Var. dúbium. Greener, not canescent, except the setose-villous bracts and calyx; the teeth of the latter shorter than the tube: leaves lanceolate. $-P$. dutbium, Gray, l. c. Ashe Co., N. Carolina, Gray \& Carey. Perhaps a hybrid between P. Tullia and P. leptodon, or even P. muticum, var. pilosum.

P. incánum, Michx. 1. c. Cinereous-pubescent: leaves ovate-oblong, with obtuse or rounded base, serrate ( 2 to 4 inches long), the lower surface or both surfaces of the uppermost canescent, at least when young, and with more or less loose or villous pubescence: calyx-teeth subulate or triangular-lanceolate and cuspidate or pointed, not exceeding half 
the length of the tube, often bearing one or two bristle-like hairs. - Clinopodium incanum, L. Spec. ii. 588. Origanum punctatum, Poir. Pycnanthemum Loomisii, Nutt. in Jour. Acad. Philad. vii. 100 ; form approaching the next. - New England and W. Canada to Ohio, and south to Florida and Louisiana.

P. albéscens, Torr. \& Gray, 1. c. Stems slender, puberulent, all the parts smaller leaves oblong- or ovate-lanceolate, obscurely serrate, small (inch or so long), canescent beneath and the uppermost on both sides with a minute close pubescence, as also are the short and beardless caly $\mathrm{x}$ and bracts; teeth of the former short, triangular-ovate, obtuse. - Am. Jour. Sci. 1. c. P. incanum, var. albescens, Chapm. Fl. 316. - Alabama and Florida to Texas.

§3. Flowers densely verticillastrate-capitate; the globose glomerules sessile and solitary at the summit of the stem and in some of the upper axils, copiously and conspicuously bracteate: calyx tubular; the short teeth nearly equal : aspect somewhat of Monarda.

P. montánum, Michx. Sweet-aromatic, glabrous or nearly so: leaves ovate- or oblong-lanceolate, acuminate, acutely serrate, membranaceous (2 to 4 inches long), shortpetioled: bracts thin, lanceolate, long-acuminate, villous-ciliate: calyx-teeth triangularsubulate, naked, very much shorter than the narrow tube. - Fl. ii. 8; Gray, l. c. Monardella montana, Benth. Lab. 331. Monarda gracilis, Pursh, Fl. i. 17? - Moist woods, Alleghany Mountains, S. Virginia and Tennessee to Georgia and Alabama.

14. MONARDÉLLA, Benth. (Diminutive of Monarda, which this wholly western American genus resembles in aspect, inflorescence, and calyx; while in the rest of the flower it is near Pycnanthemum.) - Flowers in terminal and solitary verticillastrate heads, subtended or involucrate by broad often membranaceous and colored bracts : corolla red, rose, purple, or rarely white. Pleasantly aromatic fragrant herbs, mostly entire-leaved. - Benth. Lab. 331, \& in DC. Prodr. xii. 190; Gray in Proc. Am. Acad. xi. 100.

$\S 1$. Flowers large and comparatively few, rather loosely glomerate: tube of corolla much longer than the linb: anther-cells oval-oblong, divaricate : root perenuial.

M. macrántha, Gray. A span high from creeping suffrutescent rootstocks, puberulent or pubescent: leaves subcoriaceous, ovate, obtrise, glabrate, 5 to 10 lines long, slenderpetioled: heads 10-25-flowered, with lax and thin ovate or oblong obtuse bracts : calyxteethl lanceolate, acute: corolla very much exserted, inch and a half long, scdrlet, with tube slightly trumpet-shaped, and comparatively small lanceolate lobes only 3 or 4 lines long. - Proc. Am. Acad. 1. c. \& Bot. Calif. i. 593; Hook. f. Bot. Mag. t. 6270. - San Diego Co., California, Cleveland, Palmer. Also, in a more foliaceous and less showy form (taller,

- more hirsute-pubescent, with leaves thinner and a full inch long, and flowers rather smaller), San Bernardino Co., Parry \& Lemmon.

M. nána, Gray, 1. c. Hirsute-pubescent, a span high: leaves and heads nearly of the preceding: corolla slender, less than an inch long, white tinged.with rose; pubescent tube Iittle exceeding the calyx. - S. California, in mountains behind San Diego, Cleveland.

$\S 2$. Flowers smaller, more numerous, and densely capitate: calyx only a quarter or a third of an inch long: tube of the corolla little exserted and little longer than the limb: anther-cells shorter and less divaricate.

* Perennials, in tufts, often slightly lignescent at base : corolla from whitish or flesh-color to rosepurple; the lobes linear: calyx-teeth lanceolate or triangular-lanceolate, merely or hardly acute, soft. (Seemingly transitional forms occur between all but the first species.)

+ Leaves from ovate to lanceolate, petioled, more or less obviously pinnately veined: bracts obtuse and pointless.

M. hypolequca. Pubescent, a foot or two high: leaves densely tomentose-canescent beneath, silvery-white when young, glabrate and green above, ovate-oblong, obtuse, entire, 
an inch or two long, all distinctly petioled; veins conspicuous, impressed above: heads large: bracts orbicular and ovate, nervose. - S. E. California, San Bernardino Co., Parry \& Lemmon.

M. villósa, Benth. Soft-pubescent, or the heads and lower face of leaves villous, or sometimes the whole herbage glabrate, a span to a foot high: leaves ovate, 5 to 14 lines long, all petioled, from sparsely crenate-dentate to nearly entire : veins conspicuous, widely spreading: bracts ovate, foliaceous, more or less pinnately veined. - Lab. 332, Bot. Sulph. t. 21, \& DC. 1. c. 190 ; Gray, Bot. Calif. i. 592. - Woods and banks, nearly throughout the western part of California, especially along the coast. Leaves in the typical form often tomentose beneath.

Var. leptósiphon, Torr. A rather large-flowered form, cincreous with a finer pubescence, and ovate-oblong or ovate-lanceolate nearly entire leaves. - Bot. Mex. Bound. 129. - In the central part of the State.

Var. glabélla, Gray. Minutely cinereous-pubescent or puberulent, or glabrate, except the head: leaves oblong, entire or barely and sparingly denticulate; upper ones sometimes subsessile: veins much less conspicuous. - Bot. Calif. 1. c. 1\%. Shelloni, Torr. in Jour. Acad. Philad. n. ser. ii. 99. - Pine woods, through the Sierra Nevada and valley of the Sacramento. There are transitions to the next.

M. odoratíssima, Benth. 1. c. Cinereous-puberulent or minutely tomentulose, or nearly glabrous, but pale; a span to a foot high: leaves from narrowly oblong to broadly lanceolate, entire or nearly so, short-petioled, or the upper subsessile, firm in texture, both sides alike; the veins inconspicuous or obscure: bracts thin-membranaceous and colored (whitish or purple), nervose: calyx-teeth (as in the preceding) hirsute without and within : odor of Pennyroyal. - Dry hills, Washington Terr., Oregon, and through the higher mountains of Califomia, Nevada, and Utah.

++ Leaves linear or oblong-linear, entire, thickish and nearly veinless, half to two-thirds inch long, subsessile, or the lower oblong and petioled and with a few veins.

M. linoídes, Gray. Canescent or cinereous with an almost imperceptible puberulence: stems a span to 18 inches high, strict and rigid: bracts ovate, mucronate-acute, scariousmembranaceous and white with pinkisl, pinnately nervose: calyx-teeth narrowly lanceolate, merely pubescent : odor of Bergamot. - Proc. Am. Acad. \& Bot. Calif. l. c. - Southern California, in mountains of San Diego Co. and on the Mohave, Cleceland, Palmer, Parry \& Lemmon, \&c.

M. Pálmeri. Glabrous and green, or obscurely puberulent up to the pubescent and proportionally large head, a span high: bracts ovate, very obtuse, more nervose, otherwise as in the preceding: calyx-teeth linear-lanceolate. - San Luis Obispo Co., California, under Redwoods in the Santa Iucia mountains, Palmer.

* Annuals: from a span to a foot or more high, loosely branching: leaves entire or merely undulate, more distant, narrowed at base into a petiole: calyx-teeth mostly with rather strong marginal nerves.

+ Bracts rigidly cuspidate-acuminate, white and transparent-scarious, except the nerves or veins: corolla bright rose or purple.

M. Douglásii, Benth. l. c. Pubescent: leaves lanceolate: bracts ovate and ovate-lanceolate, tapering gradually into the cusp, more or less lirsute, fenestrate, the pinnate spreading greenish veins running from midrib to stout marginal nerves, forming a firm frame for the hyaline and silvery interspaces: teeth of the hirsute calyx rigid and subulate : scent strong. - M. candicans, var. venosa, Torr. in Pacif. R. Rep. iv. 123. - California, through the valley and westward.

M. Bréweri, Gray. Puberulent: leaves ovate-oblong: bracts broadly ovate, abruptly cuspidate-pointed, less translucent, and with slender more nervose and whitish veins, only those of the outermost bracts strongly pinnate, destitute of strong marginal nerves : calyxteeth triangular-subulate, merely acute. - Proc. Am. Acad. vii. 386, xi. 102, \& Bot. Calif. i. 594. - California, in Corral-Hollow, Contra-Costa Co.

++ Bracts acute or obtuse: nervose, less translucent or the outer herbaceous : corolla rose-color or purple: calyx-teeth not subulate, short.

M. Ianceoláta, Gray. Green and almost glabrous, or the stem puberulent: leaves oblong-lanceolate or narrower, tapering into a slender petiole; the uppermost and the ovate or ovate-lanceolate bracts acute; the latter with cross-veinlets between the nerves or 
primary veins: calyx-teeth acutish, glabrate outside, densely hirsute within. - Proc. Am. Acad. xi. 102, \& Bot. Calif. l. c. - California, common nearly through the State except on mountains.

M. unduláta, Benth. 1. c. Cinereous-pubescent or glabrate: leaves spatulate-oblong to oblanceolate or linear with tapering base, obtuse, undulate-margined : heads mostly villous or pubescent: bracts broadly ovate, thin, whitish-scarious, obtuse, no cross-veinlets between the parallel nerves : calyx-teeth villous, obtuse: " odor of peppermint."-Gray, l. c. - California, near the coast.

++ Bracts obtuse or obtusely and slightly acuminate, broadly ovate, more or less whitescarious, nervose, and with some cross-veinlets between the nerves: corolla white or nearly si, small and short, not over 3 or 4 lines long: calyx-teeth villous and with white-scarious tips: herbage cinereous or canescent.

M. cándicans, Benth. Soft-puberulent, cinereous, but hardly canescent: leaves lanceolate or narrowly oblong, obtuse, tapering into a slender petiole: bracts minutely pubescent outside, ovate, greenish along the numerous nerves, at least the tip and margins white-scarious, shorter than the flowers : calyx-teeth short, rather broad and obtuse, villous both sides. - Pl. Hartw. 330 ; Gray, l. c. - California, valley of the Sacramento and footlills of the neighboring Sierra Nevada.

Var. exílis. Smaller: bracts mostly with a short scarious acumination: caly $x$-teeth acute. - S. E. California or adjacent Arizona, Palmer.

M. leucocéphala, Gray. Low, much branched, cinereous-pubescent : leaves oblong or broadly lanceolate, short-petioled : bracts ovate-orbicular with slight acumination, wholly thin-scarious and bright white, lightly nervose and with very sparing cross-veinlets (about 4 lines long and broad): calyx hirsute; the teeth attenuate-subulate. - Proc. Am. Acad. vii. 385 , xí. 102 , \& Bot. Calif. l. c. - California, on the plains near Merced, in sandy soil, Brewer.

15. ORfGanUM, Tourn. Wild Marjoram. (Ancient Greek name,

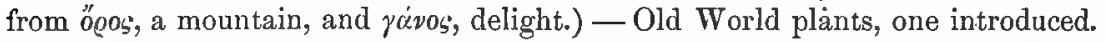

O. vULGARE, L. Branching erect perennial, villous : leaves ovate, petioled : short spiciform branches of the cymes densely panicled, crowded with ovate and obtuse purplish-colored bracts : corolla purple. - Roadsides, Atlantic States : fl. summer. (Sparingly nat. from Eu.)

16. THÝMUS, Tourn. Thrme. (Classical name, perhaps from $\theta \dot{v} \omega$, to burn perfume, Thyme having been used for incense.) - Low and small-leaved and small-flowered perennials, with persistent often somewhat woody base; fl. summer. Old World genus, one species introduced.

T. Serpýlldm, L. (CResping Timme.) Prostrate-tufted: leaves green, flat, ovate, entire, veiny, more or less ciliate, short-petioled, 2 to 4 lines long, the floral ones similar: flowers crowded at the end of the ascending branches, purplish. - Old fields, E. Massachusetts and Pennsylvania. (Sparingly nat. from Eu.)

17. SATURÉIA, Tourn. Savory. (Ancient Latin name.) - Smallleaved and low plants, sweet aromatic; the genuine species all of the Old World; the single American one almost generically distinct.

$\S 1$. Satcreia proper. Bracts of the loose inflorescence small or none: calyx mostly equalling the tule of the corolla: fl. summer.

S. horténsis, L. (Sumiter Savory.) Annual, much branched, minutely pubescent: leaves oblong-linear or lanceolate, tapering at base : flowers in axillary clusters, above becoming interruptedly spicate: corolla short, pale puiplish: stamens short. —Cult. as a sweet-herb; escaping from gardens is sparingly wild in Ohio, Illinois, Nevada, \&c. (Nat. from Eu.)

§2. Pycnothýmus, Benth. Flower-clusters crowded in a terminal oblong head or spike, conspicuously bracteate: bracts as long as the corolla: calyx very suall, thin, much shorter than the slender tube of the corolla: fl. spring. 
S. rígida, Bartram. Cespitose-procumbent, suffrutescent: leaves crowded, rigid, subulate-lanceointe, with strongly revolute margins, obtuse, quarter incl long. scabrous or becoming smooth, above passing into the broader and flatter villous-hirsute bracts : calyx equally and decply 5-cleft, membranaceous: corolla light purple; the tube ( 3 lines long) much shorter than the lips: filaments at length exserted. - Bentl. Lab. 354, \& DC. Prodr. xi. 211. - E. Florida, in sand.

18. MICROMERIA, Benth. (Mirós, small, and $\mu$ '́cos, a part, from small size of flowers, \&c) - Chiefly of the Old World. Our two species, of the section Hesperotmulis, are diffusely spreading or creeping perennial herbs, with slender stems, rounded and petioled veiny thin leaves, and 1 to 3 slender-pedicelled purplish flowers in their axils; in summer. To these an anomalous Californian species is added.

M. Brównei, Benth. Glabrous, or nearly so : leaves roundish, obscurely crenate: pedicels bractless: calyx villous in the throat; teeth laneeolate-ovate. L Lab. 372; Schmidt in FI. Bras. viii. t. 32. T7ıymus Brounei, Swartz. - River-banks, Florida. (W. Ind., S. Am.)

Var. pilosiúscula, with leaves (perhaps shorter-petioled) and sometimes stem and calyx sparscly pilose-pubescent: passes into.$T$. Xultipensis, Benth., and as such is enumerated in Bot. Mex. Bound. 129. - Texas, near San Antonio (Thurber), and southward. (Matamoras, Berlandier, Mex., \&c.)

M. Douglásii, Benth. l. c. (Yerba Busxa.) Somewhat pubescent : trailing and creeping stem elongated : leaves broadly ovate or roundish : pedicels 2-bracteolate below : calyx naked in the throat; the teeth subulate. - 1. barbuta, Fisch. \& Meyer. Thymus Douglasii \& $T$. Chamessonis, Benth. in Linn. vi. 80. - Woods, Vancouver's Island to Los Angeles Co., California.

M. purpúrea, Gray. Eręct, much branched, probably from an annual root, minutely and loosely pubescent: leaves short-petioled, lanceolate, acuminate, acutely serrate (inch long), with dense umbelliform cymules subsessile in their axils : caly $\mathrm{x}$ oblong-canpanulate, a line and a half long, about equalling the pedicels, naked in the throat; teetli slendersubulate, almost equalling the small "purple-blue" corolla. - Bot. Calif. i. 59.5. IIedeoma purpuren, Kellogg in Proc. Calif. Acad. v. 52. (All 4 stamens antheriferous.) - Webb's Landing on an island in the San Joaquin River, California, Kellorgy.

M. bricteoríta, Benth. 1. c., founded on "Hedeoma bracteolata. Pubescent, stem simple, slender : leaves linear-sublanceolate, acute at each extremity, entire : pedicels setaceously bracteolate, 3-5-flowered: calyx oblong, equal: corolla minute? In Carolina." - Nutt. Gen. Addend. This is wholly obscure.

19. Calamintha, Tourn., Monch. Calamint. (Old Greek name of some plant of this order.) - Ilerbs or undershiubs, chiefly of warm-temperate regions, of various habit, flowering all summer. Ours are perennials, and are various in habit.

C. PÁmeri, Gray, Proc. Am. Acad. xi. 100, an annual, of the Acinos section and the habit and odor of Hedeoma, belongs to Lower California, much beyond our limits.

$\$ 1$. Flowers loose, and without long-subulate bracts: calyx in ours usually villous in the throat: anthers naked.

* Herbaceous, small-flowered : corolla pale purple or nearly white.

- Introduced, pubescent: peduncles short but mostly distinct, several-flowered : calyx conspicuousiy villous in the throat.

C. Népeta, Link. (Basil Thyme.) Villous- or cinereous-pubescent, 1 to 8 feet high : leaves roundish-ovate, crenate (half inch long), short-petioled; uppermost reducecl to bracts: bractlets minute : corolla 4 lines long. - Benth. Lab. \& in DC. xii. 228. Melissa Vepeta, L. Thymus Nepeta, Smith, Engl. Bot. t. 1414. - Dry waste grounds, from Maryland to Arkansas. (Nat. from Eu.)

C. OFFICINÁtrs, Mœnch, Meth. 409, the common Calamint of Europe, is inclined to escape from cultivation in a few places. 
++ Indigenous on wet limestone river-banks, glabrous or nearly so, except a villous ring in the throat of the calyx: common peduncles in the axils hardly any: pedicels 1 to 5 : conspicuous bracts at their base subulate-acuminate: petioles short or none.

C. glabélla, Benth. Stems lax or decumbent, a foot or two long: leaves oblong or broadly lanceolate with tapering base; the larger ones serrate: axils 3-5-flowered: calyxteeth of both lips attenuate-subulate: corolla nearly half inch long, barely twice the length of the calyx. - DC. Prodr. xii. 230. Cunila glabella, Michx. Fl. i. 13. Zizophora glabella, Rœm. \& Sch. Syst. i. 209. - Banks of the Cumberland near Nashville (Michaux) and of the Kentucky River near Frankfort, Short \& Peter.

C. Nuttállii, Benth. l. c. Stems slender, branching, erect or ascending, a span or two high, copiously stoloniferous at base: leaves entire, thickish and veinless, with slightly revolute margins; cauline linear or the lower spatulate, sessile, 5 to 9 lines long; those of the creeping stolons ovate and orbicular, short-petioled, 2 or 3 lines long: flowers 1 to 3 in the axils: corolla a third of an inch long, fully twice the length of the calyx. Gray, Man. ed. 1 (1848), 325. Hedeoma glabra, Nutt. Gen. i. 16. H. Arkansana, Nutt. in Trans. Am. Phil. Soc. n. ser. v. 186. Cunila glabra, Torr. Fl. 23. Micromeria glabella (mainly) \& M. Arkansana, Benth. Lab. 730, 871. M. glabella, var. angustifolia, Torr. Fl. N. Y. ii. 67. Calamintha glabella, var. Nuttallii, Gray, Man. ed. 2, 307, ed. 5, 349. - Niagara Falls to Lake Superior, S. Missouri to Texas.

* * More or less woody or shrubby at base: a foot or two high : lips of the calyx-teeth more unequal; the broader upper one barely and mostly obtusely 3-toothed.

C. Caroliniána, Sweet. Nearly glabrous: leaves ovate, obtuse, somewhat crenate (6 to 14 lines long), abruptly narrowed into a short petiole: flowers few or several in the axils, in a crowded subsessile cyme : bracts foliaceous : calyx oblong, strongly striate, very villous in the throat, scarcely gibbous : corolla pink-purple or whitish and purple-spotted, half inch long; the upper lip somewhat concave and incurved. - Hort. Brit. 809; Bentl. in DC. Prodr. 1. c. 229. Thymus Carolinianus, Michx. ii. 9. T. grandiflorus, Sims, Bot. Mag. t. 997. Melissa Caroliniana, Benth. Lab. 388. - Dry ground, N. Carolina to Florida.

C. coccínea, Benth. 1. c. Very minutely cinereous-puberulent or glabrous, bushy : branches virgate: leaves obovate or cuneate-oblong, obtuse, subsessile, entire or obscurely crenate, with somewhat revolute margins, thickish, veinless, about half inch long: short peduncles 1-3-flowered: corolla scarlet, narrow, inch and a half long; the lips much shorter than the tube. - Melissa coccinea, Spreng. Syst. ii. 224. Cunila coccinea, Nutt. ; Hook. Exot. Fl. t. 163. - Gardoquia Hookeri, Benth. Lab. 401 ; Bot. Reg. t. 1747; Brit. Fl. Gard. ser. 2, t. 271. Satureia coccinea, Bertol. Misc. viii. 23. - Sandy soil, W. Hilorida to Mobile, Alabama, near the shore; flowering late.

C. dentáta, Chapm. Tomentulose-cinereous, diffusely branched: leaves obovate or somewhat cuneate, few-toothed at the rounded apex, subsessile, canescent and obscurely veined beneath: flowers solitary or in threes, short-pedicelled: calyx shorter than in the preceding; the short obscurely 3-toothed upper lip tinged with purple; subulate teeth of the lower lip hairy: "upper stamens abbreviated, sterile." - FI. 118. — Sand ridges near Aspalaga, W. Florida, Chapman. In foliage, \&c. much resembles $C$. coccinea, apparently smaller-flowered: no perfect corolla seen.

* * * Herbaceous to the base? and large-flowered : calyx less bilabiate; the teeth of the upper lip very like those of the lower: corolla orange.

C. mimuloídes, Benth. Tall, somewhat viscidly hirsute: leaves ovate, coarsely serrate, membranaceous, on slender petioles: flowers mostly solitary in the axils, on slender pedicels foliaceous-bracteate at base: calyx tubular ( 8 lines long), nearly naked in the throat; the teeth cuspidate from a broad ovate or triangular base, equal in length, those of the upper lip spreading: corolla inch and a half long, with a narrow tube twice the length of the calyx. - Pl. Hartw. 33. - California, on shady banks of Carmel River, near Monterey, Hartweg.

§ 2. Clinopódium, Benth. Flowers verticillastrate-capitate, and as it were involucrate with conspicuous setaceous-subulate rigid bracts : calyx nearly naked in the throat: anthers naked.

C. Clinopódium, Benth. (BasiL.) Herbaceous, hirsute: leaves ovate, obtuse, almost entire, petioled : verticillastrate heads globular, many-flowered: teeth of the narrow tubu- 
lar and gibbous caly $\mathrm{x}$ and the bracts very hirsute, nearly equalling the light purple narrow corolla. - Clinopodiun vulgare, L. ; Smith, Engl. Bot. t. 1401. - Borders of thickets and fields, common northward, and seemingly introduced: indigenous from the Great Lakes to the Rocky Mountains. (Eu., Asia.)

20. MELISSA, Tourn. BALM. (Greek name of the honey-bee, transferred to a plant the blossoms of which are songht by bees.) - Herbs, of the Old World, only one common species.

M. officixilis, L. (Common BALM.) Upright or spreading and branching perennial, pubescent; with broadly ovate or cordate crenate-toothed lemon-scented leaves, and loose axillary cymes of white or whitish flowers; in summer. - Escaped from gardens to waste grounds, eastward. (Sparingly nat. from Eu.)

21. CONRADINA, Gray. (Named in memory of Solomon W. Conrad, of Philadelphia, botanist, and publisher of his friend Muhlenberg's works.) - Proc. Am. Acad. viii. 244. - Founded on a single species; with leaves resembling Rosemary.

C. canéscens, Gray, 1. c. Somewhat shrubby, much branched, minutely canescent, leafy: the leaves also fascicled in the axils, narrowly linear, obtuse, with revolute margins: flowers solitary or in threes in the upper axils, short-pedicelled: teeth of the calyx and sometimes the tube villous with long spreading hairs : corolla pink or white, dotted in the throat, hairy outside, half inch long. - Calamintha canescens, Torr. \& Gray in DC. Prodr. xii. 220; Chapm. Fl. 318. - Sandy sea-shore and adjacent pine woods, Alabama and Florida, from Mobile to Tampa Bay (Hulse), and Indian River on the east (Palmer) : fl. summer.

22. POLIOMINTHA, Gray. (Mok $\alpha_{s}$, hoary-white, and $\mu$ iv $\theta \alpha$, Mint.) Texano-Mexican low suffrutescent plants, canescent throughout or nearly so; with entire leaves, and few-several-flowered cymes or glomerules in their axils, the uppermost sometimes diminished and bract-like. Corolla rose-color or purple, with tube either equalling or much surpassing the calyx. - Proc. Am. Acad. viii. 295, 365; Benth. \& Hook. Gen. ii. 1189. (Genus too near Gardoquia, of the Andes from Mexico to Chili, not to be distinguished if that becomes really diandrous.)

P. incána, Gray, l. c. A foot or so high, very much branched, silvery with very close and minute tomentum: branches virgate: leaves linear or the lower oblong ( 3 to 9 lines long), sessile, veinless and the midrib obscure; the upper floral shorter than the 1 to 3 subsessile flowers in their axils: calyx oblong or cylindraceous, 15-nerved, white-villous (3 lines long), with conspicuous subulate teeth, half the length of the corolla, equalling its tube, which is pilose-annulate at the summit. - Hedeoma incana, Torr. Mex. Bound. 130. Western Texas to S. Utah, Wright, Bigelow, Parry, Brandegee, Mrs. Thompson, \&c.

P. móllis, Gray, 1. c. A foot or more high, more tomentose, herbaceous nearly to the base: leaves ovate or oval, narrowed into a short petiole, 3-5-plinerved: calyx-teeth minute, unequally spreading, one-fifth the length of the 13-striate tube, which is hardly half the length of the corolla : tube of the latter not annulate but sparsely pilose within. - Hedeoma mollis, Torr. 1. c. 129. - Borders of Mexico and Texas, on cliffs of the Rio Grande at Puerto de Paysano, Bigelow.

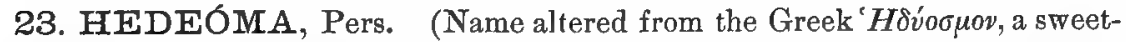
smelling herb, probably of this family. The plants have the scent and taste of the European Pennyroyal, Mentha Pulegium.) - Low herbs, all American, chiefly of Atlantic U. S. and Mexico; with small flowers, in summer. - Gray, Proc. Am. Acad. viii. 366 ; Benth. \& Hook. Gen. ii. 1188. 
$\S 1$. Euhedeóma, Gray, l. c. Flowers pedicellate, cymulose or rarely subsolitary in the axils of the leaves, the uppermost of, which are sometimes diminished and bract-like: corolla with an even open throat: throat of the calyx in fruit closed with a ring of villous hairs (except in $H$. acinoides): low and diffuse or much branched herbs, of dry soil, pungently sweet-aromatic, with small and whitish or purplish flowers: pubescence of the stem usually retrorse.

* Filaments of the posterior stamens manifest, bearing a capitate rudiment or sometimes a polliniferous anther: calyx rather short, conspicuously bilabiate; its upper and lower lips very
dissimilar.

H. pulegioídes, Pers. (American Pennyroyal.) Annual, erect, minutely pubescent: leaves ovate or oblong, somewhat serrate, narrowed at base into a slender petiole; floral similar or the upper merely smaller: caly $\mathrm{x}$ in fruit ovate-campanulate or oblong, strongly gibbous; upper lip broad and spreading, with 3 triangular teeth, about equalling the two setaceous-subulate and hispid-ciliate teeth: corolla hardly exserted, 2 or 3 lines long. - Syn. ii. 131; Bart. Med. t. 41. Melissa \& Cunila pulegioides, L. Canada to Iowa and southward; common.

* * Filaments of the posterior stamens minute subulate rudiments, or sometimes obsolete: teeth of both lips of the calyx subulate,

+ About equal in length, all erect or in fruit curved upward: bracts linear or acerose-subulate, spreading or at length reflexed : erect annuals, with the upper flowers somewhat capitately or spicately crowded.

H. acinoídes, Scheele. Minutely pubescent, slender: leaves nearly glabrous, thinnish, slender-petioled, obscurely denticulate; the lower ovate, upper oblong, or the upper floral oblong-linear: bracts equalling the slender pedicels : calyx tubular, gibbous at base (3 lines long), barely hairy in the throat; limb slightly bilabiate; the teeth setaceous-subulate, minutely ciliate, barely one-third the length of the tube: tube of the purple corolla exserted, slender (4 lines long); its lower lip much larger than the upper, and middle lobe deeply emarginate. - Linn. xxii. 592; Gray, Proc. Am. Acad. viii. 366. - Arkansas, Leavenworth. Texas, Wright, Lindheimer, \&c.

H. híspida, Pursh. Mostly low : leaves all similar, linear, entire, thickish, somewhat nervose-veined, nearly sessile, crowded, almost glabrous, but their margins at least towards the base hispid-ciliate : bracts mostly equalling tle calyx, rigid: limb of the calyx bilabiate; the lips about half the length of the oblong gibbous hispid tube; the teeth of the upper subulate, of the lower more aristiform and hispid, equalling the ( 3 lines long) bluish corolla. -Fl. ii. 414. H. hirta, Nutt. Gen. i. 16. Cunila hispida, Spreng. Syst. i. 54.Plains west of the Mississippi, from Dakota to Louisiana and Arkansas; also Illinois, there apparently lately introduced.

++ Two lower calyx-teeth decidedly longer than the three upper: bracts mostly erect and subulate.

+ Leaves entire, or in the first species with rare and obscure denticulations or crenulations, into which the few and inconspicuous veins do not run: root either indurated and perduring-annual or perennial.

H. thymoídes. Cinereous-pubescent or puberulent, about a span high, at length diffusely branched from the base: leaves ovate, obtuse ( 3 to 5 lines long), petioled; the lower little exceeding and the upper shorter than the flowers: bracts mostly sulbulate and shorter than the pedicels : calyx oblong-tubular and at length rather strongly gibbous (the tube $1 \frac{1}{2}$ or 2 lines and the setaceous lower teeth a line or sometimes more in length); teeth of the upper lip recurved away from the straightish and moderately longer lower ones : corolla little exserted, only 3 lines long. $-H$. dentata, var. nana, Torr. Bot. Mex. Bound. 130. H. piperita? Gray, Proc. Am. Acad. viii. 366, not Benth., which must have much larger calyx, flat pedicels, and more crenate leaves. - E. New Mexico to Arizona, Wright, Bigelow, Palmer, \&c.

Var. oblongifólia. Stems erect, even strict, sometimes a foot higl : leaves oblong, or the lower ovate, shorter-petioled; the reduced floral ones subsessile and acute. $-H$. piperita, var. oblongifolia, Gray, 1. c. - New Mexico and Arizona; same collectors.

H. Drummóndi, Benth. Cinereous-pubescent or puberulent, a span or two high, copiously branched: leaves from oblong (or the lowest oval) to linear, obtuse, subsessile, or narrowed at base into a very short petiole, thickish; the upper mostly rather shorter than the few flowers in their axils: small subulate bracts not longer than the pedicels: 
calyx hirsute or hispid, fron cylindraceous to at length ovate-tubular, slightly gibbous, in age more or less curved, not obviously bilabiate; the subulate-setaceous teetl at length all connivent and slightly curved upward; the lower nearly twice the length of the upper: corolla from 3 or 4 lines long, and little exserted, to 6 lines and double the length of the calyx. - Lab. 308, \& DC. 1. c. 245 ; Gray, 1.c. H. ciliata, Nutt. Gamb. 183, not Benth.Common from Texas to Arizona, and north to the plains of Colorado and even Nebraska. (Adjacent Mex.)

Var. Reverchóni. Rigid: leaves greener, coriaceous, elliptical (half incli long, 3 lines or more broad), or the floral oblong, lirsute-pubescent or at least ciliate, the few veins more prominent beneath. - Rocks, Brown Co., Texas, Reverchon.

H. hyssopifólia, Gray. Nearly glabrous throughout: stems slender, erect and simple from a lignescent perennial base, 8 to 12 inches high: leaves all sessile and entire, nervose veined (especially beneath), narrowly linear-lanceolate and about half inch long, or the lowest much shorter and oblong or oval: short peduncles linear-bracteate, 1-5-flowered: calyx obscurely pubescent, narrowly cylindrical, not gibbous (the tube $2 \frac{1}{2}$ lines long), not. bilabiate; the subulate-setaceous lower teeth nearly twice the length of the similar upper ones, all straightish : corolla much exserted, 7 or 8 lines long, purplish. - Proc. Am. Acad. xi. 96; Rothrock in Wheeler Rep. ined. t. 17. - Arizona, on Mount Graliam, Rothrock.

++ Leaves sermate with salient acute and callous teeth in which the veins terminate, all subsessile or the lower short-petioled: many-stemmed perennials: cymes few-flowered: calyx narrow, at length somewhat gibbous or curved, 2 or 3 lines long, minutely hirsute.

H. dentáta, Torr. Hirsute-pubescent: stems erect and slender, a foot high: leaves vblong-lanceolate ( 4 to 6 lines long), coarsely few-dentate; veins ascending, rather indistinct : caly $x$-tube slender; limb hardly bilabiate; subulate-setaceous lower teeth erect and moderately longer than the recurved-spreading upper ones: corolla pink, nearly twice the length of the calyx, 4 lines long. - Bot. Mex. Bound. 130, in part; Gray, l. c. - S. Arizona, near Santa Cruz, Thurber, Rothrock.

H. plicáta, Torr. 1. c. Minutely soft-pubescent, a span or more high, at length diffuse: leaves approximate, rigid, rhombic-ovate or the lower roundish-ovate and the uppermost flural oblong ( 3 or 4 lines long), numerously and coarsely callous-serrate, conspicuously lineate with the copious strong and straight mostly simple veins, which are very prominent beneath and extend from the midrib through the acute teeth: calyx of the preceding, but less slender and more gibbous or curved, also more evidently bilabiate: corolla shorter, 2 or 3 lines long. - Mountains along the Rio Limpio and Rio Grande, S. W. Texas, Wright, Bigelow. (There is a similar, but larger flowered and villous species, $I I$. costuta, S. Mex., Ghiesbreght, no. 815.)

§ 2. SтAChydeóma, Gray, 1. c. Flowers sessile or subsessile, verticillastrate in a terminal interrupted spike, the floral leaves diminished to bracts, except sometimes the lowermost: throat of the pink or purple corolla with a pair of longitudinal projecting folds under the lower lip: calyx harlly at all gibbous, rather short, long-hirsute : stem erect: leaves all sessile or nearly so, glabrous or glabrate, with at least the uppermost hirsute-ciliate.

H. ciliáta, Benth. A span or two high from an annual root: stem retrorsely puberulent and above mostly hirsute with some spreading hairs: leaves oblong, obtuse, entire, veinless (incls or less long): flowers several in the clusters of the spike: calyx moderately bilabiate; its 15-nerved tulse and the subulate-linear bractlets conspicuously white-hirsute; throat villous-bearded; teetl more naked, similar and of equal length, slender-subulate ciliolate, connivent after anthesis: tube of the rose-purple corolla not exserted; upper lip 2-lobed; throat laairy at the insertion of the short included stamens: sterile filaments wanting. - DC. Prodr. xii. 245; Gray, 1. c. 367. - Sandy ground, Texas, Bellandier (ex Benth.), Drummond, E. Hall.

H. gravéolens, Chapm. Stems numerous, a foot or more high from a perennial base or root, strict, often simple, soft-lirsute or pubescent: leaves round-ovate, subcordate, obscurely pinnately veined (the larger laalf inch long); lower short-petioled and sparingly dentate; upper passing into similar bracts, which are shorter than the usually solitary flowers they subtend: bractlets oblong, foliaceous : tube of the 12-13-nerved and conspic- 
uously bilabiate calyx oblong-campanulate; the teeth especially hispid or hirsute with long whitish hairs; those of the broad upper lip short and deltoid; the two of the lower aristiform subulate, equalling the tube of the purple and spotted corolla: fertile stamens equalling the emarginate upper lip of the corolla; sterile filaments subulate, sometimes with small rudiments of anthers. - Gray, 1. c.; Chapm. in Bot. Gazette, iii. (1878), 10. Low pine barrens, W. Florida, Chapman. From the name the species apparently is not sweet-scented.

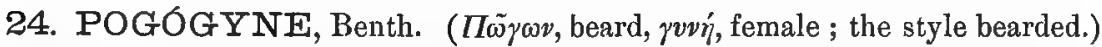
- Californian annuals, of low stature, sweet-aromatic; with oblong-ovate or oblanceolate mostly entire leaves, the lower narrowed into a petiole, the upper diminished into bracts, these and the calyx usually conspicuously ciliate-bearded with hirsute or hispid hairs. Flowers verticillastrate-glomerate and sessile, at least the upper glomerules spicate or capitate. Calyx-teeth mostly 3-nerved. Corolla blue or violet purple, sometimes paler. Fl. spring and summer. - Benth. Lab. 414, \& DC. 1. c. 243; Gray in Bot. Calif. i. 596.

$\S 1$. Stamens all four with perfect anthers : style conspicuously bearded above ; its subulate lobes or stigmas almost equal : corolla 6 to 9 lines long, with funnelform tube, and throat surpassing the (variable) calyx.

* Inflorescence oblong- or cylindrical-spicate and nearly continuous, conspicuously white-hirsute or hispid with the long and rigid marginal hairs of the bracts and calyx.

P. Douglásii, Benth. 1. c. Rather stout, a span to a foot high : leaves spatulate-oblong or narrower, veiny, rarely dentate: bracts linear, acute : flowers comparatively large, blue or violet; lower calyx-lobes twice the length of the tube, much longer and narrower than the others. - Hook. Bot. Mag. t. 5886 ; Gray, Bot. Calif. i. 597. P. multiflora, Bentl. l. c., is merely a smaller form, with rather shorter bracts. - California, through the foothills of the Sierra and westward.

P. parviflóra, Benth. l. c. More slender and lower: leaves narrower: spike shorter: bracts mostly obtuse: corolla barely half inch long: lower calyx-lobes hardly longer and the upper ones shorter than the tube. - From San Francisco Bay northward, Dougles, Bolander, \&c.

* * Verticillastrate clusters more or less distant: bracts and caly $\mathrm{x}$ inconspicuously lirsute-ciliate : anthers of posterior stamens smaller but polliniferous.

P. nudiúscula, Gray. A span to a foot high: branches slender, puberulent: leaves spatulate or narrower, obtuse, not over an inch long, glabrous: bracts lincar-subulate and cuspidate: corolla only half inch long, about twice the length of the caly $\mathrm{x}$ : lobes of the latter lanceolate- or linear-subulate and cuspidate. - Bot. Calif. i. 597. -Near San Diego, D. Cleveland.

§ 2. Hedeomoídes, Gray, 1. c. Posterior stamens sterile: style sparingly hairy, its lobes very unequal: flowers smaller, some of the lower ones often distant and solitary or nearly so in the axils of ordinary leaves.

P. Tenuiflóra, Gray, Proc. Am. Acad. xi. 100, of Guadalupe Island off Lower California, has the tube of corolla longer than the caly $x$, as in the preceding section. In the following species the corolla is only 2 lines long, and at least its tube included.

P. ziziphoroídes, Benth. Stem 2 to 6 inches ligh: leares ovate or oval, thickisb; uppermost, with the rigid narrow bracts and calyx, hirsute-ciliate with strong and white bristly hairs : inflorescence capitate or short-spicate: calyx-lobes slightly unequal, broadly lanceolate, very acute, hardly twice the length of the tube, the longer about equalling the corolla: posterior filaments as large as the anterior, but their anthers abortive. PI. Hartw. 330 ; Gray, Bot. Calif. 1. c. - Valley of the Sacramento River, Hartweg, Andrews, Bolander.

P. serpylloídes, Gray. Stems slender, branched from the base, ascending or at length diffuse, 3 to 6 inches high: leaves obovate-oval or spatulate, 3 or 4 lines long; the lower distant, most of them single- or few-flowered in the axils; upper more floriferous, approximate and becoming bracts to the obloug or of ten longer and much interrupted spike; the 
base of these and the calyx hirsute: lobes of the latter unequal, all much longer than the tube, the longer fully equalling the violet or bluish corolla: sterile filaments small, with small capitellate rudiment of anthers: style bearded above with very few coarse hairs. Proc. Am. Acad. vii. 386, \& Bot. Calif. i. 598. Hedeoma? serpylloides, Torr. in Pacif. R. Rep. iv. 123. - Monterey to Humboldt Co.; common.

25. CERANTHÉRA, Ell. (K'éus, a horn, and ievtyou, anther: cells of the anther cornute.) - Peculiar to the southern Atluntic States, nearly glabrous and slender erect annuals, a foot high, sweet-aromatic; with broadly or narrowly linear and obtuse entire leaves; the uppermost on the virgate branches diminished to similar bracts of the thyrsoid-racemose inflorescence. Flowers autumnal, haudsome: corolla pink-purple and spotted, the calyx commonly purplish. Sk. ii. 93 ; Benth. \& Hook. Gen. ii. 1191. Dicerandra, Benth. in Bot. Reg. 1300, Lab. 413, \& DC. Prodr. xii. 242.

C. linearifólia, Ell. 1. c. Inflorescence loose : cymes short-peduncled, few-flowered : caly xteeth obscurely ciliolate, hardly equalling the tube of the (about half inch) corolla : anthercells slender-aristate. - Dicerandice linearis, Bentl.. Lab. 1. c. L. Inearifolia, Benth. in DC. Prodr. l. c.; Chapm. Fl. 318. - Sandy pine barrens, Georgia, Florida, and Alabaina.

C. densiflóra. Inflorescence dense; the pedicels shorter and peduncle hardly any: calyx-teeth appressed-ciliate, equalling the tube of the corolla: anther-cells conical-cornute: leaves mostly shorter and broader. - Licerandra densifora, Benth. in DC. Prodr. l. c. -E. Florida, J. Reed, \&e.

26. ACANTHOMINTHA, Gray. ( $A * \alpha \nu \theta \alpha$, a prickle or thorn, and $\mu i v \theta_{\alpha}$, mint.) - Benth. \& Hook. Gen. ii. 1192. Calamintha? \$ Acanthomintha, Gray, Proc. Am. Acad. viii. 368, \& Bot. Calif. i. 596. - Single species.

A. ilicifólia, Gray, l. c. Low and nearly glabrous annual, slightly aromatic (rather heary-scented), branching from the base, leafy to the top: leaves coriaceous, rotund or broadly cuneate, coarsely crenate-dentate (half inch or more long, the blunt teeth of the upper ones mostly nucronate or cuspidate), contracted at base into a slender petiole: axils nearly all verticillastrate-floriferous : bracts a pair in each axil, almost as large as the Icaves, but sessile, equally coriaceous and more rigid, orbicular or dilated-subcordate, pinnately few-veined and with fine reticulated veinlets, the callous margin armed with a few distant and long slender prickles, each pair subtending 3 to 5 sessile flowers: corolla white and rose-color, half inch long. - Southern borders of California, San Diego Co., Wm. Rich, Clevelend. Allied to Glechon of Brazil, which is also referred to this tribe, rather than to the Slachydere.

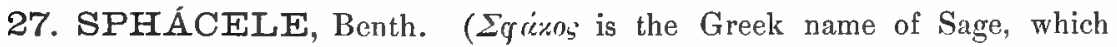
these plants resemble in foliage.) - Shrubby or suffrutescent plants (chiefly $S$. American); with the floral leaves gradually reduced in size, aud the flowers single in their axils, above forming a leafy raceme.

S. calycína, Benth. Shrubby at base, 2 to 5 feet high, tomentulose-villous or glabrate: branches leafy: leaves ( 2 to 4 inclies long) orate or ollong, obtuse, from crenate or obtuscly serrate to entire, obtuse or rarely subcordate at base, rugose-veiny, more or less petioled; uppermost and bracts of the short raceme sessile: lobes of the very loose calyx triangular-lanceolate, rather shorter than the purplish or lead-colored (inch long) corolta: anthers short. - Lab. 56r, \& DC. Prodr. xii. 255; Torr. Bot. Mex. Bound. 131, t. 37 ; Gray, Bot. Calif. i. 598. - I Iillsides, common throughout the western part of California, especially from San Francisco southward.

Var. glabélla, Gray, l. c. A minutely tomentulose and soon glabrate form, probably of sharly places. - Santa Barbara Co., and southward.

Var. Wallácei. Copionsly villous: lower cauline leaves with truncate or hastatesubcordate base: calyx-lobes attenuate-lanceolate from a narrower base, over half inch long. - Probably near Los Angeles, Wallace. 
28. SÁLVIA, L. SAGE. (The old Latin name, from salveo, to save.) - A vast genus, widely dispersed, comparatively few species N. American, and those mainly southward: fl. chiefly in summer.

S. OfFicinÁLIs, L., Common Sage, of the Old World, represents the genus in the gardens.

S. Spléndens, Sellow, of Brazil, and S. Fúlgens, Cav., of Mexico, are the two commoner red-flowered species of ornamental cultivation.

\$1. Salvístrum, Gray. Throat of the calyx conspicuously bearded and in fruit closed by a ring of long and dense villous hairs : upper lip with 3 broad and short teeth, lower 2-parted into lanceolate teeth, all cuspidate: corolla ringent (blue or purple), pilose-annulate within : upper emarginate-2-lobed; lower ample, with 3 roundish spreading lobes, middle one 2-lobed: stamens separate: lower anther-cells porrect, shorter, more or less polliniferous : nutlets abundantly spirilliferous: Texan low perennials, simple-stemmed, with copious mostly narrow and entire leaves; the diminished floral or bracts persistent, subtending 1 to 3 flowers; these racemose or spicate. - Proc. Am. Acad. viii. 308. Salviastrum, Scheele in Linn. xxii. 584; Benth. \& Hook. Gen. ii. 1196. § Trichosphace, Engelm. in Bot. Zeit. ix. 45.

S. Texána, Torr. Stems (a span or two high) with margins of the leaves and the calyx hirsute with long and spreading bristly hairs: flowers spicate, the upper floral leaves not exceeding the calyx, which equals the dilated throat of the widely ringent blue corolla. Mex. Bound. 132; Gray, 1. c. Salviastrum Texanum, Scheele, l. c.; Torr. \& Gray, Pacif. R. Rep. ii. t. 6. - Open rocky soil, W. Texas to the borders of New Mexico.

Var. canéscens, Gray, l. c., a form with leaves hoary-white with fine tomentum, all narrowly linear, with strongly revolute margins, and fewer flowers in the axils of the upper ones. - Hills of the Pecos and Rio Grande, S. W. Texas, Wright, Schott.

S. Engelmánni, Gray, 1. c. Minutely puberulent and glabrate, the setose hairs few and scattered or nearly wanting: leaves thinner; lower sometimes denticulate; floral mostly equalling the more scattered flowers : corolla (an inch or more long) with narrower tabe and throat twice the length of the calyx, light purple. - W. Texas, Wright, Lindheimer.

§ 2. Echinósphace. (§ Echinosphace \& § Pycnosphace, Benth. Lab.) Throat of the calyx villous-hairy or naked: upper lip much longer than the lower, more or less incurved, 3-2-toothed; the lower 2-parted; teeth all spinulose-aristate: corolla ringent (blue or purple); tube pilose-annulate inside; upper lip 2-lobed: stamens separate, remote from the upper lip; lower fork of the long filiform connective bearing a polliniferous anther-cell : Californian winter-annuals; with pinnatifid leaves, and densely capitate-verticillastrate inflorescence: globular heads many-flowered, involucrate with the persistent bract-like floral leaves. (Called CHIA : nutlets abundantly mucilaginous in water, infused for drink.)

S. carduácea, Benth. White-woolly with lax cobwebby haírs: stem stout, simple, a foot or two high, naked and scape-like, only at base subtended by a cluster of oblong sinuate-pinnatifid and spinulose-toothed Thistle-like leaves: verticillastrate heads 1 to 4 (an inch or more in diameter), equalled or somewhat surpassed by the involucrate whorl of lanceolate or avate-lanceolate bracts, which are oftener pectinate with spinescent teeth: caly $x$ long-lanate; the tube multi-nervulose between the principal nerves; the large upper lip strongly 3-toothed, the middle tooth much the larger, the lateral distant, mostly surpassing those of the lower lip : throat villous: corolla lavender-color (an inch long); its tube slightly exserted; upper lip erose-dentate or fimbriate and 2-cleft; lower with small lateral erose lobes, and a larger flabelliform and deeply fimbriately multifid middle one: proper filament hardly any: anther-cells pubescent. - Lab. 302, \& Prodr. l. c. 349; Hook. Bot. Mag. t. 4874; Gray, Bot. Calif. i. 599. S. (Echinosphace) gossypuna, Benth. Pl. Hartw. 330. - Dry grounds through the lower parts of California, especially southward. 
S. Columbáriæ, Benth. Soft-puberulent: stems slender, branching and leafy below, 6 to 20 inches high, naked and pedunculiform above, terminated by solitary or two proliferous heads: leaves deeply 1-2-pinnatifid or pinnately parted into oblong crenately toothed or incised obtuse divisions, muticous, rugose : involucrate floral lenves or bracts not exceeding the head, bruadly ovate, entire, resembling the more membranaceous sometimes purplish abruptly acuminate-aristate inner bracts : flowers small : caly $\mathrm{x}$ naked within; its large upper lip arcuate-concave, hispid at base outside, tipped with a pair of connivent and partly connate short aristiform teeth (the third or middle tooth apparently always wanting), very much surpassing the two small at length porrect teeth of the lower lip : corolla blue, hardly exceeding the calyx; its upper lip emarginate-2-lobed at apex, the lower with small lateral lobes and a much larger transversely oval shortunguiculate somewhat 2 -lobed but otherwise entire or merely crenulate middle one: fila. ments slender. - Common through California, and in adjacent Arizona and Nevada.

§ 3. Heterósphace, Benth. Throat of the calyx naked (or in a single species ciliate-hirsute); the upper lip broadly truncate and remotely 3-toothed; the lower 2-cleft: corolla elongated, mostly pilose-annulate inside; upper lip emarginate or entire: stamens separate: conuective shorter than the slender often exserted filament; the porrected lower fork also bearing a polliniferous anther-cell: herbs, ours Atlantic-American perennials, with mostly lyrately-lobed or toothed or pinnately divided leaves; inflorescence loosely racemose, the small bract-like floral leaves persistent.

* Corolla blue or violet, thrice the length of the calyx : leaves at most pinnatifid; the cauline, if any, sessile or narrowed at base into wing-margined petioles.

S. Iyráta, L. Perennial from a somewhat tuberous root, pilose or hirsute: sten commonly scapiform, a foot or more high : radical leaves obovate, sinuate-or repand-dentate, or Iyrate-pinnatifid; cauline of one or two somewhat similar pairs, or none; floral oblong or lanceolate and mostly shorter than the calyx: raceme of few or several at length distant about 6-flowered loose clusters, rarely branching : caly $\mathrm{x}$ campanulate, membranaceous; the broad and truncate upper lip witl short or very short widely separated aristulate teeth; lower with 2 longer lanceolate cuspidate-pointed teeth: corolla (almost an inch long) ampliate-funnelform beyond the calyx; its erect upper lip much shorter and smaller than the lower.-Spec. i. 23 (Dill. Elth. t. 175; Moris. Hist. \&c.); Michx. Fl. i. 14. S. Iyrata \& S. abovala, Ell. Sk. i. 3:3; Benth. in DC. 1. c. 353 ; the latter merely a form with thin and barely dentate leaves; caly $x$-teeth variable in length. - Sandy woodlands, New Jersey to Illinois, Florida, and Texas; flowering early.

* * Corolla scarlet-red, four times the length of the calyx: herbage softly and often canescently pubescent: cátiline leaves all slencler-petioled, at least the lower ones 3-5-foliolate.

S. Rœmeriána, Scheele. Stems (a foot or two high) and petioles below often sparsely hirsute with long spreading hairs; Teaves or terminal leaflet roundish or reniform-cordate, coarsely repand-toothed or crenately incised (an inch or two broad), membranaceous; the lower usually with 2 or 3 similar but smaller (subsessile or slender-petiolulate) lateral leaflets, these oecasionally reduced to dentiform appendages on the petiole: raceme loose and elongated: floral leaves mostly shorter than the pedicels: calyx somewhat pubescent, naked within; its upper lip 3-aristulate or with the middle tootl obsolete; the 2-parted lower one of triangular-lanceolate cuspidate-acuminate teeth: corolla (an inch or more long) deep scarlet, puberulent, narrowly tubular-funnelform, somewhat arcuace; its spreading lower lip with rounded and obcordate-2-cleft middle lobe, hardly longer than the erect strongly emarginate upper lip; lobes of the style more or less unequal. - Scheele in Linn. xxii. 586; Torr. Bot. Mex. Bound. 132. S. porphyprentha (or porphynata), Decaisne in Rev. Hort. 1851, t. 16; FI. Serres, t. 1080; Hook. Bot. Mag. t. 4929 . - In light fertile soil, W. Texas, Wright, Lindheimer, \&c. (Adjacent Mex.)

S. Hénryi, Gray. More slender, less soft-pubescent: leaves or mostly leaflets smaller, seldom cordate, angulate-lobed; lower floral ones often similar, all as long as the pedicels: caly $x$ hirsute, ciliate-bearded or villous in the sinuses and throat : corolla apparently narrower and with shorter less notehed lips; the bearded ring at base within obsolete. - Proc. An. Acad. viii. 368. S. Romeviana, Torr. 1. c., in part. - New Mexico, on the Mimbres, 
Dr. Henry, Thurber; Florence Mountains, Bigclow. Adjacent borders of Texas, Wright.Throat of the calyx rather sparsely but not inconspicuously bearded!

$\S 4$. Calósphace, Benth. Throat of calyx naked, and of corolla not piloseannulate: anterior portion of the connective deflexed, linear or gradually somewhat dilated downward, closely approximate or connate, and destitute of an anther-cell : all American species, with upper lip of corolla erect and concave.

* Corolla crimson, its tube villous-annulate towards the base inside; upper lip conspicuously larger and longer than the lower: antcrior fork of connectives free and spatulate-dilated downwards, obscurely one-toothed at base, longer than the filament.

S. pentstemonoídes, Kunth. "Perennial, nearly glalurous, or below sparsely hirsute: stems 2 to 5 feet high, leafy to the sunmit: leaves thickish, oblong-lanceolate, acute, mucronate, entire or obscurely denticulate and with ciliolate-scabrous margins, the lower ( 3 to 5 inches long) on long margined petioles; upper gradually mucl smaller and sessile; the floral and the similar persistent bracts and bractlets of the elongated racemiform or narrowly thyrsoidal inflorescence ovate-lanceolate or narrower, cuspidate: cymules subsessile, 3-5-flowered: calyx equalled by the pedicels, campanulate, strongly bilabiate (half inch long), glandular-puberulent; upper lip broad, truncate, with 3 short and broad cuspidate-mucronate teeth; lower 2-parted, its teeth lanceolate and cuspidate: corolla inch and a half long, slightly pubescent; its large and nearly straight upper lip half the length of the gradually enlarged exserted tube ; midlle lobe of the small lower lip concave and entire: style glabrous. - Ind. Sem. Berol. 1848, 13. - W. Texas, on the Cibolo and Pierdenales and towards the Rio Grande, Lindheimer, Wright.

* * Lower and sterile forks of the connectives mostly united with each other longitudinally, linear, oblong, or senihastate: corolla naked within throughout,

+ Red or scarlet, with tube exserted; the spreading lower lip longer than the erect upper one, its broad middle lobe 2-cleft: upper lip of tubular-campanulate calyx and teeth of the 2-parted lower lip orate, mucronate-acute: inflorescence naked-racemose; the small floral leaves or bracts more or less deciduous or caducous.

S. Gréggii, Gray. Shrubby, 1 to 3 feet high, glabrous or obscurely farinaceous-puberulent: branches slender, leafy : leaves coriaceous ( 3 to 9 lines long), 1-ribbed, almost veinless, oblong, very obtuse, entire, narrowed at base into a short petiole : flowers rather few in the raceme: calyx slightly pubescent or glandular (barely half inch long), with at length spreading lips fully half the length of the tube: corolla (inch long, "red" or "purplish-red ") glabrous; its tube enlarging and strongly ventrieose-gibbous; throat abruptly contracted under the lower lip, which nearly equals the slightly glandular-puberulent upper one: lower fork of connective oblong-linear: style hairy along the upper side. - Proc. Am. Acad. viii. 360. S. microptylle, Torr. Bot. Mex. Bound. 131, not IIBK. - S. borders of Texas, on the Rio Grande, Parry, Schott. (Near Saltillo, Mex., Gregg.)

S. coccínea, L. Perennial or annual, canescently pubescent or glabrate, or hirsute towards the base with long spreading hairs: leaves membranaceous, veiny, cordate or ovate, mostly acute, crenate, slender-petioled, mostly soft-tomentulose beneath : raceme virgate; the clusters few-several-flowered and ratier distant: lips of the calyx hardly half the length of its tubc: corolla (inch or less long, pubescent or puberulent outside) deep scarlet-red, twice or thrice the Fength of the calyx; its narrow tube moderately enlarging above; lower lip twice the length of the upper, from which the stamens protrude: lower forks of the connective long and narrowly linear: style glabrous. - Mant. 88; Murr. Conm. Gott. 1778, t. 1. - Var. pseudo-coccinca is it commonly tall form of this species, witl stem, petioles, and often margins of fioral leaves conspicuously beset with hirsute hairs. S. pseudo-roccinea, Jacq. Ic. Rar. t. 209 ; Bot. Mag. t. 2864 . S. ciliata, Benth. Lab. 286. - S. Carolina to Florida (but probably introduced), S. Texas. (Mex., \&c.)

++ Corolla blue or purplish, sometimes white, never red.

$$
+ \text { Herbs. }
$$

$=$ Flowers from near an inch to over half inch and ealyx fully quarter inch long: inflorescence virgate-racemose or spiciform, sometimes paniculate: small floral leaves or bracts mostly deciduous: corolla with prominently exserted tube, erect and very concave or galcate and pubescent upper lip; the lower ionger and much larger: style bearded above: perennials, 1 to 5 feet hight.

S. farinácea, Benth. Minutely and canescently puberulent, or below glabrous: stems numerous in a cluster: lower leaves ovate-lanceolate or even ovate, with obtuse or cuneate 
or rarely subcordate base, coarsely and irregularly serrate, on slender petioles; upper lanceolate or linear-lanceolate, sometimes entire; floral subulate or ovate-lanceolate, mostly caducous : spiciform inflorescence un a long naked peduncle, interrupted, of densely manyflowered clusters, finely and the calyx very densely and softly white-tomentose (often tinged with violet); the latter oblong-cylindraceous and in age striate-sulcate, as it were truncate; the teeth 3 , very broad and obtuse, exceedingly short: lower lip of the violetblue corolla with middle division obcordate-two-lobed._Lab. 274 ; Braun in Bot."Zeit. ix. 44. S. trichostyla, Bischoff, Ind. Sen. Heidelb. 1847. S. amabilis, Kunth, Ind. Sen. Berol. 1818. S. cresia, Scheele in Linn. xxii. 588. - Texas, in rich soil; common.

S. azúrea, Lam. Glabrous or puberulent: lawer leaves lanceolate or oblong, obtuse, denticulate or serrate, tapering into a slight petiole; upper narrower, often linear, entire; floral or bracts subulate, somewhat persistent: spiciform inflorescence looser, nore interrupted, and fewer flowers in the clusters, sometimes thyrsoidal or paniculate-branched: pedicels short: calyx oblong-campanulate, usually minutely puberulent, obscurely bilabiate; the very broad and obtuse upper lip and the two similar but acutish lobes of the 2 parted lower lip distinct but short: corolla deep blue (sometimes varying to white); lower lip sinuately 3-lolsed and emarginate. - "Diar. Hist. Nat. i. 409," \& Dict. vi. 625; Pursh, Fl. i. 19 ; Bot. Mag. t. 1728. S. Mexicana, Walt. Car. 65, not L. S. acuminatissina, Vent, Cels, t. 50. S. angustifolia, Michx. Fl. i. 13, not Cav. S. acuminata, Pers. Syn. i. $24 . S$. elatu, Poir, Dict. vi. 625. S. coriffolia, Scheele in Linn. 1. c. - S. Carolina to Florida and Texas. Westward varies insensibly into

Var. grandiflóra, Benth. Cinereous-puberulent: denser inflorescence and calyx tomentulose-sericeous. - DC. Prodr. xii. 302. S. Pitcheri, Torr. in Benth. Lab. \& DC. 1. c. S. elongute, Torr. in Ann. Lyc. N. Y. ii. 231, not HBK. S. longifolic, Nutt. in Trans. Am. Phil. Soc. n. ser. v. 185. - Mississippi to Kansas, Colorado, and Texas.

S. angustifólia, Cav. Slender, usually glabrous, except usually some scattered spreading bristly hairs, especially at the nodes: leaves linear ( $1 \frac{1}{2}$ to 3 inches long, 1 or 2 lines wide), entire or obscurely denticulate, acute, somewhat petioled: inflorescence virgate, slender, of distant few-flowered clusters : pedicels very short: calyx narrowly oblong or cylindraceous, with lips half the length of the tube; upper ovate, entire, acute; lower of 2 similar but more pointed lobes: lower lip of the blue corolla as wide as long; the middle lobe emarginate or undulate. - Ic. iv. 9, t. 317; Benth. 1. c.; Bot. Reg. t. 1554; Brit. Isl. Gard. n. ser. t. 219. S. reptans, Jacq. Schœnbr. t. 319. S. virgata, Ort. - (Mex.)

Var. glábra. Wholly glabrous, even the hairy ring at the nodes wanting or obsolete. - S. azurea, Torr. Bot. Max. Bound. 181, in part: that including these three species. - S. W. Texas, Wright, \&c. (Mcx., HItrtuerg.)

$==$ Flowers barely half inch long or shorter, and bilabiate calyx a quarter inch long: corollatube harlly at all exserted: style glabrous or nearly so.

a. Annuals: leares from linear- to oblongr-lanceolate, tapering into the slender petiole: inflorescence virgate-spiciform, interrupted, naked, the floral leaves or bracts very small: upper lip of calyx ovate and entire.

S. lanceoláta, Willd. Puberulent or nearly glabrous, branched from the base, 5 to 12 inches liglı: leaves lanceolate or linear-oblong, obtuse, irregularly serrate with obtuse appressed teeth or nearly entire: the inconspicuous floral ones lanceolate or subulate, somewhat persistent, seldom exceeding the pedicels : calyx minutely hairy on the nerves, deeply bilabiate; its lower lip 2-cleft, the teeth ovate and mucronate-acute : corolia small (4 lines long), little exceeding the calyx, its lower lip little prolonged: lower fork of the connective narrowly linear, bearing its lateral lohe nearer the insertion. - Enum. 37 ; Jacq. f. Ecl. i. t. 19. S. trichostemoides, I'ursh, Fl. i. 19. - Plains, Nebraska to Texas, Arizona, and southward. Also E. Florida, Leavenworth. (Mex.)

S. subincísa, Benth. More pubescent above, a foot or more ligh : leaves oblong-lanceolate, incisely dentate (inch or two long) ; the floral minute, ovate, caducous : calyx glandular-pilose, hardly equalling the throat of the (half inch) corolla; the broad lower lip merely 2-tootled: lower fork of the connective bearing its lateral lobe at the middle. - Pl. Hartw. 20. - New Mexico and Adjacent Texas, Fendler, Wright, Bigelow. (Mex.)

b. Perennials, or the Arizonian species uncertain: leaves ovate, serrate, mostly slender-petioled; those of the interrupted spiciform or racemiform inflorescence small and caducous.

S. serótina, L. A span to 2 feet high, much branchou, pubescent: leaves ovate and with truncate or subcordate base, obtuse, crenate-serrate (9 to 20 lines long); floral minute: 
racemes simple, at first oblong, and the flowers crowded: calyx glandular-hirsute, with oblong-campanulate tube ( 3 lines long in fruit) of nearly thrice the length of the lips; upper lip broadly ovate, acutish; lower deltoid-ovate, mucronate-acute: corolla 3 to 5 lines long, the whole tube included: style beardless. - Mant. 25; Jacq. Ic. Rar. t. 3; Chapm. Fl. 319. S. Dominica, Vahl, Enum. i. 233; Swartz, Obs, 18, t. 1, fig. 1, not L. S. Florida. (W. Ind.)

S. albiflóra, Mart. \& Gal. Glabrous throughout, 2 to 4 feet high, paniculately branched: lenves rhombic-ovate or ovate-lanceolate, acuminate, acutely serrate (inch or two long); floral abruptly reduced to minute lanceolate and subulate bracts: clusters of rather loose raceme approximate: calyx (often amethystine-tinged) witl campanulate tube (2 lines long), twice the length of the lips; upper lip broadly ovate and entire; lower 2-tootleed or parted into broad acute lobes: corolla (probably bluish) 4 or 5 lines long, witl tube almost included : style bearded along the base of the much longer upper lobe. - (Bull. Acad. Brux., ex Benth. in DC. Prodr. 1. e. 307 ?) Torr. Bot. Mex. Bound. 131. - S. Arizona or Mexican border near it, Thurber, Schott. (Mex.)

S. Arizónica. Glabrous, except 2 puberulent lines down the stem, a foot or more high : leaves deltoid-ovate or with abruptly cuneate base, acute, coarsely and obtusely serrate (an inch long besides the slender petiole $\}$ : inflorescence spiciform and interrupted ; clusters several-flowered : pedicels short (a line long) : floral leaves abruptly reduced to membranaceous ovate-lanceolate and caulate bracts, which equal the flowers and are caducous: calyx 4 lines long, bilabiate to the middle or nearly; its upper lip subulately 3-toothed and lower more strongly 2-toothed: corolla (blue) fully half inch long, with tube a little exserted : style beardless. - S. Arizona, on Mount Gralıam, at 9,250 feet, Rothrock.

S. urticifólia, L. A foot or two high, villous-pubescent and somewhat viscid, or glabrate: leaves coarsely and obtusely serrate, ovate, acute, with truncate or sometimes cuneate base decurrent into a winged petiole, pale beneath, 2 to 4 inches long; floral all reduced to small ovate and slender-acuminate very caducous bracts : inflorescence racemose-spiciform, of numerous and several-flowered distant clusters: pedicels as long as the tube of the oblong-campanulate calyx; the broad lips of which are divergent and half the length of the tube, the upper mucronately (often minutely) 3-toothed, lower 2-cleft, its teetl broadly triangular-ovate and mucronate: corolla blue and white (5 or 6 lines long), twice the length of the calyx, its ample sinuately 3-lobed lower lip about twice the length of the upper, its broad middle lobe emarginate: connective ciliate opposite the insertion; its subulate antheriferous fork obtusely toothed toward the base, and lower fork semilastate : style strongly villous-bearded along the base of its much longer upper fork. - Spec. i. 24. S. Clcyltoni, M. A. Curtis, Cat. PI. N. Car., not Eil. ? - Maryland and Kentucky to Georgin and Louisiana.

$==\doteq$ Flowers only a thircl or a quarter inch long: corolla tube not exserted: inflorescence slender-spicate; the flowers or small clusters mostly distant.

a. Style-lobes or stigmas one or both subulate.

S. Chapmáni. Tall and erect perennial, tomentulose or cinereous-puberulent: leaves thickish, ovate or ovate-lanceolate with short cuneate base, somewhat appressed-serrate or crenulate ( 2 or 3 inches long); the floral all reduced to small and membranaceous ovate cordate-acuminate caducous bracts: calyx campanulate, in fruit 2 lines long; teeth short and broad, mucronate: corolla 4 lines long and with the ample lower lip of the precerling species. - S. urticifolia, var, major, Chapm. Fl. 319. - Middle Florida, Chtapman. Alabama, Buckley.

S. Blodgéttii, Chapm. Fl, 319, founded on incomplete specimens from S. Florida (Key West), Blodlyett, apparently an annual, with indurated base; thin ovate leaves obtuse at both ends, about lialf inch long, on filiform petioles of equal length; bracts of filiform racemes lanceolate or subulate, rather persistent, shorter than the pedicels; these a line long; calyx 2 lines, very like that of S'. serotinct. It may prove to be cither $S$. tenella, Swartz, or S. micruntha, Vahl (referred to it by Grisebach), weedy and insignificant W. Indian species, likely to stray to Key West.

b. Style-lobes or stigmas both broad and thin, roundish, very obtuse or truncate: calyx glandularhirsute.

S. occidentális, Swartz. Diffuse annual, minutely pubescent or nearly glabrous up to the very slender inflorescence (which has the aspect of that of Verbena officinalis) : stems 2 
to 6 feet long: leaves ovate, with rounded or cuneate base, serrate; floral or bracts minute, ovate, acuminate, persistent: flowers few in the clusters, subsessile. seldon 2 lines long including the slightly exserted corolla: calyx oblong, with very short pointless or mucronate teeth, nearly closed in fruit, then only 2 lines long. - Fl. Ind. Occ. 1. 4:?; Benth. in D'C. 1. c. 296. — S. Florida, Garber. (Trop. Am., \&c.)

S. privoídes, Benth. l. c. Resembles the preceding (and both stigmas in our specimens obtuse): but flowers more pedicellate, larger; with fructiferous calyx fully 3 lines long, rather deeply bilabiate: the upper lip and the lobes of the lower abruptly aristulate. Bot. Sulph. 150 \& in DC. 1. c. S. occidentals, var.? Garberi, Chapm. in Bot. Gazette, iii. 10. - Manatee, Southern Florida, Garber. A much less hairy form than the original, and more resembling the West Indian S. microntha, Vahl, except in the style and the awn-tipped calyx-lobes. (Trop. Am.)

++ Shrubbr.

= Leares oblong or elliptical, short-petioled : calyx cylindraceous or campanulate.

S. chamædryoídes, Cav. Low, much branched, canescent and scabrous : leaves thickish, more or less crenulate, obtuse (less than inch long); bract-like floral ones calucous : flowers geminate or few in the clusters of the raceme: caly $x$ cylindraceous-campanulate (4 lines long), striate, hispidulous on the nerves; ovate upper lip and teeth of the 2-parted lower lip acute or acuminate, not half the length of the tube: corolla blue, over half inch long; middle lobe of lower lip broader thau long, obcordate-lobed. - Ic. ii. 77, t. 197 ; Bot. Mag. t. 808. S. Chamadrys, Will. Hort. Berol. t. 29. - S. W. borders of Texas, in cañons of the Rio Grande, \&c., Wright, Pany. Specimens insufficient, probably of this species. (Mex.)

S. Párryi, Gray. Low, much branched: leaves ovate-oblong, mostly with truncate base, obtuse, crenate, short-petioled, tomentulose-canescent, as are the branchlets: bractlike floral leaves ovate, acuminate. membranaceous, glabrous above, apparently persistent, Ionger than the interruptedly spicate flowers: these several in cach cluster: calyx campanulate, densely lanate with white dendritic-branched hairs; upper lip 3-toothed, lower 2 cleft, equalling the tube of the short and small (blue?) slightly dendritic-pubescent corolla: upper lip of the Iatter emarginate; middle lobe of the Iower ample, 3-lobed, with its middle portion nucl larger, rounded, and emarginate: connectives free; lower fork semihastate, as long as the subulate antheriferous one.-Proc. Am. Acad, viii. 360 . S. spicata? Torr. Bot. Mex. Bound. 131, not Ram. \& Sch. - Apache Springs on the Rin) Grande, on the borders of Texas. Lower leaves not seen, upper 9 to 5 and floral 3 or 4 lines long.

$=$ Leares mostly orate, slender-petioled: calyx short-funnelform, in fruit with ampliate reticulate-veiny 2-3-lubed limb exceeding the tube of the short corolla: lower torli of the connective linear-obloing : style ciliate-bearded above.

S. ballotæeflóra, Benth. (NAJoraxo of the Mexicans.) Shrub 2 to 8 feet high, tomentulose-canescent: leaves ovate or somewhat oblong, truncate-cuneate or subcordate at base, crenate, reticulate-veiny, mostly rugose, glabrate and green above, white beneath ( 4 to 12 lines long): flowers in short and rather dense simple racemes and in axils of upper ordinary leaves, 4 lines long: caly $x$ twice the length of the pedicel, in flower 2 or barely 3 and in fruit 4 or 5 lines long, then pendulous; narrow tube striate-nerved; its 3 lobes broadly ovate, obtuse, entire, almost equal : connective hairy opposite its insertion : throat of small bluish or purple corolla ventricose-gibbous. - Bentl. Lab. 270; Torr. Bot. Mex. Bound. 131. S. ballotreflora \& S. laxa, Benth. in DC. 1. c. 313.- Southern and Western Texas. (Adjacent Mex.)

S. Platrcheíld, Gray, Proc. Am. Acad. viii. 202, from Carmen Island in the Gulf of California resembles the preceding, but has the lower lip of the calyx similar to the upper, except that the apex is 2 -toothed.

§5. SClákeA, Benth. \& Hook. Throat of calyx naked, and of corolla not pilose-annulate : anterior portion of the connectives deflexed, abruptly dilated and connected by the callose lower extremity, destitute of an anther-cell, or with a sterile rudiment: upper lip of corolla erect and concave, or falcate-compressed. Old World species, sparingly introduced. 
S. Sclarea, L. (Clary.) Biennial, villous-pubescent, viscid; stem stout, 2 or 3 feet high : leaves ample, long-petioled, ovate and cordate, crenate, rugose; floral forming bracts of the cylindrical or interrupted spike, ovate, acuminate, tinged with white and rose-color: calyx campanulate; teeth spinulose-acuminate: corolla white and bluish, rather large, widely ringent; its short tube included; long upper lip falcate and compressed. - Pennsylvania, escaped from gardens. (Nat. from Eu.)

S. verrenÁcea, L., Muhl. Perennial, pubescent or villous, a foot or two high : leaves ovate or oblong, often cordate at base, obtuse, mostly sinuate-incised or moderately pinnatifid and the lobes crenate-toothed, rugose, almost glabrous; the few cauline mostly sessile; the floral inconspicuous, rounded-ovate: raceme interrupted: calyx refiexed after flowering; its broad and rounded upper lip recurved-spreading, with 3 minute connivent teeth; the lower of 2 longer triangular-subulate and cuspidate teeth, equalling the throat of the small bluish corolla, the upper lip of which is nearly straight. $-S$. Claytoni, Ell., excl. reference to Clayton, whose plant is $S$. lyrata? - Dry sandy pastures around Beaufort, S. Carolina, Elliott. Sparingly seen in the Middle States. (Nat. from Eu.)

29. AUDIBÉRTIA, Benth. (M. Audibert of Tarascon, Provence.)W. North American (all Californian, one species of wider range), fruticose or perennial-herbaceous, mostly canescent-tomentose; with crenate or crenulate and reticulated leaves, and flowers resembling those of Salvia of the S. officinalis type: H. spring and summer. (Noted bee-plants in S. California.)

$\S 1$. Infloresceuce densely verticillastrate-glomerate and interrupted-spicate, much bracteate: corolla with tube longer than the limb.

* Large-flowered : corolla fully inch and a half long, crimson-purple; upper lip rather erect and short, emarginate: lower leaves cordate or lastate at base.

A. grandiflóra, Benth. Stem villous and glandular, stout, suffrutescent, 2 or 3 feet high:. leaves very rugose, tomentose beneath, sinuate-crenate; lower mostly hastate-lanceolate, obtuse, 3 to 8 inches long, on margined petioles; upper oblong and sessile; floral and bracts of the large heads broadly ovate, membranaceous: calyx spathaceous, deeply cleft between the two small anterior cuspidate-tipped teeth; ample concave upper lip 3-denticulate: stamens much exserted : a conspicuons slender tooth representing the lower fork of the connective. - Lab. 312, \& DC. Prodr. xii. 350; Torr. Bot. Mex. Bound. t. 38 (sterile filaments wrongly represented); Gray, Bot. Calif. i. 600. - California Coast Ranges, \&c., from San Mateo Co. southward.

* Smaller-flowered: corolla less than an inch long, violet or bluish : leaves not cordate.

+ Bracts, upper floral leaves, and bilabiate calyx scarious-membranaceous, reticulated, usually colored, obtuse and muticous (or at most mucronate); the former large and roundish, half inch or more iong, imbricating the close heads: corolla only half inch long, narrow, and with short limb: low suffruticose species of the interior arid region.

A. incána, Benth. l. c. Closely tomentose-canescent, leafy : leaves spatulate or obovate, obtuse or retuse, not rugose, entire (or sparsely crenulate), seldom inch long: bracts obovate or oval, pubescent and ciliate, purple-tinged: caly $\mathrm{x}$ turbinate; anterior teeth ovate or oblong, rather shorter than the truncate and emarginate very broad upper lip: stamens much exserted: connective with or without a dentiform appendage. - Lindl. Bot. Reg. t. 1469 ; Gray, 1. c. - From interior of Washington Terr. and Idaho south to Arizona, and along the eastern borders of California.

A. capitáta, Gray. Cinereous-puberulent: leaves oblong, acutish, very rugose, crenulate, slender-petioled: bracts of solitary head ovate or oval, apparently whitish : flowers, \&c., of the preceding. - Proc. Am. Acad. vii. 387, \& Bot. Calif. 1. c. - Providence Mountains, San Bernardino Co., S. E. California, Cooper.

++ Bracts more or less herbaceous, at least not colored: leaves minutely rugose, crenulate: species restricted to California.

++ Corolla barely half inch long: all the calyx-teeth and bracts subulate or aristate-tipped.

A. húmilis, Benth. 1. c. Stems simple and only a span high from a thickened suffruticose base, almost leafless and scapiform : leaves crowded at the base, lanceolate or spatulate-oblong, very obtuse, finely rugose, densely crenulate, canescent, an inch or more long, 
tapering into a slender petiole; the mostly inconspicuous floral ones and the bracts villous, nembranaceous, ovate-lanceolate and lanceolate: caly $x$ distinctly bilabiate but rather more deeply cleft between the anterior teeth; these and the 3 teeth of the ample concave upper lip subulate but not rigid; lower lip of the corolla crenulate-erose: stamens and style long-exserted: connective continuous with the filament. - From the Yuba River to San Diego Co., but rare.

A. stachyoídes, Benth. l. c. Shrubby, branching and leafy, a yard or more high, cinereous-tomentulose or glabrate, rigid: leaves somewhat less rugose than in the last, more crenate, oblong-lanceolate, narrowed at base or short-petioled; the floral and ovate or oblong bracts with the teeth of the bilabiate calyx cuspidate-acuminate or spinulosearistulate (rarely almost muticous) : style and especially the stamens little exserted : subulate appendage of connective often manifest. - From San Francisco Bay to the southern borders of the State : forming thickets.

$+\div$ Corolla from two-thirts to three-foulths inch long, with tube much surpassing the calyx and short more or less pointed thinnish bracts: upper lip of the calyx 1-3-mucronate; teeth of the lower cuspidate: stamens and style moderately exserted: stems woody below, $t$ to 8 feet hirh, with herbaceous Jong and virgate branclies: glomerules rather large, scattered or rather distant: foliage minutely tomentose-canescent.

A. Pálmeri, Gray. Leaves oblong-lanceolate, acute (not unlike those of the preceding species), the larger 2 or 3 inches long: verticillastrate heads several ( 4 to 8 ) and remote in the elongated virgate spike: bracts oblong or lanceolate, slender-cuspidate or acuminate : lower caly x-teeth subulate-setaceous. - Bot. Calif. i. 601. - Near Tighe's Ranch, mountains north-east of San Diego, Palmer.

A. Clevelándi, Gray. Leaves oblong, or the upper lanceolate-oblong, all obtuse, seldom over an inch or so in length: heads fewer, often solitary or terminating short axillary branches: bracts ovate or oblong, mucronate or abruptly short-pointed, viscid-pubescent, as is the calyx; the lower teeth of which are short and subulate, the upper lip entire and cuspidate-tipped. - Proc. Am. Acad. x. 76, \& Bot. Calif. 1. c. - Mountains behind San Diego, Clevelund, Palmer.

+++ Corolla barely half inch long; its tube hardly exceeding the herbaceous obtuse and muticous bracts and calyx teeth : whole plant hoary-white.

A. nívea, Benth. Canescent with a close white-farinose tomentum, 3 or 4 feet high, shrubby below, leafy: leaves oblong-lanceolate, or the lowest ovate, obtuse; upper with truncate base, very short-petioled: bracts oval or oblong : calyx splitting down anteriorly, at length emarginate posteriorly : corolla light-purple: stamens and style much exserted: connective almost continuous with the filament. - Lab. 313 \& DC. I. c. - Dry hills, from Santa Barbara to San Diego Co.

§2. Inflorescence thyrsoid-paniculate: floral leaves, bracts, and bractlets small and loose, at length reflexed, lanceolate or subulate, cuspidate-tipped: corolla with ample lower lip twice the length of the upper; the tube very short.

A. polystáchya, Benth. 1. c. Shrubby, 3 to 10 feet high, minutely tomentose-canescent : branches and elongated naked thyrsus virgate : leaves mostly very white, oblong-lanceolate, minutely rugose and crenulate, 2 or 3 inches long: flowers subsessile, loose: upper lip of the calyx truncate or 3-toothed, at length concave or galeate, longer than the triangular-subulate lower teeth: corolla pale or white; lower lip half inch and tube quarter inch long: style and divergent stamens long-exserted : filiform connective continuous with the filament, its lower end usually indicated by a minute tooth. - Arid hills, Santa Barbara to San Diego Co. One of the shrubs called Grease-wood,

30. MONARDA, L. Honse-Mint. (Nicolas Monardes, early writer upon American medicinal plants.) - Aromatic erect herbs (of Atlantic N. America, reaching to the Rocky Mountains), usually tall; with the large verticillastrate-capitate glomerules single, or as if proliferous-spicate, or in upper axils, and involucrate by numerous sometimes colored outer bracts and floral leaves: flowers rather large, in summer. (Gray, Proc. Am. Acad. viii. 369.) 
§1. Eumonf́rda, Benth. Heads solitary and terminal or sometimes 2 or 3 , as if proliferous : stamens and style conspicnously exserted from the linear and mostly acute upper lip of the (red, purple, or white) corolla: leaves acutely more or less serrate, pinnately veiny: root perennial.

* Leaves distinctly petioled : calyx-teeth little if at all longer than the width of the tube: corolla with middle lobe of lower lip longer and narrower, emarginate.

M. dídyma, L. (Oswego Tea, Bee-Batm.) Villous-hirsute to glabrate: stem acutely 4-angled: leaves thin, ovate-lanceolate, acuminate: bracts, \&c., tinged with red : calyx slightly hirsute in the throat; teeth narrowly subulate: corolla nearly glabrous, scarletred (1 $1 \frac{1}{2}$ or 2 inches long). - Spec. i. 22 ; Sims, Bot. Mag. t. 546; Schk. Handb. t. 2. M. purpurea, Lam. Dict. iv. 256. M. fistulosa, Sims, Bot. Mag. t. 145. M. coccinea, Michx. Fl. i. 16; Desc. Ant. v. t. 369 . M. Kalmiana, Pursh, Fl. i. 17, t. 1. M. Oswegoensis, Bart. Prodr. Penn. i. 34. - Wet banks of streamlets, Canada to Michigan, and south to Georgia in the mountains; also in gardens.

M. clinopódia, L. Nearly glabrous to villous-pubescent: stem rather acutely angled: leaves ovate-lanceolate and ovate, slender-petioled, thin, coarsely and sharply serrate: bracts whitish : calyx moderately hirsute in the throat: corolla slightly pubescent, dull white or flesh-colored, an inch long. - Spec. i. 22, excl. syn. Grorfov. M. glabra, Lam. Dict. iv. 256. M1. rugosa, Ait. Kew. ed. 1, i. 36. M. altissima, Willd. Enum. 3i; ; Reichenb. Ic. Exot. ii. t. 182. Pycnanthemum Monardella, Michx. Fl. ii. 8, t. 34. Monardella Caroliniana, Benth. Lab. 332. - Shady places, ravines, \&c., W. Canada to Illinois, and along the mountains to Georgia.

M. fistulósa, L. 1. c. Soft-pubescent with short hairs, or somewhat hairy, or glabrate: stem mostly with abtuse angles: leaves commonly of firmer texture than in the preceding: bracts whitish or rarely purplish, the inner mostly hirsute-ciliate: calyx conspicuously and densely bẹarded at the throat: corolla pubescent, at least on the upper lip, purple or purplish-dotted, an inch or nore long. - Origanum fistulosum Canadense, Cornuti, Canad. 13, t. 14. Monarda oblongata, Ait. l. c., narrow-leaved form. M. longifolia, Lam. l. c., narrowleaved form. M. allophylla, Michx. Fl. i. 16. M. varians, Bart. 1. c. M. involucrata, and many others, Wenderoth, Sem. hort. Marb. M. altissima, mollis (Willd.), undulata (Tausch), \& affinis (Link), Reichenb. Ic. Exot. t. 170, 171, 181, 182. - Dry soil, Canada and Vermont to Florida and Texas, west to Brit. Columbia and Arizona. The following are the more marked forms of this polymorphous species.

Var. rúbra. Corolla bright erimson- or rose-red : habit of $M I$. didyma, but upper lip of corolla villous-bearled on the back at tip: throat of calyx conspicuously hirsute, with external bristly hairs widely spreading. $-M$. purpurea, Pursh, l. c., excl. syn. Bot. Mag,? - Alleghany Mountains, in moist ground.

Var. média. Corolla deep purple. - M. media, Willd. Enum. 32; Sweet, Brit. Fl. Gard. t. 98. M. purpurea, Lodd. Cab. t. 1896. - Alleghany and southern Rocky Mountains.

Var. móllis, Benth. Corolla from flesh-color to lilac, glandular, and its upper lip hairy outside or more bearded at the tip: leaves paler, soft-pubescent beneath, often shorter-petioled; throat of the calyx mostly filled with dense beard, with or without an external ring of more bristly widely spreading laairs. - Mr. mollis, L. Amoen. Acad. iii. 399; Reichenb. I. c. t. 171 . M1. scalra, Beck (in Am. Jour. Sci. x. 260), \& M. mentherfolia, Graham, in Bot. Mag. t. 2058; form with smaller firmer leaves and stem roughish-hirsute on the angles. M. Lindheimeri, Engelm. \& Gray, PI. Lindh. i. 20. - This extends to Saskatchewan, Brit. Columbia, interior of Oregon and Arizona.

* * Leaves subsessile or very short-petioled; floral ones often purplish or whitish : corolla fleshcolor or whitish, its lower lip usually spotted with purple: caly $\mathbf{x}$-teeth loose or stellate-spreading after flowering: stem slencler: head solitary.

M. Bradburiána, Beck. Pubeseent with slender hairs or glabrate: leaves ovate or ovate-lanceolate from a broad roundish or subcordate base, acuminate: calyx hirsute and somewhat contracted at the orifice; its teeth elongated and aristiform: tube of the corolla not exceeding the long and narrow pubescent upper lip; the middle lobe of its broad lower lip much longer than the lateral ones. - Am. Jour. Sci. x. 260; Benth. Lab. 317. M. fistulosa, Hook. Bot. Mag. t. 3310, excl. syn. Mr. amplexicaulis, Bischoff, Ind. Sem. Heidelb. 1838. M, villosa, Martens; Walp. Repert. iii. 683. - Thickets, Illinois to Tennessee and Kansas. 
M. Russelliána, Nutt. Slender, sparingly pubescent: leaves lanceolate or narrowly ovate-lanceolate from a rounded or subcordate base: calyx naked at orifice; its slendersubulate teeth muricate-glandular: corolla nearly glabrous, slender, with long and much exserted tube; lower lip shorter, obscurely 3-lobed at the extremity. - Trav. Arkans. \& Trans. Am. Phil. Soc. n. ser. '. 185; Hook. Bot. Mag. t. 2513 \& Exot. Fl. t. 130 ; Sweet, Brit. Fl. Gard. t. 166. - Arkansas, Nuttall, T. L. Harvey.

§ 2. Cheilýctis, Benth. Heads (i. e. verticillastrate glomerules) commonly in the axils of all the upper pairs of leaves, or interrupted-spicate, foliose-bracteate: upper face of the floral leaves and larger bracts often canescent and sometimes purple-tinged : corolla with shorter almost included tube, more dilated throat, and oblong lips; the upper arching, emarginate or cleft at apex (either sparsely bearded or glabrous in the same species), seldom at all surpassed by the stamens; lower with middle lobe often broadest: leaves lanceolate or oblong, sparsely serrate or denticulate, tapering into the petiole: minute pubescence more or less cinereous. - Cheilyctis, Ruf. MLonarda $\$$ Coryanthus, Nutt.

* Cornlla yellowis' with copious brown-purple spots : calyx-teeth lanceolate- or triangular-subulate: floral leaves and involucrute bracts mostly muticous: root perennial.

M. punctáta, L. (Horse-入[1хт.) Stem commonly 2 feet high : floral leaves and bracts (either whitened or purplish or both) of ten slender-acuminate : caly x-teeth rigid, soon stellatespreading, hardly longer than the width of the villous orifice of the tube- - Spec. i. 22; Andr. Bot. Rep. t. 546; Bot. Reg. t. 87. 11. lutea, Michx. Fl. i. 16. - Sandy ground, New York to Wisconsin, and south to Florida and Texas. Varies in foliage, pubescence, \&c., passing into

Var. lasiodónta, Gray, l. e,, with throat and teeth of calyx densely villous: plant sometimes robust, often smaller, and narrow-leaved. - Texas, Drummond. New Mexico and Arizona, Wislizenus, Wooodhouse, Rothrock.

* * Corolla white or pinkish, not spotted, but more or less punctate: calyx-teeth aristiform or subulate-setaceous : involucral bracts conspicuously aristate-tipped: root annual.

M. pectináta, Nutt. Rather low and slender: floral leaves and bracts of the comparatively small heads mostly green; the latter oblong, short-aristate, obscurely 3-nerved, hirsute-ciliate : calyx-teeth subulate-setaceous from a broad base, soon spreading, villous-hirsute within, twice the length of the width of the very villous orifice. - Pl. Gamb. 182. M. citriodora, var. aristulata, Gray, Proc. Am. Acad. viii. 369, in part, where Nuttall's name was inadvertently written "Mr. penicillata." - New Mexico, near Santa Fé, Gambel. Not since seen. Seemingly a hybrid between $M$. punctuta and $M$. citriodora.

M. clinopodioídes. Slender, a foot or more high : bracts of the rather small heads mostly green or greenish, erect, oblong-ovate to obovate-lanceolate, rigid, strongly $8-5$ nerver, hispid-ciliate: calyx-teeth al ways erect, rigid, aristiform-attenuate (tapering gradually from the base), fully two-thirds the length of the hirsute tube, purplish, sparsely hispid; throat densely short-villous. - 11. aristata, Hook. Bot. Mag. t. 35026, not Nutt. M. citriodora, var. aristulata, Gray, 1. c., in part. - Texas, Drummond, Wright, Reverchon. .

M. citriodóra, Cerv. Usually more robust, the larger forms ( 2 or 3 feet high) with the aspect of $M$. punctata : bracts narrowly oblong, similarly whitened or purple-tinged, at least their spreading or recurving and abruptly aristulate or slender aristate tips : throat of the calyx densely villous; the teeth slender-aristiform, at length usually spreading, half or two-thirds the length of the mostly glabrous tube, from sparsely hirsute-plumose with long soft hairs to naked. - Cervantes in Lag. Nov. Gen. \& Spec. 2 (1816); Gray, 1. c., the var. tenui-aristata. M. aristata, Nutt, in Trans. Am. Phil. Soc. n. ser. v. 186 ; Benth. Lab. 318, \& DC. I. e. 363: excl. the char. of the calyx-teeth at the close, which was taken from $M$. punctata, var. lasiodonta. - Plains of Nebraska to 'Texas, Eastern Colorado, and Arizona, (Mex.)

M. GRÁcilis, Pursh, Fl. i. 17, described from a specimen in Lyon's herbarium, said to come from the mountains of South Carolina (to which Virginia and the accustomed $v$. $v$. are added by Pursh), is not identified by the description. It may not improbably be Pycnanthemum montanum, Michx. 
31. BLEPHILIA, Raf. (From $\beta \lambda \varepsilon \varphi \alpha \rho i s$, the eye-lash, suggested by the conspicuously ciliate bracts, \&c.) - Perennial herbs, of the Atlantic United States, resembling Monarda in foliage, \&c, but with smaller verticillastrate-capitate glomerules, the upper more spicate; and small purple or bluish-white corolla, with the lower lip darker-spotted: fl. summer.

B. ciliáta, Raf. Stem a foot or two high, often simple, downy with short soft pubescence: leaves short-petioled, oblong, obtuse, obscurely serrate; the upper sessile and mostly narrowed at base; lower floral similar, uppermost and outer bracts of the mostly spicate-approximate heads ovate, cuspidate-acuminate, chartaceo-membranaceous, somewhat colored, strongly ciliate, conspicuously many-nerved from a stout midrib, about equalling the calyx : corolla villous-pubescent outside, purple. - Jour. Phys. Ixxxix. 98; Benth. Lab. 319 \& DC. Prodr. xii. 364. Monarda ciliata, L. Spec. i. 23 (Pluk. Alm. t. 164, fig. 3; Moris. Hist. iii. sect. 11, t. 8, fig. 6.) - Dry ground, Penn. (and recently at Hadley, Mass.), to Wisconsin, Georgia, and Missouri. Varies westward with more villous pubescence.

B. hirsúta, Benth. l.c. Taller, loosely branching, villous-hirsute: leaves slender-petioled, ovate or ovate-lanceolate, acuminate, with rounded or subcordate base; lower floral similar, subtending remote heads; upper floral and the bracts lanceolate and linear, subulate or aristate, few-nerved, hirsute with long hairs, as is the calyx : corolla less pubescent, pale, with some conspicuous dark spots. - B. nepetoides, Raf. l. c. Monarda hirsuta, Pursh, Fl. i. 19. M. ciliata, Michx. Fl. i. 16, not L.-Moist shady places, Canada and Vermont to Wisconsin, south to Missouri and E. Texas, and through the Alleghanies to Georgia.

32. LOPHÁNTHUS, Benth. (Aógos, crest, and ävoos, flower: application not evident.) - Perennial erect herbs (of N. America and N. E. Asia), mostly tall and coarse; with serrate and veiny petioled leaves, the lower usually subcordate and the upper ovate, and small flowers in dense and sessile verticillastrate glomerules, which are congested into a terminal spike, either continuous or interrupted below: floral leaves reduced to short ovate and acuminate bracts. Nutlets minutely hairy or glandular at the top. Fl. summer. - Bot. Reg. xv. \& Lab. 462. Agastache, Clayt., Gronov. Virg. ed. 2, 88.

* Calyx-teeth green and herbaceous, ovate, obtuse: corolla greenish-yellow, almost included.

L. nepetoídes, Benth. l. c. Glabrous or barely puberulent: stem $2 \frac{1}{2}$ to 5 feet high, acute-angled : leaves ovate, acute: spike cylindrical, linear, nearly continuous. $-H_{y}$ ssopus nepetoides, L. Spec. ii. 569; Jacq. Vind. t. 69. - Borders of woods, Vermont and Connecticut to Wisconsin, and south to mountains of Carolina and Texas.

* * Calyx-teeth acute, membranaceous, more or less colored : corolla purplish or bluish, more conspicuous.

L. scrophulariæfólius, Benth. 1.c. Stem 4 to 6 feet high, stout : leaves ovate or the lower cordate, acuminate, more or less pubescent or glabrous: spikes thickish, mostly interrupted, 4 to 16 inches long: calyx-teeth ovate-lanceolate, acute, whitish : corolla dull purplish. - H. scrophularicefolius, Willd. Spec. iii. 48. - Borders of thickets, New York to Wisconsin, Kentucky, and mountains of N. Carolina.

L. anisátus, Benth. 1. c. Glabrous or very minutely puberulent, 2 or 3 feet high : leaves ovate, often subcordate, canescent beneath, anisate-scented when crushed: spike short and narrow, interrupted, sometines leafy below and paniculate: calyx canescertly puberulent; the tecth ovate-lanceolate and merely acute, tinged with purple or violet: corolla blue, - Bot. Reg. t. 1282. Hyssopus anisatus, Nutt. Gen. ii. 27. H. discolor, Desf. Cat. Par. Stachys feeniculum, Pursh, Fl. ii. 407. - Plains, Wisconsin to Saskatchewan, the northern Rocky Mountains, and Nebraska.

L. urticifólius, Benth. 1. c. Like the last, but leaves green both sides, mostly crenate and more or less cordate, sweet-aromatic: calyx-teeth lanceolate, subulate-acuminate: corolla light violet or purplish. - Western slopes of Rocky Mountains to Oregon, Nevada, and California. 
33. CEDRONELLA, Moench. (Diminutive of Cedrus, the Cedar tree, from the sweet-scented leaves of C.triphylla of the Canaries and Madeira, the Balm-of-Gilead of English gardens.) - The following are the other species; sweet-odorous perennials; with petioled leaves, and flesh-colored or purplish flowers, in summer. - Meth. 411 ; Benth. Lab. 501.

$\S 1$. Tube of corolla little exserted beyond the ample calyx, its throat inflated: stamens shorter than the upper lip: flowers rather few, loosely and almost simply spicate.

C. cordáta, Benth. l. c. Low, hirsute-pubescent, producing long leafy runners: leaves long-petioled, cordate, crenate; the floral reduced to ovate bracts, each subtending 1 to 3 short-pedicelled minutely bracteolate flowers : calyx campanulate: corolla purplish, hairy inside, over an inch long. - Dracocephalum cordatum, Nutt. Gen. ii. 35. - Moist shady banks, W. Penn. to Kentucky and mountains of N. Carolina and Tennessee.

§ 2. Corolla slender, with tube exserted beyond the narrow calyx: stamens exserted: erect herbs of the Mexican region; with the verticillastrate glomerules or condensed cymes interrupted-spicate in the manner of Lophanthus, but less condensed.

C. Mexicána, Benth. Puberulent or almost glabrous : stems 1 to 3 feet high : leaves ovate-lanceolate, or the lower ovate and cordate, crenate-dentate; lower floral sessile and often entire; upper ones lanceolate and reduced to short bracts of the many-flowered spicate clusters: teeth of the purplish calyx subulate: corolla bright pink (an inch or more long), thrice the length of the calyx. - Dracocephalum Mexicanum, HBK. Nov. Gen. \& Spec. ii. 322, t. 160 . Gardoquia betonicoides, Lindl. Bot. Reg. xxiv. misc. 86; Hook. Bot. Mag. t. 3860. - Mountains of S. Arizona, near Santa Cruz, Wright. A form with mainly ovate and obtuse coarsely crenate leaves, resembling C. pallida, Lindl. Bot. Reg. xxxii. t. 29, but with (inch long) much exserted corolla. (Mex.)

Var. cána, Gray. Pale and very minutely cinereous, or inclined to be so: leaves smaller (half to inch and a half long), less toothed: corolla an inch long or sometimes much sinaller. - Proc. Am. Acad. viii. 370. C. cana, Hook. Bot, Mag. t. 4618; Torr. Bot. Mex. Bound. 133, chiefly. - New Mexico, Wright, Bigelow, \&c. A form with much smaller (seemingly not well-developed) flowers is C.pallida, var., Torr. 1. c. and Hyptis spicata? Torr. l. 七. 129. - S. Arizona, Wright, Thurber. (Adjacent Mex.)

C. micrántha, Gray, l. c. Puberulent: stems slender, branching above: leaves thin, slender-petioled, coarsely crenate-dentate; the lower cordate-ovate, obtuse; upper ovatelanceolate or oblong; upper floral reduced to minute bracts and shorter than the calyx: capitate clusters sessile, many-flowered, mostly approximate in a cylindrical naked spike: calyx ovate-campanulate, less than 2 lines long, greenish; the triangular-subulate teeth about half the lengtlı of the tube: corolla (whitish, barely 2 lines long) and stamens little exserted. - S. W. Texas, towards the border of New Mexico (station not recorded), Wright. Spikes 2 inches long.

34. NEPETA, L. Cat-Mint. (Probably from the Etrurian city Nepete.) A large genus in the Old World; two are naturalized weeds in the New, representing distinct sections, differing in habit and inflorescence, rather than in the flowers, which are produced all summer.

N. Catária, L. (Catrip.) Erect, branched, tall, minutely tomentose: leaves ovate or oblong and cordate, coarsely crenate, green above, canescent beneath: glomerate cymes many-flowered, spicate-crowded at the extremity of the branches, subtended by small floral leaves: bracts and calyx-teeth slender-subulate, soft: corolla whitish with some dark dots; the middle lobe of lower lip crenate-dentate. - Common eastward, especially near dwellings. (Nat. from Eu.)

N. Glechóma, Benth. Procumbent or creeping, slender, somewhat pubescent, equally leafy throughout : leaves long-petioled, reniform or round-cordate, coarsely crenate: flowers 2 or 
3 together in the axils of the leaves, short-pedicelled : bracts setaceous : calyx-teeth setaceous-acuminate from a broad base, soon spreading : corolla light blue, inch or less long: pairs of stamens very unequal: anthers in perfect flowers closely approximate in pairs; the anther-cells diverging at a right angle, and each pair forming a cross : but the plant is gynodiocious, i. e. some produce only female flowers with abortive stamens. - Lab. 485. Glechoma hederacea, L. - Damp or shady places east of the Mississippi, in woods as well as near dwellings. Popularly named Gill-over-the-Ground. (Nat. from Eu.)

35. DRACOCEPHALUM, Tourn. Dragon-head (as the name, composed of $\delta \varrho \alpha \% \omega \nu$ and $x \varepsilon q \alpha \lambda \dot{\gamma}$, denotes). - Herbs, chiefly of North Asia, one North American, peculiar for its small and included corolla.

D. parvillórum, Nutt. Annual or biennial, 6 to 20 inches high, rather stout, somewhat pubescent: leaves lanceolate or oblong, petioled, incisely dentate, or the lower pinnatifid-incised; the lower floral sinilar: flowers numerous in sessile glomerules crowded in a thick terminal leafy-bracted head or short spike interrupted at base: bracts pectinatelaciniate and the teeth aristate: upper tooth of the calyx ovate, the others lanceolate and subulate-acuminate: corolla bluish, slender, hardly exceeding the calyx. - Gen. ii. 35; Benth. in DC. xii. 400. Rocky or gravelly soil, N. New York (shore of Lake Ontario) and L. Superior, to Brit. Columbia, and along the mountains to Utah and New Mexico : $\mathbf{f l}$. spring.

36. SCUTELLÁRIA, L. SKullcap. (Scutella, a dish or platter, from the form of the fruiting calyx.) - Large and widely diffused genus, of bitter (not aromatic) chiefly perennial herbs, rarely undershrubby; with single (mostly blue or bluish) flowers in the axils of leaves, or when the floral leaves are reduced to bracts then in (commonly secund) spikes or racemes: fl. spring and summer. Corolla arrect. All but two of our species are perennial, and the flowers in all are opposite, one in each axil.

$\S 1$. Nutlets wingless, mostly marginless, on a low or slightly elevated gynobase.

* Flowers small (only a quarter inch long), in axillary and sometimes also terminal racemes.

S. lateriflóra, L. (Mad-Dog Srullcap.) Glabrous, a foot or two high, leafy : leaves thin, oblong-ovate and ovate-lanceolate, acuminate, coarsely serrate, rounded at base, slender-petioled; the lower floral ones of the terminal racemes similar: lips of the corolla short, equal in length. - Spec. ii. 598; Lam. Dict. t. 515; Raf. Med. Fl. t. 84; Bart. Fl. Ain. Sept. i. t. 21. - Wet borders of streams, Canada to Florida, New Mexico, and nortltwardly to Oregon and Brit. Columbia.

* * Flowers larger (half to full inch long), in terminal single or panicled racemes, which are commonly more or less leafy below, the floral leaves being gradually reduced to bracts.

+ Cauline leaves all cordate, crenate-toothed, and slender-petioled : lateral lobes of the corolla almost equalling the short uppor lip : anther's minutely ciliate.

S. versícolor, Nutt. Soft-pubescent: stem rather stout, erect, 1 to 3 feet high : leaves rugosely very veiny, broadly cordate, mostly obtuse ( 3 or 4 inches long); the floral ovate, entire (half inch long), crowded: racemes glandular-pubescent: corolla bright blue with lower side and lip whitish. - Gen. ii. 38. S. Caroliniana, Walt. Car. 163? S. cordifolia, Muhl. Cat. - Banks of streams, Penn. and Wisconsin to Floridn and Texas.

Var. bracteáta, Benth. Robust, with larger and firmer floral leaves, many of the lower occasionally longer than the flowers, which thus appear to be axillary rather than racemose. - Lab. 433. - Texas.

Var. mínor, Chapm. Low, slender, and thin-leaved : floral leaves small._Fl. 323. S. rugosa, Wood, Class-Book. - Mountains of Virginia, \&c.

S. saxátilis, Riddell. Slightly and sparsely pubescent, or glabrous : stems slender, weak, ascending (a span or two high), stoloniferous from the base: leaves thin, moderately veiny, cordate-ovate, obtuse, crenate-dentate (inch or tiro long); floral ovate or oblong, entire: raceme simple, loose : corolla light blue. - Cat. Pl. Ohio, Suppl. (1836) 14 ; Benth. in DC. Prodr. xii. 422 ; Gray, Man. ed. 1, 327. - Shaded moist banks, Delaware to Ohio and Tennessee. 
Var. argúta. Pilose-pubescent: thin leaves narrower, acutisl, more decply crenatedentate. - S. arguta, Buckley in Am. Jour. Sci. xlv. 175; Chapm. Fl. 323. S. saxatilis, var. ? pilosior, Bentl. I. c., at least in part. S. Chamadrys, Shuttleworth in Ind. Sem. Lips., on char. - Mountains of Carolina and Georgia.

+ + Cauline leaves crenate-dentate or serrate, only the lowest if any cordate at base, more or less petioled: lateral lobes of the blue corolla shorter than the galeate upper lip and more connected with it.

+ Corolla a full inch long, nearly glabrous: stem (a foot or two high) and loosely flowered somewhat leafy erect raceme simple, or rarely a pair of racimes at the base of the terminal one: leaves ( 3 to 5 pairs) coarsely and sharply serrate, acute ol acuminate, mostly acute at base, 2 to 4 inches long; the lowest toral usually large and similar; upper entire and lanceolate.

S. montána, Chapm. Soft-pubescent: leaves oblong-ovate or the lowest subcordate: calyx velvety-pubescent: tube of the corolla ampliate upward, and the lips very broad, the upper emarginate. - Bot. Gazette, iii. 11. - Dry woods and fields, in the mountains of the north-western part of Georgia, Chapman.

S. serráta, Andr. Glabrous, or obscurely pubescent: leaves thin, ovate or ovate-oblong: corolla with narrow tube, moderately ampliate throat, and rather narrow upper lip. - Bot. Rep. t. 494 ; Benth. in DC. 1. c. 422. - Woods, Penn. to Illinois and N. Carolina.

++ Corolla two-thirds or three-fourths inch long, canescently puberulent: racemes numerous, thyrsoid-paniculate, many-flowered.

S. canéscens, Nutt. Minutely and canescently pubescent: stem 2 to 4 feet ligh, leafy : leaves from oblong-ovate to Ianceolate-oblong, crenate-serrate, acute ( 3 or 4 incles long), the base obtuse or rounded, or of the uppermost acute, and lowest occasionally subcordate, the upper surface green and glabrous, the lower canescent, as also the racemes and especially the calyx : upper lip of corolla considerably surpassing the lower. - Gen. ii. 38 ; Benth. 1. c. S. pulescens \& S. incana, Muhl. Cat. S. serruta, Spreng. Syst. ii. 703, not Andr. - River-banks, W. Canada and Penn. to Illinois, and the mountains of Carolina and $N$. Alabama. Varies with the foliage greener, only a little paler beneatl, and in

Var. punctáta, Chapm., glabrate and minutely punctate beneath. - Georgia and Florida, Chapman.

+++ Corolla half inch long, nearly glabrous: raceme simple and terminal, or also from the axils of one or two pairs of leaves.

S. pilósa, Michx. Hirsute-pubescent: stem slender, a foot or two high: leaves rather remote, oblong-ovate, obtuse, erenate, veiny (inch or two long); the lower subcordate and slender-petioled; upper cuneate at base and subsessile; floral oblong: bracts of the oblong raceme spatulate. - FI. ii. 11; Benth. 1. c. S. Caroliniana, Walt. Car. 163? S. elliptica, Muhl. Cat.? S. polymorpha, C. Hamilton, Monogr. 39, in part, ex Benth. - Dry or sterile ground, S. New York and Mlichigan to Florida and Texas.

Var. hirsúta, a large form, sometimes nearly 3 feet high, more hirsute : larger leaves 2 or 3 inclses long, very coarsely crenate. - S. hirsuta, Short, Cat. Pl. Kentucky. - Richer soil, Kentucky, Short.

Var. ovalifólia, Benth., a form with shorter and finer pubescence, and narrower less veiny leaves. - S. oralifolia, Pers. Syn. ii. 136. - New Jersey to Virginia.

S. villúsa, Ell. Sk. ii. 90, from upper part of Georgia (villous, and with lanceolate leaves 3 or $4 \frac{1}{2}$ inches long, coarsely dentate and acute at both ends, brachiate racemes, but flowers not seein), is not identified.

+++ Cauline leaves entire (except in the first species), obtuse, narrowed at base: racemes mostly simple and terminal, leafy below: corolla blue, upwardly much ampliate and with large lips.

* These much shorter than the downwardly attenuate tubular portion: pubescence wholly soft or cinereous.

S. integrifólia, L. Manifestly pubescent or puberulent: stems mostly simple from a fibrous root, 8 to 20 inches high, slender: leaves thinnish, from oblong to nearly linear, an inch or more long; the upper narrowed at base and subsessile or short-petioled; lowest varying to ovate or even cordate and slender-petioled, often with a few coarse crenatures or obtuse teeth: corolia slightly pubescent, near an inch long; lower lip about equalling the upper: anthers long-ciliate: nutlets tuberculate. - (Pluk. Alm. t. 313, fig. 4.) S. integrifolia \& S. hyssopifolia, L. Spec. ii. 599, the latter a narrow-leaved form. S. Caroliniana, Lam. Ill. t. 515, fig. 3. S. polymorpha, A. Hamilton, Monogr. 38, in part. - Dry ground, INew England to Florida and Texas. 
S. brevifólia. Cinereous-puberulent throughout: stems numerous from a suffrutescent base, rigid, a foot or less high, very leafy : leaves thickish, narrowly oblong, 6 to 8 lines long by 2 or 3 wide, all subsessile; the floral similar, gradually smaller: corolla softpubescent, three-fourths inch long; lower lip rather longer than the upper: anthers shortciliate: nutlets granulate. $-S$. integrifolia, var. brevifolia, Gray in Cat. Coll. Tex. Hall, no. 458. - Dry banks, Dallas, Texas, E. Hall, Reverchon.

+t+ +tips of the corolla about the length of the broad tube and throat.

S. Floridána, Chapm. Obscurely puberulent : stems slender, a foot or more high, rather remotely leafy and with some axillary fascicles: leaves very narrowly linear (8 to 12 lines long, seldom a line wide), with somewhat revolute margins; the lowest minute and scalelike : raceme rather loose : corolla nearly inch long: anthers long-ciliate. - Fl. 324. - Pinebarren swamps, Apalachicola, Florida.

* * Flowers solitary in the axils of cauline leaves, or some occasionally imperfectly racemose through the reduction in size of the upper leaves of the stem or branches.

- Annuals, loosely branched from the base: corolla pubescent, half iuch or less long: nutlets muriculate.

S. cardiophýlla, Engelm. \& Gray. Puberulent, slender, a foot or two high, with virgate branches: leaves cordate-ovate or deltoid-subcordate, mostly obtuse, thin, veiny; principal cauline inch long, coarsely crenate, slender-petioled; floral gradually smaller and less toothed, the uppermost entire and subsessile ( 3 lines long, barely exceeding the caly $x$ ): corolla slender, blue. - Pl. Lindh. i. 19; Benth. in DC. 1. c. 429. - Open woods, Arkansas and Texas.

S. Drummóndii, Benth. Villous-pubescent, a span or more high, soon diffuse, leafy: leaves ovate or obovate-oblong, very obtuse, half inch or more long, contracted at base, the lower into distinct petioles; floral subsessile and about equalling the flowers; all entire or nearly so (rarely suberenulate): corolla violet purple or blue ( 3 to 5 lines long), commonly with the caly $x$ villous-pubescent, at least when young; lower lip longer than the upper, violet-spotted. - Lab. 441, \& DC. Prodr. xii. 428. - Damp or rich soil, Texas; common. (Mex.)

+ + Perennials, from a firm or ligneous stock, neither stoloniferous nor tuberiferous: nutlets granulate.

S. Wríghtii, Gray. A span or so high, many-stemmed in a tuft, minutely cinereouspuberulent, very leafy: leaves ovate, oval, or spatulate-oblong, entire, subsessile, about half an inch long; upper floral shorter than the flowers: corolla pubescent, half an inch long, usually violet; lips nearly equal in length; tube rather slender. - Proc. Am. Acad. viii. 370. - Texas, quite to the western borders, Wright, Lindheimer, E. Hall, \&c. Kansas, Gordon, $L$. Watson, with a white-flowered variety.

+++ Perennials, completely herbaceous and fibrous-rooted, mostly producing filiform stolonlike rootstocks :

$$
+\rightarrow \text { These more or less moniliform-tuberiferous. }
$$

$=$ Flower 2 to 4 lines long: leaves broadest at base and all but the lower sessile; primary veins prominent underneath.

S. párvula, Michx. Minutely (sometimes more conspicuously) pubescent, branching from the base, commonly erect, 4 to 10 inches high : filiform subterranean shoots bearing a long moniliform string of small tubers: leaves ovate or the uppermost ovate-lanceolate, sessile by a truncate or slightly cordate base, about half inch long; some of the lower with one or two coarse teeth, the lowest slender-petioled: pedicels as long as the calyx : corolla violet, pubescent, twice or thrice the length of the calyx: nutlets strongly muricate, girt with a thickish ring or border, which is conspicuous when young. - Fl, ii. 12; Hook. Exot. t. 106. S. ambigua, Nutt. Gen. ii. 37. - Sandy banks, W. New England and along the Great Lakes to Wisconsin, South Florida, and Texas.

Var. móllis, Gray. More spreading, softly pubescent throughout (the pubescence somewhat viscid) : leaves larger, less firm. - Sandy banks of the Mississippi, at Oquawka, S. Illinois, \&c., H. N. Patterson. A remarkable form, with somewhat the aspect of $S$. Drummondii. $=$ Flower half or two-thirds inch long: leaves narrowed at base or petioled: plants depressed

S. nána, Gray. Minutely cinereous-puberulent, 2 inches high, much branched: filiform subterranean shoots copiously moniliform-tuberiferous: leaves crowded, from ovate to 
spatulate-obovate, entire, thickish, nearly veinless, half inch long, tapering into a petiole : corolla white, rather broad and with dilated throat, hardly exceeding the leaves; lips of equal length. - Proc. Am. Acad. ii. 100, \& Bot. Calif. i. 604.-N. W. Nevada, near Pyramid Lake, Lemmon.

S. tuberósa, Benth. Soft-pubescent or villous: stems slender, rather sparsely leafy, 1 to 4 inches high and erect, or sometimes reaching a foot in length and trailing: leaves mostly ovate, either truncate or cuneate at base, thin, coarsely and obtusely few-toothed, or rarely entire (a quarter to inch and a half long), nearly all petioled; floral about equalling or longer than the violet or blue narrow corolla: nutlets strongly muricate. - Lab. 441 ; Gray, Bot. Calif. i. 601. - Hills, \&c., nearly throughout California.

$=\overline{=}=$ Flower larger, violet-blue: stems erect, equally leafy: leares from oblong to linear, all but the lower sessile and entire: moniliform tubers more rare or obscurc, except in the first species.

S. resinósa, Torr. Barely a span high, branched from the base, minutely pubescent ancl resinous-atomiferous, somewhat viscid: leaves uniform, oval and oblong, or uppermost narrower, obtuse, mostly sessile (5 to 10 lines long), nervose-veined : pedicels shorter than the calyx:' corolla pubescent, an inch long, with slender tube and ampliate throat; lower lip glabrous inside: nutlets tuberculate. - Ann. Lyc. N. Y. ii. 232; Benth. 1. c. - Plains of Colorado, Wyoming, and Nebraska.

S. angustifólia, Pursh. A span to a foot high, minutely puberulent or almost glabrous : stems or branches often simple and slender : leaves from linear to narrowly oblong ( 6 to 12 lines long), all but the lower acute or contracted at base; lower more petioled and sometimes few-toothed; radical orbicular or cordate and small : pedicels as long as the calyx: corolla three-fourths to nearly inch long, puberulent, with slender tube and moderately ampliate throat; lower lip villous inside: nutlets minutely granulate. - Fl. ii. 412; Gray, Bot. Calif. i. 603. - Moist ground, British Columbia and Montana to California, even as far south as San Bernardino Co.

Var. canéscens, Gray, l. c. More branching, tomentulose-canescent: corolla more arrect by the curvature of the base of the tube. $-S$. siphocampylordes, Vatke in Bot. Zeit. xxx. 717. - Western part of California, in cañons, \&c.

S. antirrhinoídes, Benth. Resembles broader leaved forms of the preceding : stems more branching, diffuse or ascending: leaves oblong ( 6 to 9 lines long), mostly obtuse at base as well as apex, more petioled: corolla shorter and broader, 7 to 10 lines long; the tube shorter and less slender. - Bot. Reg. xviii. under 1493, \& DC. I. c. 428; Gray, Proe. Am. Acad. viii. 390 . S. resinosa, Watson, Bot. King, 237. - Moist shady ground, Oregon, northern part of California, and mountains of Nevada.

- Filiform rootstocks or subterranean stolons not tuberiferous : corolla half to two-thirds inch long,

- Dull yellow or whitish, with ampliate-inflated throat, villous within (at least the lower lip), and short proper tube: all the upper leaves entire, obtuse.

S. Califórnica. Puberulent: stems 8 to 20 inches high, slender: leaves from lanceolateoblong to oval-ovate, mostly roundish at base, short-petioled; the lower an inch or more long, often somewhat serrate; upper gradually reduced to half inch or less; uppermost shorter than the flowers: lips of the corolla about equal: nutlets obseurely rugose-granulate. $-S$. antirrhinoides, var. Culifurnica, Gray in Proc. Am. Acad. viii. 396, \& Bot. Calif. l. c., mainly. - Banks of streams, California, from Tehama Co. southward, and in the Sicrra Nevada. Narrow-leaved forms resemble the preceding; broader-leaved forms are more like the following species.

S. Bolánderi, Gray. Pubescent: stem simple or branched from the base, a foot high, equably and very leafy to the summit: leaves ovate-elliptical, very obtuse, closely sessile by an obscurely cordate base, an incl or less long, veiny from the base: flowers very shortpedicelled, seldom equalling the leaf : lower lip of the corolla rather longer. - Proc. Am. Acad. vii. 387, \& Bot. Calif. 1. c. - Sierra Nevada, California, in Mariposa and I'lumas Co., Bolander, Lemmon.

$=$ Corolla violet-blue, with slender tube and less ampliate throat, naked within.

S. galericuláta, L. Nearly glabrous or slightly pubescent, slender, 1 to 3 feet high, simple or paniculately branched above : leaves membranaceous, ovate-lanceolate or oblonglanceolate, broadest next the subsessile or very short-petioled subcordate base ( 2 inches or less long), all but the upper and more reduced ones appressed-serrate: pedicels shorter than 
the calyx : corolla puberulent; lower lip nearly erect and surpassing the upper: nutlets densely muriculate-scabrous. - Spec. ii. 599 ; Engl. Bot. t. 593 ; Schk. Handb. t. 167. - Wet soil, Atlantic States, from mountains of Carolina to Newfoundland, Mackenzie River, and westward from mountains of Arizona to Brit. Columbia. (Eu., N. Asia.)

§ 2. Nutlets raised on a slender gynobase, each surrounded by a conspicuous membranaceous wing in the manner of Perilomia, the faces muricatef (Here also a Japanese species, S. Guilielmi.)

S. nervósa, Pursh. Glabrous : rootstocks or stolons filiform: stems slender, rather simple, 4-quetrous (10 to 20 inches high) : leaves membranaceous, coarsely few-tonthed, rather prominently quintuple-ribbed from near the base; the lowest cordate and short-petioled; the others sessile or nearly so; middle ones ovate; floral ovate-lanceolate, gradually smaller and more entire, much surpassing the axillary secund flowers: corolla bluish, 4 lines long, with lower lip exceeding the straightish merely concave upper one. - Pursl, Fl. ii. 412; Gray, Proc. Am. Acad. viii. 370. S. teucrifolia, Smith. S. gracilis, Nutt. Gen. ii. 37. - Moist thickets, New York to Virginia, Ohio, and Missouri.

37. SAIAZÁRIA, Torr. (In honor of Don José Salazar y Larrequi, the Mexican Commissioner of the U. S. and Mex. Boundary Survey.) - Bot. Mex. Bound. 133, t. 39. - Single species of a remarkable genus.

S. Mexicána, Torr. I. c. Shrubby, 2 or 3 feet high, with diffuse or sarmentose slender soft-canescent branches: leaves remote, glabrate, small, oblong or broadly lanceolate, short-petioled, mostly entire; floral reduced to bracts of the short and loose terminal racemes: flowers less than inch long: corolla purplish, or the spreading lower lip deep purple : fructiferous vesicular calyx half inch or more in diameter. - Bot. Calif. i. 604. Ravines, S. E. California in the Mohave desert, S. Nevada and Utah, Arizona, Fremont, Parry, Cooper, Palmer. (Adjacent Mex.)

38. BRUNÉlla, Tourn. Self-heal, or Heal-Allt. (Commonly written Prunella, but said to come from the old German word Breune or Braune, an affection of the throat, which the plant was thought to cure.) - Low perennials; with nearly simple stems, terminated by a short verticillastrate-spicate or capitate inflorescence, with imbricated round-ovate and nervose bracts or floral leaves of about the length of the calyx, each subtending 3 subsessile flowers : fl. all summer.

B. vulgáris, L. Leaves ovate-oblong, entire or toothed, slender-petioled, commonly pubescent: corolla not twice the lengtlı of the purplish calyx, violet, purplish, \&c., rarely white. - Fields and borders of copses, Newfoundland to Florida, and west to California and nortliward; evidently indigenous in some of the cooler districts. (Eu., Asia, Mex.)

39. BRAZÓRIA, Engelm. \& Gray. (Discovered on the Rio Brazos, 'Texas.) - A genus of two annuals, of rather low stature: leaves oblong, mostly sessile, denticulate; lowest tapering into a petiole; floral diminished to small ovate or oblong-lanceolate bracts to the single flowers of the virgate racemes or spikes : corolla rose-purple : f. summer. - Pl. Lindh. i. 47 ; Gray, Chloris, 34, t. 5 ; Benth. in DC. Prodr. xii. 434.

B. truncáta, Engelm. \& Gray, 1. c. Somewhat pubescent, at least the raceme and calyx viscid-hairy: spike dense and strict, simple or sometimes branching: calyx much reticulated, truncate, its broad lips of equal length, obscurely lobed, mucronately denticulate ( 3 or 4 lines in fruit): corolia three-fourths inch long; upper lip and middle lobe of lower deeply emarginate, all the lobes denticulate; palate somewhat prominent; tube pilose-annulate near the base : anthers somewhat hairy : nutlets puberulent. - Chloris, l. c. t. 5. Physostergin trunceta, Benth. Lab. 305; Hook. Bot. Mag. t. 3494. - Sandy soil, in plains and prairies of E. Texas, Berlundier, Drummond, Lindheimer, \&c. 
B. scutellarioídes, Engelm. \& Gray, l. c. Almost glabrous: spikes or racemes loose, mostly panicled: lips of the calyx unequal; the upper with 3 ovate-rounded, lower with 2 triangular-lanceolate lobes, all but the uppermost cuspidate: corolla (a third inch long) not pilose-annulate; its lobes entire or merely retuse: anthers barely ciliolate : nutlets glabrous. - Physostegia truncalu, Hook. Bot. Mag. t. 3404 (wrongly cited in DC. under preceding species). - Richer prairic soil, 'Texas, Drummond, Wright, Lindheimer, \&c.

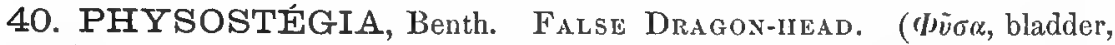
and $\sigma \tau \varepsilon^{\prime} \eta$, covering; from the turgid fruiting calyx, but more applicable to the inflated corolla.) - Perennial erect N. American herbs, almost glabrous; with lanceolate or oblong and callose-denticulate or serrate leaves; the upper ones sessile, lowest tapering into a petiole, floral reduced to small subulate bracts of the simple or panicled spikes, most of them shorter than the calyx. Flowers cataleptic (remaining in whatever position they may be turned ou the short pedicel, either right or left of the normal position). Corolla showy, rose or fleshcolor, often variegated: in summer.

P. Virginiána, Benth. l. c. Stem in larger forms 3 or 4 , in smaller 1 or 2 feet high, terminated by a simple virgate or sometimes several panicled spikes: leaves thickish: calyx tubular-campanulate or somewhat turbinate-campanulate, in fruit broader and with a narrowed base; its teeth ovate-triangular and very acute, only half the length of the tube: corolla commonly an inch long. - Dracocephalum Virginianum, L. Spec. ii. 694; Sims, Bot. Mag. t. 467. D. Lancifolium, Mœnch, Meth. 410. D. variegatum, Vent. Cels, t. 44. Prasium purpereum \& $P$. coccineum, Walt. Car. 166. - Wet grounds, N. Vermont, W. Canada and Saskatchew an to Florida and Texas: common in gardens. Varies greatly; the extremes are

Var. speciósa, a tall form, with very acutely serrate lanceolate leaves, and dense and panicled spikes. - Dracocephalum speciosum, Sweet, Brit. Fl. Gard. t. 93, with horizontal flowers. Physostegia imbricata, Hook. Bot. Mag. t. 3386 (not Benth.), a Texan form, with erect imbricated flowers.

Var. denticuláta, a more slender and commonly low form, with crenulate-denticulate or obscurely serrate leaves, and more slender or loosely-flowered spike. - Dracocephalum denticulatum, Ait. Kew. ii. 317; Sims, Bot. Mag. t. 214. - Middle Atlantic States.

Var. obováta, with oblong or obovate and often obtuse leaves. - Dracocephalum oboratum, Ell. Sk. ii. 86. - Georgia to Arizona.

P. intermédia, Gray. Stem slender, 1 to 3 feet high, remotely leaved: leaves linearlanceolate, repand-denticulate: spikes filiform, commonly rathet remotely flowered : calyx short and broadly campanulate; the triangular acute teeth about as long as the tube: corolla 5 or 6 lines long, much dilated upwards. - Proc. Am. Acad. viii. 371. Drarocephalum intermeditm, Nutt. in Trans. Am. Phil. Soc. n. ser. v. 187. - Barrens, W. Kentucky and Arkansas to Louisiana and Texas.

P. parviflóra, Nutt. Stem rather slender, leafy, a foot or two high : leaves lanceolate or ovate-lanceolate, denticulate; spikes short ( 1 to 4 inches long) : calyx short-campanulate, inflated-globular in fruit and with short mostly obtuse teeth: corolla rather narrow, half inch long. - Nutt. (ex Benth., under P. imbricala, Benth. 1. c., not Hook. Bot. Mag.); Gray, Proc. Am. Acad. viii. 371. - Banks of streams, Saskatchewan and Wyoming to Brit. Columbia, and Oregon.

41. MACBRIDEA, Ell. (In memory of Dr. James Macbride.) Glabrous or sparsely hirsute perennials (of S. Atlantic States); with simple stems, a foot or more high, lanceolate or spatulate-oblong repand-toothed or entire minutely punctate leaves; the floral becoming thickish and rounded imbricated bracts of a terminal and rather few-flowered capitate inflorescence. Flowers showy (corolla over an inch long), in late summer. (Anthers not pilose within the cell, as stated, but mainly on the inner face.) - Ell. Sk. ii. 56 ; Chapm. Fl. 324.

M. púlchra, Ell. 1. c. Leaves oblong-lanceolate, mostly acute at both ends, tapering into a petiole, thinnish; floral ones or bracts ovate, acute : lateral lobes of the calyx entire or 
emarginate: corolla rose-purple (streaked with a deeper hue and white); its upper lip entire. - M. pulchella, Benth. Lab. 505, \& DC. Prodr. xii.435. Thymbra Caroliniana \& Prasium incarnatum, Walt. Car. ex Bentlı. Melittis Caroliniana, Spreng. Syst. ii. 700. - Pinebarren swamps, southern borders of N. Carolina to Georgia and Alabama.

M. álba, Chapm. 1. c. Leaves spatulate-oblong or oblanceolate, obtuse, thickish, all but the lowest sessile; floral ones round-ovate or orbicular: lateral lobes of the caly $x$ strongly emarginate or 2-cleft: corolla white; its upper lip emarginate, - Low pine-barrens, W. Florida near the coast, Chapman.

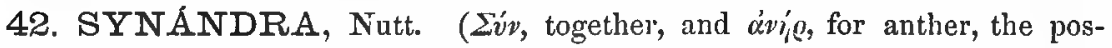
terior and sterile anthers connate.) - Single species, large-flowered, and with the aspect of Lainium.

S. grandiflóra, Nutt. Fibrous-rooted biennial, a foot or two high, hirsute : leaves membranaceous, cordate, coarsely crenate, all but the floral long-petioled; these reduced to ovate sessile bracts, each subtending a single flower : corolla incl and a half long, white or nearly so : filaments bearded. - Gen. ii. 29; Benth. l. c. - Shady banks of streams, S. Ohio to Illinois and Tennessee : in spring.

43. MARRÚBIUM, Tourn. Horehound. (From Hebrew word, meaning bitter.) - Perennials; all natives of the Old World, but one species widely dispersed and naturalized, viz.

M. vulgare, L. Hoary-woolly, branched from the base, aromatic-bitter (hence used in popular medicine) : leaves roundish, crenate, very rugose-veiny : flowers verticillastratecapitate in the upper axils: calyx with 10 short recurving teeth, these and the bracts at length hooked at the tip. - Escaped from gardens into waste or open ground : fl. late summer. (Nat. from Eu.)

44. BALLÓTA, L. Black Horehound. (Greek name, of obscure derivation.) - Weedy perennials of the Old World; with bitter and unpleasantscented herbage; fl. summer.

B. NÍGRA, L. Soft-pubescent, but not hoary, spreading: leaves ovate, crenate or toothed, slightly rugose, slender-petioled: flowers numerous in rather loose axillary verticillastrate cymes : bracts setaceous : calyx with dilated somewhat foliaceous mucronate-tipped teeth, equalling the purplish corolla. - Sparingly in waste places, New England, Penn., \&c. (Nat. from Eu.)

45. PHLÓMIS, Tourn. Jerusalem Sage. (Ancient Greek name of a woolly plant, perhaps of this genus.) - Perennials, of the Old World, one sparingly introduced, viz.

P. TuBerósa, L. Tall, 3 to 5 feet high, from a thick tuberous root, somewhat glabrous: lower leaves ovate and cordate, crenate, slender-petioled, rugose-veiny; floral oblong-lanceolate and mostly sessile, subtending dense verticillastrate-capitate clusters : bracts setaceous, hirsute: calyx-teeth setaceous-subulate from sh short and dilated truncate-emarginate base, divaricate : corolla pale purple, its upper lip densely white-bearded. $-\mathbf{S}$. shore of Lake Ontario, New York: ft. early summer. (Nat. from Eu.)

46. LEONÓTIS, R. Br. (Á́w , lion, and oüs, wizós ear, from the corolla.) - African plants; with dense verticillastrate-capitate clusters of showy scarlet or orange flowers ; sparingly naturalized on our southern borders: fl. summer.

L. NEPET fé́lia, R. Br. Tall annual, minutely soft-pubescent: leaves long-petioled, ovate, coarsely scrrate or crenate, veiny; upper floral lanceolate : verticillastrate heads large and dense: calyx about 8-toothed : corolla an inch long, orange-red, densely hirsute. - Bot. Reg. t. 281. - Waste grounds, Georgia and Florida. (Nat. from $\Delta$ fr.) 
47. LEONƯRUS, L. Motherwort. ( $\mathcal{A}^{\prime} \omega v$, a lion, and ov̉ó, tail ) -Herbs of the Old World, weeds or escapes from gardens in the New: herbage bitter : flowers small, in summer.

L. Cardíaca, L. (Common Motherwort.) Tall perenuial, more or less pubescent: leaves long-petioled, palmately cleft; the lower rounded; floral rhombic-lanceolate, 3-cleft; lobes lanceolate: flowers much shorter than the petioles; corolla pale purple; its upper lip very villous outside, narrowed at base, hardly galeate, at length often recurved; lower deflexed, spotted : stamens often recurving outwards after anthesis: anther-cells parallel. - Waste and cult. ground, in manured soil. (Nat. from Eu.)

L. Marrdiístrdj, L. Tall biennial, minutely soft-pubescent: leaves ovate or oblong, or the floral lanceolate, coarsely serrate or incised: calyx-teeth slender, rather aristiform than spinescent: corolla minute, whitish, almost glabrous; its lips less divergent: stamens little exserted beyond the throat: anther-cells diverging, - Chaiturus Marrubiastrum, Ehrh. - Waste grounds, New Jersey to Delaware, and southward; rare. Related as much to Sideritis as to Leonurus; might be placed next to Marrubium. (Nat. from Eu.)

L. Sibínicts, L. Tall biennial, minutely puberulent or nearly glabrous: leaves 3-parted; the divisions 2-5-cleft, or deeply 3-7-cleft and incised : corolla purplish, twice the length of the calyx; upper lip fornicate, lower little spreading. - Waste grounds, Pennsylvania (near Philadelphia, Martindale), New Mexico, \&c. (Sparingly nat. from Eu. \& Asia.)

48. LÁMIUM, Tourn. Dead-Netrle. (From $\lambda \alpha \mu o_{s}$, , the throat, alluding to the ringent corolla.) - Spreading or decumbent herbs, with mostly cordate incised or doubly toothed leaves; the lower long-petioled; upper becoming sessile or roundish at base, subtending sessile and loose or capitate clusters of purple or sometimes white flowers. Anthers in our species hirsute. Natives of the Old World, some naturalized in waste places or fields, eastward.

L. AMPLexicAúLE, L. Biennial or winter annual, weak and slender, low : leaves distant; lowest small, roundish-cordate, coarsely crenate, long-petioled; upper subsessile or clasping, crenately Iobed and incised : corolla slender, purple, with spotted lower lip, truncate lateral lobes, and upper lip villous on the back. - Rather common, Canada to Florida. (Nat. from Eu.)

L. PCRYÚREUM, L. Resembles the.last, but with leaves (even the upper floral) all petioled and only crenate-serrate: calyx-teeth more slender: small lateral teeth to the orifice of the corolla. - Penn. and New England. (Sparingly nat. from Eu.)

L. Álвшм, L. Stouter, a foot or two high, more leafy and hirsute-pubescent: root perennial : leaves ovate, cordate or truncate at base, acuminate, coarsely serrate, mostly petioled: corolla white, an inch long, with tube curved upwards and throat rather narrow; upper lip oblong; a long slender appendage at each side of the throat. - E. New England. (Sparingly nat. from Eu.)

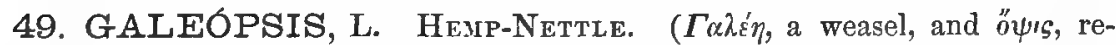
semblance, "very like a weasel" to a lively imagination only. The popular name is little less natural.) - Annual weeds of Europe : naturalized in waste places and garden soil : fl. late summer.

G. TetrAhit, L. Hispid: stem swollen below the joints: leaves ovate, acuminate, coarsely serrate : corolla light purple, variegated, 6 to 10 lines long. - Common. (Nat. from Eu.)

G. LÁDANUM, L. Pubescent, lower and smaller : leaves oblong-lanceolate : corolla red or rosecolor. - E. New England, in few places. (Barely nat. from Eu.)

50. STÁCHYS, Tourn. WoundWort. (Exáxvs, a spike, primarily a spike or ear of corn, and the ancient Greek name of this genus or of some similar plants, from the spicate inflorescence.) - A large genus, widely dispersed; ours all herbs, with the flowers verticillastrate-capitate or clustered, or sometimes few 
or solitary in the axils of the floral leaves, forming usually an interrupted spicate inflorescence; in summer.

* Root annual : corolla with short tube, mostly purplish or reddish.

+ Even the lower lip hardly exceeding the subulate or aristulate tips of the calyx-teeth: leaves obtuse, crenate, an inch or less long; lower subcordate and slender-petioled: upper subsessile: stems a span or two high: lower flower-clusters remote.

S. ARvénsrs, L. Hirsute, often decumbent: upper leaves ovate with cuneate base: verticillastrate clusters in their axils few-flowered : calyx oblong-campanulate, 3 lines or more long, almost hispid, in fruit declined; the lanceolate teeth aristulate. - Waste grounds, E. Mass. (Locally nat. from Eu.)

S. agrária, Cham. \& Schl. Hirsute pubescence finer and softer : stems slender, erect: upper leaves subcordate or oval; upper floral shorter than the small and several-flowered clusters: calyx even in fruit not over 2 lines long and not declined, short-campanulate; the subulate teeth cuspidate-aristulate. - Linn. v, 100; Benth. in DC. Prodr. xii. 479. S. Grahani, Benth. Lab. 551. - Moist or shady places, common in Texas. (Mex.)

- Lips of the corolla surpassing the slender-subulate and aristulate calyx-teeth: fructiferous calyx 4 lines long: stem a foot or two high.

S. Drummóndii, Benth. Soft-hirsute : leaves ovate and oval, obtuse, crenate, all the lower cordate: upper pairs distant; floral with narrowed base, the uppermost lanceolate or subulate and shorter than the flowers: these mostly in sixes: caly $x$-tube in fruit globular-campanulate and rather shorter than the setaceous-attenuate teeth: upper lip of the corolla nearly 2, and lower 3 or 4 lines long. - Lab. 551, \& DC. 1. c. - Moist ground, Texas, Drummond, Wright, Lindheimer. (Mex.)

S. ANNUA, L., an Old-World species, with glabrous leaves not cordate, and whitish flowers only four lines long, sparingly occurs as a ballast weed, near PhiladeIphia.

$$
\text { * Root perennial. }
$$

+ Corolla white or whitish, with tube shorter or hardly longer than the calyx-teeth; lips only 2 or 3 lines long; the upper villous-bearded or woolly on the back: flowers sessile or nearly so: herbage from soft-hirsute to white-tomentose. (Californian and one New Mexican species.)

S. Rothróckii, Gray. A span high, branched from the base, canescently lanate-pubsscent throughout : leaves all sessile and lanceolate, obtuse, almost entire (inch long); floral gradually smaller and oblong, subtending about 3 flowers: spike rather dense and short: caly $\mathrm{x}$ campanulate; the teeth ovate- or subulate-deltoid, with very acute but soft tips: corolla 4 or 5 lines long; the tube included. - Proc. Am. Acad. xii. 82. - Zuni village, New Mexico, Rothrock.

S. ajugoídes, Benth. A span to a foot high, villous with very soft white hairs : leaves oblong, very obtuse, crenately serrate, 1 to 3 inches long, roundish or acutish at base; the lower petioled; upper sessile; even the upper floral as long as the (about 3) subtended flowers: clusters mainly distant: calyx short-campanulate or in fruit turbinate, very silkyvillous; the teeth triangular-ovate, aristulate-acuminate, barely equalling the tube of the corolla. - Linn. vi. 80, \& DC. 1. c. 474 ; Gray, Bot. Calif. i. 605. - California, common in moist ground. Also (in a dubious form) Willow Spring, Arizona, Rothrock.

S. álbens, Gray. Tall ( 1 to 5 feet high), soft-tomentose or lanate with white or whitish wool, leafy: leaves oblong or ovate, usually with more or less cordate base, acutish, crenate, 2 or 3 inches long; lower short-petioled; upper nearly sessile; most of the floral shorter than the dense interrupted capitate clusters of the virgate spilze: calyx turbinatecampanulate; the teeth triangular and aristulate, nearly equalling the tube of the corolla. - Proc. Am. Acad. vii. 387, \& Bot. Calif. 1. c. S. pycnostachya (meaning S. pycnantha. Benth.), Torr. in Wilkes Exped. xvii. 408.- Wet ground, mountains and foot-hills of California, from Shasta to Kern Co.

S. pycnántha, Benth. Soft-hirsute with somewhat fulvous hairs, leafy, 2 or 3 feet high : leaves oblong-ovate and subcordate, obtuse, crenate, 2 to 4 inches long, mostly rather long-petioled; floral all reduced to small bracts of the dense oblong or cylindraceous spike (of 1 to 3 inches long), each subtending about 3 flowers: calyx-teeth deltoid, mucronulate, very hirsute, fully equalling the tube of the corolla: upper lip of the latter strongly bearded. - Pl. Hartweg. 331; Gray, Bot. Calif. 1. 605. - California, in the Coast Range, from Monterey to above San Francisco, Hartwer, Kellogg. 
++ Corolla purple or rose-red (not scarlet-red), with tube equalling or longer than the calyx: flowers sessile or subsessile,

+ Not over half inch long: tube of the corolla not exceeding the tips of the calyx-teeth: spike mostly much interrupted: stems erect from filifor'm and sometimes tubcriferous rootstocks. (Atlantic species, one extending north-wesi ward to the Pacific.)

$=$ Leaves obscurely or not at all cordate, sessile or short petioled.

S. hyssopifólia, Michx. Glabrous and smooth throughout, or sometimes a hirsute ring at the nodes: stems slender, about a foot high: leaves linear, sometimes oblong-linear ( 1 or 2 inches long, $1 \frac{1}{2}$ to 3 lines wide), entire or merely denticulate, even the lowest narrowed at base and sessile: spike rather short and slender; the clusters 2-6-flowered: calyx 2 or 3 lines long, occasionally with a few bristly long hairs; teeth broadly subulate: corolla glabrous. - Fl. ii. 4; Benth. 1. c. ; Gray, Man. ed. 2, 317, ed. 5, 358. S. palustris, Walt. Car. 162, not L. - Wet and sandy soil, coast of Mass. to Michigan and Florida.

Var. ambígua. Stouter, 1 or 2 feet high, sometimes with scattered retrorse bristles on the angles of the stem: leaves broader, 3 to 6 lines wide, serrulate. - Georgia, Le Conte. Kentucky and Illinois, Short, Buckley, E. Hall, \&c.

S. palústris, L. From densely soft-pubescent to roughish-hirsute, leafy: stem 1 to 3 feet high, hirsute or hispid: leaves from ovate- to oblong-lanceolate, crenate-serrate, mostly acute or acuminate ( $1 \frac{1}{2}$ to 3 inches long), sessile or subsessile by a brond and abrupt or obseurely subcordate base; the lowest little petioled; all sometimes almost velvetytomentose beneath: clusters of the spike mostly approximate, 6-10-flowered : calyx pubescent or hirsute; the teeth subulate, nearly the length of the tube: upper lip of corolla distinctly pubescent. - Spec. ii. 580; Fl. Dan. t. 1103; Engl. Bot. t. 1675 ; Benth. 1. c. Wet ground, Newfoundland to the Pacific in Oregon, south to Pennsylvania, and in the Rocky Mountain region to New Mexico, north to Mackenzie River. (Eu., N. Asia.)

S. áspera, Michx. l. c. Taller, 2 to 4 feet high, usually less leafy, sparsely lirsute or hispidulous-pubescent to nearly glabrous: stem mostly retrorse-hispid on the angles: leaves thinner, from oblong-ovate to oblong-lanceolate ( $1 \frac{1}{2}$ to $4 \frac{1}{2}$ inches long), acute or acuminate, rather obtusely serrate, nearly all distinctly petioled and with truncate or merely subcordate base: calyx glabrous or glabrate, or with some scattered bristles; the tube obscurely striate when dry: corolla glabrous throughout. - Benth. l. c. S. arvensis, Walt. Car. 162, not L. S. hispida, l'ursh, Fl. ii. 407. S. palustris, var. aspera, Gray, 1. c. - Wet ground, Canada to Florida and W. Louisiana. Too near S. palustris. (Japan.)

Var. glábra. Even the angles of the stem smooth and naked or nearly so: leaves more conspicuously petioled, acuminate, and serrate. - S. anma, Walt. Car. 161, not L. S. tenuffolia, Willd. Spec. iii. 100. S. glabra, Ridtlell, Cat. Ohio Pl. Suppl. (1836), $16 . S$. aspera, var. glabrata, Benth. 1. c. S. palustris, var. glabra, Gray, Man. I. c. - IV. New York to Illinois and southivard. Filiform stolon-like rootstocks more or less tuberiferous.

$==M \Gamma \sim$ t of the leaves distinctly petioled; lower all long-petioled and cordate: corolla glabrous or nearly so throughout, barely 5 lines long.

S. Floridána, Shuttlew. Barely a foot high, with filiform stolon-like rootstocks terminated by a moniliform tuber (of 2 or 3 inches in length), nearly glabrous, or the slender stem minutely hirsute, at least the angles: lower leaves cordate-oblong, very obtuse, crenate-dentate (three-fourths to 3 inches long), slender-petioled ; floral small and with cuneate subsessile base, hardly surpassing or shorter than the rather remote clusters of the short spike: calyx-teeth aristulate-subulate, little shorter than the oblong-campanulate tube.-Benth. in DC. Prodr. xii. 478; Chapm. Fl. 327, but root not annual. - E. Florida, Rugel, Buckley, Canby, Palmer, Curtiss.

S. cordáta, Riddell. Two or three feet high, rather weak, hirsute: leaves all ovate- or oblong-cordate, acuminate, crenate ( 2 to 5 inches long), nearly all long-petioled; the floral mostly minute: spikes slender, of numerous and small few-flowered clusters: calyx (only 2 lines long) with broadly subulate teeth much shorter than the campanulate tube. - Cat. Ohio Pl. Suppl. (1836), 15. S. syluatica, Nutt. Gen. ii. 30, not L., but near it. S. Nuttallii, Shuttlw, in DC. 1. c. 469. S. palustris, var. cordata, Gray, Man. 1. c. - Thickets, S. Ohio to Virginia and Tennessee. - Not rarely leaves as broad at the base as in S. syluatica.

t+ Flowers half inch long: tube of corolla somewhat exceeding the calyx. (Pacific species.)

S. bulláta, Benth. A foot or two high from a slender rontstock, hirsutc-pubescent, varying to villous or to somewhat hispid: leaves mostly petioled, ovate to oblong, usually 
obtuse, cordate or roundish-truncate at base, crenate, sometimes bullate-rugulose, not rarely villous-canescent, especially beneath: spike naked, interrupted: teeth of the calyx deltoid-subulate and aristulate-acuminate, fully half the length of the campanulate tube: corolla with the little or more manifestly exserted tube about 4 lines long, nearly equalled by the widely spreading lower lip; the short upper lip villous or pubescent on the back. - Lah. 547, \& DC. I. c. 474 ; Gray, Bot. Calif. i.606. S. Californica, \& S. Nuttallii, var.? occidentalis, Benth. in DC. 1. c. 469 . S. Nuttallii, var. leptostachya, Benth. PI. Hartw. 331. S. rigida, Nutt. ex Benth. in DC. I. c. 472. S. coccinea, Hook. \& Arn. Bot. Beech. 156, ex Benth. $S$. sylvatica \& $S$. agraria, Torr. in Wilkes's Exped. xvii. 408. - California to Oregon, near the coast, and south-eastward to the Mohave. - A variable species : leaves thinner and not rugose when growing in shade.

+ Flowers ample: tube of the rose-red corolla over half inch long, fully twice the length of the lower lip and of the cylindraceous-campanulate calyx: leaves mostly ample ( 3 to 5 inches long), petioled, oblong-ovate and subcordate, crenate, veiny: stems 2 to 6 feet high, almost always retror'sely hispid on the angles: verticillastrate clusters of the spike mostly 6 -flowered.

S. Chamissónis, Benth. Leaves softly villous-canescent beneath, sericeous-hirsute above, oblong-ovate, rather obtuse, rugose-veiny; petioles retrorsely hispid: short spike mostly naked; the floral leaves reduced to bracts and shorter than the flowers: calyx densely hirsute-pubescent; teeth deltoid and cuspidate : tube of corolla commonly threefourths inch long; outside of the lips (at least of the upper) hirsute-pubescent. - Linn. vi. 80; \& DC. 1. c. 468; Hook. \& Arn. Bot. Beech. 155; Gray, Bot. Calif. i. 606. - California, in swamps along San Francisco and Bolinas Bay, \&c.

S. ciliáta, Dougl. Green and glabrate, or sparsely pilose-pubescent: leares thin, ovate, mostly acute or acuminate: petioles and angles of the stem retrorsely hispid-ciliate: lower floral leaves often similar to the cauline and much surpassing the flowers; uppermost reduced to small bracts, merely equalling the calyx, which is more tubular than in the preceding, either nearly. glabrous or pilose-pubescent, and the teeth narrower: corolla rather smaller, nearly glabrous. - Benth. Lab. 539, \& DC. l. c. 467. - Oregon to Brit. Columbia along the coast, in damp and shady places.

Var. púbens. Soft-pilose-pubescent or villous-hirsute, especially the calyx and lower face of the leaves: flowers commonly rather smaller or shorter. $-S$. Riederi, Cham. \& Benth. 1. c. ? S. palustris, var., Torr. in Wilkes Exped. 1. c. - Washington Terr. to Fraser River, \&c. Connects $S$. ciliata with $S$. Chamissonis.

+++ Corolla scarlet-red, with narrow cylindrical tube much exceeding the calyx and the lips : flowers short-pedicelled or subsessile: cauline leares slender-petioled : pubescence short and soft.

S. coccínea, Jacq. Rather slender, a foot or two high: leaves ovate-lanceolate with cordate base, or oblong-deltoid, obtuse, crenate (inch or two long); floral sessile; the upper very small : spike interrupted: flowers generally distinctly pedicelled: calyx in flower cylindraceous, with tube twice the length of the slender-subulate teeth (in fruit more campanulate), a third to nearly half the length of the ( 9 to 12 lines long) corolla. - Hort Schœnb. iii. 18, t. 284 ; Bot. Mag. t. 666 ; Andr. Bot. Rep. t. 310 ; Benth. in DC. 1. c. 467. S. cardinalis, Kunze in Bot. Zeit. ii. 645, ex Benth. - W. Texas to S. Arizona. (Mex.)

S. Bigelóvii, Gray. Minutely cinereous-pubescent, slender : foliage, \&c., nearly of the preceding: flowers fewer in the clusters, almost sessile : calyx (only 3 lines long) oblongcampanulate; its teeth broader: tube of the (red?) corolla only half inch long; lower lip 3 lines Iong, much larger than the upper. - Proc. Am. Acad. viii. 371. - S. W. Texas, in crevices of basaltic rocks, Wright, Bigelow.

Betónica offrcinalis, L., or Stachys Betonica, Benth., Wood Betony, of Europe, has becn found in thickets near Boston, an escape from gardens.

\section{ORder CV. PLANTAGINACE E.}

An anomalous order of Gamopetalæ, chiefly acaulescent herbs with one-severalribbed or nerved radical leaves, simply spicate inflorescence, and regular 4-merous flowers having a free ovary, a filiform and entire long-stigmatose style, amphitropous and peltate ovules and seeds, a mostly straight embryo in firm-fleshy albumen, the cotyledons little broader than the radicle, and the corolla scarious 
and veinless, mostly marcescent-persistent. Consists chiefly of the two following genera; the principal genus of many species and widely dispersed over the world, but most largely European and Asiatic; the other of a single species widely dissevered in habitation.

1. PLANTÁgo, Tourn. Plantain, Ribwort. (The Latin name.) Flowers perfect or polygamo-dicecious, each subtended by a bract. Calyx of 4 imbricated sepals, persistent. Corolla salverform with a short tube, or nearly rotate; limb 4parted; lobes imbricated in the bud, two lateral exterior. Stamens 4 , or sometimes 2 , on the tube of the corolla: filaments commonly capillary: anthers 2-celled, versatile. Ovary 2-celled (or rarely falsely 3-4-celled), with one or more ovules in each cell. Style or stigma mostly hairy. Capsule (pyxidium) circumscissile toward the base, and with a loose partition falling away with the lid; the seeds attached to its face. Seed-coat developing copious mucilage when wetted. Scape from the axils of the radical or subradical leaves, mostly bearing a single simple spike or head of greenish or whitish small flowers, in summer.

\section{§1. Stamens 4: flowers all perfect: corolla not closed over the fruit.}

* Flowers dichogamous, proterogynous; the style projecting from the apex of the unopened corolla; the anthers long-exserted on capillary filaments after the corolla has expanded.

+ Corolla glabrous (as also the whole inflorescence, except in $P$. macrocarpr): seeds not hollowed (or barely concare) on the inner face: leaves 3-8-nerved or ribbed, plane: root perennial.

+ Ribs or nerves of the broad leaves mainly confluent with the thick and dilated Iower portion of the midrib: ovules only 2 in each cell : seeds by abortion sometimes solitary.

P. cordáta, Lam. Very smooth: leaves cordate or ovate (3 to 8 inches long), sometimes repand-tentate, long-petioled, 7-9-ribbed : scape fistulous, stout, a foot or two high, including the narrow spike: bracts rotund-ovate, very obtuse, as are the ovate and obovate sepals and the corolla-lobes: capsules broadly ovoid, twice the length of the calyx: seeds 4 to 2 , large, oblong. - Ill. i. 338 ; Jacq. Eclog. t. 72. P. Kentuckensis, Michx. Fl. i. 94. - Along streams (Canada? Pursh), New York to Wisconsin and Louisiana, common only westward.

++ Ribs or nerves of the leaf free quite to the contracted base.

= Leares ovate or oval, or in small forms oblong. rarely subcordate, several-ribbed, base abruptly contracted into a distinct petiole, not fleshy, glabrous or pubescent, from entire to sparingly répand-dentate: ovules and seeds at least 2 in each cell: scapes with the spike a span to 2 feet high.

P. májor, I. (Common Plantis.) Spike commonly dense, obtuse at apex : sepals rotund-ovate or obovate, scarions-margined; the exterior and the bract more or less carinate: ovules 8 to 18 : seeds as many or by abortion fewer, small, angled by mutual pressare, usually light brown, minutely reticulated : capsule ovoid, very obtuse, circumscissile near the middle and near the level of the summit of the sepals. - Waysides and near dwellings throughout the country, doubtless introduced from Europe, but also native from Lake Superior far northward. Runs into some monstrosities and several varieties, an extreme in saline soil being var. minima, Decaisne in DC. Prodr. xiii. 695 ( $P$. minima, DC.), with scapes 2 to 5 inches high, and leaves proportionally small. (Cosmop.)

Var. Asiática, Decaisne. Capsule usually more broadly ovoid, circumscissile near the base and much within the calyx. $-P$. Asiatica, L. Spec. i, 113 ; Franchet \& Savatier, Enum. P1. Jap. 384. (Includes perhaps P. Kamtschatica, Cham. and Link, or plants cultivated as such, with 4,5 , or 6 seeds.) - A very large indigenous form, coast of California near San Francisco (capsule globose-ovoid) to the borders of British Columbia; Saskatchewan to the Arctic Sea. Perhaps a distinct species. (N. Asia, Himalaya.)

P. Rugélii, Decaisne. Leaves paler, commonly thinner : spikes long and thin, attenuate at the apex: sepals oblong, all as well as the similar bract acutely carinate: capsules erect in the spike, cylindraceous-oblong (somewhat over 2 lines long, one-sixteenth 
inch in diameter), about twice the length of the calyx, circumscissile much below the middle: ovules 6 to 10 : seeds 4 to 9 , oval-oblong (about a line long), opaque and dull brown, not reticulated. - Prodr. 1. c. 700, founded on a small and slender 4-seeded form. P. major, Ell. Sk. i. 201 ; Torr. Fl. 183, \& Fl. N. Y. ii. 14; Darling中. Fl. Cest. ed. 2 , 110. P. Kumtschatica, Hook. Comp. Bot. Mag. ii. 61 ; Gray; Man. ed. 5, 311, not Cham. - Canada, Vermont to Illinois, and south to Georgia and Texas : truly indigenous.

$=$ Leaves mostly narrower, 3-7-ribbed, entire or barely denticulate, tapering at base into more or less of a petiole : ovules and seeds never over 2 in each cell.

u. Not maritime nor montane, thin-leaved: ovules and seeds solitary in each cell.

P. sparsiflóra, Michx. Leaves oblong-lanceolate (4 to 9 inches long), villous-pubescent or glabrous: scape with the filiform sparsely-flowered spike 8 to 20 inches long: bracts ovate, shorter than the oval rather rigid coriaceous sepals : capsule oblong, umbilicate, fully twice the length of the calyx. - F1. i. 94 ; Decaisne, 1. c. 721. P. Virginica, Walt. Car. 85 ? $P$. interrupta, Poir. Dict. v. 375. P. Caroliniana, Pursh, Fl. i. 98, not Walt. - Low pine barrens, S. Carolina to Elorida.

b. Montane, thin-leaved: ovules and mostly seeds a pair in each cell.

P. Tweèdyi. A span or two high from a slender root or rootstock, destitute of wool at the crown : leaves membranaceons, lanceolate-spatulate, entire or obsoletely denticulate, obscurely 3-5-nerved, 1 to 3 inches long, attenuate into a shorter margined petiole: spike slender but densely flowered, an inch or more long: bracts and sepals short (only a line long), pale with greenish midrib, little over half the length of the oblong capsule. - N. W. Wyoming, on grassy slopes of the East Fork of the Yellowstone River, Frank Tweedy, Ang., 1885 , in fruit.

c. Maritime or in saline soil: leaves thickish and somewhat fleshy: ovules a pair in each cell.

P. eriópoda, Torr. Usually a mass of yellowish wool at the crown: leaves oblanceolate to oval-obovate, 3 to 6 inches long and with short or stout petiole, mostly glabrous : scapes pubescent or glabrate, and with the dense or sparsely-flowered spike a span to a foot high; bracts broadly ovate or roundish, convex, scarious-margined, sometimes pubescent-ciliate: sepals roundish-obovate, scarious except the fuscous or greenish midrib: corolla-lobes broadly oval or ovate: capsule (2 lines long) ovoid, slightly exceeding the calyx. - Ann. Lyc. N. Y. ii. 237 ; Watson, Bot. King, $212 . \quad$ P. attenuata, James in Long Exped. i. 445, not Wall. $P$. glabra, Nutt. Gen. i. 100 ? but no specimen extant. P. lanceolata, var. $\gamma \& \beta$ in part, Hook. Fl. ii. $123 . \quad P$. virescens, Barneoud, Monogr. 33 ; Decaisne in DC. 1. c. 721. P. Richardsonii, Decaisne, 1. c. 698. - Moist and saline soil, Colorado, N. California, and north to Mackenzie River. Also on the Lower St. Lawrence and the Gulf (Pringle, Allen, Macoun), where a large form emulating $P$. Cornuti is probably $P$. cucullata, Pursh.

P. macrocárpa, Cham. \& Schl. Leaves lanceolate, acute, 4 to 15 inches long, 4 to 12 lines wide, gradually tapering into long margined petioles: scapes equalling or surpassing the leaves, bearing an oblong dense spike (in fruit 2 inches long); the rhachis, \&c., tomentose or pubescent: bracts round-ovate or oval, fleshy-herbaceous and scarious-margined: sepals similar : corolla-lobes oval : mature capsule ovoid-oblong ( 3 or 4 lines long), separating from the base and then fissile: seeds narrowly oblong. - Linn. i. 106 ; Bong. Veg. Sitk. 42. P. macrocarpa \& P. longifolia, Decaisne, 1. c.-Coast of Washington Terr. to Alaska and the farthest Aleutian Islands.

+ + Corolla with tube externally pubescent: capsule 2-4-seeded (in ours seldom incompletely 3-4-celled): seeds not excavated nor concave on the face: leaves linear or filiform, fleshy; ribs usually indistinct: commonly some wool developed from bases of leaves. (Maritime species.)

P. marítima, L. Root perennial: leaves mostly obtuse: spike dense, oblong or cylindrical : bracts mostly rotund and shorter than the calyx : sepals oval, more or less acutely carinate: corolla-lobes obtuse or hardly acute. $-P$. juncoides, Lam. Ill. i. 342 (Magellan); Decaisne in DC. 1. c. 731, partly. P. pauciflora, Pursh, Fl. i. 99 ; a dwarf form, with short and few-flowered spike, from Labrador; therefore $P$. oliganthos, Rœm. \& Sch. Syst. iii. I22. $P$. borealis, Lange in Bot. Not. 1873, 129, \& Fl. Dan. t. 2707, a similar few-flowered form.Atlantic coast north of the Gulf of St. Lawrence; the abbreviated form. Pacific coast from California to the Aleutian Islands and Behring Straits. (Eu., Asia, Patagunia.) 
P. decípiens, Barneoud. Root annual (perhaps sometimes biennial) : leaves from filiform to rather broadly linear and plane, attenuate-acute: spike slender, with flowers either sparse or dense (with the scape from 3 to 15 inches high) : lower bracts commonly ovatesubulate and equalling or exceeding the calyx : sepals ovate-orbicular: corolla-lobes very acute. - Monogr. 16, poorly characterized on a specimen from Labrador, but marked as an annual. ' $P$. juncoides, Decaisne, l. c. in part. $P$. maritima, of U. S. authors generally. P. pauciflora, Pursh, 1. c. in part. P. muritima, var. juncoides, Gray, Man. ed. 5, 311. - Salt marshes, Atlantic coast from Labrador and New Brunswick to New Jersey; flowering late.

+++ Corolla glabrous, nearly rotate: ovules and seeds 2 , solitary in each cell; the latter hollowed on the face: leaves strongly $3-5$-ribbed, not fleshy.

P. hanceoláta, L. (Ripple- or Ribgrass, English Plantain.) Root biennial or shortlived perennial: herbage villous or glabrate: leaves oblong-lanceolate, tapering into a slender petiole, usually much shorter than the (foot or two long) slender deeply sulcate and angled scape: spike at first capitate, in age cylindrical, dense : bract and sepals broadly ovate, scarious, brownish; two of the latter usually united into one. - Commonly naturalized in fields, from Eu. (Varieties said in Hook. Fl. ii. 123, to be indigenous far northward; but some or all of these plants belong to $P$. ériopoda.)

* Flowers heterogonous, in the greater number of individuals cleistogamous, but with normal corolla: this with broad cordate or ovate widely expanding lobes nearly equalling the tube: ovules solitary jn the two cells: seed cymbiform, deeply excavated on the face: inflorescence and commonly the narrow leaves silky-pubescent or lanate.

P. Patagónica, Jacq. Annual, silky-lanate or glabrate: leaves from narrowly linear to oblanceolate, acute or callous-pointed, tapering below into a petiole, entire or sparingly denticulate, I-3-nerved : scape terete, 3-12 inches high including the dense cylindrical or oblong spike: sepals very obtuse, scariously margined from a thickish and firm central herbaceous portion; the anterior oblong, posterior oval : lobes of the corolla usually a line long, roundish : seeds oblong-oval. (Filaments in the Iong-stamened individuals capillary and much exserted, and the anthers of usual ample size; style less exserted; apparently not proterogynous. Stamens and style in the other and more fruitful form short, included, or the effete anthers barely protruded from the throat; these very small, in the cleistogamous manner.) - Gray, Man. ed. 2, 269, Pacif. R. Rep. iv. 117, \& Bot. Calif. i. 661. $P$. Patagonica, Jacq. Ic. Rar. t. 306, \& Coll. Suppl. 35; Barneoud, Monogr. 38 ; Decaisne in DC. 1. e. 713 ; to which add most of the dozen species of this subdivision in the Prodromus, and their synonyms. - Prairies and dry plains, from Kentucky, Illinois, and Saskatchewan, south to Texas, and west to California and Brit. Columbia. (Mex., S. Am.)

Var. gnaphalioídes, Gray, may be taken as the commoner N. American type, canescently villous; but the wool often floccose and deciduous: leaves from oblong-linear or spatulate-lanceolate to nearly filiform: spike very dense, 1 to 4 inches long, varying to capitate and few-flowered, lanate : bracts oblong or linear-lanceolate, or the lowest deltoidovate, hardly surpassing the calyx. $-P$. Lagopus, Puxsh, Fl, i. 99, not L. P. Purshii, Rom. \& Sch. Syst. iii. 120. P. gnaphalioides, Nutt. Gen. i, 100. P. Hookeriana, Fisch. \& Meyer, Ind. Sem. Petrop. 1838, 39. - Runs through

Var. spinulósa, Gray, 1. c. (P. spinulosa, Decaisne, 1. c.), a canescent form with aristately prolonged and rigid bracts, and

Var. núda, Gray, 1. c. ( $P$. Wrightiana, Decaisne, 1. c.), with sparse and loose pubescence, green and soon glabrate rigid leaves, and short bracts, to

Var. aristáta, Gray, 1. c. Loosely villous and glabrate: leaves green : bracts attenuate-prolonged to twice or thrice the length of the flowers. $-P$. aristata, Michx. F1. i. 95. P. gnaphalioides, var. aristata, Hook. Fl. 1. c. A slender and depauperate form is P. squarrosa, Nutt. in Trans. Am. Phil. Soc. n. ser. v. 178, and P. Nuttallii, Rapin ex Barneoud, 1. c., also P. filiformis, Decaisne, 1. c. - All the forms most abound west of the Mississippi.

\$2. Stamens 4 or 2 : flowers subdiœcious or polygamo-cleistogamous; the corolla in the fertile or mainly fertile plant remaining closed or early closing over the maturing capsule and forming a kind of beak, and anthers not exserted: seeds flat or barely concave on the face. (American species.) 
* Leaves comparatively broad, short-petioled or subsessile: stamens 4: ovules and seedw 1 or 2 in eacir cell.

P. Virginica, L. Small winter-annual or fibrous-rooted biennial, soft-puibescent or more villous with spreading articulated hairs: leaves spatulate or obovate-oblong, entire or repand-denticulate, thin, obsurely 3-5-nerved: scapes 2 to 6 inches high, slender: spike Fostly dense, and an inch or two long: bracts equalling or shorter than the calyx : sepals ovate or oblong, more or less hairy on the back: corollarlobes subcordate-ovate: substerile flowers widely open, with capillary filaments, style long-exserted (the style commonly earlier), and large oval anthers: flowers of the fully fertile spikes with corolla remaining closed, small anthers on short filaments, and short style not protruded.-Spec. i. 113 (Gronov. Virg. 16 ; Moris. Hist. iii. 259; sect. 8, t. 15, fig. 8); Michx. FL. i. 94; Gray in Pacif. R. Rep. iv. 117. P. Caroliniana, Walt. Car. 84. P. purpurascens, Nutt. in Trans. Am. Phil. Soc. 1. c. ; the staminate and substerile plant. - Sandy fields, \&c., S. New England and S. Illinois to Florida and Arizona. A depauperate form (perpusilla) has a filiform scape an inch high, from an annual root, much exceeding the leaves; and 2-5-fiowered: Florida, Chapman.

Var. longifólia. Coarser : leaves oblong-spatulate, tapering into a margined petiole, often with strong salient teeth : scapes with the spike 5 to 12 inches long: flowers larger. $P$. purpurascens, Nutt. 1. c. $P$. occidentalis, Decaisne in DC. 1. c. - Arkansas to S. Arizona. (Adjacent Mex.)

P. hirtélla, HBK. Root perennial, thick : leaves oblong-ovate or oblong-spatulate, glar brate, rather fleshy, entire or sparsely denticulate, 5-7-nerved, 4-10 inches long: scape and long dense spike a foot or two high, stont, hirsute : flowers longer than in the preceding (3 lines long), with corolla-lobes ovate, acute; those of the fertile closed form with apex of slender style commonly protruding and the anthers perhaps sterile. (Staminate and openflowered form, not yet seen from California.) - Nov. Gen. \& Spec. ii. 229, t. 127 ; Decaisne, in DC. 1. c. 723. P. Hartwegi, Decaisne, 1. c. 724. P. Urvillei, Delile, Cat. Hort. Monsp.? \&. P. Candollei, Rapin? P. Durvillei, var. Californica, Fisch. \& Meyer, Ind. Sem. Petrop. P. Kamtschatica, Hook. \& Arn. Bot. Beech. 156? P. Virginica, var. maxima, Gray, Bot. Calif. i. 611. - Coast of California, from San Francisco Bay southward. (Mex., Chili.)

* Lenves linear or filiform: flowers very small: stamens only 2: small and slender annuals, minutely pubescent or nearly glabrous: the individuals having exserted stamens and style and open corolla not rarely fully fruitful.

+ Spike short, thick, and dense, in fruit an inch long: mature capsule 2 lines long.

P. Bigelóvii, Gray. Mostly glabrous and green: leaves $1 \frac{1}{2}$ to 4 inches long, rather fleshy, obtuse, entire, shorter than the scapes: mature capsule ovoid-oblong, half longer than the calyx, 4-seeded: only form known frlly fertile, with style conspicuously and the two stamens slightly exserted from the open corolla. - Pacif. R. Rep. iv. 117, \& Bot. Calif. i. 612. - Saline marshes, W. California and Brit. Columbia, first coll. by Bigelow.

+ + Spike filiform or slender, at length sparse-flowered, and half-inch to three inches long: capsule about a line long: leaves occasionally with a few denticulations or divergent lobes.

P. pusílla, Nutt. Somewhat cinereous-puberulent: leaves about an inch long and halfline wide: capsule short-ovoid, little exceeding the bract and calyx, 4-seeded : seeds elongated-oblong. - Gen. i. 110, \& Trans. Am. Phil. Soc. 1. c. (excl. syn.) ; Torr. Fl. 184, \& Fl. N. Y. ii. 16. $P$. elongata, Pursh, Fl. ii. 729 , proves to be this, a bad name. P. linearifolia, Muhl. Cat. 15? P. hybrida, Bart. Fl. Philad. \& Fl. Am. Sept. ini. t. 98, fig. 1. P. Bigelovii, Watson, Bot. King, 212, not. Gray, a rather larger-flowered form. - Sandy or gravelly soil, S. New York to Virginia, Utah, and Oregon.

P. heterophylla, Nutt. Greener or nearly glabrous, often taller, and with spikes 2 to 5 inches long: leaves sometimes 4 inches long and 1 or 2 lines wide: capsule conoidal-oblong and at length considerably surpassing the bract and ealyx, 10-28-seeded: seeds oblong, usually angled by mutual pressure, obscurely rugose-pitted. - Trans. Am. Phil. Soc. n. ser. v. 177 (char. imperfect); Gray, Man. 1. c.; Chapm. FI. 278. P. Caroliniana, Pursh, Fl. i. 98? not Walt. 'P. perpusilla, Decaisne, in DC. 1. c. 697. P. Californica, Greetre, Bull. Calif. Acad. i. 123. - Low sandy ground, Penn. to Florida, Texas, and California. 
P. médi, L., enumerated by Muhlenberg as of the United States, has once been found by Underwood, in the streets of Syracuse, New York.

P. Corónopus, L., is a rare and fugitive ballast plant.

2. LITTORELLA, L. (Litus or littus, shore, from place of growth.) Flowers monœcious; the male solitary on a mostly simple naked scape : calyx 4-parted, membranaceous, longer than the cylindraceous 4-cleft corolla; stamens exserted on very long capillary filaments. Female flowers usually 2, sessile at base of scape; calyx of 3 or 4 unequal sepals: corolla urceolate, with a 3-4toothed orifice. Ovary with a single cell and ovule, tipped with a long laterally stigmatic rigid style, maturing as an akene. Single species.

L. lacústris, L. Stoloniferous but otherwise stemless little perennial: leares terete, linearsubulate, an inch or two long. - In water on gravelly shores, Upper Canada, Macoun, Lake Champlain, Vermont, Pringle, Nova Scotia, Mrs. Britton, and Lake Utopia, St. George, New Brunswick, J. Vroom. All recent discoveries. (Eu., Antarc. Amer.) 



\title{
SUPPLEMENT TO VOL. II. PART I.
}

\author{
ADDITIONS AND CORRECTIONS.
}

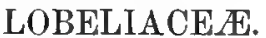

The following are additions and currections to the generic characters of this order, on p. 2 :-

1. NEMACLADUS. Filaments either partly or almost wholly monadelphous. Seeds oval or globular, obscurely costate or striate longitudinally and somewhat favose or transversely reticulate between the ribs.

11. PARISHELLA. Calyx 5-cleft, with campanulate tube wholly adnate to the ovary and shorter than the spatulate foliaceous lobes. Corolla almost rotate, shorter than the calyx, deeply and nearly equally 5-cleft. Stamens free from the corolla : filaments distinct at base only, above connate into a slender tube with inflexed summit. Style filiform: stigma depressed-capitate, 2-lobed, not annulate. Capsule turbinate, inferior, except the low-conical apex, which is circumscissile close to the base of the calyx-lobes and falls off as a lid. Seeds globose, smooth and nearly even. Otherwise nearly as Nemacladus.

12. HOWELLIA. (Under tribe Lobeliece.) Flowers of two forms; the emersed corolliferous, submersed with undeveloped corolla. Calyx with linear-clavate tube adnate for its whole length to the ovary, and a limb of five nearly equal slender-subulate or filiform segments. Corolla even in emersed flowers not surpassing the calyx; its very short tube divided nearly to base on the (apparently) upper side; lobes oblong, almost equal, three united higher. Stamen-tube nearly free, and with the included style slightly incurved: anthers oval; two smaller trisetulose, three larger naked. Ovary strictly one-celled, with two filiform parietal placentæ, each 3-5-ovulate. Upper ovules ascending; lower pendulous. Capsule clavateoblong or fusiform, with contracted apex, membranaceous at maturity and bursting irregularly on one side. Seeds few and large, linear-oblong, smooth, callous-apiculate at the chalaza. Aquatic herb.

1. NEMÁCLADUS, Nutt. Genus now increased in number of species and forms.

N. ramosíssimus, Nбтт., p. 3. Rarely a little puberulent: filaments usually monadelphous for most of their length, sometimes separating below in age. Nuttall's original is the more slender and very diffuse form, most abundant in Lower California, W. Arizona, and S. W. Utah, with very small white corolla little surpassing the calyx, and roundish seeds. $-N$. tenuissimus and N. capillaris, Greene, Bull. Calif. Acad. i. 198, 196.

Var. pinnatifidus ( $N$. pinnatifidus, Greene, l. c.) is less diffuse and has the (glabrous) radical leaves irregularly pinnatifid, and their small lobes commonly 1-2-toothed. Sierra Madre Mountains, Los Angeles Co., O. D. Allen. (All Saints' Bay, Lower California, Greene.)

Var. montánus ( $N$. montanus and $N$. rubescens, Greene, l. c.). More erect, a span or two high, with larger flowers and fruit, on less divaricate or ascending pedicels : column more 
elongated and protruded in age (carried up by the enlarging capsule): seeds from short-oral to oblong-oval. $-N$. ramosissimus, Torr. Bot. Mex. Bound. t. 35, is one of the forms of this. - From Middle and through S. E. California to the S. W. border of Texas.

N. longiflórus, GraY, p. 3. Habit of the last preceding form, well marked by its longer corolla and elongated free capsule.

N. rigidus, Currax. Stout and coarse for the genus, rather fleshy and thickish-leaved, purplish : calyx with triangular-subulate lobes somewhat surpassing the short corolla, and tube adnate quite to the middle of the remarkably large ( 2 lines wide) globular capsule: seeds (nearly half-line long) oval, under a good lens broadly costate and the ribs cross-barred as in N.rannosissimus, var. montanus. - Bull. Calif. Acad. i. 154. - Nevada, on Geiger's Grade, near Virginia City, Mrs. Layne-Curran. This might throw some doubt on the following genus; but it has the bivalvular dehiscence of Nemacladus.

1. PARISHÉLLA, Gray. (The discoverers, Samuel B. and William F. Parish, of San Bernardino, California.) - Bot. Gazette, vii. 94, \& Proc. Am. Acad. xix. 83. — Single species.

P. Califórnica, Grax, l. c. A very small and depressed winter annual, almost glabrous, with leaves and flowers glomerate in a radical tuft, whence proceed radiately spreading and naked branches bearing similar tufts: leaves spatulate, the primary ones 3 to 5 and the later only 2 lines long: flowers short-peduncled : corolla white.-Rabbit Springs, in the Mohave Desert, California, May, 1882, the brothers Parish.

\section{HOW FLIA, Gray. (The discoverers, Joseph and Thomas T. Howell.).} - Proc. Am. Acad. xv. 43. - Single species.

H. aquátilis, GrAY, 1. c. Aquatic herb, with Naias-like foliage, submersed, or summit of the stem and uppermost flowers emersed, with some scattered or verticillate branches: submersed leaves linear-setaceous and elongated, mostly alternate, entire; emersed ones shorter and broader, sometimes 1-2-toothed : flowers axillary, short-peduncled : only submersed capsules known, these half-inch long. - In stagnant ponds on Sauvies Island, Columbia River, at the mouth of the Willamette, Oregon, J. \& T. T. Howell.

\section{LOBELIA, L.}

L. paludósa, Nurt., p. 5. Exclude the statement, "even four feet high," and add :-

Var. Floridána. The larger form, 2 to 5 feet high : tube of corolla 3 or 4 lines long. - L. Floriduna, Chapm. in Bot. Gazette, iii. 9. - Common in Florida, also Louisiana according to coll. Drummond.

L. Gattingeri, Grar. (Next to L. appendiculata) Flowers smaller than in L. appendiculata: lobes of the calyx attenuate-subulate, not at all ciliate, obscurely appendaged at base only by a minute callns on each side, in fruit equalling or longer than the mature capsule (not "shorter"): pedicels often bracteolate. - Proc. Am. Aead. xvii. 221. - Cedar barrens of Middle Tennessee, Gattinger.

L. Cliffortiána, L. Transfer the reference "Michx. Fl.," and therefore the syn. $L$. Michauxii, to the var. Xalapensis.

\section{PALMERELLA, Gray.}

P. débilis, GrAY, p. 8. Not rare from mountains near Santa Barbara (Mrs. Cøoper, 1878) and San Bernardino Co. to Lower California. An interesting addition to the generic character, detected by $M r$. Nevin, is that the throat of the corolla on the (apparently) npper side bears a nectary, as if an adnate spur, forming a narrow imperfectly tnbular cavity, reaching down to the insertion of the filament-tube on that side. 


\section{DOWNINGIA, Torr. P. 9, add:-}

D. bicornúta. Most like $D$. pulchella, more ascending or erect, short-leaved : corolla intensely blue with white centre; lip with short lobes, and a strong constriction above the auriculate base, the face of which bears a pair of conspicuous conical hollow appendages. Not rare in northern part of California, coll. by Mrs. Bidwell in 1879, and in 1885 by Ratian, who indicated the characters.

\section{CAMPANULACE无.}

\section{GITHÓPSIS, Nutt. P. 10, add:-}

G. diffúsa, Grar. Slender and diffusely much branched, small-leaved, glabrous and smooth : calyx-lobes subulate-lanceolate from a broad base, about equalling the small corolla and half the length of the linear closely sessile capsule: seeds short-oblong. - Proc. Am. Acad. xvii. 221. - Cucamonga Mountain, San Bernardino Co., California, Parish.

\section{CAMPÁNULA, Tourn. After C. uniflora, p. 12, add:-}

C. scabrélla, Exyelx. Cinereous-puberulent or minutely scabrous to nearly or quite glabrous: numerous stems from the multicipital caudex 2 to 5 inches high; larger ones 2-4-flowered: leaves thickish; radical spatulate, upper cauline linear: flowers more erect and rather larger than in C. uniflora: lobes of corolla ovate-lanceolate, as long as its campanulate tube: capsule oblong-turbinate, not narrowed at summit. - Bot. Gazette, vi. 237. Higher mountains of N. California and Washington Terr., Engelmann (1880), Pringle, Suksdorf, Howell, Brandegee.

C. Párryi. A span to a foot high from elongated and creeping filiform rootstocks, mainly smooth aud glabrous: stem slender, erect, simple and with slender-peduncled flower, or with some lateral leafy branches: leaves thinnish, entire or sparingly callous-denticulate, somewhat veiny; radical and lower spatulate or lanceolate with tapering base hirsute-ciliate; upper linear-lanceolate from a sessile base, attenuate-acute : flower erect in anthesis : corolla almost crateriform, 5 -lobed to middle, spreading to a full inch in diameter, violet-blue or even purplish, little surpassing the linear-subulate often callous-denticulate calyx-lobes: ovary turbinate: capsule nearly obovate, opening close under the base of the erect calyx-lobes. C. Langsdorffiana, Gray in Am. Jour. Sci. xxxiv. 254, not Fischer. C. Scheuchzeri, Gray, Syn. Fl. ed. 1, excl. var., not Vill. C. planifiora, Engelm. in Bot. Gazette, vii. 5, not Lam. Monntains of Colorado, especially southward, subalpine and along lower streams, common, first coll. by Parry, then by Hall \& Harbour. Also S. Utah mountains, Siler, and near Fort Wingate, New Mexico, Matthews.

C. PLANIF LórA, Lam., on p. 14, a species long ago in cultivation, was wrongly gnessed to be A merican. It is very near C. pyramidalis, $\mathrm{L}$., of $\mathrm{S}$. E. Europe, perhaps a variety of it.

C. rotundifólia, L. To this polymorphous species refer all the forms assembled under "C. Scheuchzeri" (not Vill.), excepting what belongs to C. Parryi, and (to avoid the question as to what is truly $C$. linifolia, Lam, and $C$. Scheuchzeri, Vill.) adopt the nomenclature of Lange, viz. : -

Var. árctica, Lange, Fl. Dan. xvi. 8, t. 7211 (C. linifolia, var. Langsdorffana, A. DC., and probably his C. dubia and C. pratensis, also C. rotundifolia, var. linifolia, Gray, Man. ed. 2, 244, not Wahl. Fl. Lapp.), for the more rigid and one-few-flowered form, with corolla usually inch long, and very slender calyx-lobes soon spreading or deflexed. - Common from Canada and Labrador to the aretic regions.

Var. Alaskána. Leafy to the top: radical leaves cordate; lowest cauline ovate, the succeeding ovate-lanceolate to lanceolate, nearly all petiolate: calyx-lobes attenuate, soon deflexed : corolla an inch to nearly an inch and a half long. - C. heterodoxa, Bong. Veg. Sitk. 144, not of Vest, by the character. C. linifolia, var. heterodoxa, Ledeb., and C. Scheuchzeri, 
var. heterodoxa, Syn. Fl. 12, chiefly. - From the northern Aleutian Islands, Harrington, Dall, \&c., to Sitka, Mertens, and Kodiak, Kellogg, - the latter most broad-leaved and peculiar; the narrower-leaved passing into the preceding variety.

Var. velutína, DC. FI. Fr. Suppl. 432, with whole herbage canescently pubescent. Sand-hills of Burt Lake, Michigan, E. J. Hill.

C. Reverchóni. (In a separate subdivision before C. aparinoides.) Annual, hirsutulous below, glabrous above: stem a span high, slender, erect, cymosely and effusely muchbranched : leaves sparingly dentate, half-inch long; radical spatulate, Iower cauline lanceolate, those of the upper branches almost filiform and entire : flower and fruit erect on almost capillary peduncles: corolla blue, oblong-campanulate, with ovate-lanceolate lobes rather shorter than the tube : capsule obovate, crowned with the somewhat shorter narrowly linearlanceolate erect calyx-lobes, opening near the base? - On granite rocks, House Mountain, Llano and Burnet Co., Texas, Reverchon, May, 1885.

\section{HETEROCODON, Nutt. P. 14, add:-}

H. mfмтmum, Kellogg, Proc. Calif. Acad. vii. 111, by the character is clearly Alchemilla arvensis.

\section{ERICACE $A$.}

\section{GAYLUSSÁCIA, HBK.}

G. frondb́sa, Torr. \& Gray, p. 19. To this is to be added :-

Var. nána. Stems lower and strict, only a foot or so high: leaves more reticulated in age and smaller than in the ordinary plant : racemes and their pedicels shorter. - Pine barrens of Florida, \&c. Apparently there the commoner form, of which the var. tomentosa is a downy-leaved state.

\section{VACCINIUM, L.}

V. Oxycóccus, L., p. 25. To the slender and chiefly high-northern form of this belongs Oxycoccos microcarpa, Turcz. Fl. Baic.-Dahur. ii. 195. To this (as being the original species), rather than to $V$. macrocarpon, is referred the connecting form of the Pacific coasts, viz. : -

Var. intermédium. Leaves from ovate to oblong, mostly obtuse, a third to half inch long: flowers strictly umbellate from the scaly bud, but this not rarely proliferous into a leafy shoot (in the original of the species very rarely so) : berry 4 or 5 lines in diameter. Washington Territory and N. Oregon, Suksdorf, Henderson. Also, doubtless, Douglas, in Hook. FI. ii. 35 , referred to $\boldsymbol{V}$. macrocarpon, very naturally, as leaves of the specimen are elliptical, oblong, very obtuse, even more so at apex than base, obviously veiny beneath, and margins hardly at all revolute. (N. E. Asia, Sachalin, Japan, \&c.)

V. macrocárpon, Ait., p. 26. Pedicels becoming scattered along the base of a leafy shoot proliferous from the scaly bud, either squamaceous- or leafy-bracted.

\section{4. ÁRBUTUS, Tourn. P. 27, add:-}

A. Laurifólia L. f. The original of this is probably a specimen of A. Unedo (doubtless of the Old World), in the herbarium of Linnæus, on which Smith has written this name. The A. laurifolia, Lindl. Bot. Reg. xxv. t. 67, is surely $A$. Xalapensis, HBK., a variable Mexican species. The North American forms, other than the A. Menziesii of the Pacific coast, are very difficult, but seem to be best disposed as follows:-

A. Xalapénsis, HBK., var. Arizónica. Tree 20 to 40 feet high, with a whitish and thickish sealy bark on the main trunk, but with the reddish close and thin bark of A.Men- 
ziesii on the branches: leaves from oblong to lanceolate, 2 or 3 inches long, rather pale or thinnish, entire or minutely denticulate: ovary (as in A. Menziesii) glabrous. - A. Xalapensis, Sargent, Census Rep. Forest Trees, 97. A. Menziesii, Rothrock in Wheeler Rep. vi. 183, \&c. - Mountains of S. Arizova, Thurber, Rothrock, Sargent \& Engelnann, Pringle.

Var. Texána. Low tree, with older bark mostly deciduous in the manner of $A$. Menziesii: leaves from lanceolate-oblong to oval or ovate, more coriaceous, 2 or 3 inches long: orary pubescent. - A. Texana, Buckley, Proc. Acad. Philad. 1861, 460; Sargent, l. c. A. Menziesii, Torr. Bot. Mex. Bound. 108. A. Yalapensis in part, Watson, Proc. Am. Acad. xviii. 111. - Limestone hills of W. Texas, first coll. by Wright. Passes into similar Mexican forms on one hand, and is too like $A$. Menziesii on the other.

\section{ARCTOSTÁPHYLOS, Adans.}

A. nummulária, GrAT, p. 28. This grows 2 to 6 feet high, has heen collected on the Mendocino plains by Pringle, and near Santa Cruz by Anderson, by the latter with fruit; an oblong drupe, only 2 lines long, the thin pulp dry at maturity, and the whole splitting up into the (mostly 4) thin-shelled nutlets. On this account, Parry, in monograph of Arctostaphylos, in Proc. Davenport Acad. Nat. Sci. iv. 30, makes this the type of a new section, Micrococcus.

A. bícolor, Gray, p. 29. Add syn.. A. Veatchii, Kellogg, Proc. Calif. Acad. ii. 19. Also A. Clevelandi, p. 29, \& Proc. Am. Acad. xii. 61, appears to be an abnormal and autumnflowering state of this species.

A. Polifólia, in $\$ 4$. Comaristaphylis, to be replaced by

A. diversifólia, PARRY, in herb. Shrub 6 to 15 feet high : herbage minutely canescenttomentose when young, the inflorescence sometimes hirsute-pubescent and with some small glandular bristles: leaves glabrate, firm-coriaceous, short-petioled; those of flowering branches mostly spatulate-lanceolate, entire or spinulose-serrulate; of sterile shoots oblong or oval, either finely or coarsely spinulose-dentate: racemes solitary or clustered, loose: bracts lanceolate-subulate: caly $\mathrm{x}$ 5-parted into subulate divisions: corolla ovate: filaments longbearded at base: drupe only 2 lines in diameter and with solid 5-celled putamen. - A. arguta, var. diversifolia, Parry in Proc. Davenport Acad. Nat. Sci. iv. 35, not A. arguta, Zucc., which has a different calyx. - Southern borders of California, below San Diego and adjacent Lower California, O. V. Sanford, Parry, Orcutt.

A. oppositifólia, ParrY. An anomalous species: leaves opposite or in threes, linear, entire, with revolute margins, much resembling those of Andromeda polifolia: flowers paniculate: corulla globular, a line or two long: ovary canescent: drupe smooth, depressedglobose; the putamen separable at maturity into five perfectly or incompletely 2 -celled nutlets. - Proc. Davenport Acad. Nat. Sci. iv. 36. A. polifolia, Torr. Bot. Mex. Bound. 108, not HBK. - On or very near the boundary between San Diego Co. and Lower California, and southward, Parry, Orcutt, Pringle, \&c.

\section{GAULTHERIA, Kalm.}

G. Myrsinites, Ноок., p. 30. Strike out the last sentence, and add: Glabrous: leaves oval or rounded, not ovate, mostly only half-inch long: corolla depressed-campanulate, little surpassing the calyx. - Gray, Proc. Am. Acad. xix. 84.

G. Ovatifólia, Gray, 1.c. Larger, with ascending branches; and with some at length rusty-colored hairs, at least on the caly $\mathrm{x}$ : leaves broadly ovate or even subcordate, the largest an inch and a balf long, more serrulate: corolla campanulate, double the length of the calyx-lobes. - Cascade Mountains, British Columbia to Oregon, Lyall, E. Hall, S. Watson, Suksdorf, the last of whom indicated the characters.

\section{LEUCÓTHOE, Don.}

L. Catesbǽi, Grat, p. 34. The words "( 4 to 7 inches long)" in line 3, are misplaced: they relate to the leaves. To this, and not to L. acuminata, belongs Andromeda acuminata, Smith, Exot, Bot. t. 89. 


\section{RHODODENDRON, L. P. 41, after R. Rhodora, add:-}

R. Vaséyi, Grar. Shrub 5 to 15 feet high, nearly glabrous : branchlets wholly destitute of strigose bristles: flowers rather preceding the leaves, from few-scaled buds : leaves oblong, acute or acuminate at both ends, sparsely hirsute, at least the midrib and margins when young, when adult 3 to 5 inches long and 1 or 2 wide: corolla pale rose-color, rotatecampanulate, but irregular, somewhat unequally 5-parted; upper lobes shorter and overlapping, somewhat spotted, three lower diverging and widely spreading, all broadly obovate : stamens 5 to 7, commonly 7: capsule minutely glandular, oblong, acutish. - Proc. Am. Acad. xv. 48. - Mountains of Jackson Co., N. Carolina, "seven miles southwest of Webster," George R. Vasey, and Chimneytop Gap, Donnell Smith, flowering in May. Nearest $R$. Albrechtii of Japan. Requires some extension of the Rhodora subsection.

R. Califórnicum, Hook., p. 41. Extends north to Brit. Columbia; and the syn. $R$. maximum, Hook. Fl., as to the Pacific coast plant, belongs in part, if not wholly, here.

R. macrophyllum, Dor, p. 42. This is not yet well made out; but it was originally described (from the collection of Menzies) as having corolla smaller than of $R$. maximum, and white, and leaves large. It should therefore be to $R$. Californicum what $R$. maximum is to $R$. Catawliense. But it is doubtful if there are two true species on the Pacific coast.

\section{SCHWEINITZIA, Ell. Two species, characterized thus :-}

S. Odoráta, ELI., p. 49. Scales of the stem broadly ovate, imbricating : flowers in a short spike, hardly nodding: sepals oblong, about equalling the tlesh-colored corolla. - Gray, Proc. Am. Acad. Xx. 301.

S. Reynóldsiæ, Gray, l. c. More slender, with smaller and remoter scales : flowers more numerous and smaller, slightly fragrant, soon nodding and mostly secund in the narrow spike : sepals ovate or lanceolate, half the length of the white corolla. - E. Florida near the coast, on Indian River, \&c, first found by Miss Mary C. Reynolds, flowering in winter.

33. PLEURICOSPORA, Gray. P. 50 and 18, add: No hypogynous disk-glands. Placentæ apparently double the petals in number, commonly 8 . Seed-coat close and alveolate.

P. fimbrioláta, GraY. Extends to Oregon : coll. at Waldo by Howell, and on the Colum. bia at Hood River by Mrs. Barrett.

34. NEWBERRYA, Torr. P. 50 and 18, add: Bract-like sepals 2 or 4, linear. Disk of short and deflexed glands alternating with the stamens. Now two species:

N. congésta, Torr., p. 50. Flowers densely crowded in a corymbiform glomerule: lobes of the corolla ovate, one third the length of the cylindraceous or slightly urceolate tube: filaments equalling the slender style: anthers narrowly oblong, the line of dehiscence close to the connective: cauline scales ovate, obtuse, only slightly erose. - Gray, Proc. Am. Acad. xv. 44. Besides Dr. Newberry's original specimens in the Cascade Mountains of Oregon, now found in coniferous forests of Mad River, N. W. California, Rattan.

N. spicáta, GraY, 1. c. Flowers spicately crowded: corolla noore campanulate, with oblong lobes half the length of the tube: filaments not equalling the short style: anthers shortoblong, the line of dehiscence somewhat remote from the connective : cauline scales narrowly oblong, acutish, fimbriate-rose. - Woods, in the mountains of Humboldt Co., California; Rattan. 


\section{DIAPENSIACE A.}

\section{SHORTIA, Torr. \& Gray.}

S. galacifólia, Torr. \& Gray, p. 53. Add : Leaves oval-orbicular, the base slightly and uccasionally cordate : corolla white ; the lobes lightly erose-crenulate at the rounded apex: anther borizontally inflexed on the filament. - Gray, Am. Jour. Sci. ser. 3, xri. 483, \& Ann. Sci. Nat. ser. 6, vii. 171, t. 15; Sprague \& Toodale, Wild Flowers of Amer. 107, t. 24; Masters, Gard. Chron. ser. 2, xv. 596, f. 109. - Rediscovered near Marion, N. Carolina (very local), by G. M. Byams.

\section{PRIMULACE.E.}

\section{PRIMULA, L.}

P. boreallis, Duby, p. 58. Strike out the closing sentence in parentheses, and add the following species:-

P. Egaliksénsis, Horvesr. Slender, not at all mealy: leaves oval or lanceolate-ovate, entire or margins merely undalate, mostly slender-petioled : umbel 3-6-flowered : pedicels in fruit elongated and strict: calyx narrow, in fruit oblong-cylindraceous, with short teeth: limb of the corolla very small; the lobes only a line or twolong, much shorter than the tube, cleft nearly to the middle into oblong-linear segments. - Fl. Dan. t. 1511; Lehm. Prim. 63, t. 7 ; Lange, Medd. Groenl. 71. - Northern Labrador, Lieut. Turner. (Greenland.)

P. angustifólia, Torr., p. 58. Strictly 1-flowered, or very rarely 2-flowered in largest plants: involucre a single minute or small bract, sometimes the rudiment of a second bract: calyx green. Add the following nearly related species :-

P. Cusickiána. Larger: leares oblong-spatulate or narrower, 2 inches long, entire, or rarely a denticulation: scapes 3 to 6 inches high, 2-4-flowered : involucre of 2 or 3 conspicuous nnequal bracts: calyx green and with a whitish line down from the sinuses of the campanulate tube ; its lobes from lanceolate to subulate, about the length of the tube and nearly equalling the tube of the violet (rarely white) corolla; lobes of the latter retuse. $-P$. angustifolia, var. Cusickiana, ed. 1, 393. - Rocky hills, Union Co., E. Oregon, flowering in earliest spring, Cusick.

P. Rúsbyi, Grenne. Still larger: leaves 2 to 5 inches long (including the margined petiole), thinner, oblong-spatulate, mostly callous-denticulate: scapes 5 to 10 inches high, 6-10-flowered : involucre of 3 or more small subulate or ovate bracts: calyx-tube white and as if farinose at base, campanulate, longer than the ovate-triangular lobes : corolla "deep purple, with yellow eye"; its tube longer than the calyx; lobes obcordate. - Bull. Torr. Club, viii. 122. - Mogollon Mountains, New Mexico, Rusby, and summit of Mount Wrightson, Santa Rita Mountains, Arizona, Pringle.

4. DOUGLÅSIA, Lindl., p. 59. - Species re-characterized and augmented. Pubescence (when there is any) of the pedicels and stems of 3-4-forked or stellate short hairs. Flowers in most species occasionally unibracteolate under the calyx.

D. nivális, Linde. Leaves, \&c. canescent with minute and dense 2-3-forked pubescence, not ciliate, linear, mostly quite entixe, mainIy in rosulate clusters, from which the stems are repeatedly and commonly umbellately proliferous: flowers in 3-7-rayed umbels, with involucre resembling a leaf-cluster or reduced to ovate or subulate bracts : corolla-tube hardly exceeding the calyx. - To references add: Hook. Ic. Pl. ii. 130. - Montana, Brandegee, \&c.

Var. dentáta. A coarser form, with larger (4 to 6 lines long) and broader leaves often spatulate, either entire, or with a few denticulations or coarse teeth. $-D$. dentata, 
Watson, Proc. Am. Acad. xvii. 375. - Higher Cascade Mountains, on the eastern side, Washington 'Terr., Watson, Brandegee.

D. lævigáta, Gray. Leaves glabrous, or sometimes with a few minute and scurfy deciduous branched hairs, not at all ciliate, quite entire, thick, oblong-lanceolate, obtuse, mainly in rosulate radical or simply proliferous clusters : flowers in 2-5-rayed pedunculate umbels: bracts of the involucre oval or ovate, short: corolla-tube almost twice the length of the calyx. - Proc. Am. Acad. xvi. 105. - Mountains of Oregon, Howell, Mrs. Barrett, Suksdorf.

D. montána, Gray, p. 60. Leaves wholly destitute of forked hairs, glabrous or nearly so, but margins ciliolate with short simple bristles, linear or lanceolate, small ( 1 to 3 lines long), very crowded on the crowns of the pulvinate-cespitose branches, or in the larger and looser plants in successively proliferous tufts: peduncles solitary and simple (or rarely in pairs from the rosulate tuft), naked and l-flowered, and the caly $x$ often unibracteolate (in one case a second flower sessile in the axil of the bract) : tube of the corolla barely or hardly equalling the calyx. - Common in N. Montana, recently coll. by Canby, Brandegee, Scribner, \&c., both in pulvinate-depressed and in rather open and proliferous forms.

D. árctica, Hook,, p. 59. Like the preceding in the ciliate leares, but said to have the habit (of inflorescence?) of $D$. nivalis.

\section{ANDRÓSACE, Tourn. P. 60, before A. occidentalis, add :-}

A. Arizónica, Gray. Exiguous: scapes filiform, some erect, some decumbent and as if stoloniform, bearing few or several elongated capillary pedicels : radical leaves lanceolate or oblong, thin: calyx-lobes foliaceous and much accrescent in fruit, ovate, longer than the short-campanulate whitish tube: corolla minute: seeds 5 or 6 , comparatively large. - Proc. Am. Acad. xvii. 222. - Mountains of S. Arizona, Pringle, along with A. occidentalis, its vear relative.

\section{LYSIMÁCHIA, Tourn. After L. Fraseri, p. 62, add:-}

L. vULGARIs, L., - a coarse and tall Luropean species of this section, pubescent and branching, with ovate-lanceolate distinctly petioled leaves, leafy panicle, and glandular filaments united to near the middle, - has escaped from gardens and become naturalized in one or two places in Eastern Massachusetts.

\section{1. CENTUUNCULUS, Dill. P. 64, add:-}

C. pentándrus, R. BR. Pedicels equalling or surpassing the ovate leaves: flowers commonly 5-merous. - Prodr, 427 ; Griseb. Fl. W. Ind. 390 . C. tenellus, Duby in DC. Prodr. viii. 72; Chapm. in Bot. Gazette, iii. 10, \& Fl. ed. 2, 634. Anagallis pumila, Swartz, Fl. Ind. Oce. i. 345. Micropyxis pumila, Duby, l.c.-S. Florida, Chapnan, \&c. (Trop. Am., E. Ind., Australia.)

\section{SAPOTACE $刃$.}

For changes in Bumelia, see on p. 68.

\section{APOCYNACEA.}

\section{CYCLADENIA, Benth.}

C. húmilis, Bent1r., p. 83. An intermediate form, found in Southern Utah, by Siler, shows that the pubescence is inconstant, and requires

Var. tomentósa to take the place of the second species, C. tomentosa, Gray. 


\section{ECHfTES, P. Browne. P. 84, before E. Andrewsii, add :-}

E. paludósa, VArL. Habit of the succeeding : peduncle elongated, 1-3.flowered : corolla white, 2 inches long or more; tube slender, as long as the obconical-campanulate throat, about thrice the length of the oblong and mucronate spreading calyx-lobes: anthers oblonglanceolate, acuminate, not appendaged: beak of the seeds plumose to the base. - Ecl. Am. ii. 19, \& Ic. t. 5 ; Griseb. Fl. W. Ind. 415. Rhabdadenia paludosa, Muell. Arg. - Mangrore swamps, S. Florida, Chapman (published in Bot. Gazette as E. biflora), Garber, Curtiss.

\section{ASCLEPIADACE AE.}

The synoptical characters of the genera, on p. 85 and p. 87 , to be augmented as follows : -

5. ASCLEPIODORA. To character of hoods, add: At the sinuses between them are auriculate lobes, alternate with the anthers, simulating an inner corona.

141. ROTHROCKIA. Corolla rotate, deeply 5-cleft; the lobes oblong, dextrorsely overlapping in the bud. Crown simple, inserted at the junction of corolla and stamen-tube, 5-parted; the lobes opposite the anthers, thick, slightly cuneate, barely cuncave. Anthers short: pollinia oval, aftixed just below their apex to a short candicle, pendulous. Stigma abruptly produced from the top into a column having a 3-crested apex ; mamely, two divaricate and muricate-papillose crests, with a small central emarginate crest interposed.

142. HimANTOSTEMMA. (In Tribe Gonolobere?) Corolla deeply 5-parted, soon reflexed, the broadly lanceolate lobes slightly overlapping dextrorsely, the face (especially toward the base) conspicuously adorned with spatulate and stipitate corolline processes, disposed without order. Cruwn stamineal, borne on the summit of the short column, simple, with membranaceous margin bearing 10 elongated narrowly linear and stipitate liguliform divisions, which are geminately alternate with the anthers and nearly equal the unexpanded corolla; also 5 subulate and short processes, which are opposite the anthers. Anthers short, inappendiculate in the manner of Gonolobea, applied to the sinuses of the somewhat dilated and flat-topped stigma: cells opening at summit. Pollinia oval, affixed by the pellncid apex to a very short caudicle, introrsely somewhat pendulous. Follicles echinate.

143. LACHNOSTOMA. Corolla between rotate and salverform, with tube about the length of the (in bud) dextrorsely convolute lobes, retrorsely villous-barbate in the throat. Crown belonging to the corolla, adnate to its tube, with free margin 5-10-crenate or lobed. Otherwise near Gonolobus.

\section{ASCLEPIAS, L.}

A. Cornúti, Decansne, p. 91.-A. grandifolia, Bertol. Misc. Bot. xii. 47, t. 3, 4, 5, raised from seed from North America, by its flowers and follicles can be no other than this common Milkweed. Pods in this species are sometimes found with hardly a trace of the soft spinous processes, sometimes with very long and shaggy ones.

A. obtusifólia, Mrchx., p. 91, occasionally bears a second umbel at the base of the long terminal peduncle.

A. Meádii, Torr., p. 91, has leaves undulate in the living plant, the upper sometimes hroadly ovate and subcordate : umbel nodding on the peduncie.

A. glaucéscens, HBK., p. 92.-A. elata, Benth. Pl. Hartw. 290, is not different. - S. Arizona, Lemmon, Pringle.

A. brachystéphana, Exgecx., p. 94. To this belongs Asclepiodora circinalis, Fournier in Ann. Sci. Nat. ser, 6, xiv. 369, as to Palmer's 815, \& Watson, Proc. Am. Acad. xi. 114, excl. syn. Acerates circinalis, Decaisne. - Between this and the next aild : -

A. unciális, GreEve. Intermediate between the preceding and the following, dwarf and depressed, glabrate : leaves linear-lanceolate, or small lowest ones ovate: umbel sessile, few- 
flowered, overtopped by the leaves: corolla dull purple: hoods paler, little shorter than the anthers, the thickish body almost orbicular, equalled or slightly surpassed by the thin and ovate-triangular auricles or lateral appendages, the horn a semi-oval and shorter lamella of similar texture. - Bot. Gazette, v. 64. - Near Silver City, New Mexico, Greene, Colorado, Hall \& Harbous; no. 418, and Green River, Wyoming, Parry. These had been referred to A. brachystephana.

A. involucráta, Екагцм., p. 94. The leaves which usually subtend the umbel, like an involucre, are sometimes below it and scattered.

The succeeding subsection c. on p. 95 to be altered as follows, the added species all having the follicles arrect on the decurved pedicels.

c. Leaves very narrow and slender, sessile: hoods equalling or surpassing the anthers.

1. Leaves opposite.

A. macrótis, Tokr., p. 95. Filiform branches often a foot or more long, numerous in diffuse tufts from lignescent stem: hoods with very long acumination. The larger specimens coll. in S. Arizona, Pringle, Lemmon.

A. quinquedentáta, GraY; transfer from p. 97. Follicle slender-fusiform, 4 inches long, barely puberulent. - New Mexico and Arizona, Greene, Lemmon, Pringle, some with rather smaller flowers, var. Neo-Mexicana, Greene in Proc. Am. Acad. xvi. 103, but not needing a varietal name. There is really no dorsal tooth to the horn in the original specimen, that so called in the original description being only the middle tooth of the hood, up to which the horn is adnate.

\section{Leaves alternate.}

A. Linária, CAv.; transfer from p. 97. Habit nearly of A. verticillata, but with frutescent and branching stems, thickly beset with almost filiform irregularly alternate or at most imperfectly verticillate leaves : column hardly any: horn included: arrect follicles ovate and acuminate.-Ic. Pl. i. 42, t. 57 ; Gray, Proc. Am. Acad. xii. 71. A. pinifolia, Greene, Bull. Torr. Club, viii. 5.-Mountains in the southern part of Arizona, Greene, Pringle, Lemmon, Parish. (Mex.)

A. Curtíssii, Gray. To follow A. obovata, p. 95. Merely puberulent, glabrate: leaves oval, more petiolate than in $A$. obovata, and distinctly lineate by the aseending-transverse primary veins: umbels few or solitary, short-peduncled, rather few-flowered : flowers yellowish green: hoods somewhat hastate-lanceolate, erect, much surpassing the anthers, the thin auriculate supra-basal margins inflexed; horn falcate-incurved, broad, the tip assurgent: anther-wings short, broad, acute-angled: column very short. - Proc. Am. Acad. xix. 85; Chapm. Fl. ed. 2, 643. - S. E. Florida, A. H. Curtiss. - To follow this, although requiring a new subdivision:-

A. Lemmóni, Grax. Tall and robust, leafy, villous-hirsute, but the foliage glabrate: leaves large (5 to 10 inches long), oval or oblong, with rounded or retuse apex and emarginate almost sessile base, transversely veiny: umbels conspicuously peduncled, manyflowered: petals 4 or 5 lines long, ovate, glabrous, yellowish green: stamineal column as broad as high : hoods apparently white, 4 lines long, very much surpassing the anthers, ovate-sublanceolate, spreading towards the summit, angulate-toothed on each side at base; horn broad and falcate, acutish: follicles 4 inches long, pubescent. - Proc. Am. Acad. xix. 85. - Mountains of S. Arizona, Lemmon, Pringle.

A. nyctaginifólia, Grax, p. 95. Char. partly corrected on the page. Add : Follicles short, ovate, cinereous-puberulent. - A. Wrightii, Greene, ined.; Gray, Proc. Am. Acad. xvi. 102. In Wright's collection partly confounded with $A$. longicornu, which it approaches. - W. Texas, New Mexico, Arizona, and borders of California, Wright, Reverchon, Palmer, Greene, Pringle, Lemmon.

A. virgAta, Lag., mentioned p. 96. Name gives place to A. ANGUStifólia, Schweigger, Ennm. Pl. Hort. Regiomont. 1812, I3; Rœm. \& Schult., \&c. (A. virguta, Balbi, \&c., A. linifolia, HBK., \&c.), a Mexican species. Consequently

A. Michaúxii, Decaisne in DC. Prodr. viii. 569, is the proper name for the A. anyustifolia, Ell. on p. 97 . 
7. ACERÁTES, Ell. An extension of the generic character, as to the hoods, is needed to include the following, which in other respects falls under the second division, p. 99.

A. bifida, Rusbr. Generally resembling A. viridzfora, a foot. or two high, tomentosepuberulent: leaves oblong-lanceolate, tapering into short petioles : pedicels rather slender: hoods of the crown paler, rather shorter than the anthers, two-purted, the divisions lanceolate. — Gray, Proc. Am. Acad. xx. 296. - Arizona, probably in Yavapai Co., Rusby, 1883.

\section{GOMPHOCÁRPUS, R. Br.}

G. tomentósus, GraY, p. 100. Hoods dark brown-purple, the solid part not much smaller than the valves: the structure not to be confounded with that of Schizonotus, for the 2-valved portion is only apparently dorsal, the whole organ being pendulous or resupinate. It is similar in G. lanatus of S. Africa, except that the hood is ascendiug.

G. hypoleúcus, GraY. Tomentulose : stem robust, 2 feet high, leafy : leaves all opposite, oval or oblong, short-petioled, green and glabrate above, cauescently tomentose beneath: umbels long-petioled, many-flowered: corolla greenish with the upper face dull purple: hoods brown-purple, erect, much surpassing the anthers, lingulate, fleshy, nearly solid and entire, except a pair of triangular and acute strictly inflexed lobes at base. - Proc. Am. Acad. xvii. 222. - Mountains of S. Arizona, Pringle, Lemmon.

\section{METASTELMA, R. Br., § Eumetastelma. P. 101, add:-}

M. Pálmeri, WArson. Glabrous: leaves lanceolate, acutish or obtuse at base, about an inch long: cymes loosely 2-6-flowered, subsessile or short-peduncled : calyx-lobes ovate, obtuse : corolla not over a line and a half long, 5-parted; its lobes oblong or narrower, merely puberulent within: scales of the crown lanceolate and acuminate or ovate-subulate, inserted at base of extremely short column, a little surpassing the stigma. - Proc. Am. Acad. xviii. 115, as to pl. Palmer only; Gray, Rev. Metastelma in Proc. Am. Acad. xxi. - W. and S. borders of Texas, Palmer, Reverchon. (Adj. Mex.)

M. Arizónicum, Gray. Puberulent, lignescent at base: leaves thickish, narrowly linear or some linear-oblong, veinless : flowers fascicled and short-pedicelled : calyx-lobes subulate: corolla 2 lines long, thickish, deeply 5-parted; lobes linear-lanceolate, densely villouspubescent inside; scales of the crown linear-subulate, inserted at base of very short column, surpassing the stigma. - Proc. Am. Acad. xix. 85. - Hills near Tucson, Arizona, Pringle.

14. VINCETÓXICUM, Mœnch. (Derivation doubtless from vincere, to overcome, toxicum, poison, as has been well shown.)

V. palústre, p. 102. Add. syn. : Cynanchum mantimum, Maxim. in Bull. Acad. Petrop. ix. 800 .

V. scopárium, p. 102. Leafy plants not rarely bear leaves an inch or two long, a line or two wide.

141. ROTHRóCKIA, Gray. (Professor Joseph Trimble Rothrock, anthor of the Botanical Part (vol. vi.) of Wheeler's U. S. Geographical Surveys of the region in which the plant was discovered.) - Proc. Am. Acad. xx. 295. - Single species.

R. cordifólia, Gray, 1. c. Perennial herb, liguescent at base, spreading and twining, pubescent and more or less hirsute : leaves opposite, slender-petioled, cordate, acutely acuminate: flowers in simple or compound racemiform loose racemes in the axils of the leaves: 
pedicels bracteate: calyx-lobes ovate-lanceolate : corolla white or whitish; the lobes 3 or 4 lines long, thin, glabrous, indistinctly nervose and reticulated: follicles fusiform, glabrous, 4 or 5 inches long. - By water-courses, in mountains of N. W. Sonora, near the borders of Arizona, Pringle.

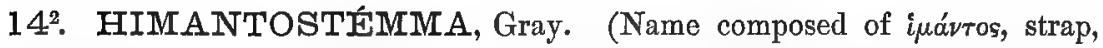

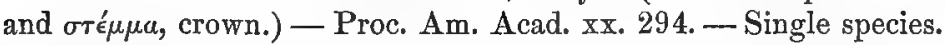

H. Prínglei, Gray, 1. c. Diffusely spreading perennial herb, with branches a foot or so in length, hardly at all twining, puberulent: leaves opposite, small, sagittate-cordate, half-inch to inch long, on petioles of nearly same length : peduncles axillary, 2-flowered: pedicels slender : calyx-lobes attenuate-lanceolate : corolla-lobes lanceolate, thickish, veinless, 3 lines long, the upper face dark brown-purple, its ramentaceous setæe whitish, or those toward the throat purplish and flatter, more spatulate and stipitate: strap-shaped lohes of the crown 2 lines long, erect, purplish : follicles fusiform, armed with rather rigid processes : seeds comose. - Water-courses in rocky hills, N. W. Sonora, south of Altar, therefore not very near the Arizona boundary, yet may reach it, Pringle, 1884.

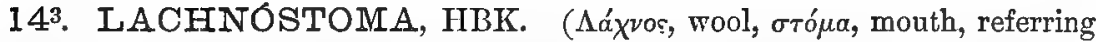
to the throat of the corolla.) - HBK. Nov. Gen. \& Spec. iii. 198, t. 232 ; Gray, Proc. Am. Acad. xii. 74; Hemsl. Biol. Centr. Am. Bot. ii. 335. - Three good species now known, two of them south of the Isthmus.

L. Arizónioum, Gray. Pubescent herb, freely twining: leaves thin, cordate-sagittate, long-petioled: peduncles slender, umbellately few-flowered: corolla white, externally glabrous, with narrow tube almost as long as the ovate-oblong lobes, these lightly green-reticulated ; throat retrorsely villous: crown simple, its thickish free margin 10-crenate : follicles ovate-lanceolate, smooth and glabrous, acutely 3-5-costate.-Proc. Am. Acad. xx. 296.Santa Catalina Mountains, S. Arizona, Lemmon, Pringle. One specimen from Lemmon, in tlower, was mistaken for Gonolobus reticulatus, another (in fruit only) for Rothrockia, in Proc. Am. Acad. 1. c. 295.

\section{GONOLOBUS, Michx.}

G. obliquus, R. Br., p. 104. The flowers of this are said to have the scent of Calycanthus. The var. Shortiz is to be excluded.

G. hirsútus, Michx., p. 104. Crown nearly as in G. obliquus, that is, with the intermediate crenatures more or less bidentate, all very short. Varies freely, as shown by Dr. Mellichamp, into

Var. flavídulus. Corolla from dingy brown-purplish to greenish and dull straw-color, the reticulated veins more evident as the hue is lighter. $\rightarrow G$. flavidulus, Chapm. Fl. 368, \& Bot. Gazette, iii. 12; Gray, in ed. 1, 394. G. macrophyllus, Eil. Sk. i. 327. - Common with the darker-flowered plants, from S. Carolina to Florida.

G. Shórtii, Grax. (To come before G. Carolinensis, in the same subdivision.) Resembles $G$. obliquis, but commonly larger-leaved, and the flowers also said to have the scent of Calycanthus blossoms; the bud conical-oblong: corolla dark crimson-purple, its lobes ligulate, fully half-1nch long: crown with about 10-dentate margin, the narrow intermediate teetl thinnish, either emarginate or two-parted, a little exserted beyond the alternate broader and thicker ones. - Bot. Gazette, viii, 191. G. obliquus, var. Shortii, Syn. Fl. 104. - Along the mountains, E. Kentucky, Short, N. W. Georgia, Chapman. Probably common.

G. Carolinénsis, R. BR., p. 104. Flowers said by Engelmann to have a cimicine odor: crown with more exserted subulate bifid teeth, but these variable. - From near Washington and S. Missouri, southward.

G. Baldwiniánus, SweEr, p. 104. Corolla clear white, accordıng to Chapman. Wherefore the G. hirsutus, Lodd. Cab., may be the var. flavidulus of that species. 


\section{LOGANIACE $Æ$.}

\section{BUDDLÉIA, Houston. After B. racemosa, p. 109, add:-}

B. Prínglei, Grar. Nearly glabrous and green, partly herbaceous, much branched : leaves oblong or lanceolate, acutish, nearly entire (inch or two long), tapering at base into a short margined petiole: flowers in globular and sessile interruptedly spicate glomerules, the upper naked and approximate, the lower remoter in the axils, some short-peduncled: corolla slightly exserted out of the white-tomentulose calyx, a little hairy in the throat: stigma thickish. - Proc. Am. Acad. xix. 86. - Arizona, in fields near Tucson, Pringle. Intermediate between the Globose and the Verticillatce.

\section{GENTIANACE无.}

To characters of genera add, on p. 111 :-

-1. VOYRIA. Corolla salverform, bearing the stamens below the throat. Anthers short. Stigma undivided. Seeds very numerous, tailed at both ends.

-1. VOYRIA, Aublet. (Unexplained name.) - Leafless and colorless (white) little herbs, of Tropical America, parasitic on decaying trunks, \&c., bearing small subulate scales for leaves, in the manner of Bartonia.

V. Mexicána, Griser. Stems a span to a foot high, slender, bearing a cyme of several flowers: corolla white or flesh. color, a quarter of an inch long. - Gent. 208, Prodr. ix. 84, \& Cat. Cub. 181. - No-name Key, S. Florida, Curtiss. (Cuba, Mex.)

\section{ERYTHR ÆA, Renealm. P. 113, before E. Douglasii, add : -}

E. nudicaúlis, ExGers. A span or two high, cymosely branched from the conspicuous tuft of rather large roundish radical leaves: cauline leaves few, linear: flowers longpeduncled : tube of corolla not surpassing the calyx; lobes a little shorter, oblong, obtuse : anthers linear-oblong: style much shorter than the ovary: seeds subglobose, reticulated. Proc. Am. Acad. xvii. 222. - Along streams in Santa Catalina Mountains, S. Arizona, Pringle.

E. venusta, Gray. Add : Bot. Mag. t. 6396.- This and all the larger-flowered American species are dichogamous in the manner of Sabbatia, the style in the earlier anthesis declined to one side.

\section{EỨTTOMA, Salisb.}

E. silenifólium, SALisB. (Parad. Lond. t. 34), is the name which should have been retained for $E$. exaltatum, Griseb. In S. California this certainly becomes perenuial, according to Parry and W. G. Wright.

\section{GENTIÁNA, Tourn. Add on p. $116:-$}

G. Gracfllima, Bertol. Misc. Bot. xiv. 19, t. 3, is Apteria setarea, Nutt. - Add on p. $119:-$

G. micrócalyx, Ismmow. Near G. Wislizeni, but taller (sometimes almost 2 feet high), thinner-leaved, and wholly destitute of crown to the corolla, in this and the habit approaching $G$. guinqueflora, freely branched : leaves ovate-lanceolate, with subcordate sessile base: 
flowers mostly numerous and crowded in the clusters, slender-pedicelled: calyx snall, 5-parted, only one line and the whitish or violet-tinged corolla 5 lines long: ovary subsessile: seeds globose, smoothish.-Pacif. Rural Press, 1882, with figure; Engelm. in Proc. Am. Acad. xvii. 222. - Chirricahua Mountains, S. Axizona, Lemmon.

G. nivális, L. In a subsection, Cyclostigma, of Pneumonanthe, with stigmas surmounting a distinct style, much dilated, forming together a circular disk. A low annual, branching. leaves ovate, quarter-inch long: flower half-inch long: calyx lobes subulate: corolla deep blue, its lobes ovate, acute: ovary sessile : seeds favose. - Fl. Dan. t. 17 ; Griseb. in DC. Prodr. ix. 103. - Labrador, coll. by Moravian missionaries. (Greenland, Iceland, Eu.)

To p. 122, add :-

G. Forwoódii, Gray. Very near G. affinis, smooth throughout: stems numerous in the cluster, cliffusely ascending, 6 to 16 inches high, equally leafy to the summit: leaves oblong or lowest ovate, and upper narrowly lanceolate, about inch long: calyx short (2 or 3 lines long), spathaceous and toothless (rarely one or two small subulate teeth), cleft more or less on one or both sides, or the sphacelate margin undulate-truncate: corolla more narrowly funnelform and smaller than in G. affints. - Proc. Am. Acad. xix. 86. - Rocky Mountains in Dakota and Montana, Dr. Forwood, Canby, \&c.

G. Bigelóvii, Grax, 1. c. Near G. affins, very leafy: leaves thicker; lower lanceolateoblong, upper linear: stems a foot or less high, muntely scabrous - flowers densely spicate: calyx-teeth filiform or slender-subulate, as long as the tube : corolla hardly inch long, cylin-, draceous, minutely scabrous outside, especially so along the salient lines which in the bud border the infolded plica; lobes short, broadly ovate, mostly erect, double the length of the bifid appendages of the plica: stipe of the capsule short and fistulous: seeds with a narrow and thickish wing. $-C$. affinis, Torr. Bot. Mex. Bound. 157, \&c. - Mountains of S. Colorado and New Mexico, Bigelow, Hall \& Harbour, Greene. Also those of S. W. Arizona, Lemmon.

G. Rúsbyi, Greene. Between the preceding and the Mexican $G$. spathacea, HBI.: stem robust, a foot high, scabrous, few-flowered at the summit: leaves thickish, narrowly oblong and upper ones lanceolate; uppermost subtending and equalling the flowers: calyx-lobes slender-subulate or linear, about the length of the tube : corolla apparently white, over an inch long, campanulate-funnelform, smooth; the short and broad lobes very obtuse, twice the length of the short teeth of the plicæ. - Mogollon Mountains, New Mexico, Rusby.

\section{POLEMONIACE丑.}

The genera are very difficult to define. Even Phlox has a species with prevailingly alternate leaves and four or five ovules in each cell. The character of unequally inserted stamens, by which to distinguish Collomia, breaks down completely (Proc. Am. Acad. xvii. 223); the declination of the filaments does not hold through Polemonium, and they are much more declinate and curved in several species of Gilia of different sections. Some, of more than one group, have an obviously but variably irregular limb to the corolla, quite as much so as in any species of Loselia. So it has become necessary to incorporate Collomia into Gilia, along with certain bractless species which had been taken to form an anomalous section of Leeselia. The principal characters now relied upon for the genera are indicated below.

4. (to be 2.) GILIA, Ruiz \& Pav. - Flowers naked, not involucellate. Calyx partly herbaceous, scarious below the sinuses; lobes narrow and acute. Corolla from salverform or funnelform to campanulate or almost rotate. Filaments not bearded at base. Seeds wingless. - Herbs or a few suffruticose. 
§ 1. Dactylophyllom, p. 137. The last of the following species connects with $\$$ Leptosiphon.

G. Harknéssii, Curran. A span or two high, smooth, extremely like the most slender and depauperate form of $G$. liniflora, var. pharnaceoides, but still smaller-flowered: flower and mature capsule only a line long: corolla hardly exceeling the calyx : capsule shortoval and equalling the calyx: ovules and oblong seeds solitary in each cell, - Bull. Calif. Acad. i. 12. - Eastern slope of the Sierra Nevada, California, Parry, Lemmon, Harkness (the latter coll. at Summit Station), and the mountains of Washington Terr., Howell, Suksdorf. Has been confounded with the above-mentioned variety of $G$. liniflora, and with G. pusilla.

G aúrea, Nutr., p. 138, not rarely has pedicels nearly twice the length of the flower. - Next to this the following :-

G. bélla, Gray. Stems diffuse from the base. simple or sparingly branched, filiform, fewleaved, glabrous and smooth : leaves very short (2 or 3 lines long), 3-parted, villous at base, thickish, the broadly linear lobes carinate: flowers sessile or short-pedicelled in axils of uppermost bract-like leaves and in the forks: calyx-lobes strongly carinate and hyalinemargined : corolla rotate-campanulate, with yellow tube, purple-spotted throat; and ample violet-colored limb (half-inch in diameter when expanded), the lobes almost flabelliform, entire : filaments a little hairy at base : ovules several in each cell. - Proc. Am. Acad. xx. 301. - Hanson's Ranch, below the boundary of S. California, Orcutt.

G. Lemmóni, Grax. Diffusely branching, a span or two high, hirsutely pubescent (at least the foliage): leaves 3-5-parted into acerose-linear lobes: flowers sometimes solitary and pedicelled in the lower forks, sessile and glomerate in the upper and at the ends of the branches, hardly surpassing the subtending leaves: calyx narrow, 5-costate; its acerose lobes resembling those of the leaves: corolla mostly white or yellowish, short-funnelform, with throat and tube inclided in the calyx, and oborate lobes only 2 lines long: capsule narrow, its cells several-seeded. - Ed. 1, 394. - S. California, on the Mohave Desert, Parry \& Lemmon, San Bernardino Co., Parish, Nevin, and below the Mexican boundary, Orcutt. (Gaadalupe Island, Palmer, mixed with G. pusilla.)

G. Rattáni. Intermediate between $G$. Bolunderi, of which it has the foliage and habit, and the section Leptosiphon, from which it is excluded by its scattered and naked flowers on elongated and filiform peduncles: stems a span or two high, erect, sparingly branched and puberulent above: calyx cylindraceous: corolla salverform, white or whitish with yellow throat; the slender tube a third to half inch long and much exserted, yet sometimes shorter and less so. (Possibly a hybrid.) - On a mountain north of Clear Lake, California, growing in company with $G$. Bolanderi, June, 1884, Rattan.

\section{§ 2. Linánthos, p. 138.}

G. Jonésii. Near G. Bigelovii (and seeds similar), smaller, only a span high, more slender and diffuse: leaves filiform, almost capillary; the upper and especially the oblong (3 lines long) caly $x$ beset with rather stout stipitate glands : corolla (withered) only 3 lines long. S. E. California, on the Colorado, at The Needles, M. E. Jones, 1884.

§ 3. LePtósiphon, p. 139. The following species again connects this section with Dactylophyllum.

G. Orcúttii, PArry. A span high, sparingly branched, nearly glabrous: leaves only 2 or 3 pairs up to the very few-flowered terminal cluster, small (barely quarter-inch long); the lobes filiform: corolla with well-exserted tube only 4 lines long, little longer than the limb with its obconical dark-purple throat, its ovate lobes purplish: stamens and style not surpassing the throat. - Proc. Davenport Acad. Nat. Sci. iv, 40. - Guadalupe Mountains bolow the boundary of S. California, but probably extending to the border, Orcutt.

$\S 5^{1}$. Collómta, under Series II. Flowers capitate-glomerate and foliosebracteate or scattered: stamens unequally inserted in the narrow tube of the sal- 
verform corolla, neither exserted nor declined: ovules solitary in the cells: seed-coat with abundant spiracles except in one species: annuals, with neither foliage nor calyx-lobes rigid or spinescent; the leaves sessile and entire (except some laciniation in G. coccinea, Collomia, Lehm., of Chili), the lower sometimes opposite.-Collomia, Nutt.; Benth. excl. spec.

G. grandiflóra, GraY, Proc. Am. Acad. xvii. 223, not Steud. Collomia grandiflora, Dougl., \&c.; Syn. Fl. ed. 1, 135.

G. lineáris, GraY, 1. c. Collomia linearis, Nutt., \&.c. - Passes by many gradations, and equally viscid herbage, into

Var. subuláta, G. tinctoria, Kellogg in Bull. Calif. Acad. i. 142. Collomia linearis, var. subulata, Gray, in part, of p. 135.

G. aristélla. A span high, with almost filiform and few-leaved stem and lax branches, minutely pubescent above and viscid: leaves lanceulate-linear and tapering to both ends (incli or less long, a line or two wide): flowers 1 to 3 in the forks and upper axils : corolla purple, with filiform tube 4 to 6 lines long and small lobes: calyx-lobes ( 2 lines long) aristiform from a triangular base: capsule obovate-3-lobed with attenuate base. - Collomia linearis, var. subulata, p. 135, as to an attenuate form. - Northern part of California, Greene, \&c., and Oregon, Kronkite, Cusick, to Washington Terr., Suksdorf, on bare hillsides. Habit of the following, and of the most dimintive variety of the preceding : calyx-lobes truly attenuate into an awn.

G. leptótes, Grax, 1. c. Collomia tenella, Gray, Proc. Am. Acad. viii. 259, \&c. - Known only from Parley's Park, Utah, coll. W'atson. The Western plants which have been wrongly referred to it belong to the preceding.

G. grácilis, Hooк. Collomia gracilis, Dougl., Benth., \&c. - Peculiar in having so many of the leaves opposite, and in the absence of spiracles in the seed-coat, as mentioned on p. 135.

$\S 5^{2}$. Codrtoísta. Flowers of $\S$ Collomia (and as in that either scattered or in foliose-bracteate clusters); foliage of Eugilia, the leaves from pinnately compound to entire, the larger petioled: ovules from solitary to several in the cells. -Collomia § Gilioides, Benth. in DC. excl. spec., and one Navarretia.

G. heterophýlla, Dougr. in Hook. Bot. Mag. t. 2895. Collomia heterophylla, Hook. 1. c. Gilia Sessei, Don, Syst. iv. 245, fide Benth., but not Mexican.

G. glutinósa. Collomia glutinosa and C. gilioides, Benth. Bot. Reg. 1833, \& DC., \&c. C. gilioides, ed. 1, 135. - Very variable in size, form and division of leaves, and degree of viscidity, but apparently all of one species.

G. capilláris, Kellogg, Proc. Calif. Acad. v. 46. Collomia leptalea, Gray, 1. c. \& Syn. Fl. ed. 1, 136. - Varies extremely in size, some of it answering well to the specific name, some more rigid and smaller-flowered; the corolla from pink to almost white. Extends northward to Washington Terr.

$\S 6$. NavarRétia, p. 141. Limb of corolla sometimes slightly irregular and stamens somewhat unequally inserted: filaments straight, or in the last two species incurved in the bud and somewhat so in anthesis.

G. cotulæfólia, Steud., p. 141. Color of the corolla various, sometimes yellow and purple.

G. Ieucocéphala, GraY, p. 142. Wholly erect, or with procumbent branches from base of primary stem, on which the first capitulum-like glomerule is more or less elevated : calyxtube nearly glabrous, except the ciliate fringe at the sinuses. - Add the following closely similar species : - 
G. prostráta, Grar. Wholly depressed and humifuse: primary capitulum-like glomerule sessile and as if radical, soon proliferous into prostrate similar thowering branches: calyxtube sparsely hirsute: corollas (white) only half the size of the preceding: ovules 4 in each cell. - Proc. Am. Acad. xvii. 223. - Low ground, S. California, especially Los Angeles and San Diego Co., Nevin, Parry, Orcutt.

G. divaricáta, Tork., p. 142. Corolla very small, not surpassing the calyx-lobes: stamens not exserted. - Mariposa Co., California to Washington 'I'err.

G. filicaúlis, Torr., p. 142. Stamens much exserted.

G. viscídula, GRAr, p. 142. Varies from obscurely to very viscid, and the corolla from violet to whitish : stamens at length fully as long as the corolla-lobes, incurved in the bud: ovules commonly 4 in each cell. - Common in California.

Var. heterodóxa, G. heterodoxa, Greene, Bull. Calif. Acad. i. 10, is a branching form, with more naked and spreading branchlets, broader bracts, and the stamens, according to Greene, "strongly declined." Some indications of this are to be seen in dried specimens of the present and the following species. - Calistoga, Parry, Greene, and elsewhere.

G. atractyloídes, Stecd., p. 142. From Santa Cruz to San Diego and southward. Corolla smaller than in the foregoing, from wholly violet to purplish or white, with or without a purple throat: stamens shorter than the lobes. According to Orcutt, a form with white Hlowers is scentless, while one with deep-colored corollas has a strong scent like that of Pennyroyal or of Pogogyne.

$\S 6^{1}$. Chет leafy-congested dwarf and at length depressed stem and branches, not bracteolate: corolla salverform ; limb comparatively large, either regular or bilabiately irregular: stamens inserted close to the sinuses; the filiform filaments either straight or strikingly declined-incurved: ovules 3 to 10 in each cell : winter annuals, with pinnately lobed or toothed leaves, their teeth and the sepals and mostly the leafmargins bearing long and slender white bristles.

* Corolla regular and stamens straight, or nearly so.

G. setosíssima, GraY, p. 142. Slightly pubescent, glabrate: leaves all broader upward, those of the branches cuneate and 3-5-lobed at summit: corolla light violet; its lobes often dotted with purple (conspicuously so only in dried specimens), obovate, obtuse, 3 to 5 lines long, and with the short throat almost equalling the tube: anthers oblong-oval : ovules 6 to 10 in each cell. - Exclude the syn. relating to the following.

* * Corolla bilabiately more or less irregular ( 3 and 2 ), and the stamens declined-incurved: anthers short. - Laeselia, Gray in Bot. Calif. ii. 466.

G. Schóttii, Watsov. Roughish-pubescent or below quite glabrous : cauline leaves linear ; those of the branches and terminal clusters slightly and gradually dilated upward and rather 3-toothed than lobed at the truncate apex: corolla "white" or "pinkish"; its lobes small (at most 2 lines long), oblong or lanceolate, acute, not half the length of the tube: stamens moderately incurved : ovules 2 to 4 in each cell. - Bot. King Exp. 267. G. setosissima, var. exigua, Gray, Proc. Am. Acad. viii. 271. Navarretia Schottii, Torr. Bot. Mex. Bound. 145. Loeselia Schottii, Gray, Bot. Calif. 1. c.-Desert region of W. Arizona, S. E. California, and S. W. Utah; first coll. by Coulter, then by Schott, in very exiguous specimens, which hardly show the characters, later and better by Parry, Lemmon, Parish, \&c. Also loose and slender specimens, from Sonora near the Gulf of California, are in the 1884 distribution of Pringle, under the name of $G$. polycladon.

G. Matthéwsii. Pubescent or hirsute with crisped hairs, somewhat robust, at length forming tufts a span to a foot in diameter: leaves nearly of the preceding: corolla purple or whitish with violet throat or stripes, strongly irregular; its lobes spatulate or cuneate, with obtuse or retuse or tridentate apex, 3 or 4 lines long, nearly equalling the tube: stamens conspicuously incurved: ovules 5 or 6 in each cell. - Loselia Matthewsii, Gray, Bot. Calif. 
1. c. Has been distributed as G. Schottii. - S. California, from Inyo Co,, Dr. Matthews (1877), to the Mohave Desert, Palmer, Lemmon, Parish, Pringle, and near Newhall, Nevin.

\section{§ 8. Elaphocera, p. 144.}

G. Wríghtii, Gray, and G. Gunnisóni, are between § Hugelia and § Ipomopsis, and might well be referred to the latter: their filaments are obscurely declined. The following may be appended to the present section, after $G$. polycladon.

G. depréssa, M. E. Joses. Small winter annual, divergently branched from the base, depressed-spreading, minutely hirsute-pubescent, slightly viscid, leafy : leaves oblong-lanceolate or narrower (half-inch or more long), entire or with one or two teeth or short lobes, acute at both ends, nearly sessile, cuspidate-mucronate: flowers solitary in the forks, short-

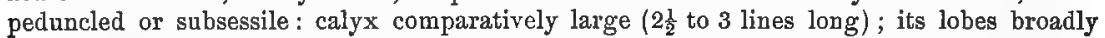
subulate and attenuate-cuspidate, nearly equalling the small salverform (whitish) corolla: limb of the latter sometimes deeper cleft at one sinus; its lobes about one third the length of the tube, equalling the stamens: seeds 4 or 5 in each cell, the coat mucilaginous but not spirilliferous. - Gray, Proc. Am. Acad. xvi. 106. - Arid districts of S. Utah, Nevada, and adjacent borders of California, M. E. Jones, Parry, Shockley.

§ 9. Ipomopsis, p. 145. - Char. revised. Flowers thyrsoid-paniculate and either glomerate or open (rarely diffuse), with narrow if any bracts: these and the calyx-teeth not pungent-tipped: corolla salverform or by gradual dilatation of the tube trumpet-shaped, mostly elongated: stamens inserted in or below the throat, either equally or unequally: filaments not rarely declined-incurved: ovules and seeds few or numerous in the cells. -- Includes Collomia $\$$ Phloganthea, and Loselia § Giliopsis, pp. 135, 136, also Gilia § Giliandra, p. 146.

G. coronopifólia, PERs., p. 145. - Although the thickened cellular seed-coat does " not develop mucilage nor spiral threads when wet," yet there are such threads in the cells, which can be drawn out.

G. aggregáta, Sprerg., p. 145. Stamens in some plants equally inserted and of equal length, in others unequally inserted, either slightly or excessively. - Collomia aggregata, T. C. Porter, in ed. 1, 394 : Rothrock in Wheeler Rep. vi. 198.

The following are additions to this section :-

* Transferred from Collomia $§ P h l o g a n t h e a$.

G. longiflóra, Don, Collomia longiflora, Don, \& p. 136.

G. Thúrberi, Gray, Proc. Am. Acad. xvii. 223, \& p. 136. Collomia Thurberi, Gray, p. 136. - Seemingly a pèrennial : corolla commonly an inch and a half long: stamens more or less unequal, either very unequally or almost equally inserted, some or all of them exserted from the throat, but all shorter than the lobes of the corolla. - Not rare in the mountains of S. Arizona, coll. Buckminster, Lemmon, Pringle.

G. Macómbii, Torr. in herb. Seemingly a suffrutescent-based many-stemmed perennial, puberulent, a foot or two high: leaves rather rigid pinnately 3-7-parted into lobes not wider than the rhachis, or entire and nearly filiform: glomerules of flowers in a narrow virgate thyrsus : corolla violet-purple, salverform, with tube half-inch and the obovate mucronulate lobes 2 lines long: stamens unequally inserted, 2 to 4 of them barely exserted from the throat, with straight filaments: ovules 5 or 6 in each cell. - Proc. Am. Acad. xx. 301.G. multiflora, Torr. Bot. Mex. Bound. 146, in part. Collomia Cavanillesiana, Gray, Syn. F1. ed. 1, 136, in part. - Mountains of Arizona, Newberry in Macomb's Exped., Wright (no. 1647), Lemmon, Pringle.

G. multiflóra, Nutr. Many-stemmed from a biennial or perhaps perennial root, a foot or two high, with paniculate or virgate branches; these cinereous-puberulent and the calyx usually hirsute: inflorescence nearly of the preceding: corolla salverform, purplish with 
slender tube less than half-inch and oblong lobes barely 2 lines long, one or two sinuses commonly deeper than the others : stamens equally or unequally inserted, conspicuously exserted, and the upper part of the filaments incurved: ovules 2 to 4 in each cell. - Pl. Gamb. 154 ; Torr. Bot. Mex. Bound. 146, in part; Gray, Proc. Am. Acad. xx. 302. Collomia Cavanillesiana, ed. 1, in part, not the Mexican Gilia glomeriflora, Benth. - Common in New Mexico and Arizona.

G. Havárdi. Many-stemmed from a perennial root, low, much branched, villous-pubescent: leaves mostly pinnately parted (or even those subtending the flowers 3-parted) into filiform rigid lobes no broader than the rhachis: flowers scattered, mostly short-peduncled : calyx hirsute; its lobes slender-subulate and almost spinulose, nearly twice the length of the capsule: tube of the nearly salverform corolla barely twice the length of the calyx (a quarterinch long) and hardly longer than the somewhat irregular or oblique limb; its lobes oval, obtuse, mucronulate : filaments equally inserted, as long as the corolla-lobes, conspicuously declined-incurred: ovules several in each cell. - Lceselia Havardi, Gray, Proc. Am. Acad. xix. 87. - Near Presidio del Norte on the Rio Grande, W. Texas, Havard. Probably most allied to $G$. Wrightii, of the same district.

* * Transferred from Loselia § Giliopsis, p. 136: corolla with manifestly irregular limb, one of the lobes being separated from the other's by deeper sinuses; corolla-lobes more or less cuneate and erose-truncate or 3-denticulate: filaments capillary, incurved-declined toward the apex in anthesis, but mostly straightening: low peremnials witli suffrutescent base.

- Red-flowered: stamens and style longer than the corolla-lobes.

G. tenuifólia, Loeselia tenuifolia, p. 136. - Since coll. in southern parts of San Diego and San Bernardino Co., by W. G. Wright, Parish, G. R. Tasey.

++ Purplish-flowered: stamens and style equalling in length but not exceeding the corollalobes.

G. guttáta. Herbaceous flowering branches a span or two long from a woody base, glabrous, leafy, paniculately several-flowered: leaves nearly filiform or acerose, all entire: corolla violet or purplish and commonly spotted with deep-colored dots; its slender tube (half-inch or less long) very much surpassing the small calyx, and longer than the narrowly cuneate 3-dentate lobes. - Loselia guttata, Gray, Proc. Am. Acad. xx. 302.- Extra-limital, in Lower California, but not far below the border, Orcutt.

G. Dúnnii, Kellogg in Pacif. Rural Press, 1879, \& Bull. Calif. Acad. i. 142. Laselia effusa, p. 136. - Cantillas Mountains, near the boundary between San Diego Co. and Lower California, Palmer, and farther south, Orcutt.

\section{§ 12. Eugilia, p. 146.}

G. débilis, WAtson, p. 147. G. Larseni, Gray, of the preceding page, is only a smaller and more condensed state of this, growing in loose volcanic ashes, there only with long and filiform root-stocks, instead of a stuuter stock: well-lleveloped stems a span or more high, equably leafy to the top. - Extends northward to the mountains of Washington Territory and N. W. Montana, coll. Cusick, Suksdorf, Watson, Canby, Brandegee.

G. Nevínii. Next to $G$. multicaulis, p. 147, much more pubescent with short and above with viscid hairs: leaves 2-3-pinnately parted into more numerous lobes which are not broader than the rhachis : flowers several and subsessile in the terminal glomerules: corolla violet, with narrow tube and little dilated throat together 4 or 5 lines long and double the length of the calyx, the limb comparatively small : capsule oblong, with 10 or 12 seeds in each cell. -G. multicaulis, var. millefolia, Gray in Watson Fl. Guadalnpe, Proc. Am. Acad. xi. I18, form with rather small corolla. - San Clemente Island, off San Diego Co., California, Nevin \& Lyon. First found on Guadalupe, off Lower California, Palmer, in a form which approaches G. lacininta, Ruiz \& Pav.

G. latiflóra, p. 147. Foliage often lightly tomentulose, when young glabrate: calyx very scarious below the sinuses to the base, glabrous or minutely glandular. Varies in size of flowers, \&c., down to

Var, exílis. Slender, effusely paniculate: flowers nearly all on elongated almost capillary peduncles: corolla only 3 to 5 lines in length and of equal breadth of limb. - 
Common in S. California and east to Nevada: has mostly been referred to G. inconspicua, var. sinuata, p. 148 .

G. tenuiflóra, Вектн., p. 147. Radical leaves often cottony-tomentose when young, soon glabrate: calyx at most 2 lines long: corolla from half-inch to inch and a quarter long (including the lobes); the slender tube dilated into the somewhat narrowly funnelform throat. - S. California to S. Utah.

G. inconspicua, Dougx., p. 148. The panicles or flowering branches when well developed are rather rigidly erect; at least not effuse ; the lateral peduncles short and erect, at least in fruit. The figures of Smith and of Hooker (from weak plants raised in Eugland, and from which Bentham has mainly drawn the character) do not very well represent the species, although the whole tube of the small corolla is often thus included. Yet it is very commonly more exserted (as in var. sinuata), even before the fructified ovary enlarges, but always salverform, having a small and narrow throat, and limb only 2 to 4 lines in diameter. The effusely-flowered plants with ampliate throat, which were included in var. sinuata, are now taken for a small-flowered variety of $G$. latiflora. Apparently there are connecting forms between all these species.

G. Brandegéi, GRAY, p. 149. Add: IJook. f. Bot. Mag. t. 6378.

3. LAESLIA, L. - Flowers involucrate or involucellate; both bracts and calyx wholly or mainly scarious. Corolla funnelform, either regular or one or two sinuses deeper. Seeds winged or margined, the surface becoming mucilaginous when wetted. - Suffruticose, rarely annual, with spinulose-toothed leaves.

L. glandulósa, DoN. Low, merely suffrutescent, roughish-pubescent with short and partly gland-tipped hairs: leaves mainly alternate, short-petioled or subsessile, lanceolate or narrowly oblong, those next the 1-2-flowered clusters similar but small, few-toothed, not scarious nor reticulated, nearly enclosing the involucre of wholly scarious oblong-lanceolate almost entire bracts: corolla violet or bluish, 6 or 8 lines long: filaments more or less declinedincurved: seeds broadly winged. - Syst. iv. 248; Benth. in DC. Prodr. ix. 319, in part (i. e. Hoitzia conglomerata, HBK., H. capitata, Willd., \& II. nepetafolia, Cham.). Hoitzia glandulosa, Cav. Ic. Rar. iv. 45, t. 367. H. Cerrantesii, 'HBK., Nov. Gen. \& Spec. iii. 164. $H$. spicata, Willd. ex Rom. \& Schult. Syst. iv. 370, - Santa Rita Mountains, S. Arizona, Pringle. (Mex.)

5. (to be 4.) POLEMÓNIUM, Tourn.-Flowers naked. Calyx herbaceous throughout, soft, usually accrescent. Corolla from rotate to funnelform. Filaments pilose-bearded at base. Leaves simply pinnate, muticous.

P. cærúleum, L. p. 151, only recently known at one or two stations in the Atlantic States, has now been detected also at Bethlehem, New Hampshire, by F.S. Beane, and on the mountains in Garrett Co., Maryland, by J. Donnell Snith.

P. flávum, Grevas. Like P. foliosissimum, but with flowers somewhat more paniculate and larger : corolla fully as large as in $P$. cceruleum, "yellow with tawny red outside," with broadly obconical throat and ovate acuminate lobes!-Bot. Gazette, vi. 217. - Highest slopes of the Pinos Altos Mountains, New Mexico, Greene.

P. pectinátum, GreENe. Glabrous and glandless up to the minutely glandular and pubescent inforescence: leaflets very narrowly linear, hardly wider than the rhachis: corolla probably white: otherwise not unlike narrow-leaved $P$. foliosissimum, of which it may be an extreme variety. - Bull. Calif. Acad. i. 10. - Eastern part of Washington Terr., $E$. W. Hilgard, fide Greene.

P. cárneum, Grax, p. 151. Extends to the southwestern part of Oregon, where it was collected at Chetco by Howell.

Var. lúteum. Corolla yellow, the lobes (as in the species) broadly obovate, with rounded or retuse apex. - Cascade Mountains, Oregon, Howell, 1885.

P. foliosíssimum, GraY, p. 151. To this probably belongs P. Mexicanum, Nutt. Jour: Acad. Philad. vii. 41, from the northern Rocky Mountains. 


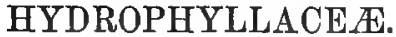

\section{NEMÓPHILA, Nutt.}

N. Menziésii, Hook. \& ARs., p. 156. Apparently this produces either cleistogamous or small and self-fertilized flowers at certain seasons. N. modesta, Kellogg, Proc. Calif. Acad. vii. 93 (1877), by the description, should be this species.

\section{ELLISIA, L.}

E. chrysanthemifólia, Bentr., p. 158. Add syn.: Eucrypta chrysanthemifolia, Greene, Bull. Calif. Acad. i. 200. Originals of Nuttall's two species, of coll. Gambel (ticketed "Angeles"), áre quite alike, with finely dissected leaves. Exclude the syn. of 'Torr. in Ives Colorado Exp., which belongs to the fullowing.

E. Torréyi, Grar. Weak and diffuse, with long internodes: leaves pinnately parted into oblong sinnate-pinnatifid dirisions (half or full inch long), the upper usually sessile by a conspicuously auriculate-dilated insertion : racemes sparsely few-flowered: calyx eylualling the small corolla and surpassing the capsule. - Proc. Am. Acad. xx. 302. Phacelia micrantha? var. bipinnatifida, Torr. in Ives Colorado Exp. Bot. 21. - S. A rizona, Yampai Valley near the Colorado, Newterry. Mountains near Tucson, in shade of rocks, Pringle.

Var. Orcúttii. Coarser and taller: upper leaves merely pinnatifid with incised or. toothed lobes : calyx in fruit still more ampliate, becoming four lines in diameter. - Eucrypta paniculata, Greene, Bull. Calif. Acad. 1. c. - Northern borders of Lower California, Orcutt.

\section{PHACELIA, Juss.}

\section{§1. EuphacéLIA, p. 158.}

P. Pringlei, Gray. Next after P. namatoides, p. 158. More slender and widely branched, glandular-pubescent, little over a span high: leaves linear with tapering base, the lower opposite, all shorter than the slender and strict racemiform inflorescence: sepals linear, about half the length of the rotate-campanulate blne corolla, longer than the globose cansule: seeds angled and not hollowed ventrally. - Proc. Am. Acad. xvii. 223. - Mountains of N. Califurnia, near the sources of the Sacramento, Pringle, and (in the same district?) Parry.

P. malvæfólia, Chaxr, has now been detected at various points from the coast of Oregon to Monterey. Next to this,

P. Rattáni, Grax. Smaller throughout, beset with slender but almost equally stinging bristles : leaves ovate or oval, with base truncate or barely subcorlate, incisely somewhat lobed and crenate, only the lower palmately veined at base : spikes slender : calyx of four spatulate and one larger obovate sepals: corolla hardly over 2 lines long, whitish: stamens and style included: seeds not unlike those of $P$. malrrfolia but only half the size, less carinate ventrally. - Along streams, N. W. California, Lake Co., and Russian River, Rattan, Mrs. Curran, to S. W. Oregon, Howell. - Seeds, as in all the preceding species, pp. 158, 159, destitute of ventral excavation with median ridge, which is common in the following.

The subdivision +++ , beginning at foot of p. 159, and ending near the foot of p. 161, is here revised and angmented.

+++ Leaves from simple (ovate-oblong or narrower) and pinnately dentate or lobed to pinnately compound: flowers crowded in the scorpioid inflorescence.

+- Seeds cymbiform and the concave face divided by a strong and salient longitudinal ridge: sepals uniform, entire. 
- Flowers racemose and much crowded (even in age) on the short axis or branches of the scorpioid cymes on which the slender and densely long-villons pedicels are spreading at right angles: sepals linear-spatulate, much longer than the globular capsule.

P. pedicelláta, GRAY, p. 160. Collected in flower, with rounded or mostly subcordate and petiolulate lobes to the leaves, in 1884, at Yucca, Arizona, by Marcus E. Jones. (Lower California, as supposed, Dr. Streets.)

$==$ Flowers spicately disposed, being sessile or short-pedicelled, and the fruit crect on the axis or branches of the inflorescence: sepals equalling or moderately surpassing the capsule: all but the later species more or less viscid or glandular, and heavy-scented, commonly more or less pubescent or somewhat hirsute, not setose-hispid nor long-rillous.

a. Leares all undivided, at most crenate-pinnatificl: stem strictly erect: seeds oblong-elliptical, thickly papillose-roughened on the back, but without distinct reticulation.

P. integrifólia, TorR., with var. Pálmeri, p. 160.

b. At least some of the leaves pinnately parted or lyrate: sepals not manifestly surpassing the globular capsule: seeds roughish with obscure reticulations on the back, the ventral ridge or the incurved margins, or both, becoming corrugate-tuberculate at maturity.

P. creṇuláta, Torr., p. 160. A foot or less high : leaves variable, from elongated-oblong to roundish in outline, from crenately pinnatifid or incised to pinnately parted into roundish or oblong lobes, the lower pair often detached and even petiolulate: corolla from deep violet-blue to "pale purple," with expanded limb commonly half-inch broad: stamens and style exserted: seeds elliptical, the largest almost 2 lines long, at maturity corrugate-tuberculate on the ventral ridge and usually on the incurved margins.

P. cærúlea, Greene. A span to a foot high, with the foliage and riscidity of the preceding, less or not at all unpleasantly scented, much smaller-flowered : corolla only 2 lines high, pale blue to purplish: stamens and style not exserted: seeds about a line and a half long, oblong-oval, nearly like those of $P$. crenulata. - Torr. Bull. viii. 122 (but seeds not "almost linear," \&c.). P. invenusta, Gray, Proc. Am. Acad. xx. 303. - Common both in N. and S. Arizona, in dry ground ; first coll. by Wright, \&c.

P. Arizónica, Gray, p. 394 of ed. 1. Depressed-diffuse, with ascending stems a span or two long, cinereous-puberulent, very slightly viscid: leaves from deeply pinnatifid into closely approximate and regular oblong and entire lobes (of 3 or 4 lines in length) to pinnately divided and the segments pinnatifid: cyme naked-pedunculate, crowded : corolla white (or at most with some blue lines), barely 3 lines high and broad: stamens and style well exserted: seeds short-oval, a line or more long, thickly transversely corrugate-tuberculate down the incurved margins and ventral ridge. - Plains of S. Arizona (and adj. Sonora), Greene, Lemmon, Pringle, Parish.

c. Leaves mostly pinnately parted, and below divided and the segments pinnatifid or incised: sepals hardly longer than the capsule: seeds oblong or elliptical, flatter and thinner, not at all corrugated or thickened on the margins, the whole surface conspicuously favose-reticulated with smooth and even meshes.

P. glandulósa, Nutr. A span to a foot high, rather stout, viscidly pubescent or in the inflorescence hilsute : primary segments of the leaves few-lobed or incised, or some entire: flowers comparatively large: corolla violet or blue, 4 or 5 lines high, with ample rounded lobes quite entire: stamens and style much exserted : capsule short-oval. $-P$. glandulosa in part, p. 160. - Rocky Mountains of Wyoming at the head-waters of the Colorado, Nuttall, Geyer, and of S. W. Montana, Watson. Also at the head of the Rio Grande, subalpine, Brandegee.

P. Neo-Mexicána, Trurrer. A span to 2 feet high, erect and strict, very leafy, viscidpubescent, sometimes also hirsute: leaves interruptedly twice pinnately parted into small and short lobes : corolla comparatively small, 2 or 3 lines long, bluish or purplish, the short lobes from minutely crenulate to erose-denticulate: stamens and style often no longer than the corolla-lobes, sometimes rather conspicnously exserted. - Torr. Bot. Mex. Bound. 143. P. glandulosa, var. Neo-Mexicana, Gray, p. 160. - Common on the plains, from N. Colorado to New Mexico. A peculiar state of a short-stamened form, with much less dissected leaves and almost oblong capsule, coll. in central part of Colorado by Brandegee, needs further inquiry. 
d. Leaves, \&ce, as of last preceding, but destitute of glands or viscidity: sepals a little or moderately surpassing the capsule: seeds with a scubrous reticulation, the uneren meshes being somewhat unuriculate at the junctions, the ventral ridge and margins not tuberculate nor corrugate.

P. Pópei, Torr. \& Gray. Habit and dissected foliage of $P$. Neo-Alexicana (with which it has been confounded) : corolla-lobes entire, little surpassed by the stamens: sepals spatulate : capsule globose.-Pacif. R. Rep. ii. 172, t. 10; Gray, Proc. Am. Acad. xx. 303. On p. 160 wrongly referred to $P$. glandulosa. - High plaius of W. Texas (first coll. by Gen. Pope) to New Mexico and the Mexican borders, coll. Wright, Thurber, Rothrock, Reverchon (in Curtiss distrib. as P. glandulosa), Havard.

P. congésta, Hook., p. 160. Calyx-lobes from linear to oblanceolate : eapsule ovoid. The common form, with comparatively few and broad lobes to the leaves, passes through that referred by $\mathrm{A}$. DC. to $P$. tanacetifolia, into

Var. dissécta. Leares more finely once or twice pinnately divided or parted into more numerous segments and lobes, with small interposed lobelets. $-P$. glandulosa, var. Neo-Mexicana, Watson, Proc. Am. Acad. xviii. 118, - Dallas, Texas, Reverchon (the extreme form in distrib. Curtiss, 2128), to the Rio Grande, Palmer, \&c., and allj. Mex.

+* Seed commonly solitary (the other cell and the companion of the fertile ovule aborting), nearly terete and with a closed ventral groove: sepals heteromorphous, surpassing the small capsule : pedicels short, ascending or erect when fructiferous: annual, not setose-hisjiid.

P. platyloba, Gray. Minutely pubescent, or the inflorescence sparsely hirsute, obscurely visciclulous: stem slender, a foot or two high, sparsely leafy : leaves pinnately divicled; the oblong or lanceolate divisions either crenately lobed and toothed or once or twice pinnatifid, small: fructiferous spikes becoming loose and slender: calyx only 2 lines long when in fruit; sepals all with narrow or petiole-like base, one or two dilated into a rounded or obovate entire or 2-5-cleft lamina, the others narrowly or broadly spatulate: corolla somewhat rotate, bluish, little surpassing the calyx. - Proc. Am. Acad. xvii. 223, now extended. - California, in Fresno Co., Parry, and Mariposa Co., Congdon.

+t +t +t Seeds rounded on the back, acute-angled or obtuse ventrally, the two sides slightly when at all concave. (Those of $P$. phyllomanica unknown.)

= Herbage soft-pubescent and partly villous or soft-hirsute, not hispid, and with little or no viscidity : sepals or most of them pinnately 3-5-parted or cleft: cymes crowded: insular species. .

P. floribúnda, Greexe. Annual, a foot or two high, freely branched, a little glandular: leaves green, pinnately divided into 6 or 8 pairs of linear-oblong segments (with some interposed lobelets), and these nearly bipinnatifid: lobes of the sepals narrowly spatulate, nearly equalling the riolet-blue open-campanulate ( 2 or 3 lines long) corolla: stamens little exserted : seeds scrobiculate and somewhat tuberculate, less than a line long. - Bull. Calif. Acad. i. 200. P. phyllomanica, var. interrupta, Gray, Proc. Am. Acad. xi. 87, \& p.161.-Island of San Clemente, off San Diego, Nevin \& Lyon, 1885. (Guadalupe Island, Palmer, Greene.)

P. phyllománica, GraY, p. 160. Perennial, with suffrutescent base, 3 to 6 feet high, very leafy, tomentulose-canescent: flowers nearly double the size of those of $P$. floribunda.Still extra-limital, again collected, just coming into blossom, on Guadalupe, by Greene, 1885.

$=$ - Roughish-pubescent, at least the inforescence beset with some strong-hirsute or setosehispid hairs: sepals entire (with rare exceptions), longer than the capsule.

a. Annual, with coarsely lobed foliage: pedicels (either short or slender) in the at length elongated and fruiting inflorescence horizontal: sepals very narrow, filiformly attenuate downward, softhispid or barbate with very long hairs, very much surpassing the small globose capsule.

P. hispida, Gray, p. 161. Common through S. California, extending to Arizona. Corolla purplish or pale rose-color. Seeds roughish-scrobiculate.

$b$. Perennial, with spreading or decumbent stems and rather coarsely lobed foliage: short pedicels ascending in the dense and not much elongated fruiting spikes: sepals spatulate or broader, one or two often much dilated, all fully twice the length of the ovoid or subglobose capsule: corollaappendages narrowly quadrate-oblong, adnate up to the throat and truncate.

P. ramosíssima, DougL., p. 161. A species of considerable diversity in foliage, viscidity, \&c., and of wide geographical range, now pretty well defined. Capsule in the Northern 
typical form short-ovoid, and seeds oblong. The prevalent Southern form, hardly or not at all more indurated or lignescent at base, is

Var. suffrutéscens, Parry, in herl. ( $P$. suffrutescens, Parry in Proc. Davenp. Acad. Nat. Sci. iv.. 38), has capsnle globose-ovoid and seeds oval : no other tangible difference. P. tanacetifolia, var. latifolia, Torr. Bot. Mex. Bound. 143.

c. Annual: calyx mostly sessile or nearly so, erect or ascending in the fructiferous spikes, considerably longer than the capsule: corolla-appendages short and broad, at or near the base of the tube.

1. Leaves finely and compoundly dissected: calyx not manifestly accrescent nor veiny: seeds rather rugose-tuberculate than scrobiculate.

P. dístans, Berrir. Mostly slender and smaller than the next, but sometimes tall, with similar but usually more finely dissected leaves: sepals unequal, from nearly linear to spatulate, or one or two more dilated upward (rarely incised or lobed): corolla 3 or 4 lines long, rotate-campanulate, from sordid-whitish or ochroleucous to violet; the internal appendages broadly semi-ovate with a free pointed tip : stamens little or not at all surpassing the corollalobes: capsule globular. - Bot. Sulph. 37, since wholly overlooked. P. tanacetifolia (var. tenuifolia, Harvey, Thurber, in Bot. Mex. Bound. 143), and P. ciliatn, in part, p. 161. - The original from Bodegas Bay, Hinds, common thence to the southern border of California, mostly near the coast, but reaching Arizona. A form with incised sepals, San Clemente Island, Nerin \& Lyon.

P. tanacetifólia, Bentr., p. 161. Stouter and larger: sepals linear, beset with more rigid bristles, in fruit seldom much longer than the oval capsule: corolla open-campanulate, 4 lines long, violet or bluish, its appendages very wide, and with inner margin wholly adnate: stamens much exserterl.

2. Leaves less dissected, usually once pinnately parted, or below divided into oblong pinnately incised segments : inflorescence less scorpioid; calyx strikingly accescent and transversely veiny in fruit, the sepals becoming oblong- or ovate-lanceolate and bristly-ciliate: stamens not surpassing the corolla-lobes: seeds scrobiculate but smoothish.

P. ciliáta, Benth., p. 161. Extends from East Oregon to Lower California.

\section{§. Whitlávia, p. 114.}

P. campanulária, Gr.1y. Add: Rolfe in Gard. Chron. n. ser. xx. 135, with figure; Hook. f. Bot. Mag. t. 6735. Now established in cultivation : corolla deep blue.

P. Párryi, Torr. Add : Hook. f. Bot. Mag. t. 6842. P. glandulosa, Kellogg, Proc. Calif. Acad, vii. 92. Commonly (not always) with five bright yellow spots in the throat, opposite to the lobes; these figured and describerl as staminodes in Bot. Mag. 1. c. This and the foregoing species are choice introductions to the gardens.

P. lóngipes, Torr. Not rare in cañons in Los Angeles and San Bernardino Co., S. California.

\section{§6. EÚtocA, p. 164.}

P. prócera, Gray, p. 166. Extends northward to Washington Territory, Howell, Suksdorf. Corolla ochroleucous.

P. Menziésii, Torr., p. 166. Appendages of the corolla conniving in pairs opposite the lobes, forming five nectariferous grooves alternate with the stamens.

The two following species come on p. 167, after $P$. infundibuliformis, to which the first is most related, but the seeds of both are of the usual form in Eutoca, not excavated and ridged on the ventral face.

P. Lyoni, Gray, Viscid-pubescent and heavy-scented, a foot or more high, robust: leaves pinnately divided into narrowly oblong and deeply pinnatifid divisions; their short lobes oval and crenate: spikes dense: corolla (pale or ochroleucous) 2 or 3 lines long, broadly campanulate; the appendages semi-oval, their base united to the filament: stamens and style not exserted: capsule narrowly oblong, many-seeded, nearly equalling the linearspatulate hispid and viscid sepals : seeds oval, scrobiculate. - Proc. Am. Acad. xx. 303. Santa Catalina, off Los Angeles, Nevin \& Lyon, 1884. 
P. ixódes, Kellogg. Viscid and villous, heavy-scented, tall and stout: leaves pinnately parted or below divided, and the coarse divisions sinuate-pinnatifid or merely incised : spikes dense : flowers considerably larger than in the foregoing: corolla open-campanulate, 4 or 5 lines in length and breadth of limb, bluish; its appendages semi-orbicular, wholly adnate, oblique, and united with the base of the filament: stamens and style not exserted : sepals in fruit 5 lines long, spatulate, a little longer than the oblong many-seeded capsule: seeds oblong, angulate, scrobiculate. - Bull. Calif. Acal. i. 6; Gray, Proc. Am. Acad. l. c. - Extra-limital, first collected on Cedros Island, Lower California, but now found so near the boundary as All Saints' Bay, Orcutt.

P. brachýloba, Gray, p. 167. Ovules often as many as 20 in each cell: appendages of the corolla sometimes obsolete.

P. circinatifórmis, Grar, p. 167. This has been collected on Mount Hamilton, Santa Clara Co., but is still very little known.

P. Paríshii, Grax. Very like P. pulchella, p. 168 , in foliage and habit: peduncles fully as long as the fruiting spike, the primary ones scape-like: flowers almost sessile, crowded: corolla (2 lines long) blue or bluish, hardly at all surpassing the calyx, the appendages obscure or none : fructiferous sepals broadly spatulate, equalling the oblong about 20 -seeded capsule: seeds over half-line in length (twice the size of those of $P$. pulchella), narrowly oblong, scrobiculate. - Proc. Am. Acad. xix. 88. - S. E. California, near Rabbit Springs, on the borders of the Mohare Desert, May, 1882, Parish.

P. Lemmóni. Near to P. pulchella and the preceding, more leafy and taller: leares thinner and rounder, coarsely angulate-dentate or crenate, lower ones subcordate: spikes shortpeduncled, in fruit rather loose and with short pedicels erect: corolla white (2 or 3 lines long), hardly twice the length of the calyx, the appendages semi-oblong; fructiferous sepals spatulate, viscidulous, harlly puberulent, a little longer than the ovoid about 30-seeded capsule : seeds short-oral, a third of a line long, minutely scrobiculate. - N. W. Arizona, on plains, at Mineral Park, 1884, Lemmon, coll. no. 3350.

P. saxícola, Gray. Near P. pusilla, p. 169, more hirsutely pubescent, a span or less high, diffusely branched from the annual root: leaves narrowly spatulate, the base narrowed into a slender petiole, entire: flowers few and sparsely racemose, short-pedicelled : sepals spatulate-livear, 2 to 4 lines long, either moderately or very much surpassing the oblong-campanulate blue corolla; internal appendages very narrow: capsule small, oval-oblong: seeds globular, smoothish. - Proc. Am. Acad. xx. 304. - N. W. Arizona, at Kingsman's Station, April, 1884, Lemmon, on rocks, which the insinuating roots cleave off in thin scales.

P. glechomæfólia. Next to $P$. rotundifolia, p. 169, larger, merely viscidulous-puberulent (no hirsute pubescence): stem a foot or less high, paniculately much branched: leaves slender-petioled, all but the uppermost cordate-orbicular, coarsely crenate, an inch wide: flowers loosely racemose, on slender and mostly filiform pedicels of half to a quarter inch in length, spreading in anthesis and mostly so in fruit: corolla funvelform, 4 or 5 lines long, lilac-purple, twice or thrice the length of the calyx ; internal appendages narrow : fructiferous sepals spatulate, a little longer than the oval aud obtuse many-seerled capsule: seeds globoseoval, deeply scrobiculate, hardly a quarter of a line long. - Between Peach Springs and the Grand Cañon of the Colorado, May, 1885, A. Gray.

\section{§ 7. Mrcrogénetes, p. 169.}

P. Ivesiána, Torr. Extends northward in the dry region to the interior of Oregon and Washington Terr., Suksdorf, Howell. - Near this and P. Fremontii come the following:-

P. Orcuttiána, GraY. Viscid, puberulent, ahout a foot high: leaves pinnatifirl, somewhat lyrate, the lobes short-ollong and entire: flowers sessile in the at length elongated dense spikes: corolla rotate-campanulate, double the length of the calyx, with limb 3 or 4 lines broad, whito with yellow eye, nearly or quite destitute of internal appendages: capsule oval, nearly equalling the narrowly spatulate (barely 2 lines long) sepals, 12-14-seeded: seeds oval, obscurely favose-reticulated between the transverse corrugations. - Proc. Am. Acad. xix. 88. - Mountains of Lower California not far below the U. S. boundary, Orcutt.

P. affinis. Between the foregoing and P. Fremontii, viscid and puberulent, less than a foot high: leaves pinnately parted mostly into linear-oblong entire or incisely toothed lobes: 
flowers short-pedicelled, less crowded or sparse in the fruiting spikes : corolla rotate-campanulate, about half as large as in the preceding, light blue, a little exceeding the calyx : capsule oblong, shorter than the spatulate-dilated ( 3 or 4 lines long) fructiferous sepals, 20-30-seeded: seeds oval-oblong, strongly favose-reticulated between the corrugations. With or near the preceding, Orcutt.

P. Fremóntii, Torr., p. 170. Add syn.: P. Brannani, Kellogg, Proc. Calif. Acad. vii. 90.

P. bícolor, Torr., p. 170. Extends northward as far as to the plains of Eastern Oregon, Howell.

P. gymnóclada, Torr., p. 170. Specific name not significant. $P$. Cooperce, Gray, Proc. Am. Acad. xy. 49, of which only a single specimen is known, sent by Mrs. Ellwood Cooper from Santa Barbara, may well be only a form of this, perhaps not collected in that district. - A wholly peculiar species of this section is the following:-

P. pachyphýlla, Gray. Stout, a foot or less high, with widely spreading branches, pubescent and very viscid : leaves thick, large (inch or two in dianeter), roundish and subcordate, repand or entire, on stout petioles usually of equal length, uppermost subsessile : spikes deuse, pedunculate: corolla campanulate, about 3 lines long, probably blue or purple, a little longer than the calyx: capsule globular, many-seeded, equalling the oblong-linear sepals: seeds oval-oblong, half a line in length. - Proc. Am. Acad. xix. 88. - Alkaline soil in the Mohave Desert, S. E. California, Palmer, Parish, Lemmon, Jones.

\section{ROMANZÓFFIA, Cham.}

R. Unalaschkénsis, Cram., p. 172. - This has been collected, quite out of supposed range, at Big Flat, Del Norte Co., N. California, by W. H. Shockley and Mrs. Ames, 1880.

R. Sitchénsis, Boxg., is commonly white-flowered, and with slight pubescence of calyx and capsule.

12. NÁMA, L. P. 173, add: Gray in Hemsl. Biol. Centr.-Am. Bot. ii. 360, for the most recent revision of the genus. Stamens not rarely with adnate portion of the filaments dilated into more or less free membranaceous margins, which answer to the internal appendages of the Phaceliea, those in one or two species extended above into a free tooth on each side of filament! No hypogynous disk, but base of calyx obscurely adnate to base of ovary in the original $N$. Jamaicense and some others, in $N$. stenocarpum calyx-tube and capsule much united! Styles sometimes united below. Valves of capsule either membranaceous or coriaceous, sometimes becoming bifid, as in $N$. Jamaicense.

N. stenocárpum, Gray, p. 174. (Biol. Centr.-Am. etc., \& Proc. Am. Acad. xviii. 118.) Calyx adherent to the base of the capsule, more or less firmly, sometimes for nearly half the length of the latter! Styles united at base or even higher, occasionally 3. - Extends to the southeastern border of California.

N. depréssum, Lemmon. After $N$. Coulteri, p. 174. Depressed, repeatedly divaricatedichotomous and with long naked internodes, cinereous-puberulent: leaves crowded at the summit of the branches, spatulate-lanceolate and tapering into a petiole: flowers shortpedicelled in the forks : corolla narrow and small (2 lines long), purplish, little longer than the calyx: sepals some linear, some spatulate-dilated at apex, equalling or moderately exceeding the oval-oblong membranaceous torose capsule: seeds (quarter of a line long) oval, with obscurely undulate thin and smooth coat. - Gray, Proc. Am. Acad. xx. 304. S. E. California, in the Mohave District near Calico, Lemmon.

N. pusíllum, Lzммок. Next the preceding, exiguons, depressed, soft-pubescent: leaves obovate-spatulate or ovate, abruptly contracted into a petiole of nearly same length (both together only a quarter or half inch long): flowers subsessile in the forks : corolla salverform and narrow (barely a line and a half long), light rose-color, a little longer than the at length 
spatulate sepals, the limb minute: capsule oval, erect: seeds globular, obsoletely rugulose, and with a very smooth thin coat. - Gray, 1. c. - With the foregoing, Lemmon.

N. dichótomum, Chors., not Ruiz \& Pav., who have it as IIydrolea dichotoma. The remarkable var. angustifolium extends well into Mexico. - Next to this species is

N. origanifólium, HBK. Perennial, herbaceous from a ligneseent base, or suffruticulose, low and small : leaves oblong or spatulate-obovate, sessile by a narrowed base or shortpetioled, soft-pubescent, a quarter to half inch loug, the margins somewhat revolute: flowers short-peduncled : corolla 3 lines long, surpassing the calyx : sepals linear, morlerately dilated upward, nearly twice the length of the oroid capsule: seeds about 20, oblong, smooth. Nor. Gen. \& Spec. iii. 130, t. 218; Gray in Hemsl. l. c. 362. - Crevices of rocks, Guadalupe Mountains, S. W. Texas, near the Rio Grande, Havard. (Mex.)

N. Lóbbii, GriY, p. 175. - Gray in Hemsl. Biol. Centr.-Am. Bot. ii. 362. Eriodictyon Lobbii, Greene, Bull. Calif. Acad. i. 202. Ovules about 8, pendulous. Capsule obovateglobose, thin-coriaceous; valves tardily bifid, the narrow placentæ breaking up. Seeds broadly oval or roundish, half a line long, large for the capsule, with a smootb minutely cellular-reticulate coat.

N. Havárdi, Gray. Near N. Palmeri and the next, a foot or more high, herbaceous from a lignescent probably perennial root, more or less cinereous with soft pubescence : stem erect and stout, freely branching : leaves oblong or uppermost lanceolate, acutish, with tapering base, lower somewhat petioled, veins very obscure: flowers cymulose, short-pedicelled: corolla 4 or 5 lines long, salverform, apparently purplish, a little longer than the calyx: filaments adnate to the middle and below membranaceous margined, toothless: capsule oblong-ovoid, membranaceous, much shorter than the narrow-linear slightly dilated sepals: seeds 16 or more, globular or short-oval, with a firm faintly scrobiculate coat. - Proc. Am. Acad. xx. 304. - S. W. borders of 'lexas, on alkaline bank of Tornillo Creek, Havard.

N. stenophýllum, Gray. Suffruticose, a foot or less high, rather stout, strigulosecinereous or more loosely hirsute: stems very leafy throughout : leaves from narrowly linear to almost filiform, about au inch long: flowers densely cymulose at the summit of the branches: corolla nearly salverform ( 4 or 5 lines long), more or less surpassing the calyx: margin of the filaments on each side terminating above in a free short denticulation : capsule ovoid-oblong, thinnish, much shorter than the narrow livear obtuse sepals: seeds abont 40, globular and angulate, a third of a line long, muricate! - Biol. Centr.-Am. 1. c. (excluding the last line of the character, the printer's error: it belongs to $N$. stenocarpum), \& Proc. Am. Acad. xviii. 118. - S. W. border of Texas, on bluffs of Delaware Creek, east of Guadalupe Mountains, 1882, Havard. (Adj. Mex., Palmer.)

N. Rothróckii, GraY, p. 175. Valves of the ovate capsule not splitting in age.

N. Párryi, Gray, p. 175. Valves of the short oval capsule splitting into two after dehiscence, the placentæ breaking up : stem 3 to 6 feet high, at base "pithy and only soft-woody"; perennial: "tube and thruat of corolla white, lobes light purple," Purish. Collected also in the Sicrra Madre of Los Angeles Co. by son of J. C. Nevin, 1884.

\section{ERIODICTYON, Benth. P. 175, 176, add:-}

E. sessilifólium, Grexne. Very leafy : pubescence partly villous and hirsute : leares oblong or upper ones lanceolate, all closely sessile by a broad and truncate or subcordate base, acntely and closely dentate (in age becoming glabrate and glutinous above): otherwise nearly like the $E$. crassifolium form of $E$. tomentosum. - Bull. Calif. Acad. i. 201. - Guadalupe Cañon, and elsewhere in Lower California, not far below the U. S. boundary to All Saints' Bay, Parry, Orcutt, and recently Greene. The seeds (with delicate striæ and transverse reticulation) appear to be quite alike, as far as seen, in all the species and forms, which are very difficult to define.

E. tomentósum, Bentr., p. 176, is founded on a plant with pannose tomentum and no villous or hirsute pubescence until the inflorescence is reached, such as Greene in Bull. Calif. Acad. 1. c., describes from Monterey Co., but with the corollas seemingly in the same imperfectly developed or deformed condition which Bentham had in his $E$. crassifolium, in 
this state "hardly surpassing the calyx (2 lines long)," and its lobes "very small, erectspreading." But well-developed flowers of $E$. crassifolium we know to be even half an inch long and much surpassing the calyx. On Santa Catalina, Lyon got a narrower-leaved form of the true $E$. tomentosum, with finer tomentum not pannose on the stem, and normally developed salverform corollas.

A multitude of forms from Lower and Southern California (including E. angustifolium, var. pubens, Gray, Proc. Am. Acad. xvii. 224), with and without villous or hirsute inflorescence, now connect $E$. angustifolium with $E$. glutinusum. This extends northward to Oregon, coll. Howell.

\section{BORRAGINACE E.}

The following changes in the synopsis of the genera are, for brevity and convenience, based on the North American representatives.

+ (P. 178, line 36.) Nutlets attached above the middle, wholly flat and thin, horizontally divergent, in pairs or radiate; margins pectinately and uncinately setiferous.

\section{PECTOCARYA.}

++ Nutlets thicker, with rentral or introrse-basal attachment.

= Glochidiate-armed: corolla short, with fornicate throat: calyx spreading or reflexed in fruit.

9. CYNOGLOSSUM. Nutlets horizontally radiate or barely ascending, much produced below the high ventral insertion upon the low gynobase, on separation each pendulous by a portion of the style which is torn away from below upward.

10. ECHINOSPERMUM. Nutlets erect or much ascending; the insertion supra-basal, central, or from the inside of base to apex.

$$
==\text { Not glochidiate, nor with loose or fleshy pericarp. }
$$

u. Corolla short, white or blue (only in an anomalous species elongated and yellow), usually with more or less fornicate throat.

11. OMPHALODES. Nutlets obliquely ascending (or in typical species depressed and nearly horizontal), with depressed or truncate-complanate back bordered by an acute margin or an at length revolute (entire or dentate or spinulose) wing: scar short, from suprabasal to supra-median.

111. KRYNITZKIA. Nutlets erect and straight, with wing or border, if any, unarmed and plane, with introrse-basal or also ventral attachment from the base upward, the scar or groove of attachment wholly naked. Fructiferous calyx erect or little spreading. (Includes also no. 14, p. 179.)

12. PLAGIOBOTHRYS. Nutlets crustaceous or rarely coriaceous, ovate or trigonous, oblique or incurved, and often incumbent orer the low gynobase, to the depressed areola of which they are attached by a median and either perforated or solid (sessile or short stipitate) false caruncle.

13. ECHIDIOCARYA. Nutlets ovate-pyramidal, with ventral keel produced at base into a conspicuous indurated stipe; the stipes united in pairs below and inserted by a common excavated base to the low gynobase. Otherwise as Plagiobothrys.

b. Corolla yellow, with usually more elongated tube and naked open throat.

14. AMSINCKIA. As on p. 179.

$==$ Not glochidiate nor appendaged, with loose pericarp soft and thin or fleshy: corolla from campanulate to trumpet-shaped, with open throat.

15. MERTENSIA. As on p. 179.

+++ (in place of $==$, p. 179.) Nutlets erect, with direct and centrally basal attachment to the depressed gynobase. (16-21.)

Aspérugo procúmBexs, L., ¿ European annual, well marked by its much enlarged membranaceous and veiny fructiferous calyx, has sparingly appeared in waste grounds around New York and Philadelphia, and at the red pipestone quarry in Minnesota.

Córdia Gréggir, Torr., p. 180, remarkable for its large flowers and small leaves, has been found by Pringle not far below the boundary in Sonora, near the Gulf of California. 


\section{BOURRERIA, P. Browne.}

B. Havanénsis, var. rádula, p. 181. Add syn.: Cordia Floridana, Nutt. Sylv. iii. 83, t. 107, the corolla depicted in the figure and described in letterpress as "yellow." Probably a mistake.

\section{EHRETIA, L.}

E. elliptica, DC., p. 181. Add syn. : E. exusperata and E. ciliata, Miers, Bot. Contrib. ii. 229,230 , founded on Lindheimer's specimens.

\section{TOURNEFÓRTIA, L.}

T. móllis, Grat, p. 183. Rediscovered on the arid plains of S. W. Texas, by Havard. T. Monclovana, Watson, Proc. Am. Acad. xviii. 120, of adjacent Coahuila, appears to be a form of this.

\section{HELIOTRÓPIUM, Tourn.}

H. convolvuláceum, Grax, p. 183. H. Californicum, Greene, Bull. Calif. Acad. i. 202, a form of the Molhave plant (coll. Cooper, Parish, Lemmon, which is hispid rather than strigose, and dwarf), remarkable for its glabrous nutlets (coll. Mrs. Layne-Curran). They are not so in Cooper's specimens; those of I'arish and Lemmon are not in fruit, nor are those of Palmer of S. W. Utah, which are more strigose in pubescence.

\section{PECTOCÁRYA, DC.}

P. setósa and P. pusillla, p. 187, both occur northward as far as to Washington Territory; the former collected by Brandegee, the latter by Howell and by Suksdorf.

\section{CYNOGLÓSSUM, Tourn.}

C. gránde, DovGL., p. 188. - Forms of this pass freely into the smooth and glabrous form, Var. lǽve. - C. leve, l. c. Not rare from Tamalpais northward.

The two dubious species forming the third division, now known in fruit, are to be excluded: see p. $422,423$.

\section{ECHINOSPERMUM, Lehm., rather than Swartz.}

§ 1. Láppula, p. 188. The first division of this section (*) is here reelaborated.

\section{Biennials, perhaps sometimes annuals.}

+ Very small-flowered and loosely racemed: corolla and nutlets not over 2 lines long: leares thin and green.

E. Virgínicum, Lенм., p. 189. Nutlets of the globose fruit equably short-glochidiate orer the whole back: racemes spreading. - Gray, Proc. Am. Acad, xvii. 224.

E. pinetórum, GreEve. Nutlets of the hemispherical-subpyramidal fruit marginally glochidiate with flattened prickles, and the depressed ovate dorsal disk only glochidiatemuriculate: racemes erect: leaves small (cauline an inch or two long), narrowly oblong, radical all acute at base. - Gray, 1. c. - Mountains of New Mexico, Greene, and of Arizona, Pringle, Lemmon.

E. defléxum, Leнм, var. Americánum, Gray, 1. c., p. 189. Nutlets of the globularpyramiclal fruit only marginally glochidiate, the flattened dorsal disk unarmed and granulate-scibrous, rarely a few small prickles on an obscure midnerve. - Extends southward to Iowa on the Mississippi, G. H. Butler. 
++++ Larger- and less sparsely-flowered, erect: dorsal disk of the nutlets flat, ovate or deltoid, unarmed, granulate-scabrous, 2 lines or more in length; marginal prickles flat and subulate.

E. ursínum, GreENe. Nutlets with ovate disk nearly plane ; the marginal prickles short, unequal, sometimes confluent into a wing-like border: stem and leaves hirsute or hispid: fruiting pedicels sparse, longer than the fruit. - Gray, Proc. Am. Acad. xvii. 224. - Mountains of New Mexico, Fendler (633), Greene, and of S. Arizona, Lemmon. Also S. Utah, Parry, without fruit.

E. Horibúndum, Lенм. Nutlets with dorsal disk deltoid and with a strong midnerve or keel; margin armed with long flat prickles : herbage soft-pubescent or the stem soft-hirsute: pedicels mostly shorter than the fruit: corolla (blue, sometimes white) with limb oniy 2 or 3 lines in diameter. - Gray, 1. c. E. floribundum in part, p. 189. - Saskatchewan to Colorado and Northern New Mexico, Utah, and Washington Terr.

++ Perennials, usually larget-flowered: pedicels mostly longer than the fruit.

- Corolla rotate: nutlets with some glochidiate prickles or processes on the flattish or convex ovate dorsal disk, but these shorter than the flattened subulate and sometimes confluent ones of the margin: leaves ustally lancenlate.

E. diffúsum, Lенм. (not of p. 189). Soft-pubescent, or at most soft-hirsute (occasionally some papillosities on the leaves): corolla bright blue, varying to white, one-third to twothirds of an inch in diameter : marginal prickles of the nutlets subulate and very flat, nearly as long as the width of the dorsal disk, this beset with a few small glochidiate processes: scar nearly central. - Gray, Proc. Am. Acad. xvii. 225. E. floribundum, p. 189, in part. E. subdecumbens, Parry in Proc. Davenp. Acad. i. 48. Rochelia patens, Nutt. Jour. Acad. Philad. vii. 44, in descr. of which the last two sentences obviously belong elsewhere. Common from the mountains of Utah to those of California, also North Montana and British Columbia.

E. híspidum, Gray. Hispid with spreading papillose-based hairs: leaves green; lowest broadly lanceolate; upper ones short and small : racemes lax : corolla "greenish white," 2 or 3 lines in diameter: marginal prickles of the obcompressed nutlets small and narrow, much shorter than the width of the oval or ovate and either sparsely or copiously glochidiate dorsal disk, their bases confluent into a thin margin or distinct wing (which is sometimes reflexed or cup-like); inner face smooth and lucid, with scar almost central. - Proc. Am. Acad. xx. 259. E. diffusum, var. hispidum, Gray, Proc. Am. Acad. xvii. 225. - Rocky hillsides, E. Oregon, Cusick, S. W. Idaho, Wilcox, and probalbly Montana, Watson.

E. ciliátum, Gray. Cinereous with a much appressed pubescence, and bristly-hirsute, especially along the margins of the linear or narrowly lanceolate leaves : stems strict, a foot or more high : corolla rather large, blue or violet : fruit unknown. - Proc. Am. Acad. l. c., excl. what relates to Cynoglossum Howardi. Cynoglossum ciliatum, Dougl. in herb. Hook., I.ehm. Pug. \& in Hook. Fl. ii. 85. - Mountains of Idaho; "near the head-springs of the Columbia," and near the narrows above Kettle Falls on the Columbia and banks of the Spokan River, 1826," Douglas. Not since seen.

++ +t Corolla short-salverform, i. e. with tube (surpassing the calyx) about the length of the ample lobes: nutlets armed all over the back with long glochidiate prickles quite like those of the margins: leaves spatulate-oblong to lanceolate or the upper ovate-lanceolate, thickish in age, with prominent midrib but no obvious veins or nerves.

E. Califórnicum, Grar, 1. c. E. diffusum, of p 189, not of Lehm. E. nervosum, Kellogg, . Proc. Calif. Acad. ii. 146, f. 42, according to specimen; but the leaves in the species are remarkably nerveless and veinless.

E. Redówskii, var. occidentále, WAtson, p. 190. Add syn. : E. Fremontii, Torr. Pacif. R. Rep. xii. ${ }^{2} 46$.

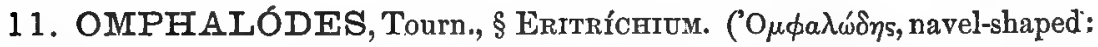
unhappily for the name, the navel is on the back of the nutlet.) - Gray, Proc. Am. Acad. xx. 262. The plants of this subgenus are low or depressed perennials, of arctic and alpine or subalpine regions in the Northern hemisphere. 
O. nána, Grax, 1. c. Eritrichium nanum, Schrad., \&c., p. 190, with its varieties, To syn. add: Hook. f. Bot. Mag. t. 5853, which well exhibits the oblique position of the forming nutlets.

O. Howárdi, Grar, l. c. Depressed-cæspitose, silky-canescent and silvery: leaves linearspatulate in the deuse tufts, linear on the few.flowered sparsely bracteate (barely span high) flowering stems, half-inch or more long: calyx-lobes linear-lanceolate : corolla bright blue, 4 or 5 lines in diameter: nutlets very smooth, obliquely truncate on the back, wingless, but the margin of the ovate acutish and flat or slightly depressed dorsal disk with a sharp margin, and its face either smooth or minutely papillose and puberulent. - Cynoglossum Howardi, Gray, p. 188. - Rocky Mountains in Montana, Winslow J. Howard, about 1866. Montana, on Mount St. Helena, Canby, 1883, with fruit! Cascade Mountains, Washington 'Terr., Tweedy, 1882.

O. AliḱsA and O. CARDiophyLlA, Gray, are Northern Mexican representatives, with a difference, of the typical Omphalodes.

11․ KRYNITZKIA, Fisch. \& Meyer, extended. (Prof. J. Krynitzki, of Cracow.) - Chiefly North American herbs, annuals and some perennials; with small white flowers, an anomalous species yellow-flowered. - Fisch. \& Meyer, Ind. Sem. Hort. Petrop. vii. 52 (1841); Gray, Proc. Am. Acad. xx. 264. Krynitzkia \& Eritrichium, sect. 5-7, A. DC. Prodr. x. 128, 134. Eritrichium \$ Krynitzkia, \& $\$$ Eueritrichium Myosotidea, \& Antiphytum, Gray, Proc. Am. Acad. x. 55, \& Syn. Fl. ed. 1, 191-197, 199.

§ 1. Amblynótus, Gray, Proc. Am. Acad. xx. 264. Nutlets cartilaginous or crustaceous (almost as in Lithospermum), ovate, with rounded back (mostly not carinate), attached next the base to the low and convex or depressed pyramidal gynobase.

K. PARry, Gray, l. c., is doubtless North Mexican rather than a Texan species.

K. heliotropioídes, GrAY, 1. ․ 265, is Antiphytum heliotropioides, A.DC., \& p. 199.

K. floribúndia, Grax, l. c., is A. floribundum, p. 199.

K. lithocárya, Greene. Low and slender annual, resembling species of the following section, somewhat pubescent: leaves linear: racemes or spike simple, sparsely-flowered, partly bracteate: corolla white, not surpassing the ferruginous-pubescent calyx: nutlets turgid-ovate, rather over a line long, very smooth and shining, lightly carinate down the rounded back and sulcate down the ventral side, attached by a short line or grooved scar from the base up a quarter of the length. - Gray, Proc. Am. Acad. xx. 265. - Lakeport, Lake Co., California, Lrs. Layne-Curran. Anomalous species, perhaps to be placed in the vicinity of $K$. leiocarpa.

§2. Mrosotínea, Gray, l. c. Nutlets less indurated, ovate, opaque, coarsely somewhat rugose, ventrally carinate, with short and merely intrabasal attachment to a low gynobase : low and slender Western species. - Eritrichium § Eueritrichium Myosotidea, p. 191.

* Small-flowered annuals, diffuse, with corolla only a line or two broad and little surpassing the calyx, which usually becomes foliose-ampliate.

K. plebéia, GraY, 1. c. 266, is Eritrichium plebeium, A.DC., p. 191.

K. Califórnica, Gray, 1. c., is E. Californictm, DC., p. 191. The var. subglochidiata includes most of the interior forms of the species, but is also in the valley of California, where also it becomes succulent in alkaline soil. The little bristles of the fruit are commonly penicillate-tipped, sometimes truly glochidiate, thus making a kind of transition to Echinoglochin of Echinospermum.

K. trachycárpa, GrAx, I. c. Less spreading than the preceding, lax : nutlets broadly ovate-trigonous, acute, finely reticulate-rugose and granulate or muriculate: scar oblong. - 
California, Sonoma Co., Brewer, and valley of the Joaquin, Greene. (Chili, Eritrichium uliginosum, Philippi, \& E. muricatum, A.DC. ?)

* Larger-flowered annuals, erect or diffuse: rotate limb of the corolla 3 to 5 lines in diameter, bright white, with the yellow fornicate appendages of the throat conspicuous : nutlets rugulose.

K. Chorisiána, GRAY, 1. c. 267, is Eritrichium Chorisianum, DC., p. 191.

K. Scoúleri, GRaY, 1. c., is Eritrichium Scouleri, A.DC.

K. Coóperi, Grax, 1. c. More diffuse or depressed-spreading, hispid throughout with spreading short bristles: pedicels very short or none: fruiting calyx less than 2 lines and nutlets hardly a line long. - Eritrichium Cooperi, Gray, Proc. Am. Acad. xix. 89. - Wet places in the Mohave Desert, Cooper, Parish.

* * Perennial by creeping and rooting stems, leafy, and with flowers of moderate size.

K. móllis, GraY, l. c. Copiously soft-villous, even to the calyx: stems rather stunt, spreading or ascending, at length a foot or more long: leaves livear-lingulate, 2 inches or more in length and 3 or 4 lines wide, obtuse : spikes at length elongated, bractless : limb of the corolla 3 or 4 lines broad: nutlets trigonous-ovate, slightly obcompressed, hardly at all carinate on the back, coarsely rugose-areolate, attached by a quarter or a third of their length to the oblong-pyramidal gynobase, the scar ovate-lanceolate. - Eritrichium molle, Gray, Proc. Am. Acad. xix. 89. - Alkaline borders of ponds, Sierra Valley, E. California, Lemmon. Also apparently near Visalia, Congdon.

§ 3. Eukrynítzkia, Grax, 1. c. Nutlets (never rugose, but sometimes papillose) attached by the ventral angle or groove from the base up at least one third or half way or for the whole length to an' elevated gynobase, the back convex and not carinate, the sides wingless, and mostly obtuse or rounded, but several in the later subdivisions acute-angled: fruiting calyx erect or closed: corolla small and white, with tube not surpassing the calyx: annuals with the flowers almost always sessile and scorpioid-spicate.

* Holócalrx, i. e. the fructiferous calyx not circumscissile, but not uncommonly articulated with the rhachis and falling away at maturity with the nutlets included. - Gray, Proc. Aun. - Acad. Xx. 268.

+ Sepals lanceolate or linear, traversed by a rigid and stout midrib : nutlets thick-walled, opaque or dull: diffusely branched and rough-hispid.

++ Nutlets either dissimilar or only one maturing, strictly enclosed in the rigid fructiferous calyx, the midribs of which are much thickened and indurated.

K. crassisépala, Grar, Proc. Am. Acad. xx. 268, is Eritrichium crassisepalum, Torr. \& Gray, p. 195. One of the nutlets larger and more persistent.

K. Texána, Gray, l. c., is E. Texanum, A.DC., p. 195. Matures a single nutlet, which never separates by a clean scar, but at length tears away.

++ ++ Nutlets all four maturing and alike, smooth, ovate-acuminate, hardly a line long, attached to a narrow gynobase, the ventral groove abruptly dilated at the very base into the triangular scar: fractiferous calyx (about 2 lines long) less closed and less rigid than in the preceding, and midrib less prominent, hispid with pungent bristles: spikes often bracteate at base.

K. Pattersóni, Grar, l. c. A span or so high, branched from the base and spreading: leaves narrowly spatulate or linear, seldom an inch long: sepals linear-lanceolate : nutlets attached up to the middle to the subulate-pyramidal gynobase, one of them disposed to be more persistent than the rest. - Base of the Rocky Mountains, probably near Denver, Patterson, and on the plains westward, to S. E. Oregon, Howell.

K. Féndleri, Gray, l. c. Erect and paniculately branched, rigid, a foot or less high: leaves linear, an inch or more long: fructiferous sepals narrowly linear: nutlets more tapering upward, affixed nearly their whole length to the narrow subulate gynobase. (Has been much confounded with $K$. leiocarpa.) - Saskatchewan to Colorado and New Mexico or Arizona, chiefly along the base of the Rocky Mountains, but northwestward to the borders of Washington Terr. ; perhaps first coll. by Fendler. 
++ Typical species, slender-stemmed, bractless in all well-developed spikes; with midrib of narrow setose-hispid sepals not conspicuonsly if at all thickened: nutlets very smooth and mostly shining, acute or acuminate, with rounded sides and rather thiu or brittle pericarp, attached by a part or even the whole of the slender ventral groove (with or without some areolar dilatation at base) to a narrow gynobase.

+ Nutlet solitary (rery rarely two maturing, the others early abortive), conspicuously acuminate, attached for not more than the lower third to the short and narrow gyaobase, which it very much surpasses: spikes commonly in twos or threes, slender in fruit.

= Sepals narrowly lanceolate, evenly beset with short and ascending hooked bristles: nutlet ovate, plano-convex, equalling the sepals: anomalous in the subdivision.

K. sparsiflóra, Greene. Small, slender, with diffuse branches, bearing simple or forked and sparsely few-fruited filiform spikes, strigulose-pubescent and the narrow linear leaves minutely hispid : calyx in fruit a line and a half to almost two lines long, ascending, equalled by the nutlet, which is attached by a line linrlly over one fourth of its length aud furcate at base. - Bull. i. 203. - Lake Co., California, IVrs. Layne-Curran.

$==$ Sepals narrowly linear or verging to filiform in age, armed with long and rigid spreading or deflexed bristles, which are more copious and stronger towards the base, their attenuate tips straight or disposed to be hooked: nutlet subterete, ovate-lanceolate and rostellate-acuminate, shorter than the sepals: flowers numerous in the spikes.

K. oxjcárya, Grar. Commonly a foot or two high and strict, strigulose with minute close pubescence, and the linear leaves minutely more or less strigulose-hispid: calyx in fruit erect, appressed to the rhachis, 2 to $2 \frac{1}{2}$ lines long; the sepals filiform-linear and thickish below, their base very hispid with deflexed and strong but not pungent bristles: nutlet hardly flattened ventrally, the groove of attachment enlarged at base but not furcate. - Proc. Am. Acad. xx. 269, where the syn. Myosotis flaccida, Dougl. is verifierl, the "uuces 4" of Hook. Fl., \&c., being a mistake. Eritrichium oxycaryum, Gray, p. 193. - Washington Terr. to California, more common northward, first coll. by Douglas.

K. micróstachys, Greese. Rarely over a foot high, more spreading, 'hispidulous or hispid : fructiferous calyx ascending or erect but hardly appressed to the rhachis, from barely a line to nearly 2 lines in length, with mostly less attenuate and less rigid sepals, hispid with widely spreading (but not deflexed) and somewhat pungent bristles : nutlet flatter ventrally, the groove of attachment divaricately forked and somewhat open at base. - Gray, 1. c. $K$. leiocarpa \& Eritrichium sp., Gray, Jour. Bost. Nat. Hist. vii. 147. K. rostellata, Greene, Bull. Calif. Acad. i. 203, the largest-flowered form, the original of $K$. microstachys being of the most depauperate. - California, from Colusa Co. southward; first coll. by X'antus at Tejon.

++ Nutlets usually all four maturing, and all alike (not over a line long), either flattish or angled ventrally, ovate in outline and acute or short-acuminate, attached for half or nearly whole length to the subulate gynobase; the slender groove not dilated at base into an open areola or scar,"

= But simple and continuous to the very base of the nutlet: spikes simple or occasionally in pairs, very often leafy at base and as it were interupted and glomerate, the lower part of the inflorescence being reduced to sessile clusters or even to single flowers seemingly axillary to a leaf, but the well-developed spikes bractless: stems or branches diffuse, a span to a foot long.

K. leiocárpa, Fisch. \& Meyer. Nutlets attached by the straight ventral groove nearly its whole length to the subulate gynubase. - Ind. Sem. Hort. Petrop. 1835, 36; A. DC. Prodr. x. 135; Gray, Proc. Am. Acad. xx. 270. Eritrichium leiocarpum, Watson, p. 194, contains this and the three following. - Washington Terr. to California near the coast.

K. affinis, GraY, 1. c. Nutlets commonly more turgid and thinner-walled, attached only up to the middle to the slender-pyramidal gynohase, the free apical portion a little diverging. - Interior of Washington Terr. and Oregon to the Sierra Nevada in California, and east to Idaho. Perhaps passes into the preceding.

$==$ Groove of the more or less trigonous nutlets divergently forked at base, but no open areola: spikes naked and more pedunculate, not rarely in pairs.

K. Torreyána, Grar, 1. c. Hirsute-hispid, and the calyx very setose: fructiferous sepals attenuate upward: nutlets ovate, acute, attached barely up to the middle to the subulatepyramidal gynobase. - Eritrichium leiocarpum, Watson, Bot. King Exp. 244, in large part. - Not rare from the coast districts of California to S. Idaho and Nevada. 
Var. calycósa, GRst. 1. c. A larger form, with flowers crowded in the short spikes: fructiferous calyx elongated and attenuate (2 or 3 lines long), becoming rigid and with stouter midrib. - Eritrichium leiocarpum, Watson, 1. c., as to "calyx-lobes linear, becoming much elongated." - E. Humboldt Mountains, Nevada, Watson, \&c., and Lake Co., California, Ratlan.

K. Watsóni, GraY, l. c. Hispidulous and the calyx and the canescently pubescent calyx sparsely hispid: fructiferous sepals barely 2 lines long, lanceolate, hardly at all attenuate: nutlets narrow, somewhat triquetrous, oblong-lanceolate in outline, attached by their whole length to the filiform-subulate gynobase. - Eritrichium leiocarpum, in part, Watson, 1. c. Wahsatch Mountains, Utah, Watson.

+++ Asperulous-fruited species, with nutlets disposed to be heteromorphous, i. e. one or two of them larger than the others, all with ventral groove widening below and by this attached for nearly their whole length to the subulate gynobase: diffuse, very small-flowered, with the spikes bractless when well evolute: fructiferous calyx only a line or two long, armed with strong and pungent divaricate bristles.

K. angustifólia, GraY, is Eritrichium angustifolium, Torr., p. 194. Low, forming broad tufts, the herbage thickly soft-hispid and grayish: leaves narrowly linear: fruiting spikes dense : sepals narrowly linear, beset with rigid bristles of nearly their own length: nutlets small, somewhat trigonous, minutely scabrous by elevated points, with ventral groove deltoid-ampliate either below the middle or next the base, sometimes all four alike, or one or two longer and of ovate-lanceolate circumscription, while the others are triangular-ovate and shorter, or these oceasionally abortive. - Proc. Am. Acạd. xx. 272 (where the word "semilineam" in the char. of section is a slip for "sesquilineam." - Belongs to the interior dry region of Arizona and S. E. California.

K. dumetórum, GreEne. Loosely branching, and among low hushes said to be almost climbing, a foot or more high: only branches seen (those in fruit); with oblong or lanceolate and papillose-hispid leaves: fructiferous sepals lanceolate: nutlets narrow, acuminate, minutely hirtellous-scabrous, three of them oblong-lanceolate in outline and almost terete, with open ventral groove wider below the middle; one much larger, fully a line long, ovate-lanceolate, persistent on the subulate gynobase and fulcrate or half enclosed by a portion of the then gibbous calyx, i. e. by two of the sepals united to the middle. (Possibly a monstrosity.) - Gray, 1. c. - Tehachapi Pass, Kern Co., California, Mrs. Layne-Curran.

++++ Muriculate- or rough-papillose-fruited, with bractless spikes, and calyx hispid with spreading commonly pungent bristles: nutlets all four alike (occasionally only one or two maturing), ovate-trigonous, more or less roughened by papillæ or tubercles on the convex back, at least in age, and with sides or lateral angles rounded or obtuse (or more acute-angled in two species), attached up to apex or nearly to the subulate gynobase by the ventral groove, with or without areola at its base: erect and mostly coarse herbs, the herbage more or less hispid.

+ Calyx (and mostly herbage) very villous-hispid or barbate with long and rather soft bristles; sepals narrowly linear and not tapering upward, with rather strong midrib, in fruit 3 to 5 lines long, loose above, usually thrice the length of the ovate-acuminate or ovate-lanceolate very rough-muricate and gray nutlets, the open groove of which is a little dilated at base.

K. barbígera, GRAT, 1. c., is Evitrichium barbigerum, p. 194. - Common through the arid region of S. E. California, Arizona, and Nevada, to adjacent borders of Oregon.

+ to Calyx (not over 3 lines long) armed with more rigid and pungent bristles, these either whitish or rusty-yellowish,

= In fruit at least double the length of the more or less acuminate nutlets; the narrow linear or more attenuate sepals with rather strong midrib, open above, at least not comivent over the fruit.

K. intermédia, GraY. Nutlets thickly rough-muricate, the papillæ usually sharp-pointed; the groove wholly or partly open and with an open areola at base. - Proc. Am. Acad. xx. 273. Eritrichium intermedium, Gray, Proc. Am. Acad. xvii. 225. - Common through all the southern part of California, and to the borders of Arizona.

K. ambigua, GraY. Nutlets minutely papillose-scabrous, moderately or hardly open at the basal bifurcation of the mostly close groove. - Proc. Am. Acad. xx. 273. Eritrichium muriculatam, var. ambiguum, p. 194, with syn. (The E. muriculatum, of Torr. in Wilkes Exp. represents the calyx rather too short.)-Common in California, Nevada, and north to 
Washington Terr. and eren W. Montana. A maritime form on San Clemente, off San Diego, Nevin \& Lyon.

K. Folíss, Greene, Bull. Calif. Acad. i. 205, extra-limital, on Guadalupe Island, is very near the foregoing, probably a stout maritime form of it.

$==$ Fructiferous calyx shorter, of lanceolate and obscurely unicostate sepals, less surpassing and more or less connivent over the more acute-ingled and hardly at all acuminate nutlets.

K. muriculáta, Gray, l. c., is Eritrichium muriculatum, A.DC., \& p. 194. $K$. denticulata, Greene, Bull. Calif. Acad. i. 205. Plant commonly robust, with well-developed spikes in age apt to be sparsely flowered: calyx 2 lines long: nutlets usually a line long, deltoidorate in outline, sharply scabrous-muricate over the back, which is hardly convex except by a slight dorsal ridge, and with distinct and thickish but acutish lateral angles, these muricate-papillose like the back; ventral groove and its fork mostly closed. - Common iu California, extending into Arizona, Nevada, and Oregon.

K. Jonésii, Grax, 1. c., 274. More slender and smaller than the preceding, a foot high, with more paniculate and lateral spikes: leaves narrowly linear, half-inch to inch long: fructiferous calyx hardly over a line long: nutlets of $K$. muriculata, but smaller and the angles perhaps less acute. - California, near Monterey Bay, Jones. Southern border of the State, in San Diego Co., Orcutt. May be only a form of the preceding.

K. micrómeres, Gray, 1. c. Slender and diffusely branched, less than a foot high : leaves a quarter to half inch long: spikes filiform, simple or occasionally in pairs: flowers minute : fructiferous calyx a line or half-line long : nutlets ovate-trigonous, acutish, rather shining, but muriculate-scabrous on the back, lateral angles acute, and inner faces commonly coucave; ventral groove abruptly dilated below. - Eritrichium micromeres, Gray, Proc. Am. Acad. xix. 90. E. angustifolium, Gray, Proc. Am. Acad. v. 165, not Torr. - California, near Santa Cruz, Jones, and Mokelumne Hill, Rattan. (Lower Calif., Xantus.)

+++++ Acute-angled-fruited and bractless-spiked annuals, erect from a somewhat indurated root, linear-leaved: sepals lanceolate, sparsely or not at all hispid: fruiting spikes of the commonly 2-3-radiate cyme short and spreading, closely flowered: nutlets lanceolate-orate in outline, tapering from near the broad base, either very smooth or with scattered papills, and with sharp lateral edges, the inner faces plane or slightly convex, attached by the whole length to the slender almost fliform gynobaze by the ventral groove and its forked or areolate-dilated base. (Allied by the fruit to $\$$ Pseudokrynitzkia, but only annual.)

K. oxygona, Grar. Less than a foot high, freely branched from the base, papillose-hispidulous: leaves an inch or less long, less than a line wide : cymes naked-pedunculate, the fruiting spikes seldom over half-inch long: limb of corolla 2 lines in diameter : fructiferous calyx 2 lines long, hirsute with erect hairs and sparsely hispid with some spreading rigid bristles: nutlets fully a line long, obcompressed-trigonous, somewhat lucid, the back and commonly the ventral faces sprinkled with small papillæ; the slender groove divaricately forked and open or closed at base.-Proc. Am. Acad. xx. 277. Eritrichium oxygonum, Gray, Proc. Am. Acad. xix. 89. - S. E. California, on hills bordering the Mohave Desert, Prinyle. The following was referred to this.

K. Mohavénsis, Greene. Quite like (and probably not permanently distinct from) the preceding species: but caly $x$ with hardly any hispid spreading bristles, and nutlets smooth and Iucid. - Bull. Calif. Acad. i. 207.-S. E. California, on the Mohave Desert, Mrs. Layne-Curran.

K. Utahénsis. Paniculately branched, a foot or less high : stem and branches strigulosepubescent or below merely hirsute : larger leaves 2 lines broad, papillose-hispidulous : cymes irregular: limb of corolla hardly over a line in diameter: fructiferous calyx only a line long, of more obtuse sepals, somewhat canescently silky-pubescent, not obviously hispid: nutlets smaller and thicker and of narrower outline than in the two preceding species, less acute-angled, somewhat lucid, the back sparsely beset with minute papillæ; ventral groove gradually widening downward to the open base. - St. George, S. W. Utah, Pulmer (referred to under K. holoptera in Proc. Am. Acad. xx. 276, and as var. submolle, p. 394 of 1st ed.), and Yucca, Arizona, Jones.

++++++ Bracteate-spiked (more or less) and mostly with nutlets acute-angled, smallflowered, the fructiferous calyx a line or less long. 
++ Nutlets short, broadly trigonous, attached at the lower half by a triangular impressed areola or scar to the acute-pyramidal gynobase, the groove above obscure and fiee, the convex back coarsely papillose: calyx of lanceolate sepals, hirsute or hispid with short but not pungent bristles: Texano-Mexican species, with partly bracted spikes.

K. pusílla, GrAY, Proc. Am. Acad. xx. 274, is Eritrichium pusillum, Torr. \& Gray, p. 194. Small : nutlets not half a line long, lucidulous, the lateral angles acute and the ventral faces concave, and the angle carinate-acute down to the deltoid hardly excavated areola of insertion.

K. ramósa, GraY, 1. c. Larger and stouter, less than a foot high, much branched, roughishhispid : nutlets dull, with rounded sides, no angles, and a large and deep areola or scar. Lithospermum ramosum, Lehm. Asperif. 328. Myosotis albida, HBK. Nov. Gen. \& Spec. iii. 91. Enitrichium ramosum, A. DC.Prodr. x. 132. E. hispidum, Buckley, \& p. 195. - Texas and New Mexico to Arizona. (Mex.)

++ Nutlets ovate-lanceolate and more or less obcompressed, the ventral face traversed its whole length by a narrow. groove (which is hardly at all forked and little areolate-dilated at base) to the nearly filiform gynobase: inflorescence tardily and incompletely evolute into secknd spikes.

= Rongh-hispid with rigid and mostly pungent bristles, low and coarse, with much branched rigid stems: fructiferous calyx or its very short pedicel readily disarticulating from its insertion at maturity, as in most preceding species: nutlets wholly smooth and lucid, only one or two maturing.

K. ramosíssima, Greene. Hispid with rather long whitish bristles: leaves thickish, linear or lanceolate, half-inch or less long: mature nutlets with roundish or at least not acute margins. - Bull. Calif. Acad. i. 203, not of Gray, which was essentially founded on the perennial and roughish-fruited species. - S. California; on Santa Catalina Island, Lyon, Mohave Desert, Mrs. Layne-Curran, and The Needles on the Colorado, Jones.

K. marítima, Grenes. Hispid with more rigid and usually shorter bristles: leaves linear, not broader at base, the longer an inch long: nutlets with acute margins. $-K$. maritima \& K. Cedrosensis, Greene, Bull. Calif. Acad. i. 204. Eritrichium angustifolium, Watson, Proc. Am. Acad. xi. 118, not Torr. - S. California on Point Loma, San Diego, Orcutt, probably of this species, but no mature fruit seen. (Lower California at Cedros and Guadalupe Islands.)

$==$ Canescently strigulose-pubescent on the slender and diffuse low stems and branches, and the small leaves and copions bracts more or less hirsute or hispid, also hispid-ciliate: fructiferous calyxes tardily disarticulating: style in age commonly thicker than the gyuobase: nutlets with roundish margins, sometimes smooth and lucid, sometimes minutely papillose-scabrous and grayish.

K. micrántha, Gray, Proc. Am. Acad. xx. 275, \& var. lepida, is Eritrichium micrantium, Torr. \& var, p. 275. - Western border of Texas to S. W. California. Routs red and giving a red stain.

* * Piptócalyx. Fructiferous calyx (5-cleft and villous-hispid) circunscissile above the base, which persists around the nutlets: these ovate-deltoid and trigonous and somewhat acuminate, very smooth, or in some specimens puncticulate with minute projecting points, acutish at the Jateral angles, the ventral angle traversed by the narrow groove of attachment, this forked at base and closed: anthers mucronulate: depressed much branched annuals, with crowded leafy inflorescence, floriferous almost from base, hirsute-hispid. - Gray, Proc. Am. Acad. xx. $27 \dot{5}$. Piptocalyx, Torr.

K. circumscíssa, Gray, 1. c., is Eritrichium circumscissum, Gray, p. 193, with syn.Extends from Lower California and Arizona through the dry region to borders of Brit. Columbia. Nutlets half to two thirds of a line long.

K. dichótoma, Grenne. Larger, coarser, more open in inflorescence, very hirsute-hispid with widely spreading hairs: lower leaves opposite: calyx at length 2 lines long : nutlets from three fourths to fully a line long, smooth and somewhat Iucid. - Bull. Calif. Acad. i. 206. - W. border of Nevada, between Boca and Verdi, Mrs, Layne-Curran.

§4. PterÝgiom. Nutlets all four or all but one scarious-winged at the margins, attached by the whole length of the rentral groove: spikes bractless. - 
Proc. Am. Acad. xx. 276. Subsect. Pterygium and winged species of PseudoMyosotss in Eritrichium, p. 195.

K. pterocárya, GRAY, 1. c., is Eritrichium pterocaryum, Torr., p. 195. The variety pectinatum too inconstant and variable to separate. The same of $K$. cycloptera, Greene, Bull. Calif. Acad. i. 207, proposed for specimens with the four nutlets winged all round the base and inner faces not muricate; characters which do not hold out.

K. holóptera, GraY, 1. c., is E. holopterum, Gray, p. 196. This and the following have the habit of the coarser species of the next section. ('The plant referred to under this species in Proc. Am. Acad. l. c. is $K$. Utahensis.)

K. setosíssima, GraY, l. c., is Eritrichium setosissimum, Gray, p. 196. - S. Utah, Ward, Palmer, and N. Arizona, Rusby, Lemmon.

\$ 5. Psecdokrynítzkid. Perennials or biennials, of coarse habit: nutlets triquetrous or trigonous, with lateral angles acute but not wing-margined, attilched for most of their length to a commonly subulate gynobase: corolla with prominent fornicate scales or folds in the throat, and at base within usually 10squamellate or annulate-glandular. - Proc. Am. Acad. xx. 276, excluding an annual species. Eritrichium § Krynitzkia Pseudo-Myosotis (excluding the two winged species), p. 196.

* Ambiguous species, small-flowered, of Eukrynitzkia babit, but suffrutescent-perennial and with sharp-margined nutlets.

K. racemósa, Greeve. Excessively branched from the persistent base, hispid with spreading bristles, a foot or two high : branches slender: leaves narrowly linear, half-inch to inch long: flowers very uumerous, loosely racemose-paniculate and with only occasional bracts; the lower commonly on spreading pedicels which nearly equal or exceed the calyx, upper subsessile: limb of the corolla only a line broad: fructiferous calyx a line or two long, setose-hispid: nutlets (usually only one or two maturing, a line and a half long) trigonous, with ovate-lanceolate outline of the back, and narrow acute margins, all the faces sparsely papillose, the ventral groove open and gradually widening to the base. - Bull. Calif. Acad. i. 208. K. ramosissima, GrAY, l. c. 277, as to all the char. and the Parish plant. Eritrichium racemosum, Watson, Proc. Am. Acad. xvii. 226. - Desert regions, in cañons, S. E. California, Parish, and Cantillas Mountains on the borders of Lower California, Orcutt. Arizona, in the Grand Cañon of the Colorado, A. Gray.

* Genuine species, more robust, larger-flowered, broader-leaved, and with mostly thyrsoidglomerate inflorescence; the spikes more or less evolute in age, here and there bracteate: flowers in some heterogone-dimorphous, in the last (anomalous) species yellow !

+ Nutlets (smouth) each a quadrant of an oblate sphere: perennial, short-flowered.

K. Jamésii, GraY, 1. c., is Eritrichium Jamesii, Torr., p. 196. Extends even to S. E. California. And $K$. Palmeri, Gray, L. c., already mentioned, is an allied species of Coahuila, Mexico, with opaque and rugulose (instead of smooth and polished) nutlets.

++ Nutlets flat or barely convex on the back, the foúr together pyramidal.

+4 Short-flowered, that is, tube of corolla not surpassing the calyx and shorter than its (2 or 3 lines wicle) limb; faucial appendages semiglobose and little exserted: sepals lanceolate: anthers oblong: nutlets ovate, more or less obcompressed, scabrous or tuberculate on the back, very acutemargined, the slightly elevated ventral face traversed by a slender groove terminating below in an areolar dilatation.

= Biennial, 2 or 3 feet high, very hispid with widely spreading long bristles.

K. virgáta, GraY, 1. c., 279, is Eritrichium glomeratum, var. virgatum, Porter, p. 196, with syn.

K. glomeráta, GraY, 1. c. 279, is E. glomeratum, DC., p. 196, the type, with syn. Only radical leaves somewhat canescent by a fine pubescence between the papillose-based bristles: nutlets thicker than in the preceding, more corrugate and carinate on the back, and narrower at the obtusish apex. - Plains along the eastern base of the Rocky Monntains, from Saskatchewan to New Mexico, and N. Arizona to Washington Terr. 
$==$ Perennial, many-stemmed from a strong root, less hispid with incumbent bristles and canescent with strigose-sericeous pubescence, at least the leaves.

K. serícea, GraY, 1. c., is E. glomeratum, var. humile, Gray, p. 196. Nutlets oblong-ovate, somewhat rugose-tuberculate on the back.

+ Long-flowered, the corolla-tube longer than the calyx and its owń limb, with faucial crests elongated and exserted: heterogone-dimorphous, sericeous-canescent, perennial. Vide p. 197.

K. fulvocanéscens, GRAY, 1. c. 280, is E. fulvocanescens, Gray, p. 197.

K. leucophǽa, GraY, l. c., is E. leucophceum, A. DC., p. 197, with syn., \&c. The remarkably long corollas are really yellow, and the polished ovate-triquetrous nutlets are peculiar, rendering this an anomalous species.

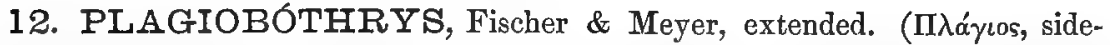
ways, $\beta$ ó $\theta$ pos, pit or hollow; so the name should have been written Plagiobothrus.) - Western American annuals, low, commonly diffuse, with small and short-pedicellate or subsessile flowers; the short corolla white: nutlets rugose or roughened, rarely smooth, ventrally carinate above the insertion, which is median or supra-basal, or rarely supra-median, only one or two commonly maturing, and then succumbent-horizontal upon the globular or depressed gynobase, tardily detached, leaving a kind of caruncle at the insertion (either projecting and solici or else annular and hollow), and corresponding depressed concavities on the gynobase. - Gray, Proc. Am. Acad. xx. 281. Plagiobothrys, Fischer \& Meyer, Ind. Sem. Hort. Petrop. ii. (1855) 46, \& A. DC. Prodr. x. 134, a single species. Eritrichium \& Plagiobothrys, Gray, Proc. Am. Acad. x. 57, \& xvii. 226.

$\S 1$. Ambiguous species: gynobase ovate-pyramidal, commonly bearing all four nutlets, and when they are detached deeply 4-sulcate, or as it were 4-lobed by protuberant thickening between the imbedded bases of the nutlets, leaving ovate-ublong or narrower depressions: nutlets tuberculate-roughened, incurved, carinate on the back ; the caruncle longitudinal, narrow, and confluent with the ventral keel above: coarse and comparatively robust plants, erect or merely spreading, 8 or 10 inches high, unusually hispid for the genus; the inflorescence evolute in fruit into mostly bractless racemiform spikes : calyx lax in fruit.

P. Kíngii, Gray. Hirsute and somewhat hispid: radical leaves spatulate; upper cauline oblong or lanceolate, half-inch long: corolla 3 or 4 lines in diameter (the largest of the genus): fructiferous calyx 2 or 3 lines long, its lobes linear-lanceolate: nutlets roughened with rather acute and scattered papillæ. - Proc. Am. Acad. xx. 281. Eritrichium Kingii, Watson, Bot. King Exp. 243, t. 23 ; also p. 192, in part. - Truckee Pass, Nevada, Watson, in flower, and in same district by Mrs. Layne.Curran, in fruit. (The narrower-leaved and smaller-flowered specimens of Lemmon, without fruit, are wholly uncertain.)

P. Jonésii. Hispid with long and widely spreading and pungent bristles, divergently branching: leaves narrowly lanceolate, inch or two long (truly radical ones not seen): limb of corolla only a line or so in diameter: fructiferous calyx 3 or 4 lines long, divided to the base into narrowly linear sepals: nutlets (a line and a half long) densely tuberculate with mostly obtuse papillæ. - S. E. California on the Colorado near The Needles, $M$. E. Jones, I884.

§ 2. Genuine species: gynobase subglobose or merely convex, with orbicular depressions left by the fall of the nutlets: these crustaceous or nearly so, very seldom more than one or two ripening, therefore horizontally incumbent at maturity, the caruncle short and broad, not stipitiform: slender or diffuse plants, 
little or not at all hispid, or papillose-hispidulous on some of the lower leaves: small-flowered.

* Typical, with an annular caruncle merely bordering a deep circular excavation, which is a kind of false umbilicus: this suggested the name for the genus.

P. ruféscens, Fischer \& Mexer, l. c. Often a fuot high, with slender stems from the tuft of spatulate-lanceolate radical leaves, only the young hirsute pubescence of the inflorescence and calyx rufescent: spikes elongated and sparsely flowered at maturity, naked, or with a leaf or two at base: fructiferous calyx lax, 3 lines long, of linear-lanceolate nearly distinct sepals : nutlets (a line long) little incurved, broadly ovate and short-acuninate, rather obcompressed, lightly carinate on the back and margined, reticulate-rugose and muriculate, the circular carunculate-bordered ventral pit about half a line in dianeter. - Gray, Proc. Am. Acad. xx. 282. Myosotis alba, Colla (Pl. Bertero, 88), fide A. DC. M. fulva, Hook. \& Arn. Bot. Beech. 38, not of 369. Eritrichim fulvum, A.DC. Prodr, x. 132; Gray, Proc. Am. Acad. xvii. 226. - W. California, from near the Oregon line, Howell, to Colusa and El Dorado Co., Mrs. Layne-Ciuran, and Sacramento Co., Nevin, perhaps not very uncommon, and perchance introduced (from Chili).

* * Solid-carunculate, that is, the caruncle of the more incurved and rentrally concave nutlets forming a broadish (commonly transverse) wen-shaped or short tongue-shaped caruncle: gynobase small and depressed.

+ Mature nutlets abruptly contracted at base and apex, so as to become cruciately 4-lobed, vitreous-crustaceous and more-or less lucid, transversely lineate-rugose on the back with straight and broadish wrinkles separated by very narrow impressed lines, and running from the low median crest to the somewhat crested margins: calyx deeply 5-cleft, persistent, or at length imperfectly circumscissile; lobes broadly lanceolate, villous with rufescent or soon pale or fulvous pubescence: plants small aud erect, a span high or little more.

P. tenéllus, GraT, 1. c., is Eritrichium tenellum, p. 192, with syn. and habitat. Nutlets a line long, muriculate-roughened. Herbage gives a violet stain to paper. - Extends from Brit. Columbia and W. Idaho to $\mathrm{S}$. California.

P. Shasténsis, Greeve. Perhaps only a larger-flowered form of the foregoing, with calyx ( 3 lines long) more closed over the fruit, and nutlets (a line and a half long) smooth or barely the margins muriculate-roughened. - Gray, I. c. 284.

$$
++ \text { Nutlets broadly orate and not at all cruciform, }
$$

+ Vitreous-crustaceous but rather dull, lineate-rugose in the manner of the preceding, but the flatter back hardly at all carinate: caly not circumscissile: plant diffusely procumbent, hispidulous, with short oblong leaves which commonly extend through the irregular spikes.

P. Torréyi, Gray, 1. c., is Eritrichium Torreyi, p. 192. Herbage gives an abundant violet stain to paper.

+ + Nutlets opaque, not ritreous nor much indurated, the back slightly carinate, rugose with sparse and somewhat reticulated lines, which are elevated above the general surface, this often minutely granulate.

$=$ Calyx divided to near the base: spikes irregular or simple, commonly leafy below: limb of corolla only a line or two in diameter: plants diffusely branched from the base, a span to a foot high.

P. Arizónicus, Greene. Hirsute or even hispid with widely spreading hairs, not canescent : leaves mostly oblong-lanceolate : fructiferous calyx not over 2 lines long, usually connivent over the acutely rugose and sparingly roughened nutlets, at length circumscissile at base. - Gray, 1. c. Eritrichium canescens, var. Arizonicum, Gray, Proc. Am. Acad. xvii. 227. - Common in Arizona, S. Utah, and adjacent parts of California, Palmer, Greene, Lemmon, Parish, Pringle.

Var. Catalinénsis has fructiferous calyx open and the broader lobes somewhat accrescent; also duller as well as rougher nutlets - Santa Catalina Island, off Los Angeles, California, Lyon.

P. canéscens, Bentr., is Eritrichium canescens, p. 192. Villous-pubescent and somewhat cinereous or canescent, especially the calyx, which when young may be fulvous or even somewhat rufescent : this 2 or 3 lines long in fruit, loosely erect or sometimes more open 
and accrescent, persistent, rarely disposed to be circumscissile at base : nutlets with obtuser wrinkles. - Common in California from Sacramento southward, first coll. by Hartweg.

$==$ Calyx cleft only to the middle, silky-villons, rufescent only when young, soon fulvous or whitish, only a line and a half long; in fruit little accrescent, comivent over the nutlets, soon circumscissile, leaving a persistent base which surrounds the lower half of the nutlets: plants erect and slender, sometimes attaining 2 feet in height: fruiting spikes slender, elongated and sparsely flowered, simple or geminate, or as if paniculate, bractless: pubescence of the herbage soft and minute, or soft-hirsute or hispidulous on the lower leaves.

P. nothofúlvus, Grax, 1. c. 285. Myosotis fulva, Hook. Fl., in part, \& Bot. Beech. 369, only. Eritrichium fulvum, A. DC., 1. c. as to Calif. pl.; Gray, Proc. Am. Acad. x. 57, \& p. 192, in part. E. nothofulvum, Gray, Proc. Am. Acad. xvii. 227. Bothriospermum spec., Benth. Pl. Hartw. no. 1873. - Common from Washington Terr. to S. California.

§ 3. Stipitate-fruited species: nutlets straightish but very oblique, carinate on the back; caruncle continuous with the ventral crest, projecting into a short indurated stipe: otherwise much as $\S 2$.

P. ursinus, GRAY, 1. c. 285. Habit rather of $P$. Torreyi, but imparting no violet stain to paper, depressed and tufted, very leafy, hirsute and hispid with short bristles : leaves short, spatulate or upper lanceolate; uppermost oblong, accompanying the clustered or at length more scattered flowers and equalling or surpassing them: corolla very small, hardly exceeding the calyx: lobes of the latter in fruit only a line long, lanceolate: nutlets delicately rugose-reticulate, smooth, the caruncle little projecting. - Echidiocarya ursina, Gray, Proc. Am. Acad. xix. 90. - S. California, in Bear Valley of the San Bernardino Mountains, Parish. Adj. Lower California, Orcutt.

P. Coóperi, Grar, 1. c. Diffusely branched from the base, with sparsely-leaved ascending flowering stems a span to a foot long, more slender, hispidulous : leaves spatulate-linear to oblong-lanceolate: spikes at length sparsely flowered, sparingly bracteate or above bractless : corolla more conspicuous, with limb 2 or 3 lines broad: nutlets more trigonous and reticulate-rugose, dentate-muriculate on the reticulations: caruncle more stalk-like and porrect. - Echidiocarya Californica, Gray, Proc. Am. Acad. xii. 164, \& p. 199. - Lower California, from San Diego to San Bernardino and southward, first coll. by $\mathrm{Dr}$. Cooper.

§ 4. Hrpsotra. Nutlets (as the name denotes) inserted by a high scar, i. e. between the middle and the apex, ovoid, obliquely incumbent, little obcompressed but rather turgid, nearly straight, rounded laterally, neither rugose nor muricate, ventrally carinate only above the round scar, which is attached to the depressed gynobase by a small and soft (when dry rather fragile) false caruncle: coarse and rough-hispid low annuals, much branched; with oblong or lanceolate leaves, the upper subtending and equalling or exceeding the flower-clusters, which apparently never extend into naked spikes; the 5-parted calyx open in fruit. - $\$$ Anomali, Gray, Proc. Am. Acad. xx. 286. Almost congeneric with Microula of Tibet.

P. híspidus, GRAY, 1. c. Half a foot high : lower leaves linear-spatulate, upper oblong: nutlets turgid, acute at apex, obscurely carinate on the back, opaque, papillose-granulate, the scar hardly above the middle. - Truckee, on the eastern border of California, Mrs. Layne-Curran.

P. glomerátus, Grsy, 1. c. Stouter: leaves mostly ovate-oblong: nutlets larger (a line and a half long), less turgid, more oval and obtuse, flatter and not carinate on the back, smooth and somewhat shining, but with obscurely undulate-rugulose surface, the scar between the middle and the apex. - Western part of Nevada, between Carson and Virginia City, Mrs, Layne-Curran. 
13. ECHIDIOCARYA, Gray.

E. Arizónica, GraY, p. 199. The genus now restricted to this species, and characterized accordingly. Collected in Arizona, also in adjacent Sonora, Mexico, by Pringle.

\section{2. (now 14.) AMSINCKIA, Lehm.}

A. intermédia, Fisch. \& MLrer, p. 198. To this belongs Echium Menziesii, Lehm, Pugill. \& Hook. Fl. ii. 89. Probably this most cummon species and A. spectabilis are one, differing only in the size and length of the corolla.

\section{LITHOSPÉRMUM, Tourn. P. 203, to first section add :-}

L. glábrum, Gray. A low species of an Old World type, somewhat like L. incrassatum, branched from the annual root, smooth and very glabrous, except some minute appressed pubescence : leaves spatulate-linear: spikes of the inforescence when evolute dense, bractless: flowers nearly sessile: calyx with spatulate-linear segments as long as the white corolla, in fruit appressed to the axis, accrescent, upper portion foliaceous, the base ind $\mathbf{n}$ rated, with midribs greatly thickened : nutlets oblong-ovate, somewhat triquetrous, opaque, nearly smooth, the basilar areola rather small. - Proc. Am. Acad. xvii. 227. - A pache Pass, S. Arizoun, Lemmon.

L. Víride, Greeve. (Of the group with habit of Onosmodium to which belongs L. discolor, L. Palmeri, Watson, \&c.) A foot or two high, paniculately branched, fiuely sericeouspubescent, not at all hispid: leaves broadly lanceolate, somervhat canescent beneath: corolla salverform (three fourths inch long), pale green, sericeous-pubescent outside, with tube nearly twice the length of the linear sericeous-hirsute sepals, slightly contracted orifice, and rounded oval lobes (only a line long) widely spreading: nutlets smooth and ivorywhite, not angled, an acute expanded margin around the scar. - Bot. Gazette, vi. 158. Mimbres Mountains, New Mexico, Greene.

L. tuberósum, RUGEL, p. 203. Exclude the Texan plants referred here (fruiting specimens only). They belong apparently to Onosmodium Bejariense.

L. multiflórum, TORR., p. 204. Flowers heterogone-dimorphous, both forms now known, as also of the following species, which ranks next to it.

L. Cobrénse, Greese, 1. c. 157. Many-stemmed from a tap-root and a rosulate tuft of radical leaves, canescently strigulose (greener in age) or appressed-hirsute, and the spatulate lower leaves hispid : cauline leaves linear, obtuse, short: corolla half-inch high and with ample equally broad limb. - Common from western border of Texas through New Mexico and Arizona ; first coll. by Wright, and wrongly referred to $L$. canescens, - from the range of which this southwestern district is to be excluded.

\section{CONVOLVULACE无.}

\section{IPOM⿻E, L.}

I. hederácea, JACQ., p. 210. A remarkảble form, seemingly of this species, perhaps a hybrid with I. purpurea, is

Var. integriúscula, with ample leaves caudately acuminate, either entire or some with salient lateral teeth. - Shell Islands, at the mouth of St. John's River, East Florida, Curtiss.

I. Thúrberi, Grax, p. 212, should be removed to the foot of p. 210 : for it proves to be of the Pharbitis section, and normally with a 3-lobed stigma and 3-celled ovary (only by variation 4-celled) : corolla 2 inches long, with slender tube much longer than the funnelform limb and throat, purple. - Proc. Am. Acad, xix. 90. - Coll. in flower in S. Arizona, Lemmon. 
I. carnósa, R. Br. Prodr. 485. This proves to be the oldest name in the genus for $I$. acetostefolia, Rom. \& Schult., and p. 211, and has been taken up as such.

I. capillácea, Dos, Syst. iv. 267. Takes the place of the preoccupied name I. muricata, Cav., p. 214. I, armata, Rœm. \& Schult., is still earlier, but is obviously false. The genuine species has an oblong tuber, erect stems and branches a foot or more in height, leaves of such slender divisions as to justify the present specific name, and peduncles hardly longer than the calyx. The commonest form in Mexico, extending to Venezuela: in Arizona forms occur between this and

Var. pátens. Stem and branches short and diffusely spreading: divisions of the leaves from filiform to narrowly linear and obtuse. - Not rare in Arizona and New Mexico. In Northern Mexico, Parry \& Palmer's 626 and Palmer's 910 are characteristic, and of the broader-leaved kind.

I. Plúmmeræ. 'Tuber globose (not half-inch in diameter) : stem declined-trailing or even disposed to twine, a foot or so long: divisions of the mostly pedate leaves from narrowly spatulate-linear to nearly filiform: peduncle hardly shorter than the (inch long) corolla: otherwise like the preceding, with which it has been confounded in the collections. $-\mathbf{S}$. Arizona, Wright, Loew, and Mr. \& Mrs. Lemmon (no. 2839), who pointed out the characters. Wherefore Mrs. Lemmon's maiden name is given to it.

I. cuneifólia, Grax. Tuber, peduncles, flowers, and habit of the preceding: leaves simple, cuneate, laciniate-dentate at the broad apex, tapering into a short petiole, coriaceous in texture, nervose.-Proc. Am. Acad. xix.90.-S. Arizona, in the Huachuca Mountains, Lemmon.

I. Lemmóni, GrAY, I. c. Very like I. leptotoma, p. 214, but perennial from a thick oblong tuber, smooth and glabrous throughout, even to the calyx : stem feebly turning: divisions of the pedate leaves narrowly linear, elongated (often 2 inches long): peduncle filiform, as long as the slender petiole, one-flowered ; the pedicel above the linear-subulate bracts very short : sepals oblong, acute, thin, with midrib slightly muriculate : corolla long and narrow (2 inches long), rose-color. - S. Arizona, in the Huachuca Mountains, Lemmon.

I. tenuíloba, Torr. Needs a separate subdivision at end of the genus: slender stems freely twining: root unknown : plant glabruus and smooth : leaves pedately parted; the divisions 5 or 7 , filiform, entire (inch and a half long), much longer but hardly broader than the petiole: pecluncle stouter and longer than the petiole, one-flowered: calyx-lobes oblong, thinnish, macronate-acuminate : corolla, \&c., apparently nearly as in I. sagittata. Bot. Mex. Bound. 148 (excl, the remark on no. 1617, which was accidentally transposed from the account of $I$. longifolia) : by oversight omitted from the Flora. - Hills near Puerto de Paysano, W. Texas, Bigelow.

\section{JACQUEMÓNTIA, Choisy. (Genus too near Convolvulus.)}

J. tamnifólia, Griseb., p. 214. Add syn.: Convolvulus condensatus, Bertol. Misc. Bot. xiv. 18, t. 2.

$J$. Prínglei, Gray. Of the $J$. violacea type, near $J$. alnutiloides, Benth., of Lower California, equally of $A$ butilon aspect, erect and diffuse from a woody base, not at all twining : leaves cordate, mostly acute or short-acuminate, entire, an inch or half-inch long, canescenttomentose, also a glabrescent form: peduncles longer than the leaves, loosely 2-4-flowered: pedicels short: sepals ovate, the two inner thin and much smaller: corolla white, with limb nearly an inch broad. - Proc. Am. Acad. xvii. 228. - Santa Catalina Mountains, S. Arizona, Pringle.

\section{CONVOLVULUS, L.}

Calystégia paradóxa, Pursh, referred to on p. 215, is to be absolutely excluded from our flora. The original, identified in Sherard's herbarinm, is Convolvulus sagittatus of Sibthorp, C. hirsulus, Bieb., of Greece. See Proc. Am. Acad. xvii. 228.

C. Catasbeidisa, Pursh, is one of the ambiguous forms between C. sepzum, var. repens, and C. spithamceus, as seen in the Sherardian herbarium. 
Convolvulus Sheránd, Pursh, Fl. ii. 730, does not belong to our flora. It was founded on an incomplete fruiting specimen, West Iudian (not from "Carolina"), of C. micranthus, Rom. \& Schult. Vide Proc. Am. Acad. 1. c.

In the first edition the character of $\S$ CALYSTEGIA has "stigmas very flat" : but in living plants, those of $C$. sepium are thick, papillose, hardly flattish, or even terete, as some authors have stated. But they are soft and flatter in drying. As a genus Calystegia entirely fails in North America, as is seen in a series of species which now, with better material, are hero reconstructed.

C. sépium, L., var. Americánus, p. 215. Stigmas in dried specimens from broadly oval (as in the Old $W^{-}$orld) to narrowly oblong: flower always solitary. - Ifere cioubtless C. Maximiliani, Nees, P1. Neuwied Trav. 17. - Extends to the Pacific const in Oregon and California. Some of it has been referred to $C$. occidentalis.

C. macrostégius, Grenxe. Like C. sepium, but "suffrutescent" and largo (leares 4 inches long and little narrower): peduncles 6 to 8 inches long, bearing 2 or 3 flowers withiu the ample (inch or more long) bracts, and lateral flowers similarly bracteate: corolla short and broad, cream-color (or "pale yellow," Greere): stigmas rather broadly linear. - Bull. Calif. Acad. i. 208. C. occidentalis, Watson, Proc. Am. Acad. xi. 118. - The original is of Guadalupe Island, off Lower California, Palmer. Also San Clemente, off San Diegro, Lower California, Terin \& Lyon.

C. Califórnicus, Chогsy, p. 215. This depressed and never twining species extends to the coast rauges of Oregon (Howell, Henderson) in a glabrous form, some flowers with broader stigmas, bearing a certain likeness to $C$. Soldanella.

C. villósus, Grar, p. 216. Not at all or only feebly twining: the tomentose bracts to the flower, although more commonly entire and erect, are occasionally, in the most wlite-velvety plants, one or both of them, hastate and short-petioled, so passing directly iuto

Var. fulcrátus. Greener, the soft pubescence short and fine : leaves either broadly hastate (as in the type) or narrow and more sagittate; the bracteal pair similar but small, either a little below the flower, or at the base of the calyx, occasionally one or both of them entire: corolla (according to Cooper) pale yellow, probably only cream-color: stigmas linear. - C. luteolus, var. fulcratus, Gray, p. 216, and the only C. luteolus of which there is good evidence of yellow or yellowish corolla! C. fulcratus, Greene, Bull. Calif. Acad. i. 208.

C. occidentális, Grar, p. 215. Character needs emendation only in reference to the extreme variability of the bracts : these either Calystegia-like and covering (but rarely surpassing) the calyx, or variously smaller and shorter, or lanceolate or liuear and more foliaceous in texture, then at a little distance below the calyx, always in a pair, except on the 2-3-flowered peduncles, when they may be disjoined. Whevever, as in the original of the species, there is more than a single flower, the bracts are small and narrow. Specimens with solitary flower and ample bracts referred here belong to $C$. sepium. Generally herbaceous or with barely suffrutescent base, but Mr. Greene finds stems woudy to a considerable height. The form with diminished bracts is C. luteolus, Gray, p. 216 (excl. var.), but everywhere with white corolla, or roseate in fading. So that this last name happily disappears.

Var. tenuíssimus, GraY, p. 215. The commoner form, throughout S. California, in the drier regions usually reaching only a foot or a yard in height: leaves from lanceolate- to linear- or even filiform-hastate : bracts Calystegia-like, either acuminate aud surpassing the calyx, or oblong and barely equalling it. This may pass into

C. lóngipes, WATson, p. 217, which was described from mere branches. It has no bracts, the uppermost reduced subulate leaves are scattered and always alternate.

C. Havanénsis, JACQ. Suffruticose, prostrate or feebly twining, canescently puberulent and glabrate : leaves thick, oblong-lanceolate or elliptical, sometimes orbicular, obtuse or retuse and mucronate, entire ( 6 to 12 lines long), abruptly contracted into a short petiole: peduncles one-several-flowered: pedicels longer than the calyx : corolla white, not over halfinch long, deeply 5-cleft: lobes acute : stigmas oblong : capsule splitting into several valves. -Obs. ii. 25, t. 45, fig. 3 (flower and leaf); Griseb. Cat. Cub. 207. C. muderarius, HBK. Nov. Gen. \& Spec. iii. 96. C. Garberi, Chapm. in Bot. Gazette, iii. 11. Ipomaca Haranensis, Choisy in DC. Prodr. ix. 368, referred to that genus at a mere venture. C. Jamaicensis, of 
some authors, hardly of Jacquin, but if they run together this (in Ols. iii. 5) is a later name. C. Valenzuelanus, A. Rich., ex Griseb. Cub. - S. E. Florida, on the Keys and near the coast, Garber, Curtiss. (Cuba, Bahamas, \&c.)

C. ARvínsis, L. Now well naturalized in California.

C. Pentapetalofues, L. Diffusely branched and slender annual, with spatulate-lanceolate mostly entire leaves: peduncles bearing a single small flower, with purplish corolla only 3 lines long and deeply 5-cleft. - Cav. Ic. ii. 20, t. 123; Sibth. Fl. Græca, t. 197. Breweria minima, Gray, Proc. Am. Acad. xvii. 228. - In. grain-fields and on hills, through W. California. (Nat. from S. Eu.)

\section{BREWERIA, R. Br.}

The first division, containing $B$. ovalifolia, p. 217, which is probably large-flowered, needs slight alteration, as to length of peduncle, for the following related and remarkable species.

B. grandiflóra, Grar. Minutely sericeous-puberulent: root tuberous : stems procumbent, 2 or 3 feet long: leaves broadly oval or some orbicular, an inch or two long, very shortpetioled: peduncles rather shorter than the leaf, one-flowered, bearing two subulate bracts at base of a stout pedicel: sepals broadly lanceolate, the two outer a little shorter than the inner (these in fruit an inch long, surpassing the capsule) : corolla funnelform from a rather long tube, blue, 3 inches in length: styles capillary, distinct nearly to base: stigmas globose. -Proc. Am. Acad. xv. 51. - Coast of S. Florida, at Manatee, \&c., Garber.

B. humistráta, p. 217. The syn. Convolvolvulus and Evolvulus? Sherardi to be erased; the plaut in herb. Sherard being Convolvulus micranthus and W. Indian.

\section{EVÓLVULUS, L. Next to E. Arizonicus, p. 218, add:-}

E. lǽtus, Grax. Sericeous-canescent throughout, and with some soft villous pubescence, much branched from a suffrutescent base, ereat or barely spreading, 6 to 10 inches high, leafy: leaves sessile, oblong-lanceolate, half-inch long: peduncles 1-3-flowered, surpassing the leaves : corolla bright blue, with limb fully half-inch in diameter. - Proc. Am. Acad. xvii. 288. - Mountains of S. Arizona, Pringle, Lemmon.

E. sericeus, Swartz, p. 218. The stouter varieties which prevail in W. Texas, Arizona, and adjacent Mexico, pass freely into

Var. discolor (E. discolor, Benth. Pl. Hartw.), a more depressed form, with the lower leaves, or those of abbreviated stems, all of them oblong or lanceolate-oblong and obtuse. Arizona and New Mexico, Greene, Lemmon, Pringle, \&c.

\section{SOLANACEA..}

Withania Morisoni, Dunal, p. 224. The original is W. somnifera, and Morison does not say that he had it, but only sometling like it, from Virginia.

\section{SOLANUM, Tourn.}

S. Douglásii, Dowal (S. nigrum, var. Douglasii, p. 228), common through California and in Arizona, and clearly indigenous, is a woody-stemmed perennial, and should rank as a species.

6. CHAM ÆSÁRACHA, Gray. Add to char.: Corolla with roundish and tomentose twin elevations at the throat, alternate with the stamens.

C. Corónopus, p. 232. Corolla greenish-white (not " yellowish"), the appendages in the throat large and protuberant. 
Chamesaracha physaloides, Greene, in Torr. Bull. ix. 122, is Physalis lobata, Torr.

Bellinia imbellata, Rœm. \& Schult. (Siaracha umbellata, Don; Gray, Proc. Am. Acad. xix. 91), a common Mexican species, was collected by Lemmon in S. Arizona, on the Mexican frontier, perhaps only adventive. The genus is known from the present and from Physalis by the enlargemeut and rotate expansion of the fructiferous calyx under the berry into a nembranaccous 5-angled plate.

\section{MARGARÁNTHUS, Schlecht. P. 237, add a second species,}

M. Lemmóni, Gray. Very much branched and decumbent, more leafy : leaves all quite entire : caly $\mathrm{x}$ more deeply 5-dentate; the teeth at length half the length of the tube : corolla white, campanulate-urceolate above the very short tube; orifice obtusely 5-lobed. (It might be $P$ hysalis minutiflora, Moç. \& Sesse, but leaves not at all repand, as they are in $M$. solanaceus. - Proc. Am. Acad. xix. 91. - Cave Cañon, S. W. Arizona, Lemmon.

\section{LYCIUM, L.}

L. Ríchii, Grsy, Proc. Am. Acad. v. 46. Name to take the place of the later L. Palmeri, Gray, p. 238 (Proc. Am. Acad. viii. 292); abundant at All Saints' Bay, Lower California. L. quadrifidum, Dunal, founded on a rude figure, might be the same, except for larger size and much shorter tube of corolla, so that it is with more probability referred to L. Carolinianum by Miers.

L. mácrodon, GkAY, p. 238. Rediscovered by Pringle, beyond the border of S. W. Arizona, on the Altar River; has remarkably long and uarrow calyx-lobes, white corolla tinged with green, and a very large hypogynous disk of a deep orange color.

L. Califórnicum, Notr., p. 238. Distinguished by its fleshy leaves, and limb of the small tetramerous corolla nearly as long as the tube. - Common on the coast of S. California from Santa Monica to San Diego.

Var. Arizónicum. Leaves bright green, extremely fleshy, the small ones of the fascicles on the branchlets pyriform or globular! - Desert of Arizona, Parry (imperfect specimen was referred to L. parviflorum), at Lowell, Parish, and Maricopa, A. Gra.

L. parviflórum, GRAY, p. 239. S. Axizona, Thurber, Pringle. May pass into L. barbinodum (which is not within our limits), but does not show the tomentulose nodes of the fascicles.

L. Fremónti, Gray, p. 239, is not uncommon in Arizona (coll. Parry, Vasey, \&c.), and it passes into the equally abondant

Var. gracílipes, L. gracilipes, Gray, p. 239, with pedicels from a third to half an inch long, often quite as long as the flower. - S. Arizona, Parzs, Pringle, \&c.

Other puberulent species, the first two more or less extra-limital, are :-

L. exsértum, Gray. Very much like the last preceding: leaves spatulate (not over halfinch long): pedicels hardly half-inch long, about the length of the corolla: lobes of the calyx acute, shorter than the tube: corolla-lobes very short, triangular-ovate, reflexed: gtamens much exserted. - Proc. Am. Acad. xx. 305. - Near Altar, in N. W. Sonora, Pringle.

L. Prínglei, Grap, 1. c. Cinereous-puberulent: branches slender: leaves spatulate and oblanceolate (about quarter-inch long): pedicels 2 or 3 lines long: calyx with oblong and obtuse foliaceous lobes equalling or longer than the tube and almost equalling the tube of the corolla, which is barely 3 lines long, and longer than its own 5 roundish lobes: stamens ghorter than the corolla lobes; filaments densely bearded at base. - In stream-beds, N. W. Sonora, near the boundary, Pringle.

L. Paríshii, Grar, 1. c. Resembling the preceding, equally small-leaved and puberulent: pedicels 2 or 3 lines long: corolla narrowly fumelform (5-lines long), thrice the length of the obtusely and rather short-lobed calyx, with short 5-lohed limb; the lobes a line long; ovate, obtuse, at length equalled by the stamens. - Mesas in the San Bernardino Valley, S. California, Parish. 


\section{CESTRUM, L.}

C. PARqui, L'Her, of Chili and Buenos Ayres, cultivated in many warm countries, appears to have become spontaneous at San Antonio, Texas, coll. Dr. Ball, Palmer. Palmer's plant is C. multinervium, Watson, Proc. Am. Acad. xvii. 128: so probably is that of Dunal.

\section{NICOTIÁNA, Tourn. Append to genus, on p. 243:-}

N. Grad́ca, Grafam. Arborescent, soft-woody below, glaucous and glabrous : leaves longpetioled, ovate and subcordate, entire or repand : flowers loosely paniculate : corolla greenish becoming yellow, inch or two long, tubular, contracted at throat, and with erect 5-crenate limb not longer than the orifice. - Bot. Mag". t. 2837. - Native of Buenos Ayres, not rare in cultivation, rather widely naturalized in $\mathrm{S}$. California and $\mathrm{S}$. Texas.

\section{SCROPHULARIACE E.}

Digitalis purpurea, L., the Foxgrove, the type of the tribe Digitalea, p. 248, is locally naturalized in British Columbia, on the Pacific coast.

\section{ANTIRRHINUM, Tourn.}

A. Virga, GRAr, p. 252, is a perennial, the larger plants branched from the base and becoming 6 or 7 feet high: corolla purple. Recently collected in Lake Co., Cleveland, Rattan.

The Californian species (of ++ ), which are prehensile by lateral shoots acting as tendrils, now augmented, may be defined as follows:-

A. Coulteriánum, Bentr., p. 252. Marked by its truly spicate inflorescence, and comparatively large corolla, with very protuberant palate greatly exceeding the short upper lip.

A. Orcuttiánum, Gray. Nearest the preceding, more slender, smaller-flowered, glabrous up to the loosely spicate inforescence, which is more disposed to bear tortile branchlets: corolla about 4 lines long; lower lip not much larger than the upper: leaves linear or lowermost spatulate-lanceolate: seeds tuberculate-favose. - Bot. Gazette, ix. 53.-Near San Diego and adjacent Lower California, Orcutt.

A. Neviniánum, Grar, 1. c. Much resembles the foregoing : seeds longitudinally cristate-costate, as in A. Nuttallianum. - Los Angeles Co., at San Juan Capistrano, Nevin, and near San Diego, Orcutt.

A. Nuttalliánum, Benтr., p. 253. Well marked by the scattered slender-pedicelled flowers (with short comparatively equal-lipped corolla not over 4 lines long), all subtended by ovate leaves or leaf-like bracts, and principal leaves distinctly petiolate: seeds acutely cristate-costate. Extends well into Arizona, \&c.

A. subséssile, Gray. Erect and less diffuse than the foregoing, which it most resembles, extremely glanclular-viscid: flowers more racemose, longer than the pedicels or even subsessile; lower lip of corolla large in proportion : leaves ovate, all sessile or nearly so : seeds of the preceding. - Bot. Gazette, ix. 53. - San Diego, \&c., Cleveland, Orcutt, and Santa Catalina Island, Schumacher.

A. subcordátum, Gray. Of the group with flowers sessile or subsessile in the axils of sessile leaves, and very unequal calyx, to which belong $A$. vagans and $A$. Breveri: rather large and stout, pubescent or below hirsute: lower leaves unknown; upper closely sessile, ovate, subcordate, thickish: flowers half-inch long: upper sepal large and oval, longer than the rest, which are linear-lanceolate: corolla half-inch long, with ample throat and almort equal lips, ochroleucous: longer filaments dilated at apex: seeds favose and the edges of the pits muriculate. - Proc. Am. Acad. xx. 306. - Stony Creek, Colusa Co., California, Rattan. 
A. vágans, Grat, p. 253. Add syn.: A. vexillo-calyculatum, Kellogg, Proc. Calif. Acad.v. 27 , fide Layne-Curran.

A. Kingii, Warson, p. 253. Extends from Arizona and the eastern border of California to S. E. Oregon. $-A$. Kelloggii, Greene, in Torr. Bull. x. 126.

\section{In $\S$ Maurandella, p. 253.}

A. stríctum, Gray, p. 253, was badly named. It becomes weak, lax, and climbs by its tortile peduncles, often to a yard in height. - Santa Barbara to San Diego.

A. fílipes, Grap, p. 354. With hardly a doubt this was founded on a depauperate-flowered and very attenuate form of the $A$. Cooperi, Gray, Proc. Am. Acad. vii. 376, which has the fully developed flowers. The characters should be combined under the former and older name. - In cañons, from N. W. Arizona to San Diego, where apparently it alșo produces small corollas.

\section{In $\S$ Gambelia, p. 354 .}

A. speciósum, Grax, p. 354 . Corolla has short or small, but not "narrow" lips, and the palate closes the throat: so that the character of the section needs correction. - Inhabits also San Clemente Island, Nevin \& Lyon.

A. júnceum, Gray, p. 354. This is Saccularia Veatchii, Kellogg, Proc. Calif. Acad. ii. 17, $\&$ Bull. Calif. Acad. i. 144, with colored plate, reproduced from "The Hesperian," July, 1860. The plate shows a plane lip, with no palate at all. The dried flowers show the palate, which, seemingly, cannot close the orifice. It has not been found very near the U. S. boundary.

\section{MOHÁVEA, Gray.}

M. víscida, Gray, p. 255. Add syn. : Antirrhinum confertiflorum, Benth. in DC. Prodr. x. 592.

\section{COLLINSIA, Nutt.}

C. lineáris, Grar. (To stand near C. grandiflora, p. 256, but peculiar.) A foot or two high, paniculately branched, glabrous or inflorescence minutely glandular-puberulent: leaves elongated linear ( $1 \frac{1}{2}$ to 3 inches long, a line or two wide), entire, or the radical ones lanceolate-spatulate and obscurely dentate; uppermost reduced to small bracts: pedicels 3 to 6 in the whorls, filiform, about equalling the flowers: calyx-lobes triangular-lanceolate, acute: corolla much declined, gibbose-saceate, half-inch long, light blue, with lips longer than the tube and throat, upper with a slightly prominent and 2-lobed callus : rudiment of sterile stamen filiform-subulate: ovules 3 in each cell : seeds meniscoidal. - Proc. Am. Acad. xx. 50. - Northern part of California, Greene, Rattan, and adjacent part of Oregon, Howell.

C. Rattáni, Gray, 1. c. (Between C. parviflora and C. Parryi.) A foot or less high, barely puberulent, and inflorescence obscurely glandular: stem strict, nearly simple: cauline leaves narrowly linear and entire (inch or two long), or lowest short and oblong, somewhat dentate; lowest or radical spatulate and very small: pedicels 2 to 4 (3 lines long), about the length of the flower: calyx-lobes broadly lanceolate, rather obtuse: corolla violet or purple, small, little declined, with lips only a line or two long, the upper with a double callosity : rudiment of sterile stamen subulate : ovules not more than two in each cell : capsule equalling the calyx : seeds meniscoidal, margined. $-\mathrm{N}$. California from Mendocino Co. northward (Rattan) to Oregon, Howell, and Washington Terr., Suksdorf.

\section{PENTSTEMON, Mitchell.}

P. Menziésii, Hook., var Scoúleri, GrAy, p. 260. Add : Hook. f. Bot. Mag. t. 6834.The two following must needs be taken as good species of this section. Both have a quite naked sterile filament, and very long-woolly anthers. 
P. Barréttro. A foot or two high, and glabrous throughout, very glaucous, rigid : flowering stems leafy up to the thyrsoid inflorescence: leaves ovate and oval, entire or serrulate, an inch or two long; cauline closely sessile by a broad base: sepals short, scarious-coriaceous, oblong-lanceolate, acute or short-acuminate : corolla an inch and a half long, rosepurple. - Mountains of Hood River, Oregon, near its confluence with the Columbia, Mrs. Barrett. Here may belong an insufficient specimen from the northern side of the Columbia, collected by Sulsdorf.

P. Lýalli. Puberulent or nearly glabrous up to the racemiform inflorescence: flowering stems 2 feet high and herbaceous (the base unknown): leaves elongated linear or linearlanceolate, 3 to 5 inches long, 2 to 4 lines wide, sparsely serrulate: sepals linear-lanceolate and attenuate-acuminate : corolla inch and a half long. $-P$. Menziesii, var:? Lyalli, Gray, Proc. Am. Acad. vi. 26, referred to on p. 260, under var. Scouleri. - N. W. Montana, on the borders of Brit. Columlia, Lyall in 1861, and Missoula Cañon, Watson, 1880; also Wigwam River, British Columbia, Macoun, 1884.

P. ternátus, Torr., p. 260. Corolla equally 4-cleft at summit, and the lobes equally ascending, upper lobe or lip sometimes a little shorter and 2-lobed at summit.

P. Rothróckil, Gray, p. 260. San Jacinto Mountains, S. E. California, at 8,000 feet, Parish. A foot or two high, woody below : curolla reddish, half-inch long.

P. baccharifólius, Gray. Not Mexican : for $P$. coriaceus, Schaffner in herb. (referred in Hemsl. Biol. Centr.-Am. Bot. ii. 443, to this species as var. Schaffneri), differs not only in the smoothness and entire leaves, but in the shape of corolla and dehiscence of the anthers.

P. labrósus, Hook. f. Next $P$. barbatus, p. 261, and much like it, narrower leaved: inflorescence almost simply racemose : corolla more slender, light scarlet, destitute of beard; limb longer; lobes of the 3-parted lower lip linear, equalling the upper, spreading, fully half the length of the tube. - Bot. Mag. t. 6738, \& Gard. Chron. 1883, ii. 536, fig. 91. P. barbatus, var. labrosus, Gray, Bot. Calif. i. 622. - S. E. California, on Mount Pinos, Kern Co., Rothrock, and Grayback, San Bernandino Co., Parry \& Lemmon, H. G. Wright. Also Cantillas Mountains over the Mexican boundary, Orcutt.

P. nudiflórus, Grar. Ambiguous between the Speciosi and the Genuini: anther-cells strictly divaricate, elongated oblong, dehiscent through the whole length, but not explanate: glabrous and glaucescent: stems simple, strict, 2 feet or more high, bearing below 2 or 3 pairs of ovate-lanceolate partly clasping leaves, above bearing a long and loose naked thyrsus: peduncles subtended by minute subulate bracts, elongated, about 2-flowered: sepals short, broadly ovate : corolla inch long (purple?), with much ampliate throat from a narrow tube of double the length of the calyx; lips short and spreading: stamens slightly exserted from the throat: sterile filament pilose-bearded for nearly its whole length. Proc. Am. Acad. xx. 206. - Northern Arizona, near Flagstaff, Lemmon.

P. Havárdi, Gray, After P. Wrighii, p. 264, which it resembles in herbage, but longflowered, wholly smooth and glabruus, glaucescent, 2 feet high: leaves coriaceous, entire, oval or oblong; lower long-petioled; upper smaller and half-clasping; those of the elongated and virgate racemiform thyrsus reduced to small or minute bracts: peduncles very short, 3-5-flowered, but pedicels slender: sepals short, oval, obtuse : corolla (apparently violet or blue) tubular, inch long (throat not over 3 lines wide), and lips only 2 lines long; upper erect, 2-lobed; lower spreading and 3-lobed; lobes roundish : sterile filament filiform, naked. - Proc. Am. Acad. xx. 306. - Guadalupe Mountains on southwest frontier of Texas, Havard. (Mex.?)

P. centranthifólius, Benth, p. 264. Flowers occasionally yellow, near San Bernardino, S. Califoruia, Purish.

P. Clevelándi, GrAy, p. 265, where it is partly mixed with the next. Leaves rigid, ob. long or ovate, acutely and rigidly dentate, uppermost usually connate into a disk : thyrsus narrow: corolla crimson, three-fourths inch long, with narrow throat: sterile filament bearded above: stem lignescent at base. - Proc. Am. Acad. xvii. 229. - Exclude the Cucamonga habitat.

'P. Paríshii, Gray. Wholly herbaceous : leaves less coriaceous, lanceolate or ovate-lanceolate, entire or minutely denticulate; upper half-clasping by subcordate base, but not connate: thyrsus more paniculate, sometimes effuse: corolla red, an inch long, with throat 
more dilated : sterile filament wholly naked. - Proc. Am. Acad. xvii. 228. - S. California, near San Bernardino, to San Diego Co., Wallace, Parish, W. G. Wright.

P. stenophýllus, Gray, p. 266. P. rubescens, Gray, I'roc. Am. Acad. xix. 32, belongs to this species, the discolored flowers having been taken for red instead of purple or violet. Common through S. Arizona, Lemmon, Pringle, and Northern Mex., Palmer, sichaffner.

Var. dasyphýllus, $P$. dasyphyllus, Gray, p. 266, a form with leaves aud lower part of stem thickly beset with short retrorse pubescence (New Mexico and adjacent Texas as well as Arizona), varies into the glabrous state of the species.

P. lanceolátus, Bentri., p. 266. Habit of the Elmigera section : stem a foot or two high, herbaceous to the base or nearly, miutely puberulent or glabrate and the simpler inflorescence glandular: leaves from lanceolate to narrowly linear : corolla scarletred, an inch and more long, narrowly funnelform; upper lip erect and 2-lobed, lower 3-parted and spreading: sterile filament glabrous: anther-cells short-oval, explanate in age. - P'l Hartw. 2.2. $\quad$ P. pauciflorus, Greene, Bot. Gazette, vi. 218, narrow-leaved form. - Bluffs of the Gila, S. W. border of New Mexico, Greene. Rucker Valley, S. Arizona, Lemmon. (Mex.)

P. pinifólius, Greene, 1. c. Next to the preceding, glabrous throughout: stems a foot or two high, decidedly shrubby, much branched, with the herbaceous flowering branches short and slender, racemosely few-flowered. leaves much crowded on the sterile stems, linearacerose (inch or less long, hardly half a line wide): sepals broadly lanceolate and acuminate, puberulent: corolla an inch or more long, light scarlet, narrowly tubular, not eularged at the throat; upper lip 2-lobed and erect; lower 3-parted and spreading; lobes nearly linear, slightly bearded at base : anther-cells short-oval: sterile filament dilated and bearded abore.-S. Arizona, in the San Francisco and Mogollon Mountains, irecne, and Rucker Valley, Lemmon.

P. miser. Next to $P$. cristatus, p. 266, every way smaller, only a span or two high, pruinosepuberulent, and the contracted inflorescence glandular-viscid but not villous : radical leaves spatulate or obovate; cauline lanceolate, an inch or less long: sepals lanceolate, merely acute : corolla violet or blnish, only half-inch long, rather tubular than funnelform, the throat little dilated, spreading lobes short, base of lower lip moderately villous : sterilc filament with dilated and curved tip hardly projecting from the throat, densely yellow-bearded down one side, the beard stronger and shorter than in P. cristatis. - Eastern Oregon, along the Malheur Rivər, C'usick.

P. Rattáni, Grar. Between P. glaucus and P. Whippleanus : a foot to a yard high, glabrous below, minutely viscidulous-pubescent above: leaves membranaceous, broally elongated-lanceolate, 3 to 8 inches long, thickly denticulate; raclical aud lowest cauline attenuate at base into a margined petiole; the others half-clasping by a subcordate base: flowers glomerate in the interrupted thyrsus: cymes from the lower axils long-peduncled, upper short-peduncled or subsessile: pedicels short or hardly any : sepals oblong-lanceolate, acuminate, soft-membranaceous, loose: corolla curved in the bud, slightly oblique in anthesis, pale purple, inch long, campanulate-ampliate above the short tube; lips short, lower villousbearded vithin : anthers and filaments glabrous : sterile filament at length exserted, bearded with some sparse and long hairs: seeds of the genus. - Proc. Am. Acad. xv. 50. - In forests of N. W. California, in Humboldt Co., 1878-79, Rattan. Except for the wingless seeds, this is most nearly related to Chelone nemorosa, p. 259.

Var. mínor, GRAY, l. c. Slender, with oblong leaves only an inch or two long, obscurely denticulate: thyrsus simple: flowers one half smaller: sepals attenuate: corolla 6 or 7 lines long. - Indian Creek, Del Norte Co., California, Rattan.

Var. Kléei. Intermediate in foliage, inflorescence, and size of flowers between the foregoing variety and the type: sepals oblong, short-acuminate or obtuse. $-P$. Kleci, Greene in Torr. Bull. x. 127. - Summit of Ben Lomond, the highest peak of the coast ranges behind Santa Cruz, California, W. C. Klee.

P. Gaírdneri, Hook., p. 270. The character of alternate leaves (specially noted by Hooker) was overlooked. This holds generally, as to most of the leaves in Washington Terr., coll. Lyall, Howell, Suksdorf, Brandegee. Stems vary from a span to near a foot high.

Var. Oregánus. Strict: leaves (narrow) even the bracteal ones and most of the peduncles opposite. - Mountains of E. Oregon, Cusick, Howell. 


\section{P. læetus, Gray, p. 272. Sepals oblong to ovate-lanceolate, and from hardly acute to} acuminate.

Var. leptosépalus, Greene, in herb. Sepals long-acuminate from a broadish base, or linear-attenuate (4 or 5 lines long), loose: occurs both with uarrow linear-lanceolate and with broader lanceolate leaves. - Butte Co., California, Mrs. Austin.

P. cásius, Gray. Next to $P$. Roezli. Low, a span to a foot high from a cespitose lignescent base, glabrous up to the peduncles, glaucescent or glancuus : leaves coriaceous, veinless; radical and lower cauline orbicular or subcordate or spatulate-obovate (half or twothirds inch long), abruptly contracted into an equal or longer petiole; upper cauline one or two pairs, narrow and sessile: thyrsus loose and few-flowered: sepals oblong, pruinoseglandular, as also the short pedicels and oceasionally thc longer peduncles : corolla violet or purple, barely three-fourths incl long, tubular with slight cnlargement upward, and with very short lobes. - Proc. Am. Acad. xix. 92 - Rocks in the San Bernardino Mountains, S. E. California, Parry \& Lemmon, W. G. Wright, Parish.

P. Cusíckii, GraY. Of the Saccanthera section, before P. Kingii, p. 272. A foot or less high, many-stemmed from a barely lignescent caudex, strict, palo and rery minuteiy pruinose-puberulent, equally leafy up to the racemiform loose thyrsus: leaves very narrowly linear (an inch or two long, little over a line wide), or some of the lower broader and spatulate: peduncles 1-2-flowered: sepals ovate, acumiuatc, glabrous, not glandular: corolla barely three-fourths inch long, bright blue with a purple tubc, a moderately cularged throat, and short lobes: sterile filament spatulate-dilated at tip, rery glabrous. - Proc. Am. Acad. xvi. 106. - N. E. Oregon, on the slopes of Powder River or Eagle Creek, Cusick.

P. Cerrosénsts (which should have been Cedrosensis), Kellogg, I'roc. Calif. Acarl. ii. 19, \& Bull. i. 145, with plate (see p. 273), from Cedros Island, off Lower California, proves to be a good species, and P. brevilabris, Gray, Proc. Am. Acad, xvii. 229, is a synonym. Color of corolla uncertain, but surely not "yellow."

P. Canoso-barbatum, Kellogg, has been identified by Mrs. Curran (in Bull. Calif. Acad. i. 145) with $P$. breviflorus, Lindl., and P. Rostrif Lorum with $P$. Bridgesii: but in the description the color of the flowers of the two has been exchanged.

P. texellos, Kellogg, Proc. Calif. Acad. i. 56, is by the same authority said to be P. azureus, Benth., probably depauperate.

\section{MIMULUS, L. P. 273.}

Revised in the light of E. L. Greene's new arrangement in Bull. Calif. Acad. i. 94-123 (Mimulus, Eunanus, Diplacus), of recent personal observations, and of the original types of Bentham, Hooker, \&c., in the Kew Herbarium. Polymorphons, but better retained entire under five subgenera than divided into as many genera. Diplacus is placed first, as having the best claims to generic distinction, being shrubby.

§ 1. Dírlacus, p. 275. Add char.: Capsule firm-coriaceous, narrow, symmetrical, tardily dehiscent down the upper suture, only after seed-shedding, also later by the lower suture into the two placentiferous valves: yet in some plants simultaneously dehiscent into the two valves. Seeds elongated-oblong. Pubescence when developed partly of branching or somewhat aspergilliform downy hairs.

M. glutinósus, WENDL. Corolla from orange or salmon-color to pale buff. Var. linearis is the most narrow-leaved form; in arid exposures, as Diplacus latifolius is the lroaderleaved and luxuriant extreme. Var. brachypus is the best-marked form, on account of the villous (but deciduous) hairs of the calyx and generally pale corolla.

M. puníceus, $\mathbf{S}$ TEdD. (D. glutinosus, var. puniceus, and part of var. linearis, p. 275), commonly tall and narrow-leaved, with brick-red or blood-red rather than scarlet corolla, and only in Southern California, may be regarded as a species until intermediate colors are met with. 
§ 2. Ǵ́sor, Gray. Corolla (with one exception) large for the plant, and with a long-exserted and slender (even filiform) tube, expanded throat, and obscurely bilabiate limb; the lower lip sometimes small or obsolete: style pubescent above: capsule cartilaginous, unequal-sided, sulcate at the dissepimental sutures, and sharp-edged at the posterior dorsal one, enclosed at first in the narrow prismatic and gibbous-based calyx, long persistent, indeed never detached, very tardily dehiscent, mainly by the posterior suture: placentæ connate in the ovary but early separating in the fruit: purple-flowered and low winter annuals, mostly blossoming from near the root. -- (Pl. Hartw. 329) Bot. Calif. i. 563. Eunanus § Enoe and part of Eunanus proper, Greene, Bull. Calif. Acad. i. 98, 100.

* Capsule small and ovate or oblong-oval, much indurated : pygmy plants, flowering from the ground and remaining very low, the stems in age seldom equalling or much longer than the long-tubed (inch or two long) corollas, barely pubescent, neither glandular nor viscid, vermal.

M. trícolor, Linde. Leaves mostly lanceolate: corolla (when well developed 2 inches long) with ample somewhat regular limb, pink or lilac with a dark crimsou blotch on each of the rounded lobes, the 3 lobes of the lower lip about the length of the two-lobed upper; the throat yellow and browu-crimson, commonly spotted, open funnelform, about half the length of the slender tube: anther-cells bearded at base: stigma of semi-orbicular and slightly unequal lobes united by their edges at base : seeds very uumerous, small, oblong, or obovate-oblong minutely scaberulous, becoming smooth in age. C Comman in the great valley of California, especially on the Sacramento. To the synonymy on p. 274, add Eunanus tricolor, Greene, 1. c. 99. The former character of the fruit aud seeds was taken from a fruiting specimen of $1 /$. Douglasii, through mismatching.

M. angustátus. Exiguous, commouly acaulescent: leaves linear and linear-spatulate: corvlla of the preceding species, except that the filiform tube is 4 to 8 times the length of the short funnelform throat, and the lower lip rather shorter than the upper: lobes of the stigma broadly cuneate: seeds (not here seen) according to Greene "few, large, favosepitted or favose-reticulate." - M. tricolor, var. angustatus, Gray, l. c. Eunanus angustatus, Greene, 1. c. - Mountains of the northern part of Califoruia; first coll. by Bulander.

M. Douglásii, Gray. Leaves obovate or oblong: corolla with crimson.purple 2-lobed upper lip forming the principal limb, the lower lip reduced to a truncate sinuately 3-crenate border, or with a more conspicuous dentiform middle lobe ; the throat brown-purplish, rather narrowly campanulate, about one thirl the length of the tube: capsule somewhat flattened and with one very sharp-eilged dorsal suture : seeds only 20 to 40 in each cell, comparatively large, scurfy-muriculate, becoming smooth in age. - Part of $1 \%$. Douglasii, Gray, Proc. Am. Acad. xi. 95, Bot. Calif. i. 563, \& Syn. F1., p. 274. M. nanus, var. subuniftorus, Ilook. \& Arn. Bot. Beech. 378, coll. Douglas.

M. atropurpúreus, Ke'logg, Proc. Calif. Acad. i. 59, partly, fide Curran \& Greene. Eunanus Douglasii, Benth. in DC. Prodr. x. 374 (not Pl. Hartw.); Greene, Bull. Calif. Acad. i. 98. - Chiefly in the central and northern parts of California, bloomiug very early. Mixed first by Bentham (in Pl. Hartw.) with the following species as to the flowering plant, with which mature fruit of $\boldsymbol{M}$. tricolor was distributed; hence a confusion to which the Syn. Fl. added, and also increased by taking fruit of $M$. Douglasii for that of $M$. tricolor.

* * Capsule short-linear, at length arcuate : caulescent, flowering later and•longer, viscidulouspubescent.

- With long-exseirted filiform tube to the corolla, as of the section.

M. Kellóggii, Currax. Erect, a span or two or becoming a foot high, with internodes longer than leaves : these ovate to obovate or spatulate-lanceolate : corolla crimson-purple; its tube inch long, expanding into a short-funnelform throat and oblique limb; short lobes of lower lip only half the length of the upper and more spreading: stigma with ovate and obtuse unequal lobes, or by their union obliquely peltate: capsule narrow, obtuse ( 4 or 5 lines long and a line thick), rather terete, moderately unequal-sided: seeds comparatively few and large, obovate. - Curran in herb. Gray. M. Douglasii, partly, Gray, Bot. Calif., \&c., as to descr. of fruit. , M. atropurpureus, Kellogg, Proc. Calif. Acad. i. 59, mainly, as to char. 
Eunanus Douglasii, Benth. Pl. Hartw, no. 1894 (excl. ripe fruit described, which is of $M$. tricolor); Gray, Pacif. R. Rep. iv. 120, mainly, not Benth. in DC. E. Kelloggii, Curran, in Greene, Bull. Calif. Acad. i. 100. - Common through middle parts of California. Mistaken by Bentham and myself for a later and caulescent form of $M$. Douglasii, first and well discriminated by Mrs. Layne-Curran.

+ + Ambiguous species, with corolla of $\S$ Eunanus, and little exserted, but with oblique latedehiscent capsule of $\S$ Enoe.

M. latifólius, Gray, p. 274. Extra-limital. The capsule in plant raised from Palmer's seeds appears to be only moderately oblique, linear-oblong, obtuse, and not indurated; but as now received from Mr. Greene, from its native habitat, and fully mature, it is lanceolate, strongly oblique, and as if bent on its broad base; the upper carpel much larger than the other, very gibbous and sharp.edged dorsally, and there very tardily dehiscent.

§ 3. Eunánus, Gray, Bot. Calif. Corolla from tubular-funnelform to nearly campanulate, with either obscurely or manifestly bilabiate limb, the proper tube either moderately exserted or included in the campanulate or oblong calyx : style glandular-pubescent above: stigma usually peltate-funnelform, obscurely 2-lobed or entire: capsule symmetrical, from firm-chartaceous to membranaceous, dehiscent by both sutures into two valves, which bear the separated placentæ: low or occasionally taller annuals, most of them glandular- or viscid-pubescent and heavy-scented.

* Corolla only a quarter-jnch long, slender, only slightly exserted out of the broad and ventricose calyx until elevated on the growing capsule: valves thin-chartaceous.

M. Rattáni, Grar. Viscid-pubescent, a span or two high : leaves oblong; uppęr about equalling the sessile flowers : calyx very viseid, when fructiferons little higher than broad, a little oblique at orifice, and with short ovate teeth : corolla rose-purple, its lobes barely a line long, equal except that the upper are united to near the middle: capsule narrowly ovate-lanceolate, nearly half exserted: seeds oblong-oval. - Proc. Am. Acad. xx. 307. Eunanus Rattani, Greene, Bull. Calif. Acad. i. 105. - Lake and Colusa Co., California, Rattan, Layne-Curran.

* * Corolla a quarter to three-fourths inch long, funnelform or narrower, well exserted beyond. the campanulate or oblong calyx: capsule-val res membranaceous or chartaceous: plants a span or two high and branching when luxuriant, when depauperate dwarf and simple, beginning to blosson from near the root.

+ Caly $\mathrm{x}$ not manifestly oblique at orifice, but lower teeth usually a little shorter. (Species of difficult discrimination.)

M. mephíticus, GreEse. Very viscid-pubescent and stroug-scented : leaves from obovate-oblong to nearly linear : calyx-teeth short, broadly lanceolate, acutish : corolla laalf to two-thirds inch long and with somewhat bilabiate limb 4 or 5 lines broad, bright yellow, often purple-dotted in the throat, sometimes whole throat or even the limb turning reddish : seeds oval. - Bull. Calif. Acad. i. 9. Eunanus mephiticus, Greene, Bull. Calif. Acad. i. 102. - Common in the Sierra Nevada from the Yosemite northward.

M. nánus, Hook. \& ARN. Puberulent and somewhat viscid, or low and early-flowering plants almost glabrous : leaves obovate and spatulate-oblong, all with tapering base : calyxteeth broadly lanceolate or triangular, acutish or when outspread obtuse, but acute when the tips are conduplicate, a quarter or a third the length of the oblong tube: corolla rosepurple with darker or yellow throat, mostly two-thircls or three-fourths inels long; the limb half-inch or less wide, evidently bilabiate and the lower lip a little shorter than the upper: seeds oval-oblong, - (Supra, p. 274, excl, the yellow-flowered form and the var.) California to interior of Washington Terr. and Wyoming, first coll. by Tolmie.

M. Bigelóvii, Gray, p. 274. Viscid-pubescent, sometimes viscidly rillous : leaves nearly of the preceding or more acute, the upper ovate and acuminate: calyx-teeth triangular and acuminate or subulate-acute, about half the length of the tube: corolla crimson, sometimes with a yellow eye, three-fourths inch long when well developed, narrow up to the abruptly 
much dilated throat and expanded slightly bilabiate limb, this half to three-fourths inch in diameter and rotately expanding : seeds oval to oblong. - Belongs mainly to the southern and eastern parts of the Sierra Nevada, and extends from the borders of Arizona to the interior of Washington Terr.

Var. ovátus. More rigid, a span to near a foot high, at length spicately flowered, all the floral and even most of the lower cauline leaves ovate from a broad base, closely sessile, acutely apiculate-acuminate. - Partly referred to $M$. nanus, partly to $M$. Bigelovii, on p. 274. W. Nevada (Torrey) and northward to the tupper Columbia River, Nevius, Hall, Howell.

M. Whitnéyi. An inch or two high, in pubescence and foliage resembling the dwarf state of $\mathbf{M}$. nanus: calyx about 2 lines long, campanulate, with narrow lanceolate and acutish teeth half the length of the tube: corolla with narrow tube ( 3 lines long) abruptly dilated into the broadly obconical throat and seemingly regular spreading limb (together 4 lines high), the latter "yellow" or probably nearly white, the throat dark purple in 8 or 10 longitudinal blotches. - M. nanus, var. bicolor, Gray, p. 275. Eunanus bicolor, Gray, Proc. Am. Acal vii. 381 ; Greene, 1. c. 103 . Too scantily known only by specimens gathered on high sierras in Fresno Co., by Brewer, in the Geological Survey under Whitney, whose name it may bear.

M. Fremónti, Grar, p. 275. At length a span or two high, from glabrate to soft-rillous or tomentulose, not glandular and little viscid : leaves from narrowiy oblong to spatulate or lanceolate : calyx-teeth short aud broadly triangular or ovate, obtuse to acutish : corolla crimson, comparatively large, trumpet-shaped, being narrowly tubular-funnelform up to the abruptly spreading almost regular limb, this half to three-fourths inch in diameter: seeds oval. Common only in Southern California. Parish finds a white-flowered variation.

+ - Calyx decidedly oblique at orifice, ovate in outline, at least in fruit, and strongly plicateangled: corolla narrow.

M. subsecúndus. Viscid-pubescent, diffusely branched from the base, the at length elongated branches bearing spicately disposed flowers chiefly turned to one side: leaves oblong, short; lower less than inch long, upper shorter than the ample (4 lines long and 3 broad) fruiting calyx : teeth of the latter all similar, deltoid-ovate, acute, about a line long: corolla "deep red," half-inch long, with narrow tube and throat abruptly dilated into the nearly regular limb of 4 or 5 lines in diameter : capsule not exserted beyond the somewhat contracted oblique orifice of the calyx : seeds ovate-oblong. - In middle and western part of California, near Mt. San Carlos in Fresno Co., Brewer, and on Pine Mountain back of San Simeon Bay, Palmer.

+++ Calyx more or less oblique at orifice, or two lower teeth manifestly shorter and smaller, the tube open-campanulate or short-oblong: leaves all entire: flowers short-pedicelled or subsessile.

M. leptáleus, Grax, p. 274. Small, an inch to a span high, viscid-puberulent or pubescent: leares spatulate oblong to nearly linear: calyx 2 or 3 lines long; the short teeth triangularsubulate, lower narrower and moderately shorter, at length spreading: corolla crimson, 2 to 4 lines long and slender in depauperate plants, half-inch long when well grown, with gradually widening throat (in withering becoming filiform) and small moderately bilabiate limb: capsule ovate to ovate lanceolate. - Described originally from depauperate form of arid places, with withering attenuate corollas, now known in other conditions along the whole drier parts of the Sierra Nevada, coll. also in Lake Co. (Curran) and Humboldt Co. (Rattan) in more luxuriant state, with comparatively large Howers, the Eunanus Layneo, Greene, Bull. Calif. Acad. i. 104.

M. Párryi, Gray, p. 275. Nothing to add, except a habitat, Mokiak Pass, S. Utah, Palmer, and syn. Eunanus Parryi, Greene, 1. c.

M. Torréyi, Gray, p. 275. Eunanus Torreyi, Greene, 1. c. There are small forms of $M$. Bolanderi which have been referred to this, in which the calyx-teeth are always short, broad, and obtuse or rounded.

* * Corolla larger, more bilabiate, and ampliate in the throat: calyx (half-inch to inch long), with strongly plicate-angled tube, unequal and oblique; upper tooth much larger than lower, all acute: very viscid, with erect and commonly simple stem 1 to 3 feet high, and salientdenticulate leaves. 
M. Bolánderi, Grax, p. 275. Eunanus Bolanderi, Greene, 1. c. 105. Depauperate plants often bear flowers little larger than those of the foregoing.

M. brévipes, Benth, p. 275. Eunanus brevipes, Greene, 1. c. Habit and corolla of a true Minulus. Besides the very viscid pubescence has when young some branching long hairs.

§ 4. Mimdlástrum, Gray. Corolla salverform; the tube and throat (which do not surpass the very unequal calyx) cylindrical, and the orifice not at all dilated, but rather contracted; the abruptly and rotately expanded 5-lobed limb almost regular but oblique, the rounded lobes picturate-veined with crimson: viscid-pubescent annuals, of S. E. California; with the habit and other characters of the section Eunanus, especially of the last preceding species. - Bot. Gazette, ix. 141.

M. Mohavénsis, Lemmor. Dwarf, minutely viscidulous-pubescent, branching: leaves (reddish) oblong-lanceolate, acute or acuminate, entire: calyx (half-inch long) oblongcampanulate, somewhat ventricose, strongly angulate-plicate; the teeth deltoid and acuminate or very acute, upper and longer one nearly half the length of the tube : corolla somewhat gibbous towards the base; the widely spreading or refracted limb (5 lines in diameter) whitish with a dark crimson eye : immature capsule chartaceous, acute. - Bot. Gazette, 1. c. 142. Eunanus (Mimulastrum) Mohavensis, Greene, Bull. Calif. Acad. i. 106. - Sandy banks of the Mohave River, coll. by the Lemmons, May, 1884.

M. pictus. Viscid-pubescent: simple stems or basal branches erect, often a foot high: leaves obovate or ovate to oblong; lower obtuse, contracted at base, sometimes few-toothed ; upper shorter than the internodes; calyx elongated oblong, prismatic, in fruit filled by the oblong-linear mucronate-pointed firm-coriaceous capsule; the very unequal teeth all broad and obtuse: corolla with rather larger limb, strongly picturate-veined with crimson on a nearly white ground. - Eunanus (Mimulastrum) pictus, Curran, in herb.; Greene, Bull. Calif. Acad., l. c. - Mountains of Kern Co., about Keene and Tehachapi stations, Mrs. Curran, June, 1884. Plant with habit of M. Bolanderi, calyx of an Enoe, and nearly the capsule of M. Kelloggii.

§ 5. Eummulus. Char. as on p. 276. The perennial species are so either by stoloniform rootstocks or by rooting from decumbent base of stems.

M. cardinális, Dougl., p. 276. Add syn. : Erythranthe cardinalis, Spach, Suites Buff. ix. 313. Type of $\S$ Erythranthe, Greene, l. c.

M. ríngens, L., extends northward to the Hudson's Bay district. This and the allied M. alatus are perennial by stoloniform rootstocks, produced rather late in the season. The corolla is not really ringent, although the lips are widely open, for the throat is personately closed.

The remaining Western species, i. e, all after M. alatus, p. 276, are re-elaborated as follows :-

* * Large-flowered to small-flowered Western species: corolla yellow and with or without dark blotches or dots, or in a few rose-colored or dark crinson: seeds mostly smooth or with slight reticulation or striation.

+ Filiform-scapigerous and stolnniferous perennial, the stolons often producing scaly bulblets after the season's growth: scattered and long hairs viscous : leaves 3-nerved.

M. primuloídes, Bentri., p. 279. Add. fig. 138 in Gard. Chron., June 11, 1881, 765.Extends from Sun Bernardino Mountains to those of Washington Terr.

+ + Leafy-stemmed and perennial by thickish-filiform creeping rootstocks, villous pubescence slimy-yiscous, commonly much so, musk-scented: leaves pinnately veined: calyx-teetl narrow and acute: capsule acute and not stipitate: seeds globular.

M. moschátus, DougL., p. 278. Weak stems sometimes 2 or 3 feet long. Runs into two extreme forms: 
Var. longiflórus, Grar. A form growing in drier soil, less viscid-villons, and with elongated corolla. - $M$. moniliformis, in part (the villous- and more or less viscouspubescent plant), Greene, Bull. Calif. Acad. i. 119. Common especially in the Sierra Nevada.

Var. sessilifólius. Leaves all sessile on upright or ascending stems (these sometimes a foot or two high, very slimy), but those on decumbent shoots from the rootstocks of the same plant not rarely well-petioled. - $M$. inodorus, Greene, 1. c., but the plaut as strongly musk-scented as the ordinary species, at least in some cases. - Not rare in wet places, from San Bernardino Co., California, northward, and passing into the ordiuary form in Oregon. Calyx-teeth in all the forms variable in length and width.

+++ Leafy-stemmed and slender, perennial by filiform rootstocks, scentless, the minnte pubescence (if any) not viscous: leares essentially pinnately veined, the peduncles seldom surpassing them: calyx-teeth acute, rather narrow and little unequal: corolla open, about inch long: capsule acute, not stipitate-contracted at base.

M. monilifórmis, Greene, in part. Filiform rootstocks ending in small moniliform tubers : stems a span or two high, simple and erect or with spreading branches : leaves orate or oblong, acute or obtuse, half-inch to inch long, sparingly denticulate : calyx-tecth triangular, a quarter of the length of the tube: corolla barely inch long or less, light yellow, narrowly funnelform, short-bearded in the throat, the obscurely bilabiate limb half-inch in diameter. - Bull. Calif. Acad. i. 119, excl. the villous plant, on which, as to herbage, the species was founded. M. dentatus, var. gracilis, Gray, Bot. Gazette, vii. 112. M. luteus, var. alpinus, Gray, ed. 1, ii. 3i7. - Rocky soil in the Sierra Nevada, from Alpine Co. to Lassen, Greene, Lemmon, Jones, Mrs. Austin, \&c.; the moniliferous rootstocks detected by Greene.

M. dentátus, Nотт. Copious rootstocks filiform : simple stems a foot or lcss high : leaves ovate to oblong, acute, one to three inches long, serrate with numerous commonly coarse and salient teeth : calyx-teeth triangular-subulate, half the length of the tube : corolla ventricose-funnelform, fully inch long, deep golden yellow, with widely open throat and comparatively short moderately bilabiate limb, the two conspicuous lines of yellow beard ex tending from the lower sinuses to near the base. - Herb. Hook., \&c.; Benth. in DC. Prodr. x. 372; Gray in Bot. Gazette, vii. 112 ; Greene, 1. c. 109. - In woods, Columbia River west of the Cascades, Nuttall, Howell, and western borders of California, Rattan. Nearly related are $M$. Orizabce, Benth., of Mexico, $M$. sessilifolius, Maxim., of Japan, which has closely sessile leaves and shorter and broader calyx-teeth; also $M$. Nepalensis, in the erect and larger-flowered form, which has broad and short abruptly pointed calyx-teeth.

++++ Leafy-stemmed, perennial by stoloniferous or creeping basal branches, or sometimes by filiform rootstocks, but seedlings flowering the first year, and precocious depauperate ones dying at maturity of fruit, glabrous or sometimes minutely pubescent (but never clammy-hairy or mucilasinous): leares several-nerved from the base or near it: peduncles in fruit spreading or else the apex nodding: calyx at least in fruit oblique-sided and more or less inflated, also oblique at orifice; the teeth all obtuse and broad (sometimes mucronulate, but never actite except when folded); uppermost larger; lower turned upward toward the upper at maturity of fiuit: corolla more or less personate : capsule obtuse or retuse, mostly contracted or short-stipitate at base.

* Small-flowered for the size of the leaves and (leafy) branches; the light yellow corolla (at most half-inch long) not twice the length of the calyx: capsule short-oval, very obtuse or retuse.

M. glabrátus, HBK. Diffuse or ascending from a creeping base : stems somewhat quadrangular : leaves round-oval or ovate, mostly denticulate or dentate; lower with margined petioles, upper sessile by broad base: flowers mostly subtended by undiminished or little diminished leaves: upper calyx-tooth much larger than the lower. - Nov. Gen. \& Spec. ii. 370; Benth. in DC. Prodr. x. 371 ; Gray, Bot. Mex. Bound. 116. M. Jamesii, var. Texensis, Gray, Syn. Fl. ii. 277. M1. propinquus, Lindl. Bot. Reg. t. 1330 ; Benth. 1. c., but not from "N. W. America." - Texas, New Mexico, \&c. (Mex. and soutliward.)

Var. Jamésii. Diffusely procumbent, rooting extensively : leaves mainly orbicular and almost entire, some approaching reniform, upper ones hardly diminished and equalling the subtended peduncles. - M. Geyeri, Torr. in Nicollet Rep., 1843 (157), 237. M. Jamesii, Torr. \& Gray, \& p. 276. The most northeastern in its range, and extends well into Mexico, if not to Guatemala. M. Madrensis, Seem. Bot. Herald, 322, t. 58, seems to be a diminutive form of it. 
Var. adscéndens. A large and robust form (as sometimes in Mexico), rising a foot or two high from the creeping base: branches freely racemosely flowered at summit; the upper and sometimes connate rounded leaves being much reduced and bracteiform. M. glabratus (chiefly), Gray, Bot. Mex. Bound. 116. M. Hallii, Greene, Bull. Calif. Acad. 113, but species not truly annual, nor calyx-teeth acute. The specimen of Hall described from was a cultivated one. - Colorado and west to the Grand Cañon in N. W. Arizona, south to Mexico. Comes nearest to the following.

+ t+ Large-flowered for the size of the plant; the golden yellow and sometimes crimson-dotted

corolla ample compared with the calyx, the larger even an inch and a half long: capsule oval or slightly obovate, short-stipitate.

M. Iúteus, L., p. 277. Exclude the syn. M. Scouleri, and from the var, alpinus exclude the syn. M. dentatus, Nutt. (which see above); and also $M$. cupreus, Regel (M. luteus, var. cuprea, Hook. Bot. Mag.), which belongs to a distinct Chilian species. The original Chilian $M$. luters, as Bentham decided, although usually distinguishable, cannot be specifically separ rated from the Northern coast form, M. guttatus, DC. Cat., and of Greene, 1. c., \&c., to which pertain $M$. luteus, Bot. Mag. t. 1501, Bot. Rep. t. 661, and Jacq. t. Ecl. t. 92. The slender shoots from the base of the stem either root and form stolons, or not rarely rise and bear small leaves and flowers.

Var. alpínus, Gray, p. 277 (excl. syn. as above). Includes a series of mountain forms, varying from two inches to near a foot high, clearly perennial, proportionally largeflowered. Small forms with round and nearly entire leaves answer exactly to $M$. Tilingii, Regel, Gartenfl. xviii. 321, t. 631, plants of which, from the same sowing, developed next year into the typical N. American species, shown in xix. 290, t. 665 ; also in the gardens under this name and as " $M$. Rcezli", the latter answering to $M$. Tilingii, Greene, l. c., from near Summit Station.

Var. depauperátus, GraY, 1. c. partly. M. microphyllus, Benth.! in DC. Growing with the larger or ordinary plants, evidently an extreme depauperate form, either seedling or showing the creeping stolons; with filiform stem 2 to 7 inches high, 1-4-flowered; leaves a quarter-inch or so long, and corolla 6 or 7 lines long. Grows with the larger forms on Columbia River: specimens exactly like those of Douglas from same district (except that some show the stoloniferous base) were received from Mrs. Barrett.

M. Scoúleri, Hoor. Erect, from a stoloniferous base, a foot or two high : leaves thick, very smooth and shining, oblong-lanceolate (an inch or two long, 4 to 6 lines wide), obtuse, evenly callous-denticulate; lower tapering into petioles of equal length; floral ones short and small, ovate and amplexicaul : flowers apparently of the preceding, but corolla shorter. -Fl. ii. 100; Benth. in DC. l. c. -- On the Columbia River, S'couler, in fruit only. Now rediscovered, in flower, in the mud on the south shore of the river (sometimes covered at high tide) about four miles above Astoria, by T. Meehan, probably near Scouler's original station.

+++++ Pure annuals, leafy-stemmed, various in habit and size: no mucilaginousclammy hairs: seeds oval or oblong, mostly with a smooth close coat.

+- Comparatively large-flowered, the yellow corolla inch long and broad: upper cauline leaves connate into orbicular disks, glancous: calyx less oblique than in succeeding.

M. glaucéscens, GreENe. Erect, often tall, glabrous and glancous, except the radical and lower cauline leaves, which are sometimes villous-pubescent; these cordate-orbicular, crenate-dentate or incised, sometimes almost lyrate, slender-petioled; the perfoliate disks denticulate or entire: inflorescence at length racemiform : corolla with ample throat: style minutely pubescent: calyx campanulate, slightly arachnoid-villous at the throat within, appearing repand-truncate, the teeth being very short and broad, in fruit nodding on the ascending peduncles, the two lower tedth incurving in the manner of the following. - Bull. Calif. Acad. i. 113. - California, along streams in the foot-hills of the Sierra Nevada, from Lassen to Butte Co., Fremont, Mrs. Austin, A. Gray.

+ Middle-sized to sthall-flowered (even in same species): herbage not glaucous: corolla yellow: calyx especially when fructiferous and ventricose oblique-sided and oblique at orifice, strongly plaitel-angled, mostly with acute or acutish teeth, the lower at maturity turned toward the larger uppermost: fructiferous perluncles mostly ppreading or the apex nodding: capsule distinctly short-stipitate. 
= Leaves 3-5-nerved at the base, from denticulate to saliently and irregularly or doubly dentate, sometimes incised, mostly petioled.

M. nasútus, GrefNe. Quite glabrous, or herbage minutely pubescent; larger forms a foot or two high, erect, with 4-augled stout stem, corolla and fruitiug calyx each half to twothirds inch long, and rounded leaves one or two inches in diameter; exignous forms abounding with the same (mostly flowering earlier or when drier), diffuse, delicate, thin-leaved, reduced to a span or so or even an inch or two high, with rounded leaves from half-inch to a line or two broad, fruiting calyx from 5 to 3 lines long, and very small hardly exserted corolla : leaves chiefly orbicular or round-ovate and lower subcordate : calyx broadly ventricose-ovate in fruit, conspicuously pointed by the triangular-lanceolate projecting upper tooth : corolla commonly with a crimson-purple spot on the lower lip. $-M$. nasutus \& $M$. microphyllus, Greene, Bull. Calif. Acad. i. 111, 112, excl. syn. W. lyratus, \&c. M. luteus, var. depauperatus, in part, of p. 277. - Common from s. California to Brit. Columbia, and eastward into Nevada, along streams and in cañons, often growing with $M$. luteus.

M. nudátus, Curras. Minutely pubescent and viscidulons, glabrate in age, diffusely branched from the very base, a span or two high, with stems and sometimes foliage purpletinged : leaves ovate to lanceolate, from denticulate to strongly and acutely dentate, tapering into a margined petiole (both together seldom inch long), upper much surpassed by the filiform at length divergent peduncles : corolla half to three-fourths inch long, with ample limb (bright yellow) : fructiferous calyx oblong-ovoid in fruit, then half-inch long or more and gibbous, with closed mouth; the short triangular teeth nearly equal and alike, but four closely inflexed upon the slightly projecting uppermost. - Greene, Bull. Calif. Acad. i. 114, name not well chosen, except for the (chiefly fruiting) specimens described. $M$. dentatus, Gray, in Pacif. R. Rep. iv. 120, partly (leafy and floriferous), not Nutt. - California in the Sierra Nevada, near Murphy's, Bigelow, and on Table Mountain, Mrs. Ames. Also Kelsey Monntain in Lake Co, Mrs. Layne-Curran.

$$
==\text { Lcaves not nervose but laciniately dissected, narrow. }
$$

M. laciniátus, Gray, p. 277. Glabrous or nearly so, a span to a foot high, slender: leaves spatulate-lanceolate or uarrower in ontline, from 3-5-cleft to irregularly once or twice pinnately parted into narrow small lobes: corolla 2 to 4 lines long, narrow, hardly twice the length of the calyx, pale yellow : fructiferous calyx 2 or 3 lines long, gibbous-campanulate with acute base, little iuflated; the triangular short teeth only slightly unequal. - $M$. Eisenii, Kellogg, Proc. Calif. Acad. vii. 89. - Sierra Nevada, in Mariposa Co., California, recently collected by Congdon, Mrs. Layne-Curran, Meehan, \&c.

++ Sinall-flowered, very minutely glandular-puberulent or glabrous, but viscidulous, and when much so musk-scented: calyx campanulate-oblong, hardly at all unequal-sided at maturity or ventricose, but nearly filled by the oblong capsule; the short-toothed orifice as if truncate and moderately oblique; the upper and two lateral at length triangular-subulate teeth a little shorter than the two larger and rounded-obtuse more united lower ones!

M. alsinoídes, Doogr.., p. 277. - British Columlia to $\mathrm{N}$. California, first coll. by Menzies. Runs down to the exceedingly tiny specimens of Scuuler, \&c. (var, minimus), while the larger are even a foot lung, and some of the (5-nerved at base) leaves are two inches long, including the petiole. Nuttall distributed this species under the name of $M$. tenell's. Now that its peculiar characters are indicated it cannot be mistaken. Yet it had been confounded with some other species, and with M. Pulsifere, Greene, l. c. Suksdorf remarks that the peduncles carry the capsules as closely as possible to the rocks.

$+4+$ Small-flowered, or sometimes rather large-flowered for a small plant: calyx not gibbous nor manifestly oblique at orifice; the teeth equal or nearly so, and erect in fruit: corolla from yellow or rarely white to rose or crimsson-red.

= Fructiferous calyx more or less ovoid and ventricose, somewhat narrowed at the nifice, the short fecth clisposed to connive: plants low and erect or ascending, glabrous or barely viscidulous-puberulent, with erect or ascending fractiferous peduncles.

a. Leares all or all but the lowermost sessile by a broad obscturely 3-nerved base, entire or occasionally denticulate: mature fructiferous calvx much ventricose and plaited-angled, 4 to 6 lines long: corolla rose-purple or pink, sometimes "white."

M. inconspicuus, GraY, p. 278. Occurs here and there from middle to southern parts of California. Well-developed plants a span to a foot high, essentially glabrous; corolla in 
best developed specimens half-inch long; the orifice of the calyx repandly 5 -toothed, the broad teeth with or without a small apiculation; in

Var. acútidens (11. acutidens, Greene, Bull. Calif. Acad. i. 117), the calyx-teeth more salient and narrowly subulate, and leaves mostly denticulate. - Southern part of the Sierra Nevada in King's River Mountains, Dr. Eisen.

Var. látidens has the triangular-ovate and acute calyx-teeth rather conspicnous in anthesis, and more so in fruit. - On the flanks of Monte Diablo, Brewer, Greene, and Chollas Valley, San Diego Co., Orcutt.

b. Leaves all contracted below into a petiole or petiole-like base, more or less 3-nerved, sparingly denticulate: fructiferous calyx less ventricose and plaited, 3 or 4 lines long, and with more distinct orate-triangular teeth : corolla yellow, or rarely the limb pinkish.

M. Pulsiferæ, Grax, p. 277. - California, from Sierra Co. to Washington Terr. Varies from obscurely to distinctly viscidulons-puberulent. Corolla light yellow.

= Fructiferous calyx campanulate to cylindraceous, little ventricose.

$u$. Leaves ovate and slender-petioled, mostly denticulate, hardly at all nervose: corolla yellow: low plants, either viscidulous or clammy-haired.

M. pedunculáris, Dougl. Frect, slender, viscid-puberulent or pubescent (not at all villous), a span or two high: leaves with blade only quarter or half inch long, usually much surpassed by the filiform (inch or two long) spreading or divaricate peduncles: teeth of the narrow and nearly glabrous calyx very short: corolla golcen yellow, half-inch long and its limb as broad. - Benth. Scroph. Ind. 49, in Prodr. wrongly referred to the next species. Sandy banks of the Columbia River, Washington Terr. and Oregon, Douglas, Suksdorf (who indicated the excellent characters of the species), Mrs. Barrett. Also on the Kooskooskie, Geyer (part of his 474), and John Day River, Howell.

M. floribúndus, DougL., p. 278. Erect or soon diffuse and spreading, villous with slimyviscid hairs, somewhat musk-scented : leaves mostly dentate, little surpassed by the (half or three-fourths inch long) ascending or spreading peduncles: calyx-teeth triangular, acute, a third or a quarter of the length of the campanulate tube: corolla light yellow, small.

b. Leaves Tanceolate-oblong, with several-nerved base, closely sessile: corolla light rose-color.

M. Paríshii, Greene. Erect and stont, a foot or two high, very villous with slimy viscid hairs, leafy to the top : leaves an inch or two long, dentate or denticulate with salient teeth : flowers mostly short-peduncler : corolla small, little surpassing the short triangular teeth of the cylindraceous calyx (this when fructiferous 5 or 6 lines long): seeds oblong-oval, with a smooth close coat. - Bull. Calif. Acad. i. 108. - Southern California, from San Bernardino and Los Angeles Co. to below San Diego, Parish, Nevin, Oliver, Orcutt.

c. Leaves narrow or small, sessile or nearly so by a tapering base; lateral ribs or nerves obscure or none: low or slender plants, erect.

1. Corolla rather large (half-inch long), conspicuously bilabiate, lower lip more or less bearded.

M. bícolor, HAR'TWEG, p. 278, Viscid-pubescent: stems a span to a foot high, sereralflowered: corolla golden yellow with the upper lip white (not the lower as stated in the original and in our description): calyx rather strongly ribbed or angled, the teeth acute : leaves dentate or denticulate.

M. montioides, Grar, Proc. Am. Acad. vii. 380, mainly. Glabrous, hardly viscidulous, half-inch to a span high, simple or at length much branched from base: flowers few on filiform peduncles: corolla with narrow and well-exserted tube, ample throat and limb yellow and purple-spotted : teeth of the narrow calyx very short and obtuse: leaves thickish, spatulate to linear, obtuse. - M. rubellus, var. latiflorus, Watson, Bot. King Exp. \& p. 278. M. barbatus, Greene, in Bull. Calif. Acad. i. 9, who has well taken up the species nuder its original name in Bull. 1.c. 115. - Known only in W. Nevada and adjacent borrder of California.

2. Corolla small eren for the small plauts, little exserted, only 2 or 3 lines long, and limb not over 2 Jines wide: throat beardless or nearly so: calyx-teeth short, triangular, mostly obtusc: placentæ of the thin-membranaceous capsule in age disposed to split in two at apex or to be bipartible.

M. Suksdórfii. An inch to barely a span high, at length much branched at base, obscurely puberulent-viscidulous, the whole herbage and especially the fruiting calyx often 
reddish-hned : leaves oblong-lanceolate to linear, quarter to half-inch long, thickish, entire : corolla yellow, all five lobes of the small limb obcordate-emarginate! $-M$. montioides, as to the form "corolla parva calyce paullo longiore," Gray, Proc. Am. Acad. vii. 380, later merged in M. rubellus. - Eastern part of the Sierra Nevada, Mono Pass, Brewer and Bolander, and near Carson, Anderson, Torrey, \&c., east to Utah, Watson, (and perhaps to Colorado,) and north to Mount Paddo, \&c., Cusick, Suksdorf. Named for the latter, who first indicated the character of the corolla, and sent specimens which verify it.

M. rubéllus, GRAY, p. 278, mainly. A span or more high, simple or loosely branched, from obscurely to manifestly viscid-puberulent : leares lanceolate, half-inch to inch and a half long, entire or denticulate: corolla rose-color or sometimes yellow and purplish-tinged or changing to purple, upper lip 2-lobed, the lower entire. - 1 . rubellus \& Eunanus Breweri, Greene, Bull. Calif. Acad. i. 116, 101, the latter the more viscid form. - Rather common, from the mountains of Colorado, New Mexico, and Arizona, to California and Washington Terr.

3. Corolla crimson, hardly at all bilabiate, the limb almost rotately spreading: plants slender, a span or two high, commonly effusely branched and with filiform peduncles, barely viscidulouspuberulent or glabrous.

M. Pálmeri, Grir, p. 278. Leaves lanceolate to spatulate-oblong, sparsely dentate or entire, a quarter to three-fourths inch long: calyx oblong or cylindraceous-campanulate, 4 or 5 lines long, with short and broad mostly obtuse teeth : corolla showy, crimson-purple, the larger three-fonrths inch long, with ample open-funnelform throat: capsule oblong, a little shorter than the calyx. - Additions to the localities cited above are San Bernardino Co., Parish, Mariposa Co., Congdon (with larger and acutish calyx-teeth, also diminutive and smaller-flowered), and 25 miles from San Diego, Cleveland.

Var. androsáceus. Very much branched, smaller-flowered: corolla barely halfinch and in depauperate plants only quarter-inch long. - . h. androsaceus, Curran in Greene, Bull. Calif. Acad. i. 121. - Tehachapi, S. California, Mrs. Layne-Curran. Mountains on the borders of Lower California, Orcutt.

M. exíguus, Gray. Effusely paniculate, with filiform stem and branches: leaves linearspatulate, a line or two long, 3 or 4 times shorter than the peduncles : calyx short-campanulate, a line long, or in fruit barely 2 lines long, with short obtuse teeth, obscurely 5-nerved, completely filled and slightly surpassed by the broadly ovate capsule: corolla (as far as seen) only a line or two in length and with minute limb. - Proc. Am. Acad. xx. 307; Greene, l. c. - Hanson's Ranch, orer the border in Lower California, Orcutt. Possibly a form of the preceding.

§6. Mrudzoídes, Gray. Char. of $\S 5$, except that the calyx is short-campanulate, deeply 5-cleft; its tube 5-sulcate, not prismatic nor even carinate-angled, and almost nerveless: placentæ tardily or incompletely dividing in the manner of $\S 3$.

M. exilis, Durand. Older name than M. pilosus, Watson, and according to the rules to be adopted for that, on p. 279.

\section{HERPESTIS, Gærtn. f.}

H. rotundifólia, Pursn, p. 280. Corolla not rarely white. - Coll., out ở ordinary range, in Fresno Co., California, Dr. Eisen, Lemmon. Published as Ranapalus Eiseni, Kellogg, Proc. Calif. Acad. vii. 113.

\section{BUCHNERA, L. P. 289, add}

B. pilósa, Bentr. Leafy up to the inflorescence : radical leaves obovate or oblong; upper lanceolate to linear, the larger not rarely few-toothed : calyz-teeth subulate, equal or nearly so, in fruit surpassing the straight but somewhat oblique capsule : tube of the corolla barely 
twice the length of the calyx, appressed-hairy outside. - Bot. Snlph. 144; Gray, Proc. Am. Acad. xix. 93. (Mexico, \&c.)

Var. Arizónica, Gray, 1. c. 92. Hispidulous, sometimes paniculately branched. S. Arizona, near Fort Huachuca, Lemimon.

\section{GERARDIA, L.}

G. tenuifólia, VAHz, p. 294. Add: Spragne \& Goodale, Wild Flowers, 9, t. 2.

Var. aspérula, Grax. Leaves all nearly filiform, and upper face hispidulous-scabrous: inflorescence more paniculate, with pedicels ascending: corolla small, the expanded limb only half-inch in diameter. - Bot. Gazette, iv. 153. - Dry and bare hills, Michigan to Minnesota and Missouri, a rather common Western form.

\section{CASTILLEIA, Mutis.}

C. indivísa, Engetm., p. 295. Add: Hook. f. Bot. Mag. t. 6376 ; the galea represented too short and thick. The only species which has yet succeeded in cultivation.

C. viscídula, Gray, p. 297. Eagle Creek Mountains, E. Oregon, along alpine streamlets, Cusick. - Next to this, but nearer C. Lemmoni, comes the following:

C. cinérea, Grax. Many-stemmed from a tap-root, 8 inches high, cinereous with a short and soft but somewhat hirsute pubescence, very leafy up to the short and dense cylindraceous spike: leares nearly erect, linear (half-inch long, a line or more wide), entire, or upper 3-cleft; floral spatulate-dilated, viscid-glandular, tinged yellow: calyx-segments twoparted into linear lobes: galea short-oblong, truncate, a quarter of the length of the tube, and about as much longer than the obtusely 3-crenate lip : stigma large and disciform. Proc. Am. Acad. xix. 93. - Rocky hills of Bear Valley, San Bernardino Mountains, S. E. California, Prrish.

C. sessiliflóra, Pursh, p. 298. Extends even to Montana, Canby, and the Mohave Desert, California, Lemmon. (Mex.)

At the end of the genus a peculiar section is to be added:-

++++ Calyx normallv bilabiate, i. e. cleft at the sides deeper than before or behind, upper lip emarginate, lower obcordately 2-cleft.

C. plagiótoma, GrAx. Puberulent : stem 2 feet high from a thick perennial root, branching: leaves narrowly linear, or upper trifid with linear lobes; floral 3-5-cleft with the herbaceous lobes linear-spatulate, cinereous-pubescent: spikes sparsely-flowered below: calyx oblong, with the lips a little shorter than the tube and about equalling the yellow corolla: galea straight, as long as its tube; lip very short. - Proc. Am. Acad, xix. 94. - S. E. California, on the Mohave Desert, Pringle.

\section{ORTHOCÁRPUS, Nutt.}

There are three (instead of two) species in the first division of $\S 2$, p. 300, to be distinguished as follows. See Proc. Am. Acad. xix. 94.

O. imbricátus, Torr. Slender, branching: stem and narrow linear leaves minutely pu. berulent : bracts chartaceo-scarions and reticulated in age, purplish, oval, entire or a pair of small basal lobes, naked or sparsely ciliate at base, loosely imbricated in the spike: calyx very short, its broad lobes with a pair of short and small subulate teeth ; corolla rose-purple, hardly half-inch long; lip and galea equal in length, the latter usually without uncinate apex: anther-cells oval. - Watson, Bot. King Exp. 458. O. tenuifolius, Gray, Bot. Calif. i. 577, \& p. 300, mainly, not Pursh. - Mountains of N. and E. California and S. Oregon, first coll. by Newberry.

O. pachystáchyus, Gray. Low and stout, above slightly hirsute : bracts imbricated in the thick spike, large (inch or more in length), chartaceo-scarious and purplish in age, ob- 
long, with one or two pairs of elongated lateral lobes : calyx half the length of the corolla, deeply 2-cleft, and divisions cleft to the middle into subulate-lauceolate lobes : corolla rosepurple, over an inch long; galea with uncinate tip surpassing the lip : anther-cells linearlunate, acute at base. - Near Yreka, Siskiyou Co., N. Califoruia, Greene.

O. tenuifólius, Bentr. Strict, branching at sumnit, sparsely lirsute, especially the bracts; of which the lower are leaf-like and 3-5-cleft, and only the oblong middle lobe of the eularged upper ones purple: calyx half the length of the corolla, its lobes bearing a pair of elongated-subulate teeth : corolla yellow, narrow, two-thirds inch long, with small uncinate tip surpassing the lip : anther-cells oval. - Mountains of Montana and Oregon, first coll. by Leu is \& Clark. In J'roc. Am. Acad. xix. 95, misprinted O. linearifolius.

O. purpureo-álbus, Grax, p. 301. Extends to Arizona, Lemmon. Corolla at first white, soon becoming rose-purple.

To $\$ 3$ there are some additions and corrections, viz. : -

O. pusillus, Bexтп., p. 301. The seed-coat is close, indeed, but cellular-appendaged at the chalaza or partly down the rhaphe.

O. floribúndus, Bextir, p. 301. Exclude syn. Chloropyron palustre, Behr, which belongs to Cordylunthus maritimus. Seed-coat close. Corolla cream-color.

O. eriánthus, BEnTh., p. 301. Corolla sulphur-yellow, or cream-color : seed-coat wholly close. Described from the form with pubescent foliage, which is low. - Apparently confined to the Californian coast district.

Var. lávis. Not rarely a foot high, glabrous or nearly so up to the inflorescence: corolla sulphur-yellow, paler in fading; the galea geuerally pale. - O. fuucibarbatus, Gray, p. 302. I'ubescence of the lip and throat variable.

Var. róseus, Grar. Either glabrous or pubescent: corolla rose-color, apparently so from the first, or "white."-Triphysaria versicolor, Fisch. \& Meyer, Ind. Sem. Hort. Petrop. ii. 52, according to original specimens : the indigenous ones rose-color, and the herbage below glabrous (but similax pubescent plants with rose-colored corollas in an early distribution, unnamed), in the plant raised in St. Petersburgh Garden "white" or cream-color.

O. Bidwélliæ, GRAY. Resembles the preceding, more slender, smaller and looser-flowered, puberdent : divisions of the leaves almust filiform : lip of the corolla light golden-yellow, not over about 2 lines broad, prominently surpassed by the brown-purple subulate galea: seed-coat loose and cellular, arilliform. - Proc. Am. Acad. xv. 51. - On the Sacramento and its tributaries in Butte and Placer Co., California, first coll. by Brrs. Ames and Mrs. Birluell.

Var. micránthus. Depauperate and few-flowered, with corolla barcly half the usual size. - Plains of Fresno Co., Greene, distributed as a species under this name.

O. Paríshii, Gray. Next to 0 . campestris, p. 302, a span or more high, nearly glabrous: leaves 3-5-cleft into linear-filiform divisions, or the lower entire; floral ones very similar, the 3-5 lobes purple-tipped : flowers in a dense short spike : calyx-lobes lanceolate, obtuse, half the length of the tube: corolla rose-purple, little pubescent in the throat; sacs of the lip as broad as long; galea lanceolate, rather obtuse, puberulent. - Proc. Am. Acad xvii. 229. S. California, on the San Jacinto Mountains, Parish. Adjacent L,ower Calif., Jones, Orcutt.

O. lithospermoídes, Bentн., p. 302. Extends to S. W. Oregon.

O. híspidus, Beritr., p. 302. Extends south to the southern part of California.

\section{CORDYLÁNTHUS, Nutt.}

C. Wríghtii, Grat, p. 303. A form apparently of this species with smaller and less exserted (yellow) corolla. only three-fourths inch long, and anther-cells glabrous except an apical fascicle of hairs, coll near Fort Wingate, New Mexico, Matthews, also Arizona, Lemmon, Jones. The original has the anther-cells only villous-ciliate.

C. Prínglei, Grax. Of the section Adenostegia, and the division with four stamens and two-celled anthers, tall, nearly glnbrous, diffusely much branched: leaves all linear-filiform, entire; lowest an inch and a half long, pubescent; uppermost very short and small, quite glabrous; bracteal leaves short, flabelliform, obtusely 3-5-lobed, crowded in the capitate 
cluster of 2 to 5 flowers : sepals nearly equal, oblong, sparsely scaberulous-glandular, hardly equalling the short-oblong pale yellow (4 or 5 lines long) corolla. - Proc. Am. Acad. xix. 94. - Dry hills, Lake Co., California, Pringle.

C. Nevínii, Gray. Next to C. tenuis, p. 304, anomalous in the division by its essentially one-celled anthers: loosely much branched, villous-pubescent; leaves either 3-parted or entire, narrowly linear, not callose-apiculate: flowers scattered along the slender brauchlets, nearly naked, much exceeding the subtending floral leaves : corolla yellowish and purplish: four stamens alike, with villous filaments, sometimes a rudimentary second cell to the anthers but commonly none: seeds smooth, scarious-apiculate. - Proc. Am. Acad. xvii. 229. San Bernardino Mountains, S. E. California, Nevin, Parish. Also San Diego Co., Orcutt.

C. marítimus, Nutr., p. 304. Add syn. : Chloropyron palustre, Behr in Proc. Calif. Acad. i. 61, fide Mrs. Curran in Bull. Calif. Acad. i. 145. Extends north to Humboldt Co., Rattan, and east to San Bernardino Co., in saline soil, Parish.

§ 4. Dicranostégia. Calyx monophyllous, posterior, 2-parted, the segments ovate, acuminate, one-nerved. - Gray, Proc. Am. Acad. xix. 95.

C. Orcuttiánus, Gray, 1. c. Hirsute or hispidulous, a span to a foot high, very leafy : leaves all pinnately parted into narrow linear or filiform lobes: flowers capitate-crowded: corolla yellowish, with broad and equal lips: filaments glabrous; anthers of the longer pair 2-celled, but lower cell remote and hardly polliniferous; of the shorter pair abortive, reduced to a 2-parted yellow-hirsute rudiment. - Tijuana, a little within the border of Lower California, Orcutt.

\section{PEDICULARIS, Tourn.}

To division +++ , p. 306 , but needing a new subdivision, add : -

P. Howéllii, Gray. A foot high, with herbage glabrous: stem stout, simple, naked or with some small scales below, above leafy up to the dense cylindraceous spike: leaves oblong ( 2 inches long); some simple and undulate-serrate or entire, on margined petioles, others pinnately 3-7-parted or upper lobes more confluent: bracts foliaceous, ovate, mostly acuminate, more or less lanate-ciliate, shorter than the flowers : calyx campanilate, sparsely villous, 5-dentate; teeth ovate, nearly entire, the posterior and lateral more connate: corolla white or whitish, with exserted tube and a rather long much incurved somewhat rose-colored beak, much like that of $P$. compacta, but its truncate tip rather broader; lip small. - Proc. Am. Acar. xx. 307. - N. California, in the Siskiyou Mountains, Howell.

P. Cánbyi. Near the Siberian $P$. compacta, but with very short-beaked galea: glabrous up to the inflorescence: stem sparsely leafy, 7 to 10 inches high: leaves pinnately divided or parted into 11 or more linear-lanceolate and laciniate-serrate divisions (of about half-inch in length): spike cylindraceous, dense : ovate bracts and irregularly 4-5-cleft calyx sparsely villous : corolla (half-inch long) yellowish, with exserted tube, and galea with a distinct but short and thickish (line long) porrect truncate beak; lip very short, almost flabellifurm, its three short lobes erose-crenulate. - Rocky Mountains of Montana, on McDonald's Peak of Mission Range, at 8,400 feet, Canby, 1883.

P. Furbíshiæ, WAtson. Next to $P$. lanceolata, p. 307 , but more allied to the Siberian $P$. striata: tall (2 or 3 feet high) and rather slender, pubescent or glabrate, sparsely leafy to the rather dense spike: leaves lanceolate, pinnately parted and the short oblong divisions pinnatifid-incised, or the upper simply pinnatifid and the lobes serrate; uppermost passing into the foliaceous and ovate laciniate-dentate bracts, which are shorter than the flowers: lobes of the calyx 5, rather unequal, linear-lanceolate, entire or with 2 or 3 teeth, about the length of the narrow campanulate tube: corolla ochrolencous, two-thirds inch long, narrow; galea straight, one third the length of the tube, beakless, the introrse truncate apex bicuspidate, the front almost rectilinear, nearly equalled by the erect truncately 3-lobed lip, which when outspread is nearly flabelliform: capsule broadly ovate: seeds oval, compressed, with the thin striate and cellular-reticulate coat wing-like, very much broader than nucleus. - Proc. Am. Acad. xvii. 375. - Banks of the St. John's River, Aroostook Co., Maine, Miss Furbish, and adjacent New Brunswick, Wetmore, Vroom. 


\section{OROBANCHACE E.}

\section{APHÝLLON, Mitchell.}

A. Ludoviciánum, Grar, p. 313. Exclude the habitat "California," which belongs to the following.

A. Coóperi, Grap. A span to a foot high from a very thick ligneous-fleshy tuberous caudex, puberulent, usually with some loose flowering branches: flowers pedicellate or the upper sessile : calyx-lobes lanceolate, as long as the capsule : corolla violet or purple, threefourths inch long, rather deeply bilabiate; upper lip 2-cleft, lower 3-parted; Iobes all lanceolate and acute: anthers glabrous before dehiscence: stigma funnelform-dilated, nearly orbicular. - Proc. Am. Acad. xx. 307; distributed by Pringle as A. Ludovicianum, var. Cooperi. - Common in S. Arizona to the borders of California; first coll. by Cooper.

3. CONOPHOLIS, Wallr. There are two species of this genus, viz.:-

C. Americána, WALLR., p. 313, excl. reference to Endl. Iconogr. Cauline and bracteal scales ovate to ovate-lanceolate, obtuse or acutish : corolla barely half-inch long. -Orobanche Americana, L. Mant. (not "Suppl.") 88. Apparently also Mexican, coll. Botteri.

C. Mexicána, Gray. Cauline (except the lowest) and bracteal scales lanceolate, mostly attenuate-acute; corolla larger. - Watson, Proc. Am. Acad. xix. 131.-C. Americana, Endl. Iconogr. t. 81, but scales rather broad.-Mountains of E. New Mexico, Irright, G. R. I'asey, and Arizona, Rusby. (Mex., Parry \& Palmer, \&c.)

\section{BOSCHNIÁKIA, C. A. Meyer.}

B. strobilácea, GraY, p. 313. Seed-coat deeply favose.-Extends northward into Oregon, Howell.

\section{LENTIBULARIACE $邓$.}

1. UTRICULÁRIA, L. See Proc. Am. Acad. xx. 287-289.

U. mínor, L., p. 315. Add syn.: L. gibba, LeConte, Ann. Lyc. N. Y. i. 76, t. 6, f. 5, not L. - Next to this, although somewhat resembling $U$. intermedia, comes the following.

U. occidentális, Grap. Stems and foliage of the preceding: scape a span long, 3-5-flowered: pedicels somewhat spreading after anthesis: corolla with rounded palate ( 3 or 4 lines in length and breadth) a little shorter than the upper lip: spur broadly conical, acutish (2 lines long), ascending. - Proc. Am. Acad. xix. 95. - Falcon Valley, Washington Terr., Sulisdorf.

U. biflóra, LAY., p. 315. Add syn. . U. longirostris, LeConte, I. c., and exclude the same from $U$. fibrosa.

U. purpúrea, WALT., p. 316. The smaller-flowered plant, with corolla only 3 or 4 lines wide, which proves to be the commoner form in the Atlantic Southern States, is probably Walter's, with "floribus parvis." Probably it passes into the larger-flowered

U. cornúta, Mıchx., p. 317. Correct char.: stem 1-5-flowered at summit: lips of the corolla half-inch long, lower with the two sides fully as broad as the ample palate: spur subulate, as long as the lower lip, porrect or descending. - A common Northern as well as Southern species.

U. júncea, VAfIL. Resembles the preceding: stem racemosely or rather spicately 4-10flowered; lower flowers more or less distant: lips of the corolla 3 or 4 lines long, the lower 
mainly consistingr of the high-arched palate. spur slender-subulate, soon deflexed. - Enum. i. 302 ; Gray, Proc. Am. Acad. xx. 287, 288. U. personata, LeConte, Ann. Lyc. N. Y. i. 77, t. $6, f .10$, as slown by original drawing. $U$. cornuta in part, of authors; Benjamin in Linn. xx. 305, \& Fl. Bras. x. 240, - L. North Carolina to Texas. (Cuba to Brazil.)

U. longeciliáta, A.DC. Filiform stem a span or morc high, 2-7-flowered ovate bracts and bractlets and the calyx fringed with long bristles: lips of the yellow corolla 2 or 3 lines long. - Prodr. viii. 23. - Tampa and Manatee, Florida, Garber. (Cuba to Brazil.)

U. símplex, C. WRlGrT. A span or two high, very slender, strict, spicately 2-6-flowered : bracts minute, ovate, bractlets subulate: sepals ovate, the larger acute or acuminate: corolla shorter than the calyx, the erect lips and obtuse spur only a line or so in length: seels oval, coarsely favose-reticulated. - Wright \& Sauvalle, Fl. Cubana, 91.- Near St. Augustine, Florida, Miss Reynolds. Probably sometimes with larger corolla. (Cuba.)

\section{PINGUICULA, Tourn.}

P. púmila, Michx., p. 317. P. Floridensis, Chapm. Fl. Suppl. 635, appears to be the same, as also the wrongly described $P$. australis, Nutt, while the $P$. anstralis, Chapm. Fl. 284, is P. elatior, Michx.

\section{BICNONIACEA.}

3. CATÁLPA, Scop. Two North American species are now distinguished, not very definitely, viz. : -

C. bignonioídes, WALT., p. 319. Low and much-branched tree, with thin bark: leaves (unpleasantly scented) moderately acuminate, and not rarely a pair of lateral salient teeth: corolla hardly inch and a half long, thickly spotted within, the tube campanulate, limb oblique, lower lobe entire: capsule very slender. - Exclnde from the syn. the figure in Duhamel. - S. W. Georgia, Alabama, \&c.; and widely cultivated.

C. speciósa, WARDER. Large and tall tree, with thick bark: leaves (inodorous) caudateacuminate: corolla larger ( 2 inches high), nearly white, inconspicuously spotted, and with broader little oblique limb, the tube obconical, lower lobe emarginate: capsule equally long but nearly twice as thick: flowering earlier (May). - Engelm. Bot. Gazette, v. 1 ; Sargent, Forest Trees, 10th Census, 115. C. cordifolia, "Jaume" in Duham. ed. nov. ii. t. 5, as to the plate. - S. Illinois and adjacent States. A more showy as well as larger and more valuable tree. First discriminated by the late Dr. J. A. Warder, and scientifically published by Engelmann ǖnder Dr. Warder's name.

Crescéntia cucurimfina, L. (see p. 320), was collected by the late Dr. Garber in S. Florida: probably not indigenous.

\section{ACANTHACE平.}

\section{CALÓPHANES, Don.}

C. oblongifólia, Dos, p. 324. The sepals much surpass the capsule, and sometimes nearly equal the corolla. The var. angusta should give place to

C. angústa. A span or two high, erect or ascending from a creeping base, only minutely puberulent, usually very leafy : leaves half to three-fourths inch long, from oblong to almost linear, obscurely veined : flower small: corolla barely half-inch long, rather narrow: sepals distinct to near the base, subulate-setaceous, hardly surpassing the capsule $-C . o b$. longifolia, var. angusta, p. 324. Dipteracanthus linearis, Chapm. Fl. 303, not Torr. \& Gray. - S. Florida, Chapman, Palmer, Garber, Curtiss.

DiptericAnthus hfspidus, Bertol. Misc. Bot. xvii. 17, t 1, is Gratiola pilosa, Michx. On the other hand, Nicotiana humilis, Bertol. 1. c. xiii. t. 1, is Ruellia ciliosa, Pursh. 


\section{ANISACÁNTHUUS, Nees. Species rearranged, as follows : -}

* Calyx-lobes attenuate, longer than the stipe and mostly about equalling the body of the capsule (a third to half an inch lovg): corolla chll red, funnelform above, with lobes much shorter than the tubular portion: flowers distinctly pedicellate, chiefly in axillary and mostly leafy fascicles.

A. Thúrberi, Grar, p. 328. From monntains of W. Texas (Ilavard) to those of S. W. Arizona, Pringle, Parish, \&c. Here belong the U. S. portion of Drejera puberula, Torr., and A. pumilus, p. 328, not X̌ees.

* Calyx shorter, not surpassing and only in A. virguluris ever equalling the stipe of the capsule: flowers usually, at least the upper ones, spicately or racemosely disposed along the branchlets aud secund, the upper subtending leaves reduced to subulate bracts.

A. insignis. Puberulent ol nearly glabrous: leaves mostly linear-lanceolate to linear: flowers pedicellate, in lateral cluster's from axils of fallen leaves and short-racemose on evolute small-bracted branchlets: calyx puberulent-glandular; the almost distinct sepals linear-subulate, 2 or 3 lines long: corolla rose-red or even salmon-color, 2 inclies long; the linear lobes shorter than the upwardly enlarged tubular portion: stipe when well developed longer than the body of the capsule. - A. pumilus, Watson, Proc. Am. Acad. xviii. 133. Drejera puberula, Torr. Bot. Mex. Bonnd. 123, as to pl. Gregg. - Chisus Monntains on the border of $W$. Texas, Havard, a linear-leaved form, with stipe to capsule a third of an inch long. (Adj. Mex. Between Parras and Chihualiua, Gregg. Palmer, with stipe as long as capsule, and in the State of Chibuahua, Pringle, with stipe half-incli long )

A. Wríghtii, GraY, p. 328. ('alyx glabrous or nearly so, remarkably short, barely 2 lines loug, and the lobes rather obtuse, seldom half the length of the stipe: corolla with throat very little dilated.

A. Púmuxs, Nees, Hemsl. Biol. Centr.-Am. Bot. ii. 522, includes A. Freggii, p. 328, and has tomentulose-pubescent and short calyx, the scarlet-red corolla of the next, but with its ligulate-linear lobes longer than the narrow tube.

A. viRG TLÁris, Nees, has a nearly glabrous calyx with slender-subulate lobes, a scarlet-red corolla with lobes shorter than the slender tube, and stipe shorter or not longer than the body of the capsule. To this belongs the plant of Berlandier referred to Drejera puberula, Torr. Also the A. pumilus, CErst. Pl. Liebm. Palmer's Mexican no. 1016 has the leaves and corolla of the most narrow-leaved A. virgularis, but the calyx of A. Mrightii. A. junceus, Hemsl., the Drejera juncea, Torr. 1. c., is founded on a leafless branch of a slender and junciform A. virgularis, like one recently collected in Chihuahua by, Pringle.

\section{DIANTHERA, Gronov. At end of the genus, p. 330, add:-}

Jacobfina neglécta, Sericographis neglecta, Oersted, a native of the Mexican coast-region, has been received, through P. J. Berckmans, in living specimens from Floricla, where it is said to be spontaneous, - probably through some mistake. It is somewhat shrubby, with oblonglanceolate or broader and acuminate leaves, flowers (inch and a half long) secund, in naked triple spikes on a slender axillary peduncle: calyx and bracts short: corolla light brick-red and narrowly tubular: connective of the anthers broad enough to refer the plant to Dianthera, the slightly higher and larger cell (or rather the connective) apiculate.

\section{DICLIPTERA, Juss.}

D. resupináta, Jvss., p. 331, covers two species. The true one is annual, with a loosely branched stem: leaves from ovate to oblong-lavceolate, rather long-petioled: involucral bracts cordate-rotund: seeds muricate with subulate minutely setuliferous processes. Gray, Proc. Am. Acad. xx. 308. - On the borders of S. W. Arizona and Sonora, coll. Coulter (557), Thurber, \&c. (Trop. Mex., \&c.)

D. Torréyi, Gray, 1. c. Low, many-stemmed from a stout lignescent perennial caudex: leaves lanceolate, not over inch and a half long (including the short petiole): involncral bracts cordate-orbicular, usually emarginate, all more or less pedunculate: seeds scabrous with acute and naked papillæ. - D. resupinata, Torr. Bot. Mex. Bound. 125, and mainly of 
p. 331. (Probably not at all D. thlaspioides, Nees, of Central America.) - Arizona, by nearly all collectors.

D. pseudoverticillaris, Gray. Intermediate between the Platystegioe and the Sphenostegice, annual, a foot high, branching and flowering from the base, nearly glabrous : lower leaves ovate, acuminate (over an inch long), long-petioled; upper much smaller, ovateelliptical, short-petioled, equalling the axillary subsessile leaf-like involucral bracts : these at first spreading, deltoid-roundish, very obtuse or retuse, rarely mucronulate, abruptly contracted at base, there commonly coalescent into a narrow cup: corolla not surpassing the involucre: seeds muricate with minutely setuliferous processes. - Proc. Am. Acad. xx. 308. - Valley of the Altar, N. W. Sowora, Mexico, not far below the boundary of Arizona, Pringle. Apparently also collected, long ago, in the same district, by Thurber.

\section{SEIAAGINACEA.}

1. LAGOTIS, Gærtn. (Axy'śs, a hare, ovs, ear.) The earlier name for Gymnandra, Pall., p. 332. Only one Northern species, viz. :-

L. glaúca, Gsrтx.; Maxim. Diag. Pl. Nov. Asiat. iv. 1881, 296. Gymnandra Gmelini and $G$. Stelleri, Cham. \& Schlecht., and p. 332 : these specific names taken by Maximowicz as varieties.

\section{VERBENACEA.}

\section{VERBÉNA, Tourn.}

V. Bonarí́nsis, L. Before V. angustifolia, p. 336. A peculiar species, mostly tall, puberulent, somewhat scabrous: stem square: leaves partly clasping, lanceolate, acutely serrate, entire toward the base, reticulate-veiny and rugose: spikes dense and short, sessile and crowded in dense pedunculate cymes : corolla small. - Dill. Hort. Elth. 406, t. 300. - Roadsides near Charleston, S. Carolina. (Widely dispersed through warm countries; nat. from S. Am.)

V. littorális, HBK. Next to $V$. angustifolia. Nearly smooth and glabrous, a foot or two high, fastigiately branched above: branches terminating in single and rather slender spikes of small purple or blue flowers : leaves lanceolate or the upper linear, more or less serrate, rugose-veiny. - Nov. Gen. \& Spec. ii. 276, t. 137. - Lower California, near the border of San Diego Co., Orcutt. (Variable and wide-spread species of Mex. and S. Am.)

V. remóta, Bentr. After $V$. canescens, p. 336, from which exclude the syn. Procumbent from a perennial or perlups annual root: leaves mostly obovate in outline, once or twice 3-5-parted into short aud narrow lobes: lower flowers sparse and in the axil of leaves (as in the nearly related species), and most of the upper exceeded by the linear or subulate bracts: fruit shorter; nutlets granulose-scabrous at the commissure. - Pl. Hartw. 21; Watson, Proc. Am. Acad. xviii. 136. V. Arizonica, Gray, Proc. Am. Acad. xix. 96. - S. Arizona, Lemmon, Pringle, the latter distributed as $V$. canescens. (Mex.)

8. CITHAREXYUUM, L. Nutlets occasionally one-celled, the seed filling the cell.

\$ Lycikstrum. Flowers solitary or subsolitary in the centre of axillary fascicles of leaves: these remarkably small.

C. brachyánthum. Slender, very much branched, puberulent: branchlets quadrangular : leaves from linear-spatulate to obovate, quarter to half inch long, veinless, subsessile; primary ones articulated (in the manner of the genus) with the pulvinus or very short persistent petiole, which after their fall often becomes spinescent (but barely a line long): calyx 
5-dentate, pubescent: tube of the white corolla campanulate (hardly 2 lines long) and barely surpassing the calyx, somewhat longer than the rounded lobes: fifth stamen sometimes antheriferous : drupes 3 lines in diameter, apparently yellow: endocarp of two 2-celled nutlets : ovules amphitropous, borne at about the middle of the cell : seed pendulous from near the summit of the cell, becoming orthotropous, with bollowed face, undulate-rugose on the back. - Lycium brachyanthum, Gray in Hemsl. Biol. Centr.-Am. Bot. ii. 426; Watson, Proc. Am. Acad. xi. 127. - S. borders of Texas, at Laredo, on the Rio Grande, Parry, Palmer. (Coahuila, Mex., Palmer, and long ago coll. by Gregg.) C.lycioides, Don in Edinb. New Phil. Jour. x. 237, coll. by Sesse \& Moçino in Mexico, must be near this, and may be the sarne. Habit very unlike the ordinary types of the genus.

\section{LABIAT压.}

\section{TRICHOSTÉMA, Gronov.}

T. ovátum, Curran. Next T. lanceolatum, p. 348. Densely villous : leaves ovate, apiculateacuminate, subsessile, 3-5-nervose; those of the branches crowded, half-inch long: tube of the villous corolla little exserted. - Bull. Calif. Acad. i. 154. - Near Bakersfield, Kern Co., California, Mrs. Layne-Curran.

T. lanátum, Bentr., p. 348. Varies much in the length and hue of the wool, passing apparently into

Var. denudátum, with the wool remarkably short. $-T$. Parishii, Vasey in Bot. Gazette, vi. 173. - S. California, in San Bernardino Co., and adjacent San Diego Co., G. $R$. Vasey, Parish, W. G. Wright.

\section{TEƯCRIUM, L.}

T. occidentále, Gray, p. 349. Extends eastward to Upper Canada (Ontario), Macoun, and to near Philadelphia, Martindale. Probably passes into T. Canadense.

\section{MONARDELLA, Benth.}

M. macrántha, Grax, p. 356. This varies through specimens with corolla only an inch long (such as figured in Bot. Mag. t. 6270, with deep red corolla) into

Var. nána (M. nana, Gray, 1. c.), with tube of the more slender and pale rose-colored corolla little exserted from the calyx; and

Var. tenuiflóra, with corolla full inch long and much exserted, pale rose-color, the tube very slender and lobes narrow. - M. tenuiflora, Watson, in Gray, Proe. Am. Acad. xvii. 230. - San Diego Co, at San Jacinto, Parish, and Lower California, Orcutt.

M. hypoleúca, GRAr, p. 356. Between Los Angeles and San Diego, Nevin, and mountains behind San Diego, Orcutt, with narrower leaves, becoming revolute and verging to linear: corolla white.

M. lanceoláta, Grar, p. 357. Heads fully two-thirds inch high and broad, or broader: but on the sonthern frontier varying into

Var. microcéphala. Much branched: heads much smaller : involucral bracts small, not over quarter-inch long. - Potrero, near San Diego, Orcutt.

M. Prínglei, Grar. Near $M$. lanceolata, and might pass for a variety of it: but the broadly ovate and abruptly acuminate bracts are nearly destitute of veinlets between the numerous nerves, and are villous, as also bractlets and calyx. - Proc. Am. Acad. xix. 96. Sandy ridges, Colton, San Bernardino Co., Pringle. Also Parry, earlier collected, probably in same place.

M. тнуміғ́́li A, Greene, Bull. Calif. Acad. i. 211, the only extra-limital species, of the islands of Lower California, Veatch, Greene, is dwarf and suffruticose, with small ovate leaves. 


\section{POLIOMfNTHA, Gray. P. 361, add a third species : -}

P. glabréscens, Grax. Frutescent, a foot or two high, canescently puberulent, at length somewhat glabrate, paniculate, very leafy: leaves linear-oblong, 3-5 lines long, obtuse, veiuless and glabrate above, conspicuonsly punctate : caly $\mathrm{x}$-teeth short, erect, ovate or triangular : corolla white, with purple dots on the lower lip, villous outside, hardly thrice the length of the calyx, which equals the tube; this pilose-annulate within; rudiments of the sterile filaments minute. - Hemsl. Biol. Centr.-Am. Bot. ii. 549; Watson, Proc. Am. Acad. xviii. 137. - At Maxon Spring, W. Texas, near the Rio Grande, Havard. (Adj. Coahuila, Mex., Palmer.)

\section{HEDEOMA, Pers. P. 363, in place of the variety substitute the} species,

H. Reverchóni. A rigid suffruticulose perennial, a span to a foot high, equably and closely leafy to the top, puberuleut: leaves elliptical, coriaceous, half-inch long or less, the floral hirsute beneath and on the margins : flowers half-inch long: corolla almost twice the length of the strongly hirsute or hispid calyx. $-H$. Drummondi, var. Reverchoni, p. 363. Common in the mountains of Kendall Co., as well as of Brown Co., W. Texas, 1877, 1885, Reverchon.

26. ACANTHOMINTHA, Gray. A second species, with similar aspect and bracteal leaves, differs remarkably in the flowers, most so in the upper lip of the corolla. 'The shorter and smaller lower lip of the calyx in both species is erect and appressed to the upper in fruit.

A. ilicifólia, Gray, p. 365. Add: Cusps of the oblong calyx short, not longer than the teeth : upper lip of corolla straight and erect, entire; lower much larger, saccate at base, its lobes roundish, lateral ones recurved, midcle one broad and deeply 2-lobed : anther-cells of fertile stamens confluent at dehiscence; posterior stamens abortive, reduced to small filar ments with rudimentary anthers. - Add : Hook f. bot. Mag. t. 6750. - This singular plant ahounds near San Diego and southward, and has been distributed by Pringle, Orcutt, \&c.

A. lanceoláta, CuRras. Stouter, pubescent: camline leaves lanceolate or oblong, sparingly spinulose-dentate; teeth of the bracteal ones long-aristate: calyx more elongated; the teeth long-aristate; middle one of the upper lip erect and the lateral turned forward in fruit; lower lip 2-parted, its lanceolate segments tipped with shorter awns: corolla with narrow and longer upper lip somewhat falcate-incurved (in the bud strongly incurved over the lower), 2-cleft at apex; lower nearly one half shorter, less saccate at base; its lobes oblong and entire, the middle one longer and narrower: all four anthers polliniferous and their cells distinct, but those of the posterior stamens smaller : style sparsely pilose. - Bull. Calif. Acad. i. 13. - California, a single specimen found in Alameda Co., by E. Brooks, 1878. Collected abundantly in Slack's Cañon, Monterey Co., 1885, by Mrs. Layne-Curran herself.

\section{SÂLVIA, L. P. 366, add : -}

S. Bernardfna, Parish, fide Greene, Bull. Calif. Acad. i. 211, is to all appearance a hybrid between S. Columbarice and Audibertia stachyoides, a single plant collected at San Bernardino, Parish. Both the parents were growing in the vicinity, and the species are much visited by bees.

S. Gréggii, Grax, p. 368. Add : Hook. f. Bot. Mag. t. 6812. Corolla with crimson lower lip. - To $\S 4$ add the following, which need separate subdivisions.

S. Régla, Cav. Shrubby, minutely scabrous-puberulent; leaves broadly deltoid-ovate or subcordate, inch long, serrate, slender-petioled, those subtending the flowers similar: calyx short-tubular or campanulate, becoming inflated and tinged with red; the lips short and 
broad : corolla near 2 inches long, scarlet; lips of equal length, nartow, little shorter than the tube, the spreading lower oue almost entire. - Ic. v. 33, t. 455; Lindl. Bot. Reg. xxvii. t. 14. - Chisos Mountains, WV. Texas, on the Mexican border, Havard. (Mex.)

S. Lemmóni, Gray. Belongs to the S. fulgens group, near \$. Gralami. A foot or two high from a barely lignescent base, puberulent: stems strict, rather simple, leafy: leaves oblong- or deltoid-ovate, crenulate (about inch loug), with either truncate or subcuneate base, rather slender-petioled: bracts small and canescent: calyx narrowly oblong, atomiferous : corolla an inch long, rose-red; lower part of the throat moderately gibbous-ventricose; lips only a third the length of the throat and tube: style bearded above. - Proc. Am. Acad. xx. 309. - Huachuca Nountains, S. Arizona, Lemmon, Pringle.

S. albiflóra, Mart. \& GAL. To the species doubtfully so determined, on p. 370, append :-

Var. Prínglei. Cauescently puberulent, or lower face of the leaves tomentulose, as in $S$. polystachya, but inflorescence lax: corolla glabrous, 4 or 5 lines long, twice the length of the pubcrulent-canescent calyx. - S. Arizona, in the Santa Catalina Mountains, Lemmon, Pringle, distributed by the latter as S. pycnostachya (meaning polystachya), Ort., var. Pringlei.

S. Spicáta, Roem. \& Scholt. Shrubby, canescent with minute and dense pubescence (which on the leaves may turn reddish or ferruginous), very leafy : leaves small, lanceolateoblong, obtuse, minutely and closely crenulate, subsessile, upper face soon glabrate and rugose-renulose; bracts of the short spike ovate, acute, rather shorter than the flowers, deciduous: corolla 3 or 4 liues long, nearly twice the length of the lanate-tomentose calyx, blue or purple. - Benth. in DC. I’rodr, xii. 315. S. pulchella, HBK. Nov. Gen. \& Spec. ii. 288, t. 140, not UC. S. breviflora, Moçino \& Sesse, ex Benth. Lab. 274. - Huachuca Mountains, S. Arizona, Lemmon. (Mex.)

S. Hispáica, L., a spicately and blue-flowered species (Mexican, not Spanish), was collected by Havard, " near a garden" in Presidio Co., 'Texas, on the Mexican border.

\section{AUDIBERTIA, Benth.}

A. incána, Berth., p. 372. At the southern part of its range this species exhibits two remarkable varieties :-

Var. pilósa, with upper part of stem and whole inflorescence villous-pubescent. Northern base of San Bernardino Monntains, on the border of the Mohave Desert, Parish.

Var. pachystáchya. Large, 2 or 3 feet high, minutely puberulent, hardly cinereous: spiciform thyrsus over an iuch in diameter: bracts over half-inch long. - Bear Valley in the San Bernardino Mountains, Parish. Southern border of San Diego Co., Palmer.

A. Vaséyi, T. C. Porter. In the division with A. Palmeri, the inflorescence and corolla of that species, but the herbage whiter, and only lower leaves rugose-venulose: bracts and calyx-teeth aristate. - Bot. Gazette, vi. 207. - S. California, at Mountain Springs, San Diego Co., G. R. Vasey, 1880. Also San Bernardino Co.. W. G. Wright, 1880, a form with bracts and all the calyx-teeth tipped with very slender and even capillary awns. In Vasey's, less attenuate and less prolonged, those of the bracts and upper calyx-tooth more rigid, or as a cusp rather than an awn. Flower (with the exserted stamens) about an inch long.

\section{MONÁRDA, L.}

M. pectináta, NuTr., p. 375. No specimen was found in Nuttall's own herbarium, now at the British Museum, and what he gave to herb. Kew under this name is M. citriodora.

M. citriodóra, CERv. in Lag, ! 1. c. The calyx-teeth are usually spreading from the first. The species is becoming naturalized in Tennessee and eastward.

\section{CEDRONELLA, Mœnch. To $\$ 2$, p. 377, add:-}

C. pállida, LrNDL. Green and nearly glabrous: leaves broadly corilate-ovate or subcordate, mostly obtuse (an inch or so in length), crenate, slender-petioled : inforescence compact : corolla dull rose-color, half-inch or rather more long, the tube very little exserted from the small calyx. - Bot. Reg. xxxii. t. 29. C. brevifora, var. IIrardi (flowers haltinch long, smaller than in Lindley's figure, but evidently of same species), and C. breviflora, 
Gray, Proc. Am. Acad. xx. 309, a form with depauperate corollas, probably abnormal. Base of cliffs in the Chisos Mountains, W. Texas, on the frontier of Mexico, Havard. Also, Santa Rita Mountains, S. Arizona, Pringle, distributed as C. breviflora. (Mex.)

C. cána, Hook. Bot. Mag. t. 4618. C. Mexicana, var. cana, Gray, p. 377. This must be separated from C. Mexicana, though hard to define. Here belongs $C$. hastifolia, Regel, Ind. Sem. Hort. Petrop. 1868, 85. It passes into an extreme form in

Var. lanceoláta. Leaves from broadly to linear-lanceolate (an inch or half-inch long), aud from sparingly dentate to entire: corolla from two-thirds to full inch long. Mountains of New Mexico, Wright, G. R. Vasey, Rusby.

\section{SCUTELLÁRIA, L.}

S. versícolor, Nutr., p. 378. Add syn. : S. Mississippiana, Martens, Bull. Acad. Brux. 1841. S. integrifólia, L., p. 379. Add syn. . S. hyssopifolia, Bart. Fl. i. t. 2.

Var. májor, CHAPM. A very striking and peculiar form, two feet or more high: lower leaves ovate and sometimes cordate, coarsely crenate-dentate, obtuse, long-petioled; upper oblong to linear-lanceolate, mostly entire. - Fl. 323. - Rich soil in low grounds, Florida, Chapman, Curtiss, distrib. no. 2060.

\section{SYNÁNDRA, Natt.}

S. grandiflóra, Nutr., p. 384. Add syn. : Lamium hispidulum, Michx. Fl. ii. 4.

\section{STÁCHYS, Tourn.}

S. palústris, L., p. 387. Add syn.: S. velutina, Schweinitz, in Keating, Narr. Long's Exped. App. 114, a downy form.

To p. 401 and p. 404 add:-

144. PHEROTRICHIS. Corolla campanulate-rotate; lobes ovate, densely bearded inside with long introrse and retrorse hairs. Crown at junction of corolla with the extremely short column, of 5 quadrate excisely truncate scales, surpassing the promineat and hyaline-tipped anthers. Stigma surmounted by a very large globular or conical appendage. Habit of Asclepias.

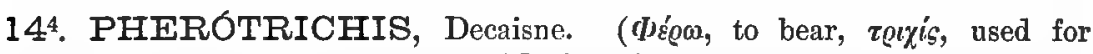
coma.) - Two erect and rather stout Mexican herbs, perennial from thick root, hirsutely pubescent, leafy : leaves oblong and lowest subcordate, petioled : flowers crowded in sessile or subsessile umbels at the axils: follicles hirsute, glabrescent. - Ann. Sci. Nat. ser. 2, ix. 322; Endl. Gen. 1798 ; Gray, Proc. Am. Acad. $x \times i$. ined.

P. Balbfsir (Asclepias villosa, Balbi, Tachnostoma Balbisii, Decaisne in DC. Prodr. viii. 602, Gonolobus pogonanthus, Hemsl. in part) is fuscous-hirsute : corolla-lobes venose-reticulate: crown-scales somewhat 2-horned, equalling the narrow-conical boss of the stigma. - Chiapas, \&c., S. Mexico.

P. Scháffneri. Less hirsute : corolla-lobes lineate-veined : crown-scales shorter and more truncate than the globular very large boss of the stigma. - Gonolobus pogonanthus, Hemsi. Biol. Centr.-Am. ii. 333, partly. - S. Arizona, Lemmon. (San Luis, Mex., Schaffner, Parry \& Palmer.) 


\section{ENUMERATION OF THE GAMOPETALOUS GENERA AND SPECIES.}

** The figures in parentheses represent the introduced species.

VOL. I. PART II.

Order CAPRIFOLIACE $Æ$, p. 7.

1. Adoxa . . . . 1

2. Sambucus . . . 5

4. Triosteum . . . 2

7. Lonicera . . 15

3. Viburnum . . 14

$\begin{array}{ll}\text { 5. Linnæa. . . . } & \text { I } \\ \text { 6. Symphoricarpos. } & 7\end{array}$

8. Diervilla . . . 2

Genera, 8. Indigenous species, 47.

Order RUBIACE无, p. $19,445$.
1. Exostema . . . 1
10. Genipa * . . 1
19. Mitchella . . 1
2. Pinckneya . . . 1
11. Cephalanthus . . 1
20. Kelloggia . . . 1
3. Bouvardia . . . 2
12. Morinda . . . I
21. Mitracarpus . . I 1
4. Houstonia . . . 13
5. Oldenlandia . . 3
6. Pentodon . . . . I
13. Guettarda . . . 2
14. Erithalis . . . 1
15. Chiococca . . . 1
16. Psychotria . . 2
7. Hamelia . . . 1
8. Catesbra . . . 1
17. Strumpfia . . 1
22. Richardia . . (1) 1
23. Crusea . . . . 3
24. Spermacoce. . . 5
25. Diodia. . . . . 2
26. Galium . . (4) 37
9. Randia . . . . 1
18. Ernodea . . . . 1

Genera, 26. Indigenous species, 81 ; Naturalized, $5=86$.

Order VALERIANACEA, p. 42.
1. Valeriana..., 8
2. Valerianella . . (I) 13

Genera, 2. Indigenous species, 20; Naturalized, $1=21$.

Order DIPSACACE无, p. 47.

$$
\text { 1. Dipsacus . . (2) } 2
$$

Indigenous species, none; Naturalized, 2. 


\title{
Order COMPOSIT AE, p. 48, 445.
}

1. Stokesia . . . . I

4. Stevia .... 6

5. Sclerolepis . . , . 1

6. 'Trichocoronis . . 2

7. Agrexatum . (1) 3

8. Hofmeisteria . . . 1

19. Gymnosperma - 1

20. Xanthocephalum . 2

21. Gutierrezia . . 5

22. Amphiachyris . 2

23. Griudelia. . . 12

24. Pentachæta. . . 4

25. Bradburia . . . 1

26. Heterotheca. . 2

27. Chrysopsis . . . 13

28. Acamptopappus . 2

2y. Xanthisma . . . 1

52. Pluçhea • . . 3

53. Pterocaulon . . . 2

54. Micropus . . . 2

55. Stylocline . . . 3

64. Plummera . . . 1

65. Dicranocarpus . 1

66. Guardiola . . . 1

67. Polymnia . . . 2

68. Melampodium . 5

69. Acanthospermum (2) 2

70. Silphium. . . 12

71. Berlandiera . . . 4

72. Chrysogonum . . 1

73. Lindheimera , 1

74. Engelmannia . . 1

75. Parthenium . . . 6

76. Parthenice . . . 1

77. Iva. . . . . 11

78. Oxytenia. . . 1

79. Dicoria . . . 2

80. Hymenoclea. . . 2

81. Ambrosia . . 8

82. Franseria . . 13

83. Xanthium • . (2) 3

84. Zinuia. . . . . 5

85. Sanvitalia . . . 2

\section{Tribe I. Vernoniacele.}

\author{
2. Elephantopas . . . 3
}

3. Vernonia, . 10

Tribe II. Eupatoriacee.
9. Mikania .. . 2
10. Eupatorium . . 39
11. Carminatia . . . 1
12. Kruhnia . . . 2
13. Brickellia . . . 31

Tribe III. Asteroides.

30. Aplopappus . . 45

31. Bigelovia. . . . 31

32. Solidago . . . 78

33. Brachychæta . . 1

34. Lessingia . . . 6

35. Bellis . . . . 7

36. Aphanostephus. . 4

37. Greenella . . . 2

38. Keerlia . . . . 2

39. Chrtopappa - 3

40. Monoptilon . . 1

Tribe IV. InUloideac.

56. Psilocarphus . . 5

57. Evax . . . . . 4

58. Filago. . . (2) 5

59. Anteunaria . . 12

Tribe V. Helianthoidea.

\begin{tabular}{|c|c|c|c|}
\hline & & & \\
\hline 7. Tetragonoth & hec & & \\
\hline 8. Sclerocarpus & & . & \\
\hline 9. Eclipta & & & \\
\hline o. Melanthera & & & \\
\hline - Varilla & & & \\
\hline 2. Isocarpha . & & & \\
\hline 3. Spilanthes . & & & \\
\hline - Echinacea . & • & . & \\
\hline . Rudbeckia. & & & \\
\hline Lepachys . & & & \\
\hline Werlelia: . & & & \\
\hline Borrichia & & & \\
\hline - Balsamorrhi & & & \\
\hline Wyethia & & & \\
\hline mia & & & \\
\hline iera. & & & \\
\hline tho & & & \\
\hline Jia & & & \\
\hline & & & \\
\hline & & & \\
\hline
\end{tabular}

86. Heliopsis . . . 4

87. Tetragonotheca . 3

89. Eclipta . . . . 1

90. Melanthera . . 3

91. Varilla . . . 2

92. Isocarpha . . . 1

94. Echinacea . . , 2

95. Rudbeckia. . . 21

96. Lepachys . . , 4

97. Werlelia: . . 1

98. Borrichia . . . 2

99. Balsamorrhiza . 8

100. Wyethia . . . 12

101. Gymnolomia . . 4

102. Viguiera * . 6

103. Tithonia $\cdot 1$

105. Flourensia. . . 1

106. Encelia . . . 9

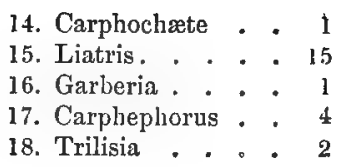

41. Dichætophora . . 1

42. Boltonia . . . 3

43. Townsendia . . 16

44. Corethrogyne . . 3

45. Psilactis . . . 2

46. Eremiastrum . . . 1

47. Sericocarpus . . 4

48. Aster . . . . 124

49. Erigeron . . (1) 72

50. Conyza . . . 1

51. Baccharis . . 19

60. Anaphalis . . . 1

61. Gaaphalium . 15

62. Inula . . . . (1) 1

63. Adenocaulon . 1

63․ Dimeresia . . 1

107. Helianthella . 10

108. Zexmenia . . 3

109. Verbesina . . . 9

110. Actinomeris . . 2

111. Synedrella. . . 1

112. Coreopsis . . 28

113. Bidens . . . . 14

114. Cosmos . . (2) 3

115. Heterospermum . 1

116. Leptosyne . . . 7

117. Thelesperma . . 6

118. Baldwinia . . . 2

119. Marshallia . . . 4

120. Galinsoga . . . I

121. Blepharipappus . 1

122. Madia . . . . 9

123 Hemizonella . 2

124. Hemizonia . . . 27

125. Achyrachæna . . 1

126. Lagophylla • • 5

127. Layia . . . 13 
Tribe VI. Helenioide.

128. Clappia . . . 1

129. Jaumea . . . . 1

130. Venegasia . . 1

131. Riddellia . . . 3

132. Baileya . . . 2

133. Whitneya . . . 1

134. Laphamia . . 10

135. Perityle . . . 9

136. Pericome . . . 1

137. Eatonella . . 2

137. Crockeria . . I

138. Monolopia . . 5

139. Lasthenia . . . 2

140. Burriellia . . . 1

141. Baeria . . . 18

170. Leucampyx . . 1 171. Anthemis . (2) 2 172. Achillea . . . 3

1781. Bebbia . . . 1

179. Tussilago . . (1) 1

180. Petasites . . (1) 4

181. Cacaliopsis . . I

182. Luina . . . 1

183. Peucephyllum • 1

195. Saussurea . . 2 196. Arctium . (1) 1197. Carduus . . (1) 1

202. Hecastocleis , 1 203. Gochnatia . . . l

207. Phalacroseris . I 208. Atrichoseris . . 1 209. Lampsana . . (1) 1 210. Apogon . . . 3 211. Krigia . . . 5 212. Cichorium . . (1) 1 213. Stephanomeria . 14 214. Chætadelpha 1 215. Rafinesquia . . 2 216. Tragopogon . (2) 2
142. Syntrichopappus. 22

143. Eriophyllum . . 12

144. Bahia . . . 10

145. Amblyopappus . 1

146. Schkuhria . . 2

147. Hymenothrix , . 2

148. Hymenopappus . 7

149. Florestina . . . 1

150. Polypteris . . . 4

15l. Palafoxia . . . 2

152. Rigiopappus . . 1

153. Chrnactis . . 20

154. Hulsea . . . 6

155. Trichoptilium , 1

\section{Tribe VII. Anthemide}

173. Matricaria . . (1) 3

174. Chrysanthemum (3) 6

175. Soliva . . (1) 2

Thibe ViII. Sexecionidee.

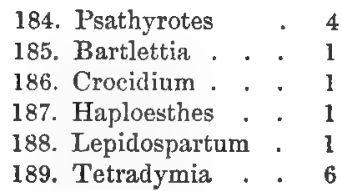

Tribe IX. Cryaroidle.

198. Cnicus . . (2) 37 199. Opopordon. . (1) 1

Tribe X. Mutisiacem. 204. Chaptalia . , 2 205. Perezia . . . 5

Tribe XI. Gichoriacere.

217. Anisocoma . . 1 218. Hypochneris - (1) 1

219. Microseris . . 20

220. Leontodon . . (1) I

220. Picris . . . . 1

221. Pinaropappus . . 1

222. Calycoseris . . 2

223. Malacothrix . . 13

224. Glyptopleura . . 2

225. Apargidium . . 1
156. Blennosperma - 1

157. Actinella . . 15

158. Helenium . . . 20

159. Amblyolepis . . 1

160. Gaillardia . . . 9

161. Sartwellia . . . 1

162. Flaveria . . . 5

163. Porophyllum . . 3

164. Clurysactinia . . 1

165. Nicolletia . . . 2

166. Dysodia . . . 3

167. Hymenatherum 14

168. Tagetes. . . ․․

169. Pectis . . . 12

176. Cotula . . (2) 2

177. Tanacetum . (1) 8

178. Artemisia . (2) 43

190. Raillardella . . 4

191. Arnica . . . . 15

192. Senecio . . (3) 58

193. Cacalia . . . . 9

194. Erechtites . . 1

200. Silybum . . (1) 1

201. Centaurea . (7) 8

206. Trixis . . . 1

226. Hieracium - . (3) 29

227. Crepis . . (3) 11

228. Prenanthes , 10

229. Lygodesmia . 6

230. Troximon . . 13

231. Taraxacum . . 1

232. Pyrrhopappus . 4

233. Chondrilla . . (1) 1

234. Lactuca . . (1) 10

235. Sonchus . , (4) 4

Genera, 239. Indigenous species, 1576 ; Naturalized, $60=1 € 36$. 


\section{VOL. II. PART I.}

Order GOODENIACE $\mathbb{E}$, p. 1.

1. Scævola . . . . 1

Order LOBELIACE $\mathbb{E}$, p. 1, 393.
1. Nemacladus . . . 3
2. Lobelia
5. Downingia . . . 3
11. Parishella . . . 1
$\cdot \cdot \cdot 1$
12. Howellia . . . 1
4. Laurentia. . . 1

Genera, 7. Indigenous species, 34.

ORder CAMPANULACE无, p. 9, 395.
1. Sphenoclea . . (1) 1
3. Specularia
5. Heterocodon . . , 1
2. Githopsis . . . 2
4. Campanula

Genera, 5. Indigenous species, 21 ; Naturalized, $3=24$.

ORder ERICACEA, p. 14, 396.
1. Gaylussacia . . 5
2. Vaccinium · · 25
3. Chiogenes . . . 1
4. Arbutus . . . 2
6. Epigæa . . . . 1
7. Gaultheria . . 4
8. Andromeda 8
9. Oxydendrum . 1
10. Leucothoe . . . 6
11. Cassandra . . 1
12. Cassiope . . . . 4

13. Calluna

14. Bryanthus

15. Kalmia

25. Chimapha '" '

16. Menziesia .

17. Rhododendron 16

18. Ledum . . . . 3

19. Bejaria . . . . 1

20. Leiophyllum . 1

21. Loiseleuria . 1

22. Elliottia. . . 1

26. Moneses . . . . 1

27. Pyrola . . . . 8

28. Allotropa . . . 1

29. Pterospora . . . 1

30. Sarcodes . . 1

31. Schweinitzia . . 2

32. Monotropa . . 3

23. Cladothamnus . 1

33. Pleuricospora . 2

34. Newberrya . . . 2

Genera, 34. Indigenous species, 136.

Order LENNOACE无, p. 50.

1. Pholisma

2. Ammobroma

1

Genera, 2. Indigenous species, 2.

Order DIAPENSIACE $\not$ E, p. 51, 399.

I. Pyxidanthera . . . 1

3 Shortia . . . . 1

4. Galax ... 1

2. Diapensia . . . . 1

Genera, 4. Indigenous species, 4.

Order PLUMBAGINACE $Æ$, p. 53.
1. Statice
2. Armeri
3. Plumbago . . , . 1

Genera, 3. Indigenous species, 4. 
Order PRIMULACE $\nexists$, p. 55, 399.
.. Hottonia . . . . 1
5. Androsace . . . . 5
9. Glanx . . . . 1
2. Dodecatheou . . . 1
6. Trientalis . . . . 2
10. Anagallis . . (1) 1
3. Primula . . 12
7. Steironema . . . 4
11. Centunculas . . 2
4. Douglasia . . . 4
8. Lysimachia . . (2) 7
12. Samolus . . . 2

Genera, 12. Indigenous species, $39 ;$ Naturalized, $3=42$.

ORDER MYRSINEACE无, p. 64.
1. Myrsine . . . 1
2. Ardisia . . . , 1
3. Jacquinia . . . 2
Genera, 3. Indigenous species, 4.
Order SAPOTACE Fi, p. 66.
1. Chrysophyllum
(1) 2
3. Dipholis .
5. Mimusops . . . . 1
2. Sideroxylon.
. 1
4. Bumelia.

Genera, 5. Indigenous species, 9 ; Naturalized, $1=10$.

ORdER EBENACEAE, p. 69.

1. Diospyros . . . . 2

Genera, 1. Indigenous species, 2.

ORDER STYRACACE无, p. 70.
1. Symplocos . . . 1
2. Halesia . . . . . 3
3. Styrax . . . . 5
Genera, 3. Indigenous species, 9.
ORDER OLEACE $\not E$, p. 72.
1. Fraxinus . . . . 12
3. Chionanthus . . . 1
5. Osmanthus . . . I
2. Forestiera . . . 8
4. Hesperelæa . . . 1
6. Menodora . . . 6

Genera, 6. Indigenous species, 29.

ORDER APOCYNACEÆ, p. 79, 400.
1. Vallesia. . . . . I
4. Haplophyton . . 1
7. Macrosiphonia . 3
2. Amsonia . . . 6
5. Apocynum . . . 2
8. Echites . . . . 4
3. Vinca . . . . 1
6. Cycladenia . . . 1
9. Trachelospermum . 1

Genera, 9. Indigenous species, 20.

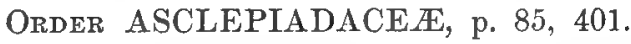

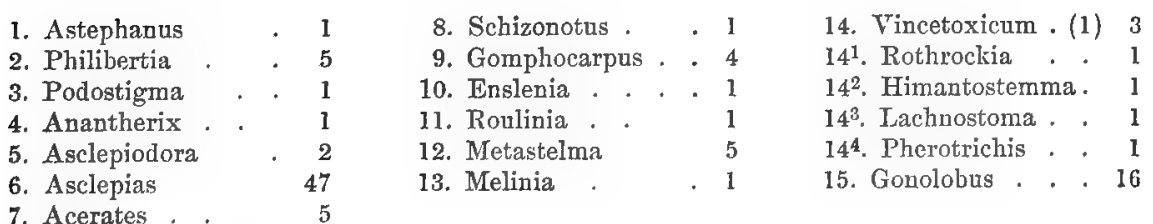

Genera, 19. Indigenous species, 97 ; Naturalized, $i=98$. 
Order LOGANIACE $尹$, p. 106, 405.
I. Gelsemium , . , 1
3. Mitreola . . . . 2
5. Buddleia . . . 5
2. Spigelia. . . . . 5
4. Polypremum . . . 1
b. Emorya. $\quad$. . 1

Genera, 6. Indigenous species, 15.

ORder GENTIANACE $尹$, p. 110, 405.
10. Voyria . . . 1
5. Gentiana . . . 42
10. Bartonia . ... 2 ,
1. Microcala. . . 1
6. Pleurogyne - . 2
2. Frythræa . . (3) 13
7. Swertia . . . 1
3. Sabbatia . . 13
8. Frasera
11. Obolaria . . . . 1
12. Menyanthes . . 2
4. Eustoma . . . 2
9. Halenia . . . . 2
13. Limnanthemum . 2
Genera, 14. Indigenous species, 89 ; Naturalized, $3=92$.

Order POLEMONIACE $\mathbb{E}$, p. 128, 406.
1. Phlox . . . . 27
3. Loselia . . . . . 1
4. Polemonium . . 10
2. Gilia . . . . 95
Genera, 4. Indigenous species, 133.

ORDer HYDROPHYLLACE $A$, p. 152, 413.
1. Hydrophyllum - 6
6. Emmenanthe
7. Conanthus
1i. Lemmonia . 1
2. Nemophila . . 9
8. Trícardia . . . 1
9. Romanzoffia . . 2
4. Draperia . . 1
5. Phacelid . . . 73
10. Hesperochiron
12. Nama . . . 15
13. Eriodictyon . . 4
14. Hydrolea . . . 4
Genera, 14. Indigenous species, 129.

Order BORRAGINACE 2 , p. 177, 420.
1. Cordia . . . . 4
9. Cynoglossum . (1) 4
15. Mertensia . . 7
2. Bourreria . • . 1
10. Echinospermum (1) 12
11. Omphalodes . . 2
16. Myosotis . . (2) 6
4. Coldenia . . 5
111. Kryuitzskia $\quad$. 49
12. Plagiobothrys , . 13
5. Tournefortia .
13. Echidiocarya 1
6. Heliotropium . (3) 14
7. Harpagonella
14. Amsinckia . . 6
17. Lithospermum (2) 14
18. Onosmodium . . 4
19. Symphytum . (2) 2
20. Lycopsis . (1) 1
8. Pectocarya 4
(1) 1

Genera, 22. Indigenous species, 142 ; Naturalized, $13=155$.

Order CONVOLVULACE E, p. 207, 433.
1. Dichondra . . 2
2. Ipomoa . . . (1) 31
4. Convolvulus
(2) 14
5. Breweria
7. Cressa .
3. Jacquemontia . . 3
6. Erolvalus • $\cdot 5$
8. Cuscuta $\cdot 1$

Genera, 8. Indigenous species, 81; Naturalized, $5=86$.

Order SOLANACE Ae, p. 224, 436.

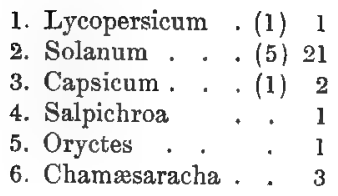

7. Physalis . . . 17

8. Margaranthus. . 2

13. Cestrum .

(2) 2

9. Nicandra . . (I) 1

14. Nicotiana

(3) 11

10. Lycium .

(1) 19

II. Datura . . (4) 5

12. Hyoscyamus

(1) 1

15. Petunia . . . I

16. Bouchetia , 1

17. Leptoglossis . . 1

Genera, 17. Indigenous species, 71; Naturalized, $19=90$. 
Order SCROPHULARIACEA, p. 244, 438.

\begin{tabular}{|c|c|c|c|c|c|}
\hline 1. Lencophyllum & & 2 & 14. Stemodia & & \\
\hline 2. Verbascum . & $\cdot(4)$ & 4 & 15. Conobea. & . & . \\
\hline 3. Linaria . . & $\cdot(4)$ & 6 & 16. Herpestis & . & " \\
\hline 4. Antirrhinum & $\cdot(2)$ & 23 & 17. Gratiola . & . & . \\
\hline 5. Maurandia . & . & 1 & 18. Ilysanthes . & & . . \\
\hline 6. Mohavea. & & $\mathbf{I}$ & 19. Micranthem & um & $\cdot$ \\
\hline 7. Collinsia. & . & 15 & 20. Amphianthu & & . \\
\hline 8. Tonella . & & 2 & 21. Limosella & - & . . \\
\hline 9. Scrophularia & • & 3 & 22. Scoparia. & . & \\
\hline 10. Chelone. . & . & 4 & 23. Capraria . & . & . \\
\hline 11. Pentstemon. & & 83 & 24. Synthyris & . & \\
\hline 12. Chionophila & • & $\mathbf{l}$ & 25. Veronica & & (5) \\
\hline 3. Mimulus . & & 51 & 26. Buchnera . & & - . \\
\hline
\end{tabular}

27. Seymeria . . 5

28. Macranthera . . 1

29. Gerardis . . . 23

30. Castilleia . . . 25

31. Orthocarpus 25

32. Cordylanthus 14

33. Schwalbea . , 1

34. Euphrasia . . . 1

35. Bartsia . . (1) 2

36. Pedicularis . . $3 \mathrm{I}$

37. Rhinanthus . . 1

38. Melampyrum . . 1

Genera, 38. Indigenous species, 367 ; Naturalized, $16=383$.

Order OROBANCHACE $巴$, p. 310, 455.
1. Orobanche. .
(1) 1
3. Conopholis
4. Boschniakia . 3
5. Epiphegus . . . : 1
2. Aphyllon. .
Genera, 5. Indigenous species, 15 ; Naturalized, $1=16$.

Order LENTIBULARIACEÆ, p. 314, 455.
1. Utricularia .
17
2. Pinguicula . . . 6

Genera, 2. Indigenous species, 23.

Order BIGNONIACEA, p. 318, 456.
1. Bignonia
3. Catalpa
4. Chilopsis . .
1
2. Tecoma. . 2
Genera, 4. Indigenous species, 6.

Order PEDALIACE E, p. 320.
1. Sesamum
(1) 1
2. Martynia . . . 3

Genera, 2. Indigenous species, 3 ; Naturalized, $1=4$.

ORDER ACANTHACE无, p. 321, 456.
1. Elytraria . . . 2
2. Hygrophila
3. Calophanes
4. Ruellia .

6. Berginia . . 1

7. Carlowrightia . . 2

8. Anisacanthus . 4

9. Siphonoglossa . 2

10. Beloperone . 1

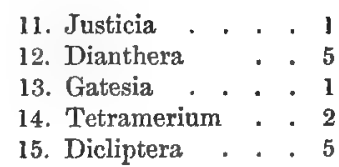

Genera, 15. Indigenous species, 41.

Order SELAGINACE无, p. 332, 458.

1. Lagotis . . . . 1 
Order VERBENACE无, p. 332, 458.
1. Phryma. . . . 1
5. Verbena . . (2) 18
9. Duranta . . . . 1
2. Priva. . . . . 1
6. Lippia . . . . 7
10. Callicarpa . . . I
3. Stachytarpheta . . 1
7. Lantana . . . . 4
8. Citharexylum . . 2
11. Avicenuia . . . 1

Genera, 11. Indigenous species, 38 ; Naturalized, $2=40$.

ORDER LABIAT $\not$, p. 341, 459.
1. Tetraclea . . . 1
18. Micromeria. . . 4
19. Calamintha. . (2) 9
2. Trichostema . . 9
20. Melissa . . (1) 1
3. Isanthus . . . . 1
4. Teucrium . . 4
5. Ajuga . . . (1) 1
6. Ocimum . . . 1
7. Hyptis . . . 4
8. Collinsonia . . . 4
9. Mentha . . (7) 8
10. Lycopus . . . (1) 6
21. Conradina . . . 1
22. Poliomintha . . 3
23. Hedeoma . . . I1
24. Pogogyne * . . 5
25. Ceranthera . . 2
26. Acanthomintha . 2
27. Sphacele . . : 1
28. Salvia . . (2) 31
29. Audibertia . . 10
30. Monarda . . 9
31. Blephilia . . 2
32. Lophanthus . . 4
33. Cedronella . . 5
34. Nepeta - . (2) 2
35. Dracocephalum . 1
36. Scutellaria . . 23
37. Salazaria . . . 1
38. Brunella . . . . 1
39. Brazoria . . . . 2
40. Physostegia . . 3
41. Macbridea . . 1
42. Synandra . . . 1
43. Marrubium . . (1) 1
44. Ballota - . . (1) 1
45. Phlomis . . (1) 1
46. Leonotis . . . (1) 1
47. Leonurus . . (3) 3
48. Lamium . . (3) 3
49. Galeopsis . . (2) 2
14. Monardella . Origanum . (1) 1
16. Thymus . . (1) 1
17. Satureia . (1) 2
50. Stachys . . (1) 17

Genera, 50. Indigenous species, 202 ; Naturalized, $33=235$.

ORDER PLANTAGINACE无, p. 388.
1. Plantago . . . (1) 16
2. Littorella . . . 1
Genera, 2. Indigenous species, 16 ; Naturalized, $1=17$.

Genera of the Gamopetalæ of the North American Flora . . . . . 567

Represented by indigenous species . . . . . . . . . . . 525

Represented only by introduced species $\quad . \quad$. . . . 42

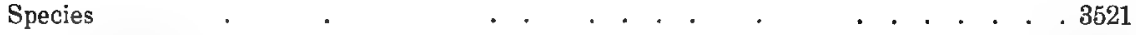

Indigenous . . . . . . . . . . . . . 3359

Introduced, mainly from the Old World . . . . . . . . . . 162

[This slip to replace corresponding portion of page 470, FLoRA of N. America, II.] 


\section{N D E X.}

NAMES of orders are in CAPITALS; of suborders, tribes, \&c., in sMaLL capITALS; of admitted genera and species, in ordinary Roman type; of synonyms, as also of subgenera, sections, and all species merely referred to, in lialic type.

ACANTHACE $\AA 2,321,456$.

Acanthomintha, $344,365,460$. ilicifolia, 365,460 .

lanceolata, 460 .

Acerates, $86,98,403$. atropurpurea, 100.

auriculata, 99 .

bifida, 403 .

connivens, 88.

cordifolia, 100

decumbens, 89.

lanuginosa, 99.

latifolia, 92 .

longifolia, 99 .

paniculata, 89.

tomentosa, 100 . viridiflora, 79 .

Achras, 69 .

mammosa, 69 .

salicifolia, 67

Sapota, 69.

Zipotılla, 69 .

Actinocyclus, 46.

Adelia, 76 .

acuminata, 76.

ligustrina, 76 .

porulosa, 77.

Adenostegia, 303 .

rigida, 303.

Adhatoda dipteracantha, 328. longiflora, 329.

Egochloa cotulafolia, 141. atractyloides, 142.

pubescens, 141.

pungens, 141.

Torreyi, 141.

Afzelia cassioides, 289.

Agerista, 33.

Agastache, 376

A qauria, 33.

Ajuga, 3.2, 349.

reptans, 349

AJUGNIDEE, 342.

Aldea circinata, 159.

Allotropa, 18, 48. virgata, 48.

Aloysia 338.

Alnifolia Americana, 45.

Amarella, 117.

Amblyanthera, 84

Amblynotus, 423 .

Amelia, 46.

minor, 46 .
American Cowslip, 57.

Ammobroma, 51. Sonoræ, 51.

Ammyrsine buxifolia. 43

Amphianthus, 247, 284. pusillus, 284

Amphistelma ephedroides, 102. filiforme, 102. graminifolium, 102. salinarum, 102.

Amsinckia, 179, 197, 420 . echinata, 178

Douglasiana, 198.

intermedia, 198, 433.

lycopsoides, 198.

lycopsoides, 198.

spectabilis, 198.

tessellata, 198.

vernicosa, 197.

Amsonia, 79, 81 . angustifolia, 81 .

brevifolia, 81 .

ciliata, 81 .

latifolia, 81

longiflora. 82.

Palmeri, 82.

salicifulia, 81 .

Tabernæmontana, 81 .

tomentosa, 81 .

tristis, 81 .

Anagallis, 56, 63 . arvensis, 64 . lutea, 62.

Anantherix, 86, 88 . connivens, 88 .

decumbens, 89

Nuttallianus. 89

paniculatus, 89 .

Torreyanus, 89 .

viridis, 88.

Anch usa canescens, 204. hirta, 205.

Virginica, 204.

Andrewsia autumnalis, 127. verna, 127.

Androcera, 231. lobata, 231.

Andromeda, 15, 30. acuminatre, 34, 397. angustifolin, 35 .

arborea, 33.

axillaris, 34 . axillaris, 34 . baccata, 20.

bracteosa, 28.

calyculata, 35

carulea, 37.

cassinefolia, 29.

Catesbei, 34.

coriacea, 32

crispa, 35.

cupressina, 36.

Davisiæ, 34 .

dealbata, 31.

ferruginea, 33

floribunda, 31 .

frondosa, 33 .

qlaucophylla, 31 .

hypnoides, 36.

lacustris, 32.

lancenlata, 34 .

laurina, 34.

ligustrina, 33 .

lucida, 32, 34 .

lycopodinlis, 36 .

marginata, 32.

Mariana, 32.

Mariana, 32.

Mertensiana, 36.

montana, 31.

myrifolia, 32.

nitida, 32 .

nitida, 31 .

obovata, 32.

paniculate, 33, 35.

phillyreifolia, 31 .

polifolia, 31 .

populifolia, 34

pulchella, 32.

pulverulenta, 31 .

racemosa, 35 .

racemosa, 33 .

reticulata, 34 .

rhomboidalis, 33 .

rigida, 33 .

rosmarinifolia, 31 .

speciosa, 31.

spicata, 35 .

spinulosa, 34.

Stelleriana, 35.

taxifolia, 37.

tetragona, 36 .

venulosa, 28.

Walteri, 34

ANDROMEDE 位, 15

Androsace, 56, 60 
Arizonica, 400. carinata, 60.

Chamxjasme, 60.

filjformis, 60

. linearis, 59, 60 .

occidentalis, 60 .

septentrionalis, 60 . villosa, 60.

Anisacanthus, 323, 328, 457 .

Greggii, (328), 457 .

junceus, 457.

pumilus, 328, 457 .

vircularis, $45 \%$

Wrightii, 328

Anistia aurea, 209. azurea, 214.

Anisucheila, 303.

Anonymos aquatica, 128. Carolinensis, 324 .

cassioides, 289.

petiolata, 108.

sempervivens, 107.

Anoplanthus, 312.

comosus, 312

fasciculatus, 312.

uniflor'us, 312.

Anoplun, 312

biflorum, 312

comosa, 312.

Antiphytum, 179, 199. floribundum, 199, (423).

heliotropioides, 199, (423).

Antivrhinastrum, 251.

ANTIRRHINIDE $2 \pm$, $2 \pm 5$.

Antirhinum, 245, 251, 438 .

Canadense, 250.

chytrospermum, 251.

confertiflorum, 439 .

Cooperi, 253, (439).

cornutum, 252

Coulterianum, 252, 438.

Coulterianum, 253.

cyatbiferum, 251.

Breweri, 253.

filipes, 254, 439 .

glandulosmom, 252.

junceun. 254, 439 .

Kelloggii, 439.

Kingii, 253, 439

leptaleum, 252.

majus, 252

maurandioides, 254.

Nevinianum, 438 .

Nuttallianum, 253, 438.

Orcuttianum, 4.88 .

speciosum, 254, 439 .

strictum, 253,439

subcordatum, 438 .

subsessile, 438 .

vagans, 253, 439 .

viroa, 252, 438 .

Aphyllon, 311, 312, 455 .

Californicum, 312 .

comosum, 312

Cooperi, 455.

fasciculatim, 312.

Ludovicianum, 313, 455.

multiflorum, 313 .

pinetorum, 313

tuberosum, 313

APOCYNACE 79.

Apocynum, 80, 82 .

androsamifoljum, 82 .

cannabintim, 8.3.

hirsutum, 104. hypericifolium, 83 .

pubescens, 83.

Sibiricum, 83

Apple of Peru, 237.

Arbute 215.

Arbutus, 15, 26.

Acadiensis, 27.

alpina, 27 .

filiformis, 26.

lanceolala, 27

laurifolia, 27, 396.

Menziesii, 27, 397 .

procera, 27.

pungens, 28.

Texana, $27,397$.

thymifolia, 26.

tomentosa, 28.

Xalapensis, 396.

Arctophila, 117, 119.

Arctostaphylos, 15, 27, 397.

acuta, 28.

alpina, 27.

Andersonii, 28.

arguta, 397.

bicolor, 29, 397.

Clevelandi, 29.

Clevelandi, 397.

cordifolia, 28.

diversifolia, 397 .

glauca, 28.

glauca, 28.

Hookeri, 28.

Nevadensis, 27.

nummularia, 28, 397.

officinalis, 27.

oppositifolia, 397.

polifolia, 29.

polifolia, 39t.

pumila, 28.

pungens, 28.

pungens, 27, 28.

tomentosa, 28 .

Uva-ursi, 27.

Veatchii, 397.

Arctous, 27.

Arclisia 65.

Pickeringia, 65.

Armeria, 54

alpina, 55 .

andina, 55.

arctica, 55

Labradorica. 55.

maritima, 55 .

sanguinolenta, 55 .

vulgaris, 55 .

ASCISEPIADAC'E

ASCLEPIADE 王, 85.

Asclepias, 86.

acer"atoides, 93 .

acuminata, 90 .

amoena, 90

amplexicaulis, 92 .

anyustifolia, 96,402 .

arenaria, 93

brachystephana, 94, 401 .

brevicornu, 89

cinerea. 98.

citrifolin, 93.

connivens, 88.

cordata, 90 .

cornuta, 100 .

Cornuti, 91, 401

cryptoceras, 92 .

Curassavica, 90 .

Curtissii, 402. decumbens, 90.

Douglasii, 91 .

elata, 401.

eriocarpa, 94.

eriocarpa, 94

erosa, 94.

exaltata, 93.

fascicularis, 97 .

Feayi, 98.

Floridana, 99.

Fremonti, 93.

galioides, 97.

glaucescens, 92, 401 .

grandifolia, 401.

Hallii, 95.

hy brida, 93 .

incarnata, 90 .

incarnata, 99

involucrata, 94, 402.

Jamesii, 92

lanceslata, 90, 99 .

lanuginose, 99 .

laurifolia, 90.

Jemmoni, 402.

lencophylla, 94.

Linaria, 97, 402 .

Lindheimeri, 98.

linearis, 96, 97.

linifolia, 96, 402 .

longicornu, 98.

longifolia, 97.

longipetala, 89, 99 .

macrophylla, 97.

macrotis, 95,402 .

Meadii, $91,401$.

Mexicana. 96.

Micliauxii, 402.

monocephala, 99.

nivea, $93,96$.

nummularia, 92

Nuttalliana, 95, 99

nyctaginifolia, 95, 402 .

obovata, 95.

obtusifolia, 91, 401.

obtusifolic, 92 .

ovalifolia, 95.

ovalifolia, 95 .

parviflor'a, 96.

paupercula, 90 .

pedicellata, 88.

perennis, 96 .

periplocifolia, 90.

phytolaccoides, 92 .

polystachia, 90.

pulchra, 91.

purpurascens, 90 .

purpurascens, 91

quadrifolia, 96 .

quinquedentata, 97, 402.

rubra, 90.

speciosa, 91 .

stenophylla, 98.

subulata, 96 .

Sullivantii, 91.

Sullivantii, 92.

Syriaca, 91, 93

tomentosa, 93 .

tuberosa, 89 .

tuberosa, 91.

uncialis, 401

vanilla, 96 .

variegata, 93.

varie 1 ata, 95

verticillata, 97 .

vestita, 94 . 
villosa, 462.

viminalis, 88.

virgata, 96,402

viridiflora, 99

viridls, 89 .

viricula, 97

Wrightii, 402 .

Asclepioctora, 86, 88, 401. curcinalis, 401 . decumbens, 89 . viridis, 89 .

Ash, 73 .

Asperugo procumbens, 420 .

Astephanus, 85, 87. Utahensis, 87.

Atropa physaloides, 237.

A Trope.E, 225.

Audibertia, 345, 372, 461 . capitata, 372.

citriodora, 375 .

Clevelandi, 373.

glabra, 374 .

graudifora, 372.

humilis, 372 .

incana, $372,461$.

nivea, 373 .

Palmeri, 373.

polystachya, 373.

stachyoides, 373 .

Vaseyi, 461 .

Avicennia, 334,340 .

nitida, 341 .

oblongifolia, 341 .

tomentosa, 341 .

A VICENYIIE.E, 333 .

Azalea, 39, 40 .

arborescens, 40 .

bicolor, 41.

calendulacea, 41 .

canescens, 41 .

frayzrans, 40.

glauct, 41.

hispidte, 41.

Lipponica, 42.

luterc, 41 .

nitidn, 41.

nudiflora, 41.

occidentalis, 40 .

parvifolium, 42

periclymenoides, 41 .

pilosa, 39.

procumbens, 44.

scabra, 41.

viscosi, 40

Azaleastrum, 40 .

Ballota, 347, 384. nigra. 384

Balm, 360 .

Balmony, 258 .

Bartonia, 111, 127.

tenella, 127.

verna, 127

Bartsia, 249.

acuminata, 297.

alpina, 305.

cocciner. 295.

gymnandra, 332

Odontites, 305.

pallida, 297.

tenuifolia, 300 .

Basil, 350, 354.

Basil Thyme, 359.

Bassovia hebepod", 224.

Batritas acetosafolia, 211.
Jalapa, 211.

littoralis, 211.

Batodendron, 20.

arboreum, 21.

Batschia, 2(14.

canescens, 204.

Carolinensis, 205.

decumbens, 205.

Gmelini, 205.

longiflora, 205

Bearberry, 27.

Beard-tongue, 259.

Bear Huckleberry, 20, 23.

Bee-Balm, 374.

Beech-drops, 313.

Befaria paniculata, 43.

Bejaria, 17, 43. paniculata, 43. racemosa, 43

Bell-flover, 11.

Bellinia umbellata, 437.

Beloperone, 323, 329 . Californica, 329 .

Belvidlere, 53.

Bene, 320.

Benthamia lycopsoides, 198.

Bergamot Mint, 352.

Berginia, 322, 327 . virgata, $32 ;$.

Betonica officinalis, 388.

Beumeriu, 180.

Bigeloria, 76.

Bignonia, 318, 319, 456 . capreolata, 319 .

Catalpa, 320.

cruciger 319

lineuris, 320.

radicans, 319.

sempervirens, 107.

stans, 319.

BIGNONIACE $2,318$.

Bilberry, 20, 23.

Billardiera, 337. explanata, 337.

Bindweed, 214.

Bird Pepper, 231.

Bittersweet, 228 .

Black Ash, 76.

Black Henbane, 240.

Black Horehound, 384.

Black Huckleberry, 20.

Bladderwort, 314 .

Blanfurdir cordata, 53.

Blephilia, 345, 376.

ciliata, 376 .

hirsuta, 376.

nepetoides, 376 .

Blue Ash, 75 .

Blueberry, 20, 21.

Blue-curils, 347 .

Blue IIuckleberry, 19, 22.

Blue Tangle, 10 .

Blueweed, 207.

Bolivaria, 78

Grisebachii, 79

Bonamia aquatica, 217. humistrata, 217.

Pickeringii, 218

Borrage. E, 178.

BORRAGINACE $A, 177,420$.

Borvago officinalis, 180.

Boryn, 76.

acuminata, 76.

ligustrina, 76 .

porulosa, 77 .
Boschniakia, 311, 313, 455. glabra, 313.

Hookeri, 313.

strobilacea, 313,455 .

Bothriospermum, 432.

Bouchen, 333, 334.

Ehrenbergii, 334.

linifolia, 335 .

spathulata, 335 .

Bouchetia, 226, 244. erecta, 244

Bourreria, 177, 180, 421. Haranensis, 181, 421. radula, 181.

recurva, 181.

succulenta, 181.

tomentosa, 181.

virgata, 181

Boxberry, 30.

Box-Thorn, 237.

Brachyglossis, 244

Brachygyne, 290.

Bracliystemum, 354 . lanceolatum, 354

linifolium, 354 .

muticum, 355. verticillatum, 355 . Virginicum, 354.

Bramia, 281.

Brazoria, 346, 382. scutellarioides, 382 .

truncata, 382.

Breweria, 208, 217. aquatica, 217.

humistrata, 217, 436.

minima, 436.

ovalifolia, 217.

Pickeringii, 217.

Brooklime, 286.

Brookweed, 64

Broom-Rape, 311.

Browallia Tezana, 244.

Brugmansice, 240.

Brunella, 346, 382. vulgaris, 382 .

Bryanthus, 16, 36 .

Aleuticus, 37.

Breweri, 37.

empetriformis, 37 .

glanduliflorus, 37 .

Gmelini, 37.

Stelleri, 35.

taxifolius, 37 .

Buchnera, 248, 289, 451

Americana, 289

Canadensis, 337.

elongata, 289.

Buckbean, 128.

Buckthorn, 68 .

Buddleia, 107, 109.

acuminata, 109.

crotonvides, 109.

Humboldtiana, 109.

lanceoluta, 109.

marrubiifolia, 109.

Pringlei, 405 .

racemosa, 109.

scordioides, 109.

Bugle-weed, 352, 35\%.

Bumelia, 67.

angustifolia, 68 .

arborea, 68.

chrysophylloides, 68.

cuneata, 68 .

ferruginea, 68. 
lanuginosa, 68 .

lycioides, 68.

macrocaspa, 68.

oblongifclia, 68.

parvifolia, 68 .

pauciflora, 68

reclinata, 68 .

reclinuta, 68.

salicifolia, 67 .

spinosa, 68.

tenax, 68.

Texana, 68.

tomentosa, 68

Burchardia Americana, 340.

Butter-and-Eggs, 251.

Butterfly-weed, 89 .

Butterwort, 317.

Calamint, 359 .

Calamintha, 343 , 359.

canescens, 361 .

Caroliniana, 360.

Clinopodium, 360.

coccinea, 360 .

dentata, 360 .

glabella, 360 .

mimuloides, 360 .

Nepeta, 359 .

Nuttallii, 360 .

officinalis, 359

Palmeri, 359.

Calibash-tree, 320 .

Calico-bush, 38.

Callibrachoa procumbens, 243.

Callicarpa, 333,340 . Americana, 340 .

Callistachya Viryinica, 287.

Calluma, 16, 36 . Atlantica, 36. vulgaris, 36.

Calonyction, 209. speciosum, 209.

Calophanes, 322, 456. angusta, 456 .

decumbens, 325.

humistrata, 324

linearis, 324 .

oblongifolia, 324 .

oblongifulia, 325,456 . ovata, 325.

Calosphace, 368.

Calyptrosper'mum, 78.

Calystegia, 214, 435.

Catesbeiana, 215, 433.

paradoxa, 215, 433 .

reniformis, 215 .

sepium, 215.

Soldanella, 215.

spithamaa, 215 .

subacculis, 216.

tomentosa, 215 .

villesa, 216.

Campanula, 10, 11, 395.

acuminata, 14

algida, 12 .

Altaica, 11.

Americana, 14

amplexicaulis, 11.

aparinoides, 13.

bifora, 11.

Coloradoense, 11.

dasyantha, 11.

declinata, 14.

divaricata, 13. dubia, 395.

erinoides, 13.

filiflora, 13.

flexuosa, 14.

Floridana, 13.

glomerata, 12.

heterodoxa, 395.

Illinoensis, 14 .

intermedia, 11.

Langsdorffiana, 12, 395.

lasiocarpa, 12.

linifolia, 12, 395 .

linnseifolia, 13.

Ludoviciana, 11.

Mediun, 11.

Montevidensis, 11.

nitida, 14.

obliqua, 14.

Pallasiana, 11.

Parryi, 395.

perfoliata, 11.

petiolata, 13.

planiflora, 14, 395 .

planiflora, 395 .

pilosa, 11.

pratensis, $12,395$.

prenanthoides, 13.

rapunculoides, 12

Reverchoni, 395.

rotundifolia, 12, 395 .

Roezli, 13

scabrella, 395

Scheuchzeri, 12.

Scheuchzeri, 395.

Scouleri, 13.

unifiora, 12.

CANIPANULLACE $刃, ~ 9,395$.

CAMPANUlEzi, 9.

Campsis radicans, 319.

Campylocera, 10. leptocarpa, 10.

Cancer-root, 312, 314.

Canchalagua, 112.

Canterbury Bells, 11.

Cantua a ggregata, $1 \pm 5$. coronopifolia, 145.

elegans, 145

Floridana, 145.

glomeriflora, 136.

longiflora, 136.

parvifora, 148.

pinnatifila, 145.

pungens, 141.

thyrsoidea, 145.

Capraria, 248, 284

biflora, 284.

durantifolia, 279

gratioloides, 283.

multifida, 279 .

pusilla, 278.

Capsicum, 224, 231.

baccatum, 231.

frutescens, 231.

microphyllum, 231 .

Carlowrightia, 322, 327 .

Arizonica, 328.

linearifnlia, 327 .

Cassandra, 16, 35.

calyculata, 35.

racemosa, 35 .

Cassanrlra, 62.

Cassiope, 16, 3ี5.

hypnoides, 36

lycopodioides, 36 .

Mertensiana, 36 .
Stelleriana, 35 .

tetragona, 36.

Castilleia, 249, 295, 452.

acuminuta, 297.

affinis, 296.

affinis, 295.

angustifolia, 298.

breviflora, 299 .

candens, 296.

cinerea, 452.

coccinea, 295

coccinea, 296.

desertorum, 296.

Douglasii, 296.

flava, 299.

foliolosa, 298.

grandiflora, 298.

hispida, 296.

indivisa, 295, 452 .

integra, 298.

lanata, 298.

latifolia, 296.

laxa, 296.

Lemmoni, 297.

linarixefolia, 296.

I.indheimeri, 298.

linoides, 299.

miniata, 297 .

minor, 295.

oblorrgifolia, 296.

occidentalis, 297.

pallida, 297.

pallida, 297

parviflora, 296.

plagiotona, 452 .

purpurea, 298.

purpurea, 298.

septentrionalis, 297 .

sessiliflora, 298, 452 .

Sibirica, 297.

stenantha, 295.

Tolucensis, 296.

tomentosal, 298.

viscidula, 297, 452 .

Castilleioides, 299.

Catalpa, 319, 456 .

bignonioides, 319, 456.

cordifolia, 319, 456 .

speciosa, 456 .

syringoefolia, 319 .

Cat-Mint, 377 .

Catnip, 377.

Cayenne Pepper, 231.

Cedronella, 345, 377, 461 . breviflora, 462.

cana, $(37 \%), 462$.

cordata, 377.

hastifolia, 462

Mexicana, 377.

Mexicana, 462.

micrantha, 377.

pallida, (377), 461 .

triphylla, 377

Centaurella cestivalis, 127.

autumnalis, 127.

Moseri, 127.

paniculata, 127.

verna, 127.

vernalis, 127.

Centaurium autumnale, 127. vernum, $12 \bar{\imath}$.

Centaury, 112.

Centunculus, 56, 64, 400 . lanceolatns, 64 .

minimus, 64 . 
pentandrus, 400 .

Ceranthera, 344, 365 densiflora, 365 .

linearifolia, 365 .

Ceropegia palustris, 102.

Cestrixe.e, 225.

Cestrum, 226, 241 .

diurnum, 241.

multinervium, 438.

Parqui, 438.

Chatodiscus, 280

Chatogilia, 409.

Chaff-seed, 305.

Chaffweed, 64.

Chaiturus Warrubiastrum, 385

Chamodaphne calyculata, 35.

Chamaledon procumbens, 44 .

Chamcephysalis, 233.

Chamesaracha, $225,232,436$.

Coronopus, 232, 436 . nana, 233.

physnloides, 437. sordida, 232

Checkerberry, 30 .

Cheilyctis, 375 .

Chelone, 246, 258. barbata, 261 centranthifolia, 264.

Dipitelis, 268.

glabra, 258.

Califulia, 259.

Lroni, 259.

majon", 259.

nemorosa, 259

obliqua, 258.

Pentstemon, 268.

purpurea, 259.

ruellioides, 261.

Chelonefi, 246.

Chia, 366.

Chickweed-Wintergreen, 60.

Chilopsis, 319,320 . linearis, 320 saligna, 320 .

Chimaphila, 17, 45 . corymbosa, 45 . maculata, 45.

Menziesil, 45. umbellata, 45 .

Chiogenes, 15, 26. hispidula, 26.

Japonica, 26. serpyllifolia, 26

Chionanthus, 73, 77 fraxinifolius, 73 Virginica, 77 .

Chionophila, 246, 273. Jamesij, 273 .

Chironia angularis, 114. calycosa, 114. campanulata, 115.

chloroides, 115.

cymosa, 114.

dichotoma, 114.

dodecandra, 115 .

gracilis, 115.

lanceolata, 114

paniculata, 114.

milchella, 112.

spicata, 112

stellata, 115.

Chlora dodecandra, 115.

Chloropyron palustre, 301, 453.

Chondrophylla, 120 .

Chrysophyllum, $66,67$.
Cainito, 67.

Carolinense, 68 . monopyrenum, 67 . oliviforme, 67

Chthamalia, 104 biflora, 105. pubiflora, 105.

Cicendia exaltata, 113. quadrangularis, 112.

Citharexylum, $333,340,458$. brachyantbum, 458 . lycioides, 459 . villosum, $3 \pm 0$

Citronella, 351 .

Cladothamnus, 17,44 . pyrolafolius, 44.

Clary, 372.

Clethra, 17, 44. acuminata, 44. aluifolia, 45 dentata, 45 . montana, 45. paniculata, 45 . pubescens, 45 . scabra, 45 . tomentosa, 45

Clethre.玉, 17.

Clinopodium, 360 . incanum, 356 . ruqosum, 350 . vulgare, 361 .

Clintmia corymbosa, 8. elegans, 8. pulchella, 9.

Clistogrammica, 220.

Cobara, 129.

Cochranea, 186

Colanthe, 120.

Calostylis loganioides, 108. Trxana, 108.

Coldenia, 177, 181 canescens, 181 Greggii, 182.

hispidissima, 182.

Nuttallii, 182 Palmeri, 182

Collinsia, 246, 255, 439 .

barbata, 255

bartsiæfolia, 255 .

bicolor, 255.

Childii, 257.

corvmbosa, 255.

grandiflora, 256.

Greenii, 256.

heterophylla, 255.

hirsuta, 255.

linearis, 439 .

minima, 257

Parryi, 257.

parviflora, 256.

pauciftora, $25 \%$.

Rattani, 430.

septemnervia, 255.

solitaria, 256.

sparsiflora, 256.

tenella, 257.

tinctoria, 255.

Torreyi, 257

verna, 256.

violacea, 256

Collinsonia, 342,351 .

anisata, 351.

Canadensis, 351.

decussata, 351.

ovalis, 351. precox, 351.

punctata, 351.

scabra, 351.

scabriuscula, 351 .

serotina, 351 .

tuberosa, 351.

verticillata, 351.

Collomia, 129, 134, (407).

aggregata, 410.

Cavanillemiana, $136,(410$.

coccinea, 408.

gilioides, 135, (408).

[411).

glutinosa, 135, 408 .

gracilis, 135, (408).

grandiflora, $135,(408)$.

heterophylla, 135, 408 .

leptalea, 136, (408).

linearis, 135, (408).

linoides, 146.

longiflora, 136, (410).

micrantha, 135.

nudicaulis, 140.

tenella, 135, (408).

Thurberi, 136, (410).

inctoria, 135.

Collomioides, 143.

Comarostaphylis, 29.

Comfrey, 206.

Conanthus, 153, 171. aretioides, 171 .

Conobea, 247, 279. borealis, 282.

intermedia, 279.

multifida, 279.

Conopholis, 311, 313, 455.

Americana, 313, 455

Mexicana, 455.

Conradia fuchsioides, 290.

Conradina, $343,361$.

canescens, 361 .

CONVOLVULACE $\mathrm{E}, 207,433$.

Convolvulea, 208.

Convolvulus, 208, 434.

acetosafolius, 211.

aquaticus, 217.

arvensis, 216.

arvensis, 216.436

Bonariensis, 217.

Brasiliensis, 211.

Caddoensis, 213.

Californicus, 215, 435.

Californicus, 216.

candicans, 211.

capillaceus, 213.

Carolinus, 213.

ciliatus, 214.

ciliolatus, 212

commutata, 213.

commutata, 212

condensatus, 434.

dissectus, 212, 217.

equitons. 217.

erianthus, 217.

fastigiata, 212.

fulcr'atus, 435 .

Garberi, 435.

glaucifolius, 217.

hastatus, 217.

Havanensis, 435 .

hederaceus, 210

Hermannia, 216.

hermanioides, 216.

hirsutus, 434.

humistrata, 217.

incanus, 216. 
Jalapa, 211.

Jamaicensis, 435.

littoralis, 211.

lobatus, 217.

longipes, 217, 435.

luteolus, (216), 435 .

macrorhizus, 211.

macrostegius, 435 .

Maximilnni, 435 .

micranthus, 213, 435, 436 .

Nil, 210.

obtusilcbus, 211.

occidentalisy 215,435 .

occidentalis, 435 .

panduratus, 211.

patens, 217.

penianthus, 214.

pentapeta]oides, 436 .

Pes-caproe, 211.

Pickeringii, 218.

Pringlei, 434.

pudibnendus, 210.

purpureus, 210.

repens, 215.

ruderarius, 435 .

sagittatus, 434.

sagittifolius, 212.

sepium, 215, 435 .

Sherardi, 217, 435, 436 .

Soldanella, 215.

speciosus, 212.

spithamsus, 215.

stans, 215.

stoloniferus, 211.

tamnifulius, 214.

tenellus, 217.

trichosanthes, 217.

trifidus, 212.

Valenzuelanus, 430.

villosus, 216,435 .

violace us, 214.

Corallophyllum, 51.

Cordia, 177, 180.

Boissieri, 180 .

bullata, 180 .

Floridana, 421.

globosa, 180.

Greggii, 180,420 .

podocephala, 180 .

Sebestena, 180.

Condies 177

Cordylanthus, 249, 302, 453.

cauescens, 304.

capitatus, 304 .

tilifolius, 303 .

King ii, 304 .

laxifforts, 303.

maritimus, 304, 454 .

mollis, 304 .

Nevinii, 454.

Oreuttianus, 454 .

Parryi, 304.

pilosus, 304 .

Pringlei, 453.

ramosus, 303

tenuis, 304.

Wrightii, 303,453 .

Coryanthus, 375 .

Cosmanthoides, 162

Cusmanthus, 162

fimbrintus, 162.

grandiforns, 164

parvitiorus, 163

viscidus, 163.

Coun'toisia, 408. bipinnatifida, 135.

Cowberry, 25.

Cow-Wheat, 310.

Cramberry, 20, 25.

Creeping Snowberry, 26.

Crematomia, 181.

Crescentia cucurbitina, 456 .

Cujete, 320.

Cressa, 208, 219.

Cretica, 219.

Truxillensis, 219.

Crossopetalim, 116.

Cross-vine, 319 .

Cryphiacanthus Barbadensis, 325.

Culver's Physic, 286.

Cunila, 343, 353 . coccinea, 360 .

glabella, 360 .

glabra, 360 .

hispida, 362 .

Mariana, 353.

pulegioides, 362.

Cuscuta, 208, 219.

acaulis, 222.

Americana, 222, 223.

applanata, 223.

arvensis, 220.

Californica, 220.

Californica, 221.

Cephalanthi, 220 .

chlorocarpa, 220.

compacta, 222.

Coryli, 221.

corymbosa, 221.

cuspidata, 222.

decora, 221.

denticulata, 221.

densiflora, 224.

epilinum, 223.

exaltata, 223.

fruticum, 222.

glomerata, 222.

Gronovii, 221.

Hassiaca, 221.

hispidula, 221.

indecora, 221.

inflexa, 221.

leptantha, 223.

neuropetila, 221.

obtusiflora, 220.

odontolepis, 223.

paradoxa, 223.

pentagonn, 220 .

Polygonorum, 220.

pulchervima, 221.

racemosa, 221.

remoliftora, 222.

rostrata, 222.

salina, 220.

Saururi, 222.

squamata, 222

sucveolens, 221.

subinelusa, 221.

subinclusa, 221.

tenuiflora, 220 .

umbellata. 223.

umbrosa, 221, 222.

verrucosa, 220,221 .

vulyivngr, 222.

Cuscutere, 208.

Cyanococcus, 21.

Cycladenia, 80, 83.

humilis, 83.

tomentosa, 83, 400 .

Cyclostigma, 406 .
Crnancheis, 85.

Cynanchum angustifolium, 102.

Carolinense, 104.

discolor, 104.

hirtum, 104.

obliquum, 104.

scoparium, 102.

suberosum, 103.

Cynoctonum petiolatum, 108. scoparium, 102.

sessilifolium, 108.

Cynoglossum, 178, 187, 420.

amplexicaule, 188.

Californicum, 422.

ciliatum, 188, (422).

glomeratum, 196.

grande, 188, 421.

Howa'di, (188), 423.

loeve, (188), 421.

lineare, 187.

Morisoni, 189.

nervosum, 189, 422.

occidentale, 188.

officinale, 187.

officinale, 188.

penicillatum, 187.

pilosum, 190.

Virginicum, 188.

CYPIILE, 2.

Cyrilla paniculata, 65.

Dactylophyllum, 137, 407.

Dactylostegium, 331.

Daphnidostaphylis, 27. Fendleriana, 27.

pumila, 28.

pungens, 28.

Dasymorpha, 192.

Dasystoma, 291.

Drummondii, 291.

patula, 292.

pectinata, 291.

pedicularia, 291.

pubescens, 291.

quercifolia, 291.

tubulosa, 291.

Date-Plum, 69.

Datura, 225, 239.

arborea, 240.

discolor, 240 .

inermis, 240 .

Mttel, 240.

meteloides, 240.

quercifolia, 240.

Stramonium, 240.

Tatula, 240.

Thomasii, 240.

Wrightii, 240 .

Dead-Nettle, 385 .

Decachana, 19.

Decamerium, 19. dumosum, 19

frondosum, 19 . resinusum, 20.

Decemium, 155 . hirtum, 155.

Deerberry, 21.

Devil-wood, 79.

Dendrium buxifolium, 43.

Dianthera, 323, 329, 457.

Americana, 329.

crassifolia, 329 .

ensiformis, 329.

humilis, 329.

ovata, 329 . 
parviflora, 330 . parvifolia, 330 .

Dianthus Carolinianus, 57.

Diapensia, 52. cuneifolio, 52.

Lapponica, 53

DLAPEXSIACE E, 51, 399.

DLAPENSUEde, 52

Dicerandra densitlora, 365 . linearifolia, 305 . linearis, 365

Dichondra, $20,208$. argentea, 208 Carolinensis, 208. macrocaly $x, 208$. repens, 208. sericert, 208.

DicITOXDRE: 207.

Dicliptera, 323, 331 . assurgens, 331 . brachiata, 331 . glandulosa, 331. Halei, 330. pseudoverticillaris, 458 . resupinata, 331,457 . resupinata, 331,458 thlaspioides, 331, 458 . Torrey ${ }^{-} 458$.

Dicranostegin, 454 .

Dictyolobus, 103.

DIGITALE, 248.

Digitalis purpurea, 438.

Dinspyros, 69. concolor, 69 . pubescens, 69 Texana, 70 . Virginiana, 69 .

Dipholis, 67. salicifolia, 67.

Diplucus, 275, 442 glutinosus, 275,442 latifulius, $275,442$. leptanthus, $2 \overline{7}$. longiflom, 276 puniceus, 275. stellatus, 275.

Dipteracanthus biflorus, 324 ciliosus, 326. Drummondirnus, 326. Drummondii, 326 . hispidus, 457 . Lindheimerianus, 32 . linearis, 324, 325, 457 . micranthus, 327. Mitchillianus, 326. noctiflomes, 326 . nudiftorus, 325 . oblongifulius. 324 riparius, 324 . strepens, 327. suffruticosus, 326.

Dittany, 353 .

I orider, 219.

Dodecatheon, 56, 57. dentatum, 58 . ellipticum, 57 . frigidum, 58 . integrifolium, 57. Joffrayi, 57 . Meadia, 57.

Dogbane, 82.

Douglasia, 56, 59, 399 arctica, 59,400 . dentata, 399 . levigata, 400 . montana, 60 .

nivalis, 59, 399.

I'italiana, 399.

Downingia, 2,8 .

bicornuta, 395 .

corymbosa, 8.

elegans, 8 .

pulchella, 9 .

Dracocephalum, $345,378$.

denticulatum, 383.

parvitlorum, 378 .

cordatum, 377.

intermedium, 383.

lincifolium, 383 .

Mexicanum, 377.

obovatum, 383 .

speciosum, 383.

variegatum, 383.

I'irginianum, 383.

Dragon-head, 378, 383 .

Draperia, 153, 158. systyla, 158.

Drejera Greggii, 328. juncea, 457.

puberula, 457.

Thurberi, 328. Wrightii, 328.

Duranta, 333, 340

Ellisia, 340 .

inermis, 340.

Plumieri, 340.

spinosa, 340 .

Dysmicodon, 11. C'alifurnicum, 11. ovatum, 11. perfoliatum, 11.

EBENACE 无, 69.

Echídiocarya, 179, 198, 420 .

Arizonica, 199, 433 .

Californica, 199.

Californicu, 432.

ursina, 432 .

Echinoglochin, 190 .

Echinospermum, 179, 188, 420. ciliatum, 422.

deflexum, 189, 421 .

deflexum, 189 .

diffisum, (189), 422.

diffusum, 42.2 .

floribundum, 189, 422.

Fremonti, 422 .

Greenei, 190.

hispidum, $4 \cdot 2 \cdot 2$.

intermedium, 189.

Lappula, 189.

Lappula, 190.

leiocarpum, 194

nervosum, 189.

patulum, 190.

pilosum, 190.

pinetorum, 421 .

Rerlowskii, 189, 422 .

scabrosum, 190.

strictum, 190.

subdecumbens, 189, 422 .

Texanum, 190.

ursinum, 422.

Virginicum, 189, 421.

Echinosphace, 366.

Echites, 80, 84.

Andrewsii, 84.

biflora, 401 .

brachysiphon, 84.

Catesuew, 84 . difformis, 85 .

macrosiphon, 83 .

neriundra, 84.

paludosa, 401

puberuba, 85 .

Sagræi, 84.

suberecta, 84.

umbellata, 84 .

ECHITIDE IE, 80.

Echium, 180, 207.

Ienziesii, 433

vulgare, 207.

Eddya hispidissimat, 182.

Ehretia, 177, 181, 421

Berbreria, 181.

ciliata, 421 .

elliptica, 181, 421.

exasperata, 421

Havanensis, 181.

radulr, 181.

tomentusa, 181

Ehretie.s, 177.

Elrohucera, 144, 410 .

t.llisia, 152, 157, 413.

acuta, 340 .

ambigua, 157.

chrysanthemifolia, 158, 413.

membranacea, 157.

microcalyx, 157 .

Nyctelea, 157.

ganunculacea, 157.

Torreyi, 413

Elliottia, 17, 44 . racemosa, 14.

Elmigera barbata, 261.

Elytraria, 322, 323.

cupressiner, 324.

fresciculate, 324.

frondosa, 324.

ramost, 324

tridentata, 324.

Tahliana, 324

virgata, 324

Emmenanthc, 153, 170.

glaberrima, 171.

glandulifera, 171.

lutea, 170.

parviflora, 170.

parviflora, 171.

penduliflora, 171.

pusilla, 171 .

Emorya, 107, 110. suaveolens, 110 .

Endotrichrt, 117.

Enslenia, 86, 100. albida, 100 .

Epicion, 101.

Epifagus, 314

Epigæa, 15, 29. repens, 29.

Epiphegus, 311 Americanus, 314 Virginiana, 314.

Epixiphium, 254

Erianthera, 259.

Erica carnea, 36. Stelleriunn, 35.

Tetralix, 35.

vullywis, 36.

ERICACE F, 14, 396.

EHICE $2,16$.

Erinus procumbens, 280

Eriodictyon, 153, 175. angustifolium, 176, 420 .

crassifilium, 176, 420. 
glutinosum, 176.

Lobbii, 419 .

sessilifolium, 419 .

tomentosum, 176,419 .

Eritrichium, 179, 190, (422). ambiguum, 426.

angustifolium, 194, (426). angust folium, 194, 427, 428. aretioides, 191.

barbigerum, 194, (426)

Californicum, 191, (423) canescens, (192), 431. Chamissonis, 191.

Chorisianum, 191, (424).

Chorisianum, 191.

circumscissum, 193, (428).

connatifolium, 191.

Cooperi, 424.

crassisepalum, 195, (424).

floribundum, 199.

fulvocanescens, 197, (430).

fulvum, 192, (431).

fulvum, 192, 432 .

glomeratum, 196.

glomeratum, 197, 429, 430

heliotropioides, 194, 199.

hispidum, 195, (428).

holopterum, 196, (429).

intermedium, 426 .

Jamesii, 196, (429).

Kingii, 192, (430).

leiocarpum, 194, (425).

leiocarpum, 425, 426 .

leucophaum, 197, (430).

micranthum, 193, (428).

micromeres, 427.

molle, 424 .

multicaule, 196.

muricatum, 424.

muriculatum, 194, $(426,427)$.

muriculatum, 194.

nanum, 196, (423)

nothofulvum, 432 .

oxycaryum, 193, (425).

oxýgonum, 427.

plebeium, 191.

plebeium, 191.

pterocaryum, 195, (429).

pusillum, 194, (428).

racemosum, 429 .

Scouleri, 191, (421).

setosissimum, 196, (429).

tenellum, 192, (431).

Texanum, 195, (424).

Torreyi, 192, (431).

uliginosume, 424.

villosum, 191.

virgatum, 197.

Erythrea, 110.

Beyrichii, 113.

calycosa, 113

Centaurium, 112.

chironioides, 112, 113.

Douglasii, 113.

floribunda, 112

Muhlenbergii, 112.

iruhlenbergii, 112.

nudicaulis, 405 .

Nuttallii, 113

Nuttallii, 113.

Pickeringii, 112.

pulchella, 112.

ramosissima, 112.

speciosa, 112.

spicata, 112.
Texensis, 112.

tricantha, 113

tricantha, 113.

venusta, 113,405

Erythranthe cardinalis, 446.

Erythrorhiza rotundifolin, 53.

Eubolrys, 34.

racemosa, 35 .

Euchroma, 295.

angustifolia, 296.

Bradburii, 296.

coccinea, 295.

grandiflora, 298.

pallescens, 299.

purpurea, 298.

Eucrypta, $15 \%$. chrysanthemifolia, $\mathbf{4 1 3}$

foliosa, 158 .

panieulata, 158, 413.

Euglypta, 169.

Eunanus, 273, 444.

anguistatus, 443.

bicolor, 275,445 .

Bigelovii, 274.

Bolanderi, 446.

brevipes, 446.

Breweri, 451.

Conlteri, 274.

Douglesii, 274, 443, 444 .

Fremonti, 274, 275.

Kelloggii, 444 .

Laynece, 446.

mephiticus, 444 .

Muhavensis, 446 .

Parryi, 446.

pictus, 446.

Rattani. 444.

Tolmiei, 274 .

Torreyi, 446.

tricolor, 443

Euphrasia, 249, 305.

latifulra, 305 .

Odontites, 305.

officinalis, 305 .

EUPHIASIE $2,249$.

Euploca, 183.

crnvolvulacea, 183.

grandiflora, 183 .

Eustachya alba, 287.

purpurea, 287.

Eustorna, 111, 116.

exaltatum, 116.

gracile, 116.

Russellianum, 116.

silenifolium, 116, 405 .

Eutoca, 164, 416.

albiflora, 163.

aretioides, 172.

brachylota, 167.

divaricata, 168.

Douglasii, 167.

Franklinii, 166.

glrandulosa, 160.

grandifiora, 164.

heterophylla, 166.

loascefolia, 165.

lutea, 171 .

Menziesii, 166.

miltiflora, 166

parvufora, 163.

patulifora, 163.

phacelioides, 167.

pusillir, 166.

sericea, 166.

speciosa, 164. strietiflora, 163.

viscida, 163.

Wrangeliana, 168.

Evolvulus, 208, 218.

alsinoides, 218.

argenteus, 219.

Arizonicus, 218.

diffusus, 218.

discolor, 219, 436.

glabriusculus, 218.

holosericeus, 218, 219.

latus, 436 .

linifolius, 218.

mucronatus, 218.

Muhlenbergii, 218.

nummularius, 218.

Nuttallirnus, 219.

ovalifolius, 217.

pilosus, 219.

sericens, 218, 436.

Sherardi, 217, 436.

Exacum inflatum, 112. pulchellum, 112. quadrangulare, 112.

Eyebright, 305.

Featherfoil, 57.

Fenzlia concinna, 138. dianthiflora, 138. speciosa, 138.

Fetterbush, 32

Figwort, 258.

Fischeria buxifolia, 43.

Floating Heart, 128.

Flowering Moss 52.

Forestiera. 73,76 . acuminata, 76 angustifolia, 77 . Jacquinianza, 77.

ligustrina, 76 .

ligustrina, $76,77$.

Neo-Mexicana, 76 .

phillyreioides, 77 .

porulosa, 77.

reticulata, 77 .

sphærocarpa, 77.

Forget-me-not, 202.

For'ster'oniu diffor'mis, 85.

Forsythia suspensa, 72 .

viridissima, 72 .

Fraxinaster, 73 .

Fr $\Lambda \times$ LNE 7 , 72.

Fraxinus, 72,73 .

ccuminata, 75 .

alba, 75 .

allicans, 75.

Americana, 74.

Americana, 75 .

anomala, 74 .

Berlandieriana, 75.

Canadensis, 75.

Carolinensis, 75

Caroliniann, 75 .

concolor, 75 .

coriacea, 74,75 .

Curtissii, 75 .

cuspidata. 74

dipetala, 73 .

discolor, 75.

epiplera, 75 .

excelsior, 75 .

expansa, 75 .

Grerroii, 74.

juqlandifolia, 75.

latifolia, 76 . 
nigra, 75, 76 .

nigrescens, 75 .

Nover-Anglios, 75.

Nuttallie, 75 .

oblongocarpa, 75 .

Oregana, $\mathbf{7 6}$.

Ornus, 73 .

prellita, 75 .

paucitlowa, 75.

Pennsyleanica, 75

pistaciæfolia, 74

pistrciafolia, 75 .

platycarpa, 75 .

pubescens, 75 .

pubescens, 76 .

quadrangulata, 75 .

sambucifolia, 76 .

Schiedeana, 74 .

tomentosa, 75 .

trialata, 75

triptera, 75 .

velutina, 74 .

viridis, 75 .

ut of culen Frasera, 111, 125.

albomarginata, 126

Carolinensis, 125.

Carolinensis, 125.

nitida, 126.

paniculata, 126.

Parryi, 126.

speciosa, 127.

thrrsiflora, 125

IV́lteri, 127

Tringe-tree, 77 .

Galacriefe, 52.

Galapagoa, 182.

Galax, 52, 53. aphylla, 53 .

Galeopsis, 347, 385 Ladanum, 385. Tetrahit, 385.

Gambelia, 254 speciosa, 254

Gardoquia betonicoides, 377. Hookeri, 360.

Gatesia, 323, 330. læte-virens, 330.

Gaultheria, 15, 29 Myrsinites, 30, 397 .

ovatifolia, 397.

procumbens, 30 .

Shallon, 30.

Gautiera procumbens, 30.

Gaylussacia, 15, 19.

brachycera, 19 .

dumosa, 19.

frondosa, 19, 396.

hirtella, 19.

resinosa, 20

ursina, 20.

Gelsemiede, 106.

Gelsemium, 106, 107.

nitidum, 107.

sempervirens, 107.

Gentian, 116.

Gentiana, 111, 116, 405 .

acuta, 118

affinis, 122.

alba, 123.

Aleuticn, 119

algida, 120

Amarella, 118. anarelloides, 119.

Andrewsii. 123.

angustifolia, 124.

aquatica, 120.

aretophila, 119.

aurea, 119.

auriculata, 118.

barbata, 117.

barbellata, 117.

Bigelorii, 406 .

borealis, 118.

brachypetala, 117.

calycina, 114.

calycosa, 121 .

calycosa, 121.

Catesbai, 122, 123.

ciliata, 117.

crinita, 117.

detonsa, 117.

dichotoma, 118.

Douglasiana, 120.

Elliottii, 122.

exaltata, 116.

fimbriata, 117.

flavida, 123.

Forwoodii, 406.

Fremontii, 120.

frigida, 120 .

frigida, 124.

glacialis, 118.

glauca, 120.

gracillimn, 405.

heterosepalia, 118 .

humilis, 120.

incarnata, 124.

intermedia, 124.

Krenigii, 118.

linearis, 123.

Menziesii, 121.

microcalyx, 405 .

Newberryi, 120 .

nivalis, 406 .

nutans, 120 .

ochroleuca, 123.

ochroleuca, 123.

Oregana, 122

Parryi, 121.

platypetala, 121.

plebera, 118.

Pneunomanthe, 123.

porphyris, 124

pratensis, 118.

propinqua, 119.

prostrata, 120.

pseudo-pneumonanthe, 123.

puberula, 122.

purpurea, 124

quinqueflora, 119.

quinquefolia, 119.

Romanzmii, 120.

rotata, 124 .

Ruritinna, 119.

Rusbyi, 406.

Saponaria, 122.

Saponaria, 123, 124.

sceptrum, 122.

serpentarin, 124.

serrata, 117.

setigera, 121.

setiflora, 119

simplex, 117.

Stelleriana, 124.

sulcata, 124.

tenelia, 117.

tenuis, 118.
Unalaschkensis, 119.

ventricosa, 116.

villosa, 124 .

Irirginiana, 124.

Wislizeni, 119.

Wrightii, 118

GENTIANACE $\mathbb{E}, 110,405$.

GeNT IANE.E, 110.

Gentiunella crinita, 117.

Gerardia, 248, 290, 482.

Afzelia, 289.

aphylla, 295.

aphylla, 293, 295.

aspera, 292.

auriculata, 292.

cuneifolia, 280 .

densiflora, 292.

divaricata, 294.

fasciculata, 293.

filicaulis, 295.

filifolia, 293.

flifolia, 293, 294.

flava, 291.

fiuticosa, 259.

glauca, 291.

grandiflora, 291.

heterophylla, 292.

integrifolia, 291.

intermedia, 293.

lavigata, 291.

linifolia, 292.

linifolia, 293.

lonyifolia, 293.

macrophylla, 290.

maritima, 293.

Mettcueri, 294, 295.

nuda, 295.

parvifolia, 294.

patula, 291.

pectinata, 291.

pedicularia, 291.

Plukenctii, 293.

purpurea, 293.

purpurea, 293, 294.

quercifolia, 291.

serrata, 291.

setacea, 294.

setacea, 294

Skinneriana, 294

spiriflora, 293.

strictiflora, 294.

tenuifoliut, 294, 452

Wrightii, 292.

Gerardieid, 248.

Germander, 349.

Gilia, 129.

achillexfolia, 147.

achillecefolia, 147.

aggregata, 145, 410 .

androsacea, 139

arenaria, 148 .

aristella, 408 .

atractyloides, 142, 409.

aul'en, 138, 407.

bella, 407 .

Beyrichiana, 145.

Bigelovii, 138.

Bolanderi, 138.

Brandegei, 149, 412.

brevicula, 139.

Bremeri, 142.

cxspitosa, 149.

Californica, 140.

campanulata, 148 .

capillaris, (136), 408. 
capitata, 147.

ciliata, $13 y$.

coccinea, 408

congesta. 144

coronopifolia, 145,410 .

cotulefiolia, 141, 408.

crebrifulia, 144.

debilis, 147, 411 .

demissa, 137.

densiflora, 139

densifolia, 143̈.

depressa, 410 .

dianthoides, 138.

dichotoma, 138

dichotoma, 138

divaricata, 142, 409 .

divaricata, 135.

Dunnii, 411.

elongata, 143.

filicaulis, 142, 409 .

filifolia, 143

filiformis, 148.

filipes, 138 .

floccosa, 143.

floribunda, 140

Floridana, 145

glomeriflora, (136), 408.

glutinosa, 408.

grandiflora, 408 .

yrundiflora, 139.

gracilis, 408 .

gracilis, 135.

Gunnisoni, 144, 410.

guttata, 411.

Harknessii, 407.

Havardi, 411 .

Haydeni, 145.

heterodoxa, 409 .

heterophylla, 408.

Hookeri, 141.

iberidifolia, 144 .

incisa, 149 .

inconspicua, 148, 412.

intertexta, $1+1$.

Jonesif, 407 .

Kennedyi, 137.

Larseni, 146, (411)

latiflora, 147, 411.

latifolia, 148 .

Lemmoni, 407.

leptomeria, 148.

Leptosiphon, 139

leptotes, 408.

lencocephala, 142, 408 .

Linanthus, 138.

Lindheimeriana, 149.

linearis, 408 .

liniflora, 137.

longiflora, (136), 410 .

longituba, 139 .

lutea, 139.

lutescens, 143.

Macombii, 410

Matthewsii, 409.

micrantha, 139

micromeria, 148.

millefuliata, 147 .

minima, 142

minutiflora, 146 .

multicaulis, 147.

multicaulis, 411 .

multiflora, (136, 410), 410

Nerinii, 411.

nurlicaulis, 140

Nuttallii, 140.
Orcuttii, 407.

Parlyx, 137.

parviflor't, 148.

pharnaceoides, 137.

pinnatificla, 146 .

polycladon, 144 .

prostraka, 409.

pulchella, 145 .

pumila, 144.

pungens, 140 .

pungens, 141.

pusilla, 137.

Rattani, 407.

rigidula, 149 .

Schottii, (142), 409

Sessei, 135, 408.

setosissima, 142, 409.

sinuata, 148.

spicata, 144.

squarrosa, 141.

stenothyrsa, 146.

stricta, 147 .

subnuda, 145.

tenella, 139.

tenerrima, 146 .

tenuiflora, 147, 412.

tenuifolia, 411

Thujberi, 410 .

tinctoria, 408 .

tricolor, 147.

trifida, 144.

virgata, 143.

viscidula, 142, 409 .

Watsoni, 140 .

Wrightii, 144, 410.

Giliandra, 146, 410.

Githopsis, 9, 10.

calycina, 10.

pulchella, 10.

specularioides, 10

Glandularia 337.

bipinnatificla, 337.

Carolinensis, 337.

Glanx, 56, 63 .

maritima, 63 .

Glechoma hederacea, 378.

Glyciphylla hispidulre, 26.

Gomphocarpus, 86. 100.

cordifolius, 100 .

hypoleucus, 403 .

purpurascens, 100.

tomentosus, 100, 403 .

Gonolobei, 87 .

Gonolobium hirsutum, 104.

Gonolobus, 87, 103, 404.

Baldwinianus, 104, 404.

biflorus, 105.

Carolinensis, 104, 404

Carolinensis, 104.

crnanchoides, 105.

flavidulus, 404 .

granulatus, 103.

hastulatus, 105 .

hirsutus, 104, 404.

hirsutus, 104.

lævis, 103.

macropluyllus, 103, 104, 404.

Nittallii, 103.

obliquus, 104, 404.

parviflorus, 106.

parvifolius, 105.

pogonanthus, 462 .

productus, 106.

prostratus, 105

pubitlorus, 105. reticulatus, 103.

sagittifolius, 104.

Shortii, 404

suberosus, 103.

tulioefilius, 103.

unitar ins, 101.

viridiflorus, 88, 103.

GOODENIACE $A, 1$

Grammica, 219.

Gratiola, 247.

acuminata, 280, 282.

anayallider, 283.

a.tenuata, 283.

aurea, 282

Carolinensis, 282.

dilatata, 283.

Drummondii, 282.

ebracteata, 281 .

Floridana, 281.

gracilis, 281.

inoequalis, 280.

megalocarpa, 283.

micrantha, 283, 284 .

Missouriana, 282.

Monniera, 281.

neglecta, 282.

officinalis, 282

officinalis, 282.

Peruviana, 283.

pi]osa, 283.

pusilla, 281.

quadridentata, 282.

ramosa, 282

repens, 280.

sphærocarpa, 282.

subulata, 283.

trtragona, 283.

Virginiana, 281.

Virginica, 282

viscosa, 282.

Gratiolaria, 281.

GRATIOLE.玉, 246

Greek Valerian, 149.

Green Ash, 75.

Gregoria, 399.

Gronwell, 203.

Ground Cher'y, 233.

Ground Laurel, 29.

Gruvelia pusilla, 187.

Gualtheriit, 29.

Gymuandra, 332, (458).

borealis, 332 .

dentata, 332.

Gmelini, 332, (458).

gracitis, 332 .

minor, 332.

ovita, 332 .

reniformis, 332.

rubra, 286.

Stelleri, 332, (458).

Gymnobythus, 163.

Gymocaulis, 312 .

Gypsywort, 352.

Halenia, 111, 127.

Brentoniana, 127.

deflexa, 127.

heteranthi, 127.

Rothrockii, 127.

Halesia, 70, 71.

diptera, 71

parvifiora, 71 .

parviflora, 72.

reticulata, 71.

tetraptera, 71. 
Haplophyton, 80, 82. cimicidum, 82.

Harebell, 11.

Harpagonella, 178, 186. Palmeri, 186.

Fieal-all, 382.

Heath, 36.

Heather, 36.

Hedeoma, 344, 361 . acinoides, 362. Arkansana, 360. bracteolata, 359 . ciliata, 363. cillitta, 363 . costata, 363 . dentata. 363. Drummondii, 362. glabra, 360 . graveolens, 363. hirta, 362 hispida, 362 . hyssopifolia, 363 . incana, 361. mollis, 361 . piperita, 362. plicata, 363. pulegioides, 362. purpurea, 359. Reverchoni, 460 . serpylloides, 365 . thymoides, 362.

Hedeomoides, 364 .

Hedrge Hyssop, 281.

Heliophytum, 186. glabriusculum, 186. gnaphaloirles, 183. Indicum, 183. molle, 183. parviflorum, 186. sidafolium, 186.

Heliotrope, 183.

HELIOTROPIE, 177.

Heliotropium, 178, 183. anchusæfolium, 186. angustifolium, 184 burstferum, 185. Californicum. +21. canescens, 185. cinereum. 185. confertiflorum, $18 \pm$. convolvulaceum, 183, 421 . Curgssavicum, 185. Europreum, 185. glabriusculum, 186. glomeratum, 185. Greggii, 184. hispidum, 185. inundatum, 185.

Leavenworthii, 185.

limbatum, 184. myosotoides, 185. parviflorum, 183. Pervivianum, 186 phyllostachyum, 185. polyphyllum, 185. procumbens, 185. tenellum, 181.

Hemianthus, 284.

micranthemoides, 284.

Hemipogon, 3.

Hemistegia, 304.

Hemp-Nettle, 385.

Henbane, 240.

Henrya, 330.

Herpestis, 246, 280. amplexicaulis, 280 .

Brownei, 281.

callitrichoiles, 283.

chamedrioides, 280.

cuncifolia, 281.

micrantha, 280, 284.

Monniera, 281.

nigrescens, 280.

peduncularis, 280.

pilosa, 279.

repens, 280 .

rotundifolia, 280, 451 .

Hesperelsea, 73, 77. l'almeri, 77.

Hesperochiron, 153, 172.

Californicus, 173 lutifolius, 172 . pumilus, 173.

Heterocodon, 10, 14, 396. minimum, 396 . rariflorum, 14.

Heterosphace, 367.

Himantostemma, 401, 404 . Pringlei, 404.

Hippoglossum maritimum, 200.

Hoitzia capitata, 412. Cervantesii, 412. conglomerati, 412. glandulosa, 412 . spicata, 412. squarrosa, 141.

Holocalyx, 424

Holopogon, 3.

Homalocaryum, 188.

Homochilus, 3.

Hopea tinctoria, 71 .

Horehound, 384.

Horse-BaIm, 351.

Horse-Mint, 375.

Horse-Sugar, 71.

Hottonia, 55.

inflata, 57.

palustris, 57.

HotToNie.E, 55.

Hounds tongue, 187.

Howellia, 393, 394. aquatilis, 3:4.

Huckleberry, 19, 20.

Hugelic, 143. densifulin, 143. lutea, 143 .

virgata, 143.

Hydronthelium Egense, 281.

Hydrolea, 15 t.

affinis, 176.

Caroliniana, 176.

corymbosa, 176.

leptocaulis, 176 .

Lurlucicirna, 176.

orata, 176.

ovatifolia, 170.

paniculata, 176. quadrivalvis, 176.

HY DROL EE_E, 153.

HY DROPHYLLACE E， 152, 413.

HYDROPHYLLEA, 152.

Hydrophyllum, 152, 154. appendiculatum, 155.

Canadense, 155. capitatum, 154. copitatum, 154.

lineare, 166.

macrophyllum, 154. macrophyllam, 154. occidentale, 154.

trilobum, 155.

Virginicum, 154.

Hygrophila, 322, 324.

Illinoiensis, 327.

lacustris, 324.

HrosCrAMETE, 225.

Hyosctamus, 225, 240. niger, 240.

Hypopitys, 49.

Europaea, 50.

lanuginosa, 50.

lutea, 50 . multiflora, 50.

Hypsusula, 432.

Hyptis, 342,350 .

albida, 350 .

Emoryi, 350.

lanato, 350.

laniflora, 350 .

pectinata, 350 .

polystachya, 350 .

radiata, 350 .

spicata, 350.

spicigera, 350 .

tephrodes, 350 .

Hyssop, 354.

Hyssopus, 343, 354.

anisatus, 376.

discolon', 376.

nepetoides, 376 .

officinalis, 354 .

scrophulariafolizus, 376 .

Ilysanthes, 247, 283.

grandiflora, 283.

gratioloides, 283.

refracta, 283 .

riparia, 283. saxicola, 283.

Indian Hemp, 82.

Indian Pink, 108.

Indian Pipe, 49.

Inomcea, 208.

acetosæfolia, 211.

armata, 434.

barbata, 210.

barbatisepala, 212.

Batatas, 211.

Bona-nox, 209.

capillacea, 434.

cardiophy]la, 213.

carnosa, (211), 434 .

Carolina, 209, 213.

cathartica, 210.

coccine: 209.

costellata, 214.

cumeifolia. 434

dissect $a, 212$

fristiginta, 210.

Havanensis, 435.

hederacea, 210,433 .

hederifulia, 209 .

heterophylla, 210.

.Talapa, 211.

lacunosต, 213.

Lemmoni, 434.

leptophylla, 213.

leptotoma, 214.

leucantha, 209.

Lindheimeri, 210.

longifolia, 211.

macrorhiza, 211.

maritima, 211.

Mechoacan, 211. 
Mexicana, 210.

Mich anxii, 211.

muricata, 214.

ivil, 210.

orbicularis, 211.

pandurata, 211.

Pes-capre, 211.

Plummerxe, 434.

purpurea, 210.

Purshii, 211.

Quamoclit, 209.

rubra, 145.

sagittata, 212.

sagittifolia, 212, 216.

santriiner, 209.

Shumarde 211.

sinuata, 212.

sinuata, 209.

tamnifolia, 214.

tenuiloba, 434 .

Thurberi, 212, 433.

trichocarpa, 213.

trifida, 212.

triloba, 213

Wrightii, 213.

Ipomeria agyregata, 145.

coronopifolia, 145.

Ipomopsis, 145, 410 . elegans, 145 . inconspicua, 148 .

Isanthus, 342,349 . cæruleus, 349.

Jacubinia Californica, 329. neglecia. 457

Jacob's Ladder, 149.

Jacquemontia, 208, 214.

abutiloides, 214.

tamnifolia, 214, 434 . riolacea, 214.

Jacquinia, 65,66 .

armillaris, 66 .

pungens, 69.

Jamestown-Weed, 240.

JASMINEE, 73 .

Jerusalem Cherry, 228.

Jerusalem Sage, 384.

Jessaminte, 107.

Justicia, 323, 329 .

Americana, 329.

ressurgens, 331.

humilis, 330 .

late-virens, 330.

pedunculssa, 329

resupinata, 331.

sexangularis, 331.

Wrightii, 329.

JUSTICIEE, 322.

Kalmia, 16, 37.

angustifolia, 38.

ciliata, 39.

cuneata, 38.

ericoides, 38.

glauca, 38 .

hirsuta, 39.

latifolia, 38

polifolia, 38 .

Kollia capitata, 354 .

Krynitzkia, (190, 193), 420, 423

ambigua, 426 .

angustifolia, 426 .

barbigera, 426 .

Californica, 423.

Cedrosensis, $4 \geq 8$.
Chorisiana, 424.

circumscissa, 428 .

Couperi, 424

crassisepala, 424.

cycloptera, 423 .

denticulata, 427 .

dichotoma, 428.

dumetorum, 426 .

Fendleri, 424.

floribunda, 423.

foliosa, 427 .

fulvocanescens, 430 .

heliotropinides, 423.

holoptera, 429 .

intermedia, 426.

Jamesii, 429.

Jonesii, 427.

leiocarpa, 425 .

leiocarpa, 193, 194.

lithocarya, 423

leucophæa, 430 .

maritima, 428 .

micrantha, 428.

micromeres, 427 .

microstachys, 425

Mohavensis, 427 .

mollis, 424 .

muriculata, 427 .

oxycarya, 425.

oxygona, 427.

Pitmeri, 429.

Parryi, 423.

Pattersoni, 424.

plebeia, 423.

pterocarya, 429 .

pusilla, 428.

racemosa, 429 .

ramosa, 428.

ramosissima, 428, (429).

rostellato, 425 .

Sconleri, 424

sericea, 430 .

setosissima, 429 .

sparsiflora, 425 .

Texana, 424.

Torreyana, 425.

trach ycarpa, 423.

Utahensis, 427.

virgata, 429.

Watsonj, 426.

Ktenosper'mum, 187.

LABIAT Ae, 341, 459.

Labrador Tea, 43.

Lachnostoma, 401, 404.

Arizonicum, 404.

Balbisiz, 462 .

hastulatum, 105.

parviflor um, 106

Lachnostoma, 104.

Lagotis, 458 . glauca (332), 458 .

Lambkill, 38.

Lamium, $347,385$.

album, 385 .

amplexicaule, 385 .

hispidulum, 462. purpureum, 385 .

Lantana, 333. 339.

Camara, 340.

canescens, 339

horrida, 340 .

involucrata, 339 .

macropoda, 339.

odorata, 339. parvifolia, 339.

Lapithea gentianoides, 115 .

Lappula, 188

Laurel, 37, 38, 42.

Laurentia, 2,8 .

carnosula, 8 .

Leadwort, 55 .

Leather-leaf, 35 .

Ledum, 16, 43.

buxifoliun, 43.

Canadense, 43.

glandulosum, 43 .

Gronlandicum, 43.

latifolium, 43 .

palustre, 43 .

thymifolium, 43.

Leiopliyllum, 17, 43 .

buxifolium, 43.

prostralum, 48.

serpyllifolium, 43

thymifolium, 43 .

Lemmonia, 153, 173.

Californica, 173

Lemon Verbena, 338.

Lenuna, 51 .

LENNOACEA, 50

Lentibularia, 314.

LENTIBUL I RIACE E， 314, 455.

Leonotis, $347,384$. nepetæfolia, 384.

Leonuris, 347, 385. Cardiaca, 385.

Marrubiastı um, 385.

Sibiricus, 385.

Lepidanche adpressa, 222. compositarum, 223.

Leptamnium Virginianum, 314.

Leptandra, 286. angustifolia, 286. purpurea, 287. Virginica, 287.

Leptodactylon, 140. ccespitosum, 141. Californicum, 140 .

Leptoglossis, 226, 244 Coulteri, 224. Texana, 244.

Leptophragma prostrata, 243.

Leptosiphon, 139, 407. androsaceus, 139. bicolor, 139.

densiflorus, 139.

grandiflorus, 139.

inteus. 139.

parviflorus, 139.

Leptostachya, 334 .

Leucanthea Romeriana, 244.

LEUCOPHYLLESE, 245.

Leucophyllum, 245, 250。 minus, 250

Texanum, 250.

Leucospora multifida, 279.

Leucothoe, 16, 33, 397. acuminata, 34 . axillaris, 34 .

Catesbri, 34, 397. $L$ d a coriacea, 32

floribunda, 31.

recurva, 35.

thomboidnlis, 33 .

spicata, 35.

spinulosa, 34 . 
Ligustrum vuIgare, 72.

Limnanthemun, 111, 128. lacunosum, 128. trachyspermum, 128.

Limosella, 247, 284. aquatica, 284 australis, 284 subulata, 284.

tenuifolia, 281

Linanthus, 138, 407. dichotomus, 138

Linaria, $245,250$.

Cauadensis, 250.

Cymbalaria, 251.

Elatine, 251.

Floridana, 250.

genistifolia, 251 .

spuria, 251.

Texann, 250.

vulgaris, 251

Linderina attenuata, 283. dianthera, 280.

dilatata, 283.

grandiflora, 283.

Monteridensis, 243.

monticola, 283.

pyxidaria, 283.

refiacta, 283 saxicola, 283.

Ling, 36.

Lippia, 333, 338

Berlandieri, 338.

citriodora, 338 .

cuneifolia, 3.38 .

geminata, 338.

graveolens, 338

lycivides, 338 .

nodiflora, 339 .

pallescens, 339 .

reptans, 339.

scorodonioides, 338.

Wrightii, 338.

Lisianthus excltatus, 116. glaucifolizus, 116. Russellianus, 116

Lithospermum, 179, 203. angustifolium, 205. angustifolium, 182.

arvense, 203.

Bejariense, 205.

breviforum, 205.

Californicum, 204.

canescens, 204.

canescens, 204.

Carolinianum, 206.

circumscissum, 193.

Cobrense, 433 .

corymbosum, 201.

decumbens, 205 .

Drummondii, 201.

glabrum, 433 .

hirtum, 205.

incisum 205.

Kamtschaticunn, 201.

latifolium, 203.

linearifulium. 205 .

longiflorum, 205.

lutescens, 213.

lycopsoides, 198.

Mandanense, 205

marginatum, 200, 201.

maritimum, 200 .

Matamorense, 203.

multiflorum, 204, 433 .

officinale, 203. pilosum, 204.

pilosum, 204.

plebeium, 191.

prostratum, 203

ramosum, 428.

sericeum, 204.

ruderale, 204.

tenellum, 184.

Torreyi, 204.

tuberosum, 203, 433.

Virginianum, 206.

viride, 433 .

Littorella, 392 .

lacustris, 392.

Lobelia, 1

Lobelia, 2, 3, 394.

amoena, 4

appendiculata, 5 .

Berlandieri,

Boykini, 6.

brevifolia, 3 .

Canbyi, 6.

cardinalis, 3 .

carmosula, 8

Cranillesii, 3.

Claytoniana, 6

Cliffortiana, 7, 394.

colorata, 4.

crassiuscula, 4, 5.

Dortmanna, 5 .

Feayana, 7.

feuestralis, 6 .

Floridana, 394

Gattingeri, 394.

glandulosa, 5 .

glandulosa, 4.

goodenioides, 6 .

gracilis, 7 .

gruina, 6.

hortensis, 4 .

Kalmii, 7 .

inflata, 7 .

laxiflora, 3.

leptostachys, 6 .

Ludoviciana, 5 .

liichauxii, 7.

nivea, 6 .

Nuttallii, 7

pallida, 6 .

paludosa, 5, 394.

pectinata, 6 .

persicafolita, 3.

puberula, 4

puberula, 4

spicata, 6.

splendens. 3 .

syphilitica. 4

Texensis, 3.

Xalapensis, 7.

LOBELIACE $A, ~ 1,393$.

LOBELIE $\mathbf{E}, 2$.

Lochnera, 82.

vincoides, 82

Lœselia, 129, 136, 412.

effusa, 136, (411).

glandulosa, 412 .

guttatr, 411.

Matthersii, 409.

nepetofolia, 412

Schottii, 409

tenvifolia, 136, (411).

I.OGANIACE, $\mathrm{E}, 106,405$.

LOGANIFA, 106.

Loiseleuria, 17, 44 .

procumbens, 44 .
Lomatogunium, 124.

Lomicera Marilandica, 108.

Lophanthus, 345,376 .

anisatus, 376 .

nepetoides, 376 .

scrophulariafolius, 376.

urticifolius, 376 .

Lophospermum, 254

Lopseed, 334.

Lousewort, 305.

Lyciastrum, 458.

Lycium, 225, 237, 437 .

Andersonii, 239

Barbarum, 237

barbinoduin, 239.

Berlandieri, 239.

Berlandier, 239.

brachyanthum, 459 .

brevipes, 239.

Carolinianum, 238, 437 .

Cooperi, 238.

exsertum, 437.

Fremonti, 239, 437.

gracilipes, $239,(437)$.

macrodon, 238, (437).

pallidum, 238.

Palmeri, 238.

Parishii, 437.

parviflorum, 239, 437.

Pringlei, 437.

puberulum, 238.

quadrifidum, 437.

Richii, 239, 437.

Torreyi, 239.

salsuni, 238.

senticosum, 239.

stolidum, 239.

rulgare, 237.

Lycopersicum, 224, 226. cerasiforme, 226. esculentum, 226.

Lycopsis, 179, 207. arvensis, 207. I'irginica, 202.

Lycopus, 343, 352. angustifolius, 353 Arkansanus, 353.

Europæus, 353.

Eurcpers, 353.

exaltatus, 353.

lucidus, 353 .

macrophyllus, 353.

obtusifolius, 353 .

pumilus, 353.

rubellus, 353 .

sessilifolius, 353 .

sinuatus, 353.

unitlorus, 353.

Virginicus, 353

rulgaris, 353 .

Lyonin, 32.

arborea, 33

calyculata, 35 .

capreafolia, 33 .

fervuqinea, 33.

frontosa, 33 .

ligustrina, 33.

merginata, 32.

Mariana, 32.

maritima, 102

multiflora, 33.

paniculatu, 33 .

racemosa, 35.

rigida, 33.

salicifolia, 33 . 
Lysimachia, 56, 62. angustifolia, 62, 63. asperulefolia, 63 .

bulbifera. 63 . capitata, 63 . ciliata, 61, 62 . decipiens, 62.

Fraseri, 62

Herbemonti, 63. heterophylla, 62 .

hirsuta, 63.

hybrida, 62

lanceolata, 62 .

longifolitr, 62.

Luomisii, 63.

nummularia, 63.

punctata, 63 .

quadriflora, 62 .

quadrifolia, 62 .

quadrifolia, 61.

racemosa, 63 .

radicans, 61 .

gevoluta, 62.

stricta, 63.

thyrsiflora, 63 .

vulgaris, 400 .

vulgaris, 63 .

Macbridea. 346, 383. alba, 384 pulchira, 383.

Macranther'a, 248, 290. fuchsioicles, 290. Lecontei, 290.

Macromeria, 205. viridiflora, 206.

Macromerioides, 205.

Macrosiphonia, 80, 83 .

Berlandieri, 83. brachysiphon, 83 . Wrightii, 8:3.

Madroña 27.

Mandevillea, 84

Manzanita, 27

Margaranthus, 225, 237, 437 .

Lemmoni, 437 .

solanaceus, 237 . tenuis, 237.

Maria, 32 .

Marjoram, 358.

Marrubium, 346, 384. vulgare, 384 .

Marsh Rosemary, 54.

Martynia, 320, 321.

altheæfolja, 321 .

ann $2 a, 321$.

arentria, 321.

fragrans, 321.

Lovisiana, 321.

proboscidea, 321.

violacea, 321.

Matalen lazis, 96

Matourea nigrescens, 280.

Matrimony Vine, 237.

Mcurandella, 253.

Maurandia. 245, 254. antirrhiniflora, 254.

juncea, 254 . personata. 254 Wislizeni, 254.

Mayflower, 29.

Meiophanes. 327.

Melampyrum, 249, 310. Americanum, 310 . brachiatum, 310 . latifolium, 310 .

lineare, 310.

pratense, 310. sylvaticum, 310 .

Melinia, 87, 101 angustifolia, 101.

Melissa, 343.

Caroliniana, 360 .

coccinea, 360 .

Nepeta, 359 .

officinalis, 360 .

pulegioides, 362

Melittis Caroliniana, 384.

Mella, 280.

Menodora, 73, 78. heterophylla, 78 . longiflora. 79 .

pubens, 79

scabra, 78 .

scoparia, 78 .

spinescens, 78

Menodoropsis, 79.

Mentha, 342. 351. alopecuroides, 352 .

aquatica, 352

arvensis, 352 .

borealis, 352 .

Canadensis, 352.

citrata, 352

crispa, 352.

nentilis, 352

piperita, 352 .

rotundifolia, 352.

sativa, 352 .

svlvestris, 351 .

sylvestris, 352

viridis, 352

Menyanthes, 111, 128.

Crista-galli, 128.

trachysperma, 128. trifoliata, 128 .

Menziesia, 16, 39.

Aleuticr, 37.

carulea, 37.

empetriformis, 35, 37 .

ferruginea, 39 .

glabella, 39.

glanduliftora, 37.

globularis, 39.

Grahami, 37.

pilosn. 39.

Smithii, 39.

Mercadonia ovata, 280.

Mertensia, 179, 199, 420.

alpina, 201

alpina, 201.

brevistyla, 201.

corymbosa, 201.

denticulata, 201.

Drummondii, 201.

Kamtschatica, 201.

lanceolata, 201.

maritima. 200 .

oblongifolia, 200

paniculata, 201.

pilosa, 201 .

pubescens, 201.

pulmonarioides, 200.

Sibirica, 200

Sibirica, 201

stomatechoides, 201

Virginica, 200.

Messersmidia or

Messerschmidic volubilis, 183.

Metagonia, 25. myrtifolia, 25.

ovata, 25 .

Metastelma, 86, 101, 403.

albiflorum, 101.

angustifolium, 102.

Arizonicum, 403 .

Bahamense, 101.

barbigerum, 101.

Blodgettii, 101.

Califernicum, 101.

Cubense, 101.

fliforme, 102.

Fraseri, 101.

Palmeri, 403.

parviflorum, 101.

Schlechtendalii, 101

Micranthemum, 247, 284

emarrinatum, 284.

Nuttallii, 284.

orbiculatum, 284.

Micrncala, 110, 112 quadrangularis, 112.

Microcarprea Americana, 280.

Microgenetes, 169, 417. Cumnngii, 169.

Aficrogilia, 146.

Micromeria, 343, 359 .

Arkansana, 360 .

barbata, 359.

bracteolata, 359 .

Brownei, 359.

Douglasii, 359.

glabellr, 360 .

purpurea, 359.

Xalapensis, 359 .

Milkweed, 89, 91.

Miltitzia, 170 .

Iutea, 171

Mimulastrum, 446.

Mimuloides, $279,451$.

Mimulus, 247. 273, 442 .

rcutidens, 450 .

alatus, 276,446 .

alsinoicles, $277,449$.

androsaceus, 451.

angustatus, 443

atropurpureus, 443 .

atropurpureus, 443 .

aurantiacus, 275.

bicolor, 278,450

Bigelovii, 274, 444 .

Bolanderi, 275, 446 .

brevipes, 275,446 .

brevipes, 275.

cardinalis, 276,446 .

cupreus, 277,448 .

dentatus, (277), 447 .

dentritus, 447, 449 .

Douglasii, 274, 443.

Douglasii, 443, 444.

Eisenii, 449.

exiguus, 451.

exilis, (279), 451 .

floribundus, 277, 450 .

Fremonti, 275, 445 .

Geyeri, 447 .

glabratus, (276), 277, 447.

glaucesceris, 448 .

glutinosus, $275,442$.

guttatus, 277, 448 .

Hallii, 448.

inconspicuus, 278, 449.

inodorus, 447 .

Jamesii, (2т6), 447.

Kelloggii, 443 . 
Jaciniatus, $277,449$.

latifolius, 274,444 .

leptaleus, 274,445 .

Lewisii, 276.

linearis, 275.

luteus, 277,448 .

luteus, 449 .

lyratus, 277

Madrensis, 447

mephiticus, $4 \pm 4$.

microphyllus, 277, 448, 449

Mohavensis, $\mathbf{4 4 6 .}$

moniliformis, 447 .

moniliformis, $44 \bar{i}$.

montioides, 450 .

montioides, 238, 451 .

moschatus, 278,446 .

nanus, 274,444 .

manus, $274,443,445$.

nasutus, 449 .

nudatus, 449 .

Palmeri, 278, 451.

Parishii, 450.

Parryi, 275, 445.

peduncularis, $\left(2^{-} 8\right), 450$.

pictus, 446.

pilosus, 279 , (451).

Pratteni, 278.

primuloides, $279,446$.

propinquus, $44 i$.

Pulsifer $x, 277,450$

puniceus, $(2-5), 442$.

Rattani, 444.

ringens, 276,446 .

rivularis, 27.

Roezli, 448 .

roseus, 276 .

rubellus, 278,451 .

rubellus, 450 .

Scouleri, $(27 i), 448$.

Smithii, 2Ti.

subsecundus. 445 .

Suksdorfit, 450 .

tenellus, 449.

Tilingï, 277, 448 .

Tогтеуi, 275, 446,

tricolor, $274,4 \pm 3$.

rariegatus, 277 .

Thitneyi, 445 .

Mimusops, 67, 68 .

dissecta, 69 .

Sieberi, 69.

Mint, 351.

Mitreola, 107, 108.

ophiorhizoides, 108.

petiolata, 108.

sessilifolia, 108.

Mohavea, 245, 254, 439 .

viscida, 254, 439 .

Monarda, 345, 373. affinis, 374.

allophyila, 374

altissima, 374 .

amplexicaulis, 374.

aristata, 375.

Bradburiana, 374.

ciliata, 376 .

citriodora, 375. 461.

clinopodia, 374

coccinea, 374.

didyma, 374.

fistulosa, 374 .

fistulosa, 374.

gracilis, 356, 375 .

hirsuta, 376 . involucrata, 374 .

Kalmiana, 374.

Lindheimeri, 374.

longifolia, 374 .

lutea, 375 .

menthofolia, 374 .

mollis, 374

oblongata, 374 .

Oswegoensis, 374.

pectiwata, 375, 461 .

penicilluta, 375 .

punctata, 375 .

purpurea, 374

rexposa, 374.

Russelliana, 375.

scabra, 374.

undulata, $3 i t$

varians, 374 .

villosa, 374 .

Monarde. 344

Monardeila, $343,356,459$.

Breweri, 357.

candicans, 358

Caroliniana, 374.

Douglasii, 357 .

hypoleuca, 3556, 459 .

lanceolata, 357, 459 .

leucocephala, 358.

linoides, 357.

macrantha, 356,45 ).

montana, 356 .

nana, (356), 459 .

odoratissima. 357.

Palmeri, 357.

Pringlei, 459.

Sheltoni, 357.

tenuiflora, 459.

thymifolia, 459 .

undulata, 358.

villosa, 357.

Moneclima Pilosella, 328.

Moneses, 17, 46 grandiftora, 46.

reticulata, 46 .

unifiora, 46.

Money-wort, 63

Monkey-flower, 273.

Monniera amplexicaulis, 280. cuneifolia, 281. rotundifolia, 281.

Monogynella, 223.

Monotropa, 18, 49.

fimbriata, 50 .

Hypopitys, 50.

lanuginosa, 50

Morisoni, 49.

Morisoniana, 49.

uniflora, 49.

MoNotrope as 18.

Monotropsis odorata, 49 .

Murella, 227.

Morning Glory, 208, 209, 210

Motherwort, 385.

Mountain Cranberry, 25.

Mountain Mint, 354 .

Mudwort, 284.

Mullein, 250.

Mylanche, 314.

Myositiclea, 191, 423

Myosotis, 179, 202.

alba, 431 .

albida, 428 .

alpestris, 202

aretioides, 191.

arvensis, 202. cosspilosa, 202.

Californica, 191.

Chorisiana, 191.

deflexa, 189.

Aricridu, 193, 194, 425.

fulver, 192, 431, 432.

glomerata, 196.

inflexa, 202

intermedia, 202.

laxa, 202.

leucophoea, 197.

lingulata, 202.

macrosperma, 203.

muricata, 194.

nana, 191.

palustris, 202.

palustris, 20:2.

Reclowskii, 189.

rupicola, 20.2.

scorpioides, 202.

Scouleri, 191.

stricta, 202.

suffirticosa, 196.

sylvatica, 202.

tenella, 192.

verna, 202

versicolor, 202.

versicolor, 203.

villosa, 191 .

I'irginiana, 189.

Irirginica, 189.

Myrica segregata, 77 .

Myrsine, 65.

Aloribunda, 65.

Floridana, 65

Rapanea, 65.

MYRSINEACE E, 64 .

MYRSINEF, 65 .

$M y x a, 180$.

Nama, 153, 173, 118 .

Berlandieri, 174.

biflorum, 174.

Coulteri, 174.

demissum, 174 .

demissum, 172 .

depressum, 418

dichotomum, 175, 419 .

dichotomum, 174.

Havardi, 419.

hispidum, 174

Jamaicense, 174

Jamaicense, 174.

Lobbii, 175, 419.

origanifolium, 419.

Parryi, 175, 419.

pusillum, 418.

racemosum, 159.

Rothrockii, 175, 419 .

stenocarpum, 174, 418 .

stenophyllum, 419 .

systyla, 158.

undulatum, 174.

undulatum, 174.

NAMER, 153.

Naseberry, 69.

Naumberria, 63.

Navarretio, 141, 408.

atractyloides, 14:2.

heterophylla, 135.

intertexta, 141

leucocephala, 142.

minima, 142.

pubescens, 141 .

pungens, 141 . 
Schottii, 142, 409 . setosissima, 142 . squar?osn, 141

Neckweed, 288

NELSONIE.T, 322.

Nemacladus, 2, 393.

capillaris, 393.

longiflorus, 3,394 .

pinnatifidus, 393.

ramosissimus, 3, 393.

rigidus, 394

tenuissimus, 393.

Nemophila, 152, 155, 413

atomarict, 156.

aurita, 156

bueviflora, 157.

discoidalis, 156.

evanescens, 157.

heterophylla, 156.

hirsuta, 156

insignis, 155.

liniflora, 156 .

maculata, 155 .

Menziesii, 156, 413.

microcalyx 157

modestir, 413.

Nuttallii, 156.

paniculata, 155

parviflora, 156.

prevififora, 157.

pedunculnto, 156.

phacelinides, 156.

pilosa, 156

racemosa, 156 .

Nepeta, 345,377 .

Cataria, 377.

Glechoma, 377.

Virginica, 354.

NEPETE $2 \pi, 345$.

Neriandr*a suberecta, 84.

Nerium Oleander, 79.

Newberrya, 19, 50, 398 . congesta, 50, 398 . spicata, 398.

Nicandra, 225, 237.

physaloides, 237.

Nicotici, 241.

Nicotiana, 226, 241, 438 .

attenuata, 242.

Birelovii, 243 .

caudata, 241.

Clevelandi, 242.

glandulosa, 242

glauca, 438 .

ipomopsiflora, 242.

tancifolin, $2+1$

lyrata. 242

multiflora, 242.

multivalvis, 243

nann, 243.

Palmeri, 242.

pandurata, 242.

parviflora, 243.

plumbaginifolia, 241.

plumbr ginifolia, 243

quadrivalvis, 243.

repanda, 242.

Remerinna, 242

rustica, 241.

Trbacum, 241

trigonophylla, 242.

Yuarrensis, 241.

Nierembergia anomala, 244. nana, 243.

staticrefolia, 244 viscosa, 244.

Nightshade, 226

Nothaphyllon, 312.

Nothocerates, 88.

Nothochelone, 259.

Nycterium, 231.

Obolaria, 111, 127. Caroliniana, 280

Virginiana, 127.

Virginica, 127.

OcIMOIDEe, 342.

Ocimum, 342, 350

Basilicum, 350

Campechianum, 350.

micranthum, 350 .

Odontites rubra, 305 .

Ennoe, 274, 443.

Oil-plant, 320.

Olea, 72.

Americana, 78.

Europæa, 72.

OLEACE $A$, 72

OLEINERE, 73.

Omplialodes, (180), 420, 422 aliena, 423.

cardiophylla, 423.

Howardi, 423.

linifolia, 180.

nana, 423.

verna, 180

Oncorrhynchus, 300 .

Onosmodium, 179, 205.

Bejariense, 206, 433.

Carolinianum, 206.

Carolinianum, 206.

hispidun, 206.

molle, 206.

Thurberi, 205.

Virginianum, 206

Opliorhiza Croomii, 109.

lanceolata, 108.

Mitreola, 108.

oralifolica, 109 .

Origanum, 343 .

incanum, 354.

punctatum, 356.

vulgare, 358.

Omus, 73.

Americana, 73.

dipetala. 73 .

OROBANCHACE $A, 310,455$.

Orobanche, 311.

Americana, 313, 455 .

biflora, 312.

Californica, 312.

comosa, 312 .

fasciculata, 312.

glabra, 313.

Ladoviciana, 313.

minor, 311

pinetir'um, 313 .

Rossica, 313.

tuberosa, 313.

unifora, 312.

Virginiuna, 314.

Viryinica, 127.

Orontium, 251.

Ortheutoca, 164.

Orthocarpus, 249, 299, 452.

attenuatus, 299

Bidwellix, 453.

bracteosus, 300 .

campestris, 302 .

castilleioides, 000 . densiflorns, 300 .

erianthus, 301, 453.

faucibarbatus, (302), 453 .

floribundus, 301, 453 .

gracilis, 302.

hispidus, 302,453 .

jmbricatus, (300), 452.

lacerus, 302 .

lasinrlyynchus, 302.

linearilobus, 802.

linearifolius, 453.

lithospermoides, 302, 453.

Iutens, 300 .

pachystachyus, 300, 452.

pallescens, 299.

pallescens, 299.

Parishii, 453.

Purvyi, 299.

pilosus, 299.

purpurascens, 300 .

purpureo-albus, 301, 453.

pusillus, 301, 453.

strichus, 301.

tenuifolius, $300,453$.

tenuifolius, 452 .

Tolmiei, 301.

Orthopodium, 348

Orthostachys, 184.

Oryctes, 225, 232.

Nevadensis, 232

Osmanthus, 73, 78.

Americanus, 78.

fragrans, 78.

Osmothamerus, 41

Oswego Tea, 374

Otophylla, 292

Drummondii, 292.

Michauxii, 292.

Ourisia Californica, 173.

Oxycoccus, 25.

erectus, 25.

erythrocarpus, 25.

hispidulus, 26.

macrocarpus, 26.

micvocarpus, 396.

palustris, 26.

vulgaris, 26.

Oxydendrum, $15,33$.

arboreum, 33 .

Painted-Cup, 295.

Palmarella, 2, 8, 394. debilis, 8,394 .

Parabryanthus, 37.

Privechites, 85.

Parishella, 393, 394.

Californica, 394

Pectocarya, 178, 187, 420. Chilensis, 187.

lateriflora, 187.

linearis, 187.

pusilla, 187, 421. setosa, 187, 421.

PEDALIACE $A, 320$.

Pedicularis, 249, 305, 454 . cequinoctialis, 367 . arctica, 309.

attenuata, 310 .

attollens, 306.

curriculata, 307 .

bracteosa, 308 .

Canadensis, 307.

Canbyi, 454.

capitata, 309.

centranthera, 309 
Chamissonis, 306.

contorta, 306.

crenulata, 307 .

densitlora, 310 .

elata, 308

euphrasioides, 307.

flummea, 309 .

Furbishix, 454

gladiata, 307

Gronlandica, 306.

hirsuta, 309.

hirsuta, 309

Howellii, 454 .

incarnata, 306.

Labradorica, 307.

lanata, 309.

lanceolata, 307.

Iangsdorftii, 308 .

Lapponica, 306.

Menziesii, 305.

nasutr, 307.

Nelsoni, 309.

ornitborbyncha, 307.

pallida, 307.

palustris, 307.

Parrei, 306.

parviflora, 307.

pedicellata, 307 .

procera, 308.

purpurascens, 309.

racemosa, 306 .

recutitu, 308.

resupinata, 307.

Romanzorii, 306 .

scopulorum, 308.

semibarbata, 309 .

subnuda, 307.

Sudetica, 308

surrecta, 306 .

versicolor, 309

rerticillata, 305 .

verticillata, 309.

Virginica, 307.

Wlassovinna, 307.

Pennyroyal, 362 .

Pentälophus longiflorus, 205. ISandanensis, 205.

Pentastemon, 259.

Pentstemon, 246, 259, 439.

acuminatus, 263 .

albidus, 266.

albillus, 265.

alpinus, 263.

ambiguus, 270 .

amcenus, 271 .

antirrhinoides, 260 .

argutus, 271

attenuatus, 267

azureus, 272.

baccharifolius, 261,440 .

barbatus, 261 .

barbatus, 440 .

Barrettæ, 440

Bradburii, 264.

breviflorus, 260

brevilabris, 442

Bridgesii, 273.

cæruleus, 261

cresius, 441.

cespitosus, 269.

caspitosus, 269.

canoso-barbatus, 273, 442.

carinatus, 260.

Cedrosensis, 441.

centranthifolius, 264, 440. centranthifolius, 262.

Cerrosensis, 273, 441.

Clevelandi, 265, 440 .

Cobsea, 205.

coccineus, 262

comarhenus, 262.

confertus, 267.

cordifolits, 260 .

coriaceus, 440

corymbosus, 260 .

crassifolius, 260.

cristatus, 266.

Cusickii, 4t2.

cyanสuthus, 263.

dasyphyllus, 266.

deustus, 269.

diffusus, 271

Digitalis, 268.

dissectus, 271.

Douglasii, 260

Eatoni, 262.

erianthera, 262, 266.

Fendleri, 264.

Fremonti, 262.

Fremonti, 267, 269.

frutescens, 261.

Gairdneri, $270,440$.

glaber, 262 .

glaber, 268.

glabra, 262.

glantulosus, 271.

glaucifolius, $2 \div 2$.

glaucophyllus, 268.

glaucus, 268.

Gordoni, 262.

gracilentus, 272 .

gracilis, 267.

grandiflorus, 264.

Hallii, 263.

Harbourii, 269

Havardi, 440.

heterander, 269.

heterodoxus, 269.

heterophyllus, 273.

heterophyllus, $272,273$.

humilis, 267 .

Jaffrcyanus, 272.

Jamesii, 265.

labrosus, 440

latus, $272,442$.

levigatus, 268.

lanceolatus, 266, 440 .

laricifolius, 270.

Lemmoni, 261.

Lewisii, 259.

linarioides, 270 .

Lobbii, 260 .

Lyalli, 440.

Kingii, 272

Kingiz, 262

Kleei, 440.

Menziesii, 259, 439 .

micranthus, 267.

microphyllus, 260 .

miser, 440 .

Murrayanus, 265.

nemorosus, 259 .

Newberryi, 259

nitidus, 264.

nudiflorus, 440 .

Nuttallii, 273.

ovatus, 266.

Palmeri, 265.

Parishii, 440 .

Parryi, 264. pinifolius, 440 .

procerus, 207.

pruinosus, 266.

pubescens, 268

pubescens, 268.

pumilus, 269.

puniceus, 264.

Rattani, 440.

Richardsouii, 271.

Rozli, 272.

rostriflorus, $273,442$.

Rothrockii, 260, 440 .

Scouler!, 261.

secundiflor'us, 263.

serrulatus, 271.

speciosus, 262.

spectabilis, 265 .

stenophyllus, 266, 440 .

staticifolius, 271.

strictus, 262.

tenellus, 442.

teretiflorus, 266.

ternatus, 260,440 .

Thurberi, 270 .

Tolmiei, 267.

Torrevi, 261.

triphyllus, 271.

tubitlorus, 266 .

venustus, 271.

virgatus, 270 .

viscidulus, 266.

Wardi, 263.

Watsoni, 267.

Wrightii, 264

Whippleanus, 268.

Pepperbush, 45.

Peppermint, 352

Periploca Grieca, 85.

Periwinkle, 82.

Persimmon, 69 .

Perrinca, 82.

Petunia, 2:6, 243 . parviflora, 243.

Phacelia, 153, 158, 413.

affinis, 417 .

Arizonica, 414.

bicoler, 170, 418 .

bipinnatifida, 161.

Bolanderi, 165.

brachyloba, 167, 417.

Brannani, 418.

brevistylis, 162.

Breweri, 159.

Califr rnica, 159.

campanularia, 164, 416.

canescens, 159.

cephalotes, 168 .

ciliata, 161, 416 .

circinata, 159.

circinatiformis, $167,417$.

conferta, 160.

Coopera, 418.

congesta, 160, 415 .

crassifolia, 170.

crassifolia, 168.

crenulata, 160, 414.

Cumingii. 169 .

curvipes, 168.

Davidsoni, 167.

demissa, 168.

distans, 416 .

divaricata, 168.

Douglasii, 167.

fimbriata, 162.

Franklinii, 166. 
Fremonti, 170, 418.

floribunda, 415 .

glabra, 162

glandulosa, 160, 414

glechomæefolia, 417 .

grandiflora, 163.

grisea, 165.

gymnoclada, 170, 418 .

hastata, 159.

heterophylla, 159.

hirsuta, 163.

hispida, 161, 415 .

hispida, 163.

humilis, 159.

hydrophylloides, 165 .

jnfundibuliformis, 166 .

integrifolia, 160, 414

Ivesiana, 169,417 .

ixodes, 417 .

Lemmoni, 417.

leucophylla, 159.

loasæefolia, 165 .

longipes, 164, 416 .

Lyoni, 416.

malvæfolia, 159, 413

Menziesii, 166, 416.

micrantha, 169.

micrantha, 158, 413 .

Mohavensis; 164.

namatoides, 158.

Neo-Mexicana, 160, 414.

Orcuttiana, 417

pachyphylla, 418.

Parishii, 417.

Parri, 164, 416.

parvitiora, 162.

patuliffora, 163

pedicellata, 160,414

phyllomanica, 160, 4.15.

plätyloba, 415 .

Popei, (160) 415.

Pringlei, 413 .

procera, 166, 416.

pulchella, 168.

Purshii, 162.

pusilla, 169.

pusilln, 163.

ramosissima, 161,415 .

ramosissima, 161.

Rattani, 413 .

rotundifolia, 169 .

saxicola, 417 .

sericea, 166.

strictiflora, 163

suffirutescens, 416

tanacetifolia, 161, 416

trnacetifolia, 160, 161, 416 .

viscida, 163

Whitlavia, 164

Phacelite, 152.

Phalerocarpus serpyllifolius, 26.

Pharbitis catharticn, 210.

diversifolia, 210 .

hederacea, 210

hispida, 210 .

Nil, 210.

triloba, 210

Phelipar biflore, 312.

Californica, 312.

erianthera, 312, 313

finsciculata, 312.

Ludoriciana, 313.

lutea, 312

tuberosn, 313

Pherotrichis, 462.
Balbisii, 462.

Schaffneri, 402.

Philibertia, 85, 87.

cyuanchoides, 87.

elegans, 87.

linearis, 88

Torreyi, 87.

undulata, 87.

viminalis, 88 .

Phillyreoides, 31.

Phloganthea, 135

Phlomis, 347, 384.

tuberosa, 384 .

Phlox, 129.

acuminata, 129.

adsurgens, 133 ,

amœna, 130.

aristata, 130, 131 .

bifida, 131.

bryoides, 132.

cæspitosa, 132.

Canadensis, 131.

canescens, 132

Caroliza, 130.

corymbosa, 129.

cuspidata, 130.

decussata, 129.

diffusa, 132

divaricata, 131.

divaricata, 133.

Drummondii, 134

Douglasii, 132.

Floridana, 130.

glalertima, 130.

glutinosa, 131.

Hentzii, 131.

Hoodii, 132.

Hoodii, 132.

Hookeri, 141.

humilis, 133.

involucrata, 130.

latifolia, 130.

linearifolia, 133 .

longiflora, 130.

Iongifolia, 133.

macrantha 134.

maculata, 129.

muscoides, 132.

nana, 134.

nitzda, 130 .

nivalis, 131.

occidentalis, 133.

ovata, 130.

paniculata, 129.

pendulifforn, 129

pilosa, 130 .

pilosa, 130.

pinnata, 137.

procumbens, 130, 131.

pyramidalis, 129 .

reflexa, 129

reptans, 131.

revolutr, 130.

Richardsonii, 132.

rigida, 132 .

Ricemeriana, 134

Sabini, 134 .

scabra, 129.

setacen, 131.

Sibirica, 133.

Siclimanni, 12\%.

speciosa, 133.

speciosn, 133, 134.

Stellaria, 131

stolonifera, 131. suaveolens, 130.

subulata, 131.

suffuruticosa, 130.

tardiflora, 130.

triflora, 130.

triavulata, 134.

undulata, 120.

Walteri, 130 .

Pholisma, 51.

arenarium, 51

Phryma, 333, 334.

Caroliniensis, 336.

Leptostachya, 334.

Phrymez, 333 .

Phyllodoce, 37.

empetriformis, 37.

Pallasiana, 37.

taxifolia, 37.

Physalis, 225, 233 .

æequata, 234

Alkakengi, 233, 235.

angulata, 234 .

angustifolia, 236.

atriplicifolia, 234

Brasitiensis, 234.

cardiophylla, 235.

Carpenteriz, 233.

chenopodifolia, 234.

crassifolia, 285.

Elliottii, 237.

Fendleri, 436.

divaricata, 437.

glabra, 235.

grandiflora, 233.

hederæfolia, 235 .

heter'ophylla, 235.

hirsutct, 235.

Jacquini, 236.

lanceolata, 236.

lanceolata, 236.

Linkiana, 234.

lobata, 233.

longifolia, 237.

maritima, 236.

minutiflora, 437 .

mollis, 236 .

mollis, 235, 236.

nyctaginea, 235.

obsctra, 234.

obscura, 235.

Palmeri, 235.

Pennsylvanica, 235, 236, 237.

Perluviana, 233.

Philaclelphica, 234.

Pliladelphica, 234.

pruinosa, 234. 235.

pubescens, 234, 236

pumila, 237.

Sabeana, 233.

tomentosa, 236

Virginiana, 235.

viscosa, 236 .

viscosa, 235.

viscido-pubescens, 235.

Walteri, 236

Wrightii, 234.

Physostegia, $346,383$.

imbricata, 383 .

intermedia, 383.

parriflora, 383 .

truncata, 382, 383

Virciniana, 383.

Pickeringicupaniculata, 65.

Picrococeus, 21.

elevatus, 21. 
Floridanus, 21. starnineus, 21.

Picrocolla, 146.

Pieris, 32. phillyreifolia, 32.

Pimpernel, 63.

Pine-drops, 48

Pine-sap, 49.

Pinguicula, 314, 317. acutifolia, 317.

alpina, 317.

australis, 318, 456.

carulea, 317.

crmpanulata, 318 .

elatior, 318.

Floridensis, 456.

yrandiflora, 317.

liten, 318.

macroceras, 317.

nicroceras, 317.

pumila, 317,456 .

villosa, 317 .

vulgaris, 317 .

Pipsissewa, 45.

Piptocrlyx, 193, 428. circumscissus, 193.

Piptolepis, 76. phillyreioides, 77.

Pittonia similis, 181.

Plantain, 389, 391.

Plagiobothrys, (191), 420, 4:30.

Arizonicus, 431 .

canescens, (192), 431.

Cooperi, 4.32 .

glomeratus, 432 .

hispidus, 432

Jonesii, 430

Kingii, 430.

nothofulvus, 432 .

rofescens, 431.

rufescens, 192

Shastensis, 431.

tenellus, 4:31.

Torreyi, 431

ursinus, 492 ?

PI.ANTAGINACEE, 388

Plantago, 389.

a ristate, 391

Asitutica, 389 .

attenunta, 390

Bigelovii, 392

Bigelorii, 392 .

borealis, 390 .

Californica, 392.

Caroliniana, 390, 392.

cordata, 389.

Coronopus, $392^{1}$.

cucullata, 390.

decipiens, 391.

Durvillei, 392.

elonrata, 392.

eriopoda, 390.

filiformis, 391

glabra, 390.

gnuphalioides, 391.

Hartwegi, 392

heterophylla, 392.

hirtella, 39-2.

Hookeriana, 391.

hybrida, 392

interrupta, 390

juncoides, 390, 391.

Lagopus, 391.

lanceolata, 391.

lanceolata, 390. linearifolia, 392.

longifolia, 390 .

Kamtschatica, 389, 390, 392.

Kentuckensis, 389.

macrocarpa, 390.

major, 889.

major, 390.

maritima, 390 .

maritinza, 391

media, 392

minima, 380.

occidentalis, 392

oliganthos, 390.

Patagonica, 391.

panciflora, 390, 391

perpusilla, 392.

purpurascens, 392.

Purshii, 391.

pusilla, 392.

Richardsoni, 390.

Rugelii, 389.

sparsiflora, 390 .

spinulosa, 391.

squarrosa, 391 .

Tweedyi, 390 .

Urvillei, 392

Virginica, 392.

Virginica, 390, 392

virescens, 390.

Wrightian 391.

Pleuricospora, 18, 50, 398 . fimbrinlata, 50, 398 .

Pleuricospore $2,18$.

Pleurisy-root, 89.

Pleurogyne, 111, 124.

Carintbiaca, 124

Purshii, 124.

rotata, 124.

PLCMBAGINACEA, 53

Plumbaginere, 54.

Plumbasn, 54,55 Floridann, 55 . scandens, 55 .

Plumerie

Preumonanthe, 1:0.

Podostemma, 98.

Polostigma, 86,88 .

pubescens, 88 . viridis, 89

Pogogyne, 34t, 364.

Douglasii, 364 .

multiflora, 364

nudiuscula, 364 .

parviflora, 364 .

serpvlloides, 364

tenuiflora, $3 i t$.

zizjphoroide- 364 .

POLEMONIACLE 126.

Polemonium, 129, 149, 412. acutiflorum, 151. antarcticum, 151.

cæruleum, 151, 412.

coruleum, 151.

cupitatum, 147, 150 .

carneum, 151, 112 .

coufertum, 150

dubium, 163 .

flavum, 412 .

foliosissimum, 151, 412.

humile, 150

lanatum, 150.

Mexicanum, 151, 412.

miclanthum, 151 .

moschatum, 151.

Nyctelea, 157 . pulchellum, 150 .

pulcherrimum, 151.

reptins, 151.

Richardsoni, 150

rubmim, 145 .

viscosum, 150 .

viscosum, 150 .

Poliomintha, 344, 361, 460 . glabrescens, 460 . incana, 361 . mollis, 361 .

Poiydiclia, 243

Polydiclis multivalvis, 243. quadrivalvis, $2+3$.

Polypremum, 107, 109. Linncei, 109. procumbens, 109.

Polyotus anqustifolize, 98. heterophyllus, 99. lanuginosus, 99. longifolius, 99.

Pongatium Indicum, 10.

Portevella carnosula, 8.

Portuna, 31. floribunda, 31.

Potato, 227.

Prasium coccineum, 383. incarnatum, 384. purpureum, 383.

Primrose, 58.

Primula, 56, 58, 399. angustifolia, 58, 399.

borealis, 58, 399 .

cuneifolia, 59.

Cusickiana, 399.

Egaliksensis, 399.

farinosa, 58.

Finmarkica, 58.

IIornemanniana, 58.

integrifulio, 58 .

Mistassinica, 58

nivalis, 59.

Parrvi, 59.

pusilla, 58.

Rusbri, 399 .

saxifiregrafolia, 59.

Sibirica, 58.

Scotica, 58

stricta, 58.

suffrutescens, 59 .

PRIMULACE 玵, 55, 399.

Primuled, 55.

Priva, 333, 334 echinata, 334

Proboscidea, 321.

Prunella, 382

Pseudocollomia, 143.

Pseudokrynitzlia, 429.

Pseudo-MIyosotis, 195, 197. 429.

Psertoronitum, 251.

PsetdoosolanI 2 , 245.

Pternspora, 18, 48. andromedea, 49

Pterostyrax, 71.

Pierygium, 195, 428.

Ptilocalyx Greggii, 182.

Puccoon, 204.

Pulmonaria alpina, 201. ciliata, 201.

denticulnta, 200 .

lancealatr, 201.

marginatr, 201.

maritima, 200.

oblongifolia, 200

paniculata, 201. 
parvifora, 200.

pilosa, 201.

pubescens, 201.

Sibirica, 200.

Virginica, 200

Purshia mollis, 206. hispida, 206.

Pycnanthemum, 343, 354.

albescens, 356 .

aristatum, 354 .

Arkansanum, 355.

Californicum, 355 .

clinopodioides, 355 .

dubium, 355 .

hyssopifolium, 354 .

incanum, 355 .

incanum, 356 .

lanceolatum, 354.

leptodon, 355

linifolium, 354 .

Loomisii, 356 .

montanum, 356 .

Monardella, 374

muticum, 355

nudum, 354.

pilosum, 355 .

setosum 354

tenuifolium, 354 .

Torreyi, 355 .

Tullia 355.

vericillatum, 354 .

Virginicum, 354, 355.

Pucnosphace, 366.

Pycnothymus, 358

Pyrola, 18, 46.

aphylla, 48 .

asarifolia, 47

bracteata, 48 .

chlorantha, 47 .

corymbosa, 45 .

dentata, 48.

elata, 48 .

elliptica, 47.

grandifiora, 48 .

Groenlandica, 48 .

maculata, 45 .

Menziesii, 45

minor, 46 .

obovatr, 48 .

occidentalis, 47 .

oxypetala, 47

picta, 48 .

renifolia, 47

rosea, 46 .

rotundifolia, 47 .

secunda, 46 .

uliginosa, 48 .

umbellata, 45 .

uniflora, 45 .

Prrole 17.

Pyrolines, 17.

Pyxidanthera, 52.

barbulata, 52 .

Pyxothamnus, 25.

\section{Quamoclit, 209.}

coccinea, 209.

hederifolia, 209.

vulgav'is, 209.

Ramsted, 251.

Ranapalus Eiseni, 451.

Rapanea Guyanensis, 65

Red Ash, 74 .

Rhabdadenia, 84. paludosa, 401.

Sagrcei, 84.

RHINANTHIDE. 248.

Rhinanthus, 249,310 .

Crista-galli, 310 .

minor, 310 .

Virginicus, 291.

RHODODENDRE环, 16.

Rhododendron, 16, 39, 398.

albiflorum, 40 .

arborescens, 40 .

bicolor, 41 .

calendulaceum, 41.

calendulaceum, 40 .

Californicum, 41, 398.

canescens, 41

Catawbiense, 42 .

Chapmanii, 42.

glaucum, 41.

hispidum, 41 .

Kamtschaticum, 40.

Lapponicum, 42.

macrophyllum, 42, 398.

maximum, 42 .

minus, 42 .

nitidum, 41 .

nudiflorum, 41.

occidentale, 40.

pulchéllım, 41.

purpureum, 42

punctatum, 42.

Purshii, 42 .

Rhodor'a, 41 .

Vaseri, 398

viscosum, 40 .

Rhodothamnus Kanztschaticus, 40.

Rhcdora Canodensis, 41. congest $\pi, 41$

Rhynchospermum, 85 .

Rhytiglossa humilis, 330 .

obtusifolia, 330 .

pedunculosa, 329.

viridiflor, 330 .

viridifolia, 330 .

Ribgrass, 391.

Ribwort, 389.

Ripple-grass, 391.

Rochelia glomerata, 196. patens, 197, 422.

Romanzoffia, 153, 172, 418 Sitchensis, 172, 418 .

Unalaschkensis, 172,418 .

Rose Bay, 39, 42.

Rothrockia, 401, 403. cordifolia, 403.

Roulinia, 86, 100. unifaria, 100.

Ruellia, 322, 325 .

biflora, 324 .

ciliosa, 326,457 .

clandestina, 325 .

Drummondiana, 326.

dulcis, 327.

hirsuta, 326

humilis, 326 .

humistrata, 324

hybrida, 326.

justiciceflora, 324.

lacustris, 324.

noctiflora, 326 .

oblongifolia, 324.

Parryi, 326.

pedunculata, 325 .

strepens, 327.

strepens, 326 . tuberosa, 325 .

tubiflora, 526.

Ruflise di, 322.

Sabbatia, 110, 113.

angularis, 114

Boylkini, 116.

brachiata, 114

calycosa, 114.

campestris, 115.

chloroides, 115.

concinn", 114.

corymbosa, 114.

cymosa, 114.

Elliottii, 115.

formosa, 115.

gentianoides, 115.

gracilis, 115.

yracilis, 114.

lanceolata, 114.

macrophylla, 114.

oligophylla, 115.

paniculata, 114.

paniculata, 115.

simplex, 116

stellaris, 115.

Saccanthera 271.

Saccularia Veatchii, 439.

Sage, 366.

Surina Virginica, 127.

Schistophragma, 279.

Salal, 30.

Salazaria, 346, 382.

Mexicana, 382

Salpichroa, 225, 231.

Wrightii, 231.

SALPIGLOSSIDE 玉 226.

Salpiglossis prostrata, 243.

Salvia, $345,366,460$.

acuminata, 369 .

acuminatissima, 369 .

albiflora, 370,461 .

amabilis, 369 .

angustifolia, 369 .

angustifolia, 369 .

Arizonica, 370 .

azurea, 369 .

ballotæflora, 371.

Bernardina, 460 .

Blodgettii, 370 .

breviflora, 461.

cæsia, 369 .

carduacea, 366 .

chamadryoides, 371 .

Chamodrys, 371.

Chapmani, 370

Claytoni, 370, 372.

coceinea, 368 .

Columbarix, 367 .

coriffolia, 367 .

elata, 369 .

elongata, 369.

Engelmanni, 366.

farimacea, 368 .

fulgens, 366 .

gossypina, 366.

Greggii, 368, 460.

Henryi, 367 .

Iispanica, 461 .

lanceolata, 369 .

laxa, 371.

Lemmoni, 461.

longifolia, 369.

lvrata, 367 .

Mexicana, 369. 
micrantha, 370.

obovata, 367.

occidentalis, 370 .

officinalis, 366 .

Parryi, 371.

pentstemonoides, 368 .

Pitcheri, 369.

platycheila, 371.

polystachya, 461.

porphyrantha, 367.

porphyprata, 367 .

privoides, 371 .

pseudo-coccinea, 368.

pulchella, 461 .

pycnostachya, 461 .

Regla, 460 .

reptans, 369 .

Roemeriana, 367.

Romeriana, 367.

Sclarea, 372

serotina, 369 .

spicata, 461.

splendens, 366 .

subincisa, 363 .

tenella, 370 .

Texana, 366

trichostemoides, 369 .

trichostyla, 369.

urticifolia, 370 .

urticifulia, 370 .

verbenacea, 372 virgate, 369 .

Salvinsloum, 366.

Texanum, 366

Samara floribunda, 65.

Samodia ebracteata, 64

SAMOLE

Samolus, 56, 64 .

ebracteatus, 64 .

floribunilus, 64 .

loncipes, 64.

Talerandi, 64 .

Sand Mrytle, 43.

SAPOTACE.E, 66.

Sappadilla, 69 .

Saracha acutifolia, 2 ;. Coronnpus, 232.

nand, 233.

sordida, 232

umbellata, 437 .

Sarcodes, 18, 49.

sanguinea, 49 .

Sarcostemme, 87.

bilobum, 88.

Brounit, 88.

clausum 88.

crassifolium, 88.

cynanchoides, 87 .

elegans, 87.

heterophyllum, 88 .

lineare, 88.

undulata, 87

Satureia, $\ddot{2} 43,358$.

coccinea, 360 .

hortensis, 358 .

origanoides, 354

rigida, 359 .

Virginiane, 354.

SATURELYE 4 , 312.

Saxifraga nutans, 172.

Savory, 358

Scæevola, 1 .

Plumieri, 1.

Schaueria linearifolia, 328. parvifolia, 330 .
Schizonotus, 86, 100. purpurascens, 100.

Schleideniu, $18 \pm$ polyph ylla, 185.

Schollera Oxycoccus, 26.

Schwalben, 249, 305. Americana, 305.

Schweinitzia, 18, 49, 398.

Caroliniana, 49.

odorata, 49,398 .

Reynoldsiæ, 398.

Sclarea, 371

Scoparia, 248, 284 dulcis, 284.

Scrophularia, $246,258$.

Californica, 258 .

coccinea, 258 .

lanceolata, 258

Marilandica, 258.

nodosa, 258

SCROPHULARIACE $\Psi, 244$, 438

Scullcap, 378

Scutellaria, 346, 378, 462 . ambigua, 380 .

angustifolia, 381 .

antirrhiuoides, 381 .

arguta. 379.

Bolanderi, 381 .

brevifolia, 380 .

Californiea, 381.

canescens, 379.

cardiophylla, 380 .

Crroliniana, 378, 379.

Chamedrys, 379.

cordifolia, 378.

Drummondii, 380 .

elliptica, 379.

Floridana, 380.

galericulata, 381 .

gracilis, 382

lirsuta, 379

hyssopifolia, 379 .

incana, 379 .

integrifolia, 379, 462 .

integrifolia, 380 .

lateriflora, 378 .

Mississippiana, 462.

montana, 379 .

nana, 380 .

nervosa, 382.

ovalifolire, 379 .

parvula, 380 .

pilosa, 379.

polymorphes, 379 .

pubescens, 379 .

resinosa, 381.

resinosa, 381 .

rugosa, 378.

saxatilis, 378

saxatilis, 379 .

serrata, 379 .

serrata, 379

siphocampyloides, 381.

teucrifolia, 382

tuberosa, 381 .

versicolor, 378, 462 .

villosa, 379 .

Wrightii, 380 .

SCUTELlarine. 345

Sea Lavender, 54.

Sea Milkwort, 63.

Sea Pink, 54 .

Sebestinoides, 180.

Secondatia, 85 .
SELAGINACE 8 , 332

Seleucia, 61

Self-heal, 382

Sericogrtuphis Californica, 329. neglecta, 457

Sesamum, 320. Indicun, 320.

orientele, 320

Seutera, 102 maritima, 102.

Seymeria, 248, 289.

auriculata, 292

bipinnatisecta, 290 .

macrophylla, 290.

pectinata, 290.

pilosa, 451.

scabra, 290.

tenuifolia, 289

Shallon, 30.

sheep-Laurel, 38.

Shin-leaf, 46.

Shooting Star, 57.

Shortia, 52, 53, 399 . galacifolia, 53, 399 .

Shuttleworthia, 337.

Sideroxylon, 66, 67. chrysophylloides, 68. decandrum, 68. leve, 68.

lanuginosum, 68.

lycivides, 68.

mastichodendron, 67 . pallidum, 67.

reclinatum, 68

sericeum, 68 .

tenax, 68 .

Silkweed, 89.

Silver-bell Tree, 71

Siphocampylus bicolor, 3.

Siphonella, 140.

Siphonoglossa, 323, 328.

longiflora, 328 .

Pilosella, 328.

snowberry, 26.

SOLAN ACE 2 E, 224, 436.

SOLAXE 224.

Solanum, $224,226$.

aculeatissinum, 230 .

alatum, 228 .

Americanum, 228.

Bahamense, 229.

Balbisii, 231.

Bejariense, 231.

Besseri, 228.

Blodgettii, 229.

brancaefulium, 231.

Californicum, 229 .

Carolinense, 230.

citrullifolium, 231.

conoides, 232.

Coronopus, 232.

cornutum, 231.

crenato-dentatum, 228.

decurrens, 251.

Dillenii, 228.

Dulcamara, 228.

Douglasii, (228), 436 .

elragnifolium, 230 .

F'endleri, 227.

flavidum, 230.

Flonidanum, 227.

yenistoides, 229.

gracile, 228.

heterandrum, 231.

heterodoxum, 231. 
Hindsianum, 230.

hirsutum, 230 .

inflatum, 231.

inops. $22 \%$.

Jamesii, 227.

leprosum, 230.

Lindheimerunum, 229.

Linsecumii, 232.

luteoliflor wm, 233.

Lycopersicum, 226.

mammosum, 227, 230.

Welongene. 227 .

miniatum, 228.

nigrum, 227.

nodiflom, 228

platyphyllum, 230 .

Pleei, 2 jo.

Pseudo-Capsicum, 228.

Pseudo-Lycopersicum, 226.

pterocaulon, 228.

ptycanthum, 228.

Romerianun, 250.

rostratum, 231 .

Sabeanum, 231.

sisymbrifolium, 230 .

Tехаnum, 227

Texense, 230

Torreyi, 230 .

triflorum, 227 .

triquetrum, 228.

tuberosum, 227.

nmbelliferum, 229.

umbelliferum, 228 .

verbascifolium, 229 .

villosum, 228.

Virginianum, 227.

$\mathrm{X}$ anti, 229

Solenandra cordifulia, 53 .

Sophronenthe, 282.

hispida, 283.

Sorrel-tree, 33.

Sour-wood, 33.

Spearmint, 352.

Specularia, 9, 10

biflora, 11.

Linsecomii, 11.

leptocarpa, 10.

Lindheimeri, 11.

ovatr, 11.

perfoliata, 11.

Speedwell, 286.

Sphacele, 344, 365. calycina, 365 .

Sphenoclea, 9, 10

Ponqatium, 10

Zeylanica, 10

SPHeNocle 2 , 9.

Spigelia, 106; 107. gentianoides, 108 .

Lindheimeri, 108.

- loganioides, 168.

Marilandica, 108.

Texana, 108.

Spondylococcus, 340 .

Squaw-root, 313.

Stachy's, 347, 385, 462

agraria, $386^{\circ}$.

agretia, 388 .

ajugoides, 386 .

albens, 386 .

annua, 386

arvensis, 386.

arvensis, 387.

aspera, 387

Bigelovii, 388 .
Betonica, 388.

bullata, 387 .

Californica, 388.

Chamissonis, 388 .

ciliata, 388.

coccinea, 388.

coccinea, 388 .

cordata, 387

Urummondii, 386.

Floridana, 387.

foniculum, 376 .

glibra, 387.

Grahami, 386.

hispidler, 387.

hyssopifolia, 387.

Nuttallii, 387, 388.

palustris, 387,462 .

palustris, 387,388 .

pyenautha, 386 .

pycnostachya, 386.

riederi, 388.

rigicla, 388.

Iiothrockii, 386 .

sylvatica, 387,388 .

velutina, 462.

STACHYUE \&, 346.

Stachydeoma, 363.

Strchyturpheia, 334

Stachytarpheta, 333,334 . Jamaicensis, 334.

Stagger-bush, 32.

Standing Cypress, 145.

Star-flower, 60

Statice, 54 .

Armeria, 55.

Bahusiensis, 54.

Brasiliensis, 54

Californica, 54.

Caroliniana, 54

Limonium, 54.

STATICE E, 54.

Stegnocarpus canescens, 181.

Steirnnema, 56, 61 .

ciliatum, 61 .

floridum, 62 .

heterophyllum, 62 .

lanceolatum, 61 .

longifolium, 62 .

radicans, 61 .

revolutum, 62.

Steenhanmera, 200

Stemodia, 247,279

durantifolia, 279.

verticillaris, 279.

Slemodiacra, 279.

Stenandrium, 322, 327.

barbatum, 327 .

dulce, 327.

trinerve, 327.

Stenhammaria, 200. maritima, 200.

Stenolobium stans, 319.

Stipecoma, 84.

Stickseed, 188.

Stornx, 71.

Stramoninm, 239.

Streptopodium, 348 .

Stylandra pumila, 88.

Stylisma aquatica 217.

evolvutoides, $217,218$.

humistrata, 217.

Pickeringii, 218

STYRACACFA, 70.

STYrace 70

Styrax, 70, 71 .
Americana, 71.

Californica, 72

grandiflorum, 72.

grandifolia, 72.

lave, 72.

loevigata, 72.

officinale, 72.

platanifolia, 72.

pulverulenta, 72.

Summer Sarory, 358

Sutera multificla, 279 .

Sweet-leaf, 70 .

Sweet Pepperbush, 45.

Sweet Potato, 211.

Swertia, 111, 124.

cor'niculata, 127.

deflex $\alpha, 127$.

difformis, 115, 125 .

fastigiata, 125 .

Michauxiana, 127.

obtusa, 125.

perennis, 124

pusilla, 124.

rotata, 124 .

Symphytum, 179, 206. asperrimum, 206. officinale, 206.

SYMIPLOCINE, 70.

Symplocos, 70. tinctoria, 70.

Synandra, 346, 384, 462. grandiflora, 384, 462

Synthyris, 248,285 .

alpina, 286.

Houghtoniana, 286.

pinnatificla, 285.

plantaginea, 286 .

reniformis, 285.

rotundifolia, 285 .

rotundifolia, 285. rubra, 286 .

Syringa, 72.

Tabacum, 241.

Taberncemontana Amsonin, 81. angustifolir, 81 .

Tecoma, 318, 319 .

radicans, 319

stans, 319.

Tessaranthium radiatum, 127.

Tetraclea, 342, 347 .

Coulteri, 347.

Tetramerium, 323, 330 .

hispidum, 330 .

platystegium, 331 .

Teucrium, 342, 349, 459 .

Canadense, 349.

Canadense, 349 .

Cubense, 349 .

inflatum, 349 .

laciniatum, 349.

lovigatum, 349.

occidentale, 349,459 .

Virginicum, 349 .

Thelria, 46.

aphylla, 48.

ascrifulist, 47 .

bracteosa, 47.

ellipticr. 47.

grandiftora, 47.

intermedia, 47. occidentalis, 47 .

spathulatrl, 48 .

TheopkikASTE $\pi$, 65.

Theronthadion, 39. 
Thevetia neriifolia, 79 .

Thrift, 54, 55 .

Thorn-Apple, 239.

Thymbra Curoliniana, 384.

Thyme, 358.

Thymus, 343 .

Carolinianus, 360 .

Chamissonis, 359

Douglasii, 359 .

grandiflorus, 360 .

ianceolutus, 354

$N \in$ pet t, 359.

Siervyllum, 358 .

Tirginicus, 354.

Thyrsanthus, 63.

Tiaridium, 185 .

Indicum, 1 s:

Tiquilia brevifolia, 182. Oregana, 18?

Tiquiliopsis, 182.

Toad-Flas, 250.

Tobacco, $2 \pm 1$.

Tulmeia occidentalis, 44 .

Tomato, 2:2.

Tonella, $246,257$. collinsioides, 257 floribunda, 257

Tournefortia, 178, 182. graphalodes, 183. heliotropioides, 186. mollis, 183, 421 . Honclovann, 421. rolubilis, 18:3.

Tournsole, 183.

Trachelospermum, 80, 84 . difforme, 85.

Trailing Arbutus, 29.

Tretrorhiza, 1:20.

Tricardia, 153, 172 . Watsoni, 17 .

Trichosphace, 366 .

Trichostema, 312, 347, 459 .

Arizonicum, $3 \pm 8$.

brachiatum, $348,349$.

dichotomum, 3.18 .

dichotomum, 348 .

lanatum, 348,459 .

lanceolatum, 348 .

laxum, 348 .

lineare, 348.

micranthum, 348.

ablongum, 348 .

oratum, 459 .

Parishii, 459.

pilosum, 348

Tridynia, 62

Trientalis, 56,60

Americana, 61.

arctica, 61.

Europrea, 61 .

Europere, 61

latifulia, 61 .

Tripetaleia, 44.

Triphysari', 301. versic, lur, 301, 453.

Trumpet-creeper, 319 .

Trumpet-flower, 319.

Tubiftora Carolinensis, 324.

Tullia pycnanthemoides, 355.

Turtle-heacl, 2058.

Utricularia, 314, 455. biflora, 315,455 .

bipartita, 315 .

bipartita, 316. ceratophylla, 315 .

claudestina, 315.

cornuta. 317,455 .

cornutu, 456 .

fibrosa, 316, 455 .

fibrosa, 316

fornicata, 315.

geminiscapa, 315.

gibba, 315 .

gibba, 455 .

Greenei, 316.

integra, 316.

intermedia, 316.

juncea, 4.56 .

longeciliata, 456 .

longirostris, 316,455 .

macrorhiza, 315 .

minor, 315,455 .

nccidentalis, 455 .

personnta, 317, 456 .

pumile, $315,316$.

purpurea, 316,455 .

resupinata. 316 .

saccata, 316

setacea, 315,316 .

simplex, +56

striatn, 315, 316.

subulata, 316

vulgaris, 315 .

Unicorn-plant, 321

Urananthus glaucifolius, 116.

Urechites, 81 .

suberect $\pi, 81$.

Usterin antirrhiniflora, 254.

Uva-Ursi, 27.

Uwarowitt, 337 .

VACCINEA, 11

Vaccinium, 15, 20, 396. albiflorum, 23.

album, 20, 21, 22.

a monum, 23.

angustifolium, 22.

arboreum, 20.

brachycerum, 19.

buxifolium, 19.

cæspitosum, 24.

Canadense, 22.

carnosim, 25.

Chamissonis, 24.

Constabloei, 23.

corymbosum, 22 .

crassifolium, 25.

decamerocarpon, 19 .

diffusum, 20.

disocarpum, 23.

disomorphum, 22 .

dumosum, 19.

elevatum, 21.

Elliottii, 22.

elongatum, 23.

elytbrocarpon, 25.

formosum, 21.

frondosum, 19.

fuscritum, 22, 23.

graliformis, 22

glibrum, 20

glcucum, 19

yaulherioides, 23.

grandiflorum, 23.

hirsutum, 23.

hivtellum, 19.

hispidulum, 26 .

humifusum, 20, 30 .

humile, 22.
Kunthicanum, 21.

lanceolatum, 25.

ligustrinum, 20, 22, 33.

macrocarpon, $26,396$.

d) arianzun, 2:3.

membranac.um, 24 .

mucronatum, 20.

multiflorum, 22 .

Myrsinites, 21.

myrtzfolium, 25.

myrtilloides, 24 .

myrtilloides, 22, 24 .

Myrtillus, 24.

nitidum, 21.

obtusum, 20.

occidentale, 23.

ovalifolium, 24.

ovatum, 25 .

(1xreoccus, 25, 396.

prillidum, 23

parviftorum, 20.

parvifolium, 24.

Pennsylvanicum, 22.

Penniylranicum, 22.

pubescens, 23.

ramulosum, 22

resinosum, 20.

salicinum, 23.

salicinum, 22.

stamineum, 21

tenellum, 22.

tomentosum, 19.

uliginosum, 23 .

ursinum, 20.

vacillans, 22 .

venustum, 19.

virgatum, 21.

virrutum, 2:2.

Vitis-Idun, 25.

Vallesia, 79,81 .

chiococcoides, 81.

dichotoma, 81 .

glabra, 81 .

Varronit bullata, 180.

globosa, 180.

Veribascese 245.

Verbascum, 245, 250.

Blattaria, 250.

Claytoni, 250.

elongatum, 250.

Lychnitis, 250.

vircatum, 250.

Verbena, 333, 335, 458 angustifolia, 336.

Arisonicn, 458.

Aubletia, 337.

bipinnatifida, 337 .

biserrata, 335 .

Bonariensis, 458.

bracteosia, 336 .

carulea, 335.

canescens, 336 .

canescens, 330, 458 .

Carolina, 335, 336.

Caroliniana, 3.36.

Caroliniana, 335.

Carolinensis, 335.

ciliata, 337.

cuneifolia, 336.

hastata, 336 .

Jamaicensis, 334

Lamberti, 337.

lninceolata, 336 .

lantanoides, 338 .

lasiostachys, 336 . 
ligustrina, 338 .

littoralis, 458

longiflora, 337.

Lucoeant, 335.

nodiflora, 339.

Obletia, 337.

officinalis, 335 .

officinalis, 337 .

paniculata, 336.

pinnatifide, 336 .

polystachya, 335 .

prismatica, 334

prostrata, 336.

Rameriana, 337.

remota, (337), 458.

rigens, 336 .

rugosa, 336 .

simplex, 336.

sororia, 335.

spuria, 335.

squarrosa, 336 .

stricta, 336 .

sirigosa, 335 .

urticæfolia, 335 .

venosa, 338 .

veronicafolia, 335.

Wrightil, 337.

xutha, 335 .

VERBENACE $\AA$, 332, 458.

VERBENEAC, 333 .

Veronica, 218, 286.

agrestis, 288 .

alpina, 288.

Americana, 287.

Anagallis, 287.

Anagrilis, 287.

apliylla, 287.

arTensis, 288.

Beccubunga, 287 .

Buxbaumii, 289.

Caroliniana, 288.

Chamædrys, 287.
Cusickii, 288.

fruticulosu, 287.

grandiflora, 287.

hederæfolia, 289.

intermedia, 287.

Japonica, 287.

Kamtchatica, 287.

Marilandica, 288, 289.

nutans, 287.

officinalis, 287 .

peregrina, 288

Purshii, 289.

reniformis, 289.

scutellata, 287.

serpyllifolia, 288.

Sibirica, 287.

Stelleri, 288.

Virginica, 286.

Wormskioldii, 288.

Xalapensis, 288.

Vervain, 335.

Villarsia aquatica, 128.

cordala, 128.

Crista-galli, 128.

lacunosa. 128.

pumila, 173.

trachysperma, 128.

Vinca, 80,82 .

minor, 82.

rosea, 82.

Vincetoxicum, 87, 102, 403. acunthocarpum, 104.

gonocarpos, 103.

nigrum, 102.

palustre, 102, 403.

scoparium, 102, 403 .

Viper's Bugloss, 207.

Viscum terrestre, 63.

VITICE E, 333

Viticella, 53, 155

Vitis-Idoea, 24.

Voyria Mexicana, 405.
Wahlenberon Californica, 13.

Water Ash, 75.

Water Horehound, 352.

Waterleaf, 154

Water Pimpernel, 64 .

White Ash, 73 .

White Mangrove, 340

Whitlavia, 164, 416. grandiflora, 164. minor, 164 .

Wicky, 38.

Wigandia Californica, 176.

Wild Marjoram, 358.

Winter Cherry, 233.

Wintergreen, 30, 45, 46 .

Withania, 232. Coronopus, 232.

Morisoni, 224, 233, 436.

somnifer'a, 224, 436 . sordida, 232.

Woundwort, 385 .

Wulfenia reniformis, 284.

Xerobotrys, 27.

argutus, 28.

cordifolius, 28.

tomentosus, 28. venulosus, 28.

Xylococcuss, 28. bicolor, 29.

Yellow Jessamine, 107.

Zapania, 338.

cuneifolia, 339.

lanceolata, 339 .

nodiflora, 339

Zenobia, 31 floribunda, 31

racemosa, 35.

speciosa, 31.

Ziziphora glabella, 360. 





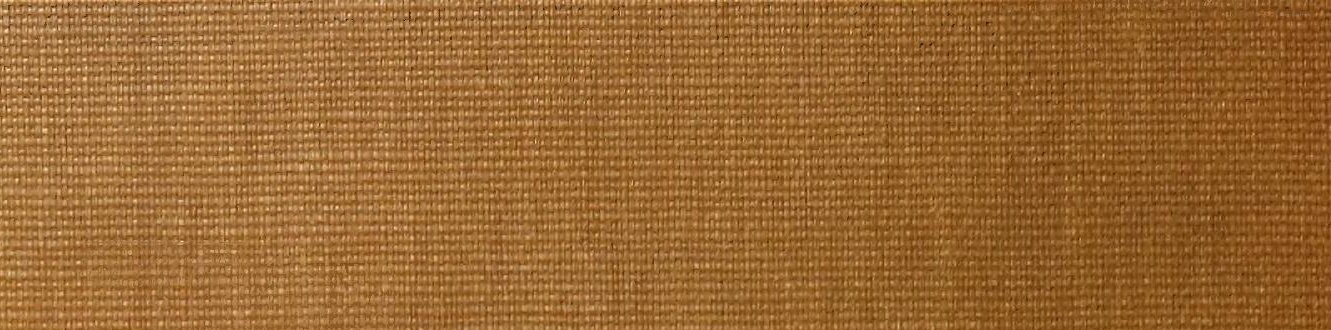

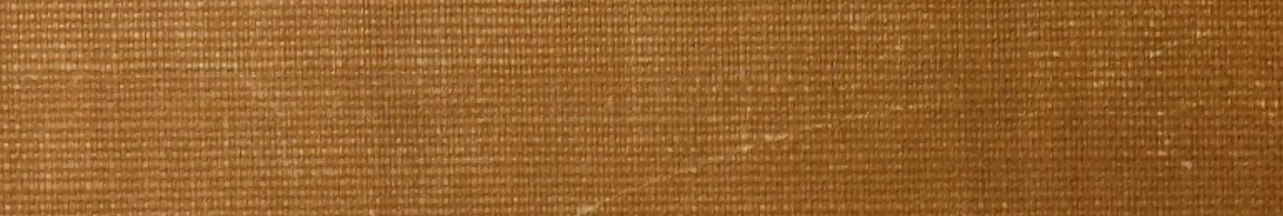

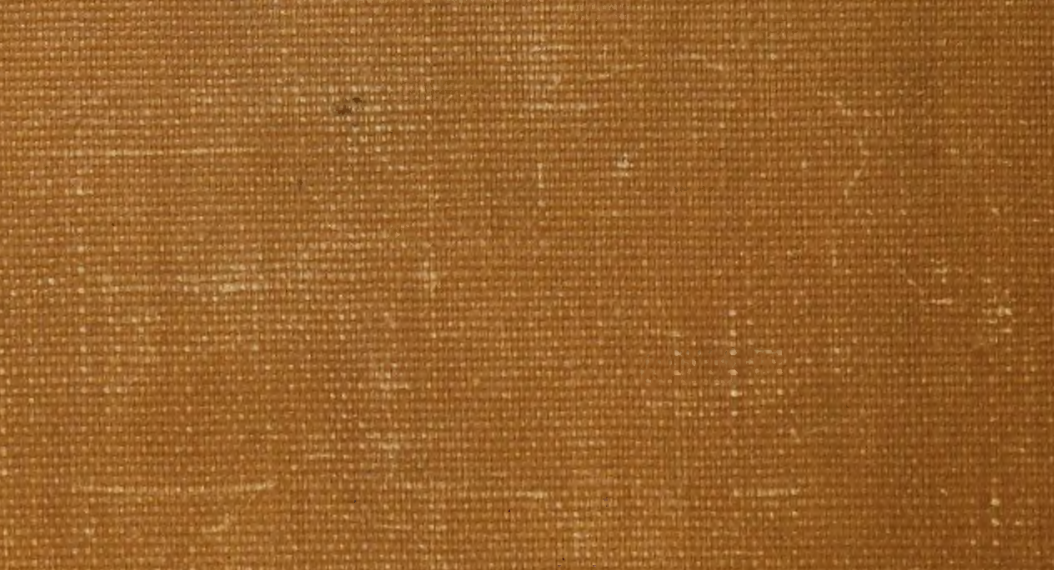
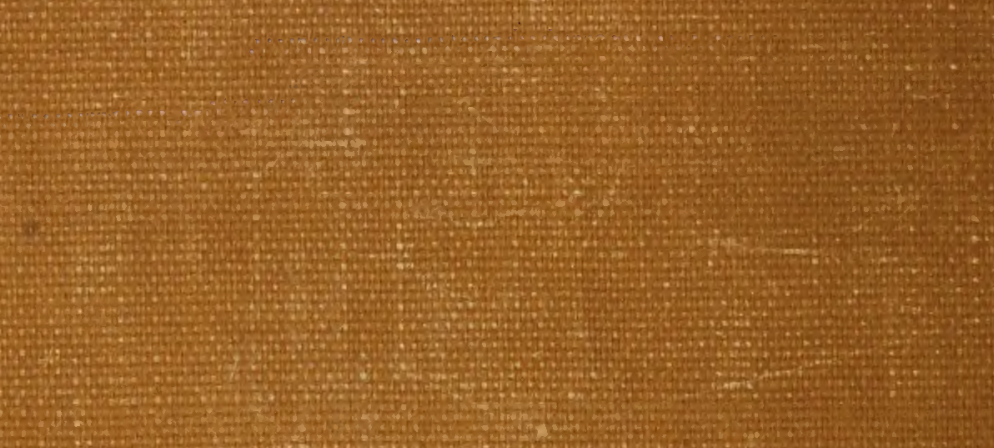

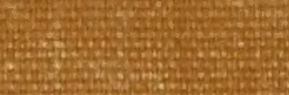

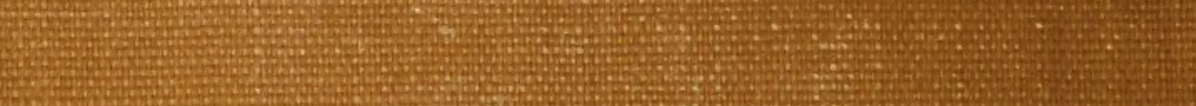

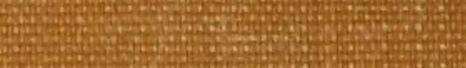

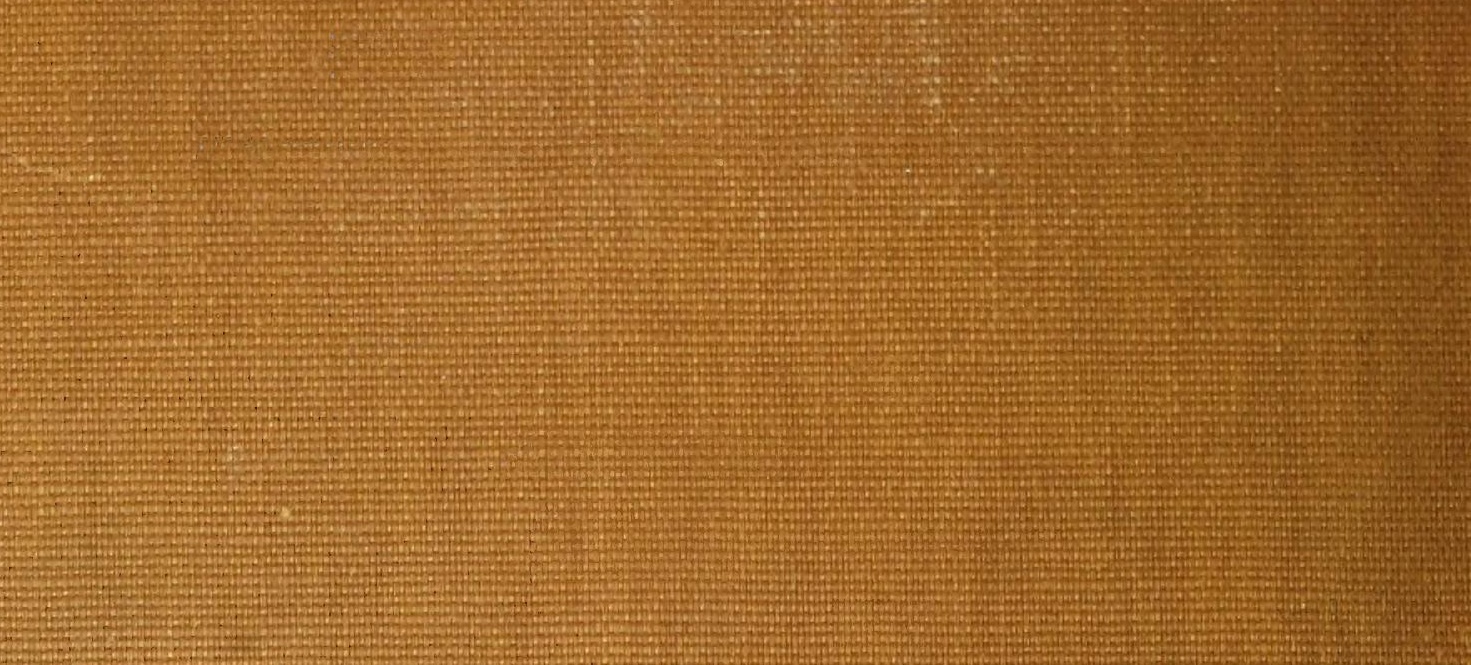

